$x^{2}=0$

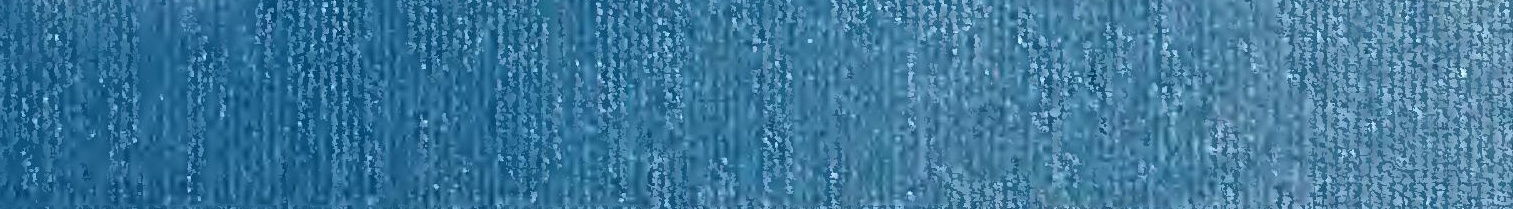

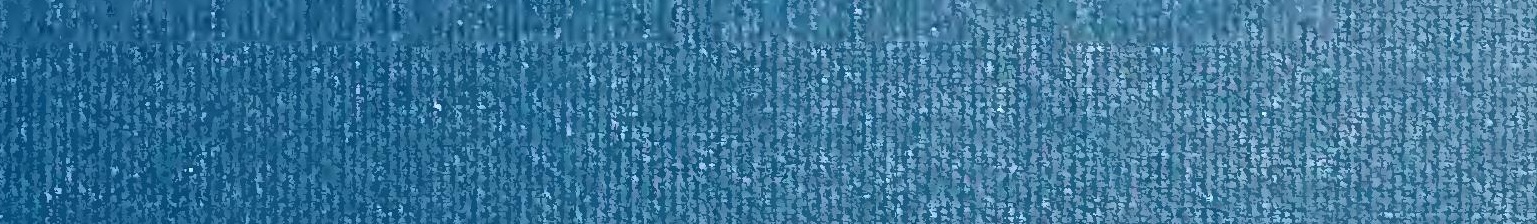

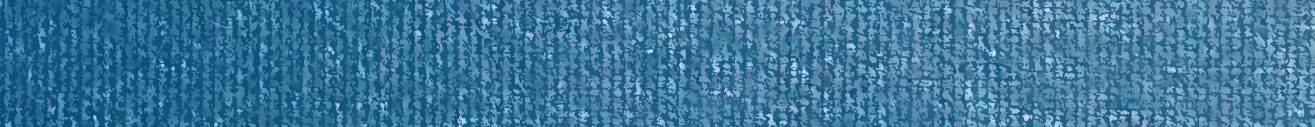

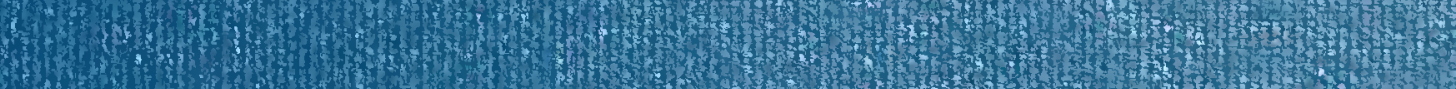
13.13

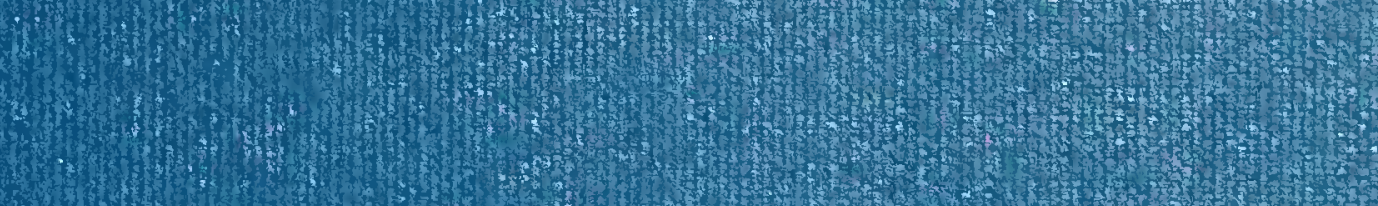

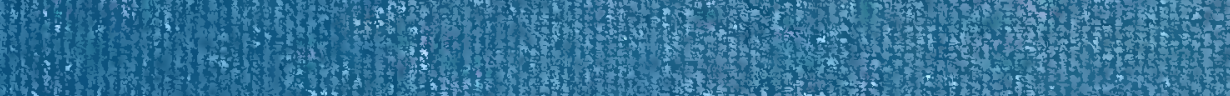
HWW

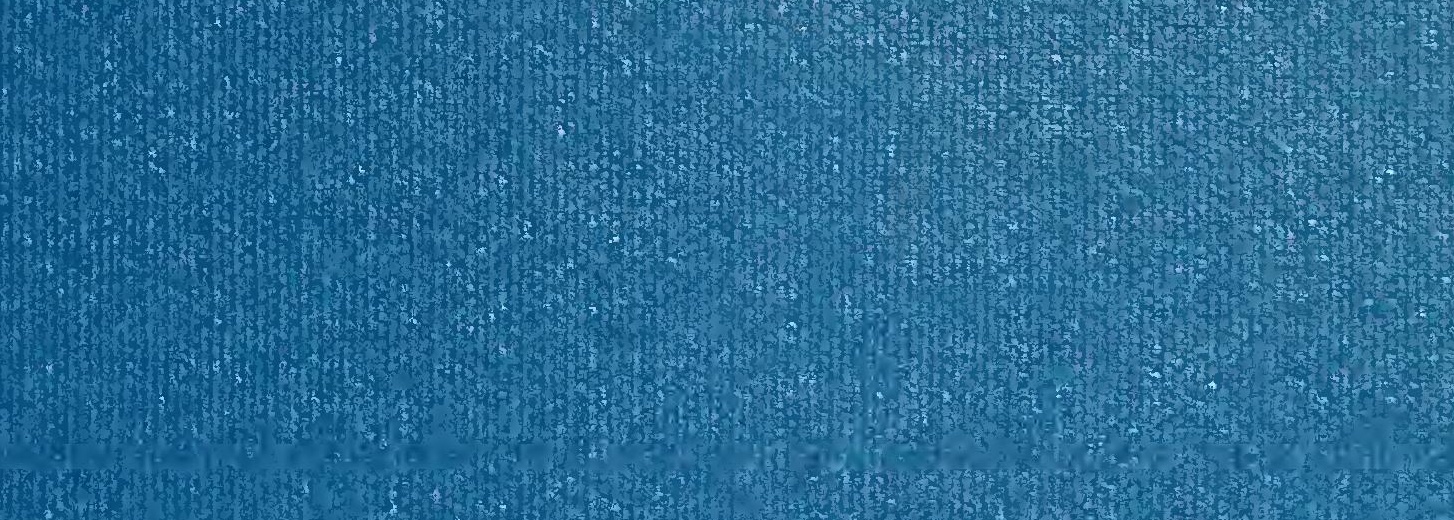
(3) W (1) 1
1 $x$

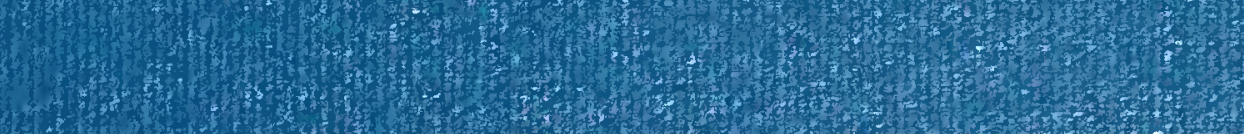
H. H. W.WW W 13.1. 17.

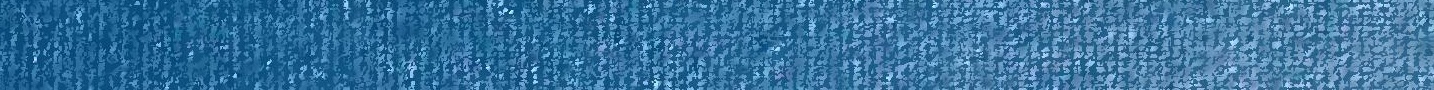

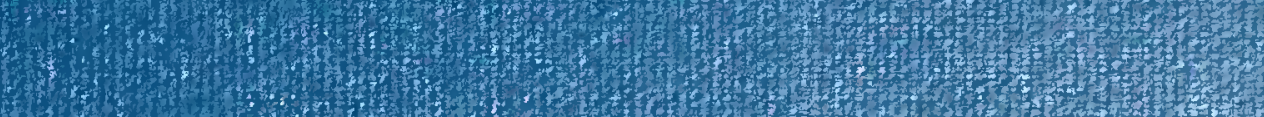
1

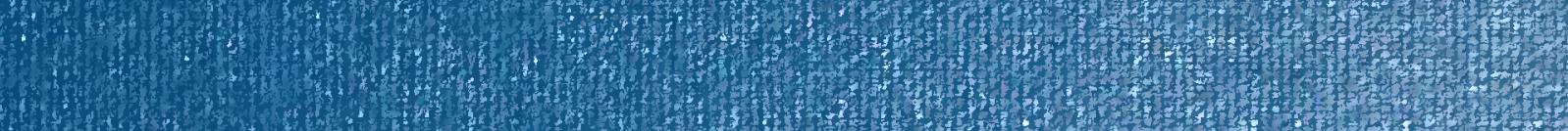

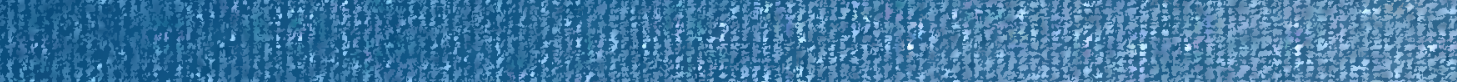
1.73 How

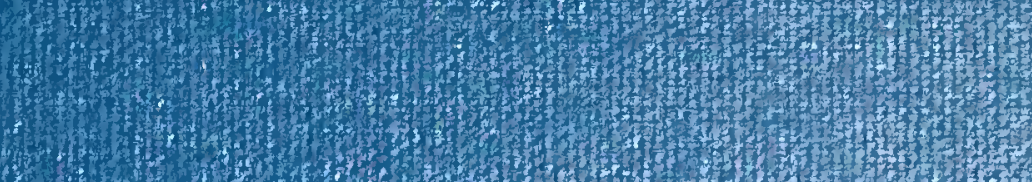
Thy 


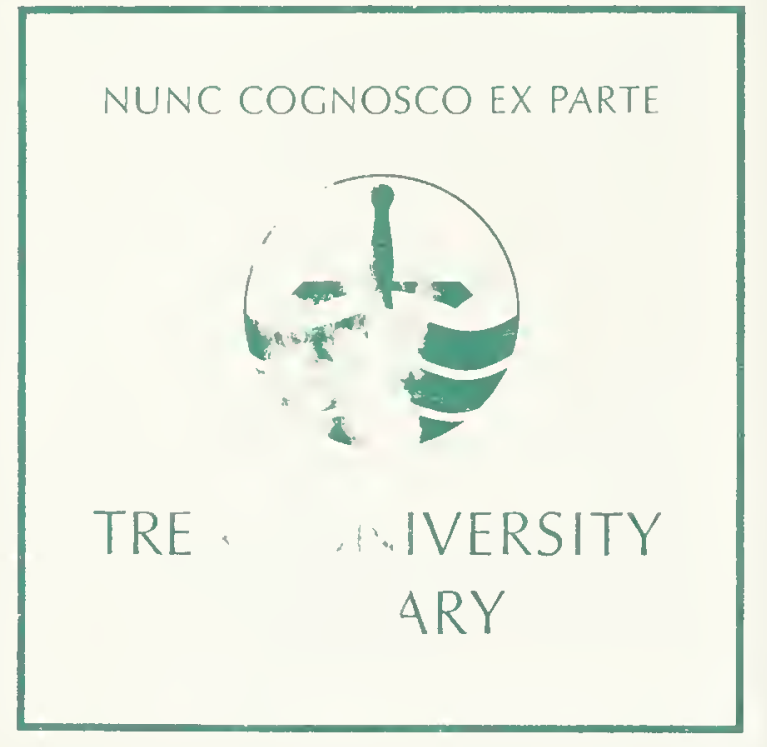


Digitized by the Internet Archive in 2019 with funding from Kahle/Austin Foundation

https://archive.org/details/viajepoliticocie0000mala 



VHAF HATICO.CIENTHE()

ALREIEUOK IEI, MUNDO 



\section{VIAJE POLÍTICO-CIENTÍFICO}

\section{ALREDEDOR DEL MUNDO}

POR I,AS CORHETAS

\section{DESCUBIERTA y ATREVIDA}

AL MANDO DE los CAPITANes de nAVio

\section{ALEJANDRO MALASPINA}

DON JOSE DE BUSTAMANTE Y GUERRA

$$
\text { DESDE I } 789 \text { Á } 1794
$$

PUBLICADO CON UNA INTRODUCCIÓN

POR

DON PEDRO DE NOVO Y COLSON

TENIENTE DE NAVÎO

ACADEMICO CORRESPONDIENTE DE LA REAL DE LA HISTORIA

SEGUNDA EDICIÓN

MADRID

IMPRENTA DE LA VIUDA E HIJOS DE ABIENZO

ISABEL IAA CATÓLICA, \& Y PAZ, 6 



\section{EXCMO. SR. 1). JUAN B. ANTEQUERA Y BOBAIMIIIA}

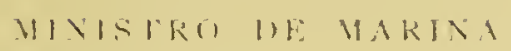

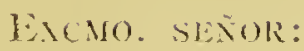

thimado por mi entranable amor a nuestra Armada, me atreve hoy a dar a luz la in apreciuble jova que durante cien años estravo encerrada cu el polvo de los archivos; y al buscar al nombre de un navegante contemporáneo à quien dignamente pudieva dedicársela, he hallado que à V. Li asiste el mejor derecho. nó por la alta posición que ahora ocupa (onal quiera que sea la gloria que en ella logre), sino por los grandes méritos que contrajo como tefe de la fragata Numancia en sn asombroso riaje de circumnaregación.

Vo es dudoso que l. Fe rerá con sumo agrado cnallecidos al fin por sus propias obras. "i esos marmos cminentes que divigieron la famosa expedicion de las corbetas Descubiertia y ATREvids. Io me felicito de que este verdadero desagravio se efectúte en momentos de eniontrarse al frente de la Marina el antiguo Comandante del primer acorazado que dió lu inelta al mundo. con sorpresa de Europa. y en momentos de hallarse á punto de emprender

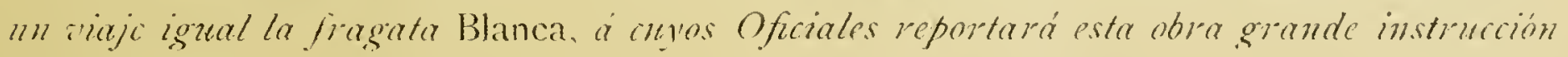
inoble cstimnlo.

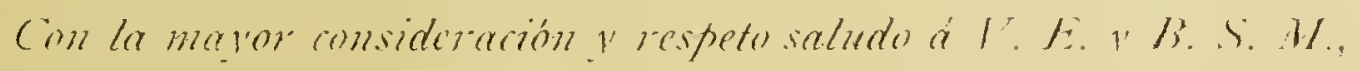





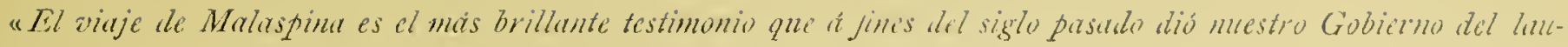
ndable interés que se tomaba en anmentar los conocimientos de la cienciar de muestro globo. . . . . . . . . . . .

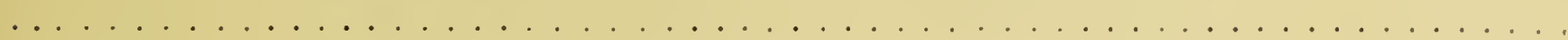
"Util para el munulo y honroso para la Nación española hubiera siblo la publicación de este viaje, coordinado por los nOficiales de la expedición y sabios que los acompañaron; pero por un trastorno de ideas inconcebible, las resultas

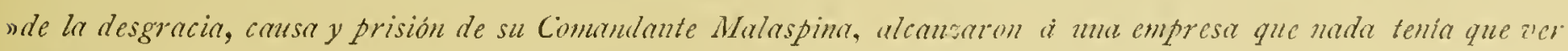
"con sus supuestos crimenes, y cn odio del autur ó Jefe de la expedición, se sepulturon todos los trabajos propios de nlos hombres cientificos y aplicados que llevio á sus orilene's. Nucho costó sacar de manos de los escribanos y gentes: nque entendieron en el proceso, los Diarios, aterroteros y descripcionc's del viaje. Lil que suscribe tuno la satis"ufacción de contribuir eficazmente à lograrlo, a reunir cuantos papcles se pudo, y depositarlos en la Dirección de "Hidrografir, que se instituyó entonces, cuyas tareas debín comenzar por las cartas y demás trabajos marinos de esta nexpedición...... Quedaronse sin imprimir todos los derroteros y cicelentes relaciones del viaje, llenas de luminosas mobservaciones astronónicas y mineralógicas, de descripciones fisicas y politicas. I' de nociones muruns solure ley Histo"ria Natural de los paises recorritos.n 


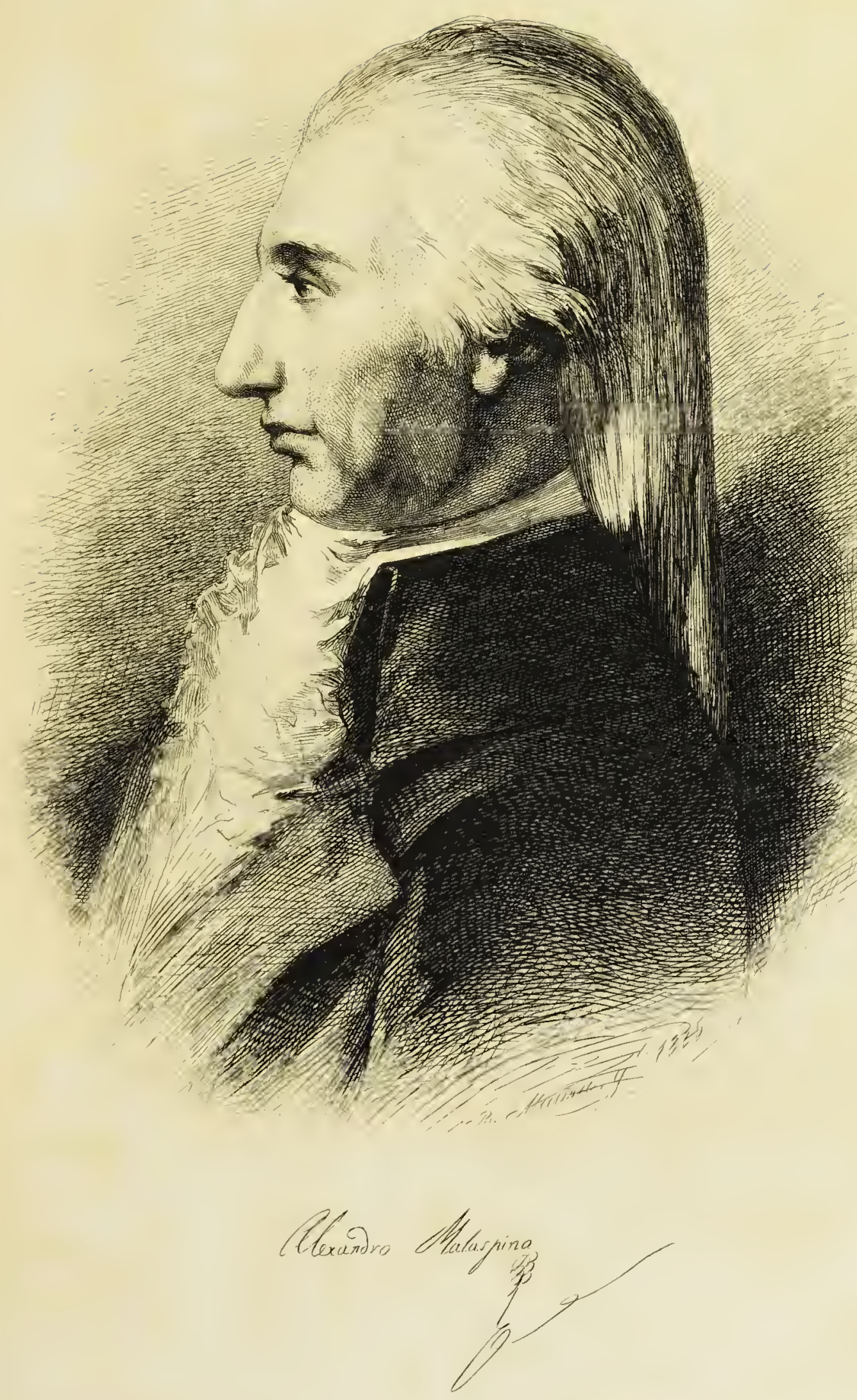



\section{INTRODUCGIÓN HISTÓRICA}

\section{I}

Algunas Reflextones sobre la conveniencia de publicar esta obra

Pocos días hace que, entregado á mi lectura favorita, fijé la atención en una página de la Historia general de los Descubrimientos Maritimos, famosa obra de W. Desborough Cooley. Con más disgusto que sorpresa, encontré en ella las apreciaciones que transcribo literalmente:

«En I 775, dos buques españoles, bajo las órdenes de D. Juan de Ayala y de D. An"tonio Maurell, contribuyeron en algo á los progresos de la Geografía, examinando su»perficialmente la costa N. O. de América entre los 47 y $57^{\circ}$ de latitud. Esta expedición »había recibido orden de llegar hasta el paralelo de $65^{\circ}$; pero los navegantes españoles $n o$ "habian estudiado tanto como los de otras naciones la ciencia de levantamientos de planos »y su examen de la costa no pasó de los $57^{\circ}$. Una gran bahía ó estrecho en $57^{\circ}$ I $7^{\prime}$ de * latitud, fué nombrado por ellos Puerto Bucarelli, en honor del Virey de Méjico.... El re"sultado de este viaje pareció satisfactorio al Virey, pues en i 779 envió una segunda ex"pedición para que continuara el examen de la costa desde los 58 á los $70^{\circ}$. Como la "ignorancia de los españoles igualaba en esta época á su RESERVA y su SILENCIO, es posible "que el Virey no supiese la existencia de un navegante inglés llamado Fames Cook, el "cual había hecho este estudio el año anterior, con el firme propósito de comunjcar sus »resultados á todo el universo. Aquella nuevà expedición no añadió nada á los conoci» mientos geográficos.... Maurelle, á su vuelta, quiso levantar una carta exacta de la costa; pero se sabe que en i 779 los españoles calculaban todavia su longitud según la estima, "mientras que los franceses y los ingleses se servían ya, desde algunos años, de cronóme"tros y de observaciones LUNAREs."

Si no fuera tan ilustre y respetado el nombre de Desborough Cooley, habría yo leído impasible una vez más ese cúmulo de inexactitudes é injusticias, cosecha añeja y frecuente que recibimos del extranjero; pero el notable historiador británico, es, desde mediados del sigło, el oráculo de muchos eruditos y escritores, así como su obra pasto casi universal de los estudiosos; y esto ya merece que conteste España vindicándose, no por conducto 
de sus sabios, que fuera inoportuna cortesía, sino por uno de los más humildes oficiales de su Armada, lo que toma carácter de severo castigo.

Tantos nombres y tantos hechos acuden á mi memoria; tan grande es el número de nuestros marinos ilustres, que necesito concretarme á los que lo fueron solamente por su sabicluría, y de ellos citaré nada más, como aludidos, á los que durante esos años de i 770 á I 780 surcaban el Océano sin otra ayuda que la brújula y la corredera, según afirmación lel historiador inglés.

¿Será cierto que D. Francisco Maurelle, ignorase en su segundo viaje al N. O. de América, que Cook existía y navegaba, y que se proponía comunicar al mundo sus trabajos? Quizás. Pero, en cambio, no admite duda que este famoso marino tuvo perfecto conocimiento de la primera expedición de Maurelle y que su DIARIo sirvió de guia y consulta á Cook, quien aprovechóse de las noticias y descubrimientos consignados en sus páginas. Más adelante fué impreso el Diario de Maurelle por Sir Barrington en su libro las Misceláneas ( I) Maurelle efectuó muchas exploraciones y una notabilísima en la fragata Princesc, en I 7 So, desde Manila á Nucva España al través del Pacífico, tardando io meses. Formó una tabla de la situación de los bajos é islas vistos durante el viaje.

Según Desborough Cooley, los españoles eran incapaces de levantar planos con exactitud en 779 y desconocían el uso de los cronómetros y de las observaciones hunares..... Con efecto, prueba todo lo contrario el hecho sabidísimo que siete años antes de aquella fecha (navegando en la fragata Venus, por cercanías del Cabo de Buena Esperanza), un Oficial español, D. José de Mazarredo, fué inventor (que así puede llamarse), del procedimiento para hallar la longitud valiéndose de las distancias lunares.

Era la noche despejada; cerca de la luna brillaba Aldevarán, y contemplándolas el sabio joven, imaginó obtener la situación de su nave, tomando simultáneamente las alturas de ambos astros y su distancia, y resolviendo los triángulos esféricos precisos para lograr la longitud de la luna como base de partida. Consultó Mazarredo á su Comandante, que lo era el insigne Lángara, y éste, lleno de fé, se dispuso á ayudarle en unión de otro inteligente Oficial, Ruiz de Apodaca. Los trabajos duraron dos días y fueron ímprobos, porque aún no se habían generalizado los almanaques náuticos ingleses, donde se daban las tablas de distancias de luna á estrellas, publicación que casi comenzaba. El éxito más feliz coronó la idea de Mazarredo, y pudo enorgullecerse de haber inventado un método importantísimo, que si bien ya había sido indicado por Lecaille, era aún totalmente desconocido para el marino español y para la inmensa mayoría de los navegantes (2). Seis años después, en I 779, usábanse mucho estos cálculos en nuestra Marina y apenas se halla un Diario de aquella época en que no se vean reunidos los adelantos todos de la Astronomía náutica.

Ninguna nación pudo jactarse de enseñar mejor á su juventud que nuestro país, desde que en I 75 I el ilustre Jorge Juan fué nombrado Capitán de Guardias Marinas. No existía por entonces en Europa obra más perfecta que su Compendio de Navegación. Quien dude de la superioridad de este sabio, recuerde el curioso fruto de su viaje á Inglaterra

(1) Véase en la Biblioteca del Depósito Hidrográfico de Madrid. Obra titulada Establecimientos Ultrannarinos, tomo IV, pág. 538 .

(2) Para mayores detalles consúltense, entre otras obras, la Biblioteca Maritima de D. Martín Fernández. de Navarrete y la Galería Biografica de Generales de Marina, por el Vicoalmirante Pavía. 
en I 749. Fué comisionado por el Gobierno para estudiar y aprender los métodos de construcción naval en aquella Monarquía, y á poco de hallarse allí, inventó un nuevo sistema, tan ventajoso y admirable, que los ingleses, abandonando todos los suyos, adoptaron inmediatamente el ideado por Jorge Juan; y este método fué el único que presidió desde entonces y aún hoy preside para las construcciones de los buques de vela.

Discípulo del autor de la inmortal obra Examen Maritimo, fué D. Juan de Lángara, hidrógrafo excelente, quien á su vez difundió los últimos descubrimientos de la ciencia entre la pléyade de Oficiales que navegaron con él; y desde I 772 á i 776 efectuó trabajos que llenaron de asombro á los marinos ingleses y franceses, capaces de comprenderlos (I).

Bajo las órdenes de Lángara sirvieron: D. Diego Alvear y Ponce, quien de Alférez de fragata fué nombrado Comisario de la demarcación de límites de España y Portugal en América, y de cuyo curiosísimo Diario (cinco tomos folio) se conserva una copia con gran estimación en el Museo Británico de Londres; D. Bruno de Heceta, que en I 773 hizo importantes descubrimientos en la Alta California y construyó cartas y planos excelentes de sus puertos; D. Francisco Millau, que en 7776 determinó los límites entre Buenos Aires y Paraguay; levantó los planos de Rio Grande, en la América del Sur, de su costa y también de las Malvinas; D. Juan Varela, que en 1774 ayudó eficazmente á marcar la situación verdadera de la Isla Trinidad y poco más tarde la de las islas del Golfo de Guinea, las de Santa Catalina en el Brasil y de los puertos del Rio de la Plata, mereciendo el título de Correspondiente de la Real Academia de París; y por último, el ilustre Mazarredo, que ya se ha citado, así como otros muchos brillantes Oficiales que sería prolijo enumerar.

Es por cierto sorprendente que desde época bastante anterior á I 779 se dieran tan buena traza para sacar partido del atraso de la cosmografía tantos marinos españoles rezagados en el estudio ó enemigos de la ciencia. Así lo prueban D. Vicente de Doz, Alférez de fragata, que en I 760 levantó el plano del Rio Orinoco y en i 769 observó en California el paso de Vénus por el disco solar, y determinó la longitud exacta de la misión de San Jorge; D. Gabriel de Aristizábal, de quien por sus profundos conocimientos dijo Mazarredo dirigiéndose al Ministro: "Suponiendo que cada Oficial de Marina valiera un ciento por ciento más que yo, no valdrían, sin embargo, todos juntos la mitad que Aristizábal.» Sus trabajos hidrográficos en Turquía y sus apuntes para la obra Viaje á Constantinopla, dieron más tarde disculpa al apasionado elogio. D. Santiago de Zuloaga, autor de las Maniobras Navales y de la demarcación de límites en Cumaná de Venezuela, en I75 I; D. Domingo Boenechea, descubridor de varias islas del Pacífico y constructor del plano de la de Otahiti; D. Juan Herrera Dávila, que levantó planos de casi todos los puertos de la Costa Firme septentrional; D. Gonzalo López de Haro, que reconoció é hizo cartas del Estrecho de Fuan de Fuca; que antes había recorrido la costa N. O. de América hasta los $60^{\circ}$, levantando su plano, y después señalado los límites del puerto de Nutka y reconocido y formado los planos de la California, la Sonora é islas inmediatas; D. Joaquín Fidalgo, que en los bergantines Empresa y Alerta realizó un amplísimo é importante trabajo hidrográfico en las costas de Tierra Firme, desde la provincia de Cumaná á Darien del Norte y Portobello, mereciendo ser en su ancianidad nombrado Director del

(1) La mayor parte de sus trabajos y de sus obras se conservan en el Depósito Hidrográfico. Su simple inspección da idea del mérito de este marino. 
Depósito Hidrográfico y luégo Director también del Observatorio Astronómico..... Pero ¿qué manifestación más elocuente é irrefutaḅle de la altura que había alcanzado España en las ciencias positivas que la ofrecida al mundo en 1735 , con motivo de la medición del yrado de Meridiano en la América Central: Recuérdese que entonces nombró Francia para el objeto á tres sabios ilustres, miembros de su Academia, y España, por su parte, envió, Ilena de confianza, á dos imberbes Guardias Marinas, que hubo necesidad de ascender á Tenientes de navio á fin de que pareciera ménos escandalosa la desproporción cle categorías, ya que lo eran tanto las edades. Aquellos sabios franceses, los Sres. Bouguer, Godin y la Conclomine, aceptaron por compañeros á los dos españoles con despecho y desdén profundo en un principio; despecho y desdén que más tarde se trocaron en admiración sin límitcs. ¿̇ómo no, si aquellos jóvenes se llamaban D. Jorge Juan y D. Antonio de Ulloa?

Del primero he hablado lo indispensable; del segundo, ¿qué puedo decir de nuevo á la Europa culta?

A más respeto y justicia eran acreedores nuestros antepasados en el ilustre cuerpo de la Armada. Haríase interminable la relación de los que le dieron honra con su ciencia; pero no he querido mencionar sino aquellos que por haber gozado larga vida y alcanzado altos puestos, consolidaron sus reputaciones envidiables, y en todo tiempo se prestan fácilmente al análisis del historiador. No cito, pues, á los que por su corta existencia sólo recogieron primeros laureles, si bien éstos son inmarcesibles y constituyen una gran parte del tesoro de nuestros Archiros.

Atento á dicho propósito, evocaré á algunos más de universal renombre, como D. Vicente Tofiño, constructor del grandioso Atlas marítimo de España, celebrado por propios y extraños; astrónomo eminente, en concepto de Bordá, Lalande y otros de iggual fuste. D. Julián Sánchez Bort, verdadero genio en el arte de construir, á quien se deben las mejores obras de nuestros arsenales, el que (desde i 748 á r 785 , que falleció siendo Capítán de navío), logró innumerables triunfos, citándose por lo difícil el yran muelle que cierra la dársena de Ferrol, levantado en 24 metros de agua. D. José de Mendoza y Rios, geómetra excelente al par que hábil maniobrista, autor de la $N a$ vogación Astronómica, libro que le conquistó el empleo de Capitán de fragata cuando aún era menor de edad; el que compuso y publicó las voluminosas Tablas que llevan su nombre, primera y única obra de su género que se hacía en Europa, y que adquirieron con avidez todos los marinos del mundo civilizado como objeto indispensable para las navegaciones prolongadas; sin las Tablas de Mondoza era largo y dificilísimo. el cálculo de la longitud por las distancias lunares: con ellas cualquier pilotín mal instruído puede utilizar este método de situación. D. Gabriel de Ciscar, comparable al marino que antecede por su ciencia profunda, y el primer hombre de la Nación considerado por su saber matemático, según escribía al Rey el Ministro Lángara al proponerle que el Capitán de navío Ciscar representara á España en un Congreso de sabios convocado por el Instituto de Francia. Y por último, D. Martín Fernández de Navarrete, miembro de todas las Academias importantes, y tan alabado como crudito, que apenas se recuerdan los diez y siete años que navegó y que combatió, ya con los franceses, ya con los ingleses, así como tampoco es del vulgar dominio que en las ciencias sobresalía hasta el punto de admirar á hombres de la talla del Barún de Zach, de Humbolt, de IVashington Irring, de Prescott, de Berthelot y de Miguet. 
Con lo expuesto, basta para contestar á las apreciaciones del historiador británico. Ahora debo añadir que no era suya la culpa de la ignorancia que demuestra respecto á los méritos contraídos por navegantes españoles: debíase en gran parte á la rescroa y el silencio que guardábamos, como acertadamente dice Desborough Cooley. Reserva y silencio que inspiraron al ilustre Vargas Ponce estas reflexiones amargas (1). "Aquellas circunstancias (las razones políticas que aconsejaron el sigilo) perdieron su valor, y la calidad de tales negocios y navegaciones no sufría un absoluto secreto; y con todo ocultaba nuestro Gobierno papeles tan instructivos. Empezaron otras naciones á hacer gala de sus trabajos marineros y á publicar, así las cartas nuestras, de que se apoderaban, según aconteció al Almirante Anson, como las que corregían con superiores auxilios; y todavía continuaba nuestro ya insensato misterio. De aquí que busquemos con ansia en viajes y derroteros extraños el conocimiento de nuestros estrechos y mares, de que fuimos los más escrupulosos investigadores; de aquí que atormentemos nuestros oídos y forcemos nuestra pronunciación con nombres peregrinos y rudos para entrambos, trascordados los primitivos españoles con que se bautizaron; y de aquí que recibamos con admiración y como recicntes noticias y objetos que supimos y con que nos familiarizamos los primeros de Europa. Si en las Islas de Salomón y tantas del Pacífico no fuera esto tan patente, bastaría citar el aparato con que se nos vendió como descubrimiento ageno la proyección de la Californiay que el Piloto Castillo, su primer descubridor, ya le señaló como península. A pesar de tan bochornosas lecciones, no há veinte años que los documentos marítimos que perdonó la polilla y el polvo yacían dispersos en distintos depósitos, tan ocultos como cuando se soterraban á principios de la dinastía austriaca, para que no se divulgaran los nuevos rumbos á las Molucas.»

Es verdaderamente sensible la indiferencia cuando nó la oposición demostrada por nuestros Gobiernos hacia las tentativas de dar á luz tantas brillantes demostraciones de lo que ha valido siempre la Armada española. Creeríase, quizás, que el abandono ó falta de propósito de nuestros marinos, hicieran difícil la compaginación y arreglo de sus apuntes para ser publicados, mas por el contrario, suspenden y arroban el espíritu las metódicas é interesantes narraciones que manuscritas yacen condenadas á perpétuo encierro. Por suerte, en ocasiones (raras) una mano audaz ó generosa arranca del estante algún legajo y lo arroja á la prensa. Esto hago yo ahora, no audaz ó generoso, sino verdaderamente subyugado, aturdido, lleno de emoción gratísima y de patrio orgullo, ante la lectura del asombroso al par que desconocido viaje de circunnavegación efectuado por los españoles desde r 789 á I 794, á bordo de las corbetas Descubierta y Atrevid.1.

¡Es triste considerar que el inapreciable tesoro de gloria y ciencia cosechado en esta expedición ha permanecido oculto cerca de cien años, á causa de la venenosa política que asomó su cabeza de Medusa; recordar que aquel tesoro estuvo condenado á desaparecer, á ser clestruído por odio ó envidia á un hombre eminente, y tocar como resultado de este anatema, que no sólo los extranjeros, sino los españoles, poseen una muy vaga idea de la notabilísima expedición, y también ideas vagas de su importancia, sólo por presentimiento ó por lo que han escuchado ả algún erudito!

(1) Importanciu de la Historia de la Marina Española, pág. 98.-Discurso por D. José de Vargas y Ponce. Madrid, I 807 . 
Para disponer el ánimo á seguir los rumbos de las corbetas Descubierta y Atrevida, necesito valerme de un térnino de comparación exacto y oportuno. Los viajes (publicados) de D. Antonio de Córdoba en 785 á bordo de la fragata Nuestra Señora de la Cabeza y en 788 mandando los paquebots Santa Casilda y Santa Eulatia, rindieron un hermoso estudio descriptivo é hidrográfico del Estrecho de Magallanes; pues bien: con no menor amplitud los Jefes de las corbetas estudiaron, levantaron planos y recorrieron cuanto solicitaba entonces la curiosidad científica, desde las cercanías de Beering á Nueva Holanda, descle la Alta California al Cabo de Hornos, desde el Círculo Boreal hasta las barreras del Polo Sur. Y si en las expediciones de Córdoba brillaron Oficiales tan entendidos como D. José de Gardoqui, D. Alejandro Belmonte, D. Miguel de Zapiain; de tan sobresaliente mérito como D. Francisco Javier de Uriarte, que por espacio de un mes reconoció en un débil bote el proceloso Estrecho descubriendo islas y puertos, de los cuales uno lleva su nombre; D. Dionisio Alcalá Galiano, que efectuó trabajos admirables; D. Ciriaco Cevallos y D. Cosme Churruca, que unidos soportaron, con valor inaudito, la inclemencia de aquellas regiones, tripulantes de otra lancha, mientras levantaban planos de la Tierra del Fuego en la totalidad de su costa, desde Cabo Dunes hasta el Pacífico....., es lo cierto que también á las órdenes de Malaspina y Bustamante, Jefes de las corbetas, sirvieron (escogidos por el primero) además de los mismos señores Cevallos y Alcalá Galiano, infatigables y entusiastas, el famoso sabio D. Felipe Bauzá, cuyos servicios fueron solicitados más tarde, aunque sin fruto, por los ingleses; el inimitable en la construcción de cartas, de las que legó un sinnúmero de portentosa exactitud, D. José de Espinosa y Tello, cuyo saber pregonan el reconocimiento que hizo de los canales de Nutbea y de los mares de la India, y años después las extensas Memorias que dió á luz siendo primer Director del Depósito Hidrográfico; D. Juan Gutierrez de la Concha, digno compañero de los anteriores y á quien estaba reservado alcanzar en América la palma de la gloria y la palma del martirio; D. Cayetano Valdés, el más jóven de esta Oficialidad, pero no el menos inteligente, según lo prueba su exploración difícil del Estrecho de Fuan de Fuca, hecha con rapidez y maestría. Y por último, los hermanos D. Arcadio y D. Antonio Pineda, notabilísimo naturalista éste, que á su muerte, acaecida durante el viaje, legó al primero el arreglo y continuación de sus observaciones y escritos.

Con tan valiosos auxiliares no sorprenderá que transcurridos los cuatro años de navegación hubiera presentado al Gobierno de España el ilustre Malaspina, para que vieran la luz pública, además de la Relación general del viaje, verdaderos tratados de cada una de las ciencias que fueron objeto de sus estudios, á saber: Astronomía, Hidrografía, Física, Historia Política é Historia Natural (r).

Antes de dar más amplias noticias de Malaspina, de su viaje y de su proceso, debo repetir las palabras del epígrafe: que es conveniente publicar esta obra:

Primero: á fuer de vindicación cumplida, y dato irrefutable que hará impresión en el pueblo inglés, marítimo por excelencia y gran maestro en las empresas navales.

(1) Para formar juicio de la extensión con que se hicieron estos estudios, basta decir que el Tratado de Historir Natural ocupa cinco tomos de 500 páginas con cerca de 40 mapas y dibujos. Para pensarlos y escribirlos su principal autor, D. Antonio Pineda, tuvo por gufa valiosa un plan ó instrucciones que el célebre naturalista de Módena, Lázaro Spallanzani, había remitido á Malaspina. 
Segundo: porque España debe á aquellos nobles hijos suyos un desagravio, aunque tardío, mostrando al mundo sus prendas eminentes y abriéndoles paso á la inmortalidad ganada por su ciencia, ya que no todos, afortunados como Galíuno y Valdés, la merecieron por las armas.

Tercero: porque tanto se adelantaron á su tiempo aquellos sabios Oficiales y tan profunda y discretamente meditaba Malaspina, que, comenzando por los preparativos de los buques y concluyendo por el desarme de los mismos á su regreso, son hoy (ipasado un siglo!) enseñanzas provechosísimas todas sus páginas para la marina actual, y más directamente para los que se disponen á emprender el viaje de circunnavegación en la fragata Blanca.

A tan buenas razones fáltanos añadir la más poderosa; evitar que España reciba una lección que le avergüence, pues vergonzoso sería que otro país, anticipándose, diera á luz esta misma obra. No era remoto el peligro. Me consta que un hombre de ciencia y alto funcionario de Chile ha sacado copia (por orden de su gobierno y con autorización del nuestro), de todos los manuscritos, cartas y hasta dibujos pertenecientes al viaje de las corbetas. Trabajo ímprobo y costoso que honra á aquella República modelo y que una vez más confirma su cultura y amor al estudio. Ignoro si su propósito es publicarlos ó enriquecer sus bibliotecas con las copias; pero en tal caso á nadie perjudica, el que impreso, facilite yo á todos una lectura selecta. Si era éste también su móvil, entonces perdóneme la patriótica Chile, considerando que desde los tiempos bíblicos es divino mandamiento el dar al César lo que es del César.

\section{II}

Don Alejandro Malaspina.-Su viaje.-Su proceso.

Este ilustre marino nació el 5 de Noviembre de I 754, descendiente de la casa soberana de Lunagiana y de Mulazzo (famosa entre los güelfos y defensora de Italia contra Federico Barbaroja). Era su padre el Marqués Cárlos Morello y su madre Catalina Melilupi, de la familia de los Príncipes de Soragna, circunstancia que facilitó á Malaspina cruzarse de Caballero de Justicia en la Orden de San Juan de Malta apenas hubo sentado plaza de Guardia Marina, en Cádiz, en I 774, entrando al servicio de España. Dos años después, con el empleo de Alférez de fragata, navegó por el Atlántico, Océano Indico y mar de China. En I 778 ascendió á Teniente y en I 779 tomó parte en el glorioso combate del Cabo de Santa María, á las órdenes de Lángara. Su navío (el San Fulian) fué uno de los cuatro que con aquel ilustre caudillo mantuvieron el choque de las triples fuerzas inglesas ( I 4 buques españoles contra 3 I ) para salvar á los restantes. En I 788 , ya de Teniente de navío, asistió al terrible bombardeo de aquella plaza inespugnable y fué de los que tripularon las famosas baterías flotantes (imaginadas por el francés d'Arson) que tan 
en cuidado pusicron al Gencral Eliot por los extragos que hacian en las murallas: Como recurso supremo, aunque opuesto al derecho de gentes, Eliot empleó contra ellas balas rojas de grueso calibre, que las incendiaron muy pronto merced al huracán deshecho que á la sazón reinaba. Más de 1.000 hombres perecieron ahogados ó carbonizados. Malaspina logró salvarse, y poco después embarcaba cn la escuadra de D. Luis de Córdoba, que atacó cn la boca del Estrecho á la del Almirante Scrope (Conde de Howe), el cual se batió en retirada.

En 1782 ascendió Malaspina al inmediato empleo, y obtuvo el mando de la fragata Asunción, con la que efectuó un largo viaje por Asia y Oceanía, hasta i 784 que, de regreso á Cádiz, fué nombrado Teniente de la compañía de Guardias Marinas, cuyo destino abandonó pronto para mandar la Astrea, magnífica fragata de condiciones excepcionales, y citada con frecuencia por Malaspina en la presente obra. En ella dió la vuelta al mundo, recorriendo primeramente varios puertos de la costa occidental de América, y, doblado el Cabo de Hornos, otros importantes de la occidental; luégo muchas islas del Pacífico, las Filipinas, regresando al fin por el Cabo de Buena Esperanza á Cádiz. Este largo y penoso viaje habíale rendido mucha enseñanza y había templado su espíritu para emprender el que hoy se publica, y para llevarlo á término tan feliz como de resultados asombrosos, ya se consideren estos resultados bajo el punto de vista científico, ó político, ó histórico ó marinero. No quicro anticipar á los lectores lo que han de hallar escrito por el ilustre navegante en estilo poco correcto sí, pero lleno de frescura, de espontaneidad y de sencillez, condiciones preferibles á todas las otras. Me concretaré, por tanto, á decir lo que no pudo ni áun sospechar que lc ocurriera cuando volvió á España ceñido de laureles.

Publícanse una serie de documentos que, á más de lo curiosos, encierran útil enseñanza. La solicitud de Malaspina y Bustamante pidiendo dirigir la expedición; la respuesta y obscrvaciones del gran Ministro D. Antonio Valdés; las cartas de Malaspina al insigne Ulloa y al Proto-Médico Salvaresa; las que el mismo escribió al Subinspector de Arsenales y al sabio Ingenicro Muño\%, son buenos testimonios del profundo conocimiento, sentido práctico y escrupulosidad con que atendía y lo preparaba todo hasta en sus menores detalles; así cono las Instrucciones que comunicaba á su inmediato subalterno, el Comandante de la A trevida son un modelo de previsión, sagacidad, cordura y sabiduría. Sólo estas Instrucciones revelan que Malaspina cra un hombre superior: el Discurso preliminar convence de que sus ideas políticas cran liberales (quizá con exceso para aquella época), sobre todo en lo referente á las colonias; y la Relación de su viaje persuade de la justicia con que de él decía cl Ministro Valdés: "Que por sus conocimientos, cuna, nobleza y clegancia de la persona y maneras, arrogante presencia, afabilidad, firmeza de carácter y talento de sociedad, era Malaspina el primero de la Armada española y el único para aquel cargo, alma de la culta y distinguida sociedad que nuestros marinos debían representar en los paises americanos, para influir farorablemente en el ánimo de los criollos y ayudar á la política y demás fines que la expedición llevaba.»

Poquísimos antecedentes se conocían de tan insigne navegante, hasta que, por fortuna, el Acadénico de la Historia y eruditísimo escritor Sr. Jimenez de la Espada publicó (I) un amplio estudio con el título de Una causa de Estado lleno de revelaciones interesantes sobre:

(1) Rezish Contemporinea, año de 188 r.-Carta dirigida al Sr. D. Gaspar Muros 
el proceso de Malaspina. Y como dicho estudio es originario de las únicas fuentes que existen, á él necesito concretarme y referirme casi en absoluto, para lo que me doy por concedida la venia del distinguido Académico y buen amigo mío.

Dice el Sr. Jimenez de la Espada «que resulta de varios papeles, unos reservados $\mathrm{y}$ »confidenciales, otros probablemente destinados al público, aunque no me consta que sa* lieran á luz, que la causa del insigne navegante se relacionaba con un grave suceso político"amoroso, que esturo á punto de dar al trasto con la más larga y fclicísima prizanza de »las que influyeron en los destinos ó fueron Destino de nuestra patria en el pasado siglo.»

Ello es que Malaspina, á su regreso, fué cariñosamente recibido en la córte y con toda bondad por María Luisa; sábese que en aquellos días algunas sombras nublaban la estrella de Godoy; pero que este favorito poseía medios para sobreponerse á las veleidades de la Reina.

Véase la luz que acerca de estos puntos nos da D. Joaquín Lorenzo Villanueva, contemporáneo de Malaspina:

*A todos nos causó sorpresa su arresto cuando estábamos aguardando la publicación de su viaje. Por largo tiempo se estuvieron haciendo castillos en el aire sobre este incidente; atribuíanle unos á escritos suyos; otros á haber comentado la vida de la Reina María Luisa, que poco tiempo antes había aparecido en Francia. Para mí lo más verosímil, y pudiera decir cierto, es que aquel célebre marino fué víctima de una intriga entre la Reina y dos damas suyas, que fueron la Matallana y la Pizarro, y el Principe de la Paz. En un intervalo de desafecto y resentimiento en que andaba la Reina á caza de medios para cortar la privanza del valido, fué buscado Malaspina por estas damas para que á la vuelta de la Lombardía, su patria, á donde iba con licencia, trajese realizado el plan de cierta carta que había de influir con el Rey para tan santa obra. Este plan, escrito incautamente por $M a-$ laspina y guardado por la Reina en una gaveta, fué revelado á Godoy por la Pizarro, estrechada de él por sospechas que le inspiró una indeliberada expresión de la Reina. La Matallana, de quien exigió primero la revelación del secreto, se negó á ello constantemente. El plan, descubierto y pintado por Godoy á Carlos IV con los colores que le convenían, sirvió de instrumento de su venganza. La Matallana fué presa y desterrada de la corte. A Malaspina, después de haber sido preso en el cuartel de Guardias de Corps y confinado en el castillo de San Antón de la Coruña, se le permitió restituirse á su país, previniéndole, so pena de muerte, que no volviese á territorio ninguno de la Monarquía española. Los achaques contraídos en sus viajes y en el encierro deterioraron su robusta salud en términos que, á poco tiempo de haber llegado á la Lombardía falleció con el desconsuclo de no haber podido volver á España, la cual llamaba patria suya en las cartas de sus amigos.»

«Lo que nunca pude atinar fué qué pecados cometió para el Príncipe de la Paz, en aquella ocasión, el docto Padre Manuel Gil, Clérigo menor de Sevilla, para que fuese llevado de Madrid á aquella ciudad á la casa de corrección llamada Los Toribios, de que había sido Director. Habíasele dado la comisión de poner en buen lenguaje español la relación del viaje de Malaspina; en su intriga nadie creyó que hubiese tenido parte ninguna, y por lo mismo fué mayor la sorpresa de los que le conocimos al ver tratado á un eclesiástico tan digno con aquella especie de escarnio. Estos frutos amargos de la desmedida deferencia de los Reyes á las pasiones de sus validos, no se cogen sino en las Monarquías despóticas. En ellos he visto yo envueltos aún á algunos de los que las aman.» 
"Hé aquí por qué perdió la causa literaria de la Marina europea la publicación de aquel viaje y de las observaciones de los sabios matemáticos que lo desempeñaron á costa de grandes trabajos y de largas expensas de la nación. Por fortuna pudieron salvarse la relación del derrotero, las observaciones hechas clurante la expedición en las costas de América, Nueva Holanda, Macao y Manila; las de Espinosa y Bauzá, en el interior de la América Meridional, con los demás documentos que se acopiaron en aquella empresa. Mas esto se debió á la suma reserva con que se depositaron tan preciosos tesoros en la Secretaría de Marina, de donde, formado ya el Depósito Hidrográfico, venciendo dificultades, pudieron trasladarse á este Establecimiento. En las Memorias sobre las Obscruaciones astronómicas que publicó el año I 809 , se imprimió una noticia de los descubrimientos y observaciones de Malaspina, única muestra de sus viajes que ha visto la luz pública.»

Este Padre Manuel Gil, era hombre de erudición y perspicacia, y aunque tal vez ageno á los planes del marino, no dejaba de agitarse en la política, pues á ello debió más tarde haber sido Embajador en Sicilia y andar en candidatura el año i 8 I 2, para Regente del Reino. Este cura escribió en la casa de los Toribios un gran tomo con la historia prolija de su proceso y su dcfcnsa, que apenas terminado en I 797, envió al Príncipe de la Paz, sin resultado favorable por el pronto. La lectura de algunos párrafos de esta Defcnsa impondrá al lector cumplidamente de cuanto importa saber.

\section{DEFENSA DEL PADRE GIL, HECHA POR EL MISMO}

E1 Marqués de Matallana había servido los Ministerios del Rey en Parma y Nápoles con aceptación, y la Marquesa lo había acompañado en ellos y había participado y áun contribuído á aqué11a. Acababan de darse al Marqués los honores del Consejo de Estado y la embajada de Venecia y la Secretaría de éste á su cuñado, hermano de la Marquesa, el Teniente de navío D. José Conock; y finalmente, aquellos dos meses antes de su prisión, había recibido de la Reina nuestra Señora la prueba más señalada de su real agrado en el nombramiento y admisión á la Real orden de Damas Nobles de María Luisa.

Malaspina gozaba igual y áun quizá mayor aprecio. Al lucimiento y brevedad con que había hecho su carrera, se había juntado la felicidad de la expedición gravísima que se le encomendó, de la cual y de los conocimientos adquiridos en ella, se había dado noticia en la Gaceta con muchos elogios de aquél, y anunciando la historia que se haría y publicaría de este viaje. A pesar de los apuros del Erario con motivo de la guerra, se habían franqueado á Malaspina por el Ministerio las considerables cantidades que había juzgado necesarias y pedido, para que nada faltase á la historia y su impresion, ni de utilidad, ni de adorno, ni áun de magnificencia. Se habían, á propuesta suya, premiado los Oficiales de la expcdición; no se habían olvidado los Capellanes, Cirujanos y demás empleados de ella; el mismo Malaspina había sido, sin consultar la antigüedad, promovido al grado de Brigadier, y acababa de solicitar y obtener licencia para pasar á Italia con circunstancias que manifestaban la gracia en que se hallaba.

Considerado mi estado, carácter y genio, podría acaso decirse que eran aún mayores las honras quc se me habían hecho. Sin que precediese pretensión mía, deseo, ni áun pensamiento de tal destino, se me propuso por el Ministerio de Marina y nombró por el Rey, para escribir la historia del riaje de Malaspina; empresa literaria sumamcnte difícil por la multitud de materias que había de abrazar, todas gravísimas y algunas bien distintas de mi profesión, y la más importante también y de extraordinario honor, así por estas razones como por la espectación y ansia con que la aguardaba la Europa sabia. La expresión verdaderamente singular de la Real orden de 26 de Julio de I795. cn que se me encomendó la comisión, el sueldo y facultades que por ella se me conceden, y sobre todo, la honrosa aprobación que cn $2 S$ de Setiembre se sirvió el Rey dar al plan de la historia que había prescntado, autorizándome para que, como yo proponía, pudiese escribir y entre- 
gar al Ministerio las Memorias secretas que estimase necesarias para el buen gobierno de las Américas, son y serán perpétuamente el testimonio más alto, no sólo de la confianza que se tenía cn mi literatura, sino áun todavía de mi prudencia, de mi amor á la Nación y al Rey, de mis conocimientos políticos, y de la rectitud, extensión, solidez y profundidad que con fundamento ó sin él, se les atribuía. Podían añadirse las públicas y no comunes señales de estimación con que me distinguían los Excmos. Sres. Príncipe de la Paz y D. Antonio Valdés, Ministros de Estado y de Marina.

¿Qué ansiedad, pues, qué pasmo y áun qué temor no debieron mover la repentina prisión de tres personas de esta clase, el impenetrable secreto de la sumaria después, y finalmente, las gravísimas penas que se les han impuesto? Si hemos de creer á la voz pública, la Matallana, desterrada del Reino con la terrible condición de no poder unirse á su marido en Venecia; Malaspina, privado de sus grados y honores y encerrado en el castillo de San Antonio de la Coruña; yo, sin duda, destinado á la casa de los Toribios de Sevilla hasta nueva orden.

XXXIV.-Yo trataba á Malaspina, y este trato, y el haberme propuesto para escribir la Historia de su viaje, denotaban confianza de aquél conmigo. Se ha querido decir también que mi tal cual erudición se extendía á la política.....

XXXV.-Se me hizo desde luego la pregunta de qué papeles suyos me había dado á leer Malaspina. Respondí señalándolos: I. ${ }^{\circ}$ Algunas memorias sueltas de su viaje, el diario de éste, y los planes de su historia. $2 .^{\circ}$ Una memoria sobre el establecimiento inglés de Bahía Botánica. $3 .^{\circ}$ Un tomo de disertaciones sobre varios ramos de Marina, que me ofreció y no llegó el caso de darme. $4 .^{\circ}$ Un plan de tratado de paz con Francia. Y habiendo yo declarado que Malaspina me había manifestado tantos papeles suyos de materias físicas, económicas, políticas y de tan varia literatura, ¿no recaía, como por necesidad y legalmente, la pregunta de si me había comunicado también algunos sobre el Gobierno ó para mudar el sistema del actual?

XXXVI.-Porque acaso no habrá ocasión de hablar otra vez de los expresados papeles de Malaspina, es muy importante añadir, que ninguno de los que me confió era reservado, sino el tratado de paz con Francia, pues los demás los tenia frecuentemente encima de la mesa y podía leerlos cualquiera de los que entraban en su cuarto. Además, á excepción del tomo de disertaciones, los otros papeles los había presentado al Ministerio mucho tiempo había, y la memoria sobre Bahía Botánica creo le oí decir que la había remitido estando en Lima.

XXXVII.-Merece especial memoria el plan del tratado de paz con Francia. Malaspina lo había trabajado y entregado al Ministerio en Diciembre de I794, cuando ni me trataba, ni yo había venido á Aranjuez, que no lo hice hasta Marzo del año siguiente, que es decir que no pude concurrir á él. Por entonces, parece que ocultó enteramente el plan y su presentación, áun de aquellos de quienes tenía más confianza; y en efecto, yo no oí hablar á nadie de sus amigos jamás del tal plan.

Hecha la paz, tuve la primera noticia de él por una insinuación del señor Príncipe de la Paz, que me hizo conocer el plan de aquella que había presentado Malaspina y los principios falsos y contrarios á los intereses y gloria de la Nación, sobre que giraba. Sorprendióme esta noticia, á que contesté por palabras generales, pues no podía de otra manera, porque nada sabía del tal plan; pero inmediatamente, sin revelar el conducto por donde la tenía, la comuniqué al Capitán de fragata D. Luis María Salazar, Oficial de la Secretaría de Marina, y á D. Juan Jacobo Ganh, Cónsul general de Suecia en Cádiz, que estaban en San Ildefonso y trataban mucho á Malaspina. Admiramos todos la poca reflexión de éste en haberse, sin ninguna orden y por sí mismo, introducido á escribir en materia tan grave, secreta y delicada de Estado; pero nada le dijimos aunque poco después pasó á aquel sitio.

Vine yo en principios de Octubre á Madrid, y espontáneamente me dió Malaspina á leer el expresado plan y contó su presentación. Preguntóme después su dictámen sobre él, y le respondí con palabras de pura atención y cortesanía. Procuré con todo, con arte, saber de él cómo había recibido el plan el Ministerio, y me contestó que muy bien, fundándose en lo que dije en mi declaración, y no hace mucho honor á sus conocimientos de córte. Inmediatamente después de esta conversación ví á Ganh, á quien había ya también confiado el plan de Malaspina, y renovamos la censura de él, pasmándonos de la osadía de haberlo presentado.

S $3 .^{\circ}$-Los indicios que hubo de mi complicidad con Malaspina, fucron levisimos, ctc., ctc.

VII.-Trato. Las preguntas que se me hicieron sobre el origen y tiempo del mío con Malaspina, y sobre tantas particularidades muy menudas y secretas de la vida privada é interior de éste, manifiestan que las personas que las extendieron suponían había entre los dos un trato antiguo, 
íntimo, familiarísimo, al cual nada se escondía recíprocamente. Se engañaron sin duda en este juicio, y por mi declaración y por notoriedad, resultó la siguiente historia de mi trato con Malaspina, su origen, progresos y estado al tiempo de la prisión.

Malaspina llegó á Cádiz de vuelta de su famosa expedición en Julio de I794, á cuya sazón me hallaba yo en aquella ciudad. No le conocía antes ni entonces lo ví, hasta un día en que comió en la casa en donde yo estaba hospedado, y segunda vez en la del Conde de Prasca, á donde también comimos juntos casualmente. Hícele en una y otra ocasión muchas preguntas de curiosidad, y no sé en cuál de ellas me previno que me enseñaría, como así lo hizo, una colección de monedas de Asia para D. Francisco de Bruna, Oidor decano de la Real Audiencia de Sevilla, con honores ahora del Consejo y Cámara. No le visité, no supe dónde vivía, ni le volví á ver ni saber de él, hasta que en Marzo del año siguiente de I795, habiendo yo venido á Aranjuez, lo hallé en este sitio y lo traté otra vez en las casas del Sr. Valdés, Ministro entonces de Marina, y de D. Juan Jacobo Ganh.

En la de éste se juntaban varias gentes por las mañanas á conversación, y entre ellas Malaspina y yo, y las mismas y otras nos uníamos por la tarde para el paseo, y las más noches en la tertulia del Sr. Valdés. Dudo si me visitó Malaspina en esta jornada; yo lo visité algunas veces, y aunque, porque debe hacerse justicia á todos, y más al desgraciado, los modales de Malaspina, la variedad y amenidad de su erudición, sus costumbres y otras circunstancias, hacían su trato muy apreciable, yo no me distinguí en él, ni el mio llegó jamás á la frecuencia é intimidad que tenía y era público, con muchas personas de las más altas de la córte.

Víneme á Madrid, y no obstante que estaba ya hecha por Malaspina la propuesta y admitida por mí la comisión de escribir la historia de su viaje, me visitó sólo una vez, y yo á éi cuatro ó cinco con motivo del paseo del Retiro, á donde íbamos por la tarde varios amigos, y para el cual era camino la casa en que estaba hospedado Malaspina, á saber, la del Príncipe de Monforte, al fin de la calle de Alcalá.

En fines de Julio marché yo á San Ildefonso, á donde pasó también Malaspina para el día de San Luis. No me visitó; nos vimos algunas tardes en el paseo, y por la noche en la tertulia del Sr. Valdés.

Volvióse en principios de Setiembre á Madrid, y yo lo hice en 24 del mismo. No me visitó tampoco, y yo le visité dos veces para hablar de los documentos de la historia y de la colección célebre de los pertenecientes á Indias, que ha juntado y posee D. Manuel Pérez, del Consejo de éstas.

Partí en 6 de Octubre á Andalucía, y ni él me escribió ni yo le escribí, aunque lo hice á casi todos los amigos de la córte. Volví en 7 de Noviembre al Escorial, en donde estaba Malaspina, y no me hizo visita, y yo le hice sola una citado por él, en la cual tratamos: $I .{ }^{\circ}$ De la Memoria de su viaje, sobre el plan de cuya historia me entregó una larguísima carta, con fecha de 3 de Octubre. $2 .^{\circ}$ Del modo de recoger y aprovechar la colección de Pérez. $30^{\circ}$ De una pretensión á favor de los Cirujanos de la expedición que seguía, y de la cual me habían hablado los interesados en Cádiz.

Las más tardes nos paseábamos juntos con otros amigos, dándonos frecuentemente Malaspina quejas de que, aunque su posada estaba al paso, jamás le avisábamos ni áun por una seña para que bajase, y tenía siempre que buscarnos en otra parte; y si cuando llegaba habíamos salido, como sucedió algunas veces, se quedaba sin companíía para el paseo. Comimos dos veces juntos con otras grentes y una de éstas fué en el día I8 de Noviembre, en que tomamos en su posada el coche y nos vinimos á Madrid, en donde el 22 del mismo, á presencia de sus criados y otros, me entregó los documentos para la historia, y el 23 fuimos presos.

LVIII.- T’éngase presente, que desde Mayo me habló Malaspina para la Comisión; que en Junio se hizo la propuesta formal; que en Julio se expidió la Real orden de mi nombramiento; que aquél se marchaba á Italia; que era preciso que antes me entregase los muchos y varios documentos originales de la historia y que me instruyese de palabra de una multitud de hechos.y circunstancias, que por los papeles, ó no podía entender ó entendería con mucho trabajo é imperfectamente; en suma, que la comisión de escribir un viaje que abrazaba tantos y tan diversos ramos y conocimientos, y del cual había sido Comandante Malaspina, pedía, por necesidad, para desempeñarse, muchas conferencias privadas con aquél y un trato grande, contínuo, íntimo y reservado. La Real orden, atendiendo á estus consideraciones, me lo encomendó expresamente con las palabras encarecidas que siguen: "Con esta fecha (la de 26 de Julio de 95) doy el correspondiente aviso á Don "Alejandro Malaspina, y le prevengo que acordándose V. R. con él, le entregue lo que sobre la "materia ticne ya trabajado, y le cntere de ello para su gobierno, y en adelante irá suministrando ") í V.R. los materiales que haya juntado, segím las órdenes, agregando á ellos lo que le dicten sus distin"guidos contocimicntos, al mís completo logro del objeto." 
No hubo con todo nada de esto. (Las conferencias íntimas y privadas que pudo y debió haber para cumplir su órden). Dios, por su admirable providencia, dispuso que, haciendo yo violencia á mi carácter, no tuviese ninguna junta secreta con Malaspina, faltando en cierto modo al desempeño de la comisión. No estuvimos, pues, encerrados una sola vez; no escribinos; no hicimos apuntaciones; no hablamos jamás reservadamente.

LX. - Y que se ha pensado así (que la propuesta de Malaspina para la comisión es indicio de delito), lo dicen manifiestamente las dos rarísimas preguntas que se me hicieron, de "quién me había propuesto al Rey para escribir la historia del viaje y por qué me había S. M. nombrado para esta comisión." Se vé que nadie como S. M. puede estar instruído de estos dos hechos; yo, sin embargo, contesté sencillamente las preguntas con las palabras de la Real orden, que dice: "que á propuesta de Malaspina, y por la confianza que el Rey tiene en mi literatura......

Había Malaspina escogido varios Oficiales de la Real Armada y otros profesores para que trabajasen en los muchos y dificultosísimos ramos á que había de extenderse la historia; velaba ince. santemente sobre todos, y áun dos Oficiales le escribían dentro de su casa desde la primavera anterior; últimamente había ya propuesto al Rey para que durante el viaje que iba á haceı́ á Italia, quedase en su lugar el Capitán de Fragata D. Ciriaco Cevallos, muy digno de este cargo por sus talentos.....

LXI.-Las mismas circunstancias particulares que sobrevinieron en mi propuesta y cuanto ha seguido á ella, muestra mi inocencia aún sobre los demás. Yo vine á Aranjuez. Malaspina había leído algunos papelejos míos impresos y oído á personas que me eran apasionadas; preocupóse y no se desengañó con mi trato: ocurriósele el extrañísimo pensamiento de que revisase y corrigiese las Memorias que había escrito de su viaje: manifestólo antes que á mí á varios; se lo aprobaron y celebraron; me lo declaró á mí y me quedé atónito; mi agradecimiento, origen de cuanto he padecido en mi vida, me representó como una obligación no negarme á propuesta tan honrosa en sí misma y en el modo con que se hacía: algunos amigos me disuadían su admisión por razones harto graves, que acaso hubieran hecho impresión en otro, pero que no la hicieron en mí; y dí al fin, el funcsto y trisle sí que me ha traído tantos y tan horribles males. Nada hubo en todo esto de misterioso ni reservado entre mí y Malaspina. Están vivos los Oficiales de la Secretaría de Marina y otras personas que concurrieron á ello, lo supieron y pueden deponer de su verdad y publicidad.

A las primeras conversaciones penetró Malaspina que no conveníamos en algunas ideas políticas; y esto le inspiró desconfianza de mí, que se descubre con claridad en esquela suya que está en autos y la cual se confirmó cuando supo de oficio que yo había presentado, y el Rey se había dignado aprobar, plan para la Historia que en muchos puntos era derechamente opuesto á los formados y entregados al Ministerio por él.....

LXII.-Supo Malaspina lo anterior que yo había obrado en la comisión, pero ignora acaso otras cosas que hice también y que, á haber tenido noticia de ellas, hubieran sido mayores y más fundadas sus desconfianzas conmigo. Cuando se me hizo la propuesta, había ya obligación gravísima en mí de mostrar todo respeto y deferencia al Excmo. Sr. Príncipe de la Paz y no podía con honor admitirla sin su expreso beneplácito. Se la manifesté, pues; la celebró mucho; insinuó no le agradaba el modo de pensar de Malaspina, que le hacía estar cuidadoso sobre esta historia por el interés general que en ella tenía el Estado: me honró diciéndome que mi nombramiento lo libraba enteramente de aquel cuidado y me mandó admitirla y que avisase lo que ocurriese.

En cumplimiento de este encargo, previne que se habían facilitado á Malaspina, por la Secretaría de Gracia y Justicia y de Hacienda sus archivos y se tomó providencia. Remití después copias de mi plan de 20 de Setiembre y de la Real aprobación de 28 , y el señor Príncipe de la Paz me contestó alabando mi celo. Finalmente, al despedirme de S. E. en el Escorial en $x 7$ de Noviembre, le renové mis protestas de respeto y volví á reclamar su alta protección para el feliz éxito del trabajo que iba á emprender, lo que repetí en carta de 20 del mismo, esto es, tres días antes de mi prisión.

LXV.-La hora escogida para la visita al confesor del Rey era la de beber y conversación, nó la más á propósito para tratar asuntos reservados.

LXVI. - La tarde en cuya noche hizo Malaspina su segunda visita al confesor del Rey, me preguntó en el paseo delante de todos si iría en aquella noche á despedirme de la tal persona. Le respondí con incertidunbre.

En la primera visita, acabado el paseo, nos esperamos unidos en la Lonja del Escorial para hacer hora de aquélla; nos separamos después del paseo en esta segunda, testimonio evidente de que no estábamos conformes en hacerla aquella noche juntos.

LXVIII.-Pero lo que deja todo en suma claridad es lo que me sucedió á mí con la tal persona (el confesor del Rey) en el martes 17 de Noviembre, en que lo visité para tomar sus órdenes. 


\section{S. - Pruébase que no ha habido en mí ninguna complicidad criminal con Malaspina.}

LXXI. - La naturaleza de los mismos proyectos ofrece la primera reflexión. A mí no se me lian mostrado ni áun dado idea clara de ellos; pero por las preguntas que se me han hecho, conjeturo $\mathrm{y}^{r}$ casi no me queda duda en que el designio de Malaspina era que se mudase todo el Ministerio, y que había escogido como medio para conseguir esta mudanza, persuadir al Rey, que de permanecer aquél, corrían peligro las preciosísimas vidas de S. M. y de la Reina Nuestra Señora, y con ellas la Monarquía, á fin de que asustada su religiosa conciencia impidiese estos horribles males en la desgracia y entera separación del Ministerio actual. Extremece sólo el decir que hayan podido concebirse ideas tan abominables, etc., etc.

LXXII.-Pero aún hay todavía más: lejos de tener esta (confianza) Malaspina conmigo, ni de haber contraido en aquel poco trato alguna amistad, desde el principio de él me miró con declarada desconfianza, que creció en rez de acabarse, y se fué haciendo cada día mayor hasta el de la prisión. Veámoslo por el orden de los tiempos.

Marzo y Abril de I795. Había precedido habernos visto casualmente dos de las veces en Cádiz, y en Aranjuez no había más que la concurrencia general y común al paseo y casas del Sr. Valdés y de Ganh.

Mayo, Funio y fulio. Un suceso de este tiempo descubre la confianza que podría haber entre mí y Malaspina, mi carácter, y la resistencia y estorbos que ofrecía éste á la comunicación de los proyectos.

Malaspina me dió á leer algunas Memorias sueltas de su viaje para que ingénuamente le dijese si, conno estaban, podríai imprimirse. No faltó alguno de sus amigos que me aconsejó disimulase ó templase mi dictamen, y no hiriese el amor propio de aquél. Ni mi carácter, ni el honor de la Nación, ni áun del Rey, que yo creía interesados en la publicación de aquellas Memorias, permitieron que siguiese este consejo. Díjele abiertamente que yo podía engañarme; pero que mi juicio del mérito de sus Mencorias era que, como tales ó documentos para la Historia, lo tenían no común, mas que no eran verdaderanzente historia, ni convenía que se imprimiese sin darles otro orden, claridad y estilo.

Algo sorprendió á Malaspina la franqueza ó sea dureza de este parecer.....

LXXIII.-Malaspina me había propuesto para censor de su obra solamente, ó como un subalterno que trabajase bajo su dirección. El Rey no tuvo á bien conformarse con su propuesta y me nombró redactor principal y sin dependencia. Conocí, desde luego, cuán temible había de serle esta mudanza y que acaso la atribuiría á manejo mío, que ciertamente no hubo, y así me esforcé á templar su queja, escribiéndole que ya tenía otro subalterno de quien disponer. En respuesta, me dice abiertamente que el subalterno lo es él, y que yo he quedado jefe. Entre mis papeles se hallará esta esquela, que manifiesta con toda cortesía, pero con no menos claridad su resentimiento.

LXXIV.-_Creció éste y su desconfianza en Agosto, Setiembre, Octubre y Noviembre. Una esquela suya de este tiempo, que se puso en autos, descubre aquéllos con suma evidencia. Me dice en ella que me había escrito otra con cosas harto graves (no recibí ésta); que acabe de manifestarle mis ideas, porque si no me he de conformar y seguir las suyas, más bien que concurrir á la historia, se echará á escritor del Diario, y usa otras expresiones que indican evidentemente que no se aseguraba de mi modo de pensar, que temía que era opuesto al suyo, y que este temor lo tenía en cuidado y desconfianza.

LXXV.-Confirmóse ésta y llegó al más alto grado, cuando en fin de Setiembre se le pasó de oficio copia de la Real orden de 28 del mismo, en que le aprobaba el plan de la historia que yo había presentado con fecha de 20. Veía en efecto un plan contrario á los dos que él había dispuesto y entregado al Ministerio mucho tiempo antes; que lo había yo formado y presentado sin acuerdo ni la menor noticia suya; que se había aprobado sin que él informase; que se me mandaba escribir la historia con arreglo á lo que proponía, y que de él no se hablaba ni se le comunicaba sino para su inteligencia y gobierno. ¡Cuántos y cuán graves motivos de dolor y queja!

Agregóse á esto, el que cuando recibió esta Real orden trabajaba una larga carta para que me sirviese de plan; que el día antes de recibir aquélla, me había leído grandes retazos de esta carta y yo ni áun le había insinuado el plan que había propuesto en la Secretaría, y cuya aprobación presumiría, y no se engañaba, que yo sabía, pues acababa de llegar del Sitio. Lo ví, é hice, pues, el mayor empeño en satisfacerlo; le mostré el borrador de mi plan, las razones sólidas en que lo fundaba y los elogios que en el mismo hacía de su trabajo y celo; le pedí continuase y acabase su carta, cuyas advertencias me serían muy provechosas y leería siempre con agradecimiento y con respeto; pero por más que doré la píldora, no pude quitarle la amargura que tenía verdade- 
ramente y cuyos efectos fueron: "I. Cortar la carta en el estado en que se hallaba, expresando sin disimulo lo hacía porque juzgaba inútil continuarla, pues mi plan aprobado ya, manifestaba no es tábamos conformes en la ideas. 2. ${ }^{\circ}$ No entregármela, sino dirigirla á la Secretaría de Marina y solicitar que se me comunicase de oficio para obligarme por esta manera indirecta á adoptar y seguir sus principios y máximas.

Trabajó en esto todo el mes de Octubre que estuve yo en Andalucía; pero como nada hubiese conseguido, me entregó al fin dicha carta con fecha 23 Octubre, á mi vuelta del Escorial en el día

de Noviembre, que estará de mi letra al fin de ella. Advierto que esta nota, que acaso parecerá inútil, y la conservación de las cartas y áun de las esquelitas de Malaspina, tenía por fin de parte mía, el que constase cn todo tiempo, no sólo de mi correspondencia literaria con aquél, sino áun de las más pequeñas circunstancias de la privada nuestra; prevención que creí merecería muy bien la importancia de la obra de que estábamos encargados, y el temor de que podría interrumpirse nuestra buena harmonía.

LXXVII.--Pero busquemos ya pruebas de mi inocencia en hechos más públicos, dando, en efecto, muchas y mứy eficaces el trato y conversaciones de las denás personas que nos acompañaban.

Cualquiera que haya observado con atención la Italia moderna, ó en el trato con sus nacionales ó en sus historiadores, habrá de convenir en que uno de los vestigios más claros que conservan del antiguo dominio del mundo que gozaron, es la violentísima propensión que los arrastra al estudio de la política y del gobierno que conviene á los demás pueblos, y áun á tomar parte en sus acaecimientos y revoluciones. Admira el ardor con que, áun en su situación actual (escribíase esto en Diciembre de I796) hablan de los intereses de las naciones grandes, de sus leyes y medios de aumentar su poder; los partidos que forman y áun el furor con que disputan á pesar de su aparente y estudiada flema. Observándolos yo con pasmo, me pareció, más de una vez, que no discurrían con más empeño y calor de aquellos puntos de política, en el Augusto Senado de Roma, los mismos Silas, Antonios, Marcelos, Flavios, Pompeyos y Césares cuando verdaderamente gobernaban desde allí el Universo y eran sus señores y quizás su azote.

Malaspina estaba dominado sumamente de este prurito político de su país; su literatura le había clado gran aumento; el viaje y la facilidad y áun orden que tuvo para recoger en él los papeles más útiles y áun los más reservados pertenecientes al comercio, frutos, cultivo y sistema de gobierno de nuestras Indias, convirtió y determinó en él este estudio general de la política á la particular que convenía á aquéllas, y creció después hasta parecęr como una especie de manía. El ejemplo de las otras naciones; la lección de tantos como modernamente, sin comisión y áun contra la voluntad de Minerva, se han tomado el alto y dificultosísimo oficio de legisladores del mundo; el superficial conocimiento de la historia de nuestras Indias, del orígen, motivo y ocultos fines de muchas de sus leyes, y quizá también el deseo de adquirir una gloria, ó sea celebridad, semejante á la buena ó mala de que ciertas gentes han encubierto al Abate Raynal y á otros eternos habladores como él, inspiraron á Malaspina algunas ideas sobre la legislación oportuna para nuestras Américas, que él creía, sin duda, sólidas y provechosas, como lo convencen la misma publicidad con que las esparcía y la confianza con que las ha dirigido al Ministerio; pero que en la verdad eran de utilidad muy dudosa, y áun sin temeridad se puede pronosticar que, establecidas, ó destruirían aquellas posesiones, ó turbarían, si no acababan del todo, el justo imperio de España sobre ellas.

Esta, pues, insanable comezón política de Malaspina hacía que apenas podía moverse en su presencia, conversación que, ó derechamente ó con arte, no la trajese al comercio, industria, relaciones de los pueblos entre sí, y demás ramos de la legislación, con la aplicación de todo esto á las Américas. Lo exótico de algunas de sus ideas, y áun de las expresiones con que las manifestaba, porque á la verdad, no poseía el idioma español con la perfección que él se había persuadido, le hicieron un lenguaje propio suyo, y muy extraordinario por no decir más. Imitábamoslo áun á su presencia los demás burlonamente y con el uso de las sonoras palabras intereses sociales y coloniales; de establecimientos, ora mineros, ora agricultores, ora comerciantes, y otras de esta especie, mostrábamos, y yo acaso más que todos, nuestra desaprobación, y qué sé yo qué más de aquellas ideas y política extravagantes. Pueden deponer en esta verdad el Brigadier D. José Bustamante y Guerra, segundo Comandante del viaje; los Capitanes de navío D. Alberto Sesma y D. Dionisio Galiano, el Capitán de fragata D. Luis María Salazar, el Teniente de navío D. José Connok, D. Juan Jacobo Ganh, y cuantos concurrían á nuestros paseos y tertulia, y además D. Francisco Saavedra, de1 Consejo de Guerra, á quien hablé yo de esto por la experiencia y profundos conocimientos que tiene de las Américas.

En mi declaración hice especial memoria, yáun dije deseaba que se conservase y recogiese una carta que habia yo escrito á Salazar tres días antes de mi prisión, en la cual remedaba este estilo medio arabesco de Malaspina, y descubría entre las burlas mi ningún aprecio por su sistema político....... 


\section{Imposibilidad moral de que Malaspina me commicase sus proyectos; necesidad moral de que, comunicados, yo los reprobase y solicitase que no tuviesen ejecución.}

LXXXV.-Malaspina tenía toda la reserva, cautela, disimulación, por no decir doblez, propias del país en que nació. Los talentos, la educación, la lección, el conocimiento y experiencia del mundo y de las córtes, habían perfeccionado y llevado en el más alto punto aquellas calidades. Basta ver los progresos que ha hecho en su carrera y la rapidez de ellos; el arte con que ha aprovechado ó buscado, como dirían sus émulos, las ocasiones de adelantarse; y finalmente, la buena harmonía y subordinación que mantuvo en los buques de su mando en su largo y penoso viaje, para persuadirse á que Malaspina sobresalía en prudencia política, en esta ciencia dificultosísima que alcanzan tan pocos, y que pide tanto tino y discernimiento de conocer los hombres, su carácter, virtudes, pasiones, inclinaciones y áun vicios, aplicarlos á los destinos más análogos á aquéllas, manejarlos, moverlos y áun doblarlos al fin que se desea y sacar de ellos todo el partido posible.

(E1 Padre Gil hace la pintura de su carácter, enteramente opuesto al de Malaspina).

Malaspina había conocido tan perfectamente este carácter mío, que hizo la descripción más cabal de él en una sola palabra. Es el caso que él y los demás quisieron sospechar que yo tendría prontamente destino, y temieron que no me encargaría de la comisión, ó que, áun cuando la admitiese, no concluiría la obra. Malaspina detuvo algún tiempo la propuesta por estos temores, y me estrechó muchas veces á que lo desengañase con ingenuidad. Díjele que las sospechas suyas y de los demás carecian de todo fundamento; pero que lo tuviesen ó no, y aunque se verificase lo que sospechaban, dada mi palabra, como la daba, de encomendarme de la historia del viaje, ningún interés, ningún honor, ningún destino que se me propusiese podría hacer que no lo acabase.

Sin embargo, aún hizo la propuesta con duda ó miedo de si la admitiría; la admití y en respuesta, entre otras chanzas, me da este título, que no había usado antes ni usó jamás después: Citoyen noir, cuyo espíritu y motivo de él no habrá quien no penetre.

XC.-Ni olvidaré tampoco, la singular con que continuó honrándome su muy digno sucesor (de Valdés) en el Ministerio de Marina, D. Pedro de Varela. Están selladas en mi espíritu las palabras con que su cortesanía y afecto, para estimularme sin duda el desempeño de la comisión, me habló al despedirme en el Escorial en la noche del I7 de Noviembre: "La Marina (me dijo) no podrá agradecer bien el obsequio que $V$. le ha hecho en haberse encargado de la historia del viaje. Cuente $V$. conmigo y con cuanto yo pueda." ¿Y por qué jurar yo la pérdida de personas que mostraban apreciarme tanto?

CCXIII.-Concluirá tan fastidiosa relación lo que ha puesto la Corona á mis tales ó cuales méritos, hasta casi envanecerme, á saber: Comisión que el Rey sin pretensión y apenas noticia mía se sirvió encargarme. Honremos esta defensa copiando á la letra la Real orden que decía así: "A propuesta del Brigadier D. Alejandro Malaspina y por la confianza que el Rey tiene en la literatura de $V . R$., se ha dignado confiarle la redacción y arreglo de los resultados del viaje, que al mando de aquel Oficial han ejecutado las corbetas DescubierTa y ATrevida, y para cuya empresa se ha prestado el celo de V. R. que ha movido el Real aprecio.

"Deja S. M. al arbitrio de V. R. la ordenación de este trabajo en los términos que le dicten sus conocimientos; pero sin apartarse de los hechos, como debe suponerse, y empleando en su narración la sencillez conveniente para cabal instrucción de todos y principalmente del Cuerpo de la Armada.

"Con esta fecha doy el correspondiente aviso á D. Alejandro Malaspina y le prevengo, que acordándose V. R. con él, le entregue lo que sobre la materia tiene ya trabajado y le entere de ello para su gobierno; y en adelante irá suministrando á V. R. los materiales que haya juntado según las órdenes, agregandoá ellos los que le dicten sus distinguidos conocimientos y sean conducentes al más completo objeto.

"Para los gastos que ha de producir á V. R. este encargo, le ha señalado S. M. mil y quinientos reales vellón al mos; pero esto se entiende sin perjuicio de mayor asignación si le fuere necesaria 6 lo exigiesen las urgencias para la adquisición de libros, manuscritos ó pago de escribientes; pues así como S. M. se persuade que el estado religioso de V. R. ni su voluntad y desinterés que ha manifestado, le permiten fijar el valor de su trabajo, tampoco quiere dejarlo sin recompensa.

"Comunícolo á V. R. de Real orden para su inteligencia, en la de que S. M. no duda que corresponderá á esta confianza con todo el esmero que exige su importancia. Dios, etc.=San Ildefonso, 26 de Julio de I795. =Valdés.=R. P. Manuel Gil de los Clérigos menores.» 
CCXIV.-Aunque sean tantas y tan distinguidas las expresiones de honor hacia mí con que se extendió esta Real orden, como que se descubre algo mis grande y extraordinario en la que sa me comunicó aprobando el plan que presenté, decía así: "El Rey se ha enterado de las reflexiones que comprende la representación de V. R. de 20 del que acaba, sobre el método conveniente en la publicación del viaje de las corbetas Descubierta y Atrevida, y S. M. las ha hallado muy oportınas y conforme á las ideas que deben seguirse en la obra. A este fin, arreglará V. R. sus pensamientos, omitiendo todo lo que no deba saber el público en cuanto al gobierno interior de las provincias de América y las variaciones que convenga hacer en él, y tratándolo por Memorias separadas y secretas en la forma que propone V. R., para hacer en los Ministerios á que competan el uso que fuere conveniente."

"Bajo este principio y el de que establecen juiciosamente las mismas reflexiones, de que deben indicarse por separado, y con la extensión científica que se requiere, los diversos ramos que ha de abrazar esta obra, de Historia Natural, Botánica, Medicina, etc., se arreglará V. R. á los tratados que con distinción escriban los profesores de aquellos ramos, para que, dando noticia en la historia general del viaje de lo que sea preciso en aquellas clases, se eviten las repeticiones de lo que abracen y traten con toda la prolijidad que se requiere los profesores de las mismas ciencias.

"Y para resolver con toda su extensión esta obra, se facilitarán á V. R. los libros, mamuscritos y documentos que conceptúe precisos de los archivos donde se hallaren, y además pedirá V. R. el escribiente ó escribientes que necesitase.

"Por Secretaría se abonará á V. R. el goce de los I,500 reales vellón al mes que el Rey le ha señalado y ha de percibir desde la fecha de su concesión.

"Todo lo que prevengo á V. R. para su inteligencia y gobierno. Dios, etc. = San Ildefonso, 28 de Setiembre de I795.=Valdés.=Al Padre Manuel Gil, de la Congregación de los Clérigos menores."

Además de las anteriores amplísimas noticias que nos da el astuto é hipócrita Padre Gil (pues no obstante extremecerse ante la idea de un cambio de ministerio más tarde presidió una Junta revolucionaria), copio otras muy interesantes debidas al señor Conde de Greppi, Embajador que fué de Italia en España ( I) y cuyo abuelo tuvo relaciones íntimas de amistad con Malaspina.

Dice el Conde de Greppi respecto al ilustre marino:

«En su ánimo apasionado, este viaje (la vuelta al mundo) le hizo impresionarse por la felicidad de sus semejantes, pensando en la absoluta precisión de un cambio radical en el sistema de gobierno y de la legislación de las colonias. No expresa en sus cartas la manera de conseguirlo, pero bastante se comprende, porque insistía en la necesidad de quitar todo cuanto estorbase al libre desarrollo, tratando de hermanar aquel imperio con más amplias y recíprocas relaciones, para que no se consideren tan lejanos dominios como depósitos de ricas minas, sino como una inmensa región capaz de todas clases de productos y apta para formar la felicidad de millones de individuos. Entre las cosas que decía, hay un concepto de singular belleza, que pronto fué el grito del siglo:

"La harmonia de la naturaleza, no obstante el torcido rumbo de tantos años que ha procurado sofocar los clamores, se oye aún gritar pidiendo que no la opriman, y atiendan sólo á encarvilarla en los lindes de su verdadero camino.

»En medio de estos argumentos, confesaba él mismo que tenía la cabeza algo caliente, y conservaba, sin embargo, bastante prudencia para comprender que era temible el acreditarse de proyectista en tal ocasión. El olvido de esta máxima fué causa de su ruina.....

(I) De un legajo que existe en la $\Lambda$ cademia de la Historia, y que contiene muchos datos biog ráficos de Malaspina y multitud de cartas dirigidas por éste á D. Paolo Greppi. El señor Conde de Greppi hizo á la Academia el donativo de este legajo. 
»En el abandono de sus confidencias epistolares con Greppi, se revelan sus intenciones, no ya sediento de poder y de gloria, sino dulcemente melancólico y demasiado delicado para sostener mucho tiempo los combates de la vida real, como nuevo Fauslo, ó como decía un escritor francés, «un hombre ocupado en los negocios de la vida, pero anhelante del reposo de una contemplación filosófica.»

En la persuasión que tenía de poder servir á España, y por lo que deseaba participación en el Gobierno, le daban ciertas esperanzas que pronto se convirtieron en desengaños. Decía Malaspina (en 24 de Diciembre de $\mathrm{r} 794$ ): He escrito cuanto mis ideas me sujerian para poder ser iutil á este pais en momentos tan tempestuosos: un solo dia me hubiera hastado para cxplicar mi sistona: todo to he visto, todo to he visitado; con un pequeño paso quizá se hubiera podido entrar on buen camino y en la sana filosofia; todo parecía prestarse á ello; me encontraba ligado con cuanto habia de más virtuoso y mejor en el pais; se me concedia grandísima atención, rectitud en mi corazón y una devoción absoluta al biencslar genural sin egoismo y sin preocupaciones; pero el síbito advenimiento del Sultán (esto es, del primer IMinistro Godoy) to hacen todo dificil: cuanto le vodea cae en la confusion y un la inacción.

No se desanimaba por eso, pues el 27 de Febrero escribía: En este momento pende de una nada el que yo sea destinado á cosas de la mayor cntidad respecto á la prosperidad del Reino cu todas sus partes, y quo yo vuelva á mi antiguo oficio de marincro.

"No se sabe si por maquiavélicas artes ó para perderlo, continuaba el Gobierno tratándole con mucha consideración. Así, en Marzo de I794 el Rey le nombraba Brigadier; en Mayo pedía licencia y le era lisonjeramente rehusada; en Agosto, los íntimos de Godoy decían que podía ser Ministro en lugar de Valdés; en Octubre, Godoy mismo, en pública corte y en su presencia, había hecho un gran elogio de sus méritos; las numerosas relaciones que él envió al Ministerio (convertidas luégo en otros tantos capítulos de cargos), le habían sido agradecidas generosamente. Esto no obstante, los presagios de los más expertos le eran siempre desfavorables, y en informes de un Ministro de Malta, Jacinto Malaspina, se expresaba el temor de que á su hermano le tocase la suerte de Colón, así como Greppi se esforzaba en inculcarle prudencia.

"Lo verdadero es que él se creía con la misión de iluminar al Rey y al país, de haberlo hecho con honradez, siendo precisa consecuencia de ello ó la ruina ó el triunfo. En cuanto á mi ánimo (decía desde la carcel), júrole que no puede estar más tranquilo, no abrigando el tomor de que me desvie de mi camino ni una despreciable apatia ni una baja precipitación. La causa que aqui me ha conducido me hace repetir que, en iguales circunstancias, MII, VECES VOLVERÍA Á HACER LO MIISMO.»

Malaspina permaneció encerrado en el castillo de San Antonio, de la Coruña, hasta i So3. 1) cbióse su libertad á influencias del Conde de Melzi cerca de Napoleón; este gran guerrero solicitó y obtuvo del Gobierno de España la libertad de Malaspina, que fué desterrado á Milán. Apenas llegado le ofrecieron el cargo de Ministro de la República italiana; pero el insignne marino lo rehusó y prefirió retirarse á su casa de Lumigiana, donde murió á 9 de Abril de i \$o9, á los cincuenta y cinco años de su edad.

Ya hemos visto que para este hombre superior eran contraricdades de fácil consuelo su prisión y su ruina; pero acaso no fuere exagerado señalar como causa de su muerte premiltura, el estúpido decreto que sepultaba en el olvido más injusto todo el caudal de sus 
trabajos; esto es, su nombre, su gloria, su eterna fama, tan costosa y honradamente adquirida hora por hora, en cuatro años consecutivos de estudios y penalidades.

Como testimonio de las últimas huellas que el pié de Malaspina dejó en España, publicamos á continuacion varios documentos que llenan el alma de melancolía. Tambien in: sertamos, á fin de que pueda apreciarse en toda su excelencia, el plan QUE PARA ESCRIBIR SU viAJE entregó el ilustre marino al clérigo Gil, cuyo plan no quiso terminar cuando supo que áun antes de conocido, estaba desaprobado.

Tanto este notabilísimo trabajo, como las cartas escritas á varios prohombres de su época, y las Instruccioncs que dió á Bustamante, han sido copiadas de borradores originales de puño y letra de Malaspina y se han impreso con todas sus incorrecciones de estilo, por respeto al autor y culto á la verdad.

El Sr. Conde de Greppi, tan amante de la memoria de su ilustre compatriota, terminaba los datos biográficos con estas palabras: «Un voto me queda que espresar; y es que desenterradas las muchas revelaciones y memorias, goce el público del fruto de tantas meditaciones sobre España y sobre América y saboree el estilo del viajero generoso».

Ya está, pues, complacido.

Y ahora, hablen solamente Malaspina y sus dignos compañeros; sean sus relatos brillantes manifestaciones de saber, timbres gloriosos que hoy surgen y se estampan en el libro de la Historia, dejándome como gratísimo premio el honor y la ventura de haber enriquecido con tan hermosas páginas nuestra CRÓNICA NAVAL.

Pedro de Novo y Colson. 


\title{
APÉNDICE
}

\section{A LA INTRODUCCIÓN HISTÓRICA}

\author{
SOBRE EL DESTIERRO DE MALASPINA (I)
}

«Excmo. SR.: Por el adjunto parte original que en 2 del corriente me dió el Capitán de este puerto, se enterará V. E. de lo ocurrido con el trasbordo que intentó y verificó en el Cabo de las Salinas, de esta isla, Don Alexandro Malaspina y su criado, procedente de Cádiz, con destino á Génova, en la fragata mercante española, su Capitán Santiago Mantica.

"Inmediatamente que reconocí en los términos que iba extendido el pasaporte, donde se advertia la circunstancia de no poder dicho Malaspina saltar en tierra de España, dispuse, no tan solamente el que se mantuviese en cuarentena el patrón Antonio Roca con su laud, á cuyo bordo se hallaba Malaspina, sino que mandé diese la vela sin pérdida de tiempo para restituirlo á la fragata, con la estrecha prevención y precepto de no saltar á tierra en la costa, caso de no hallarla, y de regresar á este puerto como lo verificó.

"Luego de restituído y manteniéndose en la cuarentena con centinelas de vista, mandé se le proveyese al Patrón Roca de los víveres que necesitase y despacharlo para las costas de Francia, con los dos pasajeros, sin convenirme con la proposición que me hizo Malaspina de permitirle su embarco para Barcelona, desde donde por tierra, pasaría á Francia. Todo lo cual pongo en noticia de V. E., por si creyese conveniente elevarlo á la de S. M.

„Dios guarde á V. E. muchos años.=Palma, 7 de Febrero de $1803 .=$ Excmo. Sr.= Juan Miguel de Vives. $=$ Excmo. Sr. D. Pedro de Cevallos.n (Original).

Al margen de esta comunicación va el siguiente decreto: «A Vives, que arreste á Malaspina si desembarca en la extensión de su mando y que avise. Igual orden al Capitán General de Barcelona para que arreste al mismo Malaspina si desembarca en Barcelona ó en otro puerto de su departamento.»

Debajo de este decreto y de otra letra: «Contestado así, ménos lo de Barcelona, que se puso en orden aparte, como también á Valencia, en 5 de Marzo, según minuta.»

El parte original del Capitán del puerto de Palma, dice así:

"El Patrón Antonio Roca, mallorquín, del laud la Virgen del Carmen, con tres marineros, venido de Alcudia, de donde salió el día 3 I del pasado, dice que en el día de ayer por la mañana, á las i I, halló fondeada en el Cabo de las Salinas una fragata española, su Capitán Santiago Mantequí (sic), que habia salido de Cádiz el día z I del próximo pasado, con cargo de azúcar y cacao para Génova. Que de dicha fragata se llamó al declarante y se le embarcó un pasajero llamado D. Alejandro Malaspina, con su criado, cuyo pasaporte y boleta acompaño. Dicha fragata, desde que salió de Cádiz, no ha tenido roce ni comunicación con embarcación alguna; por lo que me parece, siendo de la aprobación de V. E., se le puede admitir á libre plática. Dicho pasajero quería escribir á V. E. y le he dicho tuviese paciencia.=Lucus Orell.»

La Real orden causada del decreto marginal de la comunicacion de Vives, dice:

«Excmo. SR.: Habiendo sabido el Rey que D. Alexandro Malaspina á quien se embarcó para llevarlo fuera de los dominios de S. M. con prevención de que no pudiese saltar en tierra de España, ha intentado desembarcar en la Isla de Mallorca, hallándose á bordo de un buque mercante, quiere el Rey que si efectuare su desembarco en algún puerto ó costa de la Península se le arreste inmediatamente y se dé parte á S. M. De Real orden lo comunico á V.E. por lo que pertenece á ese principado de su mando (el de Cataluña.) = Dios, etc.n-Al de Valencia se le dijo además: Previniéndole lo participe cuanto antes al Gobernador de Cartagena.n=Aranjuez, 5 de Marzo de $\mathbf{I} 803 . n$

(1) A la amalibilidad de D. Gaspar Mluro debo estos documentos, que fueron hallados y copiados en el Archivo de Aicalá de Henares (legajo 3.or 3 ) por c. Sir. Jimenez de la lispada. 
Junto con la anterior minuta y los demas papeles copiados, hay estos otros:

«Excmo. SR.: Referente á lo que dije á V. E. con fecha de 7 del pasado Febrero, le incluyo el certificado original del Vicecomisario de comercio de S. M. en el puerto de Portvendre que me ha entregado el Patrón Antonio Roca, que regresó el 26 del mes último, acreditando el desembarco de la persona de D. Alexandro Malaspina.

„Dios guarde á V. E. muchos años.=Palma, 2 de Marzo de I803.=Excmo. Sr.-- Juan Miguel de Vives.=

Excmo. Sr. D. Pedro Cevallos.» (Original.)

El certificado es como sigue:

«Don Josef Miguel Burria, Vicecomisario de Comercio de S. M. C. en el puerto de Portvendre:

«Certifico: Como el Patrón Antonio Roque (sic), de la matrícula de Mallorca, embarcó el dia seis Febrero en el puerto de Palma, en la dicha isla como consta de su pasaporte, al Sr. D. Alexandro Malaspina italiano, y que hoy diez y ocho mismo Febrero lo desembarcó en este puerto; llegando el dicho patron con su barco la Virgen del Carmen.=Y porque conste á donde convenga, doy el presente certificado, que firmo y sello con el P. S. de este Vicecomisariado.=Portvendre, á I 8 Febrero de $1803 .=$ Por el señor Vicecomisario de España, Luis Bronzoni,

Sello en lacre rojo.

Esto, no obstante, el Capitán General de Cataluña dirigía al ministro de Estado este oficio:

«Excmo. SR.: La justicia del puerto de Palamós me avisa, que segun noticia dada por aquel Comandante militar de Marina, D. Alexandro Malaspina desembarcó en Marsella, adonde lo condujo un barco mercante de Mallorca, según constaba en el rol de equipaje de su Patrón. Lo noticio á V. E. consecuente á lo que se sirvió prevenirme de orden de S. M. en 5 de este mes.

Dios guarde á V. E. muchos años.=Barcelona, 22 de Marzo de I803.=Excmo. Sr. =El Conde de Santa Clara. $=$ Sr. D. Pedro Cevallos. (Original.)

(Archivo general central de Alcalá de Henares, legajo 30r3.)

\section{PLAN PARA ESCRIBIR SU VIAJE, DADO POR MALASPINA AL P. GIL.}

Cumpliendo con una orden de S. M. la cual me prescribe el que entregue á V.P. Rma. todo lo que sea relativo á la parte histórica y política del viaje de las corbetas Descubierta y ATRevida para que de este modo llegue á ser público con mayor brevedad y perfección, antes manifestaré la debida complacencia por una terminación que ciertamente refluirá toda á beneficio de la instrucción pública y luégo procuraré en los siguientes párrafos dar una idea tan exacta cuanto lo permita la extensión de un oficio, del método que me había prefijado para la dicha publicación y del estado en el cual se halla hoy en día la misma obra.

La introducción general la cual precede á la narración del viaje, bastaría á la verdad por sí sola para el objeto propuesto: la he entregado con el mismo diario á V. P. Rna. y si bien no haya aún merecido la Real aprobación la parte que en ella se comprende y es relativa á las materias políticas, debe tranquilizarme en mucho el que, aún no aprobada, en nada trastorna las demás partes del plan propuesto.

Pudiera hacerse, sin embargo, digno de reparo el estilo algo enfático del cual va vestida. Lo he preferido con el solo intento de convidar á la Nación á reunirse hacia un Gobierno prudente, que sacrificará cualquiera preocupación ó descanso al deseo del bien público. Y á la verdad, en el estado deplorable en el cual se hallan nuestra Hacienda, el crédito público y áun la seguridad individual, ó es preciso que las materias políticas se traten con aquel objeto, ó que no presenten sino el infeliz espectáculo de un hombre entregado á la adulación y al cuidado de sí mismo.... Pero hablaré más difusamente de esta materia en su lugar; básteme por ahora el repetir, que el descubrir la América, sea en cuanto á sus orillas, ó en cuanto á su estado interior, como por precisión lo hará la narración aún mas superficial del viaje, sería un acelerar ó las invasiones más temibles de las naciones rivales, ó el desmembramiento de sus partes por aquella misma reacción que agita en el día á las sociedades reunidas en los siglos pasados.

Anexo á la introducción puede considerarse el legajo nưmero I de los papeles originales: en él se comprende esencialmente todo lo que se refiere al objeto del viaje y á las medidas tomadas para su ejecución en los diferentes ramos, sean científicos ó de policía, orden, seguridad y conservación. Las correspondencias originales de algunos sabios de Europa y de varios oficiales de los más espertos de la Armada, hállanse encerradas en el mismo legajo. Pudiera por la misma razón darse la extensión que se quisiera á la misma introducción, detallando á la par de las historias de los viajes extranjeros, cuanto hubiésemos tenido presente en los aprestos. Pero lo he omitido así por ser estas materias ya harto repetidas entre las diferentes naciones marítimas, como por hallarse la mayor parte recordados ó en la misma narración y en la obra médica, si se refieren á la policía, ó bien en el diario astronómico y materiales de las cartas, si se refieren á las ciencias, que más de cerca procurábamos abrazar.

La narración del viaje debia remir precisamente tres objetos: $\mathrm{I} .{ }^{\circ}$ La responsabilidad mía inseparable 
rel honor nacional. 2. La mayor amenidad ó descripción ménos molesta de las cosas acaecidas. $3 \cdot{ }^{\circ}$ La instrucción general de la Armada, para la conducta más propia en los mares y colonias distantes de los dominios de S. M. Con igual atención he procurado no perder de vista los tres objetos indicados, y si bien hallé que la demasiada repetición de las tareas hidrográficas, sea algo cansada en el-total, he debido sin embargo decidirme á no hacerla más superficial porque era indispensable el dar una idea clara de la prolijidad con la cual habíamos trabajado en la parte principal del viaje que se reducía á la construcción de las cartas del Mar Pacífico. Opinarfa por consiguiente que ni el orden ni la extensión del dicho diario pueden variar considerablemente; sólo sí debo advertir que faltan en él dos capítulos correspondientes al libro tercero y deben tratar: el primero, del viaje de la corbeta ATrevida á Macao desde la bahía de Manila, y el segundo, del viaje de la misma corbeta en I 793 y 94 desde la Concepción de Chile hasta el puerto de Montevideo: su Comandante, el Brigadier D. José Bustamante y Guerra, ha tomado á su cargo el poner en orden aquellos dos capítulos y remitirlos después al Excmo. Sr. Ministro de Marina. Incluyo, no obstante, para cualquier evento las copias de su diario original, de las cuales sería fácil deducir los mismos capítulos y debo añadir como prevenciones sobre esta materia, para mí harto delicada, en primer lugar, que D. José Bustamante deseaba extender en un capítulo aparte el viaje de la ATrevida separada de la Descubierta en los mares de Nicaragua, el cual yo he reasumido con otras materias para el mayor orden y brevedad: segundo, que el mismo orden de la narración me ha conducido á considerar en fines del año de 1793 separadas las corbetas tan sólo desde la Concepción de Chile, cuando en la realidad debian considerarse como tales deste Lima: tercero, finalmente, que era el ánimo de Bustamante (manifestado así al Excmo. Sr. Ministro de Marina), de comprender en el capítulo del viaje á Maçao una disertación ó memoria sobre el comercio de los enropeos en la China, obra que sería sin duda utilísima para la instrucción pública, porque según el plan adoptado, no scría fácil embeber en la narración histórica del viaje.

Estas tres prevenciones exigirán ciertamente que V. P. Rma. se corresponda con el mismo Bustamante, quien se halla actualmente en Cádiz. Por mi parte no deseo sino el que quede complacido, cuando sus ideas parezcan plausibles, y de todos modos creeré acertado el que se consulten á la superioridad cuando ya estén á la vista los materiales remitidos, accediendo yo de muy buena voluntad á cualquier partido que parezca preferente, visto el todo de la obra por jueces imparciales é inteligentes: van también anexos á esta parte en el legajo número 2 los diarios originales cuales se remitian al Excmo. Sr. Ministro de Marina desde los diferentes puertos donde llegaban las corbetas. Pueden servir á las veces para aclaración de algunos párrafos oscuros, á veces de fehacientes de la verdad más escrupulosa en la narración respecto á haberse escrito puntualmente en el viaje y haberse presentado á la oficialidad de guerra para su confrontación con la verdad más exacta.

Ya la composición del segundo tomo aún no bien ordenada, pide una aplicación difusa la cual sírvase V. P. Rma. de mirar con la mayor reflexión, pues envuelve en sí no sólo el trabajo complicado de muchos, sino también el fin principal de la obra; esto es, la utilidad pública.

Un estudio no superficial de la América me había convencido años ántes, que cuanto sobre ella se había escrito, más bien servía para confundir que no para ilustrar á la nación poseedora. Gemían los archivos, ó públicos ó particulares, bajo el fárrago inmenso de las acusaciones recíprocas de los Gobernadores, ó militares ó eclesiásticos, de los proyectos soñados de la fuerza y riqueza nacionales; de las descripciones pomposas de los países invadidos y de las leyes incautas y no obedecidas de un Gobierno acosado de la necesidad é imposibilitado de examinar con cordura lo que debía juzgar. Quísose ordenar un país inmenso de modo que sobrepujase en pocos años á las riquezas, al poderío y á la población de la España; y la miseria, la debilidad y la despoblación, fueron las consecuencias inmediatas de aquel sistema funesto; pero sobre todo el malogro de unos proyectos tan plausibles no pudo ménos de acarrear con la justificación de cada uno, las descripciones más equivocadas de los países de los cuales se hablaba. La América se halló á poco tiempo á la disposición absoluta de sus Gobernadores, los cuales invadían ó abandonaban centenares de leguas, ya en una, ya en otra dirección. El suelo, los productos, los habitantes indigenas, los mismos proyectos de nuevas colonias, ya en las orillas del mar, ya en las cumbres de los montes los más elevados del orbe, fueron descritos 0 con parcialidad ó con ignorancia. La misma imposibilidad de descifrar la verdad entre tantas contradicciones hizo abandonar el estudio de un país tan inmenso, y fué nuestra única felicidad el que, ocultadas por naturaleza descripciones tan equívocas y contradictorias, los extranjeros se viesen arrastrados en pos de nosotros á las mismas ideas erradas sobre la cualidad de nuestras Américas, y finalmente, tantas causas reunidas á la superficialidad con la cual se escribe hoy en día, diesen de aquellos paises una idea aún más errada de la que teníamos en los principios de la conquista.

A la verdad, los límites de nuestros destinos á las orillas del mar; las operaciones hidrográficas y astronómicas que debían ocuparnos incesantemente; la misma celeridad con la cual debíamos correr de uno á otro extremo de la América, parecían destinarnos á contribuir más bien al aumento que á la disminución de aquellos errores, cuando hubiésemos querido mezclarnos en materias tan oscuras y complicadas; pero como quiera que visitásemos de camino á las diferentes capitales de los vireinatos, que en ellas se agolpasen alrededor de nosotros los hombres más ilustrados, creyendo hacer un buen servicio á la patria y al Gobierno, que los Vireyes y Gobernadores nos franquearan las noticias más exactas y reservadas, que nosotros mismos, ó ya con la imparcialidad de unos meros caminantes, ó ya con entrometernos entre los campos y entre los naturales de las clases atín más abyectas, como lo exigran nuestras excursiones, tuviésemos lugar á confrontarlas; finalmente, como quiera que los mismos progresos de las ciencias diesen lugar ahora á que se examinasen 
aquellos paises por los colonos con mayor empeño y utilidad, puede, por último, conocer que ni carecíamos de los materiales necesarios para dar á la Nación una idea cabal de sus colonias, ni esta empresa debía omitirse cuando se pretendiese examinar políticamente la defensa de la América de las invasiones externas ó de las revoluciones interiores.

Añadíase á estas consideraciones otro reparo de no menor extensión, y era el semblante que debíamos dar á los oljetos é historia del viaje: casi el todo de él habia tenido lugar en las colonias nacionales, de las cuales hubiera sido absurdo, después de tres siglos corridos desde su descubrimiento, el dar una idea superficial, que suele darse de un país visitado por la primera vez, en donde las nociones áun más imperfectas y frívolas, silven 6 de instrucción ó de entretenimiento para los lectores. Por consiguiente, la descripción sencilla de pocas minas, algunas piedras, etc., de nada servía sino es de un nuevo aumento para la misma confusión sobre el estudio de la América, que procurábamos evitar. Mayor empeño, ideas más extendidas nos prescribía nuestra situación imperiosamente, y se dirigían á dar una idea cabal de toda la América española, por manera que se reasumiesen en una sola masa todas las noticias útiles y verídicas, separándolas de las falsas é impertinentes, y el legislador y el vasallo pudiesen leer sus deberes respectivos en un espejo fiel, en donde la naturaleza grabase con los colores de la realidad lo que fué la América, lo que es y lo que será, siguiendo por una parte el orden suyo inalterable y por la otra los obstáculos que intenta ponerle la débil mano del hombre, conspirando tan sólo á su propia infelicidad y destrucción.

Con este solo intento tuvo á bien S. M. prescribir á los hermanos del difunto D. Antonio Pineda, que reuniesen á nuestra obra los apuntes ó notas de aquel hábil observador, sin escribir otro viaje separado, el cual ciertamente 6 debía ceñirse á pocas ideas inconexas y nada útiles para los progresos de la ciencia, ó adoptar como suyos aquellos conocimientos que pertenecían á la sola expedición: con este intento los hábiles botánicos D. Luis Nee y D. Tadeo Heenke, tributaron siempre al mismo plan aquella parte de sus diarios que tuviese relación con el examen de la naturaleza cual nos la habíamos prefijado, sin descender con particularidad á una ú otra ciencia. Este intento, finalmente, fué el que manifestó como esencial la ordenación de la obra en Madrid, en donde únicamente podían hallarse, o los manuscritos precisos para formarla, ó los hombres ilustrados y testigos de vista que pudiesen ratificar aquellas ideas. Cuál sea la principal división de la obra, y cuáles los motivos que así lo han dictado, lo demuestra la Introducción con la mayor claridad. Era preciso dividir la América Meridional de la Septentrional y de las Filipinas. La utilidad, las relaciones entre sí y con la matriz de cada una de estas partes, eran tan diferentes, que no alcanzaría a reunirlas la imaginación más viva y arrebatada. Siguiendo, pues, el mismo orden, hablar é ahora con distinción de cada uno de los libros premeditados.

\section{TOMO PRIMERO}

\section{Descripción física de la América Meridional comprendida entre los Cabos de Valdés y Hornos} y el Istmo de Panamá.

Capítulo r. Trataré del mar que cerca aquel país inmenso, de los golfos, de las islas, de las sondas, de los vientos dominantes. Grandes harmonías de la naturaleza entre los vari os elementos que la componen.

2. Trataré de los temperamentos y de las diferentes zonas correspondientes. De Sur á Norte, país montuoso y país llano. Término de las estaciones variables y de las constantes y conformes á la acción rlel sol, etc.

3. Población general de la América meridional. Indios primitivos. Invasión de los peruleros. Invasiones de los europeos. Estado actual de las colonias. Idea natural de desterrar todos los nombres de tribu y familias para un examen semejante: no se individualizan castas y números.

4." Trátase del Rio de la Plata y de las Pampas hasta el Paraguay y Tucuman. Naturaleza de este terreno. l,os ganados, sus utilidades, su multiplicación, su retiro.

5." Descripciones individuales del país reconocido por nosotros alrededor de Montevideo y Buenos Aires.

6. Descripciones del Puerto Deseado y Puerto Egmont.

$7 .^{\circ}$ Reúnense estas noticias á las de los demás navegantes españoles y se forma una idea cabal de las tierras Patagónicas y del Fuego.

8. Descripción de la isla de Chiloé y de la parte meridional del continente no sujeta á la dominación española.

9. " Kecopilación de las diferentes naciones que habitan el país inmenso desde la latitud de $36^{\circ}$ y medio hasta el Cabo de Hornos. Sus costumbres, sus enlaces, su número. Historia de los Césares y de los proyectos de Fol-Kaner.

ro. Descripción de Chile: sus naturales de todas especies, su suelo, sus manufacturas, su temperamento, minas, comunicaciones interiores con el Perú y las provincias del Vireinato de Buenos Aires, Mendoza, San Luis de la Punta y las Pampas. 
11. Del Tucuman, del Paraguay, de las misiones de Moxas y Chiquitos, clases bien distantes de los peruleros.

I 2. Descripción de las costas desde Coquimbo hasta Lima; minerales y volcanes. Uvas y aceites. Calidades del mar y de los vientos reinantes. 'Tránsitos de comunicación de los pasajeros, acarreo de mulas. Varias comunicaciones con la capital de Lima. Temblores, ingenios de azúcar.

13. La Sierra del Perú, su naturaleza y minas. Peruleros que la habitaban al tiempo de la conquista. Imperio del Cuzco. Lagunas de Chucuito. País de las Yangas. Elevación de los montes. Temperamento y estaciones que la dimanan; vicuña y llama. Minerales de azogue de Guancavelica.

I4. Descripción de Lima, sus costumbres; los colonos, los negros, los indios; mezcla de castas, influjo de las costumbres de la capital sobre toda la costa. Agricultura del valle de Rimac. Industria de los paises inmediatos de la Sierra. Costumbres antiguas de los peruleros conservadas en la Sierra; su naturaleza; viaje de los Sres. Pineda, Heenke y Nee. Conchas altas, calidad de los montes; causas del carácter actual de los limeños, vicios, elc.

I5. Pais comprendido entre Lima y Guayaquil. Navegación, pescas. Limite singular de las estaciones en Payta.

I6. Reino de Quito. La quina, el cacao y los demás productos. Misiones y curso del rio de las Amazonas ó Marañón.

I 7. Nontes de Chimborazo Pichincha y Juriguragua. Observaciones de los Académicos franceses y Oficiales españoles. Caminos de Popayan y minerales de oro.

i8. Descripción del Brasil en cuanto se combina con las medidas nuestras. Navegación del Marañón. Productos ítiles para el comercio. Límites naturales para la conveniencia recíproca. Desembocadero de nuestros frutos por el Orinoco.

I 9. Bocas del Orinoco y gobernación de Caracas. Costas de Maracaibo, etc.

20. Curso del rio de la Magdalena hasta Santafé y Popayan. Naturales indómitos que los habitan. Negros y mulatos que atienden á la agricultura. Estado de las minas.

21. El Choco y el Dánon.

22. Istmo de Panamá.

23. Resumen de la población y productos de la América meridional. Beneficio de sus minas; sus industrias rurales y azogues; costumbres de sus habitantes y causas físicas que se oponen por largo tiempo á su prosperidad.

Los materiales para estos capítulos se hallan todos reunidos, en mi entender, con una más que mediana claridad:

I. En las obras de los Excmos. Sres. Juan y Ulloa, y particularmente en las noticias americanas.

2. En las memorias manuscritas de los mismos Oficiales, presentadas al Gobierno á su regreso.

3." En los viajes y reflexiones físicas de los Sres. Bouguer y Condamine.

4." En la excelente colección de los mercurios peruanos.

5. En la historia de Chile del Abate Molina.

6." En las dos obras de los Sres. Alcedo, padre é hijo.

$70^{\circ}$ En algunos apuntes del Médico de Lima, D. Cosme Bueno, conocidos bajo el nombre de Lazarillos de los Cicgos.

8. En los papeles manuscritos de D. Antonio Pineda, de los cuales va una parte ordenada.

9. En las descripciones físicas ordenadas desde Buenos Aires hasta Coquimbo inclusive, que remitimos durante el riaje.

ro. En las Guías de forasteros de Lima y Buenos Aires de estos últimos años, que se hallarán en los archivos de Hacienda y Gracia y Justicia.

II. En la colección nuestra de papeles manuscritos relativos á las Costas Patagónicas, Malvinas, Chile, etc.

I 2. En los manuscritos y diarios de los Sres. Heenke y Nee, los cuales han atravesado filosóficamente la Anérica meridional.

13. Finalmente, en los archivos de Hacienda y Gracia y Justicia, por lo que toca á la población y mejoras interiores, y en la excelente colección de manuscritos del Sr. D. Manuel de Ayala.

Pero áun cuando supusiésemos que los escritos nacionales no adoleciesen del doble mal inevitable de haberse siempre ordenado con el interés natural de los empleados que los remitían y del respeto, ó mejor dicho, esclavitud á las leyes y costumbres patrias, siempre el semblante tan vario que toma á cada paso la América y el pormenor de los pasajes de los cuales se intenta tratar en la obra, exigirían irremediablemente que le consultasen á viva voz los muchos hombres instruídos y de autoridad que desde el Ministerio del Marqués de la Sonora han recorrido y organizado la América cual se halla hoy en día. Los escelentísimos Sres. Ex-Vireyes Vertiz y Loreto, por lo que toca al Rio de la Plata y provincias interiores de aquel Vireinato; D. N. Marien y los Directores de la Compañía marítima de Pescas por lo que corresponde al Puerto Deseado; el Sr. 1). Tomás de Acevedo, Visitador de Chile; D. Jorge Escobedo, Intendente del Potosí y Visitador del Perú, y D. José García de León y Pizarro, Visitador del Reino de Quito; el Coronel de Ingenieros D. N. Requena, último Gobernador de la provincia de Maynas; D. Francisco Saavedra y el Marqués del Socorro, exGobernadores de Caracas; D. Vicente de Rivas, ex-Director de la Companía de aquellas provincias; Don N. Calvez, ex.Presidente de Chanas, y D. Vicente Ore, Corregidor en la Sierra del Perú, son otros tantos sueretos (1ne del)en consultarse prudentemente, por manera que ni se malogren las excelentes noticias que han 
acopiado, ni la obra decline insensiblemente al plan de reforma que procuraron introducir y tantos inconvenientes ha producido en la $\Lambda$ mérica. En cuanto á Misiones, podrían también suministrar noticias importantes los Procuradores de los diferentes Colegios que residen en esta Corte, y en particular el de Santa Cruz de Ocopa; así como serán utilísimas la Historia fisica del Paraguay, escrita por el Capitán de navio D. Félix Azara, destinado en la línea divisoria del Brasil, y la de la provincia de Buenos Aires del Oidor de aquella Audiencia D. Rafael de Videsigue; pero estos dos tratados no han sido aún remitidos á Madrid; el primero se ha pedido á Roma al Excmo. Sr. D. Nicolás de Azara, su hermano, quien lo recibió en el año pasado, y el segundo debe haberse presentado ahora al nuevo Virey D. Pedro Melo. Algo queda por decir sobre la in. teresantísima colección de manuscritos de D. Manuel de Ayala; este celoso individuo ha empleado, no sólo una gran parte de su vida, si también la mayor parte de sus caudales, en acopiar la dicha colección, la cual, ofrecida reiteradamente á S. M. para que se custodiase con la debida reserva y sirviese al mismo tiempo de norma para los varios asuntos que se ofrecen tratar en su Consejo de Esstado, debía producir á su autor, no sólo los debidos aplausos de todo el que se interesa en el bien público, si también algún premio que resarciese en parte los sacrificios hechos del tiempo y del dinero. Sería tan imprudente de su parte como de la nuestra el que la obra ahora proyectada aprovechase de todas las noticias allí comprendidas, dejando despues un caput mortorum inútil absolutamente para todo lo que fuese relativo á la América. Esto parece dictar, y así lo haré presente á S. M. (dentro de pocos días), que finalmente se adquịera con regulares condiciones la colección indicada y que la apioveche en primer lugar nuestra obra, extractando libremente todo lo que pa. rezca convenir para su mayor utilidad y hermosura.

La descripción del Brasil no necesitará en nuestro plan tanta extensión como la exigen las posesiones nacionales; basta que el lector estudioso sepa la calidad de su suelo, la clase de sus moradores, sean indígenas ó colonos, sus industrias minerales y comercio, para que pueda valuar después ó la fuerza real del enemigo doméstico, ó los principios de discordia é inquietud que puede causarle su inmediación; se ha consultado en esta parte con la mayor escrupulosidad todo lo que ha escrito el Abate Rainal, y merece, según los mismos portugueses, muy poca ó ninguna fé; mucho mejores datos podrán derivarse ó de las noticias verbales del Coronel Requena, ya nombrado, ó de las que ya ha enviado y seguirá enviando el Excmo. Sr. Marqués de Oyra, Embajador de S. M. en la Corte de Lisboa.

Como lo hice ver en la Introducción, la descripción física de la América, dirigida al bien sólido nacional, debe tener siempre á la vista los tres puntos esenciales: $r .{ }^{\circ}$ La prosperidad y multiplicación de la especie hu. mana, cualesquiera sean las castas de que se compone ó los climas que habita. $2 .{ }^{\circ}$ La reunión de la sociedad, esto es, de las colonias y de la matriz, de modo que sus labores é industria conspiren unánimes á la felicidad común, siempre ligada con los sugerimientos de la naturaleza, madre y maestra común, cuyos preceptos, mal atendidos, se convierten inmediatamente en otros tantos rigores imposibles de contrarestarse. $3 .{ }^{\circ}$ Finalmente, en la defensa de toda la sociedad, la ménos molesta y más segura que dicten las conveniencias locales y los progresos de la opulencia. Fácilmente, con estos principios á la vista, se podrá conducir al filósofo desapasionado, á considerar en la América meridional las cuatro especies diferentes de habitadores que han contribuído con tanto vigor al choque contínuo de sus leyes y sistema. Los salvajes indígenas; los sermberos invasores; los españoles introducidos después, y últimamente la continua conducción de los negros, bastarian por sí solos para constituir la necesidad de un examen separado de nuestra especie; agréguese á esto el afán nacional para buscar las minas colocadas por lo común en los terrenos más áridos, elevados y desiertos; considérese el efecto que esa misma clase de industria, semejante á la del jugad or, debía producir en la robustez del hombre, en la colocación de los pueblos, en la ingratitud de los cultivos y en la suavidad de las costumbres. La his. toria civil de la América descubrirá inmediatamente á los ojos del observador desapasionado las causas directas de su estado actual; le hará remontar poco después por un orden sencillo al estado en el cual se hallaba al tiempo de la conquista, y le conducirá entre el caos de las cosas venideras, á descifrar la suerte de aquella grande porción del globo y de los individuos que la habitan. Ya no es tan difícil, al ménos tan complicado, el tratar con utilidad y amenidad el segundo libro que abraza la América septentrional desde el Istmo de Panamá hasta los límites más elevados de la California y provincias internas; sus capítulos pudieran dividirse de tal modo que la provincia de Costa Rica y Veragua, abracen el primero; el segundo el reino de Guatemala; los otros seis siguientes el reino de Méjico libre de invasiones; el sétimo las provincias internas del Oriente; el octavo las del Occidente; el noveno las Californias antigua y moderna; el décimo las costumbres mejicanas en todas sus partes comprensivas del reino de Guatemala: el undécimo las costumbres de los salvajes habitadores de la Costa Rica y Veragua al Sur y de las Californias al Norte; el duodécimo nuestras indagaciones físicas hechas sobre las orillas del mar Pacífico; el trece la costa y provincia de Campeche; el catorce la Nueva Orleans y Florida, con algunas nociones de Kentuki y de la Georgia; el quince los establecimientos ingleses de la costa de Honduras; el dieciseis, finalmente, el estado de la industria y población de todos los dominios nacionales, y como ya lo hemos manifestado en el capítulo primero, las trazas evidentes de la historia de la conquista y los indicios de Io que deben producir en una época determinada mancomunados como lo están en el día la naturaleza, la legislación y el sistema nacional, si puede llamarse así.

No se extienden las reflexiones de este libro á los paises más septentrionales del Nuevo Mejico, inclusas las costas de Juca, Nutka y los paises inmediatos á la Siberia, porque los individualizarán con más propiedad y extensión los Oficiales encargados de la redacción del viaje de las goletas Mexicana y Sutil al Estrecho de Fuca; y por lo que toca á una idea de la Isla de Habana y de las otras Antillas, el mismo orden de las ideas irá dictando si debe considerarse como útil ó como supérflua. 
Las materias para este libro deben sacarse principalmente de las Cartas de Cortés, de la Historia de Clavijero y de los muchos manuscritos útiles del Archivo de Ayala. Los jesuitas y el Oidor honorario D. José Velazquez han descrito tambien con mucha ciencia y elegancia diferentes provincias de ese gran Imperio; y como desde la visita del Excmo. Sr. D. José de Gálvez, y sus disposiciones sucesivas cuando fué Ministro, se hallan perfectamente sistemadas sus diferentes provincias, sea en cuanto á numeración de pueblos, vigor de las leyes, beneficio de las minas y cultura de los campos, como por lo que mira á los desembocaderos al mar y comunicación con la matriz de los productos útiles y necesarios; resulta que no es tan necesaria una confrontación nimia de estos elementos con las personas que la han administrado estos últimos años, tanto más que el voto íntegro y perspicaz de todos ellos puede considerarse reunido en una sola persona, y este es el Fixcmo. Sr. Conde de Revillagijedo. A estos documentos agréganse todos los que hemos adquirido y van comprendidos en el paquete número 3. Su mismo índice denota su importancia, y por lo que toca á las provincias internas y costas de California, pueden considerarse extractados los mejores documentos en la Memoria que formé en aquel entonces y ahora acompaño igualmente con los papeles indicados. En nuestro plan todo el continente de la América, del cual se ha hecho mención hasta aquí, debía manifestarse por medio de cartas geográficas, las cuales separasen en primer lugar las posesiones nuestras de las extranjeras y entre aquéllas dividiesen áun á la vista del ménos reflexivo, los paises de misiones y los que habitan los pueblos salvajes, de los que siguen radicalmente y sin violencia nuestras costumbres, nuestra religión y nuestras leyes. Esta scparación, libre de todos aquellos nombres de pueblos y naciones errantes que sólo sirven para cansar la vista y la memoria del que quiere ocuparse en estas materias, y ceñida á la misma razón tan sólo por los puntos fortificados y residencia de Jefes, Gobernadores y Obispos, facilitaría el estudio cabal de nuestros dominios; y últimamente dictaría por sí solo cuáles son las Misiones que deben promoverse, cuáles los terrenos que pueden poblarse, dónde el colono podrá estar seguro sin más reunión que la de su familia, dónde necesitaría formar una sociedad numerosa para resistir á las hostilidades traidoras de los salvajes, cuáles son, en fin, los derechos territoriales de cada nación de las que han tomado parte en la posesión de la América: semejante empresa no está fuera del alcance de nuestras fuerzas. Háse adquirido y se van adquiriendo materiales importantísimos, pero de ninguna manera pudiéramos prometernos el llevarla á debido efecto, mientras D. Felipe Bauzá, particularmente encargado de este ramo, no acabe el Atlas Hidrográfico, en el cual se halla hoy día totalmente ocupado.

Este segundo libro será, por su naturaleza, mucho más entretenido y metódico que el primero. La unidad de Méjico y varias otras de las principales del Reino, llevan consigo el semblante de la opulencia, del orden y de las antiguas costumbres españolas. En las minas situadas aquí en terrenos ménos altos y estériles que en el Perú, combinan para su labor y beneficio los brazos necesarios, la subsistencia fácil y los fondos inagotables; ábrense cada día nuevos objetos útiles en la agricultura, sca para el propio consumo ó para la exportación extranjera; y si bien á la inversa del Perú faltan aqué rios navegables que faciliten la comunicación de uno á otro extremo del Reino, pueden considerarse como ventajas casi equivalentes la no mucha distancia de los dos mares, la igualdad de los productos en todas sus partes, y el inmenso número de mulas, cuya destrucción no es tan común por la mayor suavidad del suelo. Los mejicanos, bien sea por una agricultura mejor ordenada, ó por otras mil causas que ahora es importuno el indagar, se han prestado mucho más para mancomunarse con los conquistadores de lo que se hayan prestado los peruleros, de lo cual ha dimanado, como era natural, el que las leyes tengan más vigor; que la mano de obra sea más barata y periódica; fmalmente, que en todas las empresas relativas á las industrias del suelo, pueda calcularse con la misma probabilidad con la cual se calcula en Europa. Saldrán, por consiguiente, muy luégo á la vista del observador racional, los acopios inmensos de algodones que de las provincias meridionales pasan á tejerse á Puebla: las granas de Oaxaca, los añiles y azúcares que ahora se multiplican con tanta rapidez y prosperidad. Las provincias de Yucatán y Campeche ofrecerán al paso tinte: la Nueva Orleans las maderas, y las mismas provincias septentrionales, aunque no bien sistemadas, contribuirán sin embargo, á la prosperidad y reunión de la Monarquía con aquellos productos, de los cuales no es capaz un país situado en la Zona Tórrida y en particular con la variedad y crecido número que únicamente pueden equilibrar en cierto modo nuestro comercio del Asia.

Las Misiones en la América septentrional que ahora tenemos á la vista, no son tampoco por su misma posición, tan desordenadas como en la América meridional. Las hay tan sólo en los dos extremos del Sur y del Norte, poco útiles á la verdad, tanto hacia el Istmo de Panamá como hacia los puebios rayanos de nuestras provincias internas; pero que no sería, sin embargo, prudente el abandonar, así por prometer muchos y mejores efectos en ambas Californias, como porque son por naturaleza otras tantas guardias vigilantes sobre la mayor extensión de nuestros límites relativamente á las potencias rivales de la Europa, y la menor aproximación de los salvajes á nuestras colonias ordenadas. Pero para los razonamientos más fundados del sistema político nacional, importa mucho el examinar filosóficamente aquellos países, y ver hasta dónde la naturaleza y la legislación han inflúfo para llevarlas al estado en el cual se hallan hoy en día. Una atención particular no puede omitirse relativamente al examen, del cual ahora tratamos, y es el verdadero estado de las provincias de Sonora y Pinceria, del cual, si bien he procurado dar una idea cabal en la Memoria indicada de las provincias internas, la creo, sin embargo, más bien concisa cuando se trate de destruir definitivamente los conceptos errados que años há se habían formado de aquellos paises, y que ahora pudieran conducirnos á consecuencias muy funestas cuando se tratase de establecer los límites del Imperio sobre las descripciones cmprenclidas. 
Pero ya es tiempo de pasar al tercero y último libro, el cual hablará de las posesiones españolas en Asia, esto es, de las Marianas y Filipinas. En esta parte, para el filósofo observador, la naturaleza no es ménos entretenida que la segunda, y la sola Isla de Luzón, examinada por nosctros con bastante exactitud, es capaz de suministrar materiales fecundísimos para la instrucción nacional. Con la diferencia de pocas horas, puede conducirse al lector, atónito de la suma fertilidad de un suelo cultivado con todo el arte que pueda desearse, á unos bosques impenetrables y húmedos, donde el mismo sol no tiene cabida alguna. De unos pueblos civilizados, tranquilos y el retrato de la docilidad del malayo y de su feliz multiplicación, á unas tribus errantes, montaraces y parecidas más bien á las fieras que á los hombres. Y de la suma sequedad á la lluvia casi continua de seis meses.

La salubridad del clima de las Filipinas; su posición esencialmente útil para el comercio combinado de Asia con la Europa y la América; la misma facilidad con la cual allí se multiplica la especie humana por manera que puedan surtirse fácilmente la navegación y las emigraciones periódicas en una Monarquía tan extendida como la nuestra, han merecido ya en este siglo la atención y la envidia de las naciones comerciantes y europeas, y exigen ahora de nuestra parte un examen reflexivo y dirigido del solo bien nacional. La nación malaya merece por sí el examen del filósofo. Propensa con extremo á la navegación, ha emigrado ella sola con más tino y facilidad que nuestros europeos, en cualquiera siglo se observe; propensa á la multiplicación, ha adoptado los alimentos, los trajes y la legislación que más le convenían para este intento; tan apacible en las sementeras y en las chozas, como feroz en la guerra, se lia amoldado, sí, á nuestro sistema; pero al mismo tiempo ha modificado, para hacerlos llevaderos, los varios arbitrios que habiamos introducido en ambas Américas. Finalmente, del sumo grado de civilización con el cual se presentan en nuestras Fỉipinas, han podido pasar al sumo grado de rusticidad y libertad política, con el cual se presentan en las varias islas del Mar Pacífico, sin abandonar, sin embargo, su instinto primitivo: el de vivir subordinados, multiplicarse, trabajar para su sustento únicamente y llevar una vida alegre y divertida.

No debe inferirse de las hostilidades y rencor que contra nuestros isleños esplayan los más meridionales de Borneo, Macasar, etc., que la especie no sea la misma de unos y otros. Las invasiones europeas; la tiranía codiciosa de los holandeses; nuestras guerras poco advertidas del siglo pasado en aquella parte del mundo; el mismo afán imprudente de introducir la religión y á su sombra la violación de los derechos, son las verdaderas causas que han atizado y conservan aún esta guerra fatal, la cual nos despoja anualmente de seiscientos á ochocientos vasallos y nos hace malograr los inmensos productos de un crecido número de islas fertilísimas. No es arrojo el asegurar que hallado un arbitrio para que cesase esta guerra continua, la población de las Filipinas pudiera crecer inmensamente y subsanar, siquiera en parte, la destrucción periódica de hombres que la, posesión de la América, y mucho más el beneficio de las minas, causan constantemente á nuestra Pe. nínsula.

De lo dicho se infiere que la descripción física de las Islas Filipinas debía tratar con distinción en primer lugar del clima, posición y feracidad del suelo, y después de sus moradores y de las costumbres que los distinguen, sea en cuanto á agricultura, industria y artes, como al idioma, música, vida doméstica y genio militar.

No merecen menor atención las dos clases diferentes de pueblos que habitan los montes interiores de la Isla de Luzón, y son los igorrotes y los negrillos. Octípanse contínuamente los misioneros en retraerlos de la vida brutal á la cual están entregados entre los bosques; pero la legislación, ó por mejor decir, aquella serie de órdenes que se lleva á debido efecto, se le opone directamente; y así en este momento más bien hemos perdido que adelantado en esta parte esencial de nuestros pasos, ni es fácil conocer si disminuyendo el nímero de aquellos salvajes en razón del método con el cual viven, podemos esperar para las épocas venideras un día en el cual ó se destruyan enteramente ó se agreguen á nuestra sociedad los pueblos indicados.

Las Islas Marianas, cuales son en el día, no suministran materiales para un examen tan detallado. Son ciertamente falsas las ponderadas descripciones de su numerosa población al tiempo en que las conquistamos. Al contrario, no es en nada ponderada la descripción de su fertilidad; pueden considerarse como el límite de las Monzones que causan la fertilidad en los mares del Asia; hay, sin embargo, bastante humedad para que los frutos de la agricultura, incluso el beneficio de la azúcar, pudiesen sustentar un número grandisimo de habitadores, y su division en varias islas, fáciles á comunicarse una con otra, daría tal vez lugar á que la repartición de los ramos de industria fuese más metódica, como también la segregación de los díscolos, la introducción de los colonos emigrados de las Islas Carolinas, etc. Es á la verdad bien sensible que carezcan absolutamente de puertos para un crecido número de buques. El pequeño puerto de Apra ó San Luis, apenas pudiera contener tres ó cuatro embarcaciones de no mucho porte; pero en desquite las radas de Humata y Finian, son accesibles y seguras en casi todo el año.

Después de las ideas indicadas de las Islas Marianas y Filipinas, era mi ánimo el presentar al lector un extracto juicioso de los productos y climas de las demás islas que ciñen el mar Pacífico por el Oeste. Son generalmente habitadas, ó por los malayos ó por los negros. Tal vez exigen alguna atención los habitadores de la Nueva Caledonia, Nueva Holanda y Nueva Zelanda, los cuales parecen derivar en su origen primitivo de otras castas distintas.

Concluído aquí lo que se refiere al segundo tomo, es tiempo ya de pasar al tercero; esto es, al examen político de la América. Obra delicadísima, la cual exige tal vez mayor pulso y cautela de las que caben en mi método de tratar estas materias. Yo había comprendido que después de la inmensidad de proyectos que desde la conquista se habian propuesto al Gobierno en diferentes tiempos, el proponer nuevas especies que 
no variasen de aquel método hubiera sido cansado, inútil y tal vez ofensivo para los depositarios del orden público, los cuales en el día vigilan más de cerca y con mayores conocimientos sobre la buena administración de toda la Monarquía. Advertí en las diferentes épocas y en los diferentes paises de la América que iba recorriendo, que el mal primitivo y la causa sola de nuestros desórdenes estribaba en la Constitución. Me convencía de esto mismo así al recorrer las historias políticas nacionales como al tener á la vista todos los asuntos relativos á la América que ocupaban hoy en día al Gobierno; ni á la verdad nuestro método de administrar aquellos dominios, podía llamarse rectamente una Constitución cuando atendiésemos las diferentes causas que desde los Reyes D. Fernando y Doña Isabel hasta nuestros días, ya hicieron de la América el teatro de mil hazañas de parte de nuestros conquistadores aventureros, ya separándola del Continente casi en el mismo modo en el cual estaba antes de descubrirse, la hicieron fácil presa ó de los piratas salteadores que por uno y otro mar la bloqueaban exteriormente, ó de los que gobernaban en el país interior los indios y los colonos, ó ya, finalmente, en las últimas épocas variaron tantas veces el método de gobernarla y defenderla cuantos dieron cabida á los muchos proyectos que se presentaban para este intento. Confundiéronse indistintamente con el nombre de América los paises desiertos de la parte meridional, las poblaciones colocadas sobre las cumbres más altas de los montes y las que gozaban del convenio y navegación de la orilla. Confundiéronse los paises sugetos á nuestras leyes con los que habitaban los salvajes aún no domesticados; nuestros enlaces territoriales con las potencias rivales europeas se hicieron cada día más oscuros y complicados; pretendióse aplicar al Reino de Méjico y á las Filipinas lo que tal vez podía ser oportuno para las provincias de la Plata ó del Perú; finalmente, los pedriscos áridos y desiertos de las Malvinas y costa Patagónica y los miserables anfibios de la costa de Nutka, causaron á la nación conquistadora mayores gastos y riesgos que los que tal vez le causaron las tierras fertilísimas y las ciudades populosas del Reino de Méjico y las Filipinas.

Este pequeño extracto de la historia nacional pedía mayor atención cuando lo refiriésemos al estado actual de las cosas; aún ignorábamos los límites del Imperio. Un Virey proponía invadir lo que otro había abandonado; la utilidad del sistema religioso en las Misiones se confundía con su vida escandalosa en los pueblos grandes; ya se equivocaban los abusos con las causas y las causas con los efectos; finalmente, no había cálculos ni medidas que alcanzasen á definir rectamente cuál era la influencia de las colonias sobre la matriz; cuáles los derechos legales de entrambas, cuál su utilidad recíproca, y cuál, finalmente, el efecto de una tan grande extensión de dominios sobre la felicidad individual y sobre la verdadera fuerza racional.

Un desorden tamaño de ideas, remontaba naturalmente hasta las épocas de la conquista. Era menester decidir estas grandes cuestiones: si el descubrimiento de la América y los accidentes que de él han dimanado hasta el día, pueden considerarse como una felicidad para la España actual; y si atendidas todas las circunstancias de la Monarquía, y combinadas con el estado político de todo el globo, debe prometerse una grande prosperidad de la administración ó sistema nuevamente propuesto. Porque, Rmo. Padre, jamás podrá parecer plausible una reforma si no se demuestran evidentemente los males que dimanaran del sistema anterior; jamás podrá haber harmonía en las leyes y amor de toda la sociedad hacia ellas, si no comprenden los hombres reflexivos, ó su necesidad ó su utilidad.

Esto supuesto, me parece que el tratado político proyectado debía tomar su origen á imitación del señor Roberston, del estado de España al tiempo del descubrimiento de la América. No se exigen aquí aquellas particularidades, propias tan sólo del historiador, que desmenuzan las épocas, los trances, el carácter de los sujetos, y cuanto conduce al conocimiento de las cosas pasadas. El político, parte donde acaba el historiador; el uno describe lo que ha acaecido en otras épocas; el otro, combinando lo pasado y lo presente, pasa á investigar y á dirigir con acierto lo venidero. Pero al mismo tiempo ocurríase una dificultad considerable, y era la de fijar con certeza el estado de opulencia en el cual se hallaba la Monarquía al tiempo de sus conquistas ultramarinas. La famosa feria de Medina, tomada por nuestros escritores políticos como la piedra de toque de la antigua opulencia nacional, citándola toda por la sola autoridad de Sancho de Moncada, parecía después de un examen moderno sumamente equivocada, ó bien se consultasen los armamentos de Colón y Cortés en sus cartas al Emperador Carlos V, ó examinásemos las notas á las Ordenanzas de Marina del Reino de Aragón, copiadas y publicadas por D. Antonio Capmany ó recorriésemos, finalmente, con el escritor perspicaz de la historia del Potosí, aquellos tiempos en los cuales Jacobo I, Rey de Aragón, ordenaba que ninguno pudiese comer más de dos viandas, sin exceptuarse él mismo de esta ley. Fernando el Católico decía á su tío el Almirante de Castilla: "Quedáos á comer con Nos, que tenemos pollas.» Y el mismo, pidiéndole las Córtes de Castilla dejase entrar pimienta y canela que había empezado á venir de Portugal por la India, decía: "Excusemos esto, que buena especia es el ajo.»

Sin atreverme á penetrar ahora en lo más sagrado de nuestras historias nacionales y en la presente crítica con la cual deben interpretarse, diré, sin embargo, que merece suma atención esta materia para deducir con cordura del influjo del descubrimiento y gobernación de la América, sobre la prosperidad nacional. Ni nos alucinen ó las abultadas fábricas de Segovia, ó los muchos telares de Sevilla y Granada. Tal vez no existieron, tal vez no alcanzaran en el estado de los telares de entonces, á vestir medianamente la sola Nación, cuando por otra parte los franceses, ingleses y moriscos, hallábanse aún en mayor pobreza que nosotros, y los italianos se abastecían por sí mismos de las ferias más opulentas de Alejandría. Demostrado que la Nación era pol)re al tiempo de la conquista; que sus esfuerzos militares en la América no pudieron causar su despoblación y debilidad; que después de la expulsión de los moriscos, ni siquiera las guerras de Flandes é Italia pueden compararse en cuanto á destrucción á las guerras civiles de Inglaterra, Francia é Italia; es preciso, 
finalmente, indagar una causa de la cual dimane rectamente la despoblación, la pobreza y el desorden natural de España; y esta causa no es otra, en mi entender, que la posesión ilimitada y la gobernación desordenada de América.

Pero sería el dar una extensión enfadosa á estos apuntes, si quisiese analizar uno por uno los diferentes razonamientos que me han guiado en esta senda oscura, para desenvolver los inconvenientes políticos de la posesión de nuestras colonias y los remedios que presentan sus circunstancias. En un momento en el cual todos los lazos del órden social se han examinado separadamente y unidos entre sí; en un momento en el cual se han traído á la práctica todos los abusos dictados por el demasiado abandono de los metafísicos á sus imaginaciones exaltadas, no será tal vez difícil el demostrar que el sistema de las colonias, de quien dimana el sistema mercantil, ha sido y será el origen de muchos males que agobian á la Europa en el día. Con esta atención, me ha parecido, pues, más oportuno el ordenar también esta parte de la obra en los capítulos siguientes, los cuales abrazan ó el todo ó el mayor número de los objetos que deben tenerse á la vista en el tratado propuesto. Sírvase V. S. recorrerlos con alguna atención y seguirme después en las reflexiones importantes que de allí mismo deben dimanar.

\section{TOMO III}

\section{Examen político de los dominios ultramarinos de España.}

\section{INTRODUCCIÓN}

Capitulo x." Se analiza el verdadero estado de la opulencia nacional al tiempo de la conquista de América.

2. Se hace un resumen de las emigraciones que ha causado á la matriz su posesión. Inconvenientes del sistema militar; esto es decir, pocas mujeres y muchos célibes.

3. ${ }^{\circ}$ Se examinan las costumbres políticamente y su influjo natural, sobre el no regresar los empleados ó emigrados nuevamente á España. Util efecto en esta parte del comercio libre.

4. Correspondencia de los diferentes periodos de la histurin "nacional en América y en Europa, y órdenes Reales para que procuren beneficiar en la nueva España la seda y el cáñamo, y en los reinos de Murcia y Valencia el añil y grana.

5. Análisis del sistema nacional de las minas. Historia del valor de los metales ricos en América, en Europa y en el Asia, desde la conquista hasta ahora. Por qué á medida de haber crecido el producto de las minas, ha crecido la introducción del papel moneda. Discusión sobre la libertad de la introducción del azogue é historia de los contratos y abastos de este metal desde Europa, América y Asia.

6. ${ }^{\circ}$ Análisis del sistema de emigración y agricultura americana.

$7 .^{\circ}$ Influjo de entrambos sistemas en la legislación y administración de las rentas de América.

8. Idem en la administración religiosa.

$90^{\circ}$ Idem en el sistema militar de mar y tierra para su custodia y defensa.

ı. Retroacción de estas causas en el sistema nacional del Continente y amalgama viciosísima de los intereses recíprocos de éste y de las colonias.

Ix. Estado político de la Europa en la época actual y principios sociales á que propende.

\section{LIBRO PRIMERO}

Examen politico del continente meridional de la América, desde el Istmo de Panam i hasta el Cabo de Homos.

Capitulo 1.0 Por qué toda esta parte extensísima de la América, debe, como en las primeras épocas de la conquista, formar una sola gobernación. Distinción en ella de los paises agrícolas y de las minas.

2. ${ }^{\circ}$ Enlaces y reunión recíproca de los diferentes paises que componen esta región, sus productos y sus necesidades. Sus relaciones con el Continente antiguo y sus enemigos internos y externos.

$3 .^{\circ}$ Sistema de legislación que rige en el día; sus contradicciones y su debilidad.

$4 .^{\circ}$ Método para su sistema militar, relativo á las invasiones externas.

$50^{\circ} \quad$ Método para su sistema de agricultura, comercio y población.

6. Colocación de las diferentes autoridades y medios para evitar los choques entre unas y otras.

$7 .^{\circ}$ En qué puede contribuir al bien general de la Monarquía y cuáles son sus derechos para que ésta sea garante de su conservación territorial.

9. ${ }^{\circ} \quad$ Sistema relativo á las colonias del Brasil.

ro. Idem á las colonias de Orinoco y Guayana.

I . Sistema de las Misiones y reforma del estado eclesiástico.

I 2. Subsistencia de la parte correspondiente de la Armada.

13. Determinación de nuestros límites y su ratificación con las potencias de la Europa. 


\section{LIBRO SEGUNDO}

Examen de la América septentrional desde el Istmo de Panami hasta las fronteras del Norte.

Capinulo I. Estado de las minas en el reino de Méjico, en las provincias internas y en el reino de Guatemala y Tierra Firme en el Sur.

2. $\quad$ Estado de su agricultura y productos de industria.

$30^{\circ} \quad$ En qué necesita la América septentrional española el auxilio de las demás partes constituyentes de la Monarquía para su prosperidad interna.

4. ${ }^{0}$ Utilidad de las reformas del señor Marqués de Senora.

$50^{\circ} \quad$ Su sistema de comercio.

6. Su sistema de misiones.

$70^{\circ}$ Enemigos externos é internos con los cuales debe lidiar.

8. Se examina particularmente la invasión inglesa del reino de Nicaragua.

9.0 Límites con los Estados-Unidos de la América, determinación de nuestra frontera del Norte y su ratificación con las potencias de Europa

Iо. Subsistencias de la parte correspondiente de América.

I I. Sistema económico y militar de esta parte de la Monarquía.

I2. Hasta dónde puede contribuir á la prosperidad nacional y cuáles son los enlaces suyos con la matriz.

I3. Sistema de legislación que rige en el día y sus inconvenientes y debilidad.

I4. Nueva colocación de las diferentes autoridades y medios de evitar sus choques.

I5. Enlaces de esta parte del muindo con el Asia.

I6. Emigración de la China sustituída á la de los negros.

\section{1: IEIBRO TERCERO \\ Sobre los establecimientos nacionales de las Filipinas y Marianas.}

Capitulo i. Cuál es la utilidad de las Marianas y bajo de qué sistema deben conservarse. Emigración de la China y de las Carolinas á su favor. Emigración, causa y gubernativa de los europeos y filipinos.

2. Proyectos actuales de agricultura en la Isla de Luzón.

3. Despoblación y poca seguridad de las demás Islas Filipinas.

$40^{\circ}$ Causas de esta despoblación y método de atajar estas irrupciones de los solvanos y mindanaos.

5. Sobre la civilización de los igorrotes y negrillos de la Isla de Luzón.

6." Sobre la conservación de los presidios de Batanes y Mindanao.

$70^{\circ}$ Estado de las naciones europeas en el Asia y sus conexiones con las Filipinas.

8. Sistema nuestro de defensa en el Asia.

9. ${ }^{a} \quad$ Sistema nuestro militar para hostilizar.

ro. Comercio de la Europa con la China y utilidad de hacerlo discreto con la América.

I . Manutención en las Filipinas de la parte correspondiente á la Armada.

I 2. Sistema religioso en las Islas Filipinas.

13. Utilidad que pueden rendir dichas Islas al total de la Monarquía y sus derechos para ser defendidas.

14. Sistema de gobierno y residencias de los diferentes depositarios de la autoridad pública.

\section{Conclusión}

Capitulo 1.0 Resulta de la naturaleza de los principios sentados, que el Código antiguo de la legislación de América no puede subsistir, y que en el nuevo deben atenderse las circunstancias de cada una de las tres partes indicadas, por manera que la legislación de la una no se aplique á las otras.

2.0 Unidad del sistema religioso y del militar con la matriz.

3. ${ }^{\circ}$ Grandes franquicias de navegación, industria, comercio y agricultura.

4. Indiferencia á favor de las minas.

5.․ Influencia de la posesión de la América en la población y costumbres de la España. Emigración, educación, holgazanería; ningún amor á la patria, inconstancia y debilidad de las leyes. Idea crrada de las riquezas. Efecto de la circulación violenta de la plata.

6. Se propone un sistema de comercio para la Anérica, que sea lítil, mas nunca pueda ser pernicioso á nuestro continente.

7." Idea de un puerto franco en lispaña para el comercio extranjero con la América. 
8. Reflexiones sobre el impuesto de nuestro continente.

9. Derechos recíprocos de la matriz y de las colonias.

ro. Emancipación moderada de las colonias y prosperidad y fuerza respectiva de la matriz.

I I. Unión legal de toda la Monarquía.

Dos reflexiones de la mayor entidad son las que nos vienen al encuentro después de la difusa enumeración que precede; la primera, si efectivamente el tratar de la emancipación de las colonias divididas en los tres grandes trozos ó confederaciones que se han indicado, es una proposición en realidad tan odiosa y temible cual lo parece á primera vista; la segunda, si el tratado propuesto puede ó debe sin riesgo alguno ser público para toda la Nación y áun para las demás naciones, ó émulas ó superiores á nosotros en fuerzas.

En cuanto á lo primero, dice lisa y llanamente que en todos tiempos, desde la conquista, y mucho más en el día, tanto los empleados en América por parte de S. M., como las mismas colonias, han sido árbitras de eludir cualesquiera órdenes que se opusiesen directamente á sus intereses. Pocas veces con la violencia, de la cual, sin embargo, hay ejemplos impunes en ambas Américas y en las Filipinas, y por lo común con el soborno han triunfado siempre de las trabas de la legislación, y bastaría alegar á favor de lo que aquí se asienta, casi todos los artículos de nuestras leyes, casi todos los asuntos ocurridos ó pendientes en el Consejo de las Indias y en la vía reservada para demostrar que en el mismo choque de las autoridades y de la misma idea equivocada que acá se recibe de todos los negocios de allende, dimanan por una reacción natural la inutilidad de las órdenes, la ninguna responsabilidad en quien manda y en quien obedece, y últimamente todos los síntomas, aunque solapados, de una anarquía incurable.

Lejos de mí aquellas ideas de libertad y de independencia que, sacrificando el bien público permanente al egoismo momentáneo y por lo común engañoso, sólo conspiran á subvertir el orden de la sociedad y á hacer de los hombres mansos y apacibles unas fieras capaces de levorarse unos á otros. Pero tampoco se conciba la menor esperanza de que paises sumamente distantes y que no tienen entre sí la menor conexión, pueden sacrificarse uno por otro, ó bien en el libre albedrío de sus conveniencias ó en el abandono generoso de sus hogares y de su vida doméstica.

Hay, empero, una grande conveniencia en la reunión política de las sociedades numerosas y es la mayor facilidad para resistir á los enemigos externos; con tal que el suelo que se defiende sea proporcionado al número de defensores; con tal que la ofensa de un solo individuo de la sociedad sea trascendental á los demás; con tal, finalmente, que las fuerzas de todo sean proporcionadas á las del ofensor, estos reparos demuestran con evidencia que si bien no sea justo ni útil el desmembrar la Monarquía, es sin embargo preciso el templarla de tal modo, que dividida en cuanto á sus intereses y gobernación interiores, sólo se halle reunida en un solo centro, cuando se trate ó de los grandes esfuerzos nacionales, ó de aquella equidad intrínsica que excluyendo los monopolios y trabas, sólo se dirige. á la mayor comodidad, tranquilidad y seguridad de sus individuos.

Este es el sistema de la Inglaterra, la cual, después de las lecciones recibidas en la América septentrional ha emancipado la Irlanda, y apenas conquistada la Circega, la ha mirado como parte integrante del Estado y no como una colonia ó una conquista. Así en la antigua dominación de la España, la Flandes, el Portugal y la Italia, no dependían de ella sino en la parte militar; así, finalmente, hoy en día la nueva Constitucion francesa ha acomunado los derechos de la sociedad á todas las partes del mundo y á todas las castas que quisieren agregarse. Nosotros mismos (si recorriésemos con alguna atención nuestras leyes), no veríamos acaso los derechos concedidos de comunidad á todas las ciudades populosas de la América, los fueros de ciudadanos ratificados mil veces á los peruleros, mejicanos y filipinos; los tratados solemnes que nos reunen á todos en una sola masa, la misma inmunidad y derecho de radicarse, concedidos con tanta justicia como necesiclad á los negros. Y, en fin, si después de reconocido el suelo tan feraz de nuestras Américas y comparada su despoblación actual, tanto con el Africa como con las islas fertilísimas del Asia que bajo de un mismo clima alimentan un número grandísimo de hombres, puede aún creerse que tengan remedio los males políticos de aquella parte del mundo por los medios adoptados desde la conquista: siga enhorabuena nuestra Constitución; y la despoblacion, la d ebilidad y la independencia solapada de nuestras colonias, sean los únicos garantes de aquella paz interior que con tanta razón anhelamos.

Sobre la necesidad de hacer públicos estos razonamientos cuando hubiesen merecido la sanción de S. M. y de sus Ministros, ya no es preciso insistir mucho. Cuando el sistema de gobierno no es público y constante, cada uno, alegando ó la ignorancia ó el no acceder á ello, es inocente si conspira á violarlo en aquella sola parte que se refiere á sí mismo. No así cuando todos son sabedores de lo que por su parte deben hacer cuando cuentan con la estabilidad de las medidas tomadas con las razones que las apoyaron al tiempo de adoptarlas y con las circunstancias que pueden en un tiempo hacer tan útil una reforma como antes hubiera sido perniciosa... Pero me es preciso dejar la pluma. Recibo en este momento una orden de S. M. que aprueba el plan propuesto últimamente por V. P., y se reduce á tratar estas materias con reserva y separadamente las umas de las otras. Por mi parte coä̉yuvaré en cuanto pueda á este mismo plan, y ojalá deriven de él todos bienes y felicidades que he deseado constantemente á la Monarquía y á la Nación que me adoptó por suyo.

Concluyo, pues, ofreciéndome de nuevo á las órdenes de V. P. Rma., cuya vida ruego á Dios guarde por muchos años.= Madrid, á 3 de Octubre de r795. 



\title{
De cómo two origen el viaje de las corbetas
}

\section{Descubierta $y$ Atrevida.}

\author{
PLAN de un viaje cientifico y politico alrededor del mundo, remitido al Excmo. Señor \\ Bailio D. Antonio Valdés, Ministro de Marina, por los Capitanes de fragata \\ D. Alejandro Malaspina y D. Fosé Bustamante.
}

Excmo. SR.: Desde veinte años á esta parte, las dos naciones inglesa y francesa, con una noble emulación, han emprendido estos viajes, en los cuales la navegación, la Geografía y la humanidad misma han hecho muy rápidos progresos: la historia de la sociedad se ha cimentado sobre investigaciones más generales; se ha enriquecido la Historia Natural con un número casi infinito de descubrimientos; finalmente, la conservación del hombre en diferentes climas, en travesías dilatadas y entre unas tarcas y riesgos casi increibles, ha sido la requisición más interesante que ha hecho la navegación.

Al cumplimiento de estos objetos se dirige particularmente el viaje que se propone; y esta parte, que pucde llamarse la parte científica, se hará con mucho acierto, siguiendo las trazas de los Sres. Cook y la Pérouse.

Pero un viaje hecho por navegantes españoles debe precisamente implicar otros dos objetos: el uno es la construcción de cartas hidrográficas para las regiones más remotas de la América, y de derroteros que puedan guiar con acierto la poca experta navegación mercantil; y la otra la investigación del estado político de la América, así relativamente á España como á las naciones extranjeras.

El estado del comercio de cada provincia ó reino por sus productos naturales ó artefactos; su facilidad, dificultad para resistir uná invasión enemiga ó suministrar fuerzas para intentarla contra los mismos enemigos; la situación de los puertos más conducentes á facilitar el comercio recíproco; finalmente, los interesantes ramos de construcción ó productos navales, serán otros tantos puntos cuya investigación, causa y secreto no será inútil al Estado; tanto más que procurará nivelarse á diferentes axiomas políticos sobre la prosperidad nacional, cuya admisión ó repulsa dependerá de antemano de jueces respetables que hayan de examinar estas tareas; deberán por consiguiente quedar divididas en dos partes: la una pública, que comprenderá además del posible acopio de curiosidades para el Real Gabinete y Jardín Botánico, toda la parte geográfica é histórica; la otra reservada, que se dirigirá á las especulaciones políticas ya indicadas, y en las cuales, si el Gobierno lo hallase conveniente, podrá comprenderse el establecimiento ruso de California y los Ingleses de Bahía Botánica y Liqueyos; puntos todos interesantes, así para las combinaciones de comercio como de hostilidad.

La Real Armada podıá suministrar todos los sugetos para esta Comisión, menos los dos botánicos ó naturalistas y los dos dibujantes de perspectiva, que será posible y áun fácil hallar en Madrid voluntarios. En cuanto á lá clase de buques y calidad de armamento, podrán fácilmente combinarse los tres principales objetos de seguridad, comodidad y economía; el armamento de cada uno de los dos buques necesarios se reducirá próximamente á unos cien hombres. El detall, así de cada clase como de los aparejos, repartición interior, calidad y número de embarcaciones menores y pertrechos, y finalmente, cantidad y calidad de víveres, es demasiado prolijo para exponerse en esta ocasión; además, que no puede determinarse con precisión hasta que S. M. no tuviese á bien prefijar los límites de la expedición propuesta. 
El plan siguiente pudiera ocupar próximamente el espacio de tres años y medio, á empezarsc descle $1 .{ }^{\circ}$ dc Julio de I789, épocá en la cual pudieran salir las dos embarcaciones, si S. M., dignándose aprobar desde ahora lo propuesto, ó en un todo ó modificado, diese unos ocho mcses de tiempo á los que han de ejecutarla, así para el acopio de todos los materiales precisos, como para los estudios preliminares, y principalmente el ejercicio de la astronomía práctica.

Las dos corbetas saldrán de Cádiz en $I^{\circ}{ }^{\circ}$ de Julio de $7_{7} 89$ y se dirigirán á Montevideo, cn donde se hará nuevo arre zlo de relojes, las posibles observaciones astronómicas y todas las indagaciones de Historia Natural. Se adquirirán allí también varias clases de víveres para la manutención sucesiva de las tripulaciones, como para las experiencias que han de hacerse: desde este puerto se reconocerán las Malvinas, y si el Gobierno lo hallase prudente, la bahía del Buen Suceso, en cl Estrecho Le Maire; pues que parece ya evidente que este pasaje será la escala más cómoda y más barata para la navegación del Cabo de Hornos. Desde la bahía del Buen Suceso se hará derrota á montar el Cabo de Hornos: se procurará reconocer el Cabo Victoria y alguna Tierra del Archipiélago de Chonos; finalmente, se fondeará en Chiloé, lo que podrá verificarse hacia fines del año de 89. Todo el año de I79o se empleará en las costas occidentales de América, desde Chiloé hasta San Blas. Procurará simplificarse la navegación desde Guayaquil, Acapulco, etc., hasta Lima. Se buscarán las Islas del Gallego, y desde Acapulco se hará una excursión á Méjico.

El reconocimiento de las Islas Sandwich ocupará los primeros tres meses del año I79I. Luégo se costeará la California, se seguirá al Norte, entre el Asia y la América, hasta donde lo permitan las nieves, y hecha escala en el Kamsckatka (si el Gobierno lo tuviese á bien), se seguirá al Cantón para vender las pieles de nutria en favor de las marinerías.

La salida de este puerto tendrá, pues, lugar hacia Octubre ó Noviembre de I79I. Se aprovechará esta Estación para reconocer los Cabos Bogeador y Engaño, en la contra-costa de Luzón; luégo se pasará á Marianas, y desde allí se trabajará prolijamente la carta de la navegación por el Estrecho de San Bernardino hasta Manila.

Desde esta capital se hará derrota al reconocimiento de Mindanao, y después á pasar entre Celebes y Molucas, y pasando al N. de la Nueva Holanda, desembocar en el Océano Índico.

Costeada toda la parte occidental de la Nueva Holanda, se hará derrota (hacia Marzo de 92) á la Bahía Botánica; se visitarán luégo las Islas de los Amigos y de la Sociedad, y hacia Octubre ó Noviembre la Nueva Zelanda, de donde finalmente se hará rumbo al Sur, para después navegar al Noroeste, y ya montada la Nueva Holanda, entrar en derrota para el Cabo de Buena Esperanza, y de allí regresar á Europa en Abril ó Mayo de I793.

Los Capitanes de fragata D. Alejandro Malaspina y D. José Bustamante y Guerra, deseosos de emplear todas sus faenas en cl servicio del Estado, se ofrecen á la ejecución de este plan, lisonjeándose que concurrirán á dirigirlos para el mayor acierto, no sólo la ilustración y penetración del Gobierno, sino también cuantas noticias puedan facilitar los particulares, así del Continente nuestro como de todas las Américas. En cuanto á los subalternos, la especie de Comisión exige que sean todos voluntarios y que se conozcan recíprocamente, así por lo que toca á robustez como á capacidad. = Isla de León, Io de Setiembre de I $7 \$ 8$.

\section{De la pronta y categórica contestación de un gran Ministro à un brillante Oficial, accptando su ofrecimiento de dar la vuelta al mundo con dos buques: oficio modelo de sobricdad, previsión, sencillez y sentido práctico.}

"Ha merecido la aceptación del Rey el proyecto de dar la vuelta al mundo en los términos que propone Vm. en carta de Io de Sctiembre último; y queriendo S. M. que se lleve á efecto y que para ello quede Vm. relevado de la tenencia de la compañía de Guardias Marinas de ese Departamento de Cádiz, como así lo prevengo al Capitán Comandante de este cuerpo para que pueda Vm. desde ahora dedicarse como desee á las ilustraciones y preparaciones que necesita para desempeñar con el fruto que ofrece esta Comisión, lo prevengo á Vm. para su gobierno; y también, que en el concepto de que así cn buques (los qu: $V m$. clija), sus aparejos, respetos y víveres, como cn oficialidad, pilotos, tropa y marinería ha de aprontarsc esta expedición á cutera satisfacción de $V m$. medite y proponga sobre estos puntos y demás que comprende el proyccto cuanto necesitc, á fin de que dándose las correspondientes órdenes se apronte todo como $\mathrm{T}$ m. lo considcre mís 
conveniente á su mejor desempeño. Dios guarde á Vm. muchos años. = San Lorenzo, I4 de Octubre de $1788 .=$ Valdés. $=$ Sr. D. Alejandro Malaspina, Isla de León.»

\title{
Recomienda el Ministro que los Oficiales elegidos para la expedición guarden reserva hasta el nomento oportuno.
}

"Conformándose el Rey con lo que Vm. propone en su carta del zr del corriente como consecuente á la aprobación de S. M. que mereció su proyecto, me manda decir á Vm. que encargue á todos los Oficiales con quien trate, solamente de los puntos que cita, la reserva, pues el que á faltare ella no irá al destino y merecerá el desagrado de S. M. Particípolo á Vm. de su Real orden para su inteligencia y cumplimiento. Dios guarde á Vm. muchos años.=San Lorenzo, 28 de Octubre de $1788 .=$ Valdés.=Sr. D. Alejandro Malaspina.»

\begin{abstract}
Pide Malaspina que se construyan dos corbetas expresamente para el aiaje, y el Ministro se defiende del gasto, mandando hacer una y reformar otra de buenas condiciones.
\end{abstract}

"Conformándose el Rey sobre la elección de buques y pertrechos que Vm. ha hecho en vista del reconocimiento que ha practicado en la Marina Real y mercante, ha resuelto S. M. que de la bombarda Santa Rosa de Lima se saque partido para corbeta, y se construya ahí otra según acuerdo del Ingeniero Comandante D. Tomás Muñoz, con los que hayan de navegarla; lo que participo á Vm. de orden de S. M. á fin de que trate con Muñoz sobre el expresado asunto para que se verifique en términos que se consigan las ventajas que Vm. manifiesta. Dios guarde á Vm. muchos años.=San Lorenzo, I7 de Noviembre de I788.=Valdés.=Sr. D. Alejandro Malaspina."

\section{El Ministro se ratifica en la misma decisión.}

"Los asuntos de la comisión de que está Vm. encargado, así relativos á Marina como al Ministerio de Indias, ha de tratarlos Vm. por aquél, pues yo les daré el giro que á cada uno corresponda; pero ha de procurar dividir con claridad las materias, por ser método conforme á la más facil expedición. Lo que advierto á Vm. para su gobierno en respuesta de su carta de 2I del que sigue; previniéndole al mismo tiempo no haber conveniclo el Rey en la construcción de otra corbeta á más de la mandada fabricar, respecto de ser la Santa Rosa un buque apropósito para la expecición proyectada y como tal elegido por Vm., cuya vida guarde Dios muchos años. = San Lorenzo, 28 de Noviembre de $\mathrm{I} 788 .=$ Valdés. $=\mathrm{Sr}$. D. Alejandro Malaspina, Isla de León.»

Pero Malaspina wo se conforma con buque viejo é insiste en que se deben construir las dos corbetas. El sabio Alnuirante comprende, sin duda, que él solicitaria lo misno en caso equivalente y vnelve sobre su acuerdo de buena voluntad.

"Sin embargo de tener el Rey resuelta la habilitación de la bombarda Sania Rosa para la expedición á que está $\mathrm{Vm}$. destinado, mediante á haberla considerado apropósito para el objeto; no queriendo S. M. escasear á Vm. ninguno de los medios que puedan conducir al completo logro de los fines á que ha de dirigirse el viaje; se ha servido condescender á la solicitud de Vm. de que se 
construya otra nueva corbeta, cn virtud de lo cual comunico con esta fecha la correspondiente Real orden al Capitan General de la Armada para que disponga su fábrica con exacta igualdad á la mandada construir con ackerdo de Vm., cuya vida guarde Dios muchos años.=Madrid, 9 de Diciembre de $\mathrm{I} 788 .=$ Valdés. $=\mathrm{Sr}$. D. Alejandro Malaspina.»

\section{Concede el Ministro à Malaspina que clija à su gusto hasta el último marinero de las tripulaciones.}

"En efecto, la tripulación de los buques que han de hacer el viaje confiado á Vm. deberá componerse de marineros de entera satisfacción, así por su conducta como por su robustez, habilidad, etc., según expresa Vm. en su carta de 7 del pasado; y para que pueda juntarse con la conveniente anticipación la gente necesaria, me dirá Vm. el número de la que haya de destinarse de las provincias de Galicia, Asturias y Montaña, indicando ai mismo tiempo las circunstancias que han de concurrir en ella, á fin de expedir en consecuencia las órdenes que correspondan. Dios guarde á Vm. muchos años.=Madrid, 9 de Diciembre de $1788 .=$ Valdés.=Sr. D. Alejandro Malaspina.»

\section{Donde se vé que el Ministro, con exquisito tacto, rechaza ciertas innovaciones y accpta otras que sobre la policía de á bordo propone Malaspina, llevado del mejor deseo (I).}

"Se ha enterado el Rey de cuanto Vm. tiene expuesto en cartas dc 9 y r6 del que rige, y á consccuencia se ha servido S. M. resolver lo siguiente:

La dotación de cada corbeta se compondrá del número de individuos que $\mathrm{Vm}$. ha propuesto con aumento de Contador y Despensero; pues ni á los Oficiales conviene distraerlos de su primordial objeto recargándolos con las funcioncs de aquél, ni puede suprimirse éste, tan necesario para el arreglo, cuidado y distribución de los víveres; y como el prinero puede contribuir también al desempeño de los objetos de la comisión, prevengo á ese Intendente elija en clicha clase los dos sugetos que le parezcan más apropósito, así por su robustez y aplicación como por su instrucción y buenos modales, procediendo en esto de acuerdo con Vm., quien indicará al mismo Intendente los dos individuos que le acomodase llevar por despenscros.

Los sucldos han de graduarse desde el día de la salida de la expedición de ese puerto, hasta el de su regreso, por cl Reglamento determinado para la mar del Sur: además se abonará á la tripulación el importe de vino; y queda á la consideración de S. M. el premiar á cada uno con gratificaciones correspondientes al mérito que contraiga.

La reducción dcl número de criados, aunque será muy conveniente, ha de hacersc por convenio entre Vm. y el Comandante dc la otra corbeta con sus respectivos Oficiales, pues como interesados todos en la mayor comodidad, acordarán lo conveniente; bien entendido, que cualquiera que sea cl número que se determinase, se librarán los salarios por completo.

En cuanto á las funciones de cada uno á bordo, nada hay que prevenir respecto á las que determina la Ordenanza; así como declara las facultades de los Comandantcs para el establecimiento del mejor servicio, orden y policía á bordo de los bageles: bajo este supuesto, podrá Vm. arreglar sus disposiciones según le pareciere conducente, empleando á cada uno sin sujeción á antigüedad ni escala en los encargos que mejor pueda desempeñar; pero caminando en el concepto de que el Detall ha de llevarlo el primer Teniente dcl navío, y del de que si bien el Guardia Mírina deberá instruirse como marincro y Piloto, no ha de alternar con ellos en el servicio; pues ha de hacerlo con la distinción que la misma Ordenanza le concede, alojándose después del Contador y abonándose á Vm. por él la gratificación de mesa por entero.

Tampoco al Capellán y Cirujano puede precisárseles á más trabajo que el de sus obligaciones respectivas; pero como quiera que ha de ser cle elección de Vm., no le será difícil encontrar sugetos que

(I) Los argumentos de Malaspina sobre este punto véanse en las Instrucciones que da î Bustamante. 
puedan contribuir á los fines del viaje prestándose á la ejecución de los encargos que Vm. les cometiese; cuyo mérito les será recomendable. El segundo, como igualmente el primer Piloto, se alojarán después del primero y tendrán gratificación de mesa.

Respecto de que los Oficiales de mar han de ser de la confianza y elección de V'm. adquiriendo informes de los Departamentos, me indicará los que le pareciese apropósito para providenciar su destino.

Mediante á que no hay razón de utilidad en la sustitución del título de Oficialcs de mar con el de Oficiales de segundo orden, ni en el de mozos de carpintero y calafate con el de ayudantes de los mismos, no deberá introducirse esta novedad en la actual práctica.

Como podrá ser muy necesario en el discurso de la campaña el servicio de los buzos y no será muy fácil hallar artillcros de mar que lo sean, podrá Vm. elegir dos de los de ese Arsenal que también puedan desempeñar las funciones de Cabos de guardia en el servicio ordinario: por esto, además del sueldo, se les dará en cada faena extraordinaria una gratificación proporcionada á lo que en ella hayan trabajado, llevando Vm. una cuenta exacta y circunstanciada para rendirla á su regreso.

Aunque los individuos de Maestranza no deben, según está mandado, percibir estipendio alguno por los trabajos de su oficio que ejecutcn en el buque de su destino, y sólo el medio jornal cuando vayan destinados á otros, les determinará Vm. las gratificaciones que le pareciere en las ocasiones cxtraordinarias que se ofrezcan, ejecutando lo propio con las demás clascs siempre que hagan algún distinguido mérito é individualizando el motivo en la indicada cuenta.

Conforme Vm. lo solicita, comunico al Capitán General de Ferrol la conveniente Real orden para que el T'eniente de navío D. Antonio T'oba Arredondo elija de la marinería de aquel Arserial la que considere apropósito para el viaje, y que si aquélla no la contempíase apropósito, lo manifiestc al General para que, oficiando con el Intendente, se traiga de las provincias con las circunstancias que Vm. insinia.

Desde que quede elegida esta marinería, cuya conducción á ese puerto se encargará al mismo Oficial, disfrutará su sueldo de Europa, y antes de salir para el viaje será socorrida, como el resto de la dotación de los buques, con cuatro pagas de anticipación; y durante la campaña podrá todo el que la ejecutase dejar la mitad de su sueldo por asignación de su familia.

Todo lo cual advierto á Vm. para su inteligencia y gobierno. Dios guarde á Vm. muchos años.=Madrid, 30 de Diciembre de I788.=Valdés. =Sr. D. Alejandro Malaspina."

De cómo los documentos del Archivo de Indias y de otros Archivos saldrán al encuentro de Malaspina merced á una órden del ilustre General, para quien todo lo que es provechoso le parece conveniente.

"Se franquearán los documentos que Vm. pide del Archivo de Inđias al Teniente de navío Don José Espinosa, y comunicaré al Virey de Lima la correspondiente Real orden para que remita á Chiloé los que desea Vm. encontrar á su llegada; pero no podrá hallarlos en Buenos Aires por falta de tiempo para su oportuno envío. Adviértolo á Vm. para su gobierno, en contestación á sus dos cartas de 23 del pasado. Dios guarde á Vm. muchos años.= Madrid, 6 de Enero de $1789 .=$ Valdés. =Sr. D. Alejandro Malaspina.»

El gran Ministro aprueba en absoluto el plan de operaciones propuesto por su subalterno. De éste scrá, pues, toda la gloria y toda la responsabilidad. Obturvo cuanto quiso, para asegurar el éxito. Valdés y Malaspina eran dignos mo del otro.

"Ha visto el Rey, y se ha servido aprobar, el plan de operaciones que Vm., según indica en carta de 23 del pasado, se ha propuesto para el primer año de su campaña, y lo aviso á Vm. para su inteligencia y gobierno. Dios guarde á Vm. muchos años.=Madrid, 6 de Enero de $I 789 .=$ Valdés.=Sr. D. Alejandro Malaspina." 


\title{
CARTAS que escribió el Capitán de fragata D. Alejandro Malaspina al Teniente General de la Armada D. Antonio Ulloa, solicitando de su sabiduría algunos consejos.
}

\author{
"Excmo. Sr. D. Antonio Ulloa:
}

A1 momento de haber recibido la orden de S. M. para encargarme de un viaje marítimo y científico alrededor del mundo, conocí evidentemente que la parte más difícil de esta comisión, á V. E. más bien que á mí se había confiado. Sus vastos conocimientos, su verdadero amor al progreso sólido de las ciencias, y finalmente su bondad constante y casi paternal hacia mí, son otros tantos títulos que afianzan aquel concepto. Y así estoy seguro que V. E. no desdeñará el satisfacer á mis preguntas, que para mayor orden y menos molestia sujetaré en algunas cartas.

Esta tratará particularmente de las costas españolas de la América Meridional, hacia donde se dirigirán mis primeros pasos. Su exacta investigación, así por la parte hidrográfica como por la de Historia Natural importan sumamente al Estado, y no ha de ser indiferente á las demás naciones europeas si S. M. tuviese á bien mandarla publicar.

r." La parte hidrográfica se dividirá por mí en dos ramos. Abrazará el uno la configuración y situación astronómica de las costas: el otro tratará de los vientos, mareas, corrientes, variaciones, objetos extraños visibles, y finalmente, de todo lo que pueda ilustrar al navegante que trille aquellos mares con el único objeto de transitar de una á otra parte.

2. ${ }^{n}$ Desde Buenos Aires hasta el Cabo de Hornos, debe considerarse sin duda la costa como un punto muy interesante de la navegación española, y por consiguiente tenga V. E. á bien acompañarme en el examen de lo que hay hecho y de lo que hay por hacer en aquella parte.

$3 .^{B} \quad$ Si las operaciones del Capitán de navío D. José Varela no se hubiesen extendido hasta determinar astronómicamente los límites de la boca del Rio de la Plata en los Cabos de San Antonio y Santa María, la extensión de los bancos salientes por una y otra parte y la verdadera posición de la Isla de Lobos y Banco Inglés, me parecc indispensable el verificarlo.

$4 .{ }^{a} \quad$ Pueden considerarse como guías desde este paraje, los viajes de Anson, Biron, Wallis y Cook; los reconocimientos hechos por los chambequines Andaluz y Aventurcro; los planos que se hayan sacado de la bahía de San Julián y sus inmediaciones al tiempo de establecer allí la desgraciada colonia que luégo se retiró; finalmente, todas las noticias importantes que se hallarán comprendidas en el viaje hecho últimamente al Estrecho de Magallanes por la fragata de S. M. Nucstra Señora de la Cabeza. En cuanto á las Malvinas, habrá sin duda muchas noticias por nuestra parte que podrán combinarse con las de inglcses y francescs. Pero lo dicho hasta aquí corresponde sólo á la configuración de costas, sobrc la cual, por consiguiente, podremos referirnos en mucha parte á los documentos anteriores.

$5 .^{\mathrm{R}} \quad$ No es tan fácil estrechar la parte astronómica y fiarse de lo hecho hasta aquí. Los relojes marinos y las distancias lunares serán desde luego nuestros principales medios para fijar longitudes, así como los sextantes determinarán por lo común las latitudes. Parece que en cuanto á la costa patagónica (que se procurará no perder de. vista), será bastante colocar por este método todos aquellos puntos que proporcione una navegación nó interrumpida, dando sólo por precisos el cabo Blanco, el puerto Deseado, la bahía de San Julián y las inmediaciones del Estrccho de Mayre por una y otra parte.

$6 .^{n}$ Por lo que toca á Malvinas, no será posible visitar sino la parte occidental, por no perder la estación oportuna. Si pareciese preciso avistar el extremo oriental para detcrminar astronómicamente sus límites, se procurará combinar más bicn en el último año de nuestras tareas, atravésando desde el Cabo de Buena Espcranza. 
$7 .^{\mathrm{a}} \quad$ El segundo ramo de la parte hidrográfica, no podrá reducirse á la verdad, sino á conjeturas, bien que el prolijo reconocimiento de muchos diarios, combinado con la experiencia, concurrirá sin duda á hacerlas más probables. En esta parte, deseara que V. E. esplayase en toda su extensión sus.pensamientos limitando nuestras pesquisas á lo útil, para que ni los derroteros carezcan de aquellos avisos que pueda aprovechar el navegante, ni sean por otra parte un confuso acopio de incertidumbres, más bjen para distraerle de la verdad que para dirigirle. En el importante punto dc corrientes, se hará uso contínuo del método común de examinarlas por medio de un botecito referido á la embarcación; pero creo que los puntos diarios de observación comparados con esta exacta estima, son el método más seguro y desde luego sirven de comprobación al primero. Indíqueme V. E. si halla útiles algunas pruebas en la corredera de Mr. Bouguer que en algunos días de navegación N. S. sin atención á las costas pudiéramos examinar con prolijidad, á imitación de Lord Mulgrave en su viaje hacia el polo Norte.

8." Uno de los obstáculos más terribles en la navegación mercante al Sur, ha sido hasta aquí el encuentro de los bancos de nieve. Hallándome en las altas latitudes meridionales ¿cree V. E. que sería de alguna utilidad el seguir al Sur hasta cncontrar los hielos en una estación como la de los meses de Diciembre y Enero?

$9 .^{\mathrm{R}} \quad$ Pasemos ya á los objetos de Historia Natural; y antes de tratar de los que presenta en su seno la tierra, no desagradará á V. E. un pequcño examen de los que encierra el mar y pueden ser útiles, ó en general á los conocimientos físicos, ó en particular al aumento de la prosperidad nacional. Entre estos ocupa seguramente el primcr lugar la abundancia de cetáceos en la costa patágonica, cuya pesca y sucesivo beneficio pudieran ser de mucha utilidad á la Monarquía. ¿Cuáles serán, pues, en este caso nuestras investigaciones para decidir este punto que ya tantas veces se ha sujetado ó al discurso ó á la experiencia, y que no obstante queda aún sin decidirse? Su tamaño, calidad y cantidad referidas luego á los demás ramos que componen esta pesca y particularmente (por lo que á nosotros corresponde) á los tiempos y parajes en que haya de hacerse, ¿serán datos suficientes para un juicio fundado?

Io. E1 renovar la experiencia del aceite en los mares sumamente agitados, el comparar el calor de este agua con el grado de la que está en calma y el examinar los diferentes grados de calor á las difcrentes alturas de la misma agua, ¿serán experiencias que puedan ser de alguna utilidad? Y en tal caso, ¿cuáles serán los instrumentos más oportunos y el modo más exacto para ejecutarlas?

II. No creo que en esta parte de mar nos sea posible ni áun alcanzar lo que han examinado en cuanto á las producciones terrestres los Sres. Banks, Solander y Forster por lo que toca á la Tierra del Fucgo. El tiempo algo escaso para las operaciones sucesivas en las costas desde Cabo Victoria hasta Chiloé, no me dejará árbitro en esta parte de completar las indagaciones de un ramo tan interesante. Y así sería muy bueno para el completo aprovechamiento del tiempo, que V. E. me indicase aquellas cosas hacia donde más útil fuera dirigir nuestros esfuerzos en los intervalos, aunque breves, que pasemos fondeados.

I2. Sobre las costumbres de los patagones y de los indios Pecharis, tan robustos y sociables aquéllos como éstos endebles y, digámoslo así, los más infelices de la especie humana, no omitiremos tampoco todas aquellas indagaciones que las ocasiones, los encuentros y nuestro alcance nos digan. Pero como quiera que la penetración en aquellos países, particularmente de los patagones, es un objeto de mucha entidad para la historia de la propagación de la especie humana, tal vez la perspicacia de V. E. en estas materias pudiera dictarnos ó algunas confrontaciones de costumbres ó voces, ó algunos exámenes que sirviesen ó de parcial ó de completa aclaración á este punto.

13. Antes de abandonar el Cabo de Hornos me es preciso hablar de la bahía de San Francisco, de que V. E. hace memoria al fin de su viaje para la Meridiana. ¿No pudiera ser ésta la misma que Cook en su segundo viaje denominó el Cristmas Sonnd por haber pasado en ella el día de Navidad de I774? O bien, aunque no lo sea, ¿no podrá cualquier navegante que piense hacer escala en aquellos parajes, contentarse con la segunda, en donde una entrada no difícil, una grande abundancia de agua, de pájaros y antiescorbúticos, y, en fin, la agradable vista de la especie humana, aunque en el semblante ménos lisonjero, convidan unánimes á darle la preferencia?

I4. La falta de tiempo será quien nos obliguc á abandonar aquel reconocimiento y áun á separarnos de la vista de la Tierra del Fuego para tener más franca y más espedita nuestra entrada en el mar Pacífico.

I5. De ningún modo me desentenderé de reconocer las inmediaciones de los Cabos Pilares y Victoria y terminar así con buenas observaciones las penosas tareas del Estrecho de Magallanes. Será preciso omitir la parte de la Tierra del Fuego entre Cabo Negro y Cabo Pilares, no sólo porque se nos haría muy difícil el navegar contra viento y corriente, sino también porque es este paraje cl que ménos ha de ser frecucntado en la navegación común. 
I6. Desde Cabo Victoria, ó por mejor decir, desde los Evangelistas, empczarán nuestros cuidadosos conocimientos; y aunque desde luego las navegaciones de los Nodales de Natboroscgh, Sarmientos y de los dos buques de la escuadra de Anson, como también las noticias que V. E. especifica en la aclaración ó ilustración de su carta, puedan suministrar muy buenas conjeturas sobre estas costas, mucho nos queda aún por investigar. No nos empeñaremos en el Archipiélago de Chonos sino cuanto dicte la prudencia. Para la navegación común fuera bastante el conocer sus extremos más occidentales; pero como quiera que el reconocimiento de esta parte no puede verificarse sin algún riesgo, y que es ya casi la única que en la superficie del globo navegable queda por reconocer, parece que el honor nacional cxige este tributo de nuestra empresa, y así me serán muy agradables cualesquiera indagaciones útiles que V. E. me insinúe relativamente á la parte de costa comprendida entre el Cabo Victoria y Chiloé. No creo que la especie humana, ni la vegetación en general, sean muy brillantes en aquellas regiones. No obstante, los productos y costumbres de Chiloé, y áun las noticias comunicadas por aquellos indios, darán márgen tal vez á que nuestras pesquisas sean más útiles y acertadas.

I7. De orden del Gobjerno, cn estos últimos años D. José Moraleda, Piloto de la Real Armada, ha reconocido y bajado la costa desde Lima hasta Chiloé; pero creo que lo intcrior del golfo de este nombre no está aún bien reconocido. En tal caso, no fuera inútil el intentar el paso entre la Isla y la Tierra Firme, y abrir así mayor abrigo y navegación más segura en esta colonia aún algo arriesgada.

r8. Hasta fines de Abril no considero que sea temeridad el permanecer en latitudes altas meridionales. Bastará por consiguiente quc á esta época las dos corbetas puedan fondear cn Chiloé.

Io. Franqueadas las inmediaciones de Chiloé, ya puedc considerarse la costa sin el menor riesgo, y así es mi ánimo el separar las dos corbetas para que el sucesivo reconocimiento y colocación astronómica de las costas, sin perder nada de su exactitud, duple en celeridad y no se malogre un tiempo precioso.

20. Si el tránsito por tierra ó desde Valdivia, Concepción ó Valparaíso hasta Lima cs fácil, seráa muy útil y de sumo adorno para la comisión el hacer pequeñas cuadrillas que cn las tierras inmediatas adquieran los posibles conocimientos, y con vistas dibujadas, con producciones naturales, con descripciones, ya naturales, ya geográficas, den á la oḅra aquel útil resaltc que cl curioso ó el público no navegante suelen buscar en tales comisiones. Estas cuadrillas dirigidas por instrucciones claras y ceñidas á un número detcrminado de objetos útiles, pudieran irse desembarcando en diferentes puntos por la corbeta delantera (llamémosla así), recogerse después por la postrera, proporcionando de estc modo la nccesaria ventaja de ticmpo á las tareas de ticrra sobre las de mar.

2I. Dígame, pucs, V. E. cuál es el modo mcjor y más expedito de verificar estos tránsitos, y cuáles son las indagaciones más oportunas que han de hacerse relativamente á las ciencias. Deben existir en los pueblos de la Ensenada de Arica diferentes rastros muy aprcciables de antigüiedad. El representarlos á la curiosidad europea con dimensiones y colores exactos fuera desdc luego agradable, y tal vez no dejaría de ser útil.

Acabo ya esta carta, cuya molestia no tuviera disculpa en mí si sus resultas no se refiriesen al bicn público y al honor nacional: dos objetos que desde tanto tiempo ocupan las útilcs é incesantes tareas de V. E., cuya vida ruego á Dios guarde por muchos años."

\title{
CARTA II
}

\author{
"Excmo. Sr. D. Antonio Ulloa:
}

Continuando en solicitar nuevas é intercsantes noticias sobre los parajes á dónde haya de digirse la expedición pucsta á mi cargo, no parezca á V. E. molesto que añada á mi primera carta algunas otras preguntas que para mayor orden seguirán aquellos números á los cuales $V^{\top}$. E. con tanta bondad suya é ilustración mia se ha servido responder.

22. Además de los cascabelcs y algún galón falso de oro y plata, ¿cuáles serán los objetos más oportunos para cambios con los indios de los países más meridionales que Chiloé? 
23. Reinando sobre las costas de Chile y Chiloé hacia principios del invierno los vientos Nortes tan temibles como tempestuosos, suelen saltar de contraste y con igual fuerza al Oeste y Oesudoeste; V. E. indicó ya en su viaje que había algunas señales que anunciaban esa alteración temible y áun la entrada del Norte, según la práctica de aquellos mares. ¿Considera, pues, V. E., que sería temeridad aventurarse sobre las costas en aquel tiempo?

24. La navegación desde Acapulco, Panamá y Guayaquil á Lima, al paso que es un objeto nada indiferente para la comunicación recíproca de aquellos puertos, es tan duradera, que inciertos hasta aquí los navegantes si preferir la derrota que llaman de altura á la costanera, suministran anualmente ejemplos de unos riesgos verdaderamente considerables, yá veces de un singular malogro del viaje. En el año de I757 no hubo en Lima navío procedente de Guayaquil que no tardase en su travesía cerca de cien días. V. E. hace memoria en la narración de sus viajes de otro bien singular que tardó cerca de siete años. ¿No podrá combinarse una derrota que, sin depender del acaso y estribando más bién sobre las estaciones, dicte medios de acortar mucho aquel plazo? En el tiempo de mi demora en Lima no dejaré de inquirir en aquellos diarios todo cuanto sea conducente á este punto importante; pero V. E. atravesó aquellas costas con todas las luces de un físico, y en aquellos mares poco trillados, de dicha ciencia, más bien que de la mera práctica, han de esperarse los principios sólidos que afiancen el bienestar y la felicidad de los que habitan sus orillas. Además, que descuidado al mayor punto el pilotaje en tan indolentes costas, ni en cuanto á vientos ni á corrientes podrán deducirse allá noticias seguras y claras para formar buenos razonamientos.

25. Sobre las Islas de los Galápagos y del Gallego, éstas más occidentales que aquéllas, creo que no tendré otras nociones que las que V. E. se sirva comunicarme. A la verdad, su situación no las hará jamás interesantes ni á la geografía ni á la navegación. Pero como quiera que es importante el que se examinen siquiera su latitud y longitud, sus principales productos y sus moradores (si los hay), nos será sumamente útil el tener de antemano algunas nociones que al mismo tiempo dirijan nuestros pasos y nuestras pesquisas.

26. Llaman vulgarmente en aquellos mares engorgonarse (como V. E. lo indica) el ensenarse hacia la Gorgona en unas calmas tan duraderas, que han causado siempre, y con justa razón, mucho terror á los navegantes. El tiempo infructuosamente perdido, la escasez de víveres, los frecuentes riesgos del rayo no tienen comparación con el peligro extremo de la conservación de los hombres en un paraje en donde el ánimo y el cuerpo han de ser igualmente atormentados. No obstante, hemos de trazar sus costas y áun trabajaremos con mucho tesón en esta parte de mar, para cuyo fin sírvase V. E. indicarnos cuanto le parezca útil en ellas, no sólo por lo que toca á Geografía, sino también á la Física.

27. Es tiempo ya de hablar de dos cuestiones físicas que por mucho tiempo han ocupado la curiosidad de los sabios; esto es, el nivel de los dos mares, Atlántico y Pacífico, suponiéndose más alto el Pacífico, y queriendo con esto explicar la corriente contínua que por el Cabo de Hornos se dirige al Iiste y la unión de los mismos mares. Sobre esta última parte, á la verdad, ya se sirvió V. E. manifestarme cuánto la creía fuera del alcance de la posibilidad, no sólo por lo que mira á los celos del arte, sino también á los de la naturaleza; pues que las cordilleras en el Istmo de Panamá parecian hechas para aterrar á la primera mirada cualquiera idea de esta especie. Mas por lo que toca al nivel indicado, que desde luego ( $s i$ lo hay) supongo de una diferencia muy leve, fuera útil el intentar averiguarlo, aunque dé por supuesto que ni las operaciones geodésicas ni las del barómetro, áun corregida la escala de Mr. de Lanc, puedan determinarla. Creo, no obstante, que el primer método es el que debe preferirse, si se ha de adoptar alguno; y como no conozco lo local de aquellos contornos, quisiera que V. E. me manifestase el modo y el derrotero que más acertado fuera elegir para intentar esta curiosa averiguación.

2S. No creo que sea ya prudente, después de lo hecho hasta aquí por los navegantes españoles, ingleses y franceses, el invertir un tiempo precioso en busca del paso al Atlántico por los Estrechos de Fonte ó Juan de Fuca. Todas las noticias relativas á este importante descubrimientó parecen infundadas, á ménos que no haya una ú otra no pública, ó alguna tradición probable que dé margen aún á nuevas investigaciones.

29. Si en las costas desde Guayaquil hasta San Blas (ya harto conocidas) hubiese, al parecer de V. E., algo que examinà con particularidad, además de lo que dicta el orden común de exploración, fuera muy útil que se nos indicase, singularmente en lo que toca á drogas medicinales, de que parece abundan aquellos contornos.

Acabo ya con renovar á V. E. la utilidad que nos ha de producir su dictamen, sus preceptos, y el agradecimiento y el respeto que así por este nuevo favor como por los que antes he recibido, profesa á V. E. S. S. S. Q. S. M. B. =Cádiz, á 3 I de Enero de I 89 . 


\section{CARTAS que el Sr. D. Alejandro Malaspina escribió al señor D. Fosé Salvaresa, Proto-Médico de la Real Armada, sobre varios puntos dietéticos, y del régimen profiláctico que deberan observarse en el acopio de viveres para el viaje de la vuelta al mundo.}

Con mucha satisfacción mía aprobó S. M. (que Dios haya) el que consultase con Vm. sobre los antiescorbúticos más opoitunos para usarse en el dilatado viaje que se me ha confiado: no moleste á Vm. el que yo me extienda sobre un punto de tanta importancia. La conservación del hombre es el objeto más digno de sus semejantes.

Para proceder con el orden posible en esta materia, la dividiré en tres partes, que serán objeto de otras tantas cartas: indagaremos en la primer parte el mejor método para conservar sano al marinero, y se comprenderán por consjguiente en esta carta los comestibles de ración y la policía, así en el puerto, como en la mar. La segunda carta tratará del navegante, ó como ya próximo á enfermar ó como ya enfermo; finalmente, la tercera, se dirjgirá particularmente sobre aquellas cosas que componen más bien la comida del Oficial que del marinero.

Algunas advertencias han de apuntarse, que servirán como base á nuestros razonamientos sucesivos, y serán: I. ${ }^{a}$ Que se da por supuesta la suministración de toda el agua necesaria y su renovación en bodega todas cuantas veces sea posible. $2 .{ }^{n}$ Que la marinería y parte de los Oficiales de mar, será de las provincias septentrionales de España, esto es, asturianos, montañeses y gallegos. $3{ }^{\circ}$ Que ha de ser, así esta gente, como los Oficiales mayores, libres de toda enfermedad habitual, y dotados por consiguiente de aquella robustez y resistencia, que tanto sobresalen en el navegante español.

E1 método que yo considero más útil para la conservación del marinero español es, no tanto aquella estúpida disciplina que fácil es de guardar para los del Norte, como un freno racional, y vario, según las ocasiones, adaptado principalmente á las pasiones vivas de aquéllos y á los razonamientos que de ellas dimanan. El adjunto extracto de mis reflexiones en el último viaje de la Astrea por la Real Compañía de Fìlipinas, manifestará á Vm. con la mayor individualidad el carácter del marinero español; y aunque en la preferencia á las provincias septentrionales haya procurado precaver, cuanto es posible, esta scnsibilidad excesiva, creo que convendremos en ser ésta característica propia también de aquéllos, bien que no en tanto grado como de los andaluces.

E1 cntrepuentes será desde luego espacioso, y cađa marinero tendrá su coi, para que los miasmas del que acaba de levantarse, y particularmente de su ropa, no traspasen al que le sucede inmediatamente en el descanso. El fogón estará igualmentc en la misma cubierta en donde duerme la marinería; el humo y el fuego espelerán así naturalmente mucha parte del aire infecto, tanto más que de tiempo en tiempo y con acción mayor del mismo fuego, puesto oportunamente en cualquier paraje, se frotarán las maderas de las cubiertas. En cuanto al aseo de ropa, al abrigo oportuno de los soles y de las aguas, á unas chaquetas con capucha adecuada al frío, al estar comun. monte en guardias de tres cuartos en lugar dc dos; al lavar su ropa con agua dulce más bien que con salada, y finalmente, á cuidar el aseo del buque y de todo cuanto contenga, puede Vm. estar scguro, que más bien sobresaldrá nuestra prolijidad, á todo cuanto han usado hasta aquí los Oficialcs dc la Real Armadà.

Dos cosas únicamente preguntaré á Vm. ántes de pasar al segundo objeto y son: I. ${ }^{a}$ Si considcra Vm. preferente al uso del fuego el del vinagre, $́$ ya rociado ó por vapores, para conseguir en las cubiertas el aire menos infecto. $2 .^{n}$ Si en los rápidos tránsitos del mucho frío al mucho calor, dche ser preferente á exponer la marinería á unos resfriados siempre temibles, el molestarlos (contra su genio siempre abandonado) con una carga excesiva de ropa de abrigo.

Pasemos ya á los comestibles; éstos pueden muy bien referirse á cuatro cosas principales: pan, mencstras, carnes saladas y tocino, á los cuales luégo por vía de condimento, deben considerarse agregados el aceite, el vinagre y el vino.

En cuanto al pan, uno de nuestros principales alimentos, yo creo que conviene mucho que lo ¿́ngamos de un trigo fuerte, más bien que de otro de menos sustancia, en cuyo caso, el de Anda- 
lucía y Castilla serán desde luego preferentes al de Sicilia, Cerdeña y Berbería; conviene también, que no sea el pan muy abizcochado, pues me parece que cuanta menos cochura tenga, tanto mónos habrá exhalado de aquellas partículas, que hacen á éste y á los demás vegetales tan sanos. A la verdad adquiere entonces un cierto sabor correoso, que desde luego no es agradable al paladar, y que puede áun ser de una digestión algo más difícil. Quisiera que puestas en una balanza estas dos ventajas contradictorias de la muchá ó poca cochura del pan y los inconvenientes que las acompañan, Vm. me indicase su parecer para dirigir, acorde á él, la fábrica de este importante ramo. Fuera oportuno al mismo tiempo, indagar si conviene alternar con el pan de trigo, los de maíz y centeno, pues embarcadas harinas de una y otra semilla, pudieran hacerse á bordo unas tortas que sirviendo de variedad, fuesen al mismo tiempo más saludables. A lo menos será útil que $V \mathrm{~m}$. nos dicte algunas experiencias que podrán servir de cimiento á las que hayan de hacerse en lo venidero sobre un punto tan interesante.

Las menestras son dotadas por sí de cualidades antiescorbúticas; y como quiera que así en este Continente como en el de América abundan ó ya una ú otra especie, pueden desde luego considerarse como el alimento más útil para la navegación. En el viaje que acabo de hacer, no he podido examinar sino la segunda de las dos propiedades que han de investigarse en sus clases, esto es, la mayor ó menor bondad relativa y la mís ó ménos fácil conservación relativa en campañas dilatadas, y particularmente en los climas temibles de entre Trópicos. No desagrade á Vm. que analice algún tanto estos comestibles: el arroz es el vegetal que yo he hallado de menor evaporación á bordo y áun en tierra, á lo ménos entre Trópicos; sígueseá éste el garbanzo, con preferencia á la garbanza, y finalmente la lenteja: el frijol, así blanco como cocacho, el chícharo y las habas, aquí conocidas bajo el nombre de Tarragona, son otras tantas especies que, con igual ó mayor cuidado que las demás, no han absolutamente resistido al calor y humedad, que con tanto daño se hallan mezclados en tan sumo grado entre Trópicos.

Pero como la conservación no es ni el único ni digámoslo así el punto principal en este ramo de víveres, es justo investigar si la bondad respectiva hace más bien preferentes otras semillas, tanto más que no siempre en nuestra navegación habrá de requerirse la duración, y que una gran parte de nuestras tareas serán más bien en climas fríos que en calientes. Esta parte, que más corresponde á un análisis químico que á las'experiencias marítimas, será peculiar de Vm., y cualquiera advertencia que Vm. nos especifique será de una utilidad real para el mejor acierto en la delicada elección de víveres.

Sobre la carne salada y tocino, diré lisa y llanamente que es ya casi un axioma en la Armada que el segundo ha de preferirse á la primera, y que, en mi entender, la razón misma afianza este concepto, mucho más si en el salado del tocino (particularmente entre 'Trópicos) se usan todas aquellas precauciones que con tanto provecho han imaginado los Sres. Cook y la Pérouse, y por cuyos métodos hice yo últimamente mis salados en Manila. Desde luego á causa de la abundancia de vasos sanguíneos y de otras sustancias nutritivas imposibles de extraerse, ha de ser más propensa á la putrefacción la carne que el tocino, y aunque la calidad más porosa de éste le haga naturalmente más propenso á la mayor penetración de la sal, también le hace luégo más fácil de expelerla con las dos aguas en que se infunde por largo tiempo antes de cocerse. Síguese, pues, de esto que el tocino es seguramente de mayor duración y probablemente de menor daño que la carne salada, á menos que en la diferencia de calidades entre las carnes de puerco y vaca no haya tal vez (lo que ignoro) una suficiente compensación de los inconvenientes ya indicados. Mr. la Pérouse usó del vinagre para sus salados, teniendo el tocino tres días en una moderada infusión, y después embarricándolo sin salmuera, con solo una capa superior de sal marina. Este método es bien costoso, tanto más que he experimentarlo que los vinagres de nuestras Américas no tienen las propiedades necesarias para esta operación; no obstante, es método que merece ser preferido á todos los conocidos hasta el presente.

Por lo que toca al aceite, temo mucho que no pueda generalizarse su uso tanto como verá Vm. que he hecho en la Astrea. Ya no se trata de nutrir una marinería andaluza, sino una de las costas septentrionales, en donde el aceite apenas se conoce y ya no es una producción natural. Quisiera que $\mathrm{Vm}$. me determinase los prudentes límites de su uso, particularmente por lo que toca.á sopas, ó como almuerzo ó como cena, y que me indicase algunas señales por donde pueda venir en conocimiento cuando los efectos no sanos de su crasitud y dificultad de digerirse, prevalecen á los buenos de su verdadero alimento y de un gusto agradable.

Fuera omisión el no tratar aquí del gazpacho; ¿serán tan útiles sus efectos como en las maririnerías de estas provincias? ¿Y deberemos insistir en su uso casi contínuo, aunque la marinería lo repugnase algún tanto?

Finalmente: en cuanto á vinos hallo preciso su uso casi contínuo; y por repetidas experiencias 
estoy convencido que la espirituosidad del de Sanlúcar le hace preferente á cualesquiera otros de nuestra España. Me quedan sólo dos dudas que Vm. podrá resolverme; es la primera si la cantidad de un medio cuartillo es suficiente para hacer un efecto saludable, particularmente despues que el vino con una larga navegación ha adquirido nuevo vigor; la segunda si conviene que este excelente digestivo y antiescorbútico se suministre más bien por la mañana que al medio dia; más bien á esta hora que por la noche.

La total exclusión del aguardiente y del pescado salado (incluso el bacalao) son dos cosas en que creo no discrepemos: en cuanto al queso, que también suele usarse en nuestra ración de Armada, hallo difícil de combinar su utilidad, si no se refiere á las ocasiones de tempestad en que se halle expuesto el usar del fuego, y éstos serán los únicos casos en que lo usemos.

Acabo esta carta con renovar á la memoria de Vm. cuánto interesa á la humanidad y al paternal amor de S. M. el que este punto de la conservación de los equipajes se examine con toda extensión y cuánto aprecio hará del parecer de Vm. su más afecto y agradecido amigo Q. S. M. B.= Cádiz, á 23 de Diciembre de I788.

\section{CARTA II}

Si la conservación del hombre en general, y en particular de la especie preciosa del marinero, me ha arrastrado una y otra vez á reflexiones médicas, en cuanto hayan de combinarse con los deberes de un Oficial de Marina, y si el próximo viaje mío me obliga ahora á exponerlas con el solo objeto de verlas ó aprobadas ó destruidas, sírvase Vm. mirarlas como procedentes únicamente de un verdadero celo y como dirigidas al solo alcance de la verdad.

Nada puede compararse al hombre enfermo en la mar: el alojamiento, la falta de quietud, la evaporación ó fermentación de las medicinas, los alimentos, el aire que respira, todo concurre á hacerle el más infeliz de la especie humana, y á causar una sensación no indiferente hasta al marino más sordo á las voces de la naturaleza.

Sírvase Vm., pues, acompañarme en este examen del navegante ó próximo á enfermar ó ya enfermo; unidas nuestras investigaciones ó más bien unidos los preceptos de Vm. á la exactitud mia en ejecutarlos, tendremos desde luego la satisfacción de ocuparnos con tesón de la conservación del marinero, y conseguiremos tal vez la de coadyuvar eficazmente á este punto importante de la prosperidad nacional.

Supuesto en nuestro caso al marinero de una naturaleza no viciada con enfermedades habituales ni acosado del trabajo, sus enfermedades pueden reducirse á tres únicas causas; la calidad del alimento, la calidad del aire que respira y un tránsito demasiado rápido del sumo calor al sumo frio ó al contrario: las dos primeras inclinadas directamente á la putrefacción, y ésta última á una total falta de traspiración si el tránsito es al frío, ó á un excesivo enardecimiento en la sangre si se pasa al calor. En las navegaciones muy pronto dejan verse al especulativo varios síntomas que denotan el efecto de aquellas causas cuando ya empiezan su acción: son éstas principalmente una especie de letargo ó sea un sueño excesivo, una sed frecuente, una grande dejadez ó flojera en el trabajo, y finalmente, una náusea á la comida; señales todas que no pueden ocultarse cuando diariamente se asiste por mero entretenimiento á los ranchos y en toda concurrencia con el marinero se dirigen los reparos á su conservación ó estado de salud. Ni es de extrañar que se hagan visibles estos efectos, si se considera que alimentados, alojados y atareados todos de un mismo modo, por diferentes que sean las naturalezas, no han de ser muy diferentes los males de que se adolezcan. Este es el momento en que, á mi entender, deben obrar con vigor los métodos curativos; lo exigen así la naturaleza de la sangre aún no muy viciada, la utilidad saludable de un trabajo moderado que sabe considerarse como indispensable y los efectos aún muy limitados del aire respirado, que por consiguiente puede no causar enfermedad epidémica.

Es, pues, mi ánimo, si Vm. lo aprueba, que luego que los más propensos á estas enfermedades declaren con los síntomas ya referidos, y otros semejantes, que empieza á viciarse la sangre, se adopte inmediatamente para su alimento el Sowrkrout y el Malt de cerveza: para su bebida, sudorificos con mucho azúcar, y áun el agua impregnada de aire fijo; finalmente, que por algún tiempo se les prive de todo salado, para lo cual podrán sustituirle, con las menestras mejores, el caldo en pastillas, ó alguna carne reservada en aceitẹ. 
No permite la manutención de muchas gentes á un tiempo, que con todos haya de usarse contínuamente un método seguro. El solo uso de carnes saladas bastaría para trastornar cualesquiera otras medidas, ni el caracter del marinero, áun considerándose éste sano, le permitiría el sobrellevar con paciencia y sin desorden un método largo de alimento no agradable por lo común á su paladar y ceñido á una cierta dieta. Esta reflexión es la que me ha inducido (con buen éxito hasta aquí) á no molestar al marinero ni al Erario con una especie de perenne método curativo, sino más bien atender á si se declaran en uno ú otro los primeros síntomas nada temibles del vicio é inmediatamente sujetarlos á un régimen tan sano como inalterable, apoyado tan eficazmente por la dulzura como por la disciplina.

De este modo habrá en nuestros buques una clase media entre los verdaderamente sanos y los absolutamente enfermos; y así como es difícil el reponer á éstos sin aquellos auxilios, que rara ve $z$ en la mar pueden proporcionarse, fácil será recurrir á unos remotos principios de enfermedad si el Comandante, con un régimen oportuno de aseo y trabajo, y el médico con remedios uniformes y activos, concurren unánimes á rebatirlos.

Sobre la mezcla del aire fijo con el agua potable según los preceptos de Prestley, creo también que fuera inoportuno el usarla para todos en todos tiempos, áun suponiendo que el aparato químico para impregnarla fuese más sencillo; pero también el omitir su uso con los que se inclinen ya á enfermar, creo que fuera culpable en un tiempo en que tantos sabios se ocupan de la felicidad de los navegantes y las repetidas experiencias confirman la utilidad de estos inventos. De los buenos efectos del Sowrkrout ó coles agrias no debe quedar ya duda alguna. Queda únicamente por examinar la utilidad del Malt ó cebada fermentada, aunque ciertamente convendremos que en el caso de excluirla se le haya de sustituir algún equivalente que contenga mucho aire fijo.

Una especie de crasitud inseparable de las pastillas de caldo, puede tal vez representarlas como perniciosas; pero no recayendo este uso sino sobre personas de un estómago aún fuerte, esto es, apenas propensas á la enfermedad; y por otra parte, debiendo únicamente sustituir al tocino, creo que en el indicado estado medio entre la salud y la enfermedad pueden considerarse como muy útiles.

Fuera mucha satisfacción para mí, que Vm. al justo examen de las reflexiones anteriores se sirviese también añadir su parecer en cuanto al método de servicio para esta clase media; esto es, si debemos inclinarlos al sudor con preferencia al respirar un aire libre, en cuyo caso podrán proporcionárseles faenas interiores en lugar de las que se hacen sobre cubierta; si el relente, el frío, el agua, le son muy nocivos; finalmente, si en las latitudes altas, en donde según muchas experiencias el aire está más saturado de sales, puede seguirse para esta clase de gentes el mismo método que en los climas templados de trópicos.

No entraré en el detall del hombre ya enfermo; esta parte será totalmente del Cirujano: yo me ceñiré á desearle todo el acierto y á contribuir en cuantos modos puedan combinarse al más fácil logro de lo que haya menester; no obstante, varias cosas que á mí me corresponden aún en este ramo, han de exponerse ahora á la perspicacia de Vm., para que ni en esto carezca de sus instrucciones.

Por muchas razones, así de disciplina como de utilidad real á los enfermos, nuestra enfermería no será de firme: la sustituirá un repuesto de catres ingleses que colocados unos sobre otros, si la necesidad lo pidiese, y rodeados el total de una lona pintada pero movible, tendrán las ventajas de poderse aumentar cuanto se quiera, de estar cada enfermo separado del otro, así en cuanto á persona como á ropa, de ser la curación más fácil, y sobre todo, de no tener ni la madera embebida de unas exhalaciones tan perniciosas, ni imposibilitados el contínuo aseo y ventilación de los parajes más recónditos. Fácil será remediar los pequeños inconvenientes que se ocurren á primera vista sobre la instabilidad de estas camas para las operaciones quirúrgicas, la dificultad de bajar y subir los enfermos de las camas altas, y la sujeción inmediata de todos los utensilios necesarios para un enfermo. Creo que esta distribución merecerá la aprobación de Vm., quien conoce cuantos inconvenientes dimanan de nuestro método actual de enfermería.

Una duda, nada indiferente, se servirá Vm. resolverme sobre esta especie de enfermos, pues que de ella dimana el mayor acopio de unos más bien que de otros efectos. Supuesta, como es natural, la falta de carnes frescas en las travesías largas que hagamos, chasta dónde podrá extenderse para los enfermos el uso de los caldos de repuesto, ó será más útil sustituirles en muchas ocasiones el aceite? El acopio de medicinas propuesto por nuestros cirujanos ha sido ya por Vm. aprobado; por consiguiente omitiré el hablar de él; su conservación me merecerá un cuidado particular, y áun para esto estimaré á $\mathrm{Vm}$. me indique algunas precauciones, si lo hallase oportuno.

Al concluir esta carta, sólo repetiré á Vm. que he procurado que las mismas voces denoten no ser mi ánimo tratar de una facultad, cuyos umbrales conozco apenas. La existencia á bordo de un 
estado medio entre la salud y la enfermedad, y las útiles consecuencias que dimanan de esta distinción de clases, particularmente por lo que toca á las medidas del Comandante, han producido los párrafos que anteceden. Puedan éstos llevarme á obrar con acierto en un punto de tanta importancia y acreditar con repetidas pruebas cuánto aprecia el dictamen de Vm. su más afectísimo y seguro servidor, etc. $=$ Cádiz, $r{ }^{\circ}$ de Febrero de $r 789$.

\section{CARTA III}

Muchos Oficiales se han ocupado hasta el día de hoy de la conservación del marinero en cuanto á alimentos; ninguno ha examinado aún la del Oficial, en quien, para los altos fines á que está destinado, debemos exigir, no sólo la material conservación del físico, sino una buena disposición en las potencias intelectuales, para que esté más agil en las fatigas y más dispuesto á la reflexión y al estudio. A la verdad, debe atribuirse este silencio, más bien que á descuido, á un natural pundonor en los Capitanes, quienes, recelosos de que se confundiese el espíritu de orden con el de èconomía, han preferido á cualquier otro partido el callar; muchas veces, áun con evidente daño propio y del servicio, el inclinarse más bien á una mesa demasiado expléndida que á una frugal.

Por mi parte, deseoso únicamente del acierto, y unánime en esto con los Oficiales que han de acompañarme, sin mezclarme en otros reparos que es fácil luégo destruir, tendré aún más cuidado en el método de mesa del Oficial que en la comida del marinero, con tanta más razón cuanto mayor y más progresiva es la utilidad de aquél sobre la de éste.

Tenga Vm., pues, á bien afianzar mis conceptos si los hallase justos, ó rechácelos, si pareciesen infundados. Me alegraré mucho ver guiados mis pasos de la razón y de una autoridad tan res. petable.

Convendremos desde luego que en unas campañas en donde cada uno ha de ejercitarse diariamente en tareas y cálculos complicados, es casi indispensable un trastorno de horas para las comidas; esto es, que servido á las ocho de la mañana un buen almuerzo de algunos fiambres, puede diferirse la comida hasta las seis de la tarde, y á las diez de la noche usar de una merienda de chocolate ó té, con pan tostado y manteca; consíguese así, además de un espacio más largo para las excursiones científicas ó marítimas en los puertos, un trabajo más seguido y natural en el mar; un plazo mejor y más libre para la digestión; finalmente, un par de horas bien necesarias ó para el reposo ó para el sosiego después de comer.

Ocúrrense algunas dudas para adoptar unos ú otros comestibles, unas ú otras bebidas, y las voy á exponer á Vm. inmediatamente. La carne ahumada del Norte, según muchas experiencias hechas en los mares de Noruega, parece fácilmente expuesta al escorbuto; ignoro si prefiriendo para conservar las verduras el aceite á la salmuera, se logra un beneficio en su bondad, desentendiéndome de su duración.

El uso del té y del café, éste algo flojo, creo que puede emplearse mucho, pues con el azúcar que se le agrega es un grande antiescorbútico, y también su calor coadyuva mucho á la digestión. Para condimentos deben, á mi entender, abandonarse las especias y casi todo lo craso; de suerte que las salsas en general deben mirarse como nocivas, y repetir cuanto sea posible el asado. Considero también como muy dañosa la manteca de puerco; ignoro hasta dónde puede ser útil la masa; y en cuanto á la manteca salada, creo su uso contínuo, si no saludable, á lo menos necesario, para gentes acostumbradas en Andalucía.

Omito otros muchos detalles que parecerían demasiado frívolos, y áun no carecen de este aspecto los que anteceden, si no se considera que, relativamente á la salud, no hay punto despreciable, y que por lo común en nuestro método de mesas se ha atendido más bien á la abundancia que á la calidad.

El bien de la humanidad, los progresos de la nación y del Real servicio, las recientes órdenes de S. M., el ejemplo de las demás naciones, la amistad misma que á Vm. merezco, todo concurre á que yo no me acuse de haberle molestado; y Vm. se sirva guiar con sus respuestas al que es y será siempre su más afecto servidor y amigo, etc.=Cádiz, á 5 de Febrero de r $_{7} 89$. 


\section{Reflexiones sobre la conservacion de la salud de los equipajes.}

"Fuera digno de reprensión el prefenir otro punto alguno al de la conservación de la salud en el mar, dictado al mismo tiempo por la humanidad y por el interés, y no obstante descuidado hasta aquí de tal modo en las navegaciones al Perú, que ha costado pérdidas considerables al comercio, y á la Nación el sacrificia casi anual de excelente marinería, sin que por esto hayan aún escarmentado, ó movídose á compasión los armadores de los buques que navegan á la mar del Sur.

Séame permitido no confundir en esta parte la Real Compañía con los demás, y lisonjearme que no le serán desagradables los apuntes, aunque algo extensos, sobre este interesantísimo punto, relativo á las ventajas nacionales y á la total seguridad de sus expediciones venideras.

Ojeando algún tanto los viajes modernos extranjeros, en particular los del Capitán inglés Cook, y reparando aunque levemente, en la policía de los buques de las diferentes compañías europeas del Oriente, parecerá desde luego que pueda hallarse un manantial inagotable entre ellos de preservativos. Embarcaciones ventiladas y sahumadas interiormente, mucho espacio interior libre para el acomodo de cada uno; comidas sanas y abundantes; finalmente, una disciplina vigorosísima para el aseo de las personas y del buque, son los puntos esenciales de la policía extranjera en este ramo, los que adoptados, deberían al parecer prometer tan buenos efectos en los buques españoles. Es de advertir en esta parte, que las navegaciones ordinarias de los buques españoles al Perú no pueden ser igualadas de ninguna de las que en el día emprende el comercio europeo á las demás partes del globo, pues ninguna ofrece más desigualdad de clinas, menos abrigo contra las enfermedades y las averías, ni mares tan tempestuosos, á quienes arrostran después de tres y á veces de cuatro meses de navegación.

Pero en desquite, puede asegurarse que la marinería española cstá dotada cle una robustez y de una resistencia muy aventajada á las demás naciones extranjeras; de suerte que, haciendo éstas contrapeso con los mayores riesgos de la navegación por el Cabo de Hornos, parece, finalmente, que pudiera deducirse la evidencia del buen éxito de todos los preservativos extranjeros.

Arraigado yo mismo en esta idea, desprecié en mi interior muchas veces la que me ofrecía una meditación constante de una serie de campañas de diez ú once años, sobre la necesidad de otros bien diferentes preservativos para la salud del marinero español en la mar. Mil veces comprendí (estudiado á fondo el carácter nacional) que el sosiego de ánimo era más interesante á nuestra marinería que todo lo que le rodeaba exteriormente, y mil veces creí infundada semejante idea, y la deseché, no obstante de poder sujetar esta lucha de ideas á la experiencia.

El viaje de la fragata Asirea acaba de cerciorarme de la verdad de aquella sospecha y de animarme en el día con tanto vigor á la necesidad de este preservativo con preferencia á todos los demás, cuanto había sido antes el que me hacía interponer á todo el seguir cieganente en esta parte la policía de los buques del Norte; ni se podrá tachar de imperfecta mi experiencia (bajo el fundamento de que un Capitán no tiene conexión inmediata con la marinería) cuando se sepa que mis compañeros D. Luis de Concha y D. Francisco Viana, movidos de un corazón verdaderamente noble y caritativo, y á su imitación los Contramaestres, han coadyuvado diariamente á la demostración de esta verdad, áun con mayores pruebas de las que yo podía clesear.

La tripulación de la Astrea se componía en mucha parte de excelente marinería de la carrera mercantil de Lima. Desde luego unos 60 entre ellos habían estado una, dos, tres y cuatro veces en las tempestuosas mares del Cabo de Hornos, se habían hallado en arribadas, en epidemias, etc., 10 habían pasado en invierno y en verano y habían experimentado, finalmente, la escasez como la suma abundancia. Se nos hacía, no obstante, reparable en las primeras conversaciones que cariñosamente trabábamos con ellos, el que ell medio de la abundancia y en las mares sumamente benignas, todas sus reflexiones se parasen en los riesgos muy distantes del Cabo de Hornos, y que áun entre éstos despreciasen casi el hablar de la poca ó mucha comida, de la poca ó mucha ropa de abrigo, y fijasen más bien su atención en la contínua incertidumbre de su suerte, y especificasen, en lo tocante á esa navegación, las más mínimas circunstancias con una puntualidad propia más bien de un político que de un marinero; ni cabía el pensar que esto pudiera ser de miedo, cuando al mismo tiempo se arrojaban con el mayor denuedo entre los peligros, y áun veíamos entre los polizones, alguno que por seguir tan solamente uno ó dos amigos habían preferido, áun sin ropa y sin dinero, esta navegación á otras más cómodas y menos inciertas á que estaban contratados á la sazón. Inferíamos desde luego con estos datos que el marinero nuestro, bien diferente en esta parte del extranjero, era su- 
mamente sensible y capaz de reflexión, y nuestro natural hacia ellos nos hizo aumentar las pruebas casi sin conocerlo. Sabían el rumbo que debíamos ó pensábamos seguir, y á cada paso se arrimaban á la aguja á ver cuánto distaba de aquél el que seguíamos por necesidad. Oían con el mayor agrado, y áun nos preguntaban á veces, nuestras observaciones diarias de latitud. El día del mal tiempo todo les era insufrible; un soplo de buen viento los volvía á su primera docilidad, y finalmente, á medida quc descubrían en nuestra unánime conducta una mezcla de cariño, de amor al trabajo, de inteligencia, iba aumentando cn ellos, áun en proporción adecuada, una mezcla de amor y respeto hacia nosotros. Ya en el largo tiempo que nos contrarestaron los vientos variables de las inmediaciones de la Línea se nos hizo patente el buen efecto de adoptar este principio. Yo prefería el día de viento contrario al de mal tiempo para mejorar sus comidas con carne fresca y distraerlos con el saludable vino de Sanlúcar. Se toleraron en las maniobras y áun en su misma conducta, algunos defectos leves, que nos era luégo fácil remediar ó cortar enteramente en el día de buen tiempo; aumentaron nucstros halagos y premiábamos y fomentábamos á los que dotados de un genio alegre podían excitarlo en los demás; no se hacía un zafarrancho ni otra maniobra de aseo quc no concurriese un poco de vino y nuestros razonamientos á hacer ménos gravosa la disciplina, y esta conducta, seguida con constancia, nos proporcionó ya la agradable perspectiva de verlos después de veintiocho días de chubascos, turbonadas, calma y contrariedades, más robustos aún de lo que habían salido de Cádiz. Concurrió á cimentar este anhelo nuestro de darles gusto, la derrota que nos proporcionó el relój marino de la Equinoccial hasta la Ascensión. Navegamos á viento largo cuando los pilotos vociferaban el riesgo de no montar (áun ciñendo) el Cabo de San Agustín en la costa del Brasil, y les proporcionamos por rumbo oblícuo la vista de la Ascensión, que les convenció y les hizo confesar por sí mismos, que nuestras navegaciones al O., para salir de la costa de Africa en las inmediaciones de la Equinoccial y el no haber ceñido los S. E., habían desde luégo aventajado de quince á veinte días el viaje de la Astrea. Los temporales de la costa patagónica dieron nueva fuerza á nuestro amor recíproco; las maniobras se mandaron con método y con la posible seguridad. Ellos las ejecutaron con el mayor ardor; si fué preciso varias veces ó el exponer algún tanto las gavias ó el maniobrar á cada paso, ya sabían y entendían que nucstra situación lo requería, y sacaban de los mismos peligros el mayor buen humor, de suerte que finalmente todas las contrariedades de la costa patagónica, y los semblantes de un viaje al sumo largo y dilatado, se deshacían fácilmente en su imaginación con las razones, ó ya aparentes ó ya verdaderas, quc les alegábamos. A la llegada al Cabo eran más bien nucstros amigos que nuestros súbditos; sin faltarnos al respeto, nos manifestaban sus nccesidades, ó sus deseos, ó sus ideas, ó sus aventuras; mezclaban á esto algunas chanzas y veían en nuestros rostros cuánto gustábamos de ellas; llegamos aún á complacerles en sus caprichos moderados, ó ya relativamente á comida ó bebida, ó bien cn cuanto á algunos puntos de disciplina. Los veíamos así siempre alegres y aptos al trabajo, y aumentaba su robustez casi á medida que se aumentaba la campaña.

A pesar de estas bellas disposiciones, pero en prueba de su grande sensibilidad, les trastornó muy mucho en las inmediaciones del Cabo Pilares, el ver tomar de nuevo las muras estribor, y aunque no duraran estas nunca un día entero ni nosotros nos descuidásemos en hacer comprender á fondo nuestra ventajusísima situación, y áun en reprimir los más tercos, se conocía luégo en los semblantes la mura que llevábamos.

No les faltaba cosa alguna; antes bien, crecía con el mal tiempo su ración y nuestra tolerancia, y no obstante menores que todos los trabajos que en el Cabo hacen consigo las muras estribor, desmayaban, y áun entre sí caracterizaban ya á cualquier leve achaque de escorbuto. Nuestra derrota al $\mathrm{N}$. disipó todas aquellas ideas, y los buenos tiempos sucesivos nos han proporcionado de verlos ya en inmediaciones de Concepción cn la mayor unanimidad, buen humor y tranquilidad de ánimo, y en un estado de robustez proporcionado á aquellos resortcs.

No se crea, no obstante, que este preservativo, que por su novedad exigía toda la atención que se le ha dado, nos hiciese descuidar en el uso de otros muchos; hemos contribuído al aseo personal de todos (que en verdad no necesitaba de mucho estímulo) con nuestro ejemplo, y con algunos premios, muchas alabanzas y tal cual reprensión, y no les ha sido un auxilio indiferente la repartición de ropa embarcada por cuenta de la Real Compañía, y perteneciendo más bien al ramo de aseo que al de abrigo. Daba ciertamente el mayor gusto el verles peinarse y lavar su ropa casi diariamente en los días de mayor frío; y como se tuvo la precaución de comprender en la repartición de camisas á los mismos polizones, aunque no tuviesen con qué descontar su valor para con la Compañía, puede asegurarse quc el aseo personal en la fragata Astrea ha llegado al punto más alto.

Los zafarranchos, viceversa, no fueron tan frecuentes como parecía exigirlo nuestro anhelo por la conservación de la salud; pero se omitieron varias veces, ya porque no eran necesarios, ya porque lállábamos muy sensible al marinero la molestia de descolgar su coi cuando necesitaba más 
bien dormir en él que limpiarlos. Los más tardos en esta parte, que fueron siempre muy pocos, se aguijonaban con premio, arma que hemos hallado infinitamente más poderosa que el castigo.

La ventilación interior, el sahumar y rociar con vinagre los parajes ménos ventilados, fueron preservativos que empleamos con la posible frecuencia; y á este fin áun en las mares más tempestuosas, se aprovechaban los posibles instantes para abrir algunas portas del combés y de las escotillas, y desterrar así cualquiera enfermedad y malos hábitos.

Por lo que toca al frío, se procuraron remediar con la mayor igualdad las urgencias de todos, libertando finalmente del servicio sobre cubierta y empleando en otros menesteres de la fragata en lugar de pajes, aquellos polizones que ni habian alcanzado lo bastante en la repartición, ni traían por sí prenda alguna. Fué también menester remediar las necesidades de los reclutas de trasporte; además se tuvo la precaución en los dias de agua y frío, no sólo de hacer las maniobras con atención á estos dos fuertes obstáculos de conservación de la salud, sino también de proporcionarles el posible abrigo en las guardias, para cuyo fin se entregaron á cada una diferentes capotes, que sirviesen precisamente al marinero que se hallase en puesto desabrigado.

En el régimen importantísimo de comida, se procuró combinar del mismo modo que en las demás cosas, el conocimiento del carácter y naturaleza española, con las luces que nos sugerían los extranjeros. Preferimos algunas veces lo más vario á lo más sano; el vino de Sanlúcar fué el princjpal antiescorbútico que adoptamos, así para los calores como para los fríos; la carne fresca se dí de ración una ó dos veces á la semana; hasta la altura de Buenos-Aires no se escaseó absolutamente el agua; las calabazas y el Sozvłkro ‘t alternaron en hacer más saludables y más sazonadas las comidas; y el gazpacho por cena, sólo se suspendió en las latitudes muy crecidas, para sustituirles sopa en aceite, que dimos también con el almuerzo durante el tiempo de los fríos. No titubeamos en este último partido, aunque generalmente la crasitud del aceite sea muy propensa al escorbuto, ya porque nuestros aceites eran de la mejor calidad, y ya porque esta especie de comida es muy homogénea á la naturaleza andaluza. No nos pareció conveniente distinguir en el trato unos más que otros; se suministró de un mismo caldero á los marineros, á los polizones, á los soldados de marina y á los reclutas, y todos igualmente tuvieron parte en la distribución del vino y aguardiente; finalmente, en esta nueva entrada de los calores, después de la recalada á Concepción, han crecido nuestros cuidados hacia ellos, tratándolos aún con mucho más cariño y afabilidad, proporcionándoles el preciso descanso, y dándoles por almuerzo un abundantísimo plato de Sowrkrout, acompañado con medio cuartillo de vino de Sanlúcar, y por cena un buen gazpacho: precauciones que no parecerán inútiles al que advierta en los mayores estragos que ha causado en las navegaciones al Perú la entrada de los calores más bien que la de los fríos.

Si después de un régimen como éste y de las razones que lo apoyan, puede creerse que la robustez de la tripulación de la Astrea sea uno de los muchos acasos favorables que suelen experimentarse en las navegaciones al Perú, hágasenos al ménos la justicia de no dudar, que este punto principal, así relativamente á la humanidad como al buen éxito y concepto de las expediciones de la Compañía, ha ocupado incesantemente nuestros desvelos, nuestra conducta y nuestra aplicación, y que hemos sido bastante dichosos para lograrlo, hasta el punto de ver en un estado, ó nada peor, ó algo mejor de los primeros dias de la salida hombres gravemente enfermos de mal venéreo que en todo el viaje no han podido salir de la enfermería y que parecían, por consiguiente, destinados á ser víctimas del escorbuto."

\title{
RESPUESTA del Sr. D. Fosé Saluaresa á las cartas que anteceden del Sr. D. Alejandro Malaspina.
}

\author{
RESPUESTA PRIMERA
}

Con el debido reconocimiento al favorable concepto que á Vm. merezco; deseoso de corresponder á la superior confianza y del desempeño en puntos que tan de cerca se refieren al beneficio de la humanidad, expondré bajo la consideración de Vm. algunos apuntamientos en contestación á su muy apreciable carta de 24 de Diciembre pasado, reduciéndome á solo aquellos artículos sobre que su anhelo por el acierto y su modestia no le permiten resolver con la seguridad y mano maestra que relucen en todas las providencias anticipadas por $\mathrm{Vm}$. que se sirve comunicarme y doy por 
supuestas. No puedo, sin embargo, desentenderme de las reflexiones que, dimanadas de un estudio profundo y experiencia aprovechada, extiende $\mathrm{Vm}$. sobre el carácter de nuestra marinería y medios de manejarla con ventaja á la de cualquiera otra nacion. ¡Ojalá prendan estas ideas en todos los que hayan de mandar, superando sin desaire de la gerarquía los obstáculos que susciten el amor propio y el destemple natural!

Concibo, pues, en orden al primer punto, que son preferentes en la eficacia las depuraciones del aire por el fuego en las cubiertas á las practicadas por medio del vinagre. Puede, no obstante, el estado de la atmósfera caliente y seco, exigir se rocíen con dicho licor, cuyas exhalaciones ofrecen con la virtud antipútrida bastante recreo y atemperación; y en este caso, es mejor el rocío que el vapor, por el que se disminuye la fuerza y pureza del ácido.

Por lo que respecta á graduar las resultas del desabrigo en los rápidos tránsitos del mucho frío al mucho calor y las del excesivo abrigo por la carga de ropa, hallo ser más temibles las primeras; pues por poco que se radique un resfriado en el marinero y haga tiro al pecho, lo consume insensiblemente hasta inhabilitarlo; y el exceso de ropa sólo ocasionará una molestia que se irá haciendo tolerable con el convencimiento del motivo y más á los del Norte de España, de genio ménos desaliñado en sus personas y más acostumbrados á andar cubiertos. Dejo, no obstante, en su lugar, lo que exija la ocasión, en que á presencia de excesivo calor puede quizás ser de impedimento á las maniobras ejecutivas la mucha ropa.

En materia de comestibles, siendo de tanta consideración el objeto del pan, he reflexionado mucho sobre su cochura, pesando y comparando entre sí las ventajas y perjuicios de que esta operación sea diminuta; y me parece que toda la salubridad que quedaría en el pan poco cocido, se desvanecería por las digestiones trabajosas y proximidad á criar humores glutinosos, que resultarían obstrucciones en las vísceras del vientre, y en esta situación el escorbuto hace fácilmente presa, siendo también del caso no despreciar la poca satisfacción del paladar en el uso de un alimento cuotidiano.

Considerando con igual prolijidad las resultas de la alteración del pan de maíz y centeno con el de trigo, se presenta desde luego la bondad de aquéllas semillas y su sabor no ingrato; pero induce algún temor su mayor tenacidad y crudeza, especialmente en forma de tortas infermentadas, y mucho más en uso repetido. Reflexionando, no obstante, que es alimento de gente robusta y laboriosa, y á que están acostumbrados los habitantes de nuestras provincias septentrionales, no desapruebo la tentativa de otras tortas sin frecuentarla, hasta asegurarse en lo posible, de la resistencia de sus estómagos. No por eso ocultaré que propendo más á que se suministren las harinas de estas semillas con parte de la de trigo, en forma de poleadas, y con suficiente azúcar, que además de su especial virtud antiséptica avivaría su digestión. En esta preparación es más domable la tenacidad de dichas subsistencias, que el fuego no penetra con tanta inmediación á causa del vehículo del agua. El día de este alimento podía ser menor la ración de pan.

Por lo que dice á las menestras, cuya virtud antiescorbútica es evidente, hecho cargo de que deben calificarse respectivamente á dicha calidad y á cualquiera otra saludable con preferencia á su conservación y duración bajo las circunstancias verificables en la dilatada navegación de que $\mathrm{Vm}$. se halla encargado; y en el concepto que alcanzo á formar de que la análisis química en esta parte no sugiere fundamentos decisivos, se hace preciso recurrir á experiencias, que derivadas en lo ocurrente en el ejercicio de la práctica médica, adquieren alguna presunción de asentadas. Estas me han enseñado que en el arroz y los garbanzos se encuentra cuanto beneficio contienen las demás de uso sin la tenacidad y la aspereza de las otras.

Por tanto las contemplo más oportunas; y sólo para evitar el fastidio de la uniformidad, juzgo se dé lugar para alguna alternativa á los fríjoles blancos.

Aunque el objeto de la conservación y de la duración sean distintos de virtud, estoy muy inclinado á creer, que en razón de ésta se verifiquen aquéllos en muchas sustancias; entendiéndose por conservación la corta evaporación del espíritu rector especial que las caracteriza intrínsecamente, y cuya existencia y diuturnidad no se determina por las afecciones externas. Ocúrreseme apuntar que en el arroz del Piamonte, y en el veronés, aunque de exterior ménos agradable y ménos blanco, se encuentra más proporción para el gusto de la nutrición.

Toda la ventaja que lleva en lo saludable la carne de vaca al tocino en estado fresco, se desvanece con palpable desmedro é inferioridad en el de salada, y por lo mismo se reputa como casi proscrita de la Armada. Conozco lo costoso del atocinado, y más en vista de la debilidad de los vinagres de América; pero el caso exige esforzar lo mejor conocido, esperando de las experiencias ulteriores todo lo que sin perderlo sea compatible con la prudente economía.

Sobre el artículo del aceite, á pesar de que no deben considerarse los marineros septentrionales de Lisprña como habituados á su uso, y que por lo mismo no extrañarían su falta; la bondad de 
este condimento alimenticio, la recomendable calidad del nuestro, y el que no les desagrada, persuade se le dé lugar entre las provisiones de boca.

En cuanto á determinar su uso prudente, me parece se destine á las sopas por almuerzo, ó cena en los climas fríos, y por sólo cena á los gazpachos en los calurosos; cuidando que su cantidad se tase á solo objeto de un moderado aderezo. En el segundo modo se doma algun tanto su acritud con el vinagre y tendencia á la rancidez, y en el primero mucho más agregando azúcar. No es esta muy conforme á mi paladar, pero conozco la casi natural afición de nuestros nacionales, y que esencialmente se opone á la putrefacción. Ni tampoco me atrevo á determinar si su coste excederá considerablemente los límites de una amplitud arreglada.

En los términos que van apuntados, concibo que el gazpacho será utilísimo; pero de ningún modo me parece se insista en su uso repetido si un fastidio verdadero lo hace ménos tolerable áun en amago á gente no acostumbrada á él: espero, sin embargo, que se aficionen.

Un principio de pesade $z$, y ménos soltura de los miembros con algún enronquecimiento, serán á mi ver indicios de que se van espesando los humores, y amonestarán se desista de tomar comidas con aceite hasta su disipación: cuidando no confundir estas señales con los efectos del frío excedente, que son más pasajeras.

Sobre los puntos relativos al importantísimo renglón del vino, aunque no hallo escasa para un efecto saludable la cantidad de medio cuartillo por la medida mayor que equivale á ocho onzas, me inclinaba á que se agregasen dos onzas más; y en este caso á que se compartiese en la comida de medio día y cena cuando ésta no fuera de gazpacho, pues entonces, siéndolo, podría suministrarse en el almuerzo este eficaz digestivo. Y de todos modos reputo por más oportuna ocasión la de la comida más fuerte del medio día.

La exclusión del aguardiente y del pescado salado, incluso el bacalao, me parece acertadísima, como sólida la determinación de circunstancias bajo que pueda darse lugar al uso del queso.

Es cuanto, ansioso por el acierto, he alcanzado á deducir de las más serias reflexiones; debiendo sinceramente confesar, que la precisión, solidez é inteligencia con que trata Vm. el asunto en su carta, me han hecho la costa para satisfacerla. Espero los demás artículos referentes á materia tan importante, y órdenes del agrado de Vm., en cuyo obsequio se empleará gustoso su más apasionado y afecto servidor y amigo Q. S. M. B.-Cádiz, 5 de Febrero de I789 (I).

\title{
CARTA de Malaspina al Subinspector de Arsenales, por la que se infiere la inteligencia, celo é iniciativa del Fefe de la expedición hasta en los más insignificantes pormenores.
}

\author{
Sr. D. Fermin de Sesma, Capitán de Navio y Subinspector de Arsenalcs:
}

Expondré á V. S. con el posible detalle, las pocas ideas que tengo presentes sobre armamento de las dos corbetas para la próxima expedición, no tanto para que puedan ser de alguna utilidad en el sumo caudal de conocimientos relativos particularmente á este ramo que V. S. posee, como para cumplir una orden que nos impone S. M., y manifestar por escrito aquellos sentimientos de respeto y concepto que desde tanto tiempo en mí se hallan grabados.

El aparejo pendiente (para proceder según orden de inventario) estará por completo al arbitrio de V.S. Ambos Comandantes conformes en este particular, estamos seguros que nada nos quedará que desear, y sólo atentos al número de gente que tendremos para la maniobra y á los parajes que con más frecuencia habremos de trillar y á la duración del viaje, nos aventuraremos á hacer las siguientes insinuaciones, remitiéndolas no obstante todas á la absoluta determinación de V.S.

Conviene que las menas en general, así de cabos como de motones (comprendidas áun las jarcias mayores) sean más bien con algún exceso delgadas que gruesas; que la motonería del propao

(I) Suprímense las segunda y tercera cartas, por ser éstas ininteligibles, á causa de lo deteriorado que se halla el manuscrito. 
gire sobre pernos, como en la fragata Astrca, y que se eviten en general todos aquellos casos de refuerzo, que, propios tan solamente de mares tempestuosos, en los apacibles sólo sirven de atraso en el andar y de un grave deterioro en los pertrechos. Doy por supuesto que el aparejo, crucetas, guinda y cruzamen de los juanetes y sus velas, han de seguir aquella excelente proporción que admiraban hasta los extranjeros en la Astrea. Supongo que se facilitará con rolletes el manejo de los cables y que en el laboreo en general de la maniobra se preferirá, con prudente método, no tanto un excesivo aligeramiento y desembarazo, como una sólida compensación de fuerzas que no necesite alterarse á cada paso.

En cuanto á la arboladura de respeto, sólo añadiremos á la dotación general de los buques de S. M., una jimelga y dos masteleros de juanete en lugar de astas de hierro. La igualdad de ambos aparejos de popa y proa, excepto los palos y vergas mayores, es una de aquellas ventajas indecibles que desde luego V. S. nos ha dictado y llevará á debido efecto.

Las anclas podrán llegar al número de seis, dos de á 22 quintales y cuatro de á I8. Nos ceñiremos á cuatro anclotes, dos de nueve quintales, uno de siete y otro de cinco, los cuales, si tuviesen cepos de hierro para su más fácil manejo y acomodo interior, desde luego podrían no estorbar el fácil manejo de anclas. Los cabos y calabrotes correspondientes á estas anclas, pueden, á nuestro entender reducirse á los siguientes: tres cables de I5 pulgadas, cuatro ídem de I3, tres calabrotes de siete y tres de cinco y media. Podrán omitirse los viradores y simplificarse el número de orinques, refiriendo unos y otros á las guindalezas y veteria en piezas completas, en las cuales por consiguiente, se envolverán todas las piezas cortadas, especificadas en el inventario con el nombre de jarcia de respeto. La cantidad de guindalezas y veteria de repuesto será pues adecuada, no sólo á esas necesidades en atención á cuatro años de un trabajo contínuo de amarras, sino también á los climas ordinariamente destructivos de la zona tórrida bajo la cual serán mucha parte de nuestras tareas.

De la jarcia alquitranada de peso llevaremos toda la posible, y áun mucho mayor cantidad de jarcia trozada en cables, que nos servirá también para estiva, pues que en cualquiera escala nos será tan fácil un acopio de leña como difícil, y áun imposible, uno de jarcia trozada, necesaria, por otra parte, para la conservación del aparejo.

En la motonería, herrajes y piezas sueltas, dependerán éstas enteramente del aparejo pendiente. Sólo sí llevaremos por duplicado, si pareciese oportuno, los cuadernales de tumbar que considero también suficiente para varar, si fuera preciso, una ó entrambas embarcaciones.

Los utensilios del Contramaestre y los betunes necesitarán por lo común de aumento. A estos últimos será preciso añadir una cantidad considerable de aceite de linaza y un buen acopio de pinturas en polvo.

En el velamen de lona podrá facilitar su manejo, sin disminuir de resistencia, el que sea todo de lona de gavias de fragatas, ó si fuera posible de otra más fina. Podremos llevar tres juegos completos y otras dos gavias sin relingas. El velamen de vitre podrá en general ceñirse á dos juegos; cuando más se le añadirá un juanete (según lo convenido) común á entrambos palos. En los tejidos de respeto pueden considerarse las mismas necesidades que en la jarcia. Si pareciese más conveniente para los consumos de ese Arsenal, pudiéramos emprender la salida de aquí, y por consiguiente, el primer corte de la línea, siempre destructivo para el velamen, con un juego ya usado ó de media vida. Los utensilios para coser velas y el número de cois serán proporcionados al viaje. Treinta catres ingleses por embarcación reemplazarán los de madera para Oficiales de mar y la enfermería.

Nada diré por ahora sobre utensilios de piloto, si no es que nos serán precisas un par de agujas azimutales por corbeta, ó á lo ménos una.

Nuestra artillería será (si á V. S. parece lo más conveniente) de 22 cañones de á seis, arreglada su carga á 50 tiros, 25 con bala, ro con palanqueta y I5 con metralla. Sólo sí, que cerradas para mayor comodidad de los alojamientos las primeras tres portas de popa, reservaremos en estiva cañones y cureñas correspondientes, y para esto será sumamente útil, el que se entreguen desarmados y en pequeños atados los herrajes y maderas de dichas seis cureñas. Dos cañones de á cuatro y un disparador de cohetes, entrambos para señales, y finalmente, un repuesto, no grande, de utensilios, uno muy abundante de balas para fusil y pistola, un excelcnte armamento, inclusas en él bayonetas, cinturones y vainas para sables, y cuatro ó seis pedreros sin recámara. El cargo de Armero, indispensable para nuestra comisión, se fiará á dos soldados elegidos oportunamente. Responderá de sus utensilios el Condestable.

Sobre los cargos de Carpintero y Calafate será preciso hacer algunas innovaciones en atención á las circunstancias del buque, á las faenas de una varada no muy extraordinaria, y á la existencia á bordo de un herrero. Cuanto más se disminuya el cargo de estos Oficiales de segundo orden, tanto 
más cómodo será el situar cada cosa en su lugar sin franquear á cada una paraje seguro, que en un buque, nó demásiadamente espacioso, siempre ha de ser incómodo. El visitar algunas islas del Mar Pacífico hará preciso el no fiar á muchos, antes bien el no fiar sino al Contramaestre los utensilios sueltos de hierro y cn particular la clavazón; y esta atención exigirá una alteración no indiferente en los cargos, único modo de que no sea luégo ofensiva una precaución tan necesaria como al parecer inoportuna.

En cuanto al número, calidad y aparejos de embarcaciones menores, no parezca á V. S. impropio el que suspenda el hablar de ellas hasta que sistemado todo lo relativo á los buques principales, y por otra parte, enterado ya más al pormenor de los diferentes destinos de la expedición, podamos con más acierto ocuparnos de este ramo secundario, bien que no ménos importante. Desde luego, constituídos en nuestro método de poca gente, á no nombrar patrones de las distintas embarcaciones menores, tendremos que fiar este nuevo cargo al Contramaestre, del mismo modo que en los buques de S. M. se hace con los sereníes.

Hasta aquí no nos hemos separado de los cargos comunes de las embarcaciones de la Real Armada; pero no se ocultará á V. S. que una expedición de esta especie há menester de otros mil utensilios, sin los cuales cada paso fuera un tropiezo y áun á veces temeridad el empeñarse en cosas de algún riesgo. Tales son particularmente los fogones con destilador y ventilador semejantes al que ha usado en la última campaña el Navío San Sebastín; unas fraguas bien manejables y adaptadas á todas las necesidades que pueden ofrecerse de estas excelentes máquinas; los oportunos utensilios de pesca y caza, tomados entrambos objetos en toda su extensión; varias bagatelas interiores que, á pesar de referirse á principios de comodidad, son de perdonarse en unas personas constituídas á vivir tres ó cuatro años en la mar, á encontrar no pocos riesgos, y particularmente á emplear en cálculos y detalles bien prolijos las horas libres del servicio marítimo ó del preciso descanso.

Acabo ya esta narración casi del todo inútil, si bien se considera la inteligencia y celo que guian á V. S. en cuanto mira al Real servicio ambas cualidades, de las cuales ya desde mucho tiempo así Bustamante como yo somos tan buenos testigos como elogiadores.

Nuestro Señor guarde á V. S. muchos años.=Cádiz, á 2 de Enero de I789.

\title{
CARTA de Malaspina al sabio Ingeniero Muñoz, haciéndole indicaciones sobre la colocación de pararayos.
}

\author{
"Sr. D. Tomás Muñoz:
}

Combinado el espíritu de la última Real orden sobre el establecimiento de pararayos á bordo de los buques de S. M., con lo que han escrito y experimentado los físicos y con las últimas lecciones de Mr. Le Roi, oídas en París por los Sres. de Ureña y Betancourt, he podido deducir para las corbetas Descubierta y Atrevida, la siguiente aplicación que expongo ahora al juicioso examen de V. S., á fin de poncrla en práctica si mereciere su aprobación.

Desde luego, la acción del pararayo con la cadcna eléctrica, no exige en cl largo de nuestras corbetas que sea sino uno; y éste, en mi entender, podrá colocarse del siguiente modo:

La aguja será de hierro y del largo de cinco piés, formando figura cónica sobre una base de una pulgada próximamente. Esta base podrá enroscarse con bastante fuerza en un macho igualmente de hierro puesto en el tope y macizado con resina. Encajará en la aguja con el largo de una vara desde la cúspide, una vaina ó contera de latón que termine agudísima y tenga dorada como una pulgada en su extremo superior.

Estará igualmente firme en el macho del tope el principio de la cadena, que será del largo de siete piés, y de un alambre grueso. Esta pieza se abarbetará á la encapilladura de modo que pueda zafarse cuando se quiera, ó unirse á la cadena larga cuando amenace el rayo.

La cadena para su mayor acomodo y áun colocación, será de eslabones de un pié de largo, fáciles á doblarse y áun á zafarse cuando se hayan de quitar algunos trozos según la diferente posición del mastelero de juanete. Desde el canto popel y exterior de cada mesa de guarnición mayor", 
bajará algo más grueso y hecho firme en el mismo canto otro trozo de la cadena con un peso inferior; $y$ de este modo, firme un extremo de la cadena movible en el remate del trozo alto, y el otro en el principio del trozo bajo, se logrará la deseada comunicación desde la cúspide del pararayo hasta el agua.

Las prevenciones oportunas para el mejor logro de esta conducción, serán principalmente las tres siguientes: I. ${ }^{n}$ Un brandalito á cada banda del juanete mayor de jarcia blanca, cuya encapilladura superior á todo, aproxime cuanto sea posible con el macho firme del tope. 2. ${ }^{a}$ Un botalón de dos piés de quita y pon para desatracar el conductor de la cruceta, cuando el juanete esté calado, ó sustituirle el asta de hierro. $3 \cdot{ }^{\mathrm{a}}$ Un botalón en la borda del alcázar ó en la mesa de guarnición de mesana que desatraque del costado y llame algo para popa el último trozo de cadena. Para la firmeza de este botalón se le pondrán amantes al tercio y tendrá en su extremo un guardacabo embutido en la madera y macizado jgualmente con resina, de suerte que la cadena sujeta de este modo, ni se aproxime á las cadenas de la mesa de guarnición, ni toque al forro de cobre en la cumbre del agua.

Serán, por tanto, precisos para este efecto los materiales siguientes: Un suncho de hierro de cuatro pulgadas de largo, dos pulgadas de base y una leve disminución en la parte superior en figura de cono truncado. El pararayo en forma de cono truncado, cuyo largo sea de tres y medio piés y sus diámetros proporcionados á la base del suncho y á la parte que falta á la cúspide. La otra mitad de latón enroscará en el hierro y sobre un largo de dos piés tendrá toda la agudeza posible, dorándose su extremo alto como el largo de dos á tres pulgadas. Finalmente, la cadena en tres trozos, el uno de diez piés para hacer firme en el suncho; el otro de ciento diez para venir desde éste á la mesa de guarnición, y el último de quince para pasar de la mesa de guarnición al agua. El modo de engancharlos uno con otro, se elegirá el más expedito y seguro. E] grueso de los eslabones podrá ser algo mayor de una línea; su largo de un pié ó dos, y sólo los últimos eslabones tangentes al agua, serán de un grosor doble ó triple en proporción para gravitar con más facilidad y solide $z$.

En cuanto al cabo blanco y los botalones, probaré primero usar una de las drizas de seña y de piezas sueltas de á bordo. Si fuesen necesarios, se pedirán luego los correspondientes efectos.

Nuestro Señor guarde á V. S. muchos años. A bordo de la Descubierta, á 22 de Mayo de 1789 .

\section{CARTA del Fefe de Escuadra D. Gabriel de Aristizábal á D. Alejandro Malaspina, en la que tan insigne marino se excusa modestamente de aconsejarle sobre un plan hidrográfico.}

Apruebo las sabias medidas que V. S. toma para desempeñar la Real confianza, tan dignamente depositada en V. S.: su importancia y objeto exjgen el ímprobo trabajo y las noticias fundadas que V. S. pretende acumular; como materiales náuticos y físicos para la obra que emprende, y cuya utilidad deseo se logre en lo futuro.

Yo estimo en mucho el concepto que á V. S. merezco, cuando ha creído que mis conocimientos podrían darle luces para ilustrar la parte hidrográfica de su plan en el Archipiélago Filipino; el interés con que justamente miro los progresos de la navegación, las glorias de nuestro Cuerpo (en sus empresas militares y científicas) y el mayor lustre y desempeño de un amigo como V. S., me estimularían siempre, áun sin la espuela de querer responder dignamente á su consulta, á recordar cuantos conocimientos me proporcionó en aquellos mares la experiencia de cinco años, cuantos pude adquirir de los prácticos, cuantos me pudieron prestar archivos y papeles que ciertamente consulté con varios motivos en distintas representaciones al Rey nuestro Señor en aquel tiempo, y alambicando todo lo ménos inútil hacer á V. S. un corto presente, para que conocicse mi voluntad de contribuir á sus lucimientos, más que la profundidad ni extensión de mis indagaciones; pero al cabo de catorce años que he regresado de aquellas regiones, $y$ habiendo estado durante este tiempo empleado en tan varias comisiones como á V.S. consta, apenas conservo unas ideas remotas que 
comparadas con las vivas y nuevas que V.S. logró de resultas de repetidos últimos viajes, hacen desvanecerse la conjetura de su utilidad. Tampoco conservo documentos ó copias de mis citadas re. presentaciones al Rey desde allí como Comandante de aquella Marina, ni desde aquí como consultado; pero se hallarán en la.Secretaría del Despacho universal de Marina de Indias, si acaso merecieron aceptación al Soberano y sus Ministros en aquel tiempo; todo esto es cuanto puedo reproducir á V. S. en respuesta á su favorecida del I7 de Marzo de este año, asegurándole mi eterna gratitud y deseos de su prosperidad y aciertos futuros, como la justa estimación que me merece V. S., á quien Dios guarde muchos años. $=$ Ferrol, 8 de Abril de $1789 .=S r . D$. Alejandro Ma. laspina $=$ Gabriel Aristizíbal.

\section{PRUEBA de las Descubierta y Atrevida segim nota de Malaspina.}

Estas corbetas, construídas por el Ingeniero Comandante de este Departamento, D. Tomás Muñoz, se probaron el dia 5 de Julio á presencia de este Oficial y del Excmo. Sr. D. Antonio Ulloa, uno y otro embarcados en la Descubierta. Varios otros Oficiales de la Armada asistieron á las mismas pruebas en la ATREVIDA.

Se examinaron cuidadosamente los calados y se hallaron:

En la Descubierta.

\begin{tabular}{|c|c|c|}
\hline & Pies. & Pulgadas. \\
\hline Cala de popa. . . . . . . . . . . . . . . & I 4 & $\infty$ \\
\hline Cala de proa. . . . . . . . . . . . . & I 3 & 6 \\
\hline 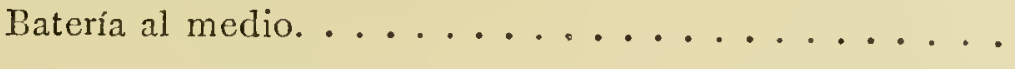 & 5 & $\infty$ \\
\hline
\end{tabular}

En la Atrevida.

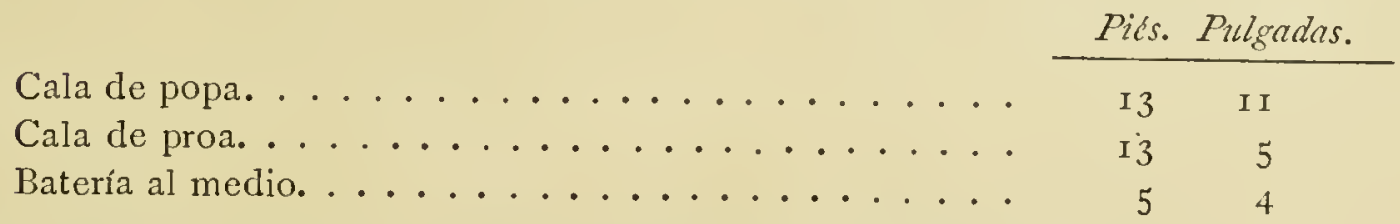

Los pesos en la Descubierta eran los siguientes sobre una aproximación de I5o quintales y deducidos del pormenor de cada una componiéndose de muchas cada partida de las que aquí se cxpresan:

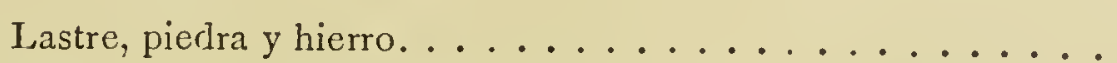

Arboladura pendiente y de respeto. . . . . . . ....

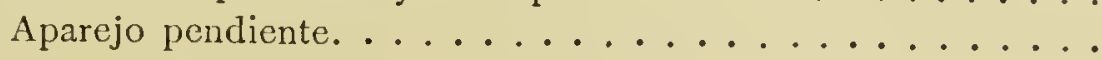

\begin{tabular}{rr}
\multicolumn{2}{c}{ Quintales. } \\
\hline I,000 & 00 \\
398 & 50 \\
150 & 00 \\
639 & 63 \\
509 & 25 \\
35 & 00 \\
1,470 & 30 \\
391 & 10 \\
1,291 & 70 \\
216 & 75 \\
836 & 50 \\
75 & 00 \\
25 & 00 \\
12 & 00 \\
9 & 00 \\
102 & 00 \\
150 & 00 \\
\hline 7,311 & 75
\end{tabular}

Artillería, pólvora y municiones. . . . . . . . . . .

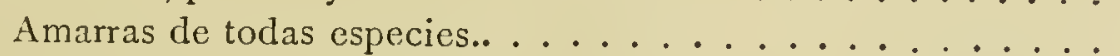

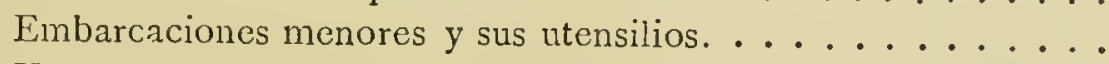

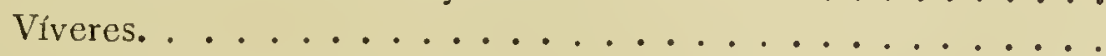

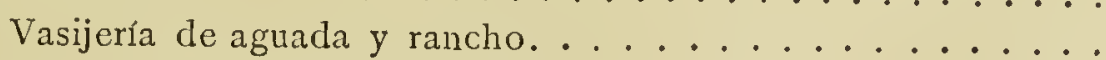

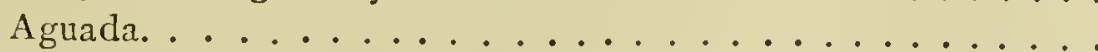

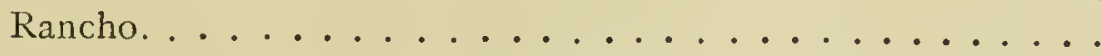

Respetos incluso la jarcia trozada. . . . . . . . . . .

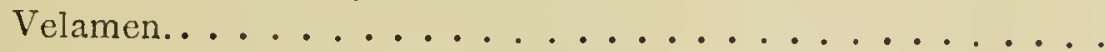

Equipajes, instrumentos, libros, etc. ..........

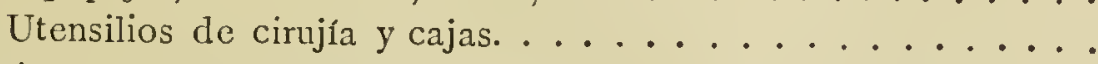

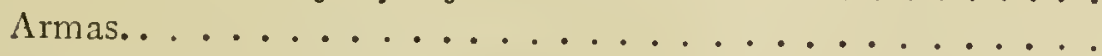

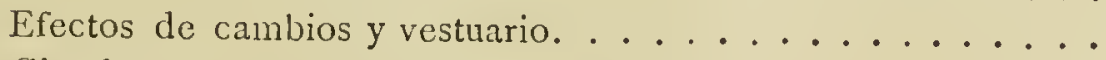

Cien hombres y parte de sus equipajes ...........

TоTAL. ............. 
Los pcsos de la ATREvid podían considerarse próximamente los mismos, pero su estiva estaba más bien proporcionada, aligerada la proa de cerca de 200 quintales de lastre, y hecha la repartición de efectos con atención á lo que se advertía en la DescubierTa, cuyos trabajos se anticiparon siempre unos quince dias, intervalo con el cual se botaron al agua.

La variedad de efectos embarcados; la precisión de tenerlos casi todos á mano; los mismos plazos de su apresto, y finalmente, la ninguna práctica del mismo buque y de sus verdaderas capacidades difíciles de graduarse dc un solo golpe de vista, nos aseguran que estamos muy lejos de haber acertado en esta ocasión con el mejor modo dc estiva, bien que nos dan esperanzas de poderlo acertar en lo venidero cuando se haga nuevo arreglo.

Consideramos nuestros repuestos existentes hoy á bordo, en la proporción que sigue. Toda especie de pertrechos para cuatro años supuestas unas regulares pérdidas y deterioros, así en las altas latitudes por los temporales, como en las inmediaciones de la Equinoccial por los efectos del sol y de las lluvias. La aguada y víveres son para diez meses, menos el pan que compone sólos seis meses de ración completa. El vino de Sanlúcar, coles agrias, vinagre y aceite, pueden considerarse suficientes para un plazo de dos á tres años. Las medicinas, todos los libros, instrumentos simples y utensilios que corresponden á la Historia Natural y á la Astronomía, todo lo necesario á dar de quilla y habilitar entre la tripulación varios obreros de Calafate, Carpintero y Herrero, y finalmente, un acopio, grande y áun excesivo de géneros de cambios, regalos y de vestuarios para la gente, forman una cantidad de efectos difícil de combinarse con la apariencia exterior de las embarcaciones cuyo calado no excede de catorce piés, y en cuyo buque se ha dejado sitio bastante para los acopios de Historia Natural.

Las corbetas dieron la vela á las siete y media de la mañana sobre las govias, juanetes, foque y mesana. La marea era entrante con la velocidad correspondiente á las inmediaciones del plenilunio y el viento bonacible del O. Fué menester pairear un buen rato, para que la ATREvidA concluyese sus faenas de ancla; luégo, con el mismo aparejo y la mura babor, empezamos las pruebas al mismo tiempo de comparación de los buques entre sí y de sus cualidades absolutas. Viramos á las diez á un tiempo por avante y se dieron las mayores y los estays; reviramos sobre los bajos de San Sebastián y dado nuevo bordo á las costas de Rota, nos hallamos bién franqueados y volvimos á virar al S. O., con viento del O. $1 / 4$ N. O.

A la una nos pusimos al pairo, y mareado nuevamente todo aparejo á las tres, se hicieron en diferentes bordos y sin sujeción una á otra, varias pruebas hasta las seis y media de la tarde, á cuya hora arribamos, y con trinquete, gavias y juanetes logramos fondear de nuevo en bahía al ponerse el sol.

\section{Deducción de las priebers.}

El andar, gobierno y aguante de ambas embarcaciones, puede considerarse igual según todas las pruebas de este día. La ATrEvida en dos ocasiones ganó algún barlovento á la DescubierTA, pero esto debe atribuirse tal vez al mejor estado de su estiva, que ya se ha manifestado.

Las corbetas han virado por avante en dos mimutos con gavias, juanetes y foques, viento de cuatro millas y marea contraria. En un minuto, con todo aparejo de bolina, andar de cinco millas y marea contraria; en dos minutos y medio con el timón á la vía, todo aparejo de bolina, marẻa favorable y andar de seis millas; han virado en redondo en dos mimutos, andar de seis millas, todo aparejo y marea contraria; bién que fué menester dilatar la virada por no poderse preparar el aparejo con la debida celeridad; finalmente la Descubierta ha virado en redondo, con el aparejo de proa en facha en dos min:ltos y la ATREvida había casi alcanzado la virada por avante que intentaron ambas sobre las gavias, juanetes y estays, con la sobremesana en facha y la mesana cargada; siéndole sin duda obstáculo además de la marea, la ola bien picada de la virazón.

Hemos ceñido constantemente en dicz cuartas en las dos vueltas. Nuestro mayor andar ha sido de siete millas corredera larga, en cinco cuartas y todo aparejo largo; y al mismo tiempo la inclinación de la batcría era en la ATREvida de tres piés y dos pulgadas y en la DescubierTA de tres piés y una pulgada. En la una se determinaban las inclinaciones con un aplomo desde el batiporte exterior; cn la otra servía un aplomo interior en cl puntal proel de la escotilla mayor, comparados sus laryos á la semimanga. El abatimiento no ha sido mayor de cuatro á cinco girados. Bien casado todo el aparejo de popa se necesitaban tres cabillas ó arribar para cquilibrar cl aparejo, y hasta csta circunstancia era jogual en ambas corbetas. 
Como la colocación de las embarcaciones menores, que llegan á cinco y todas sobre cubierta, podía parecer difícil ó á lo ménos peligrosa, se han metido las dos que deben contener las otras dos más chicas. El último bote, destinado particularmente para pescar y medir la corriente, tiene sólo once piés de quilla, igual á popa y proa. Su acomodo, por tanto, no debe dar el menor cuidado. Se ha conocido palpablemente que ni en los mares más tempestuosos correrán el menor riesgo estas cinco embarcaciones menores.

Debía hoy examinarse por medio de pesos conocidos una inclinación que resultase en la batería para deducir luégo las fuerzas comparativas necesarias á lograr la mayor inclinación. No lo han permitido las circunstancias, pero se hará á la primera ocasión oportuna.

Entre tanto, debemos asegurar que cuantas propiedades hemos examinado en ambas corbetas, al paso que acreditan más y más la pericia de su autor, nos dan las esperanzas más lisonjeras de poder desempeñar con acierto el destino que S. M. se ha servido poner á nuestro cargo.

\section{"Excmo. Sr. D. Lais de Córdoua:}

Excmo. SR.: La adjunta noticia cerciorará á V. E. de las principales ocurrencias del día de ayer relativamente á las pruebas hechas á la vela en las corbetas de S. M. Descubierta y ATreVIDA, que han fondeado nuevamente en esta bahía en la misma tarde.

Nuestro Señor guarde la vida de V. E. por muchos años.=Corbeta Descubierta, á 7 de Julio de $1789 .=$ Alejandro Malaspina."

\section{RESUMEN de los aprestos para un viaje alrededor del mundo emprendido por las corbetas Descubierta y Atrevida.}

Interesados igualmente el paternal amor de S. M. en beneficio de sus vasallos y su constantc anhelo de fomentar los conocimientos marítimos, ha determinado su Real ánimo destinar las corbetas de la Marina Real Descubierta y ATrevida á un viaje alrededor del mundo, con el doble objeto de continuar la grande obra de las cartas esféricas, en todas las costas de sus casi inmensos dominios y de contribuir á los progresos de la Geografía, de la navegación y de la Historia Natural en todos sus ramos.

Han sido proporcionados á unos fines tan humanos y tan grandes los aprestos de aquellos buques; y no debe parecer molesto el por menor, así del armamento como de las tareas que han de emprenderse.

\section{Buques y pertrechos.}

Confesando de antemano que la extensión de los dominios de S. M. en las diferentes partes dcl globo disminuyen mucho las necesidades del navegante español en un viaje de esta especie, y que por tanto los acopios, particularmente de comestibles, no han de ser tan crecidos; podemos aspirar en cualquiera otra relación en que se miren, al concepto de ser nuestras embarcaciones las más idóneas para el intento, de todas las que se han hecho hasta aquí. Un calado de catorce piés escasos, sobre una capacidad de 342 toneladas, y un aguante, gobierno, andar y barloventear, cual to han acreditado las últimas pruebas, nos hacen creer que no habrá costa cuyo reconocimiento nos sea imposible y que no habrá cala en donde no podamos ponerlas al abrigo.

Al mismo tiempo la casi total igualdad de propiedades que han manifestado entrambas y la ventilación y acomodo interior de todos, nos ponen casi á salvo de una separación involuntaria ó de unas perniciosas enfermedades. El plano númcro i deja ver claramente que la decencia y comodidad de los Oficiales y demás individuos adictos á la parte científica, están combinados con un regular alojamiento en los Oficiales de mar y con el mejor que puedan desear la tropa y marinería, de los 
cuales ni uno deja de tener su coi colgado. La misma distribución de alojamientos que ha proporcionado el buque, ha dado lugar al establecimiento metódico de nuestra disciplina, de la cual, siendo bien arraigada, pende casi todo el buen éxito de estas empresas.

Durante esta primera navegación, que ni da cuidados ni ocupaciones, correremos el tingladillo de la popa y abrigaremos algún tanto la proa para resistir con más seguridad á los temporales. De este modo, sin perder ninguna de sus buenas cualidades, las corbetas proporcionarán el mayor abrigo á la gente y áun á las plantas ó animales que se quisieran conservar en climas fríos. Las maderas con que se han construído estas corbetas son de las más selectas y bien sazonadas. Además, se ha tenido la precaución de masijar las ligazones y calafatearlas. La tablazón del firme, el zulaque, el forro de madera con clavos de metal, y últimamente el de cobre, son otros tantos preservativos que nos ponen al abrigo de muchos peligros á que estuviera expuesta una embarcación de las comunes.

La colocación del cabrestante mayor en el combés y de las embarcaciones menores sobre cubierta, ha parecido á muchos imprudente, ó á lo menos aventurado. Hemos experimentado ya la fuerza del cabrestante y la facilidad de su manejo por medio de un retorno. El uso constante de las embarcaciones inglesas de la India Oriental; el poco peso de nuestras embarcaciones menores; su mismo número y necesidad de usarlas frecuentemente, deben justificarnos cn cuanto al segundo partido.

El número de nuestros botes, que llegan á cinco, nos suministra los mayores recursos para el objeto primitivo de las tareas hidrográficas, combinadas con las precisas atenciones á la Historia Natural, á la pesca, á la caza y á las urgencias naturales de aguada, leña, etc. La lancha resistirá á levar nuestras anclas de menor peso. Con mares bonanciblcs pueden embarcarse á un tiempo 95 hombres. La aguada se hará con suma facilidad por medio de barricas que se han preparado para el intento. Los aparejos de estos botes aún no se han perfeccionado; pero la experiencia misma irá dictando diariamcnte, con la pericia de manejarlos, los que más convengan á cada especie.

Las capacidades del buque, á pesar de lo que hemos dicho al principio, son tales, que nos dan lugar á embarcar dos años de toda especie de provisiones de boca, menos el agua y la leña, que deben reducirse á seis meses, cantidad excesiva para unos buques destinados al reconocimiento constante de las costas. En el día, en que los pertrcchos navales están arreglados á cuatro años; el vinagre, el aceite y el vino, á tres; las menestras y tocino, á un año; el pan á seis meses, y el agua y la leña, á diez; se acomodan, no obstante, un grande repuesto de efectos de cambios y vestuario; muchos efectos para las operaciones de todas especies; muchos utensilios correspondientes á las ciencias con que intentamos abrazarnos, y por último, todos los equipajes correspondientes en la misma proporción.

Navegamos, no obstante, con cinco piés de batería, y el día en que hemos hecho las pruebas, un andar de siete millas, corredera larga en cinco cuartas, no nos precisó á cerrar las portas de Santa Bárbara. Estos efectos, dimanados de la inteligencia y celo del Ingeniero D. Tomás Muñoz, han sido perfectamente correspondidos en cuanto al aparejo y repuestos por el Brigadier D. Fermín de Sesma. Brillan en todo nuestro aparejo pendiente el primor y la resistencia, y á pesar de la poca pericia de una tripulación no reunida ni conocedora aún sus Oficiales, la maniobra, ni las voces, en el día de las pruebas la ATREvida ha virado por avante con todo aparejo en un solo minuto desde las seis cuartas de una amura á las seis de la otra; lo ha verificado la DescubierTa en pocos segundos más y entrambas han ceñido siempre en cinco cuartas. Nuestras mayores son proporcionadas á la manga, las gavias algo menores, los juanetes son grandes y en las mares apacibles nos dan un considerable aumento de vela, que en las tempestuosas no es incómodo, echados abajo mastelero y verga.

Seis anclas, cuatro anclotes, sicte cables y seis calabrotes, forman todas nuestras amarras. Ccrca de 200 quintales de jarcia trozada nos proporcionan conservar en buen estado el aparejo. Tres juegos de velas, un buen repuesto de arboladura y los cuadernales correspondientes á dar de quilla ó varar la corbeta para carenarla, todo nos pone al abrigo de los muchos incidentes que suelcn hacer fatal una varada ó un viaje excesivamente largo.

A imitación de los Sres. Cook y la Pérousc, parecía natural la precaución de la lancha en piezas capáz de recoger y llevar á grandes distancias toda la dotación con los víveres correspondicntes. Nosotros hemos creído inútil esta precaución por dos razones: r. ${ }^{n}$ En los dos extremos peligrosos de nuestros establecimientos del mar Pacífico, podrán las colonias inmediatas de Chiloé y Monterey, suministrarnos embarcaciones oportunas con las cuales puedan aún reconocerse más individualmente todas las calas y sinuosidades de las costas, y trabajar con más perfección sus cartas y dcscripciones. $2 .^{a}$ Que ambos navegantes, áun trillando mares más peligrosos, no las han necesitado. 
No es tan fácil como á primera vista aparece, la pérdida de una embarcación, aunque navegue en mares tempestuosas ó sobre costas muy peligrosas, ni fueran útiles las precauciones de la construcción misma del buque, de todos los utensilios para dar de quilla, varar, etc., si se tratase en una urgencia de abandonar el mismo buque.

No debe omitirse hablando de pertrechos, el hacer mención del fogón de hierro con destilador y ventilador, de que irán provistas ambas corbetas. Cuáles sean las ventajas de uno y otro, lo demuestran evidentemente, además de los razonamientos, las pruebas hechas en el navío de S. M. San Sebastián, en el pasado año de I788. A la verdad, no es tanta la economía de leña como en un número crecido de raciones á bordo de un navío de 74 cañones; pero si para cocer los tres calderos que usa nuestra marina en las navegaciones largas se necesitan próximamente diez horas de tiempo, nos aseguran repetidas pruebas que el mismo tiempo y la misma leña suministran en un solo alambique media ración de agua á cada individuo de los que componen la total dotación de una corbeta. Tenemos, no obstante, otro alambique que puede destilar por el caldero cuando unos balances excesivos ó una suma escase $z$ hiciesen necesaria una destilación más dilatada, y al contrario cuando fuese necesario cocinar para las dos dotaciones, el caldero de destilar fuera más que suficiente á este doble aumento. Los hornos, la cocina de los Oficiales y las hornillas para dos ollas de Oficiales de mar, son otras tantas comodidades de esta excelente máquina, á la cual da la mayor perfección el ventilador. Aunque nadie en nuestros buques habite en los parajes poco ventilados, lo usaremos para la salubridad de la bodega y particularmente de la sentina; el humo mismo en la cubierta habitada, será, aunque incómodo, un nuevo principio de conservación. Ambos fogones tienen un excelente acopio de repuestos; la duración por tanto no debe darnos ni el menor sobresalto.

A los utensilios de repuesto hemos añadido también una fragua y una cocinita portátil para expediciones de Oficiales. Las herramientas de Calafates y Carpinteros, se han multiplicado para que soldados y marineros hábiles puedan trabajar en cualquier apuro. Dos trozos de cadena para amarrar y utros dos para cables, nos aseguran también de no tener pérdidas en parajes de mal fondo.

\section{INSTRUCCIONES notables que D. Alejandro Malaspina. commicó á D. Fosé de Bustamante (segundo Fefe de la expedicion) sobre la policía de los buques.}

Fuera agravio recíproco el llamar instrucción á los siguientes apuntes, en los cuales expresaré únicamente el método que ha de seguirse en la Descubierta para que Vm., si gustase, lo adopte también en la corbeta de su mando.

El fin que entrambos nos hemos prefijado al abrazar esta comisión, es uno mismo: de servir á la Nación con tareas particulares, acreditar el honor que nos anima y hacernos dignos de la confianza pública y del aprecio de los Oficiales que se han brindado á encontrar bajo nuestras órdenes una serie bien dilatada de fatigas y de peligros. Pero podemos variar en el concepto de lo que nos guíc más directamente á conseguir aquel fin; y como la uniformidad es, sin la menor duda, la base esencial del servicio, podemos aún, guiados de un mismo celo y de una misma inteligencia, acertando aún entrambos en la elección de los medios, destruir sus buenos efectos con el solo inconveniente de haber tomado diferentes sendas.

Esta reflexión es la que me hace creer que no parecerá á Vm. frívola la muchedumbre de cosas que he de exponerle; si le pareciese temprana, puede considerar que los cimientos son los que deciden de la solidez del edificio, y que han de influir mucho en el concepto general las primeras ideas que aquí se formen de la expedición puesta por S. M. á nuestro cargo.

Están tan estrechamente ligadas en un buque la disciplina y la conservación de la salud; dependen tan inmediatamente una de otra la disciplina que llamaremos de policía y la militar; finalmente, dimana tan directamente de esos principios la poca ó mucha utilidad científica que puede producir la expedición, que fuera imprudencia el no eslabonar entre si estas materias, y contraerlas como á un mismo centro al más cabal cumplimiento de las ideas de S. M. Así la distinción de materias me ha parecido en este caso perniciosa, pues al paso de ser más dilatada traía tam- 
bién consigo la idea de que pudiesen mirarse estos objetos desunidos y que el uno tuviese algún rigor si se descuidase el otro.

En un viaje de.esta especie ha de prevalecer precisamente un método opuesto al de los buques ordinarios de la Armada. En éstos la disciplina militar es la que rige; en aquél debe apartarse cuanto sea posible; ni se ocultará la razón de semejante necesidad cuando se considere que la parte militar no há menester para su buena harmonía de que concurra la voluntad gustosa del súbdito; pero en la científica, que abraza un número infinito de combinaciones, sólo puede lograrse un buen resultado si cada uno, nó lo que le mandan, sino más bien lo que pueda, haya de practicar para el intento.

Multiplicados en un solo individuo los cargos á medida que se ha disminuído su número, y la misma comisión arrastrando consigo tales deberes que ya se hacen despreciables los que parecen más graves en otro buque, ¿cómo puede el rigor militar por sí solo obligar á un soldado ó un marinero que sufra el insulto de un indio, que coma más bien una cosa que otra, que se transforme, según las ocasiones, en cazador, ó en pescador ó en artesano á medida que lo exijan los infinitos acasos?

Dejando aparte la disparidad de carácter del español con el francés septentrional ó el inglés, se deja ver que en esta clase de expediciones los que nos han precedido siempre han dado la preferencia al cariño sobre el rigor, han tolerado más bien que la disciplina militar sufriese graves ultrajes, que no truncar aquella grata harmonía del súbdito con el Jefe, que hace suaves los mismos sufrimientos y suministra fuerzas y vigor para que una sociedad de pocos se alcance á sí misma y saque de los mismos peligros de que está rodeada nueva seguridad para su mejor conservación. E1 ejemplo de los Oficiales era la única arma en los buques del Capitán Cook para peŕsuadir á los marineros á comer cosas, sanas sí, pero asquerosas. Resistióse la marinería en la bahía del Rey Jorge, que es la navegación desde el Norte á las islas de Sandwich, á beber el extracto de la caña de azúcar fermentada, y se usaron el ejemplo, las persuasiones, nunca la fuerza, para atraerlos á esta útil medida; y finalmente, para conseguir la quietud en tierra y evitar un roce intempestivo vió el sabio Capitán lleno su buque de mujeres entregadas á la sed insaciable del marinero, y lo vió con indiferencia porque aquéllas eran voluntarias, y la conducta de éste y su sufrimiento en los trabajos exigían un premio análogo á su carácter.

Así es mi ánimo en esta parte que la razón y la uniformidad sean las armas siempre preferidas al rigor militar y que éste sólo se emplee agotados ya todos los demás mcdios para el buen orden de la socicdad y el buen éxito de la empresa.

Miro, no obstante, el rigor militar como cosa bien diferente de la disciplina militar, y seré tan exacto en dar á ésta cotidianamente el útil lugar que se merece, como resistente y áun opuesto á səatar el ejemplo aún más suave del primero.

\section{II}

Sentado ya que ha de constar, no sólo á los ojos de los súbditos, sino también á los del público, que la razón y el mejor desempeño de la empresa son casi la única base de nuestro sistema, ha de fijarse la consideración en otro punto igualmente importante, y que apoya el principio anterior; es á saber: que se mirará como supérfluo, y por consiguiente se apartará muy luégo todo lo que distante de aquellos dos agentes tenga sólo en su favor, ó el ejemplo de otros, aunque para mí sumamente respctables, ó el deseo de alcanzar cierta áura popular que, como una ola impelida del viento á la playa, es tan fácil á entrar como á retroceder.

Supuesto que en esta comisión es la parte facultativa más bien que la militar la que ha de contribuir á la utilidad pública, he creído que deben variar también las reglas del buen orden á bordo, esto es, que el Comandante ha de aproximarse mucho al subalterno, y áun si es posible sobrepujarlo en el ejercicio de todo lo que corresponde á la parte facultativa, aunque distase mucho de la militar. Mil razones, y nucstra misma felicidad, exigen que seamos pocos para muchas cosis: esto envuelve en sí el que todos hayan de hacer lo que puedan, y si es honorífico para un militar, cualquiera sea su esfera, el correr el primero al encuentro del enemigo, creo no será ménos gloria para el facultativo humano el correr á tirar ó arriar un cabo más bien que despertar uno 
que duerme libre de su guardia, ó atrasar y á veces contrarestar los buenos efectos de una maniobra.

Las ideas son unas en todos 'los hombres: la comparación nos hace felices ó infelices: la falta de una pequeñez da á veces una idea perniciosa de debilidad que desalienta. El Comandante, dividiendo con prudente economía, y nunca sin necesidad, el trabajo de sus inferiores, ya to hace suave en lugar de ser molesto; y además, infundiendo en cada uno nuevo aliento, les inspira aquel vigor que tantas veces suple al número, y da la más alta idea del propio alcance y resistencia. Son muchos los que en un buque de S. M. están exentos de trabajo personal: nadie lo está cuando el Comandante establece con su ejemplo un principio contrario, ni parecerá inútil el acomunar esta idea si se considera que los peligros, ó por mejor decir, las ocasiones de practicarla, serán casi diarias, antes bien serían contínuas, pues que el desempeñar más ó ménos lo que espera de nosotros la Nación, pende precisamente de las mayores ó menores fuerzas con que contemos.

\section{IV}

Como es natural me arrastrará lo que acabo de expresar, al principio de que la aproximación del Jefe con el súbdito en esta clase de destino, no sólo al trabajo, sino también debe extenderse á la manutención. Mientras llega el hablar del reparto de ración, diré á Vm. que estoy firmemente decidido á verificar esta aproximación cuanto sca posible. Nunca llegará el caso de que el enfermo carezca del alimento más saludable mientras lo haya para el hombre sano de cualquier clase que sea. La proporción de alimento desde el más alto hasta el ínfimo individuo, ha de ser siempre una misma así en la cantidad como en la calidad; an'tes bien, así como espero que el ejemplo mío sea para los Oficiales (si lo necesitasen) un nuevo estímulo para los sufrimientos, lo será la tranquilidad de éstos también para el marinero. En éste no prevalece otra razón que la necesidad; tal pudiera representársele por otra parte si condenado á nutrirse de alimentos igualmente escasos y malos, viese en la abundancia á los que deciden de su suerte y tal vez hasta el fruto han de coger de sus sufrimientos.

E1 buque además no admite en sí un gran número de cosas frescas; y en cuanto al uso de las saladas, queriendo S. M. que no se economice gasto á favor del marinero, y entregada á nosotros la dirección del apresto, no hay motivo para que sea mejor lo de unos que lo de otros ó para que las cantidades sean tan desproporcionadas, que el uno sufra escaseces mientras el otro se halla en la abundancia.

Empero esto no implica que la uniformidad sea rigurosamente la misma. Este partido sería pernicioso áun á los fines que me he prescripto, é injurioso al Oficial cuya cuna y sucesiva educación le hacen ya necesarias diferentes cosas, que al soldado ó al marinero fueran más bien molestas. El aseo de comida y el repuesto de varias cosas agradables que ni apetece el marinero ni ocupan demasiado buque, ni son emblemas de la abundancia, serán siempre un distintivo considerable que dividirá las clases una de otra y un alivio no indiferente para el Oficial.

La costumbre hace suaves, y áun bien agradables muchas cosas que llevaban en sí el semblante de sufrimientos. Hay quien aborrece los manjares más delicados. No pocos hacen depender su felicidad y su conservación del mismo método de vida que á otro fuera insufrible. La misma costumbre es la que á primera vista nos representa como insufrible la falta de variedad de las comidas, como imposible de sustituir al excelente sabor de vacas, carneros y aves domésticas y de las verduras de nuestros huertos, el de un guanaco, de un ave de mar, de una yerba silvestre. Pero también es positivo que en la clase de viajes como este á que nos hemos comprometido, hemos de ser felices ó infelices según nuestra costumbre logre mirar con indiferencia unas ú otras privaciones.

\section{$\mathrm{V}$}

Es mi ánimo, pues, por lo que toca á esta necesaria aproximación de comida, el seguir el siguiente plan. Se procurará adaptar á la mesa de plana mayor todo el aseo posible, la abundancia necesaria y la indispensable buena calidad. El uso de las harinas, del té, café, chocolate y algunas especies más delicadas de vinos, serán la distinción constante de los demás; al paso que proporcionando las primeras una diversidad grande de manjares agradables, y suministrando los segundos ó por sí ó mezclados con el azúcar un entretenimiento saludable, ni con el tiempo pierden su buena calidad, ni el volúmen que ocupan es nocivo para otras cosas de mayor importancia. Nunca me sujetaré para el acopio de cosas frescas á. la duración de la siguiente cam- 
paña; de suerte que suponiendo que en los correspondientes sitios destinados no quepan más de quince temeras y cien gallinas, la misma cantidad se embarcará para un viaje de dos meses, desde Cádiz á Buenos Aires, que para uno de veinte desde Manila al Cabo de Buena Esperanza por las islas del mar Pacífico y la Nueva Zelanda. Algunas veces será aún más sensible la privación, pues que siendo el ánimo de S. M. que los rastros de esta expedición en los paises no sujetos á la Monarquía derive más bien de efectos de humanidad que de medallas ó instrumentos destructivos, deberemos propagar en varios parajes las castas de animales más útiles á la sociedad, y por consiguiente el pescado y las carnes silvestres serán á veces nuestro alimento, mientras tendremos á la vista animales de carnes sumamente apetitosas.

VI

Bien se deja ver que semejantes privaciones, aunque guiadas de la razón, por lo común saludables y á veces necesarias, fueran, no obstante, muy sensibles si no las atemperase un método uniforme, en el cual se combinen con recto equilibrio las ocasiones de mucha escase $z$ con las de mucha abundancia. Las diferencias y las privaciones resultan así ménos reparables; la necesidad misma dicta nuevos recursos, y finalmente, se establece como sistema la debida aproximación de todos los que naveguen en un mismo buque, como ya se ha indicado.

\section{VII}

Entiendo, pues, que el método proyectado debe empezar al mismo principio del armamento. Debe quedar convencido de la constancia de este sistema, no sólo el que haya de navegar con nosotros, sino también el público, sean ó no injustas las consecuencias que luégo se deduzcan de aquéllos, dadas por gentes arrastradas de la ignorancia á veces de la emulación. A esta vista irán la seguridad de que no es el capricho el que dicta semejante medida; el navegante podrá deponer cualquiera idea de superfluidad, se irá familiarizando con una vida bien diferente de la que ha seguido hasta aquí, y podrá pesar sus fuerzas y su constancia con datos mucho más ciertos y desagradables. El público, por otra parte, verá grabadas en nuestro sistema la unidad, el buen orden, el ejemplo del sufrimiento, la independencia de todo lo que pudiera ó atrasar ó hacer más gravosas al erario nuestras operaciones; finalmente, aquel deseo natural de que emulen nuestros navegantes la constancia tan admirada de los que nos han precedido en semejantes empresas.

\section{VIII}

Admitida esta necesidad, y bajo la consideración de que el alimento es más bien un tributo á la naturaleza que un recreo para los que se han fijado satisfacer las potencias espirituales con preferencia á las animales, se hace presente que en esta especie de comisiones, no sólo ha de privarse uno á sí mismo de lo supérfluo, sino lo ha de extender á los demás, evitando, por consiguiente, toda clase de banquetes. Nuestro objeto en el día es conservarnos, no desperdiciar buque, ocuparnos enteramente de los altos fines á que se nos ha destinado y acreditar esta verdad, si es posible, á la vista de todos. Cuatro cosas se oponen al banquete. Es pernicioso á la salud, implica el embarco de mil superfluidades, distrae muchas horas útiles, y finalmente, borra la reminiscencia de aquellos mismos trabajos que se hacen sólo sufribles por el deseo de ser admirados de los demás hombres.

El que busque examinar de cerca nuestras tareas; el que quiera añadir á este favor el de disfrutar de la compañía de los Oficiales en la hora en que esté más reunida, más agradable y más chancera, será admitido con aquella confianza y agradecimiento que exige un lazo amistoso de esta naturaleza. Se le manifestarán estos sentimientos de modo que no pueda dudar de ellos. Comerá con aseo y con abundancia, pero será muy luego que el deseo de merecer su aprobación se apoya más bien en el estado de nuestros buques, nuestra disciplina, nuestras tareas y nuestras máximas, que en un número ostentoso de platos útiles únicamente al paladar, muchas veces fatales al estómago. 
IX

Consecuente á este sistema será el número de criados que se embarquen. Los he ceñido á un Mayordomo, un Repostero, un Cocinero y un Panadero, todos bien asalariados, pero constituídos á trabajar por sí cada uno en su ramo, y ayudarse recíprocamente siempre que el caso lo requiera. Seguirán á éstos otros cuatro criados, el uno como familiar del Comandante, dos para servir á los seis Oficiales y el Guardia Marina, y uno para los de las demás clases que alternen con los mismos Oficiales. Este arreglo se ha hecho de común acuerdo, según lo prescribía la Real orden correspondiente. S. M. abona el número completo, aunque no se embarquen, habiéndolo así mandado al señor Intendente general de Marina.

\section{X}

La ociosidad, temible en todas las clases embarcadas, lo es aún más en la de criados, por la facilidad con que pueden brindarse y cautivar otros regalando una ú otra cosa de rancho. Con prudente método han de intervenir los nuestros en los trabajos, particularmente en todo lance que necesite un mayor número de brazos. Pero como quiera que se les haría sumamente gravosa tal novedad, contraída á la comparación con los demas buques de S. M., han de atraerse á esta costumbre, nó con la violencia ni con demasiada prontitud, sino más bien con el tiempo, con el ejemplo y con el aprovechamiento de ocasiones oportunas; causas todas que sin el menor desagrado arrastrarán seguramente la realización del fin deseado.

\section{XI}

Contribuirá mucho á hacer útil y áun más dócil esta clase, de individuos, comunmente díscolos en todos los buques de S. M., el hacerles entender que no están depositados en ellos ni nuestra felicidad ni nuestro lucimiento, y que reduciéndose á pocas cosas el cabal desempeño de su oficio, pueden muy bien ocuparse del trabajo á que mejor se hallen dispuestos y diariamente en las muchas horas ociosas contribuir con sus mismos brazos al justo equilibrio de tarcas con todas las demás clases.

\section{XII}

Será su alojamiento parte en la repostería y parte en la Santa Bárbara: en entrambos parajes, muy próximos al escotillón de la escala. Tendr'án catres ingleses ó cois, según sea posible acomodarlos, y así estarán más separados del roce c on las demas clases de á bordo, más próximos á la Oficialidad á quien han de servir, y más fácil. la inspección de su conducta, lo que considero necesario.

\section{XIII}

En la bahía de Cádiz y áun al salï de 'la Carraca, se dividirán inristintaniente las clases por alojamiento y comida según el neetodo es tablecido; esto es, que el Piloto, Cirujano, rontador y cia de confianza del Comandante, que será proporcionad al Oficial, atento no obstante á la diferentines, Condestable, Sargento y Sangrador, comerán y alojarán y á otros; el Contramaestre, Pilola repostería, adaptado su tamaño al acomodo de los alojarán juntos en un rancho á estribor de Carpintero, primer Calafate, dos Guardianes, Armero, Velero ingleses correspondientes al primer babor.

\section{XIV}

La Real orden que acompaño con el número I, enterará á Vm. del ánimo de S. M. sobre Ios diferentes puntos relativos á disciplina que había propuesto anteriormente. Era mi ánimo con el
nombre de mozos, aproximar los segundos Carpinteros nombre de mozos, aproximar los segundos Carpinteros y Calafates al trato y servicio de marineros, 
disminuyendo así la clase de Oficial de mar y simplificando el régimen interior. Intentaré conseguirlo aunque se miren como Oficiales de mar; pues su número haría muy gravoso el alojarlos y aumentar la comida de éstos.

\section{XV}

He indicado ya cuanto considero necesario para el buen orden, toda la posible distancia en el roce entre las tres clases primordiales de á bordo: $I{ }^{a}{ }^{a}$ Oficialidad de guerra. 2. ${ }^{a}$ Oficialidad de mar. Y $3 \cdot{ }^{n}$ Tropa y marinería. Será tanto más sólida y segura y tanto ménos desagradable, cuanto más temprano sea su establecimiento. Se han dispuesto á este fin las comunicaciones de la cubierta con el alcázar, las reparticiones de comida y alojamiento y el mismo espíritu de disciplina. Bastará por consiguiente una muy leve inclinación á la balanza, para que propenda hacia este partido tan saludable. Con avisar á cada uno cuando éntre á bordo con quiénes ha de familiarizarse y á quiénes ha de evitar, indicándole blandamente si anduviese errado en sus pasos, y procurando al principio promover la buena harmonía y amistad entre los que componen una misma clase, se hará el enlace tan sólido que será luégo superior á cualquier acaso que quisiese trastornarlo.

\section{XVI}

Conviene mucho que los buzos sean de la misma clase de marineros, ó si la ciega obediencia á las Reales ordenes y la necesidad obligase á admitirlos de esta clase propietaria, sólo en el nombre se mirarán como Oficiales de mar; su agregación, por lo que toca á comida, coi y servicio, será exactamente á la clase marinera. Los que han servido mucho ticmpo en esta clase, sea en los arsenales ó en los buques armados, tienen por lo común dañado el pecho y además son muy inclinados á la bebida. Espero que los marineros suplan muy bien esta plaza.

\section{XVII}

He extendido á dos el núm ro de cocineros del equipaje para que tengan á su cargo no menos el caldero del equipaje que las ollas de Oficiales de mar y de la enfermería. De este modo, excluída toda necesidad de ranchero, pues un Grumete de la guardia ó el mismo Cocinero podrán llevar la comida al rancho; y por lo que toca al aseo del alojamiento, á una misma hora y con igual intervención del Oficial de guardia, se vigilará por medio de los grumetes sobre éste y sobre el que corresponde á la marinería.

\section{XVIII}

Al Oficial de mar se dará diariamente ración de vino y ración de carne fresca cuatro veces á la semana. El modo de recibir esto de la provisión es los domingos y miércoles; para extenderla á los jueves y lunes se determinará con la menor incomodidad de Jos buques menores, según el paraje en donde estén fondeadas las corbetas. Con este equivalente, con buenas menestras y tocino, y con una variedad agradable y proporcionada á las circunstancias, apoyaré el partido de que nadie embarque para su uso particular comestibles de cualquicr especie que sean. Importa mucho borrar las ideas de ranchos, que al paso que ocupan un crecido número de brazos, son manantial inagotable de discordias, de desórdenes y de enfermedades. La ración que se suministrará será abundante; serán tres las comidas calientes. Habrá alguna distinción en favor del primer rancho de los dos que componen esta clase. Se determinará, aunque no invariablc, la cantidad y calidad de comestibles por cada día de la semana, y con este antecedente se prohibirán toda clase de raciones, todo cambio de efectos comestiblcs que no sea en la misma despensa y con intervención y anuencia del Oficial del Detall; finalmente, toda venta particular de cualquier clase que sea, y se singularizará entre éstas la de vino ó licores, que será grave delito, áun por la primera rcz.

\section{XIX}

Apartándome nucvamente del método común de los buques de S. Mr., así como el Sargento y Condestablc rozarán mucho con Oficiales de mar, rozará igualmente la tropa con la mari- 
nería, coadyuvando yo mismo y los Oficiales á que se familiaricen unos con otros y sea tan depositaria de la autoridad la marinería como ejecutiva la tropa de todo trabajo. He indicado ya que no es el rigor militar quien ha de mover las ruedas de nuestra disciplina, y que ha de brindarse cada uno voluntariamente al trabajo, no ignorando desde el principio que es de su obligación todo lo que esté en la esfera de sus alcances y de sus fuerzas.

\section{$\mathrm{XX}$}

De ningún modo opino que hayan de nombrarse patrones fijos de las embarcaciones menores. Muy luégo formarían una nueva clase que se consideraría superior á los demás, y los gavieros, timoneles y cabos de guardia absorberían inmediatamente casi todo el número de marineros. El contramaestre ó guardián que esté de servicio, inspeccionará todos los días el estado de las embarcaciones menores y de sus pertrechos, y dimanando de él el nombrar de la gente existente aquellos que parezcan más oportunos, quedará con rapidez pronta la embarcación, y lo que más importa, todos se irán adiestrando en su manejo, práctica sin la cual nos hallaríamos envueltos en mil imposibles. Los botes chicos procurarán meterse dentro siempre que no hayan de enviarse á ninguna comisión; y en general, las mareas y el viento se combinarán y aprovecharán cuanto sea posible para sus movimientos, debiendo por lo común preferirse la lentitud á un excesivo trabajo de remos y á la necesidad de emplear mucha gente en los botes.

\section{XXI}

Hallo muy importante el infundir desde el mismo principio en todos los individuos de las corbetas una idea harto útil en lo venidero; y es que no hemos de contar con otros auxilios que los de nosotros mismos. Será oportuno bajo este supuesto el valerse de nuestras gentes, de nuestros botes y de nuestros pertrechos para muchas cosas que con más facilidad conseguiríamos pidiendo auxilios extensos á los buques de S. M., á la Capitanía del puerto ó al Arsenal. Por ejemplo, cualquiera faena de anclas, muchos transportes de efectos cuando los buques menores estén sin destino; el mismo amontonarse muchos efectos en los primeros y en los últimos días de nuestra estada en puerto, serán otras tantas lecciones útiles del alcance de las fuerzas al que ha de mandar y al que ha de obedecer. El uno moderará algún tanto el natural principio de celeridad que se mira como único en los demás buques del Rey; el otro se irá insensiblemente amoldando á no graduar por el número de brazos el éxito de las faenas por pesadas que parezcan, y sobresaldrá en este temple de tareas la inteligencia de los Oficiales de guardia y el buen ejemplo de los Oficiales de mar.

\section{XXII}

La debida atención á la comodidad respectiva, y el no hallarse aún reunidos todos los Oficiales destinados á la comisión, ha hecho que indistintamente se ocupasen otros en aquellos objetos que ya desde algún tiempo requerían la presencia del Oficial. Al principio del armamento es muy probable que ya no haya otra atención extraña sino la Astronomía, en la cual se ocuparán únicos los dos Oficiales nombrados en cada corbeta, agregándoles un Piloto para copiar y confiar el diario. Alternarán, por consiguiente, los demas Oficiales y el Guardia Marina en el servicio de á bordo, y particularmente en la asistencia al armamento. Sin superfluidades, procuraré no obstante que nada se omita de lo que implica el acto formal é importante que á la sazón llena el Oficial. A éste, sin molestarlo al principio, se procurará atraerlo cuanto ántes á la asistencia á bordo áun de noche, y con esto será tan fácil ocurrir á cualquier urgencia que necesite la intervención de un Oficial, como agradable é instructivo el no ocuparse ya de otras cosas cuando los aprestos, los estudios y los mismos ejercicios exigen todo nuestro tiempo y toda nuestra atención. Es este justo sacrificio para los más jóvenes; al cabal dešempeño de lo que S. M. ha fiado á nuestro honor, verá el público con mucho agrado que no serán vanas nuestras promesas, y la expedición, desde su misma cuna, adquirirá tal vez aquel patrocinio de los hombres sabios, sin cuyas luces y dictamen, particularmente en la parte científica, fueran muy arriesgadas nuestras empresas y muy dudoso el buen éxito de ellas. 


\section{XXIII}

Sin urgente motivo ó de servicio, de salud ó de habilitación propia, el Guardia Marina y el Pilotín no empleado en la Astronomía, estarán contínuamente á bordo. Aquél se inclinará á la vida activa de aparejar, asistir personalmente á la estiva, transporte y colocación de pertrechos en las lanchas ó botes, ó vigilar sobre la exacta observancia de las órdenes, ó soltarse en su manejo al remo ó á la vela. Esotro tendrá corrientes los libros de Detall, atenderá á las señales, será el instrumento de comunicación con el Observatorio, y se encargará, finalmente, de toda la práctica del Detall científico á que no pueda alcanzar el Guardia Marina.

\section{XXIV}

Alternarán en la guardia de puerto, uno de los cuatro Oficiales restantes como Jefes, y el Sargrento y Condestable como subalternos. El traje de uno y otros indicará el destino en que se hallan. La tropa estará dividida igualmente en babor y estribor. Bastarán para el buen orden dos centinelas; uno sobre cubierta, y otro en el combés hacia el paraje en donde esté el fogón. Los individuos de brigada harán la guardia unidos á la tropa de marina; se dividirán, no obstante, en los dos cuartos para que no falte diariamente quien pueda manejar la artillería si fuese menester alguna maniobra ó saludo.

\section{XXV}

En la división de sollado he atendido á un paraje oportuno para encerrar las cajas de la oficialidad de mar y marinería, pues de ningún modo se permitirá á los primeros sobre cubierta más que un baul y una frasquerita, y á los otros más que la ropa que quisieren tener dentro del coi. Se guardará todo lo demás en el pañol indicado, abriéndose precisamente una hora antes de mudar la guardia, y accidentalmente siempre que el Oficial ó el Sargento de guardia lo hallen oportuno para que cada uno pueda tomar ó guardar la ropa que le pareciese. El Sargento ó Condestable de guardia serán depositarios de esta llave. Las cajas y mochilas podrán dividirse por ranchos, y por ranchos bajar también al pañol los individuos, ó subir de tiempo en tiempo su ropa para orearla.

\section{XXVI}

Casi todas las operaciones periódicas de la embarcación, así por lo que mira á la parte científica como á la del Detall, se reducirán á un método uniforme con el auxilio de pliegos impresos en los cuales el alta y baja de víveres, agua y gente, los accidentes relativos al cuadernillo de bitácora y todas las observaciones meteorológicas, lograrán su lugar sin confusión de materias ni de estilo. Pero fuera imprudente el coordinar estos pliegos con demasiada anticipación, faltando aún la mayor parte de los instrumentos meteorológicos, é ignorándose hasta dónde en la situación local de nuestros buques podrá extenderse su uso. Así, estos pliegos no se imprimirán sino poco antes de la salida. Con la precaución de anotar metódicamente los acontecimientos, será luégo fácil trasladarlos á aquellos impresos, logrando ya que rija un solo método desde el principio lasta el fin de la campaña y consiguiéndose de este modo una más fácil reducción de noticias en la muchedumbre de cosas que precisamente abrazará la comisión.

\section{XXVII}

Iil papel número 2 de los que acompaño, dará á Vm. una idea cabal del estado de dotación de cada corbeta. En la de Vm. podía suprimirse el velero. Basta uno para dirigir el obrador ó recorrida del velamen de ambas corbetas, y por otra parte, el Contramaestre y guardianes, son siempre un equivalente á un Maestro de velas. 


\section{XXVIII}

Me ha parecido oportuno (y lo he verificado ya) enterar á los subalternos de la razón que dirige las innovaciones prefijadas. Debía combinarse con ellos, según la orden de S. M., el número oportuno de criados. Hallé esta la mejor ocasión para indicarles al mismo tiempo que el ejemplo en los sufrimientos, y un noble desprecio de toda superfluidad y distracción, serían lo característico de nuestra empresá; que se seguiría precisamente de aquellas máximas una reforma en la mesa, adaptada, no menos á la estrechez del buque y á la dilatada ausencia de todo paraje que proporcionase repuestos de aquella clase, sino á las reflexiones de aproximación nuestra con el Oficial de mar, el soldado y el marinero, y que para combinar con este método inalterable cl natural exceso de las gratificaciones asignadas por S. M. en este viaje, se haría un fondo sobrante reversible después así en aquellos gastos extraordinarios relativos á la comisión, que comunmente suelen ser gravosos á cada uno en particular, como en un dividendo último igual entre todos los comprendidos en el abono de las mismas gratificaciones.

Este aviso me pareció tanto más necesario cuanto mayor sería mi tesón en llevar á debido efecto desde sus mismos principios el plan adoptado de evitar toda superfluidad, y cuánto más temible sería en mis jueces externos una siniestra interpretación de mis ideas. El primer cuidado del hombre debe ser el de evitar las acusaciones de su mismo corazón; pero el inmediato es no incurrir en la crítica de los demás. Siendo un mero administrador de esta parte, la más gravosa del mando, yo evito las acusaciones así de mi corazón como de los externos; puedo libremente entregarme á los reparos de buen orden, moderación, buen ejemplo, humanidad y disciplina; puedo, finalmente, no aventurar mi propiedad ni mi honor en una administración cuyas pérdidas nadie ha de participar, y las ganancias, si las hubiere, pueden, por los dictados de mi misma conciencia, pertenecer legítimamente á otros.

\section{XXIX}

Acompaño á $\mathrm{Vm}$. en el papel número 3, las pocas señales que serrirán en puerto para la inteligencia mejor de las corbetas. Embarcados los relojes marinos, podrá examinarse su marcha por una misma señal, desde tierra, referida á entrambas corbetas y áun referida al resultado de las alturas correspundientes observadas por distintos observadores, como sea en un mismo péndulo. Esto es lo que por ahora he creído preciso manifestar á Vm., no tanto, como dije al principio, por que me parezcan preferibles estos métodos á otros, como porque constituído cada uno en el día á satisfacer á muchos, ó superiores ó amigos, sobre las medidas áun más frívolas de la expedición, muy luégo incurriríamos en una discrepancia de pareceres trascendental á nuestro concepto, al buen orden interior y á la satisfacción de los que sirvan á nuestras órdenes, cuando es fácil después en el dilatado tiempo de nuestras navegaciones, practicar todas aquellas cosas que, apoyadas en la razon, merezcan sujetarse á la experiencia aunque de su utilidad ó necesidad no quedásemos entrambos convencidos.=Cádiz, á I. ${ }^{\circ}$ de Abril de I789. 



\title{
RELACIÓN GENERAL DEL VIAJE
}

\author{
DISCURSO PRELIMINAR
}

POR

\author{
D. ALEJANDRO MALASPINA
}

Quien comparase el viaje de las corbetas Descubierta y ATREvidA de la Marina Real, á los ingleses y franceses que le han precedido desde el año I $_{75} 6_{5}$, erraría ciertamente sobremanera. Cualesquiera que sean los puntos de vista bajo los cuales se miren uno y otros, son otras tantas las disparidades que presentan, y bastará el enumerar aquí algunas para que sea fácil inferir las demás sin recelo de error.

En el año de I789, época en la cual se emprendió el viaje, cuyos resultados presentaremos ahora al público, ya el globo habitable podía considerarse enteramente conocido. Fijados en uno y otro polo los límites de la navegación por el hielo constante; detalladas las costumbres, el número y el orígen de los habitantes de las orillas del mar Pacífico; examinadas sus producciones y combinadas las derrotas más seguras y más breves que pudiesen comunicar entre sí los puntos más remotos de la tierra; el intentar un nuevo viaje de descubrimientos hubiera merecido el desprecio de los sabios y áun la mofa de aquellos pocos que buscan en esta especie de narraciones, ó el entretenimiento de una ociosidad perpétua, ó el orígen de nuevos sistemas, bien sean políticos ó referidos á las ciencias.

Los progresos de la navegación habíanme llevado á un punto todavía más alto: ni los aparejos, ni las carenas, ni la calidad y cantidad de los víveres, ni los acopios precisos de agua potable, ni finalmente, la mezcla á bordo de un trabajo contínuo y desordenado, con la rápida variación de climas y con la perpétua respiración de un aire infecto, podían mirarse como obstáculos para navegar directamente hacia los puntos más distantes del globo: todo lo venció la navegación moderna, y variado el semblante de la cuestión, se halló tan fácil, tan sencilla y barata la conservación del hombre de mar ó en los paises desiertos, ó en aquél mismo Océano que parecía amenazar por todas partes, como era difícil en los parajes poblados y particularmente en las colonias europeas del Asia y de la América.

No eran, pues, los adelantamientos de la Hidrografía y de la navegación en general los que pudiesen mover el viaje actual con la esperanza de algún suceso; pero una mirada aunque leve al estado de los conocimientos y combinaciones europeas sobre la América y el Asia, debía descubrir luégo al punto otros objetos de igual ó mayor importancia que prestasen un justo motivo para emprenderle, y prometiesen á la Nación aquella utilidad, si no aquel lustre, al cual habían aspirado los últimos navegantes extranjeros.

Esta variedad del fin propuesto, no podía ménos de influir directamente en la suma discrepancia de los medios para ejecutarle. Debíamos visitar la mayor parte de nuestras colonias del mar Pacifico y franquear la navegación fácil de unas á otras: debíamos, si fuese posible, apurar los conocimientos físicos y astronómicos para vencer, ó los riesgos, ó la rutina de las especulaciones mercantiles. ¿Cómo pudiéramos conseguirlo, sin detallar con una suma prolijidad las costas, sin hacer una larga demora en las colonias principales, sin buscar las estaciones favorables á una y otra parte de la Equinoccial, en fin, sin exponer á cada momento, al influjo combinado de los vicios y 
del clima unas tripulaciones que hubicra sido más fácil preservar en el mar, ó en las soledades de las Malvinas, de la Nueva Zelanda y de la costa Noroeste de la América?

En una palabra, dirigía á los pasos ingleses el afan de hallar nuevas posesiones y nuevas ramas de comercio en los paises aún no bien conocidos; y de allí la celebridad, la novedad, la economía, el feliz triunfo de mil obstáculos en la navegación y la fácil conservación de los navegantes; nuestras miras, al contrario, se dirigian al conocimiento cabal de unas posesiones inmensas, al prudente desprendimiento de las que fuesen inútiles ó perniciosas, y á la reunión precisa de los diferentes puntos de una Monarquía tan extendida, de donde dimanaban por precisión la nimiedad hidrográfica y política, la lentitud, los costos, los menores riesgos de la navegación, las ideas más trilladas, y sobre todo, la mayor dificultad de conservar las tripulaciones en buen orden y buena salud.

Sin embargo, como la ocasión fuese oportuna, debían sujetarse á una experiencia constante y advertida las difercntes ideas para viajes largos y distantes que sugerían las narraciones ya publicadas de ingleses y franceses. Hubiera sido tan reprensible el adoptarla sin reflexión y con una servil admiración, hija á lo ménos de la desidia, cuando no lo fuese de la ignorancia, como poco cuerdo el graduar su utilidad por nuestra sola esperiencia sin sujetarlas antes y después á los razonanientos nacionales. Son bien distintas la educación, el carácter y la constitución de nuestras marinerías; es tan raria la disposición interior de nuestra disciplina y nuestros buques, $y$ son tantas las colonias españolas esparcidas sobre toda la superficie del globo, que la mayor parte de las precauciones dictadas por el Capitán Cook para esta especie de viajes, serán siempre en nuestra Marina ó perniciosas ó impracticables.

Indicados ya los objetos generales que dictaron como útil el viaje actual y como prudente el no prefijarse una imitación servil de los viajes ingleses, es fácil descender á las ideas de donde dimanó cl pormenor de su ejecución. La construcción de un Atlas Hidrográfico para las navegaciones distantes de los buques nacionales, ora atendiesen al abasto rccíproco de las colonias con la matriz, ora á un comercio más extendido con los paises independientes de la Europa, era por sí un objeto suficiente para mover hacia el mar Pacífico buques y sujetos que lo verificasen: sin mayores costos era fácil después combinar con este examen nimio de las costas algunos progresos en la Historia Natural, referidos esencialmente al hombre y luégo al suelo y á los diferentes animales que lo habitan. Pero sin publicar los resultados de aquellas indagaciones, se malograría su fruto más bien para los nacionales que los extranjeros, y publicándolos, caería finalmente el telón espeso y misterioso que había ocultado hasta ahora á unos y á otros el semblante real de la América á fuer de su misma extensión. Entonces sí que la confesión auténtica de nuestra misma debilidad convidaría á la codicia siempre voraz de los europeos á invadirnos por todas partes y con acierto; entonces nuestro entusiasmo para la defensa gencral sería tan inútil y desmayado, como los esfuerzos que debían incitarle.... iTriste situación que parecía dictarnos como más útil el caos y la falta de sistema y de conocimientos, que una mirada cabal, generosa y científica á los límites, á la calidad y á los inconvenientes de lo que componía la inmensa Monarquía española!

Pero en fin, ¿esta debilidad podía ocultarse? Y áun oculta, ¿đebíamos mirarla como un vicio irremediable? ¿O bien existía un choque directo de los principios sociales con la naturaleza capaz de trastornar los cimientos más juiciosos de la legislación? Semejante cuestión debió, en fin, convencer á un Ministerio cauto y reflexivo, que cualquiera fuesen los males inherentes á la constitución actual de la Monarquía, no lo habría ciertamente peor que el de no analizarla por unos principios sencillos y naturales. Decidióse la publicación del Atlas Hidrogrático y con ella se decidió por precisión un examen político de la América, el cual manifestase con una filosófica indiferencia nuestros males y nuestros remedios, nuestra debilidad y nuestros recursos, nuestros errores pasados y los principios más cabales de nuestra administración del día.

¡Ojalá que semejante encargo, capaz por sí solo de reunir al mismo centro de las virtudes sociales al Monarca, á sus Ministros y á las diferentes clases constituídas á obedecer, ojalá que hubiese recaído en unas manos capaces de tratarle como se merece! Pocas verdades aisladas é independientes del fárrago de sistemas que nos abruma en el día, bastarían tal vez para variar el semblante de la Monarquía. El trabajo comán, ya no tuviera otro objeto sino la común utilidad ceñida en cada individuo á unos deseos aprobados y asequibles; suelos y climas tan fértiles y tan varios, tributarían un fruto abundante, ó al propietario ó al colono; no habría una lucha contínua entre los mismos miembros de la sociedad; cesarían la esclavitud política y la mercantil; satisfechos de nuestra misma felicidad social, ya no miraríamos con envidia ó con temor los pasos agenos, y esta sola indiferencia política bastaría por una parte para hacernos respetables á las nacioncs extranas, y por la otra, para enfrenar el abuso del sistema militar.

alcanzase para tamaño encargo la filantropía más enérgica, el estudio más asíduo de la 
naturaleza, un examen desapasionado del instinto y del derecho del hombre, referidos á la sociedad; una reflexión lenta y razonada sobre los tristes desórdenes del día; los sugerimientos, en fin, de la gratitud más viva y más indeleble al Monarca que me ha distinguido y á la Nación que me ha adoptado por suyo, no cesarían, no, mis voces para el intento; los pasatiempos del día y las vigilias de la noche fueran un tributo igualmente sencillo á la felicidad general; miraría como dicha más bien el guiar la opinión pública hacia la tranquila prosperidad social, que el conducir una falange militar contra un enemigo, quien ignora por lo común cuáles son sus motivos y los nuestros para pelear.... Pero no; es en vano el aspirar al cabal desempeño de tal empresa; otros más hábiles franquearán muy luégo los cortos límites que á mí han prescripto á la par la falta de estudios políticos y las distracciones del mar; seré feliz, sin embargo, si las pocas verdades que he de sentar y son el fruto de las tareas de muchos años, sirven siquiera de un primer escalón para el alto edificio del poderío y prosperidad nacionales.

Si dejásemos á un lado para los razonamientos políticos y económicos las ideas elementales que desde la conquista de la América y de una parte del Asia han establecido su imperio en nuestra Europa, evitaríamos, ciertamente, el ser difusos y el luchar contra una serie de principios endurecida con el tiempo, con la costumbre y con las conveniencias de cada uno. Pero al mismo tiempo, ó dejaríamos en la misma oscuridad en que yace el origen verdadero de nuestros males, ó sin tocarlos, pretenderíamos infundadamente elevar un edificio sólido y permanente sobre unos cimientos débiles y mal distribuídos. Un nuevo proyecto, parecido tal vez y y'a más cansado que los escritos del Abate Raynal, entretendría por breve tiempo al lector ocioso y superficial, al paso que alentaría al Gobierno á mirar los súbditos, más bien como enemigos que como una parte de sí mismo; y tal es la propensión de la opinión pública, que la misma insuficiencia de los remedios propuestos serviría para desalentar la práctica de los que pudiesen seguirle con mayor utilidad en lo venidero.

Es, por consiguiente, necesario en el examen propuesto de la América, abandonar el hilo de los razonamientos adoptados hasta ahora; y después de una ojeada instructiva é imparcial á ese vasto continente y á la utilidad real de sus productos y de su comunicación con la Europa, es preciso descender particularmente á la naturaleza de las posesiones españolas; á las condiciones sociales que las unen entre sí; á los motivos que condujeron á su formación; al estado en que se hallan en el día, y finalmente, á los medios que suministran ellas mismas sin violencia para restablecerse y contribuir á la felicidad pública.

El objeto de las asociaciones humanas no es otro, sin duda, que la propia seguridad y defensa y una mayor facilidad de los cambios recíprocos que conduzcan directa ó indirectamente á una vida tranquila y agradable. Pródigo el Creador hacia el hombre, al paso que su infancia penosa, su vejez inmóvil, sus armas débiles y su cutis delicado, le hacían tal vez el animal más expuesto ó á la fiereza de los otros ó á la inconstancia de los elementos, dióle un instinto y una disposición á pensar, con las cuales pudiese, sí, señorearse con facilidad sobre toda la naturaleza; pero se viese inclinado al mismo tiempo á ejercerlas contra su misma especie, movido de la envidia más bien que de la necesidad. De allí dimanan los diferentes periodos de la sociedad: triunfan al principio la edad y la fuerza para abatir los bosques y vencer las fieras que los habitan: los dictados del entendimiento se ejercen después para el abrigo de las intemperies y la fácil adquisición del alimento: síguese, en fin, muy de cerca la tercera época, la cual se dirige, ya no á triunfar de los obstáculos de la naturaleza, sino es á subyugar á sus semejantes y hacerles que trabajen á su favor: de aquí han derivado en diferentes tiempos según la varia constitución casual de las sociedades, las guerras externas para la adquisición de esclavos y la extensión de dominios; y las internas ó civiles para la destrucción de las facciones ó de las opiniones; el aprovechamiento de la navegación para los cambios y transportes voluminosos, y el afinamiento del discurso para simplificar las artes y las labores; de aquí ha dimanado, por último, el sistema de las conquistas lejanas y de U1tramar, sistema que ha acarreado consigo la multiplicación del lujo y ha confundido todos los códigos de gobierno en el solo código mercantil.

Este es el vicio social que triunfa hoy en día de las opiniones; el que elogian con tanto afan los escritores políticos, unos en pos de otros, y es este por la misma razón el que debe sujetarse á una discusión juiciosa antes que otro alguno, semejantes al cultivador industrioso, que no pudiendo ciertamente evitar que llegue á su tiempo la estación rigurosa del invierno, escoge, planta y abriga los diferentes árboles, por manera, que resistan á sus efectos; así nosotros, indagando el mal en su mismo origen y teniéndole á cada paso presente, ya no pretenderemos violentar la naturaleza, para que destruya las leyes que ella misma se ha prescripto, sino más bien sujetaremos las medidas sociales al recto equilibrio que debe siempre conservar con el instinto inconstante del hombre.

No parezca violento este orden de los razonamientos propuestos, cuando se presentan á un mismo instante á la vista del hombre reflexivo, el estado de nuestra Europa, el de las colonias en 
general, y el de los pueblos rudos en los primeros grados de la sociedad. Estos son los elementos invariables que la naturaleza ha prescripto para nuestro estudio: sus costumbres, sus leyes, su situación física y sus ideas morales, demuestran con bastante evidencia que el antojo ha de luchar siempre con aquella maestra, que la imaginación no cesará de labrar allá en el caos de las cosas venideras, mil compensaciones de los males que nos agobian en la realidad, que el mismo antojo será el que trastorne las mejores instituciones sociales, y haga, por consiguiente, necesaria su reforma periódica; finalmente, que si son ó infructuosas ó temibles por lo violento las reformas que no estriben sobre la opinión pública y uniforme del legislador y del que obedece, son, al contrario, precisas y agradables las que lleven por base el convencimiento universal.

Si preguntásemos sencillamente á la España, esto es, á toda la reunión que forma la Monarquía española: I. ${ }^{\circ}$ cuáles son en el día sus necesidades reales; $20^{\circ}$ cuáles sus temores; $30^{\circ}$ cuáles los contratos legítimos de su constitución interior, ciertamente la hallariamos bien confusa para res ponder; ni por otra parte, pudiera tacharse con razón á persona alguna que exigiese de antemano la clara y general respuesta de aquellas dudas para fundar sus razonamientos con acierto. Titubearía aún mucho más si persistiésemos en preguntarle cuáles son las necesidades reales para cuya adquisición ó dominio puede y debe usarse la fuerza pública. Si son inalterables en cualquiera estado de la sociedad los deberes del individuo, ¿hasta qué grado son útiles el comercio, la industria y las colonias? Finalmente, ¿qué es lo que entiende por el sumo grado de opulencia al cual pueda y desea llegar?

Ya una mirada, la más sencilla á esta clase de cuentos políticos, le demostraría que es preciso reconcentrarse en sí misma; que son por lo común engañosos, tanto los temores de una demasiada robustez de las demás naciones, como el afán de imitarlas ó excederlas en la opulencia, y que la naturaleza de sus posesiones ultramarinas, el deseo ilimitado de nuevas conquistas, y el juicio no cabal de lo que ellas valen, no sólo han formado un todo débil y mal urdido, sino que han alucinado también sus pesquisas constantes sobre las causas de un mal tamaño.

Al plan de una reforma útil de la constitución nuestra colonial (si pareciese últimamente necesaria), debían, pues, preceder en un orden claro é inconcuso, antes una idea cabal de lo que son hoy en día nuestras colonias, de lo que serán mediante el impulso lento y contradictorio de la legislación actual, y del influjo verdadero que causaron á la España su conquista, su posesión y sus productos; luégo un examen sencillo de los derechos originales de cada una de las partes que componen la Monarquía, y sobre todo un examen de sus conveniencias, sean internas ó externas; débese procurar después el reunirlas en el nuevo plan de legislación hasta donde lo permitan los vicics inherentes al hombre en sí, al hombre nacido en un clima y en una situación determinadas, y á los inconvenientes inevitables de la demasiada extensión de dominios.... ¿A qué servirían ó un espejo fiel de la legislación del día engendrada por la necesidad sostenida por las distracciones que ella misma causaba y robustecida por los órganos que debían impedir su acrecentamiento, ó unos clamores vanos sobre la debilidad nuestra, sobre la fuerza imaginaria de las demás naciones, y sobre las miradas tímidas, sospechosas y traidoras con las cuales debiésemos acecharnos una á otra en cada individuo, en cada palmo de terreno, en cada vara de tegidos pertenecientes á todas? Sería este un nuevo fárrago de ideas mezquinas y cansadas, tan importunas y áun despreciables para el Gobierno y para la Nación, como ignominiosas para quien se encargase de ordenarlas. Llevarían estampadas en su frente las marcas odiosas ó de la adulación, ó de la ignorancia, y sería digno de reprensión y castigo, el que intentase ó alucinar ó seducir al público.

Examinada de este modo la Monarquía, descubrirá sin duda al político nacional una nueva perspectiva agradable. La variedad de los productos en suelos y climas tan varios y tan extendidos, le presenta innumerables medios de ocurrir á sus necesidades y á sus deleites, sin auxilio de otra nación alguna. La inmensidad de sus territorios desvía de un golpe así las discordias internas en el choque contínuo de los poseedores oprimidos, como las externas en el interés mal entendido de los enlaces políticos de la Europa: conocidos los hábitos, la naturaleza, el instinto y el derecho de los indios sujetos, ya los mira como una parte preciosa de sí misma, los despierta, los hace felices con la alternativa del trabajo y del goce, y los multiplica sin temor de que le ofendan; ceden enteramente al blando halago de la vida socjable y á los pasos lentos, sí, pero pacíficos de los misioneros, todas las tribus errantes que habitan los bosques y los rios internos; ya no es el espíritu de dominio el que mueve nuestros pasos interiores. Nos basta verlos tranquilos é inclinados á la reunión y al trabajo, para que el legislador vea el fruto de sus medidas y el colono el de sus gastos. Aralúanse después en la balanza de la felicidad pública los metales ricos, los tintes, los simples medicinales, la industria, la agricultura, la de las pescas y todo cuanto tributa ó puede tributar el continente americano á nuestra Europa y á las demás partes del globó. La prosperidad de las colonias es una misma con la nuestra. No hay estancos; crece la población, su reunión es sencilla y 


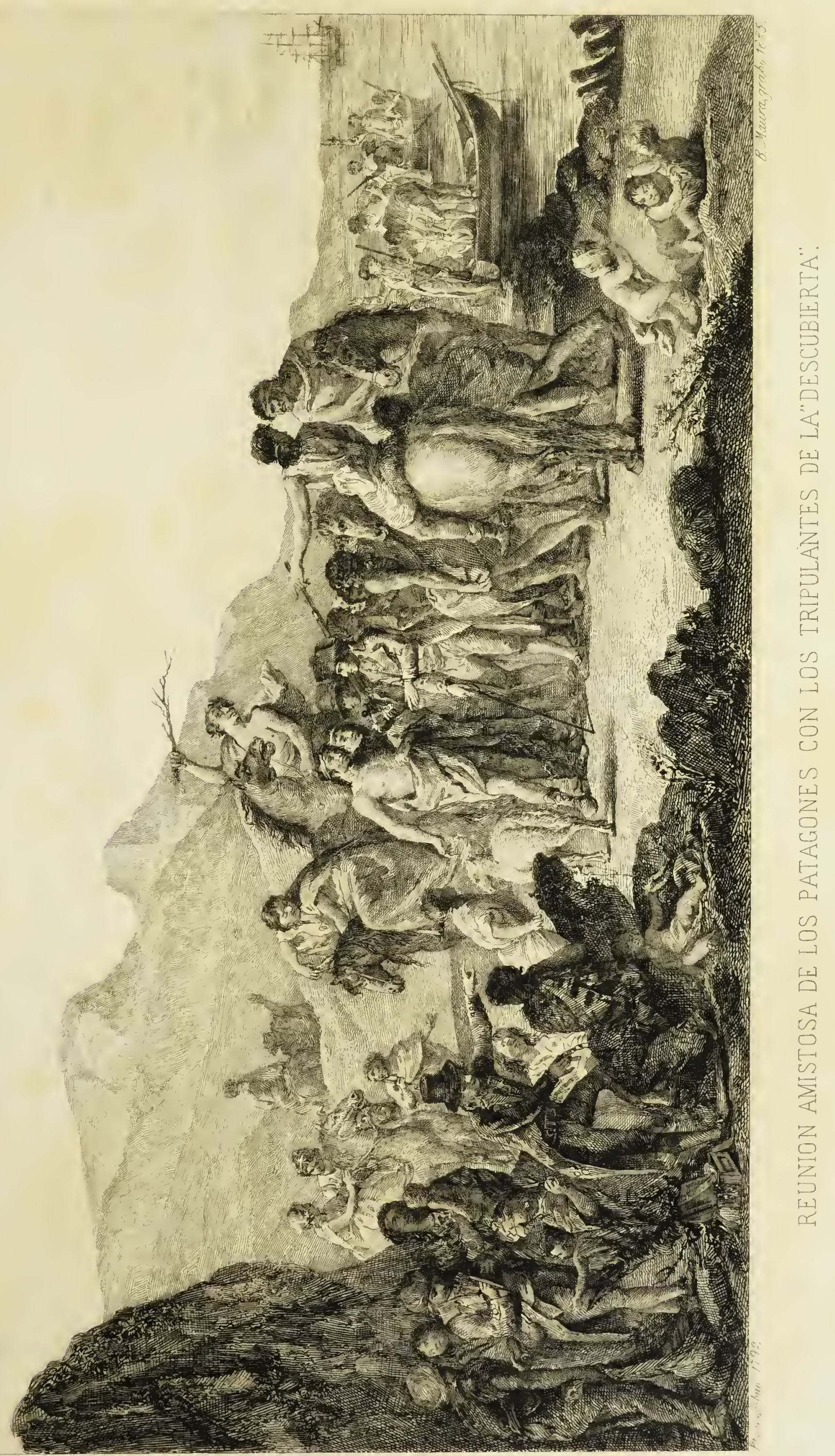



agradable; más fácil su defensa, más suave el impuesto, ménos intrincadas y quebradizas las leyes; más enérgico, sí, pero más coartado el sistema militar; y mirados, finalmente, con una igual predilección el minero y el agricultor, el colono y el habitante de la matriz, el fabricante y el cosechero, la emigración y el radicarse donde parezca. La sola idea de un semblante tan halagüeño, bastaría para excitar el patriotismo; esto es, aquella persuasión firme, de que stan útiles y justos los sacrificios prescritos al individuo para el bien público; del patriotismo, en una sociedad que nada necesita y que convida á su seno á otros muchos con la abundancia de las tierras fértiles, con la dulzura de su legislación y con la facilidad de su defensa, derivaría inmediatamente el crédito público; esto es, el concepto que adquiere una nación consigo misma y con las demás, de ser poderosa en su defensa, justa en sus pretensiones y legal en sus contratos; del crédito público, finalmente, se vería dimanar aquella noble indiferencia, con la cual deben respetarse los derechos y las propiedades de cada nación sea más ó ménos poderosa, más ó ménos distante y con la cual ya no se da cabida al sistema político adoptado en Europa; esto es, un sistema en donde los pasos de las sociedades envuelven en sí ántes la lucha de ellas mismas con su gobierno, y luégo la lucha de unas con otras sin objeto y sin utilidad.

¡Oh! si por un acaso feliz entre las convulsiones terribles que agitan la especie humana y conspiran contra su propia multiplicación; si fuese destinada la España á contener una mayor efusión de sangre y á cicatrizar unas llagas cuyos efectos serán tal vez funestos por más de un siglo á la Europa desventurada; si descollando con un noble sosiego entre la colisión general de principios y de intereses, descubriese al mismo tiempo una moral no violenta, una religión pura, una adhesión gustosa á su constitución enérgica y cariñosa, un poder extenso brotado casi repentinamente del suelo que habita, y ceñidos los límites de su territorio; unos medios indecibles para aprovecharle y defenderle, porque no sería capaz ella sola de llamar otra vez la opinión pública hacia el orden; y al sosiego de fijar los límites de la autoridad y de la subordinación; de derivar el coloso de una soñada balanza política, la cual haría consistir el bien propio en la debilidad ó en la ruina de los demás; en fin, de presentar un abrigo tranquilo y uniforme á los que quisiesen adoptar sus leyes, su gobierno y sus derechos nacionales.

Después de estos antecedentes, ya es preciso dar una idea del método seguido ahora para la publicación, el cual no podrá parecer extraño ni será tal vez desagradable. Atento á la división necesaria para tratar las materias políticas, hemos considerado los dominios ultramarinos de la España divididos en tres grandes trozos: la América meridional desde el Cabo de Hornos hasta el Istmo de Panamá; la septentrional (comprensiva de las Antillas), desde el Istmo hasta sus límites inconcusos al Norte; y las Islas Marianas y Filpinas en los mares del Asia, agregándoles como era natural los intereses nacionales en aquella parte del mundo y en el mar Pacífico, ora se refieran á las colonias europeas, ora á los habitadores independientes de aquellas regiones: á esta división preliminar ha sucedido otra inmediatamente y ha sido la de separar las materias hidrográficas de las que más directamente se referían á la instrucción y entretenimiento comunes: aquéllas no podían ser útiles ni exactas, si no las desmenuzásemos con una tal prolijidad y evidencia, que la vida de los navegantes y las propiedades del comercio pudiesen considerarse seguras en las partes más remotas del globo; esotras, al contrario, debían unir lo útil á lo agradable y convidar á su lectura con la novedad del objeto, con la claridad del método y con la seducción de las materias. ¿Cuál no sería el placer del lector patriótico, si después de una corta suspensión de ánimo al ver la lucha del navegante con la tempestad, las escaseces, la variedad del clima y aquel afán constante que le deben causar la estrechez, la monotonía, la incertidumbre de su suerte y los vicios de su imaginación, se hallase luégo trasplantado en un sólo instante entre los laboratorios más prodigiosos de la naturaleza, en donde se ven reunidas la fecundidad natural de la tierra, con la suma variedad de los climas, con la acción perpétua de un Océano inmenso que la rodea y con los efectos de un.sol más directo y penetrante? Qué, ¿no se complacería aún más si viese inmediatamente después el estado del hombre en medio de tantos agentes para multiplicarse y destruirse, para vivir errante y reunirse en sociedad, para trabajar con fruto y entregarse á una ociosidad perpétua? Y finalmente, ¿cuál no sería su satisfacción, si viese casi instantáneamente y por un orden natural referidos esos pasos y esas reflexiones á la prosperidad nacional?

Este ha sido, pues, el fin que nos hemos propuesto en la división de las materias; los asuntos hidrográficos se refieren sólo al navegante, al legislador y á los que quieran por su propia aplicación penetrar en el pormenor de la una ó la otra ciencia. La narración del viaje y la descripción física y política de los países visitados, comprenden á cualquiera clase de los hombres estudiosos: deben darle una idea justa, si no completa, de los establecimientos nuestros de U1tramar, y conducirle al verdadero patriotismo, demostrándole las ventajas permanentes de la Monarquía, la debilidad de los males que la impiden medrar, y la actividad de los remedios que nos suministra la na- 
turaleza; el todo lleva en sí además la división primordial de las diferentes partes de la Monarquía. Así es fácil á cualquiera no sólo el adquirir y el estudiar la sola mitad de la obra que crea útil, sino también el estudiarla con un método uniforme, por manera que á la par de no poderse confundir en nuestra Europa el clima, el suelo, la navegación, los habitantes y las costumbres de la Rusia y de la Ispaña, no se confundan tampoco en adelante las nevadas montañas de Chile y de la costa Noroeste de la América, con los volcanes y las inundaciones del Reino de Guatemala y de las Filipinas ó con los llanos inmensos de las provincias de la Plata y de la costa Patagónica.

Entrando ya á detallar con una mayor individualidad el plan seguido en cada una de las dos partes indicadas y dejando por ahora las materias hidrográficas, hablaremos con alguna extensión de lo que comprende la primera parte, esto es, la narración del viaje.

Hállase ésta dividida en tres tomos y cada tomo en tres libros; aquéllos llevan en sí la división natural de la descripción del viaje; de la descripción del suelo y de sus habitantes, y de la descripción de la legislación actual, juntamente con la reforma que parece adecuada al todo de los objetos é intereses nacionales: los tres libros, como ya se indicó, comprenden la América meridional, la América septentrional y nuestros dominios del Asia.

La descripción del viaje, ó sea el diario, es por su naturaleza más bien cansado; pero era indispensable el dar una idea aunque fuese mediana, del método seguido en nuestras tareas y particularmente de los objetos que han devorado el largo espacio de cinco años; era indispensable el tributar á cada uno de los hábiles individuos que han servido en la expedición la parte de trabajo y los elogios que le correspondiesen; debíamos, en finn, señalar con una especie de sinceridad marinera los inconvenientes relativos á la navegación que, ó fuesen hijos de la constitución general de la Monarquía ó pudiesen con mayor probabilidad atribuirse á defecto de nuestros armamentos y conducta: de la mejor voluntad confesaremos que en ningún modo pudiéramos aspirar á nivelar este viaje con los que ha hecho el Capitán Cook; nuestros sufrimientos y nuestros riesgos han sido en mucho menores á los de aquel navegante esclarecido; tal vez el ansia de imitarle más de cerca no auxiliándonos igual fortuna, nos hubiera conducido precipitadamente y sin fruto alguno sobre las huellas, ó del desgraciado Conde de la Péyrouse en la costa Noroeste de la América, en las Islas de los Navegantes y en los bancos no distantes de la Nueva Caledonia, ó del Capitán Rion, casi sumergido con el Guardián por acercarse á una banca de nieve, ó del Capitán Hunter, náufrago con el Supply sobre la Isla de Norfolk, ó de la Paudora, igualmente perdida sobre las tierras de Salomón; repetirémoslo una vez más todavía; el nuestro no ha sido un viaje de descubrimientos: 1le. vaba por objeto el conocimiento de la América para navegar con seguridad y aprovechamiento sobre sus dilatadísimas costas, y para gobernarla con equidad, utilidad y métodos sencillos y uniformes.

Ya el segundo tomo abraza en sí materias mucho más amenas é instructivas. Iin él, atendida siempre la división de los tres libros, se examinan el suelo con sus producciones, los habitadores indígenas y los colonos. En cada uno de estos objetos, sin omitir particularidad alguna de las que hemos advertido en el viaje, reunimos luégo en un solo punto de vista todas las indagaciones nacionales, y de allí resultan por una parte las vicisitudes que han causado y deben causar en aquel continente, el tiempq, los trámites de la naturaleza y los trabajos lentos, débiles y á veces contradictorios del hombre; por la otra las dos especies de habitantes, que se hallan en toda ella y en las Filipinas al tiempo de la conquista; esto es, unos hombres embrutecidos, errantes en corto número, entregados á la desnude $z$, al bosque y á la caza; sin principios sociales, sin leyes, sin gerarquía y sin religión; débiles en sus fuerzas, ilimitados en sus apetitos; y otros procedentes de una emigración antigua, civilizados, unidos, amantes del orden y del gobierno, bastantemente provectos en algunas artes, y sin otra inferioridad á las asociaciones europeas, más que la falta de conocer el uso de la pólvora, del hierro, del caballo y de la navegación: á estas dos perspectivas que presenta la América relativamente á su población antigua, síguese luégo la tercera, y es la que deriva de las conquistas europeas, comprendiendo las castas y costumbres mixtas que ha producido y rigen en el clía: cuanto más nos acercaremos en estas discusiones interesantes á los informes nacionales, ó impresos ó manuscritos y al rastro incapaz de borrarse que dejan tras sí la conquista, la legislación y el abuso, tanto más fácilmente veremos derivarse y caer por su propio peso la mayor parte de las novelas y de los sistemas que se han forjado relativamente á la América: sistemas y novelas dignas á la verdad de disculpa, cuando miradas con tanto halago por las naciones extrañas cuanta era la indiferencia con la cual las escuchaban los españoles, tenían además í su favor ora las exageraciones militares, ora los clamores de un celo intempestivo, ora las maravillas y milagros de una uredulidad por lo común maliciosa.

La major parte de este libro será por consiguiente una redacción de obras agrenas, más bien que 
un trabajo original. En ella tendrán una parte esencialísima las observaciones locales del Coronel D. Antonio Pineda, las de los hábiles naturalistas D. Tadeo Heenke y D. Luis Nee, pero siempre desprendidas de aquellas descripciones nimias y ordenadas que corresponden más bien al estudio científico de la Historia Natural y deben por la misma razon formar una obra separada. Las leyes unas veces, otras las historias auténticas, y por lo común manuscritos é informes fidedignos de nuestra misma época, serán los cimientos de la descripción de lo que no hemos visto. Y sin nombrar á persona alguna cuando las materias pudiesen parecer odiosas, tendremos sin embargo un particular cuidado por medio de las notas, de tributar á cada uno lo que es suyo y autorizar nues. tra obra con sus mismos nombres; por la misma razón deberemos citar á cada paso al Sr. D. Antonio de Ulloa. Este observador filósofo, que ha seguido la verdad con no seguir los sistemas, y ha estudiado los habitadores de la América con una asiduidad constante y por el largo espacio de veinte años, merecerá tal vez un nuevo aprecio entre los sabios por la claridad y sencillez de sus descripciones; y las épocas, bastantemente distantes de sus escritos y los nuestros, serán un nuevo apoyo de los pasos ordenados de la naturaleza en aquella parte del mundo.

Pero ya es tiempo de dar una idea algo más difusa del tercer tomo, que trata de las materias políticas: la prosperidad y la defensa de la América, y sus enlaces directos y naturales con la matriz, son los puntos esenciales ó más bien los únicos que debemos tener á la vista: la historia de la conquista y de la conservación de nuestras posesiones, descenderá por consiguiente muy luégo á la descripción de las demás posesiones europeas; veremos cuáles fueron las causas que las arrancaron de nuestras manos, cuáles las ventajas directas ó indirectas que de ellas sacan los poseedores, y cuáles los daños reales que á nosotros resultan de su inmediación; y demostrada la poca importancia de todos estos objetos, se procurarán establecer de tal modo nuestros derechos territoriales, que puedan evadirse de una vez en lo venidero las desavenencias que semejantes cuestiones, natural ó maliciosamente mal entendidas, han originado hasta ahora en tanto número. Fijados ya los límites del imperio relativamente á las demás potencias europeas en una parte, y á nuestra conveniencia en otras, es justo examinar en la inmensidad de paises que aún quedan, cuáles son los que forman una parte efectiva de la Monarquía gobernados ya por nuestras leyes y capaces de contribuir en algún modo á la defensa de la república, y cuáles son los que no debemos considerar como sujetos á la autoridad nuestra. ¿Convendría sujetarlos por las armas, ó dejar al tiempo, á las misiones bien ordenadas y á un comercio ligado con la humanidad el que se opere paulatinamente esta crisis deseada?

Sea como fuere, ya cada parte de los que constituyen la Monarquía ultramarina así determinada, debe organizarse de tal modo, que suministre para su propia defensa y para una cierta moderada progresión de su opulencia, antes de contribuir á la matriz. Deben, por consiguiente, establecerse el pié militar de paz y guerra para los salvajes y para los invasores antes de determinar el impuesto, examinando al paso qué es lo que contribuye neto en el día á la matriz, y disminuirle, continuar ó aumentarle según sean sus fuerzas cabalmente reconocidas.

Con estos razonamientos será fácil ver, que la existencia de nuestra marina, aplicada directamente á las colonias, no sólo suministrará unos medios eficaces para la defensa y reunión recíproca de unas costas tan extendidas, sino que aumentándose rápidamente en razón de los mismos auxilios que le presta la naturaleza, vivificará la industria de las colonias, al paso que disminuirá en mucho los gastos de la Armada recargados al Erario de España.

Or.ganizados de este modo los límites y la defensa así externa como interna de cada parte ultramarina de la Monarquía y dejados á ella misma los medios de atender á su prosperidad local, y aquella administración sencilla de policía y de justicia, que jamás pudiera ligarse ó con una pauta uniforme para todas las provincias, ó con una inmutabilidad perpétua, por cuanto varían las circunstancias y las necesidades; el orden mismo de las ideas nos guía directamente á. desenvolver los derechos legítimos de las colonias y sus deberes sociales entre sí y con la matriz. ¿Cuáles son en el día los sacrificios recíprocos y cuáles las ventajas? Este solo examen, reducido á los objetos de necesidad, de utilidad y de superfluidad, y sujetado á la enorme diferencia del derecho que traen en sí el comercio interno ó nacional y el externo ó extranjero, descubrirá con un orden sencillo el verdadero valor de los metales ricos, su circulación irresistible, su daño real en nuestro Continente, adoptadas las trabas del día y su mayor daño en la América por la persuasión errada de que sea el símbolo de la riqueza. De allí la indiferencia de la legislación en pro de esta industria; de allí la indiferencia del Continente para amontonarle con violencia; de allí, en fin, el estudio de los errores políticos que nos han conservado por tres siglos en la misma debilidad y no nos han permitido enfrenar ó hacer útiles los pasos de nuestros conquistadores.

Luego hay un medio para que las colonias nuestras de la América sean felices, se fortalezcan, puedan defenderse, y entrando en la asociación natural de la Monarquía como parte activa, tributen 
á la fuerza y prosperidad pública aquella cuota que les corresponda. ¿Cuáles son, pues, estos enlaces legítimos de la América con la Europa, enlaces que nos deben conducir á una independencia absoluta de las potencias rivales, á un sistema de gobierno y de impuestos más moderado y más equitativo, á una población y una educación más adecuadas á nuestro estado actual, y á unos principios de legislación y de opulencia que tan impresos en el español de Ultramar como en el de Europa, en el legislador como en el súbdito, no presenten ya para una misma sociedad un choque contínuo de miras, de intereses y de la fuerza parcial de cada uno?

Semejantes reflexiones, sin las cuales fuera inútil, antes bien, sería pernicioso un examen político de la América, nos conducen irresistiblemente á un examen de la administración pública de España. Emancipadas, digámoslo así, las colonias por manera que deban considerarse una parte alícuota más bien que una parte secundaria de la Monarquía, y examinada su influencia directa en la fuerza y opulencia del continente, el comercio natural de unas con otras debe inferirse por precisión, y deducir de allí el sistema del impuesto comerciante, distinguiendo lo que damos y consumimos de la Nación de lo que damos y consumimos del extranjero; aquí debemos inmediatamente probar cuántos son los vicios de la legislación actual de la Europa y en particular de la España, la cual, convirtiéndose de golpe en una nación colona industriosa y comerciante, ha hecho casi necesaria una emigración que prohibe y ha abandonado el cultivo de los mismos alimentos que necesita. Sin la infinidad de vicios políticos dimanados de la confusión de nuestros intereses con los de las colonias y de los intereses de las colonias con las discordias parciales de la Europa, acaso el desnivel de nuestros precios sería tal que los trigos de Beauce y del Orleanois, distante ciento y tantas leguas del mar, pudiesen llegar á Cádiz más pronto y con una economía de ciento por ciento en su trasporte cotejados con los de Palencia, que sólo distará 4 o leguas de Santander (I). ¿Acaso el soldado y el minero español, que en su país no pueden lograr las más veces el pago moderado de un trabajo asíduo y enfadoso, se convertirían luego al punto en la América en otros tantos ministros de la autoridad pública, distinguidos, ricos y sin necesidad de trabajar?

Pero sobre todo, desembarazada la España de los cálculos políticos en los cuales la envuelven ya la asociación, ya la defensa, ya la administración de sus colonias; sabidos los auxilios ó periódicos ó extraordinarios, que la pueden tributar; conocidos á la par los esfuerzos militares á que se halla ligada por los mismos contratos, y desterradas lejos de sí misma aquellas semillas inagotables de discordia, ora relativamente al territorio, ora al comercio, ora á los celos políticos con las demas naciones, ¿por qué no podrá ya reflexionar tranquilamente sobre sí misma y sin pensar en una mejor ó peor situación de la que permitan la naturaleza, sus brazos reunidos y los auxilios equilibrados de las demás partes de la Monarquía? ¿Por qué no podrá arreglar su impuesto, restablecer su erario, emplear directamente sus fondos para su propia opulencia y hacerse respetar sin necesidad de otro alguno por las demás potencias de la Europa?

De allí derivaría tal vez un nuevo plan del derecho público confundido en el día, como ya se ha dicho, con el derecho comerciante; derivarían la mútua dependencia de las colonias con la matriz, con medios tan directos, justificados y naturales, cuanto son torcidos, injustos y perniciosos los que rigen en el día; derivaría, finalmente, el método de captar en cada año la opinión pública y el amor al Gobierno, con hacer públicas la administración y la existencia de los caudales y fondos de la Nación. Pero esta empresa pertenece á un ramo particular que no está comprendido en nuestra esfera, y es la organización interior de la España. Para nosotros bastará el sacudirla de los pesadísimos grillos que la causan las posesiones de Ultramar, y presentarle un plan general de reunión, con el cual sean todas felices y no teman las invasiones externas, ni apetezcan las riquezas agenas.

El deseo de dar una idea algo clara del plan propuesto en la verificación y en la publicación del viaje, nos ha hecho difusos; pero era indispensable, tanto para justificar el método adoptado, como para hacer ver desde el principio el último término que hemos llevado á la vista en nuestros pasos, y es la prosperidad sólida de la Monarquía. Ahora volveremos á reasumir el hilo de la publicación para dar idea de los demás ramos que abraza el total de la obra.

A los tres tomos indicados se sigue otro relativo también á la narración, y trata del viaje que verificaron en I 792 sobre la costa Noroeste de la América, las goletas Mejicana y Sutil, del Departamento de San Blas, á las órdenes de los Capitanes de navío D. Dionisio Galiano y D. Cayetano Valdés, sirviendo en clase de sus subalternos los Capitanes de fragata graduados D. Juan Vernaci y D. Secundino Salamanca. Galiano y Vernaci han sido los redactores. Comprende además de los descubrimientos interiores del decantado Estrecho de Juan de Fuca, los trabajos hechos de mancomún con la expedición inglesa del Capitán Vancoover, una idea bien clara de las costumbres

(1) Memoria mos. de D. Gaspar Jovellanos sobre la Agricultura de España. 
y ritos de aquellas naciones, y cuanto conduzca á aclarar indubitablemente las ventajas y alcances del comercio europeo en aquellos mares. Le han añaclido después una narración extractada cle todos los viajes nacionales hechos hasta el día sobre aquella costa, y últimamente han procurado dar una idea no ménos exacta de los establecimientos rusos de la Siberia, y de las utilidades que prometen comparados á los gastos y á las pérdidas que han causado hasta ahora.

Tal vez podrán comprenderse como apéndices á este mismo tomo, los extractos de otras tres expediciones que han dimanado de la de las corbetas; y son la del Capitán de fragata D. José Meléndez del Departamento de San Blas á las costas de Tecoantepeque y Soconusco, en los Reinos de Nueva España y Guatemala; la de los Pilotos D. Juan Maqueda y D. Jerónimo Delgado en las Islas Visayas ó Filipinas meridionales y la del Capitán de fragata D. Juan de la Concha, con los Pilotos D. José de la Peña y D. Juan Inciarte, al Golfo de San Jorge en la costa Patagónica oriental, entre los paralelos de 45 y $47^{\circ}$ de latitud meridional.

Corresponden á estos cuatro tomos en una masa común setenta diseños, cuyo objeto es el de dar una idea á las veces de las costumbres de algunos paises aún no bien conocidos de los europeos, á las veces de los pobladores, ó indígenas ó colonos de nuestros dominios ultramarinos, y á las veces de la situación y hermosura de algunas capitales de América. Son todos sacados del natural por los hábiles sugetos que en diferentes épocas nos hán acompañado, y de los cuales daremos una relación individual al tiempo de hablar de los armamentos de las corbetas.

A esta parte del viaje, la cual hemos mirado como preferente, sólo porque se refería á un mayor número de personas, síguense ya los trabajos hidrográficos que distinguimos con el nombre de Atlas de la América meridional, de las demás costas de la Monarquía en el Mar Pacífico, y de las Islas Marianas y Filipinas. Se le han añadido después por una parte las cartas necesarias para las navegaciones nacionales en el Océano Atlántico desde las Islas de Cabo Verde, término de las publicadas por los Jefes de escuadra D. Vicente Tofino y D. José Varela, y por la otra todas las que indiquen los descubrimientos modernos y las derrotas antiguas nacionales. Reunida esta colección á la de los mares de la India, trabajada por los navegantes ingleses y franceses; y á la clel seno mejicano, actualmente entre manos de orden de S. M., el navegante nacional tendrá siempre á la vista datos individuales y bien claros para dirigir sús viajes con igual seguridad y presteza á do le llamen ó el servicio del Estado ó sus intereses particulares. Comprenderá nuestro Atlas unas setenta cartas, parte esféricas, parte de los planos de los puertos y parte con las vistas de las costas.

Aunque el diario 6 el primer tomo de la narración del viaje aclare en cierto modo la escrupulosidad con la cual hemos mirado esta parte esencialísima de nuestro destino, nos ha parecido, sin embargo, un deber anexo á la nimiedad que piden semejantes trabajos, el de individualizar antes los materiales de donde han dimanado, y luégo los derroteros que hagan más fácil, ménos cansado y más general su aprovechamiento.

Todos los objetos indicados se comprenderán en dos tomos: el primero se formará con el voluminoso diario astronómico, las observaciones meteorológicas hechas en los puertos y en el mar, y los estados de la declinación de la aguja; lo hará luégo sumamente útil é instructivo un tratado de navegación y geodesia que le hará preceder D. Dionisio Galiano, aplicando á una práctica bien comprobada, varios métodos tan útiles como nuevos que le ha sugerido el estudio constante de la Astronomía y de los demás ramos que corresponden al pilotaje sublime; últimamente, en una Memoria separada, el Capitán de fragata D. Ciriaco Cevallos, expone con mucha claridad el resumen de nuestras experiencias sobre la gravedad de los cuerpos, hechas con el péndulo simple constante en diferentes paralelos de entrambos hemisferios, y las refiere al mismo tiempo á la figura de la tierra, nó tan simétrica como se suponía, y luégo á una medida universal, cuya comprobación constante é invariable en diferentes parajes, dependa sencillamente de los resultados de las experiencias hechas hasta ahora, ó por nosotros ó por los viajeros que nos han precedido.

Corresponderán después al otro tomo, que será el sexto de la obra general, la recopilación de los elementos que han servido de base á nuestras cartas y los derroteros de las navegaciones que éstas comprenden. Un tratadito sobre los vientos y las corrientes y otro sobre las derrotas más breves por alta mar de uno á otro paraje del globo, cualesquiera sean las estaciones del año, hará ver á continuación, cuántas son las vías, y cuánto son fáciles para comunicarse contínuamente entre sí la América, el Asia y la Europa.

Siguiendo por naturaleza en los trabajos indicados, por una parte las noticias astronómicas que se nos han comunicado ó sabíamos de antemano, y por la otra la serie casi inmensa de los navegantes nacionales que nos han precedido para los reconocimientos parciales de la América, procuraremos no defraudar á persona alguna el fruto de sus fatigas, bien que dejando aparte aquellas cuestiones hidrográficas sobre la primacía y la legitimidad de los descubrimientos, que ya tantas veces han sido agitadas en la Europa y siempre decididas por el público imparcial á favor 
de la navegación antigua española. El mejor modo de dispersar las acusaciones, con las cuales á su salio varios escritores han tachado la España hasta estos últimos años, será ciertamente el de no impugnarlos sino con los hechos cuando se hallasen infundadas, ó el demostrarles, cuando fuesen fundadas, que ni eran absurdos nuestros misterios pasados, ni era otro, tal vez, el objeto de la publicación de sus viajes, sino el mismo que manifestaba la ocultación de los nuestros ó como prudente, ó como necesaria.

Con los seis tomos ya indicados, concluiría la obra que ahora presentamos al público, si la habilidad y" la aplicación constante de los Cirujanos de ambas corbetas, D. Francisco Flores Moreno y D. Pedro González, no diesen ocasión de ãadirles otro tomo relativo á la conservación de la salud de los navegantes españoles. En balde intentaremos recomendar esta obra tanto como ella merece; se hallan aplicados á la práctica con igual felicidad los conocimientos más modernos sobre la digestión animal, los inventos más preciosos para la depuración del aire y del agua, los métodos más seguros para preparar y conservar los víveres, y finalmente, los muchos medios que para la conservación del navegante en los climas temibles de la Zona Tórrida suministra la naturaleza en las posesiones españolas: se comparan ahora con la reflexión y tino correspondientes, la calidad del marinero español y la de los navegantes ingleses; los vicios que produce el mar y los que dimanan de los países inmediatos á la Equinoccial. El escurbuto, las fiebres pútridas y las catarrales, junta:mente con las causas que las producen, pasan por un examen igualmente científico, claro é inteligible; se enumeran las muchas bebidas fermentadas que es fácil aplicar á la navegación; tráense luégo á una comparación exacta con los principios prescritos, las varias enfermedades acaecidas últimamente en nuestras escuadras; $y$ finalmente, se prescriben por una parte los temperamentos y métodos de vida que más bien correspondan á los muchos climas que presentan nuestras posesiones dilatadísimas, $y$ por otra el sistema de disciplina que parezca más propio para los buques de S. M., reunidos en un sólo punto de vista los objetos militares, los de policía y economía y los de la conservación del individuo.

Estos son los límites actuales de la publicación del viaje. Se seguirán luégo, con un plazo proporcionado á la multiplicidad é importancia de los materiales, las diferentes obras científicas que se refieren más directamente á la Historia Natural. Los hermanos y herederos del difunto D. Antonio Pineda, tributarán ciertamente de mancomún con la Nación entera este nuevo homenaje á las ciencias y á la memoria de aquel hábil filósofo.

Luégo que regrese D. Tadeo Heenke, el cual ha recorrido por un año más la América meridional con indecible ventaja de los varios ramos de la Historia Natural, serán públicas igualmente las colecciones botánicas y zoológicas que ha formado, y describirá á la par con el otro botánico, Don Luis Nee. Tal vez no sería aventurado el asegurar quie las colecciones formadas en el viaje son las más selectas que existan en el día, por sus rarezas, variedad y número. E1 de las plantas no es ciertamente menor de 14.000 .

Describirá después el mismo Heenke, con la elegancia que le es propia, los importantes paises que ha recorrido últimamente en los Vireinatos del Perú y Buenos Aires, penetrando á Guamanga y Guancavelica, el Cuzco, Arequipa, la Paz, Potosí, los Yungas, Chucuito y el fértil país de los Moxos; las antiguiedades peruleras, estudiadas ahora en el Cuzco, darán nuevo material para conocer la arquitectura de aquellos pueblos, que ja D. Fernando Brambila había estudiado y descrito con tanto acierto á la par de la arquitectura mejicana. En fin, cuantas ideas hayamos adquirido y cuantas podamos adquirir en lo venidero sobre los objetos que abraza el viaje, otras tantas se presentarán al público como un tributo que le es debido y como una prueba de nuestro deseo incesante de coadyuvar á las intenciones benéficas de S. M.

Aclarado con alguna individualidad el objeto del viaje y el método ahora adoptado para su publicación, debemos con igual claridad manifestar. cuáles fueron los aprestos y las medidas tomadas para el intento; serán éstos una prueba bien evidente de la generosa protección del Rey á favor de las ciencias y de la navegación, y harán ver las razones por las cuales nos hemos apartado á las veces y otras hemos imitado servilmente á los navegantes que nos han precedido en esta senda.

Las dos corbetas con las cuales se ha verificado el viaje eran absolutamente iguales, y en ellas reunió el Brigadier D. Tomás Muñoz, Ingeniero Director y Comandante del Arsenal de la Carraca, todas las propiedades que parecieron más ventajosas, así para la resistencia como para la capacidad y comodidad del buque: sobre r 20 piés de eslora, 3 I 1/2 de manga y I $_{5}$ de puntal, manifestaban un arquco de 306 toneladas; macizadas las cuadernas y calafateadas sus juntas, presentaban un sesundo costado inaccesible al agua del mar, aun cuando el fatal encuentro de algún escollo hubiese roto la tablazón exterior; eran los fondos forrados antes con madera sujeta con clavos de metal y luégo con planchas de cobre, por manera que se destruyesen los perniciosos efectos de éstas sobre la clavazún interior de hierro. El calado nø excedía á popa de $13 \%$ piés, facilitando así el poder 
internar en cualquiera cala de poco fondo. Y proporcionadas luégo las dimensiones de la arboladura, para que no se opusiese un aguante extraordinario de vela á una regular velocidad, habíase logrado un excelente gobierno y una deriva más bien moderada, particularmente cuando se hiciese el debido uso de las mayores. Podían contener los buques en su bodega y sollado dos años de víveres para la dotación asignada, y seis meses de aguada y leña; los pertrechos de todas especies y particularmente de hierro, lona y jarcias, eran adaptados á la falta absoluta de estos efectos, que hallaríamos en los diferentes puertos de la América. Eran igualmente crecidos los repuestos para vestuario de la marinería y para efectos de cambios. Las embarcaciones menores llegaban á cinco para ocurrir á los diferentes objetos de la aguada, leña, caza, pesca, observatorio, Historia Natural y comunicación contínua de los buques con la playa; aumentadas las lanchas y aprestadas con cubierta de hierro, como lo verificamos después en Guayaquil y San Blas, podían las tres embarcaciones mayores contener toda la dotación de los buques en el caso de un naufragio. Al mismo tiempo, los fogones de hierro para dulcificar el agua del mar, con dos alambiques, aplicado el segundo al caldero de la comida, suministraban el agua necesaria para la subsistencia de todos. Y lo que nos pareció lo más interesante; ni había persona alguna que no alojase en la cubierta principal, esto es, en un paraje bien ventilado y en donde el mismo fogón, con una acción contínua, debía renovar frecuentemente el aire, ni en los alojamientos dejaba de haber aquel método y diferencia que exigen, sí, la conservaciọn de una buena disciplina por largo tiempo. Sería cansado, mas no totalmente inútil, el repetir uno á uno los diferentes reparos que se tuvieron presentes para esta distribución de alojamientos, la cual, luégo por lo que tocá á la Oficialidad de guerra reunía, los objetos de una total independencia entre sí, de la debida quietud para las tareas científicas y de sitio cómodo y oportuno para reunirse y no olvidar los halagos de la vida sociable, sea con el auxilio de la música ó con la lectura de libros igualmente amenos y entretenidos.

Ni en lo que mira á la buena calidad de los aparejos, velámenes y otros pertrechos, fué ménos eficaz el Brigadier D. Fermín de Sesma, Subinspector del Arsenal de la Carraca. Todo era de la mejor calidad y proporciones, y para un facultativo será buena prueba de esta aserción, el que le aseguremos haber sido una misma la driza de gavia que ha servido en la DescuBIERTA durante el largo espacio de cinco años y dos meses.

A estas dos clases de aprestos, de las cuales dependía en mucha parte la seguridad del viaje, siguiéronse luégo las no ménos importantes que se referían á la conservación de las tripulaciones. No ignorábamos (como se ha hecho ver ya), que nuestras escalas repetidas en los varios puertos de las colonias nacionales, proporcionarían el renovar los víveres cuantas veces fuese necesario; pero teníamos también á la vista el que mil alimentos de los que suministran las últimas navegaciones, pudieran á veces presentar objetos de variedad y de economía aun cuando no of reciesen (lo que parecía difícil), ventaja alguna para la conservación de la salud.

Adoptáronse con esta atención el Sorerkrout y las salazones del tocino, éstas por ambos métodos usados por el Capitán Cook y por el Conde de la Péyrouse: hicimos grande uso del vino de Sanlúcar, al cual sustituyóse el de Chile, y finalmente, el Groog ó aguardiente aguada. Turnaban después la suministración de las comidas calientes y del gazpacho, el uso de las bebidas fermentadas y la diferente distribución de horas, según los climas y las estaciones en los cuales nos hallamos. A la vez se premió el baño, siempre se animó el ejercicio con tal que fuese moderado, ni nosotros, cuando no le hallásemos absolutamente necesario, prescribimos el trabajo en las horas de la mayor fuerza del sol estando en los climas más temibles de la Zona Tórrida. Por la misma razón de promover un ejercicio frecuente en todas las clases de los armamentos, se procuró que la marinería y tropa estuviesen siempre á dos guardias y que los demás individuos fuesen tambien comprendidos porr lo general en este útil servicio. Nunca se omitieron, cuando estuvimos fondeados, la pesca, la caza y el aprovechamiento en el caldero de aquellas yerbas saludables que ofrece la naturaleza al navegante áun en los parajes más áridos y đesiertos. La narración del viaje manifestará después que muchas veces, más bien debimos reponer en el mar los armamentos harto debilitados en los puertos, que no expresar en éstos el restablecimiento de los efectos harto comunes de la navegación.

Pero el resorte principal que adoptamos para la conservación de nuestro hombre de mar, fué sin duda alguna la tranquilidad del ánimo. En balde intentaremos suponer en el marinero español aquella misma insensibilidad, que tantas veces se advierte y parece incorregible en el marinero del Norte. Los nuestros raciocinan, preven, y en una larga enumeración, por lo común abultada según los mismos efectos de la imaginación, conservan la idea de todas las desgracias acaecidas en las navegaciones harto aventuradas del mar del Sur; de allí aquel entrometimiento impertinente en todas las providencias adoptadas y en los obstáculos que se encuentran casi diariamente; de allí aquel vuelo indecible de la suma valentía á la suma abyección, según los trances 
reales ó imaginarios que se le presenten; de allí, finalmente, un tránsito igualmente acelerado de la salud más robusta á una enfermedad epidémica; enfermedad que agravan luégo más y más los mis. mos indicios de su fatal existencia á bordo. Por ventura un verdadero espíritu de subordinación les hace tener las miradas siempre fijas en la Oficialidad de guerra que los gobierna. Basta que éstos sepan templar con tino el rigor y la dulzura, la fatiga y el descanso, la severidad y la persuasión, el acomunarse en cierto modo con ellos y el apartarse repentinamente á mucha distancia, para que la generosidad nacional se despierte luégo al punto y obre con toda la energía debida para infundir ántes la tranquilidad del ánimo y triunfar después de los mayores obstáculos. Pero de las ideas relativas á la conservación de la salud, se liablará con la debida extensión en el séptimo tomo ó tratado médico. Nos ceñiremos aquí á ratificar lo que había demostrado con la mayor evidencia el Capitán Cook, y es que relativamente á los víveres y á la conservación económica del navegante, no hay plazo, no hay clima, no hay punto alguno de la tierra en donde no sea fácil conseguirlo, con tal que se modifiquen las reglas generales á los hábitos y calidades de cada nación. Por lo que toca á nuestros aprestos, el Srerkrout se mantuvo por dos años largos de buena calidad, exceptuándose, sin embargo, aquellas barricas que por falta de sal ó por una introducción del aire atmosférico entre las tongas no bien comprimidas, pudriéronse muy luego y despedían una fetidez extraordinaria. Los tocinos salados por uno y otro mśtodo, han durado por el espacio de tres años, con tal que se les renovase de tiempo en tiempo la salmuera. No resistieron tanto las menestras sin ser invadidas por el gorgojo; lo mismo sucedió al pan. No así á las harinas, particularmente de Filadelfia, las cuales conservaron la misma excelente calidad después de dos años de haberse embarcado en Cádiz. Hízose también una prueba escrupulosa con las carnes saladas de Montevideo. Las tuvimos fabricadas en el año de I786, y después de haber navegado por cuatro años y medio, se conservaban aún de buena calidad en Marzo y Abril de I794.

A estos aprestos para la conservación del hombre, fueron después proporcionados los que exigía con justa razón el hombre enfermo. Las pastillas de caldo se fabricaron por diferentes métodos, los más introducidos en Europa. Dispúsose un abundante acopio de zumos de naranja y de limón. No descuidamos el embarcar algunas barricas con cebada fermentada y molida. Las cajas de medicina variaron mucho del método común de los buques de S. M., varió también el sistema de enfermería, evitando el embarcar dietas vivas y el destinar paraje fijo para los enfermos. Cuál haya sido el fruto de cada una de estas medidas, se manifestará después con verdad y método al tiempo de hablar, en el tratado médico, de éstos y de los aprestos que se indicaron en los párrafos anteriores. Aquí añadiremos, que en la dirección de nuestras medidas para este ramo, intervino de orden de S. M. el Proto-Médico de la Real Armada, D. José Salvaresa, cuyo dictamen sobre la conservación de la salud en el mar, se halla comprendido en tres cartas responsivas á otras tantas que manifestaban nuestras dudas ó incertidumbre para apartarnos unas veces de los métodos nacionales y otras de los que nos prescribían casi invariablemente los extranjeros.

Ya es tiempo de decir algo también sobre los objetos científicos que se prefijaron en el viaje y sobre los medios empleados para conseguirlos. Han sido muchos; nos han ocupado incesantemente; los dirigían por la mayor parte hombres bien conocidos en la república literaria, y el sabio Ministro que dió el primer impulso á la expedición y la ha protegido después con igual constancia y generosidad, condescendió desde luego á que se consultasen, con aquella docilidad que es siempre inseparable de la ciencia verdadera y del deseo de coadyuvar con la mayor extensión á la utilidad sólida de nuestros semejantes. Franqueáronse desde el mismo principio los archivos de las Secretarías de Indias y Marina, para extractar los materiales hidrográficos que en ellas hubiese. Este primer examen manifestó de nuevo la necesidad del viaje próximo á emprenderse, pues confundidos en una sola masa, materiales á las veces excelentes y otras perniciosos ó en una perpétua contradicción los unos con los otros, si descubrían por una parte los esfuerzos repetidos y costosos que habia hecho constantemente el Gobierno á favor de la navegación, convencían por la otra cuánto era fácil ó debilitarlos ó hacerlos inútiles con la sola insuficiencia de los medios adoptados para conseguirlo. Tuvimos, igualmente, una orden circular para que se nos franqueasen en las diferentes capitales de la América los archivos de los expulsos jesuitas, en donde con mucha probabilidad se hallarían rastros recientes de los reconocimientos y viajes interiores que aquellos religiosos habían verificado en el siglo pasado y en el actual, ó con el objeto de coadyuvar á la conversión de las naciones no conquistadas, ó para auxiliar al Gobierno en el estudio é investigaciones de un país de tanta extensión; pero frustráronse también aquellas medidas, hallándose aquellos archivos en parte maltratados, y despojados en parte de lo que tuviesen de más precioso. Fué, finalmente, preciso recurrir á los autores impresos, bien que con la felicidad de poder comparar en las diferentes capitales de nuestros reinos ó provincias aquellas nociones que sirviesen de base para la historia de la América con los manuscritos é ideas locales que de allí mismo pudiésemos derivar. 
Sin omitir de indicar lo más difusamente en los parajes de los tomos siguientes que por naturaleza lo exijan, no debemos en esta ocasión pasar en silencio que hemos hallado en todas las persolnas ilustradas de la América, á cualquier ramo á que correspondiesen, otros tantos socios de nuestra empresa, los cuales, por consiguiente, la han facilitado sobremanera y han ratificado así, tanto la necesidad de una reforma, como las causas, harto complicadas, que han llevado la América al estado en el cual se halla hoy en día.

A estos elementos esenciales para el acierto de nuestros pasos y á los encargos más estrechos del Gobierno á los Vireyes y Capitanes Generales de las provincias para que auxiliasen esta empresa con cuantos medios les dictasen su celo y los conocimientos locales, vimos añadirse después con indecible utilidad del servicio varios dictámenes bien importantes de los Excmos. Señores D. Antonio de Ulloa, D. Juan de Lángara y D. José Mazarredo, sobre la Hidrografía y la cons. titución física de la América meridional, sobre la adquisición y el uso de la mayor parte de los instrumentos astronómicos, y sobre algunas experiencias relativas al nivel de los dos mares, Atlántico y Pacífico, y sobre varias modificaciones en el casco, en las maniobras y en la disciplina de nuestros buques. Consultóse también al Teniente General D. Gabriel de Aristizábal. El Marqués de Ureña dió varias nociones sobre la aplicación de los aires fijos á diferentes enfermedades y sobre el mejor uso de los eudiómetros, y D. José Armenteros, Secretario en Manila por la Real Compañía de Filipinas, á instancia del Gobierno, agregó á las nuestras todas las reflexiones físicas y políticas sobre aquellos establecimientos que le había suministrado el estudio más asíduo de veintidos años. Tantos auxilios bastaban por sí solos para alentar á la empresa los hombres aún más tibios y desconfiados de sus propias fuerzas. ¿Pues qué, cuando concurrieron al mismo intento varios doctos ex-jesuitas residentes actualmente en Italia, los abates Córdoba de Castro, Jimenez y de Cesaris, el Marqués Gerardo Rangone y el abate Spallanzani de la misma Italia; el Sr. La Lande, de París, y los Sres. Banks y Dalrymple, de Lóndres? Debémosles, ó unas direcciones oportunas sobre aquellos puntos á los cuales con más acierto pudiesen dirigirse nuestras investigaciones siguientes, ó aquellas correspondencias sucesivas que aclarasen particularmente, por lo que toca á la Astronomía, las dudas que debían dimanar por precisión de unas operaciones aisladas é independientes hechas á tamaña distancia de la Europa.

Intervino después el Sr. D. Alejandro Dalrymple en el acopio hecho en Londres de la mayor parte de los instrumentos astronómicos, de los cuales se dará una razón más extensa en el diario de las observaciones. Empero no fuimos tan felices por lo que toca á una excelente colección de instrumentos hecha en París para los progresos de la física. No llegó á Cádiz á tiempo de poderla embarcar en las corbetas, y equivocadas después las marcas con otras remesas correspondientes á la minería de Méjico, jamás pudimos recibirla por cuanto fuesen eficaces nuestras diligencias para el intento en los diferentes puertos en donde estuvimos.

No faltaron, sin embargo, al genio sumamente laborioso del Teniente Coronel D. Antonio Pineda, bastantes medios para esplayar constantemente su amor indecible á los diferentes ramos de la Historia Natural y aquella actividad que finalmente le trajo al fin desgraciado de su vida. Tuvo á sus órdenes una excelente librería, acopiada en parte en Madrid y en parte en París. Los hábiles botánicos D. Luis Nee y D. Tadeo Heenke, además de atender con la mayor asiduidad á su objeto principal, no descuidaron el auxiliarle con cuantas indagaciones útiles le viniesen á mano, especialmente en la Litología. Pintores y disecadores procuraron conservar cada cual en el modo que su profesión les permitía, los objetos más raros que la naturaleza iba desplegando á su vista en los varios paises que recorríamos. Encargábanse otros al mismo tiempo de la caza y de la pesca. Premiábase altamente á los naturales que presentasen algo útil para las colecciones y el estudio. Así pudimos remitir en diferentes ocasiones al Real Gabinete de Madrid unas 7o cajas con esos mismos acopios.... ;Oh! si la suerte nos hubiese concedido el reconducir sanoá su patria al mismo Pineda, ¡cuánta utilidad no debía ésta prometerse de un examen científico, tan extendido como él había procurado abrazarle y de su carácter tan investigador como filántropo. No defraudaremos á lo ménos cosa alguna á su memoria en la actual recopilación del viaje, bien sea conservada en sus manuscritos ó deducida de sus conversaciones verbales; tiempo vendrá en que siendo públicas también con el detalle debido todas sus descripciones zoológicas y los muchos objetos particulares sobre los cuales se extendieron sus incesantes observaciones, la Nación conozca la pérdida que ha tenido.

Concluiremos ya esta introducción, bastantemente difusa, con recordar al lector la juiciosa advertencia de Mr. de Bouganville al tiempo de escribir la narración de su viaje, viendo cuánto debían por naturaleza apartarse uno del otro, el estilo bronco y árido del hombre de mar, del más ameno, elegante y entretenido, que por sí exigen las narraciones de un viaje. Fielices nosotros si pueden compensarlas, á lo ménos en parte, la verdad, la sencillez y el amor del bien público que 
no hemos perdido un solo instante de vista. Felices, finalmente, si en la ejecución y en la publicación de esta obra hcmos acertado á obedecer complctamente las benéficas órdenes de S. M. y las sabias providencias de su Ministerio (I).

Las corbetas, arreglada la marcha de los relojes marinos en el Real Observatorio de Cádiz, provistas de cuanto les fué necesario y examinadas de antemano sus propiedades marineras, se hallaron prontas pará dar la vela en los últimos días del mes de Julio; eran voluntarios todos los individuos que en cllas navcgaban. Los carpinteros, calafates, herreros y 4.5 marineros, procedían del Departamento de Ferrol; completáronse los demás en Cádiz. Los armamcntos, al tiempo de dar la vela, se hallaban en el pié que á continuación se expresa:

\section{Corbeta Descubierta.}

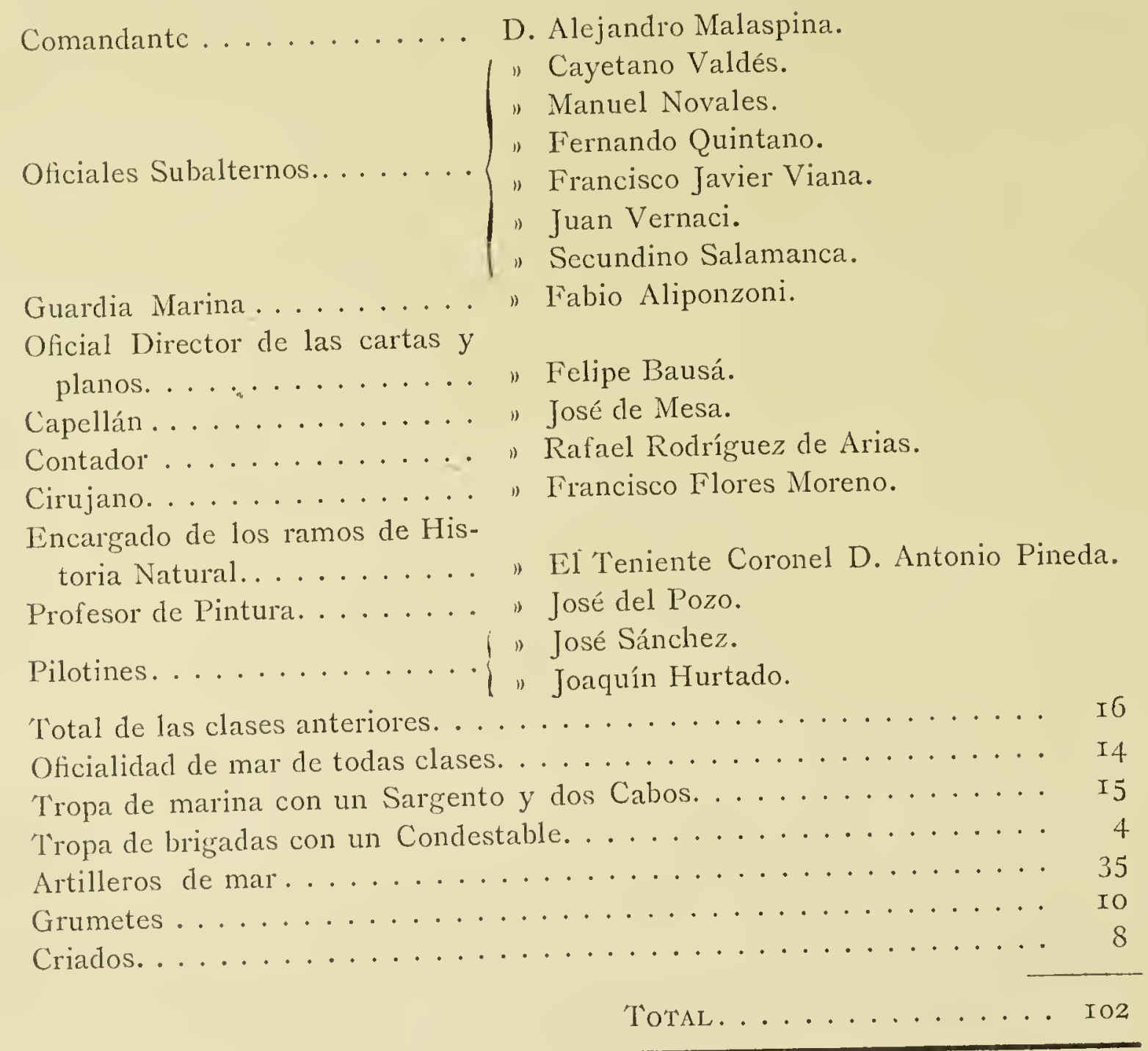

\section{Corbeta. Atrevina.}

\begin{tabular}{|c|c|}
\hline \multirow{2}{*}{\multicolumn{2}{|c|}{ Comandante }} \\
\hline & \\
\hline & "Antonio Tova Arredondo. \\
\hline & $\begin{array}{l}\text { " Dionisio Galiano. } \\
\text { " Juan Gutiérrez de la Concha. }\end{array}$ \\
\hline Oficiales Subaiternos... & "José Robredo. \\
\hline & " Arcadio Pineda. \\
\hline & " Martín de Olavide. \\
\hline Guardia Marina . . . . . . & " Jacobo Murphy. \\
\hline 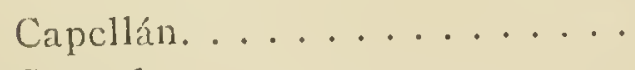 & "Francisco de Paula $\Lambda$ ñino. \\
\hline ontador $\ldots \ldots \ldots \ldots$ & " Manucl Ezquerra. \\
\hline 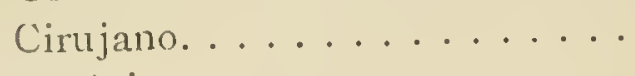 & "Pedro María González. \\
\hline ánico................ & " L \\
\hline
\end{tabular}


Piloto............... D. Juan Maqueda.

Disecador y Pintor Botánico. . . " José Guio.

Pilotines........... Jerónimo Delgado.

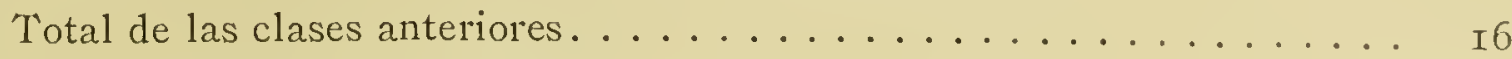

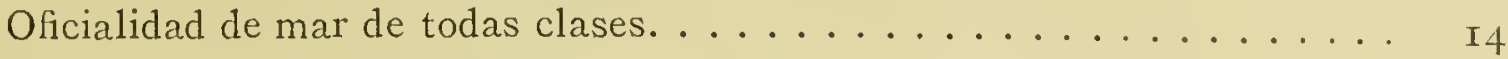

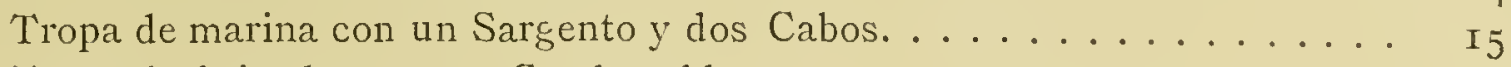

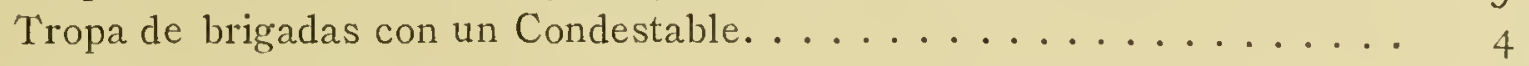

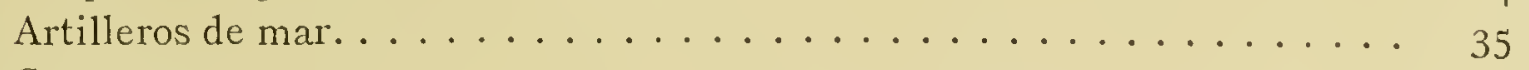

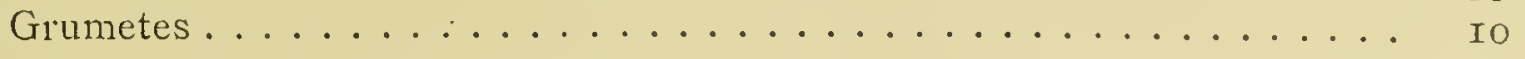

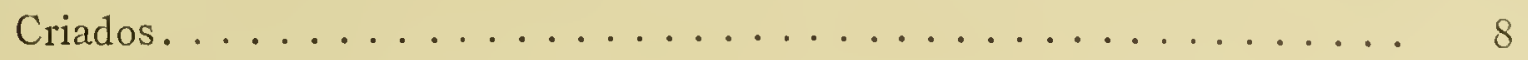

TotaL............... I 02

Agregáronse luégo á la expedición, como se verá en el diario, el Botánico D. Tadeo Heenke en Santiago de Chile; los Tenientes de navío D. José Espinosa y D. Ciriaco Cevallos, y los Profesores de pintura D. Fernando Brambila y D. Juan Ravenet, en Acapulco; y se separaron D. José del Pozo, en la primera escala en Lima; D. Dionisio Galiano, D. Cayetano Valdés, D. Juan Vernaci, D. Secundino Salamanca y el Pintor José Guío, en Acapulco; D. Martín de Olavide, D. Juan Maqueda, D. Jerónimo Delgado y D. José María Sánchez, en Manila; D. Tadeo Heenke en la segunda escala en Lima; y finalmente, D. Juan de la Concha y D. Juan Inciarte en la segunda escala en Montevideo; todos con diferentes destinos relativos á la misma comisión esencial de las corbetas, excepto los dos Pintores y el Piloto D. José Sánchez, á los cuales obligó á este particło el mal estado de su salud.

En los seis meses que estuvimos sobre la costa Noroeste de la América, nos acompañó también, en clase de Profesor de Pintura, el Académico de Méjico D. Tomás Suria. 



\title{
LIBRO PRIMERO
}

\author{
Navegación de las corbetas desde Cádiz á Montevideo, costa \\ Patagónica, Maluinas, Chile, Perí, Guayaquil y Panamá. \\ Acaecimientos y tareas en los puertos que visitaron.
}

\section{CAPITULO PRIMERO}

\author{
Navegación desde Cádiz á Montevideo.
}

Recibidas las últimas instrucciones para verificar la salida, dimos la vela en la mañana del 30 de Julio, y el viento, ya declarado al Nordeste desde el día anterior, nos fué tan favorable, que pudimos alcanzar la Punta de Naga, en Ag. 3 la Isla de Tenerife, al medio día del 3 de Agosto. La longitud determinada á esta Punta nos dió lugar á comparar los relojes marinos, entre los cuales manifestaron mucha exactitud el cronómetro 6 I de Arnold, y el número Io de Berthoud.

En la corbeta ATrevida disipóse de nuevo con marcaciones al Pico de Teide, la sospecha del Capitán Cook sobre el error de las longitudes determinadas por D. José Varela; sus resultados y comparaciones fueron las siguientes:

Longitud del Pico de Teide, por el nú-

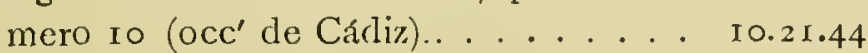
Por el reloj ro5. ................ 10.23.17 Por el cronómetro 7I........... Eran las deter- Berdun, Bordá y Pingré.. minaciones de D. José Varela ...... los señores. . . El Capitán Cook. . . . .

23.49 $21 \cdot 30$ 21.00 43.00

A este tiempo se habían ya manifestado en la DESCUBIERTA cuatro polizones ( $\mathrm{I}$ ), y otros dos en la ATrevida, los cuales habían podido frustrar nuestras pesquisas bien eficaces para evitar este desorden. La esperanza de una fácil subsistencia en América, y el no inclinarse con esta misma esperanza la educación plebeya á un trabajo asíduo y uniforme, son el verdadero principio de esta emigración constante que hemos visto ascender en muchos buques, particularmente mer-

(I) Se distinguen con este nombre ó el de llovidos los que se esconden en las embarcaciones para emigrar á la América sin licencia. cantiles, á un número no menor de 50 y 60 indi- Az. 3 viduos.

En la misma tarde desembocamos con viento favorable entre la Gran Canaria y Tenerife; eludiéronse después á la media noche las apariencias de huracán, que indicaban probable, así el plenilunio como el descenso excesivo del mercurio en el barómetro marino; antes del amanecer navegábamos de nuevo con fuerza de vela para dirigirnos á pasar entre la costa y las Islas de Cabo-Verde.

Muy luego nos abandonaron las brisas, tanto que en latitud de $19^{\circ}$ empezaron á experimentarse calmas, cerrazones y lluvias: las corrientes, según las observaciones diarias, parecían dirigidas al Este.

Ya próximos á las Islas de Cabo-Verde, alcanzamos algunas embarcaciones que seguían nuestros rumbos. Se reconoció la una, cuyo Contramaestre vino á bordo, y era la Philips-Stevens, de Liverpool, que con cinco semanas de navegación desde Inglaterra, se dirigía á Old-Calebar para cargar de negros. Se le avisó de su situación en longitud, pues traía errada la estima en grado y medio al Oeste.

No bien había llegado la lancha á su bordo y nosotros marcado todo aparejo, cuando nos sobrecogió una turbonada fuerte, la cual dió lugar á experimentar la resistencia de los buques y aparejos, ya que nos era contraria para lä derrota. Con la noche calmó el viento y al medio día siguiente nos hallamos en latitud de $I 6^{\circ} 2^{\prime}, y$ en longitud de $14^{\circ} 6^{\prime}$. No distaba el centro del Sol de nuestro zénit, sino $40^{\prime}$.

Se aprovecharon los variables en los tres días siguientes, y áun en la mañana del I 2 se logró observar algunas distancias del Sol á la Luna, de las cuales resultó la longitud de I $2^{\circ} 3^{8^{\prime}}$ igual con los relojes 6 I y I $_{3}$.

Los vientos luégo se declararon del Sudoeste, tempestuosos y acompañados de una lluvia tan copiosa como constante; nos aproximaron hacia 
Ar. $x 3$ la costa de Africa, haciendo mucho más arriesgada la conservación de la salud de la marinería.

En la.mañana del I5, nuestra estima, traída desde las últimas observaciones, había contraído un error de $44^{\prime}$ al Este, y $47^{\prime}$ al Norte, y este error, reunido á unos rumbos poco ventajosos, nos había llevado á las sondas de la costa inmediata y á solas 16 leguas de la Isla Poilón en latitud de $\mathrm{IO}^{\circ} \mathrm{II}^{\prime}$, y longitud $9^{\circ} 46^{\prime}$.

Tomamos las muras á babor y continuaron nuestros esfuerzos para aproximarnos á la línea, malogrados en mucha parte, ó por las calmas ó por la contrariedad de las corrientes.

Toda la tarde y noche siguientes, conservaron los cielos y horizontes su acostumbrado velo de celajería neblinosa. Velo que, si bien se consultase la inmediación del Sol á aquellos paralelos, debiera manifestársenos como un nuevo rasgo de la Providencia, pero que el navegante no aprecia, sólo con ser un símbolo de calmas y vientos contrarios para su viaje, cuyo término ocupa naturalmente todas sus ansias y pensamientos.

Las ventolinas varias y calmosas del tercer cuadrante, que habían hecho en la noche nuestra navegación tan molesta como poco provechosa, nos compensaron en la siguiente mañana con proporcionarnos por la primera vez una visita recíproca de la Oficialidad y gente de ambas corbetas.

Ya distábamos quinientas leguas del paraje en donde nos habíamos separado la última vez y además una estrecha amistad y un verdadero aprecio ligaban íntimamente ambas Oficialidades, á las cuales imitaba, como es natural, toda la demás gente.

No parezca, pues, extraño, que aquellas dos solas causas, sin aventuras ó riesgos que contarse, ó sin haber pasado en nuestra separación más plazo que el de dieciocho días, infundiese en todos una alegría poco común.

Hasta el medio día, los botes transitaron constantemente, ya unos, ya otros, á bordo de las dos corbetas. Los marineros de la ATrevidA regalaron á los nuestros un tiburón recien pescado; las agradables noticias de una constante buena salud, infundían en todos nuevo aliento, y las mismas ventolinas, ya del Oestenoroeste que al medio día nos obligaban á separarnos para seguir la derrota, nos daban esperanza de unas próximas singladuras más favorables.

Metjdos los botes poco después del medio día, navegamos con fuerza de vela al Sur. Las observaciones de la altura meridiana del Sol, nos determinaban la latitud de $9^{\circ} 42^{\prime}$. Casi acordes los números 6 I y I3 daban la longitud de II ${ }^{\circ}$ $40^{\prime}$ de la cual discrepaban insensiblemente el Io de Berthoud, y el ro5 de faltriquera de Arnold de la Atrevida. Los dos cronómetros recien lle- Ag. r7 gados de Londres, eran por consiguiente los únicos, cuyo movimiento parecía aún no bien sentado y uniforme.

Un objeto nada agradable y del cual es preciso hablar particularmente, hubo, no obstante, de ocupar mucha parte de nuestras conversaciones. En ambas corbetas, al abrir los pañoles del pan, concluído á los siete ú ocho días de la salida el que nos había quedado de la diaria, habían hallado toda la galleta infestada con una oruga, que D. Antonio Pineda después de haberla maduramente examinado en todas sus transformaciones y procedimientos, describió del siguiente modo:

"Es una oruga que forma su crisálida, membranosa, transparente y amarillenta, de donde sale una palomita de las que llaman polillas, blanquecina y pequeña, la que pone unos huevos amarillentos, pegados entre sí como hilitos de araña.

"La oruga á simple vista tiene como cuatro ó cinco líneas de largo y algo más de media de ancho, blancuzca, con tuberculitos y pintas coloradas, que la dan un elegante tinte de este color; la cabeza de color castaño; de los tuberculillos nacen unos pelitos blancos.

"Al microscopio simple ó con una lente de aumento, en la cabeza se registran dos grandes ojos, que verosímilmente serán compuestos de otros muchos, pues se ven tuberculados; poco detrás hay dos chapetitas. La boca se compone de chapetitas y manecillas; el cuerpo de I9 ó 20 anillos; se le registran seis piés en el pecho más distantes que los demás, terminados en puntas; luégo, á distancia de tres ó cuatro anillos, hay cuatro pares de piés y un par de éstos junto al ano, de figura cónico-truncada, cuyas plantas están bordadas alrededor, de puntos colorados. Sobre el lomo de esta oruga reinan cuatro líneas de tubérculos puestos longitudinalmente y colorados, de donde nacen unas cerdas ó pelos finísimos.

"Este insecto, cuando llega al estado de su mayor crecimiento, deja su piel ó camisa y se convierte en una crisálida membranosa amarillenta, tinturada de castaño; de ella sale una palomilla blanca, cuyas antenas van en disminución desde la base hacia la punta, y son poco mayores que el tórax ó pecho. La lengua es espiral, y las manecillas ó barbillones que tiene junto á la boca, son plumosas.

"Las alas superiores tienen su posición horizontal, son más cortas que el cuerpo, blancuzcas con manchas algo negruzquillas. Las alas inferiores son la mitad ménos anchas y también blancuzcas. El cuerpo es grande y bastante abultado, más que las otras partes. El ano termina en punta aguda; se compone el abdómen de siete 
Ag. 17 anillos. El tórax es de color más oscuro. Las patillas son de color negruzco. Esta polilla pone un grupo de huevos en la galleta, que se unen por filamentos como telas de araña. Estos huevos son amarillitos y algo cilíndricos, y se encuentran parduscos en toda la sustancia de la galleta.

"La oruga que sale primero se forma entre ellos como una tienda de tela de araña; y después entre la miga forma unos agujeritos de donde saca la cabeza, y que agranda al paso que come, hasta que, llegando á su estado de perfección, sigue las transformaciones á que la naturaleza los destina.

"Por lo visto, esta paloma es del género Tecnes; Geofroi Tennia, de Linneo. Y la especie se acerca más á la I9 de Geofroi; pero ni su descripción ni las que trae Fabricio, cuadran á lo que se ha observado en ésta; y así debe tenerse - por variedad ó especie diversa de la Temia Granitella y de la Farmalis, pues esta oruga difiere de las que dan aquella polilla."

La introducción de este insecto que nos manifestaba como homogéneo al pan, el no haberse comunicado á muchos sacos de menestras depositados en los mismos pañoles, nos dió fundados recelos, de que desde su misma conducción á bordo, el pan tuviese consigo á lo menos los huevecillos del gusano que el mismo calor interior hizo luégo fermentar y multiplicar rápidamente.

Pero como quiera que ni las calidades del gusano eran nocivas á la salud, ni faltaba oportunamente nuestro ejemplo para vencer el asco natural en sus principios, muy luego se había conseguido en ambas corbetas el no extrañar este mal, y la concurrencia de este día, haciendo común á entrambas la misma suerte, sirvió desde luego á suavizarla.

Atento siempre D. Antonio Pineda á cuanto pudiese cooperar á los progresos de sus ciencias favoritas, había sacado de la calma de la misma mañana otras dos ventajas; la una, en conseguir que un botecillo nuestro le cogiese dos Galeras Iolothuria phisalis, de Linneo, que inmediatamente sujetó al más prolijo examen: la otra, en experimentar por primera ve $z$ un vaso de su invención para sacar el agua del mar á una profundidad determinada. Aunque ésta no se sacase sino á die $z$ brazas debajo de la superficie, dió no obstante medio grado de diferencia de temperamento, sumergido inmediatamente en una y otra el termómetro de Farenheit.

Finalmente, en la mañana del 22, alcanzada la latitud de $6^{\circ} \mathrm{o}^{\prime}$ vimos entablada la brisa del Sur, con la cual nos dirigimos á la Equinoccial; pero como se mantuviese escasa y áun las aguas tuviesen una dirección á el Oestenoroeste, el corte de la línea se retardó hasta el 29 en longi- tud $I 7^{\circ} 24^{\prime}$ por los relojes marinos y $I 7^{\circ} \mathrm{o}^{\prime}$ por $\mathrm{Ig}$. $2 \mathrm{~g}$ setenta series de distancias lunares.

Cortada la línea, las brisas refrescaron hasta set. $x$. causar en la Descubierta la rendidura de dos masteleros, y se inclinaron de tal modo al Este, que nos fué fácil alcanzar los meridianos de la Isla Trinidad. Era importante la determinación en longitud de esta isla, pues discrepaban considerablemente los resultados de los últimos viajes nacionales deducidos de los relojes marinos y de las distancias lunares, con los que se habían inferido de las solas distancias en el viaje de la fragata Santa Rosalía, de la Marina Real (año de I774). Estos se inclinaban á prefijarle la longitud de $24^{\circ} \mathrm{I} 2^{\prime}$; aquéllos la limitaban próximamente á $23^{\circ} \mathrm{o}^{\prime}$.

En la tarde del 5, se dió vista á la isla y navegamos en la noche siguiente de tal modo, que al amanecer fuese aún bien visible para deducir su posición del rumbo y distancia navegada, y de las dos marcaciones en los extremos, cuyas latitudes y longitudes mirábamos por otra parte como seguras, pues las unas derivaban del solo medio día próximo; las otras, estaban observadas en el mismo extremo. Resultó, agregados á los promedios de 63 series de distancias á Antares y Alta del Aguila, que la longitud de la medianía de la isla era de $23^{\circ} 7^{\prime} 35^{\prime \prime}$; su latitud se supuso cual se había determinado en la fragata Santa Rosalia, de $20^{\circ} 32^{\prime} \mathrm{0}^{\prime \prime}$.

Al cortar el Trópico de Capricornio, empezaron á desmayar las brisas: el viento se inclinaba al Norte y eran los días sumamente placenteros y templados: siguiéronle vientos variables á veces aturbonados: luégo sobre contraste se decidieron del tercero al segundo cuadrante $y$ arreciando mucho por esta parte, con mares sumamente gruesas, lluvias contínuas y frios bien sensibles, nos dieron lugar á navegar en buena derrota, precavidos si en el aparejo, en cuanto lo exigiesen las corbetas, las cuales acreditaban su igualdad de andar y sus buenas propiedades con exceso uniformes.

Hasta el medio día del I3, no conseguimos nuevas observaciones, las cuales nos manifestaron hallarnos en latitud de $3 I^{\circ} 4^{8^{\prime}}$ y longitud de $40^{\circ} 2^{\prime}$. Después de una noche tempestuosa, los relámpagos y la cerrazón indicaban la proximidad del viento pampero ó Sudoeste. Pudimos á pesar de esto ver disipadas por la tarde aquellas apariencias y desde el día siguiente dirigirnos con tiempo claro á la entrada del Rio de la Plata.

No nos habían abandonado desde algunos días varias especies de pájaros bobos, tableros, pardelas y pamperos ó martín-placas y áun pocas horas antes habíamos visto una mata de sargazo, que en aquellos paralelos (según voz común), suelen verse de ciento cincuenta á doscientas 
Siet. r3 leguas de la embocadura del rio. Pudieron después observarse distancias del Sol á la Luna que ratificaron nuestros conceptos de que el cronómetro 72 había variado su movimiento; y al contrario, que le conservaba con una suma aproximación el cronómetro 6r. 56 series de distancias lunares indicaban la longitud de $4 \mathrm{I}^{\circ} 22^{\prime}$. Era la del número $6 \mathrm{r}$ al medio día, de $+\mathrm{I}^{\circ} 24^{\prime}$, latitud observada, $32^{\circ} 7^{\prime}$.

Al aproximarnos á la embocadura, empezamos á esperimentar una densa neblina, la cual por dos días nos precisó á valernos de los cañonazos para la conserva recíproca. Seguimos con fuerza de vela, y al anochecer del r 8 sondadas 32 brazas, arena y conchuela, arribamos á ponernos en el paralelo de la Isla de Lobos, en cuya demanda se navegó luégo desde la media noche sin acostar de aparejo.

La neblina continuaba espesa en la mañana siguiente y áun el viento ya del Nornoroeste arrafagado, nos amenazaba de una próxima alteración contraria; no obstante, pareció preferente el seguir en derrota y se avisó á la Arrevida que nos siguiese de cerca. Las sondas desde las ocho hasta las doce fueron entre I5 $_{5}$ I 3 y I $_{4}$ brazas. Arena fina, negra y blanca y á rato alguna conchuela y caracolillo, y como este fondo y el de $12 \%$ brazas que cogimos un momento hacia las diez nos indicase que estábamos algo al Sur, orzamos al Noroeste, partido que acreditó la observación de la latitud al Mediodía, aunque los horizontes sumamente cortos con la neblina, no le diesen toda la confianza necesaria.

Las sondas aumentaban paulatinamente hasta I8 y I 9 brazas; luégo encontróse la lama, y finalmente, á las cuatro, despejada algún tanto la neblina, logramos avistar la Isla de Lobos por la serviola de babor. No tardóse en atracarla á distancia de una legua escasa por fondo de I $_{5}$ á I $7_{7}$ brazas: se tomaron horarios, y últimamente, con tiempo despejado se consiguió ver claras todas las sierras de Maldonado, hasta Solis-chico.

Los carices claros y apacibles nos anunciaban la continuación del Nordeste; asi, nos quedamos con poca vela para proporcionar la distancia hasta la mañana siguiente y para sondar con mayor comodidad; nuestro andar con las gavias arriadas era de tres á cuatro millas. La corriente ó marea nos parecían favorables. A pesar de tan bellas apariencias, no bien había anochecido cuando cmpezó á cerrarse el tiempo por el Oeste y poco después tuvimos ventolinas del Norte y Noroeste con algunos truenos, muchos relámpagos y mal cariz. Pareció el mejor partido el de dar fondo á un ancla, pues que el vicnto variaba en los cuatro cuadrantes y la corriente (según las sondas), nos aconchaba hacia tierra; al mismo tiempo se tomaron dos rizos á las ga- vias, $y$ se prescribió con la bocina igual manio- set., , bra á la Atrevida. Fué la noche excesivamente lóbrega hasta las doce. A esta hora roló rápidamente el viento al Sur y Sursudeste primeramente con lluvia y últimamente con no mucha cerrazón, y á las cuatro, habiendo ya arreciado y la mar engruesado mucho, nuestras anclas, que hasta entonces habían aguantado sobre medio cable, empezaron á garrear, de suerte que descaeciamos considerablemente sobre la costa. Toda tentativa para cobrar el ancla fué, pues, inútil; se procuró resistir á la mar con el estai de gavia, la mesana y los foques, y no pudimos cobrar jamás ni dos brazas de cable. Parecía imprudente aventurar otra ancla. Así, fué preciso últimamente picar el cable y marear con las cuatro principales, las gavias en dos rizos, para montar las puntas inmediatas.

Muy luégo lo conseguimos, y como después el viento aminorase su fuerza, nos dirigimos, guiados de la sonda, á la Isla de Flores, la cual, poco después del medio día, nos demoraba al Norte distancia de una milla; últimamente, con fuerza de vela y un andar de nueve millas, nos dirigrimos á Montevideo, y precaviéndonos de los arrecifes de las Puntas Brava y de las Carretas, logramos dar fondo en el puerto á las tres y media de la tarde y á los cincuenta y un días de navegación.

Hallamos en él la fragata Santa Sabina y la corbeta San Gil, entrambas de la Marina Real; la primera de armadilla y al mando del Capitán de navio D. José Orozco, y la segunda, próxima á salir para los puertos de la costa Patagónica y al mando del Teniente de navío D. Pedro de Messa; dos bergantines pertenecientes á la plaza y confiados á Pilotos de la Armada; las fragatas correos de S. M. el Colón y la Princesa; otras siete fragatas mercantes y veintidós embarcaciones de dos palos completaban el total de buques surtos en el puerto, perteneciendo todos al comercio de Europa, si se exceptúa una que pertenecía al de Lima.

\section{CAPÍTULO II}

\section{Estado on Montevideo.-Exeursiones desde el mismu puerto y aprestos para la campaña sucesira.}

La noche apacible nos dió lugar á concluir casi de un todo la faena de amarrarnos según la costumbre del puerto, tendiendo por largo y por la proa dos cables, uno al Sudoeste y otro al Sudeste, y sujetando la popa con un calabrote al Norte. En esta posición demoraban, la cumbrc del cerro al Ocste; su punta saliente con Restin gas al Oestesudoeste; las piedras negras del fondeadero al Norte $3^{n} \mathrm{O}$; el fondo 16 piés, lamá 
Set. 20 suelta con vientos del Sur y I 3 con las vaciantes del Norte. Distábamos como un cable y medio de la Sabina y dos y medio del muelle. La ATrsVIDA se amarró del mismo modo y á corta distancia de nosotros.

No parecía á primera vista asequible el le. vantar el plano del rio. Debía ser objeto más bien de muchos meses que de pocos días. El emprenderlo sin esperanzas de concluirlo bastaba para retraernos de toda idea cle esta especie, ni por otrá parte debíamos sacrificar á esta obra un día siquiera del próximo verano, destinado con preferencia á las costas Patagónicas y tierras del liuego.

Pero examinados con más madurez estos obstículos y bien graduadas así nuestras fuerzas, como el ticmpo indispensable de nuestra permanencia en el puerto, no sólo por la estación temprana, sino también por los muchos aprestos que necesitaban los buques, empezaron á disiparse las dificultades y á parecer fácil el que una Oficialidad activa é inteligente y un acopio de instrumentos astronómicos y geodésicos, cual era el de las corbetas, combinasen en sus pasos esta nueva utilidad.

Establecido el observatorio en Montevidco, en el cual al mismo tiempo se comparasen cotidianamente los relojes marinos y se emprendiese una serie no interrumpida de tareas astronómicas, así para la determinación de la longitud como para coadyuvar á los progresos de la misma astionomía, podíamos mirar cste punto como el centro ó reunión de nuestras excursioncs, y convidaban á ello no ménos su posición casi equidistante de todos los parajes importantes que debía abrazar la carta, si también el paradero en él de las corbetas, el cual nos daba lugar á trabajar con más descanso y á no omitir el apresto más breve de ambos buques.

Desde el día siguiente quedó, pues, decidido que D. José Bustamante y los Oficiales subalternos Valclés, Quintano, Concha y Vernaci pasasen en una sumaca (I) á Bucnos Aires; y de allí, con los auxilios que el señor Virey les prestasc, emprendiesen el reconocimiento de la costa mcridional del rio desde aquella capital hasta el Cabo de San Antonio. 'Tomaron otros á su cargo el reconocimiento de la costa hasta Maldonado. No quedaría después sino la, parte comprendida entre Montevideo y la Colonia del Sacramento, lá cual scría fácil explorar al regreso de Malclonado.

Los tiempos no permitieron navegar á Buenos Aires antes del 28. En cl entretanto se aprovecharon todos los instantes para que D. Felipe Bausá midiese una base en el fondo de la rada

(1) Sumaca es una especie de goleta con cubierta y sirve sobremanera para la navegación del rio. y otra hacia la punta de las Carretas, y con mar- Set. caciones correspondientes emprendiese el plano del Puerto y la situación de los puntos adyacentes. Fué luégo en la mañana đel 26 á marcar con cl teodolito desde 10 más alto del monte Urdeo todos los puntos á la vista, entre los cuales el l'an de Azúcar y la Isla Filores tomada en sus extremos, eran objetos de la mayor importancia para nuestro intento.

Le acompañaron también D. Antonio Pineda y D. Luis Nee. Habían ya herborizado y cazado en las inmediaciones del pueblo; encontraron, no obstante, en qué pacer su curiosidad y confirmaron la primera idea de la suma abundancia en aquel suelo de plantas aún no bien conocidas en las descripciones botánicas.

Las primeras comparaciones de los relojes nos habían indicado quc su movimiento era bien diferente del que le habíamos determinado en Cádiz. El 6r había disminuido de 3 " diarios próximamente. Había aumentado su retardo el número I3 hasta I' I I" diarios y el número 72 aceleraba de $I 4^{\prime \prime}$ á $I 6^{\prime \prime}$ por cada día medio. Pero re: ducidos sus resultados á la Isla de Lobos situada por las observaciones astronómicas hechas por el Brigadier D. José Varela en Montevideo, podía conjeturarse que sólo $\mathrm{cl} 72$ había padecido esta alteración en la época en que lo habíamos sospechado. Los i3 y 6r combinaban su marcha primitiva con una longitud tan aproximada, que el primero sólo daba $4^{\prime}$ ménos y el otro I4 de la que inferimos después de nuestras operaciones (I), y así nos confirmaban en la seguridad que la situación determinada á la isla Trinidad y sujetada particularmente al Io, poco ó nada se apartaba de la verdadera.

La diferencia de meridianos entre la Isla Lobos y Montevideo fué de $I^{\circ} 24^{\prime} 42^{\prime \prime}$ por el número 6 I. Resultó la de $I^{\circ} 24^{\prime} 8^{\prime \prime}$ por un promedio de los números ro y ros de la ATrevida conformes con nuestras operaciones trigonomé. tricas.

Ya el 27 D. José Bustamante y los Oficiales destinados á Buenos Aires habían determinado emprender el camino por ticrra hasta la Colonia del Sacramento y de allí con la chasquera ó embarcación del correo transitar inmediatamente á aquella capital. Quedó Vernaci con el cuidado de conducir por agua la colección de instrumentos de la ATREVIDA y el cronómetro 61 y tuvieron orden de acompañarle un pilotín y un soldado de Marina. El camino á la Colonia, que los naturales suponen de 42 á 44 leguas apartándose mucho de la orilla para vadear con más se-

(I) Como se verá más extensamente en cl Diario Astronómico, las observaciones correspondientes a las nucstras han aproximado mucho más aqucllos resul. unclos. 
Set. 27 guridad los arroyos, resulta, no obstante, mucho más corto en nuestros planos. Pasa por cl Canelón, el Campamento, San José, Jufree, el Rosario y el Sauce, en donde hay puestos de dragones con caballos del Rey. Estos se franquean al pasajero, con un dragón que le acompaña mediante un pase ú orden de auxilios del Gobierno de Buenos Aires ó Montevideo. Los chasques ó extraordinarios, los correos periódicos y la comunicación hasta los puestos del rio Grande por Maldonado, llegan así á su destino con una brevedad de la cual fuera difícil dar una cabal idea sin temer de ser tachados de exageración. No faltan en el camino algunos pueblos y áun muchas estancias (I) en donde el pasajero pueda encontrar un buen acogimiento. La carne y la leche allí, son frutos más bien de la naturaleza que de la industria y pueden caracterizarse de ningún valor.

Los Oficiales llegaron á la Colonia en la noche del 28, y en la mañana siguiente á Buenos Aires, casi al mismo tiempo en que fondeaba la sumaca en la cual Vernaci conducía instrumentos y relojes. En una travesía de pocas horas y sujetado á comparaciones anteriores y posteriores, había determinado el número 6I la diferencia de meridianos entre nuestro observatorio de Montcvideo, y la casa de cabildo de Buenos Aires de $2^{\circ} 10^{\prime} 22^{\prime \prime}$, igual absolutamente á la que había deducido de sus observaciones el Brigagadier D. José Varela.

La actividad de nuestros Oficiales encontró la correspondiente protección en el señor Marqués de Loreto, Virey á la sazón de aquellas provincias. Establecieron un observatorio, en el cual diferentes distancias meridianas al zénit, tomadas al Norte y al Sur con el cuarto de círculo, determinaron la latitud de $34^{\circ} 6 \mathrm{I}^{\prime} 39^{\prime \prime}$. Emprendieron una serie de triángulos sobre base medida, llevándola hasta la ensenada de Barragán, sin permitirles el terreno penctrar más al Este; y dispusieron la total habilitación del paquebot Belén y una chalupa, pues era preciso preferir un reconocimiento por mar á los que pudieran intcntarse por tierra, no ménos por las dificultades que of recían las distancias y camict. nos, como por el riesgo funesto á que podía arrastrarlos la suma proximidad de los indios pampas á las orillas del Cabo San Antonio. Se encargaron de esta operación importante los Oficiales Concha y Vernaci, embarcándose en el Belén. El ro se perdieron de vista ambos buques, y el I 2 regresaron á Montevideo D. José Bustamante, D. Cayetano Valdés y D. Fernando Quintano, con una travesía de veinticuatro horas.

Llaman estancia en la provincia de Buenos dires á un terreno determinado en donde haya pastos ganado vacuno.
Desde el 29 del pasado Setiembre, sistema- Oct. 1 das como ya se indicó todas las medidas para la prontitud de los aprestos, se había emprendido por tierra también el reconocimiento de la costa desdc Montevideo hasta el Cabo de Santa María. Iban el reloj I05 del Comandante de la Atrevida, algunos sextantes, un teodolito $y$ todos los utensilios para medir bases y sondar, y sc habían unido á D. Felipe Bausá y á entrambos naturalistas, el Capitán de fragata don Santiago Liniers, segundo Comandante de la Sabina, y el Piloto D. José de la Peña, siendo de la mayor utilidad así la pericia del segundo en el conocimiento de las costas, como la destreza del primero en acopiar por medio de la caza mil objetos útiles á la Historia Natural.

El 3o, por la noche, estuvieron al pié de la montaña denominada el l'an de Azícar. Con este motivo, á la siguiente mañana determinaron subir á su cúspide Bausá y Peña para hacer marcaciones con el teodolito á todos los puntos de la costa. Pineda, Nee y Liniers, con el de examinar científicamente un suclo montuoso que en aquellos paises debía dar otro semblante á la naturaleza, del que presentan las inmensas pampas ó llanuras que le componen por todas partes.

Era bién el fin del crepúsculo, cuando llegaron á Maldonado los instrumentos y poco después en dos trozos las diferentes personas que habían subiclo al monte. La Litología y la Botánica, 1ograron en esta excursión de unas ventajas considerables: las marcaciones daban ya sujetos todos los puntos principales de la costa y á pesar de lo escarpado del monte, ni los instrumentos ni los viajeros habían padecido el más leve daño.

E1 día I. de Octubre se les presentó con un semblante aún más' favorable. Emprendieron inmediatamente el levantar el plano del puerto, el cual, con un trabajo constante hasta las cinco, quedó concluído en todas sus partes. Los naturalistas y Liniers, los cuales habían empleado la mañana en poner orden á las muchas adquisiciones hechas en el camino, fueron por la tarde al pueblo Chico, población distante de Maldonado como dos leguas y compuesta ó de familias portuguesas expatriadas del Brasil ó de españolas traíclas en los últimos años para pobladoras de la costa Patagónica y depositadas entonces en las inmediaciones de Maldonado.

El 2, concluídas ya las operaciones y examinado cl país inmediato en cuanto el tiempo lo permiticse, emprendióse el viaje de regreso, y hechas marcaciones en diferentes puntos de la costa, cuales fueron Punta de Ballena, Punta Negra y la embocadura de Pando, lograron restituirse á bordo en la tarde del 4, viendo con mucha complacencia que no se había alterado la marcha del I05, y que sus resultados, confor- 
Oct. 4 mes con las primeras determinaciones, no discrepaban sino pocos segundos de las operaciones trigonométricas traídas al Pan de Azúcar, desde Maldonado y desde Montevideo. En el entretanto, D. Francisco Viana, á cuyo cargo había quedado la corbeta por enfermedad de D. Manuel Novales, adelantaba considerablemente los aprestos.

'Todos los trabajos emprendidos procedían con igual actividad. No era menor en la ATrEvidA la del Teniente de navío D. Antonio Tova; y D. Dionisio Galiano, siguiendo con tesón las operaciones astronómicas, había observado en la mañana del 27 la inmersión del segundo satélite de Júpiter; determinada después la marcha del péndulo y de los relojes marinos, observadas casi diariamente la inclinación y declinación de la aguja, y por diferentes alturas meridianas de estrellas bien determinadas en el catálogo de Mr. de Lambre, deducida la latitud del observatorio. El trazar diariamente la órbita de la Luna y calcular con operaciones gráficas la hora y paraje de las ocultaciones de las estrellas, había sido un trabajo, que si bien infructuoso hasta entonces, denotaba no ménos la exactitud de aquel Oficjal astrónomo, que la utilidad que sacaríamos en 10 venidero de este examen incesante de la marcha de la Luna.

Los Guardias Marinas y los Pilotos destinados á sondar el puerto interior y exteriormente, no sc habían tampoco descuidado en este examen preciso para la cxactitud de nuestros planos, bien que lo hacía siempre dudoso la diferencia del nivel del agua en el puerto, más baja por lo común de cuatro á cinco piés con los Nordestes y Noroestes, de lo que lo es con los vientos del Sudeste, Sur y Sudoeste.

Ya regresado Bustamante á Montevideo, emprendióse el I3 de Octubre nueva excursión á Buenos Aires. El tiempo, algo indeciso, nos determinó á ir por tierra: los Sres. Pineda y Nee prefirieron la sumaca y tuvieron la felicidad de llegar al día siguiente por la tarde á la Colonia del Sacramento, pocas horas antes que los demás.

Era nuestro ánimo 1levando un sextante, una aguja y el relój I05, el examinar desde los parajes más cómodos la continuación de la costa hacia el Oeste, de suerte que esta parte quedase bien ligada y sujeta á enfilaciones como las demás: pero como fuese que el camino se apartaba mucho de la orilla, hallamos difícil esta empresa sin el sacrificio de dos ó tres días, el cual parecía tanto más considerable cuanto mayor era el riesgo de que unos tiempos más os curos no permitiesen luégo el observar en la Colonia, cuya latitud y longitud debían sujetar oportunamente la direccíón y extensión de la costa intermedia. Con cstas reflexiones seguimos cl camino directo apartándonos sólo hacia el arroyo de la Caballería, desde donde por medio oct. 13 de algunas marcaciones se tomó la dirección dc la costa al Este en cuanto alcanzase la vista.

Los Sres. Pineda y Nee habían ya herborizado en la misma tarde con mucha felicidad. La tuvieron aún mayor en la siguiente mañana, en la cual, habiendo pasado á la Isla de San Gabriel, paraje oportuno para las observaciones de latitud y longitud, juntaron en poco tiempo tal variedad de arbustos, yerbas y flores, que parecía más bien fruto del examen de un país entero que de una jsla pequeña.

Retirados así poco después del medio día á bordo de la sumaca, y hechas nuevas marcaciociones, dimos la vela para Buenos Aires con vientos del Sur y Sudeste galenos. Nuestro rumbo fué, por largo rato al Oeste y Oeste cuarta al Sudoeste, con el cual, y á una distancia andada de cuatro y media á cinco leguas, avistamos las torres de Buenos Aires por el Sudoeste y logramos fondear al ponerse el Sol, en sus inmediaciones. La corriente, á la sazón, era muy lenta para fuera.

Nuestra demora en Buenos Aires fué únicamente de cuatro días. Tuvimos, sin embargo, la satisfacción de ver regresar á los Sres. Concha y Vernaci, concluída completamente su comisión; y examinada á nuestra vuelta en Montevideo la marcha del I05, después de una travesía de pocas horas en la sumaca, no sólo se halló ésta conforme con las determinaciones anterio. res, si también se halló conforme la diferencia en longitud que había asignado el número 6 I cntre Buenos Aires y Montevideo.

No ménos había sido favorable esta última época para el doble ubjeto de completar el plano del rio, sin causar la menor demora en los aprestos ni en la salida. Bustamante y Valdés habían concluído casi en un todo las obras interiores de los buques y el embarco de víveres y aguada. En una pequeña balandra fletada para el intento, los Sres. Robredo, Bausá y Peña, llevando consigo el cronómetro 72, habían observado la longitud y latitud en el paralelo y el meridiano del banco Inglés, sondando hasta las inmediaciones de la Isla Flores y por su banda del Norte. Con la misma balandia Don Antonio Tova y el Guardia Marina Aliponzoni, se hallaban ahora en el rio de Santa Lucía para examinar aquel fondeadero, buscar un bajo no distante de la punta del Espinillo, y seguir los triángulos lo más al Oeste que fuese posible; y entre tanto, no se olvidaba el sondar las inmediaciones del Puerto, y Galiano continuaba sus tareas astrónomicas en el observatorio.

El 26 regresaron de Buenos Aires los señorc Pineda y Nee; el primero había hecho en una excursión á las Conchas, nuevas adquisiciones importantes para la Historia Natural. El segundo 
Oct. 26 había examinado las inmediaciones de aquella capital, y entrambos, descmbarcándose en Martín García, dentro de la embocadura del $\mathrm{Pa}$ raná, habían después, en un viajc de cinco días, reconocido el terreno comprendido entre aquel puerto y Montcvideo. Finalmente, el 3I, con la rcincorporación de los Sres. Concha y Vernaci, logramos ver reunida toda la Oficialidad.

Se reemplazaron con este mismo motivo los marineros díscolos, los enfermos y los desertores, librada una paga á la Oficialidad de mar, tropa y marinería, y se hizo señal de aprontarse para dar la vela.

Con haber anticipado á la marinería el leve socorro que indicamos, era nucstro ánimo el de manifestarles un premio al trabajo, hacer una nueva experiencia de su conducta y desapego del desorden, y finalmente, no enturbiar con sus vicios, si se inclinasen á ellos, las próximas fiestas que en Montevideo se preparaban para la jura de S. M., felizmente reinante. Concluídas las faenas á bordo, se dió licencia á todos para que fuesen á tierra por tres dias. Se detuvieron para el servicio de las embarcaciones menores ó los que habían tomado nuevamente plaza en reemplazo de los enfermos y desertores ó los que enfermos desde la salida de Cádiz, sin haber aliviado á sus compañeros en el trabajo, se hallaban en el día perfcctamente restablecidos.

Los primeros días del mes de Noviembre eran demasiado favorables para la Astronomía, para que no intentásemos aprovecharlos, tanto más, que no quedaba aún bien segura la longitud de Montevideo, ó por las circunstancias poco favorables de las observaciones del primer satélite de Júpiter, ó por la órbita de la Luna, que aún no había proporcionado ocultación alguna visible de las estrellas hasta de sexta magnitud. D. Dionisio Galiano había preparado los cálculos preliminares. El eclipse de la Luna y el paso de Mercurio por el disco del Sol, merecían toda la atención. Podía no proporcionarse esta observación en Europa, por la oscuridad bien natural en los principios del invierno; ni allá podía ser visible la emersión del planeta, la cual debía acaecer en Montevideo entre dos y tres de la tarde.

En la noche del 2, que fué sumamente clara, pudo obscrvarse el eclipse parcial de Luna: empezó á las 7 h $4 I^{\prime}$, tiempo verdadcro, y feneció á las 9 h $48^{\prime}$. Ya á esta hora habíamos observado la ocultación de la $90^{2}$ de Mayer por la Luna; tuvimos luégo la de la 93 del mismo catálogo. Asistieron todos los Oficiales libres, y en los inter. valos que dejaban las observaciones indicadas, se ocuparon en medir distancias de la Luna á las estrcllas, cuyos resultados quedaron luégo agregados á los que se habían obscrvado anteriormente.
El día 5 al amanecer, nuestro sobresalto era Nor. 5 por precisión muy grande. Una porción crecida de celajería oscura parecía quercr inutilizar los aprestos. No podían conseguirse siquiera dos alturas seguidas del Sol en el cuarto de círculo para las correspondientes de la tarde: se habían preparado los eliómetros, y, sin embargo, no bien disipada aún la celajería fué absolutamente imposible el ver el ingreso del planeta; pero luégo se observó su r'uta por Galiano con el cuarto de círculo y por Vernaci cn el eliómetro. La emersión pudo determinarse con entera satisfacción de entrambos.

En la misma noche observóse la inmersión y la emcrsión de Tauro por la Luna; y finalmente, en la siguiente del 6 fué también una observación de mucha importancia la inmersión del primer satélite de Júpiter á las 3 h $3^{\prime}$ y II" de la mañana, observación que comparada á las horas de las Efemérides dió para el observatorio la longitud occidental de Cádiz de $50^{\circ}$ $5^{\prime}$ y $45^{\prime \prime}$.

Tomadas el día 7 las alturas correspondientes para la exacta determinación de la marcha del péndulo, se encajonaron todos los instrumentos y sólo atendióse á ordenar los planos y los acopios relativos á la Historia Natural. Ii señor Virey había agregado á las dos corbetas un bergantín de la plaza mandado por el Piloto Don José de la Peña. Debía seguirnos al andar de la costa Patagónica y regresar desde allí ó desde las Malvinas con los pliegos y noticias que se le diesen; con este motivo le comunicamos ahora las instrucciones oportunas y se le dieron los auxilios necesarios para que estuviese pronto.

Concluílos así todos los objetos que podíamos abrazar en aquella parte de los dominios de S. M., metidas las embarcaciones menores y ya desamarrados, creímos poder dar la vcla en la mañana del I2; pero ni el viento fué favorable ni dejaba de inquietarnos la nueva deserción de algunos individuos en ambos buques. Lo avisamos la noche antes al Mayor de la armadilla para que trajese algunos reemplazos voluntarios. Fué preciso traerlos violentos y la mayor parte inútiles; apenas la ATrevida pudo completar su dotación; faltaban aún cuatro hombres en-la Descubierta. Hízose con este motivo una leva de gente vaga; a las seis de la tarde tuvimos á bordo los cinco hombres que nos faltaban, desechado uno inútil. La ATrevidA completó y mejoró su tripulación.

Amaneció con vientos del Nornordeste al Nordeste, frescos y algo arrafagados; emprendimos inmediatamente el dar la vela y lo hubiéramos verificado en el instante si cl Capitán del bergantín no viniese personalmente á avisarnos que el agua extraordinariamente baja y los mismos horizontes cargados por el Sudoeste, le ha- 
Lor ${ }_{3}$ cían creer no tardaría el tiempo sino pocas horas para declararse contrario y tempestuoso. Desistimos inmediatamente de la primera idea, y no bien habíamos echado abajo las vergas de juanete y calado sus masteleros, cuando el viento se declaró al Noroeste, Nordeste y Este, tempestuosos. El agua había bajado aún más que en cl dia anterior y ambas corbetas estaban varadas con proa al Nordeste. A la fuerza del viento, que ya en la tarde podía llamarse un verdadero huracán, acompañaron una lluvia abundante y no pocos truenos y relámpagos. Sólo á las dos de la mañana cesó el temporal y amaneció con ventolinas del cuarto cuadrante, las cuales cedieron luégo al Sudoeste fresquito con semblantes apacibles.

La noche inmediata fué tranquila; amaneció hermoso y con viento bonancible del Nordeste y Norte, con el cual emprendimos inmediatamente el dar la vela.

\section{CAPÍTULO III}

Navegación dcsde Montevideo hasta el Puerto Deseado. - Varios reconocimientos de la costa intermedia. Acaccimiontos en aquel puerto y algunas concurrencias con los Patagones.

Nuestra derrota, como es natural, debía gruiarnos á pasar al Oeste del banco Inglés; examinando al mismo tiempo aquellas sondas para que fuese en lo venidero más fácil y más segura la navegación del rio, y aproximándonos paulatinamente para la continuación de las tareas hidrográficas á $\operatorname{los} 37^{\circ}$ y $\%$, de latitud, término de los reconocimientos de los señores Concha y Vernaci. Empero en las tareas indicadas, debíamos también tener á la vista no sólo el que no se repitiesen ahora inútilmente, reconocimientos hechos hasta entonces particularmente por los Pilotos Tafor, Peña y Villarino en sus navegaciones harto frecuentes sobre la costa patagónica y las Malvinas, si también el que se economizase de tal modo la estación favorable del verano, que no fuese difícil verificar igualmente los reconocimientos oportunos en las costas occidentales hasta Coquimbo, término verdadero de los efectos harto temibles del invierno. Dejaremos para un lugar más oportuno el desplegar en un solo punto de vista las diferentes expediciones, que con muy varios objetos y suerte bien varia han precedido á la nuestra. Baste el decir por ahora, que el no haberlas reunido y publicado, era su mayor, ó tal vez, su único defecto; que no desmentían ni la generosidad del Erario, ni la intrepidez de nuestros navegantes, ni el sistema hasta aquí temido y aislado de nuestras medidas políticas; finalmente, que bastaba un verano para perfeccionarlas, Nuv.15 adaptando tan solo á las tareas anteriores los últimos progresos de la astronomía náutica y las útiles indagaciones de la Física, en cuanto lo permitiese la vida errante y desalinada del hombre de mar.

En el entretanto, la navegación emprendida llevaba consigo el semblante más favorable y halagüeño. Puestas las corbetas y el bergantín en una línea de frente y á regular distancia unas de otras, seguían tres líneas bien simétricas de sonda; repetíanse las marcaciones á Montevideo, así para la colocación de las mismas sondas, como para la rectificación de los relojes marinos; habíamos alcanzado y propasado el veril del Banco, por un fondo de cinco brazas, cascajo y piedra, y el viento, aunque flojo, continuaba favorable del Norte y Nornordeste; sin embargo, no bien el Sol hubo pasado del meridiano, cuando empezaron á asomarse todas las apariencias de una revolución inmediata del tiempo, y por la misma razón fueron precisas de nuestra parte otras medidas bien diferentes de las que habíamos seguido hasta entonces. Hízose fuerza de vela, abandonando ya el bergantín, cuyas cualidades con extremo zorreras nos habían atrasado considerablemente y cuyo calado y maniobras hacían árbitro á su Capitán de cualesquiera partido más seguro. Navegamos al Sursudeste y Sudeste sin abandonar la sonda, la cual se conservaba de $\mathrm{r} 2$ brazas; se tomaron algunas precauciones en el aparejo; $y$ así cuando al anochecer el tiempo empezó á declararse vario y más bien tempestuoso, ya habíamos conseguido una posición bastantemente aventajada para esperarle sin el menor recelo de la costa ni del Banco.

Efectivamente, las primeras horas de la noche no podian ser más lóbregas ni más contrarias á nuestro intento. Después de algunos aguaceros acompañados con truenos y relámpagos por los cuatro cuadrantes, el viento fué rolando al Estesudeste y nos obligó á virar al Nordeste; calmó. Declaróse al amanecer por el Sur y Sursudoeste fresco. Nuestra derrota pasada, el rumbo del Estesudeste, que seguimos inmediatamente con fuerza de vela, y el fondo de io brazas, arena negra, en el cual nos hallábamos, nos persuadían unánimes que no tardaríamos en sondar las I 4 y I5 brazas, prueba segura de tener ya una navegación libre por una y otra parte. Debió, pues; sorprendernos muy mucho el caer á las siete de la mañana en solas seis brazas arena, accidente tanto más desagradable, cuanto que no dictaba partido alguno conveniente para mejorar la derrota en el caso de ser peligrosa la que actualmente seguíamos. Por largo rato se conscrvó el fondo indicado; creció luégo paulatinamente hasta las ro y las I4 brazas, y como 
Nov. 6 hubiese continuado en este intervalo el viento fresco, al medio día nos hallamos por las observaciones, en $35^{\circ} 52^{\prime}$ de latitud y unas $I_{j}$ leguas al Este de Montevideo. Libres ya de este riesgo y con una navegación abierta, cualesquiera fuesen los vientos que hubiéramos de experimentar, debimos mirar como un acaso bien feliz el haber preferido la derrota del Sur á la que solía comunmente practicarse por el Norte del banco Inglés. La inconstancia y la contrariedad del viento nos hubieran precisado á dar fondo hacia la Isla Flores; con el Sur fresco, probablemente hubiéramos garreado sobre la costa. Las anclas, cuando no los mismos buques, hubieran sido un nuevo tributo á las inmediaciones harto temibles del Rio de la Plata.

Hasta el día 20, el viento se mantuvo al Oeste Sudoeste tempestuoso, y nuestra navegación fué por la misma razón lenta y precavida. Habíamos alcanzado la latitud de $38^{\circ} 3 \mathrm{I}^{\prime}$, apartados ya de la sonda, y ahora procurábamos con los vientos del Norte el volvernos á aproximar á la costa y emprender su reconocimiento, el cual ya no tendría lugar sino desde las inmediaciones del rio Negro, atento á la mucha extensión de los bajos del Colorado y á la imposibilidad de retroceder al Norte sin un sacrificio demasiado considerable de tiempo.

A las seis de la tarde conservábamos todavia un andar de siete á ocho millas, cuando una densa calina por el Sudoeste nos avisó que muy luego cesaría el viento favorable. Efectivamente fué así, y aturbonándose en un momento cielos y horizontes amenazaban una tempestad violenta. Ya los truenos y relámpagos fueron temibles y repetidos. El viento rolaba instantáneamente del Sudoeste al Norte, y según variase la atmósfera, variaba sensiblemente el grado de calor; una media hora de lluvia terminó al parecer esta lucha, quedando un viento fiojo del Norte, muchos relámpagos muy vivos y una cargazón fuerte desde el Oeste hasta el Sur; sin embargo, á las nueve el tiempo volvió á tomar un semblante horrible, al cual sucedieron luego un fuerte granizo, muchos truenos y relámpagos, y algunas ráfagas del Sudoeste; cedieron éstas, pero para que les sucediesen una hora después carices aún peores, una incesante variedad de vientos y una lluvia abundante, la cual no cesó sino á las cinco de la mañana, á cuya hora, habiendo entablado viento galeno del Norte, pudimos emprender de nuevo nuestra derrota $y$ navegar con fuerza de vela.

No fué difícil con el rumbo y viento indicados el alcanzar en poco tiempo la sonda. Al medio dia, por latitud de $39^{\circ}$ y un medio grado al Oeste de Montevideo, estábamos en 52 brazas arena fina negra; variación magnética I 5 " y I 3 " Nordeste, siguióse luégo una navegación más bien feliz, y á pesar de que en la noche del 23 nos sobreco- Nov. 23 giese de nuevo un contraste vivo de los vientos del tercero y primer cuadrante con los truenos y aguaceros acostumbrados, ya poco después del medio dia del 24 estábamos á la vista de la costa por latitud de $4 I^{\circ} 24^{\prime}$ y longitud de $56^{\circ} 5^{\prime}$. Corría del Norte al Oeste toda igual suavemente alomada en la orilla, y no quedaba duda, si consultásemos el fondo de 25,24 y Ig brazas cascajo y chinitos, por el cual á la sazón navegabámos, que sería la que conduce desde la embocadura del Rio Negro á la Punta de Belen y á las costas interiores del puerto de San José. Parecían formarla unas capas horizontales de tierra franca algo negra, otras blanquecinas, rojizas, y sobrepuestas una á otra en número de veinte próximamente, y se compondrían todas probablemente de arenas, margas, arcillas, etc., presentando un suelo más bien estéril y despejado en un todo, no sólo de árboles grandes, si que también de cualquiera especie de arbustos.

En éste y en el día siguiente nuestra navegación debió ceñirse al examen del golfo indicado, que los navegantes antiguos solían distinguir con el nombre de Batía sin fondo, y á pesar de que los vientos coadyuvasen muy poco á nuestros deseos, siendo ya varios, ya calmosos, y á veces ocultándonos el sol con una densa neblina y tal cual llovizna, pudimos, sin embargo, alcanzar la vista de la sierra San Antonio, colocada precisamente en el fondo, y últimamente, torcer hacia el extremo septentrional de la Península San José. Corridas diferentes bases y repetidas las observaciones astronómicas hasta donde las circunstancias las permitiesen ó las hiciesen útiles. La sonda en este intervalo había aumentado hasta las 70 brazas lama. Volvió luégo á disminuir hasta las 45 y 50 brazas, así que nos aproximamos á la Península. La mañanita del 26, con un semblante apacible y hermoso, debió, pues, mirarse por nosotros como el principio de una época mucho más feliz en cuanto á tiempos de la que habíamos disfrutado hasta entonces. Soplaban vientos del Norte y Nornordeste fresquitos. La mar era apacible, y frecuentada ya por las ballenas, ya por los lobos, ya por mil especies de aves acuáticas, las cuales volateaban alrededor de las corbetas. Una atmósfera pura descubría sobre la costa los objetos aún más pequeños; finalmente, el Sol, brillando constantemente sobre el horizonte, daba lugar á multiplicar las operaciones geodésicas y astronómicas con una exactitud, y sin embargo con un aprovechamiento de tiempo, que poco antes apénas hubiéramos alcanzado á desear. Usábamos frecuentemente de la medida do la altura del tope para deducir una base exacta; se repetían los horarios, los azimutes y la sonda. Con la claridad del dia cesaban luégo á un mis 
Nov. 26 mo tiempo (si bien por pocas horas) nuestras tareas y la continuación del viaje. Así era fácil al día siguiente coger por principio de los triángulos los mismos extremos de las tareas de la tarde anterior, y nuestros progresos eran por la misma razón igualmente útiles y acelerados. En la tarde del 30 ya las corbetas se hallaban inmediatas al puerto de San Gregorio, por latitud de $45^{\circ} 9^{\prime}$, longitud $59^{\circ} 20^{\prime}$. Habían, por consiguiente, en los cuatro días anteriores reconocido un trozo bien considerable de costa, en el cual estaban comprendidas las inmediaciones del puerto nuevo de San Antonio, Santa Elena y la Bahía de los Camarones.

El clima, el abrigo y la seguridad de la navegación sobre aquellas costas, son otros tantos incentivos para que en lo venidero las frecuenten con ménos recelo, así los buques que navegan al Perú, como los que en las épocas felices, y no muy distantes de la Monarquía, abracen los varios objetos de la pesca con toda aquella extensión de la cual es capaz y puede refluir tan extraordinariamente hacia el bien público y la opulencia nacional.

Al aproximarnos al Puerto de San Gregorio, habíamos experimentado unos remolinos bien vivos, los cuales á veces llegaban á alucinar á los vigías de nuestros topes hasta hacerles creer que serían restingas; otras veces nos hacían ó difícil ó imposible el gobierno de los buques. Así atravesamos el canal entre las Islas de Leones y Arce por una parte y la Isla Rasa por la otra; así navegamos luego á reconocer otra islita exterior guarnecida con arrecifes, la cual no era fácil descubrir á los navegantes cuando se hallasen muy aterrados; así, finalmente, se nos presentaba ésta como una nueva razón para que omitiésemos á la sazón como ageno de nuestros objetos esenciales el reconocimiento del Golfo inmediato de San Jorge.

Era, á la verdad, bien extraño que la extremada internación de este Golfo (á lo ménos según las noticias adquiridas por los Patagones) se hubiese totalmente ocultado á los hidrógrafos europeos, áun de las épocas más modernas. Había muy pocas nociones de ella entre nosotros; la derrota de Lord Anson en la carta que acompañaba á la narración de su viaje seguía en esos paralelos una tal inmediación á la costa, que nadie pudiese dudar que la llevaba contínuamente á la vista. El mismo Comodoro Biron, á pesar que aterrase sobre el Cabo Blanco y viese correr la costa hacia el Oeste, no indicaba siquiera sus sospechas sobre la existencia del Golfo. La natural actividad de nuestros navegantes fué la que en los últimos años aceleró é hizo evidente esta singular internación de la costa. E1 Piloto D. Bernardo Tafor, partiendo desde el Puerto San Gregorio con una lancha, reconoció hasta unas 30 leguas de la orilla septentrional del Nov. 30 Golfo, bien que sin poder alcanzar su término; y esta única excursión fué la que dió nuevo realce á las aseguraciones de los Patagones sobre el extenderse aquel Golfo unas 70 leguas próximamente al Oeste y no distar, por consiguiente, el mar Atlántico del Pacífico en esos paralelos sino unas 20 á 30 leguas (I).

La naturaleza de las costas reconocidas por el Piloto 'Tafor, todas ellas pedregosas, rodeadas de arrecifes y extremadamente áridas, bastaba por sí sola para disuadirnos de este reconocimiento, el cual, por otra parte, ni dejaría. de absorber la mayor parte del verano, ni evitaría el hacer inútiles las corbetas, debiéndose emprender con lanchas y éstas permanecer separadas por largo tiempo y sufrir por su debilidad y tamaño unos riesgos y fatigas que pudieran muy bien remediarse si se adoptasen con el regreso nuestro á esas costas unos auxilios más premeditados y más eficaces para el conseguimiento deseado.

Hízose con estas reflexiones derrota directa desde la caída de la tarde hacia el Cabo Blanco; se mantuvieron las sondas de 49 á 52 brazas, arena lamosa y fango; el viento fué constante. mente bonancible del Norte al Nornordeste, y así no fué difícil el que poco después del medio dia siguiente avistásemos nuevamente la costa, observadas ya la latitud de $46^{\circ} 33^{\prime}$, la longitud de $59^{\circ} 18^{\prime}$ y la variación magnética de $I 9^{\circ} I 5^{\prime}$. Había precedido á este aparecimiento, la ilusión harto frecuente en esos parajes, de una calima en el horizonte perfectamente parecida á la extructura común de las costas. Por más de una hora no hubo en entrambas corbetas quien no asegurase su extensión verdadera desde el Sur por el Occidente hasta el Norte, ni bastaban á desengañarnos ó los avisos del Comodoro Biron, después de haber caído en una equivocación semejante, ó las noticias de nuestros navegantes, los cuales mil veces la habían visto correr desde el Cabo Blanco hacia el Oeste directamente.

Disipada finalmente esta ilusión, á las tres de la tarde pudimos dar nuevamente principio á nuestras tareas acostumbradas. La costa era la misma que había señalado al medio día la Atrevida y la que Anson llamaba el Cabo Blan. co, bien que fuese en realidad el Cabo de Tres Puntas. Desde el verdadero Cabo Blanco, fácil de conocerse por un islote que tiene inmediato y que teníamos á la vista, corre como al Esnordeste hacia el Cabo ya dicho de Tres Puntas, desde donde sigue luégo hacia el Este y forma la

(I) Se verá después por el viaje del Capitán de fragata D. Juan de la Concha, verificado con un falucho y una lancha en Diciembre de r794, que esta internación no es tanta como debíamos suponerla. 
Dic. r.o parte meridional del Golfo de San Jorge. Convenía con bastante exactitud una rista de este trozo de costa inserto en el riaje de Lord Anson, y no quedaba duda que el Comodoro Biron había llamado Cabo Blanco al mismo punto que el Almirante distinguía con aquel nombre.

A la clistancia de tres á cuatro leguas eran nuestras sondas de 50 brazas chinitos y fango; pero muy luégo con el rumbo del Sur, cuarta Sudoeste, aproximándonos como á dos leguas, caímos en 28 y 23 brazas piedra. Costeamos á esta distancia y próximamente con el mismo fondo por largo rato, consiguiendo así, no sólo un cabal reconocimiento de aquellas orillas, sino también el observar por dos veces la longitud en el meridiano del islote del Cabo Blanco y últimamente el disponer la base de las corbctas en la dirección más oportuna para que las marcaciones en los extremos tuviesen la seguridad. posible.

Hechas estas operaciones y observados azimutes magnéticos, como quedase aún poco más de una hora de día, pareció lo más oportuno el emplearla en el examen del bajo hallado por el Comodoro Biron, en cuyo arrumbamiento con el Cabo Blanco nos hallábamos próximamente á la sazón. Hecha, por consiguiente, señal á la ATrEviDA de navegar por la popa, nos dirigimos á conservar la misma marcación alargando la distancia hasta las cinco leguas que señala el Comodoro. Navegábamos sobre las gavias y sin dejar el escandallo; la mar, excesivamente llana, debía hacernos más desconfiados sobre cualquier peligro que no descubrirían en esta ocasión las rompientes.

No tardamos de las 20 brazas en caer en 16 , I 4 y I 3 chinitos de una á otra escandallada. E1 rumbo del Nordeste nos apartaba de la costa, y por consiguiente, todo contribuía á confirmar la existencia del bajo hacia aquella parte. Era demasiado tarde para destinar embarcación menor á un examen más prolijo y era temerario emprenderlo con la corbeta, tanto más que, según Biron, el peligro era oculto y la sonda no indicaba su proximidad. Así, persuadidos, no sin razón, de su existencia, siguióse nuevamente rumbo del Este y de Sudeste y muy largo caímos en I 8 y 20 brazas.

Según nuestra costumbre, la navegación de la siguiente noche debía proporcionarse para amanecer al Sur del Cabo Blanco y á no mucha distancia de él. Se conservaba el tiempo sumamente placentero y debíamos ya tener algunas esperanzas de su duración. Navegamos del Sudeste al Sur una distancia de ocho leguas y las sondas pasaron casi instantáneamente de las 20 á lats 30,40 y 48 brazas piedra. Luégo fueron de 60 y 66 arena y lama; últimamente, aproximándonos í la costic con pairear de la vuclta del Sudoeste las vimos disminuir de nuevo á 55, 50 y 45 bra- Dic. x. zas arena y lama.

No podíamos desear situación más agradable de la en que nos hallamos á la siguiente mañanita. El tiempo sumamente claro, la costa y el mismo Cabo Blanco á la vista y á no mayor distancia de tres leguas, la mar agradablemente llana y muchos ballenatos que surcaban el agua con tanta tranquilidad como majestad, todo anunciaba que áun en estos climas desiertos alcanzaban los benignos efectos de la primavera.

Con las ventolinas del Sur que reinaban á las cinco de la mañana gobernamos á aproximarnos aún más. Luégo se midieron bases; y como nos hallásemos aún con poco viento y distantes de la costa sólo una legua escasa, ceñimos al primer cuadrante el viento flojo del Sudeste, el cual últimamente, llamando al Este después de habernos desatracado algún tanto de la costa, nos dió lugar á navegar zafos de ella con rumbo del Sursudeste. A las seis habíamos caído de las 43 á las 30 brazas.

El fondo que tuvimos en las restantes horas hasta el medio día, fué de I9, 20 y 2 I brazas chinitos y conchuela. Era nuestra latitud de $47^{\circ} 29^{\prime}$ y la longitud $59^{\circ} \mathrm{o}^{\prime}$.

Pasado el Sol del meridiano el viento tomó algún leve incremento y se declaró favorable al Norte, con el cual navegábamos á distancia de una ó una y media leguas de la costa, conservando un fondo igual de 22,20 y I 8 brazas chinitos. A las tres de la tarde se declaró virazón fresquita del Este y con ella pudimos ya navegar en demanda del Puerto Deseado, el cual no debía estar distante cuando vcíamos clara la Isla de Reyes. Acechada por la misma razón la piedra en figura de torre que sirve de marca para hallar la entrada algo difícil del puerto, logramos avistarla como á las cuatro y luego que la vimos demorar al Oeste arribamos sobre la costa, clando últimamente fondo á poca distancia de la boca del puerto en siete brazas cascajo.

La marea era aún vaciante con velocidad de una milla. La ATrRevida lo verificó poco después á poca distancia de nosotros. No tardamos en avistar una lancha que salía del puerto con remo y vela, y que conocimos inmediatamente ser la del bergantín Carmen con su Capitán D. José de la Peña. Vino inmediatamente á bordo de lá Descubierta y avisándonos que parada la marea era entonces ocasión oportuna de entrar en el puerto, instó á que lo verificásemos sin perder tiempo, para lo cual se ofrecía á servir de práctico aunque ya no quedasen sino pocos minutos de crepúsculo.

La marea en el puerto y particularmente en su boca, corre con una velocidad difícil de imaginarse, á lo cual se agregan los muchos escollos y el poco lugar que hay para fonclear. Debe se- 
Dic. a guramente considerársele como uno de los puertos de más difícil acceso (I).

Pero en esos paralelos el tiempo favorable era un don con el cual no debía contarse por mucho tiempo. No titubeamos, pues, en dar la vela, manifestándolo así á la ATrevidA, la cual se dispuso luego á seguirnos, pero sin poderlo últimamente verificar por habérsele corrido el cable ya suspendida el ancla.

Eran ya cerca de las nueve cuando la DESCUBIERTA estuvo á la vela, con velacho sobre mesana y foques. El viento se conservaba bonancible del Estenordeste, la mar era llana y la marea entraba con alguna fuerza. Antes ceñimos al Norte para atracarnos á aquella costa y franquear la boca huyendo de los arrecifes que salen de la punta Sur del puerto. Luégo arribamos en busca de las piedras del medio, y avistadas éstas las dejamos por estribor, penetrando así muy luego en paraje oportuno para dar fondo. A las nueve y media dejóse caer el ancla de estribor en seis brazas y combinadas clespués las horas de la marea para las diferentes faenas de amarrarnos, conseguimos que para el amanecer ya estuviese la corbeta bien segura sobre dos anclas.

Había, pues, la ATREvida debido desistir de la idea de entrar en aquella misma noche, ya que no podía seguirnos de cerca. D. José de la Peña, con su acostumbrada actividad, volvió á salir del puerto para servirle de práctico; pero como en toda la mañana soplase viento algo fresco del Sudoeste, que aún la hizo garrear considerablemente, no consiguió dar la vela sino á la caída de la tarde, y aún por largo rato no podía contrarestar la marea. Declarada ésta favorable como á las ocho, le permitió finalmente entrar y dar fondo en las inmediaciones nuestras. E1 bergantín Camen, para lograr una menor fuerza en las mareas, estaba fondeado como una milla más adentro. Su Capitán nos informó que en la noche de nuestra separación en el Rio de la Plata había arribado á la costa de Samborombon y permanecido cuatro días á su abrigo. De allí, abonanzado el tiempo, había hecho derrota directa al Cabo Blanco, y abierto el pliego de reunión que fijaba á este Cabo por primer punto de crucero, había creído preferente no exponer su débil embarcación á nuevos riesgos y entrar en el puerto. En la tarde anterior había tenido á su bordo un Cacique y algunas otras personas, la mayor parte conocidlas. suyas de una corta tribu de Patagones, la cual en el día vagaba por aquellos contornos. La componían precisamente muchos, así hombres como mujeres, que al tiempo de nuestro desgraciado establecimiento en el

(1) Con motivo de haberse establecido allí la Compañía marítima de Pescas, se ha conseguido una práctica mucho mayor de la entrada y fondeaderos. puerto habían tomado alguna idea de nuestro Dic. 3 idioma y nuestras costumbres.

Cambiada, pues, la marea de la mañana y disipada la esperanza, como ya se insinuó, de que la ATREvida fondease antes de la noche, pensamos aprovechar el día en el examen del puerto, á cuyo objeto se reunía naturalmente el deseo de trabar, si fuese posible, una correspondencia amistosa con los Patagones.

Iban en el bote D. Antonio Pineda, D. CaJetano Valclés y dos soldados armados: nos habíamos prevenido con algunas bagatelas de regalo, y mientras atendíamos á la caza en la costa del Sur, acechábamos con ansia el aparecimiento de los Patagones en la costa opuesta. Finalmente, al medio día se dejó ver uno de ellos á caballo en un altito no distante. Fuimos con el bote hacia él, y dejada la escopeta al tiempo de saltar en tierra, le ofrecimos algunas bagatelas, 10 cual visto por los demás de la tríbu, que á muy corta distancia de nosotros estaban en espera detrás de un montecito, fueron poco á poco aproximándose todos á caballo, y últimamente enviaron en busca de las mujeres, que no tardaron en reunirse y echar pié á tierra. Se componía entonces la tríbu de unas 40 personas, de las cuales eran io las mujeres y I 2 los niños, entre ellos tres ó cuatro aún de pecho; dos mujeres solas eran ancianas, y á pesar de esto sumamente ágiles. Entre el restante número de hombres, el Cacique y otro eran ancianos, y habría otros cinco cuyos años podían más bien corresponder á la pubertad que á la virilidad. En general eran todos (inclusas mujeres y niños) de una cuadratura agigantada. La talla era inferior á aquella proporción, pero naturalmente alta. El Cacique funchar, medido excrupulosamente por D. Antonio Pineda, tenía de alto seis piés y Io pulgadas de Burgos. La anchura de hombro á hombro era de 22 pulgadas y Io líneas.

Sentados ya en cerco, y desechada por una y otra parte toda desconfianza, empezó á esplayarse el deseo innato en el hombre de querer conocer más de cerca á su semejante.

En esta escena, compuesta naturalmente más bien de gestos que de palabras, las mujeres patagonas no tardaron en abrogarse la principal parte, y ó fuese curiosidad ó una mayor propensión al discurso, muy luego se hicieron cargo de nuestras preguntas, y no faltó entre ellas quien esforzándose en usar palabras españolas con aquella volubilidad de lengua que siempre han admirado los viajeros, añadiese á este nuevo cebo de la conversación un cierto agrado que áun entre un traje y unas costumbres extrañas, dejaba traslucir esta característica principal del sexo.

Les regalamos varios adornos de vidrio, al. grunas cintas y algunas gargantillas; nos dieron 
Dic. 3 en desquite una piel y un bezoar de guanaco y un guanaco viro pequeño, al cual podía muy bien aplicarse la elegante pintura que el Comodoro Biron había hecho de otro animal semejante.

Se dirigían particularmente nuestras preguntas al conocimiento de su idioma y costumbres. Convinimos con D. Antonio Pineda en cuanto al idioma, que trabajaríamos separados; que hecho un pequeño acopio de palabras en una sesión, procuraríamos confrontarlas todas en la sesión siguiente antes de aprender otras; finalmente, que siendo sumamente equívoco el enterarse de las costumbres mientras no se tuviese la menor idea del idioma, dejaríamos en mucha parte este objeto para las visitas sucesivas, en las cuales nos acompañase el Piloto Peña: así lo hicimos, y como ya se ha indicado, nos fueron principalmente útiles dos mujeres que sabían no pocas palabras castellanas, y conocían los Pilotos Tafor y Peña.

Desde el principio, los naturales habían solicitado que se apartasen los dos soldados arma dos; se les complació inmediatamente, y esta confianza nos ligó al parecer de tal modo, que habiéndole preguntado D. Cayetano Valdés si extrañarían que tirase á un ave no distante, condescendieron los hombres á ello, mas oponiéndose mujeres y niños que hacían ademán de asustarse y áun de quererse ausentar, lo omitió prudentemente y con esto causó una satisfacción general.

Eran las dos y media de la tarde, cuando pensamos en separarnos después de recíprocas aseguraciones de la amistad más estrecha y con la esperanza en nosotros de que viniesen al día siguiente á bordo, á donde los habíamos convidado y prometídoles crecidos regalos. Fuéronse todos á caballo. Nosotros con la marea ya favorable, no tardamos en regresar á bordo y no omitimos el buscar entre las muchas aves que nos pasaban á tiro aquellas que pudiesen suministrar nuevos objetos para la Historia Natural.

Fondeada la ATrevidA, debió ocuparnos esencialmente desde el día siguiente, el aprovechar los instantes para hacer tan breve y útil cuanto pudiésemos nuestra demora en el puerto.

Desde la misma noche habíamos convenido con el Piloto Peña, en una señal que nos avisase cuando los Patagones estaban á la vista para ir á su encuentro, con cuya precaución economizábamos el tiempo que hubiéramos empleado en buscarlos infructuosamente y en el entretanto la caza, la pesca, la aguada, las tareas hidrográficas y astronómicas y las investigaciones de los naturalistas, progresaban con un paso uniforme $y$ bastantemente acelerado.

Muy luégo, la caza, que por su abundancia cebaba áun á los más inexpertos, fué el entrete- Dic. 4 nimiento diario de toda la Oficialidad en sus horas de recreo. Nuestra mesa no se cubrió sino con el fruto de nuestras excursiones y pudo la marinería hallar en el marisco, el pescado y las muchas aves acuáticas de buen gusto, una variedad de comida tan agradable como abundante.

Destacados en la misma mañana los Tenientes de fragata Quintano y Salamanca, para reconocer las aguadas de la costa inmediata del Sur, en donde se había provisto el Comodoro Biron, las hallaron tan escasas y distantes de la playa, que les parecía bien incómodo el hacer una provisión mediana. Prefirióse con este motivo la aguada de la población antigua, la cual, aunque distante de las corbetas como tres leguas, debía parecernos más cómoda porque las lanchas podían ir directamente á ella con el auxilio de las mareas, sin atención á los vientos, pero siempre eran inconvenientes de alguna entidad el que á media marea no pudiese entrar ni salir lancha alguna del estero y que la misma escasez del agua no permitiese llenar sino unas doce pipas en veinticuatro horas. El viaje, además, era peligroso por las revesas ó remolinos que en diferentes recodos formaba la marea, en contraposición al impulso del viento. Así, para la seguridad de ambas lanchas, las cuales navegan juntas y en nada sobrecargadas, se destinó un tercer bote con un Oficial para que las dirigiese. Con esta precaución, habíamos ya conseguido el día 6 dos viajes de cada lancha dirigidos con mucha inteligencia por los Tenientes de navío Valdés y Tova, cuando en esa misma tarde nos obligó un nuevo acaso á dar otro destino á las embarcaciones menores. Con una ráfaga fuerte del Nornoroeste y la marea vaciante había faltado á la Atrevida el cable del Oeste, y aunque sus maniobras fuesen sumamente vivas y acertadas, no había podido evitar el que su ancla de esperanza, en lugar del fondo, agarrase nuestro cable del Oeste y ella misma nos abordase por babor, sin causar, sin embargo, daño alguno considerable. No fuimos poco felices en suspender el ancla agarrada á nuestro cable antes que le rozase ó rompiese, y después por medio de calabrotes, en devolverla á su buque sin lancha; finalmente, cambiando la marea á las nueve, la ATrevida pudo volverse á amarrar, bien que con una demasiada inmediación á algunas piedras.

Como en un paraje de mareas tan vivas no fuese posible el uso de las boyas y de los orinques, el ancla carecía de este útil medio de recobrarse; fué, pues, preciso emplear las dos lanchas en rastrearla, maniobra difícil por los pocos instantes en que está la marea parada, únicos, por otra parte, para que un buzo pudiese pasar el orinque. Se trabajó inutilmente en la mañana del $S$, pero en la del 9 tuvimos la felicidad de 
Dic. $\sigma$ encontrarla, y pasado un orinque por el buzo de la ATREvida, se levó en la misma tarde y se restituyó á su bordo.

En el trabajo del plano del puerto, extendido por su parte exterior hasta las Islas Reyes, había explayado D. Felipe Bausá su acostumbrada actividad é inteligencia. En la mañana del 7 , medida una base en la costa del Sur, había después pasado á diferentes puntos de la misma costa en donde pudiesen hacerse marcaciones útiles para ligar los parajes esenciales del puerto; luégo, cn un bote, había atravesado al extremo Norte de la boca; finalmente, ó con enfilaciones ó con nuevas marcaciones del teodolito, había extendido poco á poco los triángulos hacia dentro, navegando últimamente del io al i i con el Teniente de fragata Quintano y el Piloto Peña, hasta donde pudiese internarse el botecillo que los llevaba. Marcaban alternativamente en una y otra orilla, prefiriendo tal "cual paraje alto que sobresale y domina á las muchas islas de que está sembrado el canal. No omitían tampoco las sondas, guiados de las excelentes noticias dcl Piloto Peña; así, con la excursión actual podía considerarse también concluído otro ramo, tal rez el más esencial de nuestra comisión.

El examen de la marcha de los relojes marinos emprendido desde los primeros días por medio dc las alturas absolutas del Sol, medidas con el sextante, había indicado en todos ellos una variación tan extraña del movimiento asignádoles en Montevideo, que nos fuese preciso el desconliar de estos resultados y echar mano de las observaciones astronómicas, aunque contra la primer idea nuestra arrastrasen consigo el establecimiento de un puesto en tierra y los repetidos viajes de las embarcaciones menores así de noche como de día. En la mañana del 5 plantóse la tienda del observatorio en la costa del Sur, enfrente de las corbetas. Se llevaron á ellas el cuarto de círculo grande y el cronómetro 72 y D. Dionisio Galiano debía intentar la deducción de la longitud por los pasos de la Luna al Meridiano, comparados á una estrella, ya que no se proporcionaban á la sazón observaciones de los satélites de Júpiter, ni ocultaciones de las estrellas por la Luna.

Para seguridad del observatorio y áun para el buen orden de la gente que diariamente fuese á tierra, se plantó en sus inmediaciones una barraca, en la cual estaban constantemente un cabo y dos soldados. Se puso el asta para las señales de correspondencia con las corbetas, así de día como de noche, y siempre desde el anochecer hasta la siguiente mañana se mantuvo uno de los dos Guardias Marinas encargado de la responsabilidad del puesto. Como ya se hubiese dejado conocer el genio pacífico de los Patagones y no desamparasen la costa del Norte, parcció que nada se aventuraba en establecerse hacia $\mathrm{cl}$ Dic. 7 Sur, tanto más que siempre dirigíanse hacia el mismo lado todos los que deseasen ir á tierra ó con objetos de entretenimiento ó de caza. Fueron infructuosos en las primeras noches los esfuerzos de D. Dionisio Galiano para las observaciones de la Luna. Dedujo, sí, la latitud de 47 grados $45^{\prime} 33^{\prime \prime}$ por alturas meridianas de estrellas al Norte y al Sur. La variación en la aguja del teodolito fué de $19^{\circ} 5 \mathrm{O}^{\prime}$ al Nordeste y reunidos los Oficiales de entrambas corbetas, observaron en la mañana del 9, IgI series de distancias lunares, cuyo rcsultado fué de $9^{\circ} 29^{\prime}$ al Occidente de Montevideo, longitud algo más oriental de la que determinaban los relojes.

Más felices en sus tareas los Sres. Pineda y Nee, habían aprovechado todos los instantes para aumentar sus respectivas colecciones científicas; el primero, adicto particularmente al examen de las piedras, de las conchas, de los cuadrúpedos y de las aves, cncontró tan crecido número de curiosidades, que podían muy bien suministrarlc material de estudio en la siguiente campaña algo dilatada álrededor del Cabo de Hornos. D. Luis Nee, con su acostumbrada perspicacia, constancia y asiduidad, logró á pesar del semblante árido que tenían aquellos contornos, recoger muchas plantas de una rareza y méritos singulares.

Pcro volvamos ya á los Patagones, cuya ausencia por el espacio de cinco días debía parecernos con exceso extraña, después de la amistad con la cual nos habíamos separado en la primera concurrencia.

Al medio día del 8, hizo señal cl bergantín que estaban á la vista, y no tardamos en ir á su encuentro, acompañándonos el pintor D. José del Pozo. A nuestra llegada al bergantín, hallamos al Cacique con otros subalternos y tres ó cuatro mujeres con algunos niños de pecho. Dormían éstos tranquilaménte á poca distancia de la camarita; los demás, así hombres como mujeres, no habían cesado de comer galleta y menestras, ya crudas, ya cocidas, mezclándoles repetidas veces el uso del cigarro y del vino. Nosotros mismos los vimos fumar y beber otra vez y no pudo quedarnos duda que el uso del aguardiente, ni les era nuevo, ni dejaba de serles agradable. La fuga de sus caballos había sido la causa de no volver en los días anteriores, viéndose precisados á destinar á los más jóvenes para buscarlos, los cuales no los habían encontrado sino al tercer día de su comisión.

No nos habíamos descuidado en llevar aquellas bagatelas para regalo, que pudiesen serles agradables; algunas tijeras y cuchillitos regalados generalmente á todos, un cuchillo grande y un espejo dados con preferencia al Cacique y algunos adornos que presentamos á las mujeres, arraigaron de tal modo nuestra amistad recípro- 
Dic. \& ca, que fué fácil sacar sus relratos y la conversación se trabó larga é interesante. Rectificamos las palabras aprendidas en la primera sesión, á éstas se agregaron muchas nuevas, pudieron adquirirse ideas claras de algunas de sus costumbres y en particular de sus enlaces de parentesco y del amor hacia los padres y los hijos; finalmente, como procurásemos aún con el auxilio de Peña adquirir algunas nociones de su religion, esto nos fué llevando poco á poco á hablarles de su morada actual, distante como tres leguas de la playa, la cual nos manifestamos dispuestos á visitar al día siguiente si trajesen algunos caballos para nuestro uso. En esto se aproximaba ya la hora en que debian retirarse. Peña les habia dado un buen repuesto de galletas y menestras secas; debían llevarlas al resto de la tríbu y cada cual, fuesen hombres ó mujeres, parecía igualmente afanado, ó con el cuidado de acrecentar sus repuestos, nombrando ya unos, ya otros de los ausentes, ó con la dificultad de transportarlos no pudiendo hacer sino unos sacos pequeños con los extremos de las pieles que formaban sus trajes. Hízose en esta ocasión digna de reparo una joven patagona de edad de catorce años próximamente, cuyo regular parecer, mucho agrado y singular sagacidad, había hecho que se le prefiriese á las demás para ser retratada. La piel que la cubría, por cuanto se adaptase al intento, no era capaz de dar cabida á los muchos dones que había recibido y que destinaba con mucho amor para sus padres: no quería abandonarlos; consultaba á sí misma, consultaba á los suyos, todos le aconsejaban que usase del poncho que llevaba en forma de camisa debajo de la piel del guanaco; pero era preciso desnudarse á presencia nuestra; y luchaban á porfía sobre el partido que debiese adoptar, la honestidad por la una parte y por la otra el consejo de los demás; venció, finalmente, 110 tanto éste cuanto el amor filial; se decidió á quitar el poncho para envolver los comestibles; mas lo verificó con tal arte y tal modestia, que dió un nuevo resalte ṇo ménos á sí misma que al sexo en general, en quien es característica aquella calidad y sobresale hasta en los pueblos más incultos. Despidiéronse, finalmente, y nosotros regresamos á bordo.

Puntuales al día siguiente, concurrieron en mayor número á la orilla acostumbrada, y no tardó la mayor parte de la Oficialidad en ir á su encuentro: conducían un solo caballo para la visita proyectada en sus hogares; pero como en cste caso hubiese sido mucha imprudencia el aventurar uno solo de nosotros á tanta distancia de cualesquiera recursos que hicicsen temibles siquiera las consecuencias de un insulto, les manifestamos, que desistíamos del viaje propuesto, y les convidamos por la misma razón á que viniesen á bordo: fué imposible el persuadirlos ó bien dimanase de nuestro número algo erecido, Dic.9 ó del cabello rubio y de los trajes de la mayor parte de la Oficialidad, lo cual podía (según Peña) hacerles sospechar fuésemos de otra nación: debimos, por consiguiente, contentarnos con repetir sobre la orilla una larga sesión, animada como era natural con varios dones, particularmente de comestibles y dirigida ó bien á estrechar una amistad recíproca ó á progresar cuanto fuese posible en las nociones adquiridas sobre sus costumbres y principios socialcs: advertimos en esta ocasión cuán macilentos eran sus caballos, débiles y pequeños los perros y cuál era el afan con el cual comian, todas pruebas nada dudosas de una subsistencia más bien mezquina é incierta en todos esos contornos.

Aproximándose ya el Sol al horizonte, fué finalmente preciso el separarnos: dió el Cacique la orden para que la tríbu montase á caballo, y obedecido con puntualidad, no tardó en emprender la marcha, bien que dejando atrás algunos que 6 no habían sido tan expeditos en apretar sus toscos arneses ó esperaban con este pretexto algún otro regalo capaz de hacerles más felices que á los demás: en este número se hallaba casualmente la joven patagona, cuya modestia habíamos reparado en la tarde anterior. No se había desviado de su padre, y su mayor atención ó más bien cuidado, cra en aquel momento el de montar á nuestra vista sin ofender en modo alguno á su pudor: usan allí las mujeres el montar á caballo en el modo siguiente: forman con la brida una especie de estribo, en el cual hacen firme el pié derecho; asidas luégo con la rodilla izquierda sobre la coyuntura alta de la mano del caballo, tienen finalmente lugar para sentarse trepando sobre la albarda y después pasar la pierna derecha al otro lado; parecíanle, pues, arriesgados para su extremo pudor estos movimientos. Ya pedía á su padre que la ayudase, ya que se ocupase más bien en ocultarla de nuestra vista, y mientras tanto quedaba casi sola: determinóse por último á montar, pero fué esto con tal cuidado é incomodidad, que mal asegurada sobre el caballo, apenas se ausentó de nosotros unos doscientos pasos cuando volvió á apearse para montar con aquella libertad que le era necesaria. Un grado tan sobresaliente de honestidad entre un pueblo casi desnudo y bárbaro, no puede menos de producir en el filósofo moral y amante de nuestra especie, algunas reflexiones que la vistan tal vez á sus ojos con unos colores ménos viciosos y propensos naturalmente á la vida brutal.

Concluídas en el entretanto todas las opcraciones que nos hacían ó util ó necesario el puerto, y tocándose á cada paso con mano los muchos riesgos que en ćl sufrian amarras, embarcaciones menores y los mismos buques, pareció final- 
mente lo más acertado el abandonarle. Diéronse instrucciones al bergantín Carmen, atento á su corto andar y á la práctica de su Capitán sobre aquellas costas, para que navegase sólo y reconociese los rios de Santa Cruz y Gallegos, al Sur del Puerto San Julián. Debían las corbetas navegar en derechura al extremo occidental de las Maluinas, y allí, con una travesía directa al Cabo de las Vírgenes, ligar en uno y otro extremo con las tareas del año anterior, de los paquebotes Eulatia y Casilda, de la Marina Real; y como los Patagones no se dejasen ver más en los contornos del puerto, se aceleraron de tal modo los aprestos, que en la noche del II pudimos considerarnos prontos para dar la vela, reincorporados ya en aquella hora los Sres. Pineda, Bausá y Quintano, los cuales, como ya se dijo, habían internado en la ria con un bote chico, y dado cada cual nuevo ensanche á las tareas útiles de su profesión.

El viento al Norte que había soplado con mucha violencia en toda la tarde, nos había persuadido á meter dentro los botes; y pues que en el día siguiente la continuación del mismo viento no nos daba lugar á desamarrarnos, la empleamos en sistemar la marcha de los relojes, y trazar la carta de la costa que habíamos reconocido entre el rio Negro y Puerto Deseado.

Poco después de salir el Sol al día siguiente, pareció entablar viento bonancible del Sur, la marea debía cambiar á la vaciante hacia las diez y como por la proximidad de la ATREvida á la piedra no era posible quedase sobre su ancla del Oeste, aprovechamos entrambas-la marea entrante para levar aquella ancla. A las diez ya es. tábamos á pique de la otra y enteramente prontas á dar la vela: el bergantín que según las señales hechas de antemano lo había verificado ya, vió imposible poder montar unas isletas que mediaban entre él y nosotros, y volvió á dar fondo. No fué otra tampoco la suerte de la Descubierta por haberse declarado en el mismo instante de dar la vela ventolinas flojas del Este. Así pasamos entrambas el restante día, en el cual el viento se mantuvo flojo; por la misma parte, la marea con velocidad de tres y media á cuatro millas, y el tiempo no sólo neblinoso, sino también por la tarde algo aturbonado con truenos distantes. Siguiéronse por la noche algunos chubasquillos, los cuales, finalmente, produciendo á las cuatro de la mañana siguiente algunos soplos del terral del Oeste, dieron lugar á quc en pocos instantes, parada la marea, ambas corbetas estuviesen á la vela y franqueasen, aunque con algún riesgo, la boca del puerto. El bergantín, fondeado más adentro, no pudo seguirnos y le perdimos inmediatamente de vista.

\section{CAPÍTULO IV}

Navegación de las corbetas á las Islas Maluinas y de alli alrededor del Cabo de Hornos larsta el puerto de San Carlos de Chiloú.-Reconocimientos de las Tierras del Fuego y otros accidentes ocurridos en aquel ticmpo.

Nuestros conceptos no iban errados cuando Dic. 14 al amanecer habíamos procurado dar la vela con la posible precipitación. Apenas propasada la boca del puerto, declaróse al mismo tiempo la marea contraria y calmó totalmente el terral. En diferentes ocasiones la ATREvida se vió casi precisada á dar fondo. Ambas corbetas eran arrastradas rápidamente hacia la costa del Norte; pero á las ocho empezó á entablar viento galeno del Sur y las muras á estribor con fuerza de vela nos franquearon á poco tiempo de aquellas inmediaciones, de suerte que pudiésemos considerar como libre la navegación siguiente, cualesquiera fuesen los vientos que debiésemos experimentar.

Un nuevo bordo hacia la costa antes del medio día, nos dió lugar á multiplicar en la restante tarde las tareas hidrográticas, las cuales debían ligar varios puntos externos con el extremo interior de nuestros triángulos; repitiéronse también las observaciones astronómicas; diferentes azimutes manifestaron la variación de $20^{\circ} 4^{\prime}$ Noroeste. Al ponerse el sol ya demoraba la Isla Reyes al Sur $40^{\circ}$ Oeste, distancia de seis leguas; la mar era llana y los vientos empezaban á entablar por el Norte y Noroeste, favorables sobremanera para nuestra derrota.

Emprendimos, pues, el atravesar directamente al extremo occidental de las Islas Maluinas; crecieron las sondas hasta las 60 y 65 brazas Cango duro; creció también rápidamente la variación de la aguja hasta $\operatorname{los} 23^{\circ}$. Las ballenas, los lobos, las muchas aves acuáticas, solazándose frecuentemente alrededor de los buques, hacían más divertida la navegación, al paso que atizaban nuestros deseos de ver cuanto antes abierto por medio de las pescas este nuevo ramo, tal vez inagotable de la industria nacional.

Los rumbos del Sursudeste y Sudeste que seguíamos constantemente, no podían ménos de conducirnos en breve tiempo al término prefijado. Fueron casi momentáneas las contrariedades que experimentamos de los vientos del Sur, los cuales, aunque al principio oscuros y tempestuosos, no tardaban en rolar más claros y apacibles al Sudoeste y Oeste. Así no nos fué difícil para la tarde del I7 el avistar á larga distancia los Salvajes, Islas Altas, las más occidentales de las Naluinas, y poco después, favorecidos extraordinariamente del viento, el emprender en ese 
1.ic. 17 mismo extremo las tareas hidrográficas acostumbradas. Importaba mucho en aquellos contornos su máxima exactitud, en cuanto debían compararse al mismo tiempo con las del Capitán inglés Mac-Bride y servir de norte en las navegaciones renideras de los buques nacionales al mar del Sur, para que ni se retardasen los viajes con unos bordos retrógrados, á veces infundados, ni con las oscuridades harto frecuentes en esos mares, pcligrase algún buque en las inmediaciones de la Isla Rasa, difícil á ser vista á una mediana distancia.

Con este intento fué nuestro objcto en la restante tarde el de reconocer de cerca aquella isla y costear después entrambos Salvajes. En cada meridiano se observaban longitudes con las relojes marinos, sondábamos frecuentemente, aunque sin encontrar fondo con r ro brazas de sondaleza; observábamos desde los topes con cuanta vigilancia fuese dable, los diferentes canales que allí forman un laberinto sumamente complicado de islas, pero ya veíamos imposible el alcanzar hasta la mañana siguiente el puerto Egmont, en donde era nuestro ánimo el dar fondo y combinar con un nuevo examen de la marcha de los relojes marinos, el reemplazo completo de la aguada y un mediano reconocimiento físico de aquellos contornos.

Fué, por consiguiente, preciso el procurar mantenernos hasta la mañanita siguiente en la misma posición. Se seguían los bortos más oportunos, ya con las solas gavias, ya agregándoles mayores y estais; y sin embargo, como tuviésemos una corriente bastantemente fuerte al Norte, nuestra distancia de los Salvajes al amanecer no era menor de unas cinco leguas. Inmediatamente, entablado viento fresco del Oeste volvió á atracarse al mismo extremo de la tarde anterior; costeamos varias islitas, á muy corta clistancia, dejando las unas á estribor y á babor las otras y no tardó mucho cuando ya empezaron á descubrirse las inmediaciones del puerto y pudimos dirigirnos hacia él.

Estas inmediaciones, formadas por la mayor parte de islas, son por lo común altas y acantiladas; si hay una ú otra punta baja, despide algunas restingas, las cuales, viniendo del Oeste, se de jan á la izquierda; el mismo inconvenicnte y el de un bajo al Sur de otra isla, indica, como preciso, cl atracarse mucho á la derecha y muy luégo se hace notable el blanquizar dc arena, del cual hizo memoria el Comodoro Biron, como un paraje oportuno para dar fondo, cuando el viento ó la noche impidan internar en el puerto Egmont, pues sobre un braceaje de I 2 á 20 brazas arena, puede un buque estar bien cerca de tierra, abrigado de todos los vientos que sean contrarios á la entrada, y con un riachuelo á la vistá que le suministre en el cntrctanto cl agua que necesite. No tardamos, continuandỏ á un viento favorable del Oeste, en internar en el Dic.. puerto: navegábamos con gavias, foques y vela de estai de gavia; costeábamos las orillas del Oeste á un tiro de fusil, por fondo de I2, I I y Io brazas arena, y acechábamos cualquier riachuelo para dar fondo enfrente de él. Le vimos muy luégo y era fácil apcrcibir en sus inmediaciones muchos fragnentos de la colonia antigua inglesa; así no diferimos un instante en dar fondo y á poco tiempo quedaron amarradas las dos corbetas á corta distancia la una de la otra y cn una excelente disposición para los objetos que se habían prefijado. Algo más adentro estaba fondeada una sumaca del Rey, procedente pocos días antes del establecimiento de la Soledad, cn cl extremo oriental de las Maluinas.

En el entretanto, se habían destacado algunos Oficiales para reconocer con un bote los parajes inmediatos y dirigir con el mayor acierto la aguada. Nada había en aquellos contornos quc no debiese recordar al navegante los dones pródigos de la naturaleza, siempre uniforme en sus hechos, siempre superior á cuanto pudiesen suministrar el arte y el trabajo lento, mezquino y contradictorio del hombre. En el fondo de una ensenadita ó más bien dársena, descendía al mar un arroyuelo cuyas aguas cristalinas apenas á no mucha distancia de allí asomaban uniclas, desplomándose de los altos inmediatos; cuando se agolpaban á aprovechar de sus derrámenes y á de. berles una subsistencia lozana y saludable, varios gramenes, la coclearia y el apio silvestrc: éstas dos plantas, destinadas especialmente á la conservación del navegante, reunen en sí la otra ventaja no ménos apreciable de su constante inmediación al agua. Tanto es hallar la una cuanto encontrar el otro. Queda casi suspenso á la primera vista, el que pisando apenas la tierra se ha aproximado por el solo instinto á una ú otra de estas cañaditas; unas veces extasiado contempla la inagotable abundancia de lo que poco antes le era imposible el conseguir; el suave murmullo con el cual desciende, le recuerda un momento el rápido correr de la vida humana y de sus trances ó los más felices ó los más desgraciados; pero atónito y casi olvidado de sí mismo, teme perderla de nuevo. El apetito por una parte, el agradecimiento por la otra, le arrastran hacia ella: no bien ha satisfecho sus ansias, no bien ha besado mil y mil veces en este símbolo de la vejetación la próvida mano de la naturaleza, cuando mira en torno y ve moverse por un vientecillo suave ó por cl mismo salpicar de las aguas, el apio y la coclearia: las coge, las masca, las bendice: el cansancio y la quietud le excitan un breve sueño; disipa en un momento aquella languidez que le oprimia poco ántes.

li intanto obblia

laa nosa, é il mal de la passata via. 
Las aves acuáticas varían luégo esta escena, pero sin aminorar su semblante agradable: las hay de hermosa pluma; las hay de mil tamaños: sus voces allí no son los símbolos ó de una constante emigración según las estaciones, ó de la pérdida sufrida poco antes de la compañera fiel y de los tiernos hijuelos. Denotan tan solo aquel afán natural con el cual se hacen casi indivisibles entre sí, con el cual se llaman cuando mudan de morada ó de aposento y se convidan cuando ó el mar les presenta una subsistencia diaria y abundante ó las costas no trilladas del hombre les brindan con la facilidad de solazarse y de volatear á su albedrío. Ni es ménos entretenida la vista del mar, en donde los peces, los anfibios y á veces las mismas ballenas, ignorantes de su propio poder y del genio destructivo del hombre, se presentan casi con emulación para saludarle y no imaginan jamás que esto baste para ser destruídas.

Con un semblante tan favorable cual acabamos de describir, y sin la interrupción de aquellas distracciones que en los paises habitados son inseparables del navegante, ó ya pará precaverse de las tretas, ó para ultrajar los derechos, ó finalmente, para ser víctima de los halagos engañosos de sus semejantes, no parezca extraño que muy pocos días bastasen para cuanto nos habíamos propuesto en aquella escala. En la misma tarde tuvo cada corbeta una lancha con agua; siguióse llenando el vacío durante la noche, y al día siguiente, no bien el Sol había disipado la calima, cuando estuvieron cada cual ocupados con ansia en las tareas de su destino. Los naturalistas, los hidrógrafos, los astrónomos, los cazadores y los que se habían destacado para la pesca, subieron los primeros al monte de la Vigía, en donde D. Felipe Bausá hizo marcaciones bien importantes con el teodolito, y D. Antonio Pineda reconoció el suelo, las plantas que le vestian y los animales que le habitaban; D. Dionisio Galiano y D. Juan Vernaci, establecieron el observatorio y empezaron con las alturas correspondientes del Sol, el examen de la marcha de los relojes marinos. Midiéronse por los demás Oficiales muchas series de distancias lunares; sondaban los Pilotos; oíanse frecuentes y siempre con buen éxito, los tiros de los cazadores; la aproximación de la noche debía por la misma razón presentar á bordo un espectáculo más bien agradable, cuando llegaban por todas partes y se veían uno sobre otro los barriles del agua, los atados del apio silvestre, los peces, las aves y los anfibios, presentando cada uno, ó en su pluma y en sus caracteres, si estuviesen muertos, ó en sus graznidos y movimientos si viviesen aún, aquella variedad contínua que hace el mayor adorno de la Naturaleza.

Referidos al medio día del 20 los resultados de las tareas astronómicas, dieron para el obser- vatorio la longitud siguiente occidental de Mon- Dic, zo tevideo.

Cronómetro 6r........................... $52^{\prime} 38^{\prime \prime}$

Cronómetro 72................ $3^{\circ} 5^{1^{\prime}} 25^{\prime \prime}$ I 55 series de distancias de la Luna al Sol. $3^{\prime \prime} 49^{\prime}$ I $5^{\prime \prime}$ El promedio delos relojes de la ATREEvida,

bien conformes entre sí. . . . . . $3^{\circ} 52^{\prime} 30^{\prime \prime}$

Latitud, $5 \mathrm{I}^{\circ} 2 \mathrm{I}^{\prime} 3^{\prime \prime}$ por astros al Sur $y$

al Norte. Variación magnética, $22^{\circ} 34^{\prime}$ al N. E.

Las observaciones de la latitud, habían á la verdad encontrado un obstáculo cual no era fácil imaginarle. La hermosura del día, la conclusión de las faenas de á bordo, y la misma útil necesidad de alejar á veces la marinería de aquel yugo constante y opresivo de la disciplina, el cual en una nación sumamente viva, si bien no cause frecuentemente la desesperación, debe causar á lo ménos la melancolía, nos habían dictado como prudente, el permitir á entrambas marinerías que pasasen en tierra la mayor parte del día. Repartiéndoles jabón para que lavasen su ropa, tolerando en otras y particularmente en la tropa, el que llevasen el fusil para cazar, debían errar á su albedrío por aquellos contornos y no reunirse en la orilla sino á la entrada de la noche: dispersados así en muy poco tiempo, no tardaron en dar muestras de su genio natural, inclinado al desorden y á la destrucción. Prendieron fuego á un montón de turba en donde esta planta se hallaba más espesa, y en un momento, no sólo vimos arder por diferentes partes el monte inmediato, sino que el humo que salía del incendio, ocultaba los objetos áun más cercanos. Fué, pues, preciso enviar utensilios de la DEscubierta para atajarle. Oficiales, Contramaestres y cuanta marinería estuviese á mano, trabajaban con igual vigor, pero inútilmente. Era imposible el asolar de un todo aquellos contornos, y era por otra parte imposible el extinguir el fuego como quedase una mata siquiera. Así, después de repetidos esfuerzos y de las esperanzas por tres veces frustradas de haberlo conseguido, debimos, finalmente, retirar la gente á las nueve de la tarde y dejar que á más del destrozo siempre nocivo, nos inundase una columna de humo, la cual á veces imposibilitaba el vernos de una á otra corbeta. Debiéronse con este motivo aprovechar todas las claras que los vientos quisiesen proporcionarnos. Apenas se pudieron observar en la noche inmediata dos alturas meridianas de astros al Sur del zénit. En la mañana siguiente, en la cual debíamos deducir de las alturas de los topes la distancia verdadera de una á otra corbeta para que nos sirviese de base, fué preciso acechar por largo rato una clara favorable antes de poderlo conseguir.

En esta última operación tuvimos también la casualidad bien extraña de no poder jamás com- 
Dic. 2 binar una medida uniforme en las dos corbetas, si bien la mar estuviese en una completa calma y la elevación de los topes fuese positivamente igual. Parece difícil el adoptar para esta clase de operaciones una mayor prolijidad de la que solía usarse en las corbetas. Ixxcelentes instrumentos, medidas exactas, cálculos rigurosos, muchos observadores bastantemente expertos, no podían, sin embargo, evitar el que incurriésemos frecuentemente en errores de mucha monta, los cuales últimamente nos han convencido que en la necesaria multiplicación de las tareas hidrográficas, sin descuidar este método realmente exacto, deben, sin embargo, emplearse constantemente las bases por corredera.

Frustradas de este modo, ó ya por el humo de la quema indicada, ó á veces por las nubes que ofuscaban el cielo particularmente cuando reinasen vientos del Norte, varias observaciones astronómicas que debían acaecer en el corto intervalo de nuestra demora en el puerto, fué preciso acelerar la salida. Se había ya sustituído á la primera base otra medida con cadena en el corto terreno que permitían las orillas; se habían repetido las marcaciones en diferentes parajes altos, los más oportunos para ligar interior y exteriormente los triángulos, y completada la aguada, hecho un cuantioso acopio de apio silvestre, y dispuestos últimamente velamen y aparejo para la próxima navegación alrededor del Cabo de Hornos pensábamos dar la vela en la mañana del 23 , para lo cual se había ya levado un ancla y metidas las embarcaciones menores.

Debió, pues, parecernos bien inoportuno el viento al Norte, el cual, tomando en aquella misma mañana mucho incremento, nos hizo desistir de la idea de dar la vela. Calmó sin embargo por la tarde, roló poco después al Noroeste y declarado finalmente al Sursudoeste, después de una leve garua, nos dió lugar para que á las cuatro de la siguiente mañana entrambas corbetas estuviesen á la vela y franqueasen poco después la boca del puerto.

Empero, apenas distaríamos de él unas dos millas, cuando las ventolinas calmaron enteramente, se ocultaron con calima la mayor parte de las islas inmediatas y un marullo grueso del Norte y Noroeste empezó á aconcharnos sobre la costa occidental del puerto. Sondamos ig brazas arena y á pesar que trabajásemos constantemente para hacer algo ménos arriesgada nuestra posición, veíamos á cada paso aminorar la distancia de los arrecifes del Este. Permarecimos cerca de una hora en esta posición poco agradable, en la cual además la suma variedad de las ventolinas nos exponían frecuentemente al riesgo de un abordaje con la ATrEvidA; pero á las ocho, entablado finalmente viento fresquito del Sudoeste pudimos con fuerza de vela continuar la derrota y pasado el canal entre los Hermanos y las Pie- Dic. 24 dras blancas, islotes fronteros y distantes unas dos leguas de la boca del puerto, considerar ya libre la navegación siguiente hacia la costa patagónica. Al medio día era la latitud de $5 \mathrm{I}^{\circ} 2^{\prime}$, la longitud de $4^{\circ} 5^{\prime}$ de Montevideo y demoraba al Sur verdadero, el extremo occidental de los Hermanos.

Calmosa, sí, pero despejada la tarde inme. diata, nos dió lugar á repetir á la vista del puerto las observaciones de longitud por las distancias lunares: I02 series observadas en la DEscuBIERTA sólo discreparon en tres minutos de la longitud asignada á aquel meridiano por los relojes marinos. Era ésta una nueva evidencia del grado de exactitud que solía comunmente alcanzar esta especie de observaciones tan útil en el mar y tan fácil á repetirse.

Hasta la media noche quedamos en la misma posición; pero entablado á aquella hora casi re. pentinamente viento fresco del Norte, pudimos inmediatamente aprovecharle con fuerza de vela $\mathrm{y}$ propasar antes de las seis á distancia de cuatro leguas las Islas Salvajes y la Rasa. Con las cuatro principales y los foques, llevábamos un andar de nueve á diez millas. El viento era muy fresco y arrafagado: la mar ya gruesa y los carices bastantemente aturbonados. Emprendido de este modo el atravesar de nuevo á la costa patagónica y el ligar sobre el Cabo de las Vírgenes nuestras tareas con las de los paquebotes Eulalia y Casil$d a$, la navegación debía ser naturalmente sencilla y expedita. Los vientos fueron sumamente variables, pero comunmente frescos y achubascados. Los ceñíamos ya de la una ya de la otra mura, rara vez decidiéndose por el Oeste nos apartaban de una derrota directa. Era común á pesar de las cerrazones el conseguir las observaciones de la latitud. Para la variacion magnética, después de muchas desigualdades que la hacían vacilar entre los 22 y $25^{\circ}$, habíamos adoptado en la tarde del 26 la de $22^{\circ} 30^{\prime}$ dimanada de muchos azimutes de bastante satisfacción, y en la tarde del 28 declarados nuevamente vientos favorables después de algunas turbonadas recias del Sudoeste esperábamos de uno á otro instante la vista oportuna del Cabo de las Vírgenes.

Le avistamos efectivamente á las cinco $y$ media de la tarde. Demoraba al Oeste 1/4 Sudoeste verdadero y su longitud, atracádole después á la sola distancia de tres leguas escasás, resultaba por nuestras observaciones, bien conformes entre sí los relojes marinos de entrambas corbetas, de $12^{\circ}$ I $2^{\prime}$ al Occidente de Montevideo.

Conseguido este objeto, y siendo nuestro ánimo el atracar á la costa del Fuego desde el Cabo de Espíritu Santo, hízose señal á la ATREVIDA para que pasase á nuestra voz, y se encargó á D. José Bustamante, que pues tenía á su bordo 
Dic. 28 los diarios de Sarmiento, navegase aquella noche de tal modo que pudiésemos pasar entre la costa y el bajo que indicaba aquel navegante, adquiriendo al paso aquellas señales sobre su existencia que las circunstancias dictasen por prudente. Se le prescribía después, que la distancia por navegar hasta la mañanita siguiente, no fuese mayor de diez leguas, lo cual logrado, estaríamos seguramente á la vista del Cabo de Espíritu Santo. El viento á la sazón era del Norte, los horizontes cerrados con garua y los rumbos adoptados por la ATREvidA, variaban, según las sondas, del Sursudeste al Sudeste de la aguja.

Fueron éstos tan acertados, que á la hora indicada, nuestra posición era en efecto cual nos la habíamos propuesto. De la ATrevida nos dijeron á la voz que en la noche le había disminuído el fondo hasta las I4 brazas y aumentado después á las 45. La tierra se conservaba aún fosca y el tiempo muy calimoso y vario.

Pero declarado poco después viento bonancible del Nordeste y despejada algún tanto la tierra, pudimos dirigirnos á reconocer su verdadera posición, precavido, sí, en los rumbos, pues que el viento parecía quererse mantener fresco y la dirección de la costa se inclinaba mucho más al Este de lo que la indicasen las cartas del Capitán Cook y del viaje al Magallanes. Desde luego, guiados del derrotero de los Nodales, aunque bien confuso, pudimos reconocer la costa inmediata al Cabo. Dejamos con Anson el nombre de Cabo de la Reina Catalina á la punta más Sur de la tierra medianamente alta que es contígua al primero, y ya nuestro principal deseo se dirigía á fijar los términos del Canal de San Sebastián, con cuyo objeto costeábamos la tierra baja á distancia de dos á tres leguas. Pero como el tiempo volviese á ser bastantemente calimoso, y el viento ya fresco del Esnordeste hiciese más bien imprudente el descaecer demasiado sobre las costas, quedó finalmente alguna duda sobre el extremo Sur de dicho canal, nó á la verdad porque careciésemos de muchos datos bien probables para determinarle, sino porque no era posible combinar su latitud con la que habían indicado los Nodales. Convenía en general su configuración, particularmente la señal de empezar las tierras altas y nevadas, desde el extremo Sur del Canal de San Sebastián y desde el Cabo de Penas. Era nues tra latitud de $53^{\circ} 23^{\prime}$ y la longitud de I I ${ }^{\circ} 4^{\prime}$ $30^{\prime \prime}$, deducida ésta de un promedio de las observaciones de la mañana con la tarde, y traídas con la estima, en la cual no se hacía-visible efecto alguno de corrientes.

El viento, inclinado ya al Estenordeste, fué arreciando con la tarde y oscureciendo la tierra, de la cual no distaríamos á las cuatro sino dos á dos y media leguas, y era en nuestro entender la inmediata al Cabo de Penas. Las sondas se con- INic. 29 servaban de 39 y 35 brazas fango. Viramos al Norte, y poco después rolando el viento al Este, le ceñimos al primer cuadrante, aumentándolas á 44, 42 y 40 brazas, chinitos y caracolillo. Ya no se descubría la costa y áun á ratos se nos hacía difícil la conserva con la A Trevida. Calmó luégo en un todo el Nordeste hacia las diez, y á la media noche ya se había declarado al Sur y Sursudeste bonancible. Amaneció con tiempo hermoso; distábamos de la costa unas cinco leguas y todo nos convidaba á dirigirnos inmediatamente á su reconocimiento y situación, tanto más que alcanzábamos en las tareas de este día la vista del Cabo de Penas, en el cual habían concluído las bases del dia anterior.

En efecto, la costa desde este paraje empicza á ser alta y nevada, pero no con tal horror que no descubra en las inmediaciones del mar diferentes valles y llanuras, en donde la vegetación parece esplayar todo su verdor y hermosura. La nieve ó hielo sólo deja verse en las cimas agudas de los montes hacia la parte del Sur, y sembrada, digámoslo así, en pequeños montones en los cuales brilla el Sol, representa un contraste más bien agradable de las dos estaciones más opuestas entre sí. Esto nos dió lugar á congeturar que el verano estaha más bien adelantado sobre las costas, concurriendo unánimes á apoyar aquella idea, los tiempos apacibles que habíamos disfrutado á lo largo de la costa patagónica y la serenidad y temple agradable que experimentábamos en aquel día. A medida que íbamos entrando en meridiano, de diferentes puntos notables se observaban longitudes con el número 6I. El todo se ligaba con pequeñas bases y áun para no alterarlas se habían puesto las sondas al cargo de la ATREvidA, la cual nos señaló á las ocho y á las diez 40 y 37 brazas de fondo, distando entonces como dos leguas de la costa.

Las tareas astronómicas del Capitán Cook empezaban en el Cabo Santa Inés, desde cuyo punto hasta el Cabo San Juan de la Isla de los Estados y hasta la Isla de la Recalada al Oeste del Cabo Negro, nos aseguraba aquel navegante que todas las longitudes estaban ligadas entre sí por medio de los relojes marinos y sujetas á la que había determinado al Cabo de Hornos, por muchas series de distancias lunares en $6 \mathrm{I}^{\circ} 3 \mathrm{O}^{\prime}$ de Cádiz. Cualquiera fuese, por consiguiente, el error de esta determinación que el mismo Capitán sospechaba pudiese llegar á un cuarto de grado, debía manifestarse en el Cabo Santa Inés, del mismo modo que en cualquiera otra parte de las determinadas.

Con esta atención, luégo que estuvimos en posición oportuna, hicimos señal á la ATREVIDA de observar longitudes y las observamos nosotros 
Dic. so con el número 6r, de cuyo movimiento casi uniforme y áun sujeto á una corrección en sus pequeñas alteraciones, no nos dejaban la menor duda las comparaciones diarias con los otros relojes; sus resultados fueron para el Cabo de Santa Inés de $60^{\circ} 40^{\prime}$.

Pero no fueron tan uniformes con las suyas nuestras ilaciones de las siguientes longitudes, que referidas al Cabo San Diego en la entrada del Estrecho de Maire y al Cabo San Juan en el extremo Oriental de la Isla de los Estados, denotaron unánimes que las longitudes del Capitán inglés determinadas en su segundo viaje, estaban afectadas de un error de $2 I^{\prime}$ próximamente en longitud que las inclinaba demasiado al Oeste.

Al medio día estábamos en latitud de $54^{\circ}$ I o $y^{\prime}$ en longitud occidental de Montevideo $10^{\circ} \mathrm{I}^{\prime}$, variación magnética por diferentes azimutes 25 grado. I9' Nordeste. Marcábamos el Cabo Santa Inés al Oesnoroeste distancia de cuatro leguas y el Cabo San Vicente á la entrada del Estrecho de Maire nos demoraba al Sueste cuarta al Este distancia de 20 leguas.

Naregamos con fuerza de vela hasta las tres de la tarde, que arreciando mucho el viento del Oesnoroeste y cerrándose con carices cargados los cielos y horizontes, aferramos las velas menores y con gavias y trinquete seguimos costeando de modo que no se ocultasen ni la configuración de la costa, ni las longitudes de sus puntas salientes, ni finalmente aquellas vistas que sirriesen de guía para las recaladas venideras. Entre las últimas merecen el primer lugar los Tres Hermanos y el Pan de Azúcar; la posición que les da Frezier, nos ha parecido equivocada, aunque merezca los elogios del Lord Ansón. Es sumamente exacta la que indica en su carta el Capitán Cook.

Hasta las seis de la tarde no pudimos alcanzar el Cabo San Vicente, del cual distaríamos á dicha hora una legua y media; las corrientes no habian influído en modo alguno en nuestra derrota, pues unánimes lo denotaban así las diferentes bases corridas, las muchas longitudes observadas y la misma exacta uniformidad de nuestras latitudes estimadas con las correspondientes de la costa, según la carta del Capitán inglés.

No siendo nuestro ánimo el fondear en la bahía del Buen Suceso, ya debía parecernos preferente el costear la Isla de los Estados por la banda del Norte. Combinábanse así un reconocimiento más prolijo de las inmediaciones del puerto del Año Nuevo, una determinación más segura de la longitud del Cabo San Juan, para que en lo venidero dirigiese con más acierto las recaladas de los buques nacionales y también un mayor ¿prorechamiento de tiempo ya que contraria á la sazón la marea y amenazando el viento de inclinarse rápidamente al Sur, era preciso que nos mantuviésemos paireando al abrigo de la costa. Dic. 30 El atravesar desde el Cabo San Diego á la Isla de los Estados, debió, pues, ocupar la poca claridad del dia que aún nos quedaba; de suerte que eran bien las nueve cuando estuvimos Norte-Sur con el Cabo San Antonio, distancia de dos leguas. El viento al mismo tiempo habia girado al Noroeste fresco y arrafagado y por un acaso difícil á precaverse, apenas habíamos atracado la isla, cuando nos sobrecogió una corriente tan fuerte al Sur que nos aconchaba sobre la costa, de la cual no distaríamos á las diez sino dos millas escasas.

Fué, pues, preciso orzar al Nordeste y resistir una fuerza desproporcionada de vela, la cual, sin embargo, llevándonos á las once á propasar las islas del Año Nuevo á muy corta distancia, nos permitía finalmente á las doce navegar al Este corregido, con un aparejo regular. No podían ser más exactas la configuración y la dirección de aquellos contornos de lo que los habia descrito el Capitán Cook. Las islas que forman el fondeadero del Año Nuevo, se dejan ver á regular dis tancia y como sobresalen mucho al Norte, siendo al mismo tiempo bajas mientras toda la tierra de la Isla de los Estados es alta y escarpada, puede mirarse aquel fondeadero como el ménos equívoco para venir en busca suya.

A las tres de la mañana ya nos era fácil tomar algunas vistas de la costa. Midiéronse después horarios en diferentes horas y marcaciones y dieron unánimes al Cabo San Juan la longitud de $7^{\circ} 25^{\prime}$ al Occidente de Montevideo, atendiendo sólo al número $6 \mathrm{r}$, pues que los r 3 y 72 se apartaban de aquél considerablemente, el uno al Oeste y el otro al Este, dando, no obstante, un promedio enteramente igual á los resultados del primero.

Desde la mañanita, el viento, á veces claro á veces achubascado, había rolado al Oeste y Sursudoeste. Le ceñimos á ratos, otras veces navegamos algo arribados para contrarestar una corriente viva la cual nos arrastraba al Sur y hacia el Cabo San Juan; pero á las once, con una turbonada del Sudoeste ya se declaró viento fresco por aquella parte, y engruesando luégo el mar, nos obligó á precavernos con dos rizos en las gavias y con éstas y el trinquete á seguir el bordo del Sursueste

Siguió en toda la tarde bien fresco y arrafagado; al anochecer eran las mares excesivamente gruesas, y nuestro aparejo se había reducido al solo trinquete y á la gavia en tres rizos, arriada ó izada según lo exigiese la mejor conserva con la Atrevida.

Sólo en la mañana siguiente empezó el tiem- ${ }_{\text {En. }}^{\text {Iy.o }}$ po á minorar su contrariedad. El viento luégo fué rolando hasta el Oeste y últimamente al Sursudoeste. Tomáronse las muras á estribor con fuer- 
En. z za de vela y esto nos condujo para el medio día del 2 á la latitud de $57^{\circ} 3^{8^{\prime}}$ y longitud $57^{\circ} 6^{\prime}$.

Desde esta época la navegación del Cabo de Hornos fué para nosotros más bien una de las más placenteras de entretrópicos, que de las penosas á que la embarcación y el ánimo del navegante están ya bien dispuestos. La mar fué constantemente llana, los vientos variables del Nornoroeste al Sur, por lo común bonancibles y á veces acompañados ó de neblina ó de garua ó de alguna granizada casi momentánea; observamos siempre la altura meridiana del Sol y los horarios para la longitud. En los días 4 y 5 se proporcionó observar azimutes, los cuales dieron unánimes la variación de $26^{\circ} 30^{\prime}$.

Las distancias lunares observadas en la mañana del 8 , en número de 56 séries, aproximándose mucho á los relojes, dieron lugar á la esperanza de que su marcha se conservase uniforme.

El 6 había sido la mayor latitud observada de $60^{\circ} 43^{\prime}$. Las diferencias con la estima eran considerables, pero unas veces al Sur y otras al Norte. En la longitud no las hubo de entidad al principio; pero desde el 8 hasta el I2 se manifestaron corrientes bastantemente rápidas hacia el Este entre los paralelos de $57^{\circ}$ y $59^{\circ}$.

Fué también muy feliz para nosotros en aquellos días el encuentro que tuvimos de la fragata del comercio de Cádiz, Santa María Magdalena, su Capitán, Piloto y Maestre D. Martín Antonio de Iturriaga, la cual, con II 2 días de navegación, se dirigía á los puertos de Valparaiso y Arica. La tripulación, en número de 44 personas, gozaba de la mejor salud, ni le hacia falta la menor cosa para concluir su navegación, según lo aseguraron al Teniente de navío D. Cayetano Valdés, el cual había ido desde la mañana á reconocerla.

Metido el bote á las tres de la tarde, procuramos aprovechar para nuestra derrota las diferentes ventolinas que se nos presentaban y las cuales (si se exceptúa un chubasquillo del Este casi momentáneo) nos dejaron casi siempre sin gobierno. Sólo por la mañana entabló viento flojo del cuarto cuadrante, que ceñimos inmediatamente con todo aparejo al Sudoeste. Hablóse á la ATREvIDA para comunicarle las noticias adquiridas el día antes, y supimos en aquella ocasión, que la longitud de sus relojes, conformes entre sí, coincidía al medio día anterior en el minuto, con nuestras longitudes sujetadas al número $6 \mathrm{I}$. La latitud fué de $5^{8^{\circ}} 6^{\prime}$ y la longitud de $20^{\circ} 24^{\prime} 30^{\prime \prime}$ al Occidente de Montevideo. La fragata mercante distaba de nosotros unas tres leguas al Sudeste, y como no tardase el viento en pasar del cuarto cuadrante al tercero y aquélla le ciñese de la vuelta del Sur opuesta á la que seguían las corbetas, se perdió de vista hacia las seis de la tarde.
Restituídos poco después los vientos á su an- En, 13 tiguo semblante apacible é inclinándose paulatinamente del Noroeste al Norte y Nornordeste volvieron nuestros progresos en longitud á ser más bien considerables; los rumbos que procurábamos seguir torcían al Norte, aprovechábase tal cual hora de calma para comunicarnos con la otra corbeta aquellas dudas ó noticias las cuales pudiesen acelerar la ordenación de las pasadas. tareas 'y hacer útil en cierto modo la inacción hidrográfica en la cual vivíamos en la actualidad. Repetíanse las observaciones y los exámenes sobre los relojes marinos, y considerándonos ya en el Mar Pacífico, vencida la longitud de $22^{\circ} 33^{\prime}$ de Montevideo, se avivaba la esperanza de poder cuanto antes emprender de nuevo y para mucho tiempo aquella serie de operaciones científicas á la cual nos habíamos contraído.

La situación del navegante en aquellos mares $y$ en unas regiones tan distantes de las que le vieron nacer, es sin duda alguna de las más extraordinarias que puedan acontecerle.

La incertidumbre le rodea á cada instante; una sola mirada hacia las costas más cercanas le recuerda en una complicada perspectiva el naufragio, el frío, el hambre y la soledad. Vuélvese al Polo, y una nueva clase de peligros, aún más temibles, se desplega instantáneamente á su imaginación; campos inmensos de escollos de hielo, amenazan la frágil nave. No basta procurarlos evadir con cuantos auxilios dicta un arte falible: ellos mismos son los perseguidores, y su posición, variable á cada instante y con tantas direcciones cuantas son las islas, aumenta el riesgo y la desconfianza. La tenacidad de los Oestes parece al mismo tiempo oponerse directamente á la continuación del viaje: su violencia no permite á veces sino poca vela, las olas mo. vidas con un impulso tan violento y tan constante agitan la nave con balances extraordinarios y la exponen á cada paso á desarbolar. Las corrientes le son al mismo tiempo contrarias, el retroceso ignominioso y mil veces fatal á su misma conservación. Tales son las contrariedades que opone la navegación en aquellos parajes, y que, sin embargo, vencen cada día con más facilidad, reunidas á porfía la codicia y la ciencia del arte marinero.

Pero ya en la posición en la cual nos hallábamos, debíamos considerarnos libres de los peligros indicados, pues los vientos tempestuosos del Sudoeste podían ceñirse constantemente con las muras á babor, y este.rumbo nos conducía á disminuir rápidamente la latitud. En efecto, para el medio día del 18 , aunque hubiésemos sufrido temporales recios, nuestra latitud era de $5^{2}, 35^{\prime}$. El Cabo Victoria nos demoraba al Este $490^{\circ} 50$ leguas.

En esta disposición, y franqueado el paso al 
En. io Mar Pacílico, debíamos tomar á la vista los objetos de la expedición para dirigir con más acierto la derrota siguiente. Eran éstos de fijar los límites en longitud de la costa occidental patagónica, sin exponer intempestivamente los buques, de reunir nuestras tareas á las que se hubiesen hecho anteriormente y mereciesen alguna confianza; finalmente, de Hlegar á Chiloé en estación oportuna para continuar el reconocimiento prolijo y científico de la costa siguiente al Norte, el cual debía ocuparnos en todo el año de I79o; no ignorábamos al mismo tiempo que los vicntos reinantes sobre la costa eran travesías tempestuosas con mares gruesas, y que en los meses siguientes de Febrero y Marzo no sería tampoco extraño el aparecimiento de los vientos Nortes, los cuales por su fuerza, duración y cerrazones, han sido siempre temidos en aquellos mares. El Cabo Victoria y los Evangelistas podían ya considerarse como situados con la mayor exactitud hidrográfica, dependiendo directamente de las observaciones de los Tenientes de fragata $D$. Cosme Churruca y D. Ciriaco Cevallos (I). Por otra parte, la expedición del Piloto Machado desde San Carlos de Chiloé en I765, conducía las marcaciones por allí hasta el Cabo Corso en latitud de $49^{\circ} 30^{\prime}$. Así no quedaba realmente para reconocerse sino el trozo comprendido entre aquellos extremos ó entre los paralelos de $52^{\circ}$ y $49^{\circ}$, en donde podían mirarse como algo dudosas las determinaciones del Capitán Sarmiento, si bien hechas por un navegante tan experto é interpretadas luégo con exquisita crítica por los Tenientes de navío D. Dionisio Galiano y D. Alejandro Belmonte (2).

No tardó mucho, adoptado ya el plan que dimanaba de aquellas reflexiones, en manifestársenos tiempo al parecer oportuno para el intento. En la noche del I9, sobre algunos chubascos con granizo, se declaró viento fresco del Sur y Sursudoeste, el cual, convidándonos á naregar hacia la costa y prometiendo la ocasión favorable para hacer al mismo tiempo algunas observaciones, ya para cl medio día siguiente por latitud de $5 \mathrm{I}^{\circ}$ I $7^{\prime}$, nos había aproximado á unas 20 leguas del Cabo Santa Lucía. No parecían, pues, infundadas nuestras esperanzas de empezar en aquclla misma tarde los reconocimientos proyectados; pero muy luego debimos recordarnos del paraje en el cual nos hallábamos, siendo así que á las cuatro nos había al. canzado viento tempestuoso del Oeste con las acostumbradas cerrazones y mares gruesas, cl

(1) En la expedición de los paquebotes Enlalia y Cirsilda (ano de 589 ) mandada por el Brigadier Don Antonio de Córdoba.

(2) lineron destinados en I 786 al Estrecho de Magallanes ('n la liagata Cubest, mandada por el Brigadier J). Intonio de Córdoba. cual nos obligaba á precavernos con otros rum- En. 20 bos de los que habíamos seguido hasta entonces.

Empero como á este tiempo hubiésemos alcanzado una distancia de la costa no mayor de I7 leguas, y por otra parte, antes de cerrarse los horizontes, pudiésemos con toda certeza fijar la extensión de nuestras visuales hasta unas ro le. guas, los límites en longitud para aquel cabo podían considerarse determinados con una certeza evidente, á lo ménos por lo que tocaba á una posición más occidental. de la que le suponía la carta agregada á la narración del último viaje al Estrecho de Magallanes.

La noche fué lluviosa con viento arrafagado y mares gruesas; siguióse la vuelta del tercer cuadrante hasta la mitad de ella; viramos luégo con vientos del Oeste al Nornoroeste; así al medio día siguiente, por latitud de $5^{\mathrm{I}^{\circ}} \mathrm{I} 7^{\prime}$, el Cabo Santiago demoraba al Este $2 \mathrm{I}^{\circ}$ Norte 22 leguas próximamente; y pues el tiempo había tomado un semblante algo más favorable volvían á revivir nuestras esperanzas de avistar la costa.

El cogerla al Norte del Cabo Santiago y cl cogerla temprano para que recorriéndola por todo un día nos condujese á la vista del Cabo Corso, debió ser por la misma razón el objeto esencial de la navegación siguiente; continuáronse en la tarde rumbos del Norte; arribamos al anochecer hacia el Este, y hechas desde la media noche algunas horas de pairo, ya que la calima nos avisaba de hallarnos en muy buena posición, logramos efectivamente á las tres y media del 22 la vista de un trozo considerable de costa.

Las tierras avistadas se extendían desde el Nordeste hasta el Esueste, eran altas, entrecortadas y semejantes en un todo á las que habíamos visto en la parte oriental, y á pesar que no distásemos de ellas sino unas cinco ó seis leguas, ni la sondaleza alcanzaba el fondo con I 20 brazas, ni veíamos á nuestro alrededor aquel número de pájaros que suele comunmente solazarse en los días placenteros á la vista de la costa. Creímos desde luego unánimes con los Oficiales de la ATREvida, que era este trozo el comprendido en las narraciones de Sarmiento entre los Cabos de Santiago y Tres Morros; veíase un canal el cual debía ser el del Oesudoeste. Ambos extremos parecian sin tierra contígua; su dirección era del Norte 1/4 Noroeste y Sur 1/4 Sueste verdaderos y se veían pospuestas á larga distancia otras sierras sumamente altas y nevadas, próximamente en la dirección del Norte-Sur, las cuales serían con mucha probabilidad una continuación de la Cordillera de los Andes. Todo presentaba á la vista un semblante árido y (por cuanto pudiese conjeturarse á tan larga distancia) parecía ser su masa de granito oscuro. 
En, 22

No tardamos un instante en emprender las tareas correspondiéntes; se repetían las alturas del Sol, medidas con el sextante para deducir los horarios, se corrían bases ordenadas, aprove. chando toda vela; observáronse hacia el medio día unas ochenta series de distancias lunares, y como se consiguiese también el observar la altura meridiana del Sol, justamente cuando marcábamos á larga distancia el cabo Corso, no debió parecernos enteramente malogrado nuestro intento, aunque el viento hubiese sido débil en toda la mañana, y muy luégo le sustituyese el Noroeste y Oesnoroeste tempestuoso con las mares y cerrazones que solían acompañarle. Nuestra latitud había sido de $50^{\circ} 4^{\prime} 30^{\prime \prime}$; la longitud de $20^{\circ}$ II $^{\prime}$ al Occidente de Montevideo; la variación magnética por diferentes azimutes de $2 \mathrm{I}^{\circ} 2 \mathrm{O}^{\prime}$ y el resultado medio de las distancias lunares, diferentes de los relojes solamente en ocho minutos. Podía deducirse de los datos indicados, que la latitud del cabo Corso sería de $49^{\circ}$ $27^{\prime} 30^{\prime \prime}$ y su longitud al Occidente de Cádiz de $69^{\circ} 40^{\prime}$ algo más occidental de lo que manifestaba la carta al Magallanes, pero mucho más al Este de lo que había sospechado el Sr. D. Antonio de Ulloa.

Cerrado casi enteramente el tiempo con 1luvia, ráfagas y mares tempestuosas, fué preciso navegar al Oesudoeste de la aguja, con el solo trinquete y la gavia en dos rizos; á ratos se nos hacía difícil la conserva con la Atrevida, los balances nos amenazaban á cada instante de algunas averías en la arboladura. Pocas aves y algunos lobos marinos eran los únicos compañeros que dividian con nosotros en estos climas desiertos la tenacidad de los elementos, constantes sólo en su dureza y contrariedad.

Al medio día del 24 fué cuando pudimos concebir de nuevo algunas esperanzas de lograr unos tiempos algo más favorables: con vientos del Oeste ménos recios y algo más despejados reviramos al Norte y fué nuestro intento el resarcir las pérdidas adquiridas en la latitud, las cuales, más bien por efecto de las corrientes, que del rumbo seguido, no habían sido menores de 50 á 60 minutos. Nos fué fácil en esta ocasión el alcanzar la latitud de $49^{\circ} 32^{\prime}$ y el emprender inmediatamente después rumbos directos hacia la costa, siendo nuestro ánimo el atracarla por los $49^{\circ}$, de tal modo, que ligásemos con las tareas del día 22 sobre el cabo Corso, las que ahora se nos pudiesen proporcionar; pero no bien habíamos empezado en la tarde del 25 á aproximarnos de nuevo á la costa, cuando volvimos á vernos rodeados de las contrariedades acostumbradas.

Este tercer ensayo ya no dejaba duda de la constancia de los vientos contrarios, tanto más recios, cuanto mayor fuese la inmediación á la costa. Además, que siendo momentáneos los En. 24 vientos del Sur, igualmente cerrados y tempestuosos los del Noroeste y siempre inmediata á ellos la travesía del Oeste, ni sería asequible reconocimiento alguno, ni pudiera á veces evitarse el ser cogidos á poca distancia de la costa, con un riesgo evidente de naufragar. En el entretanto nuestras circunstancias, sea en cuanto al temporal ó en cuanto al aparejo, eran en mucho peores de las que habíamos sufrido en los días anteriores. Fué preciso ceñir de nuevo hacia el Sur y resistir una fuerza extraordinaria de vela; se nos hizo á ratos peligroso el solo aparejo del trinquete y la gavia en dos rizos arriada: pasáronse así días enteros entre esta lucha contínua con los elementos, y era, sin embargo, una perspectiva para nosotros bien desagradable, la que nos recordaba que en el espacio de seis días, apenas habíamos ganado un medio grado en latitud, si bien los masteleros y los mismos buques se hubiesen comprometido más de una vez entre las ráfagas y contrastes que nos ocasionaban frecuentemente.

Pareció, pues, haber llegado el tiempo oportuno para que abandonásemos unas regiones tan directamente opuestas á la navegación y pensásemos en transferirnos á Chiloé. Alejados de la costa con los bordos que habíamos debido seguir en los días anteriores, pudimos conservar el del Norte, y éste, conduciéndonos muy luégo á latitudes más suaves, nos presentó ya por algunos momentos las ideas casi olvidadas de los climas apacibles de los trópicos. Nos hallamos el 28 en latitud de $47^{\circ} 4 I^{\prime}$ y longitud $22^{\circ} 50^{\prime}$ de Montevideo; la variación magnética por ambos métodos de los azimutes y de las amplitudes era de $19^{\circ} \mathrm{o}^{\prime}$ al Nordeste.

Debía á la sazón complacernos mucho el estado bien robusto de una y otra tripulación. La ATREVIDA nos di jo que no tenía enfermo alguno de entidad. En la Descubierta, tres ó cuatro marineros que habían tenido algunos principios de calenturas catarrales ó tal cual ardentía de sangre, se hallaban curados en pocos días; y lo que debía parecer extraño, á pesar de los fríos y de las lluvias, apenas se hacían perceptibles en uno ú otro los síntomas terribles del mal venéreo. Atento á los principios adoptados para la conservación de la salud, y de los cuales daremos en otro lugar una idea más individual, cesó e estos paralelos la distribución del cuartillo diario de vino, se le sustituyó la ración de Sorer krout ó coles agrias por tres veces á la semana. El gazpacho tomó el lugar de las sopas de aceite, y la ventilación, el aseo y la tranquilidad del ánimo, fueron nuevamente los resortes principales que se adoptaron por nuestra parte para la conservación sucesiva de la salud, la cual en estos tránsitos rapidísimos del calor y el frío, me- 
En. $\&$ rece sin duda alguna la atención más prolija y rellexiva.

Abandonadas como se ha dicho las costas occidentales que acabábamos de visitar en parte y cur parte debíamos mirar como inaccesibles, ya nuestra derrota debió acercarnos rápidamente á las costas de Chiloé.

En la tarde del 30 , rodeados de una neblina espesísima, sondamos 90 brazas piedra, lo cual nos hizo sospechar que estaríamos inmediatos á la Isla de Guafos, no distante al Sur de la de Chiloé; y sobrecogidos en la noche siguiente de un fuerte contraste del Sudoeste, el cual nos precisó á navegar con dos rizos en las gavias, procuramos al principio seguir tales rumbos, que nos ale jasen algo de la costa, avistada al parecer hacia la media noche; después volvimos de nuevo á dirigirnos hacia ella para atracarla y aproximarnos al puerto.

La tierra á la vista era bastantemente elevada; bajaba luégo desde su medianía para el Norte y presentaba un semblante tan agradable por 10 frondoso de sus bosques, como horrible por lo cscarpado de sus costas, cuyas desigualdades sin embargo no descubrían entrada ó puerto que las hiciese accesibles. Eran las que corren desde los altos de Cucao hasta la punta septentrional de la isla y cuya vista si continuase el viento fresco del Sudoeste, hacía esperar que no sería difícil alcanzar para el día siguiente el puerto de San Carlos.

Paireamos en la noche con el mismo intento hasta que siguió el viento fresco: abonanzado éste, arribamos hacia aquel extremo; así, al amanecer no distábamos sino tres leguas de la costa y nuestra posición era tal que en pocas horas hubiéramos podido internar en el puerto; pero nos cstaba destinada una extraña equivocación la cual debía en parte apoyar con la experiencia cuánta fuese la necesidad de unos planos exactos de aquellas costas; el que nosotros teníamos era evidentemente equivocado en la escala de las distancias y en la posición respectiva de las puntas que formaban la boca, lo cual nos persuadió á que la entrada estuviese en una ensenadita al Sur de la punta de Cocotuya, confundida ésta con la Punta Capitanes en el Continentc. Es aquella ensenada no muy honda, con algunos islotes entresembrados y unos altitos notables en la tierra alta, los cuales hacen de tal modo engañosa la proyección real de la costa, que á la distancia de dos leguas no es fácil apercibir el errol, tanto más que coincide la latitud con la del pueblo interior y como sucede frecuentemente no se distingue otra tierra al Norte.

Con estos antecedentes no parecerá extraño que continuase nuestro error áun después de observada la latitud, y que aprovechando los vienlos variables á las veces del Norte, á las veces del Oeste, los cuales nos proporcionaban diferen- Feb. x. tes bordos, no alcanzásemos hasta las tres de la tarde á resolver enteramente las dudas contraídas desde el principio de la mañana. Echamos el bote al agua, paireose algún tiempo á media legua de la playa, en la cual, finalmente disipada también la neblina que la of uscaba, se conoció claramente que en lugar de abra sólo había una continuación peligrosa de arrecifes; el fondo era de 22 brazas conchuela y cascajo; al medio día le habíamos hallado de 30 brazas, misma calidad.

Fué, pues, preciso ceñir con todo aparejo para separarnos algo de la costa; hízose señal á la ATrevidA, la cual estaba á barlovento nuestro, para que reconociese con mayor individualidad las inmediaciones del puerto, y efectivamente, señaló poco después el que las distinguia claramente al Norte de la punta de Cocotuya; nosotros entonces ya nuevamente á media milla de la costa, debimos revirar al tercer cuadrante y navegar hacia el Oeste, tanto por la proximidad de la noche, como porque las apariencias del tiempo amenazaban próximo un temporal. En esta ocasión perdióse la ATrevida de vista, la cual no distinguiendo la señal de unión se habia conservado á barlovento. Y pues la noche y el día siguiente fueron con exceso cerrados y tempestuosos obligándonos sólo á cuidar del aparejo y de los bordos que nos conservasen en buena disposición, no fué fácil el reincorporarnos hasta la tarde del 3; en la noche anterior la Descubierta había atracado nuevamente la costa, y paireado á dos leguas de ella; pero reconociéndola con más claridad por la mañana de suerte que estuviese aún distante al Norte la boca del puerto, le fué preciso revirar y con este motivo encontrar la ATrevidA, la cual navegaba de la mura opuesta.

No permitieron los vientos sumamente variables y lluviosos, el conseguir ventaja alguna en la restante tarde y en la noche inmediata; pero finalmente, en la mañana del 4 entablado viento fresco del Sur y Sudoeste nos fué fácil, hecha toda vela, el atracar la punta de Cocotuya, y á pesar de la contrariedad de la marea el alcanzar para el anochecer las inmediaciones del puerto, en donde extinguidas casi al mismo tiempo las últimas ventolinas de fuera, dejóse caer un ancla en seis brazas fango: en esta posición la batería de la punta de Yaqui, extremo occidental del puerto, nos demoraba al Sudoeste distancia unos cuatro cables; no tardamos en la mañana siguiente en aprovechar de la marea para internar en el puerto con el auxilio de los remolques. Al medio día entrambas corbetas estuvieron amarradas en buen paraje y todo dispuesto para acelerar cuanto fuese posible las operaciones que debían detenernos en el puerto. 
En efecto, desde las primeras horas de la manaña se había remitido á la población la mayor parte de los instrumentos astronómicos, y franqueada casa oportuna desde donde fuese fácil la comunicación por señales con las corbetas, se había armado el péndulo y dispuesto el cuarto de círculo. Así en la noche inmediata, los Oficiales astrónomos pudieron observar diferentes alturas meridianas de estrellas al Sur y al Norte del zénit, malograda por la interposición casi momentánea de algunas nubes la observación de una estrella ocultada por la Luna; y en la mañana del 6 ya las lanchas y botes se ocupaban con tesón de los reemplazos de agua y leña, mientras los restantes Oficiales atendían cada cual á multiplicar los objetos útiles de la expedición.

Era á la sazón Gobernador de la Isla de Chiloé el Coronel D. Peđro Garoi; guarnecian á la plaza, además de una plana mayor, algunas compañías de infantería, artillería y dragones. $\mathrm{Y}$ pues que en las últimas combinaciones del Gobierno relativamente á la América Meridional, se había particularmente comprendido aquella parte hasta entónces olvidada de los dominios ultramarinos, las primeras medidas útiles para este intento eran las de atraer por una parte la amistad y confederación de los pueblos contiguos no bien sujetos á la Monarquía; por la otra, de reconocer y describir con la posible exactitud hidrográfica las costas y los muchos puertos útiles de toda la isla. Apenas habia concluído este objeto el Piloto de la Armada D. José Moraleda con algunas piraguas. Entendian con asiduidad en la pacificación indicada, así el Presidente y Gobernadores de la frontera del Chile, como los de Valdivia y Chiloé, haciendo respetar á las veces el nombre español cuando hubiese alguna traición que quebrantase la buena fé de los tratados, á las veces agasajando con regalos cuantiosos á aquellos caciques y soldados que más bien se inclinasen á la vida sociable y amistosa con nuestras colonias.

Debió, pues, parecernos una verdadera felicidad, la que nos proporcionaba en los mismos días de nuestra llegada el conferenciar por la una parte con el mismo Moraleda sobre el éxito de su pasada comisión y por la otra el asistir á las concurrencias de algunos caciques y soldados viliches, los cuales por primera ve $z$ hacían una visita al Grobernador. Tuvieron éstos su primera audiencia en la mañana del 6; eran unos cuarenta y cuatro, presididos del Cacique Catiguala; dos ó tres Capitanes de amigos procedentes de Valdivia y acostumbrados á vivir entre ellos desde mucho tiempo les servían como intérpretes; y para dar una mayor solemnidad á la visita, habíase de nuestra parte reunido la Oficialidad, y por parte de ellos, se procuraba conservar en la comitiva un cierto orden; la acompañaba con el mismo in- tento una música no muy grata y compuesta de Feb. algunas cañas largas y huecas, cerrado casi del todo el un estremo con hojas de árboles; los más robustos soplaban con mucha fuerza por un agujero lateral y cuando estuviesen cansados les reemplazaban algunos otroš inmediatamente.

Puestos nosotros en torno, los viliches, á imitación del Cacique, fueron desfilando y dándonos la mano uno á uno, acompañada esta muestra de amistad con la voz de compá, la cual seguramente aludía al epíteto de compadre. Emprendió después una arenga bien larga el Cacique Catiguala. Recordaba al Gobernador el largo plazo en el cual había sido interrumpida la comunicación recíproca; veía con mucha complacencia un suelo que habían habitado sus antepasados, y debía mirarse como una prueba evidente de la sinceridad de sus proposiciones, el que ahora viniese á visitarle y á estrechar con más solidez los vínculos ya entablados de una amistad duradera. Respondió el Gobernador asegurándole en nombre de S. M., que seria por su parte inviolable la fé de los tratados; que verían en los dones repetidos una prueba nada equívoca, así de la generosidad del Monarca, como de su deseo de atraerlos á una vida tranquila y sociable; y que en el entretanto podrían descansar de sus fatigas pasadas, pues se les darían en nombre de S. M. habitación, alimento y cualquiera otra cosa que solicitasen. Con el mismo orden y una igual formalidad, hablaron después otros caciques inferiores; y seguramente inclinados por naturaleza á esta especie de arengas solemnes, las hubieran continuado por mucho tiempo si no les interrumpiese oportunamente el refresco compuesto casi en un todo de licores espirituosos, á los cuales son por naturaleza extremadamente propensos. Bebieron por largo rato, pasearon después las calles y en breve tiempo hicieron conocer que la música que los acompa. ñaba era más bien una instancia para que los convidasen de nuevo á beber, que un obsequio y una muestra de las ideas pacíficas que les animaban.

No había sido ménos oportuno (como ya se dijo) el encuentro del Piloto D. José Moraleda, el cual no sólo había trabajado y conservado las cartas más detalladas de las costas del Perú, si también habiendo navegado por muchos años en aquellos mares, conocía mejor los vientos, las estaciones y los parajes más ó ménos trillados, los cuales debiésemos visitar. Por orden del Virey del Perú nos entregó dichas cartas y los planos y derroteros últimamente trabajados sobre toda la isla de Chiloé; el Gobernador de ta plaza nos franqueó al mismo tiempo varias noticias relativas al conocimiento verdadero de aquellos contornos, y pudieron los Tenientes de navío Tova, Valdés y Quintano, hacer una breve 
Fel. \& excursión hasta la capital de Castro, situada en la costa oriental de la isla, con el objeto de indagar más de cerca el país interior y las costumbres de los naturales.

Los días siguientes, por lo común serenos y templados, dieron lugar á que no procediesen con lentitud los muchos ramos científicos que intentábamos abrazar. D. Antonio Pineda, con un Guardia Marina, extendió sus excursiones unas veces hacia Chacao, otras hacia las orillas de Oeste. D. Feljpe Bausá, levantado el plano interior del puerto, seguía luégo los triángulos por medio del teodolito, hasta donde lo permitiese nuestra demora en aquellos contornos. Algunos soldados cazadores suministraban nuevos objetos de curiosidad y de instrucción para la Historia Natural; admiraba D. Luis Nee, vagando ya á una ya á otra parte con una actividad singular, la variedad indecible de las plantas y la fertilidad del suelo. Finalmente, los Oficiales as trónomos, aunque á veces contrariados por las nubes, habían sin embargo llevado sus tareas con tal felicidad, que el examen de la marcha de los relojes y la determinación segura de la longitud podían mirarse como hien conseguidas al poco tiempo de nuestra llegada.

La inmersión del primer satélite de Júpiter observada en la noche del 6, manifestó (corre. gidos los errores de las tablas) que el observatorio estaría $67^{\circ} 3^{6^{\prime}} \mathrm{o}^{\prime \prime}$ al Occidente de Cádiz. Los relojes uniformados con las ecuaciones correspondientes, determinaban $I 7^{\circ} 48^{\prime} 30^{\prime \prime}$ entre el mismo observatorio y el de Montevideo. Finalmente, So series de distancia del Sol á la Luna, indicaban la longitud de $67^{\circ} 2 I^{\prime}$ menor en $I 5^{\prime}$, de la que se había deducido del primer satélite expresado; variación de la aguja por muchos azimutes, $\mathrm{I} 7^{\circ} 2 \mathrm{O}^{\prime}$ Nordeste; latitud Sur, $4 \mathrm{I}^{\circ} 5^{\mathrm{I}^{\prime}} 5 \mathrm{O}^{\prime \prime}$.

Solicitada por nosotros, tuvo lugar á bordo en la mañana del II una visita de todos los viliches, de los cuales se ha hecho memoria: comieron abundantemente, manifestaron su constante propensión á las bebidas; hubo lugar para que el pintor D. José del Pozo retratase con mucha propiedad á Catiguala y á su hijo; pudimos, finalmente, en una larga y bien ordenada conversación, enterarnos de muchas costumbres suyas y de su roce y comunicación con las tribus de los Patagones.

Reconcentradas el mismo día á su destino las diferentes partidas que se habían destacado, y completados los acopios de agua y leña, se de. terminó acelerar la salida, y en el observatorio tuvieron orden los Oficiales para que hacia el I3, observadas, si era posible, algunas otras inmersiones de los satélites de Júpiter; se fijase por medio de las alturas correspondientes del Sol, la última época relativa al examen de la mar. cha de los relojes. Empero estas medidas no pudieron verificarse por algunos días, porque Feb. I las inmediaciones del novilunio inclinaron desde aquella misma tarde los vientos al Norte y al Noroeste, tempestuoso, con cerrazones y lluvia; de suerte que tuviésemos interrumpida á veces hasta la comunicación de los botes y se hiciese infructuosamente arriesgada la conducción de los instrumentos. Así sólo en la noche del I5 pudimos ver concluídas aquellas medidas y restituído el tiempo á su antiguo semblante apacible, disponernos sin perder tiempo para la salida. No se omitió en aquella misma noche la observación en la plaza inmediata de la emersión del primer satélite de Júpiter, la cual, comparado inmediatamente con señales de pistola, el reloj conducido á tierra con los demás de á bordo, confirmó con iguales resultados la longitud que habíamos deducido en la noche del 6 .

Un solo ramo en el entretanto había tras. tornado en cierto modo la felicidad con la cual habíamos podido abrazar en pocos días los diferentes objetos del viaje; y era éste la conservación á bordo de una disciplina exacta, cual convenía, ó más bien era necesaria en los muchos trances en los cuales debíamos encontrarnos en lo venidero. El puerto á do nos hallábamos, no podía á la verdad ser más oportuno para que dejando algún tanto la rienda á la disciplina militar, intempestiva por otra parte en esta comi. sión, fundásemos sobre la experiencia, más bien que sobre tradiciones ó caprichos, el método más oportuno que habíamos de seguir en los demás. El vecindario de Chiloé (mediante su ninguna comunicación con la matriz) carecía enteramente de españoles, lo cual daba un nuevo realce á los que procediesen directamente de los puertos del Continente; y los representaba á las veces como poseídos del mismo valor, constancia y dominación de los conquistadores, á las veces como los únicos capaces de dirigir y fomentar una familia entre las labores del campo y la industria del comercio. Reuníase después á estos antecedentes, por sí razonables, una suma mezquindad en las mujeres, naturalmente propensas al libertinaje, una cierta indolencia incorregible en los hombres, la cual les hacía como necesaria la bebida; finalmente, un desmayo indispensable en el sistema gubernativo, para que unas veces mirase la presencia de nuevos colonos como un aumento feliz de su fuerza y autoridad, otras no hallase resortes oportunos para refrenar los pasos uniformes de la colonia al tiempo ó de viciarlos ó de seducirlos. Tantas razones reunidas no podían ménos de dar, finalmente, al hombre de mar, una errada idea de la felicidad. Por una parte todo le convidaba al desorden y á la deserción; por la otra recordaba aún las fatigas y peligros pasados en la navegación del Cabo de Hornos. ¿Cómo resistiria á tamaña perspec- 
y no se decidiría, finalmente, á variar de suerte abandonando el buque de su destino y olvidando en un solo instante su patria y su familia?

Así, casi en los primeros momentos de nues tra comunicación con el pueblo de San Carlos, pudo advertirse la falta casi constante á la hora señalada para el regreso á bordo del mayor número de nuestros soldados, marineros y criados; algunos permanecieron varios días en tierra á pesar de una expresa prohibición para verificarlo; muchos se entregaron con abandono á la bebida; no tardó después un soldado de la ATREviDA, el cual solía permanecer en tierra para custodia de las fraguas y de la ropa lavada de los marineros, en ceder á las seducciones de un labrador no distante, quien le convidó á la deserción y al robo de muchos utensilios de la misma fragua y de toda la ropa que tuviese á mano. Tamaños desórdenes exigieron por sí unos remedios bastantemente activos; y por la misma razón, al paso que se ofrecieron premios á cualquier paisano que entregase ó soldados ó marineros, después de haberse separado los botes del embarcadero, se castigaron los delincuentes con algún rigor, según los métodos establecidos en la Armada. Aprehendióse también por la actividad del Teniente de fragata D. Francisco Viana, el soldado de la ATREvida que había robado los utensilios de la fragua, y se le castigó con tres carreras de baquetas reunida la tropa de entrambas corbetas. Esto no bastó, sin embargo, para que pudiésemos cortar del todo la deserción y el desorden; y al tiempo de dar la vela echábamos aún de ménos ocho marineros: los cinco, de la Atrevida, y tres de la Descubierta. Quien considere con alguna atención cuánto se apartaba por necesidad en una comisión como la nuestra el método de disciplina del que siguen comunmente los buques de S. M., conocerá que era imposible el no abandonar mil veces al marinero á sí mismo, siendo así que cinco embarcaciones menores estaban en un contínuo trabajo; que la sola caída maliciosa de un instrumento al tiempo de embarcarlos ó echarlos en tierra pudiera causarnos una pérdida irreparable; finalmente, que la quietud y una subordinación habitual y voluntaria serían los medios seguros para aquella harmonía de nuestras fuerzas y ocupaciones, sin la cual no se hallarían á cada paso, sino inconvenientes y lentitud.

Todo así dispuesto para dar la vela en la mañanita del I6, cuando aún fuese favorable la marea, estuvimos efectivamente á pique con las primeras claras del día, y la Descubierta, ayudada de los remolques, emprendió el aproximarse á la Punta de Yagui para estar algo más franqueada y aprovechar la otra marea. La ATrevidA no varió de posición, y como no empezasen á asomar sino á las dos de la tarde las primeras $F e b$. 6 ventolinas del Oesudoeste al tiempo que apuntaba la vaciante, sólo á esa hora pudimos entrambas dirigirnos con todo aparejo hacia la boca del puerto, y empezar una lucha con los tiempos contrarios, la cual no imaginábamos jamás que debiese durar por el espacio de cuatro días. Empero era tanta la variedad y flojedad de los vientos y tal la facilidad de la marea en oponerse directamente á nuestro intento ó en aconcharnos sobre los muchos bajos é islotes del Este, que en balde en el intervalo indicado estuvimos maniobrando á lo ménos cuatro veces al día para levarnos y dar fondo, pues siempre teníamos que volver á nuestra antigua posición con el fin de no exponernos ó al albedrío de las mareas ó á un golpe repentino de vientos contrarios y tempestuosos. El bosque espeso que cubre casi toda la isla, es sin duda alguna la causa más activa para que reinen en aquellos contornos con tanta frecuencia los vientos del Norte, húmedos en sí y directamente opuestos á la salida del puerto. Suelen durar en el invierno hasta treinta ó cuarenta días seguidos. En los veinte de la estación favorable del verano que habían corrido después de nuestra venida á la costa, á lo ménos diez habían sido lluviosos y dominados del mismo viento.

Procurábamos, sí, de eludir esta especie dc inacción, con inquirir por medio de la caza y de la pesca algún nuevo tributo para los progresos de la Historia Natural; y como se nos proporcionase á veces el poder medir alturas absolutas del Sol con el sextante, no habíamos descuidado un nuevo examen del movimiento de los relojes marinos, el cual era ahora tanto más necesario, cuanta mayor prolijidad nos habíamos propuesto para las operaciones venideras: efectivamente, en los relojes de la Descubierta habían sucedido alteraciones de mucha consideración, lo cual, combinado con las ecuaciones dimanadas de la comparación diaria, daba el siguiente resultado:

\begin{tabular}{|c|c|c|c|c|c|c|c|}
\hline \multirow{2}{*}{ Dias. } & \multirow{2}{*}{$\begin{array}{c}\text { Longitudes } \\
\text { por } \\
\text { marcación. }\end{array}$} & \multicolumn{2}{|c|}{ Longitudes del $6 \mathrm{r}$. } & \multicolumn{2}{|c|}{ Longitudes del 72 . } & \multicolumn{2}{|c|}{ Longitudes del I 3} \\
\hline & & Directa. & Correg." & Directa. & Cor & Directa. & Correg.n \\
\hline I 8 & $\operatorname{occ}^{\prime} x^{\prime} 4^{\prime \prime}$ & $I^{\prime} 3 I^{\prime \prime}$ & $I^{\prime} \times 5^{\prime \prime}$ & $6^{\prime} 10^{\prime \prime}$ & $x^{\prime} \times 6^{\prime \prime}$ & $4^{\prime} 29^{\prime \prime}$ & $0^{\prime} 43^{\prime \prime}$ \\
\hline I9 & $\Rightarrow x^{\prime} 9^{\prime \prime}$ & $0^{\prime} 30^{\prime \prime}$ & $\mathrm{O}^{\prime}$ I $5^{\prime \prime}$ & $4^{\prime} 42^{\prime \prime}$ & $0^{\prime} 5 \mathrm{I}^{\prime \prime}$ & $4^{\prime} 44^{\prime \prime}$ & $0^{\prime} 5 I^{\prime \prime}$ \\
\hline
\end{tabular}

Finalmente, en la tarde del I9, declarado viento favorable y llamados inmediatamente los botes, pudimos dar la vela ayudándonos la marea de tal modo en aquella ocasión que para el ano. checer, cuando calmó el viento, ya marcásemos la Punta Capitana al Norte $7^{\circ}$ Oeste, la de Guechucucui al Sur $23^{\circ}$ Este y el Farallon Mayor de Carelmapú al Sur $62^{\circ}$ Este. 


\section{CAPÍTULO V}

Navegaciones y tareas hidrográficas desde Chiloe hasta Linna.-Escalas cn los puertos de Concepción, Talparaiso, Coquimbo, Arica y Lima.-Excursión de algunos Oficiales á Santiago.-Varios acaecimientos ocurridos en aqual tiempo.

Feb. so Las contrariedades sufridas por el espacio de ocho días en el puerto de San Carlos de Chiloé antes de verificar la salida, y las noticias adquiridas sobre la constancia de los mismos vientos en el puerto de Valdivia, debieron hacernos desistir de la idea de visitarle, tanto más, que con motivo de las diferentes fortificaciones y de los alcances de sus baterías, repetidas veces los ingenieros del ejército habian levantado su plano escrupulosamente y le habían examinado después el mismo Piloto Moraleda y algunos otros Oficiales de la Armada.

Nuestra derrota debía por la misma razón conducirnos al andar de la costa hasta la bahía de Penco ó Talcahuano, donde haríamos nueva escala, y al paso de repetir las acostumbradas tareas, reconoceríamos con alguna escrupulosidad aquel verdadero término ó frontera de nuestras posesiones en el hemisferio austral.

No debió sorprendernos en el entretanto el ver poco después de que hubiese anochecido entablar de nuevo vientos flojos del Norte y Nornoroeste con la llovizna y calima acostumbradas. Los ceñimos con las muras á estribor y con poco aparejo. Su continuación en todo el día siguiente nos desvió de lá costa; y una extraña ilusión en ambas corbetas en la mañana del 2i (entablado ya viento fresco y claro del Sur) hizo que no la pudiésemos atracar de nuevo, sino en la tarde inmediata, siendo las tierras que ahora teníamos á la vista, las que conducen desde las inmediaciones del rio Bueno hasta la entrada de Valdivia. A las seis de la tarde ya nos hallamos á tres leguas del puerto: se determinó su longitud por Ios relojes marinos; tomáronse algunas vistas de las costas y puntas inmediatas; la ATrevida no encontró fondo con r 20 brazas de sondaleza; 62 series de distancias del Sol á la Luna observadas en la Descubierta y bien conformes entre sí, sólo discrepaban en dos minutos al Oeste de la longitud determinada por los relojes. Se continuó luégo la navegación entrada la noche, ya que los vientos, sumamente favorables, nos convidaban á aprovechar en objetos de mayor importancia los pocos restos de la estación benigna del verano. De este modo, en la siguiente mañana teníamos á la vista la Isla Mocha y una parte no mediana de las costas fronteras. Con el andar del. día nuestra derrota fué después tan favorecida del viento, que si bien siguiésemos las diferentes direcciones de la costa, ya para el anochecer Feb.2 marcábamos las puntas de Rumena y Lavapiés, y las primeras claras del día 23 nos descubrían á un mismo tiempo las T'etas de Viovio al Este, y al Sur la Isla de Santa María, á distancia de una legua. El viento abonanzó entonces mucho, asomado ya el Sol sobre el horizonte. El abrigo de la costa presentó una mar sumamente tranquila, en la cual se veían ballenas y lobos marinos en mucho número. Emprendiéronse al mismo tiempo la derrota para el puerto y los reconocimientos de la costa intermedia. Así, para las ocho y media ya habíamos atracaclo á muy corta distancia el extremo Sur de la Isla Quiriguina, y nuestros bordos sucesivos para internar en la bahía hasta el fondeadero de Talcahuano fueron tan felices, que á las dos y media pudimos dar fondo en siete brazas lama arenosa, como tres cables al Oeste de la batería de Gálvez, y quedar poco después amarrados con dos anclas en la dirección de Norte-Sur.

Era á la sazón Gobernador Intendente de la provincia el Brigadier D. Francisco de la Mata Linares, el cual, si bien ocupado en la visita de Chillán, pueblo interior de unas 30 leguas, había manifestado su ánimo de regresar á la ciudad luégo que llegásemos, y sin embargo, estaban tomadas las medidas más eficaces para que ni áun en ese corto intervalo careciésemos de cuantos auxilios nos fuesen necesarios. El Coronel D. Pedro Quijada, el cual mandaba interinamente, explayó entre tanto una atención y una generosidad que sería difícil describir. No había una persona, no había una choza en aquel suelo feliz, en donde no sobresaliesen á porfía la rectitud y la unanimidad de los Comandantes y la felicidad y subordinación de los súbditos. Desde el primer día de nuestra llegada, cuantos objetos nos rodeaban, otras tantas muestras teníamos á la vista de la sencillez é inocencia de la vida campestre.

Apenas los habitantes de la provincia empezaban á verse libres de los estragos sumamente funestos de una epidemia de viruelas, la cual, en la sola ciudad de la Mocha y en sus inmediaciones, había arrebatado casi instantáneamente la vida á unas dos mil quinientas personas sin distinción de sexos, edades ni condiciones. La inoculación no se había introducido hasta entonces, porque jamás penetraba la epidemia hasta aquella latitud. Pero en el día ya se había adop. tado aquel preservativo por medio de un mulato recién llegado de la capital de Santiago, y pudieron, finalmente, contenerse los progresos ulteriores del mal; muy tarde, sin embargo, para que á más de las víctimas indicadas no quedase también en mucho despojada de sus atractivos exteriores la mayor parte del sexo mujeril, el cual poco antes podía sin recelo alguno de pon* 
Eeb. ${ }_{3}$ deración caracterizarse como uniformemente hermoso y digno de la admiración de los de afuera.

Era también un objeto nuevo para nuestras indagaciones en aquellos contornos, el seguir de cerca las huellas de la expedición francesa de las gabarras la Bríjula y el Astrolabio, mandadas por el Conde de la Peyrouse y el Vizconde de Langle. Sus pasos, sus operaciones, el régimen interior de aquellos buques, nada debía parecernos indiferentes ó bien para que procurásemos imitarlos ó para que atizasen con nuevo vigor aquella especie de emulación que es el móvil principal de semejantes empresas. Habían permanecido unos veinte días en la bahía, en la cual nos hallábamos, y abastecidos particularmente de un buen repuesto de vinos, al paso que no descuidasen muchos ramos científicos que procuraban abrazar, habían después seguido en Marzo de 7786 una breve derrota hacia las Islas Sandwich y la costa Noroeste de la América. Debían á la sola actividad del Mariscal de Campo D. Ambrosio O-Higgins, Gobernador entonces de la provincia, el que se hubiese evitado la deserción de una parte no mediana de sus tropas y marinerías, las cuales, ó fuesen los atractivos del país ó la natural inconstancia del hombre de mar, ya no pensaban en seguirles. Los resultados de sus tareas, sea en cuanto á las observaciones astronómicas ó á los trabajos geodésicos, habían sido envueltas en un profundo silencio. Finalmente, sus atenciones y miramientos hacia todos los indivíduos de la colonia, merecían aún en el día que se recordasen á cada paso sus nombres unidos con la idea de la afabilidad y de un amor constante al bien público.

Movidos pues nuestros pasos con igual actividad, del ejemplo indicado, de los auxilios de la colonia y del tiempo favorable, el cual después de algunos días del viento lluvioso del Norte parecía haber nuevamente establecido un imperio duradero, debieron por precisión corresponder en cuanto fuese posible al cúmulo de objetos que procurábamos abrazar. Se habían aprovechado de antemano varios intervalos de una mar tranquila para sondar sobre marcaciones seguras de dos teodolitos, algunos bajos peligrosos, los cuales interceptan la navegación libre de la bahía; emprendióse ahora con tesón el levantar su plano; se estableció el observatorio en el mismo paraje donde "le había tenido Mr. Dagelet: corrían luego á su albedrío por las campiñas, bosques y habitaciones no distantes D. Antonio Pineda, D. Luis Nee y la mayor parte de los Oficiales, admirando á veces la prodigalidad y otras la variedad hermosa de la naturaleza en ese clima feliz.

Ciertamente, quien recorra aunque por poco tiempo el país fértil que baña el Viovio; quien examine con una mirada política las veces que Fub. 28 ha sido regado con la sangre de nuestros valerosos antepasados; quien vea finalmente ó en las maderas esquisitas y monstruosas de la cordillera inmediata ó en la fertilidad demasiada del suelo ó en la abundancia de los lobos, ballenas, congrios, etc., de sus orillas, los muchos y ricos dones que debiera of recer con su propio acrecentamiento no sólo á la matriz sino también á las demas colonias que componen la casi inmensa Monarquía española, no puede á ménos de ensalzar mil y mil veces una voz patriótica hacia los depositarios de la legislación y del bien público, para que sacudan de una vez los grillos que allí puso á la misma naturaleza una época ménos advertida y más tímida, y vean finalmente pros. perar un país al cual llamaba con mucha razón el docto Sr. Venegas, el Reino á porfía rico y pobre del Chile.

Asegurada en el entretanto la continuación de tiempos favorables conforme nos lo indicaban casi cotidianamente las apariencias y las noticias unánimes de los habitantes, ya el plan de nuestras operaciones en aquella parte del mar Pacífico pudo mirarse más bien como ligado al progreso súlido de las ciencias en general, que como sujeto á las estaciones y á la frecuencia de tiempos contrarios y lluviosos: cualquiera fuese el plazo de la llegada de las corbetas al Callao debían luégo esperar que cesase en las costas de Panamá y Guatemala la estación liluviosa del vendabal y le sucediesen los Nortes y Nordestes, los cuales nunca suelen reinar con alguna fuerza, sino en la mitad ó fines del mes de Noviembre: así podíamos contar con un plazo bastantemente largo para permanecer sobre las costas del Chile y Perú, las cuales favorecidas de la naturaleza con unos tiempos constantemente apacibles y con unos vientos galenos siempre firmes entre el Sursudeste y Sursudoeste convidaban igualmente á la navegación y á las tareas científicas: debían éstas luego ramificarse hacia la Hidrografía, la Astronomía, los muchos objetos de la Historia Natural y el conocimiento físico y político de aquellos dominios de S.M. Todo por consiguiente concurría á indicarnos el actual teatro, como el más oportuno para desplegar cuanta actividad pudiesen alcanzar los a1mamentos.

Con estas atenciones la separación de las corbetas pareció desde luego indispensable; diéronse á la ATREVIDA los mejores instrumentos astronómicos y algunos Oficiales de la DEScuBIERTA, para que navegando al andar de la costa hasta Valparaiso, continuase los reconocimientos acostumbrados, hiciese luégo en aquel puerto una demora más larga, y mientras que los Oficiales astrónomos trabajasen cotidianamente en el catálogo de las estrellas meridionales, otros se 
Mar. ocupascn ó en el cxamcn del país hasta la eapital de Santiago ó en condueir hacia ella. si las eireunstaneias lo dictasen prudente, una serie de triángulos que afianzase con datos positivos su situación en latitud y longritud. Quedó al cargo de la Descubierta el reeonocimiento prolijo de la bahía en la cual nos hallábamos y de otros dos puertos no distantes; el indagar las ventajas localcs para la eonstrucción de buques, ora fuesen mercantiles ó de guerra; y después el atravesar á entrambas Islas de Juan Fernández para que ni su extensión ni su posición geográfica admitiesen ya la menor duda en lo venidero.

No tardó la ATrevida en llevar á efecto por su parte el plan propuesto: determinada de antemano la latitud del observatorio, y atendido eon las alturas correspondientes el movimiento aetual de los relojes marinos, dió la vela en la mañana del 2 de Marzo, y favoreeida con vientos galenos del Sur, en poeas horas salió de la bahía, oeultándosenos eon la interposición de la Isla Quiriguina: acclcráronse al mismo ticmpo los diferentes objetos que debía desempeñar la Descubierta, tanto que en aquel día ya cmpezaban á recibirse á bordo veinte pipas de vino, eorrespondientes á los repuestos de las dos eorbetas para las campañas venideras y la mayor parte de los Oficiales sc destinaban á los varios reconoeimientos de la eosta.

Nos ocuparon aquéllos ineesantemente hasta el 8: los puertos de San Vieente, del Tomé y del Coliumo, más ó ménos abrigados del viento Norte, y por la misma razón preferentes en cjerto modo al fondeadero de Talcahuano, fueron prolijamente reconocidos; sondáronse la bahía, el canal que formala Quiriguina con la Tierra Firme y los alrededores de la misma isla; D. Fernando Quintano y D. Secundino Salamanca emprendieron el navegar con un boteeito el rio Andariel hasta donde fuese aecesiblc, y eombináronse con tal felicidad las mareaciones, quc últimamente los triángulos dimanados del teodolito se extendiesen por la cmbocadura del Viovio hasta la Isla Santa María y la Nucva Moeha, mientras por el Norte llegaban desde los extremos de la Quiriguina hasta las inmediaeiones del Coliumo: solíamos en estas exeursiones pasar indistintamente las noches en la choza de un labrador ó en las casas de los vecinos más acomodados: no nos afanaba el cuidado de la comida, pues la eneontrábamos cn todas partes igualmente exquisita, barata y abundante. El marinero, el labrador, el hacendado, deseubrían cada cual cn sus conversacioncs cntretenidas euáles fuescn sus cireunstaneias, euáles sus deseos y la posiljilidad ó reetitud de eonscguirlos. Así acomunados frccuentemcnte eon ellos y llevando las confercncias más bicn cl objeto indiferente de un cutretcnimiento quc $\mathrm{cl}$ de unas indagaeiones siempre temibles del legislador, debían, final- Mar.8 mente, nuestros resultados aproximarse tanto más á la verdad cuanto mayor era después nuestro empcño de compararlas con las notieias y observaciones de los que presidian eon tanto juicio y patriotismo á la administración pública.

Vencidos aquellos objetos muy á nuestro placer, fué preciso abandonar sin mayor dilación los contornos de Talcahuano y emprender la navegación proyectada haeia las Islas de Juan Fernández. La latitud del observatorio se había dedueido por las distaneias meridianas al zénit dc muchas estrellas, de $36^{\circ} 42^{\prime}$. La variación magnética observada con el teodolito fué de $I 5^{\circ}$ $29^{\prime}$ Nordeste y el establecimiento de la marea en los días de la oposición resultó para las ro horas $40^{\prime}$ de la mañana, siendo su mayor elevaeion de $5 \%$ á 6 piés de Burgos. Por lo que toca á los relojes, quedó bien comprobada la cons tancia del movimiento asignádoles en Chiloé y su determinacion de la longitud, aplicadas las pequeñas eeuaciones por los desvíos diarios, fué uniforme en diferentes días, de $38^{\prime} 22^{\prime \prime}$ al Oriente del último meridiano, esto es, de $66^{\circ} 5^{8}$ de Cádiz, menor tan soln en seis minutos de la que al principio del siglo había observado el padre Feuille por medio de varias inmersiones del primer satélite de Júpiter, correspondidas en $\mathrm{Pa}$ rís por los Sres. Cassini y Maraldi.

Sobre la deserción de la tropa y marinería, en lugar de que hallásemos alguna ventaja en las medidas eficaces que habíamos adoptado con los pasados esearmientos, concurrieron más bien todas eilas á manifestarnos, que en balde lucharíamos con una infinidad de abusos tan añejos como la conquista y tan arraigados como las costumbres de nuestras colonias; of reciéronse por nuestra parte treinta pesos fuertes por cada desertor que se aprehendiese: el Gobernador-Intendente destacó por la suya varias partidas de tropa y personas activas y prácticas del país. Nada bastó para nuestro intento, y finalmente, al dar la vela la Descubierta, los desertores de ambas corbetas no eran en menor número de oeho, tres soldados artilleros, uno de marina y cuatro artilleros de mar.

En la mañana del ro estuvimos ya prontos para dar la vela, reunido á su destino D. Antonio Pineda, el cual en los ocho dias anteriorcs había reconocido los eampos y fortificaciones no distantes de la frontera. Reinaron ventolinas del Norte hasta las cuatro de la tarde; pero entablado finalmente en aquella hora viento galenito del Sur, pudimos aprovecharle con toda vela y hacia el anocheeer hallarnos fuera de la bahía.

La derrota para la primera Isla de Juan Fernández, no debía mirarse en modo alguno como sujeta á errores de una mediana eonsideración, pues habían sido determinados su distancia y 
Mar. so arrumbamiento con la Is la Santa María por una estima llevada con la mayor exactitud por el senor D. Antonio Ulloa; y siendo los vientos proporcionados para que la navegación fuese directa, nada podía oponerse á que desempeñásemos con toda brevedad la excursión emprendida. Arreciaron mucho los Sures luégo que con el andar de la noche nos fuimos alejando de la costa; á las veces nos era preciso arriar las gavias á medio mastelero y eran bastantemente frecuentes los golpes de mar que se nos introducían á bordo. Esto, sin embargo, aceleró de tal modo nuestro viaje, que al amanecer del I2 ya estábamos á la vista de la Isla. Observáronse latitud y longitud en las mejores posiciones, reconocióse de cerca el extremo Sur y navegamos después con fuerza de vela para alcanzar en el día siguiente las inmediaciones de la Isla Matafuero.

Pero en aquella ocasión, mucho más calmosos los vientos de lo que debíamos esperarlo, causaron una tal lentitud en la navegación propuesta, que al amanecer del I 3 aún distábamos de ella unas nueve leguas, sin que pudiésemos contar sino con ventolinas variables del Oeste al Noroeste, las cuales no nos permitían una base ordenada siquiera; por ventura despe jadas una y otra isla, y bien determinados sus extremos, daban medios para ligar en cierto modo con tal cual evidencia el total de nuestras operaciones; esto bastó para que conseguidas al medio día unas observaciones exactas de latitud y longitud, volviésemos nuevamente la proa al Este, y con la brisa, que entabló fresquita por la tarde, atracásemos la isla de adentro por su extremo del Norte, del cual distaríamos al anochecer unas cinco leguas: Matafuero quedó situado por nuestras operaciones en latitud dc $33^{\circ} 4 \mathrm{I}^{\prime}$ Oeste y en longitud de $6^{\circ} 44^{\prime} 30^{\prime \prime}$ al Occidente de Chiloé. El extremo Norte de la de adentro en $33^{\circ} 37^{\prime} 39^{\prime \prime} \mathrm{y}$ longitud $5^{\circ} 6^{\prime} 30^{\prime \prime}$. La distancia de una á otra isla era por las mismas ilaciones de 79 millas.

A medida que nos apartábamos de ellas, andada en la noche una regular distancia, volvieron la mar y el viento á la misma fuerza que habíamos experimentado en la travesía anterior. Recibimos algunos golpes de mar, nos fué preciso navegar con ménos aparejo, los tiempos mantuviéronse claros lo más frecuentemente; nuestra derrota, interrumpida en la noche del I5 por el arrumbamiento inexacto de las costas en las cartas trazadas hasta entonces, y en el día siguiente por varias ventolinas del Norte entremezcladas con algunas calmas, sólo nos permitió el avistar nuevamente la costa en la tarde del $\mathbf{6} 6$, y fondear en la bahía de Valparaiso al medio día del 17.

Hallábase fondeada desde el II la corbeta ATrevida, cuya navegación desde Taalcahuano había sido más dilatada de lo que debiésemos sospechar á primera vista. Molestáronle mucho Mar. r7 las neblinas, calmas y la mar gruesa del Sudoeste, unas veces separándole de la costa, otras haciéndole casi indispensable el dar fondo con un anclote: había, sin embargo, trazado con la mayor exactitud las costas desde la Quiriguina por las bocas del rio Itata, hasta la Ensenada del Sorro, las inmediaciones del Morro de Topocalma, los bajos de Rapel, las playas de Cartagena, y finalmente, el trozo comprendido entre las puntas de Coronmilla y los Angeles. Ya el observatorio se hallaba establecido en el ángulo del Norte del Castillo del Rosario. Los Tenientes de navío Galiano, Concha y Vernaci, agregádoles un pilotín y un soldado, alojaban en sus inmediacioncs para que las tareas de la noche pudiesen seguirse sin la menor interrupción. Las solas cerrazones y ncblinas habían podido estorbar que no estuviese ya empezado el proycctado catálogo dc las estrellas del hemisferio austral. No había tampoco diferido cl Teniente de navío D. Cayetano Valdés en transferirse á la capital de Santiago, y ahora avisaba que el Mariscal de Campo D. Ambrosio O-Higgins, Capitán General y Presidente del Reino, volvcría inmediatamente de los baños á do se hallaba, para coadyuvar con aquel celo y actividad que le eran naturales, al mayor aprovechamiento de la expedición. Vagaba á su albedrío D. Luis Nee por aquellos contornos; no diferiría tampoco D. Antonio Pineda en internar hacia Santiago, y la cordillera inmediata; finalmente, nuestra demora en la bahía, debiendo ser algo más dilatada con atención á las observaciones indicadas, podía también un número competente de Oficiales transferirse á Santiago, y allí multiplicar en varios modos las tareas útiles de la expedición. No parecía á la verdad, asequible la conducción de los triángulos por el terreno intermedio, como nos le habíamos propuesto. Ese tránsito, aunquc corto, es todo pedregoso y con muchas vueltas; atraviesa tres hileras de montes, los cuales aumentan considerablemente su elevación á medida que se aproximan al pié de la cordillera; la primcra llanura es de bastante extensión, y algún tanto aprovechada, ó en pastos ó en siembras: el lugarejo de Casa Blanca hace más amena y útil la segunda; y si se exceptúan los valles de la Viñilla y Puangni, entrambos de muy corta extensión, el tercer llano es el hermoso valle que baña el Mapocho, y en donde á las fallas de la cordillera de los Andes, está situada la ciudad de Santiago: algunas haciendas intermedias hacen á la verdad más fácil y más entretenido el camino, explayando los que las poseen un tal grado de hospitalidad generosa, que á pesar de ser ésta una propiedad casi innata del carácter español, allí sobresale con unos colorcs y adornos difíciles para describirse; pero como los 
Mar. 17 montes sean por sí casi inaccesibles, y que á más del tiempo que debiera absorber la colocación previa de las marcas en los parajes oportunos fuesen también temibles en aquella estación los rigores del Estío, debe finalmente inferirse, que la operación proyectada excedía los límites del tiempo y de las fuerzas, que podíamos á la sazón sacrificarle.

Apoyaron estos inconvenientes la necesidad de que se transfiriese á Santiago la segunda colección de los instrumentos astronómicos, y allí se repitiesen observaciones directas para fijar la posición geográfica de aquella capital: hízose así en efecto, y si bien el mal estado del reloj Io5 no permitiese deducir por él la longitud, como lo habíamos intentado, pudieron suplirle dos observaciones del primer satélite de Júpiter, las cuales determinaron (hechas las correcciones de las tablas) la de $64^{\circ} 26^{\prime} 30^{\prime \prime}$; latitud, $33^{\circ} 26^{\prime}$ I $6^{\prime \prime}$; variación de la aguja, I $3^{\circ} 20^{\prime}$ al Nordeste. Dejaremos para otro lugar más oportuno el dar una idea adecuada de la feracidad de las tierras y de la amabilidad de los moradores de los contornos de Santiago y Valparaiso. Obra es esta que pide una mayor extension de la que permiten los límites de un diario, y cuyo detall, si bien difuso, no podrá ménos de parecer importante á los que sigan de cerca la prosperidad de la Monarquía y el bienestar de sus conciudadanos. Por ahora baste el decir que los primeros días de nuestra permanencia en la capital, nos descubrieron una tan feliz unión de los depositarios de la autoridad pública con la satisfacción subordinada de los pueblos y con los dones pródigos de la Naturaleza, que en balde procurarían el tiempo ó la multiplicidad de objetos nuevos, el borrar jamás de nuestra memoria un espectáculo tan agradable.

D. Antonio Pineda hizo al mismo tiempo una excursión á lo alto de la cordillera en las minas de plata denominadas de San Pedro Nolasco. Sirvió ésta á aumentar con algunos conocimientos de la mayor importancia la idea cabal que procuraríamos dar á la Nación de esos de. pósitos peligrosos de su opulencia y de su miseria.

Tal vez una mirada filosófica hacia ellas, guiada de la humanidad y de lo que realmente son en sí, volverá finalmente la cuestión á pocos principios sencillos, y nuestros cálculos económicos reducirán los diferentes productos de la tierra y del trabajo del hombre á su nivel verdadero: el de las necesidades recíprocas de cada uno.

Conforme á las medidas tomadas de antemano nos alcanzó también en la capital de Santiago el hábil Botánico D. Tadeo Heenke, el cual había sido agregado á la expedición por órdenes posteriorcs de S. M. Sus peregrinaciones hasta aquella época podían mirarse como sumamente penosas; pues si bien apenas determinada su ad- $\mathrm{Ab}$ misión á instancias del Consejero Born y del señor Jacquín de Viena, emprendiese precipitadamente su viaje desde Alemania, no había podido llegar á Cádiz sino en el mismo día en el cual las corbetas daban la vela; y después, á más de no alcanzarnos en Montevideo, había padecido naufragio en las inmediaciones de aquel puerto, con la pérdida lastimosa de casi todos sus libros, papeles y equipaje. Con un verdadero amor á las ciencias y particularmente á la botánica, consideraba sin embargo resarcidos en mucha parte los sufrimientos pasados, pues le habían deparado la casualidad de atravesar las Pampas o llanuras de Buenos Aires y las cordilleras del Chile, logrando acopiar hasta I.400 plantas, la mayor parte nuevas ó no bien caracterizadas.

En Valparaiso no habían sido los pasos de la expedición ménos activos y felices. Una asiduidad indecible de los Oficiales astrónomos (agre gádose ahora nuevamente D. Juan Vernaci) hacía que ni se malograse hora alguna en las noches claras, ni fuese por la misma razón ya menor dc 300 el número de las estrellas, cuya declinación y ascensión recta podían determinarse ó rectificarse con toda seguridad. Se habían repetido las observaciones de los satélites de Júpiter, levantado el plano de la bahía y sondada ésta con la mayor escrupulosidad, observadas 36 I series de distancias del Sol á la Luna, y finalmente dispuestos los buques y aparejos por manera que, abastecidos de agua y leña, ef ectos bien escasos en la costa siguiente al Norte, pudiesen dar la vela al primer instante oportuno.

Ya no debíamos extrañar los nuevos desórdenes de la tropa y marinería en un puerto donde todo estaba dispuesto para seducir y fomentar los vicios entre las marinerías harto díscolas de la carrera mercantil de Lima; ni por nuestra parte ó por la de la plaza cabía otro arbitrio, sino el de sufrir más bieṇ que comprometer el decoro de la autoridad descubriendo la debilidad de sus resortes. Así, contentándonos con que no desmayase la disciplina á bordo ni hubiese la menor demora en las tareas emprendidas, vimos casi con indiferencia la deserción de otros I5 indivíduos, ya soldados, ya marineros de las dos corbetas. Repitiéronse sí los ofrecimientos de los treinta pesos fuertes por cada desertor que se nos presentase en Lima, y al señor Capitan General se remitieron listas exactas que pudiescn coadyuvar en cierto modo á una pesquisa más exacta sobre este punto importante del servicio.

Aprovechada, finalmente, toda la noche del I3 para las observaciones celestes, y embarcadas por la mañanita siguiente la tienda, el cuarto de círculo y el péndulo, únicos efectos que habíamos dejado, levamos la amarra de tie. rra, quedando sobre un solo calabrote, y nos dis- 
Ab. 14 pusimos á dar la vela al primer soplo de viento favorable. La cuenta de los relojes marinos se había cerrado para el medio día del I2, y desde el 7 se había colocado sobre esferas el cronóme. tro 72, para ver si aquella situación le era efectivamente tan ventajosa como lo habia sido para el número 7 I de la ATREvidA.

En lugar de suceder el viento Sur á las horas de calma comunes al principio de la mañana, declaróse una neblina espesa procedente del Norte, que imposibilitaba la vista de los objetos áun más cercanos; y manteniéndose sin asomo de viento hasta las cuatro de la tarde, ya casi nos había precisado á desistir de la esperanza de dar la vela en el mismo día. Pero en fin, habiéndose disipado la neblina con algunas ventolinas del Sur, pareció que el buen andar de las corbetas, el auxilio de los remolques y de la corriente, y la muy corta distancia que era preciso navegar para considerarnos libres de todo peligro, nos proporcionarían el verificar la salida en el plazo prefijado y sin exponernos á que las ventolinas del Norte, bastantemente comunes en el mes de Abril, nos detuviesen algunos más días en el puerto. Así entrambos buques emprendimos luégo el cobrar el cable del Norte, recogiendo el calabrote de tierra.

A las cuatro y media levamos el ancla, y remolcados de la lancha, procuramos con las gavias, juanetes y estai, aprovechar las ventolinas favorables del Sur. Al principio fueron lentos nuestros progresos y estuvimos algo aconchados sobre las piedras de la entrada, luégo fué mejo. rando nuestra situación; al anochecer ya habíamos ganado dos millas al Norte de la punta de la Batería, y las ventolinas aún nos permitían el gobernar. La ATREvida nos siguió de cerca y con igual buen éxito. Metimos la lancha y determinamos á las seis por Puerto Salido según las marcaciones, la latitud de $33^{\circ} \mathrm{o}^{\prime}$, y la longitud de $2^{\circ} 7^{\prime} 39^{\prime \prime}$ al Oriente de San Carlos de Chiloé. Lra nuestro primer ánimo el fondear en el puerto del Papudo, distante ro ó I 2 leguas de Valparaiso, porque nos habían persuadido que tendría algún abrigo; indicándolo así por otra parte el que le frecuentasen mucho los buques franceses, cuando al principio del siglo concurrían en tanto número á las costas del Perú y Chile. Tuvieron allí muchas bodegas, de las cuales aún subsistían las ruinas, bien que siempre fué más bien el comercio ilícito que otra causa cualquiera, la que los guiaba hacia aquellos parajes ménos habitados. El señor Presidente previno de antemano á los Subdelegados del partido para que concurriesen á auxiliarnos; pero en fin, debimos desistir de aquella idea, no sólo por la escasez del tiempo, por los nuevos riesgos de la deserción y el actual semblante calmoso y oscuro de los horizontes, si también porque en el año anterior el Ingeniero D. Pedro Rico había Ab. t* levantado el plano, así de aquella rada, como de la siguiente de Pichichangue ó del Gobernador.

Pasamos la mayor parte de la noche en calma y rodeados de una densa neblina; al amanecer declaróse viento favorable del Sursueste con el cual, aunque flojo, gobernamos al Nornordeste y Nordeste para atracar la costa; ésta, á la sazón, se nos presentaba confusa y cargada de neblina aunque no distásemos de ella sino unas tres leguas. A las ocho pudimos ya avistar distintamente como al Sudeste $1 / 4$ Este el puertecito de Quintero, hasta donde habían llegado nuestros reconocimientos desde Valparaiso. No distábamos, por consiguiente, ni del Papudo ni de la Ligua, y pues la costa se distinguía con bastante claridad con motivo de la poca distancia, empezamos á correr bases con todo aparejo en vuelta del Norte 1/4 Noroeste, siendo el viento á la sazón muy flojo del Sursueste al Sur. A las nueve y media, á distancia de dos leguas escasas, la sonda dió 92 brazas arena gruesa blanca; á las doce, la boca del Papudo nos demoraba al Este, y la costa avistada hasta entonces parecía bajar con algunos playazos, particularmente hacia la Ligua; había tal cual islote entre el Papudo y el puerto de Quintero, y se veían algunos arrecifes en las inmediaciones del segundo: al Norte del Papudo se presentaba un monte aislado, que podía servir de reconocimiento para buscarle.

En un paraje en el cual no debíamos dudar de un efecto considerable de las corrientes y en donde la dirección de la costa no variaba del Sur al Norte, la falta de la latitud observada era precisamente un mal que debía alarmarnos para la exactitud de las tareas emprendidas. Acechábamos dos alturas del Sol en cualesquiera claras, aunque momentáneas, que se nos presentasen. Pero no nos fué posible alcanzar sino la una á las dos y cuarto de la tarde, de la cual, sin la latitud, no deduciríamos sino una longitud sumamente dudosa. La ATrEvida había ya sondado 85 brazas; y como el viento tomando algún vigor conservase su dirección del Sur, con* tinuáronse las bases hasta el anochecer, y á esta hora nos pareció preferente el seguir también la derrota, siendo así que ya sabíamos por una tradición envejecida, que los tiempos sobre aquella costa, eran por lo común igualmente oscuros y calimosos.

La noche fué apacible, pero igualmente cerrada con calima; viéronse algunas candeladas; á la una de la mañana no se encontió fondo con todo el largo del cordel; le hallamos sí á las cinco en 80 brazas, lama y chinitos; y como se hubiesen hecho algunas horas de pairo, pudimos amanecer á corta distancia de la costa, por manera, que antes de salir el sol se empezasená correr bases, navegando con todo aparejo al Nor* 
Ab. 15 noroeste. La costa que teníamos á la vista, era la que descle la silla del Gobernador por la punta del Negro, corre hasta las inmediaciones de Conchalí. Se veía aquel pueblo y la tierra parecía bastantemente alta, advirtiéndose en nuestra posición por cuanto pudiésemos combinarla con la de la tarde anterior, que no había sido excesivo el error contraído por las corrientes, limitándose á dos ó tres leguas solamente. La falta de las observaciones en el segundo día, debió inquietar'nos ya mucho más que en el anterior, pues no solo iban multiplicándose los errores irremediables en la navegación y dimanados de las corrientes de la marejada y de otras causas, sino que ya nos quedaba á la espalda un trozo no mediano de la costa sin sujeción alguna en sus posiciones respectivas; pero acechando las claras, aunque repentinas, por ventura fuimos algo más felices que en el día anterior; tuvimos varias alturas del Sol con diferentes intervalos y algunas no distantes del medio día, cuyos resultados nos prometían una latitud bastantemente aproximada á la verdadera. Finaimente, despejado por la tarde el cielo, pudimos á las tres y álas cuatro observar dos series de alturas, las cuales, multiplicando las combinaciones con las de la manana, afianzaban con mayor probabilidad nuestras pesquisas sobre la latitud, al paso que daban la verdadera longitud según el útil método hallado por D. Dionisio Galiano.

Adoptáronse á este fin las últimas dos series de la tarde y una altura en la cual dos observadores habían convenido á las I I horas $39^{\prime}$ de la mañana. Acordes entre sí entrambos resultados, dieron la latitud al medio día de $31^{\circ} 3^{6^{\prime}} 16^{\prime \prime}$ diferente en $19^{\prime}$ al Norte de nuestra estima. La longitud deducida fué de I $2^{\prime}$ al Este de Valparaiso, la altura meridiana á las seis y cuarto dió la latitud de $3 \mathrm{I}^{\circ} 3 \mathrm{O}^{\prime} 3^{\prime \prime}$ la cual, confirmando la del medio día, servía al mismo tiempo de ratificación á nuestras longitudes, de las cuales aquélla había dimanado.

Las irregularidades de los relojes 6r y I3 y la uniformidad de la marcha del 72, nos habían precisado á adoptar al último por magistral, aunque nos fuese fácil igualar los otros por medio de la ecuación diaria: sus resultados, comparados á las longitudes estimadas y á la que habíamos observado en la tarde del I5, nos proporcionaron el corregir la latitud de aquel medio día y pudo deducirse, finalmente, de tan feliz combinación, que los errores habían sido proporcionales y que nuestra posición inferida en los dos medios días anteriores era muy aproximada á la verdadera.

Luégo que empezaron á entablar ventolinas del Sudoeste y Sul con hermoso semblante, hicimos proa del Nornoroeste siguiendo así la costa á regular distancia para ligarla con la exactitud posible. Los azimutes indicaban la variación Ab. x6 de $I 4^{\circ}$ al Nordeste. Al ponerse el sol nos hallábamos casi al Esteoeste con el extremo Sur de los altos de Chuapa y la última tierra al Norte distaba de nosotros unas seis leguas.

En las horas del pairo que debimos mantenernos en la noche siguiente, se conoció claramente el efecto de la corriente al Norte en la dificultad de orzar que tenía la corbeta. Con jeturamos desde luego, que debía atribuirse á aquellas horas la mayor parte de los errores que encontrásemos en la latitud del día siguiente: amanecimos en efecto algo más al Norte de lo que debía suponerse. El rio de Chuapa y la Quebrada de Limarí, punto de tierra bien notable, eran los parajes que teníamos más inmediatos. No distaríamos sino unas cuatro millas de la costa. Nuestros rumbos de bases fueron el Norte y después el Nornoroeste, con los cuales, y un andar de tres millas con todo aparejo, se conservaba la costa á regular distancia. Observáronse al medio día la latitud de $30^{\circ} 39^{\prime}$ y la longitud de $\mathrm{I} 8^{\prime}$ al Oeste de Valparaiso. La Quebrada de Limarí demoraba al Sueste corregido de tres á cuatro leguas, y parecía la Lengua de Vaca la última tierra que se alcanzaba á la distancia de seis leguas. Con mucha propiedad en la navegación costanera se ha dado este nombre á la punta de tierra baja, muy saliente al mar, desde donde empieza hacia el Norte la grande ensenada, la cual conduce al puerto de Coquimbo y Frezier llama de Tongoy.

Fué luego más feliz y más acelerada nuestra navegación en aquella tarde, habiendo refrescado mucho la brisa sin que se acelajasen los cielos y horizontes. Así, para el anochecer ya habíamos propasado la punta indicada de la Lengua de Vaca, sobre la cual sondamos 7 I brazas arena blanca, y veíamos como á unas seis leguas de distancia la entrada del puerto de Coquimbo, de suerte que paireando en la noche inmediata no nos fuese difícil el alcanzarle al otro día con los primeros soplos de la brisa.

Descaecimos de tal modo en las horas del pairo, especialmente por el efecto de las corrientes al Norte, que al amanecer del I 8 apenas distaríamos una legua de la entrada del puertecito de la Herradura. El viento del Sur, á la sazón flojo, parecía deber tomar algún incremento luégo que saliese el sol, lo cual, combinado con el natural deseo de reconocer de cerca las inmediaciones de un puerto importante, nos indujo á atracar la costa á distancia de una milla escasa. Así hízose rumbo del Este en vuelta de la Punta de Lobo, de la cual ya no distaríamos á las ocho sino la milla prefijada.

Pero en aquel momento y en aquella situación, contra todas nuestras espectativas, dieron algunas ventolinas del Nordeste, las cuales y la 
Ab. r8 mareta gruesa del Sur, nos hicieron al mismo tiempo imposible el gobierno, por cuanto intentásemos auxiliarle con la maniobra y fueron causa para que entregados á la revesa, nos viésemos arrastrados con rapide $z$ hacia la costa in mediata, de la cual ya á las nueve y media no distaríamos sino unos cuatro cables. Ni el bote que habíamos echado de antemano al agua, ni la lancha que echamos á la sazón, podían vencer el embate de la ola para ponernos cn dirección de aprovechar las ventolinas de la virazón, que ya empezaban á dejarse sentir. Finalmente, atando al mismo tiempo la lancha por la proa y el bote por la popa en sentido contrario, conseguimos caer de la vuelta de tierra y poner la proa al Nornordeste, largando toda vela y haciéndonos al mismo tiempo remolcar de las embarcaciones menores. La ATREVIDA, que había podido mantenerse algo distante del peligro y se había valido de los remos, aunque con la mortificación de romper el mayor número de ellos, envió inmediatamente su lancha á auxiliarnos. Se mantuvo ésta corto rato por la proa, hasta que empezando á tomar vigor la virazón, la devolvimos á su bordo y metimos la nuestra, dejando sólo el bote en el agua al remolque y ayudado de sus velas.

A las doce ya habíamos pasado la boca de la Herradura, y pues el viento se mantenía flojo, pareció tan aventurado como inútil el entrar en el puerto por el canal que forma el islote de adcntro con la tierra firme: se hizo rumbo á dejar por estribor el Pájaro Niño de fuera, y antes de la una.pudimos atracarle y costearlo á tiro de pistola. Cinóse luégo por estribor; y sobre el mismo bordo acercándonos mucho á las piedras sumamente acantiladas, conseguimos alcanzar el fondeadero: algunas espías nos internaron después en parajè oportuno, y la corbeta quedó amarrada á distancia de un cable de tierra en fondo de cinco brazas. Bajamos demorando la punta Sur de la boca del puerto Norte $8^{\circ}$ Oeste y la Torre de Santo Domingo de Coquimbo al Nordeste.

La Atrevida fondeó como cable y medio al Norte, y quedó amarrada casi en la misma disposición que nosotros.

En la orilla inmediata á las corbetas, había unos almacenes bien acondicionados y pertenecientes á un vecino de Coquimbo, los cuales se nos franquearon inmediatamente para que allí estableciésemos el observatorio. En la mañana siguiente, dos destacamentos de marinería los asearon y ordenaron en cuanto fuese necesario, y armado inmediatamente el péndulo, se adoptó el cronómetro 7 I para las alturas correspondientes mientras se sistemase en cierto modo su movimiento. Ya en la noche anterior se habían observado en la playa dos emersiones del se- gundo y primer satélite de Júpiter. E1 72 acre- Al, 18 ditó en aquella ocasión, que no habian sido infundados nuestros conceptos sobre su marcha uniforme: se había deducido y cerrado la cuenta de los relojes el día 22 en Valparaiso, y las alturas correspondientes del I 3 nos habían indicado que los tres habían tenido alguna alteración en las veinte y cuatro horas anteriores; pero la del 72 mucho más corta que la de los 6r y I3, y en todos procedente tal vez del cañonazo de leva, que habíamos disparado en la mañana del I2.

La sucesiva deducción de su marcha en el observatorio de Coquimbo, ratificó esos mismos conceptos y pudimos determinar los siguientes resultados:

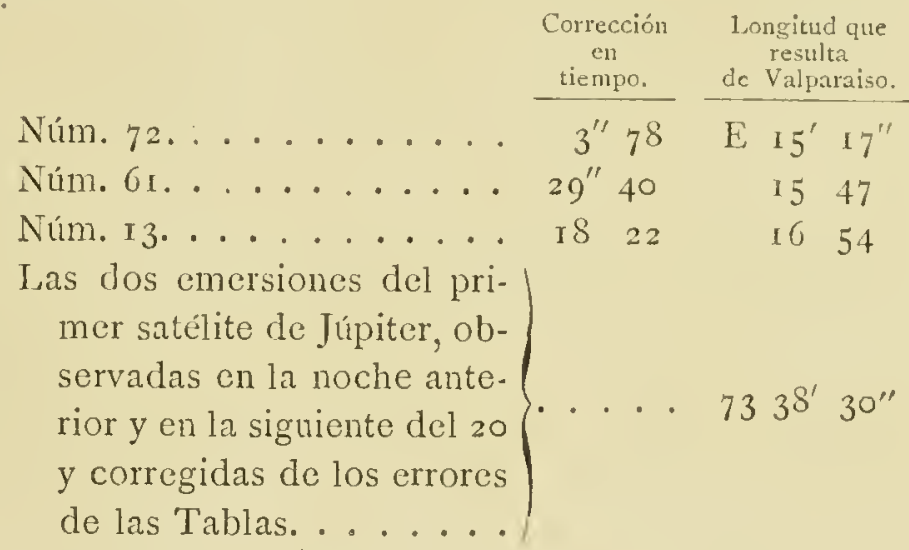

Mientras así procedían con actividad las di. diferentes tareas que debíamos abrazar en el puerto, emprendimos la mejor parte de los Oficiales una excursión á la ciudad no distante de Coquimbo ó la Serena. El camino es en mucha parte por la playa, agradable al tiempo de la baja mar, si bien algo molesto cuando la marea está alta. Luégo interna para huir del terreno pantanoso que media entre el mar y el terreno algo más elevado en el cual está situada la ciudad. Segun los naturales, son tres leguas las que comprende; pero pueden andarse con comodidad en 45 ó 50 minutos.

La situación de la ciudad no puede ser más amena ni más cómoda. La vista de la marina, la abundancia de aguas cristalinas, las llanuras inmediatas todas capaces de riego, un rio constantemente caudaloso aunque sin riesgo de inundaciones, el cual al mismo tiempo fecundiza los campos y da varias acequias para molinos y trapiches; las minas no distantes y ricas; el puerto excelente; la mar abundante en peces; los alimentos sabrosos y baratos y el clima agradablemente templado y uniforme en todo el año, forman uno de aquellos enlaces maravillosos de la naturaleza, que parecerán más bien ficciones poéticas que realidad á los que ciñan sus combinaciones al solo examen de una parte nó la más feliz del globo.

Contribuyen la labor de las minas y la fer. tilidad de los campos á que la ciudad parezca desierta. Ambas orillas del rio siguen pobladas 
A1. r8 hasta la cordillera, hasta donde llegan también las pesquisas y el beneficio de las minas, aunque disten del mar unas to ó 5o leguas. Así la poblacion de Coquimbo puede considerarse compuesta de unos I5 ó 20 comerciantes mercaderes que habilitan á los mineros; de seis ú ocho familias de conquistadores bien acaudaladas; de algunos empleados por el Rey y de un número crecido de religiosos de San Francisco, Santo Domingo, la Merced, San Agustin y San Juan de Dios; ocupan los Agustinos la casa de los expulsos jesuitas.

lil Subdelegado D. José Antonio Corvera, nos había prevenido una comida igualmente abundante y sabrosa; pero como el día se mantuviese despejado, lo que no es frecuente en aquellos parajes, nos pareció preciso el restituirnos casi todos inmediatamente al observatorio para medir algunas distancias de la Luna al Sol. Entre dos y tres de la tarde 80 series observadas con muy buenas circunstancias, determinaron para el observatorio la longitud media al Oriente de Chiloé de $2^{\circ} 24^{\prime} 50^{\prime \prime}$. Igual número y con iguales circunstancias nos indicó al medio día siguiente la de $2^{\circ}$ I $5^{\prime}$ : así el promedio de I6o series manifestaba la longitud occidental de París de $73^{\circ} 56^{\prime}$ mayor tan solamente en I5 á la que señalaban las observaciones del primer satélite de Júpiter.

Una situación tan placentera como la que acabamos de describir, la tranquilidad del puerto y el temple agradable del clima, debieron precisamente acalorar también las operaciones geodésicas del mismo modo que lo habíamos conseguido con las observaciones astronómicas. En los dos días indicados, alternando los Guardias Marinas en el cuidado de las sondas y repitiéndose las bases y las marcaciones del teodolito en cuantos puntos fuesen necesarios para el plano exacto del Puerto Grande, del de la Herradura y para la configuración de la costa hasta donde alcanzasen las visuales, pudieron considerarse concluídos también aquellos objetos; por manera, que inferida en la noche anterior la latitud del observatorio por diferentes alturas meridianas de estrellas al Norte y al Sur del zénit, á las cuarenta y ocho horas de nuestra llegada á Coquimbo ya hubiéramos podido emprender de nuevo la continuación del viaje, si la sola Hidrografía hubiese sido el objeto de nuestras tareas.

Pero el país en el cual nos hallábamos, además de contener en si una cantidad indecible de minas de oro, plata y cobre, había sido también en estos últimos años un objeto de nuevas especulaciones importantes para la Monarquía, con descubrir en las minas no distantes de Punitaqui la esperanza de una nueva suministración abundante de ázogue, lá cual, ó alcanzase is remplazar los benelicios bien desmayados de
Guancavelica, ó tal vez diese en lo venidero las crecidas cantidades que la Nación solía recibir de los minerales de Alemania. Reuníanse á estos objetos, por sí de la mayor importancia, las observaciones del eclipse de Luna y de dos ocultaciones de estrellas que debían proporcionársenos de allí á pocos días; y en el entretanto no serían tampoco inútiles ó las excursiones contínuas de los botánicos, ó un estudio algo más prolijo de las costumbres y riqueza intrínseca de aquellos contornos. Quedó pues decidido, que la salida de las corbetas para la continuación de sus tareas no tendría lugar sino en el día 30 , y que mientras por la una parte atendiésemos al estudio de los contornos de la ciudad y á las disposiciones necesarias para las observaciones indicadas, por la otra D. Luis Nee no abandonaría sus excursiones botánicas, y los señores Pineda J Heenke, con el Teniente de navío D. Fernando Quintano, internarían hacia las minas de Andacollo y Punitaqui para visitarlas y ensanchar sus conocimientos físicos en cualesquiera otros ramos que les viniesen á mano. Acompañábales el Administrador Superintendente de Punitaqui Don Miguel José Lastaría. El Teniente Coronel Don Tomás Shee, Oficial cuyas prendas morales se describirán con la individualidad correspondiente en las reflexiones siguientes, dirigía más de cerca el examen nuestro en las inmediaciones de la ciudad. La caza, la pesca, el cuidado de las tripulaciones, con una mezcla ordenada de trabajos y de entretenimientos, finalmente, la instrucción militar de la tropa con unos ejercicios diarios de fusil, repetidos después con fuego y algunos tiros al blanco, eran otros tantọs objetos, que reunidos á la suma hermosura del tiempo, debían hacer nuestra demora en el puerto con extremo agradable y entretenida.

Cuantos objetos nos habíamos propuesto, otros tantos efectivamente se llevaron con la mayor felicidad á debido efecto. Reconcentráronse á bordo los naturalistas y botánicos; se lograron las observaciones de los eclipses con tanta mayor complacencia, cuanto mayor había sido nuestro temor de malograrlas por el cielo siempre fosco después de los dos días primeros; y observadas el 29 las alturas correspondientes del Sol para el último arreglo del movimiento de los relojes, quedaron embarcados en aquella misma tarde los instrumentos, y todo dispuesto para dar la vela en la siguiente mañana.

No habían sido en el entretanto ménos escandalosas las deserciones en aquel puerto, de las que habiamos experimentado en los puertos visitados anteriormente. Y lo que debía causarnos una mayor extrañeza, era el que hubiesen incurrido ahora en ese delito, aquellos precisamente de los cuales debíamos tener mayor confianzá y en un momento en que ni los desórde- 
Ab. 29 nes diarios de la población, ni una demasiada fatiga ó un excesivo rigor en las corbetas, podían convidarlos siquiera remotamente á abandonar su destino; pero ó fuese aquella una ocasión de las que llevan á su albedrío el ánimo de la gente nuestra de mar, exactamente como una ola impelida del viento en una dirección cualquiera, ó bien (lo que no parece imposible) precediesen sugestiones y promesas de los vecinos para aumentar su número con personas bastantemente robustas y trabajadoras, ello es que en la misma no che del 28, viéronse faltar á la lista tres soldados, un artillero y un marinero de la Descubierta; y después se halló también abandonado el bote, el cual debía reconducirnos á bordo concluídas las observaciones astronómicas. En balde desde el amanecer del día siguiente D. Fernando Quintano recorrió á caballo las chozas más distan. tes, por si alguno de los fugitivos hubiese quedado en ellas durmiendo, acosado del vino ó del cansancio. Su regreso á las dos y media de la tarde, sólo sirvió para convencernos, mediante las noticias adquiridas, que la fuga era efectiva: los soldados procuraban hacerla más expedita con dos mulas que habían tomado violentamente: cuando los marineros fueron vistos, iban aún á pié, pero alcanzarían muy luégo el auxilio de los caballos para alejarse con más rapidez.

Desertaron casi al mismo tiempo otros dos marineros de la ATREVIDA. Un accidente apoplético arrebató en pocas horas al mejor gaviero de la Descubierta. Tantas pérdidas y tan repetidas, no podían á ménos de debilitar con extremo los armamentos, y no sólo hacer arriesgada en lo venidcro nuestra navegación, si también indicar bien próximo el momento en el cual, si acaecjesen nuevas deserciones, ya las corbetas se hallarían imposibilitadas para navegar hasta Lima. Esas reflexiones nos persuadieron finalmente como el mejor partido, el de cortar toda comunicación con la tierra. Se aceleró la salida para el día siguiente, y la precaución de hacer embarcar en cualquier bote un Oficial de guerra con dos soldados armados, debió tranquilizarnos sobre la conservación de los pocos restos de la marjnería.

Finalmente, en la mañana del 30 , entablado viento bonancible del Oeste Noroeste, ambas corbetas pudieron dar la vela, y con todo aparejo emprender sobre bordos la salida del puerto. Al medio día el Pájaro Niño de fuera demoraba al Oeste Sudoeste. Al anochecer ya distábamos unas tres leguas de la boca deí puerto, y le marcábamos al Norte $43^{\circ}$ Este de la aguja: variación magnética por varios azimutes 13 grados al Nordeste.

En el último examen de la marcha de los relojes, el número 72 había manifestado la misma exactitud que se le había conocido en la travesía desde Valparaiso, acreditando así no sólo las determinaciones que sobre él se habían hecho antes, si también el partido tomado de colocarle sobre esferas: el 6r, al contrario, continuaba con una extraña irregularidad en su movimiento, el cual determinado en Valparaiso de 58" I6 llegaba en este puerto á $I^{\prime} 3^{\prime \prime} 45$, promedio de todas las observaciones bien diferentes una de otra: el número 3 ya no daba la menor esperanza de que llegase á ser ni medianamente exacto: variaba considerablemente de un día á otro, aunque en la mayor quietud, en el temperamento más uniforme y manejado con el posible cuidado; el cronómetro 7I y el reloj ro5 de la ATREvida, continuaban con una marcha regular; se había notado alguna alteración en el número ro, reloj de una exactitud sobresaliente hasta aquella época.

No dejó de aprovechar D. Felipe Bausá la situación de la tarde misma para hacer nuevas marcaciones al cerro del Guanaquero y á la punta de Lengua de Vaca, las cuales, ligadas actualmente con los puntos bien situados de las inmediaciones del puerto, ratificasen nuestras determinaciones traídas desde el Sur al tiempo de dirigirnos á Coquimbo: tuvimos la satisfacción de verlas confrontar con una exactitud que no podíamos esperar, mucho más cuando se $1 c$ agregaron las marcaciones de la mañana siguiente, pues teníamos aún á la vista los mismos puntos de la tarde anterior.

Hasta la mañana del 3 de Mayo nuestras tareas hidrográficas pudieron contínuar con el método y exactitud acostumbradas. Reconociéronse bien de cerca los fondeaderos del Guasco y del Totoral; las observaciones repetidas de longitud dieron un nuevo grado de exactitud á las bases por corredera. Tomáronse varias precauciones para no propasar en la noche los extremos de los reconocimientos hechos en la tarde anterior. Así alcanzamos, finalmente, las inmediaciones del Morro de Copiapó, á cuya vista debian separarse de nuevo las dos corbetas, la una para atravesar al reconocimiento de las Islas de San Félix y describir á su regreso la costa dcl Perú desde la latitud de $5^{\circ} 3^{\prime}$ hasta Lima; la otra para continuar sus tareas al andar de la costa hasta aquella latitud, fondeando antes en Arica, y reincorporándose después en Lima. Se abrazó la ATREvidA con el segundo destino, y por la misma razón se reforzó su armamento con ocho hombres de la Descubierta; hízose nueva comparación de los relojes marinos para su mayor exactitud, y á las tres de la tarde apenas se decidían las primeras ventolinas de la brisa, cuando ya recogidas las embarcaciones menores, navegaron las dos corbetas, cada cual al rumbo de su destino. Perdiéronse después de vista apenas entrada la noche. La DEscubierTA, al ama- 
.lay. 3 necer del día siguiente ya se hallaba engolfada y con vientos más variables de los que solían experimentarse sobre la costa.

Pero á medida que aprovechados aquellos vientos la distancia andada aumentaba considerablemente, los tiempos iban tomando el más hermoso semblante, y los vientos, aunque calmosos, inclinándose más al Sur y Sueste, nos daban lugar á progresar en nuestra derrota. Se conoció por las observaciones diarias un efecto de corrientes al Oesnoroeste; y como ya en la tarde del 7 avistásemos un lobo marino y algunos pelícanos, hallándonos aún en latitudes de $26^{\circ} 25^{\prime}$ arribamos en aquella misma noche, logrando así en la mañana siguiente observal la latitud de $26^{\circ}$ oI $\mathrm{I}^{\prime} \mathrm{y}$ longitud al Oeste de Coquimbo de $5^{\circ} 5 \mathrm{I}^{\prime}$. La variación magnética, por una serie no interrumpida de observaciones de azimutes y amplitudes hechas con circunstancias las más favorables, se había conservado hasta esta época de I3 á r $2^{\circ}$ Nordeste.

Como es natural, habíamos aprovechado el cuarto menguante de la Luna para observar sus distancias al Sol. Las considerábamos como un nuevo apoyo de la posición que determinásemos á las Islas de San Félix con los relojes marinos, de cuya exactitud ya debíamos tener la más fundada seguridad, particularmente después de haber colocado ambos cronómetros sobre esferas: así las emprendimos desde la mañana del 5 , y en los siguientes días 6,7 y 8 , se procuró aplicarles toda la exactitud que estuviese á nuestro alcance, así en cuanto á las observaciones como á los cálculos. Debe pues imaginarse cuál sería con aquellos antecedentes nuestra sorpresa en ver sus resultados bien distantes de los relojes marinos: confirmábanse una á otra las observaciones anteriores con las posteriores. Concurrían el conocimiento de tiempos y el almanaque náutico en las mismas determinaciones de los lugares de la Luna; nuestras deducciones para el meridiano de Coquimbo no podían apoyar sobre datos de mayor confianza; finalmente, nuestra uniformidad en observar tan crecido número de distancias y la misma correspondencia entre las diferencias diarias en longitud deducidas de las distancias y las que indicaban los relojes, parecían exigir tanta confianza en los unos como en los otros.

\begin{tabular}{|c|c|c|c|c|}
\hline $\begin{array}{l}\text { l) ias en } \\
\text { que se } \\
\text { observó. }\end{array}$ & $\begin{array}{l}\text { Numero } \\
\text { de series. }\end{array}$ & $\begin{array}{l}\text { Longitud medida } \\
\text { por las dis- } \\
\text { tancias de Paris. }\end{array}$ & $\begin{array}{c}\text { Los relojes } \\
\text { al } \\
\text { mismo tiempo. }\end{array}$ & $\begin{array}{l}\text { Diferencia de } \\
\text { las distancias } \\
\text { á los relojes. }\end{array}$ \\
\hline 5 & 49 & $74^{\circ} 53^{\prime} 21^{\prime \prime}$ & $75^{\circ} 3230$ & E $39^{\prime} 30^{\prime \prime}$ \\
\hline 6 & I 43 & $76 \quad 47 \quad 57$ & 772600 & $3^{8} 00$ \\
\hline 7 & 88 & 78610 & $78 \quad 4700$ & 4050 \\
\hline 8 & 16 & $78 \quad 48 \quad 22$ & 792600 & 3840 \\
\hline
\end{tabular}

Así la diferencia andada cn longitud desde el día 5 hasta el 8 era:

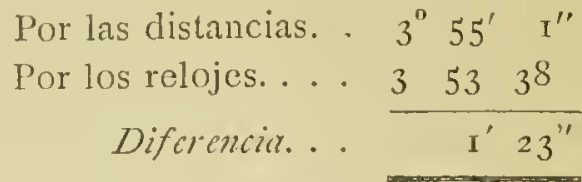

El cielo, por lo regular calimoso ó nublado en las horas próximas al amanecer, no dió lugar á observar distancias con astros occidentales á la Luna como lo hubiéramos deseado; tal vez nos darían alguna luz sobre las causas verdaderas de una diferencia tan extraña, que de ningún modo podía atribuirse á los sextantes ratificados con la mayor prolijidad y siendo casualmente de los mejores artífices ingleses Ramsdem, Dollond, Nairne, Stanchf, Wright y Troughton.

En la tarde del 9 se avistó al Oessudoestc y á larga distancia, la Isla bien alta de San Ambrosio, y con el objeto de descubrir las otras de San Félix en la mañana siguiente, continuáronse en la nochc rumbos proporcionados con fuerza de vela; por manera, que al anochecer pudiésemos marcar la primera al Norte $I 7^{\circ}$ Oeste, distancia de trés leguas, y avistar las otras más occidentales que parecían merecer el nombre más bien de pedruscos que de islas.

Varios chubasquillos, con una extraordinaria variedad en el viento hasta las dos de la tarde, hicieron luégo algo más complicados, bien que no ménos exactos, los reconocimientos que intentábamos. Lográronse las observaciones de la latitud y longitud. Reconocimos bien de cerca las calidades de la masa pedregosa de la cual se componía la isla mayor, y á las cuatro, pareciéndonos ya supérffua cualquiera ulterior demora en aquellos contornos los más áridos y malaventurados que puede presentar la Naturaleza, pusimos de nuevo la proa hacia el Continente con brisa galena del Sursudeste.

El Archipiélago reconocido se compone de una isla grande, tres medianas y un islote, además de algunos pedruscos aislados que se hallan inmediatos al extremo oriental de la isla grande, y otro que está á igual distancia en el extremo occidental. Todos presentan un semblante igualmente horrible y escarpado. Las dos capas que componen su masa, parecen contener muchas partículas férreas; son algo inclinadas al horizonte, y las negras ó ferruginosas son mucho más espesas que las coloradas, ó de una sustancia córnea. La isla grande de San Ambrosio es ciertamente inaccesible por todas partes, pudiéndose considerar como cortada á pico, si bien de una elevación no menor de Igo á 200 toesas. Sólo se advierte en una especie de meseta alta una vegetación bien mezquina, compuesta de pocos arbustos de dos á tres piés y de algunos gramenes; ningún rastro de agua, ningún semblante de abrigo que pueda convidar al navegante hacia ella. Las mismas aves y los lobos marinos que debían considerarse en crecido número en 
\lay. ro este asilo, el más seguro y el más templado para la subsistencia, parecen ahuyentados de su semblante horrible. No debe quedar duda que sean igualmente francos para la navegación todos los canales que forman entre sí las islas y los islotes. La latitud del extremo Oeste de la misma isla grande, es de $26^{\circ} 20^{\prime}$ I $5^{\prime \prime}$, su longitud de $S^{\circ} 28^{\prime}$ al Occidente del observatorio de Coquimho. La variación magnética ha quedado algo dudosa, pues fuese casualidad ó realmente un efecto de las muchas partículas ferruginosas de las cuales se ha hecho mención, no tuvimos sino $8^{\circ}$ al Nordeste en aquellas inmediaciones, cuando en la tarde anterior, á una distancia de I2 leguas, observábamos II $^{\circ} 3 \mathrm{O}^{\prime}$, cantidad proporcional á las que habíamos observado en las travesías desde la costa.

Nada ocurrió en la navegación siguiente que merezca ser referido. Los cielos fueron comunmente foscos, los vientos galenos del segundo cuadrante, y nuestros rumbos por lo común los que permitiese una bolina descansada. Arribóse últimamente al Norte y en la mañana del $x 6$ por latitud de $16^{\circ} 29^{\prime}$ ya teníamos á la vista una parte no mediana de costa, la cual, á distancia de unas cinco leguas, demoraba desde el Norte has ta el Este corregido.

Compónense allí las costas de unas andanas altas de arenales, prolongadas en su misma dirección y terminadas hacia el Oeste con puntas uniformes desde las cuales empieza nuevamente y en forma de escalón la otra andana; se advierte igualmente en todas partes un semblante casi desierto; hay algunas calas, pero son de poco abrigo, particularmente en donde bate la mar constante y siempre temible del Sudoeste.

Nuestros reconocimientos desde el paraje indicado hasta Lima, si bien emprendidos con cuanta exactitud pudiésemos alcanzar, debieron sin embargo ceder á las veces á la mucha contrariedad que allí ponen las corrientes y las calimas casi con emulación una de otra. No es fácil en algunas ocasiones el no dejarse arrastrar de las corrientes en las noches largas que hay en aquellas latitudes. Las nubes impiden otras veces ó las observaciones ó la vista de la costa más inmediata. Es preciso, que en la mucha repetición de operaciones se deslice algún error; empero, los que hayamos cometido jamás serán tales que arrastren el menor riesgo al navegante áun más descuidado, particularmente desde la Nasca y el Morro Quemado á donde suelen por lo común recalar los que vienen de las costas de Chile ó de las inmediaciones del Cabo de Hornos. Nos ocuparon aquellos objetos hasta la mañana del 20, en la cual, finalmente avistada la Isla de San Lorenzo y montado su extremo septentrional á distancia de un tiro de fusil, logramos internar en la bahía del Callao y sobre el mismo bordo dar fondo en paraje oportuno, ha. May =o cia las once de la mañana.

En el entretanto la ATrevida, la cual, como se dijo ya, debía segujr sus reconocimientos y tareas al andar de la costa, no había sido ménos feliz que la DescubiertA. Distínguese greneralmente con el nombre de ensenada de Arica y puertos intermedios, toda la costa comprendida entre Coquimbo y la Nasca. Concurren á ella diferentes embarcaciones costaneras con el objeto, ó de cargar el guano para la mayor fecundidad de las tierras, ó de extraer los diferentes frutos de la provincia de Arequipa, ó finalmente, do proveer la misma y las Intendencias inmediatas con los pocos efectos de Europa que pueda necesitar el corto número de sus moradores. La ensenada ó puerto de Arica, con el mismo intento de hacer más fácil la internación de los efectos europeos á las minas inmediatas, ha logrado ser comprendido entre el número de los puertos habilitados, lo cual, reunido á lo mucho que fué frecuentado por los navegantes franceses cuando al principio del siglo se extendieron en tanto número sobre las costas del Perú, decidió la preferencia á su favor para un reconocimiento más exacto de lo que pareciesen exigirle las demás ensenadas de Cobija, el General, Nuestra Señora, Mejillones, Iquique, Ilo y Quilca, todas ménos frecuentadas y generalmente con la sola ventaja para llamarse fondeaderos, de que haya un paraje abrigado de la mar del Sudoeste, no tanto para fondear, cuanto para atracar los botes y embarcar ó alijar los efectos.

En aquella parte bien extcndida de costas, corren siempre constantes los vientos del Sur al Este, caracterizándose luégo según el día ó la noche con el nombre de tcriales y virazones. No son raras las calmas acompañadas por lo común de algunas ventolinas casi imperceptibles del Norte. La mar del Sudoeste es el único peligro del cual debe precaverse el navegante, ó fondeado ó á la vela. Jamás hay un temporal, jamás la lluvia y el trueno interrumpen el trabajo ó el descanso del marinero. Todo allí anuncia la naturaleza tranquila, feliz y reposada, y sin embargo, en cuanto se extienda algo más adelante una mirada filosófica se apercibe inmedia tamente el contraste, ó en la sequedad indecible de los desiertos de Atacama y en los contornos de Copiapó y Guantajaya, ó en los repetidos extragos del volcán harto temible de Arequipa. Rara es la vez, por otra parte, en la cual el Sol vivifique con su brillo encantador las tierras, las plantas o los pocos moradores de aquellos contornos. Tantos inconvenientes y tantas ventajas, componen, en fin, aquella compensación universal del mal y del bien, sin la cual, soberbio el hombre y entregado al alhedrío de su propia imaginación, muy luego declararía la guerra al mismo 
May. zo cielo y apenas bastaría su propia ruina para retraerle otra vez del vuelo desmedido al cual se había entregado.

Después de una enumeración como la que antecede, de las diferentes circunstancias que debía encontrar la ATREvida recorriendo las costas indicadas, parecerá más bien extraño, que sus tareas fuesen igualmente exactas y expeditas en la dilatada extensión que le había tocado en suerte. Sustituíanse á la altura meridiana del Sol para la deducción de la latitud, otras alturas medidas en ocasiones oportunas y calculadas por los métodos más exactos. El excelente reloj número io del Sr. Ferdinando Berthoud, con un movimiento inalterable, suministraba nuevas combinaciones no violentas para el mismo intento, ó para la deducción de las longitudes, ó finalmente, para la sujeción de las bases de corredera. Los pairos durante la mayor parte de la noche y una suma aproximación á la costa durante el día, compensaban luégo la estrechez de los horizontes y lia fosquedad de las tierras. Así pudiéronse recorrer uno á uno los diferentes fondeaderos, de los cuales se ha hecho memoria; y finalmente, fondear en Arica en la noche del I4.

Son una excelente marca para el fondeadero de Iquique, el cerro de Tarapacá que está un poco más al Sur.de la boca del puerto, unos méganos de arena que hay dentro de la misma ensenada y una punta al Norte formada de piedras blancas del guano (I): el Morro de Arica no lo es ménos para buscar la entrada del puerto ó bahía de ese nombre.

Atento á los objetos que allí debía desempenar la ATREvidA, y á la epidemia de tercianas que según costumbre acosaba en aquella estación á la mayor parte de los habitadores de los contornos, fueron sólo cuatro días los que permaneció fondeada. En ese intervalo, sin embargo, fueron repetidas las observaciones de latitud y longitud por medio del sextante, y nó sin algún riesgo por la mucha mar al tiempo de desembarcarse, 1ograron el Comandante y algunos Oficiales el levantar el plano exacto del puerto, valiéndose de las bases de cadena y de las marcaciones del teodolito bien multiplicadas, por manera, que no cupiese el menor error bien en los puntos interiores ó en la costa siguiente por una y otra parte hasta donde se le alcanzase á la vista. Al mismo tiempo se sondaron á las órdenes del Teniente de navío D. José Robredo todos los parajes útiles para fondear: se observaron muchas series de distancias lunares, se examinó de nuevo con la posible escrupulosidad el movimiento de

(I) Guano es el estiércol del simnumero de gaviotas que habitan sobre aquellas costas y posan en algrumos islotes desiertos. Su cantidad y utilidad para el beneficio de la Agricultura, se detallarán despućs con la mayor claridad. los relojes, $y$ se adquirieron, finalmente, todas May. 24 aquellas noticias sobre los paises inmediatos, que pudiesen dar una idea mediana así de su opulcncia interior como de sus relaciones políticas con la matriz.

Muy poco correspondían los vientos al ansia natural de abandonar el fondeadero con la mayor presteza; fué, pues, preciso valerse de los botes para remolque, ya que las ventolinas del terral no alcanzaban en la mañanita del Ig á apartar la corbeta á una mediana distancia de la costa, ni bastó todo aquel día para que granjeasen una tal distancia cuanta era necesaria para perder el puerto de vista.

Ya desde allí, con un mejor semblante del tiempo y vientos algo más frescos y favorables, pudieron acelerarse y ser más exactos los reconocimientos siguientes. La costa ménos fosca, las bases más arregladas y varios montes internos que servían para enlazar oportunamente las marcaciones más distantes, veíanse, por otra parte, correspondidas con una mayor frecuencia en las observaciones, las cuales daban al todo un grado de seguridad hidrográfica cual no debía fácilmente esperarse en aquellos contornos. Alcanzados así los paralelos del Morro de Acarí, en donde habían empezado de nuevo los reconocimientos de la Descubierta, omitióse sólo el pairear en una parte de la noche, pero se aprovecharon de tal modo los dos días siguientes para repetir las mismas operaciones favorecidas ahora con una presencia casi constante del Sol, que pudo darse á las primeras un nuevo grado de perfección, y sin embargo, alcanzar el fondeadero del Callao en la noche del 28, quedando inmediatamente amarrada y desaparejada al lado de la corbeta compañera.

Ya en el plan propuesto y aprobado por Su Majestad, se envolvía una demora en Lima que diese lugar á un nuevo acopio de víveres, á la recorrida de las embarcaciones y de sus pertrechos, al examen prolijo de un país de tanta importancia para la Monarquía, y sobre todo á la ordenación de los muchos materiales hidrográticos que habíamos acopiado, y que ya nó sin mucha confusión se iban aglomerando y en cierto modo destruyéndose en la imaginación, se agregaba que en la costa siguiente al Norte reinaría á la sazón el vendaval lluvioso enteramente opuesto á nuestras tareas, y que, por consiguiente, á ninguna parte pudiéramos dirigirnos que no envolviese á lo ménos igual sacrificio de tiempo para retroceder á las costas desde Guayaquil á Acapulco, en donde sólo por Diciembre empiezan á entablarse las brisas.

Con estos objetos, desde Chile habíamos suplicado al señor Virey que tuviese á bien interponer su influjo con los religiosos de la Buena Muerte, para que nos dejasen establecer el 
Jun. real en su casa del pueblo de la Magdalena, mientras las corbetas permaneciesen desarmadas en el Callao.

Es la Magdalena, un pueblecito de indios, como muchos que amenizan el hermoso valle del Rimac, sito al de la ciudad y no distante de ella sino dos millas marítimas: la amenidad de su suelo, la salubridad de sus aires y aguas, la tal cual separación de la vida bulliciosa de Lima, le hacen concurrido de muchos enfermos y convalecientes, para los cuales el cielo de la ciudad es conocidamente pernicioso y funesto.

Muchas razones habían demostrado la necesidad de que nuestro real se estableciese algo distante del Callao y de Lima, de modo que combinásemos la reunión necesaria de todos para las muchas tareas á que debíamos arrostrar, con aquella natural independencia que es sola el primer móvil del descanso y del recreo. El Callao, además de ser conocidamente expuesto á unas tercianas constantes, nos arrimaba demasiado á los armamentos para que ni dejasen de incomodarnos á cada paso con su método poco arreglado de vida, ni á la inversa les incomodásemos con nuestra presencia demasiado frecuente, la cual no nos diera lugar á disimular uno ú otro desorden. Además, que si la Oficialidad estuviese distante de Lima y precisada á unas tareas casi diarias, mal pudiera dedicar las pocas horas que le quedaban á la vida sociable y no ménos instructiva con que le brindaba la capital inmediata.

No era tampoco oportuno el establecernos dentro de la ciudad misma, así porque serían las distracciones y la dificultad de reunirnos mucho más frecuente, como porque la misma curiosidad y ociosidad natural arrastrarían contínuamente hacia el centro de nuestras tareas un número crecido de personas, con un grave perjuicio de la mayor economía del tiempo que nos propo. níamos. En la Magdalena, además de evadir los inconvenientes indicados, disfrutaríamos de un cielo algo más despejado para nuestras observaciones, de un clima mucho más sano, y particularmente de una cierta libertad campestre inseparable del sosiego.

Así, desde el momento en el cual la DescuBIERTA fondeó en el Callao, como pasase el Teniente de navío D. Cayetano Valdés á cumplimentar al Virey y por la tarde lo verificasen también los demás Oficiales con los Sres. Pineda y Heenke, quedó aprobado por su excelencia el plan propuesto y accediendo los religiosos de la Buena Muerte á la total cesión de la casa ya indicada, pudieron en la mañana siguiente tomarse medidas bien activas para la verificación del establecimiento y particularmente del observatorio. Los instrumentos astronómicos y geodésicos, los acopios de Historia Natural, la mayor parte de los libros y planos, se transfirieron allí sin la menor demora y acompañándole muy lué- Jun. go algunos de los Oficiales, al paso que vigilaban sobre el buen orden y acomodo de cada cosa, acechaban cualesquiera momentos favorables para las observaciones astronómicas, tan difíciles de conseguirse en el cielo contínuamente nublado de aquellas inmediaciones.

Los días que á la sazón corrían, eran preci. samente los que la ciudad de Lima había destinado para la entrada pública del nuevo Virey del Perú, el Teniente General D. Francisco de Gil y Lemus. Este General reunía á su alto caracter y á unos talentos y cualidades personales dignas de mucha admiración, aquel amor hacia nosotros que debía dictarle el ser el mismo un individuo de la Real Armada, lo cual, al paso que nos hacia participar de aquellos regocijos públicos, excitaba también una natural curiosidad, hija de unos aprestos tan magníficos cuales eran los que por todas partes se nos presentaban á la vista. El Sr. D. Antonio de Ulloa, en la narración de sus viajes, ha descrito el pormenor de esas funciones con tanta puntualidad y elegancia; que fuera reprensible el describirlas nuevamente, tanto más, que restituídas ahoráa su antiguo lustre todas las ceremonias propias de aquella ocasión, en nada podía la narración tacharse de poco exacta, si no es en el número ya mucho mayor del pueblo y en las aclamaciones procedidas ahora de un afecto más vivo hacia el augusto Soberano noblemente representado á tamaña distancia del trono.

Verificada la incorporación de la corbeta ATREVIDA, fueron las primeras atenciones en entrambos buques la de examinar el movimiento de los relojes con alturas absolutas del Sol, medidas con el sextante. La buena posición de verticales en las primeras horas de la tarde, facilitaban mucho la exactitud de aquel método; así para los primeros días del mes de Junio, conseguido el examen indicado, pudimos proceder sin mayores dilaciones al arreglo de las cartas, las cuales debían abrazar las costas reconocidas hasta entonces. Tuvimos tambien sobre pocas claras, la casualidad de poder observar para el anochecer del día 5 la emersión del primer satélite de Júpiter, la cual, según los métodos adoptados, debía ligar las deducciones de los relojes marinos con los resultados de las observaciones celestes.

E1 primer día de Junio había sido la época en la cual empezamos el método de disciplina últimamente adoptado. D. José Bustamante, con su Oficialidad, se había establecido en una hẹrmosa casa de campo del Conde de San Carlos, á muy poca distancia de la Magdalena. Cada Oficial tuvo muy luégo un caballo con el cual nues. tras visitas al Callao, nuestra concurrencia casi diaria á Lima, y á veces nuestros paseos, eran tan fáciles y frecuentes como sanos $y$ entreteni- 
Jim. clos. La misma recopilación de los materiales acopiados que se hacía de mancomún en ambas casas y que trabadas precisamente entre sí las uiferentes materias exigía la solución continua de una ú otra duda, se hizo de este modo muy fácil, destacándose en el mismo traje de caza una ú otra persona á caballo que las preguntase y resolviese. Empero muchos más objetos debieron tenerse presentes para adaptar á aquellas circunstancias un método general y oportuno, por manera que en las clases subalternas tuviésemos á la vista la menor familiaridad entre sí, una distracción no enfadosa de los vicios harto comunes en el Callao, una regular asistencia á sus deberes, la ninguna deserción, y si fuese posible la conservación de una salud robusta en medio de los muchos riesgos que la rodeaban. Con dichos objetos, en el mismo día primero pasó á acuartelarse en la Magdalena la tropa de batallones y brigadas de ambas corbetas, haciendo que los destacamentos á bordo fuesen de cuatro hombres á las órdenes del sargento, condestable ó primer cabo. Un solo Oficial de guerra, alternando los de una y otra corbeta y los mismos Guardias Marinas, quedó encargado de la guar dia de entrambos buques fondeados en una grande inmediación uno de otro. Pasaron también á la Magdalena los pilotines y pintores y el sangrador de la Descubierta, para encargarse de las disecaciones y aprestos correspondientes á la Historia Natural. Se permitió á la Oficialidad de mar vivir indistintamente á bordo ó en tierra en el Callao, siempre que su conducta no fuese escandalosa; sólo sí que el Contramaestre y dos guardianes, debían precisamente turnar en dormir á bordo con la tercera parte de la tripulación, á cuyo cargo estarían la lancha, bote y chinchorro varados en paraje oportuno, para menor distracción las otras dos embarcaciones menores. En el día de trabajo ninguno estaría exento de él si no precediese licencia, cuyo término se encargaba á los Oficiales de guardia no excediese de tres días, castigando por otra parte severamente los que interrumpiesen aquella distribución equitativa.

Pero aunque no liubiésemos conocido de antemano los desórdenes de la marinería en el Callao, no hubiéramos podido ocultarnos que semejantes providencias en poco ó en nada se llevarían á efecto, si no ligasen con agentes mucho más poderosos que los consejos ó el castigo; aquéllos poco eficaces, cuando el halago, los ejemplos, el clima, la ociosidad y uná fácil subsistencia, convidaban al vicio; éstos otros difíciles de realizarse cuando la fuga era tan fácil como el delito. El interés debió, por consiguiente, parecer la única arma propia en aquella ocasión, y la misma necesidad en que nos hallábamos de dar algunas payas á las marinerías, así para que no echasen a menos la rratificación del vino, cuya distribución sólo debía verificarse en Manila, Jun. como porque eran acreedores á premios los pocos que en las costas de Chile no se habían abandonado á la deserción ó al desorden, dictó el medio más oportuno de reunir los objctos de interés á la conservación de una disciplina tan poco molesta como lo permitiese el buen servicio del Rey.

Rajo de estos principios, se estableció que en los meses en que permaneciesen las corbetas en el Callao, adcmás de la ración, se abonarían á cada marinero que asistiese al trabajo, cuatro reales diarios á cuenta de sus pagas; por manera que, sujetado á las listas, no sólo el ausente no triunfase de sus faltas ó vicios, sino que perdiese una parte correspondiente de su paga á favor de la Real Hacienda; debía también preferirse esta especie de castigo pecuniario, á los que deslizándose en alguna falta digna de castigo, quisiesen lavarla con el trabajo en lugar de vegetar ociosamente en el cepo. A la tropa, pilotines y Oficialidad de mar, para mayor decoro, se dió la paga á principio de cada mes, reservándose, no obstante, el detenerla oportunamente á los que no siguiesen un método arreglado de vida. Finalmente, para los enfermos se adoptó, sí, el hospital muy bien asistido de Bellavista, pero en una sala separada, bajo la inspección de nuestros cirujanos y al cargo inmediato del sangrador de la Atrevida.

Entretanto, nuestras tareas científicas se habían emprendido y llevaban adelante con todo aquel vigor que debía exigir nuestro anhelo, de que correspondiesen á las intenciones de S. M. en pro de la navegación nacional. Se examinaron de nuevo y arreglaron sobre datos más probables las marchas de los relojes marinos, particularmente en las épocas comprendidas desde Buenos Aires á Chiloé, resultando con esto alterada la posición en longitud del Puerto Deseado. Los diarios meteorológicos, los estados de variaciones y mareas, el diario astronómico, las tablas de las variaciones diarias en el movimiento de los relojes, todo recibió un nuevo orden debido á los diferentes Oficiales á cuyo cargo se puso; se repasaron y extractaron las observaciones de latitud ó de longitud que sirviesen de base á las operaciones hidrográficas; se emprendieron los derroteros por los señores Quintano y Vernaci, y D. Dionisio Galiano en una bien hilada disertación que hizo preceder á las observaciones astronómicas, explicó por extenso los instrumentos relativos así á aquella ciencia, como á la Física, y los métodos con que hasta entonces se habían aplicado á la Hidrografía los principios más sólidos de la Astronomía. No estaban tampoco ociosos los naturalistas; antes bien, encontrando por todas partes nuevos objetos de admiración en los diferentes ramos de Historia Natural, aprovecliaban de aquel 
clima uniforme para vagar á su albedrío los contornos del ameno valle de Rimac. D. Antonio Pineda, á cuyo cargo estaban los ramos de la Historia Natural, excepto la Botánica, no pudo á la verdad apartarse tan luego de la Magdalena; pero los Sres. Nee y Heenke, ya desde la mitad de Junio emprendieron excursiones dilatadas y de la mayor importancia, dirigiéndose el primero hacia las Quebradas de Canta, y el segundo por Tarma al otro lado de la cordillera hasta Guanuco, cuyo rio, vertiendo ya sus aguas hacia el Este, comunica con el Marañón y empieza á ser navegable. Se prescribieron á D. Luis Nee solos treinta días de ausencia; se amplió hasta cincuenta días la de D. Tadeo Heenke; y les acompañaban los Sres. Tafallas y Pulgar, botánicos pensionados por S. M. en Lima y dos dragones milicianos medianamente prácticos del idioma indio.

Todas las medidas indicadas necesitaban á cada momento ó bien la autoridad ó el influjo del señor Virey. No nos faltaron uno ni otro, en cualquiera ocasión que los solicitásemos; antes bien, franqueando S. E. á D. Cayetano Valdés, á cuyo cargo había puesto el examen del Archivo de temporalidades, cuantas noticias pudiesen conducir al mayor ensanche de nuestra obra, vimos que el plan propuesto podría llevarse á debido efecto en cuantos ramos nos permitiese extenderle el tiempo de nuestra demora en aquellas inmediaciones.

Los armamentos de entrambas corbetas, harto desmembrados así en cuanto á tropa como á marinería desde que entramos en el mar Pacífico, exigían también una atención tanto más seria por lo que toca á su reemplazo, cuanto que debíamos temer que las escalas siguientes de Guayaquil, Panamá y Acapulco, nos arrastrasen nuevas deserciones y desórdenes. Para la tropa y brigadas suplicamos desde luégo al señor Virey que nos permitiese completarlas con aquella gente voluntaria que del regimiento Fijo de Lima ó de la Artillería, quisiese pasar á nuestras banderas. Exigíamos las cualidades de robustez, buena conducta y de que procediesen de los regimientos veteranos de Soria y Extremadura, los cuales, al tiempo de regresar á España, habían completado dicho regimiento, y dejábamos al arbitrio de D. Cayetano Valdés el decidir, después del examen más prolijo, cuáles entre los muchos que se brindaron voluntariamente, fuesen ó no oportunos para el intento. En cuanto á la marinería, conociendo el genio inconstante de esa clase infeliz, y pudiendo combinar con el corto número que á la sazón nos había quedado así el desempeño de las faenas diarias como una prudente economía al Erario, dejamos para el último mes de nuestra estada en el Callao el completarla, ó bien con los muchos que en los navíos mercantes habían venido de Europa en aquel mismo año, ó con los que llegasen en la fragata Liebre de la Marina Real, destinada según los últimos correos á la mar del Sur y particularmente al puerto del Callao.

La policía del puerto, harto abandonada desde que no le frecuentaban los buques de la $\mathrm{Ma}$ rina Real, fué otro objeto que debió precisamente ocuparnos mientras no hubiese otra embarcación que le tomase á su cargo. Se prescribieron á este fin á. los Capitanes de los buques mercantes las precisas instrucciones sobre anclas, amarradero y número de gente á bordo, particularmente de noche, para su seguridad. Debía rondar el Oficial de guardia para el exacto cumplimiento de la instrucción indicada; debía examinar el estado de los buques que saliesen, para que, poco advertidos, no careciesen de aquellas precauciones que son indispensables áun en la más extricta economía mercantil; finalmente, debían por sí cortar con igual dulzura, rectitud y prudencia, todas aquellas quejas cliarias que ya el Capitán, ya el marinero, en los buques mercantes, encuentran en sus ideas harto contrarias y opuestas entre sí. Estas precauciones no alcanzaron sin embargo á evitar, que en la noche del 7 de Junio un buque mercante, incendiado por descuido del Oficial de mar y pocos marineros que le habían abandonado, pusiese en evidente riesgo las mismas corbetas y particularmente la DescubierTA, á cuyo orinque del ancla del Norte quedó por largo tiempo agarrado con el timón. E1 Guardia Marina D. Jacobo Murphi y los dos primeros contramaestres de las corbetas con ambas lanchas, desplegaron en aquella ocasión una actividad é inteligencia dignas de elogio, logrando remolcar y varar en la playa del Ancon el buque incendiado, ya que se habían frustrado todos sus esfuerzos para apagarle ó aprovechar los palos y alguna otra parte de sus pertrechos.

En los buques mercantes recién llegados de Europa, el Intendente general de Marina en la Isla de León, nos había dirigido varios efectos que aún no estaban prontos al tiempo de nuestra salida. Entre ellos tuvimos la satisfacción de ver comprendida una ecuatorial de Dollón, la colección de libros acopiados en París para los objetos de Historia Natural, y dos cajas de cristales, casi todos utensilios pertenecientes á las experiencias de los aires, siendo entre ellos dos máquinas de mucha importancia, los eudiometros de los Sres. Volta y Fontana; pero no pudimos ménos de extrañar y hallar sumamente perniciosa para los objetos que nos proponíamos seguir en el viaje, la falta no sólo de la excelente colección de instrumentos físicos que acopiada en París por disposición del Excelentísimo Señor Conde de Fernán-Núñez estaba ya embar- 
Jul. cada en Ruan al tiempo de nuestra salida de Cádiz, si también los pararayos y algunos otros utensilios que debían remitimos del Arsenal de la Carraca en las primeras ocasiones. Nos entregamos entre tanto de todo lo que había llegado, y no tardó D. Antonio Pineda en examinar la salubridad de los diferentes aires atmosféricos que se respiraban en los contornos de Lima.

Casi al mismo tiempo habían llegado á Lima, remitidos por los correspondientes Gobernadores, casi todos los desertores de Chiloé, y entre los de Chile un marinero quedado en Coquimbo y otro y un cabo de escuadra de la Descubierta desertados en Valparaiso; se les trató con mucha ménos severidad de la que debían esperar, obligándolos sólo á que descontasen á bordo con un grillete ó cadena el premio de su aprehensión; no les quedó tampoco cortado todo medio de evadirse de nuevo, y sólo al cabo de escuadra se obligó á que sirviese en la ATREvida en clase de soldado raso, hasta que manifestase en su conducta datos tales, quc pudiesen borrar el error pasado harto escandaloso. En nuestro sistema de armamentos, en los cuales por ningún motivo podíamos admitir gentes cuya custodia y conducta exigiesen la ocupación constante de otros muchos, esos rasgos de dulzura eran más bien necesarios que oportunos, ni dejaron de influir mucho en ligar el amor de la marinería al servicio, pues que además de que los marineros apresados eran buenos y generalmente amados de sus compañeros, no les quedó duda que la autoridad en nuestras manos era inseparable de la compasión y que al paso de perseguirles con el mayor tesón donde estuviesen, no era esto con ánimo ó de emplearlos violentamente y casi por necesidad en la misma comisión, ó desplegar sobre ellos un rigor militar intempestivo. Al mismo tiempo se examinó en Consejo de guerra junto á bordo de la ATREvida, el delito cometido en Valparaiso por un soldado de marina de su guarnición, que había mal herido á un marinero, muerto después á bordo más bien por haber ocultado por largo tiempo la herida que por su gravedad al principio. D. Secundino Salamanca, cn una defensa bien ordenada, recordó á los jueces las circunstancias del delito, la dificultad de resistir á unos ultrajes contra su misma clase y servicio en un soldado que voluntario se había alistado en el servicio de las corbetas cuando podía gozar quieto de una paz duradera; finalmente, la gallardía con la cual solo y con armas inferiores se había defendido de clos marineros; y el Consejo, reflexionando en estas circunstancias, le sentenció á seis meses de prisión, contando la que ya había sufrido, y á un recargo de cinco años en el servicio militar, bien que debia tener lugar en la fragatá Liebre más bien que en nuestros buques, para que ni los armamentos. turiesen á la vista casi impune el autor de una muerte, ni quedase entre la tropa y marinería un principio de rencor que después de largo tiempo pudiera acrecentar y ser funesto.

Añadidas á estas muestras de escarmientos la ocupación diaria, el cebo del jornal y la natural disciplina militar, haciendo la marinería freecuentes ejercicios de cañón y los de fusil la tropa, juntamente con las revistas de armas y ropa, guardia de prevención, toques de retreta diaria, etc., lográbamos ver, nó sin mucha complacencia, que el buen orden, el amor recíproco de las diferentes clases y de los mismos individuos entre sí, finalmente, que la robuste $z$ misma, iban precisamente cimentándose en el paraje donde más bien debíamos recelar su última destrucción.

En los primeros días de Julio vimos llegar la fragata Liebre de la Marina Real, al mando del Capitán de navío D. 'Tomás Geraldino; siguieron luégo con mediana actividad nuestros aprestos para las próximas campañas; así, al concluir del mismo mes, las corbetas aparejadas de un todo, la tonelería y velamen recorridos con la mayor escrupulosidad, reemplazados ó compuestos los diferentes pertrechos, completadas aguada y víveres, recibido el número de tropa que nos faltase áun excluído uno ú otro individuo de los antiguos, ó como enfermo ó como inútil, y la estación oportuna para seguir nuestras tareas ya muy próxima, todo nos avisaba que era tiempo de arrostrar de nuevo unas ocupaciones que por tanto tiempo debían tenernos á tamaña distancia de la patria. Incorporados ya por otra parte los Sres Nee.y Heenke, después de unas excursiones tan útiles como penosas, y no debiendo ser sino de muy pocos días la ausencia de D. Antonio Pineda, que intentaba un nuevo reconocimiento de la cordillera en aquellas inmediaciones, debímos poner un término á nuestro deseo de que nada faltase ni en la exactitud ni en la multiplicidad, ni en el orden ni en el aseo, en todo lo que había de componer nuestra remesa de las tareas pasadas y más bien inclinarnos á aquellos objetos cuyo cumplimiento exigiese indispensablemente nuestra demora en el Callao.

Quedó por consiguiente determinado para el 20 de Agosto el principio de las tareas hidrográficas y del restablecimiento de la mayor parte de la Oficialidad á bordo. Debía hacerse cargo del Real de la Magdalena D. José Bustamante, át quien dos meses de calentura casi contínua, hacían necesaria mucha quietud y una regular convalecencia. Sería el otro establecimiento á bordo de la Descubier'ta para acelerar las últimas tareas y disponernos á la salida, con cuyas precauciones, cada uno de los individuos de las corbetas lograría indistintamente del necesario descanso, comodidad y acogimiento donde sus 
ecupaciones principales le detuviesen, bien sea á bordo ó en la Magdalena. Aquí debían permanecer particularmente todos los encargados del ramo de la Historia Natura]; D. Felipe Bausá, el piloto Maqueda y dos pilotines para continuar el trabajo de cartas; y los Tenientes de navío Galiano y Concha que intentaban arreglar antes de la salida el catálogo de las estrellas observadas en Valparaiso. Al cargo de D. Juan Vernaci estaría el arreglo de la marcha de los relojes marinos, formado el observatorio muy oportunamente en una de las torres de la ciudadela del Callao, y el mismo Bausá, medida una base en las inmediaciones de la Magdalena, extendería poco á poco los triángulos desde el observatorio hasta la catedral de Lima, Pachacamac, Lurin y el mismo puerto de donde le encontraríamos nosotros con otra serie de triángulos emprendidos sobre otra base para extender hacia las islas de Pachacamac.

La constante benignidad del tiempo, que hace el mérito principal del hermoso clima de aquellas costas y su menor fosquedad, pues ya con la caída del invierno se iba poco á poco disipando, hicieron que las medidas indicadas pudiesen llevarse á debido efecto casi con la misma precisión con que las habíamos dispuesto, y así para los primeros días de Setiembre estaban concluídas las operaciones hidrográficas, sondado prolijamente el puerto, usando de teodolitos para la colocación de los bajos, bien encaminado el arreglo de los relojes, y hecha por el piloto Maqueda una excursión al Ancón y los Pes cadores, para ligar aquella parte adonde no alcanzasen nuestras marcaciones, examinar sus sondas y hacer una ú otra observación de latitud. Sólo D. Manuel Novales, quien con el Guardia Marina Alí debía en el falucho de las Rentas reconocer los islotes foranos de las Hormigas y determinar con buenas observaciones su latitud y longitud, tuvo la desgracia de no poderlo verificar completamente acosado de un viento extraordinariamente fresco del Sur, el cual, engruesando mucho el mar, ni le permitió permanecer fondeado entre aquellos pedruscos, ni dejó de exponerle á mucho riesgo é incomodidad para alcanzar nuevamente el puerto. Completamos al mismo tiempo, con marineros de la fragata Liebre ó de otros buques, todos los que faltaSet. 5 ban, y así para el ${ }_{5}$ de Setiembre, época en la cual cerróse la cuenta de los relojes, pudimos considerar ya todo dispuesto para dar la vela.

Dos cosas habían no obstante contribuído á la sazón á enturbiar considerablemente la natural complacencia que debía causarnos, no sólo la perspectiva de nuestras tareas del primer año, si también la aprobación de S. M. á nuestras operaciones del Rio de la Plata, que acababa de manifestarnos en carta de Marzo el señor
Bailío D. Antonio Valdés, y fueron éstas la separación del pintor D. José del Pozo del destino al cual se había contraído, no pudiendo sujetarse ni á aquella natural subordinación que sola es el principio y cimiento del buen orden, ni á aquel tesón y asiduidad en el trabajo que exigían así el ejemplo de los demás, como la harmonía de los objetos que teníamos entre manos. La segunda, fué el que no faltaron en los últimos días de nuestra demora en el Callao algunos desórdenes en ambos armamentos, in separables á la verdad del marinero cuando abandonando un país lleno en su entender de halagos y atractivos para arrostrar las fatigas del mar, intenta sepultar en un goce momentáneo la idea de los peligros que le esperan. Muchas veces la dulzura y muy pocas el rigor, se emplearon para contenerlos: la Oficialidad, ya casi toda reconcentrada á bordo, alternó en este útil objeto; y finalmente, pudo conseguirse que se reuniesen á bordo en el día anterior á la salida todos los individuos de la Descubierta, si se exceptúa un soldado de Marina y otro de los recién pasados del regimiento Fijo. No fueron mayores las faltas de la AtrevidA, según avisó su Comandante por medio de D. Francisco Javier Viana, y así, nada oponiéndose ya en la tarde del ig para la verificación de la salida, esperamos con ansia la mañanita síguiente, metidas ya dentro algunas de las embarcaciones menores y cortada cuanto fuese posible la comunicación con tierra.

\section{CAPÍTULO VI}

Navegación desde el Callao al andar de la costa hasta el Puerto de Perico en el Golfo de Panamá. Ocurrencias en Guayaquil y en aquel puerto.

Eran las diez de la mañana cuando pudimos dar la vela con la brisa ya entablada. Al medio día, el estremo Noroeste de la Isla San Lorenzo, nos demoraba próximamente al Norte distancia de media milla, y el rumbo emprendido del Oeste $1 / 4$ Noroeste debía conducirnos directamente á dar vista á los Islotes de las Hormigas, cuya posición intentábamos rectificar, malograda en mucha parte por el temporal del Sur la expedición del Teniente de Navío D. Manuel Novales, de la cual se hizo memoria. Los avistamos efectivamente á las tres y media de la tarde, cuando desde la cofa de mesana se alcanzaba todavía la vista de la Isla de San Lorenzo. Fué fácil después reconocerlos de cerca, y finalmente, á las cinco, sondadas 94 brazas arena y conchuela, y observados algunos horarios, arribar el Norte para continuar las tareas emprendidas. Los dos islotillos indicados y ya bien reconocidos por Don 
Set ao Manuel Novales, el cual había fondeado entre ellos, serían seguramente un peligro no mediano en aquellas navegaciones, así por su poca elevación, como por sus restingas salientes en varias direcciones; pero por ventura tienen buen fondo á una milla de distancia, y además es fácil evadirlos saliendo de la Isla de San Lorenzo para cl Oeste: viniendo á Lima siempre se costea la tierra firme á corta distancia, ni hay motivo alguno que pueda precisar á otro partido. Nuestras observaciones combinadas con la estima, determinaron para el islote mayor la latitud de I I $54^{\prime} 40^{\prime \prime}$ y la longitud de $34^{\prime} \mathrm{o}^{\prime \prime}$ al Occidente del Callao.

No hay tal vez en la dilatada extensión de las costas de la América sobre el Mar Pacífico, una parte más oportuna para las tareas hidrográficas, de la que se halla comprendida entre Lima y Paita, debiéndose considerar este último puerto como el verdadero término por una parte de los vientos siempre constantes del Sur, por la otra del imperio de las dos monzones opuestas del Sudoeste y del Nordeste. Son allí los cielos algo ménos calimosos que sobre las costas de Coquimbo y Arica, en donde por la misma razón no pueden repetirse con tanta frecuencia las observaciones, los vientos son muy frescos y largos, las costas ménos desiertas y por eso más frecuentes los fondeaderos ó abrigos, las sondas no se extienden á ménos de cinco leguas mar cn fuera, finalmente, frecuentan á esas orillas felices un número tan crecido de aves acuáticas, de anfibios, de ballenas y de peces, que el navegante halla por todas partes nuevos objetos agradables para satisfacer á su codicia ó al entretenimiento de su imaginación. Córrense así unas tras de otras cerca de doscientas leguas de costa casi todas en la dirección Norte-Sur. Se ven en la orilla del mar los diferentes pueblos que sirven como otros tantos albergues, para los que transitan por tierra desde Paita á Lima. La cordillera dc los Andes, sumamente elevada, descúbrese pospuesta á poca distancia, siempre calimosa y formadas al parecer sus cimas por materias areniscas y cenicientas; siguen después los arenales de Pascamayo, Cherrepe y Cechura. Las ciudades de Trujillo y Paita son las más considerables y las que por diferentes razones atraen á sí algún comercio, sea de los productos naturales ó de los artefactos.

Nuestra navegación hasta Paita ó más bien hasta el Cabo Blanco, debió con aquellos antecedentes ser igualmente sencilla y agradable. Las bases de corredera y las observaciones, sean de latitud ó de longitud, se daban constantemente la mano unas con otras. La ATrEvidA de hora en hora examinaba las sondas, las cuales desde las 8o brazas á cinco leguas mar en fuera, solían últimamente alcanzar de I6 á 20 á una legua de la costa. Paireábamos la mayor Set. 20 parte de la noche; solíamos medir una ú otra altura de los montes más elevados. La variación de la aguja disminuía paulatinamente desde el Nordeste y los derroteros antiguos, los nombres conocidos en nuestras historias de la conquista, y sobre todo, los rastros apreciables de la expedición de los Sres. D. Jorge Juan y D. Antonio Ulloa se seguían tan de cerca, cuanto lo permitiesen los límites de la exactitud que nos había. mos prefijado para la descripción hidrográfica de unas costas tan extendidas.

Para el amanecer del día 27 estuvimos efectivamente en las inmediaciones de Paita. Largas las insignias, atracóse el fondeadero por sondas de 14 y I5 brazas. Reconocimos con bastante exactitud 'ese teatro harto célebre de las haza. ñas militares del Almirante Anson; algunos buques mercantes fondeados, dos balsas grandes á la vela á pesar del mucho viento, muchas canoas varadas en aquellas inmediaciones, eran objetos que hacían más agradable la vista del puerto, y como no tardasen en ceder los últimos soplos del terral á la brisa nuevamente fresca del Sur, á las nueve nuestra derrota ya nos conducía directamente hacia el Cabo Blanco, y para el anochecer habíamos conseguido el montar aquel Cabo, orzando después inmediatamente para el golfo de Guayaquil.

Aquí anocheció con viento galeno y semblante algo calmosos. Navegamos dos ó tres leguas con poca vela, y luégo nos atravesamos de la vuelta de tierra con ánimo de aprovechar cuanto fuese posible la mañanita siguiente, y si la virazón se declarase fresca, alcanzar el fondeadero de Punta de Arenas en la Isla de la Puná. La mar gruesa sorda que oíamos romper en las orillas y la vista de la costa, nos avisaban en las horas del pairo, que nos aproximábamos considerablemente á la tierra; pero como el fondo se mantuviese aún mayor de 80 brazas y el viento galenito de la brisa pareciese no querer cesar de un todo, continuamos el pairo hasta las cuatro de la mañana, en cuya hora marcamos sobre las gavias algo desviados de la dirección de la costa.

Al amanecer no distaba ésta efectivamente sino una legua escasa y parecía según las noticias, la comprendida entre las ventas de Mero y Mancova: el Cabo Blanco y la costa reconocida en la tarde anterior aún estaban á la vista. Era el fondo de 60 y 65 brazas arena lamosa. No tardamos un instante en emprender las bases con toda vela; pero el desmayar considerablemente cl viento hizo que adelantásemos poco hasta el medio día, tanto más, que la precisión de recorrer la costa ya algo baja, no nos permitía separarnos de ella y hacer rumbos directos al islote el Amortajado. Observóse la latitud de $3^{\circ} 40^{\prime}$ y la longitud de $3^{\circ} 4 I^{\prime} 25^{\prime \prime}$ al Occidente 
Set, 28 del Callao. Floja aún la virazón después del medio día, quedó la atmósfera tan cargada de vapores, que se nos dilató la vista del Amortajado hasta ponerse el Sol. A la sazón veíamos también á distancia de dos leguas la Punta de Malpaso y las rompientes inmediatas, y nos hallábamos en fondo de 20 brazas lama. La noche fué lóbrega, la marcación al Amortajado y la sonda no nos dejaban, sin embargo, el menor recelo sobre nuestra derrota; antes bien, navegábamos algo orzados con el objeto de avalizarnos de nuevo con aquel islote y evadir los bajos de Poyana que salen muy afuera del rio de Tum. bes. Empero contra nuestras expectativas, cuando ya nos considerábamos próximos á dicho islote á las nueve y media de la noche y le acechábamos por entre la oscuridad, caímos de las 20 brazas lama en I $_{5}$ arena, y la ATREvidA sondó nueve brazas piedra. No nos quedaba duda que habíamos caído sobre bajos; orzamos por consiguiente, y hallamos de nuevo las 20 brazas lama que en un momento llegaron á 30 . Por este fondo, ya puestos nuevamente en derrota, avistamos á las II por nuestro babor el Amortajado, que supusimos distase una y media leguas, y considerándonos ya en buena derrota nos dirigimos hacia la Puná.

Era la voz común, que desde el Amortajado con el Nordeste cuarta al Este, se subía próximamente á la Punta de Arenas, aminorando el fondo hasta ro brazas lama. Este fué, pues, el rumbo que seguimos con toda vela desde las once de la noche; pero como encontrásemos á las dos solas ro brazas, inciertos del cantil hacia el cual nos habíamos aproximado, dimos fondo á un ancla, y precedida la señal correspondiente lo verificó á poco rato la ATREVIDA. Este acaso en la mañanita siguiente, debió parecernos bien favorable, pues nos hallábamos en la posición más oportuna de hacer buenas marcaciones á las Puntas de la Salina y Arenas en la Puná, al Amortajado y á varios puntos de la costa de Tumbes, sobre la cual habíamos caído con rum. bos demasiado del Este.

En el entretanto, calmado enteramente el viento, ó más bien, declarado el terral, fué nuestro primer paso el de enviar el bote con un sargento al pueblo de la Puná para que saliesen prácticos del rio á encontrarnos en Punta de Arenas. Algo elevado después el Sol sobre el horizonte, se observaron algunos horarios. Finalmente, no queriendo malograr el tiempo que la brisa algo tarda nos obligase á pasar fondeados, destacamos por cada corbeta un bote con un pilotín para que á diferentes rumbos emprendiesen dos líneas de sonda. A las diez y media empezó á declararse la virazón; llamamos luégo los botes y avisamos á la ATREvida que se manturiese fondeada hasta el medio día para ob- servar la latitud, mientras nosotros alejándonos set. zo algún tanto, proporcionaríamos una regular distancia y dirección para medir una base por alturas de topes sobre la cual los puntos principales á la vista, quedasen al mismo tiempo bien situados entre sí y sujetos á una cabal posición astronómica.

En efecto, al medio día la Descubierta había abierto una regular base sobre la cual se hicieron las operaciones indicadas, conviniendo una y otra corbeta en el ángulo medido. Nos dirigimos luego con fuerza de vela á la Punta do Arenas, en cuyas inmediaciones fondeamos á las tres de la tarde en I2 brazas arena, habiendo navegado por I 5 y I 8 brazas igual fondo. La marea á la sazón entraba con fuerza de tres millas escasas.

Toda la noche permanecimos en la misma posición; y caída, según costumbret la brisa antes del amanecer, le sucedió un terral flojo, con el cual y con carices bastantemente neblinosos. salió el Sol, dejándose ver poco después el bote que regresaba de la Puná. Sólo á las diez de la noche había alcanzado aquel pueblo atracada por equivocación la Punta Salinas en lugar de la de Arenas, é inmediatamente embarcados los prácticos, habían emprendido el regresar á bordo. El pilotín que iba destinado para las sondas, las había ejecutado muy oportunamente. Como á las siete de la mañana se nos presentaron algunas claras que aprovechamos inmediatamente para observar distancias lunares, sus resultados indicaban una longitud $38^{\prime}$ más corta quc la indicada por los relojes. Las distancias observadas en la AT்REvida fueron aún más cortas que las nuestras.

Hasta después de las dos de la tarde, ni aminoró la fuerza de la marea contraria, ni entabló la brisa regularmente fresca para que pudiésemos aproximarnos al fondeadero. Dimos pues la vela, y antes con proa del Este para rebasar el bajo de Mala, luégo arribando paulatinamente por fondo de siete á ocho brazas lama. navegamos la restante tarde para aproximarnos á la Puná. El viento escaso en sus inmediaciones nos obligó á dar un repiquete hacia los buques fondeados, pero alargándose después dió lugar á que nos propasase la ATrevida, y que entrambas favorecidas con extremo de la brisa $y$ la marea, alcanzásemos la boca del rio, en cuya angostura nos dirigían unánimes la sonda, y ambas orillas que veíamos claras, aunque la noche fuese bastantemente lóbrega.

Se aprovechó hasta las once la marea favorable navegando dentro del rio; dimos luégo fondo cerca de la Punta de Piedras en cinco brazas lama, para esperar que se declarase dc nuevo la otra entrante, la cual, aprovechada desde las seis de la mañana siguiente con los remolques 
Oct. $x^{\circ}$ y las ventolinas variables, nos condujo para el medio día á fondear á solas dos leguas de la ciudad. Finalmente, en aquella misma tarde á favor de la virazón y cesada la fuerza de la marea vaciante, volvimos á emprender la navegación para adentro, y auxiliadas de la sonda fondearon á las siete de la noche entrambas corbetas en frente de la ciudad y distantes como un cable de - la orilla. La faena de amarrarlas á son de marea ocupó después muy poco tiempo, y para evitar las vueltas procedentes de la alternativa de las mareas, se tomaron los dos cables á estribor, abozándolos uno con otro.

No bien había amanecido, cuando se presentó á la vista de todos y particularmente de los que no habían frecuentado los paises amenos de la Zona T'órida, un espectáculo tan nuevo como placentero. Las orillas agradablemente vestidas de varios verdes cuyas graduaciones mismas con un nuevo contraste aumentaban el primor de la escena, muchas aves enteramente nuevas así por el canto como por los colores, las balsas, las canoas, la mezcla de casas, árboles, agua y em barcaciones casi en un sólo grupo; todo recordaba al espectador admirado, que la naturaleza tan varia como extendida, excede en sus primores maravillosos á las imaginaciones áun más vivas y arrebatadas.

Los Oficiales astrónomos no tardaron un solo instante en dar principio á sus tareas; y á pesar de la imposibilidad de valerse de casa alguna para la colocación del péndulo y del cuarto de círculo; aquél porque la cimbra de los tablones que forman el piso alto causaba un movimiento cxtraordinario con el solo andar de las personas, el otro porque la inmediación del Sol al zénit hacía que los techos fuesen desde muy temprano un estorbo irremediable, combinaron la posición de uno y otro instrumento en la plazuela inmediata con tanta actividad, que pudo deducirse en medio día en el péndulo por medio de alturas correspondientes y referirse por las comparaciones á los relojes de una y otra corbeta. Nues. tras deducciones fueron las siguientes:

\begin{tabular}{|c|c|c|c|}
\hline & n. $r_{3}$. & Nủm. I6. & Núm. 72. \\
\hline $\begin{array}{l}\text { Cedio día verda- } \\
\text { dero en Guaya- } \\
\text { quil. . . . . } \\
\text { d. cn el Callao. }\end{array}$ & $\begin{array}{l}8.17 .56 .40 \\
8.7 .15 .25 \\
\end{array}$ & $\begin{array}{l}2.10 .38 .55 \\
1.59 .57 .23\end{array}$ & $\begin{array}{l}7 \cdot 36.48 .10 \\
7.26 .8 .14\end{array}$ \\
\hline $\begin{array}{l}\text { Diferencia de Me- } \\
\text { ridianos.. . . } \\
\text { Ecuaciones con- } \\
\text { frontadas con } \\
\text { el núm. ro... }\end{array}$ & 10.41 .15 & 10.41 .32 & I0.39 \\
\hline $\begin{array}{l}\text { Resulta la dile- } \\
\text { rencia corregi- } \\
\text { da..... . . } \\
\text { del callonomes y }\end{array}$ & $\begin{array}{r}10.38 .23 \\
\text { Occidente }\end{array}$ & $\begin{array}{l}10.38 .23 \\
2^{\prime \prime} 39^{\prime} 36^{\prime \prime}\end{array}$ & 38.23 \\
\hline
\end{tabular}

Los relojes de la ATrevida daban al mismo oct. 2 tiempo los resultados que siguen:

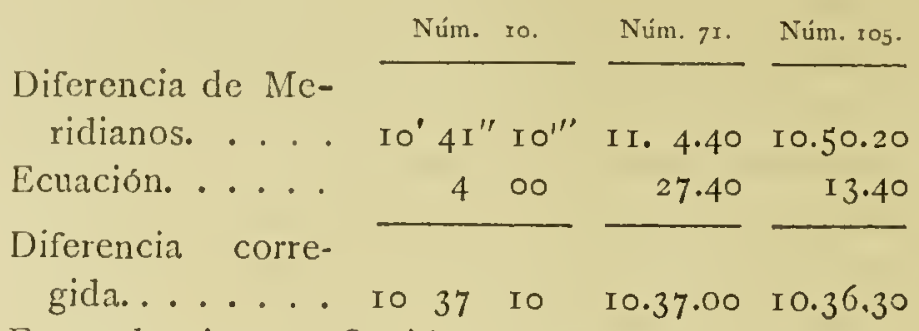

En graduaciones y Occidente

del Callao........ $2^{0} 39^{\prime}$ I $3^{\prime \prime}$

Tanta uniformidad, ya no sólo debía tranquilizarnos sobre la diferencia considerable que hallábamos con la longitud deducida por la estima desde Quito por el Sr. D. Antonio Ulloa la cual era mucho más oriental que la nuestra, si también nos autorizaba á emprender la cons. trucción de la carta de las costas reconocidas, sin esperar los resultados de las observaciones astronómicas, ó en la Luna ó en los satélites de Júpiter, que ya no discreparían sino muy poco y de una cantidad, que sólo pudiéramos emplear al tiempo de dar la última mano á la obra. Fué al mismo tiempo muy buena precaución de los Oficiales astrónomos, la de deducir por la posición nuestra y la del Chimborazo en la carta de Don Antonio de Ulloa, el rumbo y elevación á que debía verse si el tiempo claro fuese en esta parte favorable á nuestros deseos: debía demorar al Norte $59^{\circ} 40^{\prime}, \mathrm{E} . \mathrm{I}^{\circ} 2 \mathrm{O}^{\prime}$, ángulo apreciable sobre la horizontal de Guayaquil, y desde luego según los puntos hacia donde decían verle estos habitadores confrontara su posición en la aguja con la que sospechábamos. Los pasados incidentes en cuanto á los desórdenes ó extravío de la tropa y marinería, el riesgo de malograr otros con tanto mayor sentimiento cuanto mayores eran los objetos de que se habían libertado los pocos rezagos de los. armamentos primitivos; finalmen. te, las noticias no favorables del país, en el cual nos hallábamos á la sazón, precisaban á imagi nar nuevos resortes; que sin violencia ni sujeción consiguiesen el fin deseado. A este intento unánimes entrambos Comandantes fijamos nuestro sistema para la conservación de la disciplina y de la salud, en una ocupación constante mas no violenta, en una ración diaria algo crecida en dinero, que les franquease sí algún pequeño desahogo mas le sujetase á un pronto castigo y á la lista diaria; finalmente, en una frecuente suministración del vino por vía de ración, quc apagándoles algún tanto el deseo innato de la bebida los apartase insensiblemente del desórden, tan opuesto á la salud como á la disciplina. Una idea aunque remota de libertad, en dejarles elegir á su albedrío la clase de comida, debía concurrir á hacerles más agradable este refresco; nuestra intervención sólo scría necesaria cuando el des. órden ó el abandono lo requiriesen, y entre tanto 
Oct. 2 el uso constante de los refrescos sazonados según sus antojos, ahorraba para nuestros pasos venideros una igual cantidad de víveres de repuesto. No por esto se permitió la subdivisión del caldero: con igual método que en Lima, siempre se preparó una sola olla para la marinería y otra para la tropa; se repitieron las comidas calientes tres veces al día y á las horas más regulares para la recta distribución del trabajo; finalmente, suministrada á cada uno después de la lista de la mañanita la ración igual á la de Lima, se les permitió que pactasen la cantidad diaria que había de invertirse en los comestibles, y la que sobrase se dividiese entre todos por igual porción diaria ó semanalmente. En cuanto al trabajo, se ciñó por ahora á los dos objetos del aseo y del servicio de embarcaciones menores. La segunda parte era bastantemente penosa así por las ocurrencias nuestras diarias de observatorio, Historia Natural y comunicación recíproca, como por las muchas excursiones que se requerían para el cabal reconocimiento del rio y para el reemplazo mismo de la aguada, que la mucha internación de las mareas precisaba buscar á una distancia considerable.

Tanta individualidad en nuestras medidas para el mejor régimen de la marinería, parecerá tal ve $z$ tan afectada como importuna si no se tienen presentes el natural desaliño de todo marinero, las pasiones sumamcnte vivas de la marinería española y los extragos harto destructivos á que se ve sujeto en aquellos climas el europeo transeunte. Cuanto más sencillo 6 bien desconocido fuese nuestro sistema para unas gentes naturalmente opuestas á toda monotonía, tanto mayor debía ser nuestro arrimo hacia él; y á la verdad no dejaba de alentarnos á la empresá la vista agradable de una suma robustez y del semblante de una satisfacción natural en los rostros de entrambos armamentos. En el mismo paraje en donde se habían observado las primeras alturas, se colocó después la ticnda de Observatorio y se le cercó con un recinto de caña, tomando la precaución, que un soldado de marina en las horas del día y uno de la plaza en las de la noche, vigilase sobre la seguridad dcl cuarto de círculo y el péndulo. D. José Elizalde, cuya casa estaba bien inmediata, nos franqueó al mismo tiempo los cuartos oportunos para que atendiésemos con la mayor comodidad al dibujo, á la pintura y á todos los demás ramos de la Historia Natural, y un balcón por medio del cual los pistoletazos de comparación indicasen al medio día á ambos buques las horas del péndulo.

Las pequeñas excursiones que los naturalistas emprendieron en el primer día, muy luégo les dieron una idea grandiosa de la naturaleza. Todo les prometía un caudal grande de nuevas adquisiciones y excitaba su celo ardien- te para los progresos, particularmente de la Bo- Oct. tánica.

Todo el día siguiente se empleó en disponer nuestras excursiones principales, las que en efecto tuvieron lugar en las mañanas del 4 y 5 , según el plan que nos habíamos propuesto; muy poco pudo proseguirse la parte astronómica, porque las inmediaciones del novilunio, al paso que con una revolución natural en el tiempo tuvieron los cielos por lo común nublados y áun á veces achubascados, imposibilitaban toda especie de observaciones por la Luna. No debían proporcionarse antes del I7 las primeras observaciones de los satélites de Júpiter.

Nuestras excursiones científicas, según el plan propuesto, debían pues, dirigirse á los objetos siguientes: los Tenientes de navío Tova $y$ Robredo de la ATREvidA, con un piloto de la DESCUBIERTA se dirigieron en una balandra del rio, fletada para el intento, á desembocar por el naranjal y costear por Tenguel y Machala hasta la embocadura de Tumbes; quedó al arbitrio de dichos Oficiales el internar ó no hasta Tumbes; pero se les recomendó estrechamente que procurasen observar á la vista de los bajos de Poyana. E1 cronómetro 6I y los sextantes, suministrarían en esta navegación los datos principales; pues las mareas harían por lo común muy difícil é inexacto el método de las bases. La lancha de la Descubierta, provista con I5 días de ración y á las órdencs de D. Juan Vernaci, con otro pilotín, fué destinada á internar por el rio hasta las bodegas de Babahoyo. L1evaba el cuarto de círculo pequeño y el reloj I05, con los cuales no sólo pudiese hacer las precisas observaciones astronómicas, si también renovar la medida geométrica del Chimborazo sobre bases exactas para aproximarmos con estos datos á las precisas observaciones de la meridiana de Quito. Con buenas guías, D. Antonio Pineda y D. Luis Nee debían penetrar hasta el mismo Chimborazo; y el uno con objetos físicos y el otro con los botánicos, aprovechar cuanto fuese posible el plazo de quince días que se les prefijaba.

Las dos expediciones dieron la vela en la mañanita del 4 con las dos mareas oportunas. En la del 5 lo verificó también la lancha de la ATrevida á cargo del Alférez de fragata Murphy y del piloto Maqueda. Debían reconocer la Isla de la Puná por las puntas de Arenas y Salinas, hacer las observaciones oportunas con el cronómetro 7 I y los sextantes, y finalmente, determinar la extensión de los bancos de Mala. Un teodolito, una aguja y los escandallos, eran utensilios de que no carecían ninguna de las tres expediciones. Quedaba á D. Tadeo Heenke el examen físico y botánico de los contornos y una excursión á los montes de Taura, depósito de las mejores maderas; finalmente, los denás Oficia. 
Uct.455 les se ocuparían ya en una, ya en otra parte del io con los objetos reunidos de la Hidrografía, de la pesca, de la caza, de las mareas y del buen orden á bordo.

Ya no nos quedaba otro cuidado que el de la aguada, cuyo corto reemplazo confiamos á un bote chico de cada corbeta, despachándole diariamente rio adentro hasta que entrase la marea, para llenar á la baja mar siguiente; estas precauciones, que son las acostumbradas en el país, suministran desde luégo un agua enteramente dulce y de mucha duración para las embarcaciones, pero arrastran el sacrificio de tres mareas, el cual nos pareció excesivo para los usos á que debía destinarse; así, se determinó que nuestras embarcaciones penetrasen rio adentro en las últimas dos horas de la marea entrante, esperasen dos horas de vaciante para empeza1 á llenar, y con las últimas dos holas de la misma vaciante se restituyesen últimamente á bordo.

La obra intentada de agrandar $\mathrm{y}$ disponer las lanchas para expediciones dilatadas, era demasiado fácil y barata en el país donde nos hallábamos, para que omitiésemos el emprenderla; pero parcció más oportuno el trabajar antes la una que la otra, para que cualesquiera defectos que se advirtiesen en su construcción ó en su aparejo, pudiesen remediarse con mayor facilidad en la segunda. Lograríamos así tambien el ocupar con mucha economía de tiempo la maestranza de ambas corbetas en un solo buque; la cantidad y excelencia de los cedros del Realejo, Amapala y San Blas, nos darían lugar á innovar la de la ATREVIDA con igual facilidad en cualquiera de aquellos puertos á donde los objetos de Hidrografía é Historia Natural nos detuviesen por diez ó quince días. No diferimos un instante con este concepto para encargar el preciso acopio de maderas, disponer la fragua y emplear algunos ascrradores. Al cargo del Teniente de navío D. Cayetano Valdés, las nedidas corres pondientes á ese ramo debían precisamente proceder con la mayor actividad é inteligencia.

Tuvimos los días siguientes por lo común foscos y á veces achubascados, las mareas se manifestaban con una viveza y elevación considerable; cl calor fué á ratos bien sensible cuando el chariduí ó viento periódico del Oesudoeste y sudoeste, cedía á la calma ó á los terrales, y un temblor repentino que pudo percibirse también á bordo á las tres de la tarde del 7, atemorizó algún tanto los ánimos de los poco acostumbraclos á ese azote temible de la Naturaleza. En la mañana del 8 los Sres. Valdés, Hcenke y Arias, heclia con el auxilio de las mareas una excursión ¿l rio Daule, regricsaron no ménos complacidos cic la amenidad de las orillas que habían recorricio, que de las nucvas adquisicioncs, así de aves como de plantas, que traían para las colecciones oct. 8 de la Historia Natural. Tuvimos también á bordo un lagarto, caimán ó cocodrilo vivo, cuya descripción, extendida á algunos objetos anatómicos, ocupó la atención prolija del señor Hecnke.

Hasta el día 2I puede decirse que estuvieron en una acción contínua todos los individuos de la expedición. D. Juan Vernaci se había incorporado el ir: el Alférez de fragata Murphy regresó al día siguiente: vimos llegar el I5 la balandra de los Sres. Tova y Robredo: del I7 al rg otro destacamento de un Oficial y un piloto había penetrado hasta el Morro para extender descle allí las marcaciones á la Punta de Santa Elena y regresar por el canal que forma la Puná con las bocas del rio: estaban bien cerca los Sres. Pineda, Nee y Heenke; finalmente, logradas por los Oficiales astrónomos la vista del Chimborazo y varias otras observaciones importantes para la longitud, todo nos anunciaba no distante el plazo en el cual debiésemos verificar la salida y alcanzar el Golfo de $\mathrm{Pa}$ namá antes que allí cambiase la monzon del Nordeste.

D. Antonio Pineda había penetrado por Guaranda hasta el Chimborazo, y después hasta la cima del volcán del Tunguragua. Este monte, cuyas faldas con producir abundantes los dones de la naturaleza abrigan y mantienen un número considerable de familias indias y mestizas, arroja aún por diferentes bocas ó cráteres un humo espeso compuesto en la mayor parte de vapor acuoso. Examinóse la boca inmediata á la línea de la nieve, hallándose que por unas grietas dc un palmo de ancho y á veces de seis ú ocho varas de largo, era por donde el volcán arrojaba flores de antimonio y otras sustancias metálicas que se veían pegadas á las piedras inmediatas. En el año de I772 la erupción había sido temible y á primera vista se dejaban ver tambien los rastros de otra mayor y más antigua; no quedaba tampoco duda que el Chimborazo era un volcán extinguido: tanto abundaban en él las piedras pomez, las lavas, las piedras alteradas por el fuego y las tierras puzolánicas, bien que fuesen éstas comunmente calificadas con un color de ceniza.

Los resultados de las observaciones astronómicas y geodésicas no habían sido ménos favo. rables á nuestro intento, como ya se ha indicado. La elevación del monte sc midió con ambos cuartos de círculo. Su posición verdadera relativamente al observatorio, se dedujo del ángulo medido entre la cúspide y un objeto no distante, referido éste en la mañana siguiente al Sol, cuyos azimutes se observaron y calcularon. No parecerá tal vez molesta una enumeración prolija dc aquellos resultados. 
$\begin{array}{ccc}\text { Ta } & \text { Dife- } \\ \text { Toesas. muestra. } & \text { rencia. }\end{array}$

Por los Excmos. Sres. Juan y

Ulloa. . . . . . . $3.380 \quad 3.16$ I.7 2 I 8.3

Por los Sres. Bouguer y La-

condamine.......... 3.217 3.161.7

En cuanto á la longitud de Guayaquil deducida por el medio indicado en ambos mapas español y francés, que manifestaban el rumbo y distancia del Chimborazo relativamente á Quito, podía mirarse bajo los aspectos siguientes:

Segin los Excmos. Sres. Fuan y Ulloa.

Longitud occidental de París.

Por las observaciones de los satélites de Júpiter hechas en Quito. ..... Por la observación del satélite de Cayambe.............

Promedio de cuatro determinaciones por un eclipse de Luna observado en Yaruqui y correspondido en París por el Sr. I.e Monnier. . . . . . .

Promedio de siete determinaciones del mismo eclipse correspondido en $\mathrm{Pa}$ rís por el Sr. Grand Jean de Fouchi.

\section{Segin Mr. Bouguer.}

Promedio de varias determinaciones por un eclipse de Luna y algunas inmersiones y emersiones de satélites de Júpiter observadas en Quito.

\section{Seguin nosotros.}

Por la observacion del primer satélite en Lima corregida de los errores de las tablas y con los relojes marinos.

$\$ 2.00 .45$

Debía, á la verdad, sernos tanto más agradable el logro de estos resultados, cuanto que le habíamos conseguido en poco tiempo y bajo un cielo no tan favorable á la Astronomía, que no se frustrasen dos observaciones en el primer satélite de Júpiter visibles en aquel meridiano; las distancias lunares no habían tampoco logrado una mejor suerte, aunque intentásemos observarlas en la tarde que pareció la más oportuna y despejada. Una espesa calima que solía oscurecer toda la atmósfera desde la media noche hasta el medio día siguiente, se aparecía también algunas veces al anochecer, aunque ménos espesa, y ya no se disipaba en toda la noche.

Era difícil, ó más bien imposible, el continuar nuestros triángulos desde Guayaquil á la Puná, por las diferentes puntas y ensenadas que forman así el brazo principal y navegable del rio, como los muchos esteros, que ó en pleamar ó á todas mareas, circundan una porción de islas de que se compone aquel terreno anega- dizo. Pero, por ventura, los altos de la Puná y oct. 21 los de Taura, se descubrían casi desde todas partes, de modo que bien colocados éstos con operaciones trigonométricas, sería fácil luégo por medio de marcaciones, determinar cualesquiera puntos intermedios y á ellos referir el pormenor de las orillas, ligadas entre sí con enfilaciones. En cuanto á las sondas y posición de los diferentes bajos, nos parecía lo más oportuno el hacerlas depender principalmente de nuestras dos navegaciones de ida y vuelta, de los informes de los prácticos más acreditados y expertos, que constantemente le sondan para conducir las embarcaciones grandes, que vienen á carenar ó salen construídas ó carenadas; finalmente, á los exámenes parciales que con nuestro bote se harían, siempre que la ocasión lo exigiese al tiempo de bajar las corbetas á la Puná.

Con esas reflexiones, D. Felipe Bausá midió una base en una de las calles de Guayaquil, la cual, referida después al terreno de la orilla, en donde fuera inasequible una medida igualmente exacta, se hicieron marcaciones á diferentes puntos, y particularmente al alto de Guayaquil y un cerrito opuesto. Continuáronse después las mismas tareas en los días siguientes, y como en los altos indicados se alcanzase la vista de los de la Puná y de varios otros hacia Babahoyo y el Morro, pudimos, examinadas también prolijamente la dirección, extensión y posición de los edificios principales de la ciudad, considerar para el día 25 concluída aquella parte principal de la comisión nuestra.

Ya para que verificásemos la salida en la tarde del 28, como lo deseábamos, fué preciso acelerar con exceso la construcción de la lancha, dejando para un mayor despacio la perfección de la arboladura, aparejo, velámen y varios utensilios; se encargó á todos los que componían el ramo de Historia Natural que pusiesen término á sus indagaciones científicas. Los objetos de Astronomía debían ceñirse ya á la sola conclusión de la marcha de los relojes; ni los cielos, por lo común nublados, hubieran permitido mayores progresos en aquel ramo.

A la sazón había fondeado en el rio un paquebot costanero procedente de Panamá, el cual en una travesía anterior, alucinado en mucha parte por las corrientes y en mucha por la impericia del Piloto, había recalado á las Islas de los Galápagos, y navegado entre ellas creyendo al principio estar sobre la costa firme. Varias razones habían precisado al Gobernador de Panamá á detener el Piloto, y su diario, reemplazándole para la seguridad del regreso con otro sumamente práctico de las costas del Choco, en las cuales había navegado desde su edad más tierna. La adquisición de este práctico pareció, pues, un objeto de mucha entidad para la mayor per- 
fección de nuestra obra; y así, se le contrajo inmediatamente á la dotación de la Descubierta; en cuanto al diario é informe del Piloto sobre la naregación de la Copacavana, á los Galápagos; se dejó el encargo al Gobernador D. José Aguirre para que nos le remitiese á Madrid como parte de los documentos relativos á nues tra comision; según las noticias de algunos pasajeros, las islas eran muchas, y algunas tan grandes, que formaban un estrecho de 20 leguas: carecían por la mayor parte de agua, según lo clenotaba su sequedad, y el mismo suelo por la mayor parte de pomez (del cual dieron muestras á D. Antonio Pineda) las manifestaba como un fragmento de varios volcanes, destinados por la Naturaleza á ser probablemente un desierto: unánimes avisaban la duración constante de calmas y chubascos, en la inmediación de aquellas islas, y su distancia de la costa en I6o leguas, siendo su latitud próximamente entre $I^{\circ}$ al Sur $y^{\prime} I^{\circ}$ al Norte de la Equinoccial.

Estas noticias, y una voz envejecida entre los prácticos, de que los Galápagos se extendían mucho hacia el Este, debieron precisamente hacernos cáutos sobre el partido más oportuno, para que ni el tiempo dejase de aprovecharse cuanto fuese posible, ni bien comprometiésemos por cosas de poca entidad los plazos y destinos que nos habíamos propuesto en los puntos importantes de la costa siguiente al Norte. De ningún modo podía determinarse una separación de las corbetas cuando nuestras tareas en $\mathrm{Pa}$ namá, extendidas tal vez hasta Puertovelo, serían muchas, penosas y delicadas; cuando sería aquel partido probablemente necesario en las costas de la Nueva España, cuyos productos y situación debían mirarse como muy interesantes para la Monarquía; finalmente, cuando toda anticipación en la llegada nuestra á San Blas arrastraría precisamente grandes utilidades para la próxima campaña sobre la costa Noroeste.

Finalmente, en la tarde del 27, deducido el medio día por las alturas correspondientes, y cerrada la cuenta de los relojes, se embarcaron los instrumentos astronómicos y geodésicos; se habían encajonado ya las aves y cuadrúpedos disecados, y los herbarios de los Sres. Heenke y Nee; y votada al agua al anochecer la lancha, ya casi concluída, no faltaba cosa alguna para dar la vela.

La marea del 28 no debía declararse á la vaciante hasta el medio día; por consiguiente, sólo $\{$ las diez de la mañana, cedida un poco su fuerza, suspendimos ambas corbetas la amarra del Norte y quedamos á pique de la otra; y últimamente, á la una de la tarde, con prácticos del rio en uno y otro buque, dimos la vela con las solas gavias.

Como el viento, por lo común, sea del Sud- oeste, y muy estrecha y áun sembrada de bajos la oct. 28 canal navegable, es costumbre y casi siempre precisa el entregarse á la marea para bajar á la Puná; paireando siempre que se esté á media canal, y valiéndose de las gavias únicamente para arrimarse á una ú otra orilla, según el caso lo requiera: á veces es oportuno el navegar á popa para que el plazo en que se pueda buscar la canal, sea algo más largo; y entonces la inmediación de los árboles, reunida á la mayor actividad de la marea, presenta el espectáculo divertido de una navegación de retroceso: la tranquilidad del agua, la amenidad de los contornos, y el vientecillo, contrario sí, pero templado; la seguridad misma de poder con un anclote evadir cualquier peligro, hacen aquel tránsitu á lo ménos divertido, ya que debe ser muy lento: en algunas partes disminuye el fondo de tal modo en la bajamar que ya no son navegables; y en aquel caso es preciso, áun sacrificando una parte de la marea favorable, dar fondo para esperar el paso con el agua alta al principio de la vaciante. El estar la Luna en el cuarto menguante hacía que las mareas á la sazón fuesen lentas y poco elevadas.

Las causas indicadas, y principalmente la del poco fondo entre la punta Sur de Santay y la Punta Gorda, nos obligaron á fondear como á las cuatro y media de la tarde, andadas sólo dos leguas; no obstante, no se malogró el tiempo enteramente, pues se dirigieron algunos Oficiales á reconocer unos bajos no distantes y marcar en una punta de la costa del Oeste. Luégo que se declaró á las diez y media de la noche la otra marea favorable, nos levamos de nuevo, y algo favorecidos del viento, á veces con bordos cortos, á veces con otros más largos, alcanzamos á fondear entre la Punta Miel y la Punta Leon, no distantes de las bocas de Taura.

Ya á las once, declarada con alguna fuerza la vaciante, pudimos levar nuevamente el ancla', y continuar paulatinamente nuestra derrota, la cual nos condujo al Sur de la Punta de Piedras, proporcionándose también á D. Felipe Bausá el salir con el bote á reconocer la piedra sola, que angosta mucho el canal en esta parte, bien que le compensa ventajosamente, el mucho fondo que hay así á pique de la misma piedra, como de los árboles de la costa. El chanduy no nos permitió en la tarde el aprovechar toda la vaciante, con la cual, siendo muy endeble, no era fácil contrarestar el impulso opuesto del viento: dimos fondo al ancla á las dos y media, y permanecimos en la misma disposición hasta la siguiente marea. Debía ésta conducirnos hacia la Isla Verde; pero como en la dificultad de conservar la media canal, se hiciesen temibles los bajos inmediatos á la Isla Mondragón, á las dos de la manana, y con solas dos horas de vaciante 
Oct. 30 volvimos á dar fondo entre la Punta de Alcatraces y aquella isla. Luégo que amaneció fué un bote de cada corbeta á la orilla inmediata para cortar leña, y medida una base en la Punta de Alcatraces, se ligaron oportunamente con las marcaciones hechas en Guayaquil los diferentes puntos importantes á la vista, que ceñían aquella parte exterior del rio. Al medio día pudimos ya dar nuevamente la vela, y antes buscando la medianía de la canal, y conservándola después, vernos finalmente como á las cuatro y media de la tarde, casi franqueados de la Isla Verde. Sucesivamente con el auxilio de la virazón y con todo aparejo, pudimos dar un bordo con las muras á estribor, del cual revirando últimamente á las cinco, alcanzamos al ponerse el Sol el fondeadero de la Puná, en donde dejamos caer el ancla algo distante de la población, así por el efecto ya sensible de la marea contraria, como por la mejor disposición para continuar en la siguiente noche nuestra derrota. Hízose así efectivamente. Tuvimos la sonda de cinco á siete brazas lama; y como no diésemos fondo hasta las cinco de la mañana, precisados de la calma y de la marea contraria, pudimos ya hallarnos Esteoeste con los altos de las Salinas en la Isla de la Puná, demorando la Punta de Jambeli al Sur $5^{\circ}$ Este de la aguja (I).

Desde las nueve de la mañana siguiente empezaron á declararse ventolinas favorables del Noroeste, con las cuales, ya casi parada la marea contraria, dimos la vela con ánimo de proporcionarnos mejores bordos al tiempo de entablar la virazón, con cuyo fin inclinamos también nuestros rumbos hacia la Punta de Salinas y el Amortajado: no pudimos á la sazón desentendernos de las distancias de Sol á Luna que por un corto intervalo se nos presentaban fáciles y seguras, para agregar aquel dato por medio de los relojes marinos, á los demás que nos habían suministrado la longitud de Guayaquil. Treinta series observadas á bordo de la Descubierta poco antes del medio día, y calculadas con la mayor exactitud por las fórmulas del caballero Bordá, dieron una longitud de $30^{\prime} 26^{\prime \prime}$ más oriental que la de los relojes; por consiguiente, muy aproximada á nuestras deducciones por las observaciones hechas en Guayaquil.

Entablada poco después la virazón y despedidos los prácticos, continuaron nuestros bordos según lo exigían las circunstancias. No tardó cl fondo en aumentar hasta I6 brazas, disminuyendo luégo paulatinamente á Io á medida que

(I) Parecerá demasiado difusa y cansada la descripción de la salida de las corbetas de la ria de Guayaquil, si no se atiende á que son importantes aquellas noticias para las ideas sucesivas de la navegación y defensa de aquellos contornos. nos aproximamos á la costa firme. La lama nos Ou. 3 avisaba que conservábamos la canal, y las diferentes marcaciones á los muchos puntos en torno, entre los cuales ya conseguiamos también la vista del Amortajado; nos daba lugar á reunircon las actuales, las tareas de los Sres. Tova, Robredo y Murphy y áun las que las mismas corbetas habían verificado á la venida: era el tiempo agradablemente placentero, y la mar únicamente algo picada de la virazón. La noche siguiente fué algo más penosa por la necesidad contínua de maniobrar, con el fin de conservar sobre bordos el canal entre la costa de Tumbes y la Puná Preferimos este partido al de dar fondo, como por lo común debe verificarse en aquel tránsito, porque no teniendo ya los efectos de la marea, deseábamos no perder momento á pesar de ser el viento algo flojo y vario. Nuestros bordos fueron, por consiguiente, repetidos, y siempre con atención á que nos encontrásemos sobre la costa de la Puná antes del amanecer para aprovechar con más ventaja los terrales del Noroeste. Conservamos el fondo lama, y alcanzábamos por lo común las ro brazas en uno y otro extremo, no extendiéndose los bordos á más de dos leguas, y viéndonos muchas veces precisados á virar rápidamente, porque pocos minutos nos hacían caer de las I5 á las nueve brazas.

Al amanecer vimos con mucho agrado que nuestros esfuerzos no habían sido infructuosos; por fondos de i7 brazas lama, nos hallábamos entre el Amortajado y los Islotes de Payana que luégo conducen á Tumbes; y la vista del alto de las Salinas, nos proporcionaba un nuevo enlace de marcaciones con nuestra posición de Guayaquil. Demoraba el Amortajado al Norte $70^{\circ}$ Oeste de la aguja, distancia tres á cuatro leguas; á la sazón calmó enteramente el viento y creimos vernos precisados á déjar caer un anclote, pues la marea nos arrastraba considerablemente sobre la punta de los Manglares; pcro por ventura no bien habían llegado las ocho, cuando un viento galeno del Nornoroeste nos dió lugar á ceñir al Oeste y apartarnos algo de la costa de Payana: las bases corridas en aquella ocasión debían destruir por medio de la latitud observada algunas dudas sobre la verdadera latitud del Amortajado originadas de la demasiada proximidad del Sol al zénit, al tiempo de nuestras primeras observaciones con las corbetas. En efecto, observada al medio día la latitud de $3^{\circ} 20^{\prime} 30^{\prime \prime}$, y tomados de antemano diferentes horarios, nos cercioramos que la latitud del extremo Sur del Amortajado, cra dc $3^{\circ} I 4^{\prime}$, y su longitud de $0^{\circ} 32^{\prime} 40^{\prime \prime}$ al Oestc de Guayaquil.

Franqueada la navegación con el aprovechamiento de la virazón de la tarde, y evadidos al día siguiente los efectos de algunas turbona- 
das con mantenemos sobre poca vela casi en una posición uniforme, ya en la tarde del 3 de Noviembre pudieron empezar de nuevo las tareas acostumbradas al andar de la costa. Debíamos atravesar ahora los límites constantemente lluriosos de las dos estaciones opuestas en aquellos mares; debíamos luchar al mismo tiempo con las calmas, las corrientes, las lluvias y las turbonadas que casi á porfía dominan allí en todo el año; la Isla del Gallo, la Gorgona, la bahía de San Buenaventura eran nombres hasta entonces temidos con mucha razón en aquellas inmediaciones, y sin embargo, debíamos reconocerlas y sujetarlas á observaciones exactas de latitud y longitud; finalmente, las costas á donde se dirigían ahora nuestros pasos, si bien sujetas á la Monarquía, no podían á ménos de reunir á nuestra vista en una sola perspectiva, los sufrimientos de los primeros navegantes españoles, las invasiones de los filibusteros y la despoblación natural de un país aún no desmontado, y sujeto por la misma razón á unas lluvias y tempestades tan duraderas.

Atracada en el entretanto la costa para las dos de la tarde, ya que la calima no había permitido el distinguirla hasta entonces, conocimos que nuestra posición, al paso de facilitarnos la reunión prolija de las tareas emprendidas, con las que se habían efectuado en las excursiones al Morro desde Guayaquil, exigía una no mediana precaución en los rumbos siguientes, los cuales, si nos descuidásemos en no hacerlos contrarestar á la corriente, pudieran muy bien arrastrarnos sobre los muchos arrecifes de que están llenas aquellas costas: demoraba la punta Santa Elena al Norte I $8^{\circ}$ Oeste, las costas de Chanduy y los altos del 'Tambo, se extendían hasta el Esnordeste.

Vencida en la noche aquella punta, y proporcionándose después de algunas horas de pairo el marcarla de nuevo en la mañana siguiente, al ticmpo que un vientecito favorable y galeno nos conducía con bastante velocidad hacia el Norte, ya la navegación emprendida dejó aproximarnos rápidamente hacia la línea Equinoccial. Pasáronse el pueblo de Colonche, la Isleta Salango, la Isla de la Plata y el Cabo San Lorenzo: atracamos luégo el fondeadero de Manta, paraje frecuentado ó bien por un pequeño comercio de comestibles y manufacturas, ó bien por las muchas arribadas de las embarcaciones, que navegando desde las costas del Norte á Guayaquil ó al Perú, se ven al mismo tiempo contrariadas del viento de la marea y de la corriente, y como carezcan de agua y víveres, les es preciso el reemplazarlas en aquel paraje. La observación de un eclipse de Luna hecha por Mr. Bouguer en el pueblo de Innte-Christi, dió allí un nuevo dato importante para la comparación de nuestras longitudes. Fi- nalmente, en la tarde del 5 , por fondo de fo y 45 brazas lama, ya marcábamos el Cabo P’àsado al Este á distancia de tres leguas, y por consiguiente se aproximaba muy mucho nuestro ingreso en el hemisferio del Norte.

Efectivamente, como siguiesen los vientos favorables del Sur y Sursudoeste y nosotros cn la nayegación de la noche continuásemos siempre con las mismas precauciones de no propasar los límites de la tarde anterior en los extremos de la costa, ya al día siguiente observamos la latitud de $0^{\circ} 49^{\prime}$ al Norte de la Equinoccial. La longitud era de solos I $5^{\prime}$ al Oeste de Guayaquil. El cabo San Francisco se veía al Sur $25^{\circ}$ Este y la Punta de la Galera al Este; en las proximidades del rio de las Esmeraldas, la sondaleza en aquella misma tarde no alcanzaba el fondo con cien brazas, cuando á las dos y á las tres habíamos navegado por Io y I 7 brazas arena, prueba evidente, que el placer que desde la Punta de la Galera se extiende hasta la Gorgona sale á veces con el poco fondo hasta dos leguas max afuera, y conforme con los derroteros hace aquella navegación bastantemente arriesgada.

Nunca la navegación nuestra fué más fcliz que en los días siguientes, en los cuales, como ya se manifestó, debíamos luchar con unos obstáculos tan constantes como difíciles de vencerse. Las lluvias, 10 más frecuentemente, eran sólo copiosas durante la noche; y los días, al contrario, despejados, nos proporcionaban al mismo tiempo la vista individual de las costas y la repetición necesaria de las observaciones: verificadas éstas oportunamente y combinadas en una masa común las latitudes, las longitudes y las marcaciones, descubrían una á otra los errores respectivos, por manera que fuese fácil en las bases de corredera hacer frente á las variaciones complicadas y oscuras de las corrientes, las cuales ya daban diariamente un error á lo ménos de $20^{\prime}$ en latitud y otros tantos en la longitud estimada. Recolriéronse así y pudieron describirse con mucha exactitud, las costas que desde el cabo San Francisco corren por las Puntas de Mangles y Salaonda, por las Islas del Gallo y la Gorgona y por la ensenada de San Buenaventura, hasta la Punta de Chiramira y el Cabo Corrientes. En las inmediaciones del cabo ya las tierras son bien altas, cesando los Manglares que vienen sin interrupción desde el cabo San Francisco; no se encuentra fondo á tres leguas de la costa con cien brazas de sondaleza. Finalmente, siguen allí muchos rios de los que inundan el Choco, tributando al mar al mismo tiempo, los despojos de una vejetación siempre lozana y las arenas de oro, que con su brillo engañoso atraen hasta aquellos bosques al hombre codicioso.

Las inmediacioncs del Cabo Corrientes fue- 
Nor, ; ron para nosotros el verdadero término del método de tareas seguido hasta entonces con tanta felicidad. Ya las lluvias eran igualmente copiosas y constantes; los estallidos de los rayos nos indicaban próximo otro peligro mayor. Las corrientes sumamente rápidas, no podían corregirse por medio de las observaciones, ni era posible con aquellos tiempos el conservar siempre á la vista una costa á las veces baja, á las veces coronada de peligros. Navegábamos, ya con mucho, ya con poco aparejo, ya al Nordeste ya al Noroeste según parecían dictarlo las circunstancias y carices, ó lo pedían imperiosamente los vientos varios desde el Sudoeste al Oesnoroeste y entremezclados con algunas calmas.

Aprovechábase, finalmente, cualquier clara para reconocer los trozos intermedios de la costa, la cual seguíamos á distancia de cuatro leguas, pero las inmediaciones del Golfo de Panamá pusieron finalmente un término á los obstáculos indicados, y en la tarde del I I, restituída la serenidad á los cielos y horizontes, fué fácil descubrir las costas que desde el Puerto de Piñas conducen á la Punta de Garachine, extremo occidental del Golfo. En el día siguiente, á medida que atracábamos aquella punta, se percibían más eficaces los impulsos de la marea, y con este auxilio, más bien que con el del viento, la pudimos marcar al anochecer hacia el Este; veíanse al mismo tiempo una parte considerable de la costa del Darien, varias islas de las Perlas, la de la Galera y la de San Telmo.

La entrada del Golfo de Panamá se hace algo cuidadosa por una laja sumergida llamada el Bajo de San José, la cual media entre la Punta de Garachine y la Isla Galera. Las vaciantes llevan hacia ella con bastante rapidez; las entrantes arrastran hacia el Darrien también sembrado de bajos. Así, cuando el viento calma, parece el partido preferente el de fondear; y éste fué efectivamente el que tomamos á las ocho de la noche, ya que se reunía á la marea contraria un viento flojo y directamente opuesto á nuestra derrota. Pero aquella situación no duró mucho, pues á las tres de la mañana ya estábamos nuevamente á la vela para aprovechar las mareas y los vientos variables hasta alcanzar el puerto de Perico. Quien conozca la flojera inseparable de los navegantes de aquellos mares y la clase de sus buques, no extrañará que muchas veces la sola navegación desde la Punta Garachine á las Islas de Perico, les detenga después de repetidos riesgos, por un plazo de diez ó doce días. Nosotros, sin dar nuevamente fondo y contrarestados directamente del viento, el cual á veces calmaba, á veces desfogaba con algunas turbonadillas variables, no tardamos sino dos días; á las dos de la mañana del i6 se dejó caer un ancla á poca distancia del fondeadero, y apenas hubo amanccido, cuando entrambas corbetas mejora- Nor. if ron su posición y quedaron amarradas. Los es. collos y el poco fondo que rodean las orillas de Panamá, y su desabrigo con los vientos del Sudoeste, han dado la preferencia para el fondeádero á la parte Nordeste de las dos isletas de Perico y Flamencos, faltas á la verdad de agua y leña, pero bien cultivadas, favorecidas con un buen fondo de arena, y sobre todo, no distantes de la ciudad sino una legua escasa.

Era el paraje donde nos hallábamos, el más importante tal ve $z$ de cuantos habíamos visitado hasta entonces, bien le refiriésemos á los nbjetos científicos de la Hidrografía y de la Historia Natural, ó á los objetos políticos de las conquistas nacionales y de la prosperidad actual de la Monarquía; combinábanse allí, á muy poca distancia unas de otras y en una tan grande inmediación de la Equinoccial, unas playas fértiles y amenas, un país áspero y montuoso, varios bosques apenas trillados, y una variedad inmensa de maderas, gomas, aves, cuadrúpedos y conchas, dignas cada una por sí de la mayor atención del naturalista. Era precisa la determinación más escrupulosa de la longitud, en cuanto á la posición nuestra tan inmediata á los puertos de Chagres y Portovelo; podría arrastrar errores incompatibles en los arrumbamientos del Istmo por ambos mares, si las observaciones astronómicas no fuesen conformes con las que debían repetir en las orillas del Atlántico los Oficiales destinados á las cartas de la América Occidental. Por otra parte, un golfo importante y las Islas renombradas de las Perlas, nos recordaban al mismo tiempo, ó el tránsito de tantos millones de numerario ó el antíguo comercio de los galeones, ó finalmente, los extragos y proezas de los corsarios filibusteros. Era aquel el primer paso que había conducido nuestros antiguos conquistadores al mar del Sur, y debíamos mirarle todavía como el centro de las expediciones malogradas de los Almirantes ingleses Vernon y Anson; su fortificación y sus fuerzas, suficientes apenas aunque con extremo costosas, para hacer frente á los indios inmediatos del Darien; sus calles desiertas, sus casas arruinadas y el puerto abandonado; todo hacía un contraste singular en nuestra imaginación, de las vicisitudes del tiempo, de los progresos actuales de la navegación y de la diferente robustez de la Monarquía en este y en los siglos anteriores.

Desde luego el Brigadier de la Real Armada D. José Domas y Valle, á la sazón Gobernador y Capitán General de la provincia, accedió gustoso á coadyuvar á nuestras medidas para que aquellas atenciones no dejasen de realizarse hasta donde lo permitiese el plazo prefijado de nuestra demora; era entonces tanto más necesaria una cierta precipitación en nuestros pasos. 
Yov. zó cuanto que en los días inmediatos debían proporcionársenos algunas obscrvaciones las más importantes para el objeto prefijado dc la longitud; en efecto, en la misma tarde del I 6 quedó establecido el observatorio en las inmediaciones de un bastión, desde el cual era fácil comunicar á las corbetas, por medio de fusilazos, las horas del péndulo referidas á los relojes marinos, y el día IS, malogradas algunas observaciones por la interposición de las nubes, pudo á lo ménos deducirse la longitud por los relojes y compararla á algunos otros resultados.

La longitud deducida fué la siguiente:

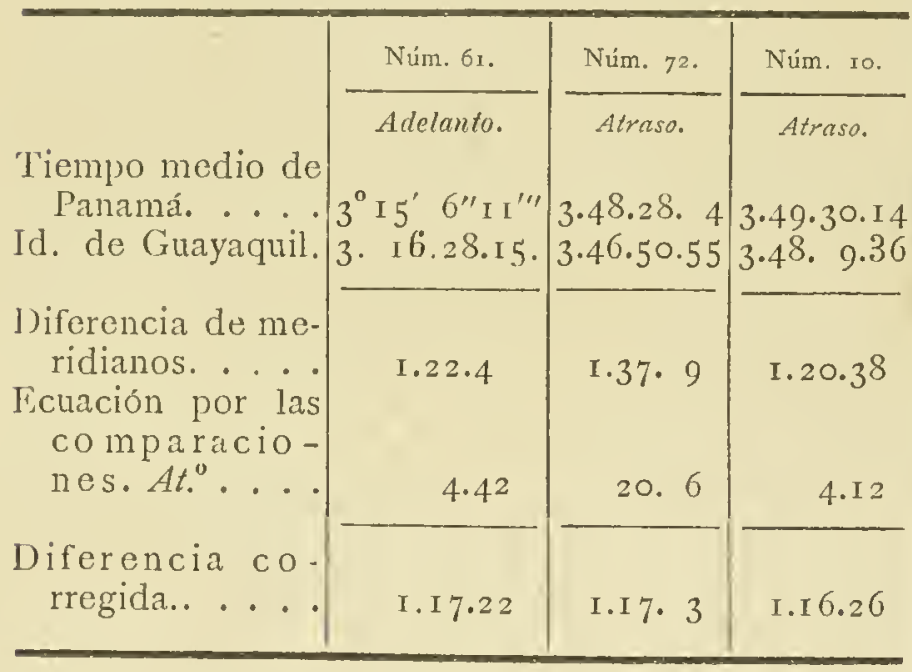

Cuyo promedio daba la longitud Oriental de Guayaquil en grados. . . . . . $0^{\circ} 19^{\prime} 14^{\prime \prime}$

Que referidos á aquel Meridiano según nuestras series.

Daban finalmente á Panamá la longitud occidental de Cádiz de. . .

73.05 .01

Era la deducción por la observación de Mr. Bouguer en Manta traída con nuestros relojes. .........

Y 243 series de distancias de la Luna al Sol observadas en los días I 3, I 4 y 5 y traídas con los relojes mari-

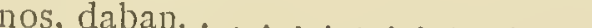

Del I9 al 23 se dispusieron y emprendieron todas las excursiones científicas de cuyo regreso depcndería únicamente el plazo de nuestra demora en el puerto. Al cargo de D. Secundino Salamanca iba la lancha de la ATREvida con un Pilotín, y sus operaciones debían limitarse á determinar con buenas sondas el fondo de tres brazas al andar de la costa desde Panamá la Vieja hasta las Islas de Majaguar y el Pclado: debía particularmente determinar la verdadera extensión del bajo de la Punta Manglares, hacer en los puntos más altos marcaciones con el teodolito, que reuniesen el pormenor de toda aquella costa con las tareas que se emprenderían en el puerto, y se le encargaba que observase algunas latitudes, ligándolas, si fuese posible, con el extremo de una ú otra base.

1). Juan Vernaci con un Pilotín de la. DEScUmierta, el cuarto de círculo de Ramsden, el reloj Io5 de Arnold y un teodolito, tuvo orden de dirigirse á Cruces, y de allí por el rio hasta Nor. 3 Chagres, con el objeto de rcferir la longitud á la orilla del otro mar.

La lancha de la Descubierta, con otro Pilotin, un práctico natural, el cronómetro $7 \mathrm{I}$, dos sextantes y un teodolito, se puso en el cargo del Teniente de navío Novales, para que recorriese y trazase cuidadosamente todas las islas, que bajo el nombre de las Perlas y del Rey, componen aquel Archipiélago. Debía examinar el bajo de San Josć, medio entre la Punta Garachine y la Isla de San Telmo; y debía procurar que todo este trabajo ligase con los otros por medio de marcaciones hechas en algunos altos con teodolito y aguja.

Quedaba luégo al cargo de D. Felipe Bausá y del Piloto D. Juan Maqueda, el poner orden á los materiales hidrográficos acopiados. Los botánicos y D. Antonio Pineda debían correr á su albedrío, ó el país llano ó el montuoso, á do les llamase su actividad indecible; ocupábanse al mismo tiempo algunos individuos en las disecaciones, y un joven bastantemente experto dc la corbeta Descubierta había tomado á su cargo cl representar con el dibujo los objetos más propios, ó bien fuesen de perspectiva ó relativos á la Historia Natural. La sondas, el corte periódico de la leña y el cuidado diario de los buques y sus pertrechos, donde era tan temible, el efecto de la bruma, como el de las lluvias y del Sol con exceso ardiente, fueron últimamente otros tantos objetos más bien de entretenimiento que de fatiga para la demás gente de entrambas tripulaciones; se añadían á la ración algunos refrescos y vino, se les permitía un esparcimiento útil en las playas inmediatas, en donde frecuentemente les convidábamos con el ejemplo á bañarse; rara ve $z$ iban al pueblo, y correspondiendo felizmente los efectos á las medidas indicadas, lográbamos combinar con el trabajo contínuo una robustez y alegría que no pueden ser comunes en aquellas regiones.

Fueron allí más frecuentes y nocivas que en otra parte alguna las inmediaciones y la sombra del árbol del manzanillo. Los botánicos, movidos seguramente de un cierto pundonor, y nuestras gentes destinadas al corte de la leña por un efecto á las veces de su antojo, á las veces de su ignorancia, en cuantas ocasiones se arrimaron á ese arbol extraño, en otras tantas sufrieron considerablemente. La hinchazón en diferentes partes del cuerpo, una grande propensión al rómito y un dolor general en todo el cuerpo, cran efectos repentinos de su sombra, los cuales no se disipaban sino después de muchas horas. Es aún más extraño el que siendo tan temible la sombra, ó lo que es lo mismo, la emanación en las hojas causada por la acción del Sol, el tronco al mismo tiempo no sea en modo alguno nocivo, y 
Nov. 23 ó conviértase en leña para quemar, ó se aplique á diferentes usos de la vida sociable, nunca cause al tiempo de emplearle el menor daño ó molestia.

La actual mudanza de la estación lluviosa del Sudoeste con la otra seca y despejada del Nordeste, la cual, como ya se ha insinuado, debía proporcionarnos la continuación fácil de las tareas hidrográficas al andar de las costas de la Nueva España, no pudo ménos de acarrearnos en aquellos días muchas lluvias mezcladas á veces con ráfagas violentas y con algunos rayos. Seguíase luégo naturalmente el correr los vientos calmosos con rapidez por toda la aguja. Entablado, finalmente, el Norte y el Noroeste, volvía el tiempo á su antiguo semblante hermoso, y á medida que se aproximaban los primeros días de Diciembre, iban esos vientos arraigando más su imperio. Estas alternativas del tiempo debieron precisamente causar alguna lentitud en las excursiones emprendidas; hicieron malograr varias observaciones astronómicas, y ocasionaron el naufragio de una lancha de la ATREvida cargada de leña, la cual, rota la amarra por una resaca extraordinaria, se desfondó sobre las piedras é hizo infructuosos los esfuerzos de la gente, que procuraba libertarla. En una playa desierta, mojada, sin ropa para mudarse y sin comida, debió por naturaleza sufrir mucho en la noche siguiente. Los auxilios que le condujo al otro día D. Antonio Tova fueron por la misma razón recibidos con el gozo correspondiente; se comprendía también entre los náufragos una partida de cazadores dirigida por el Cirujano de la ATREviDA, la cual debió malograr en aquella ocasión varias adquisiciones preciosas para nuestras colecciones naturales. Todos, finalmente, volvieron á bordo, y poco después el T'eniente de navío Robredo, con maniobras bien entendidas, condujo también la lancha para vararla en las playas inmediatas y atender á su composición.

El día 4 de Diciembre, ya se hallaron reconcentrados á bordo, además de la lancha del Teniente de fragata Salamanca, la cual lo había verificado mucho antes, tambien todos los naturalistas y D. Juan Vernaci. El primero, además de los reconocimientos que se le habían encargado, había hecho marcaciones bien importantes en los altos de las Islas Chapera y Pacheca, precisado á ir á ellas por falta de agua. El último había con la mayor felicidad repetido las observaciones en Chagres y conseguido al mismo tiempo el observar dos inmersiones del primer satélite de Júpiter y un nuevo examen en Cruces para la marcha más segura del reloj I05. Tampoco fueron ménos felices los Oficiales astrónomos en el conseguimiento de unos datos exactos para la deducción de la longitud y á pesar que se hubiescn malogrado diferentes observaciones, pudie- ron, sin embargo, agregarse á los que ya se han Dic. expresado los resultados siguientes:

Por la ocultación de la 88 del catálogo

Longitud occidental de Pa.is. de Mayer por la Luna, calculada por las tablas de Mr. Masón. . . . . . . .

Por la 243 del mismo catálogo (no observada con igual confianza). .... Por las diferencias ascensionales de la Luna deducidas por las comparaciones á Régulus, y al corazón de la Hidra con el cuarto de círculo.....

Una inmersión del primer satélite de Júpiter corregida de los errores de las tablas.

$8 \mathrm{r} .44 \cdot 32$

81.57 .15

81.46 .21

Estos resultados, cuando alcanzásemos á corregirlos é igualarlos por medio de los errores de las tablas averiguados en algún observatorio de Europa, debían ya tranquilizarnos sobre el objeto primero de evitar una contradicción ó discrepancia con las determinaciones hechas en la orilla del mar Atlántico; pues la diferencia de $29^{\prime}$ II' al Este, que indicaba el reloj Io5 para el observatorio de Panamá rclativamente al de Chagres, bastaba para la exacta comparación de unos y otros elementos. Finalmente, en la tarde del ' 7 vimos también reincorporarse la lancha de la Descubierta á las órdenes del Teniente de navío Novales. Como lo habíamos sospechado, desde el día 2 estaba detenido en la Pacheca acosándole los vientos contrarios, los cuales, una vez le habían rendido el palo mayor y otra héchole peligrar en el mismo fondeadero. Eran frutos de esta excursión, el prolijo reconocimiento de todo el Archipiélago de las Perlas y del bajo de San José, una multiplicidad grande de marcaciones á los puntos más distantes de ambas costas, y una serie de observaciones de latitud y longitud que no podían ya dejar la menor duda sobre la posición verdadera de cada punto.

Así, concluídos los diferentes objetos que hacían ó útil ó necesaria nuestra estada en el puerto de Perico y auxiliados al mismo tiempo los almacenes de la plaza enteramente exhaustos con aquellos pocos efectos que pudiesen suministrar nuestros repuestos, ya no debió diferirse por más tiempo la salida de las corbetas.

El I2 la transferimos al fondeadero de la Isla de Taboga, donde debíamos reemplazar la aguada, lo cual verificado en los dos días siguientes muy á nuestro placer por la amenidad del sitio, la abundancia, la comodidad y la pureza de las aguas; y sobre todo por la facilidad de repetir allí también varias tareas importantes relativas á los objetos esenciales de nuestra comisión; finalmente, en la mañanita del I 5 dimos la vela para la continuación de los reconocimicntos emprendidos. 



\section{LIBRO SEGUNDO}

Navegaciones desde Panamáá las costas de Guatemala y Nueva España.- Sucesiuas indagaciones sobre la costa. Noroeste de la América, en busca de la commicación de los dos mares. Atlántico y Pacífico, indicada por el navegante español Lorenzo Ferver Maldonado. - Escalas en Nutka y en Monterrey.Regreso de las corbetas á Acapulco y acaecimientos en aquel Puerto. hasta el momento de dar la vela hacia las Islas Marianas y Filipinas.

\section{CAPITULO PRIMERO}

Navegaciones y reconocimientos de las corbetas al andar de las costas de Tierra Firme y Costa-Rica.-Scparación de entrambos buques. - Tareas de la DESCUBIERTA sobve las costas de Guatemala y Nuera España.-Viaje divecto de la ATREvida á los puertos de Acapulco y San Blas.--Ultima reunión de las corbetas en Acapulco.

Dic. 15 Los vientos del Norte y Nordeste que cada día iban estableciendo más su imperio sobre aquellos mares, parecían brindarse casi á porfía con la serenidad y hermosura del tiempo que les acompañaba, para coadyuvar á la feliz continuación de las navegaciones y escalas que nos habíamos propuesto: ya el plazo en el cual pudiésemos permanecer entre los climas apacibles de los trópicos se iba á cada paso estrechando; debían muy luégo reemplazar la tranquilidad, el descuido y la lentitud de las navegaciones actuales, con el afán, los fríos y las contrariedades que naturalmente encontraríamos sobre las costas del Noroeste de la América. Llamaban por otra parte á nuestras ansias y nuestra atención, la importancia de las costas de Guatemala y de la Nueva España; la riqueza de sus puertos, la fácil comunicación de unos con otros, y finalmente, en Acapulco, en San Blas y en los establecimientos recientes de la California, debían desplegarse á nuestra vista con un cierto atropellamiento agradable la reunión de los intere- ses del Asia con los de la América, el orígen de las últimas desavenencias con la Inglaterra, nuestros confines con el imperio de la Rusia y un equilibrio de nuestros gastos y nuestras ventajas en aquella parte del mundo.

Tantos objetos, si excitaban por una parte un nuevo vigor y reunión en nuestros pasos, debían por la otra inquietarnos diariamente sobre la perseverancia de los vientos favorables. Los aprovechábamos con ansia, y efectivamente, en los primeros días de la navegación emprendida, correspondíanse de tal modo la diligencia, la exactitud y la felicidad de los tiempos, que toda la costa comprendida entre Panamá y las Islas de Coiba, se hallaba ya reconocida y trazada para el medio día del I7. El fondeadero de aquellas islas, célebre ya por las incursiones de los filibusteros, adquirió después un mayor renombre por haber sido escala del Almirante Anson, en la cual reparó las enfermedades y averías de su escuadra y se dispuso á emprender el crucero delante del puerto de Acapulco. Son aquellas costas casi enteramente despobladas de la especie humana, y las habitan por la misma razón un número infinito de aves, peces y anfibios; por manera, que á las veces esas mismas propiedades, reunidas á la seguridad del puerto, puedan hacerle más interesante para el descanso y recuperación de una escuadra, de lo que puedan sello las inmediaciones de nuestras Colonias, las más veces llenas de vicios y de desírdenes más bien que de todo lo que contribuye al bienestar. del navegante. 
Sobre las islas indicadas, era la latitud observada de $7^{\circ}$ Io'. La variación se conservaba de $7^{\circ}$ á $8^{\circ}$ al Nordeste $y$ apenas habíamos perdido la sonda, la cual desde las inmediaciones de Panamá hasta el Morro de Puercos, solía conservarse á distancia de una á dos leguas de la costa desde i 8 á fo brazas, arena negra y lama.

Muy distantes estábamos á la sazón de imaginar que eran aquellas inmediaciones el término de nuestra felicidad y del método seguido hasta entonces para las tareas hidrográficas. Ni las pocas personas que teníamos á bordo y habían navegado una ú otra vez en aquellos mares; ni los pasos antiguos de los filibusteros; ni finalmente, los derroteros oscuros de la mar del Sur, hubieran podido hacérnoslo sospechar siqujera; empero por las inmediaciones de la Isla Montuosa, alcanzándose aún á la vista hacia el Este los altos de Coiba y Quicava, y al Norte las costas del golfo del Montijo, empezáronse á combinar tal contrariedad de corrientes y tales calmas, que en balde nos esforzábamos con repeticlas maniobras y bordos en aprovechar cualesquiera ventolinas que se nos presentasen ménos contrarias.

Esta lucha infructuosa por nuestra parte, nos tuvo casi inmóviles hasta el día 28 , y apenas podíamos mirar como una compensación adecuada al malogro de tanto tiempo, el que se hiciesen en el entretanto algunos progresos para la Historia Natural. Entre unas bandadas casi innumerables de peces que rodeaban las corbetas, y que á veces con un alboroto general y repentino presentaban con sus saltos y con el hervidero del mar un espectáculo agradable, se cogieron, ó bien con la fizga ó con el anzuelo, diferentes dorados, atunes y bonitos, se logró la vista de una manta, á la cual estaban agarrados tres peces del largo de un codo; la lucha singular de un taurón con una tortuga, y el destrozo instantáneo de dos de aquéllos en una tonina herida por nuestras fizgas, ofrecieron nuevos objetos entretenidos; y se logró cojer un atigrado que nuestros naturalistas hallaron sér de la clase anfibia de los balistas, y parecido á los guaperuas del Brasil, ya descritos en Linneo. Las moluscas ó aguas malas, en sus combinaciones diferentes y multiplicadas, habían sido también un objeto digno de un examen repetido y nuevo para D. Antonio Pineda, y entre las aves consiguiéronse coger vivos dos pájaros bobos y una especie de esterna ó golondrina de mar.

No nos habíamos tampoco descuidado en abrigar del Sol, harto pernicioso y directo, las tripulaciones de ambas corbetas, cubriendo desde su salir hasta el ponerse todas las partes de la cubierta con toldos, usanclo del vinagre para los zafarranchos, no permitiendo á nadie que estuliese al siol á pié firme ni áun con objetos de pesca; finalmente, añadiendo á la ración diaria Dic. 28 medio cuartillo de vino. Con estas precauciones, y particularmente con la felicidad de que no acompañasen á las calmas (como es común) unos aguaceros frecuentes, pudimos conseguir que no se extendieran, antes bien, que se extinguiesen de un todo las calenturas, ya introducidas en ambas tripulaciones por los calores excesivos de Panamá; en una y otra corbeta llegó el número de los enfermos á I 3 y I4, y en la ATrevida, complicándose en uno de sus marineros esta enfermedad con una rotura de vasos procedida de un violento culatazo de fusil en el pecho, ocultado al Cirujano hasta los últimos días, tuvieron la desgracia de que no alcanzasen los remedios á salvarle y pagase en la misma tarde del 28 el último tributo á la Naturaleza.

D. Francisco Flores conoció desde el principio, que las calenturas de las cuales adolecían varios en la Descubierta (y entre ellos el Alfére $z$ de fragata D. Felipe Bausá), eran unas sinocales, ó simples ó pútridas, dominando en todas la plétora sanguínea y el humor bilioso, dimanadas sin duda, la primera de los efectos del Sol, y el segundo del exceso en la comida, particularmente los plátanos y otras frutas no bien maduras. Èn algunos se complicaron con malignidad; pero adaptando á éstos la quina $y$ por lo común las sangrías y los antimoniales y ácidos vegetales, no tardaron á desterrarse de un todo, bien que con una debilidad considerable en la convalecencia, que sería difícil reparar en el mar. Merecen en esta ocasión particular memoria la mixtura antimonial para excitar el vómito y la secreción de las materias biliosas, así como el uso de la rosella para los convalecientes, entrambas cosas propuestas por el doctor Masdéval y usadas ahora con el mayor acierto. E1 termómetro de Farenheit puesto á la sazón al aire libre y á la sombra, solía no pocas veces llegar á los $90^{\circ}$.

E1 último día del año, fué finalmente la época en la cual debían terminar, á lo ménos en mucha parte, los enfados de una calma de quince días, que hubiera sin duda merecido una pintura del historiador elocuente del viaje de Lord Anson, pues que había descrito con tan vivos colores el malogro de un viaje feliz á Acapulco, con la demora de sólos cinco días á la vista de la Isla de Cocos. Al anochecer empezaron á entablar ventolinas del Esueste y Esnordeste con mar algo gruesa de la misma parte, y como en esta ocasión las corrientes nos fuesen más bien favorables que adversas, pudimos, conservando la proa al Oesnoroeste, aprovechar la marea favorable, y por la mañana marcar la punta de Buricas al Norte $20^{\circ}$ Este, logrando de la vista de un trozo nuevo de costa, que por tanto tiempo habíamos deseado. 
$\Lambda$ estos objetos por sí sumamente agradables y al brillo de un día con exceso sereno y risueño, se agregó un espectáculo nuevo con la pesca de un copioso número de dorados excelentes, atraídos de la carne de algunos atunes que habíamos cogido de antemano, y rodeando la popa con una constancia poco común en su especie, fácilmente caían en uno ó en otro anzuelo de los muchos que se les presentaban, y reuniéndose a esta facilidad el riesgo de que su mismo peso (como acaecía frecuentcmente) en fin rompiese el anzuelo, ó bien con sus dcbates violentos consiguiesen zafarse antes de tenerlos sobre cubierta, resultaba con aquel contraste, y á veces con la misma fuga, la pesca más interesante y más amena.

Continuaron nuestros progresos en la tarde y noche siguiente, aunque muy lentos. El viento cra calmoso del Sudoeste y nos prometimos lué go el aproximarnos al Golfo de Nicoya: sólo sí que á la una de la mañana, ya bastantemente inmediatos á la costa, y recelando el efecto de las corrientes contrarias, viramos al Sur con viento calmoso, acompañado de algunos chubasquillos.

Desde la tierra baja, que siempre habíamos creido Isla del Caño, y desde la tierra alta inmediata, que en todos los días anteriores de calma marcábamos como extremo Oeste de la tierra firme, empieza ésta á bajar paulatinamente terminando luégo en una punta baja, extremo oriental del Golfo Dulce. Su extremo occiden tal es igualmente bajo; pero escarpado, se eleva muy luégo considerablemente y continúa así la costa por espacio de cuatro ó cinco leguas al Oesnoroeste, retrocediendo después algo más al Norte y volviendo á bajar hasta la Punta Mala, que distará de la otra una distancia casi igual á la que acabamos de expresar. Se dejaban ver á larga distancia en la parte interior del Golfo Dulce diferentes serranías algo confusas y toda la costa parecía igualmente frondosa y acantilada.

Hasta el clía 6 las calmas, las corrientes y los vientos contrarios, nos hicieron permanecer de nuevo en una inacción total, ó más bien nos costaron algunos sacrificios, particularmente en la latitud, pues en este último medio día apenas contábamos la de $6^{\circ} 29^{\prime}$, por longitud cle $4^{\circ} 26^{\prime}$ al occidente de Panamá. Habíanse, no obstan. te, aturbonado ahora los cielos y horizontes por los cuatro cuadrantes, había relámpagos al Sur y Sueste, y con esto reposábamos algún tanto del calor excesivo de tantos días dimanado de la acción no interrumpida del Sol, y nos prometía mos más próxima la revolución deseada del ticmpo.

En el entretanto, las circunstancias que nos rodeaban no podían á ménos de trastornar casi enteramente cl plan formado para nuestros pa- in. 6 sos del año empezado de I 79I; pues ó bien llegásemos demasiado tarde á Acapulco y San Blas, para poder emprender el viaje oportunamente á la costa Noroestc, ó el omitir una parte de las costas de la Nueva España nos obligase á retroceder después para reconocerlas, siemprc el atraso de un año en la totalidad del viaje parecía indispensable, y por la misma razón debíamos precaverle con la anticipación posible. Una nueva separación de las corbetas debió por consiguiente presentárscnos á la vista como el único medio para ocurrir al día á tamañas contrariedades, y así sin perder momento quedó decidido que la ATREVIDA, reconociendo la isla de Cocos y aproximándose á la derrota de Lord Anson para entrar en los límites de los vientos generales, navegase directamente hacia el puerto de Acapulco, allí se enterase de las últimas órdenes de S. M. y conforme á ellas (si exigían una campaña á la costa Noroeste), pasase á San Blas y completase lancha, víveres, pertrechos y cuanto fuese necesario antes que se le reuniese la Descubierta hacia los últimos días de Febrero. Esotra corbeta debía en el entretanto continuar las tareas hidrográficas al andar de la costa, y reconocido principalmente el puerto del Realejo, arribar por último á Acapulco y San Blas, para reincorporarse con la compañera. Hízose inmediatamente una comparación de los relojes marinos, y en aquella misma mañana, como reinasen vientos bonancibles del Oesnoroeste y los ciñéramos con las muras opuestas, perdieronse de vista y la Descubieita procuró aproximarse nuevamente á la costa.

Fueron, sin embargo, nuestros esfuerzos infructuosos hasta la tarde $\mathrm{dcl} \mathrm{I}_{3}$, acosados unas veces por turbonadas y lluvias abundantísimas que movían los vientos bonancibles del Oeste, otras veces por las calmas y la contrariedad constante de las corrientes. Pero, en fin, avistados en aquel día el Cabo Blanco y los extremos del Golfo de Nicoya, devuelto el tiempo á su serenidad primitiva, cesadas por otra parte las corrientes contrarias, y entablados con alguna fuerza y constancia los vientos del Nordeste, pudieronse emprender de nuevo los reconocimientos interrumpidos de la costa, y aproximarnos paulatinamente al puerto del Realejo.

Acosados del tiempo, ya no podíamos á la sazón sujetarnos á la prolijidad adoptada hasta entonces, sacrificando la mayor parte de la noche y navegando de tal modo en el día, que la derrota siguiese siempre de cerca todas las ensenadas de la costa: es esta sin embargo y por ventura bien alta y escarpada, de modo que no cupiesen errores considerables en su descripción, y así pudiéronse recorrer brevemente las que conducen desde la Punta de Santa Catalina 
E.w. 3 hacia el Golfo del Papagayo, golfo cuya comunicación con Nicaragua y' de allí por el rio San Juan con cl mar Atlántico, se ha mirado siempre como un punto de la mayor importancia, no ménos para la geografía general del globo que para los intereses nacionales.

Atravesamos aquel golfo $\mathrm{cn}$ la noche del i6, apercibiendo, pero sin ser muy violentas, aque llas ráfagas del Nordeste que tanto amenazan los derroteros antiguos, aunque Dampierre sólo las 1lama medianamente fuertes; aprovecháronse también diferentes estrellas para deducir la latitud y la longitud en algunas horas de la noche y referirlas á algunos puntos altos que teníamos á la vista; y continuada la navegación en todo el día siguiente, pudimos al amanecer del Is hallarnos á la vista del puerto deseado del Realejo.

Se presentaba la costa con cl semblante más noble y majestuoso. Descle el volcán de León por el de Telica hasta el del Viejo, diferentes montes, ya más, ya ménos elevados, erguían sus cabezas volcánicas y puntiagudas. Seguían al Noroeste, después de un terreno bastantemente bajo, los Sierras de la Cosivina, la Mesa de Roldán y los Montes de Peltacartepe, ya próximos á la Conchagua; una ilusión no extraña re presentándonos como fuego ó humo de los volcanes las quemas altas de los rastrojos, hacía aún más entretenida la vista; y asomándose ya con la salida del Sol los primeros soplos de la virazón, todo parecía prometernos un nuevo teatro agradable para nuestras tareas. Observóse al medio día la latitud de $\mathrm{I} 2^{\circ} \mathrm{Ig}^{\prime}$, la cual disipó cualesquiera dudas sobre el conocimiento del Volcán del Viejo, marca precisa para descubrir la boca bien oculta del Puerto; y finalmente, aprovechada la virazón para disminuir conside rablemente la distancia, distinguiéronse claramente al anochecer la Isla del Cardón y las demás inmediaciones del Puerto, á cuya vista nos obligó poco después á dar fondo la calma que sobrevino y duró toda la noche.

Aprovechado este intervalo para enviar el bote con un Piloto, el cual sondase y examinase la entrada, que sabíamos ser algo peligrosa, tuvimos la satisfacción de verle regresar al amanecer del dia siguiente, trayendo además un Práctico, el cual se hallaba casualmente en aquellas inmediaciones. No dió lugar la virazón á que nos levásemos antes de las diez; pero en el entretanto, para aprovechar todos los momentos farnrables, destacáronse en el bote los Sres. Pineda. Heenke y Valdés, con ánimo de internar hasta el pueblo del Realejo y emprender desde allí sus excursiones científicas, las cuales, por parte de los primeros, debían tener por objeto un país tan poco conocido y tan lleno de riqueyas naturales; por la del tercern una prudente investigación de cuanto fuese relativo á la cons- En.17 trucción y apresto de las naves en esas inmediaciones. No tardó después en seguirles la corbeta, declarados los primeros soplos de la virazón, fueron las sondas al principio de I4, Io y ocho brazas lama, dióse resguardo á un arrecife que sale medio cable al Norte del extremo de la Isla del Cardón, luégo orzamos al Este á atracar bien de cerca, y á ménos de medio cable la parte interior de Ja misma Isla, con el fin de huir de los bajos que salen de la tierra firme y que estrechan el canal á poco más de un cable, cayendo entonces casi repentinamente de las cuatro á las diez brazas arena y lama, cuyo fondo se en cuentra hasta tocar con los penoles en la punta; $y$ en fin, ya rebasado este paso y favorecidos más y más del viento y de la marea, fuimos por medio canal dando resguardo á algunos peligros, y comunmente por sondas de ocho, siete, seis y cinco brazas, hasta que ya á las once en el fondeadero interior del Xaquei dimos fondo á un ancla y quedamos amarrados poco después. Demoraba la cima del volcán al Norte $25^{\circ}$ Este y la punta de Icacos al Sur $10^{\circ}$ Oeste; una fragata pequeña del comercio de Lima estaba también surta á un cable de nosotros.

Era demasiado favorable la estación, y nuestros pasos eran harto acelerados por la estrechez del tiempo, para que, ó sacrificásemos un momento siquiera á objetos ménos importantes, ó no aprovechásemos cualesquiera ocasiones que pudiesen hacernos más útil aquella escala. Por ventura la claridad constante de los días y las noches, la excelente disposición del fondeadero, la multiplicidad de nuestras embarcaciones menores, y á un mediano trecho varias poblaciones numerosas que coadyuvaban á los acopios y excursiones de los naturalistas, combinaban un tal conjunto de ventajas que difícilmente hubiéranse podido hallar en otra parte alguna. Así, á pesar que la falta de la corbeta ATREvida disminuyese de una buena mitad el número de personas capaces de dirigir las diferentes excursiones científicas, y que por nuestra parte estuviesen enfermos D. Fernando Quintano y D. Felipe Bausá, fué tal el empeño de los demás, que casi al mismo tiempo de haberlas emprendido, estaban concluídas la mayor parte de las tareas proyectadas, y por consiguiente podíamos pensar de nuevo en aproximarnos á Acapulco.

En el solo plazo de diez días fueron sumamente importantes las observaciones que tuvimos para la latitud y longitud del observatorio; multiplicáronse de tal modo las tareas hidrográficas, que ni las sondas importantes de las dos bocas de la entrada, ni los canales internos, el puerto de los Aserradores, la elevación exacta del Volcán del Viejo y la deducción por ésta y el rumbo de demora de la posición respectiva de 
En. 17 algunos otros pueblos, careciesen de toda aquella prolijidad á la cual estábamos acostum. brados.

En la excursión que hicieron algunos Oficiales con dos botes al puerto de los Aserradores, se intentaba durante la noche una caza de tortugas, que solían comunmente venir á la playa, cuando se encontró, que una clase de rivales bien temibles les habían precedido en una hora, y eran éstos un número considerable de tigres, casi los únicos habitadores del terreno anegadizo y lleno de mangles y de icacos, que media entre los dos pucrtos y abriga el canal por donde se comunican entre sí, dando ingreso á los muchos esteros que conducen á los astilleros las preciosas balsas de los cedros y de los pinos. Hubo una entre aquellas fieras, que si bien acosada de las voces de nuestra gente, no abandonó la presa, y con tanta constancia como maña, fué arrastrando la tortuga desde la playa hasta el bosque. Otras, al amanecer, se veían aún en la playa, á poca distancia de nuestra barraca; puede considerarse que no fué largo ni tranquilo el sueño de los que allí se hallaban, resarcidos sí en parte con los frutos abundantes y exquisitos quc les suministraban la pesca, la caza y los mariscos.

Mientras la Oficialidad y los botes se empleaban de esa manera en los diferentes objetos indicados, no dejaba la demás gente de atender diariamente á los reemplazos de agua y leña, los cuales pusimos al cargo de un sargento y un contramaestre; sólo sí, que los cscarmientos de Panamá nos dictaron ahora como más prudente el que no se trabajase en aquellos objetos sino desde el amanecer hasta las diez de la mañana, abandonando las demás horas como excesivamente arriesgadas para las tercianas, de las cuales ahora adolecía de nuevo uno ú otro marinero; la pesca y la pesquisa eficaz del infinito número de preciosas conchas muy varias entre sí, que hermosean aquellas costas, era otro objeto que nos ocupaba diariamente. Fuimos en esta parte con exceso felices, y vimos en un momento enriquecerse considerablemente nuestros acopios para el Real Gabinete de Madrid.

Atentos como se ha indicado ya, D. Dionisio Galiano y D. Juan Vernaci á cuanto pudiese ser útil en el observatorio, habían deducido los resultados siguientes:

\begin{tabular}{|c|c|c|c|}
\hline & Cron. ${ }^{\circ} 72$. & Cron. ${ }^{\circ}$ 6r. & Cron. ${ }^{\circ} 7$ I. \\
\hline $\begin{array}{l}\text { Diferencia occi- } \\
\text { dental de Pana- } \\
\text { má. . . . . . } \\
\text { Ecuaciones con- } \\
\text { frontadas con el } \\
\text { número Io de la } \\
\text { Atrevidaltiem- } \\
\text { po de separarse. }\end{array}$ & $30^{\prime}$ I I" $28^{\prime \prime \prime}$ & $3 I^{\prime} 35^{\prime \prime} 36^{\prime \prime \prime}$ & $29^{\prime} 51^{\prime \prime} 12^{\prime \prime \prime}$ \\
\hline $\begin{array}{c}\text { Diferencia iguala- } \\
\text { da en tiempo. }\end{array}$ & 30.20 & 30.29 .24 & $30.29 \cdot 24$ \\
\hline
\end{tabular}

En grado y Occidental de Panamá.

$7^{\circ} 37^{\prime} 2 x^{\prime \prime}$ En. I7 Nuestras series corregidas le asignaban. 81. 41. 30

Era por consiguiente la longitud del observatorio. .........

Por las inmersiones del primer satélite de Júpiter observadas en los días 25 y $27 \ldots \ldots \ldots$. . . .

Ochenta y cuatro series de distancias del Sol á la Luna, traídas con los relojes marinos.

89.18 .51

89.21 .00

Omitióse por entonces el hacer uso de otros muchos materiales que se habían acopiado para el intento; resultó la latitud del observatorio de I $2^{\circ} 29^{\prime} 50^{\prime \prime}$ Norte y la variación magnética de $7^{\circ}$ I $5^{\prime}$ Nordeste; y como se incorporasen y' para la noche del 28 los diferentes individuos que se habían destacado á una ú otra parte, se pudo prefijar para el día jo la salida. Considerábanse los naturalistas con extremo felices, bien sea por las disecaciones y colecciones botánicas y de conchiología que se habían hecho, bien sea por el examen científico de los volcanes y terrenos adyacentes. La cresta del volcán del Viejo descubría un doble cráter, algunos depósitos de azufre, varias otras piedras singulares, y sobre todo, una vista realmente majestuosa, la cual compensaba en mucha parte la fatiga de dos días para álcanzarla y cl riesgo que había corrido D. Tadeo Heenke de ser mordido por una víbora de cascabel. Aunquc no tan alto el volcán de Telica, presentó á D. Cayetano Valdés objetos aún más interesantes. Su caldera, desde luego, no le era inferior, no bajando una ni otra de I.0oo varas de diámetro próximamente, ni puede darse vista más hermosa de la que pre. sentan las paredes de la caldera con un amarillo sumamente vivo é igual en todas partes, dimanado del azufre que las viste. El humo es casi general, no sólo $\mathrm{cn}$ lo interior, si también en las inmediaciones externas. Cede el terreno bien fofo aproximándose á la cima; una piedra echada á la cavidad, por largo tiempo devuelvc un murmullo distante, prueba segura de la profundidad á que penetra; se oyen á lo lcjos hacia las partes ménos altas las conversaciones de los que están en el montc; la vejetación es bien mezquina; en fin, todo denota un hueco sumamente profundo, del cual emana en mucha abundancia un vapor acuoso, y en donde parece una obra periódica é incesante dé la Naturaleza la liquidación de muchos materiales, y en particular de varios montoncitos de piedra, que con una prudente igualdad se advierten sembrados en lo interior. No era muy remota la época de los últimos extragos del volcán. En I 762 una lluvia de cenizas y arenas, cubrió las campiñas inferiores hasta el pueblo del Viejo, distante unas diez leguas. Los extremecimientos ó temblores duraron unos quince días. Los acom- 
Eil. 28 pañaban á veces los bramidos del mismo monte, y la Naturaleza, grandiosa hasta en sus convulsiones, se explayaba al mismo tiempo aún con más vigor en el volcán del Rincón de la Vieja, inmediato al Istmo de Nicaragua. Se conservaban además bien vivos en la mcmoria de aquellos naturales los extragos dimanados de las lavas del Momotambo $y$ del Nindiri, habiendo la primera indicado como prudente la traslación del pueblo de León, y la otra por casualidad, dirigido cuatro lavas diferentes hacia unos parajes no bien habitados. En general, la dirección de esta dilatada cordillera de volcanes parece próximamente del Oesnoroestc al Esueste. A sus faldas se extiende hacia el mar una porción de tierra baja, regada en parte de los rios y en parte de las mareas. Su mucha fertilidad es difícil de describirse, y las maderas excelentes que por todas partes crecen en sus orillas, convidan tanto más á una construcción activa, cuanto que el conducirlas el labrarlas es obra de poco costo.

No oponiéndose dificultad alguna á la continuación de nuestro viaje, le pudimos efectivamente emprender para la mañana del 30 , como lo habíamos proyectado; al medio día ya estábamos fuera del puerto; y al anochecer, el terral fresco con el semblante más hermoso, nos hacía continuar con bastante velocidad nuestro viaje y nuestras tareas, si juzgásemos, pues, por aquellas primeras apariencias; la travesía hasta el puerto de Acapulco no debía costarnos tanto tiempo ni tantas inquietudes como la anterior. Con solos dos días de navegación estábamos delante de Sonsonate, cuya rada fué fácil reconocer; apenas anochecía, cuando entablaba el Nordeste. La elevación de los montes y la claridad de las noches facilitaban aún más las tareas emprendidas; y era tal la útil posición de aquellos volcanes, que á la vista de Sonsonate se alcanzaban al mismo tiempo el de la Cosivina sobre el Realejo, y los de Guatemala á cuyas faldas se halla situada la capital del reino.

A pesar de su fondeadero bien incómodo, es Sonsonate el paraje por donde se extraen casi todos los frutos del reino de Guatemala, destinados á los del Perú y Méjico. Los tintes para sus manufacturas, las breas y alquitranes, el algodón y una cantidad grande de maderas preciosas, forman los ramos principales de esta extracción; siendo los de introducción los vinos, aguardientes y algunos comestibles secos del Perú y Chile, alguna azúcar del reino de Méjico, y una proporcionada compensación en dinero efectivo. Hasta las inmediaciones de los volcanes de Guatemala nuestro viaje pudo todavía caracterizarse por feliz; pcro desde aquel paraje, fueron tales las oposiciones que tuvimos por las calmas y por las corrientes contrarias, que el detallarlas por menor, fuera tan difícil como can- sado. El ig de Febrero aún estábamos á la vista de los mismos volcanes, aunque por unos ocho días hubiésemos procurado alejarnos á distancia de 40 leguas de la costa. Pocas horas del Nordeste fresco del Golfo de Tecoantepeque, nos separaron, hacia el 24 , de aquellas inmediaciones; pero como atracásemos nuevamente la costa hacia los puertos de los Angeles y de Aguatulco, volvimos á hallarnos rodeados de las mismas calmas y ventolinas contrarias, con las cuales habíamos luchado desde tanto tiempo, y la desconfianza de poder realizar en el próximo verano la campaña proyectada, debió, por la misma razón, adquirir un nuevo vigor bien desagradable. Entre tanto, los calores eran excesivos, influyendo no sólo en la salud en general, si tambien en el mal trato de la arboladura, de las cubiertas y de las embarcaciones menores. No aparecía una nube, que al paso de modificar el ardor del Sol nos indicase algunos preludios de vientos más favorables; varias especies de aves y peces se presentaban á nuestra vista mirándonos casi como los habitadores de aquellas costas; finalmente, debíamos temer que la excesiva sensibilidad de nuestra marinería no trastornase en cierto modo la mucha tranquilidad, de la cual habíamos gozado hasta entonces, influyendo la calma lo que tal vez no lograrían influirle los mismos peligros de las latitudes altas septentrionales. Ya para compensar la falta casi total de carnes frescas, debimos tambien ocuparnos diariamente de la pesca de la tortuga, valiéndonos á las veces de la fizga, á las veces de un boteci1lo, según lo requiriese la posición de la corbeta; solía esta pesca ser más abundante á medida que nos apartábamos de la costa, y éste fué el partido que adoptamos de nuevo el 6 de Marzo, si bien tampoco le hallásemos útil hasta el 2I. No debe pasarse en silencio el efecto que experimentamos en aquellos quince días por las corrientes contrarias, pues no fué menor de 92 leguas al Sur y 68 al Este, cantidad que de ningún modo pudiéramos contrarestar con las ventolinas contrarias, que por lo común nos rodeaban.

En el mismo día 2I pudimos atracar de nuevo la costa á no mucha distancia de Acapulco, y gozando ya con una mayor fuerza y duración de los terrales y virazones, hacer diariamente algunos progreśos hacia el puerto, por el cual anhelábamos con tanta eficacia. Se destacó la lancha á las órdenes del Teniente de navío D. Cayetano Valdés para que reconociese las costas fronteras; y alcanzado después el puerto de Acapulco, nos saliese al encuentro con las órdenes y avisos que allí hubiese para la expedición. Nosotros continuamos luchando hasta el 27 con las contrariedades acostumbradas; pero en fin, como lográsemos en la mañana dc aquel día el hallarnos algo á barlo- 
Mar. 27 vento de la entrada y al mismo tiempo recibir por medio de la lancha diferentes órdenes y noticias que exigían medidas complicadas para la continuación del viaje, fué preciso determinarnos á entrar en el puerto y lo verificamos así, quedando fondeados y amarrados en muy buena posición antes del anochecer.

Como se verá después, la ATrevida había hecho la escala prescrita en el puerto y emprendida luégo su navegación hacia San Blas, bien que con la probabilidad de necesitar próximamente un mes de tiempo para aquella travesía. La estación estaba extraordinariamente adelantada para la campaña proyectada sobre la costa Noroeste de la América, ni sería prudente emprenderla antes de reunir las dos corbetas abastecidas además con cuanto fuese necesario para unos reconocimientos útiles; por otra parte, atento á los vientos y corrientes que reinaban sobre la costa, parecía tan fácil este conseguimiento para la otra corbeta, como difícil para la DESCUBIERTA; así fué últimamente la medida adoptada con anticipación á todas las demás, la de encargar á la ATREvida que retrocediese con la posible brevedad á Acapulco, no descuidándonos en el entretanto en reponer aguada y víveres, y completar aquellas obras en el casco, arboladura y velamen, que el último viaje penoso dictase ya como necesarias.

Mientras cuidábamos así de la mayor economía del tiempo, y según costumbre, los Oficiales astrónomos, los naturalistas, los hidrógrafos, los cazadores y los disecadores, atendían cada cual á los muchos objetos que le suministraban los alrededores de Acapulco, no pareció intempestivo el que se destacase también un Oficial hasta la capital de Méjico, y allí, al paso de recibir verbalmente del señor Virey el Conde de Revillajigedo, las órdenes é instrucciones oportunas para las campañas siguientes, verificase algunas observaciones astronómicas, entre las cuales merecían sin duda un lugar preferente una emersión del primer satélite de Júpiter y la ocultación por la Luna de Cáncer, que de. bían acaecer en las noches del 7 y I2 de Abril, y eran visibles en Méjico, Acapulco y San Blas; contábamos con que no faltarían los instrumentos oportunos aunque la precipitación del viaje y el camino largo y pedregoso imposibilitasen el transporte de los nuestros, pues además de los que pertenecían al Real Observatorio de Cádiz y habían sido entregados al Comandante de San Blas D. Bruno de Hezeta, sabíamos que existían aún allí los que habían servido en San José de California al Abate Chappe y eran ahora propios de D. Antonio Gama, persona sumamente instruída y habitualmente inclinada á los estudios y tareas astronómicas.

Malográronse en mucha parte las observacio. nes indicadas, por las turbonadas periódicas que desde el medio día hasta la media noche suelen comunmente en aquella estación oscurecer los cielos y horizontes. No así con las combinaciones más favorables relativamente á nuestro viaje y con aquellas ideas políticas del estado general del reino que tanto anhelábamos; pues en cuanto á lo primero, dos extraordinarios de San Blas, participaron casi á un mismo tiempo al señor. Virey la llegada de la corbeta ATREvidA, las órdenes de S. M. que allí había para que verificásemos la navegación á la costa Noroeste de la América y sus activas disposiciones para reunírsenos cuanto antes en Acapulco; por la otra, el mismo señor Virey y todas las personas más ilustradas de la capital, concurrieron eficazmente ya con libros, ya con instrucciones y noticias útiles, para que extendiésemos nuestras ideas y llevasen los pasos venideros una dirección ménos incierta hacia el bien público y la prosperidad de la Monarquía.

\section{Viaje efectuado por la ATREviDA durante su separación de la otra corbeta, segin relación de Bustamante.}

Navegación de la ATREvida al reconocimiento de la Isla de Cocos, y sucesiva á los puertos de Acapulco y San Blas.

La constante tenacidad de los tiempos se En. 7 oponían tanto á los progresos de nuestra derrota, que su atraso daba ya algún cuidado para evacuar los objetos que debían ocuparnos el verano próximo. Esta justa reflexión produjo la necesidad en D. Alejandro Malaspina de dividir En. 7 desde este punto las corbetas, y prevenirme que con la de mi mando me dirigiese á los puertos de Acapulco y San Blas, combinando, si era posible en este tránsito, la posición astronómica de la Isla de Cocos por ser preferente el desempeño de otros objetos comprendidos en su instrucción.

Dando cumplimiento á ella, se trasbordó in - 
mediatamente á la Descubiert. el equipaje del liegente de Guatemala, sobre cuyas costas debía dirigirse $y$ fondear en el puerto de Realejo. A estál diligencia siguió la comparación de los relojes, y ciñendo ambos el viento del Oeste-Noroeste con muras encontradas, quedamos fuera de la vista á las diez y media de la mañana.

Al medio día observamos la latitud Norte de $6^{\circ}$ I $5^{\prime}$ y la longitud de $77^{\circ}$ o. $\prime^{\prime}$ occidental de Cádiz, aunque estas observaciones no merecían toda confianza por carecer de ella la altura meridiana. La inconstancia de los vientos entre el tercero y cuarto cuadrante alteraban con frecuencia las bordadas para seguir aquélla más próxima al Oeste. La noche fué oscura y cerrada con chubascos repeticlos que precisaban á guardar la debida precaución en el aparejo.

Del mismo modo permaneció el tiempo hasta el día ro, en términos de no permitir averiguar por observaciones nuestra posición verdadera. 'Todavía hoy no pudo conseguirse con exactitud por no estar bien determinados los limbos del Sol y el horizonte algo interlumpido. Sin embargo, siempre era muy preferente á la de estima, en la cual se habían reunido y multiplicado las causas que producen sus errores comunes. Estas observaciones señalaban la latitud de $5^{\circ} 4^{6} 6^{\prime}$ Norte, y la longitud de $80^{\circ} \mathrm{oo}^{\prime}$ con una diferencia de $34^{\prime}$ al Sur de la estima en los tres días y $30^{\prime}$ al Este.

Si la abundancia de pájaros fuese aqui señal cierta como lo es en otros parajes, de tierras inmediatas, sin duda que la Isla de Cocos no debía estar muy distante. Los alcatraces y pelícanos ell mayor número eran exactamente iguales á los que nuestros naturalistas describjeron en Coquimbo; su frecuente ejercicio de los primeros en precipitarse desde grande altura para buscar el sustento, era indicio evidente de su abundancia por estos mares. En efecto, nuestros marineros le conseguían también con el anzuelo, llegando á veces á tal exceso, que para aumentar su agradable diversión en la pesca restituían á la presa su libertad. Pero esta misma abundancia de pescado produjo algunas indigestiones y recaídas á los convalecientes, contra cuyos excesos, aunque por otra parte fuesen disculpables, no alcanzaba nuestro celo á precaverlos.

Desde el medio día nos favoreció el viento fresquito por el Nordeste hasta las cuatro que abonanzó, á cuya hora avistamos con sorpresa la Isla de Cocos al ángulo corregido de $48^{\circ}$ en el tercer cuadrante, distancia de seis á siete lezuas, cuando á la sazón nos considerábamos como 6o de ellas; error á la verdad muy considerable, que excita tanto el deseo de corregirlo como el de justificar la admiración de hallarle.

Nos era sensible á este intento no tener la maror contianza en las obserraciones de hoy por si le frustrasen las calmas ú otros accidentes Fr. 7 muy comunes en estos parajes; también el viento era flojo y desigual, circunstancias que aumentaban el error de las operaciones que emprendiésemos. No obstante, se corrió una base cuyos reresultados determinaban al centro de la isla la latitud de $5^{\prime \prime} 34^{\prime}$ Norte, $y$ la longitud de $80^{\circ} 3^{6^{\prime}}$ $29^{\prime \prime}$ occidental del Real Observatorio de Cádiz.

Durante la noche se procuró conservar la inmediación de la isla á pesar de las ventolinas variables que lo dificultaban. . Logramos, no obstante, amanecer á tres leguas escasas de ella, y dirigiéndonos á favor único de una marejada del Norte, á buscar con proa del Sur su paralelo antes de la observación del medio día, no pudimos alcanzarle, bien que la inexactitud de la observación la hizo también desatendible para el efecto.

Al día siguiente otras apariencias más favorables nos lisonjeaban de satisfacer nuestros deseos. Toda la mañana tuvo el tiempo el mejor semblante, y sólo cerca del medio día se presentó un chubasco, que sin embargo de acortal el horizonte, le dejaba bien determinado. A pesar de esto se doblaron todas las precauciones para asegurar la mayor exactitud, arreglando un reloj, y con él á la vista se observó la latitud con mucha confian$z a$, resultando á la isla la de $5^{\circ} 34^{\prime}$ por el promedio de siete observadores muy acordes entre sí, marcándose al mismo tiempo el centro de ella al Sur $73^{\circ}$ Oeste, corregido á distancia de cuatro millas. Nuestra longitud, observada por el número ro, fué de $80^{\circ} 48^{\prime} 34^{\prime \prime}$, habiéndose hallado la variación Nordeste de $8^{\circ}$.

Hasta las tres de la tarde se había barajado la isla con una ventolina de Noroeste, á cuya hora, reconocida la parte del Sur, un chubasco fuerte nos obligó á separarnos de ella, siendo mi ánimo pasar por la del Norte. No se presentaba la noche con las mejores apariencias, y aunque era correspondiente el celo y cuidado en el aparejo, no fué posible precaver un contraste fuerte por el Nordeste á las cuatro de la mañana, que por fortuna no nos causó la menor avería, y el viento cedió con la mucha agua que 1lovía.

La cerrazón impidió verse la isla hasta las ocho, que demoraba lo más Oeste de ella al Sur $30^{\circ}$ Oeste, y lo más Este al Sur $23^{\circ}$ Oeste, dis tancia como de seis leguas. Se midió luégo una base tomándose horarios. Las observaciones las mirábamos de tanta mayor importancia, cuanto que sus resultados decidirían lá situación de la isla, por no estar conformes entre sí los de los días anteriores. El viento no fué muy constante ni igual su fuerza, cuyo defecto para las bases se corregía midiendo frecuentemente la distancia de corredera. A pesar de todo, puede adoptarse sin crave escrúpulo de error una base medicl? 


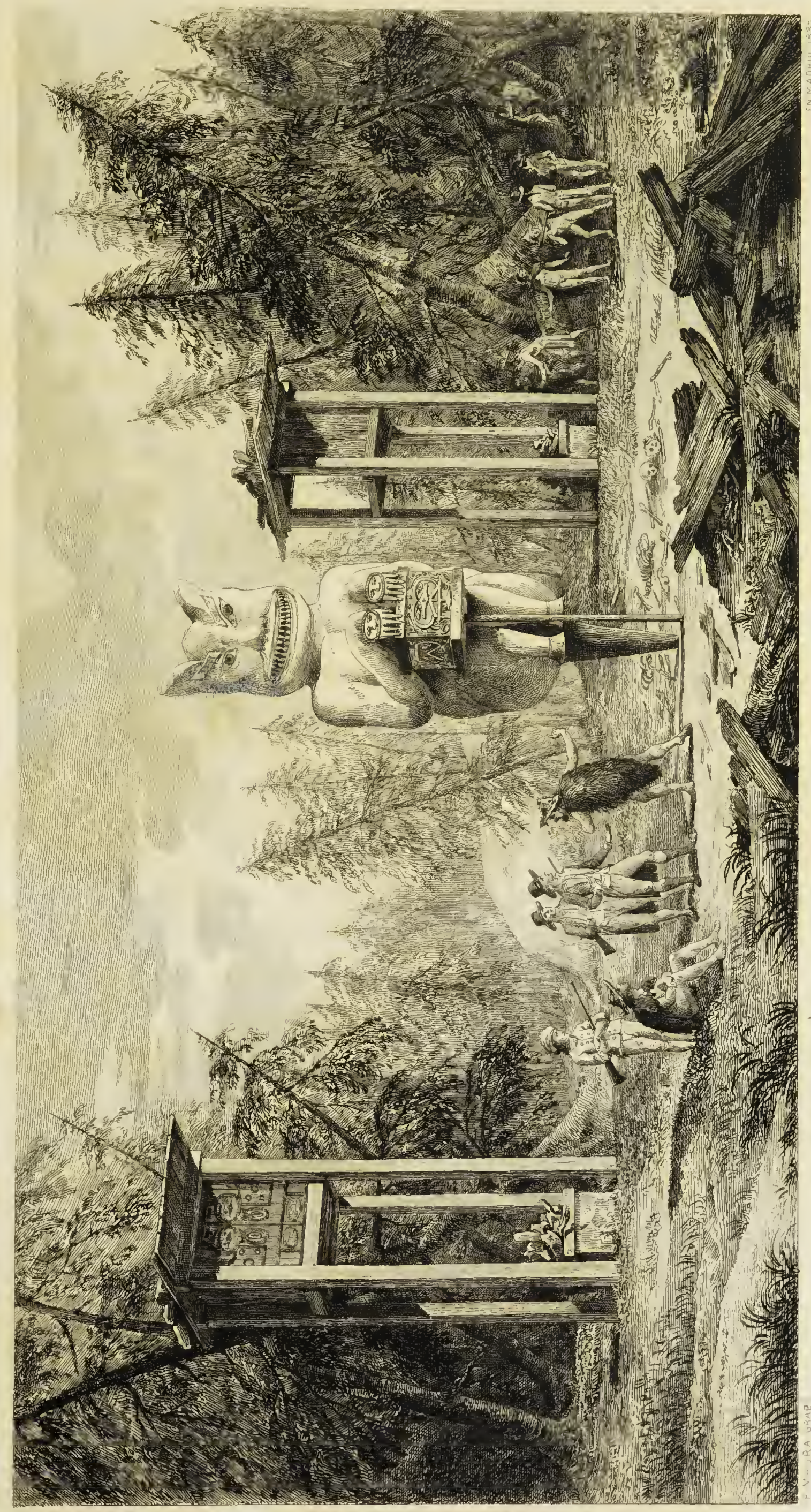



En. г3 de las dos á las cuatro de la tarde con horarios antes y después de ella, y con igual confianza se ha adoptado la latitud del medio día tomada por siete observadores.

De la relación que acaba de referirse para conocimiento de los navegantes, se puede concluir que las observaciones de los días I2 y I 3 merecen absoluta preferencia para la situación astronómica de la Isla de Cocos; por consiguiente, la que he adoptado para su latitud fué observando próximos á su paralelo, y es de $5^{\circ} 33^{\prime}$ I $0^{\prime \prime}$ y la longitud del día I 3 también casi en su me. ridiano, de $80^{\circ} 47^{\prime} 3 I^{\prime \prime}$ occidental de Cádiz.

Esta Isla de Cocos corre del Estenordeste al Oestesudoeste y tiene de extensión algo más de una legua. Desde el centro hacia la parte del Oeste es su mayor altura, y en ésta se eleva un pico agudo de donde va descendiendo suavemente para el Este, en que remata con punta baja formada por dos islotillos inmediatos entre sí y á la isla; al Noroeste hay también otro próximo; toda la superficie está cubierta de una frondosa y verde arboleda hasta sus orillas; en la parte del Nordeste tiene fondeadero al frente de unas palmas, según noticias que tenemos; y en la del Sur se vió una playa corta en donde infiero no le tenga por ser allí la isla tajada al mar.

Hay agua en ella, produce abundancia de cocos, y abriga multitud de pájaros, los cuales, en tiempos oscuros, podrán indicar sus cercanías.

Si se coloca la isla por el promedio de las observaciones antes referidas, estará su centro en latitud Norte $5^{\circ} 33^{\prime}$ I $^{\prime \prime}$ y en longitud $8^{\circ} 42^{\prime}$ Oeste de Cádiz.

Esta posición de la isla se aparta de la del Lord Anson desde $5^{\circ} 20^{\prime}$ de latitud en que la establece á $5^{\circ} 34^{\prime}$ en que ahora queda, siendo aún más notable la diferencia con la que asignan los pilotos particulares de este tráfico con la del referido Almirante.

Es de notar que en la relación elegante de su viaje, no exprese las circunstancias ó métodos para la situación de la citada isla, mucho más habiendo permanecido cinco días á su vista, cuya circunstancia induce á creer algún error en sus operaciones, ó días con observaciones de latitud muy inciertas.

No pudo perderse de vista la isla por las contínuas calmas hasta la tarde del I6, y si aprovechando ventolinas se gran jeaba algo, las corrientes para el Sur lo volvían á perder. Las diferencias en este sentido eran constantes, lo mismo que aguaceros fuertes y el calor, para aumentar el número de nuestros enfermos y de nuestros cuidados. Sin embargo, no eran aquellos de tanta gravedad que no contásemos su alivio como seguro luégo que se entrase en la región de las brisas, y este era de mucho tiempo el término de nuestros deseos.
Habíamos podido rectificar con observaciones En. x de distancias á Régulus y Aldebarán la longitud del número Io, con la cual estaban muy conformes.

Esta seguridad de la exactitud de nuestra posición verdadera después de tantos días y tantas causas para alterarla, nos era ciertamente muy apreciable y disminuía el fastidio de una navegación desagradable por todas sus circunstancias.

Esta misma oposición no nos abandonó sino después de treinta y cuatro días, declarándose las brisas aunque todavía sin pasar del Norte en la mañana del 22, hallándonos al medio día en latitud de $5^{\circ} 37^{\prime}$ Norte y en longitud de $83^{\circ} \mathrm{I9^{ \prime }}$, observando la variación de $9^{\circ} 30^{\prime}$ Nordeste.

Al día siguiente las brisas estaban en el primer cuadrante con todas las señales de su firmeza. Habían cesado las diferencias al Sur $\mathrm{y}$ nuestro objeto no era ya más que forzar constantemente de vela para llegar cuanto antes á Acapulco; nuestra longitud del número ro pudimos comprobarla con 26 series de distancias lunares el día 26 , cuyo promedio correspondía exactamente á la misma longitud que señalaba el reloj; la variación por amplitud señalaba $\delta^{\circ} 27^{\prime}$ Nordeste, hallándonos en latitud de $10^{\circ} 24^{\prime}$ Norte $y$ en longitud de $90^{\circ} 28^{\prime}$.

Al día siguiente volvimos á observar distancias cuyo promedio de sesentá y cuatro séries nos indicaba con sorpresa una diferencia de $I^{\prime \prime}$ $3^{8^{\prime}}$ al Este de la del número ro, cuya novedad tan repentina nos produjo la admiración que era consiguiente.

No podíamos acertar con la verdadera causa de esta notable diferencia, y aun cuando en esta clase de observaciones son fáciles de deslizarse algunos errores, no pudimos, sin embargo, advertirlos, ni tampoco conceder uno tan considerable en esta ocasión, para no presumir alguna causa ó alteración en el reloj, difícil de averiguarse aquí.

Se había observado desde ayer una mayor abundancia de pájaros, y un color en el agua que indicaba sonda; pero no se encontró con 90 brazas. Nuestros rumbos desde el medio día se dirigieron al Noroeste, siendo la distancia al continente como de go leguas. A las cuatro, después de calcularse los horarios, se orzó al Noroeste $1 / 4$ Norte, rumbo que nos conducía á recalar al Norte de Acapulco. Por la noche fué rolando el viento para el Este, aumentando también su fuerza desde que se puso la Luna; al amanecer era ja bastante recio por el Estesudeste, tanto que obligó á navegar con solo las principales. Estas señales anunciaban la permanencia de las brisas y con esta seguridad fué ya mi ánimo buscar el puerto directamente.

Los grandes armamentos que sabíamos des. 
fin. zs de Panamá había en Europa, daban justo recelo para que hubiesc rompimiento con la Inglaterra.

Aun cuando éste sc hubiese verificado, podíamos mirar como remoto todo encuentro de enemicos por estos mares; pero no obstante estos antecedentes, y de una debida consideración á nuestra escasa y fatigada tripulación, se procuró ejercitarla en el manejo de las armas, montándosc antes toda la artillería.

Las observaciones del medio día, advirtiendo grandes diferencias, parece querían frustrar mis deseos sobre la recalada. Observamos lá latitud de $13^{\circ} 43^{\prime}$ que diferenciaba al Sur de la estima en $\mathrm{I} 7^{\prime}$, y la longitud de $94^{\circ} \mathrm{oo}$ también se apartaba en $52^{\prime}$ al Oeste. Pareció muy considerable esta diferencia para atribuirse toda á error de la estima á pesal de que el viento recio y á fugadas y la mar muy elevada pudieran justificarle. Pero observadas nuevas longitudes por la tarde, conformaban con las del medio día, y por consiguiente repetían la misma diferencia.

Desde las siete de la mañana se gobernó al Norte para atracar la costa por los meridianos de Acapulco en que á la sazón casi nos considerábamos. La brisa fué cediendo al principio de la tarde, y siguiendo el propio rumbo se forzó al instante de vela.

Con sospecha de haberse corrompido algunos barriles de coles agrias, se procedió á su reconocimiento, hallándose sólo en estado consumible aquellas que por estar en vasijas bien acondicionadas habían conservado la salmuera, y por el contrario corrompidas cuantas carecían de ella, siendo preciso echarlas al agua como inútiles ó perjudiciales á la salud pública. Esta experiencia hace conoccr cuánto cuidado exige el acondicionar este saludable alimento con toda la escrupulosidad que merece la conservación de tan poderoso antiescorbútico.

Alcanzamos al medio día siguiente la latitud observada de $14^{\circ} 5^{6^{\prime}}$ y la longitud de $93^{\circ} 34^{\prime}$, ésta diferenciándose en $35^{\prime}$ al Este de la estima; esto es, en sentido contrario de ayer, pero no así con la latitud, cuya diferencia de I 2 ' fué hoy también para el Sur. Aunque estas diferencias hacia el segundo cuadrante venían conformes con las noticias que teníamos de la dirección de las corrientes en estos parajes, no obstante, para confirmarlas, se repararon los horarios y otros nuevamente tomados á las tres de la tarde repitieron la misma diferencia. Con esta confirmación, mandé gobernar al Noroeste ${ }^{1 / 4}$ Norte con cl viento ya inclinándose para el Sudeste bonancible. A las nueve de la noche llamó al Sudoeste y esto indicaba el término de las brisas sustituídas por los variables del $30^{\circ}$ y $4 \cdot^{\circ}$ cuadrante.

Avistóse lá tierra al amanecer, rcconociéndoe luégn las T'etas elcvadas de Coyuca. la del biste es algo más baja y redonda que lá del Oes- te, demorándonos al Norte $14^{\circ}$ Oeste. Estas se ñales y la del cerro de la Brea que está sobre el mismo puerto de Acapulco, unidas á que todo el frontón de costa era mucho más alto que las tierras al Este y al Oeste de su entrada, no dejó género de duda de haber recalado frente del referido puerto.

En efecto, por marcación hecha al medio día á las Tetas de Coyuca al Norte corregido, y la latitud observada de $16^{\circ} \mathrm{IO}^{\prime}$, nos demoraba Acapulco al Norte $13^{\circ}$ Este, distancia de ${ }_{4} 4$ leguas. Una carta española que nos guiaba en esta derrota, se le corrigió la longitud en medio grado al Oeste que se advirtió de error á las Islas de Coiba, con cuya corrección resultaba por longitud de Acapulco $93^{\circ} 5^{6^{\prime}}$ casi la misma que señalaba el reloj estando hoy en su meridiano.

Las bonanzas hicieron inútiles nuestros es- Feb.r.o fuerzos de atracar la costa hasta la mañanita del día I. "que con ventolinas del primer cuadrante gobernando al Nornoroeste, se pudo distinguir la Isla Roqueta por la proa, entre la cual $y$ el continente hay paso estrecho pero hondable, por donde entran las naves de Filipinas cuando vienen con vientos bien entablados. Esta isla escarpada, tiene unas manchas blanquizcas, muy propias para distinguirla y conocer la boca del puerto en tiempos oscuros, ó cuando la niebla, frecuente en algunas estaciones del año, oculta las altas montañas de sus inmediaciones.

Estábamos al ponerse el Sol entre el puerto Marqués y la Isla Roqueta, á distancia de ésta como dos cables y en sonda de 35 brazas lama.

Rebasada la Punta del Grifo se ciñó el viento al Nornordeste y Norte, intentando con un re. piquete alcanzar el fondeadero.

Se vió luégo la candelada que se enciende en el sitio del Vigía cuando se avistan embarcaciones, y las luces de la población; calmó el viento, y las ventolinas variables obligaron á dar fondo á un anclote en 23 brazas lama, demorando la Vigía al Oeste $5^{\circ}$ Norte, y lo más saliente de la Roqueta al Sudoeste 1/4 Sur.

A media noche por garrar el anclote con unas rachas del Noroeste, se dió fondo á un ancla, permaneciendo así hasta por la mañana.

\section{Entrada en el puerto de Acapulco.-Observaciones ejecutadas y otras ocurrencias.}

Al romper el día salí en el bote para tierra, con el fin de anticiparme las noticias sobre el estado político de la Europa y aprovechar los ins tantes para combinar con la estrechez del tiempo las providencias y aprestos necesarios. Pero antes previne al Teniente de navío D. Antonio de Tova, que echada la lancha al agua, dirigiese la corbeta á la velá al remolque alparaje donde se amarra la Nao de Manila, la cual, no viéndola en el 

pues nunca sale para su destino hasta Marzo. Sólo había fondeada la fragata marchante la Pastora, que salió de Guayaquil después de las corbetas con carga de cacao, y á los treinta y cinco días avistó estas costas sin poder cojer el puerto hasta completar los cincuenta de su salida, á causa de las corrientes para el Este y su poca diligencia; defecto común de todas las embarcaciones de este tráfico.

Por ausencia del castellano el Coronel Don José Manuel de Alava, ejercía las funciones de Subdelegado D. Diego Carrillo, quien me informó la subsistencia de la tranquilidad de Europa, pareciendo casi segura la transacción amistosa entre la España y la Inglaterra, á pesar de que existían los grandes armamentos de ambas coronas.

El referido Subdelegado me entregó las órdenes de S. M. dirigidas á D. Alejandro Malaspina, advirtiéndome se hallaba con otras repetidas del Excmo. Sr. Conde de Revillajigedo, Virey de estos dominios, para franquear á los buques de esta expedición los caudales y auxilios necesarios para la continuación de su viaje, y además tenía especial encargo del Gobernador para obsequiarnos en su nombre mientras estuviésemos en la jurisdicción de su mando.

Inmediatamente regresé á bordo, encontrando la corbeta á la vela con ventolinas del Nornordeste y ayudada de remolques dirigiéndose al fondeadero prevenido. A las ocho y media de la mañana quedó ya amarrada con un ancla afuera y dos calabrotes de reguera dados al árbol más Este de los dos inmediatos al muelle; bajo las marcaciones del asta de bandera del castillo nuevo de San Carlos (antiguamente nombrado de San Diego) al Norte $59^{\circ}$ Este; el Islote del Obispo al Norte $69^{\circ}$ Este; y el convento de San Hipólito, que ahora sirve de Hospital, al Norte $46^{\circ}$ Oeste; rumbos de la aguja, en fondo de $5 \mathrm{y}^{1} / 2$ brazas lama.

Por la tarde despaché extraordinario al Virey con aviso de mi llegada, las ocurrencias de la navegación, y pidiéndole las órdenes de S. M. relativas á la expedición que tal vez hubiesen llegado á su poder por el último correo, en inteligencia que daría la vela luégo de recibirlas y se me incorporasen los Tenientes de navío D. José de Espinosa y D. Ciriaco de Cevallos, que suponía en camino para este puerto, habiendo sabido su llegada al de Veracruz el I 9 del pasado.

Por informes que recibí snbre la comparación de precios en los víveres entre este pueblo y San Blas, hallé preferente hacer el acopio de ellos en aquel departamento, así por ser allí mucho más fácil y equitativa su adquisición, como por poder contar al mismo tiempo para su apresto con otros auxilios y recursos que no hay en este puer- to. Esta resolución nos facilitaba emplear el Feh. tiempo en otras operaciones y observaciones combinables con nuestro nbjeto hasta el momento de la salida.

Desde luego se principió al día siguiente el córte de leña, y el reemplazn de la aguada. Se armó el cuarto de círculo en el patio de la propia casa del castellano, llevándose también el reloj I0 5 para las comparaciones diarias, y el uso de otras observaciones que ofreciese la Astronomía. Por otra mano se emprendió levantar el plano del puerto, para cuya operación se midieron dos bases, la una de I.830 piés ingleses en la playa grande al Este del Islote del Obispo, y la otra de 588 inmediata á la población y á la popa de la corbeta. Las sondas verificadas en el número posible, se prefirieron aquellas más importantes, siéndolo la del canal formado por la Roqueta y la tierra firme, y la del bajo falsamente supuesto en nuestros planos cerca de la Punta del Grifo, en donde se hallaron nueve brazas de agua.

La ejecución completa de todas estas atenciones debía considerarse como segura y breve si un suceso acaecido la noche del 8 no hubiest querido malograr mis deseos. A las ocho de la noche, cuando con la Oficialidad me iba á embarcar en el muelle, hallamos que toda la esquifación del bote, excepto el patrón, le habían abandonado. A pocas diligencias practicadas á bordo. averigüé haber desertado toda esta gente, á pesar de ser de la de más confianza. Comisioné al punto á los Oficiales D. Juan Concha y D. Francisco Viana con el sargento y cinco soldados para que imponiendo del hecho al Subdelegado, tomasen de acuerdo las medidas más prontas que dictasen su actividad y las circunstancias. Estc Jefe facilitó á dichos Oficiales tropa escogida de la guarnición muy práctica del pueblo y caminos, y registrando primero las casas sos pechosas contestaron la fuga de dichos individuos al principio de la noche. Con estas noticias, se formaron dos divisiones, dirigiéndose á los caminos de Méjico y Coyuca, únicos por donde podían haber salido; siguieron sus respectivas direcciones toda la noche haciendo diligencias grandes á caballo, pero con el sentimiento de haber sido infructuosas. Sin embargo, haciendo especial encargo á las Justicias para prenderlos, también á los pueblos de su jurisdicción hicieron saber la recompensa pecuniaria que obtendrían como los cogiesen, según yo lo había prometido. Nuestros Oficiales fundaban tanto sus esperanzas en este recurso por informe de las propias justicias, que cuando regresaron, ya vieron cuadrillas de indios lanceros apostadas cautelosamente, y no dudaban de su celo lograsen resultas tan felices como podían esperarse de medidas las más oportunas.

En la mañana del 9 recibí contestación del Virey, incluyéndome pliegos de la Corte llegados 
últimamente á aquella capital, y manifestándome no ser tan fácil la pronta reunión de los Oficiales Espinosa y Cevallos como yo lo deseaba, si acaso no dilatase yo de algunos días la salida. Como al mismo tiempo me advertía el haber anticipado sus órdenes preventivas al Comandantc de San Blas para el acopio de nucstros aprestos; $\checkmark$ por otra parte, miraba de tanta importancia la aprehensión de los desertores, no pude dudar en la resolución de detenerme ni de manifestársela para que también se sirviese estrechar sus pro$\checkmark$ idencias para conseguir el coger los desertores, cuya falta, así por el número como por su suficiencia marinera, me era de notable importancia para la campaña venidera.

Se conoció muy hreve la falta que nos hacían tan buenos marineros, entre los cuales se hallaba cl gaviero mayor, pues las faenas ocurridas por la noche la justificaron. A las dicz principió á relampaguear por el cuarto cuadrante con truenos bastante frecuentes. Apuntó después el viento al Este, y dando una fuerte fugada cambió con violencia al Noroeste aturbonado, ráfagas muy fuertes y mucha agua. No tomé hasta aquí precaución alguna atendiendo á la excelencia del puerto, y hallarnos justamente en el rigor de la estación más benigna del año. La noche se puso del peor semblante, haciéndola más horrorosa la repetición de truenos y relámpagos, que causaban un estrépito espantoso entre las montañas elevadas que circundan este puerto. Pero se tomaron luégo las precauciones debidas de reforzar las amarras de tierra, en donde faltaron luégo dos de los calabrotes. Al Este se tendió el ancla de babor, y de este modo se pudo resistir la fuerza del viento hasta las ocho de la mañana, en que el tiempı serenó enteramente.

Para el I6 se consideraban ya evacuados todos los objetos que me había propuesto, y en disposición de dar la vela en el instante que llegaran nuestros Oficiales de Méjico. Nö era poca. satisfacción el verlos verificados, y agregar á ella la de haber conducido hoy presos los nueve marineros desertores, por varios individuos de las justicias que los cogieron á 30 leguas de esta población; á quienes como también á los indios llecheros que los custodiaban, se satisfizo á presencia del Subdelegado los rastos de conducción y gratificacioncs ofrecidas por este servicio, cargándoselos en sus asientos respectivos.

Se ha hecho relación prolija de este suceso para que cn 10 sucesivo pueda servir de gobierno á otros huques dc S. M. que frecuenten este puerto, por si acaso tomando iguales medidas corresponden con el mismo fruto.

La suma claridad de las aguas en este surwidero nos ha proporcionado hacer una observación importante, aunque contraria á la del Capitán Cook. Este navegante supone que el forro de cobre en las embarcaciones impide que se arrime el pescado, fundándose en que el cardenillo sea un veneno activo que le mate, en cuya opinión se apoyó para proponer al Almirantazgo el forro de madera á los buques de su último viaje, como medio de facilitar la pesca, y un alivio tan considerable en semejantes expediciones. Nosotros, aquí, después de repetidas experiencias, podemos con seguridad oponernos á la opinión de aquel ilustre navegante. Muchos días hemos notado, que acudiendo el pescado con abundancia á las conchuelillas pegadas á las planchas de cobre, se detenían en ellas para arrancar algun alimento que encontraban, probándose así que léjos de serle nocivo, le era muy sabroso y agradable.

Por el resultado de nuestras observaciones de esta ciudad nombrada de los Reyes, queda determinada su situación astronómica, referida á la casa del Gobernador en donde se colocó el observatorio, como se expresa.

Latitud observada por estrellas al Norte y al Sur del zénit.........

Longitud observada de confianza por el primer satélite de Júpiter en la noche del i 8 de Febrero por D. Juan Concha, occidental de París..... $102022^{\prime} 38^{\prime \prime}$ Longitud por el promedio de 48 séries de distancias lunares observadas el día I 2. .............. 102.22 .00

Deducción de la longitud por los relojes marinos.

Núm. ro.

Núm. I05.

Diferencia al tiem.

po medio por

las alturas co-

rrespondientes

el día 3 de Fe-

brero. .....

Por sus diarios á

Panamá....

$2^{\text {h }} 42^{\prime} 43^{\prime \prime} 20^{\prime \prime \prime} \quad 0^{h} 32^{\prime} 3 I^{\prime \prime} 40^{\prime \prime \prime}$

$4 \cdot 4 \cdot 36.20$

$0.52 \cdot 31.52$

Diferencia de meridianos con $\mathrm{Pa}$ namá . . . . . .

Longitud Oeste de

Panamá.. . .

Panamá al Oeste

de París.... $8 I^{0} 53^{\prime} 45^{\prime \prime} \quad 8 I^{\circ} 53^{\prime} 45^{\prime \prime}$

Longitud de Acapulco occiden-

tal de París. . 102.22.00 103.09.38

La variación de la aguja por el teodolito resultó de $7^{\circ} \mathbf{r} z^{\prime}$ Nordeste.

Renunciando ya la esperanza de reunirnos aquí con la corbeta Descubierta, dejé en poder del Subdelegado un cajón con los pliegos de la Córte, planos y documentos relativos á nuestras operaciones desde la separación, rotulado á Don Alejandro Malaspina, para quc á su arribo se lc 
Feb. in entregase inmediatamente. También dejábamos otro cajón de aves disecadas y preparadas por la diligencia recomendable del Cirujano D. Pedro González, para que Malaspina, si lo hallase por conveniente, pudiese determinar su remesa por Veracruz á España.

Tuve yo noticia la tarde del 24, que los Oficiales Espinosa y Cevallos debían llegar temprano en la mañana siguiente, con cuyo antecedente me dispuse á dar la vela en aquel instante. En efecto, nos hallábamos con las gavias ensunchadas é izadas cuando llegaron, pero advirtiéndome que su equipaje no estaría aquí hasta la mañana siguiente por lo malo de los caminos, cuya propia causa había también dilatado su llegada, tuve que suspender la salida, cortando toda comunicación con la tierra á fin de evitar nueva deserción en los últimos momentos que tanto favorecen á los que la intentan sabiendo también la imposibilidad de perseguirlos.

\section{Salida de Acapulco y navegación hasta San Blas.}

Apenas llegó el equipaje de dichos Oficiales por la mañana, y apuntó la brisa, dimos la vela con todo aparejo atracando la punta del Grifo, en donde escaseando el Sudoeste obligué á seguir el bordo sobre la de la Bruja y á costa de otros dos repiquetes conseguimos estar fuera de puntas al medio día; á esta hora, por marcaciones á la punta de la Bruja al Norte $26^{\circ}$ Este, la del Grifo al Norte $4^{\circ}$ Oeste, y el farallón del Obispo al Norte $5^{\circ}$ Este, resultó la latitud Norte de $I 6^{\circ} 48^{\prime}$ y longitud occidental de Cádiz de $93^{\circ}$ y $43^{\prime}$.

Siguióse la vuelta del Sur con viento fresquito del Oesudoeste, conduciéndonos este rumbo al ponerse el Sol á 6 ó 7 leguas de la costa. No podíamos esperar mutación muy favorable en los vientos, pues por noticias adquiridas en Acapulco, nuestra navegación á San Blas, debiendo hacerse con vientos constantes del $4 .^{\circ}$ cuadrante debía ser por precisión bien larga. Sobre esta causa se agregaba la de las grandes diferencias hacia el segundo cuadrante, causas que produ. cen atrasos en este viaje aunque sea corto en razón á la distancia. Por esto la derrota ordinaria que se hace, es separarse de la costa, buscando fuera de ella las variaciones favorables de vientos.

Habían conducido los Oficiales Espinosa y Cevallos dos relojes pequeños que dejamos en el Observatorio Real de Cádiz, pertenecientes á los dos cronómetros que traen las corbetas, los cuales se pusieron desde luégo en movimiento. Estas máquinas, fabricadas igualmente por Arnold, tienen los números 344 y 35I .

Los vientos desde aquí entre el Oestenoroeste y Oeste con poca fuerza, nos produjeron sacrificios considerables en la latitud y longitud á medida que fuimos saliendo para el Oeste fue. ron inclinándose paulatinamente hacia el Norte pero con las diferencias al Sur constantes y no pequeñas, aumentaban el atraso de la derrota: nuestra situación el 4 de Marzo era bien desventajosa estando en latitud Norte de $I 3^{\circ} 50^{\prime}$ y en longitud de $95^{\circ} 4^{6}$, observando la variación Nordeste de $7^{\circ}$.

Todavía hasta el 7 fuimos perdiendo en latitud, pues sin embargo de que los vientos habían tomado un giro algo más favorable llegando á veces hasta el Nornordeste, como las diferencias al Sur eran grandes, no pudimos excusarnos de bajar hoy hasta la latitud de $\mathrm{I} 3^{\circ} 4 \mathrm{I}^{\prime}$ Norte, en longitud de $97^{\circ} 26^{\prime}$, desde cuyo punto ya empezamos á sentir menores diferencias y también á lograr otros progresos para el Norte. Los vientos tomaron asímismo más fuerza y esta circunstancia con la constante fuerza de vela disminuía el abatimiento, y los efectos de las corrientes, ya en este paraje eran bien poco sensibles.

Las observaciones del día II nos manifestaron la latitud Norte de $\mathrm{I}_{4}^{\circ} 5^{\mathrm{I}^{\prime}}$, y longitud de $99^{\circ}$ I2', por las cuales, y otros indicios como abundancia de pájaros, algunos chubascos y ramas de árboles, nos indicaban la cercanía de la Isla de Posesión. Esto nos hizo navegar con vigilancia todo el día siguiente por si algún error presumible en su situación podía hacer que la avistásemos.

En los días I5 y 6 notamos una constante variedad en los vientos, pero sin salir del primer cuadrante. Esta alteración, ó nuestros deseos, nos daban esperanzas de que llegásemos breve á encontrar los vientos del Oeste y Noroeste, para tomar luégo la otra vuelta. Nos considerábamos al medio día del hoy 16 , como r oo leguas dis tantes de la costa, y á esta causa atribuíamos el ningún efecto ya de las corrientes para el Sur y también tal vez á hallarnos al Oeste del meridiano del mar de Cortes, cuyo desagüe derramándose en su misma dirección, producirá al guna corriente, cuya conjetura podremos quizá comprobarla si experimentamos sus efectos sobro las Islas Marias.

Desde la media noche dió el viento algunas llamadas del Norte al Nornoroeste, pero con tan poca subsistencia, que no permitió seguir la otra vuelta. A la mañana se tomó la del Nordeste un corto intervalo favorable, llcgando al medio clía á la latitud de $17^{\circ} 34^{\prime}$, y longitud de $105^{\circ}+{ }^{\prime}{ }^{\prime}$ Oeste. Notóse en esta última una grande dilerencia con la de estima en $x^{\circ}$ og' para el ()es te. 'T'ambién hubo 12 ' de diferencia al Sur: no obstante, como al día siguiente no encontramos alguna en la longitud, puede suponerse que aquella tan considerable dimanase de algún error cn 
las alturas, ó al contar en el reloj al tiempo de tomarlas.

Por las comparaciones de los relojes resultó haber alterado su movimiento el número ro cn $3^{\prime \prime}$ con el ro5, diferencia que no se atribuiría á defecto de aquella sobres aliente máquina, á no repetirla los otros dos relojes de Arnold, cuya uniformidad de movimiento entre sí desde España habían dado muy buenas longitudes. El tcmperamento había altera do muy sensiblemen. te, y desde luego esta repentina mutación puedc haber causado en el número Io aquella novedad. Sin embargo, en las comparaciones del día siguiente volvió á uniformar su movimiento con los relojes ro5 y $3+t$.

Los días 2 I y 22 estuvo el tiempo cubierto, y á reces achubascado ó garuando, lo cual ocasionaba variaciones de vientos con las que se tomaba la vuelta que granjease más para el Este. Estos aparatos parecían anunciarnos la próxima mutación de viento favorable, pero no tuvieron lugar estos deseos hasta pasada la media noche del 24, en que aclarando, roló el viento al Nornoroeste y Norte bien fresco al amanecer, prometiéndonos por todas las bellas apariencias con que se entabló la seguridad de su constancia y el pronto arribo al puerto deseado. Estábamos al medio día por la latitud observada en $22^{\circ}$ or $I^{\prime}$; $y$ en longitud de $108^{\circ} 34^{\prime}$ Oeste hallando la variación por amplitud occídua de $7^{\circ}$ Nordeste.

La Carta española que nos guiaba diferia en $I^{\circ}$ en la longitud entre la bahía de San José y el puerto de San Blas de la que señalaba un planito remitido por D. Francisco Maurelle, Teniente de navío de la Real Armada, residente en Méjico. Pero la longitud que resulta de San Blas según la distancia estimada de 60 leguas entre ambos puntos, y la diferencia en latitud, es de I $00^{n} 30^{\prime}$ occidental de Cádiz. El Abate monsieur Chappe, comisionado por la corte de Francia á observar el paso de Venus acaecido el 3 de Junio de I 769 , á cuya comisión le acompañaron los Oficiales de la Armada D. Vicente Doz y D. Salvador de Medina, establece la longitud de San José por la observación de $\mathrm{Doz}$ en $\operatorname{Ir} 2^{\circ} 2^{\prime} 30^{\prime \prime}$ occidental de París, ó en el mismo sentido de Cádiz de $103^{\circ} 26^{\prime} 30^{\prime \prime}$ y la latitud de $23^{\circ} 3^{\prime} 30^{\prime \prime}$ Norte. El citado Chappe es quien pone la distancia estimada de las 60 leguas, bien que las contrariedades quc sufrió para navegarlas, por corrientes, calmas, etcétera, dan motivo suficiente para creer algún error en su cálculo y conceder la prefercncia á la estima de Maurelle no habiendo tenido aquellos obstáculos.

No nos abandonó después el tiempo favorable del Nortc y Nornoroeste ni sus bellas apariencias, de modo que al medio día del 27 conLamos la Innzitud de $\mathrm{IO}_{3}^{\circ}$ I $5^{\prime}$ Oeste, por latitud de $2 \mathrm{r}^{\circ} 3 \mathrm{O}^{\prime}$ Norte, considerándonos como 50 le- Mar. = guas de las Islas Marias, demorando la del centro al Este corregido, cuyo rumbo es el que seguimos desde haber llegado á su paralelo. Esta longitud, indicada por los relojes, tuvimos en csta mañana ocasión de comprobarla por 36 series de distancias lunares, cuyos resultados sólo diferenciaban en $8^{\prime}$ al Este del reloj.

La suma confianza que teníamos en estas observaciones nos persuadía la exactitud de nuestra verdadera posición. Así, aunque el viento continuase fresco, seguimos toda la noche con fuerza de vela en vuelta de las islas, pudiendo distar de ellas al medio día siguiente como ocho leguas por una Carta reducida que teníamos; pero por el plano de Maurelle, ya estábamos al Este de ellas; sin embargo, no era de creer error considerable en su longitud considerando estuviese referida á las observaciones ejecutadas por Don Vicente Doz en el Cabo de San Lucas, y creo también en San Blas.

Efectivamente, á la una de la tarde, estando en latitud al medio día de $2 I^{\circ} 25^{\prime}$ y longitud de $100^{\circ} 25^{\prime}$ se avistaron desde los topes las islas demorando por la proa. Tardamos poco en atracarlas y barajándolas á distancia de dos leguas, nos dirigimos á pasar por el Sur de ellas. Estas islas corren Noroeste-Sueste, son muy limpias, la más Norte tiene dos puntas bajas y un isloti110 en la del Noroeste, pero carecen de puertos. Por noticias que tenemos abundan de varias y excelentes maderas, con especialidad de guaya. can que se conduce á San Blas para los usos dcl Departamento; se coge buen carei y se hace una bebida de la corteza de cierto árbol, cuyo uso está prohibido.

De las longitudes observadas á las diez horas y veinte minutos de la mañana por el número ro 1levadas con la estima hasta la hora de avistarse la isla más Norte estimando la distancia de ella de seis leguas, se dedujo la longitud de clla de $100^{\circ} 30^{\prime}$ occidental de Cádiz que diferenciaba en $7^{\prime}$ de la que indicaba la Carta es. pañola, y $I^{\circ}$ al Este de la de Maurelle. No será esta la situación que establezcamos á estas islas porque sólo hago mención para indicar aquellos errores, respecto á que en San Blas deduciremos con toda exactitud la referida situación después de averiguar el movimiento del número io, cuya marcha no fuera extraño haberse alterado después de cuarenta días que se cerró en Acapulco su diario.

Con rumbo del Estesueste íbamos á atracar la isla más Sur de la cual al anochecer por tres marcaciones hechas á las dos del Norte, señalaban la distancia á ella de diez leguas. El poco viento ó calmas desde la media noche no dió lugar á rebasarlas todavía al amanecer, teniéndola á esta hora por el través á cuatro millas. Cinoóse 
Mar. 29 luégo el viento fresquito del Nordeste en demanda del puerto, y cuando el Sol turo una competente altura, se convino estar próximos al meridiano de la isla, para correr bases en estas circunstancias y observar longitudes. Por las referidas al medio día por los relojes, llegamos á la de $99^{\circ}$ $32^{\prime}$ Oeste, y latitud observada de $2 I^{\circ}$ I $3^{\prime}$ Norte; teniendo de variación por amplitud ortiva $7^{\circ}$ Nordeste. A este tiempo demoraba lo más Norte de la isla, más Sur al Norte $75^{\circ}$ Oeste, y el isloti110 que tiene á la parte del Sur, al Norte $87^{\circ} 30^{\prime}$ Oeste.

A la una de la tarde se descubrió la costa de San Blas y notablemente el monte de San Juan por la proa, cuya elevación y figura formando dos cerros redondos en la cúspide, puede servir de marca muy segura para buscar el puerto. Perdíamos las esperanzas de alcanzarle hoy por haber entrado tarde la brisa del Noroeste, y sólo al ponerse el Sol pudo verse poco á barlovento el islote de piedra blanca, el cual dista del puerto como seis leguas.

Seguimos en demanda de él hasta las diez do la noche que calmó la brisa, sondando entonces 26 brazas lama. Por la mañanita conocimos el efecto de las aguas para el Sur, y así declarándose la brisa á las ocho por el cuarto cuadrante (que sopla aquí desde Noviembre á Mayo) se orzó al Noreste. En este paraje suele fondearse con bonanzas por no caer á sotavento del puerto, y más siendo en la estación benigna en que estamos, cuya maniobra hubiera yo ejecutado al contar ménos en la diligencia del buque, y á querer evitar este trabajo á la gente, y á los cables que tanto padecen en esta faena.

A las diez y media marcábamos la segunda piedra blanca situada cerca de la entrada de San Blas, cuya figura representa una embarcación á la vela, al Norte $72^{\circ}$ Este, por cuyo rumbo nos dirigíamos al fondeadero con todo aparejo. Después del medio día se divisaban ya las banderas del Rey en el fuerte de la entrada y en la altura de la población donde se halla la Contaduría del Departamento, cuyo edificio representa una fortaleza. Poco después llegó á bordo el Secretario del Comandante el Capitán de navío D. Juan Francisco de la Cuadra, quien me informó hallarse en el pueblo de Tepique, pero que llegaría al día siguiente.

Cerca ya de la segunda piedra blanca navegamos sobre las gavias por fondo de siete, seis y media y seis brazas lama, y rebasada se dió fondo al ancla de babor en cinco y media la misma calidad, y seguidamente se tendió la otra al Este, quedando de este modo en las marcaciones del asta de bandera del fuerte de la entrada al Norte $7^{\circ}$ Este, la que está en la Contaduría al Norte 46 Este, y el Cerro de San Juan al Sur $8 I^{\circ}$ Este.
Estada en San Blas y aprestos para la ejecución de la campaña al Norte, consecuente á las últimas órdenes de S. M. recibidas en este puerto.

En la mañana siguiente llegó de Tepique el $A b, 1$. Comandante Cuadra, y me manifestó el particular interés que tomaría en contribuir con sus providencias eficaces en que nos aprestásemos con todos los auxilios que exigiese el éxito feliz de nuestra comisión. Y á este efecto se hallaba con órdenes anticipadas y amplias del Virey, para que nada faltase al desempeño cabal de un objeto tan importante $y$ recomendado muy especialmente por S. M.

No bien se habían concluído las faenas marineras, cuando se empezaron todos aquellos reparos para el aparejo y velamen en que podía ocuparse la marinería sin auxilio del arsenal. Con igual celeridad se dió principio por la maestranza á la recorrida de costados y trancaniles, limitándose estas obras sólo á lo muy preciso para reducir los gastos grandes que aquí causan, y contando con que en la invernada en Manila se completarían con notable economía. I Las embarcaciones menores fué también preciso enviarlas á carenar al Arsenal por los terribles extragos que había hecho la broma en sus fondos, y una lancha nueva que estaba ya principiada, fué también necesario aumentarle su capacidad y resistencia, sin cuyas circunstancias no podría desempeñar los objetos á que debía destinarse.

Por el correo del 5 recibí pliegos de Su Majestad para D. Alejandro Malaspina, previniéndole expresamente la verificación de la campaña al Norte con el fin de determinar la falsa i verdadera existencia del estrecho ó paso de comunicación entre el mar Pacífico y el Atlántico. A este efecto se acompañaba una Memoria publicada en Francia por Mr. Bauche, miembro de la Academia de Ciencias, leída en aquella sabia Asamblea el I3 de Noviembre del año próximo pasado, en la cual se trata de probar como cierto el referido estrecho, fundándose sobre la autoridad de un viaje por el navegante español I.orenzo Ferrer de Maldonado.

Ignoraba yo el paradero de Malaspina, y su retardo en llegar á Acapulco siendo considerable, me hacía recelar algún contratiempo en su navegación, pues según aviso del Virey con fecha de 27 de Marzo todavía no había entrado en Acapulco, siendo así que según me indicaba en su instrucción contaba para el 20 de Febrero coger aquel puerto. Parecióme indipensable, no obstante, dirigirle por extraordinario á Méjico las últimas órdenes de S. M., suplicando al Virey las trasladase á sus manos en el instante de saber su arribada sobre cualesquiera puerto de la costa. 
b. = Yo consideraba ya muy contingente el reunirnos, por In tanto juzgué preciso avisar á Malaspina el plan de la derrota que me proponía cjecutar pará cumplir las órdenes recientes de S. M., en el caso de que las suyas para el 24 del corriente no me previniescn cl alterarle.

Era, pues, mi ánimo hacer navegación directa á la altura de $60^{\circ}$, atracar la costa y reconocerla al Norte y al Sur del monte de San Elías, en donde la cilada Memoria supone el cuestionable paso, buscándole por las señas que advierte en la entrada de esta parte; si no le hallaba, como parecía lo más probable, pensaba dirigirme para el Sur á reconocer los trozos de costa sin trazarse hasta aquí por navegantes nacionales ó extranjeros. Después entraría en Nutka y Monterey, si la estación lo permitiese, y rectificando las Cartas del Continente de la América ó corrigiéndolas de los errores que incluyen los métodos empleados en semejantes operaciones por la falta de relojes, regresaría luégo á Acapulco en ()ctubre ó Noviembre de este año.

Al mismo tiempo que con fecha de hoy participaba al Excmo. Sr. Ministro de Marina todas es tas mediclas como consecuentes á haberme ente rado de las últimas órdenes de S. M., le avisaba la llegada también del péndulo simple destinado por S. M. á esta expedición para que en el dis. curso de ella se repitiesen las observaciones con arreglo á la reducida instrucción que acompañaba el Capitán de fragata D. José de Mendoza, que lo remite desde París. Se reducen éstas á comparar el movimiento del péndulo con el tiempo medio para determinar así las distintas relaciones de la sravedad, y deducir por ellas una medida universal y la verdadera figura de la tierra.

Habíase colocado el observatorio en la plaza de la iglesia para el arreglo de los relojes, y ejecutar las observaciones celestes que ocurriesen, en cuya inmediación se tomó una casa para alojar á los Oficiales encargados de este ramo, pues la gran distancia á que se hallaba el buque de la población, hacía indispensable esta providencia para asegurar aquellos objetos. Con el propio empeño se principió á levantar el plano del puerto, y este cúmulo de atenciones para evacuarlas con la brevedad á que estrechaba el tiempo, no dejaba de hacerme recelar en un país tan mal sano el que la gente enfermase.

Por la mañana del I , recibí aviso de Don Mlejandro Malaspina de haber llegado el 27 de Marzo á Acapulco, después de 57 días de una cansada navegación desde Realejo, en la que por calmas y corrientes no le había sido posible situar la costa intermedia desde que dejaron los volcanes de Guatemala; y atendiendo á las circunstancias que nos rodeaban y á las tareas de nucstros naverantes españoles, y de los señores Jixon. sobre las costas sep- tentrionales de la California, determinaba diri- $\mathrm{Al}$. r girse á las Islas de Sandwich, y recorriéndolas en lo restante del verano, regresar por Octubre á Acapulco, atravesando después á las Filipinas. Como para la ejecución de este plan me recomendaba la mayor diligencia en trasferirme á aquel puerto, yo, descle el instante, estreché mis providencias para dar la vela pasado mañana, avisándoselo así por extraordinario que salió inmediatamente. A la sazón teníamos la aguada y leña completa, habiendo hecho también r 60 quintales de lastre para reemplazar los pesos muy disminuídos desde la salida de Cádiz, cuya falta en latitudes altas perjudicaría á la resistencia y buenas propiedades del buque, justamente en ocasión en que eran más precisas ambas circunstancias.

Habíamos concluido á la sazón así las nbselvaciones que determinaban la situación exacta de San Blas, como el plano del puerto con una línea de sonda desde la rada ó para je donde se hallaba la corbeta hasta la entrada al rumbo del Sursudoeste por fondo de $36,35,26$ y I 8 piés siempre fango. Esta calidad disminuye en parte la poca seguridad del fondeadero de la rada, con especialidad en los meses de Julio, Agosto y Setiembre por los vientos reinantes del Sur y Suceste que soplan con fuerza y frecuentemente traen turbonadas. Son pocas las embarcaciones que pueden entrar en el puerto por el poco fondo de la entrada, y para evitar la detención de alijar, fondean como á cuatro ó cinco cables del islote pequeño que está á la entrada y á tres de la punta Sudoeste de la misma. Sobre ésta se halla una batería, y se extiende para el Este de ella un arrecife de piedra comode 80 toesas, en cuyo extremo empiezan las valizas indicando el paso estrecho que conduce al interior del Arsenal. E1 fondo en pleamar (que sucede en novilunio y plenilunio á las ocho y media de la mañana) entre las primeras es de r6; I 5 y I 4 piés; continúa así hasta cerca de la chàta que baja á nueve y ocho; en la bajamar disminuye de tres á cuatro piés el fondo, $y$ éste es variable á uno y otro lado de las valizas, á causa de los cantiles ó placeres formados por cl rio de Santiago que desagua por esta parte.

Todo el día siguiente se empleó en recibir del arsenal los efectos para entrambas corbetas como eran clavazón, madera, brea, la pipería compuesta $\mathrm{y}$ nueva, 220 quintales de pan y I 50 arrobas de tocino. La lancha nueva, como también el observatorio, equipajes y los útiles de tonelero y herrero, quedarnn también á bordo, de modo, que al anochecer nada faltaba para efectuar la salida desde que apuntase el terral.

Por nuestras observaciones, habíamos establecido la posición astronómica de San Blas referida al paraje del observatorio en la forma siguiente: 
Ab. rr longitud de San Blas deducida por la emersión del primer satélite de Júpiter en 7 de Abril de 3 r occidental de París. . . . Cádiz al O. de París. . . . . . .

Longitud de San Blas occidental de Cádiz............

Longitud de San Blas por el número ro occidental de Acapulco. ...........

Acapulco al O. de Cádiz. . . . . .

l.ongitud de San Blas por el ro occidental de Cádiz. . . . . . .

L atitud observada en San Blas por estrellas al Norte y al Sur del Zenit. ............ Variación de la aguja por el promedin de seis azimutes observados á bordo por dos olsservadores. ................ F. $9^{\circ} 26^{\prime} 00^{\prime \prime}$

Descripción del departaniento de San Blas, orígen de su establecimiento, y vantajas que of recería trasladado á Acapulco.

La villa de San Blas se halla situada á un cuarto de legua del Arsenal, á la falda de una eminencia que presenta su cara á la brisa, por lo general reinante desde las diez de la mañana hasta las seis de la tarde. El terral la sustituye á pocas horas, pero la situación local impide gozar de este beneficio tan saludable en estos climas calurosos. La población, reducida á muy pocos regulares edificios, se compone de chozas cubiertas de paja, prescntando aquella vista pobre y miserable de un pueblo situado en un clima insano, habitado sólo por la necesidad ó por las ventajas que su conservación produce á los inte. reses del Estado. Algunas casas de particulares, y uno ú otro edificio del Rey, están hechos con alguna solidez, pero en la estrechez de las primeras no se ha combinado la capacidad que piden las habitaciones entre trópicos. El terreno de las calles desigual y pedregoso, hace su tránsito bastante incómodo. El temperamento de San Blas, pornaturaleza enfermo, lo es excesivamente en la estación lluviosa de Mayo, Junio, Julio y Agosto. Por estas y otras causas locales que referiremos, los naturales tienen una languidez y tristeza en sus semblantes, que las justifican tanto como la necesidad de abandonar el pueblo por aquél tiempo en que tanto allijen las enferme. dades agudas. Así no puede fijarse el número de sus habitantes como tampoco la multiplicación de la especie humana puede tener aquí aquel aumento proporcionado á su número, cuando tantas circunstancias lo embarazan. Podrá ascender la población en tiempo ménos mal sano á 4.500 almas, y á la mitad de este número cuando la abandonan trasladándose á Tepique.

Para que así este pueblo como el Arsenal sean poco sanos, concurren causas físicas que existirán Ab. rr mientras existan ambos establecimientos, y por consiguiente habrá de sufrir sus perniciosas consecuencias. Hállanse uno y otro rodeados de esteros ó pantanos, cuyas aguas y las llovedizas que los forman, comunicándose con las marinas, producen la putrefacción destructora terrible de la humanidad. Unese á estas causas una plaga casi contínua de mosquitos conocidos aquí con el nombre de gegencs ó perjuicios. Divídense en dos clases, unos son pequeños, de tamaño poco mayor de una pulga, y otros mayores que se distinguen con el nombre de zancudos. Una y otra especie de insectos tienen una actividad singular en la picada, y molestan especialmente en las conjunciones y oposiciones de un modo inexplicable. Si este es un motivo tan poco agradable para habitar en la población $y$ en el Arsenal, puede inferirse cuanto debe au mentarse á los operarios de este sitio, en donde el terreno más bajo y ménos ventilado hace insufrible su residencia, causando atrasos muy grandes en las obras que allí se ejecutan.

Fué el objeto de formar aquí este Arsenal el de resguardar y de extender los reconocimientos de la costa Noroeste de este continente y facilitar el socorro de los presidios de Monterey, San Diego, Loreto, etc. Esta idea, protegida por el Excmo. señor Marqués de Sonora, desde la visita general que hizo en este Reino el año de 1769 , empezó á formalizarse en el inmediato, destinándose un constructor y alguna maestranza para la fábrica de las pequeñas embarcaciones con que se abrió cste establecimiento. Lo enfermo del paraje y la mayor abundancia de mosquitos obligó á abandonarle $\mathrm{cl}$ año de 73 y fijar la residencia en donde hoy se halla la vi1la; en el de 74, se consideró precisa la formación de un Departamento, destinando al efecto Oficiales de la Armada y Pilotos, los cuales, después de haber hecho algunos descubrimientos sobre estas costas septentrionales, se retiraron los primeros en el de 83 . Por este tiempo, la Rusia habia emprendido sobre las mismas costas algunas expedicioncs, formando en las altas latitudes de ellas uno ú otro establecimientn para facilitar el comercio de la peletería. El examen de estos, ó el averiguar sus intenciones siendo un punto que llamaba la atención del Go bierno, volvió á restablecerse el Departamento en 89 , nombrando S. M. por Comandante, al Capitán de navío D. Juan Francisco de la Cuadra, con sus Oficiales subalternos.

Las embarcaciones que actualmente pertenecen al Departamento, son tres fragatas comn de 300 toneladas, un paquebot y una goleta. Es tos buques se hallan en muy buenas condiciones, excepto la fragata Conccpción, por cuyo motivo se ha propuesto al Virey la construcción de 
.1b. rr otra del mismo tamaño, la cual podrá estar detenida por el excesivo costo de I 20.000 pesos en que se ha presupuestado su valor. Yo creo sería preferente que así ésta como otras embarcaciones que hayan de emplearse en estos mares fueran construidas en España bajo otros principios ó conocimientos para desempeñar los objetos á que se destinen, y economizando sumas inmensas que aquí se sacrifican. No en vano asciende á una tan considerable de 374.488 pesos fuertes los gastos del Departamento, debiéndose á su celo el haberlos disminuido con árbitros que ha meditado hasta 50.000 pesos anuales el citado Comandante.

Se han hecho ver ya los inconvenientes que of rece el hallarse en este puerto el Departamento, pero todavía resta otro mucho más grave. En la relación del diario se ve la imposibilidad de entrar dentro del puerto las embarcaciones que calen I4 piés, y áun éstas no pueden ejecutarlo sin la molesta y á veces arriesgada maniobra de alijai. La capacidad del puerto no ofrece tampoco toda la que necesita un Arsenal, por muy reducido que sea, y tan solo estas dos causas pudieran convencer de la necesidad de trasladarle á paraje más conveniente y seguro. Este punto de tanta importancia al servicio de S. M., ha sido muy disputable hasta ahora, en que el actual Virey, tan celoso en su acierto, ha propuesto el traspaso del Departamento á Acapulco, precediendo varios informes y á mí me lo pidió también cuando regresé á dicho puerto.

Es cierto que no cabe comparación entre el puerto de Acapulco y el de San Blas, sin que para decidir las superiores ventajas de aquél sobre éste, se necesiten más conocimientos que el cotejo de sus planos respectivos. Acapulco ofrece la mayor comodidad para formar el Departamento con la precaución que exigen los grandes intereses que abraza, facilita para celarlos la residencia en él de todos los Jefes, su inmediación á la capital y á Veracruz disminuyc mucho el costo de la conducción de efectos, las fortificaciones grandes que tiene, y las que provisionalmente pueden formarse en tiempo de guerra para defender su entrada con el auxilio de la Marina, daría á este punto de la América todo aquel grado de seguridad que necesita para no temer un ataque por ninguna potencia marítima que 10 intente.

En cuanto al temperamento, es también preferente el de Acapulco, porque además de no tener su disposición local los inconvenientes que San Blas, también es fácil corregir los que tiene. La necesidad haría muy luego conocer la precisión de cegrar una pequeña laguna que hay á la salida del pueblo, así como éste sería necesario irln extendiendo hacia la cañada, por donde viene la brisa, cuya providencia, y la de desmontai los alrededores aumentando la ven- $A$ b. n tilación, se disminuirá la humedad que aquí tanto ofende la salud pública.

Si con estas saludables diligencias no se alcanzase el objeto á que se dirigían, siempre hay aquí el recurso de mejorar de clima á muy corta distancia de la población. Ni aquéllas son asequibles en San Blas por la localidad del terreno, ni Tepique dista ménos de I 2 leguas ó más de aquel Departamento, cuando á las doce de Acapulco se experimenta la influencia de un temperamento sano en todas las estaciones del año. Se deja, pues, conocer la utilidad que resultaría al servicio del Rey en este caso, residiendo los Jefes constantemente ó en el mismo Arsenal, para inspirar con su presencia todo el celo y actividad necesaria, ó más próximos á él, y sólo la corta estación que afligen ahora las enfermedades. A pesar de estas ventajas tan palpables, cl Comandante Cuadra me informó, cómo no faltaban opiniones para disminuirlas, ó informes á la superioridad dando la preferencia á San Blas para Departamento. No podía Cuadra suscribirse á un dictámen tan difícil de apoyarse, ó de superar las razones de la opinión contraria, y así estábamos conformes en la misma, de que algún día había de triunfar de todas las dificultadcs ú obstáculos que encontrase. No obstante, expondremos aquí los fundamentos que apoyan el sentir de los primeros para dejar al público la facultad de decidir con acierto en la opinión de que se trata.

A dos puntos reducen el apoyo de su opinión; el primero hallarse San Blas más al Norte que Acapulco, y por consiguiente, en disposición más fácil de socorrer los presidios, debiendo ser más corta la navegación, lo mismo que la que se verifica todos los años á las exploraciones en las latitudes crecidas; y segundo, en la abundancia de maderas que tiene San Blas de las cuales suponen que carece Acapulco. Para juzgar del primer punto bastará saber que la derrota para entrambos objetos es siempre una misma, por razón de los vientos constantes desde uno y otro paraje, y que debiendo separarse siempre de la costa para buscar los del Oeste y Noroeste, no hay en este caso más diferencia en distancia que la diferencia corta en latitud entre ambos puertos (I), y esta se gana justamente en donde los vientos son favorables.

En cuanto á las maderas, no creo pueda pasar de una suposición fácil de probarse. Por lo ménos yo me he informado de haberlas muy buenas no lejos de Acapulco, y cuando faltasen

(I) La navegación de las corbetas desde Acapulco habiendo atracado la costa en cincuenta y tres dias por los $56^{\circ}$ de latitud, podrá compararse á la que ejecutan los buques de San 13las, que rara vez pueden conseguirlo en ménos de sesenta días. 
113. ir en sus inmediaciones, no es un inconveniente que no pueda fácilmente remediarse. Supongamos no haya otro paraje de donde cortarlas más que en San Blas, en este caso, cuando las embarcaciones regresen del Norte por Setiembre ú Octubre, pueden al paso cargarlas en San Blas sin dispendio ni riesgo alguno por el tiempo, y conducirlas á Acapulco.

Yo quisiera saber si estas dos objeciones que se oponen, áun cuando no pudieran satisfacerse, son capaces de compensar las ventajas referidas, ni cómo cabe á los que tengan las menores nociones de la facultad, el dejar de conocer las excelentes cualidades del puerto de Acapulco para formar un completo Departamento, de las cuales carece absolutamente el de San Blas. Nadie podrá negar que la seguridad y capacidad de un puerto son las primeras $y$ esenciales circunstancias que deben consultarse para establecer un Arsenal, y si á ellas se agregan otras particulares del clima, de la localidad del terreno, facilidad de defensa, y de poderse hacer un Departamento respetable, nadie tampoco podrá resistirse á conceder á Acapulco unas ventajas $\tan$ considerables que unidas se encuentran en muy pocos puertos del Globo.

Salida de San Blas; navegación en busca de unos bajos al Noroeste de Cabo Corrientes, y rennión á la Descubierta en Acapulco.

Desde las primeras horas de la noche se principió á levar las anclas, y teniéndose al Oeste un anclote conducido del Arsenal para dar la vela sobre él, quedamos á las diez prontos á verificarlo en el momento de apuntar el terral. Faltando á la común experiencia, no se declaró hasta las dos de la madrugada, á cuya hora, largando el chicote dimos la vela con todo aparejo gobernando al Sudoeste $5^{\circ}$ Sur por fondo de io, I , I6 y 38 brazas lama hasta el medio día, distando solo al salir el Sol de tres á cuatro leguas del fondeadero.

Siendo mi objeto acelerar la llegada á Acapulco, no era posible detenernos en trazar la costa aunque las circunstancias lo facilitasen; pero no causaría atraso notable el averiguar la existencia de unos bajos nuevos de arena y piedra que había encontrado el Capitán y Piloto del paquebot San Fuan Nepomuceno, D. Máximo Domingo de Zeleta, según me informó en San Blas antes de su salida para Acapulco, conforme á sus noticias estaban al Noroeste de Cabo Corrientes, distancia de siete leguas. No dejó de sorprenderme el ver que semejantes bajos no existían en ninguna carta, ni en el Departamento había la menor noticia de ellos, que á la verdad era bien extraño estando tan inmediatos á él. Esta reflexión me hacía mirar con suma descon- fianza su existencia, á pesar de que para hacérmela creer Zeleta me aseguró había pasado en tre ellos sondando $6+$ brazas; no obstante todo, pensé dirigirme á buscar los bajos, y por si algún accidente me impedía el poderlo verificar, recomendé su reconocimiento al Comandante Cuadra para que por su parte hiciese iguales diligencias en aclarar decisivamente un punto de tanta importancia á esta navegación.

Desde el medio día en que habíamos observado la latitud de $2 \mathrm{I}^{\circ} \mathrm{I} 3^{\prime}$ Norte, y la longitud de $99^{\circ}$ Io $^{\prime}$, seguimos el rumbo constantemente por la tarde del Sudoeste $1 / 4$ Sur con viento fresco del Noroeste al Norte, y fuerza de rela para alcanzar el Cabo Corrientes ó sus inmediaciones, donde se suponían los nuevos bajos que buscábamos. A las seis logró marcarse el referido cabo al Sur $52^{\circ}$ Este á distancia de siete á ocho leguas, pero ni en esta posición ni en toda la gran distancia que se descubría con un horizonte de los más hermosos, pudo advertirse la menor señal que indicase los referidos bajos. Después de este examen tan prolijo, puede muy bien concluirse su inexistencia y condenarse como ligereza reprensible á quien forja semejantes noticias. Yo me inclino á creer que el Capitán Zeleta equivocó tal vez el paso que ejecutó entre las Islas Marias con el que se le figuró entre los supuestos bajos. La distancia que estimó de uno á otro, el fondn hallado en el canal y la calima que suele cubrir aquellas islas representándolas muy bajas, han sido las razones en que he fundado este concepto.

Convencidos á las seis de la tarde de no descubrirse nada, arribamos al Sur con intención de llevar la costa á la vista hasta Acapulco. El tiempo siguió hermoso y el viento también fresco toda la noche, arreciando más al ponerse la Luna.

Los dos días siguientes no tuvimos la brisa ni tan fresca ni tan constante; hubo vientos flojos del Este y Sursueste, circunstancias que nos habían hecho alejar de la costa, la cual pudimos tener inmediata por la tarde del día siguiente, pero el poco viento ó ventolinas variables no permitían mediana exactitud en las operaciones que emprendiésemos para colocar uno ú otro punto notable de la costa.

Llegamos al medio día del ry á la latitud de $18^{\circ} 7^{\prime}$ Norte y á la longitud de $97^{\circ} 05^{\prime}$ desde cuya hora, tesando la virazón principiamos algunas bases que se siguieron con fuerza de vela en cuanto no atrasaban nuestro viaje. Entre otros puntos notables que teníamos á la vista, era uno el de las Tetas sin nombre que equivocó el Almirante Anson con las de Coyuca por latitud de $17^{\circ} 5^{6^{\prime}}$ Norte, por cuya señal dirigió un bote sobre este paraje á reconocer la boca del puerto.

La tarde apacible, la mar muy llana, el viento igual y fresquito, con bastante inmediación á lá costa, eran circunstancias que favorecian muclio 
It 17 el trazarla con precisión, y sobre todo, las Tetas, cuyo punto, por muy notable, era tan interesante. La calima cubría tanto la tierra á la mañana siguiente, que no pudimos descubrirla, sin estar distantes de ella. Pero al medio día por latitud de $I 7^{\circ}$ $30^{\prime} y$ longitud de $95^{\circ} 43^{\prime}$, y habiendo hallado la variación por azimutes de $9^{\circ} I^{\prime}$ Nordeste, se empezó á divisar confusamente, y para atracarla con la mayor brevedad se gobernó al Este, dirigiéndonos á unos islotes blanquizcos que no se hallaban en la carta, demorándonos el más Oeste al anochecer al Norte $15^{\circ}$ Este á tres leguas, y la Lierra que se descubría al Este se nos representaba bajo las apariencias de una isla. Durante la noche llevamos siempre á la vista la costa, y el ruído de la playa, nos avisaba á veces la demasiada inmediación, y por consiguiente, la necesidad de enmendar el rumbo para fuera.

Fué rolando el viento según acostumbra de media noche al día para el primer cuadrante: amanecimos próximos á la tierra con la idea de procurar reconocer la boca del puerto de Singuatanejo, confrontando las pocas señales denotadas por el plano; en efecto, pareciéndonos estar inmediatos á ella, se corrieron bases descle este punto, continuándolas en el día para trazar la costa intermedia hasía las playas de Coyuca, cuyos arenales las distinguen bien, no habiéndolos tan seguidos sino en este paraje, y así la falta de ellos determinan sus límites. Todas las circunstancias eran las que podían desearse para conseguir en los resultados de nuestras operaciories la mayor exactitud.

Por las observaciones del medio día y supuesta la situación de Acapulco por las que practicamos allí, nos demoraba aquel puerto al Sur $57^{\circ}$ Este distancia de cuarenta millas, pero aumentábase ésta á $16 \%$ leguas adoptando la longritud observada por un satélite. Sin embargo, como la brisa estuviese fresca, hice rumbo directo al fondeadero en la esperanza de marcar al anochecer la Isla Roqueta tomando en la noche el puerto. Cesaron al ponerse el Sol las bases y la calima oscurecía tanto la costa, que no pudo marcarse punto alguno con seguridad, renunciando, por consiguiente, la probabilidad de fondear en la noche. Considerándonos á las siete, de cuatro á cinco leguas á barlovento de Acapulco, ceñimos el riento del Noroeste mura á estribor, y sobre bordos con las gavias nos mantuvimos hasta rayar el día, cuya maniobra preferí á la de pairear por no amanecer á sotavento del puerto. La brisa nos acompañó hasta hacerderrota en vuelta de la Isla Roqueta, de la cual amanecimos ádos leguas, demorándonos al Este $5{ }^{\circ}$ Sur: calmó muy luégo el viento, y entregados al arbitrio de las corrientes, nos arrastraron para el liste con tanta fuerza, que á las nueve ya estábamos Nornordeste Sursuoeste con la entrada del puerto. Tardó poco en declararse la brisa, con Ab. 20 la cual se forzó de vela para atracar la Isla Ro. queta y después la punta del Grifo, precaviéndonos antes de rebasarla con preparar el aparejo de bolina, pues escaseando el viento al Noroeste, sería peligroso tomar por avante estando tan inmediatos á ella. Seguimos sobre bordos al fondeadero, en donde se hallaba la corbeta DEscuBIERTA, cuya vista causó á todos aquella natural complacencia de volver á unirse después de una separación de cerca de cuatro meses, quedando al costado de ella poco después del medio día.

Desde que asomamos por el puerto vino á bordo D. Alejandro Malaspina, acompañado de varios Oficiales de la corbeta de su mando, y apenas concluimos las faenas ordinarias de amarrar el buque, me manifestó sus intenciones acerca de la campaña venidera.

Era, pues, su ánimo verificar en este año la averiguación del paso entre los mares Pacífico y Atlántico, buscándolo por los $60^{\circ}$ del mismo modo que yo me había propuesto en San Blas ejecutarlo, pues las órdenes de S. M., siendo terminantes á este fin, no dejaban duda sobre nuestras operaciones en el verano próximo, á pesar de que estuviésemos conformes en lo algo avanzado de la estación y en que la citada Memoria del Académico francés Mr. Bauche con los documentos en que la funda, ofrecen reparos de difícil solución para no graduar aquellos por apócrifos, y á Bauche bastante crédulo en concederles el caracter de la verdad, que sin duda no la merecen.

A consecuencia de esta resolución y de la de estar prefijado el día de la salida para el I. ${ }^{\circ}$ de Mayo, se acordaron las medidas oportunas para acelerar nuestra habilitación, sin omitir aquellos preparativos indispensables de una campaña larga, combinados con la estrechez de tiempo para ejecutarlos.

Reunion de las corbetas.-Continuan viajando en conserva.

No tardó, efectivamente, la corbeta ATREviDA, más allá del día 20 en reunírsenos en Acapulco, casi al mismo tiempo que se incorporaban también los muchos indivíduos destacados ya á una, ya á otra parte, con los objetos que se han expresado. Así pudieron, sin pérdida de tiempo, darse los últimos pasos necesarios para la salida, la cual debia tener lugar hacia los últimos días del mes, y en el entretanto, después de cuatro meses de separación, entregarnos á aquella complacencia que debía naturalmente dictar á todos los indivíduos de una y otra corbeta la amistad, la costumbre, y sobre todo, la utilidad de reunir en una sola masa unánime nuestros esfuerzos para el mejor desempeño de la comisión empren. dida. La corbcta ATrevida, luégo que se scparó de 
Ab. zo la DescubiekTA en los mares de Nicaragua, hizo derrota hacia la Isla de Cocos, cuyo reconocimiento y situación hidrográfica mirábamos como importante, siendo aquella un punto á donde solían comunmente recalar los que transitaban de las costas del Perú á las de Nueva España. Lo consiguió el día ro de Enero después de varias contrariedades en la navegación, dimanadas principalmente de los vientos Oestes, acompañados con chubascos y cerrazones, y como estos mismos inconvenientes no le permitiesen el perderla de vista sino en la tarde del I8, fueron repetidas y muy exactas los observaciones que debían determinar su posición. Hé aquí los resultados según se hallan en el Diario original del Comandante: "Puede inferirse, relativamente á la posición de la Isla de Cocos, que merecen preferencia las observaciones de los días $\mathrm{I}_{2} \mathrm{y}^{\prime}$ I 3 sobre las del ro, porque además de variar poco, fueron observadas con circunstancias bien favorables, $y$ aunque en la longitud del extremo Este se halle una diferencia de $4^{\prime}$ en las determinaciones de los dos días, es probable que en el último no se hubiese podido marcar por punto Este el del día I2; además, que la distancia para deducir aquella longitud fué estimada, y de allí puede derivar aquel error corto y despreciable. Se ha adoptado, pues, para la situación de su centro, la latitud. Norte de $5^{\circ} 33^{\prime}$ Io" observada el I 2 próximamente en su paralelo, y la longitud occidental de Cádiz de $80^{\circ} 26^{\prime}$ observada el I 3 casi en su meridiano.

Corre la dicha isla del Este Nordeste, al Oeste Sudoeste, y tiene de extensión poco más de una legua. Del centro hácia la parte del Oeste es su mayor altura; de allí se levanta un piquito agudo, de donde va descendiendo proporcionalmente para el Este, y remata con una punta baja, formada por dos islotes pequeños, inmediatos entre sí y á la isla, los cuales no pueden distinguirse á no estar muy inmediatos. Hay también otro islotillo en el extremo del Noroeste. La isla está cubierta de una espesa arboleda hasta las orillas: al Nordeste tiene un fondeadero frente á unas palmas. No pudiera creerse lo mismo hacia el Sur por estar la costa tajada al mar: tiene agua, produce abundancia de cocos y abrisa una infinidad de pájaros, los cuales en tiempos oscuros servirán para indicar sus cercanías. Il error hallado en las determinaciones del Almirante Anson es de I $3^{\prime}$ al Sur en la latitud; y de $\mathrm{I}^{0} 4^{\mathrm{S}^{\prime}}$ al Oeste para la longitud; la variación magnética es de $S^{\circ} o^{\prime}$ al Nordeste."

Verificado con tanta exactitud aquel objeto importante, la ATREVIDA continuó luchando con la variedad de vientos calmosos y la contrariedad de las corrientes hasta el día 22, en que alcanzada la latitud de $5^{\circ} 37^{\prime}$ y la longitud de $2^{\circ}$ al Oeste de la isla, vió, finalmentc, entablar lá brisa general del Nordeste con la celajería suelta acos. tumbrada, y con ella hizo derrota directa hacia el puerto de Acapulco. Cesaron entonces las diferencias considerables al Sur que se habian experimentado, mientras duraban los variables; la variación de la aguja aumentó hasta $9^{\circ} 30^{\prime}$ y variado enteramente el semblante del tiempo, fucron tan aceleradas las singladuras siguientes, que en la tarde del 30 , se avistó la costa hacia las inmediaciones del puerto, y el día I. ${ }^{\circ}$ de Fiebrero dió fondo en él, mejorándose después y quc. dando amarrada al día siguiente. Hallábasc igualmente fondeada en el puerto una fragata mercante de Guayaquil, su Capitán y maestre D. Vicente López de Escudero, la cual, con car* ga de cacao, había salido de aquel puerto pocos días después de las corbetas, y atracadas las costas algo á sotavento con sólos treinta y cinco días de navegación, había después debido emplear otros quince para vencer la poca distancia que inadvertidamente le faltaba al tiempo de la recalada. No perdió un momento D. José Bustamante para acelerar la salida, y al mismo tiempo aprovechar la demora indispensable en el puerto con aquellos objetos que suministraba por sí la comisión nuestra. Las observaciones astronómicas sc pusieron al cargo de $\mathrm{D}$. Juan de la Concha; los pilotos levantaron el plano del puerto con el teodolito, sondándole interior y exterjormente. D. Luis Nee enprendió sus excursiones botánicas, y mientras se esperaban las órdenes del señor Virey, los reparos del casco y los reemplazos de aguada, leña y algunos víveres, no hicieron desmayar un solo instante la actividad de los aprestos.

Debió, pues, en aquellas circunstancias más bien favorables, causarle una mayor sorpresa y sentimiento la deserción de doce marineros de los mejores de su tripulación. Nada podía convidarlos á aquel delito, si no es un recelo infundado de los peligros de la campaña siguiente, y por la misma ṛazón importaba con extremo el aprehenderlos, no tan sólo para que el escarmiento contuviese á los demás, sino también para que realmente no se frustrasen los planes renideros con una excesiva debilidad de la marinería. Fueron, sin embargo, infructuosos los primeros pasos dc las diferentes partidas destacadas para buscarlos á las órdenes de los Tenientes de navío Conchá y Viana y del sargento; pues pasada toda una noche en los diferentes caminos que conducen á Méjico y Coyuca, debieron retrocedercon la esperanza de hallarlos y con la sola ventaja de haber cundido la alarma entre los habitantes del país: por manera, que movidos del premio prometido. se obligasen á buscarlos y perseguirlos con rigor. Estas últimas medidas lograron el buen efecto que debía prometersc. Se les aprehendió, efectivamente, á distancia de unas treinta leguas de la orilla, y conclucidos á bordo, se entregó á los na- 
. h. zo turales la gratificación prometida. Las órdenes del señor Conde de Rivillajigedo, recibidas al regreso del extraordinario, no podían en el entretanto ser más favorables á los progresos sólidos de la expedición. S. E. había dado ya las órdenes correspondicntes en el Departamento de San Blas para la construcción de la lancha solicitada; había destinado á D. Tomás de Suria, Dibujante hábil de la Academia de Méjico, para que reemplazase la falta de D. José del Pozo, quedado en Lima; avisaba, finalmente, á D. José Bustamante que sería oportuno se detuviese en el puerto hasta que lograsen incorporarse los Tenientes de navio D. José Espinosa y D. Ciriaco Cevallos, últimamente llegados de Europa al puerto de Veracruz, y destinados de orden de S. M. á servir en las corbetas. No tardaron, efectivamente, entrambos Oficiales en llegar á Acapulco, y al día siguiente 26 , la corbeta estuvo á la vela para emprender la navegación á San Blas.

No cabía duda sobrc la preferencia de la derota de altura ó golfo á la que pudiese emprenderse por una navegación costanera, acosada igualmente de los vientos y corrientes contrarias. Efectivamente, fué aquélla la que siguió la A treVIDA, enmarándose inmediatamente con rumbos del Oeste y ciñendo con las muras á estribor los vientos del Norte, variables al principio y luégo más firmes á medida que se alejaban de la costa. Viéronse al paso todas las señales que indicaban inmediata la isla desierta de la Posesión; se aumentó después paulatinamente la latitud hasta cojer los paralelos de San Blas, unos I $^{\circ}$ al occidente de Acapulco; y finalmente, cambiada la mura cuando ya los vientos se inclinaban del Norte más bien al Oeste que al Este, en pocas singladuras se halló la corbeta á la vista de las Islas Marias, y poco después en la rada de San Blas, por cuanto fuesen precipitados los aprestos en aquel puerto, los cuales exigían la perfección de la lancha grande empezada ya, una recorrida del casco, aparejo, velamen y alguna tonelería, y el natural repuesto crecido de víveres, aguada y leña; no por eso se omitieron las acostumbradas tareas de levantar el plano de la rada y del puerto, de seguir una serie no interrumpida de observaciones astronómicas y de estudiar el estado político y natural de aquellos contornos, estudio á la verdad tanto más importante en el paraje en donde se hallaban, cuanto que estaba aún por decidirse la cuestión importante, si convcnía allí más bien que en Acapulco la permanencia de un Departamento ó depósito de las fuerzas de la Marina Rcal. La latitud del observatorio prefiriendo en csta ocasión las determinaciones de los sextantes á las del cuarto de círculo, quedó de $2 \mathrm{I}^{\circ} 3 \mathrm{I}^{\prime} \mathrm{oo}^{\prime \prime}$, la longitud de $5^{n}$ I $2^{\prime}$, al occidente de Acapulco, y la variación magnética de $9^{\circ} 26^{\prime}$ al Noreste. Son muchos los elogios y las expresiones de un juste agradeci- . 13. so miento que tributa D. José Bustamante al Comandante del Departamento el Capitán de navío D. Juan Francisco de la Cuadra, pues brillaban en él diariamente, y casi á porfía, la actividad para los aprestos y la generosidad para el regalo de todos los individuos de la corbeta. Recibidos, finalmente, en la mañana del ir los pliegos relativos á la reunión de las corbetas, dieron la vela en la madrugada del I3, y aprovecharon de tal modo los vientos favorables del Oesnoroeste y Noroeste que, sin dejar de trazar con mucha exactitud trozos considerables de costas, llegaron á Acapulco, como se ha dichu ya, en la mañana del 20.

Reunidas en una sola masa las observaciones de ambas corbetas, y adoptadas para la diferencia de longitudes entre Acapulco y San Blas, más bien que los primeros, los resultados de la última travesía de solos siete días referidos además á un mayor número de relojes, pudieron, finalmente, adoptarse para la longitud del observatorio los datos siguientes:

\section{ATREVIDA}

Determinación del núm. Io referido á Panamá. . . . . . . . . . . . . Inmersión del primer satélite de Júpiter el i8 de Febrero. . . . . . . . ,

Cuarenta y ocho series de distancias lunares. ............. De San Blas traídas con los relojes..

102.20 .00 $20.3^{8}$ 22.00 20.28

\section{DESCUBIERTA}

Determinación de los tres relojes del Realejo. ............ Inmersión del primer satélite observado el 7 de Abril con la mayor confianza y corregido de los errores de las tablas............... La diferencia de longitud entre Acapulco y San Blas quedó finalmente adoptada de . . . . . . . . . . . . . . . . $5^{\prime \prime} 6^{\circ} 5^{\prime}$
Latitud. . . . . $30^{\prime \prime}$ Variación de la aguja...... N. E. $7^{\circ} \mathrm{r}^{\prime}$

El diario astronómico manifestará después cuántos son los resultados que además de las observaciones indicadas han concurrido á afianzar la posición verdadera de aquel meridiano, por manera que pueda ya considerarse, como uno de los que sobre las orillas del mar Pacífico se han determinado con mayor prolijidad.

Al día siguiente $2 \mathrm{I}$, los Tenientes de navío D. José Espinosa y D. Ciriaco Cevallos, entregaron los instrumentos que traían á su cargo, y eran dos relojes chicos de faltriquera de Arnold números $34+4$ y 35 , y un péndulo simple constante, construído en Lóndres por dirección del Capitán de navío D. José Mendoza Rios. Según lo prevenía el Sr. Ministro de Marina en oficio particular, debían repetirse cuanto fuese posible por medio de dicho péndulo las experiencias de la gravedad de los cuerpos en diferentes paralelos de la tierra, no sólo para una medida uni- 
Ab. 2x versal dimanada del mismo cotejo de las observaciones nuestras comparadas á las que verificasen los astrónomos de Europa en el paralelo de $45^{\circ}$, si también para no perder de vista las pesquisas sobre la verdadera figura de la tierra en la cual no sin mucha probabilidad se sospechaban algunas desigualdades de uno á otro hemisferio. Inmediatamente se emprendieron las observaciones indicadas, referido como era natural el número de oscilaciones del nuevo péndulo al número de segundos del tiempo medio contados en el péndulo del observatorio, y los primeros resultados bastaron para indicarnos que de ningún modo pudiera considerarse aquella máquina arreglada al tiempo medio del Observatorio de Greenwich ó de cualquier otro paralelo de la Europa.

Entretanto, procedian con toda la actividad posible los aprestos para la próxima campaña, pues que era nuestro ánimo el verificar la salida en la mañana del primer día de Mayo: la DescuBIERTA recibió la mitad del pan y tocino que la ATrEvida había tomado en San Blas, y entregó á ésta 30 quintales del pan, mucho mejor que se había fabricado en Acapulco y Tiscla; se hizo una compensación de betunes y maderas; ambas dejaron en los almacenes del Rey una parte considerable de las arboladuras de respeto y cureñaje. La Descubierta dejó también unos diez fardos, parte de ropa de abrigo y parte de efectos de cambios. Se completaron los acopios de agua y leña y se asearon exteriormente los buques, y como al mismo tiempo lográsemos ver ya casi prontas las cartas, manuscritos y acopios de Historia Natural, que debían remitirse á Madrid, parecía que ya no pudiera trastornarse el plan proyectado.

Este, sin embargo, no era ya tan sencillo como á primera vista lo habíamos imaginado; pues un examen maduro de todas las circunstancias, que en el día rodeaban á la expedición, nos había determinado á subdividir algunas comisiones, que al mismo tiempo acelerasen la perfección de la obra emprendida y combinasen las posibles ventajas científicas á la nación: nuestras circunstancias (determinada ya la campaña al Norte), no podían dejar de recordarnos que las últimas contrariedades de los tiempos entre Realejo y Acapulco, y el regreso precipitado de la ATrevida desde San Blas, habían causado una gran imperfección en las cartas por lo que toca á aquellos parajes, la cual no pudiera corregirse ó á lo ménos se conseguiría muy tarde y con mucho extravío, si cualquier evento, ó muy feliz ó muy desgraciado, impidiese para el próximo Octubre el regreso de las corbetas á Acapulco. Y bien mirada aún la naturaleza de los reconocimientos indicados, y la importancia de que se tiazasen con exactitud no sólo las costas, si tam- bién los puertos importantes de Singuatanejo, Ab. zy Aguatulco, Los Angeles y Tecoantepeque, una embarcación menor fácil á adquirirse en San Blas, verificaría aquel objeto con una mayor puntualidad y seguramente con una mayor economía de tiempo y de caudales. Semejantes reflexiones nos conducían directamente á otras no ménos útiles, y eran la de poder los mismos Oficiales que desempeñasen aquel objeto, ocuparse después en los reconocimientos de los golfos de Amapola y Nicoya, en los cuales no habían podido internar las corbetas y examinando con proligidad el Istmo que media entre el mar Pacífico y el golfo de Nicaragua, pasar después al mismo golfo, trazar sus orillas con exactitud y penetrar por el río San Juan hasta el Atlántico. Ni nos guiaban los solos objetos hidrográficos, referidos á las cartas, si bien una nueva traslación de nuestras longitudes al otro mar por medio de los relojes marinos no debiese mirarse con indiferencia. Las inmediaciones del río y golfo de Nicaragua, eran en el día un cebo harto eficaz para las naciones émulas, por consiguiente, su conocimiento cabal debía mirarse como muy importante para la defensa marítima nacional y además era aquel el único desembocadero cómodo para el tránsito á Europa de una porción considerable de frutos preciosos hasta aquí malogrados, que producía aquella fértil provincia, sin que nuestros navegantes intentasen aún el adquirirlos ó bien por las frecuentes hostilidades de los mosquitos ó por el poco conocimiento de la navegación del río.

Este deseo de ir así comunicando á la costa opuesta nuestras longitudes y examinando cualesquiera puntos interesantes para la navegación y defensa nacionales en cuanto lo permitiesen los Oficiales, instrumentos y tiempo destinados á la expedición, debió también naturalmente inclinarnos hacia la parte del continente comprendida entre la desembocadura del Guazahualcos por el mardel Norte y el puerto de la Ventosa por el del Sur; pues no sólo la comodidad de la internación de los rios del corto terreno llano que mediaba, y de la barra transitable del Guazahualcos habían llamado hacia aquella parte la atención de los primeros conquistadores y luégo del Gobierno; si también debía mirarse como un punto de fácil invasión para el Reino de Méjico, y tal vez el único que pudiese temerse por la comunicación abrigada con el mar; por el terreno muy entrecortado con canales, y bastante despoblado, y por la dis tancia de Méjico, desde donde debieran dimanar precisamente los socorros, no sólo para aquella parte, sino también para el Reino invadido de Guatemala.

Se agregaba á las reflexiones indicadas, la de ser de tal naturaleza la próxima campaña nuestra al Norte, ceñida á pocas saliclas de lanchas des- 
11. w) tinadas á operar casi siempre debajo del cañón de las corbetas, que quedaría, sin duda alguna, ociosa y casi oprimida de su misma habilidad, una parte considerable de los buenos Oficiales é instrumentos que en el día se hallaban en ambas corbetas, y era más digno de atención este reparo, si le refiriésemos á la Historia Natural, cuyas indagaciones serían tan cautas y limitadas en las orillas harto peligrosas que intentábamos visitar, como copiosas y útiles en la Nueva España, en donde 1). Antonio Pineda, con su constante amor al trabajo, pudiera hacer una comparación sumamente util y nueva de todos sus productos con los de la América meridional, que tan recientemente y en tantos parajes había visitado.

Así concluídos para el día prefijado todos los objetos que nos habíamos propuesto, completados los armamentos hasta un total de roo personas por cada uno, y los víveres para un año, las corbetas en el último día de Abril pudieron considerarse enteramente prontas para dar la vela. y realizar en los siguientes meses el plan proyectado. Un examen de las bajas sufridas desde la salida de Cádiz que insertarémos á continuación, no parecerá tal vez molesto ó inoportuno, cuando se advierta que podrá servir de escarmiento á los buques de la Marina Real, que frecuentasen las costas del mar Pacífico con tripulaciones más numerosas y ménos escojidas que las nuestras.

\section{DESCUBIERTA}

\begin{tabular}{|c|c|c|c|c|c|c|}
\hline CLASES. & 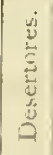 & $\begin{array}{l}\text { Wuertos } \\
\text { á bordo ú } \\
\text { en los } \\
\text { hospitales }\end{array}$ & $\begin{array}{c}\text { Dejaclos } \\
\text { en los } \\
\text { hospitales }\end{array}$ & $\begin{array}{l}\text { Trasbor- } \\
\text { clados nor } \\
\text { discolos u } \\
\text { otros ac- } \\
\text { cidentes. }\end{array}$ & $\begin{array}{c}\text { Despedi- } \\
\text { clos por } \\
\text { acciden- } \\
\text { tes habi- } \\
\text { tuales. }\end{array}$ & TоT $1 \mathrm{~L}$ \\
\hline Oficiales do & & & & & & \\
\hline mar. . & 2 & $\eta$ & $\eta$ & $»$ & I & \\
\hline $\begin{array}{l}\text { Marineros.. } \\
\text { Soldados de }\end{array}$ & 28 & I & I & 6 & 4 & \\
\hline marina. . & 8 & I & $\gg$ & 2 & $n$ & \\
\hline das.... & 2 & I & ") & $\eta$ & 》) & \\
\hline Criados. . & 》 & $n$ & 》) & $n$ & 3 & \\
\hline Pintor.. . & - & $»$ & ») & $n$ & I & \\
\hline TOTAL. & 40 & 3 & I & 8 & 9 & $6 I$ \\
\hline
\end{tabular}

ATREVIDA

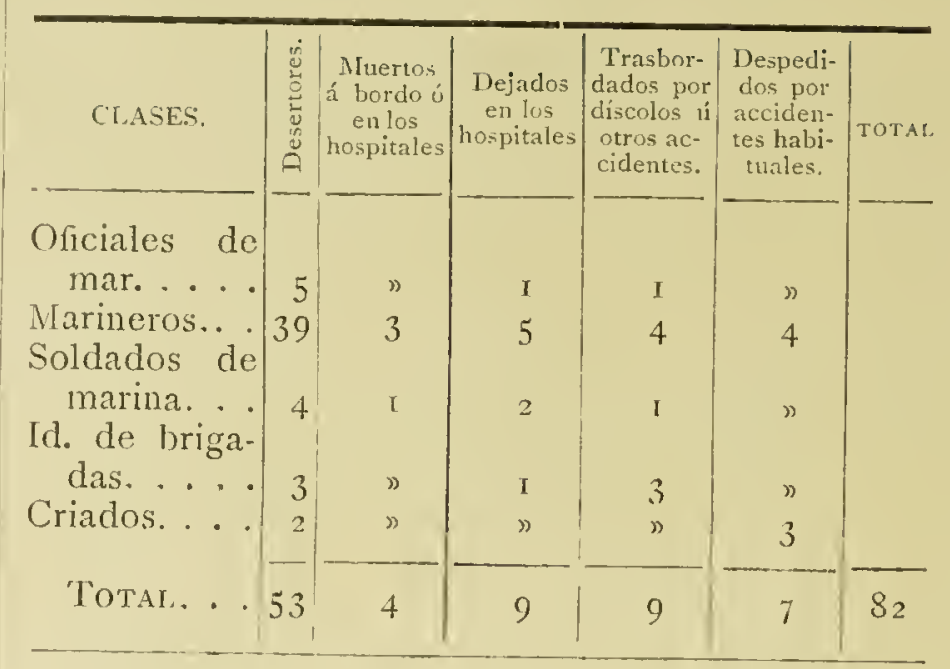

Baja total en ambas corbetas. . . I 43

\section{CAPÍTULO II}

Objetos de la sigmionte campaña sobre la costa Noroeste de la América.-Navegaciones, escalas y reconocimientos en el paralelo de 60\%.-Regreso al Archipiélago de Nutka. - Reflexiones sobre las dos Memorias que dieron lugar á estos reconocimientos.

Como se ha manifestado en el capítulo ante- May. I cedente, las últimas órdenes de S. M. prescribían un examen prolijo sobre la lejitimidad del viaje de un Lorenzo Ferrer Maldonado, el cual decía, según una Memoria hallada en los archivos del Sr. Duque del Infantado, haber pasado en I588 desde las costas de los Bacallaos ó Nueva Inglaterra, hasta el mar Pacífico, desembocando en él próximamente por el paralelo de $60^{\circ}$. - Leída esta Memoria en la Real Academia de Ciencias por Mr. de Bauche, habíanse hallado más bien probables todas las señas y parecía plausible un nuevo ensayo, el cual, por la misma razón, se nos encargaba estrechamente. No será importuna para el lector una copia literal de las dos Memorias indicadas. 


\section{RELACIÓN del descubrimiento del Estrecho de Anian que hice}

yo el Capitán Lorenzo Ferrer Maldonado, el año 1588. en la cuat está el orden de la navegación y la disposición del sitio y modo de fortalecerle. y así mismo las utitidades de esta nariegación. y' los daños que de no hacerla se siguen.

SEÑor: Ante todas cosas conviene saber cuáles son las comodidades que se pueden conseguir por la navegación del Estrecho de Anian al mar del Sur, y habiendo considerado la navegación que hasta ahora se ha tratado para las Filipinas, China y Japón, y las otras partes de aquel mar, parece por buena cosmografía, que navegando por este Estrecho se ahorra casi la mitad del camino. Donde esto se conoce bien es en un globo terrestre, ó un mapa que tenga por centro el Polo, y no en las cartas planas, las cuales, tan grande y dilatado muestran el punto del Polo como es la línea equinoccial; y por esta razón en ellas no puede parecer menor el un camino que el otro; y supuesto que esta doctrina quiere práctica visible, es escusado tratarla aquí; basta decir que por este Estrecho se ahorra la mitad del camino poco ménos; fuera de que tiene otra comodidad mucho mejor, y es que de una embarcación se puede ir clesde España á las Filipinas, y esto no puede ser por donde ahora se camina, por haber de desembarcar en la Nueva España, y caminar I5o leguas por tierra, y esto es causa que la más de la gente que se envía á aquellas partes para los presidios y socorros, se quedan en la Nueva España, ó cansados del mar, ó asidos á las delicias de aquellas tierras. Fuera de esto, tiene otra notabilísima utilidad, y es que puede V.M., navegando toda la especiería (del Maluco y todo el Archipiélago y otras partes), por este Estrecho hacerse total señor de ella con mucha facilidad; porque almacenándola en la ciudad de Sevilla, le importará más de 5.000 .000 por año, obligando á muchas naciones que vengan á España por ella, y en su recompensa traigan abundantemente todas las cosas necesarias á estos reinos, con lo cual se escusará llevarse toda la plata que cada año viene de las Indias, poniendo al reino en tanta necesidad: así mismo se considera que haciendo este Estrecho navegable, se muda el trato $y$ comercio que tiene la China con las Indias, y se pasa á España; la cual comodidad alcanza á las Filipinas y á todas aquellas partes, porque el trato de la China con las Indias ha sido dañosísimo para España: tanto, que ha impedido la mayor parte del que solía tener, lo que está probado con que V. M. (por este respecto) tiene ahora estrechado el comercio que la China y Filipinas tienen con las Indias, tanto que es imposible sustentarse aquellas partes, como es razón, para resistir sus enemigos, que son muchos, y de necesidad aquellos reinos han de venir á disminución y no poderse sustentar, y por el contrario, podrían por este camino y navegación crecer y aumentarse en tanto número y posibilidad por sus riquezas, que traerian flotas en esta carrera, tan grandes como las que van á las Indias, trayendo á España mucha abundancia de riquezas de la gran China y Tartaria y de otras partes, que serían muy baratas, porque de sólo oro se puede traer 2.000 .000 cada año, en que se puede conseguir muy grande interés, porque el oro vale en la China ménos de la mitad de lo que aquí vale, y junto con esto se traerán otras muchas cosas, las cuales ahora estos reinos se proveen de ellas de manos de sus propios enemigos: con lo cual se enriquecen y cobran fuerzas para hacer guerra.

Es de mucha consideración, así mismo, pro* veer de gente de guerra aquellas partes para la defẽnsa de aquellos reinos, y hacerlo con tanta facilidad como por este camino se puede, con lo cual se impide que los enemigos se puedan hacer señores de ellos, como es posible hacerse, por falta de gente y socorro; y siendo Dios servido de que nosotros hagamos semejante navegación, se abre con ella una puerta por la cual se facilita la conversión de aquellos gentiles habitadores de aquellas partes, por cuyas almas quiso Dios padecer, que no es esta la menor, sino la mayor utilidad. Otras muchas puede ofrecer el discurso del tiempo; empero, la más esencial de todas conocidamente, es prevenir los grandes daños que podrían sobrevenir por no reconocer el Estrecho de Anian y fortalecerle, porque siendo verdad que lo hay, como yo testifico haberlo visto, sería 
notabilísino el daño que podría suceder si fuese hallado y fortalecido de los enemigos, los cuales con mucho cuidado desean hallarle, pues sabemos cómo el año pasado de 1608 salieron unos navíos de Inglaterra á le buscar. Porque siendo tomado de enemigos pueden desde allí hacer muy grandes daños, que por la vecindad que tienen sus tierras con aquel estrecho, les sería fácil cosa enriar por él una armada, la cual repartida de 30 en $z 0$ navíos, se enseñorearan de las tierras de la Nueva España y Perú, á donde publicando ancha conciencia y libertad de indios podría ser que muchos y áun todos se les viniesen á las manos, y de tal suerte encastillarse en todo aquel mar, que no teniendo por donde enviar breve socorro quedasen por señores de él irremediablemente: $\mathrm{y}$ tanto se puede temer esie peligro, que cuando no supiéramos por cierta ciencia y vista de ojos tener esta entracla del mar del Sur, la habíamos de buscar para fortalecerla, ó para desengaño si no la hay, y quedar sosegados los corazones sin temer este peligro, y aquí se advierte, que si los enemigos no tienen hechos muy grandes daños en aquel mar, es por no tener en todo él un puerto que sea de consideración, como lo es el que tiene el Estrecho de Anian, según adelante se dirá, y porque ahora parece tratarse de semejante navegación por mandado de V. M. y su Consejo de Estado, y del modo de fortificar el estrecho, parece ser cosa al propósito hacer relación de las derrotas de la navegación, el sitio y puerto de aquella parte con todos los discursos de mi viaje, y habiendo de comenzar por la navegación, se advierta á la doctrina siguiente, según la cual todo buen marinero la podrá hacer.

Pártese de España y presupónese que es desde Lisboa, desde donde conviene poner la proa al Noroeste por camino de 450 leguas hasta llegar á los $60^{\circ}$ de altura de Polo ártico, á donde se dará vista á la Isla de Frislandia, antiguamente nombrada Tyle ó Tule. Es una isla poco menor que Irlanda, desde la cual se toma la vuelta del Oeste corriendo por los $60^{\circ}$ de altura por navegación de 180 leguas, hasta llegar á tierra del Labrador, que es á donde comienza el Estre. cho del Labrador ó Estrechoo Davis, cuya entrada es bien ancha por más de 30 leguas, y la tierra que tiene á la parte del Labrador que es al Oeste es baja; mas la parte contraria que es aquella de la cual se forma aquella boca del Estrecho es de montes muy altos: allí se muestran dos bocas en medio de las cuales están aquellos montes altísimos y la una de ellas corre al Estenordeste y la otra al Noroeste, y así conviene dejar la que corre al Esstenordeste que es la que está á la mano derecha mirando al Norte, porque esta boca la hacen la Grutlandia y unas islas por donde últimamente se torna al mar de la Frislandia; $y$ de otra suerte, tomando la otra boca se ha de poner la proa en el Noroeste entrando por aquel Estrecho por camino de 80 leguas hasta llegar á $\operatorname{los} 64^{\circ}$ escasos de altura. Allí hace el estrecho otra vuelta al Norte por I2o leguas liasta llegar á los $70^{\circ}$ de altura y allí torna aquel estrecho á hacer otra vuelta al Noroeste, por la cual se ha de navegar 90 leguas hasta llegar álos $75^{\circ}$ de altura algo escasos, con lo cual queda desembocado todo el Estrecho del Labrador, como que el dicho comienza en $60^{\circ} \mathrm{y}$ acaba en $75^{\circ} \mathrm{y}$ tiene de largo 290 leguas, haciendo tres vueltas muy grandes: la primera y última se corren de Noroeste-Sudeste y la del medio Norte-Sur, y es por donde más angosto de 20 leguas, y por donde más ancho 40 leguas, $y$ hacen muchos puertos, calas $y$ abrigos que pueden ser socorro de cualesquiera necesidad, y hasta los $73^{\circ}$ pareció ser habitado de algunas gentes, porque en muchas partes de aquellas costas se vieron humos, así en la una parte como en la otra. Paréceles á algunos inconsideradamente ser imposible navegar por tan grande altura de Polo. A esto se responde, que los anseáticos viven en $72^{\circ}$ de altura, en cuyo puerto, que es el de San Miguel y en toda aquella bahía de San Nicolás, entran todos los años casi 1.000 naves de trato, las cuales por haber de pasar al mar de Fländes, de necesidad han de subir á $75^{\circ}$ de altura para dar vuelta á la Dinamarca.

Habiendo desembocado el Estrecho de Labrador, se comienza á bajar de aquella altura navegando al Oesudoeste y Sudoeste por $35^{\circ}$ leguas y se llega á los $7 \mathrm{I}^{\circ}$ de altura, que es á donde nuestro viaje, al tiempo que volvimos, descubrimos una tierra altísima, sin que se pudiese entender si era tierra firme ó isla; mas hácese consideración que sị es tierra firme es contra costa de la Nueva España. Desde esta tierra vista á $7 I^{\circ}$ de altura se ha de caminar la vuelta del Oesudoeste por 440 leguas hasta bajar á los $60^{\circ}$ á donde ha de ser hallado el Estrecho de Anian, con lo cual será observada la misma navegación que yo hice, á lo ménos desde la Frislandia, pues es de saber que yo partí de los $\mathrm{Ba}$ callaos en demanda de esta isla por llevar necesidad de bastimentos, los cuales tomé en unas islas que están cerca de ella llamadas Gelandillas, que siendo tres solamente es habitada la una, y las otras dos son pastos para los ganados de aquella gente que es muy rústica, aunque parecían ser católicos ó cristianos. Tornando á nuestra navegación, digo, según mi parecer, que será más acertado cuando se haya desembocado el Estrecho del Labrador, costear toda la contracosta de la Nueva Espana por dos razones; la una por entender que aquel tiene población, y la otra para buscar en ella escalas y refrescos para las Armadas que por este camino han de navegar. 
Según la relación hecha, parece haber de España á la Frislandia 450 leguas, y desde allí al Labrador I30; á desembocar el estrecho suyo, 290, que todas son 920 leguas, las cuales sumadas con 790 que hallamos desde la parte septentrional del estrecho del Labrador, hasta el Estrecho de Anian, hacen I 7 Io leguas, que tanto es lo que hay desde España al Estrecho de Anian.

E1 tiempo en que desembocamos el Estrecho del Labrador fué muy riguroso por ser en los principios de Marzo, porque por el estrecho se navegó parte de Febrero; así padecimos grandísimos trabajos de oscuridades, fríos y tormentas, porque el día era breve en todo aquel tiempo, y el frío tan grande, que el agua del mar que salpicaba en el costado del navío se helaba de tal suerte que parecía el navío hecho de cristal, y había necesidad de picar los hielos porque se iban engrosando de tal suerte, que algunas veces los hallamos de más de un palmo de gruesos, y es grande yerro pensar que aquel mar se puede helar todo, porque como es grande, y aquel estrecho de grandes corrientes, estas y las grandes olas por su contínuo movimiento no le dejan helarse; mas en las orillas y partes donde el mar está quieto, creo que se puede helar, según pareció en tierra que el agua que salpicaba se helaba; solamente se sabe, y así nos fué dicho por aquellas gentes de las Gelandillas, que un estrecho de mar que hay entre la Frislandia y la Grutlandia, está helado la mayor partedel año, porque está en medio de grandes montes y cerros de la parte de la Frislandia y no da lugar á los rayos del Sol, y por estar abrigado de altísimos montes no tiene combate de vientos, que les inquieten sus aguas, y así el contínuo sosiego le hace estar helado como dicho es, y no se puede navegar, y lo mismo es en la misma bahía.

Mas cuando tornamos por aquel Estrecho del Labrador, que fué por el mes de Junio y parte de Julio, siempre gozamos de contínua claridad, y tanto, que cuando llegamos á cortar el círculo ártico, que se hacen $66^{\circ} \mathrm{y}^{\mathrm{H}} / 2$, comenzamos á no perder el Sol de vista, ni jamás se cubrió por el horizonte hasta que otra vez le tornamos á cortar. En. medio del Estrecho del Labrador, por la continuación del Sol sobre el horizonte estaba el aire tan caliente, que nos causó más calor que el que hace en la parte que mayor es en España, mas no que cuando nos poníamos al Sol, sus rayos ofendiesen mucho y siempre nos corrieron vientos largos del Norte, con los cuales se desembocó fácil y prestamente el Estrecho del Labrador. Verdad es que sus grandes corrientes del flujo y refiujo ayudan mucho á entrar y salir, aunque sean los vientos contrarios, porque así como son muy contínuos los del Norte, hay necesidad á la ida de España á Anian, de valerse de las mareas, con la cual relación se con- cluye con lo que es la derrota de esta navegación y sus accidentes.

El estrecho que descubrimos en $60^{\circ}$ de altura, que está I7Io leguas de España, parece, según tradición antigua, ser el que los cosmógrafos nombran en sus mapas, de Anian, y si es verdad que lo es, de necesidad ha de ser estrecho de la una parte del Asia y de la otra de América, 10 cual parece ser así, según el discurso siguiente.

Después que hubimos desembocado por el mar Grande, fuímos costeando por la parte de la América por más de Ioo leguas la proa en el Sueste hasta llegar á los $55^{\circ}$ de altura, en la cual costa no se halló población ni boca del mar que fuese indicio de otro estrecho, por el cual, pasando el mar del Sur al mar del Norte, pudiese aislar aquella parte; y de aquí se coligió ser toda aquella parte de América, y que continuándola podría llegar brevemente á Quivira y cabo Mendocino; dejamos esta parte, la cual como dicho es, conocimos que se iba continuando, y puesta la proa al Oeste, caminamos cuatro días con un viento tal, que se pudiera contar á 30 leguas por singladura, y habiendo caminado I 20 leguas según esta fantasía y punto de la carta estimado, descubrimos una grandísima tierra, y continuando la costa de la que nos apartamos por convenir así á nuestro intento; siempre enmarados, navegamos unas veces al Nordeste, otras al Nornordeste y otras al Norte, de donde nos pareció (por mayor) que se corria aquella costa Nordeste Sudoeste. No pudimos conocer las cosas particulares por ir (como dicho es) tan enmarados, y así tan solamente puedo afirmar que tiene población hasta muy cerca del estrecho, porque en muchas partes se vieron salir muchos humos, y así, según buena cosmografía, nos pareció ser tierra de Tártaros ó del Catai, y que á pocas leguas de aquella costa estaría la gran ciudad de Cambalu, metrópoli del Gran Tártaro; finalmente, siguiendo la dicha costa, nos hallamos en la boca del mismo Estrecho de Anian, por donde quince días antes habíamos desembocado al mar Grande, el que reconocimos ser el del Sur, donde son Japon, China, Molucas, India y Nueva Guinea, con el descubrimiento del Capitán Quirós y toda la costa de la Nueva España y Perú.

En la boca que hace el estrecho por donde desemboca el mar del Sur, hay un puerto á la banda de la América, capaz de 500 navíos, aunque en cierta parte de él es desapacible y de mal surgidero, á causa de las corrientes que en la marea que baja del Norte al Sur, entra por la boca de él, y bate fortísimamente en una punta que hace el puerto cerca de la boca, entrando en él en la mano derecha, porque se ha de entender que la boca del puerto está abierta al Nortc y entra haciendo una espiral ó caracol. Pareció no haber sido tocado aquel puerto de piés huma- 
nos, digo sus orillas, porque en cierta parte dc cl tiene un remanso, en cuya orilla se hallaron infinidad de cáscaras de huevos de las aves marítimas que á las orillas del mar suelen deshovar, y éstos pareció ser traídos de las corrientes del Norte, y eran en tan grande número, que hacían un muro de una vara de alto y ocho palmos de ancho; hallóse en este puerto un río de agua dulce muy grande, y tan fondable, que se pudo entrar con nuestro navío á hacer agua en él, y me parece que pudiera entrar una nave de joo toneladas: la mayor parte de este puerto cs arenisco, particularmente á donde se hace este l'io y á donde baten las corrientes; mas por la banda del Norte tiene un abrigo de peñas cortadas de más de dos picas de alto en algunas partes, sobre las cuales se hace un sitio llano, largo y angosto, al cual circunda el mar, dejándole un pico de tierra firme por la banda del Este, en el cual sitio se puede hacer una grandísima población, y por ahora un fuerte que será de mucha consideración. La tierra, que es continente con este puerto, es muy apacible y tiene llanos grandísimos á la parte del Sueste, haciendo punto en el puerto, y éstos son poblados de un monte bajo que en algunas partes de él se hallaron romeros, los cuales llanos siendo desmontados pueden servir de lindas labranzas y huertas, porque según su disposición, se puede regar la mayor parte de ellos, porque es de saber que aunque esta tierra está en $59^{\circ}$ de altura de Polo, es de muy precioso temperamento, porque todo aquello que está á la banda del Sur, le abrigan y le defienden los montes que tiene á la banda del Norte. Es muy templado á donde el frío del invierno no es con exceso, sino muy moderado, porque siempre está descubierto á los rayos del Sol y libre de los vientos del Norte, y solamente le soplan los del Sur cuando corren, que estos siempre son templados, y más allí que vienen por cima del mar, que es lo que suele hacer caliente el aire.

El efecto fué conocido por los géneros de fruta que allí se hallaron, y es de considerar que aunque esta tierra está en tanta altura, no por eso dejará de ser muy buena de habitar, pues 10 son otras muchas que corren por este paralelo, como son Edimburgo de Escocia y los principios de la Suevia, Hapselia y Riga, ciudades de la Libonia, Dublín de Hibernia y Nidrosia, ciudad de Noruega y muchas partes de la Moscovia y otras tierras muy buenas que son habitadas, tratadas y conocidas, que aunque están apartadas del calor de la costa son de frío tolerable. El mayor día del verano en esta tierra es de diez y ocho horas y media y lo mismo la mayor noche de invierno, y por esta razón es la noche del verano de cinco horas y media y el día de invierno de otras tantas. En el río que entra en el puerto y en otro que está más abajo á la banda dcl Sud- este, hay muchos y grandísimos árboles, y los más de ellos frutales, de frutas buenas y algunas semejantes á las de España, como son manzanas, peras y ciruelas silvestres, y otras no conocidas de diversas formas; y así por no caer en algún gran peligro (como fuera posible) ordené á mi gente no comiesen de la fruta que primero no se hallase picada y comida de las aves, y con esto se conoció no haber fruta dañosa, y todas las más de ellas eran pasadas en sus mismos árboles del año pasado, porque en aquelìa sazón no habia frutas maduras por ser el tiempo que alli tuvimos parte de Abril, todo Mayo y parte de Junio; y así de conservarse las frutas de un año para otro pasadas en sus árboles se conoció no haber sido su invierno muy riguroso. Halláronse en un valle que el río de abajo hace (que era hondo y parecía muy templado), vides de uvas silvestres, y lechias, que es una fruta sabrosa de la India, que siempre se halla en tierras templadas. Por cima del puerto, mirando entre el Norte y Este por toda aquella cuarta de aguja, hay unos montes no muy altos, sino muy tratables y abundantes de todo género de caza, á donde se hallaron perdices y conejos algo diferentes á los de España, venados pintados de pintas blancas y negras sobre lo pardo, y por cuernos unas grandes palas, aunque algunos no las tenían: viéronse dos géneros de puercos; los unos como los que se crian en las Indias, que tienen en el espinazo el ombligo, aunque mayores, y los otros como jabalíes de España. Halláronse algunos búfalos y otros muchos animales; mas no se vió ninguno que fuese feroz. El mar es abundantísimo de pesca, y todo marisco muy bueno y sabroso, aunque mayor que el que acá conocemos, porque se tomaron cangrejos de media vara de través, siendo los de nuestras costas no mayores que la palma de la mano.

La parte frontera que es á la banda de Asia ó Tartaria, tiene montes altísimos, tanto que en algunas partes de su mayor altura se sustenta la nieve todo el año, particularmente aquellos que miran al Norte, y estos son tan montuosos, ásperos y fragosos, que parece imposible poderlos tratar, y la mayor parte de sus árboles son pinos muy altos, los cuales nacen hasta la orilla del mar. En la misma parte del Asia, enfrente de la boca del puerto, se hace un remanso de aguas del mar, adonde hay un cañaveral muy grande de carrizos que nacen dentro de la misma agua, cerca de la cual hallamos ser la mayor pesquera de todas aquellas partes. Allí se mataron muchos pescados y muy grandes, y algunos conocidos como son corvinas, congrios, lenguados y otros semejantes, aunque mayores que los que por acá se hallan; viéronse pasar á veces grandes pescados los cuales iban del mar dcl Sur al mar del Norte y entre estos se conocieron 
ballenas y bufadores, y otros mónstruos muy grandes.

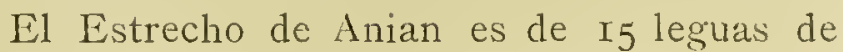
largo, porque fácilmente se desemboca y pasa con una marea que dura seis horas, y estas mareas son allí recísimas; tiene seis vueltas en todo este largo y las dos bocas que tiene de Norte á Sur, digo, que está la una con la o rra Norte Sur. La boca que tiene á la banda del Norte (que es por donde nosotros entramos), tiene ménos de medio cuarto de legua de anchura y de la una y otra parte tiene dos peñones cortados, aunque la peña que tiene á la parte del Asia, es más alta, y más pendiente que la otra, de tal suerte, que hace debajo de sí un abrigo en tal modo que ninguna cosa que cayese de la parte alta, podrá dar en el pié de ella. La boca que sale al mar del Sur por junto al puerto, es de más de un cuarto de legua de anchura y desde allí.se va siempre ensanchando y abriéndose aquellas dos costas. Tiene el Estrecho en medio de sí en el fin de la tercera vuelta, un gran peñón ó isleta hecha de una peña tajada de tres estados de altura poco más ó ménos, y porque es en forma redonda, muéstrase su diámetro de 200 pasos; está distante de la tierra del Asia un muy breve espacio, mas todo es de vagíos y arrecifes y no se puede navegar sino con barcos; mas aquella que hay desde la isleta á la tierra firme de la América es su anchura menor de medio cuarto de legua, y aunque su canal es tan fondable que dos navíos y aun tres pueden pasar juntos por él, es hacia las orillas de vagíos, y sobre los cuales con una fácil diligencia puede levantar y fundar dos baluartes en angostando la canal á tiro de mosquete; sobre esta isleta ó sobre los vagíos que se podrían levantar, y sobre la contraria costa se pueden hacer (como dicho es) dos baluartes, los cuales con la artillería podrán muy seguramente guardar y defender el Estrecho, y si las corrientes no fueran tan grandes se le pudiera poner una cadena que fuera de gran importancia aunque ya se podría hacer con tal industria que pudiese sustentarse y resistir á las corrientes. La disposición del Estrecho es en tal forma, que con tres atalayas que se miraran la una á la otra se puede descubrir treinta leguas dentro del mar del Norte y con ahumadas dar aviso á los baluartes y al fuerte del puerto si descubriesen navíos, para que se les impida el paso si fueren de enemigos, y teniendo continuamente en el puerto dos navíos aprestados para seme jantes necesidades, podrán ésto 3 atravesarse entre los dos baluartes (que para todo tendrán tiempo), supuesto que el que quisiere entrar ha de esperar la marea, y alli entretener y embarazar los navios enemigos, en el ínterin que los baluartes los cañonean y ponen á fondo, porque es de saber que aunque vengan muchos navíos ene- migos, no podrán pasar más de dos ó tres por la canal y si conviniese descubrir el mar del Sur, aunque pienso no ser necesario por ahora, tiene el Estrecho dos montes altos, uno á la partedel Asia y otro á la de América, los cuales se miran uno al otro y ambos juntos al fuerte y á las atalayas, y éstos descubren las dos costas en contrario puesto cada uno, los cuales podrán dar ariso de todos los bajeles que se descubriesen por el mar del Sur para que haga la prevención ya dicha con la que será este Estrecho defendido, y solos los españoles lo podrán navegar con gran libertad y gozarán de las grandes utilidades que promete; porque verdaderamente no sé yo, qué puerto hay en todo lo descubierto, que así tenga correspondencias con casi todas las tierras del mundo como éste, porque desde allí se puedc navegar á todas ellas, y así se puede presumit que vendrá á hacerle el tiempo una grandísima y riquísima población.

La boca del Estrecho por la banda del Norte es dificilísima de conocer, porque tiene una costa continuada de Este á Oeste, y las dos partes quo hacen el Estrecho se encubren una con la otra, porque su entrada y vuelta se describe Nordeste Sudoeste y no se deja ver desde el mar afuera. y por esta causa no es mucho que no se haya hallado de los que le han buscado, porque cuando nosotros llegamos, no lo conocimos por algunos días que allí estuvimos barloventeando por aquella costa, con tener una muy buena relación do Juan Martínez mi Piloto, que era un portugués natural de Algarbe, hombre muy viejo y de mucha experiencia, mas faltábanle las señales dc aquellos montes, que son las que yo tomé y pinté para hacer otra segunda navegación si se me ofreciera, porque aunque sabíamos haberle de hallar en los $60^{\circ}$ de altura, por ser aquella costa muy larga de Este-Oeste, nos hizo estar en dudas, tanto, que al Piloto le pareció no haber llegado á él por más de Ioo leguas, según la fantasía de su derrota, y á mí me pareció que ya estábamos sobre él, como sucedió, que saliendo en una chalupa á costear la orilla del mar, la misma corriente me embocó por el Estrecho, con que fué conocido. La razón por donde me pareció haber llegado al Estrecho y estar sobre él, fueron las grandes corrientes que allí hallé, las cuales venían de tierra, y tornaban á ella; tanto que algunas veces, estando con nuestro navío enmarado y mar en través, muy apartado de la costa, lo hallá mos junto á ella, y otras veces, estando junto á la tierra, 1o hallábamos muy enmarado.

Tienen aquellos montes junto al Estrecho una peña altísima sobre un alto monte á la banda del Asia, de color blanca, y siendo la peña tajada $y$ en forma inaccesible, tiene en su mayor altura. tres muy grandes árboles, que mirados de Norte á Sur se ven bien distintos el uno del otro, y de lá 
una y otra parte de esta al tísima peña, muestran los montes una perspectiva á manera de dos sillares muy conocidos. Una legua de la boca del estrecho, á la banda del Oeste, hay un peñón alto y pelado, al que circunda el mar, y que cuando está la marea más baja me parece que distará de la costa firme cuatro picas de largo; á la banda del Este de la boca del estrecho, hay un grande y hermoso río de linda agua y de muchos árboles, á donde hicimos agua, porque allí tiene un mediano abrigo con dos grandes peñones que se hacen en una punta: los montes que se descubren á la parte del Asia por esta banda del Norte, son altísimos mirados desde el mar del Norte y tienen grandes arboledas, y llegando cerca parece ser todo pinares; mas los montes de la América son más bajos y de árboles menores, mas no parecía haber frutales en ninguna de estas dos partes.

En el puerto donde nuestra nave surgió, que es el que está dicho en la boca del estrecho en la banda del Sur, estuvimos desde los principios de Abril hasta mediado de Junio, y en este tiempo vino por allí una nave grande de 800 toneladas de la parte del mar del Sur á embocar por el estrecho, con la que tuvimos ocasión de ponernos en armas, y habiéndonos apaciguado los unos con los otros, tuvo aquella gente gusto de darnos algunas cosas de las que traían por carga y mercancía, que era mucha y toda conocidamente, ó la mayor parte de ella eran cosas semejantes á las de la China, como son brocados, sedas, porcelanas, plumas, cajones de piedras, perlas y oro, y esta gente pareció ser anseáticos, que son los que habitan en la bahía de San Nicolás ó en el puerto de San Miguel, y para mejor entendernos con ellos nos fué forzoso hablar latín, los que lo sabían hablar con los que lo sabían hablar; mas no parecían ser católicos, sino luteranos; decían venir de una ciudad muy grande que estaba poco más de ioo leguas del estrecho, que aunque no me acuerdo bien de su nombre, me parece que la nombraban Roba ó un nombre á este modo, la cual decían ser un buen puerto, y un río navegable, y que era sujeta al Gran Can, porque dijeron ser de Tartaria, y que en aquél puerto dejaban ellos otra nave de su misma patria. No pudimos informarnos más de esta gente, porque siempre procedían con recato y poca confianza, temiéndose de nuestra gente; y por esta causa nos dividimos los unos de los otros, y habiéndolos dejado cerca del estrecho dentro del mar del Norte, nos vinimos de la vuelta de España; y es cosa muy de creer que cstos fueron anseáticos, porque como habitan en $72^{\circ}$ de altura, les es cosa fácil y muy á propósito tratar este estrecho y navegación, y pues queda bastante relación de todas las cosas particula. res de esta navegación, y los daños que de no lacerse se puede ofrecer, parece ser cosa puesta en razón tratar cuales sean las cosas que ha de prevenir la persona á quien le fuese encomendado este negocio y saber los gastos que en semejantes prevenciones se pueden of recer, para que con esto tenga efecto el intento de V. M. y su Real servicio.

\section{Prevenciones y gastos de este viaje.}

Primeramente conviene hacer tres navíos, la Capitana de 50 toneladas, y los otros dos cada uno de á roo, y éstos sean hechos con unos ca. jones debajo del agua, según la traza que para ello se dará á su tiempo, y con esto se excusa irse al fondo una nave aunque se abra por la parte de abajo, porque solamente se hinche de agua aquel cajón que responde á la rotura y los demás no, por ir todos calafateados, y también que si recibiese el navío algún bombardazo entre dos aguas por donde el agua entrase, por allí tornará á salir sin echarle á fondo, como me consta por experiencias del mismo navío con que hice la navegación y descubrimientos. Estos navíos han de ser de contracostado y emplomados, hechos con muchos y muy gruesos corbatones y pernos muy largos, cuya forma ha de ser cerrados por la parte alta, digo metidos de bordo, y por la parte baja chatos y muy bien lastrados, y siendo fabricados en este modo, podrá cualesquiera de ellos salir orzando contra el viento si se hallare cerca de la tierra en alguna tormenta con viento en travesía, que es el mayor peligro en que una nave se puede hallar, pues que siempre estos navíos son grandes bolineros y pueden meterse del Oeste cinco cuartas, y si por desgracia viniese á encallar en algún vagío, por ir por mares no conocidas, podrán salir mejor que otros mayores, porque como son chatos de abajo, no se trastornan y pueden esperar socorro de los suyos en la pleamar.

Asímismo, conviene llevar dos lanchas, una armada y otra desarmada en madera para armarla al tiempo de la necesidad si la que va armada se perdiese; y éstas han de llevar remos para mejor llegar á sus navíos en todos tiempos, ó hacer otras cosas que se puedan ofrecer, porque esta lancha ha de ir cerca de la costa y á vista de los tres navíos, los cuales, siempre han de ir apartados cuatro leguas metidos á la mar y les avise de todas las cosas particulares y señaladas que hallasen en la costa, y por esta razón conviene que su Capitán sea hombre experto, hábil, animoso, prevenido y muy fiel, y esta lancha ha de ser tan grande, que pueda en una necesidad hacer 20 pipas de agua, la cual y los tres navios y la lancha desarmada, todos envelados y puestos á punto de navegar, bien enjarciados, costarán 8.000 ducados.

Es bien llevar en estos navíos seis piezas de 
artillería reforzadas para la amura, porque siendo ellos muy fuertes, como dicho es, muy bien las podrán sustentar, y mas otras doce menores, las cuales 8 piezas se repartan en los tres navíos, que costarán I.500 ducados. Mas 200 mosquetes á tres ducados cada uno, costarán 600 ducados (I).

Mas I50 arcabuces para si se ofreciese saltar en tierra en alguna ocasión de muchas que se ofrecen en los descubrimientos, á dos ducados cada arcabuz, valen 300 ducados.

Picas, pólvora, plomo, cuerda, bombas, artificios de fuego, balas de artillería y todas municiones, 700 ducados.

Hay necesidad de tres pilotos, hombres cuerdos, fieles, vigilantes y españoles, y sus ayudantes, y dos docenas de bonísimos marineros que vayan repartidos por los tres navíos, los cuales quedan de este viaje diestros para ser pilotos de esta carrera, y finalmente, es bien llevar de toda suerte de gentes 200 hombres, y que éstos sean los más que se pudiese, hombres de mar, porque el marinero cuando es menester, sirve de soldado, mas el soldado no sabe en ninguna ocasión servir de marinero; todos los cuales se han de repartir en esta forma: que en la Capitana vayan 80 hombres y en cada navío á 50 , y los 20 res tantes en la lancha primera; que si se ofreciese tomar el remo en las manos haya gente para ello, y toda esta gente vaya pagada por un año, dándoles á los pilotos 1.000 ducados á cada uno; y todos los 200 hombres á 48 ducados cada uno, que es á razón de cuatro ducados cada mes, que montan 9.600 ducados por un año.

$\mathrm{Y}$ porque entre estos 200 hombres hay aventajados Oficiales de guerra y mar, y acompañados de los pilotos, me parece que podrán montar las ventajas de un año 3.000 ducados.

Hánse de llevar respetos de jarcia, cables, áncoras, lona, brea, estopa y todo velamen, herramientas, clavazón y tiras de plomo para reparar algún daño de la artillería enemiga, que todo montará $\mathrm{I} .500$ ducados.

Mas 200 ducados de achotes de cera para el farol de la Capitana y Almiranta, que por ser en esta navegación los días muy largos y las noches breves, no pongo más, pues es sin duda que en muchos días no se verá cubrir el Sol.

Repártanse en todos los navíos 200 ducados de botica. Y porque las cosas del mar son dudosas, es bien llevar bastimentos para dos años, porque á lo ménos, lo que es el vino puede servir á la vuelta, y así guardando la orden de las raciones ordinarias, son necesarios para los tres navíos 2.200 quintales de bizcocho, que pagados á cuatro ducados, montan 8.800 ducados.

(1) La mayor utilidad de esta relación es esta nota pormenor de los precios de aquella época.
Y porque suele dañarse el bizcocho y por esta falta venir la gente á padecer grandes trabajos, es bien llevar 400 quintales de harina, que pagados á dos ducados, montan 800 ducados.

Las raciones de vino en dos años suman 9.I25 arrobas, que pagadas á razón de seis reales, hacen 4.977 ducados.

De toda carne, cecina, tocino y gallinas para los enfermos, 2.500 ducados.

Mas 400 ducados de todo pescado.

De aceite, vinagre y legumbres, 600 ducados.

Mas 300 ducados de queso.

Mas Ioo ducados de sal, porque es de mucha importancia llevar buena cantidad, pues que en las necesidades suele aprovechar, que ó bien tomada alguna cantidad grande de pescado (como suele acaecer), ó llegando á donde se pueda hacer alguna carne, con la sal se sustenta para todo el viaje.

Todas las cuales dichas partidas y gastos suman 47.077 ducados, y esto es lo más que puede costar el despacho de unos navíos, aunque dejo algunas cosas menudas que se pueden of recer y no se pueden excusar, y mirado bien se compra harto barato un beneficio tan grande, que es uno de los mayores que ahora se pueden of recer, y se excusan grandísimos daños como de no hacerse se podrían of recer á los Reinos de V. M.; y finalmente, es bien tomar todo lo que otro puede tomar y hacernos daño con ello; porque no sé yo por qué es bien hecho que la parte descubierta y conocida por hombres españoles la dejemos tomar á extranjeros y más si con ella nos puede dañar y hacer guerra, y no sólo esto, que si la toma es sin duda, que éste tal le dará al demonio las mejores primicias de aquellos Reinos, que son las almas de sus naturales, sembrando entre ellos su mala y perversa secta, que todo este riesgo tiene desamparar esta navegación y dejarla á que la haga el enemigo, para que por ella se venga á apoderar de todos aquellos Reinos y más fácilmente de aquel nuevo descubrimiento de la tierra austral, que siendo tan grande y tan dilatado como nos informan, aquél que se hiciese señor de él lo será de todo el mar del Sur, y pues habiendo de caminar por tan largo y prolijo camino como es el del Cabo de Buena Esperanza, han tenido medios los enemigos para tener en la India y en aquellas partes siete factorías (como se dice que las tienen hoy día) y ocho fuertes en la Isleta de Terrenate con tanto perjuicio de la Hacienda Real de S. M., claro está de entender que si hallasen este camino tan breve y puerto tan acomodado, sería mucho mayor el daño que podrían hacer. Por lo cual, parece ser cosa más justa atender al daño que puede suceder de no tomar y fortalecer este estrecho, que no á los gastos que de hacerlo se pueden ofrecer, porque quien quisiera tener y gozar 
grandes haciendas, grandes y diversos son los gastos que ha de tener y grandísimos los cuidados que ha de padecer.

Finalmente, si V. M. se hiciere señor del mar, 10 será en la tierra, y si no con dificultad se podrá conservar lo que se posee; y esto lo digo como hombre que conozco mucho de las cosas del mary sć cuánto vale el imperio de él sin el cual es imposible gozar el imperio de la tierra, y estas últimas razones basten para los que saben entender materia de Estado, y para que si hay quien se descuide, despierte y se ponga en vela, que pienso que son muchos los enemigos públicos y secretos, y muchas las naciones que aborrecen á España, y no diga nadie (como pienso que se ha dicho), que no hay dinero para hacer semejantes prevenciones, porque V. M. está necesitado, y si alguno lo dijere, y hallare estar á su Rey con necesidad, ayúdele con partes de su hacienda y advierta que le estará mejor gastarla en esto, que por no hacerse se la quite toda otro día el enemigo, que por mucho que él ponga, pondrá más el que se hiciere cargo de poner en ejecución un negocio tan árduo, que yo como marinero no ignoro cuán grande es y cuántos peligros tiene. Sólo puede conocer esto el que supiere cuán grande es lá braveza del mar del Norte y su grande inquietud; en verdad que para la navegación del Golfo haciendo tan buenos navios como para este efecto se han de hacer, no hay que temer al mar por muy bravo que sea. Mas aquí se ha de costear por las razones atrás referidas y el costear en un mar tan inquieto, es sumo peligroso y tanto, que no habrá marinero á quicn no haga temblar el corazón solo el pensarlo, y así me parece que si se lallare quien lo acepte, no lo pierdan de vista, porque si hay uno, creo que no habrá dos; y adviértase que semejante jornada no le puede ser de ningunos provechos al que la hiciere, sino de muchos trabajos; por lo que es aprovechamiento no sé yo que lo tenga por esta primera vez y no hay que confiar en que los enemigos no la han de hallar esta entrada, ú otra, si la tiene el mar del Sur, pues sabemos, que son muy marineros y tan animosos como yo para arrojarse, como yo me arrojé; y digo Señor, que es tanto el cuidado que tienen de hallar alguna entrada, que tengo entendido por relación que me hizo el Capitán Baltasar de la Just, residente en Fonte labía, estando tratando conmigo de este particular á siete días del mes de Julio de este año de r6og, cómo los franceses tienen hecho un fuerte en el rio de Canadá que está 300 leguas metido tierra adentro de los Bacallaos, confiados de hallar desde allí entrada que pase al mar del Sur; digo esto, no porque entiendo que por allí puedan hallar entrada, porque es imposible que puedin atravesar aquel rín más de 1.000 lewuas que hay de travesía, y también porque yo costeé casi todo lo que estaba por descubrir de la costa de América por el mar del Sur, y no hallé ninguna entrada ni boca de río que fuese de consideración. Mas dígolo, Señor, porque se entiendan las grandes diligencias que hacen los enemigos por entrar.

Asimismo se advierte que si V. M. mandare hacer este descubrimiento sea con secreto, y de tal suerte ordenado que los pliegos y la instrucción no los abra el cabo de los navíos hasta haber entrado 40 leguas á la mar; porque con esta disimulación se pueden desmentir los espías suponiendo que se arma para otro efecto, y queriendo Dios que no sea otra vez descubierto el Estrecho, conviene luégo el primer año siguiente enviarlo á fortificar, porque se ha de entender, ser cosa imposible que tanta gente como se da en este descubrimiento hayan de callar tanto, y ser todos tan prudentes que no se publique esta navegación y sus derrotas, y siendo entendidas de los enemigos por ellos mismos lo buscarán y hallarán y fortificarán de tal suerte, que sea menester mucho, y muclos gas. tos y hombres para quitárselo, y así conviene llevar esta mira desde el día que se dé el despacho para descubrirla.

\section{Sola.}

Mandé sacar la copia que antecede del ejemplar $4 .^{\circ} \mathrm{Ms}$. acaso de letra del mismo autor, que posee el Excmo. Sr. Duque del Infantado. Del mismo ejemplar se han copiado la tabla $y$ las figuras. Todo lo he corregido con atención. Madrid, á 24 de Marzo de r78ז.= Fum Bautista Mแñoz.

Memoria sobre el descubriniento antigito del paso del Norte ó del mar Océano al del Sur por la parte septentrional de la América, leida en la Real Academia de Ciencias de París, por Mr. Bauche, Geógrafo mayor de S. M. Cristianisima (I).

"Há cerca de 300 años que se conoce la importancia del paso del Noroeste de la América, siendo este el objeto de las frecuentes indagaciones de las naciones comerciantes de la Europa y de un premio de 20.000 libras esterlinas ofrecido por el Parlamento de Inglaterra á los navegantes nacionales que lleguen á descubrirlo.

"En vista de todas las tentativas que inútilmente se han hecho con este objeto, y de los viajes que en estos últimos tiempos emprendieron el célebre Cook con el fin de reconocer las costas del Norneste de la América, donde se suponía una de las bocas del paso: Mr. Young, regis-

(1) Es traducción del original francés hecha por el Capitán de fragata D. Nartín Fernindez. Nivarrete. 
trando de nuevo la bahía de Hudson, donde se creía la otra, y Mres. Hearne y Pound, cruzando desde la bahía de Hudson hasta los confines del mar Glacial, 'al través de las tierras donde se imaginaba un estrecho, cualquiera podría inclinarse á dudar de la existencia de la comunicación de ambos mares; y ésta tal vez es la opinión general en el día. A pesar de esto, asegurado de la confianza que inspira la verdad, paso á proponer á la Academia la relación de un navegante, que desde los principios en que empezó á cuestionarse, halló el paso del Noroeste. La relación de semejante descubrimiento es auténtica. Los hechos que se citan en ella de ningún modo se oponen á las circunstancias ciertas que hemos sabido de otros navegantes, y además, nos informan de la verdad de otros muchos hechos que refieren diferentes autores, los cuales, como hasta ahora no se han podido comprender, se han mirado como fabulosos ó como disputables.

"Un navegante español llamado Lorenzo Ferrer de Maldonado, es el que en el año de I $_{5} 88$ descubrió el paso del Noroeste que voy á describir, y la relación de semejante descubrimiento se halla en una Memoria manuscrita que él mismo presentó al Rey de España en I6og, para estimularlo á que repitiese la navegación de este paso y se hiciese dueño de él. El Sr. Mendoza, Oficial de la Marina de España, conocido de la Academia por sus luces y celo y encargado de la córte de Madrid para formar un establecimiento semejante al que tenemos en Francia para la construcción de cartas marítimas, etc., es quien me comunicó una copia fiel de esta Memoria. Después de haberla leído y habiendo hecho conversación sobre ella, me la franqueó para que hiciese el uso que tuviese por conveniente. En tanto que el Sr. Mendoza se ocupa entre nosotros en juntar los objetos necesarios á su establecimiento, el Gobierno ha dispuesto que se reconozcan todos los Archivos de España y se saquen de ellos las relaciones originales de antiguos viajeros y navegantes españoles, y yo me atrevo á decir desde ahora que la Geografía puede esperar los mayores auxilios de sus conocimientos y de su celo.

"La Memoria del navegante español se intitula: Relación del descubrimiento del Estrecho do Anian, que yo el Capitín Lorenzo Ferver de Maldonado hice el año de $\mathrm{I} 588$, cn la cual se ve la derrota que es preciso seguir, la disposición local y modo de fortificarle, como también las utilidades que puede ocasionar el repetir ma mucva expedición y los inconvenientes que pudiera haber en omitirla. En dicha Memoria se halla trazada por el autor la derrota y un plano particular del Estrecho de Anian, con dos vistas, una de la entrada y otra de la salida, las cuales igualmente delineó en dichos lugares para facilitar su reconocimiento. Este plano y estas vistas, son las que tengo el honor de presentar hoy con mayor extensión á la Asamblea. Pero como en el día sólo puedo of recer una idea de este descubrimiento, no haré más que manifestar la derrota que siguió dicho navegante en I588 y hacer constar por ella la existencia del paso del Noroeste.

Hé aquí la relación del navegante:

"Partiendo de España, v.g., del puerto de Lisboa, es preciso navegar al Noroeste la distancia de $45^{\circ}$ leguas y hasta $\operatorname{los} 60^{\circ}$ de latitud, desde donde se avistará la Isla de Frislandia. Desde allí se camina I8o leguas al Oeste bajo del paralelo de $60^{\circ}$, y se arriba á la costa del Labrador, donde comienza el Estrecho del Labrador ó de Davis. Aquí hay dos entradas ó bocas, una que va al Nordeste y otra al Noroeste. Se dejará á la derecha mirando al Norte la que va al Nordeste; esta boca está formada por la Groelandia y sus islas, y vuelve á tomar la mar de Frislandia. Tomando la otra entrada, se hace derrota al Nordeste en un estrecho, el espacio ó distancia de 80 leguas y hasta la altura de $64^{\circ}$; aquí el estrecho vuelve al Norte, y sigue esta dirección I20 leguas hasta los $72^{\circ}$; desde este punto vuelve otra vez al Noroeste siguiéndolo 90 leguas, y se llega á los $75^{\circ}$ de latitud, donde acaba el Estrecho del Labrador. Este tiene 290 leguas de longitud; su mayor anchura son 40 leguas y 20 la menor. Encuéntranse en él puertos, calas y abrigos que pueden servir en caso necesario, y parece ser habitado hasta los $73^{\circ}$, á juzgar por los fuegos que se vieron allí en muchos parajes, tanto de una costa como de la otra.

"Concluído el Estrecho del Labrador se navega al Oeste un cuarto Sudoeste la distancia. de $35^{\circ}$ leguas hasta los $7 \mathrm{I}^{\circ}$. A nuestro regreso descubrimos por esta latitud una tierra muy elevada, pero no pudimos averiguar si era tierra fir me ó isla; sólo sí se pensó que en caso de ser tierra firme debiera ser la costa opuesta á la costa septentrional de Nueva España. Luégo que se ve esta tierra, y desde el $7 \mathrm{I}^{\circ}$ de latitud, es preciso correr al Oeste-Sudoeste la distancia de 440 leguas y se arriba á la altura de $60^{\circ}$, donde se debe hallar el Estrecho de Anian. Con esta instrucción se logrará hacer la misma derrota que yo conseguí desde la Isla de Frislandia, que fué el punto de mi salida.

"Cuando llegamos á la salida del Estrecho del Labrador hacía un tiempo muy riguroso: esto era á principios de Marzo. La travesía del Estrecho fué en parte de Febrero, por cuya razón padecimos mucho por la oscuridad, por el frío y por las tempestades; el día fué muy corto todo este tiempo, y el frío tan intenso, que el agua de la mar que rechazaba con el bagel se helaba súbitamente, de manera que el navío parecía ser 
de cristal. También tuvimos precisión de aferrar las relas, las cuales en muchos parajes tenían más de un palmo de espesor.

"El pensar que el mar de que voy hablando pueda helarse del todo es un error, porque como es un Estrecho muy ancho y tiene corrientes muy violentas, éstas y las gruesas olas no le permiten el helarse por su movimiento contínuo, y así me persuado, que sólo puede helarse en la orilla y en los parajes donde el agua está tranquila, á juzgar por lo que pasaba en torno de nuestro navío.

1) Cuando regresamos por el Estrecho del Labrador, que fué en el mes de Junio y parte de Julio, disfrutábamos de una claridad contínua. Desde que llegamos al Círculo Polar por $66^{\circ} \mathrm{y}^{1} /$, de latitud, comenzamos á gozar del Sol, el cual no nos faltó hasta que volvimos á pasar segunda vez este círculo, que se halla hacia la mitad del Estrecho. Con motivo de tener contínuamente el Sol sobre el horizonte, era tan cálido el aire, que sentíamos mucho más calor que en España, pero de ningún modo ños incomodaba, á pesar de estar expuestos á los rayos del Sol, porque siempre logramos un viento fresco del Norte, que al mismo tiempo nos facilitó pasar con prontitud el Estrecho del Labrador.

"Según la tradición antigua, parece que el Es trecho que hemos descubierto por latitud de $60^{\circ}$, es el mismo que llaman los geógrafos en sus cartas Estrecho de Anian; y si esto es verdad, debe ser formado de un lado por el Asia y del otro por la América. Esto es lo que igualmente nos ha parecido verosímil por la derrota que hemos hecho en la mar del Sur, que es la que voy á referir.

"Luego que entramos en la Mar Grande, seguimos la costa de la América, la proa del Sudeste por más de cien leguas y hasta la latitud de $55^{\circ}$. No se vió habitación alguna sobre esta costa, ni entrada ó embocadura que indicase algún otro paso de la mar del Sur á la mar del Norte; se creyó que esta costa era la de la América, y que continuando la derrota se llegaría en poco tiempo á Quivira y al Cabo Mendocino, que sabemos se halla en esta misma costa prolongada. Desde este punto ó de la altura de $55^{\circ}$, navegamos al Oeste cuatro días con un viento fresco que podía hacernos caminar 30 leguas por día. Después de haber andado I20 leguas siguiendo la estima, descubrimos una gran tierra de altas montañas y una costa larga y contínua que dejamos para volver al objeto principal de nuestro viaje.

"Nada pudimos averiguar en particular de esta tierra, á causa de las contradicciones que experimentamos á nuestra vuelta, y sólo podemos asegurar que se halla poblada hasta las cercanías del Esstrecho, mediante que se veía salir bastante humn de muchas partes. Siguiendo esta costa, nos volrímos á hallar en la entrada del Estrecho de Anian por donde habíamos embocado en el Mar Grande quince días antes que estuviésemos en el del Sur.

"E1 Estrecho de Anian tiene I 5 leguas de largo. Así se le pasa fácilmente con seis horas de una marea, que son aquí violentas. La boca que mira al Norte y por la que entramos, no tiene un medio cuarto de legua de anchura. La que mira al mar del Sur, no llega á un cuarto de legua. En medio del estrecho hay un islote formado de rocas escarpadas que angosta más el canal. En este sitio apénas hay un medio cuarto de legua de anchura, por 10 que no pueden pasar sino dos ó tres buques de frente.

"La boca del estrecho del lado del Norte, es muy difícil de reconocer, porque la costa se extiende aquí Este-Oeste y las dos partes que forman esta boca se ocultan una con otra demorando la entrada Nordestesudoeste. Por esto no es de admirar no la hayan encontrado los que la han buscado. Cuando nosotros llegamos, estuvimos bordeando algunos días cerca de ella sin reconocerla, no obstante de tener una relación exacta de Juan Martínez, mi Piloto, que era un portugues nacido en Algarbe, hombre anciano y muy experimentado; pero le faltaba la vista de las montañas, que yo tomé y dibujé para guiarme en otro viaje que la ocasión me presentase. Así, aunque estuviésemos bien advertidos de que el Estrecho estaba situado por $60^{\circ}$ de latitud, como la costa corre Este-Oeste un tan largo espacio, quedamos algun tiempo en duda. El piloto, según la estima de su derrota, creía hallarse á más de roo leguas, y á mí me parecía que estábamos muy cerca, como en efecto se verificó; porque habiéndome embarcado en la chalupa para costear la orilla del mar, la corriente me entró en el Estrecho y me lo hizo reconocer de este modo. Lo que me hizo creer que habíamos llegado al Estrecho ó que nos hallábamos muy cerca, fué efecto de lo que yo advertí en las corrientes de esta parte, las cuales venían de la costa, á donde volvían seguidamente; de modo, que nuestro bajel, aun estando muy en alta mar, se hallaba de repente arrastrado á la costa y desde allí era de nuevo arrojado muy adentro de la mar.

"Desde principios de Abril hasta mediados de Junio, permanecimos en un puerto que hay en la boca del Estrecho por la parte del mar del Sur. A este tiempo llegó un bagel de 800 toneladas que venía del mar del Sur á pasar el estrecho, y cuyo equipaje nos pareció ser de las naciones anseáticas que habitan la bahía de San Nicolás ó el puerto de San Miguel. Con motivo de recelarse ó cautelarse ellos de nosotros, y al parecer temiéndonos mucho, no pudimos recibir instrucción alguna de ellos; por consiguiente, nos separamos, habiéndolos dejado en el mar del Sur, y nos aparejamos para regresar á España. 
"Este es el resumen del viaje y del descubrimiento que dice haber hecho el navegante español el año de I588. En las particularidades que he omitido y que relacionaré en nuestras sesiones ó juntas privadas, se hallarán suficientes pruebas de la existencia del paso y de los conocimientos del navegante. Por ahora es mi designio examinar la derrota que nos ha trazado, y proponer algunas observaciones sobre las principales circunstancias de su descubrimiento.

"La derrota del navegante desde Lisboa á la Isla de Frislandia y de Frislandia al Estrecho del Labrador, es la que nos dan los navegantes modernos desde Lisboa al Cabo Farewell en la entrada del Estrecho de Hudson, donde se encuentran las mismas latitudes y las mismas distancias.

"El paso que después describe desde el Océano al mar del Sur, se compone, como hemos visto, de tres partes: I. $^{a}$ La travesía del Estrecho del Labrador, que va desde el Océano al mar Glacial. 2. a La navegación ó camino de 700 le-

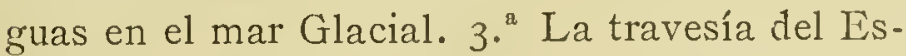
trecho de Anian, que va desde el mar Glacial al mar del Sur.

"El Estrecho del Labrador donde el navegante pone 290 leguas de longitud ó extensión, se divide en tres partes, como es fácil de comprender. La primera que dice ser de 80 leguas al Noroeste, es efectivamente el Estrecho de Hudson, desde su entrada hasta la bahía de Hudson; esto es, las mismas demoras y la misma distancia.

"En el año de I 58 todavía no se conocía la bahía de Hudson, ni tampoco pudo verla el navegante, porque siguió la costa septentrional del estrecho, la cual siempre está más libre y ménos embarazada de hielo.

"La segunda parte, que navegó al Norte y cuya longitud se ha puesto de I2o leguas, se advierte también en el Estrecho que avanza al Norte de la bahía de Hudson y que en las cartas inglesas se denomina Nameless Strait ó Straitumidiscobered, esto es, Estrecho sin nombre ó Estrecho no descubierto; donde todavía no se conoce más que una parte del lado del Sur que ha sido vista por Baffin en 1616 , por Fox en 1631 , y por Tomás James en I632.

"Estos navegantes intentaron penetrarle es. perando encontrar allí el paso que buscaban; pero se retiraron asustados con los hielos que veían venir del Norte. Es de notar que Baffin, estando al Sur de la entrada, y viendo que las mareas se dirigían al Norte, infirió de aquí que había un paso, y á consecuencia dió el nombre de Cabo Confort á una punta de tierra cerca de la cual él hizo esta observación. Igualmente Fox ha inferido del crecido número de ballenas que se ven en la parte del Noroeste de la bahía de Hudson, que debía haber en esta parte ó sitio un paso al mar del Sur, lo cual creyó hasta su muerte. Las cartas inglesas que se han publicado de cuarenta años á esta parte, hacen conmemoración de una comunicación entre el estrecho sin nombre y la bahía de Baffin, la cual, como se halla fundada solamente en conjeturas, es verosímil haya impedido hacer nuevas indagaciones, tanto más cuanto los navegantes que han ido en busca del paso á la bahía de Baffin, no han hallado más que hielos en su parte del Sudoeste, donde se suponía la salida del Estrecho sin nombre. Las cartas antiguas dan una anchura mucho menor á la bahía de Baffin, que todas las modernas; la colocan ménos al Oeste y la aproximan ménos á la bahía de Hudson; y yo pienso con Mres. de Lisle y Danville, quienes las habían adoptado, que merecen la preferencia.

"La tercera parte del Estrecho del Labrador, ó la que termina en el mar Glacial, se halla en un territorio que todavía no conocemos; por consiguiente, no contradice ninguna de las nociones que se nos han dado; antes bien, me parece confirma lo que se ha visto sin mucho interés en una carta inserta en L'Americain Traveller y en una carta grande japonesa, traída del Japón por Rempfler y depositada en el gabinete del difunto Mr. Hansloane. La carta del Anevicain Traveller manifiesta una comunicación ó un estrecho entre el mar Glacial y la bahía de Hudson, donde se ven las denominaciones de Spurle y Foulve, dadas á los dos puntos que forman la entrada de este Estrecho del lado del mar Glacial. La carta japonesa, la cual nos manifiesta todavía desconocidas las costas de la América Septentrional, nos indica igualmente un estrecho por donde se comunica el mar Glacial con el Océano, y coloca este Estrecho en el mismo sitio á donde nos ha conducido el navegante español. Por las indicaciones sabias de Mr. Guignes, sabemos que los chinos navegaban antiguamente á las costas del Noroeste de la América; también se sabe por Benjamín de Tudela, autor indio del siglo xir, que los chinos conocieron el mar Glacial, al cual llamaban Nikpha. Decían ellos, que los que entran en este mar no pueden salir y que mueren después que se les acaban las provisiones. Seixas refiere en su Teatro naval que en la bahía de Hudson se han hallado cascos de navíos chinescos; por esto podemos comprender de dónde tomaron los japoneses los conocimientos que ponen en sus cartas. El Americain Traveller no hace la menor expresión de los conocimientos que nos manifiesta la carta inserta en esta obra. Monsieur de Bogoundi, quien en el año de I774 hizo indagaciones sobre este objeto, nos dice que el autor era un Capitán inglés llamado Elmui, y que había recorrido una parte de las costas del mar Glacial al Norte de la América. Nadie ha usado de estos conocimientos desde esta época por no 
saber apreciarlos; pero hoy día se puede creer que no carecen de fundamento. Permítaseme citar aquí un artículo de la Gaceta de Londres, que al presente parecerá más digno de atención. En el día 4 de Abril de I769, se dice en ella que un Oficial que había montado navíos de la Compañía de Hudson, había hallado poco hacía, el paso deseado por el Noroeste para ir á las Indias Orientales; que había pasado felizmente desde el Estrecho de Lepulse-Bay á otro, por el cual había entrado en el Océano de Tartaria, y se añade que á instancias de la Compañía de Indias y de las de la bahía de Hudson se habían desaparecido repentinamente su diario y sus cartas en el momento que iba á publicarlas.

") En el diario de sabios del mes de Noviembre de 1773 , se halla igualmente una carta de Monsieur de la Lande, que dice que un navío danés, llamado la Corona del Norte y mandado por el Barón de Ulfeld, había pasado el año de I769 del Océano al mar Glacial, de éste al del Sur, de donde volvió á Europa por el Estrecho de Le Maire.

"Toda esta relación, unida al testimonio del navegante español, no dejan duđa, á mi parecer, de la comunicación de la bahía de Hudson con el mar Glacial, y consiguientemente del paso del Noroeste, del cual esta comunicación hace la parte principal.

"La navegación del mar Glacial, desde el Estrecho del Labrador hasta la entrada del Estrecho de Anian, tal vez parecerá difícil, pero no imposible, como se hubiera podido inferir de los viajes de Phipps y Cook. Por la derrota del navegante español se ve que la costa declina hacia el Sur á la salida del Estrecho del Labrador, y que se halla á los $7 \mathrm{I}^{\circ}$ de latitud hacia la mitad del espacio que separa los dos Estrechos. Mr. Hearne ha hallado la embocadura del río de la Mina de Cobre por cerca de $7 \mathrm{I}^{\circ} 4 \mathrm{O}^{\prime}$, y Mr. Pound, en una carta de sus descubrimientos presentada á la Academia en I786 por Mr. de la Rochefoucault, indica la embocadura del río Arabosca hacia los $65^{\circ}$. Este último no ha llegado hasta el mar Glacial; pero nos dice que parlamentó cerca del.lago Arabosca con cuarenta de los naturales que viven á corta distancia de la costa.

"Estos le confirmaron que en este mar había flujo y reflujo; le aseguraron que no conocían ninguna tierra al Norte, y que habían visto muchas veces allí hielos flotantes; pero que la navegación de los ríos que allí embocan, se hallaba franca desde principios del estío. También preguntó Mr. Pound á muchos salvajes que habían acompañado á Mr. Hearne en su viaje, y nos dice que le ocultaron las principales circunstancias de él, y que en el día es prohibido á todos ir hacia el Ocste: lo mismo sin duda sucedió en el viaje de Mr. Young, del cual jamás se ha tenido conocimiento alguno y en el del Capitán Cluny; pero en lo poco que nos enseña Mr. Pound, nos anuncia bastante que el mar Glacial no es impracticable por la parte de la América. Sólo me resta hablar del Estrecho por donde el navegante español pasó del mar Glacial al del Sur y que él llamó Estrecho de Anian, según las cartas de su tiempo. Se ve que este Estrecho, que él pone por $60^{\circ}$ de latitud y al cual no le da más que un cuarto de legua de anchura, no puedeser el Estrecho de Bering que halló Cook á los $66^{\circ}$ de latitud y de I5 leguas de anchura: luego hay otro Estrecho que todavía no conocemos en esta parte del Noroeste de la América, y por consiguiente de las islas al lugar de las tierras que nosotros tenemos por una parte del continente.

"En efecto, esto es lo que nos indican muchas cartas de los rusos, y particularmente la que Mr. S. Thælin publicó de sus descubrimientos. Se ve en ella una gran isla á continuación de otras muchas pequeñas situadas al Este del Estrecho de Bering y separadas del continente de la América por otro Estrecho.

"La relación del navegante ofrece aquí una gran dificultad, que yo no puedo pasar en silencio. E1 cálculo de su derrota al salir del Estrecho del Labrador, coloca el Estrecho de Anian al Oeste del de Bering y sobre la parte del Nordeste del Asia, donde sabemos por otro lado que allí no hay Estrecho, y así es menester suponer que hay un error considerable en la estima que ha hecho de su derrota. No me atrevo, por consiguiente, á confiar poder determinar de un modo satisfactorio la posición de este Estrecho, y solo propongo como verosímil lo que voy á decir sobre esta materia.

"La latitud del Estrecho de Anian, establecida ó fijada á los $60^{\circ}$, debe ser casi cierta, respecto que estaba así indicada en la relación del Piloto, que halló exacta el navegante, quien por otra parte permaneció allí mucho tiempo para poder asegurarse. Esto supuesto, debe estar el Estrecho hacia Shoal Ness al Oeste del rio de Cook, ó ha cia el Monte de San Elías al Este del mismo río, porque estas son las únicas partes del lado de la América que se hallan en la latitud dicha. Los rusos han reconocido todas las inmediaciones de Shoal Ness, como se ve en la última carta de sus descubrimientos, y no han hallado ningún Estrecho; por consiguiente estamos en la precisión de fijarnos en las cercanías del Monte de San Elías. Por otra parte se adoptará esta posición considerando el camino que hizo el navegante á su salida del Estrecho ó á su entrada en el mar del Sur. Se advierte que él navegó dirigiéndose al Sudeste, y hasta los $55^{\circ}$ de latitud no puede estar sino la costa de la América situada al Sudeste del Monte de San Elías. Del mismo modo la costa que halló á las izo leguas al Oeste de la Amé- 
rica y que siguió en la dirección del Nordeste y hasta el puerto, no puede ser representada sino por la costa de Alaska y las tierras vecinas al rio de Cook. El navegante ha supuesto que esta última costa era una parte de la Tartaria; pero por lo que él mismo dice bajo la fe de las cartas de su tiempo, y porque había supuesto que su Estrecho era el que significaban estas cartas con el nombre de Anian.

"Todavía me inclinaría á admitir esta posición del Estrecho, la consideración de las reclamaciones de la España y de sus pretensiones sobre esta parte de la costa de la América. No cabe duda en que los españoles han tenido conocimiento del Estrecho, supuesto de que independientemente de la relación de nuestro navegante, se lee en Purchas que habiendo entrado Drake en el mar del Sur, quiso el Virey de Méjico construir un fuerte á la entrada del Estrecho por la parte del Mediodía; y que por casualidad pasó por allí el año r6og un bajel de Acapulco, el cual vino á Lisboa. Con este motivo se reconoce la data de la Memoria de nuestro navegante y su proyecto de fortificar el Estrecho. Las cartas antiguas indicaban una continuación de costas de I.70o leguas de extensión, que iban de la punta del Sur de la California hacia el Japón, y es vcrosímil que esto fuese el resultado de los primeros descubrimientos que se hicieron y que después se ha suprimido, porque no se conocía con fundamento. Extendiendo los españoles su derecho hasta Williams Sound á la entrada del Príncipe Guillermo, sin duda que lo han hecho con conocimiento de causa, y es de presumir que han querido incluir el Estrecho en los límites que ellos han reclamado.

"En cuanto á los nuevos establecimientos que se forman en esta parte, tendremos en breve conocimientos ciertos. Se sabe que los rusos han avanzado más allá del río de Cook y tal vez intentarán de nuevo su antigua navegación por el Estrecho donde fueron vistos por nuestro navegante en I588; también es verosímil que los ingleses no esperen á publicar los conocimientos que hoy día tienen del paso del Noroeste, sino es en el mom ento en que se hallen asegurados de la posesión de esta parte de la América que disputan á los españoles.

"Se ha visto en la Memoria del navegante es. pañol, que su Piloto tenía una relación exacta del paso del Noroeste; de donde se debe inferir que semejante paso era ya conocido, ó por lo ménos se había descubierto antes del año de I $5 \$ S$, época de su viaje. El nos dice que su Piloto era portugués, viejo y muy experimentado; pero nosotros sabemos por Purchas, que un portugués llamado Martín Chaeke había descubierto en I555 un paso desde las Indias al mar Septentrional, que había hecho una relación de su viaje, y que este paso se hallaba á los $59^{\circ}$ de latitud, que como se ve es la del Estrecho descubierto por nuestro navegante.

"Un piloto inglés llamado Tomás Cowles, testificó por escrito en I 579 que había leído la relación impresa en 1567 , pero que después de este tiempo no la había podido volver á ver, á causa de haber sido prohibidos y recogidos los ejemplares por orden del Rey de Portugal, temiendo que este descubrimiento acarrease algún perjuicio á su comercio.

"T'ambién se lee en Purchas, que este paso del mar del Sur al mar del Norte fué confirmado por un portugués que aprisionaron los ingleses en tiempo de la Reina Isabel; que otro portugués de Guinea había hablado á Forbisher, como habiéndolo pasado; y en fin, que era comunmente reconocido por los pilotos de Lisboa.

"Después de todas estas consideraciones, me parece que se puede tener por un hecho constante el descubrimiento que acabo de exponer del paso del Noroeste, buscado después de tan largo tiempo. Para conservar la memoria y asegurar la gloria á quien corresponde, he creído debía dar el nombre de Ferrer al estrecho descubierto por el navegante español, tanto más, cuanto es muy incierto que esté allí el verdadero Estrecho de Anian. De este modo llamaré al Estrecho que hace la comunicación de la bahía de Hudson con el mar Glacial, y que hasta ahora se ha llamado Estrecho sin nombre ó Namess Strait. Sacando á luz cste descubrimiento, he dado la solución de un gran número de dificultades, que siendo verdades interesantes, habían declinado á la clase de fabulosas, y en adelante harán leer con mayor interés la historia de las antiguas navegaciones. Acaso habré destruído también las preocupaciones que se opondrían todavía por mucho tiempo á los progresos de la navegación en los mares del Norte, y me atrevo á confiar que el fin del siglo xviI añadirá el conocimiento de las tierras próximas al Polo, y áun del Polo mismo, á todos aquellos con que este siglo ilustrado ha enriquecido la Geografía."

Ya, pues, con las medidas tomadas anteriormente, desde el amanecer del día $r{ }^{\circ}$ de Mayo entrambas corbetas se hallaron enteramente dispuestas para dar la vela; el correo de Méjico que llegó antes de las ocho de la mañana, en nada se oponía á nuestro intento, de suerte que á las nueve y media, con las primeras ventolinas del Noroeste, pudimos zarpar la última amaria y navegar con todo aparejo á franquear con la mayor brevedad la boca del puerto.

Por un acaso poco común, el viento se llamó y mantuvo después al Sursudoeste flojo; la marea no nos era favorable sino en la mucha proximidad de la costa del Sur, y asídebimos continuar 
May u." nuestros bordos hasta las dos de la tarde, á cuya lora, inclinándose finalmente el viento al Oeste maleno, pudimos con la mura estribor pasar como á un cable y medio de la punta de la Bruja y media milla del Diamante, y últimamente, á las cuatro de la tarde, considerarnos libres de loda necesidad de dar fondo.

Si consultásemos las derrotas de las Naos de Manila, lo acaecido al Comodoro Anson próximamente en principios del mes de Mayo y la misma voz común sobre aquellas costas, no era tan fácil el alcanzar las brisas, y aun para este intento debían hacerse sacrificios considerables al Sur; pero las navegaciones últimas de nuestras corbetas parecían oponerse mucho á la infalibilidad de estas reglas, pues la Descubierta, en $\operatorname{los} 13^{\circ}$ de latitud y distante unas 70 leguas de la costa, no había hallado más que calmas y ventolinas variables, y la ATREvida había tenido la fortuna, de que las brisas en su primera travesía le alcanzasen hasta casi la vista del puerto, lográndolas también frescas en su navegación á San Blas luégo que distante de Acapulco unos 6 ó $7^{\circ}$ al Oeste, pudo reponerse en la latitud de 15 y $I 6^{\circ}$. En cuanto á la preferencia de una derrota de altura sobre las costaneras que al mismo tiempo hacían difícil los vientos del Noroeste y las corrientes muy vivas, ninguna duda podía admitirse, tanto más, que cualesquiera derrotas, si hubiesen de conducimos con brevedad á latitudes altas, siempre debían dirigirse á mucha dis tancia de la costa de California para evadir los Nortes y tener mejor bordada con los Noroestes.

Con estas reflexiones se prescribió desde luego el rumbo del Oeste aprovechándole con mayor andar, siempre que los vientos, particularmente por la madrugada, se inclinasen al terral, y aproximándonos de él con preferencia á los rumbos del Sur, siempre que estuviesen á la virazón, ó del Oeste y Oeste-Sudoeste; demasiado descaeceríamos al Sur con el solo efecto de las corrier1tes y de los vientos, sin coadyuvarles por nuestra parte con derrotas voluntarias que nos atrasasen.

No fueron sin embargo frecuentes al principio las ocasiones cn que pudimos apartarnos de la derrota común. Después de cuatro singladuras, al medio día del 5 apénas habíamos adelantado $\mathrm{I}^{\circ}$ al Oestc con el sacrificio de $2^{\circ}$ en la latitud, y los carices no manifestaban aún la proximidad de las brisas; pero al día siguiente ya los vientos se declararon algo más fresquitos y constantes del Nornoroeste y Norte, con los cuales nuestros progresos empezaron á ser considerables y los carices á indicar la brisa no distante. A la sazón, y aun al otro día de haber. perdido la costa de rista, eran pocas las aves que alcanzábamos en el horizonte, y éstas por lo común se ceñían á las dos clases de los pelícanos y laris; un solo bonito de muy corto tamaño ha- May. 6 bía sido presa de nuestros anzuelos. La claridad de los cielos y horizontes, la mar y el viento sumamente apacibles nos recordaban casi con emulación nuestra existencia en el mar Pacífico.

Las variaciones de la aguja, que observábamos diariamente, bien sea por los azimutes ó por las amplitudes, aún manifestaban casi constante la de $6^{\circ} 30^{\prime}$ al Nordeste, y la segunda comparación de nuestros relojes con los de la ATrEvida, hecha al día siguiente, indicaba muy poca diferencia entre unos y otros, manifestando las ecuaciones diarias que aquéllas debían atribuirse más bien á atrasos del número 72 que á adelantos del número Io.

Hasta entonces había sido el objeto esencial de nuestro método de disciplina, el atender á los dos únicos inconvenientes de la deserción y de la falta de asistencia al trabajo; hubiera sido imprudente con una disciplina más molesta é intempestiva, ó representar á los armamentos la idea de un peligro próximo que pidiese el uso de las armas, ó cuidarles con un tesón opresivo una salud que á cada paso podían aventurar en los diferentes puertos visitados hasta aquel momento; de este modo habíamos podido insensiblemente disponerlos para nuestro intento, infundiéndoles otras dos calidades, de las cuales ya no podíamos prescindir, y eran la robustez y un cierto amor y confianza hacia nosotros, de suerte que nos mirasen más bien como amigos que como superiores, en todas las ocasiones que no tuviesen conexión directa con el servicio militar. Pero en el día no podíamos desentendernos de la necesidad de una disciplina militar, la cual al mismo tiempo pusiese á cubierto de cualquier riesgo nuestras vidas y las de los naturales cuyas costas visitásemos, y no distrajese un roce amistoso del cual dependían nuestros progresos en las indagaciones científicas que nos habíamos propuesto; tampoco debíamos omitir cuanto pudiese conducir á la conservación de la salud, en una mudanza tan rápida de clima como la que debíamos encontrar, y en la estrechez con la cual debíamos naturalmente vivir por largo tiempo. Con este objeto se aumentaron á bordo las precauciones para el buen orden $y$ aseo, se encargó estrechamente á la Oficialidad de guardia que vigilase cuotidianamente sobre ambos puntos; pero con tal pulso que ni-un momento se perdiesen de vista el cariño y la confianza recíproca; se repartió alguna ropa de abrigo; finalmente, se formó un plan militar que trazado sobre los escarmientos de los que nos habían precedido en esta especie de viajes, pudiese al mismo tiempo combinarse con todos nuestros intentos y con cualesquiera otras costas que hubiésemos de visitar en lo venidero.

Cualquiera que conozca el carácter de nues- 
\ay. 6 tras marinerías, insensibles á otro freno más que á la razón y al ejemplo de una Oficialidad que respete, y por otra parte tan entregadas á unas pasiones excesivamente vivas como resistentes á una sujeción directa, no extrañará que nuestras medidas en esta parte lleven siempre consigo un sistema casi diametralmente opuesto al que han seguido los ingleses bajo las órdenes del Capitán Cook; bien que en las memorias relativas á la conservación de la salud se anotarán estas razones con mayor extensión, de suerte que manifiesten hasta dónde es preciso extender en el marinero español aquella sensibilidad, razonamiento y viveza de pasiones que tanto difieren del carácter de las marinerías del Norte.

Ya en la estación en la cual nos hallábamos, debimos desistir de toda idea de reconocer ó algunas ó todas las islas intermedias entre el continente y las de Sandwich. Los Comandantes Hezeta y Cuadra habían visto las del Socorro; el Piloto Maurelle la Roca Partida, y el Conde de la Peyrouse, corriendo el paralelo de las de Ulua y los Majos, había conocido ser estas mismas las de Sandwich, con el solo error en longitud, que por lo común encuentran las Naos en la travesía desde Acapulco á las Marianas: el rumbo del Oeste, fué por consiguiente, el que seguimos, y los vientos, aunque algo varios del Nornordeste al Esnordeste, nos fueron tan favorables, que al medio día del 33 habíamos alcanzado la latitud de $I 6^{\circ} 25^{\prime}$ y la longitud al occidente de Acapulco de $14^{\circ} 22^{\prime}$, demorándonos casi al Norte la Isla de Santa Rosa (ó tal vez la Nublada), según la disposición de las costas de San Blas.

La variación de la aguja había por ese tiempo disminuído hasta $2^{\circ}$ y $3^{\circ}$ al Nordeste, conformes en manifestarla así diferentes azimutes, pues que la mucha celajería imposibilitaba el observar las amplitudes occídua y ortiva. Volvió luégo á aumentar con bastante celeridad y el 23, por latitud de $27^{\circ} 22^{\prime}$ y longitud de $28^{\circ} 20^{\prime}$ al Oeste de Acapulco, ya la hallábamos de $8^{\circ} 40^{\prime}$.

Hasta ahora nos habían parecido, si no supérfluas, á lo ménos muy tempranas las experiencias de los eudiómetros, las cuales denotasen con certeza la salubridad del aire que respirábamos, y los progresos de las enfermedades sépticas á medida que la dilatación del viaje, los alimentos, el frío y cualesquiera otras causas cooperasen juntamente á producirlas; pero ya con veintidos días de viaje, con un temple bien diferente del que habíamos experimentado en Acapulco, y precisados, ó bien por el frío ó por la mar algo gruesa á cerrar la portería de barlovento en las noches, hubiera sido omisión reprensible el no darlas principio con toda aquella exactitud que requería la novedad y la importancia de esta materia: encargáronsc, pues, de diclıo examen D. Francisco Flores y D. Tadeo Heenke, May a: y los primeros resultados debieron parecernos bien agradables, pues veíamos reunida á una salubridad considerable en el aire atmosférico, una grande aproximación de todos los demás que habíamos examinado, entre ellos los de la bodega y entrada de la sentina. Renovadas las mismas experiencias en la mañana del $3 \mathrm{I}$, dieron los mis mos resultados, aunque sustituyésemos el uso del agua salada á la dulce para el traspaso de los aires. Todo conducía á convencernos que el sólo desaseo y la falta de ventilación eran las causas de respirarse un aire más infecto en el mar que no en la tierra.

Todo el mes de Mayo no podía haber sido más feliz; por latitud de $3 \mathrm{I}^{\circ}$ nos hallábamos entre los vientos variables; la distancia de la costa nos permitía indiferentemente aquellos bordos que con mayor brevedad nos elevasen hacia el Norte $y^{\prime}$ las tripulaciones más bien se habían robustecido; sólo sí, que en la corbeta Atrevida habían tenido la desazón de ver inutilizado por una extraña casualidad el reloj número ro del Sr. Berthoud: olvidado accidentalmente el darle cuerda, no fué después posible el volverle á poner en movimiento, por cuanto se adoptasen las sacudidas y un calor violento artificial; el temor de romper una máquina tan preciosa, dictó como más prudente el dejarle así parado más bien que desarmarle; pues no debía quedar duda que lo espeso y crasoso de los aceites, combinados con algún frío que le condensase, era la verdadera causa de la imposibilidad para adquirir nuevamente el antiguo movimiento.

Ya desde los paralelos indicados nuestra nan vegación hacia el Norte debió por naturaleza ser más acelerada: experimentáronse algunos temporales por el Oeste y Oesnoroeste, los cuales no tenían para nosotros sino el sólo inconveniente de hacernos descaecer algo más sobre la costa; repetidas con mucha frecuencia las distancias lunares, nos indicaban un error al Oeste de medio grado próximamente para los relojes marinos; y como á medida que nos elevábamos hacia el polo, la costa inclinaba más y más su dirección al Oeste, finalmente, por latitud de $5^{6}$ I $7^{\prime}$ avistóse el día 23 la tierra bastantemente distante y elevada.

Era la comprendida entre el Cabo Engaño y las islas septentrionales al Cabo San Bartolomé reconocida por el Capitán de fragata D. Juan de la Cuadra en I775, por el Capitán Cook en 1778 y por el capitán Dixon en I786: no tardamos en distinguir el monte Edgecumbre, llamado por Cuadra, de San Jacinto, la grande ensenada que él mismo llamó del Susto, y poco después el abra del Cabo Landers y puerto de Banks visitados por el Capitán Dixon; nos demoraban el Cabo Engaño al Norte $I 4^{\circ} 30^{\prime}$ Oeste de la aguja, la 
Iun. 5 punta Sur de la ensenada del Susto, que llamamos Serena por la serenidad del día que lográbamos á la sazón, al Norte $5^{\circ} 30^{\prime}$ Este; y los extremos al Este, al parecer una punta roma, no distante de una isla algo grande, al Norte $77^{\circ} 30^{\prime}$ Este; la descripción de este trozo bien individualizada por el Capitán Cook, nos pareció corresponder puntualmente á la exactitud de aquel navegante exclarecido: un número crecido de mogotes altos (probablemente islas) indicaba un número casi igual de buenos puertos; entre la isla y la punta roma, en el extremo del Este, se veía claramente una abra ó estrecho considerable; no se nos ocultaba tampoco que la tierra del monte Edgecumbre era otra isla; y el erguido descuello del mismo monte le hacía notable entre todos los demás, y por consiguiente, muy oportuno para guiar en este paraje al navegante incierto, que carezca, como frecuentemente sucede, de la latitud observada; las vistas que damos de este monte 10 manifiestan tal vez ménos alto de lo que pudiera inferirse del viaje del navegante inglés; logramos medir su altura con toda exactitud, y como la diferencia de latitudes determinase con mucha seguridad la distancia, podemos creer que nuestros resultados se aproximen á la verdad. D. Juan de la Cuadra había ya determinado á la Punta ó Cabo de Engaño la latitud de $57^{\circ} 2^{\prime}$; no le excede más que en un minuto la que supone el Capitán Cook, y así no debíamos tener la menor desconfianza de la distancia de leguas al monte, y finalmente, de su altura sobre el nivel del mar.

Era muy poca, á la sazón, la nieve que notábamos sobre su cumbre; antes bien, nos pareció que la conservaban más baja y más copiosa varios otros cerros interiores á la ensenada del Susto y á la Punta Serena. No se halló fondo con 120 brazas de sondaleza; la variación magnética, así por el azimute meridiano, como por varios otros azimutes, fué de $24^{\circ}$ á $25^{\circ}$ Nordeste.

La comparación de nuestras longitudes con las del navegante inglés era un punto importante para que le descuidásemos en esta ocasión, tanto más oportuna, cuanto que el Cabo Edgecumbre ó del Engaño era un paraje de los que había determinado con mayor exactitud, y dependía de una traresía de pocos días desde Nutka, después de una conformidad grande entre las distancias lunares y una observación del primer satélite de Júpiter, y después de un arreglo bien prolijo de sus relojes marinos. Se agregaba á estas razones en favor de la detcrminación indicada, el reparo de convonir exactamente en la carta inglesa la longitud del puerto de San Pedro y San Pablo en liamshatlia, con la que resultaba de las observaciones del primer satélite de Júpiter hechas en el mismo puerto por el Sr. cle Krissilinkof, y cxaminadas con tanta sagacidal por el Sr. Coxe: de suerte que sujetos ambos extremos, parecía Jun. I5 que las longitudes medias debían también considerarse como seguras.

Hé aquí nuestros resultados y los del Capitán inglés:

\begin{tabular}{|c|c|c|c|}
\hline & $\begin{array}{c}\text { Longitudes } \\
\text { occidentales } \\
\text { de Paris para } \\
\text { el Cabo Ed- } \\
\text { gecumbre por } \\
\text { los relojes } \\
\text { marinos. }\end{array}$ & $\begin{array}{c}\text { Idem por las } \\
\text { distancias } \\
\text { Junares. }\end{array}$ & Idem por el Capitán Cook. \\
\hline Cronóm. 72 & I 38.49 .13 & $\left\{\begin{array}{l}\text { I } 95 \text { series } \\
\text { en los días } \\
6,7 \text { y Io } \\
\text { de Tunio }\end{array}\right.$ & $13^{8.31 .3^{8}} 13^{8.15 \cdot 30}$ \\
\hline Cronóm. $7 \mathrm{I}$ & $\mathrm{I} 38.48 .30$ & | & is \\
\hline Cronóm. 6I & $138.38 .30^{\prime}$ & $\left.\begin{array}{c}97 \text { fd. día } \\
23 \ldots\end{array}\right\}$ & $137.3 \mathrm{I}$ \\
\hline Reloj I05. & $13^{8.42 .10}$ & ” & 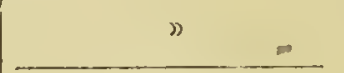 \\
\hline Promedios.. & I $38.44 \cdot 37$ & " & I38.1.1 9 I38.I 5.30 \\
\hline
\end{tabular}

Pareció preferente el adoptar los resultados del Capitán Cook, á lo ménos hasta que tuviésemos por nuestra parte observaciones celestes que determinasen más directamente su exactitud.

Algo más feliz que nosotros el Sr. Heenke en sus pesquisas para la Historia Natural, logró en el mismo día examinar diferentes especies de moluscos, entre las cuales una enteramente nueva, que distinguió con el nombre de Speciosa, merecía particular atención, no ménos por su tamaño y movimiento vivo ondulatorio, que por los colores mezclados de perla y púrpura que en diferentes partes presentaban el contraste más vivo y agradable: no debía sernos extraño que las demás especies, conocidas anteriormente con los nombres de Medusa eguorea cruciata aurita, fuesen en un todo semejantes á las que se hallaban en el mar Báltico: una grande harmonía en los productos de la naturaleza trasluce á cada paso cuando éstos se examinen y comparen, sobre todo, la extensión del globo.

No era nuestro ánimo el sacrificar un día siquiera de la actual estación favorable al reconocimiento prolijo de las costas que teníamos actualmente á la vista; antes bien, con el đeseo de alcanzar cuanto antes los paralelos inmediatos al de $60^{\circ}$ hacia donde debían dirigirse nuestras pesquisas, no podíamos desentendernos que el recalar en paralelos tan bajos era sólo efecto de los últimos vientos escasos, y que la misma corta distancia á la costa sería un nuevo obstáculo para gozar de vientos frescos y favorables. Así, luégo que pasadas algunas horas de calma, logramos en la mañanita del 24 ver entablado viento galeno del Este, hicimos rumbos más bien algo divergentes de la costa, la cual, sin embargo, lográbamos no perder de vista con el auxilio de un tiempo bien claro y placentero; á las tres de la mañana el Monte Edgecumbre nos demoraba al Norte de la aguja, y al mcdio día ya le mar. 
cábamos al Norte $72^{\circ} 30^{\prime}$ Este, viéndose al mismo tiempo el monte nevado de Tairweather ó Buen Tiempo al Norte $25^{\circ} 30^{\prime}$ Oeste; en este punto era nuestra latitud de $67^{\circ}$ Io' y la longitud por el cronómetro 72 de $37^{\circ} 23^{\prime} 30^{\prime \prime}$ al Oeste de Acapulco; la variación magnética, próximamente de $25^{\circ}$.

En balde, á la distancia á que navegábamos de la costa, intentábamos determinar la verdadera posición de los puertos de Guadalupe y de los Remedios, visitados en el año 75 por el Teniente de navío Cuadra: varios mogotes que ya en una, ya en otra parte, se hacían visibles hacia el Noroeste del Cabo de Engaño, debían naturalmente confundirse unos con otros, abriendo á veces unas al parecer bocas, que á poco rato notábamos ser más bien efecto del terreno, en partes nevado y en parte no. Pero no podía ocultársenos el Monte de la Cruz, así llamado por el Capitán Cook, desde donde sigue la cordillera que termina en el Monte Tairweather; medimos su altura y la de este último monte notable, el cual en aquella estación tan benigna estaba aún cubierto de nieve hasta la falda.

Hasta las cuatro de la tarde habíamos gozado del viento favorable del primer cuadrante, bien que ya muy calmoso, pero poco después roló al Noroeste precisándonos á ceñir al Oestesudoeste con mar algo gruesa, que en nuestro mal estado de estiva nos causaba un abatimiento considerable. Continuamos el mismo bordo hasta las cuatro de la mañana, á cuya hora marcábamos el Cabo Tairweather al Norte $15^{\circ}$ Este de la aguja, y luégo tomamos las muras á babor, lisonjeándonos que con el día el viento que aún se mantenía del Noroeste rolaría algo más á la virazón. No puede imaginarse un tiempo más sereno y placentero del que gozábamos á la sazón. D. Felipe Bausá había conseguido tomar á la una y media de la mañana una vista del Cabo Buen Tiempo, aunque bien distante, y al salir el Sol, una marcación segura á su centro nos manifestaba la variación de la aguja de $24^{\circ}$ I $5^{\prime}$ al Nordeste.

En la misma mañana, I05 series de distancias lunares conformes entre sí y medidas con circunstancias bien favorables, manifestaban una longitud aún más oriental que la del día 23 , pues se apartaba en $\mathrm{I}^{\circ}$ y $32^{\prime}$ de la del cronómetro 72 , cuyo movimiento, sin embargo, continuaba tan arreglado y uniforme como le habíamos advertido hasta entonces.

Fué nuestra longitud al medio día, de $39^{\circ} 35^{\prime}$ y la latitud de $57^{\circ} 59^{\prime}$ demorándonos á este tiempo el Cabo Buen Tiempo al Norte $3^{\circ}$ Este de la aguja, y el monte, al Norte I $^{\circ}$ Este, de suerte que ya podíamos sin el menor recelo continuar nuestro bordo hacia la bahía de Bering, tanto más que las estimas diarias nos manifestaran casi segura la dirección de una corriente favorable hacia el Norte. En efecto, ya á las ocho de la tarde conseguimos marcar el Monte Buen Tiempo al Norte $33^{\circ}$ Este, distancia como siete leguas, viéndose al mismo tiempo una parte de la costa hacia el Oeste, en la cual nuestra imaginación y nuestros deseos nos representaban como existentes algunas abras grandes que á veces sospechábamos ser las de Bering y á veces otras de una internación mayor y más favorable. A la verdad, por cuanto se ciñesen las conjeturas de Mr. de Bauche sobre la existencia del paso al paralelo de $60^{\circ}$, no podíamos desentendernos después de un examen maduro, ni de la poca exactitud de los instrumentos náuticos por los años de I588, que pudieran muy bien equivocar la latitud en $\mathrm{I}^{\circ}$, ni de las advertencias del Capitán Cook, el que había notado hacia la bahía de Bering un trozo de tierra llana que por consiguiente debía reconocerse con toda exactitud; pero temiendo que las calimas ó los vientos contrarios no permitiesen este examen con las corbetas, hallábamos preferente el verificarlo con las lanchas, mientras las corbetas en el puerto Mulgrave (I) se abasteciesen de agua, leña y lastre.

Con estas reflexiones pareció prudente el dar una mirada siquiera á la calidad de aquellas costas, de suerte que las lanchas pudiesen aventurarse con mayor conocimiento ó inclinarse hacia los parajes á donde más fácil fuese hallar un abrigo para los vientos contrarios. Con este solo intento se prolongó por la tarde el bordo hasta muy corta distancia de la tierra, y sólo á las once fué preciso tomar la vuelta de fuera, porque cerrado el tiempo con chubascos y ventolinas variables por lo común escasas y á veces calmosas, nos aconchaba demasiado sin darnos ventaja alguna ni en latitud ni en longitud: la sonda aún no había dado fondo con I20 brazas.

Ya á las dos de la mañana entabló viento fresquito del Sudoeste, que despejado mediana. mente el cielo nos dió lugar á navegar con gavias y mayores al Noroeste; pero la costa estaba aún muy cargada de arrumazón, de suerte que no pudimos verla hasta las tres, aunque á la sazón no excediese su distancia de cuatro ó cinco leguas; nos hallábamos precisamente entre las dos bahías avistadas en la tarde anterior; se nos representaba una isla que creíamos la indicada en las cartas inglesas, y los montes distantes estaban todos cubiertos de nieve hasta la falda: á las cinco ya no distábamos más que cuatro millas de la costa y particularmente de unos pedruscos amogotados, que al principio creimos islotes,

(I) Así llamado por el Capitán Dixon, que fué el primero á visitarle.

\section{Juก. 24}

(1) 
pero que vimos luégo unidos á la tierra firme por medio de un arenal: el viento era aún escaso y calmoso y la marejada algo gruesa, lo cual nos obligó á navegar hasta las siete del bordo de fuera.

Inmediata á la orilla y antepuesta á toda la cordillera nevada que desciende del Cabo Buen Tiempo, se extendía por largo trecho una faja de terreno bajo tan poblada de pinos hermosamente frondosos, que si pudiesen por algún tiempo ocultarse las nieves que le dominan, sin duda darían una idea más bien de un paralelo inmediato á la Línea, que de uno no distante del círculo polar: se agregaban á aquella hermosa perspectiva diferentes manchas de nieve en los ángulos salientes, que ó bien reflejaban con nuevo brillo los rayos benéficos del Sol ó representaban á la imaginación con diferentes sombras, ya un camino bien ancho ó ya unos campos perfectamente nivelados: muchas bandadas de chorlitos voleteaban en nuestras inmediaciones; el agua había tomado un color más verdoso y la hallábamos mucho ménos salada de la común del mar; finalmente, á medida que se iban disipando la calima ó las nubes, parecían extenderse más y más hacia el Oeste las arboledas que daban tan hermoso realce á aquella escena.

Se observaron algunas series de horarios; se corrieron constantemente bases, y al medio día se halló la latitud de $59^{\circ}$ Oeste, considerándonos en longitud de $38^{\circ} 46^{\prime}$ y manifestando el azimute meridiano una variación de $34^{\circ}$, que muy extraña si se comparase á las demás, debía sin duda atribuirse á un efecto extraordinario de la atracción de los montes inmediatos. Hacia las cuatro de la tarde, la ATREvida encontró fondo con 50 brazas, hallándonos á la sazón desviados de la orilla unas tres leguas.

En el actual reconocimiento ya disipadas cualesquiera dudas sobre la existencia de un paso ó de un abra siquiera más bien nuestras pesquisas se dirigían á combinar lo que había visto el $\mathrm{Ca}$ pitán Cook; pues no existiendo la isla que pone en la entrada de la bahía de Bering, deseábamos acertar con la parte de costa que le había causado aquella equivocación nada extraña en la distancia de siete leguas á que navegaba. La que nos había parecido isla por la mañanita, distaba mucho al Oeste de la caída de la cordillera que desciende del monte Buen Tiempo, y desde ésta hasta el principio de la otra que sigue hacia el monte de San Elías, ningún monte chico aislado se dejaba ver entre la tierra llana que efectivamente veíamos extenderse más adentro de la primera cadena de montes. Si el Comandante Bering (como lo sospecha el Capitán Cook) recaló ́́ esa parte de costa que de ningún modo puede llamarse sino una costa brava, no debía ser extrino que no hubiese podidn mantenerse fondea- do por largo tiempo, bien que el haber desem- Jul, 26 barcado sus gentes precisamente en una isla y el hallarse ésta en latitud de $58^{\circ} 28^{\prime}$, hacen creer que deba más bien suponerse su recalada hacia la entrada de la Cruz.

Las observaciones de longitud hechas á las seis de la tarde, nos indicaron una corriente no muy rápida hacia el Este, y en efecto, por cuanto nos esforzásemos en aprovechar cualesquiera ventolinas, apenas habíamos ganado desde el medio día unos diez minutos en longitud y nuestra distancia á la costa no era mayor de siete á ocho millas: advertíamos á la sazón en la inmediación de las arboledas una ú otra llamarada, señal segura de habitantes. El viento se conservaba aún calmoso del Sur, y los cielos y horizontes bien despejados y apacibles, no tardaron, sin embargo, en llenarse de calima, cuando ya puesto el Sol empezó el viento á rolar hacia el Este: con él navegóse alguna distancia, y á la media noche ya por fondo de 70 brazas arena nos habíamos alejado unas cinco leguas de la costa.

Asegurado á lo ménos por algunas horas el viento favorable, no nos descuidamos en emprender de nuevo un reconocimiento bien prolijo, orzando antes al Noroeste y luégo al Norte sobre las gavias, por manera que á las tres de la mañana sólo distásemos dos millas escasas de la playa, por fondo de 22 brazas arena negra fina: antes de llegar á esta posición, la casualidad de estar claros los horizontes del primer cuadrante, nos había proporcionado la vista de los montes traseros á la bahía de Bering, cargados de nieve y regularmente altos, formando una segunda cordillera que disipaba por consiguiente cualesquiera sospechas de la existencia de un mar hacia el Norte, como parecía indicarlo el Capitán Cook: al mismo tiempo veíamos sin la menor duda el montecito aislado que desde lejos pudiera equivocarse por isla; bien que si consultásemos la latî́ud de $59^{\circ}$ I $8^{\prime}$ determinada por el Capitán inglés, debían más bien recaer nuestras sospechas en un trozo de tierra llana que sigue al Oesnoroeste.

Continuábamos á distancia de una ó dos leguas reconociendo la costa que conduce á la Punta Carrew (I) del Capitán Dixon, y áun favorecidos del viento, ya á las seis de la mañana habíamos atracado aquella misma punta, examinando prolijamente la entrada del puerto Mulgrave, cuando en la cordillera de montes cuyas faldas baña el mar en lo más hondo de la bahía del Almirantazgo, descubrióse un abra cuya boca é internación culebreada parecían asemejarse á las tierras de Ferrer Maldonado: muy

(I) Por la comodidad de la pronunciación y ortografía española más bien que para tomar el derecho de descubridores, se ha variado el nombre de la Pun. ta Carrew y algunos otros parajes de aquella costa. 
Tul. 27 luégo la imaginación prestó mil razones aparentes al deseo: contemplábamos todo lo que parecía poderse combinar con la descripción del paso; rechazábamos ó procurábamos justificar lo que de ningún modo concurría con el terreno descrito; finalmente, cada uno á su albedrío, ó alargaba la extensión de la cañada hacia el Norte ó atribuía á la distancia y á la vista la falta de aquellas circunstancias que aún no podían reunirse para disipar las últimas dudas. Puede imaginarse que no tardamos un momento en orzarhacia el abra indicada, pues, sin embargo que no fuese nuestro ánimo el aventurar las corbetas sobre la sola relación de Ferrer Maldonado, era muy importante examinar de cerca la probabilidad de su continuación hacia el Norte, y si ésta quedase enteramente destruída, continuar nuestra derrota hacia la entrada del Príncipe Gui11 rmo.

Toda la costa que desde la bahía de Bering corre hacia la Punta Muñoz, es igualmente formada de la misma faja de arena, cascajo y tierra vegetal que en el día anterior habíamos notado hermosamente poblada de un monte majestuoso de pinos: puede creerse que á distancia de una ó dos millas conserva el mismo fondo de 20 á 22 brazas arena, pero no presenta el menor abrigo que convide al navegante á frecuentarla: ya en las inmediaciones de la punta, el fondo crece rápidamente á 50 y á 60 brazas cascajo; ni se halla menor en parte alguna de la bahía externa, luégo que se aparte una milla siquiera de las costas ó de los arrecifes.

La playa desde la Punta de $\mathrm{Muñoz}$ y mucho más desde la que le sigue, tuerce rápidamente hacia el Norte inclinándose después al Oeste, y como le estén muy próximas y frontęras diferentes islas tendidas ya en una ya en otra dirección, forma naturalmente algunos puertos tan cómodos para su seguridad y abrigo como agradables por la lozanía de la vegetación: estas islas y tierra baja salen afuera como tres leguas desde la cordillera inmediata, la cual luégo vuelve á aproximarse al mar hacia el abra indicada y fondo de la bahía, y se retira de nuevo para dar lugar á otra faja igualmente lozana de tierra baja, que después de algunas barrancas corre hacia el Oeste hasta las faldas de la montaña de San Elías.

Ya navegando hacia la boca indicada, empezamos á precavernos con la sonda de cualquier peligro, tanto más, que atravesando como á una y media milla del extremo exterior de la isla más Sur, habíamos encontrado II brazas cascajo y veíamos hacia la costa algo sospechosos los arrecifes salientes; pero muy luégo conocimos que los fondos de la bahía, áun comprendida la inmediación de las islitas internas, más bien tenían el inconveniente de un grande exceso que de una cortedad peligrosa; pues, ni nosotros con
40 y 50 brazas, ni á veces la ATREvidA, podía Jul. 27 alcanzarle con ménos de So; y (lo que ya exigía alguna atención) ambas puntas del abra eran tan escarpadas y á pique, que no debían dejar duda de un fondo probablemente excesivo y pedregoso en sus mismas inmediaciones.

A las nueve de la mañana ya con viento cal. moso del Este, horizontes achubascados y alguna garua, distábamos una y media legua de la boca sospechosa; y aunque la suma debilidad de las mareas concurriesen á la sazón á confirmar la sospecha de conocerse á la vista la muy corta internación del canal, como no pudiese esto realmente, asegurarse sin recelo de equivocación harto posible en la proyección de las quebradas, pareció debido el dirigirnos al puerto inmediato de Mulgrave para emprender luégo con las lanchas un reconocimiento prolijo, al paso que los buques se abasteciesen de agua y leña. Reviramos, por consiguiente, para alcanzar sobre bor dos el mismo canal que desde la punta Filipps conduce al puerto; el viento á la sazón se ha bía declarado al Este y Esueste bonancible con tiempo cerrado de llovizna y algunas ráfagas no fuertes.

No ignorábamos por las relaciones del Capitán Dixon, que estas islas eran habitadas por un corto número de gentes; pero ya á las diez nos lo confirmaron dos canoas grandes y una pequeña, que poco distantes una de otra salían de un canal y parecían dirigirse á la ATrevida que navegaba por nuestra popa: resonaba á mucha distancia el himno harmonioso de paz, al cual acompañaron después la señal no dudosa de los brazos abiertos, para demostrar que venían inermes y que sólo ansiaban de nuestra parte unas ideas pacíficas y amistosas.

Como casi al mismo tiempo hubiésemos determinado virar y dirigirnos al fondeadero, muy luégo pudieron ambas canoas grandes hallarse al costado de las corbetas, y finalmente, atracarle, no sin preceder algunas muestras de temor y seguir en todo las órdenes ó avisos de un viejo venerable que en la canoa pequeña vogaba yá á una ya á otra parte y daba todas las señales dc ser el caudillo de la pequeña tríbu.

Precedidas por una y otra parte las primeras muestras harto equívocas del instinto sociable, é interpretado por cada uno cada expresión ó gesto más bien por los dictados de la imaginación que del razonamiento, se dirigieron como era natural nuestros esfuerzos á convidarles á bordo, agasajándoles en primer lugar con galletas, tocino y sebo; y accediendo después á su instancia de que bajasen como rehenes á la canoa tantos hombres nuestros cuantos entre ellos subiesen á bordo, no tardaron de este modo en convencerse de la seguridad de nuestras ideas pacíficas; y como no nos descuidásemos al mis- 
1ul. 27 tho tiempo en regalar algunas frioleras á los que subieron primero, ya media hora después ni necesitábamos dar rehenes para los que subiesen, ni era precisa de nuestra parte la menor instancia para este intento, tanto más, que se dejaba ver en casi todos una propensión grande á deslizarse bajo cubierta, sin duda con ánimo de robar, ya una ya otra friolera de las que estuviesen á mano.

Se mantuvieron á bordo hasta después del medio día; en todas sus acciones manifestaron un genio vivo y alegre y no tardando nuestra tropa y marinería en desprenderse ó bien de una parte de su ración ó de sus vestidos, fueron precisas muchas instancias para que se embarcasen y apartasen la canoa del costado, la cual podía correr algún riesgo por el viento á la sazón fresco del Esnordeste y los bordos algo largos y repetidos que debíamos correr.

Con la tarde se cerró mucho más el tiempo, de suerte que apenas veíamos las dos costas que ceñían nuestros bordos, y nos era preciso virar con mayor precaución, pues que salían de la punta Muñoz hacia el Sudeste algunas restingas de bastante extensión: la marea nos fué constantemente contraria; el viento calmó casi de un todo; los bordos eran precisamente muy cortos, y así, eran las siete de la tarde cuando montada la punta de Turner, pudimos de jar caer el ancla en I2 brazas lama delante de la ran chería de la islita y no distantes más de un cable de la playa.

Desde el momento que franqueada la punta habíamos empezado á coger el abrigo y aproximarnos al fondeadero, fueron muchas las canoas que salieron á encontrarnos, repitiendo unas veces el himno de paz, otras una voz general harmoniosa al parecer de convite ó admiración, y ofreciéndonos por cambio, más bien algún salmón y artefactos de madera, que las pieles de nutria á las cuales procuraban dar un valor cuantioso. Admiraron con mucho silencio y tal vez no sin algún temor nuestia faena de echar las embarcaciones menores al agua y particular. mente la lancha; y finalmente, siendo ya las nueve de la tarde y tendido por ambas corbetas un anclote al Norte por segunda amarra, nos despedimos con recíprocas señales de amistad para lograr de un mediano descanso.

Cuál fuese nuestra posición en el puerto Mulgrave y cuál la amenidad de sus contornos, 10 indicarán más bien las perspectivas que acompañan á esta relación que cualesquiera descrip. ciones aunque prolijas y estudiadas para el intento: á pesar del tiempo lluvioso y cerrado todo anunciaba un clima apacible; el puerto podía más bien llamarse una dársena, los naturales estaban inmediatos $\mathrm{y}$ en bastante número para estudiar sin recelo $y$ sin molestias sus costumbres; $y$ el agua, leña, lastre, pescado y vegetales, todas co- Jul. 27 sas que necesitábamos, estaban tan á mano, que ni áun podía llamarse molestia la que debíamos emplear para acarrearlos á bordo.

A la verdad, el agua y lastre debían buscarse en la isla ó playa del Este del fondeadero, y aún no nos hubiera sido fácil el hallar tan luego el paraje oportuno de la primera, si un indio de los más dispuestos que habían concurrido á bordo desde la mañanita, no nos hubiese acompañado para buscarla; pero la tranquilidad constante del mar, la poca fuerza de la marea y la duración del día auxiliaban de tal modo á estas tareas, que desde luego podíamos mirarlas como agradables más bien que incómodas.

Ya desde la mañanita, los naturales habían concurrido en bastante número á bordo de una y otra corbeta, empezando á proponer algunas pieles, muchos salmones frescos y uno ú otro uten. silio de madera en cambio de ropa y hierro, únicas cosas que manifestaban apetecer con ahinco, sin embargo que admitían toda especie de botones, varios clavos y una ú otra pieza de las muchas que comprende la voz de quincallería.

Procuraron estrechar su familiaridad con las tripulaciones, y como en el carácter del navegante, el capricho ó el antojo sustituyen á la necesidad con un exceso difícil de comprenderse, desde luego, en los primeros cambios, conocieron que esta especie de mercado les sería sumamente ventajosa; y si juzgásemos por el ansia de los contratantes, más bien debíamos inferir que nuestros marineros no pudieran vivir sin la adquisición de todo lo que veían, que los naturales sin la ropa y el hierro que con tanta razón anhelaban.

Las tretas de que usan estos naturales en sus cambios ó contratos han sido muy bien descritas por el Capitán Dixon: no sólo traen ocultos los efectos que intentan cambiar, sino que nunca se presentan con mayor indiferencia que en esas ocasiones. Después de un plazo á veces mayor de una hora en que se mantienen tranquilos á la vista de los muchos objetos que se les presentan, descubren finalmente ó una tira de piel, ó una muñeca, ó una cuchara, ó cualquiera otra bagatela, solicitando cambiarla por todo lo que ven. Apelan al tamaño y á la simetría, cuando ya no pueden apelar á la calidad; convenido el cambio lo vuelven á anular; y finalmente, si entre las cosas que traen hay alguna piel realmente buena, la enseñan con tanto misterio, la retiran tan luego y vuelven después á manifestarla, que excitan en el ánimo más indiferente una mezcla singular de enfado y de antojo, difícil de sujetarse por las miras solas del interés.

No se advierte entre ellos la menor competencia ó para la adquisición ó para la alienación; antes bien, reunidos con admirable unanimidad todos los intereses, ó consultan entre sí para lic 
Iul. 27 verificación del cambio, ó bien si llegasen á verificarlo, lo aplauden con una, dos ó tres aclamaciones unánimes, según imaginan que el contrato les ha sido más ó ménos ventajoso.

Desde las nueve de la mañana, ambos botes con el mayor número de la Oficialidad, se habían dirigido á reconocer el paraje más oportuno de la aguada; uno de los naturales, con la facilidad admirable de que todos están dotados de comprender ó hacerse comprender por señas, los guió antes á un paraje no distante pero muy escaso de agua luégo los dirigió á la playa opuesta ó del Sudeste en donde efectivamente se hallaban como á un tiro de fusil diferentes manantiales, capaces cuando se les formasen algunas pozas, de suministrar toda el agua necesaria: visitaron en esta ocasión una choza no distante de la aguada, que el indio conductor parecía expresarles ser la de su familia, y tributada la natural curiosidad y admiración al desabrigo, suciedad y estrechez con que vivían dos mujeres y algunos niños, como también á los adornos, trajes, alimentos y utensilios que allí se hallaban, regresaron á bordo hacia el medio día, acompañados siempre de una lluvia bastantemente fuerte, que ocultaba la vista de cualesquiera otros objetos más distantes: no por esto se omitió en el entretanto el examinar la playa inmediata al fondeadero para la medida de una base, y particularmente el procurar estrechar la amistad de los naturales, familiarizándonos algún tanto con las voces de una necesidad más inmediata y enterándonos de sus costumbres ó inclinaciones. Desde luégo, por nuestra parte, se habían tomado muchas medidas para que nada pudiese enturbiar un roce amistoso: nuestra vigilancia á todas horas usando aún la precaución de pasar la palabra de noche de una á otra corbeta, debía disiparles cualesquiera ideas de la posibilidad de una sorpresa: podían verse prontas á bordo diferentes armas de fuego, que debieran atemorizarlos: se prohibió todo roce de las clases inferiores con las mujeres $y$ niños en sus chozas; finalmente, al paso que deseábamos apartarlos con estas precauciones de la idea de hostilizarlos, eran constantes nuestros regalos y bien expléndidos particularmente por parte de la marinería: las repetidas señales que desde el día anterior nos habían hecho de facilitarnos el uso de las mujeres cuando nos hallábamos en el puerto, aunque bastantemente claras nos parecían aún equívocas y tal vez mal interpretadas, si consultásemos la poca concurrencia en aquel paraje de buques europeos y la extrañeza de semejante of recimiento, cuando no le dirigiesen ni la veneración ó el cariño hacia nosotros, ni unas costumbres transformadas del lujo, del interés y del ejemplo: hallándose, pues, á la sazón, no distante de las chozas uno de los Oficiales é importunado ya de esta especie de ofrecimientos, quiso cer- ciorarse de su verdadera significación, tanto más, Jul. =; que si realmente existiese aquella facilidad como la suponíamos, era importante el precavernos para el buen orden de los primeros pasos de las tripulaciones, ó si no fuese verdad, debíamos disipar esta idea siniestra de su carácter y costumbres: dirigido por consiguiente de dos jóvenes naturales que con un aire misterioso le repetían la ya conocida voz de Shoüt, se aproximó á unos árboles inmediatos á las chozas y entonces fué fácil disipar cualesquiera dudas, pues efectivamente se hallaban al pié del arbol cuatro ó cinco mujeres medianamente cubiertas con pieles de lobo marino y desde luégo obedientes á la voluntad de casi toda la tribu, que parecía unánime en la intención de prostituirlas: cuanto no alcanzasen la moral ni el ejemplo á apartar toda idea de esa especie, lo hubieran conseguido ciertamente el semblante horrible y la mucha grasa y suciedad de que estaban cubiertas, despidiendo un olor difícil de describirse por lo desagradable.

El viejo caudillo que en la mañana anterior había sido regalado á bordo de la ATREvidA y á la sazón había pasado á la Descubierta á impulsos del Comandante de aquella corbeta, con quien parecía haber estrechado una amistad duradera, logramos muy luégo el que D. Tomás Suria le retratase con mucha exactitud; dejó á un hijo suyo el cuidado de atender á los cambios, en los cuales prefería los vestidos á cualesquiera otras cosas; y últimamente trabó con nosotro ‘ una conversacion seguida, cuyo objeto era en nuestro entender el de describirnos algunas reyertas tenidas no había mucho con sus vecinos: era su presencia realmente respetable, bien sea por la edad, por la estatura ó por el vigor que traslucía en todas sus acciones: cada parte de la reyerta se nos representaba con los colores más vivos: entendimos que los enemigos traían hasta seis fusiles (I), que había habido algunos muertos de una y otra parte, y que habían pedido la paz y ésta muy luégo concedida; pero lo que debió causarnos la mayor confusión para la cabal inteligencia de esta narración, fué la representación que nos hizo de que de partc de los enemigos había un hombre á caballo, llcgando sus deseos de que así lo entendiésemos. hasta hacer llamar á su hijo y ponerle en la postura de un cuadrúpedo, scñalando luégo que el enemigo le montaba: á la sazón ya se había concluído su retrato á cuya vista se complació mucho, solicitando con ansia que no sólo se re-

(1) Por cuanto hayamos combinado las noticias posteriores, no pudiéramos apropiar esta narración sino es al combate harto sangriento que tuvieron las dos lanchas del Conde de la Péyrouse, ó en aquellas inmediaciones ó en las de la entrada del Príncipe Guillermo. La descripción del caballo pudiera interpretarse tal vez por el modo europeo de tomar los botes la Oficialidad desde las playas. 
Jul. 27 \{latase también el morrión (I) (que nos enseñaba) del caudillo enemigo, vencido en la reyerta, sino que se expresase individualmente que era el fruto $y$ la señal de la victoria; finalmente, ya bien adelantada la tarde y empleados de nuestra parte cuantos halagos pudiesen estrechar la conflanza y la amistad, se despidió el Cacique de á bordo y pudimos comer tranquilamente.

Según amaneció al día siguiente, parecía que cl tiempo continuaría aún constante del Sueste con cerrazón y llovizna; debimos, por consiguiente, desistir aún de toda idea de operaciones hidrográficas y astronómicas; no así de las tareas de proveernos de agua y lastre, que se emprendieron con las dos lanchas armadas á las órdenes del Teniente de navío Tova, de la Atrevida: en las inmediaciones del paraje en donde debían hacerse estos acopios, no había, á la verdad, sino muy pocas chozas y éstas muy distantes unas de otras; pero como nuestro ánimo fuese prevenir aun el orígen más remoto de una discordia, no sólo los botes fueron siempre con un Oficial y algunos soldados armados, sino que procuramos atraer hacia nosotros el respeto de los naturales y cualesquiera quejas contra nuestras tripulaciones, distinguiendo la Oficialidad con una banda encarnada en el sombrero y manifestándoles ser ésta entre nosotros la señal de los principales ó depositarios de la autoridad.

La inclinación al robo que ya los naturales habían manifestado desde el principio, se esplayó aún más luégo que á la sombra ó de la variedad de los cambios ó de su mismo número, creyeron poderlo verificar impunemente. En la AtRevida habían robado un candado de hierro en la mañana anterior, pero por ventura lo había advertido tan oportunamente el Alférez de fragata Murphy, que detenido el reo, aunque le amenazase con el puñal, había logrado que el mismo Cacique, á la sazón presente, obligase luégo la restitución de la prenda robada; no fué así en la misma corbeta en la otra mañana con dos pasadores de hierro, cuya restitución no pudo conseguirse aunque procurásemos apremiar mucho al caudillo y éste manifestase grande empeño para complacernos; fué preciso creer á sus aseguraciones, que habían sido otros y de una familia distante los autores del robo; pero se tomaron nuevas precauciones para que no sucediera otra vez aquel inconveniente, no tan sólo evitando que los naturales subiesen á bordo, sino también asignando el paraje de los cambios en la orilla frontera á las corbetas: era ésta dominada de nuestra artillería, algo distante de los ranchos habitados y enteramente libre de escondrijos, arboledas ó abrigos: así, pareció también

Fste morrión tenía tros cercos de planclia del- la más oportuna para la colocación del observa- Jul. 29 torio.

Plantada, pues, inmediatamente la tienda y no cesando aún la lluvia, se acogieron en bastante número en sus inmediaciones y continuaron los cambios con mayor actividad; se reducían estos más bicn á la adquisición de los utensilios, armas y manufacturas que debíamos acopiar para el Real Gabinete de Madrid, que al cambio de las pieles de nutria que solían traer en poco número: fué también una nueva y esencial ventaja de este primer contrato el establecer un precio fijo por el salmón fresco, que deseabamos dar diariamente á las tripulaciones; quedó éste fijado en un clavo de tres á tres y media pulgadas por cada salmón, cuyo peso medio podía considerarse próximamente de siete á ocho y media libras, y se logró después la felicidad de conservarle invariable hasta el último día, aunque á veces por una ú otra parte, el natural des. nivel de su número convidase á trastornarle.

Ya al medio día, el tiempo parecía querer mejorar mucho; y apenas cesada la lluvia, había tenido lugar D. Felipe Bausá de medir una base desde la tienda del observatorio hasta la punta de Turner, haciendo en sus extremos todas aquellas marcaciones que permitiese la poca claridad de los objetos distantes: á las tres de la tarde empezó también á manifestarse el Sol en algugunas claras, y finalmente, hacia las cinco logramos ver ya no infructuosas nuestras prevencio. nes de haber establecido la tienda y traído á ella el cuarto de círculo de Ramsden. Se tomaron alturas absolutas, y referidas por medio de señales á los relojes marinos, fijaron con mucha satisfacción nuestra la primera época de las comparaciones de su movimiento.

La concurrencia de los naturales hacia nuestra tienda crecía á cada paso; ya deseaban mirar con los anteojos, ya aproximarse á las cajas y reconocer sus contenidos, y como la experiencia de dos días no nos dejase duda de su mucha inclinación al robo, pareció más seguro el traer á bordo todos los instrumentos y la misma tienda, que ó cansar la tropa con una contínua vigilan. cia de noche ó exponernos á las causas de una rotura que en la natural confusión pudiera ser mal interpretada é injusta: por lo que toca á nuestro roce con los naturales, no podía á la sazón llevar un semblante más halagüeño; nos habíamos familiarizado con las palabras más necesarias del idioma, visitábamos francamente sus chozas; D. Tomás Suria pudo retratar algunas mujeres y representar la no crecida cantidad de utensilios domésticos; los cambios se habían acalorado mucho por una y otra parte, y ya se nos había dado el permiso de proveernos de la leña necesaria en las mismas inmediaciones de las chozas sin contrato alguno, preliminar al cual, 
Jul. 29 sin embargo, no hubiéramos dejado de acceder inmediatamente.

En las inmediaciones del observatorio se hallaba enterrado el cadáver de un indivíduo muerto en las últimas reyertas; lo indicaba un palito plantado entre las yerbas y un tejido de juncos que con algunas piedras sobrepuestas le abrigaba: los naturales manifestaron bastante repugnancia para arrimarse hacia aquella parte, y aun insistían en que nosotros no lo ejecutásemos, acompañando las instancias con aquellas señales y aquel silencio que corresponden al temor de interrumpir un sueño tranquilo.

Entre las muchas cosas que á la sazón habían venido al mercado, se dejaban ver frecuentemente los rastros de la escala en aquel puerto del Capitán Dixon con el bergantin Reina Carlota: vimos alguna hacha y cacerolas, una cuchara de plata, dos ó tres libros y algunos vestidos: frecuentemente los más jóvenes repetían la $S a$ loma $(\mathrm{I})$ de las maniobras y una ú otra palabra inglesa; y por lo que toca á los pedazos de hierro, debíamos creer que prontamente los convirtiesen con el auxilio del fuego y de las piedras, en el puñal ó daga que llevaba siempre cada uno consigo suspendido debajo del brazo izquierdo y escondida con la piel de lobo, nutria ú oso: no era un rastro ménos evidente de aquella misma escala la continuación de las instancias para que usásemos de las mujeres, siendo preciso en este día el reprender sériamente al viejo Cacique, quien trajo una mujer hacia la tienda del observatorio á donde nos hallábamos á la sazón, y repetir las órdenes para que no se aproximasen hacia las chozas, otros indivíduos que los Oficiales de una y otra corbeta: crecieron con este motivo los halagos, y hacia las seis de la tarde vimos próxima á la popa de la DescubierTA, una canoa con tres mujeres, dos de las cuales no excederían la edad de diez y ocho á veinte años; repitieron algunas palabras inglesas, ejercitaron después por largo tiempo su natural locuacidad, y finalmente, entonaron un canto bastantemente melodioso que D. Tadeo Heenke copió con su natural exactitud é inteligencia de la música.

Pero con la caída de la tarde, despejado enteramente el tiempo, era ya igualmente nuevo y grandioso el espectáculo que se nos presentó á la vista: semejante al telón de un teatro, que corrido con la mayor prontitud descubre en un solo instante al espectador admirado un número crecido de objetos tan nuevos como varios y agradables, así disipadas las nubes y cerrazón que habian hasta entonces interceptado los objetos distantes, se dejó ver toda la cordillera majestuo-

(I) Saloma en el vocabulario de Marina, significa la $\mathrm{voz}$ del que dirige los movimientos uniformes de una inaniobra, para que repetida á un mismo tiempo por todos, sirva de señal para el esfuerzo unánime. sa que desde el monte Buen Tiempo sigue hasta Jul. so el de San Elías. El hielo de que estaban cubiertas desde su cima hasta la última falda, refiejaba con nuevo brillo los rayos del Sol: se dejaba ver antepuesto á la tierra alta por algunas leguas todo el bosque de pinos con una lozanía y frondosidad difíciles á describirse; finalmente, la atmósfera sumamente puracon un vientecito suave del Noroeste, dilatando mucho la duración del día con la mayor claridad del crepúsculo, ni aún á la media noche nos hacía carecer de esta vista agradable y majestuosa. D. Felipe Bausá, con el teodolito, inmediatamente se dirigió á uno de los extremos de la base para extender las marcaciones y rectificar las que se habían hecho anteriormente, y como ya fuesen las diez de la noche cuando regresó á bordo, debimos entregarnos por algunas horas al descanso, para aprovechar con mayor constancia la esperada hermosura del día siguiente.

En efecto, no eran aún las cuatro de la mañana cuando D. José Espinosa, en quien recaía el turno de servicio, fué con las lanchas y bombos armados á continuar los acopios de agua. Don Felipe Bausá, con un bote igualmente armado, emprendió la continuación de sus tareas hacia el canal de la entrada hasta la punta Filipps; D. Juan Maqueda examinó con otro bote las sondas interiores del puerto, y los Oficiales astrónomos empezaron á disponerse para todas las observaciones que estuviesen á nuestro al. cance: ocupaba el primer lugar entre ellas el examen de las oscilaciones del péndulo simple constante, el cual se colocó bajo la tienda en el mismo paraje del día anterior, sustituyéndose para el examen del tiempo medio, el cronómetro 7r al péndulo compuesto; pues hubiera sido imprudente entregarnos á sus resultados casi al mismo momento de ponerle en movimiento. Con el cuarto de círculo de Sissón, debían luégo tomarse las alturas correspondientes del Sol, determinar la latitud por "la altura meridiana del mismo astro y medir en el extremo de la base la elevación del monte San Elías sobre el nivel del mar.

Entendiendo aún hacia las seis de la mañana en los aprestos para estas operaciones y no siendo sino muy corto el número de los naturales que se habían aproximado al observatorio, vimos venir repentinamente hacia nosotros el viejo Ankau (I), acompañado de otra persona cuyas preeminencias entre los demás eran bien grandes, sin poder, sin embargo, alcanzar jamás ó sus derechos ó sus funciones en la tríbu: uno y otro con mucho afán y no sin las muestras de un temor grande, nos anunciaron la aproximación de

(I) Es la voz propia, con la cual distinguen al Cacique o Jele principal. 
dos canoas que acababan de descubrir y cuyas ideas ignoraban aún si serian hostiles ó pacíficas: solicitaron con ansia (no distando ya las dos canoas más que una ó dos millas del puerto) que fuésemos á la orilla frontera y disparásemos un fusilazo para obligarles á manifestar sus ideas, y entretanto, dispusieron que toda la tríbu tomase las armas, se retirasen las mujeres y se echasen al agua las dos canoas grandes que estaban varadas en la playa: desde luego determinamos complacerles en lo que solicitaban, y pasando á la playa opuesta, disparóse un fusil luego que nos hallamos en paraje oportuno para ser vistos de la gente de las canoas. Con esta señal prorrumpieron inmediatamente en el him. no de paz todos los que las esquifaban, que serían próximamente cuarenta, continuaron luégo el mismo canto á medida que se iban aproximando, y finalmente, se acercaron á la orilla interna, no sin nuevos recelos y precauciones de parte de nuestro Ankau, quien no cesaba de gritarles que mirasen bien lo que hacian, pues éramos sus aliados.

Ya disipados casi todos los recelos de una rotura pero no aún inermes los habitadores del puerto, se aproximaron á las piraguas y recibieron en sus brazos á los caudillos para conducirlos á la playa sin mojarse: fueron inmediatamente presentados por nuestro Ankau. Siguióse á esta ceremonia una pacificación general; muy luégo, unos y otros entre abrazos, regocijos y narraciones se dirigieron á las inmediaciones de las chozas; y si se exceptúa el paraje en donde enjugaban sus pieles y preparaban la comida, parecían más bien todos de una misma tríbu que personas dispuestas una hora antes á destruirse recíprocamente.

No es fácil acertar si los muchos naturales que se aproximaban al observatorio entenderían las ideas religiosas hacia el Sol con que procuramos colorear nuestras observaciones astronómicas, ó si aun entendidas conducirian algún tanto á que lográsemos de toda la quietud que nos era precisa; pero es bien positivo que en esta parte debimos considerarnos sumamente felices, pues en nada nos molestaron en el espacio de doce horas próximamente, en que estuvieron á su vista los instrumentos astronómicos: se repitieron por tres veces las comparaciones del péndulo simple al cronómetro, y no siendo menor cada una de una hora, logramos sin embargo, verlas corresponder entre sí hasta el cuarto de segundo, precaviéndonos además para la determinación segura del tiempo medio, con sujetar por repetidas señales comparativas el número 7r á los demás relojes marinos de una y otra corbeta: en cuanto A las demás circunstancias que concurrieron al tiempo de hacerse aquella observación delicada, podemos lisonjearnos, que parecerán satisfac. torias á los físicos, cuando les aseguremos, que Jul. zo el péndulo estaba con la mayor estabilidad; que el termómetro de Farenheit se mantuvo entre los 67 y $68^{\circ}$; el terreno se hallaba considerablemente distante de toda montaña y por sí mismo despejado y formado por la mayor parte de lastre; que las experiencias se hicieron inmediatas al medio día; y que la marcha del cronómetro de comparacion se halló en el mismo segundo por las observaciones del día anterior y del siguiente: examinada la salubridad del aire de la tienda en la cual se hicieron las experiencias, dió en el eudiómetro de Fontana la bondad do 0,92. No se había descuidado D. José Espino. sa en observar también en las inmediaciones de la aguada la altura meridiana del Sol con un excelente sextante de Stancliff, acompa. ñado de un pié y de un horizonte artificial: sus resultados, referidos al observatorio en nuestro plano, confirmaron la latitud deducida por el cuarto de círculo en este y en el día siguiente; y con el medio día derivado de las alturas correspondientes, pudimos ya también investigar cuál fuese la longitud del observatorio así por las distancias lunares como por los relojes marinos.

A las cuatro de la tarde rolvieron á encajonarse todos los instrumentos y la tienda, y regresados al mismo tiempo los Sres. Espinosa, Bausá, Heenke y Maqueda, que como se ha dicho habían sido comisionados á destinos de su profesión, pudimos comer tranquilamente y em. plear las horas restantes de la tarde en el examen de los habitadores de aquellas regiones.

D. Tomás Suria rectificó en esta ocasión para representarlas al vivo, todas las ideas adquiridas en los días anteriores; D. Cayetano Valdés y D. Fernando Quintano, examinando las armas y utensilios, hallaron muchos que merecían adquirirse para el Real Gabinete; se advertían por otra parte las mujeres muy ocupadas en hacer los canastillos de coser, así como los hombres en hacer muñecas, cucharas y otros utensilios de madera que la Oficialidad y aun la marinería habían adquirido con ansia; finalmente, unos en la adquisición de nuevas voces y otros en el estudio de sus costumbres domésticas, habían esplayado aquel constante amor á las ciencias y al trabajo que tantos frutos había producido á la expedición.

Fué también oportuna la ocupación de tirar al blanco, á la cual se entregaron por algún tiempo el Comandante y Oficiales de la corbeta ATREvida; pues esmerándose en el acierto y estando á la vista un crecido número de naturales, no podía á ménos este ejercicio de influir mucho en la continuación de un trato tan pacífico como debíamos desearlo: no faltó entre los expectadores uno bastantemente adverido, que 
con general aprobación ó mas bien admiración de los demás, creyó haber hallado un remedio en sus vestidos para que fuesen impenetrables á la bala del fusil: mojó muy bien la piel que le cubría, luego muy ufano la puso por blanco á la distancia prefijada, y estaba tan persuadido de la impenetrabilidad, que cuando D. Ciriaco Cevallos la hubo agujereado con la bala, se enfadó agriamente y se retiró de aquellas inmedia. ciones.

En la aguada todo había procedido con la mayor quietud, aunque se apareciesen algunos naturales más que en el día anterior; antes bien, D. José Espinosa había tenido lugar de enterarse entre una familia inmediata, de varias costumbres domésticas y adquirir una ú otra cosa de los trajes y adornos mujeriles: debió causarnos una admiración particular en cuanto al carácter de aquellos naturales, lo que acaeció en la ATREviDA con un criado natural de las Islas Filipinas: Desde el primer día que visitaron aquella corbeta le habían creído por uno de los suyos, examinándole prolijamente los cabellos, el cutis, las facciones de la cara y áun diferentes miembros: le pidieron ahora que quedase en la tríbu, y procuraron enterarse cómo estaba entre nosotros, y si había sido vendido ó aprehendido.

Los recien venidos traían, como es natural, algunas pieles buenas de nutria, las cuales, por la tarde, empezaron á aparecer en el mercado que se celebraba en las canoas, debajo del portalón de cada corbeta; pero ligados ya sus intereses con los de la tríbu antigua y aún acompañados siem pre por uno de éstos, no sólo no disminuyeron sus pretensiones con la concurrencia, sino que fueron poco á poco aumentándolas á tal extremo, particularmente para la adquisición de ves tidos, que uno ú otro marinero nuestro perdió considerablemente en los cambios aún si se refiriese el valor de las pieles al mercado de Cantón.

Era, sin embargo, un espectáculo bien singular y curioso el ver á la sazón una buena mitad de la tríbu antigua y algunos de la nueva, vestidos tan extrañamente con uniformes viejos de soldados, chaquetas de la marinería, gorros, panuelos, camisas, calzones, etc., indistintamente de invierno y de verano, que sin duda hubieran causado la mayor novedad á una embarcación á cuyo bordo fuesen, y probablemente héchole sospechar que la tripulación de un buque español hubiese sido asesinada en aquellas inmediaciones.

Según refirió D. Felipe Bausá, la parte de costa comprendida entre la aguada y la Punta Muñoz, era con exceso frondosa y los campos in mediatos tan abundantes de una especie de fresa silvestre, que en vano hubiera intentado agotarlos toda su comitiva, en la cual se hallaban unos cinco marineros; además había internado algo en Jul. $3^{\circ}$ el río contiguo y visitado no sin mucha admiración, el paraje de los entierros ya indicados por el Capitán Dixon: las circunstancias de todo lo que rodeaba aquel paraje eran demasiado curiosas y podrían dar tanta luz sobre los principios religiosos de aquellos pueblos, que hubiéramos sido culpables en no visitarle.

Así en la mañana siguiente, D. Tomás Su- Jul. ria, D. José Espinosa y otros Oficiales, fueron con el bote directamente al río, y poco después de las nueve ya estaban en el paraje indicado; se aparecieron oportunamente cuatro ó cinco naturales que erraban en los campos inmediatos buscando fresas para su alimento; parecían, á la verdad, de la última plebe, y por consiguiente, poco aptos á satisfacer la curiosidad; pero como fuese el principal objeto de aquella excursión el recojer para el Real Gabinete una ú otra cosa de los sepulcros, esta compañía era á la sazón más oportuna que cualesquiera otras de la población del fondeadero; la cual, ó por ideas de temor ó de veneración, no hubiera tal vez permitido la ejecución de las ideas indicadas: midiéronse al principio, y D. Tomás Suria representó en una vista de perspectiva, los postes y vigas que encerraban una habitación larga y dispuesta al parecer para el invierno; luego, les ocupó por largo tiempo con los mismos objetos el sepulcro antiguo, y últimamente el nuevo, que por su colocación, adornos y buena conservación, no podía á ménos de causar extrañeza y admiración: finalmente, no repugnándolo los naturales, pues se les había prevenido con algunos dones, se sacó y envió al bote una de las cajas que estaban en el sepulcro antiguo. Era ésta ligeramente adornada por fuera con los caracoles acostumbrados: encerraba otra caja menor, en la cual halláronse envueltos en una especie de esportilla, sólo pocos huesos calcinados y en mucha parte pulverizados. Empero, la vista de dichos sepulcros que acompañan á esta narración, dará mejor idea dc sus diferentes partes y de sus proporciones, de lo que pudiera alcanzar una descripción por sí difícil y cansada; sólo especificaremos aquí, que ya comprendióse por los naturales ser éstos los sepulcros únicamente de los Ankaus ó familia reinante, y que no quedó duda de la combustión de los cadáveres alrededor del figurón; pues además de señalarlo así los naturales, vieron tres ó cua. tro pequeñas fosas del largo de un hombre, en las cuales estaban cubiertas con algunas tablas y piedras los carbones ó leña que habían servido para la pira: se hablará después con más extensión de esta parte interesante de las costumbres dc aquellos pueblos y arcnturaremos nuestras conjeturas sobre la intcrpretación de cuanto hemos podido advertir.

Entretanto, á las órdencs del 'Teniente dc 
Iul in navio Concha, de la ATREvida, las lanchas y bombos armados habían hechn un nuero acopio abundante de agua, y 1). Juan Ternaci, continuando la hermosura del día con la misma claridad del anterior, había logrado otra observación de latitud y un medio día bien satisfactorio por las alturas correspondientes, el cual ratificó la marcha del cronómetro 7 I determinada en Acapulco, y manifestó una aceleración no indiferente en los cronómetros 6r y 72 . Ya, pues, concluídos los acopios de agua y lastre, para los cuales eran precisas las lanchas, no diferimos un instante en emprender el reconocimiento del abra que nos había atraído al puerto en el cual nos hallábamos actualmente; y pues era nuestro ánimo si existiese el paso deseado conducir hacia él las corbetas, quisimos examinar aquellos parajes y decidir fuera de toda duda una parte tan importante de nuestra comisión. A este fin, las lanchas bien armadas y esquifadas, se previnieron con quince días de víveres $y$ una suficiente cantidad de agua y leña: iba D. Felipe Bausá en la lancha de la DescubIerTA, y mandaba la de la ATrevida el Teniente de navío D. Antonio Tova; se embarcaron también el relój de faltriquera $35^{\mathrm{I}}$, el cuarto de círculo de Ramsden, un calafate $y$ un carpintero, con todos los utensilios necesarios.

Dejado, por consiguiente, el cuidado de las corbetas á D. José Bustamante y destinados los bombos para el acarreo de la leña, bien temprano en la mañana siguiente dimos la vela, prefiriendo el transitar por entre las islas, así porque el viento á la sazón achubascado y del Sueste nos sería más favorable, como porque haríamos un nuevo examen de la verdadera posición de sus canales: al principio debimos navegar al remo por largo trecho, pero luégo ya próximos á salir fuera de las islas, empezamos á gozar de un vientecillo galeno del Sur, que en breve tiempo nos aproximó al abra. Flotaban hacia la costa del Oeste varias bancas sueltas de hielo, y por la del Este se dejaba ver, próximo al mar, un trozo de tierra llana que estando bien abrigado del Norte por los montes contiguos, manifestaba ser el asilo de algunos indios, por el humo que advertíamos en uno ú otro paraje; sólo se encontraba un fondo de 20 ó 30 brazas á un tiro de fusil de la costa; á una mayor distancia, ni aún con 60 brazas podíamos alcanzarle, y últimamente, pasado el terreno llano, y ya próxima la entrada, acrecentaba de tal modo el fondo, que la lancha de la Atrevida, á un solo cumplido de bote de la orilla, no le podía alcanzar con I 20 brazas.

I la sazón nos había abandonado el viento del Sur. y á rcces una total calma y otras un riento contrario $y$ lluvioso del Nordeste, nos habian precisado á valernos nuevamente de los remos, aunque la gente estuviese cansada y las rul. lanchas algo sobrecargadas.

No bien habíamos pasado en las inmediaciones de las chozas, cuando vimoș venir hacia nosotros una canoa con un solo indio, cuyo trajc no era fácil distinguir aunque le contemplásemos cuidadosamente: en efecto, no era posible acertarlo, y lo juzgamos así, cuando ya próxima la canoa á nuestra lancha, no sólo vimos que el traje se componía de un gorro, camisa, calzones y uniforme, sino que el recién llegado en la canoa era un hijo del Ankau del puerto, que nos había visitado á bordo repetidas veces: con el traje nuevo parecían haberse humanizado mucho sus costumbres, pues habiéndole en diferentes ocasiones debido caracterizar por el mas altanero y provocativo de la tríbu, ahora advertíamos en su conducta una mansedumbre y subordinación, cuyas causas no fuera fácil el acertar; trasbordó á la lancha de la Descubierta; nos indicó que era el caudillo de la población inmediata y que allí estaban sus mujeres é hijos los cuales nombraba con mucha ternura; se prestó á acompañarnos precedido el regalo de algunas frioleras y una regular comida, de la cual tenía, al parecer, una no mediana necesidad.

La poca fuerza de la marea y todas las respuestas del nuevo Ankau, ya nos convencían que no sólo no existía en estos parajes el paso deseado, sino que era muy corta y ya casi terminada la internación de este canal: veíamos por otra parte guarnecida de un perpétuo hielo toda la orilla interna del Oẹste, lo que no pudiera tener lugar si las aguas en algún tiempo del año tuviesen una rapidez proporcionada ó á la comunicación de otro mar, ó á los recodos que suponía Ferrer Maldonado; pero la cerrazón del tiempo y el viento contrario, dilataron aún por dos horas nuestra jlusión, á la cual coadyuvaba únicamente, como hemos dicho, la excesiva cantidad del fondo por una y otra parte, y la tal cual semejanza en el ancho, escarpe $y$ sinuosidad de la entrada.

Como á la una de la tarde, guiados del indio pudimos alcanzar un fondeadero en la parte interna de la bahía: era una playa de bastante cascajo, frontera á una cañada de dos montes bastantemente altos, la cual, regada con un riachuelo y gozando de un poco de tierra llana, presentaba á la vista el semblante más halagüeño de la vejetación: pero exceptuando estos trozos pequeños, que pudieran con propiedad llamarse manchas verdes, todo cuanto rodeaba la bahía era una masa de piedra cubierta de hielo, y éste tan constante, que en las muchas bancas que nadaban en nuestras inmediaciones y oíamos desplomarse de tiempo en tiempo con notable estruendo de los montes vecinos, se advertíln sobre el hielo primitivo las nuevas capas recientes que 
Jul. z se le habían amontonado; y ni siquiera en los pocos parajes en donde se manifestaba la vejetación dejaban de encontrarse masas enormes de hielo, tan sólida y tenazmente afianzadas que parecía imposible pudiesen disolverse en el corto espacio del restante verano.

A pesar de que continuasen aún la lluvia y el frío, mientras ambas esquifazones aprestaban su comida, nosotros no descuidamos el ocuparnos en adquirir una idea más cabal de aquellos contornos: D. Felipe Bausá midió una base é hizo marcaciones, aunque bien limitadas, así en los extremos como en otro altito inmediato al fondeadero; D. Antonio Tova se encargó de la caza, y otros emprendieron el acopiar todo lo relativo á la Historia Natural, que sujetaríamos luégo al examen científico de D. Tadeo Heenke: insistiendo el Ankau en querer regresar á su choza antes de la noche, lo despedimos con algunos regalos y nos prometió volver á la mañana siguiente con algunos salmones frescos.

El deseo de aprovechar el tiempo y el temor de que continuasen ó aún aumentasen la cerrazón, lluvia y frío, no permitieron dejar á las marinerías más descanso del que exigían las mareas, que ya advertíamos periódicas y casi uniformes con las del puerto Mulgrave. Por consiguiente, hacia las nueve de la tarde emprendimos el internar con los remos y examinar el término de las abras contiguas á la línea del hielo constante, y el canal, que parecía dividir del continente una islita que habíamos visto frontera al fondeadero: mil circustancias hacían esta pesquisa realmente molesta y cansada á la marinería, pero más que todas lo eran sin duda la dificultad de vogar entre las muchas bancas flotantes que nos rodeaban, la precisión de dar mil tornos para evadirlas, y la dificultad de encontrar fondo, que Don Antonio Tova, mucho más aterrado que nosotros hacia la derecha, no podía alcanzar con Izo brazas.

Finalmente, á las once y media de la noche, aún antes de alcanzar la isla, encontramos la línea del hielo constante, y nos fué preciso retroceder al fondeadero antiguo, en el cual, dado fondo poco después de la media noche, pudo permitirse á la gente el descanso necesario.

El tiempo, hasta entonces cerrado con lluvia, no nos había sin embargo permitido el formar una idea tan cabal de la cordillera sobre estante á la bahía, cuanzo la deseábamos para la exactitud de nuestras operaciones: tampoco habíamos podido determinar el verdadero extremo de una entrada que notábamos al Noroeste, pues estaba comprendida en los límites del hielo constante; por último, quedaban inútiles los ins rumentos astronómicos, y mal fijadala posición geográfica de aquel puerto, aunque á la verdad, sólo pudiera ser útil á los navegantes venideros más bien para evadirle que para buscarle. La suerte Jul. a quiso favorecernos en aquella ocasión, y un vientecillo galeno del Noroeste dando lugar á que desapareciese toda la cerrazón y calima, ya nos permitía continuar nuestras operaciones. Se agregó á esta felicidad el aparecimiento de varias canoas de la ranchería contigua á la boca, que nos proveyeron con abundancia de un excelente salmón fresco, y así pudo la marinería 10. grar de un completo descanso, y nosotros finalizar poco después del medio día las observaciones emprendidas: logramos de una excelente vista de perspectiva que podrá manifestar el horror cle aquellos contornos; se observó en el cuarto de círculo la latitud de $59^{\circ} 50^{\prime} 30^{\prime \prime}$; seis azimutes del Sol indicaron conformes la variación masnética bien extraña de $32^{\circ} 49^{\prime}$; se ratificaron $y$ aumentaron las marcaciones del día anterior, y hubiéramos deducido directamente la longitud, si ó la marcha irregular del reloj ó alguna equivocación en las observaciones, no nos hiciesen malograr en aquella parte nuestras tareas, imposibles de combinarse con las marcaciones iigadas hasta el fondeadero de las corbetas.

Ya en las primeras horas de la tarde, empezando á declararse la marea favorable, y embarcados los instrumentos y utensilios, nos disponíamos á emprender el viaje de regreso, cuando entre los marineros de la ATREvidA, se advirtió la falta del artillero de mar Manuel Fernández, refiriendo sus compañeros que se había separado de los demás hacia las ocho sin decir á dónde iba, y que sólo habían extrañado su falta á la hora de comer.

Este marinero tratado en su corbeta con un rigor moderado desde que había sido aprehendi do con los demás desertores en Acapulco, ahora había solicitado con mucho empeño el ser destjnado en la lancha, para acreditar con su conducta el arrepentimiento de aquel desliz involuntario: se nos hacía, por consiguiente, tanto más difícil el combinar sus ideas, cuanto que creíamos que la puntualidad y asiduidad en el trabajo serían el único medio que alcanzase para acreditarse; por ventura, sabíamos que su ruta había sido por la orilla de la derecha hacia la isla y fondo de la ensenada, y con este antecedente no tardamos en destacar otro marinero, que siguiendo sus huellas le gritase y le trajese: puede, pues, imaginarse cuál sería nuestra confusión cuando hallamos también infructuosa esta medida, aunque el marinero, ya á mucha distancia de las lanchas y sobre unos riscos casi impenetrables, gritase á toda fuerza y casi alcanzase la vista del fondo de la bahía: ya fué preciso que D. Antonio Tova, con la lancha, emprendiese por sí mismo una nueva pesquisa. Se le encargú que internase cuanto fuera posible; que disparase de tiempo en tiempo algunos fusilazos y reconociese pro- 
Jul. = lijamente toda la orilla, por si alguna enfermedad ó caída le imposibilitasen al mismo tiempo el gritar y el regresar á bordo. A medida que la lancha internaba y casi se aproximaba al hielo, crecían los recelos sobre la suerte de aquel infeliz, pues no hallando el menor rastro, ni correspondiendo señal alguna á los fusilazos, debíase temer, ó que se hubiese dado una muerte voluntaria, ó que hubiese sido presa de algunos osos, que, según informes de los naturales, erraban en mucho número en aquellos contornos; pero finalmente, lográronse disipar estas sospechas con verle aparecer á larga distancia; y áun habiéndole recogido después en la lancha, debió reprimirse el natural enfado y deseo de reprenderle cuando satistizo con decir que era su ánimo el descubrir el Estrecho por el cual ansiábamos. En efecto, su deseo de contraer este mérito y el oir nuestras conversaciones sobre el no haber reconocido el término del abra de la derecha, le habían persuadido á dirigirse hacia ella por tierra, y temeroso de que otros quisiesen participar de esta gloria, no sólo había ocultado su pensamiento á todos, si que tambien llevado con un tesón correspondiente, caminando unas seis horas por riscos y hielos de una escabrosidad real mente difícil de imaginarse.

Ciertamente debió causarnos tanta risa el poco acierto en aquel plan, como admiración el pundonor que le dirigía; el marinero, no sólo fué perdonado de su mala entendida ausencia, si también devuelto por D. José Bustamante á su destino antiguo de gaviero mayor, y no parecerá ni frívola ni ociosa la relación de este hecho, cuando se refiera, ó bien al objeto de reflejar el noble pundonor del carácter nacional, ó de convencer cuánto yerran los que piensan asemejar el marinero á un bruto destituído casi en un todo de las facultades de sentir y de pensar.

Antes de abandonar la bahía, dejamos enterrada una botella con la inscripción de nuestro reconocimiento, la fecha en que lo habíamos hecho y la posesión tomada en nombre de Su Majestad, que acreditaba una moneda enterrada al lado de la botella; el puerto tuvo el nombre del Desengaño, el abra externa la de Ferrer, por el navegante antiguo que actualmente dirigía nuestras pesquisas, y la isla interna el de Heenke, en obsequio del Botánico, que dividía con nosotros en aquel viaje todos los peligros é incomodidades de la navegación.

Con el auxilio de la marea y del Noroeste que á la sazón soplaba galeno, creíamos que nuestros progresos en la próxima tarde serían considerables, pero muy luego, abandonándonos una y otra, debimos valernos de los remos y continuar constantemente con ellos, aunque molestasen mucho á la marinería de ambas lanchas. Los naturales mos habían precedido con sus canoas, y nos salieron al encuentro cuando inmediatos al Jul. paraje de las chozas atracamos á él para que se hiciesen algunas marcaciones con el teodolito, comprendida en ellas la del Monte de San Elías que teníamos á la sazón á la vista: el jóven Ankau continuó con la misma afabilidad que había esplayado en el día anterior, y áun trajo á bordo en una canoa dos hijos suyos de edad muy tierna, hacia los cuales manifestaba un cariño extremado, y que, por consiguiente, fueron bien regalados: el trozo pequeño de tierra llana en el cual estaban establecidas estas chozas, se hallaba á la verdad bien abrigado de los vientos sep. tentrionales, y su dirección bastantemente inclinada hacia el Sur, para que pareciese preferente para habitarle; pero en desquite era la orilla en extremo hondable y seguramente tan expuesta á la ola muy gruesa de la travesía, que muchas veces, particularmente en invierno, no sería asequible el intentar la pesca: ésta debía creerse muy abundante en aquellos contornos, si consul. tásemos los muchos salmones de que nos proveyeron en el primer día y en el siguiente.

Navegando en toda la restante tarde como á dos tiros de fusil de la costa por fondos de $25 \mathrm{y}$ 30 brazas, unas veces piedra y otras cascajo, tuvimos lugar, al mismo tiempo de reconocerla prolijamente $y$ de buscar un mediano abrigo para pasar la noche: eran las diez de ella cuando dejamos caer la amarra, y no obstante, se hicieron las marcaciones necesarias con el teodolito, sujetándolas nuevamente al Monte San Elías que aún teníamos á la vista.

El paraje donde se hallaban á la sazón las lanchas, era un canal que forma la tierra firme con una isla de mediana altura y que sería un excelente fondeadero si el fondo en una y otra orilla no subiese rápidamente á 40 y 50 brazas, y las mismas orillas no fuesen rodeadas de piedras, bien incómodas para la comunicación de embarcaciones menores: un enjambre de mosquitos nos hizo luego acelerar la salida en la mañanita siguiente; pero antes se midió una base para trazar aquel puerto, y luego, con viento bonancible del Oeste, á veces achubascado y á veces calmoso, emprendimos el continuar nuestras pesquisas sobre aquel corto Archipiélago, y últimamente alcanzar las corbetas.

La isla que actualmente reconocíamos, es sumamente frondosa, $y$ por partes llena de mariscos; adlemás se dejan ver en su costa del Sur otros sepulcros, iguales en un todo á los que habíamos visitado en las inmediaciones del puerto: se advierten sembradas, ó en la islas ó en la costa firme inmediata, muy pocas rancherías de naturales, y si juzgásemos por el crecido número de 30 ó 40 salmones que vendieron dos solas canoas á bordo de las lanchas, deben ser aquellos canales bien abundantes en pescado, y por 
Jul. 4 consiguiente de una fácil subsistencia para sus moradores.

Ya el viento continuó favorable aunque acompañado con lluvia: le aprovechamos con todas las velas, y frustrado nuestro intento de internar hacia otro canal interno, pues le conocimos cerrado y que sólo formaba una bahía bastantemente ancha; á las cinco avistamos las corbetas y poco después estuvimos á bordo.

En los tres días anteriores, según informó D. José Bustamante, habían variado mucho las circunstancias de nuestro roce con los naturales; y á pesar que ni hubiese habido el menor daño por una ni por otra parte, los trances habían sido bien delicados y exigían otra circunspección en nuestros pasos.

En el mismo día en que salieron las lanchas para el puerto del Desengaño, fueron nuestras partidas al corte de leña en un paraje poco distante de las chozas; recayó el turno de servicio en D. Cayetano Valdés, quien tomó todas las disposiciones para la seguridad, el trabajo y la conducción; y en efecto, aunque concurriesen en aquel paraje muchos naturales, ni en la asiduidad ni en el roce amistoso se había notado la menor interrupción; pero como luego se descuidase un marinero de la Descubierta en poner su chaqueta en el paraje en donde estaban las demás, y que prudentemente se había puesto al cuidado de un centinela, no faltó un natural que la quitase con lijereza, ni dejó el marinero de echarla de ménos y advertirlo así al Oficial Comandante; informado éste muy luego por uno de los circunstantes de quién era el delincuente, lo avisó al Ankau, estrechándole á que le obligase á la restitución y le castigase del mismo modo que nosotros lo ejecutaríamos con quien quisiese violar los derechos de su propiedad; sin embargo, ó fuese mengua de autoridad, ó (como es probable), no dejase el mismo jefe de ser cómplice en esos atentados, aunque siempre bajo el semblante de la mayor amistad hacia nosotros, no volvió la chaqueta á nuestras manos, y D. Jose Bustamante (aconsejándole así el mismo Ankau á bordo de la Descubierta), prohibió para el día siguiente los cambios é insistió en la restitución de la prenda robada. Los naturales habíanse irritado con esta medida, y así, cuando al día siguiente D. José Robredo emprendió con las partidas acostumbradas el corte de leña, no sólo advirtió en ellos una conducta provocativa é insolente, sino que debió presentar el fusil contra uno, que insultada la centinela á quien estaba confiada la custodia de las chaquetas, á la menor reconvención se volvió con el puñal desenvainado hacia el mismo: insistían al mismo tiempo al costado de ambas corbetas, no sin mucha altanería, que nos fuésemos luego si no queríamos continuar los cambios; finalmente, en todos sus pasos ma- nifestaban que la sola falta de una ocasión opor- Jul. + tuna los detenía de una rotura sangrienta y destructiva.

Oportunamente, á la sazón los Oficiales de la Atrevida emprendieron de nuevo, por diversión, el tirar al blanco en lá playa, y un acierto continuado con la intermación de la bala en el tronco de un árbol, perforada de antemano la piel mojada, les convenció de nuevo que la superioridad de nuestras armas decidiría muy luego cualquier refriega á favor nuestro; con estos antecedentes, regresada la Oficialidad á bordo $\mathrm{y}$ retiradas las partidas que se hallaban en el corte de la leña, continuaban sí una ú otra vez las instancias de los naturales para la verificación de los cambios, pero ni manifestaban un enojo inmediato, ni cabía el sospecharle después del escarmiento que se les había repetido á la vista, y después de las aseguraciones del Comandante de la ATrevida, que al día siguiente se renovarían los cambios: era difícil, á la sazón, acerta. con las intenciones verdaderas del Ankau: á bordo de las corbetas parecía querer coadyuvar á nuestras intenciones de recobrar la chaqueta; entre los suyos, ó peroraba con debilidad, ó manifestaba con una conducta apacible que no desaprobaba el robo; bien que como se entregase tan frecuentemente en nuestras manos y nos asegurase de la constancia de su amistad, jamás debían recelarse consecuencias funestas, tanto más, que cada uno de los nuestros se precavía con las armas oportunas para la seguridad propia.

A las cuatro de la tarde, D. José Bustamante con el ánimo de dar algunos pasos para la pacificación y continuar la diversión del blanco á la sazón ya casi necesaria, determinó bajar á tierra hacia la playa frontera á la DescubierTA: estaban los naturales amontonados alrededor de sus chozas, y algunos entre ellos iban dirigiéndose hacia la misma playa en donde atracaba el bote. Dejado, pues, éste al cuidado de los marineros que le mantuviesen á flote, los demás empezaron á aproximarse hacia las chozas, precediendo á alguna distancia el Comandante y mediando pocos marineros entre él y los Tenientes de navío Cevallos, Concha y Viana. Pareció esta ocasión demasiado oportuna á uno de los naturales para la empresa que meditaba de hacerse dueño de uno de nuestros marineros, que advertía sin armas, y probablemente obligarnos para, su recobro á la continuación de los cambios ó á cualquiera otro partido que quisiesen prescribirnos: $y$ así no tardó en cogerle por la espalda, y corriendo con la posible velocidad se dirigió hacia los suyos: el marinero era un jóven americano, el cual, ó persuadido que fuese uno de sus compañeros el que le llevaba, ó bien amedrentado con este hecho, ni aun se precavía con avisar á los Oficia- 
Jul. 4 les; pero por rentura, ni éstos podían dejar de advertirlo, ni omitieron el avisarlo inmediatamente á D. José Bustamante, el cual no tardó en amenazar al natural para que soltase al marinero; logró, en efecto, verle suelto; pero al mismo tiempo vió dirigirse hacia él con el puñal desenvainado al mismo natural de la contienda, el cual, ya á muy corta distancia, se detuvo por un momento y gritó á los suyos, que no tardaron en moverse, hallándose entre ellos el mismo Anka!l.

Ya el semblante de la contienda era bastantemente serio: el fusil de Bustamante no estaba cargado ni tenía la bayoneta; y ya el natural enfurecido le amenazaba muy de cerca: por una parte iba creciendo considerablemente el número de los naturales armados, y por la otra, los tres Oficiales ya nombrados, el Contador Ezquerra y unos dos marineros que se habían armado con sables, se disponían á defender á su Comandante, tanto más, que advertían en su adversario algunos movimientos para cojerle diestramente por la espalda: en aquel trance no olvidó Bustamante ni los principios de humanidad, ni los de la seguridad propia; presentó su fusil como si estuviese cargado, difirió el advertirle á los suyos para que aún suspendiesen las hostilidades, y llamó con denuedo al Ankan para que refrenase la osadía en sus súbditos; éste, suspenso por algún tiempo, se decidió á hablar al más alentado, bien que no en el tono acostumbrado de mando; y el otro tal vez persuadido ó atemorizado, no tardó en abrir los brazos y cantar el himno de paz.

Este paso, sin embargo, no parecía merecer aún la aprobación de los demás, quienes permanecían armados alrededor de sus chozas, y alejadas las mujeres llamaban con ansia las pocas canoas que estaban al costado de las corbetas. Advirtieron los Oficiales estas circunstancias, pero no hallaban prudente embarcarse tan luego, dando muestras de inferioridad, ni les parecía oportuno avisar á las corbetas, para que les auxiliasen con nuevas fuerzas, tal vez mal interpretadas y prevenidas por los naturales: permanecieron, por consiguiente, aún por algún tiempo en la playa, dieron nuevas muestras del desprecio con que miraban á sus adversarios y de sus deseos de una pacificación, y finalmente, regresaron con el bote á bordo.

Una mezcla semejante de tesón y dulzura, no podía ménos de dar un nuevo aspecto á estas circunstancias desagradables, y convencer á los naturales, así de nuestras fuerzas, como de nuestras ideas realmente pacíficas: no tardó el Ankan en manifestarlo así á los suyos en una arenga bien larga y enfática, que se advertía desde las corbetas; y: finalmente, en atraerlos á que pidiesen unánimemente la paz, entregada la chaqueta origen de la discordía. Con ellá, pues, se dirigió á la A TREVIDA, acompañándole las muestras más Jul. 4 solemnes de una paz verdadera, y suplicó á Don José Bustamante para que en una y otra corbeta cantasen nuestras gentes la paz, así como los suyos la ejecutarían en la orilla opuesta; muy luego este agradable estruendo repetido en ambos buques y en tierra, no sin alguna harmonía, y con la expresiva acción de los brazos abiertos, presentó á la vista de los nuestros un espectáculo bien diferente del que poco antes habían imaginado, y nuestras tripulaciones, olvidado el enojo que les había inspirado el oir el riesgo de sus Oficiales, volvieron á recibir aquellas ideas de compasión y humanidad, que con tantas ansias deseábamos inspirarles á cada paso.

Bien establecida la paz, quisieron los naturales después de puesto el Sol ratificarla aún con mayor solemnidad, y con este intento, encendidos algunos fuegos sobre la orilla inmediata á las corbetas, emprendieron algunos bailes y festejos, los acompañaron con cantos harmoniosos y alegres (que el Sr. de Heenke no omitió de copiar inmediatamente) y mezclaron con bastante frecuencia las voces de ATREVIDA y DESCUBIERTA, procurando dirigirse hacia los buques é imitando nuestro modo de llamar una y otra.

En el día siguiente que fué 1luvioso, pareció á D. José Bustamante tanto más oportuno el desistir de todo trabajo, cuanto que ya era crecido el acopio hecho de leña; la gente necesitaba de algún descansu; así pudieron examinarse con más despacio el carácter é intenciones de los naturales: los Oficiales de la Descubierta, acompañados del mismo Ankau, visitaron el paraje de los sepulcros y acrecentaron mucho en aquella ocasión sus conocimientos, así de las costumbres, como del idioma: se avivaron los cambios bajo el sistema primitivo de no subir los naturales á bordo, fué abundante la cantidad de salmones traídos al mercado sin alterar su precio, y agregada ya á las antiguas una nueva tríbu, que acababa de llegar y estaba regida por un hijo de nuestro Ankau; finalmente, al momento de la llegada de las lanchas, todo estaba en el mejor orden y tranquilidad, repitiendo el caudillo las aseguraciones de una sincera amistad y su satisfacción por nuestro regreso.

Concluídos todos los objetos que nos habían inducido á entrar en el puerto, era nuestro ánimo el abandonarle con la mayor prontitud para aprovechar la estación favorable en el reconocimiento de la costa siguiente hacia el Oeste; pero como el tiempo estuviese cerrado con lluvia, y por otra parte fuese muy útil para nuestra estiva un nuevo acopio de agua, se determinó que en la mañanita siguiente, las lanchas y bombos bien armados y á las órdenes del Teniente do navío Cevallos, se ocupasen en este servicio, mientras á bordo se acelerarían los demás apres- 
Jul. 5 tos para una pronta salida: luégo, tomando el día mejor semblante, y aún prometiendo uno ú otro aparecimiento del Sol, al mismo tiempo se destacó D. Juan Maqueda con un bote armado, para examinar algunos fondos que aún faltaban, y el Teniente de fragata D. Juan Vernaci con el cuarto de círculo de Ramsden, el reloj de longitud $35 \mathrm{I}$, un pilotín y dos soldados armados, tuvo orden de acechar algunas claras en la playa próxima por si lográsemos una nueva época distante para el examen de la marcha de nues. tros relojes.

Bien temprano el Ankau se había transferido á bordo de la ATREVIDA, atendiendo á los cambios en los cuales lograba siempre de una grande ventaja sobre los demás, con la preferencia de subir á bordo de la cual él solo disfrutaba; muchas canoas entendían igualmente en el mismo objeto; y en el paraje en donde estaba cl cuarto de círculo para esperar las alturas correspondientes de la tarde, sólo se advertía un corto número de naturales expectadorcs tranquilos de aquellas operaciones: pero poco antes del medio día, ó bien fuese un nuevo efecto de uná curiosidad ociosa, ó un nuevo prurito de abusar de nuestra paciencia, empezaron luégo á concurriv allí el mayor número, luégo á pretender tocar ya uno ya otroutensilio, y últimamentc, en rodear los soldados que procuraban apartarlos, llegando hasta pedir los fusiles no sin algunas muestras de insolencia; no omitió D. Juan Vernaci de avisar muy luégo estas circunstancias al Comandante de la Atrevida, á cuya voz estaba, y éste les participó inmediatamente avisando que tenía á su bordo el Ankau y que para obrar de concierto, deseaba se le previniese lo que había de hacer: la debilidad de nuestras fuerzas actualmente en tierra, el riesgo de la pérdida de una pieza cualquicra del cuarto de círculo difícil luégo de reemplazarle, y sobre todo el deseo de evitar una discordia que fuese tal vez funesta á unos y otros, no dejaba elección sobre el partido más conveniente: se le previno que detuviese al Ankau, y que éste instase á los suyos para que se apartasen de las inmediaciones del cuarto de círculo, y que tuviese la artillería pronta para usarla si fuese necesario: al mismo tiempo fué el bote de la ATREvida con el Teniente de navío Concha, y ya nos precedía algún tanto D. Cayetano Valdés con cuatro soldados armados.

En esta ocasión ya hubiera sido imprudencia pretender mantenernos en aquel puesto hasta la hora de las observaciones de la tarde y hacer del cuarto de círculo un paladío que fuese la causa de una reyerta sangrienta; así los primeros pasos de los Tenientes de navío Valdés, Vernaci y. Concha, se dirigieron á cubrir con la tropa el cuarto de círculo, á apartar un poco los que estaban inmediatos, y aun á convencerles (encargándonos nosotros mismos de esta opera- Jul. 5 ción), á que era necesaria esta medida, y acompañada siempre de las ideas más pacíficas y suaves; dióse después la orden al pilotín para que encajonase los utensilios, y á la marinería para que los llevase al bote: resistían los naturales el retirarse; manifestaban en sus posturas y rostros (ya bien conocidos) el deseo de usar de sus puñales si se les presentase una ocasión favorable; todas las canoas se habían retirado de las corbetas, y al mismo tiempo veíamos aproximarse algunos por la parte de la laguna y al abrigo de algunos árboles, mientras de la ATREVIDA nos avisaban, que ya toda la tríbu armada se encaminaba hacia nosotros; procuramos entonces dirigirnos con algún imperio á los naturales más adelantados y enseñándoles los fusiles les dijimos que se retirasen, pero el uno de ellos solo retrocedió dos ó tres pasos, y sacando su puñal nos manifestó que él tampoco estaba sin armas y que no temía: en balde á la sazón el Ankau detenido contra su voluntad en la ATREvIDA, gritaba á los suyos que se retirasen y les avisaba de estar la artillería pronta para ofenderlos: insistían en su primer ánimo y más bien redoblaba su furor ciego, llegando al punto de presentarse un natural pecho á pecho contra el Teniente de navío Valdés, quien tenía pronto su fusil y bayoneta: ya, pues, en este trance, pareció lo más oportuno acelerar el embarco del cuarto de círculo sin detenerse en encajonarlo, y avisar á la ATREVIDA que disparase un cañonazo sin bala, mientras nosotros nos aproximábamos en buen orden y paulatinamente á la orilla: al estruendo miraron todos en torno para ver el daño acaecido; el Ankau solicitó que no se dirigiese la puntería á las chozas, y algunos parecieron determinados á retroceder, pero muy luego volviendo á cobrar aliento, uno de ellos que nos seguía de cerca empuñó la daga con noble audacia y gritó al Ankau que pusiese su persona en salvo y entonces no tardaría en atacarnos.

Ya embarcado el cuarto de círculo, próxima á los botes toda nuestra gente cuyo número se había aumentado con la reunión de los que estaban sondando, nuestros cuidados no debían dirigirsc tanto á la seguridad nuestra como á evitar que uno ú otro natural no buscase por sí mismo la muerte entre nuestros fusiles y bayonetas; por consiguiente, se dispuso que se embarcasen algunos soldados, y después lo ejecutamos nosotros, considerándonos bien felices de haber podido evitar toda efusión de sangre humana cn una ocasión tan próxima á derramarla.

Con la retirada de nuestros botes ya variaban mucho las circunstancias de la contienda, pues sin tener los naturales objeto alguno para sus tretas y venganza, veían su jefe y otro indio de- 
Iul. 5 tcnidos á bordo de la ATREvida, y por consiguiente, de nuestra parte aquellas mismas ventajas que hubieran deseado tener en los días anteriores por medio del marinero: se agregaban á esto las repetidas voces del mismo Ankan, y la cesación de los cambios, todos agentes para que tuviese lugar muy luego una nueva pacificación; J últimamente, nuestra conducta uniforme para atraerlos á un roce amistoso, sin que dependiese ó del recelo de la ofensa ó del cebo é interés del comercio: así, no pasó largo tiempo sin que muchos naturales se aproximasen á la orilla y gritasen al tıkau que estaban dispuestos á la paz; pero como nuestras lanchas del agua no se hubiesen reunido aún á sus buques, pareció prudente á Don José Bustamante el detener aquel jefe á bordo con diferentes pretestos, hasta que se reincorporasen.

Conseguímoslo muy luego, y á las tres de la tarde, repitiendo los naturales sus instancias para la devolución del jefe y áun ofreciendo la restitución de un par de calzones que habían quitado diestramente á un marinero en el segundo día del corte de la leña; accedimos, á que se restituyese á tierra en una canoa que vino á buscarle, con las señales acostumbradas de paz; muy luego le vimos aparecer de nuevo y entonando el himno, con llevar en alto y con la mayor solemnidad los calzones robados, ratificó la paz, solicitando de nuestra parte las voces y señales acostumbradas en el pasamano, así como los suyos las repetirían desde la playa; así cesó de nuevo toda desconfianza, y no pasó media hora, cuando se hallaban á nuestro costado proponiendo una piel ó cualquiera otra friolera, los mismos indivíduos que al medio día despre. ciaban su vida por el solo placer, ó de ultrajarnos ó de ofendernos.

A las cinco de la tarde ya el viento se declaró bonancible por el Oeste despejando en un momento los cielos y horizontes: la marea debía continuar favorable hasta las diez, y así, no diferimos un momento en emprender la faena de desamarrarnos, y últimamente (metida la lancha) la de dar la vela.

No malograron los naturales estas últimas horas para la posible multiplicación de cambios, trayendo al mismo tiempo todos aquellos efectos que pudiesen agradarnos, y disminuyendo mucho sus pretensiones, que hasta entónces habían sido excesivas particularmente por lo que toca á las hachas y á los vestidos. Retiráron se al dar la rcla casi todas las canoas, y sólo quedó una inmediata á la DEscubIERTA, y en ella una mujer, la cual, entónccs, no solo quiso borrar de nuestra memoria con una acción buena el poco agrado que habíamos hallado entre los suyos, si también recordarnos, que ni aquellos climas áspcros pudician destruír el carácter dul cc y cariñoso que ha sido siempre la verdadera Jul. 5 señal característica de su sexo: nuestro cirujano, advirtiendo que esta mujer traía consigo un niño casi de pecho, le tiró desde la popa algunos cascabeles y avalorios, diciéndole que se los pusiese como adornos: subió después al alcázar y aproximándose al portalón, halló ya al costado la canoa. La compasión le movió entonces á hacer un segundo regalo de la misma especie, pero la mujer no pudiendo ya refrenar su agradecimiento, cortada con prontitud la mitad de una piel que traía, la puso en la cabeza del niño, y como si fuese en su nombre, la regaló; una acción semejante pedía de nuestra parte las muestras de una aprobación agradecida; así, no tardaron los que estaban presentes en regalarle una ú otra bagatela de las que entonces tuviesen á mano; pero la mujer léjos de ceder en aquella ocasión á los dictados de su pobreza ó de su natural inclinación á los adornos, prefirió el competir con nosotros en cuanto á la generosidad, devolviendo á medida que le alcanzaban nuestros regalos, ya una ya otra cosa en nombre del niño, y continuando con igual tesón en este empeño, hasta que estuvo enteramente despojada de las pieles que la cubrían. Puede imaginarse, que últimamente quedó de nuestra parte la superioridad de esta contienda; bien que sin mengua de la justa admiración que debía producirnos aquella conducta.

Eran ya las nueve de la tarde cuando rebasada la punta Turner, empezamos á ceñir el viento á la sazón muy flojo del Sudoeste, para salir sobre bordos del canal que forma la Isla Dixon con la punta Muñoz: en uno de estos bordos, prolongado hacia la boca de un río, en cuya punta el actual bajamar había disminuído el fondo considerablemente la Descubierta, al tiempo de virar por avante quedó varada de proa, aunque por ambos costados y por la popa no fuese el fondo menor de tres á cinco brazas: inmediatamente se hicieron las maniobras para caer con el solo aparejo; pero no siendo bastantes, tendimos con el bombo un anclote y halando por la popa, de los calabrotes, quedamos á las once á flote $y$ en ro brazas de agua, sin haber experimentado otro daño alguno.

La corbeta ATREVIDA había ya destacado su bote á las órdenes del Teniente de fragata Viana para auxiliarnos y luego arribó para dar fondo en - nuestras inmediaciones, cuando se avisó á su Comandante nuestro ánimo de esperar fondeados la otra vaciante que no empezaría hasta las cuatro de la mañana.

Efectivamentc, no bien había salido el Sol con semblante hermoso y vientecito galeno del Oesnoroeste, cuando emprendimos el dar la vela. Fueron muchos nuestros bordos hacia una y otra costa, antes que pudiésemos considerarnos safos 
Jul. 6 de la punta Muñoz, cuyas restingas salen al mar unos cuatro ó cinco cables; pero á las nueve, in clinado el viento al cuarto cuadrante, logramos rebasarlas á distancia de una media milla, y seguir al Sudoeste con todo aparejo, viento galeno del Oesnoroeste, mar bastantemente llana y tiempo hermoso y apacible.

La latitud de $59^{\circ} 24^{\prime}$ observada al medio día y diferentes marcaciones hechas á todos los puntos que teníamos á la vista, dieron lugar á una prolija confrontación de nuestras tareas desde el puerto; que pudimos reunir de nuevo á las inmediaciones del Cabo Buen 'Tiempo, al fondo de la ensenada ó abra de fierrer, y á la costa que descle este abra sigue hacia el Oeste á las faldas del Monte San Elías.

Era la navegación que ahora emprendíamos el verdadero objeto del viaje; pues como se dirigiese á la parte de costa comprendida bajo el paralelo de $60^{\circ}$, en ella debiera hallarse precisamente, según las reflexiones del Sr. de Bauche, el pretendido paso de Ferrer Maldonado: por nuestra parte, á la verdad, ya no podía subsistir ni la esperanza más remota de la legitimidad de aquella Memoria, pues á todas las reflexiones ocurridas al tiempo de examinarla y que comprenderemos para mejor orden en un capítulo separado, se agregaba ahora la seguridad, no sólo de estar estrechamente unida toda la cordillera que desde el Cabo Buen Tiempo sigue hasta el Monte de San Elías, si también de estarle antepuesta y saliente al mar una faja de tierra baja que de ningún modo indicaba el navegante Maldonado. Al Oeste del Monte San Elías no pudieran tampoco verificarse jamás sus narraciones, cuando era una precisa circunstancia de las tierras inmediatas al canal, que toda la costa del Oeste fuese sumamente alta é impenetrable, y muy lozana y capaz de toda siembra la del Este.

Sin embargo, aquel trozo de costa no había sido hasta entonces prolijamente reconocido ni por nuestros navegantes, ni por cl Capitán Cook, ni por los Capitanes Portlock y Dixon; y por consiguiente, resultaría de nuestras tareas una ventaja no mediana á la Hidrografía, aunque malográsemos el intento primitivo del descubrimiento de un paso desde el mar Pacífico al Atlántico: así, pareció conveniente emprenderlo con la posible exactitud, cualesquiera fuesen los sacrificios del tiempo que hubiese de costar, en los meses restantes del verano.

Las navegaciones anteriores á la nuestra $y$ las mismas observaciones que habían podido hacerse después de nuestra recalada sobre la costa, debían convencernos unánimemente que ningún reconocimiento pudiera hacerse con los vientos del primero, segundo y á veces del tercer cuadrante, siendo solos los Noroestes y Oestes, los que despejando la atmósfera, facilitaban la vista clara de todos los puntos de la costa y las obser- Jul. 6 vaciones correspondientes para la determinación de la latitud y longitud; movidos de estas reflexiones habíamos precipitado en la tarde anterior la salida del puerto Mulgrave luégo que asomaron las primeras ventolinas del Noroeste, y atento á ellas, dispúsose ahora la navegación que debíamos seguir.

Ninguna duda cabía ni en la calidad ni en la posición de la costa desde la entrada de Ferrer hasta la punta Barrientos: la habíamos visto en diferentes ocasiones, correr al principio algo estéril y escarpada y luégo extenderse en una frondosa arboleda más allá de la punta indicada, no descubriendo otra boca que la de una ría ó canalizo muy parecido á los muchos que forman las islas últimamente reconocidas. Además, la costa de la orilla distaría en estos parajes unas cuatro leguas de las faldas de la cordillera, $y$ presentaba el mismo aspecto lozano que habíamos notado en el puerto Mulgrave: por consiguiente, no sólo no era preciso un nuevo arrimo á esos parajes, sino que malograríamos en el caso de repetirlo, el tiempo claro y bonancible de que gozábamos á la sazón.

Prefirióse con estos antecedentes un bordo largo al Sursudoeste, declarado ya el viento al Oeste; á las ocho de la tarde cambiamos la mura, y en la mañana siguiente debimos variar el bordo otras dos veces, así para adelantar cuanto fuese posible al Oeste con los vientos variables y flojos, como para esperar ocasión más oportuna de reconocer la costa, pues que se había cerrado con calima y llovizna luego que el viento había rolado al tercer cuadrante.

No nos habíamos descuidado, sin embargo, en aprovechar de todas las claras que el tiempo nos proporcionase y áun en mantenernos en tal posición, que la tierra no pudiese ocultársenos hacia el medio día ó las primeras horas de la tarde: así el Monte Buen Tiempo y las tierras contiguas al fondeadero antiguo se habían marcado á las seis de la mañana, se habían observado luégo dos series de horarios, y conseguida al medio día la altura meridiana del Sol, podíamos ya ver extendidos algún tanto $\mathrm{y}$ cimentados con igual solidez nuestros reconocimientos: era la latitud de $59^{\circ} 30^{\prime}$ y la longitud de $55^{\prime}$ al Oeste del puerto Mulgrave, cuyo meridiano adoptamos para hacer independientes las cartas siguientes de cual esquiera dudas sobre la verdadera longitud de aquel puerto; y nos demoraban la Punta Barrientos al Nornordeste, y el extremo occidental del abra de Ferrer al Nordeste corregido.

Pasado el Sol al meridiano, la tierra despejó sí suficientemente de la calima que le cubría. pero al mismo tiempo se escaseó el viento al cuarto cuadrante obligándonos á seguir rumbos del primero para atracarla; á las dos ya no dis- 
Jul. 7 tábamos de la costa más que dos leguas y la ATrevida nos señalaba el fondo de 68 brazas, pudiéndose al mismo tiempo reconocer con individualidad el trozo de costa hasta la Punta Novales, en la cual, si bien habían llegado nuestras marcaciones desde el Cabo Munoz con el teodolito, la dirección era demasiado oblícua para determinarse con propiedad todo lo que hubiese entre los varios recodos que formaba: no fué fácil marcar con seguridad las tierras altas inciuso el Monte de San Elías; en cuanto á la baja que teníamos actualmente á la vista, no nos quedaba duda de estar perfectamente unida, y veíamos que cesada la arboleda poco después de la Punta Barrientos, se extendía luégo en una especie de barrancas rojizas con el terreno interiormente amogotado hasta la falda del mismo monte.

En esta posición viramos por avante, y casi al mismo tiempo, el viento que había estado por un corto intervalo calmoso del tercero y cuarto cuadrantes, se declaró de nuevo por el Oesudoeste, cerrando en muy poco tiempo toda la costa con calima.

Así se mantuvo también en todo el día siguiente; y como se dirigiese nuestro intento á ganar siquiera una regular diferencia al Oeste antes de recalar nuevamente sobre la costa reconocida, nos ocuparon únicamente los bordos más ventajosos, desentendiéndonos de la costa que por la mañana veíamos confusa y tomada del Nornoroeste al Noroeste.

Aunque no tuviésemos sino un conocimiento muy superficial de los anuncios del tiempo, ya los semblantes que se nos manifestaban, no nos dejaban duda de una próxima variación al Sueste, tanto más segura, cuanto que acrecentaba á cada paso la cerrazón, imposibilitándonos el medir siquiera una altura del Sol. En efecto, antes de la media noche, ya el viento había rolado fresquito al Sudoeste y Sur con agua menuda y mucha cerrazón, y podíamos, por consiguiente, navegar al Oeste, como lo ejecutamos muy luégo con todo aparejo.

Como era natural, del Sur pasó el viento rápidamente al Sueste y Este bastante fresco, pero tan calimoso, que nos haría malograr cualesquiera reconocimientos. No cabía, por consiguiente, la menor duda sobre el partido que debiese preferirse, y era el de navegar con fuerza de vela hasta la entrada del Príncipe Guillermo, y allí esperar la alteración favorable del viento para retroceder reconociendo prolijamente la costa. Para que, sin embargo, no se malograsen nucstros pasos por lo que toca á las tareas hidrográficas, desde el medio día emprendimos el navegar en una misma linea Norte-Sur, distantes los dos buques una legua uno de otro, para indagar la existencia de un bajo, visto ha- cia aquellos parajes por nuestras corbetas la Jul.9 Princesa y la Favorita, en I779.

Estábamos entonces persuadidos por la estima, de hallarnos en los paralelos proporcionados á aquel intento, combinando los diarios originales del Teniente de navío Arteaga y del Piloto Maurelle, con la carta de aquella expedición, sacada del Archivo de Indias en la Corte, pero como luégo en las inmediaciones del medio día tuviésemos con el auxilio de algunas claras la altura meridiana del Sol con bastante exactitud, y por otra parte, inclinándose el viento hacia el Esnordeste despejase regularmente la costa, nos pareció deberse omitir aquel empeño y navegar directamente hacia el Cabo Suckling del Capitán Cook, para extendernos luégo Kacia el Oeste ó al Este según los vientos lo exigiesen, en la mananita siguiente.

Hasta las seis de la tarde se mantuvo el viento fresco sin disiparse la cerrazón y llovizna, aunque se dejaba ver confusa la tierra, pero después abonanzó considerablemente, y despejando al mismo tiempo la costa, pudimos distinguir con certeza toda la Isla Kaye, el mismo CaboSuckling y unas tres leguas de costa oriental contigua al mismo Cabo, la cual, no omitimos de reconocer.

Las sondas que en toda la tarde habían estado á cargo de la ATREvidA, aunque examinadas con I oo brazas de sondaleza aún no estaban á nuestro alcance, y no obstante, á las nueve ya no distábamos más que tres á cuatro leguas de la costa y el agua tenía un color muy cargado y verdoso.

En la pasada corta travesía y áun en la recalada al Cabo Suckling, si la refiriésemos á la carta del Capitán Cook debía causarnos mucha extrañeza la variación de la aguja, la cual, bien determinada en el puerto Mulgrave de $26^{\circ} 40^{\prime}$, la hallábamos luégo en el puerto del Desengaño y por los azimutes meridianos de este día y del 6 , de $32^{\circ}$ al Nordeste; no adoptándola, hallábamos muy equívoca nuestra posición; y sin embargo, veíamos que era mucho menor la que había observado y usado el Capitán inglés para sus cartas.

Fueron muy pocas las pardelas que vimos á alguna distancia de la costa: nos abandonaron luégo que volvimos á atracarla y en su lugar ó de cualquiera otra especie de aves sólo aparecía de tiempo en tiempo uno ú otro lobo marino.

La tierra reconocida al Este del Cabo Suckling se componía en la orilla del mar de una arboleda de pinos, tan unida, espesa y frondosa, como las quc habíamos visto en las inmediaciones del puerto Mulgrave: sobresalían á la espalda, los montes medianamente altos y nevados entre los cuales se distinguía el que (según el Ca. pitán inglés) se elevaba sobre el mismo Cabo: no se advertía la menor abra en este trozo de costa, y desde su extremo oriental que terminaba en una punta no muy saliente, la costa pare. 
Jul. a cía inclinarse de nuevo y suavemente más bien al Norte que al Sur del Oeste del mundo.

A las diez y media de la tarde, por sondas de 35 y $1 / 2$ brazas lama, ya no distábamos másque dos leguas del Cabo Suckling, el cual nos demoraba al Norte $28^{\circ}$ Oeste de la aguja. Se veían distintamente el pedrusco intermedio y toda la Isla Kaye, cuyos extremos marcábamos del Oeste $26^{\circ}$ Norte, al Sur $67^{\circ}$ Oeste, y al mismo tiempo casi el viento galeno del Este como la costa bastantemente clara, convidaban unánimes á pasar entre la Isla Kaye y el Cabo Suckling (I) para reconocer la bahía Comptroler, lo que había intentado infructuosamente el Capitán inglés.

Con este ánimo y más bien con el objeto de examinar con mayor claridad este paso y no entregarnos ciegamente al viento aunque favorable que amenazaba refrescar demasiado, tomamos el partido de pairear hasta las dos de la mañana siguiente, conservando por medio de la sonda la posición en que nos hallábamos, y después, según las circunstancias, internar en el canal ó pasar al Sur de la Isla Kaye. Empero á la media noche ya el viento sopló recio y arrafagado: la mar había engruesado, y quedaba cerrada con llovizna y mucha celajería toda la costa, ocultándose, aunque no distante, la mayor parte de la Isla Kaye. Con estas apariencias hubiera sido imprudente, así el internar en un paraje de difícil salida como esperar tranquilos que declinando el viento al Sur no nos permitiese montar la Isla Kaye: hasta aquí, si consultásemos la sonda (pues las marcaciones ya no podían repetirse) $\mathrm{cl}$ efecto de la marea había sido muy corto, y debíamos, por consiguiente, considerarnos casi en el mismo paraje en el cual nos habíamos atravesado.

Así, fueron nuestros rumbos primeramente del Sur y luégo arribamos paulatinamente al tercer cuadrante á medida que disminuyendo la latitud, nos apartábamos de la isla, cuya dirección es próximamente del Sudoeste al Nordeste.

Las corbetas Princesa y Favorita del Departamento de San Blas, costeando en I779 la Isla Kaye, habían descubierto un bajo al Oeste del islote de la punta y saliente al mar unas dos millas: nos pareció preciso el reconocerle, incitándonos á esto, además de la seguridad de las navegaciones venideras, la actual marejada algo gruesa que le hacía. perceptible desde mayor distancia y nuestro deseo de pasar al regreso entre la Isla Kaye y el Cabo Suckling, ya que las circunstancias no lo permitían en la actualidad: navegamos, por consiguiente, con la vigilancia corespondiente y á tal distancia en la marcación indicada, que de ningún modo pudiese ocultárse-

(1) Iiste nombre, traducido literalmente en nuestras cartas, es el Cabo Chupador. nos aquel peligro, y así (no percibiéndolo), debi- Jul. 10 mos creer que serian éstos los mismos pedruscos salientes que había visto el Capitán Cook, bien que ni en la dirección ni á la distancia que expresaban nuestros navegantes.

Franqueada á las tres y media de la mañana la punta meridional de la Isla Ǩaye, y arreciando mucho el viento ya declarado del Esnordeste, hicimos rumbos hacia la entrada del Príncipe Guillermo, bien que procurando reconocer la costa que corre desde la isla ya nombrada hasta el Cabo Inchinbrook (I). Navegamos algo precavidos en el aparejo: sondamos dos veces sin encontrar fondo, y como aprovechásemus todas las claras para observar la longitud, á las cinco y media y á las diez y media conseguimos medir algunos horarios que ratificaron nuestras marcaciones y bases corridas.

Con el Nordeste que reinaba á la sazón muy fresco con mar bastantemente gruesa, la costa había despejado mucho y se hacía fácil un reconocimiento prolijo; pero consultando los carices, parecía que el tiempo más bien que inclinarse al Norte no tardaría en rolar al Sueste y Sur tempestuosos, haciéndonos malograr algunos días que ni emplearíamos en los reconocimientos hidrográficos, ni en los físicos; y como los tiempos oscuros sólo permitiesen los segundos, debimos inclinarnos á fondear en la entrada del Príncipe Guillermo, con ánimo de permanecer allí hasta que durasen vientos contrarios para nuestras tareas y atender en el ínterin á la Botánica, Litologia y estudios de los naturales: con este ánimo navegamos llevando un andar de ocho á nueve millas, hacia el Cabo Arcadio. Habíamos atracado la costa unas cuatro ó cinco leguas al Este de la Ensenada de Menéndez y no omitiendo el correr bases, hacíamos tales rumbos que no distásemos de lá costa más que una ó dos millas cuando nos aproximamos al Cabo (Español) Arcadio.

Este trozo de costa, reconocido con no mucha prolijidad por el Capitán Cook á causa dc los malos tiempos que le acosaban, había sido luégo avistado por nuestras corbetas Princesı y Favorita, las cuales, aunque no se aproximasen á ménos de seis ó siete leguas (según los diarios del Comandante Arteaga y del Piloto Maurelle) habían logrado de unos días bien despejados y largos, y trazadas algunas puntas salientes con la posible exactitud: mucho mayor debíamos suponerla en los trabajos hechos por D. Salvador Fidalgo en el año próximo anterior, pues penetrando con lancha por el canal interior desde el puerto de la Magdalena hasta la Ensenada de Menéndez, había observado con buen sextante la la-

(i) Es en nuestras cartas el Cabo Arcadio por la misma atención á la sencillez y ortografía. 
Ful. $x$ titud en un islote saliente, sondados todos sus contornos y determinada su extensión con bastante regularidad: con estos antecedentes, nuestro trabajo actual más bien se dirigía á la determinación de las longitudes, independiente de la pesquisa de un paso que parecía muy poco probable en aquellos contornos, y desde luego no comprendido en las combinaciones del que indicaba Ferrer Maldonado. Las tierras altas, quebradas y cubiertas de hielo, en el cual reflejaba el Sol, ya nos habían representado otras abras hacia el Este como las que habíamos notado en las inmediaciones del puerto Mulgrave; pero con aquel escarmiento, algo cautos sí en no juzgarlas como tales, bien que no precipitados en excluirlas, dejamos para el regreso hacia el Este el destruir cualesquiera dudas hidrográficas en aquella parte.

A las diez, ya veíamos el Cabo Arcadio, y hacia las once también el extremo de la Isla Montagut, aunque confuso. Se anteponía á ésta una isleta rodeada de arrecifes, de la cual no distaríamos más que unas tres millas, y dejándose ver sobre la tierra del Cabo algunos mogotes que no especificaba el Capitán Cook, podía caber alguna leve duda en nuestra actual posición, tanto más, que cerrado nuevamente el tiempo con chubascos y ráfagas fuertes, exigía mayor cautela en la navegación, y ésta misma sería muy peligrosa, si la entrada á que nos dirigimos fuese casualmente la de la Ensenada de Menénḑez.

Paireamos con este an tecedente como un cuarto de hora de la vuelta del Sur y á distancia de una milla larga del Cabo Arcadio; sondose al mismo tiempo sin encontrar fondo con 80 brazas, y luégo, confirmadas con disiparse algo la cerrazón nuestras ideas del paraje donde nos hallábamos, arribamos nuevamente para atracar la tierra del Cabo y dirigirnos sobre las gavias al fondeadero.

No fué posible por las muchas nubes observar al medio día la altura meridiana del Sol, que deseábamos con ansia, porque discrepaba mucho la latitud determinada por el Capitán Cook de la que determinaban nuestros navegantes: distábamos á dicha hora media milla de la costa, la cual corre sumamente acantilada desde el Cabo Arcadin hacia el Nordeste y Este, para alcanzar el fondeadero.

$\mathrm{El}$ viento á la sazón soplaba con ráfagas bien fuertes que venian por las cañadas de los cerros inmediatos, y además, á medida que orzábamos, se escaseaba más y más y variaba su dirección, según la figura de los montes. Puede imaginarse, por consiguiente, que ni nos descuidábamos en atracar la costa cuanto fuese posible, ni en buscar con el escandallo, ó el fondo de I 7 brazas que había hallado el Capitán Cook delante del Cabo Inchinbrook, ó los que habían proporcionado el dar fondo al Comandante Ar- Jul. sn teaga. Hubiéramos dejado caer inmediatamente un ancla, y esperado mejor ocasión para internar en el puerto; pero aunque ya á distancia de unos dos cables de la orilla, fué inútil aquella precaución, y hubimos de emprender algunos bordos entre unos pedruscos que nuestros navegantes llamaron los negrillos, y la costa sobre la cual deseábamos fondear.

Las ráfagas, demasiado inconstantes y recias, hacían estos bordos no tan sólo incómodos y arriesgados, sino también inútiles, tanto más, que la marea parecía á la sazón y debía ser más bien contraria que favorable; pero á tan co1*ta distancia del fondeadero, era desagradable el abandonarle, y el internar más hacia el Norte, ó el buscar abrigo de la Isla Montagut, parecían partidos poco convenientes para aprovechar después todas las horas del primer Noroeste que nos favoreciese en el prolijo reconocimiento de la costa que dejábamos al Este. Determínamos, por consiguiente, continuar en el mismo intento, y desde luego el Piloto Sánchez fué en el bote á buscar en la costa más inmediata y á nuestro alcance, un paraje en donde pudiese caer el ancla con alguna seguridad: poco después, no distando en el bordo del Este más que un cable y medio de la orilla, fué preciso virar por avante, aunque las ráfagas continuasen muy fuertes y varias y con ellas una misma posición del aparejo, fuese á ratos ó contraria ó favorable para el fin que deseábamos.

De este modo permanecía aún la DescubiekTA sin caer de la mura opuesta, cuando una ráfaga excesivamente fuerte partió por la cruz la verga de velacho y nos obligó á variar de idea. Tomamos la mura de babor con trinquete y gavia, y recogido el bote, metiéndole nuevamente, se sustituyó después á la rota otra verga nueva, pero ya distábamos dos leguas del Cabo Arcadio, y las rompientes al Este de la Isla Triste nos demoraban próximamente al Sur distancia de dos millas.

A la sazón el tiempo había abonanzado y despejado mucho, de suerte que parecía prometer una próxima variación al Norte y Noroeste, afianzando este concepto la vista de toclos los montes internos, que adrertíamos sin la menor celajería ó calima: tomáronse en estas circunstancias las muras á estribor nuevamente; costeamos á poca distancia la parte de la Isla Montagut, que forma su extremo septentrional, y á las seis de la tarde nos hallamos bien internados en la entrada; de suerte, que no distando de la costa más que media legua, ya marcábanos al Este y al Esueste el fondeadero de la mañana, no sin esperanzas de vermos dueño de alcanzarle, según la marea nos sostenía hacia el Este: la vuelta del Sueste pareció ahora la más conveniente, y así 
Jul. so no tardamos en preferirla, aprovechando al mismo tiempo esta ocasión favorable, así para unas observaciones exactas de la longitud y de la variación de la aguja, como para extender las marcaciones hacia los puntos internos cuanto estuviese en nuestro alcance.

No tardaron, sin embargo, la marea y el viento á oponernos nuevos obstáculos, desatracándonos la primera del paraje por el cual á la sazón anclábamos, y manifestándose el segundo con nuevas ráfagas y mal cariz que nos obligaron á precavernos en el aparejo; fueron inútiles por consiguiente nuestros esfuerzos en la restante tarde, no sólo para atracarnos al fondeadero, si también para pasar al Este de la Isla Triste; y linalmente, á las once de la noche hubimos de decidirnos á pasar al Oeste de ella para franquearnos algo de aquellas inmediaciones.

Unas tres canoas de naturales, de las cerradas con piel de lobo, ya se habían dejado ver á las seis de la tarde cuando tomamos las muras á babor: gritaron con sus acostumbradas señales y tono enfático á la DescubIERTA que navegaba algo distante, y luégo alcanzaron á la ATREvidA: fueron, sin embargo, inútiles cuantas instancias $y$ ofrecimientos se hicieron para atraerles á bordo; usaban frecuentemente de la voz Capitín; parecían poco ó nada expertos en el idioma del puerto Mulgrave; sus señales se dirigían en un todo á convidarle fondease al abrigo de la Isla Montagut; y en sus canoas se notaba una mayor perfección que en las del puerto Mulgrave: como por una y otra parte, ó no fuese fácil ó no pareciese prudente el dar cumplimiento á los deseos del otro, muy luego se separaron, dirigiéndose aquellas hacia el puerto de Santiago é incorporándosenos fácilmente la ATREVIDA.

Eran próximamente las once de la noche cuando nos decidimos á pasar al Oeste de la Isla Triste, por cuya parte no advertíamos restinga alguna, mientras las que se tendían äl Este y no podíamos rebasar, no tenían ménos extensión de media milla escasa; á la media noche la rebasamos, no encontrando fondo á dos millas de distancia con unas 30 brazas de sondaleza á pique; orzamos luégo al Sueste, é hicimos alguna fuerza de vela para separarnos algo de la Isla Montagut.

Por ventura, nuestros navegantes habian visto en aquellos contornos unas islitas (llamadas de Hijosa), que ni el Capitán Cook, ni el Capitán Dixon (I) habían comprendido en sus cartas; omisión de la cual no podía prescindir el primero por haber salido al Oeste de la Isla Montagut; pero que no debía disimularse en el segundo, así porque su derrota del primer año,

(I) En las cartas inglesas posteriores al viaje del Capitán Dixon, está scñalada clicha isla. le llevaba en aquellas inmediaciones, como por Jul. in que tachaba impávido á nuestros navegantes an. tiguos por uno ú otro error en la Hidrografía del sin número de costas que habían reconocido; los bordos sin este antecedente á que nos precisaba nuestra situación actual, y el tiempo que ya se había declarado del Este al mismo tiempo cerrado y tempestuoso, pudieran tal vez habernos acarreado algún error que nos produjese las consecuencias más funestas, pues que era natural el ceñir al segundo cuadrante, no sólo para separarnos de la Isla Montagut, si también para coger de nuevo los meridianos en que debían comenzar nuestros reconocimientos.

En efecto, poco después de salir el Sol, el tiempo se había cerrado extraordinariamente, engruesando la mar y refrescando el viento, de modo que no podíamos resistir las gavias izadas: debíamos también atender á la composición del trinquete envergado, cuya relinga estaba tronchada desde la tarde anterior, y con este objeto, sustituímos otro trinquete mientras aquél se compusiese, pero volviendo á desenvergarle de nuevo, luego que el primero estuvo compuesto.

Nuestra derrota corregida fué próximamente al Sur. Con la cerrazón perdimos muy luego toda tierra de vista, y no cediendo la mar, el viento, ni la lluvia, continuamos de la misma vuelta hasta el medio día, á cuya hora viramos en redondo sobre las cuatro principales, un rizo en las gavias, considerándonos en latitud de $59^{\circ} .30^{\prime}$.

No tardó mucho en ceder el viento, y áun en convertirse en ventolinas flojas, bien que sin variar de dirección; se disipó algo la cerrazón, y á las dos de la tarde pudimos descubrir por nuestro través de barlovento á distancia de tres leguas, una isla rasa que desde luégo creimos las de Hjjosa, aunque variase mucho su posición en latitud y longitud, y no pareciese sino una sola isla.

La calma no fué tampoco muy duradera; á las siete de la tarde el viento estaba nuevamente fresco del primer cuadrante y acompañado con mucha lluvia; sin cesar ésta, quedamos luégo en calma, habiendo disfrutado por algún tiempo de los vientos del segundo cuadrante: últimamente. al amanecer disipada en mucha parte la cerra. zón y caido el marullo considerablemente, pudimos creer que el tiempo tomase mejor semblante $y$ nos permitiese continuar nuestras tareas. La navegación, desde la tarde anterior, había tenido por único objeto el conservarnos al Sur de la isla avistada y de la de Montagut, mientras continuasen los vientos variables tan interpolados con las calmas y acompañados de una lluvia y cerrazón constantes; pero como al amanecer del día siguiente pareciese muy próxima una variación favorable, no tardamos en aprovechar con todo aparejo las ventolinas del primer cua- 
Iul. s: drante para emplear oportunamente el tiempo.

Ya á las ocho logramos nuevamente ver la isla rasa, de la cual distábamos unas cuatro leguas: el rumbo del Noroeste $4^{\circ}$ Norte nos fué luégo aproximando hacia ella, y al medio día sus extremos Norte y Sur nos demoraban del Norte $82^{\circ}$ Este, al Sur $86^{\circ}$ Este distancia tres leguas escasas, viéndose al mismo tiempo la punta Sur de la Isla Montagut al Sur $86^{\circ} y^{1} / 2$ Oeste de la aguja, y señalando la ATrevida un fondo de 67 brazas arena.

A esta hora, por dos series de azimutes habíamos deducido con mucha satisfacción la variación Nordeste de $26^{\circ}$, y aunque careciésemos de la exacta altura meridiana del Sol, los elementos acopiados para la latitud eran tales, y tan conformes, que la podíamos considerar sin equivocación de $59^{\circ} 30^{\prime}$, siendo al mismo tiempo la longitud de $6^{\circ} 5^{8^{\prime}}$ al occidente de Mulgrave. E1 viento aunque apacible, no varió en toda la tarde del Nordeste; le ceñimos al cuarto cuadrante corriendo bases para la exacta determinación así de varios puntos de la Isla Montagut, como de la rasa; según las señales de la ATrevidA, navegamos por fondo de 40 á 50 brazas; y finalmente, á las siete nos hallábamos otra vez una milla y media al Sur de la Isla Triste por fondo de 74 brazas, demorando al mismo tiempo la punta Nordeste de Montagut al Norte $4 \mathrm{I}^{\circ}$ Oeste, y el extremo interno del puerto de la Magdalena al Norte $36^{\circ}$ Oeste de la aguja.

En esta posición, nos fué preciso virar al Essueste; el viento fué refrescando paulatinamente bien que sin impedirnos el aventajar considerablemente al Este con los bordos que variamos á la media noche y á las cuatro, así, á esta última hora navegando de nuevo al Essueste, marcábamos al Norte $5_{5}^{\circ}$ Oeste de la aguja á distancias de solas cuatro leguas las puntas inmediatas al Cabo Arcadio. Los dos rizos que á las diez habíamos tomado á las gavias, porque además del viento, la mar había engruesado mucho; hubieron de largarse de nuevo al medio día para montar la isla rasa, que descubrimos al Sur $5^{\circ}$ Oeste á distancia de tres leguas. Nuestra posición en latitud y longitud á este medio día, ratificaba enteramente los resultados del dia anterior para la situación de la isla, y como dependiesen de las mismas tareas los puntos de la costa oriental de Montagut, parecía que podíamos sin temeridad asignarles un grado más que mediano de exactitud: así el extremo Sudoeste de la Isla Montagut quedó últimamente en latitud de $59^{\circ} 47^{\prime}$ y $8^{\circ}$ I $6^{\prime}$ al occidente de Mulgrave, diferiendo nuestra latitud de la del Capitán Cook en la cantidad de i I' al Sur, lo que había advertido también el Capitán Dixon, observando próximamente en su paralclo.

Montada la isla rasa á distancia de una lc- gua larga, y continuando el bordo del Sur, ya Jul, 1, nuestra posición era nuevamente la misma que en los días anteriores; y pues que el viento en todo el día siguiente y las primeras horas del I 5 se conservaba bien fresco y arrafagado con mar gruesa por el Nordeste, fué más bien nuestro anhelo la conservación del aparejo, ya tomando, ya largando los rizos, que el aventajar algo hacia el Este, lo que conseguiríamos con mucha dificultad. Sin embargo, el tiempo claro favorecía en esta ocasión algo más nuestros bordos, que pudimos siempre llevar hasta dos ó tres leguas al Sur de la isla, y finalmente, en la mañana del I5 (no sin preceder algunas ráfagas, variedad de viento y no pocas horas de calma) se aparecieron algunas ventolinas del Sudoeste, que combinadas con muy buen cariz y el semblante bien risueño de la costa, parecían anunciarnos una próxima alteración análoga á nuestros deseos; no distábamos más que dos leguas de la isla, cuyas rompientes hacia el Este se percibían con la mayor claridad; se veían á larga distancia la Isla Montagut y las inmediaciones del Cabo Arcadio, y la mar, agradablemente llana, nos presentaba un espectáculo que desde la salida del puerto Mulgrave no habíamos podido renovar á la memoria.

Para coadyuvar con la variedad á la hermosura de este día, se nos apareció hacia las diez de la mañana, no distante del costado, una canoa cerrada, con dos naturales; hablaban, ó más bien, gritaban, repitiendo las mismas voces, cuya significación no pudimos alcanzar; mantenían alta sobre un palo una piel de nutria, que nos pareció de las más finas que habíamos visto has ta entonces, y nos señalaban constantemente con el canalete, que nos dirigiésemos hacia la isla, á cuya parte del Oeste encontraríamos un buen abrigo y un regular comercio de pieles.

Fué imposible el atraerles á bordo, aunque usásemos, no solo de la señal acostumbrada de paz con los brazos abiertos, sino también de la precaución de manifestarles varios pedazos gruesos de hierro y algunas otras bagatelas. Se despidieron á las once y se encaminaron con mucha velocidad liacia la isla.

En cuanto á ésta, las observaciones del medio día y su prolijo reconocimiento por la parte del Este, conformes con las de los días I2 y I3, ya afianzaban de tal modo su extensión y posición astronómica, que podíamos considerarnos con algún derecho para asignarle otro nombre. Tuvo, por consiguiente, el de Galiano, por el T’eniente de navío agregado á esta comisión, que por su talento y amor al trabajo debía conservar en nuestra memoria un lugar bien distinguido, y quedó determinada su latitud por la medianía de $59^{\circ} 26^{\prime}$, y su longitud de $6^{\circ} 37^{\prime}$ al Oeste del puerto Mulgrave. Es casi redonda, extendiéndo. 
Iul. 15 se algo más del Nordeste al Sudoeste; presenta por todas partes en la orilla una tierra abarrancada, elevándose algo más la parte del Sur, y manifestando en el solo centro una buena arboleda; los arrecifes que la rodean de la parte del Este, deben hacer temible al navegante el atracarla por allí; no así por la del Oeste hacia donde nos convidaban los naturales, pues el verla enteramente libre de arrecifes y el fondo de arena que hemos hallado á tres leguas de distancia, nos hacen creer que presente un abrigo cómodo para los vientos del primero y segundo cuadrante, aunque á la vista no se aperciba punta alguna saliente que suministre la idea de un puerto ó bahía. La canoa de que se ha hecho mención, venía seguramente de la isla, y sin embargo, no nos aventuramos en asegurar que sea poblada constantemente, pues tal ve $z$ la pesca de las nutrias puede en ciertas estaciones atraer hacia allí los naturales. En los cuatro días que hemos estado á su vista, jamás se notó la menor humareda, y sin duda no se hubieran descuidado en esta señal, así por el deseo de un comercio, que manifestaron después, como porque hemos notado esta práctica bastantemente puntual en toda la costa.

Hasta las tres de la tarde, el viento se mantuvo calmoso del Sudoeste, y ó bien fuese efecto de alguna corriente ó de la maretita que aún permanecía del Este, nos fué preciso hacer rumbos del Esnordeste para desatracarnos de la Isla Galiano: finalmente, la perdimos de vista á las siete, y casi al mismo tiempo se rctiró otra canoa grande, que con unos 20 hombres se nos había aproximado, no omitiendo el himno acostumbrado de paz; la Atrevida que le estaba algo más próxima, orzó, le tiró un cabo para que atracase, y usó de todos los medios que pudiesen atraérla; pero no fué posible decidirlos á este paso, y así, como el viento refrescase algo más, continuamos nuestra derrota, y ella pareció dirigirse hacia la isla.

Nos dirigimos, como era natural, hacia la costa oriental del Cabo Arcadio, desde donde en la mañana del io habíamos empezado los reconocimientos; el viento se conservó bonancible, la mar sumamente llana, y el tiempo, particularmente desde las diez de la noche, bien calimoso.

Sin embargo, antes de las nueve de la maña na del I6 ya podía distinguirse claramente el extremo meridional de la Isla Kaye, del cual no distaríamos al Oeste más que unas cuatro ó cinco leguas; y aunque la costa estuviese algo calimosa, no reinando tampoco á la sazón sino unas ventolinas variablcs; muy luégro conocimos que nuestra situación, relativamente á las tareas hidrogríficas, era cual podíamos desearla: la sonda manifestaba 70 brazas lama, y la variación de la aguja, deducida de algunos azimutes de lá tárde anterior y de aquella mañana, parecía con bas- Jul. is tante probabilidad ser de $28^{\circ}$ próximamente.

Hasta las nueve y media permanecimos de este modo en una casi total inacción; pero, finalmente disipada la calima con los primeros soplos de la virazón, no sólo pudimos navegar hacia la costa, sino también extender nuestra vista y marcaciones hasta el mismo Cabo Arcadio é intentar el paso entre la Isla Kaye y la tierra firme.

En la mañana del ro habíamos creído ver al gunas abras considerables al Oeste de la Punta Sarmientos entre la cordillera no muy alta pero enteramente nevada que desde la Ensenada de Menéndez corre hasta el Cabo Chupador. No nos costó ahora mucho tiempo el disipar aquella sos. pecha con el aparccimiento de una porción de tierra baja antepuesta á la alta y poblada de arboleda, la cual presentaba una orilla igualmente cerrada y sin punta alguna saliente; pero sucedía lo contrario con otra abra que á la sazón nos demoraba al Nornordeste, y cuya existencia, así por el término de la costa como por el abra de los montes internos, parecía tanto más probable, cuanto más nos aproximábamos.

Al medio día no distábamos de ella más que tres lcguas; al mismo tiempo nos demoraban los extremos de la Isla Kaye del Su1 $75^{\circ}$ Este, al Norte $66^{\circ}$ Este de Ia aguja, eran nuestras sondas dc $6_{5}$ brazas lama y las observaciones nos indicaban la latitud de $6^{\prime \prime} 3^{\prime}$ y longitud de $5^{\circ} 20^{\prime}$ al Oeste de Mulgrave.

Como con el poco viento del Sudneste y Oe. sudoeste nuestros progresos hacia la costa fuesen bien lentos aun en las primeras horas de la tarde, eran ya las dos cuando conseguimos desengañarnos de la primer idea de la existencia del abra hacia la Punta Sarmientos. Se le anteponía otro trozo considerable de ticrra, por partes casi anegadiza y por partcs algo frondosa, y si bien hacia el Este, entre la misma tierra baja, proyectase una pequeña boca cuyo término no alcanzábamos, no podía caber duda de ser ésta la boca de un río, así por las rompientes que se manifestaban de tiempo en tiempo en sus inmediaciones, como porque en las serranías internas no aparecía la menor cañada. Ya, pues, pudimos arribar paulatinamente al Este, refrescando algo la virazón y continuando aún las sondas de $6_{5}$ á 60 brazas lama. El valle reconocido tuvo el nombre de Valle de Ruesga, y se dió el de Cabo Nodales á la punta que le terminaba hacia el Este, inclinando luégo la costa para la bahía del Contralor.

Es el Cabo de los Nodales una punta de tierra baja y arenisca, de la cual salen hacia el Este dos pedruscos notables y continúa luégo la costa interna toda de arena en la orilla, pero á muy poca distancia poblada de una hermosa ar. boleda; los montes en este paraje hurtan rápida. 
lul. 5 mente al Norte; son de mediana elevación y van á unirse luégo con la cordillera, quc postergada al Cabo Chupador, corre casi Esteoeste hasta el Monte de San Elías.

A las seis de la tarde, continuando aún la virazón bonancible, pudimos rebasar este Cabo y emprender el paso meditado, pues que veíamos va claramente el Cabo Chupador y los extremos del Norte de la Isla de Kaye: precavidos, como era natural, con el escandallo, debimos á la verdad extrañar poco después el fondo de $\mathrm{I} 2$ brazas arena; pero creyéndolo efecto de nuestra inmediación á la costa firme, inclinamos muy luégo la derrota hacia la derecha: sin embargo, el fondo iba disminuyendo rápidamente; á las nue. ve, ya le teníamos de solas cinco brazas, y la proporción con que había disminuído siendo arena, hacía creer que muy en breve no permitiría navegar, pero en esta posición nos era fácil ya examinar toda la parte interna de la bahía, y por consiguiente, disipar el concepto que hasta entonces nos había alucinado. La que nosotros habíamos creído Isla Kaye, no era más que una península unida á la tierra firme por una lengua de tierra baja toda cubierta de arboleda $y$ dispuesta en una forma casi semicircular: se le posponían el Cabo Chupador y el extremo Nordeste de la península; y si creyésemos la disposición interna de la bahía, el mismo islote alto y escarpado en cuya inmediación estábamos, debía hallarse unido á la península por otra lengua no muy extendida de tierra baja, que en la actualidad nos era difícil investigar. Le llamamos con atención á esto la Isla Dudosa : la península conservó el nombre de Kaye; á su extremo Sur se puso el nombre de Cabo Español, y dejando á la bahía en que nos hallábamos el de Contralor, que había puesto el Capitán Cook, apellidamos bahía de Burgos, la que formaba liacia el Este el Cabo Chupador con la tierra escarpada y saliente de la península.

No pareció habitador alguno en todos aquellos contornos, aunque la calidad del terreno, la tal cual distancia de los montes y el abrigo de la bahía, convidasen ciertamente á habitarlos: si hay ó no un buen puerto al Nordeste de la Isla Dudosa, fuera difícil decidirlo, atendiendo al poco fondo en que nos hallábamos no á menor distancia de dos millas; hubiéramos querido podcrlo averiguar con el auxilio de los botes, pero la necesidad de aprovechar los pocos días claros en la continuación de nuestras tareas, nos hicieron creer como preferente, el salir cuanto antes sobre bordos de la ensenada, y por el Cabo Español reconocer la costa siguiente al Este.

Muy luego aumentamos el fondo hasta I7 jrazas lama, ciñendo hacia la tierra alta de la península, pero los disminuíamos nuevamente itproximándonos al Cabo Nodales, del cual dis- taríamos dos millas largas, cuando la sonda ma- Jul. rз nifestaba solamente seis ó siete brazas arena.

Contrariados de la marea, aunque el viento se mantenía galeno y la mar sumamente llana, no hicimos muchos progresos para nuestro intento hasta las cinco de la mañana, á cuya hora la costa de la península y en general los cielos y horizontes, se habían cargado con calima, y navegábamos por I5 y I7 brazas lama.

Algunas ventolinas del Oeste dieron después lugar á ganar considerablemente al Sur; á las nueve y media, disipada algo la calima, vimos el islote que sale del Cabo Español, y á las once y media ya no distando de él más que dos millas, viramos al Oeste con viento bonancible del Sursudoeste y tiempo despejado.

Con la tarde, el vierto fué paulatinamente rolando por el Sur al Essueste galeno, que debíamos precisamente ceñir con la mura á babor, apartándonos de la costa; no cambiamos la mura hasta las tres de la mañana siguiente; aunque no teníamos otro objeto en estos bordos que el montar el Cabo Español, al medio día no lo habíamos aún conseguido; antes bien, distábamos de él unas seis leguas, marcándole al Norte $33^{\circ}$ Este, cuando apenas era este el rumbo que podíamos seguir.

Pero, después, variando el viento al Sueste, este bordo nos fué más favorable de lo que imaginamos, y nos condujo á barlovento del islote, inmediatos á las piedras aisladas que en este nuevo reconocimiento conocimos, sin la menor duda ser las mismas que el Comandante Arteaga había creído en otro arrumbamiento $y$ á mucha mayor distancia del Cabo Español.

En esta posición, y sin hallar fondo con $6_{5}$ brazas, viramos á las seis al Sur $^{1} / 4$ Sueste $y$ continuamos la misma vuelta hasta las nueve $y$ media en cuya hora declarado el viento al Sur navegamos algo al Este; y arribamos después al Norte para atracarnos al frontón del Cabo Chupador, y continuar nuestras tareas.

El Cabo Español, que en la navegación de cstas costas será siempre un punto no indiferente, se halla en latitud de $59^{\circ} 50^{\prime}$ I $5^{\prime \prime}$ y en longitud de $138^{\circ} 34^{\prime}$ I $5^{\prime \prime}$ occidental de Cádiz, y si atendemos á las diferentes observaciones que se han hecho á su vista y que concurren exactamente en las marcaciones, podemos lisongearnos quc esta determinación no admita error alguno que pueda influir ni remotamente en la seguridad de la navegación.

Nuestros proyectos para el día siguiente se deshicieron con el Sur y Sueste, que como se ha dicho se había declarado en la tarde antcrior, pues cerrándose inmediatamente con lluvia y neblina todá la costa, ya ni era posible su reconocimiento, ni careciendo de observaciones pudiéramos sujetarle como deseábamos. Al medio 
Jul. rg día por fondo de 65 brazas lama, marcábamos el Cabo Chupador al Norte Io O Oeste de la aguja á distancia de tres á cuatro leguas.

Aunque la precisión de suponer las tierras altas al Oeste para la verificación del paso de Ferrer Maldonado excluyese también de nuestro examen el trozo actual de costa comprendido entre el Cabo Chupador y el Monte de San Elías, sin embargo, en el plan adoptado de nuestras tareas, de ningún modo podíamos descuidarie, pues que le habian trazado á mucha distancia, así el Capitán Cook como nuestros navegantes; en este supuesto no quedaba duda sobre el partido preferente en la actual situación y era el de conservarnos próximamente en aquellas inmediaciones, hasta que cedido el Sur tuviésemos nuevos soplos favorables del Noroeste, que su corta duración nos hacía más preciosos á cada paso; en el día 20 y hasta el medio día del 2 I, fué éste por consiguiente el único intento de nuestras maniobras, bien que adelantándonos algo hacia el Este para aprovechar con mayor extensión las primeras claras á una y otra parte; á este último medio día por la altura meridiana del Sol, estábamos en latitud de $59^{\circ} 36^{\prime}$ y nos consideramos como ocho leguas al Este del Cabo Chupador.

Como el tiempo se mantuvieșe aún cerrado con agua, y nuestra inacción, necesaria más bien, nos obligase á retroceder algo al Oeste, intentamos en la tarde inmediata navegar al Norte, precavidos con la sonda, y examinar luégo la costa del Oeste á tan poca distancia que pudiese esta remediar la falta de claridad y evidenciarnos siquiera de su dirección y calidad hasta el Cabo Chupador, ya que no sería posible por ahora determinar su posición astronómica.

La avistamos, en efecto, á distancia de dos ó tres leguas, como á las cinco y media de la tarde, y poco después la Atrevida á cuyo cargo se había puesto la sonda, por medio de la señal correspondiente nos indicó haber hallado 87 brazas. La costa más inmediata al Norte y Noroeste era una arboleda enteramente igual á las que habíamos visto al Este y Oeste del puerto Mulgrave: la excesiva arrumazón no permitía distinguir claramente su continuación; pero no dejaban de apercibirse algo más al Oeste otras puntas al parecer escarpadas, y que no debían distar mucho del Cabo Chupador: esta idea imperfecta de la costa (ni fuera posible á la sazón conseguirla más exacta áun á la distancia de dos leguas) no pudo, por consiguiente, evitar que retrocediésemos hasta las ocho hacia el Oeste y paireásemos luégo con la mura babor. El sem. blante del tiempo, aunque continuaba el viento bonancible al Sueste con mucha lluvia, prometía, sin embargo, no distante una revolución favorable, y esto nos animaba doblemente á sostenernos hacia el Oeste.
Aquellas apariencias no nos habían engañado: Jul. 2 I en la mañana del 2 I, después de algunas horas de una total calma, empezaron á apercibirse ventolinas del tercer cuadrante, las cuales, despejados en poco tiempo los cielos y horizonte, finalmente nos proporcionaban la vista de la costa, cual la habíamos deseado; y así, al medio día por latitud de $59^{\circ} 49^{\prime}$ marcamos el Cabo Español al Sur $59^{\circ}$ Oeste de la aguja, viendo al mismo tiempo toda la costa desde el Cabo Chupador por el Sur $84^{\circ}$ Oeste hasta el Norte $2 I^{\circ}$ Este.

Desde el extremo oriental de nuestros reconocimientos del día ro (del que distaríamos ahora unas ocho leguas), la costa parecía continuar con muy poca entrada, toda compuesta de terreno bajo y frondoso en la orilla, y algo adentro, cenída de una cordillera de mediana altura, nevada hasta la falda, la cual, por una parte, estaba contígua á los montes postreros de la bahía del Contralor, marcados en la tarde del I7, y por la otra venía á unirse, después de haber formado un valle considerable, á un monte bastantemente alto, que por el modo en que terminaban sus cimas, hemos llamado el de las Coronas.

Ninguna abra considerable podía apercibirse en esta parte alta, y ni se conocía que en la baja antepuesta hubiese algún puerto ó boca del río, bien que siempre de muy poca importancia, según la dirección de la arboleda en uno y otro extremo.

Esta misma arboleda, cuya vista cogíamos de nuevo, como al Noroeste de nuestra posición actual, seguía luego sin interrupción hasta la Punta Verde, no distante de las faldas del Monte San Elías, y en toda la costa, cuya extensión Este-Oeste no era menor de diez leguas, no se manifestaba ni la más remota apariencia de un abra: por lo común, á distancia de cuatro leguas hallamos fondo de 65 á 70 brazas lama.

Las pocas horas del crepúsculo (siendo el tiempo sumamente placentero) nos habían permitido el continuar nuestras bases y marcaciones sin interrupción, y habían sido frutos de esta tarea constante los reconocimientos expresados; aunque el viento en toda la tarde anterior, y aun en la mañanita del 22 . se mantuviese sumamente flojo; así, á las dos ya marcábamos el Monte de San Elías al Norte $29^{\circ}$ Este, y á las tres, por fondo de 55 brazas, no distábamos más que dos leguas de la costa, la cual, descle la Punta Verde, es pedregosa tajada al mar y dimanada de un frontón de tierra alta que se antepone á la cordillera majestuosa en la cual está comprendido el Monte de San Elías.

Puede imaginarse, que no nos descuidamos en aprovechar la actual claridad de los cielos para todas las observaciones que estuviesen en nuestro alcance: la longitud, por los relojes marinos y por distancias del Sol á la Luna; la variación 
Jul. 22 magnética, y la continuación de las bases, fueron, por consiguiente, objetos que nos ocuparon incesantemente en las primeras horas de la manana, en las cuales procurábamos al mismo tiempo aprovechar cuanto fuese posible el viento, navegando á dos leguas escasas de la costa por sondas de 35 á 40 brazas lama.

Contra nuestras expectativas, y áun mucho más contra nuestros deseos, el viento á las nue. ve de la mañana calmó enteramente, y desde este momento nuestros progresos fueron tan lentos y el tiempo tan calmoso, que hasta la mañana del 26 puede decirse que no variamos de posición.

Las pocas ventolinas que á veces nos alcanzaban, eran sumamente flojas y por lo común del segundo ó tercer cuadrante; nuestra distancia á la costa desde dos á cuatro leguas, las marcaciones al Monte San Elías, desde el Norte $1 / 4$ Nordeste hasta el Norte $1 / 4$ Noroeste, y esta alteración, efecto más bien de las mareas las.cuales en la tarde y principios de la noche parecían correr al Nordeste y en las restantes horas al Noroeste con velocidad de una ó dos millas. La serranía, de mediana elevación, antepuesta como se ha dicho á la cordillera é inmediata al mar, termina en la Punta Olavide ó más bien se une á la falda del Monte San Elías, cuyo pico (según nuestras operaciones trigonométricas), está por la perpendicular más interna de la orilla de siete leguas y media marinas, y elevado sobre el nivel del mar 2.792 toesas: desde aquél Cabo la costa forma una ensenada poco considerable, quc en nuestras cartas tuvo el nombre de Extremadura, y en ella sólo se advierten dos abritas ó calas, la una al Oeste cerrada con hielo al parecer perpétuo; la otra al Este inmediata á la Punta del Indio y abrigo de una pequeña ranchería de naturales.

Entre estas dos puntas, la orilla aunque pedregosa no carece de alguna arboleda, la cual cesa después dando lugar á las barrancas amogotadas que por la Punta Novales se dirigen hacia el Este hasta la de Barrientos y distan algo más de la cordillera, dirigida como es natural, hacia el Norte del puerto del Desengaño.

Como en todo este tiempo nuestras sondas no variasen desde 30 hasta 47 brazas, siendo su calidad lama suelta hacia la Punta Olavide y arena fina hacia la del Indio, cansadas las tripulaciones de trabajar con los iemolques para que las corbetas, aprovechando las ventolinas no cayesen excesivamente sobre la costa, hubimos de decidirnos en la noche del 24 y en la mañana del 25, á dar fondo con un anclote grande, cuya maniobra, en este último día, nos produjo la feliz casualidad de la visita de un natural de los que habitaban las inmediaciones de la Punta del Indio.

dunque no distásemos á la sazón ménos de siete millas de la orilla, ese joven se aventuró á Jul. 26 reconocernos con su canoa; á una milla de distancia, parecía, sin embargo, arrepentido de su proyecto, y más bien se inclinaba á retroceder que no á aproximarse; pero como á la sazón se dirigiese hacia él con el bote el Teniente de navio Valdés y le repitiese las muestras ménos equívo. cas de paz y de cariño, finalmente se dejó alcanzar, y determinó venir con el bote á bordo; su poca extrañeza, sus ansias para convidarnos al fondeadero inmediato, finalmente, su prontitud á brindarnos con la misma facilidad para usar de las mujeres, que se nos había of recido tantas veces en el puerto Mulgrave, no nos dejaron duda que no éramos los primeros europeos conocidos por aquellos naturales; bien que examinando los viajes anteriores al nuestro, parece más probable que haya derivado aquel conocimiento del roce con los vecinos del puerto Mulgrave, que de alguna visita directa á sus hogares. Las costumbres, las facciones y el idioma de aquel joven, parecieron totalmente iguales á las que habíamos advertido en aquel puerto; nos regaló algunas fresas, y cambió su manto de pieles de nutria, aunque no se le concediese el hacha que tanto apetecía: finalmente, hacia las nueve, regalado con varias frioleras, se despidió de nosotros y legresó á la costa.

Tampoco habíamos omitido en la casi total inacción de estos dias, de aprovechar siquiera la uniformidad de nuestra posición para ratificación de las longitudes, no sólo repitiendo las observaciones de las distancias lunares, sino también examinando la marcha diaria de los cronómetros por medio de las longitudes comparadas á las marcaciones del Monte San Elías, y sujetas con la latitud observada. Las distancias lunares observadas en ambas corbetas volvían á ratificar con mucha admiración nuestra los resultados dcl mes anterior distantes al Este de los relojes marinos $I^{\circ} I_{5}^{\prime}$ próximamente, $y$ lo que no era ménos extraño, el movimiento de esta máquina quedaba bien acreditado con no discrepar más que en dos minutos la determinación diaria actual de la longitud del Monte San Elías, con la que habíamos deducido de las operaciones geodésicas en el puerto Mulgrave; éstas, que hemos preferido por depender del teodolito, situan el pico alto en latitud de $60^{\circ}$ I $7^{\prime} 40^{\prime \prime}$ y en longitud occidental de Cádiz de I $34^{\circ} 45^{\prime} 45^{\prime \prime}$. La determinación del Capitán Coolidifiere de la nuestra.

Finalmente, en la mañanita del 26 , entablado viento galeno dcl primer cuadrante y dada en pocos instantes la vela, pudimos separarnos de la costa como unas cuatro leguas ó cinco y considerarnos libres de la necesidad de dar nuevamen. te fondo aunque el viento hacia el medio día fuese calmoso del Sur y los horizontes cerrados 
Jul. 26 con arrumazón y alguna llovizna: á la sazón ya no hallábamos fondo con roo brazas de sondaleza; le habíamos, sí, alcanzado desde 5 r hasta 85 brazas lama al tiempo de no distar más que cinco leguas de la costa, la cual, cogidas de nuevo las puntas Novales y Barrientos que habíamos examinado y colocado con las marcaciones del puerto Mulgrave ó de la tarde del 7 , ya no dejaba la menor duda, ó bien de su calidad ó dirección, ó bien de su continuidad al Este y al Oeste contra las aseguraciones de Ferrer Maldonado.

A la verdad, cuanto más examinásemos aquellos contornos, la tierra baja que los ciñe por to. das partes á la orilla, y la alta, que tenazmente unida sin el abra siquiera de una cañada ó de un río mediano termina con una noble y natural arquitectura, por una parte en el Monte de San Elías, y por la otra, en el de Buen Tiempo, tanto más debíamos extrañar, ó bien el origen de la Memoria de Ferrer Maldonado, ó la facilidad con que se le había dado por el Sr. de Bauche un ascenso tan público y legitimado: si las tareas nuestras ya descritas (por ser posteriores á las del célebre navegante inglés) no nos dan siquiera la complacencia de poderlas considerar como importantes para los progresos de la Geografía, puedan á lo ménos, evitando en lo venidero nuevos discursos sobre la existencia de un paso hacia esos paralelos, no aventurar más en semejantes pesquisas un número no mediano de vidas y de caudales.

E1 tiempo á la sazón, con una nueva altera. ción favorable, nos dirigió hacia el partido más conveniente para nuestras tareas siguientes, pues que podíamos considerar ya concluído el objeto principal del viaje á esos paralelos: navegamos en derechura hacia el Cabo Buen Tiempo, ratificando con nuevas marcaciones y observaciones la posición y encadenamiento de toda la cordillcra que desde el Monte San Elías corrc hasta el de Buen Tiempo; repetidas observaciones magnéticas nos indicaron la variación de 29 á 29 y $1 / 2^{\circ}$ Nordeste, y á pesar que al principio mereciesen más bien el nombre de ventolinas que de viento las que á la sazón disfrutábamos del Noroeste, fueron éstas poco á poco acrecentando su imperio, de modo que al medio día del 28 nos hallábamos al Oeste del Cabo Buen Tiempo, á distancia de unas tres leguas.

Si sea aquélla ó no la misma punta que distinguió con ese nombre el Capitán Cook, fuera difícil asegurarlo en la dirccción real de la costa que veíamos casi seguida $\sin$ objeto alguno considerablemente saliente al mar; es, sin embargo, la que termina la bahía de Bering, algo amogo tada y escarpada al mar, llena de nieve hasta la orilla, y próximamente al Sudoeste del monte del mismo nombre; la cima de éste se interna desde la orilla unas $5 \mathrm{y}^{1 /} / 3$ leguas, está elevada sobre cl nivel del mar $5 \cdot 368^{\prime} 3$ varas castellanas, Jul. 25 y resulta en latitud de $59^{\circ} \mathrm{Oo}^{\prime} 42^{\prime \prime}$ y longitud de I 3 I $^{\circ} 33^{\prime}$ I $5^{\prime \prime}$ occidental de Cádiz.

Aunque hasta entonces hubiésemos navegado bien desatracados de la costa, habían sido considerables los efectos de una corriente hacia el Sur, la cual pareció cesar luégo que empezamos de nuevo á costear de cerca y sujetar con nuevas bases y observaciones la verdadera posición de las orillas. Eran bien las cuatro de la tarde, cuando perdimos de vista el Monte de San Elías, y á este tiempo con vientos frescos del cuarto cuadrante, navegamos á distancia de dos á tres leguas de la costa.

Esta, pasado el Cabo Buen Tiempo, sc deja ver poblada de arboleda, pero sin la faja de tierra llana que se nota desdc la bahía de Bering: se disipan, al atracarla, las apariencias de muchas abras, unidas luégo entre sí por medio dc tierra baja, y no pudimos dudar que estuviese poblada, advirtiendo en una humareda que veíamos por la tarde, y en otra candelada, que al principio de la noche se apercibió hacia la entrada de la Cruz: la sonda es de 70 á 80 brazas como á dos leguas de la costa del Cabo; á la misma distancia no es posible hallarla después con 90 y Ioo brazas de sondaleza.

Eran próximamente las diez de la noche, cuando la oscuridad nos obligó á terminar nues tras tareas; aprovechamos las pocas horas hasta la mañana siguiente para atracar la ensenada dc la Cruz, en cuyas inmediaciones advertimos por nuestio costado un trozo flotante de hielo, y á las tres, ya muy próximos á su extremo Sur, hubimos de variar de rumbo y pudimos emprender las bases.

Ya la costa que examinábamos era bien diferente de la que dejábamos al Oeste y correspondía con las sospechas del Capitán Cook, de ser formada de un grupo numeroso de islitas con algunas abras y puertos bien útiles para la navegación; se anteponen á no mucha distancia varios pedruscos también por la mayor parte poblados con árboles; el fondo á dos y tres millas de los pedruscos, se manifiesta de 50 á 60 brazas piedra.

La mucha calima que en toda la mañana nos había imposibilitado el renovar como deseábamos las observaciones de longitud é investigar las calidades de los montes internos, cedió al aproximarse el Sol al meridiano; de modo que D. Felipe Bausá pudo con su acostumbrada perspicacia, fijar casi sin recelo de la menor equivocación, el número y posición de cste pequeño Archipiélago, y nosotros, observando para el medio día la latitud de $57^{\circ} 29^{\prime}$ y la longitud de $3^{\circ} 28^{\prime}$, confrontar la posición de los puertos de los Remedios y Guadalupe, delante de los cuales nos hallábamos. 
La vista de aquellos puertos no podia ménos de recordarnos con mucha complacencia, así la intrepidez del Comandante Cuadra que con una goleta los había visitado en Agosto de I775, como los derechos de primacía que habíamos adquirido sobre aquella costa, igualmente que en casi todas las demás de la América, anticipándose dicho viaje unos tres años al del Capitán Cook: y si fuera posible hacer honrosa memoria de dicho viaje en pocos renglones, seguramente no ocultaríamos ahora muchas circunstancias que le acompañaron; pero se referirán en otra parte más por extenso, y áun representadas por el buril, lograrán tal vez de la Nación aquel justo tributo á que se han hecho acreedoras.

Aclarado por la tarde el tiempo y continuando viento fresco del Noroeste, nos fué fácil continuar nuestras tareas por el Cabo Engaño y Ensenada del Susto hasta las islas meridionales de aquella Ensenada: deseábamos con ansia un examen prolijo de la entrada del puerto de Banks, visitado por el Capitán Dixon, y aún paireamos algunas horas de la noche siguiente que fué lóbrega y lluviosa; pero una corriente algo fuerte al Este nos hizo malograr estas medidas, encontrándonos propasados á las seis de la mañana del 30 , hora en que pudo verse con alguna claridad la costa: nuestros rumbos fueron por consiguiente dirigidos á atracar el extremo Sudoeste de la bahía del Príncipe, lo que conseguimos hacia las ocho de la mañana, y luégo á inter. narnos algún tanto en la Ensenada, bien que prefiriendo últimamente el pasar al Sur de las Islas Nubladas del Capitán Dixon, de las cuales distaríamos al medio día una milla larga por latitud de $55^{\circ} 57^{\prime}$ y longitud $5^{\circ}$ I $4^{\prime}$ del puerto Mulgrave; ya á este tiempo no alcanzábamos fondo con go brazas; le habíamos sí cogido de unas 95 brazas chinos en la noche anterior; y en las primeras horas de la mañana, nos le había señalado la ATrevida de 76 y 82: la variación de la aguja había bajado casi instantáneamente á $26^{\circ}$ Nordeste. La felicidad con que habíamos podido describir la costa con toda individualidad, era demasiado cebo para que no intentásemos seguirla estando la elección de nuestra parte: así, apenas rebasadas las Islas Nubladas, orzamos de nuevo para atracar el principio del Archipiélago de Bucareli, reconocido también por el Comandante Cuadra en I775 y luégo examinado también prolijamente en I 779 por el Piloto Maurelle á las órdenes de los Tenientes de navío Arteaga y Cuadra. A las cinco de la tarde ya estábamos inmediatos á algunas islas, pero como por la mucha cerrazón no nos fuese fácil extender nuestras marcaciones hacia dentro, mal pudiéramos ligarlas entre sí con la exactitud que deseábamos. El viento calmó al mismo tiempo casi de un todo, se cerró el tiempo más y más con llovizna Jul. 29 y neblina, y finalmente, debimos prefijarnos por único objeto separarnos algo de la costa, tanto más que la sonda constante de 55 y 60 brazas parecía confirmarnos las sospechas de una corriente ó marea hacia los canales internos.

A la suma inconstancia de ventolinas que continuó en la noche y mañana siguiente, se agregó una neblina tan espesa, que era preciso el uso de los cañonazos para conservarnos unidos con la Atrevida. La sonda era de 70 á 76 brazas arena lamosa, y al medio día era aún imposible el acertar con nuestra actual posición, bien fuese respecto á las observaciones ó bien á las marcaciones, pero no duraron mucho esta inacción y desconfianza. A las doce y media la neblina empezó á disiparse poco á poco, y á la una y media no solo teníamos lugar de repetir con seguridad nuestras observaciones, si también alcanzábamos á la vista la costa firme próximamente desde los puntos del medio día anterior hasta las primeras Islas, extendiéndose luégo éstas en una cadena bien unida hasta la entrada grande y últimamente hasta la Isla de San Carlos: esta última demoraba al Sur $50^{\circ}$ Este de la aguja, y el Cabo San Bartolomé al Sur $87^{\circ}$ Este, distancia de tres leguas.

Con la tarde, aunque el viento nos abandonase enteramente, nuestra posición debía pare. cernos bien agradable, pues reuníamos nuestras tareas astronómicas y algunas vistas exactas de las inmediaciones de aquellos fondeaderos á los trabajos harto útiles y penosos de los navegantes nacionales que nos habían precedido sobre la costa; cuyo conocimiento y utilidades (si juzgásemos por las noticias y cartas del Capitán Dixon), podían considerarse como enteramente ocultos á la navegación Europea.

El Cabo San Bartolomé está en latitud de $55^{\circ} \mathrm{I}^{\prime}$ y longitud $6^{\circ} 5^{\prime}$ al Este de Mulgrave; es una punta de piedra que cae con poca loma de un monte bastantemente alto y frondoso, y tiene hacia el Este á poca distancia tres farallones ó más bien islotes, detrás de los cuales con una abra considerable se deja ver la costa también frondosa del otro lado de la entrada, que sale más al Oeste y va luégo á unirse con los extremos de la costa que forman el Canal de Dixon.

O bien se considere el paralelo en que se halla este número crecido de buenos puertos, ó bien su inmediación por el Sueste con el Canal de la Reina Carlota, ó por último, la muchedumbre de los naturales que lo habitan, debe sin duda mirarse como preferente á los demás parajes conocidos hasta ahora para emprender el comercio de las pieles sobre un establecimiento sólido y permancnte, bien que parece harto dudoso que puedan jamás sostenerle las combinaciones demasiado arricsgadas, pręcarias y limitadas de 
Jul. ว $^{\text {T }}$ esta especie de comercio, particularmente en manos de una nación por necesidad poco económica; pero dejaremos para su lugar esta discusión política y volveremos ahora á la sola narración del viaje.

En las horas de calma la corriente nos había llevado algo al Sur, bien que sin separarnos de la boca del puerto, de la cual distariamos unas dos leguas á las seis de la tarde, por fondo de 70 brazas, arena fina, parda y variación por varios azimutes de $23^{\circ} 30^{\prime}$ Nordeste: á esta hora se dejaron apercibir algunas ventolinas del Norte, las que declinando poco después al Nordeste, parecían convidarnos tan solamente á navegar algo más desatracados, pero no á cesar de la empresa de continuar el reconocimiento de la costa hasta Nutka, de modo que los navegantes venideros no nos tachasen de omisos en un punto tan inmediato á los objetos esenciales del viaje. A la verdad, supuesta de nuestra parte una necesidad de visitar el nuevo establecimiento de Nutka y uno ú otro puerto de nuestra California, y de no diferir de la mitad de Octubre la llegada á los puertos de San Blas y Acapulco, el reconocimiento de la parte interior del Estrecho de la Reina Carlota no pudiera ser tan prolijo que describiese toda la costa, particularmente, si como parecía probable, ésta fuese más bien formada de islas que de tierra firme ó contígua; pero á lo ménos se aseguraría la navegación y se dirigirían con más acierto las pesquisas venideras, si tuviesen por objeto el perfeccionar la hidrografía de aquella parte del Globo.

Abandonada con este intento toda idea de una escala aunque breve en el Puerto de la Cruz del Archipiélago de Bucareli, nos dirigimos á pasar al Este de la Isla San Carlos unas dos ó tres leguas y orzar deśpués hacia lo interior de la canal. Pero muy luego vimos frustradas enteramente estas medidas, con los vientos, que después de la media noche se declararon frescos del segundo cuadrante, engruesando considerablemente el mar y cerrando cielos y horizontes con calimus y lloviznas: el bordo del Sur que seguimos al principio, nos hizo perder toda tierra de vista desde las siete de la mañana, y al medio día, por latitud de $54^{\circ} 32^{\prime}$, nos considerábamos en longitud de $4^{\circ} 44^{\prime}$ de Mulgrave, variación magnética $24^{\circ} 23^{\prime}$ Nordeste.

No por esto era nuestro ánimo desistir enteramente del reconocimiento proyectado, el cual también si pareciese arriesgado ó largo intentarle por el canal interno, pudiera á lo ménos resarcirse en algún modo por la costa externa, en donde las atenciones bien diferentes del Capitán Dixon nos dieran lugar á explayar un mayor grado de exactitud, particularmente en los arrumbamientos referidos á uno y otro extremo de la costa firme; pero en estos conceptos está- bamos bien distantes de imaginar los tempora. Az.r." les que desde aquella época debíamos encontrar, pues ya poco después del medio día, rodeados de una lluvia y cerrazón constantes y con mar bien gruesa, nos fué preciso precavernos con dos rizos en las gavias y aun en el día siguiente navegar con las dos mayores y la gavia arriada.

Sin embargo, nuestros bordos habían sido tales, que para las siete de la mañana del 3 avistamos á distancia de cinco ó seis leguas el extremo oriental de las Islas de la Reina Carlota probablemente por el Cloak Bay del Capitán Dixon: era una costa medianamente alta, con algunas abras al Sur, generalmente vestida de una arbole. da hermosa, y para nosotros en la actualidad terminada en sus extremos, del Norte $72^{\circ}$ Este, al Sur $87^{\circ}$ Este de la aguja: aunque el tiempo continuaba muy oscuro y de mal cariz, navegamos hacia ella hasta las nueve de la mañana, y luégo reviramos al Sudoeste frustradas nuestras esperanzas de conseguir á su vista las precisas observaciones de latitud y longitud, tanto más necesarias, cuanto que las observaciones inmediatas no nos dejaban duda de un error considerable en la estima, que influía en ambas determinaciones; si en este caso pudiésemos dejar correr nuestras conjeturas en cuanto á la longitud (adoptada la latitud del Capitán Dixon) nos persuadiríamos, combinadas las estimas desde el día I. $^{\circ} \mathrm{y}$ desde el 4 en que tuvimos observaciones de regular confianza por los relojes marinos, que la longitud de este extremo está $7^{\circ} 5^{\prime}$ al Este del puerto Mulgrave y por consiguiente algo más interna, ó al Este de la determinada por el Capitán Dixon, según el arrumbamiento con la Isla San Carlos, que él llamó Isla de Forest.

No bien habíamos virado, cuando empezó el viento á arreciar de nuevo y á precisarnos á navegar bien precavidos en el aparejo; desde esta época hasta la tarde del 7 , puede decirse que no experimentamos más que un temporal seguido del Sueste, en el cual, sin embargo, sobresalió mucho la noche del 5 , mereciendo el viento en aquella ocasión más bien el nombre de huracan: las olas con exceso gruesas, la lluvia contínua y el viento seguramente más tempestuoso y arrafagado que todos los que habíamos experimentado desde la salida de España, dieron lugar á las corbetas de acreditar sus propiedades sobresalientes, no habiendo tenido la menor avería, sin embargo que resistiesen constantemente á la mura con trinquete y gavia en dos rizos arriada.

Al medio día del 7 , cedido este temporal, nos hallamos en latitud de $53^{\circ} 2 \mathrm{O}^{\prime} \mathrm{y}$ en longitud de $3^{\circ} \mathrm{I}^{\prime}$, distantes por consiguiente mucho de la costa y, al Sur de los extremos reconocidos. Esta posición nos persuadió de que sería el partido más conveniente el hacer derrota directa 
In 7 hacia Nutka ó á lo ménos hacia el extremo septentrional de su costa, y así pues que á las seis de la tarde se declaró viento bonancible del Sudoeste y Oeste navegamos con todo aparejo al Es-Sueste.

Los tiempos continuaron bonancibles y aún algo variables en los días 8 y 9 , en los cuales, aprovechando los cielos bien despejados, se observaron en una y otra corbeta hasta 200 series de distancias lunares: su resultado debió causarnos nuevas confusiones, aproximándose de tal modo á la longitud de los relojes marinos, que no difería ménos de $I^{\circ}$ de la, longitud deducida en Junio y Julio, y por las observaciones hechas á la vista del Monte Buen Tiempo y del de San Elías; pero nos lison jeábamos de lograr en Nutka tales observaciones, que decidirían luego con seguridad esta cuestión harto desagradable y nueva enel método seguido para nuestras tareas.

A las diez de la mañana del día rr, ya logramos ver la tierra, aunque confusa; y la latitud de $5 \mathrm{I}^{\circ} \mathrm{I} 7^{\prime}$ observada al medio día, nos convenció que no distábamos de los extremos meridionales del Canal de la Reina Carlota, entre los Cabos Cox y Woody del Capitán Dixon: próximos á este último Cabo á las tres y media de la tarde arribamos con viento bien fresco al Sueste un cuarto Sur, y empezamos á reconocer con prolijidad la costa, pues el rumbo que traíamos de mar en fuera no nos había permitid.) trazar más que los puntos altos al Norte del mismo Cabo.

Es sin duda aquel trozo de costa más tendido del Noroeste al Sudeste de lo que lo suponían las cartas publicadas hasta entonces; y el Cabo Woody, fácil de distinguirse no ménos por su hechura amogotada y frondosa que por el islote que tiene saliente al Oeste y taladrado, quedaba por nuestras observaciones en longitud de $\mathrm{II}^{\circ} 5_{5} \mathrm{O}^{\prime}$ al Este del puerto Mulgrave; de suerte, que los resultados de nuestros relojes debían acercarse mucho más en Nutka á las longitudes del Capitán Cook de lo que lo habíamos conseguido en el puerto Mulgrave y entrada del Príncipe Guillermo. Aproximándose la noche, calmó mucho el viento, y los cielos y horizontes acrecentando su claridad, hicieron que en las horas siguientes jamás careciésemos de la vista de la costa: distábamos de ésta á la sazón unas dos leguas por sonda de 50 brazas chinos; nos demoraba el islote del Cabo Woody al Oeste $20^{\circ}$ Norte unas seis ó siete leguas; y al Norte $88^{\circ}$ Este de la aguja la punta que suponíamos de la entrada de Nutka: en aquella posición pareció lo más prudente el pairear hasta las primeras claras del día próximo, siguiendo una á otra mura, según lo exigiesen, ó la sonda que alcanzamos de 35 brazas ó el viento que parecía calmar de un todo al abrigo de la tierra.

Intes de rayar el día empezamos de nuevo nuestra navegación, y aunque el viento fuese $\mathrm{Ag}$. calmoso con exceso, para las ocho de la mañana estábamos delante del puerto de la Esperanza, marcando sus islotes internos á distancia de una legua y media, y desengañados de la que creíamos en la tarde anterior ser Punta de Nutka; ésta. que ya marcábamos con seguridad al Este de la aguja, distaba aún cuatro ó cinco leguas, y sin embargo, se nos habían ya acercado algunas canoas, bien que al parecer más bien con objetos de pesca que de comercio: notamos del mismo modo que en la noche anterior varias hogueras ó fuegos en las playas contiguas.

No entabló la virazón hasta las dos de la tarde; debimos al principio apartarnos algo de la costa para evadir algunos remolinos que nos aconchaban sobre los bajos de la Punta Macuina; últimamente arribamos no sin alcanzar por fondos de r7 y 20 brazas piedras los extremos del mismo bajo que había reconocido el Capitán Cook.

Dos ó tres canoas de naturales, á la sazón habían atracado á ambas corbetas anhelando por las conchas de Monterey y por algún pan ú otra especie de comida, manifestándonos, que ni le era extraña la bandera, el idioma y las costumbres nuestras, ni ignoraban los nombres de los comandantes Martínez y Elisa: nos hicieron comprender que había una sola embarcación nuestra en el puerto, y después de algún tiempo, se separaron, para regresar á la orilla.

A las cinco de la tarde no distábamos más que unas dos leguas de la boca del puerto, cuyo extremo Sur nos demoraba al Nordes e; ceñimos hacia este rumbo las pocas ventolinas variables que aún dejaban apercibirse, y largamos las insignias con la esperanza de que en el establecimiento inmediato las viesen y supiesen nuestra proximidad. Puede imaginarse cuál sensación nos haría el ver poco después tremolar la bandera nacional en un altito inmediato á la punta Sur, y entre los árboles distinguirse los tres palos de una embarcación desaparejada: no ignorábamos de antemano la existencia de un establecimiento nuestro en estas costas; no ignorábamos cuántos caudales se habian derramado y cuánta sangre pudo haberse esparcido para sostener su posesión legítima; y sin embargo, es tal el instinto del hombre hacia la sociedad; tal el anhelo de hallarse entre los suyos libre de las trabas que dictan, ó bien la envidia, ó la codicia, ó un pundonor mal entendido, que en aquel momento nos parecía una felicidad lo que tal vez debiéramos mirar como un objeto funesto y malaventurado.

Puesto el Sol debajo del horizonte, quedamos en una total calma, no distando á la sazón media legua de la boca del puerto y una milla escasa de la costa inmediata: sondadas al mismo tiem. 
Ag. I2 po 55 brazas fondo lama, dejamos caer un anclote para esperar la virazón del día siguiente, nos alcanzó poco después la lancha de la fragata Concepción, de San Blas, que venía para auxiliarnos, y se mantuvo en la noche á nuestro costado.

El terral sopló fresquito en las primeras horas de la mañana, cedió luégo al salir el Sol, y hacia las siete le sustituyeron las primeras ventolinas de la virazón con las cuales dimos inmediatamente la vela: nos siguió de cerca la ATRE-
VIDA, y costeada á un cumplido de corbeta la As. r3 punta Oeste del puerto, logramos dar fondo en él á las nueve y media.

Evacuados de este modo los objetos esenciales que nos habían conducido en aquellos mares y particularmente al paralelo de $60^{\circ}$, ya pudimos examinar con una mayor individualidad las Memorias que habían dado lugar á la campaña anterior, y ordenar nuestros razonamientos en la disertación siguiente, la cual no parecerá tal rez totalmente inútil ó cansacla al lector:

\section{DISERTACIÓN sobre la legitimidad de la navegación hecha} en 1588 por Ferrer Maldonado desde las inmediaciones de Terranova al mar Pacifico, y al contrario. Se examinan en esta ocasión las reflexiones del Sr. de Bauche, presentadas a la Real Academia de Ciencias en 13 de Noviembre de I79o, los rastros engañosos de otras navegaciones semejantes y la utilidad verdadera para la navegación al Asia, de una commicación cualquiera entre los dos mares.

Es realmente una suerte bien desgraciada para los progresos de la Geografía y para su utilidad hacia el bien público, el que le sea más bien nociva la subdivisión natural de las operaciones que le dan origen y la fomentan, cuando en la mayor parte de las demás ciencias, esta misma subdivisión ha coadyuvado extraordinariamente á sus progresos. La Física, la Mecánica, la Medicina, divididas actualmente en otros muchos ramos secundarios, han multiplicado al mismo tiempo la ocupación útil de los sabios y sus inventos para el bien de la sociedad; con iguales ventajas les ha seguido de cerca la navegación, y ciertamente, si hubiese tenido igual suerte la Geografía, no hubieran sido otros tampoco los progresos del comercio, primitivo enlace de los hombres, juez verdadero del equilibrio de las naciones, y único móvil de la paz, de la civilización y de la opulencia, cuando se contenga en sus justos límites. Así, este fué el afán unánime de la Europa, y seguramente lo hubiera.conseguido, si su sistema científico ó su no cabal atención á las cualidades de esta ciencia, no la hubiesen arrastrado á confundirla con las otras.

Esta equivocación no debe parecer extraña. Los progresos de la Geografía, dependen como en las demás ciencias de los razonamientos y de la experiencia, y la ruda educación del navegante á quien debe fiarse necesariamente la segunda, le hace comparecer á los ojos del público como incapaz de no equivocar los primeros; de suerte, que en esta ciencia, más bien que en cualquiera otra, parece precisa una subdivisión natural del que raciocina y del que experimenta.

De aquí dimanan, sin embargo, todos los errores. El primero no interviene en las experiencias y el segundo no está autorizado á contradecir los razonamientos. Los navegantes, por consiguiente, abultan á su albedrío las narraciones. Los sabios, con igual libertad, adoptan ó desechan á veces la veracidad, á veces áun la existencia del navegante, y finalmente, este caos de ideas equivocadas, más bien trastorna que favorece los progresos deseados.

Por desgracia, con el recto conocimiento de la Geografía está enlazado estrechamente el sis tema político de la Europa, y siendo éste en el día la ocupación predilecta del mayor número de los hombres estudiosos, particularmente alrededor de las capitales, es más fácil la equivocación, ó más bien diré, la ninguna inteligencia entre el navegante y el geógrafo (I), si el magnetismo opere ó no directamente sobre los nervios;

(I) Es preciso adoptar esta voz para distinguir al que combina $\delta$ amasa los materiales suministrados por el navegante; pero á la verdad en el día no debía aplicarse sino al que observa y raciocina sobre sus nbservaciones del mismo modo que el físico, el médico, el fisiólogo, etc. 
si haya ó no existido una Atlántida; si la población de la América haya dimanado del Norte, del Este ó del Oeste, y si el estado de la Luna sea efectivamente cual nos lo describe Herschel, tal vez con igual aceptación con la cual poco há leíamos en las épocas de la naturaleza su total enfriamiento; son verdades aisladas que interesan á pocos y cuya admisión ó repulsa no influye en el bienestar de la sociedad.

Pero la existencia de un Continente austral cuyos habitadores y productos á veces enriquezcan, á veces aniquilen toda la Europa; la legitimidad de los anuncios del Capitán Carver sobre sus montañas brillantes, la seguridad de que haya una fácil comunicación por agua entre el mar Pacífico y el Atlántico sin deber navegar al hemisferio Austral, son verdades en que todas las naciones toman una parte directa, ó bien para aumentar su propio poderío ó para debilitar el ageno con el objeto de conservar un soñado equilibrio.

Aún es más desagradable en esta parte la constitución de la Geografía: las experiencias son costosas, arriesgadas para los que las emprenden, y de un éxito bien dudoso para aquella evidencia física que depende de los sentidos de cada indivíduo; de suerte que finalmente debía ser una fatal consecuencia de tantos inconvenientes, el que ó los principios fundamentales de esta ciencia se admitiesen con un respeto servil de la boca de pocos navegantes que los revelasen como oráculos, ó continuase el mismo descarrío de ideas, tanto mayor ahora cuanto mayor era el número de las noticias que concurrían á producirlo.

La Inglaterra fué la primera en conocer la necesidad de decidirse por uno ú otro de estos dos partidos, y prefiriendo con mucho acierto el primero, depositó toda su confianza en el Capitán Jaime Cook (I). La util consecuencia de una determinación tan prudente, no tardó sino muy pocos años. Desapareció el Continente Austral del Presidente de Brosse; se cerró la comunicación de los dos mares, tan sostenida por Mr. Dobbs, se confirmaron los límites del hielo constante hacia el polo del Norte, que el Capitan Phipps y los navegantes rusos habían explorado de antemano, y pudo la nación despachar sus buques á la bahía Botánica y á la costa Noroeste de la

(I) Por cuanto los ingleses se esfuercen particularmente en la introducción del tercer viaje del Capitán Cook á reunir bajo un mismo punto de vista las expediciones de los Capitanes Biron, Wallis y Carteret y las del Capitán Cook, no deben absolutamente confundirse por quien las considere atentamente. Las primeras fueron una sola consecuencia de su sistema de aproximarse á los dominios españoles de la América meridional, y combinadas sobre principios puramente militares: las segundas han manifestado siquiera un noble arrimo á los progresos de la ciencia y' en particular de la Geografía.
América con la misma seguridad, con la cual los despachaba ó al Mediterráneo ó á las Antillas.

La expedición del Conde de la Péyrouse, pareció confirmar la aceptación de este mismo sis. tema entre los franceses. Aquel viaje no tenía por objeto sino el completar las tareas del navegante inglés en las costaś, que ó no había reconocido, ó la necesidad le había hecho dejar informes: y fijados ya los conocimientos del globo habitable sobre estas dos expediciones, la Geografía podía considerarse concluída, y tanto más libre de todo razonamiento externo, cuan to que los navegantes por sí solos los habían hecho: además accedía ahora la España y áun coadyuvaba á este sistema con la expedición de las corbetas DESCUBIERTA y ATrevida, las cuales debían reconocer prolijamente todas sus costas de la América y del Asia. En efecto, tantas indagaciones ó ya públicas, ó próximas á publicarse; con aquella exactitud que suministra la Astronomía; con aquella verdad que la filosofía debe dictar; con aquella claridad metódica que ya no debe considerarse opuesta á la educación del marino; finalmente, con aquella excelencia que la perfección del buril y la generosidad de los Monarcas of recen actualmente, debían ya hacer considerar la sana Geografía como regenerada; representar los derechos de las naciones sin la menor equivocación; y guiar con toda certidumbre á los depositarios del bien público en las diferentes combinaciones de derrotas y de comercio: resultaba por consiguiente inutil la ocupación del geógrafo, y el ménos experto en esta clase de operaciones, podía, con el solo auxilio de dos compases, seguir de cerca á los navegantes venideros en los progresos útiles que hiciesen para la sociedad.

Sin embargo, no es así: han vuelto los razonamientos á oponerse directamente á las navegaciones, y si la existencia del Continente Austral no ha podido en modo alguno revalidarse, á lo ménos el Sr. Lemonier (I) ha defendido, en cuatro Memorias la existencia del Cabo Circuncisión del Capitán Bouvet; el Doctor Barrigton ha amontonado, tal vez con alguna predilección (2), diferentes noticias de viajes al Polo Norte, que han pasado del grado 82 de latitud; se ha autorizado y casi toda la nación inglesa ha suscrito á las combinaciones del Capitán Meares, quien no contento con denigrar la memoria del Capitán Cook sobre las indagaciones que hizo en la ría de su nombre, ha revivido las derrotas casi olvidadas del Almirante Fonte y de Fuca (3);

(I) Véase la introducción y el apéndice al tercer viaje del Capitán Cook.

(2) Véanse las Memorias de la Real Sociedad de Londres, año de 1774 .

(3) Véanse la introducción al viaje del Capitán Meares y su Memoria sobre la posibilidad de que exista el deseado paso del Noroeste. 
finalmente, se ha leído á la Real Academia de Ciencias de París una Memoria, en la cual, no sólo se expone como cierto el viaje hecho en I 588 por Ferrer Maldonado, hallando la comunicación de los dos mares, Atlántico y Pacífico, sino que de él se deduce la verdad de otros muchos he. chos que refieren diferentes autores, los cuales, como hasta ahora no se han podido comprender, se han mirado como fabulosos ó como disputables.

A la primera de estas aserciones respondió inmediatamente $\mathrm{Mr}$. Wales; la segunda no debe haber hallado muchos partidarios cuando no se ha tratado de hacer nuevos ensayos hacia el Polo; resolvieron en parte las goletas Mejicana y Sutil, y en el todo la expedición inglesa del Capitán Vancoaver, los términos de la internación del Estrecho de Fuca descrito por el Capitán Meares; la cuarta, finalmente, cuyo examen, de orden de S. M. fué puesto al cargo de las corbetas Descubierta y ATREvida en el año de i79r, no exigiría para satisfacerla otras pruebas que el diario de aquella navegación y las diferentes vis tas y descripciones de las costas reconocidasentonces con el mismo objeto.

Sería por consiguiente inútil y seguramente nubiéramos omitido un examen detallado de las circunstancias del viaje de Ferrer Maldonado, si no se advirtiese al mismo tiempo una facilidad grande en los geógrafos de arrimarse aún á las opiniones antiguas, cualesquiera sean los cimientos sobre los cuales estriban, y si no tuviésemos fundada razón para creer que no es el solo papel de Ferrer Maldonado el que corrió entonces, para apropiarse uno ú otro individuo ó bien el honor de un descubrimiento ya creído ó bien las ventajas de una comisión árdua y distante, la cual, por otra parte, traía consigo la administración de una suma más que mediana de caudales (I). La utilidad verdadera de una comunicación de un mar á otro es también un objeto del cual no debe absolutamente desprenderse todo razonamiento sociable; pues es bien diferente la proposición aislada de que exista una comunicación ó la hilación común, de que deba buscarseá cualquier costo y riesgo. Tal vez no será indife-

(I) Hállase en los archivos de Palacio y Santo Domingo de Manila, una copia de la Real Orden siguiente: “El Rey. D. Pedro de Acuña á quien he provefdo por mi Gobernador y Capitán General de las Islas Filipinas, Presidente de mi Real Audiencia de ellas. Con esta os mando enviar copia de una carta que Fernando de los Rios, Coronel, me escribió de las dichas islas, en que trata de un astrolabio que estaba haciendo para tomar la altura del Polo á todas horas; y del descubrimiento de dos Estrechos por donde se podía entrar en aquellas islas, uno que llaman de Anian que divide la tierra de la China y costa de Asia de la América y tierra de la Nueva España, y el otro Estrecho por el nuevo Méjico; y otras cosas sobre la navegación de aquellas islas á la Nueva rente la utilidad que derive de un examen de esta especie; y en lo venidero, ó las relaciones antiguas se examinarán con mayor pulso ó áun siendo auténticas se desecharán cuando sus hechos no influyan en modo alguno hacia el bienestar de la sociedad.

Existía efectivamente en la corte á principios del siglo XVII un Lorenzo Ferrer Maldo. nado, Cosmógrafo mayor de Indias, pero nada en el Archivo de Simancas acredita que fuese este mismo el autor del memorial presentado, ni el memorial se halla en otra parte que en el Ar. chivo del señor Duque del Infantado. Es también positivo, que en los años próximos anteriores se trataba en el Consejo de S. M. del paso del Noroeste, no sólo porque así consta en la orden citada en los párrafos anteriores, si también porque era aquella precisamente la época en la cual los esfuerzos de los navegantes ingleses Davis, Lancaster, Weymorth, Hudson, Buttons y Gibbons, más debían despertar la atención del Gobierno español.

Sin embargo, estos datos no bastaban en Madrid para que se admitiese por verídica la navegación de Maldonado: Malo de Luque (I) veía crecer á tal punto las dificultades entre la antenticidad de la Memoria y la evidencia de las pruebas contrarias, que no pudo decidirse á admi. tirla; y en el plan del viaje que debían seguir las corbetas Descubierta y Atrevida, las órdenes de S. M. sólo indicaban que se emprendiese esta averiguación en el caso que las apoyasen las noticias adquiridas en la continuación del mismo viaje.

En el entretanto, un examen de la relación hecho con tanta mayor atención cuanto más se acercaba el tiempo de deberle caracterizar á los ojos de la Nación, ó como verídico y glorioso ó como apócrifo é infundado, descubría un número crecido de incompatibilidades que se ex. pondrán ahora con la mayor brevedad.

I. Era bien extraño que no se presentase á S. M. sino en I6og la noticia de un descubrimiento el más importante para la Monarquía, que había tenido lugar en I 588, habiéndose callado por consiguiente por el largo espacio de veintiun años y precisamente en una época en la

España y sobre la mucha gente que se consume y muere en estas islas, de la que se lleva de la Nueva España, y porque todas las cosas que apunta son de mucha consideración y particularmente lo que toca al descubrimiento de los dichos Estrechos, os mando que veais la dicha carta y confirais y trateis con el dicho Fernando de los Rios, sobre lo que contiene su carta y también con las otras personas que tuviesen inteligencia de ello, si será conveniente tomar posesión de la Isla de Armiño para hacer escala alli las Naos que salen de estas islas para la Nueva España, como lo advierte el dicho Fernando de los Rios.= Fecho en Zamora á I 6 de Febrero de I603 años.

(I) Tit. IV, pág. $5^{8} 7$. 
cual estaba más encendido el deseo de semejante descubrimiento.

2. ${ }^{\circ}$ Reducidas las derrotas por rumbos y distancias, no resultaba sino la latitud de $72^{\circ}$ al extremo del Estrecho del Labrador, que Maldonado hacía alcanzar al grado 75 .

3. Mal podían combinarse la situación del navegante buscando víveres en las Celandillas, despues de haberse ocupado en la pesca de los bacalaos, y su pronta determinación ó más bien inspiración de navegar para el mar Pacífico á costa de infinitos trabajos y en la dura estación del invierno; á lo cual tampoco accederían fácilmente sus marineros no presentándoles objeto alguno de utilidad.

$4 .^{\circ}$ No era tampoco fácil averiguar cual sería el puerto de San Miguel ó bahía de San Nicolás, en donde según nuestro viajero entran todos los años casi mil naves de trato, las cuales para hiber de pasar al mar de Flandes, precisamente han de subir á $75^{\circ}$ de altura para dar la vuelta sobre la Dinamarca.

5. En un canal no ménos ancho de 40 á 20 leguas, se veian ahora fuegos, puertos, calas y abrigos á una y otra costa, y al mismo tiempo nuestro navegante ignoraba si se helaría el mar en las orillas, siendo así que se helaba el agua que salpicaba alrededor del buque y las velas tenían un palmo de espesor por el efecto del mismo hielo.

6. Como á la ida para el mar Pacífico los vientos reinantes fuesen contrarios del Norte y fuese preciso valerse de las mareas, debíamos creer que seguiría la costumbre de fondear y le. varse al principio y al fin de cada marea contraria, lo cual no solo se hacía difícil por la maniobra en sí, sino también por la precisión de navegar á medio canal con motivo de los hielos $\mathrm{y}$ de las vistas de ambas costas.

7. ${ }^{\circ}$ Se apercibió una contradicción bien clara entre la práctica del Piloto portugués y su ignorancia en el solo paraje en donde la necesitaba; entre la casualidad del beneficio de las mareas para mantener el bajel por algunos días á la vista del Estrecho de Anian ensenando el bote luégo que se echó al agua, y la consecuencia de Ferrer Maldonado de que no hubiese otro Estrecho.

8. Admirábamos también la felicidad con la cual este navegante había logrado siempre de unos vientos sumamente favorables; había en su navegación al Oeste, desde la costa de la América, encontrado después de solos cinco días la del Asia, y sacrificada á unos fines ocultos la evidente necesidad en la cual debía hallarse dc comestibles, saliendo de un puerto que según él mismo dice, parecía no haber sido tocado de piés humanos.

No cra posible combinas esta misma na- vegación en el mar Pacífico con las costas reconocidas por el Capitán Cook, de cuya posición segura nadie podía dudar.

Io. No era fácil comprender la demasiado poca cordura de Maldonado en apropiar por suyo el descubrimiento de un Estrecho, por el cual no sólo navegaba ya descuidadamente una embarcación anseática de 800 toneladas cargada de brocados, sedas, porcelanas, plumas, cajones, piedras, perlas y oro, y cuyos navegantes eran luteranos y hablaban latín, sino que había de seguirle otra muy luégo, y entrambas procedentes de una ciudad muy grande al parecer llamada Roba, sujeta al gran Can de Tartaria.

II. En estas circunstancias era aún mucho más de extrañarse, que nuestro navegante encargase repetidamente el sigilo y la celeridad en el proyecto que proponía, y sobre todo, que imaginase la construcción tosca y el tamaño reducido de los buques exploradores, cuando ni eran necesarios semejantes descubrimientos habiéndoln ya todo reconocido, ni podía haber el menor riesgo á donde él mismo había navegado en invierno y las embarcaciones anseáticas transitaban ricamente cargadas.

I2. Dejábamos aparte la improbabilidad del terreno, de las frutas, de los animales y de los pájaros que describía; el calor que experimentaba al regreso, mayor que el de verano en España; finalmente, la tenaz unión de las costas de la América y Asia en todo lo que había reconocido, de suerte que no hubiese en las 300 leguas costeadas en el espacio de once días, ya al Sueste, ya al Norte, sino únicamente la boca del Estrecho.

A tantas razones se agregaron luego el reconocimiento nuestro de la costa entre la entrada del Príncipe Guillermo y el Cabo Buen Tiempo, y las investigaciones en el año anterior del Teniente de navío D. Salvador Fidalgo hacia el fondo de la Ensenada del Príncipe Guillermo; todo contribuía á manifestar la total inverosimilitud de semejante paso y debilitaba mucho los razonamientos de la nueva Memoria, de los cuales examinaremos ahora solamente la parte que corresponde al mar Pacífico; no pudiéramos extendernos al otro mar sin envolvernos en otras hipótesis que probablemente nos apartarían de la verdad.

Omitiremos, por consiguiente, el indagar por qué el Sr. de Bauche ha dejado en el extracto de la derrota los nombres de la fabulosa Tule con los cuales distingue Ferrer la Frislandia; por qué varie al Nordeste la dirección del Es nordeste que supone Maldonado á la boca falsa que se deja para ir al Estrecho del Labrador; por qué en oposición á los hechos positivos que alega la Compañía de Hudson y á las últimas medidas del Gobierno Británico al cual segura- 
mente no hubiera aquélla ocultado todas sus noticias, sólo opone las noticias de Purchas y Seijas, las Gacetas inglesas de $\mathbf{z} 769$, el Diario de Sabios de I779, y una orden confusa del Conde de Monterey, el cual seguramente no tenía tales conocimientos, cuando por $\operatorname{los} 43^{\circ}$ de lati. tud uno de los buques del General Vizcaino, creía alcanzar el Estrecho de Anian (I) por qué finalmente, puede suponerse que no hayan arredrado en invierno á nuestro navegante los peligros y trabajos que en verano hicieron retroceder á los navegantes ingleses, de los cuales hay memoria.

Sin embargo, áun sin entrometernos en este pormenor de inconvenientes, y no apartándonos de las costas del mar Pacífico, en balde nos esforzaríamos á suponer, que ú el paralelo de $60^{\circ}$ sea el que determine la posición de la boca Sur, ó haya un paraje en aquellas innediaciones en el cual quede al Norte toda la tierra alta y montuosa y al Sur la que describe como apacible y suavemente alomada. En primer lugar, es el extremo Norte del Estrecho el que debe suponerse en $\operatorname{los} 60^{\circ}$, y el extremo Sur, por consiguiente, debe quedar en $59^{\circ} \mathrm{I}^{\prime}$, lo cual confirman, no sólo las descripciones que da Ferrer del hermoso puerto del Sur, si también la narración del viaje, haciéndole llegar con rumbo del Sueste por mas de Ioo leguas á la latitud de $55^{\circ}$.

Ya entonces sería el Monte Buen Tiempo el que debía quedar á la derecha ó al Norte del paso en lugar del Monte San Elías que supone el Sr. de Bauche; y á la verdad, sería esto algo más favorable á los defensores del viaje, porque las tierras, desde aquel monte son realmente algo más bajas, si bien se conserven nevadas aún en Agosto, y el Monte de la Cruz y el mismo Monte Edgecumbre no sean de una altura despreciable.

Pero lo que envuelve las mayores nulidades geográficas, es sin duda alguna la dirección Este-Oeste que supone Ferrer á la costa del Norte; ¿cómo es que no atraviesa el Monte San Elías, las inmediaciones del Cabo Suckling y de la entrada del Príncipe Guillermo, aún concediendo un error favorable de medio grado á las observaciones del Piloto Martínez? Es preciso confesar que si áun adoptada la veracidad de la Memoria (2) "se consiguiese evidenciar la verdad de otros muchos hechos, los cuales, como hasta ahora no se han comprendido se han mirado como fabulosos ó como disputables", siempre quedaría para los geógrafos una igual ó una mayor dificultad, debiendo mirar con aquel carácter todos los viajes modernos desde el I774.

(I) Venegas, tomo 1Il, pág. I 10.

(2) Son palabras de Mr. de Bauche al fin de su Memoria.
Era bien favorable para conservar tal cual esperanza sobre el problema propuesto, la casual expresión del Capitán Cook al tiempo de reconocer la bahía de Bering que entre los extremos de las dos cordilleras que se dirigían al Monte Buen Tiempo y al de San Elías, veía un claro de algunas leguas al cual no podía acertar si se postergaría tierra baja ó agua (I); pero tuvimos la felicidad de disipar también esta duda y ver que el solo hielo había causado aquella ilusión estando tenazmente unida toda la cordillera.

Pero aunque se hayan manifestado las razones que convencen para no admitir como legítimo el viaje de Ferrer Maldonado, falta aún para la evidencia un dato esencial, y es el de hallar el origen de una Memoria, en la cual se advierte un estilo adecuado al tiempo en el cual se escribió, un desinterés que no hace sospechoso al autor, la cita del viaje de Quirós que acababa de rendirse en I606, por último, un sello bastantemente auténtico, que es el de hallarle en un archivo bien acreditado. No es fácil dar una solución juiciosa á estas dudas ni nosotros lo emprenderemos directamente, contentándonos por consiguiente con indicar sólo algunos puntos autorizados de la Historia Nacional, los cuales pueden haber dado lugar, ó á este proyecto ó á otros semejantes, que el actual prolijo examen de los archivos manifestará seguramente (2).

Que por los años de I524 anduviese ya muy válicla en España la noticia del Paso del Noroeste, ó á lo ménos, que se hubiese dado una no extraña interpretación á las expediciones misteriosas del Caboto, nadie puede ponerlo en duda cuando atienda á la carta escrita en aquella fecha por el célebre Hernán-Cortés al Señor Cárlos V. Aquel esclarecido caudillo no sólo no se había descuidado en esta parte guiado como él mismo dice "del contínuo cuidado y ocupación " en pensar todas las maneras que se puedan te"ner para poner en ejecución y efectuar el deseo "que al Real servicio de S. M. tenía, sino que con "aquel cabal juicio que desplegó constantemen"te hasta el último término de su vída", había dispuesto dos expediciones para el mismo intento,

(I) Vol. II, del tercer viaje: "The chain of mountains is interrvpted by aplain of á feiw leaques extent, beyond Wich the sight was vnlimited, so that theve is either a level coantry, or water be hind it. $n$

(2) Al mismo tiempo que se escribía esta Memo. ria en Manila con las solas noticias adquiridas en América, el Capitán de fragata D. Martín Fernández Navarrete desenvolvía en España el carácter y circunstancias de Lorenzo Ferrer Maldonado y áun de Fernando de los Rios: hallóse bien claro lo de Maldonado en el libro $\mathrm{V}$ de los Comentarios de la embajada que de parte del Rey de España D. Felipe III hizo D. García de Silva y Figueroa al Rey Xaabas de Persia, el año de i6r8.... Publicado por el señor D. Eugenio Llaguno al in de la Historia del Gran Tamorlan de Persia y de la Crónica de D. Pedro Nino, en la imprenta de Sancha, año de 1782. 
una que costease la I'lorida en el mar del Norte y la otra que en el I'acífico ó hallase paso para el Este al Norte de la California, ó precisada por la costa á navegar al Ocste encontrasc finalmente las Iilipinas (I). Hé aquí su plan disno de emular al que ha formado el Gobierno británico en este signlo feliz para la navegación. Porque si le hay (son sus palabras), "no se pue"de esconder á éstos por la mar del Sur, y á los "otros por la mar del Norte, porque éstos del "Sur llevarán la costa hasta hallar el dicho Ẽs"trecho, ó juntar la tierra con la que descubrió "Magallanes, y los otros del Norte, como he di"cho, hasta juntarla con los Bacallaos. Asi, por "una y por otra parte, no se deje de saber el se"creto. Porque (habla de la tierra de los Baca"llaos) se tiene cierto, que en aquella costa hay "Estrecho que pasá á la mar del Sur, y si se ha"llase, según cierta figura que yo tengo del pa"raje á donde está aquel archipiélago que des"cubrió Magallanes por mandado de V. M., parc"ce que saldría muy cerca de allí, y siendo Dios "Nuestro Señor servido que por allí se topase el "dicho Estrecho, sería la navegación desde la es"pecería para esos reinos dc V. M., muy buená y "muy breve, y tanto, que scría las dos tercias par"tes ménos que por donde ahora se navega, y sin "ningún riesgo ni peligro dc los navíos que fue"sen y viniesen, porque irían siempre y vendrían "por reinos y señoríos de V. M., que cada vez que "alguna necesidad tuviescn, se podrían reparar "sin ningún peligro, en cualquiera parte que qui"siesen tomar puerto de V. M."

No merece ménos fé la aserción de que antes de terminar el siglo XVI ya estas mismas voces habían tomado preciso incremento, tanto más natural entre nosotros, cuanto que suponíamos en los ingleses igual ansia de ocultar sus descubrimientos: y ya empezado el terrible período de la decadencia de la Monarquía, no faltaban proyectistas que aspirasen á devorarla. Por los años de I6I 5, refiriendo el Padre F. Juan de Torquemada la jornada de Scbastián Vizcaino á la costa de California, y satisfaciendo á lo que había movido al Señor Felipe III para servirse mandar la ejecución de dicha jornada, añade lo siguiente:

"Supo también S. M. cómo otros Vireyes "habían intentado este mismo descubrimiento "por mandato de su padre, y cómo no habían sa") lido con él (como en adelante se dirá), halló

(1) Véanse las cartas de Cortés, páginas $38_{2}$ y $\delta_{3}$. Fn esta segunda navegacion, discrepamos cono 50 ve, de la interpretación del Fixcmo. I oremzana, el cual cree que el listrecho buscálo por Cuntés en ef mar del Sur estala hacia Panamá, más bien (jue en paralclos mas septentrionales de la Nueva España. rodo depende de la intención de Cortés de hablar a la sazón, o de las Filipinas ó Molucas, ó miśs bien de la lierra del liuego: el lixcmo. lotemzana cree lo segundo; mosotros nos arrimamos i lo primero.
"Lambién S. M., entre otros papeles, una infor"mación que ciertos extranjeros habían dado á "su padre, en que se dicen algunas cosas nota1) bles que ellos en aquella tierra habían visto, "llevados allí con fuerza de tiempos en un navío ndesde la costa de los Bacallaos, que es en Te"rranova, dando en ella razón de haber pasado "de la mar del Norte á la del Sur por el Estrecho "de Anian, que es más adelante del Cabo Men"docino, y que habían visto una populosa y rica "ciudad bien fortalecida y cercada, y muy rica "de gente política y cortesana y bien tratada y " otras cosas dignas de saberse y ser vistas.

"Confirmábase, por otra parte, esta noticia "ó sospecha por cl mismo Padre Torquemada, "cuando continuando esta narración y descri"biendo el viaje de Martín de Aguilar, volvía á "recordar que ese sería probablemente el río que "iba á dar á una gran ciudad que descubrieron "los holandeses viniendo derrotados, y que aquel "era el Estrecho de Anian, por donde el navío "que le descubrió atravesó y pasó de la mar del "Norte á la del Sur, y que sin falta era en esa "comarca ó vecindad la dicha ciudad que se "llamó de Quivira, y de este sitio parece que es "de quien trata la relación que S. M. leyó, por lo "cual se movió y aficionó á mandar que con mu"cho cuidado se hiciese este descubrimiento y sc "le diera aviso cierto de todo."

Ya, pues, no debe dudarse que fueron muchos los proyectos presentados desde el tiempo de Felipe II á la corte de España, que todos ó á lo ménos la mayor parte estribaban sobre la navegación de un buque holandés, y que nuestro Ferer Maldonado adolece de estas mismas ideas.

En tal caso, ¿por qué será absurdo el suponer una de estas tres cosas: ó que Maldonado, movido de un justo celo nacional, en un tiempo en el cual los descubrimientos eran el objeto de los afanes europeos, intentase apropiarse lo que otros habían hecho, ó que pensase en otras empresas á costa del Erario, diciendo no haber hallado la boca misteriosa, como ya se había ocultado en su presencia al Piloto Martínez; ó finalmente, que fuese éste un solo borrador, que los amigos le aconsejasen después á sepultar más bien que á producirle delante del Rey?

¿Pero á qué nos ocuparemos tanto en esta es. pecie de indagaciones; ó creeremos que pueda ser verídica la relación de Ferrer Maldonado, porque no se hallan rastros positivos de su origen, cuando á nuestros mismos ojos, en una época que 1lamamos filosóficá é ilustrada no sólo se escriben, sino se publican relaciones parecidas á la de $\mathrm{Fe}$ rrer Maldonado y del Coronel Ríos? Han revivido ya los viajes del Almirantc Fonte y de Fuca. como si la esperanza de hallar un paso en los 48 y $55^{\circ}$ hubiese de combinarse precisamente con un absurdo, y seguramente si cesasen en este 
momento las pesquisas, harto costosas para la resolución de esta cuestión hidrográfica, ¿cuál no sería la confusión de un lector del siglo XXI en leer antes los apéndices del docto Padre Veneyas, y la introducción del tercer viaje del Capitán Cook y luégo las reflexiones del Capitán Meares; cuáles no serían, finalmente, sus descarríos si creyese verídico el viaje allí citado del bergantín americano Lady Washington desechando, por consiguiente, los reconocimientos de los Oficiales españoles Quimper, Elisa, Galiano, Valdés y Caamaño, y del Capitán inglés Vancoaver, y entregándose para la diferencia de longitudes á un diario, en donde se nombra un relój marino, se citan á cada paso las distancias lunares, é intervienen en su publicación las personas más ilustradas de la nación británica?

Por ventura el Capitan Dixon, picado por diferentes acusaciones que le resultaban del mismo diario, emprendió responderle con aquellos colores que le suministraban su encono y el libro contra el cual se explayaba (I). Por ventura las juiciosas reflexiones de la instrucción dada al Capitán Cook en su tercer viaje, podrán siempre poner la cuestión en unos términos claros y seguros sin que alcancen á variarla, ó la existencia de unas islas en ligar de costa seguida ó la internación de algunos buques al Este; pero ello es que semejantes razonamientos poco á poco nos habían conducido á considerar el continente septentrional de la América como dividido en diferentes trozos que diesen otras tantas comunicaciones de un mar á otro, y á llamar, por consiguiente, bien desgraciada y tímida la navegación actual; pues no llevando otro intento, no había podido, sin embargo, encontrar lo que nuestros antiguos habían encontrado sin buscarlo, y sin los auxilios, ó de los demás viajes ó de nuestra exactitud en las determinaciones geográficas.

Aquí concluiría esta disertación bastantemente difusa, si el ansia general en Europa para descubrir el paso del Noroeste, habiendo por lo común hecho perder de vista la verdadera utilidad de semejante descubrimiento, no precisase á mirar este examen como bien importante para los intereses nacionales. Nuestros armamentos son con exceso costosos, nuestras miradas hacia lo que pasa en todo el continente de la América, aún tímidas, silenciosas y mal interpretadas; finalmente, es aún fatal nuestra disposición para oir cualesquiera proyectos, como parezcan aspi-

(I) Es frase bien insultante la cue usa al principio le sn carta responsiva y dirigida al mismo Capitán Meares. El descifrar una sola mitad de los absurdos que Vm. ha dicho, llenaría un tomo tan voluminoso como el suyo. "To point out hal fiour absurditeis would fill á volume aslange as yours.n rar á la completa restauración de la antigua opu. lencia y poderío de la Monarquía.

La cuestión del paso del Noroeste fué desde el principio conducida por los geógrafos á una latitud tan alta, que desde luego excluía toda posibilidad de ser útil, y seguramente hubiera corrido la misma suerte que ha corrido la navegación del Estrecho de Nagallanes, comparada á la de altura por el Cabo de Hornos, si la protección decidida de Mr. Dobbs ó más bien su encaprichamiento acaudalado no hubiese (según cos. tumbre) cambiado el semblante de la proposición. La cuestión primitiva era si había en el hemisferio del Norte un pasaje ítil por mar para la comunicación de la Europa con el Asja; seles sustituyó luégo la otra de si existía una comunicación cualquiera entre el mar Pacífico y el Atlántico en el hemisferio del Norte.

Esta confusión de ideas era á la verdad re. prensible al tiempo de Mr. Dobbs, pero sin duda lo es ahora mucho más, cuando se conoce la navegación del globo en un grado que no es fácil sobrepujar. El objeto de la navegación es, sin duda alguna, el comercio, y así en sus especu. laciones jamás deben perderse de vista la brevedad, la seguridad, la comodidad y la economía del viaje. ¿Cuáles son, pues, las ventajas en estas nuevas derrotas que puedan compararse á las que disfrutan los europeos navegando á la China por el Cabo de Buena Esperanza? Será preciso contar contínuamente con la felicidad del Almirante de Fonte, el cual, no sólo navegó las 866 leguas desde el puerto Abel hasta el río de los Reyes en veinte días (I), sino que las 260 eran por los canales que culebrean entre las islas del Archipiélago de San Lázaro, en el cual iban sus chalupas ó botes una milla por delante para sondear la profundidad del agua y para reconocer los bajos, escollos y rocas ciegas (2).

$\mathrm{Ni}$ imagine alguno que la utilidad de este paso, á lo ménos para los extranjeros, no esté ceñiclo sólo á la navegación de China, sino que pueda comprenderse en aquellas ventajas una comunicación más breve con el mar Pacífico, hacia donde en los siglos venideros la navegación europea sea tan numerosa y rica como es ahora mezquina, inútil y aventurada. Los escarmientos actuales de los ingleses en la bahía Botánica, y los reconocimientos bien repetidos por todas las naciones marítimas en el crecido nú-

(I) Se incluyen en estos días como completos, el de la salida y el de la llegada: la relación dice desde 26 de Mayo hasta I 4 de Junio.

(2) Se omiten por demasiado chocantes, las 86 leguas andadas el día i d de 1 gosto, pasadas las cataratas del río de Parmentieres y la facilidad con la cual el Capitán Bernardo había llegado hasta el gra. do so de latitud, reconociendo hasta las lagunas, y hallando quién se encargase inmediatamente de la. correspondencia con el Almirante. 
mero de las Islas del Mar Pacífico son pruebas bien seguras que rariará toda la constitución po. lítica del globo antes que los habitadores ó los productos de aquéllas puedan llamar á sí los menores esfuerzos de los europeos.

Por lo que toca al proyecto del Sr. de la Bastide, presentado al difunto señor Conde de Fernán Núñez en París, con objeto de detallar las operaciones oportunas para el logro de esta comunicación en el Lago de Nicaragua; debiendo luégo resarcir todos los gastos con los impuestos correspondientes á la navegación extranjera, se conoce desde luego que no están calculados los límites de esta navegación, lo cual bastaría para tachar aquella Memoria de importuna áun cuando nos desentendiésemos de los muchos errores que contiene así mecánicos como hidrográficos y políticos.

Un viaje regular á la China desde los puertos de Europa, puede considerarse de cinco meses siempre que lo haya de verificar una embarcación buena y bien gobernada, es mucho menor el pla$\%$ que necesita para las costas de Coromandel y Malabar. Todas las estaciones 10 permiten, el temple no es incómodo, las escalas al mismo tiempo sanas, agradables y útiles para los intereses mercantiles, los vientos periódicos y bien conocidos; y la navegación tan económica y tranquila que apenas puede considerarse alguna des mejora en el velamen. ¿Cómo podríamos, pues, referir estas circunstancias al único paraje en el cual quedan aún fijadas las miradas inflexibles de los geógrafos, esto es, entre 1 os $60^{\circ}$ y $80^{\circ}$ de latitud septentrional, en donde un mar eternamente helado ó un conjunto inaccesible y bien entendido de islas horribles y desiertas, no ofrecen al navegante sino riesgos y peligros?

La cuestión que en el dia vierten con tanto ardor los geógrafos, puede reducirse por consiguiente á estotra proposición desnuda ya de aquellos velos agradables con que la han coloreado hasta aquí á los ojos del público: ¿cuál será la nación cuyos navegantes, por un exceso de felicidad más bien que de habilidad, logren propasar al Norte los términos de la navegación fijados por los Capitanes Cook y Clerke y navegar, si hay paso, alrededor del extremo de la América hasta entrar en los mares de Europa?

A la vista de esta proposición desmayarán tal vez los clamores de los geógrafos sobre semejante hallazgo, cesarán sus insultos científicos hacia lá navegación moderna, y el Monarca amante de la humanidad, y el navegante desdeñado de servir para la duración de un proyecto siempre inútil, dirigirán unánimes todo su conato, ó bien al perfecto reconocimiento de los pocos puntos útiles para la navegación, que todavía no se han examinado, ó al próspero beneficio y fomento de los dulces lazos de la sociedad que suministra el comercio (I).

\section{CAPÍTULO III}

Acaecimientos en el Archipiélago de Nutka durante la demora de las corbetas en él. - Navegación sucesiva hasta Monterey y estada en aquel puerto.--Ultimos reconocinientos al andar de las costas de Califomia y Nueva España.--Escala de la DescubierTa en San Blas.-Rennión de las corbetas en Acapulco.Acaecimientos en aquel puerto y aprestos para las campañas y operaciones siguientes.

Era á la sazón Comandante de la fragata Concepción el Alférez de navío D. Manuel Saavedra, por haberse encargado del paquebot San Carlos el Teniente de navío D. Francisco Elisa con el fin de continuar con la goleta Saturnima los reconocimientos de la costa al Norte y al Sur del puerto de Nutka: estaba al cargo de aquel Oficial todo el establecimiento, comprendidas las baterías; y como se hubiese embarcado, en clase de auxiliar la compañía suelta de voluntarios de Cataluña, hallábase allí al mismo tiempo su Capitán D. Pedro Alberni, retirados ya en clase de enfermos el Teniente y Alférez que le habían acompañado.

Todos los enfermos, la mayor parte escorbúticos y en muy mal estado, se habían restituído á San Blas en la fragata Princesa á las órdenes del Teniente de navío D. Jacinto Caamaño. El es. tablecimiento había recibido los auxilios necesarios con el paquebot San Carlos y la fragata Aranzazú, y el regreso de esta última desde el puerto de Monterey á donde se había despachado en busca de carnes frescas, debía con un socorro tan importante asegurar para el próximo invierno el bienestar de la marinería y tropa existentes entonces en el presidio. Veíanse en el fondo del puerto diferentes barracas construídas con tablazón; vigilaban, para su custodia y buen orden, el mismo Alberni con la tropa acuartelada en tierra; la fábrica del pan fresco, que se suministraba diariamente á todos, el cultivo de las huertas, en las cuales la Naturaleza ya prodigaba sus dones, el cuidado de los víveres y pertrechos contra un enjambre harto destructivo de ratas, las herrerías, la misma continuación ó incremento de las casas con el corte necesario de maderas, eran otras tantas ocupaciones en las cuales brillaban con igual tesón la subordinación y constancia de los súbditos y el buen ejemplo y acierto de los Oficiales Comandantes Elisa,

(I) Siendo pública muy luégo (como debe esperarse) la Memoria escrita sobre esta cuestión por el ya citado D. Martín Navarrete, el lector hallará todas las demás noticias relativas al decantado paso del Noroeste, que aqui se han omitido. 
Saøedra y Alberni, influyendo últimamente en la coservación de la salud y en la buena harmoza que á la sazón reinaba entre todos.

io diferimos un momento en establecer el obscratorio en sitio oportuno y no distante de las arracas. Examinóse el paraje de la aguada, y I. Felipe Bausá emprendió sus marcaciones desc el castillo, ya que la tarde placentera y seren proporcionaba la vista de muchos objetos diszintes, entre los cuales sobresalía muy mucho un ico interno bien notable para el reconocimieto del puerto. Continuaron luégo estas operacines, medida una base para la exacta determinción del puerto, multiplicadas las marcaciones o algunas de las islas del Archipiélago interno y su atado el todo á otros tantos azimutes para que o influyese en la exactitud de nuestros trabajc la mucha variedad de las declinaciones mascéticas que había advertido el Capitán Cook. Ultnamente se emprendió el reemplazo de la agua con las lanchas y bombos, los cuales, com debiesen separarse una legua, aprovechar de la mareas y no enturbiar la buena harmonía con us naturales, se pusieron siempre al cargo de u Oficial acompañado de dos soldados armads.

Yrias causas (cuyo origen es extraño para esta arración) influían entonces á que hubiese de prte de los naturales una conducta tímida $y$ precyida con el establecimiento nuestro. Eran poco los pescadores que veíamos concurrir á las crbetas, y por cuanto deseásemos conocer los crerentes Caciques ó Taquis, á los tres días de nestra llegada aún no había parecido alguno, sin elbargo que varios dones á las canoas y no poca promesas á los que nos visitasen, debían ser ieentivos harto fuertes para atraerlos.

Eralmente, en la mañana del I 4 , el Cacique secunario Tlupananú, venció esta barrera, confiad: la verdad en la amistad constante que habi reinado entre él y los nuestros; y sin embarg tímido y casi asombrado á la vista de tanta fuerzas unidas, se le regaló por nuestra partebundantemente, se le prometieron dones aún lucho mayores, si nos visitase de nuevo con s canoa grande, bien esquifada, y dispuesta á vericar varias evoluciones así de guerra como de alcría. Y con estos incentivos, no tardaron en seuirle varios otros, ó subalternos ó parientes d:Macuina, Jefe principal de toda la comarc. Nos ponderaban á veces, ó la extensión de su dominios, ó la solidez de su autoridad; otras eces, sin embargo, con diferentes pretextos y isculpas daban á entender que aquel Jefe temí isitarnos, confirmándose particularmente este :mor en la mañana del I5, cuando dirigidos 1. Cayetano Valdés y D. Felipe Bausá á la rschería misma de Macuina (pues que recorrír aquellas costas con objetos geodésicos), encontraron desamparadas las casas $y$ apenas consiguieron que se les aproximase uno ú otro de los muchos que estaban escondidos en los bosques contiguos.

Esto, no obstante, luégo que se concluyó la aguada pareció un deber esencial de nuestro destino el reconocer los canales internos del Archipiélago en el cual nos hallábamos; pudiera aquel reconocimiento ser útil á la sazón para eliminar la cuestión de dominios sobre aquellos parajes, agitada con tanto vigor en Europa; nos dejaría lugar para estudiar las costumbres de los habitantes con algún despacio, ya que los diferentes viajeros que nos habían precedido habían discrepado tanto en describirlas; finalmente, nos sería fácil el atender á las diferentes ügencias del establecimiento para que no careciese de cosa alguna en el invierno próximo áun cuando no regresase la fragata de Monterer. Destináronse, pues, en la mañana del I S entram. bas lanchas para el reconocimiento proyectado. Las mandaban los Tenientes de navío Don José Espinosa y D. Ciriaco Cevallos, y estaban provistas de los instrumentos y demás útiles que pudiesen conducir á su mayor seguridad ó apro vechamiento. Se perdieron muy luego de vista, siguiendo rumbos que les guiasen hacia la caleta, en donde había fondeado el Capitán Cook. Nosotros al mismo tiempo seguimos con tesón los objetos prefijados, y favoreciéndonos extremadamente la estación y los tiempos claros y bonancibles, todos ellos pudieron adelantarse con un paso más bien acelerado.

En el observatorio, además del examen de la marcha de los relojes marinos y de las experiencias del péndulo simple, constante para la graredad, se repitieron por dos días las observaciones de las distancias lunares, ya que no era posible en la actual posición de los astros el adoptar otro método para la deducción de la longitud: 400 series manifestaron en aquella ocasión la longitud de II $^{\circ} 5^{\prime} \mathrm{O}^{\prime}$ al Occidente de Cádiz, menor en $2 S^{\prime}$ de la que había determinado el Capitán Cook. Para la diferencia de merjdianos con el puerto Mulgrave, se adoptó la que indicaban el cronómetro 7 I y el rẹloj I05: y era de $3^{\circ}{ }^{\circ} \mathrm{o}^{\prime}$ al Este, latitud observada por diferentes estrellas al Norte y al Sur del zénit $49^{\circ}$ $26^{\prime} 30^{\prime \prime}$.

Las atenciones nuestras en cuanto al bienestar del establecimiento, debieron ser al mismo tiempo bien varias é importantes. Cediéronsele una parte considerable de nuestros víreres, restuario, tabaco, medicamentos y jarcias; se compusieron las armas y los utensilios de labranza y se les enseñó con mucha utilidad el método de hacer la cerveza con la hoja del pino, que llamaremos con los franceses sapineta. A la rerdad, no era ésta sino una corta retribución de la genero- 
sidad, que la tropa y marinería del destacamento desplegaron hacia nuestras gentes franqueándoles cuantas verduras pudiesen suministrar las huertas; y brindándose á cuantas fatigas les ocurrían diariamente, si podían. llamarse tales ó las diferentes atenciones del servicio, ó un córte metódico de leña, en el cual alternaban para su mejor conservación, la tropa y marinería de ambas corbetas. En un paraje tan abundante de buenas arboladuras, hubiéramos sido por otra parte reprensibles, si no repusiésemos las piezas rotas en el viaje anterior, lo cual suministró una nueva ocupación útil á una parte de la marineríá y á nuestros carpinteros. Así corrían rápidamente los días, y además de conservarse en buen estado la robustez de todos, veíamos que no eran absolutamente infructuosos los pasos de las corbetas sobre aquellas costas, áun después de haberse frustrado el objeto primitivo del descubrimiento de un paso del mar Pacífico al Atlántico.

Nuestro roce pacífico con los naturales había á la sazón echado raíces mucho más sólidas, si bien á costa de varios regalos que pedían indistintamente los Jefes y los súbditos, además de una contínua contribución de galleta. Ya no huían las canoas á la vista de nuestras embarcaciones menores, nos rodeaban diariamente los pescadores con muchas y excelentes calidades de pescados; algunos naturales hacían noche al lado del observatorio; eran pocos los Jefes que no nos hubiesen visitado, y habíamos merecido igual atención á Macuina, si bien manifestase en su rostro mucha desconfianza y no permitiese subir á bordo á tres mujeres suyas que le acompañaban; no olvidé tampoco en aquella ocasión su interés propio con la venta de una niña esclava que traía consigo. Los Oficiales de la fraga Concepción solían adquirirlas ó con dos fusiles ó con una ó dos planchas de cobre. Esta especie de cambios demasiado ligada con las ideas de religión, de moral y de política para poderse discutir en pocos renglones, era á la sazón bastantemente introducida en nuestro establecimiento y se contaban unos 22 niños de ambos sexos, que, ó se habían transportado á San Blas, ó estaban próximos á transportarse, confiados para su educación y manutención venidera á uno ú otro individuo de los buques de S. M., siempre elegido entre los que agregasen á una buena conducta el hallarse casados en el Departamento.

Los regalos hechos á Macuina y á los que le acompañaban ó le habían precedido, atrajeron aún más en los días siguientes la concurrencia á bordo de los naturales; entre ellos se distinguió siempre el jefe Tlupananuc, el cual, en la tarde del 20 nos presentó cartas y noticias de los 'Tenientes de navío Espinosa y Cevallos que le habian entregado en la noche anterior al tiempo de dirigirse á los Canales del Tásis.
En la mañana del 23, bien temprano, vino finalmente, á visitarnos con la canoa deseada; la conducían unos 30 remeros, cuyo canto, evoluciones y destreza nos sorprendieron en las primeras vueltas que dió alrededor de las corbetas; siguiéronse varios bailes ejecutados por los mismos remeros antes á bordo de la corbeta y luégo en la playa inmediata al observatorio. Tanta eficacia de parte de aquel Jefe no podía ménos de exigir de la nuestra unos regalos correspondien. tes entre los cuales se comprendió también la vela de un bote, que deseaba con las mayores ansias y destinaba para sus canoas.

El medio día del 25 regresaron ambas lanchas con la mayor felicidad; venían de mar en fuera, pues que sus reconocimientos las habían conducido por un canal interno hasta el puerto de la Esperanza, paraje en cuyas inmediaciones estuvieron las corbetas en la mañanita del I2, y eran frutos de una tan útil excursión, no sólo el plano exacto de aquel puerto, si también un conocimiento prolijo de todos los canales internos, por manera que ni quedase ya duda de ser una isla el terreno disputado hasta entonces como parte del continente, ni dejasen de adquirirse cuantas nociones eran necesarias para juzgar con rectitud de las circunstancias y de la utilidad de aquel puerto.

Es verdaderamente singular el terreno del cual se compone el Archipiélago. Hasta cinco canales ó brazos no más anchos por lo común de un tercio de milla, internan por diferentes rumbos, terminando en unas ensenadas pequeñas, elegidas por los naturales para otras tantas poblaciones ó rancherías. Los dos canales del Esnordeste y Este, cuyos principios había reconocido el Capitán Cook, terminan en los pueblos de Tlupananuc, y el canal que conduce al puerto de la Esperanza, se ramifica al Norte en otros tres, de los cuales el primero ó más oriental va á parar al Tasis, residencia del soberano Macuina; el segundo se dirige al pueblo del jefe subalterno Natzape, y el tercero, aunque no de menor extensión, parece, sin embargo, tener desiertas ambas orillas y la ensenada del fondo. Por lo común en todos los canales no se alcanza el fondo con 60 brazas áun en la inmediación de las orillas; los árboles y las piedras suplen aquel inconveniente para dar espías una embarcación que quisiese internar en ellos, ó bien navegando desde el puerto de la Esperanza á Nutka, ó al contrario.

Según referían los Oficiales Comandantes, fueronal principio recibidos en las diferentes rancherías, con el semblante más desapacible y turbulento. En la de Tlupananuc (estando ausente este jefe) vieron retirarse las mujeres y los niños al paso que se les aproximaban varios hombres armados con bastones, y sordos así á las protestas 
de paz, como á los regalos que les ofrecían. Fué aún mucho mayor el número de gente armada que se les presentó en el Tasis ó ranchería de Macuina, tomada además por los naturales la precaución de disparar de antemano algunos fusilazos. La alarma se había difundido por todas partes; las canoas abandonaban la pesca, al momento que los apercibiesen. El mismo Macuina, áun después que los dos Oficiales le manifestaron la mayor confianza, saltando solos en tierra y haciendo apartar las lanchas á alguna distancia de la orilla, no sólo los recibió con una mezcla de enfado, de frialdad y de temor, sino que quiso ostentar su poderio, manifestándoles un armero con quince fusiles, para cuya custodia estaba inmediato un natural descansando con la mayor formalidad sobre el arma.

Esta escena bastaba, sin duda, para ocupar toda la atención de nuestros Oficiales; pero debieron muy luego torcerla á otros espectáculos dignos de una mayor admiración; y eran antes la vista de algunas vidrieras puestas en la casa de Macuina, y luégo el rostro agradable de la mujer favorita de aquel jefe: era ésta una joven de veinte á veinticinco años, hermana de Natzape y en su agrado, color y facciones, capaz de sobrcsalir áun donde estén bien determinadas las ideas de la hermosura.

En el entretanto, Macuina se había vuelto mucho más humano y afable, pues podía no dudar de las intenciones pacíficas de nuestros Oficiales; los condujo á ver su tesoro de barras de cobre, los acompañó después en un corto paseo que dieron al frente de las casas y en la visita que hicieron á Natzape, su suegro; finalmente, quiso también seguirlos hasta sus mismas lanchas, en donde se le regaló como era debido, quedando desde aquel momento bien vindicadas nuestras intenciones pacíficas y al parecer entablada con nudos mucho más estrechos una amistad sólida y duradera.

No había incurrido Tlupananuc en esta desconfianza general. Aunque fuesen las diez de la noche atracó á las lanchas al tiempo de volver de la pesca con una seguridad que manifestaba así la rectitud de sus intenciones como el conocimiento de las nuestras: brindóse á visitarnos en la mañanita siguiente, y se despidió tan sólo cuando dirigiéndose los nuestros hacia el Tasis, debió temer la indignación de Macuina, si le supusiese, ó cómplice, ó el autor de aquella navegación. Se despidió con varios pretextos, bien que prometiendo entregar muy luégo á la corbeta la carta y credenciales que le habían confiado.

Bien examinado por los Sres. Espinosa y Cevallos el número de habitantes que existían en los contornos, y formaban digámoslo así, la sociedad subordinaba á Macuina, le supusieron próximamente de 4.000 , constituídos por la ma- yor parte á vivir de una pesca no muy abundante, y alternando su morada según aquella necesidad, en el verano hacia la orilla del mar, y en el invierno hacia los canales internos. Agregaron también á esos conocimientos el examen del suelo y de la vegetación, la colocación geodésica de varios montes internos, y finalmente, la visita de un cementerio en una isla desierta, todos datos que nos proporcionarán en los capítulos siguientes el dar una idea cabal de aquellos contolinos.

Para este último intento fueron también con extremo felices para nosotros los dos días siguientes del 26 y 27 , pués concurriendo á bordo de ambas corbetas los dos hermanos Natzape y Nanikiur, jóvenes de un talento, comprensión y afabilidad singulares, nos suministraron tales ideas, tan claras y tan extrañas sobre su religión, origen, leyes, costumbres, sistema gubernativo, comercio y geografía interna, que nos parecía una ilusión el comprendernos recíprocamente con tanta velocidad. Entre los muchos Oficiales que como era natural, conociendo la importancia de esas ideas se cebaron con más ahinco á desentrañarlas de la oscuridad en que estaban envueltas, merecerá siempre en nuestra memoria un lugar distinguido el Teniente de navío D. Antonio To. va, el cual, usando oportunamente de una sin. gular paciencia y agrado, de un mediano conocimiento del idioma y, sobre todo, de un método bien claro y ordenado de preguntas, nos guió con pasos rápidos á aquella serie importante de ideas fisiológicas, que procuraremos extender con claridad en los tomos siguientes.

En la mañana del 27 tuvimos también una nueva visita de Macuina, que habíamos solicitado por diferentes emisarios, insinuándole que deseábamos con ansia ratificar nuestra amistad con él, y atestiguarle con regalos de mucho valor cuánto nos interesábamos en la solidez de una paz recíproca entrelos suyos y los de nuestro establecimiento. La conducta de las lanchas y el trato acorde de las corbetas ya no podían dejar la menor duda sobre la rectitud de nuestras intenciones, tanto más que las afianzaban así el ningún empeño para la adquisición de las pieles, como la prontitud de la salida, luégo que nos habíamos proveído de agua y leña. Tantas razones, y mucho más la esperanza de un buen rega. lo, habían efectivamente obrado con much fuerza en el corazón de Macuina, y se leía ahora bien clara en su semblante esta transformación deseada. Tomó algunas tazas de té á bordo de la Atrevida, costumbre que se hallaba bien introducida entre sus parientes y jefes subalternos; adornó la cabeza con una especie de tira de grana, en la cual se cosieron algunas estrellitas de cristal; alegó las razones de pesca y de su poca robustez, que no le habían permitido vi- 
sitarnos con más frecuencia; finalmente, encareció con colores bien vivos y nobles la actual situación suya, que precisándole á vivir á alguna distancia del mar, le hacía carecer del alimento y le tenía ahora tanto más débil y extenuado, cuanto mayores habian sido anteriormente sus fuerzas y su destreza, hasta el punto de atacar sólo una ballena para arponearla. Dos velas para canoa, cuatro cristales de ventana, una plancha de cobre, algunas varas de paño azul y pocas piezas de quincallería, fueron luégo los regalos que se le dieron en la Descubierta. Ratificó en aquella ocasión la cesión del terreno que había hecho anteriormente para el actual establecimiento nacional; nos aseguró que habría entre unos y otros una paz duradera; y últimamente, se despidió manifestando hacia nosotros, con expresiones difíciles de equivocarse, tanto agradecimiento y amistad, cuantas habían sido al principio las muestras de su enojo y desconfianza.

A la sazón todos los instrumentos y efectos se habían recibido á bordo, y las tripulaciones de las lanchas habían logrado de un regular descanso y libertad; nos pareció, por consiguiente, que en la misma noche pudiéramos dar la vela con los primeros soplos del terral, y á este fin se dispusieron ó recogieron las amarras para levarnos sobre el ancla.

Pero en este concepto no estaban bien fundados nuestros razonamientos, los cuales, á la verdad, suponían en las corbetas unas calidades demasiado aventajadas; pues que era preciso contra la revesa de la marea montar de bolina las piedras inmediatas de la punta del puerto, de las cuales no distábamos á pique del ancla sino dos cumplidos de corbeta. Dos veces la Descubier TA dió la vela, y dos veces cayó sobre las piedras, de las cuales, sin embargo, bastaban á precaverle los solos botalores por el fondo con exceso acantilado; á la sazón refrescó mucho el terral; fué inútil una espía que habíamos tendidn afuera; y las que dimos á la Atrevida para que nos sostuviese sobre su ancla, no sirvieron, sino para hacerla garrar hacia el mismo paraje.

Debimos, por consiguiente, desistir hacia la media noche de la idea de levarnos y disponer algunas espías para tomar una posición mejor, la cual se consiguió sin la menor avería hacia las dos de la mañana.

Nos francueamos al otro día sobre espías, de modo que el terral ya nos fuese favorable, y así luégo que puesto el Sol se dejaron apercibir las primeras ventolinas del Nordeste, no diferimos en dar la vela y gobernar con todo aparejo á los rumbos, que con más brevedad nos franqueasen de la punta de los arrccifes.

No fué este objeto difícil mediante el viento del Norte, el cual continuó fresquito en toda la noche. 11 amancer demoraban la punta San Es- téban al Norte $52^{\circ}$ Este de la aguja distancia cinco á seis leguas la tierra más Este al Norte $87^{\circ}$ Este, $y$ la boca del puerto al Norte $15^{\circ}$ Este, cuya posición combinada con un tiempo sumamente apacible y placentero, nos hacía árbitros de la navegación siguiente.

La costa que seguía al Sur del puerto de Nutka hasta unirsc á la de California ya podía considerarse para la oportuna dirección de nuestras tareas bajo un semblante bien diferente al con que debíamos mirar las costas más septentrionales. No ignorábamos, que en el año pasado los Oficiales Martinez y Quimper del Departamento de San Blas, habían costeado hasta entrar en cl Estrecho de Fuca; que actualmente se hallaba con el mismo objeto el Teniente de navío Elisa que no distaba, de allí sino muy poco el puerto de los Mártires, visitado en I775 por el Comandante Cuadra; que D. Bruno Hezeta en el mismo año había continuado aquellos reconocimientos hasta el puerto de la Trinidad; y que allí podía luégo fijarse con seguridad el principio de las útiles tareas de Sebastián Vizcaino en el año de 1602.

Con esas reflexiones ya nuestra derrota siguiente la cual debía conducirnos á la bahía de Montercy, pudo prefijarse para que fuese más segura y expedita, á una mayor distancia de la costa; sería fácil después el atracar y reconocer de cerca aquellos puntos que pareciesen los más importantes; y entre ellos merecía seguramcnte un lugar no postrero la entrada de Hezeta, la cual si bien conforme en mucha parte con las señas del río y entrada de Martín de Aguilar, no dejaba sin embargo de suministrar nuevas combinaciones favorables á los defensores de la comunicación de ambos mares.

Navegábamos en el entretanto á no mucha distancia de las islas que desde la Punta de San Esteban conducen hasta la entrada del Estrecho de Fuca. Vióse entre ellas antes á la vela y después fondeado al abrigo de las isletas más foranas una fragata mercante de los Estados Unidos de la América, ocupada sin duda en el tráfico de las pieles de nutria para conducirlas á Cantón. Nosotros con un mediano andar propasamos muy luego aquellos parajes, y alcanzamos cn la noche inmediata las cercanías del Estrecho de Juan de Fuca. Las sondas, á una distancia de cinco leguas de la costa, indicaban cl fondo de $5^{8}$ brazas piedra.

Nos hallábamos, pues, al amanecer del 3, delante de aquel Estrecho decantado, que en los tiempos pasados y en los presentes había sido el objeto de muchas navegaciones apócrifas, las cuales, facilitando en esos paralelos la comunicación de los dos mares, deleitaban á 10 ménos, cuando no convenciesen, las ansias del político y del comerciante. Debimos separamos dc ella, í 
Sct. 3 la verdad con algún rubor, viendo cuánto serían útiles unas pesquisas diligentes en aquel Archipiélago inmenso; pero la estación y el plan de nuestro viaje así nos lo dictaban, y por consiguiente los rumbos del Sur, muy luégo nos condujeron á paralelos más bajos.

En la navegación siguiente hasta el Cabo Mendocino ya los tiempos fueron tan apacibles y constantemente favorables, que nos recordasen más bien los climas placenteros de entre trópicos. Reconocíamos frecuentemente la costa, cuando no lo hiciesen absolutamente imposible las circunstancias. Las sondas á una distancia de cuatro ó cinco leguas alternaban desde las 40 á las 60 brazas; veíamos en torno solazarse tranquilamente las ballenas, los lobos marinos y las nuŁrias; eran más frecuentes las aves; y las costas presentaban siempre un semblante frondoso y alomado.

Delante de los Cabos Perpétua y Flattery del Capitán Cook, debíamos admirar de nuevo la exactitud de las descripciones de aquel navegante. No se equivocaba, por cierto, cuando contra el dictamen de los demás creía ser barrancas, las que tenían el semblante de ser pedazos de hielo. La costa efectivamente es toda abarrancada á la orilla, ó más bien llena de manchones blancos de arena, siendo luégo interiormente de regular altura, algo desigual, cubierta de arboleda y con varios cerritos que encadenándose terminan en otros montes más altos hacia el Norte.

Siguiéronse luégo reconociendo el Cabo Diligencia del Comandante D. Bruno Hezeta, el Cabo Blanco de Martín de Aguilar, las inmediaciones del Puerto de la Trinidad; y finalmente, en la mañana del 6 estuvimos á la vista del Cabo Mendocino. Este Cabo debe considerarse como el verdadero término de los reconocimientos de Sebastián Vizcaino; pues á pesar que la fragata destinada en su conserva alcanzase el Cabo Blanco y boca del río de Martín de Aguilar, fué esta navegación hecha con demasiados riesgos y precipitación, para que pudiese describirse la costa intermedia con la misma escrupulosidad, exactitud y primor que había empleado aquel Almirante hasta el dicho Cabo.

Ya nuestra navegación hasta la Punta Reyes, en las inmediaciones del puerto de San Francisco, debió por naturaleza ser bastantemente acelerada. Corren allí los vientos constantes del Noroeste; las aguas toman por la misma razón una dirección permanente al Sur; son las costas acantiladas, y la sonda extendida hasta unas cinco leguas mar en fuera, pero rara vez se disipa la neblina y esto hace que haya un peligro verdadero para' el navegante cuando intenta fondear en el puerto de San Francisco ó en el de Monterey. Por lo que toca á las inmediaciones del primero, fuimos bastantemente felices, logrando después de algunas horas de pairo ó bordos cortos, avistar la Punta Reyes, y áun situarla por medio de algunas observaciones en buena latitud y longitud, pero fuimos al contrario rodeados de muchos riesgos, antes navegando desde el Sur del Puerto de San Francisco á la Punta de Año Nuevo, y después desde ésta al fondeadero de Monterey: equivocáronse en el segundo tránsito las situaciones respectivas, al tiempo que refrescaba mucho el viento; oíanse confusos los cañonazos de correspondencia del presidio, $y$ la neblina se hacía aún más espesa; orzamos al Iiste ya propasada la Punta de Pinos, y el hallarnos repentinamente sobre una costa llena de arrecifes, cuando aún ignorábamos nuestra situación verdadera, nos dictó como el partido más prudente el de dar fondo á un ancla en 28 brazas arena y conchuela.

Esta posición de ningún modo podía parecernos favorable, y desde luego hubiéramos dado nuevamente la vela, si el viento, la mar gruesa, la oscuridad y la demasiada inmediación de la costa no nos lo hubiesen manifestado como impracticable. La tarde y noche del I I, debieron por la misma razón causarnos un cuidado no común. Todo nos indicaba un fondo lleno de piedras, en el cual no resistirían tal vez los cables; la mar era gruesa, y la costa á muy poca distancia tan llena de arrecifes, que pareciese imposible salvar persona alguna, si naufragásemos en ella; por otra parte, oíamos por los tiros de conserva de la ATREvida (necesarios por la neblina constantemente espesa) que se hallaba en la misma situación que nosotros. Debió pues parecernos al día siguiente bien feliz la no esperada alteración del viento que roló al Nornoroeste y al Norte, y así no titubeamos en picar el cable dada la vela sobre codera, ciñendo luégo con regular aparejo para adquirir nuevo barlovento, y dirigirnos al fondeadero.

Todo el día fué necesario para este intento. Internamos en la bahía hacia las cuatro de la tarde: la vista accidental de la costa, el ruído de sus rompientes, y á veces los cañonazos del presidio servíannos de guía para los diferentes bordos que se hiciesen preferentes, ya que el viento se había declarado flojo por el Sudoeste; final mente, calmado éste de un todo hacia las ocho, dimos fondo á un anclote en 20 brazas arena, y como después nos enterásemos con el bote cuál era nuestra posición relativamente al fondeadero, emprendimos el arrimarnos á él con espías, y en la mañanita del I3 pudimos ya quedar amarrados en paraje oportuno, distando una media milla escasa de la playa del presidio.

Hasta entonces, la idea que debíamos formar de aquel puerto era bien contraria al semblante favorable con que la habíamos mirado desde 
Set. iz lejos. Considerábamos ya bien fundados los de seos de los naregantes de Filipinas, para que no se hiciese escala en aquella rada á pesar de las escaseces que después de una navegación tan dilatada debían precisamente molestarnos hasta Acapulco: una entrada bien dudosa por falta de observaciones, y de la vista de tierra, un cielo constantemente triste y neblinoso, las inmediaciones harto peligrosas de la Punta de Pinos y la misma disposición del fondeadero, cuyo extremo del Norte mal podría abrigarie de los vientos reinantes, distando próximamente unas doce leguas por la Punta del Año Nuevo, eran otros tantos obstáculos para que pudísemos formar una idea mediana siquiera de aquellos contornos. Pero no eran fundadas nuestras conjeturas; antes bien, variando muy luégo la faz de todas las circunstancias, debíamos conocer que difícilmente pudiera proporcionarse mejor escalá para los buques, que de la costa septentrional de la América vienen ya para la caída del verano aproximándose al clima ménos temible de los Trópicos.

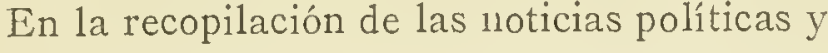
naturales de la California, se hablará con la debida extensión de cuanto sea relativo al descubrimiento y sucesiva reducción de las costas y de sus habitadores á la Monarquía española. Ahora nos ceñiremos á decir, que el presidio de Monterey, residencia del Gobernador de la provincia, se compone de un cuadrilongo cerrado y fortificado, en el cual habita una compañía de 63 hombres de á caballo con. Teniente y Alférez; habiendo lugar, aunque con alguna estrechez, para que cada uno viva con su mujer é hijos. Inmediato á la Marina está un pequeño almacén, sin duda dispuesto para el uso de los buques del Departamento de San Blas, que con diferentes objetos arriban anualmente á la rada, y no dista más de dos leguas hacia el Sueste la Misión de San Cárlos, que sobre el río Carmelo reune bajo la dirección de los Padres Franciscanos, un número crecido de indios recién atraídos á la religión y á la vida sociable.

No bien habíase disipado la neblina, cuando ya prontos en la playa los instrumentos necesarios, D. Juan Vernaci pudo tomar las alturas correspondientes del Sol y deducir la longitud por los relojes marinos, fijando al mismo tiempo la primera época para el cxamen de su marcha. Los resultados de aquclla observación, fueron los siguientes:

Longitud oriental de Nutka... $4.45 .32 \quad \frac{\text { Cronómetro } 72 .}{4.46 .3^{8}}$

De suerte que continuando la seric de nuestras longitudes y adoptada con preferencia la del cronómetro 72 por conformarse mucho su actual movimiento con el que se le había determinado en Nutka, resultaba la longitud occidental de Cá- Sêt. rz diz de $124^{\circ} 23^{\prime}$ I $4^{\prime \prime}$ para el observatorio, el cual para mayor comodidad se había transferido á una buena habitación del cuadrilongo.

Como la escala nuestra en Monterey no tuviese en sí otro objeto sino el natural progreso de aquellas ciencias, que estuviesen á nuestro alcance, y al mismo tiempo aquel descanso y alivio á las tripulaciones, que las hiciesen aptas á resistir á las enfermedades y á los trabajos con que debían nuevamente arrostrar bajo de la Zona Tórrida, muy luégo nuestras medidas debieron dirigirse por la una parte á la combinación de una ración sabrosa y abundante, con aquella libertad y diversiones que fuesen compatibles con el servicio; por la otra, á las excursiones botánicas y demás noticias instructivas del país importante que ahora trillábamos: ciertamente es difícil ha$11 a r$ otra parte alguna más adecuada para uno y otro intento: eran los días suavemente serenos, por manera que las observaciones astronómicas no tuviesen la menor interrupción; la caza, la pesca, la actividad de los soldados del presidio y los ganados excelentes que pastaban en aquellas inmediaciones, suministraban ya una comida bien sabrosa, ya varios objetos tan nuevos como instructivos para la Zoología. Proporcionábase luégo por las tardes una alegre corrida de novillos; á las veces las excursiones á caballo á la Misión no distante del Carmelo; en otras unos paseos entretenidos en aquellos contornos, y por último, la reunión puntual de todos á bordo, cuando se retiraban las embarcaciones menores, no podían á ménos de robustecer extremadamente á la marinería. Admiraba D. Tadeo Heenke que en un clima tan favorable á la vejetación, se hallase ahora una nueva fructificación casi tan completa como la de la primavera, y que las orillas frondosas del Carmelo reuniesen en sus inmediaciones al mar una tal variedad de plantas (traídas sin duda sus semillas con las vertientes del inviemo), que parecían pertenecer más bien al dilatado espacio de más de cien leguas, que al término bien limitado de nuestras excursiones.

Era natural, que ó bien por una honrosa emulación ó por aquel instinto sociable que reune los intereses de los que se hallan en un mismo trance, no nos fuesen indiferentes las noticias áun más frívolas de los accidentes de la expedición francesa mandada por el Conde de la Péyrouse. Varios le habían conocido, y todos unánimes admiraban las propiedades que caracterizaban á los individuos de aquella expedición. El observatorio de Mr. Dagelet había permanecido en el almacén de la playa. El senor Lamanon y el Abate Mongés alojaron por algunos días en la Misión, desde donde emprendían sus exámenes físicos y las excursiones botánicas, El Sr. de Vancij dejó representado con 
Set, iz mucho arte en una lámina pequeña el recibimiento hecho en la misma Misión á los señores de la Péyrouse y Langle con muchos de sus Ofciales; finalmente, hallábamos como dignos rastros de aquella expedición y de la humanidad de sus jefes, así una porción de semillas y árboles frutales ya propagados en aquella Misión y en las contiguas, como una pequeña máquina para moler trigo, que el Vizconde de Langle había regalado á los Padres de la Misión. Por lo que toca á los resultados de sus tareas científicas, no era menor al que habíamos hallado en Concepción de Chilc el sigilo que habían guardado, haciéndose por consiguiente imposible de nuestra parte una comparación cuidadosa, que diese margen á toda la perfección que deseábamos particularmente en las cartas hidrográficas. Eran varios los conceptos sobre el paraje y las caulsas de la desgraciada pérdida de las dos lanchas de la misma expedición, sobre cuyo trance la Oficialidad guardó siempre el mayor sigilo, aventurándose solo uno ú otro de las clases subalternas á hablar con los nuestros de aquella especie lastimosa, y resultando por consiguiente muy equívocas y confusas cualesquiera interpretaciones de semejantes voces.

Entre los que con más juicio y conocimiento pudieron satisfacer en esa parte á la natural curiosidad nuestra, débese sin duda el primer lugar al Presidente de las Misiones el Padre Fray Matías de Lasuen, del Orden de San Francisco, sugeto de una doctrina, un semblante $y$ una cpnducta realmente apostólicos, y de unos modales é instrucción poco comunes. Este religioso, había con mucha razón merecido el aprecio y amistad de entrambos Comandantes franceses y del mayor número de sus subalternos, logrando darles una idea de nuestro sistema religioso de las misiones, que debió causarles tanta mayor admiración, cuanto era mayor el encono mal cimentado de muchos escritores modernos contra ese sistema confundido hasta aquí, á las veces con la superstición, otras con los vicios particulares de uno ú otro individuo, y á veces con los defectos indispensables de la demasiada distancia y extensión.

Al medio día del 16 tuvimos también la satisfacción de ver aparecer inmediata al puerto una goleta nacional, que para'las dos de la tarde ya consiguió el dar fondo cerca de las corbetas. Era la Santa Satumina del Departamento dc San Blas, que en conserva del paquebot San Carlos y á las órdenes del Teniente de navío Don Francisco Elisa, había salido de Nutka para continuar los reconocimientos de la costa al Norte y al Sur, y los vientos habían precisado á entrambos buques á emprender sus tareas desde el Es trecho de Fuca, en el cual luégo habían permanecido todo el verano por la mucha extensión de los canales internos. Ultimamente, desemboca- Set. I6 dos para regresar á Nutka, se habían separado, y luchando en balde la goleta por muchos días para elevarse á la latitud precisa, había debido, por falta de agua, arribar á Monterey. Dcbía pareccinos bien feliz la llegada de aquel buque cuando la refiriésemos á una tentativa que meditábamos hacer con nuestras lanchas para el rccobro de las anclas perdidas al Sur de la Punta de Pinos.

Debía fondear á alguna distancia del rastreo para depósito de los víveres y pertrechos que se llevasen, recibir las anclas y cables si acaso pudiesen recobrarse, y convoyar las lanchas si alguna adversidad las obligase á correr al Sur no pudiendo reincorporarse á las corbetas. Se le proveyó por consiguiente con aguada, víveres y amarras oportunas, y en la noche del i 8 dió la vela con las mismas lanchas. Dirigía esta operación el Teniente de navío D. Cayetano Valdés en la lancha de la Descubierta; la de la Atrevida iba confiada á D. José Robredo, y D. Francisco Viana tuvo el cargo de la goleta, de modo que las lanchas no careciesen jamás de aquellos auxilios y abrigo que les eran tan necesarios. La ausencia se ciñó á dos días. Las instrucciones eran terminantes para que no se expusiesen ni remotamentc á un naufragio; y las esquifazones de ambos buques, se formaron con aquellos marineros que reuniesen en mayor grado la inteligencia, la quietud y la resistencia al trabajo.

Era bien extraordinario que mientras en el puerto gozábamos (particularmente desde las nueve de la mañana) de una claridad singular en los cielos y en los horizontes, nuestras lanchas tuviesen á tan corta distancia una neblina tan espesa y constante, que á veces sujetas con la rastra, no se distinguían sin embargo una á otra: un inconveniente de esta especie hubiera sido por sí decisivo para el malogro de la empresa, á no concurrir una actividad é inteligencia poco comunes en los que se habían encargado de llevarla á efecto. Trabajaban indiferentemente de día y de noche cuando una clara aunque momentánea les permitiese buscar las marcaciones del fondeadero; los cañonazos de la goleta fondeada, los avalizaban entre las neblinas; el ruído de las rompientes y la sonda, eran otras guías para las distancias; finalmente, el rastreo era tan seguido en las ocasiones favorables, que á veces no se interrumpiese en ocho y $\operatorname{die} z$ horas, pero cra un obstáculo invencible para el buen éxito, la muchcdumbre de piedras que hallaron en el fondo: con este inconveniente debieron perder mucho tiempo, interrumpir la dirección de la rastra, rozar las guindalezas, y abandonada toda esperanza de cobrar un ancla siquiera, regresar al puerto para el plazo prefijado. 
Concluidos así los diferentes objetos que nos habíamos propuesto en aquella escala, pareció ya llegado el plazo oportuno de la salida, para aproximarnos paulatinamente á Acapulco. Iá fijamos para la mañana del 25, ocupándonos en los pocos días restantes á extender las sondas de la bahía por diferentes rumbos, á proveernos de algún ganado fresco para el uso de las tripulaciones, y á completar nuestros acopios para el Real Gabinete. Las corbetas quedaron efectivamente á pique de un ancla á las nueve de la manana del día prefijado; poco después, con los primeros soplos de la virazón, se hicieron á la vela ciñendo al primer cuadrante con todo aparejo, y en la noche siguiente después de varios bordos se hallaron bastantemente enmaradas para continuar su navegación al Sur.

Era esta ya por su naturaleza bien sencilla, frecuentándola anualmente los buques de San Blas y las Naos de Filipinas; al paso que los vientos constantes y favorables del Noroeste la hacían sumamente corta y descansada, continuó con estos antecedentes nuestro método de navewar durante la noche propasando sin reconocerlos, algunos trozos de costa. Logróse sin embaryo el situar con mucha exactitud por medio de observaciones repetidas, la Punta de Pedernales á la entrada del canal de Santa Bárbara, algunas de las islas que forman el dicho canal, la otra de San Nicolás, que está al Oeste de todas, y la de Guadalupe que suele muchas veces servir de reconocimiento ó recalada para las Naos ya indicadas.

Esta última isla puede verse desde la cubierta á distancia de I3 ó I4 leguas; es más elevada por la parte del Norte, sus orillas son escarpadas y sin abrigo alguno. No se encuentra fondo á distancia de una milla y media. Parecen igualmente cortados á pico los islotes ó pedruscos del Sur; es su latitud de $28^{\circ} 49^{\prime}$ y la longitud $3^{\circ} 23^{\prime}$ al Este de Monterey.

Atracada nuevamente la costa por latitud de $28^{\circ} 22^{\prime}$, nos fué fácil reconocer de cerca las Islas de San Benito y la del Cerro. En la segunda, ya inmediatos al Cabo San Agustín admirábamos de nuevo la exactitud de las descripciones de Sebastián Vizcaino, ni las hallamos ménos prolijas sobre la Isla Navidad, el Cabo San Bartolomé y la Punta de Abre Ojos, todos parajes que reconocimos después con una atención nimia. Finalmente, alcanzados en la tarde del 4 el Morro de San Lázaro y la bahía de Santa Marina, y al día siguiente la Misión de Todos Santos, pudimos para la mañanita del 6 estar delante del célebre Cabo de San Lucas, extremo meridional de la Península de California. Nos era doblemente agradable aquella posición, así porque pudiéramos referir á nuestras cartas las obser vaciones hechas en la Misión de San José por e!
Abate Chappe y D. Vicente Doz, como porque Oct. de allí debía emprenderse con la separación de las dos corbetas una nueva multiplicación de nuestras tareas hasta Acapulco. En efecto, comparados los relojes marinos entre sí por medio de señales, y observada la longitud en meridianos del Cabo San Lucas, la ATrevida inmediatamente hizo derrota hacia el Cabo Corrientes, desde donde debía rectificar la posición de toda la costa hasta Acapulco; la Descubierta contiiiuó costeando el frontón de la península, para seguir después directamente á San Blas. Hacíase ya necesaria una breve escala en aquel puerto, así para reponer algunos pertrechos de los cuales carecíamos y en particular las anclas, como para avisar con anticipación á Méjico las medidas oportunas para nuestros pasos venideros, los cuales como es natural tenían por objeto esencial reunir los Oficiales quedados en la Nueva España, y transferirnos prontamente á los mares del Asia.

La comparación de nuestra serie de longitudes, con las que se habían determinado en la Misión de San José, correspondió á nuestros deseos aún más allá de lo que podíamos esperar á primera vista: era casi imperceptible la diferencia de unas á otras: combinábanse con una suma escrupulosidad las determinaciones del Capitán Cook en Nutka, y las de los astrónomos rusos en los extremos de la Siberia: todo manifestaba el estado actual de la navegación, pues apenas descubierta una extensión tamaña de costas, se hallaba ya con el auxilio de la Astronomía, rigurosamente ceñida á sus justos límites hidrográiicos.

En los paralelos donde nos hallábamos y mucho más en el clima que actualmente reinaba en las costas de Nueva España, debíamos temer con justa razón relativamente á las tripulaciones que degenerasen en calenturas intermitentes los resfriados dimanados por lo común del paso demasiado rápido del frío al calor. Por fortuna no nos habían alcanzado aún las lluvias ni las calmas, y sin embargo veíamos el termómetro en los 85 y $90^{\circ}$ al aire libre, y las consecuencias dc un calor tan excesivo no podían ser sino funestas. Bien nos habíamos precavido desde muy temprano, añadiendo á todas las medidas diarias el uso de los gazpachos por cena, el refresco á lass tres de la tarde de la chicha ó agua de maíz fermentado, laventilación más repetida de los cois, un trabajo moderado sí, pero frecuente; por último, la continuación del vino para ración, y fuć también preciso usar al mismo tiempo de las sangrías y refrescantes; estos preservativos suaves bastaban para que en los semblantes, en el buen humor y en la disposición al trabajo, manifestascn á la sazón entrambas tripulaciones toda la robustez que podíamos desear. 
La navegación de la Descubierta hasta San Blas, no tuvo acontecimiento alguno que merezca referirse: viéronse las Islas Marías en la tarcle del 9 , y al día siguiente costeadas de cerca la Isabela y la Piedra Blanca, fondeamos á las cuatro de la tarde en seis brazas arena á poca distancia de la entrada del río ó de la dársena.

No cabe una idea del espectáculo realmente lastimoso que presentaban á la sazón las marinerías y demás habitantes de aquellos contornos: pálidos en sus rostros, desmayados en sus fuerzas, desnudos y desidiosos en sus trajes, precisados á buscar en el mismo estrago de los vicios el único alivio de sus afanes, ya que no lo fuese de su salud, hacían un contraste singular con la robustez y la alegría de nuestros marineros: si permaneciésemos á bordo, el calor era insufrible particularmente antes del medio día á cuya hora solía entablar la virazón, y si intentábamos ir á tierra, era tal el enjambre de mosquitos y tales eran las miasmas pútridas que dimanaban de la inmensidad de aguas esparcidas en toda aquella campiña, que á más de la incomodidad, hacíanse sumamente peligrosas las excursiones. De allí es que anduvimos con extremo diligentes para proveernos de los diferentes efectos que nos fuesen necesarios; omitióse por la misma razón el establecer un observatorio, pues alcanzaba el uso de los sextantes á los objetos propuestos; y fuímos tan felices en todas esas medidas, coadyuvadas con una actividad extraordinaria antes por el Comisario Comandante D. Francisco Hijosa, y luégo por el Teniente de navío D. Salvador Fidalgo; que á los cuatro días de nuestra llegada ya pudimos dar nuevamente la vela. Las conferencias con este Oficial debie- ron sernos en aquella ocasión sumamente ins- Oct. tructivas. Había visitado en el año anterior la entrada del Príncipe Guillermo, la ría de Cook y el establecimiento ruso de Oanalaska; por manera que reunidos sus reconocimientos á los nuestros, ya no dejasen cosa alguna por desear en toda la parte de la América, comprendida entre los paralelos indicados por Ferrer Maldonado: nos cedió sus diarios; adquirimos varias noticias importantes sobre las costas del seno de la California ó Golfo de Cortés; y ciertamente hubiera sido aquella corta demora en el departamento de una utiliclad aún mayor para la expedición, si como lo intentábamos nos hubiese podido seguir, esquifada con marinería nuestra, una goleta recién construída en aquel astillero, y oportuna para los reconocimientos de las costas de Tecoantepeque y Guatemala, que las calmas nos habían precisado á omitir en la primavera anterior.

A las tres de la mañana del día I 4 estuvimos efectivamente á la vela: nos sobrecogió poco después una turbonada bien recia con muchos rayos; pero cediendo ésta muy luégo al aproximarse el Sol sobre el horizonte, púdose continuar felizmente la navegación emprendida y atracar el Cabo Corrientes al anochecer del otro día. Desde allí los vientos y las corrientes aceleraron de tal modo la navegación para Acapulco, que sin embargo de reconocerse diariamente unos trozos considerables de costa, particularmente sobre los volcanes de Colima y los puertos de Navidad y Siguatanejo, en la tarde del ro alcanzamos la Isla del Grifo y poco después fondeamos al lado de la Atrevida, la cual se hallaba en el puerto desde la tarde del r6.

\section{Separación de la ATREvida á perfeccionar el reconocimiento de la costa entre Cabo Corrientes y Acapulco.}

(6. : i Desde la mañana del + me había prevenido D. Alejandro Malaspina el separarme para completar las operaciones del mes de Abril, atendiendo á la escasez de anclas de este buque para fondear en la rada de San Blas, á donde la DEscubierta se dirigía para recibir en aquel departamento los atrilios necesarios que no pudiésemos encontrar en Acapulco; y como dejase á mi arbitrio el momento de la separación, acordamos á la vez navegar unidos hasta el Cabo de San Lucas, en cuyo meridiano pensaba yo observar longitudes.

Efectivamente, puestos á dos millas del refe- rido Cabo poco después de las ocho de la ma- ost. 6 ñana del 6 , observamos longitudes en su meridiano. Corrigióse para la marcación del Cabo con la variación de la aguja de $7^{\circ}$ Nordcste, resultando la longitud por el ro5 de $\mathrm{II}^{\circ} 5^{6^{\prime}}$ oriental de Monterey.

Según noticias adquiridas en Méjico por el 'leniente de navío D. José Espinosa, supimos que la diferencia de meridianos entre el Cabo de San Lucas y la Misión de San José, era sólo de $26^{\prime}$ y no de $I^{\circ} 00^{\prime}$ como suponían las cartas de Cuadra y la del Piloto Mendizábal; y considerando aquella deducción sin duda por una estima 
oc. 6 prolija ó por marcaciones ligadas entre ambos puntos, debíamos mirarla como bastante exacta.

Longitud de San José astronómicamente occidental de París......

El Cabo de San Lucas al Oeste por su

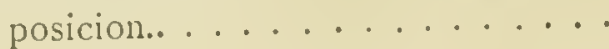
00.26 .00

Longitud del Cabo de San Lucas Oeste de Paris............ I I 2.28 .00

Monterey al Oeste del Cabo de San Lucas por los horarios. .......

Luego longitud de Monterey Oeste de

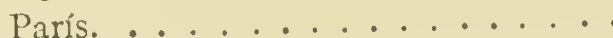

Longitud asignada por los cronómetros á Monterey... .

124.24 .00

I $24 \cdot 53 \cdot \mathrm{I} 4$

Inmediatamente que se tomaron los horarios, se forzó de vela gobernando al Sudeste $1 /{ }_{4}$ Este á buscar el paralelo de Cabo Corrientes, y la Descubierta siguió barajando la costa á la entrada del Golfo de California ó puerto de San José, y ya al medio día nos perdimos de vista.

$\mathrm{Ni}$ el tiempo hermoso, ni el viento aunque bonancible no dejó de ser constantemente favoràble, alcanzando de este modo á ver las Islas Marias en la mañanita del 9 á distancia algo más de diez leguas, según lo indicaron las bases, llegando al medio día á la latitud de $20^{\circ}+3^{\prime}$ y longitud de $15^{\circ} 13^{\prime}$ oriental de Monterey, y á las cuatro de la tarde avistamos confusamente al Este las tierras inmediatas al Cabo Corrientes. Continuóse el mismo rumbo del Este Sudeste, distando á la sazón unas ocho á nueve leguas de la costa. Cumplida la latitud del Cabo, se entretuvo la noche entre bordos y pairear, á fin de amanecer á distancia convenjente para dar principio á nuestras tareas acostumbradas. Desde las diez empezó á aturbonarse por el Nordeste con relámpagos frecuentes y algunos truenos, cuyos aparatos y la inmediación á que estábamos de la tierra obligó á ceñir el viento para fuera sobre las gavias.

$\mathrm{Al}$ rayar el día todo había despejado, y marcamos el Cabo Corrientes al Norte $60^{\circ}$ Este distantes unas cinco á seis leguas. Ceñido el viento al Norte y Nornoroeste se forzó de vela para atracar la costa: las corrientes habiéndonos arrastrado al Sur del Cabo, era imposible ya ganar su paralelo para la hora de observar la latitud como era mi deseo.

E1 Cabo Corrientes se nos presentaba formando á la vista dos puntas que creimos al principio la más distante, por el verdadero Cabo pero advirtióse luégo que rolaba ésta tanto para el Liste, que la enfilábamos con la más saliente, ó el mismo Cabo al Norte $40^{\circ}$ Este; la tierra que le domina más interna es alta y la unen dos ordenes de montañas que aumentan su número y altura hacia lo interior de ella. Al propio tiempo se alcanzaban á ver el Monte de San
Juan y las tierras inmediatas representadas por Oc!. 10 la gran distancia bajola vista de otras tantas islas como puntos descubríamos.

A las nueve de la mañana distando tres leguas del Cabo arribamos al Sudeste $1 / 4$ Este, rumbo paralelo á la costa. El viento igual y fresquito, la mar llana y un sumo cuidado en el gobierno para la exactitud de las bases, eran circunstancias todas que ocupaban justamente nuestro cuidado para esperar resultados favorables; pero frustróse esta confianza con una diferencia de $7^{\prime}$ al Sur por la latitud del medio día siendo ésta de $20^{\circ} \mathrm{O}^{\prime}$, y la longitud de $\mathrm{I}^{\circ}{ }^{\circ} \mathrm{I}^{\prime}$, marcándose entonces el Cabo Corrientes al Norte $8^{\circ}$ Oeste distancia de ocho á nueve leguas.

Desde esta hora estrechando más la distancia á la costa, seguimos por la tarde favorecidos de las mismas circunstancias para trazarla, pero la demasiada inmediación á ella nos hizo conocer visiblemente por las marcaciones, que las corrientes violentamente nos arrastraban en la misma dirección del rumbo. Esta observación nos obligó á repetir los horarios á las dos y media y cinco de la tarde, para también disminuir los errores si la corriente conservase la propia fuerza.

Los resultados de unos horarios á otros indicaban una diferencia uniforme con la estima, ascendiendo la total desde el medio día á los últimos horarios á $28^{\prime}$ para el Este. Esta comprobada experiencia autorizaba la necesidad de corregir proporcionalmente las latitudes de las bases.

La costa desde el Cabo hasta rebasar un islote de piedra poco separado de la tierra cerca del Morro Coronado es muy seguida y baja regular. mente desde una ensenada pequeña situada al Sur de dicho Cabo, de tal modo, que nos era difícil elegir para las bases puntos notables en la orilla, y sólo la inmediación á ella facilitaba el distinguir algunas manchas negras en la dilatada playa que casi limita á toda la costa recorrida hasta aquí. A medida que se interna en el continente, las tierras se elevan por varios órdenes de montañas pobladas de un bosque tan frondoso como impenetrable.

A la caída de la tarde hubo muchos truenos y relámpagos que aumentaron al anochecer y una turbonada preparada, todas estas eran circunstancias que exigieron por la noche separarnos algún tanto de la costa; pero con atención á marcar por la mañana el último punto reconocido en esta tarde. Así, después de volver áatracar la costa, reconocimos al amanecer hallarnos á la vista del puerto de Navidad según lo indicaban unos islotes que hay á su entrada, los cuales no se advertían en otro punto de lo restante de la costa. Hiciéronse rumbos paralelos á ella mientras duró el terral, al que no sustituyó 


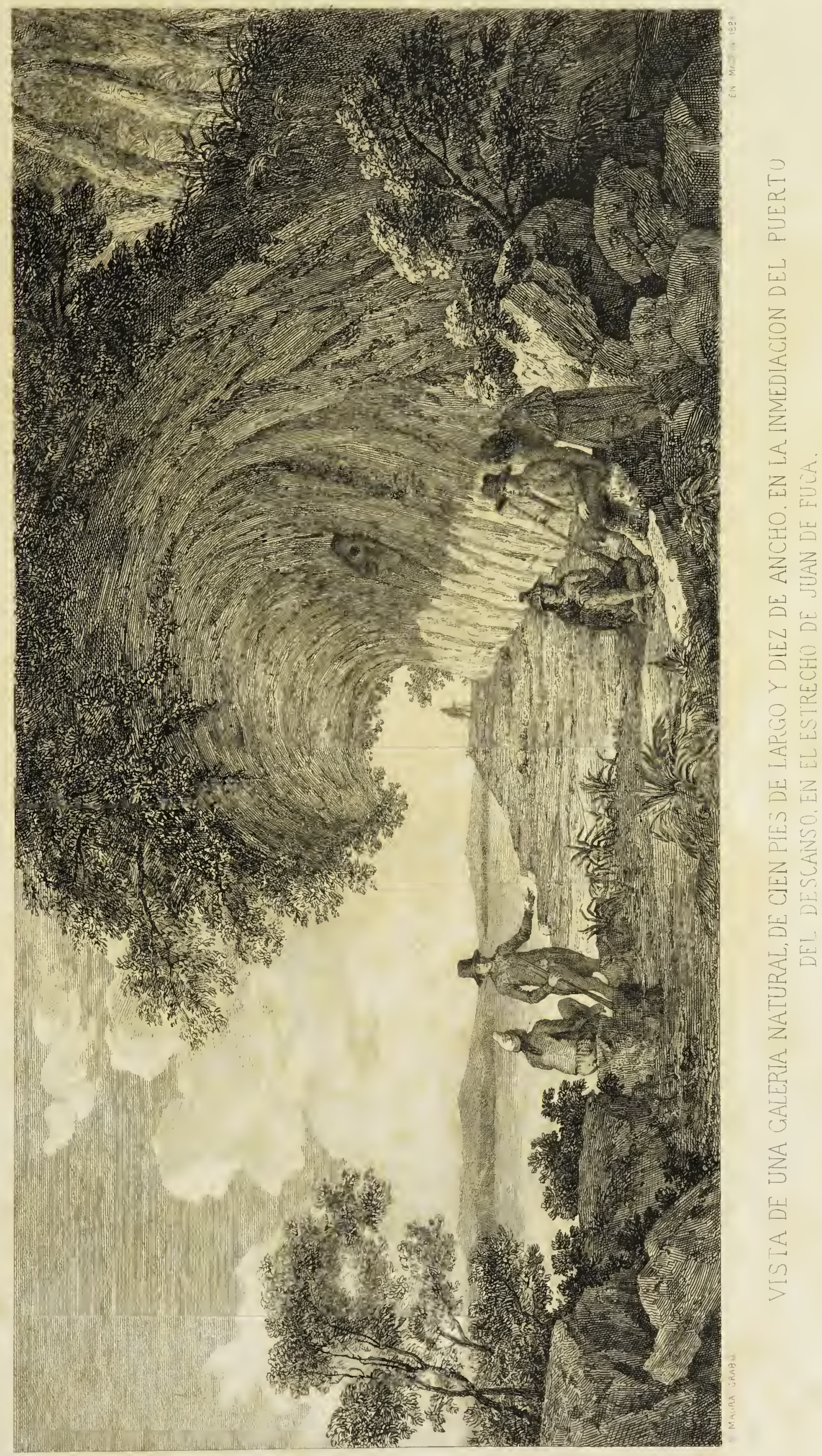



Oct. I la virazón hasta el medio día, hallándonos en latitud Norte de $19^{\circ} 06^{\prime}$ y longitud de $16^{\circ}+8^{\prime} 30^{\prime \prime}$ al Este del Meridiano de Monterey, notándose una diferencia al Sur de I $8^{\prime}$.

Habiendo por la tarde refrescado la brisa, pudimos reconocer la boca del puerto de Navidad por un frontón ó promontorio que aparece isla á cierta distancia con una quebrada notable en medio, y un islote inmediato en el extremo de fuera, y otro algo mayor al Este en la ensenada de Selagua cerca de tierra firme, po: cuyo color y no tener nombre en las cartas, le pusimos el de Islote Blanco.

La costa desde el Islote que está sobre el puerto de Navidad, es de mediana altura, con escarpados de color rojo, y en el extremo Norte tiene varios faralloncitos. Toda la ensenada de Selagua la limita una playa igual, y hacia su medianía se advierten en la falda de un montecito dos ó tres manchas blancas, siguiendo después la costa para el Este, escarpada hasta Punta de Suchiche de la cual anochecimos siete á ocho leguas.

12 y 13 Nuestras operaciones en los dos días siguien. tes, no fueron tan felices como en los anteriores: el poco viento, á veces variable, la costa tomada, y una marejada del Sur difícil de vencerla, fueron inconvenientes para malograr el trazarla por esta parte. Sin embargo, la esperanza de poderse adoptar los trabajos por este paraje de nuestro anterior viaje, hacía ménos sensible ahora la oposición de estas dificultades. También consideraba yo por otra parte, que el punto importante en este tramo de costa, era el de las Tetas que engañaron al Lord Anson con las de Coyuca, y llamaremos aquí del Engaño, las cuales quedaron exactamente situadás en aquella campaña; pues no obstante, al amanecer del I3 se reconocieron muy bien en medio de una cadena de montañas bien elevadas que las ciñen al Este y al Oeste.

Observando al medio día la latitud Norte de $I 7^{\circ} 50^{\prime}$ y la longitud de $I S^{\circ} I^{\prime}$, marcamos las Tetas del Engaño al Norte $6^{\circ}$ Oeste, cuyas observaciones indicaron la diferencia al Sur de I4 y I $8^{\prime}$ al Este.

Con la virazón bonancible del Oesnoroeste seguimos rumbos paralelos á la costa para determinar su arrumbaniento, no habiendo puntos notables en este trozo que mereciesen detenerse á reconocerlo. No fueron menores los obstáculos que tuvimos al día siguiente para la continuación de nuestras tareas, y nos consolaba la esperanza de que tal vez no los encontrase por aquí la corbeta Descubierta logrando evacuarlas con la perfección necesaria, restando sólo un corto trozo hasta el puerto Siguatanejo en dondedebian concluirse. Nos contentamos, pues, con aprovechar todo momento farorable á nuestro intento.
En la mañana del I 5 con vientecito de la Oc. sj tierra, se fué costeando á buscar la entrada de Siguatanejo, marcando al medio día una isla que está en la misma boca de este puerto al Norte $+2^{\circ}$ Este, observando la latitud de $I 7^{\circ} 22^{\prime}$ Norte, y longitud de $19^{\circ} 5^{\prime}$, á distancia de Acapulco como 42 leguas.

No fué ya mi objeto otro que el de buscar este puerto con toda diligencia, respecto á que la costa intermedia quedó bien trazada anteriormente. Al amanecer, abandonados por el terral nos favoreció luégo lá virazón fresquita, con la cual contamos coger temprano el puerto, auxiliados de las corrientes. No distaríamos de él poco después del medio día más de cuatro leguas, cuando vimos un bote dirigirse hacia nosotros, cuyo patrón me informó había salido con dos canoas grandes á buscar y socorrer la fragata particular el Sacrancento, que muy maltratada de un temporal, había quedado como abandonada y casi sin recurso para poder navegar.

Con una noticia tan poco circunstanciada para poder inferir el paradero de este buque, no se presentaba partido que tomar, no habiendo podido descubrirle desde los topes, hasta que los informes en el puerto me iluminasen para el acierto de las providencias más conducentes.

A las cuatro de la tarde, dentro ya de la Punta del Grifo, emprendimos sobre bordos con todo a parejo tomar el fondeadero, y después de muy poco llegamos á él, quedando sobre un ancla afuera, y rejera á uno de los árboles próximos al muelle.

Tercera estada de la ATREVIDA en Acapilloo, y ocurrencias hasta la remión á la DESCUBIERTA.

Considerando á la tripulación algo cansada con las maniobras de bordear y de amarrarse, no fué mi ánimo completar esta última hasta el día siguiente, fiado en las bellas apariencias del tiempo, y en mi deseo de proporcionarla algún descanso. A esta reflexión se agregaba otra no ménos atendible, cual era la agradable ocupación en que todos se hallaban con el cúmulo de cartas de Europa que habíamos recibido, cuyas noticias así públicas como particulares, tan suspiradas por tanto tiempo, debian ser las más interesantes áun para quien fuese más indiferente á sentir la complacencia que causan. Entre éstas tuvimos también la de haber merecido de la piedad del Rey, el ascenso á los grados inmediatos de varios Oficiales subalternos y yo, con otras gracias para diferentes indivíduos de la misma expedición.

Apenas nos habíamos ocupado las primeras horas de la noche en gozar el gusto de estas satisfacciones, cuando las feas apariencias del tiempo vinieron á ocupar justamente nuestro 
Oct. 16 cuidado. Preparada una turbonada por el Sudeste, y precediendo muchos truenos y relámpagos, descargó con mucha fuerza como antes de la media noche. Inmediatamente se calaron vergas y masteleros, dejando caer la esperanza antes que no lo permitiese la falta del cable ó garrásemos muy poco; con estas diligencias quedamos tranquilos, y mucho más viendo pasar por nuestro costado la falúa y canoas que habían salido á auxiliar la fragata el Sucramento, justamente en el momento en que hubieran corrido el peligro más inminente.

No bien nos habíamos desembarazado de las faenas ordinarias para asegurar el buque después de serenar el tiempo en la mañana siguiente, cuando el Subdelegado interino D. Ramón Escalante, acompañado de D. José de la Riva Agüiero, Superintendente de la Real Casa de Moneda de Lima y pasajero de la fragata el Sacramento, vinieron á proponerme que comisionase la lancha con los auxilios correspondientes para socorrerla, la cual había dejado el segundo pocos días antes en el estado más deplorable, desarbolada y sin timón. A la relación menuda de este suceso que me hizo Riva Agüero, me añadió haber podido persuadir al Capitán de la fragata para permitirle venir en el bote á este puerto desde la distancia de 40 leguas á la mar en donde la dejó para disponer y dirigir los socorros necesarios á evitar al buque ó á su tripulación el fin más funesto, contando con la seguridad de ser su paradero al Oeste de Acapulco, en cuya dirección habían notado corrientes muy violentas, y algunos días también para el Norte.

Estas últimas noticjas dirigidas á probarme el paraje donde podíamos buscar la fragata, se oponían tanto á nuestras recientes observaciones que no pude ménos de suponer en las primeras todo el error tan preciso como disculpable en quien carece de los conocimientos del arte. A uno y á otro les hice ver lo infructuosa y aun arriesgada que sería la salida de la lancha hasta donde pretendian, y más no pudiendo apoyarla sobre razones capaces de justificar las resultas. Yo no hubiera titubeado en conceder estos ó mayores auxilios, á pesar de que la tripulación nenesitaba el descanso después de una campaña tan penosa; y aún con esperanza algo probable de lograrse el objeto, yo mismo iría con la corbeta á salvar un buque considerado en el último trance según también les manifesté; y'suponiendo el que debiese tomar algún puerto ó playa al Sur de Acapulco, conducido por los vientos y corrientes constantes y favorables hacia aquella parte, sería entonces socorrido tan completamente como lo exigían la humanidad y nuestra obligación.

Con la llegada de la Descuizierta el Ig, cesaron ya mis cuidados sobre las combinaciones ó preparativos para en caso de tenerse rastro de la fragata el Sacramento, pues enterado de todo lo oct. ry ocurrido D. Alejandro Malaspina, tampoco halló por conveniente tomar medida alguna ínterin ignorásemos su paradero.

Por fortuna el día siguiente confirmándose mis conjeturas, se disiparon nuestros recelos sobre la seguridad de la tripulación con la agradable noticia de que ésta, desamparando el buque, cogió con las lanchas las orillas del río Papaga1lo, I8 leguas al Este de este puerto; logrando así salvar sus vidas y 20.000 pesos de plata acuñada que formaban la parte más rica de su cargamento. El Capitán por una buena precaución de arriar un ancla con I 30 brazas del mejor cable, logró salvar también el buque, fondeando éste después en las playas inmediatas á donde había atracado la lancha.

\section{Nueva remión do lis corbetas en Acapulco.}

Muchas causas debían concurrir á representarnos como bien agradable la escala en Acapulco, pues no sólo veíamos ahora vestidos de un verde hermoso los montes inmediatos que agostados del Sol en Abril último llevaban consigo el solo semblante de la aridez y de la quema, sino que dependían también de la llegada al mismo puerto, el término de una parte considerable de nuestras tareas, la reunión de los compañeros ausentes y el próximo abandono de aquellas costas; ni merecían en nuestro ánimo un menor aprecio las conveniencias locales del puerto para el alijo de los buques, la comodidad del observatorio, la seguridad del amarradero y dificultad de la deserción; todo, en fin, parecía prometernos una tranquilidad y descanso poco comunes.

Debía seguramente á la sazón causarnos una no mediana complacencia el estado de nuestros buques y de entrambas tripulaciones particularmente, cuando comparásemos el semblante robusto, contento y cariñoso de las últimas, con el color amarillento y la natural desidia, abyección y tristeza que se advertía en los moradores del puerto.

No tardamos, pues, un momento en aprovechar una situación tan agradable; desde el día siguiente se suspendió la suministración de víveres sustituyéndole la ración en dinero: el señor de Heenke emprendió sus excursiones botánicas, se destinaron á una y otra corbeta parajes oportunos para atender al examen de sus víveres, á la recorrida de la tonelería, al reemplazo de la aguada y al depósito de sus pertrechos; finalmente, se estableció el observatorio en una casa bien inmediata al muelle, puesto que no parecía ya prudente el usar de la casa del Castellano, que no tardaría en llegar á su destino, habiendo Su Majestad nombrado el Teniente Coronel D. Pedro de Tueros con obligación de residir constan- 
Oct. so temente ó en la plaza, ó á lo ménos en sus contornos.

Las primeras alturas correspondientes se dedicaron como era natural á la deducción de la longitud con los relojes marinos: vimos con mucha complacencia, que no sólo concurrían los cronómetros 7 y y 72 en determinar la misma diferencia de meridianos de $5^{\circ} 2 I^{\prime}$ entre San Blas y Acapulco, que había determinado el núm. Io en la travesía anterior de la ATREvidA, si también que se reunían con una exactitud difícil de imaginarse los mismos cronómetros, con el reloj I05, para determinar la diferencia de longitud de $9^{\circ} 45^{\prime}$ I $^{\prime \prime}$ entre el Cabo San Lucas y nuestro observatorio de Acapulco.

Los reconocimientos de la corbeta ATREvIDA en esta última separación, eran por otra parte bien importantes para la exáctitud de nuestras tareas, las cuales ahora ligando entre sí las determinaciones de ambos viajes de aquella corbeta y las del viaje último de la Descubierta, hacían casi independiente de las bases la colocación en latitud y longitud de cada punto de la costa, y nos ponían al abrigo de los muchos yerros que naturalmente debía arrastrar consigo la fuerza y la constancia de las corrientes al Sudcste.

Las que había experimentado la ATREvidA eran aún mayores que las nuestras. Debieron no sólo repetir á cada paso las observaciones de longitud, si también precaverse de los errores en la latitud con diferentes alturas meridianas de estrellas medidas al principio y en las últimas horas de la noche, y como después de nuestra separación en la mañana del 6 sobre el Cabo San Lucas hubiese hecho buena derrota hacia el $\mathrm{Ca}$ bo Corrientes; sin detenerse en un nuevo examen infructuoso de las Islas Marias, no le había sido difícil atracar aquel Cabo en la mañana del II después de una fuerte turbonada, y últimamente fondear en el puerto para la noche del i6 poco antes que rompiese una tempestad temible del Nordeste y Sudeste, que le obligó á dejar caer la esperanza.

Esta recalada de la ATREVIDA, que producía ya todas las ventajas propuestas, debió parecernos aún más feliz por el casual encuentro que en la misma tarde del i 6 había tenido á cuatro ó cinco leguas del puerto, de dos canoas grandes y la falúa de la plaza, las cuales con mucha gente y un mastelero de los respetos que habían dejado las corbetas, amadrinado entre las dos canoas vogaban en busca de una embarcación del comercio de Guayaquil, desarbolada pocos días antes en aquellas inmediaciones y hecha actualmente una boya sin timón ni respeto alguno con que repararse. No avistándose buque alguno desde los topes, D. José Bustamante les había mandado volver inmediatamente y no bien ha- bian alcanzado la boca del puerto, cuando la Oct. 20 turbonada que acabamos de indicar manifestó á cuánto peligro se habían expuesto aquellas gentes inconsideradamente.

Cesaron también en mucha parte al día siguiente nuestros recelos de la seguridad de la tripulación, con la noticia de que había desamparado el buque, y atracadas con la lancha las orillas del río Papagallo como i8 leguas al Este del puerto, logrando así salvar sus vidas y unos 20.000 pesos de plata efectiva que formaban la parte más preciosa de la carga. El Capitán tuvo la precaución de arriar un ancla con I3o brazas del mejor cable; y esa maniobra produjo, que también el buque desarbolado y hecho juguete del mar, se hallase seguro y fondeado en las playas no distantes del paraje á donde había atracado la lancha.

Entretanto, la casualidad de haberse atrasado mucho las aguas en aquel año, y de romper copiosas lluvias con vientos del Sudeste en los últimos días del mes, había empezado á descubrir la falibilidad de nuestras esperanzas harto lisonjeras, relativamente al estado de robustez, del cual á la sazón gozábamos. La serenidad del tiempo de vuelta en la mañana del 28 , con la total despedida de las aguas, dando lugar con la acción constante del Sol á una evaporación indecible de miasmas, las cuales por la demasiada inmediación de los montes y una vegetación harto lozana no podían disiparse con los vientos benéficos del mar, empezó á manifestar en ambas tripulaciones y en todos los contornos la existencia de las calenturas propias de aquella estación en unos climas tan temibles.

Muy luégo los dos desórdenes inseparables del marinero, esto es, el uso del aguardiente y la preferencia de los remedios propios y caseros á la útil mano del médico, enfurecieron la epidemia; y como era natural, aumentando el número de los enfermos en el hospital, aumentaba al mismo tiempo la parte correspondiente de trabajo á los que aún se mantenían sanos. Las maestranzas de ambos buques estaban á la sazón bien ocupadas en rehacer así la lancha de la Atrevida, construída en San Blas, cuyos defectos esenciales se habían advertido en diferentes ocasiones, como el bombo de la Descubierta que ya pasado de la broma y estropeado con dos años de un servicio contínuo necesitaba renovar se enteramente. Las fraguas, los toneleros y el armero, apenas daban abasto á sus diferentes obradores; y las embarcaciones menores, así con esas atenciones como con el preciso pronto alijo de los buques y los diferentes objetos científicos, no tenían otro momento de reposo que el concedido cotidianamente á las tripulaciones desde la mitad de la tarde hasta las ocho de la noche, horas destinadas para su recreo y libertad. 
Hubiera por consiguiente sido á la sazón imposible el coadyuvar al recobro y habilitación del buque desarbolado, que como se ha dicho, había cogido fondo próximamente á la embocadura del Papagallo, si el aparecimiento en la tarde del 30 de la fragata Santa Crertrudis de la Marina Real, armada completamente en guerra, no hubiese con un crecido número de brazos dado nuevo vigor á nuestros esfuerzos para la habilitación de aquel buque. El Capitán de fragata D. Alonso de Torres y Guerra, Comandante de la Santa Ger'trudis, nos informó que traía cincuenta y seis días de viaje desde el Puerto del Callao, en donde permanecían las fragatas Liebre y Santa Bírbara de la Marina Real; que este plazo sin embargo había dependido del recalar á sotavento del puerto, pues que á los veintidos clías de narega. ción estaba á la vista de las playas de Naguala; finalmente, que los últimos temporales del Sudeste le habían incomodado mucho, haciéndole rendir un mastelero y aconchándole sobre las costas de Siguatanejo; había sido bastantemente feliz para conservar en todo aquel tiempo su tripulación sana, y para esplayar los impulsos de la humanidad, auxiliando sobre Paita una embarcación inglesa destinada á la pesca de la ballena. que ya acosada extraordinariamente del escorbuto, se hallaba amenazada del último estrago.

Con este auxilio, y regresado con la lancha de la Descubierta el Capitán de fragata D. Cayetano Valdés, que había reconocido prolijamente el buque abandonado, y halládole en estado de navegar luégo que se le habilitasen gente, víveres, arboladura y timón, fué fácil ocuparnos eficazmente de dicha habilitación, y así para la tarde del 3 de Noviembre ya navegó desde el puerto un pequeño convoy de dos lanchas y dos botes á las órdenes del Teniente de navío Don Juan Gutiérrez de la Concha con la maestranza, víveres y útiles necesarios para la habilitación de aparejo y timón. La Oficialidad y tripulación del mismo buque, reunidas de antemano y completadas con voluntarios de la fragata Santa Gertrudis, un excelente gaviero de esta fragata, sustituído á aquel Contramaestre enfermo, el Alférez de fragata D. Francisco Benítez entregado del mando de la otra lancha, y las instrucciones dirigidas á que la comunicación con el puerto fuese la más segura y expedita; todo debía conspirar á que con la mayor economía y prontitud se lograse el fin propuesto.

No tardó Concha en conocer que el único particlo para el buque era el de navegar al Realejn, ó tal vez á Guayaquil, tanto más, que se habían declarado nuevamente las corrientes contrarias para aproximarse á Acapulco. Lo dictaban así también los cálculos mercantiles, pero exisía de nuestra parte un sacrificio harto considerable, $y$ cra el de la lancha, sin la cual ni la tripulación podía considerarse segura en cualquiera eventn №w. 3 ni procurarse de las costas de Guatemala y Tierra Firme, aquellos auxilios y correspondencia que pucliesen contribuir á una navegación feliz y expedita. A la verdad, el reemplazo de la lancha no era imposible en Acapulco, pero era preciso emprender hasta el corte de las maderas necesá rias y ocupar la poca gente sana, dilatando tal vez con este mismo motivo la salida.

La protección que deben los buques de la Marina Real á los mercantes, prevaleció sin embargo sobre estas reflexiones. Para el medio día del ro, cedida la lancha, concluídas las bandolas. asegurado el timón de espadilla, reemplazadas aguada y víveres, cobrada el ancla, aunque se hallase en $9^{6}$ brazas, $y$ hechas algunas pruebas del andar y gobierno del buque que fueron bien satisfactorias, D. Juan de la Concha regresó al puerto habiendo concluído su comisión con toda la actividad é inteligencia que podían desearse.

Los comerciantes comisionados en Méjico por el dueño de la embarcación, satisfacieron puntualmente así el valor de los efectos suministrados de la Real Hacienda como los jornales vencidos por las maestranzas y marinerías; accedieron también á satisfacer el valor, cualquiera fuese, de la lancha nueva que se pondría inmediatamente por obra; y manifestando en repetidas cartas cuánto se consideraban agradecidos en aquella ocasión á los esfuerzos de la Marina Real á su favor, nos dieron la satisfacción de ver correspondidas de nuestra parte no sólo las órdenes generales de S. M. por lo que toca al auxiliar el comercio de sus vasallos, si también las providencias del señor Virey de Méjico, que movidas de una actividad y humanidad poco comunes, se dirigían antes á la seguridad de los individuos y luégo del buque, si apareciese sobre la costa. Tal vez una narración tan difusa, y áun diremos nimia, parecerá á primera vista ó inoportuna, ó artificiosamente dirigida al deseo de ensalzar los que son meramente unos deberes morales: no es así; la hemos individualizado únicamente para demostrar cuánto pueden á veces las fuerzas unidas para un mismo fin recto, y cuánto debe complacerse el marino, viendo refluir á beneficio de la sociedad, aquellas mismas fuerzas y combinaciones que parecían únicamente dispuestas para destruirla.

No eran pocas á la sazón las circunstancias ó favorables ó adversas que habían variado en un todo el semblante de la expedición produciendo la necesidad de nuevas medidas, harto distantes de lo que á primera vista nos debíamos proponer. Si el temor de errar á pesar de lo que dicten la conciencia, el examen maduro de las circunstancias, y la aprobación de legítimos jueces, fuese en las grandes Monarquías una razón suficiente para no modificar las órdenes 
Sov. in primitivas según lo indiquen las circunstancias. nuestra conducta fuera 'á la sazón seguramente reprensible; pero adviértase cuánto sería culpable malograr en una parte siquiera por este temor el fruto que debía exigir de nosotros la Monarquía después de la inversión de tantos caudales, $y$ se verá que si bien el bueno ó mal éxitode aquellas medidas dependiese precisamente de mil circunstancias difíciles de precaverse, sin embargo, hubiera sido una culpa verdadera y bien reprensible el ver con una pusilánime inacción malograrse crecidas cosechas por el solo temor de arrimar una mano poco experta al hierro que debía disponerlas.

Unas órdenes recientes de S. M. al señor Virey, exigían que al mismo tiempo que se terminasen en Nutka las últimas diferencias ocurridas sobre derechos territoriales entre la Corte nuestra y la británica, se hiciese un prolijo reconocimiento del nombrado Estrecho de Fuca, el cual según las últimas navegaciones de los Capitanes Verklay, Meares y Quimper, parecía dar ingreso á una nueva extensión de mar, que los pocos cáutos hacían ya llegar hasta muy poca distancia ó hasta una comunicación con el mar Atlántico: S. E. tuvo á bien participarnos aquellas órdenes y avisar al mismo tiempo, que la goleta Mejicana del Departamento de San Blas, á las órdenes del Teniente de fragata D. Francisco Maurelle, navegaría muy luego para verificar aquel reconocimiento, mientras el Capitán de navío Don Juan de la Bodega y Cuadra, con las fragatas Gertrudis y Princesa, y otra goleta, se dirigirían á Nutka para encontrar ó esperar allí los buques ingleses destinados á la convención indicada. Quedaba luégo la goleta Sutil para que se concluyese de nuestra parte la costa imperfecta desde Aguatulco hasta Tecoantepeque, Soconusco y las embocaduras del Lempa, y debían de este modo combinarse las diferentes atenciones del Departamento, por manera que se llevasen con igual perfección hasta su término. D. Francisco Maurelle reunía á la verdad, á una suma experiencia marinera y á los conocimientos regulares del pilotaje, una resolución y entusiasmo capaces de las mayores empresas; pero ni el estado de su salud podía corresponderlos, ni la falta de los instrumentos astronómicos y geodésicos, y por consiguiente de todo medio para determinar unas latitudes y longitudes ciertas, dejaba de ser un nuevo obstáculo para la empresa, en cuyo malogro no dejaría últimamente de influir mucho el hallarse Maurelle solo, y el no tener á sus órdenes otra goleta siquiera.

Ėstas reflexiones no podian ya ocultarnos cuánto se aventuraban irremediablemente el Erario de S. M. y el honor nacional, si la expedición nuestra con la excelente Oficialidad é instrumentos de que estaba dotada no procurase aho- ra coadyuvar á las ideas del señor Virey. Eran xim 10 del mismo parecer todos los Oficiales, y diaria. mente. ya uno, ya otro, explayaban su actividad " noble pundonor, agregando por su parte nuevas tareas á las que se proponían actualmente, ! brindándose á darlas pronto y exacto cumplimiento, cualesquiera que fuesen las fatigas, las incomodidades y los riesgos á los cuales hubiesen de arrostrar.

Propúsose por consiguiente al señor Virey que los Capitanes de fragata D. Dionisio Galiano y D. Cayetano Valdés, y á sus órdenes los Tenientes de fragata D. Juan Vernaci y D. Secundino Salamanca, navegarían en las goletas desde Acapulco. Estos Oficiales harían luego derrota directa al Puerto de Nutka, y de allí, completadas aguada, víveres y gente, entrarían hacia la unitad ó últimos de Abril en el Estrecho de Fuca. y le reconocerían (si fuese preciso) hasta Setiem. bre ú Octubre, retrocediendo últimamente al Puerto de San Francisco en la California para completar los reconocimientos de las corbetas y restituirse pasada la estación lluviosa, á las costas de Nueva-España; Vernaci y Salaman ca podrían luégo recorrer con una goleta las costas no bien reconocidas de Nueva-España, y dejándola en las inmediaciones del pequeño Istmo de Nicaragua, podrían examinar la calidad, extensión y elevación de éste, para decidir la cuestión de las comunicaciones de los dos mares; y últimamente, tomarían á su cargo el formar un mapa hidrográfico bien exacto del mismo golfo de Nicaragua y de la navegación del río San Juan hasta su desembocadura en el mar Atlántico; objeto á la verdad bien importante para la prosperidad nacional, y que podía combinarse con el plazo de nuestra llegada á España, para la total conclusión de la obra.

S. E. aprobó desde luego el plan propuesto: dió las órdenes oportunas para la total habilitación y venida de las goletas Mejicana y Sutil y nosotros, en el restante tiempo, dedicamos nuestro mayor conato á la completa suministración de cuanto necesitasen: debían servirse del cuarto de círculo y péndulo de Ellicot, del acromático grande y del reloj de longitud de faltriquera que se hallaban actualmente en poder de Don Dionisio Galiano; se les agregaron el cronómetro 6r ya compuesto en Méjico, un segundo acromático, un barómetro, algunos termómetros, un círculo de reflexión con pié, un teodolito, una aguja azimutes y una de marear; se les dieron ordenados en diferentes cartas no sólo los recnnocimientos nuestros del último viaje, si también los de los Capitanes Meares y del Teniente de navío Elisa en el Estrecho de Fuca; finalmente, recibidos unos nueve marineros voluntarios de la fragata Santa Gertrudis á bordo de la DescubiekTr, diez de los mejores marincros de esta tras- 
Nov. ro bordaron voluntarios á las goletas para servir con preferencia cn todos aquellos trances peligrosos que no podian dejar de encontrarse en la campiña proyectada.

En el eatretanto eran á cada paso mís agradables las noticias que recibíamos de Méjico: D. Antonio Pineda y D. Luis Nee, con una actividad incansable, habían enriquecido sus acopios de Historia Natural, recorriendo unas 400 leguas de tarrenos varios, cuales son los que se extienden desde Acapulco á Méjico por Chilpancingo, Tistla, el Río Azul, Real de Tasco y Cuernavaca; y cleste Méjico hasta Guanajuato, por Zempoala, Pachuca, Real del Montc Santa Rosa, y Semiquilpan, Qucrétaro, las Termas de Atotonilco el Grande, San Bartolo, Quereguaro, Acambaro, las Fuentes termales de Ucarco, Salvatierra, y Salamanca: habían ádemás enriquecido la importante narración de sus viajes con muchas experiencias físicas y con diferentes vistas de perspectiva sacadas por un pintor mejicano que llevaban consigo; ni se habían descuidado en hacer una útil comparación sobre el beneficio de las minas con las nociones más selectas de la Europa y con los métodos adoptados en el Perú, todos objetos de la mayor importancia para la verdadera ilustración nacional en una parte tan esencial de sus riquezas.

D. Dionisio Galiano no había sido ménos ac tivo y feliz durante su demora en Méjico, ocupándose eficazmente en ordenar todos los elementos del viaje pasado, en continuar la serie de sus observaciones astronómicas, acopiar nuevos materiales hidrográficos y dar la última mano á su problema de deducir la latitud en el mar por dos alturas del Sol; finalmente, D. Arcadio Pineda, con no ménos actividad y penetración, había recogido un número tan crecido y tan importante de documentos útiles para el recto conocimiento del estado actual de prosperidad de aquel Reino, que sin duda no desmayarían nuestros deseos de ser útiles á la Nación, en cuantos modos estuviesen á nuestro alcance.

D. Manuel Novales gozaba ya de su primer estado de robustez, debido á la mucha inteligencia y cuidado del Doctor O'Sullivan, de Méjico; y si bien el pintor Guío, acosado de las tercianas no pudiese ya pensar sino en su regreso á España, habían llegado oportunamente á Méjico para reunirse á la expedición D. Juan Ravenct y D. Fernando Brambila, hábiles Profesores de pintura nombrados por S. M. para reemplazar á D. José del Pozo y al mismo Guío.

La reunión amistosa de tantos y tan útiles sujetos con los cuales no sería difícil en lo venidero arrostrar nuevas fatigas y peligros, debía por consiguiente coadyuvar mucho á hacernos agradable la demora cn Acapulco, tanto más que nos la constituían como un verdadero descanso las tareas así astronómicas como geo- Nor. ro désicas concluídas en lá arribada anterior y el plazo no precipitado para los aprestos: aprovecharon efectivamente de esta última circunstan. cia el Comandante de la Atrevida, D. Tadeo Heenke, D. Fernando Quintano y D. Francisco Viana, para emprender una excursión científica hasta Méjico, y los demás se prefijaron con un trabajo moderado, ó bien la ordenación y repaso de los últimos datos hidrográficos, ó las experiencias del péndulo simple, y el acechar cualesquiera observaciones que pudiesen corresponder con las repetidas en Méjico por D. Dionisio Galiano. Pero la mezcla natural en las cosas humanas, de lo dulce con lo amargo, no dejaba á la sazón de compensar tal vez con mucho exceso todas las ventajas de nuestra situación cual la acabamos de describir. Las calenturas epidémicas, que al principio parecían de poca monta, se declararon ahora por unas intermitentes inflamatorias, complicadas á veces con putrefacción, ó á veces acompañadas con delirio, cólicos biliosos y disenterías de sangre, cuya mejor terminación parecía ser el período tercianario para aprovechar el uso saludable de la quina exquisita, que con tanta generosidad nos había regalado en el año pasado el Sr. D. José Villalengua, ex-Presidente de Quito y actual Regente de Guatemala.

Muy luego unos 90 hombres de la fragata Santa Gertrudis y á lo ménos 50 de las corbetas, se vieron acosados de la misma enfermedad: una buena mitad de los Oficiales del primer buque y por nuestra parte D. Ciriaco Cevallos, D. José Robredo, D. Felipe Bausá y el Cirujano de la ATREvidA acrecentaban nuestros cuidados y nuestras desazones. Si por la mayor salubridad del aire, por el mejor orden y áun por la mejor asistencia de los enfermos parecía por una parte preferente el curar los contagiados á bordo, por la otra la demasiada estrechez, el ruído casi contínuo y la mucha inmediación de los sanos parecían disuadirlo: no podían abandonarse los obradores aunque nos costasen repetidos sacrificios: la construcción de la lancha nueva procedía paulatinamente; la de la ATREVIDA aún no estaba concluída: el corte de la leña ya no podía seguirse y apenas había los brazos suficientes á bordo para no desistir enteramente de las faenas indispensables de aguada, estiva, aparejo y compostura del velamen. Entretanto, el marinero nunca escarmentado y nunca sacio, agregaba nuevas causas á las influencias harto temibles de un aire maléfico y pretendía envolver su temor y enfado en la capa harto espesa del abandono y del estrago; tanto más, que no faltando á las horas destinadas del trabajo, parecía de nuestra parte injusto y ćun imprudente el quererle sujetar con una disciplina tan inútil 
Nor. rs como molesta. No teníamos tampoco tropas, pues se habían devuelto á la plaza las que habíamos sacado en Abril último como auxiliares; Dic. se había dado pasaporte para regresar á España á un cabo de la ATREvida, y tres soldados de lá Descubierta, enfermos habituales é incurables á bordo, y los pocos restantes además de sufrir también mucho de las enfermcdades, debían dividir con el marinero las fatigas del buque y de las embarcaciones menores.

Por ventura el método seguido desde el principio por nuestros Cirujanos é imitado en el hospital y en la fragata Gertrudis, disipó todo recelo de un fin funesto á las enfermedades indicadas por cuanto pareciesen anunciarle los síntomas lastimosos que las acompañaban; pero como los remedios dependiesen principalmente de una repetición grande de sangrías, de muchas purgas y vomitivos y de una rigurosa dieta, el convaleciente se hallaba en un estado tal de debilidad, que ó el menor exceso en la comida le producía nucvos cólicos realmente terribles, ó la misma propensión de la atmósfera les causaba nuevas recaídas de la terciana.

Agregóse después á este estado nuestro de debilidad y de sinsabores, el que el Teniente de navío D. Fernando Quintano, debió finalmente ceder á nuestras instancias y á los consejos del Doctor O'Sullivan para curarse radicalmente de sus males del estómago, harto constantes y temibles; bien que no le sería difícil el alcanzar nuevamente la expedición en Manila por medio de la Nao de Filipinas el San Andrés, que había llegado al puerto á las órdenes del Teniente de fragata D. Joaquín Berenguer de Marquina.

Fué muy oportuno el arribo de este navío para concurrir á nuestra habilitación bien atrasada. Reforzáronse por consiguiente nuestras obras de cortar la madera en el puerto Marqués, aserrarla y disponerla para la construcción de la lancha; y así pudimos contar, que si bien no acabada interiormente, la tendríamos á lo ménos para la mitad de Diciembre en estado de poderse conducir á bordo y embarcarla.

Continuaban, pues, los estragos de la epidemia con el mismo tesón con el cual se había manifestado al principio de Noviembre. Ni bastaban para evadir su imperio, ó una vida metódica y tranquila, ó las sangrías anticipadas, ó la limpieza de todos los contornos del pueblo, que según costumbre ya establecida se despojaban por aquel tiempo de las malezas que las aguas habían hecho crecer y multiplicarse.

No quedaba, por consiguiente, otro partido sino el de acelerar la salida, tanto más que conseguida ya con el observatorio de Méjico la correspondencia de una buena observación con el primer satélite de Júpiter, repetidas con la mayor escrupulosidad las observaciones del péndulo simple, embarcada la mayor parte de los instru- in. mentos, emprendido nuevo arreglo de la marcha de los cronómetros, y contando con la Nao para el transporte á Manila de aquellos efectos que no pudiésemos recibir en aquel momento, nada esencial podía detenernos luego que la lancha estuviese en estado de conducirse á bordo.

Un raro acaso debimos advertir en la manufactura del tocino para la cual habíamos preferido el método descrito por el Capitán Cook al que solía usar el Conde de la Péyrouse con el auxilio del vinagre. Aunque sobrecargásemos con pesos considerables las tandas del tocino y la sal fuese bien activa, no alcanzaba ésta á penetrarle, de modo que al principio nos malogró una pequeña parte, y hubiéramos probablemente malogrado el todo, si no adoptásemos la precaución de tajar más menudamente los pedazos y darles una buena infusión de agua hirviendo antes de cubrirlos con sal y sobreponerles los pesos. Se ha hecho memoria de este accidente aunque frívolo, para recordar á los que dispongan sus víveres para navegaciones largas, cuánto es aventurado el seguir ciegamente un método aunque bien acreditado, y cuánto es necesaria una atención constante á los diferentes trances que no hayan podido preveerse.

Es bien sabido el método con el cual en todas nuestras costas del mar Pacílico y en cl Río de la Plata sc dispone el tasajo. Muerta la res y dividida en diferentes tajadas, toda la carne sc deja vcinticuatro horas cn salmucra, y lú́go se expone al sol hasta que se saque cntaramente quedando así esta carne con muy buen gusto y no mucha sal, de suerte que no pierda casi ninguna de sus virtudes alimenticias, pero precisamente de muy poca duración por no haberse des. pojado de todas aquellas partes, que útilcs al principio para cl alimento, son luégo sumamcnte propensas á la putrefacción.

Esta especie de precipitación nuestra para abandonar el puerto, no pudo á ménos de constituirnos en la necesidad de solicitar de la fragata Gertrudis y de la Nao algunos auxilios, bien fuese en cuanto á gentes ó en cuanto á víveres, pues les sería fácil á entrambos buques, ó el omitirlos ó el reemplazarlos en San Blas y en Acapulco con un mayor despacio del que nosotros teníamos á la sazón. Se nos concedió por aquellos Comandantes todo lo que fuese absolutamente indispensable para la continuación de nuestro viaje. Llegaron al medio día del I $_{4}$ las remesas de caudales de Méjico, que en parte recibimos á bordo y en parte se repartieron en cuatro pagas á la Oficialidad, tropa y marinería, satisfaciendo además por completo hasta fines de año las pagas y gratificaciones á los que se separasen de las corbetas, ó bien con motivo de enfermedad ó para servir en las goletas Mejicana y Sutil. Los 
ivic arrieros que conducían los caudales, aseguraban que no llegarian las harinas hasta el 24; y como en esta ocasión no sólo debiese atenderse el plazo, aunque corto, de cuatro días para el aumento de las enfermedades epidémicas, si también la demasiada inmediación de las fiestas de Navidad para el recelo de nuevos desórdenes y deserciones, quedó finalmente resuelto el dar la rela en la mañana del 20 sin esperar las goletas las harinas ni otra cosa alguna.
Lo verificó el Ig la fragata Santa Gertrudis en Dic. 19 demanda del puerto de San Blas, recibidos ya todos los efectos que le estaban destinados. Nosotros el mismo día embarcamos la lancha y los enfermos, no siendo éstos en ménos número de 30 á 35 por corbeta, y emprendida al amanecer del 20 la faena de desamarrarnos, esperamos los primeros soplos de la virazón, la cual, finalmente, nos dió lugar á levar el ancla hacia las diez para salir cuanto antes del puerto. 


\section{LIBRO TERCERO}

Contimación del viaje de las corbetas á las Islas Marianas y" Filipinas.-Varias excursiones en entrambos Archipiélagos, y' navegación de la ATREviDA al puerto de Macao.-Ultimos reconocimientos en el Mar Pacifico sobre la tierra austral del Espiritu Santo, la Nueva Zelanda. la Nueva Holanda y las Islas de Vavao en el Archipiélago de los Amigos.-Regreso al Puerto del Callao.--Nuevas indagaciones hidrográficas. hechas sobre las Tierras del Fuego, las Mahinas, la Costa Patagónica y el Río de la Plata.-Regreso al puerto de Cádiz.

\section{CAPITULO PRIMERO}

Navegación desde Acapulco á las Islas Marianas, escala, reconocimientos y' observaciones en la de Guaham. Travesía siguiente á las Islas Filipinas.-Acaecimientos en los puertos de Palapa y Sorsogón, primera escala en Manila y tareas de la DescubierTa on la misma balía y sobre las costas de la provincia de Pangasinan.

Cuanto más la ciencia de la navegación ha hecho fácil á los europeos el atravesar los mares más dilatados y tempestuosos, en igual razón han crecido los riesgos, á los cuales han debido arrostrar visitando los países inmensos que yacen bajo de la Zona Tórrida; y bebiendo con el afán de su descubrimiento, posesión ó conquista aquellas miasmas pútridas que tan directamente conspiran á su propia destrucción, más bien que á su mayor felicidad. Si formásemos un paralelo de los sacrificios innumerables de gente que las posesiones ultramarinas han costado á la Europa con los beneficios sociales, que el comercio y la navegación le han producido, bien sea relativamente á la suavidad de las costumbres, ó á la multiplicación de nuestra especie, seguramente se disiparían con la mayor rapidez una porción grande de las ventajas ponderadas del descubrimiento de la América; y cesarían los proyectos abultados sobre la extensión ilimitada del dominio $y$ la rivalidad poco reflexiva de las naciones.

Estas á lo ménos debían ser nuestras refle- xiones al tiempo de dar la vela del puerto de Acapulco, enferma una mitad de las dotaciones de entrambas corbetas, y desmayados y pálidos los demás, que dos meses antes no manifestaban sino el semblante de la robu te $z$ y de la alegría. En la navegación siguiente hacia las Islas Marianas nuestros objetos esenciales debieron por la misma razón dirigirse más bien al restablecimiento y conservación de las tripulaciones que á la idea de nuevos descubrimientos. Ni á la verdad serían éstos más que imaginarios, cuando la derrota constante de las Naos por el espacio de dos siglos, había hecho aquella navegación la más fácil trillada y segura que hubiese en parte alguna del globo, cuando en el año anterior el Teniente de fragata D. Manuel Quimper con un buque del Departamento de San Blas había visitado de nuevo las Islas de Sandwich, y cuando el desgraciado Conde de la Péyrouse corriendo un mismo paralelo habíase convencido de nuevo que aquel Archipiélago era el que en I555 descubrió Juan de Gaitán, navegante español, y denominó en sus diferentes Islas de Monge, Ulua, etc.

Abandonadas pues las costas, y dirigidos los bordos de tal manera, mientras continuaban los vientos variables, que con poca pérdida en la latitud adquiriésemos constantemente las posibles rentajas al Oeste, pudimos finalmente álos diez y seis días de navegación, alcanzar las brisas entabladas por longitud de $20^{\circ}$ al Oeste de Acapulco; latitud $I 2^{\circ} 4 I^{\prime} y$ variación magnética 6 á $7^{\circ}$ Nordeste. Un número inmenso de roladores, 
bíamos visto poco antes, nos le indicaban con bastante probabilidad. Acreditaron luégo su permanencia todos los enfermos, que confortados casi instantáneamente con un aire más puro y activo, manifestaron cn la mañana siguiente una mejoría y alivio considcrables: confirmaban también los eudiómetros esa mayor salubridad del aire atmosférico, y al paso que las distancias lunares observadas frecuentemente nos indicaban los pequeños errores de los relojes marinos, crecían nuestras esperanzas de ver casi con emulación acortados los términos de una tản larga travesía, y desterradas las enfermedades epidémicas que tan de cerca nos amenazaban.

El tiempo, el sosiego, la habilidad de entrambos Cirujanos, y sobre todo, el régimen de dieta á que pudieron sugetarse los enfermos más graves encerrados en la camarita alta igualmente limpia y ventilada, triunfaron, finalmente de la perversidad del mal: así, cuando en la tarde del in de Febrero se avistaron los. altos de las Islas de Seypan y Tinian, ya casi no había enfermo alguno de cuya vida pudiésemos recelar, y por consiguiente, nuestras tareas no procederían en adelante con lentitud y desmayo.

A las cinco de la tarde terminábanse bien y podían marcarse los extremos de Tinian del Sur $7 I^{\circ}$ Oeste al Norte $84^{\circ}$ Oeste de la aguja. Se emprendieron después las operaciones acostumbradas para las bases, horarios y marcaciones. Al anochecer se veían también distintamente los canales que forman con la de Tinian las Islas de Seypan y Aquiguan. Esta última es medianamente alta y tendida, y suele pasarse el canal indicado para dirigirse al fondeadero de aquélla, como lo ejecutaron los Comandantes ingleses Anson, Biron y Wallis.

En la noche siguiente el viento fué fresco, los horizontes se conservaron nublados y nuestra navegación tuvo por objeto el dejar al Norte la Isla de Rota para atracar después los extremos de la de Guahan. Sólo en estas dos islas subsisten algunos restos de la población antigua del Archipiélago. La residencia del Gobernador es en San Ignacio de Agaña, pueblo principal de la segunda.

Logróse el todo conforme lo deseábamos: se disiparon las sospechas de la existencia de un bajo en aquellas inmediaciones que señalaban algunas cartas españolas, equivocándole seguramente con un islotillo no distante del extremo Sudeste de Rota; atracóse después el extremo Nortc de Guahan, tierra alta, bastantemente pedregosa y acantilada al mar; finalmente, largas las insignias, empezamos á costear de cerca la parte occidental, en donde se hallan los dos fondeaderos de San Luis y de Umatac. Presentan estas costas un semblante realmente agradable desde el uno al ntro extremo, ó bien se considere la frondosi- dad y la suave elevación de sus colinas alomadas Fei. in ó la mar constantemente llana, y los muchos riachuelos que le tributan sus aguas cristalinas: hacia las once y media ya nos fué fácil distinguir los edificios de la capital Agaña, y al medio día marcar su torre al Sur $6^{\circ}$ Oeste y la Punta Orote al Sur $4 \mathrm{I}^{\circ}$ Oeste de la aguja. Esta punta es la que ciñe el pequeño puerto de San Luis, único abrigo de los vendavales y cuyo reconocimiento debíamos por la misma razón mirar como interesante. Dirigimos pues nuestras proas hacia él, sin que pudiese servirnos del menor auxilio una embarcación pequeña de naturales, que vino á bordo, para saber en toda su extensión la verdadera dirección de las restingas; y esta falta de noticias pudo arrastrarnos las consecuencias más funestas, porque nos hallamos repentinamente sobre la misma restinga con cuatro brazas escasas de agua.

Vencióse fácilmente con el timón el riesgo indicado, y pudieron las corbetas dar fondo poco después en paraje medianamente seguro; pero como nos manifestase el escandallo las calidades pedregosas del mismo fondo, y todos los objetos en torno, además del reconocimiento que hizo en un bote el Teniente de navío D. Francisco Viana confirmasen ya nuestras sospechas de ser aquel fondeadero poco ó nada oportuno para nuestro intento, no bien con las primeras claras del día siguiente vimos declararse el terral, cuando dimos nuevamente la vela, no sin riesgo de perder alguna amarra, y fuimos á la rada no distante de Umatac, en donde quedaron ambas corbetas inmediatamente amarradas una media milla al Este del castillito que le defiende.

Como en la noche anterior hubiésemos ya avisado al señor Gobernador al tiempo de remitirle las cartas cuáles eran los objetos principa les de la escala de las corbetas en aquella rada, nos alcanzaron poco después de haber dado fondo cartas sumamente atentas de aquel Oficial, en las cuales nos avisaba que no tardaría sino pocas horas en llegar á la rada, en donde le sería más fácil ocurrir con oportunas órdenes y avisos á todo cuanto pudiese contribuir á la prosperidad de la comisión. En efecto, á las nueve de la noche estuvo en la villa acompañado de algunos Padres Recoletos de las misiones contíguas, pero nos habíamos retirado anteriormente á bordo después de un paseo tan agradable como útil en aquellas inmediaciones.

Esta activa inmediación del Comandante de la isla no podía ménos de producirnos las mayores utilidades. Desde la mañanita siguiente, unos $\mathrm{I}_{4}$ indivíduos de la Descubierta y seis de la ATREvidA, parte gravemente enfermos y parte convalecientes, quedaron alojados con mucha comodidad en el cuerpo de guardia de la misma casa del Gobernador: los Sres. Cevallos y Bausá 
reb. 14 que necesitaban también para restablecerse de alguna quietud y reposo, lograron un alojamiento cómodo en la casa inmediata de la Misión; en la misma pudo conseguirse un paraje oportuno para armar ambos péndulos, compuesto y simple, y custodiar los demás instrumentos: el cuarto de círculo abrigado del observatorio portátil, se colocó á muy poca distancia, y así desde el mismo día se emprendieron las tareas astronómicas con la constancia y actividad acostumbradas.

No anduvieron tampoco omisos los encargados de la Historia Natural; dirigiéndose D. Tadeo Heenke hacia Agaña y los extremos septentrionales de la isla; D. Luis Nee hacia los montes de la Vigía no distantes de la rada, y ocupándose Don Antonio Pineda con particularidad de la litología y zoología de aquellos contornos, que parecían bien importantes y curiosos.

La epidemia recibida en Acapulco, y cuyos rezagos eran por la mayor parte los enfermos que ahora intentábamos restablecer, ayudada en mucha parte de los desórdenes inevitables del navegante opuesto al régimen, á las privaciones y á la dieta, había echado en el día tales raíces, que en balde pudiera intentarse restablecer á bordo los que ya repetidas veces habían sido perseguidos de las tercianas. La debilidad era tal en un marinero de la Descubierta, que á veces no prometía veinticuatro horas de vida: otro del mismo buque y uno de la ATrevida, habían degenerado en disenterías mortales; de este mismo achaque la ATREvidA había perdido en la travesía un marinero, y para que hasta la variedad conspirase á hacer más nociva la epidemia, se agregaban á los anteriores otro soldado y un marinero de la DescuBierta, el primero con un afecto cólico ya muy arraigado, y el segundo con un vicio temible de escorbuto que podía muy bien caracterizarse de segundo grado. Debíamos lisonjearnos que los aires, la quietud de la tierra, unos alimentos sanos, y particularmente el ejercicio cuotidiano, contribuirían luégo á su total restablecimiento. Así no se omitió cuidado por nuestra parte ni por la del Gobernador sobre el bienestar y mejor asistencia de esos infelices.

La aguada fué en aquel día la principal ocupación de entrambas lanchas: la poca distancia de las corbetas, la comodidad y abundancia del riachuelo que nos la suministraba, y la actividad de la marinería, hicieron que pudiesen repetirse los viajes y que para la noche tuviésemos reemplazada casi una mitad de la que nos faltaba, proponiéndonos también éste como el objeto principal de las tareas del día siguiente.

Entretanto, se aproximaba el novilunio: los vientos se habían declarado del Norte y Nornordeste frescos, con lluvias, ráfagas fuertes y mucha mar, y el ancla de la Descubierta se hallaba casualmente sobre piedra: no pareció, pues, pru- dente el diferir más allá del siguiente día el levarla, examinar el cable, y darla fondo en are. na, tanto más, que los botes enviados á sondar, indicaban que el buen fondo apenas distaba un tercio de cable. Por la mañanita del r6, dada por consiguiente una espía á la ATREVIDA, hicimos que la lancha tendiese sobre ella otra ancla y levase por el orinque la que queríamos apartar de las piedras. Reconocimos en aquella ocasión, que ya estaba falto un cordón del cable, bien que á poca distancia de la entalingadura; enmendamos también el anclote del Oeste, y ya nos considerábamos tranquilos para los restantes días que hubiésemos de permanecer en el fondeadero.

Puede por consiguiente imaginarse, cuál debió ser nuestra desazón, al momento que el escandallo nos avisó que á pesar de las faenas ejecutadas el ancla estaba nuevamente en piedra, y que el único fruto había sido hasta entonces el de tener ambas amarras en diez ó doce brazas de mayor fondo del que teníamos antes; fué preciso emprender nuevas faenas para la mañanita siguiente, las cuales se hacían ya más complicadas por el viento fresco del Norte, la mar gruesa de la misma parte, una lluvia contínua, la necesidad de atender al mismo tiempo á un fondo con exceso acantilado, y el recelo de no molestar la ATREVIDA, que parecía bien amarrada.

Todo quedó concluído á las tres de la tarde, bien que inutilizada un ancla habiéndose partido por la cruz entre las piedras. Pero nos estaba aún reservada una serie no mediana de fatigas. El viento bien fresco y arrafagado del Nordeste que soplaba desde el amanecer, hizo que hacia las ocho empezáramos á garrar sobre el ancla y últimamente sobre ésta y el anclote: nos hallábamos ya en 42 brazas y demasiado atracados á la costa del Sur, de suerte que parecía por todas razones imprudente el dejar caer śegunda ancla; fué por consiguiente preciso el determinarse á dar la vela soltado con buena boya el calabrote para recobrar después el cable que á la sazón teníamos enteramente fuera. Por fortuna nos había alcanzado poco antes la lancha, que alijanıos luégo; siguiéronle después en la falúa del Gobernador los pocos Oficiales que á la sazón se hallaban en tierra ocupados en el observatorio ó para la Historia Natural. Pudimos por consiguiente emprender con aliento nuestra faena de meter el cable, ya tomada sobre el velacho arriado, los foques y la mesana, la mura estribor que á la sazón nos convenía.

E1 viento recio, las turbonadas, el velamen que teníamos envergado, la misma dificultad de gobernar bien sea por el ancla ó por las embarcaciones menores que teníamos en el agua, hicieron que hasta las siete de la noche no se consiguiese echar el ancla arriba; envergáronse 
reb. s8 después otras velas y á las ocho pudimos ceñir sobre las cuatro principales al cuarto cuadrante. La mar era aun gruesa y el viento fresco; pero éste ya del Esnordeste con carices hermosos, los cuales nos facilitaron en la mañanita siguiente la vista de toda la isla aunque no distásemos ménos de siete leguas de su extremo del Sur que marcamos al Essueste.

Enterados así algún tanto de la variedad de la brisa en las diferentes horas del día y de la noche, pudimos disponer los bordos con mayor acierto, aprovechando todo el día y parte de la noche siguiente en navegar con la mura estribor, y revirando luégo desde las once de la noche al segundo cuadrante.

Logramos de este modo amanecer el 20 á unas nueve leguas de la Punta de Orote que marcábamos al Sueste, y como al mismo tiempo abonanzando el mar, la brisa soplase fresquita Y algo más inclinada al Norte, fueron nuestros progresos hacia el puerto tan rápidos y directos, que para las diez apenas distábamos unas dos leguas de la punta; alcanzábamos á las once la vista del fondeadero y de la ATREvidA, y para el mismo día rendido ya el primer bordo sobre las rompientes de la Isla de Cocos, ceñíamos con todo aparejo, mura estribor, no distando sino tres á cuatro millas del Castillo de $\mathrm{Hu}$ mata: latitud observada $13^{\circ}$ I $5^{\prime} 30^{\prime \prime}$. Continuaron los bordos hasta las cuatro de la tarde, y entonces sondadas I4 brazas arena, quedó la corbeta fondeada próximamente en el mismo paraje desde donde había empezado á garrar en lit mañana del I8. La lancha de la ATREvida que había logrado coger con rastra nuestro anclote, nos le trajo y tendió inmediatamente al Noroeste; echamos luégo las embarcaciones menores al agua y se permitió en la restante tarde y en toda la noche siguiente un completo descanso á la tropa y marinería.

No había sido poca en los pasados días la actividad de D. José Bustamante, del Gobernador D. José Aslegui y de todos los demás individuos ocupados en los diferentes objetos de la comisión: los enfermos manifestaban por la mayor parte una mejoría considerable: los Sres. Pineda y Heenke, esplayada su acostumbrada actividad en los contornos de Agaña, acababan de llegar á Umatac: D. Felipe Bausá había emprendido sus operaciones geodésicas; había pasado al pue to de San Luis el Piloto Inciarte; habian llegado los abundantes refréscos mandados acopiar por el Gobernador; y en el Observatorio, los Sres, Concha y Cevallos, conseguido el examen de la marcha del Io 5, y la observación de la inmersión del segundo satélite en la noche del I8, habían dispuesto los péndulos para las experiencias de la gravedad, sintiendo sí, que una nube intempestira. les hubiese imposibilitado observar en la si- guiente noche del ig la inmersión del primer sa- Feb. $z$ télite.

Ya estando las cosas en una disposición tan favorable, y estrechando mucho por otra parte el plazo de la estación buena para la continuación de nuestras tareas, pareció lo más prudente abandonar cuanto antes aquella rada, y con el mismo intento, en la mañana siguiente del $2 \mathrm{I}$. se procuró completar la aguada; se dió con las alturas correspondientes nueva época para el examen de la marcha de los cronómetros; se emprendieron las comparaciones del péndulo simple con el tiempo medio, y el Sr. Gobernador remitió á bordo los refrescos y víveres acopiados. Destinóse al mismo tiempo al Piloto Sánchez con un teodolito á la costa opuesta para ligar con buenas marcaciones los extremos de nuestros reconocimientos á la vela; un soldado cazador inquirió para D. Antonio Pineda todas las especies de aves que pudiese alcanzar; y D. Juan Ravenet representó con la mayor propiedad dos naturales de la isla de uno y otro sexo y un natural de las Carolinas.

Con las alturas correspondientes del 22 ya los relojes de ambas corbetas pudieron considerarse sujetos á un examen seguro. En la misma tarde por consiguiente se embarcaron los instrumentos y los enfermos; de éstos sólo tres de la Descubierta y uno de la Atrevida de. bían quedarse para incorporársenos después con la Nao; y hechos por otra parte en aquel día y en el siguiente considerables acopios de leña por medio de un trabajo asíduo de la tropa y marinería, ya en la tarde del 23 pudimos considerarnos enteramente prontos para dar la vela.

Las comparaciones de los cronómetros con el tiempo medio, nos habían indicado como sospechábamos, una aceleración de 5 " próximamente en el 7 I y en el Io 5 y el atraso de $I^{\prime \prime}$ en el 72 ; y atento á lo que habíamos advertido en el mar, este segundo movimiento parecía más bien el que habian llevado aquellas máquinas que no el determinado en Acapulco: así fué lo más oportuno adoptarle para la deducción de la longitud por los cronómetros y para la ecuación total de las variaciones. Era indiferente el suponer al 105 el movimiento determinado en Acapulco, pues las ecuaciones corregirían sus trastornos, y corregidos éstos sería luégo fácil aplicar también la corrección correspondiente al 35I, que había sido en el viaje diariamente comparado al I05. Estos fueron los resultados que tuvimos

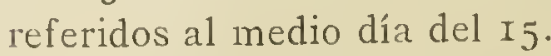

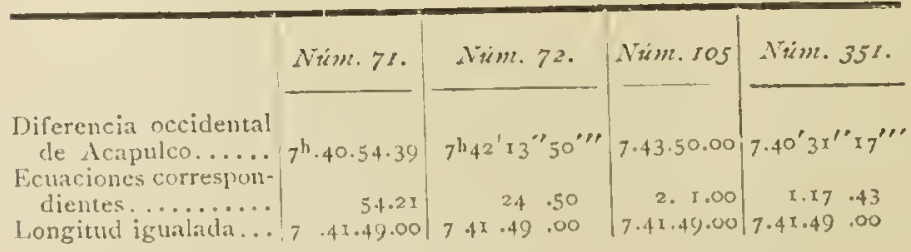


In longitud Occidental de Cádiz de................. La observación del segundo satélite en la noche del 18 (segun las tablas.) ..................................... las distancias de la Lnna á Aldebaran y Régulus observa

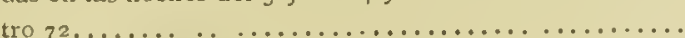
La longitud determinada en la fragata Astrea por 44 sé-

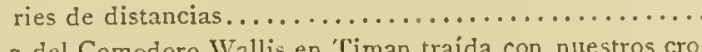
La del Comodoro Wallis en 'Timan traida con nuestros cronómetros...................................... que se veia á las $2 h^{\prime} 7^{\prime}$ con toda claridad y á las $2 \mathrm{ll}^{\prime} 9^{\prime} \mathrm{o}^{\prime \prime}$ disipada la nube ya habia sucedido la inmersión......... Latitud del Observatorio por astros al Sur y al Norte..... Por el teodolito en tierra...N. E. Variación magnética.. Por las agujas de Gilbert y Mar-

Ním. 35i $209^{\circ} \cdot 17^{\prime} \cdot 30^{\prime \prime}$ $209.2 \times \cdot 55$ $209 \cdot 26 \cdot 30$ $209 \cdot 3 \cdot 30$ $209 \cdot 9 \cdot 45$ $209 \cdot \times 8.00$ $3^{0.15}$ $2^{0} \cdot 45^{\prime}$

Se adoptó la longitud determinada por los relojes marinos y para las leves dudas que pudiesen of recerse sobre su exactitud, pareció preferente el dejar su decisión á los mismos relojes que ligasen este punto con los demás que habíamos de encontrar hasta Manila, y cuya longitud ya bien determinada por los Sres. Le Gentil y Dagelet pudiera confirmarse ahora con nuestras observaciones.

Al amanecer del 24 estuvimos efectivamente á la vela, emprendimos luégo derrota directa hacia el Cabo de Espíritu Santo en la Isla de Samar, y fueron las brisas en aquella travesía tan constantes y favorables, que para el dia 4 de Mar.+ Marzo ya estába mos delante del mismo Cabo.

Fórmase aquella parte de costa por una tieIra suavemente elevada y pedregosa, la cual con dirección al Sueste por espacio de cinco á seis le guas, declina poco á poco hacia el horizonte, de suerte que su extremo á la vista sea realmente bajo. Los montes y los llanos están igualmente vestidos de un verde hermoso, corren al andar de las orillas muy inmediatos á ellas algunos pedruscos aislados: la sondaleza con rzo brazas no alcanza el fondo á distancia de dos leguas del Cabo.

Un viento favorable del Esnordeste, regularmente fresquito y aprovechado con todo aparejo, nos condujo en poco tiempo á la entrada del puerto de Palapa. Se observaron horarios en algunos puntos importantes, se continuó por la corbeta ATREvidA aunque infructuosamente el examen de la sonda; y nosotros no abandonando el orden de las bases, nos acercamos paulatinamente á la Isla de Batag, cuyos extremos rodeados de arrecifes veíamos ya claramente á las nueve de la mañana.

Una embarcación que renga del Este puede entrar en el puerto, costeando uno ú otro extremo de la isla; la boca más costanera ó del Sur conduce más directamente al río, pero en el canal se encuentran diferentes bancos con poca agua; la del Norte entre Batag y Cagahiaga, si bien ceñida por dos restingas y casi en dirección opuesta al viento reinante, logra sin embargo la preferencia, por ser el canal más ancho yen- Mar 4 teramente limpio de los bancos temibles de arena.

Este último canal es el que se prefirió ahora para entrar en el puerto, tanto más, que el viento casi del Esnordeste proporcionaba un bordo breve y seguro: atracamos á dos cables la restinga de Batag, cuya isla en su frente del Norte habíamos costeado á casi igual distancia; ceñimos luégo al Sur por fondo de $I_{4}$ y I $_{5}$ brazas lama, logrando así contrarestar la marea que nos aconchaba sobre Cagahiaga, y hacia el medio día ya bien internados en el puerto, dimos fondo al ancla del ajuste en nueve brazas la. ma, á distancia del $2 / 3$ de milla de la costa de Batag.

Cuanto más considerábanos las excelentes calidades del puerto, así por sus abrigos, abundancia de agua y leña y poblaciones no distantes, como por su posición en la parte exterior đel embocadero ó Estrecho de San Bernardino, tanto más debían crecer nuestros deseos de acertar con una exacta descripción hidrográfica, que le franquease con toda seguridad á la navegación nacional. Era no ménos importante el examinar sus productos naturales y su opulencia; y en esas investigaciones, debían no perderse de vista el aprovechamiento de una estación realmente preciosa, y la seguridad nuestra en las diferentes excursiones que naturalmente habíamos de emprender, atento á los piratas que suelen en mucho número recorrer frecuentemente aquellos contornos. Los del puerto, por cuanto alcanzásemos á la vista, parecían enteramente desiertos.

Así, fué nuestro primer intento el destacar una lancha armada, con algunos Oficiales, para que examinasen la navegación interna, y por medio de los religiosos, curas párrocos de los pueblos no distantes, adquiriese datos ménos oscuros sobre nuestra posición. Encargóse á los mis mos Oficiales para aquella noche, la observación prolija de la latitud con el cuarto de círculo, y la de una inmersión del primer satélite de Júpiter, que sirviese á determinar la longitud, ya que el tiempo aparentaba el más sereno y apacible que pudiésemos desear. Varios accidentes contribuyeron, sin embargo, á que no fuese tan fácil para la lancha la ejecución del plan propuesto. Huían los naturales al arrimarse nuestra gente, suponiéndolos piratas, con el sólo motivo de no ser allí frecuente el aparecimiento de unos buques como los nuestros. La noche sobrevino rápidamente, debióse internar en un río, sin conocer sus fondos ni la dirección ni elevación de la marea; esto hizo que la lancha quedase varada sin esperanzas de volver á flote sino en la mañanita siguiente; y por largo rato pareció malograda enteramente la expedi ción proyectada. En balde algunos marineros filipinos de nuestras dntaciones que con la mis- 
Var + ma atención se habían embarcado para servir como iṇtćrpretes, gritaban á las canoas distantes que no temiesen, antes bien que contasen con premios en ropa ó en dinero si atracaban á bordo. Todo fué infructuoso hasta las once, á cuya hora, aproximáronse dos canoas y condujeron los Oficiales al pueblo no distante de Palapa con los instrumentos oportunos para la observación del satélite. Se abandonó ya la latitud y emprender algunas marcaciones con el teodolito, y al amanecer del día siguiente, logrados los demás objetos, pudieron los Oficiales regresar á bordo con unas noticias bastantementc exactas de aquellos contornos.

A la sazón los naturales habían depuesto toda especie de recelo, y atraídos no ménos de la facilidad nuestra de comprar, como del alto precio con que adquiríamos cualquiera objeto satisfaciéndole con plata efectiva, acudían en crecido número con sus canoas para vender todo cuanto estuviese cn la esfera de su actividad. Con este motivo fué extraordinaria la abundancia de comestibles, y en ella merecieron siempre los gallos la primera atención, pues agregaban á su utilidad intrínseca, la de distraer las tripulaciones en las horas de su descanso con unas riñas que sirven de entretenimiento áun en nuestra Europa.

Como era natural, la amenidad de los contornos, la facilidad de usar de las embarcaciones remeras de los pueblos inmediatos, la constancia de los tiempos favorables y la misma emulación nuestra en sobresalir entre los muchos ramos que abrazaba la comisión, debieron causar una actividad extraordinaria en nuestros pasos: extendiéronse las marcaciones con el teodolito hasta las inmediaciones del Estrecho de San Bernardino, enriqueciéronse las colecciones de Historia $\mathrm{Na}$ tural y particularmente la conchiología: las lanchas armadas se ocuparon en la escrupulosa continuación de las sondas así en la parte interior como en los diferentes canales que conducen al río, y pues que una islita no distante del fondeadero brindaba con sus playas un paraje excelente á los Oficiales astrónomos para las observaciones que ocurriesen, fué igualmente acelerado este ramo importante, y nuestra demora en el puerto si bien no mayor de seis días, debió parecer como bastantemente útil para la verificación del plan propuesto de tareas.

Las correspondientes á la Astronomía consistían en la determinación de una buena latitud con el cuarto de círculo, en observar la ocultación de las 4I4 del catálogo de Mayer por la Luna; y en una nueva inmersión del primer satélitc de Júpiter que pudo observarse con bastante seguridad por los Sres. Espinosa, Concha y. Cevallos, se prefirió para el cramen de la marcha de los relojes marinos el método de las alturas absolutas, pues lográbamos por la mañana de un Nlar. । buen horizonte, y con este motivo pudo concederse á las tripulaciones un regular descanso, no siendo preciso de noche custodia alguna en tierra para el observatorio.

Los resultados de las tareas indicadas fueron los siguientes:

Longitud del fondeadero al Oeste de Cá-

diz por los cuatro relojes marinos. . . . 228.53. 5 E1 satélite de la noche del 4. . . . 228.53 .48 El de la noche del 6. . . . . . . 228.53 .13 Latitud. . . . . . . . . . . N. $12^{0} 37^{\prime} 5^{\prime \prime}$ Variación magnética. . . . . . N. E. $0^{\circ} 20^{\prime} 0^{\prime \prime}$

Extendida la voz de nuestra llegada y digámoslo así, de las ventajas de nuestro comercio en las poblaciones no distantes de Palapa, se animaron á visitarnos á bordo otros tres ó cuatro rcligiosos franciscanos, y sus conversaciones fueron sumamente útiles, en cuanto pudimos formar una idea exacta de la Isla de Samar y de sus productos y habitadores: aumentaba con este motivo la cantidad inagotable de comestibles que llegaban diariamente á bordo: y como varias canoas, bien por costumbre ó por una debida precaución, fuesen tripuladas con toda la gente armada, fué fácil enterarnos de la calidad de sus danzas militares ejecutadas repetidas veces á bordo y representadas por D. Juan Ravenet con mucha propiedad. En la noche del 9 regresaron á bordo los naturalistas, y en la mañana siguiente entrambas corbetas dieron la vela para dirigirse al Estrecho de San Bernardino.

Nuestras marcaciones desde el pueblo de Laguán, manifestaban que la distancia entre Palapa y el Estrecho de San Bernardino, no excedía de unas I5 á r6 leguas.

Todo por consiguiente nos convidaba á aprovechar la tarde bien placentera para examinar la costa; aproximándonos luégo en la noche á la boca del estrecho, por manera que en la mañana siguiente con el viento y marea favorables, alcanzásemos en pocas horas el puerto de Sorso. gón: la Naturaleza parecía vestirse en aquellos contornos con el semblante más agradable: el resplandor de la Luna casi manifestaba querer competir con el del astro supremo: la continuación de una brisa fresquita sin que se notase en todo el cielo una nube siquiera, daba finalmente á la navegación toda aquella seguridad que mal pudiera combinarse con la reunión de una calma, de la oscuridad y de unas corrientes bastantementc vivas.

Para el anochecer ya la Isla Jabones nos demoraba al Sur $82^{\circ}$ Este distancia de cuatro leguas; sondáronse 50 brazas arena, y á esta distancia se hacía apenas perceptible el efecto de la marea: no distábamos á la sazón sino unas siete lcyuas de la l'unta de Viri, que nos demoraba al 
Mar. so Norte $83^{\circ}$ Oeste; pareció ésta por consiguiente una buena posición para esperar la mañanita siguiente, y así á veces ciñendo, á veces paireando con viento del Este y Essueste fresquito, procuramos eludir cualesquiera efectos de las corrientes ó mareas: á las tres de la mañana estando de la vuelta de Samar, se sondearon 40 brazas arena y cascajo: el día sumamente placentero nos aceleró luégo la vista de los muchos puntos que deseábamos marcar, y dándonos así lugar de emprender nuestra derrota con fuerza de vela, para la hora de salir el Sol ya nos hallábamos á una legua y media de la Islita de San Bernardino, que se marcaba al Sur $67^{\circ}$ Oeste. La Punta Viri al mismo tiempo demoraba al ángulo de $27^{\circ}$ en el mismo cuadrante.

Luégo que hubimos rebasado á distancia de una milla dicho islote y sujetada con algunos horarios la longitud de la parte saliente del estrecho, nuestra derrota, como era natural, fué directa hacia la Punta de Galeras en la Isla de Capul. Es bien sabido que la marea entrante y favorable, se dirige con mucha fuerza á aquella isla, aconchando á veces las embarcaciones ó por efecto de poca precaución ó por la falta del vien. to, de modo que hayan de pasar al Sur ó encontrarse remolinadas entre los Islotes Naranjos. Eista reflexión nos persuadió á atracarnos más á la costa de Luzón, en la cual ya veíamos á no mucha distancia el pueblo de Calantas. No nos descuidábamos al mismo tiempo en sujetar á marcaciones y enfilaciones cuantos puntos importantes nos rodeasen en aquél Archipiélago, de suerte que los muchos Islotes de Valiguatro, la Punta de este nombre y la de Viri, ambos extremos de la Isla de Capul; la de Muertos ó Dalupiri, los Volcanes de Albai y Bulusan y las costas todas de la Isla de Luzón, fuéronse poco á poco enlazando entre sí y haciendo independientes de las bases, que en aquellos parajes serian, si no peligrosas, á lo ménos inútiles.

A las ocho de la mañana no distábamos sino unas dos leguas del bajo de Calantas, que podíamos marcar con seguridad. Nos vimos pues algún tiempo detenidos, y áun precisados á seguir bordos poco ventajosos con las ventolinas flojas del Noroeste y Norte; pero como no tardase el viento en rolar nuevamente al Esnordeste, para las diez nos hallamos en el canal que forma la Isla de Capul con la Punta y bajo de Calantas; y al medio día navegábamos (pasados los Naranjos), entre la Isla de Ticao y la costa de Luzón. Un horizonte libre al Sur nos proporcionó la observación de la altura meridiana del Sol, y esto con las observaciones de longitud que habíamos repetido por la mañana, y renovamos poco después, daba ya tanta mayor solidez á nuestros trabajos, cuanto que debíamos ligarlos con los que verificásemos en Sorsogón con toda la prolijidad astronómica. Los volcanes de Al- Mar. ro bai y Bulusán eran los eslabones principales de esta cadena importante de marcaciones.

No es fácil para el que no haya surcado aquellos mares el formarse una idea cabal de tan amena perspectiva como la que allí se presenta: con la serenidad del cielo y la suave dirección de los vientos del Este, apenas el navegante ad. mirado tiene lugar de ocuparse de la felicidad del viaje: las escenas que se le presentan á la vista son harto varias y multiplicadas: una frondosidad uniforme, unos terrenos ó suavemente alomados ó cntrecortados con volcanes y otros montes más altos: los varios caminos que han abierto las aguas para buscar inútilmente entre esas islas un equilibrio tranquilo; las torres de uno ú otro pueblo, en Calantas, Capul y Ficao; el recuerdo mismo filosófico de las vicisitudes que han pasado esos moradores, y de lo mucho que puede extenderse allí la especie humana, sin teñir de su propia sangre la tierra, que sólo debía alimentarle, hacen casi enfadoso y molesto el viento favorable, que semejante á un telón, arrebata de golpe una vista tan agradable y reflexiva.

Costeábamos, pues, la Isla de Luzón á distancia de dos millas por fondos de I5 á I8 brazas arena fina, con ánimo de alcanzar muy luégo el puerto de Sorsogón; y seguramente le hubiéramos conseguido si al principio de la noche, declarado el terral fresco directamente opuesto á nuestro intento, no nos viésemos precisados á fondear al abrigo de la isla inmediata de Bagatao distantes unos tres cables de sus playas: fueron las lanchas armadas luégo que amaneció, á sondar y hacer diferentes marcaciones. Las corbetas dieron después la vela, y con la marea favorable alcanzaron sobre bordos un paraje oportuno para fondear y amarrarse.

El puerto de Sorsogón es sin duda alguna de los más hermosos que haya formado la Naturaleza: capaz de contener escuadras innumerables con un fondo que no excede de 55 á I 6 brazas lama; con unas orillas bastantemente acantiladas, con algunos pueblos no distantes que pueden abastecerle de lo necesario, sumamente abundante de peces sabrosos, ofrece realmente un abrigo cómodo y agradable, particularmente en la estación de los vendavales: pues mientras reinen las brisas y no se necesiten más que agua, leña y algunos refrescos, parece preferente fondear fuera del puerto algo al Sur de la Isla de Bagatao en frente de una cascadita bien notable de agua.

Una vejetación lozana, dos volcanes á la vista y la extensión indicada del puerto, no podían á ménos de atizar en sumo grado la curiosidad de nuestros naturalistas: agregáronsc la abundancia de peces y de conchas exquisitas, el cultivo del arroz, el beneficio del abacá y los 
principios de la propagación del gusano de seda, todos objetos que podían estudiarse en los pueblos inmediatos. No tardaron por consiguiente en extender cuanto fuese posible sus excursiones, y pareció aún más adecuado á la utilidad del riaje, que D. Luis Nee se separase de las corbetas, y por el espacio de tres meses, hasta el declararse de la estación lluviosa del vendaval, recorriese á su albedrío los países que median entre el extremo meridional de Luzón y la capital de Manila, á donde debía reunírsenos. Nuestras lanchas y botes en el entretanto fueron destinadas á diferentes rumbos los más distantes del puerto, por manera que no quedase informe el plan emprendido, $\mathrm{y}$ además de esto tuviesen lugar D. Francisco Viana y D. Felipe Bausá para trasferirse á la orilla oriental de la isla, y multiplicar allí las marcaciones del teodolito. Ni desmayaron por otra parte las tareas astronómicas, si bien se frustrasen por la mucha celajería algunas inmersiones del primer satélite: observamos por diferentes alturas meridianas de estrellas la latitud de $12^{\circ} 5^{2} 2^{\prime} \mathrm{Io}^{\prime \prime}$, y un promedio de los cuatro relojes marinos, adoptadas las pequeñas ecuaciones, fijó la longitud del fondeadero actual de las corbetas $I^{\circ}$ IO $^{\prime} 47^{\prime \prime}$ al Oeste del observatorio de Palapa.

Como las ocupaciones indicadas no alcanzaban tan generalmente al total de nuestras marinerías, que hubiese para todos un trabajo metódico y cotidiano el cual mirábamos como uno de los estribos esenciales para la conservación de la salud, se emprendió inmediatamente y con este solo objeto, un corte diario de leña, de la cual había una suma abundancia en las orillas inmediatas. Por lo común alternando según costumbre la tropa y marinería en aquella útil ocupación, no duraba el corte sino hasta las diez de la mañana; comían luégo tranquilamente y reposaban á la sombra de un árbol. Por la tarde embarcaban la leña cortada y regresaban á bordo. Nunca faltaron un Oficial ó un sargento que dirigiesen aquellas partidas, y un trozo, aunque pequeño de gente armada que custodiase las armas cargadas y pudiese usarlas oportunamente contra cualquiera aparecimiento de los piratas.

En la mañanita del 22 estuvimos nuevamente prontos para dar la vela: algunas turbonadillas del Este interrumpidas con la calma nos llcvaron después fuera del puerto, y reconocidas en aquella tarde las inmediaciones del puerto San Jacinto en la Isla de Ticao (abrigo acostumbrado de las Naos para esperar el momento farorable de la salida del Estrecho), antes del anochecer estuvimos en el canal que forman las Islas de Burias y Masbate. Hízose la navegación con mucha proximidad á la primera, paireamos después hasta el día con el objeto de continuir un reconocimiento útil y prolijo de las islas siguientes hasta Mindoro; y efectivamente, Mar. 23 al amanecer del 23 presentó á nuestra vista un espectáculo realmente agradable. La Isla de Burias no distante y suavemente alta; la costa siguiente de Luzón hasta la Cabeza de Rondoc con una hermosa cordillera que la cercaba interiormente; la Isla de Masbate, las del Cobrador, Romblón y Sibuyan más altas y más distantes, no podían sino entretener la vista con una hermosa variedad, mientras no se omitía medio alguno para trazarlo todo escrupulosamente.

La calma en todo el día apenas nos dió lugar á atracarnos á los islotes inmediatos á Marinduque: fuimos más felices en la noche siguiente; y si bien paireásemos en las últimas horas de ella, ya en la mañanita del 24 nos hallamos atracados á Mindoro y solas cinco leguas distantes de la Isla Verde, la cual marcábamos al Oesnoroeste de la aguja.

Un nuevo encuentro concurrió á la sazón á representarnos como más agradable aquella posición, y fué la vista de tres pancos ó embarcaciones piratas que no distaban al salir el Sol, sino una milla de nuestra proa hacia el Norte. No tardamos á ceñir con toda vela á estribor disponiéndonos al uso del cañón y del arma blanca; nos siguió la ATREvidA, y las embarcaciones sospechosas emprendieron el rumbo que más le convenía, para evadirse por medio del remo que usaban con la mayor destreza. Pasaron como dos tiros de cañón de nuestra proa: nosotros viramos luégo que nos demoraron á las ocho ó nueve cuartas de barlovento: se hizo señal á la ATREVIDA de seguir el primer bordo, y aunque no estuviésemos á tiro, se dispararon en una y otra corbeta algunos cañona$z o s$, con el objeto de que todo concurriese á infundirles algún temor y tal vez hacerles confundir las maniobras más oportunas. Pero muy luégo conocimos que no lograríamos el intento: con mucha pericia luégo que emprendieron la fuga habían abandonado la conserva entre sí, y sin em. bargo, maniobraban uniformemente virando al mismo tiempo que las corbetas. Conocieron después que no les convenía la vela y volvieron á usar del remo echado abajo el palo; finalmente. después de una hora de bordos, ya las dos mayores y mas veleras nos habían ganado una milla y media á barlovento: la tercera aunque mucho más zorrera, había ganado también considerablemente.

En esta posición sólo un viento bien fresco que no les hiciese útịl el uso del remo hubiera podido dejarnos alguna esperanza de coger siquiera la última y más zorrera; pero sin este requisito, del cual no había la menor apariencia, nada más debíamos esperar sino el sacrificio d un tiempo precioso: abandonamos por consi- 
Mar. 23 guiente la caza, y arribamos en derrota, atracando la costa de Luzón para pasar entre ésta y la Isla Verde.

No nos fué posible alcanzar el Estrecho sino después del medio día, y no debimos mirarlo como una desgracia, pues así se nos proporcionaba un excelente horizonte al Sur para la altura meridiana del Sol, de suerte que la latitud bien segura en aquel punto diese lugar tambien á una mayor exactitud en las observaciones de longitud que habíamos repetido por la mañana.

Insensiblemente el viento ya más fresco y la marea, nos condujeron á la otra parte de la Isla Verde propasada á muy corta distancia una goleta de guerra que había fondeado y dió poco después la vela: costeando la Isla de Maricaban examinamos prolijamente los bajos salientes que hacen algo peligrosa su costa del Oeste. Por último, no omitiendo el tomar horarios en meridianos de todos aquellos puntos cuya colocación nos pareciese importante, atracamos para las cuatro de la tarde la Punta de Santiago en la Isla de Luzón.

Ya á la sazón nos vimos obligados á navegar con trinquete y gavias: fuese luégo alargando el viento con la caída de la tarde y cediendo de su fuerza; sin embargo, para el anochecer no distábamos sino una legua del islote Fortún, y marcábamos el Corregidor al Norte $5^{\circ}$ Este y lo más alto de Mariveles al Norte $6^{\circ}$ Oeste. Por la misma razón desistimos después de la idea de navegar con poca vela: tuvimos algunas ventolinas del Sur, las cuales, aprovechadas con todo aparejo, nos hicieron creer hacia la media noche que nos sería asequible entrar en la bahía antes del día, teniendo á la vista la Isla del Corregidor, y hallándonos atracados á la costa de Limbones por fondo de 65 y 60 brazas arena. Ultimamente, después de una media hora de calma sin gobierno, entabló viento fresco del Esnordeste, que ceñimos de una y otra vuelta sobre las tres gavias algo arriadas para no entregarnos á los efectos de la marea contraria.

Amaneció con semblante hermoso: se veían sobre bordos para entrar en la bahía diferentes embarcaciones costaneras, entre las cuales se distinguían con la bandera del Rey las dos goletas del corso. Hallábase fondeada en Mariveles una fragata mercante; algunos pontines navegaban para afuera. Todas las tierras estaban bien despejadas; y marcábamos el Fraile al Norte $65^{\circ}$ Este; Pulo Caballo al Norte $13^{\circ}$ Este, la Monja al Norte $5^{\circ}$ Este, y la Medianía de Fortún al Sur, $5^{\circ}$ Oeste. Èn esta posición emprendimos con todo aparejo los bordos precisos para entrar, precaviéndonos al principio de la marea contraria con no atracar demasiado el Corregidor ni la costa de Marigondon; y al medio día habíamos adelantado considerablemente logrando en fin para las dos de la tarde montar Pulo Mar. 25 Caballo y costear el Corregidor por su banda del Este á distancia de media milla.

Como es costumbre en la bahía de Manila, el viento con el adelantamiento de la tarde fué rolando más fresco al Sueste, de suerte que pudimos seguir constantemente con las muras á estribor, y al ponerse el Sol marcar Manila al Norte $71^{\circ}$ Este distancia cuatro leguas, hallándonos á la sazón en fondo io brazas lama: se sondaron poco después ocho y media brazas á distancia de una legua de la costa, y en esta posición, viramos navegando con gavias y trinquetes hacia las costas inmediatas á Cavite: la res tante noche que fué con exceso hermosa, se pasó después á veces paireando, á reces ciñendo sobre las gavias para conservar un fondo de I I, I 2 y 13 brazas lama, y de este modo, logramos al amanecer hallarnos una sóla legua distantes de la barra de Manila, que demoraba próximamente al Nordeste.

Permanecimos luégo hasta las ocho, ó en calma ó con ventolinas variables, que apenas permitían el gobierno áun auxiliándonos el bote con un remolque; pero llegaron tan oportunas algunas ráfagas aunque momentáneas del Sur, que pudimos á las nueve y media dar fondo á una milla de la playa en seis brazas lama. Diferentes champanes chinos y algunas embarcaciones mercantes nacionales, se hallaban á la sazón fondeadas en aquellas inmediaciones.

La escala actual en la bahía de Manila no debía ser á la verdad sino momentánea, y más bien dirigida á la entrega de las cartas y pliegos recibidos en Acapulco y á la subdivisión útil de los muchos ramos de la expedición, que á cualquiera otro objeto extraño ó bien fuese científico ó militar. No podíamos ignorar cuánto importase ya un recto conocimiento de aquel Archipiélago feliz para el rápido incremento de la prosperidad nacional, ó bien fuesen sus navegaciones ó en sus cálculos mercantiles. No ignorábamos el periódico imperio de las monzones, que en los primeros días de Junio con la entrada de los vendavales harían infructuosas cualesquiera operaciones científicas, ó dependieren de la navegación ó de las excursiones por tierra. Debían, por consiguiente, estos reparos aunar con extremo la mejor combinación de nuestras fuerzas y su empleo más acelerado; lo cual dictó las medidas siguientes: La corbeta ATREVIDA tuvo orden de emprender viaje para el puerto de Macao, con el objeto de repetir allí las experiencias de la gravedad con el péndulo simple, ya que sería importante en el arreglo proyectado de medidas el obtener una relación directa de aquel paralelo con el primario que se admitiese: debía después regresar con la mayor brevedad á Manila, y en el entretanto la 
Iar 26 Descubierta procuraría recorrer las costas septentrionales hasta el Cabo Bojador, por manera que se franqueasen sus calas, puertos y comercio útil, no tanto á una rutina local y permanente, como á los buques más distantes, con tal que fuesen proristos de buenas cartas y derroteros.

D. Antonio Pineda recorrería al mismo tiempo á su albedrío los montes y los llanos más ó ménos distantes de $\mathrm{J}_{a}$ capital, con dos goletas de Cavite; los Alféreces Aliponzoni y Bausá trabajarían en el plano de la bahía y extenderían las operaciones hidrográficas á las islas no distantes de Cabra, Lubán, Ambil y Mindoro; finalmente, si la Descubierta pudiese verificar su viaje á las costas de la provincia de llocos, quedaría al cargo de D. Tadeo Heenke registral cuidadosamente las mismas provincias septentrionales, regresando por tierra á Manila. Así, con los destinos anteriormente indicados de Don Antonio Pineda y D. Luis Nee en el centro $y$ en el extremo meridional de la isla, ya no quedaba parte alguna por reconocer, en cuanto lo permitía la demora de las corbetas en aquellos contornos: coadyuvaron con la mayor eficacia al logro de las medidas expresadas, las diferentes personas de la colonia, de las cuales dependían. Il Brigadier de la Armada D. Félix Berenguer de Marquina á la sazón Capitán General de las islas, el Teniente de Rey D. Francisco Muñoz de San Clemente, los Directores de la Real Compañía, los Padres provinciales de las diferentes religiones que suministran los Curas Párrocos á las provincias, se esmeraban á porfía en dar aquellas órdenes é instrucciones que fuesen oportunas para nuestro intento. La ATREVIDA dió efectivamente la vela en el primer día de Abril; y el 3 ln verificó también la DescuBIERTA.

Pero en la demora indicada, si bien no excediese de ocho días. no habíamos omitido las tareas astronómicas acostumbradas; y el método de las alturas absolutas adoptado en una y o ra corbeta desde la misma tarde en la cual dieron fondo, nos había puesto en situación de continuar la serie de nuestras longitudes referidas por el meridiano de Palapa al occidente de Cádiz. El resultado de entrambos buques (descuidadas por el corto plazo las ecuaciones diarias) fue el siguiente:

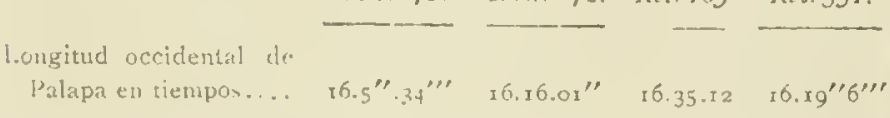

Pareció preferente en este caso el arrimarnos los resultados de los dos cronómetrons solos,

cuyo movimiento en las comparaciones actuales era más conforme con el determinado en Sorsogón y atendida la diferencia de meridianos entre el fondeadero y la catedral, quedó determinada la posición de ésta.

Por la serie de nuestras longitudes al Occidente de Cádiz.........

Por las observaciones de Mr. Le Gentil.

Por las determinaciones en el año anterior del Conde de Roselí, Comandante de la fragata francesa la $C \alpha$ lipso.............. .

Por la inmersión del primer satélite de Júpiter observada en la noche del 27. I la que acaeció en la noche del 29. .

232.53 .29

50.30

52.45

50.15 56.15

Ahora, como en muchas otras ocasiones, echábamos de ménos para la debida comparación los resultados del Sr. Dagelet en la desgraciada expedición del Conde de la Péyrouse, bien que no podíamos dudar que debiesen precisamente aproximarse mucho á las determinaciones ya indicadas.

La navegación de la Descubierta hacia el Norte y al andar de las costas de Zambales y Pangasinan, no tardó en descubrir todas aquellas dificultades que ya nos habían sugerido diferentes prácticas de Manila. Era la costa por lo común bastantemente fosca para que no pudiesen determinarse con claridad sus diferentes puntos: los vientos contrarios del Nordeste y Noroeste, entremezclados con algunas calmas y acompañados siempre con las corrientes bastantemente rápidas al Sur, hacían aún más difíciles nuestros progresos, cuando no quisiésemos alejarnos considerablemente de las playas; finalmente, á los siete días de nuestra salida apenas habíamos alcanzado la Punta Bolinao, y sin embargo la costa intermedia no podía caracterizarse por exactamente trazada.

Estos inconvenientes los cuales manifestaban el plazo del viaje emprendido seguramente más largo y ménos útil de lo que habíamos supuesto al principio, debieron finalmente sugerirnos como más oportuno el retroceso de la corbeta á Cavite, para que se destacasen Oficiales á las costas no bien reconocidas de Ilocos y Cagayan; á la laguna de Bay y á la contra-costa del Este y con embarcaciones del país y unas marchas aceleradas, aprovechasen en unas tareas tan importantes los últimos restos de la estación seca: púsose efectivamente la proa al Sur en la mañana del 9 , y el I 3 la corbeta ancló en Cavite, tomadas ya las medidas oportunas para la continuación proyectada de tareas, conforme se verá en los capítulos siguientes. 


\section{Navegación de la A TREvida desde Manila á los maves de China y entrada en el puerto de Taipa.}

Mar. 3I Recibidas las instrucciones de D. Alejandro Malaspina, al anochecer nada faltaba para poder dar la vela por la mañana temprano con los primeros soplos del terral ó de la brisa. Este Comandante me acompañaba al mismo tiempo con carta suya para el Gobernador de Macao, otra del Capitán General de estas islas, comunicándole á ambos el objeto del destino de la ATREVIDA al establecimiento de su mando, y suplicándole que para desempeñarle me franquease los auxilios necesarios. Las experiencias del péndulo simple era un punto de mucha importancia para toda Europa, y no podríamos excusarnos de ejecutarlas en aquel territorio sin dejar de cumplir las intenciones de S. M.

Al amanecer estábamos á pique del ancla y muy luégo dimos la vela con velacho y sobremesana con viento fresquito del Esueste, dirigiéndonos á pasar entre las Islas de Mariveles y el Corregidor, gobernando entonces al Oesudoeste $5^{\circ}$ Oeste. Concluídas las faenas de asegurar las anclas y meter las embarcaciones menores, se forzó de vela con la brisa ya fresca, gobernando al Oeste un cuarto Sudoeste para atracar la Punta de Mariveles, precaviéndonos del bajo de San Nicolás, cuya posición, según el práctico, no era la más exacta en el plano. Seguimos después por el canal entre las dos islas al rumbo del Oesudoeste, pasando por la parte Norte de la Monja.

La derrota común que se ejecuta en esta estación para Canton desde las Filipinas, se hace sin perder de la mano la Isla de Luzón hasta Cabo Bojador. Por esta razón los vientos suelen ser más variables y flojos, aunque este atraso lo compensan las corrientes para el Norte, con especialidad desde Punta de Bolinao y no se experimentan tan fuertes para el Oeste no separándose de la costa.

Adelantamos no mucho en los días siguientes, pues hasta la tarde del 6 no llegamos á ver el fondeadero de Santa, en el cual había tres embarcaciones pequeñas que hacen el comercio de arroz con Manila; su pueblo lo marcamos al ponerse el Sol, al Nordeste $5^{\circ}$ Este, y la Punta gorda de Santa María al Sur $72^{\circ}$ Este. Por la noche tuvimos algunas horas viento galeno del Sudeste, con el que gobernamos al Norte 1/4 Noroeste para precavernos del bajo de Salomaque distante algo más de una legua de la tierra, del cual pasaríamos á la misma distancia. Si- guióse después barajándola á corta distancia por el abra notable de Bigan, que pudimos distinguir muy bien con la claridad de la Luna llena, advirtiendo ser bastante abierta y formada por dos cerros de bastante altura.

Las marcaciones de la mañana próxima de las dos Islas de Salomaque y Sinay, que son bajas. la primera al Sur $42^{\circ}$ Este y la segunda al Norte $62^{n}$ Este, nos hicieron rer diferencias sensibles al Norte, y concebir la esperanza de ver en el día el Cabo Bojador. La latitud observada del medio día de $18^{\circ} 05^{\prime}$ diferenciándose en $I 7^{\prime}$ al Norte de la estima, comprobó también el resultado de las marcaciones. La longitud observada por el promedio de los relojes 72 y I 05 , era $37^{\prime}$ $57^{\prime \prime}$ occidental de Manila.

Hacia las cuatro de la tarde se avistó el Cabo Bojador, formado por una punta baja saliente; marcóse luégo al Norte $43^{\circ}$ Este, distancia de cinco leguas. Era mi animo hacer diligencias para corregir su situación, sin embargo de que la Descubierta debía dirigirse á este objeto, pero el viento, calmando á la sazón, no hubo medio para correr una base durante la tarde, por la constancia de la calma; no obstante, empleando la distancia estimada para establecer su posición, siempre será bastante aproximada, ó á lo ménos, con mucha más exactitud de la que le señalan las cartas de Mr. Dalrimple.

Latitud observada al medio día á bordo............ Por estima al Norte hasta las seis de la tarde, aumentando sólo dos millas de corrientes á la distancia navegada, pues apenas hubo diferencia en la marcación desde las cuatro á las seis que se marcó la última vez........... . I atitud del buque á las seis de la

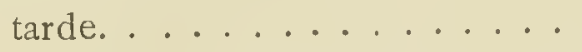

Diferencia de latitud al Norte por la marcación al Cabo, y la distancia estimada de $14{ }^{\prime} \ldots \ldots \ldots$

Latitud del Cabo......... N. Longitud observada Oeste de Manila por los relojes marinos al medio día con el promedio de los dos. Diferencia en longitud Este al Cabo por la marcación. . $18^{\circ} 05^{\prime} 15^{\prime \prime}$

$00 \cdot 10.00$

I $8 \cdot 15 \cdot 15$

oo. $9 \cdot 40$

I $8^{\circ} 24^{\prime} 55^{\prime}$

$00^{\circ} 37^{\prime} 57^{\prime \prime}$

$00 \cdot 13 \cdot 00$

Longitud que resulta al Cabo Bojador, occidental de Manila.
Ab. 6

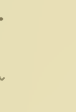

(n)

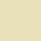

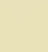


Esta longitud puede considerarse bastantemente exacta áun cuando no se hubiesen repetido los horarios á la hora de la marcación respecto de no ser necesarios por haberse seguido constantemente el rumbo del Norte desde los observados por la mañana, y las corrientes tiran también en la propia dirección.

En cuanto á la latitud puede también graduarse de suficiente confianza atendiendo á que sólo entra parte del error que incluye la distancia estimada al Cabo, y es muy corto de corrientes habiendo mediado tan pequeño intervalo al medio día; de modo, que no creo exceda el de la latitud en $2^{\prime}$ y siempre es muy preferente á la que expresa Dalrimple, pues se aparta en $\dot{\mathrm{I}} \gamma^{\prime}$ al Norte (I).

$\mathrm{Al}$ anochecer abandonamos la vista del Cabo con brisa fresquita por el Nordeste, gobernándose al Nornoroeste $5^{\circ}$ Norte hasta el medio siguiente, en que advirtiendo una extraordinaria diferencia al Norte de $33^{\prime}$ hallándonos en longitud de $\mathrm{I}^{\circ} 03^{\prime}$ arribamos al Noroeste $1 / 4$ Norte. A pocas horas de calma por la tarde sucedieron ventolinas del cuarto cuadrante, la atmósfera cargada sumamente de calima representaba á los astros con una grande refracción aparente, señal que rara ve $z$ se advierte cuando soplan las brisas y casi es inseparable de las bonanzas. Pasamos la noche en contínuas maniobras con las ventolinas variables del Nornordeste al Nornoroeste y Noroeste, advirtiendo un ruído fuerte causado por la corriente, comprobándose esta observación por los remolinos y choques fuertes de las aguas contra el buque, sin poder atinar por entonces hacia qué dirección nos arrastraban.

Las observaciones del medio día siguiente nos sacaron de estas dudas. La latitud observada de $19^{\circ} 53^{\prime}$ Norte no indicó diferencia alguna con la estima; pero la longitud por los relojes se apartaba de ésta en $30^{\prime}$ al Oeste, señalando el Io5 $I^{\circ} 50^{\prime}$, y el $72 I^{\circ} 48^{\prime}$. Por la posición de estas observaciones demoraba la extremidad Nordeste del bajo de la Plata al Norte $60^{\circ}$ Oeste distancias de I30 millas, ateniéndonos á la situación en que le establecieron el año I779 las corbetas de S. M. B. la Resolución y la Descubierta, mandadas entonces por los Capitanes Gore y King, por fallecimiento de los Sres. Cook y Clerk.

En el último tomo de sus viajes se halla la descripción que hace King de este bajo, pues le reconocieron desde su extremidad Nordeste, situándola en latitud de $20^{\circ} 58^{\prime}$ Norte, y I I $7^{\circ}$ de longitud oriental de Greenwich; y la del Sudoeste en $20^{\circ} 45^{\prime}$ Norte, aunque no pudieron determinar

(r) Esta determinación del Cabo Bojador ha resultado muy conforme con la determinada después por el Teniente le fragata D). Francisco Viana, comisionado desde Manila á situarle. con precisión sus límites al Oeste, y en longitud de I I $6^{\circ} 44^{\prime}$. Mr. Dalrimple supone de extensión seis leguas en cuadro á este escollo, el cual, puesto por la Naturaleza en la derrota directa de las Filipinas á Canton se hallará en nuestras cartas con toda la exactitud que importa á la seguridad de la navegación, debida al celo infatigable con que se interesaban en sus progresos aquellos ilustres navegantes.

Entablóse el viento desde el principio de la noche por el Nornordeste, y ciñendo mura á estribor para pasar al Norte del bajo de la Plata, cuyo paralelo de la parte más Sur alcanzamos al medio día siguiente, observamos la longitud de $3^{\circ} 9^{\prime}$, que volvió á repetirnos la misma diferencia de $30^{\prime}$ al Oeste con la estima. Nuestra posición no dejaba de ser un poco crítica, continuando yo en el ánimo de seguir la misma derrota si el viento nos abandonaba al estar por el través del bajo, y las corrientes conservasen las propias fuerzas para el Oeste. Como era mi intención también situar la Piedra Blanca, por ser un punto á donde recalan ó reconocen los buques que navegan á Canton en la estación presente, no era tan fácil conseguirlo si alterase la derrota pasando por el Sur del bajo.

Cobrando el viento más fuerza después del medio día, aunque sin pasar del Esnordeste y á veces más escaso, se arribó al Noroeste 1/ Norte para disminuir el abatimiento aumentando el andar, y desde aquí navegamos con vigilancia desde los topes, pues no sería extraño avistarse el bajo respecto á que gobernando á este rumbo y clando un error proporcional para el Oeste, pasaríamos á las cuatro y media como á cinco leguas de la parte septentrional.

Una cerrazón bastante oscura reunida sobre la situación del bajo, acortaba de tal modo el horizonte, que no le divisábamos por aquella parte más de dos leguas. A la caída de la tarde navegábamos sólo ya con las principales, por haber refrescado bastantemente el viento. Las apariencias del tiempo no eran las mejores $y$ la mar había engruesado con proporción al viento. Sin embargo, proseguimos con los mismos esfuerzos de vela en la noche, á pesar de las fugadas repetidas, $y$ de haber faltado en una de ellas la relinga del pujamen del trinquete, $y$ de consiguiente, haberse rifado este de alto á bajo, obligando envergar otro que quedó marcado á las nueve y media.

Con esta diligencia antes de romper el día avistamos ya varias embarcaciones pescadoras de los chinos. Aunque éstas conocidas aquí con el nombre de Lorchas, suelen salir á pescar hasta el bajo de la Plata, nos sorprendió, no obstante, verlas tan desatracadas de la costa con tiempo, al parecer, muy superiol á su resistencia, creyéndonos así más inmediatos á ella 
Ab ir de lo que indicaba la estima deste el medio día antecedente, considerando sus mayores errores en parajes de corrientes, y con vientos desiguales y arrafagados.

Mis conceptos se justificaron muy pronto con la vista de la tierra á las ocho de la mañana. Por una sola altura de Sol que pude acechar á esta hora, y calculado el horario con la latitud de estima, resultaba la longitud de $5^{\circ}$ oI occiden tal de Manila ó $2^{\circ}$ próximamente al Este de Macao; situación que nos aseguraba el situar la Piedra Blanca si la preferencia del Sol, al parecer tan contingente, nos lo proporcionase. Nuestros rumbos sucesivos del Oesnoroeste y Noroeste $5^{\circ}$ Oeste, nos condujeron á dar vista á los islotes de Kingao demorando al Norte $5^{\circ}$ Este distancia como cuatro leguas, y esto confirmó al práctico que llevábamos, la confianza de nuestra longitud observada. Como esta marcación nos situaba cas en el meridiano de dichos islotes, observamos longitudes resultando á ellos la de $5^{\circ}$ I9 $^{\prime}$ de Manila.

No bien observamos la latitud de $22^{\circ} 30^{\prime}$, cuando al poco rato vimos al Sur-Sudoeste Piedra Blanca, á tres y media leguas, cuya figura representa una embarcación á la vela. Puesto Norte-Sur con ella, á la una y cuarto se dedujo la longitud á este punto de $5^{\circ} 47^{\prime}$, y en latitud de $22^{\circ} 20^{\prime}$ Norte por la estima llevada prolijamente hasta la hora de los horarios. Desde aquí al rumbo del Oesudoeste $5^{\circ}$ Oeste, llegamosá las cinco y media á estar al Sur de la Isla Single á una y media legua, avistando entonces la Gran Lema al Oesudoeste, continuamos el propio rumbo para pasar por el canal que forma ésta con la Isla Pootoy, y marcando al ponerse el Sol el extremo más Sur de la primera al Sudoeste $\%$. Oes te, y la de Single al Norte, proseguimos al mis mo rumbo del Oesudoeste $5^{\circ}$ Oeste sobre las gavias, para manejarnos más fácilmente por los canales que íbamos á atravesar.

El viento al anochecer estaba fresquito, y conservando la sonda de i8 ó I 9 brazas fango que tiene el canal, seguíamos para dentro. A las diez y media teníamos cerca por babor la Isla Lema y otras diferentes por estribor. Había sido mi ánimo fondear al abrigo de algunas de estas islas durante la noche, pues la poca claridad de ella mientras no saliese la Luna, hacía algo cuidadosa la navegación; iban prontas dos anclas para fondear en el instante de obligar á ello la calma ó la corriente, y sin estas causas empezamos á navegar con las gavias arriadas braceadas unas en contra de otras para medir la distancia al amanecer á vista de Macao, con el fin de excusar la molesta maniobra de dar fondo y levarse en tan corto tiempo.

La Luna sobre el horizonte desde poco antes de media noche facilitaba el conocimiento su- ficiente de los canales, y áun hacer algunas enfi- Ab. i laciones importantes: al mismo tiempo demorando la Punta Norte y Este de Lema al Sur $28^{\circ}$ Este, y el Islote Waglaang al Norte, se gobernó al Oesnoroeste y poco después al Noroeste un cuarto Oeste: después á las doce y media se hizo rumbo al Oeste para pasar á la parte del Norte de Ling, á cuyo rumbo se marcaba, y lo más saliente de Lama al Oesnoroeste $5^{\circ}$ Oeste, y lo más Oeste de Lama al Sur. A la una y cuarto estábamos Norte-Sur con 10 más Oeste de Lama y marcábamos lo más Norte de Lingtin al Oesudoeste $5^{\circ}$ Sur. Bajo de estas marcaciones se orzó al Oeste $1 / 4$ Noroeste para separarnos un poco de Lingtin y acercarnos también al extremo Sur de Chamchow. Arribamos á las dos al Oeste buscando el paso entre Chichow y los is lotes del Norte llamados Chow. Orzamos á las tres á la isla de este nombre, gobernando al Oeste $5^{\circ}$ Sur, y á poco rato al Oesudoeste $5^{\circ}$ Oeste sondando II brazas fango suelto cuando demoraba Lingtin al Sueste $1 / 4$ Este. Estando á las cuatro y media con lo más Oeste de las Islas de Chow se orzó al Noroeste á pasar al Este de Latsame y se largó todo aparejo, amaneciendo entre la Isla de Lantao y Longsitow con viento bonancible del Esnordeste, el mismo que nos había acompañado toda la noche.

Sería difícil describir la agradable perspectiva de nuestra situación al aclarar el día hallándonos rodeados de una multitud de islas, que 110 obstante de ser áridas ó estériles, no dejaban de causar una vista tan divertida como harmoniosa, por su número, simetría y diversidad de tamaños.

A esto se agregaba una infinidad de lorchas pescadoras, que formadas en diferentes cuerpos, representaban á la distancia que las teníamos escuadras muy numerosas, para aumentar la vista lisonjera que causa la variedad de objetos.

Nuestros rumbos se dirigieron á pasar cerca de Longsitow por la parte del Norte, y cuando llegamos á estar con esta isla, ya descubríamos al Oeste $1 / 4$ Sudoeste la entrada del puerto de Taipa: como las corrientes tiraban á la sazón para el Sur, precisaron á gobernar al Noroeste. Avistábase ya la ciudad de Macao á las siete de la mañana, y tremoladas nuestras insignias, nos dirigimos para el puerto con viento del Esueste, alcanzando á estar antes de dos horas entre la Punta de Cabaret y la isleta del Norte de la entrada de Taipa: de aquí seguimos al Oeste de la Punta Sur de su entrada por fondo de tres á cuatro brazas, hasta descubrir por la boca del Norte á Macao, dando fondo en cuatro brazas escasas fango: en esta situación demoraba la fortaleza más elevada de la ciudad al Norte $2^{\circ}$ Oeste, y la Punta Norte de la entrada al Este $5^{\circ}$ 
1b. 13 Norte, quedando luégo amarrados con dos anclas Norte-Sur.

Ocurrencias en cl puerto de Taipa y en la ciudad de Macaro. - Atencioncs recibidas del Gobernador y dc las Compañias extranjeras; descripción de la ciudad con la forma de su Gobicrno; idea de su comercio, producto de sus rentas y gastos que produce su consirvación á S. M. F. - Reflexiones sobre el comercio de peleteria, con las ventajas de la España para des-

truir el de otras nacioncs que le ejccuten.

Apenas habíamos dado fondo cuando llegó el práctico portugućs que reune las funciones de Capitán de puerto, y un dependiente de rentas: el primero de orden del Gobernador para enterarle de las novedades de nuestra navegación y objeto de la arribada: el segundo venía comisionado por la aduana para cn el caso de no ser buque de guerra proceder al reconocimiento de la carga y á nombrar guardas que subsistiesen á bordo según costumbre con los melcantes. Satisfechas estas preguntas se restituyeron uno $\mathrm{y}$ otro enviando yo al propio tiempo un Oficial á cumplimentar al Gobernador y convenir en la correspondencia del saludo, el cual ejecutaría siempre de asegurarme el ser respondido tiro por tiro.

A muy poco tiempo de haber fondeado, recibí carta de los comisionados de la Real Comñía de Filipinas D. Manuel de Agote y D. Julián Fuentes, ofreciéndoseme atentamente para cuanto pudiesen contribuir á nuestro obsequio: yo les contesté agradeciéndoles el paso de aten. ción que venían de significarme, y deseoso de corresponderla.

No taldaron los Sres. Agote y Fuentes en venir á bordo por la tarde, para manifestarme rerbalmente las expresiones que les había mere. cido por escrito, convidándome á comer con toda la Oficialidad para el día siguiente en la casa de la Compañía. A este tiempo enteré por menor al primero como primer factor, cuáles eran las necesidades urgentes que nos conducían á este puerto, para las cuales contaba con su diligencia eficaz para poder remediarlas en el corto tiempo que pensaba subsistir aquí; siendo entre estas muy esenciales las de proporcionarnos una casa cómoda para establecer nuestro observatorio en donde verjficásemos las expericncias de la gravedad, objeto principal de nuestro destino; la adquisición de algún artífice inteligente para componer el reloj número Io, y la de otro pequeño dc esta misma especie, con pinturas de todas clases para proveer á nuestros profesores de las que necesitaban, sin las cuales no podían seguir en la continuación de sus trabajos.

T'ambién regresó en la misma tarede cl Oficial comisionado, quien me informó que el Goberna - Ab. 13 dor y Capitán General D. Vasco Luis Carneiro de Sousa y Faro, Caballero de la Orden de Cristo y Jefe de Escuadra en los mares de la India, le había recibido con las señales ménos equívocas de urbanidad y política, haciéndole especial encargo me asegurase cuánto anhelaba contribuir con sus facultades personales y del empleo, al desempeño de la comisión y obsequio de la Oficialidad de mi mando.

Aún no se había visto en estos mares la bandera del Rey, y la concurrencia de todas las naciones europeas en Macao exigía un celo particular sobre la conducta de nuestros equipajes. 1 este efecto se dirigieron mis primeras órdenes, intimándoselas para que su moderación y prudencia correspondiesen á mis deseos, en inteligencia de que usaría del mayor rigor para conseguirlo.

Saludamos á la plaza á la mañana siguiente con nueve cañonazos, á que respondió con el mismo número; y seguidamente pasé con la Oficialidad á visitar al Gobernador, quien nos recibió con todo el agasajo y expresiones las más atentas, agregando para justificarlas el habernos proporcionado ya una casa para el observatorio, que con gusto la cedía el Sr. Antonio José de Acosta, cuya situación y conveniencia la hacían preferiblc en su concepto á cualquiera otra.

Como después supe por D. Manuel de Agote las grandes instancias que hacía el dueño de la casa para que la admitiésemos, mandé conducirá ella todos los instrumentos al día siguiente. Las alturas tomadas por los Oficiales D. "Juan de Concha y D. Ciriaco Cevallos, dieron las siguientes diferencias de meridianos con Manila:

\begin{tabular}{|c|c|c|}
\hline & Núm. 72. & Nüm. I05. \\
\hline $\begin{array}{l}\text { ifere } \\
\text { día }\end{array}$ & $I^{\prime} \cdot 26^{\prime \prime} \cdot 48$ & $3 \cdot 26^{\prime} \cdot 3 \mathrm{I}^{\prime \prime} \cdot 14$ \\
\hline or sus diarios á Manila. & 27.47 .86 & $3.55 .4 I \quad .00$ \\
\hline la 110 & $29.14 \cdot 72$ & .2 \\
\hline & $7^{\circ} \cdot 18^{\prime} \cdot 45$ & \\
\hline
\end{tabular}

Esta diferencia de meridiano hallada en una época de pocos días y dentro del minuto por dos relojes, dan un grado de confianza para determinar la longitud de Macao, preferente á la del Capitán King, porque no habiendo ejccutado observación alguna en Macao, la que determinó fué por distancias observadas antes y después de abandonar este punto, referidas con un solo reloj. Mr. Bayly está conforme con nosotros, aunque su longitud también la deduce por dis. tancias, tomando el promedio de rarias series que discrepan mucho entre sí. Igual conformidad encontramos con la que trae el conocimiento dc tiempos del año de 88 , pero ignoramos quién, ó á qué observación absoluta se refiere. 
Como era nuestra frecuente asistencia en la casa de los Sres. Agote y Fuentes, fueron luégo á visitarnos el Gobernador, Sindicante, los primeros Sobre-cargas de las Compañías, Francesa, Sueca, Dinamarquesa, Holandesa, algunos subalternos de la Inglesa, y varios particulares de la ciudad. El Gobernador y estas Compañías exceptuando la Inglesa, nos convidaron á comer alternativamente, mereciéndoles á cada paso las mayores demostraciones de aprecio, que no son fáciles de describirse. Estos obsequios tan generales, hizo más notable al público la falta en imitarlos de Mr. Harrison, primer Sobre-carga de la Compañía Inglesa, haciéndose aún mucho más extraño por la circunstancia de hallarse con orden de Lord Cornwallis, Comandante general de sus establecimientos de la India oriental, para que, consecuente á las que había recibido de Su Majestad Británica, auxiliase con cuanto pudiesen necesitar las corbetas de S. M. C. Descubierta y ATREvida, en su viaje alrededor del mundo.

Esta conducta tan rara y contraria á la representación preferente que goza la nación inglesa por su opulencia en esta parte del globo, excitó tanto el sentimiento de los compatriotas de Mr. Harrison, como el empeño de lavarla con un esmero de urbanidad hacia nosotros, que jamás podrá borrarse sin injusticia, ni de nuestra memoria, ni de nuestro agradecimiento.

Entre éstos ocupará un lugar muy distinguido en nuestro aprecio, Mr. Daniel Beal, Cónsul de Prusia, á quien debimos frecuentes pruebas de atención y la adquisición apreciable de un reloj pequeño de longitud, número I I, que hizo venir en diligencia, de Canton, perteneciente al difunto Mr. Cox, con quien tuvo compañía para el comercio de pieles sobre la costa Noroeste de América, en cuya navegación le había servido con mucha utilidad esta máquina. Aunque el tiempo estrechaba para examinarla, como era la única que había podido encontrarse, me decidí á comprarla, así por los informes que me dió Monsieur Beal, como por las experiencias que teníamos del crédito de su autor Arnold.

La ciudad de Macao es península de la Isla de Un-zao, y se halla situada en la embocadura del río del mismo nombre. Tuvo su primer origen por una colonia de portugueses, hace cerca de dos siglos, con permiso del Emperador de la China á quien pagan tributos ó contribuyen con ciertos derechos para disfrutar la posesión de este establecimiento. Antiguamente era una ciudad muy rica, muy poblada y capaz de defenderse de los Gobernadores de las provincias inmediatas, pero en el día ha decaído de su opulencia y de su poder. La prohibición del comercio con el Japón ha disminuído la actividad de los negocios y aunque habitada por portugueses y mandada por un Gobernador nombrado por S. M. F., está, sin em- bargo, á discreción de los chinos, pudiendo pri- Ab. r? varla cuando quieran de los víveres para su subsistencia y posesionarse con facilidad de ella. Por estas razones la conducta del Gobierno aquí es siempre cuidadosa y circunspecta para no chocar ó más bien contemplar á los chinos.

Macao está situada desde la orilla del mar, en terreno desigual y por partes elevado; las calles participan de este defecto y son también irregulares y estrechas. Sus edificios consisten en una catedral, tres feligresías, dos colegios que fueron de los jesuitas, tres conventos de religiosos Agustinos, Franciscos y Dominicos; otro de mon jas de Santa Clara, una iglesia y casa de Misericordia, dos hospitales y tres ermitas y casa del Senado, la cual termina la única calle espaciosa y plana de la ciudad; pero así estos edificios como las casas de los europeos, carecen de todo gusto y elegancia exterior. La del Gobernador, situada frente del desembarcadero, goza de unas vistas las más agradables, aunque sin distinción alguna notable en su arquitectura. Inmediato á ella está la factoría inglesa, de bastante extensión, y todas las restantes factorías fabricadas bajo el mismo estilo, están rodeadas de jardines. Las alturas de la ciudad dominan unas vistas muy considerables hacia el mar y á la campaña. El puerto es muy cómodo y abrigado de los vientos, pero su profundidad no admite buques grandes. Macao está defendida en todas direcciones por cinco fortalezas que la dominan, llamadas Nuestra Señora del Monte Carmelo, Nuestra Señora de Guía, Nuestra Señora del Buen Parto, San Francisco y el Fortín de San Pedro; todas montan artillería gruesa, aunque según me informaron se hallan en bien mal estado. Las guarnecen, como asímismo á la ciudad, 300 soldados portugueses con el correspondiente número de Oficiales.

La jurisdicción de esta plaza está dividida entre los portugueses y chinos, sujetándose á cada una sus respectivos pueblos. El Gobierno político de la ciudad, por lo correspondiente á portugueses, perteneceal Senado de Cámara, compuesto de tres Veedores, dos Jueces ordinarios, un Escribano que sirve de Alférez Mayor, otro de la Mesa. y ambos los son también de la Aduana, y un Te sorero. Preside el Senado el Gobernador y Capitán general y el Oidor actual (llamado aquí el Sindicante) el Sr. Lázaro de Silva Ferreira, CabaIlero de la Orden de Cristo, desembargador de los agravos, casa da Suplicacao de Lisboa. Las sesiones de este Tribunal se tienen en la casa de que se ha tratado, fabricada el año de 1786 , y es el mejor edificio que tiene la ciudad.

La policía corresponde al Oidor y á los dos Jueces ordinarios: y el Procurador de la ciudad está encargado de conocer en los asuntos relativos á los chinos. Los empleos de Veedores. 
Ab. r3 Jueces, Procurador y' Tesorero son anuales, y se nombran en la capital de Groa por elección que se hace cada tres años: siempre se confieren á los recinos de mayor respeto, en quienes ha de concurrir la precisa circunstancia de ser porturueses, casados ó naturales de Nacao: el mando militar reside en el Gobernador.

A pesar del poco costo que produce al Rey de Portugal esta colonia por haber reducido el número de empleados y de sus sueldos, apenas las rentas del Erario alcanzan á cubrir estos gastos. El ingreso de éstas no puede sujetarse á un cálculo cierto, porque depende del mayor ó menor número de embarcaciones que llegan, y de 10 más ó ménos precioso de sus cargamentos. En los dos años anteriores ascendieron á 30.000 taleles ( $\mathrm{I}$ ) los que entraron en las diferentes cajas que administra el Senado.

Los derechos que pagan los géneros procedentes de puertos extranjeros, están reducidos á solo el 6 por roo de entrada en la Aduana sobre un avalúo moderado, y á 4 por roo sobre los que vienen de puertos nacionales: la plata y oro paga 2 por Ioo, rebajándose el uno por especial gracia á los buques españoles que vienen de Manila.

Del 6 por ioo de los géneros gruesos, cuyo avalúo no llega á diez taleles el pico (2), se aplica el uno y medio para el Convento de Santa Clara y Casa de la Misericordia. El Senado para aumentar el producto de las cajas que administra, da de sus fondos á riesgo de mar hasta 40.000 taleles sobre buques grandes, y la mitad en los de menor porte, á imitación de 10 que se practica en Manila con los grandes fondos de las Obras pías que se embarcan en la Nao de Acapulco. También sobre propiedades hace empréstitos el Senado por tiempo limitado al premio de tierra de 5 por roo al año.

Para fomentar la navegación, concede Su Majestad Fidelísima á las embarcaciones nacionales que cargan en este puerto, en los de Bengala, costa de Coromandel y Malavar, la rebaja de 22 por roo de sus reales derechos, como los efectos de sus cargamentos sean destinados á puertos extranjeros bajo el avalúo hecho á este fin por la casa de Indias. Sin embargo, no corresponden los efectos de esta franquicia á los benéficos deseos de aquel Monarca, pues el año anterior llegaron á 22 las embarcaciones de todos portes que se emplearon en este tráfico, y sólo una era procedente de Lisboa.

Las Compañías extranjeras reciben en Bampú de 30 á 34 buques cada año, de los cuales ninguno baja de soo toneladas, y de este núme-

(1) Equivalen a 40.000 pesos fuertes seguin ol cambin de 75 cunclrines.

(2) Cada pico consiste en 37 y $1 / 2$ libras por peso, que es el corriente ál yue le pasa el Senado. ro ordinariamente pertenecen los 20 á la nación Ab. ז3 inglesa. Los Factores de ella pasan á aquel sitio á despachar sus cargamentos, que por lo común lo verifican en los meses desde Octubre á Marzo, en que salen para Europa las últimas embarcaciones, que ordinariamente son de la Compañía Inglesa.

Bampú, situado como á I 8 millas de Canton es el único puerto del imperio de la China en donde es permitido el comercio á los Europeos.

Con este fin están establecidas aquí las muchas compañías europeas que comercian en esta parte oriental del globo, y estos edificios, formados bajo del estilo de la nación á quien perte. necen, se distinguen por la bandera respectiva que tremola en el paraje más notable de ellos. Issto aumenta la hermosura y población de este lugar, cuyo número de habitantes, incluyendo los que residen en los arrabales de Canton, se supone no bajará su número de medio millón de almas, que es la mitad de las que se cuentan á Canton.

No será exagerado este cálculo, cuando se comprenda el considerable número de gentes que viven y manejan las embarcaciones de aquel tráfico; siendo estas uno de los objetos divertidos que forman la navegación del río, tan ponderada por todos los que la practican.

La nación inglesa representa aquí, como en todos los demás puertos de la India, el primer lugar por su opulencia entre las demás europeas. Como sus miras se dirigen siempre á extender inmensamente su comercio, no perdonan medio alguno de elevarle al superior grado de riqueza en que hoy se considera.

Y aunque en la China goza la Inglaterra de la primacía á que pudiera aspirar atendiendo las circunstancias y leyes de este imperio, todavía no contenta su ambición ó su codicia, está meditando nuevos recursos para satisfacerla.

A este fin se está esperando en estos dominios al Lord Macrtney en calidad de Embajador de Su Majestad Británica en la corte de Pekin, con todo el aparato y pompa correspondiente á inspirar la atención y el respeto de los chinos hacia la Gran Bretaña. Las ideas de su Gobierno no pueden tener otro objeto que el de conseguir alguna preferencia ó franquicias en su comercio recíproco para no hacerle tan desventajoso como el que sufren todas las potencias europeas que aquí le ejecutan.

Ya este pensamiento había sido confiado en calidad de Ministro al Coronel Cathcarten el año I 788, de cuya misión, recayendo en persona de los talentos y circunstancias más sobresalientes para desempeñarla, se prometía el Gobierno las más completas y satisfactorias resultas. Pero la temprana muerte de este Ministro, acaecida en su riaje, malogró tan fundadas esperanzas. A 
Ab. 3 nuestro regreso á Europa, es regular sepamos cuál ha sido el fruto de Lord Macrtney, sin embargo de que no faltan quienes no le esperen tan favorable como los ingleses se prometen (I).

Uno de los objetos de comercio que ocupa en el día á las naciones concurrentes en esta parte del mundo, es el de la peletería de la costa Noroeste de la América. A nuestra llegada, me informó D. Manuel Agote, la rigurosa prohibición del Emperador en la introducción de este artículo, extendiendo la pena de este delito hasta la capital, para que no pudiera venderse ninguna clase de pieles en todos los dominios de su imperio. Esta novedad había obligado á Agote á tener en depósito como $3 \cdot 300$ pieles remitidas por el Gobierno de Manila para su venta, pertenecientes á la Real Hacienda, y conducidas de la costa de California. Al parecer, había dado lugar á esta disposición el suponer que todas las pieles procedentes de la América se consideraban de los dominios de Rusia, y como ambos imperios tenían entre sí algunas desavenencias, por esta razón se había decretado en éste la prohibición absoluta de aquel género. Las representaciones hechas por los quc las tenían al tiempo de prohibirse, fueron infructuosas; y Mr. Beal, cansado de esforzar diferentes medios con el Gobierno para vender un cargamento, se vió precisado á enviarle á las Islas del Japón, prefiriendo la improbabilidad de un éxito favorable en este

(I) Publicada en Londres en. I795 la relación de esta Embajada, resulta de ella no haberse sacado las ventajas que se esperaban, pues el Emperador rehusó clesde el principio firmar ó entrar en ninguna negociación ó tratado por escrito con la Corona de Inglaterra, ni con otra nación alguna, respecto á que semejante conducta por su parte, sería contraria á los antiguos usos, y á la verdad, una infracción de las Cons tituciones del Imperio. A esta precisa declaración añadió el Emperador las expresiones más propias para significar la mayor atención y respeto hacia Su Majestad Británica y la nación inglesa, y que, sin embargo de hallarse vivamente dispuesto á concederla mayores franquicias que á ninguna otra nación europea que comerciase en sus dominios, no dejaba de desear el hacer un nuevo arreglo de los derechos que pagasen los buques ingleses á su arribo á Canton, ya de ser éste uno de los puntos principales de la negociación. Al mismo tiempo, él no podría perder de vista los verdaderos intereses de sus propios vasallos, ni sacrificar aquéllos en lo más mínimo; y por esta razón, quitaria cualquiera gracia concedida á toda potencia extranjera, si acaso pudiese ser incompatible con los intereses de su imperio. A esta respuesta siguió la entrega de una caja exquisita al Embajador para el Rey de la Gran Bretaña, conteniendo unos retratos de todos los Emperadores que le habían precedido, á los cuales estaba aneja una descripción en verso por cada Emperador, describiendo á su persona y los principales hechos de su Gobierno, como también un modelo de la conducta recomendada á sus sucesores.

Al hacer el Emperador la entrega de este presente al Embajador, le habló en los términos siguientes:

«Entregareis esta caja al Rey vuestro amo con vuestra propia mano, y le direis que aunque este presento parezca tan pequeño, en mi estimación es el de mayor aprecio que yo puedo dar ó mi Imperio pudieso pensamiento, al riesgo que corrían de averiarse Ab. ${ }_{3}$ conservándolas á bordo (I).

Las mismas dificultades habían sufrido otras varias embarcaciones de la costa Noroeste de América. Los chinos no ignoraron desde luégo que traíamos algunas pieles del mismo paraje, pero sin atreverse á hacer reconvención alguna como lo habían hecho con lus buques particula. res, intimándoles que abandonasen el puerto. Sin duda, al respeto con que miran toda embarcación de guerra atribuímos la causa de su silencio, cuyo conocimiento, y el evitar otras consecuencias, me hizo desistir de proponer á los Factores de nuestra compañía que solicitasen su venta para alivio de los propietarios, á quienes también les prohibí el uso de otros recursos que además de poderlos comprometer, tuviesen que sufrir las vejaciones ó tropelías frecuentes de los Mandarines, siempre prontos á cometerlas cuando interviene el vil interés que los domina. Todas las pieles de nutrias que se habían reunido en este bordo desde Manila pertenecientes á los equipajes de ambas corbetas, ascenderian al número de 300 con corta diferencia. Estas se hallaban ya en pocas manos desde Acapulco, en donde las noticias de la Nao sobre la baja de precios que había dado este género en Canton, hizo á unos desprenderse de ellas con poca utilidad y á otros aprovecharse de este aviso para combinar una especulación lucrativa. Esta clase de contratos entre las tripulaciones no los ignorábamos así D. Alejandio Malaspina como yo, y no parecía justo impedirlos cuando la adquisición de las pieles estaba autorizada con nuestro permiso, y este era consecuente á las órdenes de S. M. con que nos hallábamos; sin embargo, los interesados tuvieron al fin bien poca utilidad en esta negociación, pues precisados á volverlas á Manila, no pudieron sacar allí

proporcionarle; porque habiendo sido trasmitido á mí por una serie dilatada de mis predecesores, es también la última alhaja para significar mi afecto, que yo había reservado para dejársela á mi hijo y sucesor, á fin de que le sirviese de pauta de las virtudes de sus antecesores en la cual había de ser la única que estudiase, como que así esperaba yo inspirarle la noble resolución de imitar tan brillantes ejemplos, y según ellos lo habian practicado, fijar en la práctica de ellos el grande objeto de su vida, para exaltar el honor del Trono Imperial, y promover los progresos de la felicidad y prosperidad de su pueblon.

Este ha sido hasta ahora todo el fruto de esta cos tosísima Embajada, cuyos resultados se notan aquí para curiosidad del público, y que admire la prudencia, política y dignidad con que procedió el Empera. dor: circunstancia que tal vez muchos no esperarían de este Príncipe, ni su firmeza á la avanzada edad de ochenta y cuatro años, después de cincuenta y seis de ocupar el Trono.

(I) Pocos meses después, supimos en Manila que el Emperador habia permitido en 28 de Mayo la introducción de pieles y la extracción del ruibarbo, que también estaba prohibida. 
Ab. 13 con notable diferencia, el valor que se habían propuesto conseguir en Macao.

Ha sido muy considerable lo que ha disminuído el valor de este artículo de la peletería desde el último viaje clel Capitán Cook, pues sesún dice King hubo entonces marinero que vendió su ancheta de pieles en 800 pesos, siendo el valor de cada una de las buenas no ménos de I20: en el día apenas ofrecen la mitad de esta cantidad, porque el gran número de concurrenios ha rebajado las utilidades excesivas que ofrecía este ramo de comercio á los principios; siendo también cierto que ya con dificultad se costean esta clase de expediciones, y no falta quien vaticine que en breve tiempo deberán por necesidad abandonarse.

Pero la Naturaleza parece haber concedido á la España el comercio exclusivo de este ramo mercantil. Nuestros establecimientos de San Francisco y Monterey, además de producir las pieles con abundancia, facilitan su adquisición con producciones propias por toda la costa de America hasta la ribera de Cook con ménos costos, más seguridad y mucha mayor prontitud. Su conducción á la China goza igualmente de las propias ventajas, pues cuando la Nao de Filipinas recala sobre las costas de Nueva España en Noviembre ó Diciembre, están ya de regreso en Acapulco las embarcaciones que se destinan á este tráfico; el flete y gastos desde este puerto al de Manila debe ser sumamente moderado, porque aquel buque regresa con poca carga y es capaz de una bien considerable.

Compárense, pues, ahora estas proporciones para hacer tan ventajosamente este comercio, con las que tienen los extranjeros que le emprendan: sus expediciones deben salir de Europa por el Cabo de Hornos, ó del Asia, haciendo escalas costosas en Macao, en las Islas de Sandwich ó invernando cn alguno de los puertos de las altas latitudes septentrionales de la América, á costa de mil peligros y zozobras como sufrió el año de 86 el Capitán Meares y describe con tanta elegancia. Asimismo, los efectos que conducen para cambio van perdiendo mucho su valor en la estimación de los naturales, porque convencịdos por la experiencia de que los que abordan á sus costas sólo buscan las pieles, teniéndolas en su mano pueden darles la ley en la seguridad de que han de sufrirla. No estamos nosotros en este caso con la posesión de la costa de California, la cual, no sólo nos las proporciona para eximirnos de recibirla, sino producc también el renglón de las conchas peculiares de aquel suelo, muy apreciable de los indios si se los ofrece con economía: el cobre de la Nucva España y los géneros ordinarios que en ella se fabrican, también los desearían con coclicia según nuestra propia expe-
Aun sinconocer muy bien los extran jeros estas $\mathrm{Al}$. $\mathrm{x}_{3}$ ventajosas proporciones porque todavía ignoran los cfectos favorables que deben resultar á la España, mc han concedido sin repugnancia, que nuestra concurrencia á este género de comercio arruinará siempre sus especulaciones por bien meditadas y dirigidas que sean. Las pieles entre los chinos pueden considerarse como un objeto de primera necesidad y de lujo, usándose entre todas las clases para abrigo y muchos para su adorno; y por consecuencia, aunque la abundancia haya disminuído su estimación, jamás dejará de ser un género apetecible y de mucho consumo. De todo 10 expuesto se concluye la preferencia exclusiva de nuestra nación, para un giro sin competencia y con utilidades conocidas.

No dejó de extrañarse por los chinos nuestro arribo á este puerto, como siempre lo acostumbran cuando entra algun buque de guerra. El Mandarin dc Casablanca (pueblo inmediato á Macao) acudió luégo á saber de D. Nanuel Agote cuál era la causa de nuestra llegada, y sólo pudo tranquilizarse con la seguridad de que en pocos días dejaríamos el puerto. Estas inquietudes son en el día mayores por los muchos piratas que en el mes anterior han infestado estos contornos. Los contínuos robos y vejaciones que han cometido contra cuantas embarcaciones chinas encontraban, sin perdonar las pescadoras, obligó á pedir el Gobierno á los portugueses el armamento de buques capaces de perseguirlos y exterminarlos. Este paso justifica á la verdad el atraso de la Marina de este imperio, siendo el mismo que el del siglo XVI cuando én iguales apuros apelaron á los portugueses para desalojar de Macao y de sus cercanías al famoso pirata Tchang-Silao, por cuyo particular servicio logró aquella nación europea establecerse en estos dominios.

Condescendió ahora el Gobiemo portugués con esta instancia después dc examinada en el Senado, al parecer, con las mismas ideas de lograr algún privilegio de los chinos. Compró á este efecto dos bergantines, y mientras se preparaban, pasó á Canton el Sr. Botello, comisionado por el Gobierno para pedir en premio de este servicio la libertad de edificar casas en Macao sin contribución alguna á los mandarines; eximir á las embarcaciones portuguesas del derecho de anclaje, y navegar libremente entre Canton y Macao, sin otro permiso que el del Senado; pero bien hubiesen parecido excesivas estas gracias ó porque en realidad hayan dejado estos mares los piratas, regresó Botello á fines del pasado sin conseguir otra alguna que la de manifestar el Emperador su gratitud al Gobernador y Senado por el apresto da dichos buques; y que sin embargo de haber cesado el motivo, no por esto olvidaría un mérito tan especial de la nación portugucsa, para recompensarla oportunamente: por de con- 
Ab. 3 tado las embarcaciones quedan sin destino y su costo de 22.000 pesos fuertes sin satisfacerse. Los portugueses pretenden atribuir esta inconsecuencia de los chinos á la mala fé del Mandarín Giang-Chang, quien deseoso de contraer un mérito con el Emperador alcanzando este auxilio, había prometido á los portugueses aún mayores franquicias de las que fué á solicitar el comisionado.

No pudiéramos sin injusticia omitir las particulares honras que hemos debido constantemente al Gobernador de esta plaza, ni ocultar al público las excelentes prendas personales que distinguen su carácter, unidas á una instrucción, rectitud y firmeza, cuales son necesarias para el desempeño del mando, y un mando de tanta delicadeza como complicado por todas sus circunstancias. A estas cualidades ejercidas con la conveniente prudencia, ha debido la tranquilidad y sosiego de que goza esta colonia, y á las compañías extranjeras una estimación particular, conciliándose así el aprecio de todas, el respeto del vecindario y la inclinación de cuantos le tratan.

Tan poderosos motivos no podían ménos de penetrar nuestro reconocimiento y corresponder por mi parte á tantas distinciones como habíamos merecido á este jefe. Para esto y cumplir al mismo tiempo igual obligación con otras personas principales de la ciudad, convidé á todos á comer á bordo el día 22: en la mesa se siguió la costumbre practicada en estos países, de brindarse primero á la salud del Gobernador y después por la prosperidad del comercio, acompañando á estos actos (aquí de ceremonia) el saludo al cañón. Así á este tiempo como cuando saludamos al Gobernador al cañón á su salida, correspondía la plaza inmediatamente tiro por tiro: por la tarde fuimos acompañando á tierra á este jefe varios Oficiales y yo, manifestándose en todos estos hechos tan satisfecho como agradecido, á un pequeño testimonio de nuestra parte en obsequio á su elevado carácter y satisfacer la obligación en que nos hallábamos.

Fuera asimismo culpable no hacer aquí mención de la actividad y esmero con que ha contribuído D. Manuel de Agote para cuanto hemos necesitado en este país, ni sin injusticia pudiera yo negar cuánto debo á sus auxilios para haber evacuado tan presto los objetos que me trajeron á Macao: su instrucción y conocimientos mercantiles que igualan á un genio laborioso y activo, le harán siempre digno de ocupar los primeros destinos de la Compañía, y que goce con justicia aquí de la estimación pública y del aprecio de todos los que le conocen.

\section{Regreso di Manila.}

Desde ayer habían quedado embarcados los instrumentos $y$ pinturas que llegaron el día an- terior de Canton, y nada faltaba ya para el $16=4$ cumplimiento de las órdenes con que me ha11 aba.

Empezada la faena de levarnos con la creciente para concluirla en este intervalo, se tendió al mismo tiempo una espía para franquearnos, y ya á las cinco de la tarde marcando todo aparejo con viento al Sueste, ceñimos al rumbo del Esnordeste para rebasar ambas islas de la entrada antes que volviese á crecer la marea que á la sazón nos ayudaba poco. Estábamos NorteSur al ponerse el Sol con la punta Norte de la entrada, como á dos millas; siguióse el mismo rumbo del Esnordeste hasta las siete y media en que virando al Sur-Sudoeste nos condujo la esperanza de poder montar la Isla Montaña si él viento conservase igual fuerza para exceder á la de la corriente.

Ibamos prolongando la Isla de Taipa, cuando se avistó la de la Montaña, cuyos esfuerzos para rebasarla fueron infructuosos, porque habiendo escaseado y calmado después el viento, nos obligó á dar fondo á las once de la noche en cinco brazas fango. Volvió el viento á velar durante la noche, pero siendo bonancible y por el Sueste, no era suficiente á superar la marea, que llevaba en este paraje la dirección para el Este. Al amanecer marcamos lo más Oeste de la Isla Montaña al Norte $60^{\circ}$ Oeste y Punta Peack al Nordeste.

Entrada la mañana, refrescó el viento por el Sur, y al momento de perder la corriente su fuerza, dimos la vela con viento del Sur-Sudoeste, tomando la vuelta del Sueste, y atravesando por entre una multitud de embarcaciones pescadoras; y con dos bordos, favorecidos ya de la corriente, pudimos rebasar el Gran Ladrón.

A las nueve de la mañana se avistó al Sursudeste una fragata; por cuyo tamaño y no haber llegado aún la Concepción, de Manila, nos hizosuponer fuese ella. Para confirmar nuestra presunción y poder llevar esta agradable noticia á la Real Compañía á quien pertenece, procuramos reconocerla, y nos largó la bandera inglesa. Esta fragata, según me informaron los de la Compañía de esta nación, se aguardaba por instantes procedente de la parte Norte de la Nueva Holanda, Nueva Guinea é Isla de Borneo á donde había sido destinada por la Compañía de la India para hacer reconocimientos con ideas mercantiles: nos fué sensible á la verdad, que por tan corta diferencia de tiempo no nos hubiésemos juntado en Macao para saber las resultas de esta comisión importante á la Geografía de unos parajes poco trillados ó reconocidos imperfectamente.

Al medio día demoraba el Ladrón, más occidental al Norte, observando la latitud de $2 I^{\circ} 45^{\prime}$ Norte, y desde aquí favorecidos de un viento fresquito, nos desembarazamos de las Islas Asses 
Ab. 25 ć islotes al rumbo del Sudeste $1 / 4$ Sur, perdiéndolas de rista al ponerse el Sol. Sin cesar de relampaguear y tronar por la noche, el viento no arreció hasta la madrugada, á cuya hora empezó á llover con mucha fuerza. 'Tardó poco el viento en saltar al Nornoroeste muy fresco, arreciando más con los chubascos repetidos, siendo tan frecuentes los truenos y relámpagos como en la noche. Gobernóse al Sudeste $1 / 4$ Sur, con trinquete y gavias con la precaución correspondiente á estas circunstancias. Por la tarde el viento no era ya tan constante, variando del segundo al tercer cuadrante, y cuando se acercaba al Sur, se prefería la vuelta del Oes sudoeste, porque las corrientes en esta estación tiran aquí con fuerza para el Este.

Estos aparatos del tiempo que siguieron al día đespués, nos hizo creer fuesen para determinar la crísis de la monzón del Nordeste en estos mares y sustituirla la de los vendavales. Esta suposición fundada sobre los efectos que experimentábamos, la apoyaban también las noticias de Mr. d'Apres y el Capitán King afirmando que esta última empieza ó se anticipa en Abril. Atenđiendo á esto fué preciso variar el pensamiento de hacer derrota directa, y ser preferible franquearnos de la Isla de Luzón para en el caso de anticiparse los vendavales como todas las señales 10 indicaban.

Volvió el tiempo desde el medio día á cerrarse por todas partes con espantosos truenos y relámpagos acompañados de agua muy fuerte y contínua: con el viento á fugadas entre el Este y el Sur se tomaba la vuelta más próxima ó más directa para disminuir latitud, pero sin abandonarnos durante la noche y el día siguiente las mismas feas apariencias de los días anteriores.

No logramos la presencia del Sol hasta el medio día del 29 , cuyas observaciones nos indicaron la situación de $I 9^{\circ} 7^{\prime}$ en latitud, y la longitud por el número 72 de $00^{\circ} 02^{\prime}$ al Este de Macao.

No era fácil acertar muchas veces la vuelta que sería más conveniente, por las contínuas variaciones del viento, y éste siempre bonancible por lo común, giraba rápidamente del Sudoeste al cuarto cuadrante y después al primero, de modo que nuestros progresos eran bien lentos, pucs todavía al medio día del 2 de Mayo, estábamos en $I 7^{\circ} 28^{\prime}$ de latitud Norte, y en longitud I $29^{\prime}$ oriental de Macao: notamos en estas observaciones diferencias al Sur y mayores hacia el Oeste, siéndonos bien extrañas, porque en el estado aranzado de la estación, ordinariamente se experimentan cn sentido opuesto. Toda esta singladura nos ha acompañado un tiempo hermoso, la mar muy llana y el viento ya más ya ménos fresquito del Nordeste al Listc. Nuestros rumbos han sido ciñcndo por babor, y la noche, con la inmediación al plenilunio, ha estado de las más May. ? claras y apacibles, bajo cuyas iguales circunstancias se presentó el Sol sobre el horizonte, pero sintiéndose mucho los efectos de sus rayos, en razón de la altura en que nos hallábamos y de sus cercanías al zénit.

Ya por las observaciones de hoy notamos en orden inverso las diferencias, especialmente en cuanto á la longitud, que discrepaba en $30^{\prime}$ al Este, con lo cual y la propia experiencia al día siguiente, aunque no tan grande, nos confirmó el concepto sobre el curso de las corrientes para el Este en estos parajes en la estación actual.

Desde el principio de la tarde empezó el viento á inclinar al Es-Sudeste y hasta el Sudeste con el que era preferible la vuelta del primer cuadrante, y ésta hubiera yo seguido, á no suponer, apoyado en el parecer del práctico, de que subsistirían ya los vientos por el Sudeste y probablemente más al Sur, con cuya reflexión pensé seguir la singladura con las muras á babor, pasar al Sur del bajo Scarboroug, y revirar para el Este desde la latitud de $14^{\circ} 4 \mathrm{O}^{\prime}$ á atracar la tierra por donde lo permitiesen. Estas combinaciones nos prometía el tiempo realizarlas, según las varias llamadas que dió el viento en la noche hacia la parte que deseábamos.

Nuestras conjeturas quedaron destruídas á la mañana siguiente, declarándose el viento de nuevo al Este; y áun lo que fué peor, que cuando esperábamos con ansias las observaciones del medio día para ver lo que las corrientes nos habían conducido al Este, hallamos, contra nuestras esperanzas, que lo habían ejecutado $I g^{\prime}$ en dirección contraria, y sin poder apelar á haberse deslizado algún error en los horarios, pues repetidos por la tarde comprobaron la propia diferencia para el Oeste.

Nos hallábamos á la sazón en latitud de $15^{\circ}$ o6' Norte, y en longitud de $2^{\circ} 34^{\prime}$; se siguió la vuelta del Sur-Sueste con viento del Este para pasar al Sur del bajo Scarboroug bajando al paralelo de $14^{\circ} 25^{\prime}$, ó más al Sur si los vientos hiciesen preferible rumbos en el segundo cuadrante á los de en el primero.

Al medio dia, observando la latitud de $14^{\circ} 29^{\prime}$ estábamos $3^{\prime} I^{\prime}$ al Sur de la parte meridional de Scarboroug, pero muy distante de su meridiano si suponíamos exacta la distancia de 35 á 40 leguas de la costa á que me aseguraba el práctico se hallaba. Bajo de esta suposición será preciso excluir dela carta de Mr. Dalrimple el bajo con aquel nombre que coloca á la distancia de 57 leguas de tierra, y establecer por único y verdadero Scarboroug otro que sitúa en la misma latitud, pero más próximo á ella. Yo hubiera deseado el haber debido á los vientos la proporción de correr su paralclo, siendo tan importante la posición exacta 
May. 6 de este escollo como que han perecido en él varias embarcaciones nacionales y extranjeras (I).

Continuaron las diferencias aunque ya menores para el Oeste, cuya disminución se notaba á medida que caminábamos á latitudes más bajas, 10 cual y la flojedad ó bonanza de los vientos, iba produciendo mucho atraso en nuestra llegada á Manila. Atendiendo á estas razones, y á la de no hallarnos muy abundantes de víveres, con especialidad de pan, pues sólo existe para diez y seis días completos, ha precisado á rebajar una cuarta parte de la ración diaria de este alimento, pero aumentando tres onzas de menestras de que había mayor cantidad.

Todavía al medio día del Io no habíamos podido coger mas longitud que la de $3^{\circ} \circ 9^{\prime}$ oriental de Nacao, y ésta discrepaba mucho entre la que señalaban los tres relojes: el IO5 se apartaba en $42^{\prime}$ más al Oeste respecto á la del 72 por el que nos guiábamos con preferencia; y $30^{\prime}$ en igual sentido la del I I. No habíamos tenido ocasión de rectificar algunas de estas longitudes con las de distancias, para sujetar el grado de los errores á un cálculo aproximado y dirigir con más acierto la recalada á la tierra; no obstante se presentó hoy la ocasión de observar una sola distancia por ocultarse los astros con las nubes, y los resultados de ella dieron una longitud muy conforme con el número 72, pues sólo diferenciaba en I 3 al Oeste, lo cual nos confirmaba en la justa preferencia dada á esta máquina sobre las otras dos.

A la mañana siguiente observamos I4 series de distancias cuyos resultados dieron $29^{\prime}$ de diferencia al Oeste de la longitud por el 72 y 49 en el propio sentido el día inmediato. Estas pruebas tan repetidas como averiguadas con cuanta exactitud nos era posible, hicieron atribuir alguna alteración también á esta máquina, por la sen-

(x) Hemos sabido posteriormente, que el Capitán Clawson en el navío Sofia Magdalena, de la Compañía sueca de la India Oriental, salió de Pulo Zapata á las seis do la tarde del ig de Setiembro de I793, y el 25 á la salida del Sol vió rompiente del Nornordeste al Noroeste $1 /$ Oeste como á cuatro millas de distancia.

La mañana era nublada, pero á las 8 h $20^{\prime}$, pudo obscrvar la longitud de toda confianza por medio de su cronómetro, y tuvo buena observación de latitud al medio día: con estos datos coloca el cxtremo Sudoeste del bajo, en latitud de $15^{\circ} \circ 2^{\prime}$ Norte y en longitud $\delta^{\circ}$ $22^{\prime}$ Este de Pulo Zapata y $3^{\circ} 8^{\prime}$ al Este de la Gran Lama que vió el ro de Octubre.

Pulo Zapata oriental de Greenwich. . . . $109^{\circ} 02$ Diferencia observada........ $8^{\circ} 22$

Longitud del bajo. . . . . . . . I $117^{\circ} 24$

Macao de Grecnwich. ........... $113^{\circ} 30^{\prime}$

La Isla del Gran Lama al Este . . . . . ” 44

El bajo al Este del Gran Lama... . . $3^{\circ}$ of

Longitud del bajo ......... I I $17^{\circ} 22$

Promedio ............. $117^{\circ} 23^{\prime}$ sibilidad que experimentan con las grandes va- May. in riaciones de la atmósfera, pasando de un tcmperamento medio á cualquiera de los dos extre. mos de frío ó calor, como en esta ocasión ha sucedido.

Volvimos nuevamente á tomar distancias lunares poco antes del medio día del I 4 , á fin de asegurarnos por tercera vez si las diferencias al Oeste del reloj, eran constantes. El resultado medio de 16 serjes daba ya $I^{0}$ I $5^{\prime}$ más al Ocste, y por consiguiente, no podía dudarse de hallarnos más distantes del destino. Si á esto también sc agregaba la flojedad de los vientos y éstos escasos, las pocas señales de que mejoren, la continuación de las diferencias al Oeste, y un calor tan excesivo que el termómetro de la cámara llegó á $86^{\circ} \mathrm{S}^{\prime}$, es cierto que esta navegación se nos hace una de las más molestas, y en proporción á la dis tancia, una de las más dilatadas. Para compensarnos en parte esta tediosa campaña, el viento era constantemente hermoso y apacible, y de cste modo subsistió hasta el anochecer del 16 , en que afirmó el viento fresquito por el Es-Sudeste, y pasando después al primer cuadrante, ceñimos para el Este, llegando al medio día siguiente á la latitud de $I 4^{\circ} I^{\prime} y^{y}$ á la longitud de $5^{\circ} 46^{\prime}$, aunque por estima creíamos estar I $5^{\prime}$ más al Este.

Observados por la tarde nuevos horarios, indicaban la longitud de $6^{\circ}$ oo' por el 72, y la de $5^{\circ}$ I $4^{\prime}$ por el I05: si la primera fuese exacta, la inmediación á la tierra obligaba á navegar por la noche con rigilancia, pero como nuestra confiănza en las distancias debía ser correspondiente á las repetidas pruebas que teníamos de su exactitud, adquirida en la práctica continuada con que las ejecutábamos, no podíamos ménos de creer firmemente ó atribuir á la longitud del Io5, la mayor proximidad á las distancias, y esto se confirmó con no verse la costa á la mañana siguiente con un horizonte muy despejado.

Tal vez la oscuridad que hubo por la tarde impidió la vista de las Islas de Lubang y Cabra, pues advertíamos como al Sudeste 1/4 Sur, una cerrazón más espesa, y áun algunos quisieron afirmar haber visto una de las citadas islas. Puesto el Sol, empeoró el semblante del tiempo, con relámpagos y truenos muy rcpetidos, y esperando los diferentes contrastes presentados en el horizonte: en efecto, se experimentaron éstos varias veces durante la noche, pero sin ofrecer cuidado alguno por su poca fuerza, y tan sólo la oscuridad tan grande, aumentada por frecuentes aguaceros, no nos permitía hacer la diligcncia necesaria que proporcionaba el viento del Nornordeste fresquito, á fin de amanecer en disposición oportuna para coger temprano la boca dc Mariveles, sobre cuyos parajes sería arriesgado si entraba la colla (llamados así los tcmporales do la monzón del Sudoeste) como desde lucgo la 
May, I, anunciaban las apariencias: áun el navegar para el Este era también arriesgado en el paraje donde nos hallábamos, pues si se verificaban estos recelos, era muy conveniente la posible separación de la costa, para tener más espacio en donde capear ó resistir el temporal. Pero todas estas reflexiones, al parecer fundadas, debieron desatenderse, porque la escasez de pan, y no hallarse el buque en buen estado de estiva, no daban lugar á la consulta de otras medidas que pide la seguridad en distintas circunstancias.

No cesaron los aguaceros á la mañana siguiente, ni el viento de variar entre el segundo y primer cuadrante, en ocasiones fresco, con los horizontes aturbonados por diferentes partes: forzóse de vela, no obstante, afirmando el viento por el Sur y Sur-Sudoeste, disminuídos ya los aguaceros fuertes.

Nuestra posición cerca del medio día por la estima traída desde la longitud observada de ayer, no avistándose aún la tierra ni las Islas de Lubang y Fortún, era á la verdad cosa bien ex traña, cuando por la latitud no podían estar dis tantes, á ménos de suponer corrientes fuertes para el Oeste ó para el Norte, cuya averiguación era dificultosa careciendo de la presencia del Sol, y sin esperanzas de que aclarase.

Estando en esta incertidumbre sobre nuestra verdadera posición, se aparecen á la vista las Islas de Lubang y después Fortún. Se corrió una base que determinase la distancia exacta de ellas y supliese las observaciones, en la suposición de ser bastante s egura la situación de estas islas respecto á Manila. Concluída esta operación, arribamos al medio día al Este $1 / 4$ Nordeste á cuyo rumbo nos demoraba la entrada grande; y la ce rrazón nos ocultó la vista de la tierra hasta la una que marcaba la Isla del Corregidor al Esnordeste, nos dirigimos á pasar entre ella y Mariveles, con el viento más y ménos fresco entre el tercero y cuarto cuadrante.

Antes de anochecer llegamos á estar al frente de la ensenada de Mariveles, desde donde gobernamos al Nordeste $1 / 4$ Este, advirtiendo en la carta de Mr. d'Aprés un error considerable en la posición de estos puntos de la entrada, en la cual si nos guiásemos por ella, debía gobernarse desde aquí dos cuartas más para el Este: error muy notable para un navegante de su crédito y que ha estado en estos parajes.

Luégo que se marcó al Sur lo más Este del Corregidor, y navegadas doce millas al mismo rumbo para franquear el bajo de San Nicolás, se orzó al Es-Sudeste sondando I 5 brazas, y con gavias $y$ trinquete seguimos para dentro en ánimo de coger el puerto de Cavite, hacia la media noche; pero abandonados á esta hora por el vicnto, dimos fondo en dicz brazas fango suelto.

Con unas ventolinas por el Sur-Sudeste di- mos al amanecer la vela adelantando bien poco, Nay. 20 mientras un chubasco por el Oesudoeste afirmó el viento para conducirnos á fondear al costado de la Descubierta, que ya veíamos, y lo verificamos á las nueve de la mañana en cinco brazas fango.

Poco antes llegó á bordo D. Alejandro Malaspina, y me informó haberse visto precisado á regresar á este puerto el I2 del pasado, conociendo la imposibilidad de trazar la costa hasta Cabo Bojador con mediana exactitud. Este Comandante se restituyó á Manila por la tarde, llevándose consigo los tres relojes, cuyas longitudes deducidas por las comparaciones con el 7I daban bastante diferencia, siendo así por todas razones preferente para nuestras cartas la diferencia de meridianos entre Manila y Macao de $7^{\circ}$ I $S^{\prime}$ hallada unánimemente á la ida para aquel puerto por el 72 y el to5, pues está también conforme con la que pone el conocimiento de tiempos del año de 88 , aunque ignoramos á quién se deba la observación absoluta ejecutada en Macao.

\section{CAPITULO III}

\section{Diferentes excursiones científicas en la Isla de Luzón} durante la estada de las corbetas en Cavite.-Aprestos para las campañas siguientes.-Ocurrencias principales relativas á los armamentos y á los buques. Plan de las siguientes campañas é individuos quedudos en Manila con este intento.

Sería difícil, cuando no imposible, el dar una idea cabal de las diferentes excursiones que se ejecutaron en la Isla de Luzón mientras no interrumpiesen imperiosamente nuestros pasos las lluvias abundantes, que ya en una ya en otra estación, fecundizan y hacen intransitables las costas del Este ó las occidentales de la misma isla. Ciertamente en aquellas ocasiones no se economizaron en modo alguno la salud y la misma vida de los Oficiales y Pilotos que se encargaron de su ejecución; y el no decir aquí lisa y llanamente que sus sacrificios fueron proporcionados á los deberes contraídos con la sociedad en general, y particularmente con la patria, sería defraudarles de aquellos justos elogios que han procurado merecer. En el corto intervalo de treinta y cinco días, el T'eniente de navío Viana recorrió y dejó descritas con la mayor exactitud hidrográfica, todas las costas que van desde la Punta de Bolinao hasta los Cabos de Bojador y de Engaño.

D. Tadeo Heenke desplegó en un plazo duplicado un genio tan laborioso y una tan constante aplicación, que pudo examinar científicamente las provincias de la Pampanga, Ilocos, Cagayan y Pangasinan. Sc nos incorporó el 20 de Junio D. Luis Nee, que desde la mitad de Marzo 
May. 20 corría las provincias meridionales de Albay, Camarines, Tayabas y La Laguna. Habían, por otra parte, D. Felipe Bausá y un Piloto trazado con la mayor exactitud la bahía grande de Manila y los puertos que le son contiguos: la habíamos sondado, examinando el bajo peligroso de San Nicolás. D. Juan Maqueda recorría y describía las costas orientales que desde Mauban se extienden hasta la Ensenada de Albay, término de nuestras tareas emprendidas desde Sorsogon: otro trozo, con un Oficial, un Piloto y algunos marineros, examinó en la misma contracosta las Islas de Alabat y Polillo, y el puerto de Lampon, célebre por los antiguos proyectos de la construcción y navegación de las Naos. Visitó D. Juan Rabenet en la provincia de Bataan los negrillos habitadores indígenas de la isla, y logró retratarlos con sus costumbres principales. Finalmente, al cargo del Teniente de navío D. José Espinosa siguiéronse en Manila las observaciones astronómicas por manera que no dependiesen ya la latitud y longitud de aquel punto bien interesante de los dominios de S. M., sino de observaciones directas, las cuales referidas luego á Canton por medio de los relojes de la corbeta ATREVIDA, reunían con los resultados dimanados del Oeste los que nosotros traíamos sin la menor interrupción por el Este.

Pertenecerá á las descripciones físicas, dar una idea más individual de los diferentes aspectos ó sumamente amenos ú hórridos con exceso, que tomaba la naturaleza á nuestra vista, según torciesen las excursiones á las fértiles llanuras cultivadas por los malayos sujetos á la Monarquía, á los montes ásperos, albergue inaccesible de mil insectos, de los reptiles y de los pocos habitadores indígenas, ó á las playas peligrosas, por los huracanes, por los escollos que las rodean ó por los piratas que las infestan con cuantos ardides pueden dictar el odio, el furor, la codicia y la experiencia. Si por una parte los religiosos $\mathrm{Cu}$ ras Párrocos, con un amor, un celo y una generosidad indecibles, suavizaban nuestras fatigas del día ó dirigían con mayor conocimiento nuestros pasos siguientes y los auxilios que á cada instante necesitábamos de los naturales, tan dóciles como industriosos; por la otra nos veíamos trasplantados á corto rato, donde el Sol y la humedad luchaban á porfía para hacernos igualmente peligrosos el día y la noche, ó donde fuésemos amenazados, áun en el corto intervalo de nuestro reposo, de la fatal sorpresa de unos enemigos sangrientos y traidores.

En los reconocimientos de la costa oriental entre el Cabo de San Ildefonso y el Estrecho de San Bernardino, fueron casi diarios los encuentros con los piratas, los cuales, aproximándose ahora en aquella parte la monzón clara y apacible, mientras los Sudoestes tempestuosos domi- naban en la otra, seguían á su placer el instinto envejecido de saquear nuestros pueblos y esclavizar sus habitantes, cuando más descuidados atendían al cultivo de los campos ó al transporte de sus frutos sobrantes de una provincia á la otra. Varias veces D. Juan Maqueda, amadrinadas sus tres embarcaciones de remo para multiplicar los fuegos y reunir la defensa, debió hacer aguada, leña y marcaciones á la vista de siete ó nueve embarcaciones piratas. Vió una rez en un islote inmediato al puerto de Sisiran los tristes rastros de esos piratas, apercibiéndose aún recientes los huesos de dos cadáveres humanos, devoradas sin duda sus carnes, después que rechazados del pueblo de Pambujan, vinieron á descansar en aquel islote con el triunfo bien mezquino de dos solos cautivos: otro día, dando caza á ocho embarcaciones, las obligó á huir con tal precipitación, que dejaron en la playa dos cautivos, los cuales fueron con este motivo felizmente redimidos. Eran el uno de Mauban y el otro de Mambulao, cogidos veinte días antes en las sementeras inmediatas á sus pueblos. Tenían por único vestido un collar de bejuco y una cuerda, con la cual les sujetaban de noche cabeza, piés y manos. Declararon que á bordo de los ocho pancos había unos cincuenta hombres cautivos y varias mujeres. Unos diez de uno y otro sexo habían sido cogidos dos noches antes en la visita de Poronglooc de la Isla Catanauan.

Describían al mismo tiempo D. Luis Nee, D. Tadeo Heenke y D. Francisco Viana el singular contraste de los países que visitaban. Estudiaban las costumbres de sus habitantes, los vicios ó las ventajas hacia el bien público de los diferentes ramos de nuestra legislación, y los indecibles progresos que pudieran adquirir en lo venidero á medida que fuesen enlazándose entre sí los intereses recíprocos de la Monarquía, y adoptasen aquellas islas felices como el centro de todas las operaciones políticas y mercantiles.

De lo dicho hasta aquí puede inferirse que los pocos Oficiales que habían triunfado de los climas harto temibles de la América, debieron ceder ahora á los efectos combinados del temperamento y de la fatiga; pero en fin, los tres ó cuatro meses que debíamos aún permanecer en Manila, antes que la estación oportuna del Nordeste estableciese su imperio, nos aseguraban casi con evidencia que podíamos arrostrar de nuevo con la robustez necesaria, las fatiga:s de la campaña siguiente. Emprendiéronse por la misma razón las tareas ménos violentas pero igualmente importantes, de poner en orden los muchos elementos acopiados hasta cntonces, bien fuesen hidrográficos, políticos ó económicos, y entre tanto, nuestras miradas y nuestros afanes externos ya tenían por solo objeto el regreso feliz de D. Antonio Pineda, el cual des- 
Jur. de los primeros días de Abril había emprendido una derrota sumamente penosa hacia el Norte. A cada instante, nuestros deseos nos le representaban como presente y próximo á gozar del fruto de sus penosas peregrinaciones... jvanos deseos! jesperanzas infundadas! Casi en los mismos momentos en que nos poseíamos de aquellas ideas, estaba acabando en Badoc, pueblecito de la provincia de Ilocos, una vida tan gloriosa como importante para el bien público. Tíctima de unas tareas tan asíduas, después de un riaje combinado más bien por el celo propio que por el examen del país y de sus fuerzas, y ya acelerando demasiado tarde sus pasos hacia Manila después de haber errado por largo tiempo entre unos montes y parajes casi inaccesibles, debió doblarse finalmente bajo el yugo imperioso de tamañas fatigas, $y$ perder para el beneficio directo de las ciencias y del honor nacional, una vida que mil veces se había salvado entre los peligros mayores de la guerra. No parecerá importuna al lector una narración más difusa de los últimos pasos de este hombre filósofo; la cual se ha deducido directamente de sus mismos apuntes.

Determinado D. Antonio Pineda á emprender sus excursiones científicas, quiso abrazar con los objetos más útiles la mayor extensión del país que pudiera combinarse en el corto tiempo que faltaba para la estación lluviosa en la región septentrional de la isla, para lo cual consultó á las personas más prácticas y más instruídas de ella. D. Juan de Cuellar, celoso naturalista comisionado en las islas por la Real Compañía, quiso acompañarle en sus primeros pasos, y ambos convinieron en un plan: en que después de recorrer prolijamente las amenas orillas de la Laguna de Bay, examinando el plantío de la canela en Calanan v los baños termales del Maquilin, D. Antonio Pineda atravesase de Sur á Norte La Laguna y toda la Pampanga alta para continuar después por lo largo del río de $\mathrm{Ca}$ gayan, primero hasta las misiones de Ituy y $\mathrm{Pa}$ nique, y luégo hasta Lalloc y Aparri en el extremo Norte de la isla: torcería después hacia el Oeste para retroceder á Manila por las provincias de Ilocos y Pangasinan, y siempre que se cncontrasen objetos que lo manifestasen oportuno se apartaría más ó ménos del derrotero indicado.

Debía á la verdad oponerse á este proyecto el calor excesivo que manteniendo el termómetro en una altura de 24 á $25^{\circ}$ en la escala de Reaumur, constituye un clima insufrible "que "embotando las potencias y enflaqueciendo la "memoria por la contínua disipación de espíritus ranimales, arrastra al viajero á una especie de "letarogn intcrumpido sólo por las molestas punzadas del sarpullido y los insectos, que le difi- "cultan la continuación de sus tareas reflexi- Jun. "vas" (I). Pero D. Antonio Pineda, poco escarmentado de semejantes inconvenientes en otros paises mal sanos, arrostró á todos con vigor, y entre sus útiles observaciones brillan además de su ingenuidad genial, elegantes descripciones de que resumiremos algumos trozos que acrediten el curso de sus viajes.

"Provisto de un pintor joven de mediana habilidad, que diseñase los objetos más interesantes, salió de la capital el II de Abril. Las frondosísimas orillas de la Laguna de Bay, cuyas fértiles campiñas son interrumpidas frecuentemente por arroyos y arboledas, le ofrecían escenas deliciosas. Los pueblos emboscados entre palmas y platanares, con ingeniosas calzadas rodeadas de arrozales, conservaban los indicios de la vejetación más lozana, al paso que muchas casas y tiendecillas esparcidas en desorden, constituían una población continuada, y los cuadros y cuadrilongos con que detienen las aguas y dividen los terrenos para el cultivo del arroz, daban el aspecto de un jardín artificiosamente desordenado. Se agrega la estructura de las casas bien adaptadas á las estaciones y clase de vida de los naturales; luégo al todo la contínua agitación de tareas en que se emplean los naturales para cosechar su arroz; el carabao en aquel país pantanoso presta al hombre maravillosos socorros; cualquiera otro animal metido en el lodo hasta las rodillas, se atora, se fatiga y trabaja sumamente; el flemático carabao se encuentra en su elemento, la humedad le recrea y la frescura le anima; sea enfermedad, sea comezón ó disposición particular de su piel, ama los refrigerios, las fricciones le deleitan y hasta en el color lodoso, parece que fué criado para habitar los cenagales."

A I I leguas de Manila y cinco de La Laguna, está la hacienda de Calanan, propia de D. Francisco Salgado, provista de no malas oficinas. Circunvalan su parte oriental más de dos leguas de montaña. "Los ríos de Calabang, San Nicolás, Lamot y i7 manantiales, riegan en su jurisdicción más de 5.000 canelos que ya fructifican, y otros 500.000 de varias especies que están en el mejor estado próximos ya á la fructificación; ofreciendo por todas partes terrenos aprovechados, que prometen á su dueño la crecida recompensa de sus excesivos costos bien patrióticos."

Las aguas termales del Maquilin, específico para los tumores, piedra y toda clase de obstrucciones, analizadas según el método Bergmann por el sabio Mr. Mongé en la desgraciada expedición del Conde de la Péyrouse, lograron un nuevo examen cuyos resultados comparados con los de

(I) Las expresiones y palabras así señaladas, son á la letra las de su mismo D)iario. 
aquel hábil químico, afianzasen el concepto y conocimiento de ellas, añadiéndoles ahora la dés. cripción local del terreno, que no hizo aquel viajero.

Despedido ya de Cuellar, atravesó La Laguna haciendo noche en la Isla de Falin, y al día siguiente en Binangonan, pueblo situado sobre una punta en la costa Norte, en cuya inmediación como á tres cuartos de legua hacia el Nordeste, yace un peñasco tajado por todas partes y una fuente cuyas aguas merecen el título de las frescas de Toselo: el peñasco es de una tierra argilacea amarillosa con un socabón al pié, donde se reunen las aguas que destila gota á gota. La at mósfera, que al aire libre hace llegar el termómetro de 25 á $27^{\circ}$, se mantiene en este delicioso paraje de I8 á I $^{n}$, y examinadas las aguas con reactivos á instancias de su celoso Ministro el Padre Perdigón de la Orden de San Francisco, que le acompañó al examen, resultó que podían reputarse por las más simples que se beben.

Milla y media al Sur-Sudoeste de Moróng, lugar situado en el continente firme pero que se comunica, por agua, con La Laguna, hay una fábrica de balas, cuyo đueño tiene celebrada contrata con la provisión de Manila, y por medio de un subarriendo á un Sangley las consigue á unos precios comodísimos. La fábrica es sumamente sencilla y aún lo son mucho más sus maniobras, que se reducen á cinco, sin emplear más que otros tantos operarios: calcinar, moler, fundir, vaciar y perfeccionar sobre un yunque las balas ya formadas, es todo cuanto hay que hacer; sin que sea ménos sencilla la estructura de los fuelles y'del horno, de que hizo sus descripciones.

En los días siguientes hizo nuestro naturalista una excursión á los Montes de Santa Inés, situados I 2 leguas al Nordeste de Moróng, para examinar los Mineros de que se provee la fábrica. Pasó por el mezquino pueblo de Bosoboso, y dejando en él la mayor parte de sus muebles, subió á una región elevada, por caminos ásperos y casi intransitables, en donde ni era posible sin grave riesgo seguir la marcha á caballo, ni á pié se hacía sin grande incomodidad. El equipaje, aunque compuesto sólo de una manta, una almohada, barómetro, pesalicores, estuches, algún palay (I) y la comida más penitente, formaba sin embargo un acompañamiento sumamente embarazoso en tan fragoso paraje. Ni fueron menores las molestias que luégo se siguieron de trepar los cerros sostenidos de las yerbas, pasar la noche en el campo sin otro abrigo que la manta de la cama, y sobre todo, no tener otron ali-

(1) Palay es el arroz con cáscara, y sirve para alimento de los animales á manera de nuostra ce. bada mento que fiambres, los cuales no le sufría el Jun. estómago: estos accidentes debieron causarle un quebranto difícil de reparar.

Dos erguidas cordilleras que corren del Surá Norte y de Suoeste á Nordeste hasta unirse ó estrecharse en el Monte Pola hacia el centro de la isla, forman la frondosa llanura en que está Manila, comprendiendo desde el pié del Caraba110 las provincias de Tondo, Bulacán y ambas Pampangas, con hermosísimas campiñas interumpidas por deliciosos ríos, en cuyas plácidas aguas se duplican reflejados los árboles de la orilla. "Muchos trozos de este país aplanado se "ven luégo en unas situaciones más bajas, y se "inundan tanto en las estaciones lluviosas, que "se hacen navegables, y el comercio, que se in»terrumpe por tierra, empieza á hacerse por "agua." Multitud de pueblos ocupan esta vasta extensión, en que nuestro viajero sació su curiosidad con útiles observaciones, entretanto que en ellos ejercitaban los naturales su industria en cultivar el arroz, maíz, añil y tabaco, si bien el estanco de este último, les atrajo sobre sí muchos defraudadores armados que hostilizan y desolan el país, y contra cuyas invasiones han fortificado algunos pueblos con dobles filas de estacas terraplenadas. La factoría de Gapán proporcionó la completa vista de aquella escena, marcándose desde ella el empinado Nonte Arayat al Sur $56^{\circ}$ Oeste.

E1 paso peligroso del Caraballo, única garganta ó puerto para pasar á las Misiones de los Irinayas ó de Ituy de los Padres Dominicos, se emprendió el Io de Mayo, debiendo entonces Don Antonio Pineda abandonar por algún tiempo las especulaciones de un naturalista, para sustituirles las no ménos molestas y mucho más destructivas del arte militar. La vecindad de los Igorrotes habitadores de aquellas serranías, y sordos hasta aquí á todo atractivo de una vida ménos bárbara y salvaje, obliga á los pasajeros á varias precauciones militares, si bien por fortuna estos enemigos traidores, incapaces de atacar á un hombre armado como se encuentre despierto, profesan tanto horror á toda arma de fuego, que un solo fusilazo disparado al embocar los desfiladeros, alarma toda la montaña, sin que por eso se atrevan á acometer. Pero si los pasajeros se desnudan, se descuidan ó se duermen, tienen casi seguro amanecer degollados; y por consiguiente, supérfluas cuantas precauciones se toman para evitarlo. Candeladas, guardias y centinelas que pasasen la palabra, todo se puso en ejecución en aquel pequeño campamento, para pasar una noche en despoblado. La escolta consistía en un criado europeo, un dragón, y el pintor, todos con armas de fuego, que hacían la fuerza más respetable. El resto se componía de 20 indios recien convertidos, que sobre sus cuerpos desnudos car. 
gaban cnn lanza, flechas, bolas y tablachines, en quienes debír confiarse pnco, por más que hubiesen empeñado su palabra de mantenerse leales. El paso de esta pequeña caravana, reglado por el de su infantería, fué sumamente pausado. Cuestas penosisimas, caminos tortuosos y sombríos entrecortados de arroyos y cascadas que destila el monte por todas partes, la hacían extremadamente molesta, pero en contraposición, la amenidad de la más frondosa primavera y la multitud de aves y árboles poco comunes, recreaban doblemente los sentidos. En esta extraña región en que se compiten los peligros y los placeres, el barómetro se fijó en el paraje más elevado en 24 pulgadas, seís líneas $y^{4} / 3$ sin que el termómetro pasase de $8^{\circ}$ en la escala de Reaumur, pero no es esta altura la del verdadero $\mathrm{Ca}$ raballo; otro monte á la izquierda de éste, que se eleva al parecer más de 500 varas sobre su mismo yugo y toma la forma de un pan de azúcar, cs el que ostenta este título.

Ya vencidos estos obstáculos que los mismos religiosos caracterizaban constantemente como invencibles, la continuación de las tareas de D. Antonio Pineda, resultaba sí, algo ménos penosa y más sociable; pero en desquite era mucho ménos saludable por las continuas emanaciones de un terreno al mismo tiempo cargado de minerales y de humedad. Las amenas orillas del Nuevo Tajo, en cuyas fértiles márgenes los religiosos Dominicos han formado de medio siglo á esta parte poblaciones numerosas con título de misiones, ofrecían nuevos objetos sumamente interesantes. "Estas sociedades nacientes en que bajo un gobierno semipatriarcal, se presenta el hombre en los diversos aspectos de su civilización; en que se examinan sin embozo las costumbres sencillas del salvaje, su frugalidad, sus rencores y sus necesidades recíprocas, su docilidad y su inconstancia; estas pruebas sensibles pero constantes de las debilidades del hombre cuando no subordina sus pasiones á una razón ilustrada, eran la contemplación frecuente del filósofo observador; pero sobre todo merecieron su admiración los prudentes misioneros que con la dulzura de su trato civilizan aquellos montaraces: estos benéficos hombres, condenados con un corto sínodo á habitar perpétuamente entre inficles, removidos de toda sociedad en parajes mal sanos ó arriesgados, expuestos siempre á las astucias é inconstancias de los bárbaros, sufren pacientes sus repetidos engaños; insensibles á la sed, al hambre, al cansancio, trepan á pié por las más ásperas cuestas, atraviesan los ríos, colgados ó arrastrados de un bejuco, sin apartarse jamás de su memnria el horrornso martirio en que han perecidn muchos otros."

La parte lncal la constituyen una conti- nuada serie de valles que progresivamente se sưceden, estrechados por ambas cordilleras que caminan á encontrarse. Los tejidos, el algodón y el cacao, proporcionan á sus habitantes una descansada subsistencia que empieza á ser prolífica desde la edad de doce años y da á los Pangasinanes (laboriosos catalanes de esta isla) un lucrativo comercio con el cambio de aquellos frutos. No había objeio alguno que evadiese á la atenta y filosófica especulación de D. Antonio Pineda, pero su salud empezaba á no estar de acuerdo con sus deseos, molestada desde los primeros pasos; "pues la repentina alteración "del temperamento en este nuevo terreno y los "fríos del Caraballo, le hincharon la órbita iz"quierda, y una molesta fluxión le detuvo ence"rrado algunos días.

"La común enemistad que reina entre las "varias naciones habitadoras de Luzón, no per" mite viajar pacíficamente si no es por las pro"vincias marítimas; los caminos interiores se " encuentran siempre cubiertos de armados gine"tes provistos de lanzones, corazas ó escudos "cuadrilongos y encorvados, flechas, arcos, chu"zos de caña y espartanas de la pesada palma "del burí. Para librarse de las sorpresas en los "desfiladeros y montañas, es forzoso pedir auxi"lio al Alcalde ó Teniente del partido que pro"vee la escolta y las armas necesarias. En los " parajes aboscados se echa pié á tierra, se en"vían delante las guías, y las hileras de guerre"ros siguen exactamente sus huellas, que se pro"curan borrar para encubrir la derrota. Los za"catales, sembrados á veces de duras puntas por "los enemigos, no se transitan sin un buen reco"nocimiento, y nadie pone el pié sino donde otro "lo puso: de noche se forma un pequeño campa"mento, $y$ las picas clavadas en el suelo sirven "de parapeto al cordón de centinelas."

Las cuestas de Abungul y Mamparang, siguiendo hacia el Esnordeste de Bagabag en la espaciosa cordillera que corre del Sudoeste al Nordeste, forman un puerto elevado que termina los grandes valles de Ituy, donde nuestro viajero volvió á poner en ejecución sus prácticas militares. Este elevado paraje, aunque algo menor que el Caraballo, presenta no ménos agradables perspectivas; su extensión horizontal es de ro á r 2 leguas, contiene bosques, llanadas, terrenos entrecortados, ríos y lejanas serranías, que varían y amenizan aquel cuadro.

En las faldas del Mamparang sesteaba una caravana de más de 40 personas de los pueblos de Bayombong y Bamgabag, que iban á proveerse de sal, aceite de coco, lati y algodón á las tierras bajas; se componía de hombres armados y de mujeres cada una con dos caballos, y estaban atrincherados con las petacas delante de su vivac, de que puede deducirse el penoso progreso 
Jun. de este comercio y los cortos recursos de estas provincias internas.

Todos los terrenos que corren hacia Cagayan empiezan á declinar desde el Mamparang: las eminencias se aplanan y van progresivamente suavizándose. Una veta de cerros que se descubre á trechos, ocupa todo el país desde Carig hasta Sama: estos pueblos, los de Camarag y Cagayan, formados sobre ella, carecen de frondosidad y buenos pastos. De un plantío de 3.000 piés de cacao, apenas prenden 300 , pero de calidad sobresaliente. Los recodos del río fecundan los arrozales, y á éstos les deben la subsistencia. Describiendo esta parte del país que recorría D. Antonio Pineda, lamenta la deplorable situación de algunos pueblos ó rancherías, á quienes por solo las conveniencias del camino han arrancado de su primitivo asiento, privándoles de las ventajas del riego.

No bastaban aún todas las adversidades que hasta aquí se habían opuesto con tanto tesón á nuestro viajero incansable; en Carig estuvo á punto de que pereciesen sus trabajos por un incendio repentino que redujo á cenizas el convento; este accidente, si bien no pudiese evitarse con todas las medidas que le dictó su actividad é inteligencia, fué causa de que puedan en 10 sucesivo evitarse otros muchos, mediante un reglamento de policía que entregó al Padre Misionero para semejantes casos, y que éste se ofreció á comunicar inmediatamente á las demás poblaciones.

Desde Ganig, primer pueblo de la jurisdicción de Cagayan, donde llegó el 30 de Mayo, se empieza ya á navegar por el anchuroso río: su cauce en los parajes medios no baja de roo á I5O varas, y sus frondosas orillas alimentan frecuentes objetos de admiración. Los pueblos de Ilagan, Tamavien, Guagua y otros varios, situados en sus márgenes ó comunicables por esteros, tienen un muelle ó rampa para el desembarcadero, viéndose comunmente al lado algunos camarines flotantes y una ú otra panga. Estas extrañas embarcaciones sin quilla, presentan su fondo plano en figura de una artesa; dos gruesas curvas á popa y proa fortifican las obras muertas, y tienen sus carrozas bien tejidas de bambú y palma. Todos los pueblos que constituyen la provincia hacían un buen comercio con el tabaco; sus créditos de ser el mejor de la Isla atraía á los pangasinanes é ilocos que lo compraban con ansia: estancado en el día no aprovecha cosa considerable á la renta; mantiene diez empleados y ha destruído totalmente aquel comercio. La cosecha de la cera, que exige un temperamento templado, ni muy seco ni muy lluvioso, ha disminuído también, y el cacao no progresa.

Los pueblos de Tupiparao y Puig, Amuling,
Nasipin y Gattara proporcionaron á nuestro via- Jun. jero la nación numerosa de los calingas, á quien poder examinar. El Vicario del primer pueblo, el Padre Lobato, le fué sumamente útil. "Su avan" Zada edad, su venerable semblante y su desali"ñada compostura, le daban un aspecto monacal "al cual añadían veneración, sus tareas apostóli»cas realmente singulares y las diversas obras "que ya tiene publicadas: en él encontró un "verdadero hombre de mérito á quien debió un "decidido cariño, y á su experiencia y observa"ción continuada, una multitud de noticias inte. "resantes con que aumentar y confrontar sus "trabajos."

Lalloc, cabecera de la provincia y residencia de su Alcalde, goza del título de ciudad por sólo esta circunstancia, sin que lo merezca en lo demás. Habitan en ella algunos españoles que trafican en sus barcos, pero su ténue comercio, consiguiente á las tristes circunstancias en que se halla la provincia, no les permite enriquecerse. Sus vecinos, nada afectos á la agricultura, se dedican al tráfico de la sal y otros cortos efectos que transportan por el río; hay, no obstante, bastante aplicación á los tejidos, apenas se encuentra una mujer que no tenga su telar, si bien estos son tan poco ventajosos, que duplican el trabajo y alargan infinito la labor. Cuando se les encarga hacen pañuelos que podrían competir con los finos de la costa de Coromandel, pero no tienen valor porque les falta el fomento y la salida.

La ciudad, situada entre un bosque de platanares, tiene al Este una elevada cordillera que corre en forma de barba, distante Io ó I.2 leguas, y por el Sur forma horizonte la llanada. D. Antonio Pineda daba en todas estas ocasiones una prueba nada dudosa de su excesiva atención á todas las tareas útiles, anotando las marcaciones y distancias desde todas las torres y parajes eminentes, á cuantos objetos notables se des. cubrían.

Nuestro observador advierte que las aguas impuras del Cagayan propagan entre sus habitantes las obstrucciones del hígado; hombres jóvenes, mujeres de todas edades se veían adolecer de este mal: los vientres abultados y las durezas son comunes; sin que en toda su peregrinación advirtiese media docena de personas de hábito sanguíneo; observación tanto más verídica, cuanto que empezaba á comprobarse funestamente en toda la comitiva. El pintor, achácoso desde que bebió sus aguas, se agravaba por instantes, y el mismo Pineda, atormentado de una fiebre ya dc algunos días, no podía, sin grave molestia, continuar sus tareas.

Los pueblos de Aparri y Banqui, apenas le permitieron algunas observaciones ligeras. Este último, en donde llueve lo más del año y hay seis 
meses en que no cesa, goza de un temple tan húmedo que el higrómetro indicaba $6^{\circ}$ más que en los pueblos anteriores: sus indolentes naturales, sin barcas ni cosa que indique navegación, pescan al anzuelo $\mathrm{y}$ viven en todo con gran miseria.

La salida de cste pueblo puede considerarse por la Nación como la verdadera época en la cual ha perdido uno de sus mejores adornos. Todos los apuntes de $\mathrm{D}$. Antonio Pineda, con algún desconcierto en sus noticias, con los rumbos equirocados y en perpétua contradicción, empezaban a dar las primeras muestras del fatal estado de su redactor. Enflaquecida la memoria, confundidas yá las especies, y el cuerpo postrado en un talabón ó cama portátil (conducido por indios) no dejaba desembargada otra potencia que la voluntad: envejecida ésta en el perpétuo trabajo, se esforzaba en vano á continuarlo. Debilitados los órganos y trastornada la mente, obraba á ratos con desconcicrto, anunciando en todo, los indicios de la humanidad que perecía. Perseguido de un excesivo ardor que lo iba conduciendo hacia su fin, procuraba, erradamente, templarlo con li monadas y refrescos exteriores, que sobre extre madamente ácidos le eran quizás muy nocivos; en vano le exhortaban cuantos le veían, al sosiego y á procurarse otras medicinas más análogas: seducido del pasajero deleite que éstas le proporcionaban, clamaba por seguir en sus tareas y regresar á Manila.

Conducido como en un letargo con frecuentes desarreglos de sentidos que advertían hasta los mismos indios, luchaba contra el destino que le llevaba de vencida; pero sin dejar jamás de des. cribir los terrenos y formar su itinerario. Llegó últimamente á Badoc, pueblo de la provincia de Ilocos, administrado por los Padres Agustinos, á veces nuevamente aletargado, siempre inquietó sobre la continuación de su viaje para el cual había tomado ya las providencias más activas, amante en los pocos intervalos tranquilos de conversar aún con el religioso sobre el fatal objeto desus tareas; nada dócil á las insinuaciones del Padre para la calidad de sus alimentos y la neccsidad de un reposo, ni á los dictados de sus mismos conocimientos médicos para precaverse con el útil método de laș sangrías, ó no creía tan próximo el término de sus días, ó entregado desde mucho tiempo á un celo patriótico y á un amor incansable á. las ciencias, le veía ya muy de cerca con una superioridad y tranquilidad filosóficas.

Isí pasó todo aquel día, y en aquella misma noche le sobrevino un accidente apoplético, del cual no volviendo ya (tal vez por la poca pericia del curandero indio) sino para dar mucstras al Padie de un alma tan firme en su religión como lo había sido en sus deberes sociales, telminó n la noclie del 23 la groriosa carrera de su vida los treinta y ocho años de edad.
No es fácil encerrar en pocos renglones el elo- Jun. gio de un vasallo tan esclarecido y los trances aún más singulares de su vida.

Don Antonio Pineda, después de una educación adecuada á su nacimiento, había entrado á servir en clase de cadete en el regimiento dc Reales Guardias de Infantería Española: su carácter sociable, su amor al estudio y su idea bien entendida de los deberes hacia la patria, muy luégo le dictaron la necesidad de ensanchar, cuanto fuese posible, sus conocimientos. Los que había adquirido con preferencia y eran los del arte militar, se hicieron bien patentes en los ataques de Gibraltar durante la guerra empezada en I779, quedando bien cimentados, cuando sin nombre del autor se presentó y practicó un plan suyo para el detall de las operaciones del Ejército, dirigidas en la noche del I3 de Agosto á abrir la nueva paralela: sus servicios fueron igualmente distinguidos y su vida extraordinariamente expuesta en la batería flotante La Pastora, en la cual, y en el encuentro sucesivo de las dos Escuadras á poca distancia del Cabo Espartel, sirvió á las órdenes del Jefe de Escuadra D. Bue. naventura Moreno. Finalmente, hecha la paz y desdeñando vivir en una cansada ociosidad ó tomar por único objeto de sus tareas la destrucción de sus semejantes, volvió el rostro hacia la Física y la Historia Natural, en cuyas ciencias había adquirido ya muchas nociones generales. Su constancia y su talento le llevaron muy luégo á un grado bien provecto en una y otra ciencia, y su celo patriótico y pundonoroso le dictó la ocasión de aprovecharlas en la expedi. ción de las corbetas Descubierta y Atrevida al mar Pacífico; cuál haya sido después la serie de sus tareas útiles para los hombres en general y para sus conciudadanos en particular, lo manifiestan la narración del viaje y la inscripción puesta en el monumento elevado á su memoria en las inmediaciones de Manila, y lo manifestará aún más la publicación de todas sus observaciones, las cuales redoblaron en su variedad, multiplicación y utilidad, justamente cuando las gracias del Soberano, el aplauso de la Nación, una rica herencia de los bienes de su familia, y sobre todo, los ruegos incesantes de sus compañeros de viaje, debían recordarle las satisfacciones honoríficas que le esperaban á su regreso á la patria.

Dividido así repentinamente y para siempre de sus compañeros, no pudo ménos de ocuparlos después incesantemente con su memoria. En un momento perdieron un ejemplo acrisolado, un hombre extraordinariamente humano, un filósofo con exceso jnstruído y laborioso, un amigo siempre sociable y un compañero afable y ameno. I estas pérdidas por sí solas irreparables, debieron agregarse luégo las que hạcían de mancomún con 
Ju1. Ia Nación, sus ideas tan grandiosas como cabales sobre el suelo y los habitadores de casi todo el continente americano sujeto á la ilonarquía; sobre el beneficio comparativo de los minerales; sobre el análisis de los idiomas, y sobre la policía, situación y costumbres de nuestras colonias, si bien en parte apuntadas entre sus cuadernos, perecieron casi enteramente con él. ¡Infeliz suerte del hombre, que no derivando su felicidad sino de la felicidad agena, este mismo afán le causa mil sinsabores y lo arrastra frecuentemente á malograr su intento por su propia debilidad!

Jul. ${ }_{3}$ No se supieron las noticias en Manila sino en la tarde del I 3 de Julio; para el I6 se tributaron á su memoria en la iglesia de San Agustín las pompas fúnebres y las exequias más solemnes; inmediatamente después se ocuparon D. Juan Rabenet y D. Fernando Brambila, el primero en representar con la mayor propiedad á la nación que lo ha perdido el extremado lance de este buen vasallo y el segundo en diseñar y hacer elevar en la huerta de Malate, propia de la Real Compañía, un monumento fúnebre que recordase á la posteridad nuestra pérdida y nuestras lágrimas, las que dejó grabadas D. Tadeo Heenke con la siguiente inscripción latina:

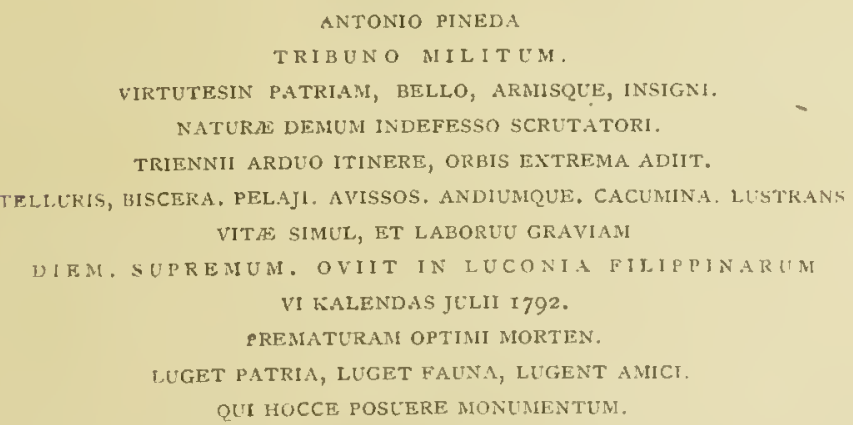

En el entretanto había establecido su imperio la monzón lluviosa del Sudoeste, la cual por un conjunto feliz de combinaciones debe mirarse en Manila como la más saludable; restable-. ciéronse nuestros enfermos, se continuaron paulatinamente los aprestos de los buques, víveres y pertrechos para la continuación del viaje, y si bien las aguas fuesen tan repetidas que en sólo cinco días no bajase la lluvia de 30 pulgadas y llegase en los cuatro meses comprendidos hasta Octubre á ochenta y seis, pudieron acelerarse las medidas de tal modo, que no esperásemos para dar nuevamente la vela sino una constancia mediana en los vientos favorables del Nordeste.

Desde la mitad de Setiembre habían ya emprendido nuevamente sus excursiones D. Luis Nee y D. Tadeo Heenke, para sus acostumbradas investigaciones de Historia Natural, dirigidas ahora en las inmediaciones de la Laguna de Bay, á un nuevo examen de los plantíos de canela, á los análisis de diferentes aguas termales, y particularmente á un reconocimiento prolijo del volcán recientemente extinguido de Taal.
Al mismo tiempo 1). Antonio Tova hizo una Jul. .: nueva excursión hidrográfica en la provincia de Tayabas, hacia las ensenadas de Paquilao y de Bondoc, donde no habían podido penetrar nuestras marcaciones con las corbetas cuando reniámos de Sorsogon; finalmente, D. Felipe Bausá examinó con una exactitud geométrica las son. clas inmediatas al tiro de cañón de la plaza, y los demás puntos al andar del rio Pasig y de la Laguna, para que en lo venidero no se ignorasen todas las ventajas locales de aquellos contornos felices.

Establecióse después el observatorio en $\mathrm{Ca}$ vite para arreglar nuevamente la marcha de los relojes marinos, completáronse las tripulaciones con naturales voluntarios, y el Capitán inglés Dunlop del navío mercante el Yarmouth, tomó á su cargo conducir á aquella colonia nuestras remesas y cartas, para que descle alli se condujesen á Lóndres y últimamente á España, ya que no había en la colonia nuestra embarcación alguna de la Compañía, que regresase al Continente. Fuera injusto de nuestra parte no hacer aquí una honrosa y particular memoria de aquel hábil navegante, el cual alcanzado en los primeros días de Mayo el puerto de Macao, habíase propuesto ahora regresar igualmente contra monzón por el Estrecho de Macassar. costeando antes las Filipinas. Un temporal violento le obligó á arribar desde el extremo meridional de Mindoro, y debió ya determinarse á esperar la otra monzón para seguir después por la derrota común del Estrecho de Malaca.

Le debimos la noticia de varias determinaciones hidrográficas en los mares de la India, según las observaciones más modernas y más exactas de sus navegantes; le debimos la nueva carta de Robertson de los mares de las Molucas, Filipinas y China, que tanta claridad producía sobre las navegaciones modernas; le debimos, finalmente. una amistad $y$ un aprecio tan instructivos quc no podrán jamás borrarse de nuestra memoria.

Antes de abandonar la bahía fué tambien una ocupación no mediana para entrambos armamentos, la de aparejar una goleta que á las órdenes del primer Piloto D. Juan Maqueda, agregádole como segundo D. Jerónimo Delgado, debía emplearse en los seis meses próximos en continuar la descripción hidrográfica de las Islas Visayas ó Filipinas meridionales. Reconociniento importantísimo, así para los desembocaderos al mar anchuroso desde los Estrechos de San Juanico y Mindanao, como para la facilidad cle las navegaciones internas que muy luégo habían de repetirse con el aumento de la prosperidad nacional. Quedó luégo al cargo del T'cniente de fragata D. Martín de Olavide continuar con la orde. nación prolija de nuestros manuscritos, y regresar últimamentc á España en la Nao de Acapul- 
oct. co con los papeles originales que formasen el duplicado de nuestras remesas anteriores. Así evitábamos el riesgo de cualquiera pérdida sucesiva $y$ se iban paulatinamente reuniendo en Europa, una parte no mediana de nuestros Oficiales, que dando la última mano á las tareas ejecutadas, acelerasen en lo posible la publicación del viaje.

Finalmente, en la tarde del $\mathrm{I}_{4}$ de Noviembre todo estuvo pronto para dar la vela; al amanecer del día siguiente las corbetas. se espiaron para fuera, y poco clespués, con los primeros soplos del viento Este, navegaron hacia la boca de Mariveles.

\section{CAPÍTULO IV}

Navegación de las corbetas hasta el presidio de Mindanao, y reconocimientos intermedios. - Escala en aquel presidio.-Derrotas sucesivas en el mar Pacífico.-Vista del extremo Sur de la Tierra austral del Espiritu Santo y de las costas immediatas á Dusky-Bay en la Nueva Zelanda. - Escala y acaecimientos en la colonia inglesa de Sidney, en la Nueva Holanda.

Cuanto más examinásemos las navegaciones de los europeos en el mar Pacífico; cuanto más se atendiesen los objetos, la fuerza, la constitución y la utilidad de los armamentos de las corbetas Descubierta y ATrevidA, tanto más debía variar nuestro plan de los que habían seguido los navegantes anteriores; y abandonada la esperanza de podernos llamar descubridores, debía. mos dirigir las investigaciones nuestras á los progresos sólidos de la navegación y al desempeño de los diferentes ramos científicos, con los cuales nos habíamos abrazado.

Exigía, por otra parte, este plan, que visitásemos una vez más los diferentes paralelos de la América meridional, en donde debían repetirse las experiencias de la gravedad de los cuerpos con el péndulo simple constante, que atento á la medida proyectada en Europa, invariable y dependiente del mismo péndulo en un paralelo determinado, se consultase particularmente el de $45^{\circ}$ en el hemisferio austral; y finalmente, que reconocido el pequeño Archipiélago de Baban, parte de las Islas y confederación de los Amigos, donde había casualmente recalado el Teniente de fragata D. Francisco Maurelle en I789, se rectificasen después varias cuestiones hidrográficas, bien sea al Oeste ó al Este del Continente de la Imérica.

$\mathrm{Ni}$ nuestros almamentos podían considerarse capaces de mayores esfuerzos, aunque tuviesen á su frente una Oficialidad hábil, constante $y$ digna de los mayores elogios, pues debilitados enn las enfermedades propias de los Trópicos y con las fatigas de tres años los pocos restos de Nov. Is las tripulaciones y tropas sacadas de Europa, y sustituídos los que faltaban con un número crecido de filipinos débiles y poco expertos; ni podíamos contar con aquella disciplina, inteligencia y humanidad que decide por lo común de la suerte de los viajes, ni su robustez era capaz de resistir unas fatigas repetidas y violentas. Se adoptaron con este mismo reparo todos los preservativos que pudiese dictar la práctica sobre la conservación de la marinería nacional; sustituímos el uso del Grog ó aguardiente aguado, al vino de Sanlúcar que habíamos embarcado en Cádiz; la calidad de los víveres, el aseo interior, un trabajo periódico mas no excesivo, y una cierta tranquilidad de ánimo, inseparable de la conservación de la salud, fueron luego los estribos principales de nuestro plan para este intento. Así, veíamos, aunque distante, la época feliz que nos proporcionase el regresar al seno de la patria y el ofrecerle aquellas nociones prácticas que reunidas á las tareas de los demás navegantes europeos, pudiesen algún clía fijar su verdadera robustez y opulencia.

En el entretanto, nuestros pasos no podían ménos de dirigirse hacia el Sur, costeando las diferentes Islas de Mindoro, Panay, Negros y Mindanao. Ceñiríamos de este modo al Oeste el Archipiélago Filipino mientras D. Juan Maqueda lo verificaría en sus canales internos; y un reconocimiento exacto del presidio de Zamboanga, nos daría lugar á examinar por aquella parte los verdaderos intereses nacionales, decidiendo la cuestión importante y agitada desde dos siglos: si era útil ó no su conservación harto costosa y sangrienta. La brisa fresca del Esnordeste no entabló en la bahía de Manila hasta las cuatro de la tarde. La aprovechamos inmediatamente con todo aparejo; al anochecer no distábamos sino una milla del Farallón de la Monja, islote forano á la bahía; y como en la noche inme. diata continuase nuestra navegación hasta pro. pasarnos de la Isla de Cabra; en la mañana del I6 ya nuestras tareas acostumbradas pudieron emprenderse con actividad, y costeadas Luban y Ambil, atracar á las dos de la tarde la Punta Calavite y las orillas fértiles de Mindoro. La mitad septentrional de aquella isla es más bien montuosa, encadenándose unos con otros cuatro órdenes de montes que terminan en la misma orilla poblada al principio con un bosque impenetrable y más llana después con unas lomas que convidan á la agricultura, cuando se hallen ménos desiertas de lo que están en el día. No se advirtieron en la noche los muchos fuegos que habian sorprendido al Capitan inglés Meares, ni ignorábamos por otra parte que apenas en toda aquella larga extensión se anidaban pocos piratas, ocupados en la estación favorable 
Nov. s6 á veces con la pesca del balate (I) en el bajo de Apo, á veces en sus correrías acostumbradas á las Calamianes y Paragua. Es luego mucho más agradable la otra mitad de la isla que recorrimos en la tarde del I 7 ayudados de una brisa fresca con el tiempo más placentero que pudiésemos desear. Ya la costa mucho más llana y fiondosa presentaba todos los halagos de la vida sociable para que bajo un gobierno pacífico y juicioso multiplicasen hacia aquella parte los habitantes tranquilos de la orilla. Diferentes riachuelos, unas playas apacibles, la poca distancia de otras muchas islas útiles y de la misma capital, todo debía recordarnos la importancia y la utilidad de semejantes poblaciones, al paso que la vista en el horizonte, de un panco ó embarcación pirata, nos demostraba que esas mismas posesiones nos eran en extremo nocivas, por ser el abrigo de los que conspiraban con tanto tesón á nuestro daño.

Pudimos en este tránsito marcar los islotes que fijan el extremo oriental del bajo de Apo, y algunos altos de las Calamianes; costeáronse de cerca las Islas de Illin, y las otras bajas de Simiraba que median entre Mindoro y Panay; y atracadas después las frondosas y fértiles orillas de esta isla, no sin algunos amagos de huracán que se disiparon luégo, reconocimos el fondeadero de Antique, llamado con mucha propiedad el granero de Filipinas, pasamos á la Isla de Negros, y logramos en los días siguientes del 2 I y 22 mantenernos á muy poca distancia de los extremos occidentales de Mindanao.

En las navegaciones indicadas nos favorecieron las brisas del Nordeste extraordinariamente. Repetíamos á nuestro placer las observaciones de longitud y las marcaciones distantes. Eran las bases y los aparejos uniformes por la igualdad en la dirección y en la fuerza del viento. Las emanaciones saludables de mil plantas aromáticas que cubrian las orillas inmediatas, embalsamaban el aire á mucha distancia. Se recreaba la vista, se enardecía la imaginación entre tantos objetos tan varios y tan agradables; y en el corto espacio de solos ocho días, habíamos disminuído la latitud de unos $7^{\circ}$, siguiendo próximamente los meridianos del observatorio nues tro de Cavite: las corrientes, como debe imaginarse, conservaron siempre una dirección bastantemente rápida al Sur, que causaba un error de I 5 ó $20^{\prime}$ diarios en la latitud de estima y la variación magnética fué constante de $\mathrm{I}^{\circ}$ al Nordeste.

En la misma tarde del 22, declarada la marea contraria para aproximarnos á la rada de Zamboanga, dimos fondo á poca distancia del

(I) Especie de marisco conocido por los naturalistas con el nombre de Mentula marina. puerto de la Caldera en doce brazas arena, y en Nov. 22 la mañanita siguiente, apenas la tuvimos favorable, cuando levamos de nuevo el ancla, y con los remolques, ya que no había viento alguno. emprendimos el aproximarnos al presidio.

Eran importantes las precauciones que nos habían indicado en Manila para este caso, y es tribaban particularmente, en la necesidad de conservar una grande inmediación á la costa para no ser arrastrados por la marea á un fondo crecido y de mala calidad, como también en la atención de no apartarnos á más de dos cables de la playa cuando diésemos fondo, para no encontrar las muchas piedras sueltas que á mayor distancia le hacen bien molesto y peligroso. Entrambas precauciones, sin embargo, pudieron costar bien caras á la DEscubierTA, pues antes conservándose á un cable escaso de la playa por sondas de I5 brazas arena, en donde la marea era más viva, se vió arrastrada por un remolino, sobre una puntita de piedra, en la cual no tuvo sino tres brazas de agua, y luégo ya inmediata al fondeadero, no logrando aún sondar sino 22 brazas, debió, en busca de mejor fondo, aproximarse de tal modo á la playa del presidio, que no pudiendo refrenar la salida aumentada á la sazón con el viento fresquito del Sudoeste, tocó, aunque levemente de proa: el alijo de las embarcaciones menores y una espía afuera, la pusieron inmediatamente en buen paraje; y para las cinco de la tarde, consiguió hallarse amarrada á dos cables de la playa, demorando la torre del castillo al Nordeste $1 / 4$ Norte. El ancla del Oeste quedó en I 2 brazas arena y en I 8 conchuelilla la del Este. La ATREvida al mismo tiempo se amarró como un tercio de cable al Oeste nuestro. El Capitán D. Francisco Aznedo, Gobernador del presidio de $Z$ amboanga, ya desde el medio día había manifestado sus deseos de explayar una atención activa, no sólo hacia los objetos de la expedición, si también hacia todos los individuos que la componían: áun hallándonos á la vela le precedió el Mayor de la plaza á cumplimentarnos; no tardó el mismo Gobernador en llegar á bordo con los pocos individuos caracterizados del presidio, y la visita sucesiva que le hicimos á la caída de la tarde, no nos debió dejar ya la menor duda que todas las medidas conspirarían unánimes á nuestro bienestar y al más breve desempeño de los objetos que traíamos entre manos.

La utilidad ó inutilidad de la conservación del presidio de Zamboanga con el doble objeto de refrenar las correrías de los piratas joloanos, mindanaos y macassares, $y$ de abrigar la fuga de nuestros cautivos, ha sido y es en el día una cuestión bien importante para los intereses nacionales: ello es, sin embargo, que la situación del presidio no puede ser más feliz, su clima más agradable ni más sano, su campiña más fértil 
Nor a y su fondeadero mís seyuro, no sólo por el natural abrigo y la casi constante benignidad de las estaciones, si también por la inmediación de dos puertos, el de la Calderáa el uno, el otro al Este. cuyo plano hará su mayor elogio. Rigen en aquella latitud las mismas monzones que en Manila, anticipándose sin embargo (como es natural) la del Sudoeste, y retardándose la del Nordeste. La casualidad de estar tendida del Este á Oeste la Isla de Mindanao, hace que sus montes no den libre tránsito al viento Norte al tiempo de mudar las estaciones, y con este motivo no alcanzan allí los huracanes, privilegio á la verdad tan apreciable como poco común en el Archipiélago filipino. La demasiada inmediación de los piratas y sus constantes osadías y ardides por lo común felices para cautivar nuestras familias, son el único inconveniente para la verdadera felicidad de aquellos alrededores.

No tardaron en hacérsenos patentes casi todas las propiedades antes indicadas. Y á pesar que no se hubiese declarado la monzón del Nordeste sino unos quince días antes, y que aún casi todas las tardes soplasen virazones frescas del Sudoeste, eran los días por lo común claros y placenteros; las noches luégo con exceso hermosas y despejadas y con unos terrales apacibles, refrescaban de tal modo la atmósfera, que nos recordaban casi el temple delicioso de las costas de Coquimbo y Lima. Pero al contrario, eran frecuentes así de día como de noche las alarmas por la inmediación de los piratas, lo cual no sólo nos debía precisar á una vigilancia contínua, si también debía hacer más tardos nuestros pasos para los reconocimientos hidrográficos; siendo preciso evitar cuanto fuese posible las correrías de noche, y emplear siempre las lanchas armadas con un crecido número de individuos. Hasta en los paseos salidas por tierra no distantes de la población, nos avisó el Gobernador que anduviésemos siempre cáutos y armados, pues no pocas veces es condidos los enemigos, aunque en corto número labían causado estragos considerables.

Desde la mañana siguiente se transportaron los instrumentos á la casa del Gobernador, quien habia insistido en querernos franquear paraje oportuno para las observaciones. Era nuestro ánimo no sólo examinar con la mayor escrupulosidad la marcha de los relojes así para las determinaciones pasadas como para las venideras, si también atianzar la longitud de aquel extremo de nuestras tareas con observaciones celestes de mucha confianza, y óbviamente repetir las expeliencias de lá graredad en un paralelo tan próximo á la equinoccial. Por casualidad, la Luna aunque brillase la mayor parte de la noche sobre el horizonte, $n o$ proporcionaba ocultación alguna de estrellas fáciles á observarse. Se cimentaban por consiguiente todas las esperanzas de los Oficia- les astrónomos sobre una inmersión del primer satélite de Júpiter visible en la mañanita del 5 del próximo mes de Diciembre.

A estas prevenciones se agregaron inmediatamente las de proporcionar á entrambos botánicos alojamiento, libertad y escolta para las sucesivas excursiones que meditaban, y la de enviar diariamente dos marineros á cortar una buena provisión de verdolagas silvestres que abundan en aquellos contornos extraordinariamente para que el caldero de la tropa y marinería no careciese jamás de tan esencial antiescorbútico. Las excursiones hidrográficas, el reemplazo completo del agua consumida, el abasto tan abundante cuanto fuese posible de la leña, y una atención constante al aseo y disciplina interiores, debían distraer y ocupar cuotidianamente á todos. Los días de fresta quedarían luégo destinados al descanso, al recreo, al esparcimiento, y digámoslo así, á los vicios, los cuales no podían á ménos de abrigarse en mucho número en un presidio de las Islas Filipinas, ni de hallar un agradable acogimiento entre unas marinerías recien salidas de Cavite: y ciertamente, cualquiera que haya recorrido con alguna atención los sucesos de este viaje ó reflexione filosóficamente sobre las calidades irremediables de los establecimientos europeos ultramarinos, no extrañará la aseguración nuestra, que mil veces, hemos deseado para la mejor conservación del marinero aquellas mismas soledades y aquellos mismos abrigos de la sola naturaleza, aunque al parecer horribles, que tanto habían ensalzado la conservación de las marinerías inglesas en los diferentes viajes dirigidos por el célebre Capitán Cook.

Hasta el medio día del 26 no se consiguieron los primeros resultados de los relojes marinos para la longitud del.observatorio. Nos había sido preciso abandonar las esperanzas de valernos del péndulo astronómico, cuya marcha resultaba con exceso irregular y sujeta á diferentes paradas, pero se le sustituyó el relój I05 de la ATrevida, al cual se agregó luégo el cronómetro 72 para las experiencias del péndulo simple, no omitiendo además la precaución de sujetarlos con los demás relojes por medio de señales para que lograsen aquellas experiencias toda la exactitud que estaba á nuestro alcance.

A las determinaciones directas de los relojes marinos para la longitud fué luégo preciso adaptar aquellas écuaciones que dictasen como más probables las comparaciones hechas en el mar y las marchas advertidas ahora. Finalmente, la longitud del observatorio pareció muy aproximada á la verdád en el modo siguiente:

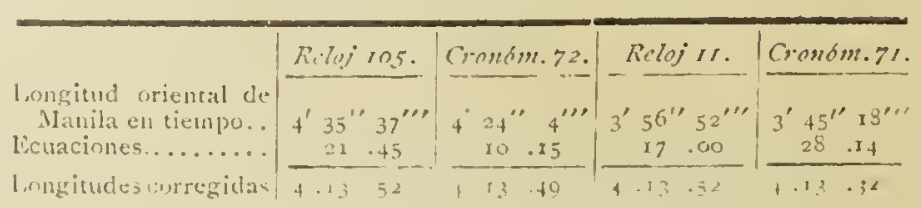


Cronom.7r.

Cuyo promedio de $4^{\prime} \times 3^{\prime \prime} 45^{\prime \prime \prime}$ daba en grado la longitud oriental de Manila de......................... I $I^{0} 3^{\prime} 26^{\prime \prime}$

Y siendo aquella por todas las observaciones del primer sa-

télite al Oeste de Cádiz. .................. 2.32.52

Resultaba finalmente la del observatorio de Zamboanga

al Oeste de Cádiz......................... $2.3 \pm .48$.30

Ya en este mismo día, que aparentaba muy sereno y apacible, se habían destacado con el beneficio de la marea de la noche los Sres. Bausá, Novales y Heenke para el puerto de la Caldera. Los conducía la lancha armada de la DESCUBIERTA, Les acompañaba un práctico con una embarcación pequeña, capaz de arrimarse á cualesquiera piedras; y como el viaje correspondiese en su prontitud á las medidas tomadas, casi desde el amanecer se había dado principio á las bases y marcaciones por una parte, y por la otra á las excursiones botánicas. Entrambos objetos pudieron considerarse completamente desempeñados para la mitad de la tarde, pero la desigualdad de las mareas no permitió el regreso hasta las dos ó tres de la mañana siguiente. Ningún rastro de piratas los había alarmado en aquella excursión.

No fué así al día siguiente, dirigiéndose Don Felipe Bausá con la misma lancha y canoa á la costa oriental del presidio, hasta donde el desagüe en el mar, del río Balabac, forma en la más occidental de sus bocas un hermoso puerto, cuya entrada en la barra del ancho de un cable no tiene en la bajamar ménos fondo de cuatro y media brazas, aumentándose luégo éstas y extendiéndose á una y otra orilla á siete, ocho y nueve brazas. Apenas habíanse concluído las sondas y marcaciones y la gente de la lancha empezado su comida, cuando de las Islas inmediatas de Numpim y Anapuyan, donde se hallaban dos canoas nuestras pescadoras, se vieron aparecer dos pancos piratas, quienes navegaban para cortarles la retirada hacia la costa, siguiéndolas luégo hacia ella, aunque viesen frustrado su primer intento, fué preciso que para el abrigo de las canoas saliese nuestra lancha, la cual, apenas avistada por los perseguidores, los hizo retroceder y dirigir sus rumbos hacia la Isla de Basilan.

No quedaban ya para terminar las tareas hidrográficas sino algunas marcaciones en las islitas fronteras de Santa Cruz, que ligasen oportunamente los extremos de nuestras operaciones con todos los puntos de la Isla no distante de Basilan. Fueron éstas en la mañana del 29 las tareas de nuestros Oficiales con la lancha armada de la ATrevida y no se omitió al mismo tiempo la ocasión de sondar con la canoa todos los alrededores, y particularmente, el canal que forma con la isla más Este, el arrecife que sale de la otra en aquella misma dirección. Medida última- mente una base en la playa del presidio y son- Nov. 29 dadas con marcaciones de dos teodolitos las in. mediaciones del fondeadero por el Piloto Inciar te de la ATREVIDA, este ramo esencial de la expedición pudo considerarse felizmente concluído, y por consiguiente, ya no distante la época de la continuación de nuestro viaje.

No se habían descuidado en el entretanto los demás objetos que indicamos al principio: los bombos armados y bajo la dirección de un sar. gento ó condestable, iban diariamente al corte de la leña en la embocadura del río inmediato de Tumaga, punto que teníamos á la vista y podíamos socorrer á cualquier instante.

Don Juan de la Concha había ya conseguido en la noche del 29 observar algunas alturas meridianas de estrellas, de las cuales resultaba la latitud del observatorio de $6^{\circ} 54^{\prime} 30^{\prime \prime}$; se habían hecho á bordo todos aquellos arreglos que fuesen necesarios de arboladuras, aparejo, velamen y estiva; las lanchas ya desocupadas podían emprender con mayor actividad el corte de leña; y los bombos trabajar con mejor éxito en la conducción del agua, que se hacía con la mayor comodidad delante del fuerte. Finalmente, nuestros rostros y la misma agilidad y satisfacción de todos, indicando ya patentes los buenos efectos de una escala tan sana como agradable, nos recordaban al mismo tiempo que ya debíamos abannarla.

Hasta el día I. ${ }^{\circ}$ de Diciembre (particularmente estando el Sol sobre el horizonte) los vientos se habían mantenido fresquitos del Noroeste al Oeste, moviendo á veces alguna marejada que en la actual posición nuestra de distar un solo cable del poco fondo, no dejaba de causar algún cuidado; agregábase que los habitadores del presidio anunciaban para el próximo novilunio un temporal por aquella parte, no bien arraigada aún la monzón nueva del Nordeste; debían por consiguiente ser doblemente fuertes los impulsos para abandonar el fondeadero, pues esta revolución (si acaso la hubiese) que podía sernos fatal estando al ancla, nos sería al contrario sumamente útil á la vela, en una navegación contrariada al mismo tiempo de los vientos y de las corrientes. Además, el tiempo favorable para nuestras investigaciones en el hemisferio austral iba pasando rápidamente, y nada podía justificar una demora más dilatada en aquel puerto, concluídas el día 2 las experiencias de la gravedad, cerrado el examen de la marcha de los relojes marinos y retirados á bordo la tienda y los ins. trumentos del observatorio.

Quedó prefijada la salida para la mañanita del 6, á cuyo tiempo lográbamos también com. binar la marea favorable con los pocos soplos del terral y proporcionar á los botánicos un plazo suficiente para la completa preparación de las 
plantas que en mucho número y de un mérito singular habían acopiado en aquellos contornos: se aprovechaba así también, como lo habíamos deseado, la inmersión del primer satélite de Júpiter, visible en la mañanita del 5, y los demás Oficiales no estarían tampoco ociosos, agregando á las determinaciones ya hechas de la longitud del observatorio, un crecido número de distancias de la Luna al Sol, que se proporcionaban con el cuarto menguante.

En los días 3 y 4 fueron efectivamente muchas las observaciones de esta especie que se repitieron en una y otra corbeta con las circunstancias más favorables. La mañanita del 5 proporcionó igualmente á los Sres. Espinosa, Concha y Ccvallos, observar con no ménos felicidad la inmersión del primer satélite de Júpiter; los resultados de uno y otro fueron los siguientes:

Por la inmersión del primer satélite de

Júpiter longitud occidental de Cádiz.

Por los relojes marinos, aplicadas las ecuaciones.

Por un promedio de distancias de la

Luna al Sol, en la corbeta ATREVIDA.

$231^{\circ} 44^{\prime} 30^{\prime \prime}$

$231 \cdot 48 \cdot 30$

Por 8 i íd. en la corbeta Descubierta.

$231.13 \cdot 15$

230.56 .15

Admitióse, como era natural, la determina ción del primer satélite de Júpiter, y las tablas de la marcha de los relojes marinos siguieron arre glándose al meridiano de Manila, atento á la diferencia que acabamos de deducir por ellos y que confirmaba el satélite.

Nos disponíamos en la misma mañanita para ejecutar la salida al día siguiente, y la lancha de la DEscuBIERTA acababa de enviarse á tierra para recoger los últimos restos de la aguada y refrescos, cuando hacia las ocho se vieron salir de las costas intermedias entre el presidio y la Caldera, tres pancos piratas, que insultando con muestras poco equívocas de audacia á las fuerzas del presidio, cuyo alcance creían imposible; acababan además de cautivar en las playas hasta seis individuos de ambos sexos que habían hallado mariscando descuidadamente. No tardaron sino pocos minutos en correr en su alcance con el mayor denuedo un panco y un batalangán ó embarcación chica de remo, entrambas con tropa del presidio; fuerzas inferiores con tanto exceso á las de los enemigos, que debían causar admiración á los poco expertos en esta especie de guerra, mucho más cuando la embarcación menor, con sólo siete hombres, aprovechaba toda su ventaja de andar sobre la conserva para estrecharse lo más pronto con los enemigos, los cuales iban alejándose por el canal que forman las dos islas chicas y navegaban (ya con vela) hacia la isla de Basilán.

La inferioridad de nuestras fuerzas perseguidoras, el insulto de los piratas y nuestro mismo deber, no nos podían dejar espectadores tranqui- Dic. 5 los de lo que pasaba, áun cuando no hubiésemos recibido al mismo tiempo una instancia del Gobernador para que nuestros buques menores cooperasen al alcance de los enemigos. Así, desde el primer instante de su aparecimiento, la ATREVIDA había aparejado y armado su lancha á las órdenes de D. Antonio Tova, de suerte que pudo con facilidad alcanzar las fuerzas del presidio, y la lancha de la Descubierta (que habíamos llamado inmediatamente) con los dos botes de las corbetas, pudo formar una segunda división capaz de operar con actividad en la caza y en los ataques: se había embarcado D. Juan de la Concha en el bote de la ATREvida: la lancha de la DEsCUBIERTa iba á las órdenes de D. Fernando Quintano, y el Piloto Hurtado cuidaba del bote; siendo á la sazón bien difícil refrenar en una y otra corbeta el deseo general de embarcarse para el perseguimiento indicado.

Favorecía mucho á las operaciones de esta segunda división, la doble casualidad de haberse ya ocultado detrás de la isla más Este los pancos piratas, de suerte que no pudiesen advertic estos nuevos perseguidores, y la de haber refrescado mucho el terral para que no fuese difícil á nuestros buques el doblar al Este de las islitas y tal vez sorprender por el frente á los enemigos: á una y otra división se había de antemano prescrito que cubriesen siempre los buques del presidio, y que en cualquier caso inopinado bien fuese favorable ó adverso, operasen de concierto, pero no se cebasen en una caza probablemente infructuosa, que pudiera alejarles de las corbetas por un plazo largo. Fueron más bien contrarias las circunstancias á la división del Oeste: entre las islas calmó enteramente el Nordeste y aún tuvieron ventolinas de la costa de Basilán, que les precisaron á valerse del remo para montar las restingas salientes y vencer la marea contraria, pudiendo así los piratas alejarse considerablemente y perderse poco después de vista al abrigo de la costa á la cual se habían atracado.

Pero todo prometía un éxito favorable á la otra división, la cual ocultada á nuestra vista con la isla grande una hora después de su salida, y no abandonada del viento, con fuerza de vela y una ventaja considerable de andar, había estrechado á los enemigos hacia una ensenada en la cual parecían determinados á varar ó á eva. dirse con el auxilio de diferentes ríos que en ella desembocan.

$\mathrm{Ni}$ efectivamente su ánimo podía ser otro, atento á las circunstancias en las cuales se ha. llaban. Sin embargo, ya dueños de este partido, y advirtiendo una calma total sobre la costa, á cuya sombra bien espesa se habían ocultado para todos ménos para D. Fernando Quintano, determinaron con mucho tino y astucia no ma- 
Dic. 5 lograr las dos ventajas considerables que estaban á su favor, y eran la de una marea ménos fuerte y de una cómoda navegación al remo. Así, hecha inmediatamente proa al Este $\mathrm{y}$ al andar de la costa, conocieron que sus conceptos eran fundados. En balde D. Fernando Quintano orzó al momento para aprovechar del viento un rumbo que los estrechase de nuevo; en balde, caído poco después el terral, hizo que los soldados ayudasen á la marinería en el remo y que ésta no omitiese esfuerzo para una boga acelerada; todo fué inútil; y á las dos de la tarde, franqueada ya una navegación libre por los piratas, fué preciso dejar la caza y determinarse al regreso.

No fué ménos activo D. Antonio Tova, el cual guiado del patalangán del presidio, recorrió un trozo considerable de costa creyendo hallar ras tro de los fugitivos; pero á las tres de la tarde debió decidirse al regreso, y todos quedaron incorporados á sus buques al principio de la noche.

Este accidente y las faenas dilatadas de anclas que debían preceder al dar la vela, nos aconsejaron como prudente el diferir la salida para el día siguiente. El descanso de las tripulaciones fué así más completo, no debieron precipitarse los aprestos, se logró un nuevo acopio cuantioso de verdolagas para la gente, y pudieron perfeccionarse los últimos frutos que la expedición debía tributar á aquella parte casi olvidada de los dominios de S. M.

Consistían éstos en los planos de unas lanchas cañoneras, adaptadas á la artillería, gente y objetos que prescribió el Gobernador y trazó con mucho tino el carpintero de la Descubierta D. Juan del Río Miranda, y en los dibujos de la iglesia y casa del Gobernador que debían reedificarse muy luégo, y que formó D. Fernando Brambila, sujetando con mucho pulso á una arquitectura bien ordenada todas las circunstancias poco favorables para estos nuevos edificios.

Al anochecer del 6 , todo quedó pronto para dar la vela, y á la media noche, empezando á parar la marea, se emprendió el levar un ancla, cuya faena no siendo (como lo habíamos imaginado) fácil, por estar esclavizada la uña nuestra con el cable de la ATREvida, nos detuvo hasta las cuatro de la mañana. A esta hora ya la marea era favorable y se apercibían algunas ventolinas del terral, con las cuales y los remolques, no tardamos en emprender la salida seguidos á corta distancia de la corbeta compañera.

A las ventolinas casi imperceptibles del Nordeste y Norte que reinaban al tiempo de abandonar las corbetas el fondeadero de Zamboanga, siguieron al rayar el día, contra nuestras esperanzas, vientos algo más entablados, los cuales muy luégo nos ocultaron de la vista del presidio, hicieron después inútiles los remolques, y nos condujeron para las nueve de la mañana á desem- Dic. 7 bocar entre la isla de Cocos y la más Norte de las de Sibaj. No podía desearse un tiempo más placentero: la costa de Basilán al Sur y la de Mindanao al Norte, se presentaban á nuestra vista con el semblante más ameno. Las muchas islitas que median entre aquéllas, no descubriendo peligro alguno en sus canales, multiplicaban así los objetos agradables para el navegante; y las marcaciones repetidas con tales ventajas á los muchos puntos bien terminados, nos hacían esperar en nuestras cartas de aquella costa, una exactitud correspondiente.

Al medio día ya nos hallábamos unas siete leguas al Este del fondeadero, por latitud de $6^{\circ}$ $48^{\prime}$. No eran sensibles los efectos de la marea, y la variación magnética, así por los azimutes como por la amplitud, parecian confirmarse de $0^{\circ} 30^{\prime}$ al Nordeste.

El plan propuesto no dejaba dudar que debíamos conservarnos atracados á la costa de Mindanao, en donde los vientos de la monzón, confundidos con los terrales, serían probablemente más largos y constantes, y en donde no sería difícil la continuación de las tareas hidrográficas, tanto más útiles ahora, cuanto que el viaje del Capitán Tomás Torrest, con unas equivocaciones tan multiplicadas como culpables, podía envolver al navegante en muchos errores sumamente peli. grosos.

Abandonados, como absolutamente ageno de nuestra derrota, todo el golfo por una y otra orilla que fuese más septentrional del paralelo en el cual nos hallábamos, y hechos rumbos del Este con los vientos flojos y variables que tuvimos desde el anochecer; para la siguiente mañana apenas veíamos al Sur $77^{\circ}$ Oeste el pico Este de Basilan, y al ponerse el Sol, ya veíamos nuevamente al Este, bien que á muy larga distancia, las costas contíguas á Mindanao, que corren luégo hasta su extremo Sur, inmediato á las Islas de Serangani. En balde á la noche anterior y en todo aquel día habíamos intentado hallar fondo, á veces con 50 , á veces con 90 brazas de sondaleza. Notábamos, sí, algo aumentada la variación de la aguja y una corriente favorable al Este. El tiempo, aunque frecuentemente calmoso, se mantenía hermoso y agradable.

Desde la mañana siguiente fué fácil emprender los reconocimientos acostumbrados, habiendo navegado en la noche anterior en demanda de la costa: á las seis sus extremos demoraban al Norte $22^{\circ}$ Este distancia 6 ó 7 leguas, y la última punta al Este que parecía formar algunas islas, se marcaba al Sur $57^{\circ}$ Este: toda la costa á la vista era montuosa y cubierta de bosque, no se advertía ensenada notable entre las muchas puntas que le sobresalían, é inferíamos la existencia de algunos naturales en sus orillas, por una hu- 
3ric. 8 mareda bien notable, aunque navegásemos á cinco ó seis millas de distancia. Las observaciones de latitud y longitud (repetidas por tres veces estas últimas) no nos dejaron dudar de la exactitud de nuestras posiciones, tanto más que no interrumpíamos en modo alguno las bases, habiéndose la ATREvida encargado de sondar aunque fuese inútil por el mucho fondo.

No fué tampoco diferente el semblante de la costa cual le vimos al otro día después que disipándose algunas turbonadas pudimos continuar nuestra derrota con vientecillo galeno del Nordeste; navegamos desviados de ella de dos á tres leguas, y ya al anochecer nos era fácil distinguir sin recelo de equivocación el extremo Noroeste de la ensenada grande de Sugud-Boyan indicada por los Capitanes Carteret y Torrest y visitada por Dampierre en los últimos años del siglo pasado.

A la verdad, al paso que se nos hacían reparables los errores desmedidos así en cuanto á la latitud como al arrumbamiento de esas costas, en los cuales había caído el Capitan Torrest, no podíamos ménos de extrañarque fuesen en mucha parte equivocadas las reflexiones del Capitán Carteret, atento á los diferentes parajes que había visitado y descrito el célebre Dampierre en la misma costa; pues no quedaba duda que temiendo pasar por falta de práctica (como él mismo dice) entre la tierra firme y las Islas Serangani, y no pudiendo efectivamente contar sino dos islas por la parte del Sur en cuyas inmediaciones había experimentado diferentes temporales del Oeste, había alcanzado una grande bahía al Noroeste de las mismas islas, la cual, por el rumbo, por la distancia y por el tamaño, era precisamente la de Sugud-Boyan. Su extremo Noroeste es más bien bajo, declinando paulatinamente la costa hacia él, desde mucha distancia. La dirección de la boca es próximamente al Sursudoeste y Sud.

En esta posición anochecimos, conservándose el semblante del tiempo bien claro y apacible; pero no abandonándonos después hasta las dos de la mañana una completa calma, la cual no tuvo otra cosa de agradable sino darnos lugar por una demasiada inmediación á la ATRE. VIDA, de experimentar el efecto de los remos que habíamos tomado últimamente en Manila. Con mucha complacencia vimos que era aún mayor de lo que nos habíamos prometido, y un corto intervalo bastó para separarnos considerablemente unos de otros, aunque la Descubierta bogase sola y con solos tres remos por banda.

Entabladas para las dos de la mañana algunas ventolinas del cuarto y primer cuadrante, pudimos navegar de nucvo con todo aparejo hacia el Sudeste, y al amanecer, hallarnos mediante el auxilio de las corrientes, á la vista del extremo Sur de Mindanao y de las Islas Se- rangani. Era noble el semblante de la costa; se Dic. Ir veían los dos extremos de la ensenada de SugudBoyan; el uno suavemente alomado, convidando casi al navegante á abrigarse de sus orillas; el otro, tenazmente unido á la tierra firme, la cual se elevaba considerablemente al Norte y al Sur; la terminaban luégo por aquella parte, y muy á lo lejos en el fondo de la ensenada, diferentes montes bien notables, entre los cuales no era difícil distinguir por su estructura al decantado volcán. Al Sur no eran ménos elevadas las montañas traseras; pero la orilla, si bien alta, parecía ya prometer el abrigo de una crecida población, como sabíamos que la había por los diarios de los Capitanes Carteret y Torrest: distinguíamos ya claro el canal entre las Islas y el continente por el cual había pasado el primero, y no nos era tampoco difícil distinguir las inmediaciones del fondeadero de la punta Butulaque, descritas por el segundo. Fueron lentos hasta después del medio día nuestros progresos: se habían observado la latitud de $5^{\circ} 28^{\prime}$ y la longitud de $3^{\circ} 54^{\prime}$, las cua les nos daban ya una determinación hidrográfica bien aproximada de esos contornos, y podíamos ratificar así los errores de más de un grado en latitud del Capitán Torrest, como la suma exactitud de la que había asignado el Capitán Carteret á la Isla grande de Serangani: en la carta inglesa moderna de Robertson convenían exactamente con las nuestras las diferencias en latitud y longitud entre las islas mismas y Zamboanga. No así la dirección y posición de la cos. ta, en la cual parecía reprensible, particularmente por lo que toca á las inmediaciones del Cabo San Agustín, que hubiese preferido las noticias á veces agenas y siempre mal combinadas del Capitán Torrest á los reconocimientos prolijos y harto costosos del Capitán Carteret.

En la mañana del I2, igualmente favorecidos del viento y de la corriente, pudimos emprender la navegación del canal de Serangani, y considerarnos ya próximos á desembocar en el Mar Pacífico. Veíanse un crecido número de chozas y plantíos amenos desde la falda hasta las cumbres elevadas de la Isla grande de Serangani; no era ménos amena, frondosa y cultivada la costa opuesta de Mindanao; hacíanse notables los extremos de las marcaciones del Capitán Carteret, el canal que forma la isla más baja y oriental y el islotillo Illitan con los arrecifes que le son inmediatos. Los montes cercanos al Cabo San Agustín, se marcaban al Norte $30^{\circ}$ Este de la aguja, y repetidas observaciones nos daban lugar á coadyuvar con una cierta exactitud á la mayor seguridad de las navegaciones venideras en aquellos mares. Ni parecían, por otra parte, infundados nuestros conceptos sobre la continuación de los terrales y virazones, los cuales muy luégo nos condujesen al Este de la Nucva Guinea; 
Dic. is prometíanlo así la estación, el novilunio próximo y lo que habíamos advertido en los dias anteriores; pero cuanto distasen de la realidad aquellos conceptos, 10 manifestaron con harta evidencia los días siguientes.

Ya bien internados en el estrecho, se nos declararon contrarios al mismo tiempo la marea y el viento; aquélla para hacernos retroceder con lá misma rapidez con que nos había favorecido por la mañana: este otro, para impedirnos, mediante una turbonada fuerte que le acompañaba, que pudiésemos intentar con bordos y aparejo proporcionado contrarestar los efectos de la primera. Nos hallábamos aún á sotavento de la bahía en donde había fondeado el Capitán Carteret, y fué inútil nuestro primer bordo para cogerla. La sonda tampoco dió fondo con 60 brazas. Retrocedimos hasta la Punta Batulagui, y de alli, con el terral de la noche, hicimos nuevamente proa al Este, prefiriendo en esta ocasión pasar al Sur más bien que al Norte de las Islas Serangani, para no exponernos de nuevo al albedrío de la corriente contraria.

Calmó el viento por la tarde cuando habíamos propasado las primeras islas, la noche siguiente fué igualmente calmosa, y no bien estuvo el Sol sobre el horizonte, cuando conocimos el efecto extraordinario de las corrientes contrarias, las cuales para el medio día, esto es, en el espacio de diecjocho horas próximamente, nos habían arrastrado 50 millas al Sudoeste $1 / 4$ Oeste hacia el Estrecho de Macassar; veíase ya próxima para el anochecer la Isla de Haykopt, los altos de Siao se marcaban á larga distancia al Sudeste, y las corrientes, siempre contrarias, inutilizaban nuestros esfuerzos para aproximarnos de nuevo á las costas de Mindanao.

En la tarde del i\& conseguimos hallarnos casi en la misma posición del I4; pero no fuímos más felices, siendo así que nuevas turbonadas del Este, ayudadas de la corriente contraria, nos obligaron á retroceder. Contrariados de esa manera por cuatro veces, ya nos creíamos destinados á luchar por largo tiempo con una serie de adversidades que no podíamos vencer, ó á seguir derrota al Oeste, que por los estreclios de Banca y Sonda nos condujese antes al Océano Indico y luégo por el Sur de la Nueva Holanda al mar Pacífico, cuando repentinamente vimos mudar el semblante indicado del tiempo, con entablar virazón fresca, que al ponerse el Sol del I9, inclinándose al Norte y Nornordeste, había adquirido una fuerza desconocida hasta entonces. Brillaba la luna casi llena sobre el horizonte, advertíanse algunas candeladas en el extremo Noroeste de la ensenada de SugudBoyan, y nuestros progresos eran tales á pesar de una corriente fuerte al Sur, que en la mañana del 20 ya marcamos los altos de Serangani al Norte $2 \mathrm{I}^{\circ}$ Oeste distancia de cinco ó sejs le- Dic. 20 guas, y quedaban rápidamente al Oeste las islas avistadas al Sur $4^{\circ}$ Este en la tarde del I2, de quienes no distábamos ahora más de unas tres leguas.

Examináronse con este motivo prolijamente, no ocultándose el canal y la restinga ya indicadas por el Capitán Meares; pero de ningún modo podía combinarse lo que veíamos, con las noticias harto confusas de los navegantes quc nos habían precedido, sin exceptuar la misma carta de Robertson. Ya no debíamos extrañar sin embargo los errores del Capitán Torrest así en la latitud como en el número y dirección de aquel pequeño grupo; á las tres primeras que pueden considerarse reunidas, siguen luégo casi con iguales intervalos de cuatro á cinco leguas en la dirección del Esueste, otras dos islas medianamente altas cuyos alrededores parecen sin peligro alguno. Las corrientes son allí tan rápidas al Sur, que navegando las corbetas con un andar de cinco á seis millas al Este corregido, apenas lograban el rumbo directo del Sueste $1 / 4$ Este según lo indicaban las marcaciones.

Sus nombres en la carta del Capitán Torrest, no eran los naturales, los cuales hubiéramos admitido con preferencia á cualquiera otros. Se les asignaron ahora por la misma razón los de Aniaga, Anda y Armadores, que les había dado el Piloto Tompson en su navegación desde Zamboanga á Acapulco, en el año de I773. Comprende su latitud desde los $4^{\circ} 4^{\prime} 8^{\prime}$ hasta los $4^{\circ} 25^{\prime}$ Norte, su semblante es árido, su elevación da lugar á que se distingan desde el alcázar á cinco ó seis leguas.

Al medio día, tanto por la altura meridiana del Sol como por otras medidas tomadas poco antes, inferimos la latitud de $4^{\circ} 40^{\prime}$. No era fácil á la sazón combinar con alguna probabilidad la verdadera longitud en la cual nos hallábamos; la isla más Este nos demoraba al Sur $23^{\circ}$ Oeste unas cuatro leguas.

En el entretanto continuaban nuestros adelantos al Este aunque con muchos sacrificios al Sur, y siendo como ya se ha dicho sumamente incierta la posición de las islas en todos aquellos contornos, navegábamos con tanta mayor vigilancia cuanto que los horizontes se habían cerra do con celajería más espesa, y era difícil de comprender la verdadera posición de los bajos inopinadamente encontrados por los Capitanes Douglas y Meares.

No presentándose nada á la vista hasta las cinco de la tarde, aunque la distancia navegada al Este desde el medio día no fuese ya menor de 30 millas, empezábamos á creer quo un error grande en su lalitud nos hubiese ocultado las islitas de Kakarcoralong al Norte y las de Salibábo al Sur, hallándonos con una nave- 
Dic. 20 gación libre y bien á barlovento del Cabo Norte en la Isla Norintay. Nuestros rumbos se conservaban al Este 1/4 Sudeste con fuerza de vela; algunas claras del Sol, y particularmente al tiempo de ocultarse sus dos limbos en el horizonte, nos habían dado lugar de observar por ambos medios la longitud en la cual nos hallábamos.

Pero próximamente á esta hora se apercibieron desde los topes y aún desde la cubierta, dos montes bastantemente elevados que marcábamos al Esueste $5^{\circ}$ Sur y creimos inmediatamente ser las Islas de Salibabo, aunque debiese hacérnoslo dudar en cierto modo la falta de una isla al Sur, que según la carta del Capitán Robertson, habían avistado pocos años antes los navegantes ingleses. De cualquier modo, no nos era posible pasarlas á barlovento y nos era preciso navegar con mucha precaución, atento á las circunstancias que nos rodeaban. La noche, mucho más clara que el día, favorecía nuestros pasos; y aunque navegásemos sin los juanetes $y$ á veces sin la mayor, ni fué difícil avistar de nuevo las mismas tierras por la proa hacia las ocho de la noche, ni mucho ménos el atracarlas hacia las diez á distancia de dos leguas próximamente, calmado ya mucho el viento y allanado enteramente el mar.

Ya no quedaba la menor duda, que nuestros primeros conceptos habían sido acertados. La dirección bien diferente de las Islas Tannalabu y Salibabo, el canal comprendido entre ellas, el otro que formaba Salibabo con la Isla Kabruang, la elevación de esta última y dirección de entrambas próximamente al Sueste $1 / 4$ Sur, todo nos lo descubrían evidentemente, así la Luna con su claridad, como la corta distancia á que navegábamos de ellas. Procuró D. José Espinosa determinar la posición del extremo Norte de Salibabo, valiéndose para la latitud de a de Eridano, y para la longitud de algunos horarios de Sirio; las bases y las vistas, que no omitió D. Felipe Bausá y las favorecían ahora el viento, la mar y la cesación de las corrientes, debían dar á esas tareas nocturnas un nuevo grado de exactitud.

Hasta la una de la mañana continuamos el reconocimiento emprendido, sin que hallásemos fondo con 60 brazas de sondaleza empezamos luégo á ceñir el viento, y para el amanecer del 2r, como hubiese refrescado mucho desde que salimos del abrigo de las islas, nos hallábamos ya distantes de ellas unas cinco leguas. El extremo Sur de Kabruang demoraba al Norte $64^{\circ}$ Oeste, su extremo Norte al Norte $53^{\circ}$ Oeste; el extremo Norte de Salibabo al Norte $5 \mathrm{I}^{\circ}$ Oeste; el extremo Sur de Tannalabu al Norte $4 \mathrm{I}^{\circ}$ Oeste, y el extremo Norte al Norte $30^{\circ}$ Oeste. Se confirmaba aho. ra de nuevo con mucha exactitud la descripción que de ellas había dado el Capitán Torrest, ha- ciéndose particularmente notable la elevación de Dic.21 la Isla Kabruang, la frondosidad y llanura de Salibabo y el semblante amogotado de Tannalabu. Ningún fuego ni canoa nos indicó en la noche la muchedumbre de habitantes que encierran todas.

No nos descuidamos luégo que estuvo el Sol elevado algunos grados sobre el horizonte, en determinar la longitud deeste pequeño grupo; adoptamos para la latitud del extremo Sur de Kabruang, la determinación de la carta del Capitán Robertson, que parecía bien cimentada según los apuntes de su Memoria, y que confirmaban ahora las bases nuestras desde el principio de la noche. La longitud se dedujo del cronómetro 7I, y fueron, ésta de $6^{\circ}$ Oeste al Este de Manila, aquélla de $3^{\circ}$ $48^{\prime}$ Norte para dicho extremo: resultaba por consiguiente en la misma carta inglesa, un error de seis á siete leguas al Oeste para la diferencia de longitud determinada entre Haycopk ó Serangani y estas islas; error á la verdad de mucha consideración, en un paraje en donde se reunen á lo ménos, según lo hemos experimentado, los vientos escasos y frescos, las corrientes extraordinariamente contrarias, y los tiempos por lo común foscos y aturbonados.

No nos decidiremos á aventurar nuestro parecer sobre la existencia de las Islas de Kakarcoralong que pudiéramos haber visto en nuestro tránsito, si fuesen medianamente altas y en su colocación relativa á Serangani regularmente exactas. Se hace sin embargo reparable, que Dampierre no las vea en los muchos bordos que debió dar por los vientos contrarios fuera de las Islas Serangani, y que el Capitán Torrest, el cual las comprende en su carta sin duda por informes de su práctico Juan Hadjée, omita las Meangis, de cuya existencia y posición aproximada relativamente al Cabo San Agustín, no nos queda la menor duda, leídas las noticias de Dampierre. En la restante mañana el viento continuó bastante fresco del Nornordeste y le aprovechamos con todo aparejo, de suerte que para las diez de la mañana ya habíamos perdido las islas de vista, y para el medio día nos hallábamos en latitud de $3^{\circ} 29^{\prime}$ y longitud de $6^{\circ} 45^{\prime}$. No era menor de $30^{\prime}$ el error contraído en la latitud desde el medio día anterior, y la mayor parte lo había sido positivamente antes de atracar las Islas Salibabo, desde cuya época nos indicaron siempre las marcaciones, que caíamos muy poco al Sur.

Ya, pues, con solas veinticuatro horas de tiempo favorable habíamos triunfado de una porción considerable de obstáculos. El Cabo Norte de la Isla Morintay demoraba al Sueste 1/. Este unas 34 leguas; el viento se conservaba fresco, y áuı por la tarde, habiéndose inclinado más al Norte, nos daba lugar á navegar al Este corregido, si bien la mar hubiese en- 
Dic. $2 x$ gruesado mucho. Las primeras horas de la noche nos la prometían igualmente serena y favorable, y lo que debía parecernos aún más extraño y feliz, la altura meridiana $\alpha$ de Eridano, medida á las ocho por D. José Espinosa y otros Oficiales, manifestaba más bien al Norte que al Sur las diferencias en latitud por efecto de las corrientes.

No tardó después en alcanzarnos en la mañana del 22 una turbonada bien fresca del Sueste, con la cual navegamos inmediatamente al Nordeste con aparejo proporcionado á su fuerza. La ATREvidA, precisada á navegar con más vela por la inferioridad que ahora tenía de andar, tuvo notables averías en su velamen; le fué necesario envergar otra mayor, otro juanete y otros foques; navegamos luégo unidos hasta el medio día, pero el viento á esta hora había calmado casi de un todo, y nos considerábamos próximamente en la misma posición en la cual habíamos amanecido. Las observaciones disiparon por fin nuestras dudas, y al medio día pudimos considerarnos como realmente introducidos en el mar Pacífico.

La latitud observada de $3^{\circ} 57^{\prime}$ y la longitud de $6^{\circ} 9^{\prime}$ por el cronómetro $7 x$, nos hacian al mismo tiempo demorar el Cabo Norte al Sur ${ }^{1} / 4$ Sudoeste 25 leguas, y nos indicaban una corriente en favor, la cual nos había llevado I $3^{\prime}$ al Norte y $3^{2}$ al Este de la estima.

Por la tarde volvieron á entablar vientos bonancibles del primer cuadrante, con los cuales y las muras á babor, continuamos nuestra derrota precaviéndonos de algunos chubascos: uno de éstos, por la noche hizo que variase el viento, volviendo luégo, sin embargo, para el amanecer, bien bonancible al primer cuadrante. Nuestra derrota ahora no tenía otro objeto sino adelantar cuanto fuese posible al Este, procurando noaproximarnos á las costas de la Nueva Guinea y Nueva Bretaña, para lograr de unos aires ménos infectos, de una navegación más seguida y tal vez de unas lluvias más intermitentes.

Las dificultades que acabamos de experimentar en la última travesía desde Zamboanga y las que han experimentado en este mismo paraje varios navegantes que nos habían precedido, nos daba lugar á aventurar algunas conjeturas no del todo infundadas sobre aquella parte de la navegación nacional, que, ó bien tenía por objeto el dirigirse luégo á las costas del Noroeste de la América y del Reino de Méjico, ó el hacer derrota hacia los Reinos del Perú y Chile. En entrambos casos, no es temeridad asegurar que debe mirarse como aventurada, y que á lo ménos, la han de emprender embarcaciones buenas, bien aparejadas y bien manejadas, cualidades todas que se echan de ménos en los buques mercantes nacionales, y particularmente en los de Manila.
Debemos llamarla aventurada, aunque lo acaeci- Dic. 22 do á las corbetas y las derrotas de varios buques ingleses denoten que no son tan rápidas las corrientes al Sur desde los paralelos de Sanguir, Siao y Kabruang, porque los Capitanes Meares, Easenbrook y Bampoon, han experimentado bien á su costa lo contrario en estos últimos años, viéndose arrastrados, el uno entre Morintay y Gilolo, y' los otros entre Gilolo y Celebes, de donde no pudieron salir sino con crecidos riesgos y peligros. Además, que no es fácil ni áun para los que salen del estrecho de Pitt, elevarse bastantemente al Este para poder montar del otro bordo á lo ménos las Palaos, y no pocas pruebas en estos años han manifestado cuánto es fuerte y contrario el efecto de las corrientes, luégo que se acercan á los paralelos de las $\mathrm{Pa}$ laos.

No dudando que en los meses de Octubre, Noviembre y Diciembre, sea fácil con las mareas y los vientos variables la salida del estrecho de San Bernardino, y resultando de las tareas del Piloto D. Juan Maqueda la navegación libre $y$ fácil del estrecho de San Juanico entre las Islas de Samar y Leyte, podemos asegurar que cualquiera de estos dos desembocaderos para el mar Pacífico, nos parece más fácil; así como en el caso de adoptarse el que nosotros hemos seguido por la precisión de tocar en Zamboanga, debemos aconsejar que se procure siempre nave. gar bien atracados á la costa de Mindanao é Islas Serangani, sacrificando á veces uno ó dos días en las inmediaciones de la bahía de Sugud-Boyan, para esperar vientos bien frescos del Norte, con los cuales se emprenda la travesía á montar el Cabo Norte de la Isla Morintay.

Por lo que mira á la navegación á Chile, séanos permitido insistir sobre la preferencia de la derrota, que desde la mitad de Diciembre conduce por los estrechos de Sonda al Océano Indico, y de allí, por los extremos de la Nueva Holanda y Nueva Zelanda á las costas de la América. Es fácil proveerse abundantemente de agua y leña antes en la isla del Norte inmediata á Sumatra, y luégo en los estrechos de Cook sobre la Nueva Zelanda, y seguramente el plazo del viaje no excederá de cinco á seis meses, por paralelos ahora bastante trillados y siempre tan saludables, como son infectos y peligrosos los que hay que correr bajo la Zona Tórrida, precisamente en la mayor fuerza de la estación lluviosa. Si al contrario, fuesen los meses de Junio, Julio y Agosto, el principio de una navegación al Perú desde Manila, nos parece que disfrutados los vendavales á lo ménos por unos 40 ó $50^{\circ}$ al Este de aquel meridiano, cualesquiera fuesen los sacrificios de la latitud, sería luego lo más seguro con los Nordestes y Estes, navegar directamente al Sur y Sueste, y cumplir el viaje en latitudes altas del 
1) ic. 22 hemisferio Austral: en ninguna ocasión debía pasarse la Línea á ménos de 50 á $60^{\circ}$ al Oeste del continente de la América.

Nuestros pasos primeros en el Mar Pacífico fueron bastantemente felices si se atendiese á la celeridad del viaje ó á la conservación de la salud en medio de los chubascos y turbonadas que casi diariamente nos acompañaban; pero si le mirásemos con aquel afán natural de los descubridores, ansiosos de encontrar algo nuevo que alimente su pundonor, con el dominio aunque imaginario de nuevas tierras por la nación que los envía, debíamos á la verdad considerarnos bien desgraciados, pues recorriendo un espacio no menor de $40^{\circ}$ en longitud entre los $4^{\circ}$ Norte y la equinoccial, no hạbíamos encontrado el menor rastro siquiera de tierras próximas no conocidas.

Nos favorecieron al principio, corrientes bastante fuertes al Norte y al Este. Interrumpidos los vientos frescos y aturbonados del Oeste con algunos días igualmente lluviosos pero con calma, nos dieron lugar á examinar, primero, la posición de Pulo Mariese, y después las inmediaciones de las Islas de Freewill y de la restinga aislada del Capitán Carteret. Navegamos comunmente de noche con poco aparejo: la una corbeta precedía alternativamente á la otra á distancia de una milla, dirigía la derrota y las maniobras según fuesen más ó ménos perceptibles los objetos en el horizonte, con el brillo casi momentáneo de la Luna ó con la más frecuente oscuridad de las turbonadas; finalmente, precavida con extremo, bien sea con la vigilancia de las guardias ó con la disposición de las señales, prometía, casi con evidencia, la seguridad del segundo buque cuando algún encuentro inopinado la pusiese en los riesgos comunes á esta especie de navegaciones.

Al medio día, solía el termómetro, puesto á la sombra, fijarse comunmente entre los 82 y $84^{\circ}$. Atravesando después por las inmediaciones de las Islas Matías y Ohonjava trilladas por los navegantes Dampierre, Bogainville, Carteret $y$ Maurelle, veíamos casi evidente la exactitud de su posición por el vuelo de las aves, la dirección de las turbonadas y el curso de las aguas; ni debimos extrañar últimamente la vista bien repetida de muchos troncos de árboles, á veces monstruosos, á veces con ramas, pero siempre con una costra casi contínua de conchas que los aseguraban entregados desde mucho tiempo á las nlas del mar. Los viajeros que han frecuentado las costas de la Nueva Irlanda siempre los han encontrado en mucho número, y Dampierre los aprovechó para proveerse abundantemente de leña.

Nn habíamos tampoco omitido en la travesía indicada, repetir cuanto fuese posible las ob- servaciones de longitud por las distancias lunares, valiéndonos de los astros orientales y occidentales de la Luna; tuvimos una prueba reciente en la Descubierta de la exactitud de aquel método, cuando en los días I 8 y 20 de Enero vimos corresponderse con una total uniformidad los resultados de éstas y de los relojes marinos en los términos que á continuación sẻ expresan:

\begin{tabular}{c|c|c|c|c}
\hline Dias. & $\begin{array}{c}\text { Número } \\
\text { de séries. }\end{array}$ & $\begin{array}{c}\text { Longitud orien } \\
\text { tal de Manila por } \\
\text { las distancias. }\end{array}$ & Id. por el 7.. & Id. por el II. \\
\hline I 8 & 34 & 36.57 .13 & 37.15 .00 & 37.3 .37 \\
20 & 30 & $39,32.46$ & 39.55 .17 & 39.38 .15 \\
\hline $\begin{aligned} \text { Diferencia contraí- } \\
\text { da en el intervalo. }\end{aligned}$ & 2.35 .33 & 2.40 .17 & $2.34 .3^{8}$ \\
\hline
\end{tabular}

Por lo que toca á la variación de la aguja, la Feb. vimos aumentar hasta los $9^{\circ}$ Nordeste cuando nos hallamos próximamente en meridianos de $32^{\circ}$ de Manila. Disminuyó después hasta los $7^{\circ}$ á medida que adelantábamos al Este, y cuando torcimos al Sur para acercarnos á las tierras de Quirós ó Nuevas Hébrides, aumentó de nuevo con bastante rapidez, por manera que en latitud de I6 $6^{\circ}$ ya volviese á los $8^{\circ} 30^{\prime}$.

A la sazón nos habían abandonado enteramente, así las brisas flojas y variables del Nordeste, como los temporales intermedios de la monzón favorable del Oeste, y les habían sucedido los vientos regulares del Esueste con los cuales ceñimos constantemente al Sur.

A las ocho de la mañana del día II de Febrero, se nos presentó á la vista (disipada algún tanto la calima) la Isla de Erroman en las Nuevas Hébrides, que conocimos luego por su corta extensión y por la elevación considerable que le había notado el Capitán Cook. No se equivocaba aquel navegante incomparable, cuando contra el dictamen del mayor número de sus Oficiales, suponía unido á la demás tierra por medio de una lengua, un Morro alto que advertía saliente al Sudoeste: puede llamarse más bien escarpada, y si juzgásemos por lo que hemos advertido en su costa del Oeste (ciertamente la más abrigada) no hay en ella población alguna.

Al medio día, con tiempo bastantemente hermoso, ya marcábamos los extremos de Erroman, del Norte $69^{\circ}$ á los $85^{\circ}$ Este, y nuestra distancia era próximamente de tres leguas, causada más bien de las corrientes fuertes al Oeste, que de los rumbos que habíamos seguido, siempre directos á la isla, cuanto lo permitiese el viento. En esta posición, nuestra latitud era de $\mathrm{I}^{\circ} 3^{\prime} 2^{\prime}$ IO $^{\prime \prime}$, exactamente acorde por las marcaciones á la que había determinado el Capitán Cook. Reservóse la deducción de las longitudes hasta que comparásemos los horarios observados en meridianos de aquella isla á los que tuviésemos á la 
reł.r vista de Annatom. Era bien singular que una calima extraordinariamente espesa, nos imposibili tase en todo aquel tiempo el ver la isla inmediata de'Tanna, á la cual hubiéramos deseado más bien el referir directamente nuestras comparaciones.

Refrescando por la tarde el viento del Essueste, no tardamos en alcanzar la vista de Annatom, cuyos extremos eran más extendidos al Este y Oeste de lo que á la distancia creida de diez leguas había podido advertir el Capitán Cook. Poco antes de ponerse el Sol, estuvimos á corta distancia del extremo Oeste, á cuyo abrigo quedamos por poco tiempo en calma. La ATREVIDA nos señaló entonces que había sondado 55 brazas, y nosotros poco después lo verificamos en 80.

Entrada ya la noche no nos quedó duda por los diferentes fuegos que advertimos en las alturas inmediatas, que la isla estaba habitada: también habíamos notado algunos cocales plantados sin orden en las orillas inmediatas, en las cuales se hacían al mismo tiempo visibles varias cascadas de agua y no pocos parajes de un fácil desembarco; sin duda alguna pudiera considerarse aquel fondeadero de mucha utilidad, si los vientos fuesen constantes del Nordeste al Sueste y no hubiese inmediato un puerto tan abrigado como el de Tanna.

La comparación de nuestras longitudes era pues el único objeto al cual debíamos atender en aquellas inmediaciones, logrados ya los horarios en posiciones oportunas relativamente á una y otra isla. Desde luego una mayor nimiedad en esta especie de operaciones, nos convenció que era mayor en $6^{\prime}$ de la que suponía el Capitán Cook la diferencia de meridianos entre las dos Islas indicadas, y esta diferencia, atento á las distancias y posiciones en las cuales se había hallado el Capitán inglés para entrambas determinaciones, nos inclinó á preferir la de Erroman como 'más aproximada á Tanna, dándole, sin embargo, la corrección de una tercera parte del pequeño error hallado. Los resultados fueron los siguientes:

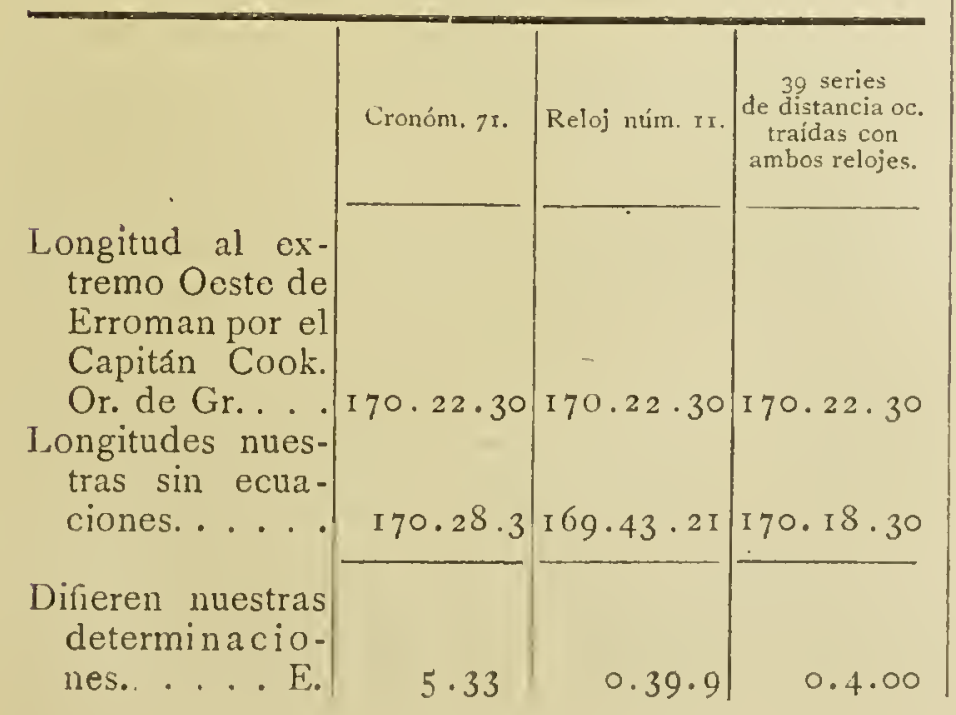

Como quiera que según nos aseguraban en Feb. rx sus narraciones el Capitán Cook y Mr. WVales, se diesen extraordinariamente la mano entre sí las observaciones de longitud hechas en Mallicolo, en Tanna, en el puerto Balade y la Isla de Pinos de la Nueva Caledonia, de suerte que conviniesen siempre las diferencias parciales del reloj marino de Mr. Rendal con las que indicaba cada promedio de las observaciones; pudimos considerar como bien auténtica esta nueva comparación, la cual, al mismo tiempo afianzaba la exactitud de nuestras últimas distancias y nos indicaba con la mayor complacencia la marcha uniforme del cronómetro 7I, después de sesenta y ocho días la mayor parte excesivamente húmedos ó ardientes.

Ya, pués, conseguido uno de los objetos que nos habíamos propuesto en la navegación actual y entablada nuevamente en las primeras horas de la noche la brisa fresca del Esueste, nuestra derrota debió precisamente continuar al Sur, tanto con el objeto de dar vista si fuese posible á la Isla de Norfolk como para dirigirnos después á la Nueva Zelanda y repetir en Dusky Bay las experiencias de la gravedad.

El día 2I ya nos hallamos en latitud de $40^{\circ} \mathrm{O}^{\prime}$ y longitud de $45^{\circ} 30^{\prime}$ al Este de Manila; nos demoraban las inmediaciones de Dusky Bay al Sur distancia de Ioo leguas, y el Cabo Farewell en el canal de la Reina Carlota al Este roz leguas.

Un nuevo temple agradable en la atmósfera, los días más duraderos, las estrellas con un hermoso brillo, todo nos recordaba ahora cuánto para la navegación eran aventajados aquellos climas á los de trópicos. No nos abandonaron ni aún en aquella latitud los vientos favorables del Este, y á medida que nos aproximábamos á la costa, tuvimos á la vista un mayor número de aves. acuáticas, cerrándose por otra parte los cielos y horizontes con una densa calima. Así, aunque desde el medio día del 24 por latitud de $44^{\circ} 34^{\prime}$ y longitud de $46^{\circ}$ al Este de Manila nos considerábamos ya bien próximos á la costa y aun la A Trevida nos la señalase á la vista, no fué posible cerciorarnos de ella por los obstáculos de la misma calima; y al principio de la noche, aunque no encontrásemos fondo con toda la sondaleza, ceñimos al Oeste las ventolinas ya bien calmosas del Nornordeste.

Debieron éstas después ceder á un viento galeno del Sursudoeste, el cual empezó á entablar hacia la media noche, despejando luego la neblina que cerraba los horizontes, de suerte, que tomadas hacia las tres nuevamente las alturas á estribor, nos hallamos al amanecer de un día con exceso placentero, á distancia de cinco leguas de la costa, la cual veíamos tendida clesde el Nordeste al Sursueste.

Las señales nada equívocas que con su acostumbrada exactitud había dado el Capitán Cook 
Fb. 2 , de aquel trozo de costa, no nos dejaron titubear ni un solo instante sobre todos los puntos que ¿eníamos á la vista. La punta Five-Fingers ó Cinco Dedos, terminaba nuestros alcances al Sur, se distinguía claramente el abra del Norte de 1) uski Bay, y el bordo que actualmente seguíamos nos conducía muy poco á sotavento de la entrada de Doubtfull Bay, de la cual, no distando á las nueve sino dos á tres millas, y reconocidos con la mayor prolijidad sus alrededores, debimos separarnos para dar un repiquete y recalar del otro bordo algún tanto á barlovento.

Sería difícil una descripción más cabal de la aspereza y elevación de aquellas costas de la que hizo ya el Capitán Cook en los reconocimientos de su primer viaje. A dos millas de la orilla no encontrábamos fondo con Ioo brazas, y en la entrada de Doubtfull Bay, si bien la isla intermedia presentase bastantes rastros de una vegetación no mezquina, todo el fondo del puerto, cerrado por una y otra parte con montañas inaccesibles y cortadas á pico, apoyaba en mucho las reflexiones del Capitán, que le habían hecho mirar aquel puerto como temible para la salida.

Sin embargo, su latitud de solos $45^{\circ} \mathrm{I} 3^{\prime}$, el tenerle á sotavento si continuasen los vientos del Sur, y la importancia del tiempo ya bien conocida sobre aquella costa, de modo que el día hermoso del cual ahora gozábamos debiese más bien amenazarnos, nos aconsejaban á no malograr aquel momento favorable para el fin propuesto; tanto más que cualquiera alteración del viento y el mismo examen del diario meteorológico del Capitán Cook en Duski Bay, debían hacernos creer que nos veríamos nuevamente acosados de los vientos del Este, directamente opuestos á la entrada dc ambos puertos.

Con estas reflexiones, conseguida al medio día una posición cómoda á barlovento para cualquiera paso sucesivo que las circunstancias manifestasen por más util, fué el bote armado de la Descubierta á las órdenes de D. Felipe Bausá, con el objeto de examinar interiormente el puerto y particularmente la facilidad de hacer agua y leña: se le prescribió el regreso más pronto, y en el entretanto, las corbetas unas veces al pairo y otras sobre bordos cortos, conservaron la misma posición relativamente á la entrada.

No regresó el bote sino á las nueve de la tarde; sólo á la entrada ó parte exterior de la isla había encontrado fondo de 20 y 25 brazas cascajo, pero clespués cn ambos canales se perdía con cincuenta, ni en parte alguna alrededor de la isla podía nuevamcnte hallarlo á un cumplido de lancha siquicra: interceptaban á uno y otro canal algunos pedruscos aunque no arriesgados para la navegación; abundaban interiormente el agua y leña; la vinictura de la costa algo más llana y arenisca en un seno más interno al Norte, prometía allí un Feb. 25 paraje seguro y cómodo para fondear; el tiempo, muy limitado, no le había permitido examinarlo con el escandallo. Seguía luégo al Esueste un canal de dos á dos y medio cables, formado en los mismos montes, los cuales caían extremadamente á pico, y últimamente el canal mucho más estrecho, torcía más al Sur á encontrar tal vez los términos de los canales, internos de Duski Bay. No se advertía una grande velocidad en la marea: según las señales en la orilla parecía el principio de la vaciante próximamente al medio día: pocas aves, ningún lobo marino, solas algunas lapas chicas por lo que toca á marisco, y ningún rastro, aunque remoto, de habitantes, eran las demás circunstancias dignas de atención en aquel puerto, á las cuales debía luégo añadirse la falta total del pino, componiéndose allí la vegetación de una especie de arbusto de mediana altura. En resumen, si no son las experiencias del péndulo simple ó una verdadera necesidad las que guien á algún navegante á di cho puerto, debemos creer que está destinado á ser perpétuamente desierto, y que Duski Bay será siempre la que convide en aquellas inmediaciones, á sus orillas, con un abrigo más cómodo, más seguro y más sano.

Ya entrada la noche y metido el bote, permanecimos algún tanto en calma sobre la costa, objeto que nos fué luégo bien fácil vencer, habiéndose declarado poco después viento flojo del Norte, con el cual á la media noche ya distábamos de la costa unas tres leguas. En esa situa. ción, deseando no perder momento, arribamos al Sur, y á las tres de la mañana, andadas sólo tres leguas de las siete que la latitud nos manifestaba faltar, orzamos nuevamente para atracar la costa y entrar en Duski Bay al rayar de las primeras claras del día. El viento á la sazón iba aumentando considerablemente; la costa se había cerrado con mucha neblina, y todo amenazaba una alteración contraria en el tiempo.

Las primeras claras del día nos debieron parecer con exceso oportunas para dirigir con mayor acierto nuestros pasos. Estas, sin embargo, ya variaban mucho de semblante, y un solo momento parecía haber trastornado enteramente nuestra situación ventajosa para alcanzar el puerto deseado. A las cuatro de la mañana, disipada por un breve intervalo la neblina, nos hallamos repentinamente á la entrada de Duslí Bay y á la sola distancia de dos ó tres millas de la Isla de las Rompientes, la cual de ningún modo nos era posible montar con el viento que á la sazón reinaba. Hallado así un error de tres leguas en la estima desde la media noche, viramos inmediatamente al Oeste, y con viento yra recio y aturbonado, reviramos nuevamente á las nueve en vuelta de tierra, aguantando para lo 
Feb. 26 grar de algún barlovento, una fuerza más bien excesiva de vela.

Pero todo fué infructuoso; recalamos nuevamente en las mismas marcaciones de la mañanita, y el viento del Nordeste, á cada paso más recio y tempestuoso cuanto más nos aproximábamos á la costa, nos avisó que una mayor tenacidad en nuestro empeño pudiera acarrearnos algunas pérdidas de la mayor consecuencia. Debimos por consiguiente decidirnos á tomar de nuevo las muras á estribor y á navegar para el medio día con las cuatro principales, las gavias en dos rizos. A esta hora se veían aún á ratos algunos trozos de la costa, y en particular la punta de Cinco Dedos cuyas señales eran bien notables.

Lejos de ceder el viento, por la tarde arreció de tal modo y con mares tan gruesas, que podía llamarse un verdadero huracán; tuvimos averías considerables en el aparejo y en el velamen. Todo el aguante de las corbetas parecía inútil para resistir el trinquete y la gavia en tres rizos arriada, velas que creíamos necesarias para que los golpes de mar no nos inundasen con exceso, y para las diez ya se nos hacía temible á cada paso una avería.

Después de la media noche empezó á ceder el tiempo, pero no pudimos considerarle concluído sino á la mañanita siguiente, á cuya hora navegábamos con las cuatro principales y las gavias en dos rizos. Sucesivamente nos alcanzaron algunos leves intervalos de calma, á los cuales últimamente sucedió un viento bonancible del Sur y Sudoeste, acompañado de una calima sumamente espesa.

Los rumbos que necesariamente habíamos seguido en el temporal pasado, nos habían desatracado considerablemente de la costa; las observaciones nos manifestaron también una corriente fuerte al Norte, y así no era menor de 3o leguas la distancia nuestra de la bahía.

En esta situación, y después del escarmiento pasado, debimos precisamente dar lugar á algunas reflexiones, las cuales nos demostraban como aventurado el empeño de internar en Duski Bay con el solo objeto de las experiencias de la gravedad: se le agregaban luégo la extraña impresión que habían hecho los fríos y el último temporal, en la ya débil y cansada marinería filipina y las lluvias abundantes que reinaban en el puerto; por manera, que á veces pudiesen pasar los quince días sin lograr de observación alguna; finalmente, debiendo nosotros trillar aún pordos veces el mismo paralelo de $45^{\circ}$ á una y otra parte del Cabo de Hornos, no sería difícil hallar ocasión más oportuna y más expedita para aquel intento. Nos convencieron estos razonamientos que sería preferente para el reparo de los buques y el descanso de las tripulaciones una es. cala en el puerto de Jakison ó en la bahía Botá- Fel,.27 nica de la Nueva Holanda; pusimos, por consiguiente la proa al Oeste sin mayor demora, y al medio día siguiente del 28 ya no distábamos ménos de 70 leguas del extremo Sur de la Nueva. Zelanda.

Nuestras longitudes referidas á las del Capitán Cook, delante de la bahía dudosa dieron lus siguientes resultados, bien entendido que en nuestras cartas habíamos ya corregido los errores de 30 y $20^{\prime}$ que á las dos islas de la Nueva Zelanda había hallado el mismo Capitán en su segundo viaje.

\begin{tabular}{|c|c|c|}
\hline & Cronóm. 71. & Num. זr. \\
\hline $\begin{array}{l}\text { Longitud por marcación oriental } \\
\text { de Manila. . } \ldots \ldots \ldots \ldots \\
\text { Longitud por el reloj. . . . . }\end{array}$ & $\begin{array}{l}45 \cdot 35 \cdot 3^{8} \\
45 \cdot 41 . \quad 1\end{array}$ & $\begin{array}{l}45 \cdot 35 \cdot 3 \mathrm{~S} \\
45.13 .12\end{array}$ \\
\hline Diferencia del reloj. . & 3) 5.23 & 0.22 .26 \\
\hline
\end{tabular}

La diferencia hallada ahora en el cronómetro 7 I era pues la misma que se había notado á la vista de Erromán, y esta uniformidad, al paso que afianzaba su buena marcha nos manifestaba hasta qué grado habían alcanzado en su aproximación las determinaciones de los navegantes ingleses. En cuanto al número II ya no quedaba duda que las últimas alteraciones en la comparación diaria, dependían de él enteramente; pero no dejaba también de hacerle recomendable la compensación hallada ahora de una parte del error que había manifestado antes á la vista de Erromán.

La variedad de vientos, que corrían á veces en veinticuatro horas toda la aguja, pero fijándose más bien y refrescando al Sur y Sudoeste, hizo efectivamente, que si bien no fuese posible con este motivo el seguir una derrota, antes bien, que las mares gruesas del Noroeste y Sudoeste y los vientos frecuentemente arrafagados y oscuros nos causasen alguna precaución en el aparejo, fuese, sin embargo, al medio día del 8 la latitud de $37^{\circ} 30^{\prime}$ y la longitud de $3^{\circ} 30^{\prime}$ próximamente al Este de Bahia Botánica. Varios azimutes habían manifestado en la tarde anterior la variación de I $^{\circ} 3 \mathrm{O}^{\prime}$ Nordeste. Sustituían á las aves acuáticas de las longitudes más altas, diferentes procelanias y algunas pardelas. El temple de la atmósfera era ahora mucho más agradable, enturbiándola sólo en éste y en el día siguiente, algunas turbonadillas distantes con truenos y relámpagos, las cuales nos recordaban la poca distancia de la costa. Estas mismas turbonadas nos quitaron al día siguiente deducir la latitud de la altura meridiana del Sol, algunas alturas medidas en otras horas y calculadas por el método de D. Dionisio Galiano nos hicieron suponer en latitud de $35^{\circ} 45^{\prime}$, longitud $2^{\circ}$ próximamente al Este de bahía Botánica; ambos resultados ma- 
\$a: 6 nifestaban con mucha probabilidad una corriente bastantemente fuerte al Nordeste.

Continuó el día io nuestra navegación hacia la costa, y en la mañanita del II, con las primeras claras del día, fué por consiguiente fácil hallarnos á no mayor distancia de siete á ocho leguas. Algunas alturas meridianas de estrellas que había medido en la noche anterior D. José Espinosa, y las mismas pinceladas maestras del Capitán Cook, no nos dejaban dudar que era la que corre desde la Punta Roja hasta las inmediaciones de la Bahía Quebrada. Se hacían particularmente notables el alto semejante á la Copa del Sombrero, y las quebradas ó mogotes de la costa algo más meridional que la entrada de la bahía: el viento bonancible del Sudoeste nos dió lugar á aproximarnos más en la restante mañana. A las diez encontramos fondo de i Io brazas arena fina, y al medio día por latitud de $34^{\circ}$ I $8^{\prime}$, no distábamos sino unas cuatro leguas de la costa del través; siéndonos fácil al misno tiempo marcar la Copa del Sombrero al Sur $62^{\circ}$ Oeste, la Punta Roja al Oeste, y la tierra más Norte al Norte $22^{\circ} \mathrm{y}^{1 /} / 2$ Oeste, todo de la aguja.

Entró poco después virazón bonancible, con la cual y todo aparejo navegamos inmediatamente en demanda de la Bahía Botánica, siéndonos ya fácil distinguir su entrada por ambas Puntas de Banks y Solander. A las tres, no distábamos sino una legua de la costa del través y dos de la boca del puerto, el cual creíamos alcanzar antes de la noche; pero á la sazón escaseándose más el viento hacia el Nordeste y notándose los efectos de la marea contraria que nos aconchaba extraordinariamente, fué preciso variar de idea, y tomar las muras á babor con la proa del Sudeste. Largamos al mismo tiempo las insignias, y no tardamos en ver desplegada la bandera inglesa en un altito intermedio entre el puerto Jackson y la Bahía Botánica. Se aproximaba en el entretanto la hora en la cual, según lo había calculado D. José Espinosa, debía acaecer un eclipse de Sol: nos dispusimos á observarle con los sextantes, y la posición en la cual nos hallábamos, nos dió lugar á esperar que no sería difícil con buenas marcaciones y el auxilio de los relojes marinos, referir sus resultados al observatorio que muy luego estableciésemos en las inmediaciones del puerto.

Las muchas nubes hicieron dudosa la determinación del principio del eclipse, cuyo apulso determinó D. Francisco Viana 4 tpe. vo 354 $39^{\prime \prime}$ y $1 / 2$. D. José Espinosa, por hilación de la partc que se advirtió cclipsada en las primeras claras, á $354^{\prime} 49^{\prime \prime}$.

Despejando después la atmósfera, emprendimos con los scxtantes las medidas bien frecuentes de la parte no eclipsada y de la distancia de los cuernos, medidas las cuales podían alcanzar un grado útil de precision por los sextantes ex- Mar. It celentes de los cuales hacíamos uso. Se midieron dos scries de horarios y compararon los relojes de la una corbeta con la otra, y finalmente se sujetó con buenas marcaciones á los puntos más notables de la costa, el paraje en el cual se logró determinar con la mayor precisión y las mejores circunstancias el fin del eclipse.

Acaeció éste por D. Francisco Viana en tiempo vario, á $5^{\mathrm{h}} 54^{\prime} 36^{\prime \prime} 9$; por D. José Espinosa, á $5^{\mathrm{h}} 54^{\prime} 40^{\prime \prime}$.

Se consideró (según las marcaciones) la latitud de este punto de $34^{\circ} I 7^{\prime} 45^{\prime \prime}$, y su longitud de II' $30^{\prime \prime}$ al Este del puerto Jackson. Bar. Mar. $29^{\circ} 73^{\prime}$. 'Termómetro al aire libre 70. 5. Con la caída del Sol, el viento se había inclinado mucho al Norte bonancible, de suerte, que ya podíamos navegar en busca del paralelo del puerto, el cual era nuestro ánimo conservar en la próxima noche, atento á las corrientes que segun el Capitán Cook y la experiencia de la tarde anterior contábamos constantes al Sur, y atento á la virazón que debíamos prometernos para el medio día siguiente. Se advirtió desde el principio de la noche una grande candelada en el mismo punto en el cual por la tarde habíamos visto la bandera inglesa, y el tiempo á cada paso nos anunciaba una noche de las más templadas del verano.

A pesar de esto, á las nueve se nos declaró un viento del Sudoeste fresco, el cual antes que acortásemos de vela nos llevó rápidamente al Norte y nos precisó por consiguiente á virar hacia las $\operatorname{die} z$. Reviramos luégo á las doce y con las gavias á medio mastelero mantuvimos de la vuelta de tierra. Cesaron las ráfagas fuertes á las tres de la mañana, se sondaron á las cuatro 90 brazas arena fina, y poco después emprendimos con fuerza de vela el atracar la costa y dirigirnos al fondeadero.

Nuestra posición luégo que amaneció, era tan agradable cuanto podíamos desearla. La entrada de la Bahía Botánica nos demoraba al Sur $87^{\circ}$ Oeste, y la del puerto Jackson al Norte $45^{\circ}$ Oeste de la aguja: no distábamos de la segunda sino unas tres leguas: se veían los extremos de la costa. Tremolaba la bandera inglesa en el mismo paraje de la tarde anterior, y el día era sumamente despejado.

Pero el viento no sólo se mantenía constante al Sudoeste con mar bastante gruesa, sino que no prometía la menor alteración en las horas siguientes. Esta circunstancia debió decidirnos á abandonar la idea de fondear en la Bahía Botánica, y preferir el puerto Jackson que teníamos á sotavento. Así aprovechada con fuerza dc vela la buena calidad de las corbetas, para las ocho pudimos recibir á bordo un práctico inglés que salió á nuestro encuentro; atracamos des. 
Ilar. ir pués la punta Sur, y las piedıas salientes de ella, como á un tiro de fusil; y á las diez, dados dos ó tres bordos dentro del mismo puerto, dimos fondo á un ancla, no permitiéndonos el viento ni la marea internar á la sazón hacia el Sidney Cove distante cinco millas del fondeadero actual y punto elegido para colonia principal: la Atrevida fondeó al Sur de nosotros á distancia de dos á tres cables.

Ya de antemano un bote esquifado con el mayor orden y aseo, había pasado al costado de la Descubierta y atracado á la Atrevida. Venía cn él un Oficial de la Plaza, el cual nos cumplimentó de parte del actual Gobernador interino el Mayor Grose, ofreció en su nombre cuantos auxilios suministrase la colonia, y debiendo regresar inmediatamente, se ofreció á conducir en el mismo bote al Alférez de fragata D. Jacobo Murphy, el cual, como experto en el idioma inglés, debía corresponder en nuestro nombre al Gobernador con iguales atenciones y manifestarle los motivos de nuestra escala en el puerto. Reducíanse éstos esencialmente al preciso reemplazo de agua y leña y al natural reparo de los buques y aparejos después de un viaje de noventa y siete días; al acopio de una colección botánica y zoológica para el Real Gabinete, cual pudiesen permitirla la estación y el tiempo; á las experiencias de la gravedad con el péndulo simple, y á un pequeño descanso á entrambas tripulaciones, antes de arrostrar á las navegaciones á las cuales estaban destinadas: Murphy debía al mismo tiempo proponer el saludo á la Plaza siempre que correspondiese tiro por tiro, y asegurar al Mayor Grose, que si bien fuese nuestro ánimo aproximarnos al Sidney Cove ya que los vientos no nos habían permitido entrar en la Bahía Botánica, serían tales nuestras medidas relativamente á la seguridad de los sentenciados y al buen orden interior de la colonia, que no se extrañaría la existencia en el puerto de dos buques de otra nación.

Despedidos con este encargo el Capitán Johnston y D. Jacobo Murphy, y no permitiéndonos aún el viento ni la marea el emprender la navegación hacia el Sidney Cove, nos pareció aquella una ocasión favorable para destinar un bote á la pesca, la cual debíamos prometernos bien abundante á favor de las tripulaciones, atento á los informes del práctico y al pescado excelente que ya nos habian vendido dos botes pescadores.

Entretanto eran ya las tres de la tarde, y aunque continuase viento fresco del Oesudoeste nos disponíamos á dar la vela para ganar sobre bordos y con la marea favorable el fondeadero deseado; pero empezaron á declararse ráfagas tan fuertes del mismo viento, con mal cariz y lluvia, que nos persuadieron á diferir la empre- sa para el día siguiente, tanto más, que habiendo garrado la ATREvida por dos veces, se había visto precisada á dejar caer la segunda ancla, y ahora necesitaba con espías buscar una posición más ventajosa para dar la vela.

A la caída de la tarde cedió mucho el riento y despejaron cielos y horizontes: con este motivo no tardó en regresar á bordo el Alférez do fragata Murphy, al cual acompañaban en el mismo bote el Teniente Rowley, Ayudante mayor. de la Plaza, el Capitán David Collins, Juez togado y Secretario de la Colonia, y el Capitán Bamb. ton, con algunos oficiales del navío Share-Harmusia, que últimamente había llegado de Bengala con efectos vendibles, logrando de una navega. ción de siete semanas desde Calcuta hasta Sid. ney. Con nuevas expresiones y ofrecimientos sumamente atentos, ratificaron las primeras idea. que habíamos podido formar por la mañana, no sólo del buen acogimiento que recibiríamos, sí también del buen orden y de la abundancia do refrescos que ya suministraban aquellos contornos.

Estas noticias agradables nos hicieron esperar con ansia la mañanita siguiente; y las ráfagas del Sudoeste con aguaceros, que tuvimos nuevamente desde las dos de la mañana, debieron ahora parecernos tanto más molestas, cuanto más nos amenazaban de poder malograr también la próxima marea favorable: sin embargo, á las cinco ya estuvimos á pique, y poco después do las seis á la vela, con viento contrario pero más claro y sin ráfagas, el cual nos precisaba á bordos frecuentes sobre las gavias, estays y juanetes.

No cabe una descripción adecuada de la hermosura del puerto y de la admiración que debe causar á todo navegante luégo que interna en él. La naturaleza ha ocurrido á cuanto podía hacerle igualmente cómodo y seguro. Las mareas mismas que ahora hubiéramos deseado más fuertes, no son bastante causa para estorbar la navegación interna á cualquiera hora del día ó de la noche. Muchas ensenaditas, la mayor parte con buen fondo para buques de cualquier porte. algunas islas pequeñas y las orillas poi lo común escarpadas por: una parte y otra, hacen la escena aún más agradable. Finalmente, una distancia de cinco millas por diferentes direcciones siempre no distantes del Oeste, conduce al Sidney Cove, pequeña cala bien situada y elegida por el Comodoro Philipps para capital de todas las colonias de la Nueva Holanda.

A las diez dc la mañana ya pudimos fondear en paraje oportuno para no hacer demasiado frecuente el roce de nuestra marinería. La ATREviDA nos alcanzó por la tarde logranclo de una virazón fresquita, é inmediatamente la Oficialidad de entrambos buques encontró en el Mayor Gro- 
Mrr. ‘z se y en los demás individuos principales de la colonia aquel acogimiento generoso que podía mirarse como propio de la Nación que representaba.

Ya entablada de este modo una confianza recíproca, de la cual no podían ménos de disfrutar al mismo tiempo las demás clases subalternas por una y otra parte, nuestras medidas en la manana del I + para ocurrir á las causas que nos habían guiado al puerto, pudieron ser bastantemente activas. Se adoptó para observatorio una punta al Este, distante de las corbetas un cable y medio, prefiriéndola al observatorio de Monsieur Deoawse, por la menor comunicación con el pueblo y la mayor inmediación á las corbetas y á la orilla del mar. Las barracas de los toneleros y herreros pudieron también colocarse en las inmediaciones del observatorio: se trabajó con tesón en el velamen y aparejo, quedó todo dispuesto para empezar la aguada al día siguiente; ambos botánicos lograron en tierra un regular sitio para el cuidado de las plantas que recogiesen, y finalmente, diéronse á bordo las instrucciones necesarias para que en los pasos sucesivos todo contribuyese á la mejor conservación de aquella amistad.

Estas medidas se reducían principalmente á que un Oficial de guerra de una ú otra corbeta presidiese diariamente la aguada, ya que era preciso hacerla en la población; que en el bote destinado á la pesca fuese un sargento ó condestable con algunas armas de fuego para evitar cualquier sorpresa por parte de los naturales, bien temibles, según nos habían informado en la colonia; que de noche se custodiase el observatorio con un cabo y dos soldados nuestros, los cuales pasarían la palabra con las centinelas de las dos corbetas; que por ningún motivo se admitiesen mujeres á bordo; que se pasasen dos listas al día para castigar rigurosamente cualquiera que faltase á ellas; que no se admitiese convicto alguno en los botes ni en las corbetas; que se evitasen desde su mismo principio las borracheras y desórdenes de la marinería, y más que todo, cualquiera alienación de su ropa; finalmente, que desde las ocho de la noche no se permitiese atracar á bordo á bote alguno extraño, á ménos que no diese una contraseña, de la cual convendríamos después reservadamente con la plaza. Enterado de estas medidas el Mayor Grose y particularmente de la última, la cual miraba más directamente á evitar la fuga de cualquier convicto, tuvo la bondad de ofrecernos la contraseña diaria de la plaza que el Ayudante Mayor nos enviaría cerrada; pero la omitimos mientras la experiencia no la indicase necesaria, agradeciendo sí esta prueba de confianza no ménos que los honores de armas que nos hacían las guardias en tierra, iguales enteramente a los de sus Generales.
Con estas precauciones y contribuyendo tan- 11ar. 25 to á su exacto cumplimiento la serenidad del tiempo, la tranquilidad del puerto y el buen orden de la colonia, pudimos para el 25 ver concluídas en una y otra corbeta la aguada y la leña, hechas con la mayor prolijidad las experiencias del péndulo simple, examinada la marcha de los relojes, y finalizados en el casco y aparejo todos los reparos que fuesen necesarios y que por su número y por su calidad no podían parecer indiferentes.

La buena conducta de entrambas tripulaciones hasta este tiempo, y el deseo de proporcionarles un justo descanso y esparcimiento, hizo luégo necesarios dos ó tres días de libertad para que lavasen sus ropas; sin embargo, para el 27 , si se exceptúan algunas obras pequeñas de herrero y tonelero, las corbetas podían considerarse enteramente prontas para dar la vela.

Pero para esta época las colecciones botánicas de los Sres. Heenke y Nee estaban aún bien informes, aunque entrambos hubiesen desplegado una actividad singular; nuestros conocimientos hidrográficos se hallaban, digámoslo así, en su niñez, y las muchas atenciones que habíamos recibido y recibíamos diariamente de los individuos principales de la colonia, exigían unas muestras nada equívocas de nuestro agradecimiento. Así, pareció que el sacrificio de pocos días á estos objetos no se miraría como absolutamente infructuoso; y le abrazamos con tanta mayor satisfacción, cuanto más favorables eran todas las circunstancias para reunir á las demás tareas nuestras el aprovechamiento de la observación última del eclipse de Sol.

Ignorábamos efectivamente no ménos los resultados de las observaciones astronónicas de Mr. Dawse, que las operaciones hid ográficas del hábil Capitán Hunter, y nos ofrecíamos por otra parte en hacer públicos antes de la salida los frutos de nuestras tareas, por manera que pudiese después hacerse la debida comparación de unos con otros y deducir la verdad con una mayor aproximación. Con este solo objeto se dirigió la lancha de la Descubierta á la bahía Botánica para levantar geométricamente su plano, y de allí traer una serie bien ordenada de triángulos hasta el mismo observatorio, por las ensenadas interiores del puerto.

Don Juan Rabenet combinó con esta expedición otra suya por tierra hasta la bahía Botánica, á la cual le acompañaron el Capitán Johsnton y el Teniente Prentice para que tuviese mejor ocasión de concurrir con algunos naturales y retratarlos con sus armas y costumbres. D. Antonio Tova hizo algunas salidas para cazar; D. Fernando Brambila emprendió algunas vistas de perspectiva; los botánicos se internaron hacia Parramata y Tungave; se continuaron las ta- 
Mar. 25 reas del observatorio y entrambos Comandantes nos dispusimos á obsequiar á bordo, para el primero y segundo día de Pascua, al Mayor Grose y á las personas más distinguidas de la colonia.

Ya en los días anteriores les habíamos merecido que concurrjesen con las señoras á almorzar en una pequeña barraca dispuesta para el intento en las inmediaciones del observatorio, y en la cual, se nos permitía sirviésemos con preferencia el chocolate y varios comestibles de nuestra España. Además de esto, no sólo entre las clases respectivas con recíprocos convites y regalos se había estrechado cada vez más y más una amistad cariñosa, sino que se advertía entre todos una unión tan estrecha, que no dejaba duda á una verdadera simpatía nacional ligada con una buena educación; y fué para nosotios un feliz acaso que por este tiempo ilegase también al puerto, con quince días de navegación desde la Isla de Norfolk, la embarcación inglesa la Ritty y en clla el Capitán Patterson, Mis Patterson su esposa, y el Teniente de navío Woodreef, de la Marina Real, quien navegaba como Superintendente en el mismo buque desde los puertos de Inglaterra. El primero, ya conocido del público por tres viajes hechos desde el Cabo de Buena Esperanza hacia los países interiores del Africa con objetos de Historia Natural, había ahora explayado su aplicación y amor á las ciencias por el espacio de catorce meses que había permanecido en Norfolk con su compañía.

El tiempo favoreció mucho el primer convite á bordo de la Descubierta en donde se hicieron al Mayor Grose los honores de Teniente General embarcado $y$ además se acompañaron con salvas los siguientes tres brindis: I. ${ }^{\circ}$ El Rey de Inglaterra, el Rey de España y ambas Reales familias. 2. ${ }^{\circ}$ El Comodoro Philipps, el Mayor Grose y la prosperidad de la colonia. $30^{\circ}$ Las señoras que nos favorecían con su presencia. Todos los convidados repitieron el brindis, anteponiendo el Rey de España al Rey de Inglaterra; hicieron eco á estos sentimientos de cariño y de respeto los juiva el Rey! de la marinería, y la música del regimiento tocando al mismo tiempo el aria God save the King dió á esta escena agradable y tierna todo el semblante majestuoso que merecía: el tiempo lluvioso y con viento algo arrafagado, no permitió al día siguiente que las señoras concurriesen á bordo de la ATREviDA, pero no faltó otro alguno de los convidados; se hicieron al Mayor Grose los mismos honores del día anterior y se renovaron los mismos brindis.

En aquel día tuvimos también la satisfacción de ver regresar la lancha, concluídas sus operaciones por la parte exterior del puerto, no quedándole, sino las marcaciones internas, que debía emprender con un bote. Efectivamente, en la mañana siguiente lo verificó el bote de la Mar. Descubierta, y en la tarde del 3 de Abril, quedaron concluídas todas las marcaciones.

No habíamos sido tan felices en el observatorio, á lo ménos por lo que toca á la deducción de la longitud, pues relativamente á esta, se habían frustrado por las nubes todas las inmersiones visibles del primer satélite de Júpiter, y no acaecía ocultación alguna de estrellas por la Luna, de suerte que aproximándose ya mucho el plazo de nuestra salida, y siendo preciso como lo habíamos prometido el presentar en un orden ostensible los resultados de nuestras tareas astronómicas para la longitud del observatorio, debimos ceñirnos á los datos siguientes:

\section{Longitud or. de Gr.}

Por el fin del eclipse de Sol acaecido en la tarde del i i observado á bor"do de la Descubierta y calculado por D. Iuan de la Concha por las fórmulas de Mr. Cagnoli.

Por los relojes marinos, adoptada la longitud de Duski Bay del Capitán Cook.

Por la inmersión del segundo satélite de Júpiter acaecida en la noche del 24 de Marzo. . . . . . . . . Por 42 series de distancias de la Luna al Sol.....

Latitud del observatorio por muchas alturas meridianas al Norte y al Sur del Z. .

Variación magnética. .. Nordeste. $151^{\circ} 02^{\prime} 30^{\prime}$

I 5 r $\cdot 15 \cdot 25$

$151 \cdot 10 \cdot 15$

I 5 I, I 8 , I 5

$33 \cdot 51 \cdot 26$

$8 \cdot 45$
Para adquirir una idea más cabal del estado y suerte venidera de aquellas colonias, nos quedaba aún el paso más interesante, y era el de una excursión á los establecimientos de Parramata y Tungave. El Comodoro Philipps, no hallando en los contornos de Sidney Cove sino un terreno sumamente ingrato é infecundo para las siembras, debió decidirse en favor de Parramata para el centro de la agricultura, con tanta más razón, cuanto que además de prometer sus tierras unas cosechas ménos inciertas y escasas, la conducción de los frutos al Sidney Cove era sumamente fácil y barata con el auxilio de los canales internos. Y era esta la única perspectiva, aunque distante, para que la subsistencia de las colonias no dependiese como en el día de la navegación complicada de una mitad ó más bien diré de todo el globo, y para que aminorasen con el tiempo los gastos crecidos que causaban á la matriz; así no hubo parte alguna de actividad, de policía y de orden, que el Comodoro y sus subalternos no desplegasen en su fomento: en breve tiempo los soldados, los colonos, los sentenciados, criaron de la nada una población bien ordenada, con buenos cuarteles y almacenes: le precedieron al andar de las orillas diferentes 
War. ss haciendas, con las moradas de algunos colonos. El maiz, el trigo y la cebada, dieron aunque mezquinos, sus productos seductores. Más abundante la papa, prometió desde luégo una subsistencia ménos dudosa en lo venidero. Los árboles frutales, la hortaliza, y sobre todo el limón y la vid, dieron nuevos resortes á la actividad y esperanzas comunes; finalmente, las primeras crias del número aunque excesivamente corto de los ganados vacuno, ovejuno y caballar, hallando en esos mismos contornos un clima saludable y unos pastos abundantes, pudieron fomentar la agradable esperanza de que no tardaría en reunirse en ese nuevo centro de la opulencia nacional, la actividad y policía inglesas con el clima y el suelo de nuestras Andalucías.

Después de esta breve pintura, no parezca extraño que fuese á lo ménos igual al nuestro el deseo de los indivíduos principales de la colonia para que visitásemos á Parramata. Esta excursión se emprendió en la mañanita del 5 por el mayor número de la Oficialidad en los dos botes de las corbetas. Nos acompañaron los Sres. Collins, White, Johnston. y Prentice. I para no olvidar enteramente nuestros objetos hidrográficos, se añadieron á una aguja y al teodolito, el reloj de faltriquera número is, y el sextante de Stanchff con horizonte artificial propio de D. José Espinosa.

El tiempo, que al rayar el día nos amenauaba con frecuentes aguaceros, tomó luégo el iemblante más apacible y hermoso. A las siete Y media de la mañana estuvimos en casa del Gobernador, desde donde emprendimos un paseo á Tungave y á la colina inmediata para alcanzar la vista de las montañas de Rickmond y Caermarthen: una senda diferente, vistos ya los sembrados, nos condujo luégo á ver los ganados.

Era la una de la tarde cuando alcanzamos de nuevo nuestro cuartel general y nos reunimos á los Sres. Espinosa y Brambila, los cuales habían conseguido, el primero observar con la mayor satisfacción la altura meridiana del Sol, y el segundo tomar con su acostumbrado pulso algunas vistas de perspectiva, que darán mejor jdea de los contornos de Parramata y de los elogios que merecen ambos Jefes de la colonia, de cuanto pudiésemos añadir aquí con una descripción mezquina y mal entretejida.

Después de cuatro ó cinco horas de paseo debió luégo ser igualmente alegre y sabrosa la comida: y conseguidas á las tres de la tarde las alturas absolutas para la deducción de la longitud, regresamos al Sidney Cove, á donde llegamos á las siete, trazada por D. Felipe Rausá una parre de los canales hasta donde lo permitía la aproimación de la noche. Dedujo en la mañana siuiente ]). José lispinosa la posición astronómi- ca de la casa ya indicada, la cual resultó en latitud de $33^{\circ} 48^{\prime}$ y $19^{\prime} 45^{\prime \prime}$ al Oeste del observatorio nuestro, distante de él por consiguiente, I6,8 millas marítimas al Norte $78^{\circ}$ Oeste del mundo.

En estos últimos días, no había sido, á la verdad, tan arreglada como antes la conducta de nuestra gente en tierra, no porque creyésemos asequible que resistiesen á las seducciones contínuas de las mujeres sentenciadas, arrastradas del vicio más bien que del interés, y tan desenfrenadas en su conducta, que pareciesen castas en su cotejo las mujeres de Tenerife cual las pinta Mr. White en su Diario, sino porque se entregaron á la bebida de algunos licores, dispuestos seguramente para aletargarlos y robarles después el poco dinero que tuviesen. Hubo marinero de la ATREVIDA, que con este motivo faltó á la lista hasta cuatro días seguidos. En la DEscubiekTa faltaron igualmente á un tiempo cinco marineros, $y$ por cuanto fuesen activas las medidas del Mayor Grose para castigar estos robos, aunque frívolos, y cortar de raíz semejantes desórdenes, no sólo no fué posible conseguirlo, sino que más bien iban aumentándose diariamente.

Esta era una nueva razón para que acelerásemos la salida de las corbetas, la cual quedó fijada para la mañanita del II. El 8 nos despedimos unidos, del Gobernador, de cuya mesa y atenciones continuamos, sin embargo, disfrutando hasta el último momento, y los restantes días, si bien se aprovechasen por cada uno en estrechar y hacer más duraderas la amistad, simpatía y agradecimiento que nos ligaban, debieron amargar mucho nuestra situación, con recordarnos una tan próxima separación y á tamaña distancia.

Merecerán siempre en nuestra memoria un lugar preferente y un aprecio y amistad incapaces de borrarse, el Capitán Nepean, el Teniente Mr. Arthur, el Párroco Johnston y los Sres. Collins y White, los cuales manifestaron desde el principio un cleseo particular de complacernos y distinguirnos. Sus casas fueron constantemente las nuestras; sus dones tan finos como apreciables, y su trato tan atento como amistoso y lleno de cariño.

El Párroco Johnston extendió aún mucho más sus principios sociales, aproximándose particularmente á nuestros Padres Capellanes con una dulzura, una humildad y una sencillez realmente evangélicas, $y$ persuadiendo con infinitas ins * tancias al Padre Mesa, de la Descubierta, á que disfrutase de la tranquilidad y hospitalidad de su casa, para restablecer (como lo consiguió) su salud bien quebrantada; ejemplo digno de los mayores elogios y agradecimiento, y el cual no recordaremos jamás sin la mayor complacencia 
Ab. 8 y deseo de imitarle, venerando los decretos incomprensibles de la Providencia.

Che tutti ascolta, e por ge a tutti aita.-FILICAJA.

Por nuestra parte, en las pocas cosas que la constitución del viaje nos permitió ofrecerles, debió más bien sobresalir la conocida imposibi lidad de satisfacer á nuestros deseos y agradecimiento, que la esperanza de corresponderlos: el Mayor Grose recibió con agrado dos vistas del puerto y una de Parramata, trabajadas por Don Fernando Brambila con mano maestra y capaces de dar en Inglaterra una idea bien cabal del estado actual de aquella colonia. El mismo Brambila ofreció al Capitán Patterson la perspectiva de una cascada en la Isla de Norfolk, cual la había descrito él mismo; y D. Juan Rabenet, desplegando en los últimos días un igual grado de destreza, de felicidad y de complacencia en hacer retratos en miniatura, pudo satisfacer los deseos de la mayor parte de las señoras y caballeros de la colonia, que se reducían á lecordar á sus amigos y parientes en Inglaterra, la extremada distancia á que se hallaban unos de otros. Correspondieron igualmente entrambos Cirujanos á las excelentes colecciones de instrumentos quirúrgicos que les ofreció Mr. White: D. Fernando Quintano y D. Felipe Bausá, repartieron la poca quina excelente que les había quedado del precioso regalo del Regente de Guatemala; finalmente, entrambos Comandantes nos desprendimos de todas aquellas provisiones que no nos hiciesen absoluta falta y tenían algún incentivo para agradar.

En la tarde del ro quedaron á bordo los instrumentos astronómicos y los demás utensilios; fueron luégo incesantes nuestras precauciones para que no se admitiese ni escondiese á bordo individuo alguno extraño; y por último, frustradas de nuevo en la noche inmediata y en las dos anteriores algunas observaciones del primer satélite de Júpiter, estuvimos desamarrados al amanecer del Ir, y poco después dimos la vela.

El terral del Sudoeste era á la sazón tan flojo, que apenas podíamos contrarestar la marea entrante, y una neblina sumamente densa nos ocultaba á veces hasta los puntos más inmediatos de la costa. Esos accidentes nos proporcionaron la satisfacción de que permaneciesen algún tiempo más con nosotros los Capitanes Nepean, Bampton y Alt y el Teniente Woodreef, que habían venido á bordo á darnos un último abrazo; pero alcanzada á las nueve de la mañana la boca del puerto, disipada la neblina y entrada casi al mismo tiempo la virazón galenita, nos despedimos, y entrambas corbetas ciñeron el viento, con el cual para las diez ya es'aban fuera del puerto.

\section{CAPÍTULO V}

Navegación de las corbetas desde el puerto Fackson hasta las Islas de los Amigos.-Escala en la Bahía Maurelle del Archipiélago de Vavao y reconocimientos interiores del mismo Archipiélago.--Navegaciones sucesivas al Sur hasta perder de vista las Islas de Tongatabu y Eua.

Navegábamos con todo aparejo para alejarnos de la costa antes que la virazón calmase ó rolase más al Este, cuando se avistó fuera de la boca del puerto el bote del Gobernador, que vogaba en nuestro seguimiento con una banderolilla ó señal en proa, la cual no dejaba duda de su deseo de alcanzarnos. Paireamos inmediatamente, y antes del medio día le tuvimos á bordo, siendo su objeto el de conducir de parte del Mayor Grose un soldado de su regimiento, culpado de fraude por algunas frioleras que le había en. tregado para venta ó cambio el carpintero de la ATREVIDA: en pago de aquellos efectos, deseaba el Mayor que se recibiesen otros equivalentes que el soldado había presentado, y lo cual no dejamos de admitir, con la esperanza de que este mismo paso diese nuevo vigor á nuestras instancias para que se aminorase el castigo que debía seguirle. Despedido el bote y observada la latitud de $33^{\circ} 47^{\prime} I 7^{\prime \prime}$ marcamos de nuevo con todo aparejo; el viento estaba á la sazón al segundo cua. drante, calmoso. Viramos al Sur á las tres de la tarde, y para la puesta del Sol, distábamos unas siete millas de la costa de través.

Entrada la noche, las ventolinas cedieron enteramente, dando lugar á que la marejada nos aconchase algo más sobre la costa, según el fondo de 53 y 6 r brazas arena que encontramos á las ocho y á las diez; pero para la media noche empezaron á hacerse sensibles las primeras ventolinas del terral, con las cuales y todo aparejo, gobernamos al Este para separarnos. Nuestra derrota debía dirigirse por el Sur de la Nueva Zelanda á las Islas de los Amigos, en cuyas inmediaciones nos lisonjeábamos que no serían enteramente inútiles nuestras pesquisas para los progresos de la Hidrografía.

Los vientos fueron al principio variables, y más bien flojos; pero las corrientes decididas hacia el Este con una velocidad extraordinaria, contribuyeron de tal modo á los progresos de nuestra derrota, que para el día 26 , por latitud de $35^{\circ}$ no distábamos sino 60 leguas de las costas de la Nueva Zelanda: variación magnética $\mathrm{II}^{\circ} \mathrm{O}^{\prime}$ al Nordeste.

Ya desde el día anterior, la muchedumbre de procelarias, los horizontes sumamente cargados, las proximidades sospechosas del plenilunio y el viento más recio y arrafagado, nos anunciaban un
Ab. It 
Ih. a's temporal no distante, el cual, si juzgásemos por las experiencias del Capitán Cook en esos mismos paralelos, podía muy bien ser excesivamente recio á pesar de la latitud tan baja y de la estación aún benigna del otoño. Desde el principio de la noche nos vimos precisados á navegar sin juanetes: al amanecer del 26 ya las corbetas no podían sufrir las gavias izadas; y antes de pasar el Sol por el meridiano, navegamos con dos rizos y se habian echado abajo las vergas de juanete.

Nada era inútil; á la media noche la mar y el viento habían acrecentado extraordinariamente, de modo que fuese más bien demasiado aparejo el del trinquete y la gavia arriada: fué preciso aferrarla á las seis de la mañana, y en las demás horas hasta el medio día, nada puede dar una idea cabal de la fuerza que habían tomado el viento y la mar: eran contínuos los golpes que inundaban las corbetas; se hacía sumamente expuesto el capear con sólo el trinquete; había faltado una cadena á la mesa de guarnición mayor; no había á bordo paraje alguno enjuto y carecíamos de la vista de la ATREVIDA por la suma cerrazón de los horizontes.

Al medio día, después de una oscuridad extraordinaria y algunas ráfagas excesivamente recias, venció por contraste el viento del Este, el cual, sin embargo, desfogando con una lluvia abundantísima, calmó á poco rato y nos dejó entregados á las olas para su juguete; capeamos, aunque inútilmente sobre el contrafoque y estays mayor y de mesana; cada balance nos amenazaba de averías considerables; y fué el solo momento para nosotios agradable en toda la tarde, el que sobre una clara nos proporcionó la vista de la ATREvida y le dió lugar para que con trinquete y velacho arribase para reunírsenos.

No cedieron la lluvia y el viento hasta el otro día, $y$ fueron precisas repetidas faenas en ambas corbetas para reparar siquiera en parte las averías sufridas; pero no bien hubo pasado el Sol del meridiano, cuando el viento roló rápidamente al Norte y Noroeste, de suerte que antes de la una ya pudiésemos navegar con las cuatro principales y las gavias rizadas.

Al medio día del 2 de Mayo, el Cabo Norte de la Nueva Zelanda nos demoraba al Sur dis. tancia de 50 leguas, y por consiguiente, nuestra navegación venidera podía mirarse como más libre y expedita.

Sólo en la mañana del día anterior habíamos tenido lugar, así en ésta como en la corbeta ATREVIDA, de observar diferentes series de distancias de la Luna al Sol, habiéndolo imposibilitado hasta entonces, las mares con exceso gruesas ó los cielos por lo común nublados y lluviosos: nuestros resultados por un promedio de 32 series y 5 observadores, dieron la longitud de $182^{\circ} 3^{\prime} 3^{\prime \prime}$ al Oeste de Cádiz: diferían de esta longitud, el número i I $25^{\prime}$ al Oeste, y el May. z cronómetro 72 sólo dos y medio minutos en el mismo sentido: las observaciones de la ATREvidA según nos dijo después á la voz su Comandante, aproximaban más bien á un promedio de nuestros dos relojes y conformaban enteramente con los I05 y 7 I á la sazón bien próximos uno de otro.

Vencidos los meridianos de la Nueva Zelanda, tuvimos nuevos temporales recios por paralelos de 29 á $32^{\circ}$ que causaron diferentes averías en el aparejo y una debilidad extraordinaria en las tripulaciones: la ATREvidA tuvo la desgracia de perder un marinero filipino que cayó al agua cuando eran más tempestuosos el viento $y$ la mar: y alcanzada próximamente la longitud de las Islas de los Amigos, y ya sensibles los primeros soplos de la brisa por latitud de $29^{\circ} 28^{\prime}$ navegamos al Nornordeste.

E1 Archipiélago de Mayorga, visitado por el Comandante Maurelle en I782, y sin duda el mismo de que había hecho memoria el Capitán Cook en su tercer viaje, distinguiéndole, según las noticias adquiridas en Annamoka y Tongatabu, con el nombre de Vavao, era ahora el paraje al cual se dirigían las corbetas para continuar sus investigaciones náuticas, y seguramente un examen atento de los pocos reconocimientos útiles que aún quedaban por hacer en el mar Pacífico, no de jaba duda que era este el que debía preferirse á todos, atento á los últimos reconocimien. tos del Conde de la Péyrouse en el Archipiélago de los Navegantes y á los anteriores del Capitán Cook en las islas inmediatas de Happai, Annamoka y Tongatabu: ni para esta preferencia eran ménos poderosas las reflexiones que nos hacían miral el Archipiélago de Vavao como un descubrimiento enteramente nacional y nos prometían en él aquel abrigo y abundancia de refrescos que difícilmente hubiéramos encontrado (á lo ménos con igual seguridad) en cualquiera de las islas inmediatas. No cabían muchas dudas sobre su posición exacta en cuanto á la latitud, ni á la verdad debía haberlas tampoco en cuanto á la longitud, atento á la estima de sólo dos días con la cual el Comandante Maurelle ligaba á las islas inmediatas de Happai los extremos meridionales de este Archipiélago. Pero para el derecho usurpado últimámente por los navegantes europeos sobre esta clase de descubrimientos, faltaban aún dos circunstancias, las cuales deseábamos revalidar ahora con la mayor autenticidad; y eran un reconocimiento científico por los métodos adoptados en el día, y una posesión pública que vindicase á los ojos de la Europa la seguridad del descubrimiento y el convenio de los naturales. ¡Triste ambición solapada con el semblante apacible de las ciencias y de la filosofía, que dictando unos pasos al mismo tiempo injustos y 
May. 9 costosos á una nación alucinada, obliga á las de. más á seguirla de cerca en sus conquistas imaginarias, no adquiridas por ventura con ríos de sangre y de dinero, sino con pocos instrumentos astronómicos, algunas bagatelas cambiadas por efectos de mucha mayor utilidad y una ú otra descripción enterrada en parajes señalados!

Con estos antecedentes, no era difícil el trazar una derrota breve á las islas indicadas, ni ya permitían distraerla con otro objeto alguno, la necesidad de alguna agua y refrescos y los muchos reparos indispensables en los aparejos y cascos de entrambas corbetas.

El viento ya fresco del Sueste, iba aumentando mucho su fuerza é inclinando á veces al Esueste, pero. con cerrazones y aguaceros particularmente de noche, los cuales nos precisaban á navegar algunas horas bien precavidos en el aparejo, sin que excediese nuestro andar de cuatro á cinco millas. El día $\mathrm{I} 6$, por latitud de $24^{\circ}$ y longitud de $I^{\circ} 30^{\prime}$ al Este de Vavao, debimos aún multiplicar nuestras precauciones en la noche, prefiriendo el capear sobre la gavia en dos rizos, el contrafoque y la vela de estay de mesana: sin embargo, eran las brisas tan frescas, que áun malogradas tantas horas de cada singladura, en la noche del is ya pudimos considerarnos próximamente en el paralelo deseado. Diferentes series de distancias de la Luna al Sol, medidas en la tarde anterior y en la del I7, nos indicaban por más exacta la longitud del número II, la cual, por la mañanita del I9, nos hacía suponer unas sólas 20 leguas distantes del Archipiélago indicado.

Pusimos inmediatamente la proa al Oeste, con vientos del Este ménos frescos que los días anteriores, pero arrafagados y acompañados algunas veces con lluvia, y fuimos bastante felices para que al medio día, por latitud de $I 8^{\circ} 5^{2}$ y longitud de $35^{\circ}$ I $5^{\prime}$ al Este del Puerto Jackson, se nos presentasen á la vista las islas deseadas: corrían á la sazón del Noroeste al Oeste, distante de nosotros unas seis leguas, y parecían sumamente bajas hacia el extremo Sur, elevándose luégo paulatinamente hacia la parte septen. trional.

A las dos y media de la tarde, nos hallamos Norte-Sur corregido con el extremo Norte, al cual se anteponían dos islas medianas y lozanamente frondosas, ligadas luégo por medio de arrecifes á otras muchas isletas de inferior tamaño: éstas se daban la mano con los arrecifes más meridionales, y sus rompientes eran ya visibles desde la cubierta. El rumbo del Sudoeste parecía conducirnos con seguridad al Sur de todos esos peligros, y era, por consiguiente, el que seguíamos; doblando la vigilancia á medida que el viento muy fresco nos empeñaba, sin permitirnos sondar al Oeste de las islas reconocidas.
No era inútil tanta vigilancia; antes de las May. Ig tres y media demorándonos ya las isletas más Sur al Oesnoroeste y distantes de sus arrecifes unas tres ó cuatro millas, descubrimos un bajo bastantemente extendido á distancia de dos leguas. La tarde adelantada y el viento bien fresco y de travesía, de modo que ni fuese fácil sondar ni posible el retroceder si hallásemos nuevos peligros, dictó muy luego como partido más prudente tomar las muras á estribol con proa al Nordeste y la posible fuerza de vela.

Aún este partido nos debió parecer sumamente arriesgado, porque caimos rápidamente sobre los arrecifes, arrastrados seguramente de la dirección de las aguas hacia los canales internos, y ya esta nueva contrariedad, á cada instante más peligrosa, nos había casi decidido á preferir antes de la noche el paso entre los arrecifes, cuando los vigías que habíamos enviado de nuevo á los topes para examinar el canal prolijamente, nos avisaron que se veían otras rompientes entre uno y otro extremo: fué por consiguiente preciso el continuar con el partido adoptado, si bien la mar fuese gruesa, el viento bien fresco y nuestras pérdidas visiblemente considerables. Por ventura las buenas cualidades de las corbetas y el viento que se alargó próximamente de una cuarta, decidieron la cuestión á nuestro favor. Para las cinco, ya libres de la corriente de las aguas, no descaecíamos en modo alguno sobre los arrecifes; á las siete marcábamos el extremo Norte del Archipiélago al Oeste distancia unas tres leguas, y poco después, tomado un rizo á las gavias, ya nuestro único intento era el de conservarnos próximamente en esta posición hảsta la mañana siguiente. La noche fué lóbrega con repetidos chubascos, con viento fresco y arrafagado. Dimos diferentes bordos sobre las principales, en los cuales no nos pareció prudente virar por avante; y á las cinco de la mañana, aunque los horizontes estuviesen bien calimosos, avistamos la costá no mucha distancia: el extremo Norte demoraba al Oeste $5^{\circ}$ Sur unas tres y media leguas, y el escarpe de sus orillas reurido á nuestro examen desde los topes, no dejaba duda de que estaba libre de todo peligro. Arribamos sin perder tiempo á atracarlo de cerca, y á medida que navegábamos después costeando sus orillas á distancia de una ó media milla sin encontrar fondo, cedían la mar y el viento $y$ nuestra situación tomaba el semblante más agradable.

Es esta parte de costa que no reconoció Maurelle, bastantemente alta y cortada á pico. No se advierte en ella sino una sola bahía con poca playa, en la cual se veían reposar á la sombra de las palmas diferentes naturales. Las demás puntas parecen más bien inaccesibles, son enteramente vestidas de un bosque espeso, y con- 
ducen inclinándose poco á poco al Sur, á las canales que dieron abrigo á la fragata Princesa.

A las nueve ya descubríamos en parte el primer canal y ceñíamos para atracarle los vientos del primero y segundo cuadrante, extraordinariamente varios en su fuerza y dirección según la diferente posición de las tierras altas que los interceptaban. Poco después tuvimos la satisfacción de ver atracar á bordo una canoa con tres naturales, á los cuales se regalaron algunas bagatelas, y á las diez pudimos despachar el bote armado á las órdenes de D. Francisco Viana, para que reconociese el primer fondeadero, mientras las corbetas procuraban sobre bordos, introducirse entre los muchos islotes y atracar la costa de la isla grande más septentrional. No tardó el bote en señalarnos buen fondo en el mismo paraje al parecer, que Maurelle había llamado Puerto del Refugio; se nos incorporó después para el medio día cuando ya teníamos al costado diferentes canoas de naturales y los bordos ya más ya ménos favorables nos aproximaban al fondeadero reconocido. Tuvimos también algunos chubasquillos entremezclados con calmas, los cuales nos detuvieron en una inacción casi completa; pero el logro de algunas ventolinas favorables nos condujo al fondeadero, en el cual, según las direcciones de D. Francisco Viana, dejamos caer el ancla de tierra en 20 brazas arena á no mayor distancia de la costa de dos cumplidos de corbeta, precaución necesaria para que la amarra de fuera no cayese en piedra y demasiado fondo: emprendimos in mediatamente el amarrarnos, y habiéndonos alcanzado poco después la ATREvida con el auxilio de los remolques y de algunas ventolinas, entrambas corbetas pudieron mirar como concluídas á la caída de la tarde estas maniobras con la sola precaución de que la Atrevida diese una codera á una piedra inmediata para evitar el borneo, el cual por la demasiada inmediación nos exponía á frecuentes abordajes. Ya amarrada la Descubierta con el ancla de tierra en 22 brazas arena, y la del Sueste en 34 arena y cascajo, marcaba la Punta Oeste del fondeadero al Norte $73^{\circ}$ Oeste, la punta Este al Sur I $5^{\circ}$ Este y varias islitas no más distantes de una á dos leguas, desde este último rumbo al Sur $64^{\circ}$ Oeste de la aguja, de suerte que no habiendo abiertas sino las dos cuartas desde el Oesudoeste al Oeste, dirección enteramente opuesta á la del viento reinante, y pudiendo en este día compararse el viento frescachón que reinaba fuera, con la calma y tranquilidad que disfrutábamos interiormente, todo parecía anunciarnos un abrigo seguro y tranquilo cualquiera fuese el plazo de nuestra demora en él.

Entre las muchas canoas que se nos habian acercado mientras estábamos aún á la vela, se hacía digna de reparo una canoa doble, de la May.zo cual vimos subir á bordo un Eije (I) anciano y corpulento llamado el Eije Dubou. Ofreció inmediatamente como regalo la macana que traía, una gallina y algunas raíces, y con el recíproco contacto de las narices (2), nos saludó amistosamente dándonos la bienvenida. Recompensada por nuestra parte con dos varas de bayeta esta atención primera, y héchole asistir luégo á nuestra mesa en la cual se condujo con mucho decoro, admirando todo cuanto le rodeaba, nos pareció que ya no se separaría de la corbeta $y$ que su presencia pudiera sernos útil para contener los desórdenes y robos inevitables en la mucha concurrencia de naturales que ya habían venido á visitarnos. No cabe una pintura de la buena fe ó más bien del descuído con el cual estos naturales se abandonan al recien venido, no trayendo por lo común arma alguna consigo, ó si la traen, siendo esta la primer cosa que cambian con cualquiera friolera sin reparar siquiera en el método precavido de nuestras centinelas armadas, de un depósito no distante de armas, y de aquella vigilancia que no puede ménos de anunciar un plan concertado que estriba particularmente sobre la desconfianza.

Ya en esta situación procuramos hacer uso para la recíproca inteligencia con los naturales, más bien de la pequeña colección de voces del Piloto Vázquez de la fragata Princesa, que de la numerosa del Capitán Cook, cuya diferencia de pronunciación nos expondría á cada paso á unas equivocaciones tan crasas como peligrosas.

En la ATREvida era aún mayor que en la Descubierta la concurrencia de los naturales. El Eije Tumoala había presentado á D. José Bustamante un puerco y una cantidad crecida de raíces, recibiendo en cambio un hacha: la plebe en general parecía igualmente tranquila, y ya procurada para entrambas corbetas una regula1 abundancia de comestibles y aproximándose la noche, exigimos que nadie quedase á bordo: precaución no sólo necesaria para nuestro reposo, si también para asegurarnos á lo ménos en la noche, de los robos casi contínuos, de los cuales nos veíamos amenazados.

Es realmente indecible la inclinación de la plebe, y aun á veces de los Eijes, á cualquiera clase de robos: sin embargo de haberse recogido cuantas frioleras pudieran excitarles este antojo de no permitirse á natural alguno el que se introdujese bajo cubierta, y que hubiese siempre muchos atentos á evitar todo desorden de esta es-

(I) Eije ó Eguí, equivale á Jefe, de los cuales hay después muchas clases. El Capitán Cook los distingue con la voz de Chief, (hef en francés.

(2) Es una ceremonia entre aquellos pueblos la de tocarse mútuamente con los extremos de las narices que equivale al abrazo de los curopeos. 
Nay. 20 pecie, se descubrió uno en la ATrevida que había robado un pañuelo de las faltriqueras de D. José Robredo, y otro en la DEscubier'TA abriendo con arte las diferentes ventanitas de los camarotes de estribor, había podido sacar algunos vestidos que llevaba consigo: se castigó el de la ATrevida con algunos azotes sobre un cañón, enseñándole al mismo tiempo el fusil; y la actividad de Dubou pudo conseguir en la DEscubIERTA que se alcanzase con otras canoas al ladrón y se readquiriesen las cosas robadas.

El reemplazo del agua era á la verdad el punto más importante que debíamos tener á la vista, tanto más que era preciso emprenderlo á alguna distancia, no siendo ya nuestro ánimo el cansar las tripulaciones y aventurar las amarras, para sustituir á éste otro fondeadero tal ve $z$ ménos abrigado. Pero al mismo tiempo no podíamos olvidar el establecimiento de un observatorio, la necesidad de algunos trabajos de fragua, un repaso grande indispensable de los cascos y aparejos bien destrozados por los últimos temporales, y sobre todo un reconocimiento hidrográfico y físico del Archipiélago en el cual nos hallábamos, hasta donde lo permitiesen lás circunstancias. La seguridad nuestra y el evitar todo motivo de discordia con los naturales, debían luégo combinarse con las operaciones antecedentes, y entrambos objetos no podían ménos de recordarnos cuántos inconvenientes pudiera arrastrar consigo la menor tolerancia en el uso de las mujeres.

Sea enhorabuena ó plausible ó digna de disculpa esta tolerancia entre los navegantes ingleses y franceses, de modo que no parezca un tropiezo para la conservación de la disciplina á bordo, el que el Oficial y el marinero se vean casi acomunados en entregarse á uno de los vicios más soeces que infestan la naturaleza humana. Ello es, que en nuestra marina, el marinero pretende (y con razón) tener mayores derechos que el Oficial, para ser vicioso; y que es esta pasión en él con exceso vehemente, de suerte que no sería extraño ver al hombre más quieto disputar con un puñal en la mano el uso de la misma mujer á sus mejores compañeros ó superiores, y á veces aspirar áun con mil ardides á suplantar en sus goces al Oficial. Debían recelarse también como una consecuencia de este permiso, los robos repetidos á bordo, los cuales confundiendo á veces al culpable con el inocente, harían incurrir á los nuestros en estos delitos, y caer probablemente la culpa sobre los naturales. Ni eran menores los tropiezos para la conservación de una buena disciplina y la inmunidad del derecho natural de los habitadores, aunque la tolerancia desterrada enteramente de los buques se ciñese sólo á los que estuviesen en tierra, pues en breve tiempo se verían aban- donados liss trabajos, insultadas las órdenes y May. zo penetrados los accesos aún más distantes de la costa inmediata, á veces para abusar del temor, á veces para alentar la osadía de los naturales que nos rodeaban. Convino la Oficialidad en la precisión de estas medidas, y dispuesta á precaver con el ejemplo y con la vigilancia tamaños desórdenes, alentó mucho el sistema que nos habíamos propuesto.

La mañana del 2x fué destinada principalmente al reconocimiento de la aguada, á la cual coadyuvaban mucho, no sólo la amenidad del día, sino también la concurrencia de un número crecido de naturales impelidos al mismo tiempo de la curiosidad, del interés y de la ociosidad en la cual viven: puntuales el Eije Dubou y otros dos amigos suyos, vinieron temprano á bordo para acompañarnos; traían consigo algunos frutos y raíces, y era el objeto del primero, ofrecer (si mal no entendíamos) una especie de monopolio en los abastos venideros, los cuales prometía abundantes, aunque acompañase estas propuestas con un sigilo misterioso y extraño, y sus ofrendas áun para cambio fuesen sumamente mezquinas. Debió en esta ocasión contribuir mucho para que le creyésemos una persona de mucha autoridad, no sólo el convenirsu nombre con el de otros dos que el Capitán Cook y el Comandante Maurelle habían hallado en Tongatabu y en Vavao, si también el ver desplegada en la tarde anterior su autoridad con buen éxito contra uno de los ladrones.

Pero esta equivocación debía disiparse muy luégo, pues ya se había transferido desde su morada á aquellos alrededores el Eije Ko-Vuna y se disponía á visitarnos. Todos los que á la sazón se hallaban á bordo ensalzaban su poderío y autoridad, extendiéndola no sólo al Archipiélago, si también á las islas no distantes de Happai, Annamoka y Tongatabu, y precedían luego á su venida á bordo algunos emisarios para hacer apartar del costado las canoas: le acompañaron después las muestras ménos equívocas de respeto de parte de los Eijes inferiores, y el regalo que ofreció de un puerco grande, muchos frutos y raíces y algunas esteras del mayor tamaño $y$ finura, debieron darnos una idea cierta de su generosidad y grandeza: el Eije Dubou, ya se hallaba á la sazón confundido en el cerco de los đemás, que sentados (I) con mucho orden, parecían prestar el debido homenaje á este nuevo Jefe, cuyo porte grave y majestuoso no coadyuvaba ménos á confirmarnos la verdad de su clase soberana.

No fueron muchas. como puede imaginarse nuestras primeras conversaciones, las cuales sc

(i) La postura de mayor respeto, es entre aquellos pueblos la de sentarse con las piernas cruzadas. 
May. 2x dirigieron al principio, á estrechar cuanto fuese posible nuestra amistad, después á un convenio no equívoco para que se contuviesen los robos, y finalmente, á que no tomase á mal que le dejásemos para transferirnos al sitio de la aguada: la promesa de que por la tarde le visitaríamos en tierra y algunos regalos, parecieron afianzar luégo la amistad; cambió nombre con D. Felipe Bausá, y finalmente, poco después de las nueve regresó á la playa, dejándonos lugar á que pudiésemos emprender el reconocimiento proyectado.

Iban en el bote armado los Sres. Heenke $\mathrm{Y}$ Bausá y el Eije Dubou con otros dos naturales, los cuales nos guiaron hacia los canales internos á una playa no distante una legua del fondeadero. La aguada que allí había, parecía al mismo tiempo, cómoda, abundante y de buen sabor.

En el entretanto, ya se habían reunido muchos naturales en el paraje donde estábamos, y no era Dubou ménos eficaz para que concurriésemos á beber el cava (I) en un sitio inmediato destinado seguramente para esta especie de reuniones, y apto desde luego á hacerlas más agradables y duraderas con la fresca sombra que procuraba y con la limpieza de las esteras que le servian de alfombra. Hombres y mujeres sentáronse en torno: tuvo lugar D. Tadeo Heenke de emprender una aunque corta herborización, y miéntras Dubou se entretenía en contar lo que había advertido de más notable en las corbetas, no era menor la eficacia de los hombres en ocuparse de los diferentes preparativos del cava, de lo que fuese la de las mujeres en solicitar regalos de cualquier friolera, ofreciendo por su parte la más fácil complacencia á nuestros antojos.

La vista de los aprestos del cava seguramente no podía alentar los deseos de beberlo; sin embargo, le admitimos con la solemnidad correspondiente; pasamos luégo á reconocer otra aguada no distante de que hacían muchos elogios; pero esta segunda excursión nos procuró más bien un paseo delicioso que el logro del fin propuesto, pues la poza era sumamente mezquina y distaba de la orilla del mar próximamente una milla. Debimos, pues, decidirnos al regreso á bordo, el cual se aceleró mucho con el viento fresco del Sueste que á la sazón se había entablado.

Inmediatamente se tomaron las precauciones para el debido orden en ambas corbetas, y á este intento quedó prohibida la admisión á bordo de toda mujer, cuya clase y objeto no fuesen bien conocidos, evitado el riesgo de toda sorpresa, quitados del medio cuanto fuese posible los alicien-

(1) El cat'a es una bebida fermentada servida por a quellos naturales á todas horas y en toda concurrencia. tes del robo, ceñidas nuestras excursiones á tie- May..2 rra á los solos objetos del servicio, animados bajo la inspección del Oficial de guardia los cambios de comestibles, y precavido particularmente el doble defecto bien común en estas ocasiones de omitir los repuestos por la desordenada profusión de la marinería, y de quedar ésta sin ropa alguna cediéndolo todo para la satisfacción de un antojo momentáneo. Para este último objeto pareció conforme con las intenciones generosas de S. M. el que más biẹn se expendiesen por cuenta del Erario los efectos embarcados para cambios, prohibiendo así todo otro medio de adquirirlos, que ó ver en un par de días alienada la mayor parte de la ropa de abrigo ó sujetado importunamente con órdenes aún difíciles de llevarse á debido efecto el apetito saludable del navegante para toda especie de refrescos. Hubiéramos deseado que pudiese llevarse á efecto al mismo tiempo otra precaución ya adoptada por el Capitán Cook, y seguramente no sólo oportuna sino necesaria en estas ocasiones, cual era no permitir cambio alguno que no fuese de comestibles, excluyendo, por consiguiente, la adquisición de mil bagatelas que satisfacen el antojo y la ociosidad más bien que el estudio de la Naturaleza, y que sin embargo atraen á bordo un número crecido é importuno de vendedores; pero son tan varias las interpretaciones del buen orden, tan vario y á veces tan plausible el antojo; tantos los que entre una nación demasiado viva sienten con extremo el freno aún más suave de la disciplina, que no creimos oportuna esta especie de prohibiciones en una ni otra corbeta sin embargo de los muchos inconvenientes que debía acarrear por precisión.

Eran las cuatro de la tarde, cuando nos dispusimos unidos los Oficiales de ambas corbetas á visitar al Eije Vuna: la marea y la clase del fondo inmediato á la playa no permitía verificar el desembarco en la proximidad de las chozas; preferimos un recodo no distante, desde el cual una sendita con exceso frondosa, nos conducía por los altos postreros al paraje deseado: fué en esta ocasión muy advertida la conducta del que nos guiaba, el cual, sabiendo que Vuna deseaba recibirnos con agasajo, nos condujo por otra sen da no distante, hacia su choza, de suerte que precedido el aviso, aunque no nos demorásemos en ella sino pocos instantes, nuestro aparecimiento á la vista de la ranchería fué saludado con el mejor orden y con las aclamaciones generales del cerco numeroso que acompañaba á Vuna.

Cantaban bastantemente acordes y acompañados de las cañas, ó huecas ó rajadas (I) unos

(1) Estos instrumentos, además de hallarse dibujados en la colección de estampas, se verán también naturales en el Real Gabinete. 
May, 21 veinte hombres sentados en el centro dcl cerco, y advertidamente dividido éste en tres trozos, de los hombres, de las mujeres y de los muchachos, dividía también naturalmente el agradable sonido de las aclamaciones, de suerte, que ya por una, ya por otra parte, las diferentes edades y sexos concurriesen con una bien ordenada harmonía á aplaudir y festejar nuestra llegada. Saludamos á Vuna y á los pocos Eijes que conocíamos y le hacían corte, y como acompañasen á este Jefe en la choza donde se hallaban, diferentes mujeres la mayor parte jóvenes, cuya clase distinguida no era fácil equivocar, muy luégo el mayor número de la Oficialidad no halló una ocupación violenta ni desagradable, la de reunirse en este pequeño cerco combinando la sencillez y el decoro con una no extraña inclinación al otro sexo; no faltaron tampoco quienes se esforzasen á manifestar á las del cerco exterior, que sus gracias y afabilidad podían muy bien compensar la más alta esfera de las otras; así, pasamos la tarde en la mayor unanimidad y alegría, y no fueron pocos nuestros progresos en el importante conocimiento del idioma.

La noche fué sumamente tranquila. Las lanchas estuvieron prontas al amanecer del día siguiente, y D. Antonio Tova pudo dirigirse con ellas al paraje prefijado de la aguada. Un acopio regular de armas, tres soldados y un artillero de brigada en cada una, algunas frioleras para regalos y compras de comestibles, y la orden de que no se escasease medio alguno para que la cesión del agua de parte de los naturales fuese absolutamente voluntaria, fueron las demás precauciones que nos parecieron oportunas - para aquella comisión.

Entretanto, los nuevos amigos no se habían manifestado perezosos. Casi desde la salida del Sol empezaron á acercarse muchas canoas á una y otra corbeta, y aunque las hiciese retirar por un corto intervalo una orden circular que las llamó inmediatamente á tierra, volvieron luégo en mayor número y emprendieron al mismo tiempo los cambios y los robos. Procurábamos á la sazón conservar en mucho valor los efectos que más abundaban en nuestros repuestos, ocultando las hachas y los adornos mujeriles para cuando aquéllos desmereciesen de valor. Dos ó tres cuchillos medianos ó bien una vara de bayeta, eran la recompensa de un puerco regular. Las navajitas, los hilos de abalorio y de coral suplian luégo para las gallinas, las raíces, los plátanos y los cocos, de los cuales parecería casi increible la cantidad que se adquiría y consumía diariamente.

Entre todos los que hasta entonces habían concurrido á bordo, se habían cautivado particularmente el amor de toda la Oficialidad, Feileua, jóven de unos ocho á diez años y Príncipe heredero de las Islas, y Tufoa, sobrino de Vu- May. zr na, algo mayor de edad que Feileua y dotado de una viveza y comprensión poco comunes: acompañaba luégo constantemente al primero como en clase de ayo, otro jóven algo más adulto llamado Latu, cuyas ocupaciones, se reducían más bien á la conservación que á la enseñanza del Príncipe. Todos tres habían sido bien regalados en la tarde anterior, y Feileua, cambiado ya nombre con D. José Espinosa, había sido completa y elegantemente vestido en ambas corbetas. Era pues natural con estos antecedentes, que fuese igual en unos y otros el deseo de estrechar csta amistad. Por nuestra parte, siempre que tuviésemos á bordo á Vuna ó Feileua, no sólo lograríamos un mejor orden y una mayor quietud, si también estariamos seguros de cualquiera restitución, si las prendas robadas fuesen de alguna importancia ó para los objetos del servicio ó para el respeto de nuestras armas. Tufoa luego se destacaba inmediatamente adonde le enviáse. mos ó le llamásemos, y su activa autoridad sobre la plebe, reunida á una más fácil inteligencia de nuestros deseos, disipaba un número no crecido de pequeños altercados, en los cuales hubiera sido tan pernicioso que la plebe triunfase con sus tretas, como triunfar nosotros con la superioridad de nuestras armas y disciplina.

Todos estos jóvenes y áun el crecido número de naturales que teníamos á bordo, nos anunciaban para la tarde próxima unas diversiones bien ordenadas; y es tal su propensión á esta clase de ocupaciones, que desde la mañana misma no era extraño verlos á cada paso bailar y cantar á nuestro lado, como si ya la música y el concurso general avivasen y pusiesen en movimiento todas sus fibras: ni á la verdad, pudieran lue. go ocultársenos estas disposiciones, cuando hacia las diez, con objeto de reconocer un pedrusco aislado que parecía oportuno para el observatorio y fragua, pasamos á la playa inmediata. La marea y la calidad con exceso desigual del fondo, hubieran hecho á la sazón arriesgado el desembarco; pero Tufoa ocurrió á este inconveniente, mandando á una porción de naturales, los más corpulentos, que nos condujesen sobre sus hombros.

Inmediatamente fuímos á saludar á Vuna, el cual, rodeado de muchas gentes y entretenido agradablemente con el cava, veía poco á poco ordenarse y crecer las pequeñas pilas de comestibles destinadas en la tarde próxima para nuestro regalo. Procuramos que entendiese los objetos que á la sazón nos conducían á tierra; y aten. to á éstos, le pedimos el permiso de llevarlos á cfecto y el de no admitir el cava y el descanso que nos ofrecía con muchas instancias.

$\mathrm{El}$ islote ó risco cuyo reconocimiento emprendimos ahora, parecía á primera vista in. 
accesible, por las infinitas desigualdades que en una materia enteramente calcárea habían labrado con igual tesón el tiempo, las intemperies y las olas; pero su mediana elevación, su entera independencia de las orillas pobladas, su grande inmediación á las corbetas y sobre todo la lacilidad de atracar á él los botes sin la interrupción de las mareas, le hacían demasiado importante y precioso á nuestra vista para que no procurásemos cualquiera medio de hacerlo útil. $\mathrm{Ni}$ se frustraron nuestros deseos hallando asequible á fuerza de picos y mazos suavizar algún tanto las desigualdades más puntiagudas para abrir una senda accesible, siquiera á un marinero, y formar en la parte más alta un terraplén suficiente para la tienda y el cuarto de círculo. Todas las inmediaciones brindaban luégo un fácil acomodo para la fragua y una pequeña barraca de guardia; y las solas piedras podían apartar á cualquiera natural, para que disfrutásemos de una completa quietud y seguridad en este depósito importante de nuestros efectos los más preciosos, sin usar de las armas de fuego para su custodia. Conseguido con la mayor felicidad este objeto que mirábamos como el más importante para la tranquilidad recíproca de los naturales y nuestra, regresamos á bordo y fueron destinados para el intento 20 hombres de la Descubierta.

La concurrencia á bordo de los naturales era it la sazón extraordinaria; se habían agregado dos embarcaciones grandes procedentes de Apay y Annamoka, y' más cargadas de personas de ambos sexos que de comestibles. Un crecido número de mujeres, la mayor parte jóvenes, insistían luégo desde las canoas que se les permitiese subir, recordando á los poco cautos admiradores de la tarde anterior ó los regalos prometidos, ó la no olvidada articulación de los apellidos cambiados, o) finalmente, la esperanza de que no fuesen sordos á las voces seductoras de la Naturaleza. Y no eran ménos eficaces los hombres, incluso Feileua y Tufoa, en persuadir á que no se retardase ya por más tiempo la preferencia á favor de una ú otra de las que parecían llamar á sí mismas una atención más general. No sería fácil sin incu. rrir en la acusación bien frecuente de las narraciones harto abultadas de los viajeros, describir con exactitud el grado de amabilidad que en aquel clima feliz ha tocado en suerte á las mujeres, y del cual no podíamos formar sino una idea bien imperfecta; pero tal cual ella era, bastaba para probar con un crisol bien fino, no tanto la virtud de unos navegantes, cuanto el vigor de la disciplina cuando la guía el buen ejemplo de los que dcben mirarse como los depositarios del buen orden. A la verdad, del mismo modo que la marincría y la tropa atentas á los trabajos importantes que tenían entre manos, se consolaban en parte de esta privación satisfaciendo sus apetitos con unas comidas del mejor sabor, abun- May. 2I dancia y variedad, no faltaba tampoco para las clases más scnsibles un consuelo eficaz en aquel amargo contraste de la razón con la naturaleza; y era el deber á estas nuevas sacerdotisas del templo de Gnido, tan contentas con recibir el regalo de un simple adorno, como debíamos imaginar, según su eficacia, que lo hubieran sido viéndose ya preferidas á las demás con la elección. Por ventura este último arbitrio de los regalos pudo aminorar las instancias por una parte y los impulsos de agradecimiento por otra, y á costa de algunos pañuelos í otras bagatelas, nuestro concepto en aquella ocasión ganó en lo expléndido, lo que podía haber perdido de lo sensible y natural.

Eran muchos á la sazón los trabajos de reparos y aprestos que se habían emprendido en ambas corbetas. Las jarcias de trinquete de la ATREVIDA habían sufrido considerables averías en la última travesía. Las cadenas de las mesas de guarnición mayores, estaban por la mayor parte altas en la Descubierta. Las mares, con exceso gruesas sobre la Nueva Zelanda, nos habían manifestado como igualmente necesarios, unos guarda mesas; el velamen pendiente necesitaba reparo; la estiva un nuevo orden y nuestras tripulaciones formadas en parte de hombres ya cansados que seguían el viaje desde España, y en parte de muchachos filipinos, no podían ó por falta de número ó de inteligencia, explayar toda la actividad necesaria; sin embargo, no podían llamarse lentos los progresos que íbamos haciendo, y los cuales se debían en mucho á la excelente Oficialidad de mar que dotaba ambos buques.

Era ya próximamente el medio día, cuando tuvimos una nueva visita de Vuna. Le acompañaban en aquella ocasión la mayor parte de las mujeres jóvenes que habíamos visto en la tarde anterior, y entre las más ancianas, las cuales apenas llegaban á tres ó cuatro, se hacía particularmente notable una Dubou, hermana de Vuna y madre de Tufoa, pues no solo á su ingreso á bordo, diferentes plebeyos le habían prestado el homenaje acostumbrado, sino que después animada de un tono igualmente lascivo y respetuoso, entonaba y dirigía para el canto el coro entero de las demas jóvenes. Se dió principioá esta música seductora luégo que estuvieron sentadas todas en torno, distinguiéndose en el lado de Vuna las dos Fatafejis, ya conocidas por sus mujeres. El canto era pausado y bastantemente vario $y$ acorde, pero no era posible acertar con el objeto de las palabras; pero si debiésemos juzgar por la facilidad con la cual todo el coro articulaba las mismas voces, podíamos inferir que su composición no era nueva, así como dcbíamos convencernos por los diferentes ademanes que la 
May. 21 acompañaban, que el placer era el móvil único ó principal de esta agradable melodía.

No acertaremos á interpretar en aquella ocasión el ánimo de Vuna, relativamente á todas las demás jóvenes que traía consigo; pues lo que toca á sus dos mujeres manifestó desde luégo decididamente que no las profanaría una mano agena. Pero lo que no admitía duda alguna, era que los regalos las consolarían enteramente, y así no tardamos en adoptar aquel partido; no siéndonos fácil á la verdad conservar entonces una recta indiferencia, para que no fuesen absolutamente preferidas la juventud, la amabilidad y la hermosura, á las edades más ancianas y ya despojadas de todo atractivo.

A los regalos siguióse luégo una comida abundante de raíces que habíamos hecho preparar de antemano. Le agregamos el condimento de la azúcar; comió Vuna abundantemente, y no le era fácil á la sazón disimular su alegría por los muchos regalos que hechos á él directamente ó á sus mujeres ó al joven Feileua, debían reconcentrarse en su Tesoro. Examinaba atentamente ya una, ya otra bagatela; usaba mil ardides á veces para prevenirlas, á veces para no encargar su custodia á otros; y no teniendo por otra parte ocupación alguna que le llamase á tierra á cada paso, se cebaba más y más á permanecer á bordo, tranquilo espectador de nuestra generosidad y de los ardides de las mujeres que le acompañaban.

Un accidente no precavido le despertó sin embargo de esta tranquila ociosidad. Ya regresadas las lanchas de la aguada, nos disponíamos á comer, y para lograr un mayor sosiego habíamos solicitado que se retirasen á tierra las mujeres, alejando al mismo tiempo de á bordo el crecido número de los plebeyos que desde la mañana habían concurrido sobre el alcázar: con este mismo intento D. Antonio Tova, quien regresaba á la ATrevidA, se había encargado de recibir en el bote las mujeres que pretextaban no tener canoa, y el Jefe por su parte, daba las órdenes para que se retirase igualmente la plebe: pero bien hubiese entre ésta alguno bastantemente osado para no obedecerle, ó le pareciese aquella una ocasión oportuna para hacer alarde á nuestros ojos de su autoridad ilimjtada, en un solo momento, el tono más tranquilo y pausado para comunicar sus órdenes, se convirtió en el más cruel y turbulento. Tres ó cuatro ejecutores bien robustos, de su voluntad se avalanzaron con sus macadras sobre la plebe, y el mismo Vuna agarrada poco después una lanzá que allí tenían para cambio, se mezcló entre los perseguidores con tanta crueldad, que hubiera muerto á un plebeyo escondido en la proa, si nosotros no le hubiéramos oportunamente refrenado. Faltó poco para que no zozobrase el bote de D. Antonio Tova por el mucho número de los May. 2t que se habían salvado en él. La mayor parte se echaron á nado y cogieron sus canoas; y finalmente, Vuna, ya bien satisfecho al parecer de las muestras dadas, así de su atención á nos otros, como de su autoridad, volvió á tranquilizarse y se acercó á nuestra mesa, en la cual se hallaban también Feileua, el ayo Latu y el hijo de otro Eije. Todos tres se resistieron al principio á comer por la consabida etiqueta de la presencia de Vuna; pero vencida esta dificultad, pudieron entregarse á satisfacer sus apetitos sin el menor sobresalto, y fueron djgnos de reparo en aquella ocasión no solo la facilidad con la cual ambos muchachos aprendieron á comer con el mayor aseo, usando del tenedor y cuchillo, si también la extremada atención de Vuna, el cual pedía permiso para tocar cualquier cosa y aun para escupir fuera de la cámara.

Se aproximaba entretanto el plazo prefijado para los bailes, y Vuna hacia las tres de la tarde nos había precedido para disponer todas las cosas necesarias al intento. Así cuando próximamente á las cuatro y media nos acercamos con los botes á la playa (para evitar los rodeos de la tarde anterior) estuvieron prontas muchas canoas para conducirnos poco á poco al paraje oportuno para desembarco, ya que el banco exterior de coral y la resaca bastantemente fuerte imposibilitaban esta maniobra para los botes. Tomáronse pocas precauciones y bien sencillas para la seguridad común.

Como quiera que la falta del idioma y de un recto conocimiento de las ideas sociales de cada uno, haga en estas ocasiones tan natural en los habitantes el deseo de frustrar la ventaja de las armas y de la disciplina á los recién llegados, como en éstos el deseo de frustrar á los otros la ventaja del número, sucede comunmente en semejantes concurrencias, que la menor equivocación acarrea las consecuencias más serias, y que entonces sin consultar mucho las circunstancias. sólo se atiende á precaver los riesgos con anticipación al adversario.

Ya reunidos en la playa, nos dirigimos á sa. ludar á Vuna, el cual, como en la tarde anterior, se hallaba rodeado de muchas mujeres, siguiendo luégo á la parte interior del tingladito el cerco grande de las clases inferiores, y siendo fácil de distinguir entre ésta la de los Eijes subalternos, por su mayor inmediación al Soberano. La música no era tampoco diferente de la que ya conociámos, si bien excediese ahora en el número de los cantores y en los vivas más alegres de la plebe, ciertamente no menor en número de I.Soo á 2.000 personas.

A los ofrecimientos no extraños del cava, á la ratificación de nuestra amistad con T'una $y$ los demás Eijes y á las instancias no desaten- 
M.y. I didas de las nujeres jóvenes para que nuestra Uficialidad se sentase á su lado, siguiéronse inmediatamente los bailes prometidos. Los ejecutaban unos treinta hombres, la mayor parte de la clase de los Eijes, y no menos dispuestos por su agilidad que por la gallardía de sus personas, á dar mucho resalte á la escena. Cantaban al mismo tiempo acompañando la música de las cañas. La cabeza, los brazos y las piernas se morían con igual compás; una media risa, bien que varonil, las diferentes actitudes de los ojos, la misma respiración modulada y concertada (disámoslo así) con la harmonia general, manifestaban que no había fibra alguna en toda la máquina que no participase del placer que á la sazón los ocupaba. A medida que el calor, la agitación y el hábito hacían más fáciles y más naturales los movimientos uniformes del baile, la música, penetrada casi de la misma sensación, aceleraba paulatinamente su compás, hasta que, llegada al mayor srado de celeridad, sin causar sin embargn el menor desorden, animaba casi con igual urado de sensibilidad y de alegría á todos los de más espectadores. Variadas por dos veces las figuras del baile, y con ellas variada también la música, debieron estos atletas entregarse por algún rato al descanso, no sin haber recibido de nuestra parte y áun de los demás espectadores lo mayores elogios y palmeteos. No quedaba ya sino una media hora del día y aún no habíamos tomado posesiónde las dos pilas ó pirámides de comestibles que reíamos inmediatas y sabíamos sel destinadas para nuestro regalo: pero esta atención, que debía ser de la mayor importancia, no lo era á la verdad para los demás Oficiales, los cuales, cambiados ya sus nombres con otras tantas jóvenes, convencidos más y más á cada paso de su amabilidad, y obviamente agotadas sus faltriqueras de cuanto tuviesen útil para el regalo, deseaban ahora ver desplegadas en un baile mujeril todas aquellas gracias y atractivns que anunciaban su trato familiar y el desen de agradarnos. Condescendió Vuna. inmediatamente á nuestras instancias, mandando que saliesen las mujeres al área; pern en esta ocasión estaba destinada á él y á nosotros una mortificación no mediana con la repugnancia de las mujeres en nbedecer esta órden, impelidas tal vc $z$, del reparo de no estar prevenidas de antemano ó más bien (en mi entender) de aquella modestia común, de la cual decía el T’asso en su . Iminta:

\section{"Iu i dolci atti lascivi 'Testi ritrnsi, é schivi.n}

Nadal extraña debía ser para nosotros esta negartiva, y ya nos disponíamos á regresar á hordo; pero no lo fué así pará Vuna, el cual en un momento, conrertida de nuevo como en la mañana inda su mansedumbre en cólera y fiereza, y correspondido admirablemente por May.zr sus ayudantes, empezó á perseguir sin distinción hombres y mujeres, amenazándolos con fuertes golpes si no corriesen con la mayor diligencia. Dos Eijes subalternos, debieron en esta ocasión esforzarse á contener la cólera de Vuna; desapareció el concurso, y aunque so juntasen después hasta una docena de mujeres para bailar, fué esto ejecutado con tal frialdad y sobresalto, que ya no debíamos desear otra cosa sino ver cesado el desórden, y poder regresar á bordo con el auxilio de las canoas que nos condujesen hasta los botes. Este tránsito fué también peligronso, y D. José Robredo y D. Luis Nee, se hallaron aún más expuestos que los demás, pues el conductor les amenazó con conducirlos á otra parte ó aventurar su vida en el mar, si no le cedían un pañuelo, á lo cual puede bien imaginarse que no tardaron en condescender.

Ya reunidos á bordo, y bien satisfechos no tanto del fin como del principio de las diversiones anteriores, nos dispusimos á continuar para la mañana siguiente las tareas emprendidas; $y^{r}$ no pareciendo inútil una confrontación metódica, así de los progresos hechos en el idioma como de los diferentes grados de autoridad y amabilidad que habíamos advertido en los Eijes subalternos, 1). Antonio Tova previno á los que debían seguirle en la dirección de las lanchas, que era mucho el concurso de los naturales, y éstos se hacían sumamente importunos en solicitar regalos; que no había Eije alguno de mucha autoridad, y que se precaviesen particularmente, de una vieja, la cual solía arrimarse y entretener, ya á uno, ya á otro, con mil caricias, of recimientos y ademanes, para que otros al mismo tiempo le vaciasen las faltriqueras.

Tuvimos la noche con exceso tranquila, y las primeras claras del día siguiente pusieron ya en movimiento las lanchas para la aguada, las cuales iban confiadas á los Tenientes de navío Don Juan de la Concha y D. Francisco Viana. Por nuestra parte nos disponíamos ya á concluir la habilitación del observatorio sin omitir los demás trabajos emprendidos á bordo, cuando antes de las siete nos sorprendieron Vuna y Feileua en una y otra corbeta, llevando cada uno la mitad de los comestibles acopiados en la tarde anterior para nuestro regalo.

Fueron correspondidos más bien con generosidad, y la amistad recíproca pudo ya considerarse de nuevo como sólidamente arraigada.

No faltaron de allí á poco diferentes causas accidentales, que podían haberla quebrantado. Vuna, concluídas sus ofrendas en la DescubierTA pasó á bordo de la AtrevidA, sin duda con el ánimo de solicitar nuevos regalos; por desgracia la centinela, la cual tenía orden de no dejar entrar natural alguno, se opuso á sus deseos, 
Muy. 23 sin que pudiesen luégo (como era natural) entenderse uno ni otro en la exacción terca de su opinión. Esto bastó para que Vuna empezase á volver á sus antiguos enojos y para que mani. festasen sus súbditos presentes, que hallaban en esta ocasión la majestad sumamente ultrajada. Pero el aparecimiento de un Oficial logró en fin disipar la contienda, y recibido inmediatamente á bordo, pudo Vuna poco después llamarse casi feliz por los ultrajes recibidos, ya que le acarrcaron el regalo de algunas quincallerías de mucha estimación.

El trabajo de suavizar el risco destinado para el observatorio, había en el entretanto progresaclo mucho; condujéronse allí al joven Túufoa y al otro Eije Dubou, los cuales evitaron el arrimo de los demás. Pudimos así para el medio día ver enteramente vencido aquel objeto, y sistemadas la fragua y la barraca en que debían custodiarla.

T'anta variedad de objetos, y el número no menor de 30 personas que estaban actualmente ocupadas en los diferentes destinos indicados, no podían ménos de atraer á Vuna hacia aquel paraje; ni á la verdad, aunque no le moviese estímulo alguno de curiosidad, podía presentársele ocasión más favorable para distraer algo más su ociosidad perenne, satisfechos en el día sus deseos ó á lo ménos sus esperanzas en cuanto á regalos, nada inquieto sobre la calidad ni sobre el plazo de sus comidas, y sin otros juzgados que los producidos por nuestras quejas sobre algún robo, el cual, en su sentir, terminaba con igual equidad, ó bien pasase á sus manos la prenda robada si el ladrón lograba ocultarse, ó éste perdiese la vida si lo aprehendíamos, podía dividir tranquilamente sus horas entre el sueño, el reposo y las bebidas del cava. Admirando atentamente y con aquella estúpida admiración de los pueblos no civilizados, todas nuestras obras y utensilios, nos confirmó que no había conocido al Capitán Cook en ninguna de sus visitas á las islas más meridionales. Traía al mismo tiempo consiço una mujer de la plebe, que ofreció con la mayor eficacia para nuestro uso, pero manifestado por nosotros un cierto enfado, mitigó sus súplicas, refiriéndose solamente á los trabajadores; y persuadido últimamente á desistir de aquella idea, no tardó en despedirla, consolándose muy•luego con sentarse en las inmediaciones de la fragua y distraerse con algunas tazas de cava miéntras concluíamos la obra cmprendida.

Era para esto la última parte la de sistemar una guardia, la cual, no sólo contuviese la idea de cualquiera robo, si también no trastornase por si las medidas introducidas para las corbetas. Se puso á cargo de los sargentos y condestables de entrambas corbctas para que turnasen por cada día con cuatro soldados: en la noclie debían pasar la palabra con las centinelas; debían avisar Muy. . á la A Trevida cualquiera novedad, pues no distaba de allí sino un cable escaso; finalmente, un depósito regular de armas y municiones y la misma situación del puerto, les daban lugar á defender la fragua é instrumentos mientras se les enviase socolro.

No parecieron indiferentes estos preparativos á Vuna: preguntó por el objeto de aquellas armas: prometió solemnemente que ningún natural se aproximaría por esos coniornos, y desde luego él mismo solicitó el permiso para que uno de la plebe le trajese algunos frutos y un poco de cava. Procuramos, por nuestra parte, disiparle cualquiera sospecha, manifestándole que nuestras gentes no ofenderían en modo alguno mientras no se intentasc robar ó aproximarse de noche al observatorio; y para que depusiese con mayor seguridad cualesquiera recelos, le prometimos que en una tarde de las inmediatas toda la tropa haría un ejercicio de fusil con fuegos en las playas próximas á la ranchería. Era ya la hora de regresar á bordo: admitió Vuna nuestras instancias para que nos acompanase á comer y le siguieron igualmente los dos Eijes Dubou y Tufoa.

Los cambios á bordo habían sido más bien escasos aunque el concurso de la plebe fuese realmente excesivo: los cuchillos y navajas conservaban un valor regular: despreciábanse por 10 común los corales y abalorios; y al contrario las bayetas, toda especie de ropa y particularmente los granates habian adquirido un valor cuantioso; divididas al mismo tiempo las ocupaciones de los naturales y nuestras, ó en procurar el robo de cualquier friolera ó en evitar que lo consiguiesen. En este contraste de intereses resultaron siempre aventajados los naturales, porque era imposible precaver todos sus ardides, y porque áun descubierto el delito, apenas podiamos contar con la restitución de la prenda robada, no pudiendo mirar con indiferencia la perdida de la vida del agresor que Vuna y los demás Eijes nos ofrecían con el mayor sosiego. No tardó tampoco en llegar la ocasión en la Descubierta de que se explayasen con mayor evidencia aquellas verdades: uno de la plebe fué cogido con un marti1lo robado á la maestranza, que trabajaba í la sazón en los guardamesas de las jarcias mayores; corrió la voz inmediatamente: Vuna, que á la sazón se hallaba á bordo, pronunció sin la menor alteración la sentencia de muerte, despidiéndose inmediatamente dos emisarios para ejccutarla en el castillo de proa, en donde se lallaba el delincucnte: fueron testigos nuestros ()ficiales así de la fiereza con que los emisarios alzaron sus macanas para vibrar el fatal colpe, como de la humillación con que el delincuente se dispuso á rccibirlo, puesto de rodillas y des- 
Yhy 23 cansada su cabeza sobre las manos cruzadas que tocaban humildemente el suelo: suspendieron inmediatamente, como era natural, la triste ejecución de la orden, no sin extrañar así la terquedad de los emisarios en quererla llevar á debido efecto, como la indiferencia de Vuna sobre la suerte de sus vasallos.

La comida de este día, á la cual como ya se dijo, habíamos convidado á Vuna, debía conducirnos á desenvolver una nueva parte considerable de los ritos y costumbres de aquellos pueblos: Vuna, ya familiarizado con nosotros, pidió que le trajesen su comida: se componía de una especie de pasta de raíces, sobre la cual el sirviente echaba oportunamente una salsa compuesta de algunos jugos y del agua de coco, y de un pescado no bien asado entre las hojas que le envolvían: las hojas frescas del corifa suministraban luégo modificadas en diferentes modos, ya los platos, ya la cuchara, y el mismo sirviente, dividida en partes proporcionadas la comida, tenía después á su cargo el conducirla hasta la boca del indolente Vuna, tomando todas las precauciones que pudiese dictarle el recelo de ensuciar los manteles y cuanto le rodeaba: despedido el sirviente después de haber recogido con mucho aseo los resíduos de la comida, fué llamada sin perder tiempo una mujer de la plebe, cuyo cuidado fué antes el de satisfacer la sed del Soberano con un coco lleno, y después el de descortezar con sus dientes algunos trozos de caña dulce, que ya limpios y subdivididos, pasaba á la boca de Vuna: satisfecho á la sazón el Monarca del papel grandioso que creía explayar á nuestra vista, y no omitiendo una seriedad y una majestad que apenas les permitían abrir la boca cuando veía próxima la comida, debió por estas mismas causas ceder muy luego á los impulsos đel sueño, á los cuales procurábamos coadyuvar por nuestra parte, ofreciéndole que se tendiese sobre los cojines inmediatos: lo hizo así sin que fuesen necesarias muchas súplicas, y entonces, como aún no se hubiese retirado la mujer que le había servido la última parte de la comida, le insinuamos que acabase de conciliar el sueño á su Soberano con el acostumbrado tuque tuque ó percusión suave y acelerada de las manos cerradas, en los lomos y muslos del durmiente. No eran precisas tantas precauciones. Los cuidados del alma no interrumpían las series de las fun. ciones animales; y así Vuna casi en un mismo inslante se acostó y quedó dormido; dejándonos en la restante comida con la sola compañía de Tufoa y Dubou, quienes algo recatados al principio sobre la precisa etiqueta de no comer á la vista del Monarca, habían después insensiblemente adquirido una mayor confianza para ocuparse solamente del alimento.

botellas de cristal y los diferen. tes utensilios de loza, eran sin embargo un in- May.z3 centivo demasiado fuerte para que el sueño de Vuna durase por largo tiempo: despertó efectivamente antes que nos sirviesen el café, y ya mucho ménos aletargado, manifestó fijar particularmente su atención en algunas bagatelas de las que estaban sobre la mesa, explayando en esta ocasión un respeto y una atencion iguales al deseo que tenía de poseerlas: no omitió tampoco para este conseguimiento el arma que con justa razón debía creer la más eficaz para nosotros, y era una nueva instancia para que usásemos de las mujeres, añadiéndoles ahora con un chiste y una eficacia realmente agradables, que condescendería enhorabuena á que uno ú otro desechase agriamente sus propuestas, pero que por esto no debían dejar de admitirlas los demás Oficiales, los cuales señalaba uno á uno recorriendo en torno los comensales.

Esta chanza realmente divertida no dejaba sin embargo de refluir hacia los depositarios del buen orden un carácter realmente ignominioso, particularmente en un país donde todo convidaba al placer, y en donde no se conocía otra ley, á lo ménos por lo que toca á la clase de la plebe, sino la que indicaba el Tasso para el siglo del oro.

La legge aurea, e felice,

Che Natura scolpi: S.e ci piace ei licé. am.

Lo cual dictó un ardid que no dejó de suministrar nueva materia á las chanzas, y que nos fué al mismo tiempo útil en los días siguientes. D. Juan Rabenet, en una de aquellas horas en las cuales el espiritu oprimido del naverante y la idea siempre varia del pintor, necesitan de un cierto alivio y distracción, se había ocupado en representar con mucha propiedad, una mujer dotada de todas las gracias personales que más comunmente solemos admirar en nuestra Europa, y vestida luégo á imitación de las Panameñas y tendida descuidadamente sobre una hamaca, formaba un conjunto de imágenes, en el cual admirábamos á las veces la pródiga mano de la Naturaleza, y á veces recordábamos la triste soledad del navegante: presentado este cuadro á Vuna, dijímosle que era el retrato de la mujer de uno de nosotros; que semejantes á aquélla eran las de los demás Oficiales; que no nos seguían, porque considerábamos los trabajos del mar demasiado sensibles para su delicadeza, y que ahora nos disponíamos á navegar directamente hacia el paraje donde las habíamos dejado, con el justo deseo de no separarnos otra vez de su amable compañía. La saludó inmediatamente Vuna con el acostumbrado contacto de las narjces, examinó después una por una sus lacciones, sus trajes y sus adornos, y á medida que las iba comprendiendo, crecía su admiración y el elogio que hacía de la persona allí represen- 
IIay. 23 tada; pero no podían ser éstos los límites de los deseos de un hombre acostumbrado á una autoridad ilimitada y reducido á los solos goces que suministra la Naturaleza. Propuso su deseo de conocerla, se siguió muy de cerca el de poseerla, anduvo inmediatamente pródigo con ofrecer en su cambio cuantas mujeres quisiésemos de las Islas de Vavao; finalmente, reconvenido por nosotros de la imposibilidad de llevar á efecto estos contratos, propuso como una feliz ocurrencia, el que Feileua viniese con nosotros para casarse en Europa, y condujese al regreso algunas mujeres con las cuales él también pudiese casarse, pareciénclole ya despreciables y no adecuadas al tálamo real, las mismas hijas del difunto Paulajo, que nosotros, á la verdad con mucha razon, preferíamos infinitamente al objeto imaginario de la pintura: no fué ésta tampoco la última combinación de Vuna para el conseguimiento proyectado: nos manifestó que se decidiría él mismo á acompañarnos, y fué preciso un nuevo ardid para disuadirlo, valiéndonos para esto del aviso que no era permitido entre nosotros sino una mujer sola, aunque á veces habitualmente enfermiza ó no constante en sus primeras inclinaciones; esta noticia, pareció moderar mucho sus deseos, ni debíamos sorprendernos que le pareciese extraña, cuando no estaban á su alcance los dulces lazos del instinto sociable que busca en la unión de los sexos, no tanto un tributo poco duradero á los dictados de la Naturaleza, cuanto la felicidad de los hijos y el mútuo alivio en los muchos males que cercan por todas partes á la vida humana.

Sumamente entretenido con estas conversaciones, y no descuidando al mismo tiempo hacer las posibles investigaciones sobre los diferentes ritos y costumbres de aquellos pueblos, lográbamos ya hacia las cuatro de la tarde de la satisfacción de ver regresar las lanchas de la aguada: un accidente extraño les había causado la demora de unas tres horas, bien que había sido últimamente útil para evitar mayores desórdenes y para cerciorarnos del respeto y de la buena fé de los naturales: un marinero de la lancha de la Descubierta, reprendido acremente por el patrón y movido de una mezcla poco proporcionada de locura y de pundonor, había tomado el partido de desertar, llevándose un hacha y una pistola: esta determinación suya no conocida sino al momento de concluir la aguada y disponer el regreso de las lanchas, había precisado á entrambos Oficiales á exigir la restitución del marinero, con un tesón proporcionado al delito; ocultaban al principio ser sabedores siquiera de la fuga; manifestaban luégo una total ignorancia del paraje á donde pudiera haberse dirigido, y á veces aún parecía que creían fingido ó sin consecuencias el natural enojo de nuestros Oficiales: debieron éstos por consi- May.=3 guiente acalorar más sus medidas, reuniendo la gente nuestra en buen orden y protestando altamente que de ningún modo abandonarían aquel paraje sin la restitución del marinero prófugo: esta declaración oportuna produjo un buen efecto; se destacaron inmediatamente muchos hombres armados, y después de un par de horas volvieron á aparecer conduciendo al desertor, el cual había pasado á la playa opuesta, sin saber él mismo cuáles eran los objetos y cuál el sistema de su vida venidera, ó más bien cuáles serían los medios de regresar á bordo sin castigo alguno. D. Juan de la Concha recompensó pródigamente este importante servicio de los naturales, que dieron en aquella ocasión una prueba inequívoca de su buen corazón, intercediendo con mucha eficacia á favor del marinero culpable: su castigo, áun sin esta atención, debió aminorarse mucho porque su edad y conducta pasada en los puertos de la América no daban la menor sospecha de una deserción derivada de causas premeditadas que ofendiesen la disciplina ó la religión; se le puso una cadena, y se le destinó dos días después en el bote armado que á las órdenes de D. Felipe Bausá debía reconocer la parte interior del Archipiélago.

Aproximándose en el entretanto la noche, Vuna había pedido permiso para retirarse, y al contrario se habían decidido á pasarla á bordo los tres jóvenes Feileua, Tufoa y Latu: coadyuvaron estos mucho á que las restantes horas hasta las once nos fuesen igualmente entretenidas é instructivas, pues ocupándose al principio en hacer varias habilidades con el cuerpo, semejantes á las de nuestros saltimbanquis, pasaron luégo á una serie bien entretejida de conversaciones, en las cuales nos fué fácil desenvolver una porción grande de sus costumbres y de los acaecimientos pasados desde la visita del Capitán Cook. Debimos sí extrañar en aquella concurrencia, que traídales la cena de tierra, el ayo Latu prestase el homenaje acostumbrado á los piés de Tufoa, y que este jóven lo exigiese también del niño Feileua, el cual según creyeron advertir algunos entre nuestros Oficiales, quiso más bien privarse de la cena que prestar á nuestra vista este homenaje humillante á Tufoa.

Hasta entonces los tiempos se nos habían manifestado poco favorables para las tareas astronómicas, siendo por lo común nublados cuando reinaban fuera los vientos casi constantes del Es-Sueste al Es-Nordeste. La mañana siguiente nos fué aún más contraria con una lluvia ince. sante, la cual, sin embargo, ni detuvo á nuestras lanchas para que continuasen la aguada á las órdenes de los Tenientes de navío Robredo y Quintano, ni retardó un solo instante la venida á boldo, antes de muchos plebeyos y poco después del 
31ay. 4 mismo Vuna, al cual acompañaba ahora otro hermano suyo llamado Xavea, menor de edad y de un aspecto y carácter extremadamente apacibles. Fué oportuna esta venida, porque echada de ménos una lantia de la bitácora casi en el mismo instante en que habían entrado los naturales, pudimos reconvenirle con algún enfado y áun exigir que saliese inmediatamente de las corbetas, cuya amenaza, como quiera que desconcertase en un momento todo su plan de enriquecerse, no pudo ménos de moverlo á dar las órdenes más estrechas para la restitución del robo y castige del delincuente.

Se logró inmediatamente el primer objeto y aprehendido el reo en la playa inmediata apenas alcanzaron todas nuestras súplicas para evitar el castigo, el cual, según nos manifestaron, debía ser precisamente el de muerte. A cada momento Vuna y los Eijes inmediatos nos instaban con la mayor eficacia á que no tuviésemos escrú pulo alguno en matar á todo ladrón: nos recordaban con este motivo los castigos del Capitán Cook en Annamoka, Happai y Tongatabu, y nos aseguraban que semejantes medidas en nada trastornarían la paz y quietud establecidas.

Adelantado ya mucho el día y recorridas se. gún costumbre entrambas corbetas por Vuna y Feileua con nuevos tributos de nuestra parte al deseo de una concordia duradera, nos manifestó aquel Jefe que no se agotarían tan pronto sus ardides para el contínuo incremento del tesoro empezado: le vimos ahora aparecer de nuevo á bordo de la Descubierta, acompañado de unas doce jóvenes, la mayor parte reunidas á la familia real y todas primorosamente adornadas con flores frescas en forma de collar, y con el acostumbrado (I) aceite en la parte superior del cuerpo. Les seguían unas tres viejas, comprendiendo entre ellas la Dubou, hermana de Vuna; llevaban todas consigo algunas frioleras para regalo, y precisadas á sentarse unidas en paraje visible, entonaron suavemente sus cantos no descuidando medio alguno de hacerlos más agradables con la harmonía y con los movimientos: era la Dubou la que dirigía el coro, la que insistía con mayor eficacia sobre la continuación del canto, y la que manifestaba, aunque anciana, la mayor sensibilidad y ternura en sus movimientos: niá la verdad era inútil semejante maestra ó directora, porque las jóvenes interrumpían á cada paso el canto, llamando á los Oficiales con quienes habían cambiado nombres con mucho cariño, con mil chanzas agradables y llenas de decoro, y con todos aquellos sobresaltos que dictan á cada paso entre los jóvenes de ambos sexos los celos, el

(1) Usamos varias veces la vo\% acostumbruto, por no repetir con demasiada frecuencia todo lo que está prolijamente escrito en los viajes del Capitán Cook y enojo y el capricho. Las flores, los peines, las May.2. flautas y una ú otra estera de poco valor se repartían luégo prudentemente y con todas las gracias del capricho; finalmente, si hubiese alguno. sordo, aún á todos aquellos atractivos, se dirigían á él particularmente las miradas, las modulaciones y las palabras más tiernas y expresivas del canto. Puede imaginarse que nuestros dones no fueron en aquella ocasión mezquinos, ni pocas las instancias para que después de satisfecha su curiosidad con la vista de las cámaras, camarotes y entrepuentes, se retiraran á tierra y nos de. jasen comer tranquilamente con los jóvenes Feileua y Tufoa, ya que Vuna había determinado el comer con D. José Bustamante en la ATrevidA.

En aquella corbeta debían á la sazón considerarse mucho más felices que nosotros, si se atendiese al progreso más rápido y más claro de los conocimientos fisiológicos: las conversaciones con Tufoa en la noche anterior les habían dado mil nociones importantes sobre los efectos de las visitas del Capitán Cook en el Archipiélago, y sobre los acaecimientos en la Isla de Kao de la lancha del Bounty á las órdenes del Capitán Bligh. D. Ciriaco Cevallos había adquirido nociones importantísimas sobre el idioma, y estrechada la amistad con el Jefe ó Arraez de una embarcación recién llegada de Tongatabu, iba desenvolviendo muchos puntos relativos á la historia, á las costumbres y á la religión de esos pueblos; finalmente, los acopios para las campañas y los aprestos del buque y del aparejo, no eran en nada inferiores á la celeridad con la cual continuaban en la Descubierta.

Nuestra aguada fué también feliz, pues no sólo hubo en ella el mayor orden y tranquilidad, sino que se consiguió la restitución de un hacha que los naturales habían robado y ocultado ya en un paraje bastantemente distante.

No aparentaba mucho más favorable del anterior el día 25, por lo que toca á las observaciones astronómicas: los aguaceros contínuos hacían aún molesta la continuación de la aguada á las órdenes de los Tenientes de navío Novales y Cevallos, y se agregaba ahora á estos inconvenientes un viento fresco arrafagado del Sursueste, que contra nuestras espectativas levantaba alguna mar en el fondeadero; sin embargo, elevándose más el Sol sobre el horizonte, no tardaron después en disiparse esos amagos, y á sucederle el día más placentero que hubiésemos conseguido hasta entonces: no tardaron en transferirse al observatorio D. Juan de la Concha y D. Fernando Brambila para atender cada uno á los objetos interesantes que debían abrazar. D. Felipe Bausá, con la escolta del joven Tufoa, emprendió el medir una base y hacer marcaciones relativas á nuestro fondeadero en la misma playa de la ranchería, y la tropa de entrambas corbetas tuvo ol- 
den de estar pronta para hacer en tierra y á la vista de Vuna algunas evoluciones militares, con tres ó cuatro descargas de fusilería.

Alegráronse mucho con estas noticias así Vuna como los demás naturales, y se dispusieron por su parte á correspondernos con unas diversiones mucho mejor ordenadas que las de los primeros días: todo anunciaba en los rostros la alegría y unión recíproca que daba lugar á estos regocijos públicos, y Vuna y Feileua no se habían descuidado antes en ofrecer dos puercos y luégo cn acompañarnos al sitio de la fragua y observatorio en donde nos habíamos transferido: manifestó entonces con menos recato el deseo de las hachas, y no fué poca su satisfacción cuando le prometimos regalarle una, pues no traíamos las bastantes para hacerlas "un efecto de cambio. Comió luégo en la ATREvida recomendando particularmente al Capitán de la embarcación de Tongatabu, del cual parecía hacer un aprecio extremado: nosotros tuvimos á Feileua y Tufoa, el primero tantas veces vestido, como luégo despojado por su padre cuando llegaba á tierra, el segundo siempre pronto á dar cumplimiento á nuestros deseos, con una autoridad y un despejo que parecían difíciles de conciliarse con su edad y su clase subalterna.

Llegada la hora que debía dar principio á las diversiones, y enviada de antemano la tropa bajo la dirección de D. Francisco Viana y D. Jacobo Murphy para que la conservasen unida y en buen orden, nos dirigimos con algunos Eijes y el mismo Vuna, al paraje destinado.

Inadvertidamente nos habíamos armado casi todos á un tiempo y á la vista de los naturales; $\mathrm{y}$ esto, aunque ni fuese extraordinario ni nuestras armas se redujesen sino á pocas pistolas y sables, combinados sin embargo con las fuerzas ya respetables que teníamos en tierra, fué inmediatamente prevenido á Vuna, y le causó todo aquel sobresalto y desconfianza que eran bien naturales: procuramos disiparlos luégo que llegaron á nuestra comprensión, pero eran vanos nuestros esfuerzos y apenas este Jefe se consideraba seguro bajo nuestra escolta. A este mismo temor debimos atribuir poco después el nuevo obsequio que se nos hizo de desplegar una larga alfombra desde la orilla hasta la casa del cava, en la cual, del mismo modo que en los días antcriores, estaban ya unidas las mujeres acostumbradas, señoreándose entre ellas la hija de Paulajo, mujer de Vuna.

Ya dispuestos los espectadores en el cerco consabido, empezó nuestra tropa el manejo del fusil. Eran generales los aplausos en cada movimiento uniforme. Sobresalían aún más en las vueltas á derecha é izquierda, en las marchas de frente y en los diferentes modos de desplegarse en batalla. La hermosura de la tarde, el brillo del Sol sobre las armas, la mezcla agradable á Mriy. veces de un total silencio, á veces de unos clamores generales y harmoniosos, el mismo sitio ameno en el cual nos hallábamos, daban á la escena un no sé qué de grande y majestuoso. Las tres descargas que se hicieron después de diferentes modos, alarmaron mucho, particularmente á las mujeres, á pesar de que las hubiésemos prevenido de antemano y que la tropa diese el frente al mar en cada descarga.

Concluído aquel espectáculo con la satisfacción general de los naturales, inmediatamente se retiró la tropa á los botes que estaban amarrados cerca del arrecife, y esta providencia, al paso qne disipó en el ánimo de los espectadores cualquier recelo, dió lugar á que con mayor saiisfac. ción emprendiesen luégo los espectáculos prevenidos.

La música fué la primera que ocupó el centro del área; Xavea, el hermano de Vuna, tocaba el palo hueco; le acompañaban, ó más bien, seguían, la caña rajada y los bombones, y sobre su compás cantaba harmónicamente un coro de 32 hombres. Cedieron éstos luégo su lugar á unos 60 hombres, que divididos en dos bandos, figuraban una batalla. Para no alarmarnos en modo alguno, habían sustituído á las macanas, remos cortos, y otros palos pequeños. No omitían el canto ni el compás; pero precipitados poco á poco uno y otro, á medida que la mayor proximidad, los ademanes más violentos y tal vez más irritados, las mismas palabras del canto, enardecían con más furor á los combatientes: finalmente, se estrechaban, y sin abandonar las filas ni entremezclarse los dos bandos, convertían su estudio en buscar una posición que les permitiese vibrar el propio golpe y evitar el del enemigo. Era común en este trance repetir todo el bando las cortas voces que entonaba su conductor; procurar con movimientos rápidos de la cabeza, que se encrespasen los cabellos, embijarse la cara con la tierra amarilla que encontraban, y variar á cada paso de posición, ya como fugitivos, ya como perseguidores: en todos estos choques se hacía particularmente digno de atención uno de los caudillos, el cual, en un momento, convertía todas las muestras del furor más vivo en otros tantus ademanes, más bien propios de un arlequín ó de un payaso, causando así frecuentemente la risa de los circunstantes, con repetidas muecas que dirigía á unos y otros.

La violencia de los movimientos no permitía que durase por largo tiempo esta diversión. Le sustituyó inmediatamente un baile de los hombres, cuyo número no era menor de cuarenta, y cuya clase, era en nuestro entender, toda de Eijes. Bailaron por largo tiempo, cantando ellos mismos y dando diferentes vueltas alrededor de la música instrumental. El placer. la hamn- 
May. 25 nía, el obsequio y la agilidad sobresalían casi con emulación. Doblaban el cuidado y la habilidad cuando desfilaban delante de nosotros, $y$ las ideas reunidas de la robustez, del placer y de la tranquilidad interna, nos recordaban á cada paso una viva imagen de la edad del oro.

Pero estas ideas debían luégo ensancharse mucho más y causarnos un grado de admiración superior á cuanto habíamos visto é imaginas do hasta entonces; cincuenta mujeres, la mayor parte de las Eguís y casi todas jóvenes, salieron al área y se dispusieron á emprender un nuevo baile. $\Lambda l$ paso que la modestia y el pudor las contenían algún tanto al principio y que atentas á la mejor compostura de sus trajes no desmentían el intento de agradar, la música compuesta ahora de un coro numeroso de hombres y la alegría universal que penetraba igualmente á todos, las incitaba á no perder momento. La sola hija de Paulajo y mujer de Vuna, se absturo en esta ocasión de manifestarse al público. Sus hermanas y las demás principales que nos habían visitado á bordo, todas estaban comprendidas en el cerco. La Dubou, hermana de Vuna, parecía la maestra. No desdeñaban las mujeres más adultas mezclarse con las más jóvenes, y aún no había empezado á avivarse el baile, cuando era ya preciso formar un segundo cerco exterior para que pudiesen bailar todas con alguna comodidad.

El compás, las figuras y el paso, no eran diferentes de las de los hombres, ni diferían mucho el vigor y la sensibilidad que ahora sobresalían. Pero cuando en lugar de estas propiedades casi innatas en aquellos pueblos, se atendiesen las gracias, la dulzura y aquella agradable sonrisa, que tan propia de la mujer descubre al mismo tiempo la voluntad, la modestia y los adornos del rostro, la escena á nuestros ojos variaba mucho de semblante, y nos representaba más bien los templos de Gnido y Amatunta que el pobre asilo de unas naciones al parecer incultas y siempre infelices. No faltaban tampoco entre unas ú otras de las más jóvenes aquellas miradas preferentes, que mezcladas con el antojo y la publicidad, deciden en nuestra Europa de la suerte del corazón de los hombres. El enfado, los celos, el amor y el pudor parecían disputarse entre sí la posesión del rostro. Al aproximarse bailando en torno hacia aquellos á quienes querían dirigir más de cerca sus cuidados, se paraban algún tanto, explayaban en los pasos nuevas habilidades, las acciones parecían más expresivas y el canto más sonoro. Se les veía un momento después, despertadas casi de las ideas que las distraían, escuchar y seguir la música con la mayor atención y entregarse todas á la ayradable clasticidad de las fibras. Entonces uceleraba el compás, los movimientos más vivos disipaban la languidez de los ojos, todo respira- May. 25 ba el placer; y no sólo los espectadores, sino la misma Naturaleza parecía tomar parte en esta escena tan agradable.

Varios objetos debían á la sazón distraer la atención nuestra para que la narración de estos hechos no careciese de la exactitud posible. Eran éstos en primer lugar, una mujer bastantemente anciana, que fuera de las filas y con mil ademanes burlescos, imitaba al payaso ya advertido en el baile de los hombres; en segundo lugar, las niñas de una edad áun menor de seis ó siete años procurar imitar y envidiar casi á las más adultas la agilidad y expresión con las cuales bailaban; finalmente, la igualdad y el compás, que dependían, al parecer, del número determinado de repeticiones del canto, y que anunciaban con bastante seguridad que eran frecuentes estos entretenimientos, aunque tal ve $z$ no tan solemnes y generales como en el día.

La continuación no interrumpida de estas diversiones, había ya ocupado casi toda la tarde, y sin embargo, era tal la satisfacción general, que si bien cansados, no cesaban aún de saltar, ya por una, ya por otra parte los hombres, $y$ Vuna, complacido, solicitaba ahora que viésemos bailar una de sus niñas. No fué ménos divertida esta vista para nosotros: tal era la agilidad y la resistencia que se veían explayar; mas aproximándose ya la noche, nos dispusimos á regresar á bordo, prevenidos con àlgunas frioleras que dejasen contentos á nuestros conductores de las canoas, para no exponernos enteramente á su albedrío.

No habían sido ménos felices los Oficiales destinados á la aguada y al observatorio. Se había establecido por las alturas correspondientes una primera época que sirviese para la deducción de la longitud, el nuevo examen de la marcha de los relojes, y las experiencias de la gravedad. La longitud determinada al observatorio por este método, fué la siguiente:

\section{Longitud oriental del puerto \\ Jackson......... $34^{\circ} 46^{\prime} 55^{\prime \prime} \quad 34^{\circ} 5 \mathrm{I}^{\prime} 24^{\prime \prime}$ \\ Resulta (según nuestras su- \\ posiciones) la longitud oc- \\ cidental de Cádiz. . . . I $167 \cdot 40.35 \quad$ 167.36.09}

Para la determinación del cronómetro 7I, fué preciso adoptar el movimiento que había indicado la última época en el puerto Jackson; pero si bien de este modo se aproximasen mucho sus resultados á las últimas observaciones de las distancias lunares, pareció siempre preferente el número I I, cuya marcha se conservaba exactamente la misma: se aproximaba mucho á esta determinación la del reloj Io5 de la ATREvida: discrepaba al contrario en una cantidad fuerte el cronó. metro 72 . 
Ni había sido ménos activo D. Felipe Bausá, pues concluído el plano de la bahía, ya se disponía para la mañana siguiente á navegar en el bote de la Descubierta al reconocimiento de los canales y fondeaderos interiores: se ofrecíó Tufoa á acompañarle. Vuna quiso presenciar el método nuestro de hacer la aguada, y efectivamente, poco después de la salida del Sol, las lanchas, á lás órdenes de los Tenientes de navío Espinosa y Pineda, y el bote á las órdenes de Bausá, dieron la vela para sus destinos.

El conseguimiento de las observaciones para la latitud debió también parecernos tanto más agradable cuanto que en realidad eran pocas las ocasiones favorables para la Astronomía, siendo aquellos contornos casi contínuamente cargados de vapores. Por algunas alturas meridianas á una y otra parte del $Z$. D. Juan de la Concha la dedujo de $18^{\circ} 38^{\prime} 45^{\prime \prime}$, y los tiempos sucesivos manifestaron evidentemente que no habían sido infructuosos sus cuidados para este fin.

Procedían al mismo tiempo, uniformes y con una actividad correspondiente, nuestros aprestos interiores: se enriquecían diailamente las colecciones de todas especies para el Real Gabinete: D. Tadeo Heenlie había dedicado ahora su estudio principal al conocimiento de las aves y de los peces, los cuales hallaba en mucho número y variedad y aún no bien conocidos en las descripciones naturales publicadas hasta aquel tiempo: en lo que sí debíamos extrañar alguna escasez, era en la adquisición de puercos, los cuales veíamos siempre en poco número, y puestos decididamente al alto precio de un hacha por cada uno. Esta falta, sin embargo, se reemplazaba con una cantidad crecida de gallinas, y de toda especie de raíces, plátanos y cocos, cuya utilidad en la conservación actual y venidera de los equipajes, era visible en cada día y prometía un feliz término al viaje emprendido. Las repetidas conversaciones con Vuna nos daban luégo lugar á estrechar diariamente nuestra amistad. Lográbamos verle bien enterado de la extensión de los dominios de Su Majestad, de sus fuerzas navales, de nuestro destino y de las visitas frecuentes que les haríamos en lo venidero; correspondiéndonos por otra parte este mismo Jefe con las aseguraciones más positivas de la mayor fidelidad de parte suya y de Feileua; fidelidad en su entender tanto más ensalzada cuanto que se cuidaría mucho en Vavao de castigar los ladrones, siendo así que en Happay, Annamoka y Tongatabu (según nos insinuaba con frecuencia) no encontraríamos ni igual legalidad, ni igual abundancia de comestibles. No eran menores nuestros progresos en las demás indagaciones que teníamos entre manos. El ayo Latu que solía pasar las noches en la Descubierta, satisfacía con la mayor proliji- May. 26 dad y paciencia nuestras preguntas que á veces se dilataban hasta las once. En la ATrevidA el Capitán de Tongatabu descifraba muchas contradicciones en lascuales veíamos incurrir los naturales á cada paso. Los Eijes principales ya con más familiaridad nos entretenian hablándonos de los viajes del Capitán Cook, de sus Oficiales con quienes habían cambiado nombre; finalmente, de la lancha del Capitán Bligh y de los últimos acaecimientos de todo el Archipiélago confederado.

No variaron mucho las circunstancias en los $27 \mathrm{y}=3$ dos días siguientes, los cuales estuvieron cons * tantemente nublados y con vientos bonancibles del Esueste al Este: se hicieron, sin embargo, las experiencias de la gravedad, esperando una época favorable para determinar la marcha de los relojes: concluyéronse las obras interiores y los acopios de agua, y se destacó la lancha de la ITREVIDA á las órdenes de D. José Robredo para que al mismo tiempo sostuviese el bote de Bausá, y le auxiliase en las sondas y reconocimientos emprendidos: era muy cómoda para este último objeto la comunicación frecuente que teníamos unos con otros con el auxilio de los naturales. El regalo más frívolo bastaba para que con us canoas se dirigiesen inmediatamente á unas otras partes del Archipiélago. D. Felipe Bausá alababa constantemente las disposiciones activas y cariñosas de Tufoa, y su inteligencia de todo el Archipiélago, de modo que conduciéndole á un alto le hubiese manifestado la vista de un crecido número de islas y la dirección de otras mucho más distantes; encarecía luégo en extremo la seguridad de los puertos, la amenidad de los campos y la hospitalidad de los habitantes; y aseguraba que para la tarde del 30 estaría reunido á las corbetas. Mucho insistía Vuna, á la sazón, para que abandonásemos el fondeadero, en donde él mismo estaba incomodado por la estrechez y distancia de la capital, y nos dirigiésemos á los interiores, en donde sus agasajos serían más proporcionados á sus buenos deseos. Manifestaba al mismo tiempo el mayor empeño para castigar los ladrones, y efectivamente, había mandado que se diese luégo la muerte, á uno que cogido en la ATREVIDA con el robo de un escoplo, le había echado maliciosamente al agua para que no le hallasen sobre su persona. Suspendió Don José Bustamante la ejecución de este castigo y le sustituyó el de cien azotes que le dieron los mismos Eijes, emisarios de Vuna, haciendo luégo (á imitación del Capitán Clerke) que se le rapase á navaja la cabeza como una señal indeleble del delito comeído.

Pero no podíamos perder de vista el estado de la expedición, de modo que evacuados los objetos esenciales que nos habian conducido á 
May 28 aquellas islas, no sacrificásemos un tiempo precioso al sólo aumento de pocas noticias, tal vez equírocas, ó á lo ménos orígen engañoso de algunos sistemas. Estas reflexiones por sí bastantemente poderosas, aumentaron su vigor mucho más en el día siguiente, en el cual, conseguida en el observatorio una serie bien satisfactoria de alturas del Sol, se declaró viento fresco del SurSueste con mar bastantemente picada del mismo, de suerte que no sólo se hiciese arriesgada la comunicación con la playa y el observatorio, si también debiese causarnos no poco cuiclado la demasiada inmediación de las corbetas á la orilla, siendo así que el ancla de fuera estaba en 36 brazas, y su cable no podía considerarse seguro por las piedras ó ratones que debíamos sospechar le fuesen inmediatos. Sin embargo, la lancha de la Descubierta á las órdenes de Don Francisco Viana, hizo un nuevo viaje á la aguada, y el Comandante de la Atrevida, acompañado de los Sres. Espinosa, Cevallos, Quintano, Brambila y Nee, emprendió con Vuna una excursión realmente importante á visitar el sepulcro de Paulajo, último Soberano de la Isla de los Amigos, y particularmente conocido del Capitán Cook, en su viaje desgraciado á aquellos mares. Los trances igualmente instructivos y curiosos que fueron las resultas de aquella excursión, han sido descritos con la mayor puntualidad por D. José Bustamante, y la copia de dicha narración inserta literalmente á continuación de estos párrafos, no desagradará seguramente al lector.

"Con grande empeño había deseado Vuna que las corbetas fuesen á fondear en las inmediaciones de Leyafú, donde habitaba. Su pretensión, en que unía á su propia utilidad nuestras ventajas, la esforzaba haciendo una pintura la más hermosa de sus contornos, y prometiéndonos una abundancia de provisiones muy superior á la que teníamos donde nos hallábamos. Hubiera desde luego condescendido á sus instancias D. Alejandro Malaspina, si nuestras urgencias esenciales no estuviesen ya remediadas, ó si la escasez de refrescos nos obligase á buscarlos en aquel paraje.

"Sin embargo, Leyafú era un pueblo digno de nuestra atención, y la circunstancia de existir en él un monumento consagrado á la memoria del Rey Paulajo, añadía un mayor motivo para nuestro examen. Vuna, á quien debíamos también esta noticia, se ofreció á acompañarnos sin que precediese de nuestra parte pretensión alguna, ya por una consecuencia en obsequiarnos, ó porque esperaba con justicia lisonjear su vanidad en nuestra excursión á Leyafú. Las atenciones importantes del servicio $y$ las circunstancias, habían dictado la providencia de que uno de los dos Comandantes no abandonase la inmediación de las corbetas, y consecuente á ella, dispuso May. 29 D. Alejandro Malaspina que yo me encargase de este viaje, acompañado de los Tenientes de navío, Espinosa, Quintano y Cevallos, el botánico Nee y el pintor Brambila.

"Para la mañanita del 29, quedó fijada la salida. Feileua, que nos había favorecido durmiendo á bordo la noche del 23 , fué á tierra temprano por la mañana á llamar á su padre, que llegó poco después de las seis; le acompañaban cuatro de sus mujeres, inclusas la madre de este Príncipe y la favorita actual Fatafegi; número de personas con quienes no habíamos contado, y que, atendida la capacidad del bote, hacían incómodo nuestro viaje.

"Nuestro único práctico de la derrota que íbamos á emprender, era el mismo Vuna. Desde que abandonamos las corbetas tomamos la costa de la izquierda, siguiendo por cerca de una hora al remo el mismo rumbo de las lanchas para la aguada. Doblada la punta Sur de esta costa ó de la Isla de Vavao, nos dirigimos como al Nordeste hacia el fondo de una ensenada, en cuyo punto veíamos la lancha de la Descubierta al Sueste muy cerca de la aguada. El poco viento que hasta aquí nos había sido contrario del Este al Sudeste, cobrando alguna más fuerza por esta última parte, nuestros progresos empezaron á ser mucho más rápidos y á prometernos un término corto á la navegación que nos faltaba.

"Otra circunstancia debió contribuir no poco á hacer sumamente agradable nuestro viaje. El encuentro de nuestra lancha y del bote de la Descubierta á las órdenes de D. José Robredo y de D. Felipe Bausá, nos produjo toda aquella complacencia que necesariamente debían causarnos las agradables noticias que dieron estos Oficiales comisionados en las operaciones hidrográficas del Archipiélago. En el fruto de sus tareas habían tenido el feliz descubrimiento de dos fondeaderos excelentes, agua delicada y todas las islas vestidas con la misma ó mayor frondosidad que la que admirábamos en la inmediata á las corbetas. Bausá nos informó de cuánta utilidad le había sido la compañía del Jefe Tufoa, no sólo para que los naturales se prestasen á cuanto deseaba, si también para dirigirlc á las aguadas buenas y á las eminencias donde dominando los objetos, había conseguido el mayor grado de exactitud en sus trabajos y el nombre propio de cada una de las islas. Entonces manifesté á T'ufoa lo agradables que nos eran sus buenos servicios, y contase por mi parte con una buena recompensa al regreso á bordo. Pero sobre todo, las maravillas con que me pintaron entrambos Oficiales el lugar á donde nos encaminábamos, dieron ocasión para acelerar nuestra despedida y doblar nuestras diligencias para alcanzarle. Vuna á este tiempo destacó una ca. 
May. 29 noa que seguía nuestras aguas para anunciar sin duda nuestro próximo arribo á Leyafú.

"En efecto, á las dos horas de navegación, desde el fondeadero llegamos á este sitio delicioso. Un crecido número de naturales de ambos sexos salieron á recibirnos á la orilla. Como en este acto no advertimos ni la curiosidad estúpida de su carácter, ni la inquietud importuna que en tales casos acostumbran, creímos fuese efecto de la veneración y respeto que les infundía la presencia de su Jefe.

"Vencida una pequeña elevación que forma la ribera en donde desembarcamos, andados cien pasos salimos á un terreno llano rodeado y cubierto de árboles frondosos y encadenados, á cuya sombra defendiendo las fuertes impresiones del. Sol en estas regiones, hacía una mansión la más deliciosa. A la derecha vimos luégo el sepulcro de Paulajo, y á la izquierda dos casas, la una mucho mayor que la otra. Vuna nos condujo al interior de la más pequeña, por cuya arquitectura y decencia nos pareció digna para alojarle y por consiguiente fuese la en que habitaba.

"Catorce columnas de madera elevadas en la figura de un óvalo perfecto, sostenían todo el edificio; su techo bajaba en forma de tienda de campaña hasta una vara del suelo, acabando de cerrar este espacio por todas partes (excepto el frente reservado para la entrada) una estera de fina palma que fácil de mover en todos sentidos, se quita ó se pone según el grado de luz ó ventilación que se desea. La elevación de la casa por el centro pasaba de cinco varas, cuyo largo ó mayor diámetro constaba de 30 piés y de I5 su ancho. La parte inferior del techo se formaba de maderas fuertes y primorosamente unidas entre sí; estas maderas bien curvas ó labradas en la forma conveniente, daban á la casa vista por dentro, una figura cóncava, simétrica y regular. El pavimento cuidadosamente nivelado, se elevaba como pié y medio, cubierto de dos esteras, la una que tocaba el suelo y otra más fina que la primera y sobrepuesta á ella. Entre las varias vigas que corrían de columna á columna para trabar y unir el edificio, se cruzaban cuatro perpendiculares en el centro, formando un cuadro que sostenido por sus cuatro ángulos de igual número de pilares, servía á sostener cinco lanzas, tres mazas y otros instrumentos semejantes á los que usan en sus bailes, y casi de la misma forma y dimensiones que sus canaletes. Estas armas, entalladas con un gusto y primor que no esperábamos del estado de las artes de estos pueblos, se hallaban carcomidas algunas de sus molduras y relieves, y el polvo que las cubría anunciaba su antigüedad y que no se usaban de mucho tiempo.

"No comprendimos por la significación que nos dió Vuna de esta casa, los objetos á que estu- Maj. 2'y viese consagrada; sin embargo, varios antecedentes nos condujeron á creerlá como un paraje destinado á la práctica de algunas de sus instituciones religiosas. Nuestros informes posteriores guiados por el nombre de Falcotua con que nos distinguió esta casa Vuna, no permitieron dudar que aquella voz equivalía á Casa de Dios, ni que su verdadero objeto era el mismo que habíamos sospechado. Vuna, desde el instante que entramos en esta casa, se sentó y procuró mantenernos en la propia actitud. El pueblo, reunido y sentado en la forma respetuosa que acostumbran, le advertíamos, como á su Jefe, penetrados de aquella profunda veneración que inspira á todos los hombres todo lugar sagrado; pero nosotros, sin conocer entonces el alto y piadoso objeto á que estaba destinado, le escudriñamos todo, y cometeríamos tal ve $z$ algunas irreverencias aunque disculpadas con nuestra propia ignorancia.

"Estaba construída esta casa en el centro de un pequeño recinto formado de cañas entretejidas con artificio y elevadas más de doce piés. Cerraba la entrada una puerta cuadrilonga de madera, que girando sobre cuerdas en lugar de goznes, podía cerrarse dando vuelta á una tornaja fija al marco con un clavo de madera. Todo el espacio cerrado era llano, cubierto de verde y menuda grama; los árboles que lo rodeaban por afuera, elevados á una altura prodigiosa; sus frondosas ramas caían con majestad sobre este edificio rústico; finalmente, el arte y la Naturaleza parece se complacían en añadir medios de inspirar á estos lugares sagrados toda la veneración y culto que les rinden los naturales.

"Después que D. Fernando Brambila había concluído el diseño de esta casa, pasamos á otra no distante, más capaz, pero construída bajo la misma forma. Habitaba en ella una Dubou de quien varias veces nos habían hablado con veneración los insulares. Todavía no sabíamos con certeza el origen y sucesión de la Corona de Vuna, quién fuese esta Dubou, cuál era el carácter que representaba en el día, ni por qué causas gozaba de los naturales y aun del mismo Vuna una consideración que casi se confundía con la de su propia persona.

"Nuestras dudas se aclararon muy presto, unas allí mismo y otras al día siguiente á bordo de la ATrevida. La Dubou era viuda de Paulajo y madre de Fatafegi y de Taufa. Feileua era hijo de la segunda, y no existiendo otro heredero que pudiese disputarle los derechos de la sucesión, recaían en él todos los de la Corona. No en vano estas dos hermanas eran el objeto de las ternuras de Vuna, á pesar de no verse tan favorecidas como otras de la hermosura, que es ordinariamente la razón que mide el cariño entre los pueblos bárbaros. 
May .9 "La noble Dubou, con un semblante dulce y majestuoso, nos recibió con tanto agrado como dignidad. Su aspecto, su compostura y hasta su color, todo la distinguía de los otros naturales, todo anunciaba la elevación de su carácter. Admitió nuestros presentes con una viva gratitud, la cual significaba añadiendo á las señales del semblante la expresión y ceremonia que acostumbran. Ninguna de nuestras bagatelas la causó el asombro que á los naturales, aunque más capaces de cau ivar el corazón de una mujer, ni su dignidad la permitió jamás de prostituirse á pedirnos una ú otra cosa de las muchas que le presentábamos á sus ojos. El único antojo que le advertimos fué una botella y dos vasos de cristal de que nos servíamos; pero para ser consecuente en su conducta y tal vez no comprometerse á una negativa, pidió á Vuna me interpretase sus deseos, los cuales dejé satisfechos; este sólo presente, creo la obligó tanto como todos los otros juntos. Por este modo de conducirse debía estimular más y más nuestra generosidad hasta que agotó los bolsillos de todos. Pero, sin embargo, como había yo dejado en el bote la parte más considerable de nuestros regalos, pensé volver á hacerle otro nuevo presente á la despedida.

"Cuando visitamos á Dubou, la acompañaban sus dos hijas: todos los Eijes que nos seguían, quedaron fuera, á excepción de Vuna, que tomó asiento casi á la entrada: sus mujeres ocupaban el lado opuesto, Dubou la testera, y nosotros en el centro de unos y otros. Poco después llegó un anciano llamado Tagacala, y se colocó á la iz. quierda de Dubou, que tenía á su derecha á la mujer del mismo Tagacala, próxima parienta de Paulajo. Estando todos en esta disposición, nuestro amigo Vuna, que no había permitido comiésemos en la casa del Otıa, me insinuó que podíamos hacerlo en ésta. Lo hicimos, en efecto, pero con el sentimiento de que los cortos principios que teníamos del idioma, nos privasen el gusto que se goza en la sociedad de una mujer amable: sin embargo, fueron suficientes para procurar lisonjearla, con la memoria de la viveza y gracias de su nieto Feileua. Aprovechando esta ocasión, le insinuamos hiciese un viaje á las corbetas, donde nos sería fácil hacerle presentes que llenasen nuestra generosidad y correspondieran á su carácter. A todo nos respondió la augusta viuda de Paulajo, con cierto rubor en su semblante dulce, para anunciarnos la impresión viva de nuestras atenciones y de nuestras of ertas, temiendo el ofendernos si no las aceptaba.

"Hasta el punto de la despedida, no habíamos aún penetrado toda la autoridad de esta Dubou. Vuna en este acto se quedó el último, y vimos (no sin poca sorpresa nuestra) rendirla todos los honores de la majestad ó de vasallaje que prcscriben las Jejes de estos pueblos. Vuna, sin faltar al ritual de ellas, se dirigió á la Dubou, le tocó con la cabeza la planta del pié, después con la mano, y besó ésta seguidamente. Dubou recibió el homenaje con la misma dignidad que presidía todas sus acciones, pero también con aquella indiferencia de quien recibe un tributo que de justicia le pertenece. Nuestras inducciones de este ceremonial, fueron tan varias como inciertas. En lo que convinimos, fué que su ejecución la reservó Vuna con estudio para cuando todos estuviésemos fuera de la casa, humillación que seguramente hubiera querido no presenciásemos, y á toda costa hubiera omitido de poderlo hacer impunemente. Pero esto nada influye para poder dudar que este Príncipe goza en el Archipiélago de Vavao de todo el poder de la soberanía y de una autoridad sin límites.

"Saliendo de la casa de Dubou da principio un llano oblongo, en cuyo extremo opuesto se deja ver el sepulcro de Paulajo. Vuna parecía poco dispuesto á conducirnos hacia él, y fueron necesarias mis insinuaciones para que nos acercásemos á distancia conveniente de examinarle. Un terraplén se elevaba sobre el nivel del llano más de tres piés, formando un cuadro perfecto, cuya área tenía 4.000 piés. El borde superior de este cuadro se cerraba con grandes piedras sillares negras, puestas de canto y bien unidas entre sí. Sobre el centro de esta superficie se veía una casa de la misma arquitectura que la descrita antece. dentemente, $y$ dentro del humilde edificio yacían las cenizas del Príncipe. Los dos lados colaterales del cuadro y el de la espalda los rodeaban á 30 piés en forma de semicírculo dos especies de árboles plantados con orden y simetría. Estos árboles, cuya aplicación usan los naturales para símbolo de la tristeza en esta especie de lugares, son conocidos por los naturalistas con el nombre de casuarina cquisetifolia el uno, y elate el otro. El primero, semejante al ciprés de Europa, y el segundo es una especie de palma, cuyas hojas son muy lustrosas y están siempre verdes.

"La multitud que nos acompañaba tomó asiento á 40 pasos del teatro, sin que se les diese orden particular para hacerlo. Vuna, Tagacala y nosotros, avanzamos hasta ro piés del terraplén, donde se nos mandó sentar, indicándonos por señas, no era permitido acercarse á lugares tan de votos sin el riesgo de profanarlos. Sentados todos, creíamos esta la ocasión más propia para hacer algunas cuestiones sobre la religión de estos pueblos, de la cual eran ideas bien escasas las que teníamos, ó muy confusas. Pero en vano 10 intentamos; Vuna y Tagacala empezaron luégo á arrancar yerbas, cuya operación que no interrumpieron mientras permanecimos allí y que repitieron después á la vista de otro Fiatoga, debe tener alguna alusión misteriosa. Estos Jefes, con sus ojos fijos en el suelo, cayeron desde el ins. 
Yay. 29 tante en un letargo tan profundo, que si nos respondían era con violencia, y cuando lo ejecutaban era sin concierto: su semblante nos representaba la imagen misma del dolor y de la tristeza; y sus frecuentes sollozos, que parecían salir de lo más íntimo del corazón, apenas nos excusaron de partir con ellos sus penas y sus sentimientos.

"La escena, por otra parte, no nos ofrecía á la vista sino objetos lúgubres y tiernos, capaces de inspirar dolor al corazón ménos sensible. La soledad del sitio, el silencio devoto de los naturales y el ruído suave de los tristes árboles mecidos por el viento, todo debía conducirnos á sentimientos profundos y á contemplaciones melancólicas. La presencia de estos lugares naturalmente suspende el espíritu humano para recordarle las hazañas y virtudes del héroe á quien se consagran. El sepulcro de Paulajo nos traía á la memoria la suprema autoridad que había ejer cido sobre todas las Islas de los Amigos, y los derechos tan antiguos como legítimos con que la Corona existía en su línea por cerca de dos siglos (I), circunstancias todas que lastimaban más la suerte de este Príncipe, y añadían horror á la infeliz catástrofe en que acabó su reinado y su existencia.

"Permanecimos en este lugar bien poco tiempo, y Vuna sin aliviarle aún la confusión que le ocupaba, nos permitió dar una vuelta al mausoleo para verlo de todas sus caras, pero sin acompañarnos. Cuando juzgó satisfecha nuestra curiosidad, nos hizo pasar á su casa poco distante de la de Dubou, de su propia forma y algo más pequeña. Preparada aquí la cava, mandó Vuna servirme la primera copa, que habiéndola yo rehusado, pasó á él mismo, y después de Vuna fueron convidados nuestros Oficiales y á continuación Tagacala y otros Eijes, según el órden de su distinción. Antes de distribuir este licor, habían repartido á cada natural un plátano cocido, del cual comieron una parte reservando cuidadosamente la otra.

"Servida la cava, entraron siete naturales cargados con otros tantos racimos de cocos que Vuna me regaló, y se hicieron conducir al bote, del mismo modo que un tambor de la propia forma y dimensiones del que sirvió en el baile del 25 y se había ya comprado en la DescuBIERTA. No obstante, la circunstancia de ser absolutamente nuevo el que acabábamos de adquirir y ser alhaja del mismo Vuna, le hizo muy apreciable. A estos presentes quiso Vuna añadir el de un cerdo, pero no habiéndolo en las inmediaciones, tan grande como lo deseaba, expidió sus órdenes para que se condujese de más lejos.

(I) Véanse los viajes del Capitán Cook y nuestras descripciones posteriores.
"La generosidad de este Príncipe estaba an- May. 29 tes bien acreditada entre nosotros, pero ahora quería esforzarla á un extremo que no conocíamos. Añadía á sus presentes un agrado ó un esmero que casi reprobaba la dignidad de su carácter, y el anhelo que á cada paso respiraba en complacernos era buen indicio de los sinceros principios que le guiaban á practicar aquella virtud noble y plausible: virtud cuyo ejercicio parece reservado á las grandes almas, porque también son las únicas capaces de sentir la dulce complacencia de ejercitarla.

"Procurábamos en esta casa girar las conver. saciones sobre aquellas materias cuya explicación estuviese más al alcance de nuestros conocimientos en el idioma, y nos facilitase el persuadir los efectos que á la sazón nos penetraban.

"Don Ciriaco de Cevallos tuvo la ocurrencia, que si se juzga por las resultas, no podía otra alguna desempeñar mejor el objeto. Hizo comprender á Vuna que desde España había de volver á Vavao para vivir y morir en su compañía. Vuna no supo como corresponder más dignamente á esta fineza sino pidiendo á Cevallos que apoyase la cabeza sobre su regazo, y cuando lo tuvo de este modo, lo adoptó por hijo suyo en toda forma. Pronunció después una arenga á los naturales, cuya sustancia no pudimos entender; pero á consecuencia, Tagacala y otros Jefes tributaron á nuestro Oficial los honores debidos á su Príncipe.

"Deseábamos dar un paseo á lo interior del país para reconocerle, y Vuna nos condujo por un camino llano que dividía hermosas y dilatadas plantaciones, entre las cuales estaban esparcidas casas en un desorden agradable. La diversidad de árboles que las cubrían y lo frondoso de los contornos todos, presentaban la vista más amena y divertida. Alguna de estas casas tenían como la de Vuna, una fosa á donde acudían las aguas manantiales y se bañan los dueños; su forma era exactamente la de un cono invertido, cuya altura no pasaría de cuatro piés, ni de cinco su base.

"En la extensión de nuestro paseo encontramos con abundancia casi todos los árboles frutales que se conocen en Vavao, pero al cultivo de los plátanos se aplican los naturales con más esmero, ó á lo ménos en su conservación. Las plantaciones de este fruto estaban dispuestas en la propia forma que nuestras viñas en España, y cerradas todas para preservarlas de los cerdos. únicos animales que pueden aquí perjudicarlas. La rima, el coco, el árbol de que sacan sus telas, etc., crecen mezclados entre sí sin sujeción á ningún orden. Nada podía compararse á la hermosa variedad de perspectivas que se presentaban á nuestra vista en esta pequeña excursión. La regularidad de las plantaciones, la graciosa har- 
Iay. 29 monía de sus contornos, y la confusión de árboles siempre matizados de flores, todo nos representaba con los colores más vivos las maravillas de la Naturaleza. La imaginación más apagada no podría resistirse en estos amenos lugares á las sensaciones dulces y apacibles que inspiran. Aquí la nuestra se suspendía tiernamente en hacer reflexiones filosóficas sobre la vida y felicidad de estos pueblos. Admirábamos el estado de su agricultura, á la cual se aplicaban como la más útil y primera ocupación de las sociedades; ocupación á la cual no sólo debían una constitución vigorosa, sino vivir tranquilamente en el seno de la abundancia $y$ de los placeres.

"En nuestro paseo no veíamos el término del camino, ni la fertilidad del suelo tampoco presentaba variaciones que interesasen nuestro examen, y Vuna, que sospechaba si llegaría el nuevo presente antes de nuestra partida, procuró entretenernos hacia estos lugares, y conducirnos después á la casa de un Eije, que lindaba con el propio camino. En nada se diferenciaba la estrechura y forma de esta casa de las que habíamos visto, aunque en su capacidad igualaría á la de Dubou. Aprovechó Vuna esta ocasión para hacer tributar á D. Ciriaco de Cevallos otras ceremonias que como Príncipe debía gozar en todos los dominios del imperio. Cevallos, un poco fatigado de la caminata, manifestó á Vuna quería entregarse por un rato al descanso, cuya prevención anticipó, por si en esta libertad se faltaba á alguna de sus costumbres.

"Tan lejos de oponerse Vuna á ella, dirigió una breve arenga al dueño de la casa, de cuyas resultas vimos ir hacia nuestro Oficial una hermosa joven con todos los encantos del agrado y de la gracia, á cumplir el mandato que se le pres. cribía. Sentada al lado de Cevallos, principió á tocarle blandamente con los puños á lo largo del cuerpo. Esta costumbre, que distinguen los naturales con la voz de Toquitoqui, la practican con los Eijes, sus mujeres; pero Vuna la exigía indistintamente de hombres ó de mujeres, siempre que á bordo la necesitaba en el uso que tiene de conciliar el sueño. Yo no sé si este auxilio le facilite á pesar de usarse como tal, en una de nuestras colonias (I) pero por lo ménos en Don Ciriaco de Cevallos, produjo virtudes muy contrarias el remedio; remedio á la verdad más propio para promover las vigilias que para conseguir el descanso. No fué interrumpida esta operación hasta asegurarse que en suspenderla no se desairaba la linda joven que la ejecutaba: y concluída r'ccibió un presentc del nuevo principe, en el cual quedaron tan satisfechos sus deseos como los derechos justos de su hermosura.

"Debicndo D. l'ernando Brambila sacar la

Lin las Islas Filipinas. vista del sepulcro de Paulajo y de la plaza don- May. 2u de estaba erigido, regresamos luégo á ella. En medio de esta plaza, y sobre uno de sus lados, hay un edificio superior á todos 1 os restantes en capacidad y magnificencia. Esta circunstancia y algunos tambores que contenía, nos inclinaron á creerlo como un lugar destinado á las juntas y regocijos públicos. Nuestros informes posteriores correspondieron á estas sospechas. Sentados aquí nosotros, Vuna y todo el pueblo, tuvimos cerca de dos horas de conversación. Notamos que la mayor parte del concurso despejó al presentarse en esta casa Fatafegi y la madre de Feileua, sin haber precedido orden para ejecutarlo; nosotros inferimos que en este acto de respeto se exceptuarían á las familias de los nobles ó de los Eijes, según el corto número de los que des. pués nos acompañaron.

"Concluídas las vistas por D. Fernando Brambila y examinadas las producciones vejetales de estos parajes por D. Luis Nee, llegó á este tiempo el cerdo que esperaba Vuna, y se hizo en el instante conducir al bote. Ya nada nos detenía en Leyafú, y sólo restaba despedirnos de la Dubou, lo cual insinué á Vuna para que nos acompañase. La multitud de dentro y fuera de la casa se levantó con nosotros, pero Vuna, á pretensión mía la hizo sentar otra vez, y únicamente sus mujeres se exceptuaron de esta orden, á quienes se permitió acompañarnos.

"Encontramos la viuda de Paulajo acompañada de la mujer de Tagacala, ambas empleadas en sencillas ocupaciones domésticas muy propias para gozar con más gusto de la sombra de un arbol bajo del cual reposaban. Nuestra introducción produjo la sorpresa de una visita inesperada y de ceremonia; pero la Dubou compuso su scmblante y su vestido como podía hacerlo la mujer más celosa de la decencia y del decoro debido á los que la visitan. Recibió los segundos presentes con la misma gratitud que los primeros, y nos dió los últimos saludos con la afabilidad y dulzura con que sabía disponer su semblante, pero sin prescindir de representar la majestad con todos los atributos del trono. Por último, no es fácil explicar toda la sensación y complacencia que nos había causado la conducta de esta mujer amable, conducta que sorprendería áun mirada como fruto de una educación ilustrada en el centro mismo de la Europa.

"La estatura de Dubou es más que mediana, su color bastante claro, la fisonomía agradable y el cuerpo gallardo; en cuanto á su primera hermosura, no creo hallamos estado todos muy conformes, tal vez por la dificultad de juzgarla á la edad de cuarenta y ocho años, ó por el modo de medir las diferentes perfecciones en que cada uno constituye este precioso don de la Naturaleza. "Antes de restituirnos á la ribera, visitamos el 
May. 29 cementerio general de los Eijes. Estaba á la izquierda del camino y como 70 toesas distante de la playa. La mayor parte de los edificios que cubrían cada cadáver, eran humildísimos ó estaban arruinados, á excepción del que contenía al pàdre de nuestro Vuna. El amor y respeto filial que distingue á estos pueblos, no pudo aquí inspirar á Vuna tanto sentimiento como las tristes cenizas de Paulajo: tal es el imperio que ejercen sobre el corazón humano los remordimientos de la propia conciencia: las virtudes de la justicia obran como innatas sobre todos los pueblos de la tierra, y apenas habrá un hombre tan depravado que se resista á conocerlas ó se niegue á respetarlas.

"La marea, cuando llegamos á la playa, estaba baja, y sin el auxilio de las canoas, no pudimos embarcarnos. En nuestro tránsito, tuvo Vuna la pretensión de que tocásemos en Lontunague, en lo cual pareció justo complacerle. Este es otro pueblo situado sobre la costa Sur y á lo largo de una hermosa playa, que hace el desembarco muy cómodo en cualquiera estado se halle la marea.

„El Eije de este pueblo Tuenuculaba, de la familia de los Dubous, á quien verosímilmente se habian anticipado noticias, nos tenía preparado un presente de cocos. Vuna, sospechando que yo no tendría ya con qué poder obsequiar á Tuenuculaba, me ofreció dos cuchillos con este destino: por fortuna, nuestras prevenciones no estaban todavía apuradas, ni fué necesario hacer uso de la generosidad sospechosa de nuestro Vuna.

"El jefe de Lontunague tenía cerca de su casa, bajo de un tinglado, la mayor canoa que hemos visto en estas islas. Tenía 75 piés de quilla, cuatro de manga, y tres y medio de puntal.

"La tarde, estando ya muy adelantada, fué necesario dejar este pueblo antes de lo que quisiéramos. Tuenuculaba y su familia no podían ser más amables ni más cariñosos. Sus acciones y sus palabras las dirigían todas á que no nos fuésemos tan pronto, $y$ aún interpusieron por empeño al mismo Vuna para dilatar la partida. La impresión que causan estos hechos no es fácil describirla; son sensaciones que penetran tanto como no se aguarda. El viento nos favoreció constantemente, de modo que antes de las cinco de la tarde, llegamos á las corbetas. Vuna me manifestó que deseaba dormir en la ATREVIDA, pero sospechando si querría le acompañasen sus mujeres, fué conducido á tierra por el bote, quedando nosotros en la Descubierta."

Poco después de haber regresado el Comandante de la ATrevida, se apareció también á la vista y se nos incorporó al anochecer la lancha mandada por D. José Robredo. Confirmó este Oficial las excelentes noticias que había escrito
D. Felipe Bausá, y anunció su llegada para la via. 2. tarde siguiente concluída ya la mayor parte de los reconocimientos útiles. El tiempo había cedido mucho y prometía ser claro, pero la mar continuaba aún gruesa é incomodaba mucho particularmente la correspondencia con la playa y con el observatorio.

La situación de las corbetas en este tiempo no podía á mónos de dictar como partido más conveniente, el de acelerar más bien que no retardar nuestra salida del actual fondeadero. Ya se habían completado así la aguada como todas las obras interiores que la última campaña nos había dictado como precisas. Los abundantes refrescos que habían disfrutado las tripulaciones, disipaban todo recelo de la existencia más remota del escorbuto. No teníamos falta alguna de leña, sino para mejorar la estiva; pero este sólo objeto no podía justificar el que invirtiésemos una porción considerable de marineros, precisamente con aquellas mismas hachas que tanto excitaban la codicia de los naturales. Ni á la verdad, si volviesen á entablarse vientos del Sur algo más frescos del que acabábamos de experimentar, el fondeadero podía considerarse en modo alguno útil ni seguro. Además que no podía ocultarse que la quietud y sosiego de nuestras tripulaciones de la cual había dependido la pacífica comunicación con los naturales, estribaba más bien en la contínua ocupación de aquéllas, que en su disposición á esta especie de privaciones.

Estas reflexiones dictaron como partido mejor el de abandonar el Archipiélago sin omitir, no obstante, todos los medios que pudiesen aumentar el acopio de nuestros refrescos. Con este último intento, en la mañanita siguiente, el Alférez de fragata D. Jacobo Murphy, fué á ver al Jefe Vuna, le presentó dos hachas y algunos otros regalos que le habíamos prometido, y le avisó que debían acelerarse los cambios ya que nos disponíamos á partir dentro de dos días; sorprendió esta noticia á Vuna y á las personas de ambos sexos que á la sazón le acompañaban en la acostumbrada ocupación del cava; pero á los primeros impulsos de un cierto cariño que empezaba á echar raíces entre unos y otros, se siguió muy luégo la atención, mucho más importante, de aumentar cuanto fuese posible los cambios y no descuidarse tampoco sobre regalos.

Efectivamente, se despacharon emisarios á las poblaciones para la pronta conducción de comestibles al mercado, y declarado en una y otra corbeta unánimemente el precio de un hacha por un puerco grande y un chico, empezaron á franquearse los cambios; de suerte, que en la DescuBIERTA, para las ocho ó nueve de la mañana, ya se hubiesen adquirido unos diez puercos. Era ésta próximamente la hora de la pleamar, y por 
consiguiente, la más oportuna para embarcar la fragua y los instrumentos astronómicos. Se dispuso, pues, que lo verificase el Piloto Hurtado con dos botes oportunamente fondeados, y esta señal pública de la verdad de nuestras aseguraciones debió acelerar la venida á entrambas corbetas de Tuna, Feileua y de todo su acostumbrado acompañamiento mujeril. Manifestaba el primero con unas expresiones y muestras realmente cariñosas, cuánto le era sensible la resolución nuestra, y que si ésta dependía de los pocos robos que habíamos experimentado, tomaría tales medidas que seguramente no los sufriríamos más. Feileua, más jóven, pero no ménos sensible, apenas podía, ya desatendidos los cariños, ocuparse de la multiplicada adquisición de trajes. Finalmente, el tropel numeroso de las mujeres jóvenes, aunque reunido en la parte de alcázar que siempre les estaba destinada, dividía sus cuidados entre el deseo de los regalos, el santimiento de la ausencia, el desengaño de los amantes y los improperios no desagradables que solían echar contra el autor verdadero de los sufrimientos actuales.

El Piloto Hurtado tuvo orden de enterrar en el sitio donde estaba el cuarto de círculo, una botella, la cual encerraba el papel auténtico de la llegada nuestra y de la posesión que habíamos tomado de todo el Archipiélago en nombre de Su Majestad con el consentimiento del mismo Vuna; y para que este acto solemne tuviese la mayor autenticidad así á la vista de los naturales como para noticia de los que nos siguiesen en aquellos mares, ya enterrada la botella se arbolaron en el mismo sitio las insignias, y las saludaron antes entrambas tripulaciones con siete veces de $j$ Viva il Rey! y luégo los naturales, que estaban en la Descubierta, los cuales, á imitación de Vuna, hicieron igual número de aclamaciones.

El restante día, que fué bastantemente placentero, se empleó por nuestra parte y la de los naturales, en dejar correr á su albedrío aquel instinto sociable que sin otra razón alguna nos liga á nuestros semejantes y nos convida á aliviarnos recíprocamente la vida: en esas inclinaciones, hijas de la misma Naturaleza, era luégo indispensable que sobresaliesen las que con mayor actividad atraen un sexo hacia el otro, y los regalos por una parte, las repeticiones de un mismo nombre por la otra, de suerte que pareciese uno sólo á la vista de estas jóvenes el Leyley, ó cosa buena, caracterizándose todos los demás con el título de anacobi ó cosa mala, debían causar una sensación tanto más viva, entretenida é inocente, cuanto que giraban sobre un conocimiento recíproco del alcance honesto de sus deseos. A las cuatro de la tarde vimos regresar á D. Felipe Bausá, concluídas felizmente con el bote de la Drscubrerta las tareas emprendidas.
Tufoa recibió nuestros agradecimientos y la pro- May. $3 \circ$ mesa de ricos regalos para el día siguiente. Con las mismas esperanzas regresó Vuna á tierra, manifestándole antes de comer un surtido completo de herramientas para que agradeciese su uso y supiese de antemano que le estaba destinado al tiempo de la despedida.

Fué increible en este día el acopio que se hizo de toda especie de frutos y raíces, las cuales, al cargo del condestable y sargento solían por lo común adquirirse con cuchillos y navajas de diferentes tamaños, ó con sartas sencillas de abalorios y coral. La noche bien tranquila nos dió lugar á un regular đescanso, y era éste á la verdad tanto más necesario cuanto que la concurrencia á bordo había sido excesiva y prometía ser aún mucho mayor en la mañana siguiente.

Era ésta nublada, pero calmosa, confirmándonos de este modo nuestros recelos que poco ya pudiera haber adelantado las tareas astronómicas. Aprovecháronse, sin embargo, algunas claras por D. José Espinosa, el cual, consegu das dos alturas absolutas con el sextante de horizon. te artificial, dió una nueva época para la determinación de la marcha de los relojes; y D. Felipe Bausá, acompañándole D. Luis Nee, dos soldados y 'Tufoa, quiso subir con el teodolito á los altos inmediatos para tomar una idea más cabal de los puntos más distantes: fueron sumamente útiles estas excursiones en cuanto procuraron la medida de una buena base y una herborización importante.

No se habían descuidado (como debe imaginarse) los naturales en concurrir á bordo desde muy temprano con cuanto tuviesen digno de venta, ni en seguirles de cerca el mismo Vuna, el cual, con el nuevo regalo de un puerco además de otro que había enviado en la tarde anterior, procuraba no desmerecer la inesperada prodigalidad de entrambos buques. La voz de of $a$, expresión para ellos que significa un pesar grande, se oía repetir á cada momento entre los Eijes. Les acompañaba la más estudiada pronunciación de uno ú otro apellido. No era extraño el verlos á veces, ó ya no pudiendo contener las lágrimas 6 dándonos estrechos abrazos, ó manifestándonos finalmente, que al tiempo de nuestra salida no omitirían las muestras de mayor dolor con darse repetidos golpes en la cara y en el pecho.

Habíamos solicitado de Vuna desde la tarde anterior que condujese consigo á la hija de Paulajo, su mujer, para que D. Juan Rabenet pudiese retratarla con la mayor propiedad. Verificádolo así, y no permitiendo que la acompañasen sino otras tres mujeres para evitar una mayor confusión, pudimos al principio conseguir el fin propuesto de verla retratada, y luégo entablar á presencia de Vuna varias conversaciones que pudieron manifestar con mayor propiedad 


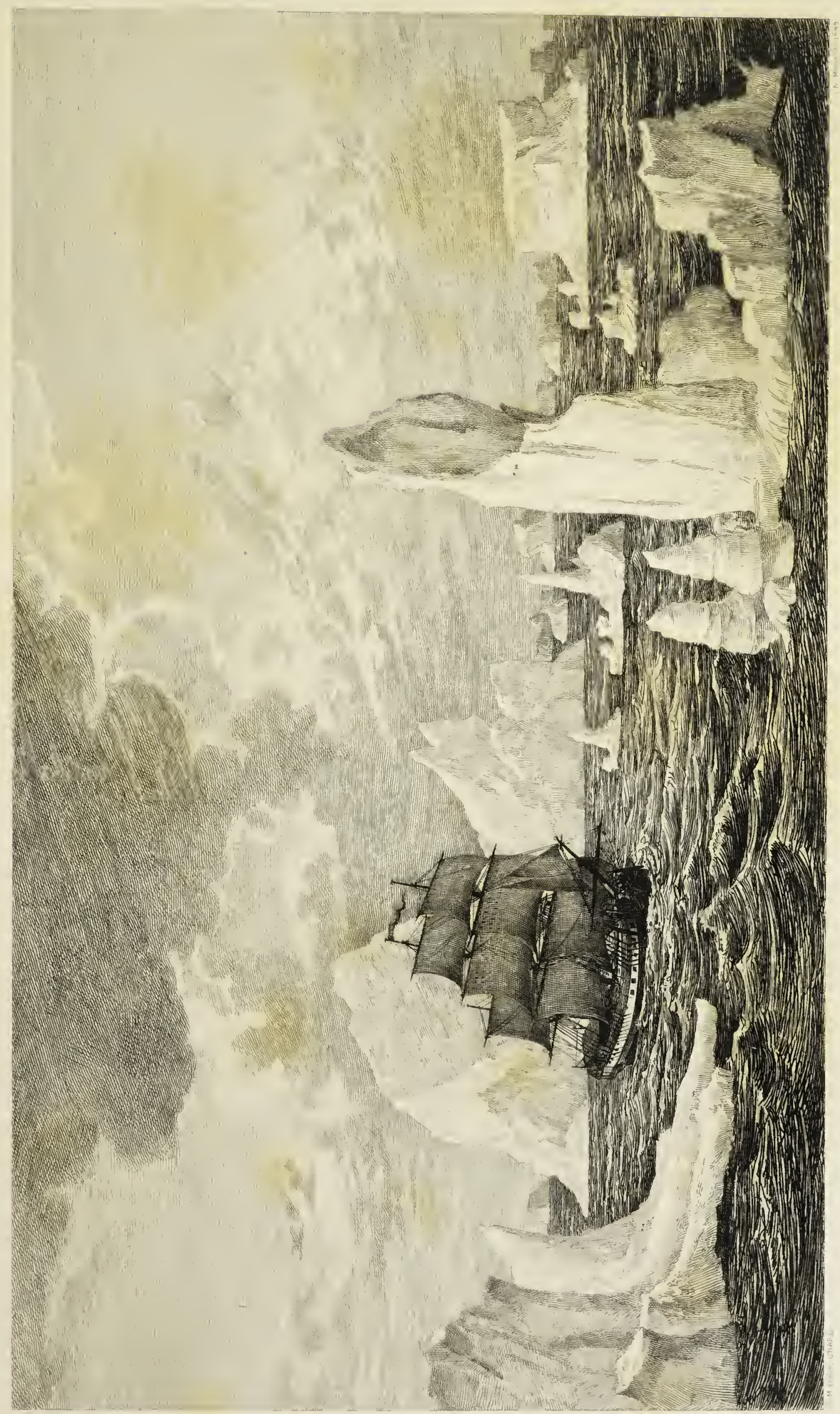

的 

May.3r el carácter de esta nación. No desagradaban á Vuna nuestras promesas de regresar luégo á las islas acompañados de las mujeres cuyo retrato le habíamos manifestado al principio; solía en estas ocasiones solicitar nuevamente el verla, y en aquel mismo día ya las conversaciones acostumbradas nos habían conducido á una nueva manifestación del retrato. Le saludó con mucha ternura la Paulajo, miró atentamente sus adornos y manifestó iguales deseos á los de Vuna de que viniesen sus semejantes á las islas. En balde procuramos entonces excjtarle los celos y mucho más el temor del desprecio, insinuándole que las persiguiese, si acaso venían, y recordaseá Vuna la amabilidad y fidelidad de las hijas de Vavao. Con la mayor dulzura respondía siempre, que antes bien procuraría agasajarlas en cuanto estuviese á su alcance, celebrando, aunque le fuesen preferidas por Vuna, el cual se mantenía constante en asegurar, que ya á sus ojos nada merecían sus mujeres, después que habia visto el retrato de las europeas.

Estas chanzas familiares y realmente agradables, nos condujeron clespués á que nos prometiesen de nuevo el cuidado de las semillas que les dejábamos. La calabaza, la papa, la sandía y el melón, formaban la parte esencial de este pequeño repuesto; y como quiera que ya habían comido las dos primeras con una grande complacencia, no nos quedó duda que procurarían con el mayor cuidado su multiplicación más breve. Eran muchas las caricias que la misma Paulajo hacía á dos gatitos, macho y hembra, que la regalamos. Cuando la veíamos en su casa, solíamos comunmente encontrarla con estos dos animalejos, envueltos en su misma ropa y con todo el cuidado posible para que no los tocase persona alguna.

Nos disponíamos ya á comer con esta compañía y la de las otras Fatafegis, cuando se nos apareció sobre el alcázar una mujer vieja y macilenta, á la cual todas las demás mujeres y el mismo Feileua prestaron inmediatamente el debido homenaje. Creimos al principio que pudiese ser la viuda de Paulajo, á quien había visitado D. José Bustamante en su excursión del 29; pero desengañados por los Oficiales que le habían acompañado, debimos extrañar é inquirir al mismo tiempo su verdadero carácter entre los demás. Nuestra juventud estaba á la sazón demasiado ocupada en el cerco cariñoso de sus conocidas, para que no desatendiesen en cierto modo los dictados severos de la etiqueta, y así fué, que apenas después de mucho tiempo esta anciana pudo encontrar quién la condujese donde debía sentarse. El único regalo que le había tocado en suerte, era el de una botella vacía, la cual sin embargo, parecía estimar en mucho, disponiéndose finalmente á regresar á tierra, ya que no debía prometerse ni mayores atenciones, ni May.3r mayores regalos. Avisados á la sazón de las cualidades de esta mujer, preguntamos á Vuna quién era; y si le importunaría que nos acompañase á comer; lo cual, concedido de muy buena voluntad por este Jefe, la hicimos bajar ́a la cámara y disfrutar de nuestra mesa. Le siguió, aprovechando de aquella ocasión también la Dubou, hermana de Vuna, y fué la única felicidad nuestra, que entrambas por su misma moderación y por los consejos de Vuna, prefiriesen dos asientos algo distantes de la mesa, á los que con mayor satisfacción nuestra, disfrutaban ahora la hija de Paulajo y sus hermanas y compañeras.

Por cuanto fuese, sin embargo, elevada la esfera de estas últimas, vimos con mucha admiración que para comer se ocultaban todas de la vista de la vieja, y que solo Vuna era el que dispensándose de aquella etiqueta, manifestaba un grado superior. Por ventura, las dos determinaron retirarse, cuyo partido le aprobamos muy de veras, y ya libres de etiquetas, pudimos aprovechar el restante tiempo en un trato más ameno y sociable.

Tufoa, Feileua y Latu eran á la sazón los que más de cerca interesaban nuestro cariño. El primero recibió en pago de sus atenciones pasadas, un hacha, un pedazo de bayeta, algunos cuchillos, y otros adornos mujeriles. Todos se esmeraban en regalar al segundo con cuanto pudiese, ó adornar su persona ó recordarle nuestro cariño, y en Latu se hacía tanto más recomendable un cierto desinterés y desprendimiento de los regalos, cuanto que le reemplazaba un triste silencio, que es el símbolo verdadero del sentimiento.

Fué, en fin, preciso que nos separásemos antes de la noche. Nuestros botes condujeron á tierra hombres y mujeres, concluídos los cambios de cuanto habían traído al mercado; y vimos poco después, no sin alguna complacencia, que en la casa de Vuna habían las mujeres arbolado y hecho tremolar un pedazo de lienzo, comoseñal positiva de los adioses que nos daban, cuando ya no alcanzaban las voces.

$\mathrm{Al}$ anochecer ya todo estaba pronto para dar la vela; á las diez de la noche avisaron los centinelas que veían rondar una canoa alrededor de la Descubierta, con un silencio y cuidado tan grande, que no se sentía el ruído de los remos ni respondía á nuestras voces de quién vive. Fué preciso dispararle un tiro de fusil con perdigones, porque debíamos recelar que intentase cortar la boya del ancla de tierra, lo cual nos hubiera causado una detención grande; esto bastó para que se retirasen.

Emprendimos los trabajos de anclas á las dos de la mañana, contando con que al amane. cer pudiésemos estar algo distantes del fondea. 
แm. r." dero; pero como se originasen luégo algunas detenciones leves, rayaba el día cuando estuvieron las corbetas á la vela, y el poco viento al salir el Sol apenas las había separado una milla de la costa. Recibimos con este motivo una nueva visita á bordo de la mayor parte de nuestros conocidos, deteniéndose Vuna y el mayor número de las canoas á bordo de la ATREvida que navevaba atrasada por nuestra popa con el auxilio de los remolques, y dirigiéndose á la DescubierTA, Feileua y I atu. Se renovaron en esta ocasión las muestras recíprocas de un cariño verdadero; aumentó considerablemente el número de los puercos cambiados, y finalmente, declarado hacia las siete viento fresquito del Esnordeste, nos fué preciso despedirnos por la última vez, y entrambas corbetas navegaron unidas á continuar sus tareas.

A medida que el Sol se iba elevando sobre el horizonte se disipaba la calima, el viento galeno aumentaba agradablemente su fuerza, y nuestra navegación hacia el Sur con todo aparejo de bolina hacía que poco á poco se confundiesen con el mar los parajes ménos elevados y más septentrionales de Vavao.

Nuestros rumbos á la sazón no podían llevar otro objeto sino completar por el Oeste el reconocimiento emprendido del Archipiélago, atendiendo á la verdad más bien aquella nimiedad hidrográfica que exigía la navegación del dia, que á la utilidad real ya bastantemente correspondida así por las marcaciones de D. Felipe Bausá desde los altos septentrionales, como por los bordos bien repetidos en aquella parte del mar por el Comandante D. Francisco Maurelle. Costeáronse al principio algunas islas de mediana extensión; y áridas y escarpadas por su parte del Oeste, no tardaron luégo en descubrirse las otras más orientales que habíamos atracado al tiempo de recalar al Archipiélago, y para las once y media ya distábamos dos ó tres millas de la islita sola, que Maurelle llamó del Sur; pareciéndonos lo más oportuno el pairear hasta el medio día, para referir con mayor certeza á aquel extremo la observación de la altura meridiana del Sol: nos hallábamosá la sazón en sondas de 59 brazas piedra y conchuela: y la latitud fué de $18^{\circ} 5 I^{\prime} 00^{\prime \prime}$.

Nada denota en la parte occiclental. del Archipiélago el semblante lozano que le favorece interiormente. Sin rastro alguno de frondosidad ni de habitadores; sin aquella suavidad en las orillas, que doma el ímpetu de las olas y abriga las obras lentas y misteriosas de la Naturaleza, presenta al navegante una perspectiva árida y triste, en la cual no es difícil descubrir al mismo ticmpo los efectos destructores de la monzón tempestunsa del Noroeste y la falta constante de la mano próvida del hombré, destinada á dar un nuevo brillo y vida á las grandes combina- Jun. r.n ciones de la Providencia.

Yá pues, para el medio día podíamos considerar concluídos nuestros reconocimientos en esta parte del mar; se descubría al Sur un horizonte despejado, el cual combinado con las navegaciones del Capitán Cook y de D. Francisco Maurelle, disipaba toda sospecha de cualquiera objeto intermedio entre estas islas y las de Happay; al Este nuestra derrota del día i 8 nos dejaba bien conocidas las restingas peligrosas que interceptaban la navegación por aquella parte, y al Oeste el solo monte volcán de Late señoreándose con una altura no indiferente, parecía llamar hacia él nuestra navegación inmediata. No titubeamos efectivamente en adoptar aquel partido como el más útil que actualmente se nos presentaba; y ya con fuerza de vela y una buena brisa del Este, pusimos la proa al Oeste, no omitiendo para la una y tres cuartos examinar con la sonda por medio de la ATREVIDA, si continuaba aún el banco hallado al medio día á no mucha distancia de la Isla del Sur. No hallamos fondo con roo brazas de sondaleza; observáronse luégo longitudes de $26^{\prime}$ al Oeste del observatorio, y como quiera que el viento se mantuviese fresquito y claro, para las cinco de la tarde ya no distábamos sino unas dos ó tres le. guas de la costa oriental de la isla, de modo que la pudiésemos reconocer antes de la noche con bastante exactitud.

Si bien no presentase por aquella parte la menor apariencia de un mediano abrigo, viéndose romper las olas en la misma orilla, y no advirtiéndose en la costa sino una dirección igual y contínua, no debía, sin embargo, desalentarnos de la esperanza de encontrar un fondeadero, el reparo de ser probablemente la costa del Norte la más abrigada. La noche, ya próxima, no daba lugar á emprender luégo esta averiguación: debimos, por consiguiente, diferirla hasta la manana siguiente, conservando ya con algunos bordos y ya con tal cual hora de pairo, próximamente la posición en la cual habíamos anochecido.

Con estas precauciones no debió sernos difícil amanecer en tal posición, que las primeras claras del día nos diesen lugar á reconocer de cerca los extremos Norte y Oeste de la misma, y así, á las seis y media, favorecidos de un viento galeno, ya veíąmos frustradas en esta parte nuestras esperanzas, pues ni á media milla de la playa se encontraba el fondo con roo brazas de sondaleza, ni se veían en la orilla más que penascos enormes, prueba nada equívoca de una costa cortada á pico. Habíamos prevenido el bote y un ancla con el ánimo de reconocer siquiera algunos de los productos volcánicos que suponíamos se encontrarían fácilmente en todos los contornos; y en esta ocasion el roce con los ha- 
Jun. a bitadores nos pudiera proporcionar nuevos conocimientos sobre los verdaderos límites de la confederación visitada: pero debimos desistir luégo de semejantes esperanzas, advirtiendoque toda la isla, desde su cima hasta las faldas, estaba igualmente poblada de arboleda silvestre, sin que se percibiese rastro alguno de lavas ó erupciones, y que eran pocos y bien mezquinos los parajes cultivados, sin verse, por otra parte, canoa ni choza que indicase un número siquiera mediano de habitadores.

Reconocida de este modo la mayor parte de la isla, á corta distaricia, de suerte que pudiése. mos determinarle la circunferencia de cuatro leguas próximamente, y desvanecer toda idea de un fondeadero mediano y algo útil; . continuamos la navegación aprovechando las ventolinas variables que al abrigo de la isla solían á veces, confundidas con una total calma, dejarnos enteramente sin gobierno. Desatracados poco después algún tanto, vimos salir una canoa mediana de los pedruscos del Oeste; no pareció oportuno esperarla, porque al mismo tiempo íbase entablando la brisa fresca y no distábamos ménos de una legua de la orilla. La embarcación retrocedió luégo y nosotros ceñimos al Sur para continuar los reconocimientos emprendidos sobre las trazas del Comandante Maurelle.

Debían éstos tener ahora por objeto otras islas que el mismo Comandante había visto en aquellas inmediaciones: atracada la una hacia las diez á distancia de una legua, descubrió inmediatamente que no era sino un pedrusco árido $\mathrm{y}$ amogotado de poca elevación y extensión, y probablemente formado de las mismas materias volcánicas que debían ser la base de la isla no distante de Late. No parecía la otra, y debíamos creer que D. Francisco Maurelle la había equivocado con las islas cercanas de Kao y Tufoa, las cuales, en aquella dirección, parecían formar una isla sola, y ésta bastantemente elevada para apercibirse desde los parajes en los cuales nos hallábamos.

La mañana sumamente placentera, no nos había hecho descuidar la ocasión bien oportuna de fijar con nuevas observaciones de las distancias del Sol á la Luna la longitud del observatorio de Vavao; fueron éstas por nuestra parte 55 series, de las cuales resultó por medio de ambos relojes la longitud del observatorio al occidente de Cádiz de $167^{\circ} 39^{\prime} 39^{\prime \prime}: 24$ series observadas en el mismo tiempo en la corbeta ATREvidA, manifestaban la longitud del mismo meridiano $167^{\circ}$ $3 \mathrm{I}^{\prime} \mathrm{oo}^{\prime \prime}$.

Navegamos luégo al Sur, y ya desde las tres de la tarde, vistas las islas de Kao y Tufoa, al mismo tiempo que podíamos aún marcar los altos de Late, lográbamos no sólo ratificar con la longitud la posición recíproca de los dos Archi- piélagos, sino también hacer más segura la navegación nuestra de la próxima noche sin quc nos condujese sobre los alrededores peligrosos de Ofolanga, Bui y Mangone, islitas las más septentrionales del Archipiélago de Happai.

Fueron el viento fresquito del Esnordeste, la mar sumamente llana, y la noche más bien oscura y calmosa, sin que se nos ocultasen, sin embargo, desde las dos de la mañana los altos de $\mathrm{Kao}$, á los cuales nos habíamos acercado considerablemente, más bien por efecto de las corrientes que de la navegación nuestra, la mayor parte invertida hasta aquella hora en ceñir de uno y otro bordo. Arribamos sobre las gavias y los juanetes, y navegando asi hasta que se disipase totalmente la oscuridad, logramos que las primeras claras del día nos descubriesen un conjunto de objetos realmente agradables é interesantes.

Las islas de Kao y Tufoa, abierto ya el canal intermedio, elevaban sus peladas cimas hasta las nubes y nos demoraban desde el Oesudoes te hasta el Oesnoroeste á distancia de tres leguas: las otras, tanto más frondosas cuanto más bajas, descubrían por el Este un semblante mucho más fértil y risueño; no eran ménos de diez las que teníamos á la vista, y entre ellas, con el auxilio de la excelente carta del $\mathrm{Ca}$ pitán Cook, no era difícil distinguir particularmente las de Fotua y Kotu, demorándonos aquélla al Sur $20^{\circ}$ Este y la última al Sur $72^{\circ}$ Este. Distaríamos de ésta unas cuatro millas, y era fácil descubrir las diferentes restingas que habían hecho en aquella parte de mar más breve feliz la navegación del Comandante Maurelle que la del Capitán Cook (I). Continuando nues tra navegación hacia el Sur, con vientos antes bonancibles y varios del primer cuadrante y luégo más entablados del Este, fué nuestro primer objeto el rectificar las longitudes; lo cual, por dos series de horarios tomados en paraje de marcaciones seguras, pudo conseguirse con la mayor escrupulosidad. La vista de Annamoka, las inmediaciones de la restinga saliente al Oeste, y por último, para las cuatro de la tarde el alcanzarse igualmente desde las cubiertas las dos islitas de Ungatonga y Ungakapai, nos recordaban luégo á cada paso las huellas harto memorables del Capitán Cook, mientras en la otra más aspera é inculta de Kao veíamos un nuevo escarmiento para los europeos, con lo acaecido al Capitán Bligh en la lancha del Bounty, acaecimiento ya muchas veces confirmádonos con la mayor desaprobación, por los habitantes de Vavao.

Adoptadas las determinaciones del Capitán

( ) Don Erancisco Naurelle, determinándose á pasar entre la restinga, atravesó directamente desde Happai á Annamoka, cuya derrota no se decidió á seguir el Capitán Cook áun después de haber enviado un bote algunos días antes para que sondase. 
Jun. 3 Cook relativas á la longitud y referidas con nuestros relojes enteramente acordes entre sí al observatorio de Vavao, podían últimamente considerarse los datos principales para esta determinación en los términos siguientes:

Longitud occidental de Cádiz.

Por el número i r con una marcha muy exacta desde el puerto Jackson. . $\mathbf{1 6 7 . 4 0 . 3 5}$

Por 75 series de distancias del Sol á la Luna observadas en la Descubierta al Este y al Oeste con las mejores circunstancias y enteramente conformes entre sí.

Por las determinaciones del Capitán Cook en Annamoka y Tongatabu. . . 167.49.18

La latitud nuestra por la altura meridiana del Sol de $20^{\circ} 2^{\prime} 30^{\prime \prime}$, confrontó exactamente con la de los navegantes ingleses, y diferentes observaciones bien conformes de la variación de la aguja dieron la de $10^{\circ} 3^{\prime}$ al Nordeste. No se habían descuidado los naturales de las islas inmediatas á salir desde la mañanita á nuestro encuentro. Varias canoas chicas y dos grandes aprovecharon la tranquilidad de la mar para acercarse, y aunque el viento, particularmente hacia las inmediaciones del medio día fuese bastantemente fresquito para que las canoas grandes usaran de la vela con la mayor ventaja, era tal la diligencia de las canoas pequeñas nunca surtidas con más de tres bogado. es que rara vez se atrasaron considerablemente de aquéllas.

Todas, hasta el número de ocho entre gran. des y chicas, atracaron á la ATREvidA, la cual, navegando por nuestra popa estaba por la misma razón ménos distante de las islas, y en esta ocasión no fueron ménos importantes las investigaciones del Comandante y Oficiales de aquella corbeta y sus nuevas reflexiones sobre el estado actual de la confederación.

Unánimes convinieron en las divisiones de la autoridad suprema, cuales se nos habían indicado en Vavao; explayaron el mayor deseo de que visitásemos sus islas, y cambiaron un puerco y una más que mediana cantidad de frutas; manifestaron después algunas tiras bastante nuevas y recién cortadas de bayetón azul; y las atribuyeron á la visita de dos buques europeos, que sólo dos meses antes había tenido lugar en Tongatabu. Nombraban como Jefe de esta expedición á Selecari, Fosebalia y Tocolo, entre cuyos nombres confusos no nos era fácil distinguir ni la expedición francesa de Mr. Entrecastault (I) ni la que nos anunciaban algunos papeles públicos debía navegar á aquellos mares por cuenta de

(1) I,as últimas noticias impresas nos han convencido, sin la menor duda, haber sido la expedición francesa de los Capitanes Mr. Entrecastault y Huon, con las gabarras la Recherche y la Esperance.
Su Majestad Imperial, ni las diferentes de los Jun. 3 Capitanes Bligh, Roberts y Vancoover, que el Gobierno Británico había despachado por varias partes al mar Pacífico.

El cuidado con el cual estos insulares traían para venta, bien acondicionados y con la correspondiente tierra, dos vástagos del árbol del pan, nos haría sospechar que á esta adquisición se había dirigido principalmente el viaje que acababan de indicarnos ( $\mathrm{I}$ ).

La misma franqueza, la misma alegre confianza, el mismo idioma y las mismas instancias $y$ ofrecimientos, no debían ya parecer nuevos ni extraños; pero no pudo ménos de atraer la admiración de todos, la singular destreza de un joven, el cual cambiada un hacha de piedra por un cuchillo y caído éste accidentalmente al agua, entregó inmediatamente el hacha á un compañero, se tiró al agua, recogió el cuchillo aunque su propio peso debiese ya haberlo sumergido considerablemente y alcanzó de nuevo la canoa y la corbeta, á pesar que llevasen á la sazón un andar no ménos de tres á cuatro millas. Era difícil el comprender el estado verdadero de los ganados si se exceptuasen las cabras, cuya multiplicación particularmente en Eua parecía confirmársenos ahora. Fué preciso que nos dejaran para retirarse antes de la noche á sus moradas, de las cuales no distábamos ya ménos de cinco leguas, hallándonos á dos millas al Oeste del bajo que cruza delante del fondeadero de Annamoka. Fueron después vanas nuestras diligencias para avistar el otro banco igualmente de coral que más al Oeste había descubierto el Comandante Maurelle, y para el ponerse el Sol marcábamos el extremo Norte de Annamoka al Norte $66^{\circ}$ Este; el extremo Sur de Annamokilla al Norte $82^{\circ} \mathrm{y}^{1} / 2$ Este y el punto alto de Tufoa al Norte ${ }_{4}$ Oeste de la aguja. La ATREvidA, aunque sondase en la menor distancia del banco, no había encontrado fondo con roo brazas de sondaleza.

Desde las últimas horas de la tarde, un calor excesivo, la menor fuerza del viento y su misma dirección del Norte, nos habían anunciado próxima una revolución del tiempo; no pasó efectivamente de las diez de la noche cuando nos sobrecogió un chubasco fuerte con ráfagas recias del Sur. Fué nuestro primer partido el pairear sobre las gavias arriadas, y á la media noche, aminorándose algún tanto la fuerza del viento é inclinado éste al Sueste, pudimos ceñir sobre las cuatro principales al Sursudoeste, único rumbo que nos daba lugar con bordos algo largos á hacer frente á la mar bastante gruesa del nuevo viento. Habíamos hecho las señales oportunas á la ATREvidA, la cual paireaba al principio á poca distancia de nosotros; pero al

(I) Listo se ha confirmado en la misma relación. 
Jun. 3 tiempo de forzar de vela se nos atrasó considerablemente y la perdimos de vista hasta el amanecer del día siguiente.

A esta hora estaban aún los cielos y horizontes cargados con celajería oscura, el viento fresco y algo arrafagado del Sueste, la ATREviDA como á una legua á nuestro sotavento, y se marcaban los dos islotes de Ungatonga y Ungahapai del Norte, $20^{\circ}$ al Norte $26^{\circ}$ Oeste de la aguja distancia siete á ocho millas: arribamos inmediatamente y acortamos algún tanto de vela para incorporarnos con la ATREVIDA, y conseguido este intento, continuamos con vela proporcionada el rumbo del Sur. A las nueve y media, disipada la mucha cerrazón de los horizontes y marcando los islotes anteriores al Norte, avistamos la isla de Tongatabu, la cual demoraba por sus extremos del Sur $39^{\circ}$ Este, al Sur $55^{\circ}$ Este. No distábamos por consiguiente de ella ménos de cuatro leguas á sotavento y todo nos anunciaba la continuación constante de la brisa fresca que había entablado en la noche anterior; nosotros la ceñimos con fuerza de vela al Sueste. La variación se mantenía de $10^{\circ}$ I $5^{\prime}$ al Nordeste; y al medio día del 5 era nuestra latitud de $2 \mathrm{I}^{\circ}$ $42^{\prime}$ y la longitud de $3^{\circ} \mathrm{I} 2^{\prime}$ al Oeste de Vavao.

\section{CAPÍTULO VI}

Navegación desde al Archipiélago de los Amigos hasta las costas del Perú. - Estada en el puerto del Callao y nuevas medidas para la feliz conchusión del viaje sabida la declaración de la guerra contra la Francia.-Segunda escala de las corbetas en la bahía de Concepción de Chile.

Los últimos pasos de las corbetas DESCUBIERTA y ATrevida en el mar Pacífico, ya no podían ser en modo alguno importantes para la Hidrografía. Una nueva visita á las Islas de la Sociedad sin motivo alguno urgente, renovaria sólo los desórdenes de los europeos en aquellas regiones, ó haría insufrible una disciplina rígida á bordo. Las Islas Desiertas reconocidas antiguamente por Quirós, sitas á más ó ménos distancia al Sueste de aquel Archipiélago, habían sido nuevamente avistadas en los últimos años por los navegantes macionales ó extranjeros; y si bién en la nueva carta de las navegaciones del Capitán Cook, se advirtiese colocado en los $32^{\circ}$ de latitud un pequeño archipiélago que decía haber sido descubierto por los españoles, todo parecía indicar que fuese apócrifa aquella noticia por mucho que examinásemos las navegaciones nacionales rerificadas hasta nuestra época. Este último reconocimiento pareció, sin embargo, debidamente anejo á la actual navegación nuestra para las costas del Perú, á donde nos conducían diferentes objetos, casi todos inmediatamente Jun.: ligados con el feliz término del viaje.

Las brisas frescas del Esueste al Sueste no tardaron en conducirnos al paralelo de $25^{\circ} 3^{\prime}$ longitud $5^{\circ} I 6^{\prime}$ al occidente de Vavao, variación observada I $^{\circ}$ al Nordeste. Contra nuestras expectativas, rolaron poco después los vientos al Noroeste con los cuales la derrota fué directa y acelerada. Así alcanzada la latitud de $29^{\circ}$ y conservándose en aquel paralelo los vientos bien frescos del Oesnoroeste al Oesudoeste, desistimos de la idea de navegar por latitudes más altas á lo ménos hasta que no nos aproximásemos á los meridianos sospechosos de las islas indicadas. Lográbamos de ese modo un andar de siete á ocho millas; los fríos se hacían llevaderos para las tripulaciones aunque poco abrigadas; y una navegación directa nos resarcía la poca diferencia favorable en los grados de longitud si hubiésemos corrido paralelos más altos: eran á la sazón nuestros aparejos de las principales y á veces del juanete mayor, solíamos luégo en la noche disminuirlos hasta quedarnos frecuentemente con las dos gavias en dos rizos y arriadas, de modo que ni nuestro andar fuese menor aún con este aparejo de seis ó siete millas, ni en el caso de avistar cualquier peligro dejásemos de ceñir en pocos instantes con las cuatro principales de una ú otra vuelta, según las circunstancias lo exigiesen.

Relativamente á esta clase de peligros, el navegante que dé una mirada filosófica á todo el globo en torno, no puede ménos de admirar y agradecer la contínua vigilancia de la Naturale za en sus obras misteriosas. En la Zona Tórrida, donde son frecuentes las restingas y los bancos de coral que sirven luégo de incremento á la superficie habitable, son los vientos más periódicos y bonancibles, la navegación más lenta y por la misma razón ménos expuesta; finalmente, las noches tan proporcionadas con el día como el invierno con el verano, $y$ la claridad de la Luna y del firmamento con el brillo vivificador del Sol; pero en apartándose hacia el uno ó el otro polo de aquella posición favorable para la multiplicacion y reposo de la especie humana, ya la escena muda de semblante; las islas se elevan extraordinariamente sobre la superficie del mar, el navegante áun en las noches frías y largas del invierno puede avistarlas sin riesgo de caer sobre ellas: el ser solas y por lo común acantiladas, favorece aún más esta fuga necesaria, á pesar de los frecuentes temporales; por último un semblante árido y triste, unas cuevas y unos pedruscos en los cuales la Naturaleza pareció tributar á mil especies de aves, de peces y de anfibios el mismo tierno cuidado que en otras par" tes lia tributado á los cuadrúpedos, todo lleva consigo unas muestras nada equírocas de su in- 
Jun. j tento verdadero, de que no sean éstas la morada del hombre, sino otros tantos vehículos que le faciliten la emigración necesaria para su navegación, comercio y multiplicación constante.

Continuaron uniformes en los dias siguientes así el viento como la navegación: solíamos á veces experimentar chubascos y ráfagas sumamente recias: el termómetro de Farenheit había ba jado y se mantenía por los 6 y y $62^{\circ}$ : no faltaba otras veces, uno ú otro día placentero en el cual la Naturaleza parecía despojarse del semblante hórrido y tempestuoso del invierno; entonces, los rabijuncos, los carneros, los tableros y algunas veces las ballenas, se presentaban en mucho número á nuestra vista, así como las procelarias y los pamperos eran, según costumbre, el anuncio positivo de la tempestad. En la noche del I6 que fué con exceso tempestuosa y oscura, preferimos capear con la gavia y el contrafoque, hasta que asomasen las primeras claras del día, con las cuales, y hecha la señal de noche á la Atrevida, emprendimos nuevamente la derrota.

En el entretanto nos aproximamos á los meridianos de las islas que el Capitán Cook había comprendido en su carta general como descubiertas por los españoles en I774. Según debíamos inferir de la narración de su viaje, había recibido esta noticia del Sr. Crozet en el Cabo de Buena Esperanza, suponiéndose que las islas descubiertas estaban en el paralelo de $32^{\circ}$ y $130^{\circ}$ de Greenwich, correspondiente ahora á $44^{\circ}$ oriental de Vavao.

Para el medio día del 2I, no contando aún $\operatorname{sino} 30^{\circ}$ de longitud, nos hallamos en el paralelo indicado de $32^{\circ}$, y empezamos á correrle con la vigilancia correspondiente. Era común en estas ocasiones no navegar de noche cuando no tuviésemos un horizonte menor de tres á cuatro leguas, y aprovechar al contrario con aparejo proporcionado, las muchas horas en las cuales por una feliz combinación brillaba la Luna sobre el horizonte: los vientos, el grado de frío y el semblante del tiempo, no habían variado en nada de los días anteriores: la rotura de una verya de gavia en la corbeta ATREvida había podido remediarse con una verga de cebadera, y por nuestra parte, atentos siempre á la mejor conservación de la tripulación, tan débil y cansada, habíamos sustituído ahora al condimento del aceite, dos onzas de tocino, fortalecíamos la guardia entrante á las cuatro de la mañana con un ponche caliente, y cuidábamos con extremo del aseo y buen orden interiores.

No faltaron para alentar las esperanzas siempre fáciles del naregante, un rocío abundante, algunas horas de calma y la vista de dos ballenas justamente cuando nos hallábamos en los meridianos sospechosos de $42^{\circ}$ y $44^{\prime \prime}$; pero no eran éstos sino halagos, y nuestra navegación Jun.25 actual combinada con las dos derrotas no distantes del primero y segundo viaje del Capitán Cook, y con las noticias sueltas de las navegaciones últimas nacionales, disipaba ya toda sospecha de la existencia de cualquier isla en aquellos contornos. La variación magnética ha. bía á la sazón disminuído progresivamente hasta 3 y $3 \mathrm{y}^{1} / 2^{\circ}$ al Nordeste, volviendo después de nuevo á aumentar á medida que nos aproximábamos á las costas del continente de América.

Muy luégo alcanzamos en el mismo paralelo los meridianos de $60^{\circ}$ mayores en $20^{\circ}$ próximamente á los que habíamos creido sospechosos, y ciertamente superiores á cualesquiera errores que pudiesen recelarse en una estima. Casi al mismo tiempo debimos considerarnos ya en los términos de la derrota que desde Guayaquil y Lima conducen á los puertos más meridionales de Chile y Chiloé, y así pudieron igualmente cesar las pesquisas hidrográficas y las cautelas indispensables de una navegación poco trillada.

No nos habíamos descuidado en los últimos días del mes, en repetir frecuentemente las observaciones de las distancias de la Luna al Sol y á las estrellas, y sus promedios (siendo precisamente el número de Ioo series) se aproximaba mucho á la longitud adoptada del número II, la cual confirmaba una alteración considerable en la marcha del cronómetro 7I, como nos lo habían hecho ya sospechar las comparaciones repetidas con los relojes de la ATREVIDA.

Al aproximarnos al continente de la América, y ya disminuídos de $2^{\circ}$ los paralelos que corríamos, empezaron á suavizarse mucho la mar y el viento, suscituyéndose ahora á los días achubascados y tempestuosos que nos habían acompañado constantemente, otros más placenteros $y$ suaves, en los cuales, entremezclada alguna calma, podíamos á veces disfrutar por largo tiempo del brillo benéfico del Sol. Conociendo ya el temperamento de estas costas en el rigor del invierno y las causas físicas que debían hacerle bien frío en la actual estación, no debimos extrañar que el termómetro de Farenheit puesto al aire libre se mantuviese en los 60 y $6 \mathrm{I}^{\circ}$. Aun con este leve inconveniente toda la débil marinería filipina pareció adquirir nuevamente algún vigor; los restantes individuos de las clases inferiores, entre los cuales había dos ó tres gravemente enfermos, dieron muestras no ménos equívocas de un próximo restablecimiento.

No faltaron en los siguientes días algunas variaciones contrarias del tiempo, aunque conservásemos aún la latitud de $30^{\circ}$; fueron éstas, sin embargo, de muy poca duración y áun menos incomodidad. Al medio día del $\mathrm{I}_{3}$ de Julio, por la latitud de $28^{\circ}$ I $9^{\prime} y$ longitud $86^{\circ} 28^{\prime}$, ya navegábamos otra vez con vientos galenos del 
Oeste; y confirmadas de nuevo en los días siguientes con 76 series de distancias del Sol á la Luna, las longitudes del número ir y el error del $7 \mathrm{I}$, pudimos ya considerarnos no distantes del fondeadero deseado.

En los pocos días que mediaron después hasta la recalada á la costa, tuvimos la desazón de perder en la DEscubierta el soldado armero que habíamos recibido en Lima, de la fragata Liebre. Era éste un hombre sumamente útil é ingenioso cuya aplicación y amor al trabajo le había hecho últimamente hábil para limpiar, cuidar y componer frecuentemente la mayor parte de los instrumentos astronómicos. Continuaba siempre, á pesar de ésto, su servicio de soldado: una tísis envejecida le arrebató casi repentinamente en la mañana del I 9 .

Ya en la noche del 2I nos fué preciso (considerándonos no distante de la costa) navegar con alguna precaución en el aparejo, tanto más que el viento era bien fresco y nuestros rumbos del Nordeste nos inclinaban á las costas más salientes del Oeste. Desde la mañana del 22 tuvimos luégo la vista agradable, aunque común en aquellos contornos, del agua de color de sonda, de los lobos marinos, de las ballenas y de un número crecido y vario de aves acuáticas, $y$, finalmente, observada al medio día la latitud de $\mathrm{I} 8^{\circ}$, se nos presentó, aunque envuelta entre calima, la deseada costa del Perú.

Era ésta precisamente la que corre desde la Nasca para el Morro Quemado, y en los parajes más inmediatos, no distando ya de ellos.á las cuatro de la tarde, más que unas dos y media leguas, nos era fácil reconocer particularmentê la Mesa de Doña María y los pedruscos los Infiernillos. Tomamos horarios para la rectificación deseada del arrumbamiento de la costa, y corrida una base para la mayor exactitud de esta especie de tareas, navegamos en derrota y con fuerza de vela á unos rumbos paralelos á la costa.

La exactitud de nuestras cartas y la excesiva claridad de la noche estando la Luna en su plenilunio, debieron luégo hacernos mirar como una nueva felicidad la brisa excesivamente fresca que tuvimos, siendo nuestro andar de ocho á nueve millas con el trinquete y las gavias arriadas, así con el aumento supuesto en la distancia por la dirección de las aguas; para la mañana del 23 pudimos ya considerarnos en una situación proporcionada para alcanzar el puerto en la misma tarde. Cedieron á la sazón el viento y la mar, y la neblina sumamente espesa que ofuscaba extraordinariamente la costa y hacía que nuestros vigías creyesen ver las rompientes de las inmediaciones de Chilca y Cañete, causó una variedad natural en nuestros rumbos hasta el medio día: á esta hora, conseguida por un acaso bien feliz la altura meridiana del Sol y calcu- ladas para la longitud algunas otras alturas, nos Jul. $3^{\mathrm{I}}$ hallamos agradablemente en latitud de $I 2^{\circ} 3 I^{\prime}$ y en meridianos de la Isla San Lorenzo, la cual, por consiguiente, no debía distar de nosotros más que nueve leguas al Norte verdadero.

Por un breve intervalo aún después del medio día, equivocada casualmente la deducción de la longitud y disipada la sospecha de los puntos de la costa que habíamos creído ver antes, ceñimos de nuevo con todo aparejo de la vuelta de tierra; pero á la una, dejándose ver sobre una clara la Isla San Lorenzo, cesaron nuestras dudas y pudimos gobernar en demanda del puerto. Teníamos á nuestro barlovento y distante como dos leguas, un paquebot guanero, que ceñía según costumbre diaria, de la vuelta de fuera.

La marejada y la corriente, más bien que el viento, nos condujeron en la restante tarde hasta el extremo Norte de la Isla San Lorenzo, del cual, no distábamos para el anochecer más que dos ó tres cables por sonda de 40 brazas; descubierta ya la bahía y puerto interiores hacia donde navegábamos paulatinamente con las ventolinas flojas y variables del Sur. Nos alcanzaron poco después el falucho de rentas destinado á reconocernos y los botes de las fragatas de S. M. Liebre y Bírbara, cuyos Oficiales venían con el mismo intento, $y$ antes de las nueve de la noche logramos dar fondo á un ancla en las inmediaciones de los demás buques surtos en el fondeadero, cuya faena verificó al mismo tiempo la corbeta AtrevidA.

En muy pocos días quedaron después las corbetas desaparejadas y desarmadas; la Oficialidad libre para atender á su sosiego y restablecimiento, y el observatorio con todos los relojes marinos establecido en la Magdalena, igualmente que los pintores y los pilotos, cuyas ocupaciones diarias eran difíciles de combinarse con el desasosiego y vida inquieta de la ciudad. La tropa de batallones y brigadas se acuarteló con sus sargentos y condestables en la misma Magdalena; se asignó á todos los que gozaban de la ración un real y medio diario; finalmente se adoptó para el buen orden á bordo, próximamente el mismo método que se había seguido en la escala anterior en el mismo puerto.

Antes de conducir los relojes al observatorio, no habíamos omitido en la DEscubierta rectificar con algunas alturas momentáneas del Sol la longitud del fondeadero, cual nos la manifes taban los relojes marinos: debía ligar en cierto modo esta nueva cadena que venía del Oeste, así como en los años pasados la habíamos conducido con igual prolijidad en la dirección opuesta. Adoptada para el observatorio de Vavao una longitud media entre nuestras determinaciones y las del Capitán Cook, esto es, considerándole I $67^{\circ} 45^{\prime}$ al Oeste de Cádiz resultaba por el: 
Nüm. rx. |Cronóm. 7r.

Longitud del fondeadero occidental de Cádiz. ...

Eran nuestras suposiciones.

$70 \cdot 54 \cdot 2571 \cdot 55 \cdot 45$ 70.46 .0070 .46 .00

Y la diferencia actual de los re. lojes.

$8.251^{\circ} \circ 9^{\prime} 45^{\prime \prime}$

Se afirmaban de este modo nuestras determinaciones de la escala anterior con el número II, el cual no ménos por las muchas observaciones de las distancias lunares que por el nuevo examen hecho ahora, había indicado una marcha uniforme: el error del cronómetro 7 I correspondía igualmente al nuevo examen y á las comparaciones diarias, de suerte que hubiese sido de $53^{\prime \prime}$ su adelanto diario al tiempo medio, en lugar de los 49 que habían indicado las observaciones de Vavao.

El cuidado de los enfermos, la mayor parte ó lastimados del pecho por el cansancio y continuación de las fatigas ó estenuados por los ataques del mal venéreo, fué en aquellos días otro punto al cual debimos atender con mucha vigilancia: el hospital que les era destinado igualmente que á los demás buques de S. M., por su desaseo, ninguna disciplina y poca pericia de los facultativos, parecía dispuesto más bien á debilitar que á fortalecer las tripulaciones, y las nuestras, ya por sí sumamente débiles y poco numerosas, hubiéranse sin duda aniquilado con este solo vicio: fué, por consiguiente, necesario buscar otro paraje en donde se evitasen aquellos inconvenientes: un hospital particular de los varios que hay en Lima, pareció lo más oportuno para el intento por los muchos enseres de que abundaba; y siendo la manutención en él mucho más cara que en el Hospital Real, quedó prefijado que se cargase el exceso á los individuos, exceptuada sólo una ú otra persona de las más beneméritas de los armamentos: un Oficial de las corbetas debía por turno visitarle diariamente; frecuentarle los cirujanos para que no permaneciesen en él por demasiado tiempo los convalecientes; finalmente, alternar los mismos cirujanos en las visitas á bordo para que ni pretextasen enfermedades ni dejasen de atenderse los achaques áun más frívolos antes que tomasen un semblante serio y temible. No eran infundados nuestros conceptos sobre deberse preferir á cualquiera otro paraje el de la Magdalena para las importantes experiencias de la gravedad; en la actual estación no debían esperarse ni un día siquiera las alturas correspondientes, y las absolutas necesitaban no sólo de una vigilancia contínua para aprovechar cualquicra clara momentánea, si también para su cálculo, del conocimiento cabal de la latitud: establecióse, pues, el cuarto de círculo exactamente en el mismo paraje en que le habíamos tenido la otra rez; y fué mucha ventura que en los primeros días de Agosto se consiguieran ya diferentes ser"es de alturas absolutas para determinar exactamente la marcha de los relojes, de suerte que no se demorasen las experiencias del péndulo simple: concurrían á estas experiencias los Tenientes de navío Don Juan de la Concha y D. Ciriaco Cevallos, no era menor de dos horas la duración de cada una, y la tranquilidad y el tiempo nos daban lugar á ensayar ahora todos aquellos medios que pudie. sen producir en lo venidero una mayor exactitud en estas pesquisas tan importantes.

Procediendo así con un paso uniforme todas las medidas que á la sazón parecían las más oportunas para el decoro y la utilidad actual de la expedición, pudimos ya mirar atentamente hacia sus pasos venideros para que se combinasen de cerca con nuestros últimos deberes en la comisión recibida. Hiciéronse algunos trasbordos en ambas corbetas. Con el dictamen de los cirujanos, quedó determinado el viaje de Don Felipe Bausá por Valparaiso y Santiago á Buenos Aires, para no exponerle al tránsito del Cabo de Hornos con exceso temible para el asma, dimanada de sus trabajos incesantes. Y fué un feliz acaso que mejorado algo en su salud también el Teniente de navio D. José Espinosa pudiese acompañarle por la misma razón; y con su sextante de horizonte artificial, con un relojito de segundos, y un amor invencible en entrambos á las tareas geográficas, pudiese prometerse la expedición nuevo lustre y nuevas utilidades.

El destino de los naturalistas era otro pun. to que debía ocuparnos sériamente; uno y otro igualmente infatigables, inteligentes y útiles, hubieran al mismo tiempo sufrido inútilmente los trabajos de nuestras navegaciones próximas y sacrificado una estación entera, mientras las partes interiores de la América meridional estaban aún desconocidas para las ciencias físicas y particularmente para la botánica. Quedó, pues, decidido con aprobación del señor Virey, que D. 'Tadeo Heenke caminaría á Buenos Aires por Huancavelica, el Cuzco y Potosí, atendiendo no sólo á la botánica, sino también á la zoología y litología; á cuyo fin le acompañaría en clase de disecador el artillero de mar Jerónimo Arcangel, de la Descubierta. D. Luis Nee dejaría la ATREvida tan solamente en Concepción de Chile, desde donde arrimado á la cordillera y á los Pehuenches, continuaría con mucho fruto sus investigaciones botánicas hasta Santiago y últimamente hasta Buenos Aires: este segundo viaje podía combinarse con la escala en Montevideo de una ú otra corbeta; no así con el viaje de D. Tadeo Heenke, el cual por la extensión del país que había de recorrer y por la importancia de los conocimientos que podía producir, 
tuvo permiso en sus instrucciones para dilatar la llegada á Buenos Aires hasta Octubre ó Noviembre del año siguiente de I794.

Desde los primeros días de nuestra llegada al Callao, ya eran acordes todas las noticias en anunciarnos un próximo rompimiento con la nueva República francesa, cuyos caudillos, quitada ignominiosamente la vida sobre un cadalso al Rey pasado Luis XVI, amenazaban con un furor arrebatado de trastornar el orden público y el sistema político de casi todos los demás Estados de la Europa.

Efectivamente, no pasó mucho tiempo sin que estas sospechas se viesen verificadas, $y$ hacia últimos de Agosto, un extraordinario desde Buenos Aires condujo la desagradable noticia de la declaración de la guerra por nuestra parte, avisándose en esta ocasión á los Gobernadores de las plazas y á los Comandantes de los buques de S. M., para que acogiesen y abrigasen todas las embarcaciones de la nación británica, la cual hacía la guerra de mancomún con nosotros.

Semejantes circunstancias no podían mirarse sino como extremadamente importunas para el feliz término de la comisión en que se hallaban las corbetas DEScuBIERTA y ATREvidA, dotadas con poca artillería y de corto calibre, armadas con un corto número de biazos, y más bien dispuestas en su casco y aparejo á luchar con los temporales, que á perseguir ó evadir los enemigos: ni era fácil combinar una mejor habilitación militar con los destinos que ahora debíamos arrostrar, ó bien con el puerto, en que nos hallábamos escasos de pertrechos de marina, particularmente cuando al mismo tiempo debían habilitarse las tres fragatas de S. M. Liebre, Birbara y Gertrudis; y sobre todo, falto de gente útil para formar una tripulación mediana. Un buque anfibio de esta especie no podía ser sino un verdadero peligro para los que le navegasen y un tropiezo contínuo, para que ni sus destinos primitivos ni sus funciones militares correspondiesen al buen servicio de S. M.

La distancia á que nos hallábamos del teatro de la guerra y la reunión de una superioridad tan grande de fuerzas navales cual era la de los enemigos de la Francia, hacía á la verdad sumamente remoto el aparecimiento de fuerzas navales francesas en el mar Pacífico, y se hacía aún más remoto para nosotros un encuentro de esta especie, luégo que vencidos los paralelos de Chiloé, debiésemos inclinar nuestra navegación hacia la costa Patagónica occidental y á las inme. diaciones del Cabo de Hornos.

Estas reflexiones, dictaron como partido más conveniente el de dejar las corbetas próximamente en el mismo estado de fuerza en que habían navegado hasta entonces, de considerarlas sin embargo envueltas en la actual guerra (I), de Ag. 7 mirar como conveniente separarlas para que multiplicasen las tareas científicas, dividiesen los riesgos de un encuentro y abreviasen la publicación del viaje en España; finalmente, de prescribirles una guerra defensiva, más bien que una ofensiva; esto es, una clase de guerra, que tuviese por objeto la sola defensa propia y no la ofensa y perseguimiento de los enemigos.

Fueron los destinos de la corbeta ATrevida, reconocer la Isla de Diego Ramírez al Sur del Cabo de Hornos, visitar el extremo oriental de las Maluinas y el Establecimiento nacional de la Soledad, determinar después la posición verdadera de algunas islitas más orientales que los navegantes del Perú distinguían con el nombre de las Islas de la Aurora; y finalmente, atracada la costa Patagónica al Norte de los ríos Negro y Colorado, arribar al Río de la Plata y al puerto de Montevideo.

Quedó al cargo de la DescubierTa un nuevo reconocimiento de la costa Patagónica occidental, si los tiempos por una rara casualidad se le brindasen favorables, desde $46^{\circ}$ hasta el Cabo Pilares; recorrer después la costa exterior del Fuego, repetir cuanto fuese posible y en los paralelos más convenientes las experiencias del péndulo simple; finalmente, rectificar la Isla de Diego Ramírez y los trozos últimos de costa in mediatos al Cabo San Antonio, que habían tocado en suerte á la corbeta A Trevida.

E1 arreglo de los buques y sobre todo el de sus víveres y dotaciones, al cual, como ya se ha dicho, debimos atender al mismo tiempo, no fue tan fácil de combinarse como sus destinos: nuestros armamentos eran por todas razones sumamente débiles al tiempo de entrar las corbetas en el puerto; puede imaginarse hasta cuál grado debían serlo después, introducidos ya entre la marinería los desórdenes del Callao, que muy luégo los arrastraban al hospital ó á la deserción. Algunos otros adolecían de achaques habituales, ó su edad cansada les imposibilitaba dc resistir la próxima campaña: debían precisamente alejarse los díscolos y poco subordinados; últimamente, el número crecido de grumetes filipinos, parecía poco apto al manejo de la maniobra así por su poca pericia y fuerza, como por la dificultad de resistir á unos climas frios tan diferentes del en quc habían nacido.

Por un acaso feliz, la natural instabilidad del marinero y tal vez el deseo nada extraño de re-

(I) Esta expresión alude á las cartas del Conde de la Lucerne, Ministro en París por la Marina y colonias en I 789 , el cual prescribió á los Comandantes generales de los establecimientos ultramarinos, que auxiliasen nuestra expedición en cuantos modos estuviesen á su alcance. El Gobierno británico nos había fran. queado iguales ordenes para todas sus colonias. 
gresar á sus hogares y familias, había hecho que la mayor parte de la marinería matriculada en la fragata Bírbrra solicitase traşbordar á las corbetas; en balde les abultaron algunos los peligros de nuestra navegación ó la parte de trabajo correspondiente á un corto número de brazos. Se mantenían constantes en su resolución, y desesperanzados de conseguir el permiso de su Comandante, presentaron un memorial al señor Virey solicitando el trasbordo, con tanta más razón, cuanto que la Bárbara saldría después de nosotros, y que siendo matriculados, tenían un derecho de aproximarse á sus hogares, con preferencia á cualesquiera otros: por nuestra parte, podíamos ofrecer un igual número de personas entre los enfermos, los díscolos y los filipinos, la mayor parte útiles en un buque dotado en pié de guerra y en los mares tranquilos del Perú, cuando no serían sino perniciosos en las corbetas, y alegar á favor nuestro, no sólo la ne. cesidad de que la marinería fuese voluntaria, inteligente y quieta, sino también las Reales órdenes que prevenían se mirase como preferente á cualquiera otros objetos, la habilitación de las corbetas en los diferentes puertos de la América.

No condescendió sin embargo S. E. á nuestras representaciones en esta parte, y seguramente (siéndonos imposible el recibir gente de leva, única que nos proponían) nos hubiéramos visto precisados á formar de los dos armamentos uno sólo en la Descubierta, para que pudiese verificarse la campaña proyectada en el próximo verano, si los Capitanes de navío D. Tomás Geraldino y D. Alonso de Torres, Comandantes de las fragatas Liebre y Gertrudis, no se hubiesen unido en auxiliarnos con un esmero correspondiente á la situación nuestra, al buen servicio de S. M. y á los vínculos de compañeros. Estos Oficiales reemplazaron desde luégo con las dotaciones de sus buques, aunque extremamente cortas, r2 de los i8 marineros matriculados de la Bárbara, que solicitaban el trasbordo, y prometieron después, completar al tiempo de la salida todos los demás que nos hiciesen una falta absoluta. Tributaremos siempre á aquellos dos Oficiales los más sinceros agradecimientos, por la eficacia con que decidieron en aquel momento de la suerte de la expedición, y evitaron que fuese molestada la corbeta ATrEvidA, como hasta entonces lo habíamos creído indispensable.

Al mismo, tiempo el señor Virey previno que podíamos considerar como agregados á las corbetas, cuatro marineros ingleses, prófugos en la costa, de varios buques balleneros, y un marinero español que debía restituirse á su patria; con éstos y los 18 hombres indicados, pareció ya remota toda demanda ulterior de gente, tanto más que ya habíamos en una y otra corbeta determi- nado conservar los filipinos, excluyendo sólo los enfermos y díscolos.

No había sido tan difícil combinar el reemplazo de víveres, si bien por otra parte debiese causarnos no poca desazón ver que el pan fabricado en Manila y depositado en un buque del comercio con objeto de aminorar el enjambre de cucarachas, se hallaba inútil no sólo por los destrozos anteriores, sino también por los efectos de la humedad: fué igualmente preciso excluir para condimento el aceite de nuestros repuestos de España, no siendo posible consumirlo sino para luces, y entre la crecida cantidad de menestras debió también desecharse una porción de lentejas ó mongos, que además de empezar á picarse del gorgojo, no podían combinarse con el natural enfado que debía causar la suministración de una misma cosa por el espacio de un año. Se reemplazaron en parte estas partidas excluídas, con otras de excelente calidad, y el repuesto de víveres de una y otra corbeta quedó reducido á las cantidades necesarias.

Tuvimos después nuevas deserciones de la mayor parte de los grumetes filipinos, los cuales fueron igualmente reemplazados con marinería voluntaria de las fragatas, y por fin, en la mañana del r 6 estuvimos prontos á dar la vela. Sólo á las tres de la tarde empezaron á apercibirse las primeras ventolinas de la brisa; las aprovechamos inmediatamente con todo aparejo, $y$ aumentando luégo paulatinamente su fuerza, para las cinco y media ya habíamos atracado la Isla de San Lorenzo por su extremo del Norte y ceñíamos con buen viento al tercer cuadrante. La ATREVIDA, que había dado la vela al mismo ins tante que nosotros, navegaba algo distante por nuestra proa, y se veía sobre las gavias, aún próxima al fondeadero, la fragata El Aguila, en la cual debían navegar á Valparaíso el Teniente de navío D. José Espinosa y el Alférez de navío D. Felipe Bausá: nuestra posición á las seis de la tarde nos hacía considerar á una legua de la Isla de San Lorenzo en latitud $12^{\circ} 4^{\prime}$ y $8^{\prime} 45^{\prime \prime}$ al Oeste del meridiano adoptado para los relojes. Fué luégo constante en toda la noche la brisa fresquita, con la cual ya para el amanecer distábamos considerablemente del fondeadero.

No nos habían engañado las apariencias de la tarde anterior sobre la ventaja de andar, tantas veces disputada, de la corbeta ATREvidA. Amaneció con los juanetes á medio mastelero y sin embargo adelantada en más de una legua; y la señal convenida que se le hizo para que navegase con total independencia de la DESCUBIERTA le dió lugar á que hecha nuevamente fuerza de vela aumentase más la distancia en todo el día.

Continuaron luégo las brisas del Sueste á aumentar su fuerza, engrosando de tal modo la mar, que cansase mucho la proa y nos obligase á ve. 
Oct. r ces á acortar algo de vela; los días se mantenían más bien nublados, el viento era á veces arrafagado, y para el medio día del ig las observaciones nos harían considerar en latitud de $15^{\circ} 26^{\prime}$ y longitud de $3^{\circ} 34^{\prime}$; variación $8^{\circ} 30^{\prime}$ al Nordeste. La ATREvida ya se había perdido de vista por la proa.

La alcanzamos de nuevo el 23 por la mañana, ayudados sin duda más bien de haber sufrido más vela, que de alguna ventaja en el andar, á pesar de que variásemos mucho la estiva, zollásemos adentro una parte de la artillería y sacrificásemos dos vergas de juanete.

Muy luego los rumbos del Sur y aún á veces inclinados al primer cuadrante nos condujeron al encuentro de los variables por latitud de $24^{\circ} 45^{\prime}$ y longitud de $10^{\circ} 13^{\prime}$. Con ellos la otra corbeta nos dejó nuevamente por la popa, y como los vientos le fuesen en esta ocasión más favorables que á nosotros, debimos abandonar toda esperanza de precederla en el puerto de Talcahuano, como nos lo hacía desear al principio una loable emulación.

Un objeto que debía á la sazón inquietarnos mucho, era el de las enfermedades bastantemente peligrosas de tres marineros, el uno un gaviero que nos acompañaba desde Cádiz y adolecía ahora de un cansancio y debilidad irreparables; el otro un grumete que había pasado de la ATREVIDA para agregarse al pilotaje y sufría de una inflamación del hígado; el tercero, una de las muchas víctimas que diariamente causa el desorden y los males venéreos: no faltaban tampoco algunas disenterias aunque fáciles de corregirse y así casi al momento de abandonar el puerto, apenas alcanzaban nuestros cuidados y el acierto de D. Francisco Flores para evitar que no se debilitase más la tripulación.

Si como lo aparentaba el día siguiente, hubiésemos ya alcanzado los vientos del Sudoeste y Oeste en la actual posición, nuestro viaje hubiera efectivamente podido ser breve; pero muy luego nos desengañaron los vientos del Sueste bien frescos y arrafagados, los cuales debimos ceñir de nuevo al tercer cuadrante, de modo que hasta el $3^{\mathrm{I}}$ no alcanzamos la latitud de $3 \mathrm{I}^{\circ}$ y á este tiempo hubiésemos caído $I^{\circ} 4^{\prime} \mathrm{O}^{\prime}$ al Oeste; esta longitud la indicaban conformes ambos relojes marinos; el termómetro de Farenheit se mantenía por los $60^{\circ}$ próximamente; y ya en este último día, alcanzados nuevamente los variables nos prometían una próxima alteración favorable, la cual nos condujese brevemente á Talcahuano.

No podía efectivamente desearse una tarde más placentera; el viento se había declarado fres. co por el Sudoeste, y con él navegábamos al Sueste en buena derrota; no se apercibía una nube sobre el horizonte, y en las primeras horas de la noche el brillo de las estrellas nos presen - Oct. 31 taba una escena que desconocíamos desde mucho tiempo: pero también esta vez quedaron nuestras esperanzas frustradas, pues á la media noche retrocedió el viento al Sur y al Sursueste arrafagado y lluvioso, con el cual aunque con las muras á estribor, salimos nuevamente de la derrota directa.

Así continuamos en los tres días siguientes en los cuales debimos á veces precavernos algo en el aparejo, logrando sin embargo hallarnos para el medio día del 3 en latitud de $34^{\circ} 2 I^{\prime}$, y longitud de $\mathrm{IO}^{\circ} 0 \mathrm{O}^{\prime}$ : en esta posición después de algunas horas de calma vimos declararse las primeras ventolinas del Noroeste, y á éstas, siguiéndose poco después vientos más entablados del Oesnoroeste y Oeste, pudimos en la mañana siguiente navegar con un tiempo placentero en demanda del puerto.

Hasta el medio día del 5 hicimos rumbos del Sursueste para entrar en los paralelos de la Concepción y óbviamente afianzar más los vientos favorables: orzamos luégo al Este corregido con vientos bien frescos del Nornordeste y Noroeste, los cuales, para el anochecer nos redujeron al trinquete y las dos gavias con un rizo tomado; fueron tempestuosas y cerradas con lluvia las primeras horas de la noche; pero antes del amanecer ya había rolado el viento al Oeste, y despejado enteramente el cielo, de suerte que pudiésemos forzar nuevamente de vela.

Ya los tres días siguientes, nuestra derrota con la continuación de vientos favorables fué bastante acelerada: corrigiéronse los rumbos oportunamente, de suerte que no nos apartasen del paralelo de la Isla Santa María, las corrientes bastante fuertes al Sur que nos indicaban las observaciones diarias de latitud: muchas series de distancias del Sol á la Luna en los días 7 y 8 confirmaron un error de $13^{\prime}$ al Oeste en el número II, siendo algo mayor en el mismo sentido el del cronómetro 7 I, y en este último día, no distábamos más que 40 leguas del puerto, habiendo á la sazón calmado casi de un todo el viento Oeste que nos había acompañado hasta entonces con mares bastante gruesas: la variación magnética alcanzaba ya los $14^{\circ}$ al Nordeste, y el color del agua y la muchedumbre de aves, lobos y ballenas, nos anunciaban próxima la vista agradable de la costa.

Sólo á las tres de la tarde nos alcanzó el viento costanero del Sursudoeste: le aprovechamos con fuerza de vela; álas diez de la noche se proporcionó luégo un andar de seis y siete millas; paireamos una hora hacia las tres de la mañana, y poco después las primeras claras del alba nos dejaron ver las Tetas de Viovio y la Isla Santa María en la distancia que suponíamos: á las siete distábamos un cable del islote Quiebra Olla: á 
Nor: 8 las ocho estuvimos dentro de la bahía, y á la una y media de la tarde después de seis bordos en los cuales procuramos seguir otras tantas líneas de sonda, logramos alcanzar el fondeadero en Talcahuano, y quedar amarrados en seis brazas fango con el ayuste al Norte. La corbeta ATREVIDA había fondeado después de la oración de la tarde anterior y experimentado los vientos algo más frescos y achubascados, por manera, que careciendo por tres días de las observaciones de latitud, no advirtiese los efectos de las corrientes que le hicieron recalar al Sur de la Isla Santa María. Se hallaron también surtos en la bahía dos buques del comercio de Lima la Barca y el Rosario, destinados á tomar carga de trigo.

Las primeras visitas á bordo de los antiguos amigos y conocidos, debieron desde luego entibiar mucho la natural complacencia nuestra de vernos en el puerto que considerábamos como la última escala del mar Pacífico: el señor Gobernardor Intendente, se hallaba distante, habiendo debido pasar á la frontera para contener á los indios vecinos, mientras transitase á Valdivia el nuevo Gobernador interino Coronel D. Pedro Quijada; no había carta alguna para nosotros y las noticias públicas posteriores á las que habíamos recibido en Lima, no nos anunciaban más que una serie de desórdenes, destrucciones y calamidades que agobiaban á nuesțra España de mancomún con los demás países de Europa; debía aún tranquilizarnos y más bien producirnos una más que mediana satisfacción, ver entre to das las demás naciones sobresalir la nuestra por el amor á su religión y á su Gobierno, ver cada clase prodigar con emulación sus bienes y su misma vida para conservar el órden y quietud públicas; ver finalmente apurados casi los medios de manifestar un valor y una lealtad incorruptibles.

Acostumbrados sin embargo á mirar de cerca el marinero por espacio de veinte años, no fiamos á los solos estímulos del ejemplo ageno la seguridad de los armamentos; en carta al señor Gobernador Intendente insistimos en que se tomasen las medidas más estrechas para arrestar á todo prófugo, y solicitamos una leva de de Io á I 2 marineros hábiles entre los muchos desertores de los buques de S. M. que se hallaban anidados en aquellos contornos harto seductores.

A la verdad, por cuanto hubiesen sido activos los auxilios en Lima del Comandante Don Tomás Geraidino, no era fácil ocultarnos que la Descubierta se hallaba aún muy mal dotada de brazos, tanto más, que ahora por una singular fatalidad, no sólo no habían podido repararse en el mar los extragos de la última escala del Callao, sino que se habían declarado entre muchos las enfermedades agudas propias de un tránsito demasiado repentino á los climas fríos: Nov.8 para el alivio de estos últimos se tomaron las precauciones más eficaces, y desde luego pasaron á ser cuidados en tierra los tres que habían sido atacados de la enfermedad con mayor violencia: al mismo tiempo se empezó á suministrar á todos ración fresca de pan, calne $y$ verduras, añadiéndoles para mejor beneficio un cuartillo diario de vino. La aguada, la leña, la conservación de una disciplina extricta á bordo y una ú otra ocupación de los botes en sondas y planos, suministrarían después aquel ejercicio contínuo y moderado para la conservación de la salud que mal pudieran haberse combinado con los desórdenes irremediables en los contornos de la Mocha: fueron uniformes con éstas las medidas tomadas por el Comandante de la ATrevida, el cual, por su parte, pensaba hacer un mayor acopio de leña, atento á la menor cantidad que había recibido en $\mathrm{Li}$ ma y á la escasez de este ramo en Montevideo.

En la mañana del Io, que fué sumamente placentera, no nos descuidamos en establecer el observatorio en el mismo paraje en que lo habíamos tenido la otra vez: se consiguió para el medio día la primera época de la marcha de los relojes, los cuales eran ahora el número II y el cronómetro 7 I para las experiencias de la gravedad, siendo así que ninguna confianza podíamos aún tener del péndulo astronómico; y en la mañana del I 2 tuvo ya lugar la primera de aquellas importantes experiencias: en la misma tarde, reunida la mayor parte de la Oficialidad de entrambas corbetas, confirmó con muchas series de distancias del Sol á la Luna la longitud del observatorio ya que las circunstancias eran las mejores que podían desearse y carecíamos ahora de todo otro medio de determinarla.

Adoptada para el fondeadero del Callao la longitud de nuestras serjes anteriores, fueron nuestros resultados en esta ocasión los siguientes:

\begin{tabular}{l|l|l|l|l}
\hline $\begin{array}{c}\text { Longitud occiden- } \\
\text { tal de Cádiz.. }\end{array}$ & Núm. II. & Cronóm. 71 & Núm. Io5. & Cronom. 72 \\
\hline
\end{tabular}

Las 55 series de distancias medidas en

el observatorio. .......... $67^{\circ} 2^{\prime} 2^{\prime \prime}$

Las 63 series observadas en los días 7 y 8

y trafdas con el número $\boldsymbol{\imath}$. ......

Promedio y longitud del observatorio.

Eran nuestras determinaciones del año

de $1790 . \ldots . . . . . .666 .56 .00$

En los dos días siguientes quedó interceptada casi de un todo nuestra comunicación con la tierra, por el viento Norte que reinó con mar gruesa, hasta rolar al Oeste con ráfagas y aguaceros bien violentos, los cuales últimamente ce- 
Now is dieron á la brisa con la serenidad acostumbrada: este viento, que en la actual estación no podía ser más que una imagen sumamente débil de los que reinan casi diariamente en los meses de Julio, Agosto y Setiembre, nos recordaba cuánto hubieran sufrido la seguridad y el decoro de la expedición, si no hubiésemos preferido el fondeadero del Callao al de la Mocha.

La mañanita del I5, con el regreso del tiempo hermoso y apacible, dió lugar á que empezasen de nuevo nuestras tareas del observatorio y pudiésemos destacar una mitad de la tripulación y tropa al corte de leña: la tropa iba armada y á las órdenes del sargento y condestable; el paraje del corte estaba bien desviado de la población; además de estas precauciones, se había tomado la de mantener á bordo los más sospechosos, y debían atenderse en esta útil ocupación, más bien que la necesidad del ejercicio y un agradable entretenimiento: tuvimos la satis facción de ver que la mayor parte, por la tarde solicitaron volver al día siguiente, al paso que no era menor de unos 70 á 80 quintales la cantidad acopiada diariamente.

Continuando así sin intermisión nuestras tareas diarias, para el medio día del I7 vimos concluídas con la mayor prolijidad las experiencias del péndulo simple, y al día siguiente se sustituyó en el observatorio el reloj Io5 de la ATREVIDA al cronómetro 7I, el cual, para una mayor seguridad en las determinaciones venideras, debía afianzar su marcha después de haberse trasportado á bordo. El I q quedaron igualmente completas la aguada y leña y los aprestos de nuestro aparejo y velamen.

Nuestras precauciones para el cuidado y restablecimiento de la tripulación, eran la única cosa á que no correspondían aún los efectos; de los tres enfermos que teníamos en tierra, dos no indicaban mejoría alguna y ya debía perderse toda esperanza de que pudiesen seguirnos; otros once que permanecían á bordo afectos también de las enfermedades del hígado y de las calenturas inflamatorias acompañadas con dolores de costado, manifestaban un próximo restablecimiento; pero á pesar de enviarlos diariamente á tierra á las órdenes del sargento, paraque en las mejores horas de la tarde, sin desórden alguno, gozasen de la amenidad del campo, era muy lenta su convalecencia y difícil de recobrarse el aniquilamiento de sus fuerzas, dimanado de las muchas sangrías que les habían sido necesarias.

Don Francisco Flores comparaba estas enfermedades á las que llaman autumnales en nuestra Europa, y dimanan comunmente de la detención de transpiración y el espasmo de los vasos pequeños de la superficie del cuerpo, influyendo últimamente, ó en el hígado ó en el pecho, según el paraje á donde se fijase el humor: cédían á beneficio de las sangrías, los emolientes y de- Nor. I más partes que constituyen el método antiflogístico, y nos recordaban á cada paso cuánto nos hubiera sido fatal tolerar el menor desórden en tierra á las tripulaciones: el acogimiento más agradable en todas las casas y la prodigalidad do los comestibles y del vino, son efectivamente unos incentivos demasiado fuertes para que el marinero no aproveche un momento de libertad y se abandone al desórden acostumbrado.

Otros dos objetos que debían ocuparnos, habían logrado de una mejor suerte; y eran éstos, el acopio de alguna tablazón y de cuatro vergas de juanete en las inmediaciones del Tomé, y la sonda y un examen más cuidadoso del puerto de Coliumo: se encargaron del segundo el Alférez de navío D. Jacobo Murphy, y los Pilotos Inciarte y Hurtado en el bote de la ATREvida; el de la DESCUBIERTA condujo al medio día del 20 las maderas del 'Tomé, sobre cuya elección había vigilado el primer carpintero nuestro, reconociendo al paso los bosques ménos distantes, para la utilidad de una construcción.

En un extraordinario despachado á Santiago al tiempo de nuestra llegada á este puerto, habíamos suplicado al señor Capitán General tuviese á bién remitir cualesquiera cartas ú órdenes correspondientes á las corbetas, sin diferirlas del día 25, plazo prefijado para la salida; llegaron efectivamente las respuestas en la manana del 23, pero tuvimos la mortificación de no recibir carta alguna, ni noticia del estado de la Europa que pudiese dirigir con más acierto nuestros pasos venideros. Por una serie poco común de combinaciones, corría ya el tercer año que carecíamos de toda contestación á nuestras cartas.

Ya las alturas correspondientes de la tarde del 24, habían fijado la última época del arreglo de los relojes marinos; y por consiguiente, en la mañana del 25, mientras embarcaban instrumentos, provisiones y utensilios, pudo el Piloto Inciarte, en el bote de la ATREVIDA, examinar prolijamente las inmediaciones del bajo, marcándole con dos teodolitos, el Alférez de navío Alí desde el Morrito de Talcahuano, y el Piloto Hurtado desde el Castillo de Gálvez; se confirmaron en esta ocasión las sondas del bajo de fuera de Choros, y se disipó toda sospecha de que existiese el otro bajo del Belén, así llamado por el Piloto Moraleda.

Si en la tarde del día 25 al tiempo de regresar el bote á bordo, no hubiesen faltado cuatro marineros hubiéramos sin duda dado la vela en la mañanita siguiente, pues ya liquidadas las cuentas, despedidos dos marineros gravemente enfermos $y$ recibidos en su lugar dos naturales sentenciados, los cuales reemplazaban con la robustez lo que les faltaba de pericia marinera. 
ㅈov. as nada absolutamente podía detenernos luégo que entablase la brisa: inmcdiatamente se destacó D. Francisco Viana á buscarlos cn las guaridas donde podían anidarse, mientras las patrullas de tropa evitasen su fuga hacia la Mocha; y efectivamente, hacia la media noche ya se habían aprehendido dos de ellos, con los cuales regresó Viana á bordo al amanecer; pero los otros dos no se nos incorporaron sino bien entrada la mañana, y este motivo, reunido al deseo de dar un buen descanso á la marinería ya que había trabajado con actividad en los días anteriores, hizo que se suspendiese la salida hasta el 27 , tanto más, que la continuación de la brisa fresca y la distancia del novilunio parecían prometernos la duración del tiempo favorable; pero en esta última suposición nos hallamos enteramente equivocados.

No bien estábamos á pique del ancla del Sur, levada la del Norte y metidas las embarcaciones menores, cuando empezaron á declararse vientos fresquitos del Nornoroeste con aguas y cerrazón; fué preciso espiarnos y dar nuevamente fondo al ancla del ayuste: continuó la lluvia en toda la tarde y noche; no así el viento que había sido reemplazado por una total calma, y ésta al amanecer del 28, por algunas ventolinas del terral acompañadas de un semblante hermoso y apacible.

Siguieron luégo los tiempos variables é indecisos hasta el 2 de Diciembre, sin que fuese posible dar la vela; pero, en fin, en este último día lo pudo verificar la Descubierta y hallarse á las dos de la tarde fuera de la bahía. La ATREvrda defirió igual maniobra hasta el día siguiente.

\section{CAPITULO VII}

Navegación de la Descubierta desde la Concepción de Chile hasta el puerto de Montevideo.-Reconocimientos de las Tierras del Fuego y de la Isla de Diego Ramirez. - Escalas en el puerto Egmont de las Islas Maluinas y on la bahía Santa Elena de la Costa Patagónica. - Experiencias de la graodad y otras tareas y acaecimientos.

Aunque no se hubiesen aún extinguido las fiebres atabardiliadas de las cuales se hizo memoria en el capítulo anterior, y cuatro ó cinco de los últimamente afectos a penas pudiesen considerarse libres de las garras de la muerte, debía consolarnos ver que la convalecencia cra por lo común bastante breve, y que ya la enfermeclad no sc cleclaraba en otro alguno: en el rostro de los demás, en su fuerza, en su agilidad y buen humor sobresalían ahora tanto las utilidades de aquella arribada, cuanto cran tristes, desmayados y macilcntos los semblantes del mayor nú- mero al tiempo de la salida del Callao. Suspen dióse en el entretanto suministrar el grog por ración hasta que consumiese cada cual el vino que había recibido de regalo de los vecinos de la Mocha, y repartida abundantemente la ropa de abrigo, se procuró combinar en los trabajos diarios que tuviesen algunas horas de sosiego para coserla y prepararla á su albedrío.

Hasta el io fueron lentos nuestros progresos por no haber salido aún de los límites de los variables; pero entablados en aquel mismo día los vientos tempestuosos del Oeste y Noroeste, nos condujeron con tanta presteza hacia el Sur, que para la noche del I4 ya habíamos alcanzado el paralelo de $49^{\circ}$. Aquí, los vientos, las mares y las cerrazones, lejos de ceder tomaron un semblante aún más horrible y tempestuoso, y en la penosa alternativa ó de luchar contra ellos iufructuosamente con las muras á babor ó de dejarnos arrollar hacia los paralelos de los Cabos Pilares y Victoria, pareció el segundo partido más adaptado á las circunstancias nuestras á la sazón, y á las ideas que nos habíamos formado sobre nuestras tareas á la otra banda del Cabo de Hornos.

Diferentes veces, la derrota que ahora seguíamos nos llevó á surcar la misma senda que habíamos corrido en el año I790, y el encontrar ahora con un mes de anticipación tiempos aún ménos favorables de los que habíamos experimentado entonces, nos convenció de nuevo cuánto era casual un momento feliz en aquellas regiones. No nos era extraña la acostumbrada compañía de un crecido número de pájaros pamperos cuando reinasen los vientos tempestuosos del Oeste, así como en los instantes más bonancibles se nos aparecían las gaviotas, las pardelas y una ú otra vez tal cual lobo marino.

Las últimas horas del I6 parecieron querer transformar en un todo la escena que nos rodeaba desde ocho días; á las ráfagas suma. mente recias del Oeste (símbolo ya casi seguro de su poca duración), á las cerrazones, á las mares ya descritas, sustitúyese ahora un tiempo sereno y apacible entremezclado ó con una total calma ó con algunas ventolinas del segundo cuadrante. Revivieron nuestras esperanzas ya enteramente desmayadas y ceñimos inmediatamente con todo aparejo al Esnordeste y Este, aprovechando interiormente para el aseo y conservación de la salud, la hermosura del día y el brillo del Sol; y como las ventolinas aunque débiles continuasen en la noche siguiente, ya para las primeras claras del 8 habíamos estrechado de unas Io leguas la distancia con el Cabo Victoria.

Poco acostumbrados á la claridad y hora temprana del crepúsculo, admirábamos á la sazón á veces el brillo lisonjero de las 'estrellas, á veces 
Dic. is la aproximación del astro vivificador de toda la Naturaleza, á veces las muchas aves y lobos marinos que parecían esperarle con ansia y saludarle cada cual con sus voces broncas y poco melodiosas, cuando contra todas nuestras espectativas se aumentó esta escena con la vista de una embarcación hacia el Sueste; y variando de un golpe el hilo de nuestras ideas, que casi nos separaban del mundo habitado, debimos sólo entregarnos á aquellos pensamientos que la inconstante ambición del hombre alimenta para su propio daño.

Reconocímosla á poco rato por una fragata ballenera americana. Enviado después el bote á su bordo, supimos con harta mortificación que había salido de los puertos de la América.unos seis meses antes, de manera que sus noticias sobre el estado de la Europa fueron aún más añejas que las recibidas en Lima y en la Concepción. Dímosle algunos refrescos y las direcciones oportunas para la navegación siguiente, ya que su ánimo era buscar paralelos más bajos para la continuación de la pesca, y la despedimos, pues el tiempo se apresuraba á tomar su semblante acostumbrado.

Era ya nuestro plan reconocer la costa desde el Cabo Deseado, y no perderla de vista hasta la Isla de los Estados. Considerábamos el Diario del Capitán Cook, para suponer que lograríamos de un viento igualmente claro y manejable que nos permitiese recalar á imitación suya con alas y rastreras; pero en esta ocasión, como en otras muchas, nos estaba prevenida una nueva oposición, la cual nos recordase que si era difícil imitar á aquel célebre navegante en su pericia y tino marineros, no era ménos intempestivo y osado aspirar á un igual grado de felicidad.

Desde la media noche del Ig, el tiempo empezó á tomar tan mal semblante y el barómetro á bajar tan considerablemente, que nos parecieron precauciones indispensables ceñir al Sur el viento ya arrafagado del Oeste y limitar el aparejo al solo trinquete y las gavias en dos rizos arriadas: no eran infundadas nuestras sospechas, ni vanas nuestras precauciones, pues á las ocho de la mañana nos sobrecogió tan fuerte contraste del Sudoeste y Sursudoeste, que á pesar de la resistencia casi indecible de nuestro casco y aparejo, se nos hacía sumamente arriesgado resistirlo: ignorábamos su duración, las mares con exceso gruesas nos amenazaban de una deriva considerable sobre la costa, si nos descuidásemos en una capa sosegada; y así nos pareció un partido inevitable conservar largos el trinquete y la gavia en dos rizos arriada, y con esta vela más bien excesiva, continuar hasta franquearnos con las muras á estribor.

Los islotes del Cabo Deseado, nos demoraban unas veinte leguas al Nordeste. Si el viento hubiese continuado por largo tiempo con la fuerza y dirección con que había entrado por la maña- Dic. 19 na, la deriva inevitable de una mar gruesa y un aparejo limitado nos hubieran acarreado sobre los islotes del Cabo Negro ó precisádonos á navegar con no ménos riesgo sobre las muras á babor; ni debía parecer extraordinaria semejante duración, cuando consultásemos las navegaciones nacionales de los últimos años, las cuales dictaban últimamente, como preferente el partido de surcar aquellos mares con atención á los vientos, más bien en la oscura estación del inviemo que en la clara pero más tempestuosa del verano: por ventura no fueron acertadas nuestras sospechas; el viento y la mar cedieron mucho en la noche siguiente, y declarados después por el Sudoeste bonancible con buen semblante, nos dieron lugar á navegar con fuerza de vela en demanda de tierra.

Fueron los vientos demasiado bonancibles para que consiguiésemos avistarla antes del oscurecer del 20, pero ya á esta hora estábamos de ella á tan corta distancia, que áun con un andar muy lento y paireando desde la media noche, para las tres y media de la mañana del 2I, veíamos á distancia de unas ocho leguas los Cabos Glocester y Negro, el primero hacia el Nornoroeste y el segundo al Nordeste $1 / 4$ Este de la aguja.

Luégo que la claridad del día y el viento aunque flojo nos permitieron combinar con la continuación de la derrota nuestras tareas acostumbradas, seguimos rumbo del Esueste, el cual nos conducía aunque paulatinamente, á pasará unas cuatro leguas del Cabo Negro: admirábamos de nuevo la exactitud de las descripciones del Capitán Cook en este nuevo teatro de su felicidad é inteligencia navegantes, y guiados así por mano, dejábamos aparte la idea de descubridores, para tomar el semblante no ménos útil del que para el bien público rectifica y á veces perfecciona con una cierta nimiedad científica las primeras obras, siempre algo informes cuanto más útiles y grandiosas.

El Cabo Glocester pareció á nuestra vista un frontón de tierra algo pendiente al mar y con un islote casi igualmente alto á corta distancia de él: seguía luégo la costa de mediana altura formada de muchos picachos todos entrecortados con canalizos, de modo que parecian más bien islas; $y$ últimamente casi Noroeste-Sueste con aquel Cabo, se dejaba ver con igual altura y con un color bien oscuro la isla grande del Cabo Negro; en ella se hacía particularmente notable una quebrada con dos piquitos agudos por su parte del Este y del Oeste; diferentes islotillos difíciles de percibirse sino á muy poca distancia, rodeaban luégo la punta más meridional; y no era posible (tal vez por la calima) distinguir lengua alguna de tierra que le uniese á latierra frrme, antes 
Dic. 2r bien, el terminar la parte oriental y baja de la isla en un mogote bastante elevado, parecía indicar que ésta fuese realmente una isla: fueron vanas nuestras diligencias para avistar los dos islotes salientes al Sur 1/. Sueste, aunque nuestra derrota nos condujese á pasar de ellos unas tres leguas apenas. El poco viento no nos permitió el estar Norte-Sur con el Cabo Negro hasta después del medio día, habíamos observado la latitud Sur de $54^{\circ} 48^{\prime} 30^{\prime \prime}$, y al mismo tiempo la longitud de $67^{\circ} 9^{\prime} 40^{\prime \prime}$ occidental de Cádiz leducida por el número II, nos daba lugar de confrontar nuestros resultados con los del Capitán Cook.

Pasado el Sol por el meridiano fué el viento aumentando considerablemente sus fuerzas y agregándosele al mismo tiempo una corriente rápida hacia el Este, de suerte que nuestros pasos fuesen en esta ocasión expeditos; antes navegamos al Esnordeste para internarnos hacia la srande ensenada en la cual el Capitán Cook había sospechado la existencia del Canal de Santa Bárbara y luégo aproximándonos para las seis hacia el Cabo Desolación, corrimos la restante tarde al andar de la costa y á una distancia de ella de tres leguas próximamente. Era el tiempo sumamente claro y hermoso y esto nos dió lugar á que avistando el golfo intermedio entre el Cabo Negro y el de Desolación tuviésemos la casual felicidad de poderle describir tal ve $z$ con alguna mayor individualidad de la quese había proporcionado al Capitán inglés.

A la parte del Nordeste del Cabo Negro, se advierte efectivamente una grande ensenada cuyos límites al Norte no es fácil descubrir á lo ménos en una distancia de seis leguas próximamente desde los extremos del Cabo; pero pasada esta distancia, se vuelve á unir la costa, y si bien las proyecciones indiquen la existencia de una ú otra isla, no parece que sean éstas las que forman la mayor porción de la costa, y no es fácil descubrir otra entrada alguna hasta llegar al Cabo Desolación. Los picachos siempre dispuestos en una figura regular volcánica empiezan aquí á multiplicarse mucho, se les vé cubiertos con manchas grandes de hielo, despoblados de arboleda y sólo en una ú otra parte de las más bajas, vestidos aunque mezquinamente de tal cual fruto de una corta vegetación.

La sonda, si consultásemos así las observaciones del Capitán Cook y nuestras, como el color del agua, no debe tampoco suponerse muy saliente al mar; y por cuanto pueda inferirse de lo acaecido á aquel Capitán en la bahía de $\mathrm{Na}$ ridad, y á los últimos navegrantes nacionales en la parte interior del Estrecho de Magallanes, no debe por ella navegante alguno entregarse descuidado a la seguridad de hallar fondeadero donde vea abrigo; la mayor parte de las veces se ha- llará sin fondo á muy corta distancia de las pie- Dic. ${ }_{2 \pi}$ dras.

Efectivamente, desde el Cabo Desolación, la Tierra del Fuego toma un semblante horrible, así por su aridez como por su elevación y escarpe: á poca distancia del Este se advierte una entrada como de cuatro millas, y con dirección al Nordeste le forma el mismo Cabo al Noroeste $y$ otra punta no ménos alta y escarpada al Sueste; no se descubren interiormente más que tres ó cuatro islotes bastante distantes, y los arrecifes ó pedruscos que bordan luégo la costa siguiente al Este, no parecen obstruir en modo alguno toda la anchura de la boca indicada; pasada ésta ya por largo trecho, no se descubre otra entrada alguna, y la costa con dirección del Esueste, corre bastante unida, hasta presentar las dos entradas grandes, de las cuales es la más oriental la de $\mathrm{Na}$ vidad que visitó el Capitán Cook.

Unas seis leguas al Este del Cabo Desola. ción, nos sobrecogió la poca luz del crepúsculo, que nos precisó á poner término á nuestras tareas, esperando con ansia que la claridad del nuevo día nos permitiese continuar con la misma felicidad que ahora parecia querernos acompañar. Unánime toda la Oficialidad, había convenido en que podía aún reconocerse un trozo re gular de costa antes de buscar el paralelo de la Isla de Diego Ramírez, cuyo reconocimiento debíamos mirar como de la mayor importancia; y con este mismo plan esperábamos paireando sobre las gavias á unas tres leguas de la costa la hora oportuna para dar principio á nuestras tareas: en esta posición, eran nuestras sondas de 65 brazas piedra y coral, y la variación magnética de $25^{\circ} 30^{\prime}$ Nordeste.

Estos conceptos realmente lisonjeros, no fueron sino momentáneos; á la una de la mañana el tiempo inclinándose el viento al Oesnoroeste, había tomado su acostumbrado semblante tempestuoso, y nos había precisado á precavernos con dos rizos en las gavias. Semejante sorpresa alteraba nuestro plan primitivo de operaciones, porque siendo probable que el temporal durase algunos días con las cerrazones inseparables, debía recelarse que la deseada Isla de Diego Ramírez, ó se nos ocultase, ó la viésemos sin poder lograr de observación alguna, ó que finalmente nos quedase al Oeste, cuando lográsemos de tiempos más oportunos para reconocerla. Con estas reflexiones abandonamos inmediatamente la costa, y sin dejarnos descaecer nada del me. ridiano en que nos hallábamos, navegamos al Sur para entrar en el paralelo de $56^{\circ} 28^{\prime}$.

Con el temporal del Oesnoroeste, que ya había establecido su imperio, nos fué fácil alcanzar la posición proyectada: capeamos inmediatamente sobre la gavia y el contrafoque, y debió, á la verdad, tranquilizarnos mucho sobre el lo- 
Dir. 22 gro de nuestros deseos, considerar que aún distábamos unas 35 leguas á barlovento de la posición probable de la isla, y que por consiguiente no la propasaríamos tan luégo. Con esta atención misma, ya que la mar y el viento eran extraordinariamente tempestuosos, y los horizontes á veces no se extendían ni á una milla siquiera, nos pareció preferente capear, que navegar con alguna más vela sobre bordos, los cuales, ó nos hubier:m separado mucho del paralelo en que quería. mos mantenernos, ó con las muras á babor hubieran en mucho menor plazo, consumido la distancia favorable á barlovento.

Nuestra curiosidad sobre la existencia de esta isla era extremada; pareciéndonos bien extraño que los solos Nodales entre nuestros navegantes la hubiesen visto, y que poco conforme en esta ocasión la Naturaleza con la harmonía general que se advierte en todas sus obras, cuasi á la vista de unas tierras elevadas, ásperas y tan pedregosas que pudiesen resistir al ímpetu de las olas, hubiese colocado como un antemuro de ellas mismas una islita baja, débil y de tan poca extensión cual nos la representaban en el día las cartas modernas, inclusa la del Capitán Cook: resolver esta duda era además un punto harto importante para la navegación nacional, y (digámoslo así) la única pesquisa útil en esos mares que había dejado el Capitán Cook á los que le siguiesen.

Atento á este plan, no sólo en la tarde y noche actuales, sino también en todo el día siguiente, no varió nuestra capa de la gavia y el contrafoque, ni nos apartaron nuestros bordos más de siete á ocho minutos á una y otra parte del paralelo sospechoso: acechábamos con vigías cualesquiera claras, aunque momentáneas, que pudiesen extender nuestra vista á una. legua en torno siquiera, y los sacrificios actuales de sufrir á costa de mil incomodidades un temporal que parecía destinado á sacarnos con brevedad de esas mareas tempestuosas, nos hubieran parecido con exceso frívolos si no los viésemos in fluir extraordinariamente en la salud y en el mismo desaliento de las clases inferiores.

A las diez de la mañana del 24, cuando más reunídos parecían los elementos para hacernos desagradable aquella demora, vimos repentinamente dividirse las nubes, rolar el viento al Sudoeste, y al mismo tiempo serenarse el cielo y tranquilizarse poco á poco el mar: no anduvimos omisos ni en examinar por medio de las observaciones nuestra posición verdadera, ni en hacer rumbos y aparejo proporcionados á este intento. Nos manifestaron aquéllas que en los solos dos días últimos habíamos contraído $I^{\circ}$ de error al Este en la estima; de suerte, que un solo día más de temporal nos hubiera hecho propasar de los meridianos sospcchosos, y los otros nos guiaron á avistar hacia las dos de la tarde Dic. ${ }_{2 .}$ al Nordeste la isla deseada.

Era bien diferente la idea que ahora podíamos formar de las Islas de Diego Ramírez, de la que antes nos habían dictado las noticias antiguas; es éste más bien un pequeño Archipiélago de una más que mediana elevación, con el mismo semblante árido y pedregoso que presentan las tierras de Cabo Desolación con una extensión tal vez mayor que la de las Islas de San Ildefonso, y con una dirección de Norte á Sur, que indica al mismo tiempo su homogeneidad con las tierras inmediatas al Norte, y su estructura simétrica según las leyes admirables de la Naturaleza.

Para las cuatro de la tarde habíamos atracado el extremo Sur á distancia de dos leguas; le vimos rodeado á corto trecho de muchos pedrus cos escarpados en los cuales rompía el mar con una fuerza extraordinaria; le situamos en latitud de $5^{6^{\circ}} 33^{\prime}$ y longitud occidental de Cádiz de $62^{\circ}$ $20^{\prime} \mathrm{oO}^{\prime \prime}$, y pareciéndonos que éste se miraría por los navegantes venideros como el verdadero tér. mino de las Tierras del Fuego, y el punto al cual debiese referirse la navegación de altura, le distinguimos con el nombre de Cabo Valdés para recordar en él al mismo tiempo el protector constante de la navegación nacional y el agradecimiento que le profesaban los que habían sido destinados á este intento en la corbeta DescuBIERTA.

El grupo de las islas conservó el nombre de Diego Ramírez, se trazaron sus términos y arrumbamientos con repetidas bases y observaciones, y como el color del agua y disposición de la tierra nos asegurase que no había sonda en aquellas inmediaciones, continuamos, hacia las seis de la tarde nuestra derrota para aproximarnos al Cabo de Hornos. Efectivamente, á las tres de la mañana siguiente logramos ya de la vista de aquel célebre Cabo y de sus inmediaciones, aunque los repetidos chubascos del Oeste nos la interrumpiesen á veces: la mar era llana y el tiempo no manif estaba en su semblante la menor apariencia de querernos contrariar.

Este Cabo, el que más se señorea sobre el mar en todos aquelios contornos, parece cortado á pico, le rodean varios islotillos, y aunque con la mayor verosimilitud, no pertenezca el mismo sino á una isla de las muchas que componen la Tierra del Fuego, se presenta, sin embargo, como el verdadero límite de unas piedras inmensas, áridas y desiertas por la parte del Oeste; y por la del Este de unos terrenos más suaves y fecundos, y por consiguiente de un clima ménos áspero y temible: no es extraña esta singular variedad de todas las circuns tancias de la Naturaleza á una y otra parte del Cabo para nuestros navegantes del Perú, los 
1)ic. 2t cuales, consiguiendo por lo común atravesar el Estrecho de Naire, y á veces aún costear con Noroeste las tierras siguientes al Cabo Buen Suceso, encuentran luégo en su meridiano aquellos temporales del Sudoeste, que han hecho siempre tan duradera y arriesgada esa navegación.

Reconocidas para las seis de la mañana todas sus inmediaciones, y poco inquietos que la cerrazón y la hora intempestiva no nos permitiesen referir á este punto ni longitud ni latitud, ya que el Capitán Cook había verificado uno y otro objeto con las mejores circunstancias, continuamos nuestra derrota hacia el Cabo Engaño y las Bernabelas, y nos favorecieron de tal modo los vientos, que para el medio día nos hallamos en latitud de $55^{\circ} 32^{\prime}$ y longitud de $60^{\circ} 5^{\prime}$, marcando al mismo tiempo la Isla Evout al Oeste $5^{\circ}$ Sur, y el extremo Sur de la isla nueva al Noroeste verdadero: el tiempo había tomado un semblante apacible y despejado, y después de veinte días de temporales casi contínuos, podíamos finalmente revivir en nuestra memoria tal cual idea de la existencia de un verano.

Los rumbos del Nornordeste al Nordeste que seguimos en la tarde con el viento del Sur-Sudoeste á cada paso más bonancible, nos condujeron muy luégo á unas tres leguas de la isla nueva, viendo sucesivamente las tierras altas interiores que parecen formar varias bahías profundas y abrigadas. A las ocho y media de la tarde, el Cabo Buen Suceso demoraba al Norte $8^{\circ}$ Este, dis tancia de ocho á nueve leguas, y el Cabo San Antonio en la Isla de los Estados al Norte $38^{\circ}$ Este de la aguja, sin que á la sazón pudiese apercibirse efecto alguno de corrientes. Poco después nos abandonaron de un todo las últimas ventolinas del Sur, y quedamos en una perfecta calma hasta las primeras horas de la siguiente mañanita, en las cuales entabló viento fresco y contrario del Norte.

La mañanita del 26 en que se nos habían declarado vientos contrarios para entrar en el Estrecho de Maire, no nos hizo tampoco variar de idea: era el tiempo sumamente placentero y despejado, la mar llana y el viento galeno, de suerte que nos parecía evidente una próxima alteración favorable que diese lugar á los vientos reinantes del Sudoeste; así nuestros bordos que se habían dirigido al principio al Este, variaron muy luego hacia las Tierras del Fuego; y como el viento fuese aumentando su fuerza á medida que el Sol se aproximaba al meridiano, ya para cl medio día por latitud de $55^{\circ} 4^{\prime}$ no distábamos más que unas tres ó cuatro leguas al Sur $6 I^{\circ}$ Este del Cabo Buen Suceso; se reía la bahía de este nombre al Norte $32^{\circ}$ Oeste y el Cabo San Antonio en la Isla de los Estados al Norte $12^{\circ}$ Este de In aguja.

Muy luego el Norte más rccio y algo más in- clinado, nos precisó á navegar sin juanetes y con Dic. 26 las gavias en un rizo, y nos condujo á poca distancia á barlovento del Cabo Buen Suceso: sabíamos que este era el extremo Nordeste de la bahía Valentín; se mantenía constantemente nuestro ánimo de acechar ocasión oportuna para embocar el estrecho y la dirección de la costa nos prometía un excelente abrigo al ancla ó á la vela mientras permaneciesen los vientos ya muy recios del Norte.

Prevenidos con el escandallo, nos dirigimos á internar cuanto fuese posible en la bahía; no encontramos fondo ni áun á media milla del frontón del Cabo, pero á distancia de dos ó tres cables, sondamos 50 brazas cascajo y piedra. Descubierta á este tiempo toda la parte interior de la bahía cuya mayor profundidad estaba en la dirección próximamente del Norte, prometía sí con la vista de una playuela, un fondo mejor en sus inmediaciones del que nosotros encontrábamos; pero daba también una idea nada ventajosa del fondeadero, enteramente desabrigado para los vientos del segundo y tercer cuadrante allí bastante comunes: el viento reinante á la sazón nos hubiera, sin embargo, inducido á mirar como una felicidad poder fondear, y á este intento ceñíamos con las gavias y el trinquete dispuestos á repetir los bordos necesarios, mas no tardamos en conocer la imposibilidad de conseguillo por las rachas fuertes del Norte que nos sobrecogieron al descubrir por la parte interior la tierra del Buen Suceso. No permitían las viradas ni la vela necesaria, y áun indicaban como precisa para el fondeadero más de una ancla, ya que las quebradas de las tierras medianamente altas que rodean por todas partes la bahía, causaban una fuerza extraordinaria en el viento.

El bordo que seguíamos nos condu jo á disminuir el fondo á 45, 37 y 30 brazas cascajo y piedra á medida que recalando al Sur de la punta frontera de la del Buen Suceso, atracábamos la costa siguiente, en la cual se hacía particularmente notable una lengüeta de tierra, indicio tal vez de un mejor abrigo: arribamos para costearla y reconocerla de cerca, y muy luégo desmayaron en esta parte nuestras esperanzas, viendo que no cubría abra alguna notable, y que á distancia de uno y medio cables conservaba aún un fondo de 28 brazas coral de la misma calidad que presentaban sus orillas: á este tiempo era fácil conocer por una grande humareda á dos millas al Sur que aquellas inmediaciones no estaban desiertas de habitantes, y que probablemente nos habían visto.

El plano de la bahía pudiera hacer inútiles cualesquiera descripciones, tanto más que su po. co abrigo ya no la hace tan útil como debíamos sospecharlo, por las noticias de los navegantes franceses que la frecuentaron al principio del 
Dic. 26 siglo. La ensenada interior promete ciertamente un mejor fondo, y una abundante y cómoda provisión de leña y agua; pero de todos modos son preferibles en mucho la bahía del Buen Suceso y otras de la costa que corre hacia el Cabo de Hornos.

Abandonada para las cuatro de la tarde la idea de fondear en aquellas inmediaciones, fué nuestro intento mantenernos á su abrigo hasta la mañana siguiente, y después, si los vientos fuesen igualmente tenaces, pasar al Este de la Isla de los Estados para navegar al puerto Egmont de las Islas Maluinas. Efectivamente, fué preciso adoptar este partido: hiciéronse rumbos y aparejo proporcionados y vencida hacia las ocho de la mañana la corriente que nos aconchaba sobre el Cabo San Bartolomé, seguimos costeando á distancia de unas tres ó cuatro leguas: el viento era variable desde el Nordeste al Noroeste, pero casi siempre recio y acompañado con lluvia, cerrazones y mal cariz; la mar no era gruesa, pero las corrientes formaban en ella remolinos frecuentes y elevados; finalmente, la tierra estuvo siempre cubierta de modo que no tuviésemos marcación segura al Cabo San Juan hasta las cuatro y media de la tarde, á cuya hora le marcábamos al Norte $78^{\circ}$ Oeste de la aguja, distancia seis leguas.

Debimos pues desistir de la idea de repetir las experiencias de la gravedad en el fondeadero del Año Nuevo, pues que la debilidad y natural cansancio de las tripulaciones iba en mucho aumento. Nos decidimos, por la misma razón, por el puerto Egmont, atento á la mayor suavidad del clima y á la facilidad de la aguada y demás objetos de las embarcaciones menores: ni á la verdad debíamos creer el plazo para alcanzar el último puerto más distante del que pudiese conducirnos á la Isla de los Estados.

Tuvimos tiempos variables y ménos tempestuosos hasta la noche del 3 I en la cual se decidió viento fresco del Sudoeste: á las diez del

En. r." día I. ${ }^{\circ}$ de Enero se avistaron los Salvajes, y al medio día, por latitud de $5 \mathrm{I}^{\circ} 5^{\prime}$ se les marcaba al Este $1 / 4$ Nordeste de la aguja, distancia cuatro y media á cinco leguas. El viento bien fresco, el tiempo bastante claro, y los conocimientos prácticos que creíamos tener ya de las inmediaciones del puerto, nos incitaron á no esperar la mañana siguiente para al canzarle aunque no distásemos de él ménos de 24 leguas: creíamos francos los canales intermedios los cuales nos permitirían una derrota más directa sin pasar al Norte de la isla Rasa; y las muchas islitas que debíamos propasar, serían otras tantas valizas para fondear siquiera en la bahía exterior de la Punta Bluff. Con estas reflexiones forzamos cuanto fué posible de vela, y prefiriendo el paso entre los Salvajes y las Llaves conseguimos para la una y media con un andar de nueve millas, En. r. hallarnos al Sur de la isla Rasa unas tres leguas. Ya próximos á los Salvajes fuimos sobrecogidos intempestivamente por turbonadas y rachas fuertes del Oeste hasta el Sur, las cuales, además de una salida demasiado precipitada sin permitirnos sondar, nos ocultaban á veces hasta los objetos más cercanos. El marinero del tope avisó al mismo tiempo que veía por la proa una cadena de restingas que unian al Salvaje inmediato: repetían más frecuentes las turbonadas; y cualquiera partido parecía en aquel trance igualmente aventurado. Como quiera que nuestros reconocimientos de I 789 nos debiesen hacer creer que el extremo Sur del Salvaje eran limpio de arrecifes contra lo que creían ver desde el tope, pareció el mejor partido atracar la isla á la menur distancia posible. Nos aproximábamos de este modo á los islotes las Llaves, cuando una clara casi momentánea nos descubrió un nuevo peligro. A distancia de una legua se apercibían dos islitas unidas con arrecife y éste se extendía luégo algún tanto al Norte formando con el Salvaje un canal de una legua escasa en el cual se notaban remolinos extraordinarios de las aguas, estrechadas sin duda por la oposición de la corriente con el viento. Por ventura era éste bastante largo para que pudiésemos orzar hasta el Noroeste, continuando así á corta distancia del Salvaje y aunque la elevación de los montes despidiese contínuamente unas rachas realmente increibles, nuestro buque y aparejo fueron capaces de resistirlas, por manera que sobre las cuatro principales, las gavias algo arriadas, pudimos poco después pasa á una milla del arrecife dejándole al Sur, y para las tres y media encontrarnos libres del riesgo indicado. Casi á un mismo tiempo cedieron de un todo las turbonadas, la mar y el viento, se serenó el cielo y manifestándonos ya todas las apariencias como imprudente el aproximarnos en la restante tarde al fondeadero, emprendimos con el trinquete y las gavias en dos rizos el esperar la mañanita siguiente sobre bordos inmediatos al Salvaje.

La noche fué hermosa y apacible: no así las primeras horas del día 2, en las cuales las turbonadas del Oeste al Sur fueron bien frecuentes (I).

Para la mayor exactitud de las experiencias del péndulo simple se atendió á que el observatorio se estableciese en paraje ménos expuesto á los vientos reinantes del Oeste, con cuyo motivo,

(r) Sin cmbargo, á las diez pudimos atracar la Punta Bluff, y antes del medio día vernos dentro del puerto con sondas de ro brazas. El viento fresco del Sudoeste nos precisó después á dar algunos bordos para alcanzar el fondeadero que habíamos tomado en ${ }^{789}$, y así cran las dos de la tarde cuando pudimos dejar cacr cl ancla á corta distancia de la aguada. 
situado en la orilla Sur de la dársena, distaba del otro del viaje anterior unos dos cables al Sur $20^{\circ}$ Este de la aguja; los cimientos para el cuarto de círculo y para el péndulo simple se formaron con losas sólidamente pisonadas. Depositados los dos relojes en una de las tiendas, se procuró también que estuviesen elevados del suelo, separados de la humedad y precavidos del frío, y si el día siguiente del 3 no hubiese sido constantemente lluvioso á causa del viento Norte, la primera época de nuestras observaciones se hubiera sin duda establecido en aquel mismo día, no pudo el tiempo contrarestarnos con iguales dificultades en los demás objetos de nuestra escala, los cuales, si bien secundarios, no podíamos mirar con indiferencia; y eran la caza, la pesca y un acopio abundante de apio silvestre: fué la primera abundante, pero no tanto que no se extrañase ya la mucha concurrencia de buques en aquellos contornos: tuvimos la felicidad en cuanto á la segunda de coger con corral cerrado en la marea alta una cantidad no menor de 40 á 50 quintales, todos de la misma especie del bacalao y de un sabor y tamaño realmente agradables.

Una atención no ménos precisa en nuestras medidas actuales era sin duda el restablecimiento de los enfermos, los cuales en mucho número y sumamente debilitados, esperaban con el esparcimiento y recreo de la tierra aquel alivio que ya de ningún modo pudiera proporcionárseles en el mar: con este intento se había ya construído una tienda, á donde pudiesen comer, descansar y abrigarse ó de las aguas ó de los rayos ardientes del Sol, y como no tardasen en disfrutarla cuando el tiempo no era absolutamente contrario, se advirtieron inmediatamente sus efectos y vimos disiparse poco á poco en el mayor número las calenturas, obstrucciones y debilidades casi invencibles hasta entonces.

No era, sin embargo, la estación actual la más favorable para este intento ni para las observaciones celestes: con mucha frecuencia nos acosaban recias granizadas y vientos del Sudoeste, los cuales hacían á veces molesta la comunición con tierra, malograban las alturas correspondientes de la tarde, é imposibilitaban la caza y la pesca; esto mismo era un nuevo inconveniente para la marcha uniforme de los relojes marinos en el observatorio, pues variaba de un momento á otro de $r 0^{\circ}$ y $r z^{\circ}$ el temperamento, y la humedad repentina nos amenazaba de variaciones aún más temibles en su movimiento.

Aprovechándose á pesar de estos inconvenientes las ocasiones oportunas para los objetos que nos habíamos propuesto, y sustituyendo cuando hubiese alguna alteración notable de los relojes el método de las alturas correspondientes á las absolutas, deducida ya de antemano la excentricidad del cuarto de círculo, pudimos en un corto plazo de ocho ó diez días, ver repetidas con bastante pulso y seguridad las experiencias de la gravedad, de modo que ya sus resultados en esta parte importantísima del hemisferio austral pudiesen mirarse como bien satisfactorios.

En el entretanto habían sido varios los incidentes ocurridos, relativamente á los diversos buques americanos surtos ó en el mismo puerto ó en sus contornos. Casi diariamente las lanchas grandes recorrían las islas interiores; había fondeado el día 9 en el puerto una goletilla de la misma nación perteneciente á un buque surto hacia la Punta Oeste de las Islas, é imposibilitado por su mal estado de navegar; todos necesitaban galleta y este último algunos efectos navales que había pedido, mas no conseguido en el establecimiento nuestro de la Soledad; finalmente, á medida quẹ se dilataban estas demoras, crecía el extrago de los lobos marinos de modo que su destrucción, como ellos mismos confesaban, parecía bastante próxima. Semejantes procedimientos combinados con la interpretación ménos equívoca del artículo $6 .^{\circ}$ del último tratado del Escorial, nos decidieron, á no ser testigos indiferentes de un daño tan considerable para los in tereses nacionales ó un medio poco cauto para que con los auxilios solicitados fuesen aún más duraderas estas pescas; combinando una y otra atención, con el derecho más inviolable de la hospitalidad, con la mayor seguridad de no enturbiar la tranquilidad pública y particularmente con el cuidado de que no se ajase el honor del pabellón con unas intimaciones fáciles de evadirse sin el menor escarmiento.

Llamados los dos Capitanes de los buques surtos en el puerto y el Capitán White de la goleta pequeña, se les hizo ver por cuántos títulos debía considerarse como posesión nuestra, todo lo que se comprendía bajo el nombre de las Islas Maluinas; cuánto eran nocivas á los intereses nacionales las pescas en que entendían; cuánto sería reprensible que fuésemos testigos indiferentes de semejantes abusos, y cuánto les sería fácil eludir nuestras medidas transfiriéndose á otros puertos no distantes, mientras durase el plazo breve de nuestra demora en aquellos contornos, el cual seguramente no excedería de doce días; de suerte, que esta última circunstancia nos precisaba á desalojarlos sin pérdida de tiempo cuando no alegasen razón alguna justificativa para una demora ulterior; razón á la cual suscribiríamos gustosos, ya que ni era nuestro animo molestarles su fondeadero ni dejar de auxiliarlos en cuanto fuese posible: semejantes proposiciones no podían ménos de estrecharlos; presentaron al día siguiente entramhos Capitanes de los bergantines surtos en el puerto, papeles que acreditaban su intención dc salir luégo que concluyesen la aguada. En las 
instancias para auxilios, todos comprendieron la condición precisa de abandonar inmediatamente las islas, y finalmente, convenido el modo de satisfacerlos, cambiando el uno una barrica de tocino por el equivalente en pan, y el otro entregando pesos fuertes según precio de Lima por otros 20 quintales de pan, quedó resuel to que el Capitán White, ya que no tenía plata efectiva ni cosas útiles de cambio, descontase los auxilios que se le daban, sirviendo con su goleta en una excursión de siete días á los puertos inmediatos, la cual se puso al cargo del Piloto Inciarte: era sobremanera interesante reconocer particularmente los fondeaderos de la Punta Oeste hacia el Cabo Percibal, los cuales, por su más fácil entrada y salida y por una igual ó mayor seguridad cómoda á la que había en el puerto Egmont, parecían desde luego Jos únicos útiles para escala en la sucesiva navegación del Perú y mar Pacífico: quedó diferida para el regreso de la goleta la entrega de la mayor parte de los efectos, y en la mañana del Io diú efectivamente la vela el Piloto Inciartc, con orden de no dilatar su regreso más allá del I6: efectivamente lo verificó así, haciendo en aquel corto plazo varios reconocimientos importantes, enterándose por menor de las pesquerías inmediatas, y logrando sobre todo, de una agradable y fina hospitalidad de parte del Capitán de otro bergantín americano fondeado en la punta Oeste, el cual, en los catorce meses que allí había permanecido, había logrado una cantidad más que mediana de excelentes hortalizas y multiplicado en una isla inmediata algunos puercos y conejos.

En conserva del Capitán White y del Piloto Inciarte, vino también al puerto otra lancha esquifada con seis marineros ingleses, tres de los cuales solicitaron y obtuvieron plaza á bordo: separados voluntariamente (según aseguraban) de la embarcación inglesa á que pertenecieron siete meses antes, y abastecidos con esa lancha y bastantes víveres, habian continuado por su cuenta la caza de los lobos marinos, y entregado últimamente á un buque americano que navegaba á la China esta especie de pacotilla para su venta sucesiva.

Concluídos así todos los objetos que nos habían conducido al puerto; hechos á la vela los dos buques americanos; auxiliados los demás para que lo verificasen en igual modo; restablecida mucho la tripulación; completada la aguada y hechos en este mismo día los posibles acopios de aves y de apio silvestre, ya pareció tiempo oportuno de abandonarle, y en la misma tarde del I 7 quedó levada el ancla de tierra, y metida la lancha de suerte que pudiésemos dar la vela con las primeras claras del día siguiente, si el viento, como lo prometía, fuese favorable del Sudoeste.

Pero sucediéndole vientos fresquitos del Nor- te, entremezclados con algunas calmas las cua- En. les absorbieron los dos días siguientes, nos fué preciso permanecer en la misma posición hasta que hubiese ocasión oportuna de dar la vela.

Se presentó ésta en las primeras horas de la mañana del 20, en las cuales se declararon con buen cariz vientos galenos del Nordeste y Esnordeste. Dimos inmediatamente la vela, y al medio día, después de algunos bordos, conse. guimos vernos fuera del puerto, y con proa al canal entre los Hermanos y las Piedras Blancas. Nada ocurrió que merezca recordarse en la siguiente travesía hasta la bahía de Santa Elena; avistamos el Cabo Blanco y observamos en sus inmediaciones para rectificar algunas dudas sobre la latitud que le habíamos asignado en I789. Los vientos del Oeste, bien frescos, nos condujeron después en pocas horas al otro extremo del Golfo San Jorge. En la tarde del 28 por sondas de 55 brazas chinos, ya no distábamos sino cuatro leguas de la Punta alta de San José, y al medio día siguiente pudimos dar fondo en ocho y media brazas arena y chinos en la caleta más Norte y Oeste.

La aparente seguridad que debían inspirarnos la estación en que nos hallábamos, la tradición de los pilotos de aquellas costas y nuestras mismas experiencias de 5789 , reunída á la inmediación de las playas y al regular abrigo de los vientos reinantes del Noroeste-Norte hasta el Sudoeste, nos hizo parecer al principio bastante agradables, así nuestra situación como aquellos contornos. aunque la una nos dejase descubiertos próximamente desde el Este al Sur, y los otros no presentasen más que unas lomas áridas en un todo semejantes á las del puerto deseado: mirósc por la misma razón como accidental la excesiva fuerza con que en toda la tarde sopló el Nordeste y Nornordeste, obligándonos á de jar caer segunda ancla; y como la noche y la mañana siguientes fueron sumamente apacibles y calmosas, tuvimos lugar de aproximarnos sobre las espías tendidas en la tarde anterior cogiendo últimamente la mayor inmediación á la tierra en la caleta indicada por fondo de tres y media brazas arena en bajamar: en esta posición, y ya amarrados con dos anclas Norte y Sur, distaríamos medio cablc de los pedruscos de la punta Este de la cala y un cable del frontón opuesto: serían otros dos cables la distancia de la playa interior en la cual habíamos determinado colocar el observatorio para las importantes experiencias de la gravedad, y por cuanto hubiésemos reconocido con el escandallo las calidades del fondo, no parecían amenazarnos peligro alguno nuestras amarras: ya tranquilos por esta parte, no tardamos al mismo tiempo en tomar aquellas medidas que pudiesen conducir á la mayor seguridad del buque y á emprender las proyectadas tareas astro- 
En. 29 nómicas: se condujeron á tierra los relojes marinos, se plantó el cuarto de círculo con la tienda, y en la misma mañana, conseguidas las alturas correspondientes, pudo deducirse la longitud del observatorio por los relojes marinos y fijarse la primera época de su nueva marcha: el tiempo á la sazón parecía sumamente favorable á las operaciones proyectadas, brillaban sobre el horizonte con igual claridad ó bien el Sol ó las estrellas: la playa inmediata al observatorio presentaba un abrigo fácil y constante para los botes y para la atención precisa á las mareas: era sumamente corta la distancia de la corbeta al observatorio, y finalmente, el viento del Sudoeste que soplando con exceso fresco en aquella tarde nos había precisado á dejar caer la esperanza, había cedido casi de un todo al ponerse el Sol.

Este semblante placentero que había tomado á nuestra vista el paraje que ahora visitábamos, no debía ser sino momentáneo, y debieran al contrario sucederle otros muchos riesgos que no podíamos imaginar. Desde las diez de la noche inmediata empezaron á entablar ráfagas sumamente fuertes del Oesudoeste y Sudoeste, las cuales, como quiera que nos aproximasen con la popa á las piedras de la punta del Este, hacían nuestra situación bastante precaria si faltara el cable ó garrara algo el ancla: era la mar gruesa, se hacía sumamente arriesgado y penoso el que la lancha, aprovechando tal cual recalmón, tendiese el anclote grande al Sudoeste para que nos sirviese al mismo tiempo de amarra y de espía si fuese preciso dar fondo á la esperanza.

No fueron vanas estas precaucioneș; el viento, poco después de salir el Sol, arreció de tal modo, que parecía imposible pudiésenle resistir los cables; fué preciso clestacar al mismo tiempo un trozo de marinería que rehiciese las tiendas derribadas; toda la restante fué empleada inmediatamente con la lancha en tender el ancla de la esperanza por la espía, y el peligro de un naufragio pareció ya tan inminente, que debieron comprenderse entre las medidas del momento las de remitir á tierra los utensilios más precisos do carpintero y calafate, diferentes armas y municiones de guerra y algunos aparejos para varar la lancha; al mismo tiempo para que no desmayase la empresa, ya que todo parecía amenazarnos la continuación de aquel viento, emprendiéronse las experiencias de la gravedad; el Piloto Inciarte se ocupó en medir una base y repetir las marcaciones con el teodolito para un. plano breve y exacto del puerto; se destacaron algunos cazadores, no tanto con el objeto de la caza cuanto con el de buscar agua en esos contornos; era este un punto demasiado importante para que le descuidásemos en semejante trance.

Pero por rentura resistieron los cables la bajamar (aunque estuviésemos en el novilunio); fué menor de lo que nos anunciaban las noticias ad- En. 29 quiridas anteriormente, y en fin, hacia las once llamó el viento de golpe al Sursueste, el cual, á pesar que nos obligaba al mismo tiempo á tender una espía y sobre ella la cuarta ancla, calmó inmediatamente y disipó todo recelo del naufragio.

Apenas bastó toda la tarde para desenredarnos algo de una parte de las amarras que teníamos en el agua, tanto más que continuaba una ola gruesa sorda del Sueste. Las primeras horas de la noche se aprovecharon en el observatorio para determinar su latitud con varias alturas meridianas, y la mañanita siguiente, sin que se interrumpiesen las experiencias de la gravedad, la pesca, la caza y las pesquisas interiores de la aguada, se dedicó también desde las primeras claras al reconocimiento de los cables que teníamos averiados, debiendo sospechar la existencia de algunos ratones, aunque el escandallo no nos la hubiese indicado.

Efectivamente, los calabrotes tendidos al Sudoeste, el cable de tierra y áun el de fuera estaban considerablemente rozados, y como al mismo tiempo el poco fondo en que nos hallábamos combinado con el incremento diario de las mareas nos expusiese á tocar en bajamar, fué preciso determinarnos á mejorar de amarradero y de amarras, antes que nuevos vientos tempestuosos sustituyesen á la calma de que gozábamos: al medio día se emprendió esta faena, y antes del anochecer ya nos hallábamos en seis brazas arena distantes dos cables del amarradero antiguo y fortalecidos ó cambiados los cables.

Este día, que fué medianamente apacible, aunque con exceso caluroso, había dado muchas esperanzas á nuestros cazadores de poder en parte con la vigilancia y destreza, y en parte con la constancia, conseguir la muerte de algún guanaco: pero eran éstos tan excesivamente finos en el olfato y ágiles en la fuga, que quedaron aquéllas enteramente ilusas, y apenas pudieron resarcirlas siquiera en parte varias perdices y otras muchas aves acuáticas que aumentaron, ó nuestra comida ó nuestras colecciones de Historia Natural. Ningún rastro de agua ni de habitantes se había hallado aún; si se exceptúan relativamente á la primera algunos pozos bien salobres inmediałos á la playa y señalados en el plano, y en cuanto á los segundos, algunas piernas de guanaco recién muertos, $\mathrm{y}$ los mismos huesos y pozos sepulcrales que ya había advertido muchos años antes el Teniente de navío D. Manuel Pando.

Entretanto, una marcha bien uniforme de los relojes, nos había dado en el observatorio resultados seguros para las experiencias de la gravedad: el plano de la bahía estaba casi enteramente concluído: reconocidas, bien á pesar 
En. $3^{\text {I }}$ nuestro las sondas, deducida la latitud, y finalmente, con nuevos resultados de los relojes marinos, comparada la longitud actual con la que habíamos determinado en el viaje anterior, resultaban ahora las longitudes al Oeste del puerto Egmont.

\begin{tabular}{|c|c|c|}
\hline & Por el núm. ${ }^{\circ}$ r. & Por el cronóm. 7 r. \\
\hline $\mathrm{Y}$ eran las del año 1789. & $\begin{array}{l}5^{\circ} 32^{\prime} 5^{2} \\
5 \cdot 24 \cdot 15\end{array}$ & $\begin{array}{l}5^{\circ} 30^{\prime} 52 \\
5 \cdot 24 \cdot 15\end{array}$ \\
\hline $\begin{array}{c}\text { La diferencia actual por } \\
\text { consiguiente. . . . }\end{array}$ & 8.37 & al Oeste 6.24 \\
\hline
\end{tabular}

Error, á la verdad, bien despreciable, mucho más si se atendiese que una parte de esta diferencia se había advertido ya sobre el Cabo Blanco; que el movimiento de los relojes había variado según el nuevo examen, y que una breve travesía desde allí á Montevideo, pudiera disiparle todavía casi de un todo. La latitud del observatorio resultó de $44^{\circ} 30^{\prime}$, algo menor de la que habían dado las bases de I789; la variación magnética de $19^{\circ} 7^{\prime}$ al Nordeste y el establecimiento de la pleamar en el día del novilunio á las cuatro de la tarde creciendo el agua hasta I7 y $1 / 2$ piés de Burgos, bien que por las señales advertidas en algunas partes de la costa, podía sospecharse que en algunas ocasiones llegase hasta 20 ó 22 piés.

Después de todo lo que habían desfogado los vientos del tercer cuadrante, debíamos prometernos en la apariencia una demora mucho ménos incómoda, tanto más que había pasado el novilunio, y que la constante serenidad del cielo parecía apoyar tales conceptos: á pesar de esto, para las diez de la noche ya nos acosaban nuevas ráfagas recias del Sudoeste con algunos aguaceros, y para la media noche ya nos habíamos visto precisados á dejar caer por cuarta vez la esperanza: tantas incomodidades y un trabajo tan asíduo de la gente, cuyo término ya no era fácil acertar, nos determinaron á abandonar lo más luego el fondeadero, con cuyo objeto se destinó todo el día siguiente, que fué bastante apacible, á repetir por dos veces las experiencias del péndulo simple, y á reconducir luégo á bor"do los relojes marinos y los muchos utensilios que en los días anteriores habíamos depositado en tierra: últimamente, para el principio de la noche quedó levada el ancla del Norte y metida la lancha y demás embarcaciones menores, prontos, por consiguiente, á dar la vela en la mañanita siguiente.

Cuanto más nos apartábamos de las latitu des altas, eran tanto más agradables y placenteros los días, más suaves los vientos y más viva la memoria de aquellos paralelos felices en el hemisferio opuesto, por los cuales ansiábamos después de cuatro años y medio. Hicimos inmediatamente derrota para atracar la costa al Fub. .." Norte de los bajos del río Colorado, siguiéronse periódicas las líneas de sonda al andar del banco y en la mañana del 9 por fondo de 24 brazas arena fina parda, se vió una larga extensión de costa presentada bajo el aspecto de diferentes islotes, según sobresalían unos á otros los muchos méganos de los cuales se compone.

La latitud en que nos considerábamos; la dirección siguiente de la costa hacia el Oeste y la misma disposición de las puntas apenas salientes, no nos dejaron duda que la tierra más inmediata era la que habíamos distinguido en nuestras cartas con el nombre de Punta San José, extendiéndose luégo los extremos más occidentales hacia la bahía de la Asunción, poco distante del río Colorado. Todo cuanto veíamos en torno desde el Oesnoroeste hasta el Nornordeste no presentaba más que un suelo arenoso y seco, en todo semejante á los méganos del Cabo San Antonio; ni era fácil descubrir ensenada alguna que presentase un abrigo siquiera mediano, ó alguno de los muchos riachuelos, ya descritos en aquellos mismos contornos por los Padres Cardiel y Quiroga.

A medida que nos habíamos acercado á la costa había avanzado mucho el viento; y áun llamádose al Sueste de suerte que nos fué preciso con la mura estribor para continuar los reconocimientos: las sondas se mantuvieron entre 2 I y 26 brazas arena fina negra, y no omitidas las bases ni las observaciones reiteradas de longitud, pudimos al medio día hallarnos á tres y media leguas de la costa por latitud de $38^{\circ} 5^{0^{\prime}}$ y longitud $6^{\circ}$ I $5^{\prime}$ de Santa Elena.

Fué igualmente clara y calmosa la tarde, la cual se aprovechó cuanto fuese posible, atracando las playas hasta una distancia de tres leguas escasas, sin que disminuyesen las sondas de las 26 á las 27 brazas: últimamente, á las cinco y media rolando ya al Este $y$ Esnordeste el viento más fresquito de la virazón, tomamos las muras á babor para disponernos sobre un bordo nuevo largo á reconocer otro trozo de costa en el día siguiente.

La calidad ya indicada del terreno de las orillas, hace que no puedan extenderse á mucha distancia las marcaciones, y muy luégo con el sólo apartarse de seis á siete leguas de la playa, se ocultan casi á un mismo tiempo todos los objetos, no quedando rastro alguno de las inmediaciones de la tierra, sino la sonda, pues no suelen avistarse las aves en toda la extensión del horizonte.

No tardó en las primeras horas de la noche cn rolar el viento algo más al Norte, siéndonos así asequible desde las nueve no descaecer más hacia el Sur, y ceñir desde las dos de la manana al Nordestc con un andar de cuatro á 
F.b. a." cinco millas, y con sondas uniformes de 30 á 34 brazas arena fina; aumentaron éstas luégo en la mañana siguiente hasta 40 brazas, mientras continuábamos el bordo de fuera, y disminuyeron al contrario, así que á las diez inclinándose nuevamente el viento al Nornordeste, viramos con todo aparejo al cuarto cuadrante.

Estos rumbos, y el mismo viento algo más fresco que en la mañana, nos proporcionaron ya para las dos la vista de la costa, cargada con mucha calima y distante en solas seis leguas: en efecto, para las cuatro y media, por sondas de I7 brazas, ya nos hallamos á dos leguas y media de la orilla, en donde veíamos sobre las lomas inmediatas pastar tranquilamente manadas numerosas de caballos: pudimos de este modo añadir á las tareas de la tarde anterior un nuevo trozo importante de costa é igualmente exacto por 10 que toca á la longitud y latitud, y terminado ahora en el Cabo San Andrés, el cual quedó situado cn latitud de $38^{\circ}$ I $2^{\prime}$ y longitud de $7^{\circ} 30^{\prime}$. Iiste punto puede considerarse como algo más notable de todos los demás que se piesentan en aquellas inmediaciones, así por su mayor entrada en el mar y por ser el principio desde donde la costa inclina mucho más al Norte, como porque tiene una pequeña altura ó montecico por su parte del Oeste, compuesto de las mismas arenas, pero mucho más elevado y con figura alomada por todas partes.

Ya, pues, nuestras tareas de este día se daban la mano con los trabajos hechos en I 789 por el Teniente de navío D. Juan de la Concha, cu- yas marcaciones se habían extendido hasta los Fel. ro $37^{\circ} \mathrm{y} / 2$ próximamente, cuando las nuestras alcanzaban ahora los $35^{\circ}$; esta reflexión debía tranquilizarnos mucho sobre los eventos venideros, aunque no fuese nuestro ánimo el alejarnos de la costa, si los vientos, variando como en los días pasados entre los terrales y las virazones, aunque siempre inclinados al Norte, hiciesen esta navegación más util y expedita.

En ef ecto, no tardamos en experimentar nuevas contrariedades, bien sea por la variedad ó por la fuerza y dirección del viento, las cuales al principio nos precisaron á navegar algo desatracados de la costa; y después, ya próximos al paralelo del Cabo San Antonio, nos dictaron como necesario ceñir al Este para pasar al Sur del banco Inglés: corría á la sazón viento tempes tuoso del Sursueste con mar gruesa y tiempo bien cerrado; por consiguiente, aunque la sonda nos guiase con bastante seguridad, siempre nos hubiéramos visto precisados, careciendo de la latitud, á dar fondo á mucha distancia de Montevideo y con una grande probabilidad de garrar.

Cedió finalmente el viento en la noche del I 3 . Al día siguiente pusimos la proa á la Isla de Lobos, y habiéndola avistado en aquella misma tarde, hicimos inmediatamente derrota para el puerto de Montevideo, y le alcanzamos en la noche del I4, con la satisfacción que de allí á pocas horas fondease igualmente la ATREvidA, y entrambas quedasen amarradas en las inmediaciones de la fragata Comandante de Armadilla.

\section{Separación de las corbetas desde el puerto del Callao y navegación de la Atrevida al de Talcahuano.}

Atendiendo á las órdenes de S. M. para los objetos en que debían emplearse las corbetas antes de llegar al Río de la Plata, y á la declaración de la guerra con la Francia, se había acordado en junta de Comandantes y Oficiales la separación de estos buques, á fin de emplearse cada uno en los trabajos convenidos; siendo muy remoto el encuentro de los enemigos por estos mares para que los mirásemos como un obstáculo a desempeñarlos.

Con este tin me mandó D. Alejandro Malaspina que desde la salida de este puerto me considerasc para maniobrar sin sujeción alguna á la conserva, y con toda independencia aunque fuésemos á un mismo destino, ó hiciésemos un mismo rumbo. La salida se prefijó para el día
I5, y era difícil verificarla si el arreglo de las listas hubiese de concluirse para este tiempo. Pero estas dificultades se vencieron, trasladándose al Callao el Comisario de Marina D. José de Tagle, y con un trabajo constante de nuestros Contadores en los últimos días, que pudo alcanzar la ordenación de aquellos precisos documentos, sin los cuales no podría ejecutarse el ajuste final de las tripulaciones en Montevideo, según S. M. lo tenía mandado.

Algunos reemplazos de gente y la conclusión de otras pequeñas diligencias, no dieron lugar á la salida hasta el día siguiente. Esta demora aumentó el concurso de diferentes amigos de Lima que vinieron á despedirse para darmos las prueloas más sinceras de su estimación, hasta el 
Oct. is momento que probablemente sería el último que nos separase durante nuestra existencia. Entre aquéllos, hemos merecido un aprecio singular á D. Matías de Larreta, á quien por las cualidades notorias que adornan su persona, se haría tanta injusticia al referirlas, como seríamos ingratos en no publicar el celo y esmero con que se ha encargado de dirigir á España todas nuestras remesas ahora y anteriormente.

Desde por la mañana nos pusimos prontos á dar la vela en el punto que apareciese la brisa, la cual no entró hasta las tres y media de la tarde, á cuya hora mareamos todo aparejo en demanda de la punta Norte de la Isla de San Lorenzo, haciendo la misma maniobra por nuestras aguas la Descubierta.

Al ponerse el Sol habíamos rebasado aquella Isla, y advertímos que daba también la vela para Valparaiso la fragata mercante El Aguila que trasportaba los Oficiales D. José Espinosa y D. Felipe Bausá, que debían desde aquel puerto pasar por tierra á Buenos Aires, atendiendo á que el estado de su salud no les permitía seguir por el Cabo de Hornos.

Durante la noche, la brisa se mantuvo fresca del Sudeste, y nuestros rumbos fueron ciñéndola al Sursudoeste, y la Descubierta constantemente por la popa: á la mañana siguiente, precedida la correspondiente señal para pedir permiso de navegar independiente, se forzó de vela alcanzando al medio día la latitud de $I 2^{\circ} 48^{\prime}$ Sur y longitud por el I05 de $72^{\circ}$ oI occidental de Cádiz; hallándose la variación de la aguja por amplitud de $13^{\circ} 7^{\prime}$ Nordeste.

Perdimos de vista á la Descubierta en la tarde del día siguiente; y desde hoy principiamos ya á establecer el plan de combate y tomar todas aquellas disposiciones compatibles con nuestras circunstancias y el estado reducido de fuerzas en que nos hallábamos, aunque siempre mirásemos sumamente remoto el encuentro de los enemigos.

Se hizo saber á cada uno el sitio que debía ocupar en aquel caso, y dividida la gente en trozos se dió principio á los ejercicios de cañón y fusil, presenciados por los Oficiales encargados de su instrucción para conseguirla tan completa como era necesaria. La ejecución de estas medidas, tenían por principio buscar los medios de hacerla lo ménos incómoda al marinero. Nuestro objeto. principal era la verificación de los ramos científicos que abraza por su naturaleza este viaje, para cuyo fin no sólo es precisa la conservación física de los individuos, sino su buena disposición del ánimo, de la mayor importancia en esta clase de comisiones. Y estos principios suaves ó contemplativos que para esta se han mirado como preferentes, no fueran adaptables ó más bien serían perjudiciales, á la disci- plina rigurosa de todo buque de la Armada con oct. r8 diferente destino.

Así este plan de combate como la orden que le acompañaba incluyendo otras prevenciones oportunas para los Oficiales, se escribieron en el libro de guardias á fin de que constasen y tuviese cada uno á la mano la instrucción competente para su destino, encargando á los de guardia la doble vigilancia en reconocer con frecuencia los horizontes y registrarlos también de noche con anteojos, particularmente en esta travesía á Montevideo mientras nos hallemos en altas latitudes, para evadir el encuentro de bancas, no poco probable en la estación que debemos transitarlas.

Nos rodeaban la tarde del 20 algunas procelarias, cuyos pájaros anuncian por lo común alteración de tiempo, aunque su presencia, siendo entre los Trópicos no podíamos recelarla, á pesar de que los carices parecían más bien los que presiden en latitudes más crecidas en la estación de invierno, que aquellos agradables y templadas de los paralelos bajos por donde navegamos. Durante la noche, soplando el viento á fugadas y con algunos chubasquillos, obligó al amanecer tomar un rizo á las gavias.

Todavía el 24, en que cortamos el Trópico, no nos abandonaban una ú otra procelaria ni los mismos chubasquillos de los días anteriores: observamos al medio día la latitud de $24^{\circ}$ I I' Sur y la longitud de $80^{\circ} 39^{\prime}$ Oeste, teniendo ya de error la estima $2^{\circ} 42^{\prime}$ al Este de la del io5: la variación de la aguja por cuatro azimutes resultó de $10^{\circ}$ I $5^{\prime}$ Nordeste.

La tarde del 25 se vió distante por la popa la corbeta Descubierta, la cual no volvió á verse al amanecer; el viento, á la sazón, había rolado al Esnordeste bonancible, y por el Norte dió la vuelta al tercer cuadrante. Se hicieron entonces rumbos del Sursueste $5^{\circ}$ Este, prefiriendo ganar más bien latitud que longitud, apoyado de informes de los que practican desde Lima esta navegación, pues suponen no encontrarse los vientos del tercer y cuarto cuadrante en esta estación, hasta de los $30^{\circ}$ para arriba.

Sin embargo de que fundados en las referidas noticias no encontrásemos los vientos por la parte y en la altura expresadas, al día siguiente por la noche apretó tanto el viento al Sueste, que poco después de amanecer fué preciso tomar dos rizos á las gavias para impedir un descalabro que sin esta precaución hubiera sido inevitable. Nos hallábamos al medio día en la latitud de $27^{\circ} 37^{\prime}$ Sur y en la longitud de $80^{\circ} 44^{\prime}$. Los mismos vientos inclinados más al Este pero no tan frescos, nos acompañaron las dos singla duras siguientes; de modo que al medio día del 30 cogimos la latitud de $30^{\circ} 42^{\prime}$ y longitud de $84^{\circ} 32^{\prime}$ Oeste de Cádiz. 
Oct. 31 Desde este punto, fueron perdiendo los vientos su fuerza, tanto, que á la media noche tuvimos ya rentolinas del Sur y Sudoeste y navegamos por la mañana con viento entablado por esta parte. Nuestros rumbos fueron al Sudeste $5^{\circ}$ Sur corregido, para precavernos en caso de llamar los vientos hacia el Polo como lo acostumbran.

Muy presto comprobamos estas conjeturas, Nov. r. pues no bien había pasado la media noche, que despejando la atmósfera, se fijó por la mañana el viento al Sur bien fresco, con la mar bastante gruesa. En los dos días sucesivos se mantuvo el viento próximo al Sur no tan fresco, y aún por la noche del 3 se quedó calma para pasar al día siguiente y entablarse por el Oesudoeste; pero presumiendo yo que volviese á llamar de nuevo al Sur los rumbos que se hicicron del Sueste $5^{\circ}$ Este, era una precaución que podría acelerar nuestra llegada á Talcahuano, si se verificasen aquellas conjeturas. Las observaciones del medio día, indicándonos la latitud de $35^{\circ} 53^{\prime}$ Sur y la longitud de $77^{\circ} 03^{\prime}$, fué ya preciso principiar la singladura del día inmediato gobernando al Este $1 / 4$ Sueste hasta tomar el paralelo de la isla de Santa María por los $37^{\circ}$. El viento había tomado más fuerza por el Oesnoroeste y nada limpio como acontece aquí cuando soplan en este cuadrante; no obstante, le aprovechamos de día y noche con alas y rastrera, sin bajar la distancia por corredera, de ocho millas por hora.

Al mismo tiempo que nos lisonjeaban estas circunstancias con la llegada próxima al puerto del destino, un accidente casual ú olvido involuntario en dar cuerda á los relojes, disminuyó en parte esta complacencia. La falta del Sol para ejecutar observaciones, produjo se olvidase esta diligencia al Oficial saliente de guardia, que ordinariamente la ejecutaba. Advertido por mí á media noche en el Io5 este olvido, le dí cuerda al instante, pero no anduvo. Esta misma novedad le había sucedido en otras ocasiones, y con dos ó tres sacudidas horizontales se había logrado restituirle luégo el movimiento: en vano repetimos ahora este recurso, ni áun esforzarle como era regular, teniendo al fin que renunciar toda esperanza y persuadirme á que correría ya la misma suerte esta máquina que el núm. io, habiendo sido las causas exactamente iguales.

Sin embargo, queriendo yo apurar los medios de repararla, me pareció podría ser la causa una contracción de los metales, originada del frío que sentíamos ya bien sensible, y que algún calor moderado aplicado al reloj podría volverle á su estado anterior; en efecto, correspondieron las consecuencias á mis deseos, pues envolviéndole en una bayeta, me acosté poniéndolo debajo del cuerpo para que recibiese suavemente el calor hasta penetrar todas sus partes interiores; y cuando al cabo de cuatro horas me pareció tiempo suficien- te de conseguirlo, logré al fin á la segunda sacu - Nov. 5 dida restituirle el movimiento, y salvar una máquina, de cuyo uso hasta Europa había perdido las esperanzas.

Una oscuridad sin intermisión de día y de noche nos había acompañado, y no nos abandonó hasta la mañanita del 7 ; por consiguiente, aunque guiados por la estima á falta de observaciones de confianza, nos pusimos en el paralelo de la Isla de Santa María, cuando aquélla nos 10 manifestó.

Por fortuna logramos observaciones seguras, estando al medio día en latitud de $37^{\circ} 47^{\prime}$, la cual se diferenciaba en $42^{\prime}$ al Sur de la estima en los tres días que carecíamos de observaciones de confianza. No bien advertimos esta novedad, que se gobernó desde el instante al Nordeste $1 / 4$ Norte, porque siendo nuestra longitud de $68^{\circ} 46^{\prime}, y$ llevando un andar de siete á ocho millas, tampoco debíamos dudar de ver la tierra por la tarde.

La mar era correspondiente al viento tan fresco entre el Oeste y Oesnoroeste, como era extraño por esta parte en las inmediaciones de la tierra en la estación presente. Como las señales del tiempo aseguraban su permanencia, se dirigió la derrota á dar vista durante el día á la Isla de Santa María.

Antes de las seis de la tarde avisaron los gavieros de verse la tierra por la serviola de estribor. Por la latitud del medio día, inferimos fuesen unos altos ó cerros más al Norte de los de Tucapel, y por consiguiente, muy breve alcanzaríamos á ver la citada isla. El tiempo estaba tan calimoso hacia la tierra, que no era fácil reconocerla sin llegar á cuatro ó cinco leguas de ella; y efectivamente, cuando cumplimos esta distancia, se nos presentó á la vista la Isla de Santa María, la cual, siendo la tierra más saliente al Oeste, no era posible confundirla. Desde el anochecer, ceñimos el viento del Oeste con muras á babor, para cumplir durante la noche la latitud de la boca del puerto.

Al romper el día, con la costa á la vista arribamos al Esnordeste con fuerza de vela, cuyo rumbo indicado por las marcaciones, nos conducía á la tierra baja antepuesta á las Tetas de Viovio, las cuales, cubiertas de calima, se nos ocultaban todavía. Por las marcaciones sucesivas á los extremos de la isla, el del Norte al Sur $58^{\circ}$ Este y el del Sur al Sur $42^{\circ} 30^{\prime}$ Este, nos demoraba la boca del puerto al Nordeste $1 / 4$ Este distancia de cinco leguas.

Nos abandonó después el viento hasta el medio día, que entablado por el Sur iba refrescan. do por instantes, y nosotros acercándonos al puerto, gobernando al Esnordeste desde que observamos la latitud de $36^{\circ} 40^{\prime}$ Sur, marcándose las 'Tetas de Viovio al Este $7^{\circ}$ Sur.

Sucesivamente se orzó á pasar muy cerca de 
Nov. 3 Quiebra-Ollas, cuyo pedrusco atracamos á las tres, y rascando luégo la punta Norte de la Isla Quiriquina, ceñimos el viento, emprendiendo tomar sobre bordos el fondeadero, en el cual no se hallaba la DescubierTa, y sólo dos fragatas del comercio de Lima. El estar la tarde ya adelantada y el deseo de fondear temprano, me hizo doblar las diligencias para alcanzarle á pesar de las fuertes rachas y á prolongar las bordadas cuanto era posible, cuya última circunstancia, siguiéndose el bordo sobre Morro Verde cerca de Talcahuano el Viejo, caímos en tres brazas, donde viramos al anochecer, cogiendo ya de noche el fondeadero en $5 \mathrm{y}^{1} / 2$ brazas lama arenosa, por la popa de los buques mercantes el Rosario y la barca Búrbara.

Por la mañana temprano me avisaron de tierra hallarse á la vista la corbeta Descubierta, y á muy poco rato la vimos pasar delante de la boca chica de la Quiriquina, dando fondo á nuestro costado á la una y media de la tarde; pero al otro día nos enmendamos hacia el castillo de Gálvez, quedando este buque bajo las marcacio. nes de la punta Sueste de la Quiriquina al Norte $2^{\circ} 30^{\prime}$ Este y el Castillo Nuevo al Sur $4^{\circ} 30^{\prime}$ Oeste de la aguja.

Salida del puerto de Talcahuano y navegación en busca de la Isla de Diego Ramirez, y al reconocimiento de la parto oriental do las Maluinas por la corbeta ATREvidA.

Dic. 3 Ayer había dado la vela la Descubierta des. pués de haber esperado inútilmente el correo de Santiago, en el cual aguardábamos la correspondencia de España, cuya falta daba lugar á presumir haya sido apresado por los franceses el correo marítino.

Nosotros desde por la mañana tcmprano nos aprontamos á dar la vela, verificándolo á las once y media, momento en que apuntó la brisa, navegando al Este hasta franquearse de los bajos: calmó aquélla estando sobre la Quiriquina, declarándose el viento bonancible por el Oesnoroeste. La marea á la sazón nos era contraria, y por lo tanto, nos costó siete bordadas el rebasar á Quiebra-Ollas hasta las nueve de la noche.

Pudimos separarnos de la costa durante la noche como cinco leguas, y amanecimos entre una abundancia de ballenas, cual jamás habíamos visto; con el tiempo aturbonado y lluvioso, no obstante, se logró observar la latitud de $36^{\circ}$ $29^{\prime}$ Sur, marcando al mismo tiempo las Tetas de Viovio al Sur $57^{\circ} 30^{\prime}$ Este. Entablado el viento á la tarde por el Sudoeste, se tomaron las muras á babor para separarse de la tierra á buscar los vientos generales y elevarse con ellos á las altas latitudes, lo cual, por la inconstancia y suavidad de los vientos, nos costó algunos días, pues el 9 sólo nos considerábamos de la tierra 73 leguas, Dic. 9 sin pasar del paralelo de $37^{\circ}$. No era ya mi ánimo salir más al Oeste, porque también los vientos desde aquí se afirmaron de tal modo, que nuestra navegación empezó á ser muy rápida diariamente.

El día I I, hallándonos en la latitud de $42^{\circ}$ I $3^{\prime}$ y en longitud de $72^{\circ} 25^{\prime}$ occidental de Cádiz, se tomaron todas aquellas precauciones para seguridad del buque ó aumentarle la resistencia necesaria en los mares que íbamos á transitar. Se metió dentro la cebadera, se pusieron las uñas de las anclas dentro de la regala con los cepos sobre las serviolas, dando á las cañas un tortor de unas á otras; en la batería se trajeron al centro desde sus chazas los cuatro cañones de proa, pues la guerra obligaba á llevar montada la artillería, contra la práctica observada en estos mares.

Ya desde hoy empezábamos á conocer por la calidad de los horizontes las latitudes en que nos hallábamos. A la caída de la tarde cargó el viento del Oeste, precisando á navegar con dos rizos á las gavias; nuestros rumbos desde el medio día al Sur nos condujeron á pasar como 60 leguas de la Isla de Guafo y 33 de la de Santa Catalina, siendo desde aquí indiferente el ir más ó ménos cerca de la costa, pues lo que importaba era ganar al Sur únicamente para entrar en el paralelo de la Isla de Diego Ramírez, como 80 á roo leguas al Oeste de ella.

Al anochecer, entrando el viento en el cuarto cuadrante, aumentó con una fuerza extraordinaria, la mar muy gruesa y la garua contínua. No aclaró la cerrazón á la mañana siguiente hasta que el viento retrocedió para el Oeste y después al Oesudoeste cuando el Sol llegaba á las cercanías del meridiano. Por nuestra propia experiencia habíamos observado, que los vientos ordinariamente principiaban por el Noroeste ó Nornoroeste, pasaban luégo al Oeste, donde cargaban más para fenecer en el Sudoeste; mientras estaban en el cuarto cuadrante el temperamento era regularmente templado, pero desde el instante de rolar al Oeste en que aclaraba, era bastante frío y desagradable. Esta misma observación, coincide con la que expresa Sarmiento hablando de estos mares, y es la propia que experimentamos en el año de I79o cuando nos acercamos á las costas de esta parte de la América. Así entonces como ahora hemos notado, de que sin embargo de ser travesías los vientos del Oeste al Oesudoeste, también puede contarse con seguridad de que su duración por esta ú otra parte rara vez excede de seis á ocho horas.

Sin dejar de tener esta alternativa de vientos entre el cuarto y tercer cuadrante, observamos al medio día del 16 la latitud de $52^{\circ} 35^{\prime}$ Sur y la 
Dic. is longitud de $74^{\circ} 3 I^{\prime}$ Oeste, por cuya situación estábamos próximamente en el paralelo de los Evangelistas á distancia de Cabo Victoria 73 leguas. No fueron tan felices las dos singladuras siguientes, pues en la primera no pudimos alcanzar la latitud de la Isla del Aterrage de Cook, ni en la segunda la del Cabo Glocester, observando sólo la de $53^{\circ} 59^{\prime}$ Sur. En estos días se había notado una mayor abundancia de pájaros negros y de carneros, y que el viento había soplado con tanta fuerza cuando estábamos en los paralelos de la boca del Estrecho de Magallanes, que sólo nos permitía navegar con el trinquete y la gavia arriada sobre dos rizos; no obstante, tuvimos también varias horas de calma ó ventolinas del primero y segundo cuadrante. La variación de la aguja observada por azimutes era de $23^{\circ} 22^{\prime}$ Nordeste.

Para entrar desde el medio día en el paralelo de la Isla de Diego Ramírez, situada por $56^{\circ} 40^{\prime}$, se gobernó al Sueste, habiendo adelantado bien poco hasta entrada bien la mañana del día siguiente, en que entablado el viento por el Sursudoeste, conseguimos cumplir la latitud de la citada isla á las nueve y media de la tarde, á cuya hora arribamos al Esnordeste $5^{\circ}$ Norte, contando en aquel momento la longitud de $7 \mathrm{I}^{\circ} \mathrm{O} 2^{\prime}$, no distando ménos de roo leguas de la isla deseada. Ya en estas latitudes crecidas era el frío tan penetrante, con especialidad soplando los vientos del tercer cuadrante, que no alcanzaba precaución alguna de abrigo en el alcázar y castillo, haciéndose mucho más sensible á los marineros filipinos, á pesar de la ropa que se les había suministrado á la salida de puerto y de estar encendido el fogón todo el día.

Algunos chubascos presentados en el horizonte al amanecer por el primero y segundo cuadrante, se disiparon muy presto, tanto, que á las seis navegábamos con ala y rastrera de estribor.

Sin embargo de precavernos en el rumbo por algunas diferencias al Sur, todavía la latitud observada de hoy de $56^{\circ} 50^{\prime}$, nos indicó una diferencia de ró al Sur, ó de exceso á la que deseábamos conservar: la longitud era de $68^{\circ}$ I 3 Oeste. En el instante se metió al Nordeste á dis minuir aquella diferencia en latitud hasta las cuatro de la tarde, y desde aquí se siguió navegando de día y de noche, pues como los crepúsculos se alcanzaban unos á otros la distancia que se descubría de horizonte á las nueve, no daba recelo de navegar con riesgo de propasar la isla, de la que al medio día inmediato sólo nos considerábamos 36 leguas en longitud observada de $65^{\circ} 26^{\prime}$, y la variación por azimutes no daba más de $21^{\circ} 28^{\prime}$ Nordeste.

$\mathrm{Al}$ anochecer, descubriéndose un horizonte de sietc á ocho leguas, distábamos i 8 de Diego Ramírez: tomáronse dos rizos á las gavias, y con éstas y el trinquete, navegamos hasta cumplir Dic. $2 \mathrm{I}$ aquella distancia mientras no aclarase.

Hacia la media noche se largaron los rizos para estar prontos á forzar de vela desde el instante de romper el día. A la una y media avisaron la vista de tierra por el través de babor como al Norte, y á poco rato se descubría con clari. dad á distancia de seis á siete leguas, dirigiéndonos al propio rumbo del Norte á que se marcaba. Todas las razones que nos asistían en aquel momento, debían convencernos con evidencia de ser la Isla de Diego Ramírez la que teníamos á la vista, bien que afectada de un error en la latitud casi igual á la distancia á que estábamos de ella, sujetándonos á la estima desde el medio día: pero esta novedad no era extraña si atendiésemos á los cortos auxilios de la navegación en aquellos tiempos en que la situaron sus descubridores. Nuestra latitud á las dos de la mañana era de $56^{\circ} 39^{\prime}$, y por la longitud de estima traída desde la observada del medio día antecedente, nos considerábamos en meridianos de las Islas de San Ildefonso y tan sólo diez leguas del de la isla que anhelábamos.

Apenas habíamos navegado cuatro millas en vuelta de la tierra, cuando me avisó el Piloto que puse en las crucetas, de no ser una sola isla la avistada, sino tres pequeñas, sin comprender varios islotillos separados como al Noroeste de ellas, lo cual comprobamos con nuestra vista, á poco rato, desde el alcázar. Esta novedad debió hacerme sospechar de que no fuese la isla que buscábamos, pues las noticias constantes hasta ahora, sólo aseguraban la existencia de una sola, cuyos antecedentes me inclinaron á que fuesen estas las Islas de San Ildefonso, situadas por el Capitán Cook en su segundo viaje en latitud de $55^{\circ} 53^{\prime}$ Sur. Es evidente que para apoyar esta suposición mía, era necesario alribuir á la esti. ma un error en la latitud de $30^{\prime}$ al Norte desde el medio día anterior; diferencia, á la verdad, bastante considerable, y más habiéndose notado en sentido opuesto en los días antecedentes; pero como éstas no fueron crecidas para atribuirse á ef ecto de corrientes hacia aquella parte, tampoco era una consecuencia infalible de que ya por esta causa y por la irregularidad de su curso, guardasen hoy con nosotros la propia dirección que en los días pasados. Por otra parte, apoyaba también mi opinión de ser las Islas de San Ildefonso, la descripción que hace de ellas Cook, diciendo: "Que son un grupo de islas y rocas sobre el "agua, distantes cerca de seis leguas de la costa, "y en latitud de $55^{\circ} 53^{\prime}$ Sur." Esta exacta correspondencia que advertíamos en esta relación con la presencia de las islas, aunque era suficiente para persuadirnos de la seguridad de esta conjetura, todavía teníamos otras razones para apoyarla. 
Dic. 22

La posición en longitud de las islas de San Ildefonso era preciso mirarla bajo aquel grado de exactitud tan comprobado por los relojes que sirvieron á establecerla; y como nuestra longitud de aquella hora por el 72 y I0 5 también estaban acordes con la que determinó Cook á dichas islas, parecían reunirse todas estas razones para convencernos á la probabilidad de que las corrientes nos hubiesen arrastrado hacia el canal entre el falso Cabo de Hornos y la Isla de la Hermita, de cuya punta occidental no distaríamos más de 16 leguas bajo de esta suposición, y era justamente el rumbo ó dirección en que notábamos la diferencia.

También era cierto que esta cuestión se decidía, ú observando la latitud al medio día, ó con navegar en vuelta de la tierra firme, para que por la distancia, siendo esta mucho menor de las islas de San Ildefonso á la costa que la de aquí á la de Diego Ramírez, nos convenciésemos así para excluir toda duda. Yo hallé preferente ir á buscar el paralelo de esta isla, pues fuesen ó no ciertos mis conceptos, la latitud debía resolverlos, con la ventaja de que si no eran equivocados, resultaría entonces la doble utilidad de observar al medio día sobre ella, sin atraso alguno en la derrota: sin embargo, á precaución de toda contingencia por lo falibles que suelen ser los juicios en la mar, se gobernó desde aquí al Sueste después de corrida una buena base, hasta cumplir la distancia de 26 millas para llegar á la latitud propuesta de Diego Ramírez, en la cual nos consideramos á las siete de la mañana favorecidos del viento fresco á lá sazón. Las apariencias del tiempo cerrado y garuando, nos prometían pocas esperanzas de ver el Sol en circunstancias oportunas á nuestro intento. No obstante, fuimos bastante felices Don Manuel Novales y yo, en acechar algunas claras desde las diez de la mañana, y se anotaban las que eran de más confianza, por si (como así sucedió) nos privase el Sol de la altura meridiana en uno de los días que más nos interesaba.

Pero esta falta nos la compensaron las alturas tomadas en las mejores circunstancias para esperar resultados tan exactos como por la altura meridiana. Calculadas las primeras inmediatamente por el método de Mr. Dowes, resultó la latitud de $57^{\circ} \mathrm{I} 7^{\prime}$ Sur: novedad que me sorprendió tanto, cuanto presumiendo error en el cálculo ó en sus elementos, mandé gobernar forzando de vela al Norte $1 / 4$ Noroeste, en ánimo de avistar, si fuese posible, las ticrras del Cabo de Hornos en lo restante del día, para que la marcación decidiera de una ve $z$ si habíamos ó no de dar por cierta la latitud averiguada.

Esta desconfianza se destruyó con los resultados uniformes de otras dos operaciones distintas, la primera con dos alturas tomadas $I \delta^{\prime}$ antes del medio día la una, y la otra el propio in - Dic. 22 tervalo después; y dando todos tres cálculos, con una igualdad que admiraba, la latitud llevada al medio día de $57^{\circ}$ I $7^{\prime}$; no quedaba ya la menor duda de ser las Islas de Diego Ramírez las reconocidas, y no las de San Ildefonso como yo lo había imaginado.

Aunque fuese ya inútil á nuestro principal objeto continuar en demanda del Cabo de Hornos, seguimos sin embargo, el propio rumbo del Norte $1 / 4$ Noroeste con las principales y el viento bastante fresco por el Oeste, con el deseo de poder avistar hasta las nueve de la tarde cste punto del globo tan famoso por su nombre como temible de los navegantes. No era sólo pura curiosidad el seguir esta derrota, sino la importancia de rectificar la longitud de nuestros relojes, á fin de que la determinada á las Islas de Diego Ramírez, tuviesen toda la exactitud que exigiesen las facultades de nuestro alcance.

A las cuatro de la tarde se observaron longitudes por los relojes y señalaron la de $6 \mathrm{I}^{\circ} \mathrm{I} 5^{\prime}$ el I05; y $6 \mathrm{I}^{\circ} 2 \mathrm{O}^{\prime}$ el 72, occidental de Cádiz: con esto y ser imposible ya verificar mis deseos en avistar la tierra, hube de abandonarlos para dirigirme á dar vista al Cabo de San Juan en la Isla de los Estados con el propio intento.

Para no perder ei orden en la relación de nuestras ocurrencias de este día y volver á tomar el hilo de las operaciones practicadas en la colocación de las referidas islas, daré primeramentc una idea de ellas que sirva de gobierno á los navegantes, y una noticia individual de los medios empleados para determinar su posición verdadera: obligación precisa en que por naturaleza de la comisión estamos constituídos, para que conste la escrupulosidad con que miramos semejantes trabajos, aplicando los auxilios que facilita la navegación moderna, y expresando las circuns tancias de su uso para no salir garantes en lo venidero si á otras más feliccs que las nuestras se unen invenciones más exactas de las que sirven en el día en la práctica y progresos de la Geografía marítima.

Las Islas de Diego Ramírez fueron descubiertas en el año de I6Ig por Bartolomé García de Nodal y Gonzalo Nodal, hermanos, marinos de reputación, que mandando las carabelas Nuestra Señora de Atocha y Nuestra Señora del Buen. Suceso, salieron de Lisboa para estos mares en 27 de Setiembre de I6I8. Según parece, tomaron el nombre del Piloto Diego Ramírez Arellano, después Cosmógrafo y Piloto mayor del Rey en la casa de Contratación en Sevilla.

Es verosímil que aquellos naveg?ntes hubiesen descubierto á larga distancia dichas Islas, y por esta razón se les hubiese representado como una sola, según acontece con los grupos de ellas, cuando un punto determinado de vista ó la dis- 
1)ic. 22 tancia conveniente, no facilitan distinguirlas con claridad. Nosotros hubiéramos padecido igual error habiéndolas avistado con el horizonte que teníamos á mayor distancia de la de seis leguas, pues desde este punto, según resultaba de las bases, ya confundíamos el todo de las islas bajo la ilusión de una sola.

Así desde la cubierta como desde los topes, no se distinguieron más que dos islotes, el uno al Este y el otro al Oeste de la isla; el primero más alto que el segundo: también se vieron algunos pedruscos inmediatos. La isla es de suficiente altura para poderla ver en días claros á diez ó doce leguas, pues careciendo nosotros hoy de esta ventaja, la perdimos de vista al cumplir 28 millas distante de ella.

Por los resultados de las operaciones y observaciones verificadas hoy, retrocedidas á la hora de haberse corrido la base sobre las islas, quedan determinados los extremos orientales y occidentales de ellas entre los meridianos de $62^{\circ}$ $35^{\prime} 42^{\prime \prime}$, y de $62^{\circ} 43^{\prime} 36^{\prime \prime}$ Oeste de Cádiz, siendo su extensión de Este á Oeste de ocho millas próximamente: en cuanto á la latitud, las hemos situado entre la de $56^{\circ} 33^{\prime} 30^{\prime \prime}$ y $56^{\circ} 27^{\prime}$ $24^{\prime \prime}$ Sur (I).

Habiéndose opuesto á mis deseos las circunstancias del tiempo á dar vista al Cabo de Hornos, nos dirigimos para la Isla de los Estados. El viento del Oeste, á la caída del Sol arreció mucho, sin abandonarnos tampoco la garua. Con trinquete y gavías arrizadas gobernamos al Nornordeste, notando que á medida de acercarnos al Estrecho de Maire soplaba el viento con más fuerza, la cual fué disminuyendo hacia la madrugada, logrando á las diez y media de la mañana avistar la Isla de los Estados á distancia de nueve á diez leguas. Mientras estuvimos á la vista de ella, apénas nos dejó una cerrazón constante, y tan sólo aprovechamos un momento por la tarde para determinar el hallarnos á I5 y 1/3 millas distantes de la isla, y por consiguiente nos consideramos en latitud de $54^{\circ} 56^{\prime}$ Sur y en longitud de $57^{\circ}$ I $8^{\prime}$.

Desde este punto, hicimos rumbo directo á la Punta de Porpus en la islita más meridional de las Maluinas. Erami ánimo recalar sobre aquel paraje para costear el cúmulo de islas pequeñas que ciñen la grande de la Soledad por la parte del Sur. El viento fresco del Sudoeste nos favoreció sin intermisión toda la singladura, y nuestro andar, no bajando de seis á ocho millas, nos prometíamos entrar en el puerto de la Soledad al día siguiente, pudiendo contar ésta como una travesía

(I) Fstos resultados vinieron conformes con los que ejecutó separadamente la corbeta DEscubierTA átun habiendo logrado en su ejecución circunstancias más favorables á las nuestras. de las más felices, pues lográbamosá los veinti- Dic 24 dos días atravesar desde Chile á las Maluinas.

No bien hubo lugar á entregarnos á esta reflexión tan lisongera, cuando un fatal accidente vino á amargarla. El marinero Jorge Ramón cayó al agua desde la uña del ancla de estribor, y aunque nuestro andar era de seis millas llevando todo aparejo, no sólo quedamos en facha sino se echó el bote al agua antes de cumplir ocho minutos de tiempo medido por el reloj; hasta este instante me aseguraban los gavieros el verle próximo á un gallinero, al cual se dirigía por estar más cerca que de la guindola, con lo cual consentimos en que nuestra presteza en las maniobras salvaban la vida de este infeliz. Pero al llegar el bote al paraje indicado ya no vieron otro vestigio de su persona que el gorro sobre el agua, ni por más diligencias que hicieron no le encontraron. Este individuo era irlandés, desertor de una embarcación inglesa destinada á la pesca sobre las costas de la América, que vióse precisada á arribar al puerto del Callao, en donde así éste como otros tres marineros, también prófugos de la propia embarcación, fueron destinados á las corbetas por disposición del Virey á consecuencia de órdenes de S. M.

Volvimos al instante á forzar de vela en la confianza de descubrir alguna de las Maluinas antes del anochecer, tanto más preciso el conseguirlo, cuanto la falta de observaciones nos hacía desearlo con más empeño para dirigirnos en la noche próxima con otra seguridad.

El horizonte que nos rodeaba era bastante calimoso para anticiparnos la vista de las islas; no obstante, á la media tarde se descubrió una isla marcando sus extremos el del Sur al Sur $71^{\circ}$ Oeste, y el del Norte al Sur $75^{\circ} 30^{\prime}$ Oeste, rumbos á los cuales se marcaron al tjempo de medirse una base, pues viéndose una islita rasa al Oeste de la otra creimos, fuesen éstas las Islas de Beauchenes, mucho más no divisándose otras hasta horas después como era forzoso si fuesen las de los Leones ú otras contiguas.

Nuestras dudas tardaron poco en disiparse, pues siguiendo al principio los rumbos del Nornoroeste y Noroeste $1 / 4$ Norte con el viento muy duro por el Sudoeste, se consiguió con fuerza de vela qne apenas podía resistir el buque avistar las islas poco después de las nueve, y á poco tiempo fué preciso ceñir el viento con trinquete y gavias arrizadas la vuelta del segundo cuadrante. El viento continuó soplando por la noche con bastante fuerza, aunque por esto no se disminuyó el aparejo, atendiendo á conservar el mismo punto y empezar nuestros trabajos en la mañana siguiente desde la parte más meridional de las Maluinas.

Después de una noche sumamente fría, y cuando el viento desde las siete de la mañana era 
Dic. 25 ya más manejable, se forzó luégo de vela para llegar á las nueve á distancia suficiente para emprender nuestras operaciones. Arribamos desde aquí con viento fresco del Sursudoeste prolongando las citadas islas á los rumbos del Nornoroeste-Norte, y después, inclinándose para el Este, según lo exigía la dirección de las islas, de las cuales navegábamos como á tres millas. Muy presto vimos la roca de Sharg, pasando de ella todavía á menor distancia sin recelo de comprometernos, pues las sondas de la carta del Capitán Mac-Bride, de 30 á 40 brazas, nos ponía á salvo de todo encuentro peligroso. No obstante, llevábamos guardias en los topes para evitar con tiempo de toda rompiente sospechosa ó escollo que pudiera habérsele ocultado al referido Capitán inglés.

Siguiendo estas operaciones, teníamos á la vista las diferentes cartas de este Archipiélago para compararlas y elegir la que resultase más exacta.

Parecía imposible tanta discrepancia entre sí, todavía mucho más extraña al considerar la diferente latitud del puerto de la Soledad entre unas y otras, justamente á donde nos dirigíamos hoy á fondear sin otro auxilio ni práctico que estas noticias tan confusas ó encontradas. Por un plano inserto en la relación del viaje al Estrecho de Magallanes por la fragata Nuestra Señora de la Cabeza, estaba colocado aquel puerto en la latitud de $5 \mathrm{I}^{\circ} 52^{\prime}$ Sur; por la carta del Capitán Mac-Bride en la de $5 \mathrm{I}^{\circ} 42^{\prime}$ y por Mr. de Bougainville en $5 \mathrm{I}^{\circ} 3 \mathrm{O}^{\prime}$.

Tanta diversidad de situaciones nos obligaba á caminar con la debida precaución para buscar el fondeadero sin riesgo de sotaventarse, siendo preciso á este efecto ir costeando de cerca la tierra, á fin de que la configuración de la entrada nos iluminase para no equivocarla. Con esta precisión nos dirigimos á toda punta saliente ó ensenada, cuya derrota tan indispensable nos puso también á riesgo próximo de un naufragio.

Encaminándonos hacia una entrada, vimos repentinamente por la mura de estribor la rompiente de un bajo sin avisar ni el que estaba de guardia al tope, ni tampoco el escandallo que íbamos voleando indicaba novedad en el fondo no hallándole con I $_{5}$ brazas. En este momento distaríamos medio cable del bajo, y aunque nuestro andar no era ménos de seis millas, antes que el buque obedeciese al timón, tan solo dió lugar al tiempo preciso para no estrellarnos, pasando de él al tenerlo por el través como 20 toesas.

En el mismo instante enfilamos este bajo con uno de los puntos más notables ligado antes por las bases, y resultó hallarse en $52^{\circ} 06^{\prime}$ Sur á dis tancia de tierra como dos y media millas; situación que puede considerarse muy exacta no habiendo pasado más de hora y media de intervalo hasta la observación de al medio día. Para que Dic. 25 no se confunda este escollo nuevo con la roca de Sharg, me pareció oportuno darle el nombre de Bajo de Pascua, por la memoria del día en que le descubrimos, y en celebridad de haberle evadido tan felizmente.

Nuestra navegación desde aquí debió mirarse más cuidadosa, y los arrimos á la costa nos eran mucho más sospechosos con encontrar en ellos abundancia de cachiyullo, en el cual ordinariamente hay poco fondo.

Antes de tomar la altura meridiana, me avisó el Piloto desde las crucetas, como al Oeste reconocía una entrada con dos islitas próximas á la costa del Sur, semejantes á las que señalaba el plano del puerto de la Soledad. Se ciñó el viento al instante sobre las gavias, la vuelta del Sueste, así para observar con comodidad la latitud, en el día muy importante, como para examinar aquella entrada y discurrir el partido preferente que hubiésemos de seguir; pero nada conseguimos sino aumentar el número de nuestras dudas y lamentarnos de la falta de exactitud en documentos que deciden la suerte de los navegantes.

Resultando la latitud observada de $52^{\circ} \mathrm{O} 2^{\prime}$ Sur, si nos ateníamos á preferir como cierta la situación del puerto, la más meridional de $5 I^{\circ} 52^{\prime}$, era muy probable que la entrada á la vista, demorando al Oesnoroeste corregido, fuese la del citado puerto.

Con este concepto viramos hacia ella, y á poco rato aumentaba tanto la abundancia del cachiyullo en la boca, que no podía dudarse de la falta de fondo en ella ó de encubrir algún esco1lo temible.

Ya desde aquí las tierras principiaban á ser bien elevadas, haciéndose notables por su altura, de las que dejábamos al Sur, de modo que esta señal por sí sola, y la seguridad de hallarse el puerto ó su entrada en la parte más oriental de la Isla de la Soledad, son dos marcas infalibles para guiar á los navegantes sin otro auxilio al fondeadero; la noticia cierta de ellas nos hubiera ahorrado los cuidados y peligros que nos produjo su falta ó el error de las que teníamos, no habiendo aquí todavía concluído los riesgos á que nos han comprometido antes de llegar al puerto deseado.

Se iba conservando la orilla del cachiyullo para mantener la inmediación á la tierra y deducir de nuestras operaciones toda la exactitud necesaria. A las tres y media de la tarde descubrimos tres islotillos ó pedruscos salientes al Este, que anteceden al Cabo de San Felipe y son también una excelente marca para el conocimiento del puerto. Rebasado aquél fuímos orzando para dentro, atracando después el Islote Pelado, y emprendiendo sobre bordos alcanzar el fondeadero antes de anochecer, para lo 
Dic. 25 cual mantuvimos fuerza de rela á pesar de las rachas fuertcs que soplaban del Sursudoeste. Antes de virar la primera rez sobre los bajos de riamon vimos dirigirse hacia nosotros una lancha del establecimiento, maniobrando cautelosamente aunque nos viese con las insignias largas, y esto dificultó atracar, cuando ya lo intentó, quedándose en poco rato á bastante distancia por lá popa, pues nuestro andar no bajaba de cinco y media á seis millas. Yo no hice diligencia de esperarla, porque hallándome con un plano que debía considerar muy exacto, me era más importante el excusar toda detención para entrar cuanto antes en el puerto.

Pero bien pronto hube de desengañarme de la confianza que atribuía á dicho plano, y arrepentirme ya de no haber esperado la lancha para haber prccaviclo con cl auxilio del práctico los riesgos en que nos pusieron los enormes errores del plano.

A las siete y media, estando en la boca estrecha formada por la Isla de las Cabras (que llaman también de la Paja) con la de los Chanchos, advertimos en la medianía de ella un bajo á flor de agua, omitido absolutamente en el plano.

Una falta tan notable, era motivo suficiente para desistir del empeño de subir al fondeadero, no pudiendo ya fiarme del único auxilio que nos guiaba, á pesar de sernos la marea á la sazón favorable. Viramos, pues, sobre la misma Isla de los Chanchos, en fondo de cinco y media brazas piedra, en ánimo de ir á fondear en la cabeza del Sur de la Isla de las Cabras, cuya situación era la más oportuna para volver á dar la vela desde allí con los vientos reinantes del tercer cuadrante y coger con más facilidad el fondeadero. Ibamos costeando el veril de la Isla de las Cabras, por fondo de seis brazas, confiados en que la cxactitud de la sonda en el plano la habíamos comprobado hasta entonces, aunque no por esto dejábamos de ir voleando el escandallo.

En vano fueron todas estas precauciones, pues continuando por la misma sonda de cinco brazas, caímos repentinamente á tres, y por mucha presteza en las maniobras para facilitar la arribada, no obedeció el timón tan pronto, bien fucse por las pocas aguas que pescaba, como por la detención que causaría el sargazo sobre el cual navegábamos, y por consiguiente, no pudo impelirse la varada descle el portalón de estribor hasta la mura de la misma parte, infiriendo de csto y del fondo en tormo de la corbeta, el que apoyaba sobre alsuna picdra clevada dcl fondo, pues sólo en aquel punto teníamos dos brazas de agua, y en todo lo restante i 8 piés largos y sólo I5 á proa, calando el buque If escasos.

La mar" ni el viento sólo fresquito 'vinjendo por cncima de la isla, nos daban el menor cuida- do. Inmediatamente se aferraron todas las velas, Dic. 25 y el buque reposaba sin moverse para no temer que sus fondos recibiesen algún daño. Al mismo tiempo advertíamos que la marea iba creciendo rápidamente, según veíamos cubrirse las piedras de la orilla de la cual distaríamos algo más de un cable. Para ganar tiempo, se tendió un anclote con el bote por la aleta de babor al Norte, y á poco de virar flotamos en tres brazas, de modo, que apénas estuvimos varados media hora de tiempo. Franqueados hasta coger seis y media brazas arena gruesa, dimos fondo al ancla de babor, sobre la cual y la espía, permanecimos en la noche.

Ya para este tiempo había llegado á bordo un Oficial comisionado por su Comandante Don Pedro Sanguineto, Capitán de fragata de la Real Armada, que á la sazón se hallaba de Gobernador de la colonia y mandando el paquebot Santa Eulalia. Por el mismo Oficial pedí el práctico para la mañana siguiente, que hasta entonces no intentaba ir para dentro.

Efectivamente, llegó este al romper el día, y advirtiéndome no debíamos perder momento de dar la vela para aprovechar toda la marea favorable, lo verificamos inmediatamente sobre las gavias y el trinquete con viento fresquito del Sur. Con dos bordos montamos el bajo omitido en el plano, llamado el Galon, y fondeamos Noroesueste antes de las nueve en seis brazas lama, demorando el asta de bandera al Norte $64^{\circ}$ Oeste, y la punta Sur del puerto al Norte $82^{\circ}$ Este.

Operaciones hidrográficas ejecutadas en el puerto de la Soledad.-.Reflexiones sobre el estado actual de esta colonia, y ventajas que ofrece su situación.

Nuestro ingreso en este puerto reunía para nosotros la doble ventaja de combinar con un regular descanso de la tripulación, el reconocimiento y situaciones exactas de estas inmediaciones. Aun ciñéndonos al canal de la entrada, las puntas salientes que lo forman, las isletas adyacentes, y el examen de los varios puertos contiguos á la colonia con sus sondas, eran objetos que pedían algunos días y diferentes manos para desempeñarlos.

A este fin pensaba comisionar la lancha por dos ó tres días luégo que se concluyese la aguada, y por otra mano se ocurrió á establecer el observatorio en el almacen del Rey, situado en la punta del puertecito donde se hallaba fondeado el paquebot.

Era uno de nuestros principales deseos resolver la cuestión sobre la latitud de este puerto, y á este intento pasamos D. Manuel Novales, Don Jacobo Murphy y yo á observarla el día 28 en la playa al Sur del establecimiento, distante como dos millas. Al mismo tiempo D. Juan Gutiérrez 
Dic. 25 de la Concha quedó encargado de observarla por el cuarto de círculo, pues las noches no eran las más despcjadas para determinarla por estrellas al zénit. El día fué uno de los más hermosos, y así no sólo conseguimos nuestros deseos, sino que Concha lograse tomar también alturas correspondientes, por las cuales resultó la longitud del observatorio de $52^{\circ} 16^{\prime} 30^{\prime \prime}$ por el núm. 72 y $52^{\circ}$ o $7^{\prime}$ I $5^{\prime \prime}$ por el 105 occidental de Cádiz. La latitud observada en la playa fué de $5 \mathrm{I}^{\circ} 33^{\prime}$ Sur á la cual restándose las dos millas que el observatorio está al Norte de aqúel sitio, resulta éste en la latitud de $5 \mathrm{I}^{\circ} 3 \mathrm{I}^{\prime}$, próximamente la misma en que estableció Mr. de Bougainville la colonia, situado también un poco más al Norte de nuestro observatorio.

Pero estas longitudes, sin embargo de no haberse rectificado con toda exactitud sobre el Cabo de San Juan, con cuyo intento dirigí aquel día la derrota para avistarle, no obstante las únicas alturas tomadas en muy buenas circunstancias aquella propia mañana, y calculadas con la la latitud hallada por la base medida al referido Cabo; producen una longitud de $9^{\prime}$ más oriental en el núm. 72 y $I 6^{\prime}$ en el propio sentido por el I05 de la que resultaba por la marcación al Cabo. De aquí se concluye que adoptándose esta corrección, es preciso aumentar á la longitud determinada por los relojes el error que indicaron sobre el Cabo de San Juan, resultando así por longitud del observatorio la de $52^{\circ}$ I $6^{\prime}$ I $5^{\prime \prime}$ occidental de Cádiz por el I05, al cual damos aquí, por más confianza, la preferencia; y de consiguiente, se acorta mucho la diferencia de meridianos entre el puerto de Egmont y este de la Soledad, según los planos que me ha enseñado el Comandante Sanguineto.

Hoy nos ocupamos en la formación del plano de estos contornos, para el cual se midieron dos bases: la una sobre la altura que está á la izquierda á la entrada de la darsenita haciendo frente al puerto de Cornejo y playa contigua, y la otra cn la parte opuesta, desde cuyos extremos se ligaban otros puntos distantes, como el Islote Pelado, los bajos de Viamon y los extremos de las islas que nos rodeaban.

El mal tiempo en los días subsiguientes, á veces con truenos y granizando, imposibilitó la conclusión de la aguada y la expedición propuesta de la lancha. Estos mismos obstáculos se opusieron también á conseguir alturas correspondientes y sólo podían lograrse absolutas una ú otra vez desde á bordo entre cinco y seis de la mañana, de modo que esta experiencia justificaba así los informes que nos daban el Comandante $y$ Oficiales del paquebot, de lo raro que era en estos climas conseguir un día cläro áun en la estación benigna en que nos hallábamos, como las fundadas quejas de Mr. Bougainville de lo ingrato de este cielo para la Astronomía. Sin Dic. 23 embargo, este navegante determinó la longitud de este punto, por las observaciones de su astrónomo Mr. Verron, en $60^{\circ} 50^{\prime}$ occidental de París, la cual concordando casi con la de nuestros relojes, se puede inferir fuese deducida á observación absoluta, aunque no lo expresa en la relación dc su viaje.

Pudo al fin la lancha desempeñar los objetos á que fué destinada al punto de haberlo permitido el tiempo: no obstante, estando fuera no le fué tan favorable para completar los objetos de su destino. En la mañana del 2 dió la vela á las órdenes del Teniente de navío D. José Robredo, prevenida de todos los auxilios necesarios y regresó á los tres días después. Este Oficial, 1levando consigo al Piloto Hurtado, se dirigió, consecuente á mis órdenes, al puerto de Salobieña y á Puerto Bueno, hallando en este último buen fondeadero en la extensión sola de dos á tres cables con fondo lama ó arena lamosa, siendo en lo restante de cascajo ó piedra: observó la latitud en la playa que le antecede de $5 \mathrm{r}^{\circ} 37^{\prime} \mathrm{y}$ determinó la línea de sonda por to y I2 brazas entre las orillas opuestas. Los malos tiempos no permitieron á Robredo pasar á la costa del Norte á reconocer el puerto de la Barra, y áun las operaciones antecedentes le costaron algunas averías en el casco y aparejo de la lancha. Para precaver yo esta contingencia había destinado al propio tiempo otra lancha de la colonia con un pilotín del paquebot, que sondase el citado puerto de la Barra, de cuya diligencia é informes resulta la inutilidad de su fondeadero en ningunas circunstancias. El mismo pilotín sondó también la costa hasta los bajos de Viamon y los canales del Galon.

Seguidamente comisioné á reconocer el puerto de Cornejo al Piloto Hurtado, cuya sonda ejecutó en bajamar y no era ménos de tres á tres y media brazas lama. Por esta razón y ser un paraje mucho más abrigado, yo hallaría preferente que las embarcaciones invernasen en estc puerto con preferencia á donde ahora lo ejccutan, y no falta ejemplar para justificarla. Lo cierto es quc sería muy remoto el desamarrarse aquí los buques con los vientos duros del Sueste y Norte en invierno como frecuentemente acaece amarrados en la dársena, exponiéndolos muchas veces á bien malas consecuencias. No sólo ofrece este sitio ventajas tan conocidas, sino que hasta la misma colonia debería establecerse en las cercanías de dicho puerto si hubiese de tomar otra forma 6 sistema político, pues siendo un terreno más bajo y mucho más abrigado que el otro, proporcionaría no sólo una mansión más cómoda, sana y agradable, sino llanuras muy oportunas para la producción de los vejetales tan útiles para la subsistencia de sus habitantes. 
Después se siguieron las sondas desde la salida de Cornejo por la orilla de la izquierda por tres y tres y media brazas cascajo hasta el bajo visible que teníamos al Sudoeste, y desde aquí vino subiendo el fondo á cuatro y cinco brazas lama dura, hasta la corbeta. Otros días se verificaron las sondas restantes, y particularmente, el veril del Este de la Isla de la Paja desde la cacabeza del Sur, cuyo fondo, á distancia de un cable de la orilla, jamás bajó de tres brazas cas cajo; de donde se infiere que nuestra varada la causó alguna desigualdad del fondo en aquel paraje, y no de piedra como habíamos imaginado.

\section{Reflexiones sobre el estado actual de este} establecimicnto.

El número de habitantes quc compone en el día esta colonia se reduce al de 38 sentenciados, y 102 individuos que forman la dotación del paquebot. Aunque parezca reducido este número para emplearse en aquellas primeras ó más fáciles labores que fructifiquen el terreno, á lo ménos siempre sería conveniente dedicar estos hombres al cultivo de la hortaliza tan necesaria para su alimento. Este útil ejercicio, mirado hasta aquí con la indiferencia que no merece, no sólo es trascendental á la salud pública, sino también á las buenas costumbres en general. En vano se pretende disculpar este descuído con la esterilidad del terreno á toda especie dc frutos, porque no faltan parajes tan estériles, ni los recursos del arte dejarían de suplir los defectos de la $\mathrm{Na}$ turaleza, produciendo las verduras suficientes para consumo de los colonos, del mismo modo que ahora las tiene el Gobernador y algún otro individuo que las busca. Esta ocupación, si es tan saludable y necesaria en todos los pueblos de la tierra, en ninguno parece más indispensable que en donde no hay otra alguna en que ejercitar á los hombres, nj que facilite más la distracción precisa de una porción de individuos á quienes la ociosidad conduce á fatales consccuencias en lo moral y en lo físico.

Otra causa contribuye también á multiplicar con exceso ambos objetos. La prohibición de mujeres aquí ha sido una cuestión muy agitada por todos los Gobernadores desde la fundación de esta colonia; pero venció al fin aquella opinión contra lo que dicta la razón y la propia experiencia. Yo me excusaré de referir los horrorosos delitos cometidos por la falta de aquel sexo que parece formó la Providencia solo para evitarlos. No pueden oirse sin espanto crímenes tan repugnantes á la Naturaleza como ofensivos á las sociedades civilizadas. Los patronos de este dictamen le han :poyado en la imposibilidad de contener otros desórdenes cuando el número de las mujeres no fuese proporcionado al de los hombres. Yo quiero suponerlos ciertos; pero negar los medios En. 3 de destruirlos no me es fácil comprenderlo, pues para estos casos tienen las leyes un derecho positivo de aumentar el rigor para conseguir el escarmiento, y jamás deja éste de lograrse en una población reducida, en donde si además de no poder ocultarse el delincuente, sabe con evidencia que ha de sufrir prontamente los efectos de la justicia.

El perjuicio de la población es también aquí un daño bien notable para desatenderse. Tal vez será esta la única colonia que carezca de la parte más esencial para fomentarse. Esta providencia dimanada de la pluralidad de opiniones por los Gobernadores comunicadas á los Vireyes de Buenos Aires, ha sido la causa de haberse adoptado, pues recientemente hemos visto la contraria para los establecimientos de la costa Patagónica con motivo de la Compañía Marítima.

Es de esperar que esta Compañía piense con el tiempo establecer su pesca en estas islas para hacerla con abundancia, prestándose aquí la mayor comodidad y seguridad al intento, y entonces es consiguiente consiga la misma forma en su plantación aquí, que la que tiene en los puestos que ocupa sobre la costa. A lo ménos, según me informó D. Pedro Sanguineto, este pensamiento estaba muy próximo á realizarse, y fuera sensible que algún informe equivocado al Gobierno, 10 embarazase. Según las noticias del propio Sanguineto, es cierto que es ya considerable el número de embarcaciones extranjeras que concurren todos los años á la pesca, y áun algunas hacen invernada en los excelentes puertos descubiertos por sí mismas en las islas occidentales de este Archipiélago, cuyo crecido número de buques es una prucba incontestable de la utilidad que aquí sacan y la razón porque le prefieren.

Sin embargo de la excesiva economía de sus armamentos para esta clase de navegaciones, llegando ya al extremo de desertarse muchos marineros á nuestra colonia, prefiriendo el riesgo eminente de su vida para alcanzarla, á sufrir las miserías que padecen, yo creo, no obstante, que las ventajas locales para la pesca no nos las podrán disputar los extranjeros; y á poco tiempo abandonarían estas islas, ó disminuiría su concurrencia cuando viesen desaparecer las utilidades que antes encontraban. Este sería igualmente el único medio político para separarlos de este Archipiélago, hacia donde tambien los llama la esperanza de poder matar furtivamente algún ganado para la subsistencia en sus invernadas. Estos recelos han dado lugar á una disposición, que aunque justificada por la necesidad, se opone á la propagación rápida que goza aquí esta especic, obligando á reducirle cl pasto 
E:1. 3 al pequeño espacio desde la población á la bahía del Oeste; á la verdad espacio bien corto para el número de 6.000 cabezas que se cuentan en el día. De esto se siguen dos inconvenientes graves; el primero de que se apurcn en breve los pastos, privándosele también de los abundantes que hay en la parte del Sur, de donde ahora se le separa para tenerlo á la vista; y el segundo debilitarse y adulterarse la excelente casta que existe actualmente.

Otra prueba convincente de las ventajas de la pesca por estos mares, es de que las invernadas han empezado á hacerse ya en el puerto de Año Nuevo, en la Isla de los Estados. Esta noticia, comprobada por relación de diferentes marineros desertores ingleses americanos, me añadieron que el Capitán de la fragata había formado allí una buena barraca para ejecutar las faenas necesarias y abrigarse del rigor de la intemperie en aquellas regiones. Yo no dudo que este ejemplar sea imitado por otros, ni que en adelante se excedan á pretensiones más formales, si encuentran medios para autorizarlas. La situación de la Isla de los Estados, teniendo un buen puerto, agua y leña abundante, son ventajas muy conocidas para que no las aprovechen y no quieran extenderlas con el tiempo á otras muy perjudiciales á los intereses de la España. Los tratados de paz prohiben en efecto todo establecimiento extranjero sobre nuestras costas é islas adyacentes, pero eludidos aquéllos con la fuerza del primer momento favorable, no se consultan para emplearla otras razones, sino la utilidad propia ó el daño ageno. Si algo sería capaz de malograr cstas intenciones venideras, yo comprendo como único medio el que la Compañía Marítima prefiriese para establecerse el puerto de Año Nuevo al Deseado; pues llevando el primero muchas ventajas sobre el segundo, así por la excelencia del puerto como por la abundancia de leña, agua muy buena, de que carece el Deseado, y creo también sea el terreno de aquél muy superior al de éste; son estas razones que justificarían siempre la preferencia, y la Compañía hallaría en las resultas de esta disposición otras utilidades que le niega la existencia en puerto Deseado.

En este caso los auxilios y comunicación entre las Maluinas, sería fácil y utilísima á entrambos establecimientos. Si el ganado no pudiese conservarse en Año Nuevo, á lo ménos no sería difícil preservar en el invierno el que hubiese de consumir una colonia reducida, imitando lo que se practica en las partes septentrionales de la España, y cuando no procrease de este modo con la rapidez que en las Maluinas, siempre sería este establecimiento de la utilidad más grande para los buques de la carrera de Lima. La derrota de éstos los conduce á dar vista á la Isla de los Estados, y sin notable atraso en su viaje, entrarían á refrescar la aguada, reemplazar En. $\varepsilon$ la leña, mejorar la estiva, dar un regular descanso á las tripulaciones, y alguna carne fresca, á lo ménos á los enfermos.

Todas estas atenciones, de una grave consideración para montar el Cabo felizmente, saliendo de aquí también preparados para resistir los fuertes temporales que cuesta el conscguirlo.

Esta escala, áun sin proponer establecimiento alguno, se halla anteriormente recomendada en la relación del viaje á Magallanes, publicada en I788, para evitar muchas veces la arribada costosa y dilatada al Río de la Plata. Una pequeña colonia trasplantada aquí de la costa $\mathrm{Pa}$ tagónica, no sólo confirmaría la posesión exclusiva del puerto de Año Nuevo, sino que esta providencia disiparía las ideas ó proyecto que puedan formar otras naciones sobre este sitio; y tal vez algún día encontrarían los registros de Lima su propia utilidad en hacer esta corta escala, pues no pudiendo separarlos para hacerla ni los riesgos ni los gastos que tanto deben consultarse en los negocios mcrcantiles, le resultaría la ventaja de disponer de más buque para la carga, con la ménos cantidad de agua y leña que en tal caso llevarían. Yo creo habría entonces una razón justa para obligarlos el Gobierno á esta arribada, sin que sea violenta ni nueva esta disposición en Europa. Los ingleses precisan á sus embarcaciones de la Compañía de la India á tocar en la Isla de Santa Elena, con solo el objeto de disminuir lo dilatado del viaje para conservación de los equipajes. Esta razón tan humana, justifica por sí sola cualquiera providencia de esta naturaleza, tanto más necesaria en nosotros, cuanto el viaje es más penoso que el de la India, y que nuestra marinería más sobresaliente es la que frecuenta esta carrera, en la cual ha perecido una parte muy considerable de ella.

Salida de las Maluinas.-Navegación a las Islas de la Aurora.-Descubrimiento de una nueva situación de todas y remión en Montevideo á la Descubierta.

Dispuesta la salida para el II, previne con anticipación al Comandante Sanguineto, que contase con cuantos auxilios pudiese necesitar para su subsistencia y conscrvación de la colonia que pudiese yo franquearle de la corbeta de mi mando, pues estaba resuelto á quedarme con solo aquellos muy precisos para llegar al puerto de Montevideo después del reconocimiento de las Islas de la Aurora á donde me dirigía; pero el próximo arribo de la corbeta Santa Escolástica, y no ser muy urgentes las nccesidades del establecimiento, hizo no admitir Sanguineto sino tal cual cosa muy precisa.

Habiamos ya observado la variación de la 
In : aguja por diferentes azimutes de $20^{\circ}$ oo' Nordeste; y la pleamar en el plenilunio la observamos también á las cuatro y media de la tarde, elevándose el agua siete piés.

Después de indecible trabajo que nos costó suspender las anclas por lo pegajoso y duro del fondo, dimos la vela á las cuatro de la mañana gobernando á rebasar la Isla de la Paja, desde cuyo punto con rumbo del Esnordeste y fuerza de vela, nos franqueamos del Cabo San Felipe á las ocho de la mañana, perdiendo dos horas después la vista de ella enteramente. Nuestra derrota se dirigió desde aquí á entrar breve en los paralelos de las islas de la Aurora por 53 á $54^{\circ}$ para correrlos con los vientos favorables y constantes del Oeste.

Hallamos por la tarde la variación de la aguja por amplitud de $22^{\circ} 59^{\prime}$ Nordeste, y con viento fresquito del Oesudoeste al Sudoeste y un temperamento agradable, llegamos al medio día siguiente á observar la latitud de $53^{\circ} I 7^{\prime}, y$ la longitud por el Io5 de $50^{\circ} 39^{\prime}$ occidental de Cádiz, en donde nos asaltó la calma sucediéndola una ventolina que afirmó por el Esste, la cual ceñimos al Sursueste hasta cumplir los $53^{\circ} 40^{\prime}$ de latitud por la misma que habíamos de buscar las referidas islas conforme á las noticias adquiridas en Lima de su situación.

Estos vientos del Este no dejaron de sorprendernos, cuando por lo común sólo soplan en la estación de invierno, en cuya experiencia se fundan algunos Pilotos mercantcs para preferir aquella estación á la de verano, con la probable esperanza de montar el Cabo de Hornos con más brevedad, y consiguientemente acortar de mucho la navegación á Lima. Sin embargo, yo creo csta opinión falsificada por la razón, y que para seguirla se prefirió el interés á otros motivos que reclama la humanidad y que no deben jamás posponerse. Los armadores en Cádiz necesitaban mucho tiempo para cargar sus buques, ya por su excesivo tamaño, como por la imprudencia con que los sobrecargaban en otros tiempos: seguíase de esto por una parte su poco andar, y por otra el temor de forzar ó de resistir la vela, hasta en los casos más seguros para embarcaciones preparadas bajo de otras precauciones. Era una forzosa consecuencia de estos dos inconvenientes el llegar al Cabo después de una navegación mucho más larga de lo que debiera ser, y que las enfermedades se propagasen rápidamente con los rigurosos efectos de aquellas latitudes, multiplicándose en razón de la debilidad de la naturaleza para resistirlas, y de las más ó ménos contra. riedades que of reciese desde entonces la navesación.

Otra causa también ha contribuído en aquellos tiempos á aumentar el número de los desastres cn estos viajes. La propia razón del interés lia inducido á los propietarios de estos buques á des- En. 12 preciar la elección de las estaciones, habiendo de ser la primera que debiera consultarse.

Por lo común, cada uno ha echado al mar sus expediciones precisamente al tiempo de ir á doblar el Cabo de Hornos en lo más riguroso del inviemo, resultando de aquí todos los males que pueden inferirse de transitar unos mares de los más tempestuosos áun en la estación de verano. Sólo los navegantes se hallan en estado de juzgar de los indecibles trabajos que acarrea á la gente de mar esta disposición, tanto más sensible cuanto sólo ha querido falsamente cohonestarla el informe de algunos Capitanes, atribuyendo una bondad de tiempos al invierno, que no encuentran en el verano. Yo quisiera preguntarles si las noches casi continuas entonces en aquellas altas latitudes, facilitan al marinero maniobrar ó hacer los esfuerzos de vela que proporciona lo largo de los días en la estación opuesta. Ni cómo puede resistir la gente el duro trabajo de sufrir la nieve, la garua y el frío intensísimo de aquellas regiones sin sentir las tristes consecuencias que padece.

Por de contado aquellos informes deben mirarse como sospechosos, porque interviene en producirlos el interés propio de los Capitanes en asegurar su opinión lisonjeando el de los dueños, los cuales no tratan de la salida de sus buques sino después de no poder admitir ya mas carga. Algunos ejemplares de navegaciones felices los ha engreído en repetir estos viajes, desatendiendo la estación, sin reparo á lo que sufre y se sacrifica la gente de mar más escogida del Estado, siendo víctima de su ambición y de su codicia.

A las tres y media de la tarde del día siguiente entramos en el paralelo. propuesto, habiendo observado al medio día la latitud dc $53^{\circ} 48^{\prime}$ Sur, y la longitud de $49^{\circ} 5^{0^{\prime}}$, advirtiéndonos una diferencia de $20^{\prime}$ al Oeste, y la propia en igual sentido tuvimos al día siguiente. El tiempo continuaba desde ayer con mal aparato, y con viento del Sursudoeste corríamos con la vigilancia correspondiente, presumiendo no estar distantes las islas, habiendo visto hoy sargazo y también abundancia de pájaros.

El horizonte al anochecer, difícilmente se extendería á más de tres millas, y el viento soplaba ya con tal fuerza, que nos obligó á capear toda la noche con trinquete y gavia con dos rizos arriada.

Desde las tres y media de la mañana, habiendo cedido el viento, se cazó el velacho, arribando al Esnordeste. Veíamos el sargazo más abundante, y también la vista de algunas gaviotas nos daban esperanza de alcanzar breve la de las islas, cuyo meridiano cruzamos antes del medio día, suponiéndole por varias noticias en $44^{\circ}$ I $5^{\prime}$ occidental de Cádiz, aunque siempre esta longi. 
En. 15 tud discreparía mucho de la verdadera: la nuestra de hoy por el Io5 era de $43^{\circ} 45^{\prime}$, apartándo. se de la de estima en I6' al Este, estando en latitud de $53^{\circ} 25^{\prime}$ Sur.

Debíamos suponer en la situación de estas islas aquel error al Este que se contrae en esta navegación desde Lima á la equinoccial, y por lo tanto, doblamos desde hoy el celo y las precau. ciones, para ni propasarnos al Este de ellas, ni navegar para evitarlo sino con latitudes muy seguras y horizontes medianamente claros. El frío á la sazón se hacía muy sensible, de modo que fué preciso relevar con frecuencia la guardia de los topes.

Antes del medio día, me avisaron éstas la vista de un bajo como al Nornordeste. Al instante nos dirigimos á reconocerle con fuerza de vela, y aunque no dejásemos de dudar de su existencia mientras la distancia no lo confirmase, sin embargo, todas las noticias de los que yo enviaba á las crucetas, escogidos entre los de mejor ojo, me las repetían con firmeza, pormás desconfianza que yo les inspirase con ser base de alguna banca pequeña de nieve sobre la cual rompiese la mar, y fuera ésta la reventazón que notaban. Pero nada pudo disuadirlos, ni aún cuando descubrí yo con un buen anteojo desde la toldilla el engaño, todavía sostenían su ilusión, aumentándola viendo otros dos bajos semejantes al primero, hasta tanto que la corta distancia fué sólo capaz de desengañarlos. Yo hago aquí mención de este suceso, tan solo para prevenir á otros navegantes la desconfianza con que debe procederse en otros casos semejantes, y que si aquí las circunstancias no nos hubiesen facilitado el desengaño, y se hubiese de ceder sin examcn al informe de los marineros, era preciso situar en la carta unos bajos en donde jamás han existido.

En la mañana siguiente se vió al Nordeste una banca no distante que iba tomando las diferentes formas en que quedaba después de desprenderse las masas que de ella se desplomaban. El sargazo nos acompañaba con más frecuencia y también bastantes pájaros. Las observaciones al medio día nos indicaron un error al Norte de la estima de $I 5^{\prime}$, siendo la latitud observada de $53^{\circ} 25^{\prime}$ Sur, y la longitud de $42^{\circ} 42^{\prime}$, la cual también diferenciaba en $28^{\prime}$ al Este. Se gobeŕnó desde luego al Sur 1/: Suoeste para coger prontamente el paralelo de las islas, cuya vista podría escapársenos con un rumbo ménos directo en las cerrazones frecuentes; y por esta causa tampoco navegamos para el Este al día siguiente sin aventurarnos ya á malograr nuestro objeto. La noche fué de las más tenebrosas, lloviendo sin cesar, $y$ estas circunstancias nos imponían el cuidado correspondiente á evitar compremeternos inevitablemente sobre las islas.

Logramos al fin hoy averiguar por observa- ciones exactas nuestro verdadero lugar al cabo En. 18 . de dos días que carecíamos de ellas, gozando un día de los más hermosos que podían apetecerse en estas latitudes: la observada de $54^{\circ}$ I $2^{\prime}$ nos manifestaba una grande diferencia al Sur, siendo no menor otra para el Este señalando el I05 la longitud de $42^{\circ} 24^{\prime}$. Al ponerse el Sol ya habíamos bajado para el Norte á entrar en la latitud de las islas, y á este tiempo se vió al Nornoroeste á distancia de siete á ocho leguas un mogote blanco por la mayor parte, que creímos fuese una banca respecto á que por la latitud no podíamos presumir fuese una de las islas.

Desde este punto ceñimos con las muras á estribor las gavias sobre dos rizos en ánimo de mantener este paraje; pero el viento ya al Oes. te $1 / 4$ Noroeste enturbió tanto los horizontes, que apenas en los dos días siguientes alcanzábamos á ver más espacio en circunferencia que el de una milla.

Estas contrariedades tan tenaces se aumentaban á medida de lo que se acercaba el reconocimiento de las Islas, para empeñar más nuestros deseos de conseguirle. Todas las circunstancias se conspiraban á malograrle. Unos tiempos ó tempestuosos ó cerrados con diferencias contínuas que nos apartaban con exceso del paralelo de las islas, en cuya latitud discrepaban tanto las noticias de los que las habían avistado, era una reunión de causas ó de estorbos difíciles de superar sin ocurrir á unos de los acasos felices de la suerte; tal era nuestra desconfianza en. conseguir ya nuestro intento, y tal era mi sentimiento de verme quizás obligado á abandonar el crucero si el conjunto de razones me estrechasen á perder la esperanza de reconocer las islas tan deseadas.

A este tiempo nos considerábamos ya $2^{\circ}$ al Este del meridiano de ellas, y ni esto ni la cerrazón, todavía continua á la mañana siguiente, desalentó mi empeño para proseguir en busca del fruto de la campaña. Apurando ya todos los recursos de la esperanza, tan solo podiamos aguardar de una suerte dichosa, la recompcnsa de nuestra constancia, digna á la verdad del premio que mereció:

Apenas hubo tiempo de formar otras combinaciones para en caso de hallarnos propasados de las islas, cuando la vista de una de ellas á las cinco de la tarde vino á eximirnos del cuidado continuo en que habíamos cstado. Por fortuna, observamos también en una clara la latitud de $53^{\circ} 40^{\prime}$ Sur y la longitud de $42^{\circ} 24^{\prime}$.

La isla, mirada á la distancia de seis leguas y cubierta de nieve, hacía dudar de su verdadera existencia. Con fuerza de vela nos dirigimos á ella al rumbo de Norte, asegurándonos á las seis y media de ser efectivamente la isla; desde entonces se arribó al Norte $1 / 4$ Noroeste con toda 
En. 20 vigilancia en los topes, para confirmar un bajo reconocido el año de I79o por la fragata Princesa, de la Real Companía de Filipinas, según constaba del Diario de su Capitán D. Martín Oyarvide, que me manifestó antes de nuestra salida de Lima. Esta fragata, habiendo capeado la noche anterior de avistar las islas, considerándose cerca de su paralelo mareó poco antes de amanecer, y no bien había empezado á aclarar cuando no solo se encontró sobre las islas sino también próxima á un bajo, demorando al Esueste de ellas distancia de unas once millas, pasando por entre ellas y el mismo bajo. Pero nosotros en vano pretendimos buscarle hasta las ocho y cuarto que nos pusimos Este-Oeste corregido con la isla á ménos distancia de una milla.

En esta situación reconocimos que la isla por muchas partes estaba cubierta de una capa muy profunda de nieve, y por otras teniéndola superficial, descubría un color oscuro ó negro, reflejado por el de la piedra ó color del terreno de la misma isla; y solamente en sus orillas se descubría la piedra, con especialidad en las del Sur, porque siendo la parte más batida de los vientos, permitía ménos á la nieve depositarse en las inmediaciones del agua en donde la marejada contínua la consumía.

Traídas nuestras observaciones del medio día á la hora de estar Este-Oeste corregido con la isla, resulta su posición en la latitud y longitud siguiente:

Latitud observada Sur al medio día. Por estima al Norte hasta estar Este

Oeste corregiclo á las ocho y cuarto.

Latitud que resulta á la isla.

Longitud por el ro5 traída al medio día................ Por estima al Este hasta el paralelo de la isla ............... Luégo longitud de la isla (r).....

$53^{\circ} 40^{\prime} 16^{\prime \prime}$ $24 \cdot 54$

$53 \cdot 15 \cdot 22$

$42 \cdot 24 \cdot 30$

$24 \cdot 30$

42.00 .00

Comparados estos resultados con nuestra situación de la tarde del i 8 en que avistamos el mogote tenido por banca, se concluye que esta isla debió ser la misma que aquel día se nos presentó á la vista.

Al tiempo de llegar sobre la isla, avisaron de las crucetas descubrirse cerca un bajo al Noroeste de ella. Maniobrando prontamente á evadirlo, advertimos el engaño de la noticia, viendo ser una banquilla de nieve desprendida de la misma isla, y que estando muy á flor de agua representaba un bajo á cierta distancia, con las apariencias más enærañosas. Este hecho me dió lugrar á pre-

(1) I todas estas longitudes deben restarse $20^{\prime}$ ‘ue í la llegada it Montevideo tenía de crror al Oeste el reloj ntim. Io5, y puedaran entónces corregidas. sumir que cometiese el mismo error la fragata En, zo Princesa, y que ocupada en desembarazarse prontamente de las islas y del bajo, atendiese pocoá reconocerle con prolijidad, siendo difícil después en tales casos destruir la ilusión primera que se concibe. Sin embargo, fué siempre mi ánimo insistir en las diligencias para aclarar la cuestión, á cuyo fin mantuvimos toda la noche la isla á la vista, no habiendo encontrado fondo cerca de ella con toda la sondaleza.

Muy poco favorable se nos presentó la mañana siguiente á completar nuestros deseos: el viento había llamado flojo al Norte y los horizontes tan cubiertos, que la presencia del Sol la mirábamos muy remota. Pasando después el viento al Oeste, gobernamos con todo aparejo al Esnordeste y Nordeste á fin de reconocer la parte del Este y Norte de la isla, para buscar de camino la otra y registrar también nuevamente la parte de horizonte por donde se suponía el bajo. A las cuatro y media avisaron verse tierra por la ser. viola de babor, la cual una hora después distinguíamos con claridad, y no dudamos fuese la otra isla, cubierta también de nieve, sólo negros los dos extremos, y un pico más elevado hacia el Noroeste: su extensión de Norte á Sur sería de unas seis millas, mucho mayor que la otra y más rasa, pues difícilmente se alcanzará á ver en días claros á cinco ó seis leguas, cuando la primera podrá conseguirse á nueve ó diez. Era mi intención acercarme á medirla y asimismo la distancia relativa con la isla más al Sur, para luégo volver á costear ésta por la parte del Este, para confirmar si era ó no cierta la existencia del bajo referido. Navegando á este fin con la misma diligencia á cruzar entre las dos islas, nos asaltó repentinamente una cerrazón y garua, que apenas nos permitió hacer las últimas marcaciones á las islas, precisándonos á estimar las distancias deseadas por si acaso no permitía el tiempo practicar luégo estas operaciones por bases, como lo anhelábamos.

Marcábamos á las seis y media la isla más meridional al Sueste y la más Norte al Norte $1 / 4$ Nordeste de la aguja, cuya variación Nordeste se observó por azimutes en la tarde, de $18^{\circ} 20^{\prime}$. En estas marcaciones nos supusimos distantes de la primera isla seis millas y de la segunda de ocho á diez. Media hora después perdimos ésta de vista y la otra á muy corto rato. El viento estaba fresco por el Oesnoroeste, el cual ceñimos al Norte sobre las gavias un poco arriadas, esperando abriese el tiempo, observásemos horarios y la latitud en las inmediaciones de las islas: á las diez se sondó con So brazas y no se halló fondo; á esta hora, continuando la oscuridad y garua cada eada rez con más fuerza, perdimos la esperanza de conseguir la rista del Sol ni tener observa. ción alguna en lo restante del día. 
Bajo de este concepto y de que las islas quedaban ya situadas dentro de aquel grado de precisión que exige la seguridad de los navegantes, arribamos al Este, así para separarnos de su inmediación como porque si acaso apareciese el Sol tuviese menos error la latitud referida á las islas.

No tuvimos al fin altura meridiana, pero por fortuna, pasando el viento al medio día del Oesnoroeste al Sudoeste, fué disipando la cerrazón y acabándose la garua. Antes de la una y media ya teníamos la vista agradable del Sol, aunque estábamos fuera de la de las islas. Desde el instante observamos alturas para horarios, y para deducir la latitud por dos diferentes, según el método de Mr. Dawes, para no omitir diligencia alguna en la exacta posición de las islas, aplicando en ella todos los medios que prescribe la navegación moderna.

\section{Resultados de estas observaciones para la situaciin} de la isla.

Latitud observada por dos alturas tomadas la primera poco mís de media hora después del medio día, y la segunda á la una y media de la tarde, cuyo resultado corresponde á esta última hora. . .............

Latitud referida al medio día. . . . . .

Por estima al Sur desde las siete de la mañana que se marcó la isla al Sur corregido distancia de seis millas. .

Réstense las seis millas que estábamos al Norte de la isla . . . . . . . . .

Luego resulta la isla en latitud Sur de. Longitud observada retrocedida al medio día desde la una tres cuartos. . .

Por estima al Este desde las siete de la mañana que se marcó la isla al Sur corregido.

Luego longitud que resulta á la isla primera. ............

\section{Situación de la isla rasa ó la mís Norte.}

Latitud del buque á las seis de la mañana. ..................

Longitud á la misma hora. . . . . . .

Por la marcación de la isla rasa á las seis de la mañana al Norte $29^{\circ}$ I $5^{\prime}$ Este corregido, suponiendo la distancia de catorce millas de una isla á otra, resulta la diferencia de latitud, 't la isla rasa I 2' $20^{\prime \prime}$ al Norte de la primera isla.

Latitud adoptada á la isla primera ó más Sur como preferente. ......
Diferencia en latitud al Norte en que resulta la segunda respecto á la primera............... 12.20

Latitud en que resulta la scgunda isla á la rasa............. 53. 2.40

Longitud del buque á las seis de la mañana. . . . . . . . . .

Diferencia en longitud Este por marcación á la isla rasa. ..........

Se deduce de las operaciones antecedentes, que hemos preferido para determinar la latitud de la primera isla la observada ayer, traída con la estima hasta la hora de llegar á su paralelo, á la de las dos alturas; pues aunque entre una y otra sólo hay de diferencia tres minutos, concurre en la primera la circunstancia para preferirse, el estar conforme con la asignada por el piloto de la fragata Aurora, poco después del medio día en el año de I762, á quien se debe el descubrimiento de estas islas. En cuanto á la longitud, se advierte la conformidad de los resultados de ayer con los de hoy, y que el error, poco despreciable al situar la segunda isla, depende del que incluyen las distancias estimadas, jamás de consideración cuando éstas no son crecidas.

Abandonamos ya las islas, tratando sólo de seguir aquella vuelta que proporcionase ganar más bien longitud al Oeste que latitud al Norte. Al medio día, sin embargo de estar el viento al Sucloeste $1 / 4$ Oeste, se tomaron las muras á es tribor, fiados en el giro para el Oeste que acostumbra á tomar.

Precediendo chubascos con rachas bastante fuertes, roló en efecto al Oeste con fuerza y la mar bastante crecida. Siguióse el bordo del Sur con preferencia al del Norte, en el concepto de que tan dificultoso como es ganar aquí al Oeste, es fácil bajar al Norte, además de la ventaja en adquirir la longitud donde los grados son más pequeños.

Por las observaciones de hoy, nos hallábamos en latitud de $54^{\circ} 49^{\prime}$ Sur y en longitud de $42^{\circ}$ r $8^{\prime}$. El viento por la tarde, entrando en el cuarto cuadrante, causó la cerrazón acostumbrada, lo cual con abundancia de pamperos y procelarias, hacían desconfiar de la seguridad del tiempo. No $53^{\circ} \circ 6^{\prime} 30^{\prime \prime}$ por esto dejó de hacerse toda fuerza de vela para 42.05.00 aprovechar los rumbos próximos al Oeste, teniendo favorable la variación crecida de la aguja.

Se presentó la mañana siguiente con lluvia y mal semblante, y el viento fresco por el Noroes te, desde donde pasando al Oeste arreció bas. tante. Nuestra situación hacia el medio día próximos á los paralelos del Cabo de Hornos, $y^{\prime}$ sin hallar los vientos del tercer cuadrante que $53^{\circ}$ I $5^{\prime} \circ 0^{\prime \prime}$ nos prometíamos, me obligó á tomar la vuelia 
In. 24 del Norte para huir de los temporales de estas latitudes, $y$ buscar en otras más bajas otra suaridad de tiempo para ganar en ellas la longitud al Oeste. No solo estas razones estrechaban la necesidad de seguir este partido, sino la novedad de alguna agua que hacíamos por la proa de resultas de la continuación de los malos tiempos. Pero este motivo no nos daba gran cuidado respecto á no ser agua baja, pues sólo aumentaba estando á la capa ó con esfuerzos de vela: de aquí inferíamos fuese defecto en las costuras de las curvas bandas, á cuya sospecha nos inducía el no haberse recorrido en Manila, no habiendo encontrado entonces causa para ejecutarlo.

No bien habíamos deducido nuestra situación al medio día de $55^{\circ} 28^{\prime}$ de latitud Sur y $44^{\circ} 20^{\prime}$ de longitud, que la fuerza del viento por el Oesnoroeste nos obligó á capear con el trinquete y la gavia hasta la madrugada siguiente, que cediendo, volvimos á marear la vela proporcionada á la serenidad del tiempo, de la cual gozamos toda la singladura próxima, soplando el viento del tercer cuadrante. Con estas proporciones ejccutamos cuantas observaciones facilitase la presencia del Sol, por las cuales estábamos en latitud de $53^{\circ} 05^{\prime}$ Sur y en longitud de $42^{\circ} 53^{\prime}$ manifestándose como ayer diferencias al Norte y también al Este pero más crecidas. La varia. ción de la aguja resultaba por diferentes azimutes de $I 8^{\circ}$ IO ${ }^{\prime}$ Nordeste y $I 7^{\circ} 20^{\prime}$ por amplitud occídua.

Hacia las cinco de la tarde que vimos pasar por el costado dos ramajes de sargazo, se avistó desde el alcázar una banca de nieve demorando al Este un $1 /$ Nordeste distancia de seis á siete leguas. Mandé luégo al Piloto á reconocerla cuidadosamente desde las crucetas, y me avisó ser desde luego una isla, cuya superficie aunque cubierta de nieve, se reconocía por el color oscuro no ser banca como lo sospechábamos. A la primera impresión de esta noticia nos inclinamos á que fuese la propia isla del día 2I, pero se falsificó muy breve este concepto, comparando nuestra posición á la de ella, y también su elevación, figura y el reconocimiento prolijo que hicimos con anteojos nos persuadió á que era una isla enteramente nueva.

Nada podría excusarnos de rectificar estos antecedentes, ni disculparía nuestra omisión sobre un punto tan importante á la navegación y en que tanto se interesaba la satisfacción de todo descubridor.

Arribamos pues al Sueste $1 / 4$ Este, navegando hasta lás diez en que ceñimos de una vuelta y otra á barlovento de la isla logrando por este medio amanecer como tres leguas dc ella marcándola al Esueste $5^{\circ}$ Este. Con rumbos convenientes fuimos á costearla enfilando con ella un islote saliente de su extremo oriental Fn, 27 al Norte $84^{\circ}$ Oeste. Cuando llegamos á estar Norte-Sur distábamos dos millas, y reconocimos que su circunferencia era mayor que la de la primera isla reconocida, pues no bajaría de dos millas; su altura también era mayor y las orillas igualmente escarpadas é inaccesibles.

Conservadas sobre las gavias la inmediación prudente, se repitieron las alturas y horarios, eligiendo las circunstancias más oportunas para conseguir resultados más exactos cuando la presencia del Sol, muchas veces interrumpida, nos la proporcionaban. También no habíamos hallado fondo con toda la sondaleza á la distancia de las dos millas, descubriendo á este tiempo un arrecife qne arrojaba la isla hacia el Sueste no de ménos extensión de las mismas dos millas, rematando el extremo en un pedrusco más ele. vado que los restantes, formando el citado arrecife algunos ocultos por la rompiente.

Al mismo tiempo de observar la latitud en esta situación con lả mayor confianza de $52^{\circ} 38^{\prime}$ Sur, se marcó la isla al Sur $89^{\circ}$ Oeste y su islote al Sur $87^{\circ}$ Oeste; y procediendo á determinar la situación de esta isla (que llamaremos Isla Nueva) resulta del modo siguiente:

Latitud observada al medio día.. . . . Diferencia de latitud por la marcación á la isla al Norte $73^{\prime \prime}$ Oeste corregido $52^{\circ} 38^{\prime} 00^{\prime \prime}$ Latitud en que resulta la isla. . . . 52.37.24

Longitud observada traída al medio día.............. 4r...4 4r.46

Diferencia de longitud por marcación á la isla al Norte $73^{\circ}$ Oeste corregido distancia de 2 millas. . . . . . . .

Longitud de la isla al medio día occidental de Cádiz. ........ 4I.46.06

Se ha preferido en esta longitud la del ro5 á la del cronómetro 72, por la mayor segurídad que nos prestaba el primero con presencia del examen de entrambos en el puerto de la Soledad: sin embargo, su diferencia recíproca no es tan grande, pues sólo se aparta hoy el 72, I I' al Oeste del I05.

Concluídas las observaciones nos dirigimos con el viento fresco del Nornoroeste al rumbo del Sur á reconocer bien los límites del arrecife, y no habiendo notado nada más de lo que se ha manifestado, franqueados de él, forzamos de vela para aprovechar el rumbo favorable del Oeste. A la una de la tarde me avisaron de los topes no descubrirse otra rompiente, ni la del arrecife se dilataba tampoco á más distancia de la que habíamos conceptuado.

Hoy también habían resultado de las observaciones diferencias al Norte y al Este; pero no se ha corregido este error para la longitud determinada á la isla por no poderse considerar 
E11. 27 proporcional en cada hora respecto á haber concurrido mayores causas para producirle desde la arribada de ayer tarde, y la navegación durante la noche, que en la de la mañana, ó por lo ménos desde la hora de los horarios hasta el medio día. Si admitiésemos este error proporcional á cada hora, es cierto que la isla resultaría $2^{\prime} 30^{\prime \prime}$ más al Este de en lo que la hemos establecido: cantidad bien despreciable aquí para tomarse en consideración.

Observada asimismo la variación de la aguja por azimutes de $19^{\circ} 2 I^{\prime}$ Nordeste, nada nos quedó que desear para añadir á la complacencia de este feliz descubrimiento, la de haber logrado todas las observaciones precisas para colocar esta isla nueva dentro de unos límites los más exactos.

Al paso de ir descendiendo el Sol, el viento arreciaba sin salir del Nornoroeste ó Norte 1/4 Noroeste, con el cual resistimos cuanta vela era posible mientras hacíamos rumbos tan ventajosos y las malas apariencias del tiempo no llegasen á realizarse.

A las cuatro y media de la tarde se avistó desde las crucetas un frontón blanco como de cuatro á seis millas de extensión de Este á Oeste. El horizonte, á la sazón fosco, hacía representar aquel objeto con una oscuridad por la distancia de seis leguas á que le mirábamos al rum. bo del Oesnoroeste, que los marineros por esta causa se engañaron creyéndole otra nueva isla. Nuestro rumbo casi hacia ella con un andar de cinco y medio millas por hora, y lo que la isla engañosa la arrastraba el viento hacia nosotros, produjo muy luego nuestro desengaño y la agradable perspectiva de ver navegar majestuosamente una banca de nieve de tan extraordinaria magnitud: por el costado pasaron otras pequeñas, y esto causaba para nosotros uno de aquellos pocos espectáculos que ocupaban con agrado nuestra vista y cuya novedad entretenía gustosamente nuestros equipajes.

El tiempo al anochecer tomó muy feo semblante, y el viento, sin permitirnos ya más que el trinquete y las gavias sobre dos rizos. La mar, creciendo excesivamente, nos ocasionó balances extraordinarios hacia la media noche, que el viento era bonancible ya por el Oeste $1 / 4$ Noroeste. La oscuridad, aumentada con la garua constante, era tan densa, que difícilmente daría tiempo para eludir el encuentro repentino de alguna banca, y esto no dejaba de ocupar justamente nuestro cuidado.

Llamando el viento al Sudoeste, á las primeraș horas de la mañana aclaró la cerrazón, y principiamos á descubrir desde el alcázar diferentes bancas, y mucho mayor número desde arriba, según avisaron los guardias de los topes. El tiempo, aunque frío, estaba hermoso y apaci- ble, y el viento permitiéndonos andar cuatro ó En. 28 cinco millas por hora.

Observada la latitud de $52^{\circ}$ I $3^{\prime}$ y la longitud de $43^{\circ} \circ 7^{\prime}$, volvimos á tener las mismas diferencias de $23^{\prime}$ al Norte y 32 para el Este. A esta hora contábamos ya como Ioo bancas de todos tamaños, y este número se iba multiplicando á medida de avanzar para el Oeste. Seguimos, sin embargo, el propio rumbo del Noroeste ó Noroeste $1 / 4$ Oeste, así porque el tiempo favorecía nuestra derrota, como por la probabilidad de rebasarlas en el grande espacio de día que nos restaba, tanto más de considerar yo siempre segura la salida por el Norte, en donde no se reconocían entonces los mismos embarazos.

A este tiempo, relevadas las guardias de los topes, vinieron á decirme llenos de espanto cómo ya se descubría un archipiélago inmenso desde el Sursuoeste al Oeste y Norte, sembrado con tal espesura, que era absolutamente imposible poder atravesarle por ninguno de los rumbos comprendidos entre ambos extremos. Parecióme un poco exagerada esta noticia, y para comprobarla, mandé al Piloto á las crucetas que desde alli me informase después de un prolijo examen en el horizonte, por los parajes indicados; pero sin necesidad ya de este informe, no tardamos todos en justificar desde el alcázar las primeras noticias, y en convencerme yo de la necesidad de variar el rumbo para separarnos del empeño á donde nos conducía el que seguíamos.

Desde luégo arribamos á la una y media con toda vela al Norte $1 / 4$ Nordeste, rumbo en cuya dirección no veíamos obstruído el paso. Mientras seguimos á este rumbo ya atravesábamos por entre algunas bancas grandes, pasando de ellas á tiro de pistola, y dejando por consiguiente á la izquierda toda la cordillera del cuarto cuadrante, prolongándola para el Norte en donde creíamos rematase. Navegamos bajo este concepto hasta las cuatro de la tarde presentándose por aquella parte á nuestra vista un campo dilatado cubierto de islas flotantes de nieve, cuya hermosa perspectiva no cabe representarla con exactitud, ni la pluma más elocuente, ni el pincel más penetrado de aquel fuego ó entusiasmo con que una habilidad de primer orden sabe imitar todas las obras maravillosas de la Naturaleza. No nos es fácil concebir, áun oprimiendo la imaginación, el contraste raro que formaba á nuestra vista este número infinito de grandes masas, por sus figuras las más extravagantes y pintorescas. Nosotros nos contemplábamos al frente de una inmensa población, que arruinada por algún terremoto, había perdido la regularidad de su planta y la magnificencia de sus edificios. Un cúmulo de objetos tan diversos y extraños sobre los cuales reflejaban los rayos del Sol para aumentar la harmonía graciosa, debía 
por precisión atraer toda nuestra curiosidad y conducirnos á consideraciones bien distintas. La imaginación no podía ménos de recordar á nuestra memoria, que la propia causa que ahora servía para suspenderla y divertirla, lo había sido para producir el naufragio á otros navegantes: á la sazón nos acordábamos de la triste reciente suerte dcl navio inglés Bomnty que se estrelló contra una banca navegando desde el Cabo de Buena Esperanza á bahía Botánica; y del riesgo inminente $\mathrm{y}$ descalabros que sufrió la fragata Limona, del comercio de Cádiz, hace pocos años en estos mismos mares.

Nos considerábamos bien distantes de vernos en semejantes peligros, creyéndonos antes del anochecer estar fuera de todo cuidado. Pero las conjcturas en la mar son comunmente muy precarias, aunque muchas veces haya de fundar en ellas el navegante su seguridad. Nosotros hasta l. xs cuatro de la tarde tuvimos viento entablado lel Sudoeste, el tiempo hermoso, y los marineros de los topes nada avisaban que pudiera darnos el menor recelo para que la tripulación estuviese toda tan agradablemente entretenida con la rista de estos objetos, como distante de los grandes peligros que la esperaban.

Cumplida aquella hora me avisaron de los topes cómo se prolongaba hasta el Este la cordillera de bancas, pero tan menudamente sembradas, que parecía á la vista impracticable el paso. De este aviso, y del deque se distinguían sólo algunas claras entre el Norte y el Oeste, debí persuadirme á ser estas dos cordilleras en dirección de Sudoeste al Nordeste, por entre las cuales era forzoso atravesar al Oeste de ellas. Con este ánimo se gobernó al Nornoroeste $5^{\circ}$ ()este, en cuya dirección se veían las islas ménos numerosas hasta las cinco en que volvió á cerrarse el canal que seguíamos, apareciéndose otras nuevas según íbamos avanzando, y esto nos obligaba á variar la dirección de la salida, buscándola sucesivamente por el Nornoroeste, Noroeste, Oesnoroeste-Oeste, y últimamente por el Oesnoroeste $5^{\circ}$ Oeste. Nuestra situación, como se conoce, principiaba á ser cuidadosa, viéndonos rodeados de bancas, no tratando ya sino de entrar por donde cupiese la corbeta, el viento con un chubasco había abonanzado, y que una calma en estas circunstancias, ó la oscuridad de las noches anteriores, necesariamente nos veríamos á cada paso comprometidos.

Reconocimos franco al ponerse el Sol el horiconte del último rumbo que seguíamos como unas tres á cuatro leguas, y todo el restante estaba cubierto de grandes jslas de nieve, entre las cuales medimos dos de ocho millas de largo cada una. io podíamos lisonjearnos de navegar con sesuridad aquella distancia, sin recelar cl encuentro de alguna banca por la frecuente alteración que tienen, originada de las varias causas que con- Fi. 28 curren en el elemento en que habitan para producirla. Con este conocimiento se tomaron antes de anochecer aquellas justas precauciones para navegar en la noche próxima con toda la vigilancia indispensable en nuestra situación, y las demás dictadas por la prudencia para tales casos.

Por de contado quedó el bote sobre los aparejos, los botalones de desatracar á la mano, y la madera de respeto pronta á echarse al agua en el instante necesario. Mandé que la gente estuviese toda sobre cubierta, señalando su lugar á cada uno; y los Oficiales por mitad alternando durante la noche, debían repartirse en los parajes convenientes para avisarme con tiempo de toda novedad, previniéndoles era mi ánimo navegar por el canal franco descubierto la distancia indicada, y si cumplida se cerrase, buscar la salida á viento largo y poca vela, para entretener de este modo la noche. Esta me pareció la maniobra más adaptable á las circunstancias, pues la de pairo ó capa privando al buque de la velocidad precisa en sus movimientos, podría esta falta aconcharnos sin recurso sobre alguna banca.

Por fortuna, la noche se mantuvo regular. mente clara, el viento también galeno del Sursudoeste, y con el auxilio de los anteojos de noche descubríamos las bancas á distancia suficiente para maniobrar sin temer el empeño. Estas, fuese ya por haber variado de posición unas, y otras desplomadas de las más grandes, no pudimos conservar el propio rumbo del Oesnoreste $5^{\circ}$ Oeste, para no tropezar con las que se atravesaban por la proa. No obstante, gobernando entre los rumbos del Oeste y Oesnoroeste, las íbamos sorteando, y tan sólo nos causaban algún cuidado las que por su corto tamaño no se distinguían sino á distancia muy corta. Hasta las once había sido nuestra navegación bastante tranquila, pero á esta hora se presentó por la proa una banca muy grande, cuya extensión no bajaria de una milla, y toda era pareja. A primera vista parecía como partido preferente el de arribar para rebasarla por sotavento, pero incluyendo los dos inconvenientes, de la calma que nos daría su abrigo, y el ignorar si habría otras inmediatas que dificultasen el tránsito, resolví prontamente orzar cuanto permitía el viento con todo aparejo, teniendo lis la la maniobra para tomar la otra vuelta si no la montábamos, y por fortuna, lo conseguimos con felicidad á muy poca distancia.

Desde esta hora fuimos viendo más raras las bancas por uno y otro costado, y cuando esta observación nos daba fundamento para esperar hallarnos al amanecer fuera de ellas, reconocimos á esta hora todo el horizonte cubierto enteramente desde el Noroeste por el Oeste y Sur hasta el Este, advirtiendo en el restante también algu- 
Eu. 29 nas. El viento estaba al Oeste, y tomamos el bordo del Norte, por donde nos parecía más probable la salida, viéndola con ménos obstáculos que la embarazasen.

El tiempo no podía ser á la sazón más agradable, y nuestro andar de bolina de 4 á 4 \% $/ 2$ llas nos prometía el libertarnos de pasar otra noche con los cuidados de la anterior. Por nuestras observaciones estábamos al medio día en la latitud de $50^{\circ} 43^{\prime}$ Sur, y en la longitud de $43^{\circ}$ $\mathrm{fI}^{\prime}$, notando de diferencia al Norte $2 \mathrm{O}^{\prime}$ y $\mathrm{Ir}^{\prime}$ al Este. A esta hora llamando el viento al Oesnoroeste y seguidamente al Noroeste, fué necesario virar con muras á estribor para no meternos siguiendo la vuelta del Nornordeste, entre la cordillera reconocida la tarde última, á donde necesaliamente nos conducía aquel rumbo. Declarado el viento por esta parte, tomó un aspecto el tiempo nada favorable, y tampoco lo eran las noticias de los topes para prometernos una noche de ménos zozobras que la pasada.

Al ponerse el Sol, los carices iban empeorando, la cerrazón creciendo, y el viento por el Nornoroeste soplando con más fuerza. Reconocido á esta hora desde las crucetas el horizonte por el piloto, me informó como todo estaba cubierto de grandes bancas; el comprendido desde el Oeste al Nordeste por el Norte, y el del Sudoeste al Sudeste por el Sur, advirtiéndose una única clara para poder seguirse su dirección entre el Sudoeste al Oeste cuatro á cinco leguas. A este tiempo fué también preciso arribar al Sudoeste $1 / 4$ Oeste por la imposibilidad de montar cuatro bancas, que rebasamos á las nueve, y desde esta hora nos preparamos con aquel aparejo más conveniente, para navegar lo ménos que fuese posible hasta cumplir la distancia reconocida; pero como el viento fué arreciando, no era verificable este pensamiento, debiendo por consiguiente meditar otro compatible con las reflexiones marineras y los apuros de la situación que nos amenazaba la noche próxima.

Esta situación nos ponía en la dura necesi. dad de resolver un partido con conocimiento seguro de ser cualquiera muy peligroso. La maniobra de capear no podía ni áun pensarse en este caso, porque en la rapidez de un movimiento consistiría salvarnos de un naufragio; y por otra parte navegar á viento largo sorteando los peligros, tampoco la fuerza del viento ni lo tenebroso de la noche lo aconsejaban. En esta triste alternativa de providencias, no era, pues, fácil adivinar la que incluyese resultas ménos funestas. Nuestra suerte estaba tan pendiente de su elección, como era dificultoso el acierto, y no es fácil sentir cuánto oprime al que manda la obligación de disponer de las vidas inocentes de los que le obedecen.

Pasando, pues, estas circunstancias críticas en que nos hallábamos, determiné mantenernos I.l. = 9 durante la noche sobre las gavias rizadas, y ceñir el viento en el claro reconocido, procurando conservarle hasta amanecer. Desde las diez ya la noche era muy oscura; el viento soplaba á ráfagas bien duras, y la garua ó llovizna aumentaba la cerrazón, al extremo á veces de no divisar un cumplido de la corbeta en su circunferencia. Sin embargo de esta grande oscuridad, siempre esperábamos que el reflejo de la nieve facilitaría alcanzar la vista de las bancas á mayor distancia, que diese tiempo á huir de su encuentro, casi inevitable por más celo y precauciones que doblásemos para impedirle.

Antes de la media noche se vieron por la serviola de sotavento dos bancas inmediatas. Era muy dudoso montarlas áun en el caso de poderse resistir y amurar las mayores con la presteza necesaria, y así, tomando prontamente la resolución de virar poniendo en facha el velacho, logramos felizmente ejecutar la maniobra.

Pero no por esto imitamos la propia maniobra en otro encuentro á las tres de la mañana, pues avistada una banca entre el portalón y la mura de sotavento, emprendimos al instante el tomar el otro bordo, cuidando mucho de aumentar la velocidad del buque más bien que disminuirle como anteriormente, debiendo así á la rapidez del movimiento escapar de este nuevo inminente peligro, á costa de haberlo consentido, inevitable: las resultas de un naufragio.

A esta hora puede inferirse cuánto ansiaríamos la claridad del día, para que disminuyendo á lo ménos los peligros, pudiésemos entregarnos á gozar de algún descanso. Como subsistía aún la cerrazón, se dilataba la noche y también el número de nuestros cuidados. Por fortuna escapamos de uno muy grande después, que absolutamente no se hubiera evadido si la noche hubiese sido poco más larga.

Presentáronse al romper el día á sotavento tres bancas situadas en una misma línea, inmediatas entre sí, y mucho más á nosotros. No había á la sazón espacio bastante para virar, y de consiguiente, no estando el viento tan recio, á favor de la actividad con que se amuraron las mayores é izaron las gavias, conseguimos montar la primera y luégo las otras dos, tan de cerca, que recelábamos varar en alguna de sus bases sumergidas: maniobras que ejecutadas de noche se hubieran sin recurso malogrado por la imposibilidad ni de combinarlas con acierto, ni ejecutarlas tan oportuna y prontamente como se requieren.

Este triunfo para nosotros fué tanto más plausible, cuanto la presencia del día y el viento ya manejable, nos ponía en el caso de no teme otros peligros semejantes, y aunque los horizontes neblinosos limitaban nuestra vista á un espacio bien corto, nos contemplábamos bastante fe- 
F.1. 30 lices en no temer ahora otro enemigo que el de la calma. Seguíamos la vuelta del Sudoeste con el mismo viento del Oesnoroeste, cuya mura era la que nos alejaba más del archipiélago de las bancas, y la misma que yo pensaba continuar mientras el informe de la vista no falsificase este concepto.

Con poca confianza observamos la latitud de $50^{\circ} 5 \mathrm{I}^{\prime}$ y la longitud de $45^{\circ} \mathrm{O} 2^{\prime}$, advirtiendo al Este una grande diferencia de $52^{\prime}$. No aclaró el tiempo hasta pasado el medio día, en que nos sobrevino la calma ó ventolinas del tercer cuadrante, y esta novedad, tan sensible como peligrosa anteriormente, nos era á la sazón indiferente con encontrarnos distantes por todas partes de las bancas. En esta forma permanecimos hasta ponerse el Sol, en que ciñendo el viento del Sudoeste bonancible con muras á babor, sólo se descubrían dos al Sursudoeste, bien que no era fácil reconocer el horizonte por calimoso desde el Noroeste al Sudeste, y el de la proa se limitaba á cinco ó seis leguas.

Lo despejada de la noche no nos daba ya cuidado, navegando hacia la parte por donde no descubríamos tropiezo alguno. El viento fresqui to por el Sudoeste permitiéndonos un andar de tres á cuatro millas con todo aparejo, nos facilitaba prevenirle oportunamente sin riesgo de empeño, y así, aunque navegábamos con el celo correspondiente, pudo seguirse el orden de las guardias para que la gente pudiese descansar de sus fatigas tan continuadas.

Hasta el amanecer no vimos bancas, y áun entonces sólo se reconocieron tres, las dos por las muras y la otra por la proa como á tres leguas. Pasando pocas horas después cerca de la de más á sotavento, volvimos á divisar otras dos también por la proa. Entretanto, el tiempo era bello, la mar muy apacible, y habiendo logrado las observaciones con toda confianza, observando la latitud de $49^{\circ} 52^{\prime}$ Sur y la longitud de $45^{\circ} 23^{\prime}$ Oeste, repitiéndose otra grande diferencia de $5^{6^{\prime}}$ al Este de la estima.

Desde las primeras horas de la tarde que roló el viento al Oesnoroeste, tomamos la vuelta del Sudoeste, prefiriendo ganar aquí la longitud que no disminuir la latitud, pues además de lo que cuesta adquirir aquélla, también era mucho más importante acercarnos á la costa en donde jamás recalan las bancas, y muy rara vez se han visto en los meridianos de las Maluinas. Por la tarde, no viéndose más que una ú otra, nos lisonjeábamos de salir de entre ellas, y las últimas que después volvimos á ver fueron dos por sotavento, á las once de la noche. Esta fué cnturbiándose, y aunque no se disminuyó de vela navegábamos con todo cl celo que exigía el deseo de triunfar al fin, de tantos peligros como nos habían rodcado.
La cerrazón y la garua crecieron considera- Fù r." blemente á la mañana siguiente, y por esto no pudimos descubrir si teníamos algunas bancas en las inmediaciones. Si hubiésemos de sacar una inducción cierta por las observaciones de nuestra experiencia, debíamos suponerlas no distantes de nosotros, atendiendo á que el color verdoso del mar como de sonda y un frío mucho más penetrante, habían sido señales seguras de hallarnos entre ellas, y las notamos aquí para que sirvan de aviso á otros y naveguen con las precauciones correspondientes, de noche ó con tiempo oscuro.

Pero nada había hecho impresión en la salud de la gente con una fatiga tan contínua por es pacio de cuatro días: su corto número les aumentaba el trabajo, por la necesidad de concurrir toda á muchas maniobras, á las cuales se han prestado con una actividad y disposición la más recomendable. Yo faltaría gravemente á mis deberes, si no hiciera aquí el justo elogio que meréce la Oficialidad en esta parte y cuánta influencia ha tenido su ejemplo para inspirar en la conducta de la gente toda la vigilancia, serenidad y celo que constantemente ha observado en los diferentes trances de la campaña. Nuestra obligación y la debida recompensa de su trabajo, nos ha conducido con gusto á procurarla todo el alivio y descanso compatible con las circunstancias. Se ha tenido el fogón encendido aún de noche, así para aumentar el abrigo en donde dormía, como para que los de la guardia bajasen alternativamente á calentarse, pues hasta en la cámara necesitábamos también de igual auxilio, teniendo siempre encendida la chimenea para poder resistir el excesivo frío que sentíamos, á pesar de hallarnos en el rigor del verano. En los días malos se distribuyó ración doble de aguardiente, y asimismo de carne fresca en estos últimos de mayor fatiga, debiendo sin duda á estos medios y á la ropa de abrigo repartida de antemano á los que la necesitaron, el tener la gente en el estado más sano y robusto, y tan sólo se contaba un enfermo del mal venéreo desde la salida de Chile.

Libres ya de los cuidados de una navegación tan peligrosa en los días antecedentes, nos entregamos á formar opiniones sobre el paraje de donde viniesen estas islas flotantes de hielo, y del modo como se forman. En este último punto hay poco ó nada que discurrir después de las observaciones del Capitán Cook en la Isla de la Georria. Su opinión se rcsiste á admitir la recibida hasta entonces, de que la coagulación de estas grandes masas se forma helándose el agua en las bocas de los ríos caudalosos, ó porque se acumulan allí por grandes cataratas hasta que se abren ódividen por su propio peso. Si seformasen en esta forma las islas de hielo que se hallan en la mar, precisamente se habían de encontrar algu- 
F×b. z. nas partes térreas entre su composición, las cuales buscaba Cook y jamás las encontró, ni tampoco pudo reconocer en toda la costa de la Georgia y otras tierras del Sur, río ni arroyo capaz de que pudieran formarse en sus entradas. Así este insigne navegante establece su dictámen sobre lo que observó en la bahía de Posesión. "Los va"lles, dice, están cubiertos de muchas brazas de "profundidad con nieve eterna, y hacia la mar se "terminan por unos promontorios de hielo de al"tura prodigiosa. Aquí es donde se forman las "islas de hielo por la nieve consolidada y la que "cae contínuamente en el invierno ó se desploma "de las montañas. Durante esta estación rigu"rosa, los promontorios de hielo es forzoso se va"yan acumulando hasta llenarse todas las bahías, "sean de la extensión que fuesen. Congregados "ya por la nieve continua que cae y la que se les "aumenta de los montes, llegan hasta el punto "de no poder resistir su propio peso, y entonces "se despedazan formando las que llamamos islas "de hielo."

Después extiende la probabilidad de sus conjeturas á determinar la causa de la diversidad de formas ó figuras que toman estas islas. Supone que las que se presentan con una superficie plana sean formadas en las bahías ó al frente de los valles; y otras que la tengan desigual es por haberse formado sobre rocas, picachos, precipicios ó terrenos de una superficie irregular. Yo pienso que su primitiva forma la reciban, sin duda, de esta causa; pero después de arrojadas de las costas deben alterarla notablemente, no sólo por el choque de las aguas y el de unas con otras, sino también por la nieve que caiga sobre ellas mientras no se deshagan. Nosotros apoyaremos esta opinión con haber notado á muchas de estas islas vestidas de varias capas concén. tricas de nieve desde cierta altura del agua, más ó ménos consolidadas según el orden de su antigüedad. También advertimos en otras un color verdoso ú oscuro, especialmente en el primer cuerpo, que probaba una ancianidad interminable. De aquí deducíamos que cuando estas enormes masas se conservaban á la caída del verano de magnitud tan considerable y de una materia tan compacta que no alcanzaban los rayos del Sol á derretirla, por precisión aumentarían su tamaño ó recuperarían el anterior con la nieve que recibiesen en el invierno próximo, y por consiguiente, no es así fácil contar la edad ni el término de la peregrinación de estos cuerpos flotantes, que navegan según el orden de los vientos en las diferentes estaciones del año.

En estas mismas causas y en la de la situación de la Georgia, me fundaba yo para creer que este vasto archipiélago encontrado por nosotros fuese procedente de aquella isla. La latitud de ella entre $53^{\circ} 57^{\prime}$ y $54^{\circ} 57^{\prime}$ Sur, y su lon. gitud desde $10^{\circ}$ hasta $I 2^{\circ} 46^{\prime}$ al Este de las Islas de la Aurora, es verosimil que con los vientos del Sueste y Este tempestuosos en el invieno se acerquen las bancas á estos meridianos, pues ordinariamente las han encontrado por aquí los que frecuentan la navegación al mar del Sur. Por esta razón yo aconsejaría para los que regresan á'España, que atracasen las Maluinas como medio muy seguro de no verse en semejantes peligros, infinitamente mayores para todo buque mercante, privado por la naturaleza de su destino, de aquellos recursos para hacer inevitable un naufragio áun sin hallarse en situación ménos crítica que la nuestra.

El pintor D. Fernando Brambila se dedicó á formar en los días que navegamos entre las bancas, el diseño de algunas que atrajeron nues. tra curiosidad, contemplando su figura rara y extraña; representando al mismo tiempo la situación y maniobras de la corbeta, ya navegando por entre las islas ó para evadir los peligros que nos han amenazado. En esta obra se reconoce la mano maestra del autor, y no pudiéramos prescindir, sin injusticia de hacer notoria su habilidad, poseyendo todas las reglas del arte para conseguir las bellezas de esta profesión agradable.

Habían sido bien pausados nuestros progresos hasta el día 3, porque los vientos soplaban comunmente cerca del Oeste, y esto nos había hecho preferir la vuelta del Norte para gozar á lo ménos de un temperamento suave y un cielo mucho más despejado. Las observaciones repitieron hoy las grandes diferencias al Norte y al Este; esto es, $\mathrm{I}^{\prime}$ en la primera dirección y $\mathrm{I}^{\circ} \mathrm{O \textrm {O } ^ { \prime }}$ en la segunda, hallándonos en latitud de $48^{\circ} 2 I^{\prime}$ Sur y $48^{\circ} 44^{\prime}$ de longitud.

La singladura siguiente, acompañados de un viento fresco por el primer cuadrante, navegamos á rumbos próximos del Oeste hasta la media noche, que se variaron al Noroeste $5^{\circ}$ Oeste, el cual nos conducía á las inmediaciones del río Colorado, por donde me proponía atracar la costa Patagónica. Carecimos al medio día de observaciones, y desde esta hora, el viento fué entrando en su estación 'acostumbrada del cuarto cuadrante, causando la oscuridad y garua consiguientes.

Con la misma alternativa de vientos, alcanzamos á estar al medio día del 7 á 7 I leguas de la tierra más próxima, que era la Península de San José, pero sin encontrar todavía fondo con toda la sondaleza.

La falta de estas noticias, la niebla muy densa y los malísimos aparatos del tiempo, me obligaron á tomar la vuelta del primer cuadrante y conservarla durante la noche con poca vela. Disipó después la niebla para sustituirla alguna agua en las primeras horas de la noche, y cesan- 
I ₹ \& do también ésta, principió después á relampaguear sin intermisión, y á declararse una tempestad horrorosa que duró hasta las once y media, arrojando precisamente muchos rayos, con especialidad por el Norte y Sudeste.

Ia á las cuatro y media de la mañana, dió lugar el tiempo á marear todo aparejo en vuelta del Norte con viento Oesnoroeste. A poco rato, se advirtió visiblemente la rapidez con que las aguas nos arrastraban hacia el Nordeste, efecto que atribuimos al desaguie de los ríos Colorado y Negro, y otros diferentes que reciben estos mares de la costa. Asaltados de nuevo por otra niebla espesa, la desvaneció un viento repentino del Sursudoeste, dejando el cielo lo más hermoso y despejado. Hicimos rumbos al Nornoroeste $5^{\circ}$ Oeste para reconocer la costa desde poco más al Norte del río Colorado, en donde próximamente habíamos dado principio á nuestras tareas en el año de 89; y el ligar este trozo de costa hasta el Cabo de San Antonio era la única operación que me restaba por desempeñar para cumplir la instrucción hasta el puerto de Montevideo.

Llegamos al día siguiente á coger sonda en 50 brazas arena fina al medio día; observando la latitud de $41^{\circ} 25^{\prime}$ y longitud de $52^{\circ} 56^{\prime}$ situándonos distantes de la bahía de la Asunción $5^{2}$ leguas. Las diferencias habían crecido en el propio sentido que en los días antecedentes, pues todavía hallamos hoy $I^{\circ} 02^{\prime}$ al Este y $2 I^{\prime}$ para el Norte, de suerte que á medida de acercarnos á la tierra, se multiplicaban las dificultades de atracarla.

Aún aumentaron éstas al día próximo según se dedujo de las observaciones, que nos situaron en latitud de $40^{\circ} 44^{\prime}$ Sur y $53^{\circ} 20^{\prime}$ de longitud, la primera apartándose en $\mathrm{r} 2^{\prime}$ al Sur, y por consiguiente, también contraria ahora esta diferencia que no lo había sido en los días anteriores, y I ${ }^{\circ} 24^{\prime}$ al Este de la longitud estimada, hallándonos de la costa 35 leguas. Esta rapidez con que las corrientes nos llevaban violentamente para el Este, hacían desconfiar de poder reconocer el trozo de costa proyectado. No era mi ánimo insistir demasiado en este empeño á costa de sacrificar mucho tiempo eli vencerle, porque no siendo de una grande importancia á la navegación nacional, sería mucho más preferente aprovechar en Montevideo los pocos restos del verano, en perfeccionar el plano del lío, cuya exactitud era más interesante para la seguridad del comercio marítimo de estas provincias, y no hubo tiempo de conseguirse en cl año de 89 por nuestra corta mansión en aquel puerto.

Manteníamos la misma sonda de las 45 brazas arena fina negra, y paulatinamente fué disminuyendo á fo á las tres de la madrugada. Desde csta hora empezaron los relámpagos y oscuridad por: el Sudoeste á indicar una turbonada hacia leb. $x$ aquella parte. Las precauciones empleadas para recibirla fueron tan inútiles, que á muy poco nos sorprendió un contraste duro por el Sursueste, de cuyos efectos ó averías no hubiéramos podido escapar sin cargar y preparar el aparejo con una presteza indecible: de aquí saltó de nuevo tempestuoso al Sudoeste, volvió luégo al Sur con agua, truenos y relámpagos, y por último, detenido un corto tiempo en el Esueste, escaseó al Norte $1 / 4$ Nordeste, con el cual más claro, ya viramos en vuelta del Este. A esta hora no distá. bamos de la costa más que unas i6 leguas, observando pocas horas después la latitud de $39^{\circ}$ $59^{\prime}$ Sur, y longitud de $53^{\circ} 22^{\prime}$ Oeste de Cádiz, encontrando una excesiva diferencia de $53^{\prime}$ al Sur y $I^{\circ} 2 I^{\prime}$ al Este de la estima. Apuntamos aquí cuidadosamente los extraordinarios efectos que producen las corrientes, para instruir á los navegantes venideros y justificar mi resolución si abandonase el deseo de reconocer la costa.

Viendo, pues, por la tarde, muy distante la esperanza de mejorar el tiempo para triunfar con nuestro intento, sin dejarnos absolutamente la misma inconstancia de los vientos, la permanencia de los feos aparatos del tiempo sin cesar los truenos y relámpagos, debí ceder al deseo de abordar la costa, prefiriendo el de dirigirme á buscar el pâralelo de la isla de Lobos, persuadiéndome á que debiendo también D. Alejandro Malaspina procurar reconocer este mismo trozo de costa, quizás sería más feliz en los tiempos para ejecutarlo.

Con rumbos del Nordeste $1 / 4$ Norte y Nordeste, nos dirigimos á buscar el paralelo propuesto, anteponiendo esta derrota á la de ir en derechura por el cabo de San Antonio á Montevideo, á causa de evitar un empeño si continuasen en aquel tránsito las mismas malas apariencias del tiempo, y que allí sería mucho más arriesgado cualquiera partido que la necesidad dictase, cuando entrando en el río por el camino ordinario siempre hay tiempo para resolverse á la entrada combinando ó esperando fuera de la isla de Lobos circunstancias favorables.

Declaróse muy pronto el viento al Sueste fresco acompañado de una suma oscuridad, lo cual justificó tanto el acierto de mi resolución, como nos prometía llegar al paralelo de la isla, en un corto plazo. Para esto sólo tratábamos ya de aprovechar con fuerza de vela el tiempo tan favorable, teniendo solo la mortificación de privarnos el Sol de su presencia, ó á lo ménos á horas oportunas para ejecutar nuestras observaciones ordinarias.

Estas mismas circunstancias que nos acompañaron al día siguiente, se opusieron también á poder determinar algunas sondas con la exactitud debida, sin cuyo auxilio me pareció inútil 
Fob. ${ }_{3}$ sacrificar el tiempo en ejecutarlas. Nuestro andar no era ménos de seis á ocho millas, navegando desde el anochecer con el trinquete y las gavias, observando poco antes la variación de la aguja por amplitud de $16^{\circ} 48^{\prime}$ Nordeste. Habíamos notado la frecuente alteración en el color del agua, tanto que á veces nos ponía en el recelo de que pasásemos sobre algunos bancos de mucho ménos fondo del que indicaban los planos, obligándonos á sondar sin atravesarse, y con 20 brazas no encontrábamos fondo.

Pudimos hoy al medio día averiguar nuestra verdadera situación por observaciones exactas; nos hallábamos en latitud de $36^{\circ}$ or $I^{\prime}$ y en longitud de $48^{\circ}$ I $2^{\prime}$ resultando de diferencias en los dos días anteriores $\mathrm{I}^{\circ} 43^{\prime}$ al Este y I $4^{\prime}$ al Sur de la estima. Sondamos á esta misma hora en 36 brazas arena negra fina. Nos considerábamos á este tiempo 26 millas al Este del Meridiano de la isla de Lobos, y como todas las señales del tiempo no nos daban el menor recelo para mirar con indiferencia el recalar al Este ó al Oeste de dicha isla, nos tiamos enteramente á la seguridad de los relojes para entrar en el río, marcándola antes, como una precaución que aconsejan fundadamente los prácticos de esta navegación, en defecto de no tener de antemano latitud observada.

Cumplida á las once de la noche la latitud de la Isla de Lobos, seguimos corriendo su paralelo con las debidas precauciones, teniendo de antemano prontas las anclas con vitadura doble la del ayuste. Desde las nueve fuimos sondando por I5, I6 y I8 brazas arena fina parda. La noche, la más clara y apacible con el viento al Estefresquito; no podía ser más oportuna la entrada en el río sin el menor cuidado. Nuestro andar con trinquete, gavias y juanetes, no excediendo de cuatro millas, nos facilitaba sondar con seguridad sin precisión de atravesarse: la calidad del fondo variaba algunas veces en arena fina y conchuela, y rara ocasión la encontrábamos mezclada con I5 cascajo y por Ig ó 20 brazas. La lama suelta no la cogimos hasta las cuatro de la mañana por 20 y 2 I brazas, que es la dirección del canal, y con esta señal nos bastaba para estar seguros de la vista de la Isla de Lobos, luégo que amaneciese.

Efectivamente; á las cinco y media de la manana se nos presentó por la proa esta isla con la tierra firme del Cabo de Santa María para Punta Negra, distando de ella por base medida dos y media millas, y demorando al Norte $52^{\circ} 30^{\prime}$ Oeste. El viento al Norte galeno tomando sucesivamente alguna fuerza, nos acompañó hasta cerca del medio día, que quedamos sin gobierno. Nuestros rumbos habían sido al Oeste, y el fondo, conservando la misma calidad de lama suelta, había disminuído á ${ }_{5} 5$ y I4 brazas, marcando á este tiempo la Isla de Lobos al Norte $68^{\circ}$ Este, la Pun- ta de la Ballena al Norte $8^{\circ}$ Este, y Punta Negra Feb. 1.5 al Norte $55^{\circ}$ Oeste.

Observada la latitud de $35^{\circ} \mathrm{o} 3^{\prime}$, demoraba dicha Punta Negra al Norte $25^{\circ}$ Este, estando en fondlo de $\mathrm{I} 2 \mathrm{y}^{1} / 2$ brazas lama suelta, sin distinguirse ya la Isla de Lobos. Declaróse luégo la brisa, y aumentando sucesivamente nuestro andar hasta seis millas, seguimos con toda vela á alcanzar la marcación importante de la Isla de Flores antes de anochecer.

Por fondo de I I y ro brazas, llegamos á divisar en este tránsito, desde los topes, una embarcación de tres palos navegando para el Este del bordo del Norte. Sin embargo de no poderle imaginar enemiga, sin alterar nuestra derrota, se hizo prontamente zafarrancho de combate. Como nuestro rumbo nos acercaba á ella, advertimos que sus maniobras se dirigían á huir á Montevideo, y contestadas las señales de reconocimiento que nos hizo entonces, volvió á tomar su primera derrota con muras á babor.

El Comandante de Maluinas me había prevenido haberse colocado en la parte más elevada de la Isla de Flores, un asta en que debía tremolarse una bandera para gobierno de las embarcaciones que se dirigiesen al puerto, y de noche izarse un farol en ella con el propio objeto. Esta providencia dictada por el Comandante actual de la Armadilla, justifica tanto su utilidad como la práctica que tiene de la navegación de este río, y su celo para contribuir á la seguridad de ella. Puede desde luégo asegurarse que el Río de la Plata es una de aquellas navegaciones más cuidadosas, sobre todo en el invierno. Los vientos frecuentes del Sudeste, sucios y tempestuosos entonces, no dejan arbitrio desde el meridiano de lá Isla de Lobos para dentro, sino á la práctica de buscar á Montevideo por la sonda ó á fondear en el placer del banco Inglés, en donde el fondo de arena impide garrar las anclas como sucede fuera de este paraje. Bien se reconoce cuán precarios son estos recursos en muchas ocasiones, pues no han sido suficientes á salvar la pérdida de muchas embarcaciones, no sólo sobre aquel escollo temible, sino también sobre la costa del Norte. Yo creo sería un auxilio grande que disminuiría mucho los riesgos por este río, si en la Isla de Flores hubiese dos ó tres cañones gruesos para corresponder á los cañonazos que.pidan las embarcaciones que entren, pues próximas ya ála isla, la rista de los fogonazos de noche ó el estrépito en todos casos, las iluminaría para salir felizmente del paso más arriesgado, cual es entre el banco y la citada isla. No dudo que la experiencia justificaría la utilidad de esta disposición, así como otra providencia semejante la ha comprobado al mismo objeto en el puerto de Monterey. No dimos vista á la Isla de Flores hasta estar bien cerca de ella al ponerse el Snl: la marcamos al 
reb. ${ }_{5}$ Oeste $1 /$ Sudoeste, y por fondo de seis á seis y media brazas lama suelta y conchuela, entramos en el canal de ella y del banco, gobernando al Sudoeste hasta tanto de ponernos Norte-Sur con el asta de bandera, y desde aquí al Oeste $1 / 4$ Sud oeste, rumbo que continuamos hasta llegar al meridiano de Punta Brava, ó navegar la distancia de I millas. La brisa permaneció fresca las primeras horas de la noche y como ésta fuese sumamente clara, seguimos con fuerza de vela, sin perdonar por esto la precaución de sondar á vo leo por una y otra banda, y dar el correspondiente resguardo al bajo de Punta de Carretas.

Poco después de las nueve divisamos ya una luz al Oeste $5^{\circ}$ Norte del pueblo de Montevideo, y á poco rato distinguíamos también con la claridad de la Luna las embarcaciones del puerto, hacia las cuales nos dirigíamos. Las sondas fueron disminuyendo desde seis á cinco y media, cinco, cuatro y media, cuatro, y más paulatina. mente hasta tres; este fondo tan corto probaba bien lo bajo que estaba el río.

Antes de alcanzar las puntas de la entrada abonanzó y escaseó el viento, imposibilitando así ir para adentro aunque fuese sobre bordos como lo habíamos emprendido; dimos luégo fondo á las once de la noche en tres brazas lama suelta demorando el cerro al Noroeste, y la punta de San José al Nordeste $3^{\circ}$ Este distantes de ella poco más de una milla.

Inmediatamente se echaron al agua lancha y bote con ánimo de ir al fondeadero aunque fuese á costa del penoso trabajo de la espía, pues aunque la serenidad del tiempo no däba sospecha alguna, suele sin embargo alterarse aquí repen tinamente formándose unas fuertes turbonadas, en cuyo caso nuestra situación no era la más segura. No bien se iba á poner el anclote en la lancha, cuando el viento á la tierra bastante fresco, obligó á arriar hasta 50 brazas de cable, $y$ desistir durante la noche de toda tentativa, como inútil para emprender la maniobra deseada.

Apenas dimos fondo, atracó á bordo la lancha del correo creyendo fuésemos el que se esperaba con ansia de la Coruña hacía más de dos meses. Los correos cuando entran aquí de noche disparan un cañonazo al estar sobre Punta de Carretas, como una señal de reconocimiento para la plaza, y entonces sale la falúa de rentas á recoger los pliegos. Nosotros ignorando esta práctica disparamos un cañonazo y produjo luégo el engaño para que también viniese la falúa en busca de la correspondencia.

Desde el momento de amanecer con el viento bonancible ya se tendió la espía con cuatro calabrotes y llegando á pique de ella pudimos con ventolinas de la brisa marear las velas de pstay, y cośer muy luégo el fondeadero por la proa de la fragata Santa Rufina que arbolaba el Feb. ró gallardetón del Comandante de la Armadilla.

Por la mañana temprano se había trasladado á bordo D. Alejandro Malaspina, quien me dijo haber fondeado la tarde anterior, sin novedad particular en su navegación desde las costas de Chile, y que sin poder vencer la tenacidad de los vientos tempestuosos ó de travesía sobre las tierras del Archipiélago de Chonos había en vano empeñado sus esfuerzos para reconocerlas; pero que con ménos contrariedades en adelante, pudo atracar después la costa al Sur del Estrecho de Magallanes, y situar también las islas de Diego Ramírez: teniendo la complacencia de que sus resultados estuviesen exactamente conformes con los nuestros, y de habernos reunido felizmente en este puerto donde contemplábamos ẹ término tan suspirado de nuestras fatigas con tanta satisfacción como la habíamos tenido en dar principio á arrostrarlas desde aquí en el año de 89 .

\section{CAPÍTULO IX}

Ultima escala de las corbetas en Montevideo: varios acaecimientos en aquel tiempo y reunión en el puerto de la fragata Gertrudis de la Marina Real, con cuatro buques mercantes de Lima: salida del convoy reunido, de Lima y Montevideo, y su navegación hasta llegar al puerto de Cádiz.

El objeto esencial de la segunda escala de las corbetas en el puerto de Montevideo, había sido al principio el de liquidar el haber de las tripulaciones, para que no sufriesen un descuento crecido á su llegada al Continente y no trastornasen los balances de las Cajas Reales; empero ahora se le agregaban otros no ménos importantes, y eran el apresto de los buques en un pié regular de guerra, y la reunión nuestra al convoy de Lima, el cual, bajo la escolta de la fragata Gertrudis, debía hacer escala en Montevideo antes de emprender la navegación para España. El primer punto nos pareció indispensable, aunque llevásemos salvo-conductos del difunto Rey de Francia Luis XVI, el cual recordaba las muchas atenciones que el conde de la Péyrouse había recibido en los establecimientos españoles: solicitaba lo segundo el Virey de Lima, y nuestras mismas circunstancias lo dictaban como prudentes, ya que debíamos recibir caudales de Buenos Aires y por la misma razón considerarnos comprendidos en los trances de la guerra.

Atento á este plan, ya la salida nuestra del puerto debió retardarse á lo ménos un par de meses, y buscar, por consiguiente, algunos objetos, en los cuales pudiera invertirse aquel plazo con ventajas del servicio. Ciertamente, no eran pocas las atenciones naturales de la expedición 
Feb. r6 hasta la mitad de Abril, en cuya época podíamos por nuestra parte considerarnos prontos para dar la vela. La renovación de la carta del río, errada en algunos puntos determinados en I789; la multiplicación de las sondas; el cuidado del observatorio; la redacción de las tareas hidrográficas emprendidas desde Lima; el mismo apresto de los buques y la instrucción militar de la tropa y marinería, bastaban solos para ocuparnos incesantemente. Multiplicáronse después más bien las ocupaciones, cuando empezaron á llegar los buques de Lima y particularmente la fragata Gertrudis. Sus amarraderos, sus reparos, las instrucciones y el traspaso de víveres de unos á otros, todo combinado con la escase $z$ de los almacenes y de gente y con la estación tempestuosa del invierno, la cual hacía imposible en muchos días la comunicación de los botes, debieron por precisión tenernos igualmente ocupados.

No merecía ménos atencion en nuestras medidas actuales el reconocimiento deseado del Golfo de San Jorge en la costa Patagónica. Hízose presente al Virey de Buenos Aires, que Su Majestad le había mandado para aquel verano, oponiéndose seguramente después, los incidentes de la guerra, á que viniesen de Europa las personas y los instrumentos que debían realizarle. Si no se verificase debían mirarse como igualmente desatendida la seguridad de nuestras pescas y la perfección de las cartas. Y era un acaso bien feliz el que se arrojase á tomarle en su cargo, aunque bien enfermo, el Capitán de fragata D. Juan de la Concha, acompañándole el piloto Inciarte, y que las corbetas pudiesen ceder los instrumentos necesarios para el intento. Fué destinado el mismo Concha á Buenos Aires para acordar estas materias con el Virey, el cual condescendió inmediatamente á cuanto solicitábamos, y no tardaron tampoco en emprenderse las excursiones necesarias para la corrección ya indicada de la costa.

Fué preciso un nuevo viaje á Maldonado y á la Isla Gorrite; se hicieron marcaciones con el teodolito en la Isla de Lobos; por tres veces se atravesó el bajo Inglés hasta conseguir el navegarlo en torno; se reconoció igualmente el bajo de la Panela frontero á la barra de Santa Lucía; otra piedra, no distante de la Isla de las Palomas, dentro del puerto de Montevideo, fué ligada con buenas marcaciones, y debimos mirar como un caso bien feliz, el que naufragado en la costa inmediata al Pan de Azúcar el falucho en el cual regresaba desde Maldonado el Piloto Hurtado con los instrumentos astronómicos y el reloj número II, pudieran éstos redimirse del naufragio sin la menor avería y conducirse salvos á Montevideo. Los Capitanes y Pilotos de los correos marítimos el Colón y la Cantabria contribu- yeron también por su parte á la perfección de la Feb. I carta con cuantas noticias útiles tuviesen particularmente por lo que toca á las sondas.

Las primeras épocas de las alturas correspondientes en el observatorio habían indicado las siguientes longitudes para los relojes marinos:

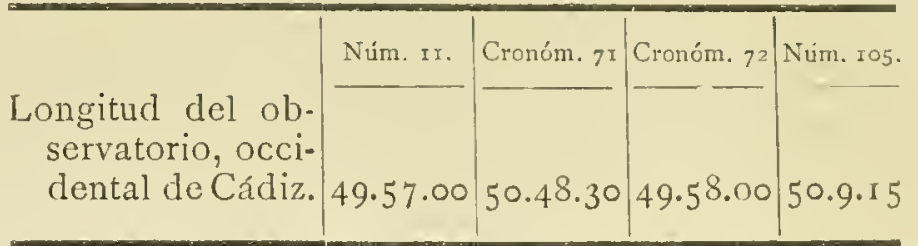

No debió sorprendernos el error del cronómetro 7 I, cuando ya por las comparaciones diarias en la última travesía desde Santa Elena habíamos advertido sus irregularidades bien extrañas, y los resultados de los relojes de la ATREVIDA debieron, por el contrario, mirarse por tanto más satisfactorios, cuanto que ligando admirablemente por dos medios diferentes la longitud del puerto de la Soledad, la cual no habían podido sujetar á otro punto alguno bien situado de las Maluinas, dejaban sin embargo bien situado aquel punto, y fuera de toda duda la verdadera extensión de las islas, del Oeste al Este.

No se descuidaron después tampoco las experiencias de la gravedad en el péndulo simple, y comparándolas el Teniente de navío D. Ciriaco Cevallos, con las demás que se habían hecho en uno y otro hemisferio, confirmaron lo que había sospechado el Abate Lacaille, esto es, que había una mayor gravedad en el hemisferio austral que en el boreal, y por consiguiente, que no debían suponerse los dos hemisferios tan simétricos como se había imaginado hasta entonces.

Para que la maestranza de á bordo no estuviese en la inacción, se agregó después á las obras interiores de las corbetas, la habilitación de la lancha de la Descubierta, á fin de que pudiese servir en la expedición de D. Juan de la Concha al golfo de San Jorge: agrandada y fortalecida esta embarcación y agregádole un falucho, sería fácil antes escoltarlas con una sumaca hasta el puerto de San Gregorio, y después verificar con ellas solas el reconocimiento interior, ya que los muchos bajos le haría más expuesto y dilatado para cualquiera otra especie de buques.

Finalmente, el día 3 del entrante Mayo, con el aparecimiento en el puerto de la fragata mercante La Princesa una de las del convoy de Lima, pudieron revivir de nuevo nuestras esperanzas de emprender muy luégo el viaje deseado para los hogares patrios.

La llegada en la noche del Io del Paquete Mas: io correo de España, no debió tampoco variar en modo alguno nuestro plan primitivo: á pesar de 
May. ro la eracuación de Tolón por nuestra parte, las fuerzas marítimas de los enemigos habían quedado harto debilitadas, y en muchos meses no se contaba tal vez una sola presa suya sobre los buques de las naciones aliadas. Las escuadras nacionales é inglesas cruzaban en los varios puntos dc recalada. 'Todo anunciaba que nuestra navegación sería feliz mucho más si la emprendiésemos con brevedad; este mismo correo traía aviso de haber sido comprendido en las últimas gracias de Su Majestad, el Brigadier D. Antonio de Córdova, Comandante de la Armadilla, para el grado de Jefe de escuadra; tributáronsele con este motivo los honores que prescribe la Ordenanza, al tiempo de arbolar la insignia en la fragata Rufuna, y se arrió por la misma razón el gallardetc distintivo de la Descubiekta.

No fueron los siguientes días tan favorables á la Astronomía como debímos esperarlo: malográronse varias ocultaciones de estrellas por la Luna y no pocos eclipses del primero y segundo satélites de Júpiter, por estar los cielos por lo común ofuscados, ó con celajería ó con calima. Las pocas observaciones que se consiguieron en el primer satélite fijaban la longitud de $50^{\circ} 9^{\prime}$, tal rez algún tanto crecida por hallarse generalmente el cielo con vapores y esta1" además el planeta proyectado con la vía láctea, la cual reflejaba una claridad siempre contraria á la exactitud de las observaciones. El invierno, en el entretanto, parecía aproximarse á paso más bien lento; eran escasas las aguas, templado el frío, y habían cesado en un todo las turbonadas temibles del verano.

Muy oportuna fué la estación tan benigna para que el Neptuno y Concordia, otros dos buques del convoy de Lima, fondeasen aquél en Montevideo y el segundo en Maldonado: lograron amarrarse con seguridad $y$ en bucn apostadero, antes que les hiciese peligrar un pampero algo recio que tuvimos para el I7, y á favor de estas mismas bonanzas pudo librarse una fragata mercante de Europa, que había varado en el banco Inglés, lográndosele traer en vandolas al puerto, alijada en otras lanchas una parte muy considerable de su carga, casi sin avería alguna.

$\mathrm{Ni}$ á la verdad podíamos considerar estos úl. timos meses por ménos útiles para la continuación de las tareas de la expedición nuestra, aunque pareciese á la sazón casi entregada á la inacción y á los objetos militares. La llegada antcs á Puenos Aires y últimamente á Montevideo de los Sres. Lispinosa y Bausá, había enriquecido nuestro diario astronómico y nuestros apuntes sobre la geografía interior de América, con mil noticias útiles: confirmábase la determinación hecha en el año go de la latitud y longitud de Santiago, esta última deducida ahora de un eclipse de Luna y de una inmersión del primer satélite de Júpiter. Las observaciones tan proli- May. 10 jas como importantes sobre la velocidad del sonido, en la misma capital, abrían un nuevo campo á esta clase de indagaciones físicas, hasta aquí no bien sujetadas á la experiencia. La elevación de la cordillera inmediata, su dirección, tránsito y albergues, la posición de Mendoza y Punta de San Luis, un examen diario de la variación de la aguja, y finalmente, una serie no interrumpida de observaciones de longitud y latitud que sujetasen la ruta de las Pampas hasta Buenos Aires, debían mirarse como adquisiciones de tanta mayor importancia cuanto que habían contribuído al mismo tiempo á que mejorase mucho la salud de los Oficiales indicados.

Llegó casi en los mismos días el botánico Don Luis Nee, cuyas excursiones habían sido bien útiles y laboriosas. Después de nuestra separa. ción en Talcahuano, había internado en las tierras de los Pehuenches, arrimándose siempre á las montañas; hecha luégo una breve demora en Santiago, había atravesado la cordillera, y her. borizado sucesivamente así en aquella parte montuosa como en las inmediaciones de Mendozay en todo el camino de las Pampas, que conduce hasta Buenos Aires. Una preciosa colección de las piedras que componen por aquella parte el hueso de la. montaña, debía servir ahora á perfeccionar mucho nuestras indagaciones litológicas: diferentes excursiones sucesivas á los minerales, no distantes de la ruta, habían por lo común derribado las esperanzas siempre lisongeras de los poseedores; y al contrario, sus reconocimientos de los surgideros de agua salada en los mismos montes, habían abierto unas combinaciones mucho más útiles para el abasto de la sal en el reino de Chile.

Pero eran aún cortas estas utilidades, cuando las comparásemos á las que nos anunciaba en dos cartas suyas D. Tadeo Heenke, la una escrita desdc el Cuzco y la otra desde Arequipa: además de sus prolijas investigaciones en la botánica y litología; además de unas excelentes y nuevas colecciones de aves en el largo trecho que había corrido, eran fruto de la mayor importancia para el público; sus análisis de muchas aguas minerales y de la célebre mina de azogue en Huancavelica; las determinaciones de la diferente elevación de la cordillera por medio del termómetro en el agua hirviendo; su reconocimiento del volcán de Arequipa y de las exquisitas aguas termales; las internaciones á los países de los Yungas y de los Chunchos; su estada en la laguna de Chucuitos y las muchas investigaciones hechas en el Cuzco. Proponíase luégo continuar su ruta hasta Potosí, visitar desde allí el país de los Mofos y de los Chiquitos, y últimamente es tar en Montevideo para los primeros meses del año siguiente.

En la tarde del 2 I estuvo á la vista y fon- 
May. 2 deó poco después en el puerto la fragata Santa Ciertrudis; la conserva con el Levante, el cual había rendido la verga mayor en el mar Pacífico y fondeó ahora al mismo tiempo, le había atrasado considerablemente. Su llegada dió, pues, lugar á que pudiese atenderse seriamente á la salida de Montevideo, en la cual ya no parecía caber otra demora que la indispensable de los aprestos en una estación y en un puerto á la verdad poco oportuno para el intento.

El estado en el cual había salido de Lima la Gertrudis, exigía una atención seria. Las dos terceras partes de su tripulación se componían de levas que jamás habían visto el mar; la mitad de su tropa de reclutas ó desechos del regimiento Fijo de Lima; mortalmente enfermo el Contramaestre; faltos el Contador, el Cirujano, el Maestre de víveres, el Condestable y un Oficial de guerra; sus víveres de reemplazo esparcidos en los cuatro buques; su velamen muy deteriorado; su artillería del corto calibre de á ocho y desfogonada; eran inconvenientes tanto más difíciles á remediarse, cuanto que por la una parte los almacenes de Montevideo carecían de todo, y por la otra debía también reemplazarse por estar gravemente enfermo el Oficial de detall D. José Quevedo, Teniente de navío: agregábase luégo á tamaños males el que mal estivada la plata, ocupaba la parte de sollado correspondiente á los cables, los cuales por la misma razón empachaban en el entrepuente; que en el costado de babor se habían quitado las hileras altas del forro del cobre; finalmente, que la fragata en la última navegación había descubierto un agua de cuatro pulgadas diarias, cantidad muy leve á la verdad, pero que no podía desatenderse atento al tiempo que había corrido desde su carena, á los caudales que ahora conducía y á la misma desproporción de estiva que éstos causaban irremediablemente.

Entre los cuatro navíos del comercio, los nombrados Levante y Princesa podían considerarse en cierto modo capaces de una mediana defensa, pero los Neptrmo y Concordia, apenas estaban dotados cada uno con catorce cañones de corto calibre, y áun tan mal abastecidos de municiones, que parecía importuno darles el semblante siquiera de una fuerza mediana; todos, por otra parte, estaban tripulados por un corto número de marineros, y según los informes más acordes, tan zorreros los últimos dos, que no pudiese prometerse sino una navegación larga y penosa. Pero el pormenor de estos armamentos se comprenderá mejor en el estado último, y aquí sólo podemos añadir que las tripulaciones eran por lo común robustas y bien disciplinadas, y que por una de las muchas contradicciones que diariamente se encuentran en el complicado sistema nuestro de la América, se hallaba autori- zado para estas marinerías el ajuste de las tra- May.23 vesías, habiendo presidido como ayudante del Virey en el Callao el Teniente de navío D. Pedro Colmenares.

Al mismo tiempo de tomarse las medidas para la habilitacion de estos buques, se avisó también á los del comercio de Montevideo que se les admitiría en el convoy siempreque estuviesen prontos para el I 5 ó 20 del entrante Junio, plazo que habíamos prefijado para la salida, bien miradas las circunstancias del puerto en la actual estación y los muchos objetos á los cuales debíamos atender para su habilitación. No parecía en modo alguno prudente una mayor clemora, áun cuando no llegasen los otros tres buques de Lima, quienes con escala en Guayaquil debían últimamente reunirse con los demás, y eran los nombrados Galga, Rosa y Santander.

Una mirada en torno á las circunstancias del viaje próximo debió manifestar en el entretantu cuáles eran las nulidades que le rodeaban, y cuáles, por consiguiente, los puntos de defensa que debían adoptarse. Los tres buques del Rey, débiles en su fuerza y en su tamaño, si por la una parte debían cuidar de la seguridad de los demás, por la otra, sienclo depositarios de una crecida cantidad de caudales, debían con preferencia atender á su propia seguridad. Los del comercio al contrario: incapaces de una resistencia mediana siquiera, presentaban, sin embargo, con su mole, aparejo y baterías, unas fuerzas bastante considerables; pero el todo era en sí débil, lento y difícil de amalgamarse, atento particularmente á la clase de nuestros armamentos y al indispensable desaliño militar de los buques mercantes. Ya con estas consideraciones no cabía alternativa en el plan nuestro de defensa, si acaso tuviésemos un encuentro con fuerzas enemigas. Habilitáronse los buques de Lima para la línea, y á cada una de las tres divisiones se hizo presidir un buque del Rey, de suerte que dirigiese con acierto y sujetase con tesón, cuando fuese necesario, los pocos movimientos militares que exigiesen las circunstancias. 'Todos á la vista de embarcaciones sospechosas debían tremolar la bandera Real, la insignia de Comandante arbolarse en el Levante, el cual era mastelote de proa de la Descubierta. La tercera división, compuesta de los navíos más zorreros y débiles, el Neptuno y Concordia, presidida de la corbeta Atrevida, debía maniobrar por lo común separada, cuidando con este motivo del convoy de Montevideo. La Santandor, cuyo aparejo, tamaño y ligereza, podían más bien equivocarla con un buque de la Marina Real (si acaso nos alcanzase) serviría en clase de batidora y repetidora, dotada en este caso con un Oficial de guerra y las correspondientes banderas: la repetición de noche de ciertas señales de cañonazos y la mayor unión, 
May. 23 debían conservar en la oscuridad aquella ilusión que fiábamos de día al órden y al bulto. Las cazas confiadas generalmente á los buques de la Marina Real, debían siempre manifestar aquella seguridad, que naturalmente infunde una escuadra fuerte: finalmente, para el caso en el cual fuese inevitable un choque, se atendían igualmente la seguridad del convoy con una pronta fuga ó desparramarse; y la seguridad de la Gertrudis, en el modo con el cual había de huir, distrayendo á los perseguidores del verdadero rumbo que esta seguía. Quedaba después para la división del centro, compuesta de los navios Levante, Princesa y Descubierta, el sostener la ilusión ó el choque cuanto fuese posible, y asegurar así la fuga de los demás. Este fué el plan propuesto, al cual se dirigieron las señales é instrucciones comunicadas, y fué á la sazón oportuna la salida del Paquete correo de España, para avisar por menor todas las medidas indicadas al señor Ministro de Marina.

Entretanto, los aprestos habían procedido con la mayor actividad. En la fragata Santa Gertrudis, aunque el tiempo y la mar gruesa interrumpiesen en muchos días un trabajo seguido y bien ordenado, y á pesar que tuviese muchos faltos, ó bien por la natural inconstancia del marinero ó bien por las hospitalidades y otros muchos inútiles y entretenidos, recibieron los víveres de los cuatro buques mercantes, completaron la aguada, se hizo la entrega complicada del contramaestre, se perfeccionaron aparejo y velamen, se mejoró la estiva de la plata, y los demás aprestos siguieron una proporción aún aventajada. En las corbetas ya nada faltaba. E1 navío Levante había podido reemplazar su verga mayor con una de la fragata Loreto, y así para el día io de Junio ya todo podía considerarse pronto para la salida.

Fué éste precisamente el día en el cual llegaron los caudales y correspondencia de Buenos Aires. Nos prevenía el Virey que ya quedaba en nuestro arbitrio dar la vela, y con este motivo pudieron tomarse las últimas medidas para verificarlo. En el mismo día se comunicaron á los buques pequeños instrucciones para su próxima navegación: eran éstos en número de diez; pero algunos, aún tan atrasados en su habilitación, que de ningún modo pudieron seguirnos: como quiera que esta conserva no estaba ligada por orden alguna, debimos mirarla por una y otra parte como voluntaria, y por la misma razón no usar de la menor violencia ó amenaza para que tuviese lugar.

Se emprendieron con igual actividad las levas, las cuales, contando con los díscolos, inútiles y algunos roluntarios que cedió el General Comandante de la Armadilla de su fragata y del paquebot Santu Eulatia, debían reemplazar no ménos de 50 hombres á la Gertrudis y aumentar Jun. ro de unos 30 la tripulación de cada corbeta. Seguramente, lo local de Montevideo convida mucho más á este arbitrio que cualesquiera otros países de los que hemos recorrido. El número de vagabundos europeos es mucho mayor, las guaridas ó escondrjjos no tan comunes, y la policía cierta mente más activa y vigilante. Túvose también la precaución de aumentar hasta cuatro meses y medio los víveres de las corbetas, además de las partidas sobrantes de tocino y menestras; y en la fragata Santa Gertrudis, con anuencia de su Comandante y del Cirujano, se adoptó en lugar de las dietas vivas, el uso de las pastillas del Conde de Liniers, del mismo modo que debíamos usarlas en entrambas corbetas.

Los Capitanes de los buques de Lima hicieron á la sazón presente, que les parecía justo y áun indispensable para la mayor puntualidad de sus marinerías, hacer un pagamento, aunque corto, entre ellas, de suerte que permaneciendo dos ó tres días en tierra según costumbre antigua, se restituyesen luégo puntualmente á sus destinos. Concedióseles este permiso, no sin previo aviso del General Comandante; y el Teniente de navío D. Francisco Viana, recorriendo los buques, intimó de antemano las multas y los castigos á los cuales quedarían expuestos los infractores de este convenio si se les aprehendiese en tierra cumplido el plazo, como parecía sumamente probable.

Bien inoportuna fué esta ausencia de las marinerías de los buques de su destino en la siguiente noche del I2, en la cual un temporal recio del Sueste los hizo garrar todos, aconchando principalmente los Princesa y Neptuno, hacia el Cerro, en donde, si no trabajasen inmediatamente con las aguas altas que siguen siempre de cerca á estos temporales, quedarían con mucha probabilidad varados por largo tiempo. Atento á esta circunstancia, que podía sernos ó muy favorable ó muy adversa para la verificación de la salida, enviáronse I 6 hombres de las corbetas con un Oficial de mar al Neptmo, cuyo Capitán había avisado que sólo tenía á bordo unos seis hombres; y manifestando el Capitán de la Princesa que estaría por sí solo en estado de trabajar, recogida la mayor parte de su tripulación, se destacó una lancha grande al Levante para que pudiese enmendar sus anclas y tender las espías.

La mañanita del I4 presentó con estas precauciones el espectáculo bien agradable de ver últimamente á flote, aunque no sin mucho esfuerzo, entrambos navíos Princesa y Neptuno; no pudo ser tan feliz el Levante, pero al día siguiente lo consiguió también aprovechando un buen repunte de aguas; y finalmente, en la mañanita del I 5 ya todos los cuatro buques estaban de tal modo franqueados, que á cualquier hora pudieran 
Jun. It dar la vela. Vencido con tanta felicidad este obstáculo esencialísimo para la salida, ya los últimos aprestos de los buques de S. M. debían acelerarse cuanto fucse posible; y á pesar que en los dos días siguientes los vientos frescos del Noroeste al Oeste con levantar mucho las olas y causar por otra parte una excesiva bajamar en el puerto, interrumpiesen en todos los buques así la facilidad del embarco como los viajes de las embarcaciones menores, consiguióse sin embargo que al medio día del I 8 todos hubiesen recibido la pólvora, ranchos y ganados, y que en la misma noche los buques de S. M. pudiesen emprender sus faenas de desamarrarse y ponerse en franquía: fueron en esta ocasión bien útiles, particularmente á la Gertrudis, los auxilios de la Armadilla y la activa asistencia á su bordo del segundo Comandante del resguardo D. Manuel Cipriano, el cual quiso servirla en clase de práctico. La Atrevida continuó sirviéndose de la lancha de las corbetas, esquifada con gente del paquebot Santa Eulalia. El correo marítimo franqueó otra grande para la Descubierta.

Cortada así casi de un todo la comunicación con tierra, pudimos al día siguiente recibir en los tres buques de la Marina Real todas las levas que nos estaban destinadas. Pero como no pudieron estar con igual prontitud las listas, atento á la muchedumbre de trasbordos, ni por otra parte se hubiese franqueado un buque pequeño siquiera, fué preciso diferir la salida en un día más, plazo para nosotros tanto más feliz y oportuno, cuanto que en todo el día no hubo sino ventolinas, las cuales coadyuvaron con extremo á que se completasen los pocos consu mos de aguada, se levase segunda ancla, todos metiesen dentro sus lanchas y botes y se franqueasen varios de los de Montevideo. Al ponerse el Sol de la misma tarde, tomó el tiempo las más bellas apariencias, y empezaron á entablar ventolinas galenas del Noroeste, y estas, á medida que adelantaba la noche, fueron tomando más fuerza é inclinándose al Norte.

Con las primeras claras del $2 \mathrm{I}$, continuando el viento fresco del Noroeste, pudo hacerse señal á todos los buques de dar la vela. La excelente disposición en la cual habían anochecido los buques de S. M., los del comercio de Lima y seis de los de Montevideo, hizo que lo ejecutasen todos con la mayor brevedad á la vez que la Descubierta. No asílos otros cuatro buques del mismo comercio, los cuales, ó por desidia ó por no estar prontos, no se habían franqueado en la tarde anterior, y ahora, disminuída el agua en el puerto, no pudieron quedar á flote en modo alguno.

A las diez de la mañana estábamos Norte-Sur con la Isla Flores á distancia de dos millas. Las aguas nos habian abatido algo al Sur, pero des- pués las marcaciones nos manifestaron que de- Jun. $2 x$ caímos aún más, lo cual, sin embargo, no debía parecer extraño atento á los vientos que á la sazón corrían.

$\mathrm{Al}$ aproximarnos á la Isla Flores, se nos habían presentado á la vista tres embarcaciones extrañas; la una un paquebot, el cual desde la parte oriental del banco ceñía con todo aparejo al Oeste; la otra grande y al Esueste de la Isla como cuatro leguas, la cual seguía la misma vuelta del Oeste; y finalmente, la tercera de mediano tamaño y más distante que ceñía con todo aparejo al Nordeste. Su semblante y su misma bandera las manifestaban que eran todas nacionales, pero jamás pudimos imaginar que dos de ellas eran una parte hasta ahora desmembrada del convoy. La Princesa nos informó á la voz que la segunda era la Galga; y efectivamente, arribados sobre ella, nos enteramos era así, por un bote que su Capitán envió á bordo. La fragata Gertrudis, á quien hicimos señal de reconocer la otra, no tardó en señalar la numeral de la Santander, y enterada después á la voz y por un Piloto suyo de las demás circunstancias que la rodeaban, vino á comunicarlas con la posible fuerza de vela.

Entrambas habían salido del puerto de Guayaquil en los primeros días de Abril y logrado una travesía sumamente feliz hasta la embocadura del río; pero acosadas después de una contrariedad constante de vientos y tempestades, en balde llevaban sacrificados veinte días para la reunión deseada en el puerto de Montevideo. La Santander había tocado con el pantoque en la cola del banco Inglés, y alijado una parte considerable de sus víveres había conseguido salir á flote sin daño alguno. La Galga, nueve días antes, había hablado á la fragata Astrea de la Marina Real, dirigida á Lima en conserva de la Rosalía; pero separada ahora y con precisión de hacer escala en Montevideo.

En ambos buques era igualmente vivo el desẹo de continuar en nuestra conserva, y á este fin no se habían descuidado en presentar estados individuales de cuanto necesitasen relativamente á aguada, víveres y rancho. La Galga además de esto se hallaba no sólo con una tripulación bien corta, sino que entre ésta había unos ocho enfermos con afectos catarrales y calenturas intermitentes, enfermedades propias, no ménos de los climas qne habían dejado, que de los que ahora habitaban.

Ya que á la sazón eran los momentos demasiado preciosos para la continuación de nuestro viaje, tuvo orden la Galga de seguirnos, pues se le habilitaría en la primera ocasión oportuna, de cuanto le fuese necesario; dejé árbitra la Santander de hacer ó no escala en Maldonado, con tanta más razón, cuanto que su destino á las costas de Cantabria debería separarla de nosotros, justa- 
I." is mente al tiempo dc la recalada, cuando el convoy parecía más necesario. Entretanto no habíamos descuidado la ocasión oportuna de rectificar con buenas marcaciones la marcha del cronómetro, ni nuestra derrota había sido ménos feliz de 10 que pudiéramos desear. La primera por dos series de horarios (si bien por alguna casualidad no bien conformes entre sí) indicaba un resultado correspondiente á la longitud de las marcaciones; la segunda, ayudándonos casi con emulación el viento y la corriente, nos había conducido para el ponerse el Sol á la vista del puerto del Maldonado, del cual distaríamos unas seis leguas apenas. La Isla Gorrite demoraba en esta posición al Norte $26^{\circ}$ Este; la de Lobos al Norte $45^{\circ}$ Este, y el Pan de Azúcar al Norte $2 I^{\circ}$ Este de la aguja, fondo I6 brazas lama, y veíamos, no sin alguna complacencia, así por éstas como por las muchas marcaciones repetidas, como ya se ha dicho, en todo el día, que la carta últimamente construída había co mbinado aquella exactitud, que solíamos y debíamos desear.

Los buques de S. M. y del convoy de Lima estaban al anochecer bastante unidos, y todos proporcionaban suvela con el Concordia y Neptuno, seguramente los más zorreros. No así los seis de Montevideo, los cuales se hallaban la mayor parte considerablemente atrasados. El viento continuó fresco y con buen semblante en toda la noche, y así no nos fué difícil estar para las nueve Norte-Sur con la isla de Lobos, ni para la mañanita siguiente haber perdido toda tierra de vista con el rumbo del Este 1/4 Nordeste que seguimos constantemente.

Todo denotaba al amanecer del día siguiente la suma disparidad de andar y áun de manejo en los diferentes buques cuya conserva nos estaba encargada. Cogían una extensión grande; se hallaban los unos muy á sotavento y otros muy atrasados: los de Montevideo ni áun cruzaban sus juanetes; el navío Concordic estaba á unas dos leguas por nuestra popa; finalmente, áun con las gavias arriadas hubiera sido difícil la incorporación del mayor número, si no nos hubiésemos á ratos atravesado: aprovechóse, sin embargo, esta ocasión para dar á la Galga las instrucciones y la orden para los buques que debían auxiliarla en los diferentes artículos de los cuales carecía. Igual orden se dió después á la Santander, y desde luégo, en aquella misma tarde quedaron una y otra completas de la cuota correspondiente á ésta y á la corbeta ATREvidA.

Hasta el 6 de Julio nuestro viaje debió mirarse como el más feliz que pudiésemos desear. Los vientos eran comunmente galenos del Oeste: los interrumpía tal cual calma, la cual no era importuna, pues coadyuvaba á la habilitación completa de los buques últimamente incorporados; y siendo también favorable el efecto de las co- rrientes (según lo indicaban los relojes mari- Jul. nos), no había sido difícil alcanzar la latitud de $30^{\circ} \mathrm{oo}^{\prime}$. Renováronse al mismo tiempo las observaciones de las distancias lunares, y pareció últimamente oportuno comunicarlas por señal á los diferentes buques del convoy, referidas, como debe suponerse, al medio día anterior.

Nuestros elementos eran los siguientes:

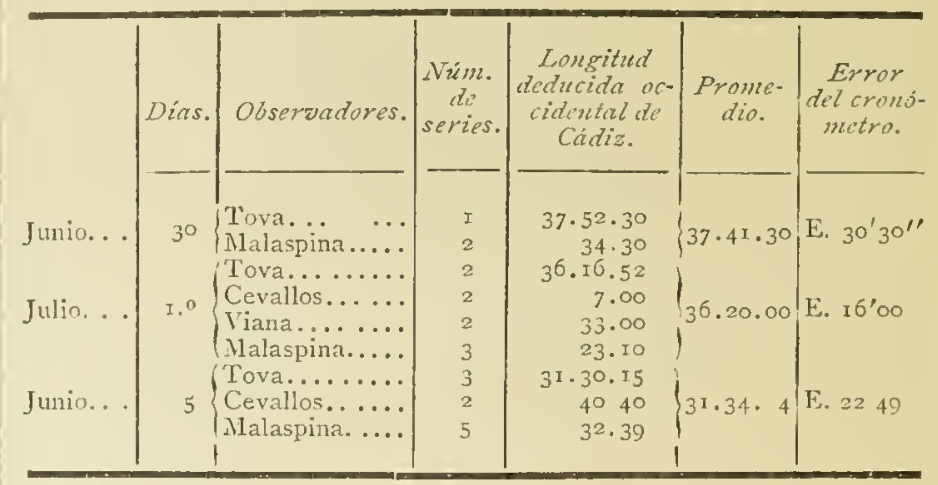

Así por ser estas últimas las observaciones de mayor confianza, como porque realmente igualaban el error medio con las demás, fueron las que se comunicaron con la longitud de $3 \mathrm{x}^{\circ} 44^{\prime}$. La ATREvida, al mismo tiempo, había señalado para igual época la de $3 \mathrm{I}^{\circ} 4^{6^{\prime}}$, y la fragata Santa Gertrudis la de $32^{\circ}$ Io'. Quedó por la misma razón admitido en el cronómetro $7 x$ este mismo error de $23^{\prime}$ al Este, el cual, sin embargo, no debió persuadirnos á variarle su marcha, porque era igual ó menor al que en los primeros días habíamos deducido de las comparaciones con el I05.

Los vientos variables, generalmente inclinaclos al primero y cuarto cuadrante, no nos permitieron abandonar las bolinas para adelantar hacia el Norte. Deseábamos dar vista á la Isla Trinidad ó á los islotes de Martín Vaz, pero los bordos nos condujeron á pasar unas 20 leguas al Este de estos últimos, y por la latitud de $20^{\circ}$ alcanzamos la brisa del Sueste, con la cual se emprendió derrota para el corte de la equinoccial.

Ya en la mañana del $x 6$, manifestándose un día apacible con viento galeno del Oeste, habíamos procurado dar una leve idea del sistema militar propuesto. Importaba demasiado que no le mirasen generalmente con ojeriza ó con desprecio, considerándole á las veces como molesto é importuno, á las veces como supérfluo é inasequible. Así, nos habíamos decidido á no exigir esta clase de movimientos cuando, ó los vientos contrarios hacían molesta la fatiga, ó las mares y vientos hacían su ejecución demasiado complicada. Pero en aquel dia, además de la mar llana y del tiempo bonancible que convidaba al uso de las bocinas, se juntaban la mucha unión en que habíamos amanecido y el rumbo que seguíamos unas nueve cuartas distante del viento. Hízose, pues, la señal al convoy de navegar á babor de la escuadra, ya que los más estaban por aquella parte, y á la escuadra la de formar la línea de combate mura babor: tomó inmediatamente su 
Jul. 22 puesto la fragata Gertrudis; el Levante y Princesa se colocaron oportunamente; fué algo más tarda la Galga; se adelantó con tino la Santander; y ya que se había últimamente prescrito á la tercera división que navegase en el convoy á estribor, la ATREVIDA dirigió oportunamente sus señales á la una y al otro, y alucinados casi de este nuevo semblante los buqucs de Montevideo, arribaron á incorporarse en su lugar con una prontitud difícil á ser expresada. Ya formada medianamente la línea, era esencial manifestar el semblante militar que podía dársela. Se hizo la señal de que ciñese el viento á un tiempo, y la de izar la bandera Real el Levante, izado también el gallardetón y disparado un cañonazo, hizo al todo de la línea que ya navegaba de bolina, realmente respetable. Una media hora después, pareciéndonos que la ilusión perdería mucho de su mérito si fuese demasiado familiar, se mandó arribar á un tiempo al rumbo de derrota, cesada la formación y arriadas las insignias.

En aquellos mismos días tuvimos también la felicidad de ver incorporado un paquebot de los rezagados en Montevideo al tiempo de nuesAg. tra salida. Entretanto navegábamos con bastante celeridad hacia la Línea; y la variación magnética que sobre la isla Trinidad había sido de $I^{\circ}$ al Noroeste aumentó después hasta 7 y $8^{\circ}$. Para el día r. ${ }^{\circ}$ de Agosto, favorccidos no solo de las brisas, si también de unas diferencias diarias al Norte, pudimos ya vernos en latitud de $0^{\circ} 40^{\prime}$ Sur y por consiguiente ya tan próximos al deseado corte de la equinoccial, que le debiésemos mirar como seguro para la noche siguiente. En efecto, fué así, y con una complacencia general quedó vencida esta nueva barrera para el feliz término del viaje; indicando á la sazón diferentes azimutes la variación de $8^{\circ} 45^{\prime}$ y el cronómetro $7 \mathrm{I}$ la longitud de I $9^{\circ} 25^{\prime}$; longitud, sin embargo, que debíamos creer errada en unos 30 ó $40^{\prime}$ al Este, ya que concurrían unánimes en manifestarlo así, no solo nuestras observaciones de las distancias lunares, si también las de la corbeta ATREvida y fragata Gertrudis, las cuales señalábamos frecuentemente al convoy para indicarle no solo la uniformidad de nuestros resultados, si también la frecuente alteración en la dirección de las corrientes.

Nada pudo justificar mejor que este viaje la preferencia de nuestra derrota, sobre la que suele seguirse comunmente y sin atención á la diferencia de vientos en el invierno ó en el verano. Enhorabuena que en esta última estación, contándose constantes los Nordestes sobre la costa, se hagan casi desde el mismo día de la salida del Río de la Plata, rumbos más bien inclinados al Norte, pero en el invierno todo convida á aprovechar los Oestes de los paralelos altos hasta po- nerse en meridianos de la Trinidad, para huir al mismo tiempo de los Nordestes costaneros, y con las brisas del Esueste navegar algo descuartelados y en buena derrota, sin recelo de caer sobre la Isla de Fernando Noroña. Ello es, que habiendo nosotros navegado ahora de tal modo que apenas pudiésemos evitar cinco ó seis grados constantes de abatimiento, sin embargo, desde e! paralelo de $20^{\circ}$ hasta la equinoccial, apenas pudimos conservar el mismo meridiano de $20^{\circ}$ al occidente de Cádiz.

Casi al mismo tiempo declinaron ya los vientos al Sur y Sursudoeste frescos, y con ellos nuestros progresos an los tres días siguientes, fueron de los más lisonjeros que pudiésemos desear.

Al medio día del 4 , ya nos hallamos en $4^{\circ}$ $45^{\prime}$ Norte y en longitud de $19^{\circ} 30^{\prime}$. El error contraído en la estima desde la entrada de las brisas, no era menor de $2^{\circ} 45^{\prime}$ al Oeste, y por consiguiente, nos indicaba como prudente el conservar aún el rumbo adoptado del Nornordeste has ta entrar en meridianos de las Islas de Cabo Verde, hacia los cuales se inclinan comunmente los que regresan del Perú, para ir con bastante barlovento al encuentro de las brisas del Nordeste.

Esta derrota nos proporcionó para la mañana siguiente el encuentro agradable y deseado de una embarcación nacional que con las muras á babor navegaba hacia el Sur: la señaló la ATREVIDA á las ocho de la mañana, y habiéndosele prescrito que siguiese dirigiendo el convoy y demás buques de Lima, hízose luégo señal á la Gertrudis para que siguiese la Descubierta, la cual, ya con todo aparejo y el rumbo del Norte $1 / 4$ Nordeste, navegaba al encuentro y reconocimiento de la embarcación avistada. El viento á este tiempo cedió mucho de su fuerza y tuvimos repetidos aguaceros: así eran bien las once, cuando pudimos atracarla, ya puesta al pairo, y enviar el bote á su bordo con un Oficial de guerra.

Era la Esmucralda de 200 toneladas y del comercio de Santander, la cual desde este puerto navegaba para el de Montevideo con carga de hierro y fardería, y treinta y ocho días de navegación; confirmó el no buen suceso de nuestras armas en el Rosellón y el encuentro bien reñido de las escuadras francesa é inglesa en la Mancha, conforme nos lo habían hecho sospechar las últimas papeletas recibidas en Montevideo: nos enteró después del grande número de buques ó nacionales ó aliados, que protegían la navegación y el comercio sobre las Azores y las costas de Cantabria y Portugal; y finalmente, enterado por nosotros de las noticias individuales del convoy para que no se equivocasen en Montevideo y en Lima, se despidió poco después de las doce, ciñendo con las muras á estribor.

No nos abandonaron los Sudoestes acompa- 
Ag. 9 ñados con mucha lluvia, sino en la tarde del 9 por latitud de $\mathrm{II}^{\circ}+6^{\prime}$. Debimos después luchar por algunos días con muchas calmas y variedad de ventolinas, las cuales nos condujeron á poca distancia de las Islas de Cabo Verde. Finalmente, sólo en la tarde del 20 por latitud de I $5^{\circ} 32^{\prime}$ pudimos alcanzar la brisa verdadera del Nordeste, y ceñirla con las muras á estribor en buena unión con el convoy. Se comunicaron al mismo tiempo con señales los últimos resultados de las distancias lunares, los cuales fueron los siguientes:

\begin{tabular}{|c|c|c|c|c|c|}
\hline Dia. & Observadores. & $\begin{array}{l}\text { Número } \\
\text { de series. }\end{array}$ & $\begin{array}{l}\text { Longitud } \\
\text { deducida. }\end{array}$ & Promedio. & $\begin{array}{l}\text { Error del } \\
\text { cronómetro. }\end{array}$ \\
\hline 18 & $\begin{array}{l}\text { Cevallos. } \\
\text { Ali. . . } \\
\text { Malaspina. }\end{array}$ & $\begin{array}{l}6 \\
6 \\
6\end{array}$ & $\begin{array}{r}23.12 .30 \\
4.50 \\
8.25\end{array}$ & 23.8 .35 & E. $I^{\circ} 8^{\prime} 35$ \\
\hline
\end{tabular}

Así referidos al medio día del 20 pudimos continuar las longitudes siguientes en los tres buques de S. M.:

\begin{tabular}{l|c|c} 
& $\begin{array}{c}\text { Longitud occidental } \\
\text { de Cádiz. }\end{array}$ & Promedio. \\
Corbeta Descubierta. . & $23^{\circ}$ I 9 \\
Corbeta ATREvidA. . . . & 23 \\
Fragata Gertrudis. ... & 24 & $23^{0} 22^{\prime}$
\end{tabular}

Variación magnética por diferentes observaciones $10^{\circ} 30^{\prime}$ Noroeste, distancia á la Isla Brava 95 leguas próximamente.

Puede inferirse de los datos antecedentes, que en los últimos días las corrientes nos habían llevado vivamente al Oeste y que en la noche última habíamos cortado casi sin precaución alguna el paralelo de una vigía situada al Oeste de la Isla Brava. En cuanto á estas vigías diremos lisa y llanamente que sin atrevernos á hacer frente á las ideas generalmente admitidas, estamos, sin embargo, bien convencidos que la $\mathrm{Na}$ turaleza, siempre consecuente en sus obras maravillosas, no ha colocado en medio de un golfo inmenso unas piedrezuelas apenas perceptibles, y que en la situación nuestra, ó de no internar velozmente en el límite no bien cogido de las brisas, ó de aventurar adelantándole uno de los buques de guerra, pareció preferente no tomar medida alguna precavida, la cual por otra parte, hubiera sido en mucho frustrada con la crecida diferencia al Norte que tuvimos al medio día sisruiente.

Cogidas las brisas, á las cuales pasando el trópico, vimos suceder, según costumbre, vientos largos variables del Este al Sur, nos hallamos en pocos días con el convoy unido en latitud de $30^{\circ}$ proximamente. En diferentes intervalos de calmas ó de vientos bonancibles, habíamos antes ,ocorrido la fragata Gertrudis con algunos víveinc que pudiesen reemplazar los que tenía ave- riados; y después los tres buques de S. M., for- Ag. 20 mados en línea, habíamos hecho un ensayo militar de las diferentes clases de ataque y defensa, logrando así soltar mucho los equipajes en el uso de las armas de fuego y del abordaje. Ni debimos tampoco descuidar una nueva repetición de las experiencias eudiométricas, la cual manifestase hasta dónde serían útiles estos datos en lo venidero para juzgar de la atmósfera interior de un buque. Para este intento se había dispuesto que además de los aires, que solíamos comunmente comparar entre sí, se examinasen ahora el de los pañoles de comestibles, y el que despedía una de las vasijas de la estiva, las cuales se habían llenado con el agua llovediza recogida sobre cubierta en las inmediaciones de la equinoccial: agua que manifestaba, al tiempo de suministrarse al ganado diariamente, una cierta fetidez, indicio casi seguro de su corrupción: el éxito manifestó de nuevo la exactitud de nuestras experiencias y la posibilidad de mantener interiormente un buque libre de toda corrupción. Los diferentes aires hecha la absorción del ácido nitroso, dieron los siguientes grados de salubridad:

Aire atmosférico á las diez de la mañana. . . . 95 Aire del entrepuentes á las once de la noche. . 87 Aire de la sentina. ............ . . 90 Aire de un pañol de comestibles de rancho. . . 89 Aire de la pipa estivada de agua 1lovediza. . . . 82

Repetidas experiencias de los físicos han manifestado ya que no siempre la fetidez es una prueba indubitable de la corrupción. Estas lo manifestaron de nuevo, á lo ménos hasta el grado, el cual nos fuese útil no ignorar.

Más importantes debían parecernos aún las experiencias de los alambiques para dulcificar el agua, los cuales bien sea por la poca necesidad que habíamos tenido, 6 por la demasiada estrechez del buque aún no se habían podido sujetar á un ensayo formal el cual nos diese lugar á conocer la máxima cantidad que pudiese conseguirse con el menor consumo de leña. Desde luego el destilador aplicado al recipiente lateral, al caldero, y único para el uso diario mientras se cociese la comida, no excedió en mucho los resultados que habíamos conseguido las demás veces: no fué necesario aumento alguno de leña: el agua destilada en cuatro horas no excedió de 64 cuar tillos. Pero luégo que concluída la comida de la tripulación pudimos aplicar al caldero el otro destilador y hacer que trabajasen los dos á la ve $z$ por el espacio de cinco horas y media, la cantidad de agua destilada en este plazo, con el sólo consumo de dos quintales de leña no fué menor de I 89 cuartillos, siendo digno de reparo que la porción de agua suministrada por el destilador del caldero excedía á la otra en mucho; probable- 
Ag. zo mente por las dos causas de ser mayor este recipiente, y de usarse de la manguera para la conducción del agua fresca condensante en lugar del cmbudo y llave del refrigerio, que á imitación de la máquina del navío San Sebastion habíamos puesto en el alambique del use diario.

Set. 2 Entre tanto las apariencias de un viaje feliz se iban á cada paso haciendo ménos equívocas, y por la misma razón más agradables. En la mañana del 2 ya navegábamos con vientos del Sur y Sursudoeste bonancibles, se sentía la mar del Noroeste y el rumbo adoptado del Nordeste de la aguja, debía conducirnos luégo á los paralelos de las Azores. Se confirmaron en la misma tarde con nuevas observaciones los primeros resultados de las distancias lunares, los cuales con una suma uniformidad asignaban al cronómetro el error siguiente:

\begin{tabular}{|c|c|c|c|c|c|c|}
\hline & Dias. & $\begin{array}{l}\text { Observat } \\
\text { dores. }\end{array}$ & $\begin{array}{l}\text { Nime. } \\
\text { de' } \\
\text { series. }\end{array}$ & $\begin{array}{l}\text { Longitud } \\
\text { deducida. }\end{array}$ & $\begin{array}{c}\text { Prome- } \\
\text { dio. }\end{array}$ & $\begin{array}{l}\text { Error del } \\
\text { cronómetro. }\end{array}$ \\
\hline Agosto. . & 3I & $\begin{array}{l}\text { Tova.... } \\
\text { Cevallos. } \\
\text { Viana.... } \\
\text { Malaspina. }\end{array}$ & $\begin{array}{l}2 \\
2 \\
4 \\
4\end{array}$ & $\begin{array}{l}30.19 .15 \\
15.40 \\
16.40 \\
26 \quad 41\end{array}$ & $30 \cdot 19 \cdot 34$ & E. $\mathrm{I}^{0} \cdot 46.29$ \\
\hline Setiemb. & 2 & $\begin{array}{l}\text { Tova ...... } \\
\text { Ali ........ } \\
\text { Malaspina. }\end{array}$ & $\begin{array}{l}4 \\
2 \\
4\end{array}$ & $\begin{array}{r}30.40 .00 \\
45.45 \\
41.00\end{array}$ & $30.4 z \cdot 15$ & E. $\mathrm{I}^{0} \cdot 44 \cdot 45$ \\
\hline
\end{tabular}

Una embarcación á la vista al amanecer del día siguiente, contribuyó también no poco, á disipar la monotonía siempre enfadosa del mar. Distaba de nosotros unas dos ó tres leguas por la proa, navegaba próximamente al Esnordeste, y su construcción, rumbo y aparejo contribuían unánimes á hacerla creer nacional y tal vez una de las atrasadas del convoy nuestro de Montevideo. Hízose inmediatamente señal á la ATREVIDA de que mantuviese unido y dirigiese al rumbo primitivo el grueso de la escuadra y convoy; y llamada la Gertrudis para que nos siguiese, nos dirigimos con fuerza de vela á reconocerla. Alcanzada á las nueve, en parte por la superioridad nuestra de andar, y en parte porque acortó de vela, largas ya las insignias nacionales en nuestros topes, dijo ser la fragata Esperanza, procedente de Montevideo, con escala en el Río Janeiro y con destino á Santander. Había dejado la costa del Brasil en ro de Julio último; había visto en aquel puerto la fragata Rosa, del comercio de Lima, única que faltaba en nuestro convoy de los registros del Sur; no necesitaba auxilio alguno; pero sí /solicitaba que se le admitiese en el convoy hasta que su derrota le permitiese navegar incorporada. La mar, algo gruesa, no hacía á la sazón fácil el uso de los botes para remitirle una copia de las seinales oportunas; pero se le dijo que siguiese á la corbeta Atrevida é imitase los movimientos de los demás, quedando luégo en la conserva. En aquella misma tarde el viento se declaró fresco y constante al Noroeste, lo cual nos decidió á preferir la derrota al Sur de las Azores; y nos Set. 2 fué este tiempo tan favorable, que al amanecer del 9 pudimos avistar al Norte la isla Santa María.

La perdimos de vista poco después del medio día, y como continuasen los mismos vientos, pudieron separarse luégo y seguir derrota al Nordeste, los buques de Santander. E1 restante convoy, si se exceptúan algunas averías que tuvo en ro y 12 los días II y I2, con viento recio y aturbonado del Nornordeste, siguió con la mayor unión y felicidad; y en la tarde del I8 estuvo á la vista del Cabo. San Vicente.

Algunas calmas, la necesidad de aprovechar los terrales y el ningún efecto de las corrientes favorables, nos detuvieron después hasta el medio día del 20 á la vista del Cabo Santa María; pero en la mañanita del 2 I estuvimos delante del puerto.

Descubriéronse ya á las cinco de la mañana las costas de Rota, la población de Cádiz y su extensa bahía, en la cual, formando un espeso bosque, se veían ancladas innumerables embarcaciones. Varios buques de guerra, la mayor parte nacionales, descollaban sus topes alterosos. Distinguíanse las insignias, y los últimos soplos del terral que continuaban aún reunían al mismo tiempo y aproximaban hacia el puerto todos los buques de nuestro convoy.

Tuvimos en breve á bordo varios botes y faluchos costaneros, otros se repartieron de igual modo por los demás buques grandes: nos alcanzaron después los prácticos, y como el viento paulatinamente rolase del Norte al Este y al Esueste, se hicieron preferentes para las nueve de la mañana las muras á estribor, y con ellas y todo aparejo navegamos en demanda del puerto, ordenándose por una feliz y casual combinación, la posición y distancia de los buques entre sí de tal modo, que se evitase todo atropellamiento y se guardase, sin embargo, un orden regular de convoy precedido por los tres buques de la Marina Real.

Fué importuna á la sazón una neblina con extremo densa, la cual precisó á los buques grandes á mantenerse cerca de una hora sobre las gavias, de la vuelta de fuera. Nosotros pudimos continuar hacia el puerto, viéndola felizmente disipada casi al mismo instante en el cual, dobladas las Puercas, atracábamos ya los primeros buques fondeados; antes saludamos la insignia del Teniente General D. Juan de Lángara, la cual tremolaba en el navío Reina Luisa, y después fuímos atravesando los muchos buques mercantes fondeados á la boca del puerto. Eran éstos por la mayor parte ingleses y holandeses, prontos á dar la vela al día siguiente bajo la escolta de cuatro buques de guerra ingleses.

A las diez, ya próximos á los Corrales y salu- 
Set. 2 dada también á la vez la insignia del General Comandante, en cuyas inmediaciones nos hallábamos, dimos fondo en cuatro brazas lama. A poco tiempo ejecutaron igual maniobra y con no menor felicidad, la corbeta ATREVIDA y la fragata Gertrudis. Fueron después entrando uno á uno los buques de Lima, dirigidos, según costumbre, á la poza Santa Isabel y quedaron amarrados los de S. M., conservándose por este tiempo sus tripulaciones en tan buena salud, que no fuese necesario enviar al hospital un enfermo siquiera.

E1 estado que sigue indicará con bastante exactitud el número y el valor de los buques que navegaron unidos desde Montevideo. Aquí ya nada tendremos que añadir sino es que, en el lar- go espacio de cinco años y dos meses, fueron las set. 21 corbetas bastante felices para no perder á bordo y en los hospitales más que diez individuos, los cuatro de la Descubierta y seis de la Atrevi$\mathrm{DA}$; pero dos de la segunda caídos accidentalmente al agua sin poderlos salvar. ¡Ojalá los demasiados halagos de la vida tranquila é independiente de nuestras colonias no hubiesen seducido para desertar á una buena mitad de la tropa y marinería! ¡Ojalá, en fin, que el demasiado afán para los progresos de la Historia Natural y para la ilustración de su patria no hubiese conducido al último término de su vida al Coronel D. Antonio Pineda, cuya muerte temprana llorarán siempre los que le han conocido en el grande teatro de sus tareas militares y científicas! 


\section{Descripción fisica de las costas del Noroeste de la América visitadas por las corbetas.}

El número crecido de descripciones de esta especie (I) que han salido ya á la luz pública, debiera sin duda aconsejar á todo hombre cauto y amante de la verdad, á no agregarle otra alguna; tanto más, que la poca congruencia de unas con otras, multiplicando más bien que disipando las dudas de los sabios, fomenta sólo el origen de nuevos sistemas y con ellos el velo espeso que envuelve actualmente la verdad.

Pero la Nación exige de nosotros este nuevo tributo, y no rendirlo por el sólo recelo de incurrir en una ú otra equivocación, fuera tanto más culpable, cuanto que ni hemos carecido de muchos excelentes medios para alcanzar la verdad, ni nos ha de tachar ó de omisos ó de adictos á otro sistema que el de la realidad.

Esta Memoria abrazará sólo las costas no sujetas á la Monarquía y al alcance de nuestros reconocimientos, esto es, desde el Cabo Blanco (2) hasta la entrada del Príncipe Guillermo. En el libro siguiente, se tratará de lo correspondiente á la California ó á los dominios de S. M. en esta parte del mundo; pues el auxilio de las Historias de los Misioneros y del Gobierno, nos dan lugar á poderlas tratar con mayor extensión y seguridad.

La costa desde el Cabo Blanco hasta la entrada del Príncipe Guillermo, comprende tres trozos totalmente diferentes uno de otro, si se considera su dirección, el clima, las cualidades y productos del suelo. Las orillas, al principio, son por lo común abarrancadas y contínuas, sin puertos ó ensenadas grandes, casi en dirección Norte-Sur ceñidas á la espalda por diferentes

(I) Después del viaje del Capitán Cook, euyos méritos sólo puede comprender el que sigue sus huellas, han parecido los de los Capitanes Dixon y Meares; será públieo algún día el del infeliz Conde de la Péyrouse; y eorren manuseritos de los que han verificado nuestros buques de San Blas, desde el año de I 774 hasta el presente de I 79 I.

(2) El Cabo Blanco es un término de nuestras posesiones, que no admite duda-alguna. Lo haee auténtieo la deelaraeión del Contramaestre de la fragata Los Tres Reyes, euyo original existe en el archivo de Simaneas con los demás doeumentos del viaje de Sebastián Vizeaino. Aunque los Pilotos Martínez y Haro han llegado hasta Oanalaska y el Comandante Arteaga hasta la entrada de la ráa de Cook, sus Diarios no suministran idea alguna relativa á los conoeimientos físicos. cordilleras de montes no muy elevados; y de un temperamento bastante benigno, si consultásemos, ó la poca elevación de los mismos montes, ó el temperamento de nuestra California, ó el que se ha advertido en dos años en Nutka. El término de esta faja de costa puede considerarse en el extremo meridional de la entrada de Fuca, desde donde empieza un archipiélago inmenso, que ramificándose hacia el Noroeste-Norte y tal vez al Nornordeste, termina, por lo que toca á la dirección primera de que ahora hablamos, al Norte del Cabo de Engaño por las inmediaciones de la entrada de la Cruz y Monte de Buen Tiempo. Ya en este último punto, la costa con una dirección casi del Este-Oeste, sigue compacta, poblada de pinos en la orilla, y cerrada á no mucha distancia por una cordillera majestuosa y constantemente nevada, entre la cual se señorean noblemente los montes de San Elías y Buen Tiempo, elevado el primero 2.792 toesas sobre el nivel del mar y el segundo 2.282 .

Nuestras conjeturas sobre el temperamento de estas costas pueden ya fijarse sobre datos ménos oscuros, pues á las repetidas noticias de los navegantes que han trillado estos mares en la estación favorable, pueden agregarse las noticias de los rusos (I) y del Capitán Meares (2), por lo que toca al primer trozo de costa, en la helada.estación de invierno; las de nuestro establecimiento de Nutka en el segundo trozo, y los viajes de Sebastián Vizcaino, relativamente á la última parte de costa entre los Cabos meri. dional de Fuca y Blanco.

Ya se ha dicho que una grande cordillera constantemente nevada hasta la falda, forma toda la costa desde el Monte de la Cruz hasta el extremo oriental de la ría de Cook. Le hará tal vez poco creible, que en los meses fuertes del estío, cuales son los de Junio y Julio, estos montes continuasen excesivamente cargados de hielo; pero las vistas, bien sea de perspectiva

(I) Esstas solo pueden inferirse de la coleceión de viajes de $\mathrm{Mr}$. Coxe y de las notieias sueltas del Ca pitán Cook, después de visitadas las islas Sehumagin.

(2) La eloeueneia (otras veces sospechosa) del Capitán Meares, no puede exagerar la situación de un buque mereante, rodeado de hielo en un paraje tan malo eomo el Sung-Corner de la entrada del Príneipe Guillermo. 
ó de marina, manifestaran que no serían encarecidas nuestras expresiones, cuando asegurásemos que estos montes, aunque no abandonados de la Naturaleza, están sin embargo destinados á ser perpetúamente la habitación de pocos osos.

El reconocimiento del puerto del Desengaño en los primeros días del mes de Julio nos dió aún más lugar de afianzar esta conjetura. El puerto está en la falda de la cordillera, su orilla del Oeste formada con algunas restingas ó pedruscos salientes al mar, sirve casi de base ó de cadena al hielo, que por consiguiente puede resistir con vigor bien sea á la internación del agua ó al efecto de una ténue marea. Mucho más aún debe resistirlos todo el banco de hielo que advertimos antepuesto á la Isla Heenke, y que ligado á la costa por todas partes ménos la del frente de la bahía, se hace firme, impenetrable y perpétuo. Ni es su separación ó disolución la que forma las bancas sueltas, en las cuales nos era fácil examinar sobrepuestas á la primera, una ó dos capas de hielo más reciente y á veces no bien formado. Una explosión contínua de los montes inmediatos, semejante á la de un volcán ó de un trueno distante, nos indicaba á cada paso que se desplomaban crecidas masas de hielo (I) las cuales, luégo ménos adherentes entre sí, por una ú otra parte, daban lugar á que el agua del mar, labrando contínuamente en ellas, las subdividiese, las varase á veces por efecto de las mareas, ó bien las extrajese del puerto á donde las veíamos flotar.

Con estos antecedentes debieron sernos tanto más agradables en aquellos contornos y entre el horror que parecía rodearles, las huellas de la próvida Naturaleza.

Cho tulti ascolta, é porge á tutti aita.-FILICAJA.

En los pocos parajes inmediatos á la orilla que dejaban libre las manchas ó pedazos interrumpidos de hielo, sobresalía una vegetación abundante y florida: anidaban en sus contornos, aprovechando este corto dcscanso del frío, varias perdices y otra especie de aves chicas (2). Los mismos peces y en particular el salmón, aproximándose siquiera á la boca del puerto en el aduar inmediato de los naturales, parecían querer por su parte coadyuvar á esta hermosa aunque momentánea escena de la Naturaleza (3).

No le son ménos favorables las orillas del

(i) Esta descripción corresponde enteramente con los efectos advertidos por los Pilotos del Teniente de navío D. Salvador Hidalgo en el puerto de Re. villagijedo de la entrada del Príncipe Guillermo.

(2) 1)on 'Tadeo Hecnke describe esta parte de la hotánica y \%oología con su acostumbrada exactitud.

(3) I a reunión de los Sres. Rabenet y Hrambila, jintores agregados á la expedición, dará lugar á que se represente esta pintura con aquellos coloresá que no puede alcanzar una descripción de mano suma-
Este que continuan hasta la Isla de Pineda, las cuales así por la dirección perpendicular del monte, como por la suma profundidad del mar(I) no dan lugar á que puedan asirse firmemente las masas del hielo, las que convertidas por consiguiente en otros tantos riachuelos ó cascadas perennes, fecundizan en un modo admirable $y$ hacen que se vista de un verde hermoso la mis. ma roca que parecía destinada á una desnudez árida y triste.

Al Oeste y al Este de esta cordillera, considerada sólo en su falda de la bahía del Almirantazgo, se extiende al mar una porción de tierra baja, cuyo semblante es bien distinto del que acabamos de describir. Diferentes canales y puertos; una vegetación extremadamente rica y compuesta de plantas útiles ó á la conservación del hombre ó á los progresos de la vida sociable; la concurrencia del salmón, del pejerey, de la nutria y del lobo marino en sus orillas, todo convida al navegante en esos contornos, así como parece asegurarle que la Naturaleza puso por término de sus pesquisas y de los pasos á una cordillera tan dilatada é impenetrable.

Ni parecerá extraño que sean tan constantes la permanencia del hielo en la parte montuosa y la lozanía de la vegetación en la parte baja, cuando se considere que son harto raros en toda esta costa los vientos del Noroeste, únicos para franquear al Sol la directa y constante acción de sus rayos benéficos; siendo al contrario muy frecuentes los del Sueste, que impregnados de vapores pueden, sí, ser sufribles en un bosque frondoso, pero son inútiles ó insuficientes para la disolución del hielo.

Desde el puerto Mulgrave á las faldas del Monte de San Elías y del Buen Tiempo, veíamos con un sólo día de Noroeste, disolverse en mil riachuelos y áun desplomarse enteros, crecidos trozos de hielo. Las aguas del mar por la bahía de Bering, áun á distancia de dos y tres leguas de la costa, conservaban un color blanquinoso y un gusto muy poco salobre. Pero estos efectos saludables no eran sino momentáneos: se declaraba el Sueste, y la lluvia, la calima, y á veces la tempestad, sus compañeras inseparables, no sólo daban al todo un semblante lóbrego y triste, si también absorbían la mayor parte de los pocos meses saludables del verano.

Hé aquí, pues, por qué en el fondo de la entrada del Príncipe Guillermo (2) en el puerto del Desengaño y en la entrada de la $\mathrm{Cr}^{*} u z$ (3), se en-

(I) La lancha de la corbeta ATrevida encargada de sondar, no encontraba á veces fondo á un cumplido de bote de la costa, con roo brazas de sondaleza.

(2) Véase el Diario ya citado de D. Salvador Hidalgo, hablando del puerto de Revillagijedo.

(3) Véase el viaje del luqque inglés la Ifigenia, recopilado por el Capitán Meares. 
contrase tan fácilmente el hielo constante y sus montes estuviesen cargados de hielo áun en los meses de Julio y Agosto. Y si no se advierte el mismo efecto en la ría de Cook, debe sin duda atribuirse á la violencia de sus mareas y á la avenida del río Grande interno, que no permiten á las aguas la estabilidad necesaria para consolidarse.

No nos aventuraremos á decidir cuál sea el estado de la cordillera hacia el lado opuesto del Norte; si hemos de juzgar por lo que hemos visto en la entrada del Príncipe Guillermo, en el Valle de Ruesga, al Nordeste de la Península de Kaye, y lo más interno de la bahía de Bering, los montes, bien sea en una ó en muchas hileras, pueden coger un espacio de 30 á 40 leguas de Sur á Norte y la misma extructura del Monte de San Elías parece confirmar esta sospecha.

¿Cuál sería, pues, la masa enorme de hielo que cubra la parte opuesta de la cordillera, á donde no alcanza jamás la dirección de los rayos del Sol, y adonde operan más directamente los vientos hiemales del Norte? ¿Cuáles los piés humanos que hayan de transitarla? ¿Cuáles, en fin, los objetos que al alcance de las débiles fuerzas del hombre puedan guiar hacia esta parte su ilimitada curiosidad ó codicia?

Lo que sí pudiéramos asegurar con mucha ménos desconfianza, es la época, no muy distante, en la cual los fuegos subterráneos causaban en esta parte del globo nuevas vicisitudes y transformaciones: áun en el día son muchos los volcanes en la ría de Cook y en las islas del dominio ruso; entre las muchas que componen el Archipiélago de Bucareli, no se cuentan ménos de siete, cuyas erupciones son también notables (I), y la misma extructura del Monte San Llías, si se compara á los volcanes de la costa de Guatemala, y se supone una cierta harmonía bien notable en las grandes obras de la Naturaleza, parece acreditar que el mismo monte, si no lo es, fué á lo ménos un volcán no indiferente: además de esto, las Islas del Puerto Mulgrave abundan en piedra póme $z$, y no es extraño hallar entre los guijarros de sus orillas y particularmente de la Punta Furner, varios ferruginosos negros, esponjosos, que no pueden ser sino erupciones volcánicas.

El Sr. de Heenke, quien examinó científicamente las diferentes piedras que de un verdadero brazo de la cordillera inmediata al Puerto del Desengaño se condujeron á bordo, las halló

(I) En el Diario de la navegación de la goleta Sonora (año de r 775) á las órdenes del actual Capitán de navío D. Juan de la Bodega y Cuadra, se lee el adjunto párrafo hablando de este Archipiélago:

«Las noches son sumamente claras y templadas á causa de siete volcanes de nieve y fuego que con sus vapores la iluminan y templan. $n$ compuestas de las calidades siguientes, las cuales pudiéramos, por consiguiente, considerar sin temeridad, que forman casi toda la masa de estos montes.

I. Calcárea cruda, compacta, granulosa, purísima y blanca.

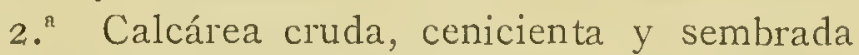
con venitas blancas también calcáreas.

$3 \cdot{ }^{a}$ Granitosa con grano blanco, compuesta de cuarzo y feldespato.

4. ${ }^{\text {a }}$ Granitosa granulosa, compuesta de mica negra y feldespato.

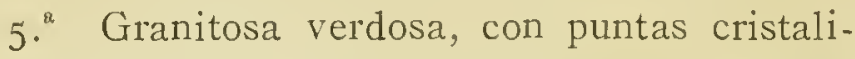
nas, compuestas de cuarzo, feldespato y basalto.

Pero no fuera fácil asegurar cuál de las dos calidades primarias componen la base de la cordillera, si bien que puede creerse lo sea la calcárea, á la cual estén después sobrepuestas varias capas granitosas que componen últimamente la cima de los montes.

Causaría mayor admiración no hallar río alguno, ni mediano siquiera, en el largo trecho indicado de costa desde la ría de Cook hasta las faldas del Monte de la Cruz por los $57^{\circ}$, si no se considerase que los montes están demasiado inmediatos á la orilla para que las aguas tengan lugar de reunirse antes de llegar al mar, y que así es una infinidad de riachuelos ó cascadas la que conduce los hielos derretidos al Océano; pero cuando se dé una mirada ó bien á la masa inmensa de hielo que probablemente existe á la parte opuesta, ó al paradero de las aguas llovedizas, que tal vez en el verano no tengan lugar de consolidarse y contribuyan á la disolución dc parte del hielo, no puede el físico dejar inmediatamente de fijar sus conceptos en aquellas lagunas inmensas que forman la admiración de los viajeros que han internado por el Este, y la esperanza de los que áun sostienen la posibilidad de un paso por esas latitudes.

Ya fuera tiempo de abandonar un cxamen tan incierto de la constitución física de esta parte del globo, si no debiésemos hacer memoria de la existencia del cobre en sus contornos y dc las reflexiones meteorológicas en cuanto tengan una conexión directa, ó con el tránsito ó con la subsistencia del navegante. Que haya cobre en los contornos del Príncipe Guillermo y del Puerto del Desengaño, podía tal vez no dudarse anteriormente (I); pero ahora nos lo ha confirmado el Ankau ó Jefe del Puerto Mulgrave, el cual presentándonos un morrión de guerra, ganado á sus enemigos en una batalla y ornado con diferentes cercos ó anillos de cobre (2) satisfizo á

(I) Véanse los viajes de los Capitanes Cook y Meares.

(2) Fi Ankau nunca quiso ceder este trofeo de sus victorias, $y$ por consiguiente debimos contentarnos con el auxilio de la pintura. 
nuestra curiosidad sobre la adquisición de este metal, con asegurarnos que lo había en las inmediaciones de la cordillera, á donde les era fácil cogerle. Sin embargo, casi se limitaron á éste los utensilios ó adornos de aquel metal que advertimos entre ellos; y así podemos tal vez asegurar, que si no es dudosa su existencia en estos montes, á lo ménos ó su cantidad ó su beneficio son sumamente limitados. Por nuestra parte, vistas las circunstancias que precisamente han de acompañar á este beneficio, no titubearemos en inclinarnos á que arredre por sí solo á todo emprendedor, aunque fuesen crecidas las cantidades que pudiera suministrar, tanto más que supliendo ahora los europeos con el útil hierro la necesidad ya conocida de los metales, mal pudieran los naturales abandonar la pesca, que les vale aquella adquisición, para ocuparse del beneficio ménos útil y más destructivo de la mina.

A pesar de la triste perspectiva con que hasta aquí hemos representado este largo trecho de costa, no es su constitución, sin embargo, enteramente opuesta á la existencia de una sociedad civilizada, y digámoslo así, á su bienestar en el vario curso de un año. La faja de tierra llana que se antepone, como hemos dicho, aunque con muy corta extensión á la cordillera, y corre casi seguida desde la bahía de Bering hasta la parte occidental de la península de Kaye (I) presenta al hombre un asilo en el cual puede al mismo tiempo precaverse de las intemperies y proveer opiparamente á su subsistencia.

E1 Sr. de Heenke, examinada científicamente la calidad del suelo y la lozanía de la vegetación en el puerto Nulgrave, y vista la singular harmonía de la Naturaleza, así en éste como en sus demás productos, no dudó en asegurar que se lograrían allí la mayor parte de nuestras semillas, debiendo probablemente llegar á su completa madurez hacia fines de Julio, pues que en sus principios advertimos ya muy adelantados los gramenes, la fresa y la mora. En efecto, si se considera el mayor número de las plantas, se hallarán éstas de las mismas especies de la Europa boreal, excepto algunas que, ó son de la América boreal, ó Alpinas de todo el globo; si los árboles, se verá que el pino abie, el pino picea y el cupreso disticha, hermosean noblemente sus bosques, sin interceptar el paso, ó al Sol ó al caminante, antes bien dejando de trecho en trecho como entre sembrados, diferentes prados en los cualeș crecen lozanamente la fresa y la mora; si la calidad del suelo, se hallará que los prados son de una arcilla arenosa igual casi al mismo fondo del mar, y en los bosques le cubre una capa alta y densa de tierra vegetal negra y friable, compuesta en el largo volver de los años de las miriades putrefactas de las plantas, árboles y musgos; si el mar intermedio, la velocidad de la marea, la tortuosidad de las orillas y la inmediata comunicación con el mar, harán creible ( $\mathrm{r}$ ) que el hielo en estos canales, no intercepte ni la navegación ni la pesca en la cruda estación del invierno; si, finalmente, el temperamento, se verá en nuestro Diario meteorológico que el termómetro de Farenheit llegó á los $67^{\circ}$ oo ${ }^{\prime}$, y nosotros podremos asegurar, que ni en el abrigo de las casas, ni en la inclinación de los árboles por efecto de los vientos reinantes, ni en las noticias que pudimos adquirir de los naturales, se halla absolutamente rastro de un invierno ó tempestuoso, ó muy frío.

No se crea, sin embargo, que se asemeje á esta pintura la de toda la demás costa que actualmente describimos. Las faldas del Monte de San Elías y un buen trecho al Este y al Oeste, no presentan sino algunos manchones mezquinos y poco internos de arboleda, la cual luégo vuelve á tomar su primer espesor y lozanía por el Cabo Chupador y las bahías de Burgos y el Almirantazgo. En esta última ensenada, agregándose á la frondosidad de las orillas las apariencias de algunos valles internos y la menor elevación de los montes contíguos, la Naturaleza parece ofrecer al hombre otro abrigo no indiferente, antes bien, tanto más agradable, cuanto que probablemente una embarcación puede considerarse segura al Este de la Isla Dudosa, si el fondo de cuatro á cinco brazas arena fina le deja internar hasta allí.

Los naturales, que desde la Isla Hijosa salieron á nuestro encuentro, nos señalaban á la verdad otro fondeadero bueno al Oeste de la isla, en el cual, si existiese, se conseguiría en el invierno un temple mucho más suave que en las inmediaciones de la entrada del Principe Guillermo, por ser esta isla al mismo tiempo baja y bien separada del Continente. Pero nosotros, que la costeamos por aquella parte á distancia de dos ó tres leguas, no pudimos advertir la menor señal de un abrigo; sólo sí haciéndosenos creible, que esta isla esté constantemente habitada, y que la concurrencia de la nutria á sus orillas le haga un objeto no indiferente para la navegación europea.

Pero es tiempo ya de pasar á los moradores, cuyo número, costumbres y relaciones recíprocas se recorrerán poco á poco con un examen filosófico, para que los progresos de la especie humana que tanto deben interesar á sus semejantes, no parezcan haber ocupado un lugar secundario en la atención nuestra á estos objetos.

Podemos desde luego sentar como una ver-

(I) La poca inteligencia del idioma y nuestros recelos de una equivocación, han dejado dudoso este punto interesante, aunque no nos descuidásemos en procurar descifrarle. 
dad incontestable, que es un mismo el origen de los habitadores de la orilla desde la ría de Cook hasta la entrada ó Archipiélago de Bucareli (I); sean enhorabuena distintos uno de otro los idiomas de la entrada del Príncipe Guillermo y del puerto Mulgrave (2), sean frecuentes las reyertas entre una y otra tríbu, antes bien, no se vean nunca juntarse entre sí sino para destruirse, no por esto podrá jamás rechazarse una verdad que estriba sobre una total uniformidad: I. 'del método de vida. $2 .^{\circ}$ De las inclinaciones y progresos sociales. $3 .^{\circ}$ De los trajes, armas y utensilios. $4 .^{\circ}$ Finalmente, de los ritos religiosos. Por ventura, en esta discusión importante 110 nos es preciso echar mano de otros conocimientos más que los nacionales; y las narraciones de D. Salvador Hidalgo por lo que toca á las rías de Cook y el Príncipe Guillermo, las de D. Ig nacio de Arteaga, relativamente al Archipiélago de Bucareli, ceñidas á la verdad sencilla y sin preocupación alguna á favor ó de la novedad ó de un sistema, nos dan ya lugar á combinar con toda seguridad algunas propiedades generales de estos moradores, que últimamente puedan guiarnos á otras indagaciones más importantes para la historia de la sociedad. Desenvolviendo poco á poco las nociones sobre los cuatro puntos ya indicados de comparación, por lo que hemos notado en el puerto Mulgrave, seguiremos al mismo tiempo lo que dicen los señores Arteaga é Hidalgo; y la descripción y la comparación seguirán un mismo paso uniforme y ménos molesto.

Las propiedades animales de estos moradores han sido ya descritas por diferentes viajeros, entre los cuales la prolija y filosófica atención de los Sres. Cook y Anderson en el Príncipe Guillermo, parece que no dejaban cosa alguna que desear: son altos, membrudos, sanos y ágiles, bien sea para la pesca, ó la caza, ó la guerra: son igualmente sanas las mujeres, aunque cons tituídas á una vida sedentaria, y si juzgásemos, ó por la disposición exterior de sus miembros, ó por el número de niños que las rodean, se puede asegurar que son igualmente dispuestas al embarazo, al parto y á la crianza, y que esta disposición les continúa hasta una edad bastantemente adulta. El semblante de los hombres, es por lo

(I) Se verá después hablando de las costas siguientes, que no sería temeridad extender esta misma Nación hasta el paralelo de 500 ó $51^{\circ}$ por las islés de la Reina Carlota y Princesa Real.

(2) Er Capitán Dixon que tocó en una y otra parte y que dió nombre al puerto Mulgrave, sospecha la total diferencia de uno á otro idioma. No así el Capitán Meares, hablando de los que habitan en latitud de $56^{\circ} 3^{\prime}$. Es muy sensible á la verdad que estos dos autores, confundiendo frecuentemente los objetos de interés y de rivalidad, con la ilustración pública, conspiren más bien á contradecirse que á confirmar lo que han visto. común algo fiero; siendo, por otra parte, fácil hallar un mayor grado de fiereza en los que se inclinan á la caza, y que no pocas veces, sin ventaja de armas, tienen que luchar pecho á pecho con osos y otras fieras (I). No así por lo común con los que siguen el oficio más apacible de la pesca, ni tampoco con las mujeres y los jóvenes, brillando á cada paso en éstos una docilidad no estúpida y en aquéllas los sentimientos de pudor y de afabilidad que puede dictar en su niñez la ruda sociedad de la especie humana.

$\mathrm{Ni}$ eran equivocadas las sospechas de] Capitán Cook sobre una grande diferencia de fisonomías entre estos naturales: nos fué fácil distinguirla entre la plebe y las familias adictas al Ankau, y D. Tomás Suria las ha representado con tanta propiedad, que ya no admitirá duda esta diferencia á lo ménos por lo que toca á los hombres. Varias veces con una leve recompensa conseguimos que algunos jóvenes lavasen sus rostros, descubriendo, por consiguiente, su color natural: era éste bastante blanco y sonrosado y la tez más bien fina, sin embargo del uso ya continuado del aceite y grasas, con las cuales se abrigan comunmente para resistir al frío, y que después de algunos años deben ya penetrar la película y variarles el color.

No omitiremos tampoco de recordar los caracteres realmente singulares que sobresalen en estas tríbus; y son el pié desproporcionadamente chico, el hueso pómulo y el ojo, ceja y borde ciliar, muy semejantes á los de los chinos, el segundo en su color y pequeñez, la tercera en la mucha escasez de pelo y la cuarta en su elevación y distancia del ojo: esta parte principal del rostro, que los físicos admiran como uno de los hechos más bien combinados en la estructura del cuerpo humano y nosotros naturalmente caracterizamos con el distintivo de sobrescrito del hombre, debe probablemente permanecer constante en una misma rama de la especie humana, por cuanto influyan ó el temperamento, ó las costumbres morales, ó la clase de vida, en variar las demás partes de su cuerpo; y adoptando este principio análogo á la bella harmonía de la Naturaleza, ¿cómo podremos no recordar al mismo tiempo las excelentes reflexiones de Mr. de Saint-Pierre en sus sublimes estudios de la misma Naturaleza, y contemplar cuantas conjeturas sobre la emigración de la especie humana se han descarnado de toda probabilidad, sólo porque se han desentendido los escritores de estos rastros patentes é invariables de la Naturaleza?

Por lo que toca á la comprensión ó amoldamiento de la cabeza desde que nace el niño, ya

(I) Para la tríbu del puerto Mulgrave, se ha podido inferir, que la caza del oso es sólo en las inmediaciones del puerto del Desengaño. 
nos han precedido diferentes viajeros en advertirla y describirla: sin embargo, como D. Francisco Flores tuvo ocasión de estar presente una tarde á esta operación, no parezca inoportuno el que le añadamos aquí una breve descripción: nacido el niño, no sólo no se ocupa la madre en corregirle la natural prolongación de la cabeza á la sazón cartilaginosa, sino que más bien coadyuva, comprimiéndola con las dos manos en varios sentidos y por algunos días, particularmente cn los huesos parietales, de suerte que la sutura sagital sobresalga con exceso y se forme una especie de cono, que desde las dos tuberosidades del hueso coronal, se incline considerablemente hacia la horizontal. La cortadura del labio inferior difiere algún tanto de la que advirtieron el Capitán Cook y D. Salvador Hidalgo en la entrada del Príncipe Guillermo. La tríbu del Puerto de Mulgrave sustituye á las dentaduras falsas 6 á los ntros adornos subdivididos de las mismas cisuras, una especie de roldana con figura elíptica, que sujeta á los labios por ambos bordes y colocada cn una posición horizontal, sirve de adorno sólo á las mujeres; esta roldana (I) muy bien bruñida por todas partes y hecha de madera de pino, tiene en su eje mayor dos pulgadas y una línea inglesas, una pulgada en el eje menor y siete líneas de grueso de uno á otro canto; suelen, sí, los hombres tener perforado el septum de la nariz, para poner algún adorno, el cual, sin embargo, nunca hemos visto compuesto sino de huesos ó clavos, en lugar de anillos, ensartas ó hileras de caracoles, que.suelen usar los habitantes del Príncipe Guillermo.

Pero ¿á qué entretenernos más sobre estas cualidades materiales, tan poco varias en la especie humana, que haciéndose apenas perceptible apoyan á cada paso las próvidas atenciones de la Naturaleza para nuestro bienestar? (2). Es preciso fijar nuestra atención en las cualidades morales: allí es donde el filósofo mira con una curio sa admiración los vicios y las virtudes naturales en el hombre, las inclinaciones innatas, ó para su sustento ó para su multiplicación; los principios informes de la Sociedad, sus progresos y sus términos; allí es donde últimamente la reflexión, caminando siempre á pasos lentos y sobre las orillas del precipicio, conduce atenta el hilo de las ideas, para dar siquiera algunos rasgos imperfectos de la importante historia del hombre.

Nuestro viaje en esta parte ha sido más bien feliz; y entre la oscuridad del idioma, la novedad

(1) Se remite uno de estos adornos al Real Gabinete.

(2) Autunt la nature (dice Mr. de Saint-Pierre) i affecte de artrietes dans les espeices d'animanx du meme grenre, quoid its habitassent le même sol, et reeussent des memes aliments, autunt elle à obsorrế d'uniformite dans T'esfece humaine malgres la difference des elimats, at des nourvitures. de las ideas y la importunidad de los sistemas, hemos podido rastrear algunos conocimientos, que desde luego no desagradaran al filósofo.

La dificultad de la subsistencia, es la causa primitiva, digámoslo así, la sola causa que impide los progresos de la sociedad y la multiplicación de la especie humana en estas tríbus: constituidos á vivir de la pesca (I), á ejecutarla con canoas bien endebles que no les permiten apartarse mucho de la orilla; finalmente, á proveer en seis meses escasos (2) á la subsistencia de todo el año; habitadores por otra parte de una costa pobre de aves marítimas y de mariscos (3), han debido precisamente subdividirse en muchas tríbus; y éstas mismas, lejos de concurrir á un mismo centro que les procurase el agradable sonido de la vida sociable, se han visto precisadas á dividirse de nuevo para poseer cada familia como propiedad un pequeño trozo de costa: en esta situación que consideraremos con el doctor Fergu. son (4) como la de las Naciones rudas antes del establecimiento de la propiedad, dos causas concurrieron muy luégo á acelerar algún tanto la civilización; éstas fueron la pesca y beneficio de la ballena, que necesitaba muchos brazos á un tiempo, y la defensa del propio terreno que sin duda alguna quisieran usurpar otras tríbus, á veces por necesidad, á veces por capricho; para ambos objetos fué, pues, preciso reunirse, ordenarse, considerar como sus intereses recíprocos, y elegir algunos que al mismo tiempo dotados de la precisa fuerza, habilidad y concepto público, guiasen la muchedumbre en los varios trances peligrosos, en los cuales se hallaban. La cordillera inmediata, no permitiendo, por otra parte, internación alguna desde la ría de Cook hasta el monte Edgecumbre ó San Jacinto, debió hacer más frecuentes estas discordias y más escasa la población; y seguramente pudiéramos inferir de la situación de la tríbu del puerto Mulgrave la de todas las clemás costaneras hacia el Sueste, si la Naturaleza, igualmente próvida en cualquiera parte del globo, no hubiese presentado á estos emigrantes marítimos un archipiélago inmenso que los acogiese y alimentase á su albedrío. Hasta aquí la historia de estas naciones, derivada de los efectos poco dudosos del instinto sociable, pare.

(I) Aunque algunos se ocupen de la caza y en particular de la muy arriesgada deloso, no por esto deben mirarse estas naciones sino como pescadoras.

(2) Véase el viaje del Capitán Meares para el principio de la pesca, en la entrada del Príncipe Guillermo. En últimos de Agosto, los habitantes de Nutka se ocupaban incesantemente en abastecerse para el invierno y áun en mudar de morada, como se verá después.

(3) El Capitán Cook no dejọo de advertir esta escasez, particularmente comparando estas costas a las de la América meridional. Véanse también nuestros Diarios.

(4) Sección II, parte.1I. 
ce al abrigo de toda equivocación, tanto más, que si se examina su estado actual, poco ó nada hay que añadir al estado rudo del hombre, que acabamos de indicar (I). Pero al momento que tratemos de indagar cuáles son los motivos que actualmente afiancen la primacía, no sólo en una familia hereditaria, si también en una familia cuyos rostros difieren mucho de los de la plebe; cuáles los límites del derecho de propiedad y del derecho público; cuáles, en fin, los cimientos de sus principios ó legislativos ó religiosos, nos vemos en la precisión de abandonar una serie hilada de ideas y hacer una narración sencilla de lo que hemos visto, dejando al tiempo ó á la perspicacia de otros el reunir estas ideas en un solo punto de vista.

Esta tríbu se llama la de los Tejunés; habita las diferentes islas del puerto Mulgrave, y no pocas familias estan establecidas en la tierra firme ó bien frontera á las mismas islas ó inmediata al puerto del Desengaño ó exterior del Cabo Muñoz; de suerte que pudieran considerarse sus límites actuales desde la bahía del Almirantazgo hasta la bahía de Bering: sin embargo, los que habitan hacia esta última bahía, no debieran en la realidad considerarse como una misma nación, porque no es fácil su comunicación con los de las islas por falta de canales internas, ni posible su reunión para la pesca de la ballena; pero como tuviesen por caudillo un hijo del Ankau Juné (2), del mismo modo que otras rancherías internas, hemos creído que precisamente en el caso de una guerra sus intereses serían comunes.

No así con los que habitan hacia el Este, á las faldas del Monte San Elías y áun más inmediatos en las puntas de Novales y Barrientos, los cuales, si bién después de su entrada en el puerto el día I $^{\circ}$ de Julio vivieron en buena unión con sus habitantes y manifestaron una estreche $z$ y amistad antigua diferentes individuos, pudimos conocer sin embargo, que sus intereses eran bien distintos, las guerras harto fáciles y sus caudillos naturalmente opuestos entre sí (3).

El indio que vino á bordo desde aquellas faldas, manifestó á la verdad muy poca idea del nivel en que habían estado nuestros cambios en el puerto Mulgrave; pero por su idioma y por sus ofrecimientos pudimos inferir indubitablemente que ni le eran nuevas las embarcaciones

(т) Las pocas alteraciones que indicaremos muy luego, son muy recientes y áun no bien cimentadas, pues dimanan en mucha parte de la concurrencia de los europeos en estas costas.

(2) Es el que se ha nombrado ya muchas veces, y se ha representado con mucha exactitud en nuestras láminas.

(3) Véase el Diario sobre los acaecimientos de aquella venida. europeas, ni sus objetos ó comerciantes 6 viciosos; y así pareció probable que habitasen algo más al Este é inmediatos á la bahía los que nos visitaron en el puerto; bien que habiendo de tiempo en tiempo alguna comunicación entre unos y otros. Parecerá también extraño que en la ensenada del Contralor, no hallásemos rastro alguno de habitantes, cuando la calidad del tereno y las mismas orillas parecían deberlos atraer allí más bien que en otras partes más montuosas de la costa; pero si como es probable, el poco fondo interno aparta los cetáceos, lobos y nutrias y tal vez también el salmón de aquellas inmediaciones, se hallará evidente la razón por qué ni en ésta ni en otras muchas partes de la costa hayan podido extenderse estos habitantes.

Ya con estos antecedentes, no será difícil deducir próximamente el número de moradores desde la entrada del Príncipe Guillermo hasta las faldas del Monte de la Cruz (I): 600 en aquella entrada, otros tantos á las faldas del Monte San Elías, 400 de la tríbu del puerto Mulgrave y otros 600 desde la bahía de Bering hasta la entrada de la Cruz, componen un número de 2.200 vivientes, que á lo sumo pueden contarse en este largo trecho de costa (2). Y si no fuese tan sólo temeridad sino también apartarse de nuestro sistema adoptado el aventurar algunas conjeturas sobre lo venidero, debiéramos decir que este número menguará más bien que crecerá con la concurrencia de los europeos en estos mares. El cebo de nuestro comercio y de la adquisición de las nutrias; el deseo de tener algunos esclavos para aumentar en nuestras manos el número de estos infelices ó franquearnos su uso si son mujeres; finalmente, la adquisición de nuevas armas, ó ya hechas ó sacadas del hierro, serán nuevos principios de discordia y consecuentemente de una destrucción recíproca.

Es, pues, indubitable, que en estas pequeñas tríbus hay una familia en quien recae por herencia la sucesión del mando, y por consiguiente, un jefe que las gobierna en la paz y las dirige en la guerra. El Ankau Juné, era en nuestro entender, verdaderamente digno de esta pública confranza, reuniendo en sí todas las cualidades de edad, valor, corpulencia y penetración, que deben precisamente acompañar la elección de un Jefe en el estado aún naciente de una pequeña sociedad. Su padre, á la cabeza de la tríbu, ha-

(1) Los rusos dijeron á D. Salvador Hidalgo que en la ria de Cook se contaban hasta 4.000 naturales sujetos al imperio, pero esta noticia parecia exagerada.

(2) Se han tenido presentes para este cómputo los viajes de los Capitanes Cook, Dixon, Meares y de Don Salvador Hidalgo. Nosotros hemos advertido dos humaredas entre el Cabo Buen Tiempo y la bahra de la Cruz. 
bía no mucho tiempo antcs, rechazado una inva sión enemigra y comprado con su vida la victoria (I).

Su hijo contaba diferentes hazañas hechas porél en el mismo choque; y un semblante audaz, varias proezas en la caza de los osos, su actual ensayo del mando en la ranchería del puerto del D)esengaño, todo manifestaba que no desmayaría en sus manos el cargo del Gobierno supremo: entre las muchas razones y datos positivos que disipaban toda duda sobre esta sucesión hereditaria en la familia del Ankau y las distinciones que merecía, debió particularmentc fijar nuestra atención el depósito de los cadáveres de la misma familia, que con toda prolijidad examinamos, y cuyas particularidades se han representado con mucho primor por el dibujante Carclero: nunca pudimos comprender si el mónstruo colosal representaba un ídolo ó era sólo un recuerdo espantoso de los estragos de la muerte; pero nos inclinaba á creer lo primero la reflexión de que existían en sus inmediaciones varias piras en las cuales se habían quemado diferentes cadáveres; y en la cajita que tenía dcbajo de las uñas ó manos, se dejaban vcr una esportilla vacía, una copa de sombrero europeo, una piel de lobo y un pedazo de tabla: la altura del mónstruo no era menor de diez piés y medio franceses: todo de madera de pino; los adornos de la caja eran de conchitas embutidas en la misma madera, y su pintura de almagra, si se exceptúan los dientes, las uñas y la parte superior de la cabeza, que estaban pintados cle blanco y negro: los dos depósitos laterales tenían en la caja superior dos canastos uno mayor que otro, bien trincados. cuyo contenido no nos fué fácil averiguar: la caja inferior cubierta con algunas tablas sueltas y suelta ella misma en el suelo, contenía una esportilla con algunos huesos calcinados y divididos en partes muy chicas, de suerte que apenas podía distinguirse que eran partes del cráneo y las dos primeras vértebras del cuello (2).

La cara del mónstruo miraba al Este; su nombre (según algunos naturales de la plebe que nos acompañaban) Iukitchetch; y los monumen. tos laterales, correspondientes á dos hijos del Ankau actual, según el mismo nos informó á nuestro regreso de esta excursión. Era aún más notable otro depósitn, no distante de los ya dés.

1) Ía se ha indicado en el Diario con cuánta ener. gía sc expresaba el Ankau en describirnos las circunstancias de esta reyerta, en la cual estaban comprendidos al parecer, seis fusiles y un hombre á caballo: uosotros jamás pudimos hacernos cargo de estas circunstancias tan distantes de todo lo que estaba a nuestro alcance, pues ni estos naturales tenían fusil al funo, ni á estas costas haloía llegado hasta aquí hom. bre alguno á caballo. La reyerta debió ser bien sangrienta.

(2) I na de estas cajas con la esportilla y huesos, al Real (iabinete. critos sino dos tiros de fusil; y aunque el objeto fuese el mismo de abrigar una cajita interior $y$ elevar otra á mucha distancia del suelo, sus adornos y pinturas más bien acabadas, los cabellos que colgaban en uno y otro extremo de los palos destinados á sostener la caja y la cúspide alta posterior puesta probablemente para recordar la memoria al pasajero de la persona cuyas cenizas allí estaban depositadas, todo daba á este sitio un resalte admirable que adquiría luégo un nuevo grado de hermosura con los amenos contornos que le rodeaban. Algunos Oficiales de la DESCUBIERTA que visitaron este sitio acompañados del mismo Ankau, pudieron averiguar que era el depósito de una mujer suya: D. Antonio Tova halló, por otra parte, en la Isla Pineda igual conjunto de monumentos, en la misma dirección y con el mismo mónstruo; lo que finalmente nos induciría á creer que cada descendencia ó familia forma su monumento particular, que compuesto de madera y descuidado después, es en pocos años víctima de las intemperies $y$ del tiempo.

No es, sin embargo, proporcionada á estos distintivos ni á la autoridad militar, la que tiene el Jefe en las acciones particulares y pacíficas: pudimos advertir bien esta mengua de auturidad, comparando las dos ocasiones militares en que le vimos, con las concurrencias diarias y comerciantes: cuando aún no habíamos fondeado en el puerto y las dos canoas de guerra salieron á nuestro encuentro, con mucha parte de los hombres útiles de la tríbu, el Ankau, en una canoa cerrada, dirigía todos los movimientos con un tono decidido; había puesto en cada canoa un hijo suyo, y á bordo de la ATREvida, á donde subió, sus órdenes fueron ejecutadas: del mismo modo, al tiempo de aproximarse las canoas sospechosas del Este en la mañana del I. ${ }^{\circ}$ de Julio, solicitó inmediatamente nuestro auxilio, examinó prolijamente sus intenciones, y no omitió tomar cntre los suyos todas aquellas prccauciones que dictaba el temido trance de un ataque. Pero en la vida doméstica no era fácil advertir una diferencia proporcionada á las ocasiones militares: su familia trabajaba como las demás para su subsistencia y bienestar; no pocas veces el mismo Ankan bogaba solo en una canoita: en los cambios no se advertía menor cesión de un monopolio, aunque seguramente la codicia le dictase cuantas tretas eran posibles para el intento; sus providencias contra los robos no eran obedecidas ( $\mathrm{I}$ ), y en los preludios de las discordias nuestras del día 3 y del 5 , ni su presencia ni sus gritos pudieron contener los más osados:

(1) Tuvimos muchas sospechas no infundadas, de que el mismo Ankau protegiese estos desórdenes; pero seguramente su conducta fué siempre muy advertida, consecuente y capa\% de alucinar á cualquiera. 
sólo, sí, sus consejos en la primera ocasión y su peligro en la segunda, fueron frenos más fuertes para retraerlos de las hostilidades que intentaban. Finalmente, en su misma persona y trajes, no se advertía otro distintivo que el de usar la piel de zorrillo, cuando los demás las usaban, ó de nutria, ó de lobo marino, ó de oso.

Este último distintivo fué entre nosotros por algún tiempo un objeto de disputa, pero últimamente pareció decidirle la pregunta del Ankau, si D. Juan Vernaci era hermano mío, pues le veía con un sobretodo forrado con piel de guanaco y semejante al que yo llevaba.

Debió causarnos á la verdad mucha admiración el uso de las mujeres que nos of recieron con ansia desde el primer día; y el orígen de esta costumbre hubiera sido un objeto no indiferente para nuestras pesquisas, si la necesidad de rechazar al principio estos of recimientos importunos y peligrosos, y las diferentes atenciones que tuvimos después por una y otra parte no lo hubieran imposibilitado. Hasta aquí sólo el Capitán Dixon había visitado este puerto, y aunque no quedase duda de haber su tripulación usado de las mujeres, un solo ejemplo no bastaba, sin embargo, para arraigar una costumbre, y mucho más una costumbre opuesta á otras diferentes muestras que notábamos, de un grado no indiferente de amor filial y conyugal en estas familias; finalmente, varias circunstancias parecieron concurrir para aclarar siquiera en parte este punto importante de sus costumbres. Las mujeres of recidas no eran más de tres ó cuatro, estaban juntas, con todo el semblante de la violencia y de la opresión; y casi toda la tríbu estaba igualmente interesada en ofrecerlas y en proporcionar su uso sin el menor rebozo ó decencia. Esto hizo sospechar desde luego que serían esclavas pertenecientes á otra tríbu, y confirmaron después esta sospecha no sólo la positiva existencia entre ellos de un hombre esclavo (I), si también el que no se renovasen estos ofrecimientos en las diferentes rancherías que visitamos después (2) y particularmente en la bastante numerosa de la entrada del puerto del Desengaño: serían sin duda también esclavas las que nos ofrecía el habitante de las faldas del Monte de San Elías, y probablemente será fácil encontrarlas en casi todas estas tríbus costaneras, como fruto de unas invasiones destructivas que multiplicarán con este nuevo motivo.

En el estado aún informe de esta pequeña

(1) El mismo Ankau me manifestó este prisionero, indicándome era de la misma tríbu, cuyas canoas se aproximaban el día $\mathbf{r}^{\circ}$ con ideas hostiles.

(2) Apoya ahora este concepto, la venta de una mujer de otra tríbu hecha en el Sung Corner al Capitán Meares por los habitantes de aquellos contornos, los cuales jamás franquearon las mujeres propias. sociedad y mucho más en el estado informe de sus costumbres y poderío, no debieron causarnos igual grado de admiración, ni la facilidad con que una madre se determinó á vender un niño suyo de pecho, ni la oposición que tenían los más adultos á separarse de los suyos; ni final. mente, el deseo que manifestaron de recobrar y apropiarse uno ú otro marinero ó criado filipino, que por la desemejanza del rostro con los demás, creían robado á alguna otra tríbu y reconocían con suma curiosidad y concurrencia. La cesión de una niña no es extraña en un país en donde el criarla acarrea á la madre no sólo inmensos cuidados y fatigas, si también una larga privación de los placeres conyugales (I), en donde el corto número de gentes aptas á las fatigas de la guerra y de la pesca, da al hombre un grado de utilidad y de valor infinitamente mayor que á la otra mitad de nuestra especie, en donde en fin, esta misma mitad desproveída de todo medio de adquirir lo necesario, no está, sin embargo, desposeída de un cierto antojo y volubilidad á favor de los adornos y de lo que ve: tampoco es extraña la oposición de los adultos á separarse de los suyos; la debilidad engendra el patriotismo y el suceso le conserva: así estos jóvenes embebidos desde sus años tiernos de la necesidad en que está la patria de su brazo y de sus auxilios, jamás proponían otra especie de cambios para esta emigración, sino la de un hombre nuestro agregado á la tríbu, mientras ellos estuviesen ausentes; y esta misma razón hacía finalmente que sus ansias mayores, sus diligencias en toda discordia, siempre se dirigiesen á la adquisición de un hombre nuestro, así como la posesión de uno suyo contenía inmediatamente todos los excesos de su furor bárbaro.

En verdad que considerando cuánto desmerece el valor particular de nuestra especie, cuando con la multiplicación de las fuerzas y del poderío natural, la emulación y el lujo elevan sus aras para que se les inmolen crecidas víctimas, no podemos dejar de envidiar este rudo estado de las naciones, en el cual la misma falta de propiedad hace que el hombre trabaje para todos y sea útil á todos. ¡Cuánto más agradable parecerá aún este estado, cuando revivamos á la memoria del filósofo, ó bien la unanimidad de todos los de esta tríbu en sus cambios, á pesar que los efectos explayados casi instantáneamente á su vista reuniesen todas las conveniencias de la novedad, de la utilidad y del lujo, ó bien la quietud y buena harmonía que se advertían en todos sus pasos y en el trabajo asíduo é interior de las familias!

Era efectivamente un contraste nada hono-

(I) Este iiltimo punto se tratará con mayor individualidad hablando de los habitantes de Nutka. 
rífico para las costumbres europeas advertir de su parte, no sólo el regocijo general de un contrato farorable que hubiera hecho cualquiera individuo, si también la legalización y garantía que todos los demás parecían prestarle con un grito acorde y majestuoso de wó, cuando por la nuestra se veían frecuentemente dos ó tres ansiosos por la misma prenda, y á veces procurando adquirirla con diferentes propuestas al mismo tiempo y sin recíproco conocimiento ó unanimidad (I).

Concurrieron muy luégo al mercado todas las clases de manufacturas que hasta aquí había dictado á estos naturales, ó la necesidad ó la perspicacia: no es difícil acertar en que todas ellas debían precisamente referirse á utensilios de pesca, á los domésticos, á las armas, y finalmente, á uno ú otro tejido (2); son aquéllos realmente ingeniosos para toda especie de pesca, inclusos los cetáceos; los segundos comprenden varios muñecos, algunas cucharas y cajitas de madera, los palillos del juego, los canastos impenetrables, para la cocina, y algunas hachas y martillos de piedra muy bien contrapesados; las armas se reducen al arco, la flecha, el puñal y una especie de vestido militar de madera; finalmente, en los tejidos merece una singular atención la manta formada de la corteza del pino, hilada y tejida, á la cual está embutido por una parte con buena simetría el pelo de la piel de nutria: fuera largo, tal vez inútil y seguramente cansado, añadir aquí una extensa descripción de cada una de estas manufacturas: la omitiremos, por consiguiente, contentándonos con indicar, que descle el momento en que los naturales advirtieron un deseo de estas cosas de parte de la Oficialidad, y á su imitación de parte de varios de las clases subalternas, no cesaron de ocuparse hombres y mujeres en su apresto y sucesiva conducción al mercado, lo que afianza la natural actividad y penetración de esta tríbu, cuando no bastasen á acreditarla, así el modo ya descrito en el Diario con que hacen por lo común sus negociaciones, como la excesiva preferencia que en nuestros cambios dieron siempre á la ropa de abrigo, comparada á cualesquiera otras cosas de adorno y áun al mis mo hierro: las hachas, entre los utensilios nuestros de este metal, fueron la única cosa que apetecían con ansia, y si no desdeñaron conservar hasta lo último el nivel convenido de un clavo por un salmón, yo creo que debió más bien atribuirse á la abundancia de éste, que al aprecio de aquél, tanto más, que al principio respondió el

(1) Este párrafo, como lo demuestra el l)iario cxtensamente, debe entenderse sólo de las clases inferiores de ambas corbetas, í las cuales se permitió la libre adquisición de todo lo que presentasen los naturales cn el mercado.

(2) Se remite una colección completa de cstas manufacturas al keal Gabincte. hijo mayor del Ankau á esta propuesta, con agarrar un puñado de clavos y tirarlos al suelo.

Concluiremos ya la descripción de lo que hemos advertido en el puerto Mulgrave, con algunas reflexiones sobre su religión y ritos, cuyas ideas, si bien limitadas, podrán, sin embargo, servir de comparación y de cimiento á los raciocinios que se hayan hecho anteriormente ó se hagan después.

Que un pueblo que á imitación de los orientales agrega la mayor solemnidad así en sus mociones como en sus cantos harmoniosos á toda acción pública y sociable; que aproximándose á los parajes en donde hay"cadáveres, manifiesta una repugnancia tímida y supersticiosa (I), depende, sin embargo, de la idea de una no total aniquilación del hombre; que finalmente quema sus cadáveres delante de una especie de ídolo y conserva una sola pa:te escogida de la injuria de los tiempos, presentando todos estos monumentos hacia el Oriente; que este pueblo, digo, carezca de todo principio religioso, es difícil á la verdad combinarlo con la historia de la especie humana: pero al mismo tiempo no podemos determinar cuáles sean en esta religión, ó bién el Dios, el sacerdote y la ofrenda, ó bien las leyes que dimanen de la interpretación de sus efectos benévolos ó injuriosos. Nos lison jeábamos que el uso de nuestros instrumentos astronómicos, dirigidos hacia el Sol, nos descifrasen en esta parte una ú otra verdad: les procuramos efectivamente agregar la idea de un culto religioso: todo fué en vano, y enterados con anterioridad por el Capitán Dixon del uso de los anteojos, asemejaron una idea á la otra y áun los impulsos de su curiosidad fueron bien moderados. Advertíamos á la verdad en todas las tardes y próximamente al ponerse el Sol, que el Ankau, paseando solo en la playa inmediata á las chozas, arengaba por algún rato con mucha solemnidad; pero nunca pudimos inferir si esta arenga se dirigía á los suyos para que vigilasen sobre su conservación, ó al Supremo Hacedor para que los conservase: tampoco pudimos confirmar nuestras sospechas sobre el empleo en la tríbu de un hombre anciano, el cual aparecía pocas veces, tenía un semblante respetable, y en la mañana del $\mathrm{I} .{ }^{\circ}$ de Julio, al aproximarse las canoas sospechosas, dividía con el Ankau el cargo de los cuidados de las providencias oportunas. Este anciano, preguntado por mí sobre el objeto de un pequeño cerco formado con piedras, á cuyo lado pasamos, me respondió que en él entraban á jugar sólo los niños suyos y del tıkau, logrando así estar separados de los demás de la plebe.

(i) Se advirtió este temor por los Sres. Tova, Bausá, Espinosa, y por mí mismo en las difcrentes ocasio. nes en que hemns visitado estos monumentos. 
Finalmente, advirtió D. Felipe Bausá al tiempo que le acompañaba un natural en sus excursiones hidrográficas, que éste, levantando los ojos al cielo, empezó á entonar un canto lamentoso y patético, al cual acompañaba la unión fervorosa de las manos, y aún instaba á que él mismo uniese su voz; pero la falta del idioma no le permitió aclarar estas ideas primitivas y sólo sí pudo inferir que no era al Sol á quien se dirigían sus preces.

Después de todas las observaciones que acabamos de referir, no parezca en nosotros inoportuno ó aventurado asegurar que estos naturales tienen algunos principios de religión referidos particularmente á la vida venidera; que admiten la poligamia, escuchando sin embargo las leyes melodiosas de la Naturaleza relativamente al respeto y cuidado paterno y al amor conyugal y filial ( $\mathrm{I}$ ); que son bastante industriosos y sumamente advertidos; que dejan traslucir en sus costumbres algunos rastros de la solemnidad oriental; que poseen el valor ó más bien la fiereza, en el grado á que suele llevarlos en un corazón bien dispuesto, el no temido conocimiento de la propia debilidad; finalmente, que ligados á su propia tríbu con los vínculos estrechos del patriotismo, raras veces enturbian la paz interna y se destruyen mútuamente, tanto más, que las ideas de la propiedad, de la distinción de clases y de la abstinencia del trabajo, no han echado aún entre ellos sus raices harto temibles y extensivas: sus cantos y su idioma corresponden bien á estas cualidades: á los himnos realmente harmoniosos de paz, guerra, regocijo y devoción, es regular que reunan los de sus pompas fúnebres que corresponderán sin duda á los monumentos con que intentan eternizar su memoria: y en el idioma ya adoptado por los Jefes para persuadir á sus súbditos lo que les convenga, pueden advertirse fácilmente no solo la harmonía y volubilidad oratorias acompañadas del gesto sumamente expresivo, si también la facilidad de adaptarle á las ideas nuevas que van adquiriendo con el roce de los europeos. $\mathrm{Ni}$ su inclinación al robo se explayó con aquella vehemencia que se ha advertido en otros puertos $y$ en otros buques: nunca comprometieron su propia seguridad, nunca parecieron reunidos en proyectos de esta especie; y el Ankau siempre pareció dispuesto á contenerlos ó á recobrar las prendas robadas: sin embargo, era esta la segunda visita de buqucs europeos, y seguramente no era el hierro un género escaso en ambos buques para que no meditasen alguna tentativa ó en las mesas de guarnición ó en los candeleros, cosas todas que tenían continuamente á la

(1) Puede versc en nuestro Diario lo acaecido en diferentes ocasiones.

vista (I), y cuyo robo podía tal vez alentar nuestra conducta sumamente pacífica.

En la formación del corto Diccionario que aquí se agrega, no nos hemos tampoco apartado del método lento y reflexivo que nos habíamos propuesto: muchos Oficiales han formado por sí un Diccionario separado, y confrontados éstos no se ha admitido voz alguna, la cual no tuviese la sanción general ó no descubriese de dónde dimanaba una ú otra contradicción.

\section{Vocabulario del idioma Mulgra't'}

\section{A}

ESPAÑOL

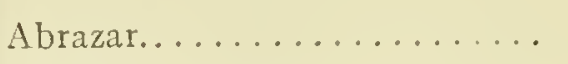

Agua: genéricamente.

Agua de lluvia ó quizá la acción

de llover................

Ama de leche.............

Amigo. . .

Apio silvestre ó yerba en general...

Arrodillarse.

Atado del pelo.

Abalorio..

Barba................ Kakti.

Barriga .............. Kayú.

Beber................ Huitennatz.

Beso............... Fklá.

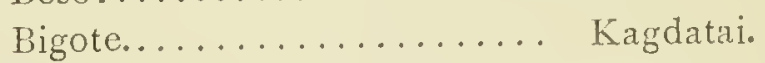

Boca................. Kategl.

Bonito................ Kanaktunikitá.

\section{C}

Cabellos................ sichejau.

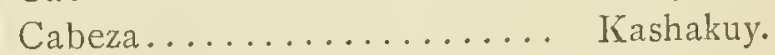

Calzones................ Keguen.

Cambiar............... Kutzek.

Canalete................ Agjá.

Canastillo.............. Kashé.

Canoa grande de madera y casa de lo mismo........... Yauk.

Canoa de cuero............ Chokuti.

Casa fúnebre ó cementerio.... Jkitá.

Capitán ó Jefe............ Ankau ó Ancro.

Cara............... Ka a gá.

Carrillos............... Kaaguish.

Ceja.............. líakag.

Chaqueta.............. Cutet. .

Choza............... Hijt.

(I) Lo que en nuestros buques que han frecuentado estas costas ha sido algunas veces efecto de una excesiva aunque prudente tolerancia, puede creerse que en los buques ingleses lia derivado del uso de las mujeres, franqueado con demasiada facilidad á la marinería. 


\begin{tabular}{|c|c|}
\hline FSPANTI, & MULGRAVF \\
\hline $\begin{array}{l}\text { Cilindros curvos de hueso y co- } \\
\text { bre que pasan por la ternilla } \\
\text { de la nariz.............. }\end{array}$ & Zuot ó Kíakletu. \\
\hline Cielo................. & Kilcháó Kurukthiz. \\
\hline Comer................. & Atimuthy. \\
\hline Costillas........... & Katzukt. \\
\hline 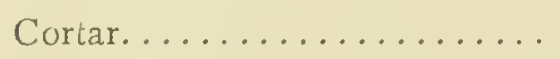 & Yguashech. \\
\hline Cuchara................ & Shetfl. \\
\hline Cuchillo................ & Cotzlá. \\
\hline 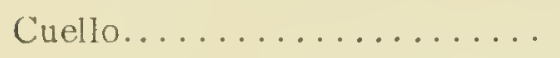 & Kashle. \\
\hline 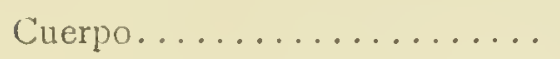 & Kagkitzén. \\
\hline
\end{tabular}

$\mathbf{D}$

Dar la mano............ Yshán.

Dedo pulgar.............. Kakutz.

Dedos: genéricamente....... Katlex.

Delinear ó pintar........... Kshekit.

Dientes................ Kauls.

Dormir................ Kantitlix.

\section{$\mathbf{E}$}

Echarse en tierra.......... Taá ó Yaá.

Efectos de cambio........... Kanaktunitz.

Escopeta.............. Unna.

Especie de cuna en que ponen los niños............ Tutu-Utú.

Estomago............ Kutexk.

Enemigo.............. Kutef ó Kutek.

\section{$\mathbf{F}$}

Figura humana colosal de madera que ponen sobre un palo en las inmediaciones de sus sepulcros, ya represente persona $\delta$ ídolo..

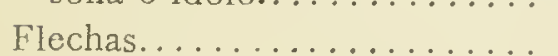

Hlor.................

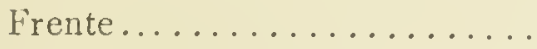

Fresas................

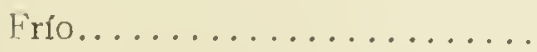
Kaniketek.

\section{G}

Gorro ó sombrero......... Zauk ó Zakuk.

$\mathbf{H}$

Hacha o la acción de cortar con ella..................

Herir................

Hombre..................

Hombro ...... Juazitim.

Kafik.

\section{J}

Juego de los palillos........ Esllehká.

L

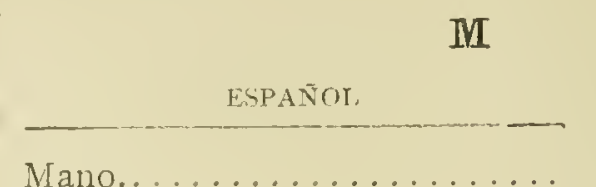

Kaachin

Manta exterior............ Kagjugu.

Manta interior........... Cudetz.

Mañana ............... Kennitk.

Mar.................. Eer ó Etch.

Mascar .............. Atjká.

Matar............... Unná.

Mirar................. Katllatini.

Monte genéricamente ó el de

San Elias............ Guá o Whuá.

\section{$\mathbf{N}$}

Nada............... Flext.

Navaja................ Zutla.

Nariz................ Kaashluu.

Niño, ó hijo............ Zannagueti.

Nieve............... Shaa.

No: negación............ Gannukut.

Nombre de cacique......... Junuelo.

Idem del enterrado y muerto según parece en la refriega.... Kataukú. Idem de la nación ó tríbu..... Tejunué. Idem á un indio de la plebe... Cheutukú. Nutria $\delta$ su piel........... Yuks. Nubes................ Aligatchin.

\section{o}

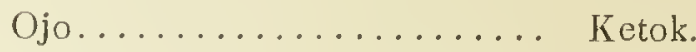

Ojos.................. Kaavak.

Orejas................ Kaakux.

Oso................... Huteh.

\section{$\mathbf{P}$}

Palma de la mano.......... Katchintak.

Pecho............... Kíasellká.

Pelo: genéricamente........ Jitil.

Pelo de la barba........... Kakanatsané

Perro................. Teitil.

Pestañas................ Kaguakjeki.

Pié................ Kagkutz.

Piel: genéricamente......... Skutí.

Piel de zorrillo............ Kakou.

Piernas............... Katzeyú.

\section{$\mathbf{R}$}

Rodilla.............. Kakxi.

Roncar............... Ackitz.

Ropa................ Iíuteutz.

Revolución diaria del Sol...... 'Titz.

\section{$\mathbf{S}$}

Salmón............. Thot.

Sentarse $\delta$ siéntate......... Kudnuk.

Sí.................. Shck Shaam ó aa.

Siéntate.............. Kannú.

Sol.................. Akín ó Kekán.

sombrero.............. Zakuk. 
$\mathbf{T}$

ESPAÑOL

Tetas...................

Tejer un sombrero..........

Tierra..................

Todo junto..............

U

Uña.

Kagkjak.

\section{V}

Ven acá.............. Jakut.

Vestido................. Kudetz.

Vete.................. Yutch 6 Yutej.

\section{Z}

Zarcillos.............. Jkenot y Cunajá.

Numerales.

\begin{tabular}{|c|c|}
\hline Uno.................. & Tlex ó Tlej. \\
\hline 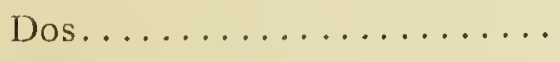 & Tejé. \\
\hline 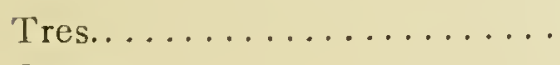 & Nutzk. \\
\hline 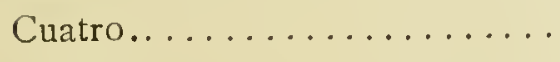 & Taajún. \\
\hline Cinco $\ldots \ldots \ldots \ldots \ldots \ldots$ & Kuhin. \\
\hline 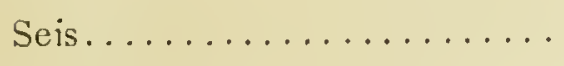 & Kletushú. \\
\hline Ocho $\ldots \ldots \ldots \ldots \ldots \ldots$ & Nutzkatushú. \\
\hline 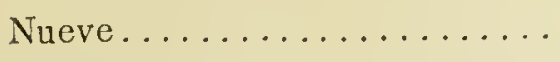 & Kutshako. \\
\hline Diez.................. & Chinkat. \\
\hline Once $\ldots \ldots \ldots \ldots \ldots \ldots$ & Chinkat-tlex. \\
\hline Doce.................. & Chinkat-tejé. \\
\hline 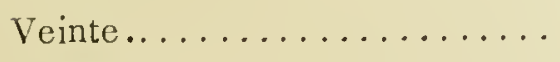 & Tleká. \\
\hline 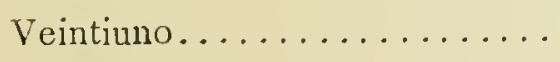 & Tleka-tlex. \\
\hline Veintidos ............... & Tleka-tejé. \\
\hline 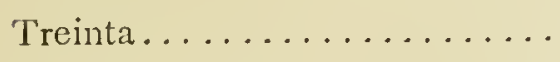 & Tleka-chinkat. \\
\hline Treinta y uno.............. & Tleka-chinkat-tlex \\
\hline Treinta $y$ dos.............. & Tleka-chinkat-tejé \\
\hline Cuarenta............ & Tejka. \\
\hline 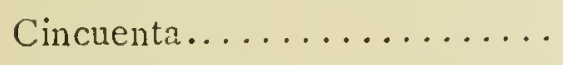 & Tejka-chinkat. \\
\hline Sesenta............... & Nuzkeka. \\
\hline Setenta ............... & Nuzkeka-chinkat. \\
\hline Ochenta .............. & Tajutiat. \\
\hline Noventa ............... & Tajutiat-chinkat. \\
\hline Ciento................. & Kechin Kaa. \\
\hline Ciento veinte. . . . . . . . & Kletushú-kaa. \\
\hline
\end{tabular}

Aunque nuestra indagación no pasó de este último número, parece que siguiendo el mismo orden pueden contar crecidas cantidades.

Por no haber sonido equivalente en castellano, hemos adaptado el sh del inglés y se hace uso de él en las voces que exigen el sonido que se le da en este idioma.

La pronunciación de la $h$ es mucho más fuerte y gutural que la nuestra aspirada.

La $k$ se ha admitido en las voces que piden una pronunciación más cargada que la de nuestra $c$, apoyando fuertemente la lengua al paladar al modo de los tartamudos.

El tiempo no permite comparar ahora éste á los dialectos de Nutka y el Príncipe Guillermo.
Pero es tiempo de volver al hilo primitivo de nuestros reconocimientos y emprender el examen del segundo trozo de costa: es éste, como ya se dijo al principio, un Archipiélago inmenso, que corre desde los $5^{8}$ escasos, pasada la entrada de la Cruz hasta los $48^{\circ}$ en la entrada de Fuca, extendiéndose considerablemente al Este, particularmente por el Archipiélago de la Princesa Real entre los 54 y $53^{\circ}$, y presentando á la navegación europea un nuevo campo inagotable, bien para los proyectos comerciantes ó para los sistemas hidrográficos: dejaremos por ahora examinar hasta dónde la imaginación ó los objetos políticos han desfigurado la realidad en ambos puntos, y nos contentaremos con una atención prolija á las cualidades del suelo y de sus moradores.

Sea cualquiera el origen de esta extraordinaria intensión de las aguas, dependa ó no de una de aquellas grandes revoluciones del globo que apenas alcanza la sublime imaginación del hombre, no cabe duda á lo ménos que la clase del suelo es una misma y bien semejantes entre sí sus productos, si se atiende tan sólo á la pequeña diferencia derivada del diferente grado de latitud: nuestras vistas (I) desde luégo manifestarán al examen del físico una estructura singular de costa desde la Ensenada de la Cruz hasta el Cabo San Agustín; pudieran seguirle luégo las pocas de los Capitanes Dixon y Meares para la parte que no hemos reconocido desde los 55 hasta los 50, y últimamente reunirles las que ahora hemos trazado de las tierras avistadas desde el Cabo Frondoso hasta la entrada de Fuca: todas concurren á demostrar, que bien sea al andar de la costa ó en el Archipiélago separado de la Reina Carlota, la composición de estas islas es de la misma naturaleza que advertimos en Nutka; esto es, una piedra granitosa, granulosa, varia en el color ya más oscuro y gris ó ya más blanco y compuesta de cuarzo, feldespato y cristalizaciones pequeñas y reunidas. Bien sea por efecto de las lluvias, del corto tiempo de esta revolución ó de la misma corta extensión de muchas islas, ello es generalmente que la capa de tierra vegetal es bien corta á pesar que la formen al mismo tiempo algunas sustancias calcáreas ó fragmentos de las conchas, y la natural descomposición anual de las plantas que la fecundiza y negrea con mil especies de miriades pútridas: el pinabete (pimus abies) parece sin duda el árbol preferente y más homogéneo á este suelo: se le encuentra con exceso lozano en los puertos de los Remedios, Gua. dalupe y Bucareli; por los Sres. Cuadra y Artea. ga en el puerto Banks; en las Islas de la Reina Carlota por el Capitán Dixon, y en las inmediaciones de Nutka hacia el Norte y al Sur, por los

(1) Don Felipe Bausá las ha representado con s 11 exactitud acostumbrada. 
muchos que han risitado aquellas costas; y es tanto más admirable la lozanía de este árbol, cuanto que no pudiendo penetrar sus raíces sino a una corta profundidad por efecto de la picdra inferior, ni le suministran todo el jugo nutritivo que fuera necesario, ni áun pueden conservarle firme por largo tiempo, desplomándose por consiguiente con mucha facilidad y frecuencia.

No siempre las partes más salientes de la costa se componen en este dilatado Archipiélago de islotillos frondosos y destacados, como al Sur de la entrada de la Cruz, al Norte de la de Fuca y probablemente en los canales de la Princesa lieal: otras veces como al pié del monte San Jacinto, en la entrada de Bucareli y en los extremos de las Islas de la Reina Carlota, se elevan desde la misma orilla algunos montes, los cuales, si bien sean también parte de otras islas y no carezcan de una frondosidad lozana, deben, sin embargo, causar un mayor grado de frío, así por su natural posición en paralelos más altos, como por la duración del hielo que ha de dilatar con su misma elevación.

En los parajes en los cuales no se presentan inmediatamente á la orilla los montes altos, no dejan de descubrirse interiormente á muy poca distancia las serranías, aunque no tan elevadas como en la costa que acabamos de describir: son estas serranías entrecortadas, puntiagudas en muchas partes, con el aspecto natural de volcanes y á veces divididas en dos y tres hileras, y por lo comun (á lo ménos en el mes de Agosto) ya libres enteramente del hielo, si se exceptúa una ú otra cañada en la cual no impidan su liquidacion, ó la poca concurrencia de los rayos del Sol, ó la misma disposición de las peñas á las cuales esté asido el trozo de hielo: consultando los Diarios de las navegaciones hasta aquí conocidas, algunas propiedades singulares de esta costa pueden desde luego sentarse como seguras, y son: primera, la existencia casi constante de las neblinas más espesas y más frecuentes que en el primer trozo descrito; neblinas que, ó bien sea la mengua del frío ó la multiplicación de las aguas internas, á medida que va disminuyéndose la latitud van condensándosc más y más y haciendo al mismo tiempo más tranquilo el mar y más incierta la navegación: segunda, la alternativa, ó de los vientos del Noroeste al Oeste ó de los del Sueste y Sursueste; aquéllos claros, manejables y no frecuentes; éstos, neblinosos, incómodos y acompañados unas veces de calma, particularmente en el verano, otras veces con temporales fuertes, In que sucede por lo común en el invierno.

La demasiada interrupción de estos terrenos, ó aislados a rápidamentc montuosos, deberá tambien arrastrar otro inconveniente de mucha monta. y este ces la falta de terrenos llanos y algo seguidos para el beneficio de las semillas, que tanto jmporta á la multiplicación de nuestra especie. Deberán, por consiguiente, sus moradores dedicarse precisamente á la pesca; deberá ésta suministrarles el único, ó á lo ménos, el principal sustento; y así podrá asegurarse de antemano que no son estas costas, ni estos paralelos del continente de la América, los que hayan algún día de ser el dulce asilo de una crecida sociedad civilizada $(\mathrm{I})$.

La Naturaleza sin embargo no ha desmentido aquí la grande harmonía que se admira en todas sus obras, y ya que el mar era un tropiezo continuo para la subsistencia del hombre, de su seno mismo ha querido que se satisfaciesen al mismo tiempo las dos necesidades esenciales del alimento y del abrigo: ni el pescador pudiera á la verdad extender sus deseos á otra situación que la que presenta este Archipiélago. La corta anchura de los canales no expone á un naufragio sus débiles canoas y permite la pesca en todo el año: la multiplicidad de las costas aumenta la cría y concurrencia de los peces: es cómodo el traspaso de sus casas de una á otra parte, con el ingenioso ardid ye amadrinar dos canoas que sufran juntas el peso y el tamaño de la tablazón; se consigue variar con facilidad de morada según las diferentes estaciones; el lobo y la nutria suministran ampliamentc para sus vestidos y para un comercio activo; las orillas inmediatas proveen con abundancia, ó bien las plantas antisépticas que les liberten del escorbuto ó los árboles corpulentos de donde saquen canoas y utensilios para la pesca; finalmente, la misma extensión de la costa favorece admirablemente la reproducción de la especie, en cuanto puedan alcanzarla unas tribus pescadoras y por consiguiente desparramadas.

Hemos indicado al principio de este capítulo, que mirábamos como una verdad casi incontestable ser del mismo origen y calidad los pueblos habitadores de este Archipiélago y los que se han descrito del Príncipe Guillermo y puerto Mulgrave: bastaría recorrer la narración de los diferentes viajes emprendidos hasta aquí para admitir esta aserción; y particularmente la descripción del Capitán Dixon de los habitantes de las Islas de la Reina Carlota (2), y los reparos del Capitán Meares al tiempo de visitar sus costas de $\operatorname{los} 56^{\circ} 28^{\prime}$. Pero estas reflexiones están públicas y sería importuno repetirlas. Nos ceñiremos, por consiguiente, á aquellas otras que de-

(I) Seguramente en una época cn la cual la sed de lo que esconde la tierra va cediendo al deseo de lo que produce su superficie, ó expontáneamente o ayudada de la mano benéfica del hombre, debe parecer muy distante la realización de las conjeturas de Mr. Carver cuan do habla de las montañas brillantes.

(2) Traducción franccsa de este viaje, carta 37 , página 558 , tomo II. 
pendiendo de los viajes nacionales, aún no han visto la luz pública.

Desde luego D. Juan de la Cuadra, en el puerto de los Remedios, advierte no sólo los adornos del septum y de las orejas muy semejantes á los del Príncipe Guillermo, si también el labio inferior cortado y la misma especie de armas: en el puerto Bucareli, D. Francisco Maurelle halla los mismos monumentos fúnebres, armas, trajes, fiereza, deseos de la adquisición de nuevos hombres, inclinación al robo y sobre todo el mismo adorno en las mujeres, del palo ó roldana eliptica colocada en el labio inferior (I); finalmente, los habitantes de Nutka enterándonos de las tríbus limítrofes de los Nuchimases (2) hacia el Norte, las caracterizan constantemente por las del labio cortado, reconocen luégo sus trajes, armas y cantos, confiesan su genio belicoso, y áun en sus costumbres manifiestan aquella uniformidad que es inseparable del roce con otra nación. Con estos datos ya la aserción indicada no debe ponerse en duda, y podemos asegurar que á lo ménos las orillas del mar, desde la ría de Cook hasta el paralelo de $52^{\circ}$, están habitadas por una clase de hombres cuyo origen, costumbres y estado de civilización es uno mismo próximamente.

No así con las naciones más meridionales, inclusa la confederación de Nutka, en la cual, si bien traslucen varias características de los pueblos septentrionales, se halla sin embargo, en un grado más provecto de civilización, que ó bien sea efecto de un clima más templado, de unos vecinos más comerciantes y apacibles, ó finalmente, de un roce más repetido y duradero con los europeos, no puede ocultarse al que mira con alguna prolijidad sus costumbres: evitaremos ya el hablar de las disposiciones materiales de estos moradores, que los Sres. Cook y Anderson describieron con tanta exactitud y verdad: son ménos corpulentos que los que habitan más al Norte; su pié es desproporcionadamente chico, su carácter belicoso y más bien fiero; finalmente, sus leyes sociales y particularmente la subordinación más bien establecidas.

No eran sino muy limitados nuestros conocimientos en esta parte, y apenas hubieran podido pretender al sacrificio de pocos momentos en su lectura, cuando en los últimos días de la demora de las corbetas en el puerto, tuvimos la felicidad de conocer á los dos hermanos Nanikius y Natzapi, cuñados de Macuina, y el segundo últimamente viudo de la hija del Jefe Nuchimás, y por consiguiente admitido entre aquellos pueblos á la

(1) Los Diarios originales de uno y otro viaje, están en nuestro poder y se han consultado.

(2) Se hablará muy luego extensamente de esta nacion importante. clase de Tahi ó Primate: entrambos son jóvenes, y Nanikius no tendrá más edad de diez y seis á diez y ocho años: en sus ojos, en su porte, en la inclinación al roce con los europeos, y en la facilidad de entender y hacerse entender estos dos hermanos, dejan traslucir una tal perspicacia, un carácter tan humano y una docilidad tan pronta á las ideas nuevas, que seguramente pudieran considerarse con facilidad, como los reformadores de estas naciones si los europeos coadyuvasen á esta útil reforma.

El acaso como en otras muchas ocasiones, dió lugar á que Nanikius, á bordo de la ATREviDA, desplegase los primeros rastros de su perspicacia: tenía inmediatos papel, pluma y tintero, al tiempo que le daban una taza de té (I): empezó á señalar con algunas rayas la posición interna de algunos canales, y como ya supiésemos por los de nuestra colonia la segura existencia de las lagunas de los Nuchimases, la curiosidad de parte de los Oficiales y el natural deseo de producirse en Nanikius, muy luego dieron á la conversación un mayor grado de interés: el joven explicó distintamente esta parte importante de la Geografía; y como en esto manifestase á cada paso nuevos grados considerables de inteligencia, D. José Bustamante me lo advirtió; y ya ni en una ni en otra corbeta nos descuidamos en aprovechar todas las ocasiones de atraerle y preguntarle; concurriendo últimamente el mismo Natzapi para confirmar separadamente las ideas que habíamos bebido de su hermano. Si no fuese al mismo tiempo impertinente y difuso manifes. tar los medios ó rodeos por los cuales alcanzamos la inteligencia recíproca de las ideas siguientes, no titubearíamos en producirlas, tanto más que de ellas refluiría un debido elogio á aquellos Oficiales que más se esmeraron en estas pesquisas: puede sin embargo, estar seguro el que recorra estas hojas, que ni nos hemos des. cuidado en disponer las preguntas de modo que no alucinasen á los dos hermanos, ni en recibir y confrontar las respuestas para que nos apartasen de toda idea de sistema; y que así tenemos la agradable confianza de que no se confundan nuestros progresos científicos en estas indagaciones con las comunes de los viajeros, que prefieren á la verdad el deseo de agradar.

La confederación de Nutka, no excede el número de 4.000 individuos, según pudieron inferir después de un examen prolijo los Tenientes de navío Espinosa y Cevallos, habiendo recorrido con las lanchas todos los canales internos; no se extiende su territorio más allá del terreno reconocido por los mismos Oficiales; y son sus limí-

(I) El uso de tomar té está bastante introducido entre estos Jefes; los Capitanes Colnet y Kendrik, han contribuído mucho á ello: no gustan tanto del vino, que comunmente llaman agua de España. 
trofes hacia la punta rompiente, los pueblos Izcuates, dependientes probablemente de Wicananish (I); otras tríbus hacia el Noroeste ó el Cabo Frondoso, cuyas circunstancias no nos fué fácil acertar, y finalmente, á la espalda los Nuchimases, cuyo número y poderío parecen muy superiores á los de Nutka: esta voz 110 denota sino Archipiélago en general; es probable, sin embargo, que de ella deriven su nombre estas tríbus confederadas, pues jamás le oimos otro alguno hablando de sí mismos.

Reconocen todos un mismo Jefe, cuyos privilegios son grandes; le son inferiores ó subordinados los Jefes de los otros distritos ó rinconadas (2), los cuales, sin embargo, tienen un número determinado de súbditos que les obedecen en las operaciones particulares de la sociedad, debiendo sólo reunirse para la causa común de la defensa ó del ataque de sus enemigos: estos Jefes subalternos, bien sea casualidad, constitución ó política derivada tal vez de unas guerras anteriores y sangrientas, están enlazados entre sí por medio de los matrimonios, y es probable que bien decidida la autoridad suprema, sirva esta reunión para conservar el buen órden y no multiplicar con nuevas incorporaciones el número de los primates: la autoridad suprema reside en poder de Macuina (3), el cual, por su parte, preside á las rancherías del fondo de la Tasis y á las que están esparcidas en la isla grande, que comprende el puerto de Yucuat (4): son tres los Jefes subalternos, Natzapi, Tlupananulk y Calacan; bien que muerto éste último por el Piloto Comandante de la fragata Princesa (5) al tiempo de establecerse en Nutka, no sabemos en quién ha recaído esta parte de dominio que Tlupananulk apellidó todavía con el nombre de Calacan.

Estas familias forman la clase de los Tahis ó Grandes, destinada á gobernar la plebe que distinguen con el nombre de Mictimis: la legislación y la religión concurren á hacer más decisiva esta diferencia; y así, ni la subordinación desmaya, ni el deseo del mando acarrea nuevas

(1) Consúltese el viajc del Capitán Meares: 'Tlupananulk, á la verdad, dijo á los Oficiales Comandantes de las lanchas, que pertenccía á Wicananish el fondo ó recodo más Este de nucstros reconocimientos; pero es probable que entendiese hablar de los terre nos que están á su espalda.

(2) Visto el plano de estas inmediaciones, no parecerá impropio esta voz de rinconadas.

(3) El Capitán Meares le llama Maquilla: llama Callicun al que nosotros apellidamos Calacan.

(4) Este puerto es el Triendly Cove del Capitán Neares, un donde estí en el día nuestro establecimicnto.

(5) Estamos bien distantes de querer justificar la ronducta del Piloto Martínez en esta ocasión, pero por los informes accidentales de Natzapi, á la sazón lresente, veinos que el Capitan Meares ha recargado este hecho con unas adiciones no necesarias. discordias: en unas tríbus débiles, pescadoras y constituídas á guerrear con frecuencia, no debe tampoco parecer extraño que llegado el Jeje á una edad incapaz de dirigir con el biazo, el valor y el ejemplo las acciones públicas, entregue el Gobierno al hijo: no pudiéramos asegurarlo así de Macuina, porque creemos no viva su padre; pero seguramente Anapi, padre de Natzapi y el padre de Tlupananulk, que vino á bordo confundido con los Michimis, no disfrutan ya ni de la autoridad ni del respeto que en el día se tributa á sus hijos: tampoco pudiéramos acertar si las hembras participan del derecho de sucesión, bien que es probable que no sea así, si debemos juzgarlo por el poco aprecio que merece entre ellos esta agradable mitad de nuestra especie: extinguidas las familias de los Tahis, la elección de otra nueva línea dominante pende del voto común de los Michimis, y combinado éste, inmediatamente recaen en ella todos los fueros de la soberanía y del sacerdocio que deben distinguir esta clase preciosa: ignoramos, sí, cuál es la especie de regencia que tomará las riendas del gobierno, cuando el heredero presuntivo, muerto su padre, no tuviese aún la edad y calidades necesarias para el mando.

Sea esto como fuere, estos pueblos veneran los Tahis, y en el respeto y subordinación que todos profesan á Macuina, como asimismo en la propiedad y gobierno de éste, resplandece sin duda un adelantamiento de la sociedad, que en nuestras ideas mal pudiera combinarse ó con su subsistencia ó con su desnudez (I). El carácter de Macuina no es en el día fácil á descifrarse: su genio parece al mismo tiempo fiero, sospechoso é intrépido; pero deben enturbiar mucho al curso natural de sus inclinaciones, por una parte las ansias de los europeos para cautivar su amistad, un tesoro amontonado en pocos años, las discordias acaecidas entre los mismos europeos, y tal vez la sugestión de unos ú otros para conseguir el monopolio de las pieles; por la otra, la debilidad de sus fuerzas, los escar'mientos sufridos, la utilidad del comercio y la demasiada frecuente concurrencia de buques europeos en aquellos contornos.

La persona de este Jefe no corresponde á su dignidad: es bajo y macilento, bien que de una constitución nerviosa y la musculación abultada: atribuía su actual estado macilento á la escasez de alimento desde que había debido abandonar el puerto de Yucuat, y recordaba, no sin dolor $y$ ' valentía, al Comandante de la ATREvidA, el tiempo feliz en el cual él solo se atrevia á arponear una ballena, gozando entonces de una salud

(1) No usan el taparabo como los pueblos más septentrionales: las mujeres, sin embargo, visten con mucha decencia. 
y robustez poco común (I). Es una cuestión muy vertida si sea ó no caníbal; y puede imaginarse que no nos hemos descuidado en indagar esta verdad, tanto más que en nuestro establecimiento todos estaban firmemente convencidos que lo era, y le habían reconvenido diferentes veces: una digresión sobre este punto no desagradará tal vez á los que recorran estas hojas, mucho más, después que el Capitán Meares le ha tratado con método y prolijidad, alegando razones positivas para decidir el hecho.

El Capitán Cook, quien reconocía con ojos realmente filosóficos las costumbres de las naciones que visitó, debió extrañar desde luégo el mucho número de huesos, cráneos y manos humanas que le presentaron por diferentes ocasiones para cambios: sin embargo, combinando últimamente el carácter de estos naturales, infirió sí, que trataban á sus enemigos con un grado brutal de crueldad no diferente del que se advierte en todos tiempos y en todas partes en el hombre no civilizado; pero no creyó que por esta razón se les pudiese acriminar con una inhumanidad extraña que los guiase á alimentarse de la carne humana por solo antojo.

Este fué el concepto que conservaron después estos pueblos, y seguramente sobre este solo concepto se aventuró á quedar entre ellos Mr. Maccay, dependiente de la expedición de Mr. Strange en el año de I786: la suma escasez que hubo á la sazón en Nutka pareció dar nuevo peso á esta idea: Maccay fué asistido con la posible abundancia, y no sólo jamás notó el proyecto de comerle, sino que no advirtió tampoco que en este estado ni Macuina ni los otros Jefes se valiesen de este recurso inhumano (2).

Sin embargo, en el año siguiente, el Capitán Meares tuvo nuevos motivos para revivir la cuestión, y decidió sobre los informes de Anapi y Callicun y sus mismas observaciones, que á lo ménos- Macuina era caníbal, y que le acompañaban á este hórrido convite mensual los demás Jefes de las tríbus.

La voz común en nuestro establecimiento era próximamente la misma; y esta idea esparcida probablemente al tiempo de concurrir allí la $I f$ genia, el Argonauta, el Ladi Washington y la Columbia, lograba ya mayor vigor con la declaración que hacian los diferentes niños vendidos en varias ocasiones á bordo de la fragata Concep. ción: decía uno de éstos, que efectivamente Macuina gustaba de la carne humana, y que la elec-

(I) Don Tomás Suria ha tenido especial acierto, asf en el retrato de este Jefe, como de todos los demás que ha formado en Nutka.

(2) Debe inferirse así, porque seguramente el Capitán Meares no omitiria un punto tan importante en su artículo Story of Mr. Maccay, tanto más que conducía á probar la calidad de caníbales á Macuina y sus súbditos. ción del niño para este horrible banquete dependía de la dirección de su mano, estando con los ojos vendados, pero no hacía memoria alguna ni de las ceremonias que indica el Capitán Meares, ni del uso de hombres adultos, ni de la asistencia de los demás Jefes: nuestros Oficiales ya le habían reconvenido y áun amenazado, manteniéndose él, sin embargo, tan constante en negar este hecho, como los nuestros en creerlo positivo.

Con estos antecedentes ya nuestras pesquisas sobre este asunto parecian á lo ménos fáciles, y el haberlas por consiguiente omitido sería en nosotros tanto más culpable cuanto que (séanos permitido el decirlo así) nos lisonjeamos aún por el honor de nuestra especie de ver de nuevo reducida la cuestión á los límites que le había prefijado el Capitán Cook.

Desde luego las primeras indagaciones nuestras nos convencieron que no había otros datos hasta aquí para acriminar á Macuina este delito extraño, sino una relación sencilla del niño (de edad de ocho á nueve años) cuya interpretación era dudosa: diferentes visitas á su ranchería desde el Establecimiento de nuestro fuerte, jamás habían proporcionado el menor indicio, ó de la existencia de este terrible repuesto de víctimas, ó de los fragmentos de un sacrificio reciente de esta misma especie ( $\mathrm{I}$ ); finalmente, cuanto más iban conociendo el carácter amable de los demás Jefes de la nación, tanto más se veían dispuestos á eximirlos de esta nota inhumana, y por consiguiente, á agregar la de singular á este cruel apetito de Macuina.

Igual éxito tuvieron nuestras pesquisas con los naturales; preguntado el joven Teyocot, cuñado de Macuina, cuáles eran los alimentos de este Jefe, satisfizo siempre con ceñirse á los peces, venados y yerbas ó raíces, sin que jamás ni remotamente nombrase la carne humana; Nanikius, que al principio había respondido afirmativamente á nuestras preguntas, muy luego nos convenció que las había entendido mal, y repugnó con horror hasta la idea de semejante convite; finalmente, Natzapi, con quien hicimos por largo tiempo una triste memoria de la venida del Capitán Cook á este puerto (2), nos aseguró que las manos, cráneos y huesos presentados á bordo

I) Pudiera agregarse que el señor de Ingraham, Piloto de la Collumbia, describiendo en una carta al Piloto Martínez todo lo que había observado entre estos naturales en el largo tiempo de un invierno, no demuestra ni la menor sospecha de esta horrible inclinación de Macuina.

(2) Natzapi, aunque á la sazón joven de solos trece á catorce años, tenía muy bien en su memoria varios trances de aquella expedición: la casa y ranchería visitadas por el Capitán Cook, fueron las de Calacan: reconoció el retrato del Capitán, nombró por sí al Capitán Clerhe, y manifestó su creencia de que el $\mathrm{Te}$ niente King fuese hijo del Capitán Cook. 
de la Resolución, no eran sino fragmentos de los cadáveres de sus enemigos, y que no serían extrañas las señales en las manos de una ú otra mordedura, porque los Michimis enfurecidos solían á veces saciar de este modo los impulsos harto vehementes de su furor: pero ni él ni Macuina serían capaces de hacer un banquete de la carne humana, idea que le chocaba extremadamente, obligándole con frecuencia á usar de la yoz Pisluck, Pisluk: malo, malo; y áun á decir á Macuina (quien poco después se halló por casualidad con él á bordo de la Descubierta) cuáles eran las injustas sospechas que de él habíamos formado.

Por otra parte, no se advirtió jamás en los Michimis, la menor señal de aborrecimiento hacia este Jefe, antes bien en la excursión de las lanchas á los canales internos, los Tenientes de navío Espinosa y Cevallos, no pudieron dejar de admirar la complacencia con la cual respondían de algunas canoas, que eran súbditos de Macuina; estos mismos Oficiales visitando su casa, armería (I), tesoro y mujeres, no advirtieron ni el menor rastro de fragmentos humanos; finalmente, la venta contínua á la Concepción de uno ú otro muchacho por cosas de muy poco valor, y el plazo de algunos días que necesitó últimamente (según voz común) para adquirir la sola niña que vendió á nuestra presencia, todo parecía convencernos que eran algo precipitadas las aserciones del Capitán Meares, sobre esta calidad de caníbal.

Nos lo convenció aún más un análisis de las razones sobre las cuales este Capitán apoyaba su concepto: la primera, de la confusión de Macuina al tiempo de presentarle la mano y anillo del infeliz Mr. Millar, del Aguila Imperial, mal pudiera atribuirse á él haber él mismo sido partícipe de sus carnes, cuando aquel asesinato acaeció en las costas de otro dominio: la declaración de Anapi y Callicum, es difícil de combinarse con el carácter humano que el mismo Capitán Meares atribuyc á lo ménos al segundo; y seguramente, si debiésemos juzgar por las apariencias, debía parecer más probable que se alimentase de carne humana quien descansaba su cabeza sobre un canasto de fragmentos humanos, que no quien chupaba la sangre de una herida propia, aunque pareciese saborearse con ella: últimamente, el vanagloriarse Macuina de la reciente celebración de uno de estos banque-

(r) Debe imaginarse cuál sería la admiración de los dos Oficiales, cuando en esta visita encontraron á la puerta de Macuina un armero con 16 fusiles, custodiados por un Michimi que descansaba sobre el arma: dos vidrieras, muchos útiles de hierro, una cantidad indecible de abalorios, botellas, planchas de cobre, etc., formaban el tesoro que Macuina des plegó en esta ocasión con mucha complacencia, á la vista de nuestros Oficiales. tes, y el atribuir repentinamente esta calidad de caníbal á todas las tríbus de Nutka, excepto el benéfico Callicum, no podrán jamás combinarse ni con el hambre que presencia Mr. Maccay en el invierno del 86, ni con el manantial ó depósito de tantos esclavos que debiera precisamente suponerse.

Pero, es tiempo ya de terminar esta digresión, la cual, desde luégo parecería tan difusa como impertinente, si no tuviese por objeto la importante justificación de nuestra especie, y al mismo tiempo no pudiese alegar en su favor igual grado de probabilidad, á lo ménos al que hasta aquí llevaba consigo la opinión contraria: el filósofo moral que halla en los hechos harmoniosos de la Naturaleza todo lo que conspire á nuestro bienestar y á nuestra multiplicación, no se complacerá tal vez en recorriendo estos renglones y el plazo á lo ménos dilatado, para admitir una verdad tan ignominiosa á nuestra especie, le recordará que hemos luchado siquiera á favor de la humanidad, y que entre las dudas hemos preferido este concepto al natural anhelo de todo viajero de distinguirse con narraciones maravillosas.

Existe entre los pueblos de Nutka un Código penal, depositado al parecer, en la tradición general y en la autoridad de los Tahis, del cual hemos podido rastrear con certidumbre las siguientes leyes.

I. ${ }^{2}$ El que mata á otro, expía su delito con una prisión de diez días; pero la reincidencia en este delito se paga irremisiblemente con la vida.

2." Al ladrón le cortan el pelo y los dedos de las manos, le hacen cortaduras en la cara y con estas señales inextinguibles de infamia le destierran como indigno de vivir en la sociedad.

3. ${ }^{\text {a }}$ El adulterio se castiga en el hombre con la muerte, modificándose este castigo en las mujeres á cuatro días de reclusión: si el adúltero es algún Jefe y la adúltera mujer de otro Tahi, se juntan el ofensor y el ofendido, se injurian de palabra y se separan luégo para siempre.

Pudiéramos añadir á estas leyes, que Natzapi nos aseguraba no haber ejemplo de un adulterio entre los Tahis, que parecía igualar en la clase de delitos la muerte de un Tahi, con la de un Michimi, y que no alcanzamos á descifrar si Macuina solo, todos los Jefes ó todo el pueblo, eran los depositarios de la potestad legislativa, si acompañaban á estos actos de justicia, ó los preliminares necesarios para la evidencia del delito ó las señales sucesivas del escarmiento y de la infamia; y si atento á las guerras frecuentes en que se hallan envue tos, existía también entre ellos un Código militar, referido especialmente á la poca puntualidad ó á la inobediencia en tomar las armas, y á la cobardía ó fuga en el tiempo de la pelea. 
A la verdad, en unas naciones naturalmente dispuestas á la guerra y que beben con la leche el odio de sus enemigos, la subordinación á sus Jefes y aquel instinto militar que depende ó de la propia debilidad ó del cebo de la venganza, es bien probable que las leyes debiesen más bien dirigirse á refrenar, que á hostigar el furor militar, cuyos excesos son luégo harto patentes en el fin trágico que está destinado á todo herido. 6 prisionero.

No será tampoco muy frecuente en nuestro entender el uso de las otras leyes criminales: 1o aseguraban así Natzapi y Nanikius, y desde luego la mansedumbre de estos naturales al tiempo de concurrir al mercado, la repugnancia de las mujeres á cohabitar con los europeos; la reunión de los pocos Jefes entre sí, y la subordinación de los Michimis, respondiendo inmediatamente cada uno á qué jurisdicción pertenece, pueden dar no poca fuerza á esta aserción. Y á la verdad, debe parecer bien extraña á un filósofo desapasionado la comparación de lo que se advierte en este puerto (I) con lo que pasa por lo común en nuestros puertos de Europa. Aquí, rodeada la embarcación de canoas con los mismos efectos de venta, y con los mismos deseos de cambio, atracando indistintamente todos con una especie de cascos sumamente endebles, cuyos choques son precisamente frecuentes, se advierte sin embargo, un silencio, una harmonía, una quietud que nada puede interrumpir, $\mathrm{y}$ bien se concluya el contrato ó la concurrencia de muchos haga que se prefiera después un segundo contratante al primero; la misma diferencia, la misma humanidad se dejan ver en todas las ocasiones: al contrario, en los puertos de Europa apenas hay dos botes de transporte al costado de un buque, apenas se tocan recíprocamente, sin daño alguno, cuando los gritos de una rivalidad indispensable se dejan oir por todas partes, y áun le sigue no pocas veces una ofensa civil que exige la intervención de la ley criminal (2).

Deben sin duda concurrir los principios de la religión á la solidez y perseverancia de esta conducta: nuestras pesquisas en esta parte fueron bien felices, partiendo, según costumbre, en las preguntas de las ceremonias ó ritos que acompañan los funerales, y dirigiéndonos después á la creencia ó supersticiones que los dirigen (3).

(1) A la conducta de los naturales en esta parte, puede muy bien apropiarse todo lo que hemos dicho anteriormente de los habitantes del puerto Mulgrave.

(2) Esta mansedumbre y harmonía general no pudo evadirse de las miradas filosóficas del Capitán Cook.

(3) Este método de penetrar en los arcanos de las diferentes religiones nos ha parecido el más expedito y oportmo: las ideas de la suerte venidera están tan ligadas con las pompas fúnebres, y los deberes sociales tan naturalmente explayados en esta crisis terrible
Son solemnes las pompas fúnebres que acompañan la muerte de Macuina (I): un llanto universal de los Tahis y Michimis, interrumpido á veces de un canto lúgubre, es el primer tributo que consagran á su memoria sus antiguos súbditos: acuden inmediatamente al Tasis convidados los pueblos vecinos de los Nuchimases; el cadáver permanece en la casa por cuatro días; un Tahi le llama frecuentemente, y como no responda, se dispone ya al cuarto día su conducción al Conuma (2); los canales internos dan lugar á que haya en esta conducción la mayor solemnidad: cuatro hileras de canoas, dos á la derecha y dos á la izquierda, acompañan la canoa que sirve de féretro: el canto es contínuo y lúgubre (3): no hay ni víctimas ni ofrendas de comestibles: 1legada al Conuma la comitiva, se le llama nuevamente, y á la falta de respuesta sigue luégo el cerrarle entero en una caja sin otra ceremonia alguna, y finalmente, el elevar la caja en alto dejándola próximamento èn la misma posición de las de puerto Mulgrave.

Macuina entre tanto, rodeado de fatigas y de peligros, con un sumo cansancio y sin comer cosa alguna, se dirige hacia el Sol, á donde no llega sino al noveno día después de su muerte, y allí encuentra nuevamente su cuerpo que ha permanecido otros cuátro dias en Conuma, y luégo ha sido llevado casí instantáneamente al Sol: reunidas nuevamente las dos sustancias, se presenta á todos sus antepasados, que le reciben amistosamente y le saludan con la voz común Guacash, Guacash Macuina: se olvidan todas las pasadas ofensas; áun el que hubiese muerto á Macuina, al llegar es recibido por él como amigo, y allí residen eternamente todos en una paz duradera y gozando una salud robusta.

No es igual la suerte de las mujeres de los Tahis: van, sí, al Conuma, pero no alcanzan el Sol, y por consiguiente, no vuelven á cohabitar con sus maridos, bien que estando en paraje no distante, tienen éstos la satisfacción de oirlas cantar de tiempo en tiempo, y hacer con esto dulce memoria de la pasada fé conyugal (4): un

de la Naturaleza, que puede muy bien considerarse como el centro de las ideas de lo pasado y de lo ve. nidero.

(r) No nos atreveremos á asegurar que sean las mismas para los demás Jefes subaltemos.

(2) La posición del Conuma en la rinconada de Tlupananulk puede examinarse en nuestros planos; y aunque esta voz en el idioma nutkeño no signifique positivamente sino monte, aquél, por antonomasia, se distingue con este solo nombre.

(3) Decía con mucha gracia Nanikius que cantaban en esta ocasión en el mismo modo en que en los buques del Rey cantamos la Salve Iirgen purcr: canto que él había oído sin duda á bordo de la Concepción.

(4) Natzapi, quien últimamente había perdido su segunda mujer en un viaje emprendido á los Muchimases, nos decía que en aquel momento la estaba oyendo cantar. 
olvido dimanado de este atropellamiento de ideas nuevas y tal vez de la estreche $z$ del tiempo, nos hace ahora echar de ménos con mucho sentimiento el detalle de las funciones de las mujeres en los funerales de Macuina.

La diferencia advertida hasta aquí entre los Tahis y los Michimis, sobresale aún más en las materias religiosas: al Michimi muerto, después de la formalidad de llamarle repetidas veces, se le hacen algunas cortaduras en la lengua y en el vientre, se le sobrepone una camiseta ó estera y se entierra en paraje separado (I): el cadáver permanece siempre en la tierra alimentándose de gusanos y de piojos; la sustancia espiritual es la que vuela al Sol y disfruta allí de una perfecta igualdad con los Tahis, concurriendo siempre á recibir y abrazar los recién venidos (2).

Lo que parece extraño en esta parte tan importante de la religión, es la ninguna distinción que se hace en la otra vida de los buenos y de los malos, lo cual nos confirmaron entrambos hermanos en muchos modos nada equívocos, dependiendo, por consiguiente, la suerte de cada uno de la clase que tenga en el mundo.

Hasta aquí llegaron nuestros conocimientos religiosos, no siéndonos posible rastrear cosa alguna relativamente á las ideas de la Creación, de la Providencia, de la Justicia, etc., adictas al Supremo Hacedor, ni mucho ménos del objeto, ritos y ofrendas del culto. No adoran las sombras de los Tahis, no el astro del día, ni la Luna; no la imagen de sus antepasados que representan probablemente los figurones de los postes y de las máscaras: no temen, al parecer, ni la voz del trueno, ni los accidentes inopinados, ni los mismos agüeros; y por lo que pudimos deducir, sus principios religiosos, desentendiéndose de lo pasado y de lo presente, parecen ceñirse sólo á lo venidero.

Estas averiguaciones, sin embargo, á pesar de su importancia, novedad y multiplicación, no nos distrajeron tanto que no aprovechásemos los talentos de Natzapi y Nanikius para otros objetos no ménos importantes; y eran éstos la división del tiempo, el origen de estas naciones, las obligaciones y fueros domésticos de cada uno, sus combinaciones mercantiles, y la geografía inter-

(I) Los Sres. Espinosa y Cevallos visitaron en su excursión con las lanchas la Isla de los Cementerios, y vieron allí varios cadáveres de Michimis cubiertos con una estera y acomodados parte en el suelo y parte en unas canoas medio cuterradas: la canoa para un pescador es tan honorífica como la espada para un militar.

(2) Nos ruedan algunas dudas en esta parte; porque si bien se dedujo de Natzapi que los Michimis muertos se alimentaban de gusanos y piojos, yque sin embargo, se presentaban en el Sol al recibimiento de Macuina, la división de las dos sustancias es un arbitrio nuestro para reunir estas ideas combinado sí con el riajo de los nueve días al Sol. na del país contíguo de los Nuchimases: describiremos las ideas adquiridas en estos ramos, con la misma sencillez que hemos procurado seguir hasta aquí.

Los nutkeños dividen el tiempo en meses lunares, diez de los cuales forman un Sol, cuya duración está derivada al parecer del tiempo del embarazo de la mujer; la división del día depende enteramente del Sol y áun más de la pesca, anticipándose ó atrasándose las horas de la comida y del reposo, según lo requieran las ocurrencias y necesarja calidad de la misma pesca: como estos naturales no exceden en su numeración de diez, les es difícil expresar los números mayores sin algún auxilio material ó de los dedos ó de otros datos semejantes: así nos manifestaban sus edades, contando siempre como se ha dicho, por Soles compuestos de diez lunaciones.

Estas nociones bien escasas é incómodas en cuanto á la importante división del tiempo, no nos hicieron, sin embargo, desmayar sobre las pesquisas del origen de estos naturales: hallamos que la ignoraban enteramente, si debiese atenderse á una tradición segura, pero sí el hábil Natzapi nos aseguró, sin recelo de duda, que su ascendencia hasta tres generaciones había permanecido en el Tasis, se perdió luégo en las épocas más distantes, á las cuales queríamos hacerle retroceder, é indicó su persuasión de que los pobladores habían venido del Norte (I).

Mucho mayores fueron nuestros progresos por lo que toca á los derechos domésticos: la poligamia está permitida á los solos Tahis, limitada sin embargo al número de cuatro mujeres, y justificada por Natzapi su necesidad de la costumbre de no usar de las mujeres que crían, y de repugnarles las muy adelantadas en el embarazo: nos contaba el mismo Natzapi, que cada mujer duerme con su estera en uno de los cuatro ángulos de la pieza, y que el marido visita á su albedrío una ú otra, usando sí en estas ocasiones no sólo del silencio, de la oscuridad y del pudor, si también de aquellos halagos que precedidos del amor conyugal nos distinguen áun en este caso de los brutos: Natzapi en el día no tenía sino una sola mujer; encarecía mucho su amor por ella y sus prendas personales; y seguramente, el detalle que nos dió de las lindas proporcio-

(I) Si quisiéramos hacer para la persuasión del que recorra estas hojas, una fiel relación de los métodos que nos han guiado á desenvolver estas ideas, sería este un objeto harto difuso y á veces ridículo, aunque instructivo: la sagacidad de D. Antonio Tova dictó para el alcance de estas ascendencias la repetición á Natzapi de la unión del hombre con la mujer; del embarazo de ésta, del sucesivo nacimiento, adolescencia, etc., por cada generacion: los padres y el hijo, se representaban después con objetos materiales, y se ponfan aparte en una mesa grande: en el Diccionario se han comprendido las voces de abuelo, bisabuelo y tatarabuelo, que usan los naturales. 
nes de su cuerpo, de la finura de su tez y de la blancura de su color, no desmiente las ideas de la hermosura que comunmente se han admitido en Europa.

No pudiéramos determinar si está admitido el repudio, pero debemos creer que no rija esta costumbre donde ni las mujeres faltan á los deberes conyugales, ni en la elección se oyen otras voces que las del instinto, desentendiéndose por consiguiente de la desigualdad de clases, de la cantidad del dote y de la posibilidad de combinar una excesiva diferencia de edades.

No fueron tan frecuentes nuestras visitas á sus rancherias que nos proporcionasen examinar distintamente la suerte de las mujeres ancianas, el grado de aprecio de las que no son favoritas, el grado de amor con que miran los hijos según el favor particular de que gocen á la sazón sus madres, finalmente, $́$ los derechos de estas mujeres (I) en la república ó los límites de es tas elecciones de los Tahis en la clase de los Michimis: pero los Tenientes de navío Espinosa y Cevallos, quienes fueron presentados por Macuina á su favorita (2), conocieron sin embargo en aquel Jefe en esta ocasión una mezcla grande de amor y consideración hacia su mujer y al mismo tiempo un caudal no indiferente de celos, aunque según confiesan, en aquel momento no dejasen de sentir la agradable sorpresa de una hermosura tan perfecta como no esperada.

Ni era Macuina quien ocultase estos impulsos de sus celos, cuando le instábamos que volviera á establecerse en Yucuat, á poca distancia de nuestras casas, respondía con mucha prontitud que muy luego los nuestros intentarían violar los derechos conyugales, aunque nuestros Jefes, con el ejemploy los castigos, procurasen sujetarlos, y que así, prefería la incomodidad y estreche $z$ de la vida actual, á este riesgo evidente.

No advirtieron nuestros Oficiales en la visita indicada, otra persona preferida en la casa de Macuina, bien que no habiendo allí á la sazón

(I) Si como es probable era la mujer de un Tahi la que dió los golpes y un Michimi el que los recibió á la vista del Capitán Douglas de la 1figenia en las inmediaciones del Cabo de la Cruz, ya este hecho no nos suministrará la idea de una costumbre bien extraña en estas costas.

(2) Hé aquí la pintura que en su Diario dieron estos Oficiales del citado encuentro agradable: «El Cacique nos presentó á su mujer, cuya bella figura no nos sorprendió ménos que el centinela y los fusiles: tendrá como veinte años de edad y se distinguía entre otras muchas por su color blanquísimo, del propio modo que por la delicadeza y la proporción de sus facciones: si después de una navegación dilatada se pudiera juzgar de la hermosura con rectitud, nos atreveríamos á decir que esta graciosa muchacha excede en belleza á las heroinas de novela, tales como nos las hacen concebir los prestigios de la poesía y la imaginación.de los poetas. sino algunas ancianas, la comparación era precisamente defectuosa.

En la segunda visita que hizo aquel Jefe á las corbetas, le acompañaron en la canoa tres ó cuatro mujeres, entre las cuales estaba comprendida la favorita: no permitió que subiesen á bordo por muchas que fuesen las instancias y ofrecimientos hechos; todas asistieron en la canoa á su comida, que se compuso aquel día de frutas silvestres, y advirtieron los Oficiales que la mujer favorita era la que le suministraba directamente la comida.

El amor de estos naturales hacia sus hijos ha sido visible en muchas ocasiones: Tlupananulk nos presentó uno, como muchacho de muchas es. peranzas: se deleitaba en mirarle y en ver que le agasajábamos, y si como es probable, el padre de Tlupananulk entró con los Michimis en la danza, sólo para dar con un mayor número y con su ejemplo nuevo resalte á la autoridad y disposiciones de su hijo, será esta seguramente una prueba del amor filial que tenga pocas semejantes.

Debimos, por consiguiente, extrañar mucho que Natzapi no titubease en acceder á la venta de un hijo suyo, que se le propuso para examinar en esta parte sus pensamientos: bien que como el hijo no estuviese presente, ni en nuestra propuesta se mezclase objeto alguno de cambio ó regalo, es creible que Natzapi no entendiese bien nuestras preguntas, ó á lo ménos nos induce á creerlo así el deseo de no suponer á ese Jefe tan desprendido del amor filial.

No cabe duda que estos pueblos eran comerciantes áun antes de las primeras visitas de los europeos, que comunicaban con los pueblos inmediatos del Sueste y del Norte, y que á veces legítimamente, á veces con la violencia, adquirían varias cosas extranjeras: el Capitán Cook hallo entre ellos no sólo una cantidad considerable de hierro, si también los cubiertos de plata que el Comandante Cuadra había perdido en la Ensenada de los Mártires en latitud de $47^{\circ}$; pero cuáles fuesen los productos de estas islas que daban los nutkeños en cambio, no fuera fácil acertarlo, á ménos que no les considerásemos como el canal por donde comunicaban los $\mathrm{Nu}$ chimases con los pueblos meridionales, ó bien no supusiésemos que el rescate de los esclavos se satisfaciese de tiempo en tiempo con estos efectos: pero si bien en aquellos tiempos sean dudosos los efectos que constituían este comercio, ya en el día nosotros le hallamos tan periódico $\mathrm{y}$ bien ordenado, que no fuera temeridad atribuirle los progresos rápidos que han hecho estos naturales en las ideas de la vida sociable.

Desde mucho tiempo los nutkeños tenían una estrecha amistad con los Nuchimases; pueblos numerosos é igualmente pescadores que ha- 
bitan en la orilla de dos grandes lagunas no distantes del Tasis al Norte, $y$ rayanas al Eiste con los pueblos del labio cortado ó de las islas fronteras á la Reina Carlota: Natzapi, consiguiendo por esposa la hija del Jefe Nuchimas, había logrado la distinción de Tahi entre aquellos pueblos (r), y ó bien él, ó su mujer, ó su hermano, se ocupaban frecuentemente en acarrear á aquellos pueblos los productos útiles del comercio europeo, cambiándolos con pieles de nutria, que los Nuchimases sacaban en mucho número de las lagunas: los objetos principales de estos cambios de parte de los nutkeños, eran el cobre y los aulunes ó conchas de Monterey (2): solían alguna vez introducir algún hierro y paños, pero eran estos artículos más bien de poco valor, particularmente si se comparasen á los primeros destinados generalmente á los adornos y usos domésticos de ambos sexos (3). Con este desen. bocadero les era fácil ocurrir con un número más crecido de pieles al mercado europeo de lo que pudiesen suministrar cualesquiera otros puntos de la costa, y una cuenta bastantemente prolija nos hacía creer que la máxima cantidad de estas pieles suministradas por los Nuchimases pudiese anualmente llegar á 6.000 , si se empleasen en su pesca todos los moradores con una felicidad correspondiente.

El viaje desde el Tasis á la residencia del Jefe de los Nuchimases (4), no deja de ser algo arriesgado, largo y penoso: es preciso llevar á hombro las canoas hasta la laguna próxima; las tempestades hacen luégo peligrosa esta navegación: en el boquete de comunicación de las dos lagunas, debe contrarestarse una vertiente rápida de las aguas, que cuelan de la más Norte á la del Sur; finalmente, queda aún por naregar la segunda laguna, que es igualmente penosa, y que limita á diez días la duración de todo el viaje: Nanikius y luégo Natzapi, trazaron en papel la posición y distancias de estas lagunas (5), y añadió el segundo que la pesca de las nutrias se imposibilitaba á veces (particularmente en el invierno) por el demasiado oleaje, el cual les exponía á un naufragio; que el agua era profunda, no teniendo á reces pié en las inmediaciones de la orilla, y que una de estas tempestades era la que había causado la muerte de su mujer

(r) Alegaba para prueba de ser Jefe de los Nuchiinases, el que llevaba una especie de cabellera postiza con los bucles prolongados, bien parecida en cuanto á la figura á la del Ankan de Mulgrave.

(2) Aliotis Myde, de Linneo.

(3) I as conchas sirven entre los Nuchimases particularmente para la comida, y así las de mayor tamano aumentan extraordinariamente de valor.

(4) Para la inteligencia (le la situación de estas lagunas, véanse nuestras cartas, y la explicación de los materiales que han servido para construirlas.

(5) Se remite este papel curioso, con el depósito de los tementos de muestras cartas. al tiempo de navegar con una porción de cobre hacia la residencia de su padre.

No eran contratos sino regalos recíprocos los que constituían el comercio con los Nuchimases, á la pronta entrega de los nutkeños de todo lo que llevasen de algún valor, correspondía el Jefe Nuchimas con el regalo de una cantidad proporcionada de pieles; y áun le acompañaba la ceremonia de sobreponerse de antemano al hombro con mucha solemnidad cada piel que entregase corno prueba de ser un legítimo regalo procedido de la hospitalidad y del buen acogimiento (I).

La pesca de las nutrias en esas lagunas, se hace (según Natzapi) con canoas esquifadas por dos hombres, de los cuales como es natural, cuida el uno de la dirección y andar de la canoa, y el otro del alcance y oportuno golpe á la nutria: no cesa esta pesca con la entrada del invierno, á ménos que no la imposibiliten los días tempestuosos; antes bien, les es ventajosa la estación fría, porque entonces la nutria pierde casi de un todo la vista y se hace mucho más fácil alcanzarla: la canoa más feliz y diestra, jamás (según Natzapi), pudiera coger en un día más de cuatro nutrias: muchas canoas, al llegar la noche, aún no han cogido ni una siquiera.

Los Nuchimases confinan y comercian al Noroeste y Oeste con los del canal de la Reina Carlota: distinguía Natzapi estos últimos pueblos por los del labio cortado, los describía por muy belicosos, fáciles á irritarse y no pocas veces en guerra con sus vecinos: dió á entender que las canoas de guerra de unos y otros eran con mucho mayores á las de Nutka. Trazó luégo una cordillera que desde el extremo de las lagunas seguía casi en la misma dirección del Nornordeste por otras I5 ó 20 leguas, haciendo diferentes tornos y presentando el abra de dosó tres canales; pero siempre manifestó una total ignorancia de los paises y habitantes que rayasen interiormente con los Nuchimases, ó bien al Sueste ó al Nordeste.

Como era debido, no nos descuidamos en preguntar cuál era el paradero de las aguas que en tanta cantidad acudían á la laguna inmediata al Tasis, á lo cual satisfizo Natzapi asegurando que no había río alguno; pero sí que el Sol en el verano absorbía una parte no indiferente de estas aguas: con mucha perspicacia consiguió no dejarnos duda de esta explicación, mojando su propia mano con saliva y señalando después que el Sol quitaba aquella saliva. Pero si como es probable, son realmente estas lagunas muy caudalosas y de una grande extensión, no debiéra-

(I) Este mismo método quiso adoptar Natzapi cambiando a bordo tres pieles de nutrias por una plancha de cobre: estas pieles que existen en la colección del Real Gabinete, darán una idea de la calidad de las nutrias de agua dulce. 


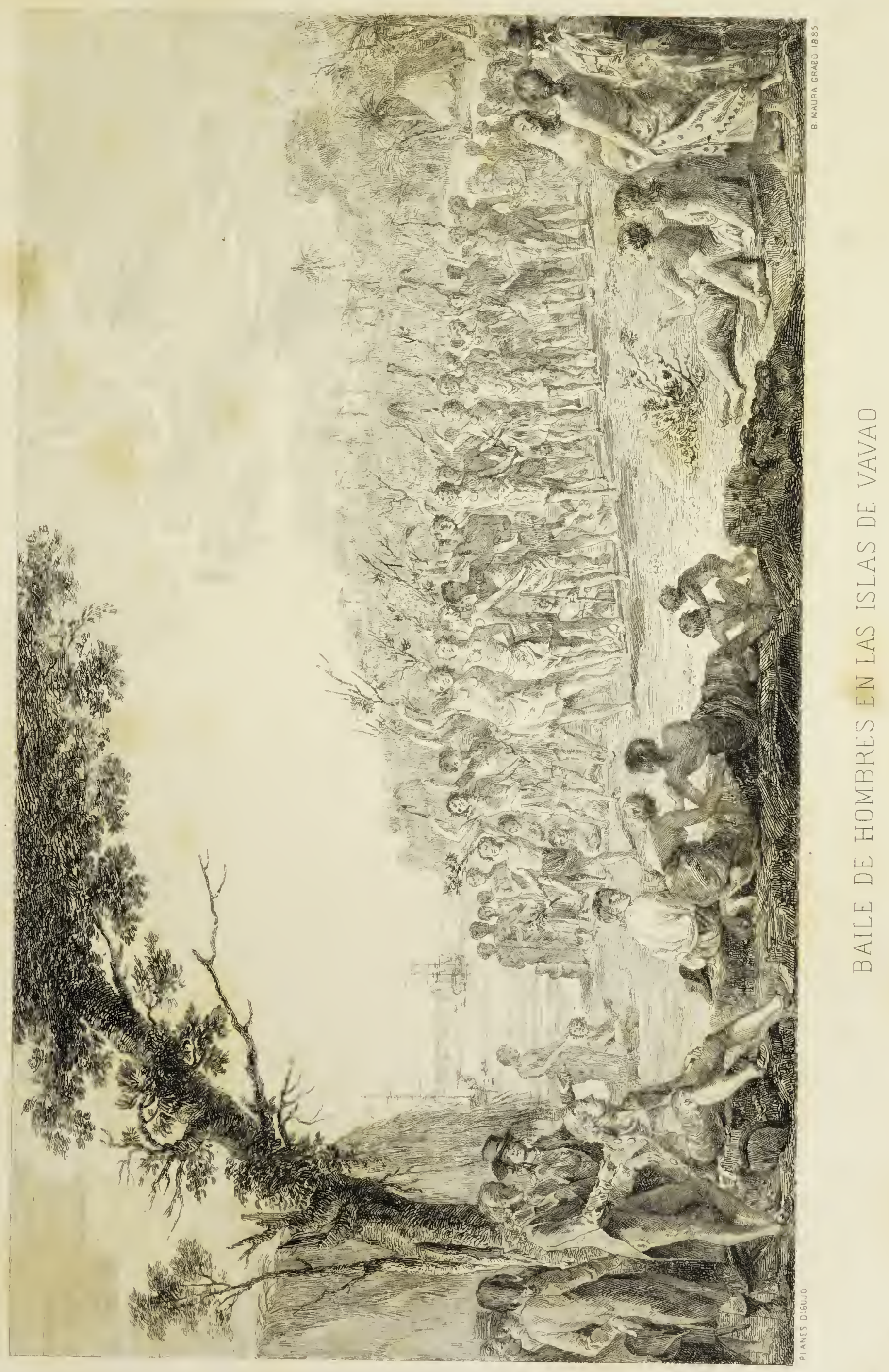



mos dudar en atribuir una parte considerable en la disminución de sus aguas á la filtración subterránea y constante hacia los canales inmediatos de Nutka, de donde derive luégo el gusto ménos salobre que en cualquiera mareas se experimenta en dichos canales.

Ni el tiempo, ni tal ve $z$ una prudente reflexión á todas las circunstancias del día, no hubiera permitido emprender un viaje á los $\mathrm{Nu}$ chimases, para el cual se brindaban Nanikius y Natzapi: pero si se examinan ó bien el actual furor de los europeos para penetrar en los parajes más escondidos del globo ó la unión amistosa de las dos naciones, podemos asegurar que la Europea á quien pertenezca últimamente la decantada manzana del puerto de Yucuat y Archipiélago de Nutka, no tardará en verificar este reconocimiento, pues ni será difícil conseguirlo con el cebo del comercio y hacerlo seguro, exigiendo en clase de rehenes en el establecimiento, á Macuina ó Natzapi mientras estén ausentes los dos ó tres indivíduos que se aventuren con el caudal necesario de ciencia, á los trabajos inseparables de esta especie de comisiones.

Dos objetos de no poca importancia no se han tocado aún en esta Memoria, y que merecen, sin embargo, la prolija atención del físico: y son, la venta repetida de niños de parte de los naturales, y las observaciones agronómicas derivadas de los ensayos hechos en nuestro establecimiento.

Casi desde el momento en que los Pilotos Martínez y Haro llegaron al puerto de Yucuat, el deseo, ó suyo ó de los Capellanes para aumentar el número de prosélitos á la religión católica, hizo que propusiesen á los naturales la venta de algunos niños, ó que accediesen á los of recimientos de éstos; y la facilidad y ansia por una y otra parte de continuar en esta especie de cambio, muy luégo arraigó esta costumbre, extendiéndose indistintamente á ambos sexos y últimamente á cualesquiera edades.

Al tiempo de nuestra salida de Nutka, no era menor de 22 el número de niños de ambos sexos rescatados en los buques de San Blas y vendidos indistintamente por Macuina ó los demás Jefes subalternos: solían llevar por cada niño una ó dos planchas de cobre y á veces algún cañón de fusil ó pocas varas de paño, distinguiéndose particularmente en el celo desinteresado para esta cspecie de adquisiciones el Padre Don Nicolás de Luera, Capellán de la fragata Concepción, el cual después vigilaba sobre sus bucnas costumbres é instrucción social y cristiana, y últimamente los fiaba para su vestido, alimento y sucesiva instrucción á aquellos individuos del armamento que pudieran cuidarlos y sacar en sus familias una utilidad de la adopción indicada de estos niños.

No fuera temeridad asegurar que estos ni- ños, hasta en su situación social, mejoraban mucho de suerte, áun cuando no fuesen verdaderas las acriminaciones hechas á Macuina sobre su propensión á ser caníbal; pero la repugnancia natural á la esclavitud de sus semejantes y el temor de que los encargados de estos niños no pretendan al abrigo de la religión justificar una especie de dominio indeleble sobre estos infelices, nos induce á desear que ó se pusiese un límite á estas adquisiciones, ó la legislación se ocupase de su bienestar sucesivo, atento á las inclinaciones que los muevan, á la pureza de nuestra religión y á los derechos inseparables del hombre.

Esto solo podrá justificar los inconvenientes procedidos de semejantes contratos: inconvenientes que advirtió Mr. Carver en el Canadá examinando el celo de los jesuitas para esta especie de adquisiciónes. "Sin duda, dice aquel escritor, son sus miras dignas de elogiarse, pues han creído que sería un medio no sólo para prevenir las barbaridades atroces y la efusión de sangre arraigadas entre estos pueblos, sino también para introducir su religión entre ellos, con cuyo motivo empeñaban los tratantes á comprar cuantos esclavos les viniesen á mano; pero los efectos no han corres pondido á las esperanzas de estos religiosos: en lugar de prevenir las crueldades y la efusión de sangre, este partido aumenta más bien sus discordias y les da mayor actividad y duración. No siendo ya la venganza ni el amor de la gloria el objeto de sus guerras, y sí la adquisición de los licores por los cuales cambian sus prisioneros, y que todos apetecen con exceso, se han hecho ahora más activos en inquietar á sus enemigos y estar siempre alerta para inquietarlos y esclavizarlos."

Deseábamos con ansia datos positivos para averiguar de dónde y cómo traen estos prisioneros, estando divididas nuestras conjeturas en interpretar lo que dijesen los muchachos mismos. Nos han quedado, sin embargo, muchas dudas en esta parte, de modo que no pudiéramos decidir si son robos diestramente hechos á los vecinos Nuchimases ó Izcuates, si son fruto del dominio absoluto de los Tahis sobre sus propios Michimis; ó finalmente, si la necesidad obliga á éstos á veces á desprenderse por cosas de poco valor de unos niños, cuya subsistencia es harto penosa y ningunas las utilidades en la última vejez de los padres.

Si juzgásemos por todas las circunstancias, nos inclinaríamos á creer que proceden casi todos de robos hechos á los Izcuates, tal vez repetidos por éstos del mismo modo (I) cuando la ocasión

(r) En este mismo año el Teniente de navio Elisa y el Piloto Carrasco, han adquirido otros cinco ó seis ninos en Cayucat é inmerliaciones de la cntrada de Fuca 
les sea farorable: á lo ménos estas dos naciones son naturalmente rivales; y los Izcuates ( $\mathrm{r}$ ) al parecer más crueles, traidores é inclinados al robo; de suerte que serían más frecuentes las hostilidades entre unos y otros, si la existencia de los europeos en Ýucuat y sus enlaces con Macuina, no diesen ya á este Jefe una preponderancia de fuerzas sobre sus enemigos.

Ello es, en fin, que á pesar de esta bárbara costumbrc de robar los niños ó descuidarlos y abandonarlos, los pueblos de Nutka pueden sin duda considerarse como bien adelantados en la civilización, si se comparan á todos los demás que pueblan las orillas orientales del Mar Pacífico al Norte del Trópico, y que no pasará mucho tiempo sin que el uso de las semillas y de los ganados, les preste para el invierno aquellos auxilios que mal pudieran derivar de la pesca anticipada en el verano: á lo ménos no parecerán intempestivas estas conjeturas cuando consideramos que Macuina nada aprecia ya sino los cristales para ventanas, las armas de fuego y el paño azul; que Tlupananulk nada ansiaba sino pólvora, velas y cabos de cáñamo para el uso de sus canoas; que el robo ya está casi desterrado (2) y que el talento de los hijos de Anapi es capaz por sí solo de causar esta revolución favorable y áun comunicarla muy luego á los Nuchimases.

Estas reflexiones nos guían ya rápidamente á los verdaderos productos útiles que pueden ofrecer estos contornos, ó bien á sus actuales habitantes ó los que hayan de acompañarles, y por rentura la activa penetración del Capitán Don Pedro Alberni y las noticias que nos ha comunicado, nos ponen en situación de poder detallar muchas circunstancias que seguramente pueden mirarse como importantes para las medidas venideras.

El temperamento de Nutka es más bien templadio, áun en el invierno (3). Los hielos no se conservan, y en el año pasado no ha helado sino dos ó tres veces; las mismas lluvias jamás pueden ordenarse hasta una completa formación de

(I) Es probable que éstos fuesen los intrusos en el comercio de la Resolución y de la Descubierta, que advirtió el Capitán Cook como próximos á causar una guerra entre las dos naciones.

(2) En nuestro establecimiento y en nuestros buques, ya desde mucho tiempo no se habla de robos, aunque el roce de los naturales sea contínuo y franco. D. Francisco Elisa y D. Pedro Alberni, debieron, si, escarmentar á los lzcuates que les molestaban do noche. Natzapi, viendo una canoa de esta nación casualmente á nuestro costado, empezó á decirnos el Pishek, Pishek; malo, malo, y cllos se retiraron.

(3) Hemos dejado al Capitán D. Pedro Alberni un termómetro de Reaumur para seguir con mayor exactitud el J)iario meteorológico en el próximo invierno. Se puede ver en nuestros Diarios que el temperamento del mes de Agosto ha sido igual al de igual mes en Europa. la nieve, y la escarcha es igualmente rara en las noches y mañanitas: las lluvias son al contrario bien copiosas y frecuentes, las mueven por lo común los vientos del Sur y Sueste y las disipan los del Norte con los cuales regresa siempre el tiempo claro, si exceptuásemos los últimos meses antes de nuestra llegada, en los cuales estos vientos han sido flojos, lluviosos y no muy claros. Las neblinas no fueron muchas, y los truenos sólo se oyeron por dos veces, en 5 de Noviembre y en 29 de Enero. A no haber temporales del Sueste y Sur, puede contarse con los terrales y virazones periódicas, en cuyas ocasiones, particularmente en el verano, el tiempo está despejado, los montes limpios y la mar llana y placentera: no se han correspondido en las variaciones meteorológicas los mismos meses de los dos años de r790 y r79r, antes bien, ha sido tanta la diferencia, que merece una mayor individualidad.

Afecciones meteorológicas.

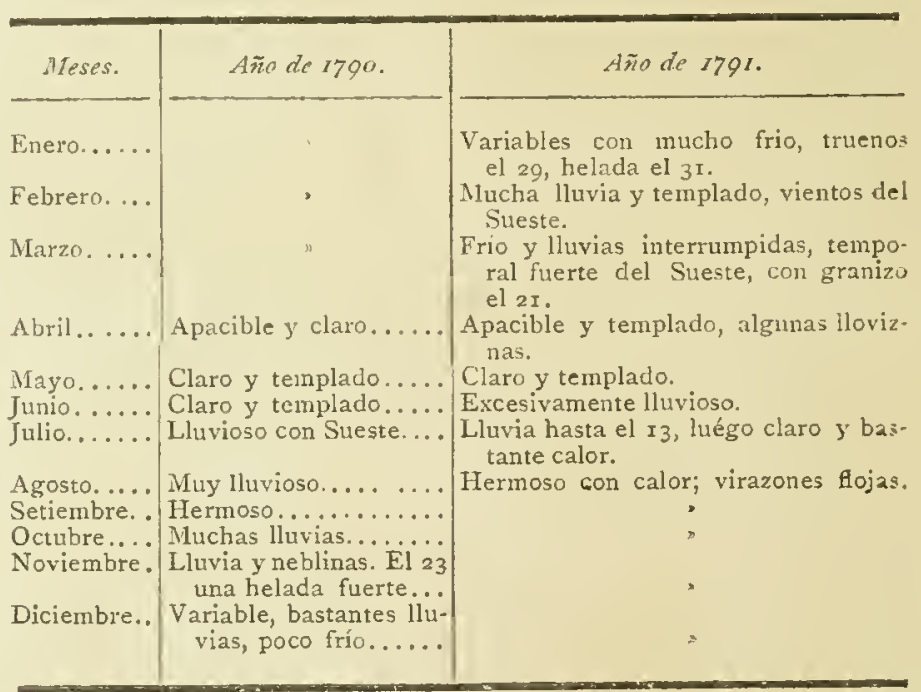

Si examinamos por otra parte el influjo de las estaciones así en la salud de los hombres como en la producción de las plantas, se nos ofrecen ya á la vista otros datos no ménos útiles y singulares, cuya individual descripción no desagradará tal vez al físico amante de la sociedad.

No serían en menor número de 250 personas las pertenecientes á las dos fragatas de San Blas que han permanecido un año entero en el puerto de Yucuat: D. Francisco Elisa y D. Pedro Alberni, conocieron muy luégo que la conservación de estas gentes dependía más bien del contínuo ejercicio, que de los preservativos con que pudiese auxiliárseles: el desmonte hacia la marina y el establecimiento de algunas huertas fueron el primer ensayo útil de estas tareas, á las cuales siguieron muy luego la construcción de una goleta y el principio de diferentes casas destinadas ó bien para obradores, para alojamiento ó para repuestos: debieron acelerarse mucho los que sirviesen á este último objeto, porque una epidemia destructiva de ratas, nada dejaba seguro en las embarcaciones; y así llegó el invierno antes que pudicra alojarse gente alguna en ticria, 
excepto la tropa; y antes que hubiese parajes cubiertos en donde la marinería pudiese en los días lluviosos ocuparse en las útiles tareas de la sierra y carpintería.

La necesidad de vivir á bordo, la falta de todo alimento fresco, excepto el pescado, la mucha humedad que se encontraba en todos los contornos y la dificultad de no suspender el trabajo en los días lluviosos, debieron por consiguiente dar mil zozobras sobre el bienestar del establecimiento: y ciertamente, á no haber prendido tan luego las hortalizas, estas circunstancias hubieran sido desagradables y tal ve $z$ funestas: pero la facilidad con la cual empezaron á prender vi gor las coles, las lechugas, las cebollas, los ajos, las acelgas, rábanos, nabos, zanahorias, peregil y alcachofas, desde luégo no sólo inclinaron muchos más á la útil ocupación del cultivo, si también pusieron un fuerte obstáculo á los progresos irremediables del escorbuto: así, á la caída del invierno, apenas se hallaban unos 30 individuos atacados de este mal con dif erentes síntomas: y como al mismo tiempo se remitiesen éstos á Monterey con una de las fragatas y se hubiesen hecho progresos considerables en todos los ramos más necesarios del establecimiento, ya éste se vió libre de enfermedades y desde entonces la más perfecta salud se arraigó en todos sus individuos.

Fué mucha la tablazón aserrada que para el pronto adelantamiento de las casas prepararon y vendieron los naturales: al mismo tiempo pudieron hacerse nuevos ensayos en las semillas, y aunque no correspondjesen á las esperanzas lo garbanzos, el trigo y el maíz (I), desde luego la cebada y las papas con muy buen éxito, y el frijol y el chícharo, siempre que las lluvias no fuesen excesivas, manifestaron que no sería ya precaria y dependiente ó de la caza ó de la pesca la cómoda existencia de una colonia en esta costa: en cuanto á la vegetación, no encarecemos nada cuando aseguremos que hemos visto rábanos de tres cuartas de circunferencia y lechugas de nueve cuartas en la parte superior de las hojas. Agregarase que las vacas y las gallinas han manifestado ya poderse multiplicar admirablemente, no necesitando aquéllas sino unos tres ó cuatro meses de pasto seco; las otras resistiendo de tal modo al frío, que extienden sus crías á dos cluecadas al año, y no necesitan otro cuidado más que el preservar los pollitos de las ratas y de los hurones, y finalmente, se podrá co-

(I) Para que las pruebas sobre estas semillas fuesen más completas, Alberni tuvo la precaución de sembrarlas con intervalos de una semana; de suerte, que repetida esta operación muchas veces, hubiese lugar de probar directamente el efecto de las estaciones; sin embargo, no han granado. La cebada ha dado de doce á catorce fanegas por una. nocer cuáles son las comodidades que para su bienestar brindan estos contornos al colono europeo.

Hé aquí las ideas de los contornos de Nutia, que nos ha permitido adquirir el corto espacio de quince días (I): si satjsfacen á la prolija curiosidad del fisiólogo; si pueden algún día contribuir á los progresos de una civilización independiente entre aquellos pueblos ó á la prosperidad de una nueva colonia europea, lograrán nuestros esfuerzos el único fin á que se dirjgen, y les será un verdadero premio el ver que otros, con más tiempo y luces, arrostren el trabajo de proporcionarlas; así como el ver que se derive su narración de las ideas de una verdad sencilla y no importuna, la misma que nos hace omitir una nueva repetición de las armas, utensilios, trajes, etcétera, de estos pueblos, que el Capitán Cook describió con su acostumbrada prolijidad elegante.

Pero es tiempo de abandonar estas orillas y continuar el examen de las costas siguientes: si consultásemos la sola fiereza característica de las naciones meridionales, no debiéramos temer de asegurar que los Izcuates se extienden á 10 ménos hasta el estrecho de Fuca y probablemente hasta la ensenada de los Mártires y el puerto de Queenkytké: es este trozo de costa el teatro de la destrucción de los europeos, y por consiguiente el que deberán mirar los navegantes venideros con más cuidado, para que no se renueven ya las trágicas comparaciones del sacrificio de un hombre por la adquisición de una piel: la pérdida de siete hombres del Comandante Cuadra en el año de 1775 por paralelos de $47^{\circ} 26^{\prime}$ (2) la del Capitán Berkley, del Aguilu Imperial, de igual número y casi en el mismo sitio; la desventurada del Capitán Duncan con cuatro marineros en el bote del Argonauta sobre la punta de los Arrecifes; los riesgos que corrió en el mismo sitio una lancha del establecimiento nuestro de Nutka; finalmente, así la prontitud con que el Capitán Meares vió sacrificar por los súbditos de Wicananisk el hombre extraño acabado de llegar, como el tesón con que los naturales del Estrecho de Fuca han atacado su lancha y la nuestra del paquebot San Carlos, todo concurre á disipar las dudas sobre el carácter fiero y excesivamente traidor de estos natu-

(1) Ya se ha indicado cuánto nos han sido útiles las experiencias anteriores del Capitán Alberni y los rudimentos del idioma entre muchos de nuestro establecimiento. Hubiéramos deseado aproximarnos algo más de las descripciones y conjeturas del Capitán Meares.

(2) Las circunstancias de esta sorpresa irremedia ble, y particularmente de la sucesiva salida al mar do la goleta Sonora, constituyen una época bien memorable en los fastos nuestros de la Marina, que en esta ocasión procurará hacerse pública y duradera con el auxilio del buril. 
rales (I). Son además muy numerosos, más diestros en el manejo de las canoas, más unidos entre sí y más belicosos que los de Nutka; y si hemos de juzgar por las adquisiciones y observaciones hechas hasta aquí, si bien abunden en estas costas con exceso las ballenas, varios otros peces y las mismas nutrias, la calidad de éstas puede considerarse desde luégo como muy inferior á las más septentrionales: en cuanto á los productos que enriquecen las orillas, además de lo que suministra el mar, creemos que no serían diferentes después de un examen físico de los que se advierten entre el Cábo Frondoso y Nutka; bien que la naturaleza del suelo y la mayor benignidad del clima pueden tal vez llevar á una mayor robustez y tamaño los árboles que ya ha descrito y caracterizado con tanta exactitud el Sr. de Heenke.

Examinando la parte interior del Estrecho de Fuca, hasta aquí navegada por nuestros buques, y comparándola, ó bien á las leyes naturales de la estructura del globo y á las noticias interiores del Capitán Corver, ó bien á los últimos detalles bien sospechosos del Capitán Meares y al ansia de las naciones europeas para ver realizados los viajes del Almirante Fonte y del Piloto Fuca, no podemos á ménos de diferir la publicación de nuestras conjeturas, tanto más, que si la espelanza no nos engaña, no tardará la Europa en deber este nuevo conocimiento científico á los progresos de la Marina española: una sola advertencia física terminará este artículo ya harto difuso, y es el peligro de los Suestes en las latitudes comprendidas entre los 45 y $55^{\circ}$ : la debida atención á los temporales de ambos equinoccios, y la influencia de la Luna sobre las alteraciones de los tiempos: el Capitán Meares advierte una extraordinaria operación de los mares del Sueste en la costa al Sur del Estrecho de Fuca: los temporales que nosotros hemos experimentado en principios de Agosto por $\operatorname{los} 54^{\circ}$, los que experimentaron el Comandante Cuadra y el Capitán Cook en los mismos paralelos, finalmente, los riesgos de los buques de D. Francisco Elisa y el desarbolo del Capitán Colnett que le obligó á arribar á Cayucat, todo parece confirmar que estas costas no deben frecuentarse sino entre los términos equinocciales de Marzo y Setiembre; á lo ménos por lo que toca al método hasta aquí introducido de seguir el comercio de las pieles recorriendo un largo trecho de costa.

\section{Apindice.}

Cuando se escribió el capítulo antecedente. no se tuvieron presentes (por no haber aún lle-

(i) Pucde recorrerse el viaje del Capitán Meares inbre cstas custas. gado de Méjico) el viaje del Piloto Pérez en I774 y el de D. Bruno Hezeta en I775: como entrambos tuviesen frecuente roce con los naturales, el primero en el extremo septentrional de las Islas de la Reina Carlota, y éste en las costas comprendidas entre los paralelos de 48 y $47^{\circ}$, sus descripciones pueden influir algún tanto en la mayor ó menor exactitud de nuestras conjeturas sobre la cualidad del suelo y los moradores de los paralelos que no hemos visitado; el tiempo no permite ahora confrontarlos, pero advertiremos, que atento á la natural estructura del globo, no nos fuera fácil suponer, que la entrada de Hezeta en los $46^{\circ}$ conduzca interiormente á una masa grande de aguas, cuando el fondo en la entrada ni es de piedra, ni es mayor de 28 brazas.

Debe advertirse igualmente, que las mantas, de las cuales se ha hecho memoria hablando del puerto Mulgrave, y se remite una al Real Gabinete, son tejidas de lana y no de cortezas del pino, bien que no nos es fácil acertar á cuál especie de animales correspondan aquellas lanas.

Examen politico de las costas del Noroeste de la Ancírica.

Examinadas en el capítulo antecedente las calidades físicas del suelo y de los moradores en las costas del Noroeste de la América, es tiempo ya de referir estos conocimientos á la prosperidad nacional. Sin un examen de esta especie, las tareas y los gastos de la actual expedición no acarrearían sino una nimiedad hidrográfica para el entretenimiento de pocos ociosos: la Nación exige de nosotros un tributo más interesante, y antes casi de franquearle la navegación de unas costas que poco há se miraban como abandonadas de la misma Naturaleza, es preciso indicarle cuál es la utilidad de semejante navegación; cuáles las medidas que pueden hacerla al mismo tiempo útil y segura al particular; cuáles, en fin, las consecuencias que del acierto de estas medidas pueden refluir directa ó indirectamente hacia la prosperidad y poderío nacional, comparado con las naciones más poderosas de la Europa.

Si no atendiésemos á la historia del hombre en todos tiempos y en todas situaciones; si su deseo innato de dominar, procedido del resorte de sus talentos ó de la fuerza adquirida de vencer sus pasiones, ó finalmente una ú otra vez del instinto social de contribuir á la felicidad de sus semejantes, pudiese ocultarse un solo instante al filósofo no preocupado, tal vez pudiéramos alucinarnoś en las razones que guiaron á los europeos hacia esta parte del globo; pero no es posible que sea así, cuando á la reflexión se reune la necesidad de desengañar á una nación sobre su situación política; cuando la sola falta de este desengaño hace que se malogren diariamente las 
más acertadas providencias de un rey únicamente ocupado del bienestar de sus vasallos.

Sean ó no verdaderos los viajes del Almirante de Fonte (I), del Piloto Fuca, de Ferrer Maldonado, de otros holandeses, etc., puedan ó no alcanzarse el fin que guiaba á estos navegantes, las derrotas que hicieron y el motivo de no hallarse rastro alguno fidedigno de aquellas navegaciones; las indagaciones nuestras sobre el examen político de estas costas no deben partir de otra fuente que la ligue directamente con los acaecimientos del día, y esté afianzada sobre documentos ciertos y despojados de toda equivocación. Así nuestros razonamientos no empezarán sino desde los viajes rusos, de los cuales han dimanado muy luégo los nacionales y los ingleses.

Nada deja que desear en esta parte Mr. Coxe, historiador tan curioso como exacto (2), el cual, reuniendo en un solo punto de vista los diferentes viajes emprendidos desde las costas de la Siberia, ó bien para intentar el paso del Noroeste ó para extender el comercio y conocimientos geográficos hacia el Sur y Este, termina su narración con los viajes del Tcniente Synd y del Piloto Otcheredin, por el año de I770, habiéndolos emprendido desde el de I747, en cuyo plazo se verificó la célebre expedición de los Comandantes Bering y Tchiricow. Los deseos de una gloriosa ć ilimitada extensión del Imperio, más bien que la utilidad del comercio, movieron sin duda los primeros pasos de los rusos en la Siberia: se conquistó un país casi desierto, y la sola comunicación con la capital del Imperio para conservarle ó regirle costó cuantiosas sumas: su situación en el Asia y su inmediación á la América, lisonjearon sin embargo la feliz imaginación dc aquella nación conquistadora: unas veces las minas (3), otras los productos felices del Asia, alentaban sus pasos escarmentados. Fué destinada una compañía de sabios y de navegantes para

(I) El Padre Venegas en sus apéndices á la Historia de la California, trata prolijamente y con mucho juicio del viaje del Almirante Fonte: seguramento cualquiera que lea aquellos capítulos extrañará que muchos sabios del día para probar la existencia de un paso, se ocupen en legitimar la verdad del viaje de Fonte ó Fonta: lo mismo pudiera decirse del de Fuca, y en cuanto al de Ferrer Maldonado, se cxaminará su legitimidad en una Memoria aparte: entre tanto no podemos á ménos de compadecernos de la triste constitución de las cosas humanas; viendo que no sólo se decida en París y en Londres, lo que había de decidirse en el mar, sino que los mismos navegantes se vean acarreados de este furor sistemático, é incurran, como sucede á los Capitanes Dixon y Meares, en muchas contradicciones y áun insultos sobre la verdad de lo que han visto.

(2) No se puede recomendar demasiado la lectura de esta historia para comprender bien las ideas que siguen.

(3) Aun con los conocimientos del dia no se ha destruido la manía harto envejecida en Europa, que tanto sca hablar de la América, ó más bien de las posesiones españolas, como hablar de las minas: nuestros reconocer prolijamente el suelo y los mares contiguos: se describió el suelo, las cartas geográficas fundadas sobre los mejores datos astronómicos alcanzaron muy luego un grado bien alto de perfección, y reconocidas las costas y archipiélagos inmediatos; muy luego diferentes buques trillaron aquellos mares, y en la corte de Peters. burgo pudieron formarse combinaciones más extensas y fundadas sobre aquella parte remota de sus dominios ( $\mathrm{I}$ ).

Debemos confesar que en la serie bien larga de cincuenta años (2) los pasos rusos denotan al mismo tiempo aquella firmeza en el sistema y aquella constancia en la ejecución, que solas pueden conducir á un feliz término las grandes empresas de las naciones: y si por una parte no se han economizado nilas medidas bien meditadas ni los caudales necesarios, ni los sabios y navegantes oportunamente escogidos, por la otra ni las pérdidas comerciantes, ni los naufragios repetidos, ni un archipiélago rodeado de bajos, de corrientes y de hielos, han podido arredrar ó al negociante ó al marino intrépidos.

Tantos afanes, tantos gastos y tantos desvelos, no lograrán jamás en nuestro entender, del fruto á que debían aspirar; pero á lo ménos han contribuído á que la Rusia abriese los ojos á sus intereses verdaderos, y ya abandonadas las conquistas, las navegaciones distantes, las minas y los proyectos mercantiles, se ciñese únicamente á una pesca y caza costaneras, hechas con la mayor economía, y dirigidas ó á la manutención propia ó al abasto de las pieles en el mercado de Kiackta. Es difícil acertar cuáles sean en el día las verdaderas ventajas de aquel comercio, que ya la concurrencia de las pieles de nutria en Canton debe haber desnivelado considerablemente del estado en el cual le consideraba Mr. Coxe (3).

establecimientos en las islas Batanes ó Bashees, que seguramente no tuvo otro origen que el furor de-conquista, 6 más bien de la extensión de dominios, hace producir así al Capitán Meares: About four yeurs before the Spaniards had tahen posession of these isles in the espectation of finding the beorvels of theim enriched withthe precions metals.

(I) Véanse los viajes impresos de los Sres. Gmeling, Muller, Pallas, etc., y los citados de Mr. Coxe.

(2) Desde el año de I 7 I 7 en el reinado de Pedro el Grande, hasta el r 770 en el cual se sistemaron algún tanto en Rusia las ideas y proyectos sobre la $\mathrm{Si}$ beria.

(3) Mr. Coxe presenta un estado de las pieles enviadas desde Inglaterra á Kiackta por Petersburgo cn los años 1775,76 y $77, \mathrm{y}$ son las siguientes:

\begin{tabular}{crr} 
Años. & Castores. & \multicolumn{1}{c}{ Nutrias. } \\
I 775 & 46.460 & 7.743 \\
I 776 & 27,700 & 72.086 \\
I 777 & 27.376 & 70.703
\end{tabular}

Anade después que la plus grande partie de ces folleteries (traídas al mercado de Kiackia), vient de lu Siberie, et des isles nownellement decouverts, de suerte que puede por las primeras inferirse la cantidad de las segundas. 
El Capitán Meares demuestra en su importante capítulo del comercio de la China con la costa Noroeste de la América, que no sería difícil á la Inglaterra destruirlo por la vía de Canton; pues que ya se han visto en esta ciudad comerciante, compradores chinos de las provincias más remotas; pero si se hace una comparación de las nutrias vendidas anualmente en Kiackta, y del total vendido hasta aquí en Canton (I), parece aún remota la época en la cual puedan realizarse aquellos conceptos; y de cualquier modo nuestras comparaciones políticas no podrán jamás referirse al comercio ruso.

Los pasos de esta nación en las costas de Siberia, no habían sin embargo llamado la atención pública hasta los años de I77x, y ó bien fuese el no buen éxito ó el silencio de la corte, apenas las empresas vigorosas de la Rusia alcanzaban los elogios y la admiración de pocos hombres científicos, únicamente deseosos de combinar sus sistemas con las noticias más estendidas del globo. Pero en el año siguiente de I773, el Conde de Lacy, Ministro de S. M. en la corte de Petersburgo, enterado de nuevas ideas de conquista, ó usurpación relativamente á las costas contiguas de la América, halló preciso avisarlo á Madrid con cuanta individualidad estuviese á su alcance; y por nuestra parte no se defirió un instante en tomar medidas eficaces para atajar este mal.

Estas medidas eran justas, y áun diré precisas; las conducían Ministros sabios y un Virey activo é inteligente (2) y debían practicarlas Oficiales acréditados é intrépidos: sin embargo, estribaban sobre los cimientos harto engañosos de nuestro sistema de la América, y csto bastó para que desde el principio nos fueran bien nocivos, y últimamente nos arrastrasen unas discordias funestas.

Plugiese al cielo que en esta ocasión un es critor amante de la verdad pudiese continuar el hilo de sus reflexiones sobre la prosperidad nacional sin tocar de cerca esta parte de la Historia política de nuestra América: un velo espeso no daría libre tránsito, sino al respeto y á los elogios que por tantos títulos habían merecido aquellos sabios legisladores; y la memoria de los males pasados se borraría con la esperanza del

(I) No comprendidas las pieles vendidas en Canton por cuenta de los españoles, las del Conde de la Péyrouse, las de los Capitanes Kendrik y Crey, americanos, y las de la Ifigenica y Felice del Capitán Mcares, quc pudieran tal vcz llegar á 4.000 las vendidas anteriormente, se componian (scgún cl Capitán Dixon), de 5.033 , cuyo valor liabía sido en el mercado de Canton de 746.8 .42 pesos fuertes, ó bien á un precio medio de 26 y $1 / 6$ pesos fuertes por picl.

(2) Lus lixcmos. Sies. D. Julián de Arriaga y Don José de Cálve\%, fueron á la sazón Ministros de Indias. F1 Excmo. Sr. D. Francisco Bucareli era Virey de Nueva lispraña. bien venidero: pero no es posible conseguirlo; un Ministerio ilustrado no advertiría en el día sino un silencio, ó adulador ó malicioso, y la falta ó de la verdad ó de la sencillez en esta ocasión, acarrearía tal vez un plazo más distante á aquella útil reforma de nuestro sistema en América que hasta aquí nos ha costado tantos sacrificios.

En el mismo momento en que se advirtieron por nuestra Corte las intenciones de los rusos, se trató de explorar con cautela sus movimientos; pero como al mismo tiempo fuesen oscuros nuestros derechos sobre unas costas cuya extensión, antes bien, cuya existencia era aún dudosa, nuestros pasos debieron encubrirse con un misterio funesto, evadir un tratado en Europa, que muy luégo hubiera descubierto los intereses recíprocos; finalmente, derramar caudales inmensos para la averiguación de una cosa que una sola pregunta á la corte de Petersburgo hubiera inmediatamente aclarado.

$\mathrm{Ni}$ eran estos los peores males que debía producir la errada idea de los límites de nuestros dominios. La Marina estaba á la sazón en su infancia; y los Vireyes no habían aún depuesto la errada máxima de sus antecesores, de retroceder cuanto fuese posible los límites del Imperio, con preferencia á las ventajas de los paises ó ya conquistados ó á lo ménos conocidos (I).

Con tales antecedentes, casi en el mismo principio se torció ó más bien se abandonó el hilo de nuestros intereses: en lugar de atravesar al Kamskatka con el fin plausible que dirigía á la sazón en otras partes del globo los Bouganville, Biron, Wallis, Carteret y Cook, navegamos ceñidos al Continente; y cuando la exploración de $I 774$, ó al sumo de 1775 hubiera podido informarnos no sólo de los nuevos, si también de los establecimiertos antiguos de la Siberia, apenas en I782 logramos satisfacernos algún tanto por el viaje del Capitán Cook del estado de los rusos en las islas de Oanalaska: pocas cruces solemnemente plantadas á veces en parajes que aúin no sabíamos si eran islas ó continentes, si eran ó no habitadas, alucinaron nuestras miras políticas con el agradable semblante de nuevas conquistas; y creyendo que no fuese necesario reva-

(1) Para los párrafos antecedentes se han tenido presentes los documentos originales existentes en el Archivo de Aléjico, y recopilados con mucho juicio por cl Tenicnte dc fragata D. Francisco Maurelle: para la justificaciỏn de éstc, baste decir que la instrucción dcl Excmo. Bucarcli al Comandante del primcr buque de cxploración, empicza cn estos términos: «La benignidad del Rey, que fió á mi cuidado cste Gobierno de Nucva España, no sólo me imponc en la obligación de conscrvarle estos vastos dominios, sino también en la dc procurar aumcntarlos en cuanto me sea posible por mcdio de nuevos descubrimientos cn la extensión de lo no conocido, etc.n Son casi iguales las expresiones del Excmo. Flores en su Instrucción de 1788 . 
lidarlas en un tratado, malogramos aún á la vista de la Europa esta pequeña utilidad de nuestros viajes, y finalmente, nos vimos en I 788 constituídos á emprender de nuevo las mismas exploraciones emprendidas en I774, y ya por los señores Cook y la Péyrouse, verificadas con el mayor suceso.

Tiembla la pluma al sólo echar la vista á los caudales inmensos que se han derramado en San Blas; y aunque en este momento no sea nuestro ánimo extender el examen político á las costas de la California y á las provincias del Nuevo Méjico, tiembla la imaginacion al solo considerar la extensión inmensa de territorio que se pensaba agregar á la Monarquía.

Entre tanto, el'Capitán King, digno heredero de los talentos y penetración del Capitán Cook, había echado las semillas de un comercio de pieles de nutria, entre Canton y la costa del Noroeste de América: su ánimo no era, á la verdad, sino el de ocurrir á los gastos de los descubrimientos y perfecta descripción de las costas que no había visitado; pero las especulaciones mercantiles, siempre dirigidas á un desnivel y á un abuso por la excesiva abundancia de fondos y de concurrentes y por la natural rivalidad de las naciones europeas, muy luégo abandonaron aquella senda, y últimamente nos han llevado á un convenio que hará una época memorable, y en mi entender feliz para la Nación (I).

Ya, pues, se han fijado límites á los dominios de la Monarquía. Ya, aunque apénas pueda alcanzarlos toda la ilustración de la Geografía moderna, están ceñidos, no por una Bula arbitraria que corra de un polo al otro, sino por tratados auténticos con las demás potencias de Europa: y si en lo interior del Continente de América, la política de las naciones rivales nos deja aún luchar en uno ú otro rincón con los indios no civilizados, ya podemos lisonjearnos que ó el aniquilamiento de nuestras fuerzas, ó un examen maduro de nuestra situación, nos desprenderán muy luego de esta senda errada: no será, por consiguiente, inoportuno el considerar toda la costa al Norte del Cabo Blanco, como no sujeta á la Monarquía; ó á lo ménos, deberemos lisonjearnos que nuestros derechos para con las naciones europeas, se limitarán en cuanto á esas costas y países internos, á exigir que nadie los posea, sin pararnos ahora en que este convenio, ó nos autorice ó nos convide á custodiarlos: así siquiera, no veremos renovados con otras naciones los pasados disturbios, y custodiando un solo palmo de terreno que nos sea útil ó necesario, miraremos

(I) Los proyectos comerciantes de D. Francisco Basadre, relativamente á la venta de pieles de nutria de la California por cuenta de la Real Hacienda, pertenecen al libro siguiente, porque no abrazan las costas de que hablamos ahora. tal vez algún día con una compasión escarmentada, derramarse la sangre y caudales agenos, por la posesión de una costa que nos hubiera tan sólo acarreado los mismos males.

Al momento que nos miremos como comerciantes en estas costas, ya caen por sí solas todas las cadenas que nos agobiaban, y al ruído espantoso del cañón y de la guerra, sustituyendo los dulces lazos de un cambio lucroso, de una navegación apacible y del auxilio recíproco de las naciones para su prosperidad y opulencia, ya las combinaciones políticas pueden seguirse con mayor agrado, y la defensa nacional fundarsc sobre la base sólida de su prosperidad.

¿Cuál es, pues, este comercio que ha merecido en el día toda la atención de la Europa, y que ha sido poco ménos que el origen de una nueva guerra, y desde luego de una nueva rivalidad entre las principales naciones comerciantes? ¿Cuáles son las ventajas que nos convida á abrazarlo, y cuáles los medios de no malograrlas?

La costa del Noroeste de la América no ofrece al comercio europeo sino una muchedumbre de pieles finas, la mayor parte de nutria, que cambiadas á poca costa á unas naciones que no aprecian ni las comodidades ni el lujo, logran luégo en el mercado de Canton un valor cuantioso, el cual es tanto más apreciable, cuanto que allí la balanza del comercio está decididamente contra la Europa.

El poco precio á que se adquieren, el mucho á que se venden y la utilidad de ocupar los brazos y fondos nacionales y sobre todo la navegación nacional, son otros tantos objetos que han hecho en el día comprender este comercio entre las grandes combinaciones políticas, llamando particularmente la atención de la España y de la Inglaterra.

Mr. Pitt, hecha la paz de 1783 , dando una mirada política hacia todas las partes del globo á donde pudiese penetrar el comercio inglés, único resorte de su sistema para extinguir ó mode. rar siquiera la Deuda nacional, comprendió que el Asia y particularmente la China, serían siempre los estribos en los cuales debía descansar todo el sistema de comercio: arreglados inmediatamente así los límites de la autoridad económica y gubernativa de la compañía, como los abusos y malversaciones de los empleados; escarmentada con un rasgo de severidad contra el Gobernador Hastingos, aquella misma autoridad que tantas conquistas mercantiles había producido á la Nación; extendida la introducción de los paños y manufacturas inglesas por Surate en la Persia y Turquía, por el Bengala en el Mogol y en el Thibet, por Canton y por Kiackta en am. bos extremos de la China; procurada últimamente la adquisición de cuantos frutos preciosos pudiese suministrar el globo entero al lujo excesivo de 
la Europa y á sus colonias, no olvidó, sin embargo, que esta opulencia nacional no había llegado al grado más alto de que fuese capaz y que tal vez una actividad y una industria oportunas pudieran dar á su nación toda aquella parte en el comercin de China, que aún dividían con ella las demás (I): la historia de Mr. Coxe y los cálculos del Capitán King, eran datos hartos positivos para que en estas combinaciones no tuviese un lugar postrero el comercio de las pieles de nutria: en éste debió luégo ver con mucho agrado, que si bien fuese al principio aventurado y no sujeto á unos cálculos positivos, lograba sin embargo la nación la utilidad de franquearse la navegación del mar Pacífico por el Cabo de Hornos y la comunicación del Asia con la América, por las decantadas derrotas de la Nao de Filipinas: propuso inmediatamente sus ideas á Bengala, á Canton y al comercio de Londres: varios particulares recibieron como orden la propuesta del Ministro y no tardaron en fiar sus caudales il unos Capitanes bien expertos, guiándolos finalmente estos mismos ensayos (2) sino á unas ganancias considerables, á lo ménos á la utilidad de la nación de ensanchar el derecho de sus pescas á todas nuestras costas de la América.

No debe suponerse, examinando los pasos del comercio inglés, que precisamente hayan de ser éstos siempre acertados, ó bien que cualesquiera sean las circunstancias de aquella nación relativamente á una empresa, pueda siempre torcerlas á su favor y áun sobrepujar en el concurso á otras naciones á quienes la Naturaleza parece brindar el buen éxito de la misma empresa: la costa del Noroeste de la Ámérica está precisamente en este caso; y ó bien se examinen la facilidad de la navegación, las combinaciones mercantiles ó los géneros de cambio que constituyen este giro, todo parece convencer que la Rusia y la España son indispensablemente las naciones árbitras de este comercio.

La adquisición de las pieles de nutria no es tan fácil ni tan sencilla como hasta aquí se ha imaginado en Europa; ni su número es tanto que puedan indeterminadamente suponerle crecido los aventureros que al principio la emprendan: desde luego cualesquiera sean las suposiciones del Capitán Meares relativamente á un contra-

(1) Se verá en las reflexiones correspondientes á las Filipinas, que positivamente el sistema del Gabinete inglés se dirige en el día á conseguir el monopolio de todo comercio del Asia, le será muy titil la actual revolución de la Francia.

(2) Mr. Pitt, hablando á los Comunes de la violación de los derechos públicos por el Piloto Martincz en Nutka, llama con mucha propiedad el comercio de la costa del Noroeste de la América l' $\mathrm{cn}$ fant contrer. Los ensayos se han hecho con todo el (mo comerciante: el primer huque del Capitín Hauna que salió de Canton en 785 , era de solas 70 toneladas con 30 hombies de rotación. bando ó á un comercio libre entre los establecimientos rusos, los cálculos mercantiles no pueden emprenderse sino desde la entrada del Príncipc Guillermo ( $\mathrm{I}$ ): ni por cuanto se extiendan las costas desde esta entrada hasta la de Bucareli, podrán jamás (según las experiencias de los años pasados), exceder las pieles de nutria de un número aproximado de 600 por año: esta aserción no parecerá temeraria cuando se considere que fuesen sólo 300 (2) las que pudo adquirir el Capitán Meares en el Sung Corner de la entrada del Príncipe Guillermo, desde el mes de Setiembre hasta el de Mayo, que nosotros apenas hemos encontrado otras tantas en el puerto Mulgrave, comprendidas algunas tríbus del Este y del Oeste; finalmente, que recorricla toda la demás costa desde el Cabo Buen Tiempo hasta el de San Bartolomé por los Capitanes Dixon, Portlock y Douglas, sus adquisiciones han sido muy cortas, 'á pesar que hayan sido muchas las diligencias para aumentarlas: una sola embarcación jamás pudiera recorrer todos estos puertos, ni consecuentemente completar el número indicado en una sola expedición.

Ignoramos los progresos comerciantes que hiciese la balandra Princesa Real en el Archipiélago de su nombre; pero debemos creer que no serían muchos, cuando no se ha hecho memoria de ellos, ni la balandra cesó después sus operaciones mercantiles para navegar hacia Canton: en tal caso pudiéramos aventurarnos á creer que las islas de una y otra parte que forman el canal de Dixon y que luego siguen hasta el Cabo Boisé, podrían cuando más suministrar I.00o nutrias anualmente (3) deducidas éstas por la mayor parte del Archipiélago de la Reina Carlota.

Ya en Nutka la inmediación de las célebres

(I) Sería muy útil comprender la Rusia en nuestro próximo tratado de límites con la Inglaterra, y así como se fijen los de la España en el Cabo Blanco, fijar los de aquel Imperio en la ría de Cook, quedando todas las costas intermedias, como las de Africa, al arbitrio del que quiera establecerse en ellas: bien entendido que para evitar principios de discordias, ningún establecimiento mercantil debe hacerse sin aviso recíproco en Europa para atender á los derechos anteriores ni alegar otras jurisdicciones en el terreno inmediato á un establecimiento, que el que se clisfrute con cortes, siembras y factorías. Nutka ó el Archipiélago de Macuina deben comprenderse en este estado; pues que á el Criendly Fove ó puerto de Y'ucuat no corresponde sino un pequeño distrito cedido por Macuina al Capitán Meares: en las expediciones del próximo año de I 792 convendrá sustituir este método de compras de un terreno señalado al plantio de muchas cruces, que en los tratados de Europa no logra luégo la revalidación necesaria.

(2) Suponemos que las 57 restantes que cita el $\mathrm{C}_{2}$. pitán Dixon, se hayan adqquirido en la ría de Cook.

(3) Aunque el Capitán Dixon pudo arlquirir algunas más, no sería prudente calcular por esa adquisición, porque siendo el primer buque que comerció con aquellos naturales, recibio las que tenían acopiadas en muchos años. 
Lagunas de los Nuchimases, ofrece una cantidad mucho más considerable de pieles, las cuales podrán tal vez sin imprudencia hacerse llegar hasta 3.000; pues que Natzapi, calculados todos los pescadores, los días inútiles del invierno y la dificultad de coger las nutrias, las llevaba en su máximo á 4 .000.

No deben ser tan abundantes las Islas de Wicananish, el puerto de Cayuclá, antes bien, si atendemos á las noticias verbales de la goleta Saturnina, á los reconocimientos hechos en el año anterior por el Alférez de navío Quimper y á los progresos bien limitados de los Capitanes Barkley y Meares, no pueden formarse ni áun unas esperanzas lison jeras sobre la mayor facilidad de este comercio: después de las desgraciadas pérdjdas del Comandante Cuadra y del Capitán Barkley, la una en la ensenada de los Mártires y la otra en el Queenithee, aventurar las lanchas á tanta distancia de sus propios buques parecerá cada día más imprudente y reprensible, y si se omiten estas expediciones, ya al Sur del Estrecho de Fuca, los puertos son tan malos ó más bien carece tanto la costa de puertos, y las neblinas y temporales son tan frecuentes, que fundar los cálculos mercantiles sobre las adquisiciones que de ella dimanen fuera sumamente arriesgado: no supondremos, por consiguiente, hasta el puerto de la Trinidad, sino una adquisición anual de 800 nutrias; de donde puede inferirse que la cantidad total de pieles de nutria que pueda suministrar la costa hasta aquí conocida en el espacio directo de 500 leguas, no excede anualmente de $5 \cdot 400$.

Ni nos alucinan contra estos cálculos los ejemplos de los rusos en sus pesquerías, bien sea de las islas ó del continente: las islas abundan ciertamente de un mayor número de nutrias: las del continente son harto dudosas en cuanto á su prosperidad; todas han costado inmensos sacrificios de gente y de dinero; la comunicación de un establecimiento con otro y de todos con la capital de Bolcheresk, les dió una consistencia y otro método gubernativo: la vida económica, y digámoslo así, más bárbara que la de los mismos naturales, á la cual se ven constituídos los emprendedores de esta pesca, debiendo además sacrificar anualmente á su propia seguridad un número crecido de naturales (I) no da lugar á una comparación cabal con otras naciones distantes, hechas á un temple, á una legislación y á una vida más sua ves que las de los rusos (2); finalmente, así el no

(I) Véanse los Diarios del Capitán Cook, del Piloto Haro y del Teniente de navío Hidalgo.

(2) A la verdad, la determinación de Mr. Maccay en quedarse y la de Mr. Strange en dejarle entre los pueblos de Nutka, que á la sazón y áun en el día tienen el concepto de caníbales, ó no hace mucho favor ¿í la civilización de los ingleses, ó hacen el mayor eloio de su codicia comerciante. haber concurrentes en las islas y costas de aquel Imperio, como el tener un desembocadero más cómodo en las fronteras de las provincias septentrionales de la China, el surtirlas con el auxilio del Canadá y de la bahía de Hudson con un nú mero proporcionado á sus necesidades, haría muy defectuosos cualesquiera cálculos que tendiesen á deducir nuestra prosperidad, del semblante con que se hallan las pesquerías rusas.

En cuanto al incremento del número indicado de pieles, que seguramente han supuesto los ingleses en sus combinaciones, es menester reflexionar que sólo podría conseguirse (áun cuando el número de nutrias lo permitiese), ó por medio de los naturales, ó por medio de los marineros nacionales de las factorías, que á imitación de los rusos, se ocupasen por sí en la pesca: lo primero no es tan fácil á suponerse, puesto que no sólo los vemos ocupados todos y casi diariamente en la pesca, sino que la necesidad de proveer en el verano á su subsistencia para el invierno; la de alcanzar algún abrigo para el frío; el corto número de población, y sobre todo, el no haber aumentado sus acopios (I) á pesar de las visitas repetidas de los europeos, con cuanto pudiese excitar sus antojos, no dejan muchas esperanzas de que por su parte pueda crecer ni medianamente este ramo industrial: la experiencia dictará tal vez en Nutka lo que hayan de aprovechar los ingleses con una pesca nacional protegida de una factoría: por nuestra parte nos ceñiremos sólo á indicar que esta experiencia probablemente los desengañará muy luego (2), y que áun en el caso de no malograrla, ni el pié de nuestros sueldos y alimentos, ni nuestra pericia en el ramo de la pesca, ni la dificultad de sujetar en la conducta y subordinación nuestros menestrales en el caso que se encuentren hábiles y constantes, nos con-

(I) Pudiéramos citar á favor de esta aserción, los chascos repetidos de las embarcaciones que han llegado postreras á la costa: el Capitán Meares en la corbeta la Nootka, precedido por el Capitán Fipping en la entrada del Príncipe Guillermo, no. encuentra una piel: los Capitanes Portlock y J)ixon, para auxiliarle en sus apuros, al año siguiente le constituyen en una obligación de no hacer más comercio en la costa, y á pesar de esto, sin el encuentro casual de las Islas de la Reina Carlota, sus acopios hubieran sido sumamente mezquinos: el Capitán Barkley, aprovechando el encuentro y aprestos anticipados de Mr. Maccay, apenas recibe 600 pieles en Nutka, é inmediatamente queda el Capitán Hanna, sin encontrar más que pocos retazos: el Capitán Colnett, á su salida de San Blas, aunque llegue por Febrero á Clayucat, se vé precisado á comprar por diez pesos fuertes cada una las pocas que había en nuestro establecimiento; finalmente, son increibles los sacrificios que en el pi esente año de I 79 I ha hecho el Capitán Kendrik en Nutka para surtirse de un corto número de pieles.

(2) Pudiera aventurarse la proposición de que no será permanente el establecimiento inglés en Nutka, á pesar de ser éste el paraje más oportuno para inten. tarlo. 
vidan á ser los primeros á engolfarnos en esta especie de empresas.

No podremos por consiguiente en nuestras combinaciones mercantiles suponer un mayor número de pieles de las que se manifestaron al principio; deberemos tener presente que deteriora mucho la calidad de las pieles á medida que se disminuye de latitud ( $\mathrm{I}$ ) y no perderemos de vista así la natural concurrencia de los ingleses y de los americanos, como la imposibilidad de que los tiempos, las estaciones y un feliz acaso, proporcionen entre los muchos concurrentes una distribución tal de distritos de la costa, que ninguno quede sin ser visitado, y por consiguiente, sin contribuir su cuota proporcionada de pieles.

En este caso apenas nuestros cálculos los más felices podrán extenderse á la adquisición anual de I.500 á 2.000 pieles, las cuales en el mercado de Canton, al precio de $26 \mathrm{y}^{1} / 6$ pesos fuertes (2) por cada una, darán un caudal efectivo de 40 á 50.000 pesos fuertes: estas álo ménos deben ser nuestras suposiciones, mientras no demuestre la experiencia una probabilidad grande de hacer exclusivo á favor nuestro este ramo de comercio, con preferencia á los ingleses y americanos.

Una comparación de ventajas con aquellas naciones, es por consiguiente, necesaria para aclarar la cuestión primitiva, reducida ya al doble objeto de examinar: $I .{ }^{\circ}$ Si debemos concurrir. 2. ${ }^{\circ}$ Si podemos excluir ó á lo ménos aventajar á los demás concurrentes. La comparación de los concurrentes á una misma especulación, naturalmente se divide en los tres ramos siguientes: I. $^{\circ}$ Cuáles son los géneros que se pueden traer al mercado. $2 .^{\circ}$ Cuál valor puede darse á los géneros recibidos. $3 .{ }^{\circ}$ Cuáles son los gastos que trae consigo esta doble importación (3). Por ventura la segunda de estas indagaciones puede omitirse, no habiendo más mercado para las pieles que el de Canton, en donde los privilegios son unos mismos para todas las naciones y una misma la necesidad de equilibrar cuanto sea posible la balanza del comercio: nuestros razonamientos no se dirigirán por consiguiente sino al primero $y$ al tercer punto.

Bien examinadas las necesidades y antojos de los naturales en las diferentes tríbus reconocidas hasta aquí, y considerado con no menor atención el efecto político dimanado en toda la

(I) Puede verse esta diferencia en nuestra remesa re pieles al Real Gabinete.

(2) Scría más prudente suponerlo algo más bajo, esto es, de 20 á 25 , si el mayor número es de paralelos más bajos que Nutka.

(3) I os cálculos mercantiles son por lo común molestos si han de ser claros: el refrán de Sir Roger we Coverly en Fil Espertador inglés, Appeny saned is "pemin fot, es el modo mís exacto de discurrir en
miteria de conercio. costa, de la concurrencia poco unánime y bien desordenada de las naciones europeas, pudiera deducirse como verdad, que las ganancias excesivas ó bien de los buques del Capitán Cook ó de los del Capitán Portlock, deben olvidarse como ya inasequibles; y que ha desmerecido de tal modo el valor del hierro, que ya este artículo puede considerarse como de segunda necesidad entre aquellos naturales: ¿cómo podíamos imaginar jamás que en las rancherías de Macuina, al tiempo que se rehusaba una piel á un marinero por 5o conchas de Monterey (I) se le diese por dos un pote de hierro de ro á I2 libras, en muy buen estado? Sin embargo, esto acaeció á nuestras lanchas al tiempo que recorrían los canales internos á las órdenes de los Tenientes de navío Espinosa y Cevallos: y por lo que toca á las partes más septentrionales, si bien tuviesen aún bastante valor las hachas en la entrada del Príncipe Guillermo y en el puerto Mulgrave, las demás cosas de hierro fueron siempre pospuestas con mucho á la ropa de abrigo y áun á los botones.

Entre los efectos de necesidad relativos á los naturales, no podremos por consiguiente comprender sino el hierro labrado y dispuesto en utensilios útiles, particularmente los que necesitan el temple del acero, y la ropa de abrigo: son inciertas y sumamente inciertas sus necesidades relativas al lujo; los abalorios, los botones dorados y plateados y los de metal con preferencia á los de hilo, fueron los efectos preferidos en el puerto Mulgrave, así como en Nutka se decidieron generalmente por los espejitos, en los cuales ya miraban con mucho empeño sus fisonomías y se justificaban á veces de no haberse lavado el rostro como solíamos recomendarles (2), pero un efecto que correspondiendo á los de lujo, puede sin embargo considerarse entre los de necesidad, y áun como el más esencial en el comercio de las pieles, es seguramente la concha de Monterey, Aullun, que describe Linneo bajo la denominación de Haliotis Myde: puede agregarse el cobre para las inmediaciones de Nutka, pues que como ya se ha dicho en el capítulo antecedente, aquellos naturales lo llevan luégo á los Nuchimases (3) y ya tenemos agotados todos los efectos que pueden concurrir en el mercado de la costa.

(I) Se verá después hablando del valor de estas conchas hasta qué punto está desnivelado el comercio europeo.

(2) No puede omitirse cl hablar del progreso en el aseo que han hecho estos naturales, particularmente los Tahis: á bordo de la Descubierta Natzapi ha pedido otro vaso de agua, porque había un mosquito en el que le presentaban.

(3) Me aseguró Natzapi qne por una plancha de cobre de las dimensiones de las del forro, pero algo más gruesa, daría siempre tres pieles de nutria de la inejor calidad. 
Ahora, pues, examinando nuestra situación política, se deja ver no con poco agrado del que desee la prosperidad nacional, que seguramente las colonias españolas parecen aventajarse á las demás en suministrar estos efectos: el hierro labrado, si es de manufactura española, es sin duda alguna mucho más caro que el de manufactura inglesa: pero como estas en sí sean cosas de poco valor, y los rendimientos no puedan ser cuantiosos, la diferencia jamás será de mucha monta ni capaz de desnivelar el comercio: en la conducción á Manila, y de allí á la costa, ó de Nueva España ó de California, ya nuestros costos pueden considerarse á lo ménos iguales á los extranjeros, ó bien vengan por Canton ó por el Cabo de Hornos: en desquite de este ramo en el cual tenemos alguna inferioridad, se nos presentan los demás muy favorablemente. El cobre y las ropas de abrigo, sacado aquél de las muchas minas de la Nueva España y éstas de Méjico y demás ciudades en clonde el temple obliga al uso del paño y de las bayetas, son efectos bien baratos y de bien fácil transporte al paraje de su consumo: y por lo que toca á las conchas de Monterey, debe creerse positivamente que siendo aún allí limitadas á un corto trecho de costa, no sólo no tendrán en los buques extranjeros quien las compita, sino que será fácil darles por nuestra parte y conservarles un valor precioso.

Estas conchas poco há no tenían valor alguno en Monterey: la más leve recompensa á un neófito de la Misión que las recogiese, bastaba para juntar centenares de ellas, tanto más, que era indiferente su principio de calcinación, por estar desde largo tiempo sobre las playas: en toda la costa las han apetecido con iguales ansias (I) pero la misma facilidad de adquirirlas, ha hecho que nuestros navegantes de San Blas las malbaratasen, habiendo caso de dar $5^{\circ}$ conchas por una piel, cuando al principio en Nutka y últimamente en la entrada del Príncipe Guillermo (2) una ó dos conchas alcanzaban una piel fina.

Sin embargo, es fácil poner un freno á este abuso; y desde luego sea como fuere, podemos ya asegurar que la parte de comercio en la costa del Noroeste de la América, correspondiente á los efectos de importación, es bien favorable á las colonias nuestras de Nueva España, sobre las demás extranjeras, ya que éstas ni pueden conseguir las conchas (3) ni suministrar

(I) Las destinan por lo común para la comida; á veces les sirven de adorno: aumentan sin proporción de precio en razón de su tamaño, el cual puede considerarse apreciable, cuando la circunferencia llega á tres gemes.

(2) Nos lo ha dicho verbalmente D. Salvador Hidalgo.

(3) Parecía que los nácares ó conchas de la perla el cobre y las ropas usadas de abrigo con tanta prontitud y tan poca distancia como nosotros.

Queda ya por examinar el ramo más importante de un comercio, y es el transporte de ambos efectos cambiados: se combinan en esta parte todas las trabas de la legislación europea que favorecen á una más que á otra nación; la posición de las colonias ó puertos amigos de cada una, á donde hayan de aprodar las naves; pero sobre todo la economía y práctica de la navegación, para que los viajes sean al mismo tiempo periódicos, cortos, lucrativos y seguros.

Desmaya, á la verdad, la pluma del que mire los intereses nacionales, cuando se considere que nos cuesta hartos sacrificios la vista de una posición como la nuestra para el comercio de las pieles: la posición es, sin duda alguna ventajosa, ó bien se emprendan nuestras operaciones mercantiles desde Acapulco, desde Monterey ó desde Manila; pero cuánto cuesten estas colonias á la Monarquía, cuánto le hayan costado hasta aquí, no fuera fácil describirlo en pocos renglones; ello es, sin embargo, que nuestros viajes desde Acapulco y San Blas son igualmente breves y seguros de ida y vuelta en todo el año, que los puertos de Monterey y San Francisco á donde nuestro navegante halla todos los auxilios así para su seguridad, subsistencia y recreo, como para la continuación de sus operaciones mercantiles, pueden muy bien considerarse un distrito de la misma costa del Noroeste; finalmente, que el puerto de Manila, mediante sus conexiones mercantiles con la Nueva España y con la China, liga de tal modo sus navegaciones para la costa del Noroeste, que pueden considerar casi libres de fletes los efectos que componen este cambio, cuando los buques extranjeros, sobre ellos solos deben recargar todos los gastos de un viaje peligroso y dilatado.

Más felices también en este ramo por lo que toca á la economía, podemos considerar nuestra navegación aventajada á la extranjera, no sólo en la multiplicidad de objetos que pueden abrazarse de ida y vuelta, si también en el poco costo de las embarcaciones, marinería y víveres que han de verificarlos: cualquiera dé una mirada, aunque ligera, á la navegación nuestra de Filipinas, á la excelencia de los buques construídos en sus provincias, á la muchedumbre de buena marinería que puede suministrar (I) y á la cali-

de Panamá, Realejo, Acapulco y Filipinas debieran ser también apreciables; pero no ha sido así, y los naturales del puerto Mulgrave han manifestado á Don Cayetano Valdés, que las tenían en aquellos contornos.

(1) Un marinero filipino de primera clase gana en la Nao I 2 pesos fuertes por mes, y en aquellos buques mercantes dos á tres: los marineros ingleses escriturados por el Capitán Meares á bordo del Rey Jorge, debian ganar cuatro libras esterlinas. El pago 
dad y abundancia de los víveres, conoccrá desde luego que mal pudieran competirle los armamentos ingleses del Canton, Bengrala y costas de Coromandel y Malavar, y mucho ménos los que saliendo de Europa por el Cabo de Hornos, lleguen á la costa del Noroeste próximamente con un año de viaje y con unos riesgos que exigen seguros no indiferentes.

Luégo cn el comercio de las nutrias están á favor nuestro los costos del transporte ó de la navegación ( I) y cl valor y calidad de los efectos de importación, debiéndonos por otra parte parecer iguales con los demás, los precios de las pielcs exportadas para el mercado de Canton: cn este caso sólo unas medidas directamente opuestas á la prosperidad de este comercio pudieran destruir esta superioridad: no será supérfluo el indicarlas, no tanto con el ánimo ó de precaverlas todas ó de ostentar una penetración inoportuna, como con el deseo de alentar á los primeros emprendedores, de suerte que sus operaciones en unos asuntos no bien experimentados, logren en sus mismos principios de toda la felicidad necesaria.

Este comercio debiera en primer lugar depender únicamente de las medidas comerciantes de un corto número de accionistas combinados en Méjico y en Manila: las primeras expediciones deberían ser sueltas, independientes una de otra y como por vía de ensayo: los buques destinados á este objeto serán de poco porte, se dirigirán á Monterey para abastecer libremente aquel presidio y encontrar allí el acopio oportuno de cobre, ropas usadas y conchas, de donde, finalmente, sc dirigirán á la costa, emprendiendo derrota directa para los puertos inmediatos al Monte San Elías: estas operaciones, movidas desde un punto distante (2) acompañadas del deseo de abarcarlo todo en un solo año y de dar un semblante

de éstos en la costa, es sin embargo, de 74 rupias 6 siete pesos fuertes próximamente. Pudieran hacerse muchas comparaciones útiles de los demás precios de estopa, cables, etc., sobre aquel viaje, como de todos los demás comestibles en el viaje tercero del Capitán Cook.

(I) Estas ideas de comercio se desplegarán aún con más claridad en el libro siguiente, cuando se unan como es debido á la prosperidad de la California, de modo que no sea ya un gravamen constante á la Mo. narquía: por ahora nos contentaremos con indicar que los paquebotes y bergantines de Filipinas empleados en el comercio costanero de las pieles, y haciendo es cala en Monterey, aunque no se ocupasen sino en esto solo, siempre lograrian muchas ventajas económicas sobre los que se habiliten en Canton y Bengala. Los pilotos de San Blas, instruídos en poco tiempo de las reglas del pilotaje mís exacto, pullieran guiar con mucho acierto aqquellas embarcaciones.

(2) I a resielencia de la dirección de la Companía de liilipinas en Madrid, sería capaz por sí sola de destruir todas las rentajas si estas negociaciones se apropiasen a aquel cuerpo: las providencias son tardías, his ideas magnfficas, los empleados muchos y los des. rarreos de la prinera senda sumamente fáciles. guerrero á las miras mercantiles, inmediatamente refluirían considerables gastos contra los emprondedores, y por último, no hallarían sino pérdidas á donde todos los cálculos les prometían crecidas ganancias.

'Tampoco será útil, que en las primeras com. binaciones de esta especie se mezcle ni remotamente la Real Hacienda, á lo ménos por lo que toca á unos prontos ahorros. Son harto frecuentes los proyectos engañosos de economía que últimamentc produciendo solo nuevos empleos vitalicios y la subvención del dcrecho público, acaban por extraer del Erario ó con nuevas promesas, ó por una compasión mal entendida, aquellas mismás sumas con las cuales se habían brindado á acrecentarle. Por consiguiente no dc. biera al principio admitirse of recimiento alguno de esta especie. Sea rico el vasallo sin vejación de sus conciudadanos, y lo será muy luego toda la Monarquía (r); manifiesten los primeros ensayos cuáles son las ventajas del comercio emprendido, y luégo que se cimente será fácil extraerle la cuota correspondiente al equilibrio de la prosperidad pública. Así, si las primeras empresas nacionales tendiesen á imitar las que han hecho los ingleses desde el Asia, con sola la diferencia de tocar ida y vuelta en Monterey, el Monarca debía desentenderse de todo derecho, á lo ménos hasta la llegada de regrcso á Manila, cn donde podrían pagar lo mismo que todos los demás, los géneros importados desde Canton.

Pero el grolpe más destructivo para la infan. cia de este comercio sería sin duda el pensar en un establecimiento. Ninguna nación debe estar en esta parte más escarmentada que la nuestra; y la constitución de estas costas ha demostrado ya, que apenas recorriéndolas todas en la esta. ción oportuna puede completarse un mediano cargamento, pues los pocos y diferentes antojos de aquellos naturales, como su ninguna inclinación á los licores nuestros (que hacen el principal objeto de los cambios del Canadá y bahía de Hudson), no dan lugar á que se tengan almacenados crecidos efectos para ocurir como es el objeto de un establecimiento, á una concurrencia frecuente y periódica de compradores (2).

Ultimamente, el temor del contrabando pudiera en esta ocasión, como en otras muchas, interrumpir la felicidad de las primcras empresas. Un celo aparente para el buen orden de las

(I) El sistema de derechos correspondientes se desplegará también al tiempo de combinar este comercio con el de las Californias y Filipinas, relativamente á la Nueva Lspaña.

(2) La facilidad con la cual (segrin se ha dicho generalmente) la Compañía de Filipinas se brindaba á entregarse del establecimiento nacional de Nutka, hace ver que no eran acertadas las ideas de este Cuerpo, sobre las ventajas de aquel comercio. 
rentas públicas no es sino el abrigo de un interés verdadero en mezclarse un mayor número de empleados en un objeto nuevo, del cual se esperan crecidas ganancias: á veces con el objeto de coadyuvar servilmente al sistema adoptado, por lo común con el afán de ostentar un nuevo mérito en el mismo momento en que ho se respira sino una ambición interesada, no bien se ha hecho público un proyecto de comercio y ha merecido para sus ensayos la justa sanción del Soberano, cuando un sin fin de planes económicos se desploman de todas partes para sofocarle en su misma infancia: no son éstas unas abejas que chupando suavemente de la flor la convierten muy luego en cera y miel: son más bien unas langostas que no dejan otro rastro de su venida á un campo sino la desolación y los llantos del que pensaba cosecharle.

El contrabando de la plata no es fácil si hay un buen resguardo en Acapulco, en donde las avenidas son pocas y los buques están anclados con mucho orden é inmediación al muelle: además, que si bien el traspaso directo á Canton del numerario daría unas ventajas enormes, no es creible por ahora quc lo alcancen los comerciantes de Méjico, para las debidas combinaciones en el giro de letras con las ciudades comerciantes de Europa (I). Fuera de este caso no es posible suponer un contrabando: el comercio de Méjico debe considerablemente al de España, $y$ este pago le absorbe anualmente todo el producto de las minas: debe también al de Manila; pero está tan distante de satisfacerle con prontitud, que además de haberle precisado á reformar la mitad de sus remesas (2) ni éstas se le satisfacen puntualmente: Iuego si no hay una deuda anterior ni puede recelarse una combinación nueva, está patente que no debe temerse la extracción de la plata, á ménos que la introducción de géneros prohibidos no haga preceder un crédito á nuestro comercio.

En este crédito ó introducción de efectos extranjeros, debe también distinguirse un comercio periódico del accidental y despreciable de las anchetas particulares de uno ú otro Capitán ó Contramaestre: éstas no merecen un lugar en los

(r) Se verá á su tiempo cuántas ventajas produciria este giro oportuno á la Monarquía; esto es, haciendo pasar los comerciantes españoles á Manila y Cauton toda la plata de la deuda extranjera, tomando letras sobre Inglaterra, Amsterdan, Lisboa, etc, y negociándolas luégo en Europa: este giro equilibra también, á lo ménos en mucha parte, el valor del dinero del Perú con el de Nueva España, da un resorte muy activo á nuestra navegación y debilita la extranjera, bajando además el valor de los efectos de sus fábricas en cl mercado de Canton: lo que más importa es que con esta precaución, la circulación en el continente viejo no es violenta ni ahogada de su mismo peso.

(2) La Nao de Manila ya no viene á Acapulco sino de dos en dos anos y nunca lleva el dinero correspondiente á sus efectos. cálculos políticos, y basta para contenerlas $\mathrm{cl}$ escarmiento del infractor, que tarde ó temprano es por lo común víctima de un delator infame: aquél, al contrario, debe precisamente tenerse á á la vista, así por lo que influve en el sistema general de Hacienda, como por lá imposibilidad de atajarle, cualesquiera sean los gastos, los ar. dides $y$ las personas que se destinen al intento: pero por ventura, vemos en el día que los efectos del Asia son más bien importunos y sobrantes en la Nueva España que necesarios; y adcmás, una asociación de comerciantes quc en estos ensayos tiene á la vista más bien el beneficio público que el particular, no puede abusar de la confianza del Gobierno para unas ganancias soeces y de poca monta.

Sería esta la ocasión de manifestar por extenso todas las combinaciones favorables que proporciona el puerto de Monterey en este giro; sin embargo, le omitiremos ahora contentándonos con decir que los fondos para el comercio dc las pieles pueden indistintamente enviarse á Manila ó á Monterey; esto es, en cuanto á los tres ramos preciosos de conchas, cobre y ropas usadas; pues como se ha dicho, el hierro labrado y las quincallerías, tal vez se adquirirá con mayor economía en aquella colonia que en las de la Nueva España occidental: por lo que toca á los gastos necesarios para la habilitación de un buen paquebot ó bergantín del comercio de Manila, que invernando en Monterey pudiese hacer scgunda campaña á la costa antes de venir á Acapulco y de allí regresar á Manila, parece quc los fondos: debían también derivarse del comercio de Méjico más bien que del de aquella colonia, pues que ćste está acostumbrado á su rutina envejecida de dar al dinero el solo giro de una ganancia cxorbitante por premio, ocurriendo principalmente las Obras Pías á la duración de este vicio morcantil (I).

Hasta aquí no se ha mirado el comcrcio del Noroeste de la América sino como referido á los naturales y al solo objcto de las pieles; pero si no nos engañan mucho las apariencias, éste pudiera tal vez extenderse á la Siberia, y en particular al Kamskatka con los objetos siguientes.

Embarcaciones construídas, arroz, trigo, a\%ucar, jarcias de abacá, tablazón de las Filipinas, vinos, aguardientes, tabaco, tablazón, betunes, jarcias de San Blas, menestras secas, carnes salada y una ú otra vez frescas del reino de Nueva Es paña, cuyos efectos, aunque no lograscn cambio directo por no producirse en aquellas provincias cosa alguna de extracción útil, pudieran compensarse sin embargo, por letras sobre Petersburgo en dondc la Corona, con motivo de las arbola-

( ) Se propone de oficio al constalado de Méjicu un ensayo de esta especie de comercio. 
duras, no tiene en el día objeto alguno de compensaeión más que el dinero físico.

Es inútil manifestar en esta parte, que semejantes empresas no pudieran aventurarse sin un tratado anterior de comereio entre las dos cortes; y particularmente sin saber el estado actual de aquellas provincias, los valores de cada efecto vendible, las necesidades á que no han podido remediar hasta ahora, la mayor seguridad de la navegación hasta Okosk, el permiso para internar hasta aquella capital, las ideas del Gobierno ruso relativamente al grado de fuerza y prosperidad á que quisiera llevar la Siberia; finalmente, una idea cabal de la actual feria de Kiackta, por si nos conviniese enviar á ella por la Siberia algunas manufaeturas nacionales (I). En cstas especulaciones es también evidente que debíamos mirar como un objeto de mucha monta conservar á favor nuestro el transporte y navegación, no permitiendo la venta sino de embareaciones de poco porte; y favoreeiendo mucho la exportación de nuestras colonias en los bajeles nacionales, finalmente, que debíamos dejar al prolijo cálculo mercantil, aquellos detalles, escalas y ramos secundarios que nunea puede aleanzar el que calcula sobre los intereses agenos á una distancia excesiva del mercado.

Ello es bien seguro á lo ménos, que nuestros viajes á la Siberia, partieularmente desde Acapulco y Monterey, no nos utilizan la estación oportuna del mismo año para comerciar en las pieles, y que dependiendo este comereio de una corta cantidad de efeetos nada voluminosos y la mayor parte útiles para lastre, el flete de los que se importen á la Siberia, aunque moderado, debe ser bien ventajoso á nuestros navegantes (2).

(I) Las noticias de Mr. Coxe son imperfectas; parece que no carecen del menor grado de exactitud las de Mr. Pallas, que no están en nuestro poder: sin embargo, serán infinitamente más individuales las que se adquieran por un comerciante inteligente de Petersburgo.

(2) Los pilotos del Departamento de San Blas, enterados en puco tiempo del pilotaje fino, son capaces de dirigir estas navegaciones: haría muy buen servicio uno ú otro Oficial de la Marina Real, que no
Si se pregunta últimamente euál ha de ser la conducta nuestra relativamente á una colonia inglesa en estos mares, insistiremos en solieitar que se aparte de ella euanto sea posible la eirculación de la plata; que en las nuestras inmediatas abunden los tabacos, vinos, aguardientes, paños, maderas, harinas, hierro, armas, ete., facilitandoá los extranjeros su compra, bien que sin más intervención de parte del Rey que la que conduzea á la eonservaeión del derecho público; que la comunicación del reino de Nueva España con las eolonias antiguas ó nuevamente establecidas, sea únicamente por Acapuleo, en donde las demás costas de Chile, Perú, Quito y Guatemala, envien aquellos efectos que puedan com: petir con Nueva España en el mereado nuevamente establecido; finalmente, que sea Acapulco el centro del eomereio de todos los dominios de S. M. que baña la vasta extensión del mar Pacífico entre sí; y de éstos con la China, la Siberia oriental y las eostas de la Amériea no sujetas á la Monarquía.

Perteneee á una époea posterior á ésta (I) sistemar las ideas de este comereio; en el día su novedad, no bien aelarada, sólo influiría en prevenir los ánimos políticos contra su admisión, euando nuestro objeto no es otro que el de eonfirmar lo que ya se indieó en los axiomas polítieos; esto es, que la plata es un fruto eomo los demás que produce la tierra á beneficio del que la habita, que es la última necesidad de las naeiones, y por consiguiente, que no está en nuestra mano el darla un valor imaginario, mientras otras neeesidades de mayor monta nos eselavicen á las demás; finalmente, que de cuantos frutos producen las inmensas conquistas españolas, es el que ménos puede contribuirá la prosperidad naeional, y el que hasta aquí ha contribuído á su total decadencia.

desdeñando los trámites no indecorosos de la Marina mercante, coadyuvase con sus conocimientos políticos y facultativos al verdadero progreso de la prosperidad nacional en estas navegaciones.

(r) Como muy luégo se han de examinar de cerca las Filipinas y la China, fuera imprudente ensanchar estas ideas antes de la comparación necesaria de unos intereses con otros. 
Examen fisico del Archipiélago de Vavao y de sus producciones y habitantes. - Se individualizan diferentes puntos historicos, relativos a toda la confederación de las Islas de los Amigos, desde las uiltimas navegaciones del Capitán Cook, y se continúa la serie importante de las reflexiones del mismo navegante.

Los capítulos que anteceden con la narración individual de lo que experimentamos en el fondeadero de las Islas de Vavao, bastarían para dar una más que mediana idea de las cualidades del suelo y de sus habitantes, áun cuando no nos hubiesen precedido en esta senda los Cook, Forster y Anderson, cuyas miradas sobre cuanto abraza la inmensa variedad de la Naturaleza, merecerán siempre los elogios y la admiración de todos los navegantes: pero el método adoptado en la serie de nuestras tareas actuales, la no difícil obligación nuestra de continuar un edificio, cuyos cimientos se hallaban ya tan sólidamente establecidos; finalmente, una nueva felicidad accidental, no diferente de la que habiamos experimentado ya en Nutka, de poder combinar al mismo tiempo, quien supiese preguntar y quien supiese responder, exigen que se abrace con mayor extensión esta especie de observaciones; ni á la verdad debemos creer, atento á su variedad y á su importancia, que parezcan absolutamente inútiles ó cansadas al hombre filósofo, el cual en toda la extensión del globo, ó se contempla á sí mismo, ó atónito admira la próvida mano del Autor de la Naturaleza.

El Archipiélago de Vavao no desmerece en modo alguno la hermosa idea que de él había formado el Capitán Cook; abraza un número grande de las islas que el mismo Capitán comprendió en la lista de las que pertenecían á la confederación de los Amigos; finalmente, abre un nuevo asilo mucho más cómado y seguro, á los navegantes que trillen en lo venidero esta parte del mar Pacífico. Se extiende desde la latitud Sur de $18^{\circ} 35^{\prime} 30^{\prime \prime}$ hasta la de $18^{\circ} 52^{\prime}$, y en la dirección de Este-Oeste es su mayor extensión de solas cinco leguas.

No son diferentes según el examen físico del Sr. Heenke, las materias de las cuales se componen estas islas, de las que ya los viajeros ingleses admitieron en las otras más meridionales; esto es, que la madre ó la parte sumergida que forma la base, es una piedra calcárea, po- rosa, gris y con exceso puntiaguda; ó bien, para decirlo en una sola palabra, es una piedra coralina; probablemente la misma también en los demás parajes que no hemos reconocido, la cubren luégo en algunas orillas las arenas blancas derivadas de los testáceos, y en la superficie interior una tierra arcillosa bastante dura, rojiza por el ocre marcial y mezclada en los parajes más cultivados, con una buena capa de tierra vegetal.

Estas islas, si bien algo elevadas, á lo ménos en su parte septentrional están muy distantes de poderse considerar como altas: sería difícil avistarlas á una mayor distancia de seis ó siete leguas, y quien las comparase con la parte más alta de Tongatabu, tal vez se aproximaría mucho á la verdad: pero las vistas de D. Felipe Bausá darán una idea más cabal de su elevación, lacual por otra parte puede considerarse también representada con igual exactitud por D. Fernando Brambila en la hermosa vista de perspectiva que ha formado del fondeadero de las corbetas.

Cualquiera que examine aunque levemente lo que acaba de indicarse, deberá naturalmente inferir que una extructura semejante, no puede á ménos de producir una variedad extrema en los muchos canales que estas islas forman entre sí. Y efectivamente, no es extraño ver unas veces algunas islas ó más bien pedruscos tan perpendiculares sobre el mar, que se hallen á pique las 50 ó 60 brazas; encontrar otras veces unas restingas tenaces, que obstruyen toda comunicación con los canales interiores, favorecidos de nuevo con un fondo proporcionado para la navegación. En todas partes en donde han penetrado nuestras embarcaciones menores, son los arrecifes de una misma calidad, y ciertamente sería este un grave inconveniente para los fondeaderos, si oportunamente la Naturaleza no hubiese for * mado diferentes playas, en las cuales es igual. mente seguro el tenedero de las amarras y el atracadero de los botes.

Es, sin embargo, una preferencia notable de 
este Archipictagro sobre los demás ya reconocidos de Happai, Innamolia y Tongatabu, el que sea más fácil y más segura la posición de sus puertos, siendo así que con cualesquiera vientos son los bordos igualmente sencillos para alcanzarlos, y que debiéndose sospechar (como después se verá con mayor extensión), la variedad de monzones (n) estos mares próximamente como en los mares cle las Molucas y Nueva Guinea, ya las cualida. des de un puerto deben referirse igualmente á los vientos del Noroeste y del Sueste para que se consideren útiles en cualesquiera estaciones: el puerto Taldés logra sin duda de todas estas ventajas en un grado bien favorable; pues á la mucha seguridad de sus amarraderos, particularmente en el sitio que hemos llamado el Carenero, reune la inmediación cómoda de los parajes oportunos para aguada y leña; un pedrusco accesible $y$ aislado para el establecimiento de un observatorio, ó de las fraguas, y la poca distancia de diferentes rancherías, seguramente las más pobladas y mejor provistas de toda especie de comestibles, no debe, por consiguiente, parecer temeraria la aseguración nuestra, de que es, con mucho, preferente al puerto de Tongatabu, en el cual, el mismo Capitán Cook tocó los inconvenientes bien graves de la casi absoluta necesidad de un viento largo para entrar y para salir, de la mucha distancia de las poblaciones y de la no buena calidad del agua: este último objeto que los navegantes deben siempre considerar en sus escalas con la mayor predilección, corresponde en las Islas de Vavao á la pintura que de ellas hizo el Rey Paulajo al Capitán Cook: pudiéramos asegurar que aprovechadas á un tiempo las diferentes aguadas, no distantes del Carenero más de una legua, pueden conseguirse diariamente y en muy pocas horas hasta 50 ó 60 pipas de agua hien limpia y despojada de todo gusto salobre.

No es fácil empresa acertar con las causas verdaderas, ó más bien diré, con unos razonamientos siquicra probables, sobre la formación primitiva de estas islas: el volcán no distante de Late, debe asemejarlas á las de Annamoka, las cuales en una casi igual distancia y dirección, ren frecucntemente los fuegos del volcán de Kao: $y$ si se comparan en unas y otras la elevación mayor, las capas ya formadas así de la arcilla, como de lá tierra vegetal, el estado excesiro de las producciones y los mismos incrementos de todas las especies animales que las habitan, no debemos dudar á In ménos que sea en entrambas una misma la época en la cual han salido clel mar ! han sido posteriomente pohladas. Pero si estos efectos hayan dimanado de la acción riva de los fuerros subteráneos, óbien le aquel natural incremento, del cual, aunyue tardo. son capaces las plantas marinas; si cle idlu yat inble la superficie del mar cn una masa desigual pero contínua, hayan debido ce- ler luégo á la acción constante de las mareas y de los vientos, franqueando los muchos canales que se advierten; finalmente, si puedan con el tiempo vigorizarse estas conjeturas con el examen sucesivo de los arrecifes que en el día se hallan aún sumergidos, son todas cuestiones que dejaremos á otros, ó más inteligentes, ó más felices, para no alucinar ahora con razonamientos infundados á los que aspiran á un cabal conocimiento de la formación del globo. La Hidrografía, cual se sigue en el día, podrá á lo ménos coactivar algún tanto á esta especie de pesquisas, y los rastros ingleses y los nuestros, después re una larga serie de años, podrán tal vez manifestar á los físicos ó el acrecentamiento perpendicular, ó la mayor extensión horizontal de los arrecifes actualmente reconocidos y anotados (I).

Si parece temeraria la empresa de querer indagar con alguna verosimilitud la época de la formación de estas islas, no lo es ménos seguramente la de investigar el tiempo en el cual fueron pobladas, aunque todo denote que no debiéramos retroceder á unos siglos muy remotos: hemos advertido nosotros y lo advirtió el Capi. tán Cook, que hay muchos parajes no sólo in. cultos, sino también sin el menor rastro de haber sido otras veces cultivados; que la población puede considerarse mezquina á pesar de la robustez general; que su subsistencia es sumamente fácil; ninguna la necesidad de la pesca; legítimos todavía los derechos de la sucesión en la familia reinante; pocas las discordias y la envidia por la posesión del terreno, á lo ménos si se comparan á las de las Islas de la Sociedad; muy reciente según el Capitán Cook la propagación de los puercos y gallinas en Annamoka y Tongatabu; y últimamente ninguno el rastro de invasiones anteriores á la clase actual de los pobladores.

Tal vez la finalización del viaje, reunidas en un solo punto de vista las navegaciones antiguas, nacionales y holandesas y las más recientes del Capitán Cook, con todo lo que hemos podido ad vertir en la grande extensión de las costas que ahora se han recorrido, nos conducirá á aven-

(1) Una carta física de esta especie no sería tal ve\% inútil á las indagaciones venideras, distingujendo en punto grande y con diferentes colnres, adcmás de la verdadera extensión de los arrecifes, los que velan y los que están aún sumergirlos á poea distaneia de la superficie. Desde luego debe parecer extraña la son. da de la misma calidad que nosotros hallamos al Sur del Archipiélago y los ingleses al Norte de Happai; . la misma dirección Norte-Sur, desde lo mas Norte de Vavan hasta el extremo Sur de Eüa y Tongatabu; la misma cordillera de restingas al Este y los mismos volcanes, y sobre todo, la mayor elevación y calidad precisamente al Oeste, acantilada de uno y otro ex-
tremo de esta cordillera. 
turar algunas conjeturas sobre este caos tan oscuro como importante de la historia de nuestra especie; pero si áun esta cmpresa así combinada sobre unas miradas generales, debe parecer no sólo arriesgada, sino más bien imprudente, ¿cuanto mayores deben ser las acusaciones y las mofas contra el que se aventurase á hacerlas depender del solo examen de pocas leguas de terreno, sin amalgamar antes, digámoslo así, las nociones de la historia del globo y las de la historia de la especie humana?

Abandonada, por consiguiente, esta doble cuestión de la época de la formación de estas islas y de su población sucesiva, séanos permitido abrazarnos con el examen más agradable y ménos incierto de las cualidades físicas y morales de los habitantes del día. Su civilización, sus principios sociales y religiosos, su constitución robusta, sus ideas de la felicidad, probablemente alcanzarán á manifestar al filósofo juicioso, que las combinaciones morales son tan limitadas como las combinaciones físicas, y que en balde nos esforzaríamos á hacer dimanar de los solos razonamientos, ó una prosperidad de la máquina, ó unas satisfacciones del alma que no pueden combinarse con las causas extrañas que nos rodean (I).

La confederación de los Amigos debe considerarse limitada por el Norte á las solas Islas de Vavao y por el Sur á las de Eüa y Tongatabu. Jamás los naturales nos han comprendido las de Hamoa como reunidas ó dependientes de este Imperio, ni atento á todas las direcciones que nos han dado desde los parajes altos, pudiéramos convenir con el Capitán Cook (2) á ·que sea otro Archipiélago. La navegación de D. Francisco Maurelle en I78r, demuestra positivamente que no hay otras islas en la dirección indicada, sino la que llamó de Amargura. Nunca pudieran considerarse como reunidas á un mismo Archipiélago las otras descubiertas por el Comandante Wallis, ó lo que es lo mismo, las Islas de Consolación, de D. Francisco Maurelle, Las cuales le suministraron diferentes refrescos para la continuación de su viaje. En lo que no debe caber duda, es en la frecuente correspondencia que tienen entre sí todos estos habitantes y también los de las Islas Fichis. El Eigui Tumoala, que frecuentó mucho en la corbeta ATRE-

(I) Es imposible en este momento poder apartar de la vista la triste escena que presenta la Europa por el soñado deseo de una felicidad imaginaria, $y$ por unos derechos que tantas veces se ultrajan cuantas se nombran.

(2) Debe advertirse, que para la mayor concisión y la precisa economía del tiempo, entendemos indistintamente bajo el nombre del Capitán Cook, ó sus propias noticias ó las de los Sres. Forster y Anderson. Un mayor despacio nos dará lugar á disipar estas pequeñas equivocaciones.
VIDA, era de los últimos; entre los que dirigían el baile de los Eiguis en la tarde del 25 , sobresalía por su agilidad y por la natural alegría, un habitante de Hamoa, seguramente igual en sus facciones y costumbres á los que ahora nos rodeaban.

La frecuencia del trato que acabamos de indicar, debe, sin embargo, considerarse proporcionada á las conexiones particulares de estos diferentes Archipiélagos entre sí esto es, que debe ser mayor entre los cuatro grupos que forman la confederación y cuyas distancias y arrumbamientos son mucho más proporcionados para la navegación; será luego más escasa con Hamoa, cuyos enlaces no son ni comerciantes ni repúblicos; finalmente, aún más tarda y remota con los Fichis, los cuales, á una distancia de 84 leguas y á una dirección de Este-Oeste, nada favorable para la navegación, reunen la misma discrepancia de intereses, y probablemente, una cierta fiereza inseparable de un suelo ménos fértil y ménos extendido en razón de su número (r).

A estos conocimientos pueden consiclerarse ceñidas las ideas geográficas de los naturales, á lo ménos por lo que corresponde á una época anterior á la venida de los ingleses y nuestra. Omai les dejó ideas bien claras de la Nueva Zelanda y de las Islas de Otahiti: Vuna y algunos Eiguis (como se ha visto ya en la narración), han podido comprender con bastante individualidad la posición de nuestro continente de la América: pero inquiriendo yo repetidas veces sobre las Islas de los Navegantes, jamás he podido descubrir que tuviesen la menor idea de su existencia; ni en la actual tradición de sus navegaciones sería fácil hallar los rastros de descubrimientos más distantes.

Sea como fuere de estas nociones, es bien positivo, que deben serles y les son sumamente indiferentes: habitan un país fertil bajo de un clima templado; pueden multiplicarse mucho, sin que los alimentos les sean ó más escasos ó ménos varios y sabrosos: la división de estos pequeños Archipiélagos, subdividiendo los enlaces y las combinaciones sociables, suministra bastantes objetos para excitar con las navegaciones, con los cambios, con la misma envidia y emulación aquella variedad contínua sin la cual, aunque llena de sobresaltos, la vida del hombre se asemejaría muy luego á la de los brutos; finalmente, la natural codicia de los Fichis para invadir $y$ hacerse dueños de un país como éste, les recuerda siempre la necesidad de la unión propia y el bien que perderían, si ó abandonasen ó dejasen indefensos sus hogares.

(I) Debemos suponer que las Islas fichis sean las del Príncipe Guillermo de los holandeses y las primeramente avistadas por el Capitán Bligh en la lancha del Bounty. 
Luego nada absolutamente debe convidarlos á nuevas empresas, ó de conquista ó de descubrimiento; ni en sus navegaciones pueden descarriarse frecuentemente cuando la dirección Norte-Sur las hace sencillas, sus precauciones son constantes para aminorar la travesía y asegurar algúu barlovento con las inmediaciones de Happai, y su comunicación deriva más bien del antojo que de la necesidad.

Este conjunto de circunstancias debe hacerlos naturalmente pacíficos, así como la abundancia en que viven y las leyes sociales que les gobiernan, atentos y amantes del decoro: tales son efectivamente sus características; sobresalen todas á cada paso; la misma diferencia de conducta entre los principales y la plebe les da un nuevo rcsorte; y seguramente no habrá navegante alguno que no ratifique en lo venidero el nombre juicioso con el cual los ha distinguido el Capitán Cook.

Ni la infracción de las leyes de propiedad, aunque común solamente entre la plebe, puede con razón tacharse por nosotros con aquellos mismos colorcs negros, con los cuales solemos caracterizar el robo: es el antojo, es la costumbre la que los guía, más bien que la codicia ó el desprecio de las fuerzas y derechos agenos; y el mismo plebeyo, el cual poco antes vió con indiferencia quo la autoridad del Eigui le despojaba del fruto de :; industria y de sus sudores, procura poco después, á costa de su propia vida, quitar indiferentcmente ó un trapo inútil, ó el hacha para él tan preciosa; de allí á un instante se le ve de nuevo rcgalar con empeño frutos y bagatelas que trae, $y$ con los cuales hubiera podido adquirir lo mismo que ha robado: se hace aún ménos feo este delito ó toma más bien el semblante de una acción inocente, cuando se advierta, que por lo común los robos de la plebe son luégo obsequio para los Eiguis; y que las ideas de la propiedad no son en esta sociedad las mismas que entre los europeos. Entre nosotros todo lo que se posee, ó es fruto de un trabajo nuestro ó de un trabajo ageno cuyo valor se nos ha cedido, ó representa el ahorro de un trabajo venidero que ya sostiene auténticamente la sanción de las leyes: constituídos por una emulación viciosa á procurar sobresalir entre los demás, nada miramos con indiferencia, y la posesión de una cosa envuelve en sí la doble complaccncia de nuestra comodidad y del envilecimiento de los demás: pero entrc estos pueblos, cuya clase inferior nada posee, cn dondc la Naturalcza no necesita de la mano del hombre para prodigar sus dones, donde visten, habitan $\mathrm{y}$ bogan igrualmente en una canoa (1 Rey y cl plcbejo más ínlimo, los derechos de lat propicdad se reducen insensiblemente á los delividuo, esto es, á la preservación de sus mujeres y de sus hijos; cua- lidades todas propias del hombre animal, tal vez en mayor grado que del hombre sociable (I).

De allí es, que ni la plebe procura evadir las usurpaciones diarias de los Eiguis, ni dejan de advertirse en las concurrencias de unos con otros aquella familiaridad, aquel cuidado común del alimento y aquella franqueza en la cesión de lo sobrante, que mal pudieran combinarse con las ideas de la tiranía y de la opresión. Cuando en la Descubierta, ó se repartió á Vuna y á las muchas personas de ambos sexos que le acompañaban una cantidad abundante de comida, ó tuvo aquel Jefe un asiento en nuestra mesa, se notó frecuentemente su cuidado para que participasen otros muchos de aquellas comidas; sus mujeres no cesaban de pedir, señalando indistintamente para estos regalos á cualquier plebeyo que se les aproximase: Feileua repetía sus viajes desde la cámara baja al alcázar siempre que le permitíamos llevar alguna cosa á sus inferiores: los mismos plebeyos, llegando la hora de la comida, dividían descuidadamente lo que tuviesen; y fué muy frecuente reparo entre nosotros, que á esta hora, aunque fuesen muy pocos los dueños de los comestibles, todos comían con la mayor alegría y unanimidad.

Esta reflexión del derecho casi universal sobre la plebe, de todo lo que sea relativo al alimento, no debe sin embargo considerarse extendiclo hasta los Eiguis, en los cuales hay un derecho de propiedad, así por lo que toca á los parajes cercados, como al trabajo de la plebe: en general, pudieran consiclerarse los límites de cada uno en los términos siguientes: los productos de la tierra son comunes, fuera de los parajes cercados, á los Eiguis y á los 'Tuas ó plebeyos; los cercados corresponden solo á los Eiguis, para su mayor recreo y más fácil subsistencia: su cultivo es fruto en mucha parte de los brazos de los Tuas, los cuales en desquite disfrutan de una especie de cesión generosa de todo lo sobrante de los Eiguis.

Los Tuas deben igualmente, sin premio alguno, contribuir al orden público con toda especie de trabajos personales; y éstos en los pequeños pueblos se dictan únicamente por los Eiguis; en toda la sociedad dependen, ó del Rey mismo, ó de los intereses de su voluntad. Los vestidos, las armas y las canoas, no deben tampoco causar

(I) El filósofo imparcial debe advertir en esta ocasión, que tnman un mismo semblante el tesón de los españoles en querer introducir sus principios religiosos y el de los ingleses en la introducción de sus principios sociales: en la violación ó repugnancia de los últimos, se hace aún más injusto el castigo de muerte, porque no precede como en aquéllos el semblante de la revelación, que apoya en cierto modo la necesidad de disipar con anticipación la barbarie. Cuántas declaraciones contra los pasos españoles en sus Américas se harían ridículas con una sola mirada á cstos datos comparativos de las nacinnes europeas' 
la menor codicia: sirven de entretenimiento estas manufacturas; y basta dar una ojeada á los adornos prolijos de las macanas, á la muchedumbre de las canoas y á la sencillez de los vestidos, para estar firmemente convencidos, que todos estos objetos deben mirarse con la mayor indiferencia.

La prueba ménos equívoca de la veleidad y ninguna codicia de estos naturales, clebe sin embargo, buscarse en el poco aprecio que manifiestan haber hecho de los efectos europeos. Ningún rastro se halló ahora en estas islas de las visitas del Capitán Cook, si bien debiesen recaer en Vuna todos los bienes del difunto Paulajo; y los mismos que habían cambiado nombre con los Oficiales ingleses y no habían olvidado circunstancia alguna de aquella época, apenas conservaban algunas cuentecitas de vidrio; ni áun contestaban con empeño cuando indagábamos el estado de los ganados en Tongatabu y Annamoka: los utensilios de labranza ó de las artes mecánicas, (pasado el furor del deseo) deben efectivamente serles poco necesarios y áun poco agradables; los adornos no pueden en modo alguno adaptarse ó á la sencillez de los trajes, ó á una cierta competencia con las flores que les ofrece la Naturaleza.

La ropa de abrigo si es útil un día, en otros muchos les es inútil, y la dificultad de guardarla debe causar su rotura inmediata. Finalmente, las armas nuestras no les parecen en modo alguno apetecibles, antes bien, en las pocas veces que nos vieron cazar, manifestaron una firme persuasión de las ventajas de las suyas, atento á los riesgos, ó de no encenderse la pólvora, ó de errar el tiro.

Con estos antecedentes, no debe parecer extraño que nos fuese difícil ó más bien imposible, descubrir cuáles eran las leyes penales relativas al robo, pues no siendo un delito entre los Eiguis, y siendo tan remoto como inútil entre la plebe, es probable que carezcan tal vez de ejemplos que hayan dado motivo á semejantes estatutos.

No así por lo que toca á los delitos correspondientes al adulterio y á la muerte alevosa: pudimos comprender, que aquél se castigaba entre los plebeyos con algunos palos; se expiaba con la muerte, si uno, ó de la plebe ó de los Eiguis subalternos, fuese el delincuente con la mujer de un Eigui, y al contrario, era una acción indiferente, ó para los Eiguis con la mujer de un plebeyo, ó para el Rey con las de entrambas clases. El solo individuo de la plebe es igualmente sujeto á la pena capital si quitase la vida á un Eigui: cuáles sean los castigos destinados en este caso á aquella clase, no nos fué fácil averiguarlo.

Ya en los párrafos antecedentes se ha heclio tantas veces memoria de la diferencia entre low Eiguis y los Tuas ó entre los principales y la plebe, que diferir por más largo tiempo las nociones adquiridas sobre este punto esencial de la subordinación, sería envolver al lector en una confusión de ideas difícil luégo á disiparso áun con digresiones bien largas: bien examinadas todas las ocasiones diarias, en las cuales debían naturalmente aclararse nuestras dudas sobre este punto, hallamos que en nada discrepan las nociones de los habitantes de las Islas de Vavao, de las que con mayor evidencia advertimos entre los Tahis y los Michimis de Nutka; esto es, que una clase se halla privilegiada con todos los goces de la vida presente y de la venidera; mientras la otra, confundida con los brutos, sólo es destinada á una vida servil en el mundo y á un total aniquilamiento después de la muerte.

Estos principios morales y religiosos, si bien absurdos en sí y en nada correspondientes á 1a nobleza del hombre y á la justicia del Supremo Hacedor de la Naturaleza, son, sin embargo, juiciosamente reunidos para no trastornar el orden público, particularmente en donde la educación respectiva de cada individuo y la más provecta organización de las leyes civiles no pueden enfrenar, como entre nosotros el libre albedrío de cada uno: la imaginación debe mirarse en la especie humana como el móvil de los razonamientos, así como éstos son el móvil de las acciones: vencida aquélla, es, por consiguiente, tanto más fácil ordenar cualquier sistema repúblico, cuanto ménos frecuentes son las ocasiones que puedan trastornarla con una influencia directa sobre los sentidos: así, el Tua de las Islas de los Amigos ya no considera en el Eigui supremo un tirano árbitro de su suerte al abrigo de la violencia y de la opresión, sino le mira como el Soberano y el Sacerclote, como un sér superior, como un semidios de la antigüedad, cuya existencia, cuyas acciones y cuyo fin están movidas y protegidas de una mano invisible y poderosa: de allí es, que los principios sociales, inalterablemente determinados desde el nacer de cada uno en la educación, en las ideas, en los hábitos y en el temple de la imaginación, logran otras tantas raíces que los hacen sólidos é inva"riables; de allí es que el Tua ve con la mayor indiferencia, que si son felices sus tretas para un robo, la prenda está destinada para el Eigui, y si son malogradas, aquel mismo Eigui le quita el único bien suyo, que es su propia vida; de allí es, finalmente, que la expiación de los delitos, la invocación de la asistencia divina, los lutos píblicos, la preservación de las leyes, todo estriba sobre los sacrificios de esta clase infeliz, la cual, sin embargo, persuadida de que así debe ser: ama á sus jefes, vive contenta y esperacon indi- 
ferencia su propia destrucción ó la privación de lo que le es preciso.

La comparación del Capitán Cook de estas leyes con las leyes feudales de nuestros antepasados, debe, por consiguiente, parecer muy poco adecuada; en cuanto el T'ua entre estos pueblos, se considera aún ménos que esclavo: esto es, como un verdadero bruto, cuya vida inútil para todo pende del solo capricho del Eigui.

Las clases de los Eiguis son, sin embargo, tan multiplicadas y guardan entre sí tal orden descendente, que no podemos creer que finalmente no se confundan casi con los Tuas: pero no sería fácil para nosotros determinarlas y mucho ménos definir sus funciones y autoridad, tanto más, que echamos muy á ménos una noticia esencial, y ésta es la de saber si la elección de los Eiguis, cuando falte alguno, dimana en primer lugar de la voluntad del Rey ó de la de los Tuas; y en segundo lugar, si recaiga sobre alguno de éstos (como en Nutka) ó sobre algún otro de las familias privilegiadas: hay positivamente una ley de sucesión ó de herencia, la cual entre una nación sana é inclinada á los placeres conyugales, puede hacer muy raras las ocasiones de necesitarse semejantes nombramientos; pero, en fin, las dos causas, de una guerra y del establecimiento de una población nueva, no pueden á ménos de dar lugar á esta especie de nom bramientos, cuya ley averiguada podrá producir en lo venidero una comparación ménos vaga de estas costumbres, con las de Nutka.

Entre tanto, podemos, sin embargo, asegurar, por lo que toca al respeto y subordinación de los Tuas á diferentes clases de Eiguis, que en la primera tarde de nuestra llegada el viejo Tubou explayó mucha autoridad sobre la plebe, hasta llegar el caso de detener un robo y de despedir á tierra todos los que nos incomodaban; siendo así que en los días siguientes llegó su temor del enfado y autoridad de Vuna hasta el término de manifestarme que le mataría si se atreviese á regalarme en presencia suya: al mismo tiempo Tufoa y los demás allegados á Vuna, nos aseguraban que la clase de Tubou era de las ínfimas; y efectivamente, todos los Oficiales que dirigieron la aguada vieron que su autoridad era sumamente limitada: al contrario, el joven Tufoa y un niño de solo ocho años, hijo de otro Tubou, que cambió nombre con D. Jacobo Murphy, ejcrcían tal autoridad sobre la plebe, que con la mayor indiferencia les arrojarían piedras para apartarla de uno ú otro paraje; y sin embargo, á la presencia de Vuna, particularmente en tierra, se sentaban con la muchedumbre $y$ apenas podían distinguirse entrc ella según el respeto y el porte de sus movimientos y acciones: Latú, ayo de Fileua é hijo de Javia sc humilló á nuestra ista delante de Tufoa; y siempre la autoridad de éste fué mayor sobre los 'Tuas que la de aquél: Javia, ó fuese por su genio ó por su rango, jamás desplegó á nuestra vista el menor rasgo de autoridad ni respeto popular en los bailes, en los cambios, en la corte á Vuna; en las concurrencias á bordo siempre parecía más bien un hom bre de la plebe que un hermano del Rey; muchos prestaban el homenaje público á la Tubou, hermana de Vuna y madre de Tufoa; y esta mujer, sin embargo, no podía conseguir que se desatracase una canoa para dejarla atracar con alguna decencia y comodidad. La vieja que nos visitó en la DescubierTa en el último día, era superior (según manifestó la etiqueta) á las mujeres de Vuna, hijas de Paulajo, y era inferior á Vuna, mientras éste se consideraba inferior á la madre de las Fatafegis. Pero los depositarios de la autoridad y de las órdenes de Vuna, los cuales probablemente sobresalían más por su robustez que por su nacimiento, manifestaron siempre, que la autoridad de este Jefe es ilimitada, áun cuando su clase reconozca otras; y Tufoa, Latu y Feileua manifestaron siempre un desprecio tan grande por los 'Tuas, que siendo admitidos á un trato más frecuente y familiar con nosotros, de modo que notasen á cada paso el servicio de nuestros criados y la obediencia de las clases inferiores, ya caracterizaban unos $y$ otros con el nombre de Tuas, pretendían ajarlos con vilipendio y poderlos echar de su presencia, con el sọlo motivo que les incomodaban.

Para no abandonar el orden propuesto, ya que hemos hecho derivar una parte esencial de la veneración de los Tuas hacia los Eiguis, de unos principios religiosos, es justo examinar cuáles son estos principios, debiéndonos ceñir en esta ocasión á los informes del Teniente de navío Don Ciriaco Cevallos, el cual por su perspicacia, constancia y nimiedad en las preguntas, y por su amistad bien oportuna con Mafi, Eigui de Tongatabu, puede con mucha razón apellidarse nuestro Anderson y exigir que se copien á continuación sus mismas palabras.

"Nadie (según Mafi) parió ni creó el Sol, la Luna ni las estrellas; estos cuerpos existían de toda eternidad tal como los vemos, pero sin sujeción á un orden regular en su movimicnto; tan pronto se apartaban á distancias inmensas, como se chocaban entre sí: la tierra, cubierta por to. das partes de una masa profunda de agua, estaba desierta, cuando repentinamente salieron del seno de las sondas todas las islas conocidas: sobre la más privilegiada de todas Tonga, aparecieron un hombre y una mujer singulares, Molum Atonlia y Tanha-Quina. Estos dos padres de cuanto tiene vida y movimiento, estaban sujetos á todas las necesidades y á todos los males de nuestra naturaleza: la necesidad les forzó á surcar las aguas y á cultivar la tierra; hicieron 
la primer canoa y los primeros útiles de pesca; cogieron las primeras rimas y los primeros plátanos: no hay instrumento cuya invención nose les deba, así como no hay planta cuyo germen no esparciesen sobre la tierra.

"Si Molnun Atonha y Tanha-Quina partieron con los mortales todas las miserias de su existencia, gozaron también los únicos placeres que pueden hacer esta existencia soportable: el primer fruto de su amor fué una mujer hermosa (Coloafu Tonha) que en el instante de nacer voló á los cielos, y tomando las riendas del Universo, sujetó á leyes invariables y eternas el movimiento de los astroṣ: su residencia ordinaria es la Luna, desde donde preside á todas las obras de la Naturaleza, manda los elementos y dirigc el destino de los mortales: al nacimiento de Coloafu Tonha sucedió el de otros seis dioses, todos ministros de su poder y que tienen á su cargo otros tantos ramos de la Creación. La relación entre el poder de estos dioses y el de Coloafu Tonha, no puede asignarse: pero como quiera que dejen algunas veces sus mansiones y metamorfoseados en pájaros ó bajo formas invisibles vaguen por los aires y desciendan á las islas, los Eiguis en consecuencia de estos principios les preparan casas que ningún mortal puede habitar y cuyo número y magnificencia son conformes al poder y clevoción de cada uno.

"El tiempo fué debilitando las virtudes productivas de Tanha-Quina: después del último dios nació el primer hombre, y muertos finalmente Mohun Atonha y Tanha-Quina, subieron después de morir á la Luna, donde gozan de una autoridad pasiva, siendo respetados de los dioscs sus hijos, pero sin influir nada en el orden del Universo.

"La cava es el único nutrimiento de Coloafu Tonka, á quien la sirven los dioses inferiores: esta diosa, la más bella criatura que ha existido ni puede existir, tiene una lengua proporcionada á sus otras facciones; pero cuando quiere la dilata y extiende desde el cielo hasta el mar, donde por su medio bebe la cava: casi todos los naturales nos aseguraron haberla visto, y de donde pudo inferirse que confundían las trombas marinas ó algún otro fenómeno natural, con la lengua de su diosa.

"No han sido con mucho igualmente extensas las nociones adquiridas sobre la inmortalidad del alma y su suerte vcnidera. Paulajo (según Mafi) se halla en la Luna, y Vuna allí ha de cncontrarse con él; pero los Tuas tienen precisamente el mismo fin de los brutos; y su muerte física es el total aniquilamiento de su existencia $(\mathrm{r})$.

(I) Véasc cuánto se asemejan estos principios religiosos á los admitidos en Nutka.
"Después de estos principios, nada extraños deben parecer á nuestra vista los diferentes rasgos que á cada paso se nos ofrecieron de las costumbres de estos pueblos: los templos ó Tale Otuas podían distinguirse fácilmentc de los sepulcros ó Tia Tukas; y éstos solo estaban destinados para los Eiguis: los Tuas, al contrario, se consideraban como las víctimas destinadas para el holocausto, siendo así que casi eran felices al verse en esta parte confundidos con el puerco y con las plantas, y que no titubeaban en confirmarnos con bastante indifcrencia la realidad de estos sacrificios humanos; y si no es poca la repugnancia con la cual se aproximan todos á un sepulcro, tal vez los despojos de un alma que ya goza de mejor suerte y puede influir cn las cosas humanas con un poder semejante al de la Divinidad, son á lo ménos iguales, si no son superiores las muestras públicas y materiales de su dolor y de su respeto: ya advirtieron los ingleses que los árboles distinguidos por los naturalistas con los nombres de Casuarina Equisetifolic y Elate anuncian siempre la inmediación de un Tia Tuka; advirtieron también con mucha propiedad hasta qué grado son aflictivas estas muestras, ó ya haciéndose algunas cortaduras sobre las carnes, ó golpeándose con piedras en diferentes partes del cuerpo, ó acompañando con suspiros y con la voz correspondiente de of á estas pruebas nada equívocas de su dolor, ó finalmente, decidiéndose con la mayor indiferencia al corte del dedo pequeño de la mano. Relativamente á esta última costumbre, nosotros hemos podido individualizar algo más sus límites verdaderos, y se reducen (con mucha probabilidad) á que la muerte del padre exige este sacrificio de parte de todos los hijos; la de la madre lo exige solamente del hijo menor, y la del Rey, de todos los vasallos sean Iiguis ó Tuas; basta en cualquiera de estos casos cortar una sola coyuntura; al tiempo de enterrarse el cadáver se echa en la fosa el trozo cortado y la operación debe parecer bastante penosa cuando se considere quc entre nuestros efectos de cambio dieron siempre preferencia grande á los cuchillos, sólo porque consideraban que les sería más fácil en lo venidero el corte del dedo.

"No siempre, sin embargo, es esta una prueba de luto ó duelo por la pérdida de los padres ó del Rey; ó digámoslo así, no es esta una etiqueta limitada solamente á las circunstancias indicadas: la expiación de un dclito ó la invocación de la Divinidad suelen cxigirlo á veces, bien que no debe ser ésta sino una acción librc á cada uno, pues que las víctimas, ó humanas ó de los animales, serán siempre las que representen las preces de toda la sociedad."

Determinados de cste modo los principios religiosos, y refundida en los Eiguis y particular- 
mente en el Rey, la autoridad y el respeto que de ellos dimanan, no es ménos fácil fijar los demás puntos de la legislación, de lo que lo hayan sido los derechos de la propiedad: si se excluye naturalmente del derecho del hombre la parte más numerosa de la sociedad, ya el gobierno público se reduce al gobierno de una sola familia en la cual los intereses son comunes y dignos de una atención particular; es igual y ménos rústica la educación; finalmente, son más frecuentes los enlaces y la comunicación recíproca de unos con otros. Este es precisamente el caso en el cual se hallan los habitantes de las Islas de los Amigos: y si son (como parece muy probable) fundadas las sospechas de D. Ciriaco Cevallos sobre el ser la bebida diaria del cava la representación de un dogma teórico de su creencia, renovada siempre con la misma solemnidad y á las mismas horas y siempre presidida por un Jefe, no hay duda que este recuerdo frecuente del influjo de una autoridad divina sobre las cosas de la tierra, debe arraigar muy mucho las ideas del orden y de la subordinación, contribuyendo últimamente á que se conserve el ánimo alegre y la salud robusta.

En la sucesión legítima de la familia reinante $y$ en su no interrumpida descendencia desde los dioses, se advierte aún más el encadenamiento feliz del sistema que examinamos actualmente. Según los naturales, el Imperio de este Archipiélago cuenta tanta antigüedad como el mundo: Tuguloto tuvo dos hijos que lo repartieron entre sí; pero esta división parece que duró poco tiempo, pues Potulaje reunió en su persona todos los derechos del primer Emperador: no ha habido después otro desmembramiento del todo de la Monarquía, sino el que dimanó de la revolución de Tutafile en dos islas llamadas Niuas, no sin sostener una guerra obstinada y cruel contra su señor legítimo, y estas islas se conservan aún separadas, mandándolas en el día Mahatu, descendiente de Tutafile: Vuna, cuando respondía á esta especie de preguntas, siempre se revestía de un aire noble y grandioso, y con la majestad correspondiente, nos explicaba que Mariagüy, él y Feileua dimanaban del cielo directamente, y el nombre de los Fatafegis anexo á la corona y la serie de los reyes conservada en una época bien larga, confirman este principio con el testimonio de los Sres. Cook y Anderson.

No es fácil, sin embargo, en el día combinar con exactitud la descendencia, después de la grande revolución que tuvo lugar entre estos pueblos hacia el año de I784. Paulajo, á quien había conocido el Capitán Cook en Happai y Tongatabu, fué destronado y muerto por una conspiración tramada entre Vuna, Monmuy y Tubou, mu jer del mismo Paulajo. Los conspiradores saIrcron de l'onga con unas 20 piraguas grandes, abordaron las Islas de Annamoka y de Happai, las cuales sujetaron después de muchos combates: de Happai pasaron á Vavao, donde Paulajo los recibió á la cabeza de sus gentes; hubo un choque, el cual terminó con la muerte de éste á manos de Vuna, después de haber peleado estos dos caudillos cuerpo á cuerpo: inmediatamente huyeron los del partido, quedando así todo sujeto á los conspirados: Vuna fué declarado Rey de Vavao; su hijo Tubou-Toa, de Happai; Monmuy, de Tongatabu, y su hijo Coloucala, de Eüa. Fatafegi, que heredaba todos los derechos de su padre Paulajo, huyó de Tonga, donde hizo partido y se opuso Monmuy, de quien fué segunda vez derrotado; llevándole, finalmente, su suerte desgraciada á ser asesinado, según algunos, y según otros á vivir confundido con la última plebe en Tongatabu: no hubiera sido posible descifrar con individualidad el pormenor de esta grande revolución sin el auxilio del astuto Mafi, el cual la detalló con toda claridad á D. Ciriaco Cevallos, añadiendo que él había sido de los conspi. rados, pero sin haber podido asistir á la guerra de Vavao porque recibió antes en Happai tres heridas, cuyas cicatrices enseñaba, y de cuyas resultas perdió un ojo: todos los demás evitaban cuidadosamente estas conversaciones, inventaban mil novelas contradiciéndose á cada paso sobre los derechos de Vuna y Feileua al trono, y dieron lugar en los primeros días, á que inadvertidamente yo presentase á la hija de Paulajo el retrato de su padre, inserto en las láminas del tercer viaje del Capitán Cook; vista que no pudo ménos que chocarle y excitar en su rostro todas las muestras de un verdadero amor filial, recordándole el fin trágico de su vida á manos de su marido á la sazón presente.

Contribuía sin duda bastante á multiplicar la variedad de estos informes el aprecio que hacíamos de los Eiguis y particularmente de cuantos tuviesen alguna conexión con Vuna; y fué un accidente bien natural, pero no ménos ridículo, que aumentase el número de las madres de Feileua á medida que aumentaba nuestro cariño hacia este joven; de modo que contándose ya tres, según las noticias adquiridas, todavía, sin embargo, nos quedase la duda, si l, era realmente alguna de ellas.

El examen atento de la verdadera ascendencia de Feileua (en cuanto pudo deducirse de la mejor combinación de las noticias guiadas sienpre por las de Mafi) parece justificar en mucha parte los pasos de Vuna en sus esfuerzos para alcanzar el trono; debiéndose, por consiguiente, inferir que más bien convenia á Paulajo el título de usurpador, de lo que convenga á los que movieron y llevaron á feliz término la conspiración indicada: Mariagüi y Tubou (entrambos conocidos por el Capitán Cook en Tongatabu, y el 
segundo por el Comandante Maurelle en Vavao) eran efectivamente hermanos: fueron hijos del primer Monmuy, Rey actual de Tonga, Tubou, viuda de Paulajo, actualmente visitada por Don José Bustamante en Leyafú y Tuyalafatai, ya muerto años hace en Torıa; los hijos de Tubou, fueron Vuna, Rey actual de Vavao, Xavea segundo Jefe, y la Tubou Filumanumá, viuda de Tuyalafatai y madre de Tufoa: han sido luégo los frutos del matrimonio de Vuna con las dos Fatafegis, hijas de Paulajo, primeramente Feileua, Principe heredero de Vavao, Happai y Annamoka, y luégo otros dos niños igualmente recomendables por sus gracias y viveza: es probable, que TubouTua, Eigui actual de Happai y Annamoka, si bien hijo de Vuna haya perdido por la madre los derechos al trono y sea más bien un Virey, hasta que la edad más adulta de Feileua lo reduzca insensiblemente á la clase de particular: de este modo á lo ménos podemos combinar las aseguraciones de todos, de ser extendidos los derechos de Feileua hasta Tongatabu y de ser infructuosos para los de Annamoka los cambios que allá hiciésemos después, porque muy luéso pasarían á manos de Vuna en la visita que ahora proyectaba á aquellas islas: á lo ménos á este intento de conducir las personas reales había venido el Comandante Mafi con su doble canoa, y seguramente si su pericia marinera corresponde á la fidelidad y al valor de que ha dado á Vuna tamañas pruebas y á la penetración que ha explayado á nuestra vista, merece con justa razón todas las distinciones con las cuales le favorecía aquel soberano siempre que lo encontraba: á pesar de las aseguraciones de Vuna, yo no creeré, sin embargo, que se extiendan ni su autoridad, ni mucho ménos los derechos de Feileua á las Islas de Tongatabu y Eüa: deben éstas ser el patrimonio preferente de Mariagüi; permanecer sujetas á sus descendientes Monmuy y Coloucala, y por consiguiente quedar divididas de la Monarquía hasta que algún nuevo enlace de una con otra familia las reuna en un solo soberano con las Islas de Vavao.

Pero áun mientras permanezca esta división, y mucho más cuando algún acaso la destruya, parece probable que durará por largo tiempo una paz tranquila entre la confederación, de suerte que puedan muy luégo restaurarse, particularmente en Annamoka, los daños de la última guerra, y estos naturales merecen al mismo tiempo el justo apellido de amigos y la felicidad que la Naturaleza les ofrece con la prodigalidad de sus dones.

Dejaremos á la excelente pluma del Capitán Cook y á su nimiedad filosófica el describir uno por uno los utensilios domésticos, los útiles para la pesca, la caza y la guerra, la calidad y construcción de sus casas y canoas, la amenidad y orden de sus cultivos, la fertilidad de sus tierras, la excelencia de sus frutos, las ocupaciones diarias del uno y el otro sexo, las enfermedades que los acosan, las diversiones que los entretienen y las diferentes especies de animales que dividen con ellos una tranquila subsistencia en estas islas felices: la traducción literal de aquellos párrafos será siempre el medio más seguro de no faltar ni á la elegancia, ní á la claridad, ni á la verdad; y así limitaremos ahora la continuación de estos apuntes, á aquellas circunstancias que miradas por nosotros ó en diferente época, ó en unas ocasiones más favorables, nos hacen discrepar algún tanto de las narraciones de aquel navegante.

El número de los habitantes del Archipiélago de Vavao fué considerado por el Comandante Maurelle de unas I 5.000 personas próximamente: nosotros, atento á las concurrencias que pudimos advertir á un mismo tiempo en el fondeade: io, en la aguada, en los parajes visitados por los Sres. Robredo y Bausá y en la excursión de Don José Bustamante, y suponiendo una cortísima población en la isla de Late que reconocimos á muy corta distancia, no pudiéramos extendernos sino á un número menor de una tercera ó cuar.a parte, en el cual, sin embargo, con mucha extrañeza nuestra, no puede considerarse una porción correspondiente de párvulos y de ancianos.

Esta especie de contradicción de la Naturaleza es tanto más extraña en estas islas, cuanto que la robuste $z$ de sus habitantes y todas las demás circunstancias que concurren á hacerlos felices, deberían sobresalir especialmente en una vida larga y en una rápida multiplicación de su especie; sus alimentos son tan sanos, que compuestos por la mayor parte de sustancias farináceas, sazonados por la misma Naturaleza y modificados comunmente por ellos con la fermentación agria, manifiestan sus efectos no ménos con el. razonamiento que con la experiencia; oportunamente el agua del coco y la caña dulce les sirven de un suave y agradable diluente, al paso que no les hacen necesario el uso del agua común, siempre algo mezclada en estas islas con partículas térreas y salinas: no precisados ni por la ambición ni por la necesidad á un trabajo asíduo y violento, pueden evitar igualmente los ardientes rayos del Sol y los tiempos fríos y lluviosos: la poca distancia á la equinoccial, jgualando casi la división del día en todo el año, concurre maravillosamente á que sean uniformes las horas de la vigilia y del sueño y á que las dirija según las leyes de la Naturaleza el as. tro que vivifica y conserva todo su sér y sus adornos: finalmente, la mansedumbre y la tranquilidad de ánimo, haciendo casi un contraste harmónico con la veleidad, con la soltura y con el instinto alegre que los acompanan, dictan uná 
muchedumbre de ejercicios entretenidos, en los cuales se enlazan casi con emulación el cuidado y el sosiego, la actividad y el reposo, el ansia de sobresalir á los demás y el deseo de no desprenderse de un verdadero amor fraternal.

11 poco abrigo y al uso inmoderado de los placeres conyugales, debe por consiguiente atribuirse, en mi entender, esta no proporcionada duración de la cspecie, confirmándose desde luego esta sospecha con la mayor falta de viejos entre los hombres, de la que se note entre ias mujeres; y con una, aunque mediana atención á la clase de alojamientos y camas de las cuales usan reneralmente: son éstos sumamente desabrigados, como lo denotan nuestras vistas y como lo describió ya con la mayor indiviclualidad el Capitán Cook; ni la estera ó biombo interno que debe abrigarlos del viento horizontal cuando duermen, puede compensar la falta de techo propio que impida la comunicación con el aire externo, áun cuando èsta especie de comodidad pudiese ser general y no fuese limitada ó á los solos Eiguis ó más bien á un pequeño número de ellos: en las noches muy bien templadas del invierno tampoco puede ser saludable dormir en el suelo, ni pueden suministrar bastante abrigo pocas esteras por lo común usadas, cortas y de un mal ajuste al andar del cuerpo: estas incomodidades á las cuales fácilmente se acostumbra el joven, no dejan por esto de influir considerablemente en el hombre anciano, hasta el caso de acelerar su destrucción unas veces con una total falta de transpiración y otras con el ingreso de las miasmas pútridas que los rodean.

Es, á la verdad, bien extraño para el que tenga á la rista las diferentes muestras de la igudeza y talento de los naturales, verlos después tan poco industriosos, relativamente á esta parte esencial de su conscrvación: el hábito puede sólo justificar scmejante descuido y el que se confundan tal vez las demandas naturales de la última edad, con las que suelen entre los jóvenes llamarse vulgarmente impertincucias del vicjo.

Pero no debe mirarse ésta sino como una causa secundaria del corto término de la vida, cuando se compare al uso inmoderado de las mujeres: los Eiguis, particularmente, con la libertad dc poder extender hasta cuatro el número de sus mujeres y con los muchos atractivos con los cuales han sido éstas favorecidas de la Naturale»a, ni dejan de aprovechar la edad áun más jóren, ni de imaginar después todos los recursos que puedan multipiicar los placeres del himeneo: en los intervalos de la noche se siguen en un órden inalterable la vigilia, la comida y el sueño, éste últino incitado siempre y luégro conservado por largo tiempo con la singular operación del toquitoqui, de lá cual están encargadas únicamunte las mujeres: la duración de la noche debe precisamente dar lugar á que se renueven estos turnos, y la fidelidad conyugal no puede á ménos de desearlos y promoverlos: cuando aseguremos que el número de las mujeres nobles de Vuna no era menor de doce, además de las plebeyas que pudiesen excitar su antojo; cuando se atienda que entre aquéllas las dos Fatafegis y otras dos le acompañaban diariamente, no debe extrañarse que con la sola edad de unos cuarenta y cinco años, ya se hallase casi ciego y con muestras evidentes de una estupidez dimanada de la laxitud de las fibras: mis chanzas en este asunto cuando á bordo solía repentinamente rendirse al sueño, no le eran de modo alguno desagradables, y sus respuestas, sin desentenderse de un más que mediano grado de pudor, no dejaban, sin embargo, de confirmar mis sospechas.

Al mismo tiempo, si debemos en esta especie de reflexiones seguir ciegamente los pasos de la Naturaleza en la manutención y acrecentamiento de todos sus productos, podemos hallar en los mismos inconvenientes que acaban de indicarse, la principal causa del estado floreciente, al cual alcanzan hasta una cierta edad todos estos naturales; sin atrevernos á contradecir lo que advirtió en esta parte el Capitán Cook por lo que toca á los habitantes de Happai y Annamoka, no podemos á ménos de ensalzar mucho la estatura y las bellas proporciones del mayor número de los de Vavao, hasta poderlos asemejar á los que habitan las islas no distantes de los Navegantes, según la excelente idea que de ellos ha dejado el Conde de la Péyrouse entre los ingleses del puerto Jackson.

La no proporcionada cantidad de párvulos, particularmente si se atiende á la robustez y a número de las mujeres, no debe al contrario parecer tan extraña: hay positivamente una ley entre estos pueblos, que previene la muerte de algunos niños, sin que podamos sin embargo prefijar si esta ley se entiende á todos los que sigan al cuarto hijo (como lo manifestó Mafi en la corbeta ATREvidA) ó si, como repetidas veces nos lo explicó Latu en la Descubierta, son el quinto $y$ el noveno solos los destinados á muerte, cualquiera sea el sexo, no sólo de estos niños, si también de los otros que les preceden.

Esta ley por sí sola no sería tan nociva, respecto al número ya bien crecido en el cual empieza á tener vigor, si no produjese de antemano indispensablemente una cierta cruel indiferencia de los padres hacia los hijos: indiferencia que puede muy bien hacerles anticipar ó prolongar este abuso, siempre que haya ó una incomodidad grave ó tal cual dificultad en la subsistencia propia.

I a edad de doce años es comunmente entre los hombres la que parece destinada á emprender la vida conyugal: Tufoa y Latu tenían ya 
dos ó tres mujeres cada uno: según ellos, Feileua no esperaba sino aquella edad para conseguir igual suerte; no nos fué posible comprender si había alguna persona ya destinada para este enlace, ó si dependería únicamente de su gusto la elección de sus mujeres: aunque lo advirtiese con mucho tino el Capitán Cook, y que la narración de nuestros acaecimientos lo confirme á cada paso, no dejaremos de disipar aquí de nuevo la errada idea de que en estas islas sea fácil y general la prostitución de las mujeres: muchas veces nos ha manifestado la experiencia que los ofrecimientos de Vuna y de los demás Eiguis se reducían á las solas plebeyas, así como los halagos y las caricias de las más jóvenes y distinguidas, no tenían otro móvil, que una mezcla de hospitalidad, de franqueza y de interés: áun en las primeras muestras de aquel instinto recíproco ( $\mathrm{x}$ ) que atrae el uno al otro sexo, distinguieron siempre (para no prodigarlas) las que en su sentir eran ménos equívocas é indiferentes: jamás procuraron atizar nuestros deseos con movimientos lascivos; jamás insultaron nuestras repulsas, ó con el vilipendio de una insensibilidad natural, ó con las quejas de las voces ultrajadas de la naturaleza: conocían una ley que ponía freno al instinto; la hallaron en nosotros y no la extrañaron, y últimamente, se manifes taron ufanas de desplegar á nuestra vista con el hermoso semblante de la inocencia, aquellas mismas ideas que entre nosotros apenas pueden conservar la educación, la religión y la disciplina.

No es mi ánimo encarecer en esta ocasión los diferentes adornos que contribuían con su hermosura á causar nuevo brillo al carácter indicado: parecerian estas pinturas tan violentas para el navegante, como enfáticas para el viajero; se confundirían el filósofo y el poeta, tal vez se caracterizaría por ignorancia ó por demencia la sola idea de una virtud natural que enseña á moderar las pasiones y á sujetarlas á los dulces lazos de la sociedad; pero no podré á ménos de reunir en un solo punto de vista aquellas gracias que son comunes á todas, y que deben naturalmente hacernos envidiará los que tengan en lo venidero ocasiones más oportunas de contemplar en este cielo feliz la Naturaleza

(I) El lector comprenderá que esto alucle á aquellos versos del Car. 'Guarini en su Pastor Fido.

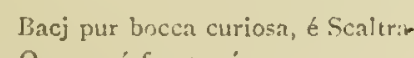

Ni debe hallar ó importunas ó poco modestas estas noticias, cuando tienen por objeto el vindicar la modestia y el pudor, representándolas como una propensión natural del alma y no como un antídoto violento:

De la legge aurea, é felice

Che natura scolpi; s'ei piace ei lice. vestida de sus más bellos adornos: las bodas de Feileua serán sin duda una ocasión de esta especie: entonces se desplegarán á la vista del filósofo viajero la honestidad medio desnuda, la sensibilidad $\sin$ educación, la subordinación $\sin$ castigo, el respeto sin mengua de la alegría; la felicidad sin envidia y la suerte del hombre combinada con la religión, con el instinto, con los principios sociales y con todos los adornos de la Naturaleza: ;felices habitadores si no oscurecen una escena tan lisongera, con el sacrificio lúgubre de las víctimas humanas, si reconocen en la Divinidad el Padre de la Naturaleza, el centro de la paz y el Arbitro justiciero del rayo, del temblor y de los límites del mar; felices finalmente nosotros si entre los cantos enérgi$\cos (\mathrm{I})$ que les dictará una natural alegría en aquella ocasión, recordaran con afecto y sin el menor. sobresalto el nombre español: y en las semillas ya multiplicadas, en los utensilios útiles para sus usos domésticos, en los adornos inocentes con los cuales se diśinguirán los novios, hallaran otros tantos rastros de una visita no entulbiada con la mengua de las costumbres ni con la destrucción de sus semejantes!

La cantidad de las provisiones que hemos hallado no ha sido correspondiente á las ideas que teníamos anteriormente formadas, á lo ménos por lo que toca á los dos ramos esenciales de gallinas y puercos: difícilmente pudiéramos suponer que haya quedado siquiera una mitad de lo que nosotros hemos adquirido y cuya cantidad no debe considerarse mayor de unas 500 gallinas y 60 puercos entre las dos corbetas: de estos últimos vimos venir al mercado los más grandes y los más chicos; vimos cruzarse las canoas en busca de uno ú otro á los parajes más distantes; vendieron hasta las hembras preñadas, y seguramente la codicia de las hachas les hubiera movido á cualquiera diligencia y á cual. quiera sacrificio para su adquisición: las frutas, las raíces y los limones parecían más bien in. agotables; y esta sola abundancia bastaría para convidar al navegante á estas orillas, particular * mente cuando un corto número de buques na. vega de los mares del Asia hacia la América meridional: no desmenuzaremos con un detalle importuno los efectos más útiles de cambio: las hachas y la ropa serán siempre de una utilidad real: lo serían aún más que aquéllas, nues. tros machetes de la Nueva España; pero por lo que toca á los adornos mujeriles, debemos avisar que podrán desde luego satisfacer un antojo momentáneo, mas nunca serían un suficiente incentivo para la cesión de las cosas más útiles.

(I) Con mucha razón suponen los Sres. Cook. Foster y Anderson, que las poesias que son entre estos pueblos el objeto del canto, sean sumamente ex. presivas y siempre adaptadas á las circunstancias. 
Terminaremos este capítulo con dos reparos que merecen verdaderamente la atención del filósofo cuando quiere reflexionar con madurez sobre sus semejantes; y son, el primero la atención con la cual entre estos pueblos se saluda á todo Eigui al tiempo de estornudar, usando oportunamente del mismo modo que nosotros, una voz destinada sólo para el intento, y es la de Seifuć; y el otro la familiaridad y frecuencia con la cual ejecutan el juego nuestro de la morra. No desdeñaba Vuna en confundirse en estas ocasiones con los Eiguis; y no bien empezaba una, cuando se veían instantáneamente otras muchas parejas ocupadas con el mismo entretenimiento. Estos datos esenciales de un mayor grado de civilización, de una semejanza de costumbres á las nuestras y particularmente del rastro de una ceremonia que es entre nosotios de origen desconocido, podrán tal vez aproximar la historia del hombre con datos ménos equívocos de los que se han usado hasta $\operatorname{ahora}(\mathrm{I})$.

(I) Un mayor despacio dará lugar á ordenar algo mejor estos apuntes y á comprender entre ellos todo lo que ha escrito el Capitán Cook y conviene con nuestras propias observaciones. Los razonamientos sobre las monzones pertenecerán á la práctica de la navegación. 


\section{VIAJE DE DON JOSÉ DE ESPINOSA Y TELLO desde Cádiz hasta Acapulco, donde se reunió á la expedición de las corbetas Descubierta y ATREvida, y contimación de este viaje. Contiene mu buenas noticias de Historia Natural. Geografia, costumbres, etc.}

Hallándome en Sevilla disfrutando de Real licencia en Abril de I790, recibí un oficio del Capitán General de la Armada con fecha I3 de aquel mes, en que me prevenía haber resuelto Su Majestad el 6 del mismo que pasase á Méjico para embarcarme en Acapulco en la expedición de las dos corbetas Descubierta y Atrevida, que habían salido de Cádiz el año anterior destinadas á dar la vuelta al mundo. Para cumplir esta soberana resolución, me trasladé inmediatamente al Departamento de Cádiz; pero como á la sazón se armasen allí varios buques sospechándose un próximo rompimiento con la Inglaterra, hice representación al Rey ofreciéndome á este servicio de mayor mérito y preferencia que el de la expedición de la vuelta del mundo, y habiendo remitido la instancia al señor Capitán General, recibí por su mano el I4 de Junio la contestación siguiente:

"E1 Sr. D. Antonio Valdés me comunica la siguiente Real orden con fecha 8 del corriente, que traslado á $\mathrm{V}$. para su gobierno y enl respuesta á su representación de $28 \mathrm{del}$ antecedente.Excmo. Sr.: El honroso deseo de permanecer en ese puerto para emplearse en el actual armamento, que manifiesta el Teniente de navío D. José de Espinosa en la representación que V. E. me dirige con carta número 734 , es muy propio del celo que tiene acreditado: le es á S. M. apreciable; pero considerando que no será de menor recomendación el mérito que contraiga en la expedición destinada á dar la vuelta al mundo, es su Real voluntad vaya á Acapulco á embarcarse se gún está mandado: 10 que advierto á V. E. para su gobierno y á fin de que lo comunique á Es pinosa."

A consecuencia de esta soberana determinación y de la de que me embarcase prontamente para Veracruz en compañía del Teniente de navío D. Ciriaco Cevallos, nombrado también para la propia expedición, se trató de nuestro embar. co en la fragata del comercio Santa Rosalia, perteneciente á D. Miguel Caraza. Detuvímonos algún tiempo á causa de varias dilaciones del dueño del buque; pero al fin dimos la vela del puer- to de Cádiz el 25 de Noviembre en la mañana, con viento flojo del Nurte.

Entre varias obras nuevas, almanaques náu. ticos y otros papeles que acababan de publicarse en Europa y podrían necesitar las corbetas durante su largo viaje, puso á nuestro cuidado el Capitán Comandante de las Compañías de Guardias Marinas D. José de Mazarredo, los relojitos

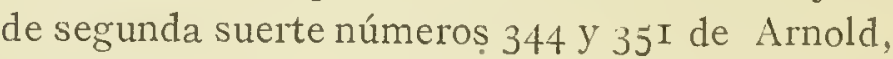
que pedimos á dicho Jefe considerando la mucha utilidad que podían rendir estas máquinas en nuestra expedición. Conducíamos asimismo un péndulo simple constante, construído de intento, que remitía el Ministerio para que se hiciesen experiencias sobre la gravedad, en todos los 1ugares donde se detuviesen algún tiempo las corbetas, y como estas experiencias tenían por objeto el poder comparar y ligar los resultados de la expedición con los que hallasen los Académicos franceses en el paralelo de $45^{\circ}$ Norte, pues se trataba entonces de arreglar en Francia un nuevo sistema de pesos y medidas, derivado de la longitud del péndulo que oscilase segundos en la latitud de $45^{\circ}$, nos fué sumamente doloroso el que los pocos días que mediaron entre la llegada del péndulo á Cádiz y nuestra salida, no nos permitiese hacer en aquel puerto las experiencias que deseábamos.

El 27 nos alejamos del saco de Cádiz, haciendo rumbos del Oesuoeste y Oeste, aprovechando con toda fuerza de vela el vientecito flojo del Norte y rumbos próximos con anuncios bien claros de vendabal, el cual lo tuvimos con efecto el 29, aunque de corta duración, pues el 30 ya vol. vió á entablarse al Nordeste calmoso con carices bonancibles, rolando al Este y acrecentando más su fuerza al paso que bajábamos de latitud.

Resueltos á no ver las Canarias ni otro puntn a lguno, sino navegar en derechura á la Isla Española por la derrota más próxima, cortamos el 6 de Diciembre el meridiano de 'Tenerife por latitud $30^{\circ} 40^{\prime}$, en cuyo punto había retardado la estima $\mathrm{I}^{\circ} 4 \mathrm{O}^{\prime}$ sobre la longitud observada. Estc atraso fué aumentando en razón del tiempo hasta que el 25 llegó á ser de $4^{\circ} 50^{\prime}$ corriendo el para- 
lelo de $20^{\circ} 40^{\prime}$. Aquí ob ervamos la variación de la aguja $2^{\circ}$ al Nordeste.

Navegábamos tan asegurados de nuestra posición con el auxilio de los relojes, que dirigimos la recalada á Cabo Cabrón por el paralelo de $I 9^{\circ} 30^{\prime} ; y$ en efecto, le avistamos á las siete de la mañana del 3 I de Diciembre, demorando al Sur $3 I^{\circ}$ Este y Cabo lrancés al Sur $6 I^{\circ}$ Oeste corregido distancia de cuatro leguas.

Desde el medio día del 30 hasta la hora de esta marcación, tuvimos $20^{\prime}$ al Norte de la estima, y nos acercamos, por consiguiente, demasiado al Bajo de la Plata, lo que debe servir de prevención para tomar rumbo más Sur en otra ocasión. Costeamos la parte Norte de Santo Domingo, favorecidos siempre del viento fresco del Este que no nos desamparaba desde el meridiano de Canarias, y el 7 de Enero marcamos Cabo de Cruz de la Isla de Cuba, que resultó en longitud de $71^{\circ} 39^{\prime}$ al Oeste de Cádiz, según la observación que hicimos con el 344 referida á dicho Cabo.

En toda la navegación por el Sur de Cuba experimentamos corrientes muy vivas, y la noche del 8, á las $10^{\mathrm{h}} 45^{\prime}$, nos hallamos de repente sobre el Caimán Chico, que felizmente montamos cerrando el timón á la banda y orzando de seis á siete cuartas. Corríamos su paralelo considerándonos todavía lejos de dicha isla; pero como nos manifestó después el reloj, estábamos 21 millas más Oeste de lo que juzgábamos, y el Caimán se halla I2 más al Este de lo que lo sitúan las cartas, de modo que lo vimos debajo de la proa cuando le considerábamos á 33 millas. Por nuestras observaciones, queda ahora situado en latitud Norte $19^{\circ} 40^{\prime}$ y longitud Oeste de Cádiz $73^{\circ}$ $25^{\prime} 30^{\prime \prime}$.

El Io del mismo mes por la tarde, avistamos la tierra, y siendo muy baja y de arboleda, la tomamos por Cabo San Antonio lo más occidental de Cuba, que demoraba al Norte $1 / 4$ Nordeste corregido distancia cinco leguas.

Continuamos al Norte $70^{\circ}$ Oeste del mundo en vuelta de la sonda de Campeche, y el I I al medio día observamos $2 \mathrm{I}^{\circ} 52^{\prime}$ de latitud. El cielo se cubrió de celajería espesa, y empezó á ventar duro por el Norte con mucha mar y lluvia muy copiosa. A las diez de la noche nos considerábamos en sonda, y lo anunció además el hervidero de las corrientes, que á pesar de lo fresco del viento Norte no permitían gobernar á la fragata. E1 I2 observamos la latitud $22^{\circ} 29^{\prime}$ y la estima era á la misma hora de $22^{\circ} \mathrm{I} 9^{\prime}$. Desde el paralelo de $22^{\circ}$ corrimos al Oeste corregido con viento duro del Norte. Al amanecer gobernamos más Sur, y á medio día nos hallábamos en $21^{\circ} 48^{\prime}$ de latitud por estima y por observación. Ultimamente, el I 5 á las nueve de la mañana estábamos en el veril occidental de la sonda que según nues- tras observaciones reducidas á medio día, no distará mucho por el braceaje de Ioo brazas de $2 I^{\circ} 3 I^{\prime}$ de latitud y $86^{\circ}$ y $1 / 2$ al Oeste de Cádiz; y desde aquí navegamos en vuelta de Punta Delgada con ventolinas del Sur y Sueste. En la noche hubo mucho relente, indicio seguro de Norte, y con efecto, lo tuvimos muy recio el día siguiente; pero cedióalguna cosa el I7 y habiéndonos permitido reconocer Punta Delgada el I8, fondeamos en Veracruz el I9 por la tarde.

No podemos dejar de advertir que la brevedad de este viaje la hemos debido enteramente á la buena determinación de navegar directamente á la Isla Española, no disminuyendo de latitud sino á proporción que lo pedía la derrota, y cuando conocíamos que por ser muy arriba no estaban los vientos bien entablados al Nordeste y Este, ó que por la propia causa y lo crudo de la estación recalaban hasta el Trópico los vientos recios y variables del Océano Atlántico. En general, cuando el objeto principal con que se navega es hacer el viaje lo más pronto posible, será bien tener presente las siguientes advertencias que nos ha sugerido la experiencia de este viaje al mismo tiempo que las noticias adquiridas de varios prácticos de la carrera.

Saliendo de Cádiz se gobernará al Oesuoeste (I), á cuyo rumbo demorará la Isla Madera, y siguiendo este rumbo se cortará su meridiano por la parte del Sur á distancia de 20 ó 25 leguas, porque hay que contar con to ó I 2 millas de diferencia al Sur en cada día de los tres primeros de navegación, y con 20 ó 25 en cada uno de los restantes hasta llegar por latitud de $32^{\circ}$. Entre los 34 y $35^{\circ}$ se encuentra ya la brisa ó viento general del Nordeste, que empieza á ventar por el Norte y Nornordeste. Se continuará al Oesudoeste, porque se consigue andar más distancia que si se navega, sea á viento más largo, como comunmente se practica para pasar entre la Gran Canaria y Tenerife. Es preferente la derota por el Norte de estas islas, porque se expelimentan vientos más frescos y más iguales, no se corre el riesgo de dar con calmas y vientos calmosos del Norte al Nornoroeste que suele haber al Sur de Canarias, siendo probable que de dos buques que salgan de Cádiz con igual andar, ganará dos singladuras el que navegue por el Norte de Canarias sobre el que dirija su derrota por entre estas islas. Desde el meridiano de la Madera y latitud de 3 I y $1 / 2$ á $32^{\circ}$, se puede hacer el Oesuoeste $5^{\circ}$ Oeste, pues no hay necesidad de disminuir mucha latitud, debiendo considerar ya entablada la brisa; siempre la deriva y la mar abaten cuatro ó cinco millas al Sur por día respecto al punto de estima, y como el viento se

(1) Todos los rumbos son corregidos de variacion y las longitudes al occidente de Cádiz. 
alarga al Nordeste y Esnordeste, se consigue con no arribar de golpe, retardar el que esté á popa, en beneficio del mayor andar.

Por latitud de $23^{\circ}$ el viento es del Este y la mar gruesa y tendida como conviene á la meridiana del Golfo. La variación de la aguja va disminuyendo al paso que se aumenta de longitud, pero no guarda una ley uniforme que pueda servir de luz para rectificarla. Sin embargo, á quien carezca de mejores datos le puede ser de alguna utilidad la noticia de que por latitud de $2 \mathrm{I}^{\circ}$ y longitud de $52^{\circ} 3 \mathrm{o}^{\prime}$ coincidía en I 790 el meridiano magnético con el meridiano verdadero. Aun antes de llegar á estos parajes, suelen verse rabijuncos, pardelas y sargazo, con otros indicios que por sí solos no deben mirarse como anuncios de tierra. Se inclinará el rumbo al Sur lo preciso para recalar al Cabo Cabrón de la Isla Samaná, que está por latitud de $19^{\circ} 22^{\prime}$ y $63^{\circ}$ y $3^{\prime}$ de longitud. Esta recalada y la navegación sucesiva por el Norte de la Isla de Santo Domingo, hace tanta ventaja á la derrota antigua con que se iba á dar vista á las Islas de San Martin, la Anegada y Puerto Rico, y por el Sur de la Isla Española se buscaba á Cuba, que en la elección no cabe duda. Las observaciones diarias de latitud dirán lo que debe enmendarse el rumbo con respecto á las diferencias al Sur que suelen experimentarse al cortar los meridianos de estas Islas, y para la longitud tendrá presente quien carezca de observaciones seguras, que por lo regular se anticipa el buque $5^{\circ}$ á la estima calculada con corredera geométrica de $47 \mathrm{y} \%$ piés de París para $3 \mathrm{o}^{\prime \prime}$ de experiencia. Reconocido el Cabo Cabrón se gobernará á pasar á regular distancia del Cabo Viejo Francés, bajo el concepto de que la corriente arrastra 20 ó 24 millas por singladura al Oesnoroeste ó á longo de costa; por lo cual, para aprovecharla y no acercarse demasiado á los veriles del Cayo de Plata, conviene navegar á 3 ó $3 \mathrm{y}^{1} / 2$ leguas de tierra. Las brisas son muy frescas por el Norte de Santo Domingo, y se anda muy pronto la distancia que media entre el Cabo Viejo Francés y la Isla Tortuga, desde cuyo meridiano se gobernará en demanda de la costa meridional de Cuba á reconocer el Cabo de Cruz, situado en latitud de $19^{\circ} 47^{\prime}$ y en $7 I^{\circ} 27^{\prime}$ de longitud. Es conveniente dar vista á este Cabo para hacer con conocimiento la travesía á las Islas de los Caimanes Chicos, cuyo extremo oriental está en latitud de $19^{\circ} 43^{\prime} 40^{\prime \prime}$ y $2^{\circ}$ oo $^{\prime}$ al Oeste del Cabo de Cruz. Se pasará al Norte ó al Sur de dichas islas según convenga, y desde su meridiano se gobernará en demanda del extremo occidental de Cuba ó Cabo de San Antonio, situado por combinaciones de estima en latitud de $2 I^{\circ} 5^{2}$ y en longitud de $5^{\circ} 7^{\prime}$ al Oeste del extremo oriental de los Caimanes Chicos. Servirá de prevención que las aguas tiran de ordinario I5 ó I6 millas al Oeste en veinticuatro horas, desde el meridiano del muelle de San Nicolás hasta los Caimanes, y desde éstos al Cabo San Antonio se experimenta ménos corriente al Oeste; pero su influjo lleva también al Norte I2 ó I 5 millas cada día. Reconocido el Cabo San Antonio se pueden hacer dos derrotas; ó bien entrar en sonda de Campeche por latitud de $32^{\circ} 30^{\prime}$ y correrla del Este al Oeste para salir por entre el Bajo nuevoy el Triángulo, ó picar sonda más al Norte y por 23 y $23^{\circ} y^{\prime} / 2$ de latitud navegar siguiendo su veril septentrional. La primera de estas derrotas es la que se practica comunmente, pero la hace ventajas la segunda, en la cual se navega más libre de cujdados, la acción de las aguas al Oeste es más rápida, y en caso de cargar un Norte recio hay mar suficiente para mantenerse ó arribar. En la derrota ordinaria luégo que por $22^{\circ} \mathrm{y}^{1} / 2$ de latitud se sonda 35 ó 40 brazas, se gobernará al Sudoeste hasta entrar en $22^{\circ}$, se corre este paralelo por I8 y 20 brazas fondo arena fina, blanca y conchuela, sin bajar de esta latitud en el primer tercio de la sonda, porque suelen abatir las aguas al Sur ocho ó diez millas por singladura. Se irá descaeciendo insensiblemente á buscar el paralelo de $2 \mathrm{I}^{\circ} 45^{\prime}$, sondando de hora en hora por I 8,20 y 22 brazas fondo arena, conchuela y coralillo, y rebasado el meridiano de la Desconocida se bajará á la latitud de $2 \mathrm{I}^{\circ} 3 \mathrm{O}^{\prime}$ en demanda del canal que forma el Bajo nuevo y el Triángulo, cuyo fondo es de arena con lama y de lama suelta. Toda la seguridad depende en este paso del conocimiento de la latitud, y así deben ponerse en práctica cuantos métodos hay de averiguarla.

Por fortuna no se experimentan dentro de sonda diferencias crecidas, siendo lo común observar seis ú ocho millas al Sur y Io ó I 2 al Oeste en veinticuatro horas. Pero con esta cantidad que abata la corriente y otro tanto que tenga de error el rumbo, si es en propio sentido, acercará demasiado á uno ú otro de los puntos por entre los cuales se ha de pasar. Pero no basta la. latitud; es asimismo preciso el conocimiento del fondo en confirmación de aquella, y para formar prudente juicio de la distancia Este-Oeste que se navega. Debe haber un cuidado especial de asegurarse del tiempo en que empieza á estar la. arena mezclada con lama, que con corta diferencia será el mismo en que de 20 y 22 brazas au menta de pronto el fondo á 26 y 28 . Entonces dista como 20 leguas el veril occidental que por observaciones exactas se considera en $85^{\circ} 24^{\prime}$ de longitud. Ya en este punto, si es de noche se espera algunas horas de una vuelta y otra $y$ se marea á la madrugada para salir de sonda al siguiente día. El fondo lama es la señal infalible de que se va por canal y por consiguiente en 
buena derrota. El braceaje va aumentando á 30 , 36 y 40 brazas, y ya en esta agua, andadas seis ú ocho millas, falta de golpe. Si después de practicadas las prevenciones anteriores y con la confianza y seguridad consiguientes se diera alguna escandallada en 28 ó 29 brazas piedra, no debe causar sobresalto, porque este fondo es de un rodal que hay en la medianía del canal; pero sicontinuase la misma calidad, se mirará como indicio de que no está lejos el Bujo muero y se inclinará el rumbo más al Sur, hasta volver al fondo lama.

La naregación por el Norte de la sonda, que es la otra derrota que se puede hacer, obliga á ménos cuidados. Cogido el veril oriental que por buenas observaciones se cuenta por longitud de $2^{\circ} 3^{\prime}$ al Oeste del Cabo San Antonio en Cuba y $80^{\circ} 33^{\prime}$ al Oeste de Cádiz, no hay más que correr el paralelo de $23^{\circ} 30^{\prime}$ por 50 y 60 brazas fondo arena. En estando á prudente distancia del paraje donde sitúan las cartas el bajo del Negri1lo (I), se gobernará al Sudoeste $1 / 4$ Oeste á pasar al Norte de la Isla Bermeja, sondando de seis en seis horas hasta asegurarse cogiendo 80 ó roo brazas, de que se ha rebasado el codillo y veril occidental de la sonda. La comparación de los puntos de estima y de observación en varios viajes por el Norte de ella, manifiesta que en esta derrota se debe contar con I 6 ó I 8 millas de corriente al Oeste en veinticuatro horas. El mayor empeño que puede ocurrir es que cargue mucho el viento si se navega con Norte, y que sea es caso para montar el bajo nombrado el Alacrán. Si tal sucediese se cambiará de bordo en vuelta del Este y con la ventaja que of rece el mayor barlovento se emprenderá la derrota primera.

Desde el veril occidental se hará derrota á recalar á barlovento de Veracruz, según los vientos reinantes. En la estación de Nortes, se reconoce Punta Delgada, que está en latitud de $20^{\circ} \mathrm{o}^{\prime}$ y según se juzga que el viento si es recio del Norte, será ó no manejable sobre Veracruz, se resuelve ó retarda la arribada. Del veril occidental al puerto hay $4^{\circ} 30^{\prime}$ de diferencia de longitud por observación, y por estima es común encontrar $3^{\circ} 30^{\prime}$ ó $3^{\circ} 40^{\prime}$, de suerte que es casi seguro el curso de i6 á r 8 millas de corriente diaria al Oeste ó rumbos próximos. Si estando en las inmediaciones de Veracruz calmase el viento, se puede dar fondo por 20 ó 25 brazas fango al Nornoroeste del castillo de San Juan de Llua, y á distancia de dos leguas de él. Es el partido más prudente para de noche y siempre que falte viento entablado con que se pueda vencer la fuerza de la corriente que tira como al Noroeste.

El muelle de Veracruz está en latitud de

1) Este bajo se halla en latitud de $23^{\circ} 24^{\prime} 54^{\prime \prime} y$ inngiturl $83^{n} 55^{\prime} 15^{\prime \prime}$ Oeste de Cádiz.
I $9^{\circ} \mathrm{I}^{\prime}$ Norte $y$ en longitud observada $90^{\circ} 5^{\prime}$ al Oeste de Cádiz; y el Pico de Orizaba (montaña muy notable y de muy fácil reconocimiento) está asimismo en latitud de $\mathrm{I}^{\circ} \mathrm{I}^{\prime}$ y en $9 \mathrm{I}^{\circ} 2 \mathrm{O}^{\prime}$ de longitud al Oeste de Cádiz: su altura sobre el nivel del mar es de 3.2r 8 toesas, y el largo de su tangente al horizonte $\mathrm{I}_{52}$ millas, distando I05 próximamente cuando aparece un grado elevado.

La ciudad de Veracruz, conocida en todo el mundo por los grandes tesoros que en ella se han embarcado para remitirse á España, no corresponde en su capacidad, riqueza, ni gentío á la idea que puede haberse formado de ella por lo extendido de su nombre. Reducida á dos calles principales que corren del Nordeste al Sudeste con otras varias pequeñas paralelas á éstas, carece de edificios suntuosos y de todos los adornos y hermosura exterior que caracterizan las grandes y ricas poblaciones. Sus casas, dispuestas más bien para recibir las mercancías que por ostentación ó grandeza, son por la mayor parte bajas, humildes y de mala vista, adornándose con rejas y barandillas de madera por no permitir el uso del hierro la cualidad salitrosa del aire, que consume en breve tiempo hasta los cañones de artillería, y ennegrece las paredes de las casas de un modo muy singular.

Las iglesias son regulares sin cosa particular. Hay una sola parroquia con dos capillas separadas, que le sirven de ayudas, y los conventos de San Francisco, Santo Domingo, la Merced, San Agustín y de San Juan de Dios, con varios hospitales y uno particular destinado para la Marina.

El vecindario de la ciudad se compone de las cuatro clases de españoles, criollos, europeos, negros y las castas que resultan de las mezclas de las anteriores, siendo muy reducido el núme. ro de todas. Entre las familias blancas hay algunas bastante acaudaladas; pero ni en éstas, ni en las demás clases del pueblo se conoce el lujo ni la opulencia. Los europeos que aquí se avecindan empiezan su fortuna por la ocupación ordinaria de pulpero. Este ejercicio, no sólo no es reparable, sino que lo hermanan también con las demás clases de comercio, que áun los hombres de más caudal tienen en las accesorias de sus casas estas tiendas pulperías, donde se vende todo género de comestible al lado de la tela más noble y rica. Por este medio adquieren algunos riquezas bastante considerables, sin que éstas se hagan visibles por la opulencia en su trato público ó privado.

Hállase esta ciudad, según nuestras propias observaciones, en latitud aproximada de $I 9^{\circ} \mathrm{I} 2^{\prime}$ $20^{\prime \prime}$ Norte, y longitud Oeste de Cádiz de $90^{\circ} \mathrm{I}^{\prime}$ según un promedio de $\mathrm{I}_{5}$ distancias de $\odot$ ( observadas en la mar y referidas á Veracruz por medio de los relojes y el movimiento uniforme 
del número 344 (I). Es cabeza de partido, y su jurisdicción se extiende, según los cálculos más aproximados, á unas 5.000 leguas cuadradas de superficie, sirviéndole de límites de Norte á Sur, por la costa el río Goazacualcos y el de Tampico, distantes entre sí I 20 leguas. En esta extensión se cuentan tres villas, diez pueblos grandes y unos I2o pequeños, de los cuales el mayor número se halla en la marina, habitados por pescadores que conducen pescados salados á Méjico y otras ciudades interiores: las poblaciones mayores están tierra adentro, y el número total de habitadores se puede computar en I60.000 personas. Su temperamento en lo general es cálido. Los frutos que produce la comarca son el maiz, cuya cosecha anual se gradúa en 300.000 fanegas, el algodón en 240.000 arrobas, el fríjol, la zarzaparrilla, pimienta, vainilla, el ixtle ó pipa floja, tabaco, azúcar, piloncillo y toda especie de legumbres, cera, achiote, seda, cacao silvestre y otros frutos, graduados todos en unos dos y medio ó tres millones de pesos de producto anual; sería también un artículo de mucha consideración y utilidad para estos naturales el de las varias y exquisitas maderas que producen sus bosques, como caobilla, cedro, roble, ébano y otras diversas, si la escasa población de la provincia y otras causas particulares que obran en su decadencia y apuntaremos más adelante, no hicieran inútiles estos dones preciosos con que convida por sí misma la Naturaleza, siendo tal la fertilidad del terreno, que con el único auxilio de los grandes rocíos de la noche, los campos y montes se mantienen siempre verdes y se cogen al año dos cosechas de las semillas ordinarias, tanto en la una como en la otra costa de las laterales del puerto de Veracruz.

Pareciera, pues, que siendo este terreno tan feraz como acabamos de decir y sus frutos naturales tan preciosos, que bastarían por sí solos para hacer rico á cualquier pueblo medianamente industrioso, debería ocupar la capital uno de los más amenos y fértiles parajes, ó aprovecharse á lo ménos sus moradores acaudalados, de las riquezas peculiares de su suelo territorial, pero ni lo uno ni lo otró se verifica en Veracruz. El territorio en que está fundada no produce ni cría cosa alguna, le faltan aguas dulces y corrientes, comestibles, verduras y hortalizas; no tiene fábricas ni industria, y en una palabra, carece de todo, siendo meramente un paraje de tránsito de cuanto extrae y recibe por este mar el Reino de Méjico. El sitio en que está fundada se compone de un arenal muerto y de méganos ó montes de arena que circuyen la población y mudan conti-

(I) Las últimas observaciones establecen esta ciudad en I $9^{\circ}$ I I' $53^{\prime \prime}$ de latitud Norte y $89^{\circ} 45^{\prime}$ I $5^{\prime \prime}$ de longitud Oeste de Cádiz. Asf la sitúan las cartas de la Dependencia. nuamente de lugar á esfuerzo de los recios vientos del Norte en la estación que éstos reinan, y aunque á cierta distancia de Veracruz en las llanuras que median entre los méganos de arena se cultivan al presente algunas huertecillas que surten en parte á la ciudad, sin embargo, la falta de aguas corrientes y la impetuosidad de los Nortes que todo lo agostan, es causa de que no prosperen, y tiene que abastecerse por agua, de comestibles y demás frutas de las poblaciones circunvecinas, especialmente de Alvarado y Talcotalpan, que son las que más remiten. Las carnes que aquí se comen no son tampoco buenas, por la falta de pastos, pero se encuentran con abundancia toda clase de aves domésticas.

Las buenas aguas que hay en estos contornos, tanto por su calidad como por su abundancia, son las del río Medellín, y es lástima no haya llegado á tener efecto el pensamiento de conducirla á la ciudad, como hubiera sido acertado, á pesar de los costos de la empresa, siendo ciertamente extraño que una ciudad como Veracruz carezca enteramente de agua dulce y corriente.

En otro tiempo fué muy temible este temperamento por la enfermedad harto conocida del vómito prieto, que ha sepultado aquí innumerables europeos. Se atribuía principalmente, á que no teniendo declive suficiente las llanuras comprendidas entre los méganos de arena, se estancaban las aguas, formando pantanos cuyos nocivos vapores causaban las enfermedades. En el día se ha remediado mucho con la providencia tomada de empedrar las calles, quitando con esto la humedad contínua que había en ellas, especialmente en el tiempo de las lluvias desde Marzo hasta Noviembre. Es de advertir que cuando las aguas son copiosas y casi diarias, el país se mantiene sano, pero cuando escasean empiezan á reinar las tercianas, enfermedad casi común, y que rara vez se quita hasta que entran los Nortes. Para la salud, los vientos peores son los Sur y el Sueste, pues si llegan á durar un día entero, inmediatamente sobrevienen pasmos mortales. En el verano, el termómetro de Reaumur sube hasta $25 \mathrm{y}^{1} /{ }^{\circ}$ en las piezas donde no bate el Sol; en el invierno varía desde I 6 has ta 22 , cuya alteración depende de los vientos Nortes, y por regla general el termómetro expuesto al aire libre durante la noche señala poco antes de salir el Sol I $y^{1} / 2$ ó $2^{\circ}$ ménos que en lo restante del día, con tal que no reciba la fuerza de aquél ni le alcance el reflejo de sus rayos.

A la parte Norte de la ciudad y á la distancia de algunas varas está el castillo de San Juan de Ulua, construído sobre un placer que en vaciante cubre el agua un pié ó pié y medio, y en creciente de cuatro á cinco.

Entre la playa de Veracruz y los placeres mencionados que entran al mar, formando como 
cordón, queda un espacio bastante grande con muchos bajos y ningún abrigo de los vientos; por esta causa carece la ciudad de puerto formal, consistiendo el que hay en el que forma el Casti1lo, en cuya muralla del Sudoeste se aseguran las embarcaciones en argollas que tiene para este fin. El modo ordinario de amarrar los buques, es dar los clos chicotes de un cable al Nordeste á las argollas, un cable de babor por largo al Noroeste y otro por la popa al Sueste.

Cuanto han observado los mejores prácticos acerca de las mareas y de los vientos que se experimentan en Veracruz y su costa, se reduce á las noticias siguientes.

El flujo y reflujo no guarda regularidad, ni en su duración, ni en su retardo de uno ú otro, notándose á reces dos en veinticuatro horas, y por lo común sólo uno. Hacia los equinoccios y solsticios ascienden las mareas de tres á tres y medio piés, y de dos á dos y medio en las demás zizigies. Crezca ó vacíe el agua, la corriente va con el viento, y así corre al Sueste si los vientos son del Nordeste al Norte y corre al Noroeste cuando los vientos son del Esnordeste al Sueste y áun con el Sur que es viento de corta duración, y en la estación de Nortes suele anunciarlos.

Sin embargo de ser el viento Este el dominante, se divide al año en dos estaciones: en el seno de Veracruz una de Nortes desde Setiembre á Abril y otra de brisas del Esnordeste al Esueste en los meses restantes. En Noviembre, Diciembre y Enero, vienta el Norte cuarenta y ocho ó cincuenta horas con gran fuerza, con carices oscuros y Noroestes más que en los meses siguientes, permitiendo orzar hasta el Nordeste. En Marzo y Abril no pasa de veinticuatro horas la mayor fuerza de este viento; vienne más de tarde en tarde y los carices que lo acompañan son más claros. De nueve de la mañana á tres de la tarde sopla por lo regular muy fresco, abonanza á la puesta del Sol y suele rolar al terral á la noche; pero si no pasa del cuarto cuadrante vuelve al Norte á la salida del Sol. Si el terral llega al Oesudoeste ó pasa más al Sur, hay probabilidad de que siga su giro al segundo cuadrante y con el día se entable la brisa. Del mismo moclo, aunque al amanecer haya Norte fresco, suele caer conforme va entrando el día y rolar al primer cuadrante hasta quedar en la brisa. Varias señales hay para conocer la proximidad de este viento temible; pero las más ciertas son el viento Sur entablado con neblina baja y espesa, despedida de la misma parte, mucho fósforo que los marineros llaman ardentía, en el agua del mar y telarañas por las jarcias. Pero el anuncio infalible le cla el barómetro descendiendo á 29 pulgadas 80 , de 30 pulgadas 20 (I) medida de Inglaterra que es su estado regular en este clima en tiempos buenos. Al menor ascenso despues de tal bajada, rompe el viento por el Norte y será más ó ménos tenaz en su duración y en su fuerza, á proporción de la menor ó mayor lentitud con que suba el mercurio.

Desde el equinoccio de Marzo hasta mediado Mayo que el Sol llega al zénit de Veracruz, soplan con fuerza las brisas en los intermedios que dejan los Nortes, y se alargan hasta el Sueste, velando algunas noches. Mientras el Sol se aparta de dicho punto para el Norte y hasta que áfines de Julio vuelve á él, son calmosas las brisas con cerrazones y turbonadas y áun suele fijarse el viento del Noroeste al Nordeste por algunos días. Finalmente, mientras el Sol baja á la equinoccial y pasa algo al Sur, esto es, desde Agosto hasta Octubre, continúan las brisas en su poca fuerza, son mayores las turbonadas con mucha lluvia y feos carices que traen viento duro si aparecen por el Este. En estos meses se experimentan huracanes en las Islas y áun en el seno mejicano. Su entrada regular es por el primer cuadrante y dan la vuelta por el segundo ordinariamente, aunque en esto no hay regla fija. Una brisa fresca con cerrazón y llovizna suele preceder estos vientos, que por fortuna no alcanzan á Veracruz, y cuando más se siente en este puerto la mar sorda del huracán que ha habido en mayor latitud. Seguidamente se entablan los vientos á la cabeza y se renueva el año.

Siendo Veracruz el único puerto habilitado del Imperio Mejicano en la costa del Océano Atlántico participa, por consiguiente, de todo el comercio de géneros que allí se descargan, y es el paraje donde se hacen las primeras compras de cuanto remite la Península. En tiempo de las flotas concurrían á él con este motivo en las ocasiones de ellas, recuas crecidas de mulas para la conducción de las mercancías á las ciudades in ternas del reino, igualmente que á los minerales; y los vecinos de Veracruz, haciendo sus compras de primera mano, las conservaban para venderlas después con ventaja, en el tiempo muerto, á los traficantes de las poblaciones interiores que alli llaman tierra-entreños, dejándoles esta especie de negociación exclusiva utilidades conocidas. En el día sólo se hace este tráfico paulatinamente y á medida que llegan las remesas de la Península; pero siempre es Veracruz el centro donde se reune todo el giro de los negociantes europeos y mejicanos.

Los efectos principales que aquellos introducen, consisten en toda clase de géneros de seda, especialmente blondas, cintas, medias y pañue.

tura, á causa de las capacidades diversas de sus cubetas; pero debe serlo la diferencia de las alturas que se comparan, y en esto estriba la observación. 
los de seda, raso, sarga, terciopelo, tafetán, etc., géneros de lana como bayetones, paños y sombreros; telas de lino y cáñamo, lienzo pintado, pañuelos y encajes y áun ropas interiores ya fabricadas; indiañas y medias de algodón, especería y licores, principalmente aguardiente y vino: varias clases de drogas y artefactos, armas, cera, ladrillos, loza, hierro labrado, acero, papel, hoja de lata, muebles y utensilios; toda clase de quincalla, vidrio y cristal, etc.

Los frutos de extracción son la plata amonedada y en barra, algunas alhajas, algodón de todas clases, azúcar, pimienta de tabasco, vainillas, grana, granilla, el palo tinte, algunas pieles y toda clase de drogas.

Según el estado publicado por la Secretaría del Departamento del fomento general y comercio del Reino, era la balanza de este giro en el año de 1792, de 3.901.00o pesos fuertes en que excedió la exportación á la importación en esta forma:

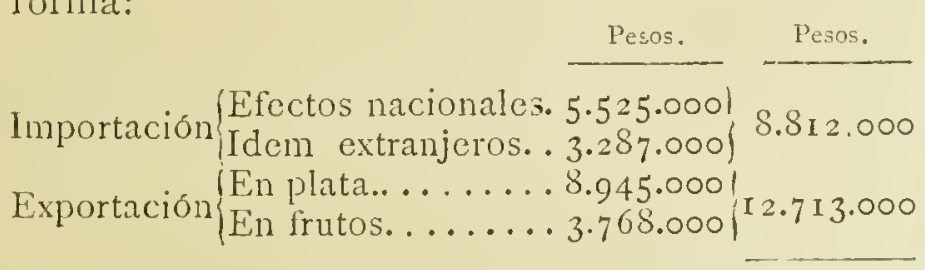

Diferencia. .........3.901.000

A cuya cantidad, agregando 3.257 .000 pesos extraídos también de Veracruz en aquel año, pertenecientes á S. M., resulta la extracción total de I 5.97 I.000 pesos y la diferencia á favor de la Península de 7. I 58.000 pesos en aquel año.

Es imposible fijar en el día á datos exactamente positivos los progresos de este giro, siendo así que ha corrido muy poco tiempo desde que empezó á tener efecto el nuevo sistema del libre comercio, y que el ansia con que han querido aprovecharse de aquel beneficio los comerciantes de la Península, ha sido causa de que se agolpen las expediciones, acumulando las remesas en mayor cantidad de lo que permiten los fondos actuales del Reino, de modo que no pueden servir de guía fiel para aquel cómputo los estados de importación de estos últimos años. Tampoco son muy seguros en esta parte los informes particulares, porque todos participan más ó ménos de la influencia de la opinión propia, no estando todavía acordes sobre la utilidad común que ha de producir el reglamento de libre comercio; además que las epidemias y esterilidad que ha padecido el reino y de las que aún se resiente su población é industria, son otros tantos obstáculos que impiden caminar con seguridad en este difícil y delicado cómputo. Sin embargo, atendiendo á los aumentos sucesivos que va teniendo el laboreo de las minas, á la grande estimación con que se venden en los mercados europeos los frutos principales de la agricultura me- jicana y á las grandes cantidades que expende el Rey en salarios y paga de empleados, que son los verdaderos artículos que constituyen la circulación del Reino, se puede establecer que en los años sucesivos no bajará de I2.000.000 de pesos fuertes la importación anual por la vía mencionada (I).

Es necesario advertir que mucha parte de esta cantidad pertenece al extranjero por los géneros con que concurre al surtido de nuestra Ámérica. Los artículos principales de su importación son los lienzos, la quincalla, alguna parte de efectos de seda, lana y las manufacturas de algodón inglesas. Ateniéndonos al estado de I792, parece que la introducción extranjera se puede reputar en algo más de la mitad de la importación nacional; pero hay fundamentos para creer que en adelante se disminuirá mucho esta perjudicial introducción por los visibles acrecentamientos que diariamente adquiere nuestra industria en el Continente. Aun ahora se notan ya los saludables efectos de las providencias dictadas por el Gobierno descle la feliz abolición del monstruoso sistema de las flotas, y todo corazón verdaderamente patriótico halla un motivo de justa complacencia en ver desterrados de estos mercados muchos de aquellos artículos con que en días más aciagos se enriquecieron á nuestra costa los enemigos de la patria. El industrioso catalán provee casi exclusivamente al consumo que hace la América de blondas, encajes, listonería, medias de seda, algodón y pañuelos, vino, aguardiente, papel y pintados. Los paños de nuestras fábricas y los tejidos de seda de Valencia, Granada, Manresa, Málaga, Sevilla, Toledo y Talavera, han sustituído en mucha parte á iguales géneros extranjeros, y nuestra marina mercantil ha recibido un nuevo impulso, al mis mo tiempo que han logrado de ventajosa estimación los frutos preciosos de nuestra agricultura colonial.

Como nuestra demora en Veracruz no podía dilatarse y era preciso que emprendiésemos la marcha sin pérdida de momento, dispusimos nuestro viaje para el 24, y con efecto, salimos de aquella ciudad el 25 de Enero en la madrugada, dejando nuestro equipaje al cuidado de un

(I) La importación media en el trienio corrido de I 802 á I 804 ha sido de I 7.929 .000 pesos. En los años anteriores y posteriores ha habido grande variedad procedida de la guerra marítima con Inglaterra; y habiendo tenido á bien permitir S. M. con este motivo el comercio de buques neutrales en América, han entrado en este puerto de Veracruz desde mediados de Setiembre de 1805 hasta fin de Abril de $\mathrm{I}^{807}, 64$ buques de diversas naciones, cuyos cargamentos ascendieron á 4.862 .556 pesos en géneros y frutos; $y$ han extraído en la misma época 12.456 .454 pesos en esta forma: 10.857.914 pesos en plata; 9.277 arrobas de grana, cuyo valor es 927.746 pesos y 670.794 pesos en otros frutos: total $\mathrm{I} 2.456 .45+$ pesos. 
conductor de confianza, que salía el mismo día para llegar poco después que nosotros á la capital.

Desde luego que se abandonan las arenosas riberas de Veracruz, se sigue al Poniente por la costa, y á las cinco leguas de distancia se halla la población de la Antigua ó Vieja Veracruz, situada en la orilla occidental de un río bastante caudaloso, distante de la marina cosa de media legua: tiene este nombre por haber sido aquél el paraje en donde estuvo á los principios la ciudad de Veracruz, y que se abandonó después por no poder llegar hasta él los buques grandes, no teniendo otro puerto que el mismo río, el cual no admite cmbarcaciones de mucho calado. La población se compone de una corta porción de casas bajas de madera con techo de paja, esparcidas por entre los árboles que cria el terreno naturalmente; hay entre sus vecinos algunos blancos, pero la mayor parte es gente de color que se mantiene con los frutos de sus sementeras, el cultivo de legumbres y la engorda de algún ganado de cerda y vacuno, con todo lo cual provee en parte á la ciudad de Veracruz; su temperamento es cálido y el terreno muy frondoso.

El río por esta parte es bastante ancho y tiene buena corriente; críase en él un delicado pez que llaman Bobo, y es tan apreciable que se lleva por regalo á Méjico y se proveen de él Jalapa, Veracruz y otras ciudades en los tiempos de su pesca.

Desde la Antigua sigue el camino para Méjico, dirigiéndose por Jalapa, hasta donde cuen$\tan x 7$ leguas. El camino, al principio, es llano aunque algo arenoso, y sigue á poca distancia el curso del río siempre acompañado de arboledas de la especie que llaman guarangos. A la legua y media ya muda el piso, convirtiéndose en una piedra cortada que parece se ha quebrado de intento para reducirla á pedazos pequeños, y de este modo continúa hasta llegar al paraje que nombran Lencero, desde donde descubre la vista parte del territorio bajo que forma valles y prados vestidos de árboles. Hasta aquí el camino ha ido subiendo por cuestas tendidas y pedregosas en cuanto alcanza la vista.

Lencero tiene ya una competente altura respecto al nivel del mar: las observaciones barométricas practicadas á las diez del día con tiempo claro y viento Este determinan su altura de I.07I varas respecto de aquel nivel.

Jalapa es pueblo de mediana extensión; sus casas son bajas y con terrados ó azoteas, según la práctica común del Reino. El temperamento de esta ciudad es templado y con muy corta diferencia el mismo que se experimenta en lo interior de aquel Reino por largas distancias. Al amanecer señala el termómetro $16^{\circ} \mathrm{y}^{1} / 2$ en $10 \mathrm{in}$ terior de las viviendas, I 5 en lo exterior, is á las dos de la tarde, y á las once de la noche I7. Estas cantidades son como constantes en todo el año, á excepción de aquellos días en que se mantiene el Sol nublado y vienta por la parte de los dos volcanes que tiene inmediatos. Examinado el barómetro en tres días consecutivos con tiempo claro y viento flojo de la parte del Este, se observó constantemente en 23 pulgadas nueve líneas, siendo su mayor variación $1 / 3$ de línea. Esta buena proporción del temperamento junto con la bondad de sus aires y lo saludable de las aguas, ha hecho elegir á este pueblo para lugar de residencia de los que enferman en Veracruz. Sin embargo, es país propenso á tercianas, y cuando las lluvias se dilatan, se experimentan otras enfermedades que molestan á los naturales igualmente que á los forasteros.

Las 1luvias son aquí muy contínuas y se advierte que mientras en Veracruz reinan los Nortes, que s̃on los que retiran las nubes, cae en Jalapa una agüilla menuda y contínua que llaman "la salud del pueblo," porque en tanto que se repite se mantiene sano el país; así los vientos que retiran las nubes de la costa y parajes bajos, las arrastran á los altos y causan esta humedad ó lluvia frecuente.

Próximo á la ciudad hay dos altos cerros que corresponden, el uno al Oesnoroeste y el otro al Oesudoeste: 1lámanse la silla de Perote y el volcán de Orizabal: el primero, sólo conserva la nieve algunos tiempos del año en las concavidades de las peñas que forman su cumbre; pero el segundo tiene tanta, que por la parte que corresponde á Jalapa aparece siempre cubierto de ella como hasta un cuarto de su altura.

El terreno es fertilísimo y se halla poblado de árboles frondosos y prados siempre verdes. El más común de aquéllos es el árbol de la Chirimoya, y entre las plantas menores lo es la del Jalapa, de que se conducen á Europa crecidas porciones.

Poï estos campos viven esparcidos los indios, habitando en sus jacales, donde cultivan sementeras de maiz ó las legumbres más análogas al clima. Uno de sus ejercicios más frecuentes es el de la arriería, en el cual se emplean por el tráfico contínuo que hay entre Veracruz y las ciudades y poblaciones del interior del Reino.

No podemos pasar en silencio el uso particular que hacen estos indios de los baños de estufa, para cuyo fin tienen en cada jacal una estufa, que llaman Temascal; y consiste en una chocita ó cuarto pequeño hecho de adobes de figura circular, en el centro del cual se levanta una piedra grande que sirve como de solería, y en uno de los lados está un hornillo, cuyo fogaril corresponde debajo de la piedra. Cuando quieren bañarse ponen fuego en el fogaril, se calienta la picdra y el indio percibe aque! calor, con el cual 
empieza á sudar abundantemente. Al cabo de algún tiempo se retira abrigándose bien, se seca el sudor y se viste. Tienen la costumbre de bañarse todos los sábados como por vía de descanso de la fatiga que han tenido en el discurso de la semana y para curarse de sus indisposiciones, ó después de saljr de una grande enfermedad, pues con ello dicen consiguen dos cosas: la una, convalecer más pronto; y la otra, limpiarse de los aceites y unturas que por regla general se aplican para curar toda especie de dolencia. E1 modo de la estufa es bastante ingenioso y parece que la experiencia confirma la utilidad de su práctica.

Saliendo de Jalapa, á las tres leguas muda el terreno, y parece que abandonando repentinamente los países de la América se ha transportado uno á los del Norte de la Europa. Las cercanías del camino están cubiertas como en aquella parte del mundo de pinares muy derechos, altos y fornidos; ya empiezan á verse sementeras de cebada, y el temperamento cambia igualmente que las producciones del terreno; el termómetro que marcaba $I x^{\circ}$ á las seis de la mañana en el paraje de las Vigas, 'cinco leguas de Jalapa, señaló r $8^{\circ}$ en el pueblo de Perote con tiempo claro y viento moderado del Noroeste. La línea que divide la parte cálida de la templada puede fijarse ocho leguas distante del mismo Jalapa en el paraje que llaman la Cruz Blanca, y es el principio de una llanura dilatada. En ésta se halla el cerro nombrado Pizarro, que señorea en aquel espacio como una isla en medio del Océano, distando dos leguas la serranía más cerca en esta llanura. En lo interior del Reino se hallan otros en la misma disposición que no dejan de causar admiración por no tener en sus inmediaciones serranías, lomas, ni otras desigualdades.

Antes de este paraje se pasa un pedazo de terreno como de media legua de extensión y sigue á lo largo del camino, al que llaman Mal País por estar cubierto de una costra que sale de la tieira vara y media en alto, de color negruzco al modo de las escorias del hierro: en su color y estructura parece á una materia ferruginosa derretida y derramada por aquella tierra; es muy dura, pesada y porosa, formando ojos, por cuyas circunstancias se hace notable aquel paraje y llama la atención de cuantos pasan por él.

Perote es un pueblo de indios situado en una llanura dilatada distante ro leguas de Jalapa; 10 único particular que tiene es una pequeña fortaleza construída de pocos años á esta parte, que ocupa casi el centro y medianía de la llanura. Observado el barómetro en este paraje, se halló á las once del día en la altura de 2 I pulgadas $2 \mathrm{y} \%$ líneas, lo cual determina la altura de este terreno. respecto al nivel del mar, de 3.186 varas castellanas. El termómetro marcó á la misma hora I $8^{\circ}$ según dijimos antes.
En las diez leguas que median entre Jalapa y Perote, no se encuentra sino un solo arroyo de agua: en general, parece que este es un defecto común á todo el Reino.

Desde Perote cuentan siete leguas á la Venta de Soto, el rumbo es al Oeste inclinado al Sur; pero así estas leguas como todas las anteriores, son cortas y pueden computarse de 5.000 varas (I). El terreno es llano y en partes arenisco. Los árboles que se encuentran son de dos especies, unos tienen la hoja al modo de cipreses, pero con ramazón abierta, y los otros son palmas y palmillas, diferenciándose de las que se crian en los temperamentos calientes, en el tronco y la hoja. El barómetro marcó en la Venta de Soto 2 I pulgadas, 3 líneas, al tiempo mismo que señalaba el termómetro $i 6^{\circ}$ estando lloviendo algunas gotas de agua, aunque no muchas.

Pasando de Soto sigue el camino Ix leguas hasta la Venta de San Diego: mucha parte del terreno es de la misma naturaleza que el anterior, pero desde el paraje que nombran Balconcillo en adelante hay sementeras de maíz en las llanadas, y de cebada en las faldas de los cerros.

A distancia de cuatro leguas de la Venta de San Diego, en la hacienda que nombran de Piedras Negras, se descubren ya los volcanes de Méjico, teniendo también al Este el de Orizabal; todos tres aparecen de igual volumen y altura. De los dos de Méjico, el de Poniente presenta una cumbre extendida como llanura; el otro remata en punta en figura de pan de azúcar, pero ésta se manifiesta cortada y desnuda de la mucha nieve que cubre en gran parte á aquel soberbio monte, por lo cual es de presumir despida algunos vapores que impidan conserve la nieve en aquel espacio. No es fácil describir la impresión que causa en el caminante la vista de estos tres majestuosos cerros, cuyas moles inmensas campean aisladas en estas dilatadas llanuras aumentando su magnificencia con los rayos reverberadores del astro del día.

Desde Acatepeque, que es una hacienda dos leguas distante de Piedras Negras, empiezan á

(r) Este camino, según lo anduvimos nosotros y es la práctica del país, se camina en litera desde Veracruz hasta Perote, por no permitir el terreno el uso de carruajes; pero al tiempo que esto se publica se ha construído ya á expensas del consulado de Veracruz y bajo la dirección del Teniente Coronel de Dragones de Méjico, D. Diego García Conde, un excelente camino real y carretero en la extensión de I 7 leguas de á 5.000 varas con 204 . I Io varas cúbicas de desmonte, 424.787 de terraplén, 42.272 de mampostería, 2 r.866 lineales de empedrado, 53.806 de contrazanja y ${ }_{5}$ I alcantarillas. En el caudaloso río de la Antigua se ha construído también un puente llamado del Rey, con 230 varas de longitud, I 2 de ancho y 16 y 1, varas de altura desde el nivel ordinario del agua hasta el piso del camino en el arco del centro. 
rerse haciendas dilatadas de maguiey, de que se hace un extracrdinario consumo, empleándolo en la bebida común en el reino, llamada pulque. El magüey es de la misma especie de las que nombramos pitas en los reinos de Andalucía y allí sirven ordinariamente para guarnecer los vallados y embaraza con sus puntas que se introduzcan los ganados y causen daño en los sembrados. En Nueva España se plantan en tierra llana y en la misma disposición que las viñas de Europa: crecen mucho y toman un color fuerte de verde oscuro: luégo que empiezan á hincharse las pencas que rodean el cogollo, cortan éste sin tocar á aquéllas, y en la concavidad que forma el corte, recogen diariamente el jugo que mana y lo llevan á bodegas destinadas al intento, donde lo ponen en vasijas grandes: allí fermenta y queda hecho el pulque. Su bebida es desagradable para los que no están acostumbrados á ella y embriaga usándola con algún exceso; para hacerla más grata al gusto, suielen prepararla con algunos otros ingredientes. El consumo que se hace de ella en todo el Reino es tal, que se considera uno de los frutos de más utilidad para los dueños de las haciendas y para el Real Erario, por el derecho que satisface anualmente: se le atribuye la propiedad de ser un específico contra las disenterías, enfermedad muy común en todo el Reino.

Una legua de Acatepeque está el pequeño pueblo de Ilangatepeque, que quiere decir "manantial de agua entre dos cerros;" toma este nombre de un arroyo que corre inmediato al lugar y es el único que se encuentra en las I 3 leguas que median desde San Diego hasta aquel paraje. Lo habitan en el día indios pertenecientes á la provincia Tlascala, cuya capital dista cinco leguas. Todavía se conservan algunas familias de las antiguas, que tanto ayudaron á los españoles á la conquista de este Reino.

La calidad del terreno of rece la particularidad del poco grosor que de aquí en adelante tiene la capa de tierra vegetal que lo cubre: en 'parajes sólo es de un pié, en otros medio, y áun de mucho ménos en las alturas y pisos trajinados. Debajo de ella sigue una especie de tierra conocida en el Reino con el nomb e de tepatate, durísima, de extraordinaria sequedad y diferente de las tierras gredosas. Caminando por encima de ella se siente un ruído como si se pasase sobre un puente de madera; indicio cierto de que contiene bajo de su supcrficie algunas oquedades, pero éstas no sc descubren en los cortes de los barrancos, ni aún ménos se reconoce porosidades. El arua no la penetra ni ablanda como lo hace con la greda, y se nota en los caminos más traficados, que ni la sequedad, ni el contínuo trajín de las bestias y carruajes, la reduce fácilmonte polvo. En los parajes desnudos cntcramente de aquella primera capa de tierra, no se cría yerba ni planta alguna.

Tres leguas de Ilangatepeque está una gran hacienda que nombran de San Bartolomé: dos más adelante la del Molino, y una legua después el pueblo de Apa. Entre estos dos últimos puntos dividen su jurisdicción los Obispados de la Puebla y Méjico: á éste pertenece el pueblo de Apa; y la hacienda del Molino al de la Puebla.

A la parte de Poniente con alguna inclinación para el Norte de Apa, se halla á diez leguas de distancia el pueblo de San Juan, cuyo vecindario es la mayor parte de indios.

A dos leguas del pueblo de San Juan empieza á bajar el territorio para entrar en el Salado, cuyo nombre dan á la planicie de la famosa Laguna de Méjico. El camino sigue entre el Poniente y Sudoeste descubriendo á largas distancias cordilleras de poca altura, y en las llanuras, cerros aislados de distintas figuras. Ultimamente, desde lu colegiata de Guadalupe situada también en la orilla de la Laguna y distante seis leguas del pueblo de San Juan, atraviesa la famosa Calzada de Méjico que tiene dos leguas de largo y es una de las obras más recomendables del Reino.

Entramos en la ciudad el 5 de Febrero y cuando tratábamos de descansar de las molestias del camino anterior, llegó un extraordinario despachado desde Acapulco por el Comandante de la corbeta ATREvidA, D. José de Bustamante y Guerra, con aviso de su llegada y pidiendo al señor Virey nuestra incorporación. Aún no teníamos todos nuestros instrumentos, pero llegaron el día I2 y en el entretanto nos ocupamos en visitar la ciudad y adquirir algunas noticias de lo más principal que hay en ella, según lo permitía la estreche $z$ del tiempo. Por esta razón no pueden ménos de ser imperfectas nuestras nociones sobrc esta grande capital, cuya descripción completa exigía otro tiempo y otros medios que los que estaban á nuestra disposición; pero tal cual la hemos podido formar la ofrecemos al público, persuadidos de que siempre leerá con interés cuanto pueda decirse sobre esta distante y rica colonia.

La ciudad de Méjico, cabeza del Reino de Nueva España, es una de las poblaciones más ricas y hermosas del orbe. Hállase situada en la medianía de la Laguna de 'Tezcuco 2.929 varas sobre el nivel del mar (I) y en el fondo del valle que lleva el nombre de la capital. Su territorio forma una llanura casi nivelada, rodeada de cerros de mediana altura cuyos derrames interiores forman tres lagunas, de las cuales la más extensa es la de Tezcuco ya mencionada. Sus aguas permanecen más ó ménos abundan-

(I) Así lo determinan las observacionos barómetricas que se inscrtarán después. 
tes según las lluvias, aunque en pocas ocasiones llegan á crecer tanto que inunden la ciudad, y sólo corren por canales atravesando algunas calles según ya se refiere desde los tiempos de la conquista.

La superficie de esta ciudad deducida del plan de faroles con que se ilumina, en su totalidad contiene 8.933 .240 varas cuadradas, de modo que considerando que la extensión de sus calles coge la octava parte del terreno y despreciando los picos por lo que ocupan las plazas, se reduce la parte fabricada á 7.800 .000 varas cuadradas, esto es á una área casi dupla de la de Sevilla, en cuya ciudad se pueden considerar 4.000 .000 de varas de superficie labrada, por otro cálculo semejante.

Según la numeración hecha de orden del Gobierno en Abril de I79I, asciende el número de casas fabricadas en Méjico á 6.227, sin incluir los conventos, colegios, hospitales ni cárceles. Las casas tienen por lo común un alto con terrados ó azoteas, portadas suntuosas, hermosas balconerías y una altura proporcionada que hermosea y da á las calles cierto aire de grandeza: éstas son espaciosas, iguales, rectas y tan largas, que su término se pierde de vista. La plaza principal es también correspondiente al casco de la ciudad: la ocupa por el Nordeste el palacio del Virey, edificio sencillo pero majestuoso, espacioso y cómodo, con hermosa balconería desde donde descubre la vista gran variedad de objetos divertidos. Al Noroeste cae la catedral, cuyo vestíbulo se adelanta hacia la plaza un espacio como de 30 varas y da la vuelta por el costado del Sudoeste conservando la misma anchura. La fachada opuesta á la catedral la ocupan las casas del Ayuntamiento construídas sobre una arquería con portal á la plaza, y la que hace frente al palacio se compone en parte de casas de particulares y de otras que las llaman del Estado, y son edificios de buena vista. Puede asegurarse que no hay en Europa plaza alguna que pueda compararse á ésta: el inmenso concurso de carruajes, recuas $y$ vendedores, y la variedad infinita de trajes $y$ castas de cuantas clases hay en la América y se ven aquí reunidas, la dan cierto aire de novedad y grandeza.

La catedral, que como se ha dicho, ocupa uno de los*frentes de la plaza, es un edificio de arquitectura regular, aunque no de mucho lucimiento por faltarle elevación proporcionada á su grande mole: esto procede de la calidad del terreno en que está fundada, que por ser en la Laguna, flaquea y se advierte se ha hundido algo el edificio por un lado. Las rentas del Arzobispo suben á I 5.000 pesos anuales, á 22.000 la del Dean, á 8.500 las de los Canónigos, los Racioneros tienen 5.300 pesos y 2.800 las medias raciones. Es probable que estas rentas crezcan en ade- lante según el fomento que va tomando el arzobispado.

El palacio arzobispal es uno de los mejores edificios que tiene la ciudad; es grande y se halla distribuído convenientemente para el giro de los negocios que pertenecen á su juzgado. En general, los edificios más recomendables son las igle. sias y los pertenecientes á establecimientos públicos. De los primeros se cuentan I 4 parroquias, 25 conventos de varias religiones y is de monjas; de los segundos, hay ocho colegios de hombres, seis de mujeres, doce hospitales, siete cárceles, dos casas de misericordia y otras dos de reclusión, una para recogidas y otra de misericordia para mujeres casadas. Entre los conventos se distinguen particularmente por su capacidad y adorno, las casas grandes, como son la de Santo Domingo, San Agustín, la Merced y San Francisco: éste tiene una hermosa iglesia y muchas capillas en el atrio, propias de ciertas provincias de España, con ricos ternos antiguos y uno de perlas regalado por el Rey Felipe II. En esta misma iglesia están los huesos, el estandarte y la cota del conquistador Hernan-Cortés, por donde se viene en conocimiento de que correspondía bien con su talento y valor la altura agigantada de este héroe memorable.

Según el padrón circunstanciado formado dc orden del Gobierno el año I79o, ascendía en aquella época el número de religiosos profesos y legós de todas órdenes á 876 y el de monjas á 907 .

Entre los colegios que se mencionan hay dos destinados únicamente para indios de uno y otro sexo: el que sirve para los varones se titula de San Gregorio y tiene por institución particular enseñarles la música á fin de que se adiestren y sirvan después á emplearse en el servicio divino; y el otro, que se llama de la Caridad, es determinadamente para niñas españolas, cuyo número está ceñido al de 33 , y tienen descle que entran el dote de 500 pesos para tomar estado. El colegio de San Ignacio es también fundación particular, hecha por los vizcainos para las viudas y solteras desamparadas de sus descendientes: allí viven con separación en cuartos competentes y con cuantas comodidades pueden apetecer, suministrándoseles ro pesos mensuales para ayuda de la asistencia miéntras que permanezcan solteras. Estos establecimientos piadosos, sin otros varios de que no hacemos mención, son de mucho beneficio y utilidad en una gran capital como esta, donde hallan refugio las personas menesterosas que por muerte de sus maridos, padres ó parientes quedan en total orfandad.

Es por demás advertir que hay en esta ciudad academias públicas y colegios donde se ensena con perfección toda clase de artes y cicncias. Sabido es el cuidado paternal con que nucstros 
católicos Monarcas á los principios de la conquista instituyeron esta Real Universidad, y en el día la sustentan como un digno plantel donde se crian y pulen los agudos ingenios de estos naturales. Modernamente se han ampliado algunos establecimientos y fundado otros varios que no tienen semejantes las demás ciudades del Nuevo Mundo y que aún figurarían mucho en otras grandes capitales del antiguo.

Dentro del Palacio y á la vista del Virey tienen su lugar y asiento los Tribunales superiores de este reino, como son la Audiencia Real, el Acuerdo, la Sala del Crimen, el Tribunal de Cuentas, el de Cruzada, la Caja Real y el de Comercio ó Consulado, sin otros varios consagrados á ramos particulares; de este modo el Virey, como cabeza de todos, puede dirigirlos y recibir oportunamente la noticia diaria de cuanto en ellos pasa. Uno de los cuerpos más distinguidos de esta ciudad es el de su ilustre Cabildo, que goza en Junta el tratamiento de Excelencia por concesión de nuestros augustos Monarcas: tiene á su cargo la recaudación de propios y arbitrios y el de los pagos y cargas anexas á estas rentas, en la misma forma que se practica en las ciudades principales de España. Los caudales que componen la entrada, sus gastos y resultados, han sido detallados últimamente en una Memoria muy extensa y curiosa presentada al Virey por D. José de la Peoza y Casas. De ella resulta que en el quinquenio de I78+ á I788 ascendieron los cargos á 686.454 pesos y la data á 759.874, esto es, que excedieron los gastos á las rentas en $73 \cdot 420$ pesos.

La Casa de la Moneda, que ocupa una cuarta parte de la cuadia que forma el edificio de $\mathrm{Pa}$ lacio, es tal vez la mejor fábrica que se conoce áun en Europa para este fin, por la disposición de las oficinas, el repartimiento de sus máquinas, etc. A ella se conduce toda la plata y oro que se saca de las minas del Reino, para acuñarse y reducirse á moneda. Esta operación se practica con la más rigurosa prolijidad, y al intento concurren los Ministros encargados de su dirección, á fin de que las monedas salgan justas y arregladas en su peso y ley. Esta Casa se incorporó á la Corona en el año I 732 y desde entonces acá corren sus labores por cuenta de la Real Hacienda. En los tiempos primitivos se solían acuñar anualmente desde 8 hasta I 4 millones de pesosfuertes, pero desde el año de I 77o se han aumentado considerablemente las labores y puede regularse un año con otro cn Is á 20 millones de pesos fuertes, habiendo sido la más notable la de 1783 en que se acuñaron 23.700 .000 pesos. I a lábor de oro es corta y regularmente no pasa (le 600 á 800.000 pesos.

I as sucrtes de moneda de plata que se labran en el día son pesos duros, medios pesos, pesetas, reales y medios reales, todos columnarios; y de oro, doblones de á ocho escudos, de á cuatro, de á dos y de un escudo que vale dos pesos fuertes. De la clase menuda de plata sólo se acuñan anualmente de 40 á 50.000 marcos para el surtido del comercio interior del Reino.

Tiene esta Casa, de fondos para su giro, 2.700.000 pesos, cuya cantidad no alcanza ordinariamente para su vasta negociación, y en estos casos le sirve de auxilio el ramo de Depósitos que por lo regular cuenta con un millón de pesos.

Diariamente se benefician y acuñan en tiempos de regular labor de Io á I2.00o marcos de plata y para esto se necesitan en sus diversas oficinas de trabajo 200.000 marcos de aquel metal de existencia diaria. En los dos días últimos del año pasado de I79o se labraron y acuñaron 42.00o marcos de plata, cuyo valor ascendió á siete millones de reales de vellón, cantidad por cierto excesiva, pues hay Casas de Moneda que no hacen otro tanto en un año. Los operarios que se emplean diariamente en estas faenas no bajan de 450 á 500 hombres, y los Ministros principales y demás empleados llegan á go. Los gastos de la Casa, inclusos sueldos, materiales, construcción y reparo de instrumentos, etc., ascienden anualmente á 350 ó 400.000 pesos y la utilidad líquida que deja su labor pasa siempre de I.300.000 pesos.

Las barras de plata que contienen algún oro, van, antes de entrar en la casa de Moneda, á otra que llaman del Apartado, por hacerse en ella la separación del oro, practicándolo con agua fuerte. Esta manipulación se incorporó á la Corona en Octubre de I778, y hasta aquel tiempo la había tenido la casa de Fagoaga con oficio de vendible y renunciable. Con él se hizo poderosa esta familia, y un tal D. Francisco tituló, tomando la denominación de Marqués del Apartado. Aún vive este primer poseedor del título, Oficial retirado con grado de Coronel. Por un cómputo prudencial, se benefician anualmente en esta oficina 200.000 marcos de metal. Los metales que sólo contienen desde I 6 hasta 29 granos de oro por marco, se benefician por cuenta del Rey por no resultar utilidad á sus dueños, deducidos los derechos de a partado, y se les paga como plata el oro incorporado en la barra; pero los metales que contienen desde 30 granos arriba por marco, se separan de cuenta de los mineros, exigiéndoles los correspondientes derechos. Diarjamente se ocupan en estos trabajos 50 jornaleros, y los sueldos y gastos de la Casa están incorporados con los de la de Moneda. Sus utilidades líquidas llegan un año con otro á 55.000 pesos. Hay en esta Casa hornos de vidrio para construir el sin número de vasos de distintas formas que se emplean en aquellas operaciones químicas. 
Igualmente se fabrica aquí el agua fuerte para la disolución de la plata y separación del oro, y esta elaboración no baja de I5.000 libras anuales, de cuyo ácido apenas tiene de costo al Rey 7 y \% reales vellón cada libra. Hay también hornos para reducir los metales á partículas pequeñas, para hacer barras de plata, para formar tejos de oro, y últimamente para fundición de tierras en la misma forma que se practica en los Rcales de Minas.

El oro que sale del apartado extraíco por la vía húmeda, que es la única que aquí se usa, tiene regularmente de 23 quilates, tres y medio granos á 24 quilates.

Debe advertirse que en estos últimos años entran regularmente en la casa de Moneda de i6 á I7.00o barras ó tejos de oro, plata y metales mixtos, de cuya cantidad la cuarta parte, más bien más que ménos, procede del Real de Minas de Guanajuato, y la mitad de lo de este Real pertenece á la sola mina de la Valenciana, de modo que esta mina rinde tanto como la octava parte de todas las del Reino, y el Real de Minas de Guanajuato, vale como la cuarta parte de todos los demás minerales.

Razón de las cantidades de oro y plata acuñadas en la Real Casa de Moneda de Méjico desde I. ${ }^{\circ}$ de Enero hasta $3 \mathrm{I}$ de Diciembre de I807, con distinción de lo labrado en cada mes.

\begin{tabular}{|c|c|c|c|}
\hline & En oro. & En plata. & TOTAL \\
\hline & - Pesos. & Pesos. Reales. & Pesos. Reales. \\
\hline Enero......... & , & $698.09533 / 4$ & $698.09533 / 4$ \\
\hline Febrero....... & $"$ & г. 898.693 & I. 898.693 \\
\hline Marzo........ & " & $1.396 .92901 / 4$ & $\mathrm{I} .396 .9290 \mathrm{I} / 4$ \\
\hline Abril .......... & " & $2.153 .05901 / 2$ & $2.153 .059 \circ \mathrm{I} / 2$ \\
\hline Mayo......... & $"$ & $1.42 x .112$ & I. $42 \mathrm{I} . \mathrm{II} 2$ \\
\hline Junio ......... & $4 \mathrm{II} \cdot 754$ & I.668.413 $61 / 2$ & $2.080 .1676 \mathrm{I} / 2$ \\
\hline Julio.......... & " & $2.076 .4902 \mathrm{I} / 2$ & $2.076 .490 \mathrm{2r} / 2$ \\
\hline Agosto........ & " & $2.050 .2073 \mathrm{I} / \mathrm{2}$ & $2.050 .2073 \mathrm{I} / 2$ \\
\hline Setiembre.... & " & $\mathrm{I} .532 .520 \mathrm{2} \mathrm{I} / \mathrm{2}$ & $1.532 .5202 \mathrm{I} / 2$ \\
\hline Octubre........ & $"$ & $3^{69} \cdot 435 \quad 33 / 4$ & $369.435533 / 4$ \\
\hline Noviembre.... & & $2.613 .95^{8}$ & $2.6 \mathrm{I}_{3} .95^{8}$ \\
\hline Diciembre.... & I. 100.512 & 2.623 .520 & $3.724 .03^{2}$ \\
\hline En todo el año. & $I .512 .266$ & $+20.502 .4337 \mathrm{x} / 4$ & $=22.014 .6997 \mathrm{I} / 4$ \\
\hline
\end{tabular}

Mejico, 31 de Diciembre de 1807 .

Ya advertimos antes, que dentro del Palacio están las Cajas Reales, donde entran los caudales pertenecientes á la Real Hacienda según las resultas que dan los Directores principales de cada ramo. No hace mucho tiempo que todos ellos se sacaban á pública subasta, dándolos en arrendamiento al mayor postor; pero en el día, mejorado aquel sistema, se administran por cuenta de la Real Hacienda con conocidos adelantamientos de ésta. Los ramos principales que componen las rentas de Méjico consisten en el derecho de alcabalas, en el de la plata y oro, amonedación de éstos, tributos, tabaco, pólvora, pulques y otros varios. El estado que sigue manifiesta cuáles han sido las entradas y salidas de las rentas de este Vireinato en los años que se expresan:

\begin{tabular}{|c|c|c|c|c|}
\hline Años & $\begin{array}{c}\text { Total de las rentas. } \\
\text { resos. }\end{array}$ & $\begin{array}{c}\text { Gastos } \\
\text { de } \\
\text { Administración }\end{array}$ & $\begin{array}{c}\text { Pensiones } \\
\text { y } \begin{array}{c}\text { cargas parti- } \\
\text { culares. }\end{array}\end{array}$ & $\begin{array}{l}\text { TOTAL } \\
\text { de } \\
\text { los gastos. }\end{array}$ \\
\hline I 775 & II. 845.130 & 3.425 .887 & 6.728 .270 & 10.154 .157 \\
\hline 1776 & $12.455 .770 \frac{1}{2}$ & 3.303 .126 & 7.030 .207 & 10.333 .333 \\
\hline 1777 & I4.II8.759 & 3.453 .658 & 8.593 .355 & $12.047 .4 \mathrm{I} 3$ \\
\hline $177^{8}$ & I5.277.054 & $3.8 \mathrm{I} 2 . \mathrm{I}+8$ & 8.485 .316 & 12.297 .464 \\
\hline I779 & I5.544.574 & $3.937 .84 \mathrm{I}$ & 10.984 .984 & 14.922 .825 \\
\hline I780 & I5.010.974 & 3.882 .739 & 12.844 .829 & 16.727 .568 \\
\hline I78I & 18.091 .639 & $4.274 .75 \mathrm{I}$ & $14.104 .18 \mathrm{I}$ & 18.378 .932 \\
\hline I 782 & 18.594 .490 & 4.568 .624 & $15.04 I .500$ & 19.610 .194 \\
\hline 1783 & I9 579.718 & 5.034 .832 & $I_{4} .922 .258$ & 19.957 .090 \\
\hline I 784 & 19.605 .574 & 4.995 .939 & $8.819 .63 \mathrm{I}$ & $13.8 \mathrm{I}+4.47 \mathrm{O}$ \\
\hline$I 785$ & 18.770 .056 & 5.010 .014 & 13.093 .055 & 18.107069 \\
\hline 1786 & 16.826 .416 & 4.553 .668 & II 527.572 & I $6.081 .2+0$ \\
\hline 1787 & I $7.983 .44^{8}$ & 4.704 .600 & 14.229 .570 & 18.934 .170 \\
\hline I 788 & 18.573 .561 & 5.228 .357 & I 4.198 .887 & 19.428 .224 \\
\hline I789 & 19.044 .840 & 4804.584 & I2.957.588 & 17.762 .172 \\
\hline I $79 I$ & $19.23^{6} .54^{8}$ & 5.316 .269 & I 4.756 .023 & 20.072 .292 \\
\hline I 792 & 19.521 .698 & $4 \cdot 745 \cdot 488$ & & \\
\hline
\end{tabular}

Por este estado se deduce el progresivo aumento que han ido teniendo las rentas del Rey á beneficio del impulso que ha recibido sucesivamente el comercio en general; también se manifiesta que el total de los gastos iguala, si no excede, en muchos años al producto de las rentas, de modo que son muy pocos ó ningunos los ahorros anuales.

El renglón que se menciona de gastos de Administración, comprende los cuatro artículos de sueldos de los empleados en ella, gastos peculiares de este ramo, compra de especies estancadas y gastos de fábrica. Tomando por término de indagación el decenio de I783 á I792, resulta que los gastos de Administración están con los productos de ésta muy próximamente en la razón de 28 á Ioo. Las pensiones y cargas particulares que anuncia la tercera columna, comprende los artículos de sueldo, varios pensionistas, cargas peculiares del Reino y cargas ultramarinas. Este último ramo es el más gravoso á las rentas de Méjico, pues sin él serían ciertamente muy crecidos sus productos líquidos. Compónese en lo principal de los situados que remite á Filipinas, la Florida, la Habana, Puerto-Rico, Campeche, Caracas y otras partes y presidios del Reino, cuya suma puede computarse en unos 9.000.000 de pesos anuales, respecto á que según los estados de Aduanas, el total de las cargas ultramarinas en el quinquenio de I785 á If 89 ha ascendido á $44.807 \cdot 365$ pesos.

El ramo del tabaco que es uno de los más considerables que componen las Rentas reales, fué libre hasta algunos años á esta parte, en que se estancó, y ahora se manufactura por cuenta del Rey, empleando al intento crecido número de personas de ambos sexos y de todas edades. Los edificios en que se hace esta manipulación, no tienen cosa particular, pues sólo consisten en grandes patios cubiertos para poder trabajar en ellos al resguardo de la intemperie; lo que sí admira es el rápido incremento que sucesiva. mente ha tomado esta renta, pues habiendo sido su producto en I 766 de $x \cdot 4$ I $7.8+6$ pesos, ya en 
cl año de 1777 cra de 6.355 .303 pesos, y finalmente, en el de 1789 de 6.294 .048 pesos.

Deseábamos mucho la llegada de nuestros instrumentos para determinar la posición geogrática de esta ciudad, ignorando se hubiese hecho algo hasta entonces sobre esta materia: pero á los muy pocos días de nuestra mansión en Méjico, supimos con harta satisfacción nuestra, que además de lo practicado por el Dr. Alzate, cuýas observaciones parecían aún capaces de mayor perfección, habian trabajado por varios años sobre el mismo asunto los Sres. D. Joaquín Velázquez y D. Antonio Gama, resultando final. mente de sus tareas una determinación así en latitud como en longitud, que apenas podía apartarse una muy pequeña cantidad de la verdadera. No obstante, habicndo recibido nuestros instrumentos el I2, nos preparamos para la observación, y al día siguiente, en una casa inmediata á Palacio, observamos el paso del Sol por el meridiano con un sextante de Stanclif. y horizonte artificial de azogue, resultando la latitud de Méjico referida á Palacio de $19^{\circ} 25^{\prime} 37^{\prime \prime}$ Norte, siendo de advertir que como no nos era dable repetir por entonces la observación, empleamos para mayor exactitud la aplicación ingeniosa de Ia fórmula de los cuadrados de los tiempos proporcionales á las diferencias en altura, como aconseja Mr. Bordá (I).

El temperamento de esta ciudad, según lo anuncian las observaciones del termómetro, difiere considerablemente del de los países de la marina. Por una observación diaria hecha en tiempo de verano $y$ en el espacio de tres meses por el Sr. D. Antonio Ulloa, resulta que el termómetro puesto al aire libre marca constantemente II $^{0} \mathrm{y}^{1} /$ a á las cinco de la mañana y á las once de la noche, y 20 á las dos de la tarde. El barómetro observado durante el mismo tiempo se mantuvo siempre en 2 I pulgadas, 6 líneas, sicndo su mayor variación, media línea por exceso ó defecto, experimentándose su mayor altura con vientos del Noroeste fríos. En el verano se goza de un temple benigno sin alteración sensible durante el día; pero en invierno cuando vientan los Nortes, se hace sentir el frío. I:l mercurio del barómetro no se altera en todo el año más de dos líneas, que sube ó baja de su atura ordinaria. En los parajes altos de la ciudad, los vientos que más frecuentemente reinan son los de la parte Norte, rara vez soplan del Sur ó Sueste, y csto sólo al fin de la primavera y principios del estío; y cuando van á en-

(1) La longitud se ha establecido en $29^{\circ} 4^{8^{\prime}}$ al Ceste de Cádiz por observaciones del Brigadier de l.1 Irmarla [). Dionisio Alcalí (Baliano, como puede rere en la llomoria que sirve de suplemento al viaje le lus goletas Sutil y. Hejicana al Fistrecho de Juan de t ablarse se dilatan las lluvias y se experiment.m fiebres y otras enfermedades. Estos vientos son por lo regular bastante húmedos; no arrecian, y en general los vientos que corren no son fuertes, ni se conoce en Méjico lo que es un verdadero huracán.

Es esta ciudad tan poco propensa á nieves, que apenas acaece este fenómeno dos ó tres veces en un siglo. Las lluvias son por el estío, así como en Europa en el invierno, y ordinariamente empiezan de Mayo á Junio; lo particular es que en la estación de verano parece que no puede caer un pequeño rocío sin que preceda una fuẹte tronada. Estas son mayores y más frecuentes cuando empiezan y acaban las $11 \mathrm{u}$ vias; el día, por lo común, se mantiene despejado hasta la mitad de la tarde, y á esta hora se presenta por el Norte alguna pequeña nube que corriendo con la mayor velocidad se acrecenta hasta cubrir enteramente el cielo; entonces se oyen truenos disformes que acaban en aguaceros copiosísimos y duran como una hora. Des pués vuelve á despejarse la tarde y queda tan serena y apacible como antes.

Parece que un clima como este, tan propenso á tempestades, estaría por 10 mismo exento de la terrible pensión de los terremotos, pero aunque aquí no sean tan frecuentes como en los países orientales del Perú, sobrevienen de cuando en cuando algunos extremecimientos cuya duración es grande. El más terrible de los que se han experimentado en este siglo sucedió el 4 de Abril de r768 á las $6^{\mathrm{h}} 47^{\prime}$ de la mañana, durando las oscilaciones seis minutos del Sueste al Noroeste; el último acaeció el 2 I de Abril de 1776 en que se verificaron dos temblores.

La menor densidad que el aire tiene en este territorio produce un efecto contrario al de los paises de la marina; allí se dijo corroe en breve tiempo el hierro reduciéndolo á escoria; pero en Méjico á pesar de la mucha humedad del suelo, de los canales que lo atraviesan y de las lluvias abundantes del verano, nunca se enmohecen los herrajes, y los alimentos y áun el azúcar se conserva en unos almacenes cuyo suelo mana en agua. Esta sequedad, parece no obstante poco favorable á la vida, pues ya dijimos que cuando las lluvias son escasas ó faltan por algunos días, empiezan á experimentarse las enfermedades; y no á otra causa puede fundamentalmente atribuirse las continuas fluxiones que padecen estas gentes, de donde resulta que sus dentaduras sean por lo general defectuosas, lo que se hace muy reparable en el bello sexo. También puede depender de la calidad del aire el mal que se padece en esta capital, de diarreas, que se haccn habituales sin causa conocida; su curación es difícil y el único remedio encontrado hasta ahora es el uso continuado del chili, nombre 
que dan aquí al pimiento, tomando además á todo pasto el pulque y retirándose á parajes donde no se respiren los vapores de estas tierras enguacharnadas. Aun así la curación no es siempre perfecta, y el enfermo por lo común viene á morir de este mal. Otra de las enfermedades que más aflijen á estos naturales es la de pleuresías, que se experimentan en la estación del invierno, y no es extraño porque entonces se une á la sequedad natural del aire, la frialdad de los hielos.

Según el empadronamiento formado en Méjico el año de I79o, resulta que el vecindario de esta ciudad, sin contar con los que pasan revista, compone un total de II 3.232 almas: de ellas se enumeran 2.359 europeos, 49.587 españoles, I 2.542 mestizos, 23.743 indios, 6.977 mulatos, 269 negros y $9.45^{8}$ de las castas mixtas; siendo lo. restantes hasta el total mencionado, I. 495 religiosos y religiosas y 6.802 seculares empleados en los conventos, hospitales, colegios, etc., y otros establecimientos públicos sin sujeción á profesión. Entre esta crecida población hay como en las grandes capitales, familias de muy ilustre nobleza, varias que gozan privilegio de títulos cle Castilla, muchos caballeros cruzados en las Ordenes militares y mayorazgos que poseen rentas crecidas. Una parte considerable del vecindario distinguido se dedica al comercio, por cuyo medio, no sólo conservan los caudales, sino que los hacen mayores: tan general es la propensión que tienen estas gentes al comercio, que clesde el grande al pequeño, desde cl rico al humilde, no hay casa en donde no se vea tienda de géneros traficables. La parte de población que componen los artesanos y gente de oficio, es muy crecida y consta principalmente de individuos de todas castas, pues estimándose cada uno en la suya tanto como los de las demás, no es sonrojoso en línea de castas ser ménos blancos los de una que los de otra. Algunos han sobresalido bastante en las artes, y han Horecido en varias épocas profesores diestrísimos de pintura y escultura, que hacen honor á su patria.

Los indios de uno y otro sexo, cuyo número es crecido, como se dijo, andan por la ciudad restidos á su modo; las mujeres usan un género de enaguas que nombran en su lengua gilotepeque, y en el cuerpo llevan una especie de chamarra ó sobrepelliz que llaman guilpil, y además, la cobija con que se cubren á modo de rebozo. Las mestizas gastan enaguas, y en el cuerpo, dc cintura arriba, el que llaman paño con que se rebozan. Los mestizos visten á la española; pero la mayor parte anda en cueros, cubiertos de un pedazo de manta ó de lona, viejo y estrecho, que les baja desde los hombros. Esta clase de gentes así vestida, se distinguen en el Reino con el nombre de Saragates: su número es considerable y ninguna su ocupación, pues todos virgan por las calles, llevando para vender, en la mano, algunas baratijas ó cosas de poca monta. Las costumbres de estas gentes se asemejan bien á su traje, y no dejan de dar en qué entender á menudo á los principales encargados de la policía y buen órden.

Como entre las personas distinguidas del vecindario hay muchas acaudaladas que pueden sostener el porte y decencia que corresponde á su estado, se vé crecido número de coches que ruedan diariamente, y trenes muy lucidos destinados para los días clásicos, particularmente en los del Rey y familia Real, que se hace paseo público al cual concurre el Virey con lucida comitiva: en estos días se presentan las damas en público con el porte correspondiente; los demás días comunes visten al modo de España, cuyas modas se imitan con brevedad. Los hombres acostumbran mucho el uso de la capa y sombrero redondo, y este es el traje cuotidiano de parte de tarde.

Acostumbra mucho esta gente ir de noche á los portales de la plaza, adonde están los mercaderes, para comer pato con chile, compuesto por varias mujeres que se dedican á este ejercicio, estando esto tan en uso, que es común y bastante frecuente en toda clase de personas. El uso del chile ó pimiento se halla tan arraigado, que entra en la preparación de cuantos manjares hay que no sean dulces, de modo que chile, pulque y cigarrillos, son tres cosas esenciales, sin las cuales parece no puede pasarse en este país. Para el despacho del pulque hay grandes tabernas públicas, adonde concurren diariamente los indios de uno y otro sexo, y regularmente pasan allí mucha parte de la tarde: esta bebida equivale aquí á la chicha de maiz, tan usada en todo el Perú: sus derechos valen al Rey 866.796 pesos por año común, deducido de los datos de un septenio.

Puede referirse por cosa particular, uno de los man jares que se acostumbran en este país, y cuyo uso parecería fabuloso á no verse. Tal es el que nombran Aguancle, y no es otra cosa que los huevos de mosquito: su tamaño es proporcionado al del animal que los produce: á la simple vista asemejan á una tierra blanquecina, pero mirados con anteojo se descubren perfectamente los huevecillos blancos y muy semejantes á los de ga1lina: con ellos sazonan los platos más delicados y dan cierto gusto á las tortillas de huevos comunes: las criollas, por lo ménos, lo encuentran exquisito, porque les comunica un sabor algo mariscoso. Los mosquitos es mercancía que tam. bién se vende en la plaza pública, y sirven para mantener los pájaros cantores que viven de esios insectos. Esta cosecha la hacen los indios y muchachos en las orillas de la Laguna y de los canalcs: los mosquitos son de la figura y tamaño de los que llamamos en España zancudos. 
Esta ciudad es abundante en comestibles, pero las carnes, aunque gordas, no tienen el gusto que las de España: lo mismo sucede en las ares: las silvestres ó de cacería de agua son abundantes, como patos de varias especies, gallinazos, etc., y su precio es correspondiente á la abundancia. Hay un tiempo en que aparecen unas aves al modo de gallinetas, y son las más gustosas entre las especies de caza: los conejos abundan mucho, igualmente que las liebres; pero no estando en uso el comer estas últimas, andan por los campos sin huir por no haber quien las persiga. El pescado escasea algo por la distancia que hay desde esta ciudad al mar; pero en la Laguna se pescan algunos peces al modo de los albures de río de España: son gustosos y no tienen más espinas que la del medio: distínguenlos de los pescados salados con el nombre de pescado blanco. Ultimamente, creemos que nada puede dar una idea más perfecta de la abundancia de esta capital que el siguiente extracto de una Memoria auténtica, que manifiesta los artículos principales que se consumieron en ella en el discurso del año de $178 \mathrm{~g}$ :

Toros y terneras...

Carneros.......

Puercos.....

Cabritos y conejos.

Gallinas y pollos.

Patos.

Pavos ò huajolotes.

Pichones, perdices y codornices.

Varias clases de pájaros.

Cargas de pescado salado de España y Campeche

Idem del Reino.

Idem de harina.

Idem de garbanzo.

Idem de arroz. .

Irlem de fríjol. .

Idem de maiz para comer..........

Idem para cebar cerdos...........

Idem de habas...

Idem de chile...

Idem de sal.

(le cacao de varias partes.......

Idem del de Guayaquil.............

Irlem de azúcar. .

Idem de panocha.

Idem de micl.

ldem de queso...

Idem de verduras.

Idem de ajonjolf.

liem de sebo.

Idem de cebada

Idein de paja.

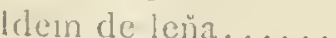

Idein de carluón..

Idem de cera.

ldem de papas...
Cargas de huevos................

Idem de pulque.................

Idem de tesquezquite..............

Idem de madera para coches.........

Idem de hierro................

Idem de cobre..................

Cajones de acero................

Arrobas de manteca que entraron de

afuera...................

Idem de pescados de varias especies...

Idem de aceitunas...............

Idem de aceite de España..........

Idem del Reino.................

Idem de nieve. . . . . . . . . . . . . .

Cuñetes de pescado de Veracruz......

Barriles de aguardiente............

Idem de vino . . . . . . . . . . . . . .

Idem de vinagre de Castilla .........

Pieles de curtiduría..............

Ladrillos......................

Brazados de piedra...............

Canoas entre grandes y chicas cargadas

de bastimentos, flores y otras especies.

7.680

$294 \cdot 790$

$9 \cdot 198$

7.3 I I

3.074

I .553

967

I 2.680

3.650

I. 154

$5 \cdot 5^{85}$

565

I 5.642

I. I 30

I 2.800

4.507

637

165.000

I. 445 . I 25

4.296

68.165

Las aguas que se beben en Méjico vienen de unos manantiales de las alturas circunvecinas sobre dos arquerías de bastante altura y buena fábrica; llaman á la una la Traspana, cuyo circuito será como de dos leguas y atraviesa la Laguna; la otra sale del paraje nombrado Chapultepeque y corre hasta la ciudad atravesando también la Laguna, aunque por distinto lado que la antecedente. Estas dos arquerías forman también dos de los paseos que tiene la ciudad, pues la primera pasa por el de la Alameda y la otra por el extremo del paseo que nombran de Bucareli. La Alameda es de figura cuadrada y está cercada de balaustrada con varias puertas: 1os coches andan por fuera de ella, y dentro pasea la gente de á pié por distintos cuadros de verdura y arboleda. Además de este paseo hay en Méjico otros varios dispuestos por los Vireyes en distintas épocas, siendo grande el esmero con que cada uno ha querido perpetuar su nombre y dejar á los venideros estos mudos testimonios de su celo y amor porla causa pública; pero sin pretender agraviar la buena memoria de cuantos han gobernado hasta ahora esta grande capital, parece cierto que la posteridad reconocida hará siempre una honrosa mención de lo mucho que aquélla debe á su actual Virey Conde de Revillagijedo. Sus reglamentos y bandos, tanto como sus obras públicas, recordarán siempre al fundador del buen orden y de una arreglada policía.

Fuera de esta ciudad y á diversas distancias de ella como de dos ó tres leguas, hay parajes de diversión, con casas cómodas á donde suelen las familias en cicrtas ocasiones del año salir á mudar de temperamento. Tales son Cacubaya, San Miguel, San Agustín y los varios pueblecillos de indios que se situan alrededor de la Laguna, en 
donde se goza en tiempo de la primavera, de la amenidad del campo y de la vista agradable de las flores. Hasta los Vireyes participan de esta clase de diversiones, y el Sr. Gálvez construyó al intento un palacio de recreo en el paraje que nombran Chapuntepec sobre las ruinas de otro que tuvo allí el emperador Moctezuma.

La Historia de la Conquista no sólo trata de la Laguna, como de un paraje que sólo contenía agua, sino que era navegable en toda su extensión; pero al presente únicamente puede navegarse por los canales, estando lo restante seco en la mayor parte del año: el suelo, no obstante, es pantanoso, y por esta razón hay construídas las célebres calzadas levantadas en la misma Laguna, lo suficiente para que el camino sea siempre traficable. El canal ó acequia principal corre por la ciudad y llega hasta muy cerca del palacio del Virey; por ella navegan diariamente cargadas de frutas, flores y comestibles, crecido número de canoas, cuya construcción difiere bastante de la que usan los indios en la costa del mar: son al modo de bateas planas, igualmente anchas en toda su longitud y por abajo de figura cuadrilonga, las manejan con palancas y canaletes, son grandes y cargan bastante peso.

De las tierras de esta Laguna sacan los naturales una sal mixta que llaman tesquezquite, la cual tiene mucha parte de salitre y alguna de sal común; la usan mucho, particularmente para ciertas comidas, por el gusto picante que les comunica; también la emplean para las tinturas, y es de creer sea grande su consumo según la abundancia con que la llevan las indias al mercado.

Como el país que rodea á Méjico en la distancia de algunas leguas forma una profundidad á donde se estancan las aguas que bajan de las alturas vecinas, sin que haya garganta natural ú otro desaguadero por donde corran aquéllas á buscar los ríos que descargan en el mar, ha resultado formarse tres lagunas en distintos niveles ó planicies y que las aguas de la más alta vayan á dar á la de Méjico, de modo que acrecentándose la altura de ésta en los tiempos de grandes 11 vias, ponen en peligro la ciudad y áun han causado daños considerables en distintas ocasiones. Para evitar en lo posible este riesgo, se construyó en lo antiguo un socavón que atravesando una garganta donde se juntan dos serranías, diese salida á las aguas de la laguna más alta, evitando así el que se aumentase en las ocasiones dichas, la masa de la Laguna de Méjico.

De este modo en los tiempos de abundantes lluvias corre por esta profundidad, á que nombran el Canal de Guaqueteca, un caudaloso río que evita el peligro que de lo contrario amenazaría á la capital, pues aunque es cierto que siempre recibe la Laguna de Méjico las aguas de su pertenencia, no son tan cuantiosas que au- menten mucho de altura, ni inspiren los temores que antiguamente.

La extensión del valle de Méjico, tomada sobre un mismo plano,rsin atender á las desigualdades naturales del terreno, ocupa próximamente una superficie de 770 leguas, teniendo 35 de largo y 22 de ancho en su término medio. Las demás particularidades que ofrece su suelo, se hallan detalladas con mucha concisión y maestría en la siguiente descripción física que formó y nos comunicó nuestro amigo D. Antonio Pineda, ya difunto, Capitán que fué de Reales Guardias Españolas y encargado por S. M. del ramo de Historia Natural en la expedición de las corbetas; dice así:

"Todas las encumbradas montañas que ro"dean el valle mejicano y sus adyacentes; las "que forman y subdividen con sus ramificaciones "los de Toluca, Cuernavaca, Amecameca y Pue"bla, poco distantes entre sí, son por lo general "de una naturaleza porfírica, más ó ménos alte"rada. Todas conservan cierta analogía en su "formación, y una figura volcánica que se anun" cia desde la primera vista, y con ef ecto, en sólo "la cordillera que rodea el valle de Méjico, se re"conocen 40 cráteres decididos, de quienes los "picos más elevados están cubiertos de nieve.

"En el fondo de este gran valle casi nivela"do, se reunen las aguas de sus derrámenes for"mando varias lagunas, entre las cuales, la de "Tezcuco, al nivel de la capital, es la más exten"sa. Todo el terreno comprendido entre ella y San "Agustín, se ocupa de unos grandes farallones "de lavas sólidas y esponjosas, compuestos de "capas inclinadas al horizonte y quebradas. Su "totalidad podría compararse á un lago extenso "de fuego, violentamente agitado de un terremoto "que le hiciese reventar las grandes ondulacio"nes y de repente se congelase. Las raíces de es"tas ondas son, no obstante, muy profundas y "forman un cuerpo continuado de bancas. Los „farallones salientes, recortados entre sí, presen"tan superficies escabrosas: algunos forman cue"vas; éstos tienen las capas concéntricas amelo"nadas, y en otros se forman estrías ó escarola"dos como las que toma un cuerpo lapídeo cuan"do en el estado de fluide $z$ se congela agitada la "superficie.

"Todos los valles que llevamos expresados, "deben considerarse como en un plano, y serían "en algún tiempo otros tantos lagos de fuego que "destruyeron y asolaron los terrenos y les dieron "nueva forma. La imaginación se sublima al con"templar cuál sería el inmenso ruído, cuál el es"trago y cuáles los torrentes de materias inflama"das que vomitarían estos montes si ardieron "todos á un mismo tiempo; cuáles serían las in"mensas masas de piedra arrojadas por los aires; "qué agente tan poderoso sería el que agitaba 
"violentamente aquel espeso licor para que to" mase forma de ondas y quedasen congeladas del "modo que ahora se encuentran después de una "serie tan dilatada de siglos.

"Además de los volcanes que forman la cor"dillera, hay otros pequeños, como los de Itza"palapa, San Isidro, la Compañía, etc., que hi"cieron sus erupciones en la parte honda del va"lle y corren, formando línea, á encontrarse con "otra serie de montes volcánicos que salen desde "las sierras nevadas entre Amecameca y Puebla. "Ellos sirven de canteras, de donde se saca el to"sonile ó lava porosa en grandes masas, para la "construcción elegante de edificios, y reunen las " circunstancias de un gran tamaño con la solidez "y la ligereza; sus fragmentos y cenizas descom"puestas, producen la puzolana y la tierra vege1) tal, que ambas contribuyen mucho á las gran"dezas de Méjico. En partes se encuentran her"mosas canteras de hidrófanos que se hacen muy "transparentes dentro del agua; pero esta rara " materia, tan preciosa en otros países, está sin " estimación y se emplea solamente en la fábrica "de vidrio. Una infinidad de pueblos y de sem"brados se han erigido sobre las ruinas de la La"guna en la parte que ocupaban en otro tiempo "sus aguas estacionarias: sea que hayan dis"minuído las lluvias ó que el terreno de la capi"tal se haya elevado, es cierto que hasta sus "aguas permanentes se han retirado de modo que "sólo ocupan una parte muy pequeña; sus orillas "despejadas, presentan por unas partes un terre"no pantanoso en que pastan los ganados, y por "otras en que se mezclan sus arenas con el te"quezquite ó álcali mineral nativo que abunda "mucho, sólo ofrece unas marismas estériles de yspecto desagradable.

"Las ciénagas y canales que rodean la capi"tal, en donde llegan las aguas perennes de las "lagunas, están cubiertas de yerba, aunque han desaparecido esos jardines flotantes conocidos con el nombre de chinamp is, que en otro tiempo cubrían la gran laguna, y de quienes aun sólo la descripción recreaba; pero se encuentran, no obstante, algunas huertas palustres, cuyo pavimento adhiere tan poco al fondo, que se mue. "ven de un sitio á otro con solo el impulso de una canoa: su extructura singular es de una es"pecie de rinfer con raiz fibrosa; sus tallos son rollizos y ligeros; su hoja, arriñonada de una pulgada de diámetro, compuesta de una sustan" cia porosa celular como la médula del sauco ó "de la enea; esta materia sobrenada y puede "sostener sin sumergirse cierta cantidad de peso "en proporción de su volumen: las hojas exten"didas cn el agrua forman planos; las raíces se entrelazan y tejen un ensamblaje; sobre estc ambulante pavimento que nada como el sarga- zo, caen las semillas del cipazus, de la grama y "otras plantas; el cieno que acarrean las aguas "ordinariamente turbias, se enreda entre las rai"ces; las hojas podridas se acumulan, se van "convirtiendo en tierras y con el tiempo forman " un suelo particular poco unido al de las lagu"nas, que sobrenada cuando aquéllas tienen agua "y resultan esos pedazos de tierra en que forman "las chimampís: sólo la laguna de Tochicalco con" serva todavía algunas tan grandes, que sostie"nen arboledas y ganados, y los transportan de " un sitio á otro á discreción de los vientos.

"La estructura local del valle, la abundan"cia de sus aguas y la benéfica tierra que resulta "de las lavas, le dan un temperamento feliz, "donde no se sufre con exceso el rigor de las es"taciones; donde no penetran con gran furia los "vientos impetuosos, por su figura aconchada; y "donde se goza, en fin, la vegetación de una "eterna primavera, bajo del temperamento mo"derado del otoño. Su atmósfera, aunque en"vuelta en ciénagas y pantanos, es no obstante, "muy reseca, como lo tiene demostrado al pú"blico el docto Alzate, por el mucho álcali mi"neral de que está impregnada, el cual absorbe "las partículas acuosas y los vapores, dejándola "purificada. En sus montes y llanadas se ha"llan admirablemente reunidas cuantas frutas y "hortalizas se cultivan en América y Europa (I). "Sus campiñas, rodeadas de arboledas y de ace"quias, ofrecen al pasajero una acogida risueña "que le distrae de contemplar los prodigios que "obró la Naturaleza en los terrenos que rodean "á la capital del Nuevo Mundo.

"En las fàldas de las montañas es donde "prospera mejor la vegetación; su flora oficinal "está ya descrita por D. Vicente Cervantes en un "discurso elocuente; este digno Profesor ha de"mostrado, como hizo en otro tiempo el gran "Hernández, los inmensos beneficios que debe á "las plantas de este suelo la especie humana, la "comparación de algunas de ellas con las que "crían las campiñas matritenses y la grande "analogía que guardan en este punto los terrenos "que rodean las dos grandes capitales de la Mo. "narquía española. En los cerros del desierto es usin dificultad mucho más copiosa; este paraje, " elegido por los religiosos carmelitas para esta- blecer la vida heremítica, es el más frondoso de "cuantos rodean el valle, casi el único en que se "conservan con feracidad los cedros que antes yadornaban todas sus inmediaciones; sus rai"ces horizontales se extienden, se entrelazan y

(1) Debe advertirse que aunque es cierto prueban bien en el suelo de este valle las plantas exóticas, á las dos ó tres veces que sucesivamente se siembran degeneran considerablemente y quedan por fin en un estado inferior al de su patria natural. Las le. gumbres son de menor tamaño y solide\%; las vituallas y plantas potajeras ménos sabrosas, y finalınente, las frutas ménos dulces y agradables. 
"fortifican bajo las piedras, sin que la poca ana"logía del terreno impida que imiten en la robus"tez á los del Líbano. Todas estas arboledas dis"minuyen á proporción que se elevan los terre"nos; de suerte que en la línea de la nieve sólo "se cría una especie de grama. El reino animal "cási se extingue en la misma proporción, y los "pocos insectos que se conservan están muy "torpes.

"El núcleo de las sierras nevadas entre Ame" cameca y Puebla (I): es el Pórfido ó Brecha por"fírica alterada por el fuego en diversas modifica"ciones. Las nubes que se elevan de los valles in"mediatos, chocan ó se rompen contra ellos. Las "montañas se cubren de espesa niebla, y estas "grandes masas colocadas en los espacios del aire " ejercen una fuerza de atracción sobre las nubes "cuando el viento ú otra causa superior no des"truye sus efectos. El barómetro estuvo sobre uno "de sus picachos en I 6 pulgadas I I líneas; y el "termómetro en $\mathrm{IO}^{\circ}$, efecto de los vapores de los "valles inmediatos.

"Todo el terreno hasta Zempoala, abunda en "tesontles y otras especies de lavas, los pórfidos "que hay en él varían mucho de colores, hay al"gunos granitos con base de esteatita shrol y 1) feldespato: se ven fragmentos de un pechstein, "que tiene lustre de pez, y algunas canteras de "basalto negro en masa. Los campos se adornan ucon los nopales silvestres, los magiielles y los " molles que á veces parecen árboles corpulentos: "los edificios arruinados de los antiguos Tulte"cas, esparcidos por estos campos, conservan el "esqueleto de una arquitectura sólida, compuesta "de los tesontles y tierra ocrácea, la cual adquie"re una dureza extremada. Otro de los objetos " más dignos de admiración que ofrece aquella "comarca, es la soberbia arquería por donde se "condujo el agua á Otumba, haciéndola pasar "de un cerro á otro por una altura de 45 varas, "poco después de la conquista de aquellos rei"nos; en ella hay arcos cuyo diámetro pasa de I4 "varas sobre una elevación de 45 .

"La tierra que sigue al Oeste de Zempoala y "comprende el resto de la provincia, es ocrácea, "al parecer cubierta de una costra calcárea.

"El Real de Pachuca (2), tal vez el más an-

(I) Nos ha parecido recibiría el público con agrado la continuación de la descripción anterior, que contiene la de la parte de Nueva España que recorrió D. Antonio Pineda. Las notas son en parte extractadas de varios apuntes de D. Antonio Ulloa, igualmente que algunas de las reflexiones que siguen á esta descripción.

(2) Pachuca dista unas 20 leguas al Nordeste de Méjico. La población se halla situada en una gran lianura, rodeándola muy. de cerca la serranía por la parte del Norte y Poniente. Sus casas están esparcidas, ocupando un gran espacio por el cual pasa un arroyo; tiene varios conventos, una iglesia parroquial y el vecindario es bastante crecido. "tiguo del Reino, comprende reunidos los cerros "de San Cayetano, Magdalena, San Cristóbal, la "Mesa y la Rejona. En ellos hay denunciadas "más de r 30 minas, de las cuales las más están "en bonanza: sus vetas corren del Este al Oeste "y atraviesan las montañas de unas á otras. Es. "tas parecen á las de Chile (r): constan de pór"fidos morados con espato blanco, su fondo es de "esteatita y petrosilex. El criadero está en es "pato calcáreo, y el metal que he reconocido de "ellos abunda en plata que contiene mucha blen"da. El temperamento de aquel Real es templa"do, por su situación local al abrigo de las mon"tañas. Los Sures, comunes en aquel país, son "los que reinan; pero no nieva y llueve muy "poco.

"Las montañas que van al Este hacia el "Real del monte, se componen del pórfido mora"do de que hablo en Chile, indicios seguros de "pertenecer á la gran cordillera, cuya materia "común es esta roca compuesta. Las vetas co"rren por lo general cruzadas: las principales "del Este al Oeste, otras de Norte á Sur y otras "inclinadas. En él se halla el famoso socavón "del Conde de Regla, admirable más por la gran"deza que por el primor de la obra, tan superior "á las fuerzas de ningún particular. Su plano en „) unos parajes corre á Ioo varas de la superficie, "en otros, en que atraviesa farallones ó crestas "de montañas, llega á 200; su excavación sigue "siempre al Oesudoeste un espacio de 3.000 "varas, atravesando por una diagonal todas las "vetas del monte; pero éstas están todas en bo"rrasca, sus planos se hallan más hondos, y era "necesario profundizar más para encontrar los "criaderos. La anchura del socavón no es más "que la suficiente al laboreo, y su altura es la de ") un hombre, aunque á veces es necesario doblar. "el cuerpo.

"La célebre hacienda de Regla en donde se "benefician los metales con una finura é inteli"gencia de que no se da ejemplar en otra parte, "se sitúa en una barranca de un emplazamiento "oval (2): su parte superior" está revestida de una

(I) El autor se refiere varias veces á las observaciones que tenia hechas en la América meridional. Cuando tratemos de aquella parte del mundo insertaremos igualmente las noticias que nos franquea.

(2) La historia de esta mina ofrece á un tiempo el ejemplo de la suerte del minero y de uno de los más raros caprichos de la fortuna. Perteneciendo estas minas á un tal D. N. Bustamante, sujeto bien ilustrado, de particular inteligencia y conocimiento de la minería, trabajaba en ellas con el fin de desaguarlas, persuadido por su antigua reputación y por algunas muestras de metales que se sacaban, que conseguido el desagiie seria dueño de las riquezasque en otro tiempo habían dado "stos minerales. En este empeño consumió todo su caudal y las cantidades que le facilitaron algunos de sus amigos, los cuales, viendo el poco acierto y lo mucho que se había gastado en un primer socavón retiraron los auxilios y sólo continuó 
"soberbia columna de basaltos, cuyas cabezas use terminan en un plano y se coronan de arbus"tos; algunas de estas columnas se quiebran, "otras se desgajan de su sitio y en las paredes "de la barranca se ven sus grupos en diversas "posiciones: los trozos de las columnas rotas "forman rampas que llegan hasta un arroyo y "son anuncios de las frecuentes ruinas que sufre "la ostentosa arquitectura, las cuales arrastran "tras sí no pocas veces pedazos de la hacienda, ") de metal. El agua de un crecido arroyo baja "oprimida entre la columnada basáltica por un "espacio de 700 á 800 varas sobre las cabezas "pentágonas de otras columnas, y se forma un "pavimento empedrado de ellas, semejante á "otro que se halla en Irlanda y ha debido á los "ingleses el título de Gianti, Cansay Way, para „indicar su grandeza. Esta cascada grandiosa, " propiamente gigantesca, se despeña últimamen"te de I2 á I4 varas, y forma con su caída un "estanque circular á quien rodea igual columna"da de 30 varas de altura, que se descubre al "través de una vegetación vigorosa. La arquitec"tura natural, el ruído del agua, la frondosidad "del sitio y la singularidad de todo el conjunto, "forman el paisaje más pintoresco que puede " crear la imaginación. La variedad de lavas po"rosas, las piedras de gallinazo y otros fragmen"tos volcánicos que hay por sus inmediaciones, "estimulan á creer que toda esta columnada sea "una cristalización formada por la vía húmeda, " contribuyendo la acción del fuego.

"En el Real de Atotonilco el Chico, se cuen-

en ellos D. Pedro Romero Terreros, comerciante acaudalado de Querétaro, de tal modo, que se asegura haberle franqueado su caudal sin interés alguno ni otro fin que el de darle esta mayor prueba de su amistad. Hallábase ya el socavón actual en la mitad de su longitud, cuando por un raro accidente murió Bustamante, dejando declarado en su testamento que las minas y cuanto en ellas había, pertenecía á Terreros por el dinero que le había facilitado, sin que sus hijos pudiesen pretender más que hasta cierta cantidad que él había gastado, suya propia.

Terreros, en fuerza de esta declaración, de haber invertido su caudal allí y del concepto que había formado de las minas por lo que había oído á su amigo Bustamante, se vió en la precisión de abandonar á Querétaro, renunciar al comercio y dedicarse finalmente al ejercicio de minero, para el cual no tenía conocimientos suficientes ni inclinación.

Empezó por continuar el socavón y ya se deja entender que trabajó en él mucho tiempo gastando nuevos caudales, antes de ver el fin de su empresa, pero una vez concluído el socavón quedo dueño de la mayor riqueza que puede haberse conocido. La plata se ha cxtraído de esta mina á millones: son infinitos los caudales que el Rey ha cobrado por razón de sus derechos, y nadie puede calcular todo lo que este hombre poseía.

Terreros, sin embargo, tan modesto en su nueva fortuna como antes, ha contribuido con mano liberal al fomento de las obras públicas del Reino, mantenía el convento de Recoletos de Pachuca, para el fin de las misiones, y últimamente, no ha cesado de contribuir al bien del listado en varias ocasiones, igualmente
" tan de I6 á I 8 vetas que todas corren igualmen"te del Este al Oeste si se exceptúan algunas "cuya dirección es Noroeste-Sudeste que aquí "llaman diagonales. Sus metales son general"mente azules ó colorados y sus matices son el "espato y la tierra blanca.

"En las inmediaciones de Tecozautla vuelven "á aparecer los indicios de volcanes, se observan "aguas termales, lavas, puzolanas y otras mate"rias de cuya descomposición resulta la hermosa "tierra que fecundiza las frondosas arboledas. "Este valle que en el día asemeja á un pequeño "paraiso, conserva en su vecindad las indelebles "señales de cuando era un doloroso teatro de las "desolaciones volcánicas. Las orillas del río que "lo ameniza, tienen enormes tesontles: hay una " colina con capas horizontales de varias tierras, "ya volcánicas, ya con calcáreos; su altura será "de 60 varas, y en ella se cuentan hasta 32 capas ) bien discernibles, cubiertas de una tierra vege"tal, que son sin duda otras tantas erupciones cu"yo intervalo se ignora, pero que tienen un es"pesor desigual y comprueban la idea de los mu" chos siglos que duraron los volcanes. Algunas " capas tienen dos varas de grueso: en ellas se " ven las pómez vitrificadas que se van subdivi"diendo hasta que se pulverizan y forman las pu"zolanas.

„Habrá muy pocos parajes en el globo, donde "se encuentren acumuladas tantas materias vol"cánicas como en las inmediaciones de Queré"taro (I): los guijarros, los farallones y hasta los "cerros son de tesontles.

que al de los particulares necesitados que imploran su auxilio. Por todas estas razones el Rey le ha concedido título de Castilla con la denominación de Conde de Regla y las minas por juro de heredad con otras gracias y privilegios que no habra ejemplar se hubiesen concedido á otro alguno. En el día ha decaído mucho el producto de las minas como se anuncia arriba.

(I) Sitúase la ciudad de Querétaro al pié de una. cuesta y al Sueste de una espaciosa llanura. Su capacidad es bien grande, las calles derechas y anchas y las casas muy cómodas, muchas de ellas con fuentes por haber abundancia de aguas corrientes que se conducen á la ciudad sobre una hermosa arqueria de 62 arcos. Tiene dos plazas grandes, una parroquia y tres ayudas de parroquia, cuatro conventos de religiosos y otros cuatro de monjas, incluso el beaterio que nombran de Santa Rosa, que es asimismo colegio para enseñanza de niñas. Las iglesias de los conventos son hermosas y están ricamente doradas en los altares y adornadas con el mayor primor. En el patio externo del convento de San Francisco hay cinco capillas grandes que hacen de otras tantas iglesias separadas de la principal, cada una con su torre y campanario. El vecindario se computa dentro de las goteras en I 8.000 almas de comunión sin comprender los indios. Hay bastantes personas de calidad y distinción y se cuentan más de 60 coches que ruedan. Su temperamento es benigno, la gente afable, y especialmente las mujeres sobresalen en lo agradable de su carácter. Hállase bien abastecida de toda clase de géneros europeos, y los naturales se ejercitan en hacer tejidos de lana y algodón, fabricar fresadas, paños vastos, lienzos blancos y listados y los que llaman paños 
"Una grande hondonada ó concha oval se pre") senta rodeada de una columnada de basaltos, cu"yas cabezas terminan en un plano: la materia de " estas columnas es una tierra argilácea con gra" nos de shorl negro y pequeños fragmentos de la"vas vidriosas de colores. En las grandes llana"das de Querétaro y Celaya (I) se ven lagunas y " abrevaderos en que a provechan las lluvias y sus"tentan los ganados. E1 suelo tiene una vara de " tierra negra esponjosa de las lavas mezcladas con "la caliza y dan el Ioo por uno de sembradura. "Están tan a provechadas que el diezmo del partido "de Querétaro asciende á 4.000 fanegas de maiz, " sin contar las simientes ni las frutas. El tempe"ramento de la ciudad se mantuvo por una serie "bien seguida de observaciones, de 65 á $7 \mathrm{I}^{\circ}$ en la 1) escala de Farenheit, en el campo no varió de 63 "á $65^{\circ}$. E1 eudiómetro absorbía 53 partes de aire "vital de Ioo del común: pero cuando sopla el "viento Nordeste, que es conocidamente el más "sano, es tan superior que absorbe hasta 75 partes.

"El cerro Cimatario, distante una legua de la "ciudad, es un pequeño volcán extinguido, todo "cubierto de lavas; su núcleo, como el de los de"más de Nueva España, es el pórfido, y se notan "algunos fragmentos ferruginosos. Este volcán, á "quien no se le reconoce crater ni respiradero al"guno, eruptó probablemente por alguna boca in "ferior, como en nuestros días el Jorrullo, y el "siglo pasado el Monte Novo en Italia.

"El Real de Guanajuato(2), el más abundante "en minas y tal vez el más opulento que se cono"ce en el orbe, ocupa varias colinas que se revis"ten de flores hasta su cúspide, pero á veces cles" cubren sus farallones desnudos de una especie de "arenario con partículas de esteatita ó serpentina

que usan las mujeres para rebozarse, cubriéndose el cuerpo desde los hombrosá la cintura. Las salidas de la ciudad son muy amenas por las muchas huertas que hay en su circuito.

(I) Celaya ocupa casi la medianía de una extendida llanura: sus plazas son cuadradas; las calles anchas y derechas, y por lo general las casas bajas con terrados $\delta$ azoteas. La torre de la iglesia parroquial es particular por su mucha altura; tiene cuatro cuerpos y en los tres superiores dos arcadas acompañadas de columnas en cada uno. La iglesia de San Francisco sirve de parroquia, y su comunidad mantiene colegio de estudios y Universidad. Además se cuentan cuatro conventos de religiosos y un beaterio con la advocación del Niño Jesús. El vecindario es bastante crecido pero de gente humilde y no de muchas conveniencias; su ocupación en parte es la fabricación de tejidos y lienzos de algodón como en Querétaro y parte la arriería para el tráfico interior del Reino.

(2) La población de Guanajuato ocupa un estrecho espacio que dejan entre sí dos cordinleras de cerros por donde empieza á entrarse desde el para. je que nombran el Marfil; de modo que yéndose uniendo aquéllas desde este punto viene á ocupar la ciudad las desigualdades de sus concurrencias. Por esta razón las calles son pendientes, bastante ásperas, y para fabricar las casas hay que hurtar á los cerros parte de sus faldas labrando á pico el suelo. Es bastante grande y su vecindario pasa de 80.000 almas, atraí- "que, endurecida, asemeja á la piedra de afilar, "y en sus inmediaciones se ven pudins de distin"tas piedras. En los bosques contiguos abunda el "palobobo, los combolbulus, el cactustuna, la "zinnia y otras diversas. El temperamento de "Guanajuato es bastante igual. El barómetro

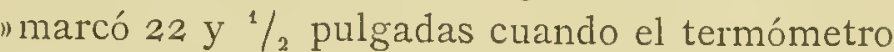
"mantenía en $I 2^{\circ}$. Hechas las correspondientes se "reducciones, resulta que se halla este Real si"tuado $997^{22} / 100$ toesas sobre el nivel de la mar, "ó lo que es 10 mismo, 2.393 55/100 varas caste"llanas: Ioo partes del aire vital que se respira "en sus calles, tuvieron ordinariamente 60 par"tes de absorción.

"La mina de Tepeyas, una de las principales, " está en un monte esquistoso con incrustaciones "ferrugíneas; su veta madre corre del Sudeste al "Noroeste con una inclinación constante de $43^{\circ}$, "sus cañones de comunicación están dispuestos "de tal manera que dan al aire una perfecta cir"culación. La profundidad perpendicularen don"de se halla el principal tiro pasa de 220 varas, "pero no es posible dar una idea del conjunto bu")llicioso y la grandeza que se observa en aque"llas cavernas subterráneas en que se emplean " cerca de 3.000 trabajadores. En ella se encuen"tran las oficinas para el despacho, los almace"nes de pertrechos, los depósitos de minerales, "las contadurías, y en fin, cada tiro ocupa para "sí más empleados que los que hay ordinaria"mente en las minas más ricas de otros parajes. "Su administración se dirige con una formalidad "cual si fuera la de un reino, y el encargado par"ticular de cada boca-mina rinde sus cuentas se"manalmente al Administrador general (I).

das únicamente por el atractivo de las riquezas, pues no tiene territorio laborable para sementeras. Hay en la ciudad algunos buenos edificios, y generalmente las casas tienen alto y balconería. Se encuentra con abundancia todo género de mercancías: tiene Ayun. tamiento, Alcaldes y Regidores, con un Tribunal de Hacienda, siendo cabeza de partido y asiento de los Intendentes de su provincia. La grande pensión que padece es en punto de anuas dulces: en tiempo de lluvias las que bajan precipitadas de los cerros ponen en peligro los edificios, porque acumulándose $\mathrm{en}$ torrentes, caen sobre ellos angostándose en el estrecho cáuce de las dos cordilleras y arrastrando consigo lo que encuentran al paso; cuando las secas, no correagua ni la hay para el consumo de la población; para estos casos hay construido un estanque que se formó á tres cuartos de legua de la población en el concurso de las dos cordilleras, atravesando una gran presa de cantería de cerro.

(x) Esta mina se descubrió en lo antiguo y se abandonó al poco tiempo por no haberse encontrado metales de ley, pero para que se comprenda en algún modo lo que contribuye la casualidad y la constancia al descubrimiènto de los metales ricos, se dirá aqui lo acaecido con esta mina.

Don Antonio Obregón había entablado en el dis curso de su vida el trabajo de varias minas sin lograr encontrar alguna regular fortuna; su corto caudal se hallaba enteramente consumido y el crédito estaba perdido porque la fortuna no le había dado propor- 
"Toda la parte de Nueva España que hemos "corrido deberá considerarse un entrelazado de "montañas, cuya dirección general es de Norte á "Sur ó del Noroeste al Sudeste; en sus faldas se "dilatan muchos valles que se formaron por los "volcanes cuando on sus respectivas erupciones "trastornaronpor esta parte la superficie del glo"bo. Sus lavas, descompuestas con el transcurso "del tiempo, con las aguas y con la estación del "ácido ácreo, se hacen tierras vegetales y han "cubierto las llanadas de Celaya, Salvatierra, "Querétaro, Méjico, Toluca, Puebla, Cuernava"ca y otros muchos que deben considerarse como "yraneros del Reino.

"Si atendemos á la situación geográfica de "todos los Reales de minas, tanto antiguos como "modernos que se conocen en Nueva España, y "estamos á los informes de los prácticos que los "han reconocido, deben considerarse comprendi"dos en tres zonas ó cordilleras metálicas, guar"dando el orden siguiente. La primera corre del "Sueste al Noroeste con alguna ligera inflexión al "Norte: en ella se comprenden los Reales de Tete"la del Río, Tepanticlan, San Juan Guetario, "Culcupaseo, Santa Clara, el Río del Oro, el del "Sombrero, Rizaclan, el Nuevo de Guadalupe y "Tecalitan, á quien sigue el de Santa María de "la Yesca y va á parar á Bolaños.

"Esta primera cordillera ocupará una extensión "de 200 leguas, porque suelen distar mucho unos "de otros. Los más de ellos están en tierra calien"te ó cuyo nivel no se eleva mucho sobre el del " mar, y sólo se exceptúan de esta regla los de "Tetela, Tepanticlan y Pisiaclan: en esta misma "cordillera se encuentran en actual indicio los "volcanes Jorrullo y Colima, cuya corresponden"cia interior está confirmada por la exacta al"ternativa que guardan en sus erupciones.

"La segunda conserva su dirección del Esnor.

ción para corresponder á los empeños que había contraído. En esta disposición tuvo la humorada de inclinarse á la Valenciana y en i 760 hizo la denuncia registrándola en la Caja Real contra el dictamen de los inteligentes y de sus amigos que con las mayores persuasiones intentaron apartarle de tal pensamiento considerando que sería el término final de su ruina; entonces tenia solo de 20 á 25 varas de profundidad y hasta 35 de tendido de veta. Durante nueve años no se hizo más labor que las que podían las fuerzas naturales del dueño ayudado de uno ó dos indios que le acompañaban., pues hallándose en la mayor incligencia carecía enteramente de todo otro auxilio. Subia cliariamente con su barreta y trabajaba cuanto podía; pero el adclantamiento era muy corto y se necesitaba mucho tiempo antes qne se conociese algún progreso. Al cabo de los nueve años en que fué necesario para subsistir la mayor constancia que se deja entender, empezó á desculbrir algunas muestras de inctales y con estos indicios solicitó y obtuvo la (o) mañó de algunos sujetos y principió el trabajo liomal con la felicidad de que á proporción que se mofundizaba, se iba haciendo patente la riqueza. Al presente es la más rica de la Nueva España, como dijimos hablando de la Ciasa de Moneda de Mléjico. "deste al Oesudoeste: en ella están comprendidos " todos los Reales que están al Sur de Guajaca, "Tejomulco que es criadero de oro, San Jeróni"mo, el Real Viejo, todos los de la Misteca, el de "Gautla, el de Cosclatlan, el de Julián, el de Cho"malpé, el de Reguilotepec, el de Tasco, los de "Zagualtepec, Sultepec y Temascultepec, el de "Tapajagu y Guanajuato, el de los Asientos de "Ibarra, Ojo caliente, el de Zacatecas, el del "Fresnillo, el de Plateros y últimamente, el del 1) Sombrerete.

"La tercera cordillera, de quien hemos reco"rrido mucha parte, sale de Teguantepec, coge las " minas antiguas de Zempoala, el de San Miguel "de Talca, el bajo de Villalta, el Real Nuevo, "los descubiertos últimamente en Guajaca, los "de Capulalpa, Santa Catharina de Chatoa, San "Pedro Mariche, los antiguos de Teguacan, de - las Granadas, los dos tetelas de oro y de Jono"cla, el Real de Monte, Atotonilco, Pachuca, "Santa Rosa, Capula, Zimapan, Cardenal, San "José del Oro, el Jacal, el Doctor, el Pinar, el de "la Targea del Sichu, el de los Catorce, Guadal"cázar, San Luis, Potosí y Boca de Leones, con "otros pequeños que no se nombran. Al lado de " esta cordillera se halla Perote y el volcán de "Orizaba."

De lo expuesto arriba, y según lo dan á en. tender las observaciones barométricas practicadas en la parte que hemos recorrido de la Nueva España, se deduce claramente que el territorio de este Reino no tiene una altura á corta diferencia igual, respecto á la superficie del mar, ni que la elevación que toma á cierta distancia de éste es por cuestas rápidas y montañas elevadas, que hacen pasar repentinamente del terreno bajo al alto. Este se va elevando insensiblemente por países altos y espaciosos hasta llegar á cierto término, el cual conserva después en largas dis$\operatorname{tancias}(I)$.

Según un estado comunicado por el Administrador de ella D. José Quijano, ha producido la Valenciana en los cuatro años y medio corridos desde $\mathbf{I}^{\circ}$ de Enero de 1787 hasta Junio de I79I, 685.22 I cargas de metal que valieron beneficiadas 13.027 .890 pesos. Jos gastos semanales ascendieron en la misma época á 2.052 .073 pesos, los consumos y pérdidas de azogue á 22.229 quintales y se gastaron I 7.540 cajas de pólvora, cuyo valor es de 2 I 3.783 pesos: se ocupan diariamente en todas las dependencias y laboreos de esta mina 3.123 personas.

(I) Desde Veracruz hasta Jalapa, que cuentan 22 leguas, las ocho primeras son enteramente llanas, y en las 14 restantes se van subiendo por cuestas tendidas las 1.667 varas que está Jalapa sobre el nivel del mar; de modo, que á cada legua de este tránsito corresponden i 9 varas de desnivelamiento, ó una vara á cada 60 de camino, suponiendo de 7.000 varas la extensión de la legua. Lo mismo se verifica desde Jalapa á Perote. Entre estos dos puntos hay diez leguas de distancia y I.5 9 varas de diferencia de nivel, en que está Perote más alto que Jalapa, por lo cual corresponden á cada legua 152 varas de desnivelamien. to ó á carlia una de estats te de distanciar de camines 
La línea que limita y subdivide la parte baja de la alta, puede considerarse pasa por el paraje nombrado de Perote, 32 leguas distante de Veracruz en la dirección del camino, y I4 y $1 / 2$ de la marina en línea recta desde la ensenada de Chachalaca ó de San Carlos. Según las observaciones barométricas que anunciamos en nuestro viaje de Veracruz á Mejico, es la elevación de Perote sobre el nivel del mar $1.365 \mathrm{y}^{1 / 2}$ toesas de París, altura igual, muy próximamente como en adelante veremos, á la que tiene la América meridional cuando allá se sube al país alto; y sin embargo, esta misma altura es la que conserva esta América en muchas leguas, casi hasta Guanajuato, como lo confirman las experiencias barométricas, las cuales determinan las alturas de los parajes siguientes sobre el nivel del mar en esta forma:

\begin{tabular}{|c|c|}
\hline & 'oesas de 1 ? \\
\hline 1 Lencero. & $4592 / 3$ \\
\hline alapa. . & 714 \\
\hline erote. . & I. $365 \%$ \\
\hline a Venta de Soto............... & I. 350 \\
\hline Iéjico . . . . . . . . . . . . . . . & I $\cdot 323$ \\
\hline $\begin{array}{l}\text { a Goleta: una hacienda } 59 \text { leguas de } \\
\text { Perote y I } 9 \text { de Guadalupe......... }\end{array}$ & I. $336^{1 / 2}$ \\
\hline $\begin{array}{l}\text { En Guanajuato la Mina de la Valenciana. } \\
\text { Fn la casa del Administrador de la Va- }\end{array}$ & I. $33^{\circ}$ \\
\hline 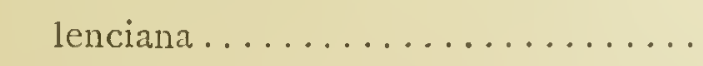 & $\mathrm{I} \cdot 34 \mathrm{I} 3 / 6$ \\
\hline 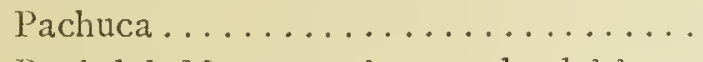 & $I \cdot 35^{\circ}$ \\
\hline 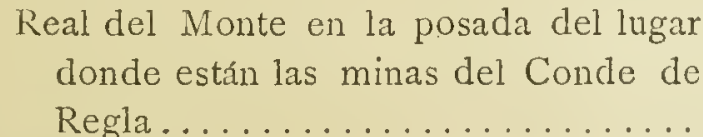 & \\
\hline
\end{tabular}

Ya se vé, pues, cuán pequeñas son las diferencias de nivel que hay entre los parajes que mencionan estas experiencias, y que pueden muy bien considerarse todos en una misma altura respecto á las grandes distancias que median de unos á otros. Nótanse, sin embargo, algunas irregularidades, que proceden particularmente del declive que forma el terreno para que corran las aguas á buscar su centro. La población de Guanajuato, por ejemplo, I28 y $1 / 2$ leguas de Perote por camino y 87 en línea recta, está más baja que lo ordinario del país unas 800 varas castellanas, según la referida observación de D. Antonio Pineda, que concuerda bien con otra hecha en I777 por el Sr. D. Antonio Ulloa; pero esta diferencia estriba únicamente en que esta población se halla situada en una quebrada cuyo suelo difiere casi toda aquella cantidad del terreno adyacente, el cual empieza á descender á distancia de $\operatorname{die} z$ leguas en el paraje que nombran la venta de Temascatio. Por el contrario, entre el lugar de San José de Jula y la hacienda de la Goleta,

cantidad con efecto bastante insensible y que prueba la poca pendiente de las cuestas por donde se sube hasta Perote. distantes entre sí cuatro leguas, se atraviesa una cordillera no muy elevada, pero lo suficiente para dividir los paises; y el nivel de altura permanece, sin embargo, con muy corta diferencia á uno y otro lado, mediante que la Goleta está sólo $5^{6}$ varas más bajo que Perote, y todo el país como 3.I50 más alto que el nivel del mar; termino que parece fijó la Naturaleza para que se experimentase en este país un temperamento templado é igual, favorable para los vivientes y propicio para las producciones de la tierra. Indícase bien esta igualdad de temple en las experiencias del termómetro: en parajes resguardados del aire frío ó de las impresiones del Sol, marca constantemente desde 17 á $20^{\circ}$ : expuesto al aire libre en los meses de Junio, Julio y Agostọ, baja á $13^{0}$ con la frescura de la mañana, y sube á 22 desde las doce á las dos del día, no dando en él el Sol ni toldándose el cielo, como sucede muy de contínuo. La misma regularidad se nota en las observaciones del barómetro: este instrumento, que en las orillas del mar padece alteraciones muy frecuentes y sensibles, permanece constante semanas enteras desde luego que se sube á la parte alta, siendo su mayor varia. ción de una línea. A este respecto conservan también igualdad las producciones del terreno, como lo manifiestan varias de las plantas que en él se crían, y tienen una analogía muy marcada con las del clima cálido de nuestras provincias meridionales de España.

En la estación que el Sol se retira al trópico de Capricornio, el frío aumenta, y en parajes llega á helar, aunque no en todos los años, y nunca con exceso. Siéntese, sin embargo, el frío, y se necesita de abrigo; pero siempre se hace sensible la influencia del Sol por su ménos distancia al zénit, y al paso que parece frío, siente el cuerpo la ardentía del Sol de un modo particular; las gentes carecen de aquella fuerza física que parece demostrar la robustez de sus cuerpos, y áun los animales no tienen todo el vigor que en otras partes. Una carreta regular, que en Europa la arrastran dos bueyes, aquí necesita de cinco ó seis para tirar del mismo peso; y bien sea que por la intensidad del calor experimentan los animales una grande disipación, ó que ésta se verifique en las plantas y sean los pastos de poca sustancia, siempre parece que este decaimiento de fuerzas procede del calor. No á otra causa debe atribuirse también la falta de vigor que experimenta aquí aquella clase de gentes, cuyas ocupaciones diarias piden un trabajo sedentario $y$ mental de muchas horas. Les faltan las fuerzas para sobrellevarlo en las tardes y noches, y el que se ve obligado á ello, siente muy luego los efectos funestos de aquellas tareas, en la mengua de su salud. Esta debilidad la experimentan los jóvenes igualmente que los de edad avanzada, y 
es una prueba de que la laxitud y flojedad que se atribuye á estas gentes procede más bien de los efectos del clima que de vicio contraido por la costumbre. Esto mismo lo confirma á cada paso la experiencia, en los europeos que se establecen aquí, pues á poco tiempo participan como los naturales de los mismos hábitos que éstos, de forma que cualquier individuo hace en su ejercicio en Europa duplo ó triple trabajo que trasladado á estos países.

Otras señales del efecto del calor que aquí se experimenta, son la debilidad de estómagos y la dificultad de perfeccionarse la digestión; la contrariedad de ciertas bebidas y particularmente el que sea nocivo el uso del vino. Parece que el cuerpo tiene necesidad de adquirir vigor con bebidas más espirituosas como el aguardiente y los licores: la experiencia ha manifestado á estas gentes, que el uso moderado de estos últimos y á ciertas horas es provechoso, así como contrario el del vino, á ménos que no se use con mucha moderación y poca frecuencia. El vino, dicen, les enciende la sangre, relaja los estómagos, irrita las bilis y causa diarreas que no se corrigen fácilmente. Las fluxiones que contínuamente se padecen, son también efecto del calor de la sangre, y la mayor parte de los accidentes que se contraen en estos paises, tienen origen en lo cálido del clima, á pesar de lo templado del aire $y$ de la frescura que manifiesta exteriormente.

No puede, á la verdad, ocultarse que esta parte de la América que ahora describimos, es la región peculiar del Sol, según las señales que muestran los meteoros de la atmósfera. Durante el verano, desde Mayo hasta fines de Setiembre, se sienten tormentas formidables de rayos y truenos que terminan en copiosas lluvias. Las mañanas de esta estación son, por lo regular, serenas, y el cielo se mantiene despejado y alegre hasta que ha pasado el Sol el meridiano; algún tiempo después empiezan á levantarse algunas nubes por el Norte, y en breve tiempo ocupan parte de la atmósfera, hasta que á las cuatro de la tarde se extienden, cubren enteramente el cielo, empieza la tormenta, y á breve rato caen aguaceros copiosísimos que templan el calor que ha percibido la tierra en el discurso del día. En estas lluvias parece consiste la sanidad del país; cuando se retardan ó dejan de ser frecuentes, son comunes las enfermedades y éstas en general las que proceden por efecto de mucho calor. Hay largas temporadas en que estos aguaceros y tormentas se repiten diariamente y con igual fuerza en unos días que en otros, sin que por esto se formen pantanos, ni la tierra se enguacharne, pues con poca pendiente que tenga el terreno se encuentra seco á la mañana siguiente. En la estación del invierno, cuando el Sol pasa al hemisferio opuesto, cesan cnteramentc las tormentas y las lluvias y reinan vientos fuertísimos y secos, que se hacen tan incómodos como las recias tormentas del verano. En cuatro meses del año no cae enteramente gota alguna de agua. Los vientos más frecuentes entonces, aunque no contínuos, son los del Norte: con ellos viene el frío, y en algunos años llega al término de helar. La falta de lluvias, la cualidad seca de la atmósfera y la frecuencia de los vientos recios que aumentan ordinariamente desde el medio día en adelante, ocasionan en esta estación enfermedades correspondientes á ella, siendo comunes las pleuresías y constipaciones.

Cuanto hemos dicho relativamente á las frecuentes turbonadas del verano en la parte altá, se verifica igualmente en la baja, siendo ordinarias las tormentas de aguaceros y truenos. La única circunstancia en que se diferencian consiste en que por lo regular empiezan después de puesto el Sol, ó bien entrada la noche, y que también vienen acompañadas de vientos violentos, cuya duración es la misma que la tormenta. Esta abundante humedad con que se templa la tierra, del calor que adquiere durante el día, hace ménos incómodo el temperamento de la parte baja: no obstante, es bien sensible, y lo sienten los cuerpos con bastante fuerza. Hay algunos años en que se adelantan los calores, y hace en Marzo y principios de Abril un bochorno y sofocación tan fuerte, como en los meses más rigurosos del verano. Esto sucede cuando reinan los vientos del Sueste ó Sur, pero pasados algunos días, vuelve á moderarse y á ser más soportable su temperamento.

Sabido es que en los parajes cálidos de la Zona Tórrida, los efectos del aire en el barómetro son más sensibles que en los países situados fuera de ella, y que áun en aquéllos lo son más donde reinan con fuerza los vientos Nortes. Esto mismo se verifica en Veracruz, y anteriormente hemos manifestado las grandes variaciones que experimenta el barómetro entre los vientos húmedos del Este ó los secos del Norte, pero en la parte alta de esta América, las alteraciones del barómetro son poco considerables, y no puede determinarse con seguridad el efecto de los vientos secos del invierno respecto de los húmedos del verano: esto parece conduce á creer que en las alteraciones del barómetro tiene más influencia la elasticidad del aire que su peso ó gravedad. El calor intenso propio de este clima, juntamente con la dilatación del aire en esta región de la atmósfera, no de ja de causar alguna novedad en la respiración, mucho más cuando se camina por terreno desigual, aunque no sea muy áspero: los naturales, como criados en el aire sútil de esta atmósfera, no encuentran novedad y trafican por todas partes con la mayor agilidad; pero los no acostumbrados sienten la fatiga desde lns prime. 
ros pasos y una sensación desagradable por la falta de densidad en el aire que se respira.

A esta propiedad del aire debe sin duda atribuirse el de que sean desabridas las carnes que sirven de alimento. Se tiene notado que en los temperamentos verdaderamente fríos y áun en los cálidos, son de gusto y sabor regular, pero aquí, á pesar de los abundantes pastos con que se nutren, son generalmente insípidas y de poca sustancia: los pichones, los pollos, pavos y gallinas y las aves de caza, tienen el mismo defecto y parece confirman la idea de que la calidad del aire que se respira contribuye mucho á que los jugos nutritivos produzcan en las carnes la variedad que se nota.

Debe también atribuirse á la calidad del aire la particularidad de que no cause perjuicio á la salud la abundancia con que se usa del picante, siendo tal, que entra siempre como ingrediente principal en el alimento común de las gentes pobres. Este consta del chile ó pimiento mojado y molido en piedra, condimentado después con sal y aceite, en cuyo compuesto que llaman cremole, mojan las tortillas de maíz, y es el único alimento que tienen y con el cual se sustentan y viven como si usasen comidas más sustanciosas. Antes digimos que el uso del aguardiente era general y que probaba bien: ahora añadiremos que sucede lo mismo con el cremole, y que á pesar de que uno y otro parecen contrarios á lo reseco del clima, viendo que los efectos no son malos, es menester convenir en que ó estas cosas obran como estimulante, ó que la costumbre las hace soportables, sin que por esto suceda lo mismo á los que no se hallen connaturalizados con ellas.

Todo lo expuesto hasta aquí debe entenderse en términos generales y sin las excepciones á que da lugar en muchos parajes las circunstancias locales del terreno. Es digno que no pasemos en silencio de que hallándose el pueblo Jalapa en la medianía de altura que corre desde el mar hasta Perote, participe de los mismos fenómenos que la parte alta del país: el aire no se altera con los accidentes que sobrevienen en la atmósfera; las plantas participan algo de las que son comunes en una y otra altura, y finalmente, el temperamento de aquel lugar es con muy corta diferencia igual al de la parte alta, como lo demuestran las observaciones del termómetro de que dimos razón anteriormente, de modo que todo nos lleva á pensar que sin elevarse en la Zona Tórrida más altura que la que tiene Jalapa, la atmósfera es inalterable. Sin embargo, puede muy bien suceder que el grado de calor constante de.esta villa sea causado en parte por la figura particular del terreno, compuesto de varios cerros medianos que forman valles y quebradas, y por la inmediación de los dos cerros de Perote y
Orizabal, que corresponden al Poniente y Sur de aquella población.

Aunque el reino de Nueva España sea de una extensión tan dilatada como lo manifiestan los mapas, es menester advertir que lo poblado y verdaderamente reconocido hasta el día se extiende únicamente hacia el Norte hasta los presidios que hacen frontero á los países habitados por naciones bárbaras. Más adelante daremos algunas noticias sobre estas naciones, y ciñéndonos á tratar por ahora de esta parte que denominamos poblada, es preciso distinguir también que nuestras ideas en Europa relativamente á lo que se entiende por país poblado no pueden aplicarse con exactitud á esta nueva región del mundo. Habítanla en el día, según los cálculos más probables, unos tres millones de almas que, como repartidas y subdivididas en tan dilatada extensión, apenas permiten se conserven en algunos parajes los rastros de la especie humana. En los puntos que se aproximan al centro y que á voz común pasan por los más poblados, se ve que esta población sólo consiste de unas haciendas de muchas leguas de extensión, en donde hay ranchos ó lugares de indios que se mantienen en paz y encuentra el caminante los auxilios que necesita á distinción de lo que sucede en provincias más distantes, en cuyos tránsitos se corre el riesgo de padecer los insultos. de los indios bárbaros. Hay no obstante algunas grandes ciudades como Méjico, La Puebla, Guanajuato, Guadalajara, Querétaro, Valladolid y otras de ménos nombre, cuyo vecindario, no sólo es crecido, sino que de algunas de ellas podrían formarse otros muchos lugares sin que sintiesen aquéllos la falta de sus vecinos inútiles; pero en contraste de estas gruesas poblaciones, se presentan otras varias que sólo sirven de llevar el nombre. La mayor parte de los pueblos constan únicamente de indios, adonde están congregados unos cuantos españoles, muy pocos son de españoles solos, y áun en este caso su número se aumenta siempre con el de indios y otras castas mixtas; los demás, aunque toman el nombre de pueblos, usurpan en realidad este título, pues no parece deba dárseles tal á unas chozas mal concertadas y confusamente esparcidas sobre un terreno habitado no en todo de indios. Tal es en realidad la constitución de los poblados á diferencia de que en algunos parajes son los negros, mulatos, coyotes y sus semejantes los que hacen la pluralidad. Esto puede traerse como una prueba irrefragable de que las frecuentes transmigraciones de nuestros europeos á ésta América no han sido capaces de indemnizar en ella los perjuicios que su falta causó desde luego al suelo patrio.

Como el comercio de este Reino se halla reducido en sus artículos de extracción á los que 
hcmos mencionado anteriormente, la agricultura por consiguiente no ha hecho hasta ahora los progresos que parecía prometer. Hablando en general, los habitantes de Nueva España sólo siembran para comer, y no es extraño porque faltando extracción y no pudiendo guardar las semillas en muclias partes, no se encuentra destino para lo sobrante, y los labradores miden sus siembras á aquello sólo que pueden vender prontamente. Esto tiene el grave inconveniente de que en dos años seguidos, uno de estcrilidad y otro de corto acudir, entra la escasez, sigue la necesidad y á ésta las epidemias, como se verificaron en los años de 1785 y 86 , de cuyas resultas retrocedió el Reino perdiendo mucha parte de su población, de la que aún no se ha restablecido enteramente, pues trastornos de esta clase no se remedian en muchos años de bonanza.

Opinan algunos que siendo cl Reino fértil y el terreno que ocupa capaz de contener al mayor número de habitantes de la Europa para cultivarlo, si se extendiese á más manos la agricultu ra, suponiendola hoy abatida, acaso por la abundancia se vería entonces arruinada, mayormente correspondiendo el terreno con su natural fertilidad. Pero estc argumento tiene origen en un principio equivocado, porque la decadencia de la agricultura no procede del número grande ó pequeño de los que en ella se emplean ni se trata tampoco de extenderla hasta llegar á cultivar el Reino entero. Hay en esto como en todas las cosas un límite que parece fijar la Naturaleza, y que ésta enseña bien á los interesados por medio de la experiencia, pues ninguno ciertamente se cmpeña en continuar las empresas que ve le arruinan.

Lo que parece cierto es que en el modo y medios de disfrutar la tierra consiste mucha parte de la fclicidad á que aspira la fatiga de conseguirla. No hay país más abundante de oro y plata que el Reino de Nueva España, y á pesar de csta abundancia son infinitos los pobres miserables, acaso sin ejemplar en otros reinos de Europa, aunque muchos lo sean voluntarios. Esto mismo puede decirse de la agricultura, su abatimiento no depende de la feracidad del terreno ni de su mucha extensión sino de los medios y modo con que se disfruta. Aclararemos esto. En los tiempos de la conquista y poco después, las circunstancias obligaron entonces á señalar por premios de servicios porciones crecidas de tierras en los repartimientos que se hicieron, y vinculadas éstas en los sucesores, sc han formado unas haciendas tan dilatadas de 20, 30 y más leguas, que es imposible las cultiven sus poseedores sin grandes fondos y una cierla probabilidad de la extracción de los frutos; tan desigual división de las tierras ha traído por consiguiente un sistema particular de agricultura. Esta honrosa y útil ocupación sólo se practica en lo general por los indios, y ellos solos cultivan los campos acaso bajo de un modo demasiado severo y falto de arte, mientras que unos pocos españoles hacen su suerte á costa del gañán, porque los demás dueños de fincas sólo las obtienen casi precariamente y sacrificando sus utilidades al obsequio de los arrendatarios y oprimiéndolos violentamente siempre que no corresponden las cosechas, vienen los demás al fin á abandonar sus rústicas tareas ó si algunos subsisten es á costa de valerse de buenos ó malos medios.

Llamámosles malos ó buenos porque no faltan de ambas clases. De la primera especie son ciertas tareas que sin paga alguna hacen vencer á los indios en ocasiones extraordinarias y días de fiesta, y de la segunda, la ganancia que suelen adquirir en los avíos de ropa y otros repartimientos que acostumbran darles á cuenta de sus salarios cuando son á precios justos. Reglados estos últimos arbitrios en las haciendas que por su situación y distancia traen comodidad al trabajo, serían indiferentes ó cómodos, pero si las poblaciones mejorasen de condición en su situación y accidentes, no serían tan precisos estos surtimientos que con facilidad caen bajo la tiranía y la usura, porque no hay otra parte de donde pueda tomarlos el trabajador sino del hacendero.

Hay otra causa no tan conocida, pero no ménos cierta, que influye de algún modo en la decadencia de la agricultura. Todos ó los más de los indios de los pueblos, hacen sus pequeñas siembras, cuyas cosechas, multiplicadas por el número de estos trabajadores, componen un todo bastante regular. Jamás entra el indio en el cálculo de costos ni cuenta con su trabajo: ve delante de sí seis ó siete cargas de trigo, necesita dineros para el tributo, para la bebida, para la obvención ó para otras urgencias ménos justas, y se deshace á cualquier precio del fruto de sus sudores. Contínuamente se ve que la carga de trigo que apenas podía salir de la era por 50 reales vellón, la dan por dos pesos, y áun por un peso en las provincias internas ménos distantes, y es claro que esta baratería ofende al valor que clebieran tener las cosechas de aquellos que necesitan diverso modo de subsistir y costear las labores; de suerte, que no aprovechándose ellos de estas semillas, ni cediendo en beneficio público por las manos en que caen, forman un comercio vicioso de regatonería, que daña al cuerpo de labradores.

También puede decirse que los consumidores no son hoy todos los que dcbían ser, porque la superfluidad de gentes cn el pequeño recinto dc un pueblo falto dc industria, es un mútuo perjuicio entre ellas mismas para tener todas ocupación. De este principio se sigue la escase $z$ de 
medios, para subsistir la miserja, el abatimiento de espíritu y todos los males que como sombra de la indigencia la acompañan generalmente. Esta necesidad hace desconocido de millares de gentes el sabor del pan, y el maiz y los fríjoles son todos los alimentos en que libran su conservación por más baratos aunque más groseros, y si algún día alcanzaron sus fuerzas á tomar un poco de mala vaca, es sin duda porque la fortuna no les mira entonces del peor aspecto. Todo esto sucede con aquella multitud de castas que componen la que llaman en el país gente de razón, pues tratando del indio, ya se dijo anteriormente que el cremole y unas tortillas de maiz eran su alimento diario. Hé aquí, pues, por ejemplo, en el trigo, una abundancia provenida de falta de consumo, á la que llamaremos mejor sobrante, que produce la miseria.

Estas son, en nuestro entender, las causas principales que contribuyen á la decadencia de la agricultura; la experiencia que el local supedita y las reflexiones de sujetos instruídos y prácticos en la materia (I), nos confirman en la idea de que el daño principal estriba en los dueños de fincas y en los trabajadores. En aquéllos, por la razón explicada, y además, porque siendo muy rara la posesión rústica que no soporta sobre sí una cuantiosa suma de principales, los más piadosos, siempre que las cosechas no corresponden con liberalidad, 6 que su abundancia hace bajar de precio los frutos, son consecuencias precisas los concursos, sesiones, embargos, etcétera, quedando perdido un hombre y con él muchos sin ejercicio, si no hay otro, pronto á tentar fortuna donde el desgraciado acaba de desengañarse de la suya (2). Finalmente, estriba también en los trabajadores, porque siendo éstos todos indios ó de otras castas de color quebrado, falta esta ocupación á los españoles, que se desdeñan de igualarles en tareas que ya han hecho ménos correspondientes á su calidad y jerarquía.

El comercio de la Nueva España se puede di vidir, como el de los demás reinos, en las dos clases de externo é interno. El primero es el que hace con la Península, y en cuanto á su estado y progresos, hemos dicho lo suficiente hablando de Veracruz, y nada nos resta que añadir á lo allí expuesto, pues los consumos de este Reino dependerán siempre de la mayor ó menor abundan-

(x) Dictamen dado por el Sr. Areche, Fiscal de Real Hacienda en Méjico, al Virey de aquel Reino.

(2) Por estas razones, y convencido el Rey de los males que causa una desigualdad tan notable en la propiedad y distribución de las tierras, ha resuelto Su Majestad entre otras cosas, á petición de muchos Cuerpos ilustrados del Reino de Nueva Espana, que los poseedores de tierra la pueblen dentro de un año con apercibimiento de perder el dominio y venderse á otros.-Real Cédula de $\mathrm{I}+$ de Febrero de $\mathrm{r} \$ 05$. cia de la plata que produzcan las minas y de los que rinda de su agricultura.

Por lo que toca al giro interior, éste se hace en parte con las cosas mismas que vienen de afuera, y los demás artículos que le componen, son muy débiles y de poca monta. El algodón y la lana únicamente pueden exceptuarse de 'esta regla, por el gran consumo que tienen ambas especies en varios tejidos que de ella se hacen; no obstante, tampoco forma un ramo opulento, ni hay operario alguno que viva socorrido de estos artefactos. Cada indio tiene en su casa los telares correspondientes para trabajar sus toscos vestidos de lana, y en las castas que llaman de razón, es casi general la inteligencia en la fábrica de manteles de algodón, y es la tela de su uso. Las hilanderas son tantas cuantas son las mujeres de estas mismas castas y las españolas pobres, porque siendo el arbitrio que más fácilmente se presenta, sin otro costo que el del algodón en greña y el de un huso á veces sin rueca, á él se aplica por necesidad un número considerable de familias. Llegada la tarde, que es la hora de este giro, y poniendo los compradores la ley del precio por la abundancia del efecto, sacrifican las vendedoras sus afanes por el miserable precio de un real ó medio que emplean luégo en un corto y grosero sustento. Los demás ejercicios requieren á estos fondos que no pueden alcanzar todos, y algunos otros ramos han mudado su giro por precisas alteraciones á que indujeron las circunstancias del Estado.

Puede también decirse en este ramo como se dijo en el de la agricultura, que los consumidores no son todos los que debían ser. Cerca de 420.000 indios tributarios que se consideran por las matrículas, son otras tantas familias que nada gastan ni reciben del comercio de nuestras manufacturas. Todos ellos se visten con una piel de venado, de que forman unos imperfectos calzones, y ocho ó diez libras de lana muy basta, que seguida á lo largo y descosida en su mitad vale por camisa, y se la atan con un orillo ó cinta de la misma materia, sin mangas ni otra figura. A esto añaden un pequeño sombrero de palma muy mal tejida, y hé aquí todo lo que necesita un indio para presentarse igualmente delante del arado que del altar. Las mujeres visten de la misma lana; en unos pueblos la dan figura de enaguas cortas, y en otros se envuelven en tres ó cuatro varas do tejido, atándolo con un cinto. E1 huipil de lana ó algodón sirve en unos parajes de sobretodo, en otros de camisa, y en algunos se ponen del mismo modo que los hombres dos varas de lanilla basta, ceñida como se ha dicho. La diferencia de temperamento, la comodidad ni la decencia les mueve á más industria; pero esta es obra de sus manos, pues poco ó nada reciben de nosotros. Sin embargo, ha decaído mucho en estos últimos 
años el trabajo grosero de sus géneros con la mejor vista que tienen los que traen los catalanes, y ya los usan preferentemente por su mejor apariencia y más cómodo precio.

Debe agregarse igualmente al número de inviduos que no concurren como consumidores al fomento interno del Reino, el que componen las diferentes castas que llaman de razón y resultan de las tres principales, blancos, indios y negros.

Estas castas son muchas y se multiplican en gran menera, como que además de ellas mismas contribuyen contínuamente á su propagación las tres ramas principales. Las inclinaciones de estos raros entes son correspondientes á su color y esfera. El número de ellos, que es excesivo, tiene por vestido unas bragas de mantas de algodón y tres varas de la misma materia, que al dormir sirve de cama y al levantarse de capa; otros llevan una colcha, sin más camisa, y no pocos andan sin calzones. Esta es la clase que constituye la pluralidad de habitantes, y la falta de arraigo les facilita mudar de domicilio cuando la miseria, la persecución ó el capricho les lisonjea de mejor fortuna en otro país.

El Gobierno, con las más eficaces providencias, ha disminuído considerablemente este tropel de gente desnuda y holgazana que inundaba antes las grandes ciudades; se han vestido muchos, otros se han ahuyentado, y últimamente no se ven ya tan frecuentemente en las plazas y calles; pero siempre faitan estos consumidores al ramo de comercio, que unidos á los indios, componen un número prodigioso.

Ya se deja inferir que á proporción del estado de los ramos anteriores debe ser igualmente débil el de la industria de este Reino. Con efecto, bien examinadas las ocupaciones que á ella tocan, se ve que en la mayor parte no son otra cosa que unos entretenimientos transitorios. El excesivo número de artistas, en todas clases, trae por consecuencia la abundancia de artefacLos; el exceso de éstos, su menor valor; éste, la poca utilidad de los artistas, y de consiguiente la pobreza.

Para persuadirse de estas pocas reflexiones, basta entrar en cualquiera de los puestos públicos de Méjico y otras grandes ciudades, y deteniendose á oir las persuaciones de los que intentan vender sus obras industriales, se verá que desde el desatinado alto precio que solicitan, bajándoseles más allá de lo creible y manteniéndose firmes, entregan por dos ó tres reales de América una pieza cuyo justo valor se acerca al de un par de pesos. Finalmente, como esta industria no hace un artículo de comercio exterior para esperarse por ella alguna riqueza dentro del Reino, tiene su orígen y destrucción, sin que su consu mo pueda ocasionar la dependencia de al- gún extraño, ya en lo relativo al lujo ó en los artículos de segunda necesidad (I).

Todas las clases, pues, de la fortuna de Nueva España, quedan reducidas según lo expuesto, á las que produce el giro y laboreo de las minas. Estas son muchas y muy ricas, y no hay duda que este Reino tiene un gran interés en su fomento y conservación. También lo tiene el Real Erario por los derechos que recauda, y lo tiene en general toda la Nación, porque cuanto mayores sean los fondos del Reino, tanto mayores serán sus consumos en artículos de lujo y otros esenciales de que le provee la Península. Pero hay que advertir que aunque los montes de la Nueva España sean unos perpétuos criaderos de los metales preciosos, no pueden, sin embargo, extraerse dc sus entrañas, sino exponiéndose á muchos riesgos, aventurando grandes capitales y exigiendo últimamente la concurrencia de varios materiales, de cuya abundancia ó escasez depende en gran manera la decadencia ó el aumento de la extracción. A tres pueden reducirse los ramos de auxilio que indispensablemente necesita el laboreo y beneficio de los metales, á saber: el azogue, la sal y los instrumentos y utensilios de hierro labrado y sin labrar, acero, bestias, sebo para alumbrarse, con otros varios enseres que se introducen en los Reales de Minas, El primero del azogue, se administra por cuenta de la Real Hacienda, que lo tiene estancado con el fin de que nunca falte y para fomentar también los consumos de las minas de Almadén en España, cuya calidad se recomienda mucho, y con cuyo motivo nunca se han aprobado los experimentos hechos para descubrir y trabajar en este Reino las minas de azogue; pero como la calidad del estanco, las crecidas cantidades de este ingrediente que se necesitan anualmente (2), los acaecimientos de las guerras, y úl timamente los varios estados que han tenido las minas de Almadén, han sido siempre causa de que escasee este preciso material, de modo que actualmente en la mina de la Valenciana, la más rica de todo el Reino, se benefician generalmente por fuego los metales que denominan polvillo y jabones, aunque con más costo y ménos producto de plata por la escase $z$ de azogue; parece consiguiente que el beneficio de las minas de azogue del Reino debería ser libre y conservar los que la labrasen la perpétua propiedad de ellas, semejan-

(I) El comercio interior de este Reino, igualmente que su industria, han recibido un nuevo impulso desde que S. M. tuvo á bien en I 795 establecer dos consulados, uno en Veracruz y otro en Guadalajara. además del que ya existía en Méjico desde tiempos muy antiguos.

(2) En I 767 rayaban en 80.000 quintales de azogue los que se consumían anualmente en las minas de Nueva España, según los datos de un quinquenio; en el día serán mucho más por el conocido adelantamiento de las minas. 
temente á lo que se practica con los dueños de las de plata y oro.

Por las mismas razones, tampoco debería es tancarse la sal, tan necesaria para el beneficio de los metales, y áun sería muy conveniente corrie. se libre de todo derecho desde sus criaderos hasta los parajes en que se consume.

Y aunque para fomentar el ramo de minería, libertó S. M. del derecho de alcabalas á los instrumentos, herramientas y otros enseres que sirven en las minas, siempre que se introdujesen por mineros, es claro que esta ventaja sólo pueden disfrutarla los acaudalados que los hacen venir desde luego por su cuenta, y no los pobres que faltos de fondos suficientes tienen que comprarlos paulatinamente á los introductores de distinta profesión y con el sobrecargo del enunciado derecho.

Estas reformas y concesiones que ya propuso el Consulado de Méjico en I788, originarían al pronto en el Erario una disminución anual de 200.000 pesos en los derechos que ahora cobra según los cómputos del mismo Consulado; pero siendo evidente los aumentos que en adelante tendrían las minas, lo es también el que este aumento produciría á la Real Hacienda otro muy superior al que ahora rinden la sal y demás renglones que se introducen por cuenta de los dueños cn los Reales de minas, conciliándose de este modo la comodidad del vasallo con las utilidades del Erario.

Habiendo recibido nuestros instrumentos en Méjico el r2 de Febrero como antes dijimos, nos preparamos para el viaje, y lo emprendimos el I5, dirigiéndonos á Acapulco, adonde ya nos aguardaban las corbetas. El camino, por consiguiente, fué precipitado y pocas las observaciones que con este motivo pudimos hacer. No obstante, indicaremos brevemente lo que advertimos, mezclando nuestras noticias con las que nos comunicó D. Antonio Pineda, y adquirió en su tránsito desde Acapulco á Méjico, advirtiendo que todo lo relativo á Historia Natural pertenece exclusivamente á éste benemérito naturalista.

Desde que se deja á Méjico se encuentran arboledas, cuya frondosidad no recrea tanto por su variedad, como las que hay en otras partes. Las componen los pinos, los madroños y algún olmo; pero lo que más abunda en esta sierra son los plantíos ordenados del magüey, de donde se saca el pulque. Hasta llegar al llano de Cuernavaca, el terreno se ocupa todó con las materias volcánicas; el casco del caballo resuena en hueco, la capa de tierra vegetal es muy escasa, los árboles disminuyen y se extenúan, signos todos positivos de que esta montaña es un volcán extinguido, en cuyo cráter, según las apariencias, se sitúa el pueblo de Guichilague. El azogue apenas llega en estos parajes á II $^{\circ}$ en la escala del termómetro de Reaumur.

Luego que se atraviesa una gran calzada y se desciende al llano de Cuernavaca, el temple varía sensiblemente y el mercurio sube has $\operatorname{ta} 20^{\circ}$.

En las inmediaciones del pueblo hay un gran pozo de mina de que se sacan piedras verdosas $y$ unos hermosos hidrófanos. En él se cuentan alternadas las capas de lava y tierra hasta el número de 20. Debajo se encubrirán otras tantas, que por lo ménos indican un número igual de erupciones, y si es aplicable en el Nuevo Mundo lo que se dice del Vesubio y Etna, será inmensa la antigüedad de este país. El pequeño volcán de Suchiltepec exhala aún humo por algunas de sus grietas, pero esto no impide el que se alojen en ellas una multitud de arañas. Sus faldas están cubiertas de arbustos que nacen entre las piedras calcáreas vitrificales. La amenidad de aquel llano abundante de aguas vivas y canales que proporcionan los riegos, es comparable, aunque en escala menor, con la frondosa Granada.

Hasta muy cerca de Aguastlán en que acaba la región de los volcanes, aparecen las bancas y pudins de lavas en abundancia; la puzolana se mezcla con la tierra vegetal, y las piedras son cenizas endurecidas, señales todas de la inmediación al volcán de Jumiltepec.

Desde aquí hasta Atquilapan, domina principalmente el granito de diferentes colores; en adelante el terreno abunda en esquisto negro $y$ arenario con partículas de shorl en capas que inclinan al Oriente. Las plantas herbáceas abundan poco, pero prosperan las arboledas. En ellas figuran los espinos blancos, amates, quiebra achas y mamanchis, cuya fruta es comestible. Los huecos se ocupan por las mimosas y los aromos plumerios que llaman en el país Tepeguajes; en la inmediación de los arroyos ó aguas encharcadas, los arums con sus hojas acorazonadas, suplen por los juncos y ranúnculos.

Los montes del Real de Tasco abundan mucho en el esquisto calcáreo, azul, blanco y atravesado de vetas; en partes se ve que esta misma piedra pasa al geneis ó esquisto magnesio. Hay algunas partes ondulantes del género de la esteatita que parece en la textura al que llaman Craye de Brianzón; las hay amarillosas, pardas, con manchas plumiformes azuladas ó cenizas, grasas al tacto. La matriz ordinaria de sus vetas metálicas es el cuarzo; todas ellas corren de Sur á Norte con alguna inclinación Noroeste-Sueste. Son casi paralelas entre sí, nacen del Oeste y se inclinan hacia el Este formando ángulos de $45^{\circ}$ próximamente. Todas las montañas próximas taladradas con galerías, socavones y lumbieras que profundizan á más de 300 varas, resuenan extrepitosamente con los golpes de martillos y barre- 
tas con que despedazan sus entrañas los codiciosos humanos.

El monte más elevado de todos los de la comarca, es decididamente el que nombran Guiteco, del cual según los prácticos, arrancan todas las retas metílicas que corren por los demás. Tiene guijarros del pórfido, fondo blanco y alguna tierra bolar muy untuosa. Hay un esquisto que se compone de arcillas, cuyos guijarros parecen maderas petrificadas; constan de capas cóncavo-convexas como dc un leño podrido con estrías que parecen las fibras longitudinales. Su vcgetación es bien lozana, cría cuatro especies de encinas. Lacuchaulla, cuya hoja de más de un palmo se dobla, formando como una teja ó cilindro, su periferia ondulada con espinas en los ángulos y la superficie inferior lamosa y blanca. Un madroño tortuoso con la corteza roja de quien el tronco se divide en tres ó cuatro; sus hojas son ovalcs, salen en hacecillos, y el fruto en racimos rojos de un agradable sabor. La mur tilla de Maluinas, una especie de echinops ó diptacus hojas radicales como el martajon de España aunque espinoso. Un napalinm parecido al oriental. Un lawel con la hoja angosta. Un aloes, varias especies del pino y cedro, y otro que llaman acle. Hay bromelias parasíticas y una especie de zacatón.

Los monumentos de la historia de la Naturaleza se ven esparcidos por todas partes de una manera indeleble, y en estos momentos se hallan en las petrificaciones submarinas. En un guijarro calcáreo había una gran glande introducida entre la sustancia pétrca, prueba segura de que el grande Océano bramó algún día sobre estas rocas.

Todo el país que media entre Iguala y la Canada del $Z$ opilote presenta generalmente muy buena tierra negra esponjosa como en casi todos los llanos de Nueva España, y se arriendan en cuatro cargas de maiz por una de sembradura, se ven bancas esquistosas, cuya dirección es siempre al Norte y otras penetradas de bancas rojas metálicas. El calor se siente extraordinariamente; el azogue sube á $30^{\circ}$ en la escala del termómetro de Reaumur, y á las ocho de la noche no baja de 27 , sin que se goce cn ellas la frescura de los pueblos de la costa, pero en invicrno es necesario vestir de paño. Los terrenos que siguen por la Cañada del Zopilote se rodean dc montes calcáreos en que abundan mucho las casias, las bignonias, la hipocratea bolubilis y varias sramas que en los rccodos del arroyo sustentan ¿ los ganados extenuados y flacos. Estos paises aunque abundantes dc ríos caudalosos, se resienten de una total sequedad porque la industria dcl hombre no ha dirigido sus cauces, ni con útiles sanerrias hacc regrar el terreno.

Antes de llegar á Chilpansingo las tierras son esponjosas, llanas y fecundas, y en los caminos se ve una piedra arcillosa, cenicienta con clavos de piedra verde que parece serpentina. Los valles de Tixtlan, Chilapa y Chilpansingo, cuyos tres pueblos forman un triángulo isósceles, se subdividen y rodean por montañas generalmcnte calcáreas en que se encuentran esquistos, y algún granito como el maisillo del Perú y Chilc. A trechos se ven bolones del mármol, conchitas con petrificaciones bien conservadas. Todas ellas sc adornan con grandes cactus comunes á toda la Nueva España aunque de especies desconocidas la mayor parte. Entre ellos numera el que asemeja á un tenebrario ó araña de cuyo tronco común salen otros varios que se van subdividiendo hasta multiplicarse en Ioo ramos ó columnas perpendiculares; cada una está surcada de ocho ó diez estrías: su flor es blanca y el fruto encarnado por dentro. Otros hay como los que llaman sirius el cual es una columna solitaria de más de diez varas de alto. Estas llanadas se cubren de una tierra negra esponjosa bastante fértil que acude generalmente con el 50 por uno. Las siembras se hacen ordinariamente en Julio y se cogen por Noviembre, pero lo que abunda más son los árboles frutales. El temperamento de estos paises suele variar mucho del día á la noche; en ésta no baja $\sin$ embargo de $18^{\circ}$ el termómetro en la escala de Reaumur y en lo fuerte del calor sube á 24 . Mucha parte del año llueve con furia; acompañado de relámpagos y truenos: en el invierno suele helar y cuajarse el agua. Los insectos y reptiles de estos países tropicales, adquieren tal agilidad luégo que el Sol está sobre el horizonte que burlan las mayores diligencias para lograr su captura. Aquí se crían tres especies de abejas particulares que todas dan buena miel aunque silvestre. Entre las diversas clases de hormigas, ya domésticas, ya silvestres, ó ya más ó ménos vẻnenosas que se encuentran, es la más particular la que llaman arriera, tan tenaz en su mordedura que jamás sueltan la presa. Los indios reunen los labios de las heridas, y los aplican de modo que los cosan perfectamente, y cortando después la hormiga por la cabeza queda su acicate asido y la herida bien cosida.

Las montañas que siguen están compuestas de piedras calcáreas de mármol arcilloso y algún granito. Los campos de estos parajes se visten de un verde agradable, y todo anuncia un país abundante de aģuas, aunque sólo se aprovechan en tal cual milpa (r) y alguna caña. En los cauces de los arroyos que rodean á Mazatlan, se ven adobes calcáreos guarnecidos de puntillos ú oquedades con surcos semicircubolares como en

(I) Este es el nombre que dan en el país á los sembrados de maíz. 
las orillas del mar. La formación de sus montañas contiguas acolinadas y bajas, parecía ser moderna; en ellas no se crían árboles, y las piedras parecían submarinas; por lo ménos estos taladros se hicieron por los insectos cuando se hallaban cubiertas de agua y en el estado de tierras, pues la disposición local del terreno no permite que se hiciesen por las lluvias.

Los cerros que continúan después de Mazatlan son deprimidos, si se exceptúan los del Cuchintlan y el Peregrino. Esta frondosa möntaña tiene cascadas y arroyos que repartiendo la fragosidad por toda ella, la convierten en un bosque delicioso. Los aromos, las gleodesias y mimosas, divididas en infinitas especies, suplen en estos paises por las carrascas. Las vides, las salizas, las bignonias, las marías, los mulatos, los dragos, el palo brasil, el bálsamo, el granadillo, el roble, el pino y otros árboles corpulentos, elevan sus cervices acopadas sobre ellos, y la diversidad de verảes hermosos de que se visten, ofrecen un espectáculo variado á que contribuye mucho el áura fresquísima que se respira.

El reino animal no es el ménos abundante en estas fragosidades; en ellas se ven los tigres, leones, jabalíes, venados, tejones, ardillas negras, pardas, grises y las voladoras que émulas de las aves, recorren las arboledas de rama en rama. Los aires están poblados de loros, cotorras, pericos, urracas, el pájaro flojo y otros varios.

El terreno inmediato al Peregrino se cubre de arcillas que después de las lluvias se endurecen y resultan varias piedras. Sus fértiles colinas remedan á las de Málaga; en ellas se encuentran con abundancia dos clases de, vides de las que la una tiene sarmientos desnudos, de una pulgada de grueso, y el grano de sus racimos del tamaño de aceitunas. Entre el Peregrino y el pueblo de los Arroyos solamente se conservan arboledas en las quebradas; se ve el esquisto con partículas micáceas negras, un arenario blanco en grandes canteras y un cuarzo con partículas de mica doradas como oropel.

Desde los Arroyos en adelante, el suelo se presenta compuesto de un arenario arcilloso blanco, con partículas de mica. El país, entrecortado por arroyos y torrentes, of rece, no obstante, la imagen de la aride $z$ en la estación de las secas; pero la superficie arenisca del terreno, sin ninguna planta herbácea, presenta, sin embargo, unos árboles pomposos y llenos de lozanía. Estos corpulentos vegetales profundizan en la tierra, donde encuentran en todos tiempos los jugos que necesitan, $y$ los ojos investigadores de un botánico hallan siempre árboles en flor y una primavera continuada. Con dificultad se encontrará un vergel más delicioso en la estación de las lluvias; las aguas cristalinas reunidas en las quebradas multiplican al infinito las plantas americanas. Una variedad maravillosa de aves de hermoso canto y plumaje se reunen en sus orillas, y todo, en fin, se resiente de una primavera deliciosa. A esta pintura agradable de las quebradas, se opone, como en contraste, la suerte de los montes y colinas condenadas á una soledad perpétua y á las quemas continuadas con que destruyen sus bosques las pocas familias que los habitan; se ven troncos denegridos, tierras rojizas y cenizas pavorosas que manifiestan la desolación que las oprime.

En vano la bienhechora Naturaleza procura sacar partido hasta de sus mismas ruinas, pues aunque aumenta la capa de la tierra vegetal, estas quemas indiscretas en los parajes inaccesibles, desbaratan unos bosques que serían de infinito precio á estar en otros parajes, y hacen eriales é intransitables aquellos montes.

El beneficio que dan á la tierra en estos paises se limita á solas tres operaciones: desmontar ó jacotear; quemar el terreno, y luégo sembrar dos años seguidos; al tercero se le deja sin cultivo, pues la experiencia acredita que da en yerba, y si se aplica el arado, es tan feraz, que da en vicio; las siembras ordinarias son de maiz y algodón en el mismo año: éste se siembra cuando aquél está crecido, y á su cosecha en el tiempo seco, prospera ya el algodón.

Todas las tierras comprendidas desde el Peregrino hasta Acapulco, pertenecen en propiedad á varios hacendados de Méjico que las alquilanó venden al que las quiere labrar: el arrendamiento ordinario son cinco pesos si crian ganados, $y$ dos si sólo las siembran sin que se les limite el terreno: tan cierto es que las mayores riquezas que ofrece el suelo valen muy poco si la industriosa mano del hombre no las dirige. Leguas cuadradas de tierras pingües, en que se cría el brasil, el palo tinte, el copal y otras diversas drogas preciosas, se ven casi sin estimación, condenadas á las llamas ó á ser abrigo de fieras. Uni terreno de cuatro leguas de largo y dos y media de ancho, se rendía en la actualidad en 500 pesos.

Antes de llegar á la Sabana, las colinas y cerros presentan una aride $z$ que se contrasta por la vegetación lozana de los Arroyos. Luégo se atraviesan varias montañas fróndosas de granito, el cual se presenta bajo diversas modificaciones, $y$ de su descomposición mezclada con alguna tierra bolar, resulta una capa vegetal que hace útiles aquellos terrenos, aunque en lo general se encuentra muy poca agua. Desde aquí se entra ya en las playas arenosas en que se sitúa Acapulco.

Las casas de esta ciudad son ordinariamente de ladrillo y teja las de la gente acomodada, $y$ las de los pobres, chozas cubiertas de paja. Los 
muebles de éstas consisten en vasijas de calaba$z a$, algunas ollas de barro y tal cual taza ó plato de china, sobre un basar de una tablilla sujeta con cordeles, en lugar de palomilla de madera. Su alimento, que es el pan de maiz, lo preparan sobre una piedra, teniendo una olla á la mano, con la cual remojan la pasta de cuando en cuando. El gallo para pelear, es mueble que no falta en casa alguna, áun en las más pobres, y se halla atado á una estaca. La hamaca es otro mueble en que emplean algunos de estos naturales una buena parte desu tiempo. Suelen poner sobre sus camas unos toldos formados de la tela que llaman miliñaque, clara y barata como las de esparto que hacen en Madrid, con cuyo arbitrio se preservan de los animales ponzoñosos que abundan aquí en gran manera. "Yo maté, dice D. An"tonio Pineda, dos escorpiones que hallé en la "casa donde vive el Gobernador, y en una excur"sión encontré dos víboras del país, cuya mor"dedura es de mucho peligro, si el enfermo no "recibe pronto socorro." Celebran mucho para ello el antídoto de una pepita que viene de China y llaman Chabalonga, mascada y tragada con la saliva: el sabor de esta pepita es amargo, y general entre estas gentes el concepto de sus virtudes.

Hállase esta ciudad en latitud Norte de $16^{\circ}$ $50^{\prime} 4 I^{\prime \prime}$ y longitud occidental de Cádiz de $93^{\circ}$ $4 \mathrm{I}^{\prime} \mathrm{OO}^{\prime \prime}$ (I). Su clima está caracterizado por uno de los peores de la América y expuesto al terrible azote de los terremotos, con que la Naturaleza compensa en estos contornos la prodigalidad de otros bienes. Hallándose fondeada en el puerto la corbeta Descubierta el 30 de Marzo de I79I, se percibió á la una y media de la mañana un temblor muy fuerte que se sintió áun á bordo, precediéndole desde algunas horas todos los amagos de una próxima tempestad, y algunos minutos antes un ruído fuerte subterráneo, acompañado del aullido acostumbrado de los perros, y de la natural propensión de una muchedumbre de peces que se aproximaban á la superficie del agrua, abandonando instantáneamente la mayor profundidad. La duración de este terremoto fué de $20^{\prime \prime}$ y su movimiento de trepidación no dejó de causar extragos considerables en algunas casas.

Hace en este país un calor excesivo, y la bebida que tienen en mayor estimación para refrescarse es el Charap:. Esta la componen cogiendo en adecuada vasija cierto rocío ó agua que destilan los racimos de cocos mientras vege-

(I) Omitimos repetir aquí los medios que han serviclo para establecer esta situación, igualmente que los de la costa Noroeste de América, pues todos se han detallado con plolijidad en la Memoria antes ritacla que sirve de apéndice al viaje del Estrecho de luan de Fuca. tan en sus altas palmas, á cuyo fluído llaman Tuba; después le echan la melaza concreta que aquí llaman panocha y es la Chancaca de la América meridional, y hecho esto la dejan fermentar y resulta una bebida agridulce, análoga á la limonada y muy parecida al Guarape que en el Perú sacan de la caña. El Charape, bebido en cantidad, hace tiro á la cabeza y embriaga. También se hace aquí la chicha de piña, conocida en varias partes y de que hablaremos luégo.

Lôs hombres de este país y de la clase que puede llamarse la plebe, que es el mayor número, andan en chaleco y calzones, usando muy raia vez las medias. Las mujeres van igualmente descalzas y en mangas de camisa. Esta es de miliñaque, y las enaguas de telas pintadas de listas de azul en fondo blanco. El mayor lujo lo ponen en lo que llaman el paño, y es una pieza cuadrilonga de algodón, bordado ó con listas. Algunas lo llevan con fondo de oro y de mucho precio.

Todos los vecinos, casi sin excepción, es gente de color y negros libres, y tienen varios privilegios por estar alistados en las compañías de milicia, y en ocasiones, de guerra se arman y ejercitan en la táctica militar.

Los vecinos más acomodados y que tienen los empleos de tropa, son los pulperos; el vecindario parece pobre y su comercio esencial se reduce al de la Nao de Filipinas y á lo que se gasta en el tiempo de la feria de ésta. El surtimiento de las tiendas es la mayor parte de efectos de la Nao, como telas de algodón listadas, miliñaque, etcétera. Para formar juicio de la calidad de este giro podrá servir el estado siguiente que manifiesta el valor parcial y general de los artículos que se introdujeron en Acapulco procedentes de Filipinas en I79r, á saber:

\begin{tabular}{|c|c|}
\hline & $\begin{array}{c}\text { Valores } \\
\text { en } \\
\text { pesos fuertes. }\end{array}$ \\
\hline éneros de oro y plata.. & $\operatorname{Ir} 2$ \\
\hline em de seda......... & $209 \cdot 309$ \\
\hline $\mathrm{em}$ de algodón......... & 311.897 \\
\hline comestibles y cspecería. . & $7 \cdot 108$ \\
\hline 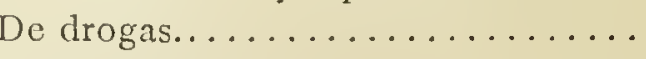 & 3.018 \\
\hline varias clases $\ldots \ldots \ldots \ldots \ldots$ & $5.87 \mathrm{I}$ \\
\hline Total.. & $537 \cdot 3$ I 5 \\
\hline
\end{tabular}

De Acapulco para Filipinas se extrajo en 1792 lo siguiente:

\begin{tabular}{|c|c|}
\hline 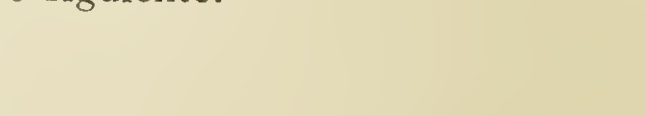 & $\begin{array}{c}\text { Valores } \\
\text { en } \\
\text { pesos fuertes. }\end{array}$ \\
\hline 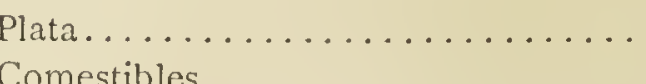 & I. 832.402 \\
\hline omestibles................... & $\mathrm{I} 0.88 \mathrm{I}$ \\
\hline Drogas........................ & 40.262 \\
\hline urias clases .................. & $7 \cdot 16 \mathrm{I}$ \\
\hline Totat & I. 890.706 \\
\hline
\end{tabular}


Los ramos comunes de la Real Hacienda, y los particulares y agenos que componen el total de las rentas Reales que entran en la Caja de dicha ciudad, ascendieron el año de I790 á 462.954 pesos fuertes, en esta forma:

\begin{tabular}{c}
$\begin{array}{c}\text { Valores } \\
\text { en } \\
\text { pesos fuertes. }\end{array}$ \\
\hline
\end{tabular}

Por los ramos comunes de derechos que pagan las embarcaciones y su cargamento á la entrada y salida del puerto.

Por los ramos comunes de tierra, como alcabalas, tributos Reales, bienes mos-

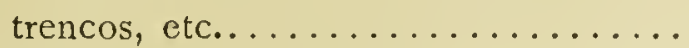

Por los ramos particulares de tabacos, in-

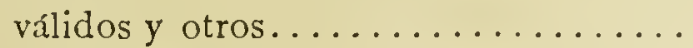

Por ídem agenos, como depósitos, Montepíos, ingresos extraordinarios, etc....

$$
\text { Total }
$$

Con el producto líquido de estos ramos se cubren las atenciones de la Caja, que se reducen á gastos de la Nao de China, aparte del situado de Filipinas, subsistencia de la tropa y hospital Real, sueldos de empleados y otros gastos eventuales, tomando ó depositando en la Tesorería general lo que falta ó sobra según los años, para cubrir las cargas referidas. Los sueldos de individuos empleados que se satisfacían en Acapulco por esta misma Caja, ascendían en I790, á I0.346 pesos.

El puerto de Acapulco, el mejor y más seguro de toda la costa meridional de Nueva España, es de figura tan circular como lo manifiesta su plano; de buen tenedero y abrigado de todos vientos. Viniendo á tomarlc del Oeste y áun del Sur siempre que no haya una seguridad absoluta en el punto de longitud, será bueno dar vista á los farallones que llaman los Ciguatanejos que están como 35 leguas al Oesnoroeste de Acapulco. Son de corta extensión, muy unidos y blanquean tanto, que se distinguen á más de cinco leguas. Entre ellos y la costa hay canal limpio con 9 , I 2 y I 5 brazas de agua, y como dos leguas al Norte está el puerto de Ciguatanejo. que es seguro y capaz, y para tomarle se dejan á estribor dichos islotes. Casi en la medianía desde ellos á Acapulco está la punta ó morro de Satlan, y sigue la costa al Esueste, alta en 10 interior pero baja hacia la marina.

Entre seis ó siete leguas al Oeste del puerto, están las playas dc Coyuca, de arena muy blanca y de más de tres leguas de extensión: delante tiene placer de 20 y 25 brazas de agua que sale dos millas y es muy bueno para fondear. Desde que se llega por el Oeste á estas playas se ven dos picos altos, cuya figura mirada en el primer cuadrante ha hecho llamarlos las Tetas de Coyuca; corren Nornoroeste, Sursueste, con la boca de Acapulco, y se enfilan uno con otro cuando demoran casi al Norte. Más al Este está un cerro aislado que llaman de la Brea, muy notable por ser igualmente que las Tetas de Coyuca, las tierras más altas de todas las inmediatas al puerto.

Corre con la boca de éste, Norte-Sur, y es muy buena marca para buscarle viniendo de mar en fuera, pues sin más que situarse de modo que demore el cerro de la Brea al Norte $1 / 4$ Nordeste, ó más Norte, y atracar la costa en esta dirección, se distinguirá la Isla Roqueta que á alguna distancia se confunde con la tierra firme, y se verá el abra que dicha isla hace con las tierras orientales que llaman del Marqués. Entre las dos se forma la entrada del puerto, y es imposible des conocerla aunque por mucha cerrazón ú otra causa no se vean las marcas anteriores, pues basta saber que está al fin de todas las tierras altas y que desde ella para el Iiste sigue por más de 20 leguas una playa de arena dilatadísima. A veces lleva el agua bastante fuerza para el Esueste, $y$ asi, si sobreviene la noche y se resuelve pasarla fuera, es preciso ceñir con tiempo á tres ó cuatro leguas del puerto y mantenerse en bordos cortos sobre las gavias para no descaecer. Al entrar se atracará la Isla Roqueta, sin otra atención que pasar á regular distancia de la isla rasa llamada la Baja, y con vientos escasos ó contrarios se darán los bordos que convengan para ganar el fondeadero delante de la población. En estos bordos se tendrá cuidado con el bajo dé Santa Ana, que es de arena y cascajo, y no tiene más de dos brazas y media de agua. Desde él se marca el farallón del Obispo al Este $6^{\circ}$ Norte, y al Sur $4^{\circ}$ Este la punta de Grifo.

Hasta el día ha sido costumbre amarrar los buques en Acapulco Este-Oeste, dando este último cable en tierra á algún cuerpo muerto de la playa, pero en esta disposición quedan las embarcaciones muy expuestas, especialmente desde Mayo hasta Octubre, que hay recias turbonadas y fuertes golpes de viento del Nordeste, Norte y Noroeste. Nuestro dictamen es que se tiendan las anclas á barba de gato Nordeste y Noroeste, con lo cual también se preservará más de la bruma, el cable que siguiendo la práctica establecida, se había de dar á tierra.

Casi es insensible la fuerza de la marea en esta costa, y en el puerto asciende y baja con poea regularidad entre cuatro y cuatro y medio piés. Siempre que anochece á la vista alguna embarcación, hacen candelada en un montecito inmediato al pueblo, donde está la vigía, lo cual sirve de buen reconocimiento durante la noche. 


\section{Noticia de las principales expediciones hechas por mestros pilotos del Departamento de San Blas al reconocimiento de la costa Noroeste de América, desde el año 1774 hasta el I79I, extractada de los diarios originales de aquellos navegantes (I).}

Habíanse abandonado ya mucho tiempo hacía los descubrimientos emprendidos por mar para conocer las costas septentrionales de la Nueva España, cuando el Conde de Lacy, Ministro del Rey en la corte de Rusia, avisó en 7 de Febrero de 1773 al Marqués de Grimaldi, Secretario entonces de Estado, que había sabido continuaban los rusos desde I764 sus expediciones de Archangel y Kamchaka á las costas del Este, que no podían ser otras que las costas de la América: que en consecuencia de las utilidades con que retornaban de dichas navegaciones por los acopios que hacían de pieles de nutrias, martas y zorras, había autorizado la Emperatriz en I766 á una compañía de negociantes de Kamchaka, para hacer este comercio exclusivo. Que dicha companía constaba de 24 comerciantes y 200 cosacos que habían formado establecimiento en la costa de América por los $64^{\circ}$ de latitud, y que se empleaban en la caza, persuadiendo y áun obligando al mismo tiempo á los indios á que pagasen tributo de pieles á la Emperatriz. Y últimamente, quc la Rusia tenía miras de mucha importancia en estas exploraciones.

Enterado de todo el Rey, mandó comunicar estas noticias al Virey de Nueva España, Don Antonio Bucareli, ordenándole al mismo tiempo precaviese los inconvenientcs que podian seguirse en el continente de América, por los descubrimientos de los rusos. Contestó el Virer que le parecía indispensable saliesen anualmente algunas embarcaciones de San Blas, para que recorriesen la costa al Norte de Monterey; y habiéndose dispuesto así, fueron nombrados á su solicitud seis Oficiales de Marina con destino á mandar dichos buques.

Mientras llegaban á California estos Oficiales, dispuso el Virey á fines de 1773 se equipa-

(I) Incorporado ya el Teniente de navío Espinosa a la corbeta de su destino, nos abstendremos de publicar aquellos puntos del Diario de su navegación que ya están expuestos al tratar del viaje de las corbetas. y nos limitaremos á insertar únicamente los estudios y datos curiosos dignos de ser conocidos que cons$\tan$ en el Diario de tan ilustrado Oficial. - Nota de $P$. de $N$.) se en San Blas la fragata Santiago, nombrando para que la mandase al primer Piloto de la Armada, graduado de Alférez de fragata D. Juan Pérez, único Oficial de Marina que había entonces en California y á cuyo cargo estaba el De. partamento. En la instrucción que se dió á este Oficial, se le mandaba salir de San Blas á principios de Enero, y que después de tocar en Monterey para dejar las Memorias que anualmente se remiten á aquel presidio, navegase hasta la latitud de $60^{\circ}$, atracase la costa reconociéndola, y que bajase al Sur, inmediato á ella. Y aunque las órdenes de la Corte mandaban expresamente que se desalojase de grado ó por fuerza á cualquier extranjero que se hallase establecido en estos parajes, tomando el Virey un partido más suave, dispuso que en el caso de encontrar algún establecimiento se subiese más al Norte y sé tomase posesión del país en latitud más septentrional á fin de poder alegar este derecho cuando las circunstancias lo exigiesen. El primer párrafo de la instrucción decía así:

"La benignidad del Rey que fió á mi cuidado "este Gobierno de Nueva España, no sólo me "impone la obligación de conservarle estos vas"tos dominios, sino también la de procurar "aumentarlos en cuanto me sea posible por me"dio de nuevos descubrimientos en la extensión "de lo no conocido, para que atraídos los nume"rosos indios sus habitantes, del dulce, suave, "apetecido vasallaje de S. M., se derrame en " ellos la luz del Evangelio con la conquista espi"ritual que les separe de las tinieblas de la idola. "tría cn que viven, y les enseñe el camino de la "salvación eterna, que son las verdaderas inten-. "cioncs que en tales empresas animan el piadoso "Real corazón de S. M. Con este objeto justo é "importante, he resuelto que D. Juan Pérez, "graduado de Alférez de fragata de la Real Ar"mada, se cncargue de este descubrimiento. En "todos los parajes en que tome posesión, pondrá "por señal una cruz grande de madera, forman"do su peana de piedras, en la que esconderá " una redoma de vidrio, dentro de la cual intro"ducirá una copia de escritura de posesión, fir- 
" mada por sí, por el Padre Capellán y los dos „Pilotos, tapándose bien la botella con pez para "que en los tiempos futuros se conserve mejor "este documento y sirva de auténtico testimo"nio."

Salió Pérez, de San Blas, el 25 de Enero de I774, y aprovechando los terrales del Nornordeste y Nordeste, procuró embocar entre las Islas Marías y la costa; pero no pudo y arribó el $3^{\mathrm{I}}$ á media noche á pasar al Sur de ellas. Los vientos continuaron del cuarto cuadrante y la mar venía picada, de forma que hasta el 20 de Febrero no pudo cambiar del bordo del Norte. A este tiempo, después de algunas calmas, roló el viento al tercer cuadrante, cuando se hallaba por $26^{\circ}$ de latitud y en $20^{\circ}$ al Oeste de San Blas. Sobre $33^{\circ}$ $5 \mathrm{o}^{\prime}$ rindió los baos mayores y arribó por esta causa al establecimiento y Misión de Santa Bárbara, que está por $32^{\circ} 44^{\prime}$ de latitud. Este puerto tiene su boca al Sur, ancha de una y media milla, y la canal corre tres al Nornordeste, inclinándose más al Este, torciendo después hasta el Sueste, de modo que no es posible hallar surgidero más abrigado. El 5 de Abril se hizo á la vela para Monterey, y con viento siempre del Norte ó Norte $1 / 4$ al Nordeste, siguió la vuelta de fuera, hasta que por $3 \mathrm{I}^{\circ} 5 \mathrm{O}^{\prime}$ de latitud y casi 200 leguas á la mar, rolaron al segundo cuadrante y áun al tercero, y atracó la costa fondeando el 7 de Mayo en Monterey. Dejó este puerto el 6 de Junio y con vientos del Norte y Nornoroeste y áun Noroeste, siguió alojándose al Oeste, descaeciendo al Sur hasta $33^{\circ}$. En este paralelo y á distancia de I 20 leguas de tierra, se le alargó el viento hasta el Nordeste y hasta el Sueste, y áun más cuando se hallaba por $37^{\circ}$ Norte y 770 leguas de tierra. Le acompaño el Sueste con cerrazón hasta $47^{\circ}$ y $\%$, y entonces, llamándose al Sur y Sudoeste, aclaró el tiempo y pudo atracar la costa. Subió hasta $55^{\circ}$, y viendo que las cerrazones le impedían examinar la costa, desistió de continuar más al Norte, y con ánimo de tornar retrocedió el 2 I de Julio, reconociéndola y costeándola á la distancia que permitían los vientos. A las tres de la tarde del 7 fondeó por 25 brazas de agua, fondo arena negra y lama, á una legua de la ticrra más cercana y en latitud de $49^{\circ} 30^{\prime}$ y $3^{\circ} 5^{\prime}{ }^{\prime}$ al Oeste de Monterey. Llamó á este surgidero, de San Lorenzo, y una punta que estaba seis leguas al Nordeste, la nombró Santa Clara, y otra que quedaba dos leguas al Sueste, la denominó punta de San Estéban. Desde ésta sale una reventazón considerable, casi una legua en vuelta del Noroeste.

Habiendo entrado viento duro de travesía, no quiso Pérez empeñarse, y dió la vela continuando su navegación, sin otra ocurrencia particular hasta su llegada á Monterey que la de haber reconocido un cabo que llamó Cabo Mendocino por $40^{\circ} 8^{\prime}$ de latitud, sin embargo de que los primitivos navegantes cuentan á aquél I $37^{\prime}$ más al Norte.

En $55^{\circ}$ de latitud trató Pérez con los indios, y observó que eran robustos, alegres y de hermosos ojos. Las mujeres de buen parecer, y tenían el labio inferior taladrado, en cuya abertura introducian un óvalo de diferentes tamaños. Hizo cambios con los naturales y advirtió tenían en sus manos una media bayoneta y un pedazo de espada, que conceptuó Pérez serían de la gente que el Capitán 'Tschirikoio mandó en su lancha en este mismo paraje y jamás volvió. Llegó Pérez á San Blas el 3 de Noviembre de 1774 .

El año de 1775 dispuso D. Antonio Bucareli se armasen en San Blas la fragata Santiago, al mando del Teniente de navío D. Bruno Hezeta que llevaba de segundo al Alférez de fragata 1. Juan Pérez; la goleta Felicidad al mando del T'eniente de fragata D. Juan Manuel de Ayala, y por su segundo el Oficial de igual clase Don Francisco de la Bodega Cuadra: el paquebot San Carlos, al Teniente de navío D. Miguel Manrique, siendo su Piloto D. José Cañizares. Este buque debía pasar á examinar el puerto de San Francisco, y los dos primeros tenían destino de descubrir y reconocer lo no visto hasta entonces en la costa Noroeste, desde los $65^{\circ}$ de latitud para el Sur. Con este objeto se proveyeron de víveres para un año, y dieron la vela, de San Blas el i6 de Marzo de I775. Lil Ig del mismo mes, por enfermedad del Comandante del paquebot se le confirió su mando á Ayala y quedó Cuadra con el de la goleta, y habiéndose echado al Oeste, reconocieron el 3 de Abril la Isla del Socorro, que no ofrece ninguno á los navegantes.

A I20 ó Izo leguas de la costa se alargó el viento hasta el Nordeste fresco, y con él navegaron al Norte y Oeste hasta los $32^{\circ}$ de latitud que calmó y roló al Sudeste flojo con tiempo oscuro; subieron al Norte y resolvieron atracar la costa para fondear en ella, como lo verificaron, en un puertecito que llamaron de la Trinidad, que está situado por $4 \mathrm{I}^{\circ} 7^{\prime}$ de latitud y $I 9^{\circ} 4^{\prime}$-al Oeste de San Blas.

Aquí permanecieron desde el II de Junio hasta el I9, hicieron agua y leña con toda comodidad, observaron las mareas que en el discurso de veinticuatro horas $4 / 5$ crecen y menguan dos veces, y habiendo sucedido la conjunción el día I3 fué la pleamar á las doce y bajó el agua nueve piés.

El Puerto de la Trinidad es un perfecto carenero, resguardado de los vientos del cuarto, primero y segundo cuadrantes, y sólo descubierto á los del tercero; es tan hondable, que pueden los buques atracarse hasta echar la plancha en tierra, pero precisa forrar los cables de tierra, porque hay mucha zahorra en las inmediaciones 
de la playa. La variación de la aguja era en esta época de $14^{\circ} y^{1} / 2$ al Nordeste. La tierra es muy adaptada para producir todos los frutos de Europa; los montes están cubiertos de elevados pinos envejecidos por los siglos, y de cuyos restos se mejora por instantes el terreno. De aquí resulta una perspectiva verde y olorosa que encanta los sentidos, pues la mezcla de la rosa, orégano, lirios, llanten, apios, cardo, manzanillas y otras infinitas, producidas con aquel vario desorden con que sabe la naturaleza divertir los ojos del observador, forman el jardín más deleitoso y agradable. Los pinos son de extraordinaria altura, y de los que se hallaban derribados en las playas, se midieron algunos de sesenta varas de largo y dos de diámetro por la parte inferior. Esta madera es muy propia para arboladuras, baos y tablazón, y de hebra tan derecha, que los naturales con sólo aplicar cuñas en un extremo, dividen aquellos grandes troncos rajándolos directamente hasta el extremo opuesto.

El I9 de Junio dieron la vela con vientos del Nornoroeste y Norte, los cuales duraron hasta hallarse I20 leguas de la costa, y entonces mudaron al Oeste y otros rumbos que permitían ganar al Norte. El I3 de Julio volvieron á fondear sobre la costa por $47^{\circ} 24^{\prime}$ de latitud y $2 I^{\circ} I 9^{\prime}$ longitud de estima al Oeste de San Blas. La goleta ancló como á una legua al Norte de la fragata, y estaba rodeada de arrecifes, entre los cuales impensadamente se metió. El I 4 rompían los bajos y fué preciso esperar la creciente para dar la vela, y queriendo aprovechar el tiempo de bajamar en hacer agua y leña, despachó una canoa con siete hombres bien armádos con sables, pistolas y diez y ocho cartuclios para su defensa; pero apenas desembarcaron cuando salieron de un bosque inmediato 300 hombres, que dando sobre los nuestros los hicieron pedazos á lo que se cree, pues sólo se vió á dos que se defendían con sus sables, y se arrojaron, por huir, al mar, donde seguramente perecieron. De los otros no se supo más, y al cabo de dos horas se retiraron los naturales abandonando la playa.

Era medio día, los arrecifes no reventaban, y perdida la esperanza de volver á ver los marineros, se dió la vela. En esto, los naturales bien persuadidos del poco número de hombres que quedaba á bordo, armaron sus canoas y llegaron por la popa de la goleta. Allí se detuvieron, y al cabo de muchas conferencias destacaron una canoa con nueve mozos de gallarda estatura, que sc acercaron á cuatro ó seis varas del costado, resticlos con hermosas cueras de defenisa, y templando los arcos para cl ataque. Dispararon sus flechas, y "nosotros, dice el Diario, aunque ape"nas éramos los suficientes para la maniobra, na"vegando por entre aquella cordillera de bajos, "teníamos preparadas las armas sobre cubierta y "les hacíamos fuego con tres fusiles, pues no "éramos en más número los combatientes."

Se hicieron á la mar los dos buques que habían atracado la costa por este paraje en busca del Estrecho de Juan de Fuca, que coloca por esta latitud la carta de Bellin de I766, y corrieron cerca de tierra desde $48^{\circ} 20^{\prime}$ de latitud para el Sur, y no hallaron puerto, ensenada ni boca que diese margen para sospechar dicha entrada. Los vientos duros del Noroeste, las enfermedades que empezaban á manifestarse en la fragata, y lo adelantado de la estación, determinaron al Comandante Hezeta á arribar, y recorriendo la costa para el Sur, tomar puerto en Monterey.

No fueron de este parecer los de la goleta, que llenos de entusiasmo de descubridores y favorecidos de la oscuridad de la noche, se separaron de intento de la fragata, ciñendo para el Oeste cuando aquélla arribó el 30 de Julio, y siguiendo después su navegación llegó á Monterey el día 30 de Agosto. Ya habían recibido en la goleta el reemplazo de los siete hombres, pero áun así, era una temeridad increible tentar á subir á mayores latitudes con un buque tan pequeño, de malas propiedades, con pocos víveres, y últimamente, sin los requisitos necesarios para tamaña empresa. Sin embargo, poseídos de su idea, el día 4 de Agosto ya estaba la goleta como r7o leguas de la costa, por latitud de $46^{\circ} I 6^{\prime}, y$ habiendo llamado el viento al Oeste, navegaron en vuelta del Norte. El 5 renovaron su conferencia el Comandante y Piloto, tomando en consideración la estrechez á que debían reducirse por los pocos víveres, siendo así que la pequeñez de la goleta les había obligado á depositar las carnes en la fragata: el corto número de tripulación que exigía la reunión de las fuerzas de todos, la falta de recursos en aquellas costas desconocidas, y otras dificultades que le sugería su buen juicio; pero ocupados del mismo entusiasmo que les obligó á separarse de la fragata, se mantuvieron firmes en su primera resolución.

El I6 vieron la costa, y notaron perfectamente un monte, que colocado sobre un cabo muy saliente, se distinguía por su figura de pan de azúcar. Su cumbre estaba cubierta de nieve, y de ella bajaban varjas canales hasta su falda. Por las cercanías á la nieve la tierra era muy encarnada, pero en los llanos se presentaba cubierta de altos pinos, y se descubrían campos verdes y limpios, formando el todo la perspectiva más agradable. Dieron al monte el nombre de San Jacinto, y al cabo el del Engaño, el cual está en $57^{\circ} 2^{\prime}$ de latitud, y en $34^{\circ}$ por estima al Oeste de San Blas; y dando la vuelta á una ensenada situada al Norte, fondeó la goleta en el puerto que llamó de Guadalupe, por latitud de $57^{\circ}$ I I $^{\prime}$ y abrigado de todos vientos, excepto del 
Sur, que le hiere de lleno en la enfilación del Cabo de Engaño.

Poco satisfechos nuestros navegantes de este fondeadero, zarparon, y costeando tirada la goleta de un remolque, navegaron al Norte y fondearon en nueve brazas arena y lama, dentro de una ensenada que los abrigaba de los vientos del primero, segundo y áun cuarto cuadrantes, á la cual nombraron el fondeadero de los Remedios. Aquí trataron con los naturales, cuyo número era corto, y viendo que los nuestros llevaban vasijas de agua, pretendieron que se les pagase, como en efecto se verificó, regalándoles muchas bujerías.

En la unión de las aguas salada y dulce había muchos salmones y róbalos; pero la falta de anzuelos y aparejos privó á los nuestros de este regalo, hasta que formando fizgas con bicheros y clavos, lograron arponar algunos peces, cuyo gusto dicen es exquisito. Los naturales sólo se diferenciaban de los del puerto de la Trinidad en las ropas, pues para defenderse de los fríos usaban pequeñas chaquetas con capuchas, al modo de los marselleses cortos de Cataluña.

Con el excesivo frío que experimentaban, enfermó la gente hasta el punto de quedar reducidas las guardias á dos solos individuos cada una. Se hicieron á la vela el 2 I, y con viento Sueste continuaron hasta el 22, que habiendo observado $58^{\circ}$ de latitud cambió el viento al Noroeste con mucha fuerza. En este punto resolvieron cambiar la vuelta del Sur y regresarse costeando, contentos en lo posible de haber subido á tal altura, aunque con el disgusto de que no bastase su arrojo y deseo á proseguir la campaña, contrarestando las enfermedades y los vientos. Propusiéronse seguir las orillas de la costa para tomar conocimiento de las entradas y puertos, y como se hallaban en la latitud del famoso Archipiélago de San Lázaro del Almirante Fonte, doblaron de cuidado y desvelo á fin de descubrirlo, pero no lo consiguieron. De noche se mantenían á la capa y de día corrían el fondo de las ensenadas y se atracaban, aunque sin fruto, á todas sus puntas.

El 24 de Agosto, por latitud de $55^{\circ} \mathrm{I} 4^{\prime}$, entraron en una ensenada tan abrigada, que las aguas parecían por su reposo á las de un sosegado estanque; fondearon en 20 brazas lama á dos tiros de fusil de tierra, levantaron el plano, tomaron posesión del puerto y se le dió á éste el nombre de Bucareli. Está rodeado de montes muy altos que se levantan rápidamente de sus orillas, con un bosque impenetrable de pinos, que derribándolos los vientos ó cayéndose de vetuste $z$, se forma de sus ruinas un terreno blando y de poca consistencia, donde se cría mucha acedera y apio silvestre. Por este paraje recaló el Capitán ruso Tschirikoio, si se supone que se ha- llaba en $55^{\circ} 36^{\prime}$ de latitud, que es la de una de las bocas del puerto y en $\mathrm{I} 42^{\circ}$ al Oeste de París.

Concluídas las faenas precisas dieron la vela nuestros navegantes el 26, sin haber visto habitante alguno. Se dirigieron á una isla que tenían al Sur distancia de seis leguas, que es la que llamó Pérez, Isla de Santa Cristina, y fondearon dos leguas al Norte de ella por 22 brazas, para mantenerse contra una corriente impetuosa. Desde allí marcaban al Este y á distancia de cuatro leguas un cabo donde terminaba la tierra, pues no se veian señales de ella más allá. Por lo recio de las corrientes coligieron, como sucedió á Pérez, que allí había otra entrada por donde desembocaba algún río caudaloso, como se infería también por el color del agua; pero no pudieron averiguarlo por los vientos reinantes del Sueste, con cuyo motivo, y considerando que éstos durarían, formaron el ánimo de subir á mayores latitudes, y cambiaron de la vuelta del Norte. Atracaron la costa entre 56 y $56^{\circ}$ y $1 / 2$ de latitud, pero habiendo rolado el viento al Oeste bien fresco, les fué preciso desistir de su empresa, temerosos de que cargasen demasiado, y salieron en vuelta del Sursueste el 29 de Agosto, en cuya época se contaban siete hombres de los once de la tripulación, acometidos de escorbuto, sin movimiento en las articulaciones de los brazos y piernas, quedando por tanto solamente cuatro hábiles para el servicio de guardias, y obligados á trabajar con ellos el Comandante y Piloto. Uno y otro resolvieron navegar á Monterey sin demora, pero á la vista de la costa, para determinar en lo posible su verdadera dirección. Los vientos, á la sazón, eran del Sueste y tan recios, que el 7 de Setiembre á las dos de la mañana, rompió un golpe de mar sobre la goleta, y arrancando batayolas, candeleros y bordas, arrastró consigo cuanto había sobre cubierta, no viéndose en ella por espacio de cinco ó seis minutos sino una mar espumosa de la cual pasó mucha agua á la cámara y bodega. Al pronto creyeron que el golpe de mar se había llevado á la gente, pero no tardaron mucho en oir lamentos de los heridos, que lo habían sido unos en la cabeza, otros en las espaldas y piernas, y el contramaestre que dió un golpe contra la uña de un ancla que estaba al pié del palo mayor, quedó enteramente inútil y murió poco después á la llegada á San Blas.

Para huir á la mar arribaron en popa sobre la tierra, con la esperanza de que antes de cumplir la distancia á ella, cediese la tempestad. Por el espacio de veinticuatro horas, el Comandante, el Piloto, un guardian y un criado, dieron á la bomba para achicar el agua que había en la bodega.

El 7 en la tarde abonanzó el tiempo y el viento se llamó al Noroeste; reconocieron rota una hembra del timón, y en esta disposición no fué 
posible atracar la costa por más arriba que los $47^{\circ}$ I $f^{\prime}$ el día 20 de Setiembre. El 2 I con vientos Sur y Sueste, ciñeron en vuelta de afuera, y aunque el 22 volvió el riento al Noroeste y aclaró el cielo, no pudieron acercarse á tierra porque el Piloto y el Comandante enfermaron y cayeron en cama con fuertes calenturas, cuyo accidente consternó mucho á la tripulación. Algo mejorados el 24 se esforzaron á subir sobre cubierta, y haciendo rumbo al Este, reconocieron la costa con $44^{\circ} \mathrm{y}^{1} / 2$, con el mayor empeño que les fué dable. Tenían sumo deseo de reconocer el río de Martín de Aguilar; pero no pudieron encontrarlo desde $\operatorname{los} 44^{\circ} 27^{\prime}$ hasta los $42^{\circ} 50^{\prime}$ de latitud, entre cuyos paralelos corrjeron las orillas viendo en ellas las piedras de la playa. En $42^{\circ} 50^{\prime}$ notaron un cabo con manchas blancas, cortado en forma de mesa y con farallones al Sudoeste: la mar se manifestaba de color de sonda, y juzgaron por esta circunstancia era dable desaguasen en él las corrientes del río visto por Martín de Aguilar. Sobre este cabo, que es el que Vizcaino llama Cabo Diligencias, tuvieron vientos del segundo cuadrante, y para el día 28 que cesaron, las corrientes les habian arrebatado al Sur, de forma que no les fué posible tomar la costa sino por $40^{\circ} 28^{\prime}$ á la vista del puerto de la Trinidad. Lo mismo había sucedido á Pérez y á Hezeta dos meses antes.

Desde la última recalada fueron por la inmediación de la costa, solicitando el puerto de San Francisco, y el 3 de Octubre por latitud de $38^{\circ}$ I $8^{\prime}$ $y$ longitud de $r 7^{\circ} 57^{\prime}$ al Oeste de San Blas, tomaron puerto en uno muy abrigado, cuyo examen convendría hacer, y entonces no fué posible. Llamaron á este puerto de la Bodega, y creyeron era el mismo que el que denominó Drake de San Francisco, desde el cual demora la Punta de Reyes al Sur distancia seis leguas. Pero este puerto es diverso del que los navegantes antiguos llamaron de San Francisco, pues éste corresponde al Sueste y á muy poca distancia de la Punta de Reyes, demorando desde él al Sursudoeste los farallones, y también lo es del Puerto de San Francisco, donde existe actualmente nuestro establecimiento, porque éste cae ocho ieguas al Este de la Punta de Reyes. Como quiera, nuestros navegantes sufrieron al ancla y entre puntas mucha mar y vientos calmados, y vieron sobre las orillas y en pequeñas balsas de tule á manera de canoas, crecido número de indios robustos, pero del mismo color que los de Nueva España. Sólo dos llegaron á bordo, y con mucha generosidad regalaron plumajes, rosarios de hueso, un tejido de piumas que traían colgado de un palo á modo de bandera, y ruedas de plumas que ponen en la cabeza como guirnaldas, correspondiendo los nuestros á estos presentes, con varias maritatas que fueron muy estimadas de los naturalcs. Observa- ron el establecimiento de la marea al medio día del plenilunio y la variación de la aguja de $I 6^{\circ}$ Nordeste. El día 4 á las dos de la mañana entró la creciente, y encontrándose con la fuerte bajante, causó tal hervidero de mares, que varias veces cubrieron la cubierta de la goleta, y arrebataron la canoa haciéndola mil pedazos contra la playa. Mucho riesgo corrieron de perderse y faltó una amarra.

Cuando cesó la fuerza del tiempo, dieron la vela, navegando al Sur para montar Punta de Reyes, y el 5 en la mañana pasaron por entre unos islotes del mismo nombre, atracaron la costa á reconocer el puerto antiguo de San Francisco, y después de costearlo fueron á dar vista al nuevo á las seis de la tarde, sondando desde los islotes 27 brazas de fondo arena y lama, que disminuyeron después hasta I2. No tomaron puerto por el mal estado de la gente, y navegaron al Sur en vuelta de Monterey, que consideraban en latitud de $36^{\circ} 40^{\prime}$ y $17^{\circ}$ al Oeste de San Blas, y fondearon en él á la caída de la tarde del día 7. El I. ${ }^{\circ}$ de Noviembre de 7775 dieron la vela: el I 8 al ponerse el Sol vieron las Marías, y pasando al Norte fondearon en San Blas el 20 á las dos de la tarde.

No será fuera de propósito advertir aquí que el editor del tercer viaje del Capitán Cook observa en su introducción que los de la goleta se glorían de haber llegado á la latitud de $58^{\circ}$, mucho más allá del punto adonde habían podido arribar los demás navegantes (I), y con este motivo, forma una comparación odiosa con los admirables descubrimientos de aquel Capitán. Pero sin que se pretenda ni competencia ni semejan$z a$, haremos la descripción de la goleta, de su tripulación y armamento, y los inteligentes juzgarán si fueron posibles mayores esfuerzos.

Tenía la goleta IS codos de quilla, cuyo largo es el mismo que el de la lancha de un navío, y se construyó con el intento de que sirviese para atravesar desde la costa de la Sonora á la Península de California. Toda su seguridad y alojamiento consistía en una cubierta y un pequeño camarote: no había más baules ni equipaje que la cama y lo poco que cabía en un cajón colocado debajo de ésta. E1 poco puntal del alojamiento, no permitía otra postura que la de estar sentado, y como la pequeñez de la cubierta no dejaba pasear, vivieron en esta inacción por espacio de diez meses.

(I) Es de advertir que el Diario de esta expedición, escrito por D. Francisco Maurelle, Piloto de la goleta y hoy Capitán de fragata de la Real Armada, lo ha publicado el inglés Barrington entre sus misceláneas, página 508. En español no se ha publicado hasta ahora, sino las noticias que contiene la introducción al viaje para reconocer el Estrecho de Juan de Fuca. 
La tripulación se componía de I $_{4}$ hombres, el Capitán y el Piloto, y entre aquella gente apenas cuatro habían navegado, y los demás eran vaqueros acabados de salir de las haciendas. El Capitán y el Piloto trabajaban igualmente que los marineros, y cuando éstos fueron heridos por el golpe de mar que se derramó en la bodega, ellos fueron los que dieron á la bomba para achicarla; de suerte que se resolvieron á esta fatiga nada conforme á su ejercicio y que sólo podían resistir dos jóvenes que ardían por reputación y fama. La menor enfermedad pedía una estrecha unión de todas las fuerzas restantes, y en la ocasión de quedar la mayor parte tullidos, sin movimiento, sin medicinas y sin facultativos, estando aún sobre $\operatorname{los} 57^{\circ}$ de latitud, debieron padecer, es creible, una congoja extrema.

Los víveres, era otro punto que exigía una constancia temeraria, pues la pequeñez del buque no había dado lugar á llevar las 72 arrobas de carne que le correspondían, y que por dicha causa se embarcaron en la fragata. Las propiedades de una lancha mal construída, tampoco daban lugar á medir por ella la viveza de la co. misión, y así es, que se vieron obligados á recibir un remolque hasta los $4 \mathrm{I}^{\circ}$ de latitud á pesar de los contínuos abordajes que esta maniobra producía. De este modo se hallaban en la latitud de $47^{\circ}$ después de haber perdido siete hombres á manos de los bárbaros, otro motivo para abatir su ánimo, cuando por razones que obligaban al Comandante y existían en su buque, se determinó á arribar al puerto de Monterey, y cuando á pesar del referido estado formaron el temerario proyecto de separarse y morir en su lancha antes que volver sin lucimiento. Tal fué la conferencia que tuvieron en su pequeño alojamiento sobre los $48^{\circ}$ de latitud el 29 de Julio desde las siete á las diez de la noche, después de haberse esforzado por la tarde en persuadir al Comandante que el temporal no les permitía dar la popa á los mares.

En dicha sesión, bien tuvieron presente que se exponían á perecer de miseria en costas desconocidas; que navegarían por mares no frecuentados; que tal vez se hallarían en archipiélagos de donde no sería fácil șaljese felizmente un solo $y$ pequeño buque; que cualquiera enfermedad los pondría en el último apuro, especialmente en una estación tan avanzada; que desde el punto de la separación debían acortar la ración por lo restante del viaje; finalmente, que si volvían al puerto sin que sus progresos fuesen dignos de la consideración de los Jefes, resultarían al punto contra ellos las acusaciones de insubordinación y otras que son naturales en un dilatado viaje. Pero nada pudo preponderar al sentimiento vergonzoso con que se figuraban estos jóvenes su regreso á San Blas desde aquella latitud sin haber hecho descubrimiento alguno, y así, forzaron de vela á las diez de la noche en vuelta del Oeste, resueltos á seguir este rumbo hasta hallar los vientos del tercer cuadrante, quedando por tanto dueños de sus acciones desde el día siguiente por la mañana.

Si este estado es comparable al de dos buques bien tripulados, bien provistos y con muchos y sabios Oficiales, júzguelo el público que administra justicia con imparcialidad, pero jamás se les quitará á los de la goleta la gloria de haber sido los primeros que corrieron desde aquella altura un vasto continente con más ó ménos averigua ción de sus costas y puertos, según fué mayor ó menor la proporción que tuvieron por las enfermedades y los tiempos. Viaje digno de servir de modelo de constancia á los navegantes futuros y de estímulo á los jóvenes que quieren sobresalir en la práctica marinera de su profesión.

Los nuevos conocimientos adquiridos en la expedición anterior, dieron causa á que desde principios de 1776 se ordenase este tercer viaje, el cual no pudo emprenderse entonces por falta de embarcaciones en el Departamento de San Blas; pero desde luego se dispuso construir la fragata Princesa y se trajo de Guayaquil la $F a$ vorita, y pronta una y otra, dieron la vela de San Blas el II de Febrero á media noche. Mandaba la fragata Princesa el Teniente de navío D. Ignacio Arteaga, siendo su segundo el Teniente de fragata D. Fernando Quirós: la Favorita tenía por Comandante al Teniente de fragata D. Francisco de la Bodega Cuadra y llevaba por segundo al Alférez de fragata D. Francisco Maurelle.

Hasta el 26 lidiaron infructuosamente con los vientos y corrientes, intentando pasar por el Norte de las Marías, pero desistieron y arribaron á pasar por el Sur con vientos del Norte y Nornordeste. Su navegación no tuvo cosa notable hasta el 4 de Mayo que fondearon en la entrada de Bucareli. Allí trabajaron en reemplazar aguada y leña, y la gente descansó de las fatigas de la campaña. El I4 dieron principio á la formación de la carta de aquella entrada, saliendo al intento armadas las lanchas á las órdenes del Alférez de fragata D. Francisco Maurelle, en cuya comisión permanecieron hasta el I 2 de Junio, que volvieron después de haber examinado muchos $y^{\prime}$ hermosos puertos, para cuyo prolijo reconocimiento sería preciso emplear muchos meses.

Observaron tambien que los naturales de esta entrada son de color trigueño claro y algunos de un blanco regular. Su estatura es buena, tienen fuerzas considerables y espíritu arrogante, lo que los hace propensos á la guerra. Su vestido consta de una ó más pieles unidas de nutria, lobo marino, venado y oso, que les cubre desde el cuello hasta media pantorrilla, $y$ de unos sombreros bien tejidos y de figura semejante á la 
parte ancha de un embudo. Usan pulseras de hierro ó cobre, y en su defecto emplean la barba de ballena.

Tienen el pelo grueso, negro y largo, y lo traen por lo común recogido en coleta. Para cubrir las espaldas gastan unas fresadas de vara y media dc ancho y una de largo, tejidas del mismo modo que la sarga, cuyo hilo medianamente torcido es de lana bien suave.

Las mujeres son de cara muy agradable, tienen el color bastante claro, las megillas muy rosadas, el pelo negro y largo, tendido en dos trenzas. Su vestido lo traen cerrado y con mangas, compuesto de pieles que las cubren todo el cuerpo. Algunas se presentan en las canoas vestidas de esta suerte, y pueden en cierto modo compararse á las bien parecidas de nuestra España; sin embargo, se desfiguran mucho á la vista de los europeos por el uso singular que tienen las casadas de introducir un óvalo de una pulgada de diámetro en un agujero hecho al intento en el labio inferior, quedando éste pendiente en aquellas que por su edad no tienen el resorte necesario para mantenerlo derecho; y áun así les sirve para que sus hijuelos reciban allí la comida que antes han masticado las madres. Las doncellas por esta razón sólo tienen un delgado alambre que mantiene abierto el conducto por donde algún día introducen el óvalo referido, ensanchando la pequeña abertura para que pueda colocarse.

Los indios, á quienes el clima y sus necesidades constituyeron de un carácter feroz y guerrero, se presentan á las batallas con un peto y espalda de la misma hechura que las cotillas de nuestras europeas, pero formados de tablitas muy angostas tramadas con muchos hilos, de tal modo, que dejándolas flexibles para ceñirlas al cuerpo con libre movimiento de los brazos, quedan sin embargo tan estrechamente unidas, que no es posible atravcsar por sus intersticios una aguja. En el cuello ponen una ancha y gruesa gola que les cubre desde el pecho á los ojos, y en la cabeza llevan un morrión de madera que representa un animal feroz. Desde la cintura á media pierna usan un delantal, el cual, juntamente que con la cuera de la espalda, los deja impenetrables á las flechas, aunque sin su agilidad ordinaria, por cuyo motivo cuando se hallan en esta disposición acostumbran hacer uso de la lanza. Esta tícne cuatro varas de largo y lengüetas de hicrro; las demás armas ofensivas son las flech.ıs, cuchillos de más longitud que nuestras bayonetas, y hachuclas de pedernal y de otro color verde, tan duras, quc partiendo cualquier madero no sc percibe mella en su filo. La difícil pronunciación de sus voces puso un notable inconveniente al conocimiento de muchas noticias que fucran apreciables entre nosotros, pero no es extraño que la articulación gutural se hiciese incomprensible en tan poco tiempo.

La vivacidad y el afecto al cambio de aquellos naturales hizo conocer los muebles y manufacturas suyas. Conducían diariamente esteras bien tejidas matizadas de varios colores, pieles de lobos terrestres y marinos y de nutrias, venados, osos y otros animales pequeños, de las cuales unas estaban bien curtidas y otras dobladas con su propio pelo. Traían también fresadas de lana mezcladas de color pardo y blanco, bien tejidas é hiladas, fajas, lana limpia tan suave como la de nuestros países, y madejas de hilo de ella, que compraron nuestras gentes. Vendían igualmente bateas, canoas pequeñas pintadas de varios colores, formando casi siempre en sus dibujos cabezas con todas sus partes, ranas de madera bien imitadas, que abriéndose como cajas de polvos, les servían para guardar sus frioleras; cajas de tabla de tres cuartas cúbicas con muchos dibujos representando animales, algunos de éstos, ya terrestres, ya volátiles, con cabos interiores; figuras de hombres representadas con cabezas por sus piés; morriones que figuraban la cabeza de una fiera tal vez no conocida; y por último, redes y cordeles de pescar, cobre en collares ó pulseras; hierro en todo género de armas, cuyos metales nunca vendían á ménos de recibir crecido precio por ellos; y pitos que tocan como flautas, de cuyos artículos compraron los Comandantes y todos los de á bordo.

Aliméntanse estas gentes de pescado fresco ó seco, bien sea cocido ó asado, de varias yerbas y raices del monte, en especial del peregil, de la carne del venado y de otros anjmales cuyas pieles manifestaban, y para cuya caza mantienen muchos perros. No fué posible adquirir ideas ciertas sobre la religión de estos pueblos, y únicamente puede decirse, que ya sea por indiferencia hacia su generación ó por el ansia con que solicitaban el hierro, vendían por éste sus hijos, especialmente aquellos que carecían de presencia ventajosa y agradable, y de este modo se compraron en la Princesa dos niñas, la una de siete y la otra de tres años, y en la Favorita tres muchachos de diferentes edades, de cuatro hasta $\operatorname{die} z$ años.

Los montcs de toda la entrada son bien elevados y pendientes hasta las playas, á excepción de las quebradas de los puertos, donde se encuentran algunas playas, y el cuerpo de todos los cerros es de piedra viva, sobre la cual crió la Naturaleza una espesura de pinos muy gruesos y derechos, á propósito para emplearlos en la construcción de buques, y tan altos, que faltándoles con el tiempo la firmeza correspondiente en las raices, caen á esfuerzo de los vientos y forman al fin un terreno de poca consistencia, cn donde nace el apio, anís, llanten, cele- 
donia, sauco, agenjo y muchas otras yerbas. En los paseos que dieron nuestros naregantes por las orillas encontraron ciertas piedras minerales que les dieron lugar á sospechar que el cobre que tanto aprecian sea metal que extraigan ellos de aquellas vetas. Las de hierro son sin duda. muy abundantes, pues las agujas de marear llevadas á tierra, perdían luégo su virtud y sus movimientos.

Observaron la pleamar el día de la conjunción, á las doce y cuarto del día, subiendo el agua I $7 \mathrm{y}^{1} / 2$ piés. El I. ${ }^{\circ}$ de Julio dieron la rela, y á las dos de la tarde se hallaban ambos buques al Sudeste de la Punta de San Bartolomé distancia de dos leguas, y por consiguiente sobre

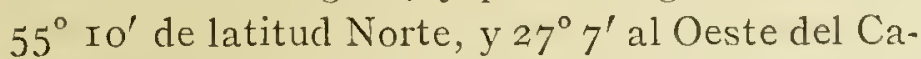
bo San Lucas, desde cuyo paraje naregaron en el tercer cuadrante hasta el día 3 , que con viento del Oesudoeste tomaron la vuelta del Norte. E1 9 de Julio á medio día vieron tierra desde el Norte $1 / 4$ Noroeste al Esnordeste, y tenían á la vista el elevado promontorio de San Elías, que tiene la forma de pan de azúcar. Con vientos del primer cuadrante continuaron en vuelta del Noroeste á reconocer el Cabo San Elías, y el r6 á las cinco de la mañana se hallaron cerca de un bajo, que consideraron en $59^{\circ} 2^{\prime}$ de latitud $y$ $35^{\circ} 40^{\prime}$ al Oeste de San Lucas. El I7 á las dos de la tarde estaban á una legua de Cabo San Elías y de la punta de la isla próxima, que llamaron del Carmen. Casi en la boca comprendida entre dicha isla y el cabo sondaron 40 brazas de agua. Dicho cabo le consideran en $59^{\circ} 53^{\prime}$ de latitud Norte, y al Oeste de San Lucas $37^{\circ} \mathrm{I}^{\prime}$, a unque no tuvieron observación aquel día.

Reconocido el cabo y la parte Nordeste de la isla, arribaron al Sursudoeste en demanda de su parte meridional, la cual montada, naregaron al Oeste $1 / 4$ Noroeste, dirigiéndose á la costa occidental que tenían á la vista, y reconocieron un gran seno que se forma al Oeste. El ig estaban en el centro de él por $59^{\circ} 57^{\prime}$ de latitud, demorándoles las tierras más distantes al Oeste y la del Cabo de San Elías al Este. Aquí experimentaron fuertes corrientes que guardaban el orden de las mareas, y que los acercaban ó alejaban de tierra según su curso. Sondaron 47 brazas lama á cinco leguas de las orillas, donde vieron bastantes bocas que seguramente producían el impetuoso curso de las aguas hacia una $y$ otra parte.

El 20 se les acercaron dos canoas con un indio en cada una, los cuales, sin detenerse, se aproximaron al costado, y mostrando las flechas con puntas de cobre, se las arrancaban y entregaban las varas como denotando sus intenciones pacíficas, al mismo tiempo que hacían muchas instancias para que entrasen los nuestros por una boca que les demoraba al Oeste.
En efecto, el 2 I fondearon las fragatas en un puerto abrigado que llamaron de Santiago, y es el mismo que denominó Príncipe Guillermo en 1778 el Capitán Cook.

Los indios que habitan estas comarcas están vestidos de pieles para abrigarse del frío; sin embargo, están endurecidos á la intemperie, son robustos, del mismo color que los de Bucareli, y naturalmente industriosos en cuanto lo exigen sus necesidades: viven de la pesca y son diestrísimos en este arte, para el cual emplean unas flechas que parecen hechas al torno, y un asta larga de madera con una vejiga llena de viento, un arpon de hueso en la punta, y cordeles bien fabricados, de tripas de animales. Este instrumento lo arrojan contra el pez, lobo ó nutria, á manera de dardo, y traspasado con él el animal, aunque pretende zambullir no se lo permite la fuerza de la vejiga, y de este modo lo cogen en la canoa. Merece particular descripción el modo con que estos naturales fabrican sus canoas. En primer lugar forman el esqueleto de varas delgadas, afianzadas con hilos de tripa ó tendones de mediana consistencia, y cubriéndolo de pieles por todas partes, dejan únicamente en la superior una claraboya semejante á la boca de una tinaja, de suficiente cavidad para cuntener la cintura de un hombre; y á fin de precaver la introducción de las aguas, visten una camisa de vejiga y la ci. ñen al borde de la indicada claraboya, quedando de este modo $\sin$ riesgo de sumergirse. La figura de estos débiles buques es la de un arpa, y son tan livianos, que un hombre solo los maneja fácilmente con la mano. El idioma de estos naturales se diferencia tanto del de los de Bucareli, que los pequeños indios adquiridos en aquella entrada no pudieron hacerse entender, ni comprendieron una sola palabra de los de este puerto.

Como los montes que atraviesan estos parajes están perpétuamente cubiertos de nieve, despiden varios arroyos que fertilizan sus faldas y en todas partes conservan una yerba de más de vara de alto, tan verde y mezclada de flores silrestres, que alegran la vista del espectador. Mientras los nuestros permanecieron en este puerto, hicieron agua y leña, descansaron las tripulaciones y experimentaron alivio los enfermos con la comida de buen pescado, salmón, pargo y la yerba que llaman acedera: observaron la variación de la aguja, que á la sazón era de $26^{\circ} 30^{\prime}$ al Nordeste y situaron el Puerto en $60^{\circ}$ I $3^{\prime}$ de latitud Norte y $39^{\circ} 46^{\prime}$ al Oeste de San Blas. La marea ascendió, según observaciones, I 8 piés.

E1 28 de Julio, en la tarde, zarparon nuestros buques, costándoles sumo trabajo levantar las anclas, porque el barro del fondo se las había tragado hasta la uña superior, $y$ el I. ${ }^{\circ}$ de Agosto anclaron en las islas que están inmediatas y al 
Sur, á las cuales llamaron de Regla. Ultimamente, el 7 de Agosto se pusieron otra vez á la vela, de regreso para San Blas, en atención á que el estado de las tripulaciones no les permitía seguir más al Norte ni atracar la costa y reconocerla en vuelta del Sur, y con vientos frescos del Noroeste hicieron breve su navegación, recalando el 4 de Setiembre á Cabo Mendocino, cuya latitud rectificaron con nuevas observaciones, resultando en ellas estar en $40^{\circ} 7^{\prime}$. Es un frontón de tierra alta, tajada al mar, colorada, con cuatro barrancas en su frente.

El día 4 estaba la fragata Favorita media legua al Sur de la punta de Reyes, marcando los farallones de San Francisco del Sur $7^{\circ}$ Este al Sur $I 7^{\circ}$ Oeste distancia de tres leguas, y el mismo día anclaron uno $\mathrm{y}$ otro buque en el puerto de San Francisco, cuya latitud observaron de $37^{\circ}$ $5 \mathrm{O}^{\prime}$ Norte y su longitud de estima $2^{\circ} 5 t^{\prime}$ al Oeste del Cabo San Lucas. La aguja variaba entonces $13^{\circ}$ al Nordeste. Recobrados los enfermos se hicieron al mar el 30 de Octubre y fondearon en San Blas el 2I de Noviembre del mismo año de I 779 .

Con motivo de la guerra emprendida contra los ingleses hacia el fin del tiempo de la expedición anterior y de la atención que exigía entonces el estado de la Europa, se abandonaron enteramente los reconocimientos emprendidos á la costa Noroeste de América, hasta que á principios del año I 787 , el Ministro de Indias, Marqués de la Sonora, á consecuencia de un aviso que le comunicó el Maestre de Campo de Concepción de Chile, de que habiendo llegado allí las fragatas Bríjula y Astrolabio, de la marina de Francia, mandadas por el Conde de la Péyrouse, le había manifestado la carta general que llevaba, expresiva de cuatro establecimientos que tenía la Rusia al Norte de California, en Nutka 767 leguas de Acapulco, en el Príncipe Guillermo sobre. $60^{\circ}$, en la Isla Trinidad y en Onalasca, de los cuales el primero distaba muy poco de nuestro establecimiento en Monterey; prevenía el Virey de Méjico era la voluntad de S. M. se armasen en San Blas dos buques apropósito para reconocer la costa hacia el Norte y averiguar si existían, con efecto, tales establecimientos. Había muerto el Virey D. Bernardo de Gálvez cuando llegó á Méjico esta orden, y gobernaba la Audiencia en su lugar, la cual dió vista al Fiscal, y sucediendo en el mando el Arzobispo de Méjico en calidad de Virey interino, se tomaron en su tiempo providencias oportunas para dar entero cumplimiento á dicha Real orden.

En 2 I de Julio del mismo año la repitió el Ministerio, y el Virey ya nombrado, D. Manuel de Flores, contestó á ella que la expedición saldría á principios de I 788 á pesar de la suma dificultad que había de encontrar sujetos á quien encomendar cosa tan importante, representando con este motivo era preciso fuesen á San Blas Oficiales hábiles de la Armada, capaces de mandar las embarcaciones y de cumplir las órdenes de Su Majestad relativas á expediciones de tanta monta; y que por lo demás, añadía, era notorio desde que regresáron en I780 los Capitanes ingleses Gore y King del tercer viaje del célebre Cook, que los rusos tenían dichos cuatro establecimientos en la costa Noroeste de América, pero que áun el más próximo estaba bien distante de los nuestros.

Equipada, pues, la expedición referida, compuesta de la fragata Princesa y el paquebot Filipino, se nombraron sus Comandantes, recayendo el mando de aquélla en el Alférez de navío graduado D. José Esteban Martínez, y el del paquebot en el primer. Piloto D. Gonzalo López de Haro, siendo el primero el Comandante en Jefe de la expedición. Su objeto, según las instrucciones del Virey, era subir hasta los 60 ó $6 \mathrm{I}^{\circ} \mathrm{y}$ examinar con certidumbre si existían ó no tales establecimientos de los rusos en aquella parte.

Salieron estos buques de San Blas el 8 de Marzo de I788 y navegaron sin ocurrencia notable hasta el i 8 de Mayo que reconocieron unas islas pequeñas y rasas que llamaron de Hijosa y se hallan situadas de Io á I2 de la Isla Montagu, por $59^{\circ} 30^{\prime}$ de latitud Norte. E1 25 fondearon en esta última isla, pero se levaron el 26 y continuando hacia el Norte anclaron el 28 en una ensenada que llamaron de Flores, por $60^{\circ} 7^{\prime}$ de latitud y $37^{\circ} .32^{\prime}$ al Oeste del Cabo San Lúcas. Aquí trataron con los naturales y reconocieron las inmediaciones, encontrando en ellas una casa de madera fabricada por europeos.

A1 atracar los indios á bordo de nuestras embarcaciones, entonaban una canción dirigida por el más respetable de ellos á cuyas voces se movían guardando compás, y dando con harmonía ciertos golpes con palos en los bordos de las canoas y últimamente extendían los brazos en señal de amistad, sin cuyas ceremonias no se aproximaban á los costados. En una de estas ocasiones llegó una canoa con IS indios, mandados por uno de figura respetable. Era blanco, tenía los ojos azules, la bảrba larga y medio rostro pintado de rojo. Su autoridad se advirtió particularmente en una especie de tributo que le pagaban los demás, de cuanto podían adquirir. 'Todos ellos son robustos, de color claro y pelo negro, y tienen el labio infcrior taladrado, por cuya abertura pasan un hueso liso, del cual cuelgan sartas de abalorios del propio modo que en las orejas. Las mujeres se distinguen de los hombres, únicamente en que ellas llevan la cabeza descubierta, y éstos usan unos sombreros cónicos de yerbas, bien tejiclos. Sus canoas son de figura de un arpa, hechas primorosamente de 
delgadas varas y forradas con pieles de animales, dejando en la cubierta una, dos ó tres fogonaduras donde se meten los bogadores, quedando de este modo defendidos de las aguas que pudieran entrar por la parte superior. Estos habitantes dieron suma estimación al hierro, que no es de admirar les tentase su codicia á robar una materia que por su grande utilidad es preciosa y de valor inestimable para ellos.

En las orillas del mar notaron nuestras gentes se cría mucho apio silvestre, cuyo uso es muy conveniente para las tripulaciones, como se advirtió en la expedición de I779, con la de las lanchas que reconocieron el puerto de Bucareli, sanando con el uso de aquella yerba y la acedera todos los efectos del escorbuto.

E1 I5 de Junio dieron la vela ambos buques de este fondeadero, dirigiéndose al Oesudoeste, y el 26 fondeó la fragata en la Trinidad, por $56^{\circ} 44^{\prime}$ de latitud. El paquebot recaló el Cabo Greenrvi1le, y habiendo fondeado en el de dos Puntas, por las noticias que le dieron los naturales de que allí había rusos, buscó y encontró efectivamente el establecimiento; su Capitán y Comandante se llamaba Haro, y esta conformidad con el nombre del Comandante del paquebot, estrechó la amistad y produjo muy buenos efectos. Dijo que era griego, natural de Constantinopla; manifestó inteligencia en el pilotaje, y habiéndole presentado una carta, señaló al punto un espacioso canal que principia al Sur del río de Cook y sale por el Cabo Trinidad. Sobre esta misma carta dió las noticias siguientes: Que en el Cabo de dos Puntas que él mandaba, había 60 rusos y dos galeotas; á la parte occidental del Cabo Elisabet, 40; en Cabo Rada, 37; sobre $5^{\circ}$ de latitud, 40 en una islita; una goleta armada con 70 hombres de tripulación para proteger el comercio de pieles á la boca del río Cook; 55 rusos en $55^{\circ} \%$ de latitud en el continente, y una goleta; y finalmente, I 20 hombres y dos goletas en Onalasca; de suerte, que en todos había 422 hombres, repartidos en seis establecimientos y seis goletas, añadiendo que cada tres ó cuatro años venían dos fragatas de Kamchaka con gente y auxilios para mudar á los empleados en estos establecimientos. Y habiéndole preguntadosi tenían alguno en Nutka, contestó pensaban formarlo el año I790. Los nuestros repararon en el buen órden que reinaba en este pequeño pueblo de europeos, cuyas habitaciones eran cómodas y muy aseadas, tenían huertas, almacenes, capilla, casa de enseñanza ó escuela de primeras letras; y vieron, finalmente, varios matrimonios y mujeres de porte y trato tan fino, como el de las mujeres educadas de Europa. El Comandante ruso Haro y sus principales Oficiales, pasaron á ver el paquebot, y extrañaron mucho la nueva bandera española, que hasta entonces no habían visto.
El 2 de Julio abandonó el paquebot aquellas orillas, y en la tarde del 3 se reunió la fragata que estaba fondeadasobre la cabeza del Nordeste de la Trinidad, cuyo fondeadero conceptúan en $56^{\circ} 44^{\prime}$ de latitud. Ambos se levaron el 5 y en vuelta del Sueste se dirigieron á Onalasca, donde fondearon á principios de Agosto, habiendo tardado tanto por los vientos flojos y variables que tuvieron, acompañados de contínuas neblinas. Las noticias que adquirieron en Onalasca, fueron las siguientes:

Contaba el establecimiento veintiocho años de fundación, y su fuerza en aquella época constaba de I2o individuos mandados por Saycof Cosmichi. Los rusos esparcidos en el continente é islas inmediatas, ascendían al número de 500 con seis goletas de seis pedreros cada una. Había en la isla 200 familias de naturales bajo la dirección de uno de ellos á quien la Emperatriz de Rusia tenía concedido el título de Juez de los habitantes de aquella parte, y todos pagaban tributo de pieles á la Emperatriz, cuyo dominio reconocían y por cuya sola circunstancia eran tan infelices con respecto á los naturales del Príncipe Guillermo y otros recinos, que parecían al pronto naciones diversas. Cosmichi aseguró que desde Bering y Schiricoof no habia pasado ningún ruso al Este del Cabo San Elías y que esperaban dos fragatas de Kamchaka el año de I789, para pasar con ellas á Nutka, dejar allí una colonia é impeđir á los ingleses el comercio de peletería, pues según había oído Cosmichi en I775 al Capitan Grey que retornaba á Cantón, se creían los ingleses autorizados á hacerle desde Nutka hasta las islas Shumagins. Añadió también que en I 786 se había perdido una fragata inglesa en la isla de Mandanoy sobre $54^{\circ} 44^{\prime}$ de latitud, de cuyo naufragio sólo escaparon dos hombres, que se enviaron á Petersburgo.

Adquiridas estas noticias, resolvió el Coman dante de la expedición el I 8 de Agosto regresar para Monterey, y así lo verificaron: el I 5 de Setiembre, estando á ménos de go leguas del continente, empezaron á ver señales de tierra, sondaron en 75 brazas de agua por $39^{\circ}$ de latitud y el I7 dieron fondo en Monterey y salieron el I4 de Noviembre para San Blas adonde fondearon el 5 de Diciembre.

Con estas noticias y persuadido el Virey de Méjico, D. Manuel de Flores, no sólo del legítimo derecho que tenía la Nación Española á todo el país que corre desde Nutka hasta los $6 I^{\circ}$ de que habían tomado posesión las expediciones de I774, 75 y 79, sino de la necesidad de precaver las tentativas de Rusia y las que podían emprender los ingleses desde bahía Botánica, dispuso al intento una ocupación provisional de Nutka, y nombró para que la realizase al mismo D. Es teban Martínez, el cual debía salir de San Blas 
con la fragata Princesa llevando á su bordo alguna tropa y cuatro Religiosos Fernandinos para que insinuasen dulcemente á los naturales la voz del Evangelio, encargando muy particularmente el Virey al Comandante de la expedición, tratase con toda suavidad á los indios.

Salió Martínez de San Blas el ry de Febrero de 1789 y sin ocurrencia particular llegó á su destino el 5 de Mayo, tomó posesión de él, formó un fuerte de ro cañones y levantó barracas para la tropa en el puerto amistoso á la izquierda y en la misma entrada. La primera embarcación que se vió fué el paquebot portugués $L a$ Ifigenia, su Capitán D. Francisco José Viana, que siguió para Macao, con pieles. Llegó después el paquebot inglés Argonauta mandado por James Colnet, Teniente de navío de la marina inglesa, y la balandra la Princesa Real al mando del Capitán Tomás Hudson. Estas embarcaciones se pusieron en facha á la boca del puerto y viéndole ocupado por nosotros, enviaron su bote á cumplimentar á Martínez y á saber si podían entrar, y con el sí de éste entraron y fondearon. Por el mismo tiempo llegó la fragata americana la Columbir mandada por el Capitán Kendric, con quien hizo mucha amistad Martínez y fué quien le sugirió que desconfiase de Colnet, diciéndole que iba éste á formar un establecimiento en Nutka. No es de este lugar el tratar sobre lo absurdo ó verosimil de esta conjetura, pero las resultas fueron echarse Martínez sobre los dos buques de Colnet y tomarlos por sorpresa á las doce de la noche con las dos lanchas armadas de nuestras fragatas, arrestar al Capitán y á los ingleses, y poniéndolos bajo de escotilla, enviar con gente nuestra los dos buques ingleses á San Blas.

Después de un año de prisión se devolvieron á Colnet y Hudson sus embarcaciones, carenándolas y equipándolas completamente. A todos los que venían en ellas se les pagó sueldo doble de San Blas, que es lo mismo que el cuádruplo del nuestro en Lima; y aunque los ingleses presentaron un avalúo de lo que habían perdido por el malogro de la expedición, haciendo subir aquél á 600.000 pesos, se les satisfizo sólo 200.000 res pecto á que habían obrado de tan mala fé que supusieron habían cargado 6.000 pieles en la costa, y que se las habían pagado á Ioo pesos por cada una de Nacao, cuando pudieran darse por satis fechos haber adquirido $2.000 \mathrm{y}$ haberlas vendido á I 3 ó I 5 pesos fuertes, que era el precioque entonces tenían en aquel mercado.

Al tiempo de comunicar al Ministerio el Virey de Nuera España los resultados de la expedición de $\mathrm{\gamma}\} S \&$, y cuanto creía conveniente sobre mucstro indispulable derecho al dominio de las cosias seplentrionales de la América, daba también cuenta de las disposiciones que había tomado acerca de la ncupación provisinnal de Nutka, acompañan- do copia de la instrucción que pasó á Martínez como Jefe de la expedición, añadiendo que quedaban entonces en San Blas las fragatas Princesa, Aransazu, Concepción, Favorita y el paquebot Filipino para las providencias ulteriores que dictase el estado de este negocio.

Todas estas providencias merecieron la a probación de S. M. (I), quien conformándose con el parecer de su Consejo de Estado, y queriendo sostener lo dispuesto por el Virey para la ocupación de Nutka con el tesón y decoro convenientes, mandó pasasen á San Blas el Capitán de navío D. Juan de la Bodega y seis Oficiales inteligentes, para emplearse en las navegaciones que dispusiese el Virey á la costa Noroeste, y que en el ínterin se haría saber por S. M. á la Corte de Rusia en términos generales, que por noticias recibidas de la América se sabía que algunos navegantes rusos se habían situado en parajes descubiertos y reconocidos con mucha anticipación por los es pañoles, y que se esperaba de la buena harmonía y sincera amistad que mediaba entre las dos Cortes, que si fuesen hacia aquellos mares y costas otros descubridores rusos, no se excediesen intentando establecerse en dichos parajes que pertenecían á los españoles.

Consiguiente á las anteriores disposiciones de la Corte, ordenó en 7 de Diciembre de 1789 el Virey de Méjico, Conde de Revillagijedo, al Comandante del Departamento de San Blas, que la fragata Concepción, el paquebot Argonauta y la balandra Princesa Real, debían salir sin falta en todo Enero siguiente, para relevar en el Puerto de Nutka á la fragata Princesa que lo ocupaba.

En estos buques, que conforme á las órdenes del Virey debían estar bien tripulados, equipados y armados, se embarcaron 50 voluntarios de Cataluña á las órdenes del Capitán D. Pedro Alberni. El todo de la expedición lo mandaba el Teniente de navío D. Francisco Elisa; el paquebot el Teniente de navío D. Salvador Hidalgo, y la balandra el Oficial de igual clase D. Manuel Quimper. Dieron la vela estos buques el 3 de Febrero, y sin ocurrencia particular cogieron el 5 de Abril el fondeadero de Nutka, en donde trataron de fortificarse formando una nueva batería, en la que arbolaron el día to la bandera nacional, haciendo con los cañones el saludo que exigía este acto.

Concluídas estas primeras formalidades, entregó Elisa al 'Teniente ele navío D. Salvador Hidalgo las órdenes é instrucciones que había recibido del Virey de Méjico, y prevenían que se reconociese toda la costa desde los $60^{\circ}$ de latitud para el Sur, facilitándole á este efecto los auxi-

(I) Oficio del Ministro de Indias, D. Antonio Valdés, al Virey de Méjico con fecha de rt de Abril de 1789. 
lios necesarios, dándole el segundo Piloto Mondofia que sabía la lengua rusa, y un marinero que hablaba inglés, con otros varios socorros que necesitó.

Preparado de este modo dió la vela Hidalgo el 4 de Mayo, y gobernando en el tercero y cuarto cuadrante, según se lo pernitían los vientos, se hallaba el I 7 en los $50^{\circ} 55^{\prime}$ de latitud, y en $3 \mathrm{I}^{\circ} 5 \mathrm{O}^{\prime}$ de longitud al Oeste del Cabo San Lucas, desde cuyo punto hicieron rumbos del cuarto cuadrante para recalar sobre el Príncipe Guillermo, como lo verificaron el 23 , entrando por su boca y continuando hacia el Norte por la inmediación de la Isla Magdalena, reconocieron toda la parte oriental de aquel espacioso seno, y fondearon en una ensenada á que dieron el nombre de Menéndez. El 9 de Junio se pusieron á la vela para doblar una islita que les demoraba desde el fondeadero al Noroeste $1 / 4$ Norte, y habiéndolo ejecutado descubrieron la boca de un puerto en la costa oriental del seno principal, adonde se dirigieron y permanecieron hasta el 2 I levantando el plano de aquel puerto, porque su mucho abrigo merecía toda atención. Llamaron á este puerto de Gravina, y lo situan en latitud de $60^{\circ} 40^{\prime}$ y longitud $36^{\circ} 53^{\prime}$ al Oeste de San Lucas.

Mientras permanecieron en el puerto Gravina despachó el Comandante dos Pilotos con la lancha, acompañados de unos indios que se ofrecieron á servir de prácticos para reconocer hasta su fin el seno del Príncipe Guillermo. Esta lancha llegó á la boca de un puerto muy abrigado, de buen fondo y que tiene dos bocas formadas por una isla, sobre la cual observaron la latitud de $60^{\circ} 54^{\prime}$; y estando en ella oyeron muchos truenos que se aumentaban al paso que el Sol se acercaba al meridiano; y conducidos por sus prácticos hasta lo interior de dicho puerto, descubrieron en su fondo septentrional una gran llanura de nieve que empezaba en las orillas del mar y remataba en las faldas de los montes más elevados. Apenas estuvieron á su vista cuando reconocieron que cada trueno despedía, con bastante elevación, una gran masa de nieve que, cayendo dentro del puerto, les impedía continuar la inspección de aquel fenómeno. A su regreso pasaron por un canal formado por la tierra oriental del seno y muchas islas que siempre habían tenido por costa firme, hasta que los indios los condujeron por él.

Concluído de este modo el reconocimiento de la parte más septentrional de la entrada del Príncipe Guillermo, resolvió Hidalgo ponerse á la vela y reconocer igualmente la costa del Sudoeste, á cuyo efecto salió del puerto de Gravina el 2 I de Junio, y ayudado de la vaciante y de las ventolinas del Este, se halló el mismo día á las doce á corta distancia de la punta Noroeste del puerto de Santiago. Las tempestades, cal- mas, aguas y neblinas que contínuamente sufrieron hasta rebasar la punta meridional de la Isla Montagu, les obligaron demorarse al ancla por aquellas inmediaciones hasta el 30 de Junio, que mejorados los tiempos, se vieron libres del canal que forma dicha isla con la de San Antonio.

Desde el 23 de Mayo que entraron en el Príncipe Guillermo, hasta el 30 de Junio que salieron de él, tuvieron muchas visitas de los naturales, á quienes regalaron con generosidad para captarse su estimación; y de la comunicación con ellos resultaron las observaciones siguientes.

Son estos indios de una estatura proporcionada, tienen el pelo negro y laxo, cortado por delante hasta media cabeza y de cuatro dedos de largo lo restante; los ojos grandes y negros, los dientes blancos é iguales, y la ternilla interior de las narices taladrada, por cuyo agujero atraviesan un cilindro de hueso de tres dedos de largo, y en sus extremos cuelgan varias sartas de abalorios. Llevan el labio inferior partido y representando una pequeña boca, por la cual sacan la lengua y hacen varios gestos que les imperfecciona. De los labios de esta boca fingida cuelgan también sartas de abalorios que los afianzan á otro hueso semejante al anterior, cosido con nerviecitos de animales. Son lampiños, pues sólo tienen bigote, con una pequeña perilla en la barba, negra y derecha. Las orejas las 1levan taladradas por toda su circunferencia, y de sus agujeros penden igualmente rosarios de abalorios de bastante longitud.

Se pintan el rostro de rojo y negro, formando varias figuras de aspecto horroroso; vis ten túnicas de pieles de animales, que les cuelgan hasta los tobillos, y una camisa formada de vejigas de peces para defenderse de las aguas; y finalmente, tienen sombreros bien tejidos de junco, cuya copa es baja, y el ala de corta extensión. Las mujeres se diferencian en que en el labio inferior atraviesan por pequeños agujeros varios huecesitos blancos que figuran dientes, debajo de los cuales tienen otros pequeños conductos que sirven para afianzar sartas de abalorios. También se pican la barba del mismo modo que suelen hacerlo en los brazos nuestros marineros, y por este medio la dejan de un color azul oscuro; en lo demás imitan á los hombres y se pintan como ellos, pero desde luego que los españoles las hicieron entender cuánto les desagradaban aquellas pinturas, tuvieron cuidado de lavarse y de presentarse limpias en 1o sucesivo. Algunas de ellas eran blancas, de facciones regulares, y tenían el pelo largo y atado en castaña. Las criaturas de muy poca edad, llevaban ya hechos los taladros en las orejas, ternilla y labios, sin duda para evitarles el sumo dolor que deberían sufrir por esta operación, ejecutada en edad más avanzada. 
Las armas of ensivas de estos naturales son una lanza de dos varas y media de largo, con su lengua de hierro, mayor ó menor, según la proporción que tienen para conseguir este metal; flechas con puntas de pedernal y algunas de cobre cuyos tiros dirigen con notable acierto. Las defensivas son unas cotillas de estrechas planchas de madera, impenetrables á las flechas, sobre la cual ajustan una túnica sin mangas, hecha de dos dobleces de piel de oso para resistir á la lanza, llevando en la cabeza un morrión de madera que representa la de un lobo marino ó de otro cualquier anfibio. Las canoas tienen la figura de un arpa y las forman interiormente de varas delgadas y flexibles, forradas luégo por la superficie exterior con pieles de ballena para que no se introduzcan las aguas, y en la parte superior dejan abiertos uno, dos ó tres agujeros por donde introducen el cuerpo, quedando de este modo sentados en el fondo del buque. Los instrumentos de pesca son flechas y unos dardos de cuatro y media varas de largo, armados con un arpón bien hecho de hueso en un extremo y una vejiga de lienzo en el otro, que sirve para que sobrenade el pez herido con el arpón.

Los animales cuadrúpedos vistos en la entrada del Príncipe Guillermo, fueron osos con mucha abundancia $y$ de gran tamaño, ciervos crecidos, coyotes y zorros: los peces, ballenas, lenguados, sardinas, salmones y rodaballo cuyo peso llegaba á seis arrobas, además de los lobos marinos y nutrias, de las cuales aprovechan la carne, el aceite y la piel. Vieron igualmente muchas gaviotas, patos de varias clases, águilas de gran tamaño y cuervos.

Las mareas guardan el orden regular de $6 \%$ horas en cada Hujo ó reflujo, y observaron que el día del plenilunio sucedió la creciente álas $12{ }^{3} / 4$ y subió el agua 24 piés: las corrientes son de poca fuerza en las inmediaciones de las orillas, pero llevan un impulso extraordinario en el centro y los canales que forman las islas. El extremo septentrional del Príncipe Guillermo, lo consideran en $6 \mathrm{I}^{\circ} \mathrm{I} \mathrm{O}^{\prime}$ de latitud, $\mathrm{y}^{\prime}$ desde este punto hasta el extremo meridional de la Isla Montagu cuentan 33 leguas de distancia. Habiendo rebasado, como dijimos, el extremo meridional del Príncipe Guillermo, continuaron con vientos variables y neblinosos hasta las inmediaciones del Cabo Elisabet y Ensenada de Regla adonde abordaron $\operatorname{die} z$ canoas de indios que manifestaron la proximidad de los rusos, cuyo establecimiento se hallaba algo más al Norte y sobre la misma costa. El 5 cle Julio fondearon en el puerto que llamaron de Revillagijedo para hacer agua y Icña, y cuando ya se disponían á continuar sus reconocimientos hacia el Norte por el río de Cook, tuvieron noticias por el Jefe ruso, que la falta de puertos y los muchos arrecifes, les expondrían á perderse en aquella navegación, y que por tanto les aconsejaba la emprendiesen con la lancha, ya que su intención era penetrar hasta el establecimiento ruso situado en $\operatorname{los} 60^{\circ} 30^{\prime}$. Persuadido Hidalgo de estas razones, envió, con efecto, la lancha al expresado reconocimiento, y habiendo regresado el día 20, se supo por ella que los rusos están en el río de Cook desde el año de 87 , que dependen de una compañía de comercio de Petersburgo que les paga cuatro pesos y dos pesos de tributo al año á la Emperatriz, y finalmente, que tenían 3.000 de los naturales catequizados y amigos que pagaban asimismo tributo á su soberana. El número de rusos sería de unos 80 hombres, armados con otros tantos fusiles, pistolas y sables y pedreros montados sobre cureñas de campaña.

El ejercicio de estos nuevos colonos es la pesca de nutria, lobos marinos, ballenas y otros peces, á cuyo efecto lleva cada ruso consigo Io ó I 2 indios que trabajan bajo su dirección y los pagan con tabaco de polvo, abalorios y ropa. En el invierno se dedican, cuando el tiempo lo permite, á la caza de diferentes cuadrúpedos, cuyas pieles benefician, y aprovechan también sus carnes, para que con ellas y el pescado no les falte el alimento preciso, pues carecen de otros frutos para su manutención. Estos indios son de la misma constitución y propiedades que los del Príncipe Guillermo, y así ellos como los rusos usan las mismas canoas, á excepción de que los últimos tienen algunas grandes en que bogan I4 remos; pero siempre están construídas de varas $\mathrm{y}$ forradas con pieles.

La costa desde las bocas del Sur del Príncipe Guillermo, está formada por una cadena de montes elevados, cubiertos la mayor parte de nieve. El Cabo Elisabet es el extremo meridional de la Isla Maurelle; y si desde este Cabo se sigue hacia el Norte costeando sus orillas, se halla luégo una enisenada de mal surgidero, de la cual sale al Noroeste un cabo que llamaron de Gastón y poco después una islilla próxima al continente oriental con algunas restingas que se extienden milla y media. Desde este paraje se ve una pequeña ensenada donde hay casa de madera en que habitan los rusos, sin que puedan anclar en ella los buques por el fondo piedra que hay en sus centros. Dos millas al Nordeste de esta ensenada se halla la boca del puerto de Revillagijedo, y algunas más adelante la Punta de Cuadra, desde donde sigue la costa rasa $y$ limpia por espacio de tres millas, al fin de cuya distancia empiezan las rancherías de indios $y$ varias piedras que salen de la tierra y siguen hasta llegar al último establecimiento que habitan los rusos de aquel paraje en los $60^{\circ} 30^{\prime}$ de latitud, por cuya causa es preciso navegar con más aproximación á la parte occidental del ca- 
nal. Esta costa occidental es una cadena seguida de montes elevados, entre los cuales se distingue por su mayor elevación y contínuas erupciones el volcán de Miranda. Su temperamento parece más benigno que el del Príncipe Guillermo y la tierra más fértil, así por el color de ella como por la abundante yerba que la cubre.

Salió Hidalgo del puerto de Revillagijedo el 8 de Agosto y fondeó en el Cabo de Dos $\mathrm{Ca}$ bezas el II del mismo, habiendo experimentado en su travesía chubascos, neblinas y oscuridades. A poco rato de haber dejado caer el ancla, llegaron á bordo tres canoas que conducían al Jefe y dos individuos del establecimiento ruso que está situado al Sudoeste del Cabo mencionado. En esta visita adquirió Hidalgo las noticias siguientes.

El establecimiento de la Isla Codiac se hallaba en el mismo estado que lo describió el Pi- loto D. Gonzalo de Haro el año de 89. Había tres galeotas, dos pilotos y 200 marineros dependientes de una compañía de comercio de Petersburgo ejercitados en la pesca de nutrias, y repartidos entre dicha isla y el rio de Cook: las galeotas se tripulan con aquella marinería, y reconocen la costa comprando pieles, de modo que el año de 89 se había despachado uno de aquellos buques á la Siberia con 9.000 pieles. Supo también que en I792 debía ser relevada aquella gente con otra que llegaría del Asia, y que entre la Isla Codiac y el río de Cook contaban con 9.0oo indios vasallos y amigos de la Emperatriz.

Adquiridas estas noticias dió la vela Hidalgo el I7 de Agosto, y el I5 de Setiembre llegó á Monterey, en cuyo puerto halló á Quimper que había reconocido parte del Estrecho de Fuca, y juntos los dos salieron para San Blas el 24 de Octubre y fondearon en este puerto el I4 de Noviembre del mismo año de I7go.

\section{Descripción física y costumbres de la Califormia.}

Divídese comunmente la California en Vieja y Niueva. Aquélla comprende toda la Península que corre desde el Cabo San Lucas hasta el puerto de San Diego en latitud de $32^{\circ} \mathrm{I} 6^{\prime}$, y por Nueva California se entiende el terreno que sigue desde este último paralelo hasta el de $43^{\circ}$ en que se halla situado el Cabo Blanco de Martín de Aguilar.

La porción que denominamos Vieja California y corre del Sueste al Noroeste entre los límites mencionados, fué mirada en lo antiguo como un país rico en minerales de oro y plata y fértil de toda clase de frutos y producciones naturales; pero los reconocimientos posteriores desmintiendo la primer idea, han dado también á conocer que esta fertilidad, si tal puede llamarse, se halla únicamente encerrada en su extremidad meridional. Descubriéronse hace algunos años varios minerales que se trabajan aún en el día, pero la escasez de sus productos hace creer que la ponderada riqueza de este suelo está limitada á la de los placeres de perlas situados dentro del seno califórnico. La Sierra Madre que empieza desde el extremo austral, divide á lo largo en oriental y occidental á toda la California hasta ahora descubierta, y de esta circunstancia unida á la de la faz que presenta el terreno en ambos lados, ha tomado origen la denominación particular que algunos dan á sus habitadores, distinguiendo á los orientales con el nombre de moradores de peñas, y á los occidentales con el nombre de moradores de piedrecitas. Esta sierra, que co- rre en la dirección indicada, se acerca siempre más al seno califórnico, apartándose del mar Oceano, aunque en ciertos parajes extiende hasta él sus ramas. Su extremidad austral está poblada de arboleda, y en la eminencia hay pinos, pero al paso que sube hacia el Norte, sigue más áspera y eriaza, componiéndose sus vertientes de peña viva ó lomas enteras de piedras sueltas y amontonadas. En los parajes adonde se cubre de tierra, su profundidad no pasa de media vara, $y$ consta, por lo general, de una especie de arcilla ó tierra blanca, como de yeso quemado, teniendo debajo peña viva y pedregales formados de cierta especie de tierra, cuya dureza no iguala á la de las otras piedras. La sierra, por lo común, se presenta desnuda, y solamente produce espinos y otras malezas. En las vertientes que caen hacia el golfo califórnico, escasean las aguas permanentes, y en parajes se encuentran algunos pozos abiertos en la tierra, de agua por lo común gruesa y salobre; pero en las vertientes occidentales falta aún este recurso, y varios buenos puertos que tienen sus costas, quedan como inútiles por aquella causa igualmente que por la carencia de leña. En la sierra vecina hay varios manantiales que forman arroyos hondos cuyo curso no exten diéndose hasta el mar, se detiene formando grandes salitrales y méganos de arena que mudan contínuamente de situación y figura á esfuerzos de los vientos recios. El agua llovediza conducida por aquellos arroyos, entra y se difunde en los 
salitrales ó méganos mencionados, y permaneciendo encharcada, se convierte con el tiempo en sal, por cuya causa se encuentran grandes comarcas cubiertas enteramente de sal maciza ó en pedazos sueltos. Finalmente, si hemos de atenernos á las pruebas que comunmente pasan como signos irrefragables de que el mar cubrió en otros tiempos paises que en el día se hallan á mucha distancia de sus aguas, no queda duda que estos parajes fueron cn lo antiguo la mansión del grande Oceano. Así lo persuaden los muchos ostiones, caracoles y conchas que se encuentran pegadas á los peñascos de los arroyos, de tal modo, que hay cerros de pura concha, como lo son particularmente los que se denominan de San Juan, tres leguas distantes de Loreto, siendo de advertir que entre ellos y el mar se interpone una cordillera de lomas altas que merecerían el nombre de sierra en otro país ménos montuoso.

A pesar de la esterilidad de que vamos hablando y de la falta de aguas tan general en la Vieja California, se cría en su suelo una planta que conocen vulgarmente con el nombre de dátil, y es una especie de la palma que produce el fruto así llamado, aunque la de las Californias es mayor y en lugar del hueso duro del dátil legítimo tiene aquélla un agregado de pepitas negras, chatas y redondas, con cáscara algo dura. Esta planta está en flor á fines de Julio y despide un olor suave y agradable; por Setiembre, Octubre y Noviembre da el fruto, y sólo se logra la cosecha en las abundantes 1luvias. La fruta, aunque dulce y laxante, debe ser muy sana y sustanciosa, según ló da á entender la constitución robusta de los naturales que la usan.

En la Sierra Madre se halla una especie de árboles altos, cuyas hojas son de un verde ameno y claso. Los llaman palo-alto ó palo-blanco, no porque su corteza sea de este color, sino porque en todas las hojas y ramas delgadas se 1lenan en Mayo de una goma blanca, transparente y dulce que agrada mucho á los naturales. La plan. ta que produce la pepita conocida vulgarmente por tohova, es un matorre útil: se halla con más abundancia en las vertientes que caen hacia el Oceano, pero siempre escasea cuando no llueve: la masa de la pepita es como de avellana muy aceitosa, con un leve sabor amargo y varias virtudes medicinales; pero la planta que hace el primer papel, es el mercal ó magüey de Nueva España, que sirre de pan cotidiano á los indios, asándolo debajo de tierra. Su tamaño y calidad varía con respecto á las latitudes en que se cría. Iin la parte austral es grande, aunque nunca jurual al de la América ulterior; por $\operatorname{los} 26^{\circ}$ queda chico, pero dulce, y en los $29^{\circ}$, especialmente entrc la sierra y el Oceano, vuelve otra vez á crecer como en el Sur, pero con el defecto de ser amargo én el todo ó en muclia parte. Para usarlo, cortan sus hojas por más arriba del tronco y envolviéndolas entre cenizas y piedras caldeadas de antemano, las dejan cubiertas por uno ó dos días, y al cabo de este tiempo se encuentra el mezcal bien asado, jugoso y dulce.

En los años que las aguas son abundantes, nace en varios parajes cierta especie de yerba llamada teda, cuya semilla es poco mayor que el anís. Los naturales la comen tostada, echando al intento una porción en una batea formada de los palos flexibles de cierta mata pequeña (I), y sobre ella carbones encendidos con los cuales se tuesta y revienta la semilla descubriendo una harina blanca. En el día, que ya tienen ollas y algunos de nuestros usos, limpian y muelen la semilla después de tostada, y la comen hecha harina, ó bien en poleadas. Otra cosecha muy agradable para estos naturales es la que llaman mede$s a$, fruta de unos árboles grandes, cuyo tronco y ramas son de color verde claro; la semilla se parece al.fríjol, aunque es algo menor, pero difícilmente se consigue todos los años.

También hay otra especie de árboles que 1laman higuera de monte por asemejarse su fruta á los higos blancos europeos, aunque son sin comparación mucho más menudos y desabridos. Estas higueras dan también como aquéllas dos frutos al año, pero crecen generalmente sobre peñascos y en los cantiles de despeñaderos. Es ciertamente maravilloso el modo con que sus gruesas raices van introduciéndose por las angostas hendiduras de los cantiles, ó bien cómo ellas mismas se forman estas hendiduras. Prosperan mucho en parajes muy secos, haciéndose altas y copudas, y aunque no dejan también de crecer en terreno húmedo, siempre ha de ser piedra. El color del tronco es blanco tirando á pajizo y su madera vidriosa y quebradiza, por cuya causa no es raro el que se despeñen algunos naturales al tiempo de asirse de las ramas para coger el fruto. Finalmente, todos los árboles restantes que produce este país y sirven de alimento á sus naturales, se pieden reducir principalmente á cuatro clases (2). La primera es la que

(I) En el Compendio del Padre Venegas, parte primera, parrafo IV, se describen estas bateas con el nombre de coritas, diciendo, en cuanto á su tamaño, que las hay tan grandes que caben dos fanegas de maiz, y en ellas pasan de una orilla á otra sus frutos sin tocarlos el agua, yendo los indios nadando $\mathrm{y} \mathrm{cm}$ pujando las bateas. Desde Acapulco remitió la expedición para el Real Gabinete algunas muestras de estas primorosas manufacturas. Merece reparo el que se halle tan extendido su uso en toda la costa Noroeste para el apresto de las comidas, que casi lo hemos visto uniforme en toda la California hasta el Puerto de Mulgrave.

(2) Estas cuatro plantas corresponden todas á la clase de los Ciactus, según los Sres. Nee y Heenke, quienes aseguran que su número es tal en los Reinos de Nueva España, Perú y Chile que tal vez no está descrita la mitad en el sistema natural. 
en Nueva España llaman viznaya, y es un troncón grueso sin brazo alguno, de dos varas y media de alto, más ó ménos, y media de diámetro, rodeado de espinas sólidas y largas, que algunos emplean por mondadientes. En su parte superior echan unas hermosas flores matizadas de varios colores, y debajo de ellas hay unas bolitas que contienen la semilla, la cual es delgada y negra. Este arbol es de tal calidad que comienza á dar el fruto desde que nace. La segunda especie que los españoles llaman garambullo, es un montón de vasos que desde el suelo nacen de un tronquito; su fruta, aunque mucho menor y ménos sabrosa, es algo parecida á la pitahaya que forma la especie tercera. Esta se divide en las dos clases de pitahayas agrias y dulces. Las agrias, que sólo se dan en las costas de uno y otro mar, forman un matorral de órganos enmarañados, cubiertos de espinas gruesas que por la mayor parte arrastran por el suelo. Su fruta se asemeja á una bola casi redonda, colorada ó morada, y rara vez es blanca ó de colores mezclados.

La pitahaya dulce, propia sólo de la sierra, admite alguna variedad, siendo blancas ó encarnadas y áun de color anteado: el arbol que las da sube del suelo en un sólo tronco, y á poca distancia se divide en muchos brazos formando una copa considerable. Cada brazo echa en su punta el fruto, y éste está lleno de espinas que fácilmente saltan cuando es tá madura la pitahaya. Las dulces son algo menores que las agrias, y éstas realmente son agridulces $y$ tan regaladas, que regularmente son más estimadas que las dulces. Su semilla es menuda como la de los higos, pero negra. La cuarta especie es el cardón que sale de la tierra muchas varas, y á alguna distancia de ella llena de brazos que suben hacia arriba, todos igualmente gruesos y tanto como el tronco del mismo arbol. Otros hay que no crían estos brazos, y suben derechos á manera de altas vigas. La fruta de estos arboles que llaman or ganos, se compone de unas bolas llenas de cierta semilla negra, más gruesa que grano de pólvora, sin masa alguna y unidas sólo entre sí por un humor grueso y viscoso; la aprecian mucho los naturales, y la comen tostada, entera ó molida. Este arbol, igualmente que las especies antes mencionadas, ofrecen la particularidad de que su carnaza, así interior como exterior, es siempre muy aguanosa, especialmente la del cardón como más gruesa, pues con sólo un pedazo que se corte y se exprima fuertemente, se logra una gran copia de agua ó caldo, siendo así que estos árboles no nacen en la humedad, sino en la tierra más seca y enjuta. Sus raíces se extienden por la superficie, y jamás profundizan mucho dentro del terreno. Este es sumamente seco, los soles muy ardientes, y siendo raro el que en estas tierras caiga sereno ó rocío, es cier- tamente digna de investigación la causa de esta aguanosidad, tanto más cuanto que por muy escasos que sean los años de lluvia, nunca se entristecen estos árboles, y siempre perseveran con la misma frescura, color y aguanosidad.

Hemos hecho esta prolija enumeración de los medios con que provee la Naturaleza al sustento de la especie humana en un suelo tan poco favorable á ella, así para manifestar cuáles sean las producciones naturales de la Vieja California, como para fijar de una vez la idea verdadera que debe tener la Nación, de un país que en otro tiempo mereció los más encarecidos elogios por una riqueza y fertilidad que sólo existía en la acalorada imaginación de los autores que la forjaron. Nuestras noticias presentes están apoyadas en el testimonio común de los Padres Misioneros que han transitado esta región del mundo, y de los muchos viajeros nacionales que han escrito de ella, entre los cuales merece un distinguido lugar la descripción del docto Padre Fernando Consag, de quien hemos extractado mucha parte de lo antecedente. Por lo que toca á la ponderada riqueza de las minas de la California meridional, oigamos lo que añade este mismo Padre para completar la descripción física de su suelo.

"Hay cerros, dice, y lomas que pintan en la " mayor parte de metales, porque echadas algunas "de sus'piedras en la lumbre, rinden plata; mas á " vista de tanta esterilidad y falta de leña, la que "cuanto más se sube al Norte escasea más, "hasta ahora solamente en la extremidad austral "que es fértil, se trabaja en minas de plata. El "cobre se halla á veces en unas piedras con un color verde muy vivo, de que los naturales se "sirven para pintar sus flechas. Este color echa"do en la lumbre, aunque blando, no se deshace, "pero se tupe de granos chicos de cobre. Se ha"llan pedazos de hierro virgen de varios tama) ños, con poca guija, pero por varias diligencias "que se han hecho no se pudo encontrar con la "veta. Azufre virgen hay en cantidad, que no "necesita más beneficio que cargar y llevarlo. "Alcaparrosa la hubo más en el mismo paraje, "donde se cogía ya no se halla, ó porque se aca"bó, ó porque falta la inteligencia y conocimien"to. Mármoles hay de varios colores que se apre"cian en Europa, y también del color que llaman "verde antico. El mármol blanco está algo más "al Norte de las misiones actuales, como tam"bién una piedra transparente, semejante al dia"mante de Almazón. Aunque varios cerros que "tienen boca parecen ser volcanes, sin embargo, "no se ha notado hasta aquí erupción alguna, si "bien humean algunas veces: se halla sí arena "caliente en el contorno de la boca de uno de "estos cerros, la que sumiéndose mucho con las " pisadas, sale inmediatamente humo. Se advier"ten también en estos parajes dos como respira- 
»deros de viento, el uno en una ladera pedregousa y el otro en un arroyo. La costa occidental "es bien fría por el contínuo viento Noroeste "que á menudo trae neblinas espesas, y por lo "común desbarata las nubes que prometían llu"vias. En la costa oriental, cuyo temperamento " puede llamarse caliente, sucede lo contrario por ") estar defendida del viento Noroeste por medio "de la Sierra Madre, de modo que por el mes "de Junio, al despuntar el Sol, en que se suda "por el mucho calor, si cruzando la sierra se "llega á paraje en donde bate este viento, aunque "sea en punto del medio día, se apetece el abrigo "de la ropa y calor del fuego."

Un terreno, pues, tan poco apto para la agricultura, debía alimentar y alimenta con efecto un corto número de habitadores, haciendo al mismo tiempo difícil su reunión y civilización. Por el empadronamiento general formado el año de I768 en la visita de este Reino, consta que el número de habitantes de la California inclusos los párvulos recién nacidos, era en aquella época de $7 . \mathrm{Sg} S$ entre españoles, indios y demás castas. Su alimento, como ya se insinuó, son las semillas cogidas en el monte y en pocas ocasiones el ciervo ú otro animal, entre los cuales se comprenden áun los más asquerosos, como la tarántula, la araña, avispa, el murciélago, el piojo y las pieles podridas del coyote, prueba evidente de que la Naturaleza, poco propicia en este suelo para la multiplicación del hombre, no lo es ménos para el fomento de las demás especies de animales. No de ja de parecer extraño cómo estos naturales, faltos de agricultura y áun de los medios de alimentarse con la caza, no han tratado de adquirírselos por la pesca, siendo así que en una y otra costa se encuentran muchos y buenos peces, entre los cuales merece, aunque anfibio, un lugar no postrero, la nutria (I). Pero si se atiende á la total falta que hay de aguas dulces en las orillas del Oceano, á la demasiada cantidad de bajíos, y á las tempestades harto frecuentes en el seno califórnico, es posible suponer que en todo tiempo han distraido de la navegación á los naturales estas causas poderosas, tanto más que para la subsistencia de un número tan corto de familias no era preciso variar las costumbres de sus antepasados. Así es, que el único producto del mar que han comprendido siempre entre sus alimentos es el marisco, y no tuvieron otro lugar en lo antiguo las conchas de las perlas (2), tan abundantes en el seno, y primer mó-

(I) En la historia del Padre Venegas se hace una larga enumeración de éstos, citando el viaje de Sebastián Vizcaino. La nutria es la que describe con el nombre de castor.

(2) Así lo ascgura el Padre Torquemada, quien dice que los indios echaban en el fuego las ostras, y (quemaban ó tostaban las perlas, aprovechándose de la carne sula. vil de nuestros últimos pasos nacionales hacia esta parte.

El estado de la Vieja California según se halla al presente, comprende varias misiones situadas de Norte á Sur sobre la costa, á mayor ó menor distancia de ella, á saber: San José del Cabo, cinco leguas de la playa del Cabo San Lucas; Nuestra Señora del Pilar ó todos Santos; Santiago de las Coras; San Francisco Javier; San José Comondú; Loreto, situada en el presidio del mismo nombre que hace cabeza de esta parte de la Península; Guadalupe; Santa Rosalía ó Mulege; la Concepción ó Cadegomo; San Ignacio; Santa Gertrudis y San Francisco de Borja. Todas estas misiones fueron fundadas y corrieron al cargo de los Jesuitas hasta el tiempo de su expulsión, y en el día se administran por los Padres Dominicos, los cuales han fundado en su tiempo las de San Fernando, Velicata, Nuestra Señora del Rosario ó Viñadaco, Santo Domingo, San Vicente, Santo Tomas y San Miguel. Según los informes dados por el Gobernador de California, D. Pedro Tages, en Diciembre de I790, resulta que estas últimas y nuevas misiones colocadas en los puntos salientes para el Norte de la Península, están rodeadas de bastante gentilidad que paulatinamente se va reduciendo. Las otras que se hallan entre el mar del Sur y el golfo, no tienen gentilidad alguna y se disminuyen poco á poco, de modo que ya las de San Javier y Santiago tocan á su último extremo. Los frutos que en estos estados se mencionan como cosecha de alguna de las misiones antiguas, se reducen á la uva, de que hacen algún vino, aguardiente y pasa, trigo candeal, considerable porción de higos de no buena calidad, carnes y la pitahaya de que antes hemos hablado, pero la cantidad de estos frutos debe sin duda ser muy limitada, si se atiende á que ha sido preciso socorrer estas misiones el mismo año I79o con porciones crecidas de comestibles que se enviaron desde San Blas con la fragata Princesa, quedando de este modo frustradas ya las muchas providencias dic. tadas en la última visita del Reino, para el sostenimiento y fomento de esta provincia.

Uno de los medios poderosos con que juzgó el Sr. Gálvez se lograría la regeneración de la península de California, según el informe que dió al Virey, D. Francisco Bucareli, fué el de "poner en corriente algunas de las mi"nas descubiertas en ella, para que sirviesen de "incentivo y movimiento á los nuevos pobladores "establecidos en los pequeños Reales de Santa "Ana y otros del Departamento del Sur." Pero aunque la experiencia de cerca de dos siglos debía habernos convencido de la verdadera utilidad de estos medios en cuanto á la población siempre que faltan otros arbitrios, parece, sin embargo, estaba reservado para esta época el 
último desengaño, creciendo la necesidad cada día más de enviar comestibles al presidio de Loreto, habiéndose también reducido todo el laboreo de las minas á dos pequeños Reales de corto producto, situados en el Sur, en que se mantenían como 500 vecinos el año citado de $I 790$.

No es fácil determinar cuánta parte tenga en la expresada esterilidad la calidad de este suelo y cuánta la frecuente sequedad de su temperamento; pero si para la subsistencia cómoda del hombre en cualquier país es preciso exista á lo ménos una cierta abundancia de los dones de la Naturaleza, no será temeridad asegurar que en toda la península de California al Sur del puerto de.San Diego en una y otra costa, no hay cosa alguna que convide á habitarla, aunque en la misión de San José, extremo meridional y próximo al Cabo San Lucas, no sea tal vez tan precaria la subsistencia como lo es en Loreto y en las demás misiones. Las lluvias escasean casi todos los años; la arena de las orillas del Oeste. no sólo absorbe el agua que le cae directamente, sino también la que derrama la Sierra Madre; y esta misma sierra, hallándose demasiado contígua á la costa del golfo, no tiene lugar para fertilizar con sus escasos dones una tierra por sí quebrada y de tan poca extensión; finalmente, siendo tan pernicioso el frío á una banda como lo es á la otra el calor, ambos extremos concurren á destruir toda esperanza aunque remota, de que alguna vez pueda llegar esta Península á alcanzar un grado mediano de opulencia.

Abandonémosla, pues, á su pobreza y dejemos la inútil descripción de las costumbres, trajes, armas y principios religiosos de los pocos moradores que aún mantiene, ya porque en el compendio de la historia del Padre Venegas se halla formada con toda la puntualidad posible, ya también porque será más fácil reunir después estas noticias á las de otras naciones más septentrionales que habremos de examinar luégo.

En las inmediaciones meridionales del puerto de San Diego, la Naturaleza varía enteramente de semblante, y ofrece á la vista una graciosa variedad de árboles, arbustos y plantas odoríferas, y cerca de la playa lindísimos prados. Alejándose de aquel puerto ya se encuentran cañadas muy vistosas y amenas con muchos pastos, arboleda y agua, y luégo sigue un país alegre compuesto de lomas de tierra negra, cubiertas de pastos, en donde hay matas y algunos árboles de los que llaman alisos.

Finalmente; el Capitán.D. Juan Bautista Ansa, que transitó en I773 desde la Sonora á la misión de San Gabriel, vadeando los ríos Gila y Colorado y atravesando la Sierra Madre por los pasos difíciles del Cerro ó Puerto de San Carlos, describe este país como formado de hermosísimas llanadas muy verdes y floridas, sierras nevadas con pinos, encinas y otros árboles propios de tierra fría, y el terreno apto para siembra de temporal y plantíos de árboles frutales, igualmente que para la manutención de ganado por sus pastos abundantes. La grande y vistosa laguna del Príncipe se halla circundada de floridos y amenos valles, y de varias sierras nevadas que les tributan sus derrámenes, además de otros veneros de agua muy agradable. Le sorprenden los dos valles siguientes de San Patricio y San José y la laguna no distante de San Antonio; Bucareli, parajes (dice) en el mes de Marzo tan llenos de frondosas alamedas, flores, pastos y otras yerbas útiles, que no es fácil adivinarlo á la vista de la nieve tan cercana. Ultimamente, el puerto mismo de San Diego de un excelente abrigo para buques de cualquier tamaño, las islas inmediatas de Santa Catalina, Santa Bárbara, San Ambrosio y San Clemente, situadas en una latitud en que no dejan de suavizarse con el benéfico viento del Noroeste, los ardientes calores del estío, y en donde los hielos de las montañas internas no pueden contrarestar el temple suave de la marina; todo indica que la Naturaleza, siempre varia, siempre admirable, ha derramado aquí sus dones para el bienestar del hombre.

Desde San Diego hasta el Puerto de Monterey y áun hasta San Francisco, puede considerarse como uno mismo el semblante halagüeño de la costa; y aunque las neblinas harto frecuentes y espesas parecen en cierto modo oponerse á la fertilidad del terreno y á la seguridad de la navegación, bien examinados estos inconvenientes, parecen, sin embargo, de ningún valor á la vista misma del país. Los vientos del Noroeste que casi reinan todo el año, son naturalmente claros, apacibles y fríos, y los del Sueste que traen las aguas y regularmente son tempestuosos y húmedos, apenas se sienten seis ú ocho veces en todo el invierno. Con este motivo las neblinas, lejos de causar un daño real, producen un beneficio positivo, en cuanto á que conservando activa la humedad del suelo, mitigan los rayos del Sol y hacen del otoño una risueña y nueva primavera.

Puede imaginarse cuál debió ser la agradable sorpresa de todos nosotros al ver en el mes de Setiembre florecer por algunas leguas en contorno de Monterey una vegetación general tan lozana y copiosa que no bajaban de roo el número de plantas que devolvían á la Naturaleza esta singular fertilidad (I). Adornábanse los campos con unos bosques ya claros, ya espesos del pinoteda, del álamo, roble y encina, y á éstos seguían en las cumbres más elevadas el pino colorado, árbol mucho más alto que los demás, varias plantas medicinales, algunas venenosas, y otras úti-

(I) Don 'Tadeo Heenke hallo en el laurel la semilla madura y la flor que empezaba á brotar. 
les ó agradables, haciendo subir como á 250 el número de las que reconoció D. Tadeo Heenke (I).

"Fecundizado por consiguiente el suelo con "doble vigor, presenta una tierra (dice D. Tadeo * Heenke), negra y pingüe de uno ó dos piés "de espesor, formada de las miriades pútridas y "sobrepuestas á una arcilla arenosa y cenicienta "que por lo común se halla en todos los con"tornos, excepto en las inmediaciones del mar, "las cuales se componen de bancos movibles de "arena, muy dispuestos para la filtración de la "sal, que aquí se produce en mucha cantidad ó "de una piedra granitosa cuyas hojas mayores "están formadas, primero de cuarzo blanco; se"gundo, de mica nigricante; tercero, de feldes"pato amarillento, formando por lo común con "el horizonte un ángulo de 80 á 90: siendo su "principal dirección al Sudoeste y atravesadas de "alto á bajo con una capa, por lo común tan es"trecha, que no excede de una ó dos pulgadas, "compuesta de cuarzo puro granuloso y blan"quizco.

"La composición de la piedra que forma el "hueso interno, digámoslo así, de las inmediacio"nes de Monterey, halló el mismo Sr. Heenke en "sus análisis, que es una piedra blanquinosa "ó amarillenta, sumamente ligera en su peso, "seca y friable al tacto, quebradiza y dispuesta "á teñir; compuesta esencialmente de marga ar"cillosa, muy propia para edificios, y que insen"siblemente se convierte en calcárea á medida "que se acerca á la cima de los montes. En to"das partes es oportuna para hacer cal, aunque "no de la mejor calidad, mezclándole una gran "cantidad de arcilla, con la cual hierve aunque "lentamente en el agua fuerte. De esta misma "clase son todas las piedras que en masas muy "enormes guarnecen y hacen temibles todas las "costas al Norte y al Sur del río Carmelo."

Según los naturales, se hallan con facilidad áun en las colinas más elevadas que conducen desde el presidio á la misión, varias petrificaciones de testáccos y áun algunos dendrites, y las playas producen con abundancia la concha cono. cida vulgarmente por concha de Monterey, y que llaman los naturalistas Alyotis Myde.

En cuanto á la dificultad que debe ofrecer á la navegación las frecuentes y espesas neblinas con que parece quiso la Naturaleza ocultar en estos parajes la vista de los astros y de la tierra,

(r) Entre las plantas medicinales cuenta este botánico, la malva, el tropcolum-najus, le arthcmisia-absintium, la arthemisia-diacumculus, la athemisia-maritina; scorconcra-dentak, solidago-civectorum, solidago-cinerca, gentiana-centaurium, salia-frulcsce'us; sambucusracemosa, zerónica anagallis, verbena carolina, rhannus maritimu, sichorinm, vit getum, melissa prostratu, oxalis prostratu, tumarca achillea, millefolium, etc.; y entre las venenosas rhusradicans, rhustéxico, deudeon, le cicutasiides; el hispomane discolor. está suficientemente compensada con una sonda bastante saliente de la costa, y con la circuns. tancia particular de que jamás corren en ella vientos de travesía, y que los mismos Noroeste ó Sueste que siguen su direćción, pocas veces ó ninguna pueden llamarse tempestuosos. Por 10 demás es claro que estas contínuas neblinas no pueden ser de una utilidad general en la agricultura para toda clase de semillas, pues es bien sabido que varias especies de granos y casi todos los frutos cultivados, necesitan más ó ménos del calor del Sol, tanto para granar como para madurarse ó endulzar. Este inconveniente causa, con efecto, una notable diferencia entre las producciones de nuestras misiones de la orilla, comparadas con las de las situadas en el país interno; no obstante se tiene notado que en el maiz, semilla la más útil para la vida humana, parece ménos sensible que en las demás, y particularmente en el trigo, los efectos de la escasez del Sol.

Debemos también exceptuar del inconveniente mencionado las misiones fronterizas al canal de Santa Bárbara, en el cual ya sea porque las islas que lo forman reciban y contraresten las neblinas, ya porque su dirección Este-Oeste no dé lugar á que obren allí los Noroestes con la misma actividad que en otras partes, logran de cierto calor más natural y permanente, y con él de unas cosechas más seguras y abundantes como repetidamente nos lo han asegurado los Padres Misioneros.

Las semillas que principalmente se siembran y cosechan en las misiones de la Nueva California (I) son el trigo, cebada, maiz, fríjol, garbanzo, lenteja, chícharos y habas. También se dan las frutas en muchas de ellas, y en las de San Buenaventura y San Diego hay parras, y en la de Santa Clara se crían particularmente ricas y abundantes peras, melocotones y ciruelas, para lo cual contribuyen mucho, así la cantidad de agua y el clima hermosamente claro y templado de aquel paraje, como los huesos ó praquetas frutales que les dejaron de Monterey los Sres. Conde de la Péyrouse y Vizconde de la Langle, los cuales estuvieron en Monterey por Setiembre de 1786 , y explayaron su generosidad dejando igualmente diferentes granos de la me. jor calidad, que en el día han multiplicado mucho en la misión de San Carlos (2).

(1) Las misiones que hay establecidas en la Nueva California son las siguientes, situadas de Sur á Norte, á saber: San Diego, San Juan Capistrano, San Gabriel, San Buenaventura, Santa Bárbara, Concepción, San Luis, San Antonio, San Carlos, Santa Clara y San Francisco. Puede verse en la relación del viaje al Estrecho de Juan de Fuca el estado comparativo de las siembras y cosechas de todas estas misiones en los años de r 785 , I 790 y $\mathrm{x} 79 \mathrm{r}$.

(2) Merecen los mayores elogios los rastros de humanidad que han dejado estos navegantes franceses en las misiones de la Nueva California. 
No podemos continuar con igual prolijidad que hasta aquí, la descripción física de las tierras contiguas al mar desde la misión de San Francisco, situada en $38^{\circ}$ escasos hasta Cabo Blanco; pero si atendemos á los conocimientos que prestan de esta parte los viajes nacionales y algunos extranjeros que ciertamente han visitado este trozo de costa, se puede asegurar que la misma suavidad del clima y la fertilidad del suelo que acabamos de indicar, se extiende por toda ella hasta el paralelo de $42^{\circ}$, teniendo siempre presente la natural diferencia de los paralelos entre sí. Así nos lo han manifestado desde el mar las frecuentes neblinas y la calidad de la costa, la cual, favorecida por una sonda bastante saliente, se compone al principio de arenales ó barrancas, siguiendo después á corto trecho un terreno alomado y bien vestido de arboleda. Los Sres. Hezeta y Cuadra, que en 1775 estuvieron en el puerto de la Trinidad y en el río inmediato de las Tórtolas, hacen mención particular de la frondosidad de estos parajes, igualmente que de la del puerto de Cuadra, que visitó este Comandante el año de I79o á su regreso del Norte. E1 río de Martín de Aguilar presenta en sus orillas y hasta en sus mismas aguas, árboles y troncos de un tamaño singular, y finalmente, el inglés Francisco Drake asemeja estas costas á las de Inglaterra por su frondosidad y ameno semblante. Lo que debe exceptuarse de esta general fertilidad son las sierras que forman el Cabo Mendocino, el cual, como más saliente al Oeste y puesto casi como una barrera á los violentos esfuerzos del Oceano, se presenta acantilado, compuesto de una sola masa de piedra y escarpado casiá pico, de modo que la vegetación parece ser un objeto secundario en este oportuno antemural.

Es bien sensible que no esté á nuestro alcance poder dar una noticia de la calidad del suelo que forman las islas del canal de Santa Bárbara, ni de las que están fronteras á las costas Norte del puerto de San Diego. Ninguno de nuestros navegantes modernos las ha descrito, y probablemente no las han disfrutado, y las noticias que da el redactor del viaje de Sebastián Vizcaino, además de no comprender aquellas particularidades que en el día son tan necesarias, parecen también algo exageradas, comparándolas con el estado actual de estos paises. Nosotros sólo hemos visto á cierta distancia las más occidentales del canal y la de San Nicolás, y á juzgar de aquéllas por las muchas barrancas blanquinosas que presentaban hasta la cina y por su mezquina vegetación, compuesta de muy pocos arbustos esparcidos en una ú otra parte, se puede aventurar la idea de que son bastante estériles. La isla de San Nicolás que costeamos más de cerca, y vimos con individualidad por su mitad del Sudoeste carece aún de estos pocos arbustos, y su superficie abarrancada no presenta la menor apariencia de que haya manantiales ó aguas corrientes; lo único que sospechamos es que esté habitada, pues así parecía indicarlo una humareda que salía de lo más alto del monte.

De lo expuesto hasta aquí se puede deducir con bastante fundamento: I. ${ }^{\circ}$ Que la California Vieja, esto es, desde los 22 hasta los $30^{\circ}$ de latitud, es un país árido, montuoso, estéril y seco, poco dispuesto para la subsistencia del hombre é incapaz de suplir con sus pobres minas todos aquellos inconvenientes, ó de convidar á una útil navegación en una y otra costa, á pesar del beneficio de las perlas en la oriental, y en la occidental de la pesca de lobos, nutrias y ballenas. 2. Que de $\operatorname{los} 30^{\circ}$ en adelante varía enteramente el semblante del país, ofreciendo una vegetación lozana que casi continua sin interrupción hasta los $37^{\circ} 30^{\prime}$ en que se hallan las misiones de San Francisco y Santa Clara y con muy corta variedad relativa sólo á la diferencia de latitudes, hasta el Cabo Blanco en los $43^{\circ}$ de latitud. Y aunque las dos cordilleras de islas fronterizas al canal de Santa Bárbara y á la punta de la conversión, parecen naturalmente estériles como dijimos, pueden no obstante ser capaces de una crecida poblacion, ya sea por la abundancia de la pesca en el mar que la rodea, ya también por la seguridad de la navegación y finalmente por su inmediación al país mucho más fértil de la tierra firme.

Proporcionada á estas disposiciones del suelo, es la concurrencia de los animales que la Naturaleza destinó para que 10 disfrutasen. Expondremos en un breve resumen cuanto contienen los viajes y descripciones nacionales de esta parte de la Monarquía, y las observaciones prácticas que pudo rectificar D. Tadeo Heenke durante nuestra mansión en Monterey.

Además de los cuadrúpedos y aves domésticas introducidas por los misioneros, se hallan en la California meridional dos especies de montería que no se conocen en la antigua ni en la Nueva España. La primera es la que los californios en la lengua Monqui llaman Tayé. Este es un animal de la corpulencia de un ternero de año y medio, y muy parecido á él en su figura: la cabeza se asemeja á la de los venados; tiene las astas extraordinariamente gruesas, aunque parecidas á las del carnero; la pezuña grande, redonda y hendida como la de los bueyes; el pelo como de venado, pero más corto y algo manchado; la cola pequeña y la carne sabrosa y regalada. La segunda especie se distingue poco del carnero manso, aunque es mucho más corpulento y crecido; los hay blancos y negros, pero todos son muylanudos y de lana á propósito para hilar y tejer. Hay también coyotes y se encuentran algunos venados, liebres, conejos y berrendos, aunque 
no en mucho número. Son más abundantes los insectos ó reptiles propios de tierra caliente, como vívoras, culebras de varias especies, salamanquesas, escorpiones, alacranes, arañas, cien piés, grillos, lagartijas, lagartos y hormigas, exceptuando, sin embargo, las pulgas, chinches, niguas y otras comunes de la América. También hay gran variedad de aves de rapiña, de caza, acuáticas y cantoras, pero no las nombraremos para referirlas después á la California septentrional, en donde su número es ciertamente mayor que en la meridional.

No sucede así con los peces, y en particular con los anfibios, los cuales abundan en una y otra costa de la Vieja California, haciéndose en el día sumamente útiles para los intereses nacionales las nutrias, los lobos marinos y las ballenas. En la costa oriental, además de los galápagos, tortugas y muchos caracoles de varios géneros, se cuenta la concha de la perla, la cual sobre ser bastantemente copiosa tiene para el buceo la comodidad de darse en solas cuatro brazas de agua y el ser ésta tan cristalina que se ven las perlas como si efectivamente estuviesen sobre la superficie del agua. Advertiremos, sin embargo, que según los Diarios del Padre Consag escasea ó falta enteramente este rico producto $y$ áun casi toda especie de peces en las partes septentrionales del golfo, desde que vencido el paso de Sal si puedes, las orillas y los bancos intermedios de la desembocadura del río Colorado no ofrecen sino montes inmensos de arena, opuestos igualmente á la navegación que al camino por tierra (I).

Mucho más fértil la Nueva California

(I) En la descripción de la California, del Padre Consag, se hace sobre las perlas las siguientes advertencias. «Lo que reparo es, que hasta $22^{\circ}$ poco más ó ménos desde el Sur, la perla es blanca y legítima pero en lo restante para el Norte la perla blanca es más rara: la mayor parte de las perlas remeda el encarnado de las nubes heridas del Sol, por lo que las llaman rosadas ó de nácar; otras remedan el azul del cielo. Las perlas verdes son raras pero hermosas por su lustre; otras se sacan en gran cantidad de colores muertos. Como se diferencian las perlas, se diferencian también las conchas, la que comunmente se llama madre de perla, es concha gruesa sólida, y en su interior de un blanco lustroso. La concha de las otras perlas es delgada y su seno de varios colores. Cuando la perla es de cuenta por su tamaño, de ordinario al abrir la concha se suele topar; sir embargo, algunas están tan metidas en el callo ó carnaza de la concha, que por más que se estruja y exprime el callo, quedan escondidas, por lo que los armadores, en unas tinas de cuero echan á podrir los callos, y deshechos éstos por la putrefacción, bajan todas las perlas de todos tamaños.n

(2) El país que así denominamos y corre con este nombre en nuestras cartas nacionales, es el mismo que llamó la Nueva Albión el inglés Francisco Drake, á quien siguen todos sus paisanos. Pero nuestros derechos en esta parte son incontestables, teniendo presente la navegación que hizo en $\mathbf{5} 542$ Juan Rondriguez Cabrillo, siendo Virey de la Nueva Es. desde los paralelos de $32^{\circ}$ de latitud próximamente, of rece no solo una mayor variedad en todas las especies de animales, sino también una proporción aventajada en sus tamaños, propios ya de estos paralelos felices. Cuéntanse particularmente entre los cuadrúpedos, los venados (I), berrendos, liebres, conejos, ardillas, gatos monteses, ratas, osos y tigres, y entre las aves, las tórtolas torcaces, las codornices, calandrias, sensotles, tordos, cardenales, chupamirtos, grajos, cuervos, gavilanes, alcatraces, gaviotas, buzos y otras aves marítimas de rapiña, sin que falten patos y ánsares de diferentes especies y tamaños. Los peces más abundantes son las centollas, langostas, cazones, sargos, pargos, viejas, caballas, roncadores, bacalaos, guitarras, barberos, puercos, rayas, educhos, salmones (2) y una muchedumbre innumerable de sabrosas sardinas.

No podemos abandonar la descripción de las costas amenas de Monterey, sin dar un leve bosquejo del hermoso semblante con que se manifestaba la naturaleza á nuestra vista desde el puerto, cuando disipada la neblina entre las diez de la mañaná y las dos de la tarde, se reunían al brillo del Sol y á la frondosidad de los contornos, los céfiros suaves de la virazón del Noroeste. Mirando hacia el presidio, la variedad de objetos en que entendían los soldados, 'sus tallas y sus rostros extraordinariamente sanos y robustos, sus mismos hijuelos ocupados en guardar los ganados ó entretenidos en enlazar una res ó montar á caballo, renovaban á la memoria la utilidad y los placeres de la vida campestre. Corriendo la vista algo más al Oeste, unas lomas matizadas con diferentes verdes y flores, al mismo tiempo que descubrían en el poco espesor de sus arboledas la amenidad y la sombra, dejaban ver ansiosamente ocupados en sus pastos las especies más útiles del ganado doméstico, á cuyo alrededor voltejeaban pacíficas mil especies de aves y saltaban tímidos y ligeros el conejo, la liebre $\dot{y}$ la ardilla. Y si un bosque no muy espeso de pinos y cipreses y una costa algo árida y muy pedregosa parecían querer oponerse por un momen-

paña D. Antonio Mendoza, Conde de Tendilla, en cuyo obsequio se llamó Cabo Mendocino el extremo de la costa saliente al Oeste por los $40^{\circ}$ de latitud. El mismo navegante, en ro de Marzo de I543, tomando altura alcanzó hasta los $44^{\circ}$ de latitud.

(i) En la vida del venerable Fr. Junípero Serra, página 207 , se habla de unos venados ó especie de ellos, tan grandes como el mayor buey, con una cornamenta de la misma hechura que la del venado, pero tan larga, que se le midieron de punta á punta I6 palmos, y habiendo muerto tres de ellos y queriendo llevar uno entero, no pudo una mula sola cargarlo y fué preciso á trechos remudar mulas.

(2) La época en que suben á desovar estos peces exquisitos en los ríos de San Francisco y del Carmelo es priximamente por Febrero y Marzo. 


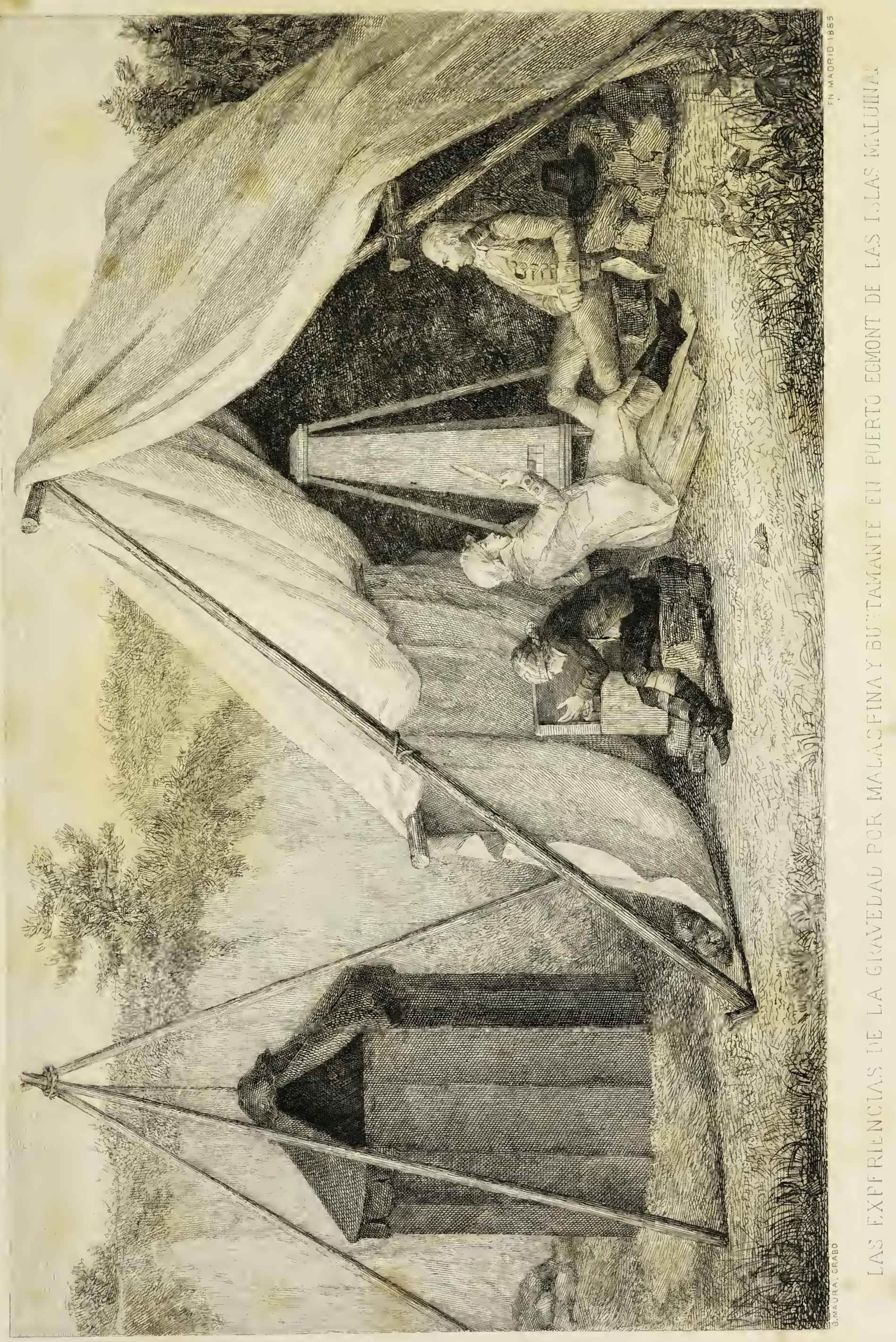



to á la continuación de esta escena maravillosa, era sólo para que apareciese de nuevo con un semblante no tan agradable y mucho más grandioso.

Con la vista de un mar sereno é ilimitado hacia el Noroeste y Norte, se aparecían al espectador mil especies de aves acuáticas, ya ocupadas en la adquisición del alimento, ya en el cuidado de su multiplicación ó en las muestras nada equívocas de su tranquila felicidad en estos parajes. La monstruosa ballena, el lobo marino y la nutria, aplaudiendo unas veces el risueño semblante de la atmósfera, otras á la suma tranquilidad de que disfrutaban, no temían solazarse casi en la misma playa, y en ésta, finalmente, azudía á la red ó al anzuelo un número casi infinito de peces tan varios como sabrosos y tan oportunos por consiguiente para el estudio ilimitado del naturalista, como para el sucesivo recreo clel navegante.

Pero dejando aparte estas ideas risueñas, pasemos ya al examen interesante de nuestra especie, con la extensión conveniente, según las noticias adquiridas y las que prestan los Misioneros. No cansaremos al lector sobre el número y los nombres de las muchas naciones que pueblan la California, desde su extremo meridional hasta el paralelo prefijado de $43^{\circ}$. Tampoco nos ocuparemos sobre su origen y los cimientos de sus principios religiosos, y comprendiendo todas estas confederaciones bajo el nombre general de Californias, examinaremos primero aquellas propiedades en que todos convienen, y distinguiremos luégo aquellas en que se aparta cada tríbu de por sí.

Averiguaremos en primer lugar el número de estos habitantes, y aunque no sea fácil determinarlo con exactitud, tampoco nos apartaremos mucho de la verdad, reuniendo á la población actual de nuestras misiones, la que indica para la Vieja California el censo ya citado de $x 768$, y las conjeturas probables á que dan lugar las diferentes exploraciones hechas hasta aquí por los viajeros nacionales. Son éstos el Ingeniero D. Miguel Costanzo, en su expedición por tie. rra en 1769 desde San Diego hasta San Francis co; los diferentes viajes del Comandante D. Juan Bautista de Ansa al Oeste del río Colorado; la excursión del Teniente Moriaga al Este de San Francisco; los diarios manuscritos de nuestros naregantes por las costas siguientes, desde San Francisco hasta Cabo Blanco; las noticias de los misioneros $\mathrm{y}$ otras adquiridas por nosotros, con cuyos datos se puede computar la población total de indios como sigue:

Habitintes de la Vieja California, según el empadronamiento del año de $\mathbf{z} 768 . .$.

Idem de los que en el día corresponden á las misiones recientement establecidas por los Padres Dominicos, y que permanecían errantes al tiempo de la visita. .

Habitantes de las naciones situadas desde San Diego hasta San Francisco al tiempo de nuestra llegada en r $769 \ldots \ldots$. . . . Idem de las tríbus desparramadas y contiguas á los Yumas y al Oeste del río Colorado, incluso los danzantes y las rancherías al Este de San Francisco, según las noticias del Comandante Ansa y las noticias del Teniente Moriaga. . . . . . Idem de las costas siguientes hasta Cabo Blanco. . . . . . . . . . . . Idem de las islas según un cómputo prudencial de los Padres Misioneros. . . . .

De este modo resulta, finalmente, toda la población de la California desde Cabo San Lúcas hasta Cabo Blanco, de 4r.ooo vivientes próximamente, al tiempo de nuestra entrada en la California Nueva por los años de I769 y 70 , y de la sucesiva comunicación por tierra entre ésta y la provincia de la Sonora en I774 y 75 , siendo la población actual de nuestras misiones de la Nueva California referida á fines del año de I 790 , de 7.718 , sin contar con los españoles y otras castas de las que nombran de razón en la América, cuyo número asciende á 997 individuos, y viven repartidos en los cuatro presidios de Monterey, San Diego, San Francisco y Santa Bárbara, y las dos colonias ó poblaciones de San José de Guadalupe y la Reina de los Angeles.

Conviene advertir, que el cálculo anterior está fundado en la seguridad positiva de que la California Nueva sólo se halla regularmente poblada en las orillas del mar, y que esta población disminuye al paso que secorre al Este hacia el país interior: todos los viajeros mencionados coneuerdan sobre este punto, y las internaciones del Padre Fr. Francisco Garcés, desde la Sonora hasta San Gabriel y desde las inmediaciones del río Colorado hacia el Norte hasta los $36^{\circ}$ de latitud, confirman la misma opinión, á cuyo testimonio puede agregarse el de los neófitos reducidos de nuestras misiones, los cuales preguntados por nosotros sobre este punto, ninguna noticia han dado de naciones algo crecidas hacia el Este, y por el contrario, queriendo individualizar las confederaciones enemigas entre sí, siempre distinguen su posición de Norte á Sur y nunca hacia el Oriente. También es un reparo digno de no omitirse para suponer una grande despoblación interna, en no haber hallado en estas orillas la menor idea del caballo al tiempo de nuestro establecimiento en la Nueva Caljforniá, siendo así que las repetidas expediciones ejecutadas en el siglo pasado hacia el Nuevo Méjico, $\mathrm{y}$ los robos consecuentes hechos por los indios contiguos, de las caballadas nuestras, hubieran seguramente hecho traspasar hacia esta parte unos animales de tanto valor $y$ utilidad si hubie- 
se algunas tríbus capaces de guerrear con ellos y de adquirirlos.

Finalmente, para no aventurarnos en el vasto campo de las conjeturas y ceñir nuestra exposición á lo que verdaderamente se ha visto y hasta ahora está reconocido, deberá tenerse presente que todo lo expuesto anteriormente y lo que siga sobre la Nueva California, está comprendido entre el mar y una línea que, partiendo del río Colorado, vaya á cortar la latitud de Cabo Blanco en dirección paralela á la costa, y unas 30 ó 40 leguas distante de ella; quedando como país incógnito el que en las latitudes altas corre al Este de esta línea á encontrar el Nuevo Méjico y las provincias internas de la Nueva España, de las cuales trataremos en otro lugar.

Todos los reconocimientos modernos nacionales verificados por gentes bastante cuerdas y sin espíritu de sistema, convienen en indicar dos naciones bien distintas, la una de cazadores y casi sin domicilio, extendida al andar de la costa desde el puerto de San Francisco hasta el Cabo de San Lucas, y digámoslo así, los indígenas de este continente; la otra, de indios arraigados en las islas y tierra firme del canal de Santa Bárbara é inclinados á la pesca, industriosos, sociables y tan propensos y adelantados en la civilización, cuanto los otros parece quieren evadirla y áun la aborrecen; y ya atendamos á las navegaciones del General Vizcaino, á nuestros últimos viajes, ó á los informes de nuestros Misioneros, no queda duda que esta nación ha emigrado de otra parte, y sería, ciertamente, una de las averiguaciones más importantes para la his toria de la especie humana, la que nos pusiese en estado de decidir si ésta es una ramificación de los malayos, tan propensos á extenderse del Oeste hacia el Este (I), ó bien si procede de las provincias septentrionales del Asia, de donde podrían haber emigrado con el auxilio de la navegación, como da lugar á sospecharlo el estado de adelantamiento en que tienen aquel arte, usando para él de cartas regularmente construídas y bien manejadas. P'ero no pudiendo aventurar sobre esta materia sino ideas vagas é imperfectas, abandonarcmos, por tanto, su indagación á los viajeros sucesivos que tengan tiempo suficiente para descnvolver este punto con la claridad que se requiere.

Los indios cuya descripción vamos á tomar entre manos, y cuyo número según nuestro cómputo no baja de 16.000 almas, esparcidos á una y otra banda del canal de Santa Bárbara en la dirección de la costa del mar, ofrecen una pers. pectiva bastantc dcsagradable y no muy lisonjera para comenzar por ellos el examen de nuestra

(1) Véanse los Diarios del Capitán Cook hasta la Isla de Sandwich. especie en esta parte del Continente. La vida errante de sus moradores, origen siempre de la despoblación y de las discordias, la falta de un abrigo adecuado para las intemperies y la escase $z$ de alimentos oportunos y seguros, son unos motivos poderosos que, entregando al hombre á sus propias pasiones y al único cuidado de su conservación animal, le degradan, le entorpecen y casi convierten su vida en una viva representación de la de los séres irracionales.

Tal es el cuadro que por desgracia presentan hoy día en naciones que denominamos aboríjenes de la Vieja y Nueva California. En los tiempos primitivos accidentales, mal interpetrados y difíciles de aclarar sin el auxilio de la experiencia, fueron sin duda causa de que alucinados al pronto los primeros exploradores, hiciesen creer que los californios eran naturalmente pacíficos, y que podían compararse á otras naciones más civilizadas de la América. Pero la historia de sus repetidos agravios contra nuestros pescadores de perlas, las contrariedades experimentadas en la costa oriental de la Península por los primeros conquistadores, la destrucción de las misiones jesuíticas en la parte meridional el año de I734, y las últimas irrupciones contra la misión de San Diego en 1775 (I) son todas pruebas de hecho que indican evidentemente que en esta especie ruda de naciones existen cierto aborrecimiento á la vida sociable, la jnsubordinación, el desprecio de la vida, el conocimiento de su propia debilidad, y por consiguiente; la desconfianza y la alevosía.

Siguiendo la historia de los rastros de estos pueblos, en cuanto pueden alcanzar las exploraciones nacionales, parece también cierto que el cuidado de alimentarse estriba principalmente en la caza, prefiriendo á ésta el uso de las semillas $y$ de los piñones en los parajes donde los hay, y sustituyéndole á veces por variedad ó por necesidad, el uso del pescado y del marisco.

Pero antes de entrar en otros pormenores sobre el carácter y ocupación de estos naturales, alegaremos aquellas razones que fundadamente convencen es una misma clase de hombres la que habita al Norte y al Sur del canal de Santa Bárbard, hasta donde se extienden nuestros reconocimientos del día. Un mismo método de vida, el mismo sistema gubernativo, los mismos ritos religiosos, el mismo semblante, y sobre todo,

(I) Ucurrió este accidente el 4 de Noviembre de 1775 , muriendo á manos de los naturales el Padre Fray Luis Jaime Mallorquín, un herrero y un carpintero. Merecen se perpetuen para singular memoria, los dos rasgos de humanidad y caridad cristiana que en esta ocasión ejercitaron el carpintern y los Padres Misioneros. El primero murió á los cinco días, y hallándose sin heredero forzoso, testó á favor de los mismos indios que le habran quitado la vida, la cantidad bastante crecida de todos sus sueldos devengados. J.os otros solicitaron y obtuvieron del Gobierno el perdón casi total de todos los agresores. 
cierto equilibrio de fuerzas y de civilización en las tríbus comarcanas, son unos datos que indican de un modo conjetural, pero probable, que todas estas naciones parten de una misma época y de un propio origen. Nuestras conferencias en Monterey con los naturales de la misión contígua de San Carlos, auxiliadas también de dos intérpretes que á la sazón se hallaban en la misión (I), nos han suministrado datos bastantes para esta útil comparación. Tres tríbus diferentes y perpétuamente enemigas entre sí, existen ahora unidas en esta misión, y en todas tres se hallan arraigadas las mismas supersticiones, los mismos trajes y adornos, un igual amor á la danza, un metodo igual de vida, un igual pudor en las mujeres, y finalmente, todas aquellas propiedades con que se hallan tan bien caracterizadas en la historia del Padre Venegas las tríbus meridionales, añadiendo sobre todo "aquella prodigiosa flojedad y languidez con que, dice el redactor de esta historia, pasan en perpétua inacción y ociosidad su vida, con horror á cualquier trabajo y afán.»

Denomínanse estas tríbus, la de los Runsien, de los Eslenes y de los Vaysh, á las cuales siguen hacia Santa Clara y San Francisco las de Ymuracan y Aspasniac. Todas ellas están en contínua guerra, concibiendo "aversión y odio y enardeciéndose á la venganza con causas ligerísimas; pero con las mismas ó sin ellas sosegándose después de tomarla y áun antes de satisfacerla» (2).

No llevaremos más adelante el hilo de nuestras comparaciones, y el que guste continuarlas, podrá leer en la relación del viaje al Estrecho de Fuca las noticias que se han insertado allí de estos naturales y son conformes á las adquiridas por nosotros en la campaña de I79I. Pero á fin de extender en cuanto nos es dable el conocimiento de los habitantes de esta parte del continente americano, extractaremos á continuación las noticias que comprende el Diario del viaje á estas costas, hecho por los señores Hezeta y Cuadra en $\mathbf{7} 775$, y son relativas á las tríbus comarcanas del puerto de la Trinidad.

Son estos indios afables, confiados y fieles en todo aquello que por nuevo y útil no cautiva su atención. Sus casas se componen de unas barracas subterráneas, cuadradas, construídas de gruesa tablazón con el techo rasante y la

(I) Fran éstos, dos jóvenes convertidos en una edad ya adulta, ambos favorecidos de un entendimiento claro, y sobre todo, tan adelantados en nues tro idioma, que no cabe duda cupiese equivocación alguna en la interpretación de nuestras preguntas ó de sus respuestas. Debe también suponerse que estos in terrogatorios se hicieron con todas las precauciones posibles de quietud, confianza, despacio y confrontaciones .

(2) Son las mismas expresiones que se leen sobre el propio asunto en el Compendio ya citado del Padre Venegas. puerta formada por un agujero circular del grueso del cuerpo humano. Su suelo está llano y limpio, y en el centro hay un hoyo cuadrado de vara de hondo para hacer y conservar el fuego. La firmeza de estas habitaciones basta para libertarlos de los animales voraces durante el tiempo de su descanso. Los hombres, si el frío les hostiga, se cubren con pieles de venado, lobo, nutria, etc., pero si aquél es tolerable, andan desnudos como verdaderos hijos de la $\mathrm{Na}$ turaleza, á excepción de algunas coronas de flores que llevan en la cabeza. Llevan el cabello largo, unas veces en castaña y otras suelto sobre las espaldas. En la parte inferior de las orejas se abren un agujero $y$ por él pasan un pernete de hueso muy liso y lustroso. Acostum bran ligarse la cintura y las piernas por la inmediación del tobillo, con una correa que aprietan fuertemente, y en los brazos tienen varios circulados picados en la misma forma que nuestros marineros suelen traer figuras ó rótulos en algunas partes de su cuerpo.

Las mujeres cubren la cabeza con una copa muy tejida de la fibra de algunos árboles flexibles ó yerbas, pero tan tupidas, que no se filtra el agua cogida en ellas. Su cabello cae en dos trenzas entre las orejas y las megillas, adornado de muchas flores, y usan los mismos pernos que los hombres en lugar de pendientes. También tienen picado el labio inferior con tres rajas, dos de las cuales bajan desde los ángulos de la boca hasta el extremo de la barba y la tercera desde la parte superior inmediata del labio hasta el punto inferior de ella. Estas señales que son tan perceptibles en las viejas, cuanto que apenas dejan algunos claros en los intermedios, son por el contrario tan leves en las niñas, que con dificultad se descubren á una corta distancia. ¿Quién sabe si serán los caracteres de su edad para que á primera vista manifiesten justamente la vida que ya corrieron?

Usan las mujeres por enaguas un tejido de pieles con fleco de hilos que les baja hasta lá pantorrilla, y cuando el frío las molesta, llevan el mismo abrigo que los hombres, y se aprietan como ellos la pierna por la inmediación del tobi1lo. En el cuello traen rosarios de pequeñas frutas, de huesos y de conchas que cogen en las playas.

Obedecen estos naturales las disposiciones de un Jefe que los divide por mar y tierra para que salgan á buscar el común sustento. Se recogen á puestas del Sol, pero después que se retiran las gentes de los buques, sale uno á reconocer la playa y las inmediaciones del pueblo. Muchas veces solicitaron el socorro de los españoles para vencer sus enemigos en la campaña, senal cierta de las guerras que sostienen con otros pueblos vecinos, sin embargo de que viven cn 
paz con varios que en bieve tiempo se alojaron en las playas, en número de 300 personas de ambos sexos y dc todas edadcs. Estos estaban divididos por cuerpos ó reuniones de familias, en una de las cuales había un niño de poco más de un año, que con arco y flecha proporcionados á su edad, daba en la palma de una mano presentida por blanco, á distancia de dos varas.

De la religión de estos pueblos no pudo adquirirse información cierta. Sólo se vióa ú uno que parecía revcstido del carácter de orador público, hablar algunas palabras volviéndose alternativamente á los puntos cardinales del horizonte, como para invocar la protección de algunas deidades (I) que considerarán árbitras de aquellos vientos. Habiendo fallecido uno de los naturales, sc notó que cumplido el llanto, quemaron el cadávcr y recogieron las cenizas.

Las armas ofensivas de esta tríbu son flechas con puntas de pedernal, cuchillos de lo mismo y algunos de hierro, mal fabreados, los cuales, scgún manifestaron, les vienen, por vía de cambio, de parajes más septentrionales, y puede bien suceder, que del Nuevo Méjico, por comunicación de unas naciones con otras, ya estables, ya errantes, circulen estos útiles y el hierro viejo hasta ponerlos en manos de los habitantes de las playas, que siempre son por las pcscas los más ricos y capaces de comprarlos. De todo cuanto se les presenta nada les llama más su atención que el hierro, bien sea en bruto ó en armas cortantes; sicndo cierto que cometerán todos los excesos por adquirirlo, siempre que se consideren superiores en fuerzas, y no es extraño, pues les facilita la construcción de sus débiles buqucs, de sus casas y el logro de la pesca, y tiene para ellos un cebo mucho más racional y poderoso que el del oro para nosotros, por cuya adquisición despedazamos, sin embargo, hasta las entrañas de la ticiтa. Reciben con aprecio los abalorios y el tabaco, que cultivan con cuidado y lo fuman en tubos parecidos á una trompa.

Cazan venados, cíbolos, osos, lobos marinos y nutrias, aunque estas dos últimas especies pueden corresponder á la pesca. Las aves que prescnta el país son cuervos, gavilanes, patos, gaviotas, tórtolas y pájaros muy pequeños y en poco numero. La pcica se hace de sardina, pejerey, morcillones y piés de cabra, de cuyas cspecies es

(I) Esta misma superstición ó costumbre se halla arraigada en todas Ias tríbus meridionales. Con motivo de un temblor que acacció en la ranchería, así llamada, en el río de los Temblores, á la sazón de hallarse alli el Ingeniero D. Migucl Costanzo, uno de lus gentiles (dice este viajero) yue sin cluda haría cntre ellus el oficio de saccrdote, estaba cntonces en el Real. y aturelido del suceso no ménos que nosotros, (mpezó con voces horrorosas y grandes demostraciones de esjanto, il deprecar al ciclo, volviéndose á torlos vientos y haciendo como que conjuraba los ticmpos. muy abundante la costa, y no hacen otras quizá, porque les faltan aparejos y anzuelos, ó porque la necesidad no les obliga á pescas más dificiles y trabajosas. Hasta el ticmpo de esta expedición parece no habían visto estos naturales embarcaciones como las 11uestras.

Fijando ya nuestras miradas sobre las costas del canal de Santa Bárbara y las islas que lo forman, parece que el espíritu cobra nuevos alientos al ver vindicados en esta tosca pero feliz colonia los nobles dictados del hombre, que tan vergonzosamente ultrajan las naciones circunvecinas. Compónenla en el día, según los cómputos más probables unas 2 I.000 personas, las I 5.000 establecidas en el continente $y$ las otras 6.000 en las islas, arraigadas de tal modo, que sus principios sociales, el método de vida, la fisonomía, el talle y hasta su misma capacidad, todo concurre á caracterizar á esta nación con mucha diferencia á las demás que habitan esta parte del continente; viven reunidos en pueblos cuyas casas son de higura esférica (I), cubiertas de enea, y de unas 20 varas de diámetro. Cada casa contiene tres ó cuatro familias: el hogar está en medio, y en la parte superior abren un respiradero para dar salida al humo. El carácter de estas gentes es afable; su talle bueno, igualmente que el aspecto: gustan mucho de pintarse, y usan por adorno grandes penachos de plumas. Andan enteramente desnudos y sólo en tiempo de frío gastan unas capas de pieles de nutria ó unos mantos formados de tiras de estas mismas pieles, las cuales las tejen torciéndolas, de modo que el pelo queda por fuera, y forman una trama con el tejido de estos hilos. Las mujeres andan con mucha honestidad, cinéndose la cintura con pieles de venado, que les cubre hasta media pierna, y un capotillo de nutria sobre el cuerpo. Son de bello aspecto y muy hacendosas: ellas tejen las bateas y vasijas de junco que les sirven para comer, beber y guardar las semillas, pues no conocen cstas gentcs el uso del barro, y dan á estas manufacturas mil formas diferentes y graciosas, según los usos á que las destinan.

Los hombres labran hermosas bateas de madera con embutidos firmes de coral ó hueso, y unos vasos de mucha capacidad y cerrados de boca, que parecen hechos á torno, con un lustre tan perfecto, que cualquiera dirá es obra acabada de la mano de un artifice hábil. Nosotros debimos al Padie presidente de las misiones de Monterey, diferentes muestras de estas preciosas manufacturas, las cuales se remitieron después para el Real Gabinete. Las vasijas grandes que sirven para el agua, son de un tejido robusto de

(I) Esta descripción se ha tomado del viaje de D. Miguel Costanzo, cuyas noticias confrman los $\mathrm{Pa}$ dres Misioncros. 
juncos embreados por dentro y de la misma figura que nuestras tinajas. Para comer las semillas que gastan en lugar de pan, las tuestan primero en grandes bateas, echando entre las semillas algunos guijarros ó chinas caldeadas; luégo mueven la batea para no quemarla, y en estando la semilla tostada, la muelen con morteros de piedra perfectamente labrados. Son ciertamente dignas de admiración la constancia y prolijidad que emplean en acabar estas piezas, tan apreciables áun entre ellos mismos, que á los que dejan á su fallecimiento semejantes obras, se las colocan encima del sepulcro como un monumento que recuerde siempre su aplicación y habilidad.

Entierran á los muertos, tienen sus cementerios dentro del mismo pueblo, y hacen con gran pompa los funerales de los Capitanes, colocando sobre sus cuerpos unas perchas altas en que cuelgan los muebles que eran de su uso. Ponen además en el mismo paraje giandes tablas de pino con diferentes pinturas, que servirán sin duda para explicar las hazañas de aquel personaje.

No es lícita la pluralidad de mujeres, y sólo los Capitanes tienen derecho de casarse con dos: los matrimonios usan de camas separadas, compuestas de tarimas que se levantan del suelo y de unos colchones ó simples petates ó esteras de enea con almohadas de lo mismo. Estas camas están colgadas con iguales esteras, que sirven á la decencia y para defenderse del frío, y últimamente asegura el Padre presidente de las misiones, han perfeccionado el uso de los catres cerrados, imitando con mucha perfección los de Europa.

Hay entre estos naturales una especie de hombres que viven como las mujeres, se acompañan con ellas, visten su mismo traje y se adornan con abalorios, pendientes, gargantillas y otros mujeriles, logrando entre ellos de grande consideración: los llaman joyas, y el vicio abominable que deriva de esta costumbre, ha trascendido ya hasta las misiones de San Francisco y Santa Clara, según pruebas incontestables de los Misioneros que han cogido ya á varios en el acto mismo de su delito.

Sobresale la industria de estos naturales en la construcción de sus lanchas de pino, las cuales tienen de ocho á diez varas de largo y vara y media de manga. No entra en su fábrica hierro alguno, y para sujetar las tablas abren unos barrenos de trecho en trecho y á distancia de una pulgada del canto, los cuales correspondiéndose unos á otros en las tablas superiores é inferiores, pasan por estos barrenos fuertes ligaduras de nervios de venado, y luégo embrean y calafatean las costuras, pintando el todo de colores muy vistosos. Para manejarlas se sirven de remos de dos palas con los cuales las comunican una indecible vclocidad y ligereza y salen mar á fuera á pescar en ellas con tres ó cuatro hombres.
Abunda el pescado sobre su costa, conocen todas las artes de pescar y tienen comunicación con los naturales de las islas inmediatas, de donde sacan ciertos abalorios de coral que corren por esta tierra en vez de moneda, aunque aprecian mucho más los abalorios de vidrio que les dan los españoles, of reciendo por adquirirlos sus bateas, pieles, jícaras, platos de madera y todo cuanto poseen.

El alimento principal de estos habitantes es el pescado fresco y varias semillas, como bellotas, atole, gachas y otras diferentes comidas. Reina en esta grande y pacífica sociedad una paz sólida, cierto amor á la concordia, á la reunión y á la vida sociable, y en general mucha atención para obsequiar á los extranjeros. Jamás se ve en sus manos ni en sus chozas otros instrumentos que los propios de su pesca, y no han dado hasta ahora el más leve motivo que indique desafecto hacia las débiles naciones sus vecinas, ni de que exista entre ellos el menor rastro de discordias pasadas, de rencor ó de celos, y los habitantes de las islas ya sea atraídos por la curiosidad, por el interés ó por la costumbre, viven ahora en mucho número entre los domiciliados en el continente. Dichosos ellos si contentos con la situación en que los colocó la Naturaleza, sin enemistades con los vecinos, sin disputas por la propiedad y libres de la ambición que atormenta á la culta Europa, subsisten largo tiempo en aquel apacible estado que les ofreció la madre bienhechora de los mortales.

No hemos podido rastrear por muchas diligencias que se han hecho, cuál sea el influjo ó autoridad de que gozan los Caciques de cada población ni si existe un Jefe supremo que domine en todas ellas.

Por las noticias adquiridas y las que dan los Misioneros, sólo puede deducirse con algún fundamento, que la autoridad de los primeros es limitada y que falta enteramente la del segundo, siendo así que ni remotamente la han podido traslucir los viajeros nacionales y que todos hablan de la unión que existe en esta confederación, citando como ejemplo el que en varias ocasiones se encuentran reunidos en una sola ranchería los caciques ó jefes de otras distintas. Si retrocedemos al tiempo de Sebastián Vizcaino cuando navegaba por estos mares, hallamos en la relación de su viaje no sólo la existencia de este Réguio supremo, sino otras varias particularidades dignas de fijar nuestra atención. "Sa„lió (dice) de tierra firme una canoa con cuatro ) remeros, en la cual venía un indio (I) que era el useñor ó rey de aquclla costa ó tierra firme.

„Esta canoa llegó á la Nao Capitana, y con ") grandísima diligencia y presteza, dió tres vuel-

(I) Venegas, parte IV, apéndice II, pág. 95. 
"tas alrededor del navío, cantando todos los que "iban en ella en su lengua, al modo que cantan " los indios en la Nueva España el mitote, y luégo "se llegaron á ella, y sin recelo alguno ni temor "entró dentro de la dicha Nao Capitana aquel in"dio reyezuelo ó cacique de aquella tierra, y lo primero que hizo en entrando, fué dar alrede"dor de la plaza de armas otras tres vueltas can" tando, y luégo, delante del General y de los de"más, hizo un largo razonamiento en su lengua, "que no se le entendió cosa de las que dijo, y "habiéndole acabado, por señas claras dijo que "los de la isla Santa Catalina le habían avisado "por cuatro vías con canoas, cómo habían llega"do allí aquellos navíos, y que era gente vestida "y barbada, y de buen corazón y buen trato los *que en ellos venían, y los habían regalado y "dado muchas cosas, que saliesen á verlos, y que "por esta información y aviso había venido allía "ofrecer su tierra y regalo si lo quisiesen recibir, "que él lo suplicaba, pedía y rogaba, que se lle"gasen con los navíos á tierra y que allí los pro"veería de lo que hubiesen menester, y como no "hubiese mujer alguna en el navío, preguntó por "ellas por señas, señalando las partes de su pu"ridad, y fué tan natural la señal, que si habla"ra en nuestro español, no pudiera decirlo más "claro.

"El General le dijo que no las llevaban ni "las habían menester; entonces el indio importu"nó al General con más eficacia se fuera á su tie" rra con la gente que traía, que él le prometía de "dar á cada uno de todos los que en el navío iban "diez mujeres, de lo cual se rió toda la gente mu"cho, y el indio, entendiendo que era por burlarse "de él, y que no había lo que prometía, tornó á "dar sobre ello, diciendo fuese un soldado en la " barca que él había venido, á su tierra, á ver si "era verdad lo que él prometía y que él quedaría "en rehenes con un hijo suyo en el navío, en el "ínterin que el soldado fuese."

Esta difusa pero verídica narración, nos conduce á desenvolver, además de la existencia de un Jefe supremo, varios otros puntos no ménos importantes sobre el carácter y las costumbres de estos pueblos. Hallamos desde luego una misión muy antigua entre los habitantes de la isla y de los del canal: hallamos á la vista de unas gentes extrañas, cierto denuedo y franqueza propia de una civilización adelantada: hallamos también una solemnidad grande, varias ceremonias y una dilatada arenga en el primer encuentro con los extraños, y hallamos finalmente, un grado tal de hospitalidad y buena fé, que no pudiera creerse sin el apoyo de la cxperiencia.

La conformidad que se nota entre las noticias anteriores, aunque de época tan remota, y las que contienen nuestros últimos viajeros, además que sirven para caracterizar á estos na. turales, muestra palpablemente el mucho tiempo que hace ha salido esta sociedad del estado rústico y salvaje en que subsisten sus vecinos del Norte y Sur. Con efecto, á excepción de la existencia de un Jefe supremo, todas las demás propiedades se han confirmado sucesivamente, pues á lo que ya manifestamos antes sobre la confederación con los de las islas, su hospitalidad y buena fé, agregan también nuestros viajeros la solemnidad de la primera arenga ó salutación con que recibe el cacique de cada ranchería á todo recien 1 legado.

Estos naturales, llevando aún más adelante los impulsos de su hospitalidad, proporcionaron á D. Miguel Costanzo alguna idea de sus bailes y de su música. "No se contentaron los gentiles (son sus propias palabras) con regalarnos de sus comidas, quisieron también festejarnos, conociéndose la porfía y contienda mútua de sobresalir cada pueblo en los regalos y fiestas para merecer nuestra aprobación y aplauso. Vinieron en la tarde los principales y caciques de cada pueblo, unos después de otros, adornados á su manera, embijados y cargados de plumajes con unos carrizos rajados en las manos, á cuyos movimientos y ruído marcaban el compás de sus canciones y la cadencia del baile, tan á tiempo y tan uniformes, que no causaban disonancia. Duraron los bailes toda la tarde, y nos costó harto trabajo desprendernos de ellos; por fin les despedimos, encargándoles mucho por señas, que no viniesen de noche á incomodarnos; pero en vano, volvieron cerrada la noche, con gran comitiva de truanes ó juglares tocando unos pitos, cuyos sonidos rasgaban los oídos."

Son mucho más confusas las ideas adquiridas hasta ahora sobre la religión y los ritos de estos naturales, y sólo se halla algún rastro en la narración de Sebastián Vizcaino, pero sin que la confirmen los viajeros últimos ni los padres misioneros. Por lo mismo, fuera desacierto el fundar conjeturas sobre aquellos débiles indicios, ciñéndonos por ahora á desear que se averigüen con toda puntualidad y sin mezcla de ideas extrañas. Advertiremos no obstante, que en nuestro concepto nunca será medio oportuno para esta clase de indagaciones, el de los Padres Misioneros, pues los naturales impulsos de su celo les hace mirar con demasiado horror todo lo que descarría al hombre de la recta senda.

A las propiedades ya indicadas, reunen estos habitantes la del agradecimiento, habiéndose ofrecido al Padre presidente de las misiones dos pruebas bien evidentes de esta cualidad; la una en un muchacho gentil, el cual habiendo recibido por la tarde unos pocos abalorios, volvió al día siguiente con su padre para presentarle en recompensa una cantidad crecida de piñones. Ocurrió la otra en un cacique anciano que habién- 
dole visitado otra vez el Padre presidente y particularmente en una noche muy lluviosa, en la cual ya muy agravado de sus achaques le había enviado á llamar, restablecido luégo, vino personalmente á la misión aunque cargado de años y de más de ocho leguas que distaba su ranchería, y manifestó cuánto le movía el recuerdo de las visitas pasadas y la esperanza de no carecer de ellas en ló venidero.

Entre los isleños fronterizos se ha notado hasta aquí una mayor dificultad para la introducción del Evangelio; se ha advertido también en las mujeres la costumbre de abortar con el auxilio de ciertas yerbas, para no ajarse, según dicen, y ser así más gratas á los ojos de sus maıidos; y en éstos, la facilidad de cortar el peloá sus mujeres por una causa aunque frívola. Los pueblos de las misiones del canal y en particular los de San Buenaventura, tejen ya muy bien las lanas y éstas alcanzan á vestir al mayor número de los neófitos. Su inclinación á la sociedad y al decoro, crecen cada día más y más y las manufacturas y siembras van echando entre ellos más sólidas raices.

Correspondía ahora, según el orden de nuestros razonamientos, explicar el método adoptado en estas misiones para la propagación de la fé católica, y para la reunión, instrucción y civilización de sus naturales; pero además de que una exacta descripción de esta especie nos dilataría mucho más de lo que permite nuestro plan, hemos querido omitirla de intento, conociendo no

podía ménos de parecer exagerada á los ojos cle un público prevenjdo de antemano por las ridículas inventivas de muchos autores extranjeros, que confundiendo á veces el sistema con los abusos, é ignorando siempre el objeto primario de semejantes establecimientos, han pintado como opresivas y temibles todas nuestras misiones de la América. Días llegarán, es probable, en que algún extranjero ilustrado que visite es tas costas suministre á la Europa un desengaño nada sospechoso, y á la parte sana de nuestra Nación un verdadero objeto de complacencia. Nosotros nos contentaremos por ahora con asegurarla, que la venida de los españoles ha traído á estos naturales, sin la más leve efusión de sangre, la cesación de mil guerras intestinas que los destruían, los principios sociales, una religión pura y santa, unos alimentos sanos y seguros, y finalmente, un grado tal de confianza entre unos y otros, que un Misionero no teme en el día atravesar sólo y sin escolta las 40 ó 50 leguas habitadas por naciones distintas y enemigas, ni el natural, aunque no convertido, deja de asistir diariamente á las misiones y presidios en busca del alimento ó de un jornal satisfecho.

El precio de los ganados, frutos y semillas, según regía por tarifa en todos los estableci- mientos de la Nueva California, el año de I79r, era el siguiente:

Por un toro de dos años arriba.......

Por un toro de tres á cuatro años.....

Por una vaca de rodeo ó novillo...... 4 n

Por un buey de yugo........... 5 n

Por un ternero ó ternera de un año.... I 4

Por una vaca chichigua.......... 5 "

Por una arroba de tasajo.......... " 6

Por una arroba de carne fresca...... n 2

Por una arroba de sebo en greña..... I I 2

Por una arroba de dicho, frito....... I 6

Por una arroba de manteca de vaca.... $2 \quad 4$

Por una arroba de velas de sebo...... 24

Por una arroba de manteca de cerdo... 3 "

Por un cerdo de dos años, capón..... 3 n

Por un cerdo de tres años......... 4 n

Por un lechón.............. I "

Por un carnero de más de dos años... 2 n

Por uno dicho, de dos años......... I I 4

Por un carnerito primal........... I I

Por una arroba de lana sucia......... I 4

Por una arroba de lana limpia...... 2 n

Por un cabrito.............. » $21 / 2$

Por un macho cabrío........... I I

Por uno dicho, de lana........... I

Por una cabra ú oveja........... » 6

Por un castrado de pelo, de dos años.... I

Por una gallina............... » 3

Por una polla ronca............ 》 2

Por un pollo...............

Por un gallo............... 》 2

Por un par de palomas caseras....... » 2

Por un par de pichones.......... » I

Por tres huevos............. \ $\quad 1 / 2$

Por una docena de codornices....... n ${ }^{n} 2$

Por un conejo............... n $1 / 2$

Por una liebre.............

Por un cuero de res, al pelo........ n 3

Por uno dicho, en vaqueta........ 2 "

Por un cuero de venado, al pelo...... » 2

Por uno dicho de macho, en vaquetillá. I 4

Por uno dicho de hembra, en idem.... I 2

Por una gamuza de macho.......... I I 4

Por una dicha de hembra......... I I 2

Por una libra de queso........... » $1 / 2$

GRA NOS

Por una fanega de trigo.......... 2 "

Por una ídem de maiz........... I 4

Por una idem de fríjol ó lenteja...... 24

Por una ídem de garbanzo......... 3 »

Por una ídem de alverjón.......... I 4

Por una ídem de cebada.......... I I

Por una arroba de harina común..... I 2

Por una arroba de harina, de un cedazo. I 4

Por una arroba de harina de flor...... 2 "

GANADOS DE CARGA Y SILLA

Por un caballo manso, de dar y recibir.

Por una yegua de tres años..........

Por un potro cerrero de tres años......

Por una potranca de hasta dos años...$$
4
$$

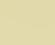
(1) (a) (1) (a) (1) 


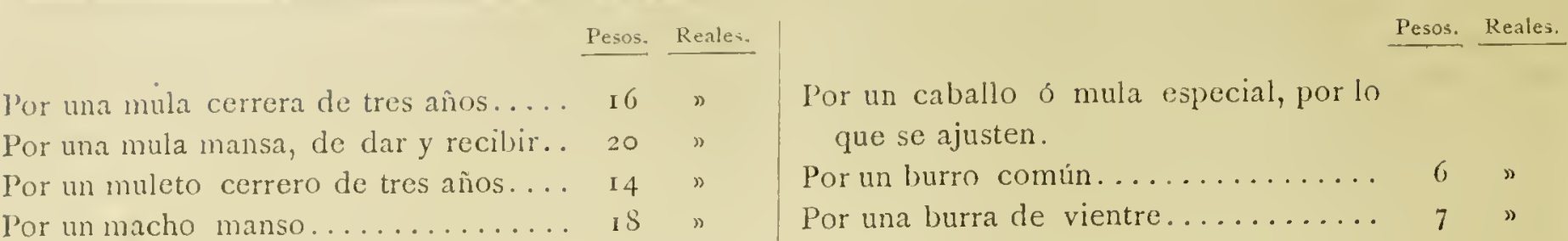

\section{Condiciones de los puertos de San Blas y Acapulco pära airsena- les.-Reconocimientos en las provincias internas. Su descripción física. producciones y' costumbres.}

Mucho se ha hablado en la Nueva España sobre cuál sea el puerto más conveniente de los de Acapulco y San Blas para que sirva de reunión y depósito de las fuerzas navales en el mar $\mathrm{Pa}$ cífico y áun para construir en él, en caso necesario, los buques de cualquier porte que requieran las urgencias de aquel reino; y aunque la única consideración de los perjuicios inherentcs al clima mal sano de San Blas, parezcan decidir desde luego la cuestión á favor del puerto de Acapulco, sin embargo, como el interés particular en unas ocasiones, en otras la falta de conocimientos facultativos, generalmente el no haber fijado la idea justa de lo que se necesita, han hecho contrarestar esta preferencia atribuyéndola á San Blas, nos ha parecido que no se considerarán como agenas de este lugar las siguientes reflexiones sobre el mismo asunto.

Dos son los objetos que pueden producir en América la idea de que se forme un arsenal en

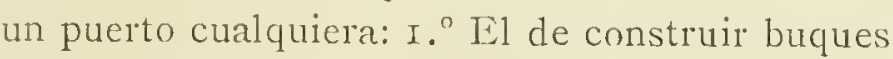
de todas clases para aumento de la Marina Real. 2. El de atender á las composiciones y reparos de las embarcaciones que arriben ó se mantengan frecuentemente en un mismo puerto ó en las costas de su dependencia. Laabundancia de muchas y excelentes maderas que hay en varios parajes de Amúrica ha deslumbrado a muchos sobre la utilidad verdadera que resultaría de que se construyesen los buques en aquella nueva región del mundo; pero la experiencia, de acuerdo con la razón, han dado á conocer cuán difícil sería el conseguir ventaja alguna en este nuevo sistema, tanto por los costos excesivos que allí tiene la mano de obra, como por la imperfección con que éstas se ejecutan, y más que todo, por los abusos que tan fácilmente se introduccn en las coInnias y que cs imposible se eviten por las causas que son bicn conocidas á todas las naciones quc tienen establecimientos ultramarinos.

Admitida, pucs, como una verdad constante, qu ni al Iirario ni a la fuerza nacional conviene el que se construyan buques grandes en la América, deben, pues, ceñirse las miras de todo astillero como el de San Blas, á los dos únicos obje tos de construir embarcaciones pequeñas ó costaneras, $y$ al de reparar con actividad las naves que los diferentes objetos de la Monarquía dirijan sueltas ó en escuadras á los puntos más distantes de sus dominios, en cuyo caso necesita el arsenal que se forme, aún más que la mera existencia de muchas maderas, otros puntos esenciales, los cuales no será inútil recapitulemos aquí con alguna individualidad. En primer lugar, un establecimiento de esta especie requiere un depósito anticipado y abundante de cuantos efectos puedan necesitarse para la existencia dilatada de varios buques grandes en las costas inmediatas, y por consiguiente, como el valor y la utilidad de estos efectos pueden llamar por sí solos la atención de un enemigo, exigen, por tanto, una defensa oportuna, cuyos costos obliga con precisión á ceñir estos establecimientos al menor número posible. En segundo lugar, debe atenderse á la utilidad que resulta de que el paraje elegrido sea también el mismo que frecuentan los buques de la Marina mercantil, porque estos buques unas veces prestando y otras recibiendo crecidos auxilios de un depósito general, no sólo evitan el monopolio de los abastos y el flete de una embarcación que suele á veces emplearse para conducir una friolera, sino que acelera en ocasiones los movimientos de la Marina Real con el auxilio de sus pilotos y marinerías, además que como el concurso de estos buques causa un comercio activo y de aquí el aumento de la población, las artes mecánicas se adelantan, y el Erario no tiene que mantener á sueldo fijo cada oficio por no exponerse á la casualidad de no encontrarle cuando lo necesite. En tercer lugar, es preciso atender también á las ventajas locales del establecimiento, tanto con respecto á la navesración como para la utilidad común de los pobladores. Estas ventajas son, por lo que tocá á la naregación, la se- 
guridad del puerto, la facilidad de seguir en sus edificios así particulares como del Rey, aquel orden y economía que háce se emplee un número menor de brazos en las conducciones, maniobras y otras faenas cotidianas; la mejor disposición del puerto para entrar y salir de él en todas las estaciones del año, su oportuna posición geográfica para comunicarse sin violencia ni extravío con las diferentes costas que ha de proteger, y últimamente, su distancia del centro del gobierno de los mares inmediatos y sobre todo de la metrópoli. En cuanto al segundo objeto de la utilidad de los pobladores, deben ser sus principales fundamentos los de un aire sano ó ménos malo, la mayor comodidad de los caminos internos, áun en la estación lluviosa, una cantidad suficiente de terreno para extenderse con comodidad y orden, al paso que lo exijan las circunstancias ulteriores del establecimiento; final mente, la mejor proporción de los contornos y de los paises distantes, para que á medida que aumenten las necesidades del establecimiento, aumente también la población sin violencia alguna ni sacrificios del Erario.

Sentadas estas reglas como preliminares precisos que deben servir de guía para la oportuna elección de un establecimiento como es el de San Blas, es fácil demostrar que en el paralelo de las ventajas y nulidades anejas por naturaleza á uno y otro puerto, es infinitamente aventajado el de Acapulco á la rada de San Blas, y también, que Acapulco es el único puerto que tiene el Rey en las costas occidentales de Nueva España, capaz de un estableciniento de esta especie.

La disposición de la costa en las inmediaciones de este puerto, es tan favorable para una re. calada, que á más de divisarse desde mucha distancia las señales infalibles de él, puede cualquier buque aproximarse á muy poca distancia sin comprometer en nada su seguridad, en caso que un temporal ú otra causa inopinada le obligue á separarse. Desde la entrada hasta el surgidero, la distancia es tan corta $y$ el fondo tan cómodo y seguro, que toda embarcación, cualquiera sea su porte, puede hallarse inmediatamente amarrada ó alcanzar sin dilación los auxilios que necesite. No hay en aquel puerto peligro alguno que exija, como sucede en otros, los gastos de prácticos, boyas y anclas sueltas, para espiarse, ni tampoco incertidumbre en el navcgante para entrar y salir: una escuadra entera puede maniobrar en él á un tiempo con actividad $y$ sin estrechez: los vientos reinantes, tanto en la estación lluviosa, desde Mayo hasta Octubre, como en la seca, de los seis meses restantes, permiten una comunicación fácil y segura con las costas de Guatemala, Guayaquil, Perú y Chile; finalmente, la seguridad interior de los buques sin el auxilio de muchas amarras y sin el menor ries- go de un botecillo siquiera, son ventajas tan considerables, que pocos puertos hay las reunan en tanto número y con tanta utilidad. Pudieran indicarse aquí también como relativas á este lugar, otras muchas ventajas que no son indiferentes entre los objetos generales que abraza la navegación. No es indiferente, por ejemplo, la imposibilidad de desertar que encuentra en Acapulco la tropa y la marinería. Tampoco lo es la inmediacion del puerto del Marqués, en el cual puede fondear una escuadra ó buque aliado y socorrérsele sin necesidad de tener con él roce alguno, y últimamente, no lo son los ejemplos de un viaje de veintidos días, hecho por la fragata Santa Gertridis desde Lima hasta las playas inmediatas de Naguala, poco tiempo antes de nuestra llegada á Acapulco, y el que acababa de hacer entonces en veintiocho dias desde Guayaquil, un buque mercante de aquel comercio.

Cuando se considera el segundo ramo de las utilidades que proporciona para un depósito de fuerzas navales la concurrencia de diferentes buques mercantes en un puerto, no podemos desentendernos de lo mucho que habrán costado en el Departamento de San Blas todos los efectos llevados de allí por tierra desde Veracruz, cuando un corto flete desde Cádiz hasta Lima ó Manila, y otro desde estos puertos al de Acapulco, haría que nuestros almacenes estuviesen bien provistos de pertrechos navales de mejor calidad, sin todos aquellos costos y con mucha mayor abundancia. Las anclas, la artillería, las jarcias de Europa ó de Chile, las lonas, y finalmente el mucho hierro labrado y en bruto que consume la navegación, todo podría transportarse á Acapulco con grande facilidad y sin los inconvenientes que ya se han tocado de tener que pasar la artillería por tierra desde el río Guaza cualcos á Teguantepec, ó de establecer una fundición en Manila, ó de tener que suplir las anclas de hierro y las jarcias de cáñamo, con otras anclas mal equilibradas de bronce y con la jarcia poco resistente de pita.

Pero la máxima utilidad que produce la reunión en un mismo paraje de los bajeles de la Marina Real y mercante, y cuya ventaja es peculiar de Acapulco, por ser éste el único puerto habilitado para el comercio que tiene el Rey en las costas occidentales de Nueva España, consiste ciertamente en la economía recíproca. El mercante compra y aprovecha todos los efectos usados que siendo útiles para sus cortas travesías, no pueden ya servir para un buque de la Marina Real que se destina indiferentemente á obrar en todos parajes y en todos tiempos: la seguridad de encontrar auxilios en caso de necesitarlos, le hace navegar con mayor economía: el jornal y asistencia de los peones, ocupados unas veces en los almacenes Reales y otras en las 
cargas y descargas de los mercantes, es inferior y más uniforme por la razón misma de que 10 encuentran periódica y constantemente: ultimamente, los reemplazos de marinería y maestranza, tanto por una como por otra parte, aceleran consiguientemente las faenas de unos y otros, y no hay precisión de precaverse de antemano, manteniendo con mucho costo un cierto número de marinería para en caso de una necesidad que tal vez no acaece en muchos años.

En cuanto al tercer objeto, que se refiere á las circunstancias locales del establecimiento, es el único en que cabe dar alguna preferencia á la rada de San Blas sobre el puerto de Acapulco, pues por lo que toca á los dos anteriores es bien palpable que están absolutamente contra el primero. Para socorrer las provincias que bordan el mar de Cortés, la situación de San Blas es preferente á la de Acapulco (I); pero las navegaciones á la California ó á las costas más septentrionales de la América, aunque pueden emprenderse indiferentemente desde uno ú otro paraje, tiene, sin embargo, el puerto de Acapulco la ventaja de que no hay necesidad de volver á fondear desde el día en que se da la vela, y de que se pueden hallar con más brevedad los vientos generales. Por lo que toca á la seguridad del puerto de Acapulco, además de las circunstancias que se expresaron ya relativamente al entrar, salir, bordear y espiarse, debe agregarse que en muy pocos cuartos de hora, el hombre más sencillo puede en toda estación conducir una embarcación desde el amarradero al carenero, cuando en San Blas, en la mitad del año, infunde mucho cuidado al navegante hasta la vista de las tierras cercanas por las travesías que le abaten sobre una costa llena de arrecifes; y en la otra mitad, las faenas de aligerar un buque para entrarle en el río, las otras mucho más complicadas, de habilitarle para la mar, las demoras é incomodidades que son consiguientes á estas faenas dilatadas y la imposibilidad de valerse para ellas de muchos botes chicos, son otros tantos inconvenientes que destruyen de un modo inconcebible la economía y celeridad en las operaciones, que tanto apetece el navegante. La sola faena de hacer la aguada, que en Acapulco no nos ocupó sino el bote más chico con un solo hombre para conducir á veces ro ó I2 cuarterolas de agua en cada viaje, no puede hacerse en San

(1) Aun esta ventaja quedaría nula, si como ya se ha verificado, continuase surtiéndose el presidio de l,oreto con cmbarcaciones menores destinadas a este (1)jeto. Del inismo modo podrían surtirse todas las custas de la Somora o bien con fletes al comercio, y es claro que sería imprudente equivocar la idea de un ritablecimicuto para cste solo fin, con el de ocurrir if las muchas necesidades que debe cubrir un departaincinto formal.
Blas sin las lanchas grandes, que ocupan Io y I5 hombres y en las horas de la virazón, que son las más cúmodas del día.

Sobre todo, una embarcación de mucho porte que necesite cualquiera obra de carena, no puede absolutamente entrar en San Blas por el poco fondo de su canal; necesita además descargar y volverse á cargar para seguir hasta Acapulco: finalmente, el costo de una recua para bajar los pertrechos desde los almacenes hasta el embarcadero, el natural deterioro de éstos en semejante faena, el riesgo de una inundación en el astillero, las demoras necesarias para la comunicación oportuna de las órdenes, y la vigilancia contínua de los Oficiales sobre los artesanos, y últimamente el limitado espacio que hay en San Blas para el astillero y embarcadero de pertrechos, son todas circunstancias que pudiendo conciliarse ventajosamente en Acapulco, manifiestan de un modo palpable cuánto se apartan de la recta senda los que no sólo opinan de que sea San Blas el depósito de las fuerzas navales en el mar Pacífico, sino también un astillero capaz de suministrar navíos para la Marina Real.

Los que apoyan este sistema se fundan en la abundancia de maderas y en la buena calidad que tienen las que hay en el Departamento de San Blas; pero convencidos como lo estamos de que es casi imposible construir en América con economía y acierto, resulta pues, que una excesiva abundancia de madera no es una ventaja verdadera para el fin á que debe destinarse un establecimiento en aquellos mares.

Es cierto que las carenas, la construcción de embarcaciones menores y el total de obras que necesariamente han de hacerse en un astillero, necesita un acopio regular de maderas, pero áun para este objeto el puerto de Acapulco no es inferior al de San Blas, pues en el puerto inmediato del Marqués no sólo hay abundancia de excelentes maderas para toda especie de construcción y arboladura, que en el día pueden conducirse por agua hasta atravesar una sola playa de 50 pasos, sino también que en lo venidero sería muy fácil cortar esta misma playa, de modo que las balsas no necesitasen para su conducción sino el auxilio de un pequeño bote. Además, supuesto que los buques que anualmente auxilian los presidios de la Nueva California retornan siempre vacíos, sería fácil el que á su regreso tocasen en San Blas y cargasen allí de maderas, particularmente de tablazón aserrada.

Se dijo que una de las ventajas á que debía atenderse para fundar un establecimiento de la clase del que vamos hablando, era la proporción de poder extender la población y de darla toda la salubridad necesaria, pero ni en San J3las hay esta facilidad, ni medios de hacerla saludable, 
ni es posible abreviar de modo alguno la comunicación con la capital, mucho ménos la de adquirir marineros que no sean sacados del campo, ni últimamente la de vencer una preocupación tal vez fundada contra aquel clima, que ya relativamente á Acapulco lo han vencido indistintamente los filipinos y los de Guayaquil.

Quedan, pues, á favor de Acapulco todas las refiexiones que nos habíamos propuesto, y demostrada la preferencia que decididamente merece este puerto sobre la rada de San Blas. En nuestro concepto, disminuída á lo ménos en la mitad la dotación de las Cajas de Méjico para el departamento de California y remitiendo á Europa aquella cantidad, pudiera muy bien sin recargo alguno del Erario, mantenerse constantemente en aquellos mares algunos buques de la Marina Real, bien construídos y dispuestos para navegar á todas partes y áun para alcanzar al enemigo, en cuyo caso estos mismos buques contínuamente armados, aunque diferentemente en tiempo de paz al de guerra, conservarían oportunamente y con muchas ventajas económicas la comunicación del Perú y Filipinas con aquellas costas, y se lograrian finalmente en Acapulco, para nuestras fuerzas navales, aquellas mismas ventajas que con igual método disfrutan los ingleses en Bombay, los holandeses en Batavia y los franceses en la Isla de Francia. En tal caso era preciso dejar al cuidado de los buques comerciantes de Manila ó á otros tomados á flete por el Rey ó por particulares, el cuidado de socorrer los presidios de la California, y que los del mar de Cortés, continuasen como hasta aquí surtiéndose de comestibles en San Blas, pero áun esto trae ventajas peculiares, como ya se dijo, al comercio y á los establecimientos.

Casi descle el trópico de Cáncer, esto es, unas 80 leguas al Norte de Méjico, empieza aquella parte de nuestros dominios que se conoce con el nombre de provincias internas $\mathrm{y}$ se comprende entre las aguas de los dos Océanos Pacífico y Atlántico, los cuales ciñendo al principio este continente en la extensión de unas I 50 leguas, se inclinan después con tal divergencia, que por el grado 43 de latitud no baja de $54^{\circ}$ I $5^{\prime}$ de longitud la distancia de uno á otro mar, ó bien de $8 S 0$ leguas próximamente; y como las colonias americanas ocupan en esta extensión unas zoo leguas contando los Kentukis hasta las orillas del Mississipí, se puede por consiguiente computar en 5oo ó 600 leguas EsteOeste la extensión de los dominios nacionales en esta parte, que nos disputan en el día los Seris, Moquis y Apaches al Oeste del Nuevo Méjico y los Lipanes y Cumanches al Este, con igual tesón y buen éxito al que tuvieron en el conti- nente austral los pueblos contiguos del reino de Chile (I).

Renovando en este lugar nuestras anteriores conjeturas sobre una grande despoblación al Este de los límites asignados á la Nueva California, y siguiendo como allí los indicios de los viajeros nacionales, no cabe ya duda en que en las tierras intermedias entre el río Colorado y la Sierra Madre, pueden considerarse igualmente estériles que despobladas; tanto más cuanto que el Comandante D. Juan Bautista Ansa, que atravesó este terreno en dos viajes consecutivos, asegura positivamente que desde las márgenes occidentales del Colorado hasta la Sierra Madre, sólo se encuentra un país árido y á reces tan escaso de aguas que el transitar por él se hace igualmente penoso que arriesgado.

El río Colorado tuvo sin duda esta denominación por el color de sus aguas, que según advierte el Padre Consag se manifiestan tales en unos pantanos inmediatos á su desembocadura. Recibe el río Gila I 8 leguas al Norte de aquel paraje, y luégo sigue casi en la misma dirección hasta los $34^{\circ} \mathrm{I} 5^{\prime}$, en donde tuerce próximamente al Nordeste; se une después por los $37^{\circ}$ con el $\mathrm{Za}$ guananas, que aumenta mucho el caudal de sus aguas, y subdividiéndose igualmente que éste en una infinidad de arroyos, remontan ambos á su origen por los $39 \mathrm{y} 40^{\circ}$ de latitud.

Por cuanto hemos podido indagar hasta ahora, sólo ha sido vadeado el Colorado en tres parajes diferentes. Una en el confluente con el Gila, por las dos expediciones del Capitán Ansa desde la Sonora á la California. Otra el año de $\mathbf{7 7 7 5}$ en los $35^{\circ}$, por el Padre Garcés (2) al tiempo de su viaje desde la Californiá los Moquis; $y$ final mente, por los $37^{\circ}$ en 1777 , por los Padres Vélez y Escalante en su riaje desde el Nuevo Méjico á las lagunas de los Yamparicas en $4 \mathrm{I}^{\circ} 2 \mathrm{O}^{\prime}$, desde donde regresaron por el pais de los Moquis al presidio de Santa Fé.

La primera idea que se ofrece al contemplar este crecido río, cuyo curso atraviesa por muchas leguas las provincias septentrionales de Nueva España, es la de que siendo navegable podía fa-

(1) Exceptramos en la descripción que sigue. á las dos Californias Vieja y Nueva de que hemos tratado anteriormente.

(2) El Padre Fray Francisco Garcés, franciscano, de la provincia de Aragón, es un sujeto cuya memo. ria merece un lugar distinguido en los fastos nacionales. Con un solo indio de compañero, anduvo muchas naciones que no se conocían antes de poblarse el Colorado; vino á la California, entró en la provincia de Moqui, y de allí pasó á la Sonora, siempre entre gentiles, sin escolta ni compañero, comía lo mismo que ellos las frutas silvestres, y le estimaban entrañablcmente. Era conocido con el $V_{i}$, a Jestis, que era su salutación ordinaria para los indios, $y$ hacía que éstos le saludasen del mismo modo. Más adelante hablaremos de su muerte trágica en las misiones del río Colorado. 
cilitar y dar movimiento á la extracción y tráfico de aquellas provincias; pero examinados atentamente los diarios de nuestros viajeros, es preciso, parcce, renunciar á tan lisonjera esperanza. No podemos individualizar, por falta del diario correspondiente, cuál fué el cauce, ni cómo se presentaban los contornos del río en el paraje por donde pasó el Padre Garcés; pero los Padres Vélez y Escalante que lo atravesaron sin guías, encontraron mil tropiezos. "Antes (dicen), en un 1) rincón todo cercado de cerros y crestones de "tierra colorada, muy elevados, que teniendo va"rias formas y siendo el plan intermedio de abajo "del mismo color, tiene un aspecto agradable"mente confuso, luégo arenales muy escarpados "y pasos difíciles con bancos peligrosísimos de "peñas, finalmente, un vado de un ascenso tan es"cabroso, que fuć preciso hacer con un pico algu"nos escalones en la piedra viva para las caballe"rías, y bajar á mano todas las cargas y aparejos. "El vado es bueno; tendrá aquí de ancho una " milla poco más, y ya vienen incorporados los "ríos de Nabajo y de Dolores. En todo lo que por "aquí vimos no se puede establecer en sus ribe"ras población alguna, ni áun caminar por una y "otra banda hacia abajo y hacia arriba una bue"na jornada con la esperanza de que sus aguas "sirvan para la gente ó caballada, porque á más "de ser el terreno malo va muy enca jonado el río. "Todo lo más inmediato al río es de peñones y "picachos muy elevados; ocho ó diez leguas al "Norte de él está una sierra alta, redonda y con "poca base, que los Puychis llaman 'Tucané ó "Cerro Negro; se encuentran también á poca dis") tancia muchas minas de yeso transparente, al"gunas de talco y también algunas metálicas. Fi"nalmente, pueden servir de un mediano alimen"to las pencas de nogal chico tostadas, y el atole de una frutilla que da en las orillas del río, "bien que el prepararla así, molida y con agua, la "quita todo el sabor que tiene por sí sola."

En el rado que halló D. Juan Bautista de Ansa en su primer viaje, cogiéndolo corto trecho al Norte del confluente, tenía 95 brazas de ancho y cinco palmos de fondo en lo común, yendo allí de ménos el brazo que forma una isla de donde habían salido: "y no se midió, dice el Diario, al mismo tiempo el Gila, por tener ya introducido cl brazo mencionado del Colorado, pero según el informe de los indios se puede regular la mitad ménos en todo, pues sólo en la mejoría de agua le excede el Gila, bien que las de ambos ríos no son las mejores, pues tiran un poco á saladas. Las orillas, miradas desde un alto inmediato, cran sumamente frondosas, con una inmensa arbolcd.u de sauces y álamos que las pueblan tanto i) zra arriba como para abajo, y hasta donde puede .lcanzar la vista, útiles lodos por su derechura para binks. Se veía igualmente una sierra inme- diata, por cuya abra sale el río Colorado al Nornoroeste; y al Esnordeste otra abra en una sierra que corta el Gila; y la conversación con un indio Soyopa proporcionó el saber que tres días de camino río a riba se partía el Colorado, siendo éste el más caudaloso, y el menor brazo tiraba á juntarse con otro río mayor que el mismo Colorado, y que aquél en la realidad tenía el agua más colorada que éste. Manifestaron los mismos naturales que el río no tenía salto alguno hasta la mar, ni tampoco sabían lo tuviese arriba en muchas leguas."

Al regresardel mismo viaje, pasaron nuestros viajantes los ríos, en balsa, un poco más abajo del confluente, por un ancho de 600 varas ( $\mathrm{r}$ ); y volviendo á pasar el Gila por más arriba, notaron que, tanto allí como en todo lo andado, no bajaba su fondo en lo general de cuatro palmos, á pesar de ser aquel el tiempo de su mayor seca. Los naturales dieron á entender que en el tiempo de las avenidas, con las ayuas del verano, no. bajaba su ancho de 500 varas, concurriendo á manifestarlo así las señales parículares del terreno.

Estaba algo más caudaloso el río en Diciembre de 7779 , cuando el mismo Comandante Ansa conducía á Monterey y San Francisco la tropa y familias destinadas á aquellos nuevos es cablecimientos, y prefirió, sin embargo, vadearle algo más arriba, en donde dividido el río en tres brazos, podía pasarse el primero en cinco palmos y medio de agua en lo general y seis en el centro, el segundo brazo en cuatro y cinco, y el último, que era el más ancho, te ía donde más seis y medio palmos de agua, y cuatro en lo común; pudiendo suponerse que, si los tres brazos es cuvieran uniclos, no bajaría su anchura de 240 varas, como las tendrá en donde no se divide.

La desembocadura del Colorado en la mar, según la carta y los diarios del Padre Fernando Consag, tendrá unas cinco leguas de ancho, áun tomando esta, dimensión en las inmediaciones de las Islas de los Reyes, empezando los bancos por mayor anchura y mucho más al Sur. "Estos ban" $\cos$ (dice el citado Padre) obstruyen casi de un "todo la navegación: la corriente del río en las "vaciantes es tan rápida, que no pueden las ca-

(I) Aqquí añade el Diario original estas palabras: "Fueron inútiles cuantas pesquisas se hicieron para naveriguar entre los naturales la existencia de la famosa Sierra Azul y laguna de azogue que noticia mel Teniente D. Mateo Maugé, companero del Padre "Kinó en una obra que rłedicó al Excmo Sr. Virey "Duque de Alburquerque, como también el río Amawrillo del otro lado del Colorado.n Demostración inanifiesta de la facilidad (lue ha habido en forjar relanciones de países maravillosos, semejantes al Dorado, a la grande Quivira, al Estrecho de Auiam, etc. Este Mange acompaño efectivamente al Padre Kinó, según noticias de la historia del P’adre Venegas, tomo II, pág. 90. 
"noas contrarestarla al remo, y no entra con "ménos fuerza la marea, tomando tal resaca y "embates, que sumergió una de las canoas y "puso toda su gente en evidente riesgo de nau"fragar. Hacia la California, toda la tierra baja "se inunda con las avenidas, de suerte que "hasta el pié de la serranía se ven los palos y "basuras que arrollan las aguas. Se nota tam"bién una especie de heras, aunque pequeñas, "en que los naturales del país limpian ódesgra" nan una especie de semillas semejante al trigo, "pero tan menuda como el anís: finalmente, 1) desde la Visitación, y mucho más desde San Felipe, la navegación parece impracticable, áun "para vasos muy medianos."

El país comprendido entre el Gila y el Colorado puede considerarse como extremadamente fértil, según el testimonio de todos nuestros viajeros. Lo habitan en el día los Yumas, y aprovechándole á veces con riego artificial y otras con las ramificaciones accidentales del agua, 1ogran de cosechas abundantes de maiz, trigo, fríjoles, garbanzos y algodón, además de un crecidísimo número de sandías, calabazas, etc., las cuales contribuyen no ménos al bienestar y recreo de los naturales que al alivio de los transeuntes. Sin embargo, es muy poca la extensión de este terreno fértil, porque aprovechándole para las cosechas y no quedando sitio oportuno para pastos, no han podido propagarse los ganados, por cuya causa carecen estas tríbus casi enteramente hasta del caballo.

A excepción de las inmediaciones del Gila todos los terrenos que rodean al Colorado parecen igualmente estériles y desiertos, siendo aún mucho peor esta perspectiva al paso que se retrocede al Sur hacia las provincias de la Sonora, costeando el seno de Cortés por su parte Este. Desde los últimos años del siglo pasado todos los Misioneros Jesuitas, y especialmente el docto Padre Kinó, habían manifestado que componiéndose generalmente la costa de la Sonora sobre el golfo califórnico de ásperas montañas y estériles arenales sin agua dulce, debía mirarse esta provincia como mediterránea ( $\mathrm{I}$ ). Lo apoyó después con mayor individualidad el Comandante Ansa, quien en el Diario de su primer viaje á la California, hablando de algunas familias Papagas ó Pimás, encontradas en las inmediaciones de Baipia dice: "Que en invielno bajan á nuestros es"tablecimientos dejando su país casi desierto, "porque éste es de los más desdichados que pue. ) den imaginarse, pues les escasea hasta el agua " precisa para su manutención, y que por falta de "ella no poseen ninguna siembra segura, siendo "los únicos frutos que alcanzan, algunas calaba"zas, sandías y melones que arriesgan al tempo-

(I) Historia del Padre Vonegas, tomo II, pág. 78. "ral, y se pierden siempre que las aguas no son "extremadamente buenas; y últimamente, que "aquí parece reunida toda la infelicidad, pues no "se ven siquiera árboles frondosos para techos". Pero aún mucho más que las reflexiones anteriores evidencian en el día la esterilidad de esta provincia los pasos sucesivos de nuestros misioneros, quienes para adelantarse al Norte se han visto precisados á establecer las misiones apartándose de las orillas, y áun así las más no han medrado y casi todas se han visto inmediatamente destruídas por los Seris no habiendo bastado los esfuerzos harto costosos del Gobierno á favor de la Sonora, para desalojar de sus estériles inmediaciones á aquellos pueblos errantes que viven de la pesca y andan particularmente en la Isla del Tiburón y sus contiguas.

Al Norte del río Gila y de los brazos orientales del Colorado, el país presenta un semblante mucho más placentero. Una cordillera bastante áspera y elevada, que corriendo en la dirección Norte-Sur atraviesa este país en la extensión de 70 leguas siendo su ancho de 30 á 40, termina al Oeste casi por meridianos del río Colorado y hasta la latitud de $4 \mathrm{I}^{\circ}$ Io' unos campos y valles sumamente fértiles y amenos, siguiendo al Sudeste las hermosas y agradabies vegas que habitan los Cosminas y los Moquis, naciones contiguas por el Oeste al Nuevo Méjico, y que en el siglo pasado fueron reducidas á la Religión y á la Monarquía, dos cosas que han abandonado después. Hállanse en estas distantes regriones (I) montes poblados de pinos y álamos de un tamaño singular, varias y grandes lagunas entre las cuales merece particular memoria una formada al Sudoeste por las aguas de la serranía indicada, de seis leguas de ancho y I 5 de largo, que corriendo al Noroeste por una angostura, comunica con otras mucho mayores, todas abundantes en peces, ánsares, nutrias y otros anfibios; varias minas de yeso transparente, un hormiguero grande de piedra alumbre muy menuda, purificada y cristalina, una cordillera de mesas altas que desde la cima hasta su mitad se compone de tierra blanca y desde allí abajo se ven uniformemente matizadas de amarillo, blanco y almagra muy subida; varias aguas termales, el origen de cuatro ríos medianos, las ruinas de dos pueblos antiguos, y para el alimento en ciertos parajes algunas truchas, en otros tal cual cíbolo, licbre y carnero silvestre, y generalmente donde hay naturales, los pínolos, semillas y yerbas que suelen recoger de antemano las mujeres para las provisiones del invierno.

En el valle de Ios Timpanogotzis al Norte del río de San Buenaventura y próximo á la laguna citada, los campos se cubren de pastos loza-

(x) Relación del viaje lc los PP. Vélez y Esca- 
nos, $y$ bajo un temple de los más benignos y suares se producen naturalmente $y$ con abundancia el lino, el cáñamo, de cuyas semillas y otras muchas yerbas se alimentan los naturales los $s a$ buaganas ó coms pescado y hacen atole logrando también de la caza de liebres, conejos y gallinas que hay abundantemente además de la de los cíbolos que tienen no muy distantes.

Las inmediaciones de Santa Fé, conocidas con el nombre de Nuevo Méjico, son montuosas, áridas e intransitables, $\mathrm{y}$ sin duda muy abundantes en minerales, pues sólo los valles dan lugar á siembras y pastos, y el terreno fértil, no vuelve á encontrarse hasta los $28^{\circ}$ caminando al Este hacia los límites de la Nueva Vizcaya con la provincia de Cohahuila. En ésta, y particularmente hacia el presidio actual de Santa Rosa y el abandonado de San Sabá, por los $32^{\circ}$ escasos, se presentan al viajante unas campiñas regadas por el río grande del Norte ú otros inferiores, y otras lomerías y bosques tan espesos de morales, ciruelos, perales, manzanos, con una infinidad de parras enlazadas, mezquites, cedros y palos blancos, que con dificultad permiten paso para un hombre á caballo. No es ménos fértil, llano y agradable, el terreno de 40 á 50 leguas que media entre San Sabá y Béjar, capital de la provincia de Tejas, desde cuyo punto, ya sea en dirección del Mississipí ó del mar, se encuentran bosques tan espesos y pantanosos, que si es molesto atravesarlos en tiempo de secas, es imposible casi verificarlo en el de lluvias ó inundaciones.

Fuera este lugar oportuno de verter la cuestión sobre la facilidad y utilidad de navegar el río del Norte hasta las inmediaciones de Santa Fé; pero careciendo de documentos suficientes para aventurar un parecer siquiera probable, nos ceñiremos por tanto, á desear que no se dilate mucho esta importante averiguación, cuyo influjo en el sistema político de estas regiones, no sería tal vez indiferente. El Ingeniero D. Nicolás Lafora, que acompañó al Marqués de Rubí en la revista general de los presidios de esta frontera, pasó en balsa el río mencionado, cerca del $\mathrm{Ca}$ rrizal, esto es, en la división, digámoslo así, del Nuevo Méjico con la Nueva Vizcaya; usó también á su regreso de San Sabá por los $3 \mathrm{I}^{\circ}$, hallando el río bastante rápido y caudaloso, y finalmente, le encontró con mucha extensión y fondo en las inmediaciones de Laredo, en el nuevo Santander; pero los datos que suministra la narración de estos viajes, son insuficientes por sí solos para fijar con alguna certidumbre la posibilidad é imposibilidad de navegar en toda su extensión este río caudaloso.

No son ménos inciertas las noticias que pueden darse de nuestras provincias septentrionales al querer penetrar más allá de los paralelos con- tíguos al Norte de los que acabamos de describir, áun fijando el límite de nuestras indagaciones en el paralelo de $43^{\circ}$, como lo hicimos para las po. sesiones de la Vieja y Nueva California. Con efecto, las lagunas de los Padres Vélez y Escalante están contíguas á las llanuras que lindan con las tierras altas del puerto de San Francisco, del Cabo Mendocino ó del puerto de la Trinidad. La cordillera ya citada de San Buenaventura va á unirse con las montañas brillantes de Carver, ó tienen esta preferencia las sierras montañosas de Cohahuila que por los $32^{\circ} \mathrm{y}$ al Este del Nuero Méjico, parece se dirigen por largo trecho hacia el Norte en un país aún no trillado por nuestros exploradores. ¿El terreno que media entre el río Norte y el Mississipí, es montuoso ó se asemeja al que entre el Ohío y el Missourí hacen en el día la felicicidad de los Kentukis y el objeto de las investigaciones comerciales de la Inglaterra? Hé aquí una porción de dudas entre otras mu. chas, que no pueden resolverse según el estado actual de nuestros conocimientos, y que dejan campo abierto para las indagaciones sucesivas de los viajeros venideros que tengan tiempo y oportunidad para hacer este servicio importante á la Geografía. En el entretanto, volviendo la espalda á estas distantes regiones, continuemos hacia el Sur el examen físico del suelo que compone nuestras provincias internas. Entre las causas principales que pueden servir de aliciente para que se pueblen algún día estas provincias como corresponde á su dilatada extensión, debe comprenderse el artículo importante de las minas, las cuales son tan abundantes así en la Sonora, como en el Nuevo Méjico, la Nueva Vizcaya y el Nuevo Reino de León, que pueden muy bien compararse con las ricas de Nueva España, y áun concederles tal vez cierto grado de superioridad; prueba de esta aserción los lavaderos de oro tan abundantes en casi toda la Sol1ora, y particularmente en las sierras inmediatas á Arispe, los de Bacuache, la Cananea y Peñuelas, que han dado granos hasta de siete marcos: la mina de Banamitzi y la de Santa Rosalía, que dió oro de $17 y^{1} / 2$ quilates, con tal abundancia, que algunas cargas llegaron á rendir $\mathrm{I} .000$ pesos, y duró esta bonanza por el dilatado espacio de veinticinco años hasta el de 1748 . Pero aún más abundantes que las de este precioso metal son las de plata, de las cuales en todo el distrito de Arispe se han abierto hasta 37 minas, siendo las más acreditadas las del Espíritu-Santo, que rendía á I 8 marcos por carga, la de Rocha á I 2 y la Babicanora y otras varias desde tres hasta seis marcos, á las cuales se pueden agregar en la misma provincia de la Sonora hacia el mar de Cortés, las inmediatas al presidio del Altar; las de San Marcelo, de Vinotac, las de Guachuca y la Longoreña cerca de Terrenate; las nuevamente descubiertas en el 
arroyo del Infierno y en el pot:ero de las Tetas, entrambas muy inmediatas al Real del Rosario (I), y sobre todo, la célebre mina de la Arizona ó las Bolas, ocho leguas del pueblo de Surie de los Pimás altos, en la cual se hallaron en I736, bolas de plata virgen hasta el peso de I 50 arrobas (2).

Siguiendo por la Nueva Vizcaya y Nuevo Méjico, se encuentran las minas de Cosaguirichí con otras varias no ménos ricas de oro y plata. En el Nuevo Santander son nombradas las de la Iguana inmediatas á Laredo, y en el Nuevo Reino de León, además de la famosa mina de Boca de Leones, existen aún los rastros de las labores de otras muchas, fijando especialmente la atención de todo curioso, las que se llamaron de San Diego y se beneficiaron por algún tiempo.

Además de estos dos metales preciosos, un terreno tan montuoso debía producir y produce con efecto otros muchos minerales que, aunque de ménos valor, son por lo común más útiles al país que los produce y á la sociedad en general. Tales son, especialmente en la Sonora, el plomo, el cobre y el hierro, á los cuales se agregan también el talco, el alumbre, el almagre, el ocre y la caparrosa.

Aunque todo el país hasta aquí descrito se considere generalmente montuoso y estéril, hay, sin embargo, en casi todos los paralelos bastante terreno llano, ó á lo ménos ciertos valles en donde puede subsistir el hombre, sana, cómoda y felizmente. El valle de San Bartolomé, por ejemplo, el pueblo de Buenavista, la villa de Santiago de Salitre, las demás inmediatas de las Colonias Tlascaltecas, las inmensas haciendas del Marqués de San Miguel de Aguaya,y las inmediaciones del río Norte desde que se separan los méganos que con las arenas movidas por los vientos tempestuosos forman una cordillera de casi 60 leguas de extensión, son todos parajes sumamente amenos y fértiles de los

(I) En el Real del Rosario, según certificación del Intendente de la provincia, publicada en la Gaceta de Méjico de 10 de Mayo de $7_{78}$, se habían presentado en todo el año anterior 27.168 marcos de plata azogue, 5296 de fuego, que pagaron á S. M por los derechos de uno por ciento y décimo 3.377 pesos. En el propio tiempo se presentaron también 702 marcos de oro, que contribuyeron por el derecho de tres por ciento 2.244 pesos, y en Junio de 86 se presentaron 30.416 marcos de plata azogue, 6.526 de fuego y 7 I I marcos de oro.

(2) Habla de estas bolas monstruosas el Compendio del Padre Venegas, tomo III, capítulo último, y el Capitán D. Juan Bautista de Ansa se expresa en estos términos: «Esta particularidad se ha dudado, pero es "tan cierta, que viven muchos de los que las poseye"ron, de lo que puede dar igualmente documentos „que lo acreditan, como que mi padre, con dictamen "de sujetos peritos en leyes, las embargó por pare"cerle pertenecer á S. M., cuya conducta no se le apro"bó por el acuerdo de la ciudad re Méjico, pero sí "por el Consejo Real de Castilla."
Reinos de Nueva Vizcaya, Cohahuila y Santander, y no lo son ménos toda la provincia de Te. jas, las inmediaciones de Monterey, en el Nue. vo Reino de León; las de Alburquerque, en el Nuevo Méjico, y las de San Miguel de Orcasitas en la Sonora; extensión vastísima de terreno, á la cual puede también agregarse el de las inmediaciones del Gila y Colorado, y el país de los Moquis y Cosminas anteriormente descrito. En todos estos parajes se dan, como es de creer, con más ó ménos abundancia todos los frutos y semillas principales y las más útiles para la vida; pero la cosecha total de las que se cultivan es demasiado corta, porque el cebo de las minas, acarreando insensiblemente la población hacia las sierras y haciendo fijar la idea de las riquezas en las entrañas de la tierra, ha descuidado enteramente la agricultura, de modo que el objeto primario de las siembras es sólo ocurrir al sustento del corto número de los colonos, y la mayor parte de las vegas útiles de estas provincias han quedado destinadas para los ganados. Estos, sin embargo, hacen un servicio muy particular en unos parajes que, como tan distantes de las costas y de la capital, escasean de todo: la lana de las ovejas suministra el vestido; los caballos el medio preciso y único para contrarestar las invasiones de los indios enemigos; las mulas sirven para el beneficio y acarreo de los metales, y las vacas, además de ocurrir hasta cierto punto al sustento de los naturales, proporcionan un ramo muy regular de comercio con la Nueva Galicia, en donde se venden con mucha estimación el tasajo, el sebo y los cueros. Finalmente, en un corto espacio de terreno beneficiado, las uvas dan los vinos y aguardientes que pueden bastar para el alivio y recreo de estos distantes vasallos.

Limitaremos á lo expuesto el examen físico de esta parte de la Monarquía, cuya prolija descripción requiere la concurrencia de otros medios que los que hasta ahora hay, y empezaremos desde luego á examinar al hombre en estos países dilatados.

Las primeras naciones que se encuentran al Noroeste de la Sonora y en el confluente ó inmediaciones de los ríos Gila y Colorado son los Yumas. Estos habían sido visitados por el $\mathrm{Pa}$ dre Kinó y otros misioneros de la expulsa Compañía, y luégo atravesó sus rancherías con muy buen acatamiento el Padre Fr. Francisco Garcés, lo cual dió lugar á que con el mismo buen éxito las transitase después en sus dos expediciones para la California el Comandante Don Juan Bautista de Ansa, y últimamente que á instancias de los mismos naturales se planteasen dos misiones ó poblaciones en las orillas del Colorado, á poca distancia del confluente.

Los dos Diarios de D. Juan Bautista de Ansio 
y las noticias anteriores, concurren en suponer esta nación de los Yumas como muy adelantada hace tiempo en la civilización. El cacique nombrado Palma, que era el jefe principal.de esta tríbu cuando pasó Ansa por ella, manifestó en todas ocasiones un grado de autoridad grande sobre toda la comunidad; explayó su opulencia, generosidad y buena fé, regalando diferentes comestibles á la expedición, cambiando á los nuestros los caballos inútiles que llevaban custodiando una parte de las cargas del convoy que no podían seguir, y castigando al mismo tiempo con el mayor rigor á un súbdito sityo acusado de un robo. Ayudó ý se afanó para que nuestras expediciones radeasen el río con la mayor seguridad, disponiendo que todos sus súbditos concurriesen á este acto, y finalmente dió pruebas nada equírocas de un carácter noble y confiado, en la franqueza con que se determinó á entregar el mando á uno de sus parientes y subalternos para seguir al Comandante Ansa como efectivamente lo ejecutó, acompañándole hasta las fronteras de la Sonora y luégo después hasta Méjico. Las cualidades esenciales que advirtió el mismo Comandante en los demás individuos de esta nación la describe en la forma que sigue:

"Esta nación, dice, es por lo general muy ro"busta, de más de ocho palmos de talla, su genio "lo mejor que se ve en indios, pues son muy "festivos, cariñosos y liberales. Su color, no " tan negro como otros, y no son de los más ra"yados; tienen naturalmente buenas caras, pero "se hacen feroces con el embije de todo el cuerpo "y en especial la cara. Van todos los hombres "enteramente desnudos sin el más leve asomo de "rubor, y esto lis tienen por hombría, y el ir. "algo cubiertos por acción mujeril, que ellos mis"mos me lo han dicho: tienen buen pelo, que se "lo componen de muchos y diversos modos, con "lodo muy fino, sobre el que se echan un polvo "de tan buen relumbron que parece lo es de "plata, y para que este peinado no se les des"haga duermen sentados. La cara se ha dicho "ya, se pintan extremadamente de los colores "negro y colorado, y en esto se incluyen tam"bién las mujeres: llevan los hombres horada"das las orejas, el que ménos con tres agujeros, "y lo más común con cinco, y en todos ellos zar" cillos. Las narices ó ternillas también se hora"dan y atraviesan en ellas un montón de plumas "ó más generalmente un palillo de palmo de "largo, y más grueso que el mayor cañón de "aves, con lo que se acaban de hacer sobre fe"roces, espantables. A las armas y guerras pa"recen poco inclinados; raro tiene carcaj y po"cos cinco llechas malas y con peor arco, de "cuyo modo va armada la tercera parte; las otras "dos sólo llevan unas astas de cuatro varas (ins"trumentn para jugar) y unos garrotes. Son los "ancianos los que usan del arco, pero á poco " frío que haga por la mañana ó tarde, general"mente las deponen adonde quiera, y cogen unos "tizones que regularmente se los pegan á los "estómagos ó partes posteriores, para calen"tarse. Atribuyo á que tres horas que solo dor" mirán de las veinticuatro del día, es por el poco "abrigo que tienen, en especial cuando están fuera "de sus rancherías, que á lo ménos en ellas tienen "sus racalillos (chozas) en terrenos bien blan"dos en que se entierran y reunen cuantos com"ponen una familia. Su lengua es fácil para "pronunciarla y lo mismo me parece para escri"birla. Les es muy fácil una buena pronuncia"ción del castellano. Las mujeres, en la robus" te $z$ y tamaño corresponden á los hombres; sus "rostros son regulares, sin apercibirse, ni extre"madamente feas, ni especialmente hermosas; "van vestidas ó medio cubiertas de la sola cin') tura á las corbas y rodillas con unas nagüillas "que hacen de las cortezas del sauce y álamo, "divididas en dos piezas, poniéndose la más "corta por delante. Hacen de las mismas corte"zas y de la del mezquite unas piezas anchas "que salen poco ménos ásperas, aunque más "tupidas que lo que en el Reino llamamos guan. "goche bruto; éstas les sirven para taparse, y la "que las lleva puede llamarse rica, y mucho "más las que consiguen otras piezas de cueros "de nutrias, liebres ú otro animal cualquiera. "Uno y otro sexo va con el pié enteramente "descalzo. Por lo que he visto de ellos é in" formado de lo que me resta, regulo habrá 3.500 "almas de esta nación Yuma, en cuyo número "conviene también próximamente el Padre Gar"cés."

En cuanto á los ritos religiosos y á las cos. tumbres sociales de esta nación, nada puede inferirse de los Diarios citados, y sólo en una ocasión, se dice, que estando Ansa repartiendo algunos dones á un crecido número de naturales, llegó á interrumpirlos uno de ellos dando unos ayes tan lastimosos, que parecía le ocupaba la mayor aflicción y dolor. Cada uno de los circunstantes correspondía á estas demostraciones, dando también otros tres gritos $\mathrm{y}$ tentando al mis mo tiempo el hombro del paciente, y preguntando Ansa la causa de semejante escena, le respondieron que aquel recién llegado era uno de las rancherías del río de abajo, que traía la noticia de habérsele muerto su padre, y que venía en consecuencia, á convidar á todos los presentes á que fueran á llorar al tiempo que daban fuego al cuerpo del difunto, que era la especie de funeral acostumbrado entre ellos. Notó también el mismo Ansa, que no parecía mujer alguna embarazada ó parida que no demostrase más de veinticinco años de edad, é indagando la causa llegó á saber les era lícita la poligamia, y que no les 
convenían las mujeres muy jóvenes, porque no sabían trabajar.

A corta distancia de las orillas occidentales del Colorado, se encuentra otra rama de la misma nación Yuma, distinguida con el nombre de Cofak, y que frecuentemente está en guerra con aquélla, aunque usa del mismo idioma, tiene las mismas costumbres, y se halla dotada de igual afabilidad.

Su número es algo mayor que el de los Yumas, $y$ el territorio que habita ménos extendido que el de éstos, lindando al Oeste con los méganos y parajes inaccesibles de la California. En los últimos años se había cimentado la paz entre unos y otros por medio de recíprocos casamientos, y esta paz, en la cual influyó el mencionado Ansa con dones, con súplicas y áun con amenazas, fué sin duda una de las causas principales de la destrucción de nuestras misiones y poblaciones del río Colorado en $x>82$ (I) con muerte de cuatro Misioneros, ocho soldados y de algunos pobladores cuyas mujeres quedaron prisioneras y se rescataron después por una crecida cantidad de ropas.

Los indios de la provincia de la Sonora, se pueden dividir en dos naciones diferentes por los dos idiomas enteramente diversos que hablan, reduciéndolos á Pimás y Opatas. Los primeros se dividen en altos y bajos, ó septentrionales y meridionales, incluyendo los que habitan los are. nales y páramos de los Papagos al Sur del Gila, los amenos valles de Sobas, Chispurís y vegas del Gila y Colorado, comarcanos á aquéllos: á los segundos corresponden los Eudebes y Tovas.

Reducircmos también á los Seris, los Guaimas y los Hiaquis, los que habitan la medianía de la parte Oeste de la provincia, pero los Seris, igualmente que los Apaches, rayanos de la parte Norte, deben considerarse como unos enemigos crueles que la han destruído y aniquilan, de suerte que son muy pocos los Reales poblados en que se trabajan las minas y hacen muy difícil la descripción política de esta provincia, porque muda al paso que sus ventajas y desventajas.

Entre todas estas naciones, los Opatas son los más aplicados al cultivo de la tierra, y también los más änimosos para la guerra, en la cual han mostrado siempre su valor y fidelidad auxiliando á nuestras armas. Sus siembras consisten en trigo, maiz, fríjol, calabazas, sandías, melones y otras varias de que hacen sus buenas cosechas.

(I) . Tuvo lugar este desgraciado accidente un domingo después de misa, habiéndose convenido los naturales en quitar la vida á todos los de ambas misiones, que distaban tres leguas una de otra. Entre las víctimas fué comprendido el Padre Garcés, de quién hemos hablado anteriormente. Puede verse el pormenor de este acaecimiento, en la vida del venerable Fray Junipero Serra, capítulos 52 y 53
Tienen cierto miramiento hacia sus mujeres, en cuyas circunstancias se distinguen de los Apaches, pues no les cargan sino el trabajo más llevadero, del cual las exceptúan también en los últimos meses del embarazo, y entonces las aplican á hilar y tejer algodón, á guisar su posole, á hacer esquite y á tostar el maiz para el pinole.

Muy adictos á sus costumbres antiguas, no quieren admitir los telares, y siguen sus tejidos en la misma disposición que antes del conocimiento de los europeos, sin embargo de que se nota en ellos una imitación particular á cualquier modelo que se les presenta. Para la fábrica, dos mujeres disponen la tela entre cuatro estacas clavadas en el suelo, determinando con ellas la extensión de la tela, después de lo cual, por medio de varios modelos mueven la urdidura según necesitan para las labores, aprietan la trama y con gran trabajo y morosidad acaban su tejido. En lo general, ningún natural de la provincia mira con cariño ni aprecio las artes de los europeos, no obstante de que algunos se aplican á ellas. Tañen instrumentos con bastante habilidad, $y$ aprenden oficios mecánicos, como los de sastre, carpintero, herrero, cantero y albañil. Hay algunos Opatas y Eudebes que saben todos éstos, y basta en ellos la voluntad para que los aprendan con la mayor facilidad.

Puede muy bien aplicarse á los Opatas la ca racterística de sufridos, industriosos, robustos y esforzados, particularmente á la vista de los es pañoles. Nada estiman tanto como aquellos honores y distinciones que acreditan su fidelidad al servicio del Rey y su valor contra los enemigos. Si alguno se casa con mujer española, no quiere ya tratarse como natural, desdeña las ocupaciones y ministerios de sus parientes, y se considera como de clase superior; lo propio sucede á las mujeres cuando casan con españoles. Unos y otros afectan nuestro traje y tratamiento y se manifiestan muy deseosos de aprender el idioma; pero el poco cuidado con que se han tratado, es causa de que aún mantengan la práctica de algunos abusos y costumbres antiguas. Sus bailes son muy bárbaros, y se acompañan del ronco ruído de una calabaza; las canciones consisten en una repetición de pocas voces, sin expresión, cadencia ni harmonía, de tal modo, que en esta parte no se diferencian de los Apaches sino en que los Opatas tienen algunos bailes de religión, que conservan todavía después de más de siglo y medio de sujeción voluntaria. Los más de sus juegos y diversiones se dirigen á ejercitar las fuerzas, la ligereza y el arco, en cuyo último ejercicio son bastante diestros, y tan aficionados á él, que áun cuando vuelven cansados del trabajo, se les ve en el camino tirar al blanco.

Los Eudebes se deben considerar bajo el mismo aspecto que los Opatas, aunque están más 
atrasados que éstos en la imitación de los europeos, y se acercan también más á sus costumbres y usos antiguos. Pero aún más zafios y agrestes que todos son los Tobas, especialmente los que no quieren reducirse á vivir en poblaciones que son la mayor parte, excepto los de Ponidá, Teoxarí y Mochopon. Viven en los campos y se mantienen de raices, yerbas y frutas silvestres, reduciendo sus siembras á tal cual mata de maiz y' á algunas calabazas y sandias. Su principal ocupación es la de hacer esteras (hipel), de las muchas y buenas palmas que se encuentran en su territorio y las llevan á los pueblos opatas para cambiarlas por semillas ó ropas. No atentan contra las vidas ni contra las haciendas, y sólo son bravos y valientes con los Apaches, á los cuales tienen un odio mortal.

Todos estos naturales tocan las puntas de las Hechas con veneno, y para curar las heridas chupan la sangre de ellas, por cuya causa muchas veces sigue á la.muerte de los heridos la de los curanderos.

Las poblaciones de los Opatas son Natora, Aritberí, Bacanora, Tonitci, Soyopa, Nacorí, Alamos, parte de Ures, Nacamerí, Opodepe, Cucuspe, Arispe, Chimaya, Bacoatzú, Curguiaratai y Babispe.

Los Pimás forman en sí una nación muy crecida: los que se denominan bajos habitan los pueblos de Taraitzí, Cumuripa, Onapa, Nuri, Moboes, Onabas, Suaquí, San José de Pimás, Santa Rosalía, Ures y Nacamerí. Hacia el Poniente hacen frontera contra los Seris, y ellos son los primeros que recibieron la fé en esta provincia, pero no están tan adelantados en ella como los Opatas, porque les falta la docilidad que éstos tienen, y tampoco los imitan en la lealtad á nuestro Soberano.

Los Pimás altos ocupan todo el terreno que hay desde Cucarpe á Santa Ana, Caborca, Dolores, Remedios, Cocospera, el presidio de Terrenate, las orillas del río de San Pedro, lo que media desde éste hasta su unión con el Gila, las dos orillas de éste hasta que se une con el Colorado, y áun la de éste hasta su desembocadura en el golfo, pero en estos trechos hay muchos espacios despoblados y varias marismas que por la falta de agua son incapaces de poblarse. Se pueden considerar los Pimás altos, divididos en cuatro parcialidades que son los reducidos á pueblos; los Papagos, los Sobaípuris y los Gilas. También se pueden llamar Pimás altos los Opas, Comaricopas, Hudcoadnes, Yu mas, Cuhuanas, Quiquimas y otros más allá del río Colorado, por ser todas estas naciones que usan de un idioma bastante semejante. Estos Pimás están aún más atrasados que los otros en la fé.

Los l'imás son en general muy inferiores en el valor á los Opatas, y sólo su número suele á veces infundirles osadía.

Las armas que emplean son el arco, la flecha y una macana ó porra de un palo muy pesado y duro con que tiran á la cabeza de sus enemigos. Los más aguerridos de los Pimás altos son los Sobaípuris fronterizos de los Apaches y encarnecidos contra ellos, pero se van retirando hacia el Sur y guareciéndose á los pueblos de Santa María Joamea, San Javier del Bacoy, Tueson y Senoytac, abandonando su ameno valle á los enemigos.

La nación de los Seris, aunque la más corta, es, sin embargo, la más cruel é indómita de todas; y aunque algunos se redujeron á vivir en las poblaciones del Pópulo, Nacamerí y los Angeles, más fué por servir de espías que con intento de continuar en la fidelidad; de lo cual se seguía que los asaltos y daños de los demás eran más ciertos y seguros. Estos indios untan sus flechas con un veneno que hace la herida mortal, por leve que sea; y tan eficaz, que acaba las más veces la vida del herido á las veinticuatro horas. Cuando se ven persegùidos acostumbran refugiarse á los cerros, que les proporcionan en sus cortaduras y picachos una defensa natural incontrastable, y á la Isla del Tiburón y sus inmediaciones en el golfo.

Aunque los Apaches viven al Norte y fuera de los límites que hemos asignado á la provincia, se hace preciso tratar de ellos en este lugar, por la inmediación que tienen con ella, y porque son la causa de su decadencia y destrucción; pues con sus contínuas correrías asolan y destruyen los trabajos, hurtan los ganados y matan los habitantes. Son muchas las minas que han obligado á abandonar cuando su estado prometía el premio de los trabajos del minero; y aunque hay presidios establecidos que sirven de barrera para contenerlos, como la extensión del país es tanta, no es posible impedir del todo sus correrías.

Estos indios andan por la mayor parte errantes, según se les presentan las cosechas naturales de las tunas, dátiles, mescales y otras frutas y raices que les sirven de sustento. Las mujeres llevan el trabajo de las cortas siembras que hacen de maiz, y curten las gamuzas de los caballos, venados y otras que emplean para vestido. Este se reduce en los hombres á un coleto que les baja hasta más abajo de la cintura, á una especie de calzones y á los zapatos, pues todos desde cliquitos andan calzados. El de las mujeres consiste en unos mantelitos ajustados al cuello; pero tan cortos, que apenas llegan á cubrirles los pechos, y además unas enaguas que no les bajan de las rodillas. Son muy ágiles y buenas jinetes.

No se encuentra entre estos indios señales de 
idolatria; sólo sí algunos usos supersticiosos: hoy día temen particularmente al diablo, y le nombran con la misma escrupulosidad que nosotros, pero esta parece idea que han recibido despues de nuestro reconocimiento. Los que 1ogran entre ellos conceptuarse de hechiceros, consiguen el mayor respeto y ventaja, apoderándose también del lucroso oficio de curanderos. Este arte tiene por principal objeto, curar las heridas que reciben en la guerra, lo que ejecutan con el preparativo de chuparlas, y aplicar después algunos bálsamos salutíferos con algodón, el cual penetra hasta 10 interior de las heridas, cuya cura se repite cada día. Las borracheras no son tan frecuentes en esta nación como entre las demás, y la bebida que usan la hacen de maiz, mescal, trigo, tunas y sauco, siendo la más fuerte la de este último. Las ceremonias de las bodas entre los que no han abrazado la $\mathrm{Re}$ ligión Católica, se hacen formando una fila de mancebos y otra de mujeres, $y$ corriendo éstas con alguna delantera, las siguen aquéllos hasta alcanzarlas, asiéndoles del pecho izquierdo; después de aquella ceremonia se restituyen al para je de la junta y se ponen á danzar, habiendo preparado de antemano dos esteras para cada matrimonio: éstos se acuestan y los demás continuan toda la noche en sus danzas, festejando á los novios.

El ejercicio que estos naturales miran como de más honor es el de las armas, y el alistarse entre el número de sus soldados les cuesta un estrecho noviciado y las pruebas más rigurosas. Tienen que tolerar con la mayor entereza que les rasguen muchas partes del cuerpo, y manifestarse tan insensibles al frío como al calor y á la lluvia, para lo cual se les hace pasar por muchas pruebas. De este modo y no de otro consiguen el honroso título de soldados, y se destinan á defender la patria contra sus enemigos, precedien do en estos casos una especie de arenga ó sermón del Capitán, que les recuerda y encarga el cumplimiento de su obligación. Cuando salen á campaña, el mayor trofeo con que á la vuelta acredit :n su gloria es traer las cabelleras de sus enemigos, y áun algunos se extienden hasta cortarles pedazos considerables; si vuelven vencidos entran de noche en sus pueblos, pero cuando alcanzan los trofeos de la victoria, se ejecuta esta entrada con toda ceremonia en el discurso del día, después de haber avisado anticipadamente para que salgan á recibirlos; entonces cada caudillo lleva una anciana que toma el trofeo, en el cual ejercitan sus iras, y á éstas siguen las celebridades de las lanzas y festejos.

No consideran estos indios que las necesidades corporales de la vida finalizan con la muerte, pues entierran á los muertos con cuanto pueden proporcionarles de sustento y ropa, echándolo todo en un hoyo, y áun las madres continúan regando por algunos días el de los párvulos, con la leche que extraen de sus pechos. Hay con todo, en esto, alguna diferencia entre las diversas clases de Apaches, pues otros dejan los cuerpos en el paraje en que acabaron la vida á ménos que sea en terreno enemigo, en cuyo caso se obstinan en retirarlos divididos en cuartos cuando no pueden conseguirlos enteros, aunque sea á costa de todo riesgo.

Parece muy propio de este lugar agregar la descripción de los Apaches quc nos ha dejado con su acostumbrada maestría el redactor de la Historia del Padre Venegas, y cuyas circunstan. cias las hemos rectificado nosotros mismos, por varios sujetos que se mencionarán luégo. "El "nombre de Apache se da ya también comunmen"te á todo gentil, apóstata, belicoso y enemigo, "siendo sin embargo los Apaches de que aquí se "trata los comprendidos en aquel tramo de tie" rra casi circular que comenzando desde el río "Chiguagua, y cruzando hacia el Presidio de Tanos, fronteras y Terrenate, llega al río Gila, y "subiendo al Norte hasta el Moqui y Nuevo Mé"jico, revuelve al Oriente al presidio del Paso "y remata hacia el Sur en el Real de Chigua"gua (I). En este terreno y vuelta de 300 le"guas, viven los Apaches en sus rancherías pe"queñas situadas entre valles y quebradas de " sierras difíciles de penetrarse por su aspereza y " escasez de agua.

"Por algunos prisioneros rescatados, se sabe "su barbarie y rusticidad, sus cortas siembras y "frutos, el mal tratamiento que sufren de ellos "los que caen en sus manos, y que hay entre "ellos algunos apóstatas. Viven desnuđos, pero "hacen sus entradas en caballos robados, sin si"llas y con solas unas pieles en que corren lige"rísimamente; de las mismas pieles hacen botines "y zapatos de una pieza, que sirven de rastros en "su huída. Acometen con tal gritería y algazara "que asusta de muy lejos; su valor no es grande "pero le hacen sus buenos sucesos; son alevosos "en el modo de guerrear; vencidos se humillan, " pero no guardan fé alguna en sus tratos; sus ar""mas son las comunes de arco y flecha (2). El mo"tivo de sus entradas es el robo, especialmente de "caballada, no sólo para montar sino para comer, "porque esta carne es su mayor regalo; de esto "nace ser hediondos en tal grado, que sienten y se "retienen de su mal olor nuestras mulas."

A las noticias anteriores añadiremos las que

(I) La voz de Apache se ha extendido tanto en el idioma de Nueva España, que hemos oído llamar asi áun á los Lipanes, Navajos y Natujes que infestan como antes digimos, la parte oriental del Nuevo Méjico.

(2) En el día hacen ya uso con bastante frecuencia de las armas de fuego. 
contiene el Padre Mífphi en su historia manuscrita de la provincia de Tejas, igualmente que la de diferentes misioneros; luces bien instructivas nos han comunicado sobre este punto importante los Coroneles D. José Rengel y Don Antonio Bonilla, Oficiales empleados por mucho tiempo en las provincias internas. Hé aquí lo que de ellos resulta:

"El indio goza generalmente de un temperamento sano, por la dureza en que se cría y la simplicidad de los manjares que le sirven de alimento: nace y vive en la inclemencia, $\tan$ insensible al frío como al calor; pues su cutis tostado le sirve de tanto abrigo como á nosotros los tejidos más compactos. Su alimento es invariable; pues su única y contínua subsistencia la deben á las frutas y carne asada, y de esta uniformiclad de principios y el incesante ejercicio de la cazá y de la guerra ponde la robuste $z$ de que ordinariamente goza.

"Los Apaches tienen una especie de creencia que puede llamarse dogma, aunque informe y sin arreglo. Titulan Capitín grande, á una primera causa que conocen, y aseguran que hay destino en la otra vida para el bueno y para el malo; pero limitan sus premios y castigos al placer ó al disgusto de oir cantar en la tierra sus acciones. Suponen que estos distintivos existen en el aire, y así, los que viven, tienen la obligación de formar una especie de canciones que rezan todos los días como oficio de difuntos; sólo son dignos de esta gioria el guerrero valiente y la esposa fiel; estas dos virtudes, que son las mayores que conocen, excluyen de toda felicidad á los que carecen de ellas, condenando á un eterno desconsuelo la cobardía y el adulterio. El solo fundamento de esta creencia guerrera bastaría para hacerlos terribles en el combate áun cuando su vida frugal y activa no fortificase sus espíritus.

"La poligamia es el uso tavorito de estas gentes, sin otro límite que el antojo; pero el demasiado trabajo á que destinan las mujeres hace ventajoso el tener muchas. Las de los hermanos se heredan tengan ó no hijos, y la afinidad no es un impedimento para el matrimonio; pero sí lo es grande la consanguinidad, que evitan escrupulosamente. Las esposas sólo se miran como unos libres instrumentos del placer para quienes no se dedican atenciones ni cuidados; las truecan ó cambalachan con grande facilidad, dando ó poniendo un ribcte, según las reconocen útiles. Finalmente, las prestan, las alquilan o las venden por un caballo, un fusil ó por cualquiera bujería.

"La ligereza es una de las propiedades características, y la que les es mis ventajosa, y que $\sin$ duda lian adquirido por la necesidad de perseguir la caza á pié antes de que tuviesen caballos, y yue hoy día la ejercitán en juegos y ejer- cicios cotidianos. Como sin ganados, sin siembras y sin cultivo no es posible que la caza baste para el sustento áun más frugal, y ménos para satisfacer los antojos, y como por esta parte estos indios carecen de caballos y de mulas, que son su delicioso alimento, desean municiones y escopetas para la guerra y la caza, y todo esto lo hallan en los españoles: este es el orígen de sus contínuas guerras.

"Cuando emprenden la campaña, si es con la idea única de robar, juntan pequeñas partidas, y si tienen por objeto destruir los pueblos, unen entónces muchas rancherías; pero en todas ocasiones es uno mismo el modo de conducirse y grandes sus precauciones. Unidas las tropas se nombra entre ellas un Jefe, sin distinción de clases, sin intrigas y sin cohecho: la causa pública preside en esta elección y siem pre decide por el más apto. Su autoriclad en campaña se extiende hasta poder quitar la vida á sus súbditos; pero queda de soldado independiente con ellos cuando se deshace el campo. Cada soldado trae su caballo sin más arneses que un fuste muy ligero, y preservan los cascos con una funda de cuero, que quitan con prontitud cuando llega el caso de montar, lo que sólo verifican el día de la acción.

"Tienen en las marchas grandísimas precauciones. Observan cuidadosamente los caminos, y si descubren algún animal que huye, por el cual seguían, mudan al momento de dirección, ó investigan la causa de aquella fuga si se dirigía hacia ellos. Marchan desunidos, pero á la vista unos de otros para evitar la polvareda y la huella; se cubren con ramajes para no ser vistos de lejos; reparten centinelas en las copas de los árboles; destacan exploradores por muchas leguas en contorno; duermen poco y siempre desconfiados; se alarman al menor aviso; la mayor parte velan mientras descansan los restantes, y contínuamente exhortan la vigilancia. Las noticias interesantes que ocurren en la provincia, se comunican por humos en que saben distinguir el que los convoca, el que les manda huir ó les intima algún cuidado; de suerte, que en un momento corre la alarma por todas las rancherías. Las ideas del valor consisten en el mayor sufrimiento; saber resistir las inclcmencias sin abrigo; despojarse de las pieles cuando hacen grandes fríos, y áun revolcarse en el hielo, son otras tantas pruebas que acreditan á un guerrero. Se asegura en las provincias que los costeños llevan consigo una yerba vulneraria con que detienen la sangre de las heridas; y de los Apaches se dice que tienen un palito detrás de la oreja, cuya virtud los hace incansables. De estos fenómenos sólo consta la tradición entre las tropas; pero acaso son nuestras malas punterias y su habituado ejercicio. este palo y aquella yerba.

"Con el precavido silencio que dejamos indi- 
cado, se dirigen á nuestras poblaciones, duplicando las astucias á medida que se acercan para asegurar el golpe. Acechan desde las alturas nuestros pueblos, haciendas y caballadas, y por la noche bajan á reconocerlas. Para este acto dejan los caballos á alguna distancia y marchan los más ligeros por parajes diferentes, para acercarse cuanto puedan. En este último reconocimiento son admirables las tretas de que se valen para lograrlo: con el cuierpo cubierto de lodo y la cabeza de ramas, dé modo que no presentan más objeto que el de un pequeño matorral, van arrastrando por el sueloy llegan al destacamento hasta contar los soldados, y en tan silenciosa espía se comunican, sin embargo, lo que observan con el canto de varias aves nocturnas y animales que imitan perfectamente. Espiado bien el paraje, quitan los cueros de los cascos de los caballos, y marchan con gran silencio hasta la precisa distancia á que consideran pueden ser sentidos, y embisten con ímpetu y algazara, sin dejar tiempo de que se acuda á las armas ni de ponerse en defensa. Esta refinada astucia, incapaz de precaverse, casi siempre acierta el golpe. Con los cautivos son crueles, y las más veces les privan de la vida con mil suertes de tormentos y crueldades; gustan de disfrutar nuestras mujercs, y no perdonan medio para hacerlas más insufrible aquel tormento. Este corto rasgo de la conducta de dichos indios en campaña, basta para dar á conocer lo inevitable de sus golpes, para cuyo buen éxito tienen la constancia de espiar meses enteros."

Con los Apaches occidentales rayan hacia el Norte los Cosminas y Moquis, á los cuales siguen los Yutas, visitados por los Padres Vélez y Escalante, y últimamente en cuanto alcanzan nuestras noticias, los Cumanches, Yamparicas, que deben darse la mano con los pueblos más occidentales de Carver.

Los Cosminas y Moquis, como ya se insinuó, fueron reducidos en el siglo pasado á la religión y al dominio español; pero diferentes causas accidentales contribuyeron dcspués á que hacia el año de 1680 sacudieran ambos frenos al mismo tiempo que los pueblos aboríjenes del Nuevo Méjico. Y aunque estos últimos admitieron de nuevo la predicación evangélica al principio de este siglo, aquéllos prefirieron su nuevo estado, y haciendo una especie de confederación han disfrutado desde entonces sus vegas excelentes, abandonando la vida errante para gozar pacíficamente del fruto de sus siembras y pastos á cuyos artículos han agregado también algunas manufacturas bastas de lana para ocurrir á su propio abrigo, y para establecer un mediano comercio con los pueblos más meridionales. Son, por consiguiente, unos vecinos pacíficos, y áun útiles siempre que se abandone de nuestra parte la idea de conquistarlos. Los Padres Vélez y Escalante, y áun el Padre Fray Francisco Garcés que les había precedido dos años antes, hallaron 'efectivamente entre los Moquis, mucha mayor hospitalidad y un sistema más bien entablado de 10 que podía imaginarse. Al principio los recibieron en el pueblo de Uribi con alguna sospecha hasta examinar sus fuerzas, su conducta y sus intenciones; mas luego con dignidad y atención les franquearon alojamiento, les vendieron los comestibles necesarios, ratificaron la amistad antigua, y cl cacique advirtió á los pueblos inmediatos que asistiesen con amor á los viajeros. Con efecto, asílo verificaron todos los demás caciques por cuyas jurisdicciones transitaron, pero siempre con cautela, por temor de que los Misioneros manifestasen sus ideas y propuestas para una nueva conversión. Sin embargo, tuvo esto lugar por medio de un anciano apóstata de las misiones de Santa Fé, el cual dió á entender la necesidad en que estaban aquellos naturales de un socorro de nuestros presidios contra los Apachesnabajos, cuyas últimas correrías les habían causado daños*considerables. No malograron, como es de suponer, nuestros Misioneros estas circunstancias tan favorables para proponerles una nueva sumisión á la Monarquía, y que se les auxiliaría con todos los medios necesarios para vengarse de sus enemigos. Juntáronse los magnates de éste y de los pueblos inmediatos en la mañana siguiente para deliberar sobre un punto de tanta importancia, y habiendo llamado á los Misioneros á la estufa de la asamblea (I), les respondieron, finalmente, que aunque deseaban algún auxilio para contener las irrupciones enemigas, y que sabrían corresponder á cste beneficio con una amistad constante, lo sacrificaban todo de buena gana y sufrirían gustosos nuevas invasiones, más bien que hacerse cristianos y entregarse al dominio nacional. Las arengas de la asamblea tenían á la sazón el semblante más solemne, empezaban á hablar los de mayor autoridad, y á éstos seguían los demás por el orden de ésta, y aunque cada.uno hablaba, la arenga parccía más bicn un diálogo, pues concluía su discurso ha. ciendo varias preguntas á los demás, quienes respondian asintiendo, ó negando respectivamente, conforme á la calidad de las preguntas. En estos discursos referían las tradiciones de sus antepasados, y se exhortaban recíprocamente á su observancia, de lo cual resultó, como era natural, una total repulsa de las proposiciones hechas de nuestra parte.

El mismo viaje de los Padres Vélez y Escalante, nos suministra también algunas ideas aunque escasas de los pueblos que habitan al Norte

(I) No individualiza el Diario las circunstancias de la estufa, y si era parecida á las de Monterey ó Nueva España, que hemos descrito. 
de los paralelos de $36^{n}$, adonde pueden conside larse acaban los Moquis, Cosminas y Apaches. Son aquéllos en muy corto número, y están reducidos á la nación ó idioma Yuta, la cual vive aún errante, valiéndose de las semillas, de las tunas, de la caza y del pescado para su alimento. Sólo tres fueron las rancherías algo numerosas que encontraron en esta exploración. Los Yutas Lagunas se presentaron por los $38^{\circ} 30^{\prime}$ en número hasta de 80 guerreros, bien montados á caballo y con otros de remuda, algunos de los cuales cambiaron con las caballerías cansadas de nuestros exploradores. Son estos indios afables, cariñosos, subordinados á sus Jefes y dispuestos á suministrar guías y á cumplir con sus contratos, cuya puntualidad arengaron á la tríbu, el Jefe principal que era jóven y casado con dos mujeres, según dijo, y otro Jefe subalterno más anciano. Advirtieron en el camino en un pedrusco bien notable señaladas con pinturas toscas, tres adargas ó chimales, una hoja de lanza y dos hombres peleando. Las comidas más comunes de estos indios, son el cíbolo y el cuervo, los capulines, garambuyos, limitas y algún piñón del mismo año, advirtiéndose en cuanto al garambuyo, que si bien en la mata es sumamente agrio, después de muy asoleado, como lo usan, resulta de un agridulce muy gustoso. Estos pueblos están en contínuas discordias con los Cumanches Yamparicas, situados al Nordeste de éstos, que son mucho más feroces y están también acostumbrados al uso del caballo.

A estos indios siguen hacia el Noroeste, y en los $4 \mathrm{I}^{\circ}$ largos de latitud, sobre las lagunas y río de San Buenarentura, los Tímpanogotzis, otra rama de los Yutas, los cuales parecen reunir afabilidad y mansedumbre de los otros, un semblante más varonil y una subordinación mayor. Vendieron á nuestros exploradores algún pescado seco, los recibieron, alojaron y despidieron con el mayor cariño y ternura, y habiéndose juntado el Capitán mayor, otros dos inferiores, varios ancianos y los súbditos de ambos sexos, determinaron unánimes afianzar con una señal auténtica sus aseguraciones de que deseaban un establecimiento nuestro en sus tierras. Consistía esta señal en una pieza de gamuza, en la cual estaban toscamente representadas con tierra y almagre cuatro figuras de hombres, alusivas, según dijeron, la más roja ó ensangrentada, al Capitán mayor Tururianchí, porque en las batallas con los Cumanches había recibido más heridas; las otras dos que no estaban tan ensangrentadas, representaban á otros dos jefes subalternos, y la cuarta, que no tenía sangre alguna, al hermano del Capitán mayor llamado Picuchi, el cual, aunque no era Capitán de guerra, tenía, sin embargo, bastante autoridad sobre los demás.
El número de estos naturales es bastante reducido; tienen buena fisonomía, y los más son cerrados de barba; llevan todos por vestido un sayo de gamuza y botas largas de lo mismo, usando además para el frío, fresadas de pieles de liebres y conejos. Alojan en unas chozas ó racalillos hechos de mimbre, de cuya materia forman también curiosos cuévanos y otros útiles necesarios. Finalmente, para evadir los encuentros con los Cumanches, prefieren para el alimento la pesca en la laguna á la caza del cíbolo, y con efecto, no pudieron vender en la expedición otros comestibles que pescado seco.

En las orillas de la laguna mayor y más septentrional, cuyas aguas son extremadamente nocivas y saladas, habita la nación Puacuanque ó hechicera, la cual habla el mismo idioma que los Cumanches del Este, y aunque no son enemigos, hay en el día alguna frialdad entre unos y otros á causa de una muerte acaecida algunos años antes. Esta nación se alimenta con yerbas, es bastante numerosa y vive repartida en chozas.

Aunque sumamente reducida, no merece ménos la atención de un curioso, la tercera tríbu ó nación que encontraron nuestros exploradores en este viaje, y la llamaron de los Barbones. Habita por $\operatorname{los} 39^{\circ} 4^{\prime}$ de latitud, casi al Sur de los Timpanogotzis, igualmente dócil, afable y pacífica que las anteriores, cobijada con fresadas de pieles de conejo y liebre, y con la barba tan cerrada y larga, que parecen Belemitas ó Capuchinos (I). Tienen la ternilla de la nariz agujereada y en el agujero traen por canalete, atravesado un hueso pequeño y pulido de ciervo, gallina ú otro animal. En la fisonomía se parecen á los españoles más que á los demás indios hasta ahora conocidos en esta. América, y esto tal vez dió lugar á algunas noticias antiguas fabulosas, equivocando al río Colorado con el que llaman río del Tizón. Entre las últimas naciones que acabamos de mencionar y los Cosminas, no existen sino pocas familias dispersas, particularmente hacia los $3^{6^{\circ}} 30^{\prime}$, distinguidas con el nombre de Yubunica ris, los que no usan la siembra de maiz y se alimentan sólo de las semillas y caza; pero éstas deben ser muy abundantes si hemos de juzgar por los comestibles que vendieron á nuestros viajeros, de carnero silvestre, tuna en torta $y$ en masa y zurrones de semillas de diferentes yerbas. Estos naturales están aliados con los Apaches mescaleros, y en la ocasión de visitarlos los mencionados Padres, había entre ellos uno de estos Apaches en calidad de huésped, el cual fácilmente se distinguía de los demás por su fisonomía poco agraciada y simpática, por el disgusto con que miraba á los españoles, y por un

(1) Esta es la expresión a la letra del Diario original. 
cierto ánimo y descoco del cual procuraba hacer alarde á la vista de los demás. Ignoramos cuáles sean los ritos y ceremonias religiosas de estos naturales, pues aunque una extraña casualidad proporcionó el medio oportuno de investigarlos, el horror con que miran nuestros Misioneros todas estas prácticas supersticiosas, nos priva del placer de publicarlas. Aconteció aquella casualidad á uno de los exploradores, el cual, habiendo - entrado en una choza en donde había algunos naturales de ambos sexos, se fingió enfermo, é inmediatamente el más anciano de los concurrentes se puso á curarle con diferentes cantos y ceremonias. Pero al llegar los Padres á esta parte de su Diario, declaman altamente contra este hecho, que reprendieron ágriamente al supuesto enfermo, y con este motivo omiten el describirnos aquellos cantos y ceremonias.

Hasta aquí, pues, se extienden nuestros conocimientos del día sobre el número y calidad de las naciones que habitan esta parte de los dominios nacionales, y se comprende entre los $30 \mathrm{y}$ $43^{\circ}$ de latitud y en los $20^{\circ}$ próximamente de longitud, ó lo que es lo mismo, desde las orillas del mar Pacífico hasta los meridianos de Santa Fé: recorramos ahora, aunque brevemente, las que desde este propio meridiano siguen al Este por los mismos paralelos.

En lo antiguo, las montañas y arenales del Nuevo Méjico dividían de los Apaches á los Keres, Tiguas, Piras, Jumos y Mansos, los cuales, aunque unidos con los Moquis y Cosminas, contribuyeron á la expulsión sangrienta de los españoles en el siglo pasado, volvieron no obstantéa escuchar de nuestros Misioneros los halagos de la religión y de la sociedad, y se redujeron á vivir reunidos bajo la dirección de los Franciscanos, parte en las amenas orillas del río Norte, á poca distancia del fuerte del Pilar, y parte en la villa de Alburquerque é inmediaciones de Santa Fé. Son estos naturales bastante humanos, y muy inclinados á la agricultura, pero se hallan contiguos al Norte los Cumanches y más al Este los Lipanes y Natajes, dos naciones sumamente feroces, y por costumbre ó por codicia enemigas nuestras, y que anidan entre las sierras ásperas de Cohahuila ó vagan por el país al Este de los Yutas.

De las eostumbres de estos naturales só]o sabemos, además de lo que se ha dicho ya, que hacia el presidio de San Sabá (I), los Lipanes dieron algunas esperanzas de civilización, aunque se malograron; que el cebo de todos ellos es particularmente el robo de nuestras caballadas; que los Mansos del Nuevo Méjico se ausentaron al tiempo de la segunda conquista, y que

(i) Pertenece á la provincia de Cohahuila y es de presumir esté abandonado en el dia. lo mismo han hecho después por los montes de Cerro Gordo los indios Pames que fueron reducidos á poblaciones por D. José Escandón, Marqués de Cerro Gordo, y que gobernaron é hicieron felices los Padres Franciscanos (I) coadyuvando con la mayor actividad y buen éxito, á las medidas de aquel vasallo exclarecido que emprendió á su costa esta conquista y la concluyó felizmente sin muchos sacrificios del Erario (2).

La Nación Cumanche se compone de 5.000 hombres de armas con corta diferencia, dividida en cinco tríbus de nombres diferentes. Es muy superior á las demás por el número de sus gentes, la extensión del terreno que ocupa, la honestidad en el traje, su hospitalidad con todos los que visitan, su humanidad con los cautivos que no son Apaches; y finalmente, por el valor que es admirable áun en las mujeres; pero su vida errante los hace malos, y es el mayor obstáculo que hay para su reducción, pues miran con fastidio la vida sedentaria, y aborreciendo las fatigas del cultivo, la necesidad de subsistir los obliga al robo: sin embargo, son generosos con lo que poseen y tan arrogantes, que uno solo arrostrará contra un ejército como no pueda verificar su fuga sin testigo.

Continuando al Este de la provincia de Cohahuila, y atravesando las provincias de Tejas, el Nuevo Reino de León y Nuevo Santander, hasta llegar á las tierras inundadas por el golfo de Méjico y el río Mississipí, el número de los indios disminuye considerablemente, y sus cualidades son tales, que si bien reducidos no nos pu-

(I) Sobre la muerte dada por los Cumanches á dos Misioneros y un soldado, sobre lo hecho en las misiones de los Pames de Cerro Gordo, pueden leerse por extenso los primeros capítulos de la vida del venerable Fr. Junípero Serra. Allí se individualiza también el ídolo C'achín, de los Pames, que era una cara perfecta de mujer, fabricada de tecale, que tenían en lo más alto de una encumbrada sierra en una casa como adoratorio ó capilla, á la que se subía por una escalera de piedra labrada, por cuyos lados y en el plan de arriba había algunos sepulcros de los principales que antes de morir habían pedido que los enterrasen en aquel sitio. La voz Cachum significa Madre del Sol. Había un sacerdote al cual acudian para que pidiese remedio en las necesidades de agua para las siembras, de salud en sus enfermedades, de felicidad en sus viajes y guerras, y de una acertada elección de mujer. Para lo úl timo se presentaban delante del anciano sacerdote con un pliego de papel en blanco por no saber leer ni escribir, el cual servía como de representación. De estos papeles se hallaron canastos 1lenos, juntos con muchísimos idolillos que se dieron al fuego.

(2) Era D. José Esc.andón Coronel del regimiento de Querétaros, cuando empezó la pacificación de este país el año I 748, estableciendo á su costa 26 misiones; visitó y reconoció el país en cuatro entradas generales, y últimamente, protejido por la superioridad, fundó en $x 755,20$ poblaciones con 1.245 familias, por cuyos servicios y otros méritos le condecoró el Rey con la merced de hábito de Santiago y título de Conde de Cerro Gordo. 
dieran acarrear la menor utilidad, estando por su lugar nos incomodan mucho. Infestan á veces las inmediaciones de Béjar, capital de Tejas, colonia española á la cual se han reunido después unos 800 indios de castas diferentes. Han hecho inútiles nuestros fuertes y misiones de los Ayseses, Nacodeches y Adaeses inmediatas al Mississipí, y particularmente los Pelones hacen muy peligroso el tránsito y difícil la subsistencia en las inmediaciones de Monterey en el Nuevo Santander. Finalmente, si hemos de creer como parece bien averiguado, que los Cumanches adquirían de los franceses del Mississipí las armas de fuego con que nos hostilizaban, no cabe ya duda en que son estos mismos los que extienden sus correrias hasta las orillas occidentales de aquel río; y por consiguiente, están fronterizos á los Kentukis, y que rayan por el Sur con las naciones visitadas por el Capitán Carver hacia los desagüies del Misouri ó del Ohío.

Hay otra nación conocida por el nombre de Norteños, muy numerosa y que habita al Norte de la provincia de Tejas, á la cual pueden aplicarse con mucha exactitud las mismas cualidades con que los anglo-americanos han caracterizado las naciones sus vecinas.

Un odio irreconciliable y antiguo existe entre éstos y los Apaches: regularmente no se encuentran sino para reñir, y muchas veces nos han avisado en las fronteras de Tejas de las traiciones que aquéllos meditaban, y que poco creídas, nos han costado en ocasiones crecidos sacrificios. Han deseado siempre comerciar con nosotros, y han mirado como pasajeras las discordias ocurridas. Finalmente, á juzgar por las diferentes muestras que han dado lugar á conocerlos, se inclinan más á la nación española que á las demás europeas, dueñas poco hace de la Nueva Orleans y de las Floridas.

Nada, dice el Padre Murphi, dará más á conocer el carácter heróico de esta nación, como el suceso de D. Antonio Treviño. Caminando este Oficial (I) con una pequeña escolta, fué asaltado de muchos Tavaoyases (una tríbu de los mismos Norteños). Desamparado de los suyos y muerto el caballo, se respaldó con un árbol, y escudado con su espada, sostuvo solo el combate por largo tiempo; pero el generoso caudillo de aquella empresa, á quien agradó su esfuerzo, hizo suspender las armas y reconvino á Treviño con su triste situación, pidiendo que se rindiese á los que le trataŕan como á su mayor amigo. Vencido en fuerza de sus heridas, fué el primer cuidado de los indios el contenerle la sangre $y^{\circ}$ conducirlo en hombros con gran cuidado al pueblo de San Teodoro, donde sc le destinó casa, quien le sirviese y mujer para su convalecencia. Esta fué larga y temible por falta de medicinas, pero llegó á conseguirse, y él ganó su confianza hasta admitirle en sus juntas reservadas como si fuese uno de ellos. Pero tan repetidas finẹas no hicieron olvidar á Treviño su religión, patria y familia; se sostuvo casi dos años, y al cabo cayó en una languidez que publicó su disgusto. Solicitado por los Tavaoyases, venció su flaqueza con declararles la causa; ellos admiraron su constancia, y declarándole que jamás había sido prisionero y que si le detenían era por creerle gustoso, le dieron su libertad proveyéndole de caballos y compañía hasta Béjar, donde le dejaron con grandes muestras de sentimiento, y la precisa palabra de que había de visitarlos, ya que ellos no podían hacerlo por la guerra que mantenían declarada. Así me lo refirió Treviño en el presidio de Béjar. lo contesta el Barón de Riperdá que le comisionó algunas veces, y 10 confirma D. Atanasio Desmesier, que fué testigo de las demostraciones de los indios y de su noble carácter.

La población total de las provincias internas, deducidos los Aboríjenes, Opatas, Pimás bajos, Keres, Pimás, Sumos, Pames y Tejas, está reducida á un corto número de colonos, y á otro crecido de soldados que guarnecen los presidios esparcidos en esta vasta extensión de fronteras. Las poblaciones, aunque no de gran extensión ni hermosura, tienen la suficiente para los objetos á que se destinan, y á fin de no cansar al lector con una explicación prolija de cada una de por sí ó álo ménos de las capitales, daremos aquí una descripción del pueblo de Arispe, destinado por S. M. para capital de las provincias internas y del modo con que se maneja en cuanto á los indios su Gobierno civil y militar, y esto bastará para deducir por ella con muy corta variedad, la disposición y gobierno de los demás pueblos de su especie.

La población de la misión de Arispe ocupa en su cabecera un terreno de $75^{\circ}$ varas castellanas de largo, sobre 400 de ancho, en la orilla occidental del río de Gondrá y en la pendiente de un cerro de piedra arenisca, que se levanta I 50 piés sobre el nivel del río. Las casas están fabricadas en dos llanos ó mesas que corren Nordeste-Sudoeste, distando un tiro de fusil del río, cuyas aguas entran en lo más bajo del lugar por una zanja mal dirigida $y$ peor conservada. Está cercada de serranías más ó ménos elevadas, que se extienden á todos rumbos por espacio de muchas leguas, y no permiten otra entradá salida que las cañadas que forman los ríos Bacuachí al Nordeste, el Bacanuchi al Nornordeste $y$ el Sinóquipe al Sudoeste. En la primera, y hasta sólo el paraje Chinapa, se vadea el rio 32 veces y algunas más en la última, lo que hace el camino bastante molesto y más en el invierno y en los meses de lluvias. 
La mayor y más lucida parte del vecindario de Arispe habita en el llano superior por estar en él la Plaza Mayor, la Casa de la misión y la iglesia. Esta ocupa, con la Casa de la misión, la fachada del Sur de la Plaza, y es un edificio muy elevado, sin método ni proporciones, de 70 varas de largo y 20 de ancho, incluso el grueso de las paredes, que son de adobes. E1 techo está sostenido por gruesas vigas. Tiene dos sacristías, aunque algo estropeadas. El adorno interior de la iglesia no sólo es decente, sino rico; los vasos sagrados, los ornamentos y otros adornos son preciosos, sobresaliendo un gran trono de plata á martillo, un cáliz de oro y un cuadro de Nuestra Señora de Loreto, cuya exquisita pintura se adorna con un marco de este precioso metal.

El Comandante general ocupa la Casa de la misión, que aunque no tiene comodidad alguna, es la mejor del pueblo y la única con vivienda alta. Esta se reduce á una gran sala con recámara para aquel Jefe y un cuarto para otros criados, y en la extremidad opuesta está la Secretaría, en tres pequeñas piezas y la principal con puerta al coro, donde se sufre la incomodidad del órgano y cantores. Hacen la habitación baja seis cuartos donde se aloja la demás familia, con botica, cocina, etc. El resto de la población forma un conjunto de r 30 casillas sin orden ni dirección, la mayor parte de adobes, pocas de piedra y lodo, y todas mal fabricadas. En el día las habitan 305 vecinos españoles y 337 Opatas.

Los oficios que mantiene la población para su gobierno se componen actualmente de un Gobernador indio, un Alcalde y dos verdugos, que llaman Topiles, por lo que toca á lo civil; pero para lo militar hay un Capitán, un Teniente, un Alférez y dos sargentos, y para el culto y servicio de la iglesia un Mador ó Maestro de doctrina, dos Fiscales y dos Tenastianes ó sacristanes.

La elección anual de estos oficios se hace regularmente con intervención del Padre Ministro y del Teniente de Justicia, á la puerta de la casa de éste, el cual propone los sujetos adecuados y el pueblo se conforma, poniéndolos desde luego en la posesión de sus empleos, sin otra formalidad que la de darles á conocer por tales Oficiales y entregar su bastón al Gobernador.

Los oficios dedicados al culto divino se eligen siempre al arbitrio del Padre Misionero y con anuencia del Juez. El Gobernador y el Alcalde se ocupan en el gobierno económico y político del pueblo, cuidando de las labores de comunidad, de la distribución de los trabajos y de la conservación del buen gobierno y quietud. E1 alguacil prende á los delincuentes, y el Gobernador ó Alcalde los castiga por medio de los To. piles; pero cuando el delito es grave se aprisiona el reo con orden de uno de los dos, y se da cuenta al Teniente de Justicia, el cual toma sús providencias. El Capitán de guerra manda en todas las salidas y campañas contra los enemigos, con facultad de castigar la cobardía, la deserción, el robo y la inobediencia.

El oficio del Mador ó Maestro de doctrina, es el que la enseña por tarde y mañana en la Iglesia á los niños de ambos sexos, é insta á los padres para que envien sus hijos á las horas asignadas, y en los días de fiesta instruye á los adultos.

La ocupación de los Fiscales es celar que ningún indio falte á misa en los días de precepto, visitar con el Mador á los enfermos, dar cuenta al Padre Ministro de su estado para que los de cuidado no mueran sin Sacramentos, acompañarle cuando los administra, y enterrar á los difuntos. Los Tenastianes cuidan de la conservación de los ornamentos y alhajas de la iglesia, de la limpieza del templo y de cuanto corresponde á los sacristanes. Finalmente, todos dependen del Teniente de Justicia, y éste del Alcalde mayor de la provincia, el cual no tiene residencia fija, porque puede vivir donde mejor le acomode en los términos de su jurisdicción, y éste últimamente depende del Gobernador militar y político de la misma provincia.

Los presidios que cubren á la población de Arispe y sus inmediatas, son al Nordeste el de Fronteras, distante 29 leguas; el de Santa Cruz, trasladado al paraje de las Nutrias al Norte $3^{\prime \prime}$ leguas; el de Tucsón á 65 Nornoroeste; el del Altar á 9o Oeste; San Miguel de Orcasitas, en el Patich, á 65 Sudoeste, y San Carlos de Buenavista Ioo leguas al Sur. De estos presidios hay varios en toda la extensión de nuestras fronteras, pero no pueden considerarse como estables, porque diferentes veces han sido trasladados de unos á otros parajes, variando al mismo tiempo su número y dotación, según lo exigen temporalmente las invasiones de los enemigos ó nuestros deseos de internarnos.

Su figura por lo general es parecida en un todo á los de California, y el soldado que los guarnece, estando por lo común casado y viviendo en un clima sano, con buenos alimentos, pocas distracciones y una vida extremadamente activa, logra de una robustez y corpulencia realmente singulares.

Son casi increibles los rasgos de valor que se cuentan de esta tropa, así como no son menore: sus desgracias, ya por el arrojo intempestivo que les causa el conocimiento de sus propia fuerzas, ya también por las sorpresas de sus astutos enemigos, que saben aprovecharse oportunamente de los terrenos poco ventajosos. Usan estos soldados de dos géneros de armas, una's 
ofensivas y otras defensivas (I). Las defensivas son la cuera y la adarga; la primera, cuya hechura es semejante á la de una casaca sin manyas, se compone de seis ó siete haces de pieles blancas de venado, agamuzadas é impenetrables á las flechas de los indios, como no se disparen desde muy cerca. La adarga es de dos haces de cuero crudo de toro, quc se maneja con el brazo izquierdo, desviando con ella las flechas, defendiéndose el jinete á sí y á su caballo. Usan además una especie de delantal de vaqueta prendido á la cabeza de la silla, con caída á uno y otro lado, que llaman armas ó defensas y les cubre los muslos y piernas, para no lastimarse corriendo en el monte. Sus armas ofensivas son la lanza, que manejan diestramente á caballo, la espada ancha y una escopeta corta, que llevan metida y afianzada en su funda. Visten calzón, chaleco y chupa de paño azul, y su número, inclusas cuatro compañías de la Nueva California, es de 3.698 plazas, las cuales, distribuidas en compañías fijas ó volantes, guarnecen toda la frontera.

Sin embargo, las circunstancias y la constitución de estos soldados, no es nada favorable para la lid á que se aventuran; su ligereza y agilidad á caballo, acaso superior á la europea, es no obstante inferior á la de sus enemigos, y las atenciones que exige para la muerte la vida común del soldado, no permiten en los últimos instantes aquella serenidad con que un Apache termina sus días cantando injurias al enemigo. Tampoco nuestros soldados sufren con igual constancia la intemperie ni le son indiferentes la escase $z$ del agua ni los ataques del hambre. Finalmente, sobrecargados con tantas armas como se ha dicho, y debiendo además llevar consigo ocho ó quince días de víveres, un calabazo con agua, una talega de pinole, la capa y manta de abrigo y una maleta con ropa, no es posible conservar de este modo la agilidad ni que resista el caballo sin cinco $́$ seis remudas, cuya comitiva multiplica el tren de campaña de un modo incompatible con la celeridad y sigilo que requieren las sorpresas.

Nuestras colonias en esta parte del Globo tuvieron por primer objeto el estrechar poco á poco la barrera con poblaciones opulentas bastantemente próximas y bien armadas, para que de este modo se lograse atemorizar al enemiso ó destruirle cuando no le atrajesen los halayos de la sociedad y el incentivo del alimento mucho ménos precario; pero como los objetos de los colonos eran bien distintos, unos quisieron establecer sus siembras, manufacturas y viñas á corta distancia de los presidios, para lograr facil despacho de lo sobrante á precios más ventajo-

ha tomado esta descripción de las armas, lel Diario de 1). Miguel Costanzo. sos (I); otros inclinados al beneficio de las minas atrageron hacia sus inmediaciones los obreros, los labradores, ganaderos y otras muchas artes necesarias para su manutención, y finalmente, los misioneros, debiendo seguir las huellas de los naturales, su método de vida y la dirección de sus casuales adelantamientos, arrastraron tras sí una porción no corta de los nuevos moradores. Tantos objetos diferentes, debieron producir naturalmente, y con efecto han producido, una población desparramada, mezquina, y por consiguiente, presa fácil de los enemigos, de suerte que la mejor prueba del fatal daño de aquéllas ideas, sería sin duda la historial harto difusa del establecimiento, y sucesiva ruina ó abandono de semejantes presidios y colonias.

En el día, estas últimas están reducidas á un número muy corto, y se componen en la Sonora y Nueva Vizcaya occidental, de algunos españoles y varias gentes de casta; en los confines orientales de la misma, en el nuevo Santander y en un valle del nuevo Méjico, de indios Tlascaltecas; y en Béjar, de algunas familias Canarias, conducidas por cuenta de S. M. para este intento. Los Tlascaltecas han prosperado mucho más que los otros colonos, particularmente en la Nueva Vizcaya, hacia la villa de Buenavista, donde se establecieron primero, y luégo se han extendido en varias colonias subalternas, las $\mathrm{Pa}$ rras, el Alamo, la Monclova, Boca de leones y otras hasta el número de siete. La villa de Buenavista tiene hasta 3.000 personas gobernadas por un protector español y un gobernador tlascalteca. La población de Santiago de la villa de Salitre, cuenta hasta 8.000 habitantes, y todas estas vegas excelentes, bien regadas y poco infestadas de enemigos, favorecen mucho la actual multiplicación de estos felices agricultores. Prosperan igualmente en el nuevo Santander, y aunque rodeados de Apaches en el Nuevo Méjico, no dejan de sostenerse unidos y defienden con tesón sus cosechas y caballadas.

Este es, con muy corta diferencia, el estado que tienen hoy día las provincias internas de Nueva España hasta los $43^{\circ}$ de latitud, y atendiendo á la cansada enumeración de circunstancias poco favorables que hemos referido hasta aquí, al frío excesivo que las persigue, á la mu-

(I) La célebro hacienda del Marqués de San Miguel de Aguayo en los confines de la Nueva Vizcaya, en la provincia de Cohahuila, tenía por los años de I 766 que la visitó el Ingeniero Lafora con el Marqués de Ruiz, hasta 600 personas: además de los ganaderos fabrican en ella paños y sombreros, atienden á las siembras y al beneficio de vinos y aguardientes: hacen el servicio de escolteros para guardar la hacienda y tener limpio el camino de Lipanes a Natages, y mo baja de 200.000 cabezas el número de las que mantiene de ganado menor, y además de otro mucho más crecido de ganado mayor caballar. 
chedumbre de sus montañas intransitables, á la poca esperanza de que puedan navegarse sus ríos, y á la mucha distancia que hay de ellos al mar, no podemos ménos de presumir que á pesar de los esfuerzos harto costosos del Gobierno á favor de estas provincias (I), está aún distante la época de que puedan figurar y mucho ménos competir, con otras de nuestras ricas colonias del continente americano.

Lo último que nos resta ahora que examinar son los rastros que existen de las antiguas emigraciones de la especie humana hacia el Sur. El Diario de los Padres Vélez y Escalante indican el más alto de estos vestigios por los $41^{\circ} 7^{\prime}$, diciendo que era un pueblo muy antiguo, en el cual había fragmentos de metales, jarros y ollas de barro, siendo su figura orbicular, según manifiestan las ruinas casi enteramente terraplenadas. El segundo fué hallado en Sutaquison, país de los Pimás, por D. Juan Bautista de Ansa, el cual tuvo la precaución de representarlo y describirlo lo mejor que pudo: dice en su Diario, que advirtió inmediatamente la continuación de

(I) El sostenimiento de la tropa y los gastos de nuestras provincias internas cuestan anualmente al Erario I.200.000 pesos, como repetidamente nos lo aseguró en Méjico el Virey Conde de Revillagijedo. otros edificios, los cuales se manifiestan bien unidos en la exténsión de más de dos leguas de largo y cerca de un cuasto de legua de ancho, fabricados todos á una legua ó poco ménos distante del río, el cual lo habian metido al centro de ellos por varias acequias del ancho por lo común de cinco varas y media, lo que se hacía bien visible en todo lo que habían andado aquel día, y de cuyas ruinas sólo tenían los habitantes de aquel río la remota y confusa noticia de que fueron de sus antiguos Soberanos. Finalmente, el tercero y último vestigio de esta especie, es el que se conoce generalmente en la Sonora, y "éste, según dice el mismo Ansa, es mayor que " el de Sutaquison: la fábrica es un laberinto de "que han sacado los inteligentes curiosas copias. "Se conoce tenía altos; hoy existen las paredes " tan altas, que se ven de más de una legua; esta "misma distancia es la que hay próximamente "al río, el cual introducían luégo por debajo del "mismo palacio y resto de la población para te"ner el agua á mano; la materia de estas obras "es de tierra puramente, pero también mixturada "con piedra menuda ó arenas gruesas, que pare"cen por su consistencia de la más fina mezcla ń "argamasa, cuya mayor prueba es su permanen"cia después de tantos años que debe tener." 


\section{CARTA ESFÉRICA del Río de la Plata desde su emboca- dura hasta Buenos Aires, y de la costa inmediata Oriental hasta el Cabo de Santa Maria, trabajada a bordo de las corbetas de S. M.; Descubierta y Atrevida.-Año de 1789 .}

El Diario astronómico indica claramente cuáles son los datos sobre que afianzan la situación en latitud y longitud de nuestro observatorio de Montevideo. Convenimos desde luégo en la latitud con las observaciones del Brigadier D. José Varela, que determinan $34^{\circ} 54^{\prime} 30^{\prime \prime}$. Nuestro observatorio es de las casas más meridionales del pueblo, y así, los I $8^{\prime \prime}$ de exceso en las observaciones nuestras, convienen con los parajes en donde se ha observado. La longitud que determinó Varela fué de $50^{\prime \prime} 7^{\prime}$, pero ignoramos si sus observaciones se han referido á las tablas celestes ó á observaciones correspondientes hechas en Europa. Como quiera que las diferencias que pueden originarse en esta materia, miran más bien á la exactitud astronómica que á la seguridad de la navegación, nos ha parecido determinar para la construcción de esta carta la de $50^{\circ}$ $5^{\prime} 45^{\prime \prime}$, reservándonos el decidir la perfección de este punto, cuando tengamos á la vista los errores de las tablas celestes en los cálculos que nos han servido de base, deducidos de las observaciones hechas en Europa sobrc las órbitas de la Luna y de los satélites de Júpiter en los días en que hemos observado.

Toda la carta está ligada en cuanto á longitudes con está determinación; pero cualquiera corrección en Esta, no influirá absolutamente en la posición respectiva de los demás puntos; pues que los relojes han determinado todas las diferencias con una exactitud en sumarcha, que debíamos más bien dcsear que esperar: las latitudes obscrvadas en diferentes puntos, ó con los sextantes, ó con el cuarto de círculo, y comparadas luéro con las operaciones trigonométricas, no dejan la menor duda en csta parte.

I a Isla de Lobos está situada por la diferencia de meridianos observada cn el número ro de la A Trevida al tiempo de venir á Montevidco, y conformccon cl número ro5 en un via je hecho después á Maldonado: depende en cuanto á latitud dc una seric de tríngulos cuyo principio cs una base de una mill cscasa, medida cn la punta del Este próxima á Maldonado, y de la misma seric está deducido el Cabo Santa María, habiéndonos sido preciso llamar así al punto que indica la carta, unánimes con algunos ingenieros y con el piloto Tafor, porque antes cada uno llamaba á su albedrío Cabo Santa María, una punta cualquiera de las muchas que salen á lo largo de la costa; hacia el Norte.

Sobre la misma base y con marcaciones repetidas desde la Isla Gorrite y desde la punta de la Ballena, estan determinados todos los puntos del puerto de Maldonado; en la misma isla se han observado, latitud con buenos sextantes, longitud en el ro5 y variación magnética en el teodolito. Los arrecifes, la boca chica ó del Este y la parte oriental del mismo fondeadero, han sido examinadas también en cuanto á sonda por nosotros. Las demás sondas se han deducido de los planos é informes más seguros, comparados con 10 que hallábamos en nuestras operaciones.

Siguen para ligar la costa hasta Montevideo, todas las marcaciones hechas desde la cúspide del Pan de Azúcar, las que se hicieron en la Punta Negra á la embocadura del Arroyo de Pando, y en la costa de D. Luis Gutiérrez; finalmente, al mismo intento otras dos bases medidas, la una en el Puerto de Montevideo y la otra en la Punta de las Carretas, y, las marcaciones hechas desde el cerro, y desde aquella Punta, no sólo sitúan los demás puntos, sino que retrocediendo á la inversa á una nueva colocación del Pan de Azúcar, unen de tal modo con los triángulos traídos desde la punta del Este, que las diferencias parciales en latitud y longitud relativamente al Pan de Azúcar, son absolutamente iguales al total de las diferencias observadas entre Montevideo y la Isla Gorrite.

La Isla Flores está igualmente situada por triángulos, y la latitud observada á su vista en ambas corbetas al tiempo de venir al fondeadero, afianzan su posición.

El Banco Inglés se ha examinado prolijamente, y obscrvadas latitud y longitud en su paralelo y meridiano, esta última por el cronómetro 72 . La extensión del banco de piedra está determinada por la reventazón á la vista en un día claro. 
El placer inmediato de arena, se ha deducido de los mejores planos y noticias, y se ha disminuído de lo que suponían muchos planos anteriores, así por ser igualmente arena todo el fondo al Sur del paralelo del mismo bajo, como por ser inútil el suponer banco en donde $t 1$ fondo ya se iguala con todos los inmediatos en calidad y en cantidad. Son nuestras las sondas entre el bajo y la Isla Flores y las que están en el paso del Norte de la misma isla; lo son igualmente todas las comprendidas desde Punta Brava hasta las restingas del cerro y todas las interiores del Puerto de Montevideo.

Siguen los triángulos hasta el río Santa Lucía: la posición de sus puntos interiores y parte de la costa siguiente al Oeste, y sobre todo, las sondas, así del río como de la barra y áun de una parte de mar en fuera, son igualmente obra nuestra: han sido vanas las diligencias repetidas por tres veces para reconocer un bajo, en el cual se han perdido algunas lanchas años há (según personas fidedignas); pero que aún parece algo dudoso, mediante el tránsito contínuo de las embarcaciones: lo hemos situado según las marcaciones que por estos prácticos se nos han indicado.

Una longitud observada en el 105, desde la maì y Este-Oeste con el cerro de Montevideo, sirve con las marcaciones hechas desde el mismo punto, á colocar otra parte de costa al Oeste clesde el término de los triángulos: la restante hasta la colonia está deducida de los mejores planos y noticias prácticas.

E1 reloj I05 y una altura meridiana del Sol, tomada con el sextante, determinan directamente la posición de un extremo de la Isla San Gabriel: las demás contíguas, los arrecifes que las rodean y los puntos de la costa inmediata, inclusa la misma colonia, están sujetas á marcaciones y enfilaciones, aunque capaces de algún leve error, por haberse tomadocon una aguja portátil y estar sujetas, noá base medida, sino á unas distancias echadas á ojo.

La diferencia de meridianos entre Monteviđeo y Buenos Aires, está đeterminada por el cronó- metro 6 I en una travesía de pocas horas, y examinada su marcha inmediatamente antes y después: la latitud se ha observado con el cuarto de círculo grande, y entrambos datos se han traído al Fuerte. Ignoramos dónde observaría el Brigadier D. José Varela, cuya diferencia de meridiano con Montevideo excede en tres minutos de la nuestra.

Desde la Plaza Mayor de Buenos Aires hasta la ensenada đe Barragán, vuelven todos los puntos á estar sujetos á una serie de triángulos determinados sobre base medida y marcaciones del teodolito. El número 6 I y los sextantes, determinan toda la costa siguiente hasta el frontón del Cabo San Antonio, cuya posición queda así fuera de toda duda, ratificándola igualmente que á todos los puntos intermedios, la determinación al regreso de los mismos puntos, enteramente conforme con la primera, y la marcha constante del número $6 I$.

Las sondas inmediatas á la enșenada de $\mathrm{Ba}$ rragán, las que rodean los arenales del Cabo San Antonio, y las que han derivado de los bordos hechos por las embarcaciones destinadas á este reconocimiento, son todas nuestras. Pero la configuración, colocación y sondas de los bancos Ortiz y Chico, y todas las que están desde el meridiano del Cabo Santa María hasta la embocadura, son deducidas, ó del plano del primer Piloto D. Bernardo 'T'afor, ó de las noticias sumamente exactas del segundo Piloto D. José de la Peña, ó de los planos y noticias de las fragatas correos de S. M.

El Brigadier D. José Varela, cuya exactitud conoce el público así en cuanto á la Hidrografía como á la Astronomía, añade á nuestras tareas la continuación de los triángulos por la colonia del Sacramento hasta el Paraná y toda la costa desde el Cabo Santa María hasta la embocadura del río Grande, que ha trazado yendo por tierra á la demarcación de límites: así, nada se echará de ménos en cuanto á la configuración de estas costas, y la navegación nacional podrá emprenderse hacia ellas con mayor seyuridad y presteza.

\section{Derrotero desde las Islas de Cabo Verde hasta Montevideo.}

Ha parecido oportuno el emprender el derrotero desde las Islas de Cabo Verde para el Sur, así porque la explicación á la carta de aquellas jslas, trazada por el Brigadier D. José Varela, debe abrazar cuantas noticias instructivas pueden dcsearse, como también porque hasta este paraje han de considerarse desunidas las derro- tas de los que navegando desde las costas de Europa al Sur, pasan unas veces al Oeste y otras entre los diferentes canales de las Islas Canarias.

Siempre que la navegación se dirija á la equinoccial, parece prudente pasar entre las islas y la costa: ni debe ser obstáculo para esta de- 
rrota el que en algunos meses del año, y particularmente en los de Julio, Agosto y Setiembre, las brisas del Noroeste se pierden en mucha altura. Las calmas en aquellos paralelos son de muy corta duración, y los mismos variables dan lugar á enmendar la situación de la nave si se inclinase demasiado á la tierra firme ó á las islas.

No parece natural que se contraigan errores considerables en la estima entre las Islas Canarias y las de Cabo Verde: á pesar de esto hay ejemplos que indican lo contrario, así para el Este como para el Oeste; con cuyo motivo será prudente hallarse 30 leguas á barlovento de Buenavista, antes de dirigirse á su reconocimiento, pues haciendo una derrota más directa para la recalada, pudiera pasarse entre las islas de Sal y San Nicolás, y hallarse después al Oeste de Buenavista cuando se creyera al Este, perdiendo así el fondeadero de Praya, como ha sucedido á no pocas embarcaciones.

La recalada á estas islas suele ser difícil muchas veces, con motivo de las neblinas que son muy frecuentes en sus inmediaciones, y esas mismas neblinas son á menudo las señas de su proximidad: en atención á esto debe navegarse con mucha cautela cuando se viene del Norte. Entre Buenavista y Santiago, cuya distancia es próximamente de 20 leguas y el arrumbamiento al Sudoeste, hay un arrecife de rocas, muy peligroso: está á seis leguas de Buenavista y el derrotero portugués le da dos cables de largo y uno de ancho (I).

La Isla de Mayo está I4 leguas al Sursudoeste de Buenavista: elevada principalmente hacia el centro, tiene en su extremo Norte un arrecife de piedras que sale á la mar sobre tres cuartos de legua: cuando se atraviesa de Buenavista á Santiago y es preciso pasar la noche sobre bordos, deben tomarse precauciones para no atracarla, como tampoco el arrecife de piedras de que ya se ha hablado.

Montada la punta del Norte de la Isla de Mayo, se ceñirá al Sudoeste para atracar la de Santiago y se seguirá costeando hasta la rada de la Praya, que es el fondeadero más frecuentado.

Tres leguas antes de llegar á esta rada se ve una ensenada cuyas orillas están pobladas de cocos, y en donde hay algunas casas, pareciéndose así á la ensenada de la Praya (2). Muchos navios, alucinados con esta semejanza, se han hallado en inminente peligro de perderse, por los muchos bajos que tiene.

Aunque el fuerte de la Praya, situado sobre un altito, sea una buena marca para no equivo-

(1) El Capitán Cook los vió en su tercer viaje.

(2) El mismo Capitán la equivocó en su segundo car una bahía con otra, lo más seguro es que la punta del Norte y Este de esta bahía falsa, es baja y ceñida de arrecifes, en lugar que la de Praya, que le sigue, es alta, escarpada $y^{\prime}$ sin escollos: para ir al fondeadero es preciso atracar á ésta muy de cerca; el asta de bandera del fuerte debe demorar al Noroeste $3^{\circ} 4^{\prime}$ Norte de la aguja, y entonces demorará al Oesudoeste, la punta del Oeste de la ensenada, en cuyo extremo se ven las rompientes de un arrecife.

En lo interior de esta bahía ó cala $y$ hacia su banda del Oeste, hay un islote llamado de las $\mathrm{C}_{0}$ dornices, y por encima de la tierra de la isla Grande, se descubre en la noche, como al Oeste, el volcán de la Isla del Fuego.

Siempre conviene más dar fondo en las inmediaciones de la costa del Norte y Este que en las del islote de las Codornices, en atención á la facilidad de dar luégo la vela sin riesgo de verse arrastrado por las corrientes sobre la punta de arrecifes que queda á babor, antes que el buque haya tomado el arranque necesario para no descaecer.

También se puede pasar al Sur de la Isla de Mayo para ir á la rada de la Praya: bastará para esto, que después de haber montado la punta del Sur de esta isla, se haga rumbo á recalar á barlovento de la punta del Este de la Praya (r).

El Capitán Cook, en su segundo viaje alrededor del mundo, examinó prolijamente el fondeadero de puerto Praya, y no será supérfluo el añadir aquí, traducida casi á la letra, la descripción que hace aquel célebre navegante.

Puerto Praya es una bahía pequeña, situada hacia la mitad de la parte Sur de la Isla de Santiago, y en latitud de $\mathrm{r}^{\circ} 53^{\prime} 3 \mathrm{o}^{\prime \prime}$ Norte, longitud $23^{\circ} 30^{\prime}$ de Gr. (2). Se conoce, en particular cuando se viene del Este, por el montecito más Sur en la Isla Grande, que es redondo, termina en pico $\mathrm{y}$ está algún tanto más adentro de la orilla y al Oeste del puerto: esta señal es tanto más necesaria, cuanto que hay una caleta, como una legua al Este, con un arenal en su fondo, un valle, y detrás de él algunos cocales, lo que puede equivocarse con el puerto Praya, como nosotros mismos lo experimentamos. Las puntas que forman la entrada del puerto Praya son más bien bajas, y corren una con otra Oeste-Sudoeste Este-

(r) Los párrafos anteriores están traducidos casi literalmente del derrotero de Mr. D'Aprés de Mannevillette.

(2) Es la longitud occidental de Cádiz de $17^{\circ}$ r 8', al siguiente viaje el mismo reloj la determinó de I $7^{0}$ x $9^{\prime}$. En el Atlas nacional, en el cual la posición del puerto Praya se ha deducido de las observaciones del Sr. Verdún de la Crenne, resulta ser en $14^{\circ} 55^{\prime}$ de latitud Norte $y$ en longitud occidental de Cádiz do I $7^{\circ}$ I $7^{\prime}$, conforme ésta con la primera determinación del Capitán Cook. 
Nordeste á distancia próximamente de media legua: inmediato á la punta del Oeste se hallan varias piedras anegadas, en las cuales se ve romper el mar: adentro está la bahía, y demora como media legua al Noroeste, disminuyendo progresivamente el fondo desde I4 á cuatro brazas. Las cmbarcaciones de mucho porte no debieran anclar en ménos de ocho brazas, en cuyo fondo, el extremo Sur de la Isla Verde (I) demora al Oeste.

La aguada se hace en un pozo que está adentro de la playa en el fondo de la bahía; el agua no es mala pero escasea, y es incómodo el hacerla por la mucha resaca. Los refrescos que pueden encontrarse son vacas, puercos, cabras, ovejas, gallinas y frutas; las cabras son de la especie antílope, y tan extraordinariamente flacas, que nada puede igualarlas. No lo son mucho ménos las vacas, puercos y ovejas; las vacas pueden adquirirse por dinero; suelen valer doce pesos fuertes por cabeza, y pesan de 250 á 300 libras inglesas. Las demás cosas pueden adquirirse cambiando con los naturales alguna ropa de vestir; pero la venta del ganado vacuno está estancada en una compañía de negociantes, á quienes se ha concedido este privilegio, y tienen un apoderado en el mismo sitio.

Son importantes los reparos del Comodoro Wallis, quien fondeó en el puerto Praya á fines de Setiembre; dice que muy luego supo que era esa la estación enfermiza, y que las lluvias imposibilitaban casi el traer cosa alguna de la campaña; no obstante, en tres días pudo reemplazar la aguada, lograr que le trajesen algún ganado y coger mucho pescado con la red que hacía tender dos veces al día. Halló también con suma abundancia en el mismo valle de la aguada, una especie de verdolaga silvestre que les pareció muy agradable, ó bien la comiesen cruda como ensalada ó la cociesen con las menestras en el caldo.

La escala en la bahía indicada de la Praya, puede ser útil muchas veces cuando ó un viaje largo desde las costas de Europa, ó un excesivo número de pasajeros, hacen indispensable abastecerse nuevamente de refrescos y agua; la suelen frecuentar mucho ingleses y holandeses; y en las navegaciones nuestras al Sur, además de los motivos indicados, puede también tener el de ser el mejor punto de reunión.

Sean enhorabuena muy acertados los preceptos de Mr. D'Aprés sobre el corte de la Línea, cuando la navegación se dirige al Cabo de Buena Esperanza, y sean plausibles sus recelos de que el inclinarse demasiado al Oeste pueda arrastrar consigo el fatal inconveniente de no montar el

(I) Es la que Mr. D'Aprés llama de las Codornices.
Cabo San Agustín; no dejará de ser verdad, que pasando la Línea actualmente á lo ménos doble número de embarcaciones de las que iban en años pasados, ninguna deje de montar dicho Cabo, aventurándose áun sobre las huellas del célebre Cook á cortar casi por el meridiano de la isla de Fernando Noroña.

En las navegaciones á la Costa Patagónica, y por consiguiente á la del Brasil y Río de la Plata, fuera inútil y más bien pernicioso procurar inclinarse á los 4 ó $5^{\circ}$ al Este del Meridiano de Tenerife, tanto más que repetidas experiencias (I) demuestran que las corrientes se inclinan al Este en razón de la mayor aproximación á la costa de Africa.

O las calmas son excesivas y por consiguiente larga la demora en las inmediaciones de la Línea $y$ puede asegurarse con mucha probabilidad que las diferencias por corrientes son al Este, ó son pocas las calmas y rápida la derrota y en este caso no hay por qué desconfiar de la estima, ratificada pocos días antes á la vista de las Islas Canarias ó de las del Cabo Verde.

Así, las únicas reglas que pueden recomendarse para un corte expedito de Línea, son las de consultar las estaciones para saber el término de las brisas, la de seguir siempre la bordada del Oesudoeste con preferencia á la del Esudeste (2) y la de resistir siempre la vela posible, y no ceñir demasiado con un afán mal entendido de ganar latitud.

Mr. D'Aprés, sobre el examen de 250 Diarios, pone por límites ó términos de la brisa en diferentes estaciones, los paralelos siguientes: en Julio, Agosto y Setiembre se pierden las brisas del Nordeste entre los I3 y I $4^{\circ}$; en Junio á los ${ }_{10}{ }^{\circ}$; en Diciembre, Enero y Mayo entre 6 y $4^{\circ}$; en Febrero entre 5 y $3^{\circ}$; en Marzo y Abril entre 5 y $2^{\circ}(3)$.

No por esto debe imaginarse que algunas veces la brisa del Nordeste no alcance al Sur de la Línea, y en otras no cese á los I8 y I9 ${ }^{\circ}$ (4), pero el piloto, atento á aprovechar de todos los elementos, podrá aceptar con grande probabilidad estos términos áun antes de alcanzarlos.

(I) Desde que los relojes marinos han dado en la navegación un punto diario de longitud observada, y diferentes navegantes se han valido de botecillos, correderas, etc., para examinar las corrientes, la dirección y velocidad de éstas pueden mirarse como determinadas con mucha mayor aproximación á la verdad.

(2) Mandando la Astrea en Setiembre de 1786 he debido hacer rumbos hasta del Oeste. El reloj marino me avisaba de un error en la estima de $7^{\circ}$ al Este desde la vista de las Canarias.

(3) El East Indic-Pilot y nuestras cartas nacionales, prudentemente lo señalan en la misma carta con una figurita que indica el viento y está puesta en los diversos paralelos en que cesa la brisa.

(4) Este último caso ha sucedido en Setiembre y Agosto de los años de 7786 y 1789 . 
Cuando las brisas se inclinen del Norte para el Oeste, cese la celajería parda y movida, se vea celajería blanquinosa, y á reces algunos relámpagos hacia el Sur, puede considerarse la brisa ya próxima á sus términos, y entonces, según las estaciones, ha de precaverse el piloto con los vientos que encontrará con más probabilidad en los meses desde Junio hasta Octubre inclusive, ha de contar con Sudoestes frescos, con los cuales por consiguiente ha de prolongar la bordada del segundo cuadrante cuanto lo permita la prudencia; y en tal caso convienc inclinarse con la derrota más bien al Oeste que al Este. En los otros meses al contrario, como quiera que los vientos ó más bien las turbonadas han de inclinarse al Sueste, será prudente alcanzar los $5^{\circ}$ en el Meridiano de Tenerife, ó cuando más I ó $2^{\circ}$ al Este, y luégo, como ya se ha insinuado, preferir indistintamente los rumbos que proporcionen mayor ventaja en latitud, como no acarreen demasiado al Este combinados con unas calmas repetidas y largas (I)

Así como es fácil pronosticar de un par de días la cesación de las brisas del Nordeste, es fácil tambièn conseguirlo para la entrada de las del Sueste: si las turbonadas que se han declarado por esta parte siguen luégo despejadas ó con celajería movida y de una regular duración; si la mar toma un color vivo azul; si los horizontes no están ni aturbonados, ni calimosos; si despiden más bien celajería parda; si á la pesadez de la atmósfera, entre la calima y los vapores de los variables, se sigue un aire de una respiración agradable y de una sensible ligereza, desde luégo la brisa no está distante; y en tal caso, los bordos del Oesudoeste y Oeste 1/. Sudoeste, son los que deben afianzarla.

Fuera arrojo después de las muchas diferencias que diariamente se hallan en las variaciones de la aguja, dictar aún este método para conocer la posición de la nave, en longitud: además que son casi contínuos los escarmientos por otra parte inaveriguables de este método, podemos asegurar sin recelo de temerarios, que la peor observación de distancias lunares (que ya en el día consideramos al alcance del piloto ménos experto) será mejor guía para el conocimiento de la longitud, que la mejor observación de la aguja.

La misma multiplicidad de bajos, sembrados desde los paralelos de las Islas de Cabo Verde hasta la Línea, ha hecho que generalmente se dudase de su existencia; bien que naturalmente

(I) La brevedad de nuestro viaje á Montevideo ha dependiclo eseneialmente de seguir el bordo del segunclo euadrante eon vientos del tercero, hasta las sondas cle la Isla Poilon y de allí eon las muras babor eortar la Línea en los $17^{\circ} 5^{\prime}$ de longitud occidental de Cádiz. cauto el piloto, sacrificase luégo muchas noches y un viento á veces precioso, al riesgo de tropezar con alguno de estos bajos.

El haberse transferido á la carta todos los peligros que en este trozo de mar supone con mucho juicio el East India-Pilot, no es con otro objeto que el de excitar más y más la vigilancia del navegante. Fuera inútil indicar peligros muy dudosos, si pudiese suponerse siempre la vigilancia, mediante la cual estarían casi de un todo á cubierto las vidas y los intereses: con los vientos largos y apacibles y las noches no lar. gas de entre trópicos, ¿qué peligro aislado se había de presentar al navegante, que el timón y una maniobra pronta no evadiesen? Pero en la desidia y abandono que reinan en los buques mercantes de casi todas las naciones, será tan prudente el incluir en las cartas de navegar cuantos bajos tengan aún la más remota apariencia de existir, como preciso en nosotros el encargar encarecidamente, que á lo ménos en esos paralelos sospechosos se navegue con vigilancia y con aparejo manejable.

E1 dar resguardo á todos estos peligros, ó bien á unos sí y no á otros, fuera ya tanto más reprensible cuanto más influye actualmente la celeridad de los viajes, así en las especulaciones mercantiles como en el honor y lustre de la Marina Real (I).

Es común, ya alcanzada la brisa del Sueste, y haciendo deriota hacia el Río de la Plata, el resarcir de algunos grados los errores contraídos al Este en la estima, al tiempo de permanecer en las inmediaciones de la Línea. Así será fácil (según la estación y plazo en que se haya permanecido

(I) No parecerá inoportuno nombrar uno á uno estos peligros: los que están al Este de Buenavista se suponen vistos, el más Norte por el Capitán Levingstone en la Bonetta año de I 730, y el más Sur por el Capitán Webb, año de 1734 . Pudieran tal vez ser uno mismo: el que está 95 leguas al Oeste de la Isla Brava depende de una estima de dos dias del Capitán Dubrewil año de 1753 , y por eonsiguiente, mereee al ménos su situaeión alguna confianza. Setenta leguas al Oeste $1 / 4$ Noroeste, está un bajo indicado en muchos Diarios ingleses y franeeses: el bajo Das Garzas de los portugueses está situado, según Van-Keulen ro7, le. guas al Oesudoeste de la Isla Brava. El Capitán Hayter, inglés, sitúa este mismo bajo al Esnordeste I 3 leguas; la vigía de Cineó Palmas tiene igualmente dos posieiones: la más Oeste es; según los portugueses, la otra es según Hinman: la roea de Longchamp, puedeser la Isla Solís de los antiguos navegantes: en los $4^{\prime \prime}$ de latitud se halla una vigía vista al pareeer por buques franeeses. Los Diarios del Capitán Hayter en $3^{\circ}$ y $1 / 2$ y próximamente en el mismo meridiano. Hay en $2^{\circ}$ unos bajos apropiados al C'sar, navío francés, que los vió en I 730. Finalmente, entre los 20 y $40^{\prime}$ Sur y I $35^{\prime}$ de la misma latitud, sospecha Mr. D'Aprés que puede haber algunos parajes de poco fondo en que hayan toeado momentíneamente algunos navegantes, cuyos nombres y Diarios eita: la longitud de estos bajos pudiera ser la de $r 4^{\circ} 30^{\prime}$ para los primeros, y la de II $^{\circ} 40^{\prime}$ al Occidente del meridiano de Cádiz para el último. 
en la Línea), graduar los errores que se hayan compensado, y dirigirse á avistar la Isla Trinidad: la vista de esta isla puede tal vez ser útil á los que se consideren muy al Este de la estima, pues en tal caso más bien han de desquitarse algunos grados de longitud en estos paralelos, siempre apacibles y con viento favorable, que en los del Río de la Plata, en donde las tempestades y pamperos pueden ser doblemente nocivos.

Pero de ningún modo es útil el ver esta isla, á los que tengan alguna confianza en su punto, y habiendo cortado la Línea algo al Oeste, no la encuentren en la derrota directa que han de seguir para el Río de la Plata.

No podemos dar mejores noticias relativamente á su posición, que la copia del extracto original de los Diarios de la Santa Rosalia, que de orden del Rey navegó en I774 directamente á esta isla (I). Es tanto más preciosa la prolijidad en esta materia, cuanto que decide al mismo tiempo la inexistencia de la Ascensión en estos mismos paralelos, y demuestra hasta qué grado habían progresado las ciencias náuticas en nuestra Marina desde aquella fecha.

Copia de lo relativo al paralelo meridional de $20^{\circ} y^{1} / 2$ en el mar Atlántico, sacada del extracto de la navegación de la fragata Santa Rosalía en I774.

Travesia en el paralelo meridional de $20^{\circ} y^{1} 1 / 2$.

Si interesa á los navegantes el conocimiento ó noticia de las diferencias ordinarias que se experimentan de ida y vuelta por sus respectivos parajes en el crucero de la $Z$ ona Tórrida en este mar, y el muy esencial de la variación para corregir por ella sus estimas, no se hacía ménos necesaria é importante una ilustración de este paralelo y sus inmediatos, en que se figuran tantos tropiezos, pues señala el derrotero portugués con las cartas holandesas cuatro ó cinco islotes con el nombre de Martín Vaz y Santa María de Agosto, entre 20 y $2 \mathrm{I}^{\circ} \mathrm{I} 5^{\prime}$ de latitud y desde los I ${ }^{\circ} 22^{\prime}$ hasta los $14^{\circ} I 6^{\prime}$ de longitud occidental de Cádiz; y corrigiendo los $7^{\circ} 32^{\prime}$ en que Pimentel y los antiguos erraban hacia Oriente la situación de Cabo Frío, y relativamente toda la costa del Brasil, debían recelarse los referidos islotes entre las longitudes de $I 7^{\circ} 54^{\prime}$ y $2 I^{\circ} 48^{\prime}$ de nuestra cuenta.

Ya Mr. D’Aprés tenía advertido, que dos balandras expresamente despachadas por la compañía oriental francesa, el año de 3 I habían recorrido las latitudes entre I9 y $20^{\circ}$, sin encontrarlos; que en el de $39 \mathrm{Mr}$. Bouvet, Capitán de

(r) El Excmo. Sr. D. José de Mazarredo, tuvo la bondad de remitirme el original, cuya copia es la que se incluye en este derrotero. un navío de la compañía, partiendo del Cabo de Buena Esperanza, se puso en la de $20^{\circ} 30^{\prime} \mathrm{co}$ rriéndola sin ver más que la Isla de la Trinidad; y que por último, el autor, volviendo de China en 52 , hizo 700 leguas, como hasta 80 de la costa del Brasil, por entre los paralelos de $20^{\circ} 50^{\prime}$ y $2 I^{\circ}$ I $5^{\prime}$ navegando con todo cuidado, y principalmente con la precaución de no hacer camino de noche, sin descubrir alguno de tales Martín Vaz, ni tener los menores indicios de su cercanía, como había sucedido á los anteriores.

Esto es lo que hace á dichos islotes; pero no han ocurrido ménos dudas y opiniones sobre la existencia de dos islas, una nombrada la Trinidàd y otra la Ascensión, sosteniendo los portugueses (y las cartas holandesas), ser dos realmente con distinta descripción de una y otra (á que ya avenían también las cartas francesas), y los demás no haber más de una, diversamente denominada, según las estimas de los que la han encontrado. Tenía esta opinión el gran vigor de acaudillarla Edmundo Halley, que continuando sus observaciones de vientos, mareas y magnetismo, á que fué sometido, recorrió el paralelo de $20^{\circ} \mathrm{y}^{1} / 2$, y sus inmediatos muy prolijamente, $y$ vió sólo una isla á que llamó Trinidad (porque venía del Este y era el nombre que se daba á la oriental), situándola $12^{\circ}$ largos al Este de Cabo Frío, de que los españoles la han contado siempre distante sólo poco más de I $^{\circ}$ (bien que denominándola Ascensión cuando la han visto), según la estableció después Mr. D’Aprés, quien primero seguía la opinión de Halley y más común, pero cedió finalmente á la autoridad de la reciente noticia de Mr. Duponcel, Capitán de la fragata $L a$ Fana, que en I 760 , navegadas desde la Trinidad como Ioo leguas al Oeste, vió la Ascensión, dando su latitud I $5^{\prime}$ meridional á la de la primera.

Pareció, pues, al Comandante necesaria una nueva travesía por el paralelo de $20^{\circ}$ y $1 / 2$ á fin de con nuestra observacion, agregada á las noticias referidas, poder determinar la seguridad ó cuidados con que deba navegarse en él en lo sucesjvo, y á este objeto arribó al Oeste el 23 de Marzo, hallándonos como se ha dicho en $13^{\circ} \mathrm{I} 4^{\prime}$ de longitud occidental por estima y todavía con $3^{\circ}$ de diferencia al Este, según tan contestes ob servaciones.

Al llegar al paralelo, y áun desde dos días antes, tuvimos frescachón el viento al Este con mar del Sueste más gruesa de lo ordinario en estas latitudes y una cerrazón de semblante tal, que nos indujo á sospechar había muy mal tiempo en altura (revolución del equinoccio) confirmándolo con la casi calma que sucedió del 25 al 28, volviendo después á entablarse la brisa bonancible al primer cuadrante, interrumpidas al principio con algunas variedades del Norte al Noroeste. 
Navegamos como pudiera hacerse para una descubierta primera, esto es, atravesándonos por la noche de uno y otro bordo, así que se caminaba la mitad y áun ménos de lo examinado con la vista al ponerse el Sol, haciendo nuestra derrota dentro del mismo paralelo, sin otra alteración, que la de las constantes diferencias al Sur que șe enmendaban diariamente.

Antes de navegar $3^{\circ}$ de longitud empezamos á ver corvas, rabi-ahorcados y bobos é inmediatamente algunos charranes, otro pájaro negro de su tamaño y vuelo, con tal cual rabijunco; si los charranes guardasen aquí la ley comunmente observada en Santa Elena, debiéramos haber tenido tierra no léjos; pero de nada nos apercibimos que nos indujese á sospecharla aún hasta que crecieron las especies de pájaros, entre otras los gaviotones, como mangas de beludo, multiplicándose al infinito el número de todas desde los $2 \mathrm{I}^{\circ}$ de longitud; y siguiendo nuestra derrota con todas las precauciones debidas, á las seis de la mañana del 4 de Abril avistamos desde el tope, tierra que demoraba al Oeste y se reconoció muy pronto, áui de abajo, ser los islotes orientales de la Isla de la Trinidad, que se vió igualmente desde el alcázar, para las ocho, á más de $x 6$ leguas de distancia.

Pusímonos para medio día precisamente en el paralelo del islote mayor, á fin de determinar exactamente su latitud, que se observó de $20^{\circ} 30^{\prime}$ por muchos buenos observadores acordes: y demorando al mismo tiempo lo más septentrional de la Trinidad al Oeste $I^{\circ} 3 \mathrm{o}^{\prime}$ Sur como I3 leguas, debimos notar que la menor latitud de aquel extremo ha de ser de $20^{\circ} 3 I^{\prime}$ y no $20^{\circ} 25^{\prime}$ en que se contaba la isla.

Aflojando entonces más el viento que era del Norte al Nordcste, se mandó al bergantin cercar-los islotes, que los contase, enfilase y sondase en sus inmediaciones y canales, dirigiéndonos con la fragata al Norte de ellos: no pudo cumplir el todo de su encargo á causa de la calma; sin embargo, estuvo por la noche entre el islote grande y mediano, no halló fondo con 70 brazas é hizo varias en ilaciones acordes á las practicadas po: nosotros desde fuera, sin que pareciese necesar:o otro examen del que se of rece á primera vistz á un mediano cuidado.

Estos islotes pueden considerarse dos, uno grande, como de tres cables de largo, casi igual en base y altura, terminada ésta en cinco puntas seməjantes, visibles éstas desde el tope á mís de diez leguas; y el otro pequeño, sumamente parecido á un torreón como el de San Sebastián de Cídiz, bien que de alguna más altura, y estará dos millas escasas al Sur del grande, el cual tiene tres hijuelos, á saber: un morro á la parte del Norie y dos pirámides del Sudocste á Sur, destacado el que más un cable, y el torreón tiene tam- bién su hijuelo muy cerca al Sueste, de figura de una vela latina y como de la mitad de su elevación; de suerte, que en todo componen seis islotes, si quiere darse este nombre á todas las piedras que aparecen separadas, y pueden sí 1lamarse de Martín Vaz por su situación oriental á la Isla de la Trinidad, respecto á haberse denominado así los que se recelabain hacia la misma parte en tan disparatadas longitudes, y que á la verdad no existen.

El 5 perseveramos entre aquéllos y ésta, algo al Norte de su paralelo, tanto porque lo flojo del viento no daba lugar á acercarse y reconocer de día la isla, como por hacer cómodamente las últimas observaciones de longitud en cotejo de las anteriores, con marcaciones seguras de ambos objetos.

Tabla de las longitudes observadas en este paralelo.

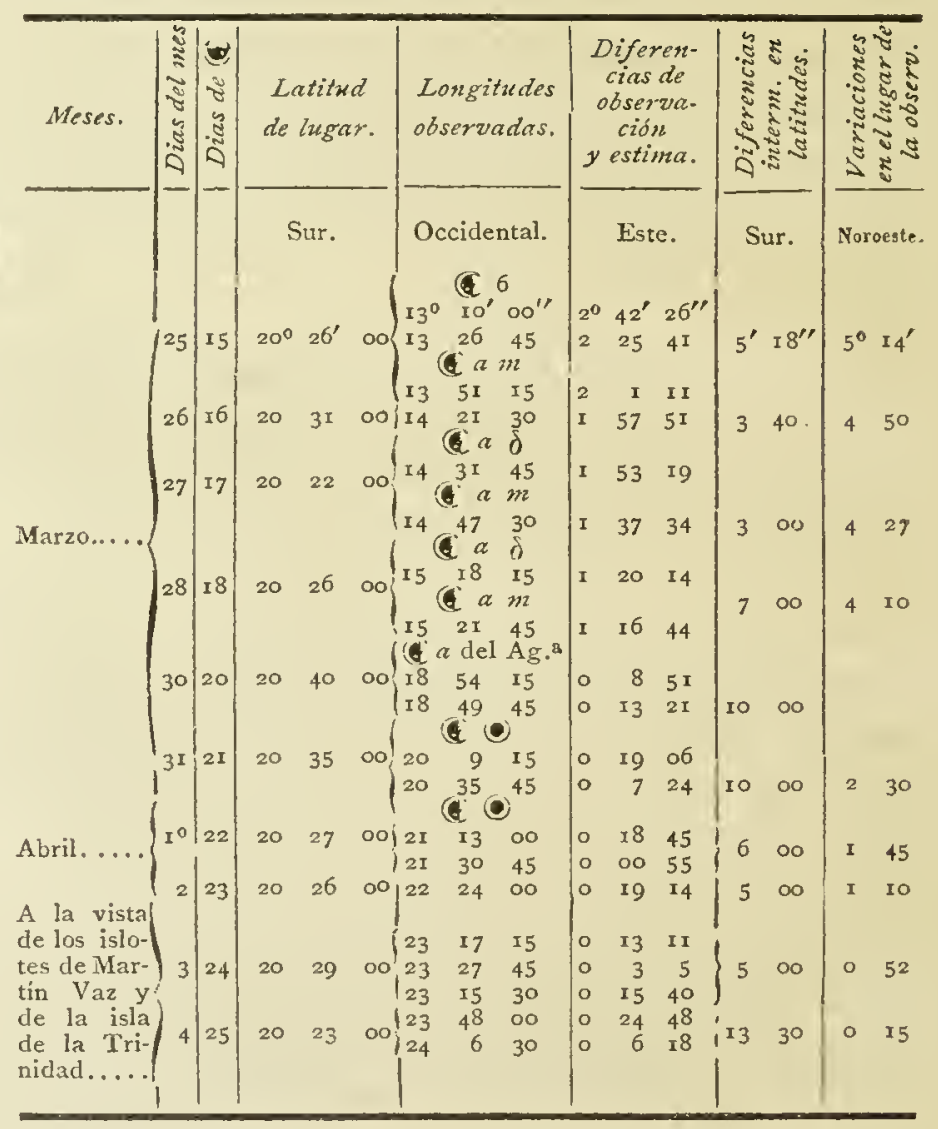

Resulta de estas observaciones, que en los I I de paralelo que recorrimos por estima, se adquirió al Oeste la diferencia ó desvío de tres que teníamos al Este, recalando en la Isla de la Trinidad con la misma estima.

Bien natural era un movimiento como este en las aguas, después de tanta parada en su dirección general hacia Occidente; y para persuadirse á que sucedió así, no parece necesario considerar más que el orden con que sucesivamente indicaron las observaciones la disminución de la diferencia: debe, sí, repararse en que todo este movimiento se muestra hecho desde los catorce hasta los veintiun dias de Luna, y no añadirá poco mérito y fé á las observaciones una reflexión semejante: y todavía más á favor de las de únicas en el período de la enunciada revolución; 
empezaron después las distancias al Sol, perígea la Luna, y el instrumento en situación muy cómoda, circunstancias á que, agregado el singular esmero con que se atendió á las demás, de que penden las buenas observaciones, no dejaron escrúpulo en su exactitud, comprobando también á vista de la tierra los días 3 y 4 , no sólo que no tiraban más las aguas al Oeste, si al contrario, por las marcaciones (bien fuese error de la estima) el que habíamos contraído en aquella singladura tres millas de diferencia al Este.

Se lograron especialmente á satisfacción las observaciones á la vista de tierra: del promedio de las tres tan acordes del tercero transferidas al islote grande de Martín Vaz con su verdadera latitud y marcación, resultó aquél en longitud de $23^{\circ} 42^{\prime} 27^{\prime \prime}$ al Oeste de Cádiz, y del promedio de las dos del 4 en $23^{\circ} 4 I^{\prime}$, por donde puede contarse seguramente con la de $23^{\circ} 42^{\prime}$, y deduciéndose de las enfilaciones y diferencia de latitud que dista 28 millas de la punta septentrional de la Isla de la Trinidad, se sigue hallarse este extremo $30^{\prime}$ más occidental, esto es, en $24^{\circ}$ I 2 de Cádiz, que es la misma longitud en que la estableció Mr. D'Aprés, contando I I $1 / 4{ }^{\circ}$ de diferencia entre este meridiano y el de Cabo Frío.

Es de observar aqui ahora, que por las longitudes astronómicas, recorrimos $I 4^{\circ}$ de paralelo hasta la Isla de la Trinidad, y habiendo entrado en él con $6^{\circ} 44^{\prime}$ de variación Noroeste bien observada, así como la de $I_{5}$ Nordeste en el fondeadero de la isla, se sigue corresponder $I^{\circ}$ de diferencia en la variación, á cada dos de longitud, y cuán infundada es la determinación de abrir las líneas magnéticas en unos meridianos y estrecharlas después en otros, siendo por otra parte más verosimil la uniformidad de los espacios, donde es una la dirección de los diversos magnetismos, lo cual debe dar más confianza á todo navegante para corregir en este golfo los errores de la estima por un medio tan sencillo y prudente, cual es el de la variación, bastando saber la que corresponde en la Trinidad para un año dado; por ejemplo, en I780, que será de $39^{\prime}$ Noroeste por los $9^{\prime}$ anuales que crece hacia Occidente, el piloto que con una aguja igual á la de estas determinaciones (ó averiguada su discrepancia), observase la de $3^{\circ} 40^{\prime}$ en el paralelo, ó si ántes reduciéndola á él por la dirección del Sur 1/4 Sueste deberá considerarse ó contar aquel punto $6^{\circ}$ al Este de la 'Trinidad, y será tan prudente su juicio, que cabrán pocos de igual exactitud en la mar, pareciendo exorbitante que pueda llegar el error á $2^{\circ}$, á que seguramente no, si se hacen repetidas observaciones en distintos dias, reduciéndolas todas á un punto para tomar el promedio de sus resultados $y$ hacer sobre éste la comparación.
$\mathrm{Al}$ amanecer del 6 demoraba la punta septentrional de la Trinidad al Sur $55^{\circ}$ Oeste distancia de poco más de tres leguas, y entablándose des. pués la brisa al Nordeste, arribamos á atracar aquélla; destacose el bergantín á que la acercase bien y la sondase, y el resto de la costa del Oeste, y se envió al mismo tiempo el bote á la punta del Sueste, para que desde ella recorriese toda la costa oriental examinándola y sondándola, quedándonos con la lancha inmediata aun. que algo adelantada, que también sondaba con frecuencia. Siguiendo en esta disposición sobre la punta del Norte, no cogimos fondo hasta una milla de ella por la parte del Oesudoeste, empezando las sondas en $3^{8}$ brazas piedra que continuó largo rato, hasta el tercio de la isla cerca de una pirámide $y$ un islote inmediato tajado en tres partes, donde comenzó á indicarse la arena, disminuyendo poco á poco el fondo hasta 27 brazas, en que á la una del día dejamos caer el ancla del ayuste, filando 60 brazas de él y á distancia como de dos tercios de milla de la costa más cercana, demorándonos la punta que aparecía septentrional al Norte $I 3^{\circ} 30^{\prime}$ Este; la pirámide dicha, al Norte $22^{\circ}$ Este; la punta meridional occidental con una islita muy pegada á ella, al Sur $73^{\circ}$ Este; y la parte interior ó es palda de un morro grande colorado, que está hacia el extremo del Sueste, al Sur $82^{\circ} 30^{\prime}$ Este.

$\mathrm{Al}$ atracar la costa enfilamos las puntas septentrional y del Sueste al Sur $49^{\circ}$ Este, y precisamente en el paralelo de la primera se ob. servó á medio día la latitud de $20^{\circ} 3 I^{\prime} 6^{\prime \prime}$.

Se empleó la tarde en buscar con la lancha atracadero, que no se encontró á causa de la gran resaca, y al anochecer se retiró el bote, que había circundado la isla descle la punta del Sueste hacia la del Norte, volviendo á la prime. ra por la costa de occidente, $y$ en todas partes encontró la misma fuertísima resaca, que á veces le precisó á echarse para fuera precipitadamente.

Al alba del 7 el Comandante y algunos Oficiales salieron en bote y lancha á enfilar las puntas de toda la costa occidental, reconocer su sonda y demás; hallaron la misma imposibilidad de atracar que el día anterior, y se retiraron poco después de la una del día con conocimientos bastantes á trazar un plano de la exactitud que cabe en semejantes operaciones.

La Isla de la 'Trinidad, á cuya figura irregular dificultosamente se hallará nombre que convenga, es una cordillera de peñones de Noroeste á Sueste que adelgazan á los extremos, y cuyo mayor grosor en la medianía hace avanzar al Sudoeste la costa occidental y que ésta quede curva-convexa y la del Nordeste algo cóncava: su extensión será de cuatro millas largas: la punta. septentrional está en $20^{\circ} 3 \mathrm{I}^{\prime}$ de latitud Sur y en 
$24^{\circ}$ I $2^{\prime}$ de longitud occidental de Cádiz, según resulta de las conformes observaciones citadas á su vista. Toda la isla es pura peña, coronada en partes de leña menuda, y más gruesa y cerrada en diversas cañadas ó ramblas, por algunas de las cuales se precipitan caudalosas vertientes de agua que deben proceder de las frecuentes lluvias, y sólo cerca de su morro meridional de Oriente se reconoce un corto trozo de terrón cubierto de verde. Por todos los puntos de su circunferencia se puede acercar á ella sin riesgo de bajo ó poco fondo hasta las mismas peñas, pues se elevan todas tan acantiladas, que á un cumplido de lancha se encuentran seis y ocho brazas de agua en piedra y coral, formándose tal resaca, que imposibilita el atracadero hasta en dos ó tres pequeñas playas que hay en los extremos del Noroeste y Sueste. La experiencia nos enseñó la segunda vez que anclamos aquí, como se verá después, que no siempre es igual tan grande la resaca, y sí accesible, con alguna dificultad, el atracadero en tal cual paraje, bien que nos enseñó al propio tiempo (y es más útil el saberlo) no sólo que de un instante á otro no es posible ya el acceso, si también que nos habíamos engañado en creer de arena limpia el placer que circunda la isla por esta parte de occidente (la única de abrigo) con 25 á 40 brazas desde poco más de media milla hasta cerca de dos de distancia de la costa, pues vimos á costo de ancla y cable y con prolijo examen, que aunque en la superficie sólo se manifiesta arena (que es lo que el escandallo señala, bien que perdiendo las más veces el sebo) es no más de una capa de ella sobre un piso general de piedra, lo que no pudimos advertir ahora faltos de antecedente de sospecharlo, ya porque lo constante del viento tuvo la fragata sin borneo las veinticuatro horas de nuestru mansión, y no pudo el cable rastrear el fondo, ó ya porque accidentalmente cayó el ancla en un paraje algo más cubierto: y así, sólo puede venirse á este fondeadero teniendo un gran trozo de cadena para las entalingaduras, precaución á que si se agrega no ser tiempo de revoluciones (naturalmente el verano) podrá evitar los perjuicios indispensables de cualquier otro modo, y se remediará una extrema necesidad de agrua y leña, caso único que deba inducir á la determinación de anclar en semejante paraje; y por lo demás, el fondeadero tiene la excelencia de no conocerse travesía en él á causa de la convexidad de las tierras, á más del buen abriyo de los vientos grenerales que deben ser bien regrlacios al Este en la propia benigna estación en que sin duda faltando las mares de los Sudoestes í pamperos, no habrá la resaca, que es en la de ahora casi constante peligrosa, ó se forma tan prontamente como lo notamos la segunda vez y acreditan varios arcos de hierro, de cuarterolas y barriles grandes, un cañón de fusil, un hacha y un martillo que se encontraron entónces en tierra, indefectiblemente de alguna lancha que se vió en el caso de largarse con más aceleración aún que lo hizo la nuestra, á que costó no poco trabajo el atracadero, lográndolo sólo detrás de un peñasco que deja canal á la isla, pasando á ésta con el agua á media pierna en bajamar é intransitable en la plea.

Se mató un jabato muy ruin que solo tenía pellejo y huesos, color ceniciento, cerda no tan dura como la del jabalí común y ningún diente, que tal vez los perdió de viejo, indicando su mal estado la falta de mantenimiento para su especie; y parece que los hay mayores, pues se percibió el rastro, y subiendo algunos marineros á reconocer el origen de una vertiente de agua más arriba de una barranca de bastante grandor, donde se enlaga, precipitándose nuevamente descle ella, vieron un chivato grande que se les paró al principio, y huyó finalmente embestido de un perro de agua. Es de creer que estos animales fuesen traídos aquí desde el Brasil, en el designio de algún establecimiento que mejor examen hizo comprender perjudicial, pues no aparece otro indicio de haberlo habido jamás, ni es sitio en que las masas flotantes de hielos destacados de las costas los transportasen á una isla engolfada; pero lo que debe causar no pequeña admiración, es cómo se ha poblado esto de una infinidad de pájaros de garganta fina, los cuales no salen del bosque cerrado que hay en las ramblas, tan cerrado que ninguno vieron nuestras gentes; oyéronlos sí cantar en una multitud que los aturdía, y por el gorjeo los consideraron ruiseñores, canarios y verdones; tal vez será exageración nacida de poco discernimiento; lo cierto es que en el Brasil se conocen muy raros pájaros de buen canto. La leña en las barrancas es mucho más gruesa de lo que se juzga desde fuera, pues tienen los árboles como tres varas de altura y de seis hasta doce pulgadas de diámetro. Pudo también observarse la segunda vez que anclamos, que el establecimiento es á las cuatro horas con cortísima diferencia, creciendo el agua al Norte y menguando al Sur, notándose en tierra ccrca de doce piés de diferencia entre mayor y menor, que como justamente hacía el plenilunio, puede decirse sea la mayor ordinaria, idéntica á la teórica de Newton, sobre la atracción de la Luna y su efecto sobre las aguas del mar cn estos parajes: 10 cual se examinó atentamente en la costa fijando un gran bichero y marcando en él la menor y mayor agua. Habitan en esta isla una infinidad de pájaros marisqueros de muchas especies, todas las que encontramos en el paralelo desde tan larga distancia, y es igual la abundancia de peces, muchos de hermosas figuras, especial- 
mente los meros cuyo atigrado es singularísimo. En la Isla de Francia causan grandes estragos estos peces de colores, que por su hermosura punzan más á los marineros, hambrientos de refrescos; sin embargo, aquí, por la gran semejanza á los conocidos buenos meros de la sonda de la Tortuga, se comieron sin recelo, encontrándolos de exquisito gusto, y sólo en los que se excedieron hubo algunas resultas de indigestiones ligeras. Hay también gran número de tiburones, á que se dió buen mate, que aprovechó la marinería, celebrando este bocado como de los más finos.

Es cuanto ambas ocasiones nos proporcionaron observar principalmente de esta isla, cuyo feísimo pedregoso aspecto anuncia bién la uni. formidad de la materia con su base; su altura es tal, que se vé distintamente de más de r 6 leguas de distancia, y su reconocimiento, viniendo de la parte del Este y Nordeste es inerrable por el encuentro de los islotes de Martín Vaz, y áun sin éstos la hace muy señalada el morro del Sueste, que desde muy lejos parece una isleta, se eleva perpendicular y tiene á su Noroeste una pirámide bastante más alta, muy gruesa en su base, algo inclinada sobre el morro, y que también parece islada desde larga distancia, como de I2 á I4 leguas. Con todo, por su figura la hace aún más conocida desde el Sursueste y Sursudoeste el agregarse á las mismas señales la de otra pirámide en el extremo del Noroeste, de casi tanta elevación como la del Sueste, pero de ménos grosor en su base, la cual en cualquiera otra marcación que no sea del Nornoroeste al Nornordeste, está confundida con las tierras más altas que tiene á su espalda, y Pimentel, que por su posición vertical la llama Fraile en Pié (más bien pudiera Dedo Pulgar) se equivoca describiendo que entre ella y la isla hay canal transitable á las lanchas, pues se eleva desde la misma riba. de ésta: es verdad que en toda su noticia y la que da de la creida Ascensión hay algo indistintamente que conviene con lo aquí visto; pero lo es igualmente que debió formarse de relaciones ignorantísimas, tanto, que indujeron al celoso cosmógrafo portugués á creer dos islas, evidenciando este juicio dos señales notables con que describe la Ascensión: la una de una lapa ó buraco grande (es agujero) que dice tiene al pié del pico más alto, donde entra mucho la mar, y debe ser el taladro en forma de ojo de puente que hemos observado en el extremo del morro colorado del Sueste, su dirección del Sursudoeste 1/2/4 Sur al Nornordeste $1 / 2 / 4$. Norte: y la otra de cinco islotes, que la sitúa inmediatos por la parte del Oeste en perspectiva desde el Norte, y aparecen así, vista la isla desde el Nornoroeste á tres leguas, sin embargo de. verse en el fondeadero, que están confundidos con la costa.
Los navegantes españoles, al encuentro de esta isla que llamamos Trinidad, la han nombrado Ascensión, cometiendo sólo un error de vo $z$, pues la han contado en $346^{\circ}$ de longitud de Tenerife, que corresponde á $24^{\circ} \mathrm{r} 8^{\prime}$ de la occidental de Cádiz, considerando mucho más oriental la que creian Trinidad, bajo la fé de las cartas; pero los portugueses al contrario, cuentan la Trinidad aún más cerca de la costa del Brasil, y entre una y otra la Ascensión.

Concluiremos este punto advirtiendo que tomadas con el octante dos alturas del picacho más alto sobre una base de 484 varas castellanas, resultó su elevación de 7 I9 y de $47 \%$ millas la tangente de su extremo al nivel del mar; de que se sigue deberse ver distintamente la isla desde cualquiera embarcación á I 7 leguas largas, y de igual operación se dedujo la altura de la pirámide septentrional de 478 varas.

\section{Salida de la Trinidad y crucero hasta volver á} fondear en la misma, y largarnos de ella.

El mismo día 7 de Abril á las dos de la tarde nos pusimos á la vela, faena en que perdió el bergantín su ancla ya suspendida faltándole el cable, lo que entonces atribuímos á mal estado de éste, y después se pudo reflexionar muy bien que le tendría cortado en parte alguna piedra.

El viento estaba flojo del Noroeste, y proponiéndose el Comandante cerciorarse de la existencia de la isla de la Ascensión, ceñimos al Oesudoeste, entreteniendo la noche y mañana siguiente en diferentes bordadas, á causa de las variedades que cesaron después de una turbonada del cuadrante tercero, entablándose el viento desde las cuatro de la tarde al Sur-Sueste fresco, poca mar y buen semblante; y así nos pusimos en derrota á conservar el paralelo de $20^{\circ} 40^{\prime}$ en que debía suponerse dicha isla, según la relación de Mr. D'Aprés, que bajo el atestado de Mr. Duponcel, la cuenta $5^{\prime}$ meridional á la Trinidad, dejando antes establecida ésta en $20^{\circ} 25^{\prime}$.

Favorecidos como estábamos del tiempo, breve se habían de caminar cien leguas, que se decía haber de una isla á otra: sin embargo, no se quiso ahora hacerlas tan presto como se podía para que en caso alguno pudiera tener lugar la sospecha de si la habríamos rebasado sin verla.

A medio día del 9 teníamos contraídas I55 millas de apartamiento de meridiano al Oeste de la Trinidad; hasta ponerse el Sol la misma tarde contragimos 4I más, y hechạ una descubierta cuyo alcance excedería de 12 leguas, para cualquiera tierra medianamente elevada, á favor de lo muy despejado de los horizontes, navegamos hasta las dos de la noche (ésta muy limpia) sólo 39 millas, atravesándonos entonces de una y otra vuelta á amanecer en el mismo paraje en 
que después de la descubierta sin novedad, pusimos otra vez en derrota, quedando al medio día del Io con 26 I y $1 / 2$ millas de apartamiento de la Trinidad, precisamente en $20^{\circ} 4 \mathrm{I}^{\prime}$ de latitud.

Empezamos á entrar en sospecha de la exis tencia de la isla, porque áun prescindiendo de que las $3^{8} \mathrm{y}^{\mathrm{H}} / \mathrm{2}$ millas que faltaban á cumplir las Ioo leguas, no eran bastante á tener la fuerza de la vista, y supuesto un error de ochoá diez leguas en la estima, no se presentaban señales ninguna de tierra cercana, estando tan acostumbrados á ver los pájaros con tanta anticipación en la de que habíamos partido; y á la verdad, no se podía comprender natural el que de dos islas sólo dis tantes roo leguas, y considerables de igual abundancia de peces, estuviese la una desierta de pájaros, sabiendo la otra habitada de infinidad de ellos, pero se doblaron los recelos al ponerse el Sol, hora en que con $26^{\prime}$ de apartamiento navegado, la suma de todas 288 , no parecía dudable deberse ver la isla en una descubierta lo ménos de I4 leguas para la elevación en que la supone Pimentel, y no aparecía.

Determinó aquí el Comandante cruzar entre los paralelos de $20^{\circ} 45^{\prime}$ y $20^{\circ} 25^{\prime}$, haciendo los rumbos del Sursudoeste y Nornoroeste á fin de granjear al Oeste sólo 27 millas entre los.puntos de salida y llegada en las referidas latitudes, medio por el cual no podía faltar á la vista una piedra que fuese del tamaño de las menores de Martín Vaz, con la circunstancia de entretener la noche ceñidos para amanecer donde se anochecía, y desde la salida del Sol contragimos así hasta medio día del I I sólo I 2 millas de apartamiento, completando cabalmente el de Ioo leguas de la Trinidad en $20^{\circ} 26^{\prime}$ de latitud.

En el punto de medio día se vió una bandada de charranes, mezclados con ella algunos bobos (desapareció presto, excepto tal cual charrán) é indujo á bajar hasta los $2 \mathrm{o}^{\prime}$, de donde volvimos al cuadrante tercero, y maniobrando en todo como antecedentemente, hicimos aquella singla dura poco más de $\mathrm{I} \delta$ millas al Oeste, observando el $\mathrm{I} 2$, en latitud de $20^{\circ} 30^{\prime}$, horizontes clarísimos que facilitaban un alcance extraordinario, y que no nos presentó más objeto que el de un charrán instantáneamente (iba del Este al Oeste) y una balandra pequeña que ceñía al Esueste mura á babor.

Del i 2 al I 3 navegamos del mismo modo, adquiriendo $23 \mathrm{y}^{1 / 2}$ millas de apartamiento, que con las anteriores hacen ya Ir4 leguas, á que agregado el alcance de la descubierta, aunque no sea más de diez, resulta un exceso, fuera del error que cabe en una travesía de roo, que ordinariamente se hace con vientos favorables; se observó la latitud de $20^{\circ} 34^{\prime}$, y empezó á cubrirse el tiempo, aparentándose una revolución de las incesantes en la costa del Brasil en esta estación.

Del I3 al I4, tampoco hubo novedad en el método de derrota descle los 25 hasta los $45^{\prime}$ del $20^{\circ}$, si la de aclarar de nuevo el tiempo; y contragimos 29 millas de apartamiento, que con las pasadas, hacen 124 leguas, y nada se descubrió, alcanzando la vista más de r2: quedamos á medio día en $20^{\circ} 46^{\prime} 47^{\prime \prime}$ de latitud.

Poco antes (cuarto día de Luna) habíamos medido dos distancias de ( $\mathfrak{c}$ á $\odot$, de que resultaron longitudes acordes, y su promedio de $39^{\prime} 37^{\prime \prime}$ al Este de la estima, que valen I $21 / 3$ leguas de apartamiento, de modo, que siempre quedaban á contar I 2 desde la Trinidad, y con la descubierta excedían en mucho al límite del error del es. tablecimiento de la Ascensión.

A estas observaciones las ponía fuera de aquella confianza que se tiene en otras, el estar la ( en apogeo, y su poca elongación que á veces causa no percibirse bien el verdadero márgen de ella, absorbido por la excesiva iluminación del $\odot$, particularmente como entonces en las inmediaciones del medio día, pero si cabía allí este defecto, produciría medir crecidas las distancias y longitud demasiado occidental, contraria á la que aparecía; y esta consideración indujo á los observadores á tener por buena la averiguada.

Del I4 al I5, cruzando de la propia suerte entre los paralelos indicados, se granjearon 32 millas al Oeste, que agregadas á la observación, componen I22 leguas de apartamiento, y sólo vimos tres pájaros negros poco menores que gaviotones: observóse al medio día la latitud de $20^{\circ} 57^{\prime}$.

Tanto por hallarnos en tan crecida latitud, como por la revolución que se aparentaba, cerrándose los horizontes, con algunas variedades interrumpidas de calmas, sólo granjeamos para el Norte, nada al Oeste, en las singladuras del I5 al I6, quedando en latitud de $20^{\circ} 3^{\prime}$, sin más vista que la de algunos martimplacas, pájaros que venían huyendo del mal tiempo que se anunciaba en altura.

Entablándose el viento al Sursueste al medio día del I6, pusimos al Nornoroeste $1 / 2 / 4$ Norte á fin de ganar poco al Oeste, por la corta descubierta que franqueaba la fosquedad de los horizontes. En esta \$jó la atención de todos á las tres de la tarde, una ceja que parecía tierra desde el Noroeste al Oesueste interrumpida al Oeste, señales que convenían con la entrada de la bahía del Espíritu Santo, en el paralelo de 20.28 en que entonces estábamos. La vista sola no se resolvía á determinar si realmente era tie11a lo que lo parecía: sondamos orzando al Sudoeste tomando fondo de 40 á 50 brazas cascajo gordo: cambiamos la cabeza, se repitió la sonda dos veces hallando de 80 á 90 brazas piedra $y$ 
cascajo colorado, y siguiendo para fuera á muy poco rato, ni después ya más se pudo coger fondo con I ro brazas.

La sonda confirmaba la vista de la costa del Brasil: la situación de ésta referente al Cabo Frío, cuya longitud está exactamente determinada, es susceptible de poco error: la comparación del punto con esta vista, daba $2^{\circ}$ de diferencia Oeste cuando cincuenta y dos horas antes la teníamos observada contraria de $39^{\prime} 37^{\prime \prime}$ : sin embargo, doblados aquí los recelos que cabían en la exactitud de aquellas observaciones (número 72) nos supusimos á la vista del Brasil, ínterin se hacían otras más seguras; y siendo indistinto el que fuese ó no, esto es, el que distase diez leguas ó cuarenta y ocho, para determinarnos con entera seguridad á creer, no hay tal isla de la Ascensión entre la de la Trinidad y dicha costa: y como por otra parte sea necesario desatracarse de ella para emprender cualquiera derrota, á más de que la actual revolución de variedades, aguaceros y truenos, no hacía practicable otra mayor cercanía, sin otro objeto que el de mera curiosidad, se mandó ganar al Este con el ánimo de atravesar de nuevo á la Trinidad, para examinar otra vez los meridianos intermedios.

La tarde del I7 se vieron al Oeste dos embarcaciones al parecer pequeñas, y á la misma parte se notó otra vez la apariencia de ceja de tierra como la tarde anterior, bien que estuviésemos ya 26 millas más al Este, consideración que destruía la posibilidad de que lo fuese, respecto á hallarnos indubitablemente á Oriente de los más puntos que habíamos cruzado en la singladura del I4 al I5, con un tiempo $\mathrm{y}$ horizontes propios para descubrirla á mucha mayor distancia que ahora.

Seis observaciones de longitud este día, las cuatro por distancias de la Luna al Sol, una á Régulo y otra á a de la Spiga, confirmaron la exactitud de las dos del $\mathrm{I}_{3}$, y no permiten creer que pudiśsemos haber visto la tierra, conviniendo también en ambos casos la variación de la aguja, con la diferencia de longitud que resultaba al Cabo Frío, donde actualmente debe contarse de $6^{\circ}$ I $5^{\prime}$ Nordeste, esto es, $2^{\circ} 8^{\prime}$ mayor que la bien observada en el momento que sondamos, y acorde á todas las anteriores y posteriores, de que se sigue, debernos faltar entonces $4^{\circ}$ para cumplir la longitud de Cabo Frío, y que no podíamos tener á la vista una costa que sólo está $I^{\circ} 33^{\prime}$ más oriental, sin que obste el hallazgo de la sonda, que persuadió á creerla, pues consta en el viaje de Jorge Anson alrededor del mundo, que la halló de ménos braceaje áun por latitud de $23^{\circ}$ muy fuera de la vista de tierra, áun supóniendo que tuviese en su estima el error de cerca de 40 leguas que deducía del punto de dos bergantines portugueses, procedentes de Ja- neiro, que encontró dos días después, y que no creyó al recalo en la Isla de Santa Catalina, teniéndole más conforme á su estima. Esta sonda debe ser Lengua de los Abrojos, como opina el Diarista de Anson.

Ya bien despejado el semblante, desde el 20 que fijó el viento al Norte y Nornoroeste (debe mirarse como no ordinario lo que perseveró), seguimos ganando al Este, tomando para el medio día del 22. la latitud de $20^{\circ} 33^{\prime}$, de donde bajamos todavía hasta los $20^{\circ} 24^{\prime}$ antes de recalar á la Trinidad, á que dimos vista la mañana del 24 , al Este 1/2/4 Sur, impidiéndonos la cerrazón de la misma parte y el poquísimo viento, volverla á distinguir hasta las ocho de la no. che, perseverando el resto de ésta inmediatos, para anclar la mañana siguiente, 25 de Abril, como 10 ejecutamos por 26 brazas arena, reconociendo $30^{\prime} 48^{\prime \prime}$ de diferencia al Oeste de la estima entre ida y vuelta; y haciendo proporcional á los días esta diferencia, resulta, que podía ser de $15^{\prime}$ al picar la sonda el I6; pero el que no se adelante á negar las evidencias de la Geometría, convendrá en que la corredera de que usamos (esto es, de 42 piés ingleses para $28^{\prime \prime}$ ) es tan defectuosa por corta, como que está próximamente en razón de II 2 á roo con la medida de la tierra, determinada por tan respetables sabios: y que por consiguiente, no podíamos hallarnos entonces una milla al Oeste de la estima, sí algunas al Este, que se habían de destruir desandando el camino con la propia corta medida, para quedar sólo la diferencia verdadera, evidenciándose por último, que fué ilusión no más la de la vista de la costa.

Excediendo en mucho los límites de una sucinta narración, cual se quiere dar no más de nuestra navegación, se ha desmenuzado aquí esta travesía, porque no ha parecido, que bastase afir. mar así como quiera, que no hay Isla de la Ascensión, estando tan reciente la afirmativa de Mr. Duponcel: expresas como quedan las derrotas, no tiene el que quiere hacerse juez, más que transferirlas á una carta ó trazarlas en otro papel, y sentencie si á 60 ni á Ioo, I 20 y hasta I 35 leguas al Oeste de la Trinidad, pucde haber isla que no hubiésemos visto, no sólo en el paralelo de $20^{\circ} 40^{\prime}$ en que se indicó su existencia, mas también en todo el grado 20 hasta el $2 \mathrm{I}$ (que es lo que se pretendía inquirir) y áun fuera de dichos límites en distintos parajes.

No parece en razón alguna, que la aserción de la inexistencia de la Isla de la Ascensión, pueda ofender al mérito é inteligencia de Mr. Duponcel, ni ménos á la fé de que serán dignas todas sus observaciones náuticas; pues apenas se examinará un Diario de los en que puntual y sabiamente se expresa lo que se nota y acaece, en que no se encuentren estas ilusiones de tierra 
desvanecida así que se ha puesto sobre ella á reconocerla; deduciéndose del contesto de monsieur D'Aprés, que no se acercó á examinarla, pues sólo dice que aparecía una eminencia poco más ó ménos de figura de chimenea, sin advertir circuito, tensión, latitudes precisas ó variación de la aguja, como lo requería el aviso de un punto tan controvertido. Tenemos un ejemplar reciente en el viaje de Cook, Banks y Solander alrededor del mundo, donde se dice, que el I 4 de Enero de 1769 , vieron una apariencia de tierra, que desde luego juzgaron la Isla Pepys, sita en las cartas inglesas en $48^{\circ}$ de latitud Sur por $64^{\circ}$ de longitud al Oeste de Londres, desengañándose de su ilusión á breve rato. Acerca de la Isla Pepys que buscó dos veces inútilmente el Comodoro Biron en su viaje-alrededor del mundo, año de 64 á 66 , le ocurre sabiamente al autor de aquel Diario en defensa del Capitán Cowley, que la denominó así en honor de Samuel Pepys, Secreta. rio de Jacobo, Duque de York (después II del nombre, Rey de Inglaterra), la justa reflexión de que no puede haber sido engañar al público el designio de los avisadores de islas imaginarias, siendo muy fácil el engañarse y creer tierras los vapores y nieblas, como les sucedió muchas veces; pero aquí es inutilísimo mendigar ejemplares ulteriores que sinceren semejantes engaños, cuando está tan fresco convencido de tal por todas razones el nuestro de la vista de la costa del Brasil. Y finalmente, si no suponemos sinceridad en los demás (que debe, no habiendo evidentes pruebas de malicia), no mereceremos que se crea la nuestra y jamás quedará decidida la verdad, cuya aclaración es el objeto de todo hombre de bien, y no ménos necesaria en nuestro oficio.

Tabla de las longitudes obseriadas en este crucero.

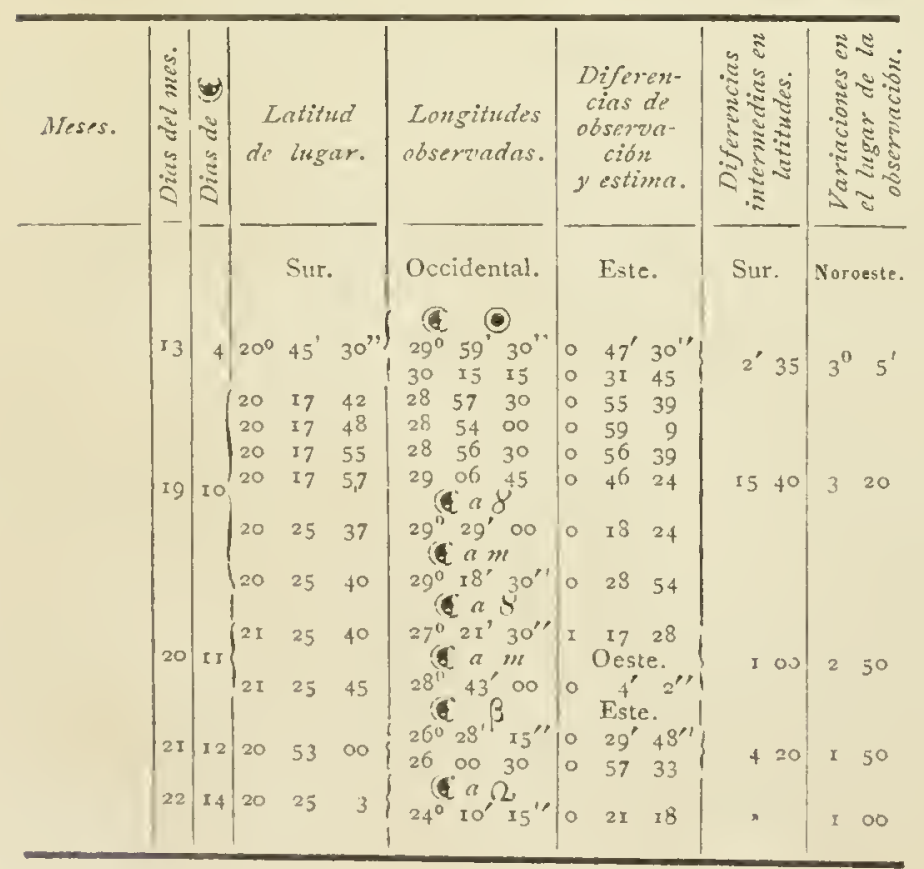

Fondeamos esta segunda vez en la Trinidad, con objeto de tentar si podía hacerse alguna agua y leña en recmplazo de la consumida, que ya era considerable; en efecto, la falta de marejada del Sudoeste desde muchos días antes, dejó accesible el atracadero en la medianía de la isla, detrás de un peñasco y se reconoció una gran vertiente de agua, que sólo podía hacerse á barriles, por no haber medio de disponer manguera, ó desembarcar pipería con seguridad, pareciendo que áun así alcanzaría á llenarse diariamente de $x_{5}$ á 20 pipas; pero llenó la marea, impidió el tráfico, y eran las diez de la mañana del 26 , sin que se observase en la lancha movimiento para regresar con sólo diez vasijas, que llevó la tarde anterior.

A la misma hora, aproando la fragata al Sur, adonde quería apuntar el viento, se notó en las enfilaciones, más rariedad de la correspondiente al rabeo: indujo á sospecha, se sondó sobre el ancla 28 brazas, habiendo caído en 26 , y que por marea debía haber igual agua: se viró sobre el ancla, con el ánimo de suspenderla, se advirtió falto un cordón del cable, que se rompió á poco rato á tres brazas de la entalingadura, y dimos fondo á otra ancla; pero reconociéndose la tajadura de piedra, metido el primer cable, sin embargo de que la sonda, en un gran círculo sobre el ancla, no indicaba otro fondo que el de arena blanca y negra, se pensó, lo que realmente es, que sólo hay una capa de ella sobre piedras como navajas; por tanto determinó el Comandante dar la vela, mandando al bergantín no levarse hasta recoger nuestra lancha, á quien se hacía señal para que se retirara, y acreditó lo fundado del juicio sobre el fondo, el cable segundo que salió muy rozado también, cerca de la entalingadura, sin embargo de que apenas estuvo media hora en el agua.

Asi que quedó entablado el viento al Sur, creció tanto la resaca en la costa, que fué inmensa la fatiga que costó á la lancha el largarse de ella, forzándola poco después á abandonar las pipas que traía arrizadas, tardando no poco aún usí en coger el bergantín, á causa de la gruesa mar que ya estaba formada; tanto, que no pudiendo ir éste sobre su ancla, pues balanceaba á embarcar agua por ambas bordas, picó el cable para ponerse á la vela.

Formó el Comandante el designio de recobrar nuestra ancla y la del bergantín, esperando inmediato á la isla á que cayese la mar; y efectivamente, el 29 por la mañana se envió el bergantín á aquella faena, que empezó por su ancla y la perdió faltando el orinque cuando la tenía ya suspendida, viéndose luégo que estaba aquél rozado de piedra: tomó el del ancla, la levantó con facilidad, y la tenía ya bien alta, cuando entrando á las dos de la tarde un ventazo del Oesudoeste al Sursudoeste con mucho aguacero y gran cerrazón, se vió en la necesidad de picar el orinque porque zozobraba sobre el ancla y se iba 
á la costa, en que estuvo en gran empeño por haberle cogido el viento de mala vuelta y no tener aguas para virar; mas logró montar el morro de Sueste, y circundando la is la por su costa oriental, amaneció el 30 incorporado.

Recogimos el bote y gente que se le había dado para aquellos trabajos, y tomándole de remolque, pusimos al Norte $1 / 4$ Nordeste, viento Sueste frescachón, observando al medio día la latitud de $20^{\circ}$ II $^{\prime} 20^{\prime \prime}$ Norte-Sur con la punta septentrional de la isla, y así quedó establecida para punto de salida la longitud de $24^{\circ}$ I2' al Oeste de Cádiz.

Esta parte de derrota, igualmente que las demás, necesita una especial atención, no sólo á las estaciones, si también á los semblantes del tiempo, combinados con las lunaciones: en el invierno, esto es, en los meses de Marzo á Octubre, suelen experimentarse unos vendavales tanto más frecuentes cuanto mayor es la latitud en que se halla, y en atención á esto conviene más bien el no llegar al paralelo de la Isla Lobos ó del Cabo Santa María hasta estar muy cerca de la costa; al contrario en verano, como quiera que la alternativa de terrales $y$ virazones influye naturalmente en las calmas y bonanzas, conviene entrar en el paralelo de la isla Lobos con una ventaja en longitud de 30 ó 40 leguas; las corrientes en este tránsito desde la Isla Trinidad hasta el Río de la Plata, suelen inclinarse más bien al Oeste.

Todo el placer puede considerarse de arena, y áun pueden sentarse sin temeridad varios principios que sirven á dirigir la recalada por la sonda. I. ${ }^{\circ}$ La arena es blanca y mezclada con conchuela y caracolillo, si en iguales meridianos se está al Norte, ó en el mismo paralelo del Banco Inglés; es al contrario parda fina y á veces lamosa, si está al Sur de dicho paralelo. 2. En iguales meridianos crece rápidamente el fondo navegando al Sur, y crece tanto más rápidamente, cuanto más se dista del meridiano de Cabo Santa María. $30^{\circ}$ La lama es el indicio seguro de estar en buena derrota. $4 .^{\circ}$ Hasta las 40 brazas no puede formarse juicio de la posición verdadera, y por consiguiente puede excusarse el sondar frecuentemente. La sonda hasta las 80 brazas sale á unas 40 leguas del meridiano de Cabo Santa María; pero su declive no es propor'cional, siendo bastante rápido desde las 80 hasta las 30 brazas, y conservándose luégo, ó disminuyendo paulatinamente á un número menor.

E1 Cabo Santa María está en latitud de $34^{\circ} 57^{\prime} 20^{\prime \prime}$ y longitud occidental de Cádiz de $48^{\circ} 36^{\prime} 40^{\prime \prime}$. El extremo Este de la restinga de la Isla de Lobos está en $35^{\circ} 4^{\prime} 35^{\prime \prime}$ y en longitud de $48^{\circ} 39^{\prime} I 7^{\prime \prime}$. Como los vientos se inclinen regularmente al Norte y Nordeste, cuando se atraque la costa parece preferente mante- nerse en paralelos del Cabo Santa María, y más bien algunos minutos al Norte, tanto más, que comunmente y con vientos foranos, las aguas corren aquí al Sudoeste.

Conservada esta latitud, y cogidas 25 á 30 brazas arena fina y caracolillo, podrá considerarse el navegante á 20 leguas de la costa; el fondo de I5 á 20 brazas le indicará que está ya cerca y que es tiempo de buscar la vista de tierra y el fondo lama.

Poco hay que decir si la recalada es con tiempo claro y vientos galenos; nada puede estorbar el navegar con todo aparejo, aunque sea de noche; pues si la latitud al ponerse el Sol es deducida de la observación del medio día pró. ximo, y no se avista tierra por paralelos algo más Norte del Cabo de Santa María, teniendo aún de 20 á 30 brazas arena y conchuela, no debe quedar duda que la distancia á la costa, es aún considerable. En este caso deben hacerse lumbos del Oeste para buscar las 16 brazas arena, y descaecer con el solo efecto de las corrientes al Sur, pues de otro modo pudiera cortar el paralelo de la lama demasiado al Este, y por consiguiente no encontrando sino arena, se. guir sin valiza para el Oeste y hacer contrarios los terrales del Nornoroeste y Norte. Las tierras del Norte del Cabo de Santa María deben verse con tiempos claros á Io ó I a leguas y por fondo de 5 brazas. Merece entre ellas particular cuidado la ensenada de Castillos, en donde han solido los correos echar oportunamente los plie. gos á tierra con un bote, cuando el pampero no les ha permitido alcanzar el puerto de Maldonado.

Cogidas las I 6 brazas, si la estima manifes tase estar aún al Norte del Cabo Santa María, podrán hacerse rumbos del Sursudoeste hasta alcanzar el paralelo de la Isla de Lobos; pero con la atención de inclinarse al Oeste si las sondas aumentasen á más de 20 brazas, y de inclinarse al Sur si disminuyesen de las I6. E1 fondo entre el Cabo Santa María "y la punta de Castillos, disminuye repentinamente y casi sobre tierra.

El rumbo indicado llevará precisamente á una arena lamosa, en la cual, y en el paralelo de la Isla Lobos, se puede ya navegar al Oeste conservando fondo lama y i 8 á 22 brazas. Puede estar se en la seguridad que este fondo llevará aún de noche, con la mayor precisión, á la vista de la Isla Lobos, la cual se procurará dejar á estribor distancia de una legua, y se seguirá en derrota.

No pocas veces, á pesar de esto, se hace algo complicada, mas no peligrosa, la entrada en el Río de la Plata: suele carecerse de la latitud observada: debe suponerse una corriente, y las neblinas ó cerrazones (particularmente en invierno) imposibilitan ver la Isla de Lobos á alguna dis tancia: en estos casos siempre conviene asegu- 
rarse de estar al Norte de la Isla de Lobos, contando para la estima con un efecto de corrientes al Sur luégo que la distancia á la costa no sea mayor de 20 á 30 leguas, ó lo que es lo mismo, luégo que la sonda no sea mayor de 40 brazas: la sola seguridad de estar al Norte bastará entonces para dirigir la derrota, pues que cogidas las I 8 brazas no se titubeará en arribar al Sursudoeste hasta que, como ya se ha indicado, el fondo no haya crecido á 20 y 22 brazas: ya en este caso, si conviniese aún afianzar más y más la posición que se sospecha, no deberá abandonarse el rumbo del Sursudoeste, y áun se inclinará algo al Sur, consigiéndose de este modo, que disminuya nuevamenie el fondo, y afiance así (xun sin el auxilio de la lama) que se ha pasado el paralelo del canal: muy luégo con esta averiguación se harán rumbos del Oeste al Norte, y paulatinamente aumentando el fondo é inclinándose á la lama, disipará toda duda para buscar la Isla de Lobos.

Importa tanto más esta precaución de averiguar por la sonda el paralelo de la Isla Lobos, cuanto que si se estuviese al Sur de él con I 6 brazas arena, pudiera ó irse á sotavento, navegando al Sur, ó dar en el Banco Inglís navegando al Oeste, rumbos indispensables en uno de los dos partidos, ó de buscar la canal, ó de avalizarse con la costa del Norte del Cabo Santa María. Si en otras ocasiones y particularmente en la ocasión precisa de saberse la latitud, el navegante puede acertadamente dirigirse al Río de la Plata, pasando al Sur del Banco Inglés, de ningún modo debe intentarlo cuando se halle sin seguridad de la lat tud, y sin haberse avalizado con la tierra; pues tanto como le son útiles las sondas para pasar al Norte del Banco Inglés, tanto le son perniciosas cuando se incline á pasar al Sur sin el auxilio de la latitud.

Ya cogidos los paralelos inmediatos meridionales de la Isla de Lobos con fondo de ig y 20 brazas lama, sólo se ocupará el navegante de conservarlo al principio y luégo disminuirlo paulatinamente con rumbos del Oeste $1 / 4$ Noroeste hasta 17 brazas, en cuyo fondo le demorará la Isla Lobos, del Norte al Noroeste dos ó tres leguas. La precaución de conservarlo al principio es importante por no pasar entre la isla y la tierra firme, hacia donde pudiera acarrear tam. bién la lama, pero bajando precisamente á I5 y 16 brazas.

La restinga del Este de la Isla Lobos sale una milla escasa, y hace que por esta parte sea imposibie el atracarla: es, al contrario, muy acantilada en todos los demis rumbos.

Es preciso advertir aquí que esta derrota puede cn alg:inos casos ser peligrosa, particularmente curndo un tiempo no dccidido en el incrno y con malas aparicncias, hace recelar de un Sueste, en cuyo caso es preferente á todo, el ponerse en paralelos más al Sur de la Isla Lobos de I5 ó $20^{\prime}$ antes de bajar de las 30 brazas de fondo. En este caso, y conocida la latitud, puede buscarse en derechura el placer del Banco por las siete ó seis brazas, y por él, ó navegar al Norte en busca de la canal, ó dar fondo si el viento saltase al Sudoeste.

El rumbo del Oeste $5^{\circ}$ Norte es el que comunmente lleva á la vista de la Isla Flores, pues como las corrientes con los vientos oportunos para entrar se dirijan contínuamente al Oeste, suele este rumbo, inclinándose algo más al Norte, resarcir aquellos efectos, y promediar la derrota más oportuna: el extremo Sur de la Isla Flores, situado en latitud de $34^{\circ} 5^{8^{\prime}}$ oo $0^{\prime \prime}$ y longitud de $49^{\circ} 52^{\prime} 30^{\prime \prime}$, corre con el extremo Sur de la Isla Lobos Este $6^{\circ} 45^{\prime}$ Sur y Oeste $6^{\circ} 45^{\prime}$ Norte $19 \mathrm{y}^{1} /$, leguas. Suele proyectar en forma de dos islas, particularmente si se ve con una marcación que incline al Sur, se alcanza á ver á distancia de cuatro ó cinco leguas, y no presenta en su superficie sino arenales y algunos escarpados bajos, que son el abrigo de una infinidad de lobos marinos.

En esta navegación ó travesía no debe abandonarse la sonda, cuyo braceaje y calidad son igualmente importantes: la canal tiene una lama suelta que casi no se pega al escandallo, y su fondo va disminuyendo progresivamente, desde las I7 brazas hasta las siete, por cuya sonda se está ya inmediatos á la Isla de Flores.

Son casi iguales los fondos al Norte de la canal; pero la calidad es una lama dura que avisa de inclinarse al Sur (I), al contrario, el menor fondo y la calidad de arena que pudieran encontrarse, avisan el estar al Sur la canal, y deberse, por consiguiente, torcer los rumbos al Norte para no caer en el Banco Inglés.

Es inútil advertir, que cuando no se hubiese avistado la Isla de Lobos, se hacen precisas mayores precauciones para cerciorarse de su situación: tales son, particularmente, el saborear el agua y el avalizarse con arena, haciendo rumbos del Sur antes que el fondo lama haya disminuído de I3 ó I4 brazas, puez si se esperase á estar en Io ú II, y se hiciesen rumbos del Sur y Oeste, pudieran tal vez arrastrar á las inmediaciones del Banco Inglés.

Con mucha prudencia y muy buen éxito, las fragatas correos de S. M. que han sido sobrecogidas de los pamperos en esta travesía, han preferido dar fondo á salir de la costa; pero como la lama suelta que se encuentra en el ca-

(x) El carecer de esta noticia hizo que ambas corhetas se ensenasen de tal inodo, que marcaron la Isla Filores al Sudoeite, y necesitaron de todos los esfuerzos y buenas cualidades para pasarla al Sur á distancia de una milla escasa. 
nal frustraría toda medida de esta especie dando lugar á que garrasen las anclas, se han inclinado al Sur á coger las siete brazas del placer de arena, en donde la tenezón segura, y el mismo abrigo del Banco, no le expondrían á perder las amarras, y luégo, con los vientos que regularmente pasan del Sudoeste al Sur, se hallarían á barlovento para navegar hacia la Isla Flores; y desde luego en mejor disposición para enmararse $\sin$ recelo de la Isla Lobos en el caso que faltasen las amarras.

Si al contrario, se escogiese para fondeadero en estas ocasiones el cantil del Norte, en donde la lama dura puede ofrecer una tenezón igualmente buena, desde luego se incurriría en los dos graves inconvenientes de exponerse á no montar la Isla Lobos, faltando los cables, y de estar á sotavento rolando el viento al Sur. Parece, no obstante, que los franceses que al principio del siglo frecuentaban estas costas, se inclinaban á esta parte, tal ve $z$ por demasiado recelo del Banco Inglés ( $\mathrm{I}$ ).

Ya cogidas las siete brazas lama suelta y con la seguridad de estar en buena derrota, así por la misma calidad del fondo que se ha traído de antemano, como por las valizas que se hayan tomado en uno ú otro cantil, se seguirá el rumbo del Oeste inclinándose al Norte, si se viesen asíla Isla Flores, como la punta de las Carretas; pero no verificándolo, si las tierras estuviesen de un todo ocultas ó confusas: el fondo en este caso irá disminuyendo hasta $5 \mathrm{y}^{1 / 2}$ brazas, y se conservará así por algún tiempo, siendo su calidad constantemente la lama suelta.

Importa mucho no inclinarse al Norte cuando no se ve la tierra, así porque pudiera no estarse aún exactamente Norte-Sur con la Isla Flores, como porque la dirección de las aguas pudiera aconchar algo más después sobre la punta Brava, cuyas proximidades son realmente sospechosas; pero andadas tres leguas, después de encontradas y ratificadas las siete brazas lama suelta, y encontradas cinco y media brazas á seis, puede estarse seguro que la punta Brava demora del Nornoroeste al Norte distancia de una legua, y que por consiguiente es tiempo de ceñir en demanda del puerto.

Los arrecifes más salientes de la punta Brava estín al Oeste $7^{\circ}$ Norte del extremo Sudoeste de la Isla Flores, á distancia de I4 millas. De-

(I) Se infiere así de los viajes del Padre Feuille y del Ingeniero Frezier: es de advertir que desde Solfs Grande para el Oeste, el fondo en las inmediaciones de la costa es más bien barro que lama. Fuera muy útil alcanzar los derroteros portugueses para la navegación del ró hasta la colonia del Sacramento. Los navegantes de esta nación, precisamente han cimentado la navegación práctica en razón del descúdo con que han mirado la navegación astronómica. mora el cerro ó monte Video al Norte $7 \mathrm{I}^{\circ} 45^{\prime}$ Oeste del extremo Sudoeste de la isla Flores, distancia I4 millas, y el paso entre la isla y el bajo de las Carretas, que de ningún modo debe emprenderse sino por necesidad, tiene de abra dos y media millas y un fondo de cinco á seis brazas lama suelta.

Ya asegurada la posición propia relativamente al puerto, si no se viese el monte Video ó la población, sería imprudente intentar coger el fondeadero. El monte efectivamente suele cubrirse con vapores tan espesos, que á veces ni aún desde el puerto y á distancia de una legua es fácil conocerlo. En tal caso parece lo más prudente ceñir algún tanto hacia el puerto, yó buscarlo haciendo navegar el bote á estribor y con la posible distancia, ó finalmente dar fondo en cinco brazas lama hasta que aclare.

En la dirección al puerto, poco hay que insinuar más de lo que dicta el mismo plano, cuyo braceaje y bajos salientes de las puntas Brava y San José, hacen ver palpablemente que es menester navegar con la proa al monte hasta franquear bien la boca, desde la cual últimamente se hará derrota á dejar caer el ancla en las inmediaciones de los demás buques y al Oeste de la medianía de la ciudad.

No deben esperarse en este paraje sino tres brazas escasas en mareas grandes y I 3 á I 4 piés en mareas bajas, de suerte, que fuera temeridad para embarcaciones grandes el intentar internarse; antes bien, como el fondo por largo trecho es casi igual, se hace sumamente molesto este puerto para embarcaciones que calen más de 18 piés, pues les es preciso fondear muy afuera, cogiendo sonda de cuatro á cinco brazas (I).

El fondo de estos parajes es todo de lama tan suelta, que arrastra consigo el grave inconveniente de no agarrar las anclas, desamarrándose los buques á cada paso, á pesar de la galga tendida en ayuda del cable del Sudoeste y de otro cable al Sueste, sobre las cuales y una coder al Norte, se mantiene contínuamente la proa hacia fuera ó al Sur.

No es leve tampoco el riesgo que de esta calidad de lama resulta á las personas que echándose ó cayendo al agua, lleguen, como es fácil al fondo: se empantanan de modo, que todo es fuerzo les es inútil, y muy en breve quedan víctimas de esta especie de fondo. En desquite de estos inconvenientes, hay, no obstante, la ventaja de poder quedar varados ó sentados en el fango, sin la menor avería, á ménos que un di ferente calado de popa y proa (por falta de cuidado) no expusiese á un quebranto, la embar-

(1) Los navlos de 74 cañones que invernaron en este puerto en el aho $\mathbf{7 7 7}$, pasaron una serie cons tante de peligros y fatigas. 
cación, que estuviese varada á popa y flotase á $\operatorname{proa}(\mathrm{r})$.

En el puerto, el agua crece de una braza y á veces de dos brazas, cuando soplan Oeste y Sudoeste. Baja mucho, al contrario, cuando los vientos son del Norte. Las mareas, trastornadas por este influjo de los vientos, no pueden, por consiguiente, considerarse periódicas; y de allí viene que todas las faenas de espiarse para ir á mayor fondo ó con el ánimo de completar la carga ó de dar la vela, han de ejecutarse precisamente cuando con los vientos Oeste y Sudoeste, aunque lluviosos, el agua sube de su nivel. Para franquearse, es menester tomar la media canal, y más bien aproximarse al cerro; y fuera imprudente el bordear cuando no lo exijan circunstancias de mucha entidad, pues ni las distancias son excesivamente largas para no usar de espías, ni el fondo es tal que dé lugar á aprovechar los bordos favorables.

En general, el nivel del agua del puerto de Montevideo no depende del nivel del río y sólo sí de la dirección de las aguas: éstas vienen hacia el puerto con los vientos del segundo y tercer cuadrantes, y crece el nivel del agua. Salen, al contrario, y siguen la vertiente del río con los vientos del primero y cuarto cuadrantes, $y$ entonces disminuye el fondo.

En cuanto á la corriente exterior, esto es, desde el meridiano del Cabo Santa María hasta el Banco Inglés, parece no admite duda que entra con todos vientos ménos el Noroeste; pero también que en una y otra costa hay revesas que corriendo contínuamente para fuera, equilibran en cierto modo las aguas que entran: siempre ha de entenderse á pesar de esto, que la fuerza de las corrientes no se extiende al Sur del Banco Inglés, en donde no encontrando tropiezo alguno, al contrario de lo que sucede en la costa del Norte, no adquiere velocidad alguna, ni por las revesas, ni por la resistencia.

En ninguna parte se convence mejor esta verdad, que en el puerto de Mald̄onado, formado únicamente con el abrigo de la Isla Gorrite: sean cualesquiera los vientos reinantes, siempre las aguas corren rápidamente del Oeste para el Este, saliendo por el freu que forman la Isla Gorrite y la tierra firme, y al mismo tiempo EsteOeste con la Isla Lobos, las aguas corren con velocidad poco menor del Este para el Oeste.

Este puerto debió ser hasta aquí muy apreciable, por la facilidad que había de cogerlo y de abandonarlo sin arrostrar los muchos riesgos que se encontraban al dirigirse á Montevideo (2), pero

(1) Ista atención es precisa, particularmente para los buques de Armarlilla: con la artillería y municiones, les es fácil igualar los calados.

(2) Murhas veces se ha insistido que fuese el Deposito de: la Marina Real. desde que se ha hecho más fácil y segura la navegación á este último puerto, y particularmente desde que puede salirse de él, más bien con los terrales y virazones diarias, que con el Noroeste y Suoeste tempestuosos, se le ha dado prefe. rencia.

Desde luego, si el ánimo fuese de fondear en Maldonado, importa mucho avalizarse, ó con el Cabo Santa María ó con la Isla de Lobos, para no equivocar otras tierras con la Isla Gorrite, que siendo baja y toda llena de blanquizares de arena, proyecta contra la costa opuesta, de modo que es difícil distinguirla: en este caso siempre es preferente el pasar al Norte de la Isla Lobos, y tan atracado á la tierra firme, cuanto lo dicte la prudencia: el canal es limpio y las virazones frescas, particularmente desde el medio día hasta después de puesto el Sol; y es un anuncio casi seguro de la virazón (particularmente en verano) el verse los horizontes cerrados con neblina, desde el salir del Sol hasta las ocho ó nueve de la mañana.

Si la virazón manifestase firmeza y las inme. diaciones del puerto se descubriesen claras, fuera tanto más reprensible el no pasar entre la Isla Gorrite y la punta del Este, cuanto más difícil fuera de otro modo el coger el fondeadero más oportuno. El bajo que hace algo peligrosa esta entrada, está en las siguientes marcaciones: la punta Sur de la Isla Gorrite al Noroeste; la medianía de la población de Maldonado, Norte $3^{\circ} 30^{\prime}$ Este; la punta más saliente de la tierra firme, llamada punta del Este, al Este, distancia á esta última punta dos y medio cables escasos. La canal entre el bajo y la Isla Gorrite, queda de media milla, y su fondo limpio hasta uno y medio cable de una y otra parte.

Como ya se ha dicho, hay en este freu una corriente bastantemente rápida para fuera; lo que exige tres precauciones para los que intenten pasarle: la primera de no dirigirse á él con vientos variables ó bonanzas; la segunda de no navegar con poca vela; la tercera, finalmente, de no poner la proa al medio freu, hasta salir de la enfilación del bajo, con el extremo Sur de la isla, atracándose más bien á este extremo que á la tierra firme, para no luchar con la corriente más rápida. El paraje mejor para amarrarse es Este-Oeste con las ruinas del cuartel de la Isla Gorrite, á distancia de cuatro cables de ella, y por fondo de cinco y media á seis brazas arena. Deben tenderse las anclas Noroeste, Sueste, y claras al Sudoeste, de modo que así se haga la mayor fuerza contra el viento por aquella parte y la corriente del Oeste.

Al deseo de coger este puerto con virazones y tiempos claros, pueden añadirse otros dos casos, de los cuales el uno es el de ser cogidos del pampero, al Oeste de dicho puerto, y el otro 
de ser sobrecogidos del Sueste en disposición de poderle alcanzar: este último caso, frecuente en invierno, pide á la verdad, que más bien se incline el navegante á tomar la vuelta de fuera, ó á dirigirse á Montevideo, porque la costa por sí se cierra con exceso, y es fácil empeñarse sobre la Isla Gorrite, hallándose luégo sin partido por el viento fresco y la travesía; pero si algún accidente hiciese precisa la determinación de entrar con Sueste tempestuoso, creo que el mejor, antes bien, el único partido es el de pasar bien cerca de la Isla Lobos, costeándola á estribor, y por ella ir á buscar la punta del Este, internando últimamente por la canal. En esta punta hay algunas chozas que pudieran verse. En la Isla Gorrite solo sobresalen una casa blanca y algunas paredes arruinadas, cuya permanencia por largo tiempo no parece probable.

La entrada con Sur y Sudoeste, que aquí son claros, no tiene el menor inconveniente haciendo proa á la punta de la Ballena hasta descubrir el extremo Norte de la isla y la entrada del puerto, en cuyo caso arribará al Este y últimamente ceñirá al Sueste y al Sursueste cuando ya salga de la dirección de la restinga del Noroeste hasta estar en paraje oportuno para dar fondo.

Con los vientos del Sur y Sueste la mar es muy gruesa en el freu de la Isla Gorrite; chocando, por consiguiente, con la corriente que sale, forma un marullo excesivamente grueso, del cual se originan balances muy incómodos: los cables al contrario, no trabajan en esta ocasión á causa del mismo choque, y la embarcación fondeada pudiera de este modo considerarse segura, si no debiese también tener recelo de algunos ratones que hay, según prácticos, en las mismas inmediaciones del fondeadero, y los cuales, según las disposiciones de las orillas, deben ser más frecuentes hacia la tierra firme que hacia la isla.

Hay dos pozos en la Isla Gorrite, de los cua. les se pudiera sacar una regular provisión de agua, además que sería fácil otros nuevos; y ciertamente debe ser preferible el hacer agua en este paraje, así porque puede conseguirse sitio más abrigado para las lanchas, en las caletas que forman los mismos pedruscos, como porque la embarcación está más próxima y la marinería no tiene distracciones ni medios de separarse de su destino.

La comunicación con la tierra firme, debe hacerse para la seguridad de las embarcaciones menores, más bien hacia las chozas de la punta del Este que hacia la playa de la aguada, en donde la menor marejada del Sur y Sudoeste hace ya difícil y expuesto el atracar: los arenales y la misma distancia hacen algo escabroso el camino á Maldonado, en donde no es difícil abastecerse de comestibles.
Cuantas razones militaban á favor del puerto de Maldonado, antes de saberse con certeza la posición del Cabo San Antonio, han perdido todo su valor desde que no deja la menor desconfianza el paso al Oeste del Banco Inglés.

Muy pocas prevenciones necesita este paso, pues que la esencial se ha indicado ya, de no buscarlo viniendo de mar en fuera sino con un pleno conocimiento de la latitud ó de la tierra. Navegando al Norte han de inclinarse los rumbos al Oeste, de tal modo, que se cojan las ocho ó diez brazas lama por latitud de $35^{\circ} 30^{\prime}$, y si no se hubiese alcanzado á ver tierra del Cabo de San Antonio ó de la punta de Piedras, cogida la lama se inclinarán luégo los rumbos al Este, de tal modo, que por los $35^{\circ} \mathrm{I} 5^{\prime}$ se cojan cinco á seis brazas arena, cascajo y conchuela; con este fondo se estará seguro de estar Norte-Sur con el cerro de Montevideo; y se hará la navegación que exijan las circunstancias.

La valiza del Banco Inglés, por las cinco brazas cascajo y arena, es también útil para la salida, y no debe omitirse, mucho más cuando se aproxima la noche y calma el viento: en este caso será siempre preferente el dar fondo en unos parajes en donde no hay peor partido que el de entregarse voluntariamente al albedrío de una corriente, que por lo común lleva hacia el Banco Ortiz.

La experiencia manifiesta, y parece dictar lo mismo la reflexión, que al Sur del Banco Inglés no son tan rápidas ni tan irregulares las corrientes, siempre que se esté ó por meridianos del mismo Banco ó algo al Este; pero en las inmediaciones de la costa de Samborombon y del mismo Cabo de San Antonio, han experimentado los Oficiales que fueron á su reconocimiento, que las corrientes tienen la misma fuerza é irregularidades que en la costa opuesta.

No creo pueda haber el menor inconveniente en reconocer las costas del Cabo San Antonio, cuando con tiempos galenos se viene al Norte en demanda de Montevideo: á lo ménos debe buscarse en su paralelo las Io brazas arena que conducen luego á la lama, y últimamente al extremo Oeste del Banco Inglés.

Parece también que no es violenta la consecuencia de deber navegar al Sur toda embarcación que ya cogida sonda, y próxima al Cabo de Santa María, se viese con señales de mal tiempo y particularmente con viento Norte; pues como quiera que ya desde el Norte el viento ha de rolar muy luego por el Oeste al Sur, esta derrota proporcionará la doble ventaja, en primer lugar de ser siempre árbitro el navegante del partido y rumbos que les convengan; en segundo lugar, de estar á barlovento, para con el tiempo claro del Sur, dirigirse sin el menor peligro al fondeadero. 
En cuanto á la navegación sucesiva á la colonia del Sacramento, ó bien á la ensenada de Barragán, puede emprenderse por la costa del Sur, y pasando entre el Banco Ortiz y otro banco pequeño que está más inmediato á la costa: la sonda y las precauciones de hacer navegar los botes, ó por la proa ó por la banda, adonde esté el peligro más inmediato, proporcionarán mante- ner un fondo lama suelta de tres y media á cuatrobrazas ( $\mathrm{I}$ ). Las embarcaciones de menor calado, pueden pasar entre el banco pequeño y la costa, no perdiendo, por consiguiente, ésta de la vista.

(r) Mr. Bougainville explica con claridad la derrota desde Montevideo á la ensenada de Barragán.

\section{Derrotero desde Montevideo á Chiloé por el Cabo de Hornos. Trata también del Puerto Egmont en las Islas Malvinas y de la descripción de toda la costa intermedia.}

Saliendo de Montevideo para dirigirse á pasar el Cabo de Hornos, estando como á dos leguas Norte-Sur con el cerro de Montevideo, podrá dirigirse al Sur $5^{\circ}$ Oeste, con cuyo rumbo irá encontrando por espacio de cinco leguas, fondo de cinco á seis brazas lama, hallándola sucesivamente mezclada con arena y conchuela, y finalmente, arena á I 8 leguas en I2 brazas. Pasará á diez leguas del Cabo de San Antonio, distancia muy proporcionada no habiendo apariencias de vientos frescos del Norte. En su paralelo encontrará I 3 á I 4 brazas arena y piedra, y á distancia de dos millas se hallarán tres brazas fondo de lama dura, por lo que en caso de necesidad se podría fondear.

Rebasado el Cabo de San Antonio, determinará su derrota al Esste de la costa Patagónica, con presencia de la carta que acompaña este derrotero, según la estación, embarcación y demás circunstancias que pueden concurrir á la necesidad de variar de rumbo.

Convendrá sí advertir, que el temor de la costa separa demasiado de ella casi generalmente á los pilotos que hallándose con los Sudoestes tan frecuentes en estos parajes, experimentan las fatales consecuencias de no poder atracarla por donde les convendría para rectificar su punto, ó siendo aquellos tan fuertes que no les pe mita ceñirlos de arribar á Montevideo con atraso de la comisión y gastos inseparables de las arribadas.

La experiencia demuestra, que desde Marzo á Setiembre soplan con más frecuencia los vientos Esueste, Sursueste Sudoeste y Sursudoeste y desde Setiembre hasta Marzo del Este al Sueste.

Las corrientes tiran mucho al Nordeste desde los 40 á $50^{\circ}$ de latitud yendo como á 70 le- guas de la costa (I), y á mayor distancia ó próximo á la costa, se han hallado casi insensi. bles; aunque éstas deben considerarse también modificadas por los vientos que hayan reinado.

Con estas prevenciones y la contínua ațención á los carices, pájaros llamados pamperos, etcétera, puede prometerse el acierto en las más de las ocasiones.

El dato de la sonda para inferir la distancia de tierra es muy erróneo, pues se tiene experimentado que suele haber más fondo á mayor distancia y uno mismo con diferencia de Io á I2 leguas. Sin embargo, respecto á que la que se ha puesto en la carta es la hecha en puntos colocados por observación, derrota segura ó noticias las más verosímiles (2), será prudente tener atención á ella y combinarla con los demás datos.

Hasta aquí, el mayor número de los navegantes se han empeñado en pasar entre las Malvinas y la tierra firme, áun cuando los vientos fuesen decididamente contrarios y sólo acarreasen considerables sacrificios de tiempo y de aparejo.

No aconsejaremos pasar al Este de las Malvinas cuando los tiempos permitan pasar al Oeste, pero estamos muy distantes de prescribir en estos paralelos otros rumbos que los más favorables á ganar considerablemente en latitud.

La prudencia ha de dictar en la travesía del Cabo de Hornos, los rumbos que deben hacerse y la distancia á que convendrá pasar de tierra.

La calidad de los tiempos, la dirección de los vientos que se experimenten y las propiedades de

(r) Primer viaje de D. Antonio de Córdova; viajo de la fragata Astrea año de r 787 .

(2) Hablando de la formación de la carta, se indica cuanto falta para que las sondas do un placer tan dilatado puedan fijarse con acierto. 
la embarcación, deben decidir de los paralelos por donde convendrá pasar el Cabo y ganar al Oeste.

Parece indudable la existencia de corrientes hacia el Este (I), al Sur de la Tierra del Fuego. Se han experimentado éstas, de mucha, de poca y ninguna fuerza, á mucha y á poca distancia del Cabo, con aquella variedad que deben producir las comunes navegaciones en que faltan medios para determinarlas con exactitud.

Lo que parece más verosímil, según las noticias de los navegantes más acreditados, es que las aguas vienen del Océano Pacífico, tocan con la parte Sudoeste de la Tierra del Fuego, y siguen su dirección en la mayor parte y variadas en pequeño según las diferentes canales que hay entre las islas y entre éstas y la tierra por donde pasan. Por lo que dice el Capitán Cook en su segundo viaje, que no teniendo precisión de tomar fondeadero, no se acercaría á tierra, porque estando separados se evitan las corrientes, que estaba persuadido perdían su fuerza á iz leguas de la tierra.

Puede parecer las hay á mayor distancia, porque soplando casi generalmente los vientos desde el Noroeste al Sudoeste por el Oeste, mantienen la dirección de la mare jada hacia el Este, y en muchas ocasiones la mucha fuerza de ella abatirá las embarcaciones más de lo que estén persuadidos sus pilotos.

Por tanto, es oporiuno llevar en cuenta el tiempo que se haya tardado en hacer la travesía, y los vientos que haya tenido para graduar el abatimiento hacia el Este.

A la ida convendrá pasar mís al Sur que á la vuelta, pues si hallándose al través de la parte Sudoeste de la Tierra del Fuego le cargasen los vientos por aquella parte, le precisarían tomar la vuelta del Sueste, á no tener el barlovento suficiente para seguir la bordada del cuarto cuadrante; pero no debe hacerse esta prevención llevado del temor, de suerte que navegue muchas leguas y dilate su viaje inútilmente, siguiendo la común inclinación de la seguridad (2).

El Excmo. Sr. D. Antonio de Ulloa determina como lo más conveniente pasar á la ida por entre los paralelos de 60 á $64^{\circ}$ y á la vuelta por entre los $5^{\mathrm{\rho}}$ á $63^{\circ}$, pero no viéndose obligados á seguir las bordadas del Sur, de suerte que no sea posible tomar la del Oeste sin una disminución considerable de latitud, parece excesivo el retiro hasta los 62 ó $63^{\circ}$.

(I) Véanse las reflexiones hechàs en la navegación indicada de la Astrea al tiempo de navegar alrededor d $: 1$ Cabo de Hornos.

(2) Los lobos mariuos en estos paralelos, no deben causar el menor recelo de una demasiada aproximación á la costa; asi en esta navegación como en la de la Astrea se han visto conocidamente á 50 leguas de distancia.
Parece suficiente la distancia de 30 á 40 leguas al Oeste de Cabo Pilares en tiempo de verano para seguir en vuelta del Norte, ó de 40 á 50 en tiempo de invierno, en medio de la poca constancia de los vientos en estos parajes.

No convendrá tampoco arrimarse mucho más á ella no precisando reconocerla, pues se experimentan tiempos más ásperos del Norte y cerrazones mucho mayores cerca de tierra que lejos de ella.

\section{Derrota de Malvinas.}

Estando Norte-Sur con Punta Negra se navegará al Sursueste de la aguja hasta llegar al paralelo de $3^{\circ}$ de latitud, de donde se dirigirá al punto del de $47^{\circ}$ que diste de la costa 25 á 30 leguas Sur, deberá encontrar 50 á 55 brazas arena, fango y piedra, y si sondase 60 , será la arena gruesecita, quizá barrosa, señal que dista 30 leguas, entre $47^{\circ} 30^{\prime}$ y $48^{\prime \prime}$ se hallarán algunos chinitos.

En esta situación parece lo más conveniente navegar al Sueste $1 / 4$ Sur para recalar á la isla Concha y difrutar los vientos reinantes. Si llegase á recalar con alguna cerrazón (que es muy frecuente) y viese tres montes altos separados que se enfilan Noroeste-Sueste, debe persuadirse son los Salvajes.

Estando Norte-Sur con ellos, puede suceder no verse otra tierra; pero si demorasen al tercer cuadrante, no siendo mucha la neblina, se verán las montañas que sobre puerto Egmont forman diversas figuras.

Al Norte de Puerto Egmont hay varias islillas: las Redondas, las de Piedra Blanca, la $\mathrm{Cu}$ lebra y las del Rosario; pero para distinguirlas es menester estar muy próximo á ellas, por ser muy bajas y rasas.

Si se avistase una sierra que hace como un pabellón en su medianía y en los extremos como picos de loro, se tendrá entendido que es la isla donde los ingleses tenían su vigía.

$\mathrm{Si}$ apareciesen siete cerros casi iguales en tamaño y figura, son los Organos ó Siete Hermanos, situados en la gran Malvina, siendo el más al Este poco mayor y le nombran el Monte de Diamantes, por estar situado en la bahía de este nombre.

Al Norte de éstos está la Isla Borbon, que tiene tres cerritos distantes unos de otros, el más al Es e es el mayor.

$Y$ asi, si se viene por las cercanías de la gran Malvina, la última tierra que se vea será la bahía de los Diamantes, pero si se viniere próximo á la Isla de Borbón estando Norte-Sur con lo más Este de ella, se verá el cerro de Buenavista, que está en la boza de la bahía de San Carlos, parecido al de Montevideo, con sola la diferencia de 
ser algo más alto y cortado á pico por la parte del Oeste.

La isla Concha es muy pequeña y está situada casi Nornoroeste, Sursueste con Cabo Leal, distante dos y media leguas, y desde cualquiera situación que se vea parece un navío á la vela, pues toda blanquea, por el excremento de las aves, de que está cubierta.

Si conviniere por algún accidente pasar por entre ella y dicho Cabo, se hará sin recelo por un buen canal de 30 brazas.

Cabo Leal es una punta rasa de barranquera cortada á pico, y á su parte del Este hay una grande ensenada que sigue hasta Cabo Alto, y en todo este espacio se ven algunos montecillos tierra adentro.

Este Cabo parecido al Leal dista de la bahía del Oeste tres leguas siguiendo la costa algo más baja.

Media legua adentro de la punta del Este de la boca de dicha bahía, se verán dos montes unidos y uno mayor que el otro, saliendo de aquel una cuchilla para el Sudoeste, bastante larga y de más de la mitad de su altura.

Estando Norte-Sur con la misma boca, se distinguirá (no estando muy cerrado) el cerro de San Simón, alto, y su cabeza rara, situado tierra adentro.

Desde este paraje se verá Cabo Corrientes ó punta del Sable que tiene muy próximos unos islotillos que sólo se distinguen yendo aterrados.

Al Sueste de esta punta y á distancia de seis á siete leguas, se hallará la restinga (que llaman Bolsa de la Barra) sale cerca de media legua, y desde la última islita de las que se quedan descubiertas se ha visto reventar una piedra á distancia como de cuatro cables; se dice haber pasado por dentro de ella muchas embarcaciones.

Rebasada esta punta se aparece el referido cerro de San Simón por medio de la bahía, en los mismos términos que se dijo en la del Oeste.

Los cerros que llaman de la Vigía son tres, y se ven estando próximos á la punta del Sable, y estando el dia algo cerrado es menester alguna práctica para reconocerlos, no se debe atender á ellos para hacer el rumbo, pues cruzándose con la tierra baja que sigue para el Este, puede uno aterrarse, de suerte que con los vientos de fucra no pueda montarse la restinga.

Si se llegase á la boca de la bahía de la Soledad con viento del tercer cuadrante duro con malos aparatos, será lo más conveniente fondear en el famoso puerto que forma la Isla Celebroña con la costa del Sur, pues hay buena tenezón de cinco, scis y siete brazas, en inteligencia, que si fuese embarcación de dieziocho piés, se atenderá á que pueda bornear por el boldroi quc sale de la isla; pcrosi fuese embarcación menor, dará fondo sobre cl mismo sargazo, sin temerá la isla que es toda acantilada y permite entrada á una y otra parte de ella.

Al Oeste de ésta, está otra que llaman Perler ó Pelada, que puede pasarse rascando.

La Isla Celebroña está al Sur de la aguja de la restinga á la Bolsa de la Barra, y porque se proyecta en la costa y no es fácil de distinguirla, se atenderá á la barranca del Oeste que blanquea más.

Cuando se fondea hacia la mitad del puerto de la Soledad, se procura siempre estar más próximo á la costa del Sur, al parecer, para precaverse de los vientos que son más fuertes por esta parte, por la mejor tenezón y porque siempre se tiene esperanza de una mejor bordada.

Cuando se está voltejeando, no debe haber el menor recelo en rendir las bordadas cerca de tierra, pues sólo hay que resguardarse de lo que se viere y de unas piedras ahogadas que están cerca de los islotillos que salen fuera de la punta rasa de Boomon ó del Rey.

Cuando se halle entre las islas que están dentro del puerto dicho, siempre fondeará más cerca de la que llaman de la Paja que de las otras que están á la parte del Norte, por ser más acantilada.

Aunque se vean unos manchones grandes de boldroi casi Norte-Sur con lo más Este de la referida Isla de la Paja, no debe haber miedo de voltejear sobre ellos; pero si el viento fuese flojo, conviene evitarlos, porque la embarcación pierde la salida.

Si estando de través con el Estrecho de San Carlos y el viento duro con cerrazón, quisiere tomar puerto, lo podrá hacer en bahía de los Diamantes ó de San Carlos, por ser las más próximas y cómodas.

Si se eligiese la de los Diamantes, seguirá en demanda de su punta del Norte que tiene una isleta alta que estando fuera parece forma la angostura del Estrecho, por lo que se hace muy conocida. Estando como á un tiro de fusil de ella, se meterá para el Oeste lo posible á fin de seguir muy cerca de la costa siguiente que es toda acantilada.

Si fuese embarcación menor puede seguir hasta estar Norte-Sur con la tercera playa grande que se verá á la parte del Norte, no temiendo pasar sobre el sargazo que sale de la punta, pues en bajamar hay dos brazas arena por todos ellos.

Siendo la embarcación mayor, conviene quedarse algo fuera de la situación dicha arriba y no pasar sobre los boldrois de las puntas, á ménos de no estar en pleamar. Navegando para dentro, se verán tres islitas, de las cuales la más Norte y Este es casi toda anegadiza sin pajonal (que tienen las más de estos parajes); es oportuno atender á ella si se llevase viento del cuarto 
cuadrante escaso y se rindiese la bordada muy cerca ó se fondease en sus inmediaciones pudiendo entrar el viento Norte.

Si se quisiese fondear en la bahía de San Carlos, mediante tener ésta sobre su punta Norte la gran valiza del cerro de Buenavista, seguirá en demanda suya, pasando á distancia conveniente de la costa, toda acantilada, y franqueada la boca se verán dos islas que se enfilan casi Este-Oeste, y dejándolas por estribor se dará fondo entre ellas y la ensenada que tiene dicho monte por su parte del Este, más cerca de ésta para tener más abrigo.

Si quisiese situarse donde con los vientos Sur y Sudoeste pueda salir cuando se le ofrezca, rebasado el cerro de Buenavista, siga la bordada por la gran boca que se ve al Sueste, y entrando por entre la punta del Oeste y el monte de Truanes (que es el primero de los de la costa del Este), dará fondo donde quiera, pues todo es limpio, buena tenezón y 7, 8, 9 y ro brazas.

En el caso sólo de no poder coger el fondeadero de los Diamantes, deberá pasar al de San Carlos, por hallarse éste en disposición que entrando los vientos al Oesnoroeste y Oesudoeste que soplan ordinariamente duros cuando el tiempo abonanza, la embarcación que sale de él con dificultad montará Buenavista, pues el viento suele permitir el voltejear cuando la marea viene para adentro.

Adviértase que si yendo por dentro đel estrecho se viere salir algún babeadero para el Este de la isleta dicha en la punta del Norte de los Diamantes que parece procedida de una restinga de piedras, no es otra cosa que un hervidero de corriente y basta pasar con cuidado del aparejo, y de no aproximarse á ménos de un tiro de fusil de la isla, que como es alta, aunque el viento sea fresco, suele perderlo la embarcación, y quedar entregada á la corriente que la aconche.

Entrando en el estrecho, conviene pasar cerca de alguna de las dos costas, pues casi á medio freu y Este-Oeste con la isleta de los Diamantes, se halla una piedra que vela estando como á dos tercios la marea y rompe aún en pleamar (á ménos de haber mucha bonanza) y como estando los vientos duros se arma rompiente por todos aquellos parajes con la corriente, se hace precisa esta precaución.

Al Norte de dicha isleta, como dos tiros de cañon, hay un manchón de boldrois que parece estar en mucha agua. Si se hubiese de voltejear en el estrecho, estando entre Cabo Leal y cerro de Bucnavista, no se rendirán las bordadas muy dentro de la grande ensenada que forman, pues hay mucha revesa de corriente en creciente; y en menguante se pierde en lo granjeado en la vuelta, $y$ es preciso sufrir, no sin peligro, con toda vela las grandes ráfagas que por lo común hay diariamente, y si se queda calma debe temerse 10 que chupan las revesas hacia el fondo de la ensenada. Si estando de través con la bahía del Oeste quisiere ó el tiempo le obligare á tomarla, seguirá en demanda de la punta más al Este de las dos islas que están al Norte de la bahía del Aceite, pasando de ella como dos tiros de fusil, porque en bajamar descubre una corta restinga. Desde este sitio se verá otra isla que llaman de Don Pedro Amores, y dirigiendo á su punta más próxima irá por medio de los dos bajos que se descubren en bajamar; para los cuales, cuando estín cubiertos en pleamar, sirve de valiza el boldroi es peso que hay cerca de las piedras áun cuando corre mucho la marea.

No es conveniente pasar sin práctico con embarcación que no sea chica, por la parte Este de la Isla de Don Pedro Amores.

Si viniendo del Oeste quisiese tomar el puerto Egmont, reconocerá las Islas de los Salvajes, y después gobernará hasta ver el monte de la Vigía, que dejándola por babor, descubrirá la boca del puerto y podrá ir cerca de la costa del Sudoeste por Io y I 2 brazas de agua, hasta que pasadas la punta de Natividad de dos bahías, y de la entrada del puerto, vea las reliquias del establecimiento inglés en la punta del Oeste, de hacia donde se dirigirá, y podrá dar fondo cerca de tierra y de la aguada en siete ú ocho brazas de agua. La extensión de este puerto, su abrigo y buen fondo, concurren á hacerlo uno de los mejores del mundo.

Hay muy buen agua, abundancia de aves $y$ mucho apio silvestre. Desde la isleta que se halla en la punta del Norte de la bahía de los Diamantes, corre la costa al Noroeste, y en distancia de cinco leguas se halla la de la Cruzada, demora al Sudoeste de la Isla Concha: lo barrancoso y pelado de la costa en que está situada, la da bien á conocer. Si desde las cercanías de la Isla Concha se fuese á buscar esta boca, se llevará por la serviola de babor el más Sur de los cerros que figuran un pan de azúcar, situado al Norte de los Organos, y es más bajo que éstos. Si no se viese dicho cerro ó hubiera duda en su conocimiento, se pondrá por la serviola de estribor el monte gordo de dicha Isla Borbon, con lo que descubrirá la boca.

Al recalar, convendrá advertir que se tiene graduado como Este-Norte á diez leguas tierra, en sonda de 80 brazas.

Descripción de las costas Patagónicas hasta Chiloé.

La costa del Sur del Río de la Plata es de tierra negra, baja, anegadiza y muy poblada de árboles por algunos parajes. A cuatro leguas del Cabo de San Antonio se repara casi de repente, compuesta de méganos de arena de mediana altura, áridos, cuyas faldas forman muy poco de- 
clive, reventando la mar en sus orillas, sin herradura alguna, de suerte, que sería muy difícil ó impracticable el desembarcar en ellas. La variación de la aguja en el río, es de $14^{\circ}$ I $5^{\prime}$ Nordeste.

Desde el Cabo de San Antonio para el Sur, va aumentando poco á poco el fondo á iguales distancias de tierra, de suerte, que por el paralelo de $36^{\circ} 46^{\prime}$, á milla y media, se encuentran cuatro y media y cinco brazas, y á distancia de $23 \mathrm{y}^{1} / 2$, I 3 arena y conchuela.

En $36^{\circ} 54^{\prime} 30^{\prime \prime}$ de latitud y $51^{\circ} 43^{\prime}$ I $^{\prime \prime}$ de longitud, hay un bajo de arena á una milla y media de la costa de través, en que revienta la mar con mucha fuerza, y se ven las espumas á mucha distancia: su extensión será de cable y medio casi en la dirección de la costa, y en su veril hay tres brazas de agua ( $\mathrm{I}$ ).

Desde el paralelo del bajo dicho hasta los del Colorado que están en latitud de $40^{\circ} 45^{\prime}$ y longitud de $55^{\circ} 39^{\prime}$, la mayor parte de la costa no es muy alta, pero se ve regularmente de seis á ocho leguas de distancia. Sigue la dirección Nordeste Sudoeste, próximamente llena de quebradas por donde desaguan muchos ríos entre los que merece atención el de San José que está como unas 4 I leguas del Colorado, pues en su embocadura forma como una especie de puertecito acomodado para embarcaciones de mediano porte, y en que se halla buen agua (2).

Al Sudoeste 1/4 Oeste, de éste I8 leguas, hay una herradura que proporciona desembarco de botes. Los bajos del Colorado salen como I 9 leguas á la mar, no viéndose tierra desde donde se empiezan á quedar descubiertos en bajamar, la variación de la aguja $I 7^{\circ} 30^{\prime}$ Nordeste. Desde el río Colorado hasta el río Negro, es la tierra baja, pues con tiempo claro no se consigue verla á más de cinco leguas, y toda tiene bajío afuera como dos ó tres leguas.

Para entrar en el río Negro, cuya punta Sur está en $41^{\circ}$ de latitud y $56^{\circ} 46^{\prime}$ de longitud, es menester atender á la marea, dando fondo fuera arrimado á la punta de la Barranca del Sur en cuatro brazas chinos, de cuyo paraje gobernará para entrar á los méganos de arena más altos que hay en la costa del Sur, pasando arrimado á otro que hay en la banda del Norte como á medio cable de distancia, rebasado el cual se puede fondear en cualquier paraje.

No pueden entrar en este fondeadero embarcaciones que calen más de nueve á diez palmos de agua (3). Desde el río Negro á la punta de

(I) Noticias de los Pilotos 'Tafor y Berlinguero.

(2) Reconocimientos del Padre Cardiel en la carta del Brigadirr Saá y 'Tarria.

La sonda de i 8 á 20 brazas chinos, denota estar próximos al meridiano del río Negro si se estuviealgo al Sur de su paralelo en demanda del puerto José.
Belén corre la costa casi Este-Oeste; es tajada á pico, de mediana altura, con algunos cerrillos y formando varias ensenadas; después corre la costa algo para el Norte hasta el puerto de San Antonio, que está en latitud de $40^{\circ} 53^{\prime}$ y longitud de $59^{\circ} 9^{\prime}$. La variación en estos parajes es de I $7^{\circ} 55^{\prime}$ Nordeste.

Desde el puerto de San Antonio hasta la punta Oeste del puerto de San José, forma la costa dos ensenadas que las divide una punta saliente, al Oeste de la cual hay unas sierras altas. La entrada de este puerto, situado en $42^{\circ} 8^{\prime} 40^{\prime \prime}$ de latitud y $5^{\circ}$ de longitud, se manifiesta bien, no obstante de formarla tierra baja, y áun muy próximo á ella se halla mucho fondo.

Sólo hay un bajo en la parte del Oeste, por cuya causa convendrá pasar cerca de la punta Este, no temiendo el escarceo formado por la corriente (que cuando es en favor conduce las embarcaciones dentro áun con viento contrario), y dirigirse al Sueste donde está el mejor fondeadero, cerca de la población, en diez brazas de agua.

Desde la punta Norte de la península hasta la punta Crueles, corre la costa al Sur $22^{\circ}$ Este; desde ésta á pico de Lobos, al Sur $15^{\circ}$ Oeste, y lo restante hasta la punta de bahía Nueva, al Oes. te $15^{\circ}$ Sur; debe hacerse atención al bajo situado en paralelo de $42^{\circ} \mathrm{I} 7^{\prime}$ y distante de la costa de cuatro á cinco leguas: nuestra navegación nos ha dejado muy fuertes sospechas de su existen$\operatorname{cia}(I)$.

La bahía Nueva es mala para fondear, pues cerca de tierra hay 40 á 50 brazas de agua y 60 en la medianía (2). Desde la punta Sur de la bahía Nueva, cuyo terreno es de mediana altura y llano en su cumbre, la costa va hurtando para el Oeste y descendiendo con igualdad hasta quedar muy baja, donde se forma una grande ensenada, y desde ella continúa la costa para el Sur, más alta que todo el terreno anterior.

Entre punta Atlas y Cabo Raso hay una grande ensenada llamada de Vera. Desde bahía Nueva al puerto de Santa Elena corre la costa al Sur $12^{\circ}$ Oeste, tierra igualmente alta: al Norte, y próximo á éste, está un puerto reconocido por tierra desde Santa Elena, que parece ser limpio y en que sólo puede perjudicar el Nordeste, que sopla poco en estos parajes.

El puerto de Santa Elena, situado en $44^{\circ} 3^{6^{\prime}}$ y $25^{\prime \prime}$ de latitud, y $59^{\circ} \mathrm{I} 9^{\prime}$ de longitud, es limpio y su entrada clara: para buscarla se gobernará á un monte que está en la punta de San José, que desde afuera parece isla, y dejándolo por la serviola de estribor se reconocerá la boca del puerto

(x) Véase el Diario de nuestra navegación.

(2) Lo manifiesta así el Piloto Tafor; pero no sabemos si la ha examinado êl mismo. 
cerca de la punta acertada: tiene una isleta que está cubierta en pleamar, pero se ve su reventazón y puede pasarse sin recelo entre ésta y la punta dicha. Entrando por la banda del Sur irá á medio freu de la isla y punta de San Fulgencio para darle resguardo al bajo Florido, y puede fondearse demorando la isleta al Sueste. El flujo máximo sucede á las cuatro y media de la tarde y sube el agua cuatro brazas.

La cala de San Sebastián, que está $2^{\circ} 30^{\prime}$ al Sur de Santa Elena, es bien desabrigada y sólo buena para barcos chicos. Inmediatamente se encuentra la ensenada de Camarones, cuya abertura es de cinco leguas y un tercio, con seis y un tercio de profundidad, y aunque su fondo es limpio y de 25,30 y 35 brazas hasta cerca de la costa en que hay ro, su desabrigo lo hace incómodo: el flujo máximo sucede á las cuatro de la tarde. La variación de la aguja $20^{\circ}$ I $5^{\prime}$ Nordeste.

Desde la ensenada de Camarones hasta el puerto de San Gregorio, es la costa limpia, pues entre la isla Arce y Chicas, todo su fondo es de 20 brazas. Para buscar este puerto, situado en $45^{\circ} 6^{\prime} 35^{\prime \prime}$ de latitud y $3^{\circ} 3^{8^{\prime}}$ y $30^{\prime \prime}$ de longitud viniendo de mar afuera se procurará pasar al Norte de la Isla Rasa dos leguas, procurando entrar entre la de Arce y Leones para descubrir libremente la boca del puerto, advirtiendo que el mejor fondeadero es próximo á la costa del Sur frente de dos ensenaditas con playa de arena, pues el demás es muy sucio y de piedra.

Si se ofrece voltejear entre las Islas Arce y Chicas, Leones y Rasa, ó entre ésta y Arce, se podrá hacer por ser muy limpios sus canales, aunque la fuerza de la corriente forma tal escarceo entre ellas que parece reventazón de bajo, y cuando en el puerto crece el agua corre entre las islas al Norte y Nordeste, y al contrario cuando baja. El establecimiento de la marea en el puerto es á las cinco de la tarde, subiendo el agua 28 piés.

Hay paso entre la Isla de Leones y la tierra firme, pues su fondo no baja de una y media brazas. En los puertos hasta aquí nombrados, se echa muy á ménos la falta casi total de leña y agua. Esta última, á la verdad, se encuentra salobre en algunos parajes algo distantes (I), pero la sola necesidad puede aconsejar su uso.

Desde puerto de Santa Elena hasta puerto Manso, son las sierras altas y peñascosas, y desde éste á Punta Taforo (hasta donde está reconocido), es la tierra baja, continuando más alta para el Oeste 4'; al Oeste de ésta se halla el Cabo del Sur, que con el Cabo Blanco forma la entrada del golfo de San Jorge (2), desde aquel

(I) Son muy contradictorias en esta parte las diferentes noticias de los que nos han precedido.

(2) Según noticias de los Patagones, interna hasta la cordillera. hasta la tierra para el Norte por espacio de cinco leguas, y luégo corre casi Este-Oeste. Desde el Cabo del Sur para el Oeste, sólo puede navegarse en barcos chicos por ser la costa muy sucia y haber mucha corriente.

El flujo y reflujo de la marea es casi igual al de San Gregorio. La parte Sur de este golfo, no está reconocida ni la medianía.

El Cabo San Jorge está en $46^{\circ} 54^{\prime}$ I $5^{\prime \prime}$ de latitud y $60^{\circ}$ Io' de longitud, y al Sur $36^{\circ}$ Este $25^{\prime}$ de éste, está el Cabo Blanco que se le antepone un islote casi Este-Oeste.

Al Esnordeste 5 Sur á distancia de cuatro leguas del cabo, está el bajo reconocido de Tres Puntas por el Comodoro Biron, y en cuyas inmediaciones nuestras sondas nos han confirmado con grande probabilidad su existencia (I).

Desde Cabo Blanco á la punta Norte de puerto Deseado, corre la costa Norte-Sur próximamente, formando dos herraduras de poca profundidad. Al principio baja, y después de una regular altura escarpada en la orilla con mucha igualdad; en lo interior tiene varios montecillos y picos bastantes notables. El fondo es limpio hasta llegar al paralelo de $47^{\circ} 42^{\prime}$ donde están las islas y arrecifes de San Francisco que salen á la mar $\mathrm{I}^{2} / 3$ millas (2).

En $47^{\circ} 44^{\prime} 37^{\prime \prime}$ de latitud y $59^{\circ} 54^{\prime}$ IO $^{\prime \prime}$ de longitud está la punta Norte de puerto Deseado; los arrecifes y piedras que están en su boca algo estrecha, exigen que para entrar en él atienda con cuidado al estado de la marea y viento. Se deberá tomar por marca una piedra, de lejos semejante á una pequeña torre (3), que se halla en la parte del Sur, y gobernando á ella se descubrirá la boca del puerto.

La reventazón de la punta del Sur se ve regularmente de cuatro á cinco millas; viniendo con viento Sur se procurará pasar á un cable de ella para franquearse de las piedras del medio, y conocerá lo ha conseguido cuando le demore la barranca de la punta de la isleta al Nordeste corregido. Y si por casualidad se viere empeñado con dichas piedras (que por lo común revientan ó velan) pođrá pasar por la parte del Norte, pues muy próximo á ellas hay cinco brazas chinos, y si quiere fondear, podrá hacerlo pasando la punta del Arenal que está en la costa del Norte dando resguardo á la piedra que se descubre en bajamar, por lo que no será bueno rebasarse mucho de la expresada punta.

Se advierte, que si se recalase allí cuando la

(I) Adviértase que el Comodoro Biron llamaba Cabo Blanco, con Anson, el que ahora es Cabo de Tres Puntas.

(2) Primer viaje de D. Antonio de Córdova. Viaje de la fragata Astrea, año de ${ }_{7} 87$.

(3) El examen local de las piedras que forman esta marca excelente, nos hacen temer que no permanezca mucho tiempo. 
marea tenga mucha fuerza, convendrá fondear afuera, donde se hallará buen fondo, y esperar que el agua esté casi parada, porque de lo contrario se expone á que le abata alguna revesa de corriente sobre una ú otra restinga por su mucha rapidez.

Dentro del puerto podrá fondearse al Nordeste de punta Rasa, ó entre la Islas Paganos y Barrancas para librarse de la mayor fuerza de la marea, que en los parajes estrechos llega á seis millas.

Los auxilios de agua y leña que proporciona este puerto, son muy poco ventajosos, pues aunque hay varios manantiales, son escasos ó distantes de las orillas y todos salobres; sólo en el que está en el paraje donde estuvo el establecimiento, se puede hacer la aguada con alguna comodidad. No hay otra leña, que espinillos, que se hallan con abundancia al Oeste de la Isla de Guanajos. La abundancia de guanacos, aves, liebres de exorbitante tamaño y buen gusto y de peces, en particular de una clase que curados se asemejan mucho al bacalao, hace útil este puerto al que venga necesitado de víveres ó necesite remediar prontamente una avería.

En este puerto merecen especial atención las embarcaciones menores, no sólo en las ocasiones en que se destaquen de á bordo, si también cuando regresen á él ó estén amarradas.

Para los viajes de la aguada (suponiendo sea la interior que se ha indicado cerca de la población) es menester calcular únicamente con las mareas sin atender al viento, excepto en el poco tiempo en que aquéllas ó están paradas ó llevan poca fuerza.

Además, si la dirección de la marea fuese contraria á la del viento, y éste algo fuerte, se arman en muchas puntas remolinos y revesas sumamente temibles para una embarcación sobrecargada, con cuyo motivo las lanchas deben navegar siempre muy marineras.

No es fácil acertar por primera vez con el sitio de la aguada si no se compara prolijamente con el plano la navegación que se haga con el auxilio de la marea. Cuando con la fuerza de la marea fuese preciso dirigirse á una ú otra costa del fondeadero, sea al remo ó á la vela, se procurará atravesar la canal, de la fuerza de la dirección de la marea con la mayor rapidez posible, sea el que fuere el paraje adonde se lleve la proa. Será luégo fácil en la inmediación de las orillas resarcir al remo lo que se haya perdido al tiempo de atravesar.

Al atracar á bordo, son también precisas muchas precauciones en la embarcación menor. Por lo común solían las nuestras ponerse muy á barlovcnto de la proa, y luégo dcjarse caer con la marea á una distancia regular, para que le alcanzase el cabo sin tocar en el costado.
Es preciso en esta ocasión, que esté suelto en la popa, y pronto á echarse un cuerpo flotante firme en dos ó tres guindalezas, cuyo peso pueda resistir auxiliándole en caso de duda para este fin con algunos otros cuerpos intermedios.

En el caso que la embarcación menor se viese arrastrada á la popa del buque antes de al. canzarle, se echará al agua la boya indicada, la cual, corriendo con la misma velocidad que la marea, podrá desde luego ser cogida por la embarcación, la cual, ó con los remos ó con las velas, resista algún tanto á dicha fuerza.

El modo de amarrarse en este puerto, es en la misma dirección de la marea con el ayuste al Este y el cable sencillo al Oeste; no parece prudente usar de boya, porque ó se anegarán, ó contribuirán á levar el ancla. Se deja ver también que para tender las anclas es menester consultar absolutamente la marea, que es sumamente dañoso al cable el no tener el timón á la vía, y que, áun fondeados, se puede evitar un abordaje con el solo timón.

La importante caza de los guanacos debe buscarse en las inmediaciones de las dos aguadas que están en la costa del Sur, en cuyo caso será oportuno que el cazador esté dentro ó en la Isla de los Guanacos, cortándoles el paso con la tierra firme al tiempo de estar alta la marea: siempre será bueno preferir el tirarles con bala.

La pesca debe emprenderse con preferencia en la Isla Pingües, pasada la de Paganos: es menester tender la red á la marea vaciante, y recogerla al instante, pudiendo así repetirse esta operación muchas veces en una misma marea, y recogerse en poco tiempo cuanto pescado se quiera, que es de la especie del bacalao.

Desde la punta de Guanacos hasta Cabo de los Reyes corre la costa al Sur $28^{\circ}$ Este, formando muchas ensenadillas, y una grande desde las Barrancas Blancas hasta la Isla de Megillones. Y tanto las que siguen próximamente á la punta dicha como las que anteceden al Cabo de los Reyes, tienen muchas piedras y arrecifes que se les anteponen.

En latitud de $47^{\circ} 35^{\prime}$ I $5^{\prime \prime}$ y en longitud de $59^{\circ} 44^{\prime} 40^{\prime \prime}$ se halla la Isla de Reyes, de mediana altura. Tiene á la banda del Oeste una pequeña herradura donde puede una embarcación quedar fondeada al abrigo. E1 intermedio entre esta isla y la costa está sembrado de isletillas y piedras, quedando sólo un estrecho canal entre las Islas de los Leones Marinos y la costa firme con dos brazas de profundidad.

Entre Cabo de los Reyes y punta Lobeira hay una ensenada de legua y cuarto de abertura, internando casi el mismo espacio (I).

(r) Es donde estaban los marineros ingleses recogidos por el Capitán de navio Cordova y los cañones hallados por el Piloto Peña. 
Desde punta Lobeira hasta el puerto de San Julián, sigue la costa la dirección del Sur Io Oeste próximamente, es bastante alta y montuosa. En la latitud de $48^{\circ} 38^{\prime} \mathrm{oo}^{\prime \prime}$ y longitud de $49^{\circ}$ $53^{\prime} 30^{\prime \prime}$, á cinco leguas de la costa, está un arrecife 1lamado el bajo Bellaco, que tiene de extensión Este-Oeste un cable, y sólo revienta en bajamar (I).

Al Sur del cabo de los Reyes hay dos cerros, de los cuales el mayor y más Norte es muy semejante al de Montevideo. El otro más pequeño, redondo y avanzado á la mar. Son muy conocidos porque cuando demoran al cuarto cuadrante (que es cuando se necesitan), no hay con qué equivocarlos.

Estos son una excelente marca para conocer el bajo dicho, pues demorando el primero al ángulo de $28^{\circ}$ en el cuarto cuadrante y el segundo al de $34^{\circ}$, se estaría sobre él. Distante de éste como un tiro de cañón y casi Norte-Sur, se descubren tres piedras á los dos tercios de marea, formando un pequeño triángulo isósceles, con cuyo motivo la corriente hace unos grandes remolinos que arrastran las embarcaciones hacia ellas; y al Sueste, á distancia de un tiro de mosquete, hay 25 brazas fondo piedra. Noroeste-Sueste con éstas y en latitud de $48^{\circ} 43^{\prime}$ distante de la costa como ocho leguas, hay otra piedra que en pleamar está escavando aunque el tiempo se halle sereno; y como la marea tiene en estos parajes cuatro y media brazas de diferencia del flujo al reflujo, éstas son las que quedan descubiertas en la bajamar.

El flujo máximo sigue en estos bajos la misma hora que en el Cabo de los Reyes, que son las once de la mañana: en la travesía de las piedras de afuera á las otras, es todo fondo igual de 25 brazas y 30 , todo piedras y chinos. De la de afuera sale otro placer de la misma calidad para el Sur á distancia de más de una legua.

Desde punta de los Desvelos á Cabo Mirabien, corre la costa al Sur $48^{\circ}$ Oeste, y desde éste á Cabo Curioso, va formando ensenada, quedando éste en el mismo arrumbamiento: toda la tierra es bastante alta y montuosa; por el paralelo de $48^{\circ} 25^{\prime}$, á 24 leguas de la costa hay 72 brazas arena y fango (2); por $49^{\circ} 3^{\prime}$ á cinco leguas dos tercios de la costa más inmediata, 32 arena fango y piedras. Por $49^{\circ}$, II á I2 leguas 40 arena, fango y piedra.

Para buscar este puerto, situado en latitud de $49^{\circ} \mathrm{IO}^{\prime} \mathrm{y}$ longitud de $6 \mathrm{I}^{\circ} 42^{\prime} 3 \mathrm{O}^{\prime \prime}$, se gobernará á un cerro llamado San Ildefonso, parecido al Pan de Azúcar del Río de là Plata, y deján-

(I) Sacadas de las noticias originales del piloto Peña, que acaba de reconocerle.

(2) Primer viaje de D. Antonio de Córdova: viaje de la fragara $A$ strea, año de I 787 . dolo algo al Norte se avistará la entrada del puerto.

Si fuese la hora de la pleamar, estando en diez brazas de agua, arena y chinitos y de una á dos millas de la punta del Desengaño, verá la reventazón de la restinga, que pasando á distancia de ella como dos cables, irá en busca de la punta de Peña para ir zafo de los islotes que descubren en bajamar, y rebasada, todo el puerto es abrigado para dar fondo.

Siendo la recalada en bajamar estando en tres ó cuatro brazas de agua chinos con greda debajo, y como dos y medio cables á la piedra más afuera de la punta del Desengaño, dará fondo hasta que haya agua en la barra, siendo conveniente se leve á media marea para pasar el banco que está más adentro y queda descubierto en bajamar antes que salga el agua, pues la velocidad de la corriente que es de cinco á seis millas, no le dejaría adelantar. El flujo máximo es en el día de la conjunción á las once de la mañana, subiendo el agua veintiocho piés.

Al Noroeste de la punta de la Base á dos y media leguas, hay manantiales de muy buen agua, y al mismo rumbo, tres cables de distancia, hay una cañada, y cavando en su suelo se encuentra agua dulce.

Hacia el fondo del puerto todas son barrancas de yeso superior, y siguiendo un arroyito que está inmediato, al fondo se encuentra una salina (I), sólo se encuentran algunos espinos, pues todo el terreno es estéril y salitroso; recompensando la naturaleza en sal lo que rehusa de vegetales; hay mucha de espuma y de piedra en una laguna de tres leguas de largo.

Desde la punta de la boca de San Julián hasta la de San Francisco de Paula, corre la costa al Sur $3^{\circ}$ Oeste, y desde éste á la punta de Santa Cruz al Sur $24^{\circ}$ Oeste próximamente: la tierra no es alta ni abarrancada y el fondo limpio, pues arrimado á tierra hay 30 y 40 brazas de agua.

Para conocer la entrada del río de Santa Cruz situado en $50^{\circ} \mathrm{I} 7^{\prime} 3 \mathrm{O}^{\prime \prime}$ de latitud y $62^{\circ} 2 \mathrm{I}^{\prime} 3 \mathrm{O}^{\prime \prime}$ de longitud, se tendrá por marca el cerro de Santa Inés, único entre este río y el puerto de San Julián, y debe darse resguardo á un bajo de piedra que está en la punta Norte de la boca del río: su terreno es peñascoso y su fondeadero bueno sólo para embarcaciones menores.

La punta Sur de Santa Cruz con la punta de Sánchez corren en dirección del Sur $12^{\circ}$ Oeste formando una grande ensenada, en cuyo fondo están Cabo Redondo y una herradura á que llaman bahía de Coy: en la misma dirección á cinco leguas de distancia está el Cabo de Barre-

(I) Estas noticias son á la letra del Pilnto Tafor, excepto las de la aguada que sun del Piloto Berlinguero. 
ras blancas, y entre éste y la punta Sánchez hay una pequeña ensenada toda sembrada de piedras.

El Cabo de Barreras Blancas (ó de Buen Tiempo) situado en $5 \mathrm{I}^{\circ} 32^{\prime}$ de latitud y $62^{\circ} 5 \mathrm{O}^{\prime}$ $25^{\prime \prime}$ de longitud, forma un frontón de mediana altura, abarrancado y con manchones blancos que á la caída al mar remata por la parte del Norte en una punta rasa y en la del Sur en una costa baja y pareja que sigue hasta el Cabo de las Vírgenes.

Como al Sur $1 / 4$ Sueste del Cabo de las $\mathrm{Ba}$ rreras Blancas, sale un bajo que parece es en el que dió el Capitán Walis. Como al Oesudoeste de dicho cabo se ven en la otra costa siete mogotes de mediana altura é iguales á que llaman los Frailes.

Desde el Cabo de Barreras Blancas va hurtando la costa para el Oeste y con el de Gracias á Dios, forman la embocadura del río Gallegos: ésta tendrá como nueve millas de ancho, después el río va estrechando hasta la punta del Carmen, donde quedia en una milla y sigue de este ancho por mucha distancia: al Oeste de esta punta está la islita Deseada.

En el reconocimiento que hizo D. Andrés Peña de este río, halló que el agua estaba solo salobre á la entrada de él y habiendo crecido algo la marea, por lo que debemos creer que en lo interior y al fin de la vaciante será enteramente dulce.

Vió grande abundancia de guanacos, admirándose pudiesen subsistir en un terreno estéril todo cubierto de chinos, y donde solo halló un matorral de leña y algunas manchas de pasto muy malo.

Desde el río Gallegos al Cabo de las Vírgenes, corre la costa al Sur $27^{\circ}$ Este, hasta la mitad de la distancia es de tierra baja y la otra mitad algo alta y rasa, por arriba toda árida y de mal aspecto. El fondo es limpio y se puede ir costeando la tierra por I2 y I 5 brazas.

El Cabo de las Vírgenes, situado en $52^{\circ}$ I $9^{\prime} 40^{\prime \prime}$ y $62^{\circ} \mathrm{Ig}^{\prime}$ longitud, es tajado al mar á poca é igual altura por alguna distancia que parece un trozo de muralla.

Al Sur $5^{\circ}$ Oeste del Cabo de las Vírgenes, está el del Espíritu Santo corriendo la costa casi en esta dirección hasta el Cabo Reina, desde donde va formando una grande ensenada, laboreado con otras muchas pequeñas, y saliendo para el Este.

En su interior, y por latitud de $53^{\circ} 28^{\prime}$ está la boca del canal de San Sebastián, como de dos leguas de ancho; este terreno es bajo hasta los $53^{\circ} 40^{\prime}$ que empieza á elevarse.

Desde la punta Adriancel hasta los Tres Hermanos, corre la costa al Sur $58^{\circ}$ Este, entre aquella y el Cabo de Santa Inés hay una pequeña en senada y en su fondo se ve la embocadura de un canal bastante estrecho. Este cabo es alto y la costa que sigue va elevándose algo más; en lo interior se ven cerros de varias figuras, entre los cuales se distinguen tres mogotes casi de una altura, muy próximos y que tienen á su espalda una montaña en figura de pan de azúcar; estas sirven para el reconocimiento de la embocadura del Estrecho de Maire, del que sólo distan cinco leguas. Esta la forman, el Cabo San Diego, de tierra muy baja, en la del Fuego, y el Cabo del Medio en la Isla de los Estados.

Es clara la utilidad de pasar por este estre. cho, y solo debe atenderse á las circunstancias, en algunas ocasiones pueden ser muy desfavo. rables y causar una incomodidad del buque. Cuando sube el agua (que entonces viene del Sur) y los vientos soplan del Norte al Nordeste se forma un escarceo muy vivo, como si hubiese barra, y además de ser detenidas en estas ocasiones las embarcaciones por la contrariedad de las corrientes, les causa los más violentos movimientos (I).

Cerca de la Isla de los Estados (é Islas de Año Nuevo) las aguas corren mucho, y por el Cabo de San Juan aumentan su velocidad, siguiendo como un torrente la dirección del Noroeste; pero no se elevan sino cuatro piés ingleses.

Dice el Capitán Cook que en este estrecho la marea y la corriente del Sur se hace en la creciente, ó en la menguante empieza á obrar precisamente á las cuatro del día del novilunio: toda es muy hondable, pues casi tocando á las piedras en la Tierra del Fuego hay 20 y 30 brazas de agua.

La costa Sueste de la Tierra de Fuego, alta, pedregosa y quebrada, proporciona un gran número de fondeaderos; pero la mayor parte no están conocidos y exigen un gran cuidado en sus cercanías por las muchas piedras ahogadas que se les anteponen y que dichosamente están muy próximas á tierra, y puede conocerse su cercanía por la sonda cuando la oscuridad del tiempo no permita su vista.

La bahía Mauricio es muy poco útil por su desabrigo; pero la del Buen Suceso, situada en la medianía del estrecho, proporciona una buena arribada para cualquier buque: se encuentran habitantes; por consiguiente, agua dulce, mucha fertilidad en la tierra y no poco pescado. Su boca tendrá una milla y tres cuartos de ancho y dos millas de profundidad. Puede fondearse en siete ú ocho brazas de fondo fango á distancia de media milla de la costa del Sudoeste.

(I) Con algún más despacio podrá construirse una tabla que determine las horas oportunas para entrar y salir del Estrecho de Maire según los días de la Luna. 
También en la bahía de Valentín, al Sudoeste $1 / 4$ Oeste de aquélla, se encuentra agua y arboleda (I). La Isla de los Estados es muy alta, su eminencia quebrada y llena de picos, cuyas sombras le dan un color arenisco. Cuatro leguas al Oeste del Cabo San Juan en la costa septen-. trional, está el puerto de Año Nuevo; es abrigado y muy hondable.

Puede también fondearse entre las islas, en las que se hallará agua, yerbas antiescorbúticas, muchas aves y leones marinos: de la bahía del Buen Suceso, para el Oeste la Tierra del Fuego elevándosenos, y va tomando un semblante más desagradable y la intemperie va siendo más incómoda.

Al Sur $40^{\circ}$ Oeste de la punta Norte de la bahía de Valentín, y á $6_{3}$ millas próximamente, está el Cabo de Engaño. En este mismo rumbo están las Islas Bernabelas, ro millas al través las Evouts y I 5 las Nuevas, todas á la parte del Oeste.

El Cabo Engaño es la punta Sur de las Islas de la Ermita, toda quebrada y rodeada de peñascos: á tres leguas de ésta está el Cabo de Hornos en latitud de $55^{\circ} 5^{8^{\prime}}$ y longitud de $6 \mathrm{I}^{\circ} \mathrm{I}^{\prime} 4 \mathrm{O}^{\prime \prime}$ : entre estos dos cabos parece haber un paso que conduce directamente á la bahía Nassau, se vén en éste una porción de islas pequeñas, y la costa parece formar á la parte del Oeste bahías buenas y abras. El Cabo de Hornos forma el extremo meridional de un grupo de islas de varias magnitudes que están delante de la bahía de Nassau y que se conocen con el nombre de Ermita. El cabo se conoce de léjos por una colina elevada y redonda que tiene.

Entre la punta Oeste de la Isla Ermita y el falso Cabo de Hornos, está la entrada para la bahía Nassau. Por latitud de $55^{\circ} 55^{\prime}$ I $5^{\prime \prime}$ y como á seis leguas de la costa, está un grupo de islas, llamadas de San Ildefonso, cerca de algunos peñascos ahogados.

Como al Oeste $1 / 4$ Noroeste del falso Cabo de Hornos, II leguas de distancia, hay un canal de siete leguas próximamente que corre al Esnordeste: fuera de esta dirección hay algunas islas, y en la punta Oeste de la embocadura hay dos colinas elevadas en forma de pico, y al Este dos colinas redondas ó islas situadas Nordeste-Sudoeste.

Del falso Cabo de Hornos hasta el Cabo de la Desolación, corre la costa próximamente al Oesnoroeste. Las altas, peñascosas y estériles montañas que presenta, cubiertas en parte de nieve que no se derrite ni con el calor de los rayos del Sol en el verano, ponen horror á los más atrevidos marineros y movieron al intrépido Cook á

(I) Fondeó en ella el chambequín Andaluz. Véanse las noticias del Piloto Berlinguero. nombrar Cabo de la Desolación, á aquél que daba principio á esta portentosa multitud de peñascos que parece desafían la bravura del Oceano, que con su violentísimo batidero ha destrozado sus orillas, y entre éstas innumerables quebradas se halla la de la Natividad en $55^{\circ} 2 \mathrm{I}^{\prime} 30^{\prime \prime}$ de latitud.

El canal de este nombre lo forman la tierra á que llamó tierra de Natividad Cook y una porción de islas: éste ofrece muchos y buenos surgideros; entre las marcas que dió el Capitán Cook para tomar el uno de ellos, son las siguientes: viniendo de la mar, déjense á babor todas las islas y peñas con que están de través, y más adentro el York Minster (cuyo nombre se da á un promontorio que hay en una de las islas que forman el canal) y á estribor el peñasco Negro que está delante de la extremidad Sur de la Isla Shagg, y estando delante de la extremidad Sur de esta isla, tírese al lado del Oeste, evitando las capas de sargazo, porque crecen siempre sobre los peñascos.

En estas abras se encuentra agua y leña, pues en los parajes en que las aguas de las 1luvias y nieves derretidas han traído escombros, se han formado capas de grama; ésta en ciertos parajes sirve de alimento á los arbustos.

Como á I r leguas del canal de Maridad está la Isla de Gilbert, de igual elevación que la costa, y presenta una superficie compuesta de muchos peñascos puntiagudos de alturas desiguales: algo al Sur de esta Isla hay otras pequeñas, y fuera de éstas, rompientes.

El Cabo Desolación está por latitud de $54^{\circ} 55^{\prime}$ : cerca de cuatro leguas de este cabo, hay un canal profundo en cuya entrada hay una isla bastante grande y otras pequeñas. Al Noroeste del Cabo Desolación, está la grande bahía de Santa Bárbara, de la que dice Cook que al pasar como unas siete leguas, apenas se veía tierra de su fondo, y que en el espacio que corre al Esnordeste de Cabo Negro, no se descubrió tierra, creyendo podría estar allí el canal de Santa Bárbara (I).

Cabo Negro, situado en $54^{\circ} 30^{\prime}$ de latitud y $67^{\circ}$ oo' de longitud, es una roca escarpada de una altura considerable y punta Sudoeste de una grande isla, que parece separada una legua ó legua y media de la tierra firme.

Como al Norte $10^{\circ}$ Oeste del Cabo Negro á 28 millas de distancia está el Cabo Glocester: es una punta avanzada, que presenta una superficie redonda de una altura considerable y parece isla.

A1 Nornoroeste $5^{\circ}$ Oeste, á I7 leguas de éste, está la Isla de Landfall. La costa comprendida

(I) Aunque se han adoptado las frases del Capitán inglés, son compatibles con la configuración de la costa en su carta. 
entre estos dos puntos, forma dos bahías sembradas de islotes y rompientes. La costa parece muy quebrada y con varios canalizos, ó compuesta de un gran número de islas.

Cabo Deseado está por $52^{\circ} 49^{\prime} 20^{\prime \prime}$ de latitud; es alto, y se ven sobre él montañas puntiagudas con sus cimas cubiertas de nieve.

Como al Nordeste del Cabo Deseado, y á dos leguas de distancia, está el Cabo Pilares, por latitud de $52^{\circ} 44^{\prime} 23^{\prime \prime}$ y longitud de $68^{\circ} 56^{\prime}$.

A la costa comprendida entre estos cabos, se anteponen por más de una legua muchos islotes ó rompientes conocidos con el nombre de los Doce Apóstoles.

El Cabo Pilares es un conjunto de peñascos que se terminan en dos rocas cortadas en forma de torres inclinadas hacia el Noroeste y forman la punta del cabo.

De seis á siete leguas al Noroeste de este cabo se ven cuatro islotes llamados los Evangelistas, tres raros $y$ el otro de figura de un haz de heno y bastante separado (I).

Al Nornordeste, y á cuatro ó cinco leguas próximamente de los Evangelistas, está el Cabo Victoria por latitud de $52^{\circ} 22^{\prime} 3^{\prime \prime \prime}$ y longitud de $69^{\circ} 00^{\prime} 30^{\prime \prime}$.

Al Norte de éste Io $\mathrm{y}^{1} / 2$ leguas, está el de Santa Isabel: no puede darse descripción de la costa intermedia por no estar reconocida.

Al Noroeste 1/4 Norte del Cabo Santa Isabel, está una punta que dista como Io millas al Sueste $1 / 4$ Sur del Cabo de Santa Lucía. Dicha punta y el Cabo de Santa Isabel forman la boca de uno de los canales que forman los destrozos de la tierra firme en esta parte.

El Cabo de Santa Lucía se conoce por su figura amogotada, y al Nordeste 1/4 Norte de él, distancia de cinco leguas, está la Roca Partida, en que Sarmiento observó $5 \mathrm{I}^{\circ}$ Io'.

$\mathrm{Al}$ Oesudoeste de ésta, dos leguas á la mar, hay dos farallones, y desde ellos sale una andana de otros muy pequeños y bajos.

Al Nornordeste próximamente de la Roca Partida, dos leguas, está la Isla de San Francisco, y Este-Oeste con ella el Cabo de Santiago, formando estos dos puntos la boca del brazo de la Concepción, que corre al Nordeste $5^{\circ}$ Este.

Recorriendo los diferentes canales que forman el gran número de islas situadas entre Cabo de Santa Isabel y Cabo Primero, se encontrarían una infinidad de ensenadillas, caletas y puertecillos, que podrían servir de abrigo á embarcaciones menores en caso de necesidad. Pero la estrechez de estos canales, las muchas y encontradas corrientes que giran ordinariamente en las direcciones de aquélla, y la multitud de islotillos y bajos de que cstán sembradas, hacen casi impo-

Noticias de Mr. Bougainville. sible el tránsito de embarcaciones de mucho porte.

De los mejores surgideros que proporciona este archipiélago, son el puerto Bueno, situado en la tierra firme, de mucha extensión y con siete, ocho y nueve brazas, limpio, arena y lama.

El puerto del Ochavario, á cinco leguas al Sueste de la Isla de los Inocentes, es una caleta abrigada y tiene fondo de 20 brazas arena.

La ensenada de Guadalupe es también abrigada.

Una legua al Sudoeste de la punta del Hocico del Caimán, hay un buen surgidero en I 2 brazas arena.

El puerto Bermejo (llamado así por tener una playa de este color), al Nordeste $1 / 4$ Norte ocho y media leguas del Cabo de Santiago, es seguro de todos vientos y de buen fondo, en siete, ocho ó nueve brazas; pero sólamente pueden entrar hasta embarcaciones de mediano porte, porque sale mucho un placer de la isleta que está en su boca.

También en la Isla de la Roca Partida, hay por la banda del Este un puertecito en que se halla agua dulce.

Desde Cabo de Santiago hasta una punta de poca altura situada en $50^{\circ} 57^{\prime} 30^{\prime \prime}$ y $69^{\circ} 3^{8^{\prime}}$, no está reconocido.

Desde esta punta corre la costa al Norte $7^{\circ}$ Oeste hasta Cabode Tres Puntas, y se representa como una cordillera de cerros de piedra, medianamente altos, tajados casi á pico, con muchas quebradas y trozos de terreno bajo, notándose un abra grande por los $50^{\circ}$.

Cabo de Tres Puntas, situado en latitud de $49^{\circ} 46^{\prime}$ y longitud de $69^{\circ} 47^{\prime} 30^{\prime \prime}$, lo forma un monte con tres puntas, velado y bajo hacia la orilla, y se reparan en él manchas blancas, pardas y negras; en la orilla hay bajos con mucha reventazón. Como al Norte $5^{\circ}$ Este seis leguas de Cabo de Tres Puntas, está Cabo Corso, ó Primero; es un morro alto y gordo, con caída hacia el Norte y parece isla, demorando al Nordeste. Tiene muchos islotes separados y muchos bajos. Estos dos cabos forman la boca del golfo de la Trinidad.

Este Cabo Corso parece formar con otra punta al Norte algunos grados al Oeste siete millas de distancia la Boca de la Campana, según la relación del Diario del Piloto Machado. Reconoció éste el canal que hay entre la tierra firme y la Isla de la Campana donde esperaba hallar el puerto de Nuestra Señora, que dice Cedillo; pero no vió otra cosa que dicho canal Nornordeste Sursudoeste, de seis á siete leguas, tan hondable que no es posible dar fondo sino muy cerca de las elevadas montañas que le cercan, y sobre piedra, y se divide después en otros angostos canales llenos de pedrones. 
Se infiere por su relación, que no hubieron hallado en todo el espacio desde la isla de la Campana hasta el extremo Sur de Chiloé, puerto que merezca mayor atención que la bahía de Quintín. Dice que tiene de ancho poco más de una legua y dos de fondo, que tira al Sudoeste; tiene $I_{4}$ brazas en la boca y siete en lo interior, con una playita en la parte del Norte.

La isla de San Javier tiene por la banda del Este una gran playa de I2 á I5 brazas de fondo arena, está abrigada de los vientos desde el Nor- noroeste al Sursudoeste, aunque con Norte hay marejada.

También cerca de la bahía de Santa Bárbara hay una ensenada que tendrá de ancho como una milla y de largo dos ó tres y corre Norte-Sur.

En el viaje del Lord Anson se celebra mucho el puerto del Pingüe Ana.

Y en las Guaitecas parece haber también algunos medianos fondeaderos; pero este archipiélago, así como el de Chonos está muy poco conocido. 


\section{Construcción de las cartas desde el puerto de Montevideo hasta el de Chiloé.}

Hasta los $37^{\circ} 30^{\prime}$ la costa está trazada por nuestras tareas verificadas en la parte meridional del Río de la Plata por los Tenientes de navío y fragata Concha y Vernaci. El primer meridiano de estas cartas es el del observatorio nuestro de Montevideo, al cual se ha supuesto la longitud occidental de Cádiz de $50^{\circ} 5^{\prime} 45^{\prime \prime}$. Cualquiera diferencia que resultase en esta longitud, calculadas las ocultaciones de estrellas por la Luna, que allí se observaron, ó bien comparada á algún observatorio de Europa, nuestra observación del primer satélite de Júpiter que da margen á aquella determinación, es una cantidad absoluta que no influye en la carta siguiente.

No está reconocido en nuestra navegación el trozo de costa comprendido entre la latitud indicada de $37^{\circ} \mathrm{y}^{1} / 2$, y la embocadura del río Negro; pero la derrota de los Padres Cardiel, Estol y Quiroga (I) y las navegaciones y derrotas de los Pilotos D. Bernardo Tafor y D. Alejo Berlinguero, no dejan la menor desconfianza. Las embocaduras del río Colorado y del río Negro y los bajos que salen á la mar en sus paralelos, están igualmente reconocidos por los Pilotos Tafor, Villarino y Peña: éste último ha intervenido en su colocación en la carta actual.

Nuestras observaciones y bases corridas desde la embocadura del río Negro hasta la punta Belén, sujetan ya con evidencia en latitud y longitud la parte comprendida de costa: pende la determinación de latitud de la observación de la altura meridiana del Sol, conforme en las dos corbetas, dos horas antes de avistar la tierra próximamente en el mismo paralelo en que se observó.

La parte interior del golfo de San José está terminada por las sierras altas que hemos avis-

(I) Esta derrota que tuvo lugar en el año de 1746 y se emprendió desde la bahía de San Julián, por mar, á las ordenes del Capítán de navío D. Joaquín de Olivares, ha sido trazada con mucha prolijidad por el Brigadier de Ejército D. José Custodio de Saá y 'Tarria, residente en Buenos-Aires: existe en mi poder una copia del original, que el mismo Brigadier ha revisado y me ha entregado en aquella capital. D. Alejo Berlinguero presentó á S. M. en 1778 una descripción de la costa Patagónica en la cual consta que reconoció por sí mismo la costa desde los méganos de irena hasta el Cabo de San Andrés. tado: su configuración depende de la derrota que hizo el Piloto Villarino en estas orillas, reconocidos los puertos de San José y de San Antonio. El plano de aquel puerto, extractado de los del Piloto Tafor, puede tal vez ser capaz de una mayor perfección, y tanto más, si, como parece probable, ha de ser aquel paraje el de mayor concurrencia de nuestros balleneros. En tal caso, las embarcaciones de S. M. que protejan la pesca, pueden fácilmente ocuparse de este objeto.

De cualquier modo esto sea, desde luego toda embarcación podrá sin el menor sobresalto dirigirse al puerto de San José, pues que la recalada, así en cuanto á sondas como á la vista de tierra, no puede especificarse con más seguridad; y la entrada del puerto y áun el paraje más oportuno para fondear, están claramente explicadas.

En el puerto de San Antonio, faltándonos el Diario de Villarino, hemos comprendido los bajos que con presencia de aquel Diario ha puesto el Brigadier Saá y Tarria. No salimos garantes ni de su existencia, ni de su exacta posición, si existiesen.

Rechazamos, sin el menor recelo, un bajo puesto en algunas cartas al Nordeste del extremo Norte de la península de San José: hemos navegado algo distantes una de otra las dos corbetas en el mismo paraje, y ni la mar ni la sonda nos han dado la menor sospecha de su existencia.

Ya desde el extremo Norte de la península de San José, toda la costa siguiente está reconocida y trazada por nosotros con la posible exactitud, y á pesar que su igualdad, la falta de puntas salientes á la mar y de parajes elevados hiciese difícil no equivocar unos con otros puntos, la continuación de las bases por corredera, la repetición de las de por altura de topes (I) y una estima llevada con una atención constante, nos ponía al abrigo de todo error que tenga el menor influjo en la seguridad de la navegación.

No sólo por lo que hiciesen sospechar los planos de Tafor, si también por lo que nos manifestaba la sonda, admitimos un banco situado en el

(1) Véase la introducción á las operaciones astronómicas sobre los resultados de nuestras bases deducidas de las alturas de los topes. 
frontón de la península, y en el paralelo de $42^{\circ}$ r $7^{\prime}$. En esa misma tarde, una continuación de corrientes y remolinos y la alteración de rumbos dimanada del trastorno de sondas, hacen que las bases de corredera sean irregulares, y difícil á deducirse la prolija determinación de los puntos de la costa.

Siguen nuestros reconocimientos sin omitir punto alguno hasta el extremo Norte del golfo de San Jorge, y confrontadas la entrada del puerto de Santa Clara y el de San Sebastián, la bahía de Camarones y la posición de las Islas Leones, Arce y Engaño, con las posiciones determinadas en el plano de Tafor, adoptamos de la carta de está habil Piloto, también la bahía de San Gregorio y el paso entre la costa firme y las islas inmediatas.

En la situación de la Isla Rasa, nuevamente avistada, y en el término de sus arrecifes, hemos puesto la mayor atención, sujetándolas á bases y observaciones particulares: pende de iguales datos la colocación del Cabo San Gregorio, del cual, parte luégo la costa reconocida por el $\mathrm{Pi}$ loto Tafor en el canal de San Jorge.

Como quiera que en todas las costas indicadas no hemos carecido diariamente ni de la altura meridiana del Sol, ni de las observaciones de longitud y variación de la aguja, conviniendo entrambas corbetas en un mismo resultado, que paireando en las pocas horas de la noche, no hemos omitido punto alguno de la costa que no estuviese sujeto á dos ó tres marcaciones, podemos responder de la exactitud de este trozo de costa, y al mismo tiempo, tributar al Piloto Tafor los elogios debidos, por la mucha aproximación con que le había trazado. Son suyos los planos interiores del puerto Santa Elena y San Gregorio: hemos tenido presentes al mismo tiempo, aunque con muy poca utilidad, los planos del Piloto Berlinguero, que navegó á las órdenes del Sr. D. Domingo Perler.

El Cabo Blanco está situado en longitud por dos series de horarios tomados en su meridiano: su latitud (I), que hubiéramos deseado determinar en su paralelo, pende, á la verdad, de bases y puntos fijados á no mucha distancia del medio día: pero no ocultaremos, que habiendo experimentado en este día errores considerables de estima, y debiendo, por otra parte, depender dicha latitud de estimas parciales, la determinación de la ATREvida difiere en 2' de la nuestra, y por consecuencia, este es el máximo error que tuviese, si no prefiriésemos próximamente la media entre las dos, y es la que le hemos asignado.

Las bases corridas desde la vista del Cabo

(1) Está equivocada la posición del Cabo Blanco en la carta que se remitió desde puerto Deseado por manos del Piloto Peña, Capitán del bergantín Carmen.
Blanco hasta el puerto Deseado, alargan la costa de $7^{\prime}$ en latitud, sobre la que determinan las latitudes combinadas del trabajo interior y exterior del mismo puerto. Es tanto más singular esta diferencia, que de ningún modo podemos combinar con el curso de las mareas, cuanto que todas las circunstancias no podían ser á la sazón más favorables.

En el Diario se deja ver la grande probabilidad de que el bajo hallado por el Comodoro $\mathrm{Bi}$ ron, esté en las mismas marcaciones y distancia á que lo pone aquel navegante; así lo hemos situado en nuestra carta, en la cual manifestaran la sonda y la derrota, que indagamos su existencia tan de cerca, cuanto lo permitían las circunstancias.

Están acordes en el minuto las latitudes de las dos corbetas tomadas cuatro ó cinco leguas al Sur del Cabo Blanco y á su vista. La latitud del puerto Deseado está observada en el cuarto de círculo, y con estrellas septentrionales y meridionales. La de la Isla Reyes, resulta de las operaciones geodésicas con que se ha trazado todo el canal interior del puerto Deseado.

Nuestra llegada á este puerto, en el cual se emprende nuevo examen de la marcha de los relojes marinos, cierra sólo una época de diezisiete días desde perder de vista el cerro de Montevideo; el número Io de la ATREvida está confrontado en el meridiano de aquel cerro el día mismo de la salida; y el número 6i de la Descubierta, conforma con aquél, de tal modo, que la longitud del fondeadero es por éste de $9^{\circ} 52^{\prime}$ al occidente de Montevideo, y por el número Io de $9^{\circ} 5 \mathrm{I}^{\prime}$ oo $\mathrm{O}^{\prime \prime}$ (I).

La marcha de estos dos relojes se halla, no obstante, considerablemente acelerada en las comparaciones del puerto Deseado, y esta diferencia nos inclinaría á hacer una corrección á la longitud última y á las intermedias, si no nos detuviesen, no sólo los resultados siguientes hasta San Carlos de Chiloé que ligan exactamente con la longitud del primer satélite de Júpiter, sino la igualdad diaria de los relojes, incompatible con una variedad tan grande en la cantidad de aceleración, cual se deja ver en sus marchas respectivas. Las distancias lunares observadas en puerto Deseado determinan una longitud menor en $23^{\prime}$ á la asignada por los relojes.

Las longitudes y latitudes desde la Isla Reyes hasta el Cabo las Vírgenes, están deducidas de las tareas de los paquebotes Eulalia y Casilda. tomada la diferencia en longitud entre la punta del Guanaco y el Cabo Vírgenes, que determinan aquellos Oficiales, tiene solos cinco minutos ménos que la diferencia que resulta por nuestros relojes: esta pequeña cantidad se ha repartido en todo el trozo de costa con proporción á las di-

(1) Véase el Diario astronómico 
ferencias de latitud, y una tan grande uniformidad como la que se encuentra en esta multiplicidad de tareas es la prueba más evidente de su seguridad.

Las determinaciones nuestras son las sigruicntes:

\begin{tabular}{|c|c|c|c|c|}
\hline & \multicolumn{2}{|c|}{ CABO VIRGENES. } & \multicolumn{2}{|c|}{ PUNTA GUANACO. } \\
\hline & Latitudes. & Longitudes. & Latitudes. & l.ongiludes. \\
\hline 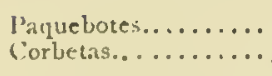 & $\begin{array}{l}52.19 \cdot 43 \\
52.19 .43\end{array}$ & $\begin{array}{l}62 . \times 9.56 \\
62 \times 8.45\end{array}$ & $\begin{array}{l}47 \cdot 47 \cdot 2 \\
47 \cdot 46 . \times 2\end{array}$ & $\begin{array}{l}60 \cdot x \cdot 10 \\
59 \cdot 54 \cdot 29\end{array}$ \\
\hline $\begin{array}{l}\text { 1)iferencias en lon } \\
\text { Diferencias totales }\end{array}$ & re & w in & & $\begin{array}{ll}\ldots & 6.41 \\
105 \ldots & 5.26\end{array}$ \\
\hline
\end{tabular}

İl Cabo Virgenes debe también considerarse ya como uno de los puntos ultramarinos á la Europa, cuya exacta colocación en longitud pueda más bien asegurarse, y no desagradará un resumen de las tareas emprendidas últimamente, que servirá al mismo tiempo de demostración en favor del método de las distancias lunares.

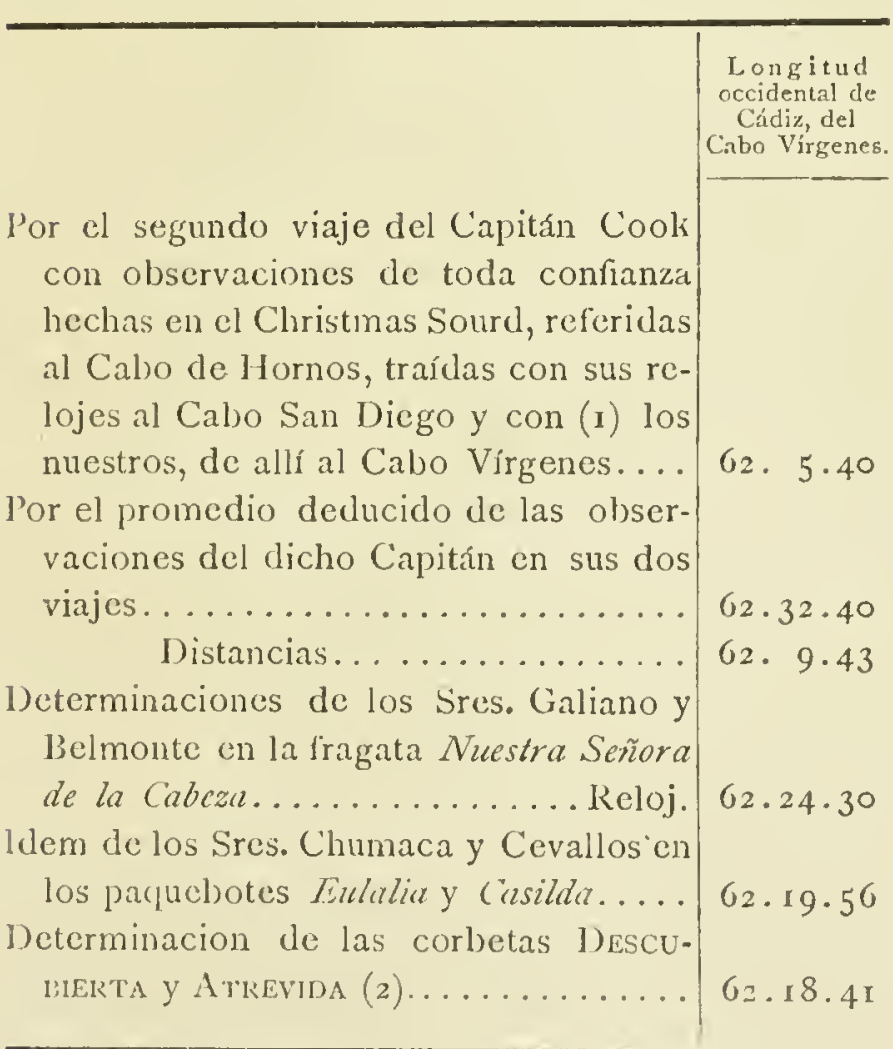

(1) Ja diferencia de merjdianos entre Greenwich y Cádiz, se ha supuesto de $6^{\circ}$ I $9^{\prime} 0^{\prime \prime}$ deducida de las diferencias parciales entre Cádiz, París y aquel observatorio. Se advierte la de $6^{\circ}$ I I' $50^{\prime \prime}$ en el Requisite tables que 110 conviene con la anterior: sicmpre ipe comparemos nuestras longitudes á las del Capitán Cook (lebe entenderse que suponemos la primera diferencia.

(2) Aunque en la Atreviwa y en la Descunierta se corriese base para deducir la verdadera distancia al Cabo Vírgenes, no la hemos adoptado por el mucho extravío que advertimos por las corrientes, comprobado en una y otra corbeta por las observaciones en longitud de arquella inañana y tarde: se ha preferido la distancia graduada á la vista, la cual no dis. crepa sino en tres minutos de la que determinan las bases de la Arkivilin: la longitud está observada ấ la vista del cabo) y la (pue se incluye es la del número 6 r porrue Ilega â Chiloé igual con la longitud del primer satélite de Jípiter: el mimero 10 no discrepaba á en dos minutos del número бi.
En esta costa, comprendida entre el Cabo Vírgenes y el puerto Deseado (en la cual como se ha dicho hemos adoptado las latitudes y longitudes de los puntos esenciales, como las determinaban los Sres. Chumaca y Cevallos), debemos particularmente á los Pilotos Tafor y Peña la descripción detallada de los trozos intermedios: son del primero los planos del puerto San Julián y Santa Cruz y la descripción de la costa intermedia. El segundo ha conseguido examinar últimamente el río Gallegos, y el bajo Bellaco, de los Nodales, completando así con la mayor exactitud esta parte esencial de la costa (I).

El bajo Bellaco se ha situado por nosotros en la misma posición, relativamente á la costa, que le determina el Piloto Peña y va inserta á la letra en el derrotero (2).

No es fácil determinar con exactitud el veril del banco: esta es obra de mucho tiempo y de resultas de un examen de muchos Diarios que en el día, ni están á mano, ni pudiéramos examinar con la madure $z$ necesaria. Hemos adoptado interinamente las sondas que determina la carta del Piloto 'Tafor.

Las Islas Malvinas se habían mantenido hasta aquí al abrigo de la navegación astronómica; de suerte, que no sólo su distancia á la costa y su verdadera posición quedaban dudosas, si también en su extensión y figura cabían diferencias notables: basta comparar la carta de monsieur de Bougainville con la del Capitán MacBride (3), y ésta con la de nuestros pilotos para ver palpablemente estas diferencias.

No es nuestro ánimo el acertar exactamente las distancias y arrumbamiento del sin fin de islas que forman este archipiélago complicado; pero podemos asegurar que toda la costa septen-

(I) Mr. de Bougainville, no haciendo memoria que esta vigía había sido vista anteriormente por los hermanos Nodales, la sitúa por $48^{\circ} 34^{\prime}$ á seis ó siete leguas de la costa: había sido la determinación de los Norlales con los astrolabios, de $48^{\prime \prime} 30^{\circ}$, dicen: Fuimos mestro camino: a las cinco ó mús de la tarale encontramos una baja que lavaba la mar en clla cinco leguas á la mar poco más ó inénos: es muy bellaio bajo, porque está debajo de la mar, que con ir con buen tiempo y poco mar, rompia y lavaba la mar en el bajo. Sondamos junto del bajo y hallamos 26 brazas y piedra.

(2) El Excmo. Sr. Virey de Buenos Aires me ha rcmitido a Santiago de Chile copia certificada de la relación del Piloto Peña. La he recibido del mismo Pilolo, á Lima.

(3) Adviértase que en la carta del segundo viaje del Capitán Cook está equivocada la extensión de las islas, segin lo notaron los Sres. Galiano y Belmonte (jág. 170 del Viaje al Magallanes). También mereco atcución el error del Dr. Hausket Worthk en la recopilacion del viaje del Comodoro Biron, determinando la distancia entre el puerto Egmont y las dos islas bajas del Nurte o Piedras l3lancas: supone ro leguas hablando de la entrada, cuando el plano y la misma navegacion de la salida 110 dan sino tres á cuatro; incurre en la inisma equivocación la traducción francesa. 
trional (que es la importante, pues conduce á los puertos de Egmont y de la Soledad) está ya sumamente aproximada á la verdad.

Nuestras tareas hidrográficas conducen desde la Isla Rasa hasta la de Borbón, y las observaciones hechas en el puerto Egmont que les sirven de llave, determinan ya sin recelo alguno la verdadera distancia á la costa firme. Desde la Isla Borbón hasta el puerto de la Soledad se ha corrido de tal modo la costa, que sin separarse de los derroteros de nuestros pilotos que anualmente costcan parte de aquellos puntos, buscásemos la latitud observada anteriormente en el puerto, que tantas veces repetida merece sin duda mucha confianza. De este modo hemos deducido rumbos y distancias, y nos lisonjeamos, que en la parte comprendida entre la Isla Rasa y el puerto de la Soledad no encuentre el navegante error alguno de entidad.

Nos ha sido preciso apartarnos de la carta del Capitán Mac-Bride, porque sus latitudes en el puerto Egmont exceden en seis minutos á las nuestras, y al contrario son menores de tres minutos á las nuestras, las que comparamos en el puerto de la Soledad. Convienen sí, próximamente, nuestras distancias de uno á otro extremo septentrional con las que prefija el Capitán inglés.

Desde el Cabo Pembroke ó extremo Sur de la bahía de la Soledad, abandonamos al contrario nuestras cartas nacionales, y seguimos la del Capitán Mac-Bride, en la cual no obstante variamos la dirección del canal de San Carlos, y las inmediaciones de la bahía San José en cuanto han sido reconocidas por nuestros navegantes, y al contrario no bien atracadas á causa de los vientos contrarios por la fragata fason, del Capitán Mac-Bride.

En general, nuestros conceptos son uniformes con los que dieron margen á la carta del viaje al Magallanes de la fragata Cabeza; el trozo comprendido entre la isla Rasa y la de Borbón procede de una serie de observaciones en latitud y longitud, acordes con las bases y con las marcaciones hechas desde la vigía del puerto Egmont; y la posición del observatorio nuestro está igualmente segura, pues su latitud se ha observado en el cuarto de círculo de Ramsden con estrellas al Norte y al Sur; y en los relojes, de los cuales se deduce la longitud, se ha hallado el mismo movimiento que en el puerto Deseado: las distancias lunares se apartan en esta ocasión poco ó nada de la longitud de los relojes.

Uno de los trozos de costa en los cuales más bien ha sobresalido nuestra felicidad, disfrutando no sólo de un tiempo hermoso y favorable, si también de una srande harmonía entre las operaciones astronómicas y geodésicas, es sin duda alguna el comprendido entre el Cabo Espíritu Santo en la Tierra del Fuego, y el Cabo San Juan en la Isla de los Estados. Son repetidas nuestras longitudes observadas, particularmente desde el Cabo de Santa Inés al de San Diego, y las latitudes sobre el canal de San Sebastián y el Cabo Santa Inés, reunen cabalmente con los extremos del Cabo San Diego y Cabo Vírgenes, á cuya vista han observado personas de la mayor confianza.

El placer de poco fondo reconocido por Sarmiento en las inmediaciones del estrecho, ha sido por nosotros confirmado, navegando en demanda del Cabo San Sebastián. La posición de este cabo es conforme con lo que advirtieron Mr. Bougainville y los Oficiales de la fragata Cabeza, haciéndole formar un ángulo ménos considerable al Sur. Hemos llamado con Anson, Cabo de la Reina Catalina, al que le sigue inmediato al Sur.

Se deja ver palpablemente que el Capitán Cook en su primer viaje, ó con alguna leve diferencia en la latitud, que le hizo tomar otro por el Cabo Santa Inés de los hermanos Nodales, ó con una marcha poco arreglada de sus relojes, determinó entre aquel cabo y el de San Diego una diferencia en longitud mucho más corta de la que nosotros hallamos (I); al contrario, estamos sumamente uniformes en la diferencia entre el Cabo San Diego y el Cabo San Juan, lo que parece comprobar la sospecha de que no merezcan tanto crédito las tareas del primero como las del segundo viaje de aquel ilustre navegante, sospecha tanto ménos extraña cuando se advierta que además de ser muclio más perfectas en esotra ocasión instrumentos y observadores, era también al fin de un viaje largo cuando las primeras operaciones tuvieron lugar al principio.

Fijada la longitud del Cabo San Juan, en la Isla de los Estados, y adoptada la latitud del Capitán Cook, son luégo frutos de las tareas de este insigne navegante, todos los puntos exteriores de la Tierra del Fuego, que insertamos en esta carta; á este fin hemos colocado el Cabo de Hornos, según nuestras diferencias, desde el Cabo las Vírgenes al Cabo San Diego, y las del Capitán inglés, desde el Cabo San Diego al Cabo de Hornos, entrambas deducidas de los relojes marinos: es, pues, la longitud del cabo de II $^{\circ}{ }^{5} 5$ y $00^{\prime \prime}$ al Occidente de Montevideo, ó bien de $6 I^{\circ}$ I $5^{\prime} 45^{\prime \prime}$ de Cádiz y $67^{\circ} 3 x^{\prime} 45^{\prime \prime}$ de Greenwich: siguen hasta la Isla del Aterraje ó Recalada, las diferencias en longitud, determinadas por los relojes marinos del Capitán Cook en su segundo viaje: del mismo hemos deducido el planito del

(1) Es la del Capitán ingle's de r" $20^{\prime}$; la nnestra de $I^{n} 5 I^{\prime} 00^{\prime \prime}$ 
canal de Navidad, en cuanto pueda ser útil á muchos navegantes; pero no nos ha sido posible hallar en las costas que ha reconocido, semejanza alguna con las inmediatas á la bahía de San Francisco que describe en su carta el Excelentísimo Sr. Ulloa, y que nos vemos precisados á omitir.

La posición de la Isla de Diego Ramírez, al contrario, está sacada de la carta de dicho señor excelentísimo, á lo ménos en cuanto á la diferencia de longitud deducida de aquel arrumbamiento y distancia, á cuyo fin se han supuesto los $10^{\circ}$ en latitud que faltan á la determinada anteriormente al Cabo de Hornos: así conforma la latitud con el Capitán Cook, y no hay contradicción con los indicios algo oscuros de los hermanos Nodales, que la han visto.

Como quiera que el canal Santa Bárbara, según lo diseña Trefier, no tiene ni en uno ni en otro extremo semejanza alguna con las abras avistadas exteriormente por el Capitán Cook é interiormente por los Oficiales de la fragata $\mathrm{Ca}$ beza, es difícil acertar con seguridad el verdadero sitio de aquel canal: así, mientras algún acaso (á la verdad difícil), no proporcione reconocimientos más prolijos de los que acabamos de nombrar, la colocación y el hallazgo del canal de Santa Bárbara serán materias harto dudosas, además que ya puede desconfiarse de la utilidad del mismo paso.

La diferencia de meridianos entre el Cabo Vírgenes y el Cabo Pilares, depende naturalmente de las operaciones trigonométricas; con las astronómicas han determinado ser esta diferende $6^{\circ} 37^{\prime}(\mathrm{I})$ algo mayor que la supuesta por el Capitán Cook, nos obliga, por consiguiente, á extender algo más la costa de la Tierra del Fuego, desde la Isla del Aterraje hasta el Cabo Deseado; y si como no debe dudarse, la diferencia determinada por los relojes entre la Isla del Aterraje y el Cabo Hornos es exacta, es claro que el Capitán inglés creyó ser el Cabo Deseado algún otro punto de la costa occidental al mismo cabo.

Como en la carta al Magallanes la dirección del Cabo Deseado relativamente al de Pilares estuviese combinada con atención á los viajes de los Sres. Walli, Biron y Carteret, nos ha parecido preferente á la que determina la carta del Capitán Cook.

El Cabo Victoria y los Evangelistas, dependen de las mismas operaciones de los Sres. Chumaca. Parecía á primera vista infructuosa cualquiera nueva combinación para trazar los reconocimientos interiores de Pedro Sarmiento, después del

(1) Fin el mismo Cabo Pilares se ha observado la latitud $y$ se ha deducido la longitud del reloj marino: estaban a la vista los Evangelistas y el Cabo Victoria. maduro examen á que les habían sujetado los señores Galiano y Belmonte; pero como en la parte exterior se nos proporcionasen nuevas combinaciones con el reconocimiento de las tierras inmediatas al Sur del canal de la Trinidad, y áun con la inmediación á que estuvimos del Cabo de Santa Lucía, hemos.hecho nuevo examen de aquellos datos, con intervención del mismo Galiano, y han resultado algunas combinaciones más felices, pues no excluyen observación alguna de latitud y longitud, y ligan mejor los arrumbamientos y distancias.

Nuestro reconocimiento no nos deja duda que la costa desde el Cabo Tres Morros para el Sur, corra Sur $5^{\circ}$ Este; al contrario, Sarmiento hallaba que esta misma costa, por sus agujas, corría Sur ${ }^{1 / 4}$ Sudoeste; luego no sería extraño que este error fuese general en los demás arrumbamientos, y así pareció lo más oportuno conservar toda la posición respectiva de los lugares de Sarmiento, girando sobre el Cabo Tres Morros toda la costa hasta el Cabo Santa Lucía, de suerte que buscase el nuevo arrumbamiento, y además demora al Norte $15^{\circ}$ Oeste, cuando Sarmiento avisa que se demoraba la vuelta del Norte, error igual al que hallamos en el Cabo T'res Morros y suponía. mos en la demás costa.

Con mucho agrado nuestro, resultó de este modo la distancia desde el Cabo Santa Lucía, al de Victoria, exactamente la misma que indicaba Sarmiento, cuando en la combinación primitiva de la carta del viaje al Magallanes aquella distancia resultaba más lata, de una cantidad considerable.

Si á esto se agrega que nuestra navegación sobre el Cabo Santa Lucía nos asegura que no puede salir más al Oeste, y que al contrario sujetada aquella punta por distancia y arrumbamiento de Sarmiento queda sujeta á la longitud segura del Cabo Victoria: si se agrega también que nuestra latitud del Cabo Tres Morros coincide próximamente con la de Sarmiento, debemos lisonjearnos que ya no admite corrección sensible este trozo de costa, y que en cuanto á la utilidad de la navegación no necesita mayor perfección, tanto más que estas costas parecen destinadas por la Naturaleza á ser perpétuamente miradas con horror por el navegante.

Reuniéndose á éstos los materiales del Piloto Machado, formados ya sobre las pocas noticias que se tenían de la costa desde Cabo Tres Morros á Chiloé, y situando en su posición el extremo Sur y Oeste de esta grande isla, cuyo plano acaba de levantar el Piloto Moraleda, se ha podido asegurar á corta diferencia el arrumbamiento total de esta parte de costa, que la derrota de las corbetas asegura no puede tener un error perjudicial á nuestras navegaciones; pero de ningún modo podemos salir garantes del pormenor de 
ella, pues áun las observaciones de latitud de dicho Machado, son incombinables con las distancias que resultan por la carta que formó (r). Este Piloto salió de Chiloé con una goleta y dos piraguas en $I 769$, con el objeto de recoger los náu. fragos de una fragata, que por noticias de los in. dios se había perdido sobre la costa, y con el encargo de que marcara y observase toda la costa hasta el Estrecho de Magallanes.

Fondeó en muchos puertos é hizo varias observaciones de latitud con el octante, particularmente en la isla de San Fernando, inmediaciones de la isla de Guayanecos, y en el extremo Sur de la de la Campana: algunas se afianzan recíprocamente, y manifiesta en su Diario haberlas hecho con buen Sol.

Su derrota, pasando las piraguas á hombro por el istmo de Ofgui, y luégo siguiendo por los canales de Tallos y del Castillo hasta la boca de la Campana, guiado de una india, merece una noticia particular: corresponden los tiempos que experimentó con los de Sarmiento y con los nuestros. Todo demuestra que el navegante debe separarse de estas costas.

De las latitudes indicadas, ha sido preciso desechar la de la isla de San Fernando en $45^{\circ} 47^{\prime}$, pues si admitiese ésta y se graduase su carta que no tiene troncos con atención á ella, quedarían los minutos desde Chiloé hasta ella, de la mitad del tamaño de los que siguen desde esta observación hasta la inmediata al Sur: al contrario, tomando la de la isla de San Pedro y la que hizo más al Sur, que fué en extremo meridional de la isla de la Campana, y dividiendo igualmente el tronco de latitudes de la carta, se acuerdan todas las demás observaciones á muy corta diferencia; pero la isla de San Fernando quedaría en $46^{\circ} \mathrm{r} 7^{\prime}$ en lugar de $46^{\circ} 47^{\prime}$. Si á esto se añade que el abra del puerto del Pingüe Ana, de la escuadra del Almirante Anson, está al Sur y la colocan en la relación del viaje de este Almirante en $46^{\circ} 1 / 2$, se aumenta la precisión de desechar la tal latitud; por otra parte, reflexionando que la península de los Tres Montes, quedaría en nuestra graduación dicha mucho más al Norte de 10 que la ponen las cartas que tenemos de esta parte, y teniendo una marcación del Cabo de Tres

(I) Machado llegó hasta el Cabo Corso, aunque dé este nombre al que ahora es Cabo Tres Morros: equivocado de unas noticias poco verídicas, y sin consultar el viaje de Sarmiento, creyó ser el Cabo Corso una tierra alta que veía desde la tierra firme, inmediata á la Isla de Santa Bárbara, así supuso que había una tierra baja en un canal que veía abierto, y que es sin duda el canal de la Trinidad, cuya anchura determina de seis leguas, exactamente la misma que determinó Sarmiento y nosotros hemos advertido. Es un acaso muy feliz que convengan las latitudes de Sarmiento y Machado con las nuestras; y esto hace tanto honor á la exactitud de aquel primer navegante como á los Oficiales que le han interpretario.
Morros, que hizo el dicho Machado estando una legua al Norte de.las Ayaotas, se ha bajado el Cabo de Tres Montes y toda la península de este nombre, 9' más al Sur para buscar así la marcación dicha, respecto al tronco de las longitudes, se ha dividido en la carta de Machado, de suerte que resulte entre el extremo Sudoeste de Chiloé y el Cabo de Tres Montes, la diferencia que hemos hallado por los relojes referidos por la carta de Moraleda al dicho extremo (I).

Además de las dudas y combinaciones indicadas, hay también la esencial para una exacta colocación de la costa que Machado no costeó la parte exterior de la penínsnla de Tres Morros, la cual, por consiguiente, en sus puntos intermedios, pudiera variar considerablemente. Lo mismo puede decirse de la Isla de Santa Bárbara: finalmente, que la existencia de la Isla de Santa Catalina pende de sola una noticia de los indios dada al mismo Machado.

Ya desde la Isla de Guajos y extremos de Chiloé, varía considerablemente la probabilidad de una exactitud constante. D. José Moraleda, primer Piloto de la Real Armada y Alférez de fragata graduado, ha costeado y trabajado prolijamente de orden del Gobierno, ambas costas del canal entre la isla y la tierra firme. Desde el extremo Sudoeste de la isla, desde los altos in. mediatos al extremo Norte, y desde algunos puntos intermedios á los cuales ha transitado por tierra, ha logrado arrumbar prolijamente toda la costa occidental, y sus latitudes comparadas á las nuestras sobre la punta de Yaqui, no dejan la menor desconfianza en esta parte (2), si se exceptúa un trozo de costa inmediato á las Tetas de Cucao, en el cual hemos trabajado nosotros mismos, y hallamos una diferencia considerable en latitud, bien que nada extraña, por no haber podido Moraleda transitar en aquella costa, y determinar, por consiguiente, diferentes distancias.

Toda la parte septentrional de Chiloé, desde el Chacao hasta la entrada del Chasco, deducida de una serie de triángulos formados con el teodolito, no hay punto en que no concurran tres ó cuatro marcaciones, y así podemos asegurar que este trozo de costa es de los que piden de nuestra parte una mayor confianza.

Las sondas únicamente son las que hemos adoptado del piloto Moraleda: las ha ratificado

(I) Se han tenido presentes la navegación desde Chiloé de un Sr. Mancilla en el año de 1767 , que parece forjada maliciosamente, y existe en la Secretaría del Vireinato del Perú; los detalles de Herrera que indica algunas distancias y arrumbamientos, y el viaje del Padre José García Alsue, de la extinguida Compañía, del que nada útil puede deducirse.

(2) Moraleda se ha valido del octante para las observaciones del frente y del cuadrinte para la de espalda: siempre se ha valido de las declinaciones calculadas en el conocimiento de tiempos. 
muchas veces, y no podemos desconfiar dc su exactitud, confrontada también en lo que hemos navegado.

La longitud de San Carlos de Chiloé es uno de aquellos puntos que merece ser desmenuzado, pues que le miramos como el verdadero concurso de las longitudes determinadas á ambas costas Patagónicas.

El número 6r de Arnold (I) la prefijó de $I 7^{\circ} 34^{\prime} I 3^{\prime \prime}$ al Occidente de Montevideo, sobre una marcha determinada en puerto Deseado, confrontada en puerto Egmont, y ratificada en los primeros días en San Carlos de Chiloé.

El número io de la ATREvidA, con iguales datos, la hacía llegar á $\mathrm{I} 7^{\circ} 38^{\prime} 30^{\prime \prime}$, y las ecuaciones correspondientes conducen los demás relojes á ese mismo resultado: ahora, pues, la observación de la noche del 6 de Febrero en el primer satélite de Júpiter, hecha por tres observadores con las circunstancias más favorables, determina la de $17^{\circ} 35^{\prime} 30^{\prime \prime}$ cuando el promedio de los relojes indicados es de solos $45^{\prime \prime}$ más occidental que ésta.

Concurren agradablemente á afianzar este resultado, no ménos otra observación de la misma especie hecha en el mismo puerto, si también los resultados de las observaciones del Padre Teville en Penco, con los cuales combina dentro del minuto la diferencia de meridianos asignada por los relojes entre San Carlos y Talcahuano (2), con cuyos antecedentes ya no es temeridad el asegurar la longitud de ambas costas intermedias en una aproximación á la verdadera cuando esté en el alcance de las operaciones marítimas.

Como los resultados del número 6r fuesen tan aproximados á las observaciones celestes, ha parecido inoportuno el variar las longitudes intermedias para el error leve de I'; tanto más, que teniendo correspondientes en Europa así las observaciones de Montevideo como las de Chiloé, cuyos meridianos son los que terminan el trozo de que se habla, puede tal ve $z$ la pequeña diferencia que resulte en las comparaciones absorber aquel error por otra parte insensible.

Estas mismas diferencias no deben ya variar las combinaciones de los relojes, sí sólo repartirse en el total de la costa proporcionalmente, á cuyo fin (como ya se dijo) se ha separado la costa en distintos trozos, dependientes de un meridiano en el cual se hayan hecho observaciones de mucha confianza.

Siendo la verdad la base esencial de nuestras

(I) Véasc para mayor claridad cl J)iario astronómico y la narración de nuestros acaccimicntos $\mathrm{cn}$ aquel puerto.

(2) Esta comparación se hará con más individua lidad hablando de la longitud de la ciudad de Concepción. tareas, no debemos omitir antes de cerrar este capítulo, que en la recalada al extremo Sur de la isla de Chiloé en la noche del I. $^{\circ}$ de Febrero, hemos creído todos unánimes ver la costa á distancia de cuatro leguas, cuya vista combinada con nuestras longitudes de la mañana siguiente y traídas con la estima á aquella misma hora, haría creer que el arrumbamiento de la costa occidental es muy diferente del que le asigna Moraleda; pero bien examinadas todas las circuns tancias, y áun hechos cargo de la distancia á que nos vimos de la costa en la siguiente mañanita á las cinco y media, nos inclinamos á creer que realmente fué aquella una ilusión que habíamos admitido sólo por la sonda que encontramos en la tarde anterior, y que no admiten duda la posición y arrumbamientos de Moraleda (I), cuyo derrotero de la isla de Chiloé va á continuacion.

Derrotero de la Isla de Chiloé por D. Fosé Moraleda, Alférez de fragata y Piloto de la clase de primeros de la Real Armada.

El modo de dirigirse de unos á otros puertos, á que el común de los náuticos llaman derrotero, no es otra cosa que dar noticia de la situación en latitud y longitud de los puertos, de los rumbos á que se ha de llevar el navío, expresando la configuración ó señales de las tierras que se deben avistar, con una noticia general de la clase y circunstancias de los vientos que suelen reinar con más frecuencia, y dirección y fuerza de las mareas ó corrientes que por lo regular se experimentan, para lograr, cuando no un perfecto conocimiento propio pues éste se consigue sólo con una dilatada serie de viajes, á lo ménos unas nociones ó luces que guien ó dirijan á ejecutarlos con el acierto y brevedad que se requiere, $y$ de cuya importante ejecución resulta tanto bien al Estado, en paz, guerra y comercio.

Supuesto lo dicho, la Isla de Chiloé, que es la mayor del mar Pacífico, si al que la circunda se le puede dar este nombre, está situada en la costa occidental Patagónica, y según mis observaciones, entre los $4 \mathrm{I}^{\circ} 4^{8^{\prime}}$ en que está la punta de Guapacho, que es lo más septentrional de la isla y $43^{\circ} 47^{\prime}$ en que está lo más fuera del grande arrecife de Chocheb, que es la más meridional de ella; de modo que tiene 40 leguas de Norte-Sur, cuya distancia concuerda con la que le. suponen los Sres. D. Jorge Juan y D. Antonio Ulloa, Cedillo y Barreda; pero con la equivocación de colocarla los citados autores entre 42 y $44^{\circ} 2^{\prime}$, bien que ninguno por inspección pro-

(I) El Diario que ha prescntado al Excmo. señor Vircy del Perú, merecc muchos elogios, no ménos por $\mathrm{cl}$ primor que pos la cxactitud con que está trabajado. 
pia. Los naturales y algunos otros que le han mirado muy á bulto y observado la latitud, lo mismo la suponen 48 y hasta 60 leguas extensión de Norte á Sur; pero las observaciones dichas de latitud deciden absolutamente y dejan fuera de duda la citada extensión de 40 leguas, ó más bien 39, si se excluye el arrecife ó bajo de Chocheb.

La dirección de la isla tomada en general por su costa del Oeste, es casi del Norte $1 / 4$ Nordeste y Sur $1 / 4$ Sudoeste, y la longitud de la medianía de dicha costa $303^{\circ} 6^{\prime}$ con respecto á la observada astronómicamente en la Concepción de Chile. La extensión de Oriente á Occidente es muy varia por los esteros y ensenadas que tiene por la parte del Este por donde más se extiende, que es entre el morro de Quicabi (es lo más occidental de la isla) y la costa opuesta, al Oeste tiene $\mathrm{I}_{3} \mathrm{y}^{1 / 2}$ leguas, y por donde ménos, que es entre Vilopulli y Cucao, no llega á siete.

Confina por el Norte, con la costa de tierra firme de Carelmapu, por el Este, con la isla del partido de Calbuco y costa firme de la cordillera Real de los Andes, por el Sur con el grande incógnito número de las Islas Huaytecas, á quienes comunmente llaman archipiélago de Chonos, y por el Oeste le sirve de término el Oceano Pacífico.

La costa occidental y del mediodía de esta isla, ni son accesibles para desembarcos, por sus escarpados, bajos, resaca de la contínua mar de leva, escollos visibles y ocultos, y estar por la mayor parte organizadas de rocas, ni tienen tampoco puerto alguno. La elevación mayor del terreno está en la medianía de la costa del Oeste próximo al mar, y en mi concepto se alcanzaráá ver en tiempo claro de I5 á r6 leguas de distancia. En esta altura se elevan algo más dos cerros contiguos, á quienes llaman las Tetas de Cucao, y son el objeto más notable de toda la isla para reconocimiento de ella y de la situación en que se está cuando se tienen á la vista; pero es menester advertir, que ninguno debe dirigir su recalada ó aterramiento á ellas, á ménos que no carezca de latitud observada y sea muy dudosa la latitud de la estima que traiga, porque de lo contrario, se expone á que la constante mar del Oeste en bonanza, ó un viento repentino de esta parte, lo empeñe en una costa brava, cual lo es toda la de esta isla que mira al Occidente. El demás terreno de ella hacia el Norte y Sur del dicho, es casi igual de un lomaje suave, que se podrá ver de II á Iz leguas de distancia estando el tiempo despejado.

La costa septentrional toda es accesible, y lo mismo la oriental hasta el Estero de Yalad, que está por los $43^{\circ} 30^{\prime}$ de altura, y este es el terreno poblado de la isla, porque el resto todo es desierto, á excepción de un corto número de ha- bitaciones inmediatas á Cucao, aunque dispersas entre sí como todas las demás de la provincia, que no se desvían media legua de la orilla de la mar.

Las cuatro estaciones del año se distinguen bien, anteponiéndose ó posponiéndose á veces al tiempo preciso por las causas naturales que suelen concurrir á perturbar el orden regular de ellas, pero la del invierno siempre se prolonga algo más que en otros paises situados en iguales alturas de Polo, y con una atmósfera contínuamente cargada de vapores de extraordinaria densidad que ocasionan frecuentes nieblas y cerrazones, reducidas probablemente de la frondosa maleza de que está cubierta la isla, las que se difunden en muy copiosas lluvias con muy pocas tempestades de truenos ni granizo duradero, y tal cual vez en poca nieve de media isla para el Sur; el frío áun en dichos días no es sensible á proporción de la latitud en que está, y al contrario, el calor que en los días de calma del verano parece excesivo respecto al clima.

Los vientos que se experimentan en esta isla y sus cercanías son varios é inconstantes, especialmente en la primavera y otoño. En esta estación dominan más los de la parte del Este, y en la otra los del Sudoeste y Oeste, pero por lo regular todos moderados con intermisión de algunas calmas, lluvia y serenidad. En el estío reinan los Sur y Sueste frescos y secos, con cielo despejado, aunque algunos muy fuertes turban la atmósfera, y los prácticos llaman Sures pardos; pero la tranquilidad que ofrece la estación, no se goza aquí sin -algunos golpes de lluvia y vientos impetuosos del Noroeste y Oeste, de modo que se pueden establecer por vientos generales los del Norte al Oeste que son propios de la estación de invierno. En ésta son tan copiosas las lluvias, y aquéllos tan fuertes, que con repetidos naufragios impiden á esta provincia, desde Mayo hasta Noviembre, la comunicación y comercio marítino con las demás de estos reinos, con notable perjuicio de ella en particular, y del Estado en general.

De dichos vientos, el que reina más y con más violencia es el Noroeste, porque aunque los Norte y Oeste le igualan en el ímpetu, no en la duración: éste vienta á ráfagas peligrosas, y aquél seguido por lo común, por lo que si en dicha estación ventando los citados vientos, el acaso ó necesidad tuviese en estas inmediaciones algún navío, deberá preparar sus jarcias, y disponer el velamen con prontitud á recibir aumento y duración de ellos, siempre que á las horas de salir y ponerse el Sol, note horizonte voxo envuelto en la oscuridad que en semejantes ocasiones tiene la atmósfera, y es la señal única que he hallado para evitar las fatales resultas de las sorpresas, ya cárgando el viento ó con repentino 
contraste del Norte á la travesía, ó de ésta á aquél, ó al Noroeste, que son muy frecuentes, y lo mismo el retroceso de los vientos del Sur y Sudoeste al Oeste habiendo pasado de éstc á aquellos, lo que en el común sentir de estos navegantes no sucede aquí sino que sigue contra el orden de la aguja al Sueste y Este hasta volver á establecerse al Norte, pero esta regla tiene muchas excepciones.

En la costa occidental de esta isla y algo fuera de ella, no se experimentan más corrientes que el contínuo choque del mar, siempre agitado de Occidente á Oriente, pero desde la entrada de los canales de Chacao y boca del Huajo para adentro, es tanta la multitud de corrientes y varias direcciones que toman las mareas, cuanto es de las inflexiones de las costas, puertos y ensenadas de la isla principal por su parte del Este, y de los canales que ésta forma con las inmediatas, y lo mismo sucede con la rapidez de su curso ó cantidad de movimiento con respecto á la mayor ó menor angostura de los citados canales, y configuración y distancia al suelo del mar en ellos, lo que se manifestará en sus respectivos lugares.

\section{Notas.}

I." Que los rumbos que se expresan en estas derrotas son corregidos de abatimiento, corrientes ó mareas y variación de la aguja, que es al presente de $\mathrm{I}_{4}^{\circ}$ en la costa del Norte de la isla y de $15^{\circ} \mathrm{I}_{4}^{\prime}$ en la del Sur de la especie del Nordeste.

2." Que en cualquiera de los puertos de estas derrotas, como en la mayor parte de las costas de la isla, se encuentra excelente agua y leña en abundancia.

Entrade al puerto de San Carlos, situado en la latitud Sur de $4 \mathrm{I}^{\circ} 53^{\prime}$ y en la longitud de $303^{\circ} 2 \mathrm{I}^{\prime}$ de Tenerife.

I. 'Todo navegante que de los mares de Europa ó de esta América venga á entrar en el puerto de San Carlos, debe proporcionar su recalada á él por los $4 \mathrm{I}^{\circ} 45^{\prime}$ á 50 de latitud, á dar vista á las puntas de Pologüe, Gabun, Huechucucuy y Huapacho, que es la más Norte de la Isla de Chiloé, las que están contiguas en la península de Huapi-Lacuy (los naturales le llaman la Isla) y no hallándose muy aterrado, tendrá también á la vista, con tiempo claro los faralloncs de Carclmapu hacia el Nordeste y acaso la Isla de Do ña Sebastiana, lo que reconocerá, notando cue de la citada punta de Huapachoó de la de Hucchucucuy corre hacia el rumbo del Sur 1/4 Sudocstc la costa de la isla grande de mediana elevación, con algunos morritos y farallones pecpueños cercar de ella, y de las puntas di- chas de Huechucucuy y Huapacho para el Norte no se verá costa alta ninguna, sino á larga distancia, pues toda la que está al Esste de los citados farallones de Carelmapu é Isla de Doña Sebastiana es la más baja de toda esta inmediación.

2. Recalando por $\operatorname{los} 4 \mathrm{~T}^{\circ}$ y $5 \mathrm{0}^{\prime}$, se llevará. casi al Este la punta de Pologüe, la que se reconocerá, porque de ella para el Sur empieza la grande playa de Cocotue, y su ensenada, que no admite confundirse ó equivocarse con otra alguna de sus inmediatas, que son pequeñas. Reconocida dicha punta seguirá el rumbo Norte $1 / 4$ Nordeste ó Nornordeste á distancia como de una legua de la costa, hasta estar tanto avante con la punta de Huechucucuy que avistará casi al Este la de Huapacho, y continuará al rumbo del Esnordeste para resguardarse del bajo de Huapacho, hasta que la punta de este nombre que se reconocerá por ser como se ha dicho la más Norte, y por un islote árido que tiene cerca, demore al Esucste, que entonces se dirigirá á ella, llevándola algo descubierta por estribor, y sucesivamente al morro de Huapi-Lacuy en los mismos términos, el cual corre con dicha punta Sueste $1 / 4$ Sur, Noroeste $1 / 4$ Norte. Montado este morro se verá al Sursueste distancia como de una legua, la punta de Agui que es la del Oeste del puerto, y tienc sobre sus lajas un pequeño cerrito frondoso que aparece un islote, poco separado del grueso de la punta, el que se llevará algo descubierto por babor hasta estar de dos y medio á tres cables de ella, que se arribará á montarla, lo que verificado se hallará ya dentro del puerto de San Carlos y á la vista de su pueblo, que le demorará al Sueste $1 / 4$ Sur, y orzando seguirá para dentro al rumbo del Sursudoeste hasta rebasar los sargazos del bajo de Pechucura, que son visibles, y conseguido orzará á atracar más á la costa para fondear entre los dichos y las puntas de Barcacura y Arenas, que es el mejor surgidero de este puerto, donde dejará caer el ancla en seis á siete brazas de agua fondo de lama y arena, á distancia de tierra como de media mi1la, y se amarrará de Nordeste-Sudoeste.

3. Advertencias. Para entrar en este puerto, especialmente de noche, se ha de tener mucho cuidado con el estado de la marea y su curso y violencia, por lo que se hace preciso advertir, que entre las puntas de Huechucucuy y Huapacho, los días de novilunio y plenilunio es la pleamar á las once del día, su curso casi de Este-Oeste y su movimiento de tres millas por hora con corta diferencia, bien entendido, que siempre la vaciante es algo más veloz que la creciente, y que aquélla se aumenta más en $\mathrm{cl}$ invierno, por razón de las avenidas de los ríos con las lluvias, y ésta por los impetuosos vientos de fuera.

4. 'También se advierte, que si cntrando en 
San Carlos con vientos escasos se intenta llegar al amarradero dicho bordeando, se ha de tener cuidado de no prolongar la bordada hacia la costa del Este más que hasta la medianía de la distancia que hay de costa á costa, porque del dicho paraje para la del Este, es placer de cuatro brazas á ménos agua; y así, con embarcación grande, es mejor ir á remolque con marea favorable ó á la espía, y no exponerse á varar como sucedió al navío de guerra San Pedro Alcántara en I780, al que una feliz casualidad de viento y mar, en las cincuenta y tres horas que estuvo varado, libertó de una pérdida, que acaso hubiera sido de mucha consideración é irreparable en la ocasión en que ocurrió aquel acontecimiento.

$5^{\circ}$ Se debe tener presente también, que la recala á la punta dicha de Pologüe, es en tiempo de verano que reinan los Sures; porque en el de invierno que vientan los Nortes, no se ha de pasar de los $4 \mathrm{I}^{\circ} 4 \mathrm{O}^{\prime}$ para el Sur por ningún caso, pero por esta altura, se presentará en aptitud de tomar el puerto con cualesquiera de los vientos propios de la estación, que como se ha dicho, son del Norte al Oeste impetuosos y con cerrazones, y la costa que desde la citada punta sigue para el Sur, toda sin guarecedero alguno, no sólo para la embarcación, pero ni áun para las vidas de los infelices que tengan la desgraciada suerte de naufragar en ella, porque toda es inaccesible.

6. Entre las puntas Huechucucuy, Huapacho y Tenuy, se halla el bajo de Huapacho, que es de arena con algunas peñas, especialmente hacia su parte del Norte; tiene de largo media milla, tendido casi del Nornordeste y Sursudoeste, y de ancho como la mitad de dicha distancia; está por enfilación al Este I $9^{\circ} 45^{\prime}$ Norte de la punta de Huechucucuy lo más Norte de él distancia de tres millas, y al Oeste $2^{\circ}$ Norte de la punta de Tenuy (ésta es el islote de Huapacho, de quien se ha hablado) distancia de una milla; y lo más Sur de él distancia del fondo de la ensenada de arena de Huechucucuy cosa de media legua, cuyo espacio es de buen fondo de I2 á I4 brazas de agua, donde por haberse guarecido el Piloto D. Juan Golindano con el paquebot Monserrate, suelen también llamar de Golindano á dicho bajo; en las peñas que tiene en su parte del Norte y Oste, se perdió la fragata $\mathrm{Bal}$ baneda del comercio de Lima la noche del 23 de Diciembre del año pasado de 1788 , conduciendo el Real situado para esta provincia, del que no se salvó nada casi más que las vidas, por lo apreciable del tiempo: y en la misma noche pocas horas antes de la Balbaneda, se perdió también en la playa de dicha ensenada de Huechucucuy el paquebot El Trínsito (alias el Papudo), de quien se salvó casi toda su carga.

7. Nota. Que el puerto de San Carlos es el principal de la provincia $y$ donde se ejecuta el comercio de ella con las demás del reino: su situación es la más ventajosa para el efecto y para la seguridad de la navegación; tiene varios sitios de excelente agua para proveerse de ella; es seguro de buen tenedero sobre fondos proporcionados, y capaz de contener bastantes embarcaciones resguardadas de los vientos que dominan especialmente en el invierno; pero se surge á una legua de distancia del pueblo, la que suele ser intransitable muchos días en la expresada estación. El terreno vecino es regular para labor, tiene muy poca, y casi todo está cerrado de espesísimo bosque, á excepción del que se desmontó para la formación del fuerte y pueblo. Este último, aunque desordenado, es el único que merece nombre de tal en toda la provincia, porque los habitantes de ésta están dispersos por las orillas del Norte y Este de la Isla Grande, y en las contiguas á ella, con las habitaciones en distancia unas de otras de media milla, una, dos y algunas mucho más. El vecindario de este pueblo consiste en 248 familias; pero desde $\mathrm{Di}$ ciembre hasta Marzo ó Abril se aumenta por ser el tiempo en que viajan á él las embarcaciones de comercio: no tiene el pueblo puerto seguro para embarcaciones menores, como lanchas, piraguas, etc., por cuya razón, aunque la escasez de víveres es general en toda la provincia, se hace más sensible en este lugar por faltarle los recursos que le proporcionarían en el particular la mayor abundancia de piraguas de otros parajes de la costa é islas pobladas, teniendo aquí un buen surgidero en que guarecerse del rigor de los tiempos de dicha estación.

8. El fuerte de San Carlos (no hay cosa más distante de serlo) sólo es provisional, muy reducido, y está casi desecho; pero en cualquiera disposición que se ponga, ó bien reedificando el actual, ó bien construyendo de mampostería, es inútil, y los 27 ó 28.000 pesos que costó, según dicen, al Rey, un sacrificio que la ignorancia hizo del Erario Real. Igualmente son inútiles, ínterin no haya tropa suficiente para su guarnición, todas las baterías provisionales que se construyeron el año de i780 (están desechas) á excepción del fuerte situado en la punta de Agui, que en mi concepto debe edificarse de obra firme, y la batería de la punta de Barcacura. Aquí, porque debajo de su cañón han de entrar indispensablemente las embarcaciones grandes y medianas que vengan á este puerto; y la batería dicha, porque el surgidero mejor y áun preciso del invierno, está bajo su tiro de cañón; por lo que concibo, que aunque sea provisional, debe tenerse siempre en estado de buen servicio. En lo demás, no creo absoluta mente preciso otra fortificación que la movible, esto es, tropa bien disciplinada, que es de lo que enteramente se carece aquí. 
Entrada al Puerto del Chacao, situado en latitud Sur de $4 \mathrm{I}^{\circ} 54^{\prime}$ en longitud de $303^{\circ} 47^{\prime}$.

9. Si desde el Oceano fuese el intento ir al puerto del Chacao, luego que haya montado el bajo del Huapacho, se hará el rumbo del Este hasta estar Norte-Sur distancia de una milla de la punta de su nombre, desde cuyo paraje se hará el Este $6^{\circ}$ Sur la distancia de 12 millas, por el que pasará una y media de la isla de Doña Sebastiana, por su parte del Sur 2 al Norte del bajo del Inglés, y como media legua de la punta de Chocoy, y morro de la Picuta de Carelmapu, sin riesgo alguno de las peñas de Punguñon; y al cumplir dichas I 2 millas, se hallará tanto avante con la punta de Punguñon, demorándole al Sur: desde este punto se hallará el rumbo del Este I $2^{\circ}$ Sur distancia de ocho millas, llevando casi por la proa algo descubierta por estribor la punta de San Gallán, que en esta situación es la tierra más Este que llevará á la vista por dicha banda, ála que se atracará hasta la distancia de dos á tres cables, y á esta misma seguirá costeando á rumbo del Sueste $1 / 4$ Este poco más de una milla, y 10 mismo al Sueste 1/4 Sur, y cumplidas ambas, se hallará tanto avante con la punta de Remolinos (es de peña tajada al mar) y con el pueblo del Chacao á la vista demorándole al Sur, cuyo rumbo se hará hasta estar Nornoroeste Sursueste con la iglesia, distancia como de un cuarto de legua ó media milla, donde se dejará caer el ancla en Io ó I2 brazas de agua fondo de lama, y se amarrará de Noroeste Sueste.

Io. Advertencias. En esta derrota es también absolutamente indispensable el cuidado con la marea para navegar con la favorable, á ménos que no sea acompañado de un viento largo capaz de vencer la violencia de la contraria, que es de cinco á seis millas por hora, particularmente de Quinterquen para el Este y áun al pasar por la boca chica, que la forman lo más Este de la isla de Doña Sebastiana, y la punta del Chocoy ó centinela de Carelmapu, si el viento no es muy superior á la acción de la marea contraria, es menester fondear en I8 ó 20 brazas de agua antes de abrir dicha boca, porque en ella adquieren una rapidez cxtraordinaria las mareas, siguiendo su curso al Norte y Nornoroeste y lo chupará, como sucedió á la fragata Favorita, propia de D. José Ostolaza, en I774, la que habiendo salido del puerto de San Carlos donde la construyó, la marca creciente la introdujo en el canal del Chacao, y la contraria la arrebató, obligándola i salir al Oceano por la expresada boca chica que es bastante hondable.

Ir. Lil curso de las mareas crecientes es casi al Iistc hasta estar tanto avante con la punta de Punguñón, y desde aquí según la dirección de la costa al Este 1/4 Sueste, Esueste y Sueste; y su velocidad tanto avante con San Gallán, donde se estrecha el canal á ménos de media legua en los días de novilunio y plenilunio, llega cerca de ocho millas por hora, y casi lo mismo en la punta de Remolinos. Los vaciantes siguen curso opuesto al dicho, y su movimiento algo más acelerado que el de las crecientes.

r2. La razón de atracarse á la punta de San Gallán y de ésta para adentro como se ha dicho, es la de libertarse del riesgo de la laja que está á media canal al Este $13^{\circ}$ Sur de dicha punta distancia de dos millas escasas, la que á un tercio de vaciante se descubre, y áun en la mar llena la indica la multitud de revesas y grande escarcéo que forma el encuentro del agua en ella; 1o que hace huir su inmediación (es bastante peligrosa) sin embargo de ser muy acantilada la peña.

I3. Si se quisiere venir á este puerto del Chacao, saliendo del de San Cárlos, se pondrá á la vela en éste á media marea vaciante, y luégo que se halle zafo de la punta de Agui, se dirigirá al rumbo del Norte $1 / 4$ Noroeste guiñando para el Norte, llevando el morro de Huapilacuy bien descubierto por babor, hasta que el dicho demore al Oesnoroeste distancia como de media legua, desde cuyo punto se hará el rumbo del Norte $1 / 4$ Nordeste hasta que la punta de Huapacho ó su farallón (éste se ha dicho que es la puntilla de Tenuy) demore al Oeste $15^{\circ}$ Sur, que estará casi enfilado con Huechucucuy, y entonces empezará á navegar al Este $6^{\circ} \mathrm{Sur}$, obrando en lo demás como se ha dicho en el número 9.

I4. El puerto de San Antonio del Chacao, desde la población de esta provincia hasta el año i768 que por Real orden se pobló el de San Carlos, era donde venían las embarcaciones del Perú para hacer el comercio de tablas dè Alersi y demás cortos ramos de industria de los moradores de esta isla, por cuyo motivo la población era bastante crecida respecto á la provincia: residian allí el Gobernador político y militar de ella, los Oficiales y tropa veterana de su guarnición, y los Tenientes de Oficiales reales, pero ha quedado como el resto de la costa con muy pocos vecinos dispersos, porque todo se ha trasladado al de San Carlos.

I5. E1 terreno vecino es bastante apropósito para cultivado, y lo está á proporción del número y circunstancias de las gentes que lo habitan, que como á todas las de la provincia domina la pereza, especialmente á los hombres.

I6. El puerto es bastante capáz y seguro en la benigna estación del verano, pero no así en la del invierno, porque para abrigarse de los vientos propios de ella, particularmente del Norte, apenas hay suficiente extensión para tres embar- 
caciones, y no á la gira, en la poza ó ensenada del Estero, que es donde pueden estar resguardadas; esto, los riesgos de bajos, largo del canal y violencia grande de las mareas, hace mucho más cómodo á los navegantes el comercio con el de San Carlos, donde entran y salen las embarcaciones, libres en la mayor parte de los citados riesgos.

I7. Sobre un pequeño ribazo á la orilla del mar, hay un fuerte provisional, como el de San Carlos en mal estado é inútil; el Cerro de la Ermita al Este lo domina á tiro de fusil, y puede ser atacado y tomado por la espalda con mucha facilidad y prontitud, desembarcando en la ensenada.de Manao que está una legua al Sur del puerto, el que para su defensa no necesita otra fortificación que la tropa, y cuando se conciba preciso algún fuerte, parece debe construirse sobre el cerro de la Ermita, cuya natural disposición y no tener otro vecino que le domine, le hace á propósito para el efecto.

I8. La pleamar en los días de Luna nueva y llena, es en este puerto á las doce del día; crece el agua 22 piés de Castilla, y en las mareas regulares $\mathrm{I} 8$; unas y otras son de á seis horas.

Derrota del puerto de Chacao al de Linao, situado en la latitud Sur de $42^{\circ} 3^{\prime}$, y en la longitud de $303^{\circ} 47^{\prime}$.

I9. Puesto á la vela en el puerto del Chacao, se gobernará al Este $1 / 4$ Nordeste distancia de tres y media millas, las que cumplidas, tendrá la punta de Tres Cruces que es la tierra más Este del Chacao al Oesudoeste como á una milla, desde donde se hará el rumbo del Sur guiñando algo para el Este la distancia de tres leguas, la que verificada, se hallará ya rebasado de la punta de Chillen, de la cual sale un pequeño bajo de arena como hasta un tercio de milla, y le demorará lo más Norte de la peninsulita Huapi-Linao al Oeste 26 ó $28^{\circ}$ Sur distancia cuatro millas, á la que llevará descubierta por babor, atracándose hasta tiro de fusil por ser muy acantilado por esta parte; seguirá para dentro al rumbo del Oesudoeste y Sudoeste $1 / 4$ Oeste hasta dar fondo en la inmediación de la Capilla sobre diez ó I 2 brazas de agua fondo lama distancia de tierra como dos á dos y medio cables.

20. Advertencias. En esta navegación se expresa el desvío de una milla de la punta de Tres Cruces, no obstante ser tan hondable, que en bajamar á 50 varas hay I 20 brazas, porque en ella tienen las mareas casi tanta violencia como en la de Remolinos, con grande escarceo y revesas que más de una vez han hecho sumergir las embarcaciones menores, y áun á principios de este siglo, una grande del comercio del Perú tocó en la laja del canal, y con la violenta acción de la marea, detenida en la punta de Tres Cruces, las revesas y el viento Sur fresco, la sumergieron, pereciendo toda la gente á tiro de pistola de tierra.

2I. El desvío de la punta de Chillen, es no tanto por su pequeño bajo, cuanto porque allí se encuentran las mareas contrarias, esto es, la que entra por el canal de Chacao y desde la punta de Tres Cruces sigue al Sur, y la que entra por la boca grande del Huajo, y discurriendo por los demás estrechos y canales sigue hacia el Norte hasta dicho punto, donde la línea de división que forma el encuentro es tanto más peligrosa, cuanto el viento sea más fresco, la embarcación más pequeña y la marea esté más próxima á su mediación. Desde dicho lugar toman las vaciantes un curso diametralmente opuesto, pues la que desagua por el canal de Chacao al Océano, retrocede hacia el Norte, y la que se dirige á salir por la boca del bajo, forma su retroceso hacia el Sur; esta raya del encuentro de las mareas, procuran cuidadosamente huir los naturales por las muchas desgracias que han ocurrido en ella; fórmase otra igualmente peligrosa entre la punta de Tres Cruces, ensenada de Parua é Isla de Abtao: en todo el canal del Chacao, hasta fuera del Huapacho al encontrarse la vaciante y creciente, con particularidad si la marea que acaba es acompañada de viento fresco: sobre los bajos de Chayhuau y en otras varias partes, pero las más peligrosas son las dichas.

22. En el tránsito de la punta de Tres Cruces á la de Chillen, está la grande ensenada de Manao, que es sondable y de buen surgidero, aunque desabrigada á los vientos del Este y Nordeste que suelen soplar algo frescos, pero resguardada de los más impetuosos y frecuentes del aก̃o.

23. En el puerto de Linao pueden abrigarse bastantes embarcaciones, pero es necesario en tiempo de invierno surgir en la ensenada de Gueldan á distancia de dos á tres cables de tierra sobre i 6 á i 8 brazas fondo lama y arena, y en el de verano á la misma distancia de la Capilla ó en el principio del Estero sobre fondo de Io á I 2 brazas arena; que de estos parajes hacia el medio del puerto va aumentando el fondo á 30,40 y 60 brazas hasta la boca, en que hay Ioo. El terreno que forma el puerto es propio para el cultivo, y lo tiene, en lo que pueden las I2 ó I4 familias naturales que pueblan su contorno.

24. Este puerto se reconoce por la península Huapi-Linao; su parte del Norte es la boca que se presenta como una isla tajada al mar por la parte del Este y Sur que es donde altea más; á corta distancia al Este se verán algunas rocas del Arrecife de Lobos, el cual sale de lo más Norte de dicha península al Este I $8^{\circ}$ Sur, distancia media milla, y á tiro de piedra de él, hay 
en bajamar de seis á siete brazas de agua; también sirve para el reconocimiento, la igualdad de la tierra algo alta que está sobre el puerto, y la playa del Llihuco, que desde Huapi-Linao corre hacia el Sueste, distancia de tres leguas, y es la mayor que hay en toda la costa oriental de la Isla de Chiloé.

25. Los días de novilunio y plenilunio es la pleamar en este puerto á las doce y tres cuartos del día, su aumento 22 piés, respecto á la bajamar de dichos días y en las aguas muertas I8 piés. La velocidad que llevan en la boca, es de tres millas la creciente y tres y media la menguante á media marea, que es su mayor fuerza.

Derrota del Puerto de Linao al de Castro, situada su boca en latitud Sur $42^{\circ} 50^{\prime}$ y en longitud $303^{\circ} 39^{\prime}$ por los canales que forman las Islas Quinchao y Chiloé, $y$ ésta con la parte del Norto de la de Lemuy.

26. Saliendo de dicho Puerto de Linao, desde la medianía de su boca se gobernará al Este hasta que lo más Sur del Barranco de Huapi-Linao demore al Sudoeste, que hallándose ya sin riesgo del Arrecife de Lobos, se gobernará al Sueste $1 / 4$ Sur, guiñando un poco para el Este y llevando la punta de Lobos de la Isla Caucahue, que es escarpada por estribor; á las I $7 \mathrm{y}^{1} / 2$ millas navegadas se hallará al Sueste $1 / 4$ Este y Noroeste $1 / 4$ Oeste, distancia como de una legua de la costa de la punta dicha, y demorándole el canal de entre Cuicabi y los Chauques al Sur, á cuyo rumbo se dirigirá, y habiendo navegado I I $1 / 2$ millas, estará en la embocadura del canal, y á medio freu de él sobre el rumbo del Sur $2^{\circ}$ Oeste, se seguirá hasta que lo más Sur de dicha Cuicabi, que se llevará por estribor, quede al Norte $1 / 4$ Noroeste, que entonces se volverá á seguir el rumbo del Sur distancia seis millas, que cumplídas se estará Noroeste-Sueste con la punta de Tenaun, demorando al Oeste el canal de Quinchau, que empieza entre la punta ó Morro Calen y la islita Linlin; desde dicho punto se navegará al Oeste siete millas, con que queda rebasada dicha isla, que es escarpada por la parte del Norte y morro Calen. Desde aquí gobernará al Oestc $6^{\circ}$ Sur, cuatro millas hasta estar NorteSur con la Capilla de Cuetalco á estribor, y punta Buyar á babor, desde cuya situación se hará el rumbo del Oeste $29^{\circ}$ Sur cuatro y media millas, que cumplidas se estará próximo á la mayor ansostura del canal de Quinchao, que es como de Soovaras, y se pasará á medio freu en vuelta del Sursudoeste, distancia de media milla hasta montar la punta de Cuyumuy, que es lo más Oeste de la Isla Quinchao; luégo se pondrá á grobernar al Sueste 1/4 Sur el espacio de tres millas hasta estar Esnordeste-Oesudoeste con la Capilla de Curaco en dicha isla; desde este punto na- vegará al Sur $4^{\circ}$ Este, distancia dos millas; luégo el Este $28^{\circ}$ Sur, y á las ocho millas estará rebasada la punta y bajo Aguantao, y á la vista demorándole al Oeste $32^{\circ}$ Sur la punta Chalihue, en la Isla de Lemuy, y distante media legua al Sur la de Chelín. Desde dicho punto navegará al Oeste $25^{\circ}$ Sur, hasta que la punta de Aguantao que llevará por estribor, demore al Norte una milla ó poco más, desde cuya situación hará el Oeste $\delta^{\circ}$ Sur, distancia ocho millas, y se hallara en la embocadura del Esteró puerto de Castro, qne la forman la punta de Tutil al Este, y la islita de Linlinao al Oeste. Del citado punto se dirigirá al Norte $8^{\circ}$ Oeste hasta estar como á un tercio de milla de la costa del Norte, que entónces gobernará al Oeste $5^{\circ}$ Norte, y á poco más de media legua se pondrá al Norte $28^{\circ}$ Oeste hasta navegar una milla, que cumplida, se hallará tanto avante con la punta de Pebque (es la más saliente de la costa del Este de este Estero) y á media canal de la mayor angostura. Desde este paraje se gobernará al Este $37^{\circ}$ Norte distancia dos tres cuartos millas, y de este sitio al Norte $14^{\circ}$ Este una y un tercio, que verificado, se hallará al Esnordeste-Oesudoeste con la ciudad, y en el mejor fondeadero respecto de ella, donde dejará caer el ancla en I3 á I4 brazas de agua, fondo lama, ó lama y arena, distante de la punta de Niculao, que es el desembarcadero de la ciudad, y se amarrará de Norte á Sur.

27. Advortencias. Practicando esta derrota, si por alguna urgencia fuese necesario surgir en la playa del Lliuco, será en 20 á 25 brazas arena, á distancia como de media milla de tierra, porque más afuera aumenta el fondo repentinamente á 50, 60 y más brazas; y de dichas 20 para la costa se encuentra el placer de poca agua con muchas piedras sueltas desde Huapi-Linao hasta la Capi1la de Lliuco para las puntas de Ahucho y Queñiau; el citado fondo de 20 á 25 se halla 400 ó 500 varas de tierra, y su aumento para fuera es pronto y considerable, desapropósito para surgidero. Toda la playa es desabrigada de los vientos desde el Sueste para el Este y Norte hasta el Noroeste, y muy peligrosa con los del Este y Nordeste; de los demás está cubierta, y tiene los ríos de Metenguen y Ahucho para aguada.

28. Continuando en la expresada derrota, se hallan los surgideros de Terraun y Calen, ambos son buenos, con 25 á 30 brazas de agua fondo lama, á 500 varas de tierra; son desabrigados de los vientos del Sudoeste para el Sur hasta el Este, pero están á cubierto de los restantes, que como se ha dicho son los más impetuosos, y tienen dos riachuelos de buen agua con particularidad el de Terraun. De Calen para el Oeste, que ya es el canal de entre Quinchao y Chiloé, cualesquiera de las dos costas que lo forman son surgidero para toda suerte de embarcaciones mé- 
nos para las que calen más de tres brazas de agua; pues no pueden pasar por entre el astillero de Dalcahue y la costa de Quinchao sino á pleamar ó antes de media vaciante, porque es necesario fondeen antes de montar la punta de Cuyurmie, que será lo mejor, é inmediatamente que se haya montado, esperar marea para pasar sin riesgo en dicho poco fondo; teniendo siempre cuidado de surgir más inmediato á la costa del Norte que á la del Sur, porque de ésta sale un bajo de arena y concha con mucho sargazo que á bajamar casi se descubre, y se avanza hacia el Norte hasta un tercio de canal, cuyo resto hasta la costa de Quinchao tiene á bajamar escorada tres y media brazas de agua, y este poco fondo sólo se extiende á un tercio de milla de Esueste Oesnoroeste, según la dirección del canal. La ensenada de Curaco en Quinchao, es también aplacerada, por cuya razón se debe pasar más inmediato á la cos ta de Quelinquehue en Chiloé que se lleva á estribor, que á la dicha de Quinchao que es la de babor.

29. De la punta de Aguantao sale al rumbo del Este hasta la distancia de media milla, un bajo de arena que remata en punta aguda, que tiene á bajamar media braza de agua cerca del extremo del Este, pero casi repentinamente se cae á cinco brazas, profundidad suficiente para un navío de guerra.

30. De la punta de Yenue cerca de la Capilla de Nercon, en el Estero de Castro, sale un bajo de arena lama y marisco, que con varias inflexiones sigue hasta la punta de Niculao, el cual se avanza en algunos parajes hasta 800 varas de la costa del Oeste, por lo que desde la punta de Pebque hasta el fondeadero de la ciudad, es necesario atracarse más á la costa del Este que á la dicha del Oeste. Este bajo queda casi todo descubierto á bajamar de aguas vivas, y á pique de su veril hay de cinco brazas de agua á más.

3I. En orden á mareas se debe advertir que desde la boca de Linao hasta la cercanía del canal ó estrecho de Quincabi y los Chauques, es el movimiento de poca consideración, pero de allí adelante son de absoluta necesidad para el viaje, y siguen con leve diferencia los rumbos que expresa la derrota y sus opuestos, y sólo resta que advertir que en dicho estrecho es la velocidad que llevan como de legua y media por hora; hacia el Sur, del de una milla ó poco más hasta la angostura entre Calen y Linlin, de aquí en adelante, su velocidad, á proporción que va angostando el canal (razón común á todos los demás que se expresarán) de Quinchao, y en la mayor angostura de éste es de tres á cuatro millas, la que luégo se disminuye á dos y media y dos hasta estar rebasado de las puntas de Aguantao y Chaliue é Isla de Chely que se disminuye más, pues apenas llega á media legua por hora hasta estar entre la punta de Tu-tin é islita de Linlinao, que se vuelve á aumentar á dos y dos y media millas para adentro del Estero de Castro; debiéndose suponer que todos estos movimientos son á media marea, y que se altera algo en las aguas vivas y tiempo de lluvias fuertes.

32. También se advierte, que en la derrota del rumbo al Sur para navegar desde la punta de Lobos de la Isla Caucahue hasta el Estrecho de Cuicabi, se halla al paso el bajo de Lumulmul, que es de peñas, y vela hasta un tercio de marea creciente: tiene de extensión Noroeste Sueste media milla, es muy acantilado, está NoroesteSueste con la punta de Quinquerquen que es la más Sueste de dicha Isla Caucahue; y siguiendo la citada derrota se deja por babor al Este distancia como de dos millas.

33. Nota. El Estero de Castro, que sin disputa es el mejor puerto de toda la provincia, y acaso también de los reinos del Perú y Chile, es excelente surgidero para grande número de embarcaciones de todos portes, con fondos muy proporcionados desde 20 hasta seis brazas que se hallan á tiro de piedra de sus costas, y en algunos parajes aún á ménos distancia, á excepción de la que comprende el placer ó bajo citado. Sobre suelo de lama por lo general especialmente de la punta de Pebque para el Norte, en él se está á cubierto de todos vientos, y su mar nunca se agita con ellos en términos de ocasionar riesgo. Todo el terreno vecino, aunque algo alto el de la parte del Este, es muy á propósito para poblaciones y siembras, con particularidad el del Oeste. La población es como se ha dicho; habitaciones dispersas por la campaña; aunque por las ventajas que ofrece este terreno desde Chonchí hasta las Capillas de Tey y Quilquico, están las casas más contíguas que en el resto de la provincia, y á consecuencia, es lo más cultivado de toda ella.

34. La ciudad de Santiago de Castro, capital, está situada en la costa occidental del Estero por latitud de $42^{\circ} 45^{\prime}$ y longitud de $303^{\circ} 39^{\prime}$. Sobre una bella y espaciosa meseta que se levanta desde el nivel del mar de 55 á 60 varas, y en el mar lleno, queda hecha una especie de península formada por el río Gamboa, que la baña por los lados de Occidente y Mediodía y el Esterito de Tenten por el Norte. Se dice que en los principios fué bastante regular la ciudad, y á pocos años de su fundación la arruinó un formidable terremoto; que reedificada de nuevo, la devastó el pirata inglés Baltasar Cordes en I600, y en el de I6 5 el holandés Jorge Spilguert.

35. En la cara del Occidente de la plaza hay un fuertecillo más despreciable que los de que se ha hablado. En la costa del Estero, y como media legua hacia adentro de su boca, hay una 
batería provisional sobre el terreno nombrado Tauco, capaz de ocho cañones, y está casi deshecha.

36. Nota 2. La derrota anterior desde el puerto de Linao hasta Castro, sólo se puede ejecutar con embarcación grande, ó mediana en una absoluta urgencia, porque aunque los canales que en ella se discurren tienen suficiente profundidad para los mayores navíos, sus angosturas é inflexiones causan por lo común varios embates de vientos diversos, ya frescos, ya bonancibles, lo que unido al defectuoso gobierno que áun á las embarcaciones más finas ocasiona la corriente ó marea en popa y sus revesas, las 1levan á aquéllas contínuamente expuestas á varar ya en una ya en otra costa, que casi son todas acantiladas y en muchos parajes con piedras sueltas y algunas lajas, por cuya causa, la derrota más segura de uno á otro de dichos puertos, ha de ser por fuera de los citados canales, Islas de los Chauques y demás que están contíguas á la costa del Este de lade Chiloé, yendoá recalarálas puntas de Detif y á Pavón, que están en 10 más Sur y Este de la Isla de Lemuy, ya sea para entrar por el canal del Norte de ésta, ó ya por el del Sur de ella, que será lo mejor, á cuyo efecto se harả la siguiente.

Derrota de Linao á Castro por fuera de los canales é islas del Este de la de Chiloé.

37. Saliendo del puerto de Linao y hallándose ya Norte-Sur con 1o más fuera del arrecife de Lobos, se gobernará al Sueste distancia de I2 leguas, las que cumplidas, se hallará Esnordeste ó Esudoeste con lo más Norte de la Isla de Cochi, que es la más Este de las de los Chauques, distancia de cuatro y media á cinco millas; desde dicho paraje gobernará al Sur la distancia de tres y media leguas, y verificada, se estará Este-Oeste con la Isla de Tac, que es baja, y está Norte-Sur con la dicha de Cochi. Desde esta situación se gobernará al Sursudoeste 22 millas, y cumplida esta distancia, se pondrá al rumbo del Oeste, y habiendo navegado sobre él seis leguas, se tendrá rebasadá la punta de Ahoni, y se hallará Norte-Sur con la de Detif: desde este punto se hará el rumbo del Noroeste distancia dos y media millas hasta estar Este-Oeste con la Punta de Terao distancia de una escasa, que se pondráá gobernar al Nornoroeste $5^{\circ}$ Norte, y habiendo navegado dos millas y media, se hará al Oesnoroeste distancia de una, y cumplida ésta, se navegará poco más de otra al Oesudoeste, 1o que verificado, se hallará á medio freu del canal del Sur de la isla de Lemuy. Desde este sitio navegaráá medio canal siguiendo el rumbo del Ocste I $5^{\circ}$ Norte una milla, y cumplida ésta dos al rumbo del Noroeste llevando por la proa la punta escarpada de Colulil en la Isla de Chiloé, y al cumplir dicha distancia, se hallará tanto avante con la punta de Lomemo, que es 10 más Oeste de Lemuy, la que se lleva por estribor: desde este punto se hará el rumbo del Norte distancia de una milla, y cumplida se hallará Este-Oeste con el Estero de Ychauc en Lemuy: desde esta situación navegando al Nornordeste dos y media millas se hallará entre la Punta de Tutil y la islita de Linlinao, que como se ha dicho es la boca del Estero de Castro, por lo que en lo demás de él hasta el fondeadero de la ciudad, se obrará como se ha dicho en el número 26.

38. Advertencias. La Isla de Cochi, que como se ha expresado es la más oriental de las de los Chauques, es algo alta, lo que se avistará en tiempo claro casi desde la boca de Linao, especialmente por la parte del Este que es escarpada y sin surgidero alguno, y lo mismo la de Tac aunque baja. Siguiendo la derrota se pasará una legua al Este de la Isla de Apiao y como cuatro millas de lo más Este de la de Chaulinec; ambas son altas y carecen de surgidero por dicha parte, las que se 1levan por estribor, dejando á babor distancia de cinco á seis millas las de Chulin, Chuit y Nayahe chica y grande, que son bajas y desiertas.

39. Montada Chaulinec, se verán al Oeste distancia de seis leguas, las puntas de Apabón y Detif, que como se ha dicho, están en lo más Sur de la Isla de Lemuy, y son su objeto más remarcable. La primera se puede ver de Io á I2 leguas de distancia y es el escarpe más elevado que se nota en toda la costa del Este y sus contiguas; al Sur del dicho se ve una pequeña abra de tierra muy baja, y luégo se eleva la Punta de Detif, que es aguda y algo alta por un cerrito frondoso escarpado por todas partes, que la forman, que desde fuera hace la apariencia de una islita, desde una á otra de dichas puntas toda es baja de piedras con sargazo, que sale poco más de un cable de la costa, pero se avanza hasta tres hacia el Sursudoeste de la punta de Detif, y cerca de dos al Esueste de la de Apabón, con peñas que velan desde media vaciante del mar hasta media creciente, formando dos islotitos.

40. Desde Chaulinec, siguiendo la derrota del Oeste en demanda de la boca del canal, se deja por estribor el bajo del medio de entre Apabón y la más Oeste de Chaulinec, pasando al Sur de él distancia de una legua, es de peñas, tiene de extensión Noroeste Sueste una milla, y media de Nordeste-Sudoeste; se descubren algunos cabezos de él antes de media marea vaciante, sus sargazos siempre están manifiestos, y es muy acantilado.

4I. La punta de Ahoni que está al Sur de las de Apabón y Detif, con quienes forma la en- 
trada del canal del Sur de Lemuy, es también alta, hace especie de morro cubierto de rerde, $y$ unas $y$ otras no admiten confundirse con alguna de sus inmediatas ni entre sí. A dicho morro lo circuye un bajo de arena y piedras, su fondo de alfaques desigual de cinco, dos y ocho brazas á bajamar está al Este del morro como tres cables, y sigue hasta la capilla de Ahoni, que está una milla escasa al Oeste del citado morro.

42. Siguiendo para adentro del canal, se verá por encima de la punta de Detif el escarpado, casi tan alto como el de Apabón, de la punta de Yal en Chiloé, que va descendiendo hacia el Norte hasta acabar cerca de la punta propia de Yal, que es baja; al Nordeste de ésta á dos tercios de milla, está el bajo de su nombre, que entre lo más Sudoeste de él y la punta dicha, deja un canalizo de I4 brazas de fondo y 200 varas de ancho, acantilado por una y otra parte; sobre el bajo, que es de arena, piedra, lastre y marisco, hay dos pequeñas islitas, la de afuera mayor, pero ambas casi las cubre la pleamar de aguas vivas, y la bajamar de las mismas descubre totalmente el bajo.

43. Las mareas son de poca consideración en esta derrota hasta estar tanto avante con la punta ó morro de Ahoni, pero de ella en adelante es sensible, pues llega á media legua por hora hasta estar al Norte de las islitas de Yal, desde cuyo punto empieza á ser de tres y más millas, hasta estar tanto avante con las puntas de Cululin en Chiloé y Luculemuy. Desde este punto disminuye su velocidad hasta la boca del Estero de Castro, de forma, que apenas llega á una milla por hora, y desde dicha boca para adentro del Estero, ya queda advertido su curso y movimiento en el número 3 I.

44. Desde la capilla de Ahoni para adentro del canal, se puede surgir en cualquier parte de la costa á dos ó tres cables de ella, particularmente en la bahía de Terao, que es de muy buen tenedero, separándose de la costa á distancia de media milla, aumenta el fondo tanto, que es desapropósito para surgir, especialmente hasta estar al Norte de la punta Yal.

45. En fondeadero citado de Castro, es la pleamar en los días de Luna nueva y llena á las I $2^{\mathrm{h}}$ y $26^{\prime}$ del día, y aumenta respecto á la bajamar de I5 á I 6 piés, y de I3 á I4 en las aguas muertas ó mareas regulares.

46. Nota. Que aunque en los Diarios de los viajes anteriores á esta derrota y en la carta hidrográfica general de la provincia, que he formado sobre las observaciones y reconocimientos que se expresan en ellos, consta el canal que forman las Islas Chiloé y Caucahue, $\mathrm{y}$ así mismo haber levantado el plano del puerto de Huytin que se halla en dicho canal, no se ha hecho mención de uno ni otro, en las derrotas de Linao á Castro, porque aunque el canal es de suficiente $y$ áun excesiva profundidad, no es de extensión para emprender su paso aún con embarcación mediana. Además de su angostura, la violencia de las mareas.y demás razones dichas para evitar el paso por estos canales, retardan mucho el viaje, entrando por él: no se ha hecho tampoco el del puerto citado, pues su extensión no permite un paquebot á la gira, sin embargo de ser tan decantado por los naturales del país.

Derrota de Castro a la bahía de Terao, situada en latitud Sur de $42^{\circ} 57^{\prime} y$ cn longitud de $303^{\circ} 44^{\prime}$.

47. Puesto á la vela en el fondeadero de Castro, se hará derrota á los rumbos opuestos á los que se han dado en el número 26 hasta estar entre la islita de Linlinao y la punta de Tutil; y desde este punto, se ejecutarán los opuestos á los que se previenen en el número 37 hasta estar Nordeste Sudoeste con lo más alto del escarpado de Yal, que se hará derrota al Sursudoeste con tal cual guiñada para el Oeste, y á poco más de dos millas navegadas al citado rumbo, descubrirá por babor la capilla de Terao, y en demorándole al Sueste $1 / 4$ Este, dará fondo al ancla en is ó 20 brazas sobre lama y arena, distante de tierra de tres á cuatro cables.

48. Advertencias. En las derrotas de Linao á Castro quedan hechas las reflexiones necesarias á la anterior, por lo que sólo resta decir aquí, que si faltase el viento ó marea para llegar al fondeadero de la capilla, se puede surgir en cualquiera paraje de la bahía sobre 30 á 40 brazas de fondo lama verde, teniendo presente, que de lo más Sur de la península de Yal y alto de su escarpado, sale hacia el mismo rumbo un bajo de piedras hasta la distancia de 300 varas, $y$ hasta 400 otro de la punta de Api que es la más Norte y Este del fondeadero dicho de la capilla.

49. La bahía de Terao está descubierta á los vientos del Este al Norte, pero agitan poco la mar y el tenedero es muy bueno; está abrigada de todos los demás, aunque no mucho del Noroeste, y siendo una ó dos embarcaciones sueltas, pueden estar á cubierto especialmente en invierno, en el puertecito de Pacatue, que está en la misma bahía media legua al Norte 1/4 Noroeste de la capilla de Terao.

5o. El terreno es algo elevado por la mayor parte, pero no faltan sitios á propósito para labor; está poco cultivado, y su población es escasa y más dispersa que hacia el Norte. Esta es la primera capilla de la jurisdicción ó territorio que llaman de los Payos, cuyo vecindario hacia el Sur todo es de indios.

5I. Las mareas suceden en esta bahía en los días de Luna nueva y llena á las doce y cuarto 
del día la pleamar; su aumento respecto á la baja de I 3 á I4 piés de Castilla, de las mareas regulares de I2 á I3, y su movimiento de milla por hora.

52. Nota. Que en el tránsito de esta derrota se halla en la costa del Oeste de la Isla de Lemuy el Esterito de Ichuac, que es buen abrigo para embarcaciones chicas y medianas, y áun para dos ó tres grandes, pero acoderadas, porque el pequeño ámbito del Estero no permite se mantengan á la gira.

Derrota de Terao al puerto de Caylen, situado en latitud Sur de $43^{\circ}$ I $x^{\prime} y$ en longitud de $303^{\circ} 53^{\prime}$

53. Habiendosalido del fondeadero de Terao, desde la medianía de la boca de la bahía, se hará derrota al Este $1 / 4$ Sueste, hasta que la punta de Detif demore al Sueste, y luégo se pondrá al Sur, cuyo rumbo seguirá hasta que el escarpado de dicha punta demore al Esnordeste; desde aquí gobernará al Sueste $1 / 4$ Este seis y media millas, y cumplidas, se encontrará demorándole Detif al Noroeste y la Punta de Aituy al Sur distancia cuatro millas; desde este punto gobernará al Sursueste distancia de siete y tercia millas, llevando por la proa la punta de Huechupicun, que es la más Este de la Isla de Tanqui é igualmente la tierra más Sur (de las del Oeste) que tendrá á la vista; cumplida dicha distancia, se hallará Noroeste Sueste con la citada punta de Aituy, y demorándole al Sursudoeste lo más Oeste de la pequeña Isla de Acuy, á donde se pondrá la proa, y habiendo navegado á este rumbo una legua, al cumplirla, se estará Nornoroeste Sursueste con la punta de Poquenco, en Chiloé que es rasa, y en la medianía del canal que hace con la islita dicha Acuy; desde este punto se hará rumbo al Oesudoeste media legua, 1levando descubierto por babor el escarpado de la punta de Mapu (en Tanqui), y por estribor la punta rasa de Queilen. Cumplida dicha distancia, se estará en medio del canal que forman las puntas expresadas, desde dondc se hará el rumbo al Oeste $1 / 4$ Norneste una milla, que teniendo rebasada, lá de Queilen ya se pondrá al Norte $25^{\circ}$ Este, y á poco más de una milla navegada á este rumbo, dejará caer el ancla en el fondeadero de Queilen I 6 á is brazas fondo arena, demorando la capilla ó iglesia al Este $1 / 4$ Sueste, quedando distante de la playa de tres á cuatro cables.

54. Advirincias. En toda esta derrota puedo fondearse cerca de tierra, especialmente en la playa de Lebrun, donde cstá el río Libon, bueno pura aguada; pero de la punta de Aituy en :delante es impracticable, porque desde clla empiesan los bajos de su nombre, cuyo placer corre Masita lia puita de Poquenco: alsunos se descu-

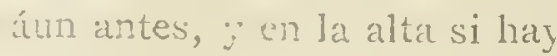

algún viento, los indica la reventazón; lo más fuera de ellos está Sueste 1/4 Sur, Noroeste 1/4 Norte con la punta de sunombre, distancia como de una milla, y á casi igual de la costa, forman un triángulo equilátero como de un cable y medio de lado, y en sus ángulos hay tres restingas de piedras de 40 á 50 varas de extensión, siendo el resto entre unas y otras, canalizos de dos á tres brazas de agua fondo arena, y entre ellos y la costa desde una y media hasta tres y media brazas á media marea, sobre arena por la mayor parte, alguna lama, tal cual manchón de lastre grueso y piedras sueltas con sargazo, y lo mismo en toda la ensenada desde punta Aituy hasta la de Poquenco, que es de una dilatada playa de arena muy aplacerada, y en tiempo de verano con contínua resaca, tan incómoda, que áun á lanchas y botes imposibilita atracar sin riesgo.

55. La punta de Poquenco es rasa y tiene en su remate un pequeño arrecife de piedras, pero cualquiera embarcación puede atracar á ella; pues á 200 varas de distancia se está en 25 brazas arena; de lo más Norte de la islita de Aqui sale en vuelta del Nordeste $1 / 4$ Norte hasta la distancia como de media milla, una restinga de piedras, algunas de las cuales velan á baja. mar, y en la alta las indica el escarceo que se forma entre ellas y el romper del mar si hay viento del primero ó segundo cuadrante.

56. En los números 39 y 4 I queda expresado el reconocimiento y circunstancias de las puntas de Ahoni y Detif; por lo que sólo resta que advertir, que desde la primera hacia el Sueste está la playa dicha Belelbum, que termina en la punta de Pellif, que es de piedra tajada al mar, y lo mismo toda la costa que sigue hasta rebasar la de Aituy, que es de la misma naturaleza, sin otra semejante en toda su mediación más que la citada de Pellif y la de Caritayhue que está entre las dos; el barranco es de mediana elevación, y sobre el de Aituy hay centinela de los indios payos, y lo mismo en la punta de Huechupicun, que como se ha dicho, es la más Este de la Isla de Tanqui. La islita de Aqui tiene poco más de una legua de circuito, es baja, y por la parte del Norte que es donde altea más, tajada al mar. Las puntas de Poquenco y Queilen, no pueden confundirse con otras, así por ser las más rasas de toda la isla de Chiloé por su parte del Este, como porque en la derrota anterior son la tierra más Sur de dicha isla. La de Queilen de media creciente en adelante, vista desde lejos parece una pequeña islita con alyunos árboles separada del resto de la costa baja por una lengua de arena que en pleamar apenas tiene 20 varas de ancho.

57. La dirccción de mareas en esta derrotá, es con corta diferencia sobre los rumbos de ella: hasta montar la punta thony es su movimiento 
de media legua por hora; desde ésta hasta el canal de entre Aqui y Poquenco es de una milla; pero desde la entrada de éste hasta el surgidero de Queilen lleva dos y media millas de andar: en el puerto dicho sucede la pleamar á la una del día en los de novilunio y plenilunio y su aumento respecto á la bajamar de los mismos, es de 20 á 2 I piés.

58. Nota. Que en el Estero de Queilen se está abrigado de todos vientos, ménos de los del Sur al Oeste, pero ni aún éstos incomodan, porque no agitan el mar con motivo de la vecindad de la Isla de Panqui; y aún cuando incomodasen, siendo una ó dos embarcaciones grandes, pueden ponerse á cubierto de todo internándose en el Estero. El terreno en que está la capilla, exceptuando el de la ciudad de Castro, es el de mejor disposición para pueblo que haya en toda la costa de la isla; bien que su campiña vecina es algo áspera por su repentina elevación, pero fértil. Habitan toda esta costa muy pocas gentes y muy dispersas, y á proporción de esto y de su natural desidia es el cultivo.

Derrota del Estero de Queilen al de Compu, situada su boca en latitud Sur de $43^{\circ}$ I I $^{\prime}$ y longitud $303^{\circ} 43^{\prime}$.

59. Puesto á la vela en Queilen, luego que la iglesia demore al Este $\%$ Nordeste, se pondrá á gobernar al Oeste siete millas, que cumplidas, se hallará en la boca de Compu, demorando punta de Yeculinao al Sursudeste distancia de una milla por babor, y por estribor la de Tumaumon, al Noroeste $1 / 4$ Norte á una milla escasa; desde este punto se hará el rumbo del Noroeste $1 / 4$ Oeste el espacio de una milla, y cumplida ésta el del Nornoroeste igual distancia, la que verificada, haciendo en adelante rumbo al Oeste $2 \mathrm{I}^{\circ}$ Norte que conduce por medio freu del Estero surgirá en cualquiera paraje de él, que todo es limpio hasta la islita de Achalá, que está cerca de su fondo, y puede dejar caer el ancla en ro ó más brazas lama y arena y lama, de que es todo el - suelo de este Estero de Compu.

6o. Advertencias. En el tránsito de esta derrota se lleva por babor la costa del Norte de la isla de Tanqui á distancia de poco más de una milla, y por estribor la de Chiloé á distancia de media con poca diferencia: aquella toda es limpia $\mathrm{y}$ acantilada hasta la islita de Conejos y en la otra se ofrecen al paso las ensenadas de Ticunetu y Estero de San Miguel de Pailar. La r. ${ }^{a}$ es aplacerada y tiene en medio (algo saliente) el islote Chaqualin que por el Sur es acantilado; en la $2 .^{R}$ se puede surgir sobre Io, I 2 ó más brazas fondo arena: una y otra tienen casi igual extensión de media legua, y riachuelos perennes para aguada.

6r. E1 Estero de Pailar se interna casi dos millas al Norte lo más, pero su excesiva angostura que apenas llega á So varas, con fondo muy desigual de alfaques, especialmente donde estuvo la capilla para adentro, le imposibilitan ser abrigo de otras embarcaciones que las más pequeñas. No tiene habitación alguna en sus orillas, y éstas por la mayor parte son de peña tajada al mar, particularmente la de Oeste.

62. La punta de Tumaumón que es la del Este de la boca de Compu, hace morro alto, tajado á pico, cubierto de árboles, tan acantilado, que á 50 varas de tierra hay de 70 á 80 de fondo, y lo mismo de toda la costa de estribor entrando, que sigue para la punta de Aulen, que también es escarpada: en el barranco de ésta hay una mancha de piedra tan blanca que aún de noche se distingue.

63. En el surgidero de Compu, es la pleamar poco antes de la una del día en los de Luna nueva y llena, y aumenta el agua respectoá su bajamar, de 18 á r 9 piés, su velocidad eś á media marea de $\mathrm{r} .800$ varas por horas, pero entre las puntas de Aulen y Yatechue que es la mayor angostura de la boca, llega á tres mil varas ó media legua casi; y la dirección de todas desde Cailen á Aqui es con corta diferencia la de los rumbos que se expresan en la derrota y sus opuestos.

64. En todo este Estero de Compu se puede surgir muy cerca de tierra, porque todo es fondo limpio y de muy buen tenedero. Su ámbito lo hace capaz de contener gran número de embarcaciones de todos portes, con bastante abrigo; y en la costa del Norte de la Capilla tiene el Estero de Pereu, que es una bella dársena natural, para las menores como lanchas y botes. E1 terreno es bastante apropósito para labor; sin embargo, hay poca población respecto á las circunstancias dichas y extensión del Estero.

Derrota del Estero de Compu al de Guildad, situada su boca en latitud Sur $43^{\circ} 24^{\prime} y$ en longitud $303^{\circ} 5^{\mathrm{I}^{\prime}}$.

65. Desde Compu se seguirá por medio freu del Estero á los rumbos del Este $2 I^{\circ}$ Sur y Sursueste hasta tanto avante con la punta ó morro de Tumaumon.

Desde aquí se gobernará al Sueste 1/4 Este, llevando por la proa el islote de los Conejos, se estará Nordeste-Sudoeste con punta Yeculinao, que es la más saliente inmediata de estribor, desde donde se harán al Sur otias dos millas y estando tanto avante con el Esterito de Charmo á estribor, se pondrá al Sueste llevando la punta de Chahua, que es la tierra más Sur y Este de la costa de estribor, algo descubierta por babor. Se harán tres y media millas á dicho rumbo, y cumplido, al del Este 1/4 Sueste hasta que la dicha punta de Chahua demore al Suoeste, desde donde se navegará al Sueste la distancia de 
dos y media millas, llevando la islita de Chaulin descubierta por estribor; luégo que se verifique dicha distancia estará zafo del bajito de Chahua, y se pondrá al rumbo del Sur, 1levando la punta Tutil, que es la tierra más Sur y Este de estribor que tendrá á la vista por la proa, y habiendo navegado cinco y media millas al citado rumbo estará Este-Oeste con la boca de Guildad, y rebasado el bajo que está al Nordeste de ella, desde dicho punto se pondrá al Oeste hasta estar Nornoroeste-Sursueste con la expresada punta Tutil distancia una milla escasa, donde se fondeará en 45 á 50 brazas suelo de arena y cascajo, distante dos tercios de milla de la boca del Estero de Gildad, la que por su angostura de I95 varas, no permite sin exponerse á una desgraeia, entrar á la vela, y se ejecuta eon espías tendidas á los rumbos siguientes:

66. La primera espía será de cinco calabrotes de 20 á 25 brazas al Oeste; la segunda, al mismo sitio de dos calabrotes, de i 6 á I 7 brazas, por la que se virará hasta estar en la embocadura del Estero; la tercera también de dos calabrotes sobre ocho á nueve brazas, fondo arena y lama, y en llegando á pique de ésta, estará dentro del Estero, habiendo pasado á medio freu de su boca; la cuarta espía de cinco calabrotes se tenderá al rumbo del Oeste $30^{\circ}$ Norte en fondo de I 2 á I3 brazas arena y cascajo; y estando á pique de ella tenderá la quinta espía de cuatro calabrotes sobre el rumbo del Norte $39^{\circ}$ Oeste en fondo de 20 á 2 I brazas, fondo arena y lastre, al fin de la cual se hallará en la boea de la angostura de Queuman; desde este paraje se tenderá la sesta espía de un calabrote sobre el rumbo del Oeste $1 /$. Noroeste en ocho á nueve brazas arena; y 1legando á pique tenderá la sétima sobre el rumbo del Oeste $30^{\circ}$ Sur de tres calabrotes, y virando por ella antes de llegar á pique, estará zafo del bajo de Cholua, dejándolos por estribor, desde donde se dirigirá al Oeste I 5 ó $20^{\circ}$ Norte con la marea, á la vela ó con espías, para dentro del estero, á surgir en las inmediaciones de la capilla sobre I 2 ó I brazas fondo lama, distante de la costa del Sur ó de la capilla de dos á tres cables, o mar adentro, que todo es hondable y limpio.

67. Advertencias. Esta derrota ofrece al paso las ensenadas de Chazmo y su Estero, y la de Colcao en la Isla de Chiloé que se lleva por estribor, y las de Chaueo y Nopue en la Isla de Tanqui que se lleva por babor; la primera está comprendida entre las puntas de Yeculinao, cuya abra cs de una legua y cuarto, pero tan poco hondable, que á bajamar apenas permite entrar piragrua, y en el Estero de Chazmn, que está en su medio, y á bajamar queda todo seco. el bajo sale de la punta de Yeculinao en ruelta del Sueste un tereio de milla, y como á esta distancia ra sicuicndo la comtiguración de la costa hasta rema- tar en Catalma; la segunda ensenada dicha de Colcao, la forma la expresada punta de Catalma, y la de Chagua es capaz, hondable, y buen surgidero con el río de su nombre para aguada; está cubierto de todos los vientos no comprendidos los entre el Este y Nornoroeste, pero no levantan mar, por venir por encima de la Isla Tanqui, que está á distancia de media legua.

68. Las ensenadas de Chauco y Nopue, situada la primera en la costa Oeste de la Isla Tanqui y la segunda en la del Sur de la misma isla, son muy acantiladas, tienen aguada, y se puede surgir en ellas, especialmente en la primera que está Este-Oeste con el Esterito de Chazmo, ambas están descubiertas á los vientos del tercer cuadrante, particularmente en la segunda, donde los vientos levantan mar, que ocasiona peligrosa resaca en la costa; entre las puntas de Chagua y Quilga en la costa de Chiloé, se puede surgir á media milla ó ménos de tierra, fondo 25 á 30 brazas arena y cascajo; hay aguada, pero se está descubierto á los vientos del Sursueste al Nordeste que soplan bien frescos y levantan mar.

69. Al Sueste de la punta de Chagua, distancia de 500 á 600 varas, está el bajo de su nombre, que á media marea tiene tres y media brazas de agua; corre Noroeste-Sueste como media mi1la. Así por éste como por el que sale de Yeculinao para Chazmo, se debe navegar más atracado á la costa de Tanqui que á la de Chiloé.

7o. Entre la punta de Huenuguildad que es escarpada, sale en vuelta del Sueste á media milla, un bajo de arena y piedra, está lo más fue. ra al Norte $60^{\circ}$ de la boca de Huildad I.50 f varas, su fondo como tres brazas á media marea.

7r. Las mareas en la derrota anterior, siguen casi sus rumbos; la velocidad desde la boca de Compu al Sur es de milla por hora, y en la mayor angostura del canal, que es entre las puntas de Yeculinao en la Isla de Chiloé y la de Lobos en la de Tanqui, de tres y media á cuatro, y en el resto del canal de ménos de tres: montada la Punta de Yagua, disminuye hasta ser de una milla al Sur. En la boca de Guildad es de poco más de dos. millas como en la angostura de Queuman; desde aquí para adentro se disminuye de forma que desde la Capilla para el Oeste es de I.500 á I.600 varas su andar. En el surgidero de la Capilla de Guildad sucede la pleamar en los novilunios y plenilunios á las $I 2^{\text {h }} 38^{\prime}$ del día, y su aumento respecto á la bajamar, es de cuatro varas en las aguas vivas, y en las muertas poco más de tres y media.

72. Nota I." Que el Estero de Guildad puede contener embarcaciones de todos portes, bien resguardadas, sobre fondos proporcionados de seis á I 2 brazas lama y arena: es el más poblado de lił costa de los payos y lo último habitado de la Isla de Chiloé: sus nrillas desde la angonstura de Queu- 
man para adentro, son de terreno bastante regular para cultivo, y lo está á proporción del número de sus moradores, pero todas estas ventajas ó buena disposición, no lo inhiben de ser puerto para una absoluta urgencia, por lo contemplativo y arriesgado de su estrecha entrada y circunstancias de la costa vecina, toda escarpada, muy acantilada, y por consecuencia desapropósito para surgir en ella, particularmente una escuadra.

73. Nota 2. Que para entrar en el citado Es. tero, por ningún caso se ha de empezar á espiar hasta que la marea esté parada ó muy próxima á parar para empezar á vaciar, porque el mal gobierno ó dirección que ocasiona la corriente en popa, lo harán varar ó tocar en cualquiera de las dos costas irremediablemente, á ménos que no se espíe acoderado y áun con todo siempre expuesto. La codera, áun espiándose para dentro con vaciante ó con la creciente para fuera, me parece precisa en las angosturas de la boca y Queuman, lo que proporcionan en dichos parajes lo corto de los espías.

74. Nota 3. ${ }^{3}$ Que en orden al tránsito por el canal de Tanqui comprendido en la derrota anterior, se ha de tener presente lo advertido en el pasaje del de Quincha para Castro al número $3^{6}$, para escusar su paso con embarcación grande ó mediana, dirigiendo la derrota desde Compu y Queilen á Guildad, pasando por fuera de la punta de Huechupicum, que como se ha dicho ya, es la más Este de la Isla de Tanqui, á cuyo efecto se hará la siguiente:

\section{Derrota de Compu y Queilen a Guildad por fueva de} la Isla de Tanqui.

75. Desde la boca del Estero de Compu se gobernará al rumbo del Oeste-Sur, llevando por la proa la punta rasa de Queilen, y estando como media milla de ella demorándole al Este, ya sea habiendo salido del citado Estero, ó ya del de Queilen, se pondrá al Este $42^{\circ}$ Sur, que conduce á pasar por medio freu del estrecho que forman la costa del Norte de Tanguí y la del Sur de la pequeña islita de Acuy, y habiendo navegado cuatro millas sobre el citado rumbo, zafo ya de dicho estrecho, se hará derrota al Esueste, y habiendo navegado ocho millas, se hará Nordeste Sudoeste con la expresada punta de Huechupicun, desde donde se hará el rumbo del Sur distancia de cinco millas, y cumplidas éstas, el del ()esudoeste hasta estar Este-Oeste con la punta de Tutil, á la que se dirigirá 1levándola descu. bierta por babor hasta rebasarla y situarse cerca de la boca de Guildad para entrar á la espía como se previene al número 66 .

76. Advertencias. La Isla de Tanqui Nordeste-Sudoeste con su punta más Este, se lleva en esta derrota por estribor á corta distancia; es después de la de Quinchao la mayor de las contiguas á la grande de Chiloé; está tendida de Esueste-Oesnoroeste en distancia de cinco leguas; es alta por su parte del Oeste, y casi con un descenso muy igual va disminuyendo su elevación hasta el término oriental, que es la citada punta de Huechupicun, la que en tiempo claro se alcanza á ver de nueve leguas de distancia. Las costas de ella son limpias y acantiladas, por la mayor parte escarpadas, especialmente la del Norte desde la punta de Mapu para afuera, y no tiene surgidero alguno cómodo sino para embarcaciones menores. Sólo está poblada la isla en la punta de su nombre, que es baja con una porción de terreno llano, contiguo, donde está la única capilla que tiene, al Sudoeste de la de Queilen distancia de una legua escasa, de modo que todas las islas contiguas á la de Chiloé pobladas, ésta es la que lo está ménos. Sin embargo, en la expresada punta de Huechupicun, puerto ventajoso para descubrir las embarcaciones que entren por la boca del Huajo, mantienen los naturales una centinela contínua.

77. Montada la punta de Huechupicun, la tierra más Sur que se descubre al Oeste es la Isla de Caylin y punta de Chayguau en Chiloé, de la cual para el Norte sigue la costa escarpada de mediana altura hasta la punta de Tutil y pequeña abra de Guildad, que se reconocerá por el dicho escarpado y por dos puntitas de arena muy blanca, que la forman la costa que sigue de dicha boca para el Norte es también alta con algunos escarpados ó barrancos, de los cuales es el mayor el de la punta de Huenu-Guildad, de donde sale el bajo citado al número 70 , la que dista de la boca del Estero media milla hacia dicho rumbo; también en esta costa hay algunas playas cortas de arena, de las que carece la del Sur.

78. Siguiendo la derrota de Huechupicun para Tutil y Guildad, se deja á estribor á distancia de dos millas la Islita de Chaulin que es aliro baja, y de lo más Sueste de ella sale un pequeño arrecife hasta las distancia de poco más de un cable, en cuyo extremo vela siempre una peña del tamaño y figura de una embarcación medianita sin arboladura, á la cual llaman el Navío; y efectivamente imita un casco, vista á los rumbos vecinos al Este y Oeste.

79. En el número $6_{3}$ advertimos á las derrotas de Queilen para Compu, se ha dicho la dirección y movimiento de las mareas, lo que se debe tener presente para ésta hasta estar fuera de la punta de Queilen. Desde este sitio hasta zafar del Estrecho de Aqui con Tanqui sigue su curso se. gún el lumbo de la derrota con andar de dos y media á tres millas por hora, pero ya al Este del Estrecho sigue el rumbo del Sur hasta el encrentro 
con la costa de 'lanqui, que lo sigue según ella corre, esto es al Sueste, con velocidad de casi cuatro millas, la que crece á cinco y algo más, con notable escarceo al montar la punta de Huechupicun, y con mucha mar si la marea vacia y hay viento de la parte del Sur ó al contrario, si creciendo aquél avienta el Nornoroeste ó Nordeste, por cuya razón se dirige la derrota á pasar una legua distante de dicha punta, para evitar el expresado encuentro ó raya, ciertamente muy temible con embarcaciones pequeñas, $y$ acaso in accesible á ellas. Desde dicha punta en adelante, es de poca consideración la marea hasta cerca de la boca de Guildad y sus costas vecinas, pues pasa muy poco de una milla por hora, y su curso es hacia el rumbo del Sur casi directo.

Derrota del Estero de Guildad al de Yalad, situada la boca en latitud Sur $43^{\circ} 30^{\prime}$ y en longitud $303^{\circ} 38^{\prime}$.

8o. La salida del Estero de Guildad desde el surgidero de la capilla hasta hallarse fuera de la la boca, se ejecutará á los rumbos opu estos á los dados en la entrada, y con el mismo método y precauciones expresadas en los números 66 y 73 .

8I. Hallándose ya fuera de dicha boca, se hará el rumbo del Este hasta que la punta de Tutil demore al Sudoeste distancia como de media legua, que luégo se hará derrota al Sursues. te el espacio de siete millas, y cumplidas, se dirigirá al Sudoeste $1 / 4$ Sur, sobre cuyo rumbo se navegará 20 millas, las que verificadas, se hallará ya zafo de los bajos de Chayhuau, Caylin y Laylec, y seguirá el rumbo del Oeste $1 / 4$ Noroeste el espacio de dos leguas, las que navegadas ya, se hará el rumbo del Noroeste 1/4 Norte distancia de dos millas, llevando por la proa la pequeña Islita de Mauchil que está en la boca del Sur del Estero de Colita; cumplida dicha distancia se pondrá al Norte, sobre cuyo rumbo navegará seis y media millas, casi á medio freu del canal que forman las Islas Laylec, que llevará por estribor, y Colita por babor; rerificada la citada distancia, tendrá la entrada de Yalad á la vista por babor, y las Islitas de Linagua que están en ella, á la que se dirigirá gobernando al rumbo de Oesnoroeste, siguiéndolo hasta estar Norte-Sur con lo más Oeste de dichas islitas, donde podrá dar fondo en I2 ó I4 brazas lama, ó ir más adentro del Estero á los rumbos del Norte 1/4 Noroeste, Nornordeste y Nordeste.

82. Advertencias. Al montar la punta de Chayhuau ó poco antes (que es la tierra más Sur de la Isla de Chiloé, que se llevará á la vista naregando cle Tutil para el Sur), se verá al Sudoeste de dicha punta la Isla de Chaulin (oculta á la de Laylec que tiene al Sudoeste), y si el tiempo está algon claro, se verán por encima de ella dos cerros elerados, poco distantes uno de otro; el más Nor- te es elllamado Machaylelo, algo tendido, y está en la Isla de Chiloé, y el más Sur en la Isla de San Pedro, algo más elevado que el primero y de figura piramidal, y ambos no pueden confundirse ó equivocarse con otro alguno de toda la isla grande ni vecinas. La Isla de Laylec está desviada de la de Caylin, por un estrecho canal que casi no se discierne desde afuera, y sólo presta paso á canoas. Estas dos islas son de mediana altura por su parte del Sudoeste, y por la del Nordeste bajas, con especialidad la de Caylin; el resto de costa de la de Chiloé es elevado, particularmente sobre Yalad.

83. Desde punta Tutil al Sur empiezan los bajos de Chayhuau, los que se continuan hasta terminarse en la de Pulileheu que es la más Sur de la Isla de Laylec: de la costa de Tutil se desvían cosa de un cable, pero este desvío se va aumentando hacia la de Chayhuau, de modo que salen al Esoeste de ésta hasta cerca de una milla, y de aquí siguen al rumbo Sudoeste por las costas al Este de las expresadas Caulin y Laylec, desviándose como hasta media milla escasa de ella. Estos bajos son de arena y rocas sueltas, ninguna se descubre, pero siempre casi rompe el mar en ellas, y áun en los días más apacibles las indica el escarceo de las mareas crecientes, cuyo choque es formando ángulos rectos una con otra. Dichos bajos cierran enteramente el paso para el Estero ó puerto de Caulin por su parte del Nordeste á toda otra embarcación mayor que las goletas, pero habiendo antecedido vientos frescos del segundo y tercer cuadrante, es temible áun para piraguas, mayormente si van de viaje al Norte: aquí es donde han perecido algunas embarcaciones y acaso el principal motivo de la despoblación de Caulin.

84. En toda esta derrota no hay surgidero en las costas inmediatas que son todas acantiladas, no obstante los bajos de las del Oriente de Caulin y Laylec, pues á poco desvío es excesiva el agua que se encuentra; sólo en la inmediación del Estero de Yalad, cerca de la punta de LileHuapí, la más Oeste de Laylec, ó ya cerca de la de Colita se puede fondear en 40 á 50 brazas, á dos ó tres cables de tierra.

85. Entrando en Yalad, al Sursudoeste de las Islitas de Linagua está el Estero de Colita, aunque de coita extensión, de abrigo y seguridad para embarcaciones pequeñas su fondo de cinco á siete brazas lama, sin más riesgos que los visibles.

86. Las mareas en esta derrota siguen su curso de Norte-Sur pero apenas llegan á una milla por hora, hasta estar entre las puntas de Yalec en Chiloé y Pulitehue en Laylec, que empiezan á seguir los rumbos de la derrota y sus opuestos, y aumentan su velocidad á algo más de dos millas: en el surgidero de las chozas es 
la pleamar los días de Luna nueva y llena á las $\mathrm{I}^{\mathrm{h}}{ }^{\mathrm{h}} 4 \mathrm{O}^{\prime}$ del día, y respecto á la bajamar en ellos crece el agua nueve piés.

87. El Estero de Yalad, es surgidero á cubierto de todos vientos, en fondos de diez á quince brazas lama, forman su entrada exterior las puntas de Yenecura en Chiloé y Colita en la isla de su nombre; en la entrada interior está la Isla de Linagua, que le hace formar dos bocas, pero la del Oriente sólo permite paso á las lanchas por sus bancos de arena y cascajo; la del Oeste no tiene más riesgos que los que están á la vista: está despoblado, y sólo en la punta de los Mamanos parece haber habido habitantes. La Isla de Colita fué habitada mientras lo fué la de Caulin, hoy hay en ella algunos caballos, el terreno es á propósito para cultivo, pero no el de Yalad, que por la mayor parte es áspero, montuoso y demasiado elevado.

Derrota del Estero de Yalad al de Caylin, situada la boca en latitud Sur $43^{\prime} 29 y^{1} / 2$ y en longitud $303^{\circ} 47^{\prime}$.

88. Saliendo del Estero de Yalad desde la medianía de su boca se gobernará al Este 1/4 Sueste distancia tres un cuarto millas, llevando casi por la proa lo más Norte de la Isla Lay lec hasta estar Norte-Sur con la punta Lua en la Isla de Chiloé, que llevará por babor: seguirá al rumbo del Nordeste $1 / 4$ Este tres y media millas, y luego al Sueste $1 / 4$ Este dos, y se hallará en la mediania del Estero de Caylin, á donde se dirigrirá haciendo el Sur, y. surgirá en cualquier paraje desde Io hasta 30 brazas fondo lama.

89. Advertencias. En el tránsito de esta derrota, no hay más surgidero que la ensenada de Cuellon en la costa de Chiloé al Norte de la punta Lua; es buen fondeadero, con aguada.está á cubierto de todos vientos ménos del Este y Esueste que no son frecuentes ni impetuosos. A1 Norte del abra de Caylin está en la costa de Chiloé el Esterito de Oquelan, en cuya boca se puede surgir, y no en su interior por el poco fondo.

90. Las mareas siguen los rumbos de la derrota, y su mayor velocidad poco más de milla jor hora; en el Estero de Caylin es la pleamar en los novilunios y plenilunios á las doce y minutos del día, y respecto á su bajamar crece el agua nueve á diez piés.

9I. L1 Estero de Caylin es buen puerto, abrigado á los vientos, de buen tenedero, en la partc del Sur y Este del terreno nombrado Huacao, se puede fondear á medio cable de tierra en I6 á IS brazas arena. La costa de Sur y Oeste es ménos hondable y aplacerada, pero casi todo el placer queda descubierto á bajamar de aguas vivas, ýa pique de él se hallan cinco á á seis brazas fondo arena, cascajo y piedras sueltas. La Isla de Caylin tiene I 5 á I 6 millas de circunferencia; estuvo habitada de los indios Huayhucles, que se trasladaron á la de Chaulinec. En la ensenada de Chohuen subsisten los fragmentos de la capilla, y hacia adentro del Estero varias casas y chozas dispersas.

92. Nota. Saliendo del Estero de Yalad debe darse la vela después de media marea vaciante á fin de encontrar la creciente, que es la que favorece la creciente en el caso, ya rebasada la Isla de Colita; pero con vientos á propósito podrá desatenderse esta circunstancia.

93. Otra. Los Esteros de Caylin y Yalad son los últimos puertos de la Isla de Chiloé hacia el Sur, que carece enteramente de todo otro surgidero; pues las islas, bajos y peñascos hacen innaccesibles á desembarcos sus ensenadas y playas, donde sólo se puede intentar surgir, en la necesidad de tirar á varar en cualquier paraje, y con la desgracia, que el interior es todo despoblado y de una maleza impenetrable.

Derrota de los Esteros de Caylin y Yalad al Oceano.

94. Desde la medianía del estero de Caylin se harán dos millas al Noroeste $1 / 4$ Oeste, gobernando luégo al Sudoeste $1 / 4$ Oeste cinco millas, y se hallará Noroeste Sueste con la Isla Linagua de la boca de Yalad, y á distancia al Este de la Isla Colita una milla escasa; desde este punto, que es común á ambas derrotas, se navegará al Sur cuatro y media millas, donde demorará la pəqueña Isla Mauchil al Noroeste, gobernando de aquí al Sursueste tres leguas, que quedará EsteOeste con la más Sur de la Isla de San Pedro, que llevará por estribor; se pondrá al Sudoeste $1 / 4$ Sur, navegando cuatio y media leguas, que estará en la latitud de $43^{\circ} 55^{\prime}$, grobernará al Oeste y á las r6 leguas rebasada ya la Isla Guazo, se encontrará el el Oceano.

95. Adiertencias. La Isla de San Pedro está en lo más Oeste de la de Chiloé, es la más alta de todas las cercanas, y se podrá ver en tiempo á propósito 25 leguas de distancia: por la parte del Este y Sur tiene algunas islitas y farallones.

96. La costa del Sur de Chiloé es de media.na altura en partes, contiene el Estero de Ayentema y las ensenadas de Cheylin, Chucahua, Atizas, Nayague, Huylanlad y otras bastantes capaces, pero inaccesibles como llevo dicho: están en ellas muchas pequeñas islas y multitud de peñascos visibles y ocultos y avanzados bastante fuera de la costa.

97. La Isla dc Huapiquilan está al Oeste $5^{\circ}$ Sur de la de San Pedro nueve leguas; no tiene surgidero y está guarnecida de rocas é islitas.

98. La Isla de Huajo está al Sudoeste de Huapiquilan siete leguas, es alta y no tiene ries- 
go que impida acerearse, pero tampoco puerto de abrigo para embareaeión que no sea chiea.

Derrota í los piertos de la Isla de Chiló, entrando porel canal del Sur, á quien llaman boca del Muafo.

99. Debe hacerse la recalada por los $44^{\circ} 4$ o 5 " más ó ménos de latitud, á dar vista á las Islas del Huajo y Huapiquilan, euyas eireunstancias y arrumbamientos están ya expresados. Aris tando la de Huapiquilan, gobernará al Este 1levando la deseubierta por la serviola de babor hasta estar Norte-Sur con ella distancia eomo de tres leguas; si la avistada fuese la de Huajo, que es más farorable, la llevará descubierta por la serriola de estribor hasta estar al Norte de su medianía dos leguas; desde este punto navegará al Este r 3 leguas ó 22 millas desde el dicho de Huapiquilan, se hallará Nornordeste Sursurdoeste con lo más Este de la Isla de San Pedio, desde donde hará el rumbo del Nordeste eineo leguas hasta estar Este-Oeste eon lo más Sur de dieha isla. De aquí navegará al Nornoroeste tres leguas si ra á Yalad, y cumplida dicha distancia estará Noroeste Sueste con la islita Mauchil, y Este. Oeste con el alto de Maehaylelo; desde aquí se hará el rumbo Norte costeando las Islas Colitas y Laylec, hasta descubrir la de Linagua, en la boea de Yalad, desde donde, si se quiere dirigir al de Caylin, lo hará por una derrota inversa á la dada al número 94 , teniendo presente las adverteneias diehas.

roo. La latitud expresada para la recalada proporciona los vientos dominantes, ya de la estaeión de invierno y verano, pero si por algún aecidente se reeala en la de verano sobre $44^{\circ} 20^{\prime}$, acompañado de los vientos propios de la estación, luégo que aviste por babor la Isla de Huafo, gobernará al Este y Esnordeste á pasar por su parte del Sur sin algún reeelo, porque entre ella y las Huaytecas, que están al Sur y Sueste, hay eanal de más de tres leguas de aneho; le demorarán del Este para el Sur, el gran número de Islas Huaytecas, cuyo conjunto se presenta en aparieneia de costa alta tendida Nordeste Sudoeste, pero la de Huafo no puede equivocarse con alguná de aquéllas, por el eonsiderable desvío que tiene de toda otra, y por ser de eorta extensión, alta y casi igual, euyas eireunstaneias la distinguen también de la de Huapiquilan, que tiene varias pequeñas inmediatas, algunas desigualdades en el terreno, y sólo se aparta de la costa de la de Chiloé, poco más de una milla.

ror. Si el tiempo está despejado, podrá verse la Isla de San Pedro casi al tiempo de la del Huafo, y áun antes que otra alguna tierra de la de Chiloé por esta parte. T'al vez será lo primern que se of rezea á la vista, la gran montana nevadí dicha el Corcobado, situada en la tierra firme, que se distingue á 40 ó más leguas de distancia, y su figura y elevación no admite equivocarse eon otras de la cordillera; está enfilada su eumbre con la más Sur de la Isla de San Pedro, Este I $^{\circ}{ }^{\circ}$ Norte y Oeste I4 ${ }^{\circ}$ Sur I6 leguas.

ro2. Las mareas de Huapicaylan, para dentro siguen el rumbo de la derrota, y son de poca eonsideración hasta entre las Islas de Chiloé y. Laylec, desde donde aumenta su movimiento eomo queda dieho.

Io3. Nota. Todas estas islas son frondosas, eubiertas de espesísimo bosque y algunos manzanos, señal dieen, de haber sido habitados de los Huayhuenes antiguamente, y aún tienen algún ganado lanar.

Derrota de los Esteros de Caylin y Yalad al de Guildad.

I04. Saliendo del puerto de Caylin, desde su medianía se gobernará al Sudoeste Io $/ 4$ Oeste pasando á media milla de la punta de Lua, y navegadas cinco millas, se hallará Noroeste Sudes te con la Islita de Linagua, desde dieha situación hará el rumbo Sur $5^{\circ}$ Este cineo millas, y al eumplirlas se hallará Noroeste Sueste eon la Islita de Mauchil, desde donde gobernará al Sueste $1 /$. Este siete millas, y verifieadas éstas, al Nordeste $1 / 4$ Norte I I y $1 / 2$, que se hallará tanto avante, y á una legua de lo más fuera de los bajos de Chauchau; desde aquí hará el Nornoroeste siete millas, y estará Nordeste-Sudoeste con punta de Tutil, y Este-Oeste con la boea de Guildad, y para entrar en este Estero obrará á la letra como queda prevenido.

105. Advertencia. Las mareas creeientes, que son las que favorecen en el easo, siguen los rumbos opuestos á las vaeiantes, que se explicó en el número 82 hasta 86 , y su movimiento es algo más lento.

\section{Derrota del Estero de Guildad al de Compu.}

ro6. A la boea de Guildad, zafo ya de espías, se gobernará al Este hasta que punta Tutil demore al Sur, desde cuyo paraje se hará al Norte einco y media millas, llevando por la proa la punta de Nopue en la Isla de Tanqui, y por estribor la Isla Chaulin, se navegará al Noroeste dos y media millas, y zafo del bajo de Chahua se pondrá al Oeste $\%$ Noroeste, sobre euyo rumbo seguirá media legua gobernando luégo al Noroeste tres y media millas, y rebasado el Estero de Chazmo hará dos millas al Norte y estará Nordeste Sudoeste eon punta I'eculinao, desde donde gobernará al Noroeste $1 / 4$ Oeste otras dos millas, y al cumplirlas estará ya en la boca de Compu Este-Oeste con el morro de Tu- 
maumón; y desde este punto hasta el surgidero hará como queda dicho en el número 59.

I07. Advertencias. Se tendrá presente lo dicho en los números 67 al 7 I y en el número I $_{5}$ en orden á mareas.

\section{Derrota de Huylad á Compu y' Queylon por fuera del canal de Tanqui.}

Io8. Fuera de Guildad se gobernará al Este hasta estar Norte-Sur con punta Tutil, desde donde se hará el Esueste cinco millas, y luego se gobernará al Nordeste $1 / 4$ Este ocho millas, donde tendrá la punta de Huechupicun al Noroeste $1 / 4$ Oeste una legua, hará el Norte por espacio de dos y media millas, conque montará dicha punta y se pondrá á navegar al Noroeste $1 / 4$ Norte Io millas, que estará Este-Oeste con punta Poquenco, llevándola por la proa al rumbo del Oeste, y luego que se halle á dos tercios de mi1la, se pondrá al rumbo del Sudoeste $1 / 4$ Oeste hasta medio freu del estrecho entre las Puntas de Queylen y Mapu; desde este punto se hará el Noroeste $1 / 4$ Oeste hasta rebasar la rasa de Queylen; si se quiere surgir en este Estero, se hará el Nornordeste; si en el de Compu el Oeste 1/4 Noroeste siete y media millas, obrando en todo como queda dicho en los números 53 y 59.

I 09. Advertencias. En los números 77, 78, 79, $56,57,6$ o y 63 , se han hecho todas las concernientes á esta derrota.

\section{Derrota desde Queylen y Compu á Terao.}

rio. Desde el Estero de Compu hasta su boca, se navegará como se expresa al número $65, y$ como al 75 hasta el Norte de punta Mapu: puesto á la vela en el surgidero de Queylen, hará el Sursudoeste media legua y seguirá al Sueste 1/4 Este hasta que punta Mapu demore al Sur. Desde este punto es común á ambos puertos la derrota siguiente.

III. Desde esta situación se hará el Nordeste $1 / 4$ Este tres y media millas, y zafo del arrecife de la islita de Aqui y punta Poquenco, navegará al Norte cuatro y un tercio millas hasta estar Este-Oeste con la punta de la centinela de Aytuy, y fuera ya del riesgo de los bajos de su nombre. Hará luégo seis millas al Nornoroeste, que quedará tanto avante con la punta de Ahony, se gobernará al Oeste $1 / 4$ Noroeste cinco y media millas, y hará el Norte, hasta que la Punta de Terao demore al Sudoeste dos tercios de milla, desde donde haciendo el Oeste entrará en la bahía á surgir en el paraje que quiera.

II2. Advortcncias. A las hechas en el número 54 hasta el 57 , resta que añadir, que siendo las mareas crecientes las que favorecen navegando al Norte, llevan su curso opuesto á las vaciantes, que se han explicado en dicho número, siguiendo unas y otras los de las derrotas.

\section{Derrota desde la batía de Terao al Estero de Castro.}

II3. Desde la medianía de su boca hará el rumbo al Nordeste $1 / 4$ Norte media legua y luégo al Noroeste 1/4 Norte una milla para rebasar las islitas y bajo de Yal, se pondrá al Oesudoeste $5^{\circ}$ Oeste media legua, y luégo cambiará al Oeste $1 / 4$ Noroeste una milla, y dos al Noroeste: navegando luégo al Norte el espacio de una, y al Norte $14^{\circ}$ Este 3 se hallará en el Estero de Castro, y Nordeste Sudoeste con lo más Este de la Isla de Linlinao, desde cuyo punto al fondeadero ejecutará lo prevenido en el número 26.

I 4. Advertencias. En los números 30, 3 , 32 , ro5 y II 2 quedan hechas las precisas á esta derrota.

Derrota de Castro á Linao por el Canal de la Islu Quinchao.

II5. Desde el surgidero de Castro hasta situarse Nordeste-Sudoeste con lo más Este de la Islita de Linlinao, se harán los rumbos opuestos á los dados al fin del número 26 entrando. En' esta suposición, desde el citado punto se hará el rumbo del Sudeste 1/4 Sur una milla, y luégo al Este 1/4 Nordeste ro millas, pasando á medio freu del canal entre las Islas de Lemuy y Chiloé, y entre la Isla de Chelin y la punta Aguantao se hará el rumbo del Noroeste $1 / 4$ Norte, y navegada media. legua estará rebasado el bajo de Aguantao, y hará derrota al Oesnoroeste $5^{\circ}$ Norte 6 y $1 / 2$ millas, que estará rebasado de la punta de Queil en Quinchao; desde aquí hará el Norte $4^{\circ}$ Oeste distancia de dos millas, luégo el Noroeste $1 / 4$ Norte $22^{2}$ : gobernará al Nornordeste media milla hasta rebasar la punta de Cuyumue á medio freu de la mayor angostura del Canal de Quinchao, se navegará cuatro y media millas al Este 29 Norte, y quedará tanto avante con la capilla de Quetalco en Chiloé, desde donde hará el Este $6^{\circ}$ Norte 1 I millas, que cumplidas, estará fuera del canal, habiendo pasado á $2 / 3$ milla de la costa de punta Tenaun; desde esta situación hará al Norte cinco millas, y se hallará Este-Oeste con punta Chilizqui, que es lo más Oeste de las Islas Chauques, gobernará al Nornordeste tres millas, y al cumplirlas se hallará fuera del Estrecho de Quicabi: hará luégo el Norte $1 / 4$ Noroeste ${ }_{4} 4$ millas, que verificadas, quedará Este-Oeste con punta de Lobos, de Caucahue, y se pondrá al Noroeste $1 / 4$ Norte ${ }_{5}$ millas, donde estará Este-Oeste con la medianía del abra de Linao, á donde se dirigirá con proa Oeste $1 / 4$ Sudoeste hasta la boca del puerto, obrando luégo como se ha dicho al número Ig.

Ir6. Advortencias. Al Esnordeste de lo más 
Sur del barranco de Quicabi, como á un cable y medio, hay una peña que se descubreá bajamar, y otra al Sueste de ésta, que sale de las Islas de los Chauques, dejando entre ambas canal de poco más de una milla, por cuya causa se ha de guardar exactamente el medio freu; ambas son pequeñas y acantiladas por fuera, con mucho saryazo la de Quicabi, la otra está oculta, y no faltan razones para dudar de su existencia; las mareas son diametralmente opuestas al número $3^{\mathrm{I}}$.

Derrota de Castro í Linao por los canales del Norte y Este de Lemuy y fuera de las demís islas.

II7. Habiendo salido del fondeadero de Castro hasta la boca del Estero, se harán los rumbos opuestos á la derrota dada al núm. 26, y luego que se halle Noroeste-Sueste con la Isla de Linlinao navegará al Este $1 / 4$ Nordeste nueve millas y cuatro al Sur $5^{\circ}$ Oeste, y se hallará entre la costa del Oeste de la isla Quehuy y la del Este de Lemuy, habiendo pasado á medio freu de entre ésta y la de Chelin; hará luégo el rumbo del Sursudoeste $5^{\circ}$ Oeste media legua y al Sursueste 1 - Sur dos millas; navegará otras dos a1 Este $\%$ Sueste, llevando por babor la Isla de Quehuy, y zafo ya del canal de Lemuy, hará el rumbo del Sursueste por espacio de cuatro millas y ${ }_{3} 3$ al Este, de donde le demorará lo más Este de la Isla de Apiao al Norte $1 / 4$ Noroeste como seis millas; navegará 2I al Nornordeste y estará Este-Oeste á cuatro millas de la Isla de Tac; hará luégo el Norte I m millas y se hallará Este-Oeste con lo más Norte de las Islas Chauques, habiendo pasado á cinco millas de la de Coy, que es la más Este; desde este punto hará 37 millas al Noroeste, quedará Este-Oeste con la boca del puerto de Linao, á donde entrará como llevo dicho en los números I9 y I I5.

II8. Advertencias. De la punta de Chalihue, que es la más Nordeste de la Isla de Lemuy, sale un bajo de piedras hasta la distancia de dos cables en vuelta del Nordeste $1 / 4$ Norte: á pique tiene siete brazas de agua en bajamar, y su veril upueda con dos y media.

II 9. Las mareas son de poca consideración hasta la entrada del canal del Este de la Isla de Lemuy, pero desde este sitio son absolutamente precisas; sus direcciones en los canales del Este y Norte son casi á los rumbos que se dirige la derrota; su relncidad en el del Norte apenas llesá á media legrua por hora, pero en el del Este no baja de cuatro millas, desde que se monta la punta de Chahihue hasta que se desemboca por la de Apabón, y entre lo más Oeste de la Isla de (uehuy y la costa de Lemuy que es casi la medianía y myor angostura de este canal, llega á seis millats por hora.

Poh. Ia derrota anterior debe preferir- se á la que le antecede, discurriendo el canal de Quinchao, así por lo dicho en el número 36 , como por la mayor prontitud del viaje, pues aunque en ésta, en el canal del Este de Lemuy hay riesgo en la violencia de las mareas en favor, es incomparablemente menor que el canal de Quinchao, donde también debe fondearse, por el bajo de Dalcahue.

I2I. Otra. En cualquier paraje de la costa del Norte de la Isla de Lemuy se fondea sobre 16 á I 8 brazas lama de dos á tres cables de tierra. Se puede surgir en la costa del Oeste de Quehuy y en la ensenada de la Capilla de Detif al Oeste de la punta de Apabón como á una milla, que es buen abrigo en verano y áun en invierno.

Derrota de Castro al puerto de Calbuco, situado el fuerte en latitud Sur de $4^{\circ} 49^{\prime}$ Sur y en longitud $304^{\circ}$.

I22. Desde el fondeadero de Castro saliendo para el puerto de Calbuco, se hará la derrota anterior hasta estar Este-Oeste, comoseha dicho, con la Isla de Tac á distancia de cinco millas, y y desde este punto, el rumbo del Norte conduce directamente á pasar dos millas al Este de lo más oriental de la de Tabón, 1levando lo más Sur de la de Peluqui por la proa: á las $4 x$ millas sobre dicho rumbo se estará Este-Oeste con la Isla Tabón distancia tres millas, desde donde se continuará el mismo rumbo hasta estar como á una milla de la costa de Pulucuy; desde aquí se pondra al Noroeste $1 / 4$ Oeste, llevando por la proa la Isla de Quenu, y por estribor las de Pulucuy y Chizhuapi, costeando á ésta como á media milla, y navegadas luégo cinco al mismo rumbo, quedará al Este de la de Quenu, y á media canal de la boca que forma ésta con la de Chizhuapi, por lo que hará el rumbo del Norte $20^{\circ}$ Oeste dos y media millas y al Nornordeste $1 / 4$ Norte tres millas, llevando la pequeña Isla de Chaulin por la proa, por estribor la de Pulucuy y por babor la de Caycahen, donde está el fuerte, y fondeará como á una milla escasa al Oesnoroeste de él en 20 ó 25 brazas lama, amarrándose Norte-Sur.

I23. Advertencias. Este-Oeste con la isla de Tac, siguiendo al rumbo del Norte selleva por babor como de seis á nueve leguas la costa Este de la isla de Chiloé, y por estribor la de tierra firme distancia de cuatro á cinco, cuya dirección es casi Norte-Sur hasta la península de Queulin lo más Oeste de ella por esta parte, y en su interior á poca distancia sigue igual dirección la cordillera de los Andes, con alturas que pueden verse á más de 40 leguas.

124. Hallándose como á seis leguas de la isla de Pulucuy se avistará la de Tabon, que está al Sudneste de aquélla como cinco millas, se presenta dividida en tres por ciones que parecen islas, pero como á dos leguas, se distinguen las gar- 
gantas ó estrechos de arena que las unen; no tiene surgidero cómodo sino para piraguas.

I25. Las islas de Chizhuapi y Quenu tampoco tienen surgidero ni leña, pero sí la de Pulucuy que tiene los esteros de Chauquicel, Chipu, Machi y Pulucuy, su costa del Este es alta, escarpada y de mucha profundidad en su cercanía. La isla de Caycahen es alta y tendida NordesteSudoeste. Las de Quenu y Chizhuapi bajas y tendidas Noroeste-Sueste, y lo más Oeste de Quenu es punta rasa de arena muy blanca, y con lo más Noroeste de Chizhuapi que también es punta de arena blanca, forman la boca del puerto, que es de una milla y acantilada por ambas partes.

I26. La Isla de Pulucuy es la mayor de las del partido de Calbuco, la de Tabon está prolongada Este-Oeste: á lo más Este de ella y lo más Este también de la de Quenu, está el bajo Tabon Norte-Sur con la medianía de la de Chizhuapi á dos millas, por esto se hace la derrota con tanta inmediación á Chizhuapi; el bajo es de arena y marisco, su extensión una milla Noroeste-Sueste, y queda casi todo manifiesto en bajamar de aguas vivas, acantilado por todas partes.

I27. Al Nornoroeste del Oeste de la isla de Tabon, como á una milla, empieza el gran bajo de Lame-huapi ó isla de Lobos, que se extiende al Nornoroeste cuatro millas y tiene de ancho una $y$ media. A bajamar quedan descubjertas varias porciones que parecen islas, $y$ velan algunas hasta pleamar; lo más del bajo es de arena y lastre, $y$ es infinito el marisco de varias clases que se coge en él; el recelo de este bajơ impide la entrada á Calbuco por la parte del Oeste de Tabon, como el de la Lagartija que está entre lo más Norte del anterior y la Isla de Abtao; es de arena, se extiende una milla de NoroesteSueste, y al extremo Noroeste tiene el pequeño islote de su nombre, escarpado por la parte del Este.

I28. El puerto de Calbuco es capaz, está desabrigado de los vientos de la parte del Norte y Sur, que son bien frescos y frecuentes en sus respectivas estaciones. Su fondo es de ro á I 2 brazas lama á ménos de un cable de tierra; forman el puerto las islas de Caycahen, la de $\mathrm{Pu}$ luqui al Este de ella dos millas, las de Quenu y Chizhuapi al Sur á distancia de una legua, y la costa de tierra firme al Norte; en la costa de Pulucuy que mira al puerto, está el estero de Chauquial y el de Chipu, ambos son capaces de algunas embarcaciones grandes: el primero se interna dos millas en fondo de 18 hasta seis brazas lama y tal cual manchón de lastre, ambos están descubiertos del Noroeste al Oeste que son los dominantes y fuertes, en la costa firme, cerca del fuerte al Norte, está el estero de Huytu, que se interna dos millas, es buen invernadero para todo género de embarcaciones, pero para pasar á su interior es lo mejor sólo á pleamar: hay cuatro brazas de agua sobre el banco que atraviesa la angostura, por lo que es necesario que entren descargadas y se amarren acoderadas más de dos que estarán á la gira. Los fondos desde el banco para adentro y fuera son desde cinco hasta 20 brazas lama, arena y lastre: para entrar se tomará el medio freu, para huir una peña que suele descubrirse algo á bajanar.

I29. El terreno de las islas es apropósito para cultivo, $y$ no tanto el de la tierra firme, en las fronteras de las Islas Abtao, Caycahen, y el Estero dicho de Huytu, hay algunas habitaciones, sin embargo de haber quemado dos veces los indios el fuerte en el terreno de Calbuco y en la capilla de San Rafael.

I30. Las mareas desde la Isla de Tac son de Norte á Sur y su curso insensible hasta cerca de la entrada de Pulucuy y Tabon, que su dirección es al Nordeste y Noroeste: al Nordeste para continuar hacia el seno de la cordillera, golfo de Reloncabi, donde llega su movimiento á cinco millas; y al Noroeste de dos y media entre Pulucuy y Tabon, y así sigue á los rumbos de la derrota, aumentando su velocidad hasta tres y media millas entre Chizhuapi y Quenu.

I3I. Nota. Al avistar la Isla de Pulucuy, ó poco después viniendo en demanda de Calbuco, se verá la península de Quehulin, que por el menor tamaño de ella, no se confundirá con la Isla de Pulucuy.

I32. Los días de novilunio y plenilunio, sucederá la pleamar en el desembarcadero del fuerte á la una del día con corta diferencia.

\section{Derrota de puerto Calbuen al de Linao.}

I33. Desde el fondeadero de Calbuco se gobernará al Sur una milla, y dos y media al Sudoeste $1 / 4$ Sur, llevando la medianía de la Isla de Quenu por la proa, se hallará á medio freu de lá boca entre Chizhuapi y Quenu, y gobernando al Sursueste dos millas, tendrá rebasada la boca, gobernará al Sueste $1 / 4$ Este dos y media millas y 4 al Sueste \% Sur, desde donde le demorara 10 más Este de 'Tabon dos millas al Oeste, hará el Sursudoeste cinco millas, y $26 \%$ al Oeste, con que estará rebasado del arrecife de Lobos de Linao, y se hallará á media boca del puerto, que tomará como se ha dicho al número I9.

I34. Advertoncias. Al Sur de la Isla de Tabon, siguiendo al Oeste se llevarán por babor casi í una vista las Islas Chauques, y por la mura misma la Isla Caucahue, por la banda de estribor las Islas Quenu, Caycahen, Quihua y costa firme. y por la mura la Isla de Abtao, y luégo se empezará á distinguir demorando al Oeste 1/4 Sudoes te la península Huapilinao que se presenta escarpada alteando algo más por el Sur. 
I35. Las mareas, desde el fondeadero del fuerte hacen su curso casi Norte-Sur y desde la punta Sur del fuerte Sursudoeste y Oesudoeste tres millas por hora, fuera de la entrada del puerto se dirige al Sueste la que sale por el Oeste de la Isla de T'abon, y al Oesudoeste la que sale por entre lo más Este de dicha Tabon y lo más Sur de Pulucuy, en velocidad de dos millas. En el resto de la derrota se navega por la línea casi divisoria de mareas de quien ya se ha hablado al número 2I. De punta Chilen al puerto de Linao, siguen su curso casi Norte-Sur con movimiento de dos millas, que aumentan á más de tres á la boca del puerto, y de ella para adentro disminuye.

\section{Derrota del puerto Linao al de Chacao.}

I36. Fuera del puerto Linao se gobernará tres y media millas al Esnordeste, y rebasada la punta de Cheylen se hará el rumbo al Norte nueve millas, y quedará rebasada la punta de Tres Cruces, demorando al Oeste $30^{\circ}$ Sur. Desde este punto se hará el Oeste $3^{\circ}$ Sur tres y media millas, fondeando en la poza de Chacao en nueve á diez brazas arena á distancia de dos cables de tierra.

I37. Advertuncia. La salida de Linao se hará antes que acabe de llenar la marea, para encontrar la vaciante rebasado ya de la punta de Chilen; al montar la punta de Tres Cruces con vientos del Sur, se orzará inmediatamente, no obstante el rumbo dado, cuanto el viento dé lugar á reparar el impulso de la corriente, no impida á tomar el fondeadero obligando á embocar el canal de Remolinos.

\section{Derrota del puerto de Chacao al de San Carlos.}

138. Norte-Sur con la iglesia del pueblo, se navegará al Norte dos millas y hallará EsteOeste á media milla de la punta de Remolinos. Desde este punto á la del Noroeste, costeando la tierra que sigue para San Gallán por babor á distancia de tres á cuatro cables, y cumplidas tres millas, gobernará al Oeste $9^{\circ}$ Norte 16 millas, y quedará con la Isla Doña Sebastiana Norte-Sur por su parte del Oeste, zafo ya del bajo Inglés: hará el Sudoeste $\%$ Sur cinco millas, y estando como á media escasa de la costa de Agui, hará el Essueste, y montada la punta de Agui, pasando ¿1 dos ó tres cables de las lajas que lo forman, hará el Sursudoeste ya dentro del puerto hasta rebasar los sargazos del bajo de Chucura, que llevará por estribor, atracando luégo á la costa de dicha banda para surgir en el paraje citado al fin del número 2.

I39. Alvartucias. Las mareas variantes favorecen en el viaje de Chacao á San Carlos ó para el Oceano, y siguen su curso por los rum. bos opuestos que se han dicho en los números ro y II. Del morro de Huapilacuy para San Carlos son de tres millas por hora en dirección Nornoroeste Sursueste.

I40. Si en esta derrota se quisiese fondear, puede hacerse en cualquier paraje en I6, I\& y 20 brazas lama, y mejor en la ensenada de Huapilacuy ó puerto del Inglés, al Sur 1/4 Sudoeste ó Sursudoeste del morro de su nombre en ocho ó nueve brazas fondo no de buen tenedero, pero con bastante abrigo y aguada.

I4I. Si quisiese salir al Oceano sin tocar en San Carlos, estando Norte-Sur con lo más Oeste de la Isla de Doña Sebastiana, el rumbo del Oesnoroeste le conducirá libre de todo riesgo.

\section{Derrota de Calbuco al Chacao y San Carlos.}

I42. Saliendo de puerto Calbuco para el del Chacao estando al Sur de la Isla de Tabon, se hará el Oesnoroeste $5^{\circ}$ Oeste 16 millas, y al cumplirlas se hallará Norte-Sur con lo más Oeste de la isla de Abtao, punta Chodoy: hará derrota al Noroeste $1 /$ O Oeste, y atracándose á la punta de Tres Cruces y costa que sigue, cuanto pueda, fondeará en la poza como se ha dicho en los números 9 y I 36.

443. Advertencias. Por el violento impulso de las mareas se atracará á la punta de Tres Cruces cuanto sea dable para asegurar tomar el puerto de Chacao.

I44. Nota. Queriendo seguir desde Calbuco á San Carlos ó al Oceano, demorando la punta de Tres Cruces media milla al Sueste, se navegará al Noroeste $1 / 4$ Oeste dos millas, y estando Este-Oeste como media milla de punta de Remolinos, obrará según se expresa en los números ${ }_{3} 8$ y I4I, sin olvidar lo advertido respecto á mareas y laja del canal.

\section{Salida del puerto de San Carlos al Oceano.}

145. Se dará la vela á marea parada para aprovechar la vaciante, especialmente si el viento es poco: zafo de la punta de Agui hará el Norte $1 / 4$ Noroeste, llevando el morro de Huapilacuy descubierto por babor, hasta que demore media legua al Oeste; gobernará al Nornoroeste dos y media millas y estará el farallón del Oeste de punta Huapacho al Oeste $15^{\circ}$ Sur, y enfilado con la punta de Huechucucuy, la tierra más Oeste de la Isla de Chiloé; desde aquí el Oesnoroeste lo conducirá al Oceano, y zafará de entre puntas, y violenta acción de las mareas de tres y más millas por hora. El encuentro de las mareas entre sí, ó con vientos opuestos, causa en el mar notable agitación y escarceo muy incómodo, formando varias líneas ó hileras de reven- 
tazón, tan semejante á la de un gran bajo, que es capaz de sorprender á cualquiera á primera vista.

I46. Advortencius. - En la derrota anterior, desde dar la vela hasta la punta del Sur de Agui, se lleva por babor el bajo de Pechucura, de quien se ha hablado en los números 2 y I $38^{8}$ cuyos sargazos están siempre manifiestos, y mucha parte de él á bajamar, tiene cuatro brazas á pique.

147. Desde que se monta punta de Agui has ta rebasar morro de Huapilacuy, se lleva lo más Oeste del bajo Inglés enfilado con la medianía de la Isla de Doña Sebastiana y fuerte San Carlos al Norte $5^{\circ}$ Este y Sur $5^{\circ}$ Oeste y casi Esteoeste con el morro de Huapilucuy en distancia de una legua, su dirección es Este $5^{\circ}$ Sur Oeste $5^{\circ}$ Norte tres millas, la reventazón á bajamar se manifiesta en su centro como de una milla, tiene de ancho de Norte á Sur de cuatro á cinco cables, $\mathrm{y}$ es todo de arena con tal cual manchón de lastre.

I48. Desde el morro de Huapilucuy hasta la distancia de un cable escaso, sale envuelta del Este el arrecife de piedras que vela en bajamar, á pique tiene seis y siete brazas fondo piedra.
Nota.-Adición al nimero 37.

No obstante mi contínua indagación en solicitud de los bajos y placeres en estas derrotas, no tuve noticia del banco de Tigui, donde suelen algunos índios pescar lobos. En el viaje de visita de provincias del Gubernador Hurtado, tuvo noticia de él, y le colocó entre las islas desiertas y Chaulin y Tac, y al Este de lo más Sur de la de Cahuache ocho y un tercio millas, dándole la extensión de dos y media de Norte á Sur y una del Este-Oeste y significó ser de rocas. Este bajo es obstáculo para la derrota que doy en el número 37 desde Linao á Castro, que lleva por el veril del Oeste del citado bajo. Para evitar este riesgo estando Este-Oeste con la Isla de Tac, se gobernará al Sudoeste $\%$ Oeste ocho millas, llevando lo más Sur de la Isla de Cahuache por la proa, y así pasará más de una legua al Norte de dicho bajo, seguirá al Sur II millas, quedará EsteOeste con lo más Este de la Isla de Caulinec á distancia de cuatro millas; desde esta situación navegará al Sursudoeste cinco millas, y cumplidas, hará el Oeste como se dice en el mencionado número 37 y lo demás de la derrota como se previene en ella. 


\section{Construcción de las cartas hidrográficas desde Chiloé hasta Coquimbo.}

Establecidas la latitud y longitud del observatorin de San Carlos de Chiloé sobre datos de la mayor confianza, pero que dependen de las observaciones correspondientes hechas en Europa, adoptamos para la continuación de nuestras tareas el meridiano de San Carlos por primer meridiano; así, cualesquiera innovaciones que causen en la longitud, se reparten en el total de la costa que abraza, pues ya las combinaciones de los relojes, no alcanzan, á lo ménos en nuestro entender, á desenvolverlas con probabilidad de una mayor a proximación.

Nuestras marcaciones con el teodolito llegan hacia el Norte hasta la punta Capitanes de la tierra firme; es inútil recordar con cuánta prolijidad se han hecho todas las marcaciones que conducen á la formación del plano del puerto San Carlos; estas mismas afianzan la posición de los islotes inmediatos y de la punta ya nombrada.

Ha sido preciso combinar con las tareas del Piloto Moraleda la continuación de la costa hasta el río Bueno: no conveníamos con él en el arrumbamiento de aquella punta, por consiguiente ha parecido oportuno referir á nuestras posiciones de la misma y del río Bueno los puntos salientes intermedios, que Moraleda había marcado. Una ilusión sobre la vista de tierra después del pequeño temporal que pasamos á la salida de Chiloé, nos arrastró involuntariamente á propasarnos de este trozo de costa.

Volvemos á cogerla por paralelos del río Bueno, y las bases nos guían desde allí hasta la entrada del puerto de Valdivia, cuyas vistas, arrumbamientos exteriores y longitud, determinamos con grande probabilidad de que se aproximen muy mucho á toda la exactitud necesaria: los relojes tienen á la sazón una época muy corta, y concurren á afianzarlos, muchas series de distancias lunares medidas con las circunstancias más favorables.

Nuestras bases referidas al medio día anterior, en el cual observamos sí la latitud con mucha contianza; pero distábamos considerablemente de la costa, viéndonos luego precisados á buscarla con rumbos del Este, determinan al Morro Gonzalo una latitud mayor en siete minutos á la que prefijaba el Piloto Moraleda. Por ventura, se reune con la exactitud natural de este hábil Piloto la casualidad de haber observado tres veces á la vista del mismo Morro Gonzalo con buen octante y declinaciones bien calculadas, de suerte que no titubeamos un momento en abandonar los resultados de nuestras tareas, y prefijar al mismo Morro la latitud de $39^{\circ} 5^{\circ}$, en lugar de la de $39^{\circ} 57^{\prime}$ que inferíamos de las bases y navegación traídas desde el medio día: el fondeadero del Milagro, inmediato al río Bueno, está comparado á las noticias del Capitán Orejuela.

La costa siguiente hasta la Isla Mocha se ha combinado con los derroteros antiguos y con la carta del Piloto Moraleda, hubiéramos á la verdad deseado dar unas vistas del Morro Bonifacio que dirigiesen la recalada al puerto con los vientos del Norte harto comunes; pero en estos paralelos, como nos pareciese lo demás costa de muy poca importancia en proporción de la que se sigue al Norte de la Isla Mocha, cuya posición pudiéramos trabajar prolijamente con el tiempo á la sazón claro y apacible, cosa no muy común en es tos mares, navegamos una noche entera omitiendo este trozo ya reconocido muchas veces, $\mathrm{y}$ de un arrimo nunca útil por las naciones que le habitan: los puertos de que carece, los tiempos por lo común tempestuosos y la costa coronada de arrecifes.

La Isla Mocha, en cuyas inmediaciones se han observado con la mayor satisfacción latitudes y longitudes, se ha situado también en cuanto á sus extremos por bases corridas con toda la prolijidad posible. El arrecife saliente en su extremo del Sur, no ha sido visto por nosotros; es de la extensión que le determinan los derroteros antiguos, $y$ no debe diferir mucho, por cuanto en la navegación costanera que antiguamente se hacía, no pudo equivocarse su distancia con otro objeto alguno extraordinario.

La lancha del navío San Pablo, del comercio de Lima, ha pasado últimamente entre la misma isla y la tierra firme: las noticias verbales de su Capitán el Alférez de fragata graduado D. Antonio Cazulo, se han tenido presentes para el derrotero y el paraje más oportuno para fondear: el preferir nosotros el paso exterior, dependió del deseo de coger su vista á una regular distan- 
cia para aclarar más y más las recaladas venideras.

Siguen las posiciones deducidas de nuestras bases desde el paralelo de la Isla Mocha hasta la punta de Rumena. Habíamos corrido nueva base para la posición y dirección de la Isla Santa María, pero por algún accidente inaveriguable, no nos fué posible ligarla con los puntos interiores de modo qne no discrepase, ni de los reconocimientos hechos por el Excelentísimo Ulloa, ni de las latitudes anteriormente observadas por el Piloto Moraleda en el mismo paralelo: las hemos adoptado con tanta mayor seguridad, cuanto conservan luégo los mismos arrumbamientos de la isla con la tierra firme, cuya descripción hidrográfica está deducida de elementos tan seguros como multiplicados: toda la parte exterior desde la Isla Santa María hasta el puerto de Coliumo pende de marcaciones del teodolito y de unos triángulos ligados con bases de la mayor satisfaccion.

La latitud del puerto de Talcahuano se ha observado con el cuarto de círculo: su longitud está determinada con los relojes marinos de la Descubierta, examinado y hallado conforme su movimiento en el mismo puerto: conviene esta longitud dentro del minuto con la que determinó el Padre Feuille por tres observaciones en el primer satélite de Júpiter, todas referidas á las observaciones correspondientes de los Sres. Maraldi y Cassini en París (I).

Discrepan en esta ocasión considerablemente los relojes de la ATREVIDA, y la ecuación que resulta de la averiguación de su marcha en Valparaíso, no alcanza con dos minutos de diferencia á igualar la que termina la Descubrerta.

Un tiempo constantemente neblinoso y acompañado de calmas realmente temibles en estas costas, imposibilitó á la corbeta ATREvida el recorrer el trozo de costa comprendido entre la embocadura del río Hitata y la punta de Lora: la hemos deducido de los mejores derroteros que merecen alguna fé en esta parte, porque con objeto de acopiar algunas maderas, y áun de construir buques pequeños, ha solido frecuentarse el río Maule, y por otra parte los ha examinado con mucha prolijidad el Piloto Moraleda.

Desde la punta de Lora por el morro de Topocalma, bajos de Rapel y punta de Coroumilla hasta Valparaíso, toda la costa está deducida de las tareas de la corbeta Atrevida, la cual, aunque no pudiese por la muchas calmas y cerrazones continuar ordenadamente sus bases, ha po-

(r) No podemos acertar con los motivos que han dado lugar á variar en el conocimiento de ticmpo la longitud del Padre Feuille, sustituyéndole otra que difiere de medio grado: es probable que proceda de una equivocación antigua de cifras y que corrobore Mr. Dagelet los resultados del Padre Feuille. dido, no obstante, observar latitudes y longitudes en unos puntos importantes; de suerte que ninguna sospecha de error considerable puede quedarnos en cuanto á los puntos esenciales de este trozo de costa: son todas bases bien aseguradas las que conducen desde la punta de Coroumilla hasta la de los Angeles.

No cabe mayor exactitud de la que se ha empleado para la latitud de observaciones de Valparaíso, como que dependía·de ella el catálogo de estrellas meridionales que se ha intentado ratificar ó arreglar por los Sres. Galiano, Concha y Vernaci: en cuanto á la longitud está deducida de dos emersiones del primer satélite de Júpiter exactamente acordes entre sí, y convienen en ella con la misma uniformidad los relojes de la ATREVIDA.

Los de la Descubierta, que determinan la longitud de las Islas de Juan Fernández, traídos luégo al observatorio de Valparaiso, sólo discrepan un minuto y medio de la longitud de los satélites, y esta cantidad en el mismo sentido relativamente á los relojes de la ATrevida, en que difieren los unos de los otros en Talcahuano, fija, finalmente, entre Concepción y Valparaiso, una misma diferencia por los seis relojes, y por las observaciones hechas en Chiloé y en este último puerto (I).

La posición de las Islas de Juan Fernández queda, pues, evidentemente segura: se ha observado la latitud á la vista de una y otra, fijada la distancia nuestra á la de más afuera por una base corrida y suficientemente proporcional, y ratificadas las determinaciones de un día con las del otro en cuanto á la de adentro: hemos sacado mucho partido de los reconocimientos hechos por el Excmo. Ulloa en su fondeadero, el cual también deducimos en cuanto á sonda, así de nuestros planos actuales (visitada ya repetidas veces esta isla por los buques de S. M.), como de las noticias harto individuales del Almirante Anson.

El braceaje de la de más afuera, el sitio desu aguada y la configuración de la parte occidental está copiado de las noticias exactas que costaron al célebre Capitán Carteret mil fatigas y peligros (2): muchas vistas que se sacaron de estas islas pudieran. completar su descripción hidrográfica; pero nos obliga la escasez del tiempo á omitirlas por ahora, igualmente que una carta

(I) El Padre Feville determina la longitud de Valparaíso medio grado más occidental que la nuestra: no parecerá extraña esta diferencia, cuando se advierta que el Padre la deduce de una sola observación del primer satélite sin correspondiente y sin una marcha bien segura del péndulo: véase el viaje del Padre Feuille tomo I, pág. 380 .

(2) Las contrariedades que experimentó y venció en esta ocasión el célebre Capitán Carteret deben mirarse como una verdadera lección para un marinero. 
que las manifieste en punto mucho mayor que el general de la costa fronteriza.

La posición de la ciudad de Santiago pende en cuanto á latitud de muy buenas observaciones en el cuarto de círculo; y en cuanto á la longitud, de una observación muy satisfactoria en el primer satélite de Júpiter. Difiere considerablemente de esta determinación la del reloj ro5 de Arnold, pero como su conducción por tierra pudo trastornar algún tanto su movimiento, y la falta del cristal de la muestra hiciese muy expuesto é incómodo el darle cuerda, no titubeamos en abandonar su resultado: el olvido involuntario de no darle cuerda á la vuelta al tiempo de llegará Valparaíso nos ha quitado el inferir nuevos resultados.

También se ha observado la latitud en Casablanca, y todo el valle de Santiago sujetado á operaciones trigonométricas; pero el tiempo no nos permite trazarlas.

Era muy difícil sin muchos sacrificios de tiempo, salud y caudales, la operación que intentábamos de conducir los triángulos desde Valparaíso á dicha capital.

Todas las inmediaciones de la rada de Valparaíso hasta el Concon, se han inferido, como era natural, de las operaciones trigonométricas en el teodolito; pero no ha sido tan fácil el ligar el trozo siguiente hasta Coquimbo.

En este trabajo concurrieron á interrumpir la exactitud que nos prometíamos, no ménos un tiempo muy calimoso y unos vientos calmosos reunidos á una corriente bastante fuerte, si también la falta casi absoluta de observaciones de latitud y longitud por el espacio de dos días y medio. El excelente método de hallar la latitud por dos alturas de Sol, propuesto por D. Dionisio Galiano, nos ha sido en esta ocasión muy útil, pero ha sido preciso su jetarlo á nuevas combinaciones, en cuanto no todas alturas en un cielo cerrado con calima eran de igual confianza, y además en el primer día teníamos una sóla altura, cuya longitud mal podía deducirse ignorando la latitud: la aplicación de los relojes á la resolución de esta duda nos ha ofrecido por ventura datos muy aproximados, pues indicándonos las marcaciones desde Valparaíso y nuestras bases, en qué longitud nos debíamos suponer próximamente, hemos inferido ser error de la latitud la diferencia que nos resultase, y así, de la longitud verdadera se ha deducido la corrección á la latitud del medio día.

Paireando en una parte considerable de la noche, navegando muy próximos á tierra, y ayudados de los datos antecedentes, podemos lisonjearnos de haber triunfado en esta parte de costa de las contrariedades que querían imposibilitarnos su exacta colocación. Los tiempos hermosos de los cuales hemos disfrutado, después nos han dado lugar á trabajar con toda la exactitud; así, las inmediaciones al Sur de la Lengua de Vaca y toda la costa comprendida entre ésta y la entrada de Coquimbo, deben ser muy a proximadas á la verdad: estas últimas están también sujetas á las operaciones trigonométricas en el teodolito, y confrontadas con diferentes marcaciones y enfilaciones, á la salida.

La latitud del observatorio nuestro de Coquimbo, observada en el cuarto de círculo, y la longitud, inferida de dos emersiones del primer satélite de Júpiter, de varias fases de un eclipse de Luna, y de dos ocultaciones de estrellas por la misma Luna; pero mientras se logren los cálculos y errores de las tablas para estas observaciones de la Luna, nos atenemos al resultado de las observaciones en el primer satélite de Júpiter, que conviene exactamente con los relojes marinos (I).

Así, la diferencia en longitud entre San Car-los de Chiloé y Coquimbo, se halla, con mucha complacencia nuestra, determinada uniformemente por los seis relojes marinos (2) de entrambas corbetas, examinado su movimiento en Chiloé, Talcahuano, Valparaíso y Coquimbo; y concurren á fortalecerle, varias observaciones hechas en el primer satélite, en los mismos puertos (3).

También deben sernos tanto más agradables estos resultados, cuanto que asegurando unánimes la longitud del puerto de San Carlos, quedan también aseguradas las diferencias entre aquel puerto y el de Montevideo, y por consiguiente todos los de ambas costas Patagónicas.

En una costa tan abundante de puertos y radas como lo es la que acabamos de describir, hubieran sido muy defectuosas nuestras tareas, si no nos hubiésemos dedicado con el mayor fervor á reconocer y trazar siquiera las que pareciesen importantes para la navegación.

(1) El Padre Feuille determina á Coquimbo una longitud bastantemente aproximada á la nuestra; si debiésemos atenernos á la observación del primer satélite, que no tiene correspondiente, pero que difiere en $10^{\prime} 15^{\prime \prime}$ de la que resulta de la observación del segundo satélite correspondida por los señores $\mathrm{Ma}$ raldi y Cassini en París; ésta diera la longitud de nuestro observatorio de $73^{\circ} 36^{\prime} \mathrm{x} 2^{\prime \prime}$, la nuestra es de $73^{\circ} 52^{\prime} 0^{\prime \prime}$.

(2) Cuando se habla de la uniformidad de los tres relojes de una corbeta, se entiende siempre que están traídos á un mismo resultado por las ecuaciones que resultan de la comparación diaria entre sí. Véanse las tablas de cstas ecuaciones.

(3) No parezca extraño que adoptemos como igual á la nuestra, la longitud del observatorio ó fondeadero de Talcahuano, determinada por el Padre Feuille, cuando las de Valparaíso y Coquimbo se nos apartan considerablemente: cualquiera que recorra su viaje verá que las observaciones hechas en Penco son tres; todas con correspondiente en París, todas en el primer satélite y todas uniformes entre sí. Están muy distantes las otras de hallarse en circunstancias iguales. 
El puerto y canal interior de Valdivia está levantado con mucha prolijidad por el Ingeniero Garlan; le ha confrontado, así en cuanto á las operaciones trigonométricas como á la sonda, el Piloto Moraleda, quien nos ha confirmado su exactitud.

La posición de los fondeaderos de la Isla Mocha y la de Santa María, se ha sacado de los derroteros; este último se ha combinado también con las noticias del Excmo. Ulloa, quien la hizo costear por la parte interior; la frecuentan en el día los pescadores de la corvina.

$\mathrm{El}$ examen de los fondeaderos inmediatos al de Talcahuano era tanto más importante cuanto que aquella rada está enteramente descubierta al viento reinante y tempestuoso del Norte; así, se han levantado con el teodolito los planos de los puertos de San Vicente y Coliumo, uno y otro abrigados de aquel viento aunque no capaces de un crecido número de buques; es nuestra la sonda del puerı́o de San Vicente, bien que no descubre un bajo que está en su entrada y que fué reconocido por el Piloto Moraleda, con cuya noticia le comprendemos en el plano; la sonda del puerto de Coliumo nos ha sido comunicada por un pescador que habitaba sus orillas desde muchos años.

A pesar de la inutilidad de la bahía de Talcahuano, no nos hemos descuidado en sujetarla á las operaciones trigonométricas más prolijas: el bajo grande se ha sondado por todas partes marcando al mismo tiempo al bote con dos teodolitos: lo mismo se ha hecho para las inmediaciones peligrosas de la costa contígua á Talcahuano, y todas las piedras que hacían antes creer, que fuese muy expuesto el paso entre la misma costa y la Quiriquina. Las inmediaciones de esta isla, las del Mogote de Quiebra-ollas y las del Tomé y Penco, se han sondado sin sujeción á los teodolitos.

Se hicieron cuantas diligencias estaban en nuestro alcance para hallar dentro de la bahía otro bajo, de cuya existencia teníamos alguna noticia confusa: fueron vanos nuestros esfuerzos para el intento, áun haciéndonos dirigir por la misma persona que nos decian haber tocado en él: el Piloto Moraleda nos asegura haberlo reconocido; la posición que le damos, por consiguiente, en nuestro plano, está deducida de las marcaciones que nos ha comunicado.

Los triángulos empezados en la bahía de Tal cahuano y prolongados al Norte hasta la Herradura, se extienden al Sur hasta las Tetas y embocadura del Viovio, de donde después continúan hasta la ciudad actual de Penco, comprendiendo también la otra banda del río: así, podemos responder igualmente de la latitud y longitud de la Plaza Mayor de dicha ciudad.

En la costa comprendida entre Concepción y
Valparaíso, los derroteros indican algunos pequeños puertos ó calas que no son absolutamente frecuentados en la navegación actual. Son éstos, corriendo Sur á Norte, los de la Natividad de Topocalma y de San Antonio, cuyo examen nos hubiera acarreado el sacrificio de un tiempo favorable que pensábamos aprovechar y realmente aprovechamos en Valparaíso: así, los hemos omitido, bien que determinando sus entradas según se han podido inferir de las tareas de la corbeta ATREVIDA.

La rada de Valparaíso está igualmente deducida de operaciones trigonométricas, y todas las sondas hasta el Concon han sido examinadas por nosotros.

El Ingeniero destinado en Chile, D. Pedro Rico, había levantado en el año de I788 los planos de las calas del Papudo y Pichichangi, intermedios entre Valparaíso y Coquimbo (I): no los creemos absolutamente útiles en el estado actual de la navegación: no obstante, nos ha parecido oportuno el comprenderlos en esta colección.

En el trabajo del puerto de Coquimbo y de sus sondas, no hemos omitido la menor atención: ésta se ha extendido también al pequeño puerto inmediato de la Caldera, que consideramos inútil, particularmente si se compara al puerto, cuyo abrigo, clase de fondo, clima sano y vientos perfectamente apacibles, le harían de un valor inmenso si no careciese absolutamente de agua y leña (2).

No ocultaremos que los errores casi innumerables en los rumbos y distancias de los derroteros más acreditados que hemos consultado á cada paso al tiempo de trazar esta carta, no nos han permitido de aprovechar la menor noticia, si se exceptúa la colocación de tal cual riachuelo ó pequeño trozo de costa, que ya las calmas y las cerrazones ó las corrientes y las noches muy largas nos hiciesen propasar involuntariamente: algún más despacio del que tenemos en la actualidad, nos permitirá algún día de intentar uná nueva combinación de la parte útil de aquellos derroteros.

A las longitudes inferidas por los relojes marinos y por las observaciones de los satélites de Júpiter, hemos agregado á la entrada de Valdivia y Talcahuano en Valparaíso y Coquimbo, un número considerable de observaciones de distancias á la Luna: sus resultados son por lo común muy aproximados á los demás; pero no intentamos adoptarlos para la determinación directa de las

(I) Nos asegura en oficio recibido en Lima por manos del señor Presidente de Chile, que esos planos están hechos conla posible exactitud geométrica, que no ha sondado por falta de recursos para verificarlo.

(2) Encontramos muy aproximado á la verdad el plano de Mr. Fiezier: se aparta mucho al contrario el del Padre Feuille. 
longitudes; súlo sí examinaremos constantemente hasta qué grado de exactitud pueden alcanzar (I).

(r) Repetidos ejemplosnos hacen creer hasta aquí, que no puedan fiarse á más de los tres cuartos de grado.
Los planos de las poblaciones que se comprenden en los particulares de este trozo, están todos conformes con el estado en que aquéllos se hallan en principios de I790. Lo mismo debe entenderse por lo que toca á fortificaciones: sólo sí quedamos por concluídas algunas que nolo están.

\section{Derrotero de Chiloé á Coquimbo.}

Saliendo del puerto de San Carlos de Chiloé deben reconocerse, ó la punta de Quedal en la costa firme de Chile, situada en $4 \mathrm{I}^{\circ} 4^{\prime}$ de latitud Sur, y en $67^{\circ} 53^{\prime} I 5^{\prime \prime}$ de longitud occidental del meridiano del observatorio de Cádiz, ó la de Capitanes, sobre la misma costa, Io millas al Sueste de aquélla. La primera es de mediana altura, y aunque escarpada, su descenso al mar es mucho ménos violento que el de la segunda, cortada á pico y de doble elevación: una y otra están cercadas de bajos como toda la costa al Norte hasta la entrada del río Bueno, que se hace distinguir á primera vista por la profunda quebrada en que desemboca.

En esta porción de costa que corre al Norte $1 / 4$ Nordeste 48 millas, se hallan de Sur á Norte las caletas de San Pedro Caramavidamo y Mamanavidamo, por los ríos de sus nombres, y entre las dos últimas, la grande ensenada de los Juncos, llamada así del nombre de la nación india que habita sus costas.

Desde río Bueno sigue la costa limpia, y sobre ella empiezan los altos de San Antonio: su dirección es al Norte $16^{\circ}$ Este, formando una grande ensenada poco profunda y dominada de aquellos cerros. La punta falsa de la Galera, en que termina, es tan semejante á la verdadera que no pueden distinguirse si no se tiene una buena observación en latitud, circunstancia poco común en este sitio, especialmente en invierno: $\sin$ embargo, como las tierras próximas á aquélla al Norte y Sur, son altas, y al Norte de ésta descienden sensiblemente, puede ser regla para el navegante esta diferencia, y tomar por punta falsa la que vea unida á tierras elevadas por una y otra parte.

Toda la costa comprendida entre esta punta y la de Capitanes, es desabrigada, mucha parte escarpada y cubierta de bajos, y especialmente desprovista de fondeadero: así por esto como por reinar sobre ella casi todo el año los vientos del Norte al Oesudoeste huracanados, tempestuosos, y siempre acompañados de lluvia y cerrazón, conviene no acercarse á clla áun en verano, estación en que sorprendiendo á poca distancia una calma, podrían ser tan funestas las mares gruesas y perennes del Sudoeste como el mayor temporal.

La estación sóla debe decidir del paraje de recalada: de Marzo á Octubre, en que reinan los Nortes, Noroestes y Oestes, parece prudente atracar la costa á barlovento respecto de ellos, para reconocer el morro Bonifacio y las tres quebradas que presenta al.Sur, llamadas de Nabos, de Valdivia y Chaininu, dirigiéndose después á la del medio, que es el puerto, y conservando por la proa ó poco descubierto por estribor el morro Gonzalo, hasta estar tanto avante con el Oeste que demore al Sur á distancia de una milla: en esta posición, tendrá ya á la vista el pequeño fuerte de San Carlos que pondrá por la serviola de estribor hasta que demore al Oesudoeste á distancia de dos cables, que se costee ahora á la mitad de esta distancia la tierra del Oeste, y pasando la ensenada de Amargos, se dirigirá á la siguiente del Corral, donde fondeará luégo que haya enfilado la puñta del Calvario con la de la Uña del Ancla: el modo de amarrarse es Noroeste-Sueste con el ayuste al primer viento, el cuerpo del buque estará en seis brazas y media de agua, fondo lama.

La entrada del puerto de Valdivia no tiene otros riesgos que los visibles, si se exceptúa la piedra sala dos cables al Nordeste de morro Gonzalo, que se cubre á media marea, pero manifiestan bien, la reventazón y escarceo de las aguas sobre ella.

Por lo que hace al interior del puerto, puede decirse que al Sueste de una línea tirada desde la punta de Niebla al extremo Este del Castillo del Corral, sólo hay de tres á tres y mcdia brazas de agua: el fondo á la parte del Oeste es de ocho á seis brazas lama.

El fondeadero del Corral, única parte abrigada, es tan pequeño, que no pueden cstar en él más de dos embarcacioncs á la gira ni más de seis acoderadas.

De Octubre á Marzo, aunque no tienen los Nortes fuerza ni constancia, puede fondearse entre el Castillo de Amargos y Chorrocamayo, en- 
frente de la ensenada que los divide: en este sitio se está desabrigado, pero el fondo es bueno, y para levarse no se necesita la espía, maniobra las más veces indispensable en el Corral.

En uno y otro fondeadero hay abundancia de excelente agua, y se hace con la mayor comodidad. Todo el puerto de la parte del Oeste está cercado de maleza, de modo, que en cualquiera parte se corta cuanta leña se necesita.

Los Nortes meten tanta mar, que no permiten el paso de las embarcaciones menores á Valdivia, por cuya razón, los castillos de la costa del Oeste tienen á prevención cierto número de raciones de repuesto.

La pleamar sucede en el fondeadero del Coral. El plenilunio á las once y media de la mañana, y su elevación sobre la vaciante de seis y medio á siete piés; cuanđo hay viento fresco del Norte, son iguales en duración y corriente, pero con Sur ó calma, la creciente es de tres millas entre los castillos, y de cuatro y media la vaciante, que suele durar siete horas por razón del desaguie del río.

Es difícil en tiempos cerrados distinguir el morro Bonifacio que sólo tiene de notable un pequeño escarpado algo colorado en lo más saliente, particularidad en que se le parecen algunos otros al Norte de morro Gonzalo: es redondo, grueso, escarpado y saliente, de modo que no puede equivocarse.

Para salir de Valdivia es necesario contar con viento de bastante fuerza que supere las varias direcciones de la marea, pues de otro modo será fácil en la angostura caer sobre la costa de Niebla y punta de la Uña del Ancla, una y otra cercadas de piedras, con vientos bonancibles y varios: conviene salir á la espía hasta ponerse fuera de los Castillos de Niebla y Amargos, de donde puede salirse con cualquier viento Hojo.

La plaza de Valdivia está á seis leguas del Corral sobre la orilla del río á que da nombre; los muchos y mudables placeres de que estálleno, hacen su navegación difícil para las lanchas cargadas, y absolutamente impracticable á embarcaciones de más de ocho piés de calado. El río desemboca en la bahía por dos canales, dejando en medio una isla bastante grande en que pastan ganados: el brazo del Sur que llaman Tornagaleones es tortuoso, y mucho más largo y aplacerado que el del Norte ó de Valdivia, de que se ha hablado; por consiguiente, está sin uso.

Las tierras al Norte de morro Bonifacio son de mediana altura y muy desiguales, se presen. tan sobre ellas los altos de Cucule, formados de muchos cerros, que prolongan la costa en su dirección hasta poco del río de Totten, donde bajan sensiblemente, y la costa hace varias pequeñas ensenadas sin abrigo; de allí se mantiene en el mismo aspecto hasta la punta de tierra medianamente alta y aplanada en su cumbre, con al gunas piedras en su pié á poca distancia; está marcada en $38^{\circ} 28^{\prime} 54^{\prime \prime}$ de latitud Sur y en $67^{\circ} 38^{\prime} 39^{\prime \prime}$ de longitud algunas millas al Norte del río Cauter de la Imperial; desde morro Bonifacio á este punto, corre la costa al Norte $10^{\circ}$ Oeste 78 millas.

La Isla de la Mocha, cuya latitud es de $3^{8^{\circ}} 23^{\prime}$ Io" y su longitud de $67^{\circ} 5^{6^{\prime}} 35^{\prime \prime}$ en su extremo Sudoeste está I $_{5}$ y media millas al Norte $68^{\circ} 45^{\prime}$ Oeste de esta punta. Su dirección es casi Norte-Sur y su extensión de ocho á nueve millas. Es montuosa, escarpada por la parte del Oeste y mucha del Nordeste, y su altura bastante para dejarse ver á I4 leguas, en días claros. El freu entre ella y la costa es de cinco á seis leguas, limpio por una y otra parte, y su fond de 28 á 32 brazas lama y arena. En su medianía forma la isla una pequeña ensenada donde puede fondear'se en necesidad, al abrigo del Noroeste. sobre $5_{5}$ brazas, á media milla de la playa.

Todos convienen en que de su extremo Sur sale una restinga de piedras al Sudoeste, pero hay variedad en su extensión; no obstante, creen los más que es de cinco á seis millas; una tercera parte suele descubrirse á mar baja, y con vientos del tercer cuadrante revienta el mar sobre ella furiosamente.

Hay en el interior algunas aguadas y excelentes potreros para cría de ganado: la posición de esta isla respecto de los puertos próximos hace tan infructuoso el paso del freu, que sería imprudencia emprenderlo sin urgente necesidad: tal es en mi sentir una recalada anticipada que acerque á la costa Sur en disposición de no poder montar con el viento al Sur y Sursudoeste el bajo, ó la tenacidad del viento al Noroeste y Oeste cogiendo cerca de la costa.

Desde la punta de Tirua forma la costa una grande ensenada que termina en el cerro ó morro de Tucapel viejo, bien notable por su figura de un morro tajado, de más que mediana altura y de color pardo confuso.

Las tierras de esta ensenada son bajas, alomadas, sin serrania á la espalda, escripadas al mar y con algunas playitas: cinco millas al Sur $\%$ Oeste de Tucapel, se ve otra punta ménos alta, que parece islote, de donde salen al Norte á distancia de tres cables algunos pedruscos bastante visibles: pasado el frontón de Tucapel, cuya extensión es de una milla, escarpado y tajadoal mar, sigue la costa al Norte formando una ensenada regularmente honda, llamada del Carnero; su territorio es desigual en la cumbre y bastante in. clinado á la playa: las tierras más bajas están en el fondo de la ensenada, y poco al Norte, parece el morro del Carnero, con punta á un pié poco saliente: se ven próximas á la costa sobre los pe- 
queños montecillos que la cercan, algunas manchas verdosas, blanquecinas y rojas.

La costa sigue escarpada hasta punta Rumena, donde empieza á ser desigual, aunque elevado, el territorio; entre esta punta y la de Lavapiés, se vé otra baja de piedra escarpada, y el terreno á que está unida se eleva insensiblemente á formar un monte de regular altura. La punta de Lavapiés es alta y escarpada pero delgada y bastante saliente.

Dos millas al Norte $2 \mathrm{I}^{\circ}$ Este está el extremo Sudoeste de la Isla de Santa María, cuya dirección es en aquel rumbo, y su extensión de cerca de seis millas; tiene algunas piedras en esta punta, y una restinga de dos y media á su parte del Noroeste; no tiene fondeadero y el paso entre ella y la costa es infructuoso y arriesgado; es baja y se crían ganados.

Desde la punta Rumena hace la costa una grande ensenada, al principio escarpada, pero en su medianía se ven las playas de Lota al Norte de la punta de su nombre, y poco después la del desaguie del río Queule: la ensenada se prolonga hasta la embocadura del Viovio, en cuya parte del Norte hay un islote unido por una restinga á la costa de la punta; es de arena aplacerada, por cuya razón es impracticable la entrada en él.

A la parte del Norte é inmediatas al Este, se presentan las Tetas de Viovio, altas, casi iguales Nornordeste-Sursudoeste, sobre un frontón saliente escarpado de piedra, con un islote tres cables al Oeste de la punta Sur: doblada la más al Norte, se ve la boca del puerto de San Vicente, formado por ella, y otra que del extremo Sur del monte de Talcahuano sale para el Sudoeste.

Este puerto está situado en $36^{\circ} 42^{\prime} 40^{\prime \prime}$ de latitud Sur, y en $67^{\circ} 7^{\prime} 35^{\prime \prime}$ de longitud occidental al Norte, y próximo á las Tetas, cuya punta saliente lo cierra al Sur: aunque bastante grande, como su mayor parte está descubierta á los vientos del Norte al Oeste, sólo puede llamarse tal aquella porción que cubre de ellos lá punta de los islotes, y presenta un excelente fondeadero capaz de seis embarcaciones á la gira; pero su seguridad y proporciones, especialmente en invierno, son tan esenciales, que lo hacen preferente á la bahía de Concepción y puerto de Talcahuano, donde á pesar del resguardo que baja de Marinao, del buen fondo, y en las mejores amarras, están siempre expuestas las embarcaciones.

Respecto á las mercantes, á la mayor seguridad de quc en él gozan pueden agregarse las ventajas de cargar y descargar sobre una playa siempre tranquila, á un cable del amarradero, y la facilidad de conducir á Concepción sus cargamentos, en carros, con mayor alıorro que en Talcahuano, donde se ven precisados á ejecutarlo sobre mulas, porque la demasiada pendiente del cerro de su nombre y los pantanos que en él forman las contínuas aguas del invierno, lo hacen intransitable á aquéllos.

La aguada es tan abundante como en Talcahuano, de igual calidad y más próxima á las embarcaciones, sucede lo mismo con la leña.

En verano 120 proporciona las mismas ventajas el puerto de San Vicente, porque los vientos de la parte del Sur que reinan entonces, atraviesan todo el puerto para llegar á las embarcaciones, levantando una mar bastante fuerte, á que se agrega, que estando aquéllas tan cercanas de la costa del Norte que sus amarras del Noroeste. están en tierra, si les falta un cable, que suele ser bastante frecuente, es fácil vayan sobre piedras, que forman esta parte del puerto, antes que agarre la tercera ancla. Convendría, pues, que en esta estación, ó se amarren á mayor distancia de la costa, dando al Sur su mejor cable, ó que tomen de Octubre á Marzo el fondeadero de Talcahuano.

Podría también amarrarse en el extremo Sur del puerto, abrigado á los Suestes de esta parte; pero á más de quedar descubierto al Norte, que tampoco es razón en este tiempo, se alarga dos leguas la distancia á Concepción por un terreno pantanoso y de difícil tránsito.

El puerto de San Vicente es limpio, y su fondo entre las puntas, de seis á nueve brazas arena y lama, fuera de ellas de I6 á I8; á su Oeste canal; y se distinguen proporcionalmente al acercarse á cualquiera de las costas.

La punta interior del Sur tiene un islote ó pedrusco un cable al Nornordeste de ella, y la del Norte á más de la restingencia ó islotillos que salen al Sudoeste y velan siempre, tiene un bajo de piedra, media milla al Oeste $7^{\circ}$ Sur.

De Marzo á Octubre parece prudente buscar el puerto por la punta de Talcahuano, á barlovento de él respecto al Norte y Noroeste, y en el resto del año por la parte Rumena, que proporciona las mismas ventajas con los vientos del Sueste al Sudoeste.

Saliendo de San Vicente sigue al Norte $1 / 4$ Nordeste seis millas, el cerro y punta de Talcahuano, bastante alto, en muchas partes escarpado de piedra y varios islotes; á dos cables de él, se ven algunas playitas de arena, pero así en ellas como en las piedras hay siempre mucha reventazón.

A tres cables escasos del estrecho Norte de la punta y á su Noroeste, hay una piedra ó islote conocido por Quiebra-ollas, con una pequeña restinga en esta dirección; puede pasarse á dos cables de él, y conviene hacerlo para conservar el posible barlovento yendo á entrar en la bahía de Concepción con vientos del Sur que obligan á bordear. Montado Quiebra-ollas se debe gobernar á la punta Norte de Quiriquina, escarpada con 
algunos pedruscos próximos, y ménos alta que las dos costas. No hay otros riesgos que los pedruscos siempre descubiertos, exceptuando dos placeres, el primero que rodea á distancia de dos cables la punta Gorda del Este de la isla, y se extiende todo el frente de la ensenada que le sigue al Sur entre él y la punta de Arenas; y el segundo que sale de esta punta al Sueste \% Este, igual distancia y se dístingue fácilmente por el color amarilloso del agua sobre el fondo de arena.

Al principio del canal se encuentran 25 y 30 brazas lama que disminuyen á proporción que se entra, hasta II, ro y 9 lama y arena.

Al Sur de la punta de este nombre, en la costa, está la pequeña ensenada del Tomé, de buen fondo, pero desabrigada al Noroeste $y$ Oeste, que producen mucha marejada, por cuya razón, la de mayor distancia á Coneepción no es frecuentada.

Doblando la punta de Arenas se halla entre ella y el cerro Sudoeste de la isla, el pequeño, pero seguro fondeadero de la Quiriquina: su fondo es desde nueve á I 3 brazas arena, y tan acantilado hacia esta punta, que se encuentran siete brazas de agua á tres toesas de la orilla: está cubierto á los vientos y mares del Nordeste al Oesudoeste: el repentino y violento descenso de la costa de punta de Arenas obliga á llevar á seco el ancla del Norte, que se entierra en la arena; la del Sur va á II brazas, pero es necesario tenderla todo lo posible al Este, huyendo la proximidad del cerro de Piedras, de que salen muchas al Sueste, que maltratan y rompen los cables. Si el concurso de muchas embarcaciones no permitiese esta precaución, podría evitarse el riesgo, dando al ancla de esta parte las brazas de cadena que basten para que el cable no roce el fondo; á falta de otras más oportunas, parece desempeñarían bien este destino las bozas de cadena de las vergas mayoies, especialmente en el invierno, que siendo los Sures bonancibles y raros, trabajan ménos sus amarras.

Este fondeadero es preferenté á los demás, para toda embarcación que no necesite una comunicación seguida con la costa: las de guerra logran en ella de la ventaja de tener en freno sus tripulaciones, haciendo de este modo ménos frecuentes la deserción, la borrachera y todos los desórdenes en que se ceban en los puertos de esta costa. La isla produce abundantemente sin cultivo, manzanas, cardos, nabos y otras legumbres antiescorbúticas capaces de restablecer cualquiera tripulación débil, mezclándolas en su caldero á la comida diaria: hay excelente agua y bastante leña; es innumerable el pescado que se cría en esta pequeña ensenada, circunstancia de que carecen las del Tomé y Talcahuano, y los mariscos de varias especies que cubren las pie- dras de esta parte de la isla pasan por los más sanos y sabrosos del reino.

El puerto en Concepción ó Talcahuano, es una espaciosa bahía que se extiende más de tres leguas de Norte á Sur y dos y media Este-Oeste. La Isla Quiriquina, situada en su boca, forma dos canales ó entradas; una y otra pueden llamarse limpias, y tienen sus particulares ventajas según las diferentes circunstancias del navegante: hemos hablado de la del Este, más ancha, preferente con los vientos al Sur que obligan á bordear, y de que constantemente hacen uso las embarcaciones mercantes. La del Oeste tendrá poco más de una milla de ancho; sus dos costas son de piedra con muchas inmectiatas: conviene sólo entrar por ella con vientos del Sur al Sudoeste ó con Norte claros, posición en que se gana mucha distancia y barlovento: su fondo es de I2 á ocho brazas arena y en las orillas piedra y conchas.

Desde la punta de la Lobería, que con la del Nordeste de la Quiriquina forma el canal del Este de la bahía de Concepción, sigue la costa al Norte $2 \mathrm{I}^{\circ}$ Este dos y media millas, hasta la de la Herrería, una y otra, como la costa intermedia, son bastante altas en el interior, pero con descenso suave á la playa. De esta última punta, se inclina al Norte $42^{\circ}$ Este cerca de dos millas, hasta el morro de Nencoché, que hace la entrada Sur del puerto de Coliumo, y á alguna distancia aparece aislado, estando unido á la costa por una estrecha y baja lengua de arena: hay algunos pedruscos en este trozo de costa, aunque muy unidos á ella: el que está al Nordeste de aquel morro, dista de él cerca de dos cables.

Nö hay obstáculo alguno para entrar en el puerto, cuyo único amarradero abrigado al Norte es la pequeña ensenada que forma aquel morro á su parte del Sur; el referido es de siete á nueve brazas lama y puede contener de seis á ocho buques.

El resto del puerto, aunque grande, está descubierto y sin abrigo contra las gruesas mares del Norte, y á pesar del cerro, deben incomodar las embarcaciones en la misma ensenada, poco profunda para librarlos de ellas; como la lengua de arena es tan baja, están expuestos también á toda la fuerza del Noroeste, pero no á la mar.

La parte del Este desde la punta del Pingueral, es limpia, y su fondo, como el del resto del puerto; hay no obstante algunos pedruscos descubiertos, próximos á la costa, que también es de piedra, y en el fondo de él un placer de arena que sale del Estrecho Sueste, donde se extiende á un tercio de milla, y tomando la figura de la costa á que está unido, termina en las piedras de la punta de los ríos, cubriendo todo el fondo Sur del puerto.

La leña es abundante, y la aguada se hace en 
el río, que desemboca en la parte interior del puerto al Sur del fondeadero. La mayor distancia de este puerto á Concepción, su poco abrigo, y la escasez de víveres y carga respecto á los de Talcahuano y San Vicente, lo han hecho hasta ahora inútil, y sólo se toma en urgente necesidad; sin embargo, dos ó tres buques pueden estar en el bastante abrigados.

Al Norte de la punta del Pingueral empiezan las lomas de Malla, de más que media altura, con algunos cerritos superiores al resto: terminan aquéllas en el río de Itata: en esta porción hay unos escarpados al mar bastante notables, que forman dos puntas bajas y salientes: al Norte entra la ensenada del Zorro que cierra á esta parte la punta de Cumaya: hay un placer que sale media milla al Oeste.

La costa que entra al Norte está igual, y la punta en que acaba tiene otro placer de igual extensión y dirección que el anteceden:e; entre las dos está situada la pequeña Islita de Carranza á dos millas de la costa. Su dirección es NorteSur y bastante baja.

Desde el río de Itata hasta la punta de Natividad, corre la costa al Norte I $^{\circ} 30^{\prime}$ Este II millas, formando varias ensenadas poco profundas y notables; en esta porción, se ven las barrancas de Huachapure, y I7 millas al Norte la embocadura del río Maule, aplacerada y cubierta de piedras su punta Sur: sigue á ésta la punta de Natividad con algunos pedruscos: á media milla de aquí sigue la costa inclinándose algunos grados más al Este hasta el morro de Topocalma, á cuya parte del Norte $I^{\circ}$ Nordeste y á Io millas, están los bajos de Rapel: el Maipú desemboca á igual distancia de ellos al Nordeste; en el fondo opuesto Este de la ensenada al Norte, está el puerto de San Antonio, y sobre él los altos de su nombre. La costa corre al Norte $I 6^{\circ}$ Oeste tres millas hasta la punta de Auquen desde la Norte de aquel río; se ven en este espacio las playas de Cartagena, arenosas y dominadas por los altos de San Antonio, y pocas millas al Sur de aquella punta, la Piedra Blanca, bastante grande, unida á la costa, y de aquel color hay otras dos sobre la punta de Tunquen sin aquella particularidad, y algo más distantes de ella.

De esta punta sigue la costa al Norte $12^{\circ}$ Oeste hasta la de Curauma, de donde hace un frontón de más de cuatro millas al Norte $30^{\circ}$ Este con algunas puntillas: montado en este frente se descubre la ensenada de Lagunillas, bastante honda y de arena la mayor parte de su fondo; termina ésta en la punta de los Angeles, que forma la entrada del puerto de Valparaíso, dos millas al Norte $6^{\circ}$ Este de la quebrada de Bueyes, honda $y$ sin playa.

El puerto de Valparaíso, que propiamente no es otrá cosa que una rada, está situado en $33^{\circ} I^{\prime} 30^{\prime \prime}$ de latitud Sur y en $65^{\circ} 39^{\prime} 5_{5}^{\prime \prime}$ de longitud occidental. La mayor parte está descubierto al Norte y Noroeste y expuesto á toda la violencia de sus mares: á pesar de estas desventajas, su proximidad á la capital de Chile y á las más fértiles campiñas de este Reino, y por consiguiente, la facilidad de reunir en él á menor costo el trigo y demás frutos que producen, lo han hecho el más frecuentad o de las embarcaciones mercantes. Es limpio, y sólo hay que resguardarse de las piedras velantes inmediatas á la punta del castillo Viejo de San Antonio. Sobre la costa del Oeste, y á la que llaman Laja, próxima tambíen á esta punta y á su parte del Nordeste á ménos de dos cables de la costa del través, puede pasarse á un cable de unas y otras sin el menor riesgo, y conviene ejecutarlo así, para no perder. barlovento y fondear lo más cerca que se pueda del fondo Sudoeste del puerto, suponiendo que la entrada se haga con vientos del Sueste al Sudoeste, como es probable suceda, especialmente en verano. De otro modo, es preciso bordear perdiendo tiempo, y algunas veces sin fruto, por la demasiada fuerza del viento que suele no permitir las gavias á medio mastelero.

Como estas brisas ceden en las primeras horas de la noche y terminan antes de la mañana dejando algunas horas de calma, parece lo más prudente en este caso arriar el ancla donde confiere la bordada, y esperar este momento para ganar á la espía ó remolque el buen fondeadero.

Es, no obstante, preciso atender al fondo de esta parte del puerto, y por un deseo de abrigarse al Norte y Sur, no meterse demasiado en la ensenadita, que abunda en ratones y hace perder las amarras; por esta razón, el mejor paraje es á un cable de la costa del Sur, demorando la punta del castillo de San Antonio al Norte $I 7^{\circ}$ Este.

El ayuste debe estar á esta parte tendido por largo, y el ancla del sencillo al Sur á dos ó tres brazas de la playa donde puede engalparse un anclote hecho firme á las estacas; así, quedará el ancla del Norte en 20 ó 24 brazas lama y el cuerpo del buque en seis ó siete arena.

El fondo del puerto es bastante desigual como su calidad. A un cable de la costa del Oeste desde la punta de los Angeles, se encuentran de I2 á ocho brazas fondo, cascajos y arena; pero atravesando á la parte del Este aumenta repentinamente casi hasta 20 y 25 arena y lama.

En caso de voltejear, pueden prolongarse los bordos hasta cable y medio de tierra en el del Oeste, ó tomar cinco brazas en el del Este. La leña es de mala calidad, hay poca, y por consiguiente es bastante cara.

La aguada puede hacerse ó en el arroyuelo que desemboca en la playa arenosa del Almendral ó en la fuente de la plazuela del Castillo Nuevo; si por medio de mangueras se consigue 
llevar á las lanchas la de éste, la operación será más pronta y cómoda que en la otra, donde la marejada del Norte, Noroeste y Oeste suele maltratar aquellas embarcaciones.

Los vientos del Sur son constantes en este puerto, de Octubre á Abril, suelen empezar á las once del dia, manteniéndose bonancibles hasta las cuatro de la tarde que refrescan de fugadas, su fuerza dura de cuatro á seis horas y cesan por el mismo orden que han empezado. El resto del año reinan los del Norte al Oeste; pero según los prácticos, no tienen en este puerto la fuerza y duración que en los anteriores. Parece probable que así suceda, pues de otro modo, las embarcaciones mercantes del comercio del Perú que lo frecuentan en todas estaciones, generalmente mal provistas de anclas y cables, perecerían sin remedio.

Saliendo de Valparaíso, puede seguirse á regular distancia la costa del Norte, y se verán dos ensenadas pequeñas que separa la punta de Reñaca; sus playas son de arena, pero desabrigadas; montada la punta de Concon, que sale al Norte pocos grados Este de ellas, se encuentra la ensenada de su nombre, tan desabrigada como aquéllas; termina ésta en la punta de la capilla, que forma al Norte una grande ensenada, donde desemboca el río Quillota. La playa desde él hacia el Norte es de arena con montañas bastante altas á su espalda; en el extremo están el islote y bajos de Quintero, que salen cerca de una milla al Norte $53^{\circ}$ Oeste de la costa más próxima; casi Norte-Sur con los de fuera y á distancia de uno $y$ un tercio millas hay una punta poco saliente y baja á que sigue la tierra haciendo una corta inflexión al Nordeste á encontrar la punta Sur que forma la entrada del pequeño y poco seguro puerto de Quintero, baja y de piedra.

A distancia de dos leguas de este puerto, demorando al Norte $53^{\circ}$ Este, se encuentran 92 brazas de agua, fondo arena gruesa. La ensenada de la Sigua que sigue al Norte de la punta Sur de este nombre, se interna inmediatamente con playa de arena, y se une á la del Norte ménos honda, formando costa pendiente. Las tierras de la ensenada y las de su punta Norte son bajas hacia el mar y algo ménos en el interior. La costa que continua después al Norte $30^{\circ}$ Oeste Ig millas y va á encontrar la punta del Gobernador ó Pichidanque situada en $32^{\circ} 2^{\prime}$ de latitud, y en el mismo de la punta de los Angeles de que dista $5^{8}$ millas, es de mediana altura, y poco al Sur en el interior se eleva un monte alto y aplanado, á que llaman la Silla del Gobernador. El puerto del Gobernador á la parte Sur de la punta de su nombre ó de Pichidanque es bastante grande y mucho más seguro que los del Papudo y Quintero. Un islote que tiene á su boca, cable y medio al Nordeste de aquella punta, resguarda una gran parte del viento y mares del
Norte; puede fondearse con entera seguridad respecto á éste, dando un cable á las piedras de su parte Sur. Sólo tiene en sus inmediaciones el curato de Quilimay que dista de él una legua: aunque el temperamento es benigno, la falta de agua tiene sus campiñas, á muchas leguas de él, áridas y enteramente despobladas; por esta ra. zón, sus contornos carecen de toda especie de producciones y consiguientemente está abandonado de las embarcaciones mercantes. La leña es escasa, mucho más el agua, y el puerto carece enteramente de pescado.

La costa sigue al Norte de él formando tres ensenadas que terminan las puntas del Salto del Negro, Matagorda y la de Ballena, á cuya parte del Norte entra la de su nombre cerca de su punta, y en el fondo se ve arena y otra pequeña ensenada donde está el pequeño pueblo de Conchali con aguada en el río de su nombre. que desemboca al Norte y cerca del pueblo. Frente de él se ven cuatro farallones ó islotes, los dos mayores y más próximos á la costa con algunos pedruscos á sus piés: distan de ella un tercio de milla y corren entre sí Noroeste Sueste con corta diferencia á los restantes; el más Oeste y Norte sale dos y un tercio millas á la costa del Este, y el cuarto más Este y Sur dista de aquel algo más de dos millas al Sueste y cerca de una, de la punta de la costa más próxima.

Al Norte del pueblo se ve un mégano de arena grande y muy notable; cerca de él hay otros pequeños que también se distinguen fácil mente: el terreno de la ensenada hacia el interior, es montuoso, descamado, pero desigual y con muchas quebradas profundas. La punta Norte de Conchali tiene algunos pedruscos próximos, y una milla á su parte del Norte un islote de regular altura y magnitud; la costa desde aquella punta, alta y cortada al mar; sigue la costa al Nornordeste formando otra ensenada que se interna poco; la punta en que termina es escarpada, de color rojo, más baja que aquélla. Ilasta el río de Chuapa sigue la costa escarpada; baja, y de piedra, desde la punta Sur á Este; de mediana altura, roja, y con arena al pié hasta la de Chuapa; es también baja la costa que forma la ensenada que corre al Noroeste $1 / 4$ Oeste cerca de dos millas. La punta Norte del río es baja de piedra, escarpada, y próxima á ella hay una piedra blanca bastante notable, sobre la misma playa: el interior es montuoso; pero con muchas llanuras altas.

De la punta de Chuapa sigue la costa al Norte pocos grados Oeste formando varias ensenaditas y puntas pequeñas: se ven sobre ella las sierras llamadas Amolanas, altas, desiguales y muy próximas á la playa; á su extremo Norte y cerca de la punta que cierra la ensenada, se ve un pequeño arenal con punta saliente; doblando 
esta punta, que también es de piedra, sigue la costa al Norte pocos grados Este, de tierras bajas con serranía á la espalda y una punta saliente escarpada.

Al extremo casi de la ensenada, se ven otros escarpados más altos que el anterior, y poco después los altos de Talinay que se extienden hasta la quebrada de Limari, río considerable, que toma este nombre del valle que riega, y cuyo desagüe es en esta parte: la dirección de la costa es al Norte pocos grados Oeste, y su terreno después de los escarpados es bajo en la orilla, é inclinadas hacia ella las sierras interiores.

La quebrada de Limari se forma de dos puntas regularmente altas y cortadas, al pié de una sierra elevada muy notable por dos picos que se ven en sus extremos: el terreno es escarpado hacia la parte del Sur, con algunas ensenadillas, y á bastante distancia de la playa se ven varias cadenas de montes elevados.

Desde la punta Norte de Limari sigue la costa igual á la anterior casi Norte-Sur 26 millas hasta la punta de Lengua de Vaca, saliente, baja y con algunos pedruscos; termina sobre ella una cordillera de montes altos y parejos que tienen su principio poco al Norte de aquella quebrada; cerca de esta punta y al Sur, hay unos peñascos bastante notables y casi pegados á la playa. Al Norte de la punta de la Lengua de Vaca, se inclina la costa al Nordeste tres millas, con una pequeña ensenada, y después al Este y Norte formando las grandes de Tongoy y Guaraquero, que divide el frontón y cerro de este nombre de mediana altura y muy ancho; una y otra son de piedra con algunos trozos de arena, y están enteramente descubiertas, aunque á la primera llaman bahía y á la segunda puerto: del fondo de ésta se inclina la costa al Norte algunos grados Oeste hasta la punta de Lobos, baja, de piedra, con algunos pedruscos á su pié y á la parte del Sur cuatro manchas blancas, las tres muy notables.

De esta punta á la Sur del puerto de Coquimbo corre la costa al Norte $42^{\circ}$ Este cinco y media millas: en el intermedio hay varias puntillas, bajas, salientes, de piedra y muchos pedruscos á poca distancia. Casi equidistante de las dos está la Caldera, ó puerto de la Herradura, pequeño y bastante abrigado; su entrada, de un cuarto de milla de ancho, no tiene riesgo alguno cubierto; se encuentran 36 brazas de agua sobre fondo cascajo, entre las dos puntas que la forman. Dentro del puerto hay I 4, I6 y I8, á dos cables de la playa de cinco á siete; en la parte del Oeste y Suoeste es frecuente el fondo piedra, en todo el resto cascajo, la costa de arena es aplacerada, la del Norte y Nordeste estí cercada de piedras desde la boca, y aunque á poca distancia, sale una restinga de lá úlima punta interior donde empieza la arena. La leña es escasa y de mala calidad; lo mismo sucede con el agua, que se hace con trabajo en un pozo ó laguna junto á los ranchos de pescadores que están en la parte Sur del puerto entre ellos y los islotes conocidos con el nombre de Ballenas. La distancia de este puerto á la Serena, es igual á la que hay desde el de Coquimbo, y tan cómodo el transporte de efectos por tierra. La costa entre estos dos puertos, es un frontón de piedra, con puntillas de lo mismo, muy desiguales, rodeadas de pedruscos, y una pequeña ensenada al principio; casi al Norte del extremo de esta parte de ella, están los islotes 1lamados Pájaros Niños, de piedra, bajos, escarpados y cercados de piedras pequeñas; el más Norte y mayor, tiene en el extremo Sur una restinga que sale cerca de la mitad de la distancia de uno á otro, y termina en una piedra casi anegada; su freu, por consiguiente, es sólo de dos décimos de milla, y se encuentran en él de I 4 á 23 brazas de agua, fondo piedra: su excesiva angostura hace muy arriesgado el paso de este canal; no sucede lo mismo con el que forman el del Sur y la costa, donde el único obstáculo son las piedras que rodean uno y otro, y que siempre velan; su fondo es igual al del anterior, pero de cascajo y conchuela. Al Oeste de el de tierra hay varios islotes, pero limpios.

El Pájaro Niño, mayor, está más de una milla al Norte $55^{\circ}$ Oeste de la Piedra Pelícano, sobre la punta de Tortuga, y el del Sur nueve décimos de milla al Norte $76^{\circ}$ Oeste: hay siempre mucha mar en este paraje, por tanto, sólo debe emprenderse el paso del segundo freu con viento fresco del Sur al Sudoeste.

Montados los islotes puede seguirse la costa á un cable ó cable y medio, por ocho, nueve y Io brazas piedra y cascajo hasta la Piedra del Pelícano, cable y medio al Nordeste de la punta de la Tortuga; la costa sigue después al Sur con piedras á la orilla, puede prolongarse á dos cables por diez, ocho, siete y seis brazas de agua, cascajo y conchuela, hasta ponerse Este-Oeste con dos cerritos bajos é iguales llamados los Hermanos, que están inmediatos á la playa en la parte del Sueste de la valiza.

Si en esta posición se está á dos cables de la tierra del Oeste, se dará fondo amarrándose Nordeste Sudoeste, y dando el cable de esta parte, á una piedra redonda que está á pocas brazas de la playa, y llaman por su figura la 'Tortuga. Así quedará casi al Oeste un pequeño almacén que hay en la playa, y se enfilará el extremo Este de un cerrito de piedras que está sobre la misma con el del Oeste de Bascuñano al Sur del fondeadero y del principio de la playá de arena.

En Coquimbo hay poca leña y muy delgada y de mala calidad: el agua es también mala y se hace con mucha dificultad. 


\section{Construcción de las cartas desde Coquimbo hasta Lima, inclusas las Islas de San Félix.}

Ya se ha manifestado con cuántas observaciones uniformes entre sí y de la mayor confian$z$ a, podíamos determinar la posición del observatorio nuestro de Coquimbo, en longitud occidental de Cádiz, de $65^{\circ}$ I $^{\prime}$ I $5^{\prime \prime}$. En este supuesto, nos pareció adoptarle por primer meridiano en lo venidero; $y$ hecho un prolijo examen de la marcha de los relojes marinos, siguió en la ATREvida como reloj magistral el número Io; en la Descubierta se sustituý de nuevo al cronómetro 6r, el número 72, que conservaba el mismo movimiento que se determinó en Valparaíso, ratificándole los horarios observados en meridianos del Pájaro Niño, cuya posición estaba determinada geométricamente á la longitud del observatorio.

Nuestras marcaciones exteriores referidas el día de la saljda al cerro de Guanaquero, ratifican su posición; $y$ las bases corridas hasta la Isla de Choros, ligando con las enfilaciones y marcaciones hechas desde el puerto á la punta de Theatinos y á la isla mayor de Pájaros, no nos dejan duda que la costa hasta los Choros, no admite la menor equivocación.

Las corrientes y la calima de la siguiente mañana, nos hacen perder de vista un pequeño trozo de costa comprendido entrc la punta de la Barranca y la punta de Choros; le hemos deducido de los derroteros, sujetándole á nuestros extremos de las puntas indicadas, en cuyas posiciones no teníamos la menor duda.

Unas observaciones exactas de latitud y longitud sobre nuestras bases de corredera, al mismo tiempo determinan con mucha scguridad la bahía del Huasco, y continuan la costa, hasta que la noche, las corrientes y la cerrazón de la siguiente mañana, nos obligan á valernos de los derroteros para otro pequeño trozo, en el cual añadimos á la diferencia en latitud indicada por nuestras estimas, otros $9^{\prime}$, según lo exigen las observaciones de uno y otro día.

Sobre el morro de Copiapó, adonde se desunen las dos Corbetas, la longitud de los relojes de uno y otro buque sólo discrepan en un minuto y medio, cuya diferencia, aunque pequeña, se atiende en la reducción de las tareas anteriores, á las que después sigue la Atrevida. Los planos de los diferentes puertos de Copiapó, son obra del Ingeniero D. Pedro Rico, de cuya exactitud no podemos desconfiar, después de haber tenido la bondad de desmenuzarnos los medios de que se ha valido para este trabajo. Los confirma, por otra parte, Mr. Frezier con una grande uniformidad de resultados.

Esta corbeta sigue después con bien concertadas bases, sin corrientes que la trastornen, y sin carecer ni un día de la latitud y longitud, observadas, hasta la bahía de Arica: reconoce al mismo tiempo las radas del Chineral, Juncal, Nuestra Señora, Cobija, Algodonales é Iquique, y las diferentes vistas de sus inmediaciones coadyuvan á asegurar más y más la navegación práctica. La rada de Arica está levantada geométricamente con el teodolito: la latitud ob. servada con los sextantes en muy buen horizonte, y por tres días consecutivos: la longitud, deducida del reloj número ro sobre muchas series de horarios uniformes, y con una marcha ratificada sobre alturas absolutas: las distancias lunares discrepan en esta ocasión $\mathrm{r}^{\prime}{ }^{\prime}$ al Este de los relojes marinos: se aparta en $46 \mathrm{y}^{1}{ }_{2}{ }^{\prime}$ en el mismo sentido, la longitud del Padre Feuille, deducida de la emersión de un primer satélite, comparada con los Sres, Maraldi y Cassini, en París.

Siguen luégo las bases uniformemente, con la misma felicidad de no tener corrientes, $y$ de no carecer dc observaciones de la mayor confianza, por Ilo, Aranta, Chilca, Morro de Acarí, Ica, la Nasca, Morro Quemado, hasta la Isla de San Gallán.

En todas las radas y puntos notables que comprende este trozo considerable de costa, se han consultado los mejores derroteros y los viajes del Padre Feuille y Mr. Frczier, y se han oído los mejores prácticos, para no trastornar los nombres envejecidos de esta navegación costanera.

En el mismo tiempo, la Descubierta sitúa por medio de dos series de horarios y con latitudes observadas en el sextante, la Isla de San Ambrosio: las contiguas de San Félix, dependen principalmente de enfilaciones entre sí y con la Isla de San Ambrosio. Las excesivas corrientes, la desigualdad suma del viento y la misma disposición muestra, no permiten aprovechar cuanto deseáramos las muchas bases corridas en est’. ocasión. La longitud determinada por los relojes, 
referida á las observaciones de Coquimbo y á -las de Lima, da unas diferencias parciales, cuyo total no difiere de la diferencia directa de observatorios sino en $45^{\prime \prime}$ en el mismo sentido de la diferencia que se encuentra en San Gallán con los relojes de la ATREvida: se le ha aplicado, por consiguiente, esta pequeña corrección, además de los $4^{\prime}$ I $3^{\prime \prime}$ que jnferimos estar más occidental la longitud deducida de la verdadera, según la alteración de movimiento. El único fondeadero que se señala, es el que ha reconocido D. Antonio Cazulo en el navío San Pablo, y conviene esta noticia con la de otro práctico que nos la ha comunicado personalmente.

Como quiera que al llegar á Lima, examinada nuevamente la marcha y observada en nuestro observatorio de la Magdalena la emersión del primer satélite de Júpiter con la mayor confian$z a$, debemos inferir que ambos cronómetros de la DEscubierta han acelerado algún tanto, conservándose, por otra parte, casi uniformes entre sí, suponemos una corrección, en progresión aritmética retrógrada, que destruya aquel error; y hallando de este modo la longitud de la Isla de San Gallán por la diferencia de meridianos con el fondeadero del Callao, ya situado por nuestras observaciones, difiere la nuestra de la que determina la ATREvida en $\mathrm{I}^{\prime} 56^{\prime \prime}$ al Oeste.

Este error casi insensible, sirve á afianzar la longitud de los relojes de la ATREvida, en Arica, los cuales, por otra parte, llegan á Lima con un error de muy poca cantidad, que no obstante se ha tenido presente en las correcciones diarias, hasta desvanecerlo.

Las bases de la Descubierta al regreso de las Islas de San Félix, empiezan por los $16^{\circ} \mathrm{y}^{1} /{ }_{2}$; pero trastornándolas considerablemente las corrientes, no se adoptan para detallar la costa; sólo sí sus latitudes y longitudes sirven para ratificar las de la ATREVIDA con la diferencia indicada de longitud, la cual, no obstante, se resuelve al ligar desde la Magdalena, con operaciones trigonométricas, la posición astronómica del puerto con la de la Isla de San Gallán, ó más bien con la de las Islas de Chincha, en las cuales terminan nuestras tareas marítimas, no siendo admisibles las que desde la Isla. de Ascia conducen á la punta de Quilca.

Sin embargo, como la Descubierta observe latitud y longitud sobre la Isla de Ascia y áun á la vista de la misma punta, nos valemos de estas observaciones para conducir la costa al Norte hasta que ligue con las tareas trigonométricas, que de este modo no es preciso conducir en tiempos cerrados, como lo son los de esta estación hasta la misma Isla de San Gallán.

Toda la costa, desde la Nasca hasta la Isla de San Grallán, cstá combinada y acorde con las tareas muy repetidas del Piloto Moraleda.
La posición astronómica de la catedral de Lima pende de los triángulos emprendidos sobre una base medida en las inmediaciones de la Magdalena: estos mismos triángulos se conducen hasta el castillo del Callao, desde donde una nueva base ratifica los resultados anteriores, y destruye cualesquiera efectos, aunque pequeños, de la multiplicación de los triángulos, de cuya exactitud, por otra parte, nos aseguraban los teodolitos.

La latitud nuestra del observatorio de la Magdalena está deducida de muchas alturas meridianas de estrellas al Norte y al Sur; se ha atendido á elegir entre éstas las que tuviesen una declinación más bien determinada. La longitud pende, como ya se indicó, de la observación hecha el día 6 de Junio en el primer satélite de Júpiter, por los Sres. Galiano, Vernaci y Valdés: puede habers̉e repetido en Europa, lo que añadirá un nuevo grado de confianza á sus resultados (I), mientras nos lisonjea mucho su grande aproximación á las ilaciones de los Excmos. Juan y Ulloa, que no conformaban con la longitud asignada por el Padre Feuille sobre las observaciones del médico Dulán, su discípulo (2).

Se ha intentado por dos veces observar distancias de la Luna al Sol y á las estrellas, pero los resultados se han apartado mucho de las otras deducciones, siéndonos, por otra parte, imposible el ratificarlas con una repetición de series que las diesen la confianza y estabilidad necesarias.

A este resumen añadiremos, que el cielo bien conocido de esta región, nos ha imposibilitado cuantas observaciones debian proporcionársenos en el dilatado tiempo que permanecimos en la Magdalena para la recopilación de todos los trabajos hechos: aún no desconfiamos poderlas renovar en el Callao, al tiempo de emprender nuevo arreglo de relojes marinos.

(I) Las observaciones de D. Jorge Juan y D. An tonio Ulloa, son seis hechas en el primer satélite de Júpiter, y determinan la longitud de Lima de $79^{\circ} 24^{\prime}$. La del Sr. D. Alejandro Durán resultaba sólo de $79^{\circ} 9^{\prime} 30^{\prime \prime}$. El Doctor Peralta la deduce de dos eclipses de Luna observados en I 7 I 7 y I 725 . Referidas las tres á la catedral, según los parajes en donde observaron, y nos ha referido el Sr. D. Cosme Bueno, resulta:

Por los Excmos. Juan y Ulloa....... $79^{\circ} 23^{\prime} 50^{\prime \prime}$ Don Perlro Peralta............. 79.20.00 Nuestros resultados.............. 79.25.30

(2) La legna de América se compone de 36 cuadras, cada una de 150 varas castellanas: resulta, por consiguiente, el total de $5 \cdot 400$. La legua marina es de 6.650 varas. En la Concepción nueva, como se determinase dar á las calles 16 varas, en atención á los temblores, en lugar de las diez que se consideran en la división común de la América, resulta que la cuadra habitada ó manzana ticne 134 varas en lugar de las 140 que se consideran â las demás: se han tenido presentes estas medidas para referir estas observaciones á un mismo punto. 


\section{DERROTEROS desde el puerto del Callao hasta el río de Guayaquil, y de este punto hasta el Golfo de Panamá, por D. Fabio Ali Ponzoni.}

Islas Hormigas.-En la navegación al Callao se presentan muchas veces á la vista del navegante las Hormigas, dos pequeños islotes que corren la dirección de Norte $30^{\circ}$ Oeste, separados entre sí dos tercios de milla: una distancia algo menor de ésta forma su canal de 7,8 y II brazas piedra. El del Sur, situado en I I, 56, 20 de latitud Sur y $45^{\prime} 50^{\prime \prime}$ occidental del Callao-al Oeste $9^{\circ}$ Norte del extremo Noroeste de la Isla de San Lorenzo á distancia de 40 millas es el mayor y algo bajo, formando tres mogotes, de los cuales el del Sueste se presenta más alto, y á su pié otro chico, cuya quebrada hasta el agua, es de suerte que parece aislado. De la parte del Sur le sale un bajo á distancia de un cable igualmente que por su parte del Sudoeste y Noroeste á la misma distancia, y por fuera de ellos se encuentran bien pronto 20 á 30 brazas cascajo. Una restinga que le sale del Noroeste al Oesnoroeste, se extiende dos terciós de milla.

El otro islote es un peñote amogotado con un farallón chico pegado á la parte del Oeste: al Sudoeste del islote, á un cable, hay dos bajos casi unidos con otro oculto á otra tanta distancia, en la misma dirección. Muy inmediato alrededor de este islote y por fuera de los bajos, se encuentra fondo de II y I 2 brazas piedras gruesas, y seguidamente I4, I5 y I6 brazas cascajo: separándose luégo un poco, aumenta el agua á 25, 30 y 35 brazas cascajo.

Los Pescadores.-A1 Norte 3 Oeste del extremo Noroeste de la Isla de San Lorenzo, y al Norte 75 Este de las Hormigas, distante de aquél I $7 \mathrm{y}^{1} / 2$ millas y de éstas $4 \mathrm{I}$ escasas, se encuentra la Isla del Pescador Grande, así llamada á dos islotillos muy unidos y situados en I I $^{\circ} 45^{\prime} 42^{\prime \prime}$ de latitud Sur y $7 \mathrm{I}^{\circ} 04^{\prime} 22^{\prime \prime}$ occidental de Cádiz. Con el nombre de Pescadores se distinguen á éstos y á una porción de farallones inmediatos, de los cuales los más distantes se apartan sólo cuatro millas de la tierra firme.

Puerto de Ancon.-Este-Oeste con el Pescador Grande á una distancia de poco más de una legua, se halla un frontón alto, que con el resto de la costa al Norte forma el puerto de Ancón ó Antón de Rada. Diferentes playas de arena rodean toda la ensenada con tierras altas en lo interior, y su dirección abriga de los vientos Sures. Desde la punta Quiebrabarcos hasta la de Mulatas, extremos Norte y Oeste de la ensenada, un buen fondo de 13 brazas va insensiblemente disminuyendo, hasta hallar tres y media brazas siempre arena á tres cables del pueblo de Pescadores situado al Sur y en la playa más interna de la misma ensenada. La entrada por el Norte de los Pescadores es enteramente limpia por fondo de 30 hasta 20 brazas arena, y la que comunmente se verifica para evitar la inmediación de todos los farallones por los fuertes hilos de costa que forman los diferentes canales: de éstos, el paso más seguro es entre el Pescador Grande y los otros. Ancón, aunque es un fondeadero exce. lente para muchas embarcaciones, le falta agua dulce, por cuya razón todas sus inmediaciones son de tierras estériles, y sólo pozas suministran agua salobre: hay buena á dos leguas por el camino de Lima en un paraje que llaman Copacavana. Los indios del pueblo de Pescadores, se entretienen en la pesca sobre toda la costa é islas inmediatas, y son casi los únicos que se avanzan hasta las Hormigas. Las mujeres la llevan luégo en la noche á Lima, por el camino de tierra, para venderla.

Punta Mulatas hasta el río Rimac.-El frontón ya nombrado, y terminado por la punta Tortuga al Sur y por la de Mulatas al Norte en dirección de Norte $9^{\circ} \mathrm{y}^{1} / 2$ Este, es muy hondable, y casi á pique se halla fondo de 23 y 24 brazas. Al Sur el río de Carabaillo y el de Rimac hacen aplacerada una gran parte de la costa inmediata, y por consiguiente no muy seguro el acercarse mucho á ella.

Las embarcaciones que vienen del Sur para el puerto del Callao y se sotaventean, dan fondo á un anclote á la vista de este pedazo de costa, para luégo sobre espías, ganar el fondeadero, en las muchas horas de calmä que reina. La mala construcción de los buques mercantes que navegan en estos mares, su mucha carga yá veces excesiva, sus maniobras complicadas y groseras, y la poca gente que llevan, hace sin duda preferente el partido que toman, aunque cueste el sacrificio de muchos días, al de aprovechar sobre bordos, los vientos que soplan siempre bonancibles.

De la punta Quiebrabarcos hasta la de Pisama. yo.--Desde la punta de Quiebrabarcos sigue la costa al Norte, al principio montuosa, hasta la punta de Tamacaya conncida por los cerros de arena que tiene en lo interior. Prolóngase luégn 
hacia el Noroeste, escarpada, para formar la punta Pasamayo, con cuyo nombre se distingue también un río que desemboca á una milla y tercio de esta última punta.

Hasta la punta de Huara.-En la dirección de Norte $47^{\circ}$ Oeste de la punta de Pasamayo se halla la de Huara á distancia de 29 millas, colocada en I $r$, I 8,55 de latitud y en $26^{\prime}$ I $8^{\prime \prime}$ de longitud. En este trechode costa se encuentra primero la punta de Chancay, que da el nombre á un río que se halla á la parte del Sur y forma al Norte de ella un pequeño puerto de una y media millas, de fondo abrigado, de tierras altas, particularmente en la dirección de los vientos del segundo cuadrante. Este fondeadero es cerca de un morro que demora al Sur, no muy adentro, sino en cuanto pueda abrigarse del viento, en siete y ocho brazas de agua.

Siguen al Norte las playas de Lacluay y del Tambo de las Perdices, que las dividen unos pedazos de costa montuosa.

Farallones de Huara.-Al Sudoeste próximamente de la punta de Huara corren varios islotes: Tombillo es el más chico y tiene una piedra junto á él: siguen hacia fuera los Diablillos, que son tres; los Chuntales, otros tres más altos con algunas piedras alrededor; y Mazorque, el mayor y más elevado, con un islotillo inmediato bastante alto. Otro chico y alto llamado el Pelado, en $\operatorname{II}^{\circ} 27^{\prime} 20^{\prime \prime}$ de latitud y $3^{8^{\prime}} 20^{\prime \prime}$ de longitud, es el más saliente á la mar y demora de la misma punta al Sur $55^{\circ}$ Oeste á I $_{4} \mathrm{y}^{1} / 2$ millas. Todos ellos, llamados los farallones de Huara, forman canales muy hondables, en donde puede fondearse sobrecogido de algunas calmas, y en el más ancho, que es de dos leguas entre los dos más distantes de tierra, se halla 70 brazas de agua. Se incluye también con ese nombre, un islotillo inmediato á la punta Huara y á milla y media al Sur de ésta. Las 'Tortugas, otros dos islotes muy unidos y cercanos de una punta.

Punta y puerto de Salinas.-Al Norte exactamente de la punta de Huara, siguiendo un trecho de costa de tres y media millas que forma una pequeña ensenada, se halla la punta de Salinas, baja y de piedra. Le da su nombre un cerro inmediato y un puerto pequeño que tiene al Norte.

Isla d: Don Martín.-Avanzando para el Norte se encuentra la Isla de Don Martín, situada en $\mathrm{II}^{\circ} 03^{\prime} \mathrm{o} 7^{\prime \prime}$ de latitud y $27^{\prime} 2 \mathrm{O}^{\prime \prime}$ de longitud, distante de la costa poco más de una milla. Es casi redonda, de una circunferencia de media legrua próximamente, tajado el extremo Norte, bajo el del Sur, y ambos con una pequeña res. tingra: se presenta su cima llana y blanca, por el zuano que la cubre enteramente.

Dos polúuciones en la costa.-En su paralelo próximo á la orilla de la costa firme, que es abarancidá, se ve una población, cuya iglesia es bastante visible desde la mar: la de Huara se distingue en lo interior á legua y media EsteOeste con el morro de Huacho.

Puerto de Huacho.-Forma éste un pequeño abrigo á la parte del Norte, al cual le han dado el nombre de puerto: sólo se presenta la utilidad de enviar allí una lancha, manteniéndose el buque á la vela, para hacer provisiones de víveres, que hay en abundancia: en sus playas se hace sentir con fuerza la resaca. El morro da el nombre á un islote que dista de él media milla; un fondo de 20 brazas arena fina se encuentra á dos millas mar en fuera.

De este punto se extiende la costa al Norte y Sur, en gran parte abarrancada y de muy poca elevación: siguen luégo en lo interior, lomas de arena algo notables, y últimamente, la corclillera muy elevada y bastante próxima.

Pico de Huara.--Entre aquéllas se hace bien visible por su elevación y por su figura de pan de azúcar, el pico de Huara, situado en II $^{\circ} 05^{\prime}$ y $30^{\prime \prime}$ de latitud y $\mathrm{I} 8^{\prime} 5 \mathrm{o}^{\prime \prime}$ de longitud á siete millas de la costa, muy parecido al de San Cristóbal de Lima; su declive por la parte del Sur se ve en gran parte libre de las colinas inmediatas, y por la opuesta, otras colinas más elevadas y que se extienden con igual altura, lo ocultan desde la mitad.

Al Norte se distingue una punta por un islo. tillo negro inmediato á ella llamado el Martinico, y luégo la de Supe, formada de piedra con una restinga de cerca una milla hacia la Isla de Don Martín.

Desde la punta Supe hasta las ruinas de Panamanga.--Seguidamente forma la costa dos ensenadas poco profundas, divididas por la punta Mamasmayo, á cuyo través hay 37 brazas lama, á cuatro millas: en la más septentrional de ellas, por unas quebradas que se ven desde la mar, desemboca el río de la Barranca, que es caudaloso y con una población de su nombre y el de la Fortaleza. Entre éstos, en un valle cultivado, se deja ver la población de Patavilca. La punta Norte de esta ensenada, que la forma un cerrito puntiagudo, negro y escarpado en la orilla, se hace bien visible por las ruinas de Panamanga que tiene al Este. Dista esta punta $I_{4} \mathrm{y}^{\mathrm{K}} / 2$ millas al Sur $\mathrm{I}^{\circ}$ Este de la Isla de Don Martín.

Hasta la punta Hurtados.-De la misma punta para el Norte 38 Este, distante 27 millas, se halla la de Hurtados con un islote inmediato hacia el Sueste: en este intermedio no of rece la costa sino pequeñas sinuosidades, cuyas puntas principales son las de Vera, Santander y de Filita.

Hasta la pinta de Francos. - La punta de Hurtados, con la de Francos, corre en la direcci jn de Norte $3 I^{\circ}$ Oeste ocho leguas, y entre varias ensenadas poco profundas que hay en este trecho, es la más notable la que está al Norte de Sora- 
1uz. Varios islotes hay en estas inmediaciones cerca de algunas puntas, entre los cuales, un grupo de ellos llamados de Fierros. Lo interior de la costa no es muy elevado, y lo forma diferentes lomas de arena respaldadas por la cordillera.

Hasta el morro de Casma.-A 28 millas al Norte 20 Oeste de la punta de Francos se halla el morro de Casma, situado en $9^{\circ} 40^{\prime} 45^{\prime \prime}$ de latitud, y r.Io.35 de longitud occidental, el cual da el nombre á un río que tiene al Sur. En lo interior se hace visible un cerro en $9^{\circ} 30^{\prime}$ de latitud, y I.48. 40 de longitud al Norte 64 Este del morro, á ocho leguas de distancia. En el trecho de costa comprendido entre las dos puntas ya nombradas, sólo merece la atención el pequeño puerto de Guarm ey, impio y hondable, formado por una punta llana en su cima, cuyo recodo es de tierra amogotada, y en lo más interior se ven manchas de arena. El fondeadero es en ocho brazas de agua á barlovento del islote de Guarmey, del cual no deben propasarse las embarcaciones para tierra, demorando al Nordeste 1/4 Este. Un pequeño pueblo de indios que está inmediato al puerto y lleva su nombre, provee de maiz, leña, carne y de muy buena agua de un riachuelo que desemboca en el mismo paraje del desembarcadero.

Bocas y puerto de Ferrol.-A media legua del morro de Casma hay fondo de 45 y 50 brazas piedra. De éste corre la costa en una dirección casi seguida de Norte $28^{\circ}$ Oeste hasta la punta Sur del puerto de Ferrol, en una distancia de $3^{6} 1 / 2$ millas. Esta última punta se hace remarcable por cuatro islotes que tiene en su inmediación, de los cuales tres están muy juntos y corren como al Noroeste la distancia de poco más de una milla, y el otro, que es el más chico, se aparta algo más al Norte, exactamente del más inmediato. Se presentan cubiertos de guano, de una altura regular y más bajo éste último. $\mathrm{Cu}-$ bren la mitad de la boca de la ensenada inmediata, y forman con ella el puerto de Ferrol, que es abrigado, de buen fondo, $y$ en donde pueden carenarse embarcaciones. La entrada es por medio de las islas, cuyos canales hondables se llaman las bocas de Ferrol, y con este nombre se distinguen las mismas islas.

Esta ensenada es de terreno muy arenoso, más bajo queresto: el termina la costa á ambos lados de ella, de una altura regular, de color negro, con algunos manchones de arena.

Isla de Guambacho.-La Isla de Guambacho, situada en $9^{\circ} \mathrm{I}^{\prime} 3 \mathrm{O}^{\prime \prime}$ y en $\mathrm{I}^{\circ} 24^{\prime} 5 \mathrm{O}^{\prime \prime}$ de longitud occidental, se hace visible al Sur: es de bastante altura, y el extremo Sur termina en un-monte algo menor, en figura de cono, con un declive igual á ambos lados: se extiende poco más de media milla, es casi redonda, y se halla frente y cerca de una pequeña ensenada con río. En su paralelo á cuatro leguas de distancia, se encuentran 50 brazas arena lamosa.

Hasta el morro ć Isla de Santa.-La punta Norte del puerto de Ferrol, y la que forma el morro de Santa, corren al Norte $9^{\circ}$ Oeste siete millas, y casi en la misma dirección su costa. En este trecho se hace visible: primero, un abra que llaman de Silva, en cuya boca hay cuatro islotes, y seguidamente la Isla de Santa situada su medianía en $9^{\circ} \mathrm{OI}^{\prime} \mathrm{IO}^{\prime \prime}$ de latitud, y $\mathrm{I}^{\circ} \mathrm{II}^{\prime}$ y Io" $^{\prime \prime}$ de longitud. Se separa esta media legua de la costa para formar un canal muy navegable acercándose más bien á la Isla, y su mayor extensión es al Norte $28^{\circ}$ Oeste poco más de milla y media. Presenta una altura regular, sus extremos bajos, de color rojo y blanco por el guano, y con varias quebradas, entre las cuales dos muy notables la dividen en tres alturas, y vista al Nordeste sólo parecen dos. Del extremo Noroeste de la isla se extiende un bajo cerca de un tercio de milla y á la parte occidental: en el paralelo del extremo opuesto, á una milla de distancia, hay un islote negro con algunas piedras al Norte.

Puerto de Santa.-El puerto de Santa es una pequeña ensenada con un río el más caudaloso de esta costa, formado al Sur del morro de ese nombre: éste es un montecito negro y una punta al Sur, es tierra alta en el fondo, y tiene un monte que visto Este-Oeste presenta dos picos con una mancha de arena de alto á bajo. Al pié de la misma punta hállase un islote con el mismo nombre del puerto, al cual no debe acercarse por no ser limpios sus alrededores: se fondea en cuatro y media brazas, y un pueblo colocado á una legua escasa de la costa, puede socorrer á las embarcaciones, de todas provisiones.

Ensenada de Chao.-Desde el morra de Santa hasta el de Chao, que distan cuatro leguas escasas, al Norte $28^{\circ}$ Oeste hurta la tierra cinco millas próximamente para formar la ensenada de Chao, cuya costa en la orilla es de arenales. La punta Corcobada, situada dentro de ella, es baja, y el principio para el Norte, de unos cerros puntiagudos y altos cubiertos de arena hasta la medianía, entre los cuales se hace más notable por alguna mayor elevación, el cerro de Vares.

El Corcobado y la Viuda._-Casi en la dirección de los dos morros ya nombrados, se encuentran dos islotes distantes entre ellos tres millas: el del Sur, que es el mayor, nombrado el Corcobado, con una pequeña restinga hacia el Noroeste, queda en el paralelo de la punta de su nombre á una legua de distancia, formando un canal navegable: llámase el otro islote la Viuda. Fuera de ambos unas cuatro millas, se coge fondo de 16 hasta 18 brazas arena lamosa y arena fina negra.

Morro de Chao y punta de Gijón.-El mo ro de Chao y la punta de Gijón, que está al Norte é 
inmediata, forman unos montes negros, unidos á la tierra firme por un terreno bajo y arenoso, en cuyo intermedio hay una pequeña ensenada.

Isla de Chao y las Tapadas.-Una isla de poca extensión, llamada de Chao, se separa una milla y un tercio de la punta Gijón en su paralelo, y al Noroeste de ella, muy cerca tiene un farallón: siguiendo esta misma dirección se encuentran dos isletillas llamadas las Tapadas, distantes entre sí dos tercios de milla, de las cuales la más Sur tiene restingas, y forma con la Isla de Chao un canal de media legua.

Hasta el morro de Guañape.-La punta de Gijón y la que forma el morro de Guañape, que corren en la dirección del Norte 29 y $1 / 2$ Oeste $r 8 \mathrm{y}^{1} / 2$ millas de distancia, comprenden una grande ensenada que la subdivide una punta saliente, en donde se avista un valle, distinguiéndose ia del Norte con el nombre del morro, que la termina por una parte. El terreno interior es de montes de arena de bastante altura, encadenados hasta la cordillera que se halla próxima.

Islas de Guañape.-Al Sur I $8^{\circ}$ Oeste del morro de Guañape, demoran á distancia de cuatro millas las islas del mismo nombre, que son dos, cubiertas de guano y distantes entre sí dos tercios de milla: cogen ambas una extensión de poco más de dos millas en la dirección de Norte $18^{\circ}$ Este: la del Norte algo baja, tiene en sus inmediaciones varios farallones, y la del Sur sólo dos. A tres leguas del morro de Guañape en su paralelo, se encuentran 32 brazas arena fina $y$ piedra.

Fondeadero del morro de Guañape.-Se puede fondear á sotavento de este morro, arrimándose á un farallón blanco que se halla en una de sus puntas, por fondo de seis brazas, en el cual se deja caer el ancla al momento que se avistan los ranchos, y se quedará en esta posición á un cuarto de legua de tierra. No hay agua, sólo sí lastre y leña.

Morro y fonteadero de Mal-abrigo.-Del morro de Guañape, siguiendo al Norte 34 Oeste una distancia de $j+\mathrm{J}^{1 / 2}$ millas, se halla el de Malabrigo, que forma al Norte, puerto con mucha mar y viento á rachas, en que fondean algunos - navíos que van á cargar allí de harina, en cinco brazas. Desde este paraje, se ve el desembarcadero en un rincón que hacen unos peñascos situados á barlovento, y ofrece una playa para colocar las cargas, siguiendo la cual media legua de tierra adentro, se encuentran pozas de agua dulce: este morro casi cubierto de arena, se presenta en ciertas direcciones aislado por las tierras bajas que tiene inmediatas. Lo hace también visible, un islote con el mismo nombre, distánte cuatro millas al Sur $10^{\circ}$ Oeste de su punta: híllase cubierto de guano, $y$ tiene pegado otro islote más pequeño al Norte y un farallón al Sueste.
Pueblo y puerto de Guanchaco. - En este trecho de costa comprendido entre los dos morros ya nombrados, se hace visible el pueblo de Guanchaco, situado en la orilla de la mar sobre una costa de arena barrancada, en $8^{\circ} 4^{\prime}$ Io' de latitud y $1^{\circ} 5^{6^{\prime}} \mathrm{I}^{\prime \prime}$ de longitud á dos leguas al Norte, 72 y $1 / 2$ Oeste de la ciudad de Trujillo. Muy cerca de la parte del Este se manifiesta un cerro puntiagudo bastante notable y á su espalda la cordillera. Han dado el nombre de puerto de Guanchaco, á una muy pequeña sinuosidad que forma la costa en estas inmediaciones, en donde la marejada sorda se hace sentir con fuer$z$ a, aunque reinan siempre vientos bonancibles. Es el puerto de Trujillo, y vienen á él varias embarcaciones á cargar de harina y otras cosas para Panamá. El fondeadero se halla á tres cuartos de legua de la playa, fuera de un bajo que llaman el Buey, demorando la iglesia de Guanchaco al Este, y el cerro de la Campana al Norte $30^{\circ}$ Este, en nueve brazas lama muy suelta, cuyo fondo entierra mucho las anclas y hace preciso levarlas á menudo. Para ir á tierra, se sirven todos de prácticos, los cuales saben cuando permite la entrada al Buey, cuyo bajo dista un cuarto de legua de tierra, levanta mucha mar, y debe pasarse precisamente sobre de él. Al Oeste de las playas de Guanchaco, siete millas, hay Ig brazas lama y chinitos, y á ménos distancia para el Norte, 16 brazas arena fina negra $y$ arena fina chinitos.

Corro de la Campana.-Desde Guanchaco. siguiendo para el Norte, continuan varias llanuras de arena hasta el cerro de la Campana, situado en $8^{\circ} 3^{\prime} \mathrm{Io}^{\prime \prime}$ de latitud y $\mathrm{I}^{\circ} 5^{6^{\prime}} 5^{0^{\prime \prime}}$ de longitud, bien visible por su elevación y por su figura bastante apropiada á su nombre, y cuyas faldas llegan á bañar las orillas de la mar.

Chicama.-Empieza luégo al Norte un valle muy ameno, poblado de muchas casas, y respaldado de la cordillera, que no es tan alta como la que se ve al Sur. Este valle, un río que tiene cerca, un cerro, una punta, y una ensenada hacia donde arrastran mucho las aguas, llevan todos el mismo nombre de Chicama.

Hasta la punta de Pacasmayo.-Al Norte $26^{\circ}$ $\mathrm{y}^{1} / 2$ Oeste del morro de Mal-abrigo, demora la punta de Pacasmayo, cuyo trecho de costa de I 8 millas es baja; y en lo interior lo forman tierras bastante altas y puntiagudas, casi cubiertas de arena. A dos tercios de legua de la dicha punta se hallan 20 brazas fondo, y en la costa, poco al Sur de ella, hay un pequeño recodo á que llaman pucrto de Pacasmayo, sin abrigo alguno.

Desde la punta de Pacasmayo hasta la de Matienzo, que corren al Norte I6 Oeste una dis. tancia de I 8 y $1 / 2$ millas, hurta la costa pare. formar la ensenada de San Pedro. De esta última punta sigue la costa casi una misma direc- 
ción, formando pequeñas sinuosidades hasta el morro de Cherepe ó Eten, cuyos extremos demoran al Norte 42 Oeste y distan unas $22 \mathrm{y}^{1 / 2}$ millas. Este morro, que á alguna distancia se presenta como una isla, por estar unido con tierra baja, es llano y cubierto de arena.

Tiene al Norte un fondeadero frente de la población de Cherepe, en ocho brazas, á sotavento de un bajo que sale á un tiro de pedrero de la punta del morro. Es sin abrigo alguno, con mucha mar, y sirve para las embarcaciones que vienen á cargar de harinas y azúcar, y otros frutos para llevar á Panamá y Lima.

Del morro de Cherepe lasta la punta de la 4 guja.-Al Norte de Cherepe es la tierra muy baja, de arena, y forma un valle de mucha extensión, respaldado de tierras de mediana altura. Sigue luégo la costa sumamente baja hasta las proximidades de la punta de la Aguja, y tan seguida, que no presenta objeto que marcar, si se exceptúa el Alto de Illescas, que es un monte de mediana altura, situado á la orilla de la mar á I 7 millas al Sur 68 y $1 / 2$ Este de la punta falsa de la Aguja. Esta punta se separa de la de la Aguja cinco millas al Sur 35 Este, y en su paralelo, distante dos y media leguas, no se halla fondo con 30 brazas. La punta del morro de Cherepe y la punta falsa ya nombrada, corren al Norte $54 \mathrm{y} \frac{1}{2}$ Oeste en la misma dirección que la costa intermedia, y coge un trecho de 91 millas, cuyo fondo sembrado de piedras es aplacerado; de suerte, que á distancia de dos y más leguas se encuentran I4 hasta I 7 brazas arena, mezclada unas veces con fango, otras con chinos, y otras, finalmente, con conchuela. Es arriesgado el atracar mucho este pedazo de costa, porque la marejada y la corriente abaten bastante hacia ella.

Islas de Lobos de tierra $y$ de fuera.-Las Islas de Lobos se presentan en estos paralelos y forman un punto notable é interesante en la navegación. La una, que se extiende cuatro y media millas al Norte $4^{\circ}$ Este, es la más septentrional, separada de la costa nueve millas, y se llama Isla de Lobos de tierra, para distinguirla de otras dos chicas y muy inmediatas que se conocen por Islas de Lobos de fuera. Se separa ésta de la otra 30 y $^{1} / 2$ millas al Sur $5^{\circ}$ Este.

Isla de Lobos de tierra.-La Isla de Lobos de tierra es baja y forma su mayor altura desde el medio para el Sur. Su medianía se halla en $6^{\circ} 24^{\prime}$ $20^{\prime \prime}$ de latitud y $3^{\circ} 43^{\prime} \mathrm{oo}^{\prime \prime}$ de longitud. Tiene varios farallones pegados á la costa del Oeste, y la cubre el guano. Sus alrededores son muy hondables, y se encuentra fondo de 30 á 40 brazas á una y dos millas por la parte Oeste. Al lado opuesto, muy inmediato á ella, una canal de legua y media de ancho permite un paso seguro por la parte de tierra. Varios fondeaderos of rece la costa al Este y Norte: no se halla en ellos agua, y en vez, una abundancia grande de pescado, de lobos y pájaros marinos.

El Coche.--Un bajo que llaman el Coche, situado en el meridiano de esta Isla de Lobos á 6 $\mathrm{y}^{1} / 2$ millas, y que demora al Sur $70^{\circ}$ Oeste del alto de Illescas, distante de la costa inmediata cinco y un tercio millas, se hace sentir desde lejos por un ruído ronco de la mar, que rompe con fuerza en él. Esta señal precursora del peligro y del cuidado del navegante, no ha bastado para salvarse varios buques, que han perecido allí.

Isla de Lobos de fuera.-La Isla de Lobos de fuera está situada en $6^{\circ} 57^{\prime} 40^{\prime \prime}$ latitud y $3^{\circ} 4^{\prime} 30^{\prime \prime}$ de longitud, y el estrecho canal de las dos islas que la forman sirve solo para lanchas, dejando á la parte Norte entre la más oriental y unas rocas, un fondeadero en Io, I 2 y I4 brazas para embarcaciones grandes, abrigado de los vientos reinantes del Sur. Ambas islas se extienden dos millas próximamente de circunferencia, y se elevan á una altura regular, de un terreno estéril sin agua alguna ni plantas, en parte pedregoso y en parte arenoso y abundante de los mismos animales que la otra isla.

Punta de la Aguja. - Volviendo de nuevo á atracar la costa firme, se hace visible la punta de la Aguja que hemos nombrado ya, por ser el punto más occidental de todo el frontón cercano, que es saliente á la mar: es baja y la forma una loma de mediana altura llana en su cumbre, de color rojo, y cubierta de arena desde la orilla de la mar hasta su medianía. Se halla en $5^{\circ} 59^{\prime} 20^{\prime \prime}$ de latitud y $4^{\circ} \mathrm{OI}^{\prime} \mathrm{I}^{\prime \prime}$ de longitud, y la rodea una restinga que se extiende cerca de una milla para fuera.

Ensenada de Sechura.-Desde esta punta va hurtando la costa para formar una grande ensenada llamada de Sechura, en que se halla el pueblo del mismo nombre, como igualmente un río cuyo caudal y rapidez aumenta con exceso en tiempo de aguas en la sierra, dejando el resto del tiempo sin indicios de su madre. Termina la ensenada al Norte en otro frontón saliente, cuyo extremo septentrional es la punta de Paita, que corre con la de la Aguja al Norte $2^{\circ}$ Este una distancia de $5^{6}$ millas. En el frontón del Sur forma la costa á la parte Norte de la punta de la Aguja, las puntas de Nonura y de Pistra; aquélla, baja, escarpada, con un manchón blanco y un farallón inmediato al Norte, llamado de Bernal, el cual tiene á la parte exterior dos bajos, de piedra visible el uno y con escarceo el otro; la segunda punta tiene igualmente manchas blancas, con varios bajos de piedra en sus inmediaciones para el Norte. Su terreno intermedio lo forma la caída de un cerro muy tendido, llano en su cumbre, algo bajo y lleno de escavaciones por algunas partes. Empieza seguidamente á ser la 
costa al Norte más baja, y la ensenada de Sechura que forma, está rodeada de bancos de arena que salen en partes una legua. En ella y en toda la ensenada que sigue luégo de Paita, se pesca en mucha abundancia, principalmente de sollo.

Frontón salicnte de Paita.-El frontón saliente de la punta de Paita corre casi Norte-Sur una distancia de siete millas. Se presenta de mediana altura, escarpado, formando varias puntas y ensenadillas de arena. En el extremo Sur se eleva un monte que domina el resto de la tierra inmediata, y una pequeña sinuosidad que forma la cima de su mayor altura, le ha dado el nombre por su figura de silla de Paita á todo él: se halla en $5^{\circ}$ Io $^{\prime} 00^{\prime \prime}$ de latitud y longitud de $3^{\circ} 57^{\prime} 40^{\prime \prime}$.

Isla de Lobos y la Oradada.-Sigue luégo al Norte una pequeña isla llamada de Lobos, y la Oradada. Aquella algo baja, escarpada, con algunos faralloncitos y un pequeño bajo pegado á la parte del Nordeste, se extiende próximamente dos millas en circunferencia, y se aparta una escasa de la costa, demorando al Norte $63^{\circ}$ Oeste de la Silla: la Oradada es un peñote muy chico, próximo á tierra, con otros menores en sus contornos, y dista de la punta de Paita una y un tercio de milla.

Puerto y ensenada de Paita.-Desde esta punta saliente á la mar, inclina la costa al Sur y Este para formar el puerto y seguidamente la ensenada de Paita, la cual termina en los Negrillos, que distan de aquella punta 2 I millas al Norte 23 Oeste. En esta ensenada se encuentra el pueblo de Colave, y al Norte de él, el de Colan á la desembocadura del río Chira, que hace curso por el pueblo de Amotape. Interna el puerto de Paita dos millas próximamente con igual anchura, $y$ su pequeña población situada en el fondo y á la orilla de la mar, se halla en $5^{\circ} 5^{\prime} 50^{\prime \prime}$ de latitud y $3^{\circ} 54^{\prime} 55^{\prime \prime}$ de longitud. Fondean las embarcaciones cerca de ella, y las mayores quedan á un cuarto de legua.

Prouisión y' agua de Colan para Paita.--La entera falta de agua en Paitá y el llover sino raras veces, por ser un país de valles, causa una total aridez en su territorio. Le precisa tener una contínua comunicación con Colan, población situada en un terreno fértil dos millas al Norte del puerto del mismo nombre, el cual dista de Paita Io millas al Norte I2 1/2 Este. Le provee por medio de balsas de agua en botijas, como jgualmente de verduras y carnes, que vienen también de Amotape. Los buques que necesitan de aquella, hacen un ajuste con los índios de ese pueblo, para que la reemplacen.

Derrota para la cutrada cn Paita. -. Para en trar en Paita las embarcaciones que vienen del Sur, procuran reconocer la Isla de Lobos de Tierra ó bien la costa inmediata sobre la punta
Nonura, desde la cual prosiguen teniéndola á la vista, y dando un pequeño resguardo á la punta de la Aguja por ser muy saliente á la mar y baja, como hemos dicho. Prefieren los prácticos esta recalada á otra cualquiera inmediata al puerto, para asegurarse de su derrota y no propasarse de su paralelo, en cuyo caso ya los vientos y el curso de las aguas contrarias, harían perder muchos días en ganar el barlovento perdido. Como todas estas costas inmediatas son bajas y las cubre ordinariamente la rumazón, atienden todos á dos señales que avisan la inmediación de ellas. La una es los lobos marinos, que se hallan en las cercanías de las Islas de Lobos, y á tres ó cuatro leguas de ellas; y la otra la infinidad de pájaros que salen casi á la misma distancia.

Avistada luégo la Silla de Paita, punto bien notable como se dijo ya, atracan sobre la Oradada para seguir costeando de cerca hasta el fondeadero, con sólo el cuidado de no acercarse mucho á la última punta, de la cual sale por el Norte una restinga de dos cables, que siempre vela. Viniendo del Norte, reconocido de antemano el Cabo Blanco, de cuya recalada se hablaráluégo, y rebasados los Negritos, se procura no empeñarse en la ensenada que le sigue por el fondo, que es muy aplacerado, y por reinar siempre en ella una mar sorda.

En Paita y en sus inmediaciones suelen experimentarse desde Noviembre hasta Mayo, que es el verano, algunos terrales muy flojos, que al fin pasan á entablarse al Sueste y Sursueste, dirección de los vientos generales. De estos últimos abriga la rada de Paita el monte ó silla de Paita: las brisas que son del Norte recalan muy raras veces y con irregularidad.

Los Negrillos hasta la punta Pariñas.-Los Negrillos, conocidos hasta ahora por unos farallones inmediatos á la tierra, por parecerlo así, no son sino dos pequeños morros de arena $y$ piedra en la misma costa, que es algo más baja: sigue ésta luégo en la misma elevación hasta la punta de Parinas, distante de los Negrillos dos millas. Desde esa punta, altea la costa con muchos arenales, muy igual en su cumbre y aba. rrancada.

De la punta Pariñas hasta Cabo Blanco.--E1 Cabo Blanco, situado en $4^{\circ} \mathrm{I}^{\prime} 30^{\prime \prime}$ de latitud y $4^{\circ} 3^{\prime} 45^{\prime \prime}$ de longitud, forma con la punta Pariñas el frontón más saliente á la mar de la América Meridional, y coge un trecho de $24 \mathrm{y}^{1} /$. millas, del cual se aranza más al Oeste la punta de Capuyana é inmediato al Sur la de Talara, que dán el nombre á dos pequeños puertos, únicos puntos notables de este pedazo de costa.

Matape. - En lo interior se hacen visibles las sierras de Matape, de una altura regular, cuyos 
extremos son más altos que el medio, y en la parte Oeste tiene tres picos notables, de los cuales dos de ellos muy unidos y más salientes que el tercero. Dan el nombre á un pueblo que se halla á sus faldas y á un río que pasa á una le. gua próximamente de él, y lo hace caudaloso la abundancia de aguas en la sierra. La mayor elevación de aquellos montes se halla en $4^{\circ} 36^{\prime} 55^{\prime \prime}$ de latitud y $3^{\circ} 5 x^{\prime} \times 5^{\prime \prime}$ de longitud.

Cabo Blanco.-El Cabo Blanco, ya nombrado, es el término que divide el Reino del Perú del de Santa Fé. Lo forma una lengua de tierra baja del color que le ha dado su nombre, pero á poca distancia tiene un morrito, que desde él empieza á elevarse con rapidez una loma de piedra muy socabada, pareja en su cumbre, con muchos arenales que caen hasta la mar, y es lo más alto de este pedazo de costa al Sur. Todas estas inmediaciones son muy hondables, hallándose 45 brazas lama á poco más de una legua de la costa. Las embarcaciones que van á Paita, del Norte, procuran atracar para su derrota al Cabo Blanco, en el cual, reinando siempre por un gran trecho de mar, vientos y corrientes contrarias, la experiencia les ha enseñado que los bordos han de ser muy pequeños, á no separarse una legua del cabo, á fin de no perder barlovento. El viento se hace sentir comunmente en él, con fuerza.

Golfo de Guayaquil.-El Cabo Blanco y la punta de Santa Elena que demoran al Norte $8^{\circ}$ Este y distan entre sí r 30 millas, son el principio de la costa que hurta al Este para formar el seno ó golfo de Guayaquil.

Cabo Blanco hasta la punta Malpelo.--La punta de Malpelo, principio de los bajos de la ensenada de Tumbes, dista del Cabo Blanco 68 millas y hurta de él $49^{\prime}$ al Este: se hace solo notable en este pedazo de costa, el surgidero de Mancora á siete millas del nombrado Cabo, y seguidamente al Norte, tres cerros inmediatos á la costa, llamado el más meridional, de Aguirre, el segundo, de Castro, y el tercero de Malonda.

Desde la punta Santa Elena, hasta su extremo meridional. - En la tierra firme al Norte, inclina la costa desde punta Santa Elena al Sur y Este $4 I^{\prime} y^{1} / 2$ de longitud en una distancia de 57 millas, para formar el extremo meridional de este trecho. Comprende la punta Carnero, coronada de bajos: su vista presenta un islote amogotado, y aproximándose á ella se transforma en un morrito en cuyo pié blanquea el terreno. Es baja luego la costa hasta los altos de Chandui, los cuales se hacen visibles por su mayor elevación que el terreno en contorno, y forman tres picos, más agudo y notable el del Sur que los otros dos. Estas inmediaciones, como igualmente la costa que le sigue para el Sur, se han hecho temibles por los muchos bajos de piedra que le rodean, y por el curso de las aguas y de la marejada, que atraen hacia ella, por cuya razón es arries gado el acercarse á ménos de dos leguas.

Nieblas que reinan en estos mares.-Concluída aquí la descripción de toda la costa comprendida entre golfo de Guayaquil y el puerto del Callao, no será fuera de propósito el incluir una pequeña descripción de las nieblas que cubren estos mares y costas una parte del año. "Son generalmente todas las costas del mar. "desde Guayaquil para el Sur, difíciles de ser "reconocidas á ménos de lograr para ello la "coyuntura del verano, porque tanto en el in"vierno como en su salida ó entrada, contínua" mente están cubiertas de espesísima niebla; " tal, que á un cuarto de legua de distancia no se "ve otra cosa que nubes, y alargándose á la mar " hasta ${ }^{5} 5$ ó 20 leguas y muchas veces más, con"servan en esta distancia la misma densidad, "pero sucede que todo lo que dura la noche y " hasta cosa de las diez ú once del día, la niebla " está pegada contra tierra: á esta hora se retira "hacia el mar, formando como una muralla, que "sirve de estorbo á la vista del que está de la "otra parte de ella, y no puede descubrirla ni " arriesgarse á buscarla, no sabiendo si la encon"trará clara ó no."

El golfo de Guayaquil es uno de los mares más frecuentados de estas costas, por su comercio de maderas, de cacao, y de las manufacturas de las provincias internas, y por su astillero, en que se fabrican muchas embarcaciones. Encierra en sí dos islas principales; la una pequeña, conocida con el nombre de Santa Clara, y mejor hoy día con el de Muerto ó Amortajado por su figura vista en la dirección del Oesnoroeste próximamente, y la otra grande llamada de la Puná, á cuya parte Norte desemboca el río Salado y el de Guayaquil.

Isla de la Purá.-Esta última isla se extiende al Norte $44^{\circ} \mathrm{y}^{1} / 2$ Este una distancia de $26 \mathrm{y}^{1 / 2}$ millas, en una circunferencia de 7o. Varios esteros se forman en la costa del Sueste por algunas isletas que le rodean de cerca, y por fuera de ellas se hallan placeres de arena interrumpidos con bastante fondo. Entre manglares y costa baja, de que se compone en gran parte esta isla, se hacen visibles dos sierras: la de Mala, cerca de la costa y del extremo Nordeste de la isla, $y$ en el extremo opuesto, pero algo interior, las de las Animas, que son más extendidas y más elevadas.

A la parte oriental de un frontón que forma la isla al Nordeste, en una pequeña ensenada con el pueblo y Estero de la Puná, se halla el fondeadero del mismo nombre. Este y otro interior frente de la ciudad de Guayaquil, son los únicos puertos buenos y frecuentados que ofrecen el golfo y el río. Prefieren casi todas las embarcaciones el puerto de la Puná, por encontrar más fácil y 
segura la entrada y salida, y porque les imposibilita el poco fondo de los canales que van al segundo, el seguir navegando cargadas. Alcanzan sólo el fondeadero de Guayaquil las embarcaciones pequeñas, y con poca carga, las grandes precisadas de alguna obra de calafate ó de carpintería. Consiguientemente, el puerto de la Puná es el punto de reunión de todos los buques que atienden á este comercio para recibir ó entregar el todo ó el completo de su carga, la cual se lleva á este paraje por medio de balsas.

El Amoriajado. - La Isla del Amortajado se hace muy interesante para la navegación del golfo, porque su vista proporciona el asegurar la posición de los buques, y determinar luégo mejor la derrota que se hace seguidamente al Este entre sonda.

Hállase situada en $3^{\circ}$ I $3^{\prime} 20^{\prime \prime}$ de latitud y $74^{\circ}$ II $^{\prime} 30^{\prime \prime}$ de longitud occidental de Cádiz, y demora al Norte $38^{\circ}$ Este del Cabo Blanco, al Norte $12^{\circ} \mathrm{y}^{1} / 2$ Este de la punta de Malpelo, al Sur $62^{\circ} \mathrm{y}^{1} / 2$ Oeste de la punta Arenas, extremo Sueste de la Puná, y al Sur $28^{\circ}$ y $1 / 2$ Este de la punta Santa Elena, á distancia del primero 83 millas, del segundo I9 $\mathrm{y}^{1} / 2$, del tercero I9 $\mathrm{y}^{2} / \mathrm{s}$, y de la última punta 72 millas. Es de regular altura y se extiende una y media milla al Norte $62 y^{1 / 2}$ Este, cuyos extremos están rodeados de bajos de arena y piedra: permite el paso á ambos lados: el del Sur lo limitan en gran parte los bajos de Payana, y la costa firme inmediata, en que desaguan muchos ríos y hace desigual su fondo; por lo cual no puede acercarse á ménos de I8 brazas, y de la isla á media legua por I 4 brazas, advertencia que hace precisa principalmente para salir del río, debiendo ganar la mar sobre bordos por los vientos contrarios.

Estos suelen alargarse en la vuelta de la tierra firme, pero no es prudente seguirla estando á medio freu.

El canal del Norte es bien pequeño, por los bajos que revientan cerca de la punta Salinas y se avanzan á la mar legua y media, y sirve para buques pequeños, los cuales deben sólo intentar. este paso, siendo muy prácticos.

Derrota del Amortajado á la punta Arenas.Admitido ya para su seguridad el canal del Sur á toda especie de embarcaciones, la derrota más acertada y practicada para internar en este golfo y río, es dirigirse en derechura al Amortajado, reconocido antes el Cabo Blanco para los buques que vienen del Sur, y atracada la punta de Santa Elena para los que recalan del Norte: dis tando de esta isla una legua próximamente al Sur, en 5 brazas, se navega al Norte $54^{\circ}$ Este unas I 9 millas, en cuya dirección después de haber aumentado el fondo á zo brazas se disminuye hasta I2 brazas, en donde se fondea para quedarse á una legua próximamente de la punta Arenas, atendiendo siempre á las mareas, que alteran no poco la derrota.

Desde este paraje, para seguir dentro del golfo y seguidamente del río, la multitud de bajos que van cambiando á menudo de posición, y aminora ó engrandece consiguientemente los canales, como igualmente su fondo, no ménos que varía la fuerza y dirección de las mareas, precisa enviar al puerto de la Puná por uno de los prácticos, que son de los examinados y admitidos de antemano por el Gobierno.

\section{Derrotero desde el vío de Guayaquil hasta el Golfo de Panamá.}

Punta de Santa Elena.-En la costa firme al Norte del golfo de Guayaquil se hace visible la punta de Santa Elena por ser muy saliente á la mar, situada en latitud de $2^{\circ}$ Io $^{\prime}$ I $^{\prime \prime}$ y I I $6^{\prime} 45^{\prime \prime}$ de longitud occidental de Guayaquil. Forma una lengua de tierra baja, terminada de un morro alto igual en su cumbre y algo más tajado por la parte del Este que por la opuesta, y se manifiesta á alguna distancia como una isla: en sus extremos oriental y occidental se extiende una pequeña restinga de dos cables.

Puevto di Sunta Elcua.-A la parte Norte de la punta, se halla el fondeadero de su nombre en una ensenada de fondo aplacerado, frente de la población, en cuatro brazas arena á una milla de la playa. İs un puerto frecuentado por el comercio de las sales y brea que se saca en este distrito. No ofrece agua dulce, y le provee el río de Valdivia, que dista 14 millas al Norte $46^{\circ} \mathrm{y} \%$. Este.

Sigue luégo internando la ensenada, y puede llamarse su término al Norte, las puntas de Salango, que dan el nombre á una isla inmediata, la cual demora de la punta de Santa Elena al Norte $13^{\circ}$ Este, 32 millas. Todo este trecho es muy hondable, y en él se hacen visibles, un islote llamado el Viejo, que se separa una y cuarto millas de la costa inmediata, en cuyo espacio se 
fondea, $y$ el Pelado, otro islote en el paralelo de la punta Valdivia, que es la costa más cercana, de la cual dista poco más de cuatro millas: aquél tiene en sus inmediaciones nueve brazas, y éste $\mathrm{r} 2$, con un seguro fondeadero por dentro, en seis brazas. Demora el primero, de la punta Santa Elena al Norte $8 \mathrm{I}^{\circ}$ y $1 / 2$ Este Io millas, y el segundo, de la misma al Norte $4 \mathrm{I}^{\circ}$ Este $\mathrm{I} 8$ millas.

Los Ahorcados.--Son dos pequeños farallones muy unidos, de los cuales, el más pequeño y el más Norte parece formar dos; se hallan en la misma ensenada, $y$ distan sólo media milla escasa de la costa y cinco millas próximamente de la Isla Salango, que les demora al Norte $19^{\circ}$ Oeste.

Ensenada y eerro de Colonehe.-Punta é Isla de Salango._-Después de la ensenada que forma el puerto de Santa Elena, que es de tierra baja y pareja, con mucho ramaje, sigue alteando el te rreno, cubierto de arboleda, el cual, visto á alguna distancia, se presenta cortado $y$ parece formar diferentes islas, de cuyas abras se hace más no. table la que se halla al Sur del río Valdivia de la pequeña ensenada de Colonche, en donde se fondea en seis y ocho brazas.

Un cerro de este nombre se hace visible en 10 interior, á poca distancia de la costa y en el paralelo de aquel río: montes que se encadenan unos con otros, corren seguidamente la costa al Norte, cubierta su orilla de arboleda, la cual termina á la mar, de piedra con algunos escarpados, hasta la punta de Salango, que es tajada á la mar, en forma de morro.

La isla de su nombre, de regular altura, con farallones á la parte del Oeste y una pequeña restinga al Sueste, se separa un corto trecho, cuyo canal no es transitable, y se extiende en circunferencia poco más de dos millas: 40 brazas arena fina y arena lama se cogen á cuatro millas de ella mar afuera, y` poca ménos cantidad en sus inmediaciones.

Ensenada al Norte de la punta Salango.-Dos objetos notables se presentan luégo al Norte. La Isla de la Plata, situada en $\mathrm{I}^{\circ} \mathrm{I}^{\prime} 2 \mathrm{O}^{\prime \prime}$ de latitud y I I I $3^{\prime} 2 \mathrm{O}^{\prime \prime}$ de longitud, y el Cabo de San Lorenzo: demoran éstos entre sí al Norte $37^{\circ} \mathrm{y}^{1} / 2$ Este r 7 millas, y de la punta de Santa Elena al Norte $7^{0} \mathrm{y}^{1 / 2}$ Oeste $50 \mathrm{y}^{1 / 2}$ millas, $y$ al Norte $3^{0} \mathrm{y}^{3} / 4$ Este $66 \mathrm{y}^{1 / 2}$ millas.

Desde la Isla de Salango hasta el cabo nombrado, cuyos puntos distan $34 y^{1 / 2}$ millas al Norte 5 Oeste, hurta la costa para dentro, formando diferentes ensenadas con fondeaderos. La primera al Sur es la que termina la punta de Salango y la de Agua Blanca, y estos extremos, distantes entre sí una y tres cuartos milla, son tajados al mar, algo bajos, elevándose luégo el terreno con suavidad: se fondea en esta ensenada en I6 hasta I 2 brazas de agua, cerca de tierra, $y$ desde un riachuelo que hay en ella hasta un is- lote inmediato á la punta de Agua Blanca, es la costa sucia.

Ensenada de Agua Blanea.--Sigue inmediatamente la ensenada de Agua Blanca, formada de las dos puntas de su nombre, las cuales se separan tres y cuarto millas, formada la del Norte por la caída rápida de un monte alto, bastante notable, en figura de mesa. Tiene un riachuelo en su medianía y un fondeadero próximo al islote que hemos nombrado poco antes, en I2 hasta I6 brazas.

Ensenada de Machalilla.-La ensenada de Machalilla es la que se presenta seguidamente, $y$ da el nombre como la otra, á las dos puntas que la terminan á tres millas próximamente entre ellas. Esta es el puerto del pueblo de Jipijapa, cuyo río desemboca en ella, y el fondeadero se halla en seis brazas cerca de tierra pegado á la costa del Norte y en ro brazas lama en la costa del Sur á la parte orjental de un islote frontero á una barranca blanca. Todo este terreno es alto y con puntos bastante notables.

Islotes de Cantagallo y del Callo.-OOtros dos fondeaderos se encuentran luégo, el primero al Sur del islote Cantagallo en ro brazas en la en senada inmediata; y el segundo en cinco brazas cerca de un bajo, es el puerto del Callo, que 10 forma un islote de este nombre y la ensenada que sigue al Norte llamada de Picoasa, en la cual hay aguada y una población. En esta última en senada empieza á ser más bajo el terreno, y parajes en la orilla hasta la medianía de ella, en que vuelve á altear hasta el Cabo de San Lorenzo. Toda esta costa que hemos descrito, está bien provista de agua y leña, y se fondea en lama, conociéndose la demasiada proximidad de tierra en el fondo arena: á siete millas de dicho cabo, mar en fuera, no se coge fondo con 90 brazas.

Isla de la Plata.-La Isla de la Plata está tendida de Norte á Sur una legua, con una anchura poco menor $y$ de una altura regu'ar, llana en su cumbre y más alta por la parte del Norte que por la del Sur. Este extremo tiene varios farallones llamados de Guatimozin, que dan el nombre á la punta inmediata. Vista esta isla al Norte próximamente á seis ú ocho leguas de ella, se presenta dividida en tres trozos, de los cuales los dos más occidentales son iguales, y el tercero parece islotillo. Un fondeadero no muy bueno por los ratones, se halla al Este, y ofrecen sus costas mucho pescado, leña y agua ś́lo en el invierno.

Canal por entre la costa firme y la Isla de la Plata.-El canal que forma esta isla con la tie. rra firme, lo limita por la parte más estrecha la punta Blanca ó de la Canoa á una distancia de cinco leguas, en cuya medianía se encuentran de 20 á 25 brazas arena lama y arena conchuela. En su navegación debe sólo no acercarse á esa punta, por una restinga que le sale dos millas al 
Sudoeste, en cuyo extremo encuéntranse dos brazas de agua.

Cabo de San Lorenzo. - El Cabo de San Loren$z O$, situado $\mathrm{x}^{\circ} 4^{\prime} \mathrm{IO}^{\prime \prime}$ de latitud y $\mathrm{I}^{\circ} 2^{\prime} \mathrm{IO}^{\prime \prime}$ de longitud, es tajado al mar, de color negro con manchas rojas, y tiene inmediatos dos farallones, que llaman el Fraile y la Monja. Un morrito termina su extremo, el cual, visto desde el Sur á alguna distancia, parece un islote: altea bien pronto el terreno interior para formar un cerro de regular altura, desde el cual, en una elevación algo menor, continua hasta el puerto de Manta.

Este fondeadero y otros varios, se encierran en un seno que forma la costa entre el Cabo de San Lorenzo y el Cabo Pasado, los cuales demoran al Norte $32^{\circ}$ Este á 46 millas. Compréndese entre los dos cabos: primero, la ensenada de $\mathrm{Pa}$ cocha, en donde se fondea en Io brazas arena y desemboca el río de su nombre: queda terminada por la punta de San Mateo y la de Pacocha, distantes entre sí poco más de dos millas, y esta última, más inmediata al Cabo San Lorenzo, se separa de él cuatro y media millas.

Ensenada de San Mateo.-La ensenada de San Mateo es la que sigue luego, y fórmala la punta nombrada de San Mateo y la de Barbasquillo á la parte opuesta, cuya abra es de una milla. Son ambas puntas algo abarrancadas: la primera con un islote de su nombre á media milla, y la segunda ticne una restinga de un cable que descubre la bajamar, y á su parte Norte se fondea en Io y ocho brazas. No of rece agua esta ensenada.

Puntas de la Baja y la de Manta.-Corren seguidamente un mismo paialelo la punta de la Baja y al Este la de Manta, principio de su ensenada, ambas con un bajo inmeảiato de medio cable, y la orilla comprendida con un pequeño placer. La costa que viene bajando del Cabo de San Lorenzo hasta la punta de Manta, termina ésta, tajada á la mar con arenales á su pié. Al Norte $64^{\circ}$ Oeste de esta punta, hay un bajo do piedra que dista una y media milla, y forma con la costa cercana un pequeño canal de cinco brazas en marea llena y de cuatro en la marea baja.

Punta de Manta.-El fondeadero de Manta se halla al Norte de la punta de su nombre, á poco más de una milla de distancia. Como se alcanza este puerto siempre por la parte del Oeste, pues que reconocen todas las embarcaciones el Cabo de San Lorenzo, se procura no disminuir de II brazas, por motivo del bajo, hasta que se descubrc en la punta de Manta una bodega situadáa un lado de un morrito, el cual es un peñasco srandc que se aisla en la marea crecida, y frente de él se fondea en siete brazas, demorando al Sur $24 \mathrm{y} / 2$ Liste, un cerro bien visible en esta costa, llamado de Mlonte-Cristi. Ln tiempo de brisa sc proliere este fondeadcro al del Callo.

Iinsenalu de Manta.-Termina la ensenada de
Nanta la punta de su nombre y la de Camas, que distan cuatro y media millas, y en cuyo espacio se fondea también desde I $_{5}$ á siete brazas. En aquel fondo queda descubierto el islote de San Mateo, que sirve de marca para las embarcaciones grandes, y las demás no disminuyen de siete brazas por hallarse el fondo sembrado de ratones. Todo lo interior del país inmediato es sumamente montuoso, y pobladas sus montañas de árboles espesos y corpulentos.

Monte Cristi.-Es un cerro de regular altura que se distingue entre los demás por su elevación y proximidad á la costa. Se extiende hacia el Sudoeste con un declive muy suave para terminar en un morrito, á que le han dado el nombre los naturales, de Rabo ó Cola del Ccrro, y al contrario, baja la parte opuesta con una inclinación muy sensible, y á su falda se avista el de su nombre.

Desde la punta de Camas sigue la costa para el Norte, más alta y abarrancada con manchones blancos, y su fondo proporciona diferentes fondeaderos.

Punta de Charapoto.-La ensenada de Faramillo y de Charapoto, se encuentran hasta la punta de este último nombre, la cual es regularmente alta, y frente de ella se fondea en siete brazas, encontrándose á ro millas fuera de la misma punta 35 brazas lama, cuyo fondo se conserva próximamente á la misma distancia de la costa que le sigue para el Norte, con sola la diferencia, que es á veces la lama verdosa.

Sicrra del Bílsamo.-Por el paralelo de la punta de Charapoto da principio la sierra del Bálsamo, que es de una mediana altura, con algunos picachos notables, y se extiende hacia el Cabo Pasado, á poca distancia de la costa. Continúa ésta de una altura regular, cubierta de arboleda y con muchos manchones blancos.

Balía de Caracas.-La bahía de Caracas, que se halla en este pedazo de costa, permitía antiguamente una segura entrada, pero ya hoy día queda enteramente ciega.

Cabo Pasado y su fondeadero.-Hállase situado el Cabo Pasado en $24^{\prime} 25^{\prime \prime}$ de latitud y $37^{\prime} 50^{\prime \prime}$ de longitud occidental, $y$ forma para el Sur un frontón saliente de tres cuartos de legua, de una mediana altura, cuyo intermedio lo cubren arboledas hasta la mar. Termina abarrancado el extremo del cabo, cuyo ferreno va descendjendo con mucha suavidad un corto trecho. Le sale una restinga hacia el Sursudoeste, de un cuarto de legua, y á la parte opuesta hállase su fondeadero muy cerca á él en 20 hasta $\mathrm{x} 2$ brazas arena y conchuela, frente de una ensenadita con riachuelo en la costa, que inclina al Norte y Este, y pone á cubierto de los vicntos generales.

Sitración del Cabo de San Francisco.-E1 Cabo de San Francisco, situado en $38^{\prime} 45^{\prime \prime}$ de latitud 
Norte y II' $20^{\prime \prime}$ de longitud occidental, demora al Nordeste del Cabo Pasado. Comprende desde ésta para el Norte un pedazo de costa de regular altura, en que se hallan las Sierras de Cuaques, y su Ensenada terminada por las puntas de Ballena, y de Pedernales ó Palmar y seguidamente los $A l$ tos del Tambor. Estos y la punta de Porteto limitan luégo un terreno pantanoso y lleno de manglares, llamados los Cogimies, por varios brazos de mar que entran á él, á los cuales dan el nombre de ríos, y en su interior se ven algunas sierras de poca altura. Sigue últimamente la ensenada de Bunches, de terreno bajo, con un río y población de su nombre, la cual termina en el Cabo San Francisco.

Toda la costa entre los dos cabos es muy hondable, y puede atracarse á ella si se exceptúa la que comprende los Cogimies, quienes hacen aplacerado su fondo hasta dos leguas próximamente de tierra, y no es prudente el acercarse á ménos de I 8 brazas: diez millas fuera de ellos se cogen 40 á 45 brazas lama verdosa.

Punta de la Ballena.-Desde el Cabo Pasado hasta la punta de la Ballena, que es baja y con pedruscos en su inmediación, hállase la costa cubierta de arboleda y con algunas barrancas blancas. Esta última punta, y la que sigue luégo poco distante de un islote blanco, forman la ensenada de Sama, en que desemboca su río, y no debe aproximarse á ella á ménos fondo de ocho brazas.

Punta de Pedernales. - Se halla distancia de la equinoccial dos tercios de milla al Sur; es baja, formándole así un terreno alto que va descendiendo con suavidad: á la parte Norte, no lejos, se encuentra el río de su nombre. Finalmente, la ensenada de Bunches sirve de fondeadero desde I2 hasta 20 brazas fondo lama, como igualmente frontero á la punta Porteto, que es algo baja y llena de arboleda: en aquella ensenada, aunque el viento que sopla desde el Mediodía hacia el Sudoeste sea casi travesía, no es peligroso por saltar en la noche al terral.

Cabo San Francisco hasta la punta de la Galeva.-El Cabo de San Francisco y la punta de la Galera, limitan un pedazo de costa saliente, medianamente alta, cubierta toda de arboleda y con algunas piedras. Comprende hasta la punta del Plátano, el frontón del Cabo de San Francisco, que corre dos leguas Norte-Sur, y se presenta como una isla visto al Norte y Oeste; y casi en su medianía entra un Estero con una braza de agua. Sigue luégo al Nordeste un trecho de cuatro millas terminado por la punta de la Galera, en el cual se halla un islote llamado el Corcobado, á media milla de la costa, con un bajo de cerca á la parte exterior. Dos riachuelos clesaguan en el Cabo, el uno á su parte Norte, y el otro á la opuesta inmediato á una casa situa- da á la orilla de la mar, en una pequeña sinuo. sidad de la costa, entre el mismo Cabo y una punta con dirección al Sur, desde la cual fórmase un recodo para el Este, en que pueden surgir. embarcaciones pequeñas para hacer agua y leña: dos islotes muy unidos se separan de esta última punta, media milla al Sueste. La punta de la Galera es baja y llana su cima: tiene en sus inmediaciones dos farallones, $\mathrm{y}$ por fuera de ellos algunos pequeños bajos.

Fondeadero de la punta de la Galera.-La costa que hurta luégo para el Este, en que se halla una laguna salobre, una población de indios y un riachuelo de agua dulce, sólo en invierno of rece un fondeadero á un cuarto de legua de la punta al Nordestc, desde Io á cuatro brazas lama y arena al Noroeste de esta misma punta.

Desde la punta de la Galera inclina sensiblemente la costa para el Este, al principio de una altura regular, y seguidamente va descendiendo á formarla baja, de manglares, interrumpida de muchos esteros y ríos, los cuales abrazan una gran parte de la costa al Norte incluyendo la de la Gorgona, y se internan entrelazándose para formar diferentes islas. Algunas casas se ven esparcidas en la orilla de la mar, y su fondo aplacerado permite fondear en muchas partes de ella.

Aquella punta y la de Manglares, que corren al Nordeste, comprenden primero un pedazo de costa, en que la punta Ostiones es el término de la tierra alta, y en medio de la mucha arboleda que la cubre, se ven varios manchones rojos.

Punta de Atacames. - Se hace visible en ella primeramente la punta de Atacames, que desciende de un monte regularmente alto, y termina á la mar en un pequeño morro llamado de Azua. Al Nordeste de csta punta se fondea desde seis á I 2 brazas arena y cascajo, en cuyo fondo suele haber algunos ratones, $y$ en la costa que le sigue al Este, hállase el río y población de Atacames.

Bajo fondo de Atacames. - Un bajo fondo de ocho á I4 brazas piedra y cascajo, se avanza en el meridiano de la misma punta á dos y media hasta cuatro leguas, cuyo límite conocido en partes de I7 á 20 arena gruesa, termina bien pronto á alcanzar mucho fondo, de suerte que al Noroeste de la punta de Atacames á ocho millas, hállase 40 brazas lama piedra y al Nordeste de la misma á If millas, no se encuentra fondo con 50 brazas. Su extensión y dirección y su menor fondo, no está determinado, pero por el braceaje del puerto de Atacames, de que se ha hablado ya, por noticia de prácticos, parece poderse deducir que hay una canal hondable por dentro del bajo y cerca de tierra.

Siguiendo la costa, hállase después del río de Atacames, la bahía de San Nicolís, con algunos riachuelos, terminada al Este por la punta de su 
nombre: tiene ésta una de las manchas de que se ha hecho mención.

Un pequeño bajo que se extiende un cumplido de fragata, y revienta sólo en mareas vivas, se separa media legua al Norte exactamente de esta última punta, y alguna cosa ménos, de otra que le sigue al Nordeste. Algunas embarcaciones han tocado en él, con la sola desgracia de suspenderles el timón. Forma con las nombradas últimamente un pequeño canal con cuatro brazas de agua.

Continua la costa á hacer visibles la punta de Bernal con mancha y la punta Gorda, á la cual siguen hasta la de Ostiones, tres ríos, el de Esmeraldas, río Verde y el de Santiago. Se puede fondear en la boca del primero en nueve brazas y en la del segundo en cuatro, pero adviértese que un bajo coge toda la extensión de estos dos ríos hasta media legua fuera de la costa, la cual comprende el Valle de San Mateo.

Ancon de Sardinas.-La punta Ostiones, que es el principio de la costa baja, en parte anegadiza y de manglares, forma una ensenada algo profunda, poblada de indios, á la cual llaman Ancon de Sardinas, y la termina al Norte la punta de Manglares, de que está cubierta. Demoran las dos puntas al Nordeste, cuya ensenada comprendida, la interrumpen varios ríos pequenos, que despiden algunos bajos cerca de la costa.

Punta Manglares.-La punta Manglares situada en $I^{\circ} 36^{\prime} 20^{\prime \prime}$ de latitud Norte y $5 I^{\prime} 25^{\prime \prime}$ de longitud oriental, se presenta baja, pero en sus inmediaciones se ven unas pequeñas alturas. Queda aislada, como también un pedazo de la costa cercana, por unos brazos de mar que se internan: algunos ríos la bañan igualmente, y parecen subdividirla en otras islas menores.

Se encuentra 60 brazas fondo á 23 millas al Sudoeste de aquella punta, á la cual no puede acercarse, por unos bajos que se extienden de ella hasta una legua escasa á la mar.

En la dirección Nordeste corren seguidamente las puntas de Manglares y de Guascama, distantes entre sí 20 leguas. Su costa comprendida es aplacerada por los muchos ríos que desembucan en ella, extendiéndose más afuera el bajo fondo desde la primera punta nombrada hasta la Isla del Gallo, en cuyo trecho es preciso navegar con cuidado y con repetidas sondas desde dos leguas á la mar. Entre las dos puntas, se hace primero visible una pequeña isla situada cerca de la costa á I 9 millas de la punta Mangla res, en la cual se forma el morro de Tumaco, que es un monte no muy alto, con un pico de árboles. A su parte exterior y muy cerca, hállase un farallón llamado el Qucsillo, j entre ella y la costa lirme, dondé se encuentra la población de Tumaco formada de españolcs é indins, hay dos islas menores, dc las cuales la más meridional es la Isla Viciosa. Ofrece un buen puerto al Norte del morro Tumaco, para cuya entrada, rodeada de bajos de piedra, es preciso avalizar la canal, que es á veces variable con fondo de seis á ro brazas: hállanse en él diferentes especies de provisiones, si se exceptúa de pan, que no se encuentra en toda la costa desde Guayaquil para el Norte.

Desde el morro Tumaco hasta la Isla del Ga1lo, que es otro objeto notable del pedazo de costa que vamos describiendo, forma la costa firme una ensenada algo profunda, llamada de Usmal, por unas pequeñas lomas cubiertas de arboleda, que se levantan cerca de la mar, sobre un terreno anegadizo y de manglares. En lo in. terior se ven las sicrras de Barbacoas, que se distinguen por su mayor elevación.

El río Rosario, bastante caudaloso, desemboca en este trecho, del cual se avanza á la mar poco más de una legua el Viudo, islote pequeño, rodeado de bajos que se extienden bastante para fuera.

Isla del Gallo.-La Isla del Gallo se sepa. ra de la costa por un pequeño estero: es de poca elevación, más elevada por la parte Norte que por la del Sur, en cuya dirección próximamente coge su mayor extensión, que es de dos millas. Su fondeadero es al Norte en ocho bra. zas arena, llamado puerto de Salaonda, por la pequeña ensenada que le está inmediata, en que se halla una población á la orilla del río de su nom. bre, con el cual se distingue también la punta. que termina la ensenada al Norte, en la que se eleva un morro de mediana altura, cubierto de arboleda, y lo más alto de esta costa inmediata.

Sigue luégo cl terreno para el Norte, más bajo, no con tanta arboleda, y en lo interior se ven algunos cerritos poco notables: lo interrumpen diferentes ríos, algunos de los cuales considerables, y su fondo aplacerado permite fondear en diferentes partes de la costa.

Punta de Guascama.-La punta de Guascama, temible por los bajos que la rodean, se extiende más de una legua á la mar: es el pricipio de la costa de la Gorgona, la cual hurta mucho para el Este, y la forma un terreno bajo, lleno de manglares, entrelazado de los muchos ríos y esteros, cuyas aguas despiden varios bajos y placeres. Al Noroeste de aquella punta, á ocho y media millas de distancia, se cogen 35 bra. zas conchuela.

Isla de la Gorgona.-La Isla de la Gorgona que da el nombre á su costa inmediata, queda situada á 24 millas al Nordeste de la punti Guascama y á diez millas de la costa inmediata. Es de mediana altura, cubierta de árboles, y avis tada al Nordeste $1 / 4$ Este, se presenta formando tres alturas igualmente distantes, de las cuales la mayor es la del medio, y le sigue luégo por si: 
elevación la del Sur: su mayor extensión es de una legua escasa en la dirección de Norte pocos grados para el Este. De esta isla se separa muy poco hacia el Nordeste un pequeño islote llamado el Flanenco, y al Sur de la misma, poco más distante, hállase la Gorgonillı, que es una isleta rodeada en gran parte de faralloncitos. Son muy hondables todos los alrededores de estas islas, y al Este de la mayor, ofrece el mejor fondeadero en 20 brazas de agua cerca de tierra, en donde unas playas de arena facilitan el atracar á ella para proveerse de agua de los varios arroyos que la bañan, como igualmente de leña y plátanos, pero sin otros auxilios que proporcionaría una población que allí hubiese. A diez millas por la parte Oeste de la Gorgona no se halla fondo con 55 brazas.

Isla de Malpzlo. - No será fuera de propósito incluir aquí, antes de seguir la descripción de la costa firme, las pocas noticias que se tienen de la pequeña Isla de Nalpelo, cuya posición demora al Noroeste de la Gorgona. Uno de los prácticos de esta carrera, favorecido del tiempo y de una mar llana, saltó en tierra por la banda Norte, en una meseta que tiene, y subidos 30 escalones hechos á mano, encontró en la cima de él una gran laguna de agua llovediza, que estaba poco limpia y con algunas plumas de pájaros: se aprovechó de esta agua para llenar algunas pipas, por la suma falta que tenía. A esto se reduce cuanto pueda hablarse con seguridad de Malpelo.

Costa de la Gorgona.-Volviendo de nuevo á la costa de Gorgona, diremos que el exacto conocimiento de ella, como de un gran trecho de la que corre al Sur, merece una descripción más prolija de la que podamos dar, y á la verdad interesante, por los muchos ríos y esteros, varios de los cuales son considerables. Los placeres despedidos por estas aguas, que se creían enteramente avanzasen más á la mar, las diferentes corrientes encontradas que forman los mismos ríos, la tierra baja y de manglares, y las estaciones sujetas, ó á muchas cerrazones, lluvias y turbonadas, ó bien de los vientos de afuera, han sido otros tantos estorbos para no tener unas descripciones exactas y conformes de los que han emprendido estos reconocimientos por partes. Ciñámonos, pues, á los objetos notables para su navegación costanera, y se reconocerá primero en la costa de la Gorgona unos pequeños altos llamados Altos de la Tortıga, á I 8 leguas de la isla de aquel nombre, poco distante de la orilla de la mar, de donde se extienden los bajos más afuera que en el resto de la costa, exceptuada la punta de Guascama, y es á poco más de una legua. Al Noroeste de estos altos se cogen $+\mathrm{I}$ brazas lama y al Nordeste de los mismos 33 brazas igualmente lama, distante aquel fondo de la costa inmediata 2 I millas y éste 23.
Golfo de Chocó.-De los altos de la Tortuga hasta la Isla de la Palma, compréndese el golfo de Chocó, en cuya costa se hacen visibles los altos del Mallorquín, que forman un morrito en figura de pan de azúcar, antes de los cuales profundiza una ensenada con varios ríos, para contener la Isla de los Camachos, que se extiende cinco millas en circunferencia. Sigue al Norte la bahía de San Buenaventura, rodeada de bajo fondo, interna una legua, y una igual distancia que abraza su boca, queda terminada por la punta del Soldado al Sur, aplacerada, y por la de San Pedro al Norte, inmediata á dos islotes, cuyas puntas demoran al Noroeste á una legua de distancia. Sirve de fondeadero para las cmbarcaciones pequeñas cerca de la Isleta del Cascajal, situada en medio de la bahía en cuatro ó cinco brazas arena, y para las grandes en la costa del Sur en ocho ó nueve brazas lama frente de la playa del Soldado, la cual toma el nombre de la punta ya citada, que determina su extremo occidental. Forman esta bahía tierras bajas interrumpidas de algunos ríos y esteros, pero en lo interior se ven montes de regular altura.

Desde la punta de San Pedro continúa la costa algo más alta, de piedra, un poco escarpada, con manchas blancas hasta la bahía de Málaga, en donde desaguan y se entrelazan varios ríos. No es de tanto placer su fondo, y en su medianía se hallan los Negrillos, así llamados á dos pedruscos bastante unidos, que siempre velan, y se separan poco más de dos millas de la tierra firme, para formar una canal de ocho brazas, y por fuera de ellos, á diez millas, se encuentran 35 brazas lama suelta.

Isla de Palma y bahía de Málaga.-La Isla de la Palma, baja y de manglares, y varios islotes al Norte, de igual formación, ocupan la boca de la bahía de Málaga, cuyo terreno es en partes algo más elevado. A la parte exterior de aquéllos, hay bajos, como igualmente al Sudoeste de la isla, pero en su paralelo, dos y media leguas á la mar, hállanse 30 brazas arena fina y arena, conchuela y cascajo.

Su mayor extensión es de media legua, y se separa de la costa inmediata, que es la punta Sur de la bahía, media milla, con fondo de cuatro á seis brazas.

Punta de Chivamira. - La punta de Chiramira, visible por ser bastante saliente á la mar, demora al Noroeste de la Isla de la Palma.

Aquella punta y la costa comprendida hastid esta isla, la defiende un pequeño placer, y se presenta baja y de manglares, pero el terreno interior es algo más alto, de piedra y lleno de arboleda. Los ríos de San Juan, Chavica, Estebanicn y Cacagual, desembocan poco al Sur de la punta nombrada, y al Norte de ella el río Chiramira, todos los cuales se reunen á diferentes distancias 
y los dos primeros más en lo interior, esto es, á Io leguas próximamente de la costa.

Sigue ésta al Norte de la punta de Chiramira, igualmente baja y llena de manglares, con varios ríos y esteros hasta los Altos de Bando.

Son estos unos cerros bajos, algo interiores, llenos de picos, bien visibles por ser el principio de la tierra más alta, la cual forma algunas puntas de piedra, escarpadas y con arboleda. Seis leguas al Sur de ellos, se levanta cerca de la costa una altura notable.

Cabo Corrientes.-E1 terreno que lo forma es de bastante altura, y avistado á la parte del Sur, parece aislado con sólo un pico, como igualmente la costa inmediata, formando á alguna distancia varias islas, pero mayores y más altas que la tierra del Cabo. Cerca de éste, á la parte Sur, hay fondeadero en ro y I2 brazas, y suministra agua un manantial que despeña del mismo, y se ve á corta distancia. Interna en esta costa la Ensenada del Palmar, en que desaguan los ríos de Tarifa y del Platanal, y es de tierra baja su orilla, y alto el terreno interior: la limita al Sur la punta de la Balsilla y al Norte el Cabo Corrientes, cuyos extremos distan cuatro leguas.

Altos de San Francisco Solano.-Una punta saliente, en que dan principio los altos de San Francisco Solano, de poca elevación, corre con el cabo nombrado, al Noroeste. Su costa comprendida, baja y de manglares, en que desembocan varios ríos, de los cuales el más meridional, llamado de Sandio es caudaloso, le dan el nombre de Anegadas por los muchos bancos anegadizos que la rodean.

Punta de Guarachine.-Desde esa punta saliente hállase la de Guarachine en la dirección próximamente dcl Noroeste. Termina en ésta la costa corrida para dar principio al Este al golfo de San Migucl, y lo forma su extremo á la mar, un terreno bajo, cubierto todo de arboleda; cerros algo bajos corren dos leguas la costa al Sur' desde donde siguen montes de más que mediana altura, de los cuales el más próximo á la orilla llaman Cerro del Sapo. Una legua y media al Norte de la punta de San Francisco Solano, hállase la bahia de su nombre, cuya boca es de cuatro y media millas. A ésta sigue el Puerto Quemado que es pequeño con varios farallones á la boca, y da el nombre á un morro muy inmediato al Norte, el cual es un punto de recalada para los buques que navegan del Sur á Panamá, para no abandonar las cercanías de la costa hasta la punta de Guarachine: en este trecho se encuentran otros tres puertos igualmente pequeños, que el que nombramos últimamente.

Puerto de Piñas. - De ellos, el de Piñas es el más meridional y el más capaz: ofrece un fondo limpio por todas partes, no menos que alrededor de dos islotes que resguardan la boca, al Sur de los cuales se verifica la entrada. Desagua en él el río de su nombre, y es el principio para el Norte de la tierra alta. Los dos al Norte, sólo buenos para pequeños buques, son puerto Escondido y el de Caracoles.

Golfo de Pananix--La punta de Guarachine y la de Mala, que demoran al Oeste-Sur, comprenden el gran golfo de Panamá. En él se encierra el archipiélago de las Perlas, cuyas costas muy hondables dejan con la tierra firme una canal ancha y de sondas. La entrada por la parte oriental de estas islas, es la que practican las embarcaciones que vienen del Sur, y la opuesta las que bajan del Norte. Aquélla lo limitaría la Isla de la Galera, la más meridional de las Perlas con la punta Guarachine, si no la estrechase un pequeño bajo llamado de San Fosé, temible antes por el poco fondo que le suponían, y por su posición nada exacta, á que se añadía la fuerza de las aguas del golfo de San Miguel, con dirección hacia él. Reconocido últimamente con la mayor escrupulosidad, se ha visto que su menor fondo, de ocho brazas piedra, ocupa un muy pequeño espacio, y en sus alrededores tiene I2, I5 hasta 20 brazas, igualmente piedra. Una línea de sonda tirada desde la Isla de la Galera hasta el bajo, cuyo trecho es de cinco millas poco más, manifiesta que su fondo de ocho brazas piedra cerca de aquélla va aumentando poco á poco á $x_{5}$ brazas de igual calidad, y luégo de arena ó arena y conchuela á 25 brazas en la medianía de la canal, y hasta 40 en las cercanías del bajo. A la parte oriental de éste, y poco distante, hállanse 25 y 30 brazas lama.

Golfo de San Miguel.--Siguiendo la descripción de la costa, se verá que la punta Guarachine y la punta Gorda al Norte son el principio del golfo de San Miguel, considerable por los muchos ríos que desembocan en él, entre los cuales es el más principal por su caudal y por su largo curso el río Tuyra. Compréndese en este golfo, en su costa Sur la ensenada y población de Guarachine, que sigue á un pequeño frontón formado de la punta de Flores con la de Guarachine.

Bajo de Guarachine.--Para mayor seguridad del navegante, advertimos aquí que algunos planos, aunque no el mejor y levantado últimamente, colocan un pequeño bajo al Norte próximamente de esta última punta á una milla escasa de distancia.

Punta Gorda y punta de San Lorenzo.-La punta Gorda y al Este pocos grados al Sur de ella, la de San Lorenzo, forman un frontón saliente, de una legua, ambos notables por ser el principio de la costa que hurta casi al Norte; aquélla para seguir la dirección del golfo de $\mathrm{Pa}$ namá, y ésta para formar una de las ensenadas del golfo de San Miguel. 
En la costa baja y en gran parte de manglares, de que fórmase todo el golfo de Panamá, se distinguen las sierras de Manjue, no distantes de la orilla de la mar, en que desemboca el río de su nombre. Frente de este trecho de costa se encuentra á media legua de distancia una pequeña isla llamada Majaguei y otra á una legua con el nombre de Las Sierras y conocida también por el Tigre. Ambas corren un mismo meridiano, y en el espacio de media legua que se separan, hay un pequeño bajo fondo. Son altas, escarpadas y cortadas á pique, lo cual y los varios pedruscos que las rodean las hacen inaccesibles áun para botes.

Islote Pelado.-Este islote queda en el paralelo del Tigre en la parte occidental, y forma con un farallón que le demora al Este-Norte, una canal de cuatro y media millas; su fondo es de I 2 brazas lama arena á medio cable del Pelado, $y$ va disminuyendo gradualmente hasta encontrar dos brazas de la misma calidad á igual distancia del farallón, y en su medianía es de nueve brazas lama.

Al Oeste del Pelado, á una legua, hay I5 brazas lama.

Placer que corre la costa del golfo de PanamíUn placer de arena fina y á veces de lama, corre toda la costa desde el río Manjué hasta Panamá, y más al Oeste con alguna diferencia, en su mayor ó menor extensión, á la mar. La canal navegable hasta el fondeadero de Panamá, siempre de fondo lama, va disminuyendo sensiblemente desde su medianía hacia la costa firme, pero con graduación, y anuncia desde las ocho y nueve brazas su mucha proximidad al placer. Este se extiende en la punta Manglares más que en el resto de la costa, y precisa muchas veces acercarse á ella cuanto sea posible á fin de aprovechar mejor de los bordos para montar la más septentrional de las Perlas llamada Pacheca. Demora la punta Manglares de esta isla al Nordeste; su fondo, á cuatro millas distante de ella es de dos brazas, y de nueve igualmente lama á dos leguas.

En toda la costa que le sigue al Oeste hasta Panamá se halla fondo de tres brazas en baja mar á una legua de distancia de tierra sin temor de bajo alguno, pues los que hay de arena en las bocas de los ríos son muy poco șalientes y sólo se encuentran algunas piedras en las cercanías de Panamá Viejo y en los alrededores y bajos de la Isla Chepillo. Esta isla que demora al Noroeste de la Pacheca y al Oeste-Sur de la punta Manglares, forma un canal con la costa firme, que en bajamar tiene de dos á tres brazas de agua. Es muy frondosa, llena de matorrales y despeñaderos y su terreno peñascoso: en la parte Norte formase una pequeña cala, en cuyas inmediaciones se encuentra agua en posa cantidad, pero muy buena; fué habitada por una ranchería de negros hasta el año de 8I.

Río Chepo.--El río Chepo hállase en la costa firme, frente de la isla que acabamos de describir: la punta oriental de su embocadura la forma un morrito llamado el Griego, y la de Sasino que es la opuesta, tiene una casa donde se ha puesto una guardia de sargento, porque los indios se avanzaban á las canoas que se veian precisadas á fondear por allí. Entre los infinitos ríos que abrazan toda la costa del golfo, es el de Juan Díaz, al Este de Panamá Viejo, uno de los frecuentados por las canoas: éstas entran y salen por medio de las mareas, y lo frecuentan para recoger hermosos tablones de caoba, que se cortan en un cerro redondo y bajito, que se ve allí cerca en su costa oriental.

Panamá Viejo. - Las ruinas de la antigua $\mathrm{Pa}$ namá distan una y media leguas al Este de la que ocupa hoy día: se hallan en la inmediación de un río y á la orilla de la mar, sobre una punta, la cual forma, con la de Paitilla al Sudoeste, un trecho de costa seguida y baja, resguardada de piedras y bajos fondos, muy cerca de tierra.

A esta última punta sigue una pequeña ensenada en que desemboca á poca distancia de aquélla el río de su nombre, desde el cual le rodea una playa de arena, interrumpida sólo en la medianía de dos puntas de piedra inmediatas, llamadas de Peñas Prietas y de Negros. Demora de la punta Paitilla, al Sudoeste á una y media milla, el otro extremo de la ensenada, en que se eleva la Ciudad de Panamí, defendida de un castillo á la parte meridional y más saliente á la mar. Rodeada ésta de diferentes piedras hasta media milla poco más, obliga á los botes separarse esta distancia en las mareas bajas, en que se descubren casi enteramente. El fondo de la -ensenada nombrada queda igualmente seco en gran parte, por cuya razón, colocado el desembarcadero al Norte de la ciudad, hace también preciso para saltar en tierra, ganar un pequeño trecho de mar, en canoas. Tal es la fuerza de las mareas en estos parajes, que cuando llenas, no sólo permite con las lanchas acercarse al desembarcadero, sino que también se atraca sin recelo la punta del Castillo. Rodeada la ciudad en gran parte, de la mar, la respalda por la parte de tierra un pequeño valle formado de varios cerritos, entre los cuales el mas inmediato, llamado el Alarcón, se eleva IoI toesas por medida geométrica, sobre aquel 1lano. Demora éste como al Noroeste, y otro, poco más distante al Oeste, es el de Gavilán: en lo interior se hace visible el Peñón, que es un monte alto al Norte exactamente de la ciudad.

Islas de Flamenco, Naos y de Perico.-Interrumpamos por un momento la descripción de la costa que le sigue, para hablar de su fondeadero que se halla al abrigo de las Islas de Flamenco, 
de Pericn ý de Nans, á las cuales se añade otra menor llamada Culebrilla, con dos farallones de cerca á la partc Sur y Oeste, todas muy frondosas y las dos primeras montuosas. La Isla de Perico, que es la del medio de las tres principales, redonda y de tres cuartos de milla de bojeo, dista de la punta del Castillo de Panamá muy poco más de dos millas, y demora su medianía de la misma punta, al Sueste. A la parte Norte fondean las embarcaciones á dos cables de distancia, en cinco y seis brazas fondo lama, cuyo buen tenedero las asegura de los vientos á que están descubiertas, los cuales no levantan mar por su dirección que sale de la tierra inmediata. Un bajo fondo sembrado de piedras que se descubre en las mareas bajas, une esta isla á la de Naos, situada al Oeste media milla escasa, y á la Culebri1la, que se halla entre una y otra, pero más cerca de ésta y con alguna inclinación al Sur. Ocupa la Isla Flamenco una extensión casi igual á la de Perico, de la cual se separa por un pequeño canal, y su dirección es de Norte-Este. La de Naos, algo más pequeña, es una lengua estrecha de tierra que se extiende al Nordcste. Ambas y la Culebrilla descubren.su fondo por algunas partes de su orilla en las mareas bajas, como se verá bien por el plano, $\mathrm{y}^{r}$ son aquellas dos, las únicas de este grupo de islas habitadas por algunas familias de pescadores, que cultivan también una pequeña porción de su terreno. Compréndese, finalmente, en este mismo grupo, un islote llamado de San José, que demora al Sueste en la enfilación de los dos extremos Nordeste de Perico y Flamenco, $y$ distante casi media milla de esta última, cerca de la cual se encuentran siete y media brazas cascajo, y va disminuyendo el canal que forma, hasta tres brazas, poco distante del farallón. Queda ya sólo para advertir, que hay un pedrusco con muy poca agua á la parte oriental del Flamenco, á un cable de distancia, en cuyo espacio aumenta el fondo á seis y un cuarto brazas, y otro pedrusco igualmente anegado, al Norte y muy cerca del islote.

Islas de Saroga, Savoguilla y de Uraba.-La falta de agua en estas islas obliga á las embarcaciones, concluído el objeto de su estada en ellas, transferirse á la de Savoga, frente de su población, en donde un buen fondeadero, una pequeña playa abrigada de la mar, y unas pozas inmediatas dc agua manantial, no ménos excelente que abundante, proporciona el concluir su aguada en muy breve tiempo. Otras dos islas menores, igualmente montuosas, pero no de tanta elevación, ocupan sus cercanías; la de Savoguilla al Nordeste una y cuarto millas por la parte más inmediata; y la de Uraba, que es la más pequeña, da su nombre á un canal de poco más de un cable quc forma con el extremo Sueste de Saroga. Lista isla que se extiende al Noroeste una y' media millas, estrecha algo al Sur de su medianía, acercando sus dos costas opuestas á un cuarto de milla de distancia: vuelve luégo á ensanchar y forma en esa angostura dos ensenadas, la del Atillo al Norte, pequeña, y mucho mayor la del Sur, llamada de Iprocá. Entre aquella ensenada y un islote cercano á tierra, que se eleva en morro, llamado de Savoga, hállase la población que hemos nombrado, en medio de platanales, en el peque. ño llano que se extiende desde el pié de los montes y la orilla de la mar. E1 fondeadero es en II y I 2 brazas lama á un cable de tierra, y á poca mayor distancia del morro. Este tiene varios pedruscos muy inmediatos en todo el frente del Este al Sur, fuera de los cuales se encuentra luégo siete brazas cascajo, y el pequeño trecho que se separa de la Isla Savoga, descúbrese en las mareas bajas: su demora del Islote de San José es Sudoeste, cuyo rumbo se navega para alcanzar este fondeadero pasando á un cable de dis. tancia poco más por fuera de ambos islotes y por fondo de II y I2 brazas lama, aumentando sólo á I6 y I7 brazas no muy distante de los dos. Todo el espacio de mar comprendido por las tres islas, es de un fondo de 2 hasta 20 brazas lama. Permite una salida segura por entre las Islas de Savoguilla y de. Uraba, aproximándose á ésta para evitar un pequeño bajo, muy hondable en sus alrededores, que se separa una milla en la dirección Este-Norte de su extremo septentrional, y distante tres cuartos de milla al Sudoeste de un farallón llamado de Sube la Vaca, situado al Sur y no lejos de Savoguilla: el canal que forma el bajo con la Isla de Uraba, es de 20 brazas á un cable de distancia de ambos, y de 22 en su medianía. Otro pequeño bajo igualmente hondable por sus alrededores, se halla entre el bajo y el islote nombrado últimamente.

Costa frme.--Retrocediendo ahora para seguir la descripción de la costa firme, se verá que des. de la punta en que se halla la ciudad de Panamá, hurta sensiblemente la costa al Este para formar con la de Guinea, que le demora al Sudoeste, una ensenada cuyo fondo se descubre en las mareas bajas, y en ella desembocan varios ríos, de los cuales el principal y más interior es el Río Grandc. A la punta de Guinea sigue un frontón, coronado en la orilla de una pequeña restinga de una y media millas, hasta la punta de playa de Tejas: de ésta se separan poco más de una milla los islotillos de Cangame, de los cuales el mayor demora al Este-Sur, y una lengua de bajo fondo descubierto en las mareas bajas, la une á la punta de Guinea. En este pedazo de costa firme se eleva el Cerro de Cabra. La punta ya nombrada de playa de Tejas y la de Chame, al Sudoeste de ella, forman una ensenada en partes montuosa con varios islotes cerca de tierra, y por estos paralelos, cuatro más distantes, que 
son la Tórtola y Tortolilla, Cocabe y el islote Melo. nes, de los cuales los dos primeros, distantes entre sí media legua, están situados en la medianía próxima del arrumbamiento en que corren la Isla de Naos con la Savoga, y el último se separa de esta isla dos y media millas al Oeste, pocos grados Norte.

Punta de Chame.-La punta de Chame, resguardada de un bajo fondo que se descubre en las mareas bajas hasta media legua á la mar, y se avanza más que en las costas inmediatas, es una lengua estrecha de tierra baja, saliente al Nordeste tres millas, no muy distante de un morrito de su nombre, desde el cual se eleva un monte bastante alto, de color rojo.

Isla de Otoque y de Bona.-Al Sueste de esa punta, y al Sudoeste de la isleta Uraba, queda situada la isla de Otoque, poco distante de otra llamada de Bona, ambas montuosas, y entre ellas algunos faralloncitos. El canal que forman estas dos islas con la de Savoga, lo interrumpen dos islotes, distantes entre sí dos millas escasas, llamado el del Sur Valladolid y el otro de Chame, el cual tiene un farallón á la punta Norte.

Golfo d: Parita. - La punta de Chame y la de Mala, que demora al Sudoeste, son los dos extremos de una ensenada algo profunda que llaman golfo de Parita, interrumpida de diferentes ríos: forma su orilla un terreno bajo con varias puntillas escarpadas y playas de arena, y lo interior algunas sierras, en las cuales se hace visible un monte llano en su cumbre. Tres islotes hállanse cerca de tierra: el de Chiru en la costa del Norte, al Este de la punta de su nombre, que es baja, llana, con arboleda y escarpada: el de Guarave ó Cuvita en la costa opuesta; al Norte de la punta Mala, el de Iguanas: ésta tiene dos millas de circuito, y se presenta baja con mucha arboleda, rodeada de arrecifes á la parte exterior, en la cual hay dos pequeñas playas, y limpia á la opuesta: entre ella y la costa firme con playa, fórmase un canal con fondo de cinco, seis $y$ siete brazas, en que puede fondearse: al Nordeste de esta isla, poco más de una legua, encuéntrase fondo de 34 brazas arena: I9 y 20 brazas lama á la parte exterior de Guarave, á cinco millas escasas.

Punta Mala.--Es baja pero se eleva en lo interior á formar un terreno medianamente alto, y es fácil de reconocerse, tanto porque más baja la tierra inmediata á una y otra parte, como porque se halla no lejos de la Isla Iguanas, bien visible por su arboleda. Fórmase con otra punta al Sudoeste un frontón saliente rodeado de un pequeño arrecife, y á través de este extremo meridional, se encuentra á cuatro de distancia 30 brazas piedra.

Archipiélago de las Perlas.-El Archipiélago de las Perlas, del cual se omitió hablar antes, 10 forman la Isla del Rey y muchas otras más pequeñas, entre infinitos farallones. Todas ellas son muy frondosas; y después de aquella isla pueden contarse entre las principales, por su extensión, á su parte oriental, la de la Galera, San Telmo, de Puercos y de Cañas, y á la opuesta la de San José, de Pedro González, Vivero, Casaya y la de Savoga.

Isla del Rey.-Esta isla es montuosa, y se extiende cinco y media leguas al Noroeste, en una circunferencia de poco más de I 5 ; termina al Sur en un frontón de media legua con un farallón inmediato, y su punta al Este, llamada de Cocos, es la más meridional, y tiene en sus inmediaciones, fondo de I 4 brazas arena y conchuela. En la costa que mira al Norte, cerca de la Isla Viveros, se halla la población, compuesta de unas 70 casas ó chozas, con el nombre de Nuestra Señora del Rosario, en un altito que termina á la orilla de una ensenada, cuyo fondo descúbrese en gran parte en las mareas bajas hasta fuera de las tres islas de Tutu poco distantes al Este, y no permite acercarse á la playa con lanchas ó piraguas, áun favorecido de la marea.

Isla de la Galora.-La Isla de la Galera, de cuyo arrumbamiento y distancia con la punta de Guarachine y con el bajo de San José, se habló ya, demora al Este-Sur de la punta de Cocos, nom. brada poco antes. Es algo alta, y su mayor extensión de media legua corre próximamente EsteOeste, formando al Norte una playa que ocupa los dos tercios de su frente, y con fondo de siete y nueve brazas arená á menos de un cable de ella; pero está rodeada de reventazón, en parte por los bajos inmediatos, y en parte por la mucha marejada que siempre reina, de modo que no permite acercarse á ninguna embarcación.

Islote Elefante y bajos immediatos.-El Islote Elefante, uno de los extremos orientales del Archipiélago, tiene á una milla de distancia dos muy pequeños bajos con seis y ocho brazas en sus alrededores. El uno al Noroeste y el otro al Sueste.

Isla Pacheca.-Esta isla es bien interesante para la navegación de este golfo por ser la rnás septentrional del Archipiélago: una regular elevación la hace bien visible, y su mayor extensión es al Noroeste cerca de una milla, formando al Este una pequeña ensenada, en donde se fondea, y en ella se hallan algunas casas de pescadores, en medio de un platanal. Un canal de medio cable separa esta Isla de otra muy pcqueña al Noroeste llamado Pachequilla, y el fondo al Norte de ambas, á tres cumplidos de lancha, es de seis, siete y ocho brazas. Las embarcaciones ya en estas cercanías son visitadas de los que pueblan varias de estas islas, y les proveen de los diferentes frutos de que ellas abundan. En su arrumbamiento hasta la Isla de Perico se en- 
cuentran 46 brazas á dos millas de la primera, 29 y \% á tres y media leguas de la misma, y nueve brazas á una y media milla de la segunda.

De todas las islas del Archipiélago de Perlas, se comprenden entre las bajas, de alguna extensión, la de Cañas, Viveros, Bayoneta, Gibraleón y Chapera; á excepción de la primera todas estas son habitadas, y pueden contarse en el mismo número, á más de la del Rey y de Pacheca, de que hemos hablado particularmente, la de Savoga y la de Casaya.

Vientos y marcas.-Los vientos en la ensenada de Panamá son los mismos que se experimentan en toda la costa: las mareas ó cursos de las aguas, cerca de las islas son más sensibles que apartados de ella, y no se puede dar regla individual del rumbo que siguen, porque es según el paraje en donde se halla la embarcación, respecto de las canales que forman aquéllas entre sí, y varían en unos mismos conforme los vientos que reinan. Así, bastará quede advertido, que tienen movimiento las aguas, para que cualquiera pueda aprovecharse de este aviso. Consiguientemente, las embarcaciones que se hallan, después de montada la punta de Guarachine, contrares. tadas de los vientos y mareas contrarias, para internar en el golfo de Panamá suelen, principalmente en la noche, fondear en 20 hasta 30 brazas lama. A este aviso se añade otro no ménos interesante al navegante, y es que en toda la travesía desde Panamá á Guayaquil no se experimentan mares alteradas, porque aunque se levante alguna cosa cuando hay ráfagas ó turbonadas, es muy poco lo que se agita, y cesa luégo que se echa el viento. 


\section{ESTUDIO sobre las costumbres, y descripciones interesantes de la América del Sur, por Espinosa.}

\section{Noticias relativas á Montevideo.}

El Río de la Plata puede compararse á un mar ó golfo: hace horizonte; y si se cuenta su boca desde Cabo San Antonio (I) hasta el de Santa María (2), será su anchura de 40 leguas. La Isla de Lobos es un islote compuesto de rocas peladas, y sólo se le advierten algunos manchones con arbustos, estando poblado de lobos marinos y de muchas gaviotas, zaramagullones y otras aves. Más adentro se presenta la orilla Norte del río, formada de tierras bajas cubiertas de vegetales, y á cierta distancia, cadenas de montes y colinas.

La Isla de Flores (3) se compone de morros alomados y de rocas foliosas, como la que precede: tiene en su pié mucha peñolería, donde revienta la mar. Pudiera llamarse Isla de Pájaros, según la multitud de ellos que contiene.

Descubierto el cerro de Montevideo y la punta de Carretas, se presenta la población: sus casas, de un alto, y sus alrededores, llenos de casas cubiertas de paja, de corrales y ganados. Los corrales son formados de estacas y revestidos de cueros. Hay una fortificación de cuatro baluartes ó castillos ó ciudadela al Este de la ciudad, en un paraje elevado, de manera que la domina. La ciudad se sitúa en una lengua de tierra que sale al Oeste cosa de una milla. Está cercada de una muralla regular con ocho baluartes: baña el mar su circunferencia, excepto por el Este, y se halla cercada de peñascos en que se estrellan las olas.

Las murallas viejas no están muy bien conservadas, y sus fosos están llenos de yerba; de manera que al autor de estas Memorias no le parecía plaza de mucha confianza, por las pocas dimensiones de sus fosos y los barrancos y desigualdades de las cercanías, que no se distinguen bien desde la plaza. Una batería á barbeta que se halla enmascarada á la orilla del río (parece que en la parte más occidental de la lengua en

(I) La situación de este punto se ha hallado en $36021^{\prime}$ latitud Sur y $50^{\circ} 36^{\prime} 37^{\prime \prime}$ longitud occidental de Cádiz.

(2) Latitud $34^{\circ} 57^{\prime} 20^{\prime \prime}$ : longitud occidental de Cá$\operatorname{diz}, 48^{\circ} 36^{\prime} 40^{\prime \prime}$.

(3) Su extremo Sudoeste se halla en latitud $34^{\circ} 56^{\prime}$. l.ongitud occidental de Cádiz, $49^{\circ} 52^{\prime} 30^{\prime \prime}$. que se sitúa la ciudad), proporciona más sólida defensa contra las embarcaciones que se acerquen al puerto. En tiempo de paz tienen desmontados sus cañones; las esplanadas, durmientes, batientes y demás pertrechos, se guardan en el parque de artillería, y se tienen prontos para ponerlos en batería siempre que la ocasión lo exija.

El Capitán de fragata Liniers tenía la idea de adoptar para defensa del Río de la Plata un número de lanchas cañoneras, que bajo los fuegos de la plaza hiciese la más vigorosa oposición contra cualquier enemigo. Cuánto se pueda esperar de estas máquinas, lo acreditan los sucesos de ellas en Gibraltar, Argel y últimamente en el Mar Negro y en el Báltico. Estos habitantes son muy diestros ginetes y prácticos en el terreno, y formarian sin duda un respetable cuerpo de caballería contra cualquier invasión.

Se construyó esta plaza (I) en r724. Fué su primer Gobernador y poblador D. Joaquín Viana (2). Se emplearon los brazos de los indios Tapes. Por los años de 1776 , según las noticias de D. Cosme Bueno, tendría mil familias de población; pero por las más recientes que hemos adquirido, es en el día mucho más considerable, como luégo se dlrá.

Sitúase la ciudad en la parte Norte del Río de la Plata. Tiene su jurisdicción 40 leguas de Norte á Sur, y 40 de Este á Oeste, y su población se decía ser de 20.000 almas en toda ella; pero según el padrón circunstanciado hecho en I 78 I, parece era sólo de 8.973 españoles, 586 indios, 7 Ir mulatos libres, 352 negros y r.760 esclavos, que hacen el total de 12.382 ; incluyendo la población de Montevideo, enumerada en 4.405 españoles, 350 indios, 673 negros y mulatos libres y r.088 esclavos.

Tiene la ciudad un Gobernador militar, un destacamento de dragones, compañías de infantería, algunos artilleros, una fragata de guerra $y$ pequeñas embarcaciones de armadilla; sus Ofi-

(I) Está en latitud $34^{\prime \prime} 54^{\prime} 48^{\prime \prime}$ y en longitud $50^{\circ} 5^{\prime}$ y $45^{\prime \prime}$

(2) El autor del Lazarillo, 1). Alonso Carrio, dice que en I 73I, con poca diferencia, dió principio Don Bruno de Zabala á su fundación con I 4 familias que se trajeron de Canarias; pero parece se equivoca, al ménos, en la fecha. 
ciales keales y Administrador de Aduana, con correspondientes suardas del registro; un curato con una irlesia de no buena arquitectura, y un hos piciode Franciscanos, cuya iglesia es también de pobre fábrica. Las casas de la ciudad son dc un alto, de mampostería; las calles mal empedradas, pero rectas de Norte á Sur y de Liste á Oeste, que dividen la ciudad en varias cuadras: muchos solares, poca limpieza y curiosidad: en tiempo de lluvias se transitan con trabajo: hacia la marina hay muchos albañales y estercoleros, donde se crían muchas y grandes ratas quc infestan las embarcaciones: en los arrabales no se ven sino mataderos y carnicerías; toros que huyen de los ginetes que los desgarretan, toros que mueren, $y$ hombres ensangrentados que con la mayor agilidad los desuellan, y extienden y clavan las pieles con estaquillas en el suelo, preparándolas así para que las embarquen los catalanes, que hacen el principal comcrcio.

Muchos propietarios hacen venir su ganado á las inmediaciones de la plaza para ahorrarse el transporte de los cueros, por lo cual se ven tan repetidas matanzas.

En los alrededores de Montevideo se respira el desagradable olor alcalino de. las carnes: la vista se ofende con hosarios y despojos de animales, sobre los cuales caen espesas nubes de pájaros voraces, gaviotas, gallinazas, caranchos y otros, que oscurecen el aire.

Tantos despojos animales engrasan considerablemente las tierras, y se conocen por su negrura ó color más oscuro, las que fueron antiguos mataderos.

La población de Montevideo crece de día en día con la franquicia del comercio y la concurrencia de buques de los puertos habilitados de la Península especialmentc y de las embarcaciones catalanas (I).

Un clima análogo al de muchas provincias de España, la ocasión del transporte frecuente, y la facilidad de vivir donde los alimentos de prime-

(I) Cuando estuvieron allí las corbetas DescubierTA y ATREVIDA, se contaron veinte embarcaciones, inclusos dos correos marítimos y los buques de armadilla; 70 tiendas de catalanes, donde se vendia todo género de lienzos pintados, indianas, pañuelos, lienzos, cintas, zapatos y demás manufacturas de Cataluña. Los ducnoos de la cmbarcación establecen en tierra sus tiendas, y permanecen allí los meses que necesitan, hasıa que venden su cargamento: llevan en cambio cueros al pelo, cuyo consumo es considera b)le, y madera del aire, á que han dado valor en estos uiltimos anos, y dan un real de aquella moneda por cada par de astas. El frugal catalán no pierde el ticmpo clurante su forzada detención: pescan en el río, se alinentan de pescaclos, venden el sobrante, y cuando no hallan compradores, secan mucha parte para cl rancho de su viaje le vuelta. Otros hacen pe qucĩos viajes á Maldonado y hacen otros pequeños comercios. Resplandecen en estas colonias, principal mente los progresos del comercio y el acierto de las sabias providencias que lo animan. ra necesidad están casi de balde, atrae muchos españoles. La mayor parte de la población está dispersa por los arrabales: las casas, ya apiñadas, ya en grupos, cogen mucha extensión. Allí los guazos ó mestizos, ó gente de campo del país, viven en ociosa libertad que suele parar en libertinaje, sustraídos de la vigilancia de la policía. Hay en el terreno inmediato algunas huertas, que no se cultivan con el mayor esmero.

Algunos europeos son los que se dedican á la agricultura, y es su mayor trabajo destruír las muchas yerbas que produce el vicio de la tierra.

Uno de los parajes más amenos de las inmediaciones de Montevideo, es el río Miquelete, que descarga sus aguas casi en el centro del puerto, á más de dos millas de la ciudad, en la parte septentrional, flespués de haber atravesado huertas y bosques de melocotones, donde hay algunas buenas casas de campo.

El puerto de Montevideo es una ensenada en el Río de la Plata, de forma de herradura ú otra que se acerca; de tres millas de mayor diámetro. En la punta oriental de su boca se halla la ciudad, y en la occidental un cerro elevado en forma de pan de azúcar, que le debió dar nombre. El braceaje disminuye desde la mera línea de la entrada, considerada entre la punta más Sur de dicho cerro y la de San José del pueblo, desde tres y media brazas hasta una. El fondo es un fango ó limo muy blando, en el cual encallan las embarcaciones, sin riesgo en tiempo de pampcros: sólo padecerán algo en sus obras vivas los bajeles poco reforzados. Por otra parte, la naturaleza del puerto las defiende de los Estes.

El cerro al Oeste de Montevideo (I) tiene la figura de pan de azúcar, pero su altura es pequeña respecto de su base. Es la única eminencia que la naturaleza puso en estos parajes, y la mejor marca con que se reconoce el puerto.

Las tierras de la jurisdicción de Montevideo yacen á la orilla Norte del Río de la Plata: se componen de dilatadas llanuras, que no guardando un perfecto nivelamiento, se inclinan unas á otras y forman senos, de donde salen venas de agua que forman arroyos y continuos prados donde se crían los más pingües pastos.

Los arroyos considerables y los ríos, vienen de las montañas vecinas: todos desaguan en la orilla Norte del Río de la Plata: sus cauces son otıas tantas alamedas que cruzan esta uniforme llanura, y suministran leña y agua para las pocas poblacioncs que en ella se hallan. Las haciendas de los montevidenses son grandes dehesas que se contienen por el frente por el Río de la Plata, y por el Este y Ocste por dos ríos colaterales que descargan en él: por el Norte se hallan abiertas, por cuya razón sitúan por aque-

(r) Su latitud $34^{0} 53^{\prime} 4^{\prime \prime}$, longitud $49^{\circ}$ I $3^{\prime} 45^{\prime \prime}$. 
1la parte las casas de los capataces y guardas. Estos andan contínuamente á caballo, rondan el ganado y hacen los rodeos correspondientes. Se sorprenden los europeos que por la primera ve $z$ ven las inmensas caballadas y vacadas que vagan por estos llanos, que hacen horizonte en muchas partes. El caballo padre con la crin tendida capitanea la yeguada. El toro se encara al pasajero á distancia: estan vacas con muchos y pintados colores, con becerrillos que las acompañan. Al acercarse el pasajero, yeguas, toros, vacas, todos corren: temen que los vayan á enlazar: esta insidiosa arma es el terror de los animales.

Entre Montevideo y Maldonado se hallan los ríos de Solís Chico, de Mosquitos y Solís Grande. Entre ellos se cuentan algunos arroyuelos de poco nombre: todos tienen arboleda, aunque de poca magnitud. En los parajes bajos se encuentran muy pequeños y desiguales fragmentos de conchas, que el mar depositaría en algún tiempo. De dos en dos leguas se ven casas de paja, que son lo que en España llaman cortijos ó ranchos de ganaderos. Otras habitaciones pertenecen á los puestos de Dragones, donde hay pequeños destacamentos para servicio de la posta, y cuidado de la caballada que la mantiene. Estos puestos, según su importancia, están á cargo de cabo, sargento ú Oficial, con correspondiente número de tropa; la que, tan dividida y esparcida, apenas tiene de tal sino el nombre: hay destacamentos de dos y de tres hombres: rara ve $z$ ven su compañía: cuando estuvo el autor de esta descripción se hallaban sin vestuario: solo por el bigote se reconocían por Dragones.

Si se extiende la vista entre Montevideo y la colonia del Sacramento, se registran los ríos de Santa Lucía, San José, Jufre, Coya, Los Padres y el Sauce, que son los más considerables, vadeables en verano $y$ aun con poca agua muchos de ellos. En sus orillas tienen asiento las siguientes poblaciones: las más son modernas, hechas por el Rey y por particulares: unas son formales, y otras, casas esparcidas, á saber: según un estado hecho por la ciudad de San Felipe de Montevideo en 1787.

Casas. Personas.

Miguelete y Pantanosos..........

Piedras y Colorado..............

Arroyo de las Brujas ........... Canelones Grande, Chico y Cerrillos.

Santa Lucía Grande...........

El Fala....................

Santa Lucía chico, Pintado y la Cruz. Arroyo de la Vírgen............

San José, Cagancha de una y otra

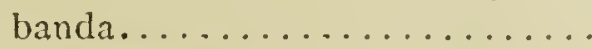

Carreta quemada.............. I $62 \quad 647$ $88 \quad 484$ $54 \quad 252$ $62 \quad 220$ 55200 $54 \quad 353$ $21 \quad 17 I$
$420 \quad 1.430$ $240 \quad 854$ $83 \quad 378$
Casas. Personas

Chamizo................ 30 231

Arroyo de Sierra y Mereles........ to 316

Sauce y Pando................ $37 \quad 207$

Solís Grande y Chico y Villa de Mi-

$50 \quad 371$

Aumentó la población desde I78I hasta 87 , en número de 2.360 personas, y se levantaron 529 casas más; siguiendo cada día el aumento por las causas que se dijeron.

En varios de los arroyos que desaguan en los de Santa Lucía y San José, se encuentran pepitas de oro; y en el paraje que llaman de las Minas, según_les informaron, las de plata, plomo, oro y cobre. De oro vieron en Montevideo pepitas cogidas en la jurisdicción. Pero estas minas se hallan en abandono por falta de inteligentes que las trabajen.

La ocupación y comercio de los habitantes de Montevideo es la cría de ganados caballares y vacunos, en la cual tiene la mayor parte la naturaleza, pues estos útiles animales se crian en las regiones bonarienses por sí mismos, sin que el hombre ponga otra diligencia que plantar el hierro al ganado que paste por su hacienda. La abundancia de los pastos y la vasta extensión de las dehesas, promueven la propagación de estos animales en razón de la cantidad de alimentos que encuentran; sin embargo de que hasta aquí matan el ganado sin distinción de jefes, edades, ni tiempos, 10 que debe contribuir á la disminución de su número, como verdaderamente se verifica. Otro cuidado de estos provinciales es rondar las entradas y salidas de las haciendas, las matanzas, etc. Se emplean también en sacar el sebo. En el día se hacen ensayos para hacer extracciones de carne salada, la que preparan muy bién, según el método de Irlanda.

Hacen del cuero de vaca cuantos utensilios y muebles necesita la vida humana. Como el cuero humedecido es una lámina flexible que recibe cualquier forma, y ésta la retiene cuando se seca, le aprovechan maravillosamente. Hacen cofres, petacas que se conocen bien en España, jaulas para cotorras, botas, cuerdas de toda especie; y sobre todo, graneros en que guardan trigo $y$ otras semillas. Esta manufactura merece particular descripción. Sacan la piel de la vaca mediante una incisión en la región del vientre y ano, con tanta perfección, que en rellenándola de cualquier materia, parece de lejos, que vive la res. Estas singulares trojes ó arcas las llenan de semillas y dicen que se conservan muy bien.

Los cueros tienen el valor de ro rs. de plata dentro de la hacienda, y concurre á su extracción gran número de embarcaciones catalanas. 
Las astas, que han tomado valor de pocos años á esta parte, valen un real de plata.

Los caballos prestan no ménos útiles servicios. Sin ellos no se manejarían unas haciendas tan dilatadas y desiertas. Los montevidenses se acostumbran tanto á su ejercicio, que ni pobres ni áun esclavos andan á pié: se ve pedir limosna á caballo y picar los bueyes que arrastran una carreta. Regularmente caminan, ó á trote vivo, ó á gran galope. Los caballos sufren la fatiga á un grado increible, si no se viera. Los que dieron para las excursiones á que concurría el autor, estuvieron un día en el foso sin comer, y después corrieron dos ó tres postas seguidas: guardan después igual ayuno si no los sueltan á los pastos; aguantan igualmente la sed; los dejan con la rienda caída y permanecen como postes; tienen regularmente buena conformación, y sólo ceden á los buenos caballos de Andalucía y Chile, sin que degeneren de la excelente raza de que provienen. Se ven también caballos enteros que conservan cuantas ventajas se desean en una buena estampa. No sólo aguantan tan prolija abstinencia, sino que hacen las más extraordinarias diligencias de velocidad. Según cuentan, en aquella tierra es común andar el propio caballo 30 ó 40 leguas en un día. El bajo precio en que se venden estos nobles brutos (la mejor conquista del hombre) hace que los expongan á rudas y extraordinarias pruebas. El mejor caballo se vende, á escoger, por un peso, si está cerril; pero los enseñados á buen paso se venden respectivamente con estimación. Una yegua paridera vale dos reales de plata.

De las costumbres de los montevidenses, no puede ménos de alabarse su generosidad, hospitalidad y buena índole que los caracteriza. Entre la clase noble y acomodada, unos viven de sus chácaras, en que cultivan por medio de sus esclavos el trigo y otras varias semillas de Europa. Aquel suele dar ciento por uno, y aseguran, que el dejado en los rastrojos, suple por una nueva siembra, y se coge nueva cosecha en el año venidero. Es de la mejor calidad; y si tuviera extracción, constituiría un nuevo y extenso ramo de comercio, y remediaría much os años las necesidades de la metrópoli. Hay tierras inmensas de pan llevar, de la mejor calidad. Pero está la navegación ahora en su infancia para que se adopten expeculaciones que, piden unos transportes baratos. Se dedican también á la cría de sus ganados, al comercio de cueros. Gustan mucho de andar á caballo hombres y mujeres; beben mate a todas horas; hablan con cierta languidez, mayor que en otras partes; se resienten de la falta de trato, que produce cierto encogimiento. Por lo demás, soll de buena disposición, tanio de potencias como de cuerpo. Los sucesivos aumentos que debe esperar en su comercio aquella po- blación, la hermosearán en su planta natural, mejorarán su policía y los habitantes adquirirán progresivos grados de ilustración. Las poblaciones grandes se hallan á mucha distancia.

La gente plebeya, á quien la educación no restringe las pasiones, y la civilización no enseña aquellas fórmulas de saludos y palabras que llaman de buena crianza (mentiras permitidas), vive con cierta independencia y franqueza que les permite la facilidad de los alimentos y la naturaleza del país que habitan. La siguiente viva pintura, franqueada por un europeo, excelente observador, no desagradará á nuestros lectores:

\section{Descripción del que llaman guazo it hombre de campo.}

Un caballo, un lazo, unas bolas, una carona, un lomillo, un pellón hecho de un pellejo de carnero, es todo su ajuar de campo.

Una bota de medio pié, unas espuelas de la. tón del peso de dos á tres libras, que llaman nazarenas, un calzoncillo con fleco suelto, un calzón de tripe azul ó colorado, abierto hasta más arriba de medio muslo, que deje lucir el calzoncillo, de cuya cinta está preso el cuchillo flamenco; un armador, una chaqueta, un sombrero redondo, de ala muy corta con su barbiquejo, un pañuelo de seda de color y un poncho ordinario, es la gala del más galán de los gauderios.

Su vida, siempre monótona, se reduce á salir al campo, siempre á caballo, y correrlo de rancho en rancho sin cuidar jamás de su manutención propia, seguro de encontrarla en la primera parte donde se apee, pues cualquiera recibe hospitalidad franca, sin el empeño de tener siquiera que agradecerla, porque siempre están surtidos los ranchos, de charque, que es una carne secada al Sol y cortada en delgadas tiras, que se asa en cuatro minutos, sin otro condimento que un poco de agí, ni otro pan que el jugo de la gordura que produce el mismo charque; y este es el alimento que más usan.

No será supérfluo exponer el diálogo que acostumbran para presentarse al rancho más desconocido. Se ponen á caballo delante de la puerta de él: le dice el amo:

- Di-os lo guarde aa-mi-go, pronunciado con mucha lentitud.

R. - Y á Vd. lo mis-mo.

-A-pe-ese si gusta.

$R$. No hay para qué.

-Va-ya, no sea son-so.

R.-Valdreme de su fa-vor.

-Deje ahí el ca-ba-1lo, no más.

R.-Deo gra-cias (ahora va entrando).

-Ca-ba-llero sién-te-se y no más.

R.- ¿Habrá un fuegui-to? 
-Alcán-celo por su vi-da, que ahí está á la vuelta.

Con estas palabras, que se pueden tomar como formulario, se sientan á comer en una banqueta de la figura de un asiento de zapatero, donde la hay, ó sobre una calavera de vaca. Se fija el asador en el suelo, que es lo más común, y puestos en rueda alrededor del asado, cada uno le tira tajos á su salvo hasta que concluyen con él, sin otra bebida que el agua. Si es verano se van detrás del rancho á la sombra y se tumban: si invierno, juegan ó cantan unas laras seguidillas, desentonadas, que llaman de Cadena, ó el Perico, ó Mal-Ambo, acompañándolo con una desacordada guitarrilla que siempre es un tiple. El talento de cantor es uno de los más seguros para ser bien recibido en cualquier parte y tener comida y hospedaje. Una hora antes de ponerse el Sol se despiden de esta suerte:

-Que-de con Di-os, aa-mi-go.

- Vaya con Dí-os; y se va á la primera llanura: desensilla el caballo, lo monta en pelo y le da cinco ó seis carreras, que á esto llaman varearlo: vuelven á ensillarle y se van á otro rancho donde les hacen el mismo hospedaje. Adereza su cama con el pellón por colchón, el lomillo por cabecera y el poncho por manta y sábana. Si en aquellos días ha carneado algunas reses y ha grangeado por peonaje ó robo de cueros algunos reales, muda de estilo y rumbo, y se va á emplearlos en aguardiente en la más inmediata pulquería, de donde no sale hasta haber acabado su caudal.

Sus pasiones favoritas son el juego de c11alquiera especie que sea, carreras de caballos, corrida de patos, naipes, bochas y mujeres.

La corrida del pato merece una particular descripción: consiste, en que se junta una cuadrilla de estos guazos, que todos son ginetes más allá de lo creible: uno de ellos lleva un cuero con muchas argollas, y el brazo levantado: parte como un rayo llevando I5o varas de ventaja, y á una seña, él y todos corren á mata caballo, formando grita como los moros: todos persiguen al del pato y pugnan por quitarle la presa: son diestrísimas las evoluciones que éste hace para que no lo logren, ya siguiendo una carrera recta, ya volviendo á la izquierda, á la derecha, ya rompiendo por medio de los que le siguen, hasta que alguno, ó más diestro ó más feliz, lo despoja del pato, para lo que no es permitido que le cojan el brazo. En este feliz momento todos le vitorean y le llevan entre los aplausos, alaridos y zambra, al rancho suyo, al que frecuenta, ó bien al de la dama que pretende. Reinan todavía entre estas gentes muchos restos de la antigua gallardía española. Nuestro venturoso ginete presenta á su dama la presea: ella le convida á mate, y suele á veces premiar el valor con los mayores favores.
Los sucesos de la corrida de patos, dan materia para mucha conversación: puestos en cuclillas (postura que guardan horas enteras) cuentan con más viveza que acostumbran los diversos lances de la fiesta.

La sencille $z$ de estas gentes trasciende en medio de sus pasiones $\mathrm{y}$ vicios, y es singular el modo con que enamoran. Si ven á una china, mulata, etc., ú otra mujer que les guste, pasan por junto á ella, y quitándose el sombrero hacia atrás por cima de la cabeza (ó por costumbre, ó por no espantar el caballo: es de suponer que siempre andan á caballo) la dicen: qué linda habrá sido (1o mismo que: qué linda es:) y ella sólo responde: oz; y tira adelante, $y$ así repiten este manejo hasta que la dama se para, y le permite más claras explicaciones. No pocas veces paran estos preludios en los desórdenes nocturnos que llaman gateo, ya por condescendencia, y muchas veces por sorpresa y timidez natural en el bello sexo.

Muchos de estos guazos ó gauderios libertinos, violan el derecho de hospitalidad que tan francamente se les dis pensa. Como todos duermen en la misma casa, pues la estrechez de las habitaciones no permite las separaciones que pide el buen orden y la decencia; cuando todos duermen, salen á gatas, y con el mayor silencio asaltan el lecho de las mujeres que apetecen, las que si no están de acuerdo sufren la violencia de su honestidad por evitar unos escándalos que también las violenta y exponen su crédito, y usan de la defensa que permite la sorpresa y la confusión.

Reina no poco desórden en las costumbres de la clase pobre de nuestras Américas, por la de dormir juntas las personas de ambos sexos en la misma habitación, y lo mismo sucederá en cualquier otra parte que no se precaucionen.

Muchas veces estos ladrones de la honestidad, son sentidos por su poca destreza, y áun las mismas que están de acuerdo, son las primeras que les arañan, y todos lo burlan y denuestan.

Otras veces se ven nuestros gauderios en compañía cuatro ó cinco de ellos, y se convidan (I) á comer una pierna de vaca ó novillo: le enlazan, derriban y trincan de piés y manos, $\mathrm{y}$ casi vivo, le sacan toda la rabadilla, le hacen algunas sajaduras hacia el lado de la carne, la medio asan, y la comen con sal, si por casualidad la llevan. Otras, matan una vaca para comer el mata-hambre, que es la carne entre las costillas y pellejo. Otras, se les antojan caracues, que son las canillas y huesos que tienen médula: les sacan, descarnan bien y ponen punta arriba sobre brasas, hasta que hierva dentro de la caña, y en-

(I) Noticia del libro de Carrión El lasarillo ite Ciegos, impreso en 1773 . 
tonces un palito sirve para que saquen y coman aquella sabrosa sustancia.

También estos carnívoros sibaritas hacen de las vacas un asado que merece particular descripción: la abren por el vientre, le sacan intestinos, entrañas, etc., juntan toda la gordura en el centro de la cavidad, pegan fuego á aquellas materias grasas, y se forma una gran luminaria: unen las canales de la res, y el fuego encerrado respira por boca y orificio: al cabo de algunas horas, se halla la carne suficientemente asada, y estos hombres cortan de la parte que les place y. áun llevan á sus casas y la sazonan con agí, que es su ordinario condimento.

En las casas de estas gentes no se ven otros muebles que charque, una cama, un fogón, asientos como banquillos de zapatero ó calaveras de vaca, un cuarto de carne colgado, algún mueble de cuero, los aderezos del caballo y apenas algún otro mueble.

\section{Noticias de varios pueblos de la provincia de Buenos-Aires.}

Maldonado es una pequeña villa situada en una llanura cubierta de pasto verde, con muchos terrenos húmedos y bañados. Habrá cuarenta años que se edificó con criollos de la provincia: consta de Ioo casas, cubiertas de paja las más y muy pocas con teja, y las paredes de todas consisten en adobes ó estacas. Cada casa tiene su huerto con frutales, calabazas y otras plantas trepadoras, de manera, que á distancia forman un agradable paisaje: las casas forman calles rectas, y con los huertos y corrales ocupan un área considerable.

El terreno de su jurisdicción es reducido. Se extiende por la parte del Oeste hasta Pan de Azúcar: hacia los demás rumbos apenas llega por ninguno á una legua de distancia. Le limitan por otra parte dos dehesas del Rey; una en el Rincón de José Ignacio, sobre el Cabo de Santa María, y otra que se halla desde la barra de la Laguna hasta Pan de Azúcar. Todo él se compone de dehesas que contienen pocos ganados y algunas tierras labrantías.

Ha sido recientemente erigida en villa con su competente número de regidores, etc. Lil Jefe de las armas, que actualmente es un Capitán de dragones destacado con su compañía, es su Gobernador. Iil vecindario elige sus alcaldes.

'Tendrá 200 vecinos, la mayor parte bastante pobres. Carecen de frutos preciosos, de comercio y de industria.

Su poco comercio consiste en corambres, queso y manteca, que venden á las embarcacioncs y á Montevideo, y en algún trigo, que los que ticnen carros propios llevan á aquella plaza, y los que no, venden á los pulqueros por los géneros yue les suministran.
El mar pudiera proporcionarles ocupación y subsistencia, pues abunda de mucho y excelente pescado; y los lobos marinos les convidan en las islas desiertas de sus mares con los ricos despojos de sus pieles; pero carecen de embarcaciones y se atienen á la pobre y ténue pesca de la caña.

Suelen ser sus regulares cosechas de trigo, de quince por uno; pero faltan brazos y extracción áun cuando los hubiera.

Existen todavía en esta villa varios de los colonos gallegos que se trajeron para el nuevo establecimiento de la costa Patagónica, y tiene aquí su residencia un Comisario de Marina.

Otro pueblo pequeño se halla á distancja de dos leguas al Norte de Maldonado, que de lejos presenta no ménos agradable vista. Las casas campean entre los huertos que las cercan, cubiertos siempre de verdura. Sus pocos habitantes son portugueses que desertaron de Río Grande. Su comercio, como el de Maldonado. Aquí se hallan parte de los colonos gallegos y maragatos, que como gente de país frío se creyó más propia para poblar en las altas latitudes de la costa $\mathrm{Pa}$ tagónica, y cuyas colonias se abandonaron por la esterilidad del país, que se presta poco á la vegetación del trigo y otras plantas necesarias.

La subsistencia de estas gentes parecería muy costosa, y poco correspondientes las u.ilidades del establecimiento. Los colonos repartidos en varios de estos pueblos, serán 6oo, á quienes el Rey pasa para su subsistencia un real plata diario.

Este pueblo, que há pocos años que se fundó, se llama Pueblo Nuevo, y tiene 200 vecinos. Su Comandante suele ser un Oficial subalterno, ó sargento, que manda un corto destacamento de tropa que aquí reside.

Se halla en los cerros de los montes más cercanos á Maldonado, en los que llaman de Verdes y el Campanero, hermosas dunas de cristales, ó riscos como los que los nuestros llaman de cristales de roca. También en otros, ó acaso en los mismos, hierro atraible por el imán.

La vaca es la principal riqueza de estas gentes: sus quesos, leche y demás esquilmos, proveen á sus principales necesidades, y aunque pobres, distan mucho de la indigencia. Las rentas del Rey pasan de 3.000 pesos, por las alcabalas, ganado y pesca de lobos marinos.

No habiendo población alguna desde Montevideo hacia el mar, sino tales cuales chácaras de dos en dos leguas, y puestos de dragones de dos á cuatro hombres que sirven de postillones y maestros de posta; este regimiento, pues, forma un cordón de cerca de 80 á 90 leguas en los varios puestos que ocupa, desde Maldonado hasta Martín Chico; y si no pueden defender, ocupan, atalayan y exploran el vasto terreno que yace á la orilla Norte del Río de la Plata, y que se 
interpone con otras tierras despobladas, entre los establecimientos lejanos de los portugueses, que si hubiera abandono, intentarían, ó la usurpación ó el contrabando. Estos vecinos, que muchas veces se han mostrado inquietos y emprendedores, obligan á la cautela.

Si al Este de Montevideo no se hallan poblaciones, no sucede así hacia el Oeste ó Nornoroeste. En el espacio que media hasta la colonia del Sacramento, se hallan nuevas poblaciones, todas á la inmediación de algún arroyo que viene de un cordón de sierras que guarda algún paralelismo con el Río de la Plata. Siguiendo su orilla hacia la colonia, se encuentran los pueblos llamảdos Canelon, Santa Lucía (que se avista en número de 40 casas reunidas, cubiertas de paja) y San José con unas 60 de la misma fábrica.

Este tiene nueve años de población, y son sus colonos castellanos viejos, maragatos y gallegos. Alrededor de estos pueblos hay sus sementeras de trigo, de que subsisten y áun se enriquecerían si hubiera mayor industria y extracción de frutos. Esta colonia está enclavada en una hacienda de Doña Gabriela Serisa, que tiene roo leguas de extensión, según dicen, y parece que por cierta oposición de interés, no les permite la propietaria que se extiendan, de cuya prohibición, en efecto, se quejaban. El arroyo inmediato, que abunda en arboleda, les provee de la leña necesaria.

El Rosario, ténue población de solas I 8 barracas, está también en la propia orilla. Aquí reside un Capitán de dragones que tiene á su cargo la principal caballada del Rey aplicada al servicio de postas y correos, y para los pasajeros que traen pasaporte; y está también á su mando alguna tropa y 50 peones para manejo del ganado. Esta sola caballada se componía de 6.000 caballos más que toda la caballería de España. Todos los caballos desmandados que no están en su propia dehesa, ni con el hierro correspondiente, se reputan por del Rey, y los llaman rayunos, distinguiéndolos por un pico de oreja que les cortan.

Es lástima que estas colonias, situadas en un país fertilisimo, tan apto para la producción de los frutos más necesarios á la vida humana, en lugar de crecer en proporción de su antigüedad, mengiien sensiblemente. Algunos colonos las abandonan y se establecen en los ranchos de campo, donde se acostumbran á mantenerse de solo carne, dando de mano al cultivo de la tierra, y viviendo una vida floja y licenciosa. Domina el mal genio del país; el laborioso y trabajador gallego imita y se hace á las costumbres que ve, y su hijo suele degenerar en un gauderio.

A vista de estas poblaciones tan pequeñas, $y$ de estos ranchos, se ofrecen algunas reflexiones que nacen inmediatamente de los objetos, y que deben instruirnos sobre los grandes medios de la felicidad y multiplicación de los hombres. Los axiomas de los mejores economistas, no pueden entenderse como suenan. Todos asientan que los hombres se multiplican en razón de los alimentos. Comparan el linaje humano al ganado, cuyas cabezas se multiplican en razón de la cantidad de pasto, para que mayor número de individuos se alimente; pero esto, aplicado á lo racional, no parece suceda así. Si así fuera, no habría región más poblada que la bonariense; pues ninguna abunda tanto en carnes y que apenas tiene precio la que consumirá la más numerosa familia. La caza casi se coge con la mano, y la pesca abunda, de modo que en Buenos-Aires se tira mucha parte. Con todas estas ventajas, no se ven sino campañas desiertas, caballadas y vacadas numerosísimas á veces como ejércitos, bandadas de avestruces que de cinco ó de seis en seis corren con sus alzados cuellos por las inmensas llanadas. Los ranchos son como una isla en un vasto mar; y ya se vió de cuán pocá consecuencia sean las poblaciones. Las necesidades del hombre no sólo se reducen á la del alimento; la del vestido igualmente le urgé, y áun cuando ésta la satisfaga aquí fácilmente, pues ya se vió que un calzón de tripe dura muchos años al guazo y al hombre de campo, y se añade que las botas y otros arreos les dan las pieles de yeguas, que sacan como un guante de su pié y lo aplican para botines en los suyos; hay con todo, para que el hombre se multiplique, necesidad de una vida moral y arreglada. No es el hombre uno de aquellos séres en quien todas sus acciones se dirigen exclusivamente á la multiplicación: si gratifica demasiado las pasiones que conducen á ella, debilita sus órganos y no se consigue el fin de la Naturaleza. Unos placeres rapturosos, una vida vaga, no fijan al hombre con una compañera; no toma apego ni al terreno ni al hogar; emplea su vida en la corrupción del débil y amable sexo, cuyos vicios crecen con los de los hombres que las seducen, $y$ que por tanto aborrecen una fecundidad que las embaraza; y aunque en estos países la delicadeza y el punto del qué dirán no ha introducido la horrorosa práctica del aborto, y las mujeres, obedeciendo á las sagradas leyes de Naturaleza aunque sean solteras, crían sus hijos sin que las molesten, con todo, la falta de un padre de familia, de un hombre á quien la ley fije para que la sostenga; que cujde de la prole, las hace considerar su estado como una desgracia, se abstienen de otro nuevo fruto, su prole desamparada queda sin un establecimient y sólo constituirá un nuevo y estéril individuo. ¡Ol Santas Leyes! ¡Oh Religión, cuán precisál es tu observancia, no ménos para la vida futura que para la presente!

Mientras la agricultura no se radique en esta 
feraz región, sus habitantes no se fijen en el suelo que cultiven, gusten de comer sus hortalizas, y no se cansen del monótono y uniforme alimento de la carne, tendrá grandes obstáculos la población, sus costumbres no se arreglarán á una vida civil y religiosa.

Siguiendo, pues, la serie de poblaciones al Oeste de Montevideo y Río de la Plata arriba, se encuentra la que llaman Colonia del Sacramento, en una punta frontera á las Islas de San Gabriel. Los portugueses ocuparon furtivamente (I) el sitio en tiempo del Regente de Portugal el Infante D. Pedro. El Gobernador de Buenos-Aires les desalojó con algunas tropas españolas y 3.000 indios guaranis, entre infantes y caballos, que bajaron de las misiones jesuitas; y tomó la plaza, ya correspondientemente fortificada por los portugueses, con pérdida de 200 de los sitiados, y de los sitiadores, con la de seis españoles y 30 indios, además de otros varios heridos por el valor con que se expusieron. Los portugueses entablaron después negociación, y pidieron un lugar de asilo en el Río de la Plata para refugiarse en caso de temporales ó de piratas; y se les concedió esta colonia, sin atender á las consecuencias, pero con las condiciones de que la propiedad del puerto fuese sólo de la Corona de Castilla; que sólo se permitiesen catorce familias portuguesas; que las casas fuesen de madera cubiertas de paja; que no se construyese fuerte alguno; que los Gobernadores de Buenos-Aires pudiesen visitar el establecimiento, como también los navíos que llegasen á él; y que restituyese Portugal 300.000 indios que los Paulistas habían robado de las tierras del Rey Católico. Pero los portugueses sólo verificaron el establecimiento que deseaban, y en el año de I 7or, siendo el Rey de Portugal garante del testamento de Carlos II, se suavizaron las anteriores condiciones.

En I704, durante la guerra de sucesión, se desalojó nuevamente á los portugueses con los mismos auxiliares guaranies, huyendo los lusitanos en cuatro navíos que vinieron á su socorro; pero se les volvió á ceder en I7I5 por las paces de Utrech.

En ry62 la tomó nuevamente el Gobernador D. Pedro Cevallos, y la defendió contra el socorro que les enviaban los ingleses. Volvióse otra vez á Portugal, y establecióse una especie de línea ó trinchera que llaman el Real de San Carlos, desde donde se observaba la plaza y se estorbaba

(1) Don Cosme Bueno, en su Calendario de 1776 dio una descripción de las varias provincias del obispado de Buenós-Aires. Escribió sus noticias por documentos que le remitieron los Gobernadores y Jefes de las varias provincias, etc., que entonces dependian del Vireinato de Lima; corren con crédito, y se citarín en las precisas ocasiones que no se tengan otras más presentes y auténticas. el considerable contrabando que hacían. Hoy, sólo se ven las ruinas de este Real, pues el mismo Don Pedro Cevallos, primer Virey de BuenosAires, volvió á tomarla en la última guerra, y desde entonces acá, demolidas sus fortificaciones, quedó por España. Era esta plaza tan inmediata á Buenos-Aires, que sólo distaba de aquí diez leguas un almacén de contrabandos, y se introducían géneros, no sólo á las provincias cercanas, sino á otras muy interiores. En Portugal calculaban algunos que hacían entrar nueve millones en dinero efectivo. Por ella salían cuantiosos caudales, tanto para emplearlos en Europa, como para pretensiones de particulares que pasaban de Lisboa á Madrid. Finalmente, padecía un grave perjuicio el Real Erario, y muy considerable el comercio de la Nación, siendo sólo algunos particulares los que se enriquecían.

En el sitio de la colonia forma el Río de la Plata una herradura. Una especie de gneis, compuesto de banclas ó vetas blancas y cenizosas, untuoso al tacto y que centellea al eslabón, compone las rocas que bordean las orillas de este río. Se hallan en este pasaje amenos bosques de melocotones que, aunque sin cultivo, producen agradable y sazonada fruta. La población está medio arruinada: sus calles se componen en el día de pocas casas de piedra y muchos solares llenos de yerba; de murallones desmantelados: se presentan todavía ruinas y escombros; el cam. panario y torres, como esqueleto de la que fué iglesia matriz. Pareciera que esta ciudad paga la pena de la ambición portuguesa. Hállase pobre y atrasada, su vecindario reducido, los pocos edificios que existen son los que quedaban y libraron cuando llegó la orden de suspender su demolición. Después acá se repobló algo, y el Rey, á costa de su Erario ha puesto algunos colonos.

Su puerto sirve en el día de escala para el correo: una sumaca mantiene la comunicación por agua con el Sacramento y Buenos-Aires, y los pasajeros que vienen por tierra de Montevideo, se embarcan en este puerto para el de Buenos-Aires. El Comandante de la tropa, que suele ser un Oficial de graduación del Regimiento fijo de Dragones, manda también la plaza.

A poca distancia de la colonia está la Isla de San Gabriel. Aquí tenían los portugueses sus casas de placer, y poseían huertas con varias es pecies de frutales y de flores que recreaban la vista y el olfato; mas ya sus frutales se volvieron silvestres, y las plantas europeas que allí plantaron se confunden con las expontáneas que como propias se producen con más abundancia: los rudes cactus, muchas plantas espinosas y matas y arbustos de muchas especies, confunden á los granadillos, duraznos, nogales, almendros, rosales, alelíes, manutisas y otras plantas que ador- 
nan los jardines. Existen las vallas de los suyos y los cimientos de sus edificios, corrales, estanques, etc. Sin embargo, el sitio es agradable, la isla parece que nace de entre las ondas, como otras que se divisan en el confluente del Paraná, y entre sus amenos bosques se esconden muchos pajarillos que recrean la vista con sus colores y el oído con su canto.

Desde la colonia se pasa el Río de la Plata para la capital, Buenos-Aires, y aquí tiene el río Io leguas de latitud. Llegamos (dice el autor) á la ciudad al ponerse el Sol, y el cariz y la escena que presentaba la atmósfera era de las más interesantes. El astro del día aumentaba su resplandor con la refracción terrestre, y escondiéndose grandioso detrás de la ciudad y de una gran masa de sombras y nubes, contrastaban con ellas sus brillantes rayos: diez torres descollaban sobre los demás edificios, que se confundian en las sombras; presentándosenos estas vistas en la dirección del Oeste, fondeadas al Sur pequeñas embarcaciones, y extendida al Norte una costa baja con varias quintas y arboledas.

Aquí está la ensenada de Barragán, formada á la embocadura de un pequeño río que entra en el de la Plata á to ó I 2 leguas de Buenos-Aires Esueste, cuya abertura se opone directamente al curso del río, porque se vuelvẹ al Oesnoroeste: será como de un cuarto de legua de ancho, y tie. ne en medio un estrecho canal que se llena cada día, y sólo permite bajeles de 12 piés de calado, fondeando los que calan más agua, en la punta de Lara, á legua y media Oeste, donde, aunque expuestos á todos los vientos, encuentran buen tenedero, pero tiene esta ensenada otras muchas incomodidades.

El que arriba á Buenos-Aires no encuentra á su desembarco ni muelle cómodo, ni barcos á propósito que le transporten á tierra. Salen muchachos con caballos ó carretas, que el poco fondo del río permite se introduzcan mucho trecho agua adentro. A todos choca este extraordinario desembarco, que, sin embargo, es el ménos incómodo si se considera que los botecillos se encallan, hay que sacarlos á fuerza de brazo, y de ellos se toma tierra en hombros de marineros. Es una gran multitud la que se presenta de estos solícitos vadeadores, que arman bullas y ruido porque se les prefiera.

La ciudad de Buenos-Aires se halla situada en un llano; la baña el río por la parte Este, y por otras direcciones se sale á hermosas campiñas cubiertas de verde, y á huertas y quintas que hay en sus cercanías.

Su extensión, según el autor del Lazarillo ó Guía de caminos, es de 22 cuadras Norte-Sur y Este-Oeste: sus calles están tiradas á cordel: en las aceras se eleva el piso cerca de vara y media (lo que llaman los franceses trottoirs) para la gente de á pié, y se ponen maderos perpendiculares á proporcionadas distancias, con faroles para alumbrar á los que tiansiten. El medio de la calle, que todas son anchas, iguales y capaces, se abandona á los carros y caballerías, y á la sazón de estar allí el autor de estas Memorias no se observaba la correspondiente policía, tolerándose el echar en ellas despojos que las ensuciaban. En tiempo de lluvias hacen grandes lodazales, en que se atascan las grandes carretas que hay para los abastos y las caballerías, y suele imposibilitar el paso á la gente de á pié. La plaza es imperfecta, y sólo tiene portales la hacienda de Cabildo, en la que están la cárcel y otras oficinas públicas.

El palacio del Virey es una especie de fortaleza rodeada de un foso profundo, á la que se entra por sus puentes levadizos. Caen también hacia esta plaza la catedral y el palacio del Obispo con otros edificios. Se halla bien abastecida de provisiones: se contaban en la insinuada ocasión 60 grandes carretas que cada una hacía oficio de una gran carnecería, ó tabla adornada de grandes cuartos de vaca, que á lo más se vendían por dos reales. Los días magros se ven las mismas carretas cargadas de sabrosos pescados que da el río con abundancia y profusión, como dorados, sábalos, corbinas, bagres, palometas, etc. Mucha parte de esta pesca queda sobrante, y la arrojan por los arrabales. Su putrefacción perjudicaría á la salubridad, si la bondad é ímpetu de los vientos que suelen correr, no arrastraran á otra parte los pútridos miasmas. Es de esperar que el superior gobierno de aquel Vireinato establezca en tan principal ciudad la policía que corresponde. Se conocen, á vista áun de los ménos atentos observadores, los considerables progresos que hace en comercio y población, ya por las franquicias y libertad que se han concedido á aquél, ya por la agregacion de ricas provincias al nuevo Vireinato, la creación de nuevos Tribunales y de Real Audiencia, etc., como también por la internación de efectos y correspondencias para Chile y el Perú. Se ven muchas nuevas tiendas, y se hallan los efectos de Europa en mucha abundancia, y con bastante baratura respecto de los precios que antes tenían: en los gréneros más caros se consideraba que la diferencia de la plata, dos y medio por uno, era el precio más excesivo.

Gobierna en Buenos-Aires, para lo espiritual, un Obispo con su correspondiente número de Canónigos y dignidades, cuyas rentas no son tan considerables como en otras partes de América.

Los conventos contenían en 1770 , según el estado que trae el autor de las postas por Buenos- 
Lires y el Perú, ya citado, el siguiente número de religiosos:

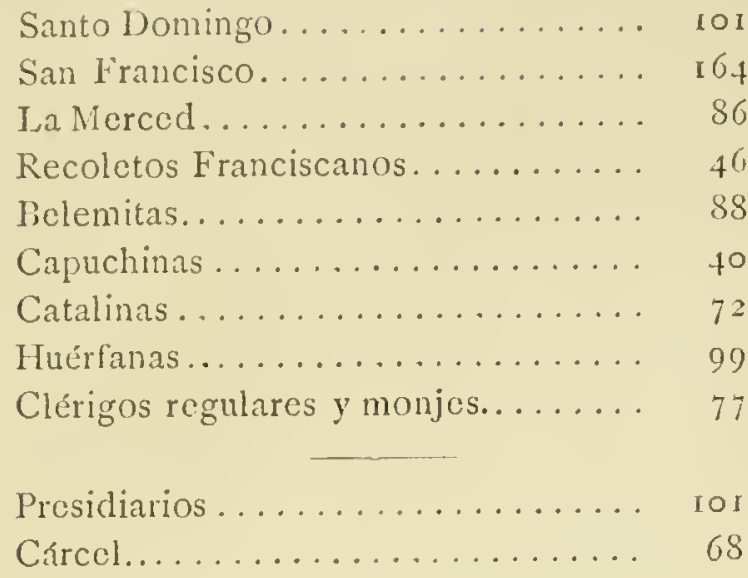

Tiene cinco parroquias, á saber: la Catedral, San Nicolás, la Concepción, Monserrate y la Piedad. Los más de los españoles que se hallan en la propia ciudad y no tienen empleos públicos que lo impidan, están alistados en diferentes cuerpos de milicias para tomar las armas en caso de invasión, en compañías de caballería de vecinos, en compañías de forasteros y de artilleros provinciales. Hay también compañías de las diversas castas que componen la población, como de indios, de mestizos, de mulatos libres y de negros libres. En I770 era el total de la población de 22.000 almas: los dos tercios españoles, y mucha parte europea, á quien convida la analogía del clima y la baratura del país.

Hay muchos esclavos ncgros, y varias familias no tienen otra propiedad que la de sus esclaros. A éstos obliga la ley á que contribuyan á sus dueños con cierto jornal, que la humanidad de los legisladores ha moderado, y queda á be. neficio suyo el exceso que ganaren. Muchos de ellos se emplean en vender agua por las calles, subidos en sus altos caballos como timbaleros; otros, en peones de albañil y en otros varios oficios mecánicos; por lo cual, las más molestas de tales artes, no encuentran sino muy pocos profesores blancos, y sale bastante cara cualquier mano de obra y sin honor: son pocos los hombres libres que las ejercen, especialmente en Montevideo: gentes de castas son las que principalmente se emplean en ellas.

Carece esta ciudad y su egido de fuentes y manantiales: la lluvia es el único riego que tienen: beben muchas veces, ó casi siempre, turbias las aguas de su río; pero los vecinos acomodados, las posan en unos grandes tinajones: otros recogen en aseados algibes las aguas llovedizas.

El traje de la gente ciudadana es como en España en hombres y mujeres: el de la gente de campo ya se describió. Las costumbres, como las de Montevideo; pero en una gran capital autorizada con tribunales, Virey y concurrencia de comerciantes, empleados y gentes acomodadas, reinan proporcionalmente mayores grados de civilización, lujo y policía.
Los bonarienses se recrean mucho en sus quintas, en donde pasan las familias con sus amigos entre fiestas y banquetes algunos días alegres. La juventud gusta de montar en briosos caballos, y se engalanan con ponchos bordados magníficamente. No hay la desunión de la nobleza que en otras grandes capitales de América: se juntan á sus tertulias y diversiones con más frecuencia. Las damas se presentan, como no estén de cumplimiento, rebujadas en sus mantillas, con to cual toman hábitos que perjudican á su natural garboso talle. Es natural que la nueva situación é importancia (decía el autor) que va á tomar la ciudad, haga crecer su lujo y corrompa las costumbres, en las cuales no se nota ni el escándalo ni la disolución que en otras partes.

El temperamento de Buenos-Aires, y lo mismo el de Montevideo, es muy saludable: sus aires parecen bastante puros. El invierno empieza en Junio, y llueve con abundancia. Algunas veces caen escarchas, que algunos guardan para helados: suelen acompañar á las lluvias truenos terribles que espantan á los no acostumbrados. Las brisas, que suelen empezar antes de las doce, templan los ardores del estío. Corren vientos violentísimos que llaman pamperos, y soplan del Poniente y del Sudoeste: vienen dc la cordillera, y atravesando varias llanuras de 200 ó 300 leguas, sin bosques ni montes que moderen su ímpetu, conservan toda su violencia, degeneran en verdaderos huracanes, y si corren por el Río de la Plata, no hay á veces embarcación que los resista. Dicen que en ocasiones ha quebrado á algunas los palos, áun con los masteleros calados, y que en tierra ha hecho cejar una carreta con 200 arrobas y tirada de seis bueyes.

Las casas de Buenos-Aires tienen capaces patios, $\mathrm{y}$ todas son de un alto: gustan de parras y limoneros en los patios; las adornan á las modas de España: los criados son esclavos, ó bien mulatos ó bien negros africanos.

Buenos-Aires recibe por su río la leña del Paraná; las maderas para edificar, que son muchas y exquisitas, la yerba del mate, los géneros de Castilla y todos los artículos de su comercio. Por desidia de sus habitantes, que se descuidaron en poner plantíos inmediatos de árboles para leña y construcción, se traen estos artículos de algunas distancias del Paraná y de los montezuelos de las Conchas.

El principal artículo de su comercio es el de cueros al pelo, sebo, carne salada, harina $y$ trigo: el primer artículo que remiten á España, y los otros á la Habana; pero el comercio de los tres últimos artículos es nuevo, y parece que hará considerables progresos, como se podrá inferir por el siguiente estado de tres años cor. secutivos. 


\begin{tabular}{|c|c|c|c|c|}
\hline Años. & $\begin{array}{c}\text { Sebo. } \\
\text { Arrobus. }\end{array}$ & $\begin{array}{l}\text { Came salada. } \\
\text { Cuurterolus. }\end{array}$ & $\begin{array}{l}\text { Harina. } \\
\text { Libras. }\end{array}$ & $\begin{array}{c}\text { Trign. } \\
\text { Firnegras. }\end{array}$ \\
\hline 1787 & 21.770 & 13.925 & 0.356 & " \\
\hline I788 & I 5.228 & 10. I 35 & 6.127 & I. $9^{\delta_{5}}$ \\
\hline I 789 & $3^{6} \cdot 543$ & $33 \cdot 327$ & 5.086 & 470 \\
\hline
\end{tabular}

Se ve por estas noticias el progreso que hizo en los últimos años el comercio activo del país con la extracción de los sebos y carnes saladas. Estos preciosos esquilmos quedaban en los últimos años abandonados á las aves de rapiña, á las fieras y perros cimarrones: esquilmos que deberían constituir su principal riqueza. Sin embargo, hay todavía un considerable desperdicio, pues ni los habitantes consumen las carnes de los muchos toros que matan, ni las que se extraen equivalen á las muchas cantidades de vianda que se abandonan. Los pocos Capitanes de estos comerciantes, á veces por falta de noticias y por miedo de exponer sus riquezas en un nuevo comercio que juzgan aventurado, se retraen de este tan lucroso que la Naturaleza les proporciona. Las cálidas islas del Seno Mejicano tienen un suelo donde el trigo no vegeta, donde las vacas no multiplican, pero donde crece la caña de azúcar, los algodones, etc. La Naturaleza varía las producciones de los terrenos y parece que para convidar á los hombres á unos mútuos cambios que produciendo 1 ecíprocos intereses les haga á todos felices, consigue que cada país disfrute de las producciones de todos.

El Vireinato de Buenos-Aires, erigido de pocos añós á esta parte, se extiende en su mayor longitud Norte-Sur desde los I $8^{\circ}$ Sur (T) hasta el Cabo de San Antonio á la embocadura del Río de la Plata en los $36^{\circ} \mathrm{Sur} ;$ y de Oeste á Este se puede considerar desde los $307^{\circ}$ hasta los $322^{\circ}$ longitud Oeste desde el meridiano de París; pues se deben considerar los límites de su vasta jurisdicción, por el Este desde las fronteras del Brasil, donde terminan los terrenos que tuvicron las misiones que fueron de los jesuitas y ocupan varios y espaciosos países á las orillas del Uruguay (río que corre Nordeste-Sudoeste para entrar en el de la Plata) y que se extienden hasta cerca de la Asunción. También se sitúan sus misiones en el país central á las orillas del gran río Paraná, que viene del Nordeste al Sudoeste, y á los $59^{\circ}$ de longitud se inclina al Oeste para incorporarse en el vasto río del $\mathrm{Pa}$ raguay, donde en su confluencia se sitúa la ciudad de Corrientes. Muchas bárbaras naciones, poco conocidas, habitan errantes entre nuestras misiones y las fronteras portuguesas que parecen tener una dirección Sudoeste-Nordeste desde río Negro hasta los orígenes del Paraná por

(r) Tierras adyacentes al Marañón y término del Vireinato de Santa Fé. los $20^{\circ}$. Al Poniente confina, pues, este Vireinato con las faldas orientales de la gran cordillera de los Andes por la parte en que se extienden descle los 35 hasta $\operatorname{los} 20^{\circ}$ (I).

"No se pretenda (añade el autor) que dé aquí unos exactos límites, pues se trata en el día de fijar los que deben separar las posesiones de España y Portugal, negocio que hace muchos años se trata y no se concluye. Por otra parte, carecemos de las noticias de los puntos por donde pasa la línea que divide las provincias desmembradas del Vireinato del Perú, y agregadas al de Buenos-Aires; nuevo Vireinato, á cuyos límites tal vez no se habrá dado perfecta demarcación. Contentarémonos por ahora con dar noticia de las principales provincias, reservando para cuando tengamos más tiempo, oportunidad y materiales, tratar de este punto con la extensión que merece."

Comprende este Vireinato, además de los países de Montevideo ya descritos, el vasto país que compone el Obispado del Tucuman, en el cual hay vastos desiertos, que les corren los indios Aucaes, Ituarpes ó Pampas, Pehuenches, Puelches, Uncos y otros. Se extiende el 'Tucuman desde los $22^{\circ}$ hasta los $33 \mathrm{y}^{1} / 2$ latitud Sur, pero tiene de largo desde el arroyo Quiaca, que divide esta provincia de Chiches, hasta Melinque hacia Buenos-Aircs, con 370 leguas itinerarias; y de ancho tiene por donde más rgo leguas Es. te-Oeste.

Elpaís del Tucuman puede considerarse compuesto de siete provincias, donde se hallan las respectivas ciudades que les dan nombre, á saber: Córdoba, residencia del Teniente de Rey; Santiago del Estero, San Miguel de Tucuman; Salta, residencia del Gobernador, con título de Capitán general; Jujuy y Catamarca, todas con Cabildos, Alcaldes y Oficios correspondientes, y son cabezas de otras tantas provincias con varios ranchos y pequeños pueblos.

En el día se considera la provincia de Córdoba de 230 leguas de extensión Este-Oeste y I40 Norte-Sur, poco más ó ménos, y su población de 80.000 almas, entre las cuales se contaban 26.750 españoles y $\mathbf{5 2 . 0 0 0 ~ d e ~ c a s t a s ~ d e ~ m u l a t o s , ~}$ indios, negros, etc., que pueblan las ciudades de la capital, San Luis de Loyola, Mendoza, San Juan y la Rioja.

En Córdoba tiene el Obispo su residencia con su correspondiente Cabildo eclesiástico, con tres dignidades y tres canónigos.

(r) Parece sea equivocación la existencia de la laguna de Jarelles, pues según los reconocimientos hechos en r75 I por el Marqués de Valdelirios y Don Jorge Meneses, Comisarios de las Cortes de España y Portugal para el arreglo de límites, se reduce á una vasta porción de terreno anegadizo, cubierto de agua una parte del año. 
Se regula que mantiene el terreno de esta ciudad 200.000 vacas, igual número de caballares y de 6 á 7.000 mulas y más de un millón de ovejas, de que se provee el resto de la provincia y mucha parte de Santa Fé. Tiene con el Perú un comercio activo de extracción de mulas. $\mathrm{Ha}$ cia el año I789 sería como de 12.000 en cada uno. Parece que compran gran número de Buenos-Aires. Adquiere considerables ganancias en el tráfico de sus carretas, con que transportan é internan los efectos de Buenos-Aires al Perú: tiene las más distinguidas familias $\mathrm{y}$ caballeros del Tucuman, buenos edificios, curato en una capilla de la Catedral, servido por dos curas con cuatro anexos, y en la provincia se cuentan i2 de mucha extensión. La gente pobre se aprovecha de las lanas, de que teje mantas, bayetas, ponchos, pellones y jergas, que cambian por lienzos, cintas, tripes y paños ordinarios; y también fabrican algunos curtidos. A distancia de 22 á 24 leguas de Mendoza se halla la famosa mina de Uspalata en la cordillera, de muy rica plata, que por varias dificultades locales y rigidez del sitio frío y nevado, no se beneficia: se hallan también minas de cobre, oro y plata, plomo etc., y en uno de sus montes mana alquitrán con grande abundancia. El terreno es llano, de buenos pastos; pero carece de madera: otra parte de él es montuoso y continua á unirse á la cordillera. Se cultiva trigo, maiz, habichuelas y otras semillas; $y$ hay varios ríos, que se nombran desde uno hasta cinco, los cuales nacen y mueren en la misma provincia, desapareciendo sus aguas en medio de las arenas.

La ciudad de Santiago del Estero, se halla, según las noticias de D. Cosme Bueno, en $28^{\circ}$ Io' latitud Sur y en $3 \mathrm{r} 2^{\circ} 20^{\prime}$ de longitud, fundada en las inmediaciones de un lago ó estero que forma el Río Dulce, en un sitio arenoso. Su población era en r789 de 32.500 alnıs, á saber: I8.000 españoles, 8.00o mestizos, 4.500 indios, I.000 negros y I.ooo mulatos. Tiene una parroquia y tres conventos, de Santo Domingo, San Francisco y la Merced, y un colegio que fué de los Jesuitas. Comprende su jurisdicción seis curatos, cada uno con varias capillas.

San Miguel del Tucuman se halla en latitud $27^{\circ}$ Io' y en 3 I $3^{\circ} 4^{\prime}$ de longitud en un campo ameno, pero escaso de agua, que nola tiene sino de pozos y en una acequia de un río que corre á una legua de distancia. Tiene una parroquia, dos conventos de Mercenarios y Franciscanos y otro de los ex-Jesuitas, y tres curatos en su jurisdicción. Su población en 1789 era de 5.800 españoles, 7.201 mestizos, 6.508 indios, 600 negros, 2.700 mulatos y 22.809 de total.

La ciudad de Salta se halla en $24^{\circ} 45^{\prime}$ de la. titud y en $3 \mathrm{rr}^{\circ} 5^{8^{\prime}}$ de longitud, extcndiéndose su provincia en aquella época á crecido número de leguas (que no determinó el autor por falta de documentos:) habitada por 22.389 almas; á sa ber: $5 \cdot 386$ españoles, 4.436 mestizos, 7.620 indios, 2.640 negros y 2.3 Io mulatos.

En esta ciudad asiste el Gobernador de toda la provincia, pues el Teniente de Rey se halla en Córdoba. Tiene dos parroquias, conventos de San Francisco y la Merced, y otro que fué de los Jesuitas: dos curatos con varias capillas en la provincia; y al Poniente de ella, los valles nombrados de San Carlos y Chalchaqui, fértiles en vinos y otros frutos. Se halla esta ciudad en terreno húmedo y pantanoso, en un valle de cinco leguas más ó ménos largo, y media de ancho: abunda en trigo y pastos, con fácil riego. La residencia aquí del Gobernador es principalmente por estar á la vista de los indios del Chaco. Por Febrero se abre una gran feria de mulas y dura todo Marzo: algunos años se juntaban hasta 50.000, se repartían por todo el Perú, y la mayor parte, ó muchas por mano de los Corregidores en sus respectivos repartimientos.

La ciudad de Jujuy está vecina á las fronteras del Perú, en una quebrada de más de 30 leguas de largo, situada en latitud $23^{\circ}$ I $8^{\prime}$ y en longitud $3 \mathrm{I}^{\circ}{ }^{\circ} \mathrm{Io}^{\prime}$, y poblada en I 789 por I 9.266 personas: españoles 923 , mestizos 3.500 , indios I3.570, negros 505 y mulatos 768 . Tiene Cajas Reales, parroquia con cinco capillas en las inmediaciones de la ciudad, y conventos de San Francisco, Merced y ex-Jesuitas. Pertenecen á su jurisdicción tres curatos con cinco capillas: en el curato de Cochinoca y Canvirido, fabrican los indios buena pólvora y se encuentran minas de oro. El principal comercio de Jujuy es la cría de ganados, con que proveen de carne y sebo las riberas del Potosí. También se aprovechan de sus potreros para criar y engordar las mulas que se atrasan para la gran feria de Salta. Rodea á esta ciudad un caudaloso río que se hace cle dos arroyos grandes.

La ciudad de San Fernando del Valle de Catamarca se halla en $28^{\circ} \mathrm{I} 2^{\prime}$ latitud Sur y $3 \mathrm{II}^{\circ} \mathrm{de}$ longitud. Tiene convento de San Francisco, hospicio de la Merced y un curato á que pertenecen ocho capillas y dos pueblos de indios, y tres en la provincia con varias capillas. Contenía 20.390 almas: españoles 5.900 , mestizos 4.900 , indios 6ro, negros 834 y mulatos 8. г46. Al Oeste del valle hay un cerro llamado Ambato, en el que se oye gran ruído y causa grandes extremecimientos. A la parte Oeste de la ciudad, corre una serranía Norte-Sur, en cuyas faldas hay por muchas leguas haciendas de sembradíos y pastos para ganados, principalmente mulares. Hacia el Noroeste, siguiendo la serranía del cerro de Ambato, se halla el de Aconguija, cubierto de nieve, que domina á todos. Esta provincia, como las demás del Tucuman, es pobre; y así, corriendo 
poca ó ninguna moneda, se reciben los efectos reales en artículos de la tierra, como algodón, telas, agí, aguardiente y trigo.

Los bárbaros que bordan estas provincias, y que suelen hacer frecuentes incursiones cn ellas, obligan á mantener tropas y presidios y á que se arme una parte de sus habitantes; por lo que no se puebla como corresponde á su suelo, fertilidad y bondad de temperamento. Los presidios que contienen á los barlazos que la amenazan contínuamente y que se situan en los pasos más expuestos á sus excursiones, son el del río Negro, el de Ledesma, Santa Bárbara, el Piquete, San Fernando en el río del Valle, otro Piquete, el Tunillar, San Luis de los Pitos, la Estancia del Rey, Fuerte de Valbuena y San Estéban de Miraflores; y hacia Córdoba, el fuerte del Sauce y el del Tío, para contener á los Pampas; aunque hảcía algunos años que con este freno y la vigilancia que había, no hacían excursiones. Los indios convertidos y los que reduzcan los celosos misioneros, servirán de ménos costosa barrera. El temperamento de este país es generalmente caliente, y se observa la anomalía que, al paso que se acerca á la Zona T'órrida, se refrigera, porque adquieren mayor elevación las montaĩas que le bordan, al paso que se acercan á la gran cordillera: las estaciones son arregladas. La tierra, pingüe y esponjosa en común hasta cierta profundidad, produce cualesquiera semillas y abunda en copiosos frutos. Crían buenos vinos en Mendoza, que tien en reputación. Pudiera mantener cuatro millones de habitantes. Se crían buenas maderas, de que hacen comercio, conduciéndolas reducidas á tablas, en carretas, de San Miguel, que es donde más abunda, á Salta, Santa Fé y Buenos-Aires, siendo cedro, y también proveen de madera la ribera del Potosí para las máquinas de las haciendas de beneficio. Un eje del fortísimo Quiebra-hachas, suele valer I.80o á 2.000 pesos. Abundan también las preciosas maderas de guaya, bojes, laureles, pinos, nogales y palmas muy altas. Se coge miel de I2 es pecies de abejas, sin otro trabajo que cogerla: unas fabrican sus panales en los troncos de los álboles, otras debajo de la tierra: todas las mieles tienen distintos sabores, y aunque ni la industria del hombre las sujeta ni las domestica, parece que ellas le convidan con sus esquilmos, pues no defienden sus casas con rigor. Se halla también grana silvestre y añil, seda de gusano y de algunas especies de araña, y otros preciosos frutos que enriquecerían cualquier país, cuyos habitantes no se contentaran con el monótono alimento de la vaca, como los naturales de Buenos-Aires. El desperdicio de aguas forma en muchas partes atolladeros, en que se atascan los ganados que transmigran á la feria de Salta. Se dividen las tierras en vastas haciendas, mal ó no cultivadas, y los habitantes de los pequeños pueblos y campañas no conocen otro regalo que carne, yerba del Paraguay, tabaco, azúcar y aguardiente; pero si no el primero, los demás no los gastan tan comunmente. Críanse tígres, leones pequeños, puercos, venados, antas, quirquinches, es pecies de armadillos, liebres rizcachas y osos hormigueros. Sus ríos abundan de peces, como dorados, sábalos, bagres, dentudos y bogas, y excepto dos, todos se pierden ó quedan en el Tucuman, después de haber corrido, unos muchas, otros pocas leguas, en que desaparecen, ó filtrándose por las tierras ó formando lagunas. Los principales ríos son el Salado, que rccibe varios nombres; el del Estero, que va á formar cerca de Santa Fé una laguna de 40 leguas de circunferencia, que llaman Mar chiquito, y que en otro tiempo entraba en el Paraná, hasta haber ocurrido una revolución física; el Jujuy, que pasa por la ciudad de este nombre; el río Dulce, que va por San Miguel y Santiago, y el llamado río Cuarto, que baña los términos meridionales del Tucuman, corriendo del Oeste al Este, y termina también en laguna.

Varios apéndices de la gran cordillera internan en este país y forman serranías al Oeste de él, y cadenas de montañas que diversifican el suelo y varían las producciones, que no tuviera todo el país si Pampa fuera nivelada ó llanos como lo son hacia el Este y hacia Buenos-Aires. Críanse, pues, en estos montes varios minerales de plata, que por temor á los indios del Chaco se abandonan, como en el ya nombrado cerro de Aconguija. También los hay en el de Pulares, junto al Valle de Calchaqui, y en el de Acay; y de oro en las fronteras de Atacama, en Incahuais y Olazos, en el cerro de la Puna, jurisdicción de Jujuy, en la jurisdicción de Córdoba, y en el cerro de Famatina, jurisdicción de la Rioja; pero la falta de caudales, el genio de los habitantes y su ignorancia en el beneficio, harán pocos progresos en la minería. El comercio que principalmente prevalece en el Tucuman es el de las mulas, que conducen de Buenos Aires, Cór doba y Santa Fé, compradas á tres ó cuatro pesos: pasan su invernada en la jurisdicción de Salta para que engorden y se fortalezcan, y se venden allí millares de ellas á siete ú ocho pesos, cuyos compradores las internan al Perú, vendiéndolas por el año de I789 á r4 pesos; pero era de creer, según el autor, que hubieran subido ya hasta 20.

La provincia del Paraguay tiene 280 leguas de largo y 240 de ancho, formando gran parte de su población las misiones jesuíticas. Corren en ella grandísimos ríos: por la parte del Este el Uruguay, por el Centro el Paraná, y por el Oeste el Paraguay, que naciendo de la gran láguna de Jareyes, según las cartas de Mr. d'An- 
ville, degenera en el Río de la Plata. El Paraná entra en el Paraguay, donde está la ciudad de Corrientes, y el Uruguay, donde ya empieza á llamarse Río de la Plata. Otros varios mayores que el Tajo, corren según lo ancho de la provincia y engrosan á los expresados; todos los cuales fertilizan necesariamente estas provincias (I). Se regula su población de 96.000 almas, europeos los 2.500 y el resto de indios; y algunos neyros se hallan en las ciudades de San Ignacio, Espíritu-Santo, Concepción, San Pedro Guarepoy, el Rosario, Nuestra Señora de Nemboy. Trece pueblos civilizados é igual número de misiones estuvieron á cargo de los Jesuitas. Eran 30 los pueblos de indios Huaranis: I 3 del Obispado de la Asunción, y los 17 de Buenos-Aires. En r77 r mandó S. M., que sin variar la jurisdicción espiritual, se hiciese provincia con un Gobernador y tres Tenientes para otros tantos partidos. El del primero comprende los seis pueblos de San Francisco Javier, Santo Angel, San Lorenzo, San Luis, San Nicolás y San Miguel, lugar de su residencia. El segundo partido comprende los cinco pueblos de Nuestra Señora de la Fé, Santa Rosa, San Cosme, Santiago y San Ignacio Gazu, con residencia en uno de los dos últimos. Y el tercero otros cuatro; Yapelles, La Cruz, Santo Tomé y San Borja, con residencia en el primero. El Grobernador principal debía mandar próximamente I 5 pueblos, que se deben considerar como un cuarto partido, y se nombran: la Candelaria, Itapua, Trinidad, Jesús, El Corpus, San Ignacio Miní, Loreto, Santa Ana, San José, San Carlos, Santos Apóstoles, Santos Mártires, Santa María la Mayor, San Juan Bautista y la Concepción, con residencia en la Candelaria.

También mandó S. M. se construyese para seguridad de estas colonias un fuerte para observar y contener á los portugueses, que en algunas ocasiones entraban de mano armada á robar indios para sus labores. En tiempo de los Jesuitas tenía cada pueblo dos curas de aquella religión, á quienes se acudía con sínodo del ramo de tributos, el que pagaban los indios desde I 666 á razón de peso por cabeza. Después de su expulsión se dicron dichos curatos á los religiosos de San Francisco, Santo Domingo y la Merced.

Son estos indios industriosos y aprenden con facilidad cuantas artes liberales y mecánicas les enseñan: música, escul.ura, estatuaria, la herrería, etc.; tejen finas telas de algodón y las tiñen

(I) Segín el cosmógralio 1). Cosme Bucno, el terreno de las misiones de que se trata enipieza desde el espacio que baña el Uruguay desde $\operatorname{los} 26^{\circ}$, caminando 200 leguas hasta entrar en el Paraná, cerca de Buenos Aires en los $32^{\circ}$ latitud Sur. Para mayor claridad, se entenderá que las misiones entre el Uruguay y el Paraná tienen el nombre general de Gnarauics. de los mís finos colores; y lienzos que exceden á la más rica holanda y áun á la seda.

Hay en la provincia considerable cantidad de ganado mayor y menor, habiéndose encontrado al extrañamiento de los Jesuitas 769.859 cabezas del vacuno, 8r.078 caballares, r 3.905 mulares, 7.493 burros, 596 cabras y $22 \mathrm{r} .537$ lanares; y hay además muchos ganados cerriles en los países orillas del Uruguay.

La práctica que la piedad de nuestros Misioneros sigue en denominar los pueblos, produce no poca confusión en la Geografía, pues aunque pudiera bastar un nombre de Santo, agregado á un apelativo ó patronímico, sucede con frecuencia que los geógrafos omiten el segundo, y se da un mismo nombre á pueblos diversos y muy distantes: el de San Ignacio se repite tanto en las misiones jesuíticas, que cuesta trabajo hallarlos en las cartas sin equivocar su representación.

También comprenden muchos las misiones del Paraguay, que tenían los mismos Jesuitas entre los indios Chiquitos en un llano y vasto país del Obispado de Santa Cruz de la Sierra, de que se hablará después.

La ciudad de la Asunción del Paraguay, situada en las orillas del río de su apellido, se puede considerar como la principal en el vasto país que se extiende desde las fronteras portuguesas del Brasil, de la capitanía de San Vicente, y hasta las faldas de Santa Cruz de la Sierra. Es residencia de un Obispo con su correspondiente cabildo, cuyas parroquias estaban al cuidado de los Padres de San Francisco.

La población de su capital (síguese tratando de hacia el año I789), parece era de 5.250 personas, y la de la provincia de 48.456 : indios criollos, 4.459; metayos, 27.977; negros, 5.3 ro; y mulatos, ro.7Io.

Abundan las montañas de estas regiones, de excelentes maderas, que sirven para diversos usos: los cedros son de grandísimo tamaño; y exquisito para papeleras y otros adornos curiosos el urunderay, hallándose también otras que llevan por ríos á Buenos-Aires. Entre las ricas producciones de este país, hay una planta parásita, tal vez especie de la familia de los áloes, agauses, bromelias, etc., que da unas excelentes hebras, sin otro beneficio que echarlas en agua á que se pudran, y la emplean en calafatear pequeños barcos, coser zapatos y cuanto exija hilo fuerte: una hebra de cuatro líneas de circunferencia ( 96 por roo del pié de Castilla), y dos varas de largo, sostuvo, sin romperse, I 23 libras, y faltó á las I 24 ; resistencia que se supone superior á la del mejor cáñamo.

El principal comercio de esta provincia es el de la yerba del Paraguay, que tiene muy gran consumo en todo el Vireinato y en el Reino de Chile, computándose el del primero en 68.000 
arrobas, 86.000 el del segundo, y 22.000 la mis ma provincia. Sirve para infusión con el teiforme, que se usa tanto en la América meridional con el nombre de Mate. En el Reino del Perú disminuyó mucho el grande consumo de ella, al paso que se introdujo el muy considerable de café y chocolate. Este ramo producía á la Real Hacienda 24.00o pesos al año.

Uno de los principales productos de estos países, es el tabaco, que se regula en 58.528 arrobas de cosecha anual: y también se coge azúcar.

Compréndese en este Vireinato la provincia de los indios Chiquitos, que se extiende desde las orillas occidentales del Paraguay hasta las faldas de Santa Cruz de la Sierra (I); esto es, hasta las orillas del Guapay, que va Norte-Sur á descargar en el río de las Amazonas (2). Al Sur se limita el país de los Chiquitos, y de otras naciones que se comprenden bajo esta denominación. por el río navegable el Picolmayo, que viene en dirección, cuando esta región atraviesa Noroeste-Sueste. La extensión de este vasto terreno es en su mayor longitud como 200 leguas Norte-Sur, y roo de Este-Oeste.

Habitan este terreno varias naciones indias, que se confunden, aunque con varios nombres, en la apelación general de Chiquitos, que les dieron los primeros descubridores al ver lo bajas de las puertas de sus chozas, por lo que les juzgaron de muy pequeña estatura. Al tiempo de su conquista espiritual se les denominó piococas, punajicas, huarayos, anaporecas, bohococas, tubacicas, cibacas, quimomecas, yurucaricas, cucicas, tapacuracas, paunacacas, quitemocas, napecas, pizocas, tanipicas, juberecas, parisicas, jamanucas, tapuricas, taos, bazozocas, y hasta 22 naciones más, incluso los guayviros. Cada nación tiene su idioma particular, y algunos difieren tanto como el griego del castellano. Están distribuídas en parcialidadesóaillos, y hay pueblo de cinco, seis y once de estas naciones. La lengua más general es la de los Chiquitos, sumamente dificultosa, pues además de otros tropiezos, tiene el de que el dialecto de los hombres es diverso del de las mujeres, y les clisuena tanto si no se usan con propiedad, que si los curas en sus pláticas refieren palabras de la Vírgen ó de Santas en el dialecto masculino, todo su auditorio se 10 rie.

Los pueblos reducidos son los de San Javier, el primero hacia el Norte en $16^{\circ} \mathrm{y}^{1} / 2$, La Concepción, San Miguel, San Ignacio, Santa Ana, San Rafael, San José, San Juan, Santiago y el Santísimo Corazón. Hay todaría por reducir gran

(I) Don Cosme Bueno. Descripción de la provincia de Santa Cruz. Almanaque de 177 I.

(2) Cartas de Mr. d'Anville. número de estas naciones bárbaras hacia el Marañón, Picolmayo y otros varios parajes. Los Paulistas portugueses han hecho varias excursiones contra estos indios, bajando el Paraná en piraguas por el Añembí que viene de su distrito y del Paraná, entrando por el Pardo ó Río Colorado, y de allí pasaban por tierra y sobre ruedas las embarcaciones al inmediato río de Ficuary, que descarga en el Paraguay en frente de los Chiquitos, en donde cautivaban con el engaño y con la fuerza millares de indios, que llevaban á vender á las haciendas portuguesas.

Todo este terreno es cálido y bajo respecto de la cordillera, y se extienden por él muchos espesos bosques que impiden la ventilación y lo hacen sombrío, refrigerándolo alguna cosa el vicnto Sur. Abunda en lagunas y ciénagas que forman las aguas desde Noviembre á Mayo, y ellas son de las que beben los'naturales, cuyo número era de 24.000 en I768. Acabarían con ellos las epidemias si no fuera por la fecundidad de las mujeres, que paren cada año, y el celo de los neófitos que traen á los infieles de sus respectivas naciones. Abunda este país en grillos, molestísimas culebras, vívoras y arañas de extraordinaria magnitud, cuyos hilos, tendidos de un arbol á otro, son fuertes, que dificultan el paso d́ un hombre, y se ha visto un casquete fabricado de esta hilaza, que tenía mucha fortaleza y la propiedad de extenderse cuando le mojaban, y de disminuir tanto su volumen en secándose, que cabía en el puño. Hay también otra pequeña araña venenosa, roja, de una y media línea de diámetro, que hace una tela suave y amarilla, que parece seda. Se cuentan entre sus animales, osos hormigueros, llonos, la especie de mono barbudo, antas, tigres, leopardos, tuesruces y especies de tortugas. Son estos indios por lo general vivos y de buena estatura, con que desmienten su nombre, ágiles y hábiles para cuanto se les enseña. Las casas son de extructura regular, con ramadas al Sur y al Norte, y forman los pueblos con las calles derechas, dejando cuadradas y espaciosas plazas. Están bastante civilizados, tienen talleres de todos los oficios en las casas de sus curas, y conservan las artes y disciplina que les dejaron sus antiguos misioneros. En lo temporal les mandan sus correspondientes vitalicios con Alcaldes y subalternos, etc.

Pertenece también á cste Vireinato, pornueva disposición cuando se erigió en tal, el Obispado de Santa Cruz de la Sierra, que está en latitud Sur de $I 7^{\circ} 25^{\prime}$ en una dilatada campina que se tiende por el Este, poblada de estancias y chácaras de ganado hasta un río que llaman Grande ó Huapay; por el Sur, 28 leguas liasta el mismo río; por el Oeste, is liasta el pié de la cordillcra, y 24 por el Norte, también con rarias haciendas. La población de esta ciudad era en I77 I 
de 6.000 almas con 1.500 de servicio, gente de castas. Es silla obispal con su correspondiente Cabildo, y tiene un convento de la Merced; mandando en lo temporal un Gobernador por el Rey y dos Alcaldes.

A 20 leguas de esta ciudad hay cuatro pueblos de Chiriguanos, que son auxiliares de los españoles; $y$ aunque no han querido cristianarse, sirvieron con fidelidad en varias guerras contra los bárbaros, y se nombran estos pueblos Piray, Cabeza, Abapo y Trinchera: se gobiernan por sus Capitanes y ponen entre todos 500 hombres de flecha y lanza. El Huapay los divide de los demás bárbaros.

A cuatro leguas de Santa Cruz ó San Lorenzo, se halla el pueblo de San Juan Bautista Porongo, de I.200 almas, que sirven de barrera contra los indios Yucaraes.

Al Oesudoeste de dicha capital, se halla el pueblo de españoles Samaypata, con 600 almas. A r 2 leguas Sur de él está la ciudad de Vallegrande, ó de Caballeros Pardos de Jesús de Montes-claros, con 3.500 almas. Se hallan también en esta provincia los pueblos de Chilon, San José de Buenavista y Santa Rosa, y contendría á la época de I77 I I6.00o almas, y se hallan en toda ella siete curatos.

Al Oeste, de Santa Cruz ó San Lorenzo, se halla la provincia de Mizque, cuyo temperamento es por la mayor parte caliente, pero tiene también parajes templados y sanos. Produce trigo, maiz, legumbres, vino y algún azúcar; mas por lo gencral es pobre y malsana, y está por tal causa casi despoblada, de modo, que por el año de I789 contendría I2.000 almas, habiendo sido en otro tiempo considerable su población. Tiene siete curatos, y abunda en maderas.

Al Norte de Santa Cruz está la provincia de Moxos, que se extiende en dirección hasta el río Itenes ó Huapore. Hacia el Sueste, interpuestos muchos bosques, cae la provincia de Chiquitos, que termina por el Sudoeste con los Andes de Apolo Vamba, y con las misiones de dicho por el Oeste, de que los divide cl río Beni á $I^{\circ}{ }^{\circ} 7^{\prime}$ de latitud y $305^{\circ}$ ó 3 I I $^{\circ}$ de longitud; tiene I 20 leguas Norte-Sur y otras I20 Este-Ocste. La bañan é inundan tres caudalosos ríos, además de otros ménos considerables, el Mamore y el Itenes, navegables en canoas y balsas, desde sus orígenes hasta el río de la Madera, que desemboca en el Marañón. Compónese de I5 pueblos, cada uno con dos curas, y se divide en tres partidos: Moxos, Bauces y Pampas; el primero, yace á una y otra banda del Mamore, y consta de seis pueblos; el scgundo al Este del mismo río, con otros seis; y cl tercero al Oeste con los tres restantcs, acercándose á 22.00o el número de indivíduos que los poblaban hacia el repetido año de i 789 .
Su temperamento es húmedo y caliente por los muchos ríos y bosques que contiene, $y$ forman innumerables lagunas y pantanos, tanto, que en tiempo de lluvia se cubren las campiñas y sólo asoman las copas de los árboles, teniendo los pueblos que comunicarse con balsas y sucediéndoles no encontrar en dos días de camino un pedazo de tierra en que asentar el pié, en cuyo tiempo enflaquecen los ganados, y consumiendo el calor una parte de las aguas, produce después calenturas y epidemias. Por naturaleza, se resiste este país al trigo, pero abunda de los frutos de tierra caliente y húmeda, como caña de azúcar, cacao, maiz, yuca, arroz, camotes, plátanos, mani y agíes, etc. Tiene también cosecha de algodón, y en algunos parajes un mantecoso y muy a preciable cacao. Hállanse en sus bosques los preciosos guayacanes, canelos, marías, que dan el aceite de su nombre; quinaquina, cuya semilla, quemándose, exhala fragante olor; cedros, palmas, tagibos, especies de almendros, copaibas, dragos, vainillas y otros. También hay en ellos antas, osos hormigueros, venados, conejos y tigres; muchos insectos dañosos comunes á tierras calientes, culebras boas y de cascabel y murciélagos de tamaño extraordinario. Los ríos abundan de pesca, que los indios matan á flechazos: se hallan rayas, palometas, caimanes, y un autor dice que toninas ó delfines, lo que parece extráño y áun equivocación.

El gobierno de estos indios de Misiones, semejante á los de los Guaraníes y Chiquitos, merece la aprobación de los príncipes y de los verdaderos amigos de la religión: un gobierno patriarcal que acomoda y prevalece con estas gentes; y que en Estados civilizados no tiene la aprobación de los políticos: dícenles misa todos los días, y al anochecer rezan el rosario y se les explica la doctrina. El cura nombra los Alcaldes, Alguaciles, Capitanes para losaillos, y enfermeros. Estos Jueces vigilan sobre los desórdenes, visitan las chácaras de los vecinos para que no descaezcan y mantengan sus familias. El cura corrige á los delincuentes, les manifiesta la gravedad de su delito, y decreta el castigo. Hay grandes vacadas en potreros que pertenecen al común para el abasto de carnes. Cada indio desde que se casa, debe formar una chácara, cultivar frutos para alimento, y algodón para vestidos de su familia. La chícara del cura se labra á costa del común para que de sus productos se mantenga y acuda al fomento de los varios oficios mecánicos, á cuyo fin la hacen capaz para contener talleres $\mathrm{y}$ oficinas, en que se tejen telas finas, se fabrica azúcar y chocolate y se beneficia cera silvesire. El sobrante, ó parte de estos productos, se extrae por dirección del cura para proveer á las otras poblaciones, de aquellos necesarios artículos que les faltan. 
Sobresalen estos indios en las artes, imitan cualquier cosa, y con pluma han llegado á hacer un breviario antuerpiano que no se distinguía sino én faltarle el vestigio de la impresión.

La provincia del Potosí, según las noticias adquiridas, que parecen arregladas á las últimas disposiciones, tiene I8o leguas Norte-Sur, 2ro Este-Oeste y 600 de circunferencia; dividiéndose en cuatro partidos, cuyas capitales son Potosí, Porco, Chayanta y Lipes. La población del primero y su distrito contenía 80.000 almas; la del segundo 3I.7I2; la del tercero I3.864 y la del cuarto I0.228, agregándose 20.000 cholos trabajadores. Por falta de documentos no pudo asegurar el autor la precisa extensión que se había dado á sus límites cuando se agregó al nuevo Vireinato. En las descripciones de D. Cosme Bueno, se da por territorio peculiar de la villa de Potosí, ro leguas Este-Oeste y siete de Norte á Sur. Reside en ella el Jefe de la provincia y Oficiales Reales; tiene Cabildo secular, Magistrados y subalternos, Casa de moneda con Superintendente, doce parroquias, seis conventos de religiosos, dos de monjas, una casa de recogidas y siete curatos más en su jurisdicción inmediata.

Sitúase esta villa, que nombran Imperial, en latitud de $\operatorname{Ig}^{\circ} 48^{\prime}$ en una loma, dividida del cerro de su nombre, por una quebrada, por donde desciende un arroyo que provee de aguáa las haciendas y oficinas de metales. La rodean nevados cerros, y la altura de su sitio hace muy frío su temperamento. Según las observaciones barométricas de Mr. Godin, se halla á 600 varas sobre la superficie del mar. El país cstá lleno de cerros, riscos y quebradas; su temperamento es seco y el aire raro; los no acostumbrados experimentan fatigas en cualquier ejercicio; lo frío del temperamento hace conservar los comestibles.

El cerro del Potosí, según unos, tiene figura de un gran pabellón; otros dicen que de un pan de azúcar; le dan de altura perpendicular sobre su base 640 varas, y una y media leguas de circunferencia; otros, como D. Cosme Bueno, se la dan de I.ooo varas, y todos convienen en que está horadado como un panal, todo acribado.de bocas-minas que pasan de 5.000. Se trabaja con indios Metayos y con bastante economía; los metales bajaron de ley en los últimos años hacia el de 1789 , y un cajón de 50 quintales de mina apenas daba cuatro marcos; pero los auxilios del banco del Rey sostienen este famoso mineral; y á pesar de su decadencia, producía anualmente 300.000 marcos de plata, que se vendían en el banco á siete ó siete y medio pesos según su calidad; quedando de cada uno al Rey cerca de un peso por los derechos de diezmos y cobros; á que se agregan los Hicates de las demás provincias que producen al Rey I00.000 pesos. La casa de la moneda dejaba I80.00o, la Aduana I40.000, los tributos 200.00o; los tantos de bulas y papel sellado, tres y medio por ciento del oro, y diezmos de vajillas ascenderían á 350.000 pesos fuertes, de manera que la totalidad de las rentas montaba $\mathrm{I} .280 .000$.

La villa y su distrito inmediato, ó sus alrededores, se computa tener 25.000 almas. Sus riquezas fomentan á las provincias vecinas, y áun se extienden igualmente á las remotas. Unas dan operarios ó Metayos; los valles que la cercan, verduras, frutas y caza; Cochabamba y Arequipa, vinos, trigos y granos; Tucuman y Salta, ganados mulares, etc.; Chile y el Paraguay, la yerba de su nombre, nueces y cocos; Guamanga, ropas de la tierra, azúcar, coca y pinturas; la costa de Arica, congrio, aceitunas y otros efectos; la gran laguna de Chicuito 'y otros ríos inmediatos, sábalos, dorados y suches, pino, aguardiente, etc.; el Picolmayo, gran río que nace á sus inmediaciones, deberá ser navegable á no mucha distancia, y contribuir su navegación al fomento de estos países; finalmente, Lima y Buenos-Aires proveen esta población de géneros de Castilla. El montante de lo que recibe por la última vía, llegará á 280.000 pesos.

Sin embargo del crudo clima de esta villa, se disfrutan en ella los mayores regalos y comodidades de la vida: los alimentos se conservan frescos mucho tiempo: son abrigadas las casas, y las calles estrechas. El sexo femenino que acude de muchas partes, hermosea el pueblo, al paso que influya en la corrupción de las costumbres con sus trajes y lujo.

El partido de Porco tiene 40 leguas NorteSur, y 60 de Este á Oeste. Es de temperamento frío, á excepción de uno ú otro valle contiguo al Picolmayo: casi en su centro se sitúa la villa del Potosí. Produce los frutos que dan en esta parte del mundo las tierras elevadas y serranías, como papas, cebada, habas, y algún trigo: en las tierras bajas ó valles, varias frutas y uvas, y producen algún vino de parrales. Críanse llamas, que sirven en los minerales, vicuñas y huanacos. Hállanse términos en las inmediaciónes del Potosí (cuyo cerro, en opinión de algunos, es extinguido volcán), que su principal riqueza consiste en sus minerales, que han sido célebres y fructifican aún; y 20 ó $2+$ años antes de la época en que trata el autor, ya repetida, tuvo un particular una bonanza de tres mil millones. Tiene I8 curatos, y reside el Corregidor en el de la Venta de Talavera de Putra.

El partido de Chayanta ó Charcas, tiene Este á Oeste 36 leguas y 44 de Norte á Sur. Su temperamento es vario por las sierras y valles de que consta, y son también varias sus producciones. Las sierras abundan de trigo y maiz, que condu- 
cen en harina á las provincias confinantes. Hay sanado de toda especie; minas de oro, aunque de poco fruto. Sus mejores minas de plata han dado en agua. En la de Aullagas hubo mucha riqueza algunos años há, y se ignora si subsiste. Tiene esta provincia I 7 curatos, los dos en la misma capital.

El partido ó provincia de Lipes, es largo y angosto. Corre 60 leguas Noroeste-Sueste, y tiene por donde más 20 de ancho. Su temperamento es seco y frío, á excepción de los terrenos de Lica $y$ Tahua, donde se coge quinoa, papas $y$ cebollas: hay abundancia de vicuñas, vizcachas, grandes perdices y avestruces. Sus ríos son pequeños y se pierden en la arena. Se halla mucha sal en los llanos, $y$ salitre en otros parajes; y no escasea el buen azufre en cuatro volcanes que hay en la provincia, de cuyas proporciones se valen los indios para fabricar pólvora de la calidad que se les pide, no en molinos, sino dentro de pellejos, en que trituran los ingredientes con piedras de mano. En el distrito de San Antonio, anexo al curato de San Pablo, se hallan vetas de pedernales redondos, como balas de 24 , que suelen re. ventar con estrépito, y se ven en su parte cóncara unas puntas que brillan como diamantes.

Hay minas de cobre rojo y blanco que tocan en plata y oro; de hierro, de imán y de plata en :asi todos los cerros de la provincia. Es de las más poderosas, y aunque sus metales tuvieron decadencia, los vestigios manifiestan que sus pueblos fueron más considerables. Tiene tres curatos con muchos anexos.

El pueblo de San Antonio de Lipes, capital, fué mucho más considerable. Tiene dos anexos, el segundo curato uno, y el tercero cinco.

Habiendo descrito las provincias del vasto $y$ nuevo Vireinato de Buenos-Aires, resta dar alguna idea del dilatado y poco conocido país que está en su centro, y que debe considerarse como almáciga y criadero de los bárbaros, que escondidos en sus inmensos bosques y atrincherados por sus lagunas, no sólo se sustraen al imperio de nuestros monarcas y al infatigable celo de los Misioneros, sino que conservando sus feroces y áun abominables costumbres, infestan y molestan nuestras posesiones por cuantas fronteras $y$ lados bordan sus llanos y desicrtos. Tiene este dilatado país cl nombre del Granchaco.

Confina por el Este con el río Paraguay, por el Nordeste con los Chiquitos, por el Norte con Santa Cruz de la Sierra, por el Oeste con muchas provincias situadas de Norte á Sur, 'Tomina, Pomabamba, etc., y últimamente el 'Tucuman; y por el Sur, donde se estrecha, llega hasta la prorincia del Río de la Plata. Tiene hacia el Norte, de ancho I50 leguas por donde más Este-Oeste, y 250 de Norte á Sur.

El nombre Chaco significa Junta ó Compañía, por las muchas naciones que aquí se congregaban, $y$ que en otro tiempo huyeron del dominio de los Incas, y después, de las conquistas de los españoles. Se internan y destacan ramos de la cordillera por el Oeste, en cuyas elevaciones se experimenta frío; pero entre estas sierras se extienden llanos que toman vasta extensión hacia el Este; y así resultan inmensos bosques, malezas, pantanos y lagunas, que unas duran y otras se secan, debiendo todas su origen á las crecidas lluvias de invierno.

Riéganse estas regiones por varios considerables ríos, que deben su primer origen á los nevados Andes orientales, y descargan en el Paraguay después de andar grandes espacios: el Salado, el Bermejo ó Colorado y el Picolmayo, que empieza desde cerca del Potosí. En los dos últimos se crian hasta 22 especies de pescado, y entre ellos, sábalos, dorados, pejeblanco, bogas, dentudos, bagres, cangrejos, anguilas, etc., y un gran pez que llaman palometa, cuyas quijadas emplean para cuchillos.

El Bermejo, antes de entrar en el Paraguay, forma una laguna donde dicen que se crian grandes ostras perleras. Sobre el propio río se fundaron tres ciudades en diferentes tiempos, pero todas se abandonaron.

E1 Picolmayo es seguramente navegable mucho trecho: en I72I buscaron por él los Jesuitas comunicación con el Paraguay y el Perú, navegando en un barco y dos botes espacio de 350 leguas por grandes tornos que hace; pero por falta de hondura hubieron al cabo de retroceder al Paraguay; mas como esta tentativa se hizo en tiempo de secas, cual Setiembre, Octubre y No. viembre, se cree fundamentalmente que en la estación propia de lluvias se hallará agua suficiente para navegar hasta el Perú, aunque sea con barcos grandes, aptamente construídos, respecto lo mucho que crecen los ríos. Divídese el expresado Picolmayo en dos grandes brazos, 70 leguas antes de su entrada en el Paraguay.

No hay duda que importará mucho al Estado y á la Religión el reconocimiento de estas navegaciones interiores $y$ vastos canales con que nos convida la Naturaleza, que facilitarían las importantes comunicaciones entre los vastos países del mundo español, para el comercio, para la población, para la introducción de Misioneros que civilizasen tantas bárbaras naciones.

El país del Chaco, en opinión de quienes le han visto, pasa por uno de los más fértiles y hermosos de la América, ya por sus llanos, vegas y bosques frondosísimos, ya por sus lagunas y pes. cadosos ríos que le riegan. Entre sus arboledas hay cedros, nogales, guayacanes, quiebrahachas, algarrobos, marías, bálsamos, palmas, almendros, cacaos, cerbos, algodones, místoles, cuyos corazones emplean para dardos y macanas, aro- 
mos, sasafras, quinaquina y árboles cuya interior corteza sirve de papel y parece fina holanda; el palo-borracho, que á dos varas de la raiz tiene una gran jiba, cuya corteza se deja labrar en forma de vasijas en que los indios guardan su chicha; y se hallan también cañas de bastones como las de Asia.

El hombre, á cuya fuerza y maña están sujetos los demás animales, no es aquí rey de la Naturaleza, donde muchos indios viven á guisa de ellos. Andan errantes, especialmente los del Norte, con una estera, que se plantan hacia donde viene el viento ó el agua, y así forman sus aduares hasta que consumen los víveres de aquel paraje. Viven de la caza, pesca, frutos y raices. Los Chirihuanas y Churumaras tienen pueblos fijos, pero de chozas miserables, dispersas y cubiertas de palma. Son 50 las naciones que se cuentan en el Chaco, y muchas se confunden con los Chiquitos.

Son estos indios toscos, incontinentes, vagamundos, flojos, groseros en sus conceptos, y grandes guerreros.

Hay entre ellos gran número de lenguas y de costumbres. Antiguamente andaban á pié, pero se han hecho ya con caballos y son muy diestros ginetes: suelen andar en pelo, y de un cabestro de cuero hacen rienda y freno, corrienco ligeramente y ayudando al caballo con un gran azote.

Sus habitos de flojedad, de vida holgazana y licenciosa, han hecho que tantas veces cuantas se han catequizado y reducido á pueblos, otras tantas, quemando sus chácaras y robando el ganado y matando á sus Misioneros, se hayan retirado á sus bosques. Los Matahuayos, vecinos y fronterizos al Tucuman, han manifestado su perfidia diferentes veces, pidiendo Misioneros, reduciéndose en la apariencia, y repentinamente sin motivo alguno desampararon sus reducciones y huyeron á los bosques y guaridas. Aunque á vista de sus perfidias aconsejaron muchos algunas veces que se les hiciese esclavos, nunca lo permitió la piedad de nuestros Reyes; antes se les exhorta á la paz y se les admite siempre que la pidan. En más de dos siglos que se puso mano á su conversión, sólo se tienen siete reducciones hacia la provincia del 'Tucuman: en las fronteras ó términos del Chaco al Sur de Santa Cruz de la Sierra hay otras cuatro de Chiriguanos: otras dos de los mismos hacia Tarija; y otra se fundó de Abipones á cinco leguas Sur de la Asunción. Nótase que todas estas reducciones están en los confines del Chaco, que las que se fundaron dentro experimentaron su destrucción, y que entre todas no pasan de tres mil almas entre cristianos é infieles.

Pertenecen al Vireinato de Buenos-Aires las Islas Maluinas y los establecimientos que se ha- gan en la costa Patagónica: siendo una de sus principales atenciones, vigilar sobre los que hagan otras naciones, con cuyo objeto y otros importantes mantiene S. M. una armadilla que se compone de una fragata y otras embarcaciones menores.

En los últimos años (hacia el I 789) se hicieron varios reconocimientos de sus costas, puertos y ensenadas. No merecerá ménos cuidados al Jefe de estos dominios observar los movimientos de la nación portuguesa, que aunque no haga la principal figura en la Europa, la hace muy considerable en esta parte del globo, ya por las fuerzas que tiene en sus colonias, ya por las usurpaciones que clandestinamente hace. Si al principio se tolera una chácara ó aldea, pasa á establecimiento considerable y lucrativo; que arrastra el empeño de una corte de sus aliados, $\mathrm{y}$ al fin una costosa guerra.

Los muchos ríos navegables que atraviesan esta gran porción de la América meridional, unos del Nordeste al Sudoeste como el Uruguay y el Paraná, y otros del Noroeste al Sueste, cual el Rojo y el Picolmayo, que entran en el rey de los ríos, el Paraguay, que atraviesa todas estas regiones, de suyo fertilísimas, producidoras de los mejores frutos, preciosidades y alimentos, proporcionan un vasto comercio interno, y tal vez la mayor navegación interior, por agua dulce, que haya en el globo. Hasta ahora parece que estas importantes navegaciones se han hecho sólo por unas especies de hombres animados de fines muy opuestos. Los Jesuitas por el ardor de convertir infieles y aumentar la gloria y conquistas de su Compañía, y los portugueses por hacer es clavos y adquirir brazos para sus haciendas.

Unos y otros han hecho estas molestas navegaciones, y enseñado á sus Soberanos, que la Providencia, sin parte alguna del arte humano, ha puesto los mejores canales cle navegación que podrían desearse, para que se transporten las riquezas de tantas y tan vastas provincias, crezca el comercio, se civilicen los pueblos y aseguren al Estado y á la Religión los de neófitos que principia el Misionero, pues por mucho que se les predique é instruya, la miseria que acompaña á sus recientes colonias, será causa en muchas ocasiones de que desconociendo la mejora de su estado se vuelvan á las selvas.

Las rentas que saca el Soberano de estos dominios, y son al modo que en los demás Estados y Vireinatos de la América española, se expresarán por una breve indicación; debiéndose tener presente que la mayor parte de su extensión es estéril para la Corona, y áun gravosa, por los presidios que se mantienen y misioneros que se costean, pues la mayor parte de sus provincias confinan con naciones bárbaras, y algunas como las del Paraguay, los tienen por todas partes. Lin 
Corrientes se mantienen tropas armadas de cuera, lanza y adarga: los Pampas cortan la comunicación é impiden que se pueblc aquella parte del Tucuman casi hasta Chile; de manera, que muchas partes de las poblaciones son fronteras, se hallan los vecinos listos y con el caballo para el primer ariso; $y$ aunque sea cierto que en los últimos años (hacia el de 89 ) ni los Pampas han invadido las caravanas de carretas que salen de Buenos-Aires para Chile, ni los del Chaco hecho correrías en el Tucuman, ni en general se haya oído noticia de sus insultos, mediante las sabias providencias y máximas de los que gobiernan; no es, pues, todavía, un estado de seguridad absoluta, mientras estos bárbaros, al ménos los más confinantes é inquietos, no se reduzcan, ya por el celo de los misioneros, especie de hombres dignos de la humana veneración, que no sólo extienden la santa religión que predican, sino que primero hacen civiles á los hombres para que sean cristianos. Los Príncipes, no sólo se libertan de enemigos molestos, sino que suelen adquirir vasallos fieles sin efusión de sangre, sin estipendio de sus erarios.

Aun cuando no ardiera en el corazón de nuestros católicos Monarcas tan ardiente celo por la religión santa que profesan, el interés y la razón de Estado lo piden.

Un hombre con un breviario, un crucifijo, una pequeña escolta y una asistencia de 300 pesos ánuos, que por regla general señala Su Majestad para su manutención, penetra por los inmensos países, entre la multitud de los bárbaros, que le dan paso y áun salvaguardia, á un hombre desarmado é indefenso. Los donecillos, la persuasión, el ejemplo, la paciencia, recaban con el tosco salvaje, no sólo oir una nueva doctrina al principio por curiosidad, sino conocer las ventajas que le ofrece el nuevo estado de pacífico agricultor, en que asegura sus alimentos y subsistencia, y despreciar el de errante y sanguinario cazador, que después de mil carreras y fatigas, apenas adquiere alimentos para cuatro días.

La política de asegurar la subsistencia á los convencidos, de situarles sus habitaciones entre gentes fieles, hará durables y seguros los frutos que adquiera el misionero. Las excursiones de gente armada contra los indios, deben compararse á una batida contra fieras: ellos, al estrépito y ruido de las armas, huyen y se esconden; pero retirados los que les espantaban, salen de nuevo, sorprenden y matan al que se descuida.

Los países productivos del Vireinato son la provincia del Río de la Plata, la del Paraguay y las del Potosí. Las rentas principales son: las que pagan los indios varones desde su juventud hasta la vejez (esto es, desde I 8 ó I6 hasta $5^{\circ}$ años), que según el cálculo hecho en I 785 hasta
I788 inclusive, importa I 9. I 2 I pesos: la del diezmo eclesiástico, que percibe el Monarca como patrono de las iglesias de América, y asciende, deducidos varios gastos, á 754: los quintos del oro, cosa muy corta, tal vez por ser al principio y no estar bien afirmada la jurisdicción de este nuevo V'ireinato, 955; los oficios vendibles como escribanías de cámara, fielatos, regidurías, etcétera, 9.255; las varias tesorerías del Vireinato en sus principales capitales, dan el mayor renglón de I.472.253; el papel sellado, 3.492; el azogue que se vende de euenta del Rey á los mineros, de que hay mucho consumo en el Potosí, etcétera, II 3.002 ; las pulquerías, tributo de $3^{\circ}$ pesos más ó ménos, que paga cada tienda, nombradas así en América, en que se venden comestibles y licores, 8.or3. Los demás ramos reales que se omiten por su poca monta, son: vacantes mayores y menores, aprovechamientos, medias annatas, depósitos, penas de Cámara, donativo, Inválidos, Montes-Píos y el Municipal de guerra, que por sí sólo llega á 82.I9o. Y el total producto de las rentas expresadas, junto con el no individualizado de las últimas, asciende á I.906.250 pesos, un año con otro; pero siendo de creer que no se incluya la del tabaco, renta que siempre debe ser considerable, pues se administra particularmente.

El Real Erario tiene contra sí varias cargas para la buena administración y conservación de tan vastos y distantes dominios, á saber;

Sueldos de empleados de policía y judi-

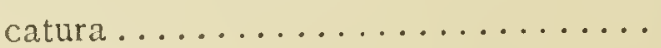

Idem de los de Real Hacienda........

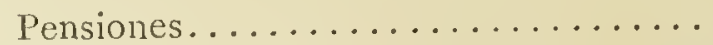

Sínodos á los curas...............

Gastos de lana de vicuña............

Idem de las embarcaciones del Río de la

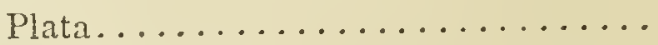

De la Real Armada...............

De la costa Patagónica.............

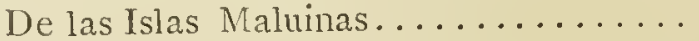

Gastos de la expedición de límites.....

Gastos de compra y administración de

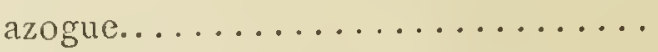

Gastos de Municipal de Guerra.......

Viudedades y administración del Montepío militar.................

Retiros ó Inválidos................

$\mathrm{Y}$ con otros varios ramos de gastos, según las noticias adquiridas por el autor, monta el total de cargas de este $\mathrm{V}$ ireinato................. 1.672.635

Por manera, que vienen á quedarse estos países con la mayor parte de las rentas que producen, quedando sólo á favor de la metrópoli $233 \cdot 5$ I 4 pesos.

La erección del nuevo Vireinato hará circu-
$88.39^{1}$ 69.644

2.495

15.016 25.065

9.088

1 28.183

84.027

23.869

60.693 I 00.889

$5 \cdot \mathrm{I}_{3}$

$3 \cdot 5^{8} 5$
I 34 . I 97 
lar en todo él mucha parte de los preciosos metales que regurjitan en los países de minas, pues las provincias que le agregaron del Perú es preciso envien mucho de su numerario á la capital. Si el comercio de España y los capitales con que se retiran á ella los particulares, no extrajeran el numerario que dan las provincias del Potosí y las otras de minas, fuera la plata una de las más viles mercaderías; pero por la extracción que hay en las más de nuestras provincias americanas, corre sin duda ménos numerario que en las más pobres de España.

\section{Descripción politica de la Isla de Chiloé.}

El Jefe principal de la isla de Chiloé, era en I 789 un militar con graduación de Coronel, con título de Gobernador é Intendente; y le es anejo el mando de la tropa, teniendo su Sargento Mayor, Ayudantes, un Oficial de artillería que manda la tropa de su cuerpo, y un Ingeniero que entiende en las cosas de fortificación.

Hay en toda la isla tres conventos: uno de la Merced, otro de Franciscos y una residencia de los mismos, y todos por la pobreza del país mantienen corto número de religiosos, teniendo los últimos á su cargo las misiones que estaban al de los Jesuitas, y se esperaba la reforma de los dos Observantes y un Mercenario que únicamente había extra de I $_{5}$ misioneros, respecto la Real orden en que se determinó la de conventos que no tuvieran al ménos cinco religiosos.

Toda la jurisdicción eclesiástica de la isla reside por la mayor parte en un cura castrense, y se cuentan en toda su extensión sólo cinco pueblos, de suyo muy dispersos: la ciudad de Castro al Este, el Chacao, Calbuco, San Carlos y Carelmapu, cuya apariencia es más de campamento desordenado que de arreglada población, dispersas sus casas entre los umbrosos y desmontados bosques, formando paisajes agradables á los ojos.

Divídese la población de la isla, en curatos, y éstos en capillas. Llaman capillas, á cierto número de vecinos dispersos junto á las costas, que concurre á cada una de ellas para el sacrificio de la Misa.

El curato de Castro comprende el partido de su nombre, Chonchi, Puquelon, Queilen, Achau Meulin y Tenaun: Castro tienc I c capillas, Chonchi 5, Puquelon 6, Queilen 8, Achau 8, Meulin 5 y Tenaun 8 , habitados por ro.032 españoles y 8.750 indios.

El curato de Chacao comprende el partido de su nombre y el de Puderu, con I7 capillas inclusa la Real, 3.Io7 españoles y r.404 indios; y el curato de Calbuco contiene sólo el partido de su nombre, con I4 capillas, I.334 españoles y 1.403 indios. De manera que el total de sus habitantes sube hasta 27.000 con algunas per- sonas que no se incluyen, siendo $I_{5} \cdot 300$ españoles é indios I. 700 .

La ciudad de Castro se fundó en tiempo del Licenciado Lope García de Castro, Gobernador del Perú, por Martín Ruiz de Gamboa, en I $_{5} 66$, habiendo sido al principio bastante regular, pero fué después arruinada por un temblor de tierra, y hoy está, así como el pueblo de San Carlos, compuesta de casas de madera, techadas de paja, esparcidas y desordenadamente colocadas. Tiene además de los tres conventos expresados, una iglesia parroquial, Cabildo secular, Corregidor, dos Alcaldes ordinarios y cuatro Regidores, Escribano y demás oficios: un fuerte hacia la playa para su protección. Habitan aún en está ciudad muchas familias antiguas y nobles de la isla, la cual fué saqueada en I.6oo por el pirata inglés Corder, y en r6 5 por Jorge Spilberg, ambos saqueadores y crueles de ejercicio. Se conoce que en aquel siglo se descuidó mucho la protección de estos fieles vasallos, que sin duda mal armados y sin tropa alguna, eran víctimas de osados corsarios. En el día se hallan alistados sus vecinos capaces de llevar armas, en I3 ó cierto número de compañías de Milicia, entre ellas, dos de la caballería que llaman de la Nobleza y otra del Corregidor, con un destacamento para servicio del fuerte.

Chacao (Santiago del) está en $4 I^{\circ} I 6^{\prime}$. Sus habitantes todos toman las armas excepto cuatro, y forman una compañía con Capitán, Teniente, Subteniente, dos sargentos, cuatro cabos y 48 soldados.

Antes era aquí el surgidero de navíos que venían del Perú y Chile, entrando por un canal que por los bajos, lajas, remolinos y furiosas corrientes en tiempo de calmas, les dejaba sin gobierno $y$ á veces se perdían, por lo que se escogió otro puerto más seguro.

San Carlos está en el puerto de Lacui, cerca de Puerto-Inglés, en una espaciosa y bien abrigada bahía. Tiene un fuerte escavado en la misma tierra, cuatro baluartes, foso y camino cubierto (que se hallaban, así como el fuerte de Chacao, en estado de deterioro), capaz de 24 ca- 
nones, y una batería situada en un alto collado á la entrada del puerto, que le defiende y toma el nombre á las embarcaciones que arriban á él.

Otra respetable batería ábarbeta, se situa en el mismo desembarcadero, al lado de la cañada que lo forma. San Carlos es la población más considerable de la isla, y reside en ella el Comandante General, los Oficiales Reales ó sus Tenientes, el Estado Mayor, Comandante de Artillería, y algunas pulquerías que son los únicos negociantes que se ven. A este puerto acuden las embarcaciones del Rey las pocas veces que arriban, y los barcos peruleros. Su muelle, que es la simple playa, se cubre de canoas y pequeños barcos del país, y hay que desembarcar en hombros de marineros, sin embargo de que la abundancia de maderas ofrece facilidad para la construcción de un mue1le. Se tiene en él una respetable guardia, y es uno de los parajes á que concurre gente.

El cura de esta población es también Capellán Real del fuerte, y D. Cosme Bueno dice también, que tiene $\mathrm{x} 8$ capillas de indios en su jurisdicción, dos islas pobladas y tres sin gente. Las ror familias que componen el curato se extienden á 14 leguas de costa, distante una casa de otra cerca de una milla, entre Cauli hasta Coacague, formando un pueblo cierto número de ellas, y este es el sistema general de población en toda la isla, excepto en San Carlos y Castro, en que se agrupan algo las casas.

La bahía puede decirse un seno rodeado de collados frondosísimos. Al Noroeste del fondeadero que tuvieron las corbetas, yace una punta, y en ella una batería que defiende el puerto. Al Sursudoeste hay un seno ó estero que forma el mar introducido entre las sierras, y al Esueste está la desparramada población de San Carlos, que parece un Real ó campamento, situada en una rambla donde se apiñan las casas, y en las faldas de los montes que la cercan; de cuya vista se sacó un buen diseño por el dibujante Cordero.

El pueblo de San Miguel de Calbuco, según las noticias del citado cosmógrafo, se sitúa hacia el Nordeste en una isla poco distante de tierra firme. Tiene un fuerte á la orilla del mar, y la población que lo circuye debe considerarse como militar.

Pertenecen á su jurisdicción I2 islas poblaclas y I $_{3}$ despobladas. Hay dos reducciones que llaman de los indios del Rey; una la de Calbuco y otra la de la Isla de Abtao. Estos indios fueron de Osorno, y siguieron el partido de España cuando abandonó aquella ciudad: acompañaron á los habitantes que se refugiaron á ella, y ayudaron á hacer el fuerte en tierra firme; pero siendo atacado muchas veces por los Juncos, se construyó otro para mayor scguridad en la isla en que se halla. Sirven á S. M. cuando se les requiere, y sc les da una gratificación cada año.
Al Nordeste se ve el majestuoso volcán de Huañauca, notándose en la cordillera, gruesas nubes del humo que arroja, y se dice que vomita llamas mucha parte del año.

Los habitantes de Calbuco, en concurrencia de los de Carelmapu que habitan el continente al otro lado del canal de Chacao, se emplean en el corte de alerce en la vecina cordillera.

Aquí hay un fuerte que llaman de Maullin á orillas del río del Peñón. Carelmapu fué el primer puerto que poblaron los españoles cuando vinieron á la Isla de Chiloé, cuya población en I789 se reducía á algunos ranchos, á lo que parece, desde que el pirata holandés Enrique Breaut la saqueó en $\mathrm{I} 6+3$ y se llevó los habitantes á Valdivia, donde quiso hacer población y establecimiento.

En las islas inmediatas, hay misiones al cuidado del colegio de Franciscos de Ocopa del Arzobispado de Lima. Las misiones son la de Hachao para los Huayquenos y de los Chonos, que habitan las islas de este nombre cerca de tierra firme al Sueste de Castro: frente de ésta, la, de la Isla de Quinchao, que es de las mayores: la de Conchi, en los Payos, que habitan en la costa de la isla Grande ó Chiloé, que corre de Castro para el Sur: la de las orillas de la Laguna de Cucao, en su costa occidental: y la de Raylen ó Caulen.

\section{Estado militar.}

En la descripción de Castro se dió ya alguna noticia de la gente alistada para en caso de invasiones. Las tropas regladas que guarnecían la isla, constaban de tres compañías deá 70 hombres y debían aumentarse dos más; unas eran de dragones y otras de infantería.

El Gobernador tenia de sueldo anual. 6.600 pesos. El Ayudante Mayor............ 480

El Capitán de Artillería, al mes.... 90

Los de Infantería, ídem.......... 50

Los de Dragones, ídem........... $55^{1 / 2}$

Los de Asamblea, al año........ $\quad 780$

Los sargentos de Asamblea, ídem,... $\quad 288$

Los cabos ídem............. 216

$Y$ los soldados.............. I 20

Los ramos Reales son el tributo de cinco pesosque parga cada indio desde la edad de veintidos años hasta la de cincuenta, y por cuya pobreza se les cobra parte en tablas de alerce y parte en jamones, y deja de cobrárseles en invierno por los perjuicios que experimentaban en la pérdida de sus canoas con los malos tiempos y de los frutos que llevaban.

La renta del tabaco asciende á 4.000 pesos anuales, sea en dinero ó en frutos.

La Aduana, en que se perciben las alcabalas, tiene Ministro é Interventor. Los soldados sirven 
de guardas, y cuando los emplean en este servicio tienen un sobresueldo de ocho pesos. Los derechos parece que se cobran principalmente de las embarcaciones.

Los habitantes criollos españoles, ó no pagan ó pagan poco las imposiciones, pero hacen los servicios de armas sin paga ni ración y otros servicios pecheros, porque los indios, ocupados en adquirir para pagar el tributo, no pueden distraerse de sus trabajos.

Según el estado de la Tesorería general, importaban los tributos en $\mathrm{I} 789,86.85^{\circ}$ pesos.

El exterior comercio de esta isla es con el Perú, por cuyos navíos recibe el situado que envían de Lima para pagar al Gobernador, Plana Mayor y tropa, siendo muy corto número el de otra especie de empleados. Por el mismo conducto le vienen los géneros de España y de otras partes de América; uno ó dos navíos que llegan al año forman como una especie de feria, y allí reciben, necesariamente recargados, los géneros que les remiten los comerciantes de Lima (I). Estos artículos se reducen á lienzos, felpas, listones, pañuelos, medias de Barcelona, azúcar, mate, etc., comprándolo todo los Chilotes con la misma plata del situado, y con los productos de su industria y algunos de los frutos que da la isla.

El principal artículo es el de tablas de alerce, de las cuales cortan en el continente 200.000 al año. Para esta pequeña navegación, la interior de la isla y sus pescas, según averiguó el laborioso Intendente Hurtado, tenían los Chilotes $35^{2}$ canoas y 472 piraguas. El alerce es propio para las más de las obras de carpintería, la

(I) Géneros que introdujo una embarcación en I 789 , y precios á que se mandaron vender, calculándose 30 por 100 de ganancia al comercio de Lima.

\begin{tabular}{|c|c|c|}
\hline & Pesos. & Rs. \\
\hline Docena de redecilla de torzal. & 24 & 7 \\
\hline Pieza de medio listón............. & 2 & o \\
\hline Idem de Bella unión... . . . . . . . . . . . & 5 & 4 \\
\hline Docena pañuelos de Barcelona....... . & 19 & I \\
\hline Vara zaraza ordinaria de 1 dem....... & I & 7 \\
\hline Pieza de bayeta inglesa............ & 105 & $\circ$ \\
\hline Vara de felpa de Valencia........... & 4 & .2 \\
\hline Idem de paño de Quito............. & 3 & 5 \\
\hline Idem de paño inglés de segunda...... & 3 & 4 \\
\hline Docena de medias de mujer......... & 87 & 0 \\
\hline Sortues de bayetón con sus chupines... & 14 & $\circ$ \\
\hline Docena de medias de lana de Burgos... & 24 & 5 \\
\hline Docena de sombreros negros sevillanos. & 74 & 5 \\
\hline Capotones de paño de segunda, forrados & 23 & 6 \\
\hline
\end{tabular}

\section{Comestibles.}

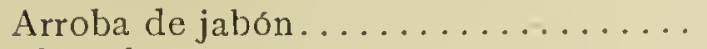

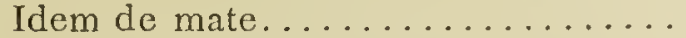
Aguardiente de ica, la botija.........

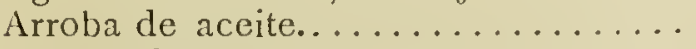
Fanega de agí.

$\begin{array}{lll}7 & 4 & \\ 8 & 5 & \\ 0 & 2 & 1 / 4 \\ 6 & 9 & \\ 8 & 5 & 1 /\end{array}$

$Y$ se omiten otros artículos menores por no abultar demasiado esta relación. usan los carpinteros de Lima más comunmente, se parece al cedro en el color y tiene muy buenas propiedades ( $\mathrm{I}$ ).

Los ponchos constituyen otro ramo de industria. El poncho es en toda la América meridional la especie de vestuario que suple por capa, y se pone encima de todo; es una pieza de un tejido como de sarga, más ó ménos fino, bordada de labores encarnadas, amarillas, azules, etcétera, por el gusto de las mantas jerezanas, que tiene la extensión de cuatro varas en cuadro; y vale por lo regular I 2 pesos cada uno, llegando algunos hasta Ioo, y se extraen muchos para el Perú.

Labran también otras varias telas de algodón y lana, sarguilla ó cosa que lo parece, pero en poca cantidad: de manera, que los Chilotes, teniendo muy imperfectas sus máquinas, no pueden multiplicar los frutos de su industria.

El cerdo es el animal doméstico que se multiplica más en la isla, contribuyendo mucho á su abundancia la proporción y facilidad para el pasto, y las raíces, y se extraen cantidades considerables de ricos jamones para el Perú, comparables á los mejores de Galicia.

Salan el róbalo y la sardina, pero no parece que en cantidad considerable, y venden el quintal de aquél á ro ó I 2 pesos. La falta de sal, que les va de Lima precisamente cara, atrasará sus salazones y pescas, y ellos mismos aseguraban que no se costeaba con Io pesos el quintal de róbalo.

Estos son los principales artículos de comercio de los Chilotes, y no se duda tengan otros varios de que no pudo hacer mención el autor, según así lo insinua.

Las mujeres trabajan la lana, el lino y el poco algodón que se coge, de que tejen los ponchos, bayetas, mantas, manteles, sabanillas ó sarga bastante buena, y sobre-camas bordadas; todo en telares los más sencillos que pueden darse.

El telar es una especie de bastidor cuadrilongo, formado de cuatro palos de dos varas de longitud, y una $y$ cuarta de ancho. Cuelgan del techo dos peines que suben y bajan la urdimbre. Las tejedoras, que son dos en un mismo telar, meten á mano la trama de los hilos de varios colores para que formen las diversas labores. Esta máquina, recomendable por su poco costo $\mathrm{y}$ facilidad de su construcción, pide de parte del fabricante mucha paciencia y tiempo para los tejidos.

Un poncho de los ordinarios cuesta dos meses de trabajo; los superfinos, hasta seis $y$ doce meses: y así. es, que por poco que cobren

(I) Cada tabla de alerce de 4 y $1 / 2$ varas de largo y $1 / 3$ de ancho, vale dos reales de América.

Idem de 2 y $1 / 2$ de largo y sobre io pulgadas de ancho, un real, disminuyendo ó aumentando los precios según las dimensiones. 
estas pobres gentes, no pueden dar una manufactura barata.

Son dignos de noticia los fáciles modos con que tiñen sus hilazas, de que resultan los más vistosos colores en las varias telas que urden, que aunque no resisten las pruebas del agua fuerte, permanecen sí hasta que se gasta el vestido. Carecen estas gentes sencillas de las artes europeas, y sin tales conocimientos, aciertan á teñir igualmente bien las materias animales, como la lana, y las vegetales, como el lino y algodón.

Generalmente ponen las hilazas en disolución de agua y alumbre, cuya sustancia salina se encuentra con abundancia en el país; es blanca y ligera y de sabor estítico y adulzorado, que descubre bien el alumbre que contiene: llámanlo los naturales porcura.

Para el amarillo emplean las raeduras del árbol espinoso que llaman mechaí, poniéndolas en infusión de agua, en que echan la hilaza preparada, hirviendo después el todo hasta que ha adquirido ésta los colores que quieren.

Para el rojo, hacen un cocimiento proporcionado de salvado lavado, en que ponen por veinticuatro horas una planta macerada de la familia de las asperilolias y verriciladas, que llaman velhbun, y tiene las hojas en rodajuela y la faz de la aparine, pareciendo una especie de valantia, en cuya infusión echan la hilaza ya preparada y la dejan hervir todo el tiempo que conviene.

El modo de dar el azul, dice el autor según lo que le informaron, parece singular y puerco. Ponen el añil en agua por ocho días hasta su disolución, y esto y la hilaza preparada ya con la porcura, lo echan en orines antiguos y fermentados, por veinte ó treinta días á lo ménos.

Mojados los hilos en este último cocimiento, y ya que han tomado el color azul que llaman sajón, echan la hilaza en las mismas preparaciones que para el amarillo, y resulta en ellas un hermoso verde.

Para teñir de negro echan la hilaza en agua en la disolución de una tierra negra que llaman greda, y que no tuvo ocasión de examinarla cl autor.

Para calafatear las canoas y piraguas usan de una planta fibrosa, machacada, que llaman ziaca, y de una resina que les dispensa de la brea por su propiedad de impedir la penetración del agua.

Hacen cuerdas de una planta que llaman nocha, cuyos tallos delgados, largos y flexibles se dejan torcer como cáñamo, y hacen cuerdas zruesas y de bastante resistencia.

Usan también para cordajes, de una especie de bejuco que llaman boqu, y se cría entre las hendiduras y grietas de la corteza del alerce, teniendo esta planta parasítica más largo que el mismo árbol en que se cría, una y media pulgada de diámetro, raices y barbas por toda la corteza á que se pega. La machacan los naturales, y salen hebras flexibles y delgadas como las de pita, con que hacen toda especie de cordelería, de tres pulgadas hasta cables. Con ellas ensamblan sus piraguas y se excusan de clavazón: sobre el costillaje de la piragua ponen las tablas del forro con correspondientes agujeros, las cosen unas con otras, y mojadas las cuerdas, encojen de modo que aprietan las tablas sin que pueda introducirse agua alguna por entre ellas.

Son los Chilotes bastante buenos carpinteros y manejan el hacha diestramente. Hacen sus casas bastante sólidas; clavan las columnas perpendiculares, á tres varas de distancia, según las dimensiones que eligen; hacen un canal de dos pulgadas de profundidad, según la longitud de la columna, y asientan en él las tablas que han de formar la pared, y las montan unas á otras como las tejas, de manera que impiden la entrada al viento y agua, por cuya misma idea hacen los techos cuando no los cubren de yerba: los piés derechos son de luma, madera incorruptible de un pié en cuadro, y no usan clavos de metal, sino de madera.

\section{Frutos de Chiloé.}

Nada satisfará tanto sobre esta materia, como la copia del estado formado por el Intendente Hurtado, cuyo extracto es como se verá:

\section{Piés de árboles frutales.}

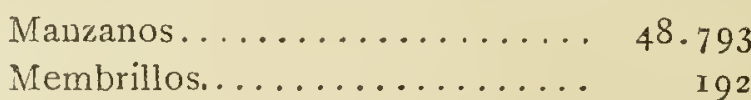

Cosechas de semillas.

\begin{tabular}{|c|c|c|}
\hline Tabas & $3.27 \mathrm{I}$ & \\
\hline Porotos............. & 33 & \\
\hline Fríjoles............ & 152 & \\
\hline Quinoa.............. & 222 & \\
\hline Bellotas............ & 200 & \\
\hline 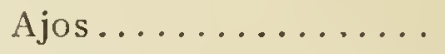 & 160 & \\
\hline Trigo.............. & 17.557 & \\
\hline Cebada............. & 11.420 & \\
\hline 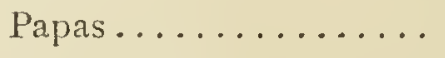 & 65.000 & \\
\hline Número de repollos.... & 4.800 & \\
\hline Zapotes............. & 500 & \\
\hline Lino.............. & 109 & \\
\hline
\end{tabular}

Por este estado se ven los frutos que constituyen el principal alimento de estos isleños y la cantidad de sus productos al año, con lo que se juzgará de algún modo sobre el estado de su agricultura.

Animales itiles que se luallaban en Chiloé.

Toros................ I.024

Vacas.............. $3 \cdot 780$ 


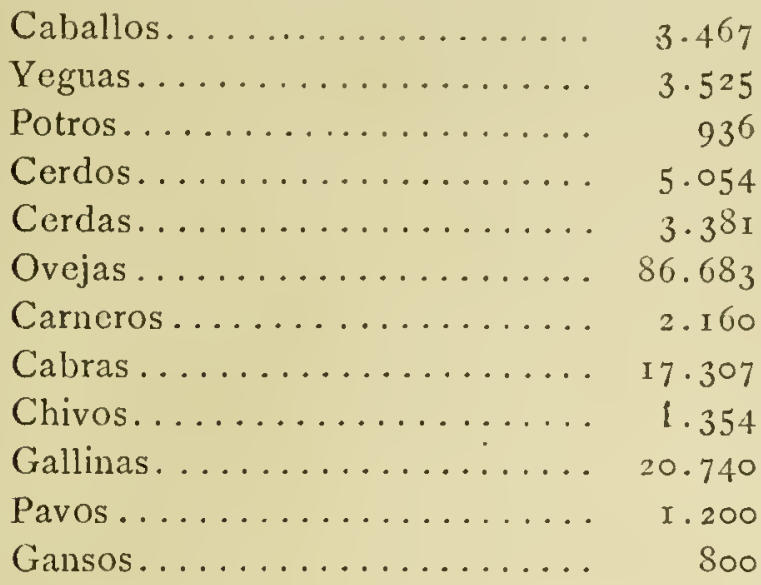

E1 manzano, así como en el vecino continente, es el frutal que más abunda en esta isla, y las cervezas ó sidras hechas de él, podrían ser un ramo de su comercio; pero como son pocas las embarcaciones que arriban á sus puertos, serían también pocos los consumidores que tendría. El trigo, las papas y las demás semillas, como frutos que abundan en el vecino reino de Chile, no hacen ramos de extracción en esta isla. Pero sí suministran suficiente alimento á unos hombres frugales que se alimentan comunmente de vegetales y de los productos del mar. Si se suman las partidas de semillas comestibles explicadas (dice el autor, conforme le informaron) que todas lo son ménos el lino, resultan Io3.3 I 5 fanegas, que repartidas entre 24.000 habitantes, sin contar los 3.000 restantes, por considerarse niños de pecho, que sólo sus madres los alimentan, caben cuatro fanegas á cada uno y cerca de un tercio de otro, que viene á ser á más de 5 I celemines al año, y así corresponde á celemín por semana, cantidad suficiente para mantener á un indio. De lo que se infiere cuánta población podría mantener esta isla si recibiese su agricultura todos los fomentos, y su suelo las mejoras que no tiene.

Las semillas y legumbres son su ordinario alimento. Consiste el principal en harina de trigo groseramente molida y tostada, á que agregan una tercera parte de cebada preparada del mismo modo, y deslien el todo en agua caliente, cuya especie de polenta reputan por sano y excelente alimento.

También usan de las papas asadas al rescoldo, en lugar de pan, y ocupan siempre una parte de sus hogares, pudiendo asegurarse que comen estas raices, más que otros alimentos que entran en gran número de sus guisados. Son muy sabrosas, y ellos las asan con inteligencia, revolviéndolas con un palito para que reciban el fuego con igualdad.

Comen también muchas especies de mariscos comunes á las playas de Chile, y que se encuentran con grande abundancia en las de Chiloe; varias especies de megillones y de lapas, y varios grandes cangrejos, cuya comida es tan grata como variada. Los isleños de la parte oc- cidental son los que mariscan más; y decían que casi no comían otra cosa.

Se alimentan también de una especie de fucus parecido al sargazo ó fuc'ss giganteus aunque diverso, que usan asimismo para condimento, el cual tiene unas vejigas que sirvieran para sostenerlo en el agua, y sirven de pelotas á los muchachos. Sus tallos parecen correones de coche, su color negruzco y por dentro blanco y celuloso; lo usan asado al rescoldo y de otros modos, que en todos pareció insípido y glutinoso.

Aliméntanse igualmente de muchas fruti. llas silvestres del género del arbustus y de la fragaria y murtillas como la que llaman luma, y la fresa chilena, é igualmente los frutos óflores de una especie de bromelia que se nombra quiscal, y por comerlas chupando las llaman chupones.

Sería largo de contar el todo de algunas otras plantas que usan para alimento, especialmente en tiempo de las hambres que suele padecer la isla, en cuyo número cuentan algunas criptogámicas.

Usan bastante de la pesca que les ofrece el mar con abundancia, como róbalos, lisas, sardinas, jureles y otros comunes á los mares de Chile.

Es particular el modo con que la hacen: forman, pues, unos grandes corrales con espesas estacadas, que se cubren de agua en pleamar, en los cuales queda al bajar la marea gran número de peces que entraron á cebarse, ó de cangrejos, ó de restáceos que se crian en las playas. Aseguraban haber pescado entre esta abundancia una especie del giotinovos ó pez eléctrico; pero no fué posible su adquisición, con toda la diligencia con que lo procuró D. Antonio Pineda, así por éste como por otros peces raros.

No es indiferente la pesca de ballenas, que no pocas veces varan en las playas de Chiloé, y cuyas barbas, espermas y aceite aprovechan. Pescan también sobre cueros inflamados de viento, cuyo artificio se describirá cuando se trate de Concepción.

\section{Carrícter de los Chilotes ó Chiloenses y su modo de} vida.

Esta es la parte histórica más odiosa y de más difícil desempeño; porque á veces, si se pinta la humanidad como es, ó se hace su sátira, ó su panegírico. No se trasluce fácilmente el corazón del hombre, sino por un largo trato, y transcurso de intereses que se chocan. Un viajero que reside poco tiempo en un país, aunque dotado de genio observativo, poco ó nada alcanzará por sí; pues las operaciones comunes de la vida, apenas descubren lo que esconde el carácter interior. No obstante, pues, se darán algunas pin- 
celadas sobre el de los habitantes de Chiloé, conformes á los informes franqueados por personas de larga residencia y trato en esta isla.

Viven generalmente con la mayor frugalidad entile los bosques que tocan cercanos á las orillas marítimas, excepto los que están en los pueblos ya descritos, cuyo terreno rozaron, pero que siempre brota y reverdece. Cada habitante tiene huerto en la inmediación de su casa, con plantío de habas, quinoa, papas, etc. Las casas son de madera, cubiertas de paja, que no hacen mala vista: por dentro tienen dos ó más divisiones, una tarima que sirve de estrado y dos ó tres ponchos por alfombra; tres ó cuatro platos y algunas vasijas de cobre, y lo que puede llamarse vajilla, siempre muy descabalado.

Los más acomodados tienen braseros y materas de plata, y las casas, aunque por el mismo gusto, más espaciosas y amuebladas. Y los más pobres de la sociedad sólo tienen su fogón, tarimas de caña y pocas vasijas de barro.

Son los Chilotes, tanto indios como criollos, de buena índole, dóciles, humildes, pacíficos y obedientísimos á quien les manda: y es lástima que haya quien abuse del sagrado nombre del Soberano y de la disposición de tan buenos vasallos, exigiéndoles bagajes, guías y otros servicios personales $\sin$ estipendio alguno. Los españoles, que parecen están exentos de algunas imposiciones ó no pagan tributo, tienen por tanto algunas cargas pecheras; pero los indios, que pagan tributo, en toda la América cobran nada por correos, guías, etc., tanto en el Perú como en Nueva España; lo cual parece sin duda un grave abuso.

Son laboriosos; en especial las mujeres, que siempre se las veía en los telares, y ya traían agua, ya leña, ya'hilaban, cardaban y hacían cuantas operaciones tocaban á sus artefactos, al menaje y á la cocina, tanto faenas delicadas como gravosas. Las casadas respetan y obedecen á sus maridos, y no se permiten la licencia que algunas solteras, cuya familiaridad con el otro sexo favorecen los bosques y las distancias en que unas habitaciones se sustraen del examen y la murmuración de las otras. Su traje parece inmodesto á los ojos del europeo, acostumbrado á ver las mujeres siempre tapadas; pero la costumbre, la pobreza y la constitución física del país, las dispensa que cubran el pié y pierna (I). Es, pues, el traje ordinario de estas hembras (em-

(I) Discúlpanlas y áun las justifiean tal vez: primero, la pobreza del país, lo earo del ealzado, así medias como zapatos, pues viene de Lima muy reeargado, después de muehas manos, y no de Europa direetamente como debiera: segundo, la lluvia y los lodazales que tienen que atravesar eada vez que salen á sus haeiendas, por agua, leña, ete., haeiendas que son casi exelusivamente de las mujeres, en euyas eireuns. tancias es muy cómodo no llevar calzado, y más sien. pezando por la cabeza, en que nollevan cosa alguna, sino pelo largo, negro y bien conservado, dividido en I 2 colgantes trenzas), camisa cerrada por el cuello como en los hombres, que cubre muy bien sus abultados pechos, un babador ó volador, como llaman, un jübón y un faldellín con muchos pliegues alrededor de la alforza y cubo que tiene una forma campanuda y tersa, que sólo cubre hasta debajo de la rodilla, quedando descubiertos pié y pierna. "Como estas mujeres laboriosas y robustas tienen una presencia hermosa, te $z$ generalmente bastante blanca, buenos cabellos y buena conformación en sus piernas, que siempre llevan muy limpias, y se las encontraba en quebradas y arroyos, ya lavándose los piés, ya jabonando sus cabellos (I), ya cargadas de sus cántaros, parecía Chiloé (dice el autor), á muchos de nuestros compañeros, la misma Arcadia que pintan los poetas, donde discurrían mujeres de bella presencia, de sencillez y simplicidad en el vestir, y en que las princesas lavaban en los ríos."

Como desde ocho á die $z$ años hacia el de $x 789$ se hallaban emancipados los indios de la esclavitud de las encomiendas en que trabajaban para los criollos sin propias utilidades, se recibió en estos la laboriosidad y la industria á que no estaban acostumbrados, sirviéndose ya todos á sí mismos, y todos trabajan ya por necesidad. La hija del capitán, la mujer del labrador, las hembras de todas clases, todas concurren igualmente á los arroyos y lavaderos: y la nobleza no tiene el privilegio de la ociosidad, pero en cambio se distinguen, no por la debilidad de su constitución y pálidos colores, sino en una modestia más interesante y en mayor aseo, faltando el aparato de hombres que se mueven á la voluntad agena, y la sumisa $y^{*}$ ociosa turba que acompaña á los nobles; ni se conocen los jueces de una nobleza que insulta á lo restante del pueblo.

Acaso será la isla de Chiloé uno de los países civilizados en que las condiciones se acercan más á la igualdad, y en que sin embargo, se reconoce la nobleza y se la guardan todos los fueros legales que les concede la constitución española.

Los hombres se emplean en cortar leña, en las labores de sus pehujales, cuidado de sus ganados y en el servicio militar. Son de robusta complexión, de mediana estatura, y de color blanco; y muchos son mestizos, cuya naturaleza se cono-

do caro, que se destruiría á los primeros días; euando los piés desnudos se lavan en el primer arroyo, la ropa alta no toma lodos, les dura más y embaraza ménos: tereero, ser eostumbre del país, que trajo la necesidad de que todas vistan de la misma manera; y como viven en una isla que pocos de afuera los visitan, no tienen rubor unos de otros y viven como en familia.

(I) Lavan sus cabellos con la eorteza de un arbol que tiene jugo saponáceo. 
ce por la poca barba. Los indios chiloenses son generalmente más blancos que en otras partes de América y de la misma suave índole y subordinación.

Los vicios de ellos son alguna indolencia, pues dejan al bello sexo la mayor parte del trabajo, y sin embargo de que carece la isla de muchos artefactos, no se esmeran por su introducción y viven en el mismo atraso que siempre.

E1 vicio del amor en las mujeres suele producir tan rabiosos celos, que los venenos no son demasiado raros, para lo que emplean las muchas yerbas que produce el país.

Los robos suelen ser frecuentes, pero sin efusión de sangre, y suceden pocos asesinatos.

La superstición no está desarraigada, ni áun en los criollos. No pudo el autor ver ejecutar las operaciones de la tintura, porque aquellas mujeres (así, dice, se lo dijo una de las mejores tintoreras) creen que si presencia alguno la operación, hará mal de ojo á su tintura. Los indios creen en hechizos y encantos, y se curan con huesos, cabellos y otros símbolos supersticiosos.

\section{Temperamento.}

La espesa arboleda que cubre toda la superficie de Chiloé, atrae mucha humedad de la atmósfera, y así suele estar ésta nebulosa y húmeda.

La costa también suele cerrarse mucho por los Nortes, Noroestes y Estes, que son lluviosos, y los que más dominan: vientos declarados de invierno, que empiezan por Mayo y duran mucho período.

Las granizadas son frecuentes y las nevadas en la parte oriental de la isla, suceden así como en Castro, pero en los demás parajes de ella nieva y fulmina poco. A los Noroestes de por la mañana siguen después los Sures.

La vegetación es muy viciosa, y así debe considerarse muy sombría esta isla y fangosa, como lo es en parajes.

\section{Estado politico, militar y comercial de la ciudad de Concepción.}

Se tratará del estado de la ciudad de Concepción conforme á algunas noticias que pudieron adquirirse y á las observaciones del autor: y supóngase todo en la precitada época de I789.

Trasladóse, pues, esta ciudad, al sitio que hoy ocupa en el valle de la Mocha en 2,4 de Noviembre de 1764 , de resultas del furioso terremoto que sufrió la antigua Penco en I75I, con inundación de sus campos y total destrucción de sus edificios; quedando situada á tres leguas Sur de Penco, entre los ríos Andarien y Biobio.

Aunque esta relación se ciña al estado que tenían las cosas al tiempo de esta excursión, y no deba abultarse con acontecimientos de la antigua historia de Penco, que se hallarán ya en varios libros impresos, no parece excusado decir que fué fundada por Pedro Valdivia, personaje que figura mucho en nuestras historias, en I $55^{\circ}$, donde se halla ahora la Vieja Penco.

En ella se erigió Audiencia Real en $\mathrm{I}_{56} \mathrm{6}_{7}$, que se extinguió á los siete años, y se renovó el de I6og en la ciudad de Santiago. Ha padecido varias ruinas, así por invasiones de los indios, como por los terremotos: fué la más principal y memorable la de 1603 , cuando aquellos destruyeron siete ciudades; y el más tremendo terremoto, el de I73o, ocurrido el 8 de Julio, que empezó por grandes estremecimientos á la una de la mañana, y á que siguió retirarse mucho el mar, acrecentar la altura de sus aguas, volver á cobrar su nivel, traspasar sus costas y extenderse por las campiñas hasta que anegó la infeliz ciudad. El repentino suceso obligó al consternado vecindario á guarecerse en las eminencias próximas, siendo desde allí expectador de los estremecimientos de la tierra, repetidos por tres ó cuatro veces, hasta que á las cuatro de la mañana crecieron tanto los vaivenes, que cayeron los pocos edificios que aún se mantenían; retirándose después el mar, y volviendo á inundar las tierras con mayor furia que antes.

No se logró noticja de los particulares fenómenos del último terremoto, que sucedió en I 75I, elevándose el nivel del mar con movimientos como en el antecedente, y anegando la ciudad, en tales términos, que sólo quedaron cimientos, tapias y pilares: et seges ubi Troya fuit.

La actual ciudad de Concepción se gobernaba en 779 por un Intendente que reunía el mando de las armas y el empleo de Maestre de Campo. Tiene su cabildo, compuesto de dos Alcaldes ordinarios y cuatro Regidores, que se mudan anualmente, cabildo eclesiástico presidido de su Obispo, que residía en la Imperial, hasta el gran levantamiento de I6oI, y compuesto de Dean, Arcediano y dos Canónigos. Se estaba construyendo la catedral, pero con lentitud por falta de fondos: tiene cinco conventos de religiosos: Santo Domingo, San Agustín, San Francisco, la Merced y San Juan de Dios, y un monasterio de Trinitarias 
Descalzas, un Colegio conciliar y una casa de ejercicios, todos edificios pobres, y que aún tenían sin concluir algunas fábricas.

En otros tiempos residía aquí seis meses del año el Presidente de la Audiencia Real, pero ya sólo está el Maestre de Campo é Intendente de la provincia, cuyos empleos recaen en un bien opinado militar, enviado por la Corte, teniendo también á sus órdenes las tropas de la jurisdicción.

\section{Descripción geogrífica del Obispado é Intendencia de Concepción.}

El terreno de esta provincia, que hace parte del Reino de Chile, corre casi de Norte-Sur, y se contiene entre el mar y la cordillera. Por el Norte le divide el río Maule del Obispado de Santiago; por el Oeste confina con el mar del Sur; por el Este con la cordillera, y por el Sur se extiende la jurisdicción civil algunas leguas más allá del Biobio; pero la espiritual comprende hasta vastísimos límites, y se reputa alcanzar donde la religión haga prosélitos, hasta el mismo Cabo de Hornos. Desde luégo comprende la vasta Isla de Chiloé, sus islas y establecinientos adyacentes, y el Archipiélago Chonos. Tendra de largo la provincia, entre los ríos Biobio y Maule, como 40 leguas, y de ancho entre el mar y la cordillera de 20 á 25, más ó ménos, según la disposición de valles y terrenos. Varios ríos, que todos nacen de la cordillera, interceptan su suelo y forman amenísimos valles: cuéntanse por principales el Maule, Laja, Itata, Nuble y el Biobio; ninguno navegable sino en balsas, á excepción del último, que admite barcas hasta cuatro leguas de su boca. Entre varias pequeñas lagunas de que abundan los valles y cañadas que forman esta provincia, hay tres considerables, que son: la de Quinel y la de Avendaño, situadas álas inmediaciones del Itata, y distantes 18 leguas de la capital, y la otra en el partido de Chillan. En la primera dicen que hay perlas cle buen oriente, cuya pesca descuidan los naturales por desidia. En la de Avendaño, dice D. Cosme Bueno, que se hallan caballos marinos, pero la relación y descripción que hacen de estos anfibios, y su comparación con los caballos terrestres, es tan poco verosímil, que, ó es un animal imaginario, ó cuando más, alguna es pecie de foca, con que se les puede asemejar por tener los piés á manera de aletas, y no será extraño que los no acostumbrados á esta clase de objetos, no acierten con una descripción legitima.

Los partidos de la Intendencia, son: el de la capital Concepción, cuyo corregimiento antes de la ruina se ceñía á la ensenada que forman las lomas altas en el contorno de la ciudad destruída, pero ya se extiende hacia el Sur hasta el Biobio, y costa que corre hasta su boca, con todo el
Hualpen y Talcahuano. Además del curato de la Catedral tiene los de Hualqui y Talcahuano.

Cauquenes, que su corregimiento se contenía en el de Maule, pero por su mucha extensión se estableció a parte al Sur de este río. Confina la jurisdicción de Cauquenes por el Este con la cordillera, por el Oeste con el mar, por el Sur en la parte alta con Chillan, y bajando para la costa con el de Itata. Es su capital la villa de las Mercedes de Manso, á orillas del estero Tutuben. Tiene tres curatos; el de la Capital, el de la Isla de Maule y el de San Francisco de la Puerta, con convento de franciscanos. Abunda en ganados y tierras de pan llevar.

Chillan, que sigue al Sur del anterior, y confina por el Este con la cordillera, por el Oeste con el de Itata, y por el Sur con el de Puchacay. Tiene por capital la ciudad de San Bartolomé de Gamboa, cabildo, iglesia parroquial y tres conventos, de Santo Domingo, San Francisco y Merced. En I753 se erigió el de San Francisco en colegio de misioneros apostólicos destinados de España para la conversión de infieles y salen también á hacer misiones por todo el obispado. Pertenece á este corregimiento el curato de Perquilaben. Además de los frutos de la tierra y matanzas de ganados, tiene este partido la utilidad de finos vellones de lanas de que hacen algunos tejidos; y sus campiñas son hermosas y despejadas, y producen con abundancia ( $\mathrm{I}$ ).

Itata, que sigue al Sur del último, confinando por el Norte con el de Cauquenes, por el Este con el de Chillan y parte de Puchacay, y por el Oeste con el mar. Tiene dos villas en su jurisdicción, la de Jesús y la de María, y se extiende hasta más allá del Itata: tiene corregimiento, tres curatos, el de Quipolemu en la villa de Jesús, y los de Ninhue y Quirihue; y comercia en trigos, vinos, sebos, charques y curtidos.

Puchacay, que sigue al Sueste del anterior y confina con él por el Norte, con las orillas del Biobio por el Sur, con la jurisdicción de Concepción por el Oeste, y con los términos del Rere por el Este. Es su capital la villa de San Juan Bautista de Hualqui, y tiene dos curatos, el de Conuto y el de la Florida. Su comercio es en los mismos artículos que el partido precedente. Y el de Rere, que confina con el anterior por el Oeste y Noroeste, y por el Este y Sur con los términos y jurisdicciones de las plazas de la frontera. Es su capital la villa de Buena Esperanza, llamada ya San Luis Gonzaga, alias la Estancia del Rey, en donde tiene un curato, y su comercio es como en los partidos antecedentes.

Algunos de los referidos curatos tienen una

(I) Fué fundada la capital por Rui de Gamboa en 1580. Molina: Historio de Chile, escrita en italiano, página 190. 
gran extensión, como de I $_{5}$ ó 20 leguas, y se introducen en otras provincias, por lo que deberán pertenecer á entrambas. Hay varias parroquias rurales que administran el pasto espiritual á varios colonos que se extienden por los valles y quebradas de la provincia, sin hacer poblaciones formales; aunque ya el Intendente, en 1789 había podido reducir á tal, algunas habitaciones dispersas.

El autor, después de haber reconocido los alrededores de la capital y bahía hasta cierto punto, examinó también parte de las orillas del Biobio, Norte y Sur hasta la plaza de Santa Juana, espacio de I4 leguas; y á juzgar de toda la provincia por la parte que vió de ella, opina que abunda de excelentes terrenos para pan llevar, que casi toda se cubre de bosques de hermosísimos árboles de que se visten todas sus montañas, muy apreciables unos por sus maderas y otros por sus frutos, que la mayor parte del país es montuoso, y que sus montes suben hasta el pié de los Andes, donde vió llanos dilatados hacia el volcán de Tucapel, y que los ríos que entran en el Biobio forman algunos interesantes valles, capaces de la mayor población, si la poca vecindad de los indios los constituyeran tranquila morada.

Constituye la parte más principal de la Intendencia, la población que se halla al abrigo de los presidios en ambas riberas del Biobio. Los presidios están situados en la parte Sur de la provincia á las orillas de este río, ya á la del Norte, ya á la del Sur, en los parajes más oportunos, bien para cerrar el paso al enemigo, bien para protejer las poblaciones; y corren, empezando desde la cordillera para el mar en este orden: en la orilla Norte ó de la parte de acá, Santa Bárbara, Puren, Angeles, Tucapel, Yumbel, Talcamavide y Concepción; y en la parte de allá, el Nacimiento, Santa Juana, San Pedro, Colcura y Arauco.

\section{Estado militair.}

Las fuerzas destinadas para la guarnición de estas plazas consisten en dos batallones de tropa reglada, el primero de siete compañías de infantería, y el otro, que vino de España en I770 con el nombre de batallón fijo de Chile, consta de seis de infantería y una de artillería. Hay además un cuerpo de seis compañías de caballería, que se distribuyen en las varias plazas y otros servicios. También hay diez compañías en los distintos partidos, compuestas de vecinos alistados para servir en los alzamientos y casos necesarios con sus armas y caballos; y varios cabos y sargentos de asamblea para que los disciplinen. Se componen estas tropas, de criollos del país, que son buenos soldados, según se acredi- taron en varias ocasiones en la guerra contra los indios sus comarcanos; gente valerosa, que aunque no disciplinada á la Europea, pelea con obs tinación y con cierta táctica que le es propia.

No será fuera de propósito dar una idea de las plazas que constituyen las fronteras chilenas. Las distancias, al paso que abultan 6 disminuyen los objetos, alteran también el sentido de las palabras; y así, no se entienda que estas plazas sean fortalezas como las que tienen tal nombre en Europa. Las falsas ideas que se fijan á los vocablos, son el manantial de nuestros errores. Tanto el hombre público como el particular deben conocer el verdadero estado de las cosas.

Los fuertes que visitó el autor, se parecen á los de Chiloé, y no son en realidad más que unos fuertes de campaña, capaces de poca guarnición y de resistir solo á los indios.

El fuerte de San Pedro se halla al otro lado del Biobio, y es el primero que se encuentra frente á la ciudad de Concepción. El río tiene de ancho en esta parte 2.700 varas ó I 8 cuadras (I) que es como cuentan allí y en muchas partes de nuestra América. El fuerte, y una corta población que protege, pegada contra las barrancas de la orilla del río, forman un paisaje de nacimiento: las casas son chozas de pobres vecinos y de algunos soldados de la guarnición. La fortaleza es un cuadrado con cuatro pequeños bastiones, cercados de estacada y rodeados de foso, excepto por el frente del río, que baña su pié: toda la obra es escavada en el propio te rreno, y así no se gastan ni ladrillos ni mampostería, y la excavación del foso figura toda la fortaleza: se guarnecen sus baluartes con pequeña artillería de campaña, y encierra en su recinto dos ó tres edificios militares para la guarnición; $\mathrm{y}$ alrededor de él hay varios pequeños huertos, que cultivan los militares y vecinos.

El fuerte de Porcura, que no se hallaba en tan buen estado como el antecedente, está sobre unà loma, y tendrá unas Ioo varas cuadradas de área; su cortina estaba encorbada, tenía á su inmediación algunos pequeños ranchos, y no protegía algún terreno de consecuencia.

El Santa Teresa parece de los más bién situados, entre el río y una laguna, y la parte que queda abierta se cierra con competente estacada. Guarda uno de los pasos por donde se vadea el río, cuyo mismo vado defiende también la opuesta plaza de Talcamavide; y ojalá estuviese mejor despejado y expedito el terreno que yace á la inmediación del fuerte, y no dejasen que se criara yerba, matorrales y broza. Los vecinos,

(I) La cuadra tiene $\mathbf{1} 50$ varas castellanas, y en otros reinos de América es más ó ménos. El río tiene profundidad para barcos, pero muy desigual el fondo, como se deduce de la práctica de pasarlo en balsas. 
que muchos son soldados, prefieren por su comodidad la habitación inmediata al fuerte; pero las razones de guerra no debieran permitir tal abuso. Consiste la plaza en un pentágono fortificado que consta de cinco pequeños baluartes capaces de artillería de campaña, construidos como los que preceden; y tiene ocho ó nueve cañones de á dos y de á cuatro, y cuatro ó cinco edificios militares. Al abrigo de ella hay unas Ioo casas, y por un ameno valle muchos ranchos de colonos que pertenecen á esta población. Este valle está lleno de grupos de hermosos árboles, de pehujales, de sembrados, y tendrá dos leguas de largo y una de ancho, siendo su terreno de los que más producen, regado por el Biobio que lo atraviesa, ó bien por algunos arroyos que entran en él, presentando una vista ciertamente hermosa, y cuya forma era cuadrilonga en dirección de Norte á Sur, cercado de varios montes.

Talcamavide está en la orilla Este opuesta, frente á Santa Juana para estorbar el paso de los indios enemigos por cualquier parte que vengan: es un cuadrado fortificado de cuatro pequeños baluartes de unas 70 varas de lado, y circundado đe buen foso, á cuyo abrigo, á la parte aquende del río, hay alguna población y ranchos.

Según las noticias que adquirió el autor sobre los otros fuertes, la plaza de Yumbel contiene en su recinto cuatro ó cinco edificios militares, y se guarnecían sus baluartes con cuatro cañones de á dos y una culebrina, con sus pertrechos todos inútiles.

Tucapel, plaza de mayor consideración, al parecer, tiene foso y estacada, y se guarnecían sus baluartes con tres cañones de hierro, uno de bronce y dos de montaña, con diferentes pertrechos, encerrando su recinto cuatro ó cinco edificios militares.

El Nacimiento tenía cuatro cañones de bronce de á cuatro y de á ocho, y de varios calibres, con sus correspondientes pertrechos y edificios militares.

Santa Bárbara tiene algunos baluartes y un rebellín, y está circundado dé un profundo foso de nueve varas de hondo. Tenía nueve piezas de artillería de á dos y de á cuatro, y dos pedreros, $y$ en su recinto cinco edificios militares.

Antuco y Villacura, tienen dos fortines y artillería de campaña cada uno.

Puren, es plaza de mayor consideración, mejor artillada, y tenían sus baluartes ir pequeños cañones y su recinto cinco edificios militares.

Finalmente, la plaza de Angeles tiene para su defensa, baluartes con siete cañones.

Aunque la paz que reinaba con todas las naciones indias desde el Biobio hasta los paralelos de Chiloé, y que la sabia cautela de mantener entre la indiada enemigra un gran número de espías y amigos, aseguraban nuestros fuertes acordonados en el Biobio contra cualquier sorpresa; no pudo el autor (dice) ver sin disgusto, como buen español y vasallo, el mal estado y entretenimiento de estas fortalezas; aunque por el buen concepto que le merecía el Maestre de Campo que había entónces, y que como recién entrado en este cargo no habia podido visitar todavía convenientemente el cordón de presidios, esperaba que providenciaría el remedio de todo; tanto más, pues era Presidente de Chile un militar que había obtenido el propio empleo, conocía las fronteras y su importancia, y mejor que otros, la guerra contra estos indios, en la que había acreditado su valor y singulares talentos.

Tuvieron su origen estas fortificaciones y barrera del Biobio, el año de $I 608$, en que cansado el Gobierno de sostener la costosa guerra de Arauca, que consumía remesas de gente de 600 en 600 hombres y correspondientes sumas de dinero y pertrechos, especialmente después de la pérdida de las siete ciudades, hubo de recurrir á providencia tan oportuna para evitar consecuencias tan desgraciadas, dotando la barrera de fuertes con 2.000 hombres pagados de presidio, y con el situado de 270.000 pesos, que desde dicha época empezó á enviarse del Perú.

Aunque el valor español había triunfado muchas veces de la desesperada oposición de estos belicosos indios, y acabado con sus Jefes en varios encuentros, no parece sino que esta nación era una hidra, que cortada una cabeza brotaba otra. No siempre estuvo la victoria por las armas españolas: obtuvo muchas la constancia é intrepidez de los chilenos, como lo manifiestan la suerte de varios fuertes perdidos y recobrados, el hado de Valdivia, las victorias de Lautaro, la destrucción de Concepción, de Cañete, y finalmente, la que sufrieron en $\mathrm{I}_{603}$ las siete ciudades, Villarica, Osorno, Imperial, Valdivia, Cañete, Angcl y Coya, en tiempo del General Paillamachu; bien que contra estas desgraciadas ciudades contribuyó principalmente el levantamiento de las naciones indias de los Conchos y Viliches, y otras que apenas ó ninguna parte habían intervenido en las guerras anteriores.

Las victorias españolas antes y después de este tiempo fueron de las más brillantes. Don García de Mendoza humilló la cerviz de Arauco, no dejó Hulmen ó Jefe con vida, y conquistó á Chiloé. Cañete vió perecer en sus muros los ejércitos araucanos: no hubo presidio español que no les rechazase con pérdida y escarmiento, ni célebre General araucano que no cayese bajo la espada española. Pero la bien manejada conjuración de $\mathrm{I}_{603}$ hizo época en esta destructiva y disputada guerra; y el sabio Gobierno, movido de los sanos consejos del jesuita Valdivia, adoptó el sistema de catequizar con la paz y el Evange- 
lio á los que la fuerza de las armas destruía y no conquistaba.

Nadie extrañe que los conquistadores de la América, que llevaron sus armas vencedoras por todas las cuatro partes del mundo, encontrasen en este rincón de él tan obstinada resistencia. Estos indios no opusieron contra los españoles una multitud indisciplinada y mal armada, cuyo número á veces por una ignorante confianza se amontona y embaraza. Las naciones araucanas; viliches, juncos, etc., y pehuenches, escogen para la guerra los más robustos; y esos opusieron á sus enemigos, conservando aún su disciplina militar, á que debieron espíritu de arrojo más que á su número, que á veces fué igual y algunas inferior. Forman el cuadro y algunas otras formaciones; se arman de grandes lanzas, con que, al modo de la falange macedónica, oponen una muralla de picas á la caballería que les acomete; ponen caballería en las alas, al modo de otras naciones antiguas y modernas, para que sostengan la infantería; y también usan machetes y lazos, que manejan diestramente, y no hicieron ménos en las guerras con los fusiles que ganaron á los españoles. Los pehuenches defienden aún sus cabezas con morriones guarnecidos de una plancha de hierro, y cubren con corazas el tronco y parte del brazo. Los viliches también usan corazas y se quitan los calzones cuando pelean, para que noles embarace. Igualmente usan estas naciones la formidable arma del laqur, ó bolas enramadas atadas al lazo. Acostumbran no presentar batallas formales, sino atacar en pelotones, emboscadas, asaltos y correrías repentinas que llaman malocas, con cuyo método, sin tanto riesgo suyo, cansan y destruyen al enemigo. Los pehuenches son entre todas estas naciones los más atrevidos, aguerridos y bien equipados.

No sacan poca ventaja estas naciones guerreras de la frugalidad con que subsisten. El mantenimiento de las tropas es en las guerras europeas el artículo más dificultoso. Pero el guerrero chilense lleva todas sus municiones de boca, con una bolsa llena de harina de habas ó de cebada, y con su huampar ó vaso de cuerno. Los caballos, cuya carne comen también, les constituyen otro recurso, pues cuando les aqueja el hambre, los sangran, y hacen alimento para un par de días. La harina la mezclan con agua, y tienen asi el condimento necesario.

Hacen nula la ventaja de las armas de fuego avanzando intrépidamente hasta ellas, y según noticias de algunos Oficiales se meten por las bayonetas, y emprenden otras acciones de extraordinario valor, que hacen verosímil lo que cantó de ellos el poeta español Ercilla. "Me referían (dice el autor) que uno á quien no daban cuartel (que los chilenos ni lo dan ni lo reciben) como no le cortaran pronto la cabeza, dijo á su enemigo, sacando su arma: toma mi cuchillo, que el tuyo no corta."

También, dice, le informaron, que no poseen estos indios arte alguno de atacar las plazas, para lo que se valen de simples bloqueos, formando cuerpos de caballería que embisten los fuertes, y les cortan así los socorros, manteniéndose fuera del alcance del cañón: idea que no corresponde á la pericia que se les supone en las otras partes de la guerra.

Pero ya se contienen en justos límites, manteniendo un recíproco comercio, y algunos, alian$z$ a con los españoles; además de que ellos mismos con las recíprocas é intestinas guerras se destruyen, de modo que dan poco cuidado á sus vecinos, á los que la experiencia de lo pasado deberá tener alerta.

Finalmente (pues no parece de omitir), en la bahía de Concepción hay una respetable batería en un emplazamiento sobre un collado, que llaman de Gálvez, con suficiente número de piezas de á 24 , que se hizo para defensa del puerto en la última guerra de 5780 hasta la paz de $I_{7} 83$.

También subsiste el antiguo castillo delante del viejo Penco, que proteje aquel fondeadero. El mar metió allí tantas arenas, que sólo se descubre el dintel de la puerta que hace frente al mar, á cuya orilla se sitúa, y donde se registra el escudo de armas de la casa de Austria. 


\section{Noticias de la mamfactura de carnes saladas de Buenos-Aires.}

Malogradas por varios incidentes las tentativas hechas antes de ahora para el establecimiento de este comercio, se ha brindado á practicarle D. Tomás Antonio Romero, vecino y comerciante $\tan$ inteligente como acreditado de BuenosAires (I). La cuenta individual de esta manufactura, hace ver que este ramo es uno de aquellos que parece particularmente destinado á las inmediaciones del Río de la Plata: no está en oposición con otras provincias: excluye una porción no indiferente de comercio extranj ero, y favorece nuestra navegación, nuestros fondos y nuestros bra$z o s$, objetos esenciales que nos hemos propuesto para la opulencia nacional. No será tal vez desagradable al Gobierno ver el pormenor de esta fábrica, la cual, of reciendo á primera vista una ganancia considerable para los emprendedores, no solicita por otra parte más protección del Gobierno que unas providencias duraderas y una preferencia en los Derechos Reales sobre la introducción de carnes extranjeras.

PRESUPUESTO de productos y gastos de la fábrica de carnes saladas, en tres años, supuesto un empeño de 90.000 pesos contra las existencias de la fíbrica.

\section{PRODUCTOS POR LO MENOS}

Existen de rodeo, 24.00o cabezas de ganado.

Su anual procreo.

Novillos............ 4.000
Vacas............ 4.000

Distribución de vacas.

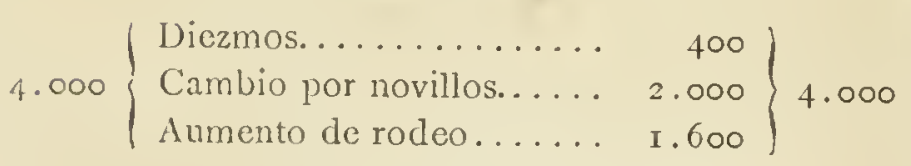

Total de novillos.

Del procreo............ 4.000

Cambio por vacas.......... I. I.000

SUMA......... 5.000

(r) Fil papel rle estas propuestas ha sido remitido lescle Montevideo al excelentísimo señor Inspector (ieneral de Marina, el Teniente General D. Félix de 'Tejada. El patriotismo que realmente mueve á Romero, merece alguna protección de parte del Gobierno.
Distribución de los 5.000 novillos.

\begin{tabular}{|c|c|c|c|c|c|c|c|c|}
\hline Princips. & 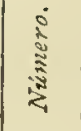 & $\begin{array}{c}\text { Quin- } \\
\text { tales } \\
\text { Carne }\end{array}$ & $\begin{array}{l}\text { Quin- } \\
\text { taxles } \\
\text { Charq }\end{array}$ & $\begin{array}{l}\text { Quin- } \\
\text { tales } \\
- \\
\text { Grasa }\end{array}$ & $\begin{array}{l}\text { Quin- } \\
\text { tales } \\
\text { Sebo. }\end{array}$ & Cueros. & $\begin{array}{c}\text { Qui- } \\
\text { jadas. }\end{array}$ & $\begin{array}{l}\text { Len- } \\
\text { guas. }\end{array}$ \\
\hline $\begin{array}{l}\text { Diezmo.. } \\
\text { Consumo. } \\
\text { Salazón... } \\
\text { Tasajo... }\end{array}$ & $\begin{array}{r}400 \\
500 \\
3.000 \\
1.100\end{array}$ & $\begin{array}{c}n \\
12.000 \\
\infty\end{array}$ & $\begin{array}{c}n \\
n \\
2.200\end{array}$ & $\begin{array}{l}" 1 \\
85 \\
510 \\
187\end{array}$ & $\begin{array}{c}n \\
85 \\
510 \\
187\end{array}$ & $\begin{array}{c}7 \\
500 \\
3.000 \\
1.100\end{array}$ & $\begin{array}{c}11 \\
1.000 \\
6.000 \\
2.200\end{array}$ & $\begin{array}{r}700 \\
3.000 \\
1.100\end{array}$ \\
\hline Sumas. & 5.000 & 12.000 & 2,200 & 782 & 782 & 4.600 & 9.200 & 4.600 \\
\hline
\end{tabular}

Reducción de productos a pesos corrientes.

I. 000 quintales de carne salada vendidos en Montevideo á 20 rs............. 5.000 dichos de íd. registrados para España y vendidos allá á 6 pesos......... 6.000 dichos de íd. remitidos de la Casa á íd...................... 36.000

Charque.

2.200 quintales vendidos en Montevideo

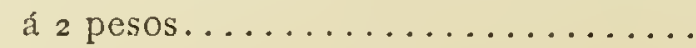

Grasa.

782 quintales de grasa á 4 pesos........

$3 \cdot 128$

Sebo.

782 quintales de sebo á 4 pesos........

$3 \cdot 128$

Cueros.

4.600 cueros al pelo vendidos en España á 3 pesos................... I 3.800

\section{Quijadas.}

9.200 quijadas á medio real..........

Lenguas.

4.600 lenguas á I rs................

Retornos.

Fletes de retornos del Bergantín y el Ber-

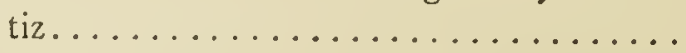
I 8 por roo de ganancia en el retorno del dinero de España............. I $4 \cdot 364$

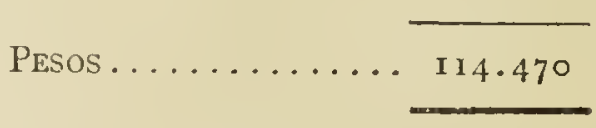

GASTOS Á LO SUMO

En particular carns de Montzvidso. 500 barriles................... 
SUMA ANTERIOR.....

Carne registrada para España.

2.500 barriles .

Seguro de su importe á 2 y $1 / 2$ por

I $00 . . \ldots \ldots \ldots \ldots \ldots \ldots$

Fletes por barril. ........... 7503.750

Almacenaje y descarga........

66

\section{Carne remitida para la Casa.}

3.000 barriles . . . . . . . . . 3.000

Seguro de su importe á 2 y $1 / 2$ por

roo....................

Seguro de las $3 \frac{1}{4}$ de los barcos

á $3 \mathrm{y}^{1 / 2}$ por $100 \ldots \ldots \ldots$. . . .

Gente de mar..............

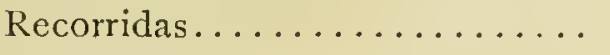

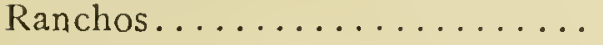

Almacenaje y descarga.........

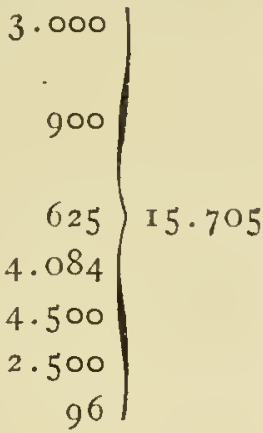

Grasa.

I 60 barriles

Sebo.

160 barriles.

Cueros.

Seguros á 2 y $1 / 2$ por $100 . . . \ldots$.

Almacenaje y descarga........

Quijadas.

23 barriles.

................

\section{Lenguas.}

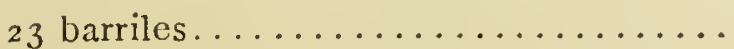

Fletes de vuelta.

Avería......................

Retornos de F.spaña. Seguro de las $3 / 4$ de los barcos á $3 \mathrm{y}^{1 / 2}$ por roo......... Salarios de la gente de la es-

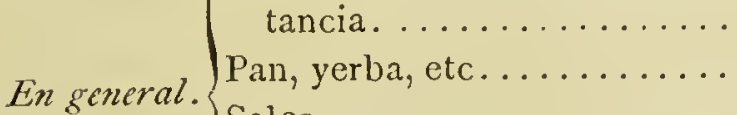

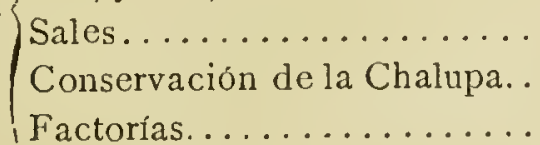

I. 6 I 2

II .500

600

I I 447

$5^{6} .101$

Presupuesto de lo necesario para emprender el negocio.

Para I 2.000 quintales de carne, 6.000 barriles......................

Para la grasa y sebo, 320 íd...........

Para quijadas y lenguas, 46 íd..........

Para seguros de la carne remitida por la

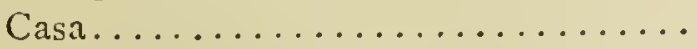

Para seguro de los barcos............

Para ranchos...................

Para recorridas...................

Para almacenaje y descarga de la carne..

Para seguro de cueros...............
6.000

320

46

900

625

$2 \cdot 500$

$4 \cdot 500$

$9^{6}$

345
Suma PESOS..... I $5 \cdot 332$
Suma ANTERIOR.... I5.332

Para almacen y descarga........... $\quad 3^{6}$

Para salarios de la gente de la estancia... $\quad 5.699$

Para atrasos de id............... 2.849

Para íd. de la íd. de mar.......... 2.040

Para sales, incluso gastos de Zumaca y

Balandra................... I I .500

Para conservación de la Chalupa...... $\quad 600$

$$
\text { Suma pesos..... } 38.056
$$

Dése que la Casa deba............ 50.000

Dése que se la supla por la anterior cuenta. 40.000

Quedará empeñada en deber.......... 90.000

Tiene de productos anuales.... II 4.470

Tiene de gasto.......... 56. 5 . I I

La restan cada año........ 58.369

Pague el interés de 90.000 pesos

al 6 por roo........... 5.400

Le restan aún.......... 52.969

Dése que pierda por casos ines-

perados............ 22.969

Tendrá cada año sobrante lí-

quido................ 30.000

Pagará en otros dos años...... 60.000$\} 90.000$

Ha emprendido, á la verdad, un comercio de esta especie con la Habana el hacendado D. Juan Balbin: tiene una fábrica dirigida con buena economía, en las inmediaciones de aquelia plaza, camino de Maldonado, y sus exportaciones no han sido indiferentes; pero como quiera que dicha fábrica carece de fondos, y que por otra parte no aspira á aquella perfección que se solicita en Europa, de ningún modo el proteger la una destruiría esotra, tanto más, que es natural que la protección del Gobierno no sea violenta, dirigiéndose á la sóla preponderancia en la balanza contra el extranjero, sin envolver igual especie del comercio nacional.

Sucede á este ramo, el de la sal, que tantas veces ha hecho creer en Europa la imposibilidad de una conducta fácil á Montevideo ó á los demás parajes en donde fuese necesario transportarlo para el aprovechamiento de la corvina y del bacalao.

Hasta aquí ha sido costumbre en BuenosAires el traerla por medio de carretas, desde la Laguna, quę está unas 150 leguas al Sursudoeste: se juntan en una especie de caravana, cuyo total subirá anualmente de 300 á 350 : cada carreta carga i 6 fanegas. Esta sal, que suele costar de seis á ocho pesos la fanega, es tan buena, que no se ha deshecho puesta un año en el tocino. No le es muy inferior la sal del puerto de San José, en donde unas I 2 ó 5 carretas pudieran amontonar en poco tiempo ro ó I 2 cargamentos de á 
500 fanegas cada uno (I). Abunda jgualmente en el Río Negro, pero la navegación es allí peligrosa y sólo al alcance de embarcaciones de poco calado, cuando en el puerto de San José pueden entrar y cargar sin riesgo, las que á él se dirijan. Finalmente, en el puerto de San Julián, aunque

(r) En I 785 informa D. José Salazar al excelentísimo señor Virey D. José de Bertiz, que en quince dias, nueve hombres acopiaron $9 \mathrm{x}$ montones de más de una estatura de un hombre cada uno.
10 de tan buena calidad, es tanta, que además de poder abastecer cualesquiera salados, alcanzaría sola á proveer todas las provincias.

La navegación hasta aquí poco segura por falta de pericia marinera y poco repetida por falta de objetos comerciables y de fondo, no ha establecido aún como únjco medio el conducir la sal por mar: en este caso abaratará aún mucho, y desde luego, há pocos años que se ofreció á cuatro pesos fanega, traída del puerto de San Julián.

\section{Reflexiones politicas sobre los dominios de S. M. desde Buenos- Aires hasta Chiloé por el Cabo de Hornos.}

Una región que pareció hasta aquí abandonada de los benéficos influjos de la vegetación, y que compuesta de costas casi inaccesibles, batida de unos vientos constantemente tempestuosos y colocada en los extremos del continente, casi como un dique contra la cólera de las olas, parecía destinada á ser el asilo únicamente de los peces y aves silvestres, ha llegado, en fin, á excitar la codicia de los europeos; y después de haber sido la causa de unas desavenencias considerables ( 1 ), y haber fomentado una guerra (2), aún en el día amenaza nuevas discordias y exige en el Gobierno una atención seria y constante.

El bergantín C'amen que ha navegado en conserva de las Corbetas hasta el Puerto Deseado, y que reconocidos luégo los ríos de Santa Cruz y Gallegos ha regresado felizmente á BuenosAires, es buen testigo de la aserción que antecede: más de 30 embarcaciones inglesas, francesas y americanas ó independientes, ó realistas, estaban ocupadas en la pesca de la ballena en la sonda desde los 47 hasta los $39^{\circ}$. En la Isla de los Estados, al referir de la fragata francesa Ene Kar, había las barracas y demás utensilios necesarios para el beneficio de la pesca: en el río Santa Cruz y en el puerto San Gregorio se había intentado distraer los Patagones de nuestra amistad, se les prometía un establecimiento en el Puerto Deseado: no pocas veces habían invernado en el puerto Egmont varias embarcaciones extranjeras: finalmente, á nuestras reconvencio-

(I) En el año de 1770 estuvo muy próxima una rotura con Inglaterra, por la expulsión de la colonia inglesa del puerto Fgmont en las Islas Malvinas.

(2) Los proyectos rlel ex-jesuita Falkaner sobre el internar por los Ríos Negro y Colorado hasta Valdivia, debieron dar muchas esperanzas á la Inglaterra de ofendernos sénsiblemente, y desde luégo nos causaron unos gastos enormes. nes sobre el no frecuentar estos mares, respondía el Capitán inglés Botel que tenía pasaportes de su Monarca: al mismo tiempo, varios buques ingleses y americanos (entre ellos algunos bergantines) transitan el Cabo de Hornos, visitan nuestras costas, y por consiguiente, en el año de I789 puede considerarse ya, relativamente á esta parte, franqueada la doble barrera de los tratados y de la navegación.

La España, en sus combinaciones, está siempre ligada con tres objetos difíciles de reunirse sin que choquen y se ofendan mútuamente (I), y son: $I .^{\circ}$ sus fuerzas y ventajas; $2 .^{\circ}$ sus relaciones en la baldnza de Europa; $30^{\circ}$ sus relaciones con los indios moradores; y aunque en los países más fértiles, poblados y ricos de nuestras conquistas no pasen de los ya citados los puntos políticos de vista bajo los cuales ha de considerarse la Monarquía, ya las costas Patagónicas, á pesar de no tener circunstancia alguna favorable, han llegado á abrazar todos estos objetos, en un grado tanto más interesante, cuanto más capaz es de un remedio temprano y oportuno.

Que la internación de cualquiera fuerza europea por la costa oriental Patagónica sea un peligro imaginario, y un peligro que no debe ocupar ni un momento nuestro sistema defensivo, es punto tanto más decidido, cuanto más influyen los materiales acopiados, á hacer conocer la verdadera Geografía de esta parte del Continente.

Ya los Sres. Varela y Saá y Farria habían rebatido en Buenos-Aires estas ideas (2), cuan-

(r) Axiomas políticos.

(2) Documentos existentes en la Secretaría del Vireinato: el ${ }^{0}{ }^{0}$ responde al Marqués de Sobre-Mornte; y el $20^{\circ}$ al señor Vircy D. José de Bertiz. 
do el Piloto Villarino por el Este, y los Oficiales Espinosa, Orejuela, Piñuer y Callejas por el Oeste, intentaron examinar esta comunicación y descubrir los Césares y Extranjèros (I) establecidos entre los $43^{\circ}$ de latitud y el Cabo de Hornos.

Si se admite, pues, como base de nuestros razonamientos, que una invasión al Sur de Buenos-Aires y Chiloé pudiera más bien desearse que temer, en cuanto distraería con escarmiento propio algunas fuerzas enemigas, podrá reducirse ya la cuestión á unos términos más claros y sencillos, que son: $I .^{\circ}$ ¿A qué pueden sernos útiles las costas Patagónicas? 2. ¿Cuáles son los medios de conseguirlo? $3 \cdot^{\circ}$ ¿Cuál ha de ser nues tra conducta con los extranjeros así en tiempo de paz como en el de guerra?

Muy poco debe ocuparnos el primer objeto después del examen algo prolijo que se ha hecho del suelo Patagónico; una navegación escasa y violenta, unos puertos sumamente arriesgados, la falta casi absoluta de agua y leña; últimamente, unas naciones ó más bien tríbus quietas y sin resorte alguno de los que constituyen ó el recelo de una guerra ó el cebo del comercio, muy luego dejanconocer que fuera reprensible el proponer la menor idea de establecimientos. Además de que, nuestro sistema de establecimientos temible ya en cualesquiera otras provincias, debe serlo aún más en la costa Patagónica, porque unos presidios en donde no hay el menor recurso ni para un comercio mediano (2), ni para una subsistencia cómoda, han de reèmplazar precisamente con sueldos crecidos y con la misma malversación de la Real Hacienda, la suerte de los empleados, quienes desde luégo fabricaron sobre el mismo empleo la idea de una fortuna.

Examinemos un momento nuestras colonias de la costa Patagónica y Malvinas, y para no re. novar á la memoria la cadena fatal de mil gastos enormes á que han dado lugar en tiempos pasados (3) examinémoslas únicamente in statu

(I) No permiten estos discursos internarnos en la cuestión sobre la existencia de los Césares, y además fuera inútil cuando el actual señor Virey de Lima ha tomado la medida más opcrtuna para averiguarlo, que es la de los Misioneros, pero en cuanto á establecimientos internos extranjeros, que amenazaba el Capitán Orejuela, el solo examen de una colonia separada del mar y aislada entre bárbaros en un suelo inútil, basta para rechazar aquellas ideas. „Cómo se asemeja nuestra situación política, á la de un viejo rico y codicioso, al cual todo ruído parece el de los ladrones que intentan robarle!

(2) Córrase un velo sobre las especulaciones soeces de comercio á que ha dado lugar esta situación. Merecen una aténción seria del gobierno, en cuantos influyen en el modo de pensar de unas personas que pueden luégo ser depositarias del honor nacional.

(3) La muchedumbre de pobladores traídos de España, como ya se indicó hablando de Maldonado, y las expediciones malogradas de Puerto Deseado quo. Nadie ignora las causas que dieron lugar á nuestro establecimiento en el Puerto de la Soledad en las Islas Malvinas; fueron irremediables entonces, pero después se han conocido ya sin acción, tanto más, que si no bastase á probarlo la misma reforma que se ha hecho en su pié de fuerza, población y asignaciones, lo evidenciarian las repetidas veces que embarcaciones extranjeras han invernado después ó en el puerto Egmont ó en los otros muchos que forman el laberinto casi incompresible de las Malvinas.

Los establecimientos del río Negro y del puerto de San José, únicos que nos han quedado en la costa, ya no fueron dictados por combinaciones útiles ó de comercio ó de defensa, sino por las órdenes de hacer establecimientos adaptados á los parajes, en donde algún agua aunque salobre y un poco de tierra vegetal, prometiesen siquiera una subsistencia penosa á los pocos colonos: entre tanto que se proponían grandes ventajas de comercio, de construcción, de navegación y comunicación internas; que no dejaba de mezclarse el acostumbrado celo de la conversión de pocos indios errantes, y que se revivían las ficticias ideas de un nuevo País del Dorado en las latitudes casi inaccesibles; el Erario expendía sumas cuantiosas y aumentaba la infelicidad de unos colonos cuya transmigración desde España era ya un paso opuesto á la prosperidad nacional. ¡Oh, cuándo llegará la época feliz de la Monarquía en la cual los proyectos para la conservación ventajosa de la América no envuelvan ni sacrificios graves del Erario, ni multiplicidad de empleados, ni un semblante de religión y riquezas que ya no admiten, ni el conocimiento del suelo, ni el del hombre (I), y en la cual no sea el Monarca el único móvil de los ensayos harto equívocos, costosos y multiplicados para la opulencia nacional!

Finalmente, estas dos colonias, después de haber sido en su origen sumamente costosas, haber interrumpido y casi cortado nuestra amistad con los Patagones (2) y habernos hecho sufrir un choque sangriento é ignominioso con los indios Pampas (3) y haber casi recibido en el Puerto Deseado la memoria de la infeliz Colonia de Sarmiento en el Puerto del Hambre, absorben aún en el día 84.000 pesos fuertes próximamente, si

y San Julián, ocuparían un lugar no indiferente en estas cuentas.

(I) No parezca importuna esta digresión, en quien recorriendo las Américas las ve de cerca con ojos filosóficos.

(2) Diario último del Piloto Peña, año de 1789.

(3) La muerte desgraciada del Piloto Villarino con otros muchos en el primer año del Vireinato del señor Marqués de Loreto, se ha cotejado verbalmente con un Oficial del regimiento Fijo de Buenos-Aires, que fué prisionero en aquella misma refriega, y en cuyo trato han manifestado aquellos indios, que ni son crueles, ni sordos á la dulzura y al agradecimiento. 
se ha de juzgar por el promedio de cuatro años en el Estado de cajas Reales de Buenos-Aires. ¿Ahora, cuáles son sus ventajas? ¿Tal vez el abasto de sal en Buenos-Aires á precios más equitativos? Ni se ha conseguido, ni esta atención debe ser del Rey, cuando los particulares pueden cargarla si quisiesen impunemente; y cuando con una caravana de carretas, anualmente extraen de aquellas inmediaciones todo lo que quisiesen. ¿Será acaso la protección de la pesca ó cubrir del enemigo ó competidor un país inmenso? Aquella no tiene otra protección que la de los buques de la Marina Real, respecto á que pueden darle eficaces auxilios de gentes, pertrechos, escoltas, etc., y seguirla á medida que vaya siguiendo la ruta de los cetáceos ó peces que anhela: en cuanto á la saca de aceites ó á los salados, bastaría para trastornar todas sus medidas económicas el obligarla á frecuentar uno más bien que otro paraje, el obligarla á emplear los suyos, ó los brazos agenos en esas manufacturas fáciles y sencillas; además que ó el Erario cobraría el equivalente, y es probable que la pesca quedaría recargada, ó el Erario lo sacrificaría en beneficio de ese nuevo ramo de industria nacional; y que no hay motivo para semejantes sacrificios, tanto más que la opulencia nacional nunca ha de prosperar si son sacrificios del Monarca las ventajas del vasallo, siempre con aquella proporción que llevan las unas con los otros (I). En cuanto á cubrir todas las costas inmediatas con aquellos puertos, es proposición harto errónea para controvertirla; pero lo será aún más, cuando se asegure que ni áun á sí mismos pueden defenderse, dotados con un corto número de malcontentos é indisciplinados, y con una batería tal vez de cañones inútiles, en donde hay mil parajes para fondear y hacer desembarcos.

Esta pintura rápida, puede casi en un todo aplicarse también al puerto de la Soledad en las Malvinas, el cual, en una guerra, igualmente que los dos establecimientos indicados, sería fácil presa de un corsario atrevido y bien armado, agregándose el poco tiempo que emplearía en esta conquista, para ajar más y más el honor del pabellón y del poderío nacional.

Insensiblemente hemos venido á hablar de las pescas, único punto de vista, bajo el cual podemos mirar como ventajosa á la opulencia nacional, la costa Patagónica: se insinuó ya hablando de las escalas en Montevideo, que áun fomcntadas considerablemente las pescas, serían poco

(1) Es rarísimo el caso entre particulares (á no suponerse abusos), que la ventaja sea igual al sacrificio, pues entonces los males y bienes estarian en una exacta balanza. El Monarca, cuando media como contrayente, no como legislador, no puede ménos de ser sacrificado, si se miran su amor al vasallo y la multiplicidad de trámites por los cuales pasa el Bienhecho. útiles á aquella colonia, en cuanto exigía una economía indispensable, que evadiese toda ocasión de gastos supérfluos. Por ventura, los extranjeros, que con tanta ansia se han inclinado á la pesca de la ballena y á la adquisición de las grasas de lobo marino, pelucón ó leon marino, y del pinguancho, nada dejan que desear en cuanto al modo de calcular con seguridad sobre este importante ramo de industria: el huir de nuestras colonias, el navegar con poca gente, tener sus pasos libres, conservar las tripulaciones y hacer la aguada donde y como convenga; invernar á veces en uno ú otro puerto para el acopio anticipado de las grasas; finalmente, el no ser molestados ni maltratados, sino únicamente auxiliados y dirigidos de la Marina Real, serán los preludios positivos de la prosperidad ó decadencia de nuestra nueva compañía de pesca, emprendida con tanto amor al bien nacional, bajo la protección del Excmo. Sr. Bailío D. Antonio Valdés.

Los sucesos de la fragata Ventura, que arponeó en un mes 50 ballenas en el año de I784 y regresó á Montevideo con II 3 pipas de aceite, parecen deben inclinar la pesca hacia los paralelos comprendidos entre el Río Negro y el Cabo Blanco; pero también debe tenerse presente, que la escala verdaderamente ventajosa para los pescadores, y sobre todo, el único paraje donde pueden invernar con facilidad y comodidad, es el puerto Egmont: una aguada cómoda, un puerto abrigado, una abundancia grande de plantas antiescorbúticas y de marisco, y sobre todo un puerto desierto, pudieran tal vez inclinar los pescadores hacia aquella parte, ó bien hacia el puerto de Año Nuevo en la Isla de los Estados, en donde, no sería prudente el invernar, particularmente en la alternativa con puerto Egmont.

Pero no es la sola pesca de la ballena la que puede hacernos útil la costa Patagónica; D. 'Tomás Antonio Romero, vecino y del comercio de Buenos-Aires, con un espíritu verdaderamente patriótico, y con bien meditados cálculos, apoyados sobre un caudal no indiferente (I) ha propuesto la pesca y salazón del bacalao en el puerto de San Julián y sus inmediaciones, con unas condiciones harto ventajosas á la Real Hacienda, mucho más si ésta se desentiende de la cesión de aquellos enseres, después de un término señalado, y deja al libre albedrío del primer propietario la inversión ó alienación de los efectos.

A la verdad, las proposiciones de este vasa1lo pudieran tal vez combinarse con las de la nueva Compañía Marítima, si se advirtiese que los fondos de aquélla no alcanzan seguramente á

(I) Véase la noticia remitida desde Buenos.Aires al Sr. Inspector general de Marina. Merecen particular atención las Memorias del celoso Ministro, el Intendente pasado de Buenos-Aires, D. Francisco de Paula Sanz. 
abarcar la sola pesca de la ballena, de modo que excluya al extranjero, y que el detall de una salazón de una pesca sobre costas, con embarcaciones menores, jornaleros, etc., y de unos cargamentos dispuestos con cuidado, exigen unas atenciones bien diferentes de las que implica la pesca de la ballena, siendo probable que con tanta precisión haya ésta de evadir el Río de la Plata, como la otra depender de él enteramente.

No ocultaré á la rectitud del Gobierno, que á pesar de deber las colonias en cuanto al comercio, ser útiles y tributarias á la matriz, no deben no obstante, perder el derecho de emplear sus fondos en los productos de su territorio, siendo este el único derecho que les queda, cuando en la importación y en los cambios ya se les hace tributarios: sin este derecho, se hallarían sentenciados á una pobreza tanto más duradera, cuanto más se le estrechase el modo de explayar su industria y de emplear ó formar sus propios fondos.

Si como ya se ha indicado, es preciso que la prosperidad de la pesca dependa del no frecuentar el Río de la Plata, por consiguiente no se han de emplear en ella resortes de su industria, y tal vez ó no se han de admitir sus fondos ó han de servir al fomento ageno, es patente que hay violación de derechos territoriales, y que la nueva Compañía Marítima, ó se desentiende del beneficio que debe producir, ó ella misma ha de hacer considerables sacrificios.

Por ventura, examinadas maduramente las circunstancias de estas dos pescas, del bacalao y de la ballena, sale en claro que la naturaleza misma de los intereses particulares, ha combinado que sea tan exclusiva la pesca de la ballena á la Compañía Europea, como debe serlo la del bacalao á la colonia. En efecto, si se advierte que la economía y despachos de aquélla han de depender directamente de la Europa, y que al contrario, el detall, reparos, abastos, etc., de esotra, han de dirigirse precisamente desde BuenosAires, quedará bien demostrado que para sus mismas ventajas se ha de agregar á la primitiva compañía una subalterna para la pesca del bacalao dirigida y manejada desde Buenos-Aires, ó se ha de malograr el semblante de esa nueva y útil ocupación de industria.

En tal caso, Romero pudiera, ó como nuevo accionista invertir el fondo proyectado en los ensayos, en tal caso nada peligrosos, obligándole á los cuatro años á entregar toda la pesca á la Compañía, ó desde luego se le admitiría como di rector en este ramo, que como se ha dicho, de ningún modo debe confundirse con el ramo de la ballena.

Concluiremos esta pequeña digresión sobre la pesca, con advertir que de ningún modo debe tratarse de establecimientos en la costa Patagónica, mucho ménos de establecimientos en los cuales el Erario ó la Autoridad Real, tenga la menor parte, y que será muy útil ocupar al principio los Pilotos Tafor y Peña, de la Marina Real, en unas navegaciónes y proyectos mercantiles que exigen tantos conocimientos marineros, como buen sistema y harmonía en el trato con los Patagones.

En cuanto á las embarcaciunes de la Marina Real que protejan la pesca, alcanzarán seguramente á todos los objetos, y no serán muy gravosas al Erario si se componen de dos corbetas y dos bergantines en dos divisiones, á las cuales seguirá con intervalo de dos meses, ó desde Europa ó desde Buenos-Aires una embarcación con víveres, que cumplida su comisión en puerto Egmont, adonde acudirian en diferentes tiempos las dos divisiones á tomar lo que necesitasen, pudiera también hacer su retorno con aceites ó grasas.

Estas dos divisiones deberian, aunque separadas, reconocer un solo jefe, quien sería responsable de todos los incidentes de la pesca y cruceros: darla sus instrucciones, y en un par de encuentros de las dos divisiones, la una al tiempo de reemplazar los víveres, combinaría sobre los reconocimientos hechos y las noticias adquiridas los pasos más acertados para el plan que había de adoptar. En general, las Malvinas, los Ríos de Santa Cruz y Gallegos, la entrada del Estrecho de Magallanes, la Tierra del Fuego y la Isla de los Estados, serían la parte correspondiente á una división; mientras la otra cruzaría el mar comprendido desde el puerto de San Julián hasta los 37 ó $38^{\circ}$, se reconocerían los puertos con una conducta fundada sobre una disciplina firme, y con regalos oportunos se atraerían más y más á nuestra amistad los pocos habitantes de estas dilatadas costas, y si no me engaño, fuera fácil y no violento habitando algún tiempo entre ellos, enterarse á fondo, así de la geografía como de la poblacion interior.

Las fuerzas indicadas dotadas sin superfluidades, así en cuanto á clases como al número de gentes, podían servir en la escuadra de evoluciones hasta fines de Agosto: navegar después unida cada división á la costa Patagónica, cruzar hasta Marzo y Abril del año siguiente, y luégo restituirse á España: puede asegurarse sin temeridad, que tomados oportunamente los puertos, dados á las tripulaciones unos intervalos suficientes de descanso y la precisa ropa de abrigo, aprovechados los guanacos, aves marítimas, mariscos, peces y plantas antiescorbúticas, y finalmente, explayada aquella mezcla de dulzura, aseo y disciplina, sin la cual el marinero español caerá casi en un momento de la tristeza á la enfermedad, podrán conservarse buques y tripulaciones, á muy poca costa, en el mejor estado y con una verdadera instrucción de la marina, lo- 
grarse una reforma de tantos buques extraños, que seguramente no infundirán la mejor idea del respeto á que es acredora la Nación, en sus costas y dominios.

Bien se deja ver que las fuerzas indicadas bastarían para ahuyentar de las costas los pescadores extranjeros, ó para cobrarles una contribución que denotase siquiera el dominio. Pero fuera temeridad grave de nuestra parte el penetrar en los arcanos del Gabinete, ni al hombre filósofo le será jamás lícito el mover la menor idea que pueda conducir á unas hostilidades ó á una guerra, siempre perniciosa, no ménos al Monarca que á sus vasallos.

Finalmente, hemos de rechazar una dificultad que pudiera oponérsenos sobre el abandono del Puerto de la Soledad en las Malvinas, y es la abundancia de ganado que allí existe, y que se multiplicaría mucho con ventaja de los enemigos en tiempo de una guerra: en cuanto á los edificios, desde luégo creo que es corto sacrificio el abandonarlos, cuando se haga memoria que áun en el día, además de la manutención de la corbeta guarda-costas, cuesta el Puerto de la Soledad $2+.000$ pesos al año (I).

No hay dudas que estos ganados no deben dejarse si se abandona el Puerto de la Soledad, pero puede sacarse grande ventaja de su actual existencia y conocida multiplicación cediéndolos á particulares de Buenos-Aires, que se obliguen á costear el regreso de los empleados y colonos, así de este establecimiento como de la costa Patagónica, y á proveer en lo venidero á la subsistencia de los colonos, dándoles tierra para labor.

Esta sola combinación cortaría muchos cálculos intrincados de las Cajas Reales, que con el tiempo serían indisolubles, y un sacrificio aparente arrastraría tal vez unas economías sólidas, que nunca pueden ligarse con la Administración Real de América.

Con el puerto Egmont, oportunamente desierto, se ofrece á las escuadras que en lo venidero hayan de pasar al Perú, particularmente en tiempo de guerra, un verdadero asilo para el descanso y aguadas que le son necesarias: es, sin duda, preferente á cuantos hasta aquí se han propuesto para este fin, y con la seguridad de poderlo tomar sin exponerse á los vicios y á las deserciones que tanto extrago hacen en los bajeles de la Armada, podrá una escuadra no exponerse á los riesgos á que le expone ó un embarque excesivo y empachoso, ó una administración mc $\angle$ quina del agua dulce: fuera importuno el precisar ni á esta ni á otra escala los buques que comunmente transitan al Sur, sean de la Ma-

(I) Víanse los listados de las cajas Reales de inenos-Aires, año de 1788 rina Real ó del comercio, aunque en los primeros merezca ya alguna atención el modo en que salen de Cádiz (I).

Tal vez la única ó la principal razon que movió al Excmo. Sr. Marqués de Loreto á no protejer, antes bien, á oponerse á los proyectos útiles de la pesca, fué la del comercio ilícito, contándose que muy luego alguno de los puertos desiertos de la costa Patagónica sería el nido adonde reunidos extranjeros y nacionales cambiarían la plata, ilícitamente extraída, con géneros de una introducción ó prohibida ó recargada de derechos.

Esta idea, hija á la verdad de un celo distinguido á favor de la Real Hacienda, acarreó y puede acarrear de nuevo consecuencias funestas á la pesca, no sólo obrando directamente como hizo entónces, si también interponiendo algunos estorbos que, á pesar de influir muy poco en el bien, puede, empero, causar perjuicios de mucha monta: la pesca es uno de aquellos ramos indus triales cuyos riesgos son muchos, las ganancias moderadas y las especulaciones y combinaciones tan varias y extendidas como el Oceano que las suministra. Si los recelos del contrabando le pusiesen la menor traba; si se le obligase á ir á uno más bien que á otro puerto; si se le ciñesen por el Gobierno las estaciones, los plazos ó los parajes de su industria; si no se le dejasen combinar en sus dilatados viajes de ida y vuelta algunas otras expeculaciones, ó relativamente á los cambios con los indios, ó con relacion á algunos productos útiles de las costas desiertas que frecuenten, debe temerse que el ramo de industria sea violento, y que unos precios muy altos, al abrigo de la exclusiva, hagan que la Nación pague con sus sacrificios la ganancia de pocos particulares y los gastos de una administración siempre costosa en la Corte (2).

Ya el examen algo prolijo de la costa Patagónica Oriental nos ha llevado á la demostración casi evidente de las verdades siguientes: I. ${ }^{a}$ Que conviene abandonar todos los establecimientos, incluso el del Puerto de la Soledad, porque además de ser muy gravosos al Erario y violentos al vasallo, sólo sirven en tiempo de guerra para comprometer más y más nuestras fuerzas marítimas; siendo fácil, por otra parte, la verificación de este abandono sin el menor recargo de gastos, con la sola cesión de los ganados de Malvinas al que haga todos los transportes y ocupe las pocas

(1) La fragata Licbre ha liegado hasta la Isla de los Estados, consumiendo el agua que llevaba sobre Bocas.

(2) El existir en Madrid la dirección de la Compañía de Filipinas, hace que la Casa comisionada de Cádiz tenga un 4 por roo de comisión en las negociaciones de Cádiz: si la dirección estuviese en Cádiz, ó los gastos que causa, ó la comisión, se evitarían seguramente. 
familias del río Negro (r) en el Río de la Plata. 2. Que la pesca es el único producto que podemos sacar de aquellas costas dilatadas, pero ha de dirigirlas la economía, excluyendo todo establecimiento y trabas, $y$ ha de protegerla la Marina Real apartando á los extranjeros, según lo toleren los tratados ó antiguos ó recien hechos: podrán lograrse algunos cambios con los $\mathrm{Pa}$ tagones, muchos conocimientos del país interior, y unos vínculos nuevos de amistad recíproca que nos afiancen su fidelidad. $3 \cdot{ }^{\circ}$ Las escalas en la costa Patagónica, para los buques que transiten al mar del Sur, son muchas é irremediablemente comunes á nosotros y á los extranjeros; no debe precisarse á ellas á embarcación ninguna mercantil, mucho ménos en tiempo de guerra; para la Marina Real, particularmente si navegase con transportes ó escuadras numerosas, la del puerto Egmont parece la más segura y cómoda, suponiendo que dicho puerto se conserve desierto. $4 \cdot{ }^{2}$ Finalmente, que no debe absolutamente pensarse en recelos, ni de establecimientos, ni de invasiones enemigas, que sólo servirían en escarmentarlos: las pocas y débiles empresas de particulares que sin intervención pública del Gobierno intentan pequeños establecimientos ya en una, ya en otra parte del globo, pueden ahogarse en sus mismos principios, dejando á los buques de la Marina Real el ejecutar por sí estas pequeñas providencias, bajo el semblante de una dureza natural, tal vez adoptada de las mismas naciones sobre las cuales se explaya: así muchas veces no se comprometerían las Cortes, y el particular intruso llevaría el escarmiento correspondiente.

Pasaremos rápidamente las Tierras del Fuego y la costa Occidental Patagónica, cuya época de merecer la atención de los Europeos, parece ó no debe llegar jamás, ó á lo ménos ser sumamente remota y fuera de nuestros alcances. E1 puerto Inchin (2) y los del Sur de Chiloé, serán siempre el asilo único de una embarcación, como el Pingue-Ana, destituída de cuantos medios contribuyen á una subsistencia aunque penosa en el mar; ni el arrimo á aquellas costas particularmente para una embarcación que esté en muy mal estado, dejará de arredrar muy luego á los que le comprendiesen en sus cálculos: un poco de agua y algún marisco nunca serán un cebo suficiente para escalas, después que bien conocidas la Tierra del Fuego, las Malvinas y la Isla de los Estados, y franqueados á la navegación otros auxilios que los que estaban al alcance del Almirante Anson, ya ninguna embarcación podrá

(I) No hubiera inconveniente en dejarlas, inclinándose a este partido si el Gobierno se desentendiese de su sustento, defensa y prosperidad.

(2) Véase el viaje de Anson: lo ha reconocido el Piloto Machado en 1769. hallarse en las mismas circunstancias en que entonces estaban el Pingue-Ana y el Wager.

Se nos presenta ya la Isla de Chiloé, la cual por su. situación, clima y productos ha ocupado desde el año de 1778 la atención del Gobierno. Esta isla, como ya se ha indicado, no es escasa de pobladores, abunda de muchos productos útiles, tiene buenos puertos y es el verdadero principio de la dominación española en el mar $\mathrm{Pa}$ cífico. Pero como hasta aquí se ha dicho, han de dividirse en su examen político los objetos mercantiles de los militares, y ligarse con unos y otros la prosperidad nacional y la economía del Erario.

Es efectivamente singular la vista de los muchos errores políticos á que expone el no dividir las materias entre sí: la defensa se fija á veces en parajes donde no pueda concurrir el comercio, y el comercio se fija luégo en parajes indefensos, de suerte que la Nación en éstos y el Erario en aquéllos, sufren iguales sacrificios, y se multiplican los puntos en los cuales puede el enemigo hostilizar y ofendernos, aumentando además nuestra imposibilidad de fijar un sistema de defensa. Opinaba D. José Orejuela en sus propuestas al Excmo. Sr. D. José de Gálvez, que para fomentar la isla de Chiloé, debían obligarse á hacer escala en el puerto de San Carlos todos los buques que transitasen al mar del Sur, de suerte que la compra de pocas verduras arrastrase los extravíos y tal vez la pérdida de muchas embarcaciones: para insistir en la reconquista de Osorno, suponía que la población de Chiloé fuese excesiva, cuando los diferentes censos nos indican no sólo que es muy corta en proporción del suelo, que puede ser capaz de labor y del comercio de tablas y pescas, á que puede dedicar una parte considerable de sus brazos, si también que disminuye rápidamente ( $\mathrm{I}$ ) por diferentes causas, de las cuales se han indicado ya algunas, y otras se apuntarán muy luego.

Dejemos á un lado estos y otros proyectos, y ocupémonos únicamente del recto conocimiento de la isla. Puede establecerse en primer lugar como axioma, que la administración de tributos, derechos y diezmos, es tanto más nociva al contribuyente y tanto ménos útil al Erario, cuanto mayor es la distancia del centro y buen orden de la Monarquía, y más inasequibles los esfuerzos para el remedio de cualesquiera abusos. No parezca temeridad el asegurar, que aumentadas considerablemente las contribuciones de los Chilotes en este siglo, al mismo tiempo la población ha disminuído de la mitad, y

(r) En I7r3 era la población de 59.000 almas; en 1772 de 32.000 y se ha visto que en 1787 solo llega á 27.000 . 
el Erario se ha visto recargado de un situado doble, no habiendo además en el puerto de San Carlos ni una fortificación que pueda alejar un solo buque enemigo, ni un soldado cuyas armas no quede dudoso si han de obrar contra el invasor ó contra su mismo Soberano: son buenos testigos los Sres. Tova, Valdés y Quintano, que pasaron á Castro, del grave daño que produce al contribuyente ese pequeño tributo que se le exige. Las tablas han de presentarse en un plazo determinado sean los que fueren los tiempos, las estaciones y los obreros, además que muy poco fundados son los cálculos que fijan la contribución y sustento sobre el producto de un suelo ageno, inundado de gente militar y enemiga del nombre español (I).

Por falta de caminos y de cobradores, el habitador de la parte meridional de la isla sacrifica á veces su salud y su labranza para traer á las Cajas de San Carlos solos cinco pesos, que por lo común no producen al Rey sino otros tantos de gasto (2). Entre tanto un cuantioso número de soldados y ministros de la justicia corre de un extremo á otro, no para cobrar periódicamente este tributo, sino para oprimir á los que omisos ó imposibilitados no le hayan pagado: usurpa, vende $y$ nada trae.

La población de San Carlos toda se mantiene del sueldo del Rey, y de las vejaciones que de allí dimanan á la restante provincia, y finalmente, un país en donde ni el mismo alimento alcanza á las necesidades, es un nido de pleitos y de un enjambre de escribanos.

Pero ¿á qué hacer una descripción importuna de aquellos inconvenientes, que hijos más bien de una constitución errada (3) tantas veces han llegado á los piés del Trono, y no se ocultan al que vea de cerca esos dominios extensos? Baste decir que áun sin el aumento de la cuarta compañía de tropa veterana, aprobado ya por S. M., el importe del situado anual que se remite desde Lima es de 22.00o pesos, á pesar de lo que producen tributos, alcabalas, tabaco, aduanas, papel sellado y servicio personal de los milicianos.

Esta reflexión debe ser tanto más sensible, y guiarnos para las medidas que se propongan,

(1) Fsta expresión de la cordillewa fronteriza á Chiloé, es irinica y alusiva á las ponderaciones de los proyectistas.

(2) Los Oficiales ya nombrados encontraron un contribuyente de Cucao, que empleaba cinco días en venir á San Carlos, y otros cinco en volver á su casa: le era preciso ir al Sur para coger el único camino que hay de comunicación.

(3) Admirese en hora buena la legislación y sistema nuestro de América: siempre será verdad que su ejecución es inasequible según se ha demostrado en los axiomas proliminares, y que variados el sistema militar de la Furopa, uuestras relaciones con los inclios no conquistados y el mismo número de éstos, dche variar precisamente el sistema político y militar. cuanto que el comercio de Chiloé, fảvorecido de unos productos industriales y mucho más de su posición aventajada, debiera conservar, antes bien, aumentar su masa circulante, principio de la prosperidad.

La Isla de Chiloé (I) extrae hoy en día 200.000 tablas de alerce: Io ó I2.00o jamones, seis ú ocho ponchos finos de valor de 60 á 80 pesos, 900 á I.ooo de los que llaman toltenes del valor de ro á I2 pesos cada uno: como 2.00o bordillos (2) que el Rey abona á peso en el cobro de tributos: Ioo colchas bordadas (con poca diferencia), de valor de ocho á nueve pesos: de 50 á 60 quintales de bacalao seco de valor de II á I 2 pesos quintal: de 30 á 40.000 sardinas curadas que se regulan á dos pesos el millar: corta cantidad de sayal y menor de lienzo burdo, cuyos efectos, respecto á los valores y cantidades citadas, y puestos á cuatro reales cada jamón y cada tabla á real y tres cuartos, resulta por valor próximo de los géneros de industria, que la exportación equivale á 54 ó 56.000 pesos anuales: cantidad no indiferente si se advirtiese que pudiendo la isla suministrar abundantemente para el sustento, y áun en mucha parte para el vestido, quedaba este sur-plius en beneficio de los objetos de lujo, para una vida más cómoda, cuyos influjos benéficos serían muy luego el progreso de la población y el mismo progreso de la agricultura y de la industria: pero los tributos, el tabaco, alguna ropa de abrigo y una excesiva opresión en los cambios, dimanada no ménos de la suma necesidad de los unos, que del abuso y estanco en los otros (3), absorben esa cantidad de parte de los indios, mientras de parte de los criollos la holgazanería dimanada en mucha parte de los sueldos habituales del Erario (4), los pleitos, la existencia de un sin número de asalariados, y los pocos mercaderes publicanos que siguen siempre esta clase de colonias, devoran la clemás parte, en la cual el Rey es también, como se ha visto, un contribuyente de no poca monta.

En general, el cambio de estos efectos se hace del modo más perjudicial, pero sí el único, que permiten la falta de circulación y la extrema miseria de la industria rural ó del suelo.

El que vive de su trabajo vende sus frutos al

(I) Son noticias verídicas y bien detalladas del Piloto Moraleda, comparadas con las que hemos adquirido en el mismo terreno.

(2) Bordillo es una especie de poncho más basto y angosto que los toltenes.

(3) El Intendente Gobernador Hurtado había dispuesto un Arancel para el valor de todos los géneros de importación: era justo y equitativo, pero diff́cil á llevarse á debido efecto: se ha abandonado posteriormente.

(4) Todos los soldados en Chiloé son criollos casados; sus vicios, sus ardides y los de sus mujeres, producen una nueva circulación gravosa al Erario y á la población. 
precio ínfimo que alcance, y el que por la posesión del fondo necesario para proporcionar el cambio, le prefija aquel precio, al mismo tiempo sube excesivamente el valor de aquellos efectos que le suministra en cambio. El comerciante en un país de esta especie, es un cedazo que no deja salida sino á las partículas más sutiles, y cuyos hilos puede impunemente estrechar cuanto se le antoje.

¿Quién dirá que en este comercio con Lima, que apenas absorbe cinco meses de tiempo, los géneros de Chile duplen de valor á la salida y lo duplen los de importación á la entrada? (I). Ni se crea que una navegación de esta especie envuelva crecidos riesgos, aunque la suma ignorancia de los pilotos y la mala calidad de los buques y sus armamentos hayan arrastrado pérdidas harto frecuentes. No es tampoco fundada la objeción de que la necesidad de dar fiado exponga á crecidas quiebras y demoras en el recobro del caudal anticipado: los productos de Chiloé son periódicos; luego el comercio podía ser periódico y semejante á una ó más ferias, en la cual, para mayor comodidad de los transportes y cambios, podían pactarse anteriormente los plazos y depender los precios de una libertad recíproca de contratos fundada en el valor real de cada $\operatorname{cosa}(2)$.

Los efectos de importación se reducen particularmente á génerosque llaman de Castilla, y á otros que llaman de la tierra; son los primeros las bayetas, los lienzos, la listonería de Granada, paño de segunda, papel, hilo, algunos tripes y buches, y toda suerte de quincalleria: los segundos son principalmente el tabaco, paños de Quito, pañetes, bayetas, tocuyo, aguardientes, vinos, sal, azúcar, yerba del Paraguay, añil, miel, palo de tinte, agí, jabón, sebo, poco aceite y algunas otras cosas de muy poca entidad, cuyo valor será anualmente de 60.000 pesos, precio de venta. Lo demás hasta el total del completo, compone el fondo de los empleados ó mercaderes, que unas veces entra en circulación, otras veces sale, como perteneciente al particular que lo adquirió lícita ó ilícitamente.

No es mi ánimo recibir aquí las llagas del monopolio, ni demostrar cuánto es opuesta á la concurrencia libre de vendedores la intervención en el comercio de la autoridad Real, por 10 común abusada: una traba de una Aduana, una acusación de un calumniador, una interpretación siniestra de una Real orden pueden trastornar las medidas más bien combinadas de un comer-

(r) El Arancel estableciala ganancia de 30 por 100 sobre factura de Lima: se ignora si comprendía los gastos de derecho.

(2) Véanse las distinciones del valor real al nominal en el tratado del Sr. Smith sobre el bienestar de las naciones. ciante honrado que reuniese sus ganancias lícitas con los progresos de aquella industria, y hacer triunfar el monopolio que ya en los cálculos subalternos se supone como seguro en Juan Fernández, Valdivia y Chiloé.

Se han insinuado únicamente los inconvenientes anteriores para que no pareciesen luégo extrañas ó con semblante de proyecto las proposiciones de que Chiloé es capaz de un comercio ventajoso á sí mismo y al total de la Monarquía, y que el Monarca puede conservarle si no con ventajas, á lo ménos sin recargo de su Real Erario; pero antes es preciso examinar si la conservación de Chiloé es útil á la Monarquía; esto es, si compone tal vez uno de aquellos preciosos anillos, sean comerciantes ó militares, de los cuales ha de resultar la cadena del poderío nacional.

En cuanto al comercio, Chiloé en su pequeñez abraza seguramente cuatro puntos de vista bien distintos. El comercio con Europa, con nuestras colonias de Chile, Perú y Río de la Plata, con los indios comarcanos, y últimamente el interno: se ha indicado éste en último lugar porque pende de una existencia de fondos, la que jamás puede preceder al comercio externo, principio y base de las riquezas: en cuanto á la parte militar (supuesto siempre que se dirija únicamente á la defensiva), ha de dividirse precisamente en la que mira á las potencias rivales de Europa, y en la que mira á los indios comarcanos. Es difícil determinar hasta qué punto pudiera alcanzar el comercio de Europa con la Isla de Chiloé; pues desde luego debiera absorber, no sólo todos los efectos que actualmente se extraen de Lima y que han procedido en mucha partede Cádiz, si también varias especies de manufacturas, que del mismo modo que en BuenosAires, sólo se han conocido desde que los catalanes, con considerable ventaja propia, las han introducido: tales son los zapatos, los gorros, las camisas, las herramientas, y sucesivamente varios pequeños útiles de comodidad que en el día no se conocen en un país en donde los artefactos no han logrado aún la menor cabida. En la actual balanza económica del comercio, y áun en el sistema que nos hemos propuesto de determinar á cada país de la Monarquía aquellos ramos industriales que naturalmente les corresponden, es positivo que se deja ver palpablemente las infinitas ventajas que tiene el comercio de Europa sobre el de Lima para los abastos de Chiloé. La embarcación de Europa que pagando en Cádiz un derecho proporcionado á la libertad de vender en Chiloé ó en Chile, cambie sus surtidos con maderas ú otros frutos vendibles, complete su carga con los frutos de Chile, descargue en Lima, é inmediatamente regrese á Europa, seguramente ó abaratará el comercio 
costanero del mar Pacífico, ó hará considerables ganancias, que recaerán todas sobre los fondos europeos.

No paran aquí las consideraciones relativas al comercio de Europa con Chiloé, si como más por extenso se propondrá luégo, pudiese afirmarse un comercio periódico con los Viliches, que en unas ferias bien ordenadas adquiriesen nuestros tabacos, licores, quincallas, armas, etc.: las remesas de Europa aumentarían considerablemente; y tal vez por su misma voluntad esos pueblos sacarian de la cordillera inmediata los mis mos metales que ya tanta sangre costaron á la nación que intentó conquistarla.

Si no nos engaña el semblante filosófico de unas ideas sencillas, fijadas más bien sobre el conocimiento del hombre y de la navegación, que sobre sistemas, hijos ó de un soñado poderío irresistible, ó de un celo engañoso de la religión, ó finalmente, de un cebo envenenado por la plata, ¡oh, cuánto pueden ensancharse para la prosperidad nacional las ideas que acabamos de indicar! Tal vez nos llevarían á una paz duradera y segura que no nos costase ni unas contínuas $z 0$ zobras ni el sacrificio de muchos caudales, ni, finalmente, el ajamiento del honor nacional (I): tal vez se abrirían las puertas á nuevos comercios ventajosos, y ni el Erario costearía un ejército tan gravoso como ficticio, ni concurriría el miliciano chilote á aumentar solamente su lista imaginaria á costa de mil sacrificios positivos.

Pero áun sin permitir al navegante europeo que continuase su navegación en las costas del mar Pacífico, con atención al comercio de Lima, podían tal vez un par de buques europeos, de no mucha capacidad, lograr un retorno útil para Buenos-Aires, con la tablazón y maderas grandes, que en el día, ó con muy poca ventaja se sacan del Paraguay, ó se traen del Brasil con ventaja de los extranjeros: la tabla de alerce serviría á mil usos domésticos, y particularmente á la fábrica de lọ muchos barriles que las carnes saladas y las harinas han de ocupar precisamente (2). Tal vez lograrían de una salida ven-

(I) En Valdivia, Chiloé, y á su imitación á bordo de la Descubierta, se han hecho honores de armas, y particularmente de cañón, á los Caciques Viliches, que sólo vienen á emborracharse, y que pueden dirigir, mas no enfrenar los robos que se intentan por sus súbditos sobre los nuestros. El Cacique Catiĝuala hizo alarde en su semblante de no temer el cañón que se disparó sobre el alcázar y en sus inmediaciones: preguntado si le causaría algún temor, dijo decididamente que no, y inanifestó un semblante impávido.

(2) Se ha de tener presente que la duela se ha dado como uno de los recursos para que aumente el número de los buques que naveguen desde Europa al Río de la Plata, pues como los géneros de exportación sean voluminosos, y al contrario, lo sean muy poco los de importación, no se nivelan los fletes. Esta consideración aparente hace ver cuánto es fácil chocar los intereses de unos ú otros on una grande monarquá, tajosa también lus jamones y los ponchos, siendo este último además un género que pudieran surtir con igual abundancia y bondad los Viliches: luego Chiloé puede abastecerse á precios mucho más cómodos de los efectos que necesita, puede influir en la prosperidad del continente y proveer á las colonias del Río de la Plata y del Perú, unos productos de fácil consumo, que desde luégo reemplacen las comodidades que necesitan, ya puestas á un precio equitativo, y puedan luégo dejarle un sur-plus que sirva al fondo del comercio y fondos interiores.

Crece aún la probabilidad de este aumento así en las cosechas como en los cortes y áun en los tejidos, cuando se considere que en el día los indios son los únicos que se ocupan en estos ramos, y particularmente en los cortes, siendo así que más de la mitad de la población se compone de criollos, los cuales subsisten en mucha parte, de los sacrificios del Erario. A la verdad, estos mismos criollos, áun cesadas las encomiendas, y áun viéndose descalzos, conservan al mismo tiempo tanto apego á la nobleza de sus antepasados, y tal costumbre de no ajarla con ocupaciones serviles y comunes con el indio, que les fuera harto sensible y lastimoso el verse abandonados del padre cariñoso que á pesar de su conducta é inutilidad, los ha alimentado con sacrificios considerables de su parte; pero les quedaba el recurso de la emigración al Perú, ó del servicio de armas en Chile, en el caso de que no prefiriesen el trabajo saludable de la agricultura, ó los cortes periódicos del alerce en la cordillera.

Puestos así en su balanza natural la industria, la agricultura y el comercio de Chiloé, desde luego un pequeño fondo nacional ó perteneciente á sus moradores, les diera lugar: primero, á no acelerar las ventas ó cambios, dando por consiguiente mayor valor á sus frutos: segundo, á mejorar el suelo con los desmontes: tercero, finalmente, á ocuparse de la pesca, que excluídos los pastos, y adaptado mayor terreno á la agricultura, pudiera doblar el alimento de una población numerosa: los desmontes, á nuestro entender, deben emprenderse á un mismo tiempo desde los dos extremos de la mitad septentrional comprendida entre el puerto de San Carlos y la Laguna de Villunco. Serán muy asequibles si se dirigen además á derecha é izquierda del camino de Castro, desde donde la comunicación con San Carlos y la conducción de los frutos, sería más fácil y sencilla. Pudiera destinarse un pequeño derecho sobre los géneros de ingreso para propios de la isla, los cuales al principio se invertirían de

pero aquí por ventura se disipa la contradicción, por cuanto estos buques, descargando en Buenos-Aires, ocurrirían precisamente á la'necesidad de buques vacios en aquella colonia. 
un todo en auxilios y premios del desmonte (I) dados para mayor utilidad en enseres de labranza ó industria, según la calidad del terreno que hubiese desmontado. Es probable que el núcleo ó parte montuosa de la isla, que corre inmediata á la orilla occidental, casi á lo largo de toda ella, sería bastante para abrigar la parte baja oriental, de los vientos tempestuosos del Noroeste y Oeste; no obstante pudieran también dejarse bosques en la orilla exterior para el uso mismo de los habitantes; serían un nuevo freno para los extragos de las tempestades, á ménos que no precisase también á destruirlos la continuación de las aguas en tanta cantidad como hasta aquí se ha experimentado.

Se ha hablado de la posibilidad de entablar con los Viliches unas ferias periódicas que sedirigiesen al mismo tiempo á un mayor despacho de nuestros frutos, á la adquisición de algunos otros que nos fuesen útiles, y últimamente, á una sólida unión con aquella Nación, fundada sobre la base de la tranquilidad y necesidades recíprocas: la utilidad de estas ferias ó plazos de cambio es, sin duda alguna, evidente, y sus tiempos periódicos son naturalmente los meses de verano, en los cuales la navegación y los caminos por tierra son tan fáciles como impracticables en el invierno (2). Pero no es tan fácil determinar el paraje de estas negociaciones, ni el modo de celebrarlas, pues que fuera imprudente tratar sin desconfianza á los Viliches, cuyo ánimo belicoso, excitado con las bebidas y con la mucha concurrencia, á veces los arrastraría á robar, á veces también á hostilizar.

Si en los parlamentos de Concepción, ó en los que se hiciesen en Chiloé, se especificasen condiciones claras para esta especie de negociaciones, y los caciques saliesen garantes de su cumplimiento, exigiendo particularmente que no concurriesen en demasiado número, y que se evitase todo desorden, desde luego la celebración de estas ventas sería más oportuna en Carelmapu que en San Carlos, por la concurrencia de los compradores: en tal caso se resguardarían nuestros efectos con una especie de trinchera que favorece el terreno, se prohibiría á los indios el entrar armados y el permanecer allí de noche; se les prescribiría el

(I) Debe hacerse al alto de un hombre de la raíz del tronco, al cual luégo se da un fuego leve para destruirle la vegetación: las ramas son fáciles de cortarse, y luégo pueden quemarse en pequeñas pilas ó invertirlas én carbón. El labrador de la Punta de Agui, que favoreció el robo del soldado destinado á la fragua de la Atrevida, tenía hech' por sí solo un desmonte considerable, y aprovechado el campo para semillas.

(2) No debe considerarse ó extrañarse como nueva esta propuesta, cuando se advierta que el actual señor Presidente de Chile, el Mariscal de Campo Don Ambrosio Higgins convino en su último Parlamento con los cuatro Mutalmapus que se celebraían cuatro ferias al año. acampar ó armar sus tolderías á una prudente distancia, y se guarnecería el paraje señalado, con algunas milicias armadas y áun con alguna artillería y tropa arreglada, si una corbeta ó buque menor de los de la Armadilla en el mar Pacífico combinase sus cruceros para hallarse á la sazón en el puerto de San Carlos. Este partido de celebrar las ventas en la tierra firme, nos produciría sin duda la gran ventaja de que concurriesen también las mujeres de los Viliches, las que probablemente aumentarían los cambios y harían más remotas las hostilidades.

Perosin las precauciones indicadas, y cuantas otras dicte una verdadera desconfianza, será prudente el preferir la misma ciudad de San Carlos, franqueando sí la venida de los indios comarcanos, pero en número y plazos prefijados y siempre con algunos efectos de cambio que indiquen su ánimo de comerciar: se les determinarán los parajes de su residencia, la que costearán enteramente por sí; se les hará justicia en todas las cuestiones ó disputas que presenten los contratos; pero se les vigilará de cerca y tratará casi con la misma desconfianza con que nos han tratado hasta aquí.

Dejamos á la consideración del hombre filósofo, y mucho más del nacional que recorra sus historias, el determinar hasta qué punto la rec. titud, la buena fe, el desinterés, la suposición de una verdadera igualdad de derechos, y la misma compasión hacia unos hombres entregados á sus pasiones, deben ser la guía de los que interven. gan y los que dirijan particularmente en los primeros años estas concurrencias ó mercados, y dejamos al político el investigar de antemano hasta qué punto esta idea nuestra es compatible con las verdaderas utilidades de la prosperidad nacional, único objeto que jamás debe perderse de vista.

Insensiblemente las reflexiones sobre el comercio de Chiloé, nos han llevado al examen de uno de los dos puntos que constituyen la parte militar ó defensiva, y es el que mira á los indios comarcanos; pues es evidente que mientras no salgamos de la isla en la cual está á ló ménos segura la subsistencia (si no lo está el comercio dependien ie de los cortes), ni jamás nos comprometeremos en discordias, ni habremos de temer el menor insulto, acreditando la experiencia, que la navegación será siempre el único teatro en el cual los europeos aventajarán considerablemente á la naciones conquistadas.

Luego sólo nos queda el examen de lo que pueda importar en la balanza con las naciones rivales, y este examen nos guía naturalmente á un rápido cotejo con la plaza de Valdivia. Es positivo que en el tiempo de las conquistas fué sumamente acertada la elección de aquel sitio, que reunía al mar las ricas colonias interio- 
res (I), un río caudaloso la cubría en mucha parte de los insultos del enemigo. El puerto inmediato aseguraba al mismo tiempo un rico comercio y los auxilios necesarios para una buena defensa ó una retirada segura: fuć muy luego el centro de las fuerzas militares, y la Casa de Moneda, el Obispado y su misma antigüedad, la hacían mirar como una de las colonias principales.

Es, pues, probable que reconcentrados después de mil desgracias los confines de nuestros dominios hacia el Biobio, se hubiese conocido la total inutilidad de Valdivia si acaso al mismo tiempo las irrupciones de los extranjeros por el Cabo de Hornos al mar Pacífico no hubiesen 1lamado de nuevo la atención del Gobierno hacia el Sur: se le caracterizó muy luego de antemural del Perú, y sin atender á que no estorbó jamás las hostilidades é insultos de cuantos doblaron el Cabo de Hornos, crecían considerablemente sus fortificaciones y se les honró con los nombres jlustres de Niebla, Mancera, etc. A medida que crecían las fortificaciones, fué preciso aumentar el número de defensores; y finalmente, importando la sola conservación de las fortificaciones unos gastos perpétuos, llegando á 20.000 pesos el pié de paz, y habiéndose aumentado considerablemente en la última guerra, siempre se creyó indefensa, y la total falta de víveres y su misma situación apartó de su puerto una escuadra compuesta de solo tres navíos.

Luego Valdivia es por su posición inútil para contener las invasiones de otros europeos, y en cuanto á los Viliches, es un nuevo punto en que puedan ofendernos, sitiándonos hasta por hambre si algún acaso hiciese imposible ó difícil nuestra comunicación por mar. A lo ménos Chiloé puede considerarse al abrigo de cualesquiera insultos de los indios, y lo que es más, cualquiera invasor enemigo no puede combinar sus fuerzas con los indios indicados: á lo ménos, allí no serán precarias ni la subsistencia ni los reparos de una escuadra; á lo ménos, los mismos habitadores podrán defender sus propias familias y haciendas si ellas solas fuesen capaces de llamar algún invasor hacia aquellas costas, y finalmente, la misma posición del puerto de San Carlos asegurará que se reunan todas las fuerzas en defenderle, cuando la comunicación de los muchos fuertes de Valdivia es por sí misma inasequible, ni es fácil á una embarcación evadirse en Chiloé de los tiros de la batería de Agui y de otra que se puede poner en la Isla de los Cochinos; cuando en Valdivia una embarcación que cale ménos de tres piés puede desde luego evadirse del fuego del mayor número de baterías.

¡Oh! se dirá, será luego preciso abandonar un nido importante á los buques enemigos, y

(1) Véase la Kistoria civil, por el Abate Molina. además se desvanecerán todas las ideas de economia, si en lugar de unos reparos á las fortificaciones de Valdivia, se proyectan nuevas fortificaciones para Chiloé.

Pero es fácil conocer la debilidad de estas contradicciones cuando se considere que las fortificaciones ó han de cansar caudales inmensos ó han de estar en muy mal estado al tiempo de una declaración de guerra, en cuyo caso la gente y los caudales que se inviertan entonces son realmente los útiles, no los que se hayan invertido en el tiempo de una paz duradera: además, que si abandonado el puerto de Valdivia, se supone fácil y útil para un enemigo el posesionarse y establecerse en él, ¿por qué no lo haremos antes nosotros con mucha ménos distancia y con auxilios mucho mayores?

En cuanto á las fortificaciones de Chiloé, fuéramos desde luego culpables si las propusiésemos áun cuando consideremos que Valdivia de ningún modo le abriga, y que muchas más razones harían creer la necesidad de defender á los enemigos la entrada del puerto de San Carlos, en cuanto proporcionándoles ya la misma reunión con los Viliches le franquearía áun sin esto la facilidad de mantenerse y de emplear muchos brazos útiles ó en las fortificaciones ó en los reparos asequibles de una escuadra: pero no olvide. mos en esta parte el ejemplo harto juicioso de los ingleses en sus colonias de la India Oriental: sus fortificaciones son siempre proporcionadas á las riquezas que defienden. Si se exceptuan Madrás, Calcuta y Bombay, este último defendido más bien de la Naturaleza, todas las demás factorías y establecimientos, ó están absolutamente indefensas, ó un torreón, un fuerte de madera, sólo sirven para resistir un ataque de los naturales $y$ cubrir en algún modo sus riquezas de un insulto inesperado que nunca puede ser considerable por la atención y vigilancia con que se miran recíprocamente las naciones europeas, hasta en las más remotas regiones del globo (I).

En una palabra, ó nuestros enlaces políticos y la opulencia nacional nos llevan á equilibrar las fuerzas marítimas de las naciones rivales, y nuestros navíos serán nuestros fuertes, ó no es asequible esa igualdad, y tanto más prudente será nuestro sistema de defensa, cuanto más se reconcentre en pocos puntos, capaces por sí de muchos resortes y desde luego dispuestos á cu-

(I) La defensa de Pendichey por Mr. de Bellicombe en la última guerra, consistió toda en el valor de los defensores; pues ni la mayor parte de las murallas estaban levantadas: ténganse presentes, po: nuestra parte, las circunstancias de los fuertes ingleses de Nueva Orleans, y de las islas de la Providencia; suenan rn las Gacetas de todas las naciones que tienen establecimientos ultramarinos, muchas fortificaciones que sólo sirven para hacer la fortuna del que ataca y del que defiende. 
brir la riqueza y el comercio de nuestras colonias. Así, Chiloé sólo debe tener un pequeño fuerte de madera para abrigar de un insulto la corta propiedad de los colonos, y un par de baterías volantes: la una desde luego en la Punta de Agui, que recuerden á un enemigo el riesgo á que se expone igual á lo ménos á las ventajas que se propone, pues la destrucción de pocas casas y siembras y el acopio de pocos comestibles, nunca serán bastante cebo para un invasor, ni pudieran evitarlo las fortificaciones de San Carlos, cuando advertidamente el enemigo se dirigiese, ó á los puertos de la parte meridional ó al de Castro. En esta situación, ya serán inútiles el gobierno y pié militar y político que en el día anidan la causa de tantos gastos y tal vez de no pocas opresiones. Un solo Corregidor militar, costeado, ó del derecho sobre el comercio de importación, cobrado en igual cantidad sobre factura formada en el puerto de donde salga el cargamento, para evitar guardas, administraciones $\mathrm{y}$ trabas; ó del tabaco que pudiera en tal caso continuar estancado para la sola introducción y comercio de los Viliches, serviría á mantener la dominación nacional en esta parte: la visita de un Oidor de la Audiencia de Chile ó de Lima, cortaria decisivamente todos los pleitos y determinaría los derechos de posesión de cada uno; y desterrados el papel sellado y el enjambre de Escribanos, debía el Corregidor decidir amigablemente todos los pleitos, á ménos que las partes litigantes no quisiesen, personalmente en la Audiencia correspondiente. Libres las milicias de muchos servicios harto penosos, formarian únicamente sus asambleas en la estación correspondiente á las ferias, y el aparecimiento de uno ú otro buque de la Marina Real, serviría para auxiliar cualesquiera medidas activas, si fuesen necesarias para el buen orden y seguridad de la colonia.

Finalmente, sean las que fueren las propuestas de los que han creído hasta aquí ser el único modo de aumentar el Erario, ó las imposiciones, ó unos crecidos derechos que implican siempre un nuevo aumento de administradores ociosos, nos atreveremos á asegurar al Gobierno, que la provincia de Chiloé exige muy luégo una total franquicia de tributos y derechos para beneficiar su suelo, no ser gravosa á la Monarquía, y prometer siquiera con el tiempo un asilo útil para los progresos de nuestro comercio, navegación y opulencia.

No se crea que cualquiera medida indulgen - te que se adopte para Chiloé relativamente á los derechos é impuestos, sea trascendental á otras provincias, en donde no convienen ó no pueden practicarse iguales medidas: precisamente esa provincia aislada, sin minas, y distante á muy largo trecho de la reunión de nuestros dominios, nos demostraría, si la verdadera opulencia de la matriz y de las colonias depende ó de un anchuroso comercio, ó del actual sistema de tributos é impuestos que conspira á atajarle no ménos con una comunicación coartada de los pueblos vecinos, que con una circulación estancada, escasa $y$ violenta.

En la reforma que se propone del pié militar y político de Chiloé, hay además una atención no indiferente á favor de la necesidad de abolir todas sus contribuciones y casi todos los impuestos con que está en el día sobrecargada, y es la de proporcionar un método fácil de vida á los muchos vecinos que hasta aquí se han mantenido con los sueldos y administraciones del Rey, siendo prudente y justo el no acosarlos á un mismo tiempo con la total carencia de los auxilios con que han subsistido hasta aquí, y con una dificultad indecible de inclinarse á la nueva senda que se les propone.

Se ha omitido expresamente el hablar del sistema eclesiástico de Chiloé, el cual depende en mucha parte de las misiones de los Franciscanos, costeadas por el Erario, y ya inútiles. No es nuestro ánimo ni recordar al Gobierno que existen aún en Castro (contra las últimas Reales órdenes) un convento de Observantes y otro de Mercenarios, que sólo tienen dos religiosos inútiles, ni hacerle presente que en el sistema indicado de pacificaciones, será la prueba segura de la necesidad de un curato ó de una misión el que el Gobierno no la costee, dependiendo, por consiguiente, su existencia, ó de la justa parsimonia del ministro evangélico, ó de la voluntaria contribución de los feligreses. Desde luego el ejemplo de dos siglos debe convencernos, que la conversión de los Viliches ha de depender más bien de otras causas que de la predicación evangélica, á la que se han manifestado hasta aquí enteramente sordos: así, cualquiera gasto relativo únicamente á misiones, puede omitirse con facilidad; cuatro ó seis curatos repartidos oportunamente en toda la isla, podrán ser costeados por los mismos feligreses, concurriendo últimamente las mismas cosechas y algún aumento de comercio á hacer más suave esta debida contribución para su bienestar. venidero. 


\section{Descripción fisica del terreno y habitadores de las costas com- prendidas entre Chiloé y Coquimbo.}

Si se consideran con una aunque leve reflexión el rápido vuelo de prosperidad que alcanzaron en pocos años nuestras colonias meridionales de Osorno, Imperial, Villarrica, etc., las producciones que con una mala agricultura sacan anualmente los Viliches, y la semejanza del suelo nuestro de Chile en cuanto á producciones y temperamento, debemos creer que es grande la fertilidad del terreno llano, comprendido de los $43^{\circ}$ hasta la embocadura del Biobio: terreno que otras veces regamos abundantemente con nuestra sangre, y que han sabido conservarse con una constancia poco común los habitadores primitivos.

Tampoco debe quedar duda cuando se recorran nuestras historias, que abunda en minerales la misma cordillera que fecundiza esas tierras con sus riegos, las abriga del Levante, próvidamente les refleja los rayos benéficos del Sol y proporciona á los vientos Nortes que oportunamente las vivifiquen con las lluvias hiemales.

Diferentes ríos caudalosos no sólo atraviesan casi á iguales distancias este hermoso país, si también conservan hasta la misma orilla una abundancia de árboles útiles, bien sea para el uso doméstico ó para la navegación: la cordillera suministra luégo los que fuesen necesarios de una medida extraordinaria.

O fuese, pues, cebo militar, óbien la idea errada de que pudiesen á un mismo tiempo lograrse los dones benéficos de la agricultura y los violentos de la excavación, debemos confesar que merecen mucha disculpa los que reñían con tanto valor para la adquisición de este país. Lo habitan en el día los Viliches, los Juncos, los Araucanos y los Pehuenches, todos pueblos de un mismo origen, si hemos de creer á su idioma, su fisonomía y sus costumbres; pero luégo, desunidos entre sí y frecuentemente en guerra con los mismos motivos que en todas partes suelen originarse entre vecinos.

El Abate Molina ha caractcrizado estos pueblos con muchas pinccladas maestras, que debiéramos mirar como dimanadas de una reflexión madura y cuerda, áun cuando el tiempo y la situación nos hubiesen permitido examinarlas prolijamente: así dcjaremos como importuno el comparar nucstras ideas á las suyas, refiriendo únicamentc lo que ha podido aicanzar nuestro examen casi momentáneo de los Pehuenches y Viliches, aquéllos en Santiago y éstos en Chiloé.

Los Pehuenches habitan la comarca (I) comprendida desde el fuerte de San Carlos hasta el de Santa Bárbara, y, ó sea su corto número ó bien su posición rodeada de muchas tríbus antagonistas, son naturalmente muy belicosos, y parecen haberlo sido aún antes de la conquista, en cuya época, ya por diferentes veces habían repulsado de sus tierras los invasores comarcanos.

Preguntados, á la verdad, si son de la misma especie de los Viliches, responden que no, y alegan la señal del zapato que los Viliches gastan partidos ó falto de la mitad delantera, y ellos gastan entero; pero si se comparan su idioma y acento, sus ritos religiosos, sus facciones, su arrimo á la poligamia, etc., son realmente de una misma especie, y separados tal ve $z$ por alguna revolución dimanada de los derechos de sucesión, sostenidos por diferentes partidos: este mismo principio puede haber influído en que cuanto más se enardeciesen nuestras guerras con los Araucanos y Viliches, tanto mayor fué su apego hacia nosotros, y la reunión de sus fuerzas con las nuestras; de suerte, que podemos considerarlos como verdaderos amigos, que nos han sido y serán sumamente útiles. Debe atribuirse á su corto número la absoluta oposición á la labranza, á la cual se han inclinado los Viliches. Esotros tienen muchos ganados, particularmente caballos y ovejas, y se alimentan de ambas especies, prefiriendo la yegua. E1 país que habitan es más bien montuoso, tejen la lana para sus vestidos, adquieren otros muchos efectos en los cambios con nosotros, se inclinan á la bebida; sus trajes se parecen regularmente á los nuestros.

Debe creerse que consideren unidos los Juncos á los Pehuenches, cuando los estados de Chile (2) indican la población de los Llanos y Pehuenches de $43 \cdot 0 \$ 9$.

(I) Estas noticias se han logrado verbalmente en Santiago, y con el auxilio de un intérprete del Cacique D. Francisco Carilegu, quien habiendo hecho juramento de fidelidad, en Mendoza, al Sr. D. Carlos IV, venía á mauifestarlo así al Presidente de Chile.

(2) Lista de reducciones que nos ha entregado el señor Presidente de Chile, y no habla de los Juncos. 
Los Viliches ( $\mathrm{r}$ ) entre los cuales presentamos ahora muy bien imitados por D. José del Pozo, los retratos sacados del original, del cacique $\mathrm{Ca}$ tiguala y de su hijo, conservan en todo su porte un semblante militar: y así su disciplina como el estado de la agricultura y de las mismas artes, indica en toda su fuerza una nación sociable y civilizada (2).

Estos pueblos son de mediana estatura, una fisonomía militar y ardiente, el color aceitunado, y una grande agilidad en sus miembros: distinguen nuestros Capitanes de amigos que desde muchos años habitan entre ellos, dos especies de caciques, los unos de bastón y los otros sin bastón; y parece puede muy bien entenderse esta distinción, interpretando que los unos gobiernen sólo la población que habitan, los otros la provincia ó Mutalmapu, componiéndose luégo de estos últimos el cuerpo federativo para la defensa nacional (3).

Los estados de la población de los Pehuenches atribuyen 30.000 habitantes á las provincias meridionales, contando Io.0oo desde Mendoza hasta Osorno, y.20.000 entre Pehuenches y Viliches. En este número consideran tres décimos en clase de Lanzas, ó gente apta para el servicio de las armas, que ascienden, por consiguiente, á 9.000 , caracterizados entre ellos con el nombre de mocetones. Esta clase, si hemos de conjeturarlo por los que se presentaron en Chiloé, admite aún las edades de diez y doce años probablemente; basta que puedan seguir el ejército á caballo y usar de la lanza.

Sistema gubernativo. - Bien sea entre los caciques primarios ó los subalternos, estamos seguros que este empleo es hereditario, recayendo, no obstante, antes en los hermanos que en los hijos, á ménos que éstos no estén ya en edad de aconsejar y dirigir los mocetones. Entre éstos se confunden inmediatamente los demás parientes del cacique, y por cuanto pudimos advertir, ningún derecho absolutamente les concede aquel enlace. Es grande la subordinación al cacique, y parece que consultando los adivinos el dictamen de aquél, ó más bien el de éstos, es la ley ejecutiva. Habitan unidos, $y$ naturalmente, los campos labrados y los ríos, deben ser los términos de las jurisdicciones respectivas, las que,

(I) Así de esta voz como de la de los Pehuenches y Puelches, véase el verdadero origen en el Abate Molina.

(2) Véase nuestro Diario de Chiloé, en cuyo puerto los tuvimos á bordo.

(3) El sargento Negrón, de la plaza de Valdivia, quien ha trabajado en abrir amistosamente la comunicación por tierra entre Valdivia y Chiloé, es sumamente querido en estos pueblos, ha concurrido á nuestro bordo con el cacique Catiguala $y$ nos ha referido muchas de sus costumbres. Es original suya la lista de los caciques quo pára en nuestro poder. no obstante, son causa de discordias muy frecuentes.

Adivinos y principios religiosos.-Ó sea en los delitos de la república ó en las hostilidades ya ofensivas ó defensivas, procede y áun es la norma de todos los pasos la consulta del adivino, ó á ménos que éstas no sean efecto de un arrebato, ó aquéllas no dejen en toda su luz al delincuente.

Entre los Pehuenches, consultado el $\mathrm{Ma}$ guí (I) sobre las causas de una muerte inopinada, éste inmediatamente abre el costado derecho del cadáver, y consulta el hepar ó la hiel: si ésta se halla llena y limpia, caracterizan la muerte de natural, pero si se encuentra con la bilis exaltada, inmediatamente infieren que la muerte no es natural, y en este caso deben pronunciar arbitrariamente el delincuente, el cual no tarda en ser castigado de muerte (2). En la usurpación de tierras ó agravios recíprocos, son igualmente los adivinos los que deciden del partido que convenga. No pocas veces se juntan los de una y otra parte para consultar sobre el derecho de cada uno antes de llegar á las armas: son ellos igualmente quienes después de una pérdida considerable atribuyen la causa á cualquier individuo que caracterizan de brujo ó autor del maleficio (3):

Con estos antecedentes, ya no se debe dudar que estos Magui sean temidos: que la política de los caciques procure mantenerlos siempre unidos, y que la religión de estos pueblos les dicte la idea de un principio malo, origen de todas las cosas siniestras ó favorables, según de ellas se mezcle ó se aparte.

Efectivamente, nos confirmaron unánimemente este principio religioso, y supimos que además de tener en grande concepto á estos adivinos, los mantienen del fondo público, y áun los consultan para los objetos domésticos además de los nacionales.

Sistoma militar.--Aunque estos pueblos realmente guerreros hagan consistir mucha parte de la victoria en el tesón con que pelean, la misma necesidad de ser á veces sorprendidos y á veces con fuerzas naturalmente inferiores, les ha pre-

(I) Mucho se asemeja esta voz á la griega Mavoo, que significa lo mismo, y está adoptada en el latín, español é italiano.

(2) En una nación en donde hacen mucho uso del veneno, no debe parecer absurdo este método de averiguar si una muerte es ó no violenta. Es bárbaro, sí, el método de averiguar el delincuente; pero se conoce que depende de la excesiva credulidad.

(3) Estando á nuestro bordo con el sargento $\mathrm{Ne}$ grón, los Viliches del cacique Catiguala, entre los cuales había un Maguí, Negrón les dijo que yo me haría á la vela llevándolos distantes de sus mujeres, las cuales quedarian presas de otros; inmediatamente todos miraron al adivino, el cual los tranquilizó avisándoles que no era verdad. 
cisado á usar de las estratagemas y á introducir en sus tropas un orden militar: por lo común la infantería forma un cuadro, y la caballería divilida en diferentes cuerpos, pero todos situados sobre las alas, está dispuesta á ofender al enemigo y rodearle, ó bien á cubrir la retirada de los suyos: los caciques pelean á las cabezas de sus tropas. Ignoramos si retiran sus mujeres é hijos (le modo que no las alcance cl furor de la guerra. Desde luego usan de banderas. Son sus armas, principalmente las lanzas, los sables, los machetes y los lazos: conocen el uso del fusil, pero no es comín entre ellos.

Los Viliches usan de una coraza de cuero casi impenetrable, pero parece que así la cabeza como los brazos quedan desnudos, quitándose también las bragas en ocasión de combate, porque estando mal atadas pueden quitarles el andar, si se cayesen del caballo. Los Pehuenches añaden á estas precauciones las de usar de la honda, cubrir la cabeza con un morrión guarnecido de una plancha de hierro, y alargar más la cota, haciendo también que cubra parte de los brazos.

Por lo común, concluída la refriega, hay una especie de tregua para recoger y enterrar los muertos; pero nunca se devuelven los prisioneros, de los cuales ordinariamente suelen mataise los hombres y guardarse las mujeres en clase de esclavas. Parece que hay más crueldad de parte de los Pehuenches, probablemente ó por el menor número, ó porque se crean autorizados por la amistad nuestra, á esta especie de guerra.

Vida sociable.--Ya se ha indicado, que los Viliches en esta parte exceden mucho á los Pehuenches, á lo ménos por lo que alcanzan nuestras nociones: aquellos pueblos cultivan toda especie de semillas, incluso el lino: han adoptado nuestro método de labranza con bueyes y arados y azadas; solo sí, que sustituyen en el arado unas piedras afiladas, al hierro. Comen indiferentemente las carnes ó crudas ó asadas; pero sobre todo, usan de las menestras ó sustancias harináceas, entre las cuales el maiz y la papa parecen llevar la primacía.

La misma ley de la sucesión, que indicamos, cxige la admisión de una mujer verdadera, cuyos hijos pueden mirarse como los únicos legítimos: castigan el adulterio con la muerte; quieren mucho á sus hijos; pero admiten el uso de concubinas sean éstas libres ó esclavas.

Una nación militar como ésta, naturalmente hace mucho mayor aprecio de los hombres que de las mujeres; así casi no se apercibe el doInr en la muerte de las mujeres: es, al contrario, muy grande y manifestado en muchos modos, cuándo mueren los parientes ó amigos. Esta mis- má inclinación á la guerra, hacc que el cacique scáa más respetado que el adivino, aunque éste tenga en la suerte de cada uno, tanto influjo como ya se ha indicado.

Debe depender de la idea de que la educación sea la que influya mucho en las inclinaciones, el uso singular que hay entre estos pueblos de unir ambos sexos en edad muy corta, valiéndose además, de la formalidad de que la niña destinada á la boda del hijo sea precisamente, robada á otra familia, lo que como es costumbre, jamás origina discordias: ignoramos si ha de ser precisamente legítima, y. cuál sea la suerte de los hijos ilegítimos.

Usan de la música, especialmente con trompas: nos informaron que usaban también como música de guerra, de los clarines que se le habian dado en Valdivia: son frecuentes sus concurrencias, en las cuales cantan y bailan, bien que no hemos alcanzado á comprender cuáles son estas ocasiones de regocijo.

La naturaleza y alimento de estos naturales, y el clima que habitan, los haría sin duda de una vida igualmente sana y duradera, si las guerras en muchas partes, y algún tanto las enfermedades, no concurriesen á trastornarla: adolecen principalmente de tabardillos y evacuaciones de sangre: no les es desconocido el mal venéreo; pero es probable que les haya pasado de nuestras colonias: el uso de las yerbas les es común: las infusiones son, no obstante, en agua fría, $y$ su aplicación á las heridas es bastante feliz. No conocen el arte de escribir; pero las tradiciones son bastantemente exactas. Es probable que las sujeten á lunaciones, conocidas sí, pero no combinadas en período alguno. Ninguna utilidad sacan para sus épocas, del año solar, según pudimos comprender, bien que esto se hace más dudoso y extraño cuando se advierte que un pueblo agricultor trae precisamente consigo la división de las estaciones, la cual depende directamente del período solar.

Sus manufacturas, que corresponden precisamente á los hombres en cuanto á la parte militar, y á las mujeres por lo que toca al vestido y demás usos domésticos, deben mirarse como realmente industriosas: tejen la lana en muchos modos, para ponchos, calcetas, etc.; usan de la greda para amoldar y unir el hierro; conocen los hornos; varias piedras les sirven, ya para afilar las armas, ya para amoldar los metales que usan como adorno; la suela está adoptada para zapatos, y sus caballos están regularmente enjaezados.

Habitadores inmediatos y comercio.-Conocieron inmediatamente el retrato de los Patagones, los que con justa razón llaman Pehuenches ó gente de Levante. No obstante, sólo uno de los 44 que concurrieron á bordo, los había visto: unánimes contaban que había algunos cambios entre unos y otros por un boquete de los Andes, en cuyo 
tránsito, el cacique Viliche dueño de las tierras inmediatas, había formado una especie de monopolio, no permitiendo á los demás el tomar parte en este comercio: aseguraban, los había que no podían estar á caballo por excesivamente altos, y conocieron las pieles de guanaco (I). Los Pehuenches de Santiago sólo dijeron haberlos oído nombrar. Son los verdaderos enemigos de estos pueblos, los Juncos ó habitadores de la Marina, con los cuales, al parecer, son más comunes las refriegas que con los Pehuenches: jamás, según se manifestaron, han chocado con los Araucanos.

Pasado el terreno de los pueblos que llamaremos confederados á la España y cuya población es muy probable que prospere, desde que el señor D. Ambrosio Higgins, en Concepción, y el Sr. D. Mariano Pusterla, en Valdivia, con una conducta recta y uniforme en nuestra frontera, los han inclinado á la agricultura, á la paz y al buen orden y á la imitación de nuestra vida sociable, sin mezclarse de una reducción violenta de poblaciones (2), ya se presenta el suelo bajo otro semblante: los volcanes se remueven de la orilla; las costas presentan un semblante ménos tempestuoso; una infinidad de cetáceos, al mismo tiempo le pueblan y hermosean, y la harmonía del mar se combina admirablemente con la de un suelo fértil y apacible.

Los veteranos españoles, que por tantos años habían peleado para conseguir unas tierras en las cuales todo conviclaba al descanso y á la agricultura, debieron muy luego preferir la inmediación del mar de donde esperaban contínuos socorros, á la internación hacia la cordillera donde pudieran nuevamente ver el triste espectáculo de las siete ciudades arruinadas: desde Coquimbo hasta la Concepción, muy luego toda la superficie varió de semblante: las semillas de Europa, todos sus frutos, las viñas, los olivares, una abundancia indecible de caballos y ganados, anunciaban casi con emulación, que la Naturaleza prodigaba aquí sus dones para una subsistencia fácil y tranquila. Se vieron entre los campos dirigiendo sus siembras y beneficios, los soldados envejecidos, ó en las guerras de Flandes, ó en las de Araucanos. Aún en el día resuenan en aquellos pueblos los apellidos más ilustres del Continente, y su desgracia, al decir de los mis mos ciudadanos de Santiago, es la excesiva

(I) Esta facilidad con que hablaron de los Patagones, no se puede combinar con el sigilo que guardan (según algunos) sobre la existencia de otros pueblos meridionales, y en particular de los Césares. El sargento Negrón estaba muy convencido de este sigilo: muy luego se disiparían estas dudas si con un total abandono de ideas políticas, nuestras medidas les indicasen sólo unas miras apacibles y comerciantes.

(2) En la historia del Abate Molina pueden verse los efectos de un ensayo de esta especie. abundancia con la cual la tierra prodiga sus frutos. E1 5 o por uno en todas las semillas, es muy comun de un extremo á otro de este reino feliz, á pesar de que en la Concepción llueva muy mucho, en Santiago y Valparaíso poco ( $\mathrm{I}$ ) y en Coquimbo nada.

Como quiera, no obstante, que la misma abundancia ha hecho abaratar, antes bien, envilecer de tal modo los frutos, que ya fuera de los valles inmediatos á Santiago son más bien molestos que útiles, los habitadores han debido ceñirse á una vida campestre, y no alcanzando ni las cosas de lujo, ni áun el costo de los transportes, les ha sido preciso huir de la reunión, y por consiguiente, las ciudades, ó no se han formado, ó han quedado despobladas: baste decir, que siendo la jurisdicción de Coquimbo de Ioo leguas de Sur á Norte y 70 de Este á Oeste, ó de mar á cordillera, los últimos padrones sólo indican una población de 17.200 almas, esparcidas de tal modo, que cada valle en este dilatado país, es el receptáculo de pocas familias pobres.

Se hallarian casi en el mismo estado las inmediaciones de Santiago, si no siendo éste el centro del Reino, y por consiguiente, la residencia de una multiplicidad de empleados que causan una circulación cuantiosa, no tuviese además la felicidad de abastecer al Perú con sus trigos y sebos y charques ó carnes secas. No obstante, es tanta la disparidad entre la masa circulante, incluso el producto ánuo de las minas, y los productos de la tierra, que una lista de precios medios de los principales, no desagradará tal vez al que recorra estos apuntes: nos han faltado las noticias de Concepción, bien que muy luego las alcanzaríamos, y pudiéramos agregarlas para la verdadera balanza de los precios de Chile (2).

En cuanto á la población, debemos creer, según las listas originales de algunos partidos, que es mucho mayor de las 240.000 almas entre indios y europeos que asigna D. Cosme Bueno á los dos obispados de Santiago y Concepción. Es aún mucho más probable esta aserción, cuando se considere que en los cuatro curatos de Santiago, se ha manifestado en los dos años anteriores la proporción siguiente á pesar de que los estados de

(I) Don José Perez García, quien ha continuado en Santiago la historia del Padre Figueroa, incluye el artículo siguiente: "Siempre ha padecido la jurisdicción de Santiago escasez de lluvias, pero nunca tanto en los tiempos anteriores como en el presente año de $8 \mathbf{I}$, que no llovió más que setenta y ocluo horas, cuando según los anales de los doce añosprecedentes, que de todas las lluvias lleva un curioso, el año que ménos, había llovido ciento treinta horas, que á prorata con el que más, que habia llegado el año de la avenida á doscientas noventa y nueve horas, salen un año con otro á doscientas veinte horas. Por esto en el expresado año hubo mucha mortandad de ganado.»»

(2) Esta lista puede deducirse de nuestros manuscritos correspondientes á una y otra ciudad. 
hospitales no denotan el mayor aciertoen las curaciones, siendo así que en el hospital de mujeres de San Francisco de Borja, en donde el aseo y la asistencia casi sobresalen una á otra, ha sido la proporción de las muertas con la de las curadas, como ro á 57 , en un promedio de siete años.

\begin{tabular}{|c|c|c|}
\hline Años. & $\begin{array}{l}\text { Númcro } \\
\text { de bautizados. }\end{array}$ & $\begin{array}{l}\text { Nuinero } \\
\text { de enterrados. }\end{array}$ \\
\hline $\begin{array}{l}I_{7} s 8 \ldots \ldots \\
\text { I }_{7} s_{9} \ldots \ldots\end{array}$ & $\begin{array}{l}\mathrm{SO}_{3} \\
757\end{array}$ & $\begin{array}{l}362 \\
2(13\end{array}$ \\
\hline
\end{tabular}

Las costumbres de los españoles chilenos (pues que el númcro de indios es sumamonte corto) se lian conservado en un estado que debo realmente complacer á la nación de donde derivan, una presencia y robustez realmente admirables en ambos sexos, una hospitalidad constante, un trato fino $y$ amable, un idioma castizo, unos modales inocentes y cariñosos, son cualidades casi generales, á las que añaden los hombres un talento y agilidad poco comunes, y las mujeres una buena educación á sus hijos, una fidelidad conyugal sin afectación, y una pasión poen común para la música.

Ya advertía D. Cosme Bueno, que la proporción de las mujeres con los hombres en el Chile, era de tres á uno: hemos corroborado particularmente en Santiago esta misma verdad, y desde luégo nos lo han confirmado varias personas scnsatas, dándonos lugar á asegurar que á lo ménos de dos á uno es la proporción de las mujeres con los hombres.

Pero el tiempo no nos permite entrar en aquellos detalles que requiere el examen prolijo de estos habitantes: daremos, por consiguiente, una mirada rápida á las orillas. La descripción de los minerales y de los volcanes es obra harto prolija, ni áun pudiera emprenderse sin combinarla científicamente con los que se han examinado después en el Perú.

I a ciudad de Penco, arruinada por un temhlor en 2.5 de Mayo de $175 x$, fué transferida hacia el Biohio entre dos cerros granitosos cubiertos do tierra franca, rojiza, mezclada con arenas gordas ó cuar\%uelos y otros materiales del granito que el ácido aéreo descomponc: se dejan ver algunas porcioncs del granito, que se cristalizan en esferas, dentro de su misma matriz de otro más tierno; y dehe conjeturarse que la sola utilidad de usar de la piedra para los edificios nucros, fuć la que dictó esta situación incómodá y desacra. dable.

Lin el terreno del fondo de la bahía hacia donde estaba construida la ciudad antigua, se conscrvan aúm varios fragmentos, y particularmente, una portada con las armas de la casa de Austria: las costas en su inmediación son altas y escarpadas: se componen de muchos guijarros de areniseo grises, $y^{r}$ de otros bancos de arenisco gordo, mredoso, que parce sirven de base á las rocás granitosas que componen el núcleo de este suclo: cmbutidas en estos escarpados sc encuentran unas esferas grandes de hasta cinco cuartas de diámetro del mismo arenisco que procede: en estas inmediaciones hay bancos de ticrra carga da de Ocra-ferni rojisa en capas horizontales que se rompen al aire, en fracmentos angulares, planos de tres á cuatro pulgadas de diámetro. Entre cllas se incrustan criaderos de hierro esites, y según informes, se cncuentran también minas de hivro palustri y de cobre, á no mucha distancia de estos parajes.

Al Cerrillo Verde siguc inmediatamente la Cucsta de I orgunen, y en ellat hay abundancia de guijarros, bancos de tierras ocráceas y manclas de tierras bolares color de sombra: el mar bate las playas que están al pié de estos cerros, estre llándose contra una grande peñolería de wranitos durísimos y sonoros como se dice del Saxum tintimas de algunos autores: consta de cuarzo, feldespato y prismitas oblongos de una sustancia de color argentino oscuro ó de plomo. Es parecida á este granito la piedra campana que se halla en algunos parajes de Bnenos-Aires.

Es verdaderamente singular la abundancia de excelentes mariscos que se hallan en cstas costas: sobresalen entre ellos el Pico, que es una especie de bollotas do mar, que tiene hasta cinco y seis pularadas de diámetro: el (horo, el Loco, que son especies de piñas marinas y varios erizos de cuatro y cinco pul sadas de diámetro.

En la pirte del collado que corre del morro de Talcahuano hacia el Occidente, hay canteras de Gucis de piramar micicur de esquisto negro: el terreno, en la parte superior del collado, es bastante pingüe y útil para la labranza.

Detrás de la iglesia de T'alcilhuano hay una mina de conchas, de la misma especie de los Locos: se hallan las mismas detrás del P'enco Viejo en altura de jo toosas del mar: cstán en un estado de calcinación y tan frescas, que no parece que indiquen una srande antiçücdad.

Se encuentran también en las inmediaciones de Pcneo y en el terreno intermedio entre éste y Talcáluano, bancos grandes de carbón de piedra o mina manteada, scgún la vo\% del país: es carbón fósil, arde muy bien en las fraguas y de calidad muy ventajosa.

Aunque en los valles que licrmosean estas inmediaciones, el fondo del suelo sea de arena como la del mar, algo neșruzca y por partes shorlácea y micícea, se eleva sobre ella una capa de ticrra vegetalle, cuya calidad es de las más fertiles, según lo anuncia la lozanía de las plantas y árboles que en ellil crecen.

El país montuoso que desde el mismo puerto continua suavemente hacia el Norte y se diri- 
ge también hacia el Este formando valles hermosos que llevan consigo el verdadero semblante de la vegetación más próspera, abunda extraordinariamente en maderas, las que no obstante parecen demasiado escasas de resinas para que sean útiles, como debieran, á la construcción.

El lingue, el pellin, el keule, el littre, el mañi, son las especies más grandes y útiles: su conducción es sumamente fácil, particularmente hacia las orillas del Tomé y Coliumo.

En los pasos de algunos arroyos intermedios á esas serranías, hacia la plaza de Santa Juana, se halló abundancia de cuarzo pingüe blanco en fragmentos, y en la parte que llaman Piedra Agujereada, se vuelve á ver el gneis, que parece ser uno de los materiales de estas montañas.

Desde el alto de Guanabuch se descubrían como á 28 leguas de distancia, las sierras siempre nevadas de la cordillera, y á éstas se anteponía bien visible el volcán de Tucapel.

Abandonando ya estas orillas y pasando á las de Valparaíso, se encuentra en los cerros altos que rodean la rada, una madre de granito, bordada con vetas de pequeños fragmentos de cuarzo en varias direcciones, ya verticales, ya inclinadas al horizonte: en otros parajes se encuentran yancas de greda, ya amarilla, ya blanca; la hay en algunos, bolar encarnada, y sirve para los búcaros y otras vasijas.

A medida que el suelo examinado se va apartando del mar, los valles abundan más en tierra vegetal: el mismo nivel de las tierras bajas y los muchos montes que las rodean, van elevándose considerablemente hasta terminar aquéllas en el valle delicioso del Mapocho, esotros en la cordillera majestuosa de los Andes, cuyas nieves exteriores y ricos metales interiores, descubren al mismo tiempo unos grandes objetos de cebo y de escarmiento.

No cabe duda que estas mismas ramificaciones de la cordillera, compuestas por la mayor parte de tierras cuarzosas y micáceas, dimanadas de la descomposición del granito ó de algunas variedades del esquisto y del asperón ó piedra de afilar, contengan en sí algún oro, bien que no tanto que pueda decididamente corresponder á su beneficio: parece también p:obable que los cerros aislados que se dejan ver en algunos valles y particularmente en el de Santiago, ó hayan sido volcanes ellos mismos, ó hayan dimanado de algunos volcanes extinguidos. Entre estos cerros inmediatos á Santiago, merece particular meınoria el de Santo Domingo, que provee toda la piedra para la ciudad. Estas piedras son aisladas y de tamaños enormes: se com jonen principalmente de bravalte gris, y extraidas á muy poca costa, son luégo de una resistencia grande á la intemperie.

Ya con el examen de la cordillera del volcán inmediato á Santiago y las minas de San Pedro Nolasco, se descubren nuevas maravillas á nuestros naturalistas, que exigen otro examen litológico del que permiten estos apuntes (I) y el tiempo actualmente muy limitado: nos ceñiremos, por consiguiente, á indicar que estas célebres montañas se componen aquí de hermoso pórfido de las especies más bellas que se conocen y áun de algunas de que no hay noticia. De tiempo en tiempo se descomponen muchos de sus cerros, y con sus tierras terraplenan las quebradas: otros se desquebrajan y presentan montones horrihles de grandes fragmentos de piedras, que forman rampas desde sus vértices hasta el cáuce de los ríos: finalmente, en no pocos parajes se ven frecuentes efectos de los terremotos y conmociones que agitan estos pináculos del globo (2).

No tiene menor elevación de las ya indicadas la mina de plata de San Pedro Nolasco. Sus productos han sido hasta aquí muy favorables á los que han emprendido su beneficio, cuyo detalle omitimos ahora, siendo enteramente igual al de Coquimbo y Lima: será oportuno, sin embalgo, avisar que la misma elevación, causando una respiración difícil con la refracción del aire, se deja ver á cada paso en todos los que liabitan violentamente este paraje. Pálidos, con una respiración asmática, casi desnudos, sin otro goce que el de la bebida, cansados al menor esfuer\%o: ni áun en el invierno abandonan la mina (3): se encierran durante los cinco meses de esta cstación cruel en los subterráneos indicados y prosiguen con lucesartificiales las mismas tareas que en el invierno, entre tanto que la nieve no sólo cubre la región alta, si también los valles vccinos. Cuando nieva, es precisa la contínua vigi. lancia de una centinela para que no se obture la única ventana por donde se les comunica el aire externo, sin cuya precaución quedarían precisamente sofocados.

Dejemos ya á un lado este triste espectáculo, y siguiendo la navegación, examinemos, aunque superficialmente, el suelo de Coquimbo, de cuya fertilidad interior ya se lian dado algunas breves noticias.

Al Sur de la playa de Coquimbo, y á tiro de fusil de la Bodega, se ven canteras compuestas de granito de cuarzo plúmbco y feldespato, con puntas que parecen micáceas brillantes; su superficie es llena de concavidades: su textura es lat-

(r) D. Antonio Pineda y D. Tadeo Hecnke explayan en esta ocasión una serie sumamente importante de observaciones físicas.

(2) El A rquit:cto 'Tuesca, que acompañó í D. Antomio Pincda en esta excursion, ha sacarlo vistas muy oportunas de algunos de estos derrumbos.

(3) Há muy pocos años que se ha emprendido el beneficio, también en invicruo. 
minosa; aquellas provienen de la descomposición al aire de algunos de sus mayores componentes: hay granito blanco, petro-silex blanco; el granito plúmbeo, que es sumamente pesado, se despoja también en láminas como si fuera esquisto. Hállanse también granitones blancos.

La tierra de este terreno, que se cubre de varios arbustos, es una franja amarillosa arenisca, con algo de arcilla, mica suelta y friable. La roca que compone la lengua de tierra, parece por lo greneral un granito en masa, con hendiduras en varias direcciones. Su color amarilloso, su grano cuarzo cubóide, feldespato brillante blanco, echados unos cristales sobre otros. La superficie escabrosa, y los fragmentos de la roca cubóides.

Este granito parece análogo al plúmbeo ó gris, ménos el color, que provendrá de la diversidad de matcrias metálicas. Hay otro granito parecido al que acabamos de describir, que se deshace en el aire y forma cóncavos esféricos y mechinales.

El suelo ya indicado por las tierras que le componen, produce varios arbustos, y se intercepta en parajes, por lagunas de aguas salinas, que cuando se evaporan dejan cristales de sales alcalinas que contienen también algo de las marinas, pues hierven por una parte con el agua fuer- tc, pero noafectan el gusto con sabor ácido. Esta sal cubre parte de estas marismas con una costra de algunas líneas, y presenta una superficie esponjosa. Las muchas salicornias quc aquí crecen contribuirán también á esta producción; no se ha conocido que los naturales hagan el menor uso de estas sales.

La piedra de concha se halla más de 20 varas elevada sobre el nivel actual del mar, y se distingue su formación en el puertecito de la Herradura, por la simple aglutinación de conchas y guijarros. Las playas abundan en porcelana de varias especies, en patelas con su espiral y su cámara abajo; en caracolitos buicínicos negros, con líneas blancas longitudinales; de ellos se cubren con una sobrecapa calcárea los peñascos donde se arriman á la playa.

Abundan las inmediaciones de Coquimbo de minerales ricos de oro y cobre, $y$ algunos de plata, y el de azogue de Punitaqui: ni su examen ni su beneficio han podido aún sujetarse á datos positivos: tanto la falta de principios mecánicos y mineralógicos, y principalmente la grande es case $z$ de fondos y la opresión consecucnte en que vive el minero, han concurrido hasta ahora al malogro de este suelo, cuyos productos, así en cuanto á cultivos como en cuanto á minerales, podrán con el tiempo acrecentarse mucho.

\section{Examen politico del pais comprendido entre Clizloé y Coquinbo.}

Después de las nociones que se han indicado relativamente á los Viliches y á nuestra situación política de la parte meridional de Chile, fuera cxcusado el examinar más de cerca esos pueblos, si ya no nos arrastrasen las reflexiones á considerarlos como vecinos.

Abandonada Valdivia y reducidas todas nuestras combinaciones políticas del Sur, á no salir de Chiloé sino como comerciantes, olvidando ya el caracter de conquistadores y el de introductores del Evangelio, no debíamos á la sazón considerar los naturales habitadores de la Tierra Firme, sino como personas á quienes arrimásemos ó apartásemos de nuestra colonia, según nos conviniese: pero examinando el Chile, ya se nos presenta la cuestión bajo otro semblante, bien que por ventura puesto en toda su ley por la $H$ istoria civil del Abate Molina (I).

(r) Fistán en el día trabajando en refutarle una parte considerable de sus noticias, dos hombres doctos de Chile, pero esto no influye en nuestros razonainientos, que no dependen de los detalles, sino sólo de las verdades primordiales.
El Chile es sin duda el país entre todos los que ha conquistado la España en América, que más sangre y caudales le ha costado, y ménos ventaja le ha producido: áun en el día en que una administración complicada, ya puestos en movimiento casi todos sus resortes (I) ha asegurado al Erario una renta no indiferente, todo lo absorben, ó la misma administración ó el sistema militar: su posesión es gravosa al Perú por una contribución anual para Valdivia y Chiloé: á la matriz por una emigración constante, bien que en los cálculos de emigración, atribuida ó á Buenos-Aires ó á Lima, parajes en donde desembarcan.

Empero el Chile es un país cuyos vecinos no son temibles (2), cuyos montes y orillas abundan en minas, cuyo suelo y clima son tal vez de los más fértiles y favorables á una población cre-

(I) Estancos, Aduanas, Beneficios de minas, Capitaciones, Comercio libre y servicio personal.

(2) Se ha demostrado en parte y se demostrarí luégo con mayor individualidad. 
cida: finalmente, cuyas costas, guarnecidas de buenos puertos, abren al mismo tiempo su seno á una defensa marítima, á un comercio fácil y directo, y á unas pescas tan lucrosas como abundantes.

¡Oh, cuánto esta pintura nada exagerada ha de incitarnos á examinar más de cerca los defectos constitucionales, cuya enmienda en una época en que ya la ilustración no pende de un arrimo servil á los preceptos antiguos, guíe la Nación á aquel próspero renacimiento, en el cual únicamente estriba su verdadera robustez!

Desde el reinado de D. Felipe II, nuestro sistema de la América se estableció sobre unos principios tan naturales entonces como violentos ahora. La Monarquía era semejante al minero; abandonaba un objeto de mediana riqueza por un hallazgo imaginario de otras inagotables; cada palmo de un terreno que absorbía más sangre y sudores de lo que produjese ó metales ú otras labores, parecía el cebo de todas las naciones europeas, y el objeto de una guerra perenne de parte de los naturales, cuando los europeos sólo codiciaban robarnos en un momento nuestros acopios de muchos años (I), y los naturales hu bieran cedido inmensos terrenos, y particularmente los montes por la sola libertad de vivir y trabajar á su albedrío: hubieran tal vez á la sombra de unos cambios pacíficos y sociables, beneficiado aquellas mismas minas que arrastraron nuestra ruina política y la suya natural (2), se fortalecía, por consiguiente, un terreno que al día siguiente debía propasar el ansia constante de la conquista y de la riqueza. Una Nación belicosa, viva, que seguía sus propios impulsos en lo primero, y en lo segundo coadyuvaba á la complicada situación política de la España relativamente á la Europa, debió precisamente enagenarse en la idea harto fatal de la extensión; muy luego el español, con el auxilio ó de unas marchas inauditas, ó de unas navegaciones que admiran aún en el día, vió suyas unas provincias, cuya extensión, riquezas y productos aún no alcanza á comprender; y confundido, ya con el cebo de despojarlas, ya con la precisión de aumentarlas (3), ya con el objeto de defenderlas contra un invasor, trajo en la legislación un sis.

(I) Véase particularmente la historia de los filibusteros, en la cual están exageradas, sí, las acciones de valor que hicieron aquellos piratas; mas no están exagerados ni áun individualizados los daños que nos hicieron.

(2) Sea permitida está reflexión filósófica, á quien mira desde algún tiempo con atención la constitución de la América, y ve cuánto es fácil combinar la opulencia de la Monarquía con la felicidad de los vasallos que la forman.

(3) Las marchas é invasiones dimanadas de los intereses particulares y guerras civiles, nunca se combinaron con los intereses nacionales, queáun entonces se hubieran hallado en una contradicción constante. tema político y militar que envolviese aquellas miras bajo un aspecto plausible.

Concurrían las descripciones de cada conquista recién hecha á alucinar al Monarca y al Cuerpo legislativo (I), semejante á la piedra rica que el minero presenta al que ha de habilitarle para la continuación de su juego aventurado, cada descubridor forjaba á su albedrío un semblante halagüeño del nuevo descubrimiento: se prometían las riquezas y se pedían los socorros; se prometía la felicidad de los pueblos y se notaba diariamente la disminución de su número (2).

Pero en el día, en que ha variado de un todo nuestra situación, y que ya, no temidos, ó por tal cual grado de civilización, ó por su aniquilación política los diferentes pueblos no conquistados que rodean nuestras provincias, debemos al estado de nuestra Marina la seguridad de nuestras costas, ya debemos subsanar aquellos males con el sistema político que exige nuestra situación.

Los fondos nacionales ya nos permiten una circulación periódica, en la cual, el producto de la mina se mire con igual valor que el cacao, la cochinilla, el añil, la cascarilla, etc.; un escarmiento harto dilatado nos convence que no son las minas las que constituyen nuestra riqueza, sino en cuanto la plata y el oro (3) son efectos de venta mucho más pronta y segura que los demás frutos; y que sólo el agua, el viento, la mecánica y la moderación deben emplearse en su beneficio, más bien que los brazos del hombre destinados á la agricultura y á la industria. Fi nalmente, podemos muy bien escarmentar al enemigo, no sólo con una oposición directa, si también con cebarle en unas conquistas imaginarias.

Estas reflexiones eran precisas para el examen de Chile, en cuya conquista tanto sobresalieron el valor y constancia de los guerreros y de su primer caudillo Pedro Valdivia, como eran frívolos los objetos que podían moverlos á unas guerras tan reñidas y sangrientas. Luego ese suelo de la Concepción distante de la cordillera, de modo que ni se conoce si hay minas, ni aunque las haya pueden labrarse, ¿por qué hubo de disputarse con tanta sangre? ¿Por qué las siete ciudades tan prósperas antes, y luégo tan igno-

(I) Véase la descripción de Quirós de su descubrimiento de la Tierra del Espíritu-Santo, en su Memorial al Rey $\mathbf{N}$. S., que no existe en mi poder, pero he visto en manos del Oidor actual de Méjico, D. Ciriaco González de Carvajal.

(2) Es preciso rebatir este sistema con alguna energía, porque áun en estos años, el Gobernador pasado de Filipinas ha llamado conquista la posesión inútil de las islas Batanes; ha enviado tropa adonde pedian misioneros; $y$ ha recargado el Frario con 4.00o pesos de gasto, para unas islas que sólo producirán la pérdida de algunas embarcaciones.

(3) No es posible explayar estas ideas con toda la claridad necesaria: será obra del tiempo y de la quietud. 
miniosas para el nombre español, se establecieron en parajes rodeados de un enemigo indómito, de modo que pocas minas costaron una emigración funesta de españoles? ¿Por qué, finalmente, aún en el día se proponen al Gobierno la reconquista de Osorno y demás tierras al Sur, cuando la supuesta conservación de las tierras orientales á la Concepción nos cuesta la manutención de un ejército y de muchos fuertes, en desquite de unos frutos cuya abundancia los hace perniciosos al mismo colono?

Ya se ha indicado anteriormente cuál sea la fertilidad de Chile y cuál debemos conjeturar lo sea también la del país de los Viliches; pero esta misma abundancia es perniciosa si el disfrutarla depende de una emigración, la cual, además de ser naturalmente opuesta al bien nacional, nos envuelve en unos gastos y defensas harto gravosas: esta es precisamente su constitución, si la considcrásemos bajo tres puntos de vista: I. ' Lo que influya en la opulencia de la matriz como colonia. 2. Lo que influya en la seguridad de nuestras posesiones del mar Pacifico. $30^{\circ}$ Lo que influya recíprocamente en la prosperidad de las otras colonias.

En este examen nos desentendercmos de Chiloé, que en adelante puede considerarse como una provincia separada y marítima, sujeta al Perú en cuanto á la harmonía de las medidas militares $y$ de la correspondencia mercantil: bien que en cuanto á está última hemos manifestado que sería casi ninguna, luégo que el comercio de Europa, con una navegación libre en el mar Pacífico, se apropiase el tráfico costanero y abriese una nueva correspondencia ó compensación de frutos con Buenos-Aires.

El Chilc, considerado como colonia española, se asemeja mucho á las provincias del Río de 1a Plata, y enteramente á las colonias americanas: es un país de una fertilidad extrema, de un suelo casi inagotable, de un clima verdaderamente análogo al europeo y de una posición rentajosa para su defensa; pues le abrigan la cordillera al Este y el mar al Oeste. Raya al Norte con nuestras provincias del Perú y al Sur con las tierras de los Viliches, Araucanos, Puelches y Pehuenches; pueblos ya poco temibles para. invasores, no sólo por su corto número, si también por los muchos progresos que ha hecho cn estos últimos años su inclinación á la labranza y al nombre español; pero por un acaso desrraciado, esa misma posición marítima, tin vcntajosa para su bienestar absoluto, no le permite cambio alguno útil con la matriz, apartíndole, por consiguiente, tanto de las colonias americinas y de las del Río de la Plata en sus ventijas intrínsecas, como se le asemeja en su clinu y producciones. Si la Iispaña, sobrante de ge 1.e, como lo s on la Isla de Malta, la ribera de
Génova y la misma provincia de las montañas de Santander, necesitase un país en donde con el auxilio de la navegación se aumentase el suelo á proporción del incremento y opulencia de sus habitantes, seguramente el Chile sería el país más oportuno para este objeto. Ni se nos oponga que no fué la sobrada población de la Inglaterra la que dió margen al incremento rápido de sus colonias, pues que las colonias inglesas han crecido á la verdad con una rapidez extraordinaria, pero esto ha sido al abrigo de unos privilegios y quietud constante y por los efectos de la persecución de una ú otra secta, como también por la concurrencia de alemanes, irlandeses y france. $\operatorname{ses}(I)$.

Más diremos aún. Si en el espacio próxima. mente de unos treinta años la España quisiese ver duplicar la población europea de Chile, pudiera conseguirlo demostrativamente, sólo con la introducción de una libertad política, que influye directamente en el ciudadano la idea de su sola prosperidad y reproducción.

Pero ni la España puede suministrar una emigración ventajosa, ni la excesiva población de Chile le sería útil, cuando el fruto de su suelo ó de sus brazos no suministre cambios oportunos para la opulencia recíproca. Las minas, á la verdad, pudieran aumentar mucho, y este producto (cualquiera fuese luégo su valor aumentando su cantidad en Europa), pudiera atraer una cantidad igual de frutos y géneros manufacturados del Continente; pero mientras no se gradúe en España el verdadero efecto del oro y de la plata, y mientras el beneficio de las minas dependa sólo de los brazos, séanos permitido el no considerar entre los productos de Chile sino un millón de pesos anuales, que es lo que producen sus minas, áun inclusas las de Copiapó, que muy luego demostraremos deberá pertenecer al Perú.

Ya se dijo hablando de Buenos-Aires, relativamente á sus provincias internas, que la unidad de intereses es la que debe dirigir la división de Gobiernos; y así como el sistema gubernativo de Chile haya de atender más bien al aumento de la población que al aumento de minas (2), parecía que le perteneciese cl suelo fértil que media entre los paralelos de Coquimbo y Concepción, esto es, entre los 29 y $37^{\circ}$ de latitud, para que el cuidado de las minas no fuese sino acceso-

(x) Véanse las notas del Dr. Schherson sobre los Estados de Virginia, y el examen histórico y político sobre las provincias de la América septentrional.

(2) La extracción de 1789 fué la siguiente: en doblones, 680.rg\& pesos. En plata, 291.043. 'Total, 97 1.24r. El balance del quinquenio, hecho por el Superintendente Acevedo, año de 1786 , sólo da por cantidad mcdia 521.644 pesos fuertes; pero se conoce el aumento progresivo desde que se cstableció para el rescatc la Real Casa de Moneda, y además es regular que torciesc alguna plata al Perí. 
rio, y el principal esfuerzo de la legislación sólo aspirase al bienestar de los colonos.

$\mathrm{Ni}$ se imagine que disminuyendo las minas del Guasco y Copiapó, que en el día fertilizan la Casa de Moneda de Santiago, hayan de disminuir las cantidades que hemos supuesto en la circulación de Chile. Coquimbo es capaz de un aumento grande en el beneficio de las minas, y al mismo tiempo que se dirigen las providencias gubernativas al progreso de sus cultivos, puede también progresar algún tanto con el aumento de población, en el mayor beneficio de sus minas.

Ya, pues, nuestros cálculos pueden analizarse con mayor método, y examinar de cerca cuáles son los fondos de Chile, cuáles sus efectos sobrantes, y cuáles los que necesita anualmente: para sujetarnos al mótodo prescrito, nos referiremos de nuevo á la sola España.

El fondo de circulación de Chile, debió precisamente ser considerable, no sólo por la contínua suministración de las minas, precisamente útiles en un país que por sí mismo abastecía el alimento y el vestido, si también por los gastos necesarios de una guerra casi de dos siglos, y por el aumento último de tropas y empleados por los diferentes ramos de la Administración civil y económica: proporcionándose así, que muchos poseedores de fondos pueden emplearlos en un giro prudente con Europa ó con el Perú, resulta su conservación al Reino, pues que su producto alcanza á satisfacer al lujo moderado y á la subsistencia muy barata en todo el Reino.

En el día recibe de Europa, ó directa ó indirectamente (I) (si hemos de deducirlo de los estados de Aduana de Santiago) I.052.4I2 pesos, poco más de la mitad extranjeros y la otra parte nacionales. Los satisface casi todos con el numerario y el cobre ó bien con algún sobrante sobre su comercio con el Perú: le es contraria la balanza con Buenos-Aires.

Este comercio con la matriz, debe, pues, considerarse como alcanzado á su máximo, á ménos que, ó crezca el producto de las minas, ó se sus tituyan á los actuales algunos frutos útiles á la Europa, ó finalmente, se cambien estos mismos frutos con alguna otra colonia que produzca algo que restituir á la matriz. Este último, parece precisamente el caso en que se halla el Chile: puede, abandonando la yerba, sustituirle el culen de cosecha propia, en cuyo caso será una deuda considerable con Buenos-Aires ó más bien con el Paraguay, la que sube anualmente á 280.000 pe-

(I) Se ha visto en los estados de Aduanas de Valparaíso, y se ha notado en Concepción, que los pocos géneros europeos que consumen, proceden de Santiago. sos, precio de la Aduana de Santiago (I). Puede en el distrito de Coquimbo beneficiar los azúca res, sus ituyéndolos á lo ménos en parte, á la mucha cantidad que recibe anualmente del Perú, y que asciende á más de 400.000 pesos; al mismo tiempo, suministrando á este último, no sólo los trigos, charques, sebos, cobre, comestibles, grasas y cáñamos, si también algunos efectos manufacturados que su menor abundancia de metales y la excesiva fertilidad del suelo desde luégo hacen más ventajosos, puede contraer un sur-plus relativamente al Perú, con el cual satisfacer una nueva deuda que contraiga con el Continente en efectos de lujo.

A estos objetos, debe, por consiguiente, in clinarse la legislación, favoreciendo inmediatamente la agricultura con la multiplicación de villas esparcidas en 10 interior, de modo no obstante, que la conducción de los frutos sea fácil y barata, y que se incline el cultivador más bien á los que deben extraerse, que á los que sean de consumo interno, aunque sea algo más penoso el trabajo. Bien lo conoce el actual Presidente y Capitán general de este Reino, el Mariscal de Campo D. Ambrosio Higgins: bien 10 apercibe ya en los pocos meses de su Gobierno é Intendencia el Brigadier Gobernador de la Concepción, D. Francisco Mata Linares: entrambos protegen, naturalmente, la agricultura; entrambos, en sus últimas visitas, reunjendo la equidad y la dulzura á otras muchas cualidades admirables que les caracterizan, han fundado nuevas villas, han propuesto mercados públicos y pósitos, y con medidas de esta especie harán progresar considerablemente la población (2).

Con una regular multiplicación de fondos y con el aumento de gentes, sería fácil luégo á los comerciantes de Santiago emprender por sí el transporte de sus frutos al Perú, en cuyo caso las 260.00o fanegas de trigo que se exportan anualmente á precio de Io reales y suelen en Lima valer de I8 á 20 con menor ganancia, darían al mismo tiempo un nuevo rédito, y excluirían más y más el aprovechamiento de igual cosecha en Lima, que en el día, no obstante, no puede costearse con 24 reales (3). Ahora, que la mano de obra haya de ser precisamente más barata en un país en donde es mayor la población útil, mucho

(I) Se hace esta advertencia, porque la yerba, al llegar á Santiago, entre transportes, alcabalas, derechos y ganancias del comercio de Buenos-Aires, ha duplicado su valor.

(2) Son muy defectuosos los cálculos de D. Cosme Bueno en esta parte.

(3) Hay una ley agraria en Lima, en nuestro entender no bien meditada y por ventura infructuosa que obliga á los panaderos á comprar el trigo criollo ó del país á 24 reales fanega. Los Sres. Mendiburu, de Lima, estableciéndose en Concepción con algunos fondos, y traficando con buques propios, han hecho una fortuna tan rápida como considerable. 
menor el lujo y más fácil la subsistencia, no debe dudarlo persona alguna. No sería extraño, por consiguiente, que muchos muebles, varias partes del vestido, y particularmente los zapatos, pues que los cordobanes se curten en el Maule y en Concepción, se fabricasen en Chile para Lima, que de allí procediesen preparadas las tablas de alerce para duelas, como las traen del Norte á los puertos de España, que allí se fabricasen harinas, que las mismas embarcaciones de Europa invernasen una ú otra vez, ó esperasen carga en los puertos de Chile.

Bien se deja ver que cuanta deuda contrajese el comercio del Perú con el de Chile y la satisfaciese en dinero, otro tanto ménos embarcaría aquél para Europa; ¿pero sería ésta acaso una desventaja? Antes bien, ¿no resultaria un verdadero principio de opulencia, si este dinero, dirigiéndose siempre á la matriz, vivificase en su tránsito á otra colonia?

No olvidaremos en las proposiciones que acabamos de adelantar, cuánto sería difícil, bien que no imposible, el realizarlas, y que además pudieran tal vez llevar un semblante de luchar con aquella harmonía general que nos hemos propuesto para la verdadera opulencia de la matriz con sus colonias: excluyendo ó en el todo ó en mucha parte la yerba para sustituirle el culen, se seguiría una pérdida considerable no sólo para el Paraguay que la produce, si también para el Erario, que en su traspaso cobra considerables derechos; y lo mismo sucedería relativamente al azúcar con el Perú; pero quedan fácilmente destruídas estas dificultades, cuando se considere que el Paraguay es una provincia interna, cuya prosperidad es indiferente, pues que ni debe costear su defensa, ni puede comunicarse con la Metrópoli; que el Erario cobra indiferentemente los derechos en una ú oira circulación como la haya, siendo aún esta balanza más sencilla cuanto más directo sea el comercio con la Metrópoli; finalmente, que Lima, con la inversión de sus fondos en el comercio interno y en la labor de las minas, podría conservar aquella misma opulencia que en el día la hace el depósito de una cuantiosa circulación.

Pueden aún ensancharse algo más las combinaciones favorables de Chile con el Continente, cuando se considere que conducidos directamente los efectos europeos de consumo, pudieran proporcionarse retornos completos á los buques, ó con el cobre, ó con los cueros, omitiendo usar de ellos para empaques del charque y otros muchos usos domésticos (I), ó con los productos de

(i) El señor Regente actual de Santiago, me ha asegurarlo pudieran remitirse anualmente á Europa como 30.000 cueros. Lifectivamente, la matanza de unvillus para cl charque y de vacas para el sebo y la yrasa, cs considerable. la pesca, si en la recta balanza de los intereses públicos pareciese oportuno que la navegación doméstica fuese exclusiva de las colonias como lo es del comercio de Europa.

Es imposible en el día sujetar á cálculos exactos todas las operaciones así del comercio como de la administración y defensa que mueven la circulación de este Reino: pero podremos asegurar sin recelo de equivocación, que no es tan ventajoso al Perú y al Paraguay, como es dañoso á la Metrópoli; 'que ningún aprovechamiento resulta al Erario, y sí una emigración considerable al Estado; que las mismas rentas, áun administradas con la mayor puntualidad y economía, no sufren los edificios magníficos que se han emprendido, y particularmente, la Casa de Moneda (I); finalmente, que la recaudación de derechos es muy gravosa para el progreso de la agricultura y de la población, y que es extraña en un país tan despoblado, la existencia de dos Obispos, y la manutención por el Erario de tanto número de eclesiásticos y misioneros, que pudieran vivir frugalmente de los mismos dones de la tierra, que gustosos le tributarían los feligreses.

Debe advertirse que los fondos que se han indicado como propios de Chile, son relativamente propios de la sola ciudad de Santiago, y que los dos extremos del Reino, tan abundante el uno en productos de la tierra como el otro en minas, carecen absolutamente hasta del caudal necesario para la circulación más escasa y ceñida (2).

No caben los remedios de este mal en las fuerzas actuales del Reino, pues que fueran precisos dos fondos (3); el uno de rescate de minería para Coquimbo, y el otro de Monte-pío para las cosechas de Concepción, en cuyo beneficio, no obstante, habían de comprender sólo aquellos frutos que, ó por su calidad ó su poca distancia á la orilla lograsen de una venta regular y segura. Siempre fuera oportuno que los buques de la Marina Real existentes en el mar Pacífico hiciesen escala en Concepción, y allí se abasteciesen á lo ménos de vinos para una ración diaria, cuyo importe debía descontarse del sueldo crecido de que goza el marinero en la mar del Sur; y en cuanto á Coquimbo, mejorado con algunos fondos el método de sus labores, pudiera tal vez una

(r) Su arquitectura, obra sobresaliente del señor Tuesca, merece la atención de cualquier hombre culto. Estará concluída dentro de tres ó cuatro años.

(2) La escuadra, en tiempo de la tiltima guerra, gastó en la Concepción r.300.000 pesos fuertes, traídos en diferentes años, del Perú. El país se había vivificado; la falta de comercio activo yel ningún valor de sus vinos en Lima, los han vuelto á hacer salir.

(3) Se ha manifestado cuánto importa á los cosecheros de Santiago tener un fondo, no sólo para fabricar géneros propios, si también para no precipitar sus ventas. La colonia holandesa del Cabo de Buena Esperanza, se asemeja en muchas cosas al Chile. 
reunión de accionistas del Perú dirigir sus fondos á esta nueva especulación, introduciendo metódicamente los efectos y azogue necesarios, y no permitiendo que pocos individuos concurriesen á la opresión del minero, con recargarle el valor de efectos casi inútiles.

La pesca en tal caso encontraría un objeto esencial de consumo: se sustituiría la esperma á la cera para el culto religioso, y una cantidad de grasas ó aceites proporcionaría algunos retornos útiles para la Europa, pudiendo así este útil ramo competir, aunque más distante, con las costas Patagónicas, en cuanto beneficiado de antemano el producto del mar en estas orillas pobladas, fuera capaz de unas ganancias que no permiten al otro lado la necesidad de pasar al Sur casi sin carga, y al tiempo preciso para la misma pesca.

El Sr. D. Ambrosio Higgins, con medidas bien concertadas, ha empezado ya á mover esta importante máquina, y la comunidad de Coquimbo apercibirá muy luégo este beneficio; pero si no pareciese imprudente el aventurar sin los correspondientes cálculos mercantiles algunas propuestas de esta especie, pudiéramos insinuar, que las pescas de la costa de Chile merecen la atención del Gobierno, el cual pudiera ó exigir de la nueva Compañía marítima, que dirigiese allá también sus medidas, ó permitir que la exclusiva en su favor no se extendiese al mar Pacífico, en cuyo caso pudiera emprenderse este nuevo ramo de industria por un número de accionistas ó chilenos ó limeños: un fondo de 50.000 pesos alcanzaría tal vezá estos objetos: dos paquebotes remitidos con carga desde Europa á Valparaíso y construídos en Vizcaya ó comprados á americanos con la mayor economía, costearían sobre sus fletes á lo ménos un año de manutención propia, y su primer costo y habilitación no excedería de 20.000 pesos; otros I5.00o se destinarían á la construcción de las lanchas en el Coliumo, San Vicente y Tomé, puertos inmediatos á la Concepción: bastarían 5.000 pesos para clavazones, lonas, herramientas y aperos de la pesca: los otros Io.00o costearían las sales, almacenes y jornales necesarios, bien que en unos países, en los cuales los comestibles son de una abundancia excesiva, la marinería natural y mucha europea desocupadas y casi aburridas de la facilidad ociosa del alimento, que luégo no les suministra medio alguno para vestirse, y cebar sus ideas de lujo, vicios, etc., se proporcionaría sin duda la adquisición de víveres, maderas, gente y áun almacenes, sin la menor anticipación de fondos.

Los puntos de la dirección debían ser el Tomé en la bahía de Penco, y el puerto de Coquimbo. Por ventura, dos sujetos igualmente hábiles, activos $\mathrm{y}$ honrados, pudieran encargarse en ambos parajes, de esta dirección: D. Agustín
Ferrer ( $\mathrm{I}$ ), en el Tomé, y el Teniente Coronel D. Tomás Shée, en Coquimbo (2). Los paquebotes se ocuparían de la pesca de la ballena en alta mar, y harían un viaje á Juan Fernández en busca del bacalao y congrio que allí se pescase: entre tanto, las lanchas repartidas desde Copiapó á la Isla de Santa María se ocuparían, ya en las pescas de los mismos róbalos, congrios y corvinas, ya en el beneficio mismo de las ballenas, de las cuales está llena la costa, particularmente hacia Concepción.

El róbalo y la corvina se venden en Concepción á las embarcaciones de Lima, de seis á ocho pesos quintal; pero si se atiende al informe del Cabildo de Copiapó, dado al señor Presidente Higgins al tiempo de su última visita, el congrio comprado á los pescadores sobre precios muy bajos y en cambio de efectos bien recargados, como el mate, la harina, el trigo y el aguardiente, transportado luégo, suele valer en Potosí, Santiago y Lima sobre 30 pesos quintal. En Coquimbo mismo no baja de I6 á I8. Bien se deja ver con cuánta ventaja de precio pudiera beneficiarse en Juan Fernández y rescatarse en cambio de efectos útiles á aquel presidio.

Pero es tiempo de abandonar las ideas económicas, en las cuales hemos procurado demostrar, que Chile espera su incremento de la agricultura y la pesca más bien que de las minas, las cuales no deben por consiguiente fomentarse de parte de la legislación, siempre que envuelvan el menor sacrificio de gente útil, que ambos objetos pueden proporcionarle un comercio ventajoso con la Europa; pero refluyendo los frutos de la agricultura sobre un nuevo débito del Perú que debe satisfacer en dinero sin daño propio, no obstante, ni de su comercio con la Metró-

(I) Don Agustín Ferrer, Teniente Corregidor del Tomé, de quien hablamos ya en la Memoria del Río de la Plata, es un verdadero Patriarca que mantiene en la mejor harmonía y subsistencia, sobre 260 vecinos, extendidos desde el Coliumo al Tomé. Le obedecen como á un padre: les habla y corrige más bien como hijos que como súbditos: les dirige sus labores, emprende cortes, siembras y pescas para que semantengan sinvicios; y el cenar con él entre marineros, labradores y peones, ha sido uno de los instantes más agradables que han tenido nuestros Oficiales. Este buen ciudadano es natural de Granada.

(2) En D. Tomás Shée, Oficial que fué del regimiento de Irlanda, destinado á un corregimiento del Perú y luégo empleado en Chiloé en tiempo de la última guerra, brilla el verdadero filosofo. En un clima de los mas placenteros, entre una familia que no cesa de multiplicar y quererle, con una salud robusta á pesar de una edad bien avanzada, ve crecer sus rentas con el bien general; y ya sembrando ó plantando, ya introduciendo nuevos riegos, y ya promoviendo la pesca, coadyuva en mil modos á la Naturaleza y éstale corresponde no ménos con sus dones muy amplios, que con el semblante risueño que le presenta. Es inútil recordar que ha dejado toda idea de ambición, ciñéndose únicamente á la de ser feliz y hacer á otros felices. 
poli: que la división natural de este Reino relativamente á sus miras económicas, implica que Copiapó se agregue al Perú, haciéndole, por consiguiente, un país de minas, sin mezclarse otra industria ni agricultura: que para acopiar los fondos necesarios al establecimiento de esta prosperidad, sea relativamente á la agricultura ó á la pesca, se necesita inmediatamente, ó una concurrencia de fondos de Europa por medio de la Compañía Marítima, ó una apertura de acciones en el Perú y Chile para Bancos correspondientes á una y otra industria: que el Gobiemo no debe tomar en estos objetos más parte que la de las franquicias, poniendo estos establecimientos tiernos al abrigo de la complicada administración subalterna de la Hacienda: finalmente, que en el permiso de conducir directamente á Chile los géneros de Europa, y áun la yerba desde BuenosAires, sin conceder franquicias al paso por esta última colonia (I), se logrará que en los cobres, en la plata, en los infinitos productos de la pesca y en la manutención económica de los armamentos, consigan sus retornos varios buques que anualmente transiten por el Cabo de Hornos al mar Pacífico, con cargas para Chiloé, Valparaíso y Coquimbo, inclusos los azogues, ferreterías y mil otros útiles para el beneficio económico de las minas.

Examinemos ya atentamente el estado militar, el cual nos lleva directamente á la Concepción de Chile, único punto que hasta aquí se ha considerado como igualmente expuesto á las invasiones de los indios comarcanos y de las naciones rivales europeas. A este fin ha sido siempre aquella ciudad la residencia del Maestre de Campo ó segundo Jefe militar: lo era antes por seis meses del mismo Capitán General; y toda la tropa veterana en un número no indiferente, sostenida de un cordón de pequeños fuertes y de algunas baterías á la mar, parece asegurar á la Monarquía la posesión de unos dominios que á la verdad no le son muy útiles (2), pero le han costado hartos sacrificios de sangre y de caudales.

Si debemos creer á nuestra misma experiencia, y particularmente á todo lo que pasó en el último Parlamento de $\mathrm{I}_{7} 84$, en el Valle de Lonquilmo, ni puede ya haber una confederación militar entre todos los indios comarcanos, particularmente apartándose tanto los intereses de los pehuenches, de los Juncos y Viliches, y entre

(I) Ya todos los comerciantes de Chile piden la remesa de los géneros de Europa, por Valparaíso con preferencia á Buenos-Aires, por lo que se ajan y pierden de su vista y hermosura en el transporte de las carretas. El malogro de éstas y de algunos paraguayes, no sería finalmente un mal considerable, como se ha indicado.

(2) Se habla del territorio í Obispado de la Concepción. estos mismos, los de unos con otros; ni nuestras enemistades recíprocas tienen ya el cebo que tuvieron en tiempos pasados, el de un ciego empeño por nuestra parte, de avasallarlos: el de una obstinación perpétua en ellos en resistirnos, y final. mente, poner un término á nuestras conquistas (I). Luégo que una disciplina bien ordenada en nuestras fronteras les ha asegurado no tanto de la conservación y existencia de nuestras fuerzas, que ya conocieron y no temieron mucho más considerables, como del pacífico sistema que en el dia se ha adoptado, han dado todas las señales de sumisión y de amistad, que pudiesen combinar con su libertad moral; se han estrechado con algunos de nuestros Capitanes de armas, como no abusasen de su imaginaria autoridad; han condescendido á un comercio recíproco; nos han hecho repetidas veces jueces de sus pequeñas desavenencias; finalmente, abandonando casi de un todo su vida militar, se han inclinado más y más á la agricultura, y probablemente lo apercibe el aumento de su población.

Pero, ¿á qué engañarnos aún en nuestros cálculos políticos con una dominación imaginaria? ¿Por qué intentaremos suponer que los indios comarcanos sean súbditos de la Monarquía, cuando la manutención de fuertes y tropa en la frontera, denota que los tememos: cuando los regalos casi diarios, las súplicas, los sufrimientos y los honores que les tributamos, todo convence que su amistad nos es necesaria? En tal caso pueden ya revivirse nuestras ideas sobre el comercio de Chiloé, haciendo que este enlace tan útil como poderoso, sea el único que en adelante nos reuna á esos pueblos, más bien que una mezcla de soberanía y humillación incapaz de un sistema uniforme, y tan varia como los genios, ó pávidos ó altaneros que la dirigen y manejen; podemos, sobre todo, paulatinamente, descender al examen de los gastos enormes que causa el pié de tropa existente en Concepción. Esta provincia, cuyos frutos por falta de salida no tienen valor alguno, cuyos habitadores son pocos y ceñidos á sus haciendas por falta de aquellos recursos que deben precisamente acompañar la vida sociable, no reditúa al Erario, áun después de la administración más económica, sino de I 6 á I8.00o pesos, cuando los gastos ascienden hasta I 50.000 (2). Este desnivel del Erario es tanto más de advertirse, cuanto menores son las ventajas que produce.

Es difícil indagar el verdadero plan que se propuso el Gobierno en el establecimiento de los diferentes fuertes que en el día forman las fronteras: parece increible que intentasen cubrir con

(x) Véase la Historia civil, del Abate Molina.

(2) El Excmo. Ulloa cuenta por menor hasta 160.87 r pesos fuertes. Véanse sus Memorias secretas. 
ellos pocos campos sembrados, que no ofrecían al indio invasor otros productos que los que él tenía en sus campos; no parece tampoco probable que esperasen de los indios más que correrías, las cuales, de ningún modo pudieran concretarse ni con una doble línea de fuertes: estos mismos necesitaban un contínuo gasto para su manutención, y los temblores los amenazaban cada clía de una ruina irremediable (I). Finalmente, sólo pudieran idearse cuando la comunicación de las siete ciudades hacía preciso el defender palmo á palmo un terreno por tantas partes disputado de unas naciones igualmente unidas y belicosas.

Pero en el día, en que debemos estar conven. cidos que la economía es el brazo principal de nuestro sistema, hemos de graduar precisamente nuestras fuerzas con lo que hayamos de conservar, y no empeñarnos en la defensa de unos terrenos que nada valen, sólo porque fueron nuestros y pudieran quitárnoslos de nuevo: supongamos por un momento una invasión de los indios: en este caso, ó es menester reforzar cada fuerte con un aumento de gente y municiones, ó deben abandonarse unos para resistir en otros: si lo primero, no es asequible contra unos indios cuya invasión ha de ser momentánea y sin atención á derecho de gentes, ni de la Concepción pueden enviárseles socorros sin quedar desierta la ciudad misma: si lo segundo, más vale abandonarlos ahora y no encenagarse en nuevos gastos: aunque el Erario se destruyese en el solo objeto de las fronteras de Chile, no nos queda duda que siempre nuestro número militar fuera inferior muy mucho al de los enemigos; luego si además de esta ventaja les concedemos la de desunirnos y la de cubrir un país inmenso con pequeños cuerpos arraigados á uno ú otro punto, ¿cómo pretenderemos vivir en aquella tranquilidad económica, á la cual precisamente debe dirigirse un sistema que haya de ser permanente? No desaprobaremos la existencia de un cuerpo militar en Concepción, pero sea éste reducido al solo cuerpo de Dragones, los cuales, reunidos y ejercitados á usar de la artillería entre sus formaciones, puedan marchar inmediatamente á donde convenga; y entre tanto el Biobio, tantas veces perdido y tantas ganado, sea nuevamente nuestra barrera defensiva, pues en balde nos esforzáramos á tener un cordón al Sur de este río, cuando no hay puentes ni áun barcas que proporcionen, ó la remesa de un nuevo socorro, ó una prudente retirada. Al mismo tiempo procure combinarse una prudente defensa de la misma Concepción, asegurando los dos altos inmediatos

(r) Los temblores del r 9 y 20 de Marzo de este año de 1790 , han hecho considerables extragos en algunos de los mismos fuertes de la frontera. con dos baterías cubiertas, que crucen, si es posible, los dos frentes de la antigua ciudad: en el caso de un ataque, sea siempre la posición de nuestro cuerpo de defensa en la misma ciudad, cubriendo las familias hacia el río y haciendo frente hacia el Nordeste, resguardadas las casas y calles con palizadas, etc., que resistan un asalto: finalmente, procuren reconcentrarse en la misma ciudad los pocos bienes que posean estos colonos infelices: su mayor daño fuera que pensasen en defender sus tierras, y no viniesen inmediatamente á la capital para coadyuvar todos juntos y con un sistema bien dirigido, á la defensa ver. dadera de la provincia.

No obstante, no aconsejaremos que esta novedad ó abandono se haga en modo alguno que llame la atención de los vecinos : creemos inútil pactarlo, á ménos que algún Parlamento casualmente no lo proporcione; parece pernicioso el hacerlo de un golpe, pues en tal caso pudiera infundir en los vecinos, siempre atentos á nuestros pasos, ideas ó de temor ó de insidia de nuestra parte; pero sí podrá abandonarse, ya uno ya otro fuerte, á medida que se vayan arruinando; y entre tanto disminuir de tal modo el número de sus guarniciones, que sólo haya seis ú ocho hombres en los fuertes interiores, quedando siempre los últimos áevacuarse los fuertes más inmediatos al mar, y por consiguiente, á la Concepción. Este solo partido trae consigo la reforma de la mitad de los gastos actualmente inclusos en la cuenta terrible de la Concepción, pues toda la infantería debería en tal caso reformarse.

Pero ya no merecen mayor examen los pacíficos poseedores de un terreno fértil y vasto: veamos ya cuáles serían las miras de un invasor europeo.

Desde luego no serían otras que las de saquear el país, ó tal vez ocurrir á la escasez de víveres: nunca pudiera llevar las miras de un establecimiento, porque inmediatamente su situación sería tan precaria como lo es en el día la nuestra; antes bien sería peor, porque á nuestras fuerzas marítimas que viniesen á desalojarlos se agregarían inmediatamente las milicias, que con otra especie de guerra, con unos ataques casi diarios, y con un conocimiento extraordinario del terreno, harían una guerra casi irresistible.

En una invasión enemiga, que las fuerzas marítimas no puedan resistir, parece lo más prudente el no oponerse directamente al desembarco, ni jamás presentar el frente al enemigo, á lo ménos en mucho número: las escaramuzas y las retiradas oportunas, el atacar de noche más bien que de día, el convidarle más bien á que se divida encontrando un terreno vasto sin obstáculos, que á permanecer unido, viendo al frente el enemigo, son obstáculos que darán la victoria 
algo más tarde, sí, pero mucho más segura y decisiva.

Que el enemigo, aunque sea con una embarcación pequeña, no desembarque en nuestras costas entre Chiloé y Coquimbo, parece imposible conseguirlo por medio de baterías y tropa arreglada. Dando una mirada á la vasta comprensión de estas costas, á los muchos puertos que encierra, y á las islas de la Mocha, Santa María y Juan Fernández, en las cuales puede no sólo desembarcar si también anidarse, debemos deducir dos consecuencias útiles para nuestro sistema económico, y son; I. Q Que no podemos evitar que el enemigo desembarque en estas costas, y que áun estableciéndose en ellas, no nos conviene sitiarlo ó combatirle á cara descubierta, pues son demasiadas las fuerzas de una tropa hambrienta y disciplinada para que las contrarresten unos soldados y milicias sin disciplina, acostumbrados á la opulencia, y que no olvidan sus familias, su quietud y sus campos. $2 .^{\text {a }}$ Que la defensa esencial de nuestras colonias pende de la conservación de una ú otra ciudad, no del inmenso territorio que les corresponde: todos los corsarios que han recorrido estas costas, nos manifiestan que su ánimo y su necesidad siempre fueron dirigirse á una ú otra colonia para saquearla, y jamás pensaron en buscar para sus desembarcos un terreno desierto, ó para sus insultos un país interior (I).

Luego ó no defendamos las costas mientras la pobreza de nuestras colonias marítimas no las haga un cebo al enemigo, ó descendiendo á éstas la opulencia de las colonias internas, varíe nuestra constitución, y por consiguiente nuestro plan de defensa: una colonia marítima opulenta, exige á la verdad unas fortificaciones que la sostengan, así porque no es fácil reunir las fuerzas con la misma celeridad con que se esparce y desembarca un invasor, ligadas, por otra parte, las fuerzas marítimas con las de tierra, como porque los mismos objetos de opulencia que la rodean, le constituyen los gastos y los recursos para una buena defensa: una colonia interna, al contrario, cuyos ataques ya no son sino de la mitad de las fuerzas, pues se frustran en estos casos todos los auxilios de la escuadra que condujo al invasor, debe fijar su defensa en una guerra abierta y defendiendo en cuerpos suel tos el terreno, de modo, no obstante, quc sus retiradas vayan siempre convergiendo á un mismo punto, el cual se elegirá en una posición militar, que no permita, mediante las ventajas del terreno, el adelantarse sin un ataque de las mayores desventajas, dilatado por otra parte de unas marchas penosas, de un ticmpo precioso y de unos gastos enormes cuan-

(i) Palmestron y Simón Des-Cordes, en Chiloé; Sparhs, en Coquimbo; Enrique Clerk, en Valdivia. do se refieren á la utilidad que han producido (I). ¿Pero qué es lo que emprendemos defender en la Concepción? ¿Cuáles medidas económicas, áun diré, mezquinas, alcanzarán á poner los gastos de una defensa en el preciso nivel con las ventajas del territorio? Son tan cortos los caudales y riquezas de aquel país, que pocos momentos bastan para examinarlos hasta Santiago. Es tan corto y mezquino el beneficio de la tierra en las labranzas, que podemos decir que ella misma brota los frutos y que un sólo año basta para reponerla. ¿Será acaso el puerto el que intentemos defender? Coronemos luégo de baterías, no sólo toda esa gran bahía, si también los puertos del Coliumo, San Vicente é isla de Santa María, desde los cuales en pocas horas, hasta la artillería ó por tierra ó por el Biobio puede conducirse á la Concepción.

Despoblemos la España, agotemos el Erario, todo concurrirá á demostrar que la invasión momentánea no puede contrarestarse, y que la duradera no hallará sus verdaderos obstáculos sino en la guerra abierta, la cual, por otra parte, se nos hace necesaria en cuanto no absorbe otros caudales que los del momento en que se ejercita (2).

Esto no obstante, ya que la vigilancia conque debemos vivir para con los indios comarcanos (á lo ménos mientras que esta especie de guerra no se represente bajo sus colores verdaderos en nuestra España) nos obliga á mantener un pié de tropa, consideremos en adelante este terreno como un puerto de defensa nacional; pero ni se crea ésta precisa, ni sea tan terca y reñida que refluya luégo en la mengua de fuerzas para la capital, adonde en la realidad ha de explayarse toda la actividad de una guerra reñida.

Desde luego inferimos después del plan propuesto, que las milicias en todo el Chile son las que han de coadyuvar á la defensa verdadera, procurándose, por consiguiente, que uno ú otro Oficial veterano, ó como cultivador ó como Jefe militar ó político, resida en paraje en donde sea fácil la reunión de las milicias y la combinación de un plan antes meditado (3). Que se ha de

(I) En el ataque y toma de Manila por Mr. Draper, se conoció la ventaja y necesidad de la guerra abierta en el propio país. La plaza se tomó en un momento; pero luégo el país se defendió tan oportunamente, que ya al concluirse la paz, los mismos ingleses se veían precisados á abandonarlo.

(2) Las reflexiones de los Excmos. Ulloa y Juan en sus Memorias secretas, apoyan las nuestras. Demuestran la poca utilidad de las baterías de Penco y la facilidad de un desembarco en el puerto de San Vicente, ó una escala en la Isla Santa María.

(3) Don 'Tomás Shée en Coquimbo, es el verdadero modelo de esta especie de militares: la historia del Norte-América los manifiesta en tanto número, que la multiplicación de los Cincinatus no debe parecer extraña. 
fomentar la multiplicación de caballos, y no ha de haber miliciano que sirva á pié; que con el motivo de algunas ferias, fiestas ó diversiones han de reunirse anualmente estos pequeños cuerpos, procurando sus jefes en estas ocasiones cautivarse su amor; pero no siendo posible ordenarlos como regimientos, cuyo número, disciplina y manutención, piden ya otras medidas que las que alcanza la simple milicia; que de ningún modo se excluyan el poncho, el uso del lazo y del alfanje; podrán agregárseles las pistolas, pero jamás la carabina ó fusil; que en uno ú otro paraje interior y desde luego en la Concepción, se deposite alguna artillería de campaña con sus cureñas y carros municioneros, dispuestos de modo que puedan seguir la milicia á caballo; agregán dose á estas prevenciones las de la madera, pernería y jarcia oportuna para formar planchas de artillería en los muchos ríos que haya que atravesar para buscar ó para evadir el enemigo; que no se influya una especie de aborrecimiento al servicio de la milicia, con distraerla en otros mil objetos extraordinarios, ó contratarla en sus penosas tareas como una tropa asalariada, debiendo comprender evidentemente que el Rey no exige del cultivador más de lo que le exige su bienestar; esto es, la defensa de su país, en mancomún con los del distrito embestido: finalmente, que no sea el Erario, sino las comunidades, que ocurran á estos acopios, dando el Rey tan solamente la artillería en la orilla del mar (I). Si aliviado el Rey de unos gastos harto enormes de defensa, cediese luego á esos pueblos alguno de aquellos impuestos, que nunca útiles, á veces perniciosos á su Erario en los países pobres y dilatados, siempre son el instrumento de la opresión del vasallo y de los vicios del opresor subalterno, tal vez vería esta parte de sus dominios persuadida de poder por sí sola contrarestar las invasiones comunes, segura del auxilio del Monarca con sus fuerzas marítimais en los casos extraordinarios, y cebada en su agricultura, en sus pescas y en el beneficio de sus minas al abrigo de un comercio próspero y arreglado contribuir considerablemente á la prosperidad de la matriz, sin faltar al debido alimento del Erario (2).

Omitiremos ya el hablar de Coquimbo, el cual, en cuanto á defensas, no ha ocupado hasta aquí el menor sacrificio del Erario, ni debe ocuparle en lo venidero, según el plan propuesto:

(x) Los pedreros y trabucos son también armas muy útiles para la defensa del país propio, en una casa, iglesia, molino, etc.

(2) Puede asegurarse que ni en Concepción ni en Cocquimbo producen las administraciones la menor ventaja, cuando en Valparaíso, pueblo de alguna opulencia y de una concurrencia considerable de buques, demuestra un balance desde i 780 á 1784 , que sólo resultan en cinco años á beneficio de las cajas, 7.094 pesos fuertes. sólo sí que en el caso de ser ó el paraje de concurrencia de muchos buques mercantes, particularmente en el invierno, como lo es en el día Valparaíso, se asegure en tiempo de guerra el fondeadero con una ó dos baterías artificiales, ó con una embarcación de guerra que les dé al mismo tiempo convoy, pero de ningún modo debe emplearse en la menor cantidad en tiempo de paz, antes bien, verlas arruinar con aquella indiferencia que trae consigo un sistema fundado sobre principios inalterables.

No es nuestro ánimo, hablando de las reformas oportunas y casi necesarias, hacer penetrar la pluma al examen del sistema legislativo, el cual nos guiaría tal vez á demostrar, que en la extensión y multiplicación de Audiencias tuvo la legislación más bien por objeto el contrarestar la autoridad militar, que el administrar una justicia fundada. La historia interna de nuestras Américas, la sola parte de las últimas revoluciones de la America meridional, que ha podido alcanzar el público, tal vez lo evidenciaran más bien que cualesquiera razonamientos; nos contentaremos ahora de manifestar que caben muchas reformas en la administración de Chile, sin que menguie la autoridad Real, y al contrario aumentando considerablemente la prosperidad y nervio de los vasallos y su amor al Soberano y á la constitución que los gobierna.

En cuanto á la existencia de una escuadra para cubrir los puertos de Chile en tiempo de una guerra, la creyéramos útil si pudiese combinarse al mismo tiempo la defensa del Perú, como se proyectó en la última guerra: pero cuando se considere que puestas en un regular estado de defensa nuestras colonias, sólo debemos abrigarlas del apercibimiento de un corsario, siempre temible, reservándonos á enviar igual número de bajeles cuando una prudente cautela nos indique que el enemigo piensa pasar áaquellos mares (I), ceñiremos el pié de guerra en el mar Pacífico á un solo navío de 74 y cuatro fragatas, todos buques sumamente veleros, y confiados á Oficiales de la mayor actividad, unión y economía. Estos deben estar en un contínuo crucero, carenar si fuese posible y necesario en el puerto de San Vicente, proveerse de víveres, incluso el vino, precisamente ó en Concepción ó en Coquimbo, y permanecer en este último puerto como de invernada. En dos divisiones mientras no haya cnemigos, recorrerán periódicamente la costa desde Chiloé hasta Lima, protegiendo la pesca, el co. mercio costanero y la tranquilidad pública, con aquel vigor que tanto trasciende al bien general, pudiendo cada división dejarse ver descansada mente, á lo ménos dos veces al año en cada paraje:

(I) Este era precisamente el caso de las escuadras infelices de los Almirantes Anson y Pizarro. 
apartarán así todo corsario ó contrabandista, y en el caso de una invasión no prevista, concurrirán inmediatamente á la defensa de Lima, con sus gentes, buques y artillería.

Pero quien se interese en el bien nacional, no pucde ménos de recordar al Gobierno que la escuadra fondeada en T'alcahuano en la última guerra, seguramente no abrigaba las costas de un solo corsario, á quien no hubiera podido alcanzar, y al mismo tiempo perdía mil ocasiones oportunas, no sólo de destruir en Macao todo el comercio inglés de la China, quemando y varando sus buques, si también de decidir luégo en la India la balanza en favor nuestro, reuniéndose al Bailío Suf-Crein, con una fuerza considerable de grente y de pertrechos (I), y obligar á los enemigos á que en los años siguientes, ó abandonasen el comercio de la China con un daño indecible, ó empleascn crecido número de buques de guerra en su defensa sucesiva: supuesto, pues, que cualquiera otra guerra nacional haya de ser precisamente con la Inglaterra, será éste un golpe de mano que deberá seguir inmediatamente á las noticias de la rotura, que no es preciso consultar con nación alguna aliada, y que el mismo Virey del Perú puede poner en práctica con una parte de los buques del comercio, armados en guerra, si el temor de que lo penetrasen con tiempo hacía difícil el desfilar algunos buques de la Marina Real al mar Pacífico: ni se aleguen las dificultades del derecho de gentes con los portugueses ó chinos, las fortalezas de Macao ó el número de los buques mercantes: todo es frívolo para un Oficial que sepa dirigir esta operación, graduar con realidad los peligros, y sobre todo, evitar la confusión de las lanchas incendiarias, en las cuales, no obstante, sería preciso disponer Oficiales de inteligencia y reflexión para apartar el daño cuanto fuese posible, de los demás buques.

Ultimamente, ya que hemos hablado de las carenas en el puerto de San Vicente, inmediato á T’alcahuano, añadiremos que á la verdad puede ser probable que las maderas de los bosques contíguos á la Concepción (2) no tengan aquella cluración que se cree necesaria: pero que la tendrán seguramente las maderas de la cordillera, que con consentimiento de los Araucanos y Pehuenches, y tal vez con los mismos enlaces benéficos del comercio, pudiéramos conseguir por el Biobio hasta el mismo puerto (3).

1) Este pensamiento, que sólo se apunta superficialmente, debe hacer comprender, que bien dirigida nuestra Hacionda y fijarlo á pocos puntos nuestro sistema de defensa de la América, las fuerzas de una Nonarquia como la española son muchas é irresistibles.

liste es el parecer de D. Antonio Cazulo, Ingeniero carpintero en Lima.

(3) l'articularmente los pinos y cipreses para ta blazone's y haos: las ligazones son muy buenas á lo
Ya se han construído en él buques de mucho porte, entre otros el San Migucl, de 60 cañones, Los Angeles y otros chicos, todos del comercio de Lima: no faltan peones, cuyo jornal es sumamente corto, mucho más si se envuelven en la ración mensual, tabaco, yerba y aguardiente: los obreros, sean carpinteros ó calafates, pueden conducirse: pueden llevarse también todos los utensilios, sean clavazones, fraguas ó herramientas: pueden aprovecharse las tropas de Concepción en clase de peones, y conservarlos así en una vida activa: finalmente, puede establecerse un sistema de construcción que resista tal ve $z$ al sin fin de abusos fáciles de deslizarse en la América en cualquiera proyecto, áun el más bien combinado.

Sin embargo, no es nuestro ánimo proponer directamente una construcción en el puerto de San Vicente, por cuenta del Erario: sólo sí pudiera por el señor Gobernador Intendente, tantearse un contrato con los Araucanos, para que reunidos con algunos hacheros españoles, proveyesen unas ú otras cantidades de madera: se les darían, en cambio, utensilios de labranza, algunas armas, varios adornos, algunos ganados si los quisiesen, y cualesquiera otras bagatelas, incluso el aguardiente, que más pudiesen ocurrir á sus antojos, y al mismo tiempo se anularia el derecho de posesión, á los que han creído, sobre una sola demanda, considerarse dueños de un país inmenso, que ni fué conquistado ni lo será jamás, sino devolviéndolo á sus antiguos dueños, y haciéndolo útil á los cambios (I). Conseguido este punto esencial, pudiera tal ve $z$ con mucha probabilidad de buen éxito, emprenderse por el Real Erario un ensayo de construcción, próximamente sobre el siguiente plan: una de las embarcaciones de S. M. que naveguen el mar Pacífico, había de fondear ó en Talcahuano ó en San Vicente con las clavazones y demás utensilios correspondientes para construir un bergantín ó una corbeta: llevaría á su bordo, en lugar de 24 marineros, 18 carpinteros, seis calafates y cuatro herreros, éstos con sus correspondientes fraguas: el mismo Capitán del buque, con sus Oficiales y Contador, serían los Directo-

largo de la costa del Tomé, Coliumo, Pingueral, etc. El Capitán de fragata D. Isidoro García del Postigo, ha hecho un viaje á la cordillera para cortes de madera para la escuadra: sería bueno consultarle; pero advirtiendo, que la actividad y la maquinaria no han penetrado aún on la América, y que los dos únicos medios que el Rey hasta aquí ha puesto en acción para adquirir las cosas, ha sido, ó la fuerza ó el derramar sus caudales.

(I) Como en la concesión de tierras al tiempo o después de la conquista se considerase nuestro todo el país conocido, se han repartido las tierras de los A raucanos, y estas escrituras se revivirán luégo que con los cortes pacíficos se diese algún valor á esas ticras. 
res de la construcción: se evitaría todo establecimiento duradero, de suerte que concluída la construcción, nada absolutamente quedase allí del Rey, y cimentado el método, podía la embarcación de la Real Armada hacer sus cruceros periódicos y regresar siempre al mismo puerto, dejando el Capitán, cuando se ausentase, el cargo de la construcción, á dos Oficiales de su confianza y al Contador, quien asistiría constantemente á las listas y consumos.

Debían evadirse todas las subdivisiones de autoridad marítima, aunque niveladas sobre nuestro método actual de arsenales, cuando no reconcentrasen toda la responsabilidad en uno solo; debían darse al Comandante, de las cajas de Santiago ó Lima, las cantidades de dinero necesarias para los sueldos y raciones, interviniendo él solo en todos los gastos é inversiones; pero al mismo tiempo debía encargarse así al señor Gobernador Intendente (I) como al mismo Comandante, que la menor desavenencia sería no sólo muy desagradable á S. M., sino un motivo suficiente para que abandonase la construcción meditada, de la cual tantas ventajas podían resultar no ménos al país que al Erario y poderío nacionales (2).

(I) Fuera inútil esta cláusula si pudiese haber seguridad de que todos los Gobernadores Intendentes fuesen como el Sr. D. Ambrosio Higgins y el señor D. Francisco Mata Linares, á quienes todo Uficial de Marina tributará siempre todos los respetos y elogios que merecen.

(2) Debe entender todo Oficial de Marina, director de estas construcciones, que la misma economía sería perjudicial si tendiese á atropellar el buen orden civil ó militar con fueros mal apropiados $\delta$ mal interpretados: concluída la construcción, debe hacer presentes á S. M. las mejoras que hallase admisibles.
Iguales pruebas y tal vez al mismo tiempo podían renovarse en Coliumo; se omitirían en uno y otro buque varios adornos que en los países distantes sólo sirven para desfigurarlos á costa de mucho dinero, una popa y león entallados, una cámara interior adornada, debían ser obras que se reservasen para Europa, pero al mismo tiempo no dejarían de hacerse comparaciones de sus verdaderos costos y mermas, comparadas con la brea de Paita, alquitrán de Sonsonate y estopas ó cáñamos de Chile.

La brea, el alquitrán y la estopa debían también traerse de Europa. En cuanto á las fábricas de jarcias en este último puerto, convendrá siempre que se conserven, así porque son de muy buena calidad y sumamente útiles al país, como porque aliviados del derecho del alquitrán de Europa y economizados varios rodeos, pudieran sin duda surtir el comercio del mar $\mathrm{Pa}$ cífico, y sobre todo el departamento de San Blas, hacia donde toda conducción, sea por las Filipinas ó por tierra, ha de hacerla precisamente más cara.

La falta de sosiego y de tiempo, no nos han permitido ensanchar como debiéramos las reflexiones antecedentes, las que llevando en sí el semblante de la verdad, pueden tal vez convencer al Gobierno, que Chile es capaz de muchos progresos así en cuanto al comercio nacional como á la prosperidad interior; que puede resistir una invasión sin aumento de gastos; finalmente, que auxiliado de los oportunos extipendios del Erario, puede refluir luégo hacia él, cantidades considerables que fortalezcan el poderío de la Monarquía. 


\section{INTRODUCCIÓN al vocabulario de Vavao, por el Teniente de navio D. Ciriaco Cevallos.}

Son tantas las causas que promueven la emigración de los pueblos, que verosímilmente no se hallaría sobre toda la extensión del globo una sola tríbu ó nación, cuyo idioma sea rigorosamente nuevo ab origine ó no tenga conexión con alguna otra. Ciertamente no lo es tampoco la de los pueblos del Archipiélago de los Amigos, como lo demuestra su afinidad con el Malayo, el Visaya, el de Sandwich, y con otros muchos dialectos conocidos al Sur y al Occidente. Los idiomas, lo mismo que las demás instituciones sociales, siguen en su formación el mismo orden de las necesidades que las dictaron. Hay, pues, voces que corresponden al origen de los idiomas, otras á sus progresos, á su perfección; y el que conozca bien la naturaleza humana y sea capaz de pesar y calcular las circunstancias de lugar y tiempo, se equivocará pocas veces determinando la antigüedad de las voces, el orden en que fueron compuestas, y la mayor parte de las variaciones que han debido sufrir. Sigue de esta teoría, que si la identidad ó semejanza de varios dialectos prueba un origren común á todos los pueblos que los hablan, el examen particular de las voces idénticas ú homólogas puede también conducir á conjeturas bastante seguras sobre la antigüedad de las colonias, y el orden en que se difundieron. Si se considera por otra parte que las voces no son otra cosa sino el signo de las ideas, se percibirá que las costumbres de los hombres deben leerse en sus propios idiomas: y si se añade á todo, la utilidad que puede resultar á los navegantes futuros, de conocer (aunque groseramente) el lengruaje de un pueblo con quien la necesidad le obligue á comerciar, se convendrá en que la aplicación á esta clase de conocimientos, ni es el ménos importante ni debe mirarse como el último objeto de un viajero ilustrado y filósofo. De estas consideraciones ha nacido la diligencia con que en todos tiempos, y particularmente en los modernos, han procurado los navegantes adquirir la significación de algrunas voces entre los pueblos que visitaron. Pero sería de desear que estos hombres tan justamente acreedores á nuestra gratitud, hubieran sacrificado á la precisión de las voces una partc de su número. Es preciso confesarlo: en el sistcma indispensable de nues- tros viajes, la copia y abundancia de un vocabulario debe mirarse como la primera prueba de su inexactitud. Para percibir la seguridad de esta regla, considérese por un momento el acceso de nuestros buques á estos pueblos desconocidos y remotos, con nociones aunque confusas de la mayor parte de nuestras artes. ¿Qué asombro no debe causarles las ventajas de nuestras obras á las suyas? Nuestras embarcaciones, armas, trajes y nuestras mismas bagatelas, ¡cuántos motivos para excitar su admiración! Sus primeros sentimientos ceden al deseo de poseer las cosas admiradas; uno pide, aquél cambia, el uno roba, y todos procuran adquirir lo que desean, sin pararse en la legitimidad ni decencia de los medios. Hasta el respetable cacique (siempre blasonando las prerogativas de su dignidad) se prostituye y confunde con nuestras últimas clases por la adquisición de una cuenta de vidrio. Si en medio de estos accesos tumultuosos de la codicia se llama á un natural para saber el significado de una voz, ó no entiende lo que se le pregunta, ó no está con humor de responder. Pero supongamos que á expensas del tiempo y la paciencia, que á fuerza de gestos extravagantes y de contorsiones energúmenas lo pusimos en el camino de nuestras ideas: el brillo de un botón, el ruido de una campanilla, cualquier cosa, es suficiente para distraerlo del asunto, y áun para hacerle fastidiosa nuestra curiosidad, si insistimos en volver á recoger el hilo de la cuestión. No se puede ponderar la displicencia con que satisfacían á nuestras preguntas, por lo ménos cuando pasaban de cierto número. Latu me dijo un día con mucha gracia, que se había de coser los labios para evitar la molestia de mis preguntas ó para no responder.

La necesaria oscuridad de nuestras preguntas, lo ambiguo de sus respuestas, y la propia sed de saber, son otros nuevos estorbos para conseguirlo. No pudiendo alejar la idea del poco tiempo que podemos permanecer en el lugar de nuestras observaciones, las hacemos al mismo tiempo sobre cien objetos distintos, y como es natural concluiremos con saber poco de cada uno.

De la combinación de todos estos obstáculos y de la insuficiencia de los idiomas para copiar los sonidos de los otros, han nacido las 
enormes diferencias que se notan entre los vocabularios de un propio lenguaje, formados por distintos viajeros: diferencias de que no están exentos los observadores más hábiles y diligentes. E1 Sr. Cook dice que á la Isla Koa, la llaman los naturales de Aghao, y á la de Taman Hay-Bay. Mr. Forster da el nombre de Nipoara al mismo jefe que llama Anderson, Siboula, etc. Pudiéramos escribir mil ejemplos de estas diferencias que han servido para despertar nuestra atención y para limitar nuestro diccionario de Vavao, á pocas más de trescientas voces. E1 mayor número está á la verdad bien comprobado; pero ¿quién podrá asegurar, sin embargo, que no hemos tomado algunas veces la voz figurada por la propia, la equivalente por la directa, etcétera?

Si es difícil formar en pocos días un diccionario copioso, no lo es ménos hacerse cargo de la propiedad, extensión y modo de las voces así como de la sintaxis del idioma. Cuando vemos que con una sola palabra, Majale, por ejemplo, dicen, ir fui, fuiste, irse, etc., creemos que no distinguen los tiempos ni las personas; ¿pero por qué no se pueden dar á las vocales de aque1la palabra tantos sentidos como son precisos para hacer estas distinciones? Si nosotros distinguimos los tiempos variando las terminaciones, ¿por qué otros no harán la misma distinción variando de acentos, particularmente cuando se sabe que los acentos hacen casi todo el juego gramatical en los idiomas no escritos?

Supongamos la existencia de una lengua que tuviera los cinco tonos enteros de nuestro diapasón (por ejemplo); pregúntese á un calculador: ¿de cuántos modos realmente distintos podría pronunciarse en este idioma la palabra Majale? Y responderá que de 123.860 maneras diversas, sin pronunciar nunca más de cuatro sílabas y cuatro tonos, y sin tardar más tiempo en la pronunciación de la voz entera del que tardamos nosotros en decir Majale, según nuestro modo de pronunciar: quiere decir, que este idioma (tal vez poco más entonado que el de Vavao), no sólo podría distinguir los modos de los verbos et cétera, por medio de los acentos, sino dar á una misma voz más de cien mil significaciones que nosotros no podríamos distinguir en la escritura. Tal vez parecería extravagante hacer una aplicación del binomio de Newton, hablando del mecanismo del idioma, y convendremos en ello como se convenga en la exactitud del cálculo. Por lo demás, no queremos decir que el dialecto de Vavao distingue precisamente cinco acentos, ni que pronuncie cuatro sílabas de diez mil modos: nuestro objeto es solo indicar que constando su prosodia de más acentos que la nuestra, y acentos verdaderamente musicales, no sólo puede distinguir por ellos lo que nosotros con las terminaciones, sino también multiplicar inmediatamente las acepciones de las voces. Después de lo dicho, no entendemos al Sr. Anderson, cuando dice que siendo el idioma de esios naturales bastante clicico para emmiar todas sus ideas, sus talentos son poco numerosos (I). Supongo que este sabio observador no habla de los elementos de la palabra, porque los insulares no sólo pronuncian nuestras cinco vocales y la mayor parte de las consonantes, pero usan de otras articulaciones que no pueden expresar las letras de nuestro alfabeto, de cualquier modo que se combinen.

E1 uso de sincopar la mayor parte de las voces, y el de anteponer á todas las partes de la oración la palabra coe, pueden mirarse como dos propiedades características del lenguaje de estas islas. No sólo abrevian las dicciones suprimiendo las sílabas del medio, que es lo que constituye la verdadera síncopa, sino suprimiendo también el fin, á lo cual llaman nuestros gramáticos apócope: hé aquí una voz sincopada longajulu, diez, en lugar de toncojongo julu: hé aquí un apócope sua (grande en número ó cantidad), en lugar de suave. La mayor parte de las voces que incluye nuestro diccionario están sincopadas.

El intento del artículo en nuestras gramáticas es distinguir el género de los nombres; pero como los naturales anteponen el coe no sólo á los nombres sino también á los verbos, etc., no se puede decir que coe, es un artículo, á lo ménos un articulo como nosotros lo entendemos.

La misma naturaleza indica el orden en que deben colocarse las palabras para formar las oraciones. Fatafegi, concibió á Feileura, esta es una oración de régimen natural; pero los insulares dicen así: Fanau, Feileua e Fatafegi. Estas transposiciones son frecuentísimas entre ellos, y no pueden tener otro objeto que el de hacer más harmoniosa la conversación. Volvemos á repetirlo: la observación ha hecho conocer que en los idiomas no escritos, la cadencia ha dictado casi todas las reglas. El coe que por sí solo no tiene significación alguna; la á, que tampoco la tiene, y suelen anteponer á muchas voces, pueden tal vez compararse á las partículas, cuyo único y primer destino fué aumentar la sonoridad de los períodos.

En medio del poco tiempo que hemos permanecido en Vavao, nos atrevemos á decir que el idioma de los naturales es rico, prosódico y sonoro. Hacen tanto uso de las vocales, que en-

(r) Tercer viaje de Cook, tomo II, pág. i 18 , de la traducción francesa. E1 juicio de Anderson es tanto más inconcebible, en cuanto su propio diccionario de estas islas consta de muchos sinónimos; esto es, de muchos signos de abundancia, etc. 
tre todas las voces de nuestro diccionario, apenas se encuentran dos solas que terminen en consonante, distinguiendo más acentos que nosotros, y supliendo tal vez con ellos la variedad de nuestras terminaciones: cuando hablan, parece cantan ó recitan. Un idioma de esta naturaleza, nacido y conservado en climas tan felices, y donde apenas es necesario el trabajo para gozar las comodidades de la vida, debe ser todo él hijo de las pasiones, al contrario de nuestras lenguas de Europa, exactas, pero frías; copiosas, pero sin expresión: casi todas ellas son tristes como el cielo bajo que han nacido: casi todas ellas tan duras como las necesidades que las han formado.

El dialecto del Archipiélago de los Amigos, compuesto, figurado, músico y dictado por el sentimiento, debe por consecuencia prestarse mucho á la verdadera poesía; pero nosotros sólo podemos hablar de su parte mecánica, y áun de esto imperfectamente.

Todas sus canciones están sujetas á una medida rigorosa y la mayor parte rimadas. En los bailes del 23 y 25 pudimos percibir dos clases de metros: los unos cuya cadencia casi corresponden á las de nuestros versos conocidos con el nombre de arte mayor, desterrados de la poesía moderna, y cuyo uso fué muy frecuente entre los antiguos romanceros. Tuisua, Tacaola y Feileua, que comieron á bordo el 24, cantaron otros dos géneros de versos, cuya correspondencia á los nuestros no me atrevo á determinar.

En todas estas composiciones rimas, pareando las consonantes, verosímilmente sabrán combinarlas de otros modos diversos, y verosímilmente tienen más variedad en las composiciones, de la que nosotros hemos notado. La poesía, este arte celestial tan antiguo como las sociedades y consagrada en todos tiempós y lugares á conservar las primeras tradiciones de los pueblos, es tal vez el más perfeccionado en el Archipiélago de los Amigos: y ¿quién sabe si la poesía de estos hombres podrá sostener una comparación con la nuestia? Suplico á los que califiquen de ridícula esta duda, que tengan presente lo que eran los griegos cuando Homero empezó á recitar los cantos de la Iliada; digo, cuando empezó á recitar, porque según una opinión bastante probable aunque poco común, el principio de la epopeya no alcanzó el tiempo de la escritura.

Por lo que hace á las diferencias que se encuentran entre este pequeño Diccionario y otros que tengan las mismas voces, nada podemos alegar en nuestro abono. Nous croyons (dice Mr. de Bougainville) avoir bicn entendu, et bien rendu les sons qu: plisicurs fois ont frappé nos oreilles; les anglois sont aussi dans la méme persuation: se serait au naturel in nous suget.

Notas.

Para suplir los efectos de nuestra escritura, y con el fin de aproximar en cuanto sea posible nuestra pronunciación á la de los naturales, se han puesto algunas notas al lado de las voces á quienes corresponden.

Cuando se vea una $g$ sucedida de algunas sílabas, quiere decir que estas sílabas deben pronunciarse guturales.

$A s p . h$, quiere decir que la $h$ se debe aspirar, por $a s p . h$, quiere decir que la $h$ se aspira poco.

Una línea (-) cubriendo una parte de la voz, quiere decir que la parte cubierta se pronuncie con mucha celeridad.

Una línea (-) dividiendo unadicción, quiere decir que la dicción se pronuncia en dos tiempos.

A

ESPAÑOL

A. Preposición..............

Abajo ..................

Abalorios.

Abrazar.............. Tonga-Túa.

Aceite de coco........... Te-ete.

Acostarse .............. Togo-too (g-to-go).

Adelgazar............... Oloy.

Actitud.............. Unima (I).

Afeitarse.............. Fafay.

Agua................. Bay.

Agua dulce............. Bay-litey.

Agua salada............. Bay-touha (asp. $h$ ).

Aguja ................. Usi.

Almohada (de palo)......... Cali (g. li).

Amanecer (primera claridad del

día hasta la salida del Sol)...

Amigo....................

Amistad .................

Amistad (término más expresivo).

Arco y flecha..............

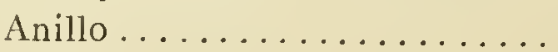

Anoche................. Anapó.

Anular (dedo)........... Tegia (g. gi.)

Anzuelo.................. Paa.

Arbol................. Acau.

Arbol (de los que tenfamos á la

vista)...............

.

Así es, bueno(como aprobación). Coya.

A travesar una cosa.......... Joca tonga.

Ayer................. Aneafi.

Arriba................ Tavo.

Afeitar................ Amuch-abusa.

\section{B}

Bailar.............. Guiliguili.
(I) La actitud que toman en ciertas solemnidades los plebeyos delante de los Jefes, y que equivale á la última expresión de respeto. Esta actitud consiste en sentarse con las piernas cruzadas del mismo modo que las manos, inclinando la cabeza casi hasta el suelo y hacia el objeto de respeto y veneración. 


\begin{tabular}{|c|c|}
\hline ESPAÑOL & VAVAO \\
\hline 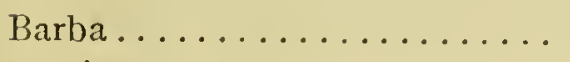 & Cava. \\
\hline 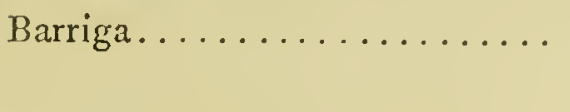 & $\begin{array}{l}\text { Fata (con los labios } \\
\text { la } f \text {.) }\end{array}$ \\
\hline Basta... . . . & $\begin{array}{l}\text { Mahna (poco aspir. } \\
\text { h). }\end{array}$ \\
\hline Bien hecho (como aprobando). & Mahesi. \\
\hline 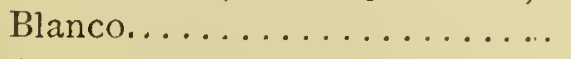 & Taya. \\
\hline 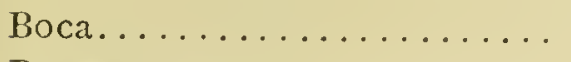 & Vtu (g. n.) \\
\hline Bostezar. . . . . . . . & Mamao. \\
\hline Beber'................ & Ynu \\
\hline Brazo.................. & Nimaa. \\
\hline Bueno (como aprobando)...... & Coya. \\
\hline Buscar una cosa............ & Nono. \\
\hline
\end{tabular}

\section{C}

Cabeza............... Ulu.

Cabecera de palo......... Cals.

Cables................ Taula.

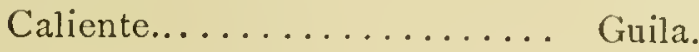

Callar................ Laya.

Camino............... Yeda.

Canalete.............. Foge.

Canastilla redonda......... Cato.

Canastilla oblonga.......... Cato-Cafa.

Cambiar.............. Facatau.

Canoa................ Taja-haya (poc.

................ V-pé (g. v.)

Casa................. Fale.

Casa sagrada............ Fale-tua (la $u$ cerrando los labios).

Caracol ............... Quetitogue.

Cejas................. Lau-mata.

Cerdo................. Puaca (g. ca.)

Chico................ Chi.

Ciego............... Cui-na.

Cementerio.............. 'Tiatoga.

Clavo.................. Tau.

Coco................ Neu.

Comer.................. Kay.

¿Cómo se llama esto?........ Koe-kay-caca-hio (asp.h.)

¿Cómo te llamas?.......... Jau-natea.

Concebir ó parir.......... Fanau.

Correr............... Fatuchi.

Cortar................. Cochi.

Cortar (en la madera)........ Gifi.

Crudo................. Hota (poc. asp. h.)

Cuanto................. Fia.

¿Cuánto tiempo hace?....... Fia-magina

Cuando el Sol está en zénit.... Laa-to.

Cubrir.................. Pubou.

Cuchillo, ó cosa parecida..... Geele.

Culebra............... Tuca-gali.

Cuchillas............. Chigue.

Calvo ............. Cu-ulu.

\section{D}

Dame.

Dar.

Dar gracias.
Mahu (poc. așp.h.) Mahi (poc. asp. h.) Afetai.

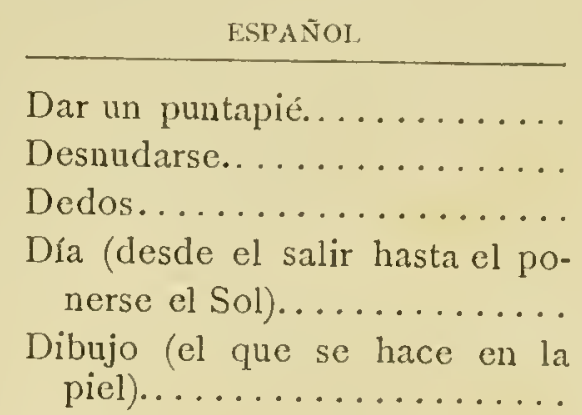

Dientes............. Niso.

Dios............... Otua (la u apretando mucho los labios).

Dormir............... Moge (g. ge.)

Dame algo............. May-jamea.

Dame de comer........... May-jamea kay.

Descubrir á uno que está tapardo. Tatalautu.

Despertarse............. Ha (asp. h.)

Dar porrazos........... Chilonaga.

\section{$\mathbf{E}$}

Enterrar ............. Tanu.

El empeine............. Paali.

Envolver, doblar.......... Fatu-fatu.

Embarazada............ Fey-tama.

Embarcación............ Baca.

Escopeta............. Mea fana (voz compuesta.)

Espaldas............. Tua.

Espejo................ Chiota (poc. la o).

Espinillas............. Chipu-bay.

Entender ó desenvolver....... Folage (g. ge.)

Estera.............. Faale.

Estofa (lo que visten)........ Bala ó Natu.

Estrellas................ Ofetu.

Esconderse............. Iola.

Embarcación chica......... Baca-chi.

\section{$\mathbf{F}$}

Falto.............. Cu.

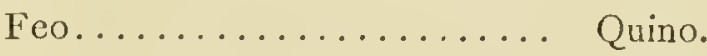

Flauta............... Fangu-fangu.

Flecha y arco............ Fana.

Fondo $\left\{\begin{array}{l}\text { mucho } \ldots \ldots \ldots \ldots \ldots \ldots \\ \text { poco } \ldots \ldots \ldots \ldots \ldots\end{array}\right.$

Fornicar.............. Feichi, copi (I).

Frente............... Lae.

Frío................. Moco-chjo.

Fuego.............. Hafi.

\section{G}

Gallina ó Gallo.......... Moa.

Garganta.............. Monga. (Se pronuncia poco la $g$ y gutural).

Golpes (castigar) Patu.

(r) A la palabra Michi michi dan la misma significación; pero esta voz introducida aquí por los equipajes del Capitán Cook, no debe mirarse como propia del idioma de estas islas, no obstante de estar adoptada generalmente entre ellos. 


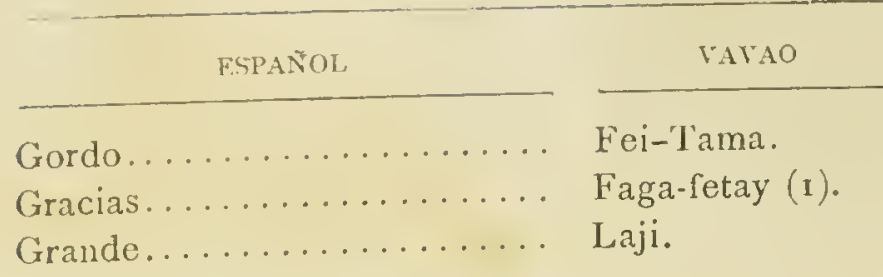

\section{$\mathrm{H}$}

Hablar ............... Lea.

Hace poco ticmpo.......... Fuo.

Harto, repleto, satisfecho..... Magunna.

Hermano.............. Jona-cainha (asp. la h.)

Herida $o$ enfermedad....... Mate.

Hermoso............... Liley.

Hijo............... Toja.

Hombre............... Tan-hata (poc. asp. la h.)

Hombros................ Huma (ídem).

Hoy, luégo, esta tarde....... Anay.

Huirse, escaparse.......... Gipuna.

Hacha................ Toqui.

Hacer aire............ Alo-Alo.

Huevo de gallina........... Jo-moa.

Hermano.............. Caigha (asp. h.)

\section{I}

Incisión (la que hacen en el pre-

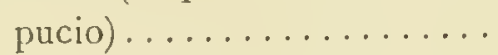

Indice $($ el dedo)............

Injurioso . . . . . . . . . . .

Ir, iré, vóime.............

Iris $(\mathrm{el}$ arco $) \ldots \ldots \ldots \ldots \ldots$.

Isla..................

Islote . . . . . . . . . . . .

Inmediato

Letcfe.

Falu.

Tua.

Majale.

Humata (poc. asp. la h.)

Motu.

Motu-Chi

Feilatu.

Quene.

\section{J}

Jaula................ Calay.

Jefe............... Eigui.

L

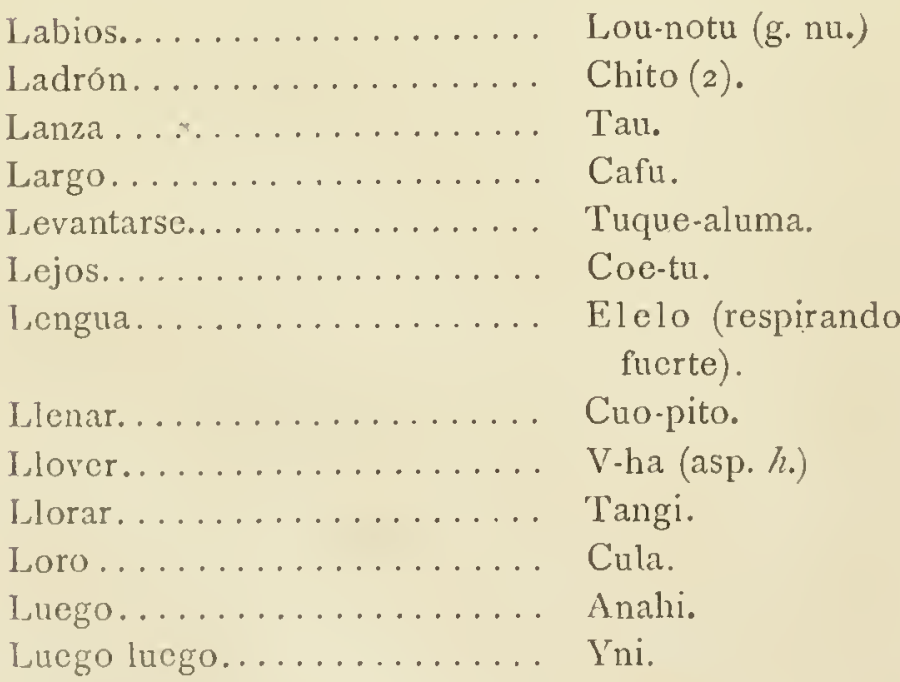

(I) Cuando se hace un presente lo ponen sobre la cabeza y dicen esta palabra.

(2) Término de uso común entre ellos, pero introducido por el Capitán Cook.

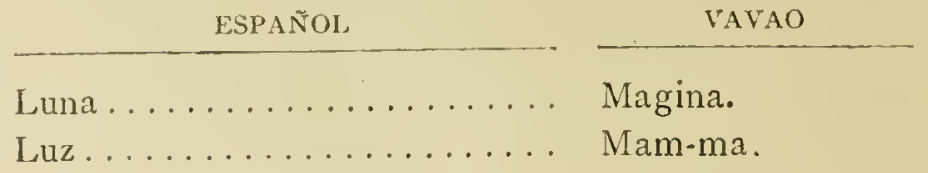

\section{M}

Madre.................. Ona.

Mamar............... Jufu.

Manos................ Afinimaa.

Mañana............... Pongui-pongui (ordinariamente anteponen la a.)

Mar.................. Peao.

Marejada.............. Peau.

Mas................... May.

Masa (composición de rima y

plátanos que comen)....... Moheya.

Matar................ Fana.

Matrimonio............. Ojoana.

Medio (el dedo del)........ Tujulito.

Medio día............... Tonumario.

Mejillas............... Mata-tugui.

Mellado............... Nijo-cu.

Mentira............... Loge.

Meñique (el dedo)......... Lougi.

Micmbro viril. .......... V-le.

Mio................... Guhu (poc. asp. h.)

Morir................ Mate.

Muchacho............... Tamochi (poc. asp. la o.)

Muchos................ Lau-ale.

Muelas.................. Ahu (poc. asp. h.)

Mujer................. Fefine.

Muchacha............. Fefine tamoachi-i.

Muslos................ Ten-ha.

Mucho fondo............. Loto.

\section{$\mathbf{N}$}

Nadar. ............... Anu-anu.

Nadie, nada............ Cot-gi.

Naranjas............... Moli.

Narices.............. Yfu.

No................. Ykay.

Negro............... Vli.

Noche... . . . . . . . . . . . Pouli.

Nubes ................. Hao.

Nueces............... Ameguta.

Número (un gran)......... Fua.

Nucvo, sin romperse........ Amu.

No vale nada............ Chin.

No corta............ Pegu.

\section{$\mathrm{O}$}

Oscuridad............... Pouli.

Ojos................... Mata.

Olor Bueno............. Kacula.

Olor Malo.............. Namuga.

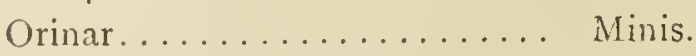

Obrar................ Chico.

\section{$\mathbf{P}$}

Poco fundo............... Mamara.

Pillo, insolente........... Angha-covi-tua (asp. la h.) 


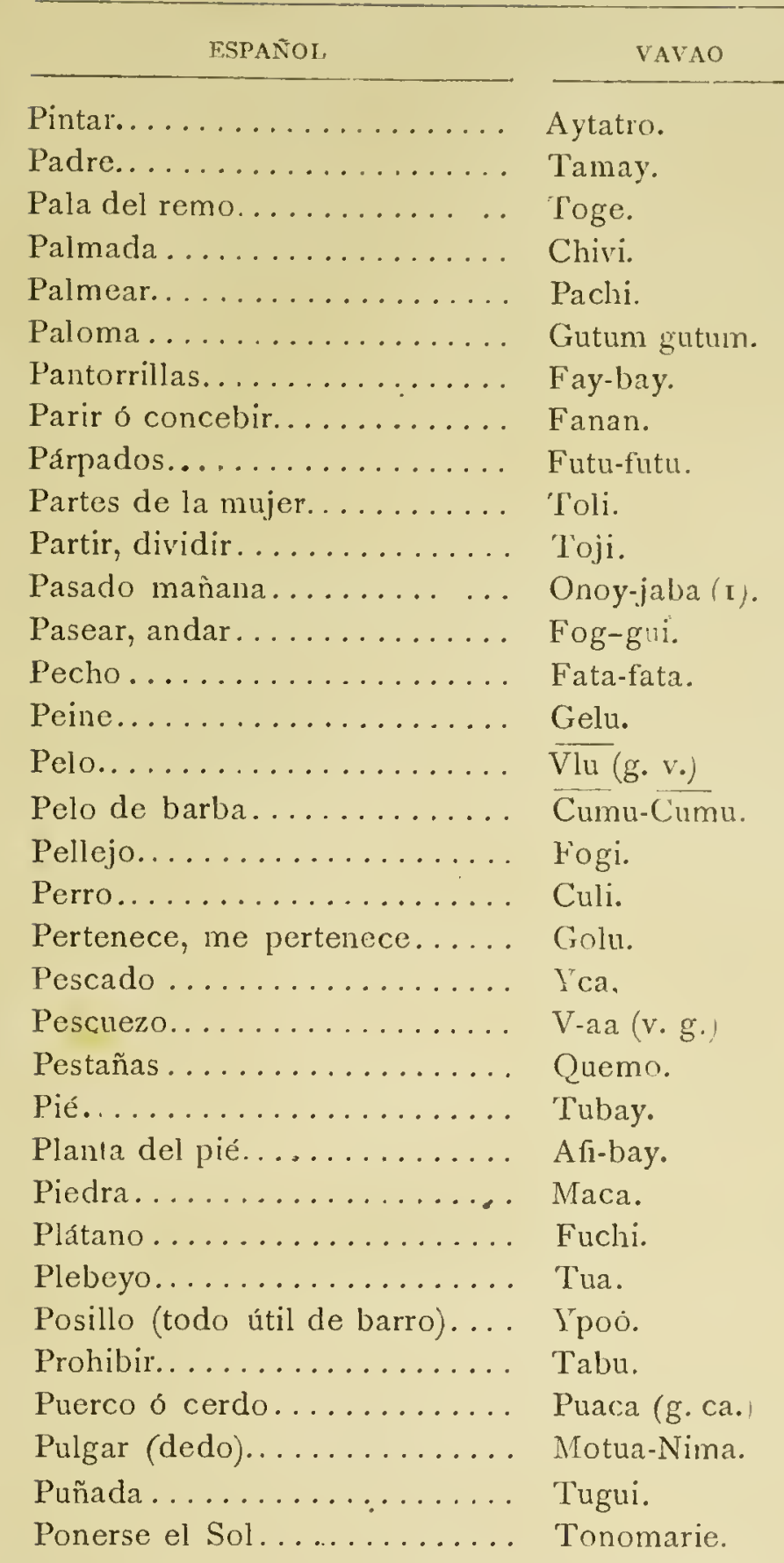

\section{$\mathbf{Q}$}

Querer ver alguna cosa.......

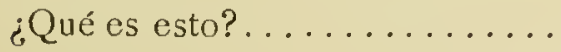
Quítate................

Mamata. Coe-jae. Quitu.

\section{$\mathbf{R}$}

Raices comestibles..........

Regalo.................

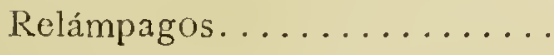

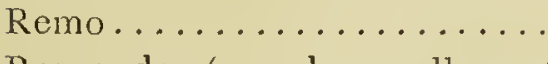

Responder (cuaıldo uno llama á otro responde ordinariamente asi)..................

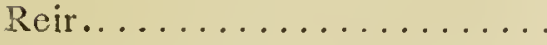

Rodillas................

Rojo (color) .............

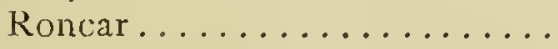

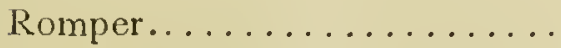

Roto.................

Rima................ Mey

Ranchería............. Fonua.

Risa............... Cata.

(I) La expresión onoy, se antepone siempre al día que se quiere señalar; por ejemplo, se quiere decir: para el día 5; se dirá onoy nima.

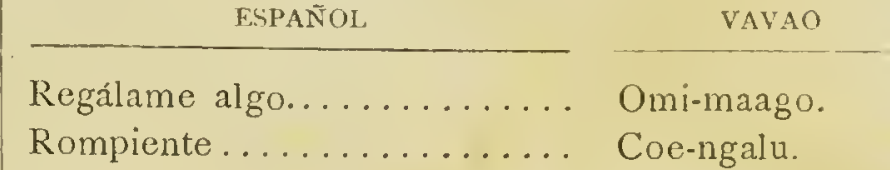

S

Sentado con las piernas cruzadas. Fagatane. Sentarse.............. Nofo.

Saludo................ (I).

Sazonado (fruto)........... Pay.

Sangre............... Toto.

Sí. ............... Hio.

Silbar.................. Mapú.

Salida del Sol............ Alujague.

Soñar................. Talanoa.

Sentimiento ó dolor......... Ofa.

Sanar, de enfermedad....... Muy.

Sordo................ Tafanga.

Sol................. La-a (2).

Sueño............... (3).

\section{$\mathbf{T}$}

Toma............... Coe-na.

Timonel............... Toutcoy.

Tirar algo.............. Lafu.

Tela de árbol............ Natu.

Toronja............... Mori.

Tapar............... Pulou.

Tartamudo............ Chiguilea.

Techo................ Faca-malu.

Testículos.............. Lajo.

Tetas............... Julu.

Tierra............... Yuta.

Tierra rica, buena.......... Yuta-bu.

Timón. . . . . . . . ....... Lasifoque.

Tobillos................ Tonga-ibay.

Tocar, pa!par........... Tetar.

Tocar la flauta............ Yofi.

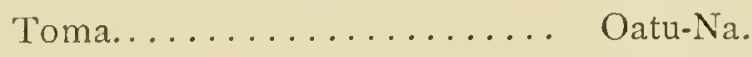

Tortuga............... Fonu.

Trueno............... Fatulichi.

Tuerto.............. Cui.

\section{$\mathrm{U}$}

Uñas. ............... Echiminin.

Usado................ Modua.

\section{V}

Ven acá, ven conmigo....... Jau.

Vete de ahi.............. Fale.

Venir, ven, voy........... Fogui-mahy.

(I) El saludo ordinario entre los naturales consiste en tocar nariz con nariz. Cuando esto se hace do hombre á hombre le llaman Huma, y cuando de hom. bre á mujer Feguita. Cuando alguna persona de distinción estornuda, los circunstantes dicen Sey-sua.

(2) La última a se pronuncia gutural y como tosiendo al mismo tiempo. Esta voz es de muy difícil pronunciación.

(3) Para conciliar el sueño á los Eiguis, sus mujeres les tocan suavemente con las manos á lo largo del cuerpo; que á esto llaman toqui-toqui: voz cuyo sonido corresponde bien á la acción que significa. 


\begin{tabular}{|c|c|c|c|}
\hline FSPANOLL & VAVAO & ESPAÑOL & VAVAO \\
\hline 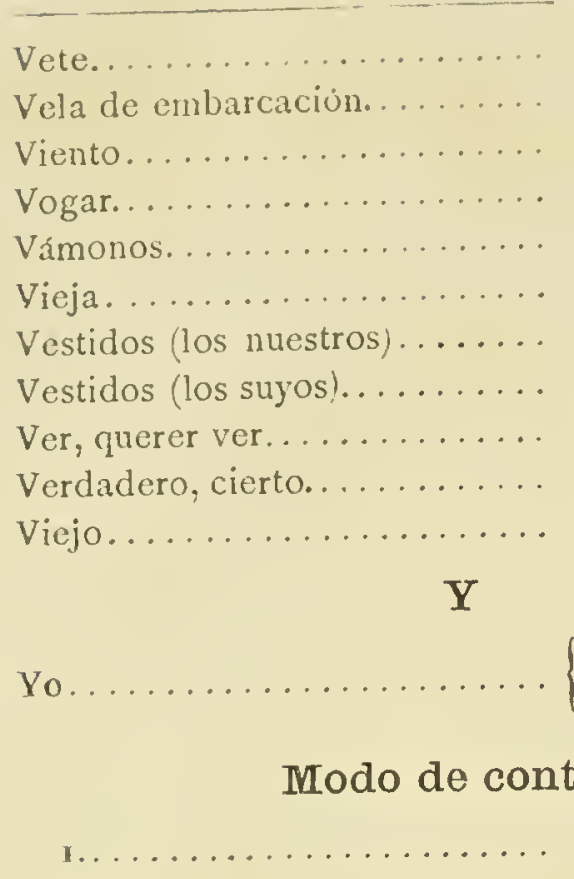 & $\begin{array}{l}\text { Falu. } \\
\text { Coe-la. } \\
\text { Yfi. } \\
\text { Alo. } \\
\text { Tau-vo. } \\
\text { Feu-feu. } \\
\text { Papaa-langui. } \\
\text { Cofu. } \\
\text { Maumeta. } \\
\text { Moni. } \\
\text { Papanga. } \\
\text { Fuca. } \\
\text { Au. } \\
\text { ar. } \\
\text { Taja. }\end{array}$ & 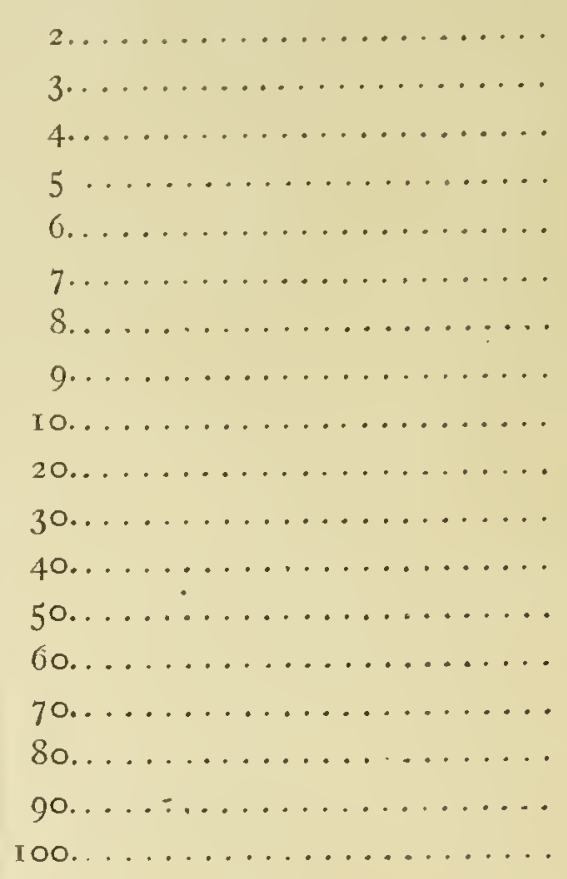 & $\begin{array}{l}\text { Hua. } \\
\text { Tolu. } \\
\text { Faa. } \\
\text { Nima. } \\
\text { Ono. } \\
\text { Fito. } \\
\text { Faula. } \\
\text { Guiba. } \\
\text { Tao congo fulo. } \\
\text { Wfulo. } \\
\text { Tacungo-Fulo. } \\
\text { Fangu-fulu. } \\
\text { Nuna-no fulo. } \\
\text { Onongo fulo. } \\
\text { Filongo fulu. } \\
\text { Balugo fulo. } \\
\text { Giba gofulu. } \\
\text { Teau. }\end{array}$ \\
\hline
\end{tabular}




\section{DISCUSION sobre las longitudes de las costas de Chile y Perú, por D. Felipe Banzá.}

Es sabido que las observaciones más propias para situar los puntos del globo astronómicamente, son las ocultaciones de las estrellas por la Luna, los eclipses del Sol, los de los satélites de Júpiter y eclipses de Luna, y en su defecto, por medio de los cronómetros marinos cuando se puede averiguar su movimiento en cortos períodos de tiempo; pues de lo contrario, la experiencia ha manifestado de cuántas anomalías son susceptibles estas máquinas, y mucho más cuando no se atiende á la temperatura de la atmósfera para su uso y en sus conducciones de á bordo á tierra y á la inversa, y como dice el célebre astrónomo Barón de Zach, hasta en su posición horizontal ó vertical. Por ln tanto, en esta pequeña discusión manifestaré no sólo los datos que hay por observaciones hechas por indivíduos nacionales, sino también aquellas que hayan hecho los extranjeros, para poder proceder con acierto en asunto de tanta importancia.

\section{San Carlos de Chiloé.-Castillo.}

Por las Corbetas Descubierta y Atrevida en I790, y por estrellas al Norte y al Sur del zénit, se dedujo la latitud del Castillo, Sur.... .

El 6 de Febrero de I79o, por la inmersión del primer satélite de Jú-

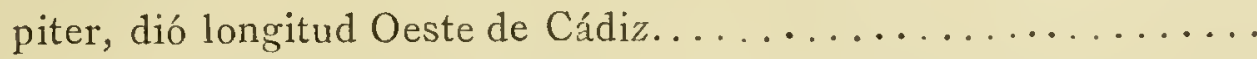

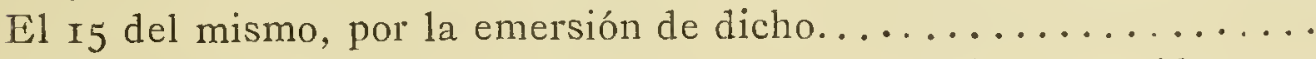
Por los cronómetros de la Descubierta, al Oeste de Montevideo.... Idem por los de la ATREvida, unos y otros en noventa días........

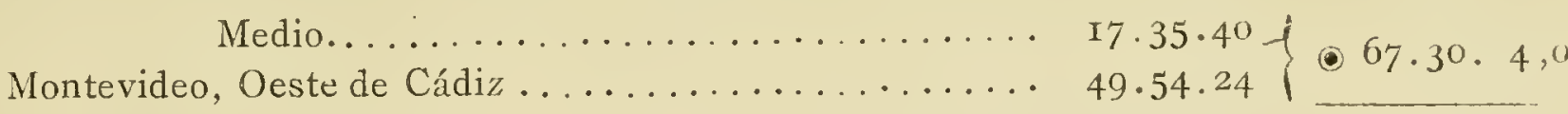

$$
\begin{aligned}
& \text { El promedio es longitud del observatorio de Chiloé.... . . . . . . . . . . . 67.30.9 } \\
& \text { El Castillo al Este del observatorio ......................... } 6 \\
& \text { Longitud del Castillo de San Carlos de Chiloé, O. de Cádiz... . . . . . . . . . 67.30. } 3
\end{aligned}
$$

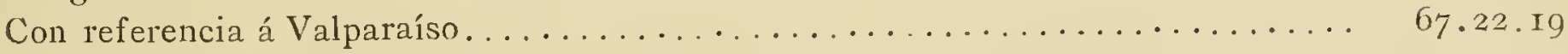

Sin embargo de la admirable conformidad que se advierte en estas tres longitudes, más adelante se verá, que retrocediendo de punto bien situado, y en muy corto intervalo de días, no resultan tan conformes como aparecen, y á mi entender, las muchas diferencias que se observan en estas combinaciones deben depender de no contar en el uso de los cronómetros con la temperatura, particularmente cuando se pasa de pronto de los climas fríos á los ardientes de trópicos, como lo manifiesta D. José Luyando en el extracto de su Diario desde Cádizá Veracruz en el año de I8.

\section{Talcahuano.}

Las corbetas Descubierta y ATrevida establecieron el observatorio en una casa próxima á la orilla del mar, la misma en que el Conde de la Péyrouse colocó el suyo cuatio años antes.

La latitud se observó por estrellas al Norte y Sur del zénit, de.. Sur.

Los cronómetros de la Descubierta dieron diferencia al Este de

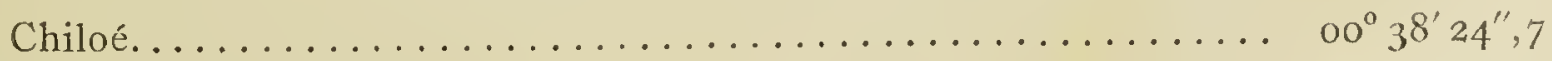

Los de la Atrevida........................ 00.4I.54,0

Promedio..................... oo.40. 9,3 
San Carlos de Chiloé como se ha dicho, O. de Cádiz.........67.30. 3,o

Longitud de Talcahuano al $\mathrm{O}$. de Cádiz.............. 66.49.53,7

E1 Capitán Hall, de la Marina inglesa, en $x$ \$20, 2 I y 22, coloca á Tal -

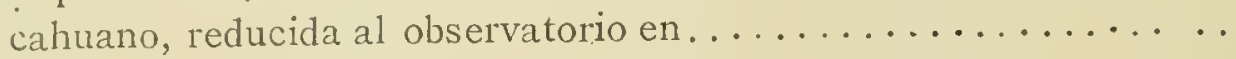

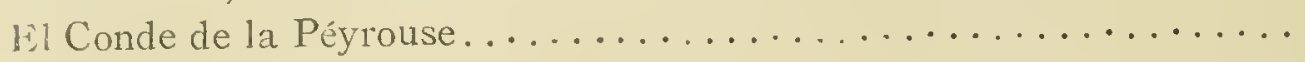


Resumiendo estas observaciones, tendremos:

For la ocultación de Antares.................. 65.13.55,7

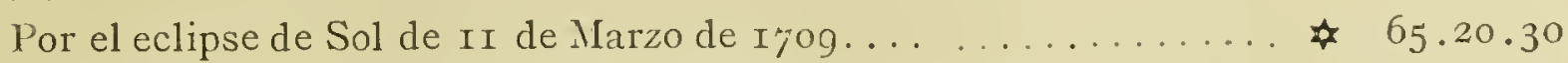

Por los satélites de Júpiter, según Mechain . . . . . . . . . . . \$ 65.20.00

Por distancias lunares, al Oriente y Occidente, por Galiano............๑ 65.16 .46

Por los cronómetros, diferencia con Chiloé..................... 65.21 .46

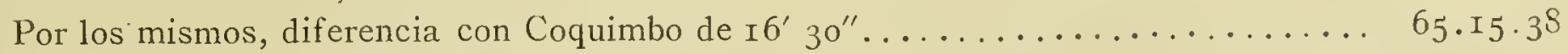

El promedio de las ocultaciones, eclipse de Sol y satélites, será.... 65.I6.29, 5

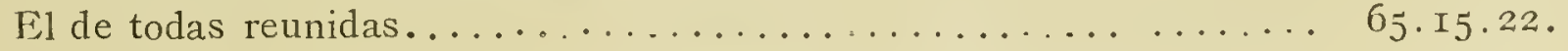

Que sólo difiere de $I^{\prime} 36^{\prime \prime}, 4$ de la ocultación de Antares, pero la calidad de esta observación la hace preferible á todas las demás; por lo tanto es longitud del Fuerte del Rosario

$$
\text { i......... } 65 \cdot 13 \cdot 5^{6}
$$

\section{Coquimbo.}

En IS de Abril de I 890 se establcció el observatorio de las Corbetas en una casa situada en la playa occidental del puerto, cuya latitud por el paso de estrellas al

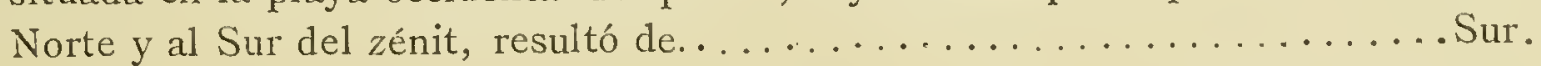

En 28 de Abril se observó la ocultación de $2 a$ de Aries inmersión y emersión y

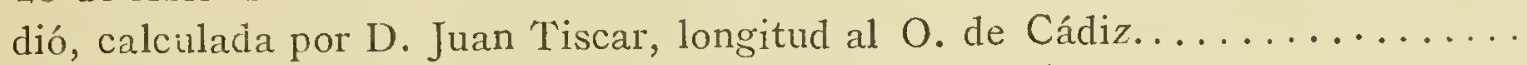

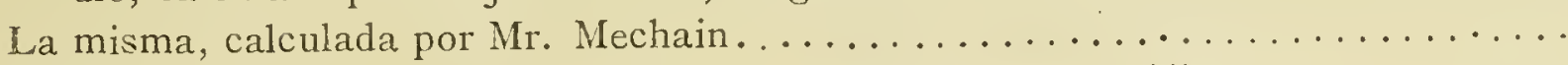

El mismo día, ocultación de la I. ${ }^{a} a$ de Aries, calculada por Tiscar . . . . . . . . .

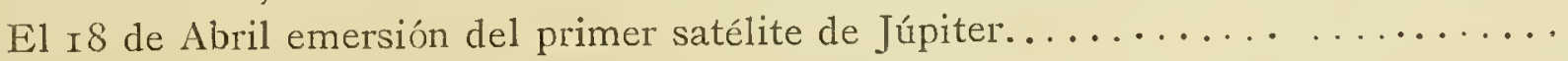

El 20 " " " " $"$ "

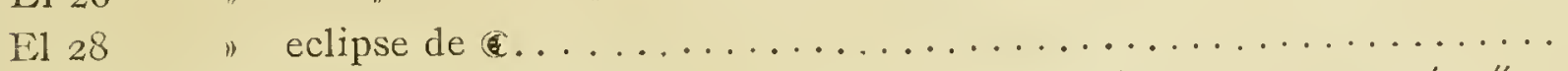

$65 \cdot 00 \cdot 40,5$ $64 \cdot 5^{6} \cdot 5^{\mathrm{I}}, \mathrm{O}$ $65.05 \cdot 4 \mathrm{I}, 0$ $65 \cdot 02 \cdot 30$

$64 \cdot 57 \cdot 15$

65.02 .45

Por los cronómetros de la Descubierta al Este de Valparaíso...... I I 5 '54

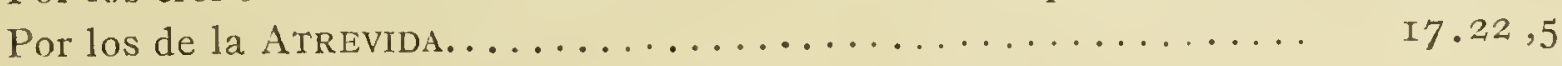

Por el Capitán Hall, reducida al observatorio............ I5.32

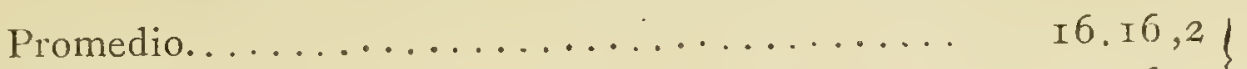

Valparaíso, Occidente de Cádiz.......... $65 .{ }_{5} 3 \cdot 5^{6}$

$64 \cdot 57 \cdot 39,8$

El Capitán Hall sitúa la bahía en $64^{\circ} 5^{\prime} 2^{\prime \prime}-1-28^{\prime \prime}$ será para el observatorio.... 64.59.9, 0

Resumiendo las observaciones celestes, tendremos:

Por la ocultación de $2 a$ de Aries, calculada por Tiscar................. 65.00.40, 5

La misma, calculada por Mr. Mechain........................ 64.56.5 I, o

Por la ocultación de la $I{ }^{\text {a }} a$ de Aries, calculada por Tiscar.............. 65. 5.4I, o

Por $\operatorname{los}$ satélites de Júpiter, promedio. . . . . . . . . . . . . . . . . . . . 64.59.52, 5

Por el eclipse de Luna.................................. 65. 2.45, o

Por los cronómetros de las corbetas y del Capitán Hall . . . . . . . . . . . . . . . 64.57.39, 6

Promedio será longitud del observatorio de Coquimbo...... $65.00 \cdot 34,9$

ó........ $65.00 \cdot 35$

La conformidad que se advierte en estas observaciones, tanto las celestes como las cronométricas indican la buena posición de Coquimbo, así como también la de Valparaíso; por lo tanto, estos dos puntos deben tomarse como de partida para los demás, tanto al Norte y al Sur de ellos.

\section{Castillo del Callao.}

Las corbetas Descubierta y ATREvida establecieron su observatorio en la Chacara de la Buena Muerte, en el pueblo de la Magdalena, el día 2I de Mayo de $x 790$, desde donde por operaciones geo- 
désicas se estableció la 'Torre del Castillo del Callao 5' 5", 2 al O. y I' 7 " al Norte del observatorio.

Por pasos de estrellas al Norte y al Sur del zénit se dedujo la latitud del observatorio de $12^{\circ} 4^{\prime} 38^{\prime \prime}$, que deducida al Castillo del Callao es de ......... Sur. I2 ${ }^{\circ} 3^{\prime} 3 \mathrm{I}^{\prime \prime}$

Por la emersión del primer satélite de Júpiter el 5 de Junio de 1790 , resultó la

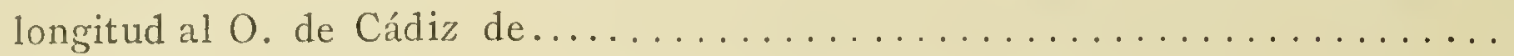

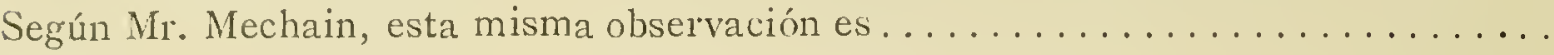

Los cronómetros de la Descubrerta dieron al O. de Coquimbo.... $5^{\circ} 5^{\mathrm{I}^{\prime}} 26^{\prime \prime}$

Los de la Atrevida....................... 5.43.30

Promedio.

Por eí Capitán Hall, es la diferencia de longitud con Coquimbo..... 5 5.47. I9

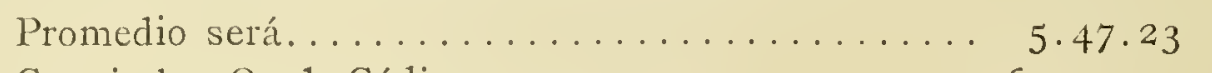

Coquimbo, O. de Cádiz...............65.00.35

Estas son las únicas observaciones que se pudieron hacer, por la estación de nieblas en aquellos climas, en la época que la expedición de Malaspina estuvo en Lima: á continuación voy á manifestar otras hechas antes y después de esta época, para que se pueda venir en conocimiento de la verdadera longitud del Callao de Lima.

Hay una observación interesante que pudiera fijar la longitud de Lima con la mayor exactitud, si el Barón de Humboldt, que la hizo, hubiera tenido toda la seguridad con la observación clel contacto exterior de Mercurio, como la tuvo en el interior. Véase su observación (Obscrvaciones astronómicas, etcétera, tomo II, redactadas por Jacobo Oltmanns, pág. 42I).

Día 9 de Noviembre de I802. Paso de Mercurio por el disco del Sol, página 42 I y siguientes, en la pág. 426 da el resultado medio por esta

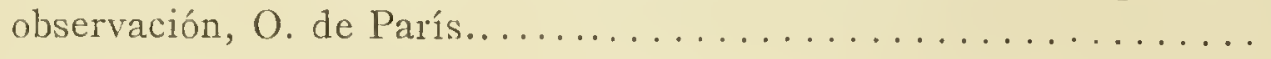
Que es de Cádiz.

En la pág. 403, por seis emersiones del primer satélite de Júpiter ob-

$$
\begin{aligned}
5^{\mathrm{h}^{\prime \prime}} \mathrm{r} 8^{\prime} \mathrm{I} 6^{\prime \prime}, 5 & =79^{\circ} 34^{\prime} 7^{\prime \prime}, 5 \\
& 70.5^{6.22,5}
\end{aligned}
$$

servadas por D. Jorge Juan y D. Antonio Ulloa, eligiendo sólo dos de mejores circun. ${ }^{3}$.

Reducida al Callao. .

$79 \cdot 24 \cdot 46,5=70 \cdot 47 \cdot 1,5$

Por los eclipses de en I7I3, observados por D. Pedro Peralta, reducidas al Callao.

Por los cronómetros del Barón de Humboldt. . . . . . . . . . . . . . . . .

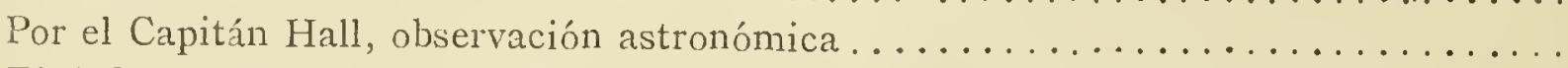

El Alférez de navío D. Antonio Martínez, observó en Noviembre y Diciembre de I 8 I4 y Enero de I8I5, 26 series de distancias lunares, al Oriente y Occidente, que reducidas al Callao dió por longitud.

Resumiendo todas las observaciones, tendremos:

Por el paso de Mercurio de 9 de Noviembre de 1802 , O. de Cádi Por dos emersiones del primer satélite, por D. Jorge Juan y D. Antonio Ulloa.

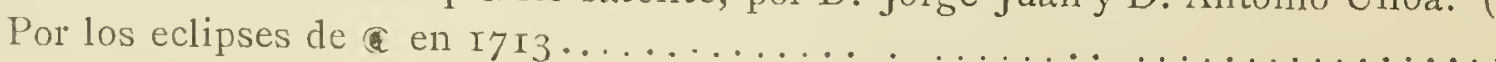

Por los cronómetros del Barón de Humboldt.

$\ldots \ldots \ldots \ldots \ldots \ldots \ldots$

Por el promedio de los cronometros de ambas c mes, difercna corbetas y del Capitán Hall, confor. Po coquimbo......................... Por la inmersión del primer satélite de Júpiter en I79o............... (4)

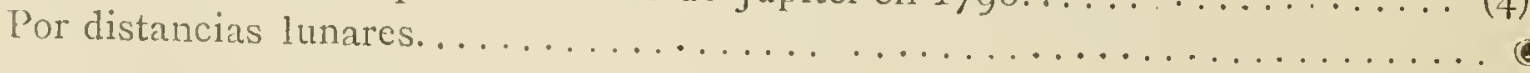

$70 \cdot 50 \cdot 30$

İl promedio de todas será.

Por el promedio de las observaciones astronómicas (I) (2) (3) y (4) desechando la que más se separa, es longitud.

Por lo tanto parece debe adoptarse para observaciones

$70 \cdot 5^{6} \cdot 22,5$ $70 \cdot 52 \cdot 6,7$ $70 \cdot 59 \cdot 4 \mathrm{I},(1)$ $70 \cdot 5^{2} \cdot 33,0$ $70.48 \cdot 55,0$ $70 \cdot 47 \cdot 58,0$ $70 \cdot 47 \cdot 35,0$ $70 \cdot 50 \cdot 3^{0}, 0$

$70 \cdot 5^{\mathrm{I}} \cdot 57 \cdot 6$ $70 \cdot 5$ I. I 4,8 $70.51 \cdot 57,6$ 


\section{Grayaquil.}

En el año de I79o se colocó el observatorio de las corbetas DescubierTa y ATrevida, en una casa próxima á la orilla del río en la ciudad de Guayaquil nueva, situada 6", 5 al Norte y I $3^{\prime \prime}$, 5 al Este de la Iglesia matriz.

La latitud se dedujo por pasos de estrellas al Norte y Sur del zénit de....... Sur.

El r4 de Octubre de r79o se observó la inmersión de la 798 de Mayer ó é de Sagitario por la parte oscura de la ๔ y hecho el cálculo por el Capitán de navío

D. Juan Tiscar, dió longitud al $\mathrm{O}$. de Cádiz reducida á la matriz.........

El 23 del mismo por el eclipse de con correspondiente en Cádiz y Greenwich, cuya diferencia de meridianos es $6^{\circ} \mathrm{I} 7^{\prime} \mathrm{I} 5^{\prime \prime} \ldots \ldots \ldots \ldots \ldots \ldots \ldots \ldots \ldots \ldots \ldots$

Los tres cronómetros de la Descubierta conformes en o", I dieron Gua-

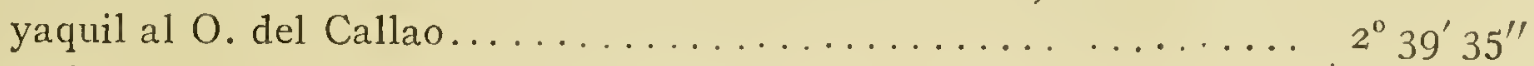

Los très de la ATrevida bastante conformes .............. 2.39. I4

Promedio, diferencia de Guayaquil O. del Callao................

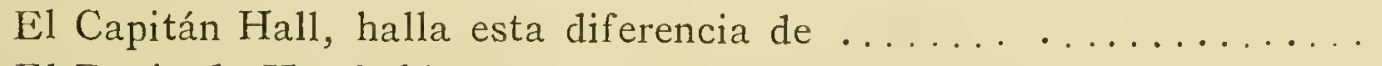

E1 Barón de Humboldt, pág. $439 \ldots \ldots \ldots \ldots \ldots \ldots \ldots \ldots$

$2 \cdot 39 \cdot 24 \odot 73 \cdot 3$ I $.24,0$

$2.3^{6} \cdot 34 \odot 73 \cdot 28 \cdot 34,0$

$2.43 \cdot 40 \bigcirc 73 \cdot 35 \cdot 40,0$

El promedio de todas será..................

$73 \cdot 32 \cdot 52,8$

Sin embargo de la conformidad que se advierte en estas longitudes, me parece debe adoptarse la que resulta por la ocultación de $\underline{e}$ de Sagitario, de.............

$70 \cdot 31 \cdot 53,5$

\section{Panamá.}

El observatorio se estableció en esta ciudad en la sala de armas del Castillo de Chiriqui, que está 6", 5 al Sur y I 3 " al Este de la torre de la Catedral. La latitud se dedujo por paso de estrellas al Norte y al Sur del zénit de.......... Norte.

Deducida á la Catedral. . . . . . . . . . . . . . . . . . . . . . . .

$8^{\circ} 57^{\prime}$ I0 $^{\prime \prime}$

$8 \cdot 57 \cdot 16,5$

E1 I9 de Noviembre de I79o se observó la inmersión de O. de Aries por el limbo oscuro de la y hecho el cálculo por D. Juan Tiscar, dió longitud al $O$,

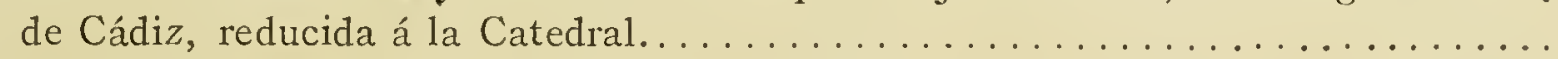

El 2 de Diciembre ocultación de $\lambda$ Virgo por la parte clara de la ๔ emersión é inmersión calculada por Tiscar dió longitud reducida.

El promedio de estas dos longitudes tan conformes es.

$73 \cdot 00 \cdot 42$

E1 26 de Noviembre, por la inmersión del primer satélite de Júpiter. . . . . . . . . . .

73.11 .30

El 3 de Diciembre por ídem.

Los cronómetros de ambas corbetas dieron con corta diferencia el promedio de $\mathrm{Ig}^{\prime} 2^{\prime \prime}$ la Catedral al Este de Guayaquil.......... $70^{\circ} 3 \mathrm{I}^{\prime} 53^{\prime \prime}, 5$ )

La Catedral de Panamá al Este. Ig. 25 $73 \cdot \mathrm{I} 2.28,5$

Aquí se observa una de aquellas anomalías de que hemos hablado, pues entre dos puntos situados por observaciones astronómicas, y las diferencias cronométricas tan iguales como se pudieran desear, sin embargo la longitud varía una de la otra en $\mathrm{II}^{\prime} 4^{\prime \prime}$, 5. Sin embargo, no se puede prescindir de adoptar para la Catedral de Panamá al $O$. de Cádiz el promedio de las dos ocultaciones tan conformes..................................

\section{Arica}

E1 i6 y I7 de Mayo de I79o, la corbeta ATREvida estuvo en este fondeadero, y en él se observaron varias latitudes, cuyo promedio dieron.. 
Los cronónctros dieron lá longitud al Este de Coquimbo........

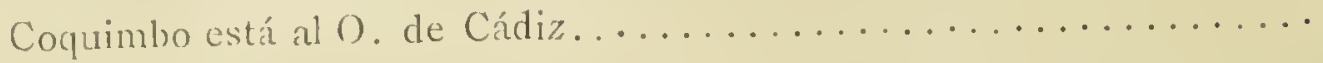

Será lon

Será para la Iglesiár

El Capitán Hall, halla la diferencia de longitud entre C'oquimbo y Arica:
I. 3.08

$65 \cdot 0 \cdot 35$

Arica al O. de Cádiz.

Promedio será longitud de Arica la Iglesia.

Veamos el resultado de la longitud de Arica con referencia á Lima:

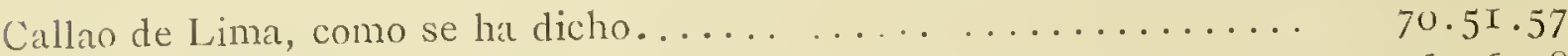

Arica al Este, por los cronómetros.................. 6.46 .38

Longitud de Arica con referencia á Lima................64.05.19-22" 64 $4^{\prime} 57$

Promedio será Iglesia de Arica..................6 64. I. r

El Capitán Hall, hallá lá diferencia de longitud cronométrica entre

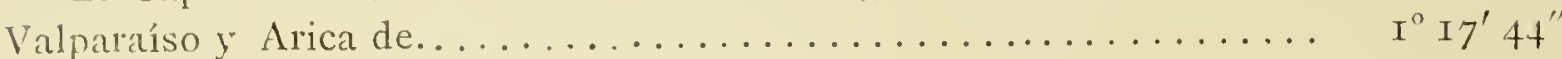

Valparaíso, como hemos dicho................ $65.13 \cdot 56$

Longitud de la Iglesia de Arica.

(b) $63 \cdot 5^{6} .12$

$63^{\circ} 5^{6^{\prime}} 12^{\prime \prime}$

Por lo dicho, parece preferible para la longitud de Arica el promedio de las dos lon-

gritudes $(a)$ y $(b)=0$. de Cádiz.......................... $63 \cdot 56 \cdot 3^{8}, 5$

Estos apuntes manifestarán al inteligente tridrógrafo, que no se puede errar mucho en la situación de los lugares que se establezcàn por ellos; en la elección de las longitudes será algo difícil para aquellos que busquen una exactitud demasiado nímia, porque como se ve en esta corta discusión, áun en aquellas observaciones que no debían dejarnos duda alguna en cuanto á sus resultados, sin embargo, se hallan algunas diferencias bien notables que dependen de muchas causas que no se ocultan al inteligente en estas materias y no deja de ser una el modo de calcularlas, como lo hemos visto en la célebre ocultación de Antares por la c observada en Puerto-Rico por el difunto D. Cosme de Churruca, cuya memoria debe ser eterna en la Marina española.

Se notarán también algunas pequeñas diferencias en las latitudes, y á mi entender, dimanan de que no se hizo uso del barómetro y termómetro para corregir las declinaciones de refracción.

\section{Posiciones de los lugares de que trata cister Memaria.}

\begin{tabular}{|c|c|c|}
\hline & Latitudes. & $\begin{array}{l}\text { Longitudes } \mathrm{O} \\
\text { de Cádiz. }\end{array}$ \\
\hline s de Chiloé (Castillo)..................... Sur. & $4 I^{\circ} 5 I^{\prime} 23^{\prime \prime} \circ$ & $67^{\circ} 26^{\prime} I I^{\prime \prime}$ \\
\hline 10 (P'ueblo). . & $3^{6} \cdot 42.32 \odot$ & $66.42 .2 \mathrm{I}$ \\
\hline Valparaíso: Castillo del Rosario. & .55 & $65 \cdot 13 \cdot 56$ \\
\hline Coquimbo: Observatorio en el pucrto. . . . . . . . . . & 29.56 .22 & $65 \cdot 00 \cdot 35$ \\
\hline Lima: Castillo del Callao. & I2.03.3I & 70.5 I. 57,6 \\
\hline Guayaquil: Iglesia matriz... & 2.12 .03 & $73 \cdot 3 \mathrm{I} \cdot 53,5$ \\
\hline anamá: Catedral. & 8.57 .10 & $73 \cdot 00 \cdot 42,0$ \\
\hline
\end{tabular}

Con estos datos, y teniendo á la vista las bases corridas por las corbetas en los intermedios de estos puntos principalcs, las diferencias por el Capitán Hall y los trabajos de la expedición hidrográfica del Perú y Chile, podrán corregirse los demás puntos de las costas, asi como las Islas de Jun lierníndez $y$ San Félix, que dependen de Valparaíso y de Coquimbo. 


\section{Discusión sobre las situaciones astronómicas de las costas de Chile, Perú é islas adyacentes.}

Para poder fijar con más acierto la posición geográfica de muchos puntos de estas costas, se hace preciso manifestar antes las de aquéllos que por tener observaciones absolutas, sirven de base á las demás con quienes hay diferencias cronométricas ú operaciones geodésicas, practicadas desde la mar y en tierra.

\section{Callao de Lima.}

La observación astronómica de mayor importancia que se ha hecho para fijar la verdadera situación geográfica de este punto, es la que hizo el Barón de Humboldt, del paso de Mercurio por el disco del Sol el día 9 de Noviembre de I802: esta interesante observación, calculada por el Señor Oltmans (Observaciones astronómicas por Mr. Humboldt, tomo II, páginas 4I8, 4I9, 42I y 426 ) resultó para la longitud del Callao, Occidente de París, $79^{\circ} 34^{\prime} 30^{\prime \prime}=70^{\circ} 56^{\prime} 45^{\prime \prime} \mathrm{O}$. C.

Además hay otras observaciones hechas anteriormente, que pueden servir de rectificación de esta, y son las siguientes:

El tiempo no permitió que el Sr. Malaspina pudiese hacer otra observación que la emersión del primer Satélite de Júpiter el día 5 de Junio de I79o en el pueblo de la Magdalena, en donde fijó el observatorio. Esta observación, según el Sr. Oltmans, comparándola con las tablas corregidas de Mr. Delambre dió:

Longitud O. de París.

Seis emersiones del primer satélite de Júpiter observadas por los señores

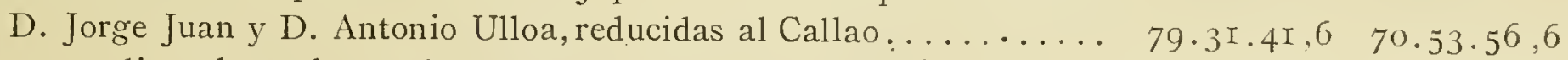
Por un eclipse de observado por D. Pedro Peralta.......... 79.37.26,6 70.59.4I,6

El promedio de estas observaciones será............. 79.35.00,7 70.57.15,7 E1 de las cuatro, contando con el paso de Mercurio.......... 79.34.53,0 70.57.09, o

que sólo difiere en $23^{\prime \prime}$ de arco, de la observación del paso de Mercurio, de consiguiente es la longitud del Torreón del Castillo del Callao, $70^{\circ} 57^{\prime} 09^{\prime \prime}$ Occidente de Cádiz.

\section{Guayaquil.}

Las observaciones hechas en esta ciudad durante el tiempo que permaneció en ella la expedición de Malaspina, al paso que fijan la verdadera situación geográfica de este punto sirven de confrontación á la longitud del Callao. El día r4 de Octubre de I79o, se observó la inmersión de $e$ de Sagi. tario por el limbo oscuro de la $₫$, cuyo fenómeno, calculado por el Sr. Oltmans, dió longitud al

Occidente de París.

El 22 de Octubre se observó también el eclipse de @, que calculado

$$
82^{\circ} \text { I } 8^{\prime} \text { I I } \text { I }^{\prime \prime} \quad 73^{\circ} 40^{\prime} \quad 26^{\prime \prime}
$$

por Oltmans, comparándolo con seis observaciones hechas en Eu-

ropa, dieron longitud.

$\frac{82.18 .25,5}{82.18 .18,25} \frac{73 \cdot 40 \cdot 40,5}{73 \cdot 40 \cdot 33,25}$

El promedio es longitud de Guayaquil

Suponiendo la longitud del Callao como se ha dicho $70^{\circ} 57^{\prime} 9^{\prime \prime}$ Occidente de Cádiz, véase como resulta la de Guayaquil por diferencias cronométricas. 
Malaspina halló la diferencia de longitud entre el Callao y Guayaquil, por varios cro-

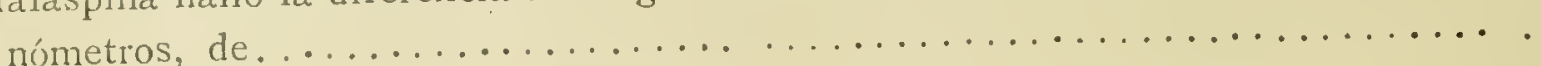

El Barón de Humboldt. . . . . . . . . . . . . . . . . . . . . . . . .

El Capitán Hall de la Real Marina británica..................... $2^{\circ} 39^{\prime} 24^{\prime \prime}, 5$

$2 \cdot 43 \cdot 40,5$

$2 \cdot 37 \cdot 34,0$

Promedio será............................ 2.40. I3

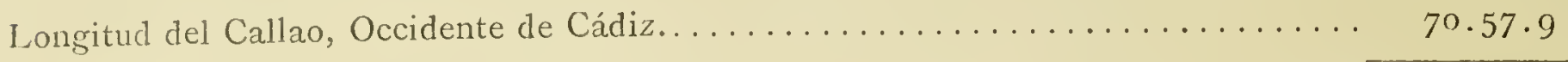

Longitud de Guayaquil, Occidente de Cádiz...................... $73 \cdot 37.22$

Por observaciones astronómicas. . . . . . . . . . . . . . . . . . $73 \cdot 40.33$

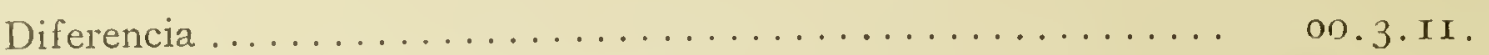

Si se adopta la diferencia cronométrica $2^{\circ} 43^{\prime} 40^{\prime \prime}, 5$ que halla el Barón de Humboldt, resultará para Guayaquil $73^{\circ} 40^{\prime} 49^{\prime \prime}, 5$, que sólo difiere de las observaciones astronómicas, la despreciable cantidad de $I 6^{\prime \prime}, 5$ de arco; de consiguiente, parece que la longitud de Guayaquil debe fijarse en $73^{\circ}$ $40^{\prime} 33^{\prime \prime}$ al Occidente de Cádiz y que la del Callao es igualmente tal como se ha fijado.

\section{Valparaiso.}

Malaspina estableció el observatorio en el ángulo Norte del Castillo del Rosario, cuya latitud observada fué de........................ Sur.

I. ${ }^{a}$ Por una inmersión y dos emersiones del primer satélite de Júpiter observadas en los días ig y 25 de Marzo de I79o y i I de Abril con correspondientes en Green-

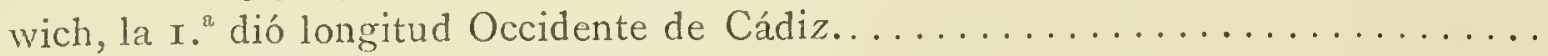

2." Pero siendo la de más confianza la emersión del 25 de Marzo, según los apuntes del Diario astronómico de aquella expedición, resulta Occidente de Cádiz......

3." Según una carta del difunto Mr. Mechain, data del 25 de Mayo de r8or, dice este astrónomo, que habiendo comparado las inmersiones y emersiones del ig y 25 de Marzo y i d de Abril con las tablas corregidas, resultó para Valparaíso

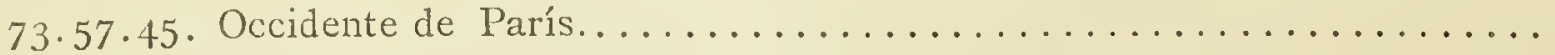

4. El mismo Mr. Mechain, por el eclipse de Sol de II de Marzo de r 709 (Efemérides di Visna, pág. 385) comparando la correspondiente en Marsella y disminuyendo $3^{\prime \prime}$ de tiempo que Mr. Triesnecker supone Marsella más al Oriente de Pa-

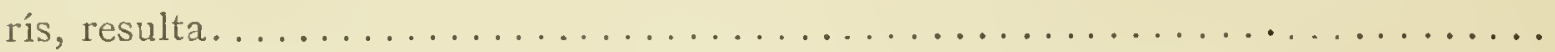

Posteriormente se han hecho en Valparaíso dos observaciones de importancia. El Capitán Hall, de la Marina británica, y el Teniente Foster, del buque Contray, observaron la inmersión de Antares por la ce el 29 de Octubre de I82 y y el mismo día la 644 de Escorpión: por la primera, según los cálculos originales que he visto, resulta el fuerte de San Antonio al Occidente de Greenwich.......... $7 \mathrm{I}^{\circ} 30^{\prime} 50^{\prime \prime}, 5$ Por la segunda......................... 7 I. 28.46

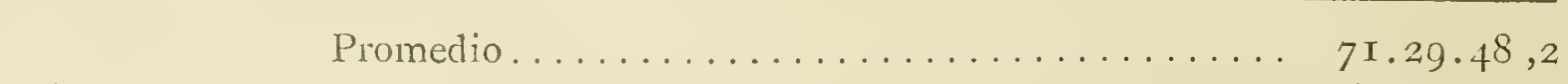

El fuerte del Rosario al $0 \ldots \ldots \ldots \ldots \ldots \ldots \ldots \ldots \ldots \ldots \ldots$ Io, 7

Longitud de Valparaíso, fuerte del Rosario................ 7 I.29.59

Occidente de Cádiz.......................... $65^{\circ} \mathrm{I} 2^{\prime} 44^{\prime \prime}$

5." En la tabla de posiciones (Viaje del Capit in Hall y Memoir on the navigation of So:tth Amsica, pág. 43), se halla 7r.3I.oo para el Castillo de San Antonio

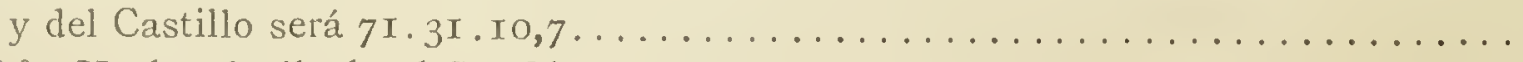

6. Hecho el cálculo el Sr. Oltmans de la ocultación de Antares, resulta Valparaíso al Occidente de París 74. I . 40 ó de Cádiz reducida al Castillo del Rosario.

$33^{\circ} \mathrm{I}^{\prime} 55^{\prime \prime}$

$65 \cdot 23 \cdot 5 \cdot$

$65 \cdot 25 \cdot 30$

65.20 .00

$65 \cdot 2 \mathrm{~T} \cdot 34,5$

$65 \cdot 34 \cdot 5,7$

Resumiendo las observaciones astronómicas, tendremos:

I. Occidente de Cádiz.

$65 \cdot 23 \cdot 5$

$65 \cdot 25 \cdot 30$ 


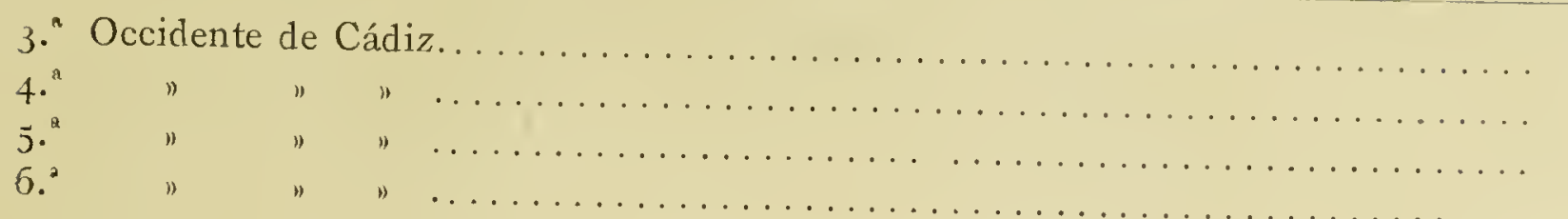

$65 \cdot 20.00$

$65 \cdot 2 \mathrm{I} \cdot 34,5$

$65 \cdot 13 \cdot 55,7$

$65 \cdot 34 \cdot 5 \cdot 7$

Promedio

$65 \cdot 24 \cdot 50,8$

Longitud de Valparaíso por diferencias cronométricas:

Según Malaspina por los cronómetros de la Descubierta. Valparaíso al Oriente del

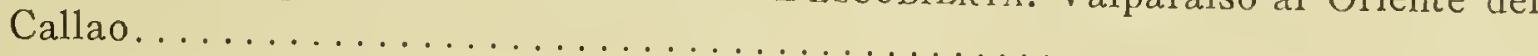

Idem por los cronómetros de la A TrevidA . . . . . . . . . . . . . . . . . . $5 \cdot 35 \cdot 32$

Por el Capitán Hall. ... . . . . . . . . . . . . . . . . . . $5.25 \cdot 49,5$

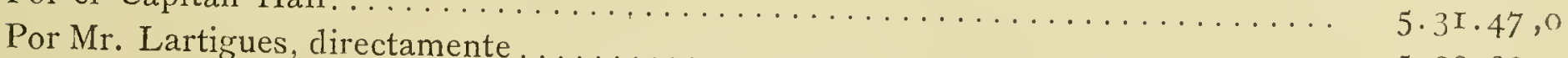

$5 \cdot 30.23$

Promedio.

$70 \cdot 57 \cdot 9$

Valparaíso, al Occidente de Cádiz.

$6 \overline{5} \cdot 26.16,2$

Por el promedio de las observaciones astronómicas. . . . . . . . . . . . . . $65.24 \cdot 50,8$

Diferencia

Promedio, longitud de Valparaíso.

$65 \cdot 25 \cdot 33,5$

Coquimbo.-Puerto.

Malaspina estableció el observatorio en una casa situada en la playa occidental del puerto, desde donde demora la ciudad de la Serena al Norte $5^{\circ}$ Este distancia cinco millas.

La latitud del observatorio se halló de.................. Sur. $29^{\circ} 56^{\prime} 22^{\prime \prime}$

Para la longitud tenemos las siguientes observaciones:

E1 día I8 de Abril de I790 se observó la emersión del primer satélite de Júpiter (Me-

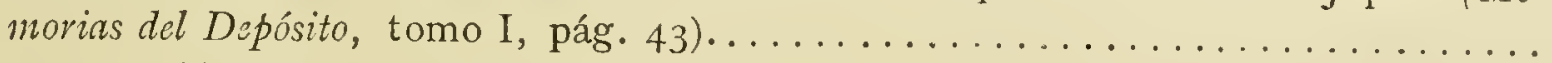

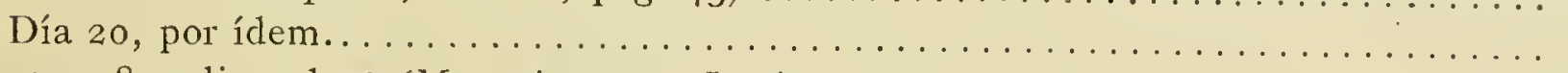

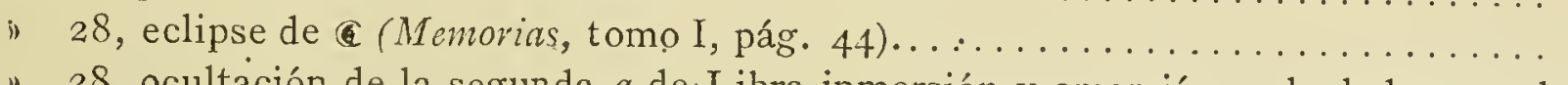

" 28, ocultación de la segunda a de Libra inmersión y emersión, calculada por el

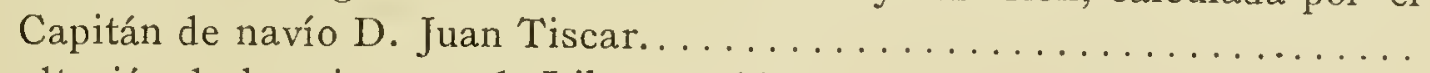

$65 \cdot 2 \cdot 30$

$64 \cdot 57 \cdot \mathrm{I}_{5}$

$65.2 \cdot 45$

$6_{5} \cdot 0.40,5$

$65 \cdot 5 \cdot 4 \mathrm{I}, \mathrm{O}$

Promedio, Coquimbo O. de Cádiz............... 65. $1.44,3$

Con fecha de 25 de Mayo de I8or nos dijo Mr. Mechain, lo siguiente:

"He comparado las fases del eclipse de observado en Coquimbo el día 28 de Abril de I79o, con "las que yo he observado aquí, y me dan por un medio entre los resultados:

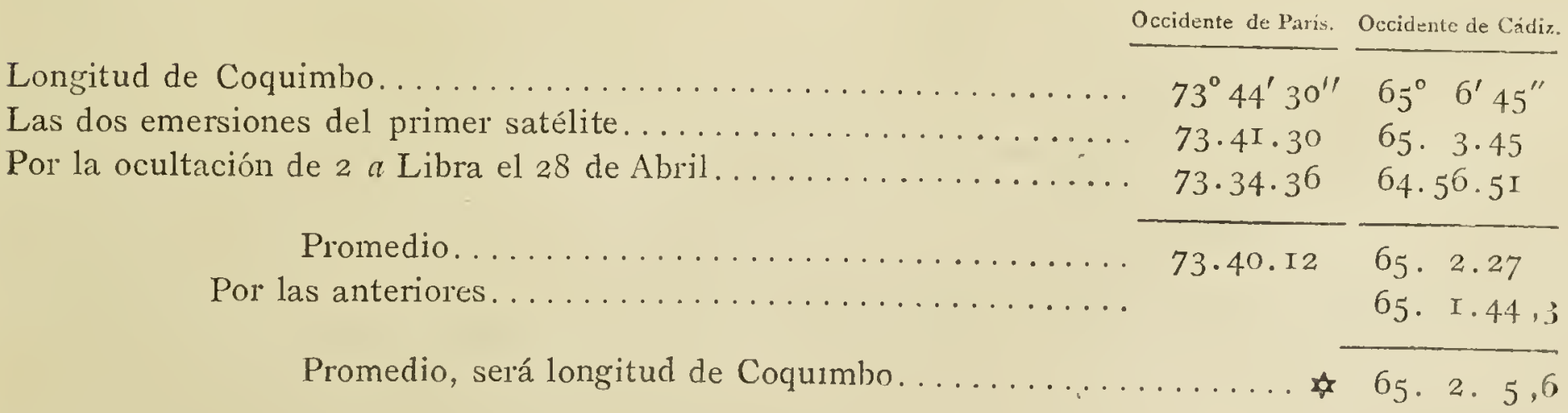


Diferencias cronométricas entre Coquimbo y el Callao:

Por los cronómetros de la corbeta DescubierTA....................

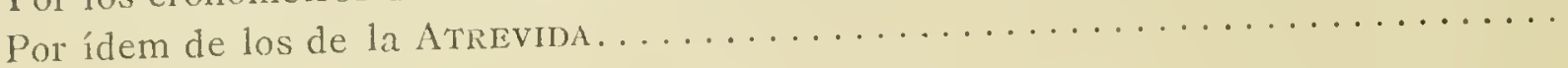

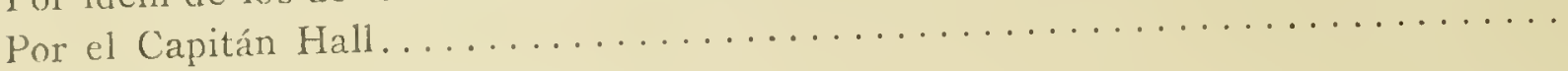

Promedio.

(a)

$5^{\circ} 51^{\prime} 26^{\prime \prime}$

$5 \cdot 43$. I2

$5 \cdot 47 \cdot 19$

$5 \cdot 47 \cdot I 9$

Longitud en que se ha supuesto el Callao....... $70^{\circ} 57^{\prime} 9^{\prime \prime} \quad 70^{\circ} 57^{\prime} \quad 9^{\prime \prime} \quad 70 \cdot 57 \cdot 9$

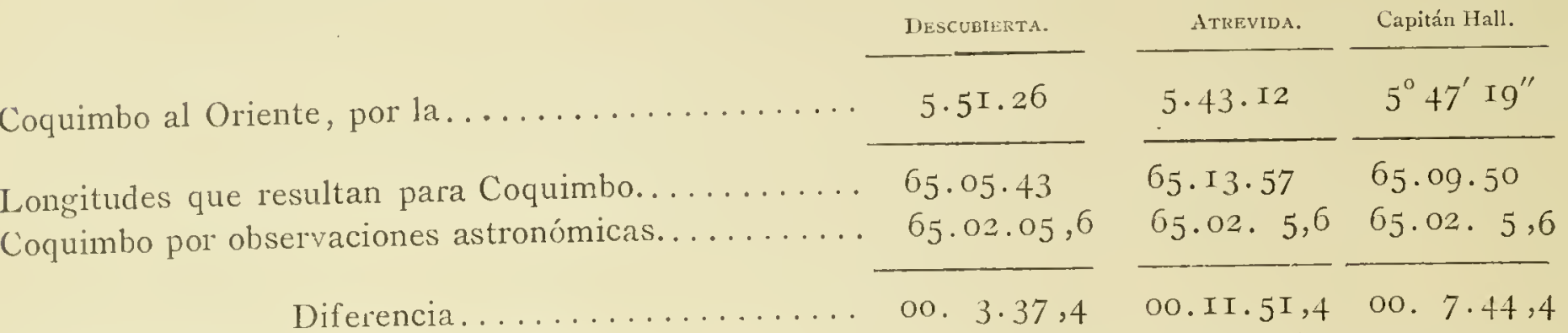

Si se adopta la diferencia promedio de las tres................. (a) 5.47. I9

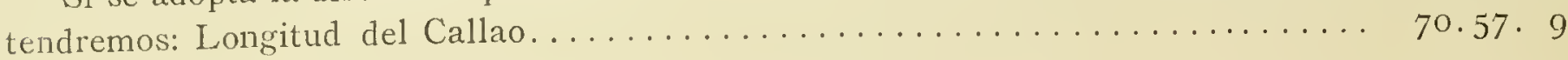

Longitud de Coquimbo.

(b) $65.09 \cdot 50$

La diferencia cronométrica de Coquimbo al Este de Valparaíso por Malaspina......

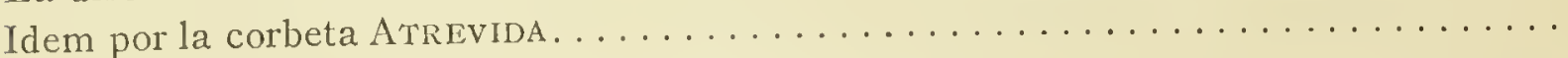

Por el Capitán Hall, reducida al fuerte del Rosario...................

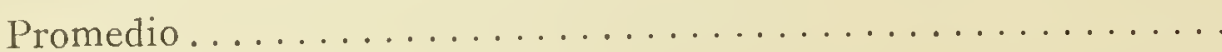

Longitud adoptada de Valparaíso.................... $65.25 \cdot 33,5$

Longitud de Coquimbo por diferencias cronométricas con Valparaíso.......... 65.09. I7,5

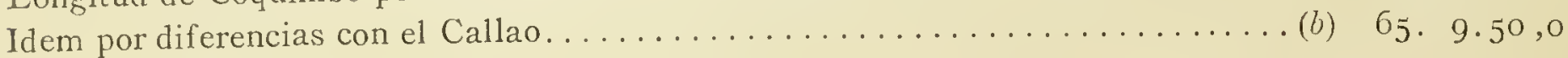

Promedio

(- $65.9 \cdot 33,7$

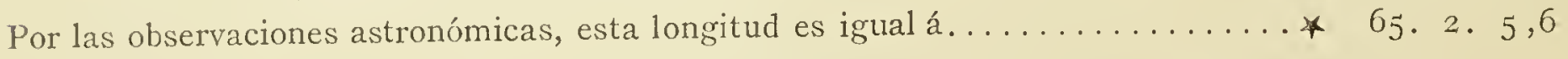

Medio.

$65 \cdot 5 \cdot 49,6$

Diferencia .

$7 \cdot 28, \mathrm{I}$

Cuando se recalculen las observaciones practicadas en la expedición de Malaspina, quizás desaparecerá esta diferencia; miéntras será longitud de Coquimbo $65^{\circ} 2^{\prime} 5^{\prime \prime}, 6$ ó más bien $65^{\circ} 5^{\prime} 49^{\prime \prime}, 6$ promedio de las observaciones astronómicas y difcrencias cronométricas.

Arica.

Malaspina halló por dos cronómetros la diferencia de longitud entre Arica y el Ca-

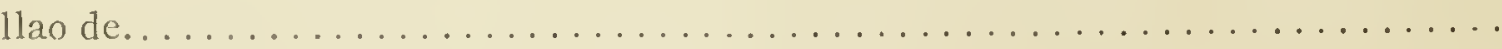

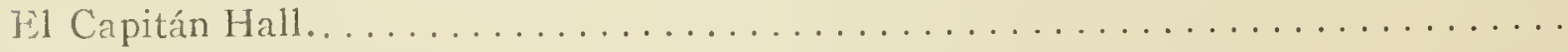

$M r$. Lartigues . . . . . . . . . . . . . . . . . . . . . . . . . . . .

$6 \cdot+8 \cdot 5^{6}$

6.49 . I I

Promedio............................ 6.48 .15

Callao al Occidente de Cádiz, según hemos dicho.............. 70.57• 9

Longitud de Arica.

$\left(\mathrm{I} .^{n}\right)$

T'enemos también Arica al Este de Valparaíso por Lartigues................ 64.08 .54

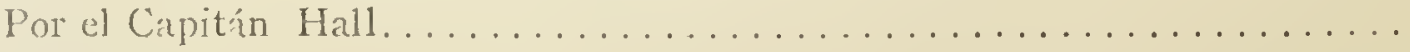

I. I8.28

Malaspina.

I. 17.44

I. I9. IO 
Promedio Arica Este de Valparaíso (por las tres posiciones anteriores). I. I 8.27

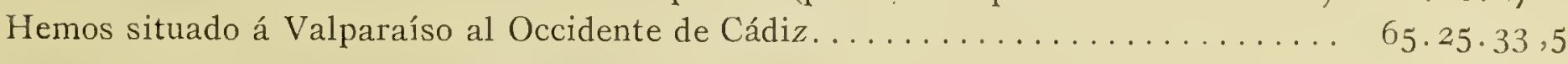

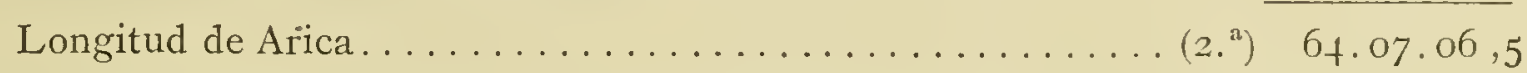

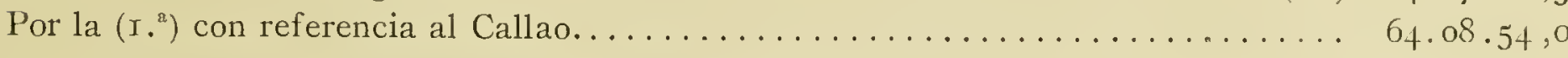

Promedio: Longitud de la Iglesia de Arica................. . 6+. 8.0o,2

Aunque parece no ser de este lugar las longitudes de Cartagena de Indias, Panamá, Acapulco, San Blas de Californias, San José y Cabo San Lucas, que van á continuación, lo son atendiendo á que todas están ligadas entre sí y cada una de ellas con los puntos de las costas de que habla esta Memoria.

\section{Cartagena de Indias.}

En el tomo II de las Observaciones astronómicas del Barón de Humboldt, calculadas por Oltmans, desde la página I46 en adelante se hallan los cálculos y discusiones sobre la longitud de esta plaza, concluyendo en la página I8I con los resultados siguientes:

I. Por las observaciones antiguas del Padre Feuille, D. Juan Herrera, D. Jorge Juan, D. Antonio Ulloa y Mr. de Puysegur: Cartagena Occidente de París. . (I. ${ }^{a}$ )

2. ${ }^{\circ}$ Por el eclipse de observado en la Iglesia Baru en 30 de Marzo de I8or por el

Barón de Humboldt, y referido á Cartagena por el cronómetro........... (2. ${ }^{\mathrm{a}}$ )

3. ${ }^{\circ}$ Por la ocultación de $a$ de Escorpión, en 23 de Marzo de I8o2, observada por No-

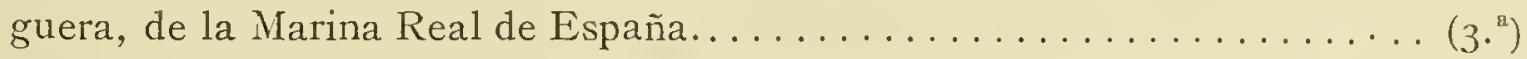

$4 .^{\circ}$ Por las observaciones del primer satélite, por el mismo, comparadas á las tablas y con correspondientes. $\left(4 \cdot^{\mathrm{B}}\right) \quad 77 \cdot 5^{\mathrm{I}} \cdot \mathrm{I} 5$

Promedio ........................... $77.49 \cdot 36,7$

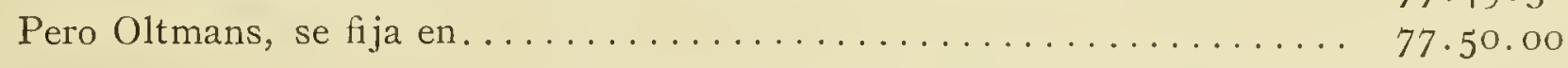

Después de estos datos, el Capitán de navío D. Juan Tiscar nos ha facilitado las siguientes obervaciones que él mismo ha calculado:

I803 2 de Abril. Ocultación de Regulus por la $\ldots \ldots \ldots \ldots \ldots \ldots \ldots \ldots{ }^{n}{ }^{n}$

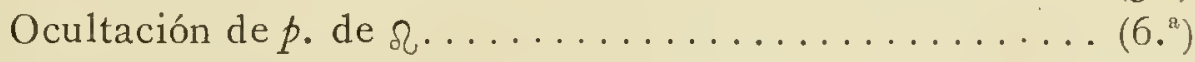

2 I de Febrero. Eclipse de Sol con correspondiente en la Habana........ $\left(7 \cdot^{a}\right)$

1802 "Desprendimiento de Mercurio del disco del Sol, con correspondiente en Vivieres, circunstancias dudosas. . . . . . . $\left(8 .^{a}\right)$

Por la ocultación de $a$ de Escorpión calculada por Ferrer.. $\left(9 .^{\mathrm{a}}\right)$

Idem íd. por Tiscar. ........................ (Io)

$77^{\circ} 52^{\prime} \mathrm{oo}^{\prime \prime}$

$77 \cdot 46 \cdot 57$

$77 \cdot 48 \cdot$ I $5^{2}$

Resumiendo estas longitudes, tendremos:

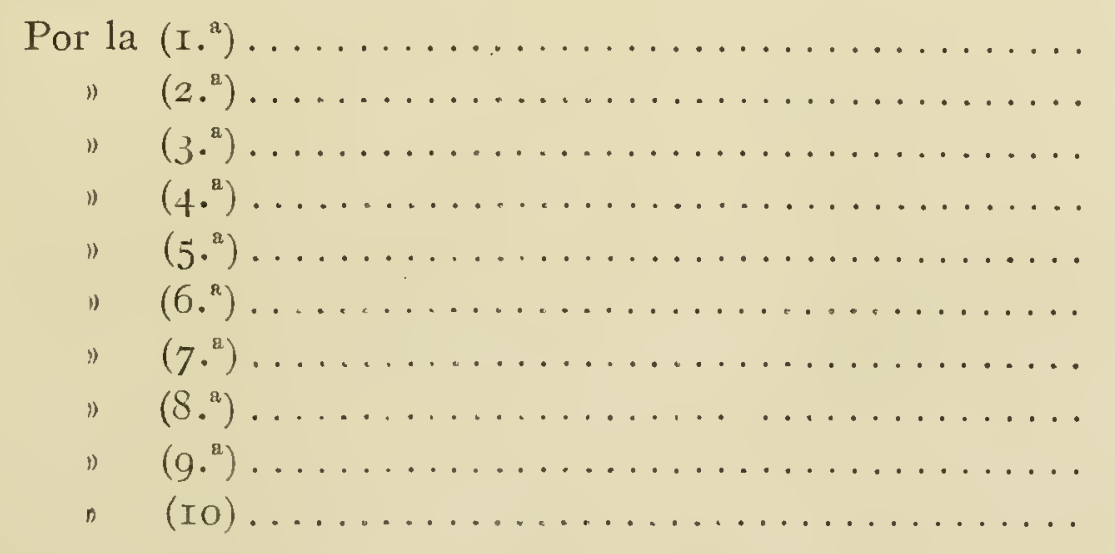

$77 \cdot 52.00$

$77 \cdot 46.57$

$77 \cdot+8 \cdot 15$

$77 \cdot 51.15$

$77 \cdot 47 \cdot 26,2$

$77 \cdot 48 \cdot 22,5$

$77 \cdot 49 \cdot 55,5$

$77 \cdot 46.00$

$77 \cdot 5^{\mathrm{I}} \cdot+5$

$77 \cdot 5$ I. II, 2

Occidente de París Occidente de Cádiz.

Promedio. Longitud de Cartagena de Indias............. $77^{\circ} 50^{\prime} 18^{\prime \prime}, 7$

Oltmans la fija.

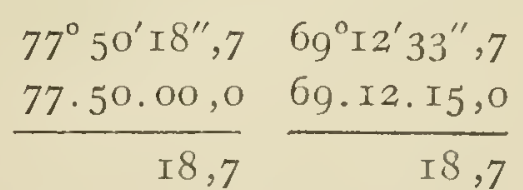

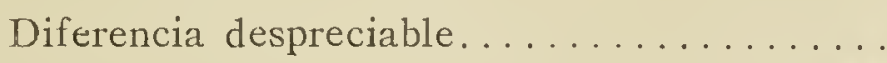

Por tanto, es la longitud de Cartagena, Occidente de Cádiz...... ^. 69. I2.33,7 ó 69. I2.34. 


\section{Panamá.}

Malaspina estableció el observatorio en la sala de armas del Castillo de Chiriqui, que está $6^{\prime \prime}, 5$ al Sur y I3" al Este de la torre de la Catedral.

Por estreilas al Norte y al Sur del zénit, se dedujo la latitud Norte del observatorio.

$8^{\circ} 57^{\prime}$ I0 $^{\prime \prime}$

De la Catedral.

$8 \cdot 57 \cdot 16,5$

El día Ig de Noviembre de I79o se observó la inmersión de $O$. de Aries por el limbo oscuro de la đe, y hecho el cálculo por D. Juan Tiscar.

Dió longitud al Occidente de París.

$8 \mathrm{I}^{\circ} 38^{\prime} 45^{\prime \prime}, 4$

Día 2 de Diciembre. Ocultación $>$ de Virgo. Cálculo del mismo......

$8 \mathrm{I} \cdot 37 \cdot 48,4$

Promedio longitud de Panamá. Observatorio............... (d) 8I.38. I7

O. de Cádiz

26 de Noviembre de I7go. Inmersión del primer satélite...........

$73^{\circ} \mathrm{Oo}^{\prime} 32^{\prime \prime}$

3 de Diciembre

id.

id..........................

73 . II. 30

$73 \cdot 7 \cdot 30$

Promedio.

73. $6 \cdot 30,7$

Como se ve, el resultado de las ocultaciones de estrellas varía bastante de las observaciones del primer satélite de Júpiter; de consiguiente, nos valdremos de otros medios (como á continuación se expresan) para hallar la longitud de Panamá, y que al mismo tiempo nos manifiesten cuál de estas longitudes es la preferente.

Malaspina halla la diferencia cronométrica entre Panamá y Guayaquil por dos cronó-

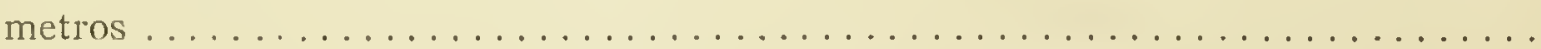

Un cronómetro de la corbeta ATREvida, de la misma expedición. . . . . . . . . . . .

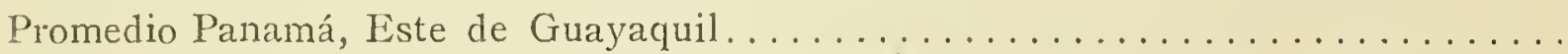

Guayaquil, Occidente de Cádiz según hemos dicho....................

Panamá, Occidente de Cádiz. .

$19^{\prime} 25^{\prime \prime}, 5$

I9. 3,9

I $9.14,7$

$73^{\circ} 40^{\prime} 33^{\prime \prime}, 0$

$73.21 .18,3$

\section{Longitud de Panamá con referencia á Cartagena.}

Hemos visto que la longitud de Cartagena es al Occidente de Cádiz.............

Porto Belo (fuerte de San Jerónimo) O. de Car-

tagena......................... Por Puysegur $4^{\circ} 7^{\prime} 35^{\prime \prime}$ Por Fidalgo.

Cartagena. O. de Cádiz ............... 69.12.34

Longitudes de Porto Belo..............

$\begin{array}{r}69.12 .34 \\ 73.20 .09 \\ \hline\end{array}$

$69 \cdot 12 \cdot 34$

$4^{\circ} 6^{\prime} 23^{\prime \prime}$

$69 \cdot 12 \cdot 34$

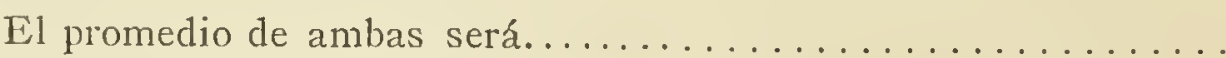

Según Fidalgo, el Castillo de Chagres al O. de Porto Belo.

73.18 .57

$73^{\circ} 19^{\prime} 33^{\prime \prime}$ $20^{\prime} 30^{\prime \prime}$

Longitud del Castillo de Chagres.

(b)

En el tomo I de las Memorias del Depósito, Memoria segunda, pág. 53, se ve que:

El Castillo de Chagres está al O. de Panamá, por el cronómetro..............

Por la observación del primer satélite en ambos puntos.

$73 \cdot 40.03$

$28^{\prime} 4 I^{\prime \prime}$

$33 \cdot 30$

Está diferencia parece preferible á la que resultó por el cronómetro, cuya máquina pudo tener alte. raciones, ya por el clima como por las sacudidas que sufría en el viaje, por lo que tendremos:

Longitud del Castillo de Chagres. (b) $73^{\circ} 40^{\prime} 03^{\prime \prime}$

Panamá al Este.............................. 33.30

Longitud de Panamá con respecto á. Cartagena................. 73.06 .33

Idem por el promedio de las observaciones astronómicas ............. (c) 73.06.30.7 


\section{Longitud de Panamá con referencia à Acapulco.}

Según las Memorias del Depósito, la longitud entre Panamá y Acapulco es de...... 20.33. 5

La longitud de Acapulco se ha fijado al Occidente de Cádiz.............. $93 \cdot 3+\cdot 56$

Será longitud de Panamá....................... 73.01.5T

Muy conforme con el resultado de las ocultaciones $(d)$ calculadas por 'Tiscar de. 73.00.32

Resumiendo estas longitudes, tendremos:

Por el promedio de las ocultaciones de estrellas................. (a) 73.00 .32

Por el primer satélite en 26 de Noviembre..................... (b) 73.11.30

Por ídem en 3 de Dicicmbre..................................... 73.7 .30

Por diferencias cronométricas con Guayaquil................... (e) 73.2I. I8

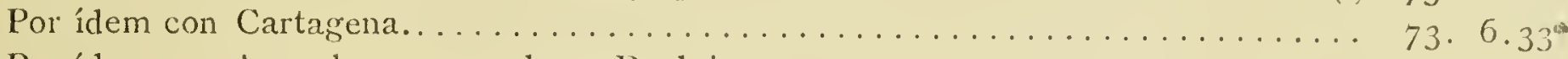

Por ídem con Acapulco con escala en Realejo.................... 73. I.5I

Desechando la (e), será el promedio de las cinco restantes............. $73.5 \cdot 35,3$

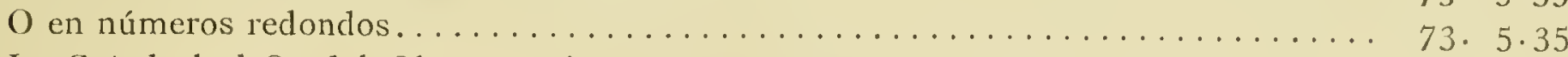

La Catedral al O. del Observatorio ...........................

Longitud de Panamá, Occidente de Cádiz.................... 73.5 .48

Por el promedio de las tres observaciones astronómicas $(a),(b),(c)$ reduciclas á la

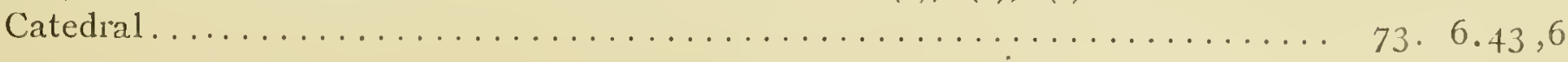

Diferencia........................... $00.0 .55,6$

\section{San Fosé de California.}

El paso de Venus observado en esta Misión el día 3 de Junio de I769 por el Abate Chape, D. Vicente Doz y D. Salvador Medina, ha sido calculado por el Sr. Oltmans, (Observaciones astronómicas, pág. 6I6), concluyendo la longitud Occidente de París II $2^{\circ} 0 I^{\prime} 07^{\prime \prime}, 5$ y I03 $23^{\prime} 22^{\prime \prime}, 5 \mathrm{O}$. de Cádiz.

Este mismo cálculo con los datos originales de Doz y Medina, ha sido támbién calculado por D. José Joaquín Ferrer, en esta forma:

Contacto intcrior del ingreso en el centro de la Tierra...... En Paris, por el conjunto de observaciones de Europa y Asia.

Diferencias de meridianos, ingreso

Idlem por el egreso........................

Promcdio.

Suponiendo la Paralaje Solar 8",590 y excluída la obser-

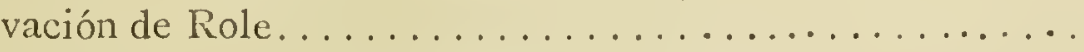

Será longitud de San José, Occidente de París...........

Según Oltmans..................

Promedio, verdadera longitud de San José ......

$$
\begin{aligned}
& 0^{\text {h }} \text { I } 5^{\prime} 28^{\prime \prime}, 7 \text { egreso } 5^{\text {h }} 57^{\prime} 23^{\prime \prime}, 3 \\
& 7 \cdot 43 \cdot 32,6 \quad \text { I } 3 \cdot 25 \cdot 27,6 \\
& 7 \cdot 28 \cdot 3,9 \quad 7.28 .04,3 \\
& 7 \cdot 28 \cdot 4,3 \\
& 7 \cdot 28 \cdot 4, \mathrm{I}
\end{aligned}
$$

\section{Cabo de San Lucas.}

Por una base medida con todo cuidado desde la mar á bordo de los buques de lá expedición de Malaspina, resultó el Cabo de San Lucas al Occidente de San José... 


\section{San Blas de Califormias.}

Malaspina estableció su observatorio en una casa de lá Plaza Mayor, y le dedujo la latitud de la Contaduría.

Por el cuarto de círculo............................ Norte. (a) $2 \mathrm{I}^{\circ} 32^{\prime} 46^{\prime \prime}$

Desde el fondeadero................................. 2I.3I. 5 .

Por el Capitán Hall. ........................... (b) 2 I. 32.24 .

El promedio de las dos más próximas $(a)(b)$ será............... Norte. 2I.32.35.

Para la longitud tendremos:

El día 7 de Abril de r79 se observó la emersión del primer satélite de Júpiter en buenas circunstancias, que según los cáleulos de Oltmans (Observaciones astronómicas, pág. 6r6), dió longitud al Occidente de París.............................. I07.34.45. Promedio.

El día I I de Octubre, fin del eclipse de calculado por el mismo.. Io7.36.52,5 El día 26 de Mayo de r822, el Capitán Hall observó la ocultación de $A$ de Leo, y scgún su cálculo

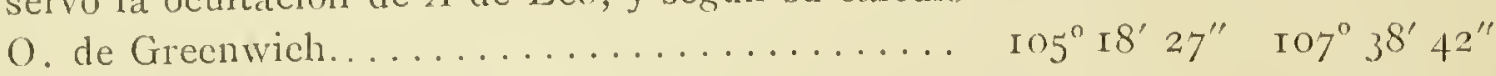
Por las distancias lunares, Capitan Hall......... I05. I7. 9. I07.37.24.

Longitud de San Blas por diferentes cronómetros con Cabo San Lucas:

Malaspina halló esta diferencia por los cronómetros números 7 I y 72 de Arnold... $\quad 4^{\circ} 33^{\prime} 25^{\prime \prime}$ El Cabo San Lueas se ha cstablecido al Occidente de Cádiz.... . . . . . . . . . . I03.32.42

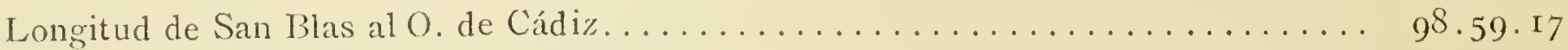

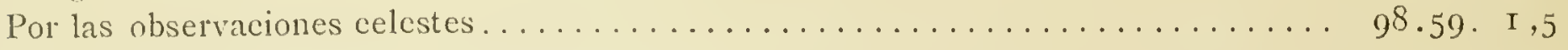

Diferencia despreciable..................... o. 0. I5,5

Se ve desde luego que la conformidad de estas longitudes nada dejan que desear: por lo tanto, reuniéndolas, tendremos:

Por el promedio de las observaciones celestes, Occidente de Cádiz. . . . . . . . . 9 98 $59^{\prime} \mathrm{I}^{\prime \prime}, 5$ Por diferencias cronométricas con el Cabo San Lucas.................... 98.59. I7,o Por las distancias lunares, Capitán Hall . . . . . . . . . . . . . . . . . 98.59.39

Promedio longitud de San Blas al Occidente de Cádiz... . . . . . . . . . . 98.59. I9,2

\section{Acapulco.}

Malaspina estableció el obscrvatorio en I79 en el castillo de San Diegro, y en cuyo paraje por estrellas al Norte y al Sur del zénit, se dedujo la latitud de... Norte.

Para la longitud el día rg de l'ebrero de r 79 I se observó la ocultación de v de Leo por I 6.50 .40 el limbo oscuro de la $(\boldsymbol{c}$, cuyo cálculo hecho por el Sr. Oltmans, dió longitud $O$. de París..................................... I02. Io. 6

Por la misma estrella el 15 de $A$ bril idem................ I02.15. o Portres inmersiones y cinco emersiones del primer Satélite comparadas I02. I4.30

Promedio longitud de Acapulco........... I02. I3. I2 93.35.22 Pero Oltmans, dando la preferencia á las ocultaciones, fija la longitud en In $2.12 .33 ¥ 93 \cdot 34 \cdot 48$ Don Juan 'l'iscar, habiendo calculado las ocultaciones, hace esta longitud de..... 93.30. I9,5 


\section{Longitud de Acapulco por diferencias cronométricas.}

Malaspina halla la diferencia entre estos dos puntos:

Cronómetro número ro.............................. $5^{\circ} 20^{\prime} 15^{\prime \prime}$

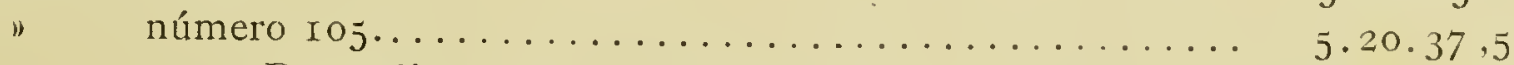

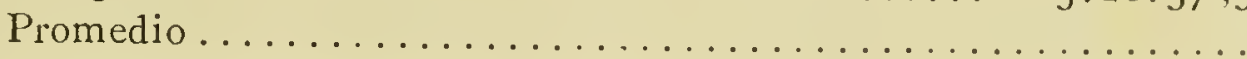

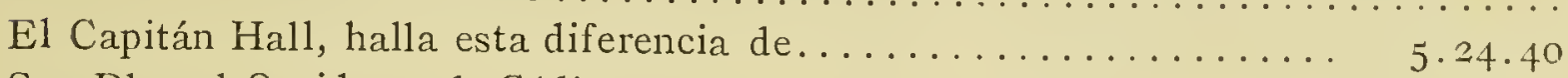

San Blas al Occidente de Cádiz..................... 98.59.19,2 98.59.19,2

Longitud de Acapulco por diferencias cronométricas...........

Por las observaciones celestes O. de Cádiz............ 93.34.48, o 93.34.48,0

Diferencia....................... $0.08,8 \quad 0.4 .05,0$

Se ve desde luego que la diferencia cronométrica que el Capitán halla entre Acapulco y San Blas, es muy conforme con las observaciones astronómicas y desde luego preferible á la que halla Malaspina; por tanto, se puede fijar la longitud de Acapulco, sin error de consideración, en esta forma:

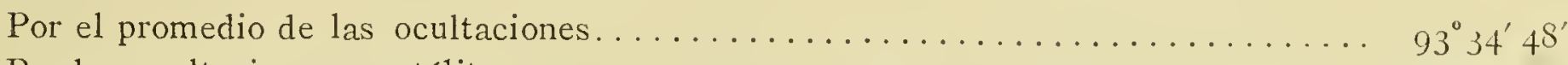

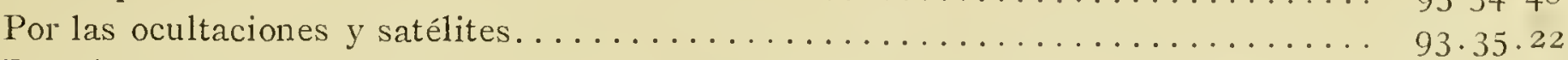

Por dif erencia cronométrica con San Blas: Capitán Hall. . . . . . . . . . . . 93.34.39

Promedio de longitud de Acapulço.............. $93 \cdot 34.56$

\section{Realejo.}

Malaspina colocó el observatorio en la parte meridional del puerto, y á la voz del paraje en donde estaban fondeados los buques de su mando.

La latitud se observó por pasos de estrellas al Sur y al Norte del zénit, de $12^{\circ} 29^{\prime} 50^{\prime \prime}$ Norte. El 24 de Enero de r 79 r se observó la inmersión del primer satélite de Júpiter (Mcmo-

rias, tomo I, pág. 55) y dió longitud al Occidente de Cádiz............. $80^{\circ} 47^{\prime} 00^{\prime \prime}$

Día 26 , otra inmersión del mismo satélite..................... 80.46.15

Promedio longitud de Realejo................ $80.46 .37,5$

La diferencia cronométrica entre este puerto y Acapulco, hallada por

Malaspina con tres cronómetros, fué de............... $\mathrm{I}^{\circ} 54^{\prime} 59^{\prime \prime}$

Según se ha visto, Acapulco O. de Cádiz............... 93.34.56 $80.39 \cdot 57$

El mismo Malaspina halló también la diferencia cronométrica con $\mathrm{Pa}$ -

namá, después de muchos días de calmas y vientos contrarios.... $7 \cdot 38 \cdot 5$ |

Panamá se ha situado en........................... $73 \cdot 5 \cdot 48\} 80.43 .53$

Promedio será longitud de Realejo.............. 80.43.29

\section{San Carlos de Chiloé.}

Malaspina colocó su observatorio en una casa inmediata á la orilla del mar $27^{\prime \prime}$ al Sur y 6" al (". del centro del fuerte de San Carlos.

La latitud se observó por estrellas al Sur y al Norte del zénit, reducida al fuerte.. $4 \mathrm{I}^{\circ} 5 \mathrm{O}^{\prime} 23^{\prime \prime}$

El 6 de Febrero de 1790 se observó la inmersión del primer satélite de

Júpiter: dió longitud Occidente de París.......... $76^{\circ}$ o $8^{\prime}$ oo"

El I5 de dicho, emersión del mismo satélite........ 76.08 .00 .

Promedio longitud de Chiloé, O. de París.. $\overline{76.08 .00 .}=67.30 .15$ O. de Cádiz. 
Los cronómetros de Malaspina en la corbeta Descubierta dieron Chiloé al O. de

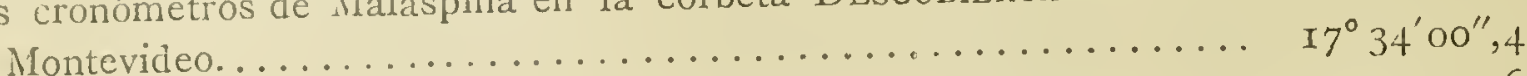

Los de la corbeta AtrevidA.................... I7.37. 3,6

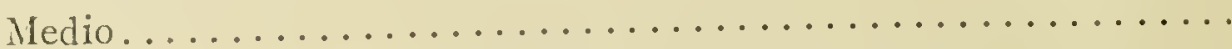

Montevideo al Occidente de Cádiz......................... $49.56 .26,6$

Longitud del observatorio de San Carlos de Chiloé.................... 67.3I.44,6

La diferencia de meridianos fué hallada también por Malaspina, entre Chiloé y Val-

paraíso, de 2.7 .39 y 2.9 .8 cuyo promedio es igual.................. 2. 8.23

Hemos supuesto á Valparaíso al O. de Cádiz..................... $65 \cdot 25 \cdot 33,5$

Longitud ........................ $67 \cdot 33 \cdot 56,5$

Resumiendo las longitudes, tendremos:

Por los satélites................................. 67.30.15

Por diferencias cronométricas con Montevideo.................... 67.31.44,6

Por ídem con Valparaíso............................. 67.33.56,5

Promedio longitud del observatorio de Chiloé.................. $67 \cdot 3 \mathrm{I} \cdot 57,5$

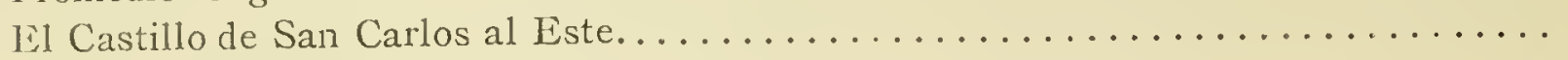

Longitud del Castillo de San Carlos al Occidente de Cádiz...๑

Determinadas las situaciones geográficas de los puntos que deben servir de base para corregir los intermedios, debe tenerse presente que Malaspina situó los puntos de las costas, por bases desde la mar, á más y ménos distancia de ellas, según las circunstancias, anotando los nombres que el Piloto práctico indicaba, por cuyo motivo no debe parecer extraño que en las cartas publicadas por el Depósito Hidrográfico de Madrid, se hallen algunas equivocaciones.

\section{Costa de Chile y Archipiélago de los Chonos.}

Cabo de Tres Puntas. - Noroeste de la Isla de Madre de Dios.

Malaspina, á distancia de 34 millas, sitúa esta punta en latitud Sur de..........

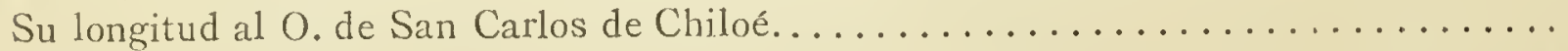

$\mathrm{Y}$ al $\mathrm{O}$. de $\mathrm{Cádiz.}$

$49^{\circ}+6^{\prime}$ oo"

I. $52 \cdot 5^{\circ}$

$6 I \cdot 24 \cdot 42$

Isla del Huafo. - Punta Sur. Su latitud, deducida de la observada al día siguiente,

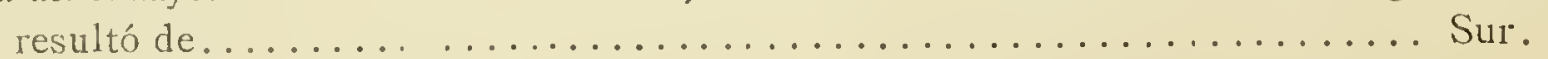

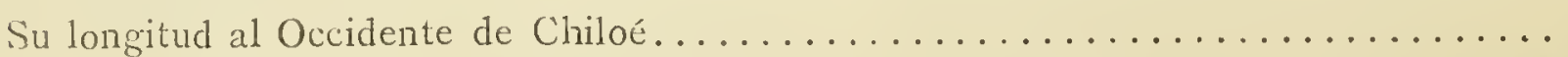

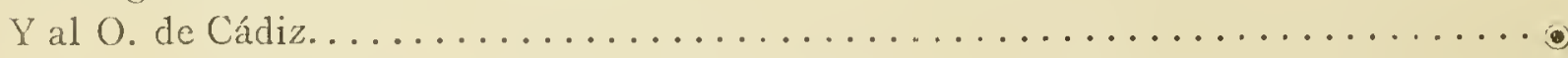

44. $4 \cdot 30$

49.20

68 .2I.II

Punta de Inentemo.-.-Isla de Chiloé. La latitud de esta punta se halló de...... Sur.

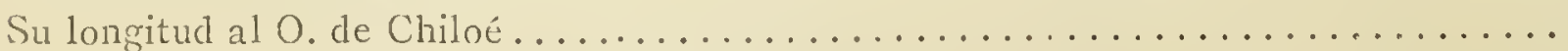

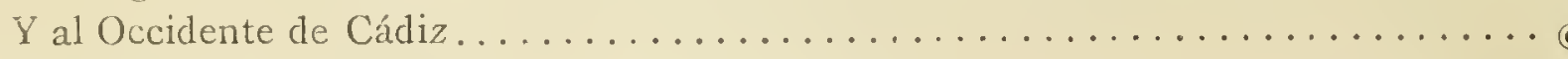

$42 \cdot 46 \cdot 40$

$16.5^{0}$

$67 \cdot 48 \cdot 4 \mathrm{I}$

Volcin de Purarraguc.-Continente. La situación de este monte depende de las operaciones geodésicas ejecutadas en Chiloé y sus inmediaciones. Su latitud resultó ser de ................................... Sur $\Delta$

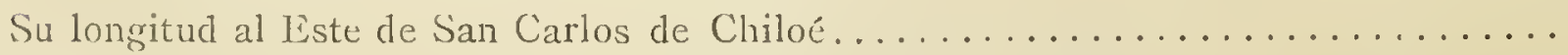

De consiguiente, O. de Cádiz.........................

Panta Pargá ó Estaquillas. - Esta punta se colocó igualmente como la anterior. Su la-

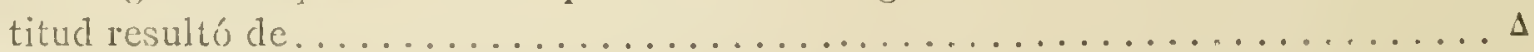

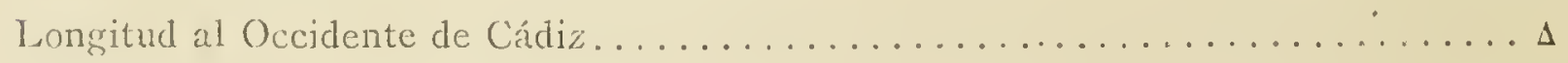

I'unta (Quedal. - Iil Piloto Vila, que observó en su paralelo, la coloca en la itud de. ............................................. \pm

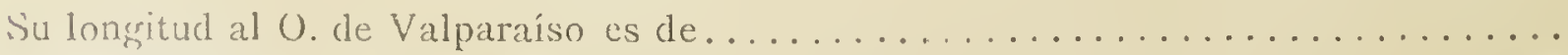
I) consiguiente, al O. de Cádiz.. 
Punta de la Galera.-Malaspina, desde la mar y á distancia de seis á siete millas, coloca esta punta en latitud. ......................... Sur.

Su longitud al Este de Chiloé, resultó ser de ............... . Sur. 39.53.30

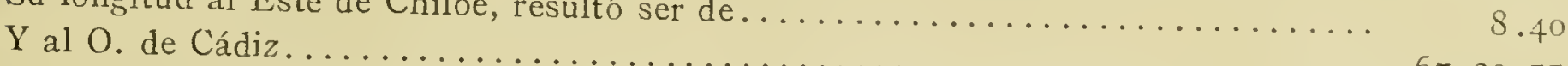

La punta de la Galera está al O. del Castillo del Cor.................. 67.23.II,5

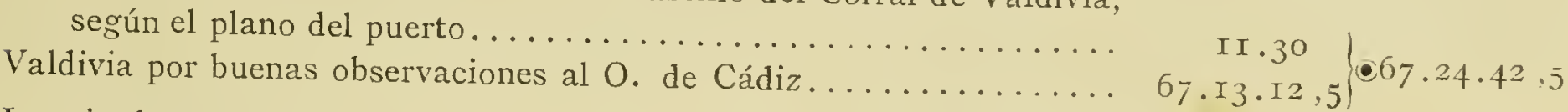

Longitud que parece debe preferirse á la anterior, aunque se diferencia en muy corta cantidad.

Castillo del Corral.-En Valdivia. Mr. Lartigue halla la latitud (Eclaircissements sur les positions geographiques determinées en I82I, 22 et 23 par Mr. Lartigue, etc. Connaissance de temps, année $\mathrm{I} 827$, pag. 238$) \ldots \ldots \ldots \ldots \ldots \ldots \ldots \ldots \ldots \ldots \ldots+$

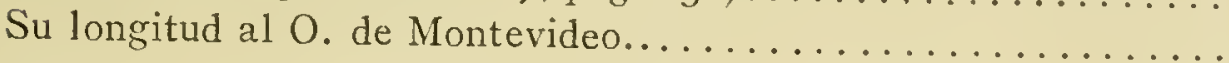

Montevideo al O. de Cádiz................................ $775.20,7$ !

Suponiendo Valparaíso, como se ha dicho, al O. de Cadiz......... 49.56.26,6 $67.14 .47,3$

Mr. Lartigue halla que el Castillo del Co, al O. de Cádiz................ $65.25 \cdot 33 \cdot 5$

(

Será longitud del Castillo del Corral, O. de Cádiz................ 67.14.37,5

Pero por diferencia con Montevideo es.............................. $67.47,3$

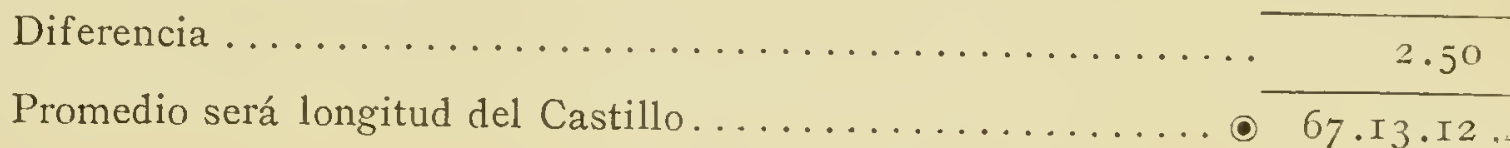

Rectificada la longitud de Valparaíso, probablemente desaparecerán estas pequeñas diferencias. que ellas mismas manifiestan, que la longitud de Valparaíso, tal como se fija, no está muy lejos de la verdadera.

Punta Maquin.-Dice el Piloto Vila, que la latitud observada de esta punta, es de $39^{\circ} 26^{\prime} 00^{\prime \prime}$ Sur, Y su longitud al O. de Valparaíso=á i ${ }^{\circ} 8^{\prime} 45^{\prime \prime}$. - Será longitud O. de Cádiz...... $67^{\circ} 24^{\prime}$ I $8^{\prime \prime}$

Río de la Imperial. - Según el mismo Vila, es su latitud de........... Sur. 38.39.00

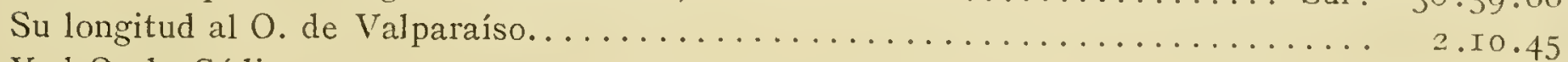

Y al O. de Cádiz............................................ 678

Isla Mocha.-Don Mariano Isasviribil levantó el plano de esta isla, y da las situaciones siguientes:

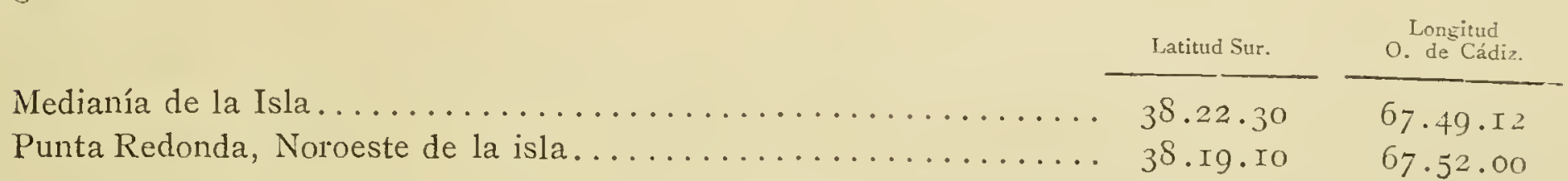

Estas longitudes parece que fueron determinadas con cronómetro; pero se duda á qué punto ó puerto de la costa las refiere; por tanto, es preciso valernos de la situación que da Malaspina á esta isla, que es como sigue. Este Oficial, desde la mar á distancia de cinco á seis millas, y en el meridiano y paralelo de la Isla de la Mocha, deduce:

Punta Noroeste de ella, latitud Sur........................ 38.r9.oo

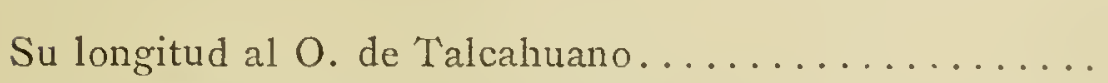

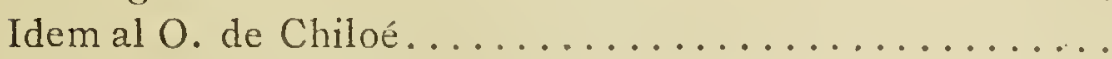

Idem al O. de Valparaíso.....................

Promedio longitud de la Punta Redonda, Noroeste de la

Isla Mocha..................... (h)

Según el Capitán Hall, esta Punta está en latitud Sur...

O. de Cádiz.

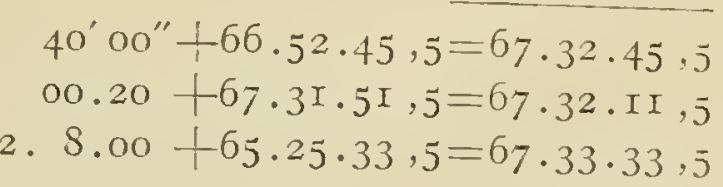

La longitud al Occidente de Valparaíso....

Anteriormente............... (h)

Diferencia

$67 \cdot 40.50$

$67 \cdot 32 \cdot 5^{\circ}$

8.00 
No pudiendo ser despreciables las autoridades de Malaspina y del Capitán Hall, veremos por otro medio cuál de las dos longitudes debe ser preferida.

Más adelante se ve que la longitud de la punta Norte de la Isla Santa María, es, Oc-

cidente de Cádiz................................. 67.20 .10

Malaspina halla la diferencia de longitud entre ambas puntas, de............. II.40

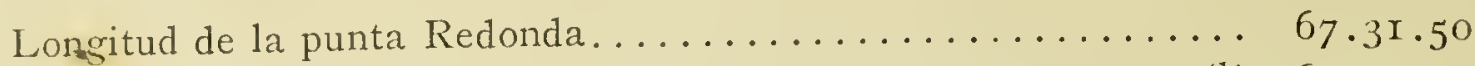

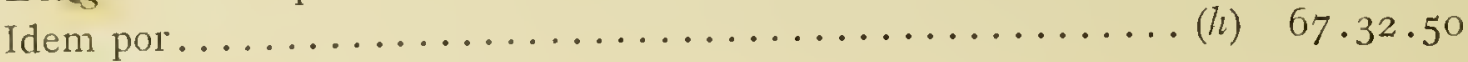

Diferencia ......................... I. 00

Promedio. Longitud de Punta Redonda. Noroeste de la Isla Mocha..........๑ $67^{\circ} 32^{\prime} 20^{\prime \prime}$

Latitud según Isasviribil, observada en tierra..................... $+3^{8}$.I9.1o

Isla de Santa María.-Según el exacto plano levantado por D. Mariano Isasviribil, resulta la punta Sur de la isla ó punta de Lobos. Latitud . . . . . . . . . . . . 37. 3.5 I

Su longitud al Oriente de Chiloé $=\mathrm{I} 2^{\prime} 4^{\prime \prime}+67^{\circ} 3 \mathrm{I}^{\prime} 5^{\mathrm{I}^{\prime \prime}, 5}=$ será longitud..... 67. $19 \cdot 47,5$ La punta Norte ó del Cansancio, íd. Ir.49 + íd. $=\ldots \ldots \ldots \ldots \ldots$ (I) $67.20 .2,5$ Punta de Lavapié, en el Continente, íd. 8. I - íd. $=\ldots \ldots \ldots \ldots \ldots \ldots 67 \cdot 23 \cdot 50,5$ Malaspina desde la mar, á distancia de ocho millas y fuera del paralelo, sitúa la punta Norte de la isla en latitud de $37^{\circ} \mathrm{OO}^{\prime} \mathrm{Oo}^{\prime \prime}$ y $28^{\prime}$ al Occidente de Talcahuano, suponiendo 'Talcahuano al Oeste de Cádiz $66^{\circ} 5^{2} 45^{\prime \prime}, 5$, será para la punta Norte.................. $67.20 .45,5$ El mismo Malaspina, al Este de Chiloé $\mathrm{II}^{\prime} 2 \mathrm{O}^{\prime \prime}-67^{\circ} 3 \mathrm{I}^{\prime} 5^{\prime \prime} 5,=\ldots \ldots \ldots \ldots .67 \cdot 20 \cdot 3 \mathrm{I}, 5$

Promedio. Longitud de la punta Norte de la isla, por Malaspina........... (2) 67.20.38,5

E1 Capitán Hall sitúa dicha punta Norte en latitud de $36^{\circ} 5^{8^{\prime}} 35^{\prime \prime}$, sin determinar su longitud; pero situando el pueblo de Arauco en latitud de $37^{\circ} 4^{\prime} 30^{\prime \prime}$ y $\mathrm{I}^{\prime} 42^{\prime \prime}$ al O. de Valparaíso la referi remos á la punta Norte d e la isla.

En el plano que ha publicado el Capitán Hall en r82 I, la punta Norte de la Isla de Santa Ma.

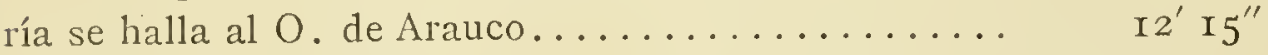

Arauco al O. de Valparaíso..................... ${ }^{\circ} 4200$

Occidente de Cádǐ.

Longitud á la punta Norte al O. de Valparaíso..... I $5+$ I $5+65.25 \cdot 33,5=67^{\circ} \times 9^{\prime} 48^{\prime \prime} 5$

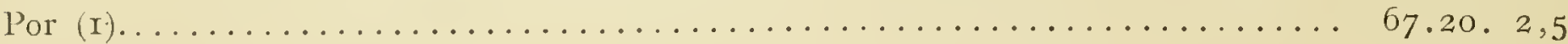

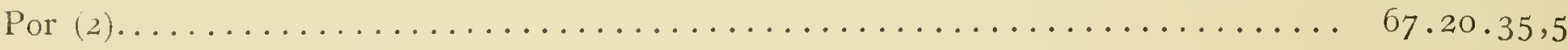

Promedio. Longitud de la punta Norte de la Isla de Santa María, números redondos . 67.20.10

Punta Norte de la Isla de Santa María......

Plano de Isasviribil, punta de Lavapié.... O.

Longitud de la punta de Lavapié..........

La punta Sur de la Isla ó de Lobos está al Este de la punta Norte o' r 5 ". Será de Cádiz...

Pueblo de Arauco por el Capitán Hall $1^{\circ} 42^{\prime}$ de

Valparaíso.

Talcahumno.-Malaspina situó el observatorio en una.casa inmediata á la orilla del mar y en el fondo Sudoeste del puerto, la misma en que Mr. Pagrelet estableció el suyo cuatro años antes, en la expedición del desgraciado Conde de la Péyrouse.

La latitud fué observada por estrellas al Norte y al Sur del zénit de Sur.

Por tres cronómetros de la corbeta Descubierta resultó Talcahuano,

al Este de Chiloé............................

Por tres íd. de la $\Lambda$ Trevida ........................

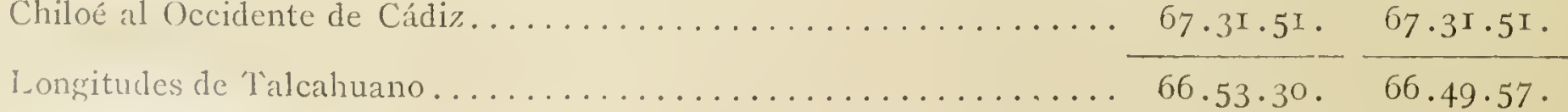


El Capitán Hall, halla quc Talcahuano está al Oeste de Valparaíso, reducida al observatorio de Malaspina....................

Según Malaspina.

$\mathrm{I}^{\circ} 29^{\prime} \mathrm{I} 5^{\prime \prime}$

I.28.00.

Promedio

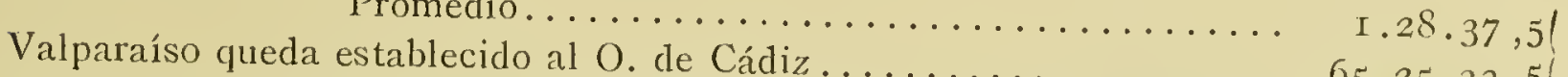

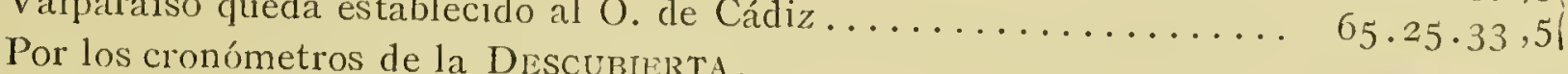
66.54 .10 $66.53 \cdot 30$.

Longitud de Talcahuano.

$66.53 \cdot 50$.

Tetas de Biobio. - La más Norte. Por las operaciones geodésicas hechảs en Talcahua-

no por la expedición de Malaspina, resultó latitud...................

Su longitud al O. de Talcahuano........................... $3^{\prime} 40^{\prime \prime}+66.53 \cdot 50=\Delta$

$36^{\circ}+5^{\prime}+2^{\prime \prime}$

$66.57 \cdot 30$

Río Itata.-Punta Sur. Malaspina, desde la mar y á distancia de I 2 á I 3 millas, sitúa este río cn latitud de...............................

Su longitud al Este de Talcahuano................ $8-66^{\circ} 53^{\prime} 50^{\prime \prime}=$ al O. de Valparaíso.................. $\mathrm{x}^{\circ}$ г $0-65 \cdot 25 \cdot 33,5=$

$35 \cdot 5^{8} \cdot 30$

$66 \cdot 35 \cdot 50$

$66 \cdot 35 \cdot 33 \cdot 5$

Promedio longitud del río Itata, O. de Cádiz.......... 66.35 .42

Río Maule.-Dil Piloto D. Claudio Vila sitúa la boca de cste río latitud $35^{\circ} 4^{\prime} \mathrm{Oo}^{\prime \prime}$ con el signo 4 de situación geodésica; pero dudamos qué género de operaciones practicó. La longitud dice ser de $65^{\circ} 42^{\prime} \mathrm{oo}^{\prime \prime}$ al $\mathrm{O}$. de Cádiz; mas, como vamos á ver, hay un error de consideración, dimanado sin duda de la posición del punto á que este Piloto refiere sus longitudes.

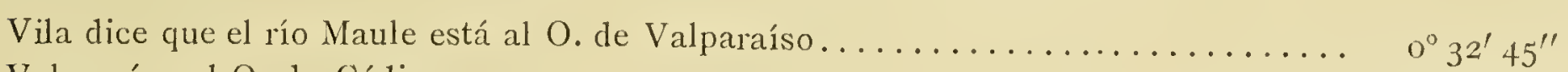

Valparaíso al O. de Cádiz................................. $65 \cdot 25 \cdot 33,5$

Longitud del río Maule al O. de Cádiz.................... $65.58 .18,5$

El mismo da la diferencia de longitud entre los Bajos de Rapel ó Topocalma y el

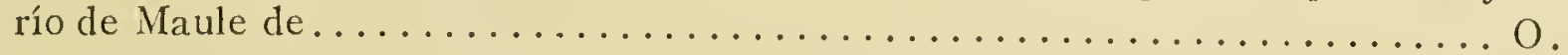

Los Bajos están al O. de Cádiz...

Longitud del río Maule............................ 66.3 .2

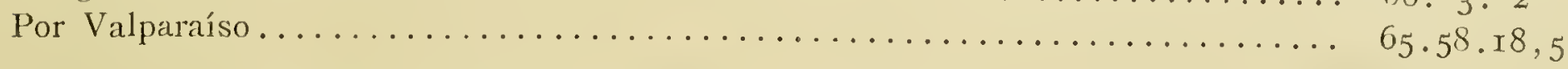

Promedio, longitud del río Maule, O. de Cádiz............ 66.00 .40

Latitud.................................. 35. 4.00

Bajos de Topocalma ó de Rapel. - Según las observaciones de Malaspina están en la-

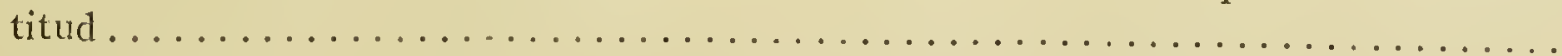

Iongitud al 0 . de Valparáso................... I $4.20=65.39 \cdot 53.5$

al Este de Talcahuano................ I.13.40=65.40.10

Medio.................. 65.40 .2

El Capitán y Piloto D. Claudio Vila llama á éstos Bajos de Rapel, y según sus observaciones, la latitud es la misma que la que les asigna Malaspina, y la longitud al Occidente de Cádiz $65^{\circ}$ I $9^{\prime}$; pero contando Vila la longitud de Valparaíso $65^{\circ} 9^{\prime}$ I $5^{\prime \prime}$, será la diferencia entre estos dos puntos

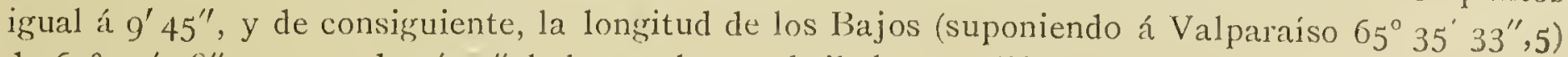
de $65^{\circ} 35^{\prime}{ }^{\prime \prime} 8^{\prime \prime}$, menor de $4^{\prime} 44^{\prime \prime}$ de la que hemos hallado por diferencias con Valparaíso y 'Talcahuano.

Punta de Piedra Blanca. - Malaspina coloca esta punta, á muy corta distancia de ella,

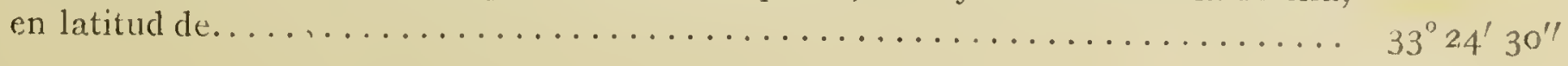


Su longitud al O. de Valparaíso........ $6^{\prime} 30^{\prime \prime}+65^{\circ} 25^{\prime} 33^{\prime \prime}, 5=0$. de Cádiz 65.32. 3

Al O. de Coquimbo................ $25 \cdot 30+65 \cdot 5 \cdot 49 \quad=65 \cdot 3$ I . I9

Promedio longitud de Punta de Piedra Blanca............ $65.3 \mathrm{I} \cdot 4 \mathrm{I}$

Pinta de Corma Alta.- La colocación geográfica de esta punta depende de operaciones desde la mar $y$ de tierra.

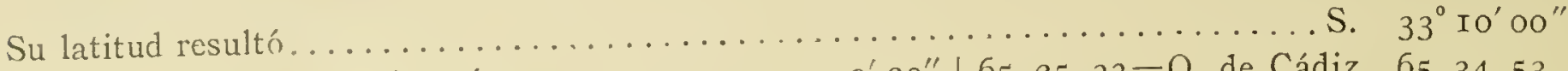

La longitud al O. de Valparaíso.......... $9^{\prime} 20^{\prime \prime}+65 \cdot 25 \cdot 33=0$. de Cádiz $65 \cdot 34 \cdot 53$

Punta del Concon.-Malaspina colocó esta punta por operaciones geodésicas desde

Valparaíso, resultando su latitud de ........................ s. $32.55 \cdot 30$

La longitud al Este de Valparaíso......... $6^{\prime} 35^{\prime \prime}-65 \cdot 25 \cdot 33=0$. de Cádiz $\Delta 6_{5} \cdot$ I $^{8} \cdot 5^{8}$

Campana de Quillota.-Montaña en el interior: se colocó por el mismo Malaspina y por operaciones geodésicas desde Valparaíso en latitud Sur................

Longitud al Occidente de Cádiz.......................... $64^{\circ} 59^{\prime} I 3^{\prime \prime}$

Herradura de Quintero.-Por las operaciones geográficas de la expedición de D. Mariano Isasviribil, se colocó la punta de Molles, que está en el fondo meridional del puerto por latitud de.............................

Su longitud al Este de Valparaíso $6{ }^{\prime} 2^{\prime \prime}$. Será O. de Cádiz.............. 6 5.I9.3I

Puerto del Papudo.-Lo más Sur por el mismo Isasviribil:

Latitud. ..................................

Longitud al Este de Valparaíso I2' $52^{\prime \prime}$. Al O. de Cádiz............... 65. I2.4I

Puerto de Pichidangui.-Punto en la parte Sur de la isla de este nombre: por dicho,

latitud.................................... 32.8 .27

Longitud al Este de Valparaíso $\delta^{\prime}$ I $_{7}^{\prime \prime}$. Será de Cádiz.................. J 65.I7. I6

Punta de las Amolanas.-Malaspina, á corta distancia de la costa sitúa esta punta en

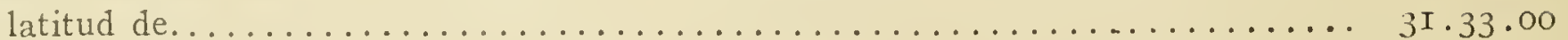

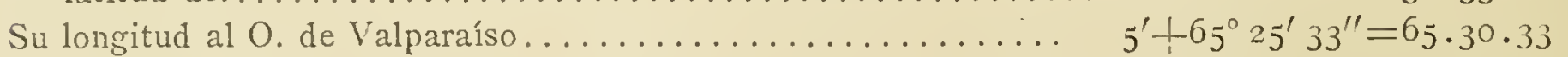

Idem al $O$. de Coquimbo.................... $24 \cdot \frac{1}{4}-65 \cdot 5 \cdot 49=65 \cdot 33 \cdot 49$

Promedio longitud de la punta, O. de Cádiz........... $6_{5} \cdot 32$.I I

Punta de Longua de Taca.-A muy corta distancia de la costa se situó esta punta por

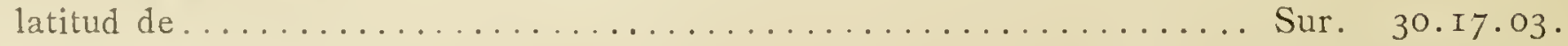

Su longitud al O. de Coquimbo................. $25^{\prime}+1-65^{\circ} 5^{\prime} 49^{\prime \prime}=65 \cdot 30.49$.

Idem al O. de Valparaíso................... $6 .+65 \cdot 25 \cdot 33 \cdot=65 \cdot 3 \mathrm{I} \cdot 33$.

Promedio es longitud de la punta, al O. de Cádiz......... 65.3I.II.

Ciudad de la Serena ó Coquimbo.--Por operaciones geodésicas desde el puerto de Coquimbo, resulta latitud Sur..........................

Longitud 0. de Cádiz ............................. $465.00 \cdot 56$. 
Monte de Fulir Soldado ó del Cobre.-Desde Coquimbo se colocó este cerro por operaciones geodésicas como el anterior, resultando en latitud de.......... Sur. I

Su longitud al Este del observatorio de Coquimbo 2' $30^{\prime \prime}$. Longitud O. de Cádiz... j

$29 \cdot+2 \cdot 30$

$65 \cdot 3 \cdot 19,6$

Isla de Choros. - La más Norte. A distancia de dos millas sitúa Malaspina esta isla

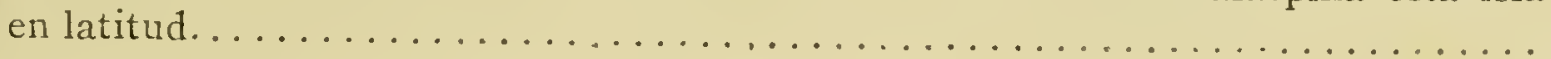

Su longitud al $O$. de Coquimbo $\sigma^{\prime}+5^{\prime \prime}$. Será al O. de Ć́diz...................

$65 \cdot 22 \cdot 34,6$

Islas de Pájaros.-La más Sur. A distancia de ménos de tres millas sitúa Malaspina lo más Sur de la isla meridional en latitud de................. Sur.

Su longitud al $O$. de Coquimbo $00^{\prime} I^{\prime \prime}$. Será longitud de Cádiz........... $65.6 .4,6$

Isla Chanaral ó Cañaveral.--Los Oficiales de la Marina Real, Isasviribil y Colmenares, situan esta isla en latitud de $29^{\circ} 2^{\prime}$ oo $^{\prime \prime}$ Sur, y dicen que dista de la costa de dos á dos y media milias. Su extensión de Norte á Sur es de media legua y piede verse en días claros, á cinco leguas de distancia.

Punta del Huasco.-Malaspina, á distancia de dos millas sitúa esta punta en latitud

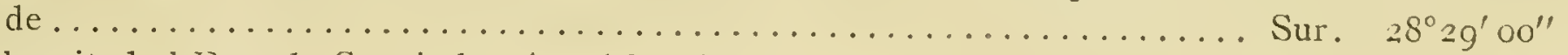

Su longitud al Este de Coquimbo $3^{\prime}$ será longitud O. de Cádiz..... 65.2.49,61

Al O. de Arica..................... I ${ }^{\circ} \mathrm{oo}^{\prime} 5^{\prime \prime}+64 \cdot 8.00=65.8 .50,0$ $65 \cdot 5 \cdot 49,8$ $0 \ldots \ldots \ldots \cdot 65 \cdot 5 \cdot 50$

El Capitán Hall coloca la roca exterior de la punta, en latitud. . 28.27 .00

Su longitud al Este de Valparaíso $2 I^{\prime} 55^{\prime \prime}$, pero el punto que coloca

Malaspina está al O. 2' $30^{\prime \prime}$ : será la diferencia al Este de Valparaíso.

Valparaíso al Occidente de Cádiz....................... \begin{tabular}{l|l}
$00 \cdot 19 \cdot 25 \cdot$ & $65 \cdot 25 \cdot 33,5$
\end{tabular} $65 \cdot 06 \cdot 5$

Por el promedio anterior................................ $65 \cdot 5 \cdot 49,8$

Longitud de la punta del Huasco, promedio.................... 65. 5.59,0

Morro de Copiapó.-Punta Oeste. Malaspina, como á distancia de cuatro millas, casi en su paralelo, sitúa este Morro en latitud de.................. Sur. 27.9.00

La longitud al Este de Coquimbo, de.............. I $2^{\prime} 15^{\prime \prime}-65^{\circ} 5^{\prime}+9^{\prime \prime}, 6=64.53 \cdot 34,6$ Al O. de Arica........................... $5{ }^{I} \cdot 45+64.8 .00,0=64.59 \cdot 45,0$

Promedio

El Capitán Hall, que fondeó en este puerto, coloca la punta que lo forma por la parte occidental llamado Puerto Inglés, en latitud.......................

Su longitud al Este de Valparaíso..... 40 $40^{\prime} 9^{\prime \prime}-65^{\circ} 25^{\prime} 33^{\prime \prime}, 5=$ Longitud de Cádiz $\overline{64 \cdot 45 \cdot 14,5}$ $\mathrm{Y}$ al O. de Arica............... $37.25+64.8 .00=64.45 .25$

Promedio, longitud de la punta O. de Puerto Inglés.............. 6... 64.45.19,7 El punto del Morro que colocó Malaspina, está al O

Longitud del Morro.

$64 \cdot 5 \mathrm{I} \cdot \mathrm{Ig}, 7$

No conforme con el resultado (a) de $64^{\circ} 56^{\prime} 39^{\prime \prime}, 8$, y mucho ménos con la latitud, cuya diferencia es de Io'; de consiguiente, es muy probable que Malaspina desde la mar colocó un punto distinto del que se conoce por Morro de Copiapó, nada extraño respecto á que el práctico de la costa, que llevaba y embarcó en Valparaíso, se equivocaba á cada momento: por tanto, será la situación geográfica de Copiapó:

Punta O. del Puerto Inglés: latitud $27^{\circ} \mathrm{I} 9^{\prime}$. Longitud O. de Cádiz $64 \cdot 45 \cdot 20$, pudiéndose deducir por el plano la situación del Morro. 
Morro de Mcgillones. Malaspina, á distancia de cinco á seis millas, lo sitúa en la-

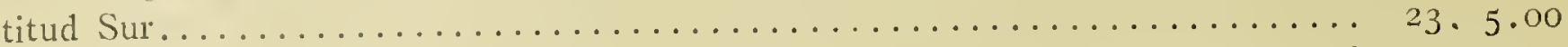

Su longitud Este de Coquimbo................................... $56+65 \cdot 5 \cdot 49,6=64 \cdot 9 \cdot 49,6$

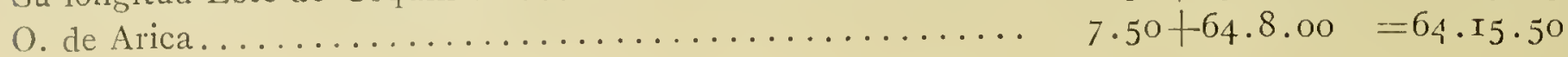

Promedio longitud del Morro O. de Cádiz............. 64.12.49,8

o....... 64.12 .50

Cobija.-Malaspina, á la distancia de 20 millas, sitúa este puerto en latitud...... 22.29.00

El Si. Roberto Hunter. . . . . . . . . . . . . . . . . . . . . . . . . . 22.30.00

Medio................................ $22.29 \cdot 30$

Malaspina, al Este de Arica.

Idem al Este del Callao................ 7.00.12-70.57.9= " 63.56.57

El Sr. Hunter ídem................... 6.59.20-70.57,9= " 63.57.49

Promedio longitud de Cobija al O. de Cádiz.......... $63 \cdot 5^{6.45}$

Pabellón de Pica. - Monte en forma de tienda de campaña, situado sobre la costa y punto muy notable de ella: la larga distancia de 27 millas á que Malaspina pasó de este punto, hace algo dudosa su situación.

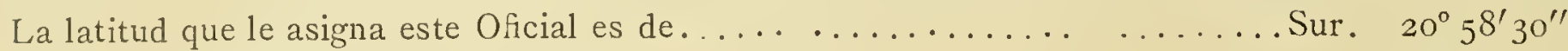

Por el Piloto Campos. ................................ 20.2.40

Por ídem Bandini............................... 2I. I.

Promedio de las dos últimas: es latitud del Pabellón........ 2I . I.50

La longitud, según Malaspina, es al Este de Arica........ I $2^{\prime} 30^{\prime \prime}-64^{\circ} 8^{\prime} 00=063 \cdot 56 \cdot 30$

Según una carta construída por el Teniente de fragata en

Lima, D. Andrés Baleato................ 5.20-64. 8.00 =64.2.40

Mientras no se sepa bajo qué datos formó Baleato su carta, se adopta la longitud

para el pabellón de Pica, la hallada por Malaspina de................ $63 \cdot 56.30$

Isla de Iquique.-Malaspina sitúa esta isla á larga distancia, pues pasó de ella I9 mi-

llas, hallando su latitud de ........................ $20^{\circ} \mathrm{II}^{\prime} \mathrm{OO}^{\prime \prime}$

El Piloto Vila la sitúa en............................ 20. I3. 5

La longitud, según la carta de Malaspina, Este de Arica 2' oo"

Según el Piloto Vila, ídem.............. o.5o.

Promedio.............. I. $25 \cdot-64^{\circ} 8^{\prime}=0$. de Cádiz $64 \cdot 6 \cdot 35$

Quebrada de Camarones. - Como el punto anterior, adolece éste de haberse colocado á larga distancia, y según se verá en adelante debe haber alguna equivocación del práctico en la indicación de este punto.

Malaspina, á distancia de I $_{5}$ millas, sitúa la quebrada de Camarones en latitud Sur de. $\mathrm{Ig}^{\circ} \mathrm{I}^{\prime} 3 \mathrm{O}^{\prime \prime}$

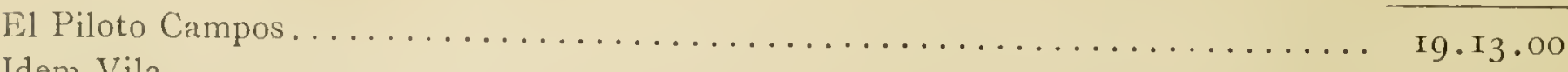

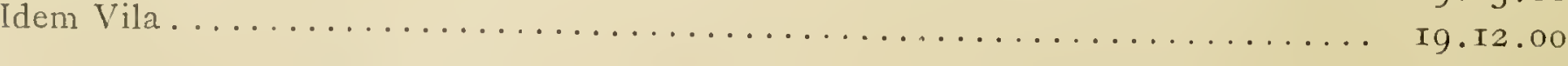

Promedio latitud de la Quebrada................... I La longitud por Malaspina al Este de Arica............ I' $45^{\prime \prime}-64^{\circ} 8^{\prime} \mathrm{oo}^{\prime \prime}=64$. 6 . I5

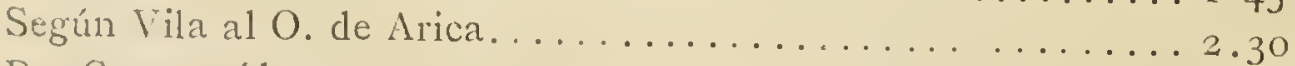

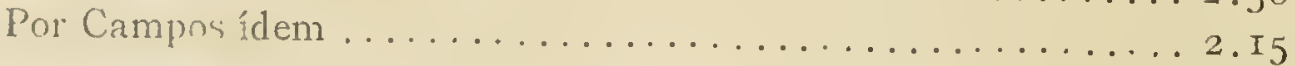

Promedio................. (I) $2.27,5+64.8 .00=64$ I0.27, 5 
Malaspina al Este del Callao. (2) $6^{\circ} 48^{\prime} 35^{\prime \prime}-70^{\circ} 57^{\prime} 9^{\prime \prime}=64 \cdot 8 \cdot 34$

Promedio total es......................... 64. $8.25,5$

El promedio de las dos últimas................ (I) (2) $0=64 \cdot 9 \cdot 30,7$

Es, pues, la situación de la quebrada de Camarones, latitud .............. Ig.r2.30

Longitud al O. de Cádiz..................... 64. 9.3

Quebrada de Victor._Casi en su paralelo, y á distancia de siete millas, sitúa Malas-

pina esta quebrada, que el práctico llamó de Víctor, en latitud de......... I $8^{\circ} 43^{\prime} 30^{\prime \prime}$

Observada por el Piloto Vila.......................... I 8.51 .00

La longitud por Malaspina al Este del Callao........... 6 $6^{\circ} 44 \cdot 5 \rightarrow 70.57 \cdot 9=64.13 \cdot 4$

Al O. de Arica.................... 2. $45+64 \cdot 8.0=64 \cdot 10.45$

Promedio longitud de la Quebrada de Víctor........... 64.Ix.54,5

Morro de Fuan Díaz. - Su latitud y longitud resulta de marcaciones hechas desde el Morro de Arica y observaciones desde la mar: latitud ..................... $18^{\circ} 9^{\prime} \mathrm{oo}^{\prime \prime}$

Longitud al O. de Arica.. ................................................. $66^{\circ} .8^{\prime} .00^{\prime \prime}=64^{\circ} 24^{\prime} \mathrm{oo}$

Carta de Baleato...................... $3.45+64.8 .00=64.2 \mathrm{I} \cdot 45$

Promedio longitud del Morro.............. 64.22 .52

Morro de Sama.-Latitud según las observaciones de Malaspina............ I7.57.20

Según la carta de Baleato................. $77.5^{8} .00$

Promedio será latitud.................... Sur 17.57 .40

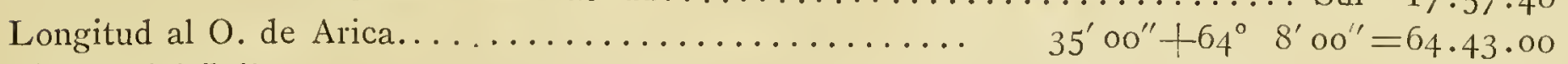

Al Este del Callao....................... 6.Ir.50 -70.57. $9=64 \cdot 45 \cdot 19$

Promedio longitud del Morro de Sama............... 64.44. 9,5

Pnnta de Coles.-Por las operaciones practicadas á distancia muy corta desde la mar, y próximos al paralelo de esta punta, Malaspina la sitúa latitud $I 7^{\circ} 42^{\prime} 0 \mathrm{O}^{\prime \prime}$, igual á la que le asignan el Capitán Hall y Baleato.

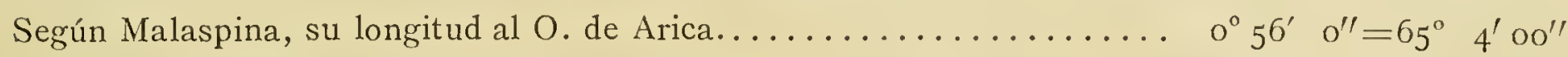

Al Este del Callao.............................. 5.50.50 =65.6. 6.19

Por el Capitán Hall, Este de Valparaíso.................. $\quad$ Ir.25 $=65 . \mathrm{I}_{4} .8$

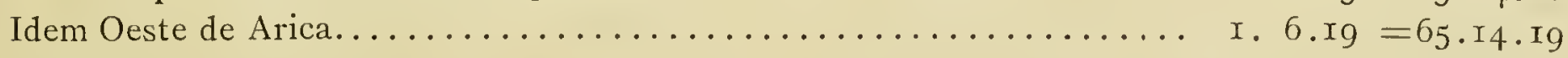

Idem Este del Callao........................ $5.46 .35=65.10 .58$

$5 \cdot 42 \cdot 37=65 \cdot 14 \cdot 32$

El promedio de todas estas seis longitudes será igual á $65^{\circ} 10^{\prime} 42^{\prime \prime}, 7$, muy conforme con la que resulta de $65^{\circ} 10^{\prime} 58^{\prime \prime}$, adoptando la longitud del Callao astronómica del Capitán Hall, $77^{\circ} 6^{\prime} x 0^{\prime \prime}$ O. de Greenwich, y la diferencia cronométrica con punta de Coles $5^{\circ} 46^{\prime} 35^{\prime \prime}$ : por lo tanto, fijamos á Punta de Coles en longitud O. de Cádiz, $65^{\circ}$ xo' $43^{\prime \prime}$ y latitud $I 7^{\circ} 42^{\prime}$ Sur.

Punta de Islay ó Ilay. - Sin duda hay también una equivocación del práctico que tenía Malaspina, pues las diferencias de los resultados con el Capitán Hall son muy notables, como se vé á con. tinuación:

Según la carta de Malaspina, se halla esta punta en latitud.............. I6 $43^{\prime}$ oo $^{\prime \prime}$

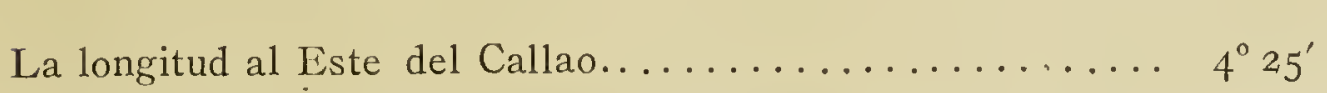

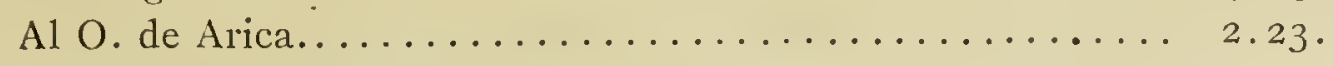

$66^{\circ} 32^{\prime} 9^{\prime \prime}\left\{66^{\circ} 3 I^{\prime} 34^{\prime \prime}\right.$
66.3 I. o. de Cádiz.
$\ldots$... Sur. I7. I.00

El Capitán Hall sitúa esta punta en latitud. 


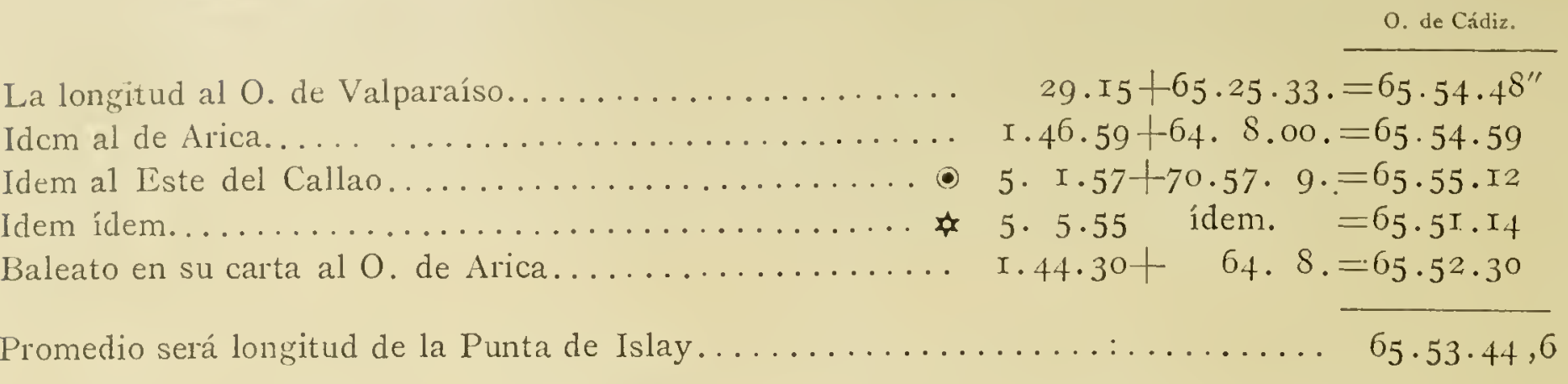

Es evidente que lo que colocó Malaspina por Punta de Islay, es otro punto de la costa, y que debe colocarse por aquella latitud y longitud.

Quilca-Caleta.-Los buques de Malaspina pasaron á nueve millas de la costa, que señaló el práctico estar la caleta de Quilca, la que se situó por operaciones practicadas desde á bor do, resultando:

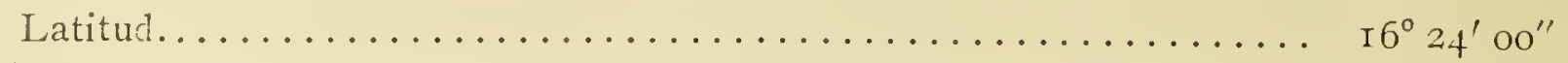

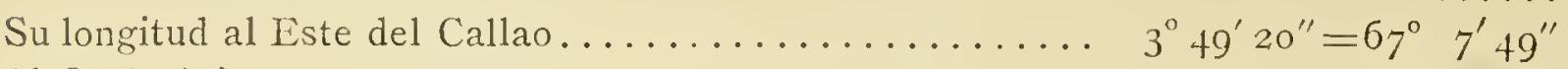

$\mathrm{Al}$ O. de Arica......................... 2.57.30. $=67 \cdot 5 \cdot 30$.

Promedio........................... $67.6 .39,5$

O. de Cádiz.

El Capitan Maclean sitúa lo que llama Seal

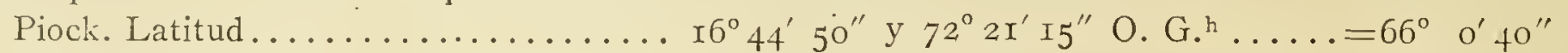

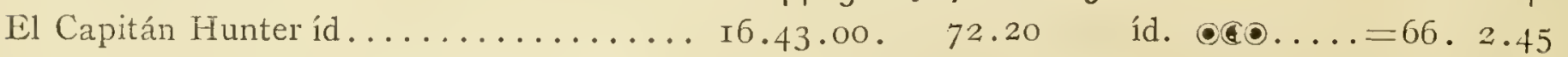

Apuntes del Piloto del bergantín peruano.. I6.40.00................ 66. 7.00

Los Pilotos y Capitanes Vila, Bandini.... I6.4x.oo. Carta de Baleato......... 66. 8.00

Colmenares, Isasviribil............ I6.4工.20. O. de Arica $2^{\circ} 9^{\prime} \ldots \ldots \ldots$. . . 66.00

Mr. Lartigues sitúa esta caleta en....... r6.4I . Io.

La longitud al O. de Arica... $2^{\circ} 6^{\prime} 3 \mathrm{I}^{\prime \prime}=66 . \mathrm{I}_{4} \cdot 3 \mathrm{I}$ )

Idem al O. de Valparaíso... $\left.\quad 49 \cdot 2,5=66 . I_{4} \cdot 3^{6}\right\}$ Promedio verdadero, longitud 66.I4.33, o Latitud............ I6.4T. Io.

Es también claro que Malaspina situó otro punto que creyó (por mal informado) era la caleta de Quilca.

Morro de Acari.-A distancia de siete millas de este Morro y tres y media de la costa lo situó Malaspina en latitud Sur........................... I $5^{\circ} 20^{\prime} 0^{\prime \prime}$

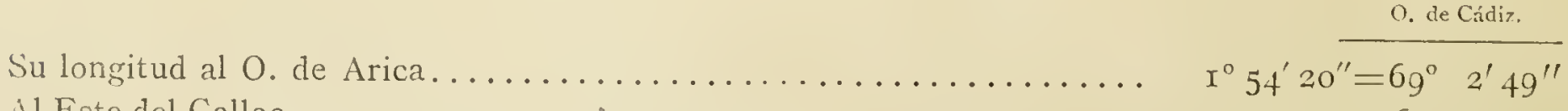

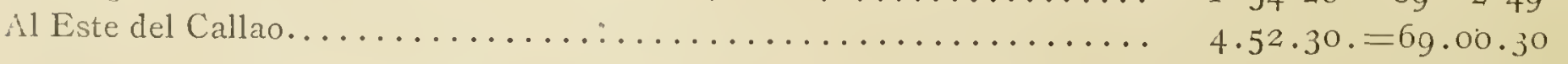

Promedio........................... 69.01.39

Así como en otros puntos de la costa, puede haber muchas dudas, por poco conocimiento del Piloto práctico, el cual dió este nombre á muchos morros ó montes, que se presentaban á la vista, por cuyo motivo hubo en Lima, una junta de Pilotos prácticos de la costa, y habiéndoles presentado las vistas de la costa y de otros morros, decidieron ser el Morro de Acari el quc se detcrmina aquí.

. Morro de la Nasca. - A distancia de seis millas se situó este morro ó punto más sa-

licnte al Sudoeste en latitud de........................ I $5^{\circ} 6^{\prime} \mathrm{oo}^{\prime \prime}$

$\begin{aligned} & \text { Su longitud al O. de Arica........ } 5^{\circ} 9^{\prime} 30^{\prime \prime}=69 \cdot 19 \cdot 49 . \\ & \text { " al Estc del Callao...... Il O. de Cádiz. 69. I8.40 }\end{aligned}$ 
El Capitán Hall sitúa también este punto ó próximo á él, con el nombre de Nasca ó

Punta de Caballas, en latitud Sur de.................... I4 $50^{\prime} 53^{\prime \prime}$

La longitud al O. de Arica........ 5.10.4I $=69.18 .4 \mathrm{I}$.

Este del Callao...... I.40.I4 $=69.16 .55$.

Al O. de Cádiz. $69 \cdot 17 \cdot 48$

Se ve, pues, lo conforme que se hallan las longitudes de Malaspina y Capitán Hall; pero lo mucho que discrepan en la latitud. La situación del primero fué hecha por bases desde la mar y en el intermedio de un día al otro; de consiguiente, cuando se observaron las latitudes, se estaba muy distantes del Morro, y no es extraño, á pesar que se corregian las bases por las latitudes y longitudes observadas, que resultase esta diferencia, aunque la considero demasiado crecida; por tanto, y considerando que el Capitán Hall haría su observación en circunstancias más favorables.

Situamos al Morro de la Nasca ó Punta Caballas, en latitud de............. I $4^{\circ} 58^{\prime} 53^{\prime \prime}$

Su longitud el promedio de ambas al O. de Cádiz................... 69.18.14

Mesa de Doña María.-A distancia de 5 millas se situó este cerro notable, que sirve

de punto de recalada para la navegación á Lima, en latitud.............

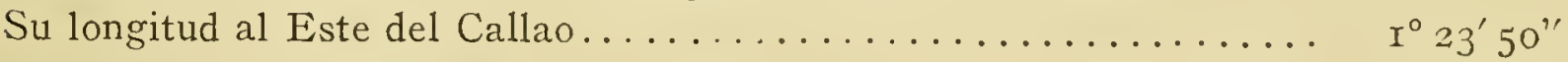

$14 \cdot 42 \cdot 45$

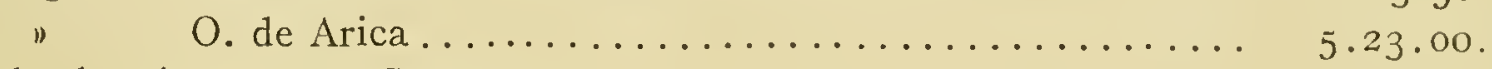

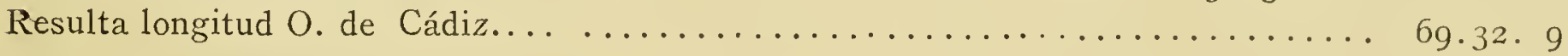

Islotes Infiemillos._La situación de Malaspina, según la Carta (en lo que puede haber algún error) es, de latitud Sur. ...................... 4.44 .00

$\left.\begin{array}{rrrr}\text { Su longitud al O. de Árica.... } & 5^{\circ} 30^{\prime} & =69.38 .00^{\prime \prime} \\ \prime \prime & \text { Este del Callao.. } & \text { r.r7 } & =69.40 .9 .\end{array}\right\}$ Promedio O. de Cádiz. $69.39 \quad 4$

El Capitán Hall determina la latitud de estos islotes en............... I4.42. 5

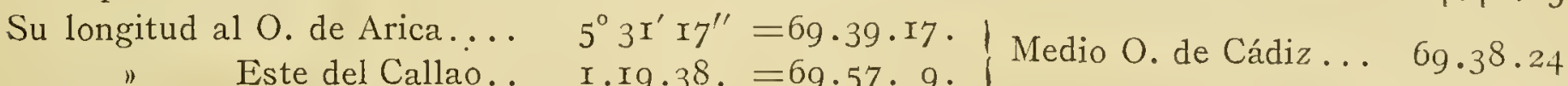

Por Malaspina.................................. 69.39.4

Promedio longitud de los Infiernillos, O. de Cádiz.:........ 69.38.44

Latitud: el promedio de ambas..................... $4.43 \cdot 3$

Monte de las Mercedes.-A este monte dió nombre Malaspina, situándolo á la distancia de diez millas por latitud de $14^{\circ} 3 \mathrm{I}^{\prime} \mathrm{oo}^{\prime \prime}$ fuera de su paralelo.

$\left.\begin{array}{rrr}\text { Su longitud al O. de Arica.... } & 5^{\circ} 36^{\prime} 30^{\prime \prime}=69 \cdot 44 \cdot 30 . \\ & \text { Este del Callao... } & \text { I.II.oo. }=69 \cdot 46.9 .\end{array}\right\}$ Medio......... (a).=69.45.I9.

El Capitán Hall determina su latitud de...................... I4.35.29.

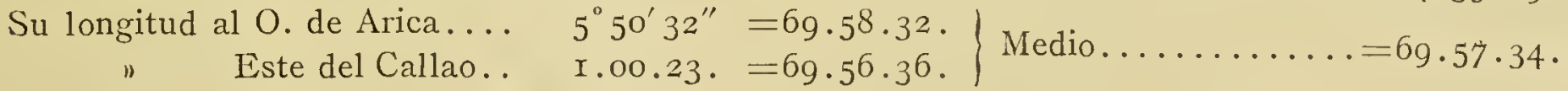

El mismo Capitán Hall, en su tabla de posiciones dice, que este monte está al Occidente Greenwich $76^{\circ} 3^{\prime} 48^{\prime \prime}-6^{\circ} \mathrm{I}^{\prime} \mathrm{r} 5^{\prime \prime}=(b) 69^{\circ} 46^{\prime} 33^{\prime \prime}$. Longitud que está muy conforme con la que halla Malaspina; quizás el Capitán Hall situó algunos de los cerros inmediatos, por lo que resulta esta diferencia: mientras que otros datos nos sacan de esta duda, determinamos la posición geográfica del Monte de las Mercedes, promedio de ambas, latitud.............. Sur. $\mathrm{r}_{4}^{\circ} 33^{\prime \prime} \mathrm{r}^{\prime \prime}$ Longitud igualmente promedio de $(a)$ y $(b) \ldots \ldots \ldots \ldots \ldots \ldots \ldots \ldots \ldots \ldots \ldots \ldots .45 \cdot 56 \ldots$

Los Amigos.-Montes situados al Norte de una punta con islotes, distancia de cuatro millas.

Malaspina sitúa uno de estos montes en latitud.................. $14^{\circ} 23^{\prime} 00^{\prime \prime}$

$\begin{array}{ll}\text { Su longitud al O. de Arica..... } & 5^{\circ} 4 \mathrm{I}^{\prime} \text { oo" }=69 \cdot 49 \cdot 00 . \\ \text { Este del Callao ............. } & \text { I. 5.00.=69.52.9. }\end{array}$ Promedio O. de Cádiz. 69.50.34

El Capitán Hall da el nombre de los Amigos á las rocas que hemos dicho estar al Sur de los montes que Malaspina llama Amigos: 
La latitud de Hall es de.

Estando los montes al Norte $4^{\prime}$ millas, resultaría para estos. I4.I6.00. D

demasiado considerable.

La longitud del Capitán Hall es al $O$. de Greenwich $76^{\circ} 7^{\prime} \mathrm{I}^{\prime \prime} \cdot=\mathrm{O}$. de Cádiz $69^{\circ} 50^{\prime} \mathrm{I}^{\prime \prime}$ muy conforme con la longitud que establece Malaspina: no sucede así determinando esta longitud por las diferencias con Arica y Callao, que en los puntos anteriores ha habido tanta conformidad.

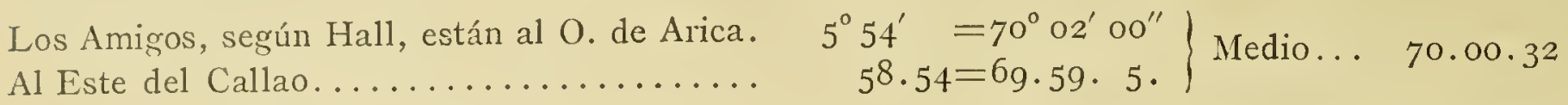

En vista de estas anomalías, parece que los Amigos (montes) deben situarse según los establece Malaspina.

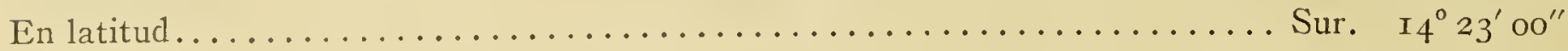

Longitud al O. de Cádiz............................. 69.50.34

Isla de Sangallan.--Punta Sur, estando próximo á su paralelo, sitúa Malaspina este

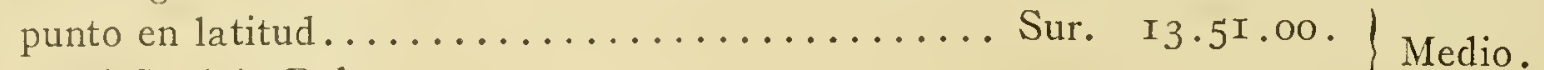

Según el Capitán Robson .................... I3.5I.50. Medio. I3.5I.25

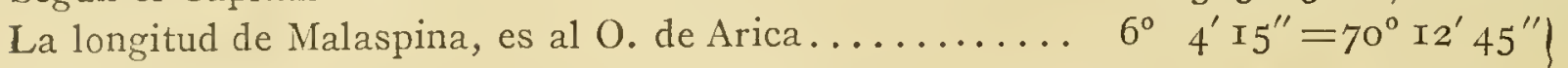

Este del Callao.............................. $0.42 .=70.15 .04$

Según la carta del Capitán Robson al Este del Callao............. 42.20 70.I4.49

Promedio longitud de la Punta Sur de Sangallan: O. de Cádiz...... 70. I4.2I

Islas de Chincha. - La más Norte á distancia de I2 millas: se situó este islote por Ma-

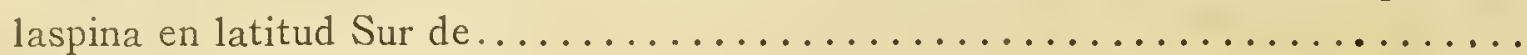

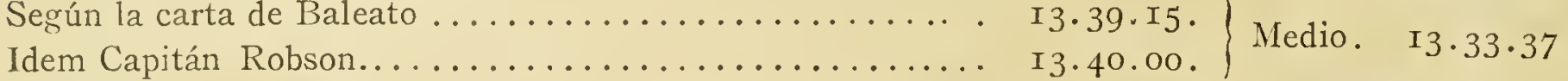

Longitud al O. de Arica......... $6^{\circ} I^{\prime} 45^{\prime \prime}=70.9 \cdot 45 \cdot$
Este del Callao.............

Morro Lechuza.-A muy corta distancia situó Malaspina la cúspide de este morro en

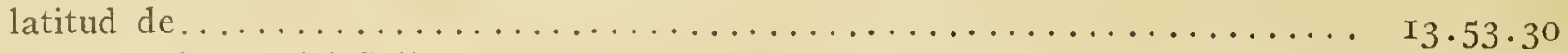

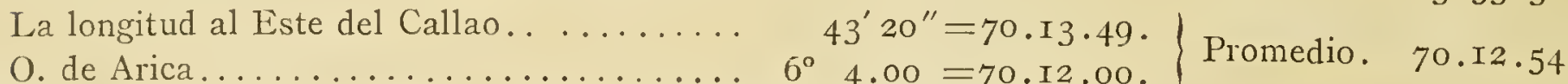

Este Morro además se halla al Este de lo más Sur de la Isla de Sanga-

llan, por operaciones geodésicas desde el mar...... I... 5 .

Longitud. 70.I3.06

El extremo Sur de la isla se situó en.............70.I4.2I.

Promedio será longitud del Morro Lechuza, O. de Cádiz...

70.13 .00

Valle de Tambo.-El Capitán Hall sitúa este valle en latitud de ..........Sur. I7.I3.oo

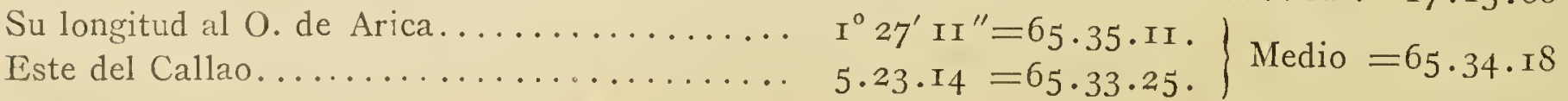

Mollendo: pueblo.-Por el Capitán Hall está este pueblo en latitud...........Sur I7. 2.I5

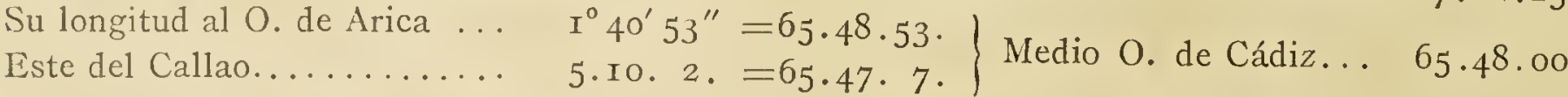

Valle de Camana.-Según Colmenares é Isasviribil, es su latitud............ Sur I6.37.30

Punta do Chilca.-Malaspina, á muy corta distancia de la costa, sitúa esta punta en

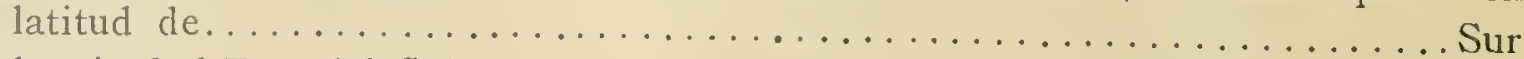

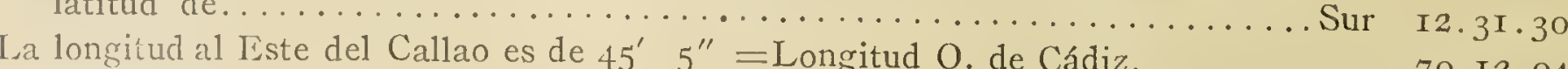
........... 70.04 
Esta longitud puede rectificarse por las marcaciones hechas desde tierra, en las operaciones practicadas en Lima y Pachacamac, que no se pueden verificar por no tener. presentes estos documentos.

Isla de Fuan Ferníndez, de tierra.-Malaspina se dirigió desde Talcahuano á situar estas islas, y desde ellas volvió sobre la costa al puerto de Valparaíso; por tanto, tenemos estos dos puntos y el de Chiloé, con cuyas diferencias cronométricas pueden situarse con toda precisión.

Estando á muy corta distancia del estremo occidental, se situó este puerto en latitud. $33^{\circ} 45^{\prime}$ La longitud al $\mathrm{O}$. de Talcahuano............. $5^{\circ} 5^{\mathrm{I}^{\prime}} \mathrm{o0^{ \prime \prime }}+66^{\circ} 53^{\prime} 50^{\prime \prime}=\mathrm{O}$. de Cádiz $72^{\circ} 44^{\prime} 50^{\prime \prime}$

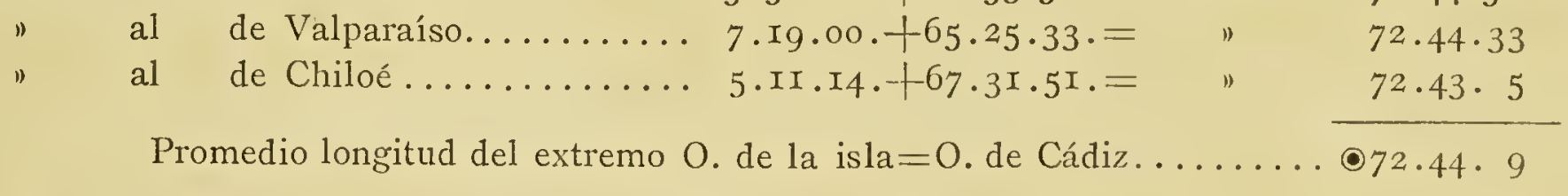

La conformidad de estas longitudes no deja duda sobre la buena situación de esta isla, y al mismo tiempo, de estarlo entre sí, Chiloé, Talcahuano y Valparaíso. Sin embargo, manifestaremos á continuación las situaciones que han dado varios navegantes á esta isla, para que en adelante pueda rectificarse, no obstante que por lo dicho parece no debe quedarnos ningún género de duda.

El Capitán Pipón sitúa el fondeadero en latitud Sur de

Su longitud al O. de Greenwich........ $78^{\circ} 49^{\prime}$ oo" -6 .I7.I5.=O. de Cádiz .

La punta O. de la isla al O.

$33^{\circ} 38^{\prime} \pm 3^{\prime \prime}$

$72 \cdot 31 \cdot 45$

7.00

Longitud del extremo O. de la isla.

y estando el extremo O. de la isla al Sur del fondeadero, próximamente $4^{\prime}$, será latitud del extremo $0 . \ldots \ldots \ldots \ldots \ldots \ldots \ldots \ldots \ldots \ldots \ldots \ldots$

El Oficial de la Marina Real de España, D. Antonio Martínez, halla la latitud de lo

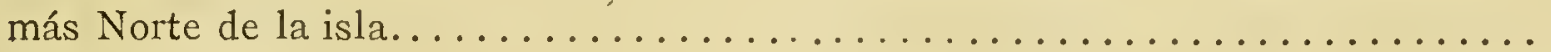

Idem D. Eugenio Cortés la misma punta...................... 33.37.00

Promedio latitud de lo más Norte de la isla............ 33.36.40

La punta 0 . al Sur próximamente .......................... 7 .

Latitud de la punta $O$. de la isla................ 33.43.40

Martínez, por cronómetro y distancias lunares, la punta Sueste, O. de Cádiz...... 72.47.27

Cortés, por cronómetro, sin referirse á punto de la costa................ $72.49 \cdot 30$

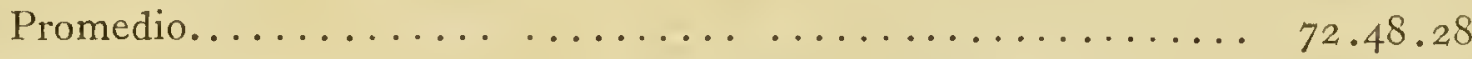

La punta O. al Occidente................................... II

Longitud de la punta $\mathrm{O}$ por Martínez y Cortés................... 72.59.28

Resumiendo estas longitudes, tendremos:

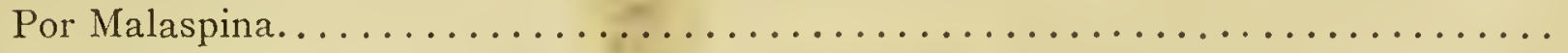

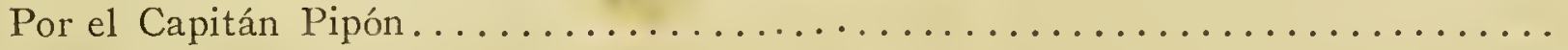

Por Martínez y Cortés.............................. 72.59.28

El promedio será longitud de la punta de $0 \ldots \ldots \ldots \ldots \ldots 72.47 .27$

Pero en vista de lo expuesto, fijamos la latitud del extremo O. de la isla, en latitud de...............................

Longitud al Occidente de Cádiz...................

Isla de mís afuera.-A la distancia de 28 millas de la isla y á su parte oriental, se si-

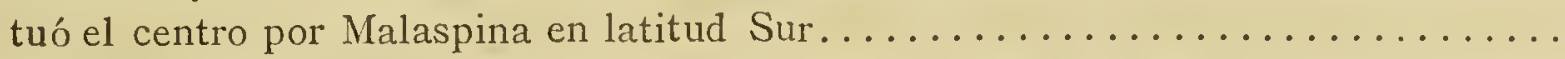
Por el Capitán y Piloto Mestre, en su paralelo á distancia de cuatro leguas...... Por el Capitán Carteret, fondeado en ella........................

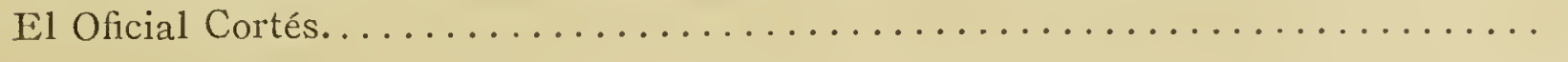

Promedio latitud del centro de la isla $\ldots \ldots \ldots \ldots \ldots \ldots \ldots \ldots \ldots \ldots .45 \cdot 16,7$ $33^{\circ} 45^{\prime} 00^{\prime \prime}$

$33 \cdot 45 \cdot 7$

$33 \cdot 45 \cdot 0$

$33 \cdot 46$. o 
Malaspina determinó la longitud por una base desde la mar, en malas circunstancias, y dedujo longitud al 0 . del extremo occidental de la Isla de tierra........ I $34=74$. I 8 . 9

Según el Capitán y Piloto Vila por cronómetro................... I ${ }^{0} 5^{6}=74 \cdot 40.9$

El Oficial de la Armada D. Antonio Martínez la sitúa en ... . . . . . . . . . . . . 74.36.35

Idem D. Eugenio Cortés . . . . . . . . . . . . . . . . . . . . . . . 74.44.00

Desechando la primera por lo dicho, será el promedio de las tres, Longitud de la Isla 74.40. I4

Latitud Sur......................... 33.45.16, 7

Isla de San Ambrosio.-La más oriental de las de San Félix.

Malaspina, partiendo de las inmediaciones del Morro de Copjapó para la situación de estas islas, verificó la del extremo O. de la de San Ambrosio por latitud.... Sur 26.20.00

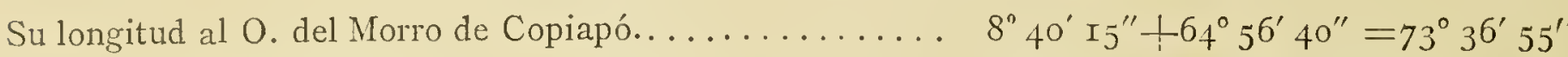

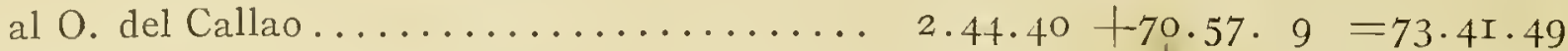

al O. de Coquimbo............... 8.28.00 +65. $5.49=73 \cdot 33 \cdot 49$

Promedio longitud del extremo O. de la Isla de San Ambrosio . . 73.37.3 I

Pero se ha dicho que el Capitán Hall coloca la punta O. del Puerto In-

glés en Copiapó, en longitud de.................. 64.45.19,7

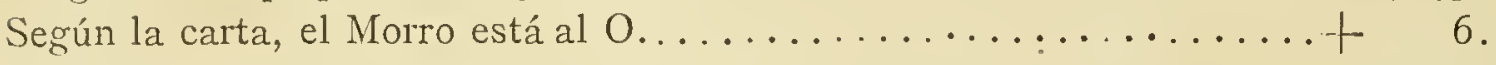

Longitud del Morro.......................

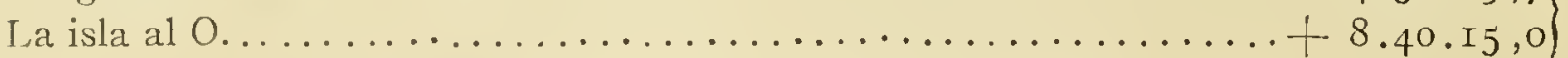

$73 \cdot 31 \cdot 35$

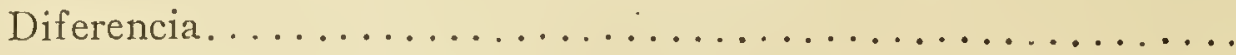

Por tanto el promedio de ambas longitudes $73^{\circ} 37^{\prime} 3 I^{\prime \prime}$ y $73^{\circ} 3 I^{\prime} 35^{\prime \prime}$ será igual á

longitud del extremo 0 . de la isla de San Ambrosio . . . . . . . . . . . . . = $73 \cdot 34.8 \dot{8}_{3}$

Islotes Hormigas.--Malaspina dispuso la salida de un falucho con un Oficial de su expedición, para que desde el Callao situase estas islas: los movimientos violentos del falucho hacen algo dudosa la situación de ellas.

El resultado fué: Latitud de la Hormiga chica. $\operatorname{II}^{\circ} 56^{\prime} \mathrm{oo}^{\prime \prime}$. S.O. del Callao. $46^{\prime} 4 \mathrm{O}^{\prime \prime}=7 \mathrm{I}^{\circ} 43^{\prime} 49^{\prime \prime}$ Idem de la Hormiga mayor.............. II.56.20. ídem 46. Io. $=7$ I.43. I9 Diario de Malaspina.--Hormiga mayor..... II.54.40. ídem 34.00.=7I.3I.9

El Piloto Vila dice que el farallón Sur, ó el

mayor, está en............... II.55.48. ídem 36.50.=7I.33.59

Posición que adoptamos, mayormente, cuando en el Diario de Malaspina se leen estas expresiones: "Salieron en el falucho el Teniente Don Manuel Novales con el Guardia Marina Alí-Ponzoni para reconocer y situar los Islotes Hormigas, lo que no pudo verificarse á satisfacción, y sí con duda, á causa de viento extraordinariamente fresco del Sur, el cual, engruesando mucho la mar, ni les permitió permanecer fondeado entre aquellos pedruscos, ni dejó de exponerles á mucho riesgo el poder alcanzar nuevamente el puerto del Callao." Sin embargo, cuando los buques de la expedición salieron del Callao, se dirigieron á rectificar esta posición, y según el Diario de Malaspina, la posición geográfica del islote mayor de las Hormigas; es de:

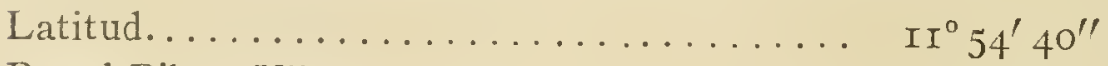

Por el Piloto Vila.................. II $55 \cdot 48$.

Promedio........... II.55.I4.
Longitud .

7I.3I. 9

7 I. $33 \cdot 59$

$71 \cdot 32 \cdot 34$ 
RESULTADOS de las situaciones geográficas de que trata esta Memoria.

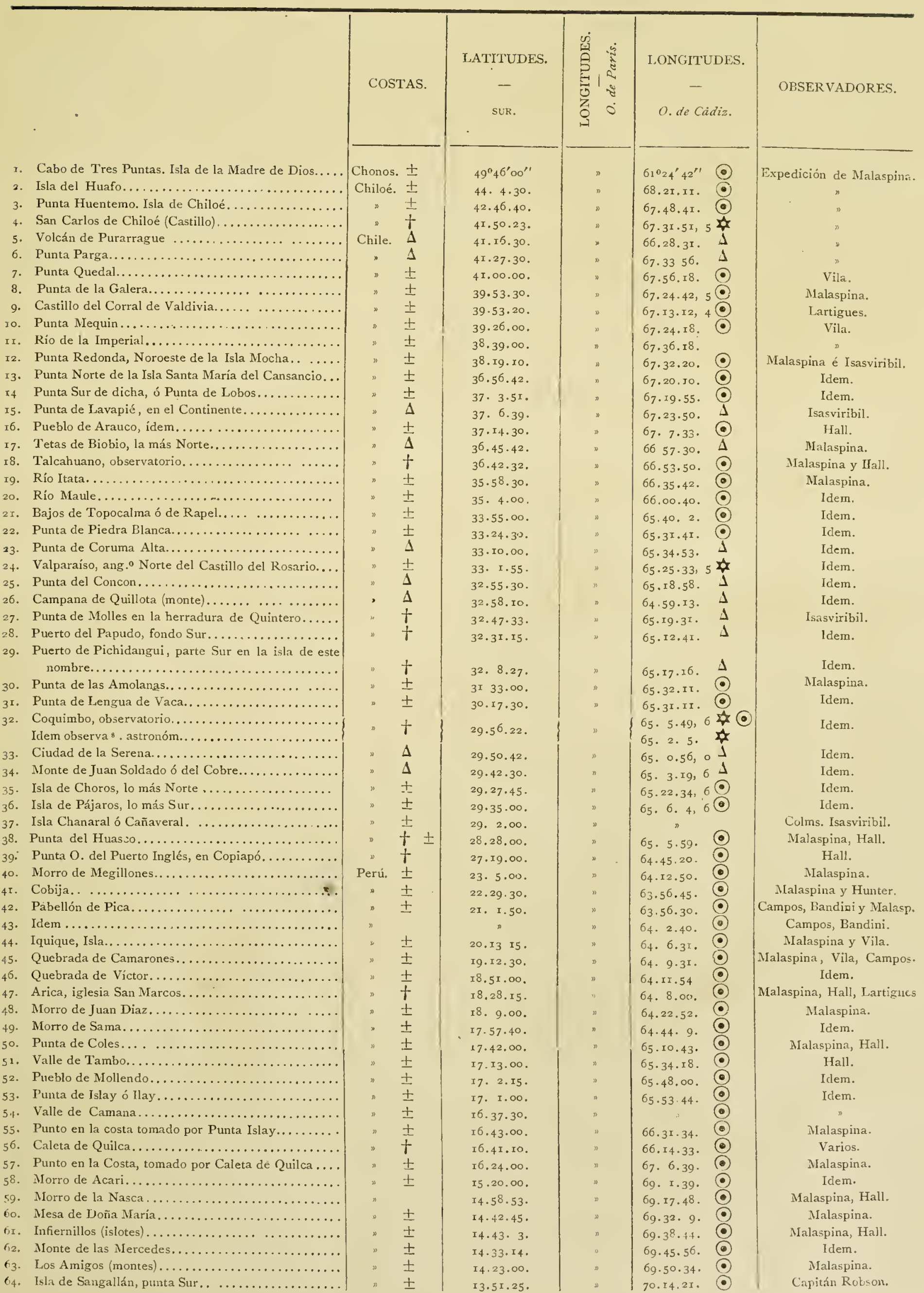


65. Islas de Chincha, la más Norte...

Morro de Lechuza (cưspide)

. Punta del Chilca..

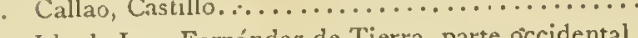

Isla de Juan Fernández de

. Isla de más afuera, centro.

r. Islas de San Félix, lo más Oriental de la de San Am-

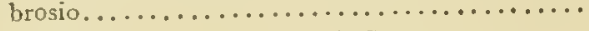

72. Islotes Hormigas, el mayor más Sur............

3. Guaynquil, Iglesia matriz...

74. Panamá, Catedral.

75. Cartagena, baluarte Santa Catalina...

76. Puerto Belo, Castillo San Jerónimo...

7. Chagres, Castillo.....

78. San José de Californias.

7abo de San Lucas, en r539 se llamó Santiago....

80. San Blas de Californias, contad. .

8r. Acapulco, Castillo San Diego.

82. Realejo, observatorio en el puerto

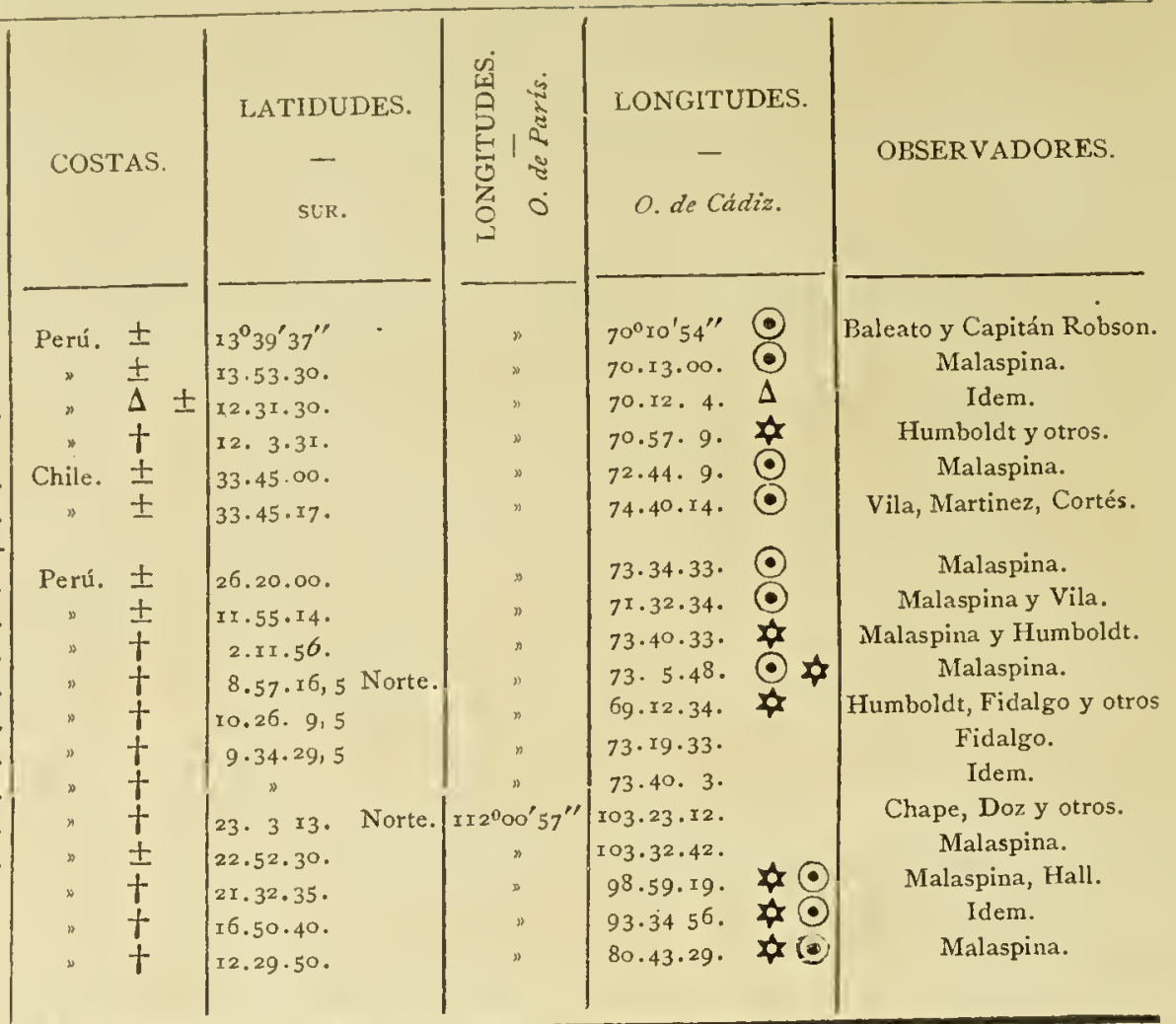




\section{OBSERVACIONES de la velocidad del sonido, de latitud, longitud y variaciones hechas en Santiago de Chile, por el Teniente de navio D. Fosé Espinosa y el Alférez de navio graduado D. Felipe Bauzá.}

De la velocidad del sonido.

Ha manifestado la experiencia, que el sonido nace del movimiento de vibración que ócasiona en el aire el temblor de las partes insensibles de un cuerpo sonoro, las cuales, puestas en acción por el choque de otro cuerpo, hacen vibrar en todas direcciones las partículas del fluído que 10 rodea. Ya sea fuerte el sonido, ya sea débil, corre espacios iguales en tiempos iguales, de modo que el sonido que se extiende, por ejemplo, á una legua, tarda en andarla lo que tardaría en hacer la primera legua ú otra cualquiera de ellas, el sonido que anduviese mayor número, y así es que el estrépito del cañón, aunque llega más lejos que el del fusil, por ser mayor la masa de aire á que comunica, no va más veloz, si no tarda más tiempo á proporción de la mayor distancia que alcanza. Como las pequeñas variaciones que en esto se advierten proceden de la imperfección de las experiencias mismas y de varias circunstancias de tiempo y de lugar, fundándose en los hechos anteriores, puede decirse que la propagación del sonido nace de la acción de un resorte iścrono, asímismo en todas sus vibraciones, que las hace de la misma duración, mientras conserva la misma elasticidad, aunque esté impelido con diversos grados de fuerza. Aplicando estos principios al aire, considerado como el medio que nos transmite los sonidos, y rellexionando las vicisitudes que sufre de contínuo su densidad y su resorte, se echa de ver que la propagación del sonido debe variar por aquellas causas, como varía la constitución de la atmósfera en que se produce; pæro cuáles sean los límites de esta variación, sólo pueden decirlo las experiencias. Por eso las han practicado en todos tiempos, sujetos celosos de los progresos de la Física general, y nosotros, animados del propio espíritu, hemos hecho las siguientes en el llano de Maipó en el Reino de Chile, donde no se habían practicado hasta ahora. Consultándolas, se verá que la ley con que se propaga el sonido no es una misma en todos los climas; que varía bastante de unos á otros para que pueda servir de fundamento en ningún caso á las operaciones geográficas exactas, y que áun para emplearla con utilidad en los usos ordinarios de la navegación, convendrá repetir todavía algunas experiencias en varios lugares, y hacer un análisis reflexivo de las que hay, para todo lo que tenemos muchos materiales preparados que ordenaremos con gusto si la superioridad aprobase este trabajo.

\section{Experiencia de la velocidad del sonido.}

Toda la observación se funda en el principio siguiente. Cuando se ve la explosión de un arma đe fuego á alguna distancia, percibe la vista la luz de la pólvora inflamada mucho tiempo antes que se oiga el sonido, y como la luz se propaga con tanta rapidez que no tarda dos segundos en venir de la Luna á la Tierra, puede decirse que la vista la percibe en el mismo momento que sale del cuerpo sonoro, en vez de que el estrépito producido al propio tiempo por éste, emplea en llegar al órgano del oído un tiempo sensible y determinado. Luego midiendo con precisión este tiempo y la distancia del observador al sitio donde se produce el sonido, se sabrá la velocidad actual de éste: para la medida de éste nos valimos de dos buenos relojes de segundos, ajustados al movimiento medio por observaciones del Sol, y comparados frecuentemente á dos péndulos de medios segundos que construímos, y usamos ya uno ya otro de estos instrumentos en las experiencias, para que fuesen más independientes los resultados. Con esta mira, las repetimos en varias direcciones y á diversas distancias desde dos hasta ocho millas, trasladándonos á los puntos $C, D, E, F$, cuyas posiciones hallamos respecto al punto $B$ del modo siguiente: En el paraje que llaman el Conventillo se midió la base $A B$, de 2.9oo piés de París. Sobre un terreno perfectamente horizontal que ofrece el llano de Maipó por esta parte, se había alineado de antemano la distancia por medio de jalones verticales colocados de ro en ro toesas, enfilándolos unos por otros y con dos perchas perpendiculares que servían de señales en los extremos $A$ y $B$ de la base 
en dichos puntos, de ro en io toesas se clavaron estaquillas de un pié, y puestas sus cabezas á cuatro pulgadas de altura, se hizo firme á la primera un cordel, pasándole bien tirante de unas en otras, $y$ así quedó determinada una línea paralela á la del terreno; para medirla nos servivos de tres perchas de á tres pulgadas de grueso y nueve piés de largo cada una: la operación era facilísima, pues bastaba poner las perchas sobre el terreno cuidando de ajustar sus aristas al cordel con el auxilio de pequeñas cuñas, y adelantar siempre la percha más inmediata al principio de la cuenta, poniéndola con precaución para evitar todo retroceso en las fijas. Con estas atenciones se midió por dos veces la base en sentidos opuestos, y sólo hubo seis pulgadas de diferencia. Para tomar los ángulos, empleamos un buen teodolito y aunque nos aseguramos de su exactitud, midiendo el contorno del horizonte subdividido en varios ángulos, cuya suma fué siempre igual á cuatro rectos, no se excusó la observación del tercer ángulo en todos los triángulos en que lo permitió el terreno. La figura manifiesta la situación ventajosa de la base medida y de las distancias que por ella se concluyeron, y han dado á conocer con todo el rigor de la Geometría las de

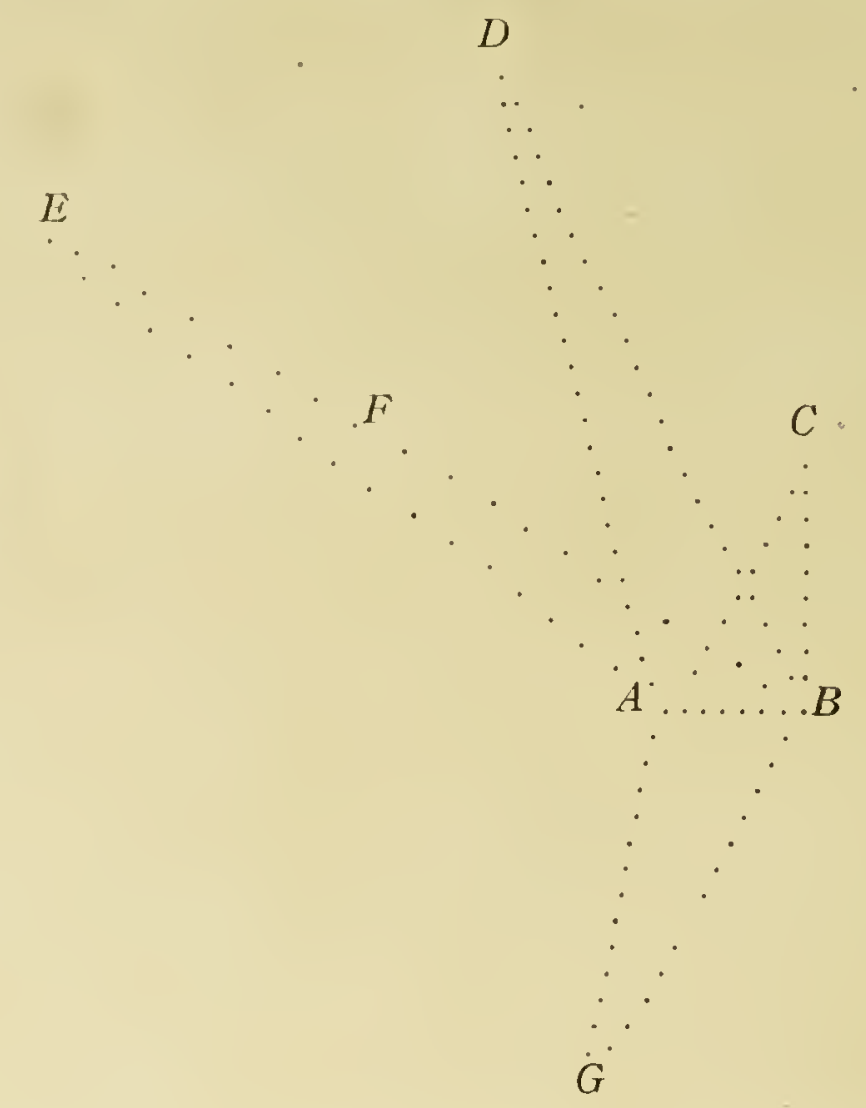

los puntos $C, D, E, F$ del llano al extremo $B$ de la base.

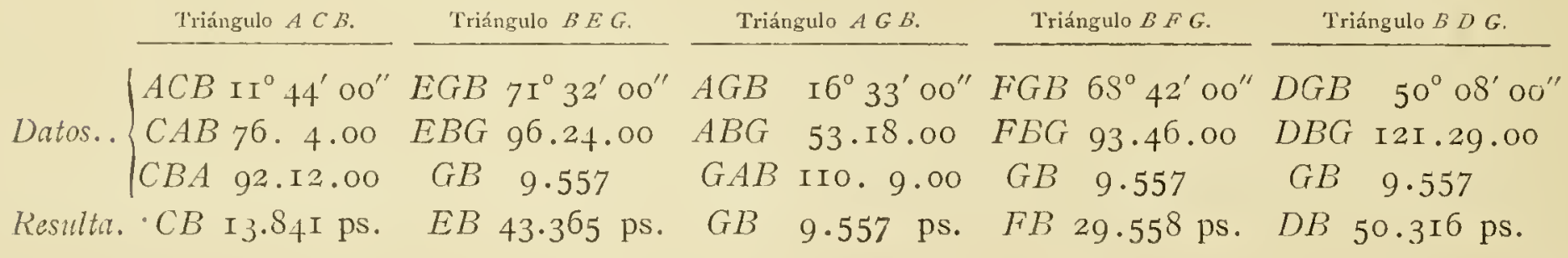

Concluídas las operaciones geométricas, se colocó en el punto $B$ un cañón de á ocho, y se dió principio á las operaciones en la forma siguiente:

Día I 3 de Enero al anochecer: experiencia primera observada desde la Chácara de Cañas $E$, á $7^{\mathrm{h}} 5 \mathrm{O}^{\prime}$ de la tarde, cohete en el Conventillo, señal de preparación, contestado desde Cañas á $7^{\mathrm{h}} 52^{\prime}$.

Tiros en el Conventillo.
á $8^{\text {h }}$ OO' $00^{\prime \prime}$
8 I0.00
820.00

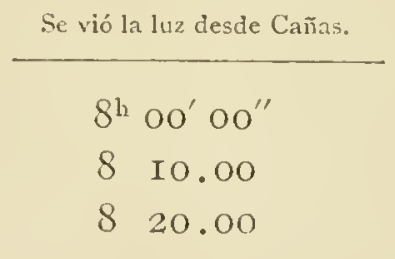

\begin{tabular}{l} 
Se oyó el estallido. \\
\hline $8^{\text {h }}$ oo $^{\prime} 3^{\prime \prime}$ \\
8 10.38 \\
$820.3^{8}$
\end{tabular}

Viento Sudoeste, muy flojo, casi calma, atmósfera cargada.-Barómetro, 25 pulgadas, 9 líneas. Termómetro I $8^{\circ}, \mathrm{o}$.

Día If de madrugada; en el propio paraje á $3^{\mathrm{h}} 50^{\prime}$ de la madrugada, cohete de preparación en el Conventillo, contestado desde Cañas á $3^{\mathrm{h}} 52^{\prime}$.

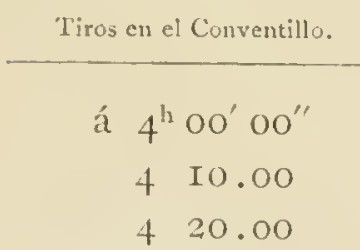

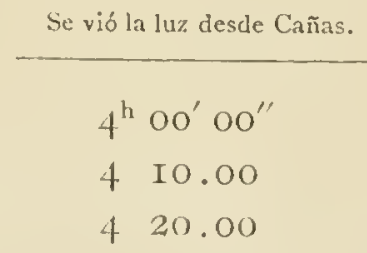

\begin{tabular}{|c|}
\hline Se oyó el estalli \\
\hline $4^{h} 00^{\prime} 38^{\prime \prime}$ \\
\hline 4 IO. $3^{8}$ \\
\hline $420 \cdot 3^{8}$ \\
\hline
\end{tabular}

En calma: alguna calima.-Barómetro, 25 pulgadas.--Termómetro, $16^{\circ}, \mathrm{o}$.

1)esde Cañas demora el cañón situado en el Conventillo, Norte $69^{\circ}$ O. del mundo. 
Dia $r_{4}$ de Enero al anochecer, experiencia segunda observada desde la Chácara del Peral $D$.

\begin{tabular}{|c|c|c|c|c|}
\hline \multicolumn{2}{|c|}{ Tiros en el Conventillo. } & Se vió la luz en el Peral. & Se oyó el estallido. & \\
\hline á & $7^{\mathrm{h}} 3 \mathrm{o}^{\prime} \mathrm{oo}^{\prime \prime}$ & $7^{\mathrm{h}} 3 \mathrm{o}^{\prime} 0 \mathrm{o}^{\prime \prime}$ & $7^{\mathrm{h}} 3 \mathrm{o}^{\prime} 43^{\prime \prime}$ & \multirow{5}{*}{$\begin{array}{l}\text { Viento Sudoeste fresquito en el } \\
\text { Conventillo; en el Peral algunas bo- } \\
\text { canadas de Norte.-Barómetro } 25 \\
\text { pulgadas, } 9 \text { líneas.-Termóme- } \\
\text { tro } 23^{\circ}, 0 \text {. }\end{array}$} \\
\hline & 40.00 & 40.00 & +0.43 & \\
\hline & $\begin{array}{r}50.00 \\
8.00 .00\end{array}$ & $\begin{array}{r}50.00 \\
8.00 .00\end{array}$ & $\begin{array}{c}50.43 \\
8.00 .43^{1 /}\end{array}$ & \\
\hline & $\begin{array}{l}10.00 \\
20.00\end{array}$ & $\begin{array}{l}10.00 \\
20.00\end{array}$ & $\begin{array}{l}8.00 \cdot 43^{1} \% \\
\text { No șe oyó. }\end{array}$ & \\
\hline & 20.00 & & 8.20 .43 & \\
\hline
\end{tabular}

Día 5 de madrugada en el propio sitio.

\begin{tabular}{|c|c|c|c|c|}
\hline \multicolumn{2}{|c|}{ Tiros en el Conventillo. } & \multirow{2}{*}{$\frac{\text { Se vió la luz en el Peral. }}{4^{\text {h }} \mathrm{OO}^{\prime} \mathrm{Oo}^{\prime \prime}}$} & \multirow{2}{*}{$\frac{\text { Se oyó el estallido. }}{4^{\mathrm{h}} \mathrm{oo}^{\prime} 43^{1} /_{2}^{\prime \prime}}$} & \multirow{6}{*}{$\begin{array}{l}\text { En calma, alguna calima._- Ba- } \\
\text { rómetro } 25 \text { pulgadas, } 9 \text { líneas.-CTer- } \\
\text { mómetro } 20^{\circ}, 0 \text {. }\end{array}$} \\
\hline á & $4^{\mathrm{h}}$ oo $^{\prime}$ oo' & & & \\
\hline & 4.10 .00 & 4.10 .00 & 4.10 .43 & \\
\hline & $4 \cdot 20.00$ & 4.20 .00 & $4.20 .43^{1} / 2$ & \\
\hline & $4 \cdot 30.00$ & $4 \cdot 30.00$ & $4 \cdot 30 \cdot 431 / 2$ & \\
\hline & $4 \cdot 50.00$ & $4 \cdot 5^{0} .00$ & $4 \cdot 50 \cdot 43^{1} / 2$ & \\
\hline
\end{tabular}

Desde el Peral demora el cañón del Conventillo, Norte $44^{\circ} \mathrm{O}$.

Día I6 del mismo, al anochecer; experiencia tercera, observada desde la Chácara de Macul $F$ á las $7^{\mathrm{h}} 5^{\mathrm{o}^{\prime}}$ de la tarde. Cohete señal de préparación en el Conventillo, contestado desde Macul á $7^{\mathrm{h}} 52^{\prime}$.

\begin{tabular}{|c|c|c|c|c|}
\hline \multicolumn{2}{|c|}{ Tiros en el Conventillo. } & Se vió la luz en Mlacul. & Se oyó el estallido. & \\
\hline á & $8^{\text {h }}$ oo $^{\prime}$ oo $^{\prime \prime}$ & $8^{\text {h }}{ }^{\prime} o^{\prime} 0^{\prime \prime}$ & $8^{\mathrm{h}} \mathrm{oo}^{\prime} 26^{\prime \prime}$ & \multirow{5}{*}{$\begin{array}{l}\text { Viento Nordeste flojo en Macul y } \\
\text { Sudoeste fresquito en el Conventi- } \\
\text { 1lo.-Barómetro } 25 \text { pulgadas, } 9 \text { lí- } \\
\text { neas.-Termóm etro } 20^{\circ}, 0 \text {. }\end{array}$} \\
\hline & 8.10 .00 & 8. ro.oo & 8.10 .26 & \\
\hline & 8.20 .00 & 8.20 .00 & 8.20 .26 & \\
\hline & 8.30 .00 & 8.30 .00 & $8 \cdot 30.26$ & \\
\hline & 8.40 .00 & 8.40 .00 & 8.40 .26 & \\
\hline
\end{tabular}

Desde Macul demora el Conventillo, al Norte $72^{\circ}$ O. del mundo.

Día I7 del mismo al anochecer; experiencia cuarta; observada desde el punto $C$ del llano: á las $7^{\mathrm{h}} 20^{\prime}$ de la tarde. Cohete de preparación contestado á $7^{\mathrm{h}} 22^{\prime}$.

\begin{tabular}{|c|c|c|c|c|}
\hline \multicolumn{2}{|c|}{ Tiros en el Conventillo. } & \multirow{2}{*}{$\frac{\text { Se vib la luz en } C \text {. }}{7^{\mathrm{h}} 3 \mathrm{o}^{\prime} \mathrm{oo}^{\prime \prime}}$} & \multirow{2}{*}{$\frac{\text { Se oyó el estallido. }}{7^{\mathrm{h}} 30^{\prime} \times 2^{\prime \prime}}$} & \multirow{6}{*}{$\begin{array}{l}\text { Viento Sudoeste fresquito: tiempo } \\
\text { claro:-- Barómetro, } 25 \text { pulgadas, } \\
9 \text { líneas.-Termómetro, } 18^{\circ}, 0 .\end{array}$} \\
\hline á & $7^{\mathrm{h}} 3 \mathrm{o}^{\prime} \mathrm{oo}^{\prime \prime}$ & & & \\
\hline & $7 \cdot 35 \cdot 00$ & $7 \cdot 35 \cdot 00$ & $7 \cdot 35 \cdot 12$ & \\
\hline & $7 \cdot 40.00$ & $7 \cdot 40.00$ & $7 \cdot 40.12$ & \\
\hline & $7 \cdot 45.00$ & $7 \cdot 45.00$ & $7 \cdot 45 \cdot 12$ & \\
\hline & $7 \cdot 50.00$ & $7 \cdot 50.00$ & $7 \cdot 50 \cdot 12$ & \\
\hline
\end{tabular}

Desde el punto $C$ demora el Conventillo, al Norte $20^{\circ} \mathrm{O}$. del mundo.

Todas las experiencias que anteceden son de entera confianza, y examinándolas con cuidado, se vé que en la determinación del tiempo cabe cuando más medio segundo de error, que repartido en el número de las hechas en cada lugar, es un error despreciable.

El viento sólo pudo tener algún influjo en la cuarta experiencia, retardando el sonido media toesa por segundo: en las experiencias restantes, ó no hubo viento, ó fué exactamente transversal y siempre flojo: de suerte, que repartiendo el número de toesas que distan cada uno de los puntos $C, D, E, F$, del punto $B$ por el número de segundos que tardó el sonido desde el cañón al observador, se hallan las velocidades siguientes:

Por las observaciones hechas en Cañas. : $190^{1}, 2$

Por la del Peral.............. r 93 . 5 Velocidad del sonido en Chi-

Por la de Macul. ............ I 89,5 le, Igr toesas por segundo.

Por la del punto $\quad \ldots \ldots \ldots \ldots \ldots$ r....... 89,6 


\title{
Algunas observaciones astronomicas hechas en Santrago de Chile desde Enero á Marzo de 1794, por Bauzá.
}

\author{
Observación de latitud, día II de Marzo.
}

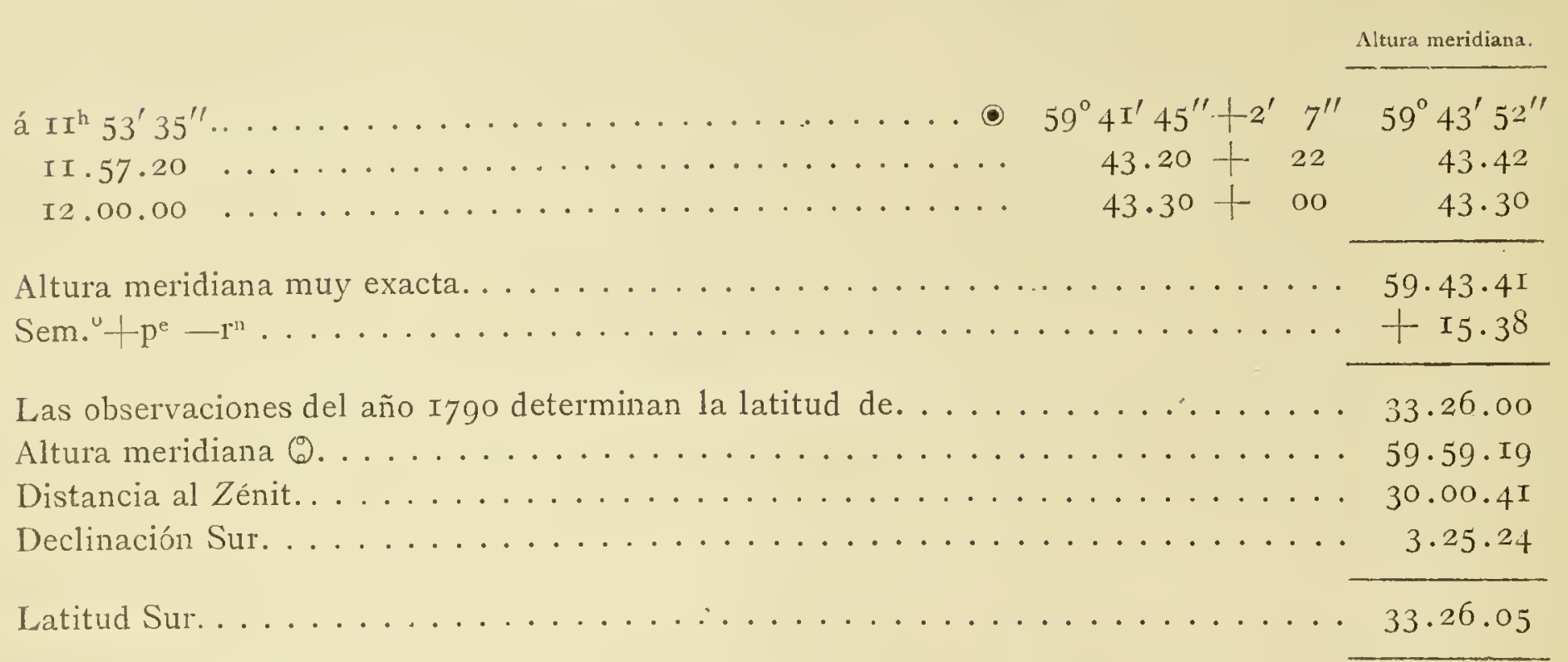

Observaciones de longitud.

A I $4^{\text {h }} 53^{\prime}$ del 29 de Enero cuenta astronómica en Santiago de Chile inmersión total del primer satélite de Júpiter: la atmósfera estaba clara, se distinguían las bandas del planeta, buena observación, comparándola con el cálculo, da longitud de Santiago O. de Greenwich $7 \mathrm{I}^{\circ} \mathrm{I}^{\prime}$. Se observó con un anteojo de nueve ps. de largo, propio de D. Manuel Cotapos.

A $7^{\mathrm{h}} 20^{\prime} 53^{\prime \prime}$ de la tarde del 20 de Febrero, hora verdadera en Santiago, fin del eclipse de Luna, observado con el anteojo dicho: la atmósfera estaba clara, observación de confianza, resulta longitud de Santiago O. de Greenwich $70^{\circ} 55^{\prime}$ oo".

Las observaciones del año I 790 determinaron la longitud de $70^{\circ} 56^{\prime} 00^{\prime \prime}$.

\section{Observaciones del termómetro.}

No se puede llamar riguroso el calor del verano en Santiago, pues raras veces se ve á $24^{\circ}$ el termómetro de Reaumur, y esto al medio día, en aquellos en que no hay virazón, y nunca permanece más de tres minutos cortos en este esṫado. Los ascensos y descensos del termómetro han sido diariamente este verano como sigue: al salir el Sol, en I6 ó I $8^{\circ}$; en $20^{\circ}$, á las $10^{\mathrm{h}}$; á medio día, en $22^{\circ}$ y $24^{\circ}$ á la siesta, faltando la virazón, que sucede pocas veces; por la tarde y noche, 20 , I8 y I6 $6^{\circ}$ y aún $I_{4}{ }^{\circ}$ á la media noche: á la madrugada vuelve á subir, continuando la misma marcha.

\section{Observaciones del barómetro.}

Es tan constante el estado de la atmósfera de este país, que casi no se hacen sensibles en el barómetro, sus variaciones, de suerte que dentro de un tercio de línea ha estado en 25 pulgadas desde Diciembre hasta Marzo. Es cierto que en estos meses no han pasado de cuatro los días nublados, ni ha caído una gota de agua, ni soplado un viento recio. La excesiva sequedad sirve de algún contra- 
peso á estas ventajas del temperamento: comparando dicha altura del barómetro con la que tiene el nivel del mar, y valiéndonos de las fórmulas de Mr. Bouguer, hemos hallado la elevación del suelo de Santiago de $957^{2} / 3$ varas castellanas sobre el nivel del mar.

\section{Observación de la variación de la aguja.}

Repetidas veces hemos observado azimutes magnéticos con el teodolito, $y$ ha resultado de $14^{\circ} 28^{\prime}$ la variación Nordeste, promedio de muchas observaciones que no se apartan medio grado entre si.

\section{Observaciones del barómetro, de latitud, longitud y variación de la aguja, hechas desde Santiago de Chile á Mendoza y Buenos- Aires, en Marzo y Abril de 1794.}

Observaciones del barómetro y determinación de la altura de varios puntos del camino principal de la cordillera de los Andes.

\begin{tabular}{|c|c|c|c|c|c|c|c|c|}
\hline \multirow[b]{2}{*}{$\begin{array}{l}\text { Nombres } \\
\text { de los lugares de las observaciones. }\end{array}$} & \multicolumn{2}{|c|}{$\begin{array}{l}\text { Altura del mercurio en } \\
\text { el barométro. }\end{array}$} & \multirow{2}{*}{$\begin{array}{c}\text { Termónetro. } \\
\text { Farh } k n r .\end{array}$} & \multirow{2}{*}{\multicolumn{2}{|c|}{$\begin{array}{l}\text { Elevación ó depresión } \\
\text { de los lugares entre sí, en piés } \\
\text { ingleses. }\end{array}$}} & \multicolumn{3}{|c|}{ Elevaciones sobre el mar. } \\
\hline & & Pulg. franc & & & & $\begin{array}{l}\text { Piés de - } \\
\text { Inglaterra. }\end{array}$ & $\begin{array}{l}\text { Piés de } \\
\text { Castilla. }\end{array}$ & $\begin{array}{l}\text { Toesas } \\
\text { de Francia. }\end{array}$ \\
\hline \multicolumn{9}{|l|}{ Valparaíso al nivel del } \\
\hline & 30,00 & $28, I_{4}$ & $62, \mathrm{I}_{4}$ & Elevación & 0000 & 00000 & 00000 & 0000,0 \\
\hline Santiago de Chile... & 2739 & 2575 & $72 \quad 18$ & Id. & 2620 & 02620 & 02864 & 0409,7 \\
\hline Casa de las Calab.s . . . & $206_{4}$ & I9 40 & 6 I 13 & Id. & 7984 & I060 & II & I6 $58, \mathrm{I}$ \\
\hline Casa de la Cumbre.. & I9 & I7 83 & 45 & Id. & 21 & 12739 & I3 & $\operatorname{Ig} 87,4$ \\
\hline Casa de las Cuevas.. & $20 I 6$ & I 892 & 54 IO & Depresión. & $I_{5} I_{4} 1 / 2$ & II225 & $1224 \mathrm{I}$ & I 747,2 \\
\hline Casa de los Puquios... & $2 \times \quad 45$ & 20 IO & 57 II & Id. & I7IO $1 / 2$ & $095 \mathrm{I} 4$ & I0399 & $\mathrm{I}_{4} 87,7$ \\
\hline Mendoza. & $269 I$ & 2525 & $68 \mathrm{I} 6$ & Id. & $50391 / 4$ & 04475 & $0489 I$ & 0699,7 \\
\hline
\end{tabular}

Nota. Aunque estas observaciones no sean de una exactitud incontestable, merecen confianza por el cuidado y esmero con que las hicimos con un buen barómetro de tubo capilar, en cuyo uso, así como en el cálculo de las observaciones, nos hemos guiado por las reglas y advertencias de los observadores más exactos.

Observaciones de latitudes, longitudes y variación.

Nombres de los lugares.

Días del ines.

Alt. ap. me.

Latitud Sur.

Santiago

Marzo II $\odot 59^{\circ} 43^{\prime \prime} / 2 \quad 33^{\circ} 26^{\prime} 20^{\prime \prime}$

Los Andes.............

Casa de los Puquios......

Uzpallata ...........

Mendoza ............

Idem

$$
\begin{aligned}
& \begin{array}{lllll}
11 & \text { I5 } & 5^{8} .45^{1 / 2} & 32.49 \cdot 3^{0}
\end{array} \\
& \text { IS } 57.26 \\
& \text { 1) I } \\
& \text { * } 22 \bigcirc 55.57
\end{aligned}
$$

$24 \quad 55.9 \% \quad 32.53 .00$

Idem por el gnomon.....

La Ramada..........

Desaguadero...........

Ciudad de San Luis pr. a de Leo..............

$$
\begin{array}{cccccc}
" & 26054.4 I & 32.5 I .0 & " 1 \\
\text { Abril } & 3 I & 53.8 & 32.27 .0 & \text { I5 } \\
\text { A } & 52.22 \% & 32.27 . & \text { I4 }
\end{array}
$$

$$
3 \$ 43.43 \% \quad 33.18 .30
$$

Vn. Ne.

$14^{01} / 2$

Longitud O. de Cádix.

64.4 por el eclipse del primer satélite del 30 de Enero y el de Luna. de $r 6$ de Febrero.

$$
\begin{aligned}
& \text { I5 }^{1 / 2} \\
& \text { I4 }^{\prime \prime}
\end{aligned}
$$

62. 3 por distancias de (-) el $25 y^{2} 26$ de Marzo. 


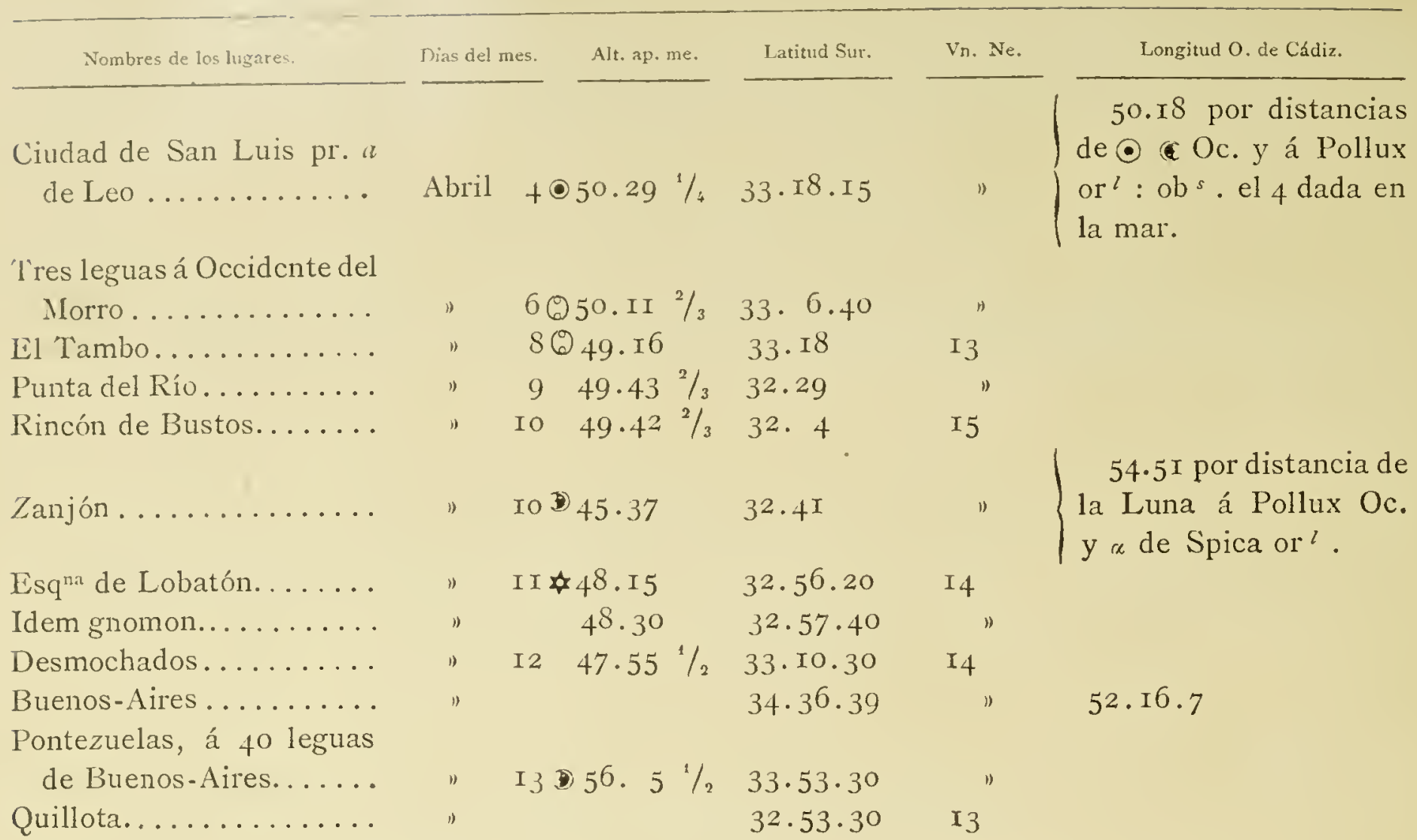

Nota. Las alturas meridianas referidas al centro con esta señal (), se observaron con un gnomon de seis pulgadas de alto que construimos en Mendoza, porque necesitábamos, corriendo en posta, de un instrumento de uso más expedito que el sextante y suficientemente exacto, como manifiestan las observaciones hechas en muchos parajes con los dos instrumentos.

El tiempo hermoso, la precisión de ver amanecer y correr todavía algunas horas después de puesto el Sol, en que nos ponía la diligencia del viaje, las llanuras interminables de las Pampas y el deseo de sacar algún partido del tiempo, nos movió á observar muchas veces la duración del crepúsculo y á calcular la depresión del Sol cuando apuntaba ó se confundía en el horizonte la luz crepuscular; daremos una de estas observaciones hecha el 7 de Abril en latitud de $33^{\circ}$ entre el Tambo y la Punta del Río.

A $5^{\mathrm{h}} 36^{\prime} 30^{\prime \prime}$ de la tarde, hora verdadera, se ocultaron las luces últimas del • en el horizonte.

A $7^{\text {h }} 4^{\prime} \mathrm{Oo}^{\prime \prime}$ de la noche, tiempo verdadero, se confundió con el horizonte la luz crepuscular, formada en arco.

I $27^{\prime} 30^{\prime \prime}$ duración del crepúsculo, y calculando con este ángulo horario la latitud del lugar y la declinación del Sol, que era á la sazón $7^{\circ}$ I I' Norte, la depresión del astro resulta de I $7^{\circ}$ I $8^{\prime}$. Otras observaciones han dado $I 7^{\circ} 30^{\prime}$ y $I 8^{\circ}$, de suerte, que confirman de nuevo estas observaciones, yue el Sol dista del horizonte entre 17 y r $8^{\circ}$ cuando empieza ó finaliza el dia.

Alturas de varios montes de la tierra.

\begin{tabular}{|c|c|c|}
\hline & NOMBRES DE LOS LUGARES. & $\begin{array}{c}\text { Piés ingleses } \\
\text { sobre nivel del mar }\end{array}$ \\
\hline \multirow{3}{*}{ América. . } & Chimborazo . . . . . . . . . . . . . . & $20.575,8$ \\
\hline & Ei Corazón. . . . . . . . . . . . . . . . . . . & I $5 \cdot 78_{3}$ \\
\hline & La ciudad de (quito. . . . . . . . . . . . . . . & $9 \cdot 242$ \\
\hline \multirow{7}{*}{ Africa... } & Pico de Tenerife. . . . . . . . . . . . . . . & I I . 022 \\
\hline & Pico Ruivo en la Isla Madera. . . . . . . . . . . . . & $5 \cdot I+I$ \\
\hline & Monte Blanco, más alto Alpes. . . . . . . . . . . . & $I_{5} .672$ \\
\hline & El Vesubio en $x_{77} 6 \ldots \ldots \ldots \ldots$ & $3 \cdot 93^{8}$ \\
\hline & 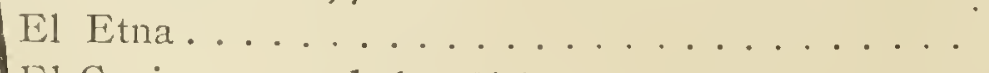 & 10.954 \\
\hline & El Canigou, uno de los Pirineos ........... & $9.2 \mathrm{It}$ \\
\hline & San Bartolomé, en el país de Foes . . . . . . . . . & $7 \cdot 5^{6} 3$ \\
\hline \multirow{5}{*}{ Europa... } & Monte de Oro, en la Aubernia. . . . . . . . . . . . & 6.696 \\
\hline & E1 Puy de Done. . . . . . . . . . . . . . . . . . . . & $5 \cdot 285$ \\
\hline & El Hecla. . . . . . . . . . . . . . . . . & $5 \cdot 000$ \\
\hline & Pico de Orizaba. . . . . . . . . . . . . . & 20.595 \\
\hline & I Camino principal de la cordillera de los Andes... & 12.739 \\
\hline
\end{tabular}


ESTADO donde se manifiesta la relacion de gravedades entre diversos lugares del mundo. segin las experiencias hechas por las corbetas del Rey, Descubierta y A Trevida, formadu por el Teniente de navio D. Ciriaco de Cevallos.

HEMISFERIO ÁRTICO

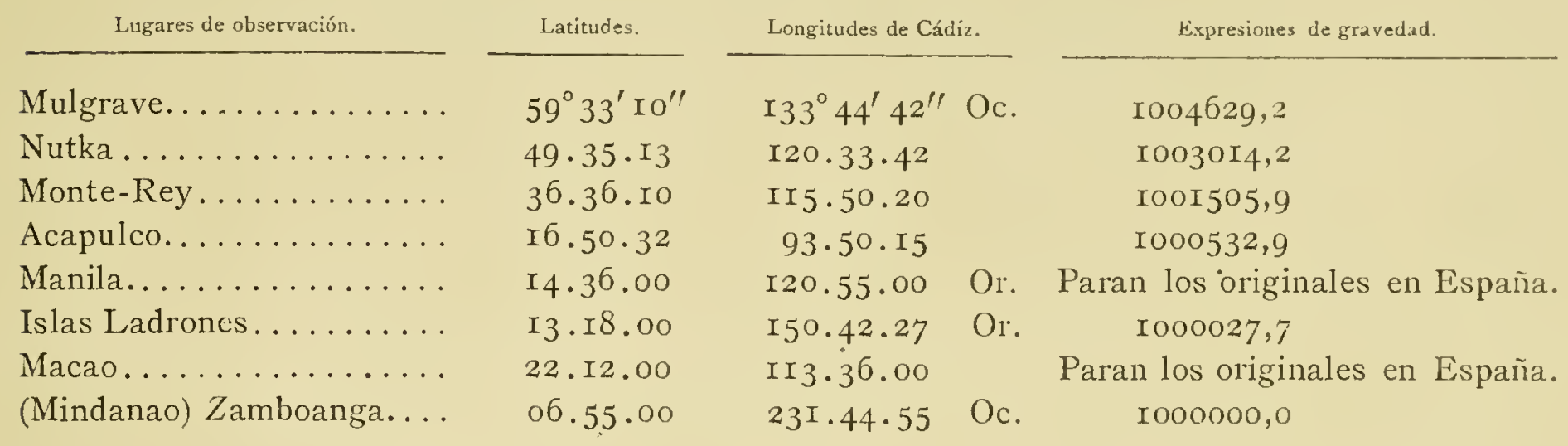

HEMISFERIO ANTÁRTICO

Lugares de òbservación.

Puerto Egmont. . . . . . . . . .

Santa Elena...........

Talcahuano ...........

Montevideo............

Puerto Jackson...........

Vavao (Islas Amigos).....

Magdalena (en Lima).....
Latitudes.

$$
\begin{aligned}
& 5 I^{\circ} 2 I^{\prime} 08^{\prime \prime} \\
& 44.29 \cdot 55 \\
& 36.42 . I 8 \\
& 34 \cdot 55.08 \\
& 33 \cdot 5 I .28 \\
& I 8.38 .45 \\
& I 2.04 \cdot 3^{8}
\end{aligned}
$$

Longitudes de Cádiz.

$53^{\circ} 54^{\prime} 30^{\prime \prime} \mathrm{Oc}$.
$59.25 \cdot 30$
67.02 .53
$50.00 \cdot 45$
$202.27 \cdot 30$
$167.49 \cdot 18$
70.52 .30

Expresiones de gravedad.
I0032I9,7
I 002882,6
Ioor 895,2
IOOI 889,4
I OOI 789,3
I 000623,3
IOOOII9, 2

La incertidumbre en que estamos relativamente á la longitud del péndulo de observación, embaraza la deducción de los resultados absolutos, así como la comparación de nuestras experiencias con las hechas por otros filósofos en diversos lugares del mundo. Pero cualquiera que sea aquella longitud, como estas corbetas han repetido sus observaciones en ambos hemisferios, pueden determinarse las relaciones de la gravedad entre todos los puntos de observación. 'Tal es el objeto de la tabla anterior, cuya forma hemos tomado de Mr. Maupertui en el estado general que hizo de todas las experiencias del péndulo hechas hasta su tiempo. Este geómetra omite las fórmulas que le condujeron á sus resultados, y que nosotros hemos suplido.

Se sabe que un cuerpo sumergido en un fluído pierde de su peso el peso del fluído que desplaza. Según este principio, la lenteja del péndulo, en virtud de cuyo peso se hacen las oscilaciones, debe perder una parte de este peso igual al peso del aire que ocupa. Si el aire fuese un fluído igualmente denso en todas las regiones de la Tierra, no habria necesidad de ninguna corrección, porque produciendo entonces dísminuciones iguales, no había causa que alterase la relación entre las gravedades; pero como los pesos del aire son distintos en diversos lugares, y para un mismo lugar en distintas circunstancias, de aquí nace una corrección sin la cual confundiríamos muchas veces las disminuciones reales de la gravedad, con las causas que sólo son un estorbo de ejercerse. Nuestras experiencias están todas reducidas á las $29 \%$ pulgadas del barómetro.

Según Nevton la gravedad se ejerce en razón inversa de los cuadrados de las distancias al centro. Nos hubiéramos salido de este principio para reducir las experiencias de una propia altura; pero no ha sido necesario, porque todas se han hecho al nivel del mar, con diferencia de cuatro á seis toesas, cantidad absolutamente despreciable. También se ha hecho atención á la corrección que deben tener las oscilaciones, por la circunstancia de no ser cicloidales, etc.

Después de lo dicho, y mientras no se da la historia individual de estas experiencias, basta añadir, que para hacerlas se han tenido presentes todos los principios fundamentales de teoría, y la conducta de los que nos han precedido en esta clase de observaciones. 


\section{ESTADOS DE DERROTA}

ESTADO de derrota correspondiente á los meses de Fulio y Agosto: manifiesta la posición de la corbeta DESCUBIERTA en cada medio dia, los errores de la estima, vientos, fuerza, estado del mar y variaciones de la aguja.

Salida de Cádiz para el Río de la Plata.-1789.

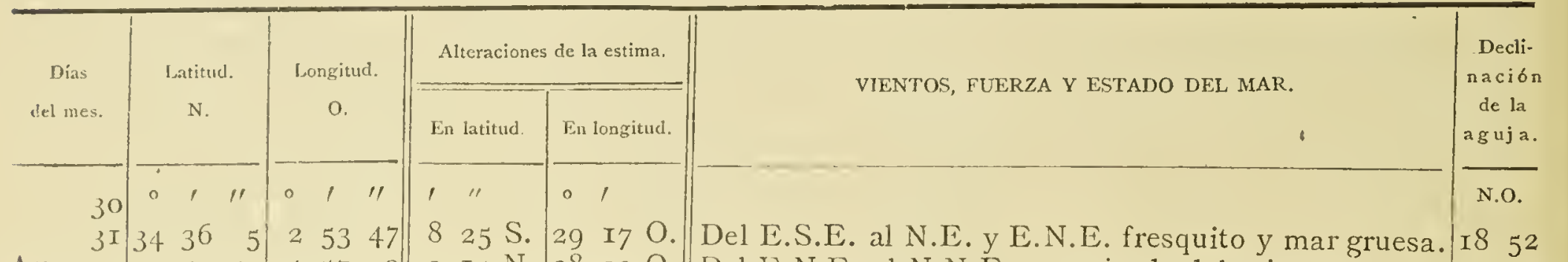

Ag. I 3259 I9 457 9 3 I4 N. 28 39 O. Del E.N.E. al N.N.E. mar picada del mismo...... Io oo

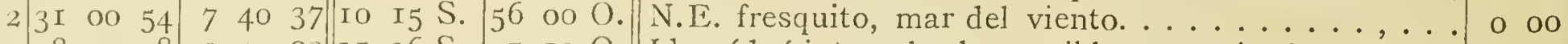

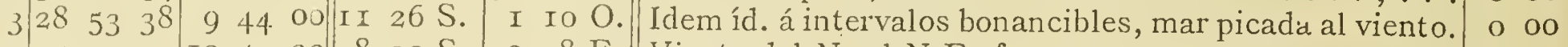

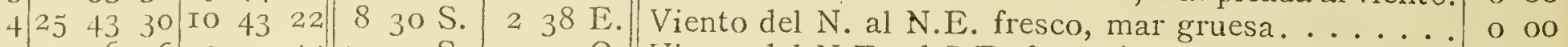
$5233^{6}$ I6 6 I2 I5 45 I4 37. S. 3I I5 O. Viento del N.E. al S.E. fresquito, mar picada. . . . I 545 6 I I Io 30 I4 oo 35 I7 5I S. 40 I5 O. E. bonancible y calmoso, marejada del mismo.... I5 48 7 I9 4 Io I4 Io 32 I7 50 S. 23 I2 O. Del N.N.E. al O.N.O., mar del E. .......... I3 3 8 I7 56 fo I 4295528 oo S. 39 4I O. Viento N.N.O. al N.O. bonancible, ventolinas varias. I 244 9 I6 $40 \quad 44$ I 4 I $559 \quad 5$ 40 N. $3^{8} 42$ O. S.E. bonancible, mar picada del N.E. ....... I3 6

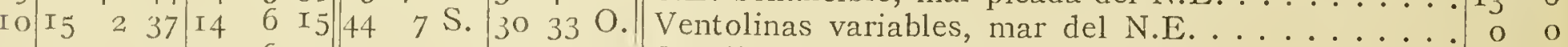

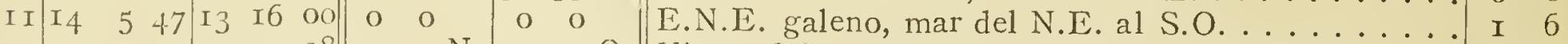
I2 I3 I 59 I2 3928 I7 N. 23 24 O. Viento del N. al E., mar picada del mismo...... I2 54 I3 I I 49 I5 I2 8 I 3 o 0 o 0 o $\quad$ Viento S.O., mar del mismo .............

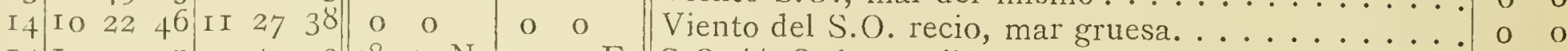

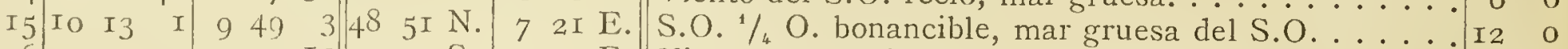
I6 Io oo 7 I I I I2 359 S. 23 I2 E. Viento S.S.O. fresco, mar del mismo........ I2 20 I7 94 I I6 II 4358 4 4 I S. 8 5I E. Viento calmoso del tercer cuadrante, marullo de él. . I 2 5o

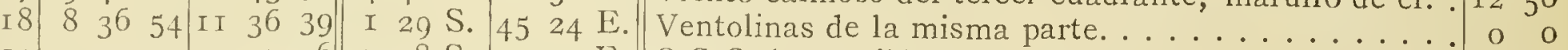

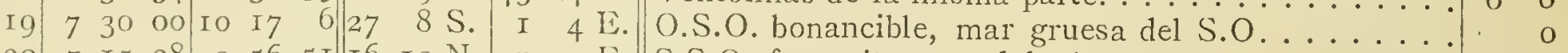

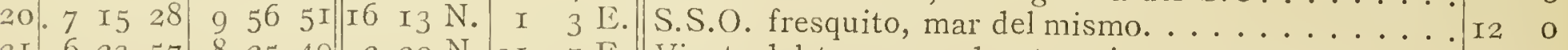

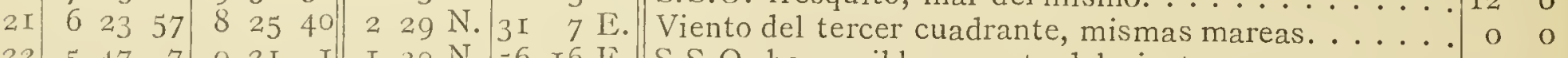

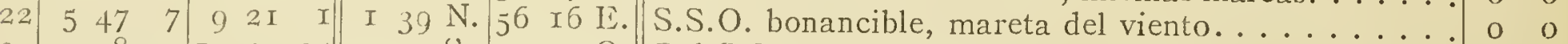
2343840 I0 2925 I4 27 S. I I I O. Del S.S.E. al S. bonancible, mar del mismo. . . . I 225

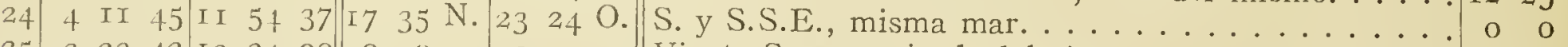

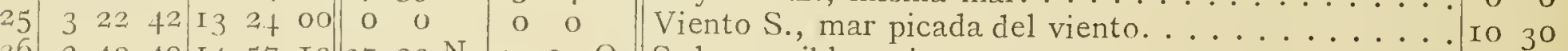
2624949 I4 57 I3 27 32 N. 5924 O. S. bonancible, misma mar. . . . . . . . . . . . . .

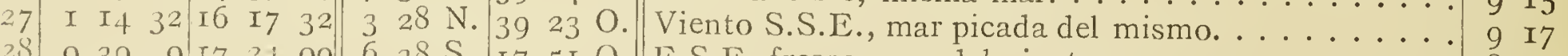
28 o 30 o r7 24 oo $63^{8}$ S. $\mid$ I7 5 I O. E.S.E. fresco, mar del viento. . . . . . . . . . . . . 8 .

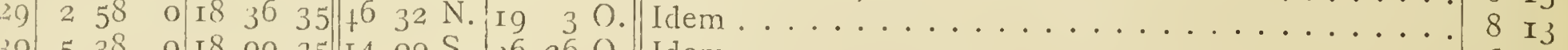

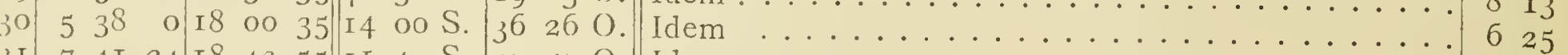

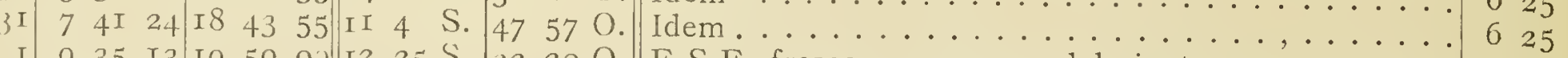

Set. I 935 I3 I9 50 o 32 I2 25 S. 3220 O. E.S.E. fresco, mar gruesa del viento. . . . . . .

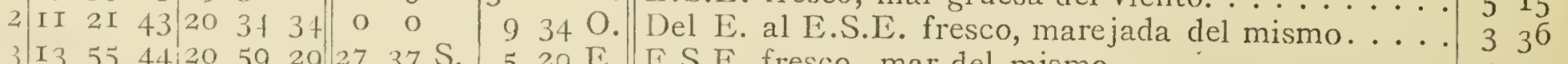

3 I 355442059292737 S. 5 29 E. E.S.E. fresco, mar del mismo............ . . 49

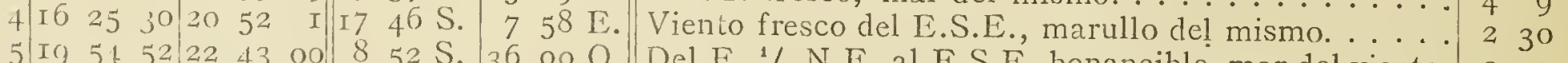

5 If) 5 \& 5222243 oo 8 52 S. 36 oo O. Del E. $1 / 4$ N.E. al E.S.E. bonancible, mar del viento. o o 6 2I 33030242440 I 36 S. I 38 O. N. E. bonancible, mar de la misma parte......... I 3 I

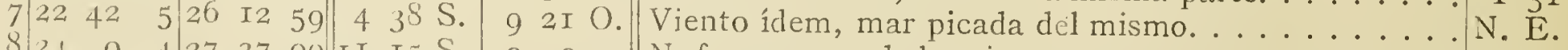

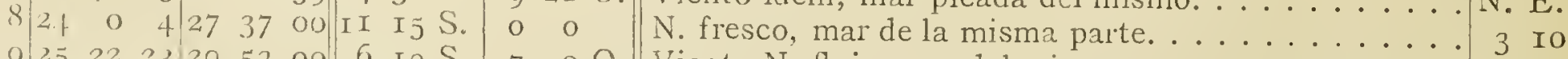

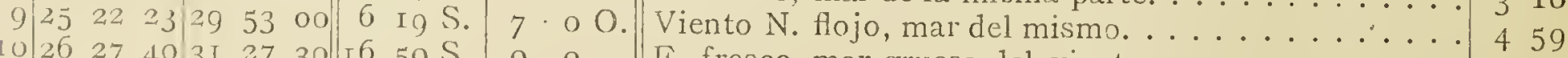

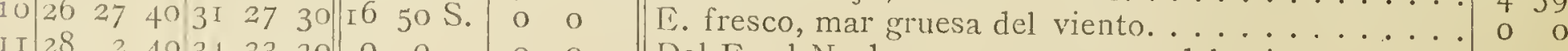

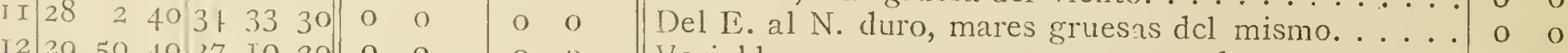

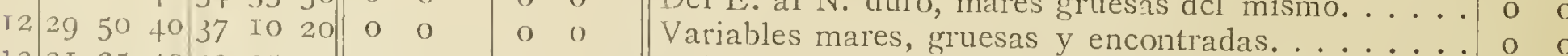

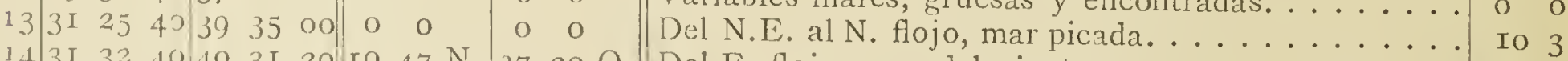

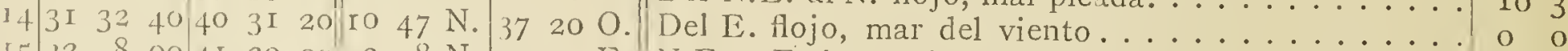

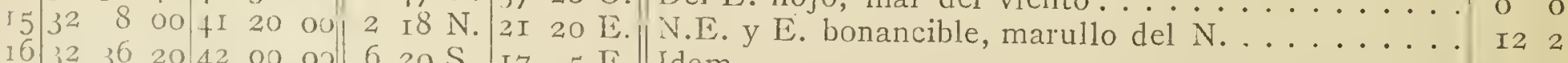

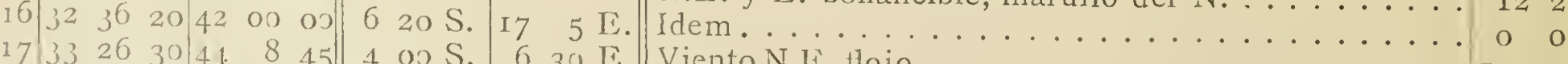

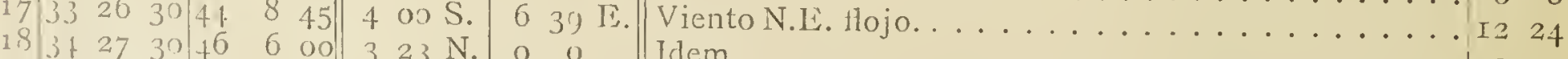

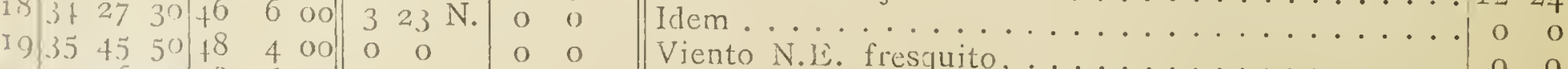

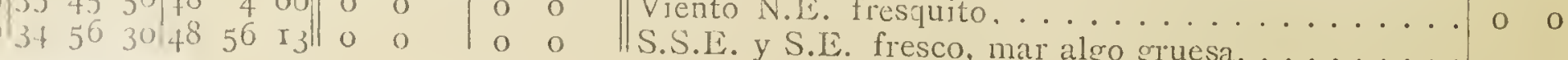


Salida del Río de la Plata para el Puerto Deseado.-Mes de Noviembre.-1789,

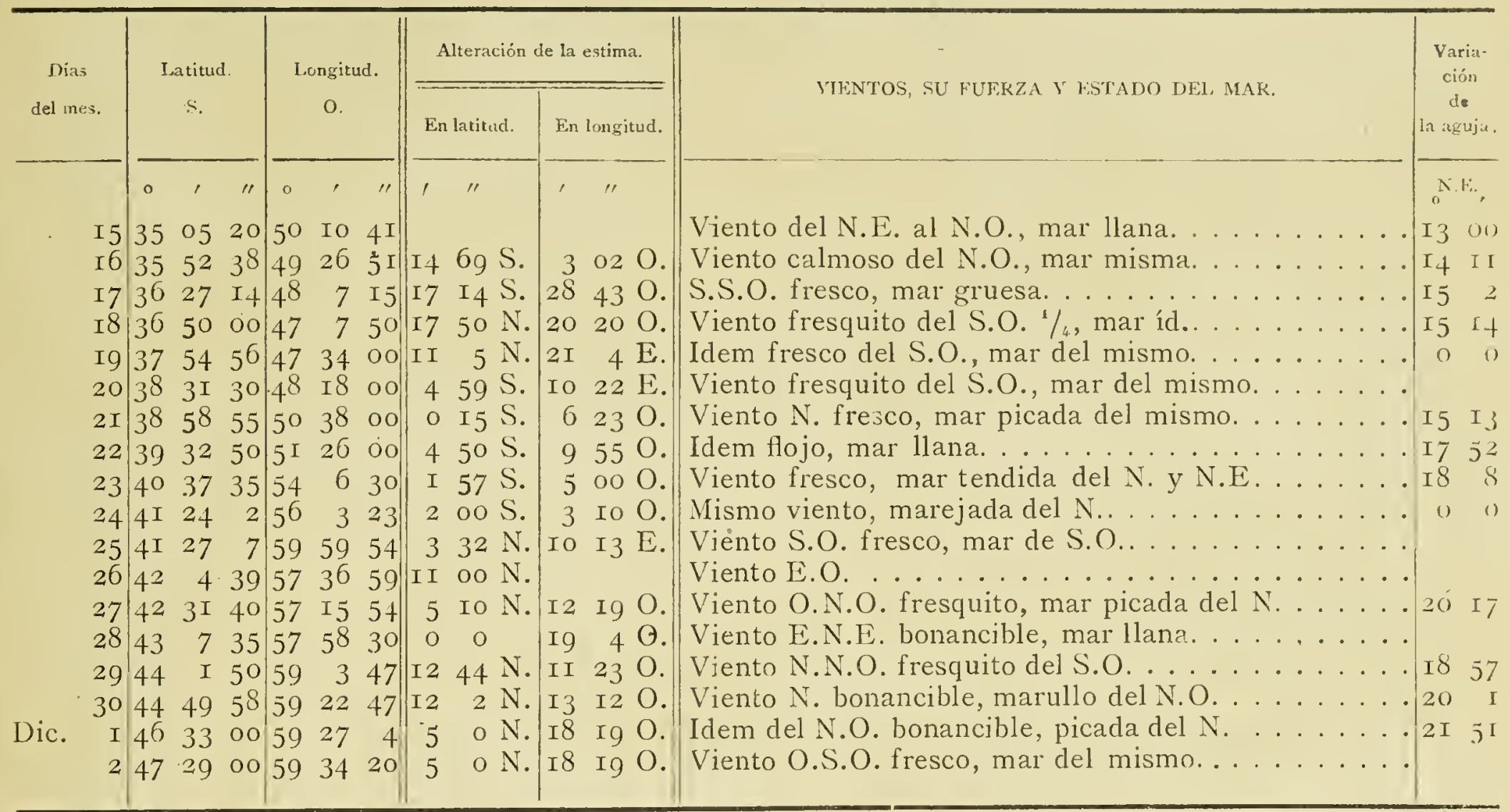

Salida del Pierto Deseado para el de Egmont.-Mes de Diciembre.-1789.

\begin{tabular}{|c|c|c|c|c|c|c|c|c|c|}
\hline \multirow{2}{*}{$\begin{array}{c}\text { Dias } \\
\text { del mes. }\end{array}$} & \multirow{2}{*}{\multicolumn{3}{|c|}{$\begin{array}{c}\text { Latitud } \\
\text { observada. } \\
\text { S. }\end{array}$}} & \multirow{2}{*}{\multicolumn{2}{|c|}{$\begin{array}{c}\text { Longitud } \\
\text { o bservad a. } \\
0 .\end{array}$}} & \multicolumn{2}{|c|}{ Alteración de la estima. } & \multirow{2}{*}{ VIENTOS, SU FUERZA Y ESTADO DEI MAR. } & \multirow{2}{*}{$\begin{array}{l}\text { Varia- } \\
\text { ción } \\
\text { de } \\
\text { la aguja. }\end{array}$} \\
\hline & & & & & & En latitud. & En longitud. & & \\
\hline - & & , & $\prime \prime$ & $\circ$ & , $" 1$ & , ' & , '1 & - & N.E. \\
\hline I4 & 47 & 37 & 00 & 59 & $33 \quad 38$ & oo S. & 2000 & N.N.O. galeno, mar llana. . . . & $2 I \quad 3$ \\
\hline 15 & 48 & 49 & 00 & 59 & I I 47 & o 0 & 0 & Viento N.O. bonancible, mar gruesa del mismo.. & 2220 \\
\hline 16 & $5^{\circ}$ & I9 & 3 & 56 & 4959 & I $47 \mathrm{~N}$ & $17+80$ & N. frescachón, mar gruesa del N.O... & $22+5$ \\
\hline 17 & & $\mathrm{I}$ & & 55 & 3259 & $556 \mathrm{~N}$ & $\mathrm{O} \quad \mathrm{O}$ & Viento fresco del O. y O.N.O... & $22 \quad 34$ \\
\hline
\end{tabular}

Salida del Puerto de Egmont.-Diciembre.

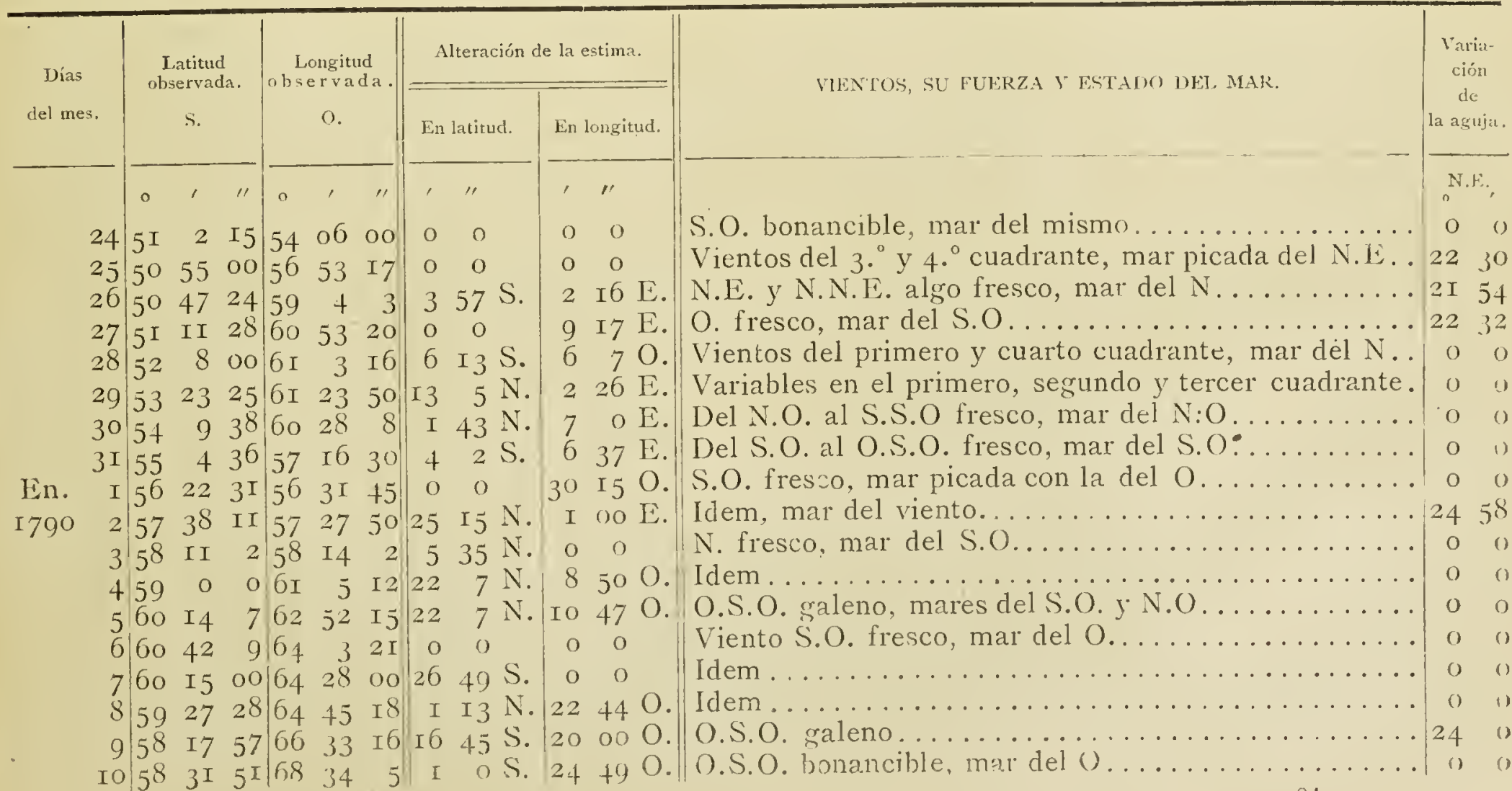


Continuación de la misma campaña en los meses de Enero y Febrero.-1790.

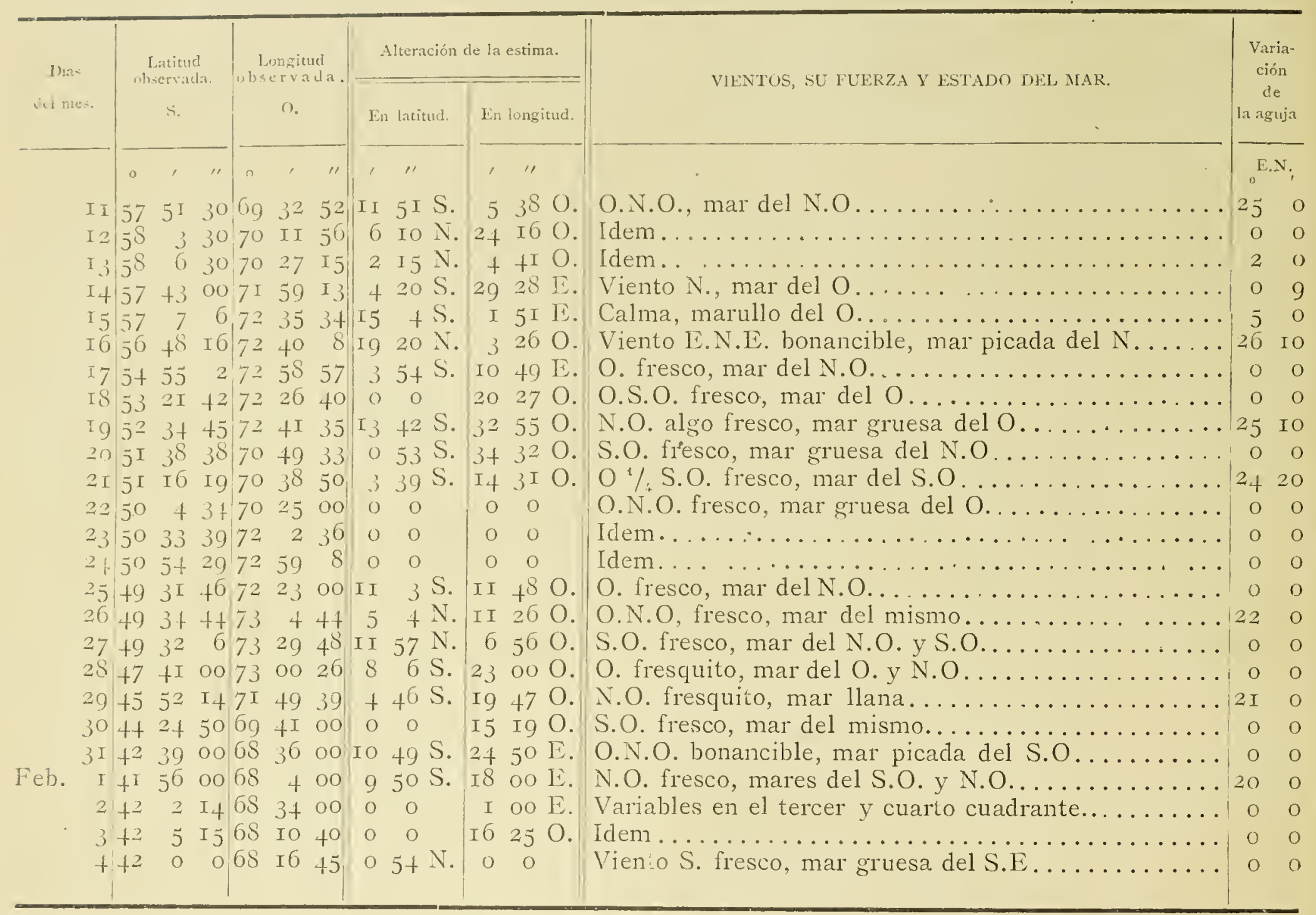

Salida del Puerto de San Carlos, en la Isla de Chiloé, al de la Concepción._-Mes de Febrero._-1790.

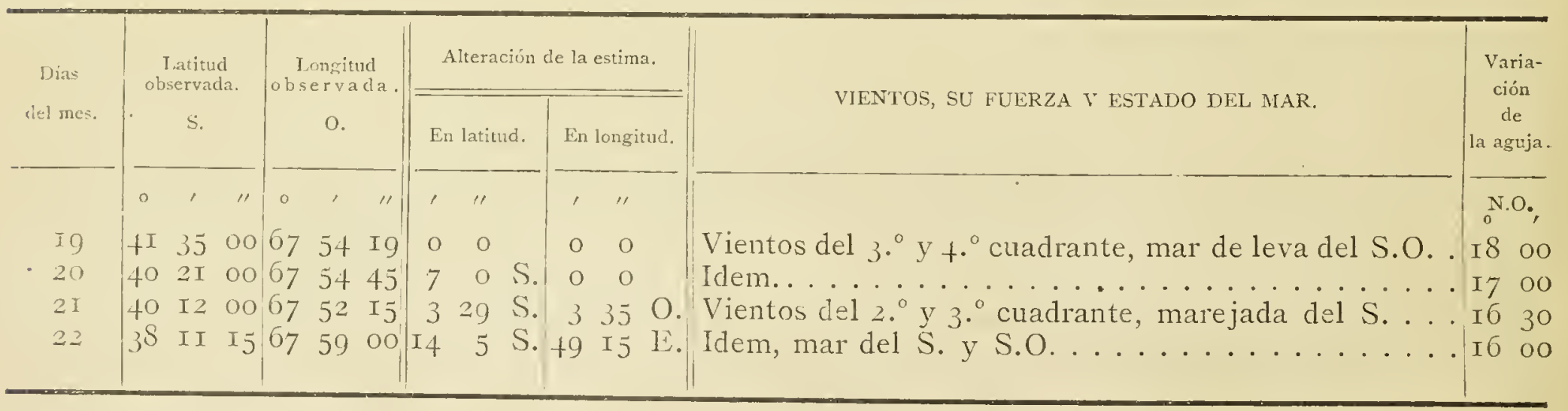

Salida de Concepción á las Islas de Juan Fernảndez y regreso á Valparaíso. - Mes de Marzo de $\mathbf{1 7 9 0 .}$

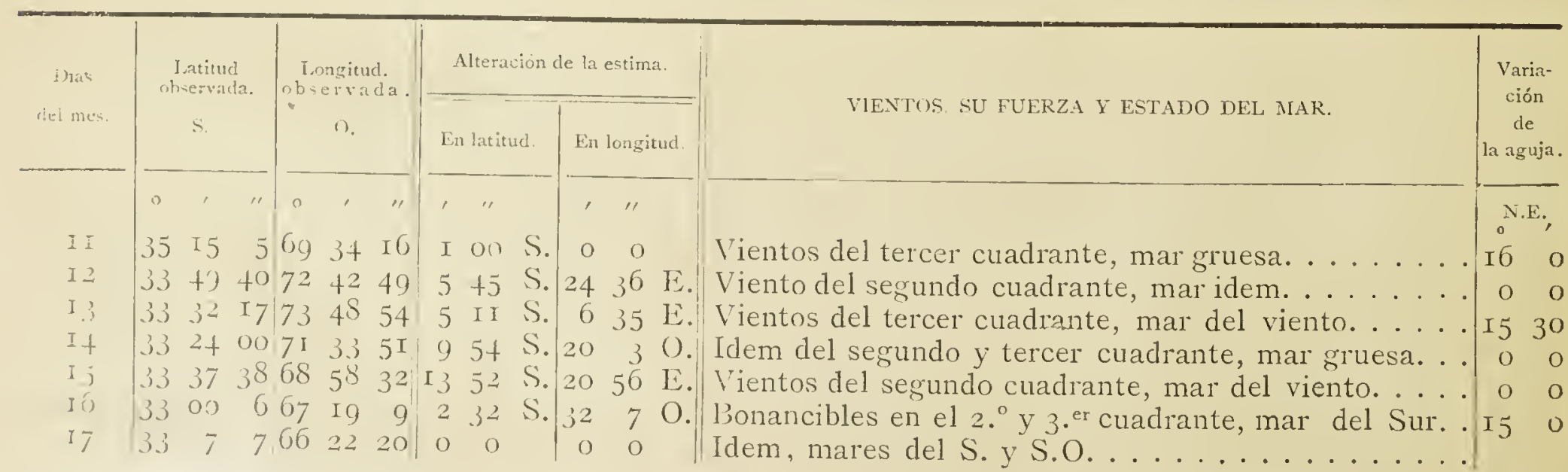


Salida de Valparaiso para Coquimbo.-Mes de Abril.-1790.

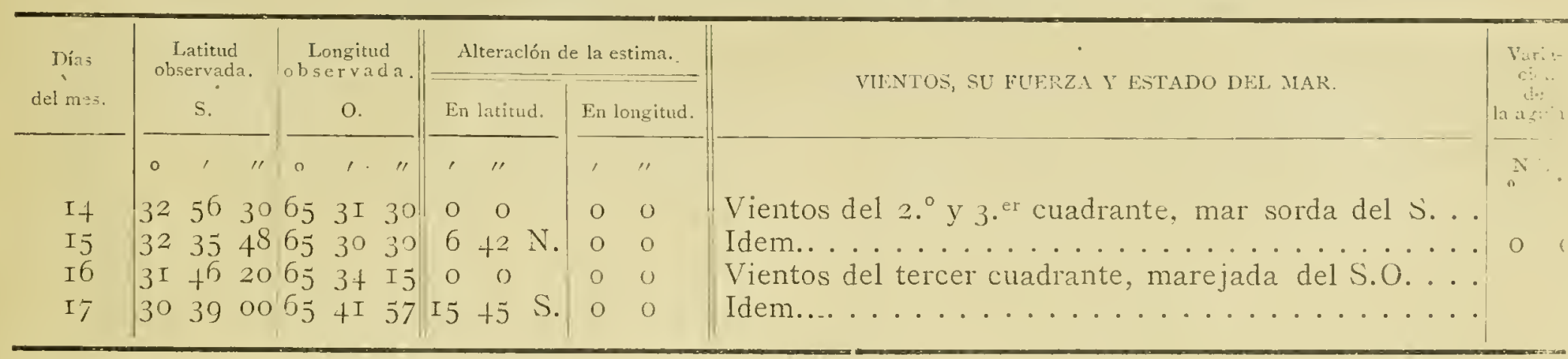

Salida de Coquimbo para Arica.-Mes de Mayo. - 1790.

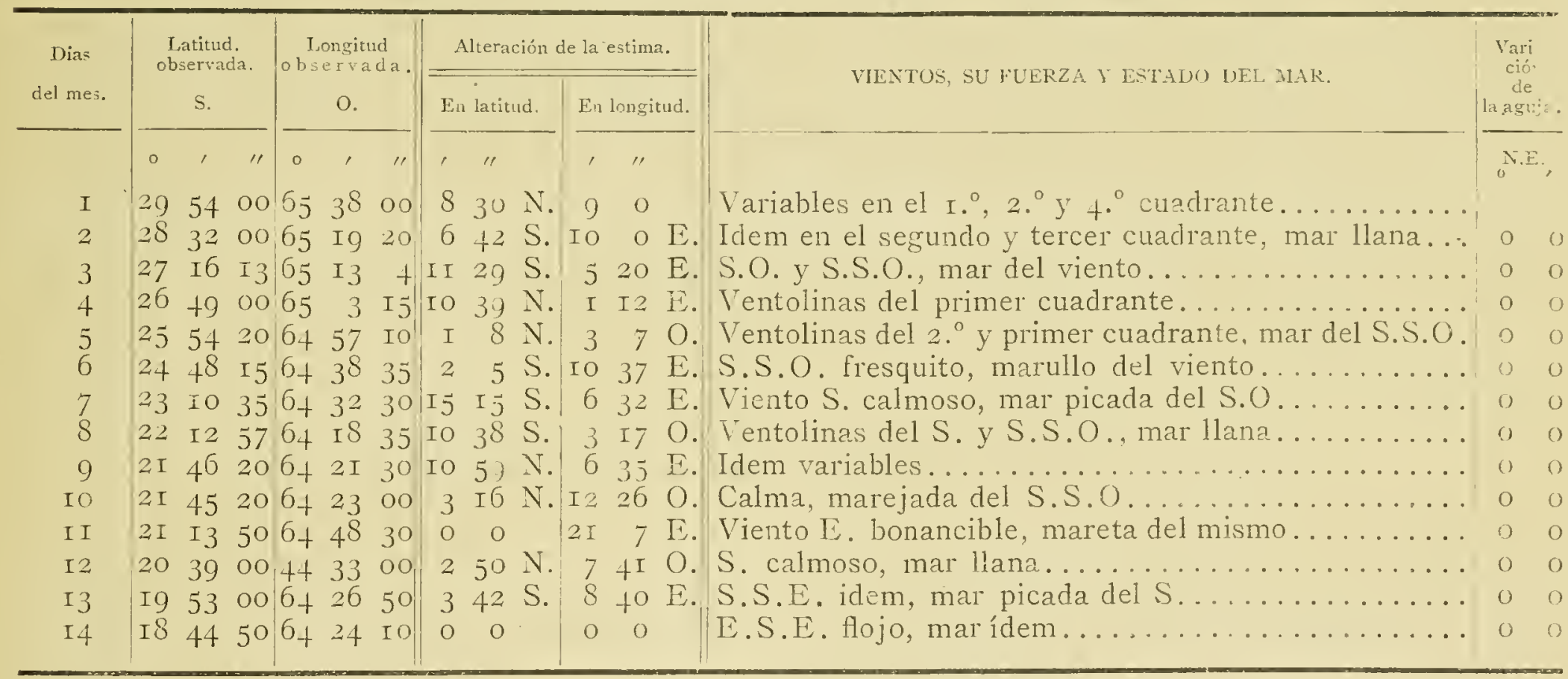

Salida de Arica para el Puerto del Callao de Lima._-Mes de Mayo.-1790.

\begin{tabular}{|c|c|c|c|c|c|c|c|c|c|c|c|}
\hline \multirow{2}{*}{$\begin{array}{c}\text { Días } \\
\text { del mes. }\end{array}$} & \multirow{2}{*}{\multicolumn{3}{|c|}{$\begin{array}{c}\begin{array}{c}\text { Latitud } \\
\text { observada. }\end{array} \\
\text { S. }\end{array}$}} & \multirow{2}{*}{\multicolumn{3}{|c|}{$\begin{array}{c}\text { Longitud } \\
\text { observada } \\
0 .\end{array}$}} & \multicolumn{3}{|c|}{ Alteración de la estima. } & \multirow{2}{*}{ VIENTUS, SU FUERZA Y ESTADO DEL MAR. } & \multirow{2}{*}{$\begin{array}{c}\text { Varia- } \\
\text { ción } \\
\text { de } \\
\text { la aguja. }\end{array}$} \\
\hline & & & & & & & & a latitud. & Fn lnngitud. & & \\
\hline & o & & & & , & & & & , " & & N.E. \\
\hline Ig & I 8 & 30 & & $6+$ & 26 & 5 & o & o & 30 & Viento S.O., marejada del S.O. & \\
\hline 20 & I 8 & 20 & 50 & 64 & +7 & 25 & 4 & $25 \mathrm{~N}$. & I3 $55^{2} \mathrm{O}$. & S.E. galeno, mar ídem... & :) \\
\hline $2 I$ & 17 & to & 30 & 65 & I2 & I5 & & $2 S$. & Io Io $\mathrm{O}$. & N.N.E. fresco, mar llana..... & $\therefore$ \\
\hline 22 & 17 & & I5 & 65 & 58 & IO & & $7 \mathrm{~S}$. & $555 \mathrm{E}$. & E. calmoso, marejada del S.O. sorda. . . . . . & $\cdot$ \\
\hline 23 & 16 & 39 & 20 & 66 & 58 & 30 & & 0 & I5 It E. & S.S.E. rresquito, mar del S.S.E. . . . . . . & 3 \\
\hline 24 & I5 & 37 & $2+$ & 68 & 49 & I5 & 2 & $16 N$. & $2++5 \mathrm{E}$. & S.E. frescachón, mar del S.S.E. . . . . . . & ) \\
\hline 25 & 13 & $5 \mathrm{I}$ & 20 & 70 & 22 & 55 & 9 & $22 \mathrm{~S}$. & 5 to E. & S.S.E. fresco, mar del mismo. . . . . & \\
\hline 25 & I 2 & 43 & 30 & 70 & 50 & 45 & & $22 \mathrm{~N}$. & $826 \mathrm{E}$. & Iden................. & $\therefore$ \\
\hline 27 & 12 & 38 & 30 & 70 & 52 & I 5 & & +8 N. & $65+\mathrm{E}$. & Ventolinas del S.S.O., mar del mismo. . & \\
\hline
\end{tabular}

Salida del Callao de Lima para el Río de Guayaquil. - Mes de Setiembre.-1790.

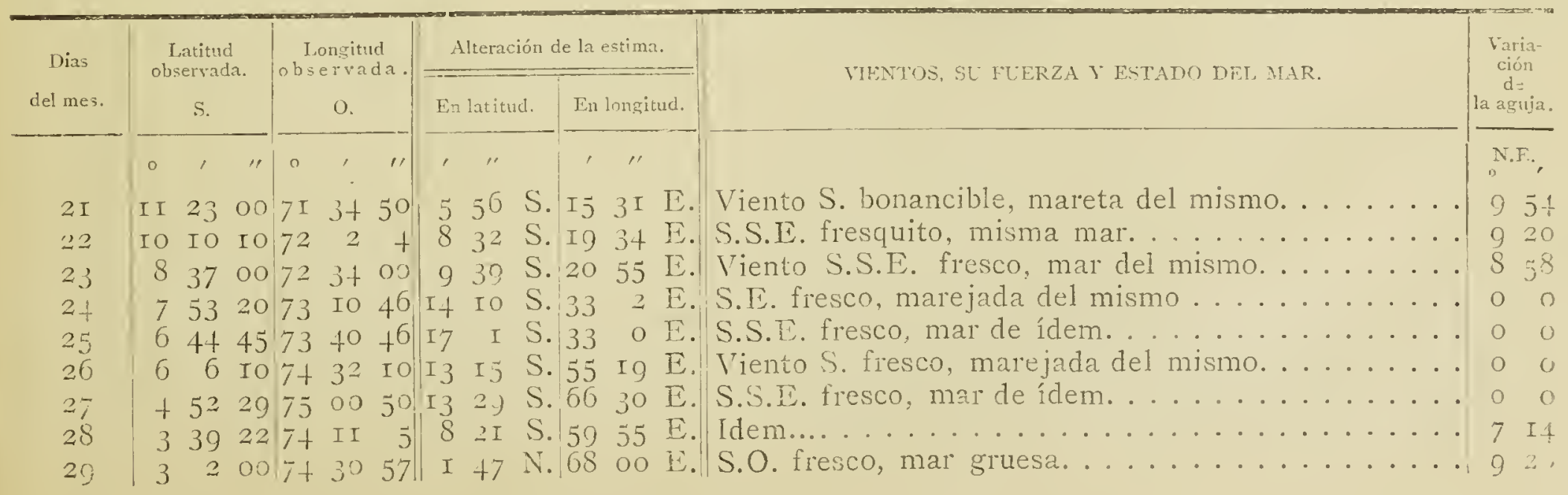


Salida del Río de Guayaquil para el 'Puerto de Panamà.-Mes de Noviembre.-1790.

\begin{tabular}{|c|c|c|c|c|c|c|c|c|c|c|c|}
\hline \multirow{2}{*}{$\begin{array}{l}\text { inas. } \\
\text { ir mec. }\end{array}$} & \multirow{2}{*}{\multicolumn{3}{|c|}{$\begin{array}{l}\text { Latitud } \\
\text { observada. } \\
\text { S. }\end{array}$}} & \multirow{2}{*}{\multicolumn{3}{|c|}{$\begin{array}{c}\text { Lougitud } \\
\text { observada. } \\
\text { O. }\end{array}$}} & \multicolumn{3}{|c|}{ Alteración de la estima. } & \multirow{2}{*}{ VIENTOS, SU FUERZA Y ESTAUO DEL MIAR. } & \multirow{2}{*}{$\begin{array}{c}\text { Varia- } \\
\text { ción } \\
\text { de } \\
\text { la aguja. }\end{array}$} \\
\hline & & & & & & & & in latitud. & En longitud. & & \\
\hline & & , & & & . & & & " & , " & & N.E., \\
\hline I & & & & 74 & I I & 27 & & 0 & $0 \quad 0$ & Viento fresco, fresquito y bonancible del $3{ }^{e r}$ cuadrante & $0 \quad 0$ \\
\hline 2 & & 329 & 24 & & $3^{6}$ & 29 & & oо N. & $0 \quad 0$ & Bonancible en el cuarto, mar del S.O. . . . . . . & $\begin{array}{ll}0 & 0\end{array}$ \\
\hline 3 & & & $3 I$ & 74 & 57 & 26 & 27 & $3 I N$. & $\begin{array}{lll}I_{3} & \mathrm{O} & \mathrm{O} .\end{array}$ & Bonancible del O.N.O., marejada del mismo...... & $\begin{array}{ll}0 & 0\end{array}$ \\
\hline+ & & & I7 & & 34 & $3^{6}$ & I 4 & $52 \mathrm{~N}$. & $2 \mathrm{I} 24 \mathrm{O}$. & Viento del O.S.O. y S.O. fresco, mar de él. & o $\quad 0$ \\
\hline 5 & & & Io & 74 & 27 & IO & & $46 \mathrm{~N}$ & $4+\mathrm{E}$ & Del O.S.O. al S. fresco y bonancible, mar ídem. . . & \\
\hline 6 & & o 50 & & 74 & 25 & I6 & & $20 \mathrm{~N}$ & $232 \mathrm{E}$ & Fresco en el tercer cuadrante, mar agitada.. . . . . & $0 \quad 0$ \\
\hline 7 & & I 57 & I 8 & & $\mathrm{I}_{3}$ & & & $t^{8} \mathrm{~N}$ & I 2 I 4 I & 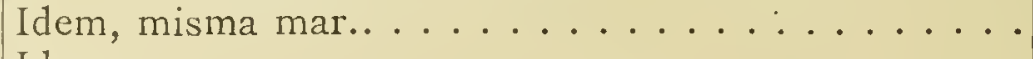 & \\
\hline$s$ & & 332 & $5^{\circ}$ & $7 \mathrm{I}$ & 43 & & & $2 \cdot 2 \mathrm{~N}$. & $23 \quad 90$. & 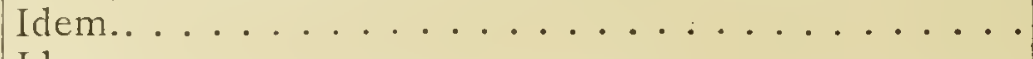 & o $\quad 0$ \\
\hline 9 & & 442 & 30 & $7 \mathrm{I}$ & 44 & & & $20 \mathrm{~N}$. & 300. & Idem.. . . . . . . . . . . . . . . & \\
\hline Io & & $6 \mathrm{IS}$ & 40 & $7 \mathrm{I}$ & 39 & 20 & I 2 & $49 \mathrm{~N}$. & 28 oo 0. & 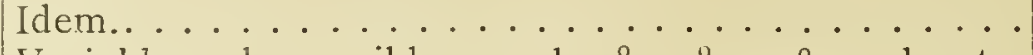 & \\
\hline I I & & $6+6$ & $4^{6}$ & & 5 & $3^{8}$ & & 0 & 0 & Variables y bonancibles en el $2 .^{\circ}, 30^{\circ}$ y $4 .^{\circ}$ cuadrante. & o $\quad 0$ \\
\hline 12 & & $75^{2}$ & I 2 & 73 & 33 & I3 & 43 & $44 \mathrm{~N}$. & $6940 \mathrm{E}$. & Idem en el tercero y cuarto cuadrante. .......... & \\
\hline I 3 & & 821 & 50 & 73 & 38 & I5 & & IO N. & 2 IO E. & Bonancible y calmoso en el $\mathrm{r}^{\circ} \mathrm{y} 4 .^{\circ}$ cuadrante. . . . & 840 \\
\hline
\end{tabular}

Salida de Panamá para el Puerto de Acapulco.-Mes de Diciembre.-1790.

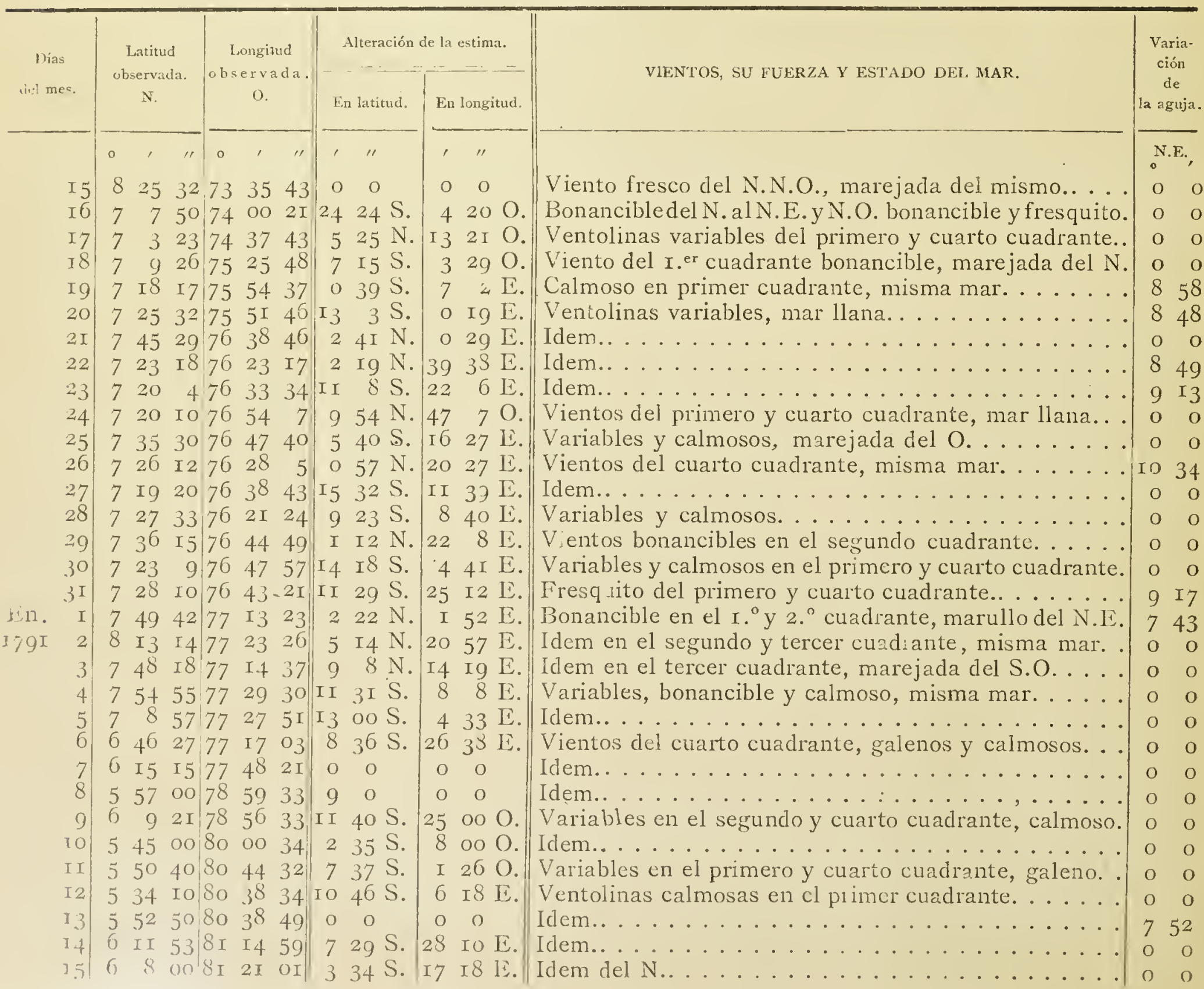


Continuación de la salida de Panamá.--Mes de Enero.-1791.

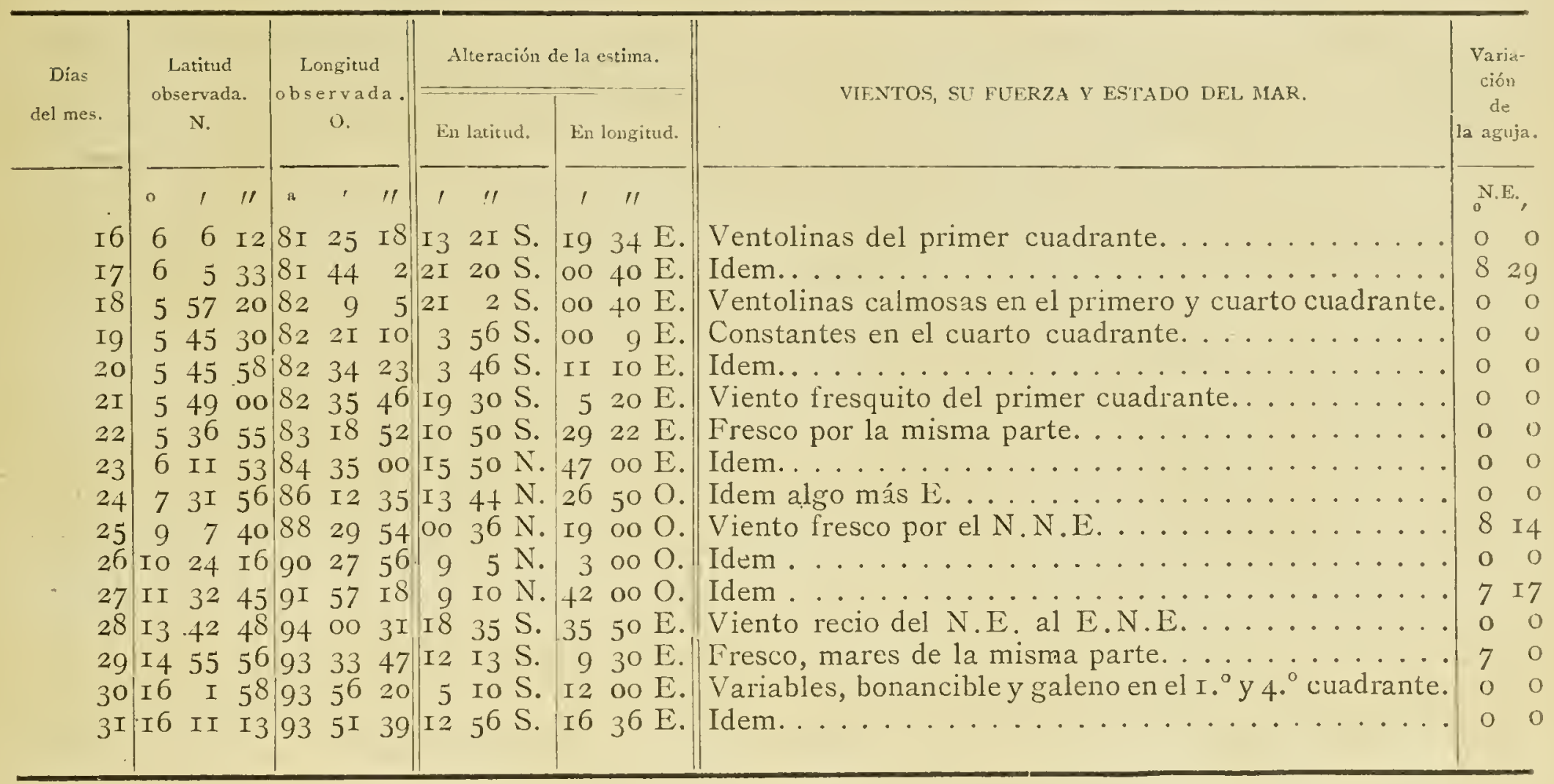

Salida del Puerto de Acapulco al de San Blas._-Meses de Febrero y Marzo._I79I.

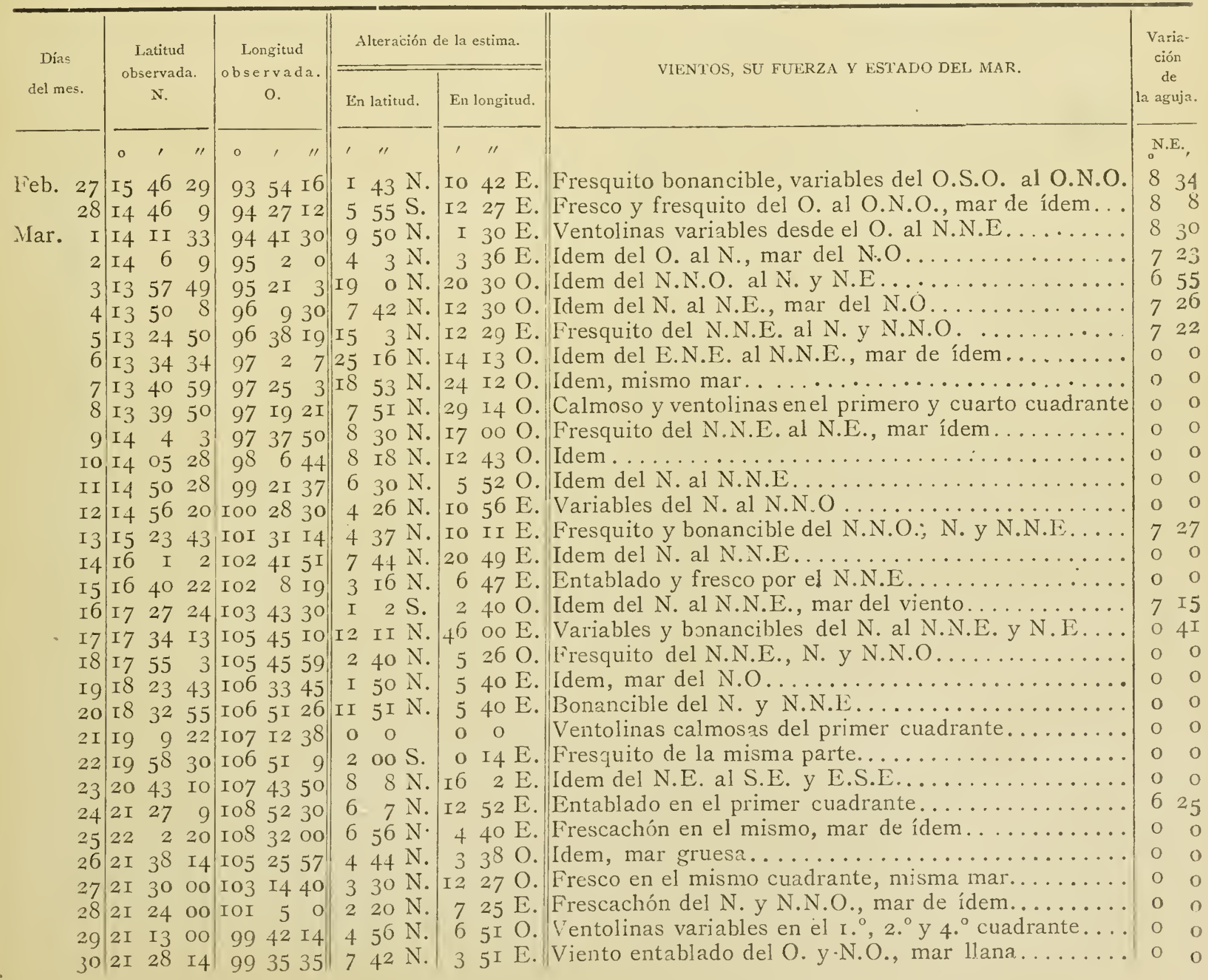


Salida del Puerto de San Blas para el de Acapulco.--Mes de Abril.

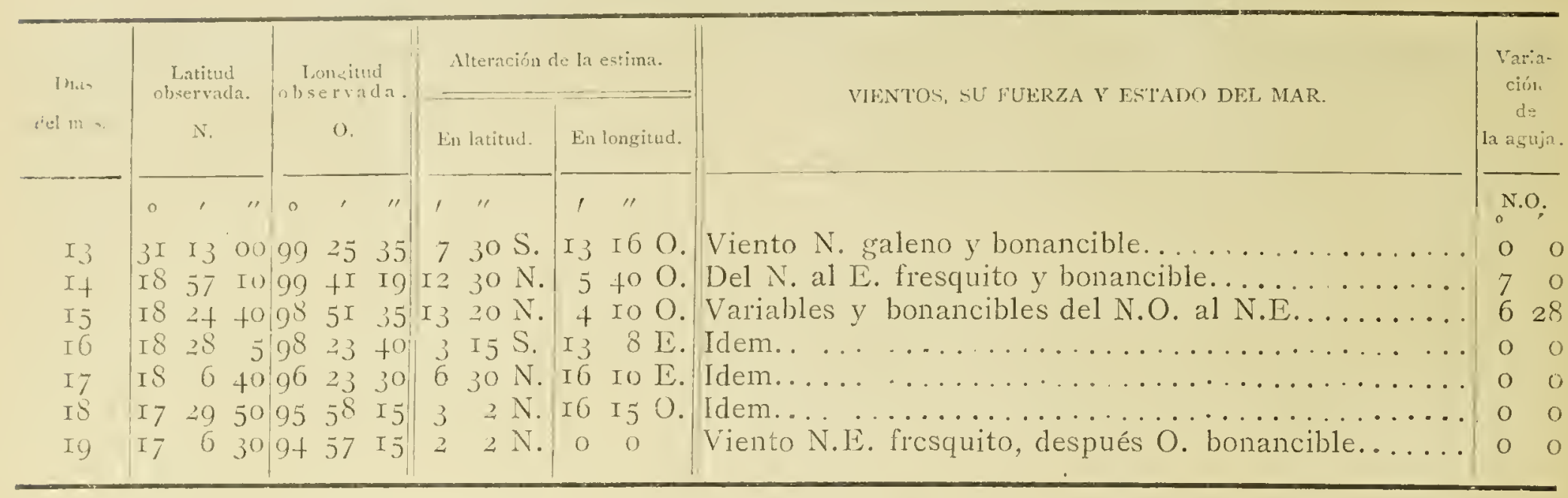

Salida del Puerto de Acapulco para el de Mulgrave.-Mes de Mayo.

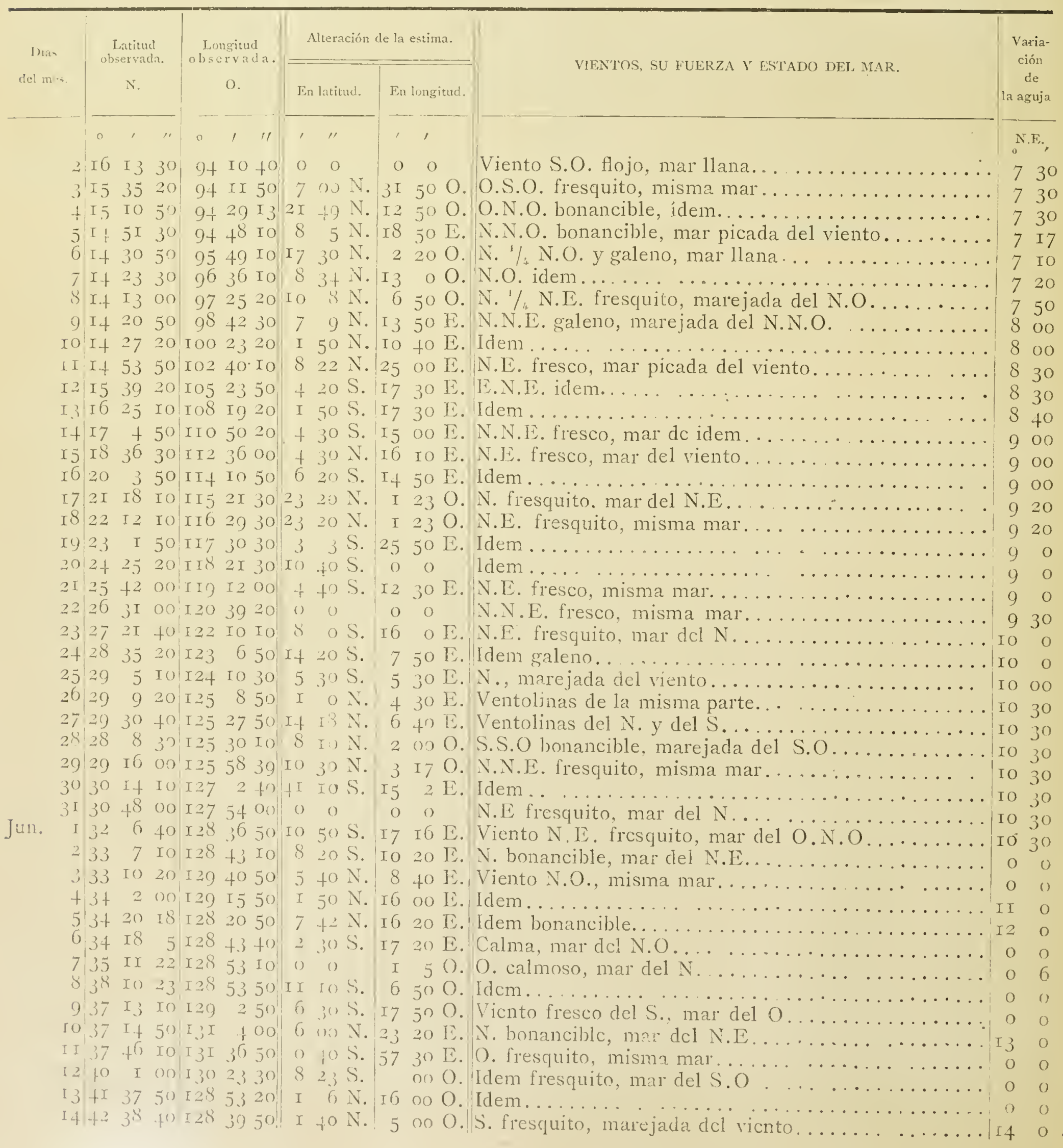


Continuación de la misma campaña._- Mes de Junio.

\begin{tabular}{|c|c|c|c|c|c|c|c|c|c|}
\hline \multirow{3}{*}{$\begin{array}{l}\text { Días } \\
\text { del mes. }\end{array}$} & \multirow{2}{*}{\multicolumn{3}{|c|}{$\begin{array}{c}\text { Latitud. } \\
\text { observada. } \\
\text { N. }\end{array}$}} & \multirow{2}{*}{\multicolumn{2}{|c|}{$\begin{array}{c}\text { Longitud. } \\
\text { observada. } \\
n\end{array}$}} & \multicolumn{2}{|c|}{ Alteraciones de la estima. } & \multirow{2}{*}{ VIENTOS, SU FUERZA Y ESTADO IDEL MAR. } & \multirow{2}{*}{$\begin{array}{l}\text { Varial- } \\
\text { cion } \\
\text { de } \\
\text { la aguja. }\end{array}$} \\
\hline & & & & & & En latitud. & En longitud. & & \\
\hline & $\dot{\circ}$ & ' & & o & ' 11 & & & & N.E., \\
\hline I 5 & +5 & 2 & IO & 129 & 1740 & $\mathrm{I}+20 \mathrm{~S}$ & I6 IO 0 & O.N.O. fresco, mar del viento........... & O \\
\hline I6 & 45 & 52 & 40 & $12 \bar{S}$ & 5830 & $\mathrm{O} \quad \mathrm{O}$ & $830 \mathrm{E}$ & 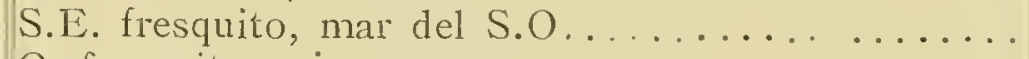 & $\mathrm{O}$ \\
\hline I7 & 47 & $5^{I}$ & IO & I $3 I$ & I I I 5 & I6 Io $\mathrm{S}$. & 8200 & 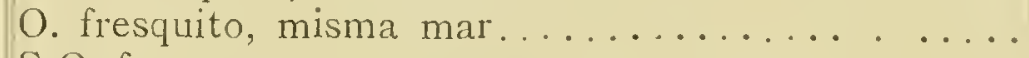 & 15 \\
\hline I 8 & 48 & $3^{6}$ & 50 & $I_{32}$ & 700 & $640 \mathrm{~S}$. & $95 \mathrm{O} \mathrm{E}$ & 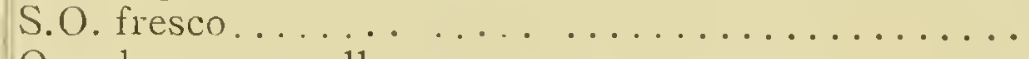 & I 5 \\
\hline Ig & 48 & $4+$ & $5^{I}$ & $I_{32}$ & 44 I 5 & $750 \mathrm{~N}$. & $5356 \mathrm{E}$ & 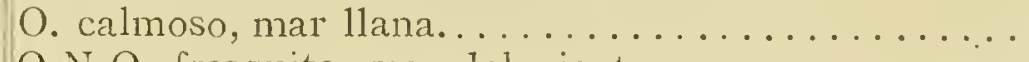 & o \\
\hline 20 & $5^{2}$ & 8 & IO & I 32 & 25 & I2 oo S. & $\mathrm{I}_{4}+\mathrm{O} \mathrm{O}$ & 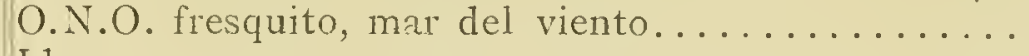 & O \\
\hline $2 I$ & 53 & I5 & $\mathrm{OO}$ & I 33 & 950 & 8 oo S. & $520 \mathrm{E}$ & 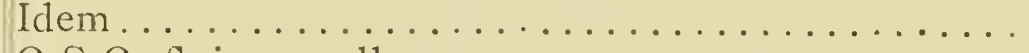 & 16 \\
\hline 22 & 54 & $3 I$ & $3 I$ & I3I & $3+50$ & 4. I7 S. & $\mathrm{I}_{4} 5 \mathrm{O} \mathrm{O}$ & 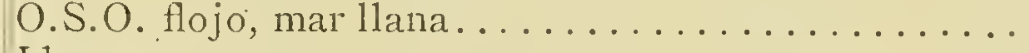 & 17 \\
\hline 23 & 56 & I7 & 30 & I30 & 2650 & $3^{8}+0 \mathrm{~S}$. & I $30 \mathrm{E}$. & 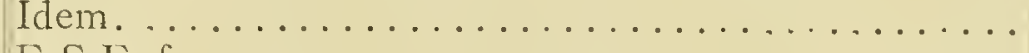 & 17 \\
\hline 24 & 57 & IO & IO & I3I & 36 Io & I2 $50 \mathrm{~S}$. & $0 \quad 0$ & 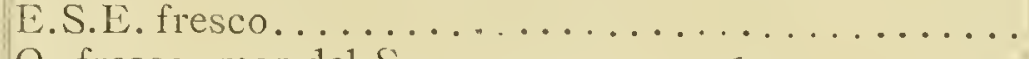 & 24 \\
\hline 25 & 57 & 59 & 40 & I32 & 5850 & 4 Io S. & $320 \mathrm{E}$ & O. fresco, mar del $S_{\ldots \ldots \ldots \ldots \ldots \ldots} \ldots \ldots \ldots$ & $2+$ \\
\hline 26 & 59 & OO & 30 & I 32 & $4+40$ & $2+0 \mathrm{~N}$ & 6400 & S.S.O. fresquito, marejada del S.O.... & 24 \\
\hline
\end{tabular}

\section{Salida del Puerto de Mulgrave para el de Nutka._Mes de Julio._-179|.}

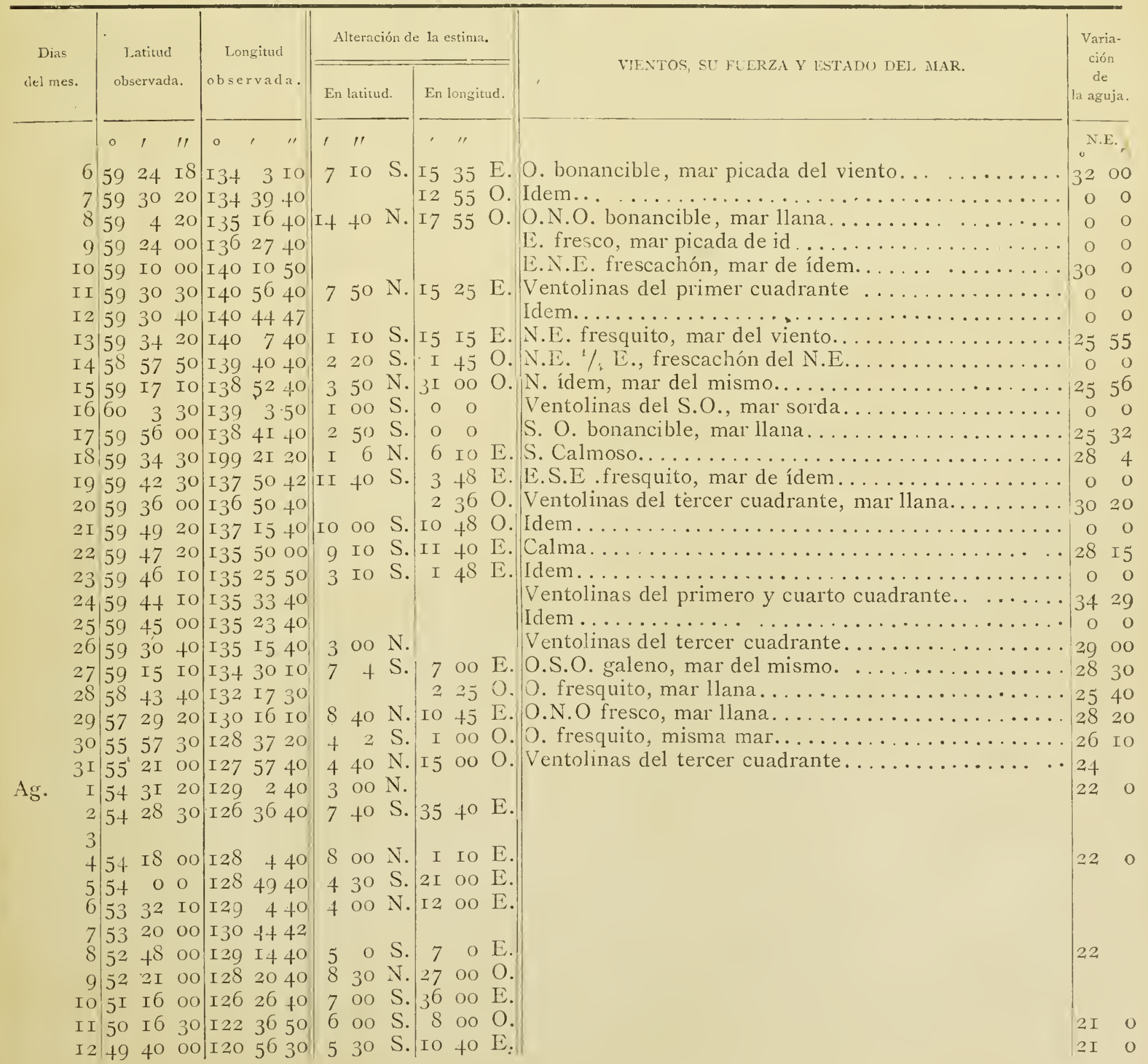


Salida de Nutka para el Puerto de Monterey. - Mes de Agosto.

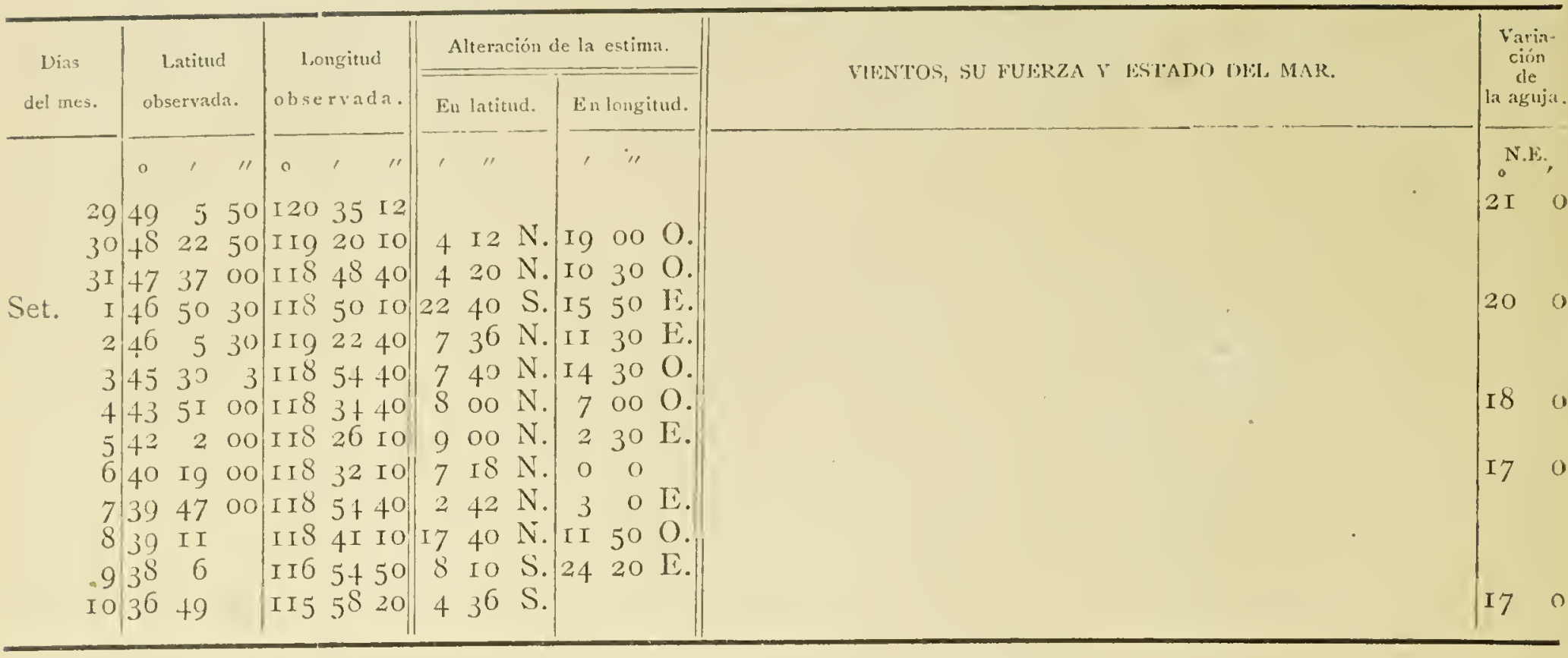

Salida de Monterey para el puerto de Acapulco.- Mes de Setiembre.

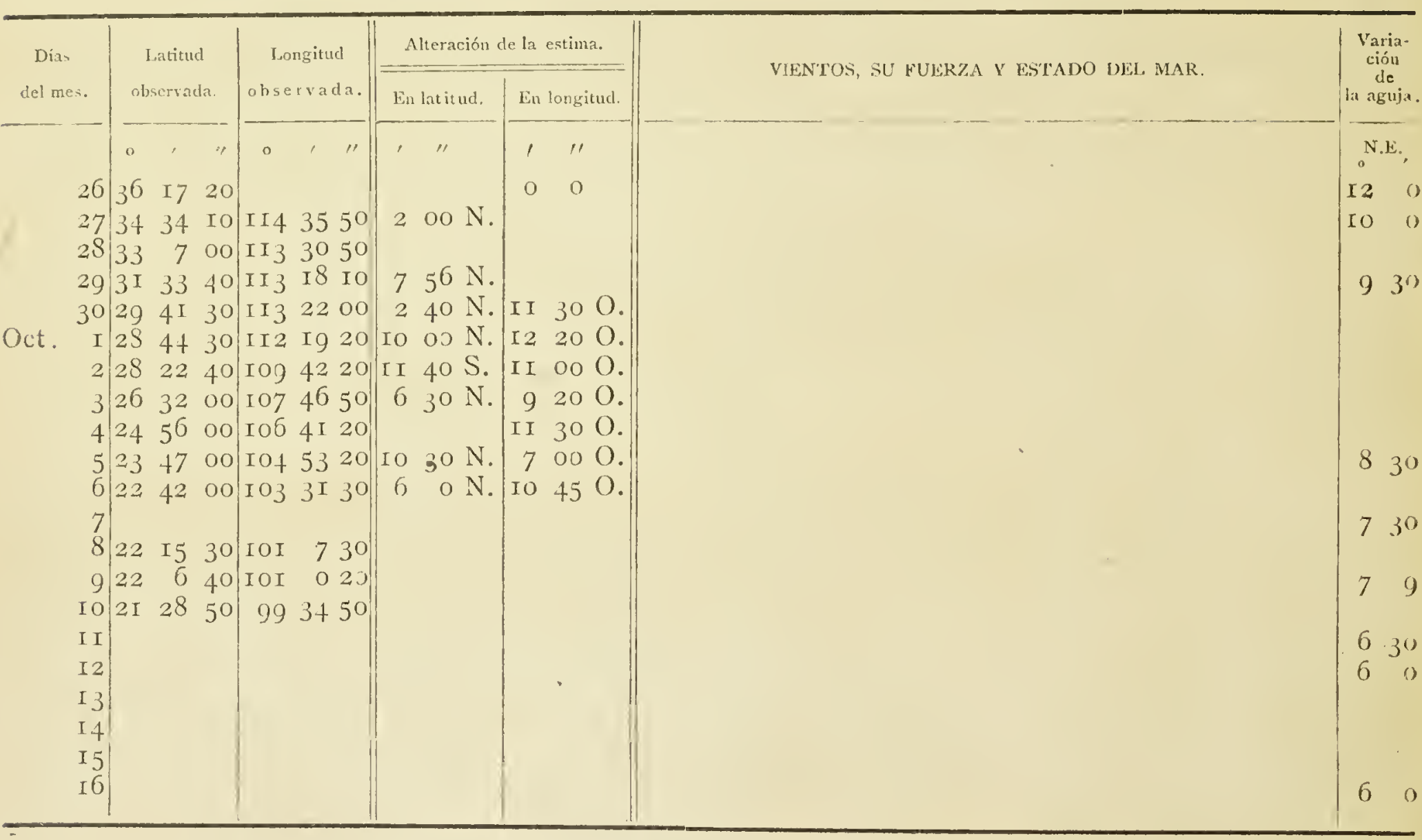

Salida del Puerto de Acapulco para el de Humata. - Mes de Diciembre.

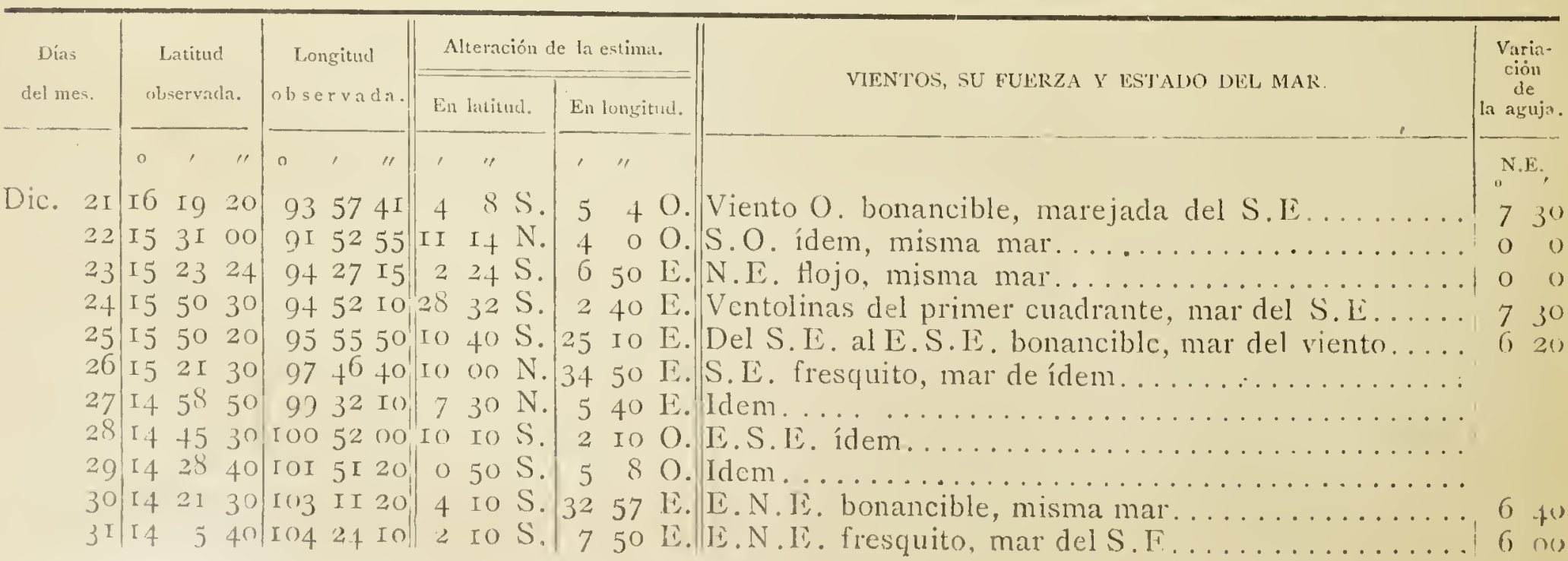


Continuación de la salida de Acapulco. - Mes de Enero.-1792.

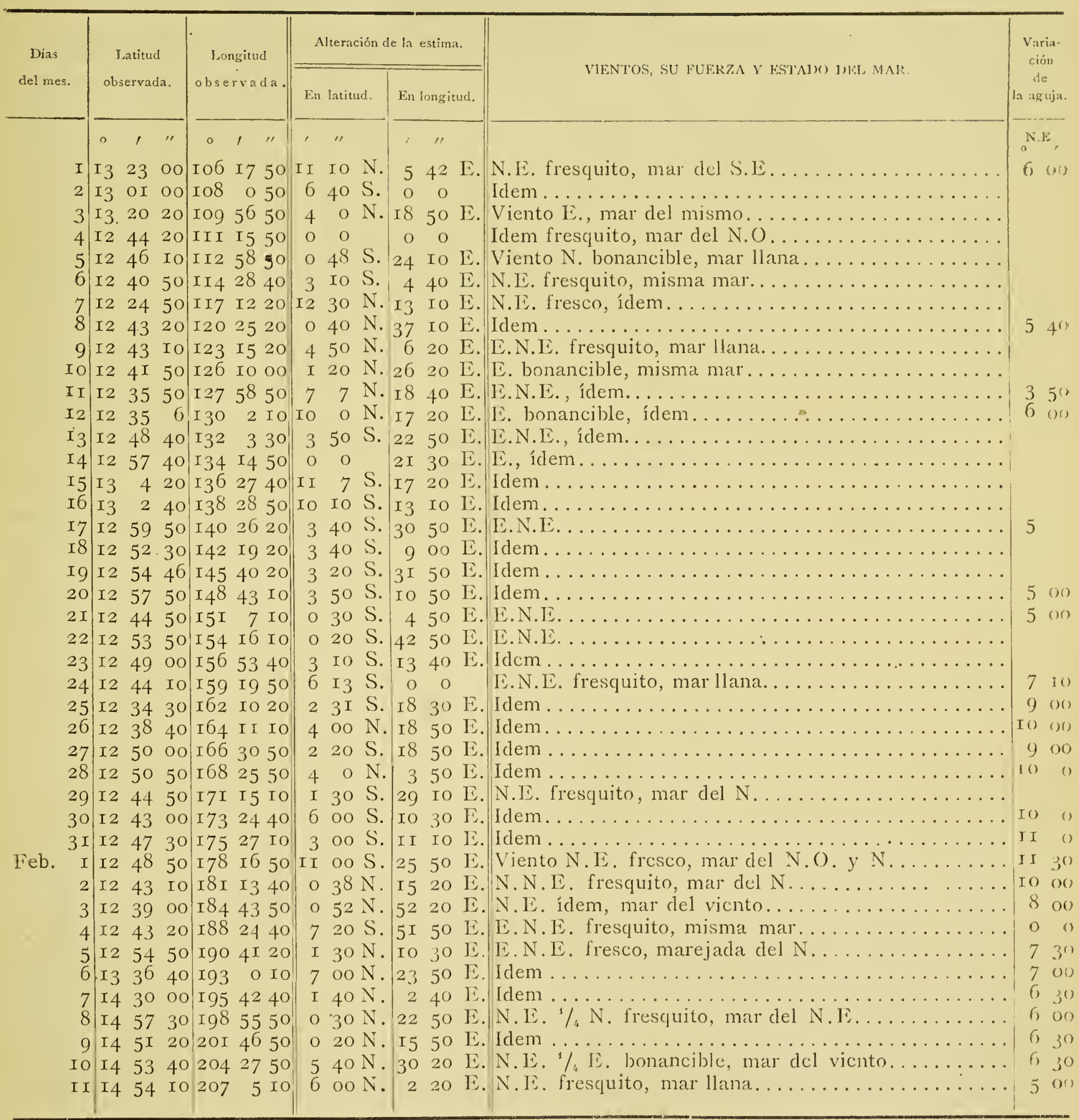

Salida del Puerto de Humata hasta la boca del Estrecho de San Bernardino._-Mes de Febrero._-1792.

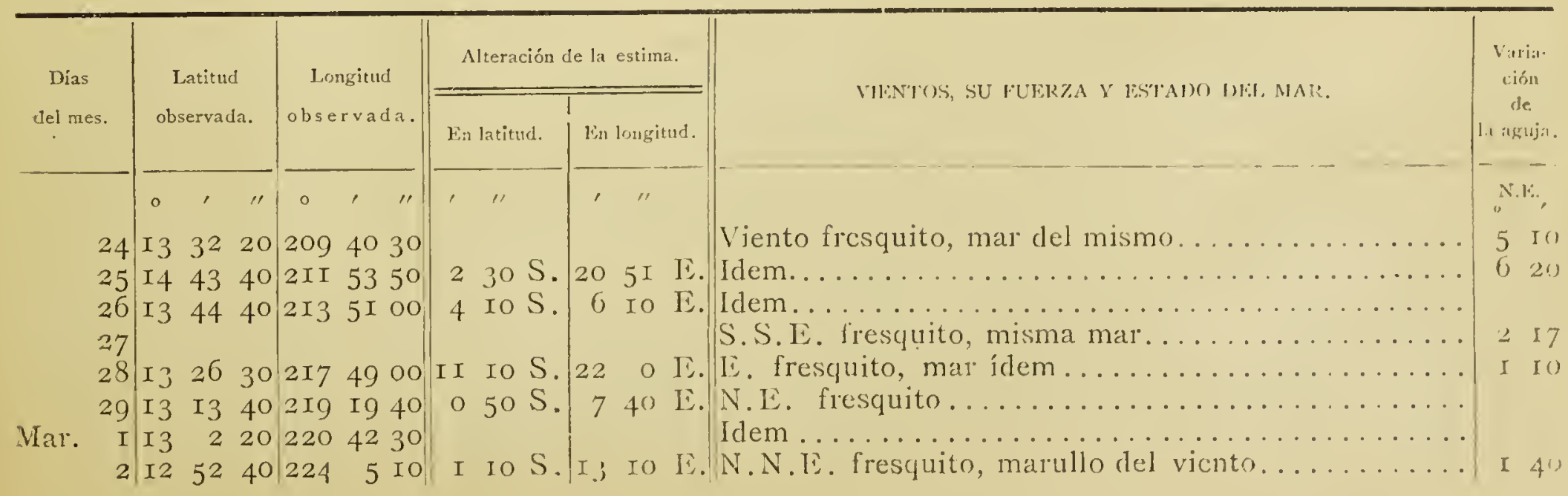


Salida de la bahia de Manila para el Puerto de Zamboanga, en la Isla de Mindanao. Mes de Noviembre.-I792.

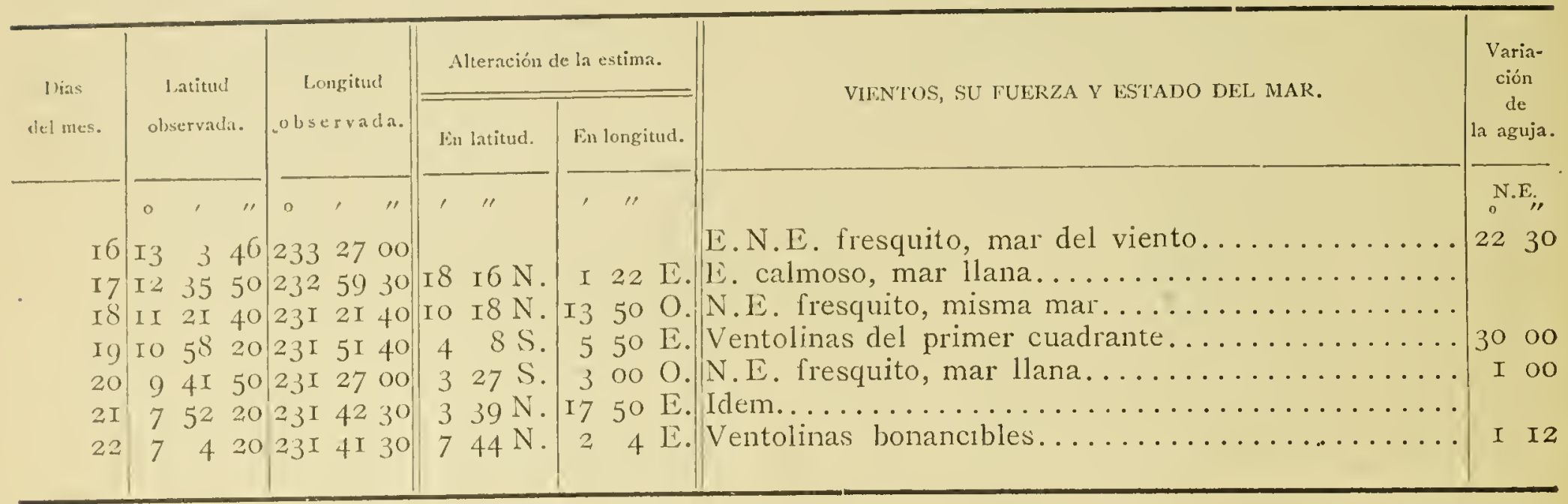

Salida del Puerto de Zamboanga para el de Jackson, en la Nueva Gales Meridional. Mes de Diciembre.-1792.

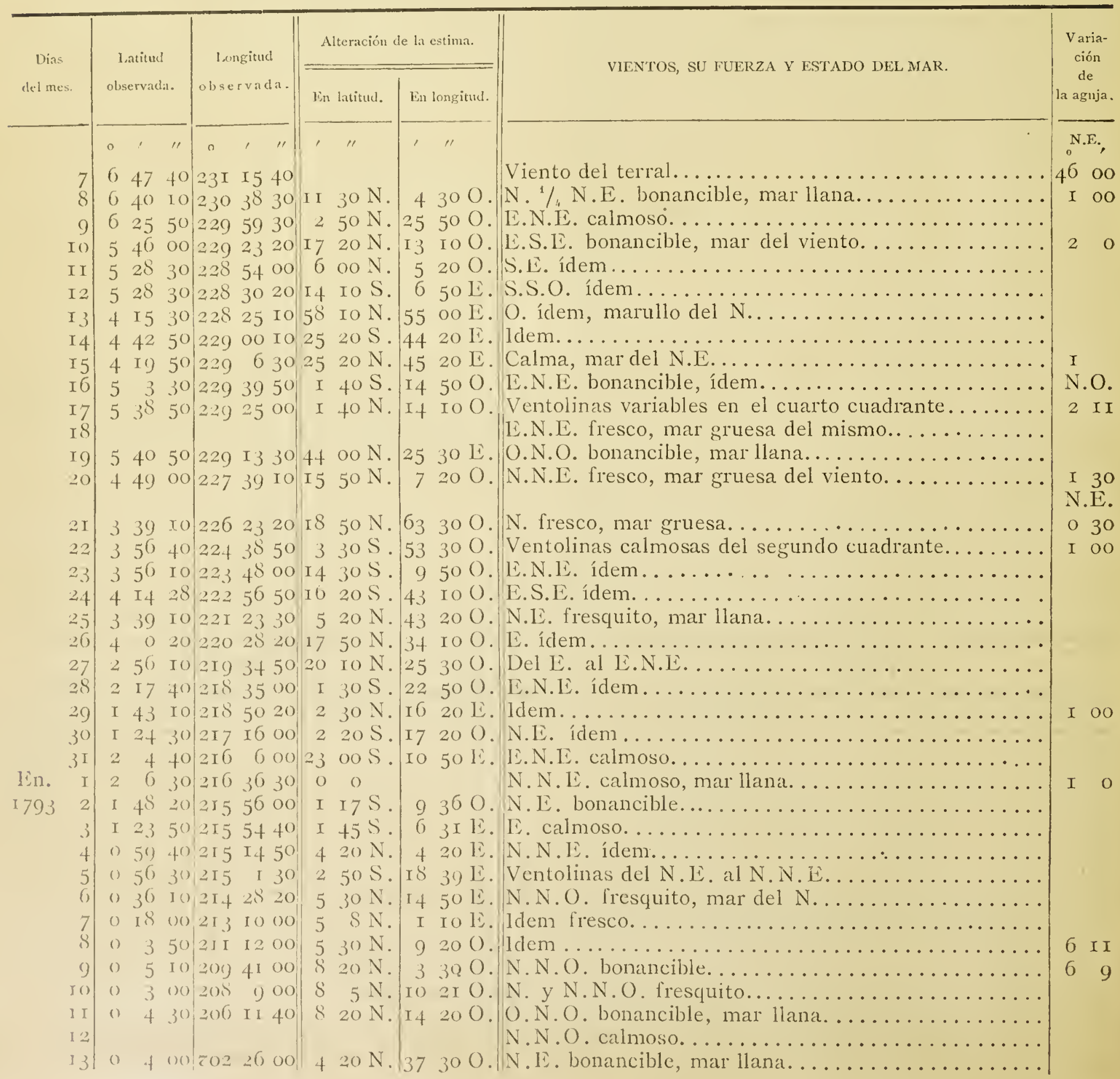


Continuación de la misma campaña.--Mes de Enero.-1793.

\begin{tabular}{|c|c|c|c|c|c|c|}
\hline \multirow{2}{*}{$\begin{array}{l}\text { Dias } \\
\text { del mes. }\end{array}$} & \multirow{2}{*}{$\begin{array}{c}\text { Latitud } \\
\text { observada. }\end{array}$} & \multirow{2}{*}{$\begin{array}{c}\text { Longitud } \\
\text { observada. }\end{array}$} & \multicolumn{2}{|c|}{ Alteración de la estima. } & \multirow{2}{*}{ VIENTOS, SU FUERZA Y ESTADO DEL MAR. } & \\
\hline & & & En latitud. & En longitud. & & \\
\hline
\end{tabular}

I4 S. $2003900 \quad 55^{\circ} \mathrm{S} .375^{\circ}$ O.. N.E. bonancible, mar llana.

I5 0 I 30 I 9943 00 I2 $50 \mathrm{~S} .40$ Io O. N. $1 / 4 \mathrm{~N}$. E., mar gruesa del N...

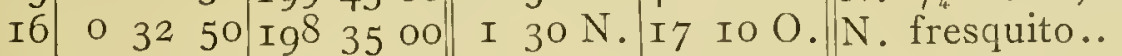

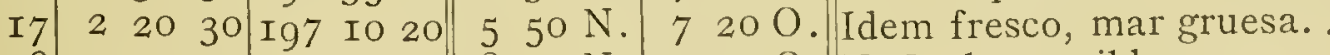

I 8 2 2 IO 20 I95 244028 30 N. I7 30 O. N.O. bonancible.

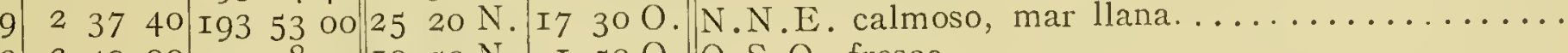

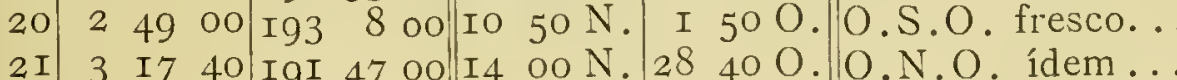

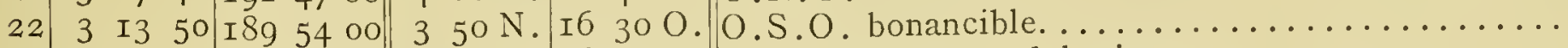

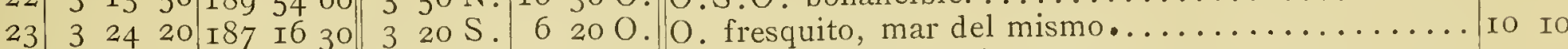

$24 \quad 4 \quad 4820$ I85 7 OO IO $30 \mathrm{~N} .2530$ O. O.N.O. calmoso, misma mar................. I0 20

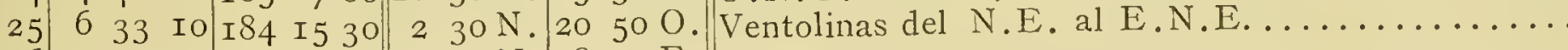

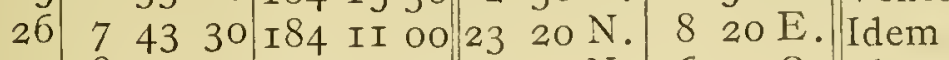

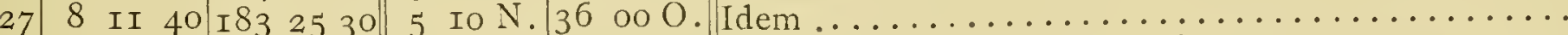

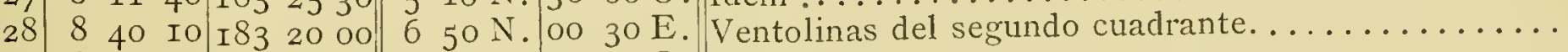

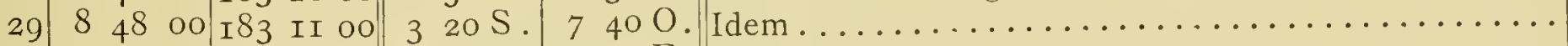

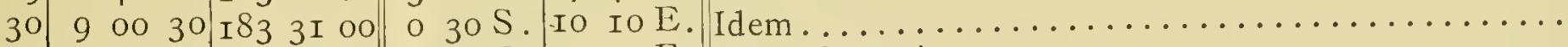

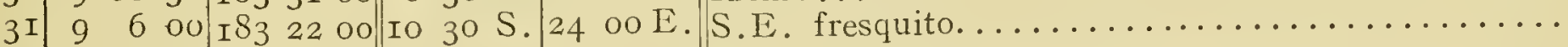

Feb. I $\begin{array}{lllllll}9 & \text { I9 } & 33 & \text { I } 82 & 34 & \text { IO }\end{array}$

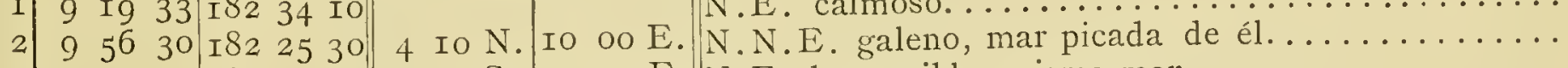

3 Io 3 I 30 I 82 y Oo I4 $20 \mathrm{~S}$. 2 I $40 \mathrm{E}$. N.E. bonancible, misma mar................. I0 20

4 II 33 40 I8I 32 Io 4 Io N. Io 20 O. E.S.E. ídem.

5 I2 I6 IO 18 I 750 o 50 N. 7 50 O. N.E. ídem.

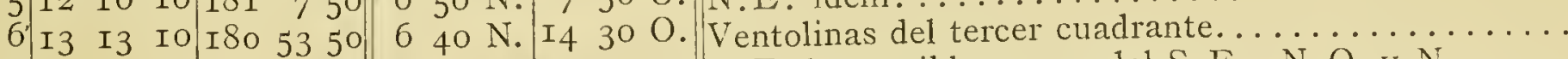

78 N.E. bonancible, mares del S.E., N.O. y N.....

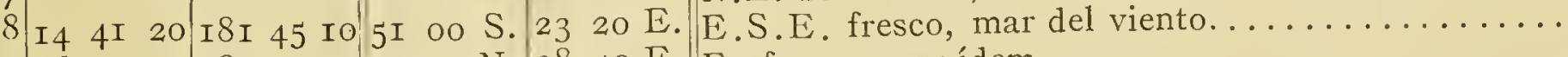

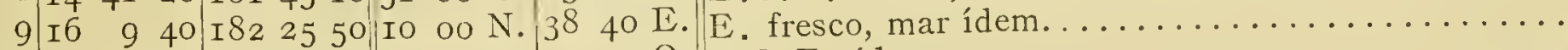

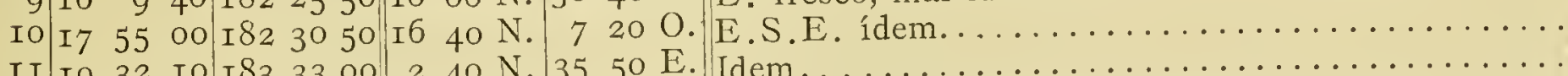

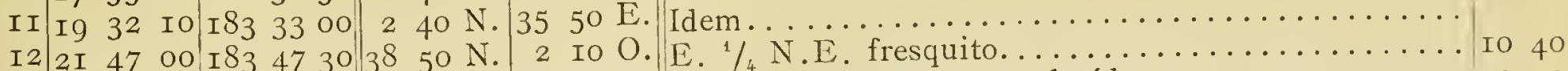

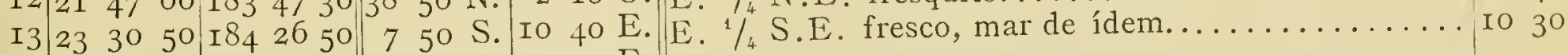

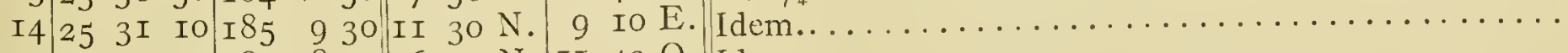

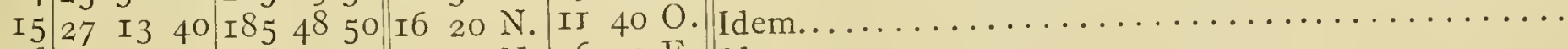

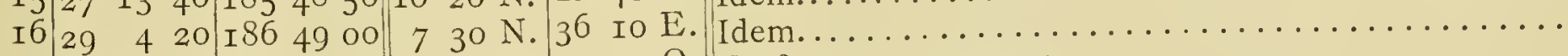

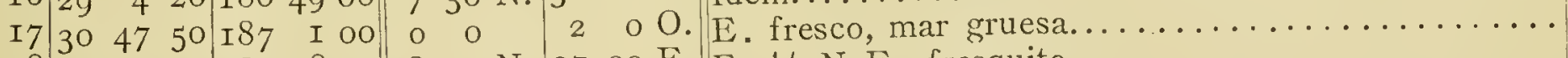

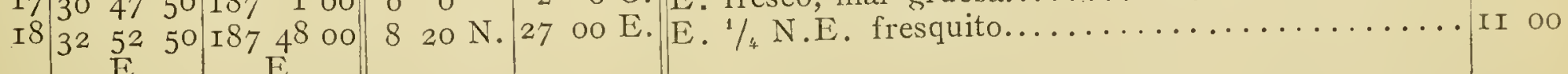

$\begin{array}{lllllllll}19 & 34 & 49 & 20 & 18 & 7 & 57 & 40\end{array}$

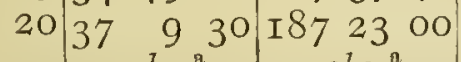

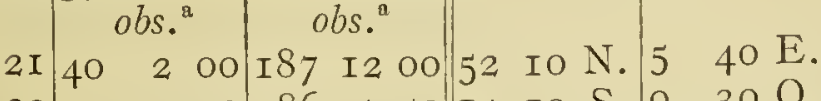

N.E. recio. . .

Idem.

224 I 4350 I 865750 I4 Io S. 0

234324 OO I 87 I 5 O0 16 I6 00 S. 3933 O.

244428 oO I 865930 2 5 oO S. 58 50 O.

$25 \quad 45$ I3 00 I 87 IO 0020 II S. 20 00 O.

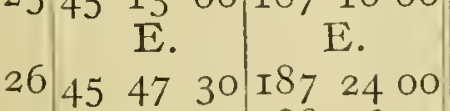

$\begin{array}{lllllll}27 & 44 & 43 & 40 & \text { I } 88 & 26 & 00\end{array}$

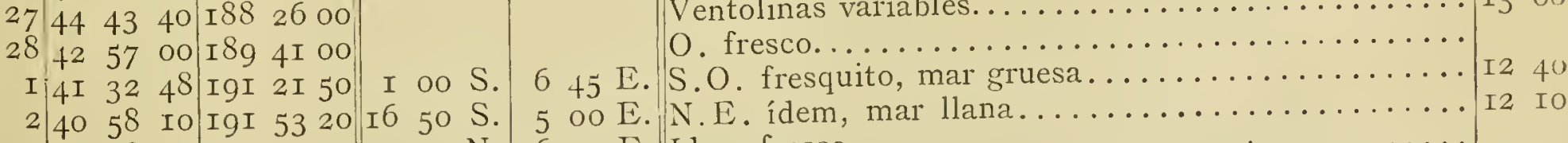

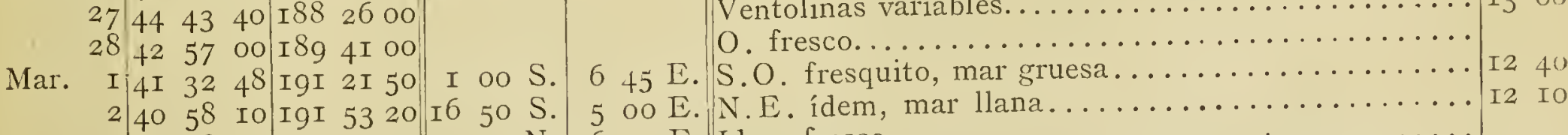

$340 \begin{aligned} & 48 \\ & 40\end{aligned}$

$440 \quad 430$ I94 4330 30 $20 \mathrm{~N}$. I3 oo O. Ventolinas del S. y S......................... I2 oo

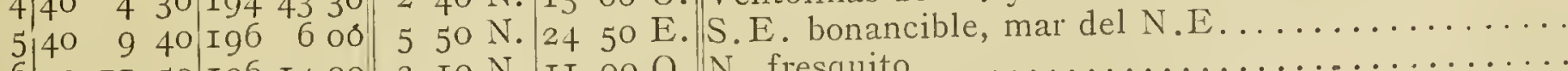

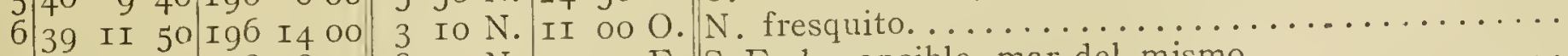

$73^{8} \quad 230$ I9 828 o0 850 N. I2 $20 \mathrm{E}$. S.E. bonancible, mar del mismo............. II $5^{\circ}$

8372830 I $992950 \quad 620 \mathrm{~N} .22$ 50 E. S. E. fresquito, marejadas del S........................ II IO

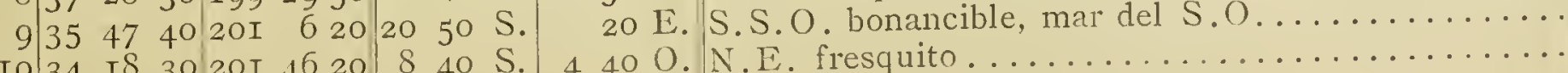

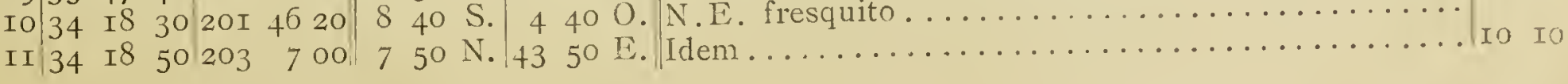


Salida del Puerto de Jackson hasta las Islas de Vavao.--Mes de Abril.-1793.

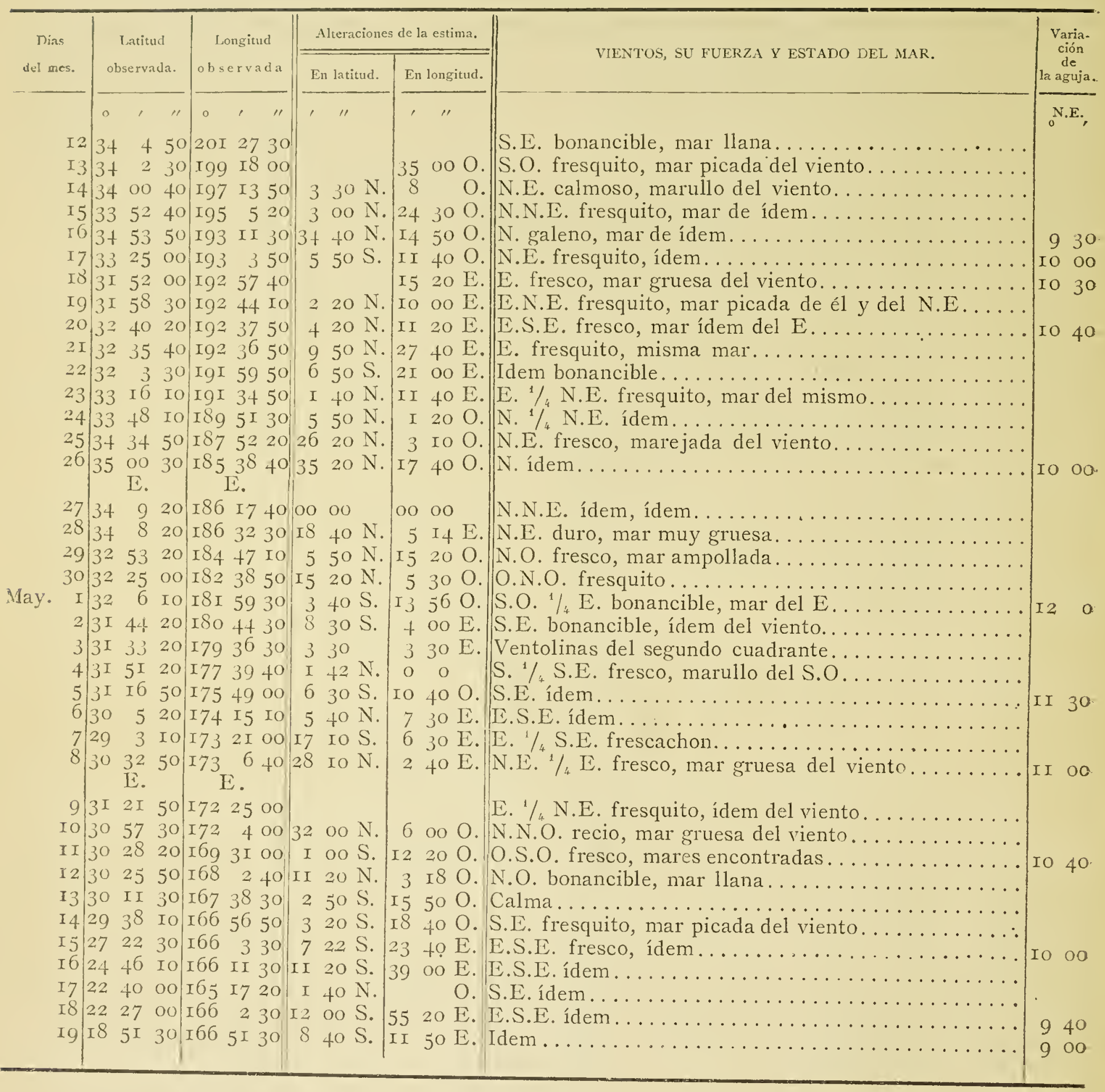

Salida de las Islas de Vavao para el Puerto del Callao de Lima._Mes de Junio.-1793.

\begin{tabular}{|c|c|c|c|c|c|c|}
\hline \multirow{2}{*}{$\begin{array}{l}\text { Dias } \\
\text { del mes. }\end{array}$} & \multirow{2}{*}{$\begin{array}{l}\text { Latitud } \\
\text { observada. }\end{array}$} & \multirow{2}{*}{$\begin{array}{c}\text { Longitud } \\
\text { o bservada. }\end{array}$} & \multicolumn{2}{|c|}{ Alteración de la estima. } & \multirow[b]{2}{*}{ VIENTOS, SU FUERZA Y ESTADO DEI, MAR. } & \multirow{2}{*}{$\begin{array}{c}\text { Varia- } \\
\text { ción } \\
\text { de } \\
\text { la aguja. }\end{array}$} \\
\hline & & & En latitud. & En longitud. & & \\
\hline I & $\begin{array}{ccc}0 & , & 11 \\
\text { I8 } & 5 \mathrm{I} & 00\end{array}$ & 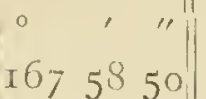 & , 1" & , "1 & & N.E. \\
\hline 2 & 19.300 & $I 68 \quad 2550$ & 2 Io N. & $335 \mathrm{E}$. & 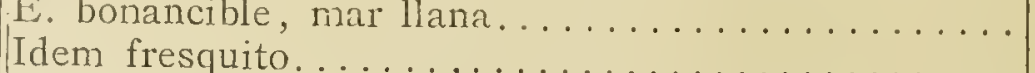 & 950 \\
\hline 3 & $20 \quad 2 \quad 20$ & 168 to 50 & $832 N$ & $950 \mathrm{E}$. & 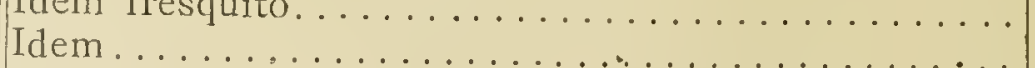 & \\
\hline 4 & $20 \quad 55$ IO & $16927+0$ & $4-0 \mathrm{~S}$ & I 4 IO E. & 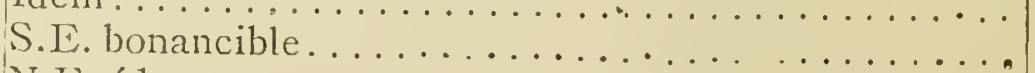 & IO IO \\
\hline 5 & $\begin{array}{lll}2 \mathrm{I} & 4 \mathrm{I} & 50 \\
22 & 2(3) & 00\end{array}$ & I 7 I 0040 & 3 to S. & $3000 \mathrm{E}$ & 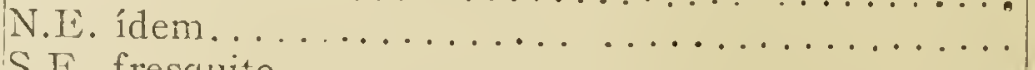 & IO 30 \\
\hline 7 & 225940 & $\begin{array}{lll}17 & 40 & 10 \\
I 7 & 22 & \text { IO }\end{array}$ & 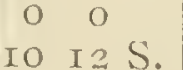 & 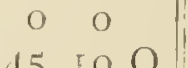 & 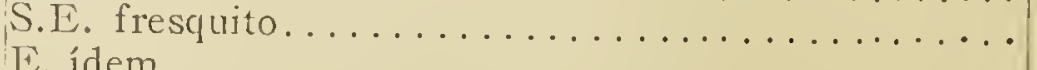 & 900 \\
\hline 8 & $24 \quad 1720$ & I72 IS IO & $240 \mathrm{~N}$ & $\begin{array}{lll}45 & \text { IO } & \mathrm{U} \\
\mathrm{I} 5 & \text { to } & \mathrm{E}\end{array}$ & 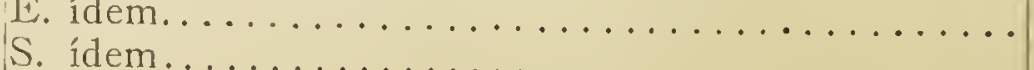 & IO 00 \\
\hline (1) & 25.39301 & I7.3 5 Ioll & 55 I S. & 5 oo 0 & 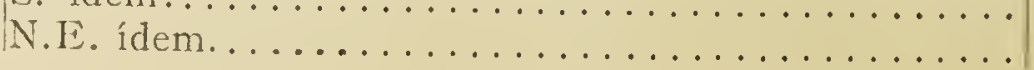 & IO 30 \\
\hline
\end{tabular}


Continuación de la misma campaña.-Mes de Junio.-1793.

\begin{tabular}{|c|c|c|c|c|c|c|}
\hline \multirow{2}{*}{$\begin{array}{c}\text { Dias } \\
\text { del mes. }\end{array}$} & \multirow{2}{*}{$\begin{array}{l}\text { Latitud } \\
\text { observada. }\end{array}$} & \multirow{2}{*}{$\begin{array}{c}\text { Longitud. } \\
\text { observada. }\end{array}$} & \multicolumn{2}{|c|}{ Alteración de la estima. } & \multirow{2}{*}{ VIENTOS, SU FUERZA Y ESTADO DEL MAAR. } & \\
\hline & & & En latitud. & En longitud & & \\
\hline
\end{tabular}

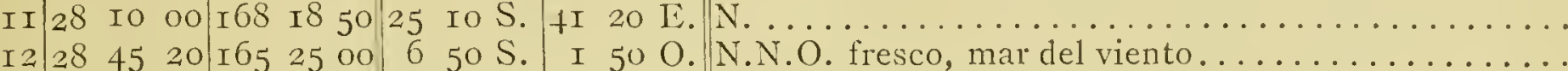

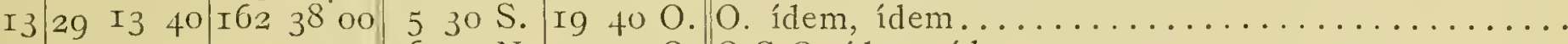

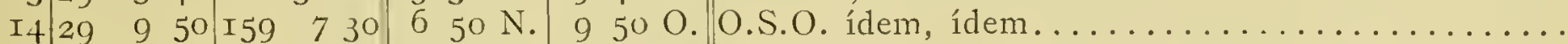

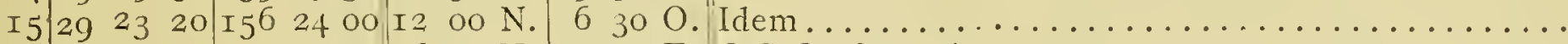

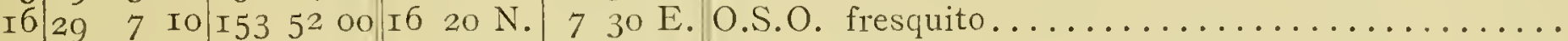

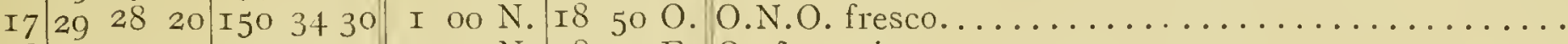

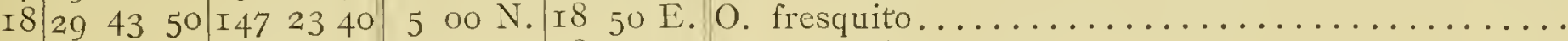

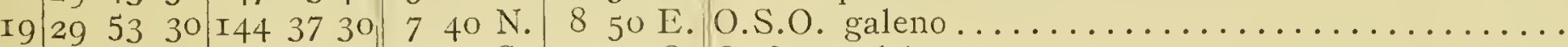

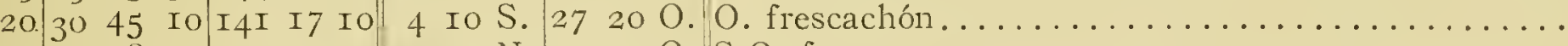

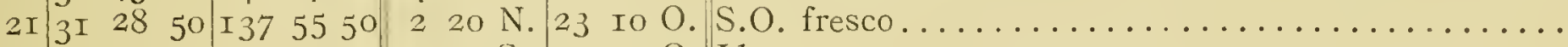

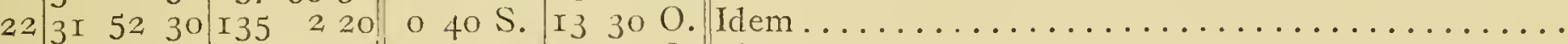

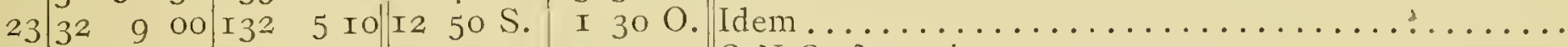
24 3I 45 OO $129 \quad 540$

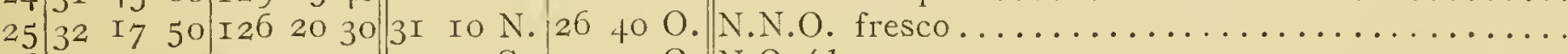

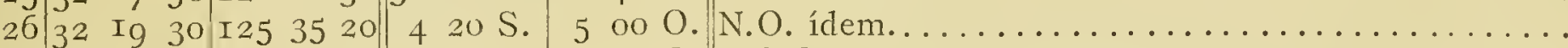

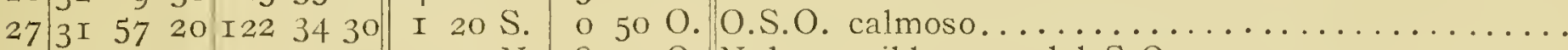

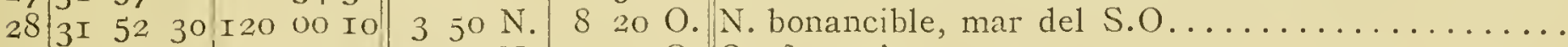

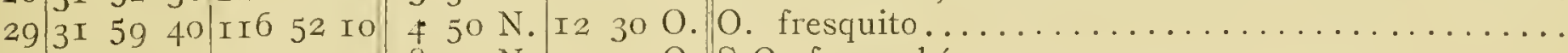

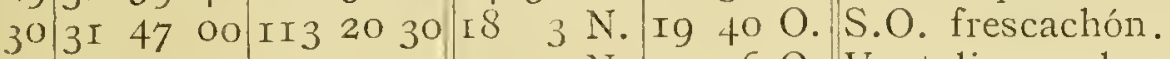

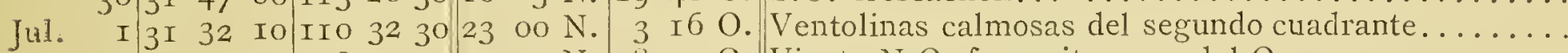

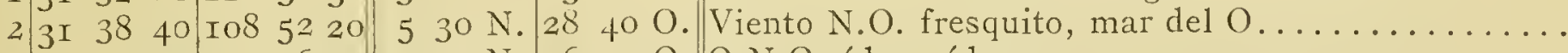

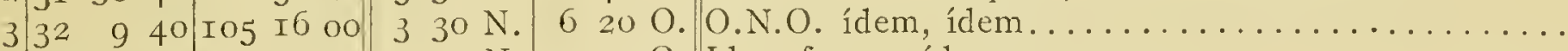

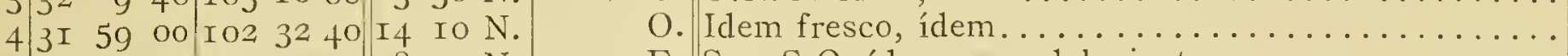

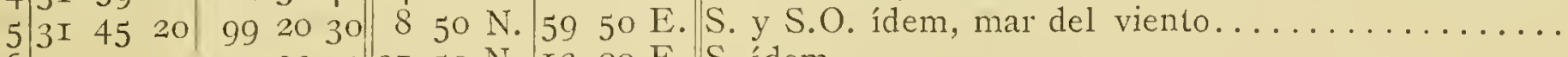

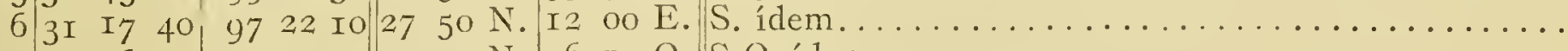

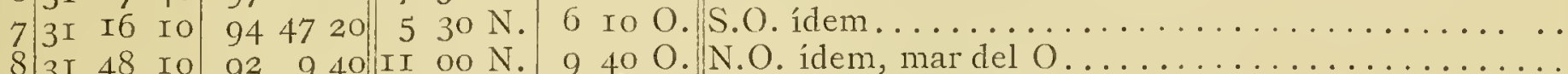

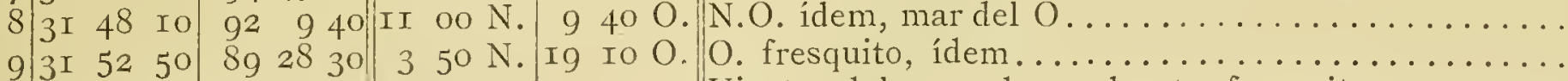

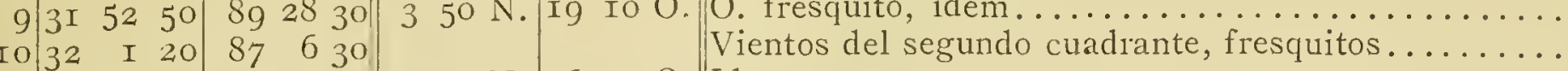

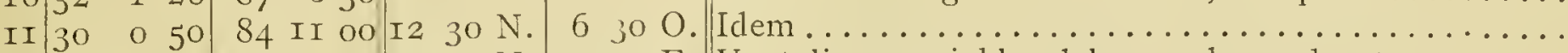

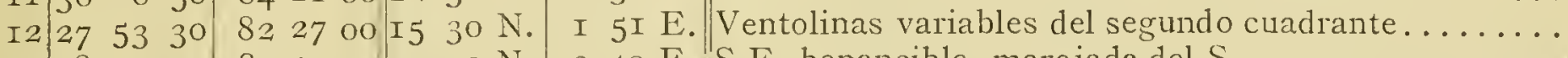

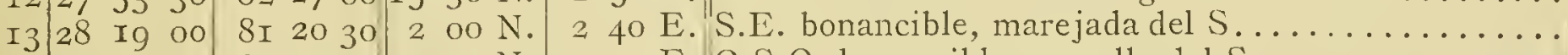

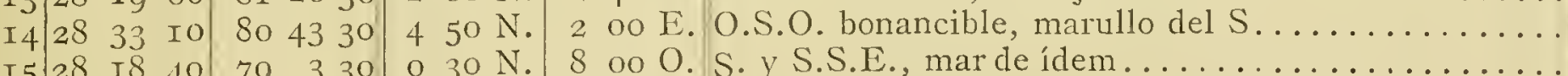

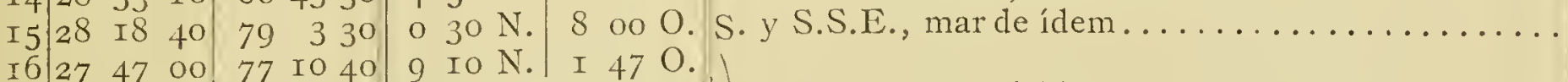
I6 2747 o0 77 I0 40 9 9 Io N. I 47 O.

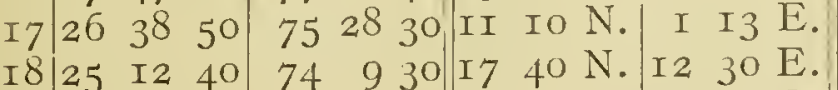

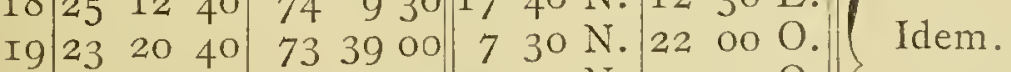

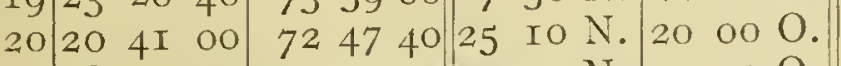

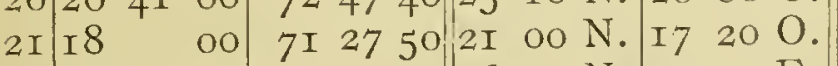
22 I5 22 00 $70 \quad 2$ 00|I 6 30 N. I9 $10 \mathrm{E}$. 23 I 2 3I 00 7I 4 O0 9 oo N. 24 oo O.

Salida del Callao de Lima para el Puerto de Talcahuano.-Mes de Octubre.-I793.

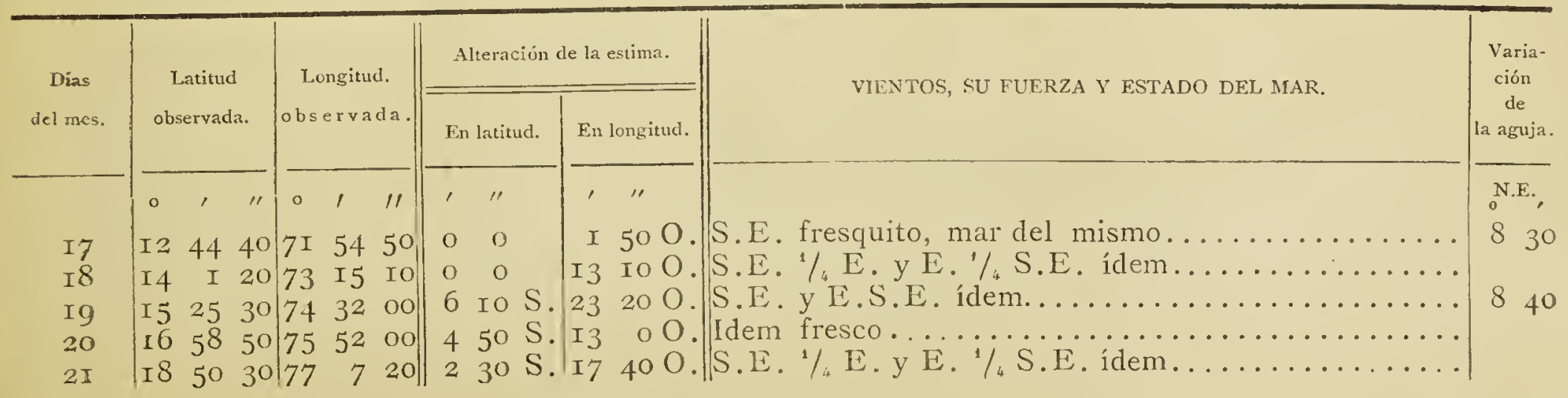


Continuación de la misma campaña. - Mes de 0ctubre.-1793.

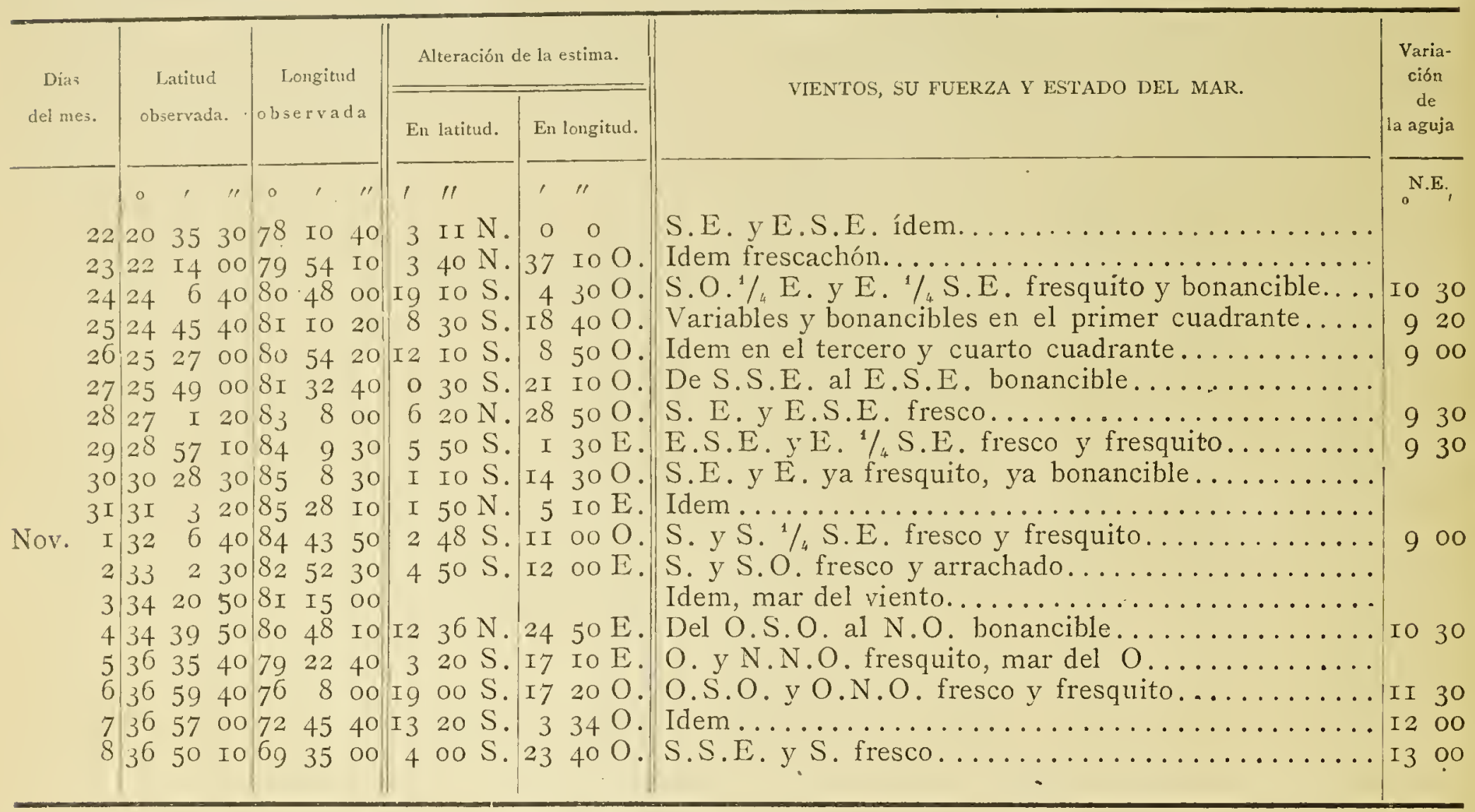

Salida del Puerto de Talcahuano para el de Egmont.-Mes de Diciembre.-1793.

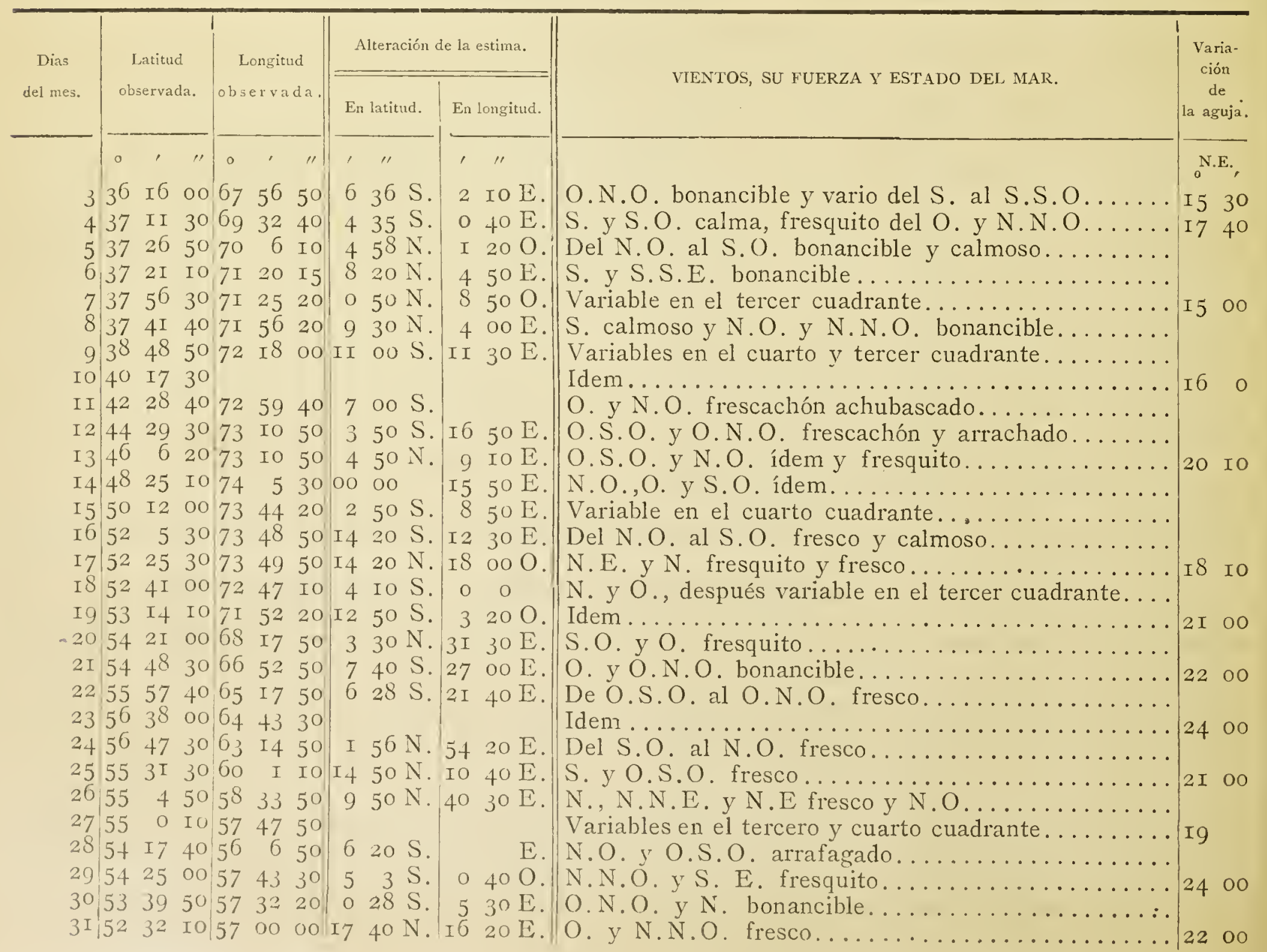


Salida del Puerto de Egmont para el de Santa Elena en Ia Costa Patagónica._Mes de Enero.-1794.

\begin{tabular}{|c|c|c|c|c|c|c|c|}
\hline \multirow{2}{*}{\multicolumn{2}{|c|}{$\begin{array}{c}\text { Dias } \\
\text { del mes. }\end{array}$}} & \multirow{2}{*}{$\begin{array}{c}\text { Latitud } \\
\text { observada. }\end{array}$} & \multirow{2}{*}{$\begin{array}{c}\text { Longitud } \\
\text { o b servada. }\end{array}$} & \multicolumn{2}{|c|}{ Alteración de la estima. } & \multirow{2}{*}{ VIENTOS, SU FUERZA Y ESTADO DEL MAR. } & \multirow{2}{*}{$\begin{array}{c}\text { Varia- } \\
\text { ción } \\
\text { de } \\
\text { la aguja. }\end{array}$} \\
\hline & & & & En latitud. & En longitud. & & \\
\hline \multirow{8}{*}{ En. } & & 0,11 & , " & , " & 111 & \multirow{8}{*}{ 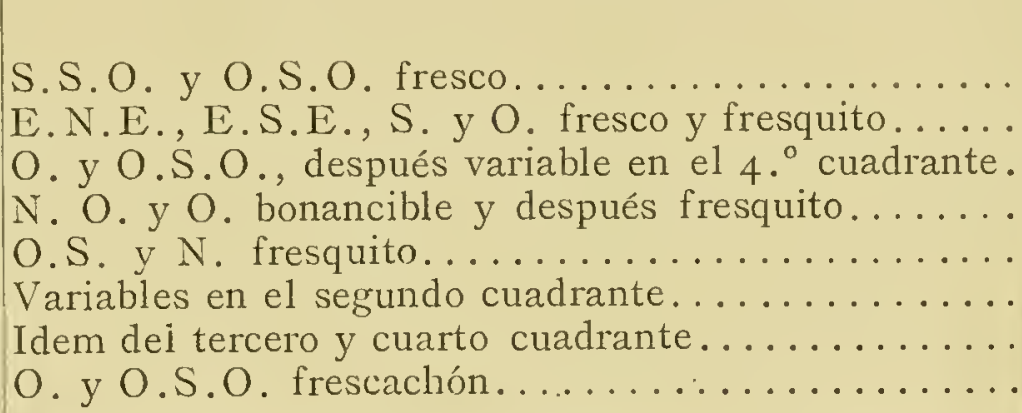 } & N.E, \\
\hline & I & $5 \mathrm{I} \quad 430$ & $\left|\begin{array}{lll}55 & 22 & 50\end{array}\right|$ & II $24 \mathrm{~N}$. & I3 Io E. & & \\
\hline & 2 I & $\begin{array}{lll}49 & 3 & 3 \\
1 & 30\end{array}$ & $\begin{array}{lll}55 & 29 & \text { I }\end{array}$ & $\begin{array}{cc}0 & 0 \\
2 & 55\end{array}$ & $\begin{array}{cc}0 & 0 \\
& 0\end{array}$ & & $2 \mathrm{I}$ IO \\
\hline & $\begin{array}{l}22 \\
23\end{array}$ & $\left|\begin{array}{lll}47 & 5 \mathrm{I} & \text { 10 } \\
47 & 45 & \text { 10 }\end{array}\right|$ & $\left|\begin{array}{rrr}54 & 57 & 00 \\
57 & 7 & 40\end{array}\right|$ & $\begin{array}{rrr}\text { I2 } & 55 & \mathrm{~N} \\
4 & 40 & \mathrm{~N}\end{array}$ & $\begin{array}{r}\text { I2 } 50 \mathrm{E} . \\
440 \mathrm{E} .\end{array}$ & & 2 I 00 \\
\hline & 24 & 475930 & $\begin{array}{lll}57 & 7 & 00\end{array}$ & $640 \mathrm{~N}$. & $640 \mathrm{E}$. & & o 00 \\
\hline & 25 & $47 \quad 3620$ & $\begin{array}{lll}59 & 4 & 30\end{array}$ & $330 \mathrm{~S}$. & 7300 & & 2000 \\
\hline & 26 & $4^{6} 45^{0}$ & I 30 & 3 IO N. & $2 \mathrm{I} 5 \mathrm{O} \mathrm{E}$. & & \\
\hline & 27 & 445920 & $5^{8} \quad 32$ IO & I oo N. & I $50 \mathrm{E}$ & & I 840 \\
\hline
\end{tabular}

Salida del Puerto de Santa Elena para el de Montevideo.-Mes de Febrero.-1794.

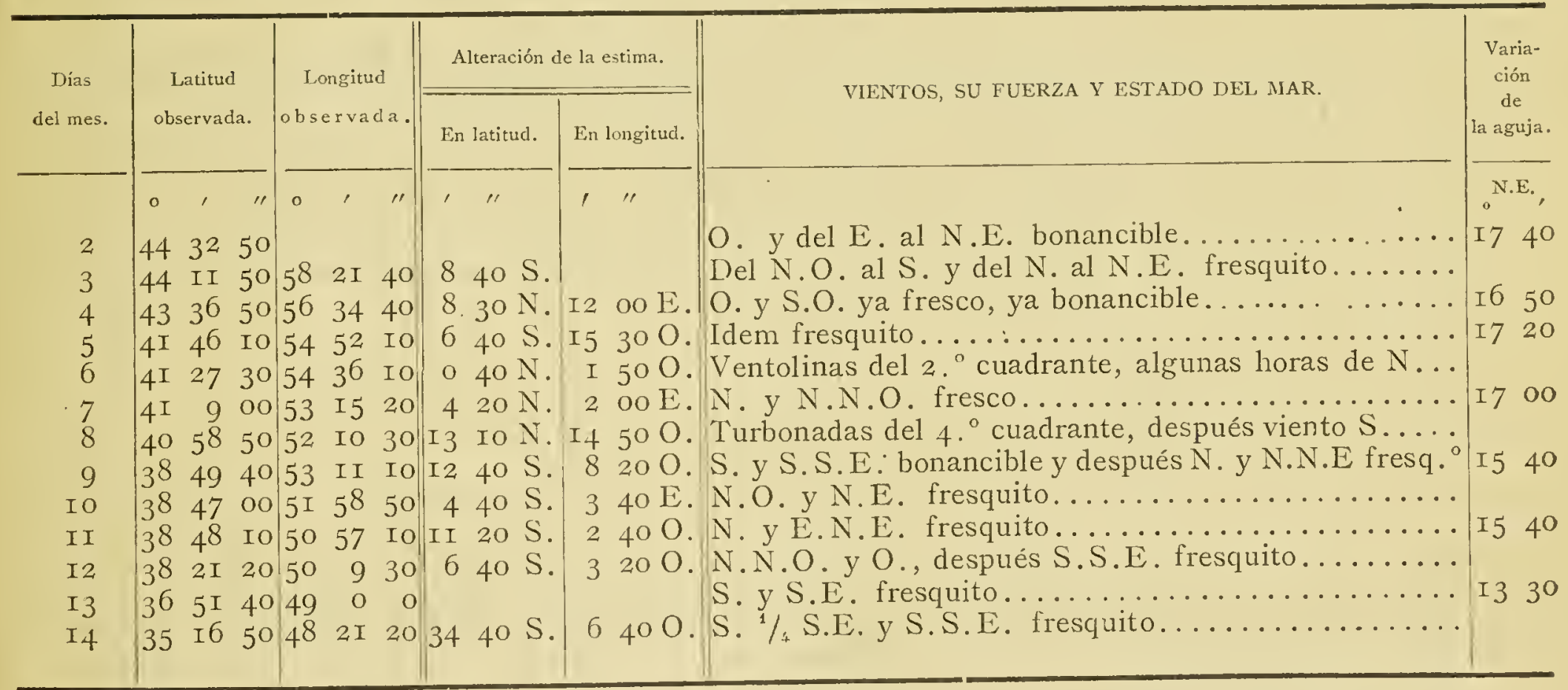

Salida del Puerto de Montevideo.--Mes de Junio.--1794.

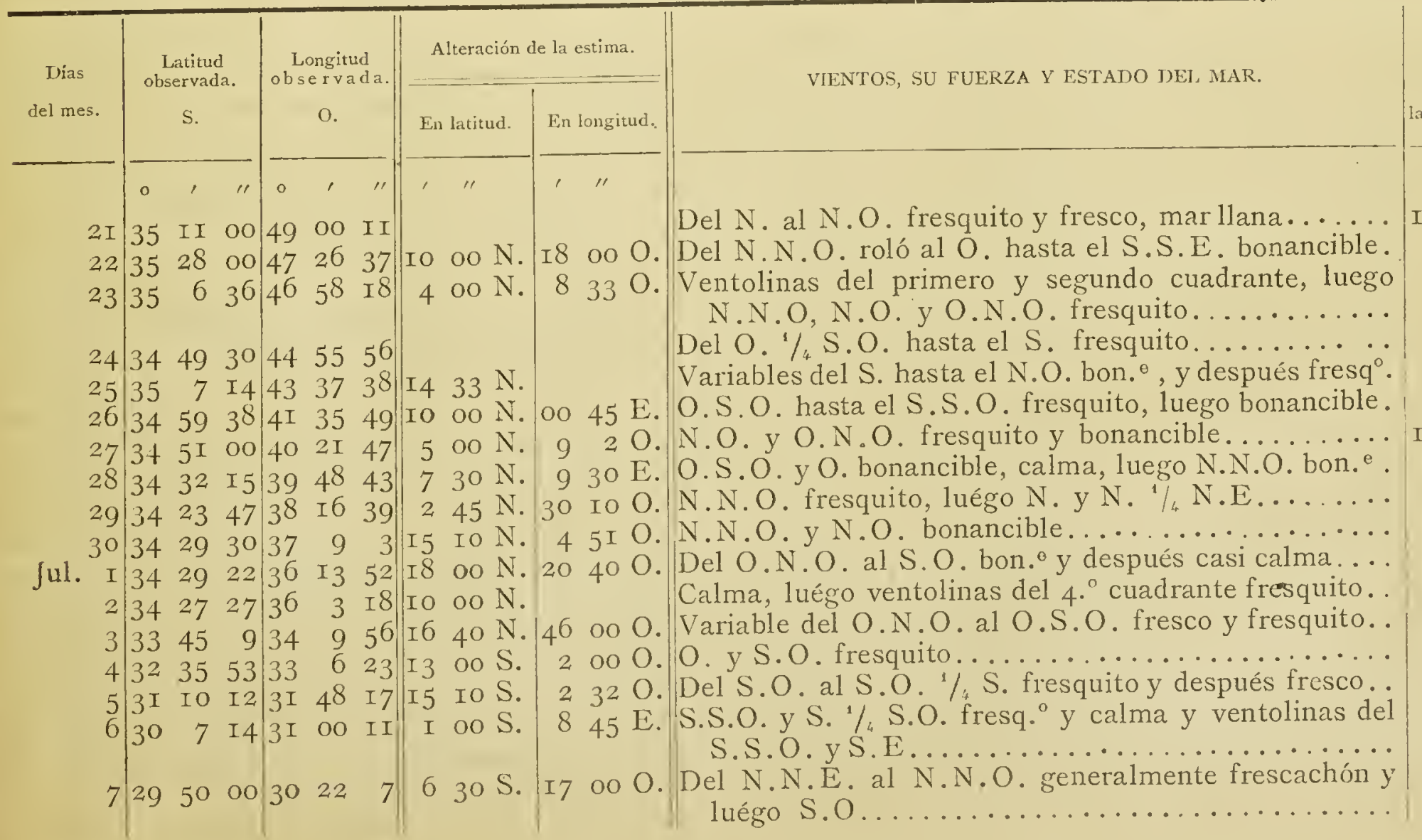

$293423 \quad 4738$ I6 39.245 N. 30 Io O. N.N.O. fresquito, luégo N. y N. $1 / 4$ N.E....... 850

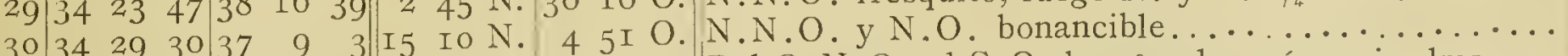

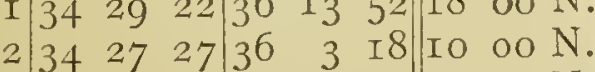


Continuación de la misma campaña.--Mes de Julio.-1794.

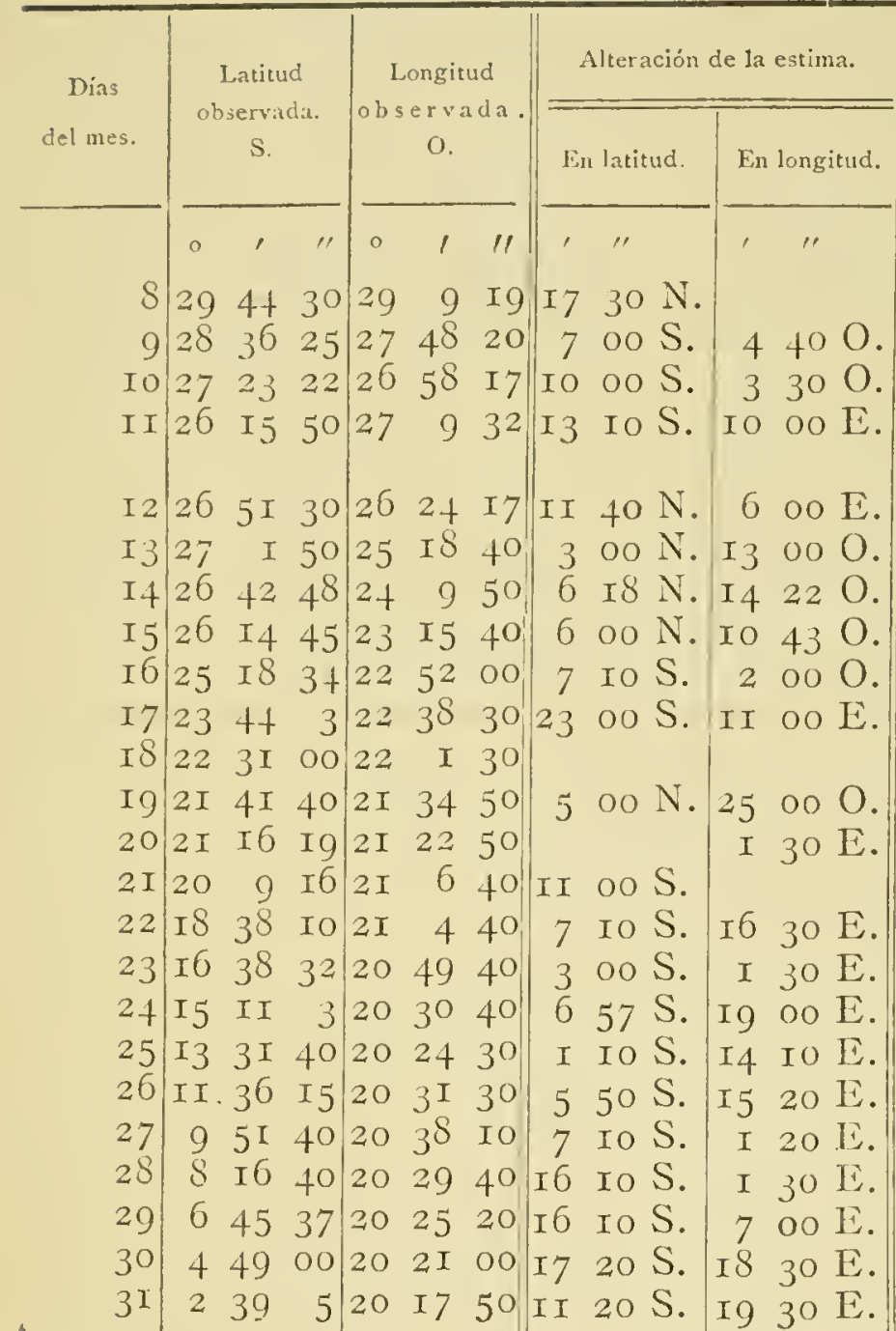

Ag.
N. $1 / 4$ N.O. y N.N.O. fresco y fresquito........ S.S.O., S.S.E. y S.E. fresquito y galeno........ I 30 Del S.E. al E. ídem, ídem............... o I 3 Del E. al N.N.O. fresquito y bonancible............ o 4 N.N.E. Y N.E. $1 /$ N idem, idem............... Del N. N. al $\mathrm{N}$ 1/ $\mathrm{N}$. O fresquitc .

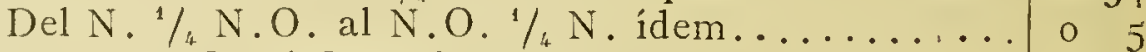

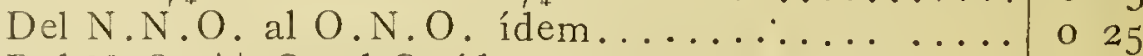
Del N.O. $1 / 4$ O. al O. ídem................ o 29 Idem ídem............................ o O.N O. fresquito, calma y S.S.E. fresquito...... Del S.S.E. por el E. hasta el O.N.O. fresq. ${ }^{\circ}$ y bon. ${ }^{\text {e. }} 358$ Del N.O. al O.N.O. ídem................ 350 Del O.N.O. por el S.O. hasta el S.S.E. fresquito. Del S. al S.E. $1 /$ S. fresquito y luégo fresco...... Variable del S..E $1 / 4$ S. hasta el E.N.E. fresq. ${ }^{\circ}$ y bon ${ }^{\mathrm{e}} \cdot 627$ Del S.E. hasta el E.N.E. ídem............ 540 S.E. y E.S.E. fresquito y desigual porlos chubascos. 7 Io

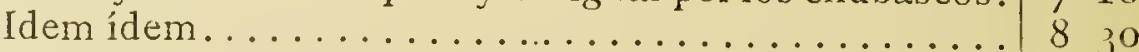
Idem ídem............................ 730 Del S.E. $1 / 4$ E. al E. $1 / 4$ S.E. fresquito.......... 545 Idem ídem...................... 8 5

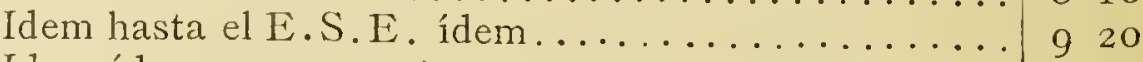
Idem ídem...................... I0 50 Del E.S.E. al S.S.E. fresquito bon. ${ }^{e}$, mar de ídem. $84^{\circ}$

Variables del S.S.E. al S S.O. fresquito y bon.e .. 820 S.S.E. y S. $1 / 4$ S.E. fresquito y fresco......... S.S.O. bon. ${ }^{\text {e }}$ y fresq. ${ }^{\circ}$, achu. ${ }^{\circ}$ y lloviendo S. S..... Io 25 Idem idem ....

Del S.S.O. al O. fresquito, bonancible y fresco ídem.

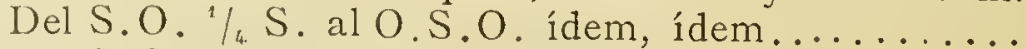
Del S.O. al O. ídem............................ 9 I6 Variable del S.O. al N. N.O fresquito y bon. e ídem. Del S.O. por el N.O. hasta el N.1/4 N.E. bon.e calm. ${ }^{\circ}$ Variable y bonancible del N.N.O. al N.N.E...... II 36 Idem en todos los cuad.s achubascados y agua...... Io I7 Variable en el $3 \cdot{ }^{\circ}$ y $4 \cdot{ }^{\circ}$ con mucha agua........... I2 48 Del S.S.O al O. N.O. bonancible y calmoso....... Del O.N.O. al N.N.E. algunos chubasquillos..... Del N. al N.E. bonancible y fresquito........... N.N.E. y N.E., después variables y algunos chubascos. Del S.S.E. al S.E. 1/4 E. flojo............. Del S.E. al N.E. ${ }^{1 / 4}$ E. bonancible y fresquito..... I2 ${ }_{4} 6$ Del N.E. al IE. $1 / 4 \mathrm{~N}$. E. fresquito y fresco........ Del E. al E.N.E. bonancible y fresquito.......... Io oo E. fresquito.......................... Io 40 Idem desigual en fuerza, marullo del $\mathrm{N} . \mathrm{E} \ldots \ldots \ldots$. Del E.N.E. al E. $1 / 4$ S.E., generalmente fresco.... I 2 oo E. $1 / 4$ S.E. y E. fresco .............. Del E. ${ }^{1}$, N.E. al E.S.E................... II 58 Del E. al S.E. $1 / 4$ E. fresco y fresquito........... I2 30 Idem fresquito y últimamente bonancible............ I4 24

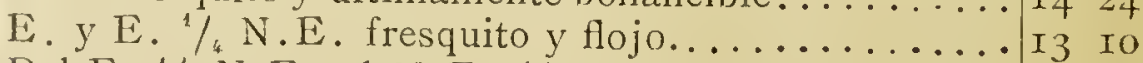
Del E. $1 / 4$ N.E. al N E. $1 / 4$ E................ I5 34 Del E.N.E. al S.E. 1/4 E. fresquito y fojo....... I5 23 Del E. ${ }^{1 / 4}$ N.E. al S.E. flojo, marejada del N.O... I 5 S.E., S. Y S.S.O. bonancible............... It 4 I

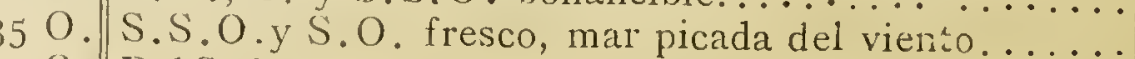
Del S.O. roló al N.O. fresco, chubascos, mar del vin| 



\section{NOTA CURIOSA}

Al dar por terminada la publicación del viaje de Malaspina y sus compañeros, debo hacer presente que este libro puede considerarse, no obstante sus dimensiones, como un extracto ó compendio, siendo así que los originales manuscritos ocuparían siete volúmenes iguales al presente. Como dato curiosísimo de las dimensiones de la obra y del costo calculado á su publicación, léase la siguiente carta dirigida por el sabio D. Felipe Bauzá al ilustre D. José de Espinosa, ambos Oficiales de las corbetas.

\section{Madrid y Enero 9 de 1795.}

Amadísimo Espinosa: Cuánto celebro la mejor salud de Vm., y cuánto más celebraría poder contribuir á ella con la robustísima que disfruto, sin embargo de un duro constipado que acabo de pasar.

Yo apruebo la resolución de Vm., y mucho más con este desbarajuste; cada momento se piensa una cosa y en nada hay orden. Fabio está encargado de los Derroteros; por mi parte hay que fundir las cartas y quedar en las longitudes que incluyo á Vm.: por fortuna dejan á mi arbitrio y sin responsabilidad el nanejo de ellas: haré todo lo posible para que no les falte nada, y si Vm. me insinúa ó advierte algunas cosas, no vendrán fuera del caso. El cómputo de toda la obra, con 70 cartas y 70 láminas y figuras y siete tomos, asciende á Dos MiLloNeS DE REALES; hágame Vm. el favor de decirme de dónde saldrá esto y si no estamos borrachos.

Hace dos días que el Rey y Reina vieron las monas y presentaron á los dos Pintores; éstos, por fin de fiesta, fueron á comer en casa del Embajador de Alemania. D. Juan, con esto, está inaguantable; peru gracias á Dios que lo veo de veinte á veinte 6 treinta á treinta días un minuto, y esto por precisión la mayor parte de las veces.

Hace pocas noches que el Sr. D. José Mazarredo me volvió la carta y estuvimos hablando más de hora y media: me hizo muchas preguntas de la América, y preguntándome por Vm., me dijo que Vm. debía venir á Madrid; saldrá para Cádiz el 20 lo más tardar.

Galiano, en el Sitio, escribiendo la Introducción para el libro de observaciones: éste va á tener una riña matemática con Mendoza sobre el cálculo de latitudes por dos alturas. Vernaci continúa su obra, y creo se unirá á ella toda nuestra campaña á la costa Noroeste.

No hay más que D. Adan no habla porque no le acaben de conocer.

Estos señores saludan á Vm. y le dan muchas expresiones; igualmente Sesma y su familia: Vm. me ofrecerá á los piés de su madre y hermana, dando muchas expresiones á sus hermanos, sin olvidar á Vargas.

Quedo en noticiar cuanto ocurra, y entretanto sabe $\mathrm{Vm}$. que lo ama con todo su corazón.=Bauzá.

No ménos de siete tomos en folio y no ménos de dos millones de reales hubiera inportado en aquella época la impresión completa y digna del viaje. Cierto que eran entonces de suma utilidad las setenta cartas levantadas por ellos, así como los dibujos que hoy ya carecen de importancia en su mayoría.

Pero sin embargo de llamar compendio al presente volumen, hemos procurado encerrar en él todo lo más interesante y práctico, todo lo que puede aún servir de enseñanza á la Marina y de provecho á los navegantes.

$$
\text { P. DE N. Y C. }
$$





\section{N D I C E}

\section{INTRODUCCIÓN HISTÓRICA}

Algunas reflexiones sobre la conveniencia de publicar esta obra................

D. Alejandro Malaspina.-Su viaje.-Su proceso...................

Apendice a la Introducción histórica.-Sobre el destierro de Malaspina.........

Plan para escribir su viaje, dado por Malaspina al P. Gil................

De cómo tuvo origen el viaje de las corbetas Descubierta $y$ Atrevida.-Plan de un viaje científico y político alrededor del mundo, remitido al Excmo. Sr. Bailío D. Antonio Valdés, Ministro de Marina, por los Capitanes de fragata Don Alejandro Malaspina y D. José Bustamante...................

Cartas que escribió el Capitán dè fragata D. Alejandro Malaspina al Teniente General de la Armada D. Antonio Ulloa, solicitando de su sabiduráa algunos consejos.

Carta I...................

Carta II...................

Cartas que el Sr. D. Alejandro Malaspina escribió al Sr. D. José Salvaresa, Proto-médico de la Real Armada, sobre varios puntos dietéticos y del régimen profiláctico, que deberán observarse en el acopio de víveres para el viaje de la vuelta al mundo.

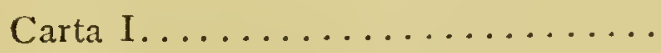

Carta II .................

Carta III...................

Respuesta del Sr. D. José Salvaresa á las cartas antecedentes del Sr. D. Alejandro Malaspina...............

Carta de Malaspina al Subinspector de Arsenales Sr. D. Fermín de Sesma, por la que se infiere la inteligencia, celo é iniciativa de! Jefe de la expedición, hasta en los más insignificantes por-

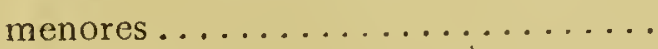

Carta de Malaspina al sabio Ingeniero Don Tomás Muñóz, haciéndole indicaciones sobre la colocación de pararayos.

Carla del Jefe de Escuadra D. Gabriel de Aristizabal á D. Alejandro Malaspina, en la que tan insigne marino se excusa modestamente de aconsejarle sobre un plan hidrográfico...............

Prueba de las Descubierta y Atrevida, según nota de Malaspina...........

\begin{abstract}
Páginas.
Resumen de los aprestos para un viaje alrededor del mundo, emprendido por las corbetas Descubierta y Atrevida.

Instrucciones notables que D. Alejandro Malaspina comunicó á D. José de Bustamante (segundo Jefe de la expedición), sobre la policía de los buques..
\end{abstract}

Páginas.

RELACION GENERAL DEL VIAJE Discurso preliminar por D. Alejandro Malaspina.....................

LIBRo PRIMERo.- - Navegación de las corbetas desde Cádiz á Montevideo, costa Patagónica, Maluinas, Chile, Perú, Guayaquil y Panamá.-Acaecimientos y tareas en los puertos que visitaron.

Capitulo 1.--Navegación de Cádiz á Montevideo.

Capitulo IT. - Estada en Montevideo, excursiones desde el mismo puerto y aprestos para la campaña sucesiva........

Capitulo III. - Navegación desde Montevideo hasta el puerto Deseado.-Varios reconocimientos de la costa intermedia.-Acaecimientos en aquel puerto y algunas ocurrencias con los patagones.

Capitulo IV.-Navegación á las islas Maluinas, y de allí alrededor del Cabo de Hornos, hasta el puerto de San Carlos de Chiloé.-Reconocimiento de las Tierras del Fuego y otros accidentes ocurridos en aquel tiempo...........

Capitulo V.-Navegaciones y tarcas hidrográficas desde Chiloé hasta Lima.Escalas en los puertos de Concepción, Valparaíso, Coquimbo, Arica y Lima. -Excursión de algunos Oficiales á Santiago.-Varios acaecimientos ocurridos en aquel tiempo............

Capitulo V1.- Navegación desde el Callao al andar de la costa hasta el puerto de Perico, en el Golfo de Panamá.--Ocurrencias en Guayaquil y en aquel puerto.

Libro SEGUndo. - Navegaciones desde Panamá á las costas de Guatemala y Nueva España.- Sucesivas indagaciones sobre la cista N.O. de la América, en busca de la comunicación de los dos mares, Atlántico y Pacífico, indicada por el navegante español Lorenzo Ferrer Maldonado.-Escalas en Nutka y en Monterey.--Regreso de las corbetas á Acapulco y acaecimientos en 
aquel puerto hasta el momento de dar vela hacia las Islas Marianas y Filipinas.

Cafitulo I.-Navegaciones y reconocimientos de las corbetas al andar de las costas de Tierra lirme y Costa Rica. - Separación de entrambos buques.- Tareas de la Descubierta sobre las costas de Guatemala y Nueva España.Viaje directo de la ATrevida á los puertos de Acapulco y San Blas.-Ultima reunión de las corbetas en Acapulco......................

Viajc efectuado por la ATREvida durante su
separación de la otra corbeta, según relación de Bustamantc...........

Navegación de la ATREvida al reconocimicnto de la Isla de Cocos, y sucesiva á los puertos de Acapulco y San Blas.

Salida de Acapulco y navegación hasta San Blas. .

Descripción del Departamento de San Blas, origen de su establecimiento y ventajas que ofreceria trasladado á Acapulco ....................

Salida de San Blas; navegación en busca de unos bajos al N.O. del Cabo Corrientes, y reunión á la Descubierta en Acapulco...................

Reunión de las corbetús. - Continúan viajando en conserva..............

C'apitulo II.-Objetos de la siguiente campaña sobre la costa N.O. de la América. - Navegaciones, escalas y reconocimiento en el paralelo de $60^{\circ}$.- - Regreso al Archipiélago de Nutka.-Reflexiones sobre las dos Memorias que dieron lugar á estos reconocimientos.

Relación del descubrimiento del Estrecho de Anian, que se atribuyó cl Capitán Lorenzo Ferrer Maldonado.........

Memoria sobre este descubrimiento, leída en la Real Academia de Ciencias de París por Mr. Bauche, geógrafo mayor de S. M. Cristianísima........

Disertación sobre la legitimidad de la navegación hecha en 1588 por Ferrer Malilonado, desde las inmediaciones de Terranova al mar Pacífico y al contrario. Se examinan las reflexiones del Sr. Bauche presentadas á la Real Academia de Ciencias de París en 13 de Noviembre de 1790 ; los rastros ongañosos de otras navegaciones semejantes y la utilidad verdadera para la navegación al Asia, de una comunicación cualquiera entre los dos mares.

Capitulo III.-Asacimientos en el Archipiślago de Nutka durante la demora de las corbetas en él. - Navegación sucesiva hasta Monterey y estacla en aquel puerto.-Ultimos reconocimientos al andar de las costas de California $y$ Nucva lispaña. - Escala de la Descu- merta en San Blas. - Reunión de las corbetas en Acapulco.-Acaecimientos en aquel puerto y aprestos para las campañas y operaciones siguientes... Separación de la ATrevida á perfeccionar el reconocimiento de la costa entre Cabo Corrientes y Acapulco........

Tercera estada de la Atrevida en Acapulco y ocurrencias hasta la reunión á la Descumierta................ Libro terCero. - Continuación del viaje de las corbetas á las Islas Marianas y Filipinas.-Varias cxcursiones en entrambos Archipiélagos, y navegación de la ATrevida al puerto de Macao.Ultimos reconocimientos en el mar Pacífico sobre la tierra austral del Es. píritu Santo, la Nueva Zelanda, la Nueva Holanda y las Islas de Vavao en el Archipiélago de los Amigos.--Regreso al puerto del Callao. - Nuevas indagaciones hidrográficas hechas sobre las Tierras del Fuego, las Maluinas, la Costa Patagónica y el Río de la Plata.--Regreso al puerto de Cádiz.. Capitulo I.-Navegación desde Acapulco á las Islas Marianas; escala, reconocimientos y observaciones en la de Guaham.-Travesía siguiente á las Islas Filipinas. - Acaecimientos en los puertos de Palapa y Sorsogon; primera escala en Manila y tareas de la DescUBierta en la misma bahía y sobre las costas de la provincia de Panga$\operatorname{sinan} . . . \ldots \ldots \ldots \ldots \ldots . . . . . .$.

Navegación de la Atrevida desde Manila á los mares de China y entrada en el pucto de Taipa................

Ocurrencias en el puerto de Taipa y en la ciudad de Macao.-Atenciones recibidas del Gobernador y de las Companías extranjeras.-Descripción de la ciudad con la forma de su gobierno: idea de su comercio, productos de sus rentas, y gastos que produce su conservación á $S$. M. F. - Reflexiones sobre el comercio de peletería, con las ventajas de la Lspaña para destruir el de otras naciones que lo ejecuten.....

Regreso á Manila................

Capitulo RII.-Diferentes excursiones científicas en la Isla de Luzón durante la estada de las corbetas en Cavitc.Aprestos para las campañas siguientes.-Ocurrencias principales relativas a los armamentos y á los buques.Plan de las siguientes campañas é individuos quedados en Manila con este

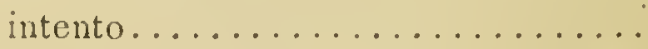

Coptulo $1 \%$. Navegación de las corbetas hasta el presidio de Mindanao, y reconocimientos intermedios. - Fscala cir aquel presidio.-Derrotas sucesivas 
en el Mar Pacifico. - Vista del extremo Sur de la tierra austral del Espíritu Santo y de las costas inmediatas á Dusky-Bay en la Nueva Zelanda.--Es: cala y acaecimientos en la colonia inglesa de Sidney, en la Nueva Holanda.....................

Capitulo $V$.-Navegación de las corbetas desde el puerto Jackson hasta las Islas de los Amigos.-Escala en la bahía Maurelle del Archipiélago de Vavao y reconocimientos interiores del mismo Archipiélago. - Navegaciones sucesivas al Sur hasta perder de vista las Islas de Tongatabu y Eua.......

Capitulo VI.-Navegación desde el Archipiélago de los Amigos hasta las costas del Perú.-Estada en el puerto del Callao, y nuevas medidas para la feliz conclusión del viaje, sabida la declaración de la guerra contra la Francia.--Segunda escala de las corbetas en la bahía de Concepción de Chile.

Capitulo VII.-Navegación de la Descu. BIERTA, desde la Concepción de Chile hasta el puerto de Montevideo.-Reconocimiento de las Tierras del Fuego y de la Isla de Diego Ramírez.Escalas en el puerto Egmont de las Islas Maluinas y en la bahía Santa Elena de la costa Patagónica.-Experiencias de la gravedad y otras tareas y

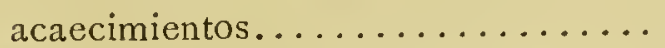

Separación de las corbetas desde el puerto del Callao, y navegación de la Atrevida al de Talcahuano.........

Salida del puerto de Talcahuano y navegación en busca de la Isla de Diego Ramírez, y al reconocimiento de la parte oriental de las Maluinas, por la corbeta Atrevida..............

Operaciones hidrográicas ejecutadas en el puerto de la Soledad.-Reflexiones sobre el estado actual de esta colonia y ventajas que ofrece su situación...

Salida de las Maluinas.-Navegación á las Islas de la Auróra.-Descubrimiento de una nueva situación de todas, y reunión en Montevideo á la Descu-

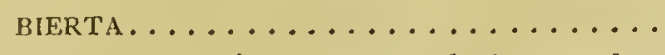

Capitulo IX.-Ultima escala de las corbetas en Montevideo.-Varios acaecimientos en aquel tiempo, y reunión en el puerto de la fragata Gertrudis, de la Marina Real, con cuatro buques mercantes de Lima.-Salida del convoy reunido de Lima y Montevideo, su navegación hasta llegar al puerto de Cádiz.................. Descripción física de las costas del Noroeste de la América, visitadas por las corbetas................... Vocabulario del idioma Mulgrave.......
Examen político de las costas del Noroeste de la América...................

Examen físico del Archipiélago de Vavao y de sus producciones y habitantes. Se individualizan diferentes puntos históricos relativos á toda la confederación de las Islas de los Amigos, desde las últimas navegaciones del Capitán Cook, y se continúa la serie importante de las reflexiones del mismo navegante.............................

Viaje de D. José de Espinosa y Tello, desde Cádiz hasta Acapulco, donde se reunió á la expedición de las corbetas, y continuación de este viaje. Contiene muy buenas noticias de Historia Natural, Geografía, costumbres, etc.....

Noticia de las principales expediciones hechas por nuestros Pilotos del Departamento de San Blas, al reconocimiento de la costa Noroeste de América, desde el año $x 774$ hasta el 179 I, extractada de los Diarios originales de aquellos navegantes..............

Descripción física y costumbres de la California..................

Condiciones de los puertos de San Blas y Acapulco para arsenales.-Reconocimientos en las provincias internas.Su descripción física, producciones y costumbres................

Carta esférica del Río de la Plata, desde su embocadura hasta Buenos Aires, y de la costa inmediata oriental hasta el Cabn de Santa María, trabajada á bordo de las corbetas, año de I $789 . .$.

Derrotero desde las Islas de Cabo Verde hasta Montevideo............

Derrotero desde Montevideo á Chiloé por el Cabo de Hornos. Trata también del puerto Egmont en las Islas Maluinas y de la descripción de toda la custa intermedia...................

Construcción de las cartas desde el puerto de Montevideo hasta el de Chiloé...

Derrotero de la Isla de Chiloé, por D. José Moraleda, Alférez de fragata y Pileto de la clase de primeros de la Real Armada...................

Construcción de las cartas hidrográficas desde Chiloé hasta Coquimbo.......

Derrotero de Chiloè á Coquimbo........ Construcción de las cartas desde Coquimbo hasta Lima, inclusas las Islas de

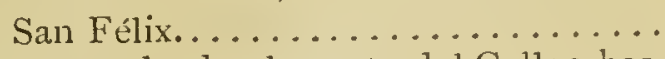

Derroteros desde el puerto del Callao hasta el Río de Guayaquil, y de este punto hasta el Golfo de Panamá, por D. Fabio Ali-Ponzoni.............

Estudio sobre las costumbres y descripciones interesantes de la América del Sur, por Espinosa.............. $44^{8}$

Noticias relativas á Montevideo........ 
Noticias de varios pueblos de la provincia de Buenos-Aires...............

Descripción política de la Isla de.Chiloé.

Estado político, militar y comercial de la ciudad de Concepción............

Noticias de las manufacturas de carnes saladas dé Buenos-Aires...........

Reflexiones políticas sobre los dominios de S. M., desde Buenos-Aires hasta Chiloé, por el Cabo de Hornos........

Descripción física del terreno y habitadores de las costas comprendidas entre Chiloé y Coquimbo...............

Examen político del país comprendido entre Chiloé y Coquimbo............

Introducción al Vocabulario de Vavao, por el Teniente de navío D. Ciriaco Ce-

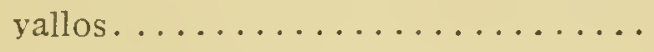

Discusión sobre las longitudes de las costas de Chile y Perú, por D. Felipe Bauzá.

Discusión sobre las situaciones astronómi-
Páginas.

\section{2}

577

583

588

590

602

608

620

627 cas de las costas de Chile, Perú é islas adyacentes..................

Observaciones de la velocidad del sonido, de latitud, longitud y variaciones hechas en Santiago de Chile, por el Te. niente de navío D. José Espinosa y el Alférez de navío graduado D. Felipe Bauzá..................... $6_{57}$

Observaciones del barómetro, de latitud, longitud y variación de la aguja, hechas desde Santiago de Chile á Mendoza y Buenos-Aires en Marzo y Abril de $1794 \ldots \ldots \ldots \ldots \ldots \ldots \ldots$

Estado donde se manifiesta la relación de gravedades entre diversos lugares del mundo, según las experiencias hechas por las corbetas, formado por el Teniente de navío D. Ciriaco de $\mathrm{Ce}$ vallos....................

Estados de derrota de la corbeta DescuBIERTA. ....................
Páginas. 






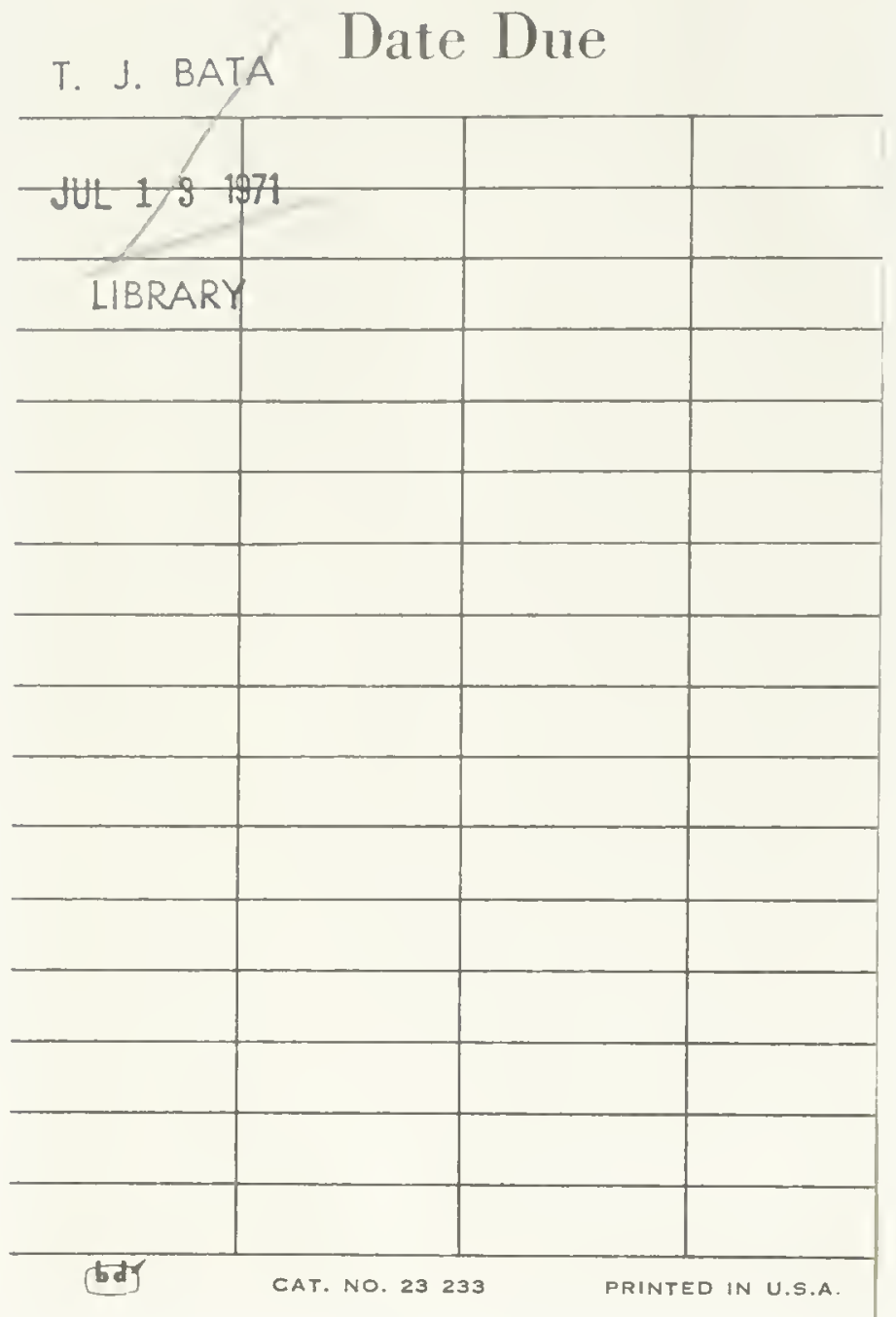


f G420 .M23 1885

Malaspina, Alessandro

viaje politico-científico

alrededor " "mundo por

Dessubi.

Jtt

idor las corbeta

130064

2.7

$15 \%$

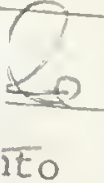

130064 
